\title{
Wie zal de opvoeders opvoeden? : kindermishandeling en het recht van het kind op persoonswording
}

Citation for published version (APA):

Willems, J. C. M. (1998). Wie zal de opvoeders opvoeden? : kindermishandeling en het recht van het kind op persoonswording. [Doctoral Thesis, Maastricht University]. Universiteit Maastricht. https://doi.org/10.26481/dis.19981218jw

Document status and date:

Published: 01/01/1998

DOI:

10.26481/dis.19981218jw

Document Version:

Publisher's PDF, also known as Version of record

\section{Please check the document version of this publication:}

- A submitted manuscript is the version of the article upon submission and before peer-review. There can be important differences between the submitted version and the official published version of record.

People interested in the research are advised to contact the author for the final version of the publication, or visit the DOI to the publisher's website.

- The final author version and the galley proof are versions of the publication after peer review.

- The final published version features the final layout of the paper including the volume, issue and page numbers.

Link to publication

\footnotetext{
General rights rights.

- You may freely distribute the URL identifying the publication in the public portal. please follow below link for the End User Agreement:

www.umlib.nl/taverne-license

Take down policy

If you believe that this document breaches copyright please contact us at:

repository@maastrichtuniversity.nl

providing details and we will investigate your claim.
}

Copyright and moral rights for the publications made accessible in the public portal are retained by the authors and/or other copyright owners and it is a condition of accessing publications that users recognise and abide by the legal requirements associated with these

- Users may download and print one copy of any publication from the public portal for the purpose of private study or research.

- You may not further distribute the material or use it for any profit-making activity or commercial gain

If the publication is distributed under the terms of Article $25 \mathrm{fa}$ of the Dutch Copyright Act, indicated by the "Taverne" license above, 
WIE ZAL DE OPVOEDERS OPVOEDEN? 


\section{Aan Annet}

en allen die durven vechten en liefhebben, hoezeer zij ook door het leven of door hun ouders zijn verwond 


\title{
WiE ZAL DE OPVOEDERS OPVOEDEN?
}

\section{Kindermishandeling en het Recht van het Kind op Persoonswording}

\author{
Who will educate the educators? \\ Child abuse and the right of the child to become a person \\ (with a summary in English)
}

\section{PROEFSCHRIFT}

ter verkrijging van de graad van doctor aan de Universiteit Maastricht, op gezag van de Rector Magnificus,

Prof. dr. A.C. Nieuwenhuijzen Kruseman, volgens het besluit van het College van Decanen in het openbaar te verdedigen op vrijdag 18 december 1998 om 14.00 uur

door

Johannes Cornelius Maria WILLEMS geboren te Nijmegen 


\section{Promotores}

Prof. mr. Th.C. VAN BOVEN

Prof. dr. H.E.M. BAARTMAN (Vrije Universiteit Amsterdam)

\section{Beoordelingscommissie}

Prof. mr. C. FLINTERMAN (voorzitter)

Prof. mr. J.E. DOEK (Vrije Universiteit Amsterdam)

Dr. F. VAN DUN

Prof. mr. M.J.C. KOENS

Dr. D.J. DE RUYTER (Vrije Universiteit Amsterdam)

De publicatie van dit boek is mede mogelijk gemaakt door

financiële steun van de Nederlandse Organisatie voor Wetenschappelijk Onderzoek (NWO), het BERT VOSKUIL FONDS en de Faculteit der Rechtsgeleerdheid van de Universiteit Maastricht. 
Een handelseditie van dit proefschrift is verschenen bij T.M.C. Asser Press, Den Haag, ISBN 90-6704-106-8

Opmaak: Jan C.M. Willems

(C) 1998, J.C.M. Willems, Maastricht

Alle rechten voorbehouden. Niets uit deze uitgave mag worden verveelwoudigd, opgeslagen in een geautomatiseerd gegevensbestand, of openbaar gemaakt in enige vorm of op enige wijze, hetzij elektronisch, mechanisch, door fotokopieën, opnamen of enig andere manier, zonder voorafgaande toestemming van de copyrighthouder. 
'Like art, law does not just reproduce the visible: it makes visible.'

Anne MCGLLIVRAY, 'Reconstructing child abuse: Western definition and non-Western experience,' in: Michael FREEMAN, Philip VEERMAN (eds.), The ideologies of children's rights, Dordrecht 1992, pp. 213-236, op p. 213. 


\section{INHOUDSOVERZICHT}

Uitgebreide inhoudsopgave

Woord vooraf en dankwoord

Boek 1: Kernrechten

1. Inleiding, opvoedingsverantwoordelijkheid en persoonswording

1.1 Inleiding invalshoek, doel en Leitmotiv van deze studie

1.2 Aard, onderwerp en methode van onderzoek

1.3 Vraagstellingen en enkele begrippen

1.4 Opzet

2. Mensenrechten, en het kind?

2.1 Inleiding: mensenrechten, en het kind?

3. Mensenrechten als rechtsbeginselen

3.1 Inleiding: mensentechten als rechtsbeginselen

3.4 Mensenrechten zijn rechtsbeginselen 107

3.5 Mensenrechten tussen natuurrecht en rechtsverfijning: enkele conclusies

4. Grondbeginselen en kernrechten

5. De rechten van het kind tussen parentiarchie en persoonswording

5.1 Inleiding: de rechten van het kind tussen parentiarchie en persoonswording

5.5 Het Verdrag inzake de rechten wan het kind: uitzicht op persoonswording? 
6. Kerninhoud van kinderrechten

6.1 Inleiding: kerninhoud van kinderrechten

6.2 Algemene mensenrechten en speciale kinderrechten

6.3 Het veiligheids- en ontwikkelingsbelang van kinderen

6.4 Kinderrechten en het gelijkheidsbeginsel

6.5 Kinderrechten en het ontplooiingsbeginsel

6.6 Individuatie en (westers) individualisme

7. Kernrechten van het kind in de Trias pedagogica

7.1 Inleiding: kernrechten van het kind in de Trias pedagogica

7.2 Sociaal-pedagogische (natuurlijke) rechten

7.3 Rechten en actoren in de Trias pedagogica

\section{Boek 2: Persoonswording}

8. Persoonswording en het belang van het kind

8.1 Inleiding: persoonswording en het belang van het kind

8.2. Het belang van het kind

8.3 Persoonswording

8.4 Persoonswording als het ultieme belang van het kind

9. Persoonswording als pedagogisch criterium

9.1 Inleiding: persoonswording als pedagogisch criterium

9.2 Criterium-DE RUYTER: de voorwaarden

9.3 Persoon = 'een mens die adequaat kan handelen' en de drieslag rationaliteit, moraliteit, authenticiteit

9.4 Criterium-DE RUYTER: toevoeging en toespitsing

9.5 Criterium-DE RUYTER: toetsing en bezwaren

9.6 Uitleiding

10. Persoonswording en het Verdrag inzake de rechten van het kind

10.1 Inleiding: persoonswording en het Verdrag inzake de rechten van het kind

10.2 Het Verdrag inzake de rechten van het kind

10.3 Het recht wan het kind op optimale persoonswording

10.4 Het recht van het kind op minimale persoonswording

10.5 Addendum: De opvatting van het Comité inzake de rechten van het kind

\section{Boek 3: Kindermishandeling}

11. Kindermishandeling als schending van het recht van het kind op minimale persoonswording

11.1 Inleiding: kindermishandeling als schending van het recht van het kind op minimale persoonswording

11.2 Definities, vormen en "oorzaken' van kindermishandeling

11.3 Opvoedingsstijlen en persoonswording

11.4 Kindermishandeling als bedreiging of beschadiging van minimale rationaliteit, moraliteit of authenticiteit 
12. Kindermishandeling als ernstige en passief-systematische mensenrechtenschending

12.1 Inleiding: kindermishandeling als ermstige en passief-systematische mensenrechtenschending

12.2 Kindermishandeling als ernstige mensenrechtenschending (1): de cijfers

12.3 Kindermishandeling als ernstige mensenrechtenschending (2): de gevolgen

12.4 Kindermishandeling als passief-systematische mensenrechtenschending: culturele en structurele ouderschapsverwaarlozing als passiefsystematische kinderrechtenschending

\section{Boek 4: Staatsaansprakelijkheid}

13. Staatsaansprakelijkheid en systemische sociaal-pedagogische discriminatie

13.1 Inleiding: staatsaansprakelijkheid en systemische sociaal-pedagogische discriminatie

13.2 Staatsaansprakelijkheid en de tria onera paedagogica

13.3 Systemische sociaal-pedagogische discriminatie

13.4 Staatsaansprakelijkheid en overheidsverantwoordelijkheden

13.5 En niemand bood hulp

14. Persoonswording en modaliteiten van staatsverantwoordelijkheid

14.1 Inleiding: over de opbouw van dit hoofdstuk

14.2 Persoonswording en modaliteiten van staatswerantwoordelijkheid

14.3 Sociaal-Pedagogische Steun als geintegreerde preventieve benadering

14.4 Respect voor kinderen begint met respect voor ouderschap $\quad 875$

14.5 De Trias pedagogica als constitutionele grondslag 901

14.6 Rehabilitatie en reparatie

14.7 WU HEBBEN U, O ABEL ...

Bijlagen

I. Verdrag inzake de rechten van het kind

II. Voorbeeld-strafbepalingen kindermishandeling

III. Criteria kindermishandeling

IV. Lijst van afweermechanismen en coping-stijlen

V. Persoonlijkheidsstoornissen

VII. Persoonlijkheidsstijlen

VII. Opwoedingswrijheid en persoonswording

vII. Korte omschrijving van enkele samenhangende termen 


\section{UITGEBREIDE INHOUDSOPGAVE}

Woord vooraf en dankwoord

Post scriptum

Boek 1: Kernrechten

1. Inleiding, opvoedingsverantwoordelijkheid en persoonswording

1.1 Inleiding: "invalshoek, doel en Leitmotiv van deze studie

1.1.1 Invalshoek: het kind als subject van rechten

$\begin{array}{ll}\text { Extra bescherming van fundamentele rechten en speciale rechten } & 17\end{array}$

Merselijke waardigheid 18

Rechtsverfijning: SPS 19

Het kind als rechtssubject: KOENS $\quad 19$

Het kind als eigendom: DE LANGEN

Het belang van het kind: DOEK $\quad 25$

$\begin{array}{ll}\text { Criterium-DE RUTTER } & 27\end{array}$

1.1.2 Doel van deze studie: het recht van het kind op persoonswording als

kernrecht van het kind $\quad 28$

Staat of overheid? $\quad 30$

1.1.3 Reprise: persoonswording als resultaats- en inspanningswerplichting 31

1.1.4 Leitmotiv van deze studie: geen bevoegdheid zonder verantwoording 33

$\begin{array}{ll}\text { Macht comumpert } & 35\end{array}$

De pedagogische kwestie en de 'schulduraag' $\quad 36$

De taak van de jurist $\quad 38$

1.2 Aard, onderwerp en methode wan onderzoek 39

Aard van het onderzoek: het eigenlijke onderwerp 39

Het directe onderwerp van onderzoek 40

Methode van onderzoek $\quad 41$

Parafraseren of citeren? 41

1.3 Vraagstellingen en enkele begrippen 41

1.3.1 De centrale probleemstelling (en enkele begrippen) 41

Enkele begrippen

1. Overheidsingrijpen 43

2. Gezin 43

3. Ouders/opvoeders 43

4. Pedagogische hulp 44

5. Opleggen van hulpverlening 44

6. Machtsmisbruik door de staat 44

7. Kindervolkenrecht 45

1.3.2 Bijkomende probleemstellingen 46

1.3.3 Hoofd-en subvragen: een inventarisatie 46

\begin{tabular}{ll} 
Overlap & 48 \\
\hline
\end{tabular}

$1.4 \quad$ Opzet 
2. Mensenrechten, en het kind? 51

2.1 Inleiding: mensenrechten, en het kind? 51

2.2 Korte historiek 51

2.2.1 De rode draad: machtsbeperking, democratisering en emancipatie 51

2.2.2 Van kwelrecht wan de vorst tot interventierecht van de Veiligheidsraad 51 Jus ad bellum en jus ad tormentum. $\quad 51$ Jus ad bellum als jus contra tormentum $\quad 52$

2.3 Documenten in vogelvlucht 54 De Unie van Utrecht: het eerste mensenrecht 54 Van de Nederlandse tot de Amerikaanse onafhankelijkheidsverklaring 55 De Verklaringen van de rechten van de man en de bunger 59 Slavenhandel en slavemij, Solferino en de sociale kwestie: de eerste mensenrechtenverdragen

De periode van de Verenigde Naties 64

2.4 Het verhaal van de mensenrechten 67

2.4.1 Het eerste mensenrechtenverhaal 67 Het institutionele verhaal 68

2.4.2 Het tweede mensenrechtenwerhaal 69

Het homo sapiens-verial $\quad 69$

$\begin{array}{ll}\text { Joden, geesteszieken, dissidenten } & 71\end{array}$

$\begin{array}{lll}2.5 & \text { En het kind? } & 72\end{array}$

Het lot van het kind

Is het tweede mensenrechtenverhaal 'af?

2.5.1 Horizonverbreding en perspectiefverschuiving 74

$\begin{array}{ll}\text { Discussie } & 77\end{array}$

De mentselijke mogelijkheid tot lijden $\quad 77$

Speciesisme, ageïsme en art. 3 EVRM $\quad 79$

Perspectiefverschuiving $\quad 80$

2.5.2 Exit jus ad tormentum: op weg naar 'humanitaire interventie' in het
gezin?

Het Verdrag inzake de rechten wan het kind 86

3. Mensenrechten als rechtsbeginselen 88

3.1 Inleiding: mensenrechten als rechtsbeginselen $\quad 88$

3.2 Bronnen en jus cogens 88

3.2.1 Rechtsbeginselen: frappez towjours 88

Frappez toujouts: $\quad 89$

3.2.2 Jus cogens 91

3.2.3 Rechtsbeginselen in het internationale recht 92

$\begin{array}{ll}\text { Natururrechtelijke beginselen } & 92 \\ & 93\end{array}$

$\begin{array}{lll}3.3 & \text { Natuurrecht en rechtspositivisme } & 93\end{array}$

$\begin{array}{lll}3.3 .1 & \text { Natuurecht } & 94\end{array}$

De jure belli ac pacis $\quad 96$

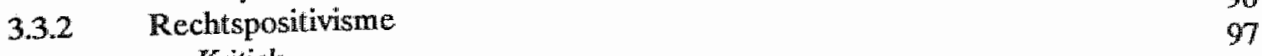

$\begin{array}{ll}\text { Kritiek } & 98\end{array}$

3.3.3 Bezwaren tegen het natuurrecht: 'cultuurrecht" 99

3.3.4 Toetsing aan mensenrechten en andere grondslagen van het recht 100

$\begin{array}{ll}\text { De kritische attilude van de jurist } & 101 \\ & 102\end{array}$

3.3.5 Het 'cultuurrecht' van westerse samenlevingen 
3.3.6 De 'religieuze' fundering

3.3.7 Persoonswording als natuurlijk recht

3.4 Mensenrechten zijn rechisbeginselen

107

3.4.1 Reprise: natururrechtelijke beginselen 107

3.4.2 Het rechtskarakter van rechisbeginselen 110

Beginsel eist Applikatio

110

Beginsel verwijst naar moraal

Hiërarchie

111

Mensenrechten zijn rechtsbeginselen

Rechtskracht: directe werking.

Rechtenmetafoor: gevaar van ideologie $\quad 112$

Rechtsvinding: teleologie

113

3.5 Mensenrechten tussen matuurrecht en rechtsverfijning: enkele conclusies

113

Rechtsbeginselen en moraai

113

Mensenrechten zijn rechtsbeginseien

Rechrsbeginselen (en dus ook mensenrechten) zijn richting gevend

Rechisbeginselen zijn legitimerend, matstaf voor toetsing en rechtsvormend

Mensenrechten doorlopen een aantal stadia

Balans

4. Grondbeginselen en kernrechten 121

4.1 Inleiding: grondbeginselen en kernrechten 121

4.2 De menselijke waardigheid als grondslag van het recht 121

4.2.1 De menselijke waardigheid van het kind 123

De staatspedagogische taak 124

De waardigheid van het kind $\quad 125$

$\begin{array}{ll}\text { Conclusie } & 126\end{array}$

4.2.2 Menselijke waardigheid en gelijkheid $\quad 128$

De strijd gestreden 129

4.2.3 Menselijke waardigheid en ontplooiing 132

4.2.4 De oorsprong: morele autonomie 135

The ultimate unit of all law 136

4.2.5 Conclusie: gelijkheid en ontplooiing als grondbeginselen 138

$\begin{array}{ll}\text { Trias pedagogica } & 139\end{array}$

4.3 Kerninhoud en kernrechten $\quad 140$

4.3.1 Uniwersaliteit en kernrechten $\quad 141$

$\begin{array}{lr}\text { Verdragsrecht } & 144\end{array}$

Jurisprudentie $\quad 145$

Doctrine $\quad 145$

4.3.2 Kernrechten, participatierechten, tertiäre rechten 148

1. Kernechten (1-15) 153

2. Participarierechten (16-35) 1.54

3. Derde-categorierechen (minder fundamentele mechten) (36-45) 155

Voortplantingsvijheid 156

$\begin{array}{ll}\text { Privacy } & 157\end{array}$

Opvoedingsvrijheid $\quad 157$

4.3.3 In de ruimste mate 
5. De rechten van het kind tussen parentiarchie en persoonswording

5.1 Inleiding: de rechten van het kind tussen parentiarchie en persoonswording

$5.2 \quad$ Korte historiek 160

5.2.1 Een slok van de Lethe 161

5.2.2 Van patriarchie naar parentiarchie: John LOCKE 168 Mene tekel 169

5.2.3 LOCKE's ideeen en het recht: voortschrijdende juridisering?

5.2.4 Sentimentalisering 173

5.2.5 Juristen en monitoring children's rights 178 Conclusie

5.2.6 Een blinde vlek op de liberale retina 181 Kinderrechten in discussie 182

5.3 Drie treden in het internationale recht 184

$5.4 \quad$ En Nederland? Nederlands familierecht 191 Canonieke invulling vant het ouderlijk gezag? 196

5.5 Het Verdrag inzake de rechten van het kind: vitzicht op persoonswording?

6. Kerninhoud van kinderrechten 199

6.1 Inleiding: kerninhoud van kinderrechten 199

6.2 Algemene mensenrechten en speciale kinderrechten 200 Algemene en speciale rechten $\quad 204$

6.3 Het veiligheids- en ontwikkelingsbelang van kinderen 206

6.3.1 Lichamelijke en geestelijke integriteit 207

6.3.2 Huiselijk geweld 210 Huiselijk geweld tegen wrouwen 210 Ouderijk geweld tegen kinderen $\quad 213$ De moraal van dit verhaal $\quad 215$

6.4 Kinderrechten en het gelijkheidsbeginsel 216

6.4.1 Het gelijkheidsbeginsel 217

6.4.2 De public/private dichotomie en het gelijkheidsbeginsel 219

$6.5 \quad$ Kinderrechten en het ontplooingsbeginsel 222

6.5.1 Het ontplooiingsbeginsel 223

6.5.2 Het persoonswordingsbeginsel :

Menselijke waardigheid, persoonswording, ontplooing 228 Mimesis, faimess, appetitus societatis Mensenrechten - dierenrechten?

6.6 Individuatic en (westers) individualisme 232 Individuatie 232

Westers individualisme $\quad 235$

Westers individualisme

Persoonswording en individua(lisa)tie als westers concept? 239
Trias pedagogica

7. Kernrechten van het kind in de Trias pedagogica 241

7.1 Inleiding: kernrechten van het kind in de Trias pedagogica

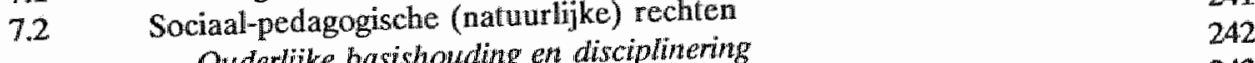

Ouderlijke basishouding en disciplinering $\quad 243$

Hoogste drieëentheid 
7.2.1 Morele (natuurlijke) rechten 246

$\begin{array}{ll}7.2 .2 & \text { Kinderrechtencatalogi } \\ & 249\end{array}$

Commentaar 251

7.2.3 Sociaal-pedagogische kernrechten van het kind 259

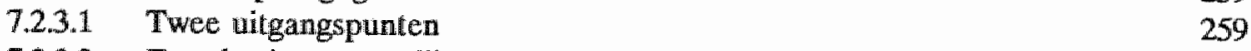

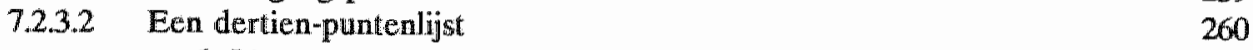

1. Lichamelijke en geestelijke integriteit. 261

2. Koestering 261

3. Lichamelijke en geestelijke zorg en zorgvoorzieningen 262

4. Gelijke opvoeding $\quad 264$

5. Ontploouing 267

$\begin{array}{ll}\text { 6. Leiding } & 267\end{array}$

$\begin{array}{ll}\text { 7. Begeleiding } & 267\end{array}$

8. Eigen mening hoorrecht/eigen rechtsingang 268

9. Gezinstaken 268

10. Gelijke sociale omstandigheden en voorzieningen $\quad 270$

11. Opvoedingsonderwijs 271

12. Opvoedingsgeld 272

13. Opvoedingsondersteuning 273

$\begin{array}{lll}\text { 7.2.3.3 Een schema } & 277\end{array}$

$\begin{array}{ll}\text { Pedagogische dwang } & 279\end{array}$

7.3 Rechten en actoren in de Trias pedagogica 280

7.3.1 Fundamentele kinderrechten in de Trias pedagogica 280

73.2 Kernrechten van kinderen als fundamentele (rechts)beginselen 284

7.3.3 Nog iets over de actoren in de trias: kind, ouder en staat 286

7.3.4 De Trias pedagogica en Gezinswaarden 286

Boek 2: Persoonswording 291

8. Persoonswording en het belang van het kind 293

8.1 Inleiding: persoonswording en het belang van het kind 293

8.2 Het belang van het kind 294

$\begin{array}{ll}\text { Nederland } & 294\end{array}$

Intermationale auteurs: $\quad 297$

8.2.1 Het belang van het kind: een rechtsbeginsel? 300

$\begin{array}{ll}\text { Tegenvoeter } & 302\end{array}$

8.2.2 Het belang van het kind: een pedagogische kern? 306

$\begin{array}{ll}\text { Nederland } & 307\end{array}$

Kindervolkenrecht $\quad 312$

Grundnom $\quad 313$

Grondwettelijke verankering $\quad 314$

8.2.3 Het belang van het kind: een tussenbalans 315

Het kind als machtsobject $\quad 320$

Misbruik van een vaag criterium $\quad 321$

$\begin{array}{lll}8.3 & \text { Persoonswording } & 324\end{array}$

8.3.1 Het kind als animal educandum: persoonswording als (universeel)
opvoedingsdoel

Het spanningsveld van de pedagogiek $\quad 325$

Het jonge kind in het gezin. $\quad 326$

$\begin{array}{ll}\text { 'Zwarte pedagogie" } & 327\end{array}$ 
8.3.2 Het pedagogisch belang, wan het kind: persoonswording als Grundnorm (meta-kernrecht)

8.4 Persoonswording als het ultieme belang van het kind

9. Persoonswording als pedagogisch criterium

9.1 Inleiding: persoonswording als pedagogisch criterium 337

9.2 Criterium-DE RUYTER: de voorwaarden 338 $\begin{array}{ll}\text { Vier voorwaarden } & 340\end{array}$

Samengevat $\quad 344$

Optimum en minimum 344

9.3 Persoon = "een mens die adequaat kan handelen' en de drieslag rationaliteit, moraliteit, authenticiteit

9.3.1 Minimale rationaliteit (cognitieve vaardigheden) 349

9.3.2 Minimale moraliteit (gewetensworming) 350

Discussie

9.3.3 Minimale authenticiteit (identiteitsontwikkeling) 353

9.4 Criterium-DE RUYTER: toevoeging en toespitsing 355 $\begin{array}{ll}\text { Toevoeging } & 355\end{array}$

Toespitsing van de toevoeging $\quad 357$

$\begin{array}{ll}\text { Staatsaansprakelijkheid } & 358\end{array}$

9.5 Criterium-DE RUYTER: toetsing en bezwaren 359

$\begin{array}{lll}\text { 9.5.1 Toetsing van de voorwaarden } & 359\end{array}$

Filosofische rechtvaardiging $\quad 361$

$\begin{array}{lll}9.5 .2 & \text { (Mogelijke) bezwaren } & 362\end{array}$

$\begin{array}{ll}\text { Correctie-KOENS } & 363\end{array}$

$\begin{array}{lll}9.6 & \text { Uitleiding } & 367\end{array}$

10. Persoonswording en het Verdrag inzake de rechten van het kind

10.1 Inleiding: persoonswording en het Verdrag inzake de rechten van het kind

$\begin{array}{lll}10.2 & \text { Het Verdrag inzake de rechten van het kind } & 372\end{array}$

Bijna-universele gelding: Scylla en Charybdis $\quad 375$

Voorbehouden $\quad 380$

De 6 P's uit het Verdrag 386

10.2.1 Het kind als persoon-in-wording: welzijns-en beschermings-

$\begin{array}{cc}\text { bepalingen in het Verdrag inzake de rechten van het kind } & 389 \\ \text { Preambulaine owenwegingen } & 390\end{array}$

Artikelen $\quad 393$

10.2.2 Het kind als persoon-in-wording: de zelfbepalingsrechten in het
Verdrag inzake de rechten van het kind

Preambulaire overwegingen $\quad 402$

Arrikelen $\quad 403$

10.3 Het recht wan het kind op optimale persoonswording 412

10.3.1 Optimale persoonswording in het Verdrag 413

10.3.2 Optimale persoonswording in andere instrumenten $\quad 416$

10.3.3 Optimale persoonswording als achterliggend rechtsbeginsel van het

Verdrag inzake de rechten wan het kind $\quad 428$

Interpretatiekader $\quad 433$

Minimale persoonswording $\quad 436$ 
10.4 Het recht van het kind op minimale persoonswording

10.4.1 Minimale persoonswording als het recht van het kind op een buitenstaander

10.4.2 Minimale persoonswording als quasi-resultaatsverplichting

10.4.3 Conclusie: minimale persoonswording als primordiaal en absoluut kernrecht wan het kind

Conclusie

10.5 Addendum: De opvatting van het Comité inzake de rechten van het kind

11. Kindermishandeling als schending van het recht van het kind op minimale persoonswording

11.1 Inleiding: kindermishandeling als schending van het recht van het kind op minimale persoonswording Algemene inleiding Vraagstelling

11.2 Definities, vormen en 'oorzaken' van kindermishandeling

11.2.1 De nemo plus-regel en transgenerationaliteit

Nemo plus

Transgenerationaliteit

Het afgunst-motief

Begin en einde van de tumnel

11.2.2 Definities en vormen van kindermishandeling

11.2.2.1 Kindermishandeling als 'sociaal construct'

11.2.2.2 Cultureel relativisme en 'natural love'

1. Psychische kindemishandeling $\quad 498$

2. Affectieve verwaarlozing $\quad 501$

3. Lichamelijke kindermishandeling $\quad 502$

4. Lichanelijke verwaarlozing $\quad 504$

5. Sexuele kindermishandeling $\quad 505$

Child sexual abuse accommodation syndrome $\quad 512$

Definities van serueel misbruik $\quad 513$

Reacties op (het sexuele van) sexwele kindermishandeling 515

11.2.2.4 Pedagogisch besef

Striking a balance

Classificatiesysteen

$\begin{array}{llr}\text { 11.3 } & \text { Opwoedingsstijlen en persoonswording } & 528 \\ \text { 11.3.1 } & \text { Ouderlijke opvoedingsstijlen } & 529\end{array}$

Warmie en toezicht $\quad 530$

11.3.2 De autoritatieve opvoedingsstijl als recht van het kind? 533

11.4 Kindermishandeling als bedreiging of beschadiging van minimale rationaliteit, moraliteit of authenticiteit 
12. Kindermishandeling als ernstige en passief-systematische mensenrechtenschending

12.1. Inleiding: kindermishandeling als crnstige en passief-systematische mensenrechtenschending

12.2 Kindermishandeling als ernstige mensenrechtenschending (1):

de cijfers

12.2.1 Definiêring, prevalentie en incidentie

Definiëring

Prevalentie en incidentie

Kindermishandeling als doodsoorzak

545

Onderrapportage

12.2.2 Cijfers

Fysiek geweld

560

Psychiatrische patiènter en criminelen

561

12.2.3 Ten minste 80.000 kinderen per jaar

564

Balans

12.3 Kindermishandeling als ernstige mensenrechtenschending (2): de gevolgen

12.3.1 De psychische en psycho-sociale gevolgen 573

Trauma en herstel

573

BOWLBY's gehechtheidstheorie

577

De verraadstraumatheorie

585

Brede range van postraumatische psychopathologie (sequelae) 589

Traumatisering en revictimisering

593

Verwerking

596

600

12.3.2 De maatschappelijke gevolgen

603

Psychische en maatschappelijke gevolgen: een overzicht

605

Criminaliteit (1): het kleine onrecht

Criminaliteit (2): misdaden tegen de mensheid en misdaden tegen het kind (psychopathie of kindemishandeling?)

Criminaliteit (3): jeugd en gezin

12.4 Kindermishandeling als passief-systematische mensenrechtenschending: culturele en structurele ouderschapsverwaarlozing als passief-

systematische kinderrechienschending

\section{Boek 4: Staatsaansprakelijkheid}

13. Staatsaansprakelijkheid en systemische sociaal-pedagogische discriminatie

13.1 Inleiding: staatsaansprakelijkheid en systemische sociaal-pedagogische discriminatie

13.2 Staatsaansprakelijkheid en de tria onera paedagogica

13.2.1 Staatsaansprakelijkheid en 'allermensenrecht" 635

WAN VOLLENHOVEN

Allernensenrechi

652

1. Egoisme/eigenbelang

656

2. Broederliefde, wederkerig allruisme

3. Geweten(svorming)/moraal 
13.2.2 De tria onera paedagogica: preventie, interventie, reparatie 670

13.2.2.1 Grove schendingen van mensenrechten van kinderen 672

$\begin{array}{ll}\text { Recapitulerend } & 680\end{array}$

13.2.2.2 Preventie, interventie en reparatie in de Trias pedagogica 681

1. Preventie: The duty to prevent (in het bijzonder met betrekking tot 'gross violations')

682

2. Interventie: The duty to investigate and to take appropriate action;

The duty to prosecute and punish perpetrators (of crimes under intemational law)

3. Reparatie (1): The duty to afford reparation

4. Reparatie (2): The duty to afford remedies

Eén raket: Preventie, interventie, reparatie: samenvloeing in de

Trias pedagogica

13.2.2.3 Compensatie: kindermishandeling voor de rechter

685

688

697

698

699

13.3 Systemische sociaal-pedagogische discriminatie 705

$\begin{array}{ll}\text { 13.3.1 Systemische discriminatie } & 705\end{array}$

$\begin{array}{ll}\text { Publick/privë } & 707\end{array}$

$\begin{array}{ll}\text { Trias pedagogica } & 713\end{array}$

$\begin{array}{ll}\text { Materièle gelijkheid } & 714\end{array}$

13.3.2 De systemisch-discriminatoire schending van sociaal-pedagogische grondrechten

Transgenerationaliteit

716

718

13.3.3 Staats-transgenerationaliteitsaansprakelijkheid 720

$\begin{array}{ll}\text { Toelichting bij het schema. } & 723 \\ \end{array}$

13.4 Staatsaansprakelijkheid en overheidsverantwoordelijkheden 725

13.4.1 Staatsaansprakelijkheid: enkele deductieve conclusies 731

Toetsing aan de hand van getuige-deskundigenverklaringen 756

$\begin{array}{ll}\text { Conclusie } & 788\end{array}$

13.4.2 Staatsaansprakelijkheid en het dominante positivisme 789

"T must retrace my steps (...)"

$\begin{array}{ll}\text { De taak van de jurist } & 794\end{array}$

De huidige stand van het internationale recht 797

13.4.3 Staatsaansprakelijkheid en overheidsverantwoordelijkheden:
een grijze zone

$\begin{array}{ll}\text { Eindconclusie } & 815\end{array}$

$\begin{array}{lll}13.5 & \text { En niemand bood hulp } & 818\end{array}$

14. Persoonswording en modaliteiten van staatsverantwoordelijkheid

14.1. Inleiding: over de opbouw van dit hoofdstuk 820

14.2 Persoonswording en modaliteiten van staatsverantwoordelijkheid 821

14.2.1 Persoon en persoonswording: minimale en optimale rationaliteit, moraliteit en authenticiteit

$\begin{array}{ll}\text { Mentale representaties } & 821\end{array}$

Het brein en individuatie $\quad 822$

Bewordering en bewaking van persoonswording: handelen naar inzicht 825

Het dynamische persoonsbegrip: de mens als persoon in potentie $\quad 827$

14.2.2 Ontwikkeling van het kind: leiding en begeleiding bij de ontplooing naar bovenminimale rationaliteit, moraliteit en authenticiteit als kemrecht

14.2.3. Het 'belang van het kind' als pedagogisch recht: het recht wan het kind op optimale persoonswording 
14.2.4 De sociaal-pedagogische kwestie: en naturijk en verdragsrecht op een evenwichtige en geweldloze opvoeding zonder effectief recht op opvoedingsbegeleiding en -bewaking als growe mensentechtenschending

14.2.5 Modaliteiten van staatsverantwoordelijkheid: blauwdruk van cen kind- en gezinsvriendelijke samenleving

14.3 Sociaal-Pedagogische Steun als geintegreerde preventieve beriadering

14.3.1 Monitoning parenting als schrikbeeld

Mensenrechtenschending

Monitoring parenting

Tertium datur: de derde weg

14.3.2 Preventie van kindermishandeling is preventie van (jeugd)criminaliteit

14.3.2.1 Externaliseren/internaliseren

14.3.2.2 Als het kalf verdronken is

Privésfeer is heilig persoonswording niet?

Interventie geslaagd, patient overleden

14.3.3 Een integrale aanpak en een glijdende schaal van ouderschapsondersteuning (inluiding/intermezzo)

De eerste deskundige

De tweede deskundige

Reacties

De derde deskundige

14.4 Respect voor kinderen begint met respect voor ouderschap

14.4.1 Respect voor kinderen: bevordering van optimale, waarborging van minimale persoonswording (het recht van het kind op een buitenstaander)

14.4.2 Respect voor ouderschap: sociaal-pedagogische voorzieningen 877

14.4.3 Respect voor ouderschap: formele en materiële elementen $\quad 878$

14.4.3.1 Secundaire opvoedingsverantwoordelijkheid: formele elementen $\quad 883$

14.4.3.1.1 Publiekscampagnes, politieke programma"s

$$
\text { [Overheidscampagres:] }
$$

Een kind is geen pop. Het heeft rechten - nèt als U!

883

Uw buurkind is ook eer mens. Niet witstellen: het Meldpunt bellen!

Ouders, geeft Uw kind geen dreun, wij sfacn klaar met hulp en steunt

Ouders, eis hulp! Vecht vóor - niet legen Uw kind!

886

Opvoedingsproblemen? gezinsproblemen? venwerkingsproblemen? bedenk en onthoud: Spreken is ziver, zwijgen is Foult

Bent U nooit kind geweest? of heefi U nooit kind mogen zijn?

Voor gezinnen zorgen: wandaag niet morgen/ [CDA; klein rechts]

Nederland: rechtsstaat. Ook woor kinderen! [VvD; D66]

Een land zonder mishandelde kinderen vóór 2010: elk jaar 10.000 mishandelde kinderen minder! Het kan! Het moet! We gaan ervoor! [D66; PvdA; GroenLinks] 
14.4.3.2 Secundaire opvoedingsverantwoordelijkheï: materiële elementen

Voorkomen is beter dan genezen, doch de kost gaat voor de baat wit

De trits Opwoedingsonderwijs-Opvoedingsondersteuning-

Opvoedingsgeld

14.5 De Trias pedagogica als constitutionele grondslag

14.5.1 Constitutionalisering wan sociaal-pedagogische grondrechten

14.5.2 Operationalisering van Opvoedingsondersteuning, Opvoedings-

onderwijs en Oproedingsgeld

Op weg naar een sociaal-pedagogisch beleid

907

907

14.5.2.1 Een wettelijke meldplicht en een juridisch statuut voor meldpunten $\quad 910$

Stelling

Kinderwerlating

910

Niet witstellen: het AMK bellen!

910

911

14.5.2.2 Ouderschapsondersteuning en Persoonswordingsvindicatie in plaats van Ondertoezichtstelling

14.5.2.2.1 Ouderschapsondersteuning: het aanbieden van hulp en steura in drie echelons

Het eerste echelon: het BAARTMAN-gesprek

Het tweede echelon: het hulpaanbod bij moeilijke gezinsomstandigheden:

Het derde echelon: de gezinscoach

14.5.2.2.2 Persoonswordingsvindicatie: hel opleggen van hulp en steun als raad en daad niet baat (de maatregel wan hulp en steun)

KOENS' maatregel van hulp en steun

Persoonswordingsvindicatie

Rechtswaarborgen: minimum-normen en algemene beginselen van behoorlijk gezinsrecht

Rechtsbescherming

14.5.2.2.3 Ouderschapsondersteuning: het eind van de eeuw van het interventionisme

14.5.2.3 Opvoedingsonderwijs: jong geleerd is oud gedaan, maar men is nooit te oud om iets te leren

Lessoort 1: het goede voorbeeld

1. Rights of the child in constitutions

2. A 'comprehensive national strategy' for children

3. Budgeting and budgetary analysis

4. Effective coordination/permanent government mechanisms

5. Child impact analysis

6. The child's right to protection from corporal punishment/ traditional practices involving violence and/or prejudicial to health

7. Protective and preventive measures: ast. 19(2)

Lessoon 2: ondenwijs aan kinderen als de toekomstige generatie opvoeders

Lessoort 3: ouderschaps(dieficiënile-) cursussen

A. Echelon 1: de algemene DOEK-cursus

B. Echelon 2 en 3: speciale ouderschaps(deficiëntie-) cursussen/trainingen 
14.5.2.5 Persoonswordings-Effect-Rapportage 965

1.4.5.2.6 Kinder-KALSBEEKrapportage 967

14.5.2.7 Beleidsintegratie en -coördinatie: de (Eerste) Minister voor Kind en Gezin

14.5.3 De trits en de trias: uitzicht en uitleiding 974

$\begin{array}{lll}14.6 & \text { Rehabilitatie en reparatie } & 978\end{array}$

Transgenerationaliteit $\quad 980$

Verwerking 981

Donum fac remissionis (wil het woord wergeving spreken) 981

Mihi quoque spem dedisti (hopen durf ik ook ... en leven) 983

14.7 WU HEBBEN U, O ABEL ... 984

Samenvatting 993

$\begin{array}{lr}\text { Kindervolkenrecht } & 993\end{array}$

$\begin{array}{ll}\text { Universele kinderrechten } & 994\end{array}$

Kindermishandeling $\quad 994$

Enstige en systematische mensenrechtenschending? 995

Positieve (preventieve) maatregelen $\quad 996$

Trias pedagogica $\quad 996$

$\begin{array}{ll}\text { Sociaal-pedagogisch vangnet } & 998\end{array}$

Sociaal-pedagogische kwestie $\quad 999$

$\begin{array}{ll}\text { Summary } & 1001\end{array}$

$\begin{array}{ll}\text { Bijlagen } & 1009\end{array}$

I. Verdrag inzake de rechten van het kind 1009

II. Voorbeeld-strafbepalingen kindermishandeling
(Misdrijven en overtredingen tegen de persoonswording van het kind) 1034

III. Criteria kindermishandeling

(Definities en gradaties per subtype)

1038

rv. Lijst van afweermechanismen en coping-stijlen

(Beschadigde persoonswording en aanpassing/onaangepastheid) 1063

V. Persoonlijkheidsstoornissen

(Verminkte persoonswording en maligne ontwikkelingspsychopathologie) 1068

VI. Persoonlijkheidsstijlen

(Omgeving/opvoeding en ontwikkeling van stijl en stoornis) 1076

viI. Opvoedingsvrijheid en persoonswording

(Het doorbreken van het privacy-paradigma)

vur. Korte omschrijving van enkele in deze studie gehantecrde samenhangende termen

$\begin{array}{ll}\text { Lijst van aangehaalde literatuur } & 1087\end{array}$

Auteursregister

Index 



\section{WOORD VOORAF EN DANKWOORD}

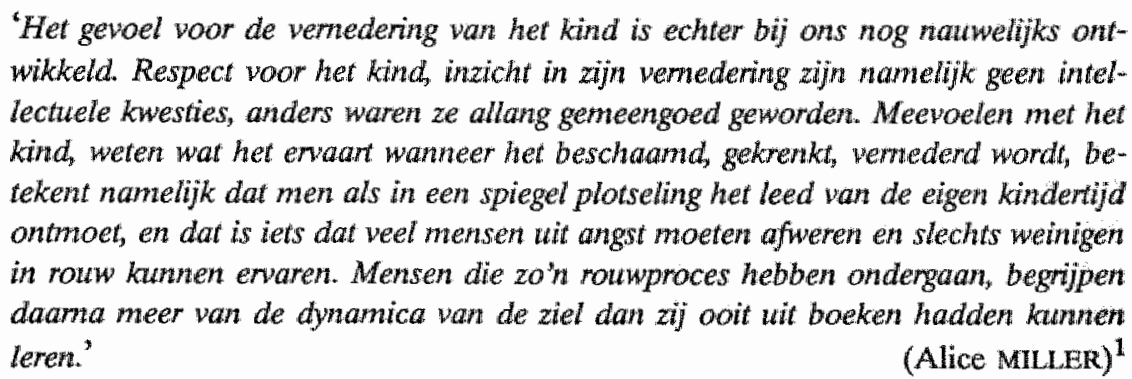

HET NATUURRECHT - OF LIEVER DE CHRISTELIKK-HUMANISTISCHE OFwel stoisch-grotiaanse variant van het natuurrecht - is de uitdrukking van een rechtsgevoel dat bestaat uit de (onvoorwaardelijke) liefde voor (morele en rechts)beginselen, het (rotsvaste) geloof in (menselijke) redelijkheid en de (ongeduldige) hoop op (universele) gerechtigheid. Er zijn (volkenrechts)juristen die dat rechtsgevoel (er)kennen en er zijn (volkenrechts)juristen die dat gevoel als achterhaald of onwetenschappelijk van de hand wijzen. Tot de eerste categorie behoren VERDROSS en KOECK: ${ }^{2}$

\footnotetext{
'It is the firm conviction of the authors of the present study that it will not be possible to solve the present and acute problems of the international community, especially the problems of maintaining world peace and bringing about the necessary development of the Third World, without having due regard to the principles and norms of natural law to which the long tradition of universal reason and authority refers usi.'
}

In de spirit van deze woorden is de voor $U$ liggende studie geschreven zonder schroom voor "authority' in de vorm van een breed fundament van citaten. Wat is echter haar 'object and purpose'? Laat ik om elke schijn van verheven of hoogdravende pretenties te vermijden, proberen "voorwerp en doel' (in beter Nederlands: zin en strekking) te verduidelijken aan de hand van een alledaagse, zo niet banale parallel.

1 Alice MILlek, In den beginne was er opvoeding, Bussum 1983 (derde druk), pp. $171 / 172$.

2 Alfred verdrosst, Heribert Franz KOECK, "Natural law: the tradition of univer" sall reason and authority, in: R.St.J. MACDONALD, Douglas M. JOHNSTON, The structure and process of intemational law: Essays in legal philosophy, doctrine and theory, Dordrecht (etc.) 1986, pp. 17-50, op p. 42 i.f. 
Als, naar de krant bericht, ${ }^{3}$ mensen in straatarm land ' 1. ' gewend zijn, al generaties lang, in het openbaar te defeceren, met alle gevolgen voor de volksgezondheid vandien, dan zal geen zinnig en zindelijk denkend jurist, al of niet om duur advies gevraagd, beweren dat probleem binnen 24 uur te kunnen oplossen door het onderbrengen van zulk gewaar zettend gedrag in een wettelijke delictsomschrijving. Veeleer zal hij, of zij, ervoor pleiten door voorlichting over en subsidies voor sanitaire inrichtingen, vergezeld van door slimme reclamemensen ontworpen wervende campagnes met uitgekiende premies en slogans (bonussen voor bolussen!'), kortom door een samenstel van faciliterende wetgeving en stimulerend beleid, een mentaliteitsverandering te bewerkstelligen, waarop het strafrecht dan de bekroning vormt. Dat wil zeggen: pas als de meerderheid om is, kan het strafrecht een nuttige functie vervullen, kan strafdreiging de laatste schaapjes over de dam duwen. Is dit niet de weg van elk beschavingsproces? Eerst wordt de norm gesteld en verkondigd, voorgehouden en aangeprezen, vervolgens wordt zij ingescherpt en haar handhaving aangescherpt. Een norm wordt verinnerlijkt, tot rechtsregel gemaakt, met het strafrecht als sluitstuk. ${ }^{4}$

Als, naar de krant zelden of nooit bericht, mensen in welvarend land 'N.' gewend zujn, al generaties lang, in overwegende mate de andere kant op te kijken als ouders hun kinderen mishandelen, ${ }^{5}$ terwijl in dat land, naar voorzichtige schattingen, jaarlijks minimaal 80.000 kinderen blootgesteld worden aan pedagogische praktijken die hun evenwichtige ontwikkeling en uitgroei tot zelfstandige staatsburgers in ernstige mate belemmeren of schaden, met alle gevolgen voor de lichamelijke en geestelijke gezondheid van betrokkenen, èn met alle maatschappelijke gevolgen vandien - in termen van kosten voor medische en GGZ-voorzieningen, kosten van criminaliteit en vandalisme, kosten in verband met en

Intermediair 22 maart 1996, pp. 31 en 33: Hilde JANSSEN, "Een volk dat niet naar de WC wil.' Volgens dit artikel poept driekwart van de Indiase bevolking altijd in het openbaar.

Volgens VERHELLEN is het hier bedoelde dubbelproces van socialisering en sociale controle evenwel geen wetmatigheid: Eugeen VERHELLEN, Jeugdbeschermingsrecht, Gent $1996, \mathrm{p} .1$.

5 Nog het minst wordt gemeld door personen uit de sociale omgeving van het künd. Slechts in éen op de vijf gevallen wordt daadwerkelijk ergens aan de bel getrokken. Van de personen die beroepshalve met kinderen werken (de zgn. beroepsbeoefenaren zoals leerkrachten, peuterspeelzaalleidsters en huisartsen), gaat $27 \%$ nooit over tot een melding, hoewel ze frequent vermoeden dat een kind thuis mishandeld wordt. Van de personen die een hulpverleningsrelatie met het kind of het gezin hebben, zegt 19\% nooit te melden." Aldus de WERKGroeP MELDPUNT KINDERMISHANDELING, Het melden van vernoedens van kindemishandeling, Onderzoeksrapport, Roermond 1996, p. 5. 
in de vorm van verknoeid of verknoeiend arbeidsvermogen en gederfde levensvreugde voor slachtoffers èn hun omgeving, en niet in de laatste plaats de kosten van een verminderd of verminkt pedagogisch besef: de prijs die wordt betaald door de volgende generatie -, tja, wat moet een zinnig en zindelijk denkend jurist dan bepleiten?

De minimaal 80.000 gevallen van kindermishandeling per jaar (gevallen van lichamelijke en psychische mishandeling, verwaarlozing, sexueel misbruik) zitten verstopt in het volgende staatje wit De staat van jeugdig Nederland 1996, onder het kopje 'Problematische gezinssituatie:"6

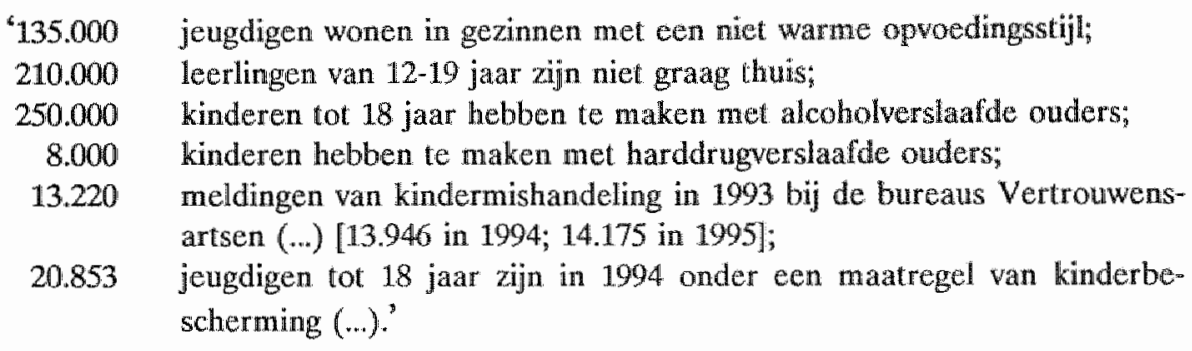

Aan dit cijfermateriaal kunnen worden toegevoegd de minimaal duizend kinderen alleen al in Amsterdam die jaarlijks getuige zijn van de ernstige of zeer ernstige mishandeling van hun moeder, ${ }^{7}$ hetgeen, los van wat de kinderen van gewelddadige vaders en mishandelde moeders direct aan geweld en misbruik overkomt, ${ }^{8}$ op zich al een vorm van kindermishandeling kan worden genoemd. ${ }^{9} \mathrm{Al}$ met al bevinden vele tienduizenden, en misschien wel enkele honderdduizenden kinderen in ons land zich op zijn minst in een geestelijke gevarenzone. Bij hun 'evenwichtige ontwikkeling en uitgroei tot zelfstandige staatsburgers' kunnen op zijn voorzichtigst grote vraagtekens worden geplaatst.

Aangezien het bij kindermishandeling gaat om ernstige en structurele schendingen van fundamentele rechten van weerloze en kwetsbare

6 J. VAN KAMPEN (red.), De staat van jeugdig Nederiand 1996; Een sociale kaart van de jeugd van Nederland, Delft [1996], p. 17.

7 Aleid VAN DEN BRINK en Jan JÜNGEN, 'Thuisgeweld tegen vrouwen; het Meldpunt vrouwenopvang Amsterdam, 1991-1994,' Tijdschrift voor Criminologie 1995/4, pp. 315-332, op p. 331 (onder 'Kinderen').

8 BROWNE en HERBERT merken op: "The most important fact for prediction and prevention is that the various forms of family violence do not occur in isolation. If spouse abuse occurs, then there is a wery high probability that child abuse is also occurring, and wice versa." (Kevin BROWNE, Martin Herderr, Preventing family violence, Chichester etc. 1997, p. 18.)

9 Vgl. Ola W. BARNETT e.a., Family violence across the lifespan; An introduction, Thousand Oaks (etc.) 1997, Chapter 6: 'Children exposed to marital violence." 
mensen, namelijk kinderen, en jonge tot zéér jonge kinderen, ernstige schendingen op grote schaal, verankerd in eeuwenoude en eerbiedwaardige structuren en instituties als (de beslotenheid en intimiteit van) het gezin, het ouderlijk gezag, de vrijheid van opvoeding en onderwijs, de onverbrekelijke band tussen ouders en kinderen en wat dies meer zij, zou het door een jurist bepleiten van een oplossing in en door het strafrecht symbolischer en absurder lijken dan ooit. Maar ook frivole voorlichtingscampagnes lijken hier minder dan ooit op hun plaats. Toch is het duidelijk dat we de rechten van kinderen niet met de mond kunnen belijden, in verdragen kunnen vastleggen, en in voorlichtingscampagnes kunnen verkondigen, terwijl we de ogen gesloten houden voor de ernstige en structurele schendingen in de gezinssfeer.

Het belang van het kind is wel een toverformule genoemd, ${ }^{10}$ het kan en mag geen bezweringsformule zijn - of blijven. Het belang van het kind is in de eerste plaats gelegen in zijn evenwichtige ontwikkeling en uitgroei tot zelfstandig staatsburger: ontwikkelingspsychologische en pedagogische basisvoorwaarden zijn hier in het geding. Een nadere analyse van enerzijds de pedagogische rechten van het kind, en anderzijds het structurele pedagogisch te kort schieten van de samenleving, met een omvang en ernst die de betiteling daarvan als 'de pedagogische kwestie' aan het eind van de twintigste eeuw alleszins rechtvaardigt, alsook de verantwoordelijkheden en de aansprakelijkheid van de staat ter zake van deze kwestie, lijkt een noodzakelijke eerste stap.

Hiertoe wordt in dit boek gepoogd een aanzet te geven door het recht van het kind op optimale respectievelijk minimale persoonswording als rechtsbeginsel en kernrecht van het kind te stipuleren. En well als tweeledig kernrecht: als interacterend recht op leiding en op ontplooiing. Kindermishandeling wordt geherdefinieerd als schending van het recht van het kind op minimale persoonswording. De contouren worden geschetst van de verantwoordelijkheden van de staat op het vlak van preventie, protectie en 'reparatie' (rehabilitatie en genoegdoening van slachtoffers). Gepoogd wordt, kortom, het recht van het kind op (optimale c.q. minimale) persoonswording uit het grotiaanse schaduwland ${ }^{11}$ te laten

Vgl. J.E. DOEK, 'Ondertoezichtstelling en het belang wan het kind: een toverformule in het kwadraat?' In: Ad VAN DER LINDEN, Paul VLAARDINGERBROEK (red.), Met het oog op het belang wan het kind; Opstellen aangeboden aan (...) Madzy ROOD-DE BOER (...), Deventer 1988, pp. 97-107, op p. 97.

11 Vgl. P.H. KOOIJMANS, "How to handle the grotian heritage; GROTIUS and VAN VOLLENHOVEN,' Netherlands International Law Review 1983/1, pp. 81-92, op pp. 90 e.v.; met verwijzing naar R. FALK, 'Introduction: The grotian quest,' in: Ch.S. EDWARDS, Hugo GROTIUs: the miracle of Holland; $A$ study in political and legal thought, Chicago 1981, pp. xiii-xxi. 
treden om zich, als beginsel in het land en in het licht van het positieve recht, uit de cocon van 'het belang van het kind' te ontpoppen tot een kernrecht, hèt kernrecht van het kind.

WEINIG JURIDISCHE HOBBIES ZULLEN FASCINERENDER ZIIN DAN HET IN woorden vangen van het moment waarop aan de boom van de menselijke rede en moraal een nieuwe knop ontluikt en zich ontvouwt tot een blad: het rechtsbeginsel; het rechtsbeginsel in het prille stadium waarin zijn concretisering in regels en rechterlike beslissingen zich nog in het schaduwland bevindt. Een fascinatie die in dit geval evenwel overschaduwd wordt door de emst van het onderhavige onderwerp: kindermishandeling.

Aan het eigenlijke schrijven van dit boek, vanaf het najaar van 1996 tot in het voorjaar van 1998, ging een lang proces van studie, waaronder een driejarige psychologiestudie in Antwerpen (1992-1995), maar ook het schrijven van deels gepubliceerde, deels ongepubliceerde voorstudies' (inclusief een uitgewerkte en breed gedocumenteerde opzet voor een proefschrift over incest en een lijvige autopsychobiografische "thesis" ten behoeve van de Antwerpse opleiding - alsmede enkele duizenden senryū's) vooraf. Een 'leerproces' dat begon nadat ik in 1988/89 het (polemische) hoofdstuk 'recht en kernwapens' afsloot en het (verraderlijke) hoofdstuk 'recht en incest' opensloeg. Dat ik in het najaar van 1995 aan de opzet en documentatie van dit boek en in het najaar van 1996 aan het uitschrijven van (de eerste 400 pagina's van) die opzet ongestoord heb kunnen doorwerken, is te danken aan de concentratie van onderwijstaken in de tweede helft van de desbetreffende academische jaren, welke mogelijk was doordat collegae VAN BOVEN en FLINTERMAN in beide jaren het blok Historical and current issues in international law voor hun rekening namen. Toch zou dit boek - ondanks de voorstudies die in voorafgaande jaren waren verricht - niet zo snel zijn afgekomen zonder de bestuurlijke druk van directeur en twee decanen. Hun allen, maar ook alle anderen die, binnen en buiten faculteit en universiteit, in de loop der jaren nimmer hun vertrouwen in mijn wetenschappelijke output hebben verloren, ben ik dank verschuldigd. "Toch is er maar één die nog steeds, elke keer als zij mijn 'bibliotheek' binnenloopt, dat vertrouwen uitdrukt met de stellige toekomstverwachting dat ik nu toch wel gauw professor zal worden: Ilse MARTINUS, met wie ik gedurende mijn eerste Maastrichtse jaren lief en leed heb gedeeld, en die gelukkig zo'n groot hart heeft dat ze nooit uit mijn leven is verdwenen.

Van de club collegae die aan de wieg hebben gestaan van ons aller troetelkind: de blijvend jong(st)e juridische faculteit van de UM, wil 
ik er twee die mij op moeilijke momenten van bijzondere steun zijn geweest, hier met naam vermelden: Rob BAKKER, die inmiddels de gelederen van de Maastrichtse rechterlijke macht is gaan versterken, en Fred GRÜNFELD. Fred verdient extra dank woor zijn kritisch commentaar bij 66 stellingen, waarvan er helaas maar 11 bij het proefschrift konden worden gevoegd, doch wel heel in het bijzonder voor het vervaardigen van het auteursregister in die laatste slopende weken voór 22 november. Mijn vakgroepgenoten en werkbazen - vanaf oktober 1981 - Cees FLINTERMAN en Theo VAN BOVEN hebben mij altijd alle academische vrijheid gelaten, en ik ben mij er terdege van bewust hoe belangrijk dat voor mijn persoonlijke en wetenschappelijke ontwikkeling is geweest.

Twee personen van buiten de Limburgse universiteit zijn in mijn academische jaren steeds een lichtend voorbeeld geweest. Ook hen wil ik hier met name noemen: Arthur EYFFINGER en Meindert STELLING. Arthur, eerst verbonden aan het (toenmalige) GROTrUs-Instituut van de Koninklijke Nederlandse Academie van Wetenschappen, en daar belast met de uitgave van de dichtwerken van Hugo DE GROOT, vervolgens aan het Vredespaleis en het Internationaal Gerechtshof, maar onverminderd groot grotioloog, deed in de loop der jaren vele (ook eigen) werken het licht zien waaruit zijn enorme eruditie als neolatinist en (neo-)grotiaan bleek. Maar ook in de redactie van (de nieuwe) Grotiana en in het landelijk overleg van volkenrechtshistorici getuigde hij van zijn ernorme betrokkenheid bij zijn onderwerp. Pas nu kan ik daar een eigen boekwerk tegenover stellen, al heb ik Arthur in het verleden één keer bijzonder kunnen verblijden met het boekwerkje van een ander: de latijnse versie van een Ollie B. BOMMEL-verhaal. ${ }^{12}$

Meindert, eerst verbonden aan het Ministerie van Defensie, maar inmiddels al weer verschillende jaren in dienst van een iets minder van kernwapens (in Limburgse asbestbunkers) afhankelijk departement, dat van Binnenlandse Zaken, en al weer vele jaren voorzitter van de Vereniging van Juristen voor de Vrede, produceerde in zijn topjaren als juridisch activist hele boekwerken waarin hij verslag deed van zijn rechtsstrijd tegen het Befehl ist Befehl, de onvoorwaardelijk van hem, als militair, geëiste gehoorzaamheidsplicht ten aanzien van Nederlands hand- en spandiensten aan de Amerikaanse nucleaire overbewapening. Waar er ook - op basis van juridische argumenten - tegen kernwapens gestreden werd, kwam ik Meindert tegen: de Stichting Verbiedt de Kruisraketten, het Tribunaal voor de Vrede ... totdat zelfs de BVD lucht van onze ont-

Voor belangstellenden: De Thoma Fele nec non et de larwa Bommelsteiniana, scripsit picturisque linearibus examavit Marten TOONDER; vertit Latine K.H.E. SCHUTTER, Litt. hum. Dr., Hagae Comitis MCMXCV. 
moetingen kreeg, en bij mij op de stoep stond. Want het recht kan kennelijk voor de staat erg gevaarlijk zijn.

Een bijzonder woord van dank past ten aanzien van mijn beide promotoren, Herman BAARTMAN en Theo VAN BOVEN, in wie ik niet alleen in hun respectieve vakgebieden uiterst deskundige en vooraanstaande wetenschappers heb getroffen, maar ook uitzonderlijk integere en bescheiden mensen. Het is gemakkelijk en fijn te werken met en voor mensen die op zo'n groot respect aanspraak kunnen maken - zonder dat ooit te doen. Het minste dat ik van het product van onze samenwerking kan zeggen, is dat het boek niet alleen nog dikker zou zijn geworden maar op diverse plaatsen ook een minder evenwichtige redactie zou hebben gehad zonder beider gedetailleerde kritische commentaar.

Dank ook op deze plaats aan de vijf leden van de leescommissie: J. DOEK, F. VAN DUN, C. FLINTERMAN, M. KOENS en D. DE RUYTER, die zich, in een fin de siècle van bijna anti-academische overhaasting en ontlezing, binnen vier keer vier weken na ontvangst van het manuscript door 'Vier boeken over het recht van het kind' hebben geworsteld. Alsmede aan Caroline FORDER, lofwaardig op aanverwant gebied gepromoveerd, die de correctie van de vertaling van de samenvatting voor haar rekening en aldus de correctheid ervan (mede) voor haar verantwoording nam.

Dankbare vermelding verdienen voorts de beide facultaire computerbeheerders Paul ADRIAANS en Roger SNIJDERS. Roger stond vanaf het eerste moment dat ik mij de beginselen van het tekstverwerken al doende eigen maakte, steeds klaar om vragen te beantwoorden. Waren er 'technische' problemen, dan hoefde ik maar te piepen of hij, en later ook Paul, de vriendelijkheid zelve, hadden ze al opgelost. Toen mijn lay-out volledig ontregeld dreigde te raken door de installatie van een nieuwe vakgroep-printer, hebben zij maandenlang gedoogd dat de oude printer op mijn kamer stond - daarbij manmoedig demarches bij de directie trotserend van wetenschappers die 'ook een printer op de kamer' wilden.

Doordat in 1995 mijn vrije tijd werd opgeslokt door mijn werk zaamheden ten behoeve van de in een ernstige bestuurs- en cultuurcrisis gedompelde Woningstichting Sint Servatius en vanaf zomer 1995 tot en met zomer 1996 tevens door de totale verbouwing van ons huis, heb ik pas in najaar 1996 alle tijd en energie in het werken aan dit boek kunnen steken. In 1997 heb ik mijn energie weer moeten verdelen tussen een geconcentreerde (en daardoor 100\%'s) onderwijstaak en het afronden van de 'bovenbouw' (naar begin 1998 bleek: zo'n 600 pagina's) van dit boek. Van april tot 22 november 1998 ging vervolgens alle tijd zitten in het tussen de onderwijsbedrijven door gereedmaken van summary, bijlagen en literatuurlijst, het up to date brengen van het manuscript, het verzorgen van lay-out en correcties en, last but not least, het vervaardigen 
van de index (opnieuw met dank aan Paul voor het ijlings ter beschikking stellen van een snelle computer). Ik kijk op deze vier jaren, ondanks de vele spanningen, ondanks het afscheid van Servatius, waar, de doorbraak ten spijt, nog veel Maaswater langs zal moeten stromen, en ondanks het feit dat de motor langdurig in de berging moest blijven, tentoonstellingen van Afrikaanse kunst niet konden worden bezocht en zelfs het vereiste aantal schietbeurten bijna drie jaren op een rij niet werd gehaald, met grote voldoening terug. Zonder de steun echter van vrienden in de Ondernemingsraad en de Raad van Toezicht van Servatius, zonder de steun en bemoediging van vriend en wapenbroeder Gerard MOMMERS, die bijna geheel in zijn eentje ons huis tot een 'villa in de binnenstad' heeft omgetoverd, en zonder de steun, het vertrouwen en het geduld van Annet WAAMELINK, was ik deze periode beslist niet zonder kleerscheuren doorgekomen. Dank ook aan hen allen. Aan Annet, die haar eigen jeugd, vol verwaarlozing en respectloosheid, en latere zware tegenslagen geheel op eigen kracht en op wonderbaarlijke wijze is te boven gekomen, die met haar vrolijke lach de donkerste wolken verjaagt, die (professioneel) dansend en musicerend door het leven gaat, en die mij onder alle omstandigheden - hoe zwaar (vooral op het eind van de verbouwing) voor haar ook - in mijn waarde en aan het werk heeft gelaten, draag ik dit boek in liefde op. In haar persoon is dit boek tevens opgedragen aan allen die (met zichzelf) durven vechten en (om te beginnen zichzelf durven) liefhebben, hoezeer zij ook door het leven of door hun ouders zijn verwond.

********

ER BESTAAT GEEN RECHT KINDEREN TE KRIJGEN. ${ }^{13}$ GELUKKIG IS HET krijgen van kinderen ook geen (godsdienstige en/of maatschappelijke) plicht meer - zij het wel nog steeds te veel een vanzelfsprekendheid. Kinderen zijn nooit vanzelfsprekend. Ook daar ligt een (ped)agogische les - en dus mede een taak van de overheid: bezint eer gij begint. Dit boek gaat evenwel niet over het krijgen van kinderen, maar over de rechten van het geboren kind - waaronder uiteraard ook het (postnatale) recht op goede prenatale zorg. Een recht, naast vele andere, in de waar-

13 Juridisch gezien is het onzinnig om te spreken over een (afdwingbaar) recht op woortplanting/een kind. Dit volgt alleen all uit het feit dat volgens ons recht ieder mens vanaf zijn geboorte drager is van rechten (rechtssubject) en geen voorwerp van rechten (rechtsobject) kan zijn (vergelijk artikel 1:1, lid 2 BW [Persoonlijke dienstbaarheden, van welke aard of onder welke benaming ook, worden niet geduld]).' Aldus A.C. HENDRIKS, G.J.M. VEERMAN, 'Kinderen krijgen - een (voor-) recht? Enige grond- en mensenrechtelijke beschouwingen,'Justitiële Verkenningen 1996/8 ("Wenskinderen"), pp. 56-69, op p. 57 . 
borging waarvan (aanstaande) ouders en/of de staat (ernstig) te kort kunnen schieten. Hetgeen het - geboren - kind, al of niet inmiddels volwassen soul survivor, ${ }^{14}$ recht op erkenning en 'reparatie' geeft.

Volwassenen hebben rechten met betrekking tot gezinsplanning: het spreiden, uit- of afstellen van kinderen, met inbegrip van - onder zekere temporele voorwaarden - het recht op abortus. Daarbij hebben zij al vóor de daad van conceptie zich rekenschap te geven van het recht van het kind gewenst, en zo gezond mogelijk, ter wereld te komen. Die rekenschap houdt na de daad niet op. Vóor de geboorte kan hun rekenschap worden gevraagd door de samenleving en de staat. Vanaf de geboorte óók door, of namens, hun kind, wiens opvoeding hoogste ouderlijke plicht is. Een plicht waarin samenleving en staat hen nimmer alleen mogen laten staan. De rechten van het kind zijn in essentie de pendant van die interacterende ouderlijke en statelijke plicht. De staat vult aan, stuurt bij, en neemt desnoods het roer over; niet als staatsopvoeder maar als behoeder van de persoonswording van het kind, als verantwoordelijke voor een effectief sociaal-pedagogisch vangnet. Wat is dit in feite anders dan onder ogen zien en handelen naar het inzicht dat in een rechtsstaat de rechten van de zwaksten het beste moeten worden beschermd?

Gezien de ernst en de omvang van het maatschappelijk fenomeen kindermishandeling, gezien dus de ernst en de omvang van de schending van de meest fundamentele rechten van het kind in ons land, is hiermee, meer dan recht in statu nascendi (zich aankondigend recht), of zelfs in statu pupillari (bestaand maar nog niet uitgerijpt recht), in essentie de noodzaak geschetst van een mentaliteitsverandering ten aanzien van (het nemen van en de omgang met) kinderen. Niet alleen de lichamelijke en geestelijke integriteit maar ook - daarmee verweven en in het verlengde daarvan - een verantwoorde opvoeding is zo'n fundamenteel recht, een recht dat staat of valt met ouderlijk pedagogisch besef, door de gemeenschap geruggesteund of waar de gemeenschap de rug naar toekeert.

De titel van dit boek ontleen ik aan éen van Nederlands grootste psychiaters, qua wijsheid en betrokkenheid ten aanzien van vermijdbaar menselijk lijden: VAN DANTZIG, die ooit, filosoferend over een film, prikkelde met een even prangende als intrigerende slotverzuchting: ${ }^{15}$

'Als je ziet hoe vaak en grondig homo sapiens er naast heeft gezeten en, gedreven door de behoefte om oorzaken te weten, maar wat verzon [en zichzelf en

14 De term ontleen ik aan J. Patrick GANNON, Soul survivors; A new beginning for adults abused as childrer, New York (etc) 1989.

15 A. VAN DANTZIG, "Heavenly Creafures," filmbeschouwing in Maandblad Gecstelijke volksgezondheid 1995/10, pp. 1134-1135, resp. op pp. 1134 r.k., 1134/1135 en 1135 r.k. (curs. jw). 
anderen maar wat wijsmaakte, jw! dan onderscheidt hij zich door die behoefte wel wan de andere dieren, maar lijkt weer veel op hen in de manier waarop hij er gebruik van maakt. Wat wij wetenschap noemen, is daarom een omwenteling: een orgaan, de rede, wordt niet meer gebruikt om zekerheid, dat wil zeggen veiligheid, te scheppen, maar om waarheid te ontdekken. (...)

Ik bedacht dat zoeken naar oorzaken van menselijk gedrag een recente hebbelijkheid is. Zo ergens, dan wist hier iedereen hoe het kwam dat je niet werkte: je was lui; waarom je niet vocht: je was laf; waarom je zwanger werd: je was een del; waarom je je moeder vermoordt: je bent door en door slecht. Morele categorieên scheppen niet alleen maatschappelijke orde, maar ook de veiligheid waar ik over sprak. Je weet hoe het komt: door een moreel defect waar wij fatsoenlijke mensen gellukkig niet aan lijden, zodat we blij zijn in het zweet ons aanschijns ons brood te moeten verdienen in plaats van het moeiteloos van een ander weg te nemen. De moraal [voor zover product van menselijke angst en arrogantie, jw] slaat veel vliegen in eén klap, maar de waarheid is daar niet bij. (...)

Wanneer we [evenwel] aannemen dat de daden van de mens tot de natuur behoren en daarom met "natuurkunde" moeten worden verklaard, ontstaat er een heel andere werkelijkheid, zoals dat in de materielle natuorkunde ook gegaan is [eppur' si muove, jw]. De "natuurkunde" heeft aangetoond dat trauma's traumatiseren, dat cen multipele persoonlikkheid samenhangt met mishandeling, neurosen met gezinsstructuren - naast alle andere determinanten die in het gebied van de materiele natuurkunde liggen. Dat is het grote avontuur van de GGZ [geestelijke gezondheidszorg]; zij [lees: de gedrags-'natururkunde,' ofwel de (ontwikkelings)psycho(patho)logie, jw] zou magie door kennis van de mens kunnen vervangen. Uit de manier waarop de GGZ behandeld wordi, blijkt dat dat nog lang een heroïsch gevecht zal blijwen. Om dat gevecht te winnen, is in de eerste plaats nodig dat de GGZ beseft dat dat gevecht geleverd moet worden. Maar wie zal de opvoeders opvoeden? (...)

Een verzuchting die men - gelijk JUVENALIs' sed quis custodiet ipsos custodes? (maar wie zal de bewakers bewaken?) ${ }^{16}$ - kan opvatten als retorische vraag, doch die ik als - uitdagend en hoognodig - 'gedragsnatuurkundig' èn natuur- en mensenrechtelijk vertrekpunt voor dit boek heb genomen.

Jan C. M. WILLEMS

Maastricht, 22 november 1998

Satiren 6, 346-348: 'Audio quid veteres olim moneatis amici:/Pone seram; cohibe. Sed quis custodiet ipsos custodes?/Cauta est, et ab illis incipit uxor.' (Mijn vert.: 'Ik hoor jullie zeggen, oude vrienden: "Zijn er dan geen grendels, geen bewakers meer?" Maar wie zal de bewakers bewaken? Een gehaaide vrouw windt ze in een oogwenk om haar vinger.') 


\section{Post scriptum}

Een opmerking tot slot. Dit boek is afgesloten in het najaar van 1998. Het begin 1998 onder auspiciën van UNICEF verschenen Implementation handbook for the Convention on the rights of the child (geschreven door Rachel HODGKIN en Peter NEWELL) kwam evenwel te laat om eerder dan in (slot)hoofdstuk 14 in de beschouwingen te kunnen worden betrokken. Het Handbook bevat een gedetailleerde weergave en analyse van de visie van het Comité inzake de rechten van het kind op de verschillende verdragsbepalingen (met name ook in hun onderling verband). Hoewel deze visie (zoals niet alleen in hoofdstuk 14 blijkt) volledig spoort met de verdragsanalyse in (eerdere hoofstukken van) deze studie, ontbreken in de desbetreffende hoofdstukken verwijzingen naar dit belangrijke standaardwerk. Aangezien het Implementation handbook echter artikelsgewijze is opgezet, kan het zeer eenvoudig naast de in de bedoelde hoofdstukken (in het bijzonder hoofdstuk 10) behandelde verdragsartikelen worden gelegd (waarbij in de uitgebreid aangehaalde opvattingen van het Comité aanvullende steun voor het in deze studie betoogde kan worden gevonden). 



\section{Boek 1: Kernrechten}


'[D]e strijd om een menswaardig bestaan voor het kind [is] nog lang niet gestreden (...).'

A. VAN DANTZIG, bespreking yan H.E.M. BAARTMAK, Opvoeden met alle geweld, in: $M G v 1993 / 10$, pp. 1142-1144, op p. 1143 r.k. 


\section{INLEIDING, OPVOEDINGSVERANTWOORDE- LIJKHEID EN PERSOONSWORDING}

Men kan het jonge kind geen rechtssubjectiviteit, dat wil hier zeggen: het als mens drager van (in principe gelijke) rechten zijn, ontzeggen omdat het nog onmondig is. Onmondigheid is bovendien in belangrijke mate een sociale constructie (VERHELLEN). ${ }^{1}$ Werd ook de vrouw niet lange tijd als onmondig beschouwd? Mulier taceat in ecclesia. ${ }^{2} \mathrm{Zij}$ had geen recht van spreken. Net als het kind was zij moreel en geestelijk niet volwaardig, werd haar, geheel of ten dele, rechtssubjectiviteit ontzegd, of werd zelfs haar mens-zijn in meerdere of mindere mate ontkend:

"Wij betreden [hier] het terrein [van] de "yrouwenkwestie" welke van anthropologisch standpunt uit niet juist in den vrouwen aangenamen zin kan worden beantwoord. Ik ten minste stel mij volkomen aan [de] zijde [van den Engelschman] ALLAN, als hij zegt:

"Mijn meening is, dat een ingrijpend, natuurlijk en bestendig ver chil in geestelijke en moreele ontwikkeling tusschen de beide geslachten bestaat, hand aan hand gaande met de physische organisatie. Men vergelijke het mannelijk en vrouwelijk skelet, men bestudeere man en vrouw in physiologisch en pathologisch opzicht, in zieken en gezonden toestand; men ga philosophisch hare resp. verlangens, bezigheden, genoegens, neigingen, enz. na, men merke op welke rol elk ge-

VERHELLEN spreekt van '[d]e sociaal geconstrueerde afhankelijkheidspositie van kinderen' (Eugeen VERHELLEN, Verdrag inzake de rechten van het kind; Achtergronden, motieven, strategieën, hoofdlijnen, Leuven/Apeldoorn 1993, tweede druk, p. 24). Vgl. ook Mare DEPAEPE, 'De eeuw van het kind in historisch"pedagogisch perspectief, in: H. CAMMAER en E. VERHELLEN (red.), Onmondig en onvolwassen; De jonge mens in de eelw van het kind, leuven/Amersfoort 1990, pp. 9-37, op pp. 9-17 en 28-29; Jacques CLAEs, 'Jeugd als moratorium," a.w., pp. 39-51; VERHELLEN, 'Naar een snel veranderend kindbeeld?' A.W., pp. 53-73, op p. 60; en VERHELLEN, Jeugabeschemingsrecht, Gent ed. 1996 , pp. 3 e.v.

2 Mulieres in Ecclesiis taceant (...): Dat uwe vrouwen in de Gemeenten zwigen; want het is haar niet toegelaten te spreken, maar bevolen onderworpen te zijn gelijk ook de wet zegt. En zoo zij iets willen leeren, laat haar te huis haren eigenen mannen vragen; want het staat leelijk voor de vrouwen, dat zij in de Gemeente spreken. (1 Kor. 14:34-35.) Zie in dit verband Karlheinz DESCHNER, De kerk en haar kruis; Geschiedenis van de seksualitein in het Christendom, Amsterdam 1978, pp. 57, 232. 
slacht in de geschiedenis speelt; - en men zal niet spoedig de paradoxale stelling onderschrijven, dat er geen geslachtsverschil des geestes bestaat en dat het intellectueel onderscheid tusschen beide geslachten alleen een gevolg der opvoeding is. Een vrouw met mannelijke neigingen is een even abnormaal wezen als een met een mannenborst, een mannelijk bekken, mannelijke spieren of met een baard." (...)

RUNGE zegt: "De emancipatie (der vrouw) eischt gelijkstelling der beide geslachten en wel gelijkstelling in de praktijk, steunend op de stelling: De vrouw heeft dezelfde waarde en alzoo dezelfde rechten. Doch dit is de grootste dwaling, welke voortvloeit uit een absolute onbekendheid met het physiologisch verschil, dat de natuur tusschen de beide geslachten heeft gemaakt. De vrouw is volstrekt niet gelijkwaardig met den man, doch van geheel andere waarde.

Het behoeft waarlijk geen nader betoog, dat de gevolgen der emancipatie niet alleen opheffing van het huwelijk, maar het eindresultaat een [ener? - jw] verbitterde concurrentie tusschen man en wrouw zullen teweegbrengen, met terzijde stelling van de ter bescherming der vrouw ingestelde sexueele wetten, en het is wel niet aan twijfel onderhevig of in dezen strijd moet de voor den strijd met de buitenwereld zwakker toegeruste vrouw het onderspit delven. In het belang der vroww moeten wij mannen ons daarom tegen de emancipatie zoo krachtig mogelijk verzetten." (...)

(...) Een volledige emancipatie zou het familieleven opheffen en leiden tot een openbare opvoeding der kinderen, een staat van zaken, welke slechts op de laagste trap van menschelijke beschaving kan worden gevonden. (....)

(...) SCHOPENHAUER zegt: "(...) Voor de verpleging en opvoeding onzer eerste kindsheid zijn de vrouwen uiterst geschikt, omdat zij zelf kinderlijk, nietig en kortzichtig m.a.w. omdat zij haar leven lang groote kinderen zijn, een soort middenrang innemend tusschen kind en man, welke laatste de eigenlijke mensch is." ( $\ldots . .$.

Besluiten wij dit hoofdstuk met een paar aanhalingen van den zeer modernen philosoof Nietzsche [volgen nog enige belasteringen van de vrouw, jw]. ${ }^{93}$

Hoe ongerijmd en ergerlijk klinken ons de wetenschappelijke inzichten van onze (over)grootouders thans in de oren. Hoe ongerijmd en ergerlijk zou het ons in de oren horen te klinken wanneer een kind als persoon-inwording rechtssubjectiviteit, dat wil zeggen het principe van de gelijkgerechtigdheid, als manifestatie van de gelijkwaardigheid van alle mensen, zou worden ontzegd omdat wat groeit, niet volwaardig zou zijn, wat zich slechts hulpeloos kan uitdrukken, geen recht van spreken hebben zou. Groeien wij niet allen, althans voor zover we geestelijk gezond zijn, tot onze dood? Is niet elk verwerkingsproces een groeiproces? Geldt de vrijheid van meningsuiting niet ook voor de sprakelozen en de met stomheid geslagenen, ook wanneer anderen voor hen het woord voeren? On-

H. PLOSS en Max BARTELS, De vrouw in natutu- en volkenkunde; Anthropologische Studiën, Amsterdam/Weltevreden 1918 (zesde druk), deel 1, resp. pp. 26, $27,30,31$ en 32 (curs. van de auteurs). 
geacht de groeifase waarin een mens, van wieg tot graf, zich kan bevinden, heeft hij of zij recht op respect, het recht serieus genomen te worden, het recht op gelijkgerechtigdheid. VERHELLEN drukt dit aldus uit: ${ }^{4}$

'SS]oms voert men aan dat kinderen nog onaf zijn. Maar fundamenteel is ieder mens on-af. Precies uit dit on-af zijn van iedereen, uit dit in ongelijke mate on-af zijn, uit deze ongelijkheden, voeit voort: de creativiteit, de diepe communicatie, de wederzijdse afhankellijkheid, de cultuur.... Er zijn tussen mensen onnoemelijk veel verschillen: geslachts-, etnische, leeftijdswerschillen.... Geen van die werschillen legitimeert, hoe dan ook, een ongelijkwaardige benadering."

\section{Extra bescherming van fundamentele rechten en speciale rechten}

Niet alleen moet evenwel een ongelijkwaardige benadering, in de zin van een in principe mindere gelijkgerechtigdheid, van de hand worden gewezen, er moet juist op gewezen worden dat het kind extra c.q. speciale rechten kan doen gelden.

De verhoogde kwetsbaarheid van het kind als persoon-in-wording maakt dat het op extra bescherming van zijn fundamentele rechten, èn op speciale, op zijn afhankelijkheid van zijn ouders toegespitste rechten, aanspraak heeft. Extra bescherming ten aanzien van de persoonlijke veiligheid, de lichamelijke en geestelijke integriteit, de vrijwaring van wrede en vernederende behandeling en bestraffing, alsmede de lichamelijke en geestelijke verzorging. En speciale rechten ter waarborging van de evenwichtige ontwikkeling en uitgroei van het kind tot zelfstandig persoon, ter waarborging - in eén woord - van de 'persoonswording,' dat wil zeggen: de ontwikkeling tot een (optimaal) rationeel, moreel en authentiek perSOOn (DE RUYTER). ${ }^{5}$

We zouden kunnen zeggen: het kind heeft als mens veiligheidsrechten, als kind extra veiligheidsrechten, als mens zorgrechten, als kind extra zorgrechten, èn als kind speciale rechten: ontwikkelings(beschermings)rechten ofwel 'persoonswordings'-rechten. Op dezelfde wijze zou 'het belang van het kind' kunnen worden uitgesplitst in een veiligheidsbelang, een verzorgingsbelang en een ontwikkelingsbelang, die extra bescherming(srechten) en speciale (beschermings)rechten vergen - en daarmee, dat is eo ipso, rechtvaardigen.

Aangezien optimale, of zelfs minimale persoonswording zonder een basis van veiligheid, zorg en geborgenheid niet wel denkbaar is, zo niet uitgesloten moet worden geacht, zal het duidelijk zijn dat deze belangen, en de daaruit voortvloeiende rechten, wel te onderscheiden maar 
niet (steeds) strikt te scheiden zijn. In het hiernavolgende zal het veiligheidsbelang en het ontwikkelingsbelang van het kind in dier voege worden onderscheiden dat het eerste vooral refereert aan de veiligheids- c.q. integriteitsrechten (waaronder ook zorgrechten) die wij allen, als mens, hebben, en het tweede aan rechten die (meer specifiek, in enge zin) met de persoonswording van het kind te maken hebben, aan te duiden als persoonswordingsrechten of pedagogische rechten. Het onderscheid hangt dus samen met de dubbele status van het kind: mens èn persoon-in-wording. Een mens die aanspraak maakt op veiligheid, geborgenheid (dat is: extra veiligheid) en bijzondere verzorging. Een persoon-in-wording die aanspraak maakt op opvoeding (dat is leiding en begeleiding op basis van geborgenheid in de - pedagogische - zin van warmte en ondersteuning). Een mensenkind is immers op opvoeding aangewezen.

Samengevat: het kind maakt aanspraak op extra bescherming ten aanzien van de algemene fundamentele (mensen)rechten en heeft bovendien preferentiële (kinder)rechten. Het kind is immers niet alleen mens, en als mens bekleed met mensenrechten, maar ook persoon-in-wording, kind-mens met pedagogische rechten. VERHELLEN: ${ }^{6}$

'De pedagogiek, als de leer van de omgang met kinderen, heeft (...) als taak de realisatie van de fundamentele [algemene: kind is mens] en de preferentiële [beschermings] rechten [kind is persoon-in-wording] te garanderen en te bewaken. Dit is een ethisch imperatief. Pedagogiek is dus op de eerste plaats een kwestie van mensenrechten.'

\section{Menselijke waardigheid}

Deze extra en speciale beschermingsrechten, de persoonlijke veiligheid en integriteit en de ontwikkeling tot persoon betreffende, vinden hun grondslag in dezelfde universele waarde die het internationale recht onder alle mensenrechten heeft gelegd: de menselijke waardigheid. Een waarde die elke intrinsieke superioriteitspretentie op grond van (blanke) huidskleur, (mannelijk) geslacht, (koninklijke) geboorte of (leeftijdsgebonden) volwassenheid uitsluit. Een waarde waarvan de universaliteit in de geschiedenis is bevochten op racisme en sexisme, fenomenen die hoewel in de praktijk nog allerminst uitgebannen - algemeen als negatie van de mensenrechtenidee worden beschouwd (hetgeen zou kunnen verklaren waarom zelfs godsdienstig-sexistische regimes, zij het met tal van nationaal-godsdienstige voorbehouden, het Vrouwenverdrag hebben geratificeerd). 
Een waarde waarvan de universaliteit ook overeind gehouden kan en zal (moeten) worden tegenover elke overheid ${ }^{7}$ die de rechten van het kind niet serieus neemt, die geen werk maakt van haar verplichting onder het Verdrag inzake de rechten van het kind (VRK) tot het nemen van alle wettelijke, bestuurlijke, sociale, onderwijs- en opvoedkundige en overige passende maatregelen die nodig zijn om het kind tegen (geweld, misbruik en verwaarlozing door) zijn ouders te beschermen (art. 19 VRK) en tot een optimaal rationeel, moreel en authentiek persoon te doen uitgroeien (in elk geval de artt. 2-6, 9, 18, 20, 24-29, 31-34, 36, 37 en 39 VRK).

\section{Rechtsverfijining: SPS}

De idee van het kind als mens èn als persoon-in-wording impliceert immers dat zijn integriteits- en pedagogische rechten worden veilig gesteld. De pedagogische rechten van het kind hebben twee kanten die zouden kunnen worden aangeduid als (de kant van) het recht op ontplooiing, dat is op warmte, ondersteuning en begeleiding (wachsen lassen), en (de kant van) het recht op leiding, dat is op opvoeding in enge zin: toezicht, begrenzing en disciplinering (führen): twee rechten die elkaar aanvullen en onlosmakelijk met elkaar verbonden zijn.

Ter waarborging van zowel de extra veiligheidsrechten (integriteitsrechten) als - in het bijzonder ook - de speciale ontwikkelingsrechten (pedagogische rechten: recht op ontplooiing, recht op leiding) is noodzakelijk: rechtsverfijning, dat wil zeggen juridische uitwerking en voortschrijdende operationalisering van het rechtsbeginsel 'het recht van het kind op persoonswording.'

Het conglomeraat van wettelijke, bestuurlijke, sociale, onderwijsen opvoedkundige en alle overige passende maatregelen dat daartoe vereist is, wordt in deze studie alangeduid als SPS: sociaal-pedagogisch stelsel/sociaal-pedagogische steun.

\section{Het kind als rechtssubject: KOENS}

Invalshoek van deze studie is met andere woorden de opvatting dat kinderrechten mensenrechten zijn: algemene èn bijzondere mensenrechten. Algemene mensenrechten die extra worden beschermd, want het kind is een kwetsbaar mens. Bijzondere mensenrechten die speciaal op de persoonswording van het kind zien, en die derhalve essentieel zijn om geleidelijk aan - in het volle genot van de mensenrechten te kunnen geraken. Die zowel aan de volle uitoefening van de mensenrechten vooraf gaan, als deze mogelijk maken en faciliteren. Kinderrechten zijn - in het

Zie voor deze term, als min of meer 'synoniem' voor de term staat, hierna par. 1.1 .2 . 
perspectief van deze studie - dus tegelijk mensenrechten en mensenrechten die kinderen mensenrechtenbekwaam maken. Men zou kunnen zeggen: mensenrechtenbekwaamheid is een pre-mensenrecht; niet het voorrecht van 'goed opgevoede' kinderen, maar een vóór-recht voor ieder mens. Geen privilige, maar iets dat door het recht veilig gesteld, gewaarborgd moet worden.

De aanduiding 'de rechten van het kind' impliceert - achter en bovenop dit perspectief, deze invalshoek - dat het kind niet als object (van bescherming) wordt gezien, maar als subject, dat wil zeggen: als tegelijk mens èn persoon-in-wording. Dit impliceert op zijn beurt de feitelijke en juridische eis dat het kind als rechtssubject wordt bejegend, dus, nogmaals, niet als object van bescherming (zoals het dier), noch als verlengstuk van zijn opvoeder(s), een verlengstuk waarvan het belang 'in principe' met de belangen, vrijheden en rechten van die opvoeder(s) samenvalt: het kind als eigendom, althans als object van beperkte zakelijke rechten, van zijn ouders.

Dit moge wellicht een academische open deur zijn, maar de praktijk in en ten aanzien van tal van gezinnen laat helaas iets geheel anders zien. Hoewel de meesten van ons de notie 'kind-als-subject' van harte zullen onderschrijven, blijkt de doordenking en verwezenlijking, zo men wil: de verinnerlijking van deze notie, en dus de toepassing daarvan, het vanzelfsprekend daarnaar handelen, eufemistisch gezegd, nog veel te wensen over te laten.

In zijn inaugurele oratie komt KOENS tot een aantal 'uitgangspunten voor een nieuw stelsel van maatregelen van jeugdbescherming":

"a) [E]en toekomstig stelsel van maatregelen van jeugdbescherming moet uitgaan van het kind als rechtssubject.'

En zelfs:

b) [I]eder kind heeft recht op een harmonische ontplooïng van zijn persoonlijkheid.'

Dan volgt evenwel een opmerkelijke zinswending:

'c) [D]it recht op harmonische ontplooiing valt in principe samen met het recht van ouders om het kind naar eigen inzichten te verzorgen en op te voeden.'

M.J.C. KOENS, Jeugdigen in de knel; Maatregelen van jeugabescherming in de toekomst, inaugurele rede Maastricht, Deventer 1994, p. 37. 
Natuurlijk zou dit 'in principe' zo kunnen worden verstaan dat in het gros van de gezinnen, de gezinnen die een bron van warmte voor kinderen zijn, waarin kinderen volop kunnen gedijen en volledig tot hun recht kunnen komen, althans de gezinnen waarin kinderen niet te kort wordt gedaan en waar kinderen materieel noch geestelijk iets te kort komen, of laat ik het zo zeggen: de gezinnen waar de persoonswording van kinderen geen geweld wordt aangedaan, waar de persoonswording van kinderen niet wordt beschadigd, waar kinderen zo al niet tot een optimaal dan toch tot een boven-minimaal persoon kunnen uitgroeien, dat in het gros van die - Nederlandse - gezinnen, het recht van het kind op ontplooiling spoort met de ouderlijke opvoedingsautonomie. Of zelfs: dat de ouderlijke inzichten een alleszins gelukkige bijdrage leveren aan het ontplooiings-, het persoonswordingsrecht van het kind.

Als 'uitgangspunt' zou een dergelijke interpretatie dan betekenen dat bij het beleid of in het recht niet van een botsing van de rechten van ouders en kinderen moet worden uitgegaan. Een juridisch uitgangspunt kan dit dan nauwelijks worden genoemd. Een jurist houdt zich immers niet bezig met wishful thinking, maar is bij uitstek botsingsminded.

Daar staat tegenover dat deze zinsnede gemakkelijk kan worden misverstaan - juist gegeven de context van de culturele dominantie in ons land, zo goed als in andere westerse landen, van de ouderlijke opvoedingsautonomie, een dominantie die ik elders als "parentiarchie" heb aangeduid. ${ }^{9}$ Het moet dan ook niet uitgesloten worden geacht dat dit uitgangspunt zo wordt gelezen als zou het meest fundamentele recht van het kind in principe tot een recht van de ouders zijn te herleiden. Welke kern van waarheid in een zodanige herleiding, een gelijkstelling als het ware van het recht van de één met het recht van de ander, ook mag zitten voor het gros ( 80 tot $90 \%$ ?) van de gezinnen waar alles 'koek en ei' is, een dergelijke herleiding c.q. gelijkstelling is niet alleen als rechtsfiguur een rechtsfictie, maar is in duizenden gezinnen, dat wil zeggen voor tienduizenden kinderen, ${ }^{10}$ in ons land een feitelijke fictie, die de botsing

J.C.M. WILLEMS, 'Van parentiarchie naar Vadertje Staat; over 't verwekken, mishandelen en beschermen van kinderen,' Nemesis 1992/3 (mei/juni), pp. 8-23, op pp. 9 1.k. en 17 nt. 22.

Er worden in Nederland jaarlijks, volgens voorzichtige schattingen van de Stichting Voorkoming van Kindermishandeling (VKM, Den Haag), tenminste 50.000 kinderen mishandeld. Dit cijfer is een extrapolatie van Amerikaanse onderzoeksgegevens, die - op basis van strikte maatstaven - uitkomen op een geschatte ondergrens van 1,6\% van alle kinderen (VKM Info 'Kindermishandeling in getallen,' febr. 1996). Men komt in de literatuur ook percentages, en dus aantallen, tegen die ongeveer twee keer zo hoog zijn (Ben RENSEN, Kindermishandeling: voor het leven beschadigd, Utrecht 1990, p. 55; zie ook de 'becijfering' in hoofdstuk 12, die 
tussen het recht van het kind op persoonswording en de ouderlijke opvoedingsautonomie verhult. Terwijl bij overheidsinterventie, en de rechtswaarborgen daarbij, voor alle betrokkenen nu juist die botsing van rechten het uitgangspunt is.

Het mag duidelijk zijn dat een dergelijke gelijkstelling het eerste uitgangspunt volledig teniet doet: het recht van de zwakkere partij zou in die interpretatie immers grotendeels of zelfs geheel opgaan in het recht van de machtige partij, en dat kan niet de bedoeling van de auteur zijn geweest.

Vanwaar dan toch dit uitgangspunt, deze opmerkelijke "clausulering"? Tenzij ik iets over het hoofd heb gezien, lijkt het vermoeden gewettigd dat hier bij de auteur zelf, ondanks het als eerste uitgangspunt geponeerde kind-als-rechtssubject, toch weer ouderlijk objectsdenken de theorievorming is binnengeslopen. Dit zou dan haaks staan (en daarom mag men er niets achter zoeken), niet alleen op dat eerste, maar ook op alle volgende uitgangspunten die KOENS formuleert. Deze zijn niet alleen op zich behartenswaardig, maar bovendien voor deze studie zodanig pertinent, dat ik ook deze resterende uitgangspunten hier weergeef: ${ }^{11}$

uitkomt op een ondergrens van 2,5\% ofwel tenminste 80.000 kinderen per jaar). Het Human development report 1996 van de UNDP (United Nations Development Programme, het ontwikkelingsprogramma van de VN) schrijft ower de kinderen van de wereld: 'Children, who should be most protected in any society, are subject to many abuses. In the United States nearly three million children are reported to be victims of abuse and neglect every year. More than 200,000 children live on the streets in Brazil. Each year an estimated one million children, mostly girls in Asia, are forced into prostitution. An estimated 100 million girls, mostly in Africa, have suffered genital mutilation.' (Human development report 1996, New York/Oxford 1996, p. 24 l.k.) Als we er, veronderstellenderwijs, van uitgaan dat 'reported' (per saldo) op de helft van alle gevallew van kindermishandeling slaat (de terecht gemelde gevallen zijn dan het bekende topje van de ijsberg), en we de Amerikaanse 3 miljoen kinderen 'omrekenen' naar Nederland (factor circa $15 / 255)$ - er gemakshalve van uitgaande dat beide landen ongeveer even kinderrijk zijn en dat Nederlandse ouders gemiddeld niet minder hardvochtig of onverschillig zijn dan Amerikaanse -, dan zouden we uitkomen op een - viteraard zér grof - aantal van circa 350.000 mishandelde en/of verwaarloosde kinderen in ons land (circa éen op de tien). Wellicht kan 50.000 als ondergrens en 350.000 als bovengrens worden gezien? Het gemiddelde (200.000 kinderen) is dan de tussenverdieping, let wel: bij een stringente definitie van kindermishandeling (mishandeling, misbruik of verwaarlozing door ouders of volwassenen met opvoedingsverantwoordelijkheid). Het probleem krijgt dan bij benadering de omvang van dat van de straatkinderen in Brazilie,, een land met meer dan 155 miljoen inwoners A.w., pp. $37-38$ (curs. jw). 
"d) [D]e overheid heeft als positieve verplichting de ouders in de gelegenheid [lees: in staat? -jw] te stellen hum opwoedings - en verzorgingsplicht naar behoren te vervullen;

'e) geen overheidsinterventie als het beoogde resultat ook langs de weg van de vrijwillige hulpverlening is te bereiken;

'f) iedere minderjarige heeft bij (dreigende) (ernstige) schade aan zijn persoon voorzover de ouders deze noch op eigen kracht noch met behulp van vrijwillige hulpverlening kunnen of willen tegengaan - recht op beschermende overheidsinterventie;

'g) de interventienormen moeten zodanig concreet zijn geformuleerd dat voor de ouders en de minderjarige voorzienbaar is wanneer zij bepaalde vormen van overheidsinterventie kumnen verwachten;

"h) hoe ingrijpender de overheidsinterventie, hoe strenger en concreter de voorwaarden moeten zijn op grond waarvan die inmenging gerechtvaardigd kan worden;

i) de interwentienormen mogen niet een zodanig limitatief karakter hebben dat daardoor overheidsinterventie in beschermingswaardige situaties ten ontechte achterwege blijft;

j) noodzakelijke overheidsinterventie in de ouderlijke opvoedings- en verzorgingsautonomie mag niet verder gaan dan nodig is om het beoogde doel te bereiken; "k) overheidsinterventie mag niet langer duren dan nodig is om het gestelde doel te bereiken;

1) gedwongen uithuisplaatsing is alleen toelaatbaar als de oorzaak van de (dreilgende) ernstige schade voor het kind ligt in nader omschreven zwaarwichtige tekortkomingen van de ouders in hun minimale verzorgings- en opvoedingsverplichtingen;

'm) overheidsinterventie is alleen geoorloofd als er voldoende waarborgen zijn dat daardoor een verbetering in de bedreigde situatie van het kind komt;

" $\mathrm{n}$ ) het doel van de overheidsinterventie is het waarborgen van het recht op een hamonische ontplooing van zijn persoonlijkheid van de jeugdige door het mogelijk maken van hulpverlening op maat.'

\section{KOENS vat zijn voorstellen als volgt samen: 12}

'A. [Ten aanzien van] de maatregel tot ambulante hulp-en steunverlening:

- de grondslag van deze maatregel is gelegen in een (dreigende) inbreuk op het recht van de jeugdige op harmonische ontplooing van zijn persoonlijkheid en de noodzakelijke bescherming van de jeugdige tegen (dreigende) beschadiging van zijn persoon;

- het doel is het waarborgen van het recht van iedere jeugdige op een harmo* nische ontplooing van zijn persoonlijkheid;

- het middel is niet-vrijwillige ambulante hulpverlening aan ouders en/of kind door het verstrekken van een hulpverleningsopdracht op maat door de rechter;

- het te verwachten resultaat moet zijn het realiseren van die ontplooiingskansen van de jeugdige waarop deze ten minste recht kan doen gelden. 
B. [Ten aanzien van] de gedwongen uithuisplaatsing:

de grondstag van de[ze] maatregel is gelegen in een (dreigende) ernstige schending van het recht wan de jeugdige op een harmonische ontplooing van zijn persoonlijkheid en bescherming van de jeugdige tegen (dreigende) ernstige beschadiging van diens persoon als gevolg van zwaarwichtige tekortkomingen van de ouders in hun minimale ouderlijke verzorgings- en opvoedingsplicht;

- het doel is het waarborgen van het recht van iedere jeugdige op een harmomische ontplooiing wan zijn persoonlijkheid;

- het middel is het woorzien in een zodanige niet-vrijwillige niet-ambulante hulpverlening op maat aan ouders en/of kind dat een verantwoorde hereniging van ouders en kind (uithuisplaatsing van bepaalde duur) of [een] alternatieve verzorgings- en opwoedingssituatie (uithuisplaatsing van onbepaalde duur) gerealiseerd kan worden;

- het [te] verwachte $(n]$ resultaat moet zijn het realiseren van die ontplooingskansen van de jeugdige waarop deze ten minste recht kan doen gelden."

In het bovenstaande kunnen belangrijke en waardevolle aanzetten tot rechtsverfijning worden gezien (met name) op het punt van interventie. Ook op het punt van preventie zal operationalisering van het recht van het kind op persoonswording tot tal van meer of minder concrete en uitgewerkte voorstellen aanleiding kunnen geven. Onder de noemer 'modaliteiten van staatsverantwoordelijkheid' zullen in hoofdstuk 14 enkele voorbeelden van rechtsverfijining op (met name) dit punt de revue passeren.

\section{Het kind als eigendom: DE LANGEN}

De hier gekozen invalshoek: het kind als subject van rechten, gaat lijnrecht in tegen de tendens tot objectivering (zelfs 'reificatie' of verdingelijking genoemd ${ }^{13}$ ) van het kind, die door DE LANGEN als volgt werd aangeduid: ${ }^{14}$

'Geconstateerd moet ten slotte worden, dat mede onder invloed van art. 8 EVRM ouders kinderen steeds meer als eigendom en als consumptiegoed zijn gaan beschouwen. Ouders beroepen zich soms al op een recht om kinderen te krijgen. En als dat niet op een natuurlijke wijze lukt, dan moet dat via cen medische vorm van kinderen krijgen of via een juridische vorm, namelijk via adoptie. Ook kunnen zij al een kind bestellen en het vervolgens weer weigeren als het produkt niet aanstaat.

Voorts leggen ouders in vele betekenissen, namelijk biologische, juridische en verzorgende ouders, steeds meer claims, op kinderen. $\mathrm{Z}_{\mathrm{ij}}$ eisen erkenning van kinderen, gezag over kinderen, adoptie en omgang met kinderen; en op grond van het discriminatieverbod kunnen geen ouders uitgesloten worden. Maar kinde-

13 Zie hierna VAN SLOUN.

14 M. DE LANGEN, 'De betekenis van artikel 8 EVRM voor het familierecht,' Preadvies NJV, Artikel 8 EKRM, Handelingen Nederlandse Juristen-Vereniging 1990-I, Zwolle [1990-1], pp. $85-183$, op p. 183 . 
ren hebben niets te eisen, zij worden hooguit gehoord in de desbetreffende procedures. Hun positie is relatief gezien in de tachtiger jaren slechter geworden, al wordt veelal het tegendeel gesuggereerd. De fundamentele rechten van kinderen worden in ons recht nog nauwelijks erkend of, wanneer zij al erkend zijn, wordem kinderen miet competent geacht om ze zelf te realiseren.'

In een betoog dat hij met de eerste hierboven aangehaalde zin van DE LANGEN opent, spreekt VAN SLOUN van een 'falende juridische grondhouding' en merkt hij op: ${ }^{15}$

'[D]e veranderde rol van de wetgever - van aanpassing achteraf van de wetten aan de heersende inzichten in de samenleving naar het doelbewust nastreven van veranderingen in die maatschappij middels legislatieve activiteiten, c.q. van codificatie naar modificatie - gaat [ten aanzien van ouderlijke bevoegdheden, jw] kennelijk gepaard met een transformatie van het kind en de jeugdige tot juridisch stoffelijke objecten. Dit ontwikkelingsproces kan het best omschreven worden met het begrip reificatie, afgeleid van het Engelse woord reify, wat "verstoffelijken" c.q. "tot ding maken" betekent. Het is weliswaar geen fraai woordgebruilk, doch het geeft exact aan wat bedoeld wordt: de reductie van de kwaliteit "mens" tot kwantiteiten en ruilwaarden teneinde door deze functionalisering het beheersen wan menselijke verhoudingen en relaties mogelijk te maken."

Wat hiervan - en van de achterliggende 'materialistische mentaliteit (...) in onze samenleving en in een ieder van ons afzonderlijk ${ }^{16}$ - ook de oorzaken mogen zijn, duidelijk is dat de notie 'rechten van het kind' hetgeen betekent: het kind als drager, als subject van rechten - als geen andere een breekijzerfunctie kan worden toegedacht om deze pedagogisch schadelijke mentaliteit te 'kraken' en het reificerende tij te keren.

\section{Het belang van het kind: DOEK}

Vertrekpunt daarbij is 'het belang van het kind' (the best interests of the child) als leidend beginsel, $60 \mathrm{k}$ in het Verdrag inzake de rechten van het kind. Over dit beginsel schrijft RUTTEN-ROOs: ${ }^{17}$

"Met het belang van het kind kan iedereen de kant uit die hij wil: de moeder naar het verbreken van het contact tussen kind en vader, de vader naar een om-

15 T.H.J.G. VAN SLOUN, 'Reificatie als resultante van "codificatie naar modificatie", in: Ted DE BOER e.a. (red.), De kant wan het kind; Liber amiconim Prof. mr. Miek DE LANGEN, Arnhem 1992, pp. 279-289, op pp. 279/280.

16 T.a.p., op pp. 280 juncto 289.

17 A. RUTTEN-ROOS, 'Kind en wetgever,' in: Ted DE BOER e.a. (red.), De kant wan het kind; Liber amiconum Prof. mr. Miek DE LANGEN, Arnhem 1992, pp. 291-299, op p. 298. 
gangsregelirg en de (kinder)rechter naar een ondertaezichistelling omdat het kind in de strijd tussen de ouders in de verdrukking dreigt te raken.'

Hier wordt de, met de (ogenschijnlijke) abstractie van het beginsel samenhangende "verdingelijkende" - en dus averechtse - werking, van het beginsel pregnant getypeerd.

Die abstractie zou al dadelijk een stuk minder zijn als het beginsel (c.q. rechtsbegrip) als kernrecht van het kind zou kunnen worden geherformuleerd, in de zin zoals DOEK, aansluiting zoekend bij de Verklaring van de rechten van het kind ter bepaling van "het centrale belang van het kind,' dat heeft gedaan: ${ }^{18}$

\footnotetext{
'We kunnen deze beginselen [beginsel 2, 6 en 7 uit de Verklaring van de rechten van het kind, 1959], die verder zijn uitgewerkt in de Conventie [inzake] de rechten van het kind, aldus samenvatten dat het kind bovenal recht heeft op een volledige en harmonische ontplooing naar lichaam en geest. Dat recht zal het centrale beginsel moeten zijn bij de verzorging en opvoeding van een kind, waarvoor de verantwoordelijkheid in de exste plaats bij de ouders ligt (...). (...) Als dit beginsel door de ouders ernstig wordt verwaarloosd of zelfs met voeten wordt getreden (...), dan is het de taak van de overheid om in te grijpen (...).'
}

Verder aanknopingspunt vinden we ook bij VAN WIJK, waar zij spreekt van het recht van het kind op verzorging en opvoeding conform minimaal te stellen eisen. ${ }^{, 19}$ En zij de vraag aan de orde gesteld wil zien in deze studie, die in het bijzonder (dat wil zeggen binnen het algemene en ruime kader van de bevordering van de optimale persoonswording) ziet op de waarborging van de minimale persoonswording van het kind door de staat, van indirect, maar daarom (met het oog op de operationalisering van het recht van het kind op persoonswording) van niet minder principieel en praktisch belang - naar "wat kinderen minimaal van ouders mogen verwachten., ${ }^{20}$

J.E. DOEK, 'Het belang van het kind en het recht,' in: J.B. WEENINK (red.), Het belang van het kind in het geding, Over opvoeding en kinderbescherning. Amsterdam 1990 , pp. 73-92, op p. 75.

19 Hanneke VAN WIJK, "Ouderlijke verantwoordelijkheid en het recht van het jonge kind op eerbiediging van "family life", in: Ted DE BOER e.a. (red.), De kant van het kind; Liber aniconum Prof. mr. Miek DE LANGEN, Arnhem 1992, pp. 147-158, op p. 157.

20 Hanneke VAN WUK, 'Gronden voor kinderbeschermingsmaatregelen; discussie voortgezet,' Nemesis 1992/6, pp. 27-29, op p. 29 m.k. (enigszins verminkt aangehald door N.A. STEGERHOEK, De publieke kant van het jeugdrech; Publieke aspecten wan het civiele jeugdrecht nader beschouwd, diss. Leiden, Zwolle 1995, p. 132). 


\section{Criterium-DE RUYTER}

Pas bij DE RUYTER ${ }^{21}$ vinden we evenwel een nader uitgewerkt pedagogisch criterium, als recht van het kind geformuleerd, dat als meer richting gevend en tegelijk als subjectiverend ten aanzien van het kind kan worden beschouwd: het recht van het kind op minimale persoonswording als interventie-criterium voor de staat. Als groot voordeel van dit criterium zie ik het gegeven dat in dit criterium mensenrechtelijke, ontwikkelingspsychologische en pedagogische elementen in elkaar vloeien, waardoor een systematische juridische en ontwikkelingspsychologische/pedagogische operationalisering van het criterium mogelijk wordt.

In verschillende juridische exposés, voornamelijk van civiel- en strafrechtelijke signatuur, wordt het pedagogische gehalte van 'het belang van het kind' weliswaar aangestipt of zelfs onderstreept, ${ }^{22}$ maar een expliciete herformulering van het belang van het kind in ontwikkelingspsychologisch/pedagogische zin ben ik in de juridische vakliteratuur niet tegengekomen. Toch biedt met name het internationale recht (en sinds november 1995 ook ons Burgerlijk Wetboek ${ }^{23}$ ) daarvoor - in tal van instrumenten - tal van aanknopingspunten. NU DE RUYTER haar criterium heeft gepresenteerd, is er alle aanleiding te onderzoeken in hoeverre dit criterium, na om-etikettering als mensenrecht c.q. mensenrechtelijk rechtsbeginsel, en nadere classificering als kernrecht van het kind, kan worden ingelezen in het internationale recht met betrekking tot de rechten van het kind, en (dus) in het bijzonder in het Verdrag inzake de rechten van het kind, en welke verbeteringen dit belooft, of liever: zou kunnen inhouden, voor de positie van het kind in het gezin, in het bijzonder het kind dat in de knel zit of dreigt te raken in het dysfunctionele gezin.

21 Doret DE RUYTER, Met recht ingrijpend; Een pedagogisch criterium voom het opleggen van hulp, diss. VU Amsterdam, s.l. 1993; D. DE RUYTER, 'Het recht om persoon te worden:" een criterium voor het opleggen wan pedagogische hulp,' in: dez. en P.A. DE RUYTER, Opvoedingshulp geboden; Pedagogische criteria voor het opleggen van hulp, theoretisch en praktisch bezien, Utrecht 1995, pp. 15-27.

Zie bijwoorbeeld $H$. FRANKEN, 'Het belang van het kind voor wetgeving en bestuur, ' in: Ad VAN DER Linden, Paul VLAARDINGERBRoEk (red.), Met het oog op het belang van het kind; Opstellen aangeboden aan professor m. Madzy ROOD-DE: BOER ter gelegenheid van haar emeritaat, Deventer 1988, pp. 27-42; J. HEINER, A.A.J. BARTELS, 'Jeugdstrafrecht en het belang van het kind: het belang van het kind nader omschreven,' FJR 1989/3, pp. 59-67.

23. Art. 1:247, lid 1 BW bepaalt: Het ouderlijk gezag omvat de plicht en het recht van de ouder zijn minderjarig kind te verzorgen en op te woeden.

Lid 2 van dit artikel geeft aan deze rechtsplicht de volgende nadere invulling: Onder verzorging en opvoeding worden mede verstaan de zorg en de verantwoordelijkheid voor het geestelijk en lichamelijk welzijn van het kind en het bevorderen van de ontwikkeling van zijn persoonlijkheid. 
Dat laatste zal met name afhangen van de vraag in hoeverre het recht van het kind op minimale respectievelijk optimale persoonswording als mensenrecht (mensenrechtelijk rechtsbeginsel) en kernrecht van het kind de staatsaansprakelijkheid verduidelijkt en aanscherpt, en daarmee, als spiegelbeeld van die aansprakelijkheid, de verantwoordelijkheden van de overheid en de overige staatsorganen, niet in de laatste plaats ook van de volksvertegenwoordiging en van de (kinder)rechter, in een feller licht stelt.

\section{1 .2}

Doel van deze studie: het recht van het kind op persoonswording als kernrecht van het kind

Deze studie heeft tot doel het recht van het kind op minimale respectievelijk optimale persoonswording te presenteren als uit het Verdrag inzake de rechten van het kind voortvloeiend grondbeginsel voor het nationale kinder(beschermings) recht. Aangezien het hier om kernrechten van het kind gaat, moet dit grondbeginsel fundamenteler worden geacht dan het grondbeginsel 'van het Nederlandse familierecht [betreffende] het garanderen van het ouderlijk gezag' (VAN DER LINDEN). ${ }^{24}$

De rechten van ouders betreffen immers geen kernrechten van de menselijke persoon. ${ }^{25}$ VAN DER LINDEN: ${ }^{26}$

'Onder omstandigheden kan het gezag van ouders dus beperkt of ontnomen worden. Steeds is daarbij de afweging waarmee het belang van de jeugdige persoon het meest gediend is: handhaving van het gezag of een imbreuk maken daarop. Ouders en kinderen hebben rechten, ook bijwoorbeeld op ondersteuning van hulpverleningsinstellingen. Maar de verschillende rechten van de onderscheiden actoren kunnen met elkaar botsen. Bij het afwegen van de belangen moet dan het belang van de jeugdige persoon de doorslag geven. Immers, zijn positie is een bijzondere, zolang het proces van "grootgroeien" niet afgerond is. Die positie vraagt om een bijzondere rechtsbescherming en een duidelijke rechtspositie van de betrokken kinderen. Ulit de praktijk van de justitiele jeugdhulpverlening blijkt echter dat deze afweging een zeer gecompliceerde aangelegenheid is en dat (jeugd)hulpverleners zich soms meer identificeren met de ouders dan met de kinderen.'

A.P. VAN DER LINDEN, 'Maatregelen van justitiële jeugdhulpwerlening, in: M.J.C. KOENS (red.), Het hederudaagse personen-en familierecht, Zwolle 1995, pp. $265-$
302 , op p. 267 . Voor het onderscheid tussen kernrechten en andere categorieën rechten zie hierna hoofdstuk 4 .

26 A.w., op p. 268. 
Op grond van het Verdrag inzake de rechten van het kind heeft de staat, als internationaalrechtelijk aanspreekbaar/aansprakelijk rechtssubject, c.q. hebben de wetgever (regering en parlement: 'de politiek' ${ }^{27}$ ), het bestuur (de overheid) en de rechter, als staatsorganen, de primaire plicht (a) kind en ouders (het gezin) alle met het oog op de persoonswording van het kind benodigde hulp en steun te verlenen, alsmede de primaire plicht (b) kinderen, waar nodig, tegen hun ouders te beschermen. Dit impliceert dat de staat (c) een secundaire (aanvullende, ondersteunende en desnoods vervangende, subsidiaire) plicht heeft ter zake van de verzorging en opvoeding van kinderen (secundaire verzorgings- en opvoedingsverantwoordelijkheid).

Tevens beoogt deze studie te laten zien:

(1) dat de mate waarin het recht van het kind op (minimale) persoonswording in ons land wordt geschonden, dat wil zeggen zowel qua omvang als qua ernst van de gevolgen - zowel de (vaak levenslange) gevolgen voor de betrokkenen als de gevolgen voor de maatschappij in haar geheel - enerzijds, (2a) als de mate waarin de staat zijn verdragsverplichtingen tot hulp en steun aan kind en ouders niet nakomt, (2b) de mate waarin het de staat schort aan zorgvuldigheid (due diligence ofwel due care) bij de nakoming van zijn verdragsverplichtingen tot bescherming van het kind tegen zijn ouders c.q. de mate waarin de staat zijn concrete verdragsverplichtingen op dit punt niet nakomt, (2c) alsook de mate waarin de staat te kort schiet in zijn aanvullende, ondersteunende dan wel vervan-

27 In Nederland is de wetgever (in formele zin) niet het parlement maar regering (rijksoverheid; strikt genomen: minister(s)/staatssecretaris(sen) met de formele handtekening van het staatshoofd) en parlement (Tweede en Eerste Kamer) tezamen. Gezien het in Nederland vigerende monisme in de verhouding tussen beide, worden zij evenwel ook buiten de wetgevingstaak well bijeen genomen als 'de politiek" - waarmee wordt aangeduid dat er op het punt wan checks and balances een oud evenwicht (het gematigde dualisme) kenruelijk nog niet door een nieuw is vervangen: doordat de regeringsfracties veelal te weinig onafhankelijk tegenover de regering staan, wil de parlementaire controlletaak er wel eens bij inschieten. De controletaak van de rechter krijgt daardoor meer gewicht: de rechter komt meer tegenover de politiek te staan; 6ók wetten in formele zin, als politieke producten bij uitstek en per definitie, blijken steeds vaker de toets van de rechterlijke kritiek niet te kunnen doorstatan.

Vgl. met betrekking tot de 'vervanging' van de driedeling overheid, parlement, rechter (trias politica) door de tweedeling rechter en politiek: J.C.M. WLLEMS, 'Recht en rechter in de "dyas politica"; enkele gedachten over internationaal recht, juridisch activisme en de rolperceptie van de rechter vanuit staatsrechtelijk perspectief en met het oog op de rechtshulp aan vreemdelingen," in. T. HOOGENBoom e.a. (red.), Sociale advocatuur en de rechten van de mens, Ars Aequi Libri, Nijmegen 1989, pp. 114-145, op p. 121 ("Dyas" politica"). 
gende verzorgings- en opvoedingsplicht, in het bijzonder door (ad 2a-c) het onvoldoende ter beschikking stellen van geldelijke en andere middelen en een ontoereikend aanbod c.q. een inadequate inzet van (zoveel mogelijk geïntegreerde) deskundige vrijwillige en justitiële hulpverlening (op basis van de in deze studie bepleite glijdende schaal van hulp en steun aan kind en ouders) anderzijds, tot de conclusie vermag, en bijgevolg dient, te voeren dat in ons land de rechten van het kind op ernstige en structurele wijze worden geschonden.

Dit heeft consequenties niet alleen voor de staatsaansprakelijkheid van Nederland (te midden van tal van andere rijke landen), maar ook voor de mate waarin ons land als rechtsstaat kan worden beschouwd. Erkenning van mensenrechten is - naast wetmatigheid van bestuur (government by law, not by men), machtenscheiding (checks and balances) en rechtsbescherming tegen de overheid door een onafhankelijke rechter immers één van de vier hoofdpilaren van het rechtsstaatsideaal, en tevens het meest materiële element van de rechtsstaatsidee (de rule of law). ${ }^{28}$

Zoals hierboven is betoogd, worden ook suggesties aan de hand gedaan in deze situatie (een mogelijk begin van) verbetering te brengen.

\section{Staat of overheid?}

In deze studie wordt veelvuldig gesproken van de staat: de staat als drager van internationaalrechtelijke verplichtingen èn de staat als nationaalrechtelijke actor. Hierbij dient het volgende te worden opgemerkt. In het nationale recht is het, in tegenstelling tot het internationale, niet gebruikelijk van de staat te spreken. Veeleer wordt hier de term overheid gehanteerd. Dit is juist, en ook meer adequaat, indien exclusief gedoeld wordt op het bestuur c.q. bestuursorganen van de centrale (rijks-) $\mathrm{en} /$ of decentrale overheid (provincie, gemeente). Niet zelden schuilt hier echter een addertje onder het gras, namelijk wanneer van overheid wordt gesproken terwijl intussen de statelijke dimensie (het openbaar-rechtelijke karakter) van het toepasselijke recht wordt 'verdonkeremaand.' Hierop wijst nadrukkelijk, en specifiek met betrekking tot jeugdigen en het jeugdrecht, STEGERHOEK in haar dissertatie De publieke kant van het jeugdrecht. Zij merkt op: ${ }^{29}$

J.C.M. WILLEMS, discussiebijdragen in De Volkskrant: Open forum van 29 oktober ('Democratie te formalistisch') en 16 december 1980 ("VAN AGT misbruikt term rechtsstaat"). Vgl. ook R.M. VAN MALE, 'Artikel 89, "in: P.W.C. AKKERMANS en A.K. KOEKKOEK (red.), De Grondwet; Een artikelsgewijs commentaar, Zwolle 1992 (tweede druk), pp. 781-830, op p. 783 (e.v.).

29 N.A. STEGERHOEK, De publieke kant van het jeugdrecht; Publieke aspecten wan het civiele jeugdrecht nader beschouwd, diss. Leiden, Zwolle 1995, pp. 21-22 (Van staat naar overheid?"). 
'De algemene tendens om veeleer in termen van de owerheid te denken dan in termen van de staat (...), onderstreept hoe belangrijk het is om op wetenschappelijk en politiek niveau waar dat relevant is, expliciet te spreken over de statelijke dimensie van het recht, en de statelijke dimensie van de matschappijstructuur.'

Doelend op het concept 'verzekeringsstaat,' vervolgt zij..30

\begin{abstract}
'Expliciete erkenning van deze statelijke dimensie kan met name ook van belang worden geacht voor de bescherming van bescherming-behoevende minderjarige burgers, die weinig risicodraagkracht hebben en niet of minder goed in staat zijn tot het effectueren van hun eigen "polis"."
\end{abstract}

Vanuit een internationaalrechtelijke optiek kan met staat in beginsel elk staatsorgaan bedoeld zijn: wetgever, overheid, rechter. Uit de tekst (het op dit punt min of meer expliciete verdragsartikel) of de context moet blijken of àl deze staatsorganen, dan wel één of enkele bedoeld zijn. In deze studie wordt de term overheid soms gehanteerd als pars pro toto, en dus als synoniem aan staat: namelijk dan wanneer een internationaalrechtelijke verplichting weliswaar alle staatsorganen kan betreffen, maar niettemin het initiatief dan wel een actieve opstelling van in het bijzonder dit staatsorgaan vooronderstelt: de overheid is bij uitstek de hoedster van de rechten van het kind, hoezeer zij ook door het parlementaire deel van de politiek 'achter de broek' behoort te worden gezeten, en hoezeer de rechter ook gehouden is de steken die de politiek laat vallen, zo veel mogelijk recht te breien.

\title{
1.1.3 Reprise: persoonswording als resultaats- en inspannings- verplichting
}

Opzet is niet het belang van het kind (the best interests of the child) als internationaalrechtelijk rechtsbegrip/rechtsbeginsel in kaart te brengen, maar om de link te leggen tussen enerzijds het pedagogisch criterium van DE RUYTER en anderzijds het beginsel van het belang van het kind in verband met andere noties, beginselen en rechten in het Verdrag inzake de rechten van het kind, zoals het beginsel van de zich ontwikkelende vermogens van het kind en het gelijkheidsbeginsel (resp. artt. 3, 5 en 2, lid 1 VRK), alsmede/c.q. de rechtenconceptie ('rights/-ism/') die in het Verdrag inzake de rechten van het kind, naast de welzijnsconceptie ("welfarism'), haar uitwerking vindt. Het recht van het kind op persoonswording wordt gepresenteerd als de juridische schakel tussen de beginselen 
van het belang van het kind en de zich ontwikkelende vermogens van het kind enerzijds en de operationaliseringen (de rechtsverfijning) van het recht op persoonswording anderzijds.

De gekozen mensenrechtelijke invalshoek: de (internationale) rechten van het kind, en in het bijzonder het recht van het kind op minimale respectievelijk optimale persoonswording, alsook de (in hoofdstuk 14) gedane suggesties zijn bedoeld - om STEGERHOEK te citeren ${ }^{31}$ - 'als aanzet voor verdere wetenschappelijke en politieke discussie over [de] verbetering van" (1) de bescherming van met name het (zeer) jonge kind in het gezin, alsmede (2) de sociaal-pedagogische steun aan het gezin, met name aan ouders in sociaal-economische en/of sociaal-emotionele achterstandssituaties, zoals minvermogende, laag opgeleide, jonge en alleenstaande ouders, of ouders die zelf als kind door hun ouders ernstig te kort zijn gedaan in de honorering van hun rechten, en (3) het onderwijs op ontwikkelingspsychologisch, pedagogisch, kinder(volken)rechtelijk alsook relationeel en sociaal-emotioneel gebied.

Dit boek is derhalve niet een pleidooi om een nieuw recht aan de catalogus van rechten van het kind toe te voegen, maar om de betrekkelijk vage rechtsnotie van het belang van het kind ${ }^{32}$ - een centraal begrip in en achter het Verdrag inzake de rechten van het kind ${ }^{33}$ - in verband met andere noties, beginselen en rechten in het Verdrag te vervangen door, althans te vangen onder een meer in pedagogische zin richting gevend rechtsbeginsel: het recht van het kind op persoonswording; alsmede om dat beginsel te beschouwen als een achterliggend rechtsbeginsel van het VRK c.q. een in het Verdrag in te lezen rechtsbeginsel.

Een dergelijke pleidooi lijkt gewettigd niet alleen gezien de pluriinterpretabiliteit van het belang van het kind (the best interests of the child) in het recht, ${ }^{34}$ maar evenzeer - en in verband daarmee - gezien de kloof die gaapt tussen het concept van het kind-als-subject dat in het Verdrag tot uitdrukking komt, enerzijds en anderzijds de feitelijke situatie van het kind in het gezin, de situatie van minimaal tachtigduizend kinderen in Nederland wier kernrechten op lichamelijke en geestelijke integriteit en op ontwikkeling jaarlijks op flagrante wijze worden geschonden. Het concept van het kind-als-subject wil immers zeggen: (1) het kind als drager van, ook tegenover de ouders te handhaven rechten, in het bijzon-

A.W., p. 1 .

32 Zie Joachim WOLF, "The concept of the "best interests" in terms of the UN Convention on the rights of the child,' in: Michael FREEMAN, Philip VEERMAN (eds.), The ideologies of children's rights, Dordrecht (etc.) 1992, pp. 125-133. Vgl. Erica BURMAN, 'Local, global or globalized? Child development and international child rights legislation,' Childhood 1996/1, pp. 45-66, op p. 57. BURMAN, ta.p., op pp. 55; WOLF, ta.p. 
der op (a) bescherming door de staat tegen die ouders; en (2) het kind als subject van aanspraken op de overheid krachtens (b) de verdragsrechtelijke primaire plicht van de staat kind en ouders (het gezin) alle benodigde hulp en steun te verlenen, alsmede (c) krachtens de secundaire opvoedingsverantwoordelijkheid van de staat.

Betoogd zal worden dat op de staat een resultaatswerplichting rust met betrekking tot de minimale persoonswording van kinderen en een inspanningsverplichting met betrekking tot de optimale persoonswording van kinderen, alsmede dat minimale persoonswording tot het corpus van kernrechten van de mens behoort en kernrecht van het kind is.

Vervolgens zal, aan de hand van de omvang en de ernst voor individu en samenleving van het fenomeen kindermishandeling in Nederland, betoogd worden dat de omvang en de ernst van de schending van het recht van het kind op (minimale) persoonswording in Nederland de conclusie wettigt dat de rechten van de mens in Nederland met betrekking tot kinderen op ernstige en structurele (passief-systematische) wijze worden geschonden. Tevens zal de verplichting ex art. 19, lid 2 VRK tot sociale programma's om het kind (tegen de ouders) te beschermen, worden ingekleurd aan de hand van modaliteiten van SPS (sociaal-pedagogische steun) om te laten zien hoeveel op dit gebied mogelijk is en op dit moment al gebeurt, zij het niet structureel noch op de schaal die het belang van het kind in Nederland eist.

\section{1 .4}

Leitmotiv van deze studie: geen bevoegdheid zonder verantwoording

Naar analogie van cultureel relativisme, voor zover dat niet een òntkenning van universaliteit maar de èrkenning van de mogelijkheid van culturele/regionale nuancering in de toepassing en interpretatie van niet-kernrechten inhoudt, en van gender-relativisme, ${ }^{35}$ zouden we de term kindrelativisme kunnen introduceren om aan te geven dat de rechten van de mens met betrekking tot kinderen op een aan de persoonswording van het kind gerelateerde wijze dienen te worden geïnterpreteerd en toegepast. Een dergelijk kind-relativisme, niet ten aanzien van, maar consequent vertrekkend vanuit het kernrecht van het kind op persoonswording, zou de, nog ver(der) achter de horizon gelegen, consequentie van het doordenken en het handhaven van de rechten van het kind zijn. De (pa-

Jenny E. GOLDSCHMIDT, bespr. van Rebecca [J.] COOK (ed.), Human rights of women; National and intemational perspectives (Philadelphia 1994), NQHR 1996/ 2, pp. 229-231, op p. 229. 
tri- en) parentiarchale cultuur, ${ }^{36}$ c.q. - om een term van VERHELLEN te gebruiken - het adulto-centrisme ("het overtrokken egocentrisme van de volwassene'), ${ }^{37}$ belet veelal reeds het uitzicht op het kernrecht zèlf. Men zou kunnen zeggen: in de dominante - lees: westerse - (rechts)cultuur en $(-)$ praktijk is niet zozeer het probleem dat we niet alle kinderen willen beschermen (hoewel ook dat voorkomt: het de facto afschrijven van kinderen uit bepaalde, 'zwak-sociale' milieus, ${ }^{38}$ of kinderen die 'toch niet meer te redden' zijn $^{39}$ ), noch dat we niet alle kinderen gelukkig zouden

Zie voor deze term hierboven par. 1.1.1.

tieven, strategieëh, hoofdlijnen, Leuven/Apeldoorn 1993 (tweede druk), p. 23. Vgl. Rene DrEKSTRA, 'Wie waakt, slaapt niet; over oplettendheid, overheid en opvoeding; cen reactie op KOHNSTAMM en BRINKGREVE,' Jeugd en Samenleving 1994/2, pp. 91-97. DIEKSTRA merkt op (t.a.p., op pp. 91/92): "Van verschillende kanten wordt er mijns inziens terecht met bezorgdheid op gewezen dat ex een toenemende neiging in de Nederlandse samenleving lijkt te bestaan om bepaalde groepen definitief af te schrijven. Onder het mom van nieuw realisme worden steeds vaker uitspraken gedaan als: "We moeten de moed hebben toe te geven dat er in belangrijke mate ongelijkheid in de samenleving bestaat en altijd zal bestaan," of: "Er is nou eenmaal een bepaalde groep jongeren die hoe je het ook wendt of keert, uit de boot zal blijwen vallen," of: "We moeten ons er bij neerleggen dat er een groep is waarvoor we geen werk meer zullen hebben." (...) [V]oor [een] staat of een overheid die een bepaalde groep mensen definitief afschrijt en in termen van maatschappelijke participatie en produktiviceit als "surplus people" benadert, [geldi] dat [zijn c.q.] haar legitimiteit in het geding is.' (Zie ook J.C.M. WLLEMS, 'Kirderen in ons midden; enkele cultuurkritische notities naar aanleiding van artikel 25 van de Universele Verklaring en het Verdrag inzake de rechten van het kind,' Recht en kritiek 1994/4, pp. 322-339, op pp. 330/331 nt. 25.

39 Vgl, voor thet afschrijven van mishandelde kinderen door de BVA's: Marian ROELOFS, Kindermishandeling en hulpverlening; De aanpak van lichannelijke kindermishandeling door het BUREAU VERTROUWENSARTS, [diss. VU] Amsterdam 1996, p. 197 (curs. jw): 'In bijna eenderde van het totaal kwam een hermelding voor [dat will zeggen: na hulpverlening en afsluiting van het dossier, jw]. Dit grote aantal hermeldingen heeft ons verbaasd. Voor een deel van deze gevallen was de hermelding geen verrassing voor het BVA, want bij de voorgaande afsluiting was al bekend dat de mishandeling nog doorging. Blijkbaar zag het BVA in die gevallen geen mogelijkheden meer tot verbetering en wellicht was men daarom van mening dat de energie van de hulpverleners effectiever in andere zaken kon worden geïnvesteerd.'

Deze - naar het mij voorkomt in principe toch strafbare feiten (art. 255 WvStr: in hulpeloze toestand brengen of laten van 'afhankelijken') - brengen de auteur tot de volgende aanbeveling (a.w., p. 198): 'Wanneer men zich realiseert dat de periode van mishandeling voor veel van de gemelde [en hermelde, jw] kinderen een groot deel van hun kindertijd beslaat, pleit dat voor uitbreiding van de capaciteit en voor financiële middelen voor een verdere deskundigheidsbevordering van de medewerkers van de BVA's en van de overige hulpverleningsinstellingen." 
willen zien, maar zit de pijn veeleer in de huiver zwakken in de samenleving ó6k te ontwaren achter het parentiarchale gordijn rondom het kerngezin, achter het - dikke maar wel erg stoffige - gordiin, om het maar wat huiselijker te zeggen, van de intimiteit en de privacy van het veilige gezin met de liefdevolle ouders.

Leitmotiv van dit proefschrift is de verwachting (overtuiging èn wens) dat het recht van het kind op optimale respectievelijk minimale persoonswording als rechtsbeginsel en kernrecht van het kind ons dwingt die zwakken, in het bijzonder de zwaksten, het nog spraakloze kind, wèl te zien, en ons over hem te ontfermen, zijn ouders zowel bij de les te houden als bij te staan. Vanuit de optiek van de jurist zou dit ook negatief, zo men wil: minder hoogdravend, kunnen worden geformuleerd, namelijk als een zich, beroepshalve, keren tegen machtsmisbruik c.q. een falend toezicht op machtsuitoefening.

\section{Macht corrumpeert}

Voor de jurist geldt immers als professionele grondnorm het adagium: geen bevoegdheid zonder verantwoordelijkheid, geen verantwoordelijkheid zonder verantwoording. Als geen ander is de jurist doordrongen van de levenswijsheid dat macht corrumpeert - dus ook ouderlijke macht, alle mythes over ouderliefde en het veilige gezin ten spijt. ${ }^{40}$

Hoewel dit laatste voor een jurist vanzelfsprekend zou moeten zijn, is het evenwel niet weinig verontrustend zich te realiseren dat juristen - toch altijd in de weer met procedurele waarborgen om macht te mitigeren ${ }^{41}$ - tegenover deze feitelijkheid als het om het gezin gaat, zo weinig waarborgen hebben gesteld, zo weinig uitwerking en toepassing

Tevens onderschrijft zij het pleidooi (t.a.p.) 'dat binnen de nieuwe meldpunten niet alleen artsen en maatschappelijk werkers worden aangesteld, maar dat de deskundigheid zou moeten worden uitgebreid via het aanstellen van pedagogen en psychologen."

40 De vertrouwensarts zegt het ten overvloede: "Wat dat betreft, ben ik het wel eens met oud-politicus Joop DEN UYL, die altijd al riep dat macht corrumpeert. Dat zie je in gezinnen ook, terwijl je in feite als ouder een dubbele verantwoordelijkheid hebt [namelijk als ouder en als oudere, jw] om die macht niet te misbruiken.' Aldus A.J. KOERs in Katrien DE KLEIN en Maricke PRINSEN GEERLIGS, Het blifft toch onder ons; Opening van zaken over incest, Zutphen 1995, hfdst. 7: 'Wij zullen die viezeriken mores leren; gesprek met een vertrouwensarts, pp. 101-117, op p. 107 .

41 En gelukkig maar: "Vooral in kwesties van procedure (....) vindt de jurist zijn specilieke competentie en kan hij zijn bijdrage leveren tot een echte, en democratische rechtsorde. Aldus A.A.G. PETERS, aangehaald door STEGERHOEK, a.w., p. 96. 
van bestaande waarborgen hebben gestipuleerd. ${ }^{42}$ Alsof de rechtsstaat ophoudt achter de voordeur. Alsof in de privésfeer redelijkheid en billijkheid moeten wijken voor 'romantiek' en willekeur.

Daarin verandering te brengen, althans daar tegenin te gaan en daar iets tegenover te stellen, kan evenzeer als Leitmotiv van deze studie worden beschouwd: als keerzijde namelijk van dezelfde medaille.

\section{De pedagogische kwestie en de 'schuldvraag'}

De kwestie van ouderlijke bevoegdheid, verantwoordelijkheid en verantwoording is in Nederland kennelijk zo gebrekkig aan de orde gesteld en geregeld, dat daarvan tienduizenden kinderen elk jaar het slachtoffer kunnen worden. Gezien hun aantal en de diep ingrijpende gevolgen van dit maatschappelijk, structureel tekort op het gebied van de verzorging en opvoeding van kinderen, kan - in navolging van 'de sociale kwestie' mijns inziens gerust van 'de pedagogische kwestie' gesproken worden. ${ }^{43}$ Toch moet deze kwestie - de pedagogische kwestie rond bevoegdheid, verantwoordelijkheid en verantwoording, vertrekkend vanuit het kernrecht van het kind op persoonswording, en daarop steeds betrokken volledig los worden gezien van welke morele schuldvraag dan ook.

Het gaat in deze studie vooral om de verantwoordelijkheid van de staat, hoezeer deze ook samenhangt met de verantwoordelijkheid van de ouders: waar de ouders (dreigen) te kort (te) schieten, dient de staat immers klaar te staan. Bij verantwoording gaat het in de eerste plaats om de verantwoordingsplicht van de staat in internationaalrechtelijk perspectief, de verantwoording ten opzichte van andere staten, of liever ten opzichte van de statengemeenschap in haar geheel: de staatsaansprakelijkheid. Hoewel op de achtergrond natuurlijk de nationaalrechtelijke verant-

Hier zal mede een rol gespeeld hebben wat STEGERHOEK noemt het taboe de staat als actor' in het kinderbeschermingsrecht te zien, hetgeen weer samenhangt met de civilistische kijk (bij STEGERHOEK: 'de "geciwiliseerde" zienswijze') op dit rechtsgebied. Zo constateert zij bij civilisten een 'blokkade in het denken' als het gaat om de associatie van het civiele jeugdrecht met het strafrecht, een associatie die, gezien de statelijke dimensie van beide, toch woor de hand ligt. (A.w., resp. pp. 97,12 en 92.)

43 Gedoeld wordt dan in het bijzonder op de de facto vrijwel rechteloze positie van kinderen (onder de twaalf jaar), in het bijzonder van jonge kinderen (van nul tot zes jaar) bij hun ouders, maar ook de vrijwel rechteloze positie van ouders als het gaat om opwoedingsondersteuning (in de breedste zin), alsook de onwoldoende structurele aandacht voor de sociaal-emotionele ontwikkeling van kinderen (onder meer aan de hand van vakken als 'relaties' of 'opvoeding') in het onderwijs.

De connotatie is duidelijk: zoals de generaties vór ons zich gesteld zagen voor 'de sociale kwestie," zo zien de huidige en toekomstige generaties zich gesteld voor "de pedagogische kwestie." 
woordingsplicht meespeelt: de verantwoording van de overheid tegenover het parlement; maar ók van de politiek, en van de rechter, tegenover het publiek. Het betreft immers publiek-, dat is openbaar-rechtelijke organen: stáátsorganen; met een openbaar-rechtelijke taak: de bescherming van kinderen.

Opmerkelijk is in dit verband wèl dat het publiek, en de publieksmedia, ernstige incidenten daargelaten (die dan vaak ook nog als schendingen van ouderrechten worden gepresenteerd ${ }^{44}$ ), de politiek nauwelijks ter verantwoording lijkt te roepen. Men kan dit opvatten als bewijs van de dominantie van de parentiarchale cultuur en het adulto-centrisme. Doch evengoed zou men er op kunnen wijzen dat, zodra de storm van incidentele excessen is weggeëbd, er geen pressiegroepen van of voor kinderen klaarstaan om te eisen, en desnoods met inzet van burgerlijke machtsmiddelen, zoals het stakingswapen, af te dwingen, dat de daad bij mooie politieke woorden wordt gevoegd.

Maar ook de eigen - staatsburgerlijke - verantwoordelijkheid van de samenleving is hier geen onderwerp van studie. Hetzelfde geldt voor de staatkundige verantwoordelijkheid van politieke partijen, welker verantwoordingsplicht zich oplost in de verkiezingen.

Al evenmin gaat het in deze studie om de verantwoordingsplicht in morele of ethische zin (althans boven of buiten het strafrecht of het leerstuk van de onrechtmatige daad) van hetzij overheidsdienaren (met inbegrip van dienaren van de kroon), hetzij ouders. En dus uitdrukkelijk niet om 'de schuldvraag' van met name de laatste categorie. De morele schuldvraag van ouders zou overigens veelal, gezien wat we weten van de onbewuste transgenerationele overdracht van geweld (of liever van onveilige gehechtheid), terugverwijzen naar de grootouderlijke schuldvraag, en vandaar naar de overgrootouderlijke, en zo verder, à outrance, naar de voorouderlijke schuldvraag tot de zondeval. Of althans tot Abraham, die bereid was en daadwerkelijk op het punt stond zijn zoon te slachten. ${ }^{45}$

Met als meest schrijnende voorbeeld wel de zogenaamde 'Bolderkar-affaire': zic J.C.M. WLLLEMS, 'Ouderbescherming en kinderbescherming: wordt het geen tijd voor een meldplicht?' Nederlands Juristenblad 1990, pp. 1243-1247, op pp. 1244 l.k. en 1245 nt. 11-12.

45 Izaäk zeide tot zijn vader Abraham: 'Mijn vader!' Deze antwoordde: 'Wat is er, mijn zoon?' Hij zeide: 'Hier is het vuur en het hout, maar waar is het schaap ten brandoffer?' (...) Nu stak Abraham zijne hand wit en greep het mes, om zijn zoon te slachten. (Gen. 22:7 en 10.)

Andere bijbelse voorbeelden zijn: de dochters van Lot worden door hun vader ter verkrachting aangeboden aan alle mannen van Sodom en later door hem in zijn slaap' zwanger gemaakt (Gen. 19:8 en 36); Tamar, de dochter van David, door haar halfbroer verkracht, krijgt te horen: 'Zwijg er maar over, zuster; het blijft uw broer' ( 2 Sam. 13:20, tweede volzin); wader David zelf geeft niet thuis ( 2 Sam. 
Deze caveat lijkt mij op zijn plaats gezien de morele geladenheid van het onderwerp: niet zelden leidt dat er toe dat degene die het onderwerp aansnijdt, wordt toegedicht een morele lading aan zijn onderwerp te hebben gegéven. ${ }^{46}$ Hoewel men dat, al bij voorbaat toegepast op deze studie, weliswaar zou kunnen duiden als het positieve gevolg van een expliciet aandacht vragen voor de morele oorsprong en lading van het recht, in het bijzonder ook van rechtsbeginselen (zie hoofdstuk 3 en hierna onder De taak van de jurist), moet men toch vrezen dat daarmee niet, minzaam, gedoeld wordt op een bijdrage in positief-kritiserende of -confronterende zin, doch veeleer in negatief-incriminerende of zelfs veroordelende zin. Het aansnijden van het onderwerp, althans de poging het te doorgronden, wordt met andere woorden betrekkelijk snel opgevat als 'provocerend' - met de stilzwijgende connotatie van een gebrek aan wetenschappelijke distantie, of op zijn minst van een stijl en een methode die de lezer zo weinig ruimte laten zijn of haar eigen conclusies te trekken, dat zij alleen al daardoor hun - wetenschappelijke èn maatschappelijke - doel voorbij schieten.

Zonder het gevaar van stilistische valkuilen te willen ontkennen, herhaal ik dus nogmaals: het gaat in deze studie met betrekking tot de pedagogische kwestie om de verantwoordelijkheden en (eventueel) de aansprakelijkheid van de staat, niet om (ouderlijke) schuld.

\section{De taak van de jurist}

Tegen de achtergrond van zowel het hierboven gereleveerde Leitmotiv van deze studie als het zojuist aangekaarte verband tussen recht en moraal, permitteer ik mij nog de volgende wetenschappelijke (althans beroepsmatige) 'ontboezeming.'

Het recht kan men zien als een brug tussen de wereld zoals zij is, en de wereld zoals zij behoort te zijn. De jurist die een brug te ver gaat, maakt een kunstfout. Hem of haar treft de blaam recht met moraal, met ideaal, met wenselijkheid te hebben verward. Maar hetzelfde geldt voor de jurist die niet over de brug komt, die, aan de veilige kant van de brug, op de vaste oever van een regelgerichte en regelgeleide beoefening van rechtswetenschap, recht met (wettelijke) feiten, de gegeven (jurisprudentiële) werkelijkheid, de (legaal-maatschappelijke) status quo vereenzelvigt. Ook hij (of zij) maakt een kunstfout.

13:21); het kleine (en vooral mooie) meisje Abisag moet de stokoude David "opwarmen' op zijn sterfbed (1 Kon. 1:1-4).

$\mathrm{Vgl}_{\text {w, }}$ als ik haar goed heb verstaan, VAN WIJ, t.a.p. (Nemesis 1992/6), op p. 27 1. $k$. 
Hoewel deze studie geschreven is vanuit een beginselgerichte en beginselgeleide visie op het recht, dient zij uiteraard in het bijzonder de internationaalrechtelijke erfenis te verdisconteren van wat AKEHURST/ MALANCZUK de dominante 'positivist doctrine of international law' ${ }^{\text {s7 }}$ noemt: een erfenis die een beginselgerichte en beginselgeleide beoefening van het internationale recht nauwelijks enige speelruimte laat, en de beginselgerichte en beginselgeleide volkenrechtsbeoefenaar al helemaal het gevoel geeft een danser op het slappe koord te zijn. Eén misstap en hij (of zij) bijt niet slechts in het zand, doch verdwijnt voorgoed in het land waarvan men hem (of haar) verwijt het recht te hebben beschreven: Utopia.

Toch wil ik hier staande houden dat het de taak is van de jurist, op welke plaats en in welke tijd hij of zij zich ook bevindt, door middel van interpretatie, presentatie van argumenten en deductie vanuit en kritische reflectie in het licht van algemene (rechts)beginselen de oevers te verbinden, de kloof te overbruggen, althans aan die verbinding, die overbrugging een steentje bij te dragen, tussen de wereld zoals zij is, op de plaats waar en in de tijd waarin hij of zij haar aantreft, en de wereld zoals zij behoort te zijn, in zijn of haar (natuur-, dat is thans mensenrechtelijke) visie op waar de mensheid, of althans de gemeenschap waartoe hij of zij behoort, zich naartoe zal hebben te bewegen teneinde menselijk lijden, teneinde onrecht, teneinde misbruik van publieke en particuliere macht te verzachten en te voorkomen.

Uiteraard is hiermee niet gezegd dat er geen (beroepsmatig in acht te nemen) onderscheid zou bestaan tussen recht en moraal. Ontkend wordt slechts dat tussen beide een principieel, een wetenschappelijk/ filosofisch houdbaar, laat staan een absoluut onderscheid zou bestaan. Het onderscheid is veeleer gradueel: er is altijd een zekere spanning. Zowel een ont-spannen (op de veilige oever het voorzichtige midden kiezende, centripetale) als een overspannen (een brug te ver springende, centrifugale) rechtsbeoefening treedt buiten hetgeen professioneel is te achten. Ars aequi, de kunst van het billijke, is in zekere zin de kunst van de juiste spanning.

Aard, onderwerp en methode van onderzoek

Aard van het onderzoek: het eigenlijke onderwerp

Het primaire (directe) onderzoeksobject betreft de rechten van het kind toegespitst op de problematiek van de kindermishandeling. Hiertoe is 
met name verdragsanalyse alsmede betrekkelijk uitgebreide multidisciplinaire literatuurstudie verricht.

Leidend beginsel ten aanzien van de rechten van het kind is het belang van het kind (the best interests of the child). Een benadering van de problematiek van de kindermishandeling vanuit de internationale rechten van de mens, de pedagogiek en de psychologie drukt ons als het ware met de neus op wat de kern, de grondslag, van het belang van het kind is: zijn recht op 'persoonswording.' Deze studie kan in die zin als een interdisciplinair grondslagenonderzoek naar het belang van het kind (the best interests of the child) worden gezien; deze 'grondslagenstudie' is het achterliggende - of eigenlijke - onderzoeksobject (zie ook par. 1.3.1 onder Kindervolkenrecht). Aangezien deze studie evenwel niet als een systematisch grondslagenonderzoek is opgezet, wordt in deze paragraaf uitsluitend van het primaire (directe) onderzoeksobject uitgegaan.

Dit doet niet af aan het feit dat, wat de aard van deze studie betreft, het hoofdaccent op het fundamentele (grondslag en richting), niet op het praktische (operationalisering, juridisering) ligt.

\section{Het directe onderwerp van onderzoek}

Het directe object van studie zijn de internationale rechten van het kind, zoals deze in het bijzonder te vinden zijn het in Verdrag inzake de rechten van het kind (New York, 1989). Daarnaast zijn direct object van studie onderdelen of aspecten van de psychologie, in het bijzonder van de ontwikkelingspsychologie, de persoonlijkheidspsychologie en de psychopathologie (meer in het bijzonder de persoonlijkheidsstoornissen), en van de pedagogie: beide (hulp)disciplines voor zover zij voor het primaire onderzoeksobject: de rechten van het kind toegespitst op de problematiek van de kindermishandeling, van direct of zijdelings ${ }^{48}$ belang zijn.

48 Met name de psychopathologie zou - op het eerste gezicht - als van zijdelings belang kunnen worden beschouwd. Het gezonde benaderen vanuit het zieke geeft echter een scherp beeld van het ziek-makende. Dit geldt mijns inziens ook in de rellatie persoonswording versus (psychische en met name) persoonlijkheidsstoornissen. Althans dat is precies mijn benadering van het onderwerp geweest: vanuit de psychopathollogie heb ik het terrein in de loop der jaren steeds verder verkend. Steun voor deze benadering vindt men in CICCHErrI's opvatting van ontwikkelingspsychopathologie (Dante CICCHETr, 'How research on child maltreatment has informed the study of child development: perspectives from developmental psychopathology,' in: dez. en Vicki CARLSON (eds.), Child maltreatment; Theory and research on the causes and consequences of child abuse and neglect, Cambridge etc. 1989, pp. 377-431, op p. 378): 'Developmental psychopathology emphasizes the argument put forth by many of the great synthetic thinkers in the behavioral and neurosciences that we can learn more about the normal functioning of an organism by studying its pathology and, likewise, more about its patho- 


\section{Methode van onderzoek}

Hierbij zijn de volgende wegen bewandeld: juridische tekstanalyse (met name verdragsanalyse); juridische (waaronder volkenrechtshistorische) en pedagogische en psychologische (waaronder psychiatrische) literatuurstudie (in mindere mate ook medische en sociologische alsook historische en filosofische); enig (summier) jurisprudentieonderzoek (met betrekking tot 'achterliggende' rechtsbeginselen, het belang van het kind, schadevergoeding bij incest/sexueel misbruik, kindermishandeling en ouderlijke 'immuniteit'); en tot slot: juridische interpretatie en toetsing.

\section{Parafraseren of citeren?}

Bij de keuze tussen het parafraseren dan wel citeren van auteurs is in deze studie de voorkeur gegeven aan citeren. Daaraan ligt niet zozeer de (ethische) gedachte ten grondslag dat daarmee meer recht zou worden gedaan aan de desbetreffende auteur - een auteur kan immers ook, te goeder dan wel kwader trouw, uit zijn verband worden geciteerd -, doch veeleer de (esthetische) gedachte dat aldus ook een duidelijke visuele indruk wordt gegeven van het feit dat verreweg de meeste bouwstenen voor deze studie van elders zijn aangesleept.

De hierna volgende vraagstellingen dienen als leidraden voor deze studie te worden beschouwd. Zij kunnen worden gegroepeerd onder een centrale probleemstelling (welke in par. 1.3.1 wordt geformuleerd en nader uitgesplitst) en onder afgeleide of bijkomende probleemstellingen (omschreven in par. 1.3.2). Vervolgens keert een aantal vragen terug in een ietwat bredere inventarisatie van (elkaar deels overlappende, deels in elkaars verlengde liggende) hoofd- en subvragen welke relevant zijn voor deze studie (par. 1.3.3). De bedoeling van deze inventarisatie is een duidelijk beeld te geven van de vragen die in deze studie ex- of impliciet aan de orde worden gesteld c.q. dienen te worden beantwoord. En passant worden hierbij enkele begrippen (alvast) kort toegelicht.

\subsubsection{De centrale probleemstelling (en enkele begrippen)}

De centrale probleemstelling van deze studie kan als volgt worden omschreven: in hoeverre kan het recht op persoonswording als pedagogisch criterium worden ingelezen in het VRK/het corpus van de rechten van het kind c.q. als achterliggend beginsel van dit corpus worden beschouwd; 
wat is daarvan de relevantie/waarom is dat wenselijk vanuit een oogpunt van rechtsontwikkeling/rechtsverfijning (de betekenis van het recht van het kind op persoonswording als fundamenteel rechtsbeginsel). Deze centrale probleemstelling kan als volgt worden uitgesplitst:

1. Wat is de achtergrond, de betekenis, de reikwijdte en de inhoud (definitie en mogelijke operationalisering) van het recht van het kind op persoonswording (dissertatie Doret DE RUYTER)? Dit criterium luidt als volgt: ${ }^{49}$

'Pedagogische hulpverlening moet aan een gezin worden opgelegd' indien het recht van een kind om zich te ontwikkelen tot een minimaal rationeel, minimaal mareel of minimaal authentiek persoon wordt geschonden of indien zijn minimale rationaliteit, minimale moraliteil of minimale authenticiteit wordt beschadigd door het handelen [dat is: door toedoen of nalaten, $j w$ ] van zijn ouders."

2. Wat is de mogelijke betekenis van dit (morele) recht - het recht van het kind om zich te ontwikkelen tot een minimaal rationeel, minimaal moreel of minimaal authentiek persoon - als (internationaalrechtelijk) fundamenteel beginsel/kernrecht?

3. In hoeverre is dit recht verankerd in het internationale recht inzake de rechten van het kind? (Artt. 3 en 5 VRK: het belang van het kind; de zich ontwikkelende vermogens van het kind; overige verdragsartikelen en andere instrumenten.) Kan dit recht ingelezen worden in het VRK? Kan dit recht als achterliggend beginsel van het VRK worden beschouwd?

4. Heeft het kind (tevens c.q. in het verlengde hiervan) een internationaalrechtelijk gefundeerd recht:

a.) om zich te ontwikkelen tot een optimaal rationeel, moreel en authentiek persoon?

b.) op pedagogische hulpverlening aan zijn gezin van, herkomst indien dit recht (zijn recht op optimale persoonswording) door toedoen of nalaten van zijn ouder(s)/opvoeder(s) wordt geschonden?

c.) op juridische interventie in zijn gezin van herkomst indien zijn recht op minimale persoonswording wordt geschonden? leerd:

De vragen onder a.) en c.) kunnen ook aldus worden geformu-

5. Is er in het Verdrag inzake de rechten van het kind (en andere internationaalrechtelijke instrumenten) steun te vinden voor de opvatting 
dat het kind recht heeft (primair in het gezin) op te groeien tot een optimaal rationeel, moreel en authentiek persoon (optimum)?

6. Is er in het Verdrag inzake de rechten van het kind steun te vinden voor de opvatting dat het kind recht heeft op overheidsingrijpen in het gezin indien het kind dreigt op te groeien tot minder dan een minimaal rationeel, moreel en authentiek persoon (minimum)? (Dat is het recht van het kind op het opzij zetten van het privacy-recht van de ouders; het recht van het kind op beperking van/inbreuk op thet recht op gezinsleven van kind en ouders.)

\section{Enkele begrippen}

\section{Overheidsingrijpen}

Onder overheidsingrijpen dient in dit verband te worden verstaan: het (aanbieden en desnoods) opleggen van hulp aan ouder en kind, al of niet in combinatie met plaatsing van een kind in een residentiële instelling of in een pleeggezin, zulks met het oog op terugplaatsing in thet gezin, of, indien dat niet in het (veiligheids-/ontwikkelings-)belang van het kind is, de plaatsing van een kind voor onbepaalde duur in een alternatieve gezinssituatie. ${ }^{50}$

\section{Gezin}

Onder gezin dient te worden verstaan: een primaire leefeenheid met ouder(s)/opvoeder(s) en één of meer kinderen.

\section{Ouders/opvoeders}

Onder ouders worden in deze studie verstaan: zij die een kind verzorgen en opvoeden (in beginsel, maar niet per definitie de biologische ouders), dat wil zeggen zij die, binnen een gezinssituatie, de opvoedingsverantwoordelijkheid voor een kind dragen ('mensen met opvoedingsbevoegdheid'). De term ouders dient in deze studie dus in de ruime zin van opvoeders te worden verstaan; opvoeders in enge zin, dus instellingsopvoeders, daaronder niet begrepen. Opvoeders in ruime zin zijn zowel gezinsals institutionele opvoeders.

De term ouders is anderzijds beperkter in zoverre (biologische) ouders zonder opvoedingsverantwoordelijkheid buiten het bestek van deze studie vallen.

Waarbij zeer wel ook alternatieven die in ons land niet bestaan, zoals bijwoorbeeld kinderdorpen volgens de filosofie van INTERNATIONALE KINDERHULP, in ogenschouw genomen zouden kunnen worden. 


\section{Pedagogische hulp}

Onder pedagogische hulp wordt verstaan: "de hulp die aan éen of meer leden van een gezin wordt geboden naar aanleiding van het bestaan van opvoedingsproblemen." 51 Zoals bijwoorbeeld: 'ouderbegeleiding, semiresidentiële hulpverlening aan het gezin, thuishulpverlening, en residentiële hulpverlening aan het gezin' alsook 'de ouders verplichten tot het volgen van een oudercursus. ${ }^{52}$

\section{Opleggen van hulpverlening}

Onder opleggen van hulpverlening wordt verstaan: 'het verplichten van één of meer gezinsleden tot het accepteren van hulpverlening. Dit impliceert dat gezinsleden zelfs met sanctiemaatregelen gedwongen kunnen worden hulpverlening te ontvangen. ${ }^{, 53}$

Sanctiemaatregelen zouden kunnen zijn: tijdelijke korting/intrekking kinderbijslag c.q. opvoedingsgeld, administratieve boetes, maatregelen van kinderbescherming (ontzetting/ontheffing), gijzeling, tewerkstelling/dienstverlening e.d.m./e.t.q. (dat wil zeggen: in principe het hele civiel-, administratief- en strafrechtelijke arsenaal, eventueel met uitbreiding van het WvStr met nieuwe delictsomschrijvingen ${ }^{54}$ ).

\section{Machtsmisbruik door de staat}

Uiteraard betekent het opleggen van hulp: het uitoefenen van pedagogische macht door hulpverleners/de staat. Daarmee is het risico van machtsmisbruik gegeven; en de noodzaak van rechtsbescherming van gezinsleden/ouders vastgesteld. Machtsmisbruik kan daardoor deels worden geredresseerd. Machtsmisbruik voorkómen kan niet, wel kan het vóórkomen van machtsmisbruik worden tegengegaan/gemitigeerd door het werken met een glijdende-schaalscenario: van snelle en gemakkelijk toegankelijke vrijwillige opvoedingshulp (cursussen en ouderbegeleiding) bij consultatiebureaus en scholen/schoolartsen (drempelverlagend éenloket-aanbod), via vrijwillige vormen van thuishulpverlening, (semi-)residentiële hulpverlening aan het gezin en (semi-)residentiële hulpverlening aan het aangemelde kind naar de verplichte vormen van cursussen, ouderbegeleiding, thuishulpverlening, enzovoorts.

Het opleggen van hulpverlening is dan niet een donderslag bij heldere hemel, maar het (psycho)logisch sequeel van herhaaldelijk mislukte afspraken en mislukte pogingen. Een sequeel dat, naar de mate van de

Diss. DE RUYTER, p. 2.

52 Diss. DE RUYTER, p. 3.

53 Diss. DE RUYTER, p. 3.

54 Zie, bij wijze van illustratie/voorbeeld, bijlage II (Voorbeeld-strafbepalingen kindermishandeling). 
kwaliteit van de voorafgegane hulp, minder als een overval, laat staan als een ontmaskering zal worden gezien. Terwijl ook bij dat sequeel, net zo goed als in de vrijwillige fase, naar een verfijnd instrumentarium, en niet naar de botte bijl, wordt gegrepen.

De goede wil van ouders dient immers in het recht net zo zeer te worden voorondersteld ${ }^{55}$ als de feilbaarheid en niet-alwetendheid van de staat: adequate rechtsbescherming op dit punt is altijd geboden. Maar voorop staat: het recht van kind èn ouders op voldoende capaciteit en kwaliteit van de hulpverlening.

\section{Kindervalkenrecht}

Hoewel psychologie - in het bijzonder ontwikkelingspsychologie en (ontwikkelings)psychopathologie - en pedagogiek in deze studie een bepalende rol spelen, is dit werk toch eerst en vooral het verslag, in vier boeken, van een zoektocht naar grondslag en geest van het kindervolkenrecht en als zodanig een beschrijving, vanuit mensenrechtelijke optiek - of liever: vanuit een optiek van mensenrechten als rechtsbeginselen -, van (recente) aanvang en (prille) voortgang van dat (in neologische zin) nieuwe rechtsgebied. Kindervolkenrecht nu kunnen we omschrijven als het (internationaalrechtelijke) rechtsgebied dat - vertrekkend vanuit (het fundamentele rechtsbeginsel van) het recht van het kind op optimale persoonswording (dat is het opgevoed worden tot optimale rationaliteit, moraliteit en authenticiteit) en met als bodem het kernrecht van het kind op minimale persoonswording (het geheel van sociaal-pedagogische waarborgen tegen kindermishandeling in de vijf varianten fysieke of lichamelijke mishandeling, fysieke of lichamelijke verwaarlozing, psychische of emotionele mishandeling, psychische of emotionele/affectieve verwaarlozing en "incest'/sexueel misbruik/sexuele kindermishandeling) - de omtrek en inhoud van de secundaire opvoedingsverantwoordelijkheid van staten in kaart wil brengen met het oog op de sociaal-pedagogische operationalisering van de persoonswordingsrechten van het kind c.q. met het oog op de juridisering (nationaal-constitutionele verankering en vastlegging/uitwerking in nationale wetgeving en beleid) van de Trias pedagogica (de rechtsstatelijke driehoeksverhouding staat-ouders-kinderen).

De overheid in een democratie dient burgers/ouders niet a priori te wantrouwen: VAN DER PLOEG noemt dit een eils van politieke bescheidenheid (Piet VAN DER PLOEG, Opvoeding en politiek in de overleg-democratie; Democratische verdeling en normering van pedagogische auforiteit, diss. Utrecht, Baarn 1995, p. 271 en passim). Op zijn visie kom ik in hoofdstuk 14 terug ('monitoring parenting'). 
Naast de centrale probleemstelling kunnen als afgeleide of bijkomende probleemstellingen de volgende vragen worden geformuleerd:

1. In hoeverre kan het recht van het kind op optimale persoonswording als inspanningsverplichting van de staat onder het VRK worden beschouwd?

2. In hoeverre kan het recht van het kind op minimale persoonswording als resultaatsverplichting van de staat onder het VRK worden beschouwd?

3. In hoeverre kan kindermishandeling in Nederland, opgevat als schending van het recht van het kind op minimale persoonswording, als ernstige en structurele mensenrechtenschending worden gekwalificeerd?

4. Welke structurele aanpassingen zijn en/of welke herallocatie van middelen is nodig om staatsaansprakelijkheid van Nederland te voorkomen/te verminderen?

\subsubsection{Hoofd- en subvragen: een inventarisatie}

De centrale en bijkomende probleemstellingen bijeen genomen leiden tot de volgende inventarisatie van (elkaar deels overlappende, deels in elkaars verlengde liggende) hoofd- en subvragen welke in deze studie exof impliciet aan de orde worden gesteld c.q. dienen te worden beantwoord.

1. Wat is de betekenis van het recht op persoonswording als pedagogisch criterium? Wat wordt bedoeld met minimale/optimale rationaliteit, moraliteit, authenticiteit?

2. Wat is de relevantie van dit criterium voor de rechten van het kind, in het bijzonder voor de beschermingsrechten van het zeer jonge kind? In hoeverre kan door dit criterium een aanscherping en inkleuring van 'het belang van het kind' worden verwacht? Dat wil zeggen: een juridische aanscherping vanuit het recht op onschendbaarheid van de persoonlijke integriteit en een pedagogische inkleuring vanuit het veiligheids- en ontwikkelingsbelang van het kind?

3. In hoeverre kan dit criterium als richtinggevend worden beschouwd ten aanzien van pedagogische operationalisering en, op basis daarvan, juridisering (dat is: rechtsverfijning) op het vlak van preventie, interventie en 'reparatie' (compensatie/rehabilitatie)?

4. Kan een recht op persoonswording, mede in samenhang met andere verdragen/verklaringen c.q. achterliggende beginselen, worden ingelezen in het VRK? 
5. Kan een recht op minimale persoonswording worden ingelezen als resultaatsverplichting (erkenning/waarborging, verplichting tot preventie/interventie/reparatie)? Kan een recht op optimale persoonswording worden ingelezen als inspanningsverplichting (verplichting tot bevordering)?

6. Hoe verhoudt dit "nieuwe' (ingelezen) recht zich tot het fenomeen kindermishandeling?

7. Zijn enerzijds de omvang (minimaal tachtigduizend kinderen per jaar) en de ernst (gevolgen in termen van psychopathologie en criminaliteit: individuele, relationele, collegiale/sociale, transgenerationele èn maatschappelijke kosten) van dit fenomeen, en is anderzijds de nalatigheid/het te kort schieten van de overheid op het gebied van preventie, hulpverlening (van vrijwillig naar opgelegd volgens een glijdende-schaalscenario) en compensatie/rehabilitatie, zodanig dat van ernstige en systematische, althans structurele mensenrechtenschending gesproken kan c.q. moet worden?

8. Althans: is er sprake van staatsaansprakelijkheid onder/ex het VRK (schending van resultaats- en/of inspanningsverplichtingen)?

9. Wat kan/moet worden gedaan? Wat valt te verstaan onder c.q. kan worden beschouwd als adequate sociaal-pedagogische steun (SPS), met inbegrip van adequate hulpverlening en kinderbescherming?

10. In hoeverre zijn ouderrechten ('ouderlijke immuniteit"/souvereiniteit-in-eigen-gezin/privacy/reproductie-vrijheid) een 'alibi' vour de overheid om de status quo te handhaven (dat wil zeggen geen reallocatie van hulpmiddelen te bewerkstelligen - en zelfs op essentiële voorzieningen te bezuinigen)?

11. In hoeverre is er met betrekking tot deze handhaving van de status quo c.q. dit stilzitten van de overheid sprake van irrationele traditionele culturele opvattingen/praktijken ('collectieve mythen'), bijvoorbeeld vergelijkbaar, maar dan omgekeerd, met de - criminogene - handhaving van de Opiumwet? Althans van bepaalde sociale en/of politieke concepties die een adequate bescherming van het kind belemmeren of beletten, bijvoorbeeld vergelijkbaar met het om pragmatische of gemakzuchtige redenen 'wegredeneren' van de verdragsverplichtingen op grond van het Internationaal Verdrag inzake de uitbanning van rassendiscriminatie (IVUR) tot het ontbinden van racistische politieke partijen en het verbieden van racistische demonstraties?

12. Kan (bovenbedoelde, tot de patri- en parentiarchale cultuur te rekenen ${ }^{56}$ ) privacy-idiosyncrasie (als dieptesociologisch fenomeen ${ }^{57}$ ) 
als een traditional practice (in de zin van art. 24 , lid 3 VRK) worden beschouwd, die schending van het recht van het kind op persoonswording in de hand werkt? Of is hier veeleer sprake van een weliswaar historisch gegroeid fenomeen, dat evenwel in de allereerste plaats samenhangt met de onmogelijkheid tot emancipatie van het jonge - ongeorganiseerde, niet stemgerechtigde, stemloze - kind?

13. Wat is de verhouding tussen het recht van het kind op minimale respectievelijk optimale persoonswording en de praktijk (de kloof tussen pays légal en pays réel)? Dat wil zeggen (zie vragen 7-9 hierboven):

a.) Hoe ernstig en systematisch/structureel is de schending van dit recht/deze rechten in Nederland?

b.) I(n hoeverre i)s er sprake van staatsaansprakelijkheid?

c.) Welke passende wetgevende etcetera (art. $19 \mathrm{VRK}$ ) maatregelen zijn nodig/gewenst om staatsaansprakelijkheid te verminderen/op te heffen ten aanzien van: preventie van schending; interventie in het gezin; compensatie/rehabilitatie van survivors?

\section{Overlap}

Sommige van deze vragen overlappen elkaar, of zijn maar ten dele van elkaar te scheiden. Sommige vragen liggen weliswaar in het verlengde van andere, maar kunnen niet worden uitgediept zonder allerlei zijpaden te betreden, terwijl zij toch als leidraden voor deze studie moeten worden gezien. Dit brengt ons op de vraag naar het behandelingsplan, de opzet van deze studie.

\section{4}

Opzet

Deze studie is als volgt opgezet. Na het inleidende betoog in hoofdstuk 1, waarbij naast de invalshoek, het doel en het Leitmotiv van deze studie ook enkele begrippen zijn beschreven, wordt in hoofdstuk 2 gezocht naar de uitkomst voor het kind van het verhaal van (de wordingsgeschiedenis van) de mensenrechten. In hoofdstuk 3 komt zowel de betekenis als de

M. VAN DEN DUNGEN, 'Het broelkaseffect: gezin en samenleving rond 2000,' in:

Gezin; Tijdschrift voor primaire leefvormen 1989/3, pp. 164-180, op p. 165-166. van het idealiseren van de ouders en aan bet diepte-psychologisch fenomeen paard aan - een zo mogelijk nog verrade eigen jeugd door survivors, veelal geverklaren aan en (mede)verantwoordelijk achker valkuil - het zichzelf schuldig Alice MILLER, Gij zult niet merken; Tachtig jaar psychoanalyse, Hout. hierover (derde druk); Herman BAARTMAN, 'KAFKA's brief aan zijn groeien als verworpen kind, " Overwegingen en enaringen, Barm 
juridische status (het rechtskarakter) van mensenrechten aan de orde: mensenrechten als rechtsbeginselen, hun plaats tussen natuurrecht en nationaal recht (nationaalrechtelijke concretisering).

In hoofdstuk 4 wordt gekeken naar de grondslag van de mensenrechten, naar grondbeginselen als kerninhoud en naar het onderscheid tussen kernrechten en overige mensenrechten. In hoofdstuk 5 worden de rechten van het kind historisch-filosofisch geïntroduceerd. De drie treden van het volkenrecht voor kinderen worden beklommen en kort wordt afgedaald naar de familierechtelijke situatie van het kind in Nederland.

In hoofdstuk 6 komt de kerninhoud van de rechten van het kind aan de orde: gelijkheid en ontplooiing als grondbeginselen óok van kinderrechten. Daarna worden, in hoofdstuk 7, enkele uit kerninhoud (dat is uit beide grondbeginselen) voortvloeiende sociaal-pedagogische (natuurlijke) rechten voorgesteld, welke samenhangen met het veiligheidsbelang en het ontwikkelingsbelang van het kind. Beide zijn dermate fundamenteel en essentieel voor de persoonswording dat zij als fundamentele (natuurlijke) rechten van het kind kunnen/moeten worden beschouwd. Het ontwikkelingsbelang bestaat dan uit een dubbel pedagogisch recht: het recht van het kind, van elk kind, op ontplooiing (geborgenheid, affectie, ondersteuning) en het recht van het kind, van elk kind, op leiding (toezicht, controle, disciplinering/opvoeding in enge zin), zo zal in dit hoofdstuk worden beschreven. De voorgestelde kernrechten worden vervolgens nader in de Trias pedagogica, de juridisch-pedagogische driehoek kind-ouder-overheid, gesitueerd.

In hoofdstuk 8 wordt het 'belang van het kind' als rechtsbegrip op zijn pedagogische inhoud, dat wil zeggen aan het veiligheidsbelang en het ontwikkelingsbelang van het kind, getoetst. De vraag wordt alvast opgeworpen of 'persoonswording' (het recht van het kind op minimale c.q. optimale persoonswording) als wezen en kern van het 'belang van het kind' kan worden beschouwd. En daarmee als meta-kernrecht ('natuurrechtelijk' rechtsbeginsel, supra-positief mensenrecht en natuurlijk kernrecht) van het kind zou kunnen worden aangeduid. Ter beantwoording van die vraag wordt allereerst, in hoofdstuk 9 , het pedagogische interventie-criterium van DE RUYTER beschreven en wordt "persoonswording" ontleed op basis van de drieslag rationaliteit, moraliteit en authenticiteit.

De vraag: in hoeverre kan 'persoonswording' als een achterliggend rechtsgoed worden beschouwd, noopt tot nadere analyse van verdrags- en andere teksten. Dit gebeurt in hoofdstuk 10. Dit hoofdstuk bevat een analyse van de (internationale) regelgeving ter 'opsporing' van het recht van het kind op minimale respectievelijk optimale persoonswording. Het hoofdstuk wordt afgesloten met een conclusie inzake minimale persoonswording als absoluut kernrecht van het kind. 
De relatie tussen kindermishandeling en 'persoonswording' en de vraag van de rechtsschending (schending van het recht van het kind op minimale/optimale persoonswording) komt aan de orde in hoofdstuk 11 . In dit hoofdstuk passeren enkele definities met betrekking tot kindermishandeling de revue. Aangesloten wordt bij de ontwikkelingspsychopathologische benadering van CICCHETTI/TOTH ${ }^{58}$; betoogd wordt dat deze benadering en de daaruit voortgekomen - als bijlage III in dit proefschrift opgenomen ${ }^{59}$ - criteria inzake kindermishandeling duidelijke aanknopingspunten bieden voor de operationalisering van het recht van het kind op minimale persoonswording. Kindermishandeling wordt als schending van dit laatste recht geherdefinieerd.

Omvang en ernst van kindermishandeling, dat wil zeggen: de cijfers zowel als de aard en de ingrijpendheid van de psychische, psychosociale en maatschappelijke gevolgen, worden behandeld in hoofdstuk 12 . De omvang en ernst van deze schending van het recht van het kind op minimale persoonswording, en het structurele karakter daarvan, brengen ons op de vraag van de staatsaansprakelijkheid. Deze wordt (uitgebreid) behandeld in hoofdstuk 13. Zowel met het oog op de schending van het recht van het kind op minimale persoonswording als op de schending van het recht van het kind op optimale persoonswording komt in hoofdstuk 14 een mogelijke invulling van SPS (gewenste sociaal-pedagogische overheidsmaatregelen) aan de orde. Gevolgd door een korte samenvatting van betoog en conclusies in het Nederlands en in het Engels.

58 Douglas BARNETT, Jody Todd MANLY, Dante CICCHETT, 'Defining child maltreatment: the interface between policy and research;' in: Dante CICCHETTI; Sheree L. TotH (eds.), Child abuse, child development, and social policy, Advances in applied developmental psychology, vol, 8, Norwood, New Jersey 1993, pp. 7-73.

59 Vertaling uit de 'Appendix: Maltreatment subtype definitions and severity ratings,' t.a.p., op pp. 51-73, van de pp. 54-73. 'System for quantifying child protective service records; subtype definitions and severity scales..' 
In dit hoofdstuk wordt het mensenrechtenthema geïntroduceerd. Er wordt een rode draad aangereikt waarmee dit thema historisch kan worden benaderd. Vervolgens wordt deze rode draad aan de hand van enkele historische hoogtepunten geilllustreerd. Gepoogd wordt van het mensenrechtenthema een mensenrechtenverhaal te maken waarin ook de plaats van het kind kan worden bepaald. Wat is de uitkomst voor het kind van het verhaal van de mensenrechten?

\section{Korte historiek}

2.2.1

De rode draad: machtsbeperking, democratisering en emancipatie

De beperking van macht en willekeur van enkeling of elite door het toekennen van steeds meer rechten aan ieder mens, althans aan steeds meer categorieën mensen, is de rode draad in de mensenrechtenhistoriek die hier, aan de hand van enkele historische hoogtepunten, wordt uitgezet. De civiliserende, humaniserende en emancipatoire betekenis van de mensenrechten krijgt aldus gestalte: begonnen als afzwering van vorsten die de vrijheid van godsdienst en geweten (èn adellijke privilleges) vertrapten, via de erkenning van de rechten van de burger en de man, tot aan de toekenning van rechten en vrijheden aan slaven, arbeiders, vrouwen, politieke gevangenen, migranten, èn kinderen.

Van kwelrecht van de vorst tot interventierecht van de Veiligheidsraad

Jus ad bellum en jus ad tormentum

Eeuwenlang had de vorst, later de staat, binnen zijn territoir, internationaalrechtelijk gezien, ten aanzien van zijn onderdanen een vrijbrief tot handelen. Deze binnenlandse internationaalrechtelijke vrijbrief zullen we hier aanduiden als jus ad tormentum: het vexatie- of kwelrecht van de staat. Zulks naar analogie van het begrip jus ad bellum: de buitenlandse vrijbrief van vorst en staat tot het voeren van oorlog.

De nationaalrechtelijke 'vrijbrieven' aan Adolf HITLER waren ervoor nodig om internationaalrechtelijk aan jus ad bellum en jus ad tor- 
mentum paal en perk te stellen. Beide vrijbrieven in het interstatelijke verkeer stierven een lang verbeide dood in het Handvest van de Verenigde Naties. ${ }^{1}$ Sinds 1945 heeft de 'personele soevereiniteit' van de staat plaats moeten maken voor internationaalrechtelijk erkende, en veelal ook in nationale grondwetten als grondrechten verankerde mensenrechten, terwijl in het onderlinge verkeer tussen staten het geweldverbod (art. 2, lid 4 van het Handvest) geldt. In de woorden van SIEGHART: ${ }^{2}$

\begin{abstract}
'According to [the] principle [of national sovereignty], a sovereign State ha[d] complete freedom of action, in international law, to deal with its own nationals ("personall sovereignty") and (...) to make war, though the scope of that sovereign freedom [the jus ad bellum] has now been reduced to the use of force in selfdefence, and the right to remain neutral when others are at war.'
\end{abstract}

\title{
Jus ad bellum als jus contra tormentum
}

Het jus ad bellum is, behoudens de nationale en bondgenootschappelijke zelfverdediging (art. $51 \mathrm{HVN}$ ), van het domein van de statelijke soevereiniteit overgeheveld naar de supranationaal opererende Veiligheidsraad, die, onder hoofdstuk VII van het Handvest van de VN, niet alleen tegen agressie kan optreden (Saddam HUSSEINs invasie van Koeweit ${ }^{3}$ ), maar 66́k tegen mensenrechtenschendingen, dat wil zeggen tegen grootschalige (ernstige of systematische) schendingen van de rechten van de mens die, naar zijn oordeel - dat is het oordeel van de Veiligheidsraad zèlf $f^{4}$, een bedreiging of verstoring van de (inter- of transnationale ${ }^{5}$ )

Hierna: Handvest, Handvest van de VN of HVN.

Paul SIEGHART, The international law of human rights, Oxford 1983, p. 11.

Zie P.H. KoolsMANS, Intemationaal publiekrecht in vogelvlucht, Groningen 1996 (zesde druk), pp. 144 en 166.

4 De Veiligheidsraad heeft in dezen 'absolute discretie' - aldus KoOUMMANS (a.w., p. 164). Toch lijkt het mij geen uitgemaakte zaak dat toetsing van de vraag of de Veiligheidsraad in redelijkheid tot zijn oordeel heeft kunnen komen (dat wil zeggen het oordeel, vereist in art. $39 \mathrm{HVN}$, dàt zich een bedreiging of verstoring van internationale vrede en weiligheid voordoet, waarna de handhavingsbevoegdheden van hoofdstuk vir, met inbegrip van die tot gewapende interventie, in werking treden), aan het Internationale Gerechtshof onthouden is. Aangezien er noch in het Handvest noch in het Statuut van het Hof een expliciet toetsingsverbod te vinden is, en het hier toch een typische rechterlijke functie betreft (in het Nederlandse bestuursrecht marginalle toetsing genoemd, op grond van het willekeurverbod, door STROINK 'een typisch rechterlijke toetsingsgrond' genoemd: F.A.M. STROINK, Algemeen bestuursrech; Een inleiding, Zwolle 1994, p. 82), lijkt het mij beter vooralsnog (hooguit) te spreken van een nagenoeg absolute discretie.

Vgl. in dit verband de Lockerbie case, waarover W. Michael REISMAN, 'The constitutional crisis in the United Nations,' $A I L$ 1993/1, pp. 83-100; Vera GowL- 
vrede en veiligheid opleveren (de humanitaire interventies ${ }^{6}$ in de "failed states' Somalië en Bosnië-Herzegowina ${ }^{7}$ ).

Een bedreiging of verstoring van de vrede bestaat niet alleen in geval van schending van het geweldverbod tussen staten, maar ook in geval van ernstige of systematische schending van de fundamentele rechten van de eigen burgers of tussen burgers onderling (zoals in voormalig Joegoslavië, Somalië, Haïti en Rwanda ${ }^{8}$ ). Dwangmaatregelen voor humanitaire doeleinden van of met machtiging van de Veiligheidsraad zijn dan mogelijk: de situatie van grootschalige mensenrechtenschendingen in een bepaald land wordt niet (meer) geacht een strikt binnenlands karakter te hebben."

Mensenrechtenschendingen zijn na 1945 in toenemende mate een zaak van internationaal recht geworden. Ernstige, grootschalige mensenrechtenschendingen zijn - na het einde van de koude oorlog - zelfs zaak

LAND-DEBBAS, "The relationship between the International Court of Justice and the Security Council in the light of the Lockerbie case,' AIIL 1994/4, pp. 643-677, in het bijzonder op p. 663 (nt. 105) voor de redelijkheidstoetsing naar intermationaal recht ('abuse of rights'; 'marge d'appréciation'), en op p. 664 (nt. 116) met betrekking tot een constitutioneel toetsingsrecht dan wel -verbod (judicial review') in het Handvest.

Het internationale zit hem niet zozeer in het in territoriale zin grensoverschrijdende gevaar dat van de mensenrechtenschendingen uitgaat, maar in de grensoverschrijding in internationaal-normatieve zin waar het om enga omnes-verplichtingen gaat, dat wil zeggen om fundamentele normen betreffende de menselijke persoon waarvan de schending op grote schaal de wereldgemeenschap en de rechtsorde van die gemeenschap: de internationale rechtsorde, bedreigt (Barcelona Traction case: vgl. GOWLLAND-DEBBAS, ta.p., op pp. 675-676; KOOUMANS, a.w., p. 142 i.f.).

Onder meer wegens mogelijke vluchtelingenstromen is er natuurlijk ook het gevaar van transnationale spill-over van massale binnenlandse mensenrechtenschendingen, waarvan in die zin een bedreiging van de internationale wrede en veiligheid uitgaat. Hierop wijst KOOUMANS in zijn voordracht Maintaining the peace in the shadowland between the old and the new international order, UHLENBECKlecture X:1992, NIAS, Wassenaar 1992, pp. 12/13.

VAN BOVEN noemt het 'een ervaringsfeit dat ernstige schendingen van de rechten van de mens een bedreiging vormen woor de internationale vrede en veiligheid. Van dit feit," zo stelt hij, "was men met name tijdens de tweede wereldoorlog sterk doordrongen (...).' (Th.C. VAN BOWEN, De wolkenrechtelijke bescheming van de godsdienstvrijheid, [diss. Leiden], Assen 1967, p. 71.) Vgl. voor dit begrip Renske DOORENSPLEET, 'Humaniteit boven soevereiniteit; over humanitaire interventie en het voorbeeld Haïti,' NJCM-Bulletin 1995/7, pp. 957-967. 
van de Veiligheidsraad geworden - en daarmee, in principe, een zaak van supranationaal recht. Het oude jus ad bellum van de staat als voortzetting van de politiek met andere middelen' is het nieuwe jus ad bellum, het recht om (desnoods) met militaire middelen te interveniëren, van de Veiligheidsraad geworden, een (in laatste instantie militair) interventierecht dat mede, en niet in de laatste plaats - al zijn de ontwikkelingen nog pril en precair -, kan worden ingezet om binnenlandse mensenrechtenschendingen te keren, dus: contra tormentum.

Deze ontwikkeling van jus ad tormentum naar jus contra tormentum, van vorstelijk kwelrecht tot supranationaal interventierecht, zou evenwel niet mogelijk zijn geweest als niet op het fundament van het Handvest een indrukwekkende internationale Bill of rights was opgebouwd. Alleen daardoor kon allengs worden afgerekend met het statelijke jus ad tormentum.

Alvorens we naar de aftocht van dit kwelrecht terugkeren (in par. 2.5.2), wordt nu eerst, met zevenmijlslaarzen, een schematisch overzicht gegeven van de ontwikkeling naar die internationale Bill of rights toe.

\section{3}

\section{Documenten in vogelvlucht}

In deze paragraaf wordt een opsomming gegeven van enkele historische highlights die met betrekking tot bovenbedoeld thema: de voortschrijdende beperking van macht en willekeur van enkeling of elite door het toekennen van steeds meer rechten aan ieder mens c.q. aan steeds meer categorieën mensen, als bakens kunnen worden beschouwd. Op een aantal plaatsen wordt, door uit de desbetreffende documenten kort of iets uitgebreider te citeren, het thema enigszins geillustreerd.

\section{De Unie van Utrecht: het eerste mensenrecht}

Het eerste recht dat in een juridisch instrument aan ieder mens wordt toegekend, is de 'geestelijke vrijheid van het individu' (VAN BOVEN), ${ }^{10}$ ofwel de gewetensvrijheid, samenhangend met het einde van de interchristelijke godsdienst(burger)oorlogen en de, schoorvoetend, beginnende secularisatie van de staat (VERMEULEN). ${ }^{11}$ Het stamt uit:

Unie van Utrecht: ${ }^{12}$

VAN BOVEN, De volkenrechtelijke bescheming van de godsdiensturijheid, a.w., p. 6. B.P. VIERMEULEN, De wijheid van geweten, een fundamenteel rechtsprobleem, diss. Rotterdam, Arnhem 1989, pp. 56 e.w.

12 [W.J.C.] VAN HASSELT, F.R. BÖHTLINGK (red.), Werzameling van Nederlandse Stautsregelingen en grondwetten, Alphen aan den Rijn 1964 (15e druk), pp. 5-16, op p. 11. Aangehaald door VERMEULEN (a.w., p. 57; curs. BV). 
[Art.] XII.

(...) [D]at een yder particulier in sijn Religie vrij sal moegen blijven, ende dat men myemant ter cause van de Religie sal moegen achterhaelen ofte ondersoucken $(\ldots ..) .^{1.3}$

\section{Van de Nederlandse tot de Amerikaanse onafhankelijkheidsverklaring}

In het verlengde van dit eerste mensenrecht, of, zoals VERMEULEN het ook aanduidt: "de eerste positivering van de idee der mensenrechten in een concreet vrijheidsrecht, ${ }^{\text {,4 }}$ ligt het recht op opstand of verzet tegen onderdrukking, althans het recht tot afzwering van een tiran, eveneens te vinden in een instrument van vaderlandse bodem: het Plakkaat van Verlatinge, ${ }^{15}$ dat later buitenlandse 'navolging' vond.

Plakkaat van Verlatinge (Nederlandse 'Onafhankelijkheidsverklaring,' 26 juli 1581): ${ }^{16}$

DE STATEN-GENERAAL VAN DE VERENIGDE NEDERLANDEN groeten allen die dit zullen zien of horen lezen [en laten weten:] Het is algemeen bekend dat een vorst van een land door God tot hoofd van zijn onderdanen is aangesteld om dezen te beschermen en te bewaren woor alle onrechtvaardigheid, schade en geweld, zoals een herder zijn schapen moet beschermen, en dat de onderdanen niet door God geschapen zijn ten behoeve van de vorst, om hem in alles wat hij beveelt - of dat nu godwruchtig of niet godvruchtig, rechtvaardig of niet rechtvaardig is - onderdanig te zijn om hem als slaven te dienen. Integendeel, de vorst is er ter wille van de onderdanen, zonder welke hij geen vorst is, om hen rechtvaardig en verstandig te regeren en te verdedigen, en hen lief te hebben zoals een vader zijn kinderen en een herder zijn schapen; hij zet zijn lichaam en leven op het spel om hen te beschermen. Wanneer hij dit niet doet, maar in plagts van zijn onderdanen te beschermen, probeert hen te onderdrukken, overmatig te belasten, te beroven van hun oude vrijheid, privileges en oude gewoonterechten, en hen als slaven te bevelen en te gebruiken, moet hij dus niet

Aan deze bepaling lag, schrijft VERMEULEN, het "principiële argument ten grondslag dat het geweten begrepen moet worden als de kern wan ieder mens (...).' Hij vervolgt: "(...) Derhalve is art. XIIn Unie van Utrecht vermoedelijk de eerste juridische bepaling waarin aanvaard wordt dat aan ieder mens als zodanig een onaantastbare private sfeer, gewaarborgd door de vrijheid wan geweten, toekomt." (T.a.p.)

14 VERMEULEN, a.w., p. 58.

15 VERMEULEN waarschuwt terecht dat het hierbij niet om een individueel recht gaat: het wolk als totaliteit, en enkel onder de hoede van de standen, mag tegen de vorst in opstand komen (a.w., p. 59). We zouden hier een vergelijking kunnen trekken met het collectieve recht van zelfbeschikking in het gemeenschappelijke art. 1 van IVBPR en IVESCR.

16 Overgenomen uit: M.E.H.N. Mour, Plakkaat wan Verlatinge 1581, Den Haag 1979, pp. 95, 97, 119, 121 . 
als een vorst maar als cen tiran worden beschouwd. Dan statat het zeker zijn onderdanen wrij hem niet meer als vorst te erkennen - vooral nadat er in de Staten van het land overlegd is -, maar hem te verlaten en in zijn plaats een ander tot soeverein te kiezen om hen te beschermen, zonder dat dit verkeerd is. Dit is des te meer toegestaan wanneer de onderdanen hun vorst niet hebben kunnen vermurwen door nederige betogen en hem niet van zijn tirannieke voornemens hebben kunnen afbrengen, en dus geen ander middel meer hebben om de aangeboren vrijheid van hen zelf en van hun vrouwen, kinderen en nakomelingen te verdedigen en te beschermen. Hiertoe zijn zij volgens de wet der natuur verplicht goed en bloed op het spel te zetten. (...)

[Volgt een lang relatas van feiten en grieven.]

Desondanks hebben wij niet willen nalaten voortdurend, met schriftelijke, nederige remonstranties door bemiddeling van de voornaamste vorsten van de christenheid, pogingen in het werk te stellen ons met de koning te verzoenen en tot overeenstemming te komen. Onlangs verblewen daarom onze gezanten langdurig in Keulen, in de hoop daar (...) een zekere vrede te krijgen met enige goedgunstig verleende vrijheid, in het bijzonder van de godsdienst, die vooral een zaak is van het geweten en wan God. Maar wij hebben de ervaring opgedaan dat wij door deze remonstranties en onderhandelingen niets van de koning gedaan konden krijgen, maar dat deze onderhandelingen en contacten alleen maar geopperd werden en ertoe dienden om de landen tegen elkaar op te stoken en onderling te verdelen, om des te gemakkelijker de een na de ander te onderwerpen en het oorspronkelijke plan tegen hen met alle hardheid te volvoeren. Dit is later wel duidelijk gebleken uit het plakkaat van de ban [de 'fatwa' tegen WILLEM DE ZWUGER, jw], uitgevaardigd door de koning, waarbij wij en alle ambtsdragers en ingezetenen van de verenigde provincies met hun aanhangers tot rebellen werden verklaard zodat zij leven en goed verbeurd zouden hebben. Dit dleed hij om ons nog meer tot wanhoop te brengen, overal gehaat te maken en verkeer en handel te dwarsbomen. Bovendien zette de koning ook een grote som gelds op het hoofd van de prins van Oranje.

Wij wanhoopten daardoor geheel aan alle mogelijkheden om tot verzoening te komen en hadden ook geen enkele andere remedie noch hulp. Wij zijn daardoor gedwongen andere middelen te gebruiken die ons juist woorkomen om onze rechten, privileges en vrijheden te handhaven en te beschermen en de koning van Spanje met recht te verlaten, wolgens de wet der natuur die ons gebiedt de rechten van ons en onze landgenoten, de privileges, oude gewoonterechten en vrijheid van ons vaderland en het leven en de eer van onze vrouwen, kinderen en nakomelingen te beschermen en te handhaven, opdat zij niet in slavernij onder de Spanjaarden zouden vervallen. (...)"

Een eeuw later ${ }^{17}$ volgt de bekende(re):

Na de opkomst van de maatschappelijke contractsleer: VERMEULEN, a.w., pp. 5960. En dus van een 'echte mensenrechtentheorie, welke de staat verklaart vanuit de fundamentele rechten van het individu.' (A.w., p. 59.) 
Bill of rights (aangenomen in Engeland bij de troonsbestijging van Willem III VAN ORANJE en Mary STUART).

De Glorious Revolution van 1688 leidde tot de troonsafstand van James (Jacobus) II. Zijn opvolger, koning-stadhouder Willem IIr, werd door de Bill of Rights grondig in zijn macht beperkt. ${ }^{18}$

$\mathrm{Na}$ weer een eeuw ${ }^{19}$ zijn ook de Amerikanen hun vorst (de Engelse koning George III) beu. Een parallel met het Plakkaat van Verlatinge, de afzwering van Filips II in 1581, vinden we in de Amerikaanse Onafhankelijkheidsverklaring, ${ }^{20}$ twee eeuwen na dato:

'WHEN, IN THE COURSE OF HUMAN EVENTS, it becomes necessary for one people to dissolve the political bands which have connected them with another, and to assume, among the powers of the earth, the separate and equal station to which the laws of nature and of nature's God entitle them, a decent respect to the opinions of mankind requires that they should declare the causes which impel them to the separation.

We hold these truths to be self-evident: That all men are created equal; that they are endowed by their Creator with certain unalienable rights; that among these are life, liberty, and the pursuit of happiness. That, to secure these rights, governments are instituted among men, deriving their just powers from the consent of the governed; that, whenever any form of government becomes destructive of these ends, it is the right of the people to alter or to abolish it, and to institute a new government, laying its foundation on such principles, and organizing its powers in such form, as to them shall seem most likely to effect their safety and happiness. Prudence, indeed, will dictate that governments long established should not be changed for light and transient causes; and accordingly all experience hath shown, that mankind are more disposed to suffer, while evils are sufferable, than to right themselves by abolishing the forms to which they are accustomed. But when a long train of abuses and usurpations, pursuing invariably the same object, evinces a design to reduce them under absolute despotism, it is their right, it is their duty, to throw off such govermment, and to provide new guards for their future security. Such has been the patient sufferance of these colonies; and such

18 Vgl. woor de mensenrechtelijke betekenis van de Bill: Scott DAviDSON, Human rights, Buckingham/Philadelphia 1993, pp. 2-3.

19 Contractsleer en gewetensvrijheid gaan nu samen: VERMEULEN, a.w., p. 62 nt. 421.

20 Vgl. voor deze vergelijking BERKELBACH VAN DER SPRENKEL, vermeld in MOUT, a.w., p. 18 (marge)nt. 17; VAN DER POT/DONNER, Handboek van het Nederlandse staatsrecht, Zwolle 1972 (negende druk), p. 77; 1995 (dertiende druk), p. 64.

21 Overgenomen uit: Peter H. ODEGARD, The American Republic, New York (etc.) 1969, p. 831; William EBENSTEIN et al., American democracy in world perspective, New York (etc.) 1970, pp. 571-572. 
is now the necessity which constrains them to alter their former systems of govermment."

Verschillende Amerikaanse mensenrechtenverklaringen zien het licht:

$1776^{* 22}$

$1776^{*}$

$1780^{*}$
Virginia Bill of rights (12 juni 1776).

Pennsylvania Bill of rights (28 september 1776). Massachusetts Bill of rights (2 maart 1780 ).

Tussen de Amerikaanse en de Franse en Bataafse mensenrechtenverklaringen in verscheen in Nederland (precies twee eeuwen na het Plakkaat van Verlatinge) een opmerkelijk pamflet, waarin de vrijheid van de burger tot deelneming aan het staatsbestuur, tot het dragen van wapens èn de vrijheid van drukpers tegen zowel regenten- als Oranje-onderdrukking in stelling werd gebracht: ${ }^{23}$

1781 Aan het Volk van Nederland (van Joan Derk VAN DER CA-
PELLEN): ${ }^{24}$

${ }^{6}$ Verzamelt Ulieden elk in uwe Steden en ten platten Lande in uwe Dorpen. Komt vreedzaam byeen, en kiest, uil het midden van Ulieden, een maatig getal brave, deugdzame, wroome Mannen: kiest goede Patriotten daar Gylieden op vertrouwen kunt. (...)

Zorg voor de vryheid der drukpers, want zy is de eenige steun van Ulieder Nationale vryheid. Als men niet vry tot zyne Medeburgers kan spreken, nog hen bytyds waarschouwen, dan valt het den Onderdrukkeren des Volks zeer gemakkelyk

22 De teksten wan de jaartallen die van een asterisk zijn voorzien, zijn te vinden in: F.H. VAN DER BURG, H. BOELS, Tweehonderd jaar rechten van de mens in Nederland, Leiden 1994, pp. 36 e.v; de Verklaring van 1795 is te vinden op de pp. 3-6 (ook opgenomen in NJCM-Bulletin 1995/7, pp. 869-872); voor de artt. XXI en Xxill Verklaaring 1793 zie pp. 59-62, op pp. 61-62.

23 Zie H.L. ZWTIZZER, "Joan Derk WAN DER CAPELLEN TOT DEN POL als schrijwer van het pamflet Aan het Volk van Nederland,' in: Joan Derk VAN DER CAPELLEN, Aan het Volk van Nederland,' ed. Amsterdam 1987, pp. 7-16, op pp. 11-13.

VAN DER CAPELLEN was niet de anti-Oranjeklant waarvoor hij lange tijd is aangezien, maar juist voorstander van een imperium mixtum. Vandaar het belang dat hij hechtte aan de burgerbewapening, zodat het leger niet tegen de eigen bevolking zou kunnen worden ingezet. Een 'orangistische geschiedschrijving' heeft over persoon en pamflet evenwel 'alle lelijks gezegd.' Zie voor een eerherstel: Jan \& Annie ROMEIN, Erfaters wan onze beschaving, Amsterdam 1976 (elfde druk), pp. 541-565. De ROMEINs noemen VAN DER CAPELLEN 'de grondlegger van de moderne democratie in Nederland" en een '18de-eeuwse MULTATULI.' (Aanhalingen resp. op pp. 558,542 en 564 i.f.) 
hunne rol te spelen: hierom is het dat zy wier gedrag geen onderzoek kan lyden, altyd zo tegen de vryheid van schrywen en drukken yveren, en wel gaarne zouden zien dat niets gedrukt of verkogt wierd zonder permissie. Wapent Ulieden allen, verkiest zelven dezulken die U commandeeren moeten (...).'

\section{De Verklaringen van de rechten van de man en de burger}

De eerste Europese mensenrechtenverklaring was een Franse tekst ten behoeve van de Bataven:

$1788^{*} \quad$ Déclaration des droits de tout peuple qui veut la liberté.

Kort daarna breekt de Franse revolutietijd aan. Vrijheid, gelijkheid en broederschap voor de burger en de (blanke) man:

1789* Déclaration des droits de l'homme et du citoyen (26 augustus 1789).

Vrijheid, gelijkheid, èn zusterschap?

1791

Déclaration des droits de la femme et de la citoyenne (van Olympe DE GOUGES). ${ }^{25}$

In deze - dissidente - verklaring wordt onder meer verkondigd:

\section{Artikel I.}

De vrouw is vrij geboren en behoudt dezelfde rechten als de man. De sociale verschillen kunnen slechts gebaseerd zijn op het gemeenschappelijk nut.

Artikel II.

Het doel van ieder politiek verbond is het behoud van de natuurlijke en onaantastbare rechten zowel van de vrouw alls van de man. Deze zijn: het recht op vrijheid, eigendom, rechtszekerheid en bovenal het recht op verzet tegen onderdrukking.

Artikel IV.

Vrijheid en gerechtigheid bestaan in het teruggeven wat een ander toebehoort. Zo wordt de vrouw in thet uitoefenen van haar natuurlijke rechten alleen beperkt door de voortdurende tirannie waarmee de man zich tegenover haar opstelt. Deze belemmeringen moeten door de wetten van de natuur en van de rede weggenomen worden.

Artikel $X$.

Niemand mag vervolgd worden wegens zijn/haar mening, al is die nog zo radicaal. De vrouw heeft het recht het schavot op te gaan; ze moet eveneens het

25 Olympe DE GOUGES, Verklaring van de rechten van de wrouw en burgeres (Parijs 1791), uitgegeven door Hannelore SCrRöDER, Kampen 1989, pp. 35-40, aangehaalde artt. op pp. $36-38$. 
recht hebben thet spreekgestoelte te beklimmen, mits door haar optreden de openbare orde, zoals die door de wet is vastgelegd, niet verstoord wordt.

Van dit laatste "dubbelrecht" - schavot èn spreekgestoelte - is Olympe DE GOUGES al snel de eerste helft toegestaan: in 1793 sterft zij onder de guillotine. Het verklaren van en opkomen voor de rechten van de vrouw was zo dissident, dat zij haar strijd met de dood moest bekopen. ${ }^{26}$

$\mathrm{Na}$ de afschaffing van de monarchie neemt de Convention een nieuwe grondwet aan, waarin is opgenomen:

1793* Déclaration des droits de l'homme et du citoyen (24 juni 1793).

In vertaling $\left(1793^{*}\right)$ : Nieuwe verklaaring der rechten, zoo als dezelve bij de conventie is aangenoomen op maandag den [24?] Junij 1793. In deze verklaring paraisseert ook een tweetal sociale grondrechten ${ }^{27}$ :

[Art.] XXII. De algemeene onderstand is eene geheiligde schuld. De maatschappij is verpligt voor het onderhoud der ongelukkigen te zorgen, 't zij door hun werk te verschaffen, of door middelen van bestaan te beschikken aan dezulken, welke onbekwaam zijn tot werken.

[Art.] XXII. Het onderwijs is een vereischte van een ieder, en de maatschappij behoort uit all [sic, jw] haar macht de voortgangen der algemeene reden voor te staan; en het onderwijs binnen het bereik van ieder burger te brengen.

Inmiddels is ook de Bataafse victorietijd aangebroken. In de "eerste $\mathrm{Ne}$ derlandstalige (...) mensenrechtencatalogus' wordt 'de grondslag voor onze hedendaagse rechtsstaat gelegd ${ }^{28}$ :

S.W. COUWENBERG, 'Constitutionele vruchten van de Franse Revolutie na twee eeuwen," in: dez. (red.), Opstand der burgers; De Franse Revolutie na 200 jaar, Kampen 1988, pp. 163-179, op p. 163. Zie ook Hannelore SCHRÖDER, 'Olympe DE GOUGES 1748-1793; leven voor vrowwenbevrijding - sterven op de guillotine,' in: Olympe DE GOUGES; Verklaring van de rechten wan de vrouw en burgeres, a.w., pp. $16-23$.

27 Pas een eeuw later zou deze draad weer worden opgepakt (vgl. sIEGHART, a.w., p. 9 nt. 12): in 1891 verschüjnt de pauselijke encycliek Rerum novanum; in 1917 krijgt Mexico een grondwet met sociale rechten, gevolgd door Rusland (1918) en Duitsland (1919). Nederland volgt overigens pas in 1983: twee eeuwen later.

E.A. ALKEMA, 'Voorwoord: Tweehonderd jaar rechten van de mens in Nederland 1795-1995,' in: Tweehonderd jaar rechten van de mens in Nederland, a.w., pp. 1-2, resp. op p. 1 en p. 2. 
1795* Verklaring van de rechten van de mens en van de burger, geproclameerd door de Provisionele Representanten van het Volk van. Holland op 31 januari 1795.

Een aantal bepalingen verdient hier vermelding:

[Art.] 1. Dat alle Menschen met gelyke rechten geboren worden, en dat deze natuurlyke rechten hun niet kumen ontnomen worden. ${ }^{29}$

[Art.] 2. Dat deze rechten bestaan in gellykheid, vryheid, veiligheid, eigendom en tegenstand aan onderdrukking.

[Art.] 3. Dat de vryheid de magt is, welke ieder Mensch toekomt om te mogen doen al het geen anderen in hunne rechten niet stoort: dat dus hare natuurlyke bepaling [is beperking, jw] bestaat in deze stelling: Doe niet aan eenen anderen, het geen gy miet wilt dat U geschiede.

[Art.] 4. Dat hel ieder dus geoorloofd is zyne gedachten en gevoelens aan anderen te openbaren, het zy door de Drukpers of op eenige andere wyze.

[Art.] 5. Dat ieder Mensch het regt heeft, om God zoodanig te dienen, als hy wil, of niet wil, zonder daarin op eenigerlei wyze gedwongen te kunnen worden.

[Art.] 6. Dat de veiligheid bestaat in de zekerheid van door anderen niet gestoord te zullen worden in het uitoeffenen van zyne rechten, noch in het vreedzaam bezit van wettig verkregene eigendommen.

[Art.] 16. Dat een iegelyk het regt heeft om van ieder Amptenaar van het publiek bestuur rekening en verantwoording van zyn bewind te helpen afvorderen.

Na een staatsgreep krijgt de Bataafse Republiek haar grondwet, de eerste Nederlandse grondwet met grondrechten ${ }^{30}$ :

LEITTEN merkt op: '[H] het heft gedourd tot het in werking treden van de huidige grondwet van 1983 voordat het recht van gelijkheid opnieuw als artikel 1 in een staatsrechtelijke beginselverklaring werd opgenomen.' (J.C.M. LEUTEN, 'De Verklaring van de rechten van de mens en van de burger - Pieter PAulus lof" NJCM-Bulletin $1995 / 7$, pp. 873-881, op p. 873.)

De Advocaat-Generaal is met betrekking tot dit recht evenwel nogal sceptisch: Bij wat (...) de viering van 200 jaar mensenrechten werd genoemd, stel ik vast dat er nog niets te vieren valt; dat het wel lijkt of de krachten van het kwade ons weer gaan overspoelen, dat betekent dat het beginsel van de gelijkheid dat aan het begin staat van elke ware beschaving, weer verdrongen gaat worden voor de waarde van de grootste bek en de volste portemonnaie.' (T.a.p., op p. 881.)

30 Nederland is hierin derde, na Framkrijk (1789) en de Verenigde Staten (1776/ 1791): SIEGHART, a.w., p. 9 nt. 11.

31. WAN HASSELT, Nederlandse staatsregelingen en grondwetten, pp. 17-103 (curs. overgenomen). 
Hieruit breng ik een algemeen beginsel (het gelijkheidsbeginsel van art. 3) en een viertal burgerlijke en staatkundige grondregels (artt. 49, 50, 60 en 63) onder de aandacht:

[Art.] 3. Alle leden der maatschappij hebben, zonder onderscheiding van geboorte, bezitting, stand, of rang, eene gelijke aanspraak op derzelver voordeelen. kinders.

[Art.] 49. Er zal gezorgd worden voor de opvoeding van verworpen

[Art.] 50. De maatschappij ontvangt alle vreemdelingen die de weldaaden der vrijheid vreedzaam wenschen te genieten, in haar midden, verleenende denzelven alle zekerheid en bescherming.

[Art.] 60. De maatschappij wil dat de verlichting en beschaaving onder haare leden zoo veell mooglijk bevorderd worde.

$\mathrm{Nu}$ het (ten gevolge van welke historische gevoeligheden toch?) gemiste gedenkjaar 1998 ten einde loopt, moet nog vermeld worden:

[Art.] 63. Er zullen nationaale feesten worden vastgesteld om de Bataafsche omwenteling, en andere merkwaardige gebeurdtenissen, jaarlijks te herinneren; voords om de broederschap onder de burgers aantekweeken, en hen aan de Staatsregeling, aan de wetten, aan het vaderland en de vrijheid te verbinden.

Slavenhandel en slavernij, Solferino en de sociale kwestie: de eerste mensenrechtenverdragen

Maken we wederom een sprong van een eeuw, en tevens van het nationale naar het internationale vlak, dan zien we dat aan de ontwikkelingen die na 1945 in een stroomversnelling zullen raken, verschillende verdragen en verklaringen voorafgaan. ${ }^{32}$ Deze betreffen het humanitaire oorlogsrecht (1862: Henry DUNANTs Un souvenir de Solferino; 1863: de oprichting, als non-gouvernementele organisatie, van het Rode Kruis; 1899: de Eerste, 1907: de Tweede Haagse Vredesconferenties); de afschaffing van de slavenhandel en de slavernij (1885: de Algemene Akte van het Congres van Berlijn, waar de Europese kolonisatie van Afrika op de agenda stond; 1890: de Algemene Akte van de Conferentie van Brussel; 1926: het Verdrag inzake de slavernij); het internationale arbeidsrecht (de oprichting, als reactie op de sociale kwestie, van de Internationale Arbeidsorganisatie, de ILO, in 1919 krachtens de vredesverdragen na de eerste wereldoorlog, waarvan het bekendste, het Vredesverdrag van Versailles, ook aan de wieg stond van de Volkenbond ${ }^{33}$ ); en het stelsel van

32 Vgl. DAVTDSON, a.w., pp. 8-11; SIEGHART, a.w., p. 13.

33 Vgl. Gerard J. TANJA, 'De volkenbond,' (hoofdstuk 6) in: A.C.G.M. EYFFINGER (red.), Compendiunt volkenrechtsgeschiederis, T.M.C. ASSER Instituut Den Haag, 
de minderhedenbescherming van de Volkenbond. ${ }^{34} \mathrm{Ik}$ licht hier slechts twee jaartallen uit:

Eerste Haagse Vredesconferentie: DE MARTENS-clausule.

In de preambule van het Landoorlogverdrag (Verdrag nopens de wetten en gebruiken van de oorlog te land), getekend in 1899 tijdens de Eerste Haagse Vredesconferentie, is een befaamde clausule opgenomen, die als vindicatie van de rule of law, ó6 in het oorlogsrecht, ${ }^{35}$ kan worden beschouwd. Ingevolge deze, als DE MARTENS-clausule bekend geworden passage, erkennen de verdragsluitende partijen dat in niet door verdragsregels voorziene gevallen: ${ }^{36}$

'(...) zowel de burgers als de strijdenden beschermd worden door - en onderworpen blijven aan - de beginselen van het volkenrecht, zoals die voortwloeien uit de tussen beschaafde volken gevestigde gebruiken, de wetten van de menselijkheid en de eisen wan het algemeen rechtsbewustzijn.'

Deventer 1991 (tweede druk), pp. 182-198, op pp. 183 en 186.

35 Het humanitaire oorlogsrecht en de rechten van de mens worden als aparte onderdelen van het internationale recht gezien. $\mathrm{Zjj}$ kunnen evenwel onder dezelfde noemer worden gevat: de bescherming van de fundamentele rechten van de mens in vredestijd èn tijdens gewapende conflicten. In toenemende mate gebeurt dit ook. Zowel de klassieke (burgerlijke en politieke) als de sociale (economische, sociale en culturele) mensenrechten worden in het internationale recht in toenemende mate als 'universal, indivisible and interdependent and interrelated' gezien (vgl. World Conference on Human Rights: Vienna Declaration and Programme of Action, UN doc. A/conf.157/23, part I, para. 5; 25 juni 1993). De humanitaire rechten staan evenwel niet buiten deze ontwikkeling. Dit blijkt onder meer uit uit het Verdrag inzake de rechten wan het kind, waarin burgerlijke, sociale, politieke en humanitaire rechten (art. 38 VRK), voor het eerst in een international werdrag, samenwloeien. Behalve op het Verdrag inzake de rechten van het kind kan gewezen worden op de Declaration of Minimum Humanitarian Standards, de zogenaamde Turku-Declaration, van 2 dec. 1990, opgesteld door een groep van internationale deskundigen, onder wie de Nederlandse hoogleraar Theo VAN BOVEN (UN doc. E/CN.4/Sub.2/1991/55; AJIL 1991/2, pp. 377-381), welke is gebaseerd op een combinatie van humanitair recht en mensenrechten. Zie ook Allan ROSAS, Monika SANDVIK, 'Armed conflicts,' in: Asbjørn EIDE, Catarina KRAUSE, Allan ROSAS (eds.), Economic, social and cultural rights; A textbook, Dordrecht (etc.) 1995, pp. 341-352, op p. 342, waar de auteurs still staan bij the fact that humanitarian law has increasingly become related to human rights law.' Vgl. F. KALSHOVEN, Zwijgt het recht als de wapens spreken? Den Haag 1985 (tweede druk), p. 18. 
Verdrag inzake de slavernij (door SIEGHART 'the first true international human rights treaty" genoemd $\left.{ }^{37}\right):^{38}$

Artikel 2.

De Hooge Verdragsluitende Partijen verbinden zich voor zoover zij nog niet de noodige maatregelen hebben genomen, en ieder voor zoover betreft de gebieden geplaatst onder haar souvereiniteit, rechtsmacht, protectie, suzereiniteit of woogdij:

a.) den handel in slaven te voorkomen en tegen te gaan;

b.) de volledige onderdrukking van slavernij in al haar vormen geleidelijk en zoo spoedig mogelijk tot stand te brengen.

\section{De periode van de Verenigde Naties}

De hierna volgende jaartallen horen tot de periode van de Verenigde Naties, en de bijbehorende instrumenten maken deel uit van de VN-mensenrechtenfamilie. Regionale (Europese, Amerikaanse, Afrikaanse) ontwikkelingen en verdragen zijn in dit overzicht buiten beschouwing gelaten.

Eerbied voor de rechten van de mens wordt opgenomen onder de doelstellingen van de VN (art. 1 aanhef en lid 3 van het Handvest); de lidstaten van de VN committeren zich tot het nemen van stappen ter verwezenlijking van de universele eerbiediging en naleving van de mensenrechten (art. 56 juncto art. 55 sub c Handvest vN).

Universele Verklaring van de rechten van de mens (resolutie Algemene Vergadering van de VN, 10 december 1948):

\section{Preambule}

Overwegende dat erkenning van de inherente waardigheid en van de gelijke en onvervreemdbare rechten van alle leden van de mensengemeenschap grondslag is woor de vrijheid, gerechtigheid en vrede in de wereld; (...)

Overwegende dat het van het grootste belang is dat de rechten van de mens beschermd worden door de suprematie van het recht, opdat de mens niet gedwongen worde om in laatste instantie zijn toevlucht te nemen tot opstand tegen tirannie en onderdrukking; (...)

38 Voor Nederland, niet de kleinste onder de slavenhandelsnaties, in werking getreden in 1928. Opgenomen in: H. VAN MAARSEVEEN e.a. (red.), Internationaal recht en wrouwen; De betekenis van het intermationale recht voor vrouwen in Nederland, deel II, Teksten van verdragen, resoluties, statuten en andere internationale documenten, Zwolle 1987, pp. 111-116 (curs. jw). 
Op grond daarvan proclameert de Algemene Vergadering deze Universele Verklaring van de rechten van de mens (...) opdat ieder individu en elk orgaan van de gemeenschap (...) er naar zal streven door onderwijs en opvoeding de eerbied voor deze rechten en vijheden te bevorderen (...).

\section{De Universele Verklaring (UV) was de aanzet tot het volgende zevental verdragen:} vormen van rassendiscriminatie (IVUR, inwerkingtreding 1969):

\section{Preambule}

De staten die partij zijn bij dit Verdrag,

Overwegende (....) dat alle mensen gelijk zijn voor de wet en aanspraak hebben op gelijke bescherming door de wet tegen elke vorm van discriminatie en tegen elke vorm van aanzetting daartoe, $(. .$.

Ervan overtuigd dat elke leer die uitgaat van de superioriteit van een bepaald ras, wetenschappelijk onjuist, op zedelijke gronden verwerpelijk, en sociaal onrechtvaardig en gevaarlijk is (...),

Vastbesloten alle maatregelen te nemen die nodig zijn on snel een einde te maken aan alle vormen en alle uitingen van rassendiscriminatie, alsook op rassendiscriminatie berustende leerstellingen en praktijken te voorkomen en te bestrij$\operatorname{den}(\ldots)$.

(2.) (a.) Internationaal Verdrag inzake burgerlijke ${ }^{39}$ en politieke rechten (IVBPR, inwerkingtreding maart 1976);

(3.) (b.) Internationaal Verdrag inzake economische, sociale en culturele rechten (IVESCR, inwerkingtreding januari 1976):

(Vrijwel gelijkluidende) preambule

De staten die partij zijn bij dit Verdrag, (...)

Erkennende dat (...) het ideaal van de vrije mens, vrij van vrees en gebrek, slechts kan worden verwezenlijkt indien er omstandigheden worden geschapen waarin een ieder zowel zijn burgerlijke en politieke als zijn economische, sociale en culturele rechten kan uitoefenen, (...)

Zich ervan bewust dat op de individuele mens, wit hoofde van de plichten die hij heeft tegenover anderen en tegenover de gemeenschap waartoe hij behoort, de

39 En niet - zoals steeds vaker te lezen valt - burgerrechtew: "Ten onrechte wordt (...) "civil rights" vertaald door "burgerrechten" in plaats van door "burgerlijke rechten"." (A.M. STUYT, Driewerf urede; Afscheidsgeschrif, KU Nijmegen, Kerstm is 1982 , p. $36 \mathrm{nt}$. 45.) Wat is immers het werschil tussen burgerrechten en politieke rechten? 
verantwoordelijkheid rust te streven naar bevordering en inachtneming van de in dit Verdrag erkende rechten (...).

(4.) Verdrag inzake de uitbanning van alle vormen van vrouwendiscriminatie (VUDV, inwerkingtreding 1981; voor Nederland: 1991):

\section{Preambule}

De staten dile partij zijn bij dit Verdrag, (...)

Indachtig de belangrijke, tot dusverre niet wolledig erkende bijdrage van vrouwen aan het welzijn van het gezin en aan de ontwikkeling van de maatschappij, alsmede de maatschappelijke betekenis van het moederschap en de rol van beide ouders in het gezin en bij de opvoeding van kinderen, en beseffend dat de functie van vrouwen bij de woortplanting geen basis voor discriminatie mag zijn, maar dat de verantwoordelijkheid voor de opvoeding van kinderen door mannen, vrouwen en samenleving als geheel gezamenlijk moet worden gedragen (...).

(5.) Verdrag tegen foltering en andere wrede, onmenselijke of onterende behandeling of bestraffing (Anti-Martelverdrag, inwerkingtreding 1987; voor Nederland: 1989):

\section{Preambule}

De staten die partij zijn bij dit Verdrag, (...)

Geleid door de wens de bestrijding van foltering en andere wrede, onmenselijke of onterende behandeling of bestraffing in de gehele wereld doeltreffender te doen zijn $(. .$.$) .$

(6.) Verdrag inzake de rechten van het kind (VRK, inwerkingtreding 1990; voor Nederland: 1995):

\section{Preambule}

De staten die partij zijn bij dit Verdrag, (...)

Erkennende dat (...) een ieder recht heeft op alle rechten en vrijheden (...) zonder onderscheid van welke aard ook (...),

Eraan herinnerende dat (...) kinderen recht hebben op bijzondere zorg en bijstand,

Ervan overtuigd dat aan het gezin, als de kern van de samenleving en de natuurlijke omgeving voor de ontplooiing en het welzijn van al haar leden en van kinderen in het bijzonder, de nodige bescherming en bijstand dient te worden verleend opdat het zijn verantwoordelijkheden binnen de gemeenschap volledig kan dragen,

Erkennende dat het kind, voor de volledige en harmonische ontplooing van zijn of haar persoonlijkheid, dient op te groeien in een gezinsomgeving, in een sfeer van geluk, liefde en begrip, Overwegende dat het kind volledig dient te worden voorbereid op het leiden van een zelfstandig leven in de samenleving $(. .),.(\ldots)$ 
Erkennende dat er, in alle landen van de wereld, kinderen zijn die in uitzonderlijk moeilijke omstandigheden leven, en dat deze kinderen bijzondere aandacht behoeven (...).

(7.) Internationaal Verdrag inzake de bescherming van de rechten van alle migrerende werknemers en hun gezinsleden (IVBRM, nog niet in werking getreden):

Art. 30

Each child of a migrant worker shall have the basic right of access to education on the basis of equality of treatment with nationals of the state concerned.

Access to (...) schools shall not be refused or limited by reason of the irregular situation with respect to stay or employment of either parent (...).

Over de betekenis van het Handvest, en de op het fundament daarvan opgebouwde Bill of rights, met name voor de afrekening met het statelijke jus ad tormentum, komen we later te spreken (par. 2.5.2). Allereerst zal nu worden gepoogd de reeks historische documenten op te nemen in een mensenrechtenverhaal.

Het verhaal van de mensenrechten

In deze paragraaf wordt de voorafgaande rij rechtshistorische feiten, aan de hand van CLITEUR, tot een verhaal - of eigenlijk tot twee verhalen gemaakt.

\subsubsection{Het eerste mensenrechtenverhaal}

Tegen de achtergrond van de hiervoor opgesomde mijlpalen kan thans gepoogd worden het mensenrechtenthema te periodiseren. Dit gebeurt allereerst aan de hand van de indeling van CAPPELLETTI (1971), zoals weergegeven door CLITEUR. ${ }^{40}$ haal: ${ }^{41}$

CAPPELLETTI onderscheidt drie stadia in het mensenrechtenver-

1. Het stadium van 'het klassieke natuurrecht, de periode van "natural justice"."

Deze periode 'begint ergens in de Griekse oudheid'; De Unie van Utrecht en het Plakkaat van Verlatinge (en wat de doctrine betreft: GRO-

40 P.B. CLITEUR, 'De Verklaring van de rechten van de mens en van de burger zijn de mensenrechten "af"?' NJCM-Bulletin 1995/7, pp. 882-892, op pp. 883/884.

41 Geciteerde zinsdelen zijn van CLITEUR, t.a.p. (pp. 883/884). 
TIUs' De jure belli ac pacis van $1625^{42}$ ) horen tot deze periode.

2. "Het tijdperk van "positieve" of van "legale" rechtvaardigheid (...) gekenmerkt door het primaat van geschreven constituties en formele verklaringen van mensenrechten."

Deze periode loopt vanaf de Engelse Glorious Revolution, via de Amerikaanse, Franse en Bataafse revoluties, door tot (ver) in de twintigste eeuw. $\mathrm{Zij}$ 'wordt gekenmerkt door het primaat van geschreven constituties en formele verklaringen van mensenrechten.'

3. Het derde 'stadium is dat van de "constitutional justice".'

Met betrekking tot deze, feitelijk nog maar sinds kort aangebroken periode, schrijft CLITEUR: ${ }^{43}$

'Door het moderne constitutionalisme wordt het natuurrecht praktisch en realistisch gemaakt, [door]dat men aan de rechter de bevoegdheid geeft wetten aan het gecodificeerde hogere recht te toetsen.'

Een rechterlijke toetsingsmogelijkheid, weliswaar niet van de wet in formele zin (de wetten van regering en parlement tezamen) aan de grondrechten in de grondwet, ${ }^{44}$ maar wel van wetten in het algemeen (wetten in materiële zin, met inbegrip van de wet in formele zin) aan de mensenrechten in verdragen, die in Nederland sinds 1953 bestaat (invoering van het huidige art. 94 van de Grondwet ${ }^{45}$ ).

\section{Het institutionele verhaal}

Bovenstaande periodisering, door CLITEUR het eerste - 'institutionele' mensenrechtenverhaal genoemd, vat hij als volgt samen: ${ }^{46}$

'De mensenrechtenidee begint in de wijsgerige begrippenhemel van het natuurrecht. Geleidelijk begint men echter te zien dat we aan het natuurrecht alleen vaste vorm geven wanneer we het codificeren, dat wil zeggen: vastleggen in ge-

Waarbij zowel gewrezen kan worden op GRoTuS' natuurrechtsleer in het algemeen - volgens welke alle recht te herleiden is, niet tot goddelijke of wereldlijke willekeur, maar tot fundamentele rechtsbeginselen die voortvloeien uit de redelijke en sociale natuur van de mens - alsook op, bijwoorbeeld, GROTIUS' opvatting over de humanitaire interventie (zie par. 2.5.2).

43 T.a.p., op p. 884 .

44 Krachtens het toetsingsverbod van art. 120 Grondwet, dat toch wel als een grondrechtelijke anomalie kan worden gezien. En de achterliggende "status" van de formele wet(gever)" (M.G. BOEKHORST, 'Artikel 94,' in: P.W.C. AKKERMANS en A.K. KOEKKOEK (red.), De Grondwet; Een antikelsgewijs commentoar, Zwolle 1992 (tweede druk), pp. 873-887, op p. 880) als een anachronisme. BOEKHORST, t.a.p., op pp. $873-875$.

46 T.a.p., op pp. $884 / 885$. 
schreven documenten. Tenslotte ziet men dat het geschreven document alleen een praktische betekenis heeft wanneer men an de rechter de bevoegdheid toebedeell om te oordelen of de wetten van de statelijke wetgever niet in strijd zijn met het hogere recht.'

Met de introductie van rechterlijke toetsing was volgens CLITEUR het eerste mensenrechtenverhaal 'af.' In Nederland weliswaar pas in 1953, maar in Amerika al anderhalve eeuw eerder, toen, in 1803, Chief Justice MARSHALL, in Marbury versus Madison, de befaamde uitspraak deed dat het rechterlijk toetsingsrecht behoorde tot de very essence of judicial duty. ${ }^{47}$

Parallel aan de periodisering natuurrecht-documenten-toetsingsrecht is evenwel nog een ander, een tweede mensenrechtenverhaal denkbaar.

\subsubsection{Het tweede mensenrechtenverhaal}

\section{Het homo sapiens-verhaal}

Naast het eerste mensenrechtenverhaal is er - in de opvatting van CLITEUR - nog een tweede mensenrechtenverhaal, dat in de tijd parallel aan het eerste verloopt: het homo sapiens-verhaal, het verhaal van de historische uitbreiding van de 'sociale soort homo sapiens':48

\footnotetext{
"We weten nu dat er een biologische soort homo sapiens is en een sociale soort homo sapiens. Wie tot de eerste categorie behoort, behoort nog niet tot de laatste categorie. Slaven, vrouwen, kinderen, zwarten, gelen, bruinen, roodhuiden - eeuwenlang was op hen de kwalificatie "mens" niet van toepassing."
}

We hebben hierboven gezien dat Olympe DE GOUGES met haar Verklaring van de rechten van de vrouw en de burgeres (1791) aandacht vroeg voor het standpunt dat De Verklaring van de rechten van de (mannelijke) mens en de burger (1789) zich ook tot de vrouwelijke mens diende uit te strekken. Als de vrouw het recht heeft het schavot op te gaan, dan moet zij ook het recht hebben het spreekgestoelte te beklimmen, zo stelde zij. Het is meer dan de ironie van het lot geweest dat haar binnen de kortste keren het eerste recht werd gegund. Zoals we hebben gezien, stierf zij in 1793 onder de guillotine.

Dadelijk in het begin van hoofdstuk 1 hebben we gezien hoe volgens de wetenschappelijke inzichten van antropologen die onze (over-) van het staatsrecht, Deventer 1994 (zevende druk), Pp. 256-257. 
grootouders hadden kunnen zijn, de vrouw een wezen was dat een middenpositie innam tussen kind en man, "welke laatste de eigenlijke mensch is." De vrouw was minder dan een volwaardig mens - en het kind nòg minder. Deze gedachte, hoewel formeel in $1945^{49}$ verlaten, heeft nog lang daarna doorgewerkt. De emancipatie van de vrouw uit de maritale macht heeft in Nederland tot 1957 (lex-Van Oven) op zich laten wachten.

Het lot van vele miljoenen Afrikaanse slaven tot ver in de negentiende eeuw zou, gezien Nederlands rol als slavenhandelsnatie, ${ }^{50}$ voor een Nederlander een historische last horen te zijn vergelijkbaar met de historische last van het nazisme voor de Duitser, een last die eerder verlicht wordt door de vergetelheid van de tijd dan door de nationale worsteling met een weinig verheffend verleden. In dat opzicht lijkt de Nederlander tegenover de Duitser enkel de voorsprong te hebben zo niet van de genade dan toch van het gemak van de latere geboorte.

VAN DEN HEUVEL is een van de weinigen die op de verborgen achterkant van de vaderlandse geschiedenis, en de rol van de driekleur, heeft gewezen: ${ }^{51}$

Preambule HVN, tweede overweging: 'Wij, de volken van de Verenigde Naties, vastbesloten (...) opnieuw ons vertrouwen te bevestigen in de fundamentele rechten van de mens, in de waardigheid en de waarde van de menselijke persoon, in gelijke rechten woor mannen en wrouwen (...).'

50 Het Nederland van de gouden eeuw is wel "het zakelijk hoofdkwartier van de slavenhandel" genoemd. Curaçao was "een van de belangrijkste slavendepots van de Amerika's.' Om de wreedheid Jegens slaven was Suriname berucht. Zie: Jan NEDERVEEN PIETERSE, Wit over zwart, Beelden van Afrika en zwarten in de westerse populaire cultuur, Amsterdam/Den Haag 1990, pp. 55 en 56.

In een uitgebreide studie van de Nederlandse Atlantische slaventhandel merkt POSTMA op: "The experience [of slaves in transit] has been likened to the concentration camps in Nazi Germany, except that the Africans' enslavement was motivated by economic profit and not by racial hatred or genocide.' Niettemin concludeert hij:: '(...) [T] The overall loss to the enslaved population may' well have reached 70 percent before the survivors were adjusted to life in the Western Hemisphere." Van de door Nederland vervoerde slaven stierf ca. 15\% tijdens de overtocht. De Nederlanders transporteerden ongeveer 550.000 Afrikanen, 5\% van het totaal. Op de ranglijst van slavenhandelsnaties stond Nederland op de vierde plaats, na Engeland, Portugal en Frankrijk. Gedurende enkele jaren in de zeventiende eeuw evenwel the Dutch may well have been the largest Atlantic slave vendors." (Johannes Menne POSTMA, The Dutch in the Atlantic slave trade 16001815, Cambridge etc. 1990 , resp. pp. $300,258,302$ en 303.)

51. Aad VAN DEN HEUVEL, Willem BOSMAN in goud en slaven, Amsterdam 1981, p. 12. Overigens verwijst POSTMA (The Dutch in the Atlantic slave trade, a.w., p. 11) - en na hem "THOMAS (zie hierna) - al naar een zeer vroeg Nederlands protest tegen onze slavenhandel:

'Onmenselijk gebruik! Godloze schelmerij!

Dat men de mensen vent, tot paardse slavernij! 
"Er zijn dingen waar men maar liever niet over spreekt, bedekt met de mantel van de tijd, uit de geschiedenisboekjes geweerd. Bijna drie eeuwen vaderlandse geschiedenis op afstand zijn verdonkeremaand, weggemoffeld. Maar de slavenschepen woeren en hun vlag was bekend.'

Joden, geesteszieken, dissidenten

Niet alleen vrouwen of Afrikanen waren tot voor kort geen volwaardige mensen. Tot mei 1945 gold dit, in elk geval in Duitsland, ook voor joden, zigeuners en geesteszieken. ${ }^{52}$ En waren in de voormalige Sovjet-Unie

Hier zijn er ook in siad, die zulk'n handel drijen,

in Famabock: maar 't zal God niet verholen blijven.'

(Gerbrand Adriaensz BREDERo, Moortje (Amsterdam 1615), regels 233-236, Het Nationale Toneel Den Haag, Amsterdam 1993, pp. 15/16.) VAN DIS (verwijzend naar Hugh THOMAS' The slave trade [The history of the Atlantic slave trade 144018707, New York 1997) noemt deze regels "het eerste literaire verzet tegen de slavenhandel' en voegt daaraan toe: 'Al vanaf het begin van de Europese slavenhandel gingen er in Nederland stemmen van protest op, vooral theologen roerden zich in het debat, maar uiteindelijk won gewin toch van God. De Amsterdanse slavenkooplui hebben nooit in hoog aanzien gestaan; vandaag zou je de wijze waarop ze hun kapitaal vergaarden, nog het best kunnen vergelijken met de mores van onze drugsbaronnen. Hoe opmerkelijk is het niet dat hun erven zich thans tot het patriciaat mogen rekenen en dat zij de negerhoofden boven hun museale grachtenpanden op kosten van monumentenzorg laten opzwarten. Zo koestert ieder zijn eigen geschiedenis.' (Adriaan VAN DIS, 'De slavernij voorbij,' in: Frits VAN OOSTROM (red.), Historisch tableau; Geschiedenis opnieuw verbeeld in schoolplaten en essays, Amsterdam 1998, pp. 97-105, op pp. 102/103.)

Overigens is de directe aanleiding voor het vlammende protest in Moortje de dreigende verkoop aan '(...) Turken of Barbaren' van een blanke slavin: 'Dat witte meisje, dat daar ginder zit en schreit' (regels 232 en 273). Moortje (Negra) is een zwarte slavin, gekocht en aan zijn liefje cadeau gedaan door hetzelfde personage dat de Hollandse paardse (wij, gemotoriseerde paardenvrienden, zouden zeggen: hondse) slavenhandel in Farnabock (Pernambuco, Brazillié) fel veroordeellde: 'Onmenselijk gebruik! Godloze schelmerij! Dat men de mensen vent, tot paardse slavernij!

52 Alice MLLER oppert de mogelijkheid van een verband tussen de Duitse euthanasiewetgexing en het feit dat 'vanaf zijn geboorte, zijn hele kindertijd lang' een schizofrene, gebochelde tante in het gezin woonde waarin HITLER door zijn despotische, gewelddadige vader en slaafse moeder werd 'opgevoed.' Uiteraard geldt dit verband niet de enkele aanwezigheid van deze tante, maar het spreekverbod, of liever: het 'gevoelsverbod' daaromtrent: "Ook de aanwezigheid van een schizofrene tante kan door een kind positief verwerkt worden, maar alleen wanneer het met zijn ouders op emotioneell niveau vrijuit kan praten en zijn angsten met hen kan bespreken.' Ten overvloede waarschuwt MLLER dat het onderzoeken van deze en dergelijke verbanden op geen enkele manier als een "verontschuldiging" van HITLER daden mag worden opgevat. (Alice MLLER, In den beginne was er opvoeding, Bussum 1983 (derde druk), pp. 187-188.) 
en zijn vandaag in China dissidenten wel meer dan Untermenschen?

\section{Het lot van het kind}

Worden kinderen tegenwoordig wel alom als mensen beschouwd? En als mens behandeld? Wat is vandaag het lot van het kind? Niet alleen het kind ver weg, dat in Brazilië op straat wordt afgeschoten, of dat in Thailand of op de Filippijnen een Nederlander aan zijn gerief moet helpen, maar - om te beginnen - het kind in eigen land? VAN DANTZIG heeft enkele jaren geleden - met betrekking tot het sexuele misbruik van kinderen in ons land, maar zijn betoog kan in essentie ook op andere vormen van kindermishandeling worden betrokken, of daartoe worden uitgebreid - opgemerkt: ${ }^{53}$

'Op dit moment zijn duizenden, misschien wel tienduizenden kinderen in Nederland weerloos blootgesteld aan seksuele benadering door volwassenen, die jaren heeft geduurd of zal gaan duren. Het betreft vooral meisjes, maar toch ook een paar honderd [intussen weten we: enkele duizenden, ${ }^{54}$ jw] jongens. (..) [Zij] komen uit alle lagen van de bevolking, wat betekent bij $\mathrm{u}$ en mij uit de straat.

Tot voor kort wist niemand dit; dat het bekend geworden is, is én van de vele verworvenheden van de vrouwenemancipatie. (...) Binnen het incestgezin wordt er over gezwegen - al is het veelal bekend aan de moeder, en soms ook aan andere kinderen. Er wordt ook naar buiten toe over gezwegen (...).

Wil men ooit een werkelijke oplossing van het incestprobleem bereiken, dan moet men zich bezinnen op de maatschappelijke structuren die mogelijk maken dat het ontstaat, en vooral dat het zo lang onzichtbaar is gebleven. Het kon onzichtbaar blijven omdat aan het gezin, aan de ouders, de verantwoording voor de opvoeding is toevertrouwd. Dit lijkt vanzelfsprekend, is zelfs heel lang gezien als onderdeel van de goddelijke orde, maar is in wezen een maatschappelijke keus. Het is de gemeenschap die [haar] verantwoordelijkheid tegenover het kind als staatsburger uitoefent door de ouders aan te wijzen als de belangenbehartigers van het kind. Daarmee is ook gezegd dat de gemeenschap de ouders daar in principe toe in staat acht. Pas bij gebleken ongeschiktheid van de ouders grijpt de gemeenschap in. En nu blijkt dat deze maatschappelijke opstelling in duizenden gevallen leidt tot ongeweten marteling van kinderen. Alleen daarom al zou incest moeten leiden tot herbezinning op de maatschappelijke positie van kinderen. Kinderen zijn niet automatisch veilig bij hun ouders.

(...) Uit onderzoekingen van incestgezinnen blijkt steeds weer dat de ouders in dergelijke gezinnen ongelukkige, karakterologisch deficiënte mensen zijn, zelf

A. VAN DANTZIG, "Vraagtekens bij ouderliefde; Hulpverleners en incestslachtoffers door Jos FRENKEN en Bram VAN STOLK, (Deventer) 1987 (...), ' boekbespreking in het Zaterdags bijwoegsel van NRC Handelsblad van 16 januari 1988 (curs. jw).

Vgl. Ron VAN OUTSEM, Seksueel misbriik van jongens, Amsterdam 1992, pp. 2932; Bijlage 1, pp. 165-170. 
vaak incest- en geweldsslachtoffers, voor wie de incestueuze en/of [fysiek of emotioneel, jw] gewelddadige relatie met het kind een manier is om zich een compensatie aan macht en liefde te verwerven die ze buitens- en binnenshuis in de volwassen wereld schromelijk te kort komen. Het lijkt me duidelijk dat dergelijke ouders, 6ok wanneer ze niet tot incest of lijfelijk [en psychisch, jw] geweld overgaan, zelf geen leven hebben, en het hun kinderen niet kunnen geven.

Waar ik nu over spreek, zijn grote maatschappelijke processen, die men niet even kan invoeren. Maar men zou een begin kunnen maken. Schoolartsen zouden verplicht kunnen worden, na daar eerst voor opgeleid te zijn, actief te zoeken naar incest en geweld, en daarover ook meldingsplichtig moeten zujn. Ouders zouden verplicht kunnen worden om een daaruit voortwloeiend gezinsonderzoek toe te staan. Voor wie dat een ridicuul voorstel vindt: dit gebeunt al bij adoptiekinderen. Hun ouders worden zorgvuldig getoetst en vooral, zover mogelijk, begeleid. Wie nu meteen aan de nadelen van zo"n voorstel denkt, plaatse die naast de madelen van incest. Wanneer AMNESTY INTERNATIONAL zou berichten dat in Nederland tienduizenden gevangenen dagelijks en jarenlang gemarteld worden, zou ons land zonder meer naast Chili, Zuid-Afrika en de Sovjet-Unie geplaatst worden. En dit is precies wat er gebeurt.'

\section{Is het tweede mensenrechtenverhaal 'af'?}

Het was nodig VAN DANTZIG zo uitgebreid aan het woord te laten ondat ten aanzien van kinderen vraagtekens kunnen worden geplaatst bij de conclusie van CLITEUR: ${ }^{55}$

'Het tweede verhaal van de mensenrechten is dus een verhaal over erkenning. Langzaam aan gaat men alle subcategorieën van de biologische soort Homo Sapiens als mensen in de zin van ethisch gelijkwaardig en onderworpen aan hetzelfde mensenrechtenregime erkennen. Blank of zwart; man of vrouw; kind of volwassene - het zijn allen mensen. (...)

[I]ncidentele oprispingen daargelaten, lijkt het erop dat ook het tweede verhaal "af" is. Let wel: ik heb het niet over de implementatie. Ik heb het over het intelllectueel dominant worden van een idee: mensenrechten gelden werkelijk voor alle mensen.'

CLITEURs tweede mensenrechtenverhaal kan met betrekking tot kinderen misschien beter verteld worden onder de titel horizonverbreding en perspectiefverschuiving.' We kunnen dan zien dat zijn visie wel klopt met betrekking tot de horizonverbreding, maar niet met betrekking tot de perspectiefverschuiving. Deze laatste is ook nog vereist wil het verhaal van de rechten van het kind 'af' zijn. En inderdaad." over de implementatie hebben we het dan nog (lang) niet. 
Onder horizonverbreding kan dan worden verstaan: de verschijning van het kind vanachter de horizon van de rechtssubjectiviteit; in de terminologie van CLITEUR: de erkenning van het mens-zijn van het kind. Helaas blijkt die horizon gedeeltelijk verduisterd te zijn. Het gordijn van de parentiarchie belet het zicht op het kind-als-mens binnen het gezin, belet het zichtbaar worden van het kind-als-mens achter de ramen van het gezin. De ramen op hun beurt werken, als de gordijnen al eens opengaan, als een dikke glasplaat die het perspectief toebuigt naar de ouders. Vanuit dat ouderlijk perspectief lijken de rechten van het kind binnen de gezinssfeer 'per definitie' gewaarborgd. Elke ouder houdt immers van zijn kind.

Helaas zijn er ook zieke vormen van liefde, vormen die te zeer met eigen onverwerkte jeugdtrauma's zijn verweven, vormen waarin onmacht, vermenigvuldigd met onwetendheid en isolement, met een alom in de kou staan, de liefde tot een ambivalent gif heeft gemaakt; hoe dan ook: vormen van ouderliefde die het kind niet tot zijn recht doen komen. Helaas is het gezin voor het kind niet altijd een veilige plaats, het warme nest waarin het kan gedijen, maar een arena van fysiek, verbaal, geestelijk geweld, dat diepe, en vaak blijvende wonden achterlaat.

Waarom lijkt de horizonverbreding die de biologische soort homo sapiens, na een strijd van eeuwen, in beginsel in staat heeft gesteld tot mede-leven en mede-lijden met al zijn soortgenoten, vrouwen en vreemdelingen incluis, voor het mensenkind maar niet tot het juiste perspectief te leiden: een verschuiving wèg van het parentiarchale 'valse' perspectief, een perspectiefverschuiving die het mensenrechtenverhaal ook ten opzichte van het kind 'af' zou maken? Om een antwoord op die vraag te vinden, is het nodig en nuttig opnieuw VAN DANTZIG uitgebreid aan het woord te laten. In 1992 schreef deze: ${ }^{56}$

"De mythe dat gezinnen zijn zoals ze horen te zijn, belet bijwoorbeeld dat er een bevolkingsonderzoek naar incest gedaan wordt, zoals dat zeker gebeurd zou zijn als bekend was dat duizenden kinderen in Nederland aan een (andere) ernstige ziekte leden, (van wie) er maar enkelen gevonden waren. Dan zou een gezin zich geholpen gevoeld hebben in plaats van ontmaskerd - en wie van ons is bereid het masker af te leggen, zelfs om een kind, duizenden kinderen, van de beul te redden? (...) (W)ij kunnen onze huizen niet openstellen voor onderzoek omdat Geestelijke volksgezondheid 1992/5, pp. 568-571, op pp. 569 1.k. en 570 1.k. (curs. jw). 
wij ons schamen voor onze geheimen. Dat nowmen we dan respect vragen voor onze privacy, de privacy van ons gezin. (...)

[We zien wat met kinderen gebeurt] niet als cen bewijs dat er tets mis is met het systeem dat zulke dingen kunen gebeuren. Onze gedachte is niet in de eerste plaats: dat kan ook niet, weerloze kinderen aan de eerste de beste toevertrouwen, je hebt geen enkele garantie dat daarvan geen misbruik gemaakt wordt. Zo vanzelfsprekend is voor ons de positie van het kind bij zijn ouders dat gevallen waarin het fout gaat, in de eerste plaats vanuit de psychologie van de ouders en het kind worden gezien, en niet (...) vanuit het systeem waarin de mensen moeten leven.'

Met betrekking tot dat 'systeem' had VAN DANTZIG in 1989 een belangrijk geluid laten horen (waarbij hij tevens de lijn van 'incest' doortrekt naar andere vormen van kindermishandeling).57

'Wanneer incidenteel bekend wordt dat arrestanten op het politiebureau of gevangenen in de gevangenis gemarteld worden, wordt dat belefd als een schending van de mensenrechten, waartegen de natie in het geweer treedt, on waar zo nodig internationale organisaties zich mee gaan bemoeien. Een systeem waaronder het martelen van gevangenen mogelijk is, wordt maatschappelijk niet geaccepteerd. Maar tot voor kort gaf het bekend worden wan een geval wan incest eigenlijk nooit aanleiding tot zo'n principiëlle stellingname. De vraag: "Zijn de rechten van kinderen in de huidige bedeling wel woldoende gewaabongd?" werd niet gesteld. Dat kwam niet omdat niemand geinteresseerd is in de rechten van kinderen [dat wil zeggen: buiten het gezin, of buiten de landsgrenzen, jw], verre van dat. Het kwam, denk ik, omdat de algemeen geldende maatschappelijke opvatting is dat de rechten van kinderen wolledig gewaarborgd zijn door hun ouders. Die ouders zijn dan, volgens die opvatting, ook in staat de plichten te vervullen die uit die rechten van kinderen voortvloeien. Ouders die dat niet kunnen, zijn dan uitzonderingen die als zodanig behandeld worden; ze worden bijwoorbeeld uit de ouderlijke macht ontzet. De maatschappelijke consensus over dat model is zo groot dat het geldt voor alle betrokkenen: hulpverleners, ouders, kinderen, de hele maatschappij. Incest kon dus niet als maatschappelijk probleem zichtbaar worden ondat er geen probleem was; alles was al geregeld. $Z 0$ is diefstal ook niet cen aanleiding om het principe van de eigendom onder de loupe te nemen.

Het slaan van gevangenen roept principieel verzet op, omdat dan twee maatschappelijk erkende systemen botsen: strafoplegging en mensenrechiten. (Onder "system" versta ik dan een samenlevingsvorn waarin een aantal waarden zo vanzelfsprekend voor juist wordt gehouden dat verschijnselen die ook binnen die samenlevingsvorm voor ongewenst worden gehouden, miet aan het functioneren van die waarden kunnen worden loegeschreven.) Incest is onzichtbaar gebleven omdat

57 A. VAN DANTZIG, "DRAIJER, Nel - Sexued misbruik van meisjes door verwanten; of: Incest: hoe is het mogelijk,' Gezin;, Tijdschrift voor primaire leefvormen 1989/4, pp. 235-238, resp. op pp. 235/236 (curs. jw). Ook opgenomen in: Psychotherapie - een vak apart; Opstellen over mogelijkheden en grenzen van psychotherapie, Meppel/Amsterdam 1990, pp. 160-167 (citaten op pp. 161-163). 
er niet zo'n botsing van systemen door geactiveerd werd, het mishandelde kind werd niet representatief woor cen werkeerd werkend systeem, de vanzelfsprekendheden waardoor de maatschappelijke positie van kinderen bepaald wordt, werden geen onderwerp van maatschappelijke discussie. Dat er tegenwoordig zo veel aandacht voor incest is, dat een onderzoek als dat van [Nel] DRAUER gedaan kon worden, duidt er op dat er nu well zon systeem-botsing aan de hand is, en datt incest nu niet mee incidenteel gezien wordt, maar als een maatschappelijk ontoelaatbaar verschijnsel. En inderdaad: het onderzoek, en de interesse voor incest in zijn geheel, zijn een verschijnsel van een belangrijke maatschappelijke stroming: de vrouwenemancipatie. En niet van een intrinsieke belangstelling voor de rechten van het kind. Het is dan ook niet toevallig dat incest als onderwerp is gekozen, en niet bijwoorbeeld geweld. Dat is niet sexe-specifiek, en werd daarom niet zichtbaar gemaakt door die maatschappelijke stroming. Incest is, door de vrouwenemancipatie, wèl, geweld tegen künderen niet gepolitiseerd. Zolang incest niet politiek geduid kon worden, moest het als maatschappelijk verschijnsel verborgen blijven, en geweld tegen kinderen zal dat blijven zolang het niet gezien zal worden als een symptoom van een verkeerd werkend systeem, in het licht van een alternatief systeem - zollang het niet gepolitiseerd is.

Hier wordt duidelijk hoe een fenomeen dat zichtbaar wordt doordat het zijn plaats krijgt in een maatschappelijk relevante optick, door die zelfde optiek zijn grenzen krijgt toegewezen. Aam de grenzen van de incest met meisjes ziet men al de incest met jongens, en in het algemeen lichamelijke en geestelijke mishandeling van kinderen, contour krijgen. Maar dat zal onzichtbaar blijven totdat het representatief geworden zal zijn woor een politiek programma, wat dan wil zeggen: totdat de ongewenste verschijnselen worden gezien als voortvloeiend wit het functioneren van waarden die vanzelfsprekend voor juist werden gehouden.'

VAN DANZTG gewaagt in dit citaat van een systeem van vanzelfsprekende waarden. Privacy, ouderrechten, ouderliefde, het gezin kunnen als zulke systeem-waarden worden gezien: waarden die het systeem gesloten houden. Dat systeem is hierboven al enkele malen als parentiarchie aangeduid. Parentiarchie is het systeem dat het lijden van kinderen binnen het gezin 'toedekt'; dat de schending van de rechten van het kind door de ouders "afdekt." Dat de ouders beschermt, en kinderen afschermt. Dat de achterkant van het gezin verborgen houdt. Dat gezinsgeheimen, en daarmee een diepe menselijke tragiek, in stand houdt.

Parentiarchie is $66 \mathrm{k}$ het systeem dat ons belet te zien dat opvoedingsverantwoordelijkheid een zaak niet alleen van individuele ouders/ ouderparen is, maar een zaak van àlle ouders, van àlle volwassenen, van de hele samenleving. Parentiarchie is het systeem dat ons belemmert te zien dat opvoeding ook een gedeelde maatschappelijke verantwoordelijkheid is. En dat de verwezenlijking en handhaving van de rechten van het kind binnen het gezin tot het domein behoren van de politiek en van het recht. 


\section{Discussie}

Ik stel dus ter discussie of ten aanzien van kinderen het mensenrechtenverhaal wel zo 'af' is als CLITEUR lijkt te beweren. Het verhaal is wellicht àf in potentiële zin, dank zij (de achterliggende waarden van en de aanknopingspunten in) het Verdrag inzake de rechten van het kind; maar nog (lang) niet in concrete conceptuele zin, qua maatschappelijke houding, qua mentaliteit. Althans als het gaat om de positie van het kind in het gezin. Hier dient voor het grootste gedeelte de revolutionaire idee van het kind als drager van rechten, te handhaven ook tegenover de eigen ouders, nog door te breken, en vervolgens geoperationaliseerd te worden.

Met andere woorden: de horizonverbreding heeft wèl plaats gevonden: we hebben een steeds scherper oog voor de positie van het kind buiten het gezin, als slachtoffer bijvoorbeeld van pedofielen (waarmee dan niet incestvaders worden bedoeld); en voor het kind ver weg, in Brazilië of op de Filippijnen. Maar de perspectiefverschuiving nog niet: we zien nog niet dat het in de eerste plaats om de rechten van het kind, om het recht van het kind op veiligheid en persoonswording gaat, en pas daarna, in de tweede plaats, om de privacyrechten van ouders. Dat wil zeggen dat het er primair om gaat de rechten van het kind vanuit het perspectief van het veiligheids- en ontwikkelingsbelang, vanuit het persoonswordingsperspectief, te bezien. Dat het dus primair gaat om vragen (en om de rechterlijke toetsing daarvan) als: kunnen in dit gezin de rechten van het kind worden gewaarborgd? Heeft het kind in dit gezin hulp van buiten nodig? Heeft hulp in dit gezin zin? Moet hulp worden opgelegd? Moet hulp buiten het gezin worden opgelegd (bij een pleeggezin? in een instelling? - afhankelijk van wat pedagogisch noodzakelijk/wenselijk is).

Het gaat om rechterlijke toetsing, dus om rechterlijke beslissingen, waarin ook de belangen van ouders worden meegewogen, waarin ouders net zo goed als het kind (c.q. de hulpverlener van het kind) worden gehoord. Maar getoetst wordt aan het recht van het kind op persoonswording, dat recht moet (minimaal) zijn gewaarborgd, of anders/elders (optimaal) worden veilig gesteld.

Veeleer dan een (radicaal) ander systeem is daar, in mijn optiek, een andere mentaliteit voor nodig, een andere kijk op de werkelijkheid: een perspectiefverschuiving, nu de buit van de horizonverbreding, althans in het rijk van de ideeën, binnen is.

\section{De menselijke mogelijkheid tot lijden}

CLITEUR onderscheidt nog een derde verhaal: het verhaal van de uitbreiding van de 'mensenrechten' tot niet-menselijke levensvormen (denk aan 
dierenbescherming 'versus' dierenrechten). Een verhaal dat zeer zeker nog niet 'af' is - en dat in sommige moderne oren net zo 'maf' klinkt als het verhaal van vrouwenrechten klonk in de oren van tijdgenoten van Olympe DE GOUGES' Déclaration des droits de la fermme et de la citoyenne, (1791) of, CLITEUR wijst erop, ${ }^{58}$ van Mary WOLLSTONECRAFTs Vindication of the rights of woman (1792). ${ }^{59}$

Van cruciaal belang acht ik evenwel de rechtsgrondslag voor dit derde verhaal. Deze wordt niet zozeer gezocht in de waardigheid van het dierlijke etc. leven, maar in de mogelijkheid tot lijden: 'The question is not, Can they reason? nor Can they walk? but, Can they suffer?' (Jeremy BENTHAM, 1780/1789, aangehaald door CLITEUR. ${ }^{60}$ )

De mogelijkheid tot lijden (bij CLITEUR: 'het vermogen tot lijden') impliceert de - menselijke - mogelijkheid lijden, voor medemensen èn voor andere wezens, te verzachten of zelfs te voorkomen. Een 'lelijke' kakkerlak doodtrappen, of een 'lastige' vlieg doodslaan is dan, omdat en voor zover kakkerlakken en vliegen kunnen lijden, in strijd met de rechten, i.c. het recht op leven, van deze - overigens onmiskenbaar uiterst complexe - levensvormen.

Er zal wel niemand (meer) zijn die het vermogen tot lijden van kinderen, zelfs van baby's, of van foetussen, waagt te ontkennen. Ontkend wordt veeleer, en op grote schaal (óók maatschappelijk, juist maatschappelijk), dat kinderen daadwerkelijk lijden door toedoen van hun eigen ouders. Ouders die immers door de band van 'natuurlijke liefde' met hun kind verbonden zijn. Maar die soms uit onmacht mishandelen. Alsof die onmacht het lijden van kinderen verzacht. Alsof die onmacht - juridisch, mensenrechtelijk gezien - ouderlijke almacht ( $I k$ doe met mijn kind wat $i k$ will') rechtvaardigt. Alsof onmacht-en-almacht de prijs zijn die kinderen moeten betalen voor de maatschappelijk - in beginsel terecht - gekoesterde waarde van de privacy, of voor de maatschappelijk - onterecht elders liggende financiële prioriteiten.

Onterecht, art. 4 van het Verdrag inzake de rechten van het kind (VRK) bepaalt immers (curs. jw.):

De staten die partij zijn, nemen alle passende wettelijke, bestuurlijke en andere maatregelen om de in dit Verdrag erkende rechten te verwezenlijken. Ten aanzien van economische, sociale en culturele rechten nemen de staten die partij zijn, deze maatregelen in de nimste mate waarin de hun ter beschikking staande middelen dit toeloter en, indien nodig, in het kader van internationalle samenwerking.

T.a.p., op pp. $887 / 888$.

60 T.a.p., op p. 890. 
Speciesisme, ageïsme en art. 3 EVRM

Overigens is het opmerkelijk dat er al wel een term bestaat voor het ongerechtvaardigd onderscheid maken tussen mensen en dieren: speciesis$m e,{ }^{61}$ terwijl voor het ongerechtvaardigd onderscheid maken tussen kinderen en volwassenen een term moet worden geleend die eigenlijk vooral ziet op leeftijddiscriminatie ten aanzien van ouderen: ageïsme. ${ }^{62}$

Dit 'ageïsme' (overgenomen uit het Engels ${ }^{63}$ ) is in het bijzonder navrant met betrekking tot art. 3 van het Europees Verdrag tot bescherming van de rechten van de mens en de fundamentele vrijheden (EVRM): het verbod van onmenselijke of vernederende behandeling of bestraffing, toegepast, of liever: niet toegepast, op het gezin. DoEK heeft zich al eens, in een discussie over de invoering van een meldingsplicht ter zake van kindermishandeling, bijna vertwijfeld, afgevraagd of we dit artikel maar niet beter uit ons recht konden schrappen: ${ }^{64}$

"Het invoeren van een meldingsplicht kan deze situatie ingrijpend veranderen. De discussie daarover zal om te beginnen de beleidsmakers en politici confronteren met de vraag of, en zo ja in welke mate, zij bereid zijn kindermishandeling als een serieus en ernstig probleem aan te pakken en daarvoor ook de benodigde middelen ter beschikking te stellen. Dit hoeft niet noodzakelijk te leiden tot weer meer grote uitgaven; men zou ook kunnen trachten de bestaande middelen anders [DoEK bedoelt: minder verkokerd, en dus verkwistend, jw] aan te wenden.

In elk geval zal de meldingsplicht beleidsmakers en politici dwingen tot een duidelijke en minder vrijblijvende standpuntbepaling dan tot nu toe. Immers, in de discussie over [een] meldingsplicht zall hoe dan ook de vraag centraal staan of men bereid is thet meest waarschijnlijke gevolg van [een] meldingsplicht - een toename van bekend geworden gevallen van (seksuele) kindermishandeling - van passende hulp te woorzien. Of geeft men er de voorkeur aan de problemen van (incest)slachtoffers pas te behandelen nadat ze alles achter de rug hebben? Zo ja,

CLTTEUR, t.a.p., op p. 890 i.f.

62 Zie woor deze term: H. VAN MAARSEVEEN, 'Ageism (age + ism),' NJB 1987, p. 501; reactie met naschrift: pp. 729-730.

Wellicht zou het beter zijn deze door VAN MAARSEVEEN gepropageerde term (ageisme, uit te spreken als: eedzjisme), ter aanduiding van leeftijddiscriminatie ('iemand benadelen vitsluitend wegens zijn leeftijd. Ageistisch handelen noemen we dat: VAN MAARSEVEEN, 'Vooroordelen over leeftijd zijn nog wijd verspreid," Open Forum, De Volkskrant 16 mei 1987), wegens thet anglicistische karakter ervan, te vervangen door de term aevisme (of evisme), afgeleid van het Latijnse aewum (is leeftiyd, ouderdom). De term 'aevisme' dient dan als algemene term voor leeftijddiscriminatie dienst te doen. Voor zover men naar leeftijd wil differentiëren, zouden ter aanduiding van respectievelijk kinder-, jeugdigen- en ouderendiscriminatie de termen infantilisme, juvenilisme en senilisme geintroduceerd kunnen worden.

J.E. DOEK, 'Meldingsplicht, ja of nee?' In: H. BAARTMAN e.a., Incest en hulpverlening, Amersfoort/Leuven 1990, pp. 274-279, op p. 276. 
zullen we dan artikel 3 wan het Europees Verdrag voor de rechten van de mens maar uit ons recht schrappen?"

Art. 3 EVRM kàn niet uit ons recht - of überhaupt uit het recht - worden geschrapt: het is nauwelijks nog omstreden dat het de status van jus cogens, van dwingend internationaal recht, in de zin van art. 53 Weens Verdragenverdrag, heeft verkregen. De staat schendt art. 3 EVRM $606 \mathrm{k}$ als hij zijn burgers onvoldoende effectief tegen onmenselijke of vernederende behandeling door andere burgers beschermt. Aangezien art. 3 een absolute norm is, kan er nimmer een rechtvaardiging zijn voor schending van deze norm. ${ }^{65}$ Op de cri de coeur-vraag van DOEK is dan ook maar éen antwoord mogelijk: het centraal stellen van art. 3 EVRM, van het wreedheidsverbod, 6́6k binnen het gezin. De harde kern van om het even welk recht van het kind zou toch het wreedheidsverbod dienen te zijn. Om die harde kern te zien, is evenwel nodig: het verschuiven van het perspectief van ouderlijke rechten naar de rechten van het kind.

\section{Perspectiefverschuiving}

De perspectiefverschuiving van (privacy-)rechten van ouders naar (persoonswordings-) rechten van kinderen: het zal even wennen zijn. Net zoals we nog moeten wennen aan de gedachte van een 'Universele Verklaring van de [rechten van] Levende Wezens,' welke CLITEUR ${ }^{66}$ voor 'over vijftig jaar' voorspelt. De mens is een gewoontedier. We kiezen eerder voor wat we gewend zijn, zelfs als dat lijden is, dan voor het onbekende. Zoals de Amerikaanse Onafhankelijkheidsverklaring het al aanduidde: ${ }^{67}$

[A]ll experience hath shown, that manikind are more disposed to suffer, while evills are sufferable, than to right themselves by abolishing the forms to which they are accustomed.'

Vgl. Oscar SCHACHTER, Intemational law in theory and practice, Dordrecht (etc.) 1991, pp. 211-212 ('torture or other inhuman treatment' als enga ommes-verplichting); vgl. ook a.w., pp. 338, 342-344; Theodor MERON, Human rights and humanitarian noms as customary law, Oxford 1989, pp. 162-171 ('due diligence'); T.P. SPLJKERBOER; B.P. VERMEULEN, Vhuchtelingenrecht; Serie Migratierecht III, NCB Utrecht 1995, pp. 189-190 (art. 3 EVRM als absolute norm; foltering/onmenselijke behandeling); alle(n) met vindplaatsen in doctrine of jurisprudentie. Zie verder hoofdstuk 13.

67 Overgenomen uit: F.H. VAN DER BURG, H. BOELS, Tweehonderd jaar rechten van de mens in Nederland, Leiden 1994, p. 33. 
Terecht verwijst CLITEUR ${ }^{68}$ op het punt van de macht der gewoonte naar John Stuart MILL (De onderwerping van de vrouw, 1869), die, even na de door CLITEUR aangehaalde passus, nog op een ander mechanisme wijst, dat mutatis mutandis op de situatie van kinderen kan worden (en in feite door MILL wordt) toegepast: ${ }^{69}$

'In geen ander geval (behalve bij een kind) wordt iemand die gerechtelijk bewezen letsel is toegebracht, weer onder de macht geplaatst van de persoon die zich aan die mishandeling heeft schuldig gemaakt. Als gevolg hiervan durven vrouwen, zelfs in de meest extreme en langdurige gevallen van mishandeling, bijna nooit gebruik te maken van de wetten die voor hun bescherming zijn gemaakt. En mochten zij in een moment van onbedwingbare verontwaardiging of door toedoen van buren hiertoe overgaan, dan spannen zij zich naderhand tot het uiterste in om het zoveel mogelijk geheim te houden en smeken dat hun tiran zijn welverdiende straf ontloopt."

Er is echter één verschil. Mannen en vrouwen onder een dictatoriaal regime, vrouwen onder de dictatuur van hun man kùnnen er, in principe, voor kiezen het lijden waaraan zij 'gewend' zijn geraakt, te vervangen door de angst voor de daad van verzet en de onzekerheid van de gevolgen. Een klein kind heeft die - principiële - keuze nooit.

Exit jus ad tormentum: op weg naar 'humanitaire interventie' in het gezin?

Zoals we hierboven zagen (par. 2.2.2) was er vóor de tweede wereldoorlog sprake van een soeverein jus ad bellum (statelijke oorlogsvrijheid), alsook van een soeverein jus ad tormentum: een niet door het internationale recht beperkte vrijheid van de staat de eigen onderdanen te vexeren - in de woorden van HEHIR: 'the right of the sovereign state to be monstrous to its citizens. ${ }^{70}$

Vijftig jaar geleden werd, als reactie op die tweede wereldoorlog, de VN opgericht vanuit de idealen: nooit meer oorlog en nooit meer barbarij, nooit meer die aantasting à outrance van de menselijke waardigheid: het racisme en de genocide die in Duitsland waren geculmineerd in

T.a.p., op p. $890 \mathrm{nt} .25$.

69 John Stuart MILL, De onderwerping van de vrouw, ed. Londen 1929, vert. Meppel/ Amsterdam 1981, p. 65.

70 J. Bryan HEHIR, symposiumbijdrage Harvard University, Human rights at Harvard, Cambridge 1995, pp. 14-17, op p. 14. 
de fabrieksmatige verdelging ${ }^{71}$ van mensen. Beide idealen vinden we als volgt in de preambule van het Handvest van de VN verwoord:

Preambule HVN, eerste overweging:

'Wij, de wolken van de Verenigde Naties, vastbesloten [1] komende geslachten te behoeden woor de gesel van de oorlog (...).'

Preambule HVN, tweede overweging:

"Wij, de volken van de Verenigde Naties, vastbesloten (...) [2] opnieuw ons vertrouwen te bevestigen in de fundamentele rechten van de mens, in de waardigheid en de waarde van de menselijke persoon (...).'

Zie voor een 'nuancering' van het fabrieksmatige karakter van de Duitse volkenmoord evenwel Michel KORZEC, 'De mythe van de efficiënte massamoord,' Intermediair 15 december 1995, pp. 19, 21, 23.

KOAZEC stell (op p. 21, vierde kol.) dat de bewering van B.V.A. RÖLING en anderen (wgl. Röling, Volkenrecht en wede, Deventer 1985 (derde druk), p. 178; RÖLING, Vredeswetenschap, Utrecht/Antwerpen 1981, pp. 256-266) dat de atoombommen op Japan niet nodig waren om de capitulatie te bespoedigen, maar dienden om Stalin te intimideren, in zoverre onjuist is dat, naar sinds kort bekend is/ zou zijn, Stalin en Japan over een bondgenootschap onderhandelden. Stalin moest daarvan worden afgehouden, en bij de les worden gehouden van de afspraken van Teheran en Jalta. Hetgeen - in tegenstelling tot het intimidatie-revisionisme wel een (morele) rechtvaardiging van de Amerikaanse oorlogsmisdrijven ten aanzien van Hiroshima en Nagasaki zou zijn.

Een tweede mythe (naar eigen zeggen) die KORZEC bestrijdt, betreft de "industrieel-bureaucratische" interpretatie' (p. 23, vierde kol.) van de Duitse judeocide. Er waren veel meer mensen bij deze massamoord betrokken dan 'enkele' bureaucraten en moordfabrieksarbeiders. Van de naar (zijn) schatting vijf miljoen vermoorde joden zijn er minder dan een miljoen (700.000 of 800.000) fabrieksmatig vermoord (vergast). Dit is 'helemaal geen ontkrachting van de Holocaust, maar well een ontkrachting van de mythe dat de Holocaust een perfect geplande massamoword was, uitgevoerd dankzij de verworvenheden van de moderne techniek en organisatie. De meeste joden werden omgebracht met primitieve middelen: neerschieten, doodslaan, ophangen, withongeren. (...) Als het vandaag mogelijk is om in $R$ wanda cen half miljoen mensen of meer in enkele weken om te brengen, watarn zou het dan technisch zo moeilijk zijn om in enkele jaren tijd miljoenen joden in Oost-Europa met ongeveer dezelfde primitieve middelen uit te roeien?' (Op p. 23, derde/vierde kol.)

KORZEC besluit: 'Een serieuze bestudering van het Holocaust-revisionisme leidt tot de conclusie dat er nog nooit zovelen de schuld voor eigen misdaden afschoven op zo weinigen.' Deze laatste conclusie sluit dan fraai aan bij het centrale thema van GOLDHAGENs recente Hitler's willing executioners: het beklemtonen van de massale besmetting met het virulente ideologische gif van het racisme (i.c. antisemitisme) en de vanzelfsprekendheid en zelfs onverholen trots waarmee zovelen zich kweten van de opdracht tot uitroeiing (en fabrieksmatige verdelging) van medemensen. (Daniel Jonah GoLDHAGEN, Hitler's willing executioners; Ordinary Germans and the holocaust, New York 1996.) 
Het ideaal nooit meer oorlog heeft geleid tot de beperking van het jus ad bellum tot de militair aangevallen staat (die zich militair mag verdedigen) en tot de Veiligheidsraad (voor zover) die een bedreiging van de vrede constateert. Het ideaal nooit meer barbarij heeft, in 1948, geleid tot zowel het Genocide-verdrag ( 9 december 1948; inwerkingtreding januari 1951) als de Universele Verklaring van de rechten van de mens (10 december 1948; resolutie Algemene Vergadering), en via die Verklaring tot het zevental mondiale mensenrechtenverdragen dat we hierboven (par. 2.3) tegenkwamen:

1. IVUR (CERD, 1965): Rassenverdrag;

2. (a.) IVBPR (ICCPR, 1966): Bu[rgerlijke-en-]Po[litieke rechten]-verdrag;

3. (b.) IVESCR (ICESCR, 1966): E[conomische]So[ciale en]Cul[turele rechten]-verdrag;

4. VUDV (CEDAW, 1979): Vrouwenverdrag;

5. AMV (CAT, 1984): Folterverdrag/Anti-Martelverdrag;

6. VRK (CRC, 1989): Kinderrechtenverdrag;

7. [IVBRM (ICPRAMWMF, 1990): Migrantenverdrag].

Driekwart tot bijna 100\% van de staten is inmiddels partij bij deze verdragen (de helft bij het Anti-Martelverdrag, en het Migrantenverdrag, dat nog niet in werking is getreden, buiten beschouwing gelaten):

AANTAL LIDSTATEN VN=VERDRAGEN PER 1 JANUARI $1998^{72}$

$\begin{array}{lllr}\text { 1. IVUR } & 150 & \text { (van de 193) } & 78 \% \\ \text { 2. IVBPR } & 140 & \text { (van de 193) } & 73 \% \\ \text { 3. IVESCR } & 137 & \text { (van de 193) } & 71 \% \\ \text { 4. VUDV } & 161 & \text { (van de 193) } & 83 \% \\ \text { 5. AMV } & 103 & \text { (van de 193) } & 53 \% \\ \text { 6. VRK } & 191 & \text { (van de 193) } & 99 \% \\ \text { 7. [IVBRM] } & {[9]} & & {[-]}\end{array}$

De universaliteit van de in deze verdragen verankerde menselijke waarden en fundamentele rechten kan daarom moeilijk worden betwist, hoezeer ook de westerse politieke filosofie (teruggaand tot de Grieken) als de bakermat van de mensenrechten wordt beschouwd. En hoezeer ook, in meer directe en praktische zin, een ander westers fenomeen: de Duitse

Bron: Jean-Bernard MARIE, International instruments relating to human rights; classification and status of ratifications as of 1 January 1998,' Human Rights Law Joumal 1998/2-4, pp. 117-134. In dit overzicht ontbreken de Cookeilanden, die als 191e staat partij werden bij het Verdrag inzake de rechten van het kind (vgl. Traciatenblad 1998, nr. 62, p. 6 onder F). 
geïndustrialiseerde judeocide (en romanocide), als bakermat van bovenstaande mensenrechtenverdragen kan worden aangewezen. Met JOHNSON ${ }^{73}$ moet worden geconstateerd dat "human rights represent a crosscultural consensus on fundamental human values. ${ }^{, 74}$

'Human values' die, alleen al gezien het universele, intrinsieke menselijke vermogen tot lijden, in essentie als van alle tijden en van alle culturen moeten worden beschouwd. Het zien van het lijden van de medemens kan, om antropologische redenen, niet als typisch-westers, en dus ook niet als van westerse origine worden beschouwd. Wel zou misschien kunnen worden opgemerkt dat, door bepaalde historische omstandigheden, de wreedheid van de westerse mens zulke massale proporties kon aannemen (inquisitie, godsdienstoorlogen, slavernij, judeocide) dat, in combinatie met weer andere historische omstandigheden, de strijd om civilisering, humanisering en emancipatie er evenredig door werd aangewakkerd en versneld.

Al in 1625 bepleitte Hugo DE GROOT de mogelijkheid van humanitaire interventie: ${ }^{75}$

"Noch word getwist, of "it ook een regtmatige oorzaak is, als men oorlog voert voor eens anders onderzaaten, om haar tegen den overlast van haaren Heere te verdedigen. Doch zeker, na dat de borgerlijke gezelschappen zijn ingestelt, hebben de regeerders van yder gezelschap eenig byzonder regt over haar eigen volk verkregen. Euripides (...): Dit is der Goden aart:/"t Geen een van hen doet, mag een ander niet beletten. Namelijk, gelijk het Ambrosius zeer wel verklaart: $O p$ dat zy met malkanderen niet in oorlog zouden raaken, als d'een zig met de zaaken van den ander bemoeide. (...)

David JOHNSON, 'Cultural and regional pluralism in the drafting of the UN Convention on the rights of the child,' in: Michael FREEMAN, Philip VEERMAN (eds.), The ideologies of children's rights, Dordrecht (etc.) 1992, pp. 95-114, op p. 112.

T.a.p. Dit betekent uiteraard niet dat er geen cultureel bepaalde opvattingen zijn die aan die universaliteit zouden willen knagen. Met betrekking tot de totstandkoming van het VRK onderscheidt JOHNSON viff zulke culturele "topics of debate': 1. abortus (the unborn child): RK/Vaticaan; 2. godsdienstvrijheid: islam/Iran; 3. genitale verminking van meisjes, ook wel aangeduid als clitoridectomie (al of niet gepaard gaande met infibulatie) of als vrouwenbesnijdenis (traditional practices, de traditionele besnijdenis van meisjes door vrouwen): Afrika; 4. interlandelijke adoptie: Zuid-Amerika; 5 . plichten van het kind tegenover diens ouders: Senegal/AfChHPR.

75 De jure belli ac pacis II.25.8. Laatste volledige Nederlandse vertaling: Hugo DE GROOT, Van "t Regt des oorlogs en vredes, behelzende Het Regt der Nature en der Volkeren, mitsgaders het voomaamste van 't openbaare Bongerlyke Regt; Van nieuws vertaalt (...) door Jan WAN GAVEREN, (...) Tweeden druk, Amsterdam 1732. Hier wordt geciteerd uit de eerste druk van 1705, pp. 592-594. 
Maar daar uit volgt niet, byaldien het geweld blijkbaar is, en een Busiris, Falaris, of Tracische Diomedes indiervoegen met zijne onderdaanen omspringt, als geen redelijk mensch kan verdragen, dat in zulken gevalle het regt van de menschelijke maatschappye zoude gekluistert zijn. (...)

Ja schoon men al toestond, dat d'onderzaten, ook in den hoogsten nood, de wapenen niet mogten aannemen (van welke zaak doch, als we gezegt hebben, getwijffelt word, zelf van die geenen, wellke hun werk gemaakt hebben van de koninglijke magt ten uittersten voor te spreken), zoo is dlat geen bewijs, dat anderen die woor haar niet zouden mogen aannemen. (...) Alzoo pleit een voogd, of iemand anders voor een onmondig weeskind, wiens persoon in regten niet bestaan kan (...).

Zoo meint Seneka, dat ik oorlog mag voeren tegen den geenen, die buiten mijn volk zijnde, het zijne plaagt (...). Wy weten wel uit d'oude en nieuwe geschiedboeken, dat de begeerlijkkheid tot het goed wan een ander zig zoodanige dekmantels zoekt: maar daarom zal echter iets niet nalaten regt te zijn, schoon het van de boozen misbruikt word. Want de Zeeroovers valuen mêe t'scheep, en de Moordenaars hebbien ook zwaarden. ${ }^{.76}$

We staan nu, gezien het - aarzelende en gebrekkige - optreden van de Veiligheidsraad in humanitaire kwesties, aan de vooravond van een supranationale vertaling van dit pleidooi. Een ontwikkeling die met het verzet tegen tirannie van enkeling of elite begonnen is, en via een proces van democratisering en internationalisering ${ }^{77}$ nu de eerste - nog wankele - stappen naar haar supranationale bekroning heeft gezet, belandt daarmee in een nieuwe internationaalrechtelijk fase. Het minste evenwel dat we kunnen zeggen als we de rechtshistorische balans opmaken, is dat het jus ad tormentum, het statelijke kwelrecht ofwel de personele soeve-

76 De bekende slotpassage luidt in het fraaie Latijn van DE GROOT: '(...) [N]on ideo statim ius esse desinit si quid a malis usurpatur. Navigant et piratae: ferro utuntur et latrones.' (Hugo GRormus, De iure belli ac pacis libri tres in quibus ius naturae et gentium item iuris publici praecipua explicantur; Curavit B.J.A. DE KANTER-VAN HETTINGA TROMP; Editionis anni 1939 quae Lugduni Batavonum (...) emissa est, exemplar photomechanice iteratum; Annotationes novas addiderunt $R$. FEENSTRA et C.E. PERSENAIRE, adiuvante E. ARPS-DE WILDE, Aalen 1993, p. 598.)

77 Voor de periodisering van het mensenrechtenthema aan de hand van de trits democratisering (van uitsluiting naar insluiting van mensen), socialisering (de - met die insluiting samenhangende - opkomst van economische, sociale en culturele rechten ter aanvulling van de burgerlijke en politicke rechten) en internationalisering (van nationale verklaringen en grondwetten naar internationale verklaringen en verdragen) zie: Theo VAN BOVEN, 'The Déclaration des droits de l'homme et du citoyen of 1789 and its influence on the Constitutions,' in: E.H. HONDIUS, G.J.W. STEENHOFF (eds.), Netherlands reports to the thirteenth International Congress of Comparative Law, Montreal 1990, Den Haag 1990, pp. 363-373, op pp. 366 e.v. 
reiniteit van de staat, door de mensenrechtenverdragen ten grave is gedragen.

\section{Het Verdrag inzake de rechten van het kind}

De vraag is of het Verdrag inzake de rechten van het kind hetzelfde zal doen met het 'kwelrecht' van de machtige volwassene tegenover het machteloze kind: dat 'kwelrecht' ten grave zal dragen. Een kwelrecht dat niet krachtens toekenning door het positieve recht als recht kan worden betiteld, maar als pseudo-recht, als on-recht, voortvloeit uit de duistere keerzijde van de in het positieve recht verankerde 'soevereiniteit in eigen kring: de ouderlijke autonomie.

Een autonomie die weliswaar in de (overgrote?) meerderheid van de gevallen geen misbruik impliceert van het recht van de ouders om hun kind naar eigen inzichten te verzorgen en op te voeden, en in die zin 'in principe samenvalt' (KOENS ${ }^{78}$ ) - dat wil zeggen: in meerdere of mindere mate spoort - met het recht op harmonische ontplooiing van het kind; maar die ten aanzien van tienduizenden kinderen in ons land tot een schending leidt van dat persoonswordingsrecht, tot een behandeling die, met VAN DANTZIG, als 'het martelen van kinderen"79 kan worden gekwalificeerd.

Dat 'martelen' is dan te verstaan als een aantasting van de lichamelijke en geestelijke integriteit van het kind-als-mens in een mate of op een wijze die een ernstige beschadiging van de persoonswording van het kind impliceert. Dat - men zou bijna kunnen zeggen: dubbele - martelen blijkt voor te komen op een schaal die we, als samenleving, ten aanzien van meerderjarige slachtoffers nooit, onder geen enkele omstandigheid en in geen enkele (nood)situatie, zouden tolereren. Een rechter zou, als de daders van deze slachtoffers aan hem werden voorgeleid, geen enkele rechtvaardigingsgrond, geen enkel beroep op soevereiniteit in eigen $\mathrm{kring}$, of op welke vrijheid ook, accepteren.

We kunnen wat kinderen wordt aangedaan, niet op de koop toenemen - zoals we dat doen met winkeldiefstallen. Evenmin kunnen we het ongeluk van tienduizenden kinderen wegstrepen tegen het geluk van honderdduizenden andere. Zo werkt een democratie niet - die wil ìnsluiten, niet uítsluiten. Zo gaat dat niet in een rechtsstaat - welke waakt tegen machtsmisbruik, en de zwaksten méer, niet minder bescherming biedt.

De excessen van de ouderlijke autonomie zijn met andere woorden te talrijk en te ernstig om niet als samenleving namens het kind in 
verzet te moeten komen. Niet met als doel het gezin aan het kind te ontnemen - hetgeen in strijd met het gezonde verstand, en met alle verdragen zou zijn. Maar met het doel aan die autonomie zodanig paal en perk te stellen dat het gezin, kind en ouders, adequaat wordt geholpen, en het kind adequaat tegen misbruik van het ouderlijk gezag wordt beschermd.

De vraag is, met andere woorden, of het Verdrag inzake de rechten van het kind 'het martelen van kinderen' in gezinnen kan helpen voorkomen, als instrument om te beginnen in een juridisch en maatschappelijk bewustwordingsproces, en aan dat 'martelen' door middel van een 'humanitaire interventie' in het gezin, oplopend van een adequaat hulpaanbod tot en met het opleggen van pedagogische hulp, een einde kan maken.

Om die vraag te kunnen beantwoorden is een nadere analyse van - en een speuren achter - dat Verdrag vereist: een op zoek gaan naar de pedagogische rechten van het kind. Vooraleer die speurtocht kan aanvangen, zal echter eerst moeten worden gekeken naar wat in het algemeen de betekenis en de reikwijdte van mensenrechten is. 
De volgende vragen liggen aan dit hoofdstuk ten grondslag c.q. worden in dit hoofdstuk aan de orde gesteld: wat is de (functionele) betekenis en de (hiërarchische) plaats van rechtsbeginselen in het internationale recht? Wat is de (historische en actuele) relatie ten opzichte van (natuur)recht en moraal? Dienen de mensenrechten als (specifieke categorie) rechtsbeginselen te worden aangemerkt? Hoe beïnvloeden rechtsbeginselen c.q. mensenrechten het internationale (en nationale recht), hoe werken zij daarin (door)? Met andere woorden: in dit hoofdstuk staat het rechtskarakter van de mensenrechten centraal.

\section{2}

Bronnen en jus cogens

Om ons een beeld te kunnen vormen van het rechtskarakter van mensenrechten, is het goed te beginnen bij de bronnen van het internationale recht. De belangrijkste (formele) bronnen worden genoemd in art. 38 van het Statuut van het Internationaal Gerechtshof (Statuut IGH), dat een integrerend onderdeel uitmaakt van het Handvest van de VN. Art. 38 noemt als directe rechtsbronnen: het verdrag, het gewoonterecht en de algemene rechtsbeginselen (de beide laatste tezamen genomen worden ook wel aangeduid als algemeen internationaal recht). Het verdrag bindt de partijen, het (algemeen) gewoonterecht bindt in beginsel alle staten, de algemene rechtsbeginselen binden alle staten in abstracto.

Op dat laatste aspect wordt ingegaan in par. 3.2.1. In par. 3.2.2 wordt stil gestaan bij het jus cogens, dat sommige rechtsbeginselen een hogere status toekent. In par. 3.2.3 ten slotte wordt SCHACHTERs indeling van de algemene rechtsbeginselen weergegeven.

\section{2 .1}

\section{Rechtsbeginselen: frappez toujours}

Hierboven werd gesteld: de algemene rechtsbeginselen binden alle staten in abstracto. Daarmee bedoel ik dat staten verplicht zijn zich naar het beginsel te richten, hetgeen zowel een verplichting tot nalaten als positieve verplichtingen kan inhouden. Bijvoorbeeld positieve verplichtingen het beginsel te concretiseren en aldus operationeel te maken, waaruit dan positieve verplichtingen dan wel verplichtingen tot nalaten in concreto voortvloeien. Veelal gebeurt dat laatste in verdragen, maar een beginsel 
kan zich ook tot gewoonterecht verharden. ${ }^{1}$ Soms ook ligt een beginsel zo dicht tegen een (gewoonte)rechtsregel aan dat nadere concretisering achterwege kan blijven. Tot slot kan een staat het beginsel ook hard maken in zijn nationale recht, door middel van nationale regelgeving. Voor zover het beginsel dat impliceert, is de staat daartoe ook verplicht. Andere staten, en soms ook zijn eigen burgers, kunnen hem aan die verplichting houden. ${ }^{2}$

\section{Frappez toujours}

Die burgers kunnen dan een beroep doen op hun eigen nationale rechter, of op een internationale rechterlijke instantie, een verdragsorgaan. Die rechter of instantie kumnen dan het beginsel door hun uitspraak concreet, hard maken voor de burger. Een verdragsorgaan kan overigens alleen over individuele klachten oordelen als het verdrag die mogelijkheid kent, de verdragsstaten het orgaan bovendien bevoegd hebben verklaard, en nadat de nationale rechter door de burger tevergeefs is beproefd.

Voor de Nederlandse burger die het rechtsgehalte van een politieke wet (een wet dus van 'de politiek': van regering en parlement tezamen) wil laten vaststellen door deze voor de Nederlandse rechter tegen het licht van een rechtsbeginsel te houden, geldt als bijkomende voorwaarde dat dat rechtsbeginsel in een verdrag waar Nederland partij bij is, te vinden moet zijn (de zogenaamde Nyugatleer van de Hoge Raad $^{3}$ ).

KOOLJMANS noemt het voorbeeld van het zelfbeschikkingsbeginsel/-recht: Internationaal publiekrecht in vogelvlucht, Groningen 1996 (zesde druk), pp. 25 en 27.

2 In par. 3.4 wordt de betekenis van rechtsbeginselen, op geleide van MEUWISSEN, nader bellicht.

3 Vgl. BOEKHORST, 'Artikel 94,' in: De Grondwet, a.w., pp. 873-887, op p. 876; KOOPMANS' Compendium van het staatsrecht, Deventer 1994 (zevende druk), pp. 71/72, 255, 258-260, 265-266 (Harmonisatiewetarrest). Zie voor "s Hogen Raads opmerkelijke a contranio-leer ook KOOIJMANS, a.w., p. 88.

De a contrario-interpretatie van (huidig) art. 94 Grondwet is in feite (ook) een per analogiam-interpretatie van het toetsingverbod van politieke wetten aan de Grondwet. En dus een uitbreiding wan het in art. 120 Grondwet besloten liggende primaat van de politiek. De a contrario-logica: verdragsbepalingen toepassen met terzijdestelling van politieke wetten: dan géén ongeschreven recht(sbeginselen), lijkt op het eerste gezicht op de reactie van Jantje op het ouderlijk verbod om over het gras te lopen: 'Oh,' denkt Jantje, 'dan mag ik dus wèl over de bloemen!' Deze logica kan echter verklaard worden door de art. 120-huiver van de rechter om 'op de stoel van de wetgever' te gaan zitten, dat wil zeggen door de per analogiam-logica: politieke wetten niet toetsen aan de Grondwet: dan 6́6k niet aan rechtsbeginselen. De logica dus van het ontzag voor het primaat van de politiek. De Nederlandse Juristenvereniging(svergadering van 1992) heeft kennelijk voor iets anders ontzag: zij wil wel van de art. 120-anomalie af, dus wil well toetsing van de wet aan de Grondwet, maar will geen toetsing van de wet aan rechtsbe- 
Tal van gewoonterechtsregels en algemene rechtsbeginselen zijn sinds 1945 in verdragen gecodificeerd. Zij zijn daarmee verdragsrecht voor de verdragspartijen geworden, gewoonterecht c.q. ongeschreven rechtsbeginselen voor niet-partijen gebleven. Is een beginsel dus niet gecodificeerd, of is het (enkel) opgenomen in een verdrag waar Nederland geen partij bij is, dan laat de Nederlandse rechter de burger dus tegenover 'de politiek' in de kou staan. Dit wordt het primaat van de politiek genoemd, een nationaal (Nederlands) constitutioneel fenomeen. Internationaalrechtelijk betekent dit dat Nederland als staat aansprakelijk is voor het niet toepassen van het rechtsbeginsel, want een staat kan zich nu eenmaal niet achter zijn organen verschuilen, ook niet als dat orgaan de onafhankelijke rechter is.

Maar ook als een rechtsbeginsel wèl is gecodificeerd in een verdrag waar Nederland partij bij is, houdt de Nederlandse rechter zich de bevoegdheid voor de desbetreffende verdragsbepaling niet toe te passen. Het heet dan dat de verdragsbepaling geen rechtstreekse werking heeft (niet self-executing, niet zelfwerkend is), dat wil zeggen: zich niet leent voor toepassing op de burger - die dan tegenover de politiek net zo goed met lege handen staat. Soms wrijft de rechter - in een 'terzijde' van zijn vonnis of arrest, een obiter dictum - de politiek dan wel in werk te maken van haar concretiseringsplicht, haar verplichting door middel van nationale regelgeving de verdragsbepaling operationeel te maken. Uiteraard kan een dergelijk abiter dictum op den duur niet zonder gevolgen blijven. Vandaar het belang voor de burger de rechter te blijven benaderen. De politiek bewuste burger laat niet alleen stilzwijgend zijn of haar stem horen bij verkiezingen, hij of zij houdt zich ook aan andere staatkundige maximen, zoals het frappez toujours le juge.

Rechtsstaat en democratie functioneren nu eenmaal niet alleen bij de gratie van een systeem van elkaar onderling controlerende en in evenwicht houdende organen (een systeem van checks and balances), maar zijn ook afhankelijk van het publiek en publieksmedia die alle organen, de rechter incluis, geregeld 'om de oren slaan.'

Door bij de rechter en de politiek - nationaal en internationaal steeds te hameren op de noodzaak rechtsbeginselen te operationaliseren op een wijze die in de pas blijft met maatschappelijke ontwikkelingen en die tegemoet komt aan maatschappelijke noden, dragen de burgers er het

ginselen (zie F.A.M. STRorNK, Algemeen bestuursrecht, Zwolle 1994, pp. 143/144 nt. 27; Handelingen Nederlandse Juristen-Vereniging 1992-11, Verslag van de op 12 juni 1992 te Maastricht gehouden algemene vergadering over: Toetsing, Zwolle [1992-2], p. 93). De a contrario-uitleg wan art. 94 staat na schrapping van het rechterlijk toetsingsverbod wan art. 120 echter wel bijzonder wankel. Alleen Jantje kan dat nog volgen. 
hunne toe bij dat verdragen levende - en levendige - instrumenten blijven.

\section{2 .2}

\section{Jus cogens}

Sommige rechtsbeginselen worden door de statengemeenschap in haar geheel zo essentieel geacht voor die statengemeenschap als rechtsgemeenschap, dat zij tot het dwingende volkenrecht worden gerekend. Dit dwingende volkenrecht, ofwel jus cogers, wordt ook wel als een aparte, nieuwe bron beschouwd. ${ }^{4}$ Slechts een handvol beginselen, veelal in verdragen opgenomen en in verdragsregels uitgewerkt, heeft intussen deze status verkregen. Regels of beginselen van jus cogens staan bovenaan in de internationaalrechtelijke hiërarchie: een verdrag in strijd met een regel of beginsel van jus cogens is nietig (art. 53 Verdragenverdrag, Wenen 1969).

Tot deze voor de internationale rechtsorde essentiële beginselen behoren de volgende verboden erga omnes, dat zijn verboden ten opzichte van de statengemeenschap als geheel (dus niet enkel tussen verdragspartijen): ${ }^{5}$ het geweldverbod (verbod van agressie tussen staten: art. 2, lid 4 Handvest VN); het genocideverbod; het verbod van rassendiscriminatie; het verbod van slavernij; het verbod van kolonialisme; het martelverbod (verbod van wrede, onmenselijke of vernederende behandeling of bestraffing); het verbod van het plegen van 'internationale misdrijven' (oorlogsmisdrijven, misdrijven tegen de mensheid, Apartheid, ernstige schendingen van het recht op zelfbeschikking van volkeren, ernstige of systematische schendingen van de rechten van de mens).

\section{Hiërarchie}

Het jus cogens drukt ons met de neus op het feit dat er een hiërarchie van rechtsbeginselen bestaat. ${ }^{6}$ Daaraan doet niet af dat sommige rechts-

Met de introductie van jus cogens in de zestiger jaren werd evenwel niet beoogd een nieuwe bron van volkenrecht te creëren - zoals in 1920 was gebeurd met de 'door beschaafde naties erkende algemene rechtsbeginselen' wan art. 38 van het Statuut van het Permanente Hof van Internationale Justitie (en na 1945 van het Internationale Gerechtshof, en in en na 1945 met besluiten van (orgamen van) internationale organisaties (Veiligheidsraad, EG) -, doch een verhoging van de status van bepaalde rechtsbeginselen c.q. gewoonterechtelijke of verdragsnormen, met andere woorden: de introductie van (een) hiërarchisering in het volkenrecht (zie Antonio CASSESE, International law in a divided world, Oxford 1988, pp. 175). Vgl. Oscar SCHACHTER, Intemational law in theory and practice, Dordrecht (etc) 1991, pp. 211-212, 338, 342-344.

6 Op deze hiërarchie, en het hiërarchisch denken in het recht, wordt nader ingegaan in (de derde paragraaf van) hoofdstuk 4. 
beginselen, zoals het verbod van sexediscriminatie, het 'martelverbod' in de zin van vrijwaring van vrouwen en kinderen tegen geweld in het gezin - of, om vast een voorschotje te nemen: 'het belang van het kind' in de zin van het recht van het kind op minimale persoonswording, dat is op minimale geborgenheid en opvoeding (ontplooiing en leiding) -, nog niet de status van jus cogens hebben bereikt. Ook het jus cogens is een levende materie. En niets wordt recht of het hoogste recht zonder individuele en maatschappelijke bewustwording en politieke en juridische strijd. Zo iets dan is dat de les uit de mensenrechtenhistoriek. Het is de les van een Olympe DE GOUGES of een Joan Derk VAN DER CAPELLEN: niet klagen, maar aanklagen - en voor (je) rechten vechten.

\section{2 .3}

Rechtsbeginselen in het internationale recht

We keren terug naar de internationaalrechtelijke rechtsbeginselen (in de zin van art. 38 Statuut IGH). Voor een nadere indeling daarvan gaan we te rade bij SCHACHTER. ${ }^{7}$

SCHACHTER onderscheidt vijf categorieën van algemene beginselen "that have been invoked and applied in international law":

1. nationaalrechtelijke rechtsbeginselen 'recognized by civilized nations" (de door beschaafde naties erkende algemene rechtsbeginselen: art. 38, lid 1 aanhef en onder c Statuut IGH);

2. algemene rechtsbeginselen 'derived from the specific nature of the international community [MOSLER]';

3. beginselen "intrinsic to the idea of law and basic to all legal systems [O'CONNELL]';

4. beginselen 'valid through all kinds of societies in relationships of hierarchy and co-ordination [Judge TANAKA]";

5. natuurrechtelijke beginselen: "[p]rinciples of justice founded on "the very nature of man as a rational and social being" [FITZMAURICE].'

\section{Natuurrechtelijke beginselen}

Het zou te ver voeren SCHACHTERs indeling hier uitputtend na te lopen. Voor het onderwerp van deze studie: het recht van het kind op minimale respectievelijk optimale persoonswording, is evenwel SCHACHTERs laatste categorie van bijzonder belang. Deze categorie verwijst naar de redelijke en sociale natuur van de mens, bij Hugo DE GROOT (ofwel GROTIUS), de 'vader' van het 'natuur- en volkenrecht,' de bron van alle recht. ${ }^{8} \mathrm{De}$ hier bedoelde natuurrechtelijke beginselen brengen ons op het klassieke

8 De jure belli ac pacis (1625), Prolegomena 6-8 (zie hierna). 
onderscheid tussen natuurrecht en rechtspositivisme. Voordat we naar SCHACHTER terugkeren (in par. 3.4.1), gaan we eerst nader op dit onderscheid in.

\section{3}

\section{Natuurrecht en rechtspositivisme}

\subsection{1}

\section{Natwurrecht}

Natuurrecht zou men kunnen omschrijven als het geheel van fundamentele beginselen, normen en waarden die essentieel zijn voor de statengemeenschap als rechtsgemeenschap, dat wil zeggen: voor de internationale rechtsorde, ongeacht of zij reeds in (universele) verdragen zijn opgenomen en/of tot gewoonterecht zijn verhard, ${ }^{9}$ of zelfs al tot het jus cogens zijn gaan behoren. Ook het zogenaamde 'soft law' zou daar dus onder kunnen vallen: beginselen en regels die in niet bindende teksten ${ }^{10}$ zijn erkend; normen die ondanks hun fundamentele karakter en sterk morele appèl nog steeds met beide benen in de politieke, zij het al met één teen in de rechtswereld staan. ${ }^{11}$ Voor wat deze laatste categorie betreft, is natuurrecht dan iets tussen moraal en (volken)recht in: het is meer dan moraal, maar minder dan (positief) recht. Samengevat: natuurrecht is 'hoger recht' dat absoluut (universeel) geldt, of zou moeten gelden. In dat laatste geval is de statengemeenschap naar die (absolute/ universele) gelding, met vallen en opstaan, op weg.

Achter deze omschrijving gaat (althans ten dele) een klassiek natuurrechtsdenken schuil dat - ondanks het bestaan van verschillende (meer of minder historische) varianten - de volgende, door FRANKEN op een rij gezette 'normaaltypische' elementen bevat: ${ }^{12}$

'1 dat er een absoluut geldig recht bestaat'; een aantal fundamentele beginselen (zie onder 6);

Vgl. KoOUMANS, a.w., p. 25.

10 Waarbij men niet alleen aan resoluties van (bijwoorbeeld) de Algemene Vergadering, besluiten van de Mensenrechtencommissie of General Comments van (mensenrechten-) verdragsorganen kan denken, maar, onder omstandigheden, wellicht ook aan verklaringen van (belangrijke) NGo's (non-gowvernementele organisaties), uitspraken van non-gouvernementele tribunalen, of zelfs aan de doctrine, de opinies van 'de meest bevoegde schrijwers der verschillende naties' - walaronder art. 38 Statuut IOH rechtsgeleerde auteurs verstaat.

11 In geval van 'soft law' heeft de 'verharding tot cen regel wan gewoonterecht' nog niet plaatsgevonden, maar is er sprake van een 'zich geleidelijk uitkristalliserende rechtsovertuiging' (KOOLMANS, a.w., p. 27).

12 H. FRANKEN, Inleiden tor de rechiswetenschap, Arnhem 1993 (zesde druk), pp. $38 / 39$. 
dat dit recht kan worden afgeleid uit de menselijke natuur of de aard van de werkelijkheid;; bij GROTIUS: de sociale aard van de mens (appetitus societatis) en de zorg voor de gemeenschap, de publieke zaak (societatis custodia);

'3 dat voor het kennen van dit recht de redelijke vermogens van de mens toereikend zijn' (dat zijn immers de riemen waarmee we, als mensen, moeten roeien);

'4 dat er een inhoudelijke toets in de vorm van natuurrechtelijke beginselen wordt gehanteerd voor de gelding van het positieve recht';

'5 dat positief recht dat die toets niet kan doorstaan, in principe niet als geldig erkend kan worden';

"6 dat deze inhoudelijke toets bestaat uit een verzameling van metafysische ideeën' (ideeën over goed en kwaad).

Kenmerkend voor het natuurrecht zijn dus: ${ }^{13}$ "de bron waaruit het voorvloeit: de natuur (2)' (bij GROTIUS: de redelijke en sociale natuur van de mens); 'een status: de absolute gelding (1)' (bovenaan de hiërarchie, onveranderlijk en universeel); "het keninstrument waarmee het gekend wordt: de rede (3)'; 'de functie die het vervult: een kritische toets (4 en 5)'; 'de inhoud die het heeft: metafysische ideeën (6).'

\section{De jure belli ac pacis}

Deze metafysische ideeën zijn bij GROTIUS de fundamentele beginselen die aan het (eeuwenoude) civiele recht, aan het (jongere) strafrecht en (bijgevolg ook) aan het (zeer jonge) volkenrecht ten grondslag liggen. (Wat dat betreft, kan men bij GROTIUS nauwelijks van 'metafysische abstracties" of 'speculaties' spreken.) In de paragrafen 6 tot en met 8 van de Prolegomena van zijn De jure belli ac pacis (Over het recht van oorlog en vrede, Parijs 1625) stelt hij: ${ }^{14}$

'\$ 6. (...) Een van [de] eigenschappen nu die kenmerkend zijn voor de mens, is zijn gemeenschapszin [appetitus societatis]; ik bedoel zijn behoefte aan een geregeld, vreedzalam en op zijn intelligentie afgestemd samenleven met zijn soortgenoten (...).......)

"\$ 7. (...) [U]it het feit dat [de mens] in staat is onder gelijke omstandigheden gelijk te reageren [dat is: te leren van zijn ervaringen, jw], walt op te maken dat hij naast deze opmerkelijke gemeenschapszin - waarvoor hem als enige onder de levende wezens ook een bijzonder middel ter beschikking staat, namelijk de taal

14 A.C. EYFFINGER, B.P. VERMEULEN (red.), Hugo DE GROot: Denken over oorlog en wrede, Geschiedenis van de wijsbegeerte in Nederland, deel 8, Baarn 1991, p. 44. 
- ook het vermogen bexit te begrijpen en te handelen volgens algemene regels (...).

'\$ 8. Deze zorg voor de gemeenschap [societaris custodia] (...), die past bij het menselijk verstand, vormt de bron woor dàt recht dat in eigenlijke zin als zodanig mag worden aangemerkt [dat is: het natuurrecht in strikte zin, te begrijpen als het stelsel van subjectieve rechten (recht op leven, eigendom c.d.), nt. AE/BV]. Daartoe behoort [1] het gebod zich niet te vergrijpen alan andermans bezit en [2] de verplichting dat, wanneer wij iets van een ander hebben of daaruit winst verkregen hebben, wij dit teruggeven; verder [3] de verplichting tot het nakomen van beloften, [4] het vergoeden van schade door schuld veroorzaakt, en [5] het toepassen van de verdiende straf [poenae meritum] onder de mensen."

Als we ons de geschiedkundige zonde veroorloven dit naar het moderne (en zich nog steeds ontwikkelende) volkenrecht te 'vertalen,' dan kunnen we hier al 'inlezen': het agressieverbod, het pacta sunt servanda, staatsaansprakelijkheid en de restitutie- en compensatieverplichting, de bestrijding en bestraffing van internationale misdrijven. Heel erg groot is deze zonde overigens niet: ${ }^{15}$

1. GROTIUS' scherpe onderscheid tussen bella justa en bella injusta (rechtmatige en onrechtmatige oorlogen) is door het systeem van collectieve veiligheid onder het Handvest van de VN (agressie-oorlog als bellum injustum, zelfverdediging en VN-optreden als bella justa) na een afwezigheid van eeuwen teruggekeerd in het internationale recht;

2. pacta sunt servanda (art. 26 Weens Verdragenverdrag 1969) was bij GROTIUS natuurrechtelijke grondslag van het volkenrecht (stare pactis: Prolegomena par. 15);

3. oorlog is bij GROTIUS nimmer een politiek, altijd een - uiterste - rechtsmiddel, dat wil zeggen: oorlog is, buiten de zelfverdediging, alleen gerechtvaardigd indien restitutie of compensatie (rechtsherstel) achterwege blijft of indien misdrijven zijn gepleegd (Prolegomena par. 25: slechts ter verwerkelijking van het recht mag de oorlog begonnen worden, en eenmaal begonnen, mag hij niet worden gevoerd dan binnen de grenzen van het recht en de goede trouw);

4. oorlogsmisdadigers zijn bij GROTIUS individueel aansprakelijk onder het internationale recht (De jure belli ac pacis III.10.4-5), militairen

Vgl. met betrekking tot de hierna volgende opsomming: J.C.M. WLLEMS, "GROTIUS and the atomic weapon: the nuclear weapon-discussion in the light of the theory of "just war" with Hugo DE GRoor, Grotiana, New Series, vol. 2, 1981, pp. 103-114, op pp. 104-106; WILLEMS, 'Hugo DE GROOT en het volkenrecht," Wijsgerig perspectief 1982/1983 nr. 3, pp. 66-70; WILLEMS, 'GroTIus als filosoof,' Algemeen Nederlands Tijdschrift voor Wijsbegeente 1983/1, pp. 49-55; Ben VERMEULEN, "GROTIUS on conscience and military orders," Grotiana, New Series, vol. 6,1985 , pp. 3-19. 
zijn dus internationaalrechtelijk rechtssubject; zij hebben het recht en de plicht dienst te weigeren indien zij in geweten overtuigd zijn van of zelfs maar twijfelen aan de rechtmatigheid van de oorlog (II.26.3-5).

Op dit laatste punt week GROTIUS niet alleen radicaal af van zijn voorgangers, maar de ruime gewetensvrijheid die hij hier de soldaat toestaat, is in de latere doctrine niet overgenomen en gaat zelfs verder dan de erkenning van gewetensbezwaren in menig modern nationaal rechtsstelsel. ${ }^{16}$ GROTIUS geeft hier dan ook een krachtige impuls aan het concept van de individuele autonomie, waarbij we kort zullen stilstaan in hoofdstuk 4 (par. 4.2.4).

Wat de individuele aansprakelijkheid van oorlogsmisdadigers betreft, deze keerde in het internationale recht terug door de verwerping van de respondeat superior-doctrine (beter bekend in de Duitse vertaling Befehl ist Befehl) door het Tribunaal van Neurenberg. Het Joegoslavië- en het Rwanda-tribunaal zijn twee recente voorbeelden van de introductie van het poenae meritum - het toepassen van de verdiende straf, en daarmee de erkenning niet alleen van aangedaan leed en onrecht op zich, maar tegelijkertijd van de noodzaak en het belang van rechtsherstel in de vorm van internationaal-strafrechtelijke erkenning van zodanig massaal en genocidaal leed en onrecht - in het internationale recht.

Tussen GROTIUS en (het doorsijpelen van zijn leerstellingen in) het moderne volkenrecht ligt evenwel een lange periode in de volkenrechtsgeschiedenis waarin niet 'het' natuurrechtsdenken maar 'het' rechtspositivisme dominant was.

3.3.2

Rechtspositivisme

Hierover lezen we bij FRANKEN het volgende: ${ }^{17}$

[1. Fomele kijk] Als reactic op de opvatting dat recht uiteindelijk is gebaseerd op metafysische speculaties, stelt de stroming die met de naam rechtspositivisme wordt aangeduid, dat recht uitsluitend bestaat uilt een geheel van door mensen gemaakte gedragsregels. Deze regels betreffen meestal de voorschriften die door de overheid als zodanig voor een bepaalde samenleving zijn vastgesteld. Het betreft een louter formele kijk op het recht, omdat de aanhangers van deze stroming er van uitgaan dat alle rechtsregels die op formeel juiste wijze zijn tot stand gekomen, rechtskracht toekomt (geldig zijn). Daarmee laat men de vraag of de inhoud van die regels in overeenstemming is met bepaallde waarden of beginselen, buiten beschouwing. (...) 
[2. Scheiding Sein en Sollen! In de benadering van het rechtspositivisme houdt men een scherpe scheiding aan tussen feiten (hoe iets is) en normen (hoe icts moet zijn) - tussen Sein en Sollen. (...)

[3. Scheiding recht en moraal \[H] et recht dient te worden gescheiden van moraal, ethiek en politiek.'

\section{Kritiek}

FRANKEN formuleert op het rechtspositivisme de volgende kritiek: ${ }^{18}$

'De rechtspositivisten benadrukken alleen het formele karakter van de rechtnorm: de wijze waarop deze is tot stand gekomen. Zij pretenderen niet te toetsen aan waarden of beginselen die aan de rechtsnormen ten grondslag liggen. Een gevaarlijke en hypocriete pretentie. Gevaarlijk, ondat ook inhoudelijk verwerpelijke wetten zouden moeten worden nageleefd (vgl. de nazi-wetgeving); hypocriet; omdat justitiabelen en rechters met een tekst vele kanten uitkunnen (...). Het empirisch kunnen waststellen wat de inhoud van een rechtsnorm is, zegt dan nog weinig omdat men deze hoe dan ook interpreterend of waarderend zal hanteren (het rechtsvindingsaspect). Vanuit hun eigen situatie geven justitiabelen en rechters aan de tekst betekenis of zin.

Met de kloof tussen feit en norm die in (de hoofdstroom van) het rechtspositivisme wordt gemaakt, is woor een jurist ook niet te werken. (...) [H] et gaat [immers] niet om recht dat iets is (statisch), een voorwerp van kennis (object) dat onafhankelijk zou zijn van een subject, maar we spreken steeds van recht-doen, [dat wil zeggen] een proces van het op elkaar afstemmen van feit en norm (Sein en Sollen). Dit is een activiteit, een Akt. In de Amerikaanse literatuur spreekt men wan law in action. Dit vereist een analyse van de situatie aan de hand van uitspraken die gedrag voorschrijven [dus van normatieve uitspraken, jw]. Deze uitspraken, rechtsregels, vormen de theorie, die als het strijklicht de waargenomen verschijnselen belicht. De verantwoording (of legitimatie) van de wijze waarop de belichting de verschijnselen kleurt of de theorie de feiten vormt, vindt plaats in het rechtswormingsproces door het kiezen van bepaalde waarden (bijw grelijkheid, vertrouwen) of het toepassen van bepaalde beginselen (aldus hanteren wij aen element uit het natuurrechtsdenken). Voor de vraag welke waarden of beginselen dit moeten zijn (bijv. gelijkheidsbeginsel), zijn waardeoordelen nodig. Zonder waarderend uitgangspunt is analyse van de feiten of gebeurtenissen en interpretatie van de regels of normen onmogelijk. Analyse en interpretatie enerzijds en waardering anderzijds kunnen niet als twee van elkaar gescheiden activiteiten worden beschouwd. Dat waarderende uitgangspunt is de voorwetenschappelijke stellingname die, hoewel soms onbewust en heel vaak niet expliciet, allijd een rol speelt bij het beantwoorden van vragen. Je moet onvermijdelijk woor ieder oordeel eerst een filosofische knoop doorhakken. Daarom werken wij in deze dyna mische conceptie van het recht slechts met uitspraken die "relatively true" zijn.'

Als we deze kritiek proberen samen te vatten, zouden we kunnen zeggen: het rechtspositivisme poogt recht en moraal te scheiden, wat 'per defini- 
tie" niet kan. Immers: rechtsregels zijn te herleiden tot rechtsbeginselen en rechtsbeginselen verwijzen naar de moraal, naar het onderscheid tussen goed en kwaad. In de woorden van Paul SCHOLTEN: ${ }^{19}$

"We vinden thet [rechtsbeginsel] in het positieve recht, in het systeem van regels, beslissingen en instellingen in zijn geheel, doch het wijst boven het positieve uit naar het zedelijk oordeel, de scheiding van goed en kwaad, waarin het recht is gegrondvest."

Men zou kunnen stellen: rechtspositivisme is logisch niet houdbaar (zie ook het citaat van EYFFINGER en VERMEULEN in par. 3.3.6) en ethisch niet (meer) verdedigbaar. Niet meer althans sinds halverwege de twintigste eeuw. Zoals SIEGHART schrijft: ${ }^{20}$

'[T]he first true international human rights treaty - the Slavery Convention - was adopted in 1926 and entered into force in the following year. Nonetheless, during the first part of the twentieth century the theory of legal positivism remained in the ascendant. Combined with a strict application of the doctrine of national sovereignty, it effectively excluded the possibility of judging, and therefore criticizing, the treatment of any people by its own government. (...) While those events [in nazi-Germany and in the USSR] spelt unprecedented tragedy for huge numbers of people, they also spelt the reductio ad absurdum of strict legal positivism, and of a strict application of the doctrine of national sovereignty.'

\subsubsection{Bexwaren tegen het natuurrecht: 'cultuurrecht'}

Bovenstaande 'afrekening' met het rechtspositivisme doet de vraag rijzen in hoeverre aan de principiële bezwaren tegen het natuurrecht(sdenken) kan worden tegemoet gekomen. Tot deze bezwaren zou ik met name willen rekenen: de individuele, a-historische rede als keninstrument; het principieel-speculatieve karakter van zijn inhoud; de eeuwig- en onveranderlijkheidspretentie van zijn status; en het probleem van de 'religieuze' fundering (dat met beide laatste bezwaren samenhangt).

FRANKEN meent deze (althans de drie eerste) bezwaren te kunnen ondervangen door het introduceren van het begrip 'cultururrecht':21

'Culturrecht is dan overeenkomstig de [hierboven] gegeven aanduiding van wat we (...) een interactiebenadering van recht [kunnen noemen: law in action], het geheel van rechtsbeginselen, grondrechten en mensenrechten waarover wij in de

Paul sCHOLTEN, Algemeen deel, ASSER-serie (Mr. C. ASSERs Handleiding tot de beoefening wan het Nederlands burgerlijk recht), Zwolle 1974 (derde druk), p. 65 .

20 Paul sIEGHART, The international law of human righis, Oxford 1983, pp. 13/14.

21. FRANIKEN, a.W., p. 53. 
westerse samenlevingen een zekere mate van consensus hebben kunnen bereiken.'

Een vergelijking van dit cultuurrecht met het klassieke natuurrecht levert het volgende beeld op: ${ }^{22}$

\begin{abstract}
'Wanneer we het cultuurrecht in de vorm van het geheel van beginselen zoals we dat in de westerse samenlevingen als de normatieve grondslag hebben aanvaard, vergellijken met het klassieke natuurrecht, zouden we kunnen stellen dat het wat betreft de status, geen absollute gelding heeft, maar evenmin volstrekt willekeurig kan worden genoemd; dat de bron waaruit het voorvloeit, niet de natuur is, maar het handelen wan mensen, ingebed in culturele waarden van traditie en geschiedenis; dat het wat betreft het keninstniment, niet kan worden gekend door de individuele rede, maar alleen door een gemeenschap als geheel door de eeuwen heen; dat het wat betreft de functie, dezelfde functie kan vervullen als het klassieke natuurrecht, namelijk een kritische toets voor het positieve recht; dat het wat betreft de inhoud, gaat om een geheel van redelijk omlijnbare beginselen (en dus niet on metafysische abstracties)."
\end{abstract}

\title{
Natuurrecht en cultuurrecht: een kritische toets
}

Wat er verder zij van bovenstaande verschillen tussen 'cultuurrecht' en natuurrecht, ${ }^{23}$ in elk geval hebben zij één ding gemeen: de functie van kritische toets voor het positieve recht. Kennelijk is de rechtswetenschap inmiddels zover van het rechtspositivisme verwijderd dat KUNNEMAN, in een inleidend werkje over Rechtswetenschap, het uitoefenen van deze kritische functie, met inbegrip van de toetsing aan buitenwettelijke beginselen, tot het takenpakket rekent van 'alle rechtswetenschappers die werken binnen het standaardbeeld van rechtswetenschap, ${ }^{24}$

KUNNEMAN onderscheidt als taken van de rechtswetenschap c.q. van de jurist: de beschrijvende taak, de analyserende taak, de systematiserende taak, de interpreterende taak en de (kritische) ontwikkelingstaak. Deze laatste taak omschrijft hij aldus..$^{25}$

'Het werk van de rechtswetenschapper houdt niet op bij het beschrijven, analyseren, systematiseren en interpreteren van wetgeving en jurisprudentie. Een belangrijke taak van de rechtswetenschap is het bevorderen van de ontwikkeling van het

A.w., pp. $61 / 62$.

23 Het komt mij voor dat FRANKENs cultuurrecht in essentie minder verschilt van GROTTUS" natuurrecht dan op het eerste gezicht wellicht lijkt. Het is hier niet de plaats dit wit te werken. $\mathrm{Vgl}$. in dit verband evenwel, naast de hïerna aangehaalde inleiding van EYFFINGER en VERMEULEN, J.C.M. WILLEMS, "GROTIUS als filosoof,' Algemeen Nederlands Tijdschrift voor Wijsbegeerte 1983/1, pp. 49-55. Frank KUNNEMAN, Rechtswetenschap, Ars Aequi Libri, Nijmegen 1991, p. 9. A.w., pp. 8-9 (curs. jw). 
geldende recht. Recintswetenschappers doen dat vanuit hum eigen opvatting over (wenselijk) recht. Zij maken aldus ook een knitische functie waar. De rechtswetenschapper tracht met kracht van argumenten leden van het juridisch en politiek for um te owertuigen van zijn standpunt. De rechtswetenschapper formuleert dit standpunt in een kritisch perspectief. Het huidige recht wordt door de rechtswetenschapper getoetst aav criteria voor zijns inziens wenselijk recht. Als deze toets negatief uitvalt, zal naar het oordeel van de rechtswetenschapper het bestalande recht door het door hem gewenste recht moeten worden vervangen. Zo zal in veel gevallen een beschrijuing en analyse van het geldende recht leiden tot voorstellen om regels te schrappen, aan te vullen, te wijzigen enzovoort. Het is dan vervolgens weer aan de wetgever en de rechter om uit de verschillende voorstellen cen keuze te doen.

De criteria op grond waarvan de rechtswetenschapper tot het oordeel kan komen dat het bestaande recht niet in overeenstemming is met het wenselijke recht, werschillen. Zo kan het bestaande recht bijvoorbeeld worden getoetst aan de interne logica van het rechtssysteem zelf ("past de wet in het systeem van het recht?"). Het bestaande recht kan ook worden getoetst aan bepaalde binnen- dan wel buitenwettelike beginselen ("is deze regeling in overeenstemming met het gelijkheidsbeginsel?"). Het bestaande recht kan ook worden getoetst aan (verwachtingen omtrent) de mate waarin een regeling te handhaven is ("is een effectieve controle op de naleving van deze regeling mogelijk?"). De rechtswetenschapper is aldus de luis in de pels van wetgever, bestuur en rechter. Zo dragen rechtswetenschappers hun steentje bij aan de ontwikkeling van het recht.

Deze algemene kritische functie hebben alle rechtswetenschappers die werken binnen het standaardbeeld van rechtswetenschap.'

In hoeverre is deze algemene kritische functie evenwel in natuur-/cultuurrechtelijke zin te verstaan?

Toetsing aan mensenrechten en andere grondslagen van het recht

FRANKEN omschreef 'cultuurrecht' als 'het geheel van rechtsbeginselen, grondrechten en mensenrechten waarover wij in de westerse samenlevingen een zekere mate van consensus hebben kunnen bereiken.' De kritische functie van het cultuurrecht kan dus worden waargemaakt door (actieve en voortdurende) toetsing aan rechtsbeginselen, grondrechten en mensenrechten. KUNNEMANs "binnen- dan wel buitenwettelijke beginselen' kumnen geacht worden daarmee samen te vallen. Doch ook toetsing aan 'natuurrechtelijke' soft law-beginselen dient in mijn optiek tot de kritische functie te worden gerekend, wil deze waarlijk het predikaat 'kritisch' verdienen. ${ }^{26}$

Overigens is 'soft law; omdat het nog geen (hard) recht is, daarom nog niet rechtens onverbindend. Zoals SIMMA zei: '(...) I consider it not really state of the 
Wel kan de beperking worden gesteld dat voor de beginselen waaraan getoetst wordt, aanknopingspunten in het (internationale) recht ('hard' dan wel 'soft') te vinden zijn. Hoewel dit, gezien het uitgebreide corpus van internationale en regionale mensenrechten, en de nog steeds voortschrijdende codificatie, al spoedig het geval zal zijn, blijft de waarde van een natuur(-/cultuur)rechtelijke benadering het centraal stellen van kritische reflectie, dat wil zeggen: het consequent bezien van het positieve recht in het licht van hogere beginselen en (aldus) de structurele aandacht voor de grondslagen van het recht. Ik zou zelfs willen stellen dat de natuurrechtelijke benadering in de notie van rechtsbeginselen en/ of mensenrechten ligt besloten. Gecodificeerde rechtsbeginselen in het algemeen en mensenrechten in het bijzonder zijn - om de woorden van VERHEY te gebruiken: ${ }^{27}$

'(...) niet alleen de verzamelterm (...) voor een aantal voor eens en voor altijd vaststaande positiefrechtelijke regels, maar ook een levend en dynamisch ideaal, dat door juristen steeds weer opnieuw positiefrechtelijk uitgewerkt moet worden. Dat illustreert wel dat juristen die beweren slechts geinteresseerd te zijn in harde positiefrechtelijke regels, zichzelf veroordelen tot achter de feiten aanhollen, en eigenlijk gewoon slechte juristen zijn.'

\section{De kritische attitude van de jurist}

In de rechtswetenschap is kritische reflectie op recht - en op de vraag welk recht in een gegeven maatschappelijke situatie zou moeten gelden vanuit rechtsbeginselen en mensenrechten evenwel heel wat minder vanzelfsprekend dan men door KUNNEMANs uiteenzetting en VERHEY's verwijt aan 'slechte juristen' wellicht zou vermoeden. De professionele kritische attitude van de jurist is immers veelal beperkt tot de meer technische toetsing binnen het rechtssysteem of de meer beleidskundige toetsing van het doelmatigheidsgehalte. Toetsing aan fundamentele mensenrechten en andere grondslagen van het recht vindt, buiten specifieke onderzoeksgroepen, nog steeds eerder incidenteel dan structureel plaats.

art jurisprudentially to regard "soft law" as "legally non-binding," especially in a field like international human rights where the use of "soft law" for defining the precise content of hard law is more the rule than the exception.' (Bruno SIMMA, 'International human rights and general international law: a comparative analysis,' in: The protection of human rights in Europe, Collected Courses of the Academy of European Law Vol. Iv, Book 2, 1993, The Hague etc. 1995, pp. 153-236, op pp. 234/235.)

27 (Naar) N. verHey, 'Deuken in het ideaal,' Publiek Domein 1989/6-7, pp. 237242 , op p. 242. VERHEY schrijft hier over het beginsel van de wetmatigheid wan bestuur als "centraal element van her ideaal van de democratische rechtsstaat" (t.a.p., op p. 241 r.k.). 
Wat in FRANKENS omschrijving in het oog springt, is de culturele beperking tot "westerse" samenlevingen. De universele gelding van de internationale bill of rights - dat is de vrijwel geheel gewoonterechtelijk van karakter geworden Universele Verklaring en de beide door bijna driekwart van de staten geratificeerde mensenrechtenverdragen die die Verklaring uitwerken: IVBPR en IVESCR,$-{ }^{28}$ alsook het door ruim $80 \%$ van de staten (zij het niet zelden met feitelijk en juridisch dubieuze voorbehouden) geratificeerde Vrouwenverdrag, en het door bijna $100 \%$ van de staten geratificeerde Verdrag inzake de rechten van het kind, maken deze westerse beperking strikt genomen overbodig. Tenzij men natuurlijk (stilzwijgend) de implementatie (worden de erkende mensenrechten ook nageleefd?) in de definitie zou willen betrekken. Dan begeeft men zich evenwel al dadelijk op glad ijs: vreemdelingen-, vrouwen-, homo- en leeftijddiscriminatie, waaronder ernstige schending van fundamentele rechten van het kind, zijn zeker geen zaken die in het Westen zijn uitgebannen. Vervangt men het woord 'westerse' door het woord 'meeste,' dan kan men evenwel met FRANKENs cultuurrecht zeker vrede hebben. ${ }^{29}$

Als in het hiernavolgende van natuurrecht(elijk) gesproken wordt, is dat vanwege het burgerrecht dat deze term gekregen heeft. FRANKENS cultuurrechtelijke correcties dienen dan grosso modo als verdisconteerd in het moderne begrip van natuurrecht te worden beschouwd, dat wil zeggen met de uitbreiding tot soft law-beginselen waarvan ik hierboven (in par. 3.3.4) sprak. Hetzelfde geldt met betrekking tot de bron van het natuurrecht, de redelijke en sociale natuur van de mens; wanneer deze aanduiding wordt gehanteerd, is dat grosso modo in de beperkende zin die FRANKEN daaraan geeft, dat wil zeggen: het (redelijk en sociaal)

Een algemene plicht tot eerbiediging van de mensenrechten is deel van het internationaal gewoonterecht geworden (KOOIJMANS, a.w., p. 297). Dit betekent dat ook staten die geen partij zijn bij mensenrechtenverdragen, in geval van emstige of systematische mensenrechtenschending aansprakelijk zijn. Er dient dan sprake te zijn hetzij van een vast patroon, hetzij van een grootschaligheid die de internationale publieke opinie schokt. Een schending van gewoonterecht vindt echter ook al plaats in één enkel geval van deelneming aan of begunstiging van genocidale handelingen, slavernij, massamoord of marteling. (SCHACHTER, a.w., pp. 341 en 357 nt. 44.)

29 Enigszins schertsend (maar wellicht didactisch te verantwoorden) zouden we, de lijn van GROTIUS tot FRANKEN doortrekkend, de historische conclusie kunnen trekken: Natuur-en volkenrecht, een gehuwd paar ten tijde van Hugo DE GROOT, gescheiden in de positivistische eeuwen na DE GROOT, leven thans in concubinaat, alls meneer Internationaal Recht en mevrouw Cultuurrecht, voorzien van een door FRANKEN opgesteld samenlevingscontract. 
'handelen van mensen, ingebed in culturele waarden van traditie en geschiedenis.'

De clausulering 'grosso modo' ziet op het raakvlak van deze bron met de grondslag van de mensenrechtenidee. Hiermee bedoel ik, kort gezegd, het volgende. De redelijke en sociale (kanten van de) aard van de mens impliceert (impliceren) dat mensen zich ten opzichte van elkaar ook redelijk en sociaal hebben te gedragen (zie hierna, par. 3.3.7), met andere woorden: zegt (zeggen) ook iets over de inhoud van het natuurrecht, en daarmee over de door mij bepleite natuurrechtelijke benaderingswijze: het toetsen van het positief recht en het, als jurist, benaderen van de werkelijkheid vanuit (de grondslag van) de mensenrechten(idee). (Over dat laatste aspect, de mensenrechtelijke grondslag, kom ik in par. 3.4.1 kort en vervolgens uitgebreider in hoofdstuk 4 te spreken.) Deze natuurrechtelijke benaderingswijze brengt met zich mee dat culturele waarden, hoe belangrijk op zich en als bron ook, uiteindelijk nooit doorslaggevend kunnen zijn. Doorslaggevend kan alleen het postulaat van de redelijke en sociale menselijke aard zijn, zoals deze in de mensenrechtenverdragen als grondslag is vastgelegd of wordt voorondersteld (meestal onder de benaming: waardigheid of waarde van de mens). Vanwege het raakvlak of de wisselwerking die in mijn optiek (kort toegelicht in par. 3.3.7) tussen bron en inhoud bestaat, moet bovenstaande clausulering dus worden aangebracht.

\section{3 .6}

\section{De 'religieuze" fundering}

Als recht in laatste instantie is terug te voeren tot de moraal, tot het onderscheid tussen goed en kwaad (SCHOLTEN), waarop is dan - in allerlaatste instantie - de moraal gebaseerd? Hoewel over het ontstaan van de moraal tal van evolutionaire speculaties mogelijk zijn (evolutionisme), is het antwoord op deze vraag even vaak creationistisch van aard, dat wil zeggen dat hier naar God - bijna 'gemakshalve' bij wijze van Deus ex machina - wordt verwezen. We zijn hier aanbeland bij het probleem van de Baron-von-Münchhausen-achtige 'ophanging' van het natuurrecht die uiteindelijk op een evolutionistisch dan wel creationistisch 'geloof - in een geloof in Lot of God - berust. Om die reden duidde ik dit vraagstuk hierboven (in par. 3.3.3) aan als het probleem van de 'religieuze' fundering van het natuurrecht, welk probleem daar als laatste bezwaar tegen het natuurrecht(sdenken) werd vermeld. Valt er ook aan dit bezwaar tegemoet te komen?

Om een antwoord te vinden op deze vraag, gaan we te rade bij de inleiding van EYFFINGER en VERMEULEN bij het door hen beiden verzorgde deel uit de serie Geschiedenis van de wijsbegeerte in Nederland, 
HugO DE GROOT: Denken over oorlog en vrede. De auteurs gaan allereerst in op het argument dat de mens zijn eigen 'allerlaatste instantie' is: ${ }^{30}$

[G]esteld [zou] kunnen worden dat het naturrecht besloten ligt in het wezen van de mens, en derhalve een (...) religieus fundament [dat is een dieper fundament, een fundament buiten zichzelf, $j w]$ niet nodig heeft. Maar wat is dan wel het wezen wan de mens? Niet kan bedoeld zijn de empirische aard: wit feiten kunnen geen normen afgeleid worden [althans niet zonder meer, ${ }^{31}$ jw]. Dus moet het hier gaan om de normatieve essentie van de mens, om datgene wat hij möet zijn. Maar vooronderstelt dat weer niet een finaliteit die door een hogere instantie in de mens geplant is?"

\section{Maar wat is het alternatief? De auteurs vervolgen:}

'Dergelijke kritiek kwelt een ieder die heden ten dage een of andere natuurrechtswariant - meestal in de vorm van onaantastbaar geachte mensenrechten aanhangt. Haar principieel weerleggen lijkt onmogelijk. Het alternatief, het rechtspositivisme, dat slechts de door de staten gegeven en aanvaarde regels als recht erkent, is echter evenzeer problematisch. In essentie komt deze opvatting er op neer dat de staat slechts aan (...) rechtsregels gebonden is voor zover en zolang hij ze aanvaardt. Dit impliceert dat hij zich niet aan deze regels gebonden hoeft te achten wanneer dat in strijd is met zijn eigenbelang. Aldus vormt het rechtspositivisme de leer van de staatsraison in vermomming."

\section{Dus toch weer de redelijke en sociale natuur van de mens? EYFFINGER en VERMEULEN:}

'Tegengeworpen zou kunnen worden dat volgens het rechtspositivisme de staat gebonden is aan de eenmaal door hem aanvaarde volkenrechtelijke regels. In dat geval rijst echter de vraag waarop het bindende karakter van het volkenrecht dan wel berust. Het standaardantwoord van de rechtspositivist is dat dit recht (verdragen, gewoonterecht) gebaseerd is op de wilsovereenstemming van de staten, die op grond van de regel pacta sunt servanda (afspraken moeten nagekomen worden) verplicht zijn dienovereenkomstig te handelen. Maar waarom zou een staat zich aan het pacta sunt servanda moeten houden? De verplichting hiertoe kan immers niet gebaseerd worden op een eerdere wilsovereenstemming, omdat het

30 A.C. EYFFINGER, B.P. VERMEULEN (red.), Hugo DE GROOT: Denken over oorlog en wrede, Geschiedenis van de wijsbegeerte in Nederland, deel 8, Baarn 1991, pp. 11-29, op pp. 28-29.

31 Niet zonder meer, immers: '[D]e scherpe scheiding van Sein en Sollen (...) betreft (...) een abstractie die in de werkelijkheid niet bestaat. Het is onmogelijk om het feitelijk gebeuren als waarde-vrij te zien en warden als losstaand van de feiten." Aldus FrANkEN, a.w., p. 21 (curs. Hr). Het rechtspositivisme, dat door FRANKEN als onhoudbaar ('gevaarlijk en hypocriet') wordt afgewezen, gaat juist van die scheiding uit (zie par. 3,3,2). 
bindende karakter daarvan ook weer de gelding van deze regel - die juist bewezen moet worden - vooronderstelt! Derhalve komt de rechtspositivist er niet onderuit aan te nemen dat aan het positieve recht deze natuurrechtelijke - niet op de staatswil gebaseerde - regel ten grondslag ligt. Maar vindt deze regel niet haar rechtvaardiging hierin dat een vreedzame en ordelijke samenleving slechts mogelijk is als zij in acht genomen wordt? En vooronderstelt een dergelijke rechtvaardiging niet de redelijke en sociale natuur van de mens, die het uitgangspunt van DE GROOTs stelsel vormt?

Nogmaals, de gelding van DE GROOTs natuurrecht valt niet empirisch te bewijzen. Slechts wordt hier (...) volstaan met de constatering dat zijn denken op dit terrein harmonieert met tendensen in het volkenrecht volgens welke bepaalde rechtsregels - het jus cogens, de meest ellementaire mensenrechten en de daarmee correlerende discriminatie- en oorlogsagressieverboden - staten ook binden indien zij ze niet aanvaard hebben. Is dit jus cogens niet een herlevend natuurrecht, gebaseerd op dezelfde gedachtengang als DE GROOT in zijn De jure belli ac pacis ontwouwd heeft?'

Een 'herlevend' natuurrecht - zonder dat de vraag naar zijn 'religieuze' fundering anders kan worden beantwoord dan door te verwijzen naar het nog 'ongerijmdere' (en kwalijke) rechtspositivisme. Het door ons gezochte antwoord op het probleem van de 'religieuze' fundering, de Baron-vonMünchhausen-achtige 'ophanging' van het natuurrecht, lijkt er dus op neer te komen dat voor het natuurrecht geldt wat wel beweerd wordt ten aanzien van de democratie: het is het minst slechte, dus het menselijkerwijs beste, wegens het ontbreken van deugdelijke alternatieven. Een echt (bevredigend) antwoord is dat niet. De keuze voor het minste kwaad laat ons immers toch nog met vuile handen achter.

Hoewel aldus de opvatting wordt onderschreven dat het rechtspositivisme niet als een deugdelijk alternatief kan worden beschouwd, is hier toch een waarschuwing op haar plaats. Het kapitalisme is niet het beste systeem omdat (bijvoorbeeld) het communisme of het katholicisme (c.q. het corporatisme) historisch niet bleken (of thans blijken) te deugen, maar met elementen van (nogmaals: bijvoorbeeld) communisme en katholicisme komt het vrije-marktdenken wel een eind in de goede richting. De natuurrechtelijke benadering, met de cultuurrechtelijke correcties (ook wel 'functionele rechtsleer' genaamd ${ }^{32}$ ), beoogt c.q. poogt hetzelfde: een eind, en liefst zo ver mogelijk, in de goede richting te komen.

Om toch nog even op bovenstaand 'antwoord' terug te komen: misschien zouden we het erop kunnen houden dat de redelijke en sociale natuur of 
aard van 'de' mens, ${ }^{33}$ als product van de evolutie - waar dan $\operatorname{Lot}^{34}$ of God $^{35}$ achter zit -, impliceert dat de mens, dus elk van ons, zich ook zo redelijk en sociaal mogelijk hóort te gedragen. ${ }^{36}$ Is het toegroeien naar je 'ware aard' immers niet de essentie van zelfontplooiing? ${ }^{37}$

33 Waarmee uitteraard niet wordt ontkend dat 'de' mens, wij allemaal dus, er een aardje naar heeft het kwade te doen. Integendeel: mensenrechten zouden anders niet modig zijn.

34 Lot, of toeval, in de zin van radicale contingentie: vgl. Wim KAYZER, (red.), Een schitterend ongeluk; WII KAYZER ontmoet Oliver SACKS, Stephen Jay GOULD, Stephen TOULMIN, Daniel C. DENNETT, Rupert SHELDRAKE en Freeman DYSON, Amsterdam/Antwerpen 1993, pp. 124, 125, passim.

35 Althans een zeker vitwendig intelligent principe (vgl. Hugo DE GROOT, Het recht van oorlog en vrede, Prolegomena par. 7; vertaling LINDEMANS, Baarn 1993, pp. 42 en 232 nt. [33]). Een Principe als laatste oorzaak zonder oorzaak, dat dus aan alle heelallen en oerknallen vooraf gaat.

Een geloof in dit Principe (dan wel in Radicale Contingentie) dient los te worden gezien van religieuze beleving en uiting, welke in principe zonder 'waarheidsclaim' (VAN DANTZIG, aangehaald door Arjan VISSER, '10 Geboden," in Trouw van 29-30 augustus 1998) of -pretentie mogelijk zijn. Hier past - zonder afbreuk te doen aan de emotionele, psychologische en culturele waarde van religiositeit de relativerende voorstelling van LABUSCHAGNE van religie als doorontwikkeld 'knuffeldier' (d.i. overgangsobject): 'Belangrijk is de rol van de zogeheten "overgangsobjecten." Bij zeer jonge kinderen zijn dat knuffeldieren, rammelspeeltjes en dergelijke. Deze zijn zeer belangrijk bij het ontwikkelen van het vermogen om alleen te kunnen zijn. De betekenis van deze overgangsobjecten is overigens niet te onderschatten. In wezen zijn spel, cultuur, kunst en religie in zekere zin doorontwikkelde vormen van deze overgangsobjecten.' (B.C. LABUSCHAGNE, 'Wat maakt menselijke waardigheid tot menselijke waardigheid? Iets over de waarheidspretentie van mensenrechten,' Ciwis Mundi; Tijdschrift woor politieke filosofie en cultuur $1998 / 3$, pp. $122-130$, op p. 127 r.k.)

36 In het wezen ligt het lot, en in het lot de lotsbestemming, dat is de opdracht, niet tot berusting noch tot afwijzing of ontkenning maar tot optimalisering, besloten (in ontwikkelingspsychologische termen: de opdracht de psychische ontwikkelingstaken te volvoeren). Sein en Sollen lijken hier tot de dood met elkaar verbonden. Wat de mens op zijn best is, is ook datgene waar hij/zij voortdurend naar dient te streven - op straffe van zijn/haar eigen ongeluk.

37 We kunnen dit ook van de andere kant benaderen: vanuit de mens die van zijn of haar "ware aard" is weggegroeid, die, veelal ten gevolge van vroege traumatische ervaringen, is scheefgegroeid, waardoor hij of zij op belangrijke levensgebieden niet alleen een vast patroon van onechtheid maar ook van irrationaliteit en/of $a(n t i-)$ socialiteit vertoont. We spreken dan van een mens met gestoorde trekken of zelfs met een gestoorde persoonlijkheid. De betrokkene is zichzelf en zijn of haar omgeving tot last, al zal hij/zij de oorzaak niet in maar buiten zichzelf zoeken, en vinden dat hij-/zijzelf prima functioneert. Het gaat met andere woorden om zieke mensen die zich niet ziek voelen, maar die anderen, hun omgeving, wel ziek maken: die het leven voor zichzelf en anderen verzieken. Hoezeer zij het ook met zichzelf getroffen kunnen hebben, het zijn geen gelukkige, in wezen vaak 
En wat is zelfontplooiing anders dan het streven naar, en het werken aan, optimale rationaliteit, moraliteit en authenticiteit; een algemeen menselijk streven - individueel vorm gegeven door individuele keuzes, de individuele zelfbeschikking (wellicht beter: zelfbepaling), ten aanzien van het ware, goede en schone - waarvoor de staat, als instrument van de gemeenschap, en dienaar van de vrijheid en gelijkheid van, en solidariteit tussen haar leden, de basisvoorwaarden dient te scheppen en te waarborgen. En dat dan wel heel in het bijzonder voor de mens die nog aan het begin van dat (persoonswordings)proces staat: het kind. Welke basisvoorwaarden zijn immers basaler dan die welke de toekomstige uitoefening van het individuele zelfbeschikkingsrecht überhaupt mogelijk, en minimaal zinvol, moeten maken?

Aldus beschouwd, zouden we al op deze plaats de voorafschaduwing kunnen zien van het 'recht' van het kind op persoonswording, een natuur(rechte)lijk recht dat kan uitgroeien tot een in het algemeen rechtsbewustzijn levend beginsel, een rechtsbeginsel (wat het in de vorm van 'het belang van het kind' in essentie al is), en vervolgens - zoals het zelfbeschikkingsrecht van volkeren - van rechtsbeginsel tot rechtsregel kan verharden, of liever: in een veelvoud van rechtsregels kan uitkristalliseren. Naar de mate dat het geoperationaliseerd is, zal immers duidelijk(er) zijn wat dat 'recht' concreet (zoal) inhoudt.

Die operationalisering ligt echter nog wel heel ver in het schaduwland. Om de contouren ervan te kunnen onderscheiden, moet eerst nog meer voorwerk worden verricht. De kluwen van de rechtsbeginselen waar we hierboven enkele natuurrechtelijke draden uit hebben getrokken, moet nu verder (positief-/mensenrechtelijk) worden afgewikkeld.

Mensenrechten zijn rechtsbeginselen

Reprise: natuurrechtelijke beginselen

Volgens de indeling van SCHACHTER, weergegeven in par. 3.2.3, behoren natuurrechtelijke beginselen tot de algemene beginselen die in het internationale recht worden ingeroepen en toegepast. Deze term verwijst naar het natuurrechtsdenken, dat - aldus SCHACHTER ${ }^{38}$ - door zijn nadruk

zeer eenzame mensen. (1k doel hier met name op persoonlijkheidsstoornissen uit het B-cluster van de DSM-T: vgl. JJ.L. DERKSEN, Handboek persoonlijkheidsstoomissen; Diagnostiek en behandeling van de DSM-IV en ICD-10 persoonlijkheidsstoomissen, Utrecht 1993, pp. 18-20, 29-31, 59-81, 150-152, 163/164, 170, 174, $175 / 176,187-200,218-220,233-236,256-257$.) Zie ook bijlage $\vee$ bij dit proefschrift. 
op de redelijke en sociale natuur van de mens, dat wil dus zeggen van in principe èlke mens, tevens een mensheids-, een universalistisch denken is, een denken dat uitgaat van de eenheid van de menselijke soort (bij GROTIUS: magna illa humani generis societas, die grote gemeenschap van het menselijk geslacht, de wereldgemeenschap ${ }^{39}$ ). SCHACHTER schrijft hierover: ${ }^{40}$

"The universalist implication of this theory [het natuurrechtsdenken, jw] - the idea of the unity of the human species - has had a powerful impetus in the present area. This is evidenced in at least three significant political and legal developments. The first is the global movements against discrimination on grounds of race, colour and sex. The second is the move toward general acceptance of human rights. The third is the increased fear of nuclear annihilation. These three developments strongly reinforce the universalistic values inherent in natural law doctrine. They have found expression in numerous international and constitutional law instruments as well as in popular movements throughout the world directed to humanitarian ends. Clearly, they are a "material source" of much of the new international law manifested in treaties and customary rules.

In so far as they are recognized as general principles of law, many tend to fall within our fifth category [de natuurrechtelijke beginselen]."

Het natuurrechtsdenken is kennelijk bij SCHACHTER een materiële bron, vergelijkbaar met wat ik hierboven de natuurrechtelijke benadering heb genoemd, doch de normen die uit die bron voortvloeien, zijn pas rechtsbeginselen als zij door erkenning (door staten, door de statengemeenschap) tot de formele bron 'algemene rechtsbeginselen' kunnen worden gerekend. Dit lijkt ons in een cirkelredening te brengen. Dit hoeft evenwel niet het geval te zijn indien we het begrip materiële bron louter als natuurrechtelijke benaderingswijze, zoals hierboven in par. 3.3 .4 (en het sllot van 3.3.5) omschreven, opvatten. SCHACHTER zelf lijkt iets in die zin te doen als hij stelt: ${ }^{41}$

'The fact that equity and human rights have come to the forefront in contemporary international law has tended to minimize reference to "natural justice" as an operative concept, but much of its substantive content continues to influence international decisions under those other headings [namelijk 'equity' (redelijkheid en billijkheid) en mensenrechten, jw].'

Zie hiervoor W.J.M. VAN EYSINGA, Gids voor DE GROOTs De iure belli ac pacis, Leiden 1945, pp. 1 e.v.

40 SCHACHTER, a.w., pp. 54/55.

41 A.W., p. 55. 
Met andere woorden: 'redelijkheid en billijkheid' en 'mensenrechten' hebben de natuurrechtelijke implicatie dat de wil van staten aan hun postulaten ondergeschikt is. Het effect geven aan natuurrechtelijke beginselen is een vereiste dat - aldus de door SCHACHTER aangehaalde rechter FITZMAURICE: ${ }^{42}$

"(...) natural law in the international field imposes a priori upon States, irrespective of their individual wills or consents".'

Nog anders gesteld: de natuurrechtelijke benadering is een benadering van het positieve recht vanuit de grondslag van de mensenrechtenidee respectievelijk van de idee van 'equity,' dat is vamuit de natuurrechtelijke inhoud van deze ideeën. De grondslag van de mensenrechtenidee c.q. van de idee van redelijkheid en billijkheid, die we hierboven tegenkwamen onder de ruime vlag van (publieke en private) 'moraal' - zij het de moraal voor zover zij enigermate 'erkenning' vindt in het internationale recht, dat wil zeggen: voor zover het internationale recht (in mijn optiek: met inbegrip van soft law) aanknopingspunten voor haar toepassing biedt -, vinden we bij SCHACHTER aldus geformuleerd: ${ }^{43}$

\footnotetext{
"Natural justice" in its international legal manifestation has two aspects. One refers to the minimal standards of decency and respect for the individual human being that are largely spelled out in the human rights instruments. We can say that in this aspect, "natural justice" has been largely subsumed as a source of general principles by the human rights instruments. The second aspect of "natural justice" tends to be absorbed into the related concept of equity which includes such elements of "natural justice" as fairness, reciprocity, and consideration of the particular circumstances of a case."
}

In het hierna volgende vat ik de equity-idee op als besloten in de mensenrechtenidee (de deels processuele voorbeelden die SCHACHTER geeft, zijn immers ook in mensenrechtenverdragen en -verklaringen, c.q. in internationale jurisprudentie, terug te vinden). Tevens sluit ik mij aan bij de grondslag van dat idee zoals door SCHACHTER verwoord: minimum standaarden van fatsoen en respect voor de individuele mens. Het behoeft geen betoog dat onder mens ook het kind is begrepen.

Deze grondslag is uitgewerkt in ideeën over vrijheid (het zelfbeschikkingsrecht, bescherming tegen aantasting van de lichamelijke en geestelijke integriteit, overige burgerlijke en politieke vrijheden), gelijkheid (het gelijkheidsbeginsel en discriminatieverbod) en solidariteit (de 
economische, sociale en culturele rechten). Deze ideeën zijn op hun beurt in verdragen 'neergeslagen," waardoor er een netwerk - en 'vangnet" - van elkaar onderling aanvullende en versterkende mensenrechten/ mensenrechtsbeginselen is ontstaan.

Een andere omschrijving van deze grondslag, die we in tal van verdragen tegenkomen is: de waardigheid en de waarde van de menselijke persoon (vgl. bijvoorbeeld de preambulaire overwegingen van het Handvest van de $\mathrm{VN}$ ). Ook voor deze omschrijving geldt dat onder menselijke persoon ook de mens en persoon-in-wording: het kind, is begrepen. Dat wil zeggen: niet als theoretisch uitgangspunt van deze studie, maar als ethisch, natuurrechtelijk en mensenrechtelijk postulaat. Immers: ook de preambulaire overwegingen van het Verdrag inzake de rechten van het kind beginnen met verwijzingen naar 'de waardigheid inherent aan (...) alle leden van de mensengemeenschap' c.q. 'de waardigheid en de waarde van de mens.'

\section{4 .2}

Het rechtskarakter van rechtsbeginselen

Nu we aldus de natuurrechtelijke 'abstracte' trekken van rechtsbeginselen enigszins zijn langsgelopen, is het van belang de functie en betekenis van rechtsbeginselen in het positieve recht, in het bijzonder het mensenrechten-recht, nader in kaart te brengen. Deze taak wordt zeer vergemakkelijkt door de verhelderende interventie van MEUWISSEN in de vergadering van de Nederlandse Juristenvereniging van 1995 (te Amsterdam) naar aanleiding van het preadvies van ALKEMA, één van de vier preadviseurs over het onderwerp: De reikwijdte van fundamentele rechten. In deze paragraaf laat ik MEUWISSEN daarom aan het woord. ${ }^{44}$

\section{Beginsel eist Applikatio ${ }^{45}$}

"Rechtsnormen hebben altijd de vorm hetzij van rechtsbeginselen, hetzij van algemene regels of concrete beslissingen, hetzij van combinaties van deze. Deze vormen bevinden zich op een glijdende schaal: de overgang tussen hen is vloeiend. Het precieze punt van overgang tussen het rechtsbeginsel aan de ene kant en de rechtsregel of rechtsbeslissing aan de andere is gelegen in de mate waarin het rechtsbeginsel is bepaald naar inhoud (object) en adressaat (subject). Het is steeds de functie van de rechtsregel een rechtsbeginsel nader te concretiseren en wel met betrekking tot zijn inhoud en adressaten. Deze nadere bepaling van het rechtsbeginsel is de Applikatio (zoals bedoeld in GADAMERs Wahrheit und Metho-

D.H.M. MEUWISSEN in Handelingen Nederlandse Juristen-Vereniging 1995-II, Verslag (...) over: De reikwijdte van fundamentele rechten, Zwolle [1996], pp. 1423, op pp. $15-19$ (curs. DM).

In de in deze studie gehanteerde terminologie: operationalisering c.q. juridisering. 
de) en zij kan resulteren in hetzij een subjectief recht [bijwoorbeeld van een kind/ het kind, jw], hetzij een subjectieve plicht [bijvoorbeeld van een ouder/de ouders, jw], hetzij een bevoegdheid of taakstelling (van de overheid of andere institutie [zoals 'het gezin,' dat is: de ouder(s), jw]).

Rechtsbeginselen zijn dus rechtsnormen welke met betrekking tot hun object (inhoud) en de subjecten of adressaten tot wie ze zjjn gericht, (...) betrekkelijk onbepaald zijn, terwijl ze nochtans naar hun strekking nader bepaalbaar zijn. Die nadere bepaling geschiedt inderdaad steeds via regels of beslissingen en resulteert in het toekennen van subjectieve rechten, het opleggen van subjectieve plichten, [het] toekennen [van] bewosgdheden of taakstellingen, dan wel het instellen van een juridische status.'

\section{Beginsel verwijst naar moraal}

'Naar hun inhoud genomen hebben rechtsbeginselen een hoge rang omdat ze direct verwijzen naar een moreel gekwalificeerde inhoud (bijvoorbeeld gelijkheidsbeginsel, maatschappelijke zorgvuldigheid, behoorlijk bestuur, bona fides). De rechtsbeginselen articuleren steeds de overgang van moraal naar recht, precies door een bepaald facet van de kritische moraal als relevant voor het recht te poneren. Het morele gehalte van het rechtsbeginsel blijkt onder andere daaruit dat het nooit terzijde mag worden gesteld, dat het een absolute gelding heeft. We moeten echter goed zien wat dit betekent: als beginsel is het rechtsbeginsel absoluut. Nadere concretisering (via regels en beslissingen) is echter steeds en per definitie (en dus "absoluut") noodzakelijk en daarin precies ligt de relativiteit met betrekking tot het rechtsbeginsel. Die concretisering immers is niet absoluut, want juist - met betrekking tot object en subject - gebonden aan tijd en plaats, en [zij] had derhalve ook wel anders kunnen uitvallen, wanneer de context een andere zou zijn geweest of de afweging aan een ander element een gewicht zou hebben gegeven. Dit relatieve is precies de absoluutheid van het beginsel.'

\section{Hiërarchie}

(*..) [V]oor zover er sprake is van afweging (van belangen), dan geschiedi die precies hier: de wetgever, rechter, bestuurder of burger die een rechtsbeginsel implementeren, voltrekken een nadere concretisering van de inhoud van het beginsel met betrekking tot degenen voor wie die concretisering in de onderhavige casus heeft te gelden. Dat zijn zelfstandige beslissingen (van rechtsvinding), waarbij het (absoluut geldende) beginsel de maat is aan de hand waarvan de concrete belangen (dat is "juraspeak" voor: hetgeen in de betrokken feitelijke constellatie blijkbaar relevant wordt geacht) in het gelid worden gezet. Rechtsbeginselen en regels staan dus in een (betrekkelijk) hiërarchistische verhouding tot elkaar (...)."

\section{Mensenrechten zijn rechtsbeginselen}

'Deze uitwijding was noodzakelijk ondat ik (...) meen dat de mensenrechten, zowel binnen de sfieer van de moraal als wan het recht, als beginselen moeten worden beschouwd. Juridisch gesproken dienen de mensenrechten dus te worden begrepen als rechtsbeginselen, dus als mensenrechtsbeginselen. En wel met een hoge rang, omdat ze immers direct voortwloeien uit de menselijke wrijheid [lees: 
waardigheid, $\left.{ }^{46} j w\right]$, welke de grond is van recht en moraal überhaupt. Hier gelldt dus ook dat sprake is van een glijdende schaal, een vloeiende overgang tussen mensenrechtsbeginselen aan de ene kant en hun nadere bepaling (via regels of rechterlijke beslissingen) tot subjectieve rechten, subjectieve plichten of taakstellingen en competenties van de overheid aan de andere. (...) We moeten dus vasthouden dat de mate van nadere bepaalbaarheid van het mensenrechtsbeginsel (via regel of beslissing tot recht, plicht of competentie) de maatstaf is om uit te maken of we juridisch te maken hebben met een subjectief recht, dat voor de rechter kan worden ingeroepen (bijvoorbeeld de meeste klassieke vrijheidsrechten), een subjectieve plicht tegenover anderen (bijwoorbeeld horizontale werking), of een overheidsbevoegdheid, veelal gekoppeld aan een taakstelling (bijvoorbeeld bij veel sociale en culturelle mensenrechten). $Z_{0}$ is de "freedom of speech" uit het First Amendment van de Amerikaanse Constitutie een rechtsbeginsel. Het moge dan in de vorm van cen regel zijn geformuleerd, (...) we weten nog niet veel over zijn inhoud, noch ower de subjecten die zich erop kunnen beroepen, zollang de vereiste nadere bepaling door de wetgever of de rechter niet heeft plaatsgevonden. Deze nadere bepaling was noodzakelijk om bijwoorbeeld aan te geven in hoeverre voorafgaand verlof van de overheid krachtens deze bepaling toelaatbaar is of in hoeverre beperkingen toelaatbaar zijn.'

\section{Rechtskracht: directe werking}

'De rechtskracht van het mensenrechtsbeginsel is dus, zoals bij elk rechtsbeginsell afhankelijk van de mate waarin het - naar analogie met het verdragsrecht als self-executing, zelfwerkend of een ieder verbindend kan worden uitgelegd. Het zelfwerkend mensenrechtsbeginsel kent subjectieve rechten toe en is dus waarlijk een mensenrecht. Het niet zelfwerkende mensenrechtsbeginsell is ook juridisch bindend, maar dan als taakstellend, of competentie-scheppend. In de interpretaties van het mensenrechtsbeginsel zijn in dit opzicht verschuivingen en ontwikkelingen mogelijk (...). (....)

\section{Rechtenmetafoor: gevaar van ideologie}

'Niettemin worden in internationale documenten allerlei verschillende bepalingen als subjectieve mensenrechten aangeduid (bijvoorbeeld collectieve rechten, het recht op vrede, ontwikkeling, een goed milieu). We moeten hierbij bedenken dat hier meestal in een politieke of ethische context metaforisch gebruik wordt gemaakt van een juridische categorie (namelijk het subjectieve recht). Het kan dan ook verwarrend zujn wanneer we het metaforische karakter van deze uitdrukkingswijze uit het oog verliezen en de juridische categorie zonder meer overplanten naar een politiek vertoog.

De bedoelde documenten hebben immers een overwegend niet-juridisch karakter en de rechtenmetafoor drukt dan met name uit dat er iets gedaan moet worden en dat dit ook erg belangrijk is. Tevens wordt echter geimpliceerd dat het de taak van het positieve recht is wit te maken hoe dit politieke mensenrechtsbeginsel in de rechtsorde wordt opgenomen: als subjectief recht, subjectieve plicht, bevoegd-

Althans in de optiek van de mensenrechtenverdragen, waarbij ik mij aansluit: zie par. 3.4.1 hierboven, en hierna. 
heid of taakstelling, waaruit blijkt dat het verschil missen de verschillende categorieën zijn pointe heeft verloren. Bij de genoemde derde-generatierechten is dus geen sprake van subjectieve rechten. Het gaat hier om nobele beleidsdoelstellingen met soms een hoog moreel gehalte, maar waarvan de zeggingskracht wordt overspeeld wanneer men de rechtenmetafoor te nadrukkelijk hanteert. Het mensenrechtenethos slaat dan om in ideologie en schiet zijn doel voorbij.

\section{Rechtsvinding: teleologie}

Tegen de achtergrond van het eerder betoogde ligt het voor de hand bij de interpretatie van juridisch bindende mensenrechtsteksten de zogenaamde teleologische interpretatiemethode te volgen, welke zich oriënteert aan de strekking of het telos van het mensenrechtsbeginsell, dat is de implementatie van de vrijheid. (...)"

Op dit punt moet van MEUWISSEN afscheid worden genomen. Vrijheid is immers een zodanig vaag begrip, ${ }^{47}$ en staat bovendien in zodanige wisselwerking met andere waarden zoals gelijkheid en solidariteit, dat de bedoelde teleologie niet anders dan op die wisselwerking kan worden betrokken (zie hierboven par. 3.4.1 en hierna par. 4.2.3).

\section{5}

Mensenrechten tussen natuurrecht en rechtsverfijing: enkele conclusies

Uit het voorafgaande kan een aantal conclusies worden getrokken. Deze zullen, voor zover ze het bovenstaande samenvatten, zo kort mogelijk worden geformuleerd. Voor zover ze hiervoor niet expliciet aan de orde zijn geweest, wordt er iets meer over gezegd. Op enkele conclusies wordt voortgeborduurd in hoofdstuk 4.

\section{Rechtsbeginselen en moraal}

Algemene (fundamentele) rechtsbeginselen zijn terug te voeren op het onderscheid tussen goed en kwaad (de rechtsidee) en het onderscheid tussen goed en kwaad (de rechtsidee) is mèt de mens in de wereld gekomen: de mens als redelijk en sociaal wezen is homo juridicus. Het rechtsbeginsel is niet gelijk aan de moraal maar verwijst naar de moraal, en eist uitwerking in rechtsregels. Dus:

Conclusie 1: recht en moraal zijn niet te scheiden maar moeten wel goed worden onderscheiden. abstract concept and thus is particularly vulnerable to ideological manipulations.' Aldus Winfried BRUGGER, "The image of the person in the human rights concept,' Human Rights Quamterly 1996/3, pp. 594-611, op p. 601. 
Conclusie 2: rechtsbeginselen moeten door de wetgever in rechtsregels worden uitgewerkt èn door de rechter worden toegepast.

In senryü-vorm: ${ }^{48} \quad$ Een rechtsbeginsel

verwijst naar de moraal en

eist een rechtsregel.

\section{Mensenrechten zijn rechtsbeginselen}

Mensenrechten hebben hetzelfde rechtskarakter als rechtsbeginselen: zij zijn er een subcategorie van. ${ }^{49}$ Dat wil zeggen dat mensenrechten vertrekken vanuit de moraal (als idee/concept) en vervolgens, via ontluikende en groeiende rechtsovertuiging (opinio juris), in verdragen worden gepositiveerd. Aldus zijn het natuurlijke rechten die een positieve gelding hebben (gejuridiseerde moraal). Grepositiveerde mensenrechten behouden hun morele lading: zij zijn gemoraliseerd recht. ${ }^{50}$

Dit dubbele karakter van (gejuridiseerde) moraal en (gemoraliseerd) recht deed BADRAN (voorzitter van het Comité inzake de rechten van het kind) spreken van 'the major ethical principles which are called human rights.' Tot deze 'major ethical principles/human rights' rekent BADRAN: 'Realising the needs of children and the importance of giving them comprehensive care. ${ }^{51}$

Behalve in deze 'natuurrechtelijke" zin (het morele moment) zijn mensenrechten ook rechtsbeginselen in de meer technische/terminolo-

48 Senryü's (senrioes) zijn drieregelige versjes, van oorsprong uit Japan, van respectievelijk vijf, zeven en wijf lettergrepen. In tegenstelling tot de haiku (haikoe), die dezelfde versvorm heeft maar meer over de natuur gaat, gaat de senryü meer over de mens en zijn zieleroerselen. (Vgl. Bart MESOTTEN, Haikoe-boek, Kapellen 1986, pp. 7-10; met betrekking tot de schrijfwijze: p. 11.)

49 Vgl. in dit verband ook de verhelderende analyse van Bruno SIMMA, 'International human rights and general international law: a comparative analysis,' in: The protection of human rights in Europe, Collected Courses of the Academy of European Law, Vol. IV, Book 2, 1993, The Hague (etc.) 1995, pp. 153-236, op pp. 224-229 (The 'general principles" approach').

Op p. 229 merkt SIMMA op: '[I]n the development of human rights, law principles have always preceded practice." Met andere woorden: eerst de opinio juris, dan (hopelijk) de praktijk. Dit in tegenstelling tot het gewoonterecht, waarbij een bepaalde praktijk op een gegeven moment als recht wordt beleefd en aanvaard. Met andere woorden: eerst de praktijk, en dan de opinio juris.

50 WILLEMS, "Recht en rechter in de "dyas politica"; enkele gedachten over internationaal recht, juridisch activisme en de rolperceptie van de rechter vanuit staatsrechtelijk perspectief en met het oog op de rechtshulp aan vreemdelingen,' in: T. HOOGENBOOM e.a. (red.), Sociale advocatuur en de rechten wan de mens, Nijmegen 1989, pp. 114-145, op p. 114 .

51 Hoda BADRAN, "Foreword," in: Geraldine VAN BUBREN, The international law on the rights of the child, Dordrecht (etc.) 1995, pp. xv-xvi, op p. xw. 
gische betekenis (het functionele moment) die MEUWISSEN beschrijft. Ter illustratie kan gewezen worden op de jurisprudentie van het EG-Hof van Justitie (BARENTS en BRINKHORST) ${ }^{52}$ volgens welke EVRM/mensenrechtenverdragen/grondrechten behoren tot de algemene rechtsbeginselen welke door het Hof, krachtens art. 164 EG, worden toegepast. Het EGHof gebruikt de term algemene beginselen van gemeenschapsrecht als omvattende de grondrechten en beginselen van behoorlijk bestuur. In zijn rechtspraak heeft het EG-Hof 'erkend dat de algemene rechtsbeginselen, waartoe ook de grondrechten behoren, een integraal onderdeel vormen van het gemeenschapsrecht.' Naast EVRM kan hierbij gedacht worden aan het Europees Sociaal Handvest (ESH), IVBPR en no-conventies waarbij de lidstaten partij zijn. Een en ander is inmiddels gecodificeerd in het Verdrag van Maastricht (zie art. F, lid 2 en art. K.2, lid 1).

Rechtsbeginselen (en dus ook mensenrechten) zijn richting gevend In zijn Handboek gezondheidsrecht gaat LEENEN in op de grondbeginselen van dat recht, in het bijzonder op de beide rechtsbeginselen waarop het gezondheidsrecht in zijn (vrijwel algemeen aanvaarde) visie berust: het (sociale) recht op gezondheidszorg en het (individuele) recht op zelfbeschikking. ${ }^{53}$ In een voetnoot merkt hij op: ${ }^{54}$

52 R. BARENTS en L.J. BRINKHORST, Grondlinnen wan Europees recht, Alphen aan den Rijn 1994 (zesde druk), pp. 69 en 71.

53 Zeer kritisch met betrekking tot dat laatste beginsel (het zelfbeschikkingsrecht als grondslag van LEENENs gezondheidsrecht en daarmee in het bijzonder van de mogelijkheid van euthanasie) is RUTENFRANS in een tot nadenken stemmend betoog in Civis Mundi: C. RUTENFrans, 'Zelfbeschikking en euthanasie,' Civis Mundi; Tijdschrift woor politieke filosofie en cultuur 1998/3 (Mensenrechten'), pp. $146-152$.

Hoewel RUTENFRANS gelijk heeft met zijn opmerking dat het zelfbeschikkingsrecht 'buiten het volkenrecht eigenlijk niet bestaat' (vgl. ook mijn 'Zelfbeschikkingsrecht en nationalle cultuur: pervers en subversief?' Recht en kritiek 1985/4, pp. 351-363, op pp. 352-355), gaat hij te ver in zijn stelling dat LEENEN het zellbeschikkingsrecht 'uit het niets' heeft geschapen. Op grond wan zijn eigen toelichting kan eerder worden geconcludeerd dat LEENEN het zelfbeschikkingsrecht heeft ingelezen in 'een aantal mensenrechten die, onder meer, zijn neergelegd in de [Universele Verklaring] en [het EVRM]' (RUTENFRANS, t.a.p., op p. 146 1.k./r.k.). Of zulks op (juridisch-technisch) degelijke en (juridisch-ethisch/natuurrechtelijk) deugdelijke gronden is gebeurd, kan hier buiten beschouwing blijven. Wel zij hier opgemerkt dat wij in deze studie niet van zelfbeschikking doch van zelfbepaling spreken (als het de persoonswording bekronend element naast - en in beginsel uiteindelijk van gelijk gewicht als - de beide de persoonswording in eerste instantie bepalende - eveneens in beginsel evenwaardige - elementen 'nature' en 'nurfure'). Tegelijk met de zich ontwikkelende vermogens van het kind neemt het element van de zelfbepaling (bij een 'normale' aanleg en een 'normale' opvoeding/ 
'Door hun normatieve aard geven beginselen ook de richting van te maken normatieve keuzen aan, zonder dat zij daarmede (...) het antwoord bevatten voor elke concrete vraag."

Rechtsbeginselen zijn legitimerend, maatstaf voor toetsing en rechtsvormend In een andere voetnoot citeert hij ELDERS: ${ }^{55}$

"[R]echtsbeginselen vormen in onderlinge samenhang de grondslag van iedere ontwikkelde rechtsorde, zij zijn tegelijkertijd legitimerend, maatstaf voor toetsing van rechtsregels, en rechtsvormend. Ten slotte vervullen zij een brugfunctie tussen oud en nieuw recht."

\section{Mensenrechten doorlopen een aantal stadia}

Mensenrechten kennen een wordingsdynamiek waarin vier stadia kunnen worden onderscheiden (EIDE/DRZEWICKI). Puttend uit een voetnoot in een ander werk, kunnen we het volgende schema samenstellen: ${ }^{56}$

1. idealisering (natuurrechtelijke claims);

2. conceptualisering (internationale verklaringen);

3. juridisering:

3.1 positivering (verdragen);

3.2 normativering (toepassing van de verdragen): de gepositiveerde regels bereiken een zekere mate van normatieve rijpheid, bijvoorbeeld door de jurisprudentie (uitspraken en/of commentaren/aanbevelingen) van verdragscomité's/-organen (Rassencomité, Mensenrechtencomité,

en 'normaal' milieu) toe. In dit verband verdient RUTENFraNs lof voor de aandacht die hij vraagt voor het innemen van een (pre- en postnataal) 'ontwikkelingsperspectief op autonomie' (t.a.p., op pp. 147 r.k. en 151-152). Waaraan ik volledigheidshalve toevoeg: abortus is in dat perspectief (inderdaad) geen zaak van zelfbeschikking, maar (wel) van (bijna bovenmenselijke) 'belangen'-afweging: namelijk die tussen de "vrije" beschikking over ontwikkeling of (vroege) dood enerzijds en anderzijds de ontwikkelings- en persoonswordingskansen die voor foetus en kind in thet verschiet liggen. Kansen die niet altijd geheel of grotendeels afhankelijk zijn van de (pre- en postnatale) 'opvoedingssteun' die de maatschappij (vooralsnog niet of nauwelijks) te bieden heeft. (Het mag duidelijk zijn dat - in mijn visie - de maatschappij over het beschikkingsrecht van de zwangere vrouw minder te zeggen heeft naarmate zij haar minder - qua psychische, praktische, materiële en professionele opvoedingssteun - heeft te bieden.)

54 H.J.J. LEENEN, Handboek gezondheidsrecht [Deel 1]; Rechten van mensen in de gezondheidszorg, Alphen aan den Rijn 1988 (tweede druk), p. 20 nt. 2.

55 T.a.p. nt. 4 (ELDERS 1987). Zie ook zijn verwijzingen naar VAN DIJK, SCHOLTEN, RAWLS, DWORKIN, SCHELTENS, KELK en EIKEMA HOMMES, t.a.p. nt. 3 en 4.

56 Krzysztof DRZEWICK, 'The right to work and rights in work,' in: Asbjørn EIDE et al. (eds.), Economic, social and cultural rights; A textbook, Dordrecht (etc.) 1995, pp. 169-188, op p. 172 nt. 6 . 
Vrouwencomité, Anti-martelcomité, Comité inzake de rechten van het kind, Europese Commissie en Europees Hof inzake de rechten van de mens);

4. realisering (statenpraktijk): de verdragsnormen zijn zo gezegd alledaagse werkelijkheid geworden (hetgeen niet betekent dat er geen incidentele schendingen meer voorkomen).

In volgende hoofdstukken zullen we zien dat het recht van het kind op minimale/optimale persoonswording zich zowel in stadium 1 als in stadium 2 als in stadium 3.1 bevindt. In stadium 1 als natuurlijk recht, in stadium 2 als pedagogisch criterium, in stadium 3.1 als achterliggend beginsel van het Verdrag inzake de rechten van het kind.

Voorafgaand aan stadium 1 zou nog een ander stadium, het nulstadium, kunnen worden onderscheiden: het stadium van de noden, behoeften, belangen. SIEGHART heeft dat zo onder woorden gebracht: ${ }^{57}$

'It is the paramount objective of human rights law - both national and international - to seek to protect individuals from man-made, and so awoidable, suffering inflicted on them through deprivation, exploitation, oppression, persecution, and other forms of maltreatment by organized and powerful groups of other human beings. In order to approach that objective, human rights law uses the classical transformations of political philosophers and lawyers: from needs to morall claims, and from those claims to "rights, "founded first on morality, and ultimately on positive and enforceable law.'

Bij het doorlopen van deze stadia spelen rechtsbeginselen een cruciale rechtsvormende rol. De LAWYERS' COMMITTEE ON NUCLEAR POLICY heeft dat zo uitgedrukt..58

'The law in all its majesty would not, by itself, have brought an end to the divine right of kings, slavery, child labor, exclusive male suffrage, racial discrimination or the Vietnam War. But social progress with respect to these and many other issues would not have occurred without the intervention of legal principles in the political debate, or the confirmation of changing values in the form of legal principles.'

Paul SIEGHART, The intemational law of human rights, Oxford 1983, p. xix.

58 The LAWYERS" COMMTTTEE ON NUCLEAR POLICY, Statement on the illegality of nuclear warfare, New York 1984, "Conclusion:" on the relevance of the law and the role of lawyers,' pp. 13-15, op p. 14 i.f. (aangehaald door JJ. GLLIGAN, 'Law, the path to justice; justice, the road to peace; ; Address to the First IALANA Congress, The Hague, Sept. 22-24, 1989). 


\section{Balans}

We kunnen thans de balans van deze paragraaf (en van dit hoofdstuk) opmaken.

Moraal wordt recht via de 'draaideur' van het natuurrecht, dat is: de be-rede-nering van wat noodzakelijkerwijze - gezien de aard van de mens en de zorg voor de menselijke samenleving - recht is (GROTIUs) c.q. rechtens hóort te gelden maar in de context van de gegeven (gebrekkige) menselijke samenleving hier en nu (nog) geen geldend (althans afdwingbaar) recht is of kan zijn. Met andere woorden: de statengemeenschap is, met vallen en opstaan, op weg.

Een mooi voorbeeld van dat laatste is de opvatting van het Mensenrechtencomité, het 'rechterlij.jk' verdragsorgaan van het IVBPR, met betrekking tot de onrechtmatigheid van bezit en gebruik van kernwapens: ${ }^{59}$

'The production, testing, possession, deployment and use of nuclear weapons should be prohibited and recognized as crimes against humanity."

(Hier kunnen we zeggen dat de statengemeenschap nog een lange weg heeft te gaan. ${ }^{60}$ )

Door de draaideur nu van het natuurrecht betreedt men als het ware het rechtsgebouw, en staat dan in de grote hal van de rechtsbeginselen. Een hal die leidt naar brede zalen als die van het gelijkheidsbeginsel, en naar achterafkamertjes als dat van het belang van het kind (the best interests of the child). Een achterafkamertje omdat het desbetreffende beginsel ternauwernood in rechtsregels is uitgewerkt (volgens sommigen niet eens als rechtsbeginsel kan worden beschouwd), kortom nog te veel het rommelhok (of de donkere kamer) van de (kinder)rechter is. Hoe dan ook, het is vanuit de grote hal van de rechtsbeginselen dat de

MENSENRECHTENCOMTtE, Kemwapencommentaar: General comment [onder art. 40, lid 4 IVBPR] 14 (23), Art. 6 ICCPR, 563rd meeting (23rd session), 2 Nov. 1984, par. 6 (curs. jw); vgl. J.C.M. WILLEMS, 'Kernwapens en mensenrechten; enkele aanzetten voor studie en discussie," in: A. BEIRLAEN e.a., Kernwapens en recht, Antwerpen 1985, pp. 57-96, op pp. 72-76.

60 Vgl. ook het recente advies van het Internationaal Gerechtshof inzake de (on-) rechtmatigheid van kernwapens d.d. 8 juli 1996, (volledig) gepubliceerd in HRLJ 1996/7-10, pp. 253-392 (INTERNATIONAL COURT OF JUSTICE (ICJ), The Hague, Legality of the threat or use of nuclear weapons; Advisory opinion of $8 \mathrm{July} 1996)$, en inmiddels ook in Nederlandse vertaling verschenen: N.M.P. STELNEN, M.J.F. STELLING (red.), De rechtmatigheid van de bedreiging met of het gebruik van kernwapens; Uitspraak wan het Intemationaal Gerechtshof van 8 juli 1996 (vert. LJ. REINDERS en B.J. VERHEU), Stichting Tribunaal voor de Vrede, [Amsterdam] 1998 (368 pp.). 
'march of human civilisation' (BADRAN), ${ }^{61}$ de lange mars door de instituties begint.

Het recht op persoonswording dan, als ik weer even vooruit mag lopen, is - in mijn voorstelling - niet een nieuw kamertje (dat in de toekomst tot een brede zaal zal worden uitgebouwd), maar een ruimte die ontstaat doordat het achterafkamertje van het belang van het kind wordt vertimmerd, en er andere ruimtes aan worden toegevoegd: het beginsel van de zich ontwikkelende vermogens van het kind, het beginsel van de passende leiding en begeleiding, het beginsel van de "views of the child" (het horen en het respecteren van de mening van het kind), het recht op overleven en ontwikkeling. Een ruimte die in directe verbinding staat met de zaal van het gelijkheidsbeginsel. En wellicht ooit die zaal in grootte en 'civilising' pracht zal evenaren. De ruimte van een beschaafd beginsel ${ }^{62}$ die tot de zaal van een beschavend beginsel wordt. Door het beschavende (volwassenen-educatieve') effect der rechtsverfijning, dat is: operationalisering in de vorm van uitwerkings- en uitvoeringsregelgeving.

Maar nu loop ik te ver vooruit, zowel op de stof als op de werkelijkheid. Het is hier niet de plaats voor luchtfietserij, al heeft het rechtsgebouw, afgezet tegen de statenpraktijk, ontegenzeglijk wel iets weg van een luchtkasteel. En al is het juist de functie van het recht, door operationalisering van rechtsbeginselen, de kloof tussen beginsel en praktijk te dichten. Hoewel we daarop moeten blijven hameren, en daarin moeten blijven geloven - gesteund door de geschiedenis die ons behalve geweld, ja tegen geweld en het kwaad in de wereld in, ók laat zien, en dus leert, dat 'je ideeën kunt laten gebeuren door erin te geloven' ${ }^{63}-$, is een ge-

In VAN BUEREN, t.a.p., op p. xw.

62 PESSERS noemt het belang van het kind 'Iejen van de belangrijkste beginselen van onze rechtsorde' (aangehaald door wrLLEMs, 'Van parentiarchie naar Vadertje Staat; over 't verwekken, mishandelen en beschermen van kinderen,' Nemesis 1992/3, pp. 8-23, op p. 10 1.k.). Zie ook hoofdstuk 8, par. 8.2.1. CLITEUR heeft dit van William IAMES geleerd: P.B. CLITEUR, 'Macht en vrijheid; een reflexie over het werk van S.W. COUWENBERG,' in: S.W. COUWENBERG, Geschiedenis als noodlot; Over de historiciteit van het menselijk bestaan en het machtsmotief als primaire drijkracht, Kampen/Kapellen 1995, pp. 117-140, op p. 136 iff.

In dit opstel staat CLrrEur stil bij de grote (staatsrechts)wetenschappelijke verdienste van COUWENBERG, doch werwijt hij deze tevens ambivalentie tegenover zijn 'westers project' (t.a.p., op pp. 131-132), een ambivalentie die, naar zich laat vermoeden, verband houdt met de kloof tussen de intellectueel bereikte inzichten en onbewuste emotionele weerstanden daartegen; weerstanden die soms te ver kunnen doorschieten, bijwoorbeeld in COUWENBERGs opinies ten aanzien van Zuid-Afrika (t.a.p., op p. 131) of ten aanzien van de vreemdeling in 'de nationale cultuur' (vgl. J.C.M. WILLEMS, 'Zelfbeschikkingsrecht en nationale cultuur: per- 
zonde dosis realisme ${ }^{64}$ hierbij noodzakelijk. SIEGHART houdt ons een behoedzaam optimisme voor ten aanzien van onze verwachtingen van mensenrechten, waarmee dit hoofdstuk op een veilige plaats tussen wens en werkelijkheid in kan worden afgesloten: ${ }^{65}$

'It would of course be naive to expect that international human rights law will miraculously abolish the oppression and exploitation of man by his fellows. But by making at least some of these [acts of oppression and exploitation, jw] visibly illegitimate, it can help to diminish their intensity and their extent, and so justify a position of guarded optimism about its prospective utility.'

vers en subversief?' Recht en kritiek 1985/4, pp. 351-363). Een ambivalentie die COUWENBERG zelf lijkt toe te schuiven naar 'het ambivalente karakter van het beschavingsproces' ('Voorwoord,' a.w., pp. 7-8, op p. 8).

64 Het andere uiterste, een cynisch realisme, lijkt echter dichter te liggen bij wat we bij de doorsnee jurist aantreffen. CLITEUR steekt niet onder stoelen of banken dat hij het realisme van juristen, althans van de gemiddelde staatsrechtsjurist, wetenschappelijk gezien bepaald niet gezond vindt. DONNER als hun kwade genius nemend, verwijt hij hen wars te zijn van elke andere beoefening van de (staats-) rechtswetenschap dan het 'nauwgezet commentaar leveren op wetgeving en rechterlijke uitspraken' (t.a.p., op p. 134): 'Vaak blijft de afkeer van een andere dan de positivistisch-detaillistische benadering echter onuitgesproken (...). De meeste juristen voelen $(\ldots .$.$) een soort instinctieve afkeer van theorievorming. Het is iets$ waaraan zij niet "gewend" zijn.' DONNER zelf houdt hij voor (t.a.p., op p. 129 i.f): '[W]at hier als wereldwijs realisme verkocht wordt, is in feite wetenschapsfilosonische naivitieit.' 
Wat is de uiteindelijke (gepositiveerde) grondslag van de mensenrechten - en dus van de rechten van het kind? Welke grondbeginselen zijn elementen van die grondslag? Is er een rangorde van mensenrechten? Wat kan (dan) als kerninhoud van de rechten van de mens en de rechten van het kind worden beschouwd? Welke mensenrechten kunnen tot de universele - kernrechten worden gerekend? En welke mensenrechten liggen, in weerwil van de onderlinge verwevenheid van alle rechten, toch meer van die kern af? Dit zijn de belangrijkste vragen die aan dit hoofdstuk ten grondslag liggen c.q. in dit hoofdstuk aan de orde worden gesteld. De bedoeling van dit hoofdstuk is daarbij niet een filosofisch overzicht te geven, of in filosofische (laat staan in theologische) discussies te treden, doch slechts om enkele belangrijke mensenrechtshistorische en -theoretische elementen langs te lopen, welke uiteindelijk, geheel of ten dele, expliciet of impliciet, (ook) hun neerslag hebben gevonden in het Verdrag inzake de rechten van het kind.

In hoofdstuk 2 namen we als rode draad voor het mensenrechtenthema: machtsbeperking, demacratisering en emancipatie. We kunnen deze rode draad omschrijven als: de beperking van macht en willekeur van enkeling of elite (civiliserend aspect) door het toekennen van steeds meer rechten aan ieder mens (humaniserend aspect) en/of aan steeds meer categorieën mensen (emancipatoir aspect). Onder de vaan van vrijheid, gelijkheid en broederschap (solidariteit) kwamen in de loop van enkele eeuwen in toenemende mate machtsbeperking, democratisering en emancipatie tot stand. Vrijheid, gelijkheid en solidariteit werden uitgewerkt in mensenrechtenverklaringen en -verdragen. Zo kwam art. 1 van de Universele Verklaring (UV) te luiden:

Alle mensen worden wij en gelijk in waardigheid en rechten geboren. $\mathrm{Zij} \mathrm{zijn}$ begiftigd met verstand en geweten, en behoren zich jegens elkander in een geest van broederschap te gedragen. (Curs. jw.)

De mensenrechten waren - en zijn - aldus instrumenten in een historische civiliserende, humaniserende en emancipatoire missie. 
In hoofdstuk 3 (par. 3.4.1) werd aangesloten bij SCHACHTERs formulering van de aan deze mensenrechten ten grondslag liggende (minimale) natuurrechtelijke mensenrechtenidee: het waarborgen van minimum standaarden van fatsoen en respect voor de individuele mens als postulaat van de redelijke en sociale menselijke natuur. ${ }^{1}$

De universele en gelijke gelding van deze idee vloeit uit het menselijke van deze natuur voort: zij betreft alle mensen zonder onderscheid, waar zij zich ook bevinden. Dit is de betekenis van de in het Handvest van de $\mathrm{VN}$, in de Universele Verklaring en in alle mensenrechtenverdragen (respectievelijk) beleden 'waardigheid en waarde van de menselijke persoon" (HVN); "de inherente waardigheid van alle leden van de mensengemeenschap" (UV); 'de inherente waardigheid van de menselijke persOon' (IVBPR, IVESCR); 'de menselijke waardigheid" (Tweede facultatieve protocol, het doodstrafprotocol, bij IVBPR); "de waardigheid en de gelijkheid van alle mensen' (IVUR); 'de waardigheid en de waarde van de mens' (VUDV); 'de inherente waardigheid van de mens' (AMV); 'de waardigheid inherent aan alle leden van de mensengemeenschap' (VRK). Aldus is de menselijke waardigheid geproclameerd als grondslag van het internationale recht, als grondslag van de mensenrechten, en als grondslag van recht $\ddot{u}$ berhaupt.

Dat laatste vinden we bijvoorbeeld treffend verwoord in de dissenting opinion van rechter WEERAMANTRY van het Internationaal Gerechtshof bij het Kernwapenadvies van het Hof: $^{2}$

'Judge WEERAMANTRY's Opinion is based on the proposition that the use or threat of use of nuclear weapons is illegal in any circumstances whatsoever [curs. Comm.]. It violates the fundamental principles of international law, and represents the very negation of the humanitarian concerns which underlie the structure of humanitarian law. It offends conventional law and, in particular, the Geneva Gas Protocol of 1925, and Article 23(a) of the Hague Regulations of 1907. It contradicts the fundamental principle of the dignity and worth of the human person

Een postulaat is een 'rationele maar onbewijsbare vooronderstelling' (H.Ph. VISSER 'T HOOFT, 'De menselijke waardigheid in tradïtie en actualiteit," Wijggerig perspectief 1985-1986/5, pp. 151-162, op p. 154 r.k.). Annex bij communiqué IGH van 8 juli 1996, no. 96/23, pp. 6/7. Omdat hier sprake is van een dissenting opinion, is het nuttig te refereren aan de verklaring, Annex, p. 1, van de voorzilter van het Hof BEDJAOU, waarin wordt gesteld dat het oordeel van het Hof op geen enkele manier mag worden uitgelegd 'as leaving the way open to the recognition of the lawfulness of the threat or use of nuclear weapons.' Volgens de president (t.a.p.) 'it would be very rash to accord, without any hesitation, a higher priority to the survival of a State than to the survival of humanity itself.' In zijn opvatting bestaat er een erga omnes-onderhandelings- èn -resultaatswerplichting met betrekking tot nucleaire ontwapening (t.a.p., i.f.). 
on which all law depends [curs. jw]. It endangers the human environment in a manner which threatens the entirety of life on the planet."

En in het slotdocument van de tweede mondiale mensenrechtenconferentie, de Vienna Declaration and Progranme of Action (1993), lezen we dadelijk in de eerste preambulaire overweging: ${ }^{3}$

"Recognizing and affirming that all human rights derive from the dignity and worth inherent in the human person (....).'

Voor we de elementen en de oorsprong van de menselijke waardigheid enigermate in beeld proberen te krijgen, dient eerst te worden bezien of deze grondslag ook als de grondslag van de rechten van het kind kan worden beschouwd, in algemene zin dan wel toegespitst op de waardigheid van het kind.

\subsubsection{De menselijke waardigheid van het kind}

De menselijke waardigheid is niet alleen neergelegd in preambules, rechterlijke opinies of internationale politieke verklaringen en programma's, zij is ook gepositiveerd, dat wil zeggen is, als rechtsbeginsel, terug te vinden in verdragsartikelen. Een tweetal verdragsbepalingen uit de internationale Bill of rights kan hier als illustratie dienen:

Art. 10, lid 1 IVBPR:

Allen die van hun wrijheid zijn beroof, dienen te worden behandeld met menselijkheid en met eerbied voor de waardigheid, inherent aan de menselijke persoon.

Art. 13, lid 1, tweede volzin IVESCR:

[De staten die partij zijn bij dit verdrag] zijn van oordeel dat het onderwijs gericht dient te zijn op de volledige ontplooiing van de menselijke persoonlijkheid en het besef van haar waardigheid (...).

Wat is de oogst als we op zoek gaan naar dit rechtsbeginsel in het Verdrag inzake de rechten van het kind? We staan eerst kort stil bij de preambule om vervolgens enkele verdragsbepalingen de revue te laten passeren. by intergovemmental organizations, intemational non-governmental organizations and professional associations, The Raoul WALLENBERG Institute Human Rights Guides vol. 1, Den Haag (etc.) 1995, pp. 20-25, op p. 20. 


\section{De staatspedagogische taak}

In de preambule van het Verdrag inzake de rechten van het kind wordt op verschillende plaatsen gerefereerd aan de staatspedagogische taak, of liever: de staatspedagogische verantwoordelijkheden, ten aanzien van kind en gezin. In de vierde, achtste, negende en elfde preambulaire overweging gaat het om de algemene financiële, medische en pedagogische middelen, gericht, zo gezegd, op goede voeding en opvoeding, verzorging en ontwikkeling: het kind heeft recht op 'bijzondere zorg en bijstand,' heeft 'bijzondere bescherming en zorg' nodig. Met name het kind 'in uitzonderlijk moeilijke omstandigheden' behoeft 'bijzondere aandacht.' Waarmee bijzondere politieke aandacht en aandacht van de verantwoordelijke staatsorganen zal zijn bedoeld.

In de vijfde preambulaire overweging wordt gewezen op het belang van het gezin voor de samenleving en voor alle gezinsleden, kinderen in het bijzonder, en dus op de verantwoordelijkheid van de staat het gezin te beschermen en bij te staan. In de zesde preambulaire overweging wordt gewezen op het belang van een gezinsomgeving, en in het bijzonder een gezinsklimaat van geluk, liefde en begrip, voor de ontwikkeling van het kind. Hieruit kan worden afgeleid dat de verantwoordelijkheid van de staat tot bescherming van en bijstand aan het gezin ook in pedagogische zin dient te worden verstaan.

In de zevende preambulaire overweging ten slotte worden opnieuw enkele staatspedagogische verantwoordelijkheden aangegeven. Deze zien in de eerste plaats op het te bewerkstelligen pedagogische einddoel en in de tweede plaats op het algehele pedagogische klimaat. Het einddoel: bij het bereiken van de meerderjarigheid (ingevolge art. 1 VRK: op achttienjarige leeftijd) dient het kind 'volledig' te zijn 'voorbereid op het leiden van een zelfstandig leven in de samenleving.' Aan dit einddoel(-ideaal) dient de staat het zijne bij te dragen. Wat dit concreet inhoudt of zou kunnen inhouden, dient uit het Verdrag zelf te worden afgeleid. Uiteraard komen we daar later nog uitgebreid op terug.

Met betrekking tot het algehele pedagogische klimaat (dus: gezinsklimaat, onderwijsklimaat, het politieke en culturele klimaat) betreffen de verantwoordelijkheden van de staat de geest waarin kinderen worden opgevoed. Kinderen dienen namelijk te worden opgevoed 'in de geest van de in het Handvest van de Verenigde Naties verkondigde idealen, en in het bijzonder in de geest van vrede, waardigheid, verdraagzaamheid, vrijheid, gelijkheid en solidariteit' (curs. jw). Anti-militarisme, anti-racisme en het bijbrengen van het gedachtengoed van de menselijke waardigheid, mensenrechten en gemeenschapszin behoren dus tot het publieke domein van de opvoeding, dat wil zeggen tot de ingrediënten van de opvoeding 
waar de staat niet alleen op heeft toe te zien, maar ten aanzien waarvan hij ook een actieve rol heeft te spelen.

Betreft het hier, evenals in de hierboven (par. 4.2) aangehaalde eerste, alsook in de tweede preambulaire overweging, de menselijke waardigheid in algemene zin, de vraag kan worden gesteld of het Verdrag inzake de rechten van het kind deze grondslag ook onder de rechten van het kind legt en/of meer specifiek van de menselijke waardigheid van het kind gewaagt.

\section{De waardigheid van het kind}

Als antwoord op deze vraag kan de volgende korte inventarisatie volstaan.

Art. 23, lid 1 VRK: bescherming van het gehandicapte kind met verzekering van de waardigheid van het kind en bevordering van zijn zelfstandigheid.

Art. 28, lid 2 VRK: bescherming tegen slaan op school; handhaving van de discipline op scholen dient verenigbaar te zijn met de menselijke waardigheid van het kind. ${ }^{4}$

Art. 37, aanhef en onder c, eerste volzin VRK: een kind in hechtenis of gevangenschap wordt behandeld met menselijkheid en met eerbied voor de waardigheid inherent aan de menselijke persoon, en zodanig dat rekening wordt gehouden met de behoeften van een persoon van zijn leeftijd.

Art. 39 VRK: bevordering van de rehabilitatie (lichamelijk en geestelijk herstel en maatschappelijke herintegratie) van slachtoffers van welke vorm ook van verwaarlozing, exploitatie of misbruik (kindermishandeling), van foltering of welke andere vorm ook van wrede, onmenselijke of onterende behandeling of bestraffing, of van gewapende conflicten; rehabilitatie vindt plaats in een omgeving die bevorderlijk is voor de gezondheid, het zelfrespect en de waardigheid van het kind.

Het Afrikaanse Handvest inzake de rechten en het welzijn van het kind (OAE, 1990, nog niet in werking getreden; per 1 januari 1998 door 8 staten geratificeerd) bevat ook een expliciete bepaling over handhaving van de discipline in thet gezin. Art. 20 ('Parental responsibilities"), lid 1 aanhef en onder $\mathrm{c}$ van het Handvest luidt: Parents (...) shall have the duty (...) to ensure that domestic discipline is administered in moderation and that the child is treated with humanity and with respect for [its] inherent dignity.

Het Afrikaanse Handvest (African Charter on the rights and welfare of the child) is opgenomen in: Geraldine VAN BUEREN (ed.), International documents on children, Dord[r]echt (etc.) 1993, pp. 33-48; Philip E. VEeRMAN, The rights of the child and the changing image of childhood, Dordrecht (etc.) 1992, pp. 579-597 (de laatste tekst is gevolgd; curs. jw). 
Art. 40, lid 1 VRK: in het jeugdstraf(proces)recht wordt geen afbreuk gedaan aan het gevoel van waardigheid en eigenwaarde van het kind, en wordt rekening gehouden met de leeftijd van het kind (enz.).

\section{Conclusie}

Aan bovenstaande opsomming mag de gevolgtrekking worden verbonden dat kinderen rechten hebben omdat zij, hoewel persoon-in-wording, dragers zijn van de inherente - aan hun mens-zijn (dat is hun lid zijn van de magna humani generis societas ${ }^{5}$ ) verbonden - menselijke waardigheid.

We kunnen dit thans ook zo formuleren. Een mens is een persoon met rechten: het bezit en genot van rechten, het bekleed zijn met rechten en het daarnaar behandeld worden, maakt deel uit van de waardigheid van het mens zijn, en maakt een mens tot een persoon(lijkheid): rechten horen bij de persoon, constitueren de persoon. ${ }^{6}$ Kinderen zijn bovendien bekleed met extra c.q. speciale rechten omdat zij zich ontwikkelende mensen, persoon-in-wording, zijn.

Persoon en persoon-in-wording zijn hier bedoeld in psychologische c.q. filosofische zin. Persoon in juridische zin betekent immers niet meer dan (bloot) rechtssubject, en dat is "een ieder die drager van rechten en plichten kan zijn." Kàn zijn: dus ook de zuigeling en de oligofreen zijn persoon in de zin van ons recht; zij zijn immers geen zaak, zoals de slaaf in de voormalige koloniën tot in het midden der vorige eeuw. ${ }^{8}$

We kumnen dus concluderen dat (respect voor c.q. de onschendbaarheid $\operatorname{van}^{9}$ ) de menselijke waardigheid geldt ten aanzien van alle personen in juridische zin. We zullen nog zien, en sommigen hebben misschien al vermoed, dat de grondslag van de menselijke waardigheid (6́k)

GROTUS' grote wereldgemeenschap van mensen. 'DE GROOT gaat hier uit van de stoïsche gedachte van een de staten overstijgende universele gemeenschap van mensen, welke voortdurend in zijn werk terugkeert (...); noot EYFFINGER/VERMEULEN bij Prol. 17 (Denken over oorlog en vrede, p. $155 \mathrm{nt} .28$ ). Naast de plaatsen die deze noot geeft uit boek II en III van De jure belli ac pacis, kan gewezen worden op Prolegomena 14 (gemeenschapszin, "appetinus societatis," immers: alle mensen stammen af van dezelfde voorouders); 17 (die grote gemeenschap van volkeren); 23 (die gemeenschap die de gehele mensheid of meerdere volkeren onderling verbindt); en 24 (vorsten dienen niet slechts rekening te houden met hett ene hun toevertrouwde volk, maar met de gehele mensheid). Vgl. VISSER 'T HOOFT, t.a.p., op p. 156 1.k./r.k.

7 Gr. VAN DER BURGHT, M. ROOD-DE BOER, Personen-en familierecht, PTTLO-serie deell 1, Arnhem 1996 (tiende druk), p. 30.

8 T.a.p.

9 Waarvan de Duitse Grundgesetz gewaagt; art. 1, lid 1 GG luidt: Die Würde des Menschen ist unantastbar. Sie zu achten und zu schïtzen, ist Verplichtung aller staatlichen Gewalt. 
voor de rechten van het kind, en de waardigheid van het kind als specifiek rechtsbeginsel, geen oude wijn in nieuwe zakken is, doch dat zich hier een radicale breuk aftekent met de traditionele maatschappelijke conceptie van het kind als verlengstuk, of zelfs bezit van de ouders. Dit impliceert een principieel andere kijk op kinderen, waardoor het niet langer mogelijk wordt op willekeurige en minachtende wijze met hun rechten en belangen om te gaan.

Wat zich hier met andere woorden, als directe en impliciete belofte en boodschap van het Verdrag inzake de rechten van het kind, aftekent is dat - net zoals, binnen één generatie, wat nu heet sexuele intimidatie, ${ }^{10}$ algemeen opgevat ging worden als minachting van de vrouw en ontkenning van haar menselijke waardigheid - in toenemende mate bepaalde pedagogische praktijken opgevat zullen gaan worden als minachting van het kind en ontkenning van zijn menselijke waardigheid, als ontkenning en bruuskering van de waardigheid van het kind. De sleutel steekt als het ware al in het slot, maar zal nog moeten worden omgedraaid alvorens het acquis humanitaire ${ }^{11}$ gezin en kinderkamer kan binnenstappen.

Het Verdrag inzake de rechten van het kind bevat deze belofte en boodschap, los van specifieke beginselen en regels, rechten en verplichtingen, op de enkele grondslag van de menselijke waardigheid. Dit hoeft niet te verbazen. Menselijke waardigheid heeft als (meta-)rechtsbeginsel immers niet alleen morele maar ook rechtspolitieke betekenis. SCHACHTER heeft dat ooit zo uitgedrukt: ${ }^{12}$

"The "dignity of the human person" and "buman dignity" are phrases that have come to be used as an expression of a basic value accepted in a broad sense by all peoples. (...) It has acquired a resonance that leads it to be invoked widely as a legal and moral ground for protest against degrading and abusive treatment. No other ideal seems so clearly accepted as a universal social good.'

10 Nog maar betrekkelijk kort gelleden spraken we van 'ongewenste intimiteiten' waarbij ongewenst masculien werd uitgellegd als heimelijk gewenst, al of niet met toepassing van het 'bestwil-criterium." Voor zover er, vanuit de optiek van de geprivilegieerde, al behoefte aan een uitleg, aan zelfrechtvaardiging was. De sociale sensitivering ten aanzien van het vernederende en ontmenselijkende van het 'bestwil-criterium' heeft nog niet die uitbreiding bereikt dat ook 'het belang van het kind" binnen haar empathische werkterrein is gekomen.

11 De term is van Bruno SIMMA, 'International human rights and general international law: a comparative analysis,' in: The protection of human rights in Europe, Collected Courses of the Academy of European Law, Vol. rv, Book 2, 1993, The Hague (etc.) 1995, pp. 153-236, op p. 173.

12 Oscar SCHACHTER, "Human dignity as a normative concept," American Joumal of International Law $1983 / 4$, pp. 848-854, op pp. 848 en 849 . 
We gaan twee eeuwen terug in de tijd. Van de 'nieuwlichterij' van het Verdrag inzake de rechten van het kind naar de nieuwlichterij van de (anonieme) auteur van Aan het volk van Nederland: Joan Derk VAN DER CAPELLEN (1741-1784). Jan \& Annie ROMEIN schrijven in hun Erflaters van onze beschaving over deze '18de-eeuwse MULTATULI,' die in en door zijn strijd voor de rechten van de burger, en dus tegen de regentenkaste en de Oranje-dynastie, de grondlegger van de Nederlandse democratie werd: ${ }^{13}$

'Door zijn wil om zich zelf te hervormen, werd VAN DER CAPELLEN een hervormer van zijn land, opgetild en gedragen door het nieuwe denkbeeld der "menselijke waardigheid" dat in zijn leeftijd wan algemeen humanistisch ideaal tot ideologisch fundament werd van de zich emanciperende burgerij. Wil men VAN DER CAPELLEN eren, men doe het hem als eerste woordvoerder dier burgerij bij haar nog onzeker tasten om dat ideologisch fundament tot grondslag van politieke actie uit te bouwen."

Politieke actie, wel te verstaan, tegen de meest formidabele tegenstanders die zich laten denken: geprivilegieerden. Geprivilegieerden die Joan Derk rauw lustten:

'Zoals alle bevoorrechten die zich in hun voorrechten bedreigd zien, streden zij mateloos en gewetenloos.'

Het zal geen verbazing wekken dat de regenten ook het beproefde middel van de verdachtmaking niet schuwden. Alom lieten zij aanplakken hoe infaam en ongehoord VAN DER CAPELLEN hen wel niet beledigd had, zeer wel wetende ...

"dat het geijkte "fatsoen" altijd de publieke opinie achter zich heeft tegenover de nieuwlichter, die eo ipso "onfatsoenlijk" is."

'Het nieuwe begrip der "menselijke waardigheid"' werd door VAN DER CAPELLEN evenwel consequenter dan door menig tijdgenoot, in binnenen buitenland, in stelling gebracht. In het jaar van de Amerikaanse Onafhankelijkheidsverklaring, dus ...

13 Jan \& Annie ROMEIN, Erflaters van onze beschaving, Amsterdam 1976 (elfde druk), pp. 541-565, op pp. 546/547. De hierna volgende citaten zijn te vinden op resp. pp. $555,(554 /) 555,554$ en 556 . 
(...) reeds in 1776 , toen de kwestie rees of uit de koloniën naar Nederland gevluchte slaven aan hun meesters moesten worden teruggegeven, [had hij] de slavernij bestreden (...) met het argument dat alle mensen "door dezelfde magtige Hand geschapen, allen onderling gelijk zijn"."

De idee van de menselijke waardigheid is bij VAN DER CAPELLEN kennelijk vanaf het moment dat zij politiek vertaald ging worden, niet alleen met het burgerlijk emancipatiemotief verbonden, maar ook met een universeel gelijkheidsbeginsel verknoopt geweest. Althans op enigerlei wijze met de gedachte dat menselijke waardigheid menselijke waardigheid is, en dus alle mensen-'rassen' betreft. ${ }^{14}$ Hoezeer VAN DER CAPELLEN de slaven houdende - Amerikaanse founding fathers ook bewonderde, een ‘kritiekloos bewonderaar van de Amerikanen' was hij daarom zeker niet:

"Hij was een der eersten die hun onverdraagzaamheid laakte in hun houding tegenover de negers."

\section{De strijd gestreden}

VAN DER CAPELLEN heeft noch de Franse noch de Nederlandse 'opstand der burgers' mogen meemaken. Hij overleed enkele jaren nadat, in 1781 - twee eeuwen na de geboorteakte van de Nederlandse staat: het Plakkaat van Verlatinge -, zijn magistrale Aan het volk van Nederland, de geboorteakte van de Nederlandse democratie, anoniem verscheen.

In de bundel Opstand der burgers merkt ZIJDERVELD met betrekking tot de Franse revolutionairen op: ${ }^{15}$

"Naast solidariteit (broederschap) stonden vrijheid en gelijkheid in het vaandel van de bourgeois revolutionairen. Voor de meesten van hen (...) waren vrijheid en gelijkheid twee woorden voor hetzelfde fenomeen, maar hadden ze een keuze moeten maken, dan zouden zij voor gelijkheid hebben geopteerd.'

14 Ook Olympe DE GOUGES nam stelling tegen de slavernij, in haar toneelstuk L'esclavage des noirs, ou l'Heureux naufrage, dat gereed kwam in 1785, maar dat - door interventie van hogerhand en doordat acteurs het beneden hun waardigheid vonden zich zwart op te maken - pas in 1789 kon worden opgevoerd. Het leidde toen dadelijk tot relletjes tussen aanhangers wan de slavernij en abolitionisten - en tot hoon jegens de femme auteur. Het dissidente - en dus "ongehoorde" - van ook dit geluid maakte dat het stuk snell van het repertoire werd verwijderd. (Hannelore SCHRÖDER, 'Olympe DE GOUGES 1748-1793; leven voor vrouwenbevrijding - sterven op de guillotine,' in: Olympe DE GOUGEs; Verklaring van de rechten van de vrouw en burgeres, a.w., pp. 16-23, op pp. 19/20.)

15 A.C. ZUDERVELD, 'Schimmen en schaduwen van de rewolutie der revoluties,' in: S.W. COUWENBERG (red.), Opstand der burgers; De Franse revolutie na 200 jaar, Kampen 1988, pp. 39-49, op p. 46. 
Was voor de Amerikaanse kolonisten veeleer vrijheid - liberty - een precaire waarde, ${ }^{, 16}$ bij Fransen en Bataven, althans bij VAN DER CAPELLEN, lag dat kennelijk een slag anders. Wat daarvan verder zij, het lijkt erop dat de nazaten van de Europese revolutionairen, van Franse of Bataafse stam, uiteindelijk aan het langste eind hebben getrokken. Anderhalve tot twee eeuwen later laten de preambules van het Handvest van de $\mathrm{VN}$, van de Universele Verklaring en van de VN-mensenrechtenverdragen zien dat menselijke waardigheid en waarde steeds aan gelijkheid en gelijke rechten zijn gekoppeld, daarmee onlosmakelijk verbonden zijn. Eén van VAN DER CAPELLENS geestelijke nakomelingen, de Nederlandse Advocaat-Generaal J.C.M. LEIJTEN, laat zich in een opstel ter herdenking van 200 jaar Verklaring van de rechten van de mens en van de burger (geproclameerd door de Provisionele Representanten van het Volk van Holland op 31 januari 1795) zelfs ontvallen 'dat het beginsel van de gelijkheid (...) aan het begin staat van elke ware beschaving." ${ }^{.17}$

VAN BOVEN merkt in dit verband op: ${ }^{18}$

'Hoezeer een recht dat eertijds niet gold als een essentieel recht van de mens, in het werk van de VN thans is uitgegroeid tot een van de meest fundamentele mensenrechten, kan worden aangetoond aan de hand van het recht op gelijkheid voor de wet en het recht op gelijke bescherming tegen discriminatie. RoUGIER ging ervan uit dat het gelijkheidsbeginsel niet per se verbonden was aan het mens-zijn en derhalve niet kon worden gerekend tot de "droits humains." In de minderhedenverdragen en -verklaringen van na de eerste wereldoorlog gold het gelijkheidsbeginsel voor de onderdanen van de betrokken staten, maar niet woor de mog wijdere kring van alle inwoners, zodat dit beginsel onder het stelsel van de minderhedenbescherming van de Volkenbond nog niet als een algemeen erkend internationaal mensenrecht kon worden beschouwd. In het Handvest van de Verenigde Naties echter wordt het gelijkheids- of non-discriminatiebeginsel bij herhaling genoemd (...) en in de activiteiten van de Verenigde Naties op het gebied van de rechten van de mens alsmede in het bewustzijn van de grote meerderheid der volkeren is geen aangelegenheid zo prominent als het gelijkheids- of nondiscriminatiebeginsel."

Op papier is vanaf 1945 niet alleen de strijd tegen de dominantie en het superioriteitsdenken van prinsen en regenten, maar ook van blanken, èn van mannen gestreden. Op niet vrijblijvend, en dus ongeduldig papier, verdraagt de waardigheid van de mens geen klasse-, rasse- en sexe-privi-

T.a.p.

17 J.C.M. LEITTEN, 'De Verklaring van de rechten van de mens en van de burger Pieter PAULUS lof!" NJCM-Bulletin 1995/7, pp. 873-881, op p. 881.

18 Th.C. VAN BOVEN, De volkenrechtelijke beschemning van de godsdienstvrijheid, [diss. Leiden], Assen 1967, pp. 80-81. 
leges, geen klasse-, rasse- en sexe-justitie meer. De tweede overweging van de preambule van het Handvest van de VN kan hier opnieuw, maar $\mathrm{nu}$ iets vollediger worden geciteerd:

Wij, de volken wan de Verenigde Naties, vastbesloten (...) opnieuw ons vertrouwen te bevestigen in de fundamentele rechten van de mens, in de waardigheid en de waarde van de menselijke persoon, in gelijke rechten woor mannen en vrouwen (...).

Uit de preambule van het Rassenverdrag kan hier de passage worden herhaald:

Ervan overtuigd dat elke leer die uitgaat van de superioriteit van een bepaald ras, wetenschappelijk onjuist, op zedelijke gronden werwerpelijk, en sociaal onrechtvaardig en gevaarlijk is (...).

Soms blijkt het ongeduld van het papier met zoveel woorden, zoals in de preambulaire overwegingen van het Vrouwenverdrag (VUDV):

De staten die partij zijn bij dit verdrag,

Erop wijzend dat het Handvest van de Verenigde Naties opnieuw het vertrouwen in de fundamentele rechten van de mens, in de waardigheid en de waarde van de mens en in gelijke rechten van mannen en vrouwen bevestigt, (...)

Evenwel verontrust over het feit dat ondanks deze verschillende fverklaringen en verdragen] wijdverbreide discriminatie van vrouwen nog steeds bestaat;

Eraan herinnerend dat discriminatie van vrouwen schending van de beginselen van gelijkgerechtigheid en eerbied voor de menselijke waardigheid is (...).

Deze laatste overweging vinden we terug in de volgende verdragsverplichting:

Art. 5, aanhef en onder a VUDV:

De staten die partij zijn bij dit verdrag, nemen alle passende maatregelen om (...) het socialle en culturele gedragspatroon van de man en de wrouw te weranderen ten einde te komen tot de uitbanning van vooroordelen, van gewoonten en van alle andere gebruiken die zijn gebaseerd op de gedachte van de minderwaardigheid of meerderwaardigheid van én van beide geslachten of op de stereotiepe rollen van mannen en vrouwen (...).

Menselijke waardigheid impliceert gelijkwaardigheid, menselijke waardigheid eist dan ook de gelijke behandeling van gelijke gevallen - en bijgevolg de ongelijke behandeling van ongelijke gevallen naar de mate van de ongelijkheid - zonder onderscheid naar klasse, rang, ras of sexe, of welke niet te gerechtvaardigen grond dan ook. Dit gelijkheidsbeginsel vindt men 
niet alleen opgenomen in de Universele Verklaring (art. 2, lid 1; art. 7), maar is ook in verschillende verdragen gepositiveerd: art. 2, lid 1 en art. 26 IVBPR; art. 2, lid 2 en art. 3 IVESCR; art. 2, lid 1 VRK.

In de preambules van het Handvest van de VN en van alle VNmensenrechtenverdragen wordt gelijkheid, of gelijke rechten, steeds in één adem met menselijke waardigheid genoemd. Om enkele voorbeelden te geven: "erkenning van de inherente waardigheid en van de gelijke en onvervreemdbare rechten' (IVBPR/IVESCR); 'de waardigheid en de gelijkheid van alle mensen' (IVUR); 'erkenning van de gelijke en onvervreemdbare rechten (...) [welke] voortvloeien uit de inherente waardigheid van de mens' (AMV).

\subsection{3}

\section{Menselijke waardigheid en ontplooiing}

De menselijke waardigheid is evenwel niet alleen met het gelijkheidsbeginsel vervlochten geraakt: met de toenemende democratisering en socialisering (VAN BOVEN) ${ }^{19}$ in de eeuwen na het emancipatoire activisme van VAN DER CAPELLEN groeide allengs het besef dat menselijke waardigheid evenmin los kan worden gedacht van zelfbeschikking - zelfbeschikking in de (geestelijke) zin van vrije ontplooiing van de persoonlijkheid. ${ }^{20}$ Het verband tussen socialisering, waardigheid en vrije ontplooiing wordt in de Universele Verklaring zelfs nadrukkelijk gelegd. ${ }^{21}$

Voor de periodisering van het mensenrechtenthema aan de hand van de trits democratisering (van uitsluiting naar insluiting van mensen), socialisering (de - met die insluiting samenhangende - opkomst van economische, sociale en culturele rechten ter aanvulling van de burgerlijke en politieke rechten) en internationalisering (van nationale verklaringen en grondwetten thaar internationale verklaringen en verdragen) zie: Theo VAN BOVEN, "The Déclaration des droits de lhomme ef du citoyen of 1789 and its influence on the Constitutions," in: E.H. HONDIUS, G.J.W. STEENHOFF (eds.), Netherlands reports to the thirteenth International Congress of Comparative Law, Montreal 1990, Den Haag 1990, pp. 363-373, op pp. 366 e.v.; dez., 'General course on human rights,' in: The protection of human rights in Europe, Collected Courses of the Academy of European Law, Vol. IV, Book 2, 1993, The Hague (etc.) 1995, pp. 1-106, op p. 10.

20 Zo vermeldt de Duitse GG, na de menselijke waardigheid onschendbaar te hebben verklaard in art. 1, als eerste mensenrecht in art. 2 (lid 1): Jeder hat das Recht auf die freie Entfaltung seiner Persönlichkeit, soweit er nicht die Rechte anderer verletzt und micht gegen die verfassungsmäßige Ordnung oder das Sittengesetz verstöBt. (Het gelijkheidsbeginsel volgt dan in art. 3.)

21 Vgl. in dit verband Bård-Anders ANDREASSEN, 'Article 22,' in: Asbjorn EIDE e.a. (eds.), The Universal Declaration of human rights; A commentary, Oslo(/Oxford) 1992, pp. 319-355, op pp. 343 en 352. 
Art. 22 UV:

Een ieder heeft als lid van de gemeenschap recht op sociale zekerheid en heeft er aanspraak op dat door middel van nationale inspanning en internationale samenwerking, en overeenkomstig de organisatie en de hulpbronmen van de betreffende Staat, de economische, sociale en culturele rechten, die onmisbaar żjn woor zijn waardigheid en voor de vrije ontplooiing van zijn persoonlijkheid, verwezenlijkt worden.

Socialisering staat in nauw verband met gelijkheid, is de expressie van een steeds materiëler (en in het Westen ook steeds materialistischer) invulling van de gelijkheidsidee. Wat is begonnen als formele (passieve of negatieve) gelijkheid voor de wet als burgerlijk en politiek recht is thans uitgedijd tot een netwerk van economische, sociale en culturele rechten die aan die formele gelijkheid, en aan burgerlijke en politieke vrijheden überhaupt, althans in het welvarende Westen, betekenis en inhoud hebben gegeven. Een menswaardig bestaan laat zich zonder materiële basisvoorzieningen en ontplooiingsmogelijkheden niet (meer) denken. Deze voorzieningen en mogelijkheden kunnen als de materiële uitdrukking van het gelijkheidsbeginsel worden beschouwd, welke vrijheid in meer waarachtige zin heeft mogelijk gemaakt - door deze namelijk ook tot vrijheid van gebrek ${ }^{22}$ uit te breiden. ${ }^{23}$ Een vrijheid, noem haar materiële, actieve of positieve vrijheid, welke op haar beurt zonder gemeenschapszin, zonder solidariteit niet in stand kan blijven. ${ }^{24}$

22 Eén van de vier vrijheden genoemd in de tweede preambulaire overweging van de Universele Verklaring: 'Overwegende dat terzijdestelling van en minachting voor de rechten van de mens geleid hebben tot barbaarse handelingen, die het geweten van de mensheid geweld hebben aangedaan, en dat de komst van een wereld waarin de mensen rijheid van meningsuiting en geloof zullen genieten, en vrij zullen zijn van vrees en gebrek, is verkondiggd als het hoogste ideaal van iedere mens.' De vrijheid van vrees ziet op wereldwijde wapenvermindering (Louis $B$. SOHN, 'How American international lawyers prepared for the San Francisco Bill of rights," AJIL $1995 / 3$, pp. 540-553, op p. 541).

23 Zeer kernachtig is dit gezegd door VAN DIJK: 'Daar wrijheid slechts effectief genoten kan worden wanneer deze gepaard gaat met voldoende ontplooingsmogelijkheden, vereist de realisatie van het vrijheidsbeginsel de erkenning en realisatie van het gelijkheidsbeginsel. Anders zullen de bevoor rechten de minderbedeelden in die ontplooiing steeds verder overtroeven en daardoor beperken." (P. VAN DUK, "Rechten van de mens en ontwikkelingssamenwerking, enige rechtsbeginselen, ${ }^{\prime}$ NICM-Bulletin 1980/1, pp. 4-20, op p. 9.)

24 Hier kan VAN DIJK (t.a.p., op p. 10) fraai van het statelijke naar het individuele niveau vertaald worden: 'Zoals het zelfbeschikkingsbeginsel [zellbepalings- c.q. ontplooiingsbeginsel, jw] slechts betekenis heeft indien het stoelt op het beginsel van de formele en materiële gelijkheid (...), zo is de realisatic van die gelijkheid, gegeven de bestaande verschillen, alleen mogelijk op de grondslag van verantwoordelijkheid van de [statelijke] gemeenschap als zodanig en van de individuele 
Toch kan er, ondanks alle verwevenheid, naast het gelijkheidsbeginsel als eerste, meer uitwendig element van het waardigheidsbeginsel. een ontplooiingsbeginsel als tweede, meer inwendig element van het beginsel van de menselijke waardigheid worden onderscheiden. In het eerste element, het gelijkheidsbeginsel, komt de menselijke gelijkwaardigheid tot uitdrukking. In het tweede element, het ontplooiingsbeginsel, komt de menselijke vrijheid in de zin van individuele zelfbeschikking tot uitdrukking. Aldus zijn op de grondslag van de menselijke waardigheid twee grondbeginselen tot ontwikkeling gekomen: het gelijkheidsbeginsel en (wat hier genoemd wordt:) het ontplooiingsbeginsel. Het gelijkheidsbeginsel als meer uitwendig, meer op "vreedzame coëxistentie" gericht beginsel, met de nadruk op 'hetgeen aan mensen gemeenschappelijk is'; het ontplooiingsbeginsel als meer inwendig, meer op de 'ruimte voor morele autonomie (d.w.z. voor het persoon-zijn zelf)' gericht beginsel, met de nadruk op 'hetgeen mensen van elkaar onderscheidt. ${ }^{25}$

Het bindmiddel tussen beide is de zowel uitwendig als inwendig werkzame appetitus societatis, GROTIUs' gemeenschapszin, de Franse en Bataafse broederschap, de huidige burgerlijke solidariteit. Beide beginselen hebben in 'de strijd tegen bevoogding' ${ }^{26}$ door staat, kerk en knellende maatschappelijke verbanden en instellingen een grote rol gespeeld, al is het heden ten dage de vraag of het bindmiddel tussen beide, de burgerlijke solidariteit, sterk genoeg zal blijken om ons te behoeden tegen een materialistisch egalitarisme als tot het uiterste doorgevoerd gelijkheidsbeginsel, en tegen een losgeslagen individualisme als tot het uiterste doorgevoerd - maar tragisch verkeerd begrepen - ontplooiingsbeginsel. Een dergelijke reductio ad absurdum van het ontplooiingsbeginsel zou een terugkeer van het recht van de sterkste - in de woorden van de A-G LEIJTEN:: ${ }^{27}$ 'van de grootste bek en de volste portemonnaie" - betekenen: 'ontplooiing' als ultieme pervertering van de gelijk(waardig)heid.

Het is daarom - dunkt me - van het grootste belang, al gaat het het bestek van deze studie te buiten, ook solidariteit tot de status van beginsel te verheffen, en gelijkheids-, ontplooiings- en solidariteitsbeginsel

[leden van die gemeenschap] voor deze realisatie (...).

25 De aangehaalde formuleringen zijn van H.Ph. VISSER 'T HOOFT, 'De menselijke waardigheid in traditie en actualiteit;' Wijsgerig perspectief 1985-1986/5, pp. 151162 , op p. $156 \mathrm{l}$.k. en p. 157 r.k. (Morele autonomie dient hier in ruime zin , als zedelijke en geestelijke autonomie, te worden verstaan.)

26 VISSER "T HOOFD, t.a.p., op p. 157 1.k. Even verderop spreekt de auteur van "de tyrannie wan talrijke sociale bindingen (...) waarvan wij ons $n u$ gelukkig pogen wrij te maken (...).' (T.a.p., op p. $1581 . k$; curs. jw.)

27 J.C.M. LEIJTEN, 'De Verklaring van de rechten van de mens en van de burgerPieter PAULUS lof!' NJCM-Bulletin 1995/7, pp. 873-881, op p. 881. 
steeds in hun onderlinge relatie en hun relatie tot het 'moederbeginsel' van de menselijke waardigheid te bezien. ${ }^{28}$

In het vervolg van deze studie wordt nog uitgebreid op het ontplooiingsbeginsel, toegespitst op (de persoonswording van) het kind, ingegaan. Op deze plaats moeten we, ten einde ook de oorsprong, de juridische afstamming, van het beginsel van de menselijke waardigheid enigszins in beeld te krijgen, wel verre van ons aan toekomstbespiegelingen te bezondigen, nogmaals een sprong in de geschiedenis wagen, terug naar het jaar 1625 .

\subsubsection{De oorsprong: morele autonomie}

Kan men op grond van het bovenstaande wellicht enigermate de rechtshistorische gang bevroeden van het gelijkheids- alsmede het ontplooiingsbeginsel, zo niet als fillosofisch dan toch als psychologisch sequeel van de idee der menselijke waardigheid, die idee zelf kon in de menselijke geschiedenis pas ontstaan toen de mens als individu werd geboren, dat is vanaf het moment dat het concept van de morele autonomie van de individuele mens het levenslicht zag. We zijn dan terug bij de gewetensvrijheid, die bij GROTIUS, in De jure belli ac pacis van 1625, op radicale wijze juridisch gestalte kreeg in het recht en de plicht van de militair dienst te weigeren indien hij in geweten overtuigd was van of zelfs maar twijfelde aan de rechtmatigheid van de oorlog. ${ }^{29}$ VERMEULEN merkt hierover op: ${ }^{30}$

'The important place conscience occupies in his system leads GroTIUs to the conception of individual moral autonomy. (...)

[I]n De jure belli ac pacis individual conscience is valued much higher than in scholastic theology. GROTIUs accepts the basic premiss that one should not do anything contrary to one's conscience, however crroneous it may me (...). Therefore soldiers must refrain from a war they mistakenly believe to be unjust (...).

(...) We may conclude that in his treatment of the military duty to obey Grorus does not (as the majority of the writers on the subject did) accept superior orders as a prima facie justification of war acts, while he does not presume the lawfulness of these orders, but makes it mandatory upon every soldier to act in accordance with his conscience. Another remarkable aspect of GRoTIUs' exposition is that this duty to act in conformity with conscience is joined with a corresponding right to do so. If subjects doubt in regard to the justice of a war (and a fortior if

Vgl. ook art. 1 (eerste èn tweede volzin) van de Universele Verklaring (aangehaald aan het begin van par. 4.2).

29 Zie hiervoor par. 3.3.1 (onder het hoofd De jure belli ac pacis).

30 Ben VERMEULEN, 'Grotius on conscience and military orders, Grotiana, New Series, vol. 6, 1985, pp. 3-19, resp. op pp. 14, 15, 16 en 19. 
they are convinced of its injustice) the state may not compel them to serve (...). It seems that GROTIUS is the first to speak in favour of such a large sphere of immunity in case of conscientious objections against military orders. I believe this has been an important contribution to the development of principles such as moral autonomy and freedom of conscience. (...)

GROTIUS' exposition of the military duty to obey in De jure belli ac pacis presupposes individual responsibility and moral autonomy.'

\section{The ultimate unit of all law}

Hier daagt aan de kim het individu als 'the ultimate unit of all law' - en van daaruit de internationaalrechtelijke rechtssubjectiviteit van het individu: het individu als drager van internationaalrechtelijke rechten en plichten - waarvoor GROTIUS de volkenrechtelijke kiem heeft gelegd.

Dit was in wezen mogelijk door de grotiaanse parallellie tussen staat en individu, de (in de woorden van LAUTERPACHT) 'analogy - nay, the essential identity - of rules governing the conduct of States and of individuals. ${ }^{31}$ Met andere woorden: de opvatting bij en van GROTIUS dat voor staten (vorsten) in principe geen andere regels gelden dan voor (gewone) individuen. Deze principiële parallellie ...

'(....) is not asserted for the reason that States are like individuals; it is due to the fact that States are composed of individual human beings; it results from the fact that behind the mystical, impersonal, and therefore necessarily irresponsible personality of the metaphysical State there are the actual subjects of rights and duties, namely, individual human beings. This is the true meaning of the Grotian analogy of States and individuals. The individual is the ultimate unit of all law, international and municipal, in the double sense that the obligations of international law are ultimately addressed to him and that the development, the wellbeing, and the dignity of the international human being are a matter of direct concern to international law. (...)

At the end of the nineteenth century WESTLAKE was propounding, without compromise or circumlocution, the same doctrine as matter of sound international law and of international morallity. "The society of States," he says, "(...) is the most comprehensive form of society among men, but it is among men that it exists. States are its immediate, men its ultimate members".,32

Op enkele individuele rechten na (zoals het recht zijn land te verlaten en het recht op asiel), ${ }^{33}$ was van een ontspruiten in GROTIUS' hoofdwerk

Hersch LAUTERPACHT, 'The Grotian tradition in international law,' in: The British Yearbook of Intemational Law 1946, pp. 1-53; reprinted in: E. LAUTERPACHT (ed.), Intemational law, being the collected papers of Hersch LAUTERPACHT, Vol. 2, Part 1, Cambridge (etc.) 1975, pp. 307-365, op p. 336.

A.w., pp. 336-337 (curs. HL).

Vgl. LAUTERPACHT, a.w., pp. 358 en 360-361. 
zelf van de idee van 'fundamental rights and freedoms of the individu$\mathrm{al}^{34}$ enkel sprake ten aanzien van het geweten van de militair. Waaraan ongetwijfeld GROTIUS' principiële onderscheid tussen rechtmatige en onrechtmatige oorlogen ten grondslag ligt. ${ }^{35}$ Een onderscheid dat, in combinatie met individuele gewetensvrijheid en verantwoordelijkheid, inderdaad moet worden gezien als van cruciaal belang ${ }^{36}$ ter beteugeling van een barbaarse oorlogswellust. ${ }^{37}$

Hoewel bij GROTIUS dus nog hoofdzakelijk beperkt tot de militair, kon vanaf dat moment, vanaf 1625 , het concept van de individuele morele autonomie in de ideeëngeschiedenis ontkiemen om ten slotte uit te botten in de idee van de menselijke waardigheid, welke op haar beurt dat concept verder politiek en juridisch kleur en geur ging geven. Politiek gebeurde dat - in Nederland - door VAN DER CAPELLEN en zijn medepatriotten. Politiek-juridisch liep dat uit op verschillende mensenrechtenverklaringen. Juridisch - internationaalrechtelijk - klonk dat door in het Handvest van de $V N$, en werd dat uitgewerkt in de Universele Verklaring van de rechten van de mens en de daarop gebaseerde VN-mensenrechtenverdragen. Om ten slotte in het slotdocument van de tweede mondiale mensenrechtenconferentie, de Vienna Declaration and Programme of Action (1993), tot de erkenning te leiden die in par. 4.2 verkort, maar hier volledig kan worden aangehaald: ${ }^{38}$

LAUTERPACHT, a.w. pp. 354-358.

35 Vgl. WLLEMS, 'GROTIUS and the atomic weapon: the nuclear weapon-discussion in the light of the theory of "just war" with Hugo DE GROOT," Grotiana 1981, pp. 103-114, op p. 104/105.

36 Anders RöLING, die van mening is dat GRoTIus' doctine 'in de praktijk [leidde] tot de oorlogsvrijheid.' (B.V.A. RÖLING, Volkenrecht en wede, Deventer 1985, derde druk, p. 16.) Daargelaten de historische juistheid of onjuistheid van deze opvatting, zij gaat lijnrecht in tegen de inhoud, geest en strekking van GRoTius' hoofdwerk. Anderzijds moet worden erkend dat in de geschiedenis zelfs de bijbel, of de koran, tot het meest gruwelijke misbruik heeft geleid (en soms nog leidt). Welke tekst is veilig of heilig in de handen van fanatici of kwaadwilligen? Vandaar juist het belang van ruimte voor individuele autonomie: de individuele gewetenswrijheid - voorzien van het zwaard van de vrijheid van meningsuiting. (Vgl. ook Jan C.M. WILLEMS, 'Hugo DE GRoOr,' NRC Handelsblad 6 mei 1983, 'Brieven.')

37 GRoTTus, De jure belli ac pacis, Prol. 28: 'Op grond van het bovenstaandle kwam ik tot de overtuiging dat er een volkenrecht - zowel de oorlogsverklaring (jus ad bellum) als de oorlogvoering (ius in bello) beheersend - moest bestaan. Niettemin zag ik in de christelijke wereld een oorlogswellust waarvoor zelfs de heidenen zich zouden schamen.' (WILLEMS, 'Hugo DE GROOT en het volkenrecht,' Wijsgerig perspectief $1982-1983 / 3$, pp. 66-70, op p. 68 l.k.)

38 ALFREDSSON/TOMAŠEVSKI (eds.), A thematic guide to documents on the human rights of women, pp. $20-25$, op p. 20 i.f. 
${ }^{6}$ Recognizing and affirming that all human rights derive from the dignity and worth inherent in the human person, and that the human person is the central subject of human rights and fundamental freedoms, and consequently should be the principal beneficiary and should participate actively in the realization of these rights and freedoms."

\section{2 .5}

\section{Conclusie: gelijkheid en ontplooiing als grondbeginselen}

Het concept van de morele individuele autonomie, bij GROTIUS al beperkt juridisch vertaald in de gewetensvrijheid van de militair - zijn plicht èn recht dienst te weigeren als hij zelfs maar twijfelde aan de rechtmatigheid van de oorlog -, heeft, gehuld in het kleed van de menselijke waardigheid, in toenemende mate politieke en juridische erkenning gevonden. Verburgerlijkende (civiliserende), vermenselijkende (humaniserende) en vermaatschappelijkende (ìnsluitende democratiserende, socialiserende en emancipatoire) ontwikkelingen sedert het eind van de achttiende eeuw droegen ertoe bij dat steeds meer draden van vrijheid, gelijkheid en solidariteit in dat kleed werden geweven. Aldus is de menselijke waardigheid allengs geworden tot - in de woorden van VISSER 'T HOOFT: ${ }^{39}$

(...) een maatschappelijke topos, tot een inspirerend beginsel in het licht waarvan men de samenleving dusdanig vorm tracht te geven dat de medemens concreet "in zijn waarde" wordt gelaten."

In zijn waarde wordt gelaten, en in zijn waarde bevestigd wordt - zoals aan deze woorden nog kan worden toegevoegd.

$\mathrm{Na}$ tweede wereldoorlog en concentratiekampen hebben mensenrechtenverdragen het kleed ten slotte van een internationaalrechtelijke kraag voorzien, zodat nu gesteld kan worden dat de menselijke waardigheid fundamenteel rechtsbeginsel, mensenrechtelijk meta-beginsel, en zelfs algemeen juridische Grundnorm geworden is. Voortaan geldt, niet enkel als morele, maar als morele èn juridische norm: $:^{40}$

'De medemens dient concreet, door de maatschappelijke ordening, "in zijn waarde" te worden gelaten."

Dit betekent, met andere woorden, dat - als we de menselijke waardigheid in haar naoorlogse juridische kraag grijpen - op de staat de bodemverplichting rust ervoor te zorgen en erop toe te zien dat mensen worden behandeld conform minimale standaarden van fatsoen en respect. Op

40 VISSER 'T HOOFT, ta.p., op p. $1561 . \mathrm{k}$ (curs. jw). 
zodanige minimale standaarden kan elk mens, zwart of blank, vrouw of man, jong of oud, onder alle omstandigheden aanspraak maken. Het was, is en blijft de taak van het recht deze standaarden te formuleren, deze aanspraken te operationaliseren, en aan de geleidelijke verhoging van die standaarden en verbetering van hun operationalisering voortdurend werkzaam te zijn.

De menselijke waardigheid als meta-beginsel impliceert in elk geval gelijkwaardigheid, gepositiveerd in het gelijkheidsbeginsel; en zelfbeschikking in de zin van de vrije ontplooiing der persoonlijkheid, uitgewerkt niet alleen in tal van burgerlijke en politieke, maar ook - in samenhang en wisselwerking daarmee - in tal van economische, sociale en culturele rechten. Impliceert met andere woorden het gelijkheidsbeginsel en het ontplooiingsbeginsel als mensenrechtelijke grondbeginselen.

\section{Trias pedagogica}

Tot slot: de menselijke waardigheid is ook 'de grondslag voor een bepaling en veiligstelling van fundamentele rechten ${ }^{341}$ van het kind. De menselijke waardigheid in het algemeen en de waardigheid van het kind in het bijzonder liggen aan de rechten van het kind ten grondslag en zijn in het Verdrag inzake de rechten van het kind gepositiveerd. Als meta-beginselen, of liever: als dubbel metabeginsel, eisen zij 'een concretisering, een interpretatie, van hetgeen "waardigheid" in maatschappelijk opzicht betekent. ${ }^{32}$ Hetgeen in het bijzonder ook geldt ten aanzien van de triade kind-ouder-staat, welke ik hierna zal noemen: de Trias pedagogica.

Rechten en verplichtingen in de Trias pedagogica dienen dan ook opgesteld, en voor zover opgesteld, getoetst te worden aan het waardigheidsbeginsel, en daarmee aan de elementen gelijkheid en ontplooiing, die tot het waardigheidsbeginsel (zijn gaan) behoren, dus aan het gelijkheids- en aan het ontplooiingsbeginsel. Het ontplooiingsbeginsel dat, zoals we nog zullen zien, zich niet laat denken, niet bestaanbaar is zonder het persoonswordingsbeginsel, met andere woorden denknoodzakelijk in het verlengde van 'persoonswording' ligt. Persoonswording, c.q. het persoonswordingsbeginsel, zal dan ook als derde element van de waardigheid van het kind moeten worden betracht, als derde mensenrechtelijk en als eerste kinderrechtelijk - grondbeginsel. ${ }^{43}$

VISSER 'T HOOFT, t.a.p.

42 VISSER 'T HOOFT, t.a.p.

43. Op deze plaats kan inmiddels gewezen worden op het verhelderende en boeiende opstel van LABUSCHAGNE (B.C. LABUSCHLAGNE, "Wat maakt menselijke waardigheid tot menselijke waardigheid? lets over de waarheidspretentie van mensenrechten,' Civis Mundi; Tijdschrift voor politieke filosofie en cultuur 1998/3, pp. 122130), waarin HONNETHs HEGELreceptie (erkenningstheorie) voor het voetlicht 
Hoezeer in alle geledingen van de maatschappij de democratisering ook mag voortschrijden, in het recht blijft een hiërarchisch denken niet alleen als traditionele vanzelfsprekendheid maar ook als wezenlijke noodzakelijkheid voortbestaan. De lagere regel moet getoetst kunnen worden aan de hogere, deze weer aan de nog hogere, de nationaalrechtelijke aan de internationaalrechtelijke, de regel weer aan het beginsel, het beginsel in de natuurrechtelijke benadering - weer aan het hogere beginsel, de grondslag, de kerninhoud van het recht. Bij de gratie van de hiërarchie vervult het recht zijn kritische functie.

Het is dan ook niet verwonderlijk dat ook - misschien wel juist mensenrechtenjuristen zich bezighouden met de vraag naar kerninhouden en kernrechten, hetgeen meestal gebeurt tijdens de zoektocht naar universaliteit.

De jurist is een praktisch en kritisch ingesteld mens, al heeft het kritische wel eens onder het praktische te lijden. De waarschuwing van filosofen dat '[e]very attempt at an absolute principle has proved to be groundless $^{24}$ neemt hij of zij voor kennisgeving aan zolang zich in de juridische gereedschapskist voldoende beginselen en fundamentele rechten bevinden om daarmee uit de voeten te kunnen. Ook beginsellen, gronden mensenrechten kunnen botsen, en juist daar ligt een dankbaar werkterrein voor de jurist. Uit de resultaten van praktisch-kritische arbeid kristalliseert dan vroeg of laat vanzelf wel een hiërarchie uit - of niet.

Toch is het niet alleen nuttig of boeiend maar voor een goed functioneren van het recht zelfs noodzakelijk ook op het hoge niveau van beginselen en mensenrechten een zekere hiërarchisering in te voeren, zodat in het licht van een centrale waarde of van een kerninhoud de botsing van rechten kan worden benaderd. ${ }^{45}$ In plaats dat steeds opnieuw dezelfde argumenten naar voren moeten worden gebracht, kan dan naar het

wordt gebracht, in welke sociaal- (MEAD) en ontwikkelingspsychologische (WINNICOTT) elementen zijn geîntegreerd.

44 Norberto BoBbio, The age of rights, Cambridge 1996, p. 5.

Vgl. ook het 'overzichtsartikel' van Michael FrEEMAN, 'The philosophical foundations of human rights,' in Human Rights Quanterly 1994/3, pp. 491-514; de eerder aangehaalde bijdrage van Winfried BRUGGER, "The image of the person in the human rights concept,' Human Rights Quarterly 1996/3, pp. 594-611; alsook de recente bijdrage van Jerome J. SHESTACK, "The philosophic foundations of human rights,' in Human Rights Quarterly 1998/2, pp. 201-234.

Uit deze formulering blijke dat ik hiervoor wel zwaarwegende argumenten noodzakelijk acht. Voor de redenen voor deze voorzichtigheid verwijs ik naar Theodor MERON, 'On a hierarchy of international human rights,' American Joumal of Intemational Law 1986/1, pp. 1-23 (op p. 22). 
fundamentelere karakter van het desbetreffende rechtsbeginsel worden verwezen. Vooropgesteld dat over dat fundamentele(re) karakter globale consensus bestaat, dat wil zeggen dat er op dit punt van een opinio juris (algemene rechtsovertuiging) of ten minste van een opinio necessitatis (denknoodzakelijke rechtsovertuiging, een overtuiging van evidente of noodzakelijke rechtslogica) sprake is ${ }^{46}$

Wanneer ik in het voorafgaande gesproken heb van de menselijke waardigheid als (gepositiveerde) grondslag van het recht, en daarin een meer uitwendig en een meer inwendig element als grondbeginselen namelijk respectievelijk het gelijkheidsbeginsel en wat ik genoemd heb het 'ontplooiingsbeginsel' en het 'persoonswordingsbeginsel' - heb onderscheiden, dan is dat vanuit het standpunt van de jurist die het praktische en kritische nut van een hiërarchie bepleit, zij het zonder filosofische en historische overwegingen (geheel) uit het oog te verliezen. Ik mag hierbij verwijzen naar wat in een vorig hoofdstuk over een cultuurrechtelijk op te vatten (dat wil zeggen: historisch en metafysisch relativerende) natuurrechtelijke benadering is gesteld. Hieraan doet niet af of toe dat in dat pleidooi psychologische overwegingen zullen worden betrokken.

Tegen deze achtergrond kunnen het gelijkheidsbeginsel enerzijds en de - verderop in deze studie uit te werken - idee van ontplooiings- en persoonswordingsbeginsel anderzijds als elementen van het waardigheidsbeginsel thans ook aangeduid worden als kerninhoud van de rechten van de mens in het algemeen en de rechten van het kind in het bijzonder. Deze aanduiding is om te beginnen een uitnodiging om een uitstapje te maken naar de hiërarchische indeling in kern- en overige rechten die in de literatuur is gemaakt.

\subsubsection{Universaliteit en kernrechten}

'The dignity of the human person? The expression means nothing if it does not signify that by virtue of natural law, the human person has the right to be re-

Van dat laatste is in mijn opvatting sprake in de stellingname van SCHERMERS ten aanzien van niet gecodificeerde, doch niettemin hoog in de hiërarchie staandle fundamentele mensenrechten. SCHERMERS' stelling luidt, voor zover hier van belang: 'Onvermijdelijk blijft echter dat bij conflict tussen twee mensenrechten het "mindere" mensenrecht moet wijken voor het meer fundamentele mensenrecht. In een hiërarchie van mensenrechten moeten ook de niet gecodificeerde rechten (zoals het recht op eten en het recht op onderdak) als fundamentele mensenrechten worden meegeteld.' Zie: C.J. BAX e.a. (red.), Universaliteit van grondrechten, Mededelingen van het Juridisch Instituut van de Erasmus Universiteit Rotterdam nr. 48,1989 , p. 118. 
spected, is the subject of rights, possesses rights. These are things which are owed to man because of the very fact that he is man.'

VAN DUKK ${ }^{47}$ laat op deze door hem aangehaalde woorden van MARITAIN (1944) volgen: ${ }^{48}$

'De menselijke waardigheid wordt hier door MARITAIN opgevoerd als een conceptie waarin bepaalde rechten krachtens natuurrecht besloten liggen. In de Westerse traditie wordt daarbij primair aan het recht op leven en dat op persoonlijke vrijheid gedacht, maar een menswaardig bestaan veronderstelt daarnaast andere rechten, waartoe ook bepaalde economische, socialle en culturele rechten kunnen behoren.'

De menselijke waardigheid kleeft niet alleen de idee van het met rechten bekleed zijn aan, maar die idee komt ook in bepaalde rechten tot uitdrukking. Om welke rechten gaat het dan?

De zoektocht naar universaliteit en de discussie "universaliteit versus cultureel (waarden)relativisme' heeft veel pennen in beweging gezet. De hiërarchisering van mensenrechten en de categorisering van kernrechten en overige rechten is daarvan de meest in het oog springende (pennen)vrucht. Zoals zo vaak in filosofische en antropologische discussies bleek het ook hier niet om een òf- df maar om een èn-èn te gaan. De uitkomst van zulke discussies - en dat is één van de redenen dat wij de universaliteitsdiscussie hier niet zullen nalopen - is steevast dat beide kanten een kern van waarheid bezitten. De universalisten hebben gelijk omdat en in zoverre internationaalrechtelijk (de) mensenrechten universeel zijn aanvaard. De relativisten hebben gelijk omdat en in zoverre dat zelfde internationale recht ruimte laat voor nationale discretie ten aanzien van de interpretatie en implementatie van (de) mensenrechten. Een discretionaire vrijheid - zie hier de èn-èn-uitkomst - die zich evenwel nimmer tot de essentie, de kern van de norm c.q. tot kernnormen uitstrekt.

Duidelijkheidshalve is het nuttig de volgende vormen van universaliteit te onderscheiden:

a.) positiefrechtelijke (de jure) universaliteit: heeft het mensenrecht in kwestie mondiale juridische gelding? (is het door alle staten c.q.

P. VAN DUK, Rechten van de mens; universaliteit versus waardenrelativisme, Mededelingen van de Koninklijke Nederlandse Akademie van Wetenschappen, Afdeling Letterkunde, Nieuwe Reeks, Deel 57 no. 2, Amsterdam (etc.) 1994, pp. [61$90 /] 5-34$, op p. 11. 
de statengemeenschap in haar geheel uitdrukkelijk of stillwijgend aanvaard?);

b.) natuurrechtelijke universaliteit: dient het mensenrecht in kwestie mondiaal te gelden? (is er sprake van een van de menselijke waardigheid c.q. de redelijke en sociale menselijke natuur afgeleide opinio necessitatis?);

c.) antropologische universaliteit: wordt het mensenrecht in kwestie mondiaal, door alle volken en gemeenschappen, als recht (norm, waarde) beleefd en aanvaard? (is er sprake van een universele opinio juris?);

d.) praktische (de facto) universaliteit: wordt het mensenrecht in kwestie mondiaal nageleefd/gehandhaafd? (is er een universele statenpraktijk?).

Omdat er van universaliteit in praktische zin nergens sprake is, en ook wel nooit helemaal zal zijn, en natuurrechtelijke en antropologische universaliteit pas bij ontstentenis van duidelijke (verdrags)normen of bij normconflicten om de hoek komen kijken, dienen we ons hier tot de positiefrechtelijke universaliteit te beperken. Universaliteit in positiefrechtelijke zin nu houdt een even positiefrechtelijk discretionair cultureel relativisme in. De erkenning van een 'zwak cultureel relativisme,' aldus BAEHR $^{49} \ldots$

'(...) hoeft echter nog niet te betekenen dat ook de zogeheten "kernrechıen," of rechten ter bescherming van de menselijke persoon, mogen worden aangetast."

VAN DIJK zelf zegt daar dit over: $:^{50}$

'Het ene recht biedt meer ruimte voor variaties bij de interpretatie en implementatie dan het andere recht, omdat bij bepaalde rechien een gedifferentieerde implementatie de universele gelding van de norm in zijn essentie aantast, terwijl dat bij andere rechten niet het geval behoeft te zijn.'

Hij verbindt daaraan de voor de hand liggende consequentie: $:^{51}$

'Het komt mij nuttig voor hiertoe de rechten van de mens in bepaalde caltegorieën in te delen. Ik ga daarbij uit wan een eerder door mij voorgestelde indeling, namelijk die tussen [1] kernrechten en daarvan afgeleide rechten, [2] participaticrechten en [3] overige rechten.' 
Alvorens we de door VAN DIJK voorgestelde indeling voor het voetlicht brengen, is het goed op te merken dat de mensenrechtelijke classificatiegedachte, dat wil zeggen de (hiërarchische) idee van zeer fundamentele mensenrechten, een stevige basis in het verdragsrecht, de jurisprudentie en de doctrine heeft.

\section{Verdragsrecht}

Voor de verdragsbasis kan in de eerste plaats gewezen worden op art. 4, lid 2 rVBPR, dat een aantal artikelen opsomt welke fundamentele rechten bevatten waarvan zelfs bij de in lid 1 omschreven 'algemene noodtoestand die een bedreiging vormt voor het bestaan van het volk en die officieel is afgekondigd,' niet mag worden afgeweken: de zogenaamde 'non-derogable' of 'notstandsfeste" rechten (zie hieronder).

Daarnaast kan gewezen worden op het in burgeroorlogssituaties van toepassing zijnde gemeenschappelijke art. 3 van de vier Verdragen van Genève van 1949 (de zogenaamde Rode-Kruisverdragen). Dit artikel bevat, in de woorden van KALSHOVEN:.52

'(...) in de meest letterlijke zin minimum-normen, die geen zich fatsoenlijk noemende regering lang opzij kan zetten zonder haar aureool van fatsoen te verliezen.'

Ten aanzien van niet rechtstreeks aan de vijandelijkheden deelnemende personen zijn krachtens dit artikel met name 'at any time and in any place whatsoever' verboden: ${ }^{53}$

(a) aanslagen op het leven en de lichamelijke integriteit, in het bijzonder elke vorm van levensberoving, verminking, wrede behandeling en marteling;

(b) het nemen van gijzelaars;

(c) aanranding van de persoonlijke waardigheid, in het bijzonder vernederende en onterende behandeling;

(d) het uitspreken en ten uitwoer leggen van vonnissen zonder voorafgaande berechting door een op regelmatige wijze samengesteld gerecht dat alle door beschaafde volken als onmisbaar erkende rechtswaarborgen bïedt."

F. KALSHOVEN, Zwijgt het recht als de wapens spreken? Den Haag 1985 (tweede druk), p. 54 i.f.

53 KALSHOVEN, a.w., pp. 54/55. Vgl, ook de meer uitgebreide opsommingen in art. 75 van Protocol I van 1977 bij de Rode-Kruisverdragen en in de Turku-Declaration of Minimum Humanitarian Standards van 1990 (AJIL 1991/2, pp. 377-381); vgl. in het bijzonder art. 10 van de Turku-Declaration met betrekking tot kinderen. 
In de derde plaats kan gewezen worden op het Genocideverdrag (New York 1948) dat genocide, samenspanning, opruiing en poging tot genocide en medeplichtigheid aan genocide 'verheft' tot internationaal misdrijf. Ingevolge art. II van het Verdrag zijn verschillende handelingen, gepleegd met het opzet een nationale, ethnische, raciale of religieuze groep geheel of gedeeltelijk uit te roeien, als genocide aan te merken, waaronder het doden van en het toebrengen van ernstig lichamelijk of geestelijk letsel aan leden van de desbetreffende groep.

Ten slotte zou nog gewezen kunnen worden op de DE MARTENSclausule uit 1899, opgenomen in Protocol I van 1977 bij de Rode-Kruisverdragen (art. 1, lid 2), met haar verwijzing naar de zeer fundamentele categorieën 'beginselen der menselijkheid' en 'eisen van het openbare rechtsbewustzijn' als bodem onder en juridisch vangnet voor de bescherming van burgers en combattanten. ${ }^{54}$

\section{Jurisprudentie}

Wat de jurisprudentie betreft, dient hier de Barcelona Traction-zaak vermeld te worden. In deze zaak kwam het Internationaal Gerechtshof tot de volgende uitspraak: ${ }^{55}$

"[A]n essential distinction should be drawn between the obligations of a State towards the international community as a whole, and those arising vis-ât-vis another State (...). By their very nature the former are the concern of all States. In view of the importance of the rights involved, all States can be held to have a legal interest in their protection; they are obligations enga omnes.

Such obligations derive, for example, in contemporary international law, from the outlawing of acts of aggression, and of genocide, [and] also from the principles and rules concerning the basic rights of the human person, including protection from slavery and racial discrimination.'

\section{Doctrine}

In de doctrine komen we verschillende gezaghebbende bronnen tegen. Om te beginnen kan gewezen worden op de erga omnes- (en dus actio

VAN BOVEN wijst op een drietal andere voorlopers: de minimum-standaard voor de behandeling van vreemdelingen, het leerstuk van de humanitaire interventie ter bescherming van zeer elementaire "droits humains' en het minderhedenstelsel onder de Volkenbond (Theodoor C. VAN BOVEN, 'Distinguishing criteria of human rights,' in: Karel VASAK; Philip ALSTON (eds.), The intemational dimensions of human rights, Westport, Ct./Paris 1982, vol. 1, pp. 43-59, op p. 44). 1992, pp. 125-134, op p. 125, par. 33/34 (curs. jw). 
popularis-)lijsten ${ }^{56}$ van de International Law Commission en de American Law Institute. ${ }^{57}$ In the 'Third Restatement' van laatst genoemde organisatie paraisseren onder meer: marteling en andere onmenselijke behandeling, systematische rassendiscriminatie en 'consistent patterns of gross violations of internationally recognized human rights. ${ }^{.58}$

Op deze plaats is het aardig ook te wijzen op een tweetal vooroorlogse voorlopers van opsommingen van fundamentele rechten: de (hoofdzakelijk anti-discriminatoire) mensenrechtenverklaring van het Institut de Droit International uit 1929 en de 'statement of essential human rights' van de American Law Institute uit 1944. De tekst uit 1929 is de eerste waarin ook het verbod van sexe-discriminatie is opgenomen. De tekst uit 1944 bevat ook verschillende elementaire sociale rechten. ${ }^{59}$

Uit de preambule van het Handvest van de vN, waarin sprake is van herbevestiging van het vertrouwen in de fundamentele rechten van de mens, leidt VAN BOVEN af dat bepaalde fundamentele rechten al vóór 1945, dat wil zeggen vóor hun positivering in mensenrechtenverdragen, deel uitmaakten van de internationale rechtsorde: $:^{60}$

'Such fundamental rights can also be called elementary rights or supra-positive rights, i.e. rights whose validity is not dependent on their acceptance by the subjects of law but which are at the foundation of the international community.'

In die opvatting lijkt het Handvest de classificatie-gedachte, het concept van zeer fundamentele mensenrechten, slechts te bekrachtigen. Daarbij betreft het een dynamische lijst van rechten. DAVIDSON verwijst naar VAN BOVEN als hij opmerkt: ${ }^{61}$

'As [VAN BOVEN] says: "These [fundamental, 'supral-positive' or "elementary'] rights lie at the foundation of the international community as presently represented in the United Nations (...)." This statement would seem to suggest that fundamen-

Dat wil zeggen: lijsten waarop verplichtingen staan ten opzichte van alle staten c.q. de statengemeenschap (enga omnes) en ter zake van welker schending elke staat namens alle staten c.q. de statengemeenschap kan ageren (actio popularis). Vgl. SCHACHTER, Intemational law in theory and practice, a.w., pp. 211 en 338.

58 SCHACHTER, t.a.p.

59 Zie Louis B. SOHN, "How American international lawyers prepared for the San Francisco Bill of rights, AJIL 1995/3, pp. 540-553.

Vgl. over de rol van (MANDELSTAM en) het International Law Institute ook: Jan Herman BURGers, "The road to San Francisco: the revival of the human rights idea in the twentieth century;' Human Rights Quarterly 1992/4, pp. 447-477, op pp. $450-454$.

60 VAN BOVEN, t.a.p., Op p. 43.

61 Scott DAVIDSON, Human rights, Buckingham/Philadelphia 1993, p. 40 (curs. SD). 
tal rights are not static but dynamic and that other human rights may be exalted to such a status.'

\section{En hij voegt daaraan toe .62 $^{62}$}

"[I]f (...) non-derogable [notstandsfest, jw] rights are indeed fundamental and do bear the [erga omnes-, jw] characteristics of ius cogens, then it is possible to argue, as VAN BOVEN does, that these rights are "binding on States, even in the absence of any conventional obligation or of any express acceptance or comment".'

Behalve VAN BOVEN ${ }^{63}$ en DAVIDSON ${ }^{64}$ gaan ook andere auteurs uit van de (hiërarchische) classificatie-gedachte, zoals: O'MANIQUE ${ }^{65}$; CAS-

DAVIDSON, a.w., pp. 40/41.

DAVIDSON, a.w., pp. 39-41.

John O'MANIQUE, 'Universal and inalienable rights: a search for foundations,' Human Rights Quarterly 1990/4, pp. 465-485.

Uit de evolutionaire en existentiële 'drive, both for the development of the individual and the community" en de daarmee verbonden 'needs for human development' leidt O'MANIQUE 'an essential common core of human rights throughout our species" af (t.a.p., op p. 482 i.f.).

Bij deze auteur zien we dus een individuele (meer inwendige) en een community-, een sociale (meer uitwendige) morele 'drive' (een ingeboren en vitaal streven) aan de mensenrechten ten grondslag liggen, die ik hierboven heb proberen (samen) te vatten onder respectievelijk het ontplooiings- en het gelijkheidsbeginsel. Het is immers mijn stelling dat zonder gelijkheidsbeginsel duurzame maatschappelijke ontwikkeling niet mogelijk is. Te grote ongelijkheid wordt in de geschiedenis nooit geaccepteerd. En zal in de toekomst - zie de zich fundamentalistisch sterk makende "derde wereld" - ook niet geaccepteerd worden.

Wat O'MANIQUE hier aan GROTTUS toevoegt, is het evolutionaire perspectief op de (redelijke en sociale) menselijke natuur. Mensenrechten zijn dan nodig om deze natuur tegen onmenselijkheid te beschermen en opgewassen te doen zijn. Want, zoals DELFGAAUW treffend heeft opgemerkt: 'De menselijkeid van de mens is van dien aard dat de mens ook onmenselijk kan zijn.' (Bernard DELFGAAUw, De mens en zijn rechten, Kampen 1993, p. 34.) O'MANIOUE maakt de conclusie inzïchtelijk dat mensenrechten de menselijkheid vindiceren zodat de menselijke soort zich kan ontwikkelen, dat is: overleven. Want leven is groeien tegen de verdrukking in. Dat geldt voor het individu en voor de soort. Dit heeft niets van doen met een naiief vooruitgangsoptimisme. Want het alternatief, uitsterven, is, evolutionair gezien, even reëel. Mensenrechten en mensenrechtenactivisme kunnen evenwel misschien verhinderen dat de mens; door milieuverwoesting of nucleaire broedermoord, het Toeval een al te destructief handje helpt. (Eerlijkheidshalve moet ik hieraan toevoegen dat ik geloof dat God de schepping haar eigen weg, en dus de mens zijn eigen gang laat gaan. In deze visie is God de alfa en de omega, maar beweegt zich tussen alfa en omega, op een stip 
SESE $^{66}$; VAN HOOF ${ }^{67}$; KÜHNHARD. ${ }^{68}$ En uiteraard VAN DUK, naar wie we in de nu volgende (sub)paragraaf terugkeren.

In een bijdrage in het NJCM-Bulletin van 1980 bepleit VAN DIJK een hiërarchische indeling van de mensenrechten met aan de top zogenaamde kernrechten: ${ }^{69}$

"Tot de kernrechten moeten mijns inziens al die rechten gerekend worden welke de meest primaire materiële en immateriële levensbehoeften van de mens, zijn "basic needs," betreffen, en zonder de realisatie waarvan niet van een menswaardig bestaan kan worden gesproken. (...) Op de eerste plaats het recht op leven

of jota tussen oer- en eindknal, of kmalloos einde, ten goede of ten kwade, de mens. Maar ik sluit niet uit dat ook dit niet meer is dan een dwaze - immers met het uitdijen van kosmologische kennis inkrimpende - zingevingsprojectie.)

66 Antonio CASSESE, Human rights in a changing world, Cambridge 1990, pp. 64-65.

67 G. VAN HOOF, 'Human rights in a multi-cultural world: the need for continued diallogue, in: Ronald St.J. MACDONALD (ed.), Essays in honour of WANG TIEYA, Den Haag 1994, pp. 877-891.

VAN HOOF geeft een vergelijking tussen de classificaties van VAN DUK enerzijds en DONNELLY en HOWARD anderzijds (op pp. 883-886), en presenteert ook een eigen lijst (op p. 890).

68 L. KUUNHARDT, Die Universalïtät der Menschenrechte, München 1987, pp. 329-334; Bonn 1991 (tweede druk), pp. 262-267.

Aansluitend bij MARITAINs indeling in 'Menschenrechte der körperlichen, Menschenrechte der geistigen und Menschenrechte der politisch-sozialen Person,' komt KUHNHARDT tot drie onderling verbonden centrale categorieën mensenrechten: "Körper, Geist und Sozialnatur" bepalen de mens in ruimte en tijd (a.w., pp. 264-266). Tot de hiërarchisch hoogste rechten binnen deze categorieën zouden gerekend kunnen worden (ik interpreteer hier vrij naar KÜHNHARDT): het recht op (1) lichamelijke (leven, habeas corpus, voedsel, gezondheidszorg, woning, kleding, inkomen/arbeid) en (2) geestelijke (gewetens-, gedachten-, uitingsvrijheid) integriteit en het recht op een (3) democratische (recht op pluralisme, recht op periodieke wrije en geheime verkiezingen, recht op openbaarheid van bestuur, recht op inspraak) en (4) rechtsstatelijke rechtsorde (recht op machtenscheiding, recht op wetmatigheid van bestuur, recht op rechtsbescherming bij een onafhankelijke rechter, recht op mensenrechten).

De mens is zijn lichaam èn zijn gedachten: 'Das Denken des Menschen gehört zu seinem Wesen wie der Körper selbst' (a.w., p. 265). De mens is echter ook een sociaal en politiek wezen. Het politiek-sociale wezen wan de moderne mens kan niet meer worden los gedlacht van het principe van de democratische (en sociale) rechtsstaat.

69 P. VAN DIJ, Rechten van de mens en ontwikkelingssamenwerking, enige rechtsbeginselen," NJCM-Bulletin 1980/1, pp. 4-20 (pp. 11-14: 'Rechten van de mens als "basic needs"'), op p. 12. 
zelf en daarmee verbonden het recht op adequate voeding, kleding, huisvesting, medische verzorging en andere noodzakelijke behoeften voor een lichamelijk en geestelijk gezond leven."

Men zou kunnen zeggen: het recht op leven en het recht op overleven. Daartoe zijn in de eerste plaats een aantal fundamentele economische en sociale rechten vereist. In dit verband merkt hij op dat "de rechten aangaande de primaire levensbehoeften,' opgenomen in het IVESCR, 'zo nauw verbonden [zijn] met het recht op leven dat zij in het absolute karakter van dat recht delen.'

Naast 'leven en overleven' noemt de auteur: ${ }^{70}$

'(...) [H]et recht op een minimum aan veiligheid en op de integriteit van de persoon, alsmede vrijwaring tegen slavernij, dienstbaarheid [horigheid, jw], foltering, opzettelijke wederrechtelijke vrijheidsberoving, discriminatie en andere behandelingen die de menselijke waardigheid in haar wezen aantasten. Vervolgens thet recht op vrijwaring tegen de terugwerkende kracht van strafbepalingen. En ten slotte de vrijheid van owertuiging, geweten en godsdienst.'

Hij merkt op: $:^{71}$

'De kernrechten vormen het absolute minimum aan rechten dat aan iedere menselijke persoon toekomt ongeacht geslacht, leeftijd, nationaliteit, land wan inwoning, of enige andere kwaliteit of omstandheid. De concrete inhoud van deze rechten kan enigszins verschillen naar leeftraditie, klimaat en dergelijke omstandigheden, maar dat doet niet af aan hun absoluut karakter. Aan hun realisatie komt prioriteit toe, ongeacht het politieke, economische, sociale en culturele systeem van het betrokken land. Alle staten zijn daartoe internationaal verplicht, ongeacht of zij zich daartoe uitdrukkelijk hebben verbonden of niet. Of men de rechtsgrondslag daarvoor nu zoekt in de constitutionele beginselen van het VNHandvest als uitgewerkt in verdragen, verklaringen en andere documenten, dan well in het gewoonterecht, het natuurrecht of algemeen erkende rechtsbeginselen, er zal binnen de huidige rechtsopvatting consensus over bestaan dat deze primaire behoeften van de mens in ieder rechtsstelsel gegarandeerd moeten zijn en bij iedere met overheidsgezag beklede instantie voorrang moeten genieten, en als zodanig grenzen stellen aan de soevereine wrijheid van de staten.'

En aan de autonomie van ouders, de soevereiniteit in eigen - kleine kring, zo kunnen we daaraan toevoegen, zij het uiteraard door tussenkomst van de nationale wetgever. Rechtsgrondslag daarvoor is in elk geval het Verdrag inzake de rechten van het kind. Doch ook kan, althans waar het de lichamelijke integriteit van het kind betreft, ten overvloede, 
gewezen worden op art. 5 rVUR, dat een aantal fundamentele rechten opsomt, waaronder (onder b):

(... ) het recht op persoonlijke veiligheid en bescherming door de Staat tegen geweld of lichamelijk letsel, hetzij toegebracht door overheidsdienaren, hetzij door enige andere persoon, groep of instelling. (Curs. jw.)

De hiërarchisch volgende categorie rechten noemt VAN DIJK participatierechten of ondersteunende rechten. Hieronder rekent hij onder meer: ${ }^{72}$

${ }^{6}[\mathrm{H}]$ et recht op erkenning als persoon door de wet; het recht op participatie in de besluitvorming binnen het land (...); het recht op participatie in het arbeidsproces (...); het recht op participatie in het sociale leven en op behoud en ontplooiing van de eigen culturele "dentiteit, en het recht op godsdienstbeleving; de voor al deze vormen van participatie vereiste vrijheid van vereniging en vergadering, vrijheid van meningsuiting, recht op voldloende basisonderwijs (...); ten slotte het voor de handhaving van de rechten essentiële recht van toegang tot de rechter (....).'

Onder 'overige rechten' somt hij enkele rechten uit de hiërarchisch laagste categorie op: ${ }^{73}$

'[H]et voor de menselijke waardigheid belangrijke recht op privacy en op zelfbeschikking ten aanzien van de inrichting van het eigen leven (huwelijk of andere samenlevingsvormen, kindertal e.d.), het (...) recht op een nationaliteit, op toegang tot het land van nationaliteit en op asiel, en het voor het materiële en geestelijke welzijn belangrijke recht op een leefbaar milieu.'

Wat VAN DIJK stelt ten aanzien van kernrechten geldt/gelde natuurlijk ook (we komen er nog op terug) ten aanzien van de kernrechten (persoonswording in ruime zin: veiligheid/integriteit en ontwikking/persoonswording in enge zin) van het kind: ${ }^{74}$

'Stelt de regering dat realisatie op het internationaal voorgeschreven niveau niet mogelijk is, dan zal onderzocht moeten worden, of bet overheidsbeleid er inderdaad op gericht is zoveel mogelijk middelen voor deze realisatie te mobiliseren, ook via een politiek van herverdeling van de welvaart.' 
Het land in kwestie kan zich evenwel beroepen op overmacht: ${ }^{75}$

\begin{abstract}
"Is evenwel duidelijk dat een bepaald land inderdaad in de situatie verkeert dat het niet alle kernrechten volledig kan realiseren, hetzij door een structureel tekort aan eigen middelen en buitenlandse hulp, hetzij door incidentele factoren als het mislukken wan de oogst, een natuurramp, een grote vluchtelingenstroom e.d., dan verkeert dat land in een overmachtssituatie waarop het zich ter rechtvaardiging kan beroepen."
\end{abstract}

Passen we deze woorden, om het maatschappelijke thema en eigenlijke onderwerp van deze studie weer even op de voorgrond te plaatsen, al op deze plaats toe op Nederland en het probleem van kindermishandeling en incest, dan moeten we constateren dat, voor zover er in Nederland sprake is van een structureel tekort, zulks een structureel tekort niet aan financiële, maar aan sociaal-pedagogische middelen is. En dus, gezien het vele dat op dit vlak denkbaar en mogelijk is, en op vrijwillige, en dus vrijblijvende schaal ook wel - al of niet gesubsidieerd - gebeurt, aan

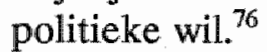

Kindermishandeling en incest kunnen ook niet als een natuurramp worden beschouwd, nu mensen - de eigen ouders - er de aanstichters en bedrijvers van zijn. Weliswaar zitten botte agressie, machtswellust, wraakzucht, afgunst, egocentrische sexualiteit in de menselijke natuur, maar dat is dan ook precies de reden waarom we mensenrechten - en kinderrechten - hebben. ${ }^{77}$

T.a.p. op p. 17.

76 Voor zover dit als een verwijt kan worden opgeval aan 'de' politick, dient wel te worden beseft dat het een verwijt is, en een ernstig verwijt, dat terugslaat op de hele maatschappij. De politiek zall immers altijd - verdragsverplichtingen of niet - een maatschappelijk draagwlak zoeken, en zelden op matschappelijke ontwikkelingen vooruitlopen. Zelfs niet als de in internationale fora plechtig beleden en bekrachtigde rechten wan de allerzwaksten in het geding zijn.

77 De fillosofische/morele/natuurrechtelijke grondslag van de mensenrechten mag dan de menselijke waardigheid zijn - in grotiaanse termen: de redelijke en sociale menselijke natuur -, maar de praktische grondslag kan welhaast geen andere zijn dan de donkere kant van de menselijke natumr en de noodzaak elkaar tegen die kant in onszelf en onze soortgenoten te beschermen. Met andere woorden: mensenrechten hebben zowel de (theoretische en teleologische) kant van GROTIUS" nihil homini utilius homine (niets is beter voor de mens dan zijn medemens) als HOBBES (praktische en realistische) homo homini lupus (de mens is voor zijn medemens een wolf). Het is niet zozeer de onderkenning van beide kanten in de mens - ook GroTIUS staat bij 's mensen duistere zijde stil als hij de versregel aanhaalt: Pernities homini quae maxima? solus homo alter (in DAMSTÉ's vertaling: 'Wat is voor den mensch het grootste ongeluk? Eenig en alleen zijn nevemmensch') - als wel de vraag welk van beide kanten men tot uitgangspunt 
Van een grote vluchtelingenstroom is in ons land al evenmin sprake, of het moest zijn bij wijze van hyperbolische politieke retoriek (ter toedekking van een falend uitzettingsbeleid ten aanzien van uitgeprocedeerden), die soms inderdaad de indruk wekt alsof de dijken van de nationale cultuur op doorbreken staan. ${ }^{78}$ Daarmee is een beroep op over-

van zijn filosofisch stelsel neemt, die in dezen alle verschil maakt. In De jure praedae (rond 1605 geschreven, voor het eerst gedrukt in 1868), Huigh DE GROOTs Verhandeling over het recht op buit (vert. Onno DAMSTE 1934), caput XV, pars I, stelling $\mathrm{V}$ en $\mathrm{V}$, lijkt GROTrus zijn uitgangspunt nog in het midden te laten. Als hij bovenstaande versregel aanhaalt in stelling $\mathrm{V}$, is dat na in stelling IV te hebben opgemerkt: In omni hoc aniverso past Deum immortalem nihil homini est utilus homine (In het gansche Heelal is na den eeuwigen God niets heilzamer voor den mensch dan zijn naaste'). In De jure belli ac pacis 1.5.2:1-2 lezen we: (...) nihil esse homini utilius homine altero, in een passage die in de vertaling van EYFFINGER/ VERMEULEN luidt:" "Terecht menen zij die over de plichten van de mens geschrewen hebben [CICERO, De officiis], dat niets een mens meer tot nut is dan de medemens. Er zijn dan ook banden wan de meest uiteenlopende aard tussen mensen, die uitnodigen tot wederzijdse steun. (...) Maar al zouden de overige banden ontbreken, dan volstaat nog [de band van] de gemeenschappelijke menselijke natuur. De mens immers is niets menselijks vreemd. [Ab homine enim nihil humani alienum est.]' Dit laatste lijkt enigszins dubbelzinnig, maar dan haalt GROTIUS de versregels van MENANDER aan die ik ooit (in het Jaarboek Robert REGOUT 1978-1979, Rechtsgeleerd Instituut KU Nijmegen 1980, pp. 55-92, op p. 83 nt. 22) zo vertaalde:

Als wij, onderling verbonden en met vereende krachten, Als onszelf aangedaan beschouwend wat anderen is geschied, Stuk voor stuk de schaamteloze bedrijuers van onrecht Met sancties zouden treffen,

De driestheid der kwaadwilligen zou de goedmoedigen

Niet langer drukken; aan alle kanten in de gaten gehouden

En wetend dat ze hun gerechte straf niet zouden ontgaan,

Zouden ze spoedig geheel verdwenen, althans zeer gering in aantal zijn. (MFNANDER was een Griekse blijspeldichter die 2300 jaar geleden leefde in Athene. Bovenstaande versregels komen uit de Dicta poetarum quae apud Io. STOBAEWM exstant, door GROTIUS geëmendeerd en uit het Grieks in het Latijn vertaald, dat in 1623 in Parijs, GRoTuUs' ballingsoord na de staatsgreep van Maurits, de onthoofding van OLDENBARNEVELT en de vlucht in de boekenkist, verscheen. Het zijn de slotregels van titulus XIIII, Peri politeias/De republica, van STOBAEUs' Florilegium, de tweede band in de Dicta poetanm, editio princeps, p. 170.)

Dat GRoTius een HoBbessiaanse leer afwijst, blijkt ten overvloede uit De jure belli ac pacis III.25.1:3: 'Een leer die de mens zijn medeleven met de medemens afneemt [doctrina quae hominem hominibus insociabilem facit], kan op den duur niet tot voordeel strekken - en is gehaat in de ogen van God.'

78 Venijniger is het argument dat op grote schaal islamitische vrouwen- en meisjesonderdrukking aan de voordeur wordt binnengehaald die we zelf - en dat is dan metteen het antwoord - nog maar nawwelijks, en nog altijd meer als norm dan als praktijk, door de achterdeur hebben verjaagd. Kortom, het is alsof de Hollandse 
macht voor Nederland feitelijk uitgesloten. En is staatsaansprakelijkheid in principe vastgesteld.

Maar ik onderbrak VAN DIJK. Veertien jaar later hervat ${ }^{79}$ VAN DIJK zijn hiërarchische indeling van de mensenrechten in een Mededeling (gedeeltelijk) uitgesproken in de vergadering van de Afdeling Letterkunde van de Koninklijke Nederlandse Academie van Wetenschappen, gehouden op 11 april $1994 .^{80}$ Hij merkt op: ${ }^{81}$

'Overigens is het maar de vraag of, als we de internationaal erkende rechten van de mens ieder afzonderlijk onder ogen zien, de opvattingen over de gelding en inhoud van deze rechten onderling wel zoveel verschillen. Zeker bij de hierna nog te noemen kern-rechten, die aan de kern raken van het menselijk existeren en de menselijke waardigheid, ligt dit al niet voor de hand omdat zeker in de ogen van de subjecten van deze rechten deze kern niet of nauwelijks cultureel is bepaald.'

Hij komt dan tot de volgende indeling en opsomming, die hier in extenso, van nummering voorzien, wordt weergegeven: ${ }^{.2}$

\section{Kernrechten (1-15)}

'Bij de kernrechten gaat het om die rechten zonder welke er fysiek en psychisch van een menswaardig bestaan geen sprake kan zijn: (1) [1] recht op leven en [2] op een adequate levensstandaard (artt. 3 en 25 [UV]) [waaronder [3] bijzondere zorg en bijstand voor moeder en kind en [4] sociale bescherming van elk kind (art. 25 , lid 2 UV), jw $\left.{ }^{83}\right]$; (2) [5] recht op persoonlijke vrijheid en [6] integriteit van de persoon [security of person/onschendbaarheid van de persoon] (art. 3 [UV]); [7] vrijwaring van slavernij en horigheid (art. 4 [UV]); [8] vrijwaring van foltering en wrede, onmenselijke en onterende behandeling en bestraffing (art. 5 [UV]); [9] vrijwaring van willekeurige vrijheidsberoving (art. 9 [Uv]); [10] vrijwaring van

haan op de eigen mesthoop kraait in plaats van, na eigen erf, ook buurmans erf te helpen opruimen.

80 P. VAN DUJ, Rechten van de mens; universaliteit versus waardenrelativisme, Mededelingen van de KNAvW, Afd. Letterkunde, Nieuwe Reeks, Deel 57 no. 2, Amsterdam (etc.) 1994, pp. [61-90/]5-34. (Vgl. ook de 'edited' Engelse vertaling: Pieter VAN DUK, 'A common standard of achievement; about universal validity and uniform interpretation of international human rights norms,' Netherlands Quarterly of Human Rights 1995/2, pp. 105-121.)

81 T.a.p., op p. 20.

82 VAN DIJK, t.a.p., op pp. 25-27. Duidelijkheidshalve wordt niet in klein lettertype geciteerd.

83 Zie hoofdstuk 6 en 7. 
discriminatie (artt. 1 en 2 [UV] [en artt. 7 en $30^{84} \mathrm{UV}$, jw]); [11] recht op erkenning door de wet als persoon (art. 6 [UV]); [12] vrijwaring van de terugwerkende kracht van strafbepalingen (art. 11 [lid 2 UV]); en [13] vrijheid van gedachten, [14] geweten en [15] godsdienst (art. 18 [UV]).

Dat het hier om de harde kern van de rechten van de mens gaat, komt ook tot uitdrukking in het feit dat vrijwel all de hier door mij genoemde rechten en vrijheden in het tweede lid van artikel 4 van het [IVBPR] "notstand/s]fest" worden verklaard, dat wil zeggen opgesomd worden onder de rechten waarvan zelfs in geval van een algemene noodtoestand geen afwijking mogelijk is.'

\section{Participatierechten (16-35)}

' $\mathrm{Bij}$ de participatierechten of ondersteunende rechten gaat het om die rechten waarvan de uitoefening op een zeker minimum-niveau gegarandeerd moet zijn wil het volledig genot van de kernrechten verzekerd zijn en de belanghebbende ook zelf voor dat volledig genot kunnen opkomen. Naast deze ondersteunende functie hebben deze rechten ook een zelfstandige waarde met het oog op de menselijke waardigheid. Te denken valt hier aan:

[16] het recht op participatie in het bestuur van het land teneinde mede vorm te kunnen geven aan de voorwaarden voor en het toezicht op de eerbiediging van de kernrechten ${ }^{85}$ en [17] het recht op periodieke en geheime verkiezingen (art. 21 [UV]); [18] het recht op participatie in het sociale leven (en [19] op behoud en ontplooiing van de eigen culturele identiteit [art. 27 UV juncto art. 27 IVBPR]) en [20] het recht op onderwijs (artt. 26 [lid 1 en 2] en 27 [lid 1 UV]); [21] de vrijheid zijn godsdienst of levensovertuiging tot uiting te brengen en [22] het recht op vrije meningsuiting (artt. 18 en 19 [UV]); [23] het recht op vrije ontplooiing, [24] op participatie in het arbeidsproces als voorwaarde om zelf een adequate levensstan-

84 De bescherming tegen discriminatie die dit artikel biedt, is mïns inziens gelegen in een op rechtswerwerking gelijkende figuur; het artikel verbiedt misbruik van (het beroep op) rechten en vrijheden om de rechten en vrijheden van anderen te vernietigen. Zo zal de vrijheid van meningsuiting of de vrijheid van vergadering miet zo mogen worden uitgelegd dat daaraan een recht zou kunnen worden ontleend om ook maar iets te ondernemen dat zich tegen de rechten en vrijheden uit de UV keert. Dit kan dus, in mijn opvatting, zowel het discriminatieverbod (artt. 1,2 en 7), als (materiële) hoeksteen van de democratie, als de (formele) democratische participatierechten (art. 21) betreffen.

85 Het door mij gecursiveerde gedeelte is weggelaten in de Engelse versie in NQHR. 
daard [een menswaardig bestaan] te realiseren, en subsidiair [25] op toereikende sociale zekerheid (artt. 22, 23 en 25 [UV]); en [26] het recht op bescherming van de eigendom voor zover deze een essentiële basis vormt voor de materiële en geestelijke existentie (art. 17 [UV]) [alsmede [27] het recht op bescherming van de intellectuele eigendom (art. 27, lid 2 UV)? $-j w] ;[28]$ het recht van vereniging en [29] vergadering, met inbegrip van [30] de vakverenigingsvrijheid (artt. 20 en [23, lid 4 UV]) [en van [31] vrijwaring van verenigingsdwang (art. 20, lid 2 UV), jw]; en [32] het recht op daadwerkelijke rechtshulp in geval van aantasting van grondrechten, [33] op toegang tot de rechter en [34] een eerlijk proces voor de vaststelling van [burgerlijke en bestuursrechtelijke] rechten en plichten en in strafzaken en [35] op eerbiediging van de onschuldspresumptie (artt. 8, 10 en 11 [lid 1 UV]).

Voor zover de uitoefening van deze rechten niet onontbeerlijk is voor het volledig genot van een of meer kernrechten, komt er geen absolute waarde aan toe. Die uitoefening kan, indien de wet $^{86}$ daarin voorziet, aan bepaalde beperkingen worden onderworpen ter bescherming van de rechten van anderen [dus ook van kinderen, $\mathrm{jw}$ ] of ter bescherming van bepaalde publieke belangen. Artikel 29 van de [UV] bevat daarvoor in het tweede lid een algemeen geformuleerde bepaling, die in het [IVBPR] op de afzonderlijke rechten is toegespitst. Voorts geldt voor deze rechten in veel sterkere mate dan voor de kernrechten dat hun reikwijdte mede wordt bepaald door de concrete situatie in het desbetreffende land.'

\section{Derde-categorierechten (minder fundamentele rechten) (36-45)}

'Ten slotte is er een catogorie van rechten te noemen die wel een zeker verband met de kernrechten kunnen hebben, maar toch voornamelijk op zichzelf staan en in het algemeen als minder fundamenteel worden ervaren. Het gaat hier bijwoorbeeld om:

[36] het recht op eerbiediging van de privacy (art. 12 [UV; curs. jw]); [37] het recht op bewegingsvrijheid binnen de staat, [38] het recht een land te verlaten, [39] het recht in zijn eigen land terug te keren en [40] het recht asiel te zoeken en te genieten [tegen ver-

Dat wil zeggen: enig wettelijk voorschrift of zelfs een regel van ongeschreven recht. Vgl. Reiner DE WINTER, De overheid; Overzicht van het Nederlandse staatsrecht, Den Haag 1994 (tweede druk), p. 158. Zie ook P. VAN DUJ, G.J.H. VAN HOOP, De Europese Conventie in theorie en praktijk, Ars Aequi Libri, Nijmegen 1990 (derde druk), p. 637. 
volging] (artt. 13 en 14 [UV]); [41] het recht op een nationaliteit (art. 15 [UV]); [42] het recht te huwen en een gezin te stichten (art. 16 [UV; curs. jw]); [43] het recht op rust en vrije tijd (art. 24 [UV]); en [44] het recht op vrije keuze van opvoeding en onderwijs (art. 26 [lid 3 uv; curs. jw]). [Aan deze opsomming kan worden toegevoegd [45] het recht op een maatschappelijke en internationale orde waarin de rechten van de mens ten volle kunnen worden verwezenlijkt (art. $28 \mathrm{UV}$ ), jw.]

Wat hun beperkingsmogelijkheden en uniforme toepassing betreft, geldt hetgeen hierboven met betrekking tot de participatierechten is gesteld, zij het dat, als men afgaat op de latere specificatie in het [IVBPR], voor deze rechten niet steeds expliciet in beperkingsmogelijkheden is voorzien, zodat moet worden nagegaan of er sprake kan zijn van inherente beperkingsmogelijkheden."

\section{Voortplantingsvrijheid}

In dit verband verdient vermelding dat art. 23 , lid 2 IVBPR (recht te huwen en een gezin te stichten) geen beperkingsclausule kent, zij het dat het vierde lid (tweede volzin) gewaagt van de bescherming van kinderen bij echtscheiding en art. 24 IVBPR van het recht van elk kind op beschermende maatregelen. Het EVRM (art. 12) bevat de toevoeging: 'volgens de nationale wetten die de uitoefening van dit recht beheersen.' Gezien het ontbreken van doelcriteria heeft 'de nationale wetgever grote vrijheid ten aanzien van beperkingen, zij het dat deze niet zover mogen gaan dat daardoor het recht in de kern wordt aangetast. ${ }^{87}$

Niettemin lijkt het mij in het licht van het bovenstaande ${ }^{88}$ zeer moeilijk (zij het met het oog op de kernrechten van kinderen niet absoluut onmogelijk) de voortplantingsvrijheid (van minder- of meerderjarigen) wettelijk te beknotten, laat staan feitelijk (door gedwongen medische ingrepen) te ontnemen, ook al zou dat laatste uiteraard niet alleen

L.E. KALKMAN-BOGERD, "Artikel 8 en artikel 12 in verband met kunstmatige voortplanting en draagmoederschap,' in: J.K.M. GEVERS (red.), Het EVRM en de gezondheidszorg, Ars Aequi Libri, Nijmegen 1994, pp. 119-135, op p. 121.

Zie ook P. VAN DUK, G.J.H. VAN HOOF, De Europese Conventie in theorie en praktijk, Ars Aequi Libri, Nijmegen 1990 (derde druk), pp. 488 e.v., in het bijzonder pp. 491 iff. en 494 . Voor de vergelijking met art. 23 IVBPR zie a.w., pp. $501-$ 502. Met betrekking tot art. 5 Protocol 7 zie a.w., pp. 570-572, in het bijzonder p. 572, par. 5. Zie ook A.H. ROBERTSON, J.G. MERRILLS, Human rights in Europe; A study of the European Convention on human rights, Manchester/New York 1996, pp. 164 e.v.

Zie met name ook VAN DUK/VAN HOOF, a.w., pp. 491 iff en 494. 
op formeel-wettelijke grondslag geschieden maar ook met alle denkbare (en nog ondenkbare) rechtswaarborgen zijn omringd.

\section{Privacy}

Wat de privacy betreft, beperkt art. 17 IVBPR het inmengingsverbod uitdrukkelijk tot willekeurige of onwettige aantasting. Het is evident dat ook interventie met het oog op het recht van het kind op minimale persoonswording een formeel-wettelijke grondslag behoeft (en te onzent heeft) en de toepassing van de wet te allen tijde onder de werking van het willekeurverbod en de overige beginselen van behoorlijk bestuur valt. ${ }^{89}$

Art. 8 EVRM bevat de bekende beperkingsclausule in het tweede lid. Krachtens de formule 'voor de bescherming van de rechten en vrijheden van anderen' (lees: kinderen) in dat lid, dan wel krachtens de interpretatie van het recht op gezinsleven in het eerste lid als mede omvattende het recht van het kind op een zijn persoonswording bevorderend gezinsleven c.q. als mede omvattende het recht van het kind op (positief) respect voor zijn privacy in de zin van zijn lichamelijke en geestelijke integriteit, laat zich eenvoudig het Verdrag inzake de rechten van het kind (mede gezien art. 3 van dat Verdrag), in art. 8 EVRM inlezen.

\section{Opvoedingsvrijheid}

Met betrekking tot de opvoedingsvrijheid van ouders bepaalt art. 26, lid 3 UV (curs. jw):

Aan de ouders komt in de eerste plaats het recht toe om de soort van opvoeding en onderwijs te kiezen welke aan hun kinderen zall worden gegeven.

In de eerste plaats, niet in de enige plaats: het betreft niet een exclusief ouderlijk recht. Er kan geen sprake zijn van een exclusief recht nu ook de gemeenschap en de overheid een eigen, zij het aanvullende dan wel plaatsvervangende (dat is: secundaire) verantwoordelijkheid hebben ten aanzien van de opvoeding en vorming van kinderen. Dit wordt nog eens bevestigd doordat de ouderlijke vrijheid is beperkt tot de soort van opvoeding en onderwijs: er kan, met het oog op de eigen rechten en belangen van het kind, en de daarop geënte secundaire opvoedingsverantwoordelijkheid van de staat, geen sprake zijn van een absolute ouderlijke vrijheid ten aanzien van de inhoud van opvoeding en onderwijs. ${ }^{90}$ Cruciaal

90 Zie ook art. 18, lid 4 IVBPR, art. 13, lid 3 IVESCR en art. 2 Protocol 1 EVRM. Zie voorts Pentti ARAJÄRvi, 'Article 26,' in: Asbjørn EIDE e.a. (eds.), The Universal Declaration of human rights; A commentary, Oslo(/Oxford) 1992, pp. 405-428, op pp. 410, 411 i.f., 414/415, 418-419 en 422 . 
voor de huidige stand van het (internationale) recht is art. 18 VRK (inkleuring primaire en secundaire opvoedingsverantwoordelijkheid), waarover later zal worden gesproken.

\subsubsection{In de ruimste mate}

Met betrekking tot de ruimte die partipatie- en tertiaire (derde categorie-)rechten laten voor nationale interpretatie en implementatie merkt VAN DIJK op: ${ }^{91}$

'Bij de participatie-rechten en de derde categorie rechten is er meer ruimte voor beïnvloeding van de interpretatie en toepassing vanuit verschillen in opvattingen over waarden en rangorden in het kadler van de belangenafweging die aan de toepassing van expliciete of inherente beperkingen ten grondslag dient te liggen. De "margin of discretion" die de internationale rechtspraak de staten hier pl[ee]gt te laten, kan als een algemeen geldend kenmerk van deze normen worden opgevat. (...) Steeds geldt echter als grens dat het recht [in kwestie] door deze verschillen in interpretatie niet van zijn essentie mag worden beroofd.'

Alsook: ${ }^{92}$

'Naast de culturele bepaaldheid van sommige in de normen voorkomende begrippen, kunnen ook de economische en financiële mogelijkheden [van een land] tot verschillen in interpretatie nopen. Soms houdt de formulering van de norm daar all rekening mee. Zo bevat artikel 2 van het [IVESCR] voor de verdragsstaten de verplichting "to take steps (...) to the maximum of its available resources, with a view to achieving progressively the full realization of the rights recognized in te present Covenant".

Een verplichting die we al tegenkwamen in het Verdrag inzake de rechten van het kind:

\section{Art. 4 VRK:}

Die Staten die partij zijn, nemen alle passende wettelijke, bestuurlijke en andere maatregelen om de in dit Verdrag erkende rechten te verwezenlijken. Ten aanzien van economische, socialle en culturele rechten nemen de Staten die partij] zijn, deze maatregelen in de ruimste mate waarin de hun ter beschikking staande middelen dit toelaten en, indien nodig, in het kader van internationale samenwerking.

We zullen nog zien dat de eerste volzin betekent: er geldt geen financieel excuus ten aanzien van het recht van het kind op minimale persoonswor- 
ding (alle passende maatregelen). En de tweede volzin: ten aanzien van het recht van het kind op optimale persoonswording geldt een absolute financiële prioriteit (de ruimste mate).

Met deze aankondiging sluit ik het vierde hoofdstuk af. Er zijn nu genoeg bouwstenen aangedragen om (de idee van) grondbeginselen en kernrechten op de rechten van het kind te gaan toepassen. 


\section{DE RECHTEN VAN HET KIND TUSSEN PARENTIARCHIE EN PERSOONSWORDING}

Inleiding: de rechten van het kind tussen parentiarchie en persoonswording

In dit hoofdstuk worden de rechten van het kind historisch-filosofisch geïntroduceerd. $\mathrm{Na}$ een korte historiek van John LOCKE tot 'monitoring children's rights' bestijgen we - in drie reuzenstappen - de drie treden van het volkenrecht voor kinderen. Om daarna even op adem te komen tijdens een korte afdaling naar de juridische situatie in Nederland. Terug op de derde trede: het Verdrag inzake de rechten van het kind, kijken we uit over een vergezicht waarin we straks, in hoofdstuk 10 , het recht van het kind op persoonswording moeten zien te ontwaren. De voorbereidingen voor die exercitie treffen we in hoofdstuk 6 tot en met 9, waar we, vanuit de kerninhoud van kinderrechten (hoofdstuk 6), de kernrechten van het kind in de Trias pedagogica in het vizier proberen te krijgen (hoofdstuk 7), het belang van het kind onder de loep nemen (hoofdstuk 8), en persoonswording als pedagogisch criterium gaan aftasten (hoofdstuk 9). Maar eerst kijken we, nu met een kinderrechtenbril op, achterom - naar hetgeen vorige generaties filosofen, en in hun kielzog juristen, hebben tot stand gebracht, generaties op wier schouders wij staan.

De aan dit hoofdstuk ten grondslag liggende hamvraag is dan: hoe stevig staan we op die schouders? Met andere woorden: wat is er door filosofen en juristen bedacht dat ons verder helpt bij ons speuren naar sociaal-pedagogische kernrechten van het kind? Mocht immers blijken dat die schouders te smal zijn, zodat we onvoldoende houvast hebben, dan is daarmee de noodzaak vastgesteld op breder geschouderde beginselen terug te vallen, dat wil zeggen: te pogen kernrechten direct vanuit grondbeginselen af te leiden.

\section{2}

\section{Korte historiek}

Van absolute vaderlijke naar niet onbeperkte ouderlijke macht: ziedaar de - theoretische - bijdrage van John LOCKE (1632-1704). Van ouderlijke (al)macht naar rechten van het kind in het gezin blijkt evenwel - in theorie, laat staan praktijk - nog een lange, moeizame weg. Voor het langslopen van deze weg, door een uithoek van moraalfilosofenland, stel ik zelf geen filosoof - voor RAES als gids te nemen. Hier en daar zal ik 
RAES met enkele (diepte)psychologische kanttekeningen pogen aan te vullen.

\title{
5.2 .1
}

\section{Een slok wan de Lethe}

\begin{abstract}
'Geruime tijd vormden noch kinderen, noch het ouderlijk gezag onderwerpen die door moraalfilosofen veel aandacht waardig werden geacht, misschien wel omdat zij overwegend mannen waren, terwijl de primaire zorg voor het kind door vrouwen werd verstrekt."
\end{abstract}

Aldus opent RAES zijn essay over 'De morele betekenis van het vertoog over de rechten van het kind., ${ }^{1}$ Hoewel deze vrouw(on)vriendelijke verklaring voor 'de verwaarlozing van kinderen in het dominante morele vertoog' ${ }^{\prime 2}$ op het eerste gezicht plausibel lijkt (geven mannen niet immers doorheen de geschiedenis blijk van minachting jegens vrouwen en vrouwelijk gedachte taken?), komt toch al snel de vraag op: hoe dat? Zijn al die mannelijke filosofen dan zelf geen kind geweest? Zijn zij soms allen - net als het wonderkind Hugo DE GROOT ${ }^{3}$ - als man geboren? Of hebben zij met hun jongelingsjaren ook elke herinnering achter zich gelaten aan de onmannelijke afhankelijkheidsperiode aan moeders boezem en rokken?

Knagende vragen die het vermoeden doen dagen dat de werkelijke verklaring toch dieper moet zitten dan mannelijke minachting voor, of op zijn minst onverschilligheid tegenover het vrouwelijke - in en buiten de man zelf. En dat vermoeden blijkt al dadelijk in het vervolg van RAES' betoog te worden bevestigd. Zij het enkel tussen de regels door.

Niet specifiek mannelijke maar algemeen menselijke vergetelheid - de vermoedelijk eeuwenlang vanzelfsprekende en pas bij FREUD bewuste grote-mensenslok van de Lethe ${ }^{4}$ - ten aanzien van de eigen jeugd

1 Koen RAES, 'De morele betekenis van het vertoog over de rechten van het kind; naar een differentiële mens- en maatschappijopvatting,' in: E. VERHELLEN e.a. (red.), Kinderrechtengids, Gent 1994 (losbladig), Deel 1 (Commentaren), 1.1 (Algemeen), RAES, pp. 1-47, op p. 3 .

2 Titel van hoofdstuk 1 van RAES' essay, t.a.p.

3 'GROTIUS vir natus est' - heeft HEINSIUS geschreven (Erik WOLF, Große Rechtsdenker der Deutschen [sic, jw] Geistesgeschichte, Tübingen 1963, vierde druk, 'Hugo GROTIUs,' pp. 253-310, op p. 264)'.

4 'Sigmund FREUD verdrong eigen incest-werleden,' bericht De Volkskrant van 19 mei 1994 op de voorpagina, met een verwijzing naar P. DE VRIES-EK, 'Een slok van de Lethe, een verwaarloosde uitspraak uit het werk van Sigmund FREUD' [Pety E. DE VRIES, "A draft of Lethe: a neglected statement from the works of Sigmund FREUD'], in: Psychotherapy (1993, nr. 3, pp. 524-530).

Vgl. ook Han isRaËLS, Het geval FREUd; [Deel] 1. Scheppingsverhalen, Amster- 
dam 1993, pp. 174-215, in het bijzonder p. 197 (en p. 198). ISRAẺLs heeft mett betrekking tot het verlaten van de Verleidingstheorie door FREUD geen behoefte aan 'dieptepsychologische verklaringen' a la (onder anderen) Marianne KRŬLL (FREUD und sein Vater; Die Entstehung der Psychoanalyse und FREUDs ungelöste Vaterbindung, Minchen 1979, Frankfurt am Main 1992; Engelse vert: FREUD and his father, New York/London 1986) en dus, mogen we aannemen, à la DE VRIESEK. Hetzelfde geldt kennelijk met betrekking tot het door FREUD later tot een karikatuur maken van zijn eigen theorie (a.w., p. 205) en andere vormen van freudiaans (zelf)bedrog. Voor ISRAËLS is FREUD een fraud (al gebruikt hij andere termen), iemand met een 'uitzonderlijke' houding tegenover de feiten (a.w., pp. 112-116) waar hij niet veel van begrijpt, iemand van wie de wijze waarop zijn brein werkt alls het om onwelgevallige feiten gaat, voor hem een raadsel is (a.w., p. 111 i.f.). Mij lijkt de vraag evenwel pertinent, en zelfs brandend, niet waarom FREUD niet integer wàs, maar waarom hij - naar het zich laat aanzien - niet integer kòn zijn. Ik vermoed daar wel degelijk een vaderetiologie. Of men deze nu in haar verloop als 'ungelöste Vaterbindung' (KROLL) of onverwerkte incestproblematiek wil (aan')duiden.

FREUD incestslachtoffer? In een brief aan de door hem geadoreerde FLIESS d.d. 8/11 februari 1897 schrijft FREUD: 'Unfortunately, my own father was one of these perverts and is responsible for the hysteria of my brother (...) and those [the hysteria] of several younger sisters.' (J.M. MAssoN (ed.), The complete letters: of Sigmund FREUD to Wilhelm FLIESS 1887-1904, Cambridge/London 1985, Pp. 230/231.) Wat hij onder 'perverts' verstaat, blijkt uit de zin die eraan voorafgaat: 'Hysterical headache with sensations of pressure on the top of the head, temples, and so forth, is characteristic of the scenes where the head is held still for the purpose of actions in the mouth. (Later reluctance at photographer's, who holds head in a clamp.)' Heeft FREUD het hier (alleen) over een patiënt(e) of (ook) over zichzelf? Is het de kleine Sigmund ook overkomen dat zijn hoofdje werd vastgehouden zodat vader hem in het mondje kon copuleren?

Volgens FREUDs Oedipustheorie is er bij het jongetje sprake van identificatie met de agressor: de vader. Hieraan ligt echter niet incest ten grondslag, maar castratieangst wegens de sexuele fantasieën van het jongetje over de moeder (Diane $E$. PAPALIA, Sally Wendkos OLDS, Human development, New York etc. 1992, 5th ed., pp. 211/212). Ik vrees dat ik in het licht van de aangehaalde passage uit de brief aan FLIESS de Oedipustheorie niet anders kan zien dan als de projectie van een in wezen zieke geest. Inmiddels is er voldoende gedocumenteerd over FREUDs gebrek aan persoonlijke en wetenschappelijke integriteit, en is FREUD, die overal weerstand en afweer zag, zelf "accused of an elaborate defense mechanism' (PAPALIA/OLDS, a.w., p. 213 l.k.). De combinatie van een gebrek aan untegriteit en het optreden van allerlei afweermechanismen ('overlevingsstrategieën') duidt niet zelden op niet verwerkte/verdrongen vroege trauma's - uiteraard niet noodzakelijkerwijze incestueus van aard. Of FREUD nu als klein kind 'verleid' was of niet, in zijn geschriften was hij zelf een verleider, en helaas laten nog steeds velen zich 'door zijn retorische stijl (...) manipuleren' (José RIJNAARTS, Dochters varn Lot, Amsterdam 1987, p. 68). Willem DERKS (Zo waarlijk helpe mij FREUD almachtig; De invloed van de psychoanalyse op het strafrecht, Amsterdam 1986, pp. 135 en 221 nt. 101) spreckt zelfs van 'woordmagie' en stelt: 'FREUD weet de toon te vin- 
den waar een goedgemanierd publiek van houdt, om het vervolgens zand in de ogen te strooien ten aanzien van zijn werkelijke bedoelingen.' Hiermee wil ik uiteraard niet gezegd hebben dat FREUD alleen maar onzin heeft beweerd. De misleiding zit - zoals zo vaak - in de combinatie van zin en onzin.

Wanneer ik spreek van een zieke geest, distantieer ik me bovendien nadrukkelijk van MASSON (Traumatische ervaring of fantasie; FREUDs rampzalige herziening van de verleidingstheorie, Amsterdam 1984; in de Duitse vertaling: Was hat man dir, du armes Kind, getan? Sigmund FREUDs Unterdrickung der Verfühnungstheorie; in het Engelse origineel: The assautt on truth; FREUDs suppression [!] of the seduction theory), die van FREUD een verraderlijke streber maakt (KRÜLL, a.w., p. 12). Door zijn weigering op 'dieptepsychologische' (lees: gezinsdynamische) verklaringen in te gaan, ontneemt ISRAËLS zich de kans MASSON te ontmaskeren (zoals dat wel gebeurt, zij het indirect, door Janet MALCOLM, In het FREUD-archief, Amsterdam 1985 - door ISRAËLS in het Nederlands vertaald!). Ook RIJNAARTS (a.w., p. 70 noot 12) lijkt zich door MASSON op het verkeerde been te hebben laten zetten. Door zijn weigering op 'dieptepsychologische' verklaringen in te gaan, ontneemt ISRAËIS zich echter met name de kans FREUD recht te doen. Het is m.i. van belang goed voor ogen te houden dat bij FREUD niet zonder meer van doelbewuste fraude sprake was, maar tegelijk, niet los daarvan, van pathologie, een vorm van creative madness. $\mathrm{Zij}_{\mathrm{ij}}$ het met de destructieve (en anti-sociale) aspecten die onvermijdelijk aan (geëxternaliseerde vormen van) psychopathologie verbonden zijn. ISRAËLS toont het frauduleuze topje van de ijsberg, de gezinsdynamische ijsberg zelf brengt KRÜLL boven water. Waarmee ik uiteraard FREUDs fraude allerminst goedpraat. Het minste wat we daarvan namelijk, in FREUDs nadeel, kunnen zeggen, is hetgeen treffend door BAARTMAN is verwoord: 'Status lijkt nogal eens tot de tegenprestatic te leiden de maatschappij aan [haar] mogelijkkeden tot loochening te helpen. Bovendien, wie zijn status wil handhaven, moet enige terughoudendheid betrachten bij maatschappelijk controversiële onderwerpen.' (Herman BAARTMAN, 'Onderkenning en miskenning van seksueel misbruik van kinderen; enkele historische en actuele aspecten,' in: dez. (red.), Op gebaande paden? Ontwikkelingen in diagnostiek, hulpverlening en preventie met betrekking tot seksueel misbruik van kinderen, Utrecht 1995, pp. 13-27, op p. 25 if.) Wie will weten hoezeer deze woorden, toegepast op FREUD, die de psychoanalyse heeft opgericht niet als ook - en juist - zichzelf niet ontziende (en dus ver van de Lethe blijvende) man van wetenschap maar als (narcistische) hogepriester van persoonlijke macht, een understatement zijn, leze er DElks op na (a.w., bijv. pp. 133-140). Hoe dit ook zij, dat FREUD zijn in de Over de etiologie van de hysterie ontvouwde Verleidingstheorie (lees: Verkrachtings-, Sexueel-misbruik- of Sexueel-traumatheorie) kort na 1896 zou herroepen, en vervolgens zou ombouwen tot de Oedipus(complex)-theorie - kort gezegd: niet de verleidingsrealiteit van de vader maar de verleidingsfantasie van de dochter ligt ten grondslag aan de hysterie - , heeft vooral hiermee te maken dat de vader als dader voor them onaanvaardbaar was. Zoals ALBACH schrijft: 'Eén van zijn [FREUDs] voornaamste argumenten [om zijn eigen Verleidingstheorie - nota bene een 'caput Nili' - al snel te herroepen] was zijn ongeloof ten aanzien van de mogelijkheid dat vaders zich aan seksueel misbruik schuldig maken. Toen hij bezig was om de consequenties van zijn ideeën in de Verleidingstheorie uit te werken, stuitte hij telkens op rapportages over seksu- 
brengt ons, naar het mij voorkomt, op het spoor van die diepere - en dan ook meteen meer dieptepsychologische - verklaring voor dit morele zwijgen. ${ }^{5}$ RAES zelf zegt dit: ${ }^{6}$

eel misbruik door vaders. (In de Verleidingstheorie noemt hij deze nog niet als daders.) Vanaf dat moment kreeg hij er echter steeds meer moeite mee om de verhalen van zijn patiëntes over seksueel misbruik te geloven, en hij begon hun geloofwaardigheid in discrediet te brengen.' Dit ongeloof verwoordde FREUD zelf aldus: '(...) [D]e verbazing dat in alle gevallen de vader, met inbegrip van de mij$n e$, moest worden beschuldigd van perversiteit (...).' (Francine ALBACH, FREUDs verleidingstheorie; Incest, trauma en hysterie, ac. diss. Amsterdam, Middelburg 1993, resp. pp. 80/81, [66 en 79] en 86 i.f; ; curs. jw.) Een 'ongeloof' na ... een slok van de Lethe. Zoals FREUD zelf schrijft in een brief aan FLIESS van 6 september 1897, de laatste brief aan FLIESS vó́r de vermaarde 'herroepingsbrief' (ALBACH, a.w., p. 86) van 21 september (The complete letters, a.w., pp. 263 resp. 264-267; vgl. ook pp. 286, 335 en 350, voor passus in brieven waarin de Lethe terugkeert). Overigens betoonde FREUD zich zeer ambivalent ten aanzien van zijn retractie van de Verleidingstheorie: "Even after the first denial of the incest theory [de Verleidingstheorie, jw], in the letter [to FLIESS] dated September 21, 1897 [vide supra], [FREUD] returned time after time to it, and at the end of that year proposed to FLIESS a quote from GOETHE as the motto of a new publication of his: "What has been done to you, you poor child?" [Was hat man dir, du armes Kind, getan?], referring to the "father-etiology" (...).' (DE VRIES, 'A draft of Lethe,' t.a.p., op p. 527 r.k.)

Wat er van dit alles zij, het drinken van de Lethe is - en blijft - niet zozeer freudiaans als wel een volksziekte. Al heeft FREUDs slok wel heel verstrekkende gevolgen gehad.

$5 \quad$ Zo is ook 'bimnen de feministische morele filosofie van de afgelopen tien jaar' weinig over rechten van kinderen geschreven, constateert SEVENHUUSSEN (Selma SEVENHUIJSEN, 'Feministische ethiek en rechten van kinderen,' in: Carol VAN NIINATTEN (red.), Kinderrechten in discussie, Amsterdam/Meppel 1993, pp. 42-63, op p. 43), die deze 'relatieve stillte" als uitgangspunt voor haar bijdrage neemt en naar een verklaring zoekt voor de feministische "blinde vlekken als het over rechten van kinderen gaat' (t.a.p., op p. 45). $\mathrm{Z} \mathrm{ij}$ noemt het 'verbazingwekkend dat in de uitgebreide feministische literatuur (...) belangen en rechten van kinderen maar weinig ter discussie staan, in tegenstelling tot een heel scala aan onderwerpen, zoals militarisme, ecologie, medische ethiek, en de houding ten opzichte van dieren' (t.a.p., op p. 54). Tot een meer (diepte)psychologische verklaring van dit fenomeen komt zij echter niet - al bezigt zij, op een halve pagina, wel psychoanalytische termen als 'idealiseren,' 'afsplitsing,' 'ambivalenties,' 'projecties' en 'preoccupaties' (t.a.p., op p. 55). Haar bijdrage blijft steken in de - overigens terechte - constatering van een oneigenlijke tegenstelling tussen een zorg- en een rechten-ethiek (t.a.p., op p. 57). Niettemin durft zij de moedige vraag te stellen: 'Waarom bijvoorbeeld is er zo weinig feministische reflectie geweest over kindermishandeling en seksueel misbruik door moeders?' (T.a.p., op p. 43.) RAES, t.a.p., op p. 3 (curs. jw). 
"Het doel van de opvoeding was weliswaar de individuering van het kind dat als volwassene uit de gezinsverhoudingen loskomt om zelf een gezin op te starten. Maar zolang het deel was van het gezin, primeerden de rechten van dit "natuurlijk geheel" over de rechten van de leden. En werd [door de vrouwenbeweging, jw] het ouderlijk gezag als patriarchaal gezag gecontesteerd en uiteindelijk gelijk verdeeld over de ouders, dan bleek er minder reden om het als gezag in vraag te stellen. "Kinderdom" en "ouderschap" werden gerekend tot de "natuurlijke orde der dingen." Het had niet veel zin om ze normatief te problematiseren.'

Vermoedelijk was het evenwel niet zozeer omdat het 'niet veel zin' had, als well omdat een 'natuurlijke orde der dingen' hier naar een zodanige mate en - vooral - soort van vanzelfsprekendheid van de status quo verwees dat zelfs moraalfilosofen niet tot nadenken werden gestemd. En dit ondanks het feit dat een 'natuurlijke' orde - in tegenstelling tot een natuurrechtelijke orde - normaal gesproken toch direct aan het recht van de sterkste doet denken. Daar geldt niet de rule of law maar de willekeur van de man, zo is nu eenmaal de status quo van de natuurtoestand.

Maar sinds vrouwen hun rechtmatige aandeel in de publieke sfeer hebben opgeëist, en mannen op hun plichten in de private sfeer hebben gewezen, is het kind alleen in de natuurlijke orde van het gezin achtergebleven. Nog steeds even onopgemerkt door moraalfilosofen - en juristen - als in de eeuwen daarvoor.

Waarom was het zolang voor de mens ondenkbaar en ondoenlijk vanuit de eigen jeugd naar de situatie van het kind te kijken? Was het MILLER stelt het met grote $\mathrm{kracht}^{7}$ - vanuit de onbewuste en dus onbegrepen nood van het kind de eigen ouders te ontzien? Op latere leeftijd gevoed door een vorm van onbewuste zelfbescherming om niet met een mate van willekeur, hardvochtigheid of onverschilligheid te worden geconfronteerd uit de individuele en collectieve persoonlijke geschiedenis

MILLER spreekt van het idealiseren wan de eigen kindertijd en het ontzien van de ouders (vgl. bijv. Alice MLLer, In den beginne was er opwoeding, Bussum 1983, derde druk, pp. 107-108 en passim). Zij stelt hierover onder meer (a.w., p. 189; curs. overgenomen): "[D]at het ontzien wan de ouders, zoals het Vierde Gebod en de "zwarte pedlagogie" dat voorschrijven, ertoe leidt dat men beslissende factoren in de vroege kindertijd en de latere ontwikkeling van een mens over het hoofd ziet (...)." Vgl. ook MILLERs overige werken, zoals: Het drama van het begaafde kind; Een studie over het narcisme, Bussum 1983 (wijfde druk), in de achttiende, geheel herziene druk met de ondertitel: Op zoek naar het ware zelf, Houten 1995; Gij zult niet merken; Tachtig jaar psychoanalyse, Weesp 1983, Houten 1988 (derde druk; waaraan toegevoegd: 'De dochters zwijgen niet meer' en 'Nawoord'); Een kindervijd in beeld; 66 aquarellen en een essay, Weesp 1986; Zelfkennis in ballingschap; De verdringing van de kindentijd, tot welke prijs? Houten 1989; De gemeden sleutel; De kindertijd en onze cultuur, Houten 1989; De mutur van zwijgen; De waarheid van de feiten, Houten 1990; Levenspaden; Zeven geschiedenissen, Houten 1998. 
die een aanslag zouden betekenen op het zelfbeeld en het zelfrespect van de zich emanciperende mannelijke en vrouwelijke burger? ${ }^{8}$ Een vorm van zelfbescherming die op haar beurt werd gevoed door een even onbewuste behoefte om, eenmaal zelf ouder, niet onder ogen te hoeven zien hoeveel ouderlijke willekeur, hardvochtigheid en onverschilligheid in andere vormen, in nieurwe gedaanten - maar steeds dezelfde verzuurde wijn, hoe liefdevol ook aangelengd, hoe goed ook bedoeld -, aan een nieuwe generatie werden doorgegeven ${ }^{9}$ De behoefte, met andere woorden, om niet onder ogen te hoeven zien hoeveel ouderlijke almacht thans de kinderlijke machteloosheid van vroeger compenseerde? Kortom, ligt de verklaring in een cumulatief effect van kinderlijke nood en volwassen behoeften die verre van bewuste processen te zijn, eeuwenlang niet tot het collectieve bewustzijn konden doordringen? Liep de Lethe eeuwenlang dwars door ieder mensenhart?

BRAND en VERVAET lijken het water van de Lethe in de grijze cellen te zoeken: ${ }^{10}$

'De psychologische verklaring voor het feit dat mishandelde kinderen aanvankelijk [en soms levenslang, jw] het gedrag van hun opvoeders vergoelijken, moet gezocht worden in de ontwikkeling wan het denken van kinderen. Gewoonlijk zijn kinderen pas vanaf een jaar of twalf in staat na te denken over dingen die ze hebben meegemaakt. Ze maken zich dan los van de feitelije gebeurtenissen. Daardoor komt er ruimte vrij om te bedenken dat sommige pijnlijke voorvallen onnodig waren geweest en dat degenen die ervoor verantwoordelijk waren, ze desondanks niet hebben trachten te vermujden. Een basisschoolkind kan dus nog niet consequent doordenken dat en hoe de dingen anders hadden kunnen zijn. Bij een mishandeld kind zal een restant van deze denkwijze langer blijwen bestaan

BAARTMAN formuleert dit zo: 'In dat opzicht lijkt voor de samenleving als geheel - een verzameling volwassenen die allemaal ooit kind waren - enigszins te gelden wat ook geldt voor elk individueel kind afzonderlijk: verlies van het geloof in de betrouwbaarheid van ouders is verlies van het geloof in de betrouwbaarheid van het bestaan. Men kan het zich dus nauwelijks permitteren die betrouwbaarheid in twijfel te trekken.' (H. BAARTMAN, 'Kindermishandeling en botsende belangen,' in: I.B. WEENINK (red.), Het belang van het kind in het geding; Over opvoeding en kinderbescherming, Amsterdam 1990, pp. 59-72, op p. 66 iff.)

9 Vgl. H. BAARTMAN, "Transgenerationele aspecten van kindermishandeling," in: P.B. DEFARES, J.D. VAN DER PLOEG (red.), Agressie; Determinanten, signalering en intenentie, Assen/Maastricht 1991, pp. 150-161; Herman BAARTMAN, "KAFKA's brief aan zijn vader; over het opgroeien als verworpen kind,' in: Willem BERGER e.a. (red.), Geweld in relaties; Ovenwegingen en ervaringen, Baarn 1991, pp. 24-42, op pp. 29-34; Herman BAARTMAN, "Geweld in het gezin," in: H. BAARTMAN en A. VAN MONTFOORT (red.), Kindermishandeling, resultaten van multidisciplinair onderzoek, Utrecht 1992 , pp. 15-39, op pp. 29-31 en 32 .

10 Ed BRAND en Ewald VERVAET, 'Kaspar HAUSER, een gewoon mensenkind?' Psychologie juli 1991, pp. 32-34, op p. 34 r.k. 
naarmate de mishandeling ernstiger was. Dat maakt dat mensen die in hun jeugd mishandeld zijn, geneigd zijn hun situatie te zien als "vervelend, maar normaal"."

Wellicht schuilt in deze uitleg ook de kern van een verklaring voor het feit dat het verband tussen traumatische jeugdervaringen en later psychisch, sociaal, relationeel, beroepsmatig èn ouderlijk dysfunctioneren zolang voor zovelen verborgen kon blijven. Dat de mens lijdt onder zijn geschiedenis, zoals VAN DANTZIG het uitdrukt, en met zijn onverklaarde en voor hemzelf onverklaarbare lijden ook zijn omgeving besmet en verziekt, kan evenwel geen inzicht zijn dat pas sinds gisteren uit de boom van de kennis van goed en kwaad is geplukt. In de woorden van VAN DANTZIG: ${ }^{11}$

'Bijna nooit is er ernst gemaakt met de bevinding van de onderzoekers van het individuele universum van een mens, dat deze mens [de neuroticus] lijdt onder zijn geschiedenis, onder wat hij heeft moeten meemaken in de tijd toen hij als kind weerloos was uitgeleverd aan volwassenen, die ook niet beter wisten.'

Dit 'bijna nooit' kan hooguit enkele generaties betreffen. Al kunnen we vermoeden dat er in alle tijden - lang vóór FREUD - enkelingen, volgelingen van het eerste gebod der wijsheid: 'mens, ken uzelf,' zullen zijn geweest die weet hadden, of althans een vermoeden, van wat voor de meesten zolang verscholen bleef achter de dageraad van de psychologie.

Daartegenover staat dan weer het feit dat tal van omstandigheden en mechanismen kunnen worden aangewezen waarvan kan worden bevroed dat zij versterken wat hierboven - tentatief - werd geschetst. Om een voorbeeld te noemen: is het niet altijd makkelijker, als volwassenen, hoeveel moed het op zich ook vergt, te strijden tegen het machtsmisbruik van wie boven ons zijn gesteld, dan tegen het machtsmisbruik dat we zelf maken? Dat wil zeggen: makkelijker, oneindig makkelijker, om de vijand buiten onszelf, en niet in onszelf te zien? Kennelijk is het mogelijk de slachtoffers die we maken, net zo goed weg te denken of op afstand te houden als het slachtoffer dat we zelf, als kind, eens waren. Want het moet uitgesloten worden geacht dat de jeugd altijd en voor iedereen zo'n paradijs is geweest, dat niemand zich kan voorstellen dat kinderen soms, en veel te vaak, in een hel leven.

Hoewel deze en dergelijke zaken thans enigermate bekend zijn en ook steeds breder bekend worden, blijven er vele vragen. Maar hoezeer het daarom ook een morele plicht is en altijd blijven zal, tegenover ons- 
zelf en tegenover (onze) kinderen, naar antwoorden, in het bijzonder ook individuele antwoorden, die betrekking hebben op onze eigen jeugd en onze eigen levens, te zoeken, het is - om een lang verhaal kort te maken - op zijn minst een opmerkelijk fenomeen dat sinds GROTIUS' nuancering van de absolute gehoorzaamheid aan ouders, in De jure belli ac pacis van $1625{ }^{12}$ sinds LOCKE's - op GROTIUs" natuurrechtsleer geënte ${ }^{13}$ maar veel verder gaande - betwisting van de absoluutheid van de vaderlijke macht, in de Two treatises of government van $1689 / 1690{ }^{14}$ het morele voortborduren op die zeventiende-eeuwse natuurrechtelijke gedachten aan vele grote denkers uit latere generaties niet was besteed.

5.2 .2 Van patriarchie naar parentiarchie: John LOCKE

RAES schrijft over LOCKE: $:^{15}$

"Volgens LOCKE zijn alle mensen van nature gelijk. Weliswaar worden kinderen niet in deze "full state of equality" geboren en hebben hun ouders aldus "a sort of Rule and Jurisdiction over them" [\$ 55], maar dat is maar een voorlopig mandaat dat met de tijd verdwijnt. Alle ouders hebben, op grond van de natuurwet, "an obligation to preserve, nourish and educate the children, they had begotten," niet omdat kinderen de resultaten zijn van hun "workmanship," maar omdat zij aan God toebehoren [\$ 56]. (...)

$[\mathrm{H}] \mathrm{et}$ ouderlijk gezag [is] niet arbitrair; het is een "hoederecht," geen beschikkingsrecht [\$ 65]. (...) Het [ouderlijk hoederecht] normeert (...) in de eerste plaats ouderlijke plichten, zoals de plicht om de kinderen te voeden, te verzorgen en op te voeden. LOCKE is er vrij gerust [op] dat ouders geen misbruik zullen maken van hun ouderlijke macht. Immers: "God hath woven into the Principles of Hu-

12 'Onder de mensen vormen de ouders immers welhaast een soort goden, aan wie men weliswaar geen onbeperkte, maar wel heel bijzondere gehoorzaamheid verplicht is.' (Hugo DE GROOT, Het recht van oorlog en vrede (1625), Prolegomena, par. 14 i.f., uit: Hugo de Groot: Denken over oorlog en vrede, deel 8 uit de serie Geschiedenis van de wijsbegeerte in Nederland, Baarn 1991, p. 46.)

13 Vgl. hiervoor de inleiding van G.A. DEN HARTOGH in: John LOCKE, Over het staatsbestuur /Tweede werhandeling over het staatsbestuur: De ware oorsprong, reikwijdte en doelstelling van burgerlijk staatsbestuur, 1689], Amsterdam 1994 (tweede druk), pp. 7-61, op p. 23-28.

14 De editio princeps draagt het jaartal 1690 op het titelblad, doch het werk verscheen al in 1689, het jaar van de Bill of Rights na de Glorious Revolution, het jaar dat Mary, in hetzelfde schip als de maar de Republiek gevluchte LOCKR, vanuit Holland naar Engeland voer om zich bij haar echtgenoot stadhouder Willem III van Oranje te voegen en zich samen met hem tot de nieuwe koningin en koning van Engeland te laten kronen.

RAES, t.a.p., op pp. 4-5. De hier overgenomen aanhalingen van RAES zijn uit The second treatise of government; An essay concerning the true originat, extent, and end of civil government, Chapter VI, 'Of paternal power' (par. 52-76), ed. 1698. 
mane Nature such a tenderness for their Off-spring, that there is little fear that Parents should use their power with too much rigour; the excess is seldon on the severe side, the strong byass of Nature drawing the other way $[\$ 67]$.'

Leefde LOCKE in zulke idyllische tijden? In tijden waarin excessen vooral getuigden van te grote ouderlijke lankmoedigheid en permissiviteit ${ }^{16}$ maar bijna nooit - zelfs gemeten naar de hardhandiger maatstaven van andere zeden en andere tijden - van te grote ouderlijke hardvochtigheid of zelfs wreedheid ten opzichte van kinderen? Het is niet aannemelijk. En dus moeten we concluderen dat - hoe revolutionair en vooruitstrevend, maatschappelijk en in het rijk van de ideeën, LOCKE's poging ook was het ouderlijk gezag 'zowel te begrenzen als doelgebonden te interpreteren ${ }^{917}$ - hij tegelijkertijd een mythe heeft verwoord die van vór zijn tijd tot op de dag van vandaag de natuurlijke toewijding van ouders ten opzichte van hun kinderen zo fel belicht dat we verblind raken voor de vele gevallen waar in weerwil van die natuurlijke neiging kinderen worden mishandeld, verwaarloosd en misbruikt.

\section{Mene tekel}

LOCKE richtte zijn pijlen niet alleen tegen het absolute van de vaderlijke macht maar ook - niet minder revolutionair - tegen het vaderlijke van die absolute macht: ${ }^{18}$

'[De term vaderlijke macht] wijst de macht van ouders over hun kinderen geheel aan de vader toe, alsof de moeder er geen deel aan had, terwijl wij zullen vinden dat zij gelijke aanspraak heeft indien wij bij rede [het natuurrecht, jw] of openbaring [de bijbel, jw] te rade gaan. Dit kan ons reden geven te vragen of [deze macht] niet juister ouderlijke macht genoemd zou moeten worden. (...)

Hoewel deze macht zonder grote wanklank de naam van absolute heerschappij en koninklijk gezag kon dragen zolang zij onder de titel vaderlijke macht leek te zijn toegewezen aan de vader, zou zij toch wel een vreemde klank hebben gehad, en door de naam zelf de absurditeit hebben getoond, als deze veronderstelde absolute macht over kinderen ouderlijk geheten had, en daarmee had onthuld dat zij ook aan de moeder behoorde. Want het zou de lieden die zozeer strijden voor de

Liberty and Indulgence can do no Good to Children: Their want of Judgement makes them stand in need of Restraint and Discipline,' waarschuwt LOCKE in zijn Some thoughts conceming education uit 1693. Al gaat hij daarbij niet zover dat hij lichaamsstraf zou toestaan. Zie over LOCKE"s opvoedingsopvattingen en -ideeën C.W. MARIS, "Patriarcha," in: Ted DE BOER e.a. (red.), De kant van het kind; Liber amicorum Prof. mr. Miek DE LANGEN, Arnhem 1992, pp. 59-88, op pp. 62-64 (aanhaling uit Some thoughts concerning education op p. 63). 
absolute macht en het gezag van het vaderschap, zoals zij het noemen, maar heel slecht van pas komen dat de moeder er enig aandeel in had.'

Aldus kan LOCKE worden beschouwd als de filosoof die de kentering van patriarchie naar parentiarchie, van absolute vaderlijke naar beperkte ouderlijke macht als teken aan de wand schreef. Een mene tekel aan de wand van een macht die geteld, gewogen en gedeeld was ... maar nog eeuwen vrijwel absoluut zou blijven. Want ook al ...

"(...) ontwikkelde LOCKE als eerste een kader waarin kinderrechten minstens "denkbaar" worden, [d]at kader werd door latere filosofen niet nader uitgewerkt. Integendeel werd het kind steeds meer in een "natuurlijke orde" gesitueerd en in a-juridische termen gedacht $(. ..){ }^{, 19}$

\section{2 .3}

LOCKE's ideeën en het recht: voortschrijdende juridisering?

Ook juristen met een (zo niet natuurlijke dan toch beroepsmatige) hang naar moraalfilosofie, of althans geïnteresseerd in mensenrechten, ja in deze tijd gegrepen door de rechten van het kind, hebben eeuwenlang, tot op de dag van vandaag, LOCKE's paradigma niet als een juridische uitdaging gezien. Sterker nog, als het om het gezin gaat, lijkt juridisering nog heden ten dage bijna een vies woord. Zo kunnen we in 1993 in een rechtsgeleerde bundel met juridisering als thema ${ }^{20}$ lezen: ${ }^{21}$

"De term juridisering wordt in de literatuur en politieke discussie steeds vaker gebruikt om een bepaalde ontwikkeling wan het recht in relatie tot het gezin te beschrijven. Voorstellen die een bepaald aspect van de opvoedingsrelatie juridisch vorm willen geven, wordlen afgewezen met een beroep op de nadelen die juridisering van gezinswerhoudingen met zich zou brengen. Maar een ander uiterste kan ook opgetekend worden: "Het juridiseren van totale instituties is een dwingende eis van beschaving: ook binnen het gezin moet het recht als schokbreker kunnen functioneren." [WILLEMS 1992]."

RAES, t.a.p., op p. 5 .

20 A.R.J. GROOT e.a., 'Zonder meer recht; een inleiding,' in: A.R.J. GROOT en H.J.L.M. VAN DE LUYTGAARDEN (red.), Zonder meer recht, Zwolle 1993, pp. VIIXVII, Op p. VII.

21 G.W. BRANDS-BOTTEMA, 'Recht in de opvoedingsrelatie,' in: a.w. pp. 49-94, op p. 49 (curs. jw). 
Nog steeds - ruim 300 jaar na LOCKE - is het kennelijk extreem, ${ }^{22}$ een 'ander uiterste,' rechtsnoties ook op de situatie van het kind in het gezin te willen betrekken, meer en betere rechtswaarborgen voor kinderen èn meer en betere rechtsbescherming voor ouders te bepleiten, mensenrechten en rechten van kinderen ongevraagd door de brievenbus te willen duwen. (Hier geen juridisch drukwerk alstublieft!)

Nog niet zo heel lang geleden stelde DOEK, in verband met de politieke weigerachtigheid tot het invoeren van een eigen rechtsingang voor minderjarigen: ${ }^{23}$

'Het eerste [argument tegen de eigen rechtsingang, jw]: "gezinsconflicten moeten niet in een juridisch kader worden geplaatst" [het juridiseringsgevaar-argument, jw], geldt kennelijk niet voor vele reeds bestaande regels. Denk aan de (....) regeling voor conflicten tussen ouders maar ook aan de echtscheiding en de vele gezinsconflicten die in dat verband dagelijks aan rechters worden voorgelegd.

Het tweede argument: "het is te duur," is volstrekt onatanvaardbaar voor een welvarende staat als de Nederlandse, die [bovendien, jw] pretendeert een rechtsstaat te zijn, [een staat derhalve] waarin ook (...) de meest kwetsbaren/de minst machtigen tot hun recht moeten kunnen komen.'

Betekent dit alles dat er sinds LOCKE in (het denken over) de juridische relatie tussen ouders en kinderen dan helemaal niets is veranderd? We wenden ons weer tot RAES: ${ }^{24}$

'De politieke maatschappij werd gedacht als een "gewilde orde," het recht als een "gemaakt recht." De ouderlijke autoriteit berustte daarentegen op "natuurlijke beginselen," zoals de behoeftigheid en dus behoefte van het kind aan leiding. De private sfeer is van een andere orde dan de publieke sfeer.'

En - zo moeten we daaraan toevoegen - van een zodanig andere orde dat zij zich bijna bevindt aan gene zijde van het recht. Maar laat ik niet de schijn wekken het beter te willen zeggen dan RAES, die ik zelf als gids heb gekozen: $:^{25}$

22 Als het mij is toegestaan, daartoe uitgedaagd, heel even te polemiseren. (Vgl. ook WILLEMS, "A world of wanted children would make a world of difference"; antwoord aan(gaande) RUTENFRANS,' Nemesis 1992/6, pp. 20-26; wILLEMS, 'Reactie op "Het zelfbeschikkingsrecht van de zwangere vrouw", "Ars Aequi 1993/1, p. 22.)

23 J.E. DOEK, "Het belang van het kind en het recht," in: J.B. WEENINK (red.), Het belang van het kind in het geding: Over opvoeding en kinderbescherming, Amsterdam 1990, pp. 73-92, op p. 89 i.f. (curs. overgenomen). 
'Op grond van hun onvolwassenheid werden kinderen, zoals vrouwen, in juridisch opzicht beschouvyd als "de anderen," $\mathrm{Zij}$ behoorden tot een andere orde dan die van "het recht." $Z$ ij hadden geen deel aan de publieke huishouding die door de politiek werd beheerd en werden evenmin als gelijken beschouwd in de burgerlijke maatschappij. Hun primaire orde was die van het gezin en die werd veeleer door "statutair-natuurlijke" dan door "[maatschappelijk-]contractuele" regels beheerst. Daarom werden zij aan een bijzonder juridisch regime onderworpen dat vooral werd gekenmerkt door gehoorzaamheid aan de ouderlijke macht en door de onmogelijkheid dat het kind zelf zijn rechten kon uitoefenen. Hoewel de rechteloosheid van het kind steeds meer in het teken van thet "belang van het kind" kwam te staan, en hoewel de eigenheid van het kind steeds meer werd benadrukt, werd pas recent de mogelijkheid ernstig genomen om de maatschappelijke positie van kinderen mede op basis van (niet alleen morele maar ook "gepositiveerde") kinderrechten die door henzelf kunnen worden uitgeoefend, te normeren. Ook kinderen worden aldus als leden van de politieke en burgerlijke maatschappij erkend en niet slechts als leden van de pre- en a-politieke orde wan het gezin.'

\section{RAES laat daarop volgen: ${ }^{26}$}

'Op zich vormde de verantwoording van het ouderlijke en van het [publiek]rechtelijke gezag in termen van "het belang van het kind" naturlijk reeds een aanzienlijke vooruitgang die de ideeën van LOCKE uiteindelijk materialiseerde. In tegenstelling tot een louter discretionair gezag dient een paternalistisch gezag zich immers te verantwoorden; aangetoond moet worden dat dit gezag in het belang van het kind wordt uitgeoefend. Een paternalistisch gezag legt plichten op aan diegene die het uitoefent. Het kind kon vanuit die optiek niet meer als een louter instrument worden ondergeschikt aan de doeleinden van ouders of overheid; het had eigen belangen (...). Niettemin werden die belangen uitsluitend door volwassenen vastgelegd. De bellangen van het kind waren belangen die volwassenen aan kinderen toeschreven, ook tegen hun wil.'

Veel verder dan de - arbitrair ingevulde - rechtsnotie "het belang van het kind' lijken we dus niet te zijn gekomen. Voor we evenwel conclusies trekken, laten we RAES een tussenbalans opmaken: ${ }^{27}$

'Het zou overigens een vergissing zijn te menen dat LOCKE's denkbeelden representatief waren voor zijn tijd. In werkelijkheid waren zij ronduit revolutionair en zou de gedachte dat de vaderlijke/ouderlijke macht begrensd is èn slechts in functie staat van het "belang van het kind" maar heel geleidelijk veld winnen. Precies omdat men de verhoudingen tussen ouders en kinderen - evenals die tussen echtgenoten - als "natuurlijk" opvatte, en dit in tegenstelling tot politieke verhoudingen, werden zij in normatief opzicht nauwelijks geproblematiseerd. Men 
rekende als het ware op de voldoende kracht der "natuurlijke sentimenten." Dat die in feite niet altijd aanwezig waren, werd weggemoffeld.'

De geschiedenis werkt niet zelden als een slinger. Als zij vandaag weer bij LOCKE uitkomt, en aan de vooravond lijkt te staan van de juridisering van zijn ideeën, dan moet de slinger in de eeuwen tussen LOCKE en ons welhaast een heel andere kant zijn uitgegaan. Om die slingerwet te toetsen, flitsen we van de laat twintigste eeuw kort terug naar de zestiger jaren van de achttiende eeuw.

\section{2 .4}

\section{Sentimentalisering}

In de achttiende eeuw zal Jean Jaques RoussEAU (1712-1778), auteur niet alleen van $D u$ contrat social maar ook van Emile, ou de l'éducation, beide uit 1762 , de draad van LOCKE bepaald niet oppakken: ${ }^{28}$

[O]ok RousSEAU situeerde het kind buiten de civiele maatschappij en plaatste het in een natuwrlijke orde. Die orde werd niet gekenmerkt door een onderlinge strijd die de nood aan rechtsregels met zich brengt.'

Een natuurlijke orde die ook na ROUSSEAU - tot in onze tijd - idyllisch lijkt te zijn afgedekt. Geen onderlinge strijd? Inderdaad, want hoe zouden we ons die - op het eerste gezicht - moeten voorstellen? Tegengeweld van de te veel huilende en daarom, voor straf, geslagen zuigeling $^{29}$ tegen de getergde vader of moeder? Een geketende slaaf zien we in onze verbeelding eerder in opstand komen. Geen wonder dat er, oppervlakkig bezien, geen onderlinge strijd valt te bespeuren. Niet dat kindermishandeling, met inbegrip van baby-mishandeling, niets met machtsstrijd te maken zou hebben. Zij het vooral met een machtsstrijd van de (on)machtige ouder, gericht tegen het machteloze fantoomkind in hem- of haarzelf, welke zich keert tegen het kind van - eigen - vlees en bloed. ${ }^{30}$

RAES, t.a.p., op p 8 .

29 Het slaan van kinderen vóór de eerste verjaardag was (en is?) eerder regel dan uitzondering: H.E.M. BAARTMAN, Opvoeden met alle geweld: Hardnekkige gewoontes en hardhandige opvoeders, Utrecht 1993, p. 25; Herman BAARTMAN, "Wie zijn kind licfheeft...; over slaag, geweld en mishandeling,' in: Afra GROEN en Adri VAN MONTTOORT (red.), Kinderen beschermen en jeugd hulp verlenen, Arnhem 1993, pp. 37-58, op p. 49.

30 "Als mishandeling zich [in de volgende generatie, jw] herhaalt, dan is dat onder meer omdat in een nieuwe ouder/kind-verhouding de opvoeder alsnog zijn geschiedenis van verworpen zijn ongedaan wil maken ten opzichte van zijn eigen kind.' (BAARTMAN, 'KAFKA's brief aan zijn vader, 't.a.p., op p. 31.)

Dit zijn geen bewuste processen en mede daardoor zaken die sterker zijn dan alle 
Want hoewel de ouder geen kind meer is, is het kind dat hij of zij was, vaak niet geïntegreerd in de volwassene en afgesneden van diens gevoelens. ${ }^{31}$ De daardoor veroorzaakte fantoompijn blijkt niet zelden sterker dan de gevoelens van erbarmen ten opzichte van het eigen kind. Wie zich niet over het gekwetste kind in zichzelf kan ontfermen, kan dat vaak ook niet over het eigen kind. Hoezeer de rollen zijn omgekeerd, lijkt niet tot het bewustzijn door te dringen.

Doch niet doordat men die gecompliceerde (geëxternaliseerde, in en door het eigen kind beleefde en op het kind uitgeleefde intra-ouderlijke) machtsstrijd niet ziet, valt er, op het eerste gezicht, geen strijd te bespeuren. Men ziet, aan de oppervlakte, geen strijd om de simpele reden dat de wapens in die psychodynamische machtsstrijd veel te ongelijk zijn. Tegen de wapens van de ouder verzet het - jonge - kind zich niet. Integendeel, de psychisch ondraaglijke last en trouwens nog onmogelijke opgave van het zich rekenschap geven van de 'bad parent' doet diens wapens zich dubbel tegen het kind keren, als een weerhaak met in twee richtingen scherpe punten. En wel doordat het kind die ouder enkel als 'good parent' en daarmee zichzelf onvermijdelijk als 'bad child' ziet, als slecht kind dat terecht wordt gestraft of gekweld. Zo houdt het kind - ten koste van de ontwikkeling van een gezond gevoel van eigenwaarde, ja soms van enig gevoel van eigenwaarde ${ }^{32}-$, het beeld van de goede ouder

goede voornemens en bedoelingen, ja alle liefde van de ouder. Hinc illae lacrimae liberum (vandaar zovele kindertranen).

31 Juist daardoor is de ouder in zekere zin nog wèl kind, namelijk emotioneel niet uitgegroeid of scheefgegroeid. Vgl. over deze 'onvolwassen opvoeder': Herman BAARTMAN, 'Onderkenning en miskenning van seksueel misbruik van kinderen; enkele historische en actuele aspecten," in: dez. (red.), Op gebaande paden? Ontwikkelingen in diagnostiek, hulpwerlening en preventie met betrekking tot seksueel misbruik van kinderen, Utrecht 1995, pp. 13-27, op pp. 23 i.f.-25, in het bijzonder op p. 25, waar de auteur opmerkt: 'De onderkenning dat veel volwassenen, opvoeders incluis, in emotioneel en seksueel opzicht onvolgroeid gebleven zijn, vormt een bedreiging voor het geloof in een veilige samenleving en vooral voor het geloof in een veilig gezin. De laatste 20 jaar hebben we, in het kader van het onderzoek naar en de klinische ervaring met de achtergronden van kindermishandeling, ingezien dat volwassenen soms hun affectieve hebzucht botvieren op hun kinderen. Kinderen moeten dan tegemoet komen aan de verkrampte behoeften van de volwassene aan respect en macht en intimiteit."

32. Een gebrek aan eigenwaarde dat later de eigen kinderen naar alle waarschijnlijkheid zullen 'erven': '(...) [V]oor het merendeel van de mishandelende ouders [geldt] dat ze lijden aan een gebrek aan zelfwaardering. Hoe geringer die zelfwaardering, hoe gemakkelijker men zich door een kind gekwetst kan voelen en hoe groter vervolgens de kans deze pijn weer middels geweld of verwaarlozing op het kind te verhalen.' (H. BAARTMAN, 'Kindermishandeling en botsende belangen,' in: Het belang van het kind in het geding, t.a.p., op p. 69.) 
in stand. Niet omdat het daarvoor kiest, maar omdat het alternatief: opstand tegen de 'bad parent,' in de totale afhankelijkheidsrelatie niet alleen figuurlijk maar in de meest letterlijke - symbiotische - zin niet denkbaar is. En dus niet bestaat.

Zoals FERENCZI schreef - in 1933: ${ }^{33}$

"De kinderen voelen zich fysiek en moreel hulpeloos; hun persoonlijkheid is nog niet krachtig genoeg ontwikkeld om hen zelfs maar in gedachten te laten protesteren; de verpletterende macht en autoriteit van de volwassene brengt hen tot zwijgen, en berooft hen zelfs vaak van hun zinnen.'

Is het derhalve geen wonder dat zonder minimaal inzicht in deze en dergelijke psychische en ontwikkelingspsychologische mechanismen ${ }^{34}$ - en dus zonder dat de mensheid bepaalde stappen in haar beschavingsgeschiedenis heeft gezet - niet alleen geen 'machtsstrijd' maar ook geen onderlinge strijd, geen fysiek of zelfs psychisch verzet wordt gezien, ${ }^{35}$ wel is het opmerkelijk dat dit zolang, tot ver in de twintigste eeuw, als natuurlijke harmonie, als te koesteren en buiten het recht te houden idylle kon worden voorgesteld. Wat we immers bij en na ROUSSEAU zien gebeuren, is meer nog dan het omgekeerde van juridisering: een romantisering namelijk die in sentimentalisering ontaardt: ${ }^{36}$

Sandor FERENCZI, 'Spraakverwarring tussen de volwassenen en het kind (De taal wan de tederheid en die van de hartstocht), in: J.M. MASSON, Traumatische ervaring of fantasie; FREUDs rampzalige herziening van de verieidingstheorie, Amsterdam 1984, App. 2, pp. 182-193, op p. 188; aangehaald door José RLNA.ARTS, Dochters van Lol; Over vader-dochter-incest, Amsterdam 1987, pp. 114/115; eveneens aangehaald door BAARTMAN, Opvoeden met alle geweld, a.w., p. 131.

34 : Zie hierover BAARTMAN, 'KAFKA's brief aan zijn vader," t.a.p., passim (i.h.b. op pp. 25, 26 i.f. 27, 35, 37, 39, 41); BAARTMAN, "Onderkenning en miskenning van seksueel misbruik van kinderen," t.a.p., op p. 25 (splitsing op collectief en individueel niveau versus de integratie van ambivalenties/ambivalente ouderbeelden), en op p. 26 (neurotische beroepskeuze c.q. parentificatie bij hulpverleners dic ouders - nict alleen hun eigen ouders maar ook de ouders van hun cliënten en pupillen - 'de hand boven het hoofd' houden); BAARTMAN, Opvoeden met alle geweld, a.w., pp. $27 / 28$ (idealisering van de eigen jeugd en psychische gezondheid), en pp. 131-132 (ontwikkelingstaken met betrekking tot good/bad parent en good/ bad $m e$; de ontwikkelingspsychopathologie van het tot zwijgen gebracht, tot stomheid geslagen zijon).

FERENCZI spreekt hier van identificatie met of introjectie van de agressor, welke als 'belangrijkste transformatie in het gevoelsleven van het kind' met zich brengt 'de introjectie wan het schuldgevoel wan de volwassene' (t.a.p.). RAES, t.a.p., op p. 8. 
"Ook ROUSSEAU slloot het kind buiten de "normale" orde van moraliteit en redelijkheid (...). (...) [M]et zijn Emile èn met zijn Julie ou la nouvelle Héloise (1761) [heeft hij] bijgedragen tot een sentimentalisering van de gezinsverhoudingen die in het teken van de spontaneiteit en van het "affectief-emotieve register" werden gestelld en radicaall werden tegengesteld aan de artificiële, rationele en zakelijke orde van recht en politiek.'

Maar laten we die sentimentalisering niet een romantische ROUSSEAU aanrekenen - hoe en met welk recht zouden we dat trouwens kunnen doen als kinderen van een geheel andere tijd -, maar haar op deze tijd betrekken. Sentimentaliteit is, op zijn ergst, een perversie die - we zien het griezelig uitvergroot in bloederige wreedheid met broeierige moederen madonna-verering afwisselende maffia-films - theatraliteit aan sadisme paart. Sentimentaliteit is evenwel geen typisch zuidelijk fenomeen. Van de sentimentaliteit, met zuidelijk of noordelijk cachet, en niet zelden met perverse gevolgen, van (westerse) denkers en juristen in de lieflijke maar platgetreden voetsporen van Emile en Julie zijn heden ten dage alleen al in Nederland jaarlijks minimaal 80.000 kinderen de dupe. De diepe sporen van verlatenheid en verslagenheid, en het Kaïnsmerk van 'bad child,' hen op het voorhoofd gedrukt door de willekeur, de hardvochtigheid en de onverschilligheid waaraan een sentimentele maatschappij hen heeft overgeleverd, dragen zij niet zelden hun hele leven met zich mee. Nog steeds behoren slechts weinigen tot de uitverkorenen die door aanleg en omstandigheden in staat worden gesteld zulke verwoestende ervaringen in meer- of mindere mate te verwerken.

In het Jaarverslag 1995 - het laatste ${ }^{37}$ - van de LSBVK (Landelijke Stichting Bureaus Vertrouwensarts inzake Kindermishandeling) merkt stichtingsvoorzitter KOPER, na twee voorbeelden te hebben gegeven van het stilzitten en stilzwijgen van de overheid, op: ${ }^{38}$

"Het heeft er alle schijn van dat de overheid (nog) niet goed weet hoe te kiezen in het dilemma van tegengestelde belangen tussen ouders en kinderen. Dat levert een extra handicap op voor de praktijk van de BVA's.

Nog steeds ...."

Per 1 januari 1996 zijn de landelijke steuntaken van de LSBVK overgedragen aan het bij het NIZW (Nederlands Instituut voor Zorg en Welzijn te Utrecht) ondergebrachte LSMK (Landelijk Steunpunt Melden van Kindermishandeling). De BVA's (Bureaus Vertrouwensarts) zijn aan provinciaal of regionaal werkende instellingen overgedragen. De LSBVK zelf is in liquidatie gebracht.

A.J.M. KOPER, 'Tien jaar LSBVK - een mild kritische terugblik,' Jaarverslag 1995 LSBVK, Utrecht 1996, Bijlage 5, pp. XXV.XXIV, op p. XXVIII. 
Hoe valt het toch te verklaren dat een maatschappelijk probleem met de omvang en ernst van kindermishandeling nog steeds en alsmaar vertaald wordt in een dilemma van tegengestelde belangen - alsof er niet óók, en bovenal, zeer fundamentele rechten, rechtsstatelijke principes en menselijke waarden in het geding zijn? Of bestaat het dilemma juist in enerzijds die zeer fundamentele rechten, rechtsstatelijke principes en menselijke waarden en anderzijds een bolwerk van in de ideeëngeschiedenis nooit ten principale geproblematiseerde, maar daarentegen juist sentimenteel toegedekte ouderlijke macht? Fundamentele rechten en beginselen, letterlijk en figuurlijk zonder tanden, tegenover tot de tanden bewapende, en alles te verliezen hebbende, volwassenen ${ }^{39}$ Of is dit een valse - maar nog niet als vals doorgeprikte - tegenstelling? En dus een vals dilemma? Althans tot op zekere hoogte ? $^{40}$

39 Illustratief hiervoor is de woordkeuze in een kwaliteitskrant (zoals men zegt) wanneer het kabinet plannen aankondigt om zijn pedagogische verantwoordelijkheid (enigszins) vorm te geven. In de Notitie Gezin (door de staatssecretaris van vws namens het kabinet in september 1996 aan de Tweede Kamer gezonden) wordt deze verantwoordelijkheid als volgt (lapidair maar lacuneus) omschreven (NRC/Notitie, p. 8): 'Wanneer de kernfuncties van het gezin niet worden vervuld en [wanneer daardoor] de rechten wan kinderen worden bedreigd [of aangetast], moeten [kinderen verzekerd kunnen zijn van bescherming en ondersteuning of behartiging van hun] belangen door de overheid.' Tevens wordt aan de hand van algemene noties en beginselen opvoeding omschreven (NRC/Notitie, p. 5): [H] ]et [bieden] van [geborgenheid], veiligheid en behaaglijkheid, [kortom] nestwarmte, [maar ook] socialisering, [de overdracht van waarden en normen], [de] zorg voor gezondheid, onderwijs en educatie, [de woorbereiding op maatschappelijke functies en de] bescherming van de lichamelijke integriteit. [Bij het opvoeden hoort het geven van aandacht, het uitoefenen van toezicht en zeker ook het scheppen van ruimte voor een eigen inbreng en eigen verantwoordelijkheid wan het kind.]p In de krantekop (herhaald in de tekst) wordt dit: 'Kabinet presenteert strikte regels voor de opvoeding.' Strikte regels die in de Notitie zouden zijn 'vastgelegd," aldus het bericht in NRC Handelsblad wan 17 september 1996, p. 32 (bijlage Rijksbegroting 1997). (Uit de vele teksthaken hïerboven blijkt overigens dat de krant, in weerwill van haar zware kwalificaties, niet woordelijk citeert.)

Een maand later verscheen in Dagblad de Limburger (van 17 oktober 1996) een bericht onder de kop 'SORGDRAGER wil dwang bij hulp bij opvoeding.' Op de reacties die dit bericht opriep, zal ik hier niet ingaan. De (verborgen, "sentimenteel" afgedekte) teneur is echter steeds deze: kom niet aan de verworven rechten (en de historische privileges) van volwassenen. Ook zijn er in Nederland al ouderbonden, belangenverenigingen niet van ouderen maar van ouders, opererend onder zulke 'sentimentele' benamingen als 'Ouders voor Kinderen."

40 Ik werp de vragen hier enkel op; in hoofdstuk 7, bij het langslopen van de actoren in de Trias pedagogica, kom ik er (zijdelings) op terug; pas in hoofdstuk 14 ga ik er nader op in. 
Maar niet alleen filosofen, ook juristen dienen nog uit een lange slaap te worden gewekt. Opmerkelijk is bijvoorbeeld dat nog in 1996 een bundel van bijna 1000 pagina's over Monitoring children's rights verschijnt met daarin welgeteld twee bijdragen (van de in totaal 82, afkomstig van over de 100 auteurs) over toch niet de geringste - en zeker in het Westen de belangrijkste - juridisch te 'monitoren' schending van de rechten van het kind: kindermishandeling. Twee bijdragen waarvan er én over een project voor straatkinderen in Kenia blijkt te gaan, en een ander over een informatie- en registratieproject in Bulgarije? Wat nu? Im Westen nichts neues?

In het register van dit lijvig boekdeel ${ }^{41}$ komt het trefwoord parent(s) of parental (bijvoorbeeld in verbinding met power, rights, obligations, responsibilities, behaviour, practices - religious, traditional of anderszins) niet voor. Hetzelfde geldt voor het trefwoord child development c.q. development of the child, ${ }^{42}$ zij het dat er wel een trefwoord evolving capacities of the child is - met de verwijzing naar éen pagina. ${ }^{43}$ De trefwoorden child abuse en children at risk verwijzen naar twee bijdragen met de titels: "Children at risk and defence of their rights in Bulgaria (...), ${ }^{44}$ en 'The Undugu Society approach in dealing with children at risk to abuse and neglect. ${ }^{45}$ Eerstgenoemd trefwoord verwijst bovendien naar een pagina in het artikel 'Towards a European law on children; the European Charter of rights of the child. ${ }^{.46}$ Op deze pagina trof ik eenmaal het woord child abuse aan, in de volgende moedige zinsnede: ${ }^{47}$

'But referring to our so called advanced societies, we have to recognize that child abuse is under a social taboo which is very difficult to change. The cases for which the judicial system comes into action, are extreme and obviously represent a very small percentage of the total number of cases, probably a lot more important, which actually happen. All over the world, but also in Europe and even in our surroundings, sometimes due to our silence, children suffer from the conse-

Eugeen VERHELLEN (ed.), Monitoring children's rights, [Den Haag] (etc.) 1996 (XXvi plus 940 pp.).

Een term die ik overigens wel aantrof in het artikel van Dieter WINDELs, 'Social and educational assistance for children and their mild[ly] mental[ly] retarded parents,' a.w., pp. 797-801, op p. 799 iff.

Malfrid Grude FLEKKøY, 'Children's participation and monitoring children's rights, a.w., pp. 57-65, op p. 59. 
quences of the incomprehension, the selfishness, the indifference, the lasciviousness or the cruelty and brutality of adults [lees: parents (and other adults), jw]."

Het trefwoord child welfare verwijst nog naar een artikel dat (onder meer) over kindermishandeling in België blijkt te gaan - en waarin zowel de woorden child abuse als parents meermaals paraisseren: 'Monitoring children's rights: a specific task for "Child \& Family"? ?48 Ook hieruit mag een veelzeggende passage worden geciteerd: ${ }^{49}$

'Social nurses of Child \& Family pay home wisits to every family in which a baby is born. This type of care is completely on a voluntary basis and free of charge. If the parents do not want it, our work is done, so to speak.'

Een trefwoord (corporal) punishment of (parental) discipline daarentegen schittert door afwezigheid. En hoewel child pomography en child prostitution, vormen van sexueel misbruik van kinderen buiten het gezin, ${ }^{50}$ als trefwoorden zijn opgenomen, ontbreekt een trefwoord sexual abuse als ingang voor monitoring-voorstellen of zelfs maar -bespiegelingen met betrekking tot sexueel misbruik binnen het gezin.

Het wel figurerende trefwoord family ten slotte levert de verwijzing op naar een viertal op zich alleszins lezenswaardige pagina's: twee pagina's uit een artikel van QVORTRUP, ${ }^{51}$ één pagina uit het artikel van een auteur (CANTWELL) ${ }^{52}$ die, op die pagina, QVORTRUP een 'aggressive or unnecessarily provocative' trekje in zijn benadering van het gezin verwijt, na op de voorafgaande pagina al van een - tegendraadse - 'antifamily'-, 'anti-parent'-boodschap gesproken te hebben. Dergelijke nieuwlichterij is niet ongevaarlijk:

'If such arguments were to be heard outside the hushed walls of academic fora, they would constitute an open invitation to totally discredit the rights of the child and the Convention in the eyes of the public, including decision-makers and policy-makers'....,

48 Lieven VANDENBERGHe, Ankie VANDEKERCKHOVE, a.w., pp. 587-592.

49 T.a.p., op pp. $589 / 590$.

50 Vgl. Geert CAPPELAERE, "Possible Optional Protocols to the UN Convention on the rights of the child: improving or undermining the Convention and its monitoring? The case of child prostitution, child pornography and sale of children," a.w., pp. 403-430, op p. 407.

51 Jens QVORTRUP, "Monitoring childhood: its social, economic and political features,' a.w., pp. 33-48, op pp. 38-39.

52 Nigel CANTWELL, 'Monitoring: back to basic questions,' a.w., pp. $67-72$, op pp. 68 resp. 67 . 
... voegt deze auteur zijn opponent op bijna vaderlijk-bezorgde toon toe. ${ }^{53}$ Vaderlijk met de bekende bijklanken van vaders wil is wet, en wat vader doet, is welgedaan. Maar daarom niet minder bezorgd om de rechten van het kind - vooral buiten het gezin (waar we misschien wel een Marc DUTROUX ${ }^{54}$ maar gelukkig niet onszelf als ouders tegenkomen).

De vierde pagina betreft een artikel van THERBORN, ${ }^{55}$ die, op die en de volgende pagina, gewaagt van de feministische deconstructie en decollectivisatie van het gezin, welke de rechten, althans het uit de schaduw van het gezin te voorschijn komen van het kind, mogelijk (zouden) hebben gemaakt.

Hoewel uit deze steekproef uiteraard geen pertinente conclusies kunnen en mogen worden getrokken, spreken alleen al de ontbrekende trefwoorden juridische boekdelen - van 1000 ongeschreven pagina's elk.

\section{Conclusie}

Eén conclusie, verwoord door VAN NIJNATTEN, kan ik evenwel niet nalaten hier weer te geven.

Wanneer juristen die met meer of minder nadruk belijden aanhangers te zijn van de kinderrechtenbeweging, of op zijn minst deze beweging een goed hart toe te dragen, er niet in slagen, of zich er niet eens toe zetten, voorstellen te formuleren die 'laten zien dat er mogelijkheden zijn om in het familierecht de plichten van volwassenen jegens kinderen centraal te stellen, ${ }^{56}$ dan rijst de vraag of die kinderrechtenbeweging zelf wel op het goede spoor zit. In dit verband merkt VAN NIJNATTEN op: ${ }^{57}$

\footnotetext{
'Het recht is tegelijkertijd uitdrukking van ongelijke machtsverhoudingen en gericht op de bescherming van zwakkeren. Het grote belang van de kinderrechtenbeweging is dat zij de wetgever op de machtsverschillen tussen wolwassenen en kinderen attendeert en voorstellen doet om aan kinderen rechten te verlenen die hun op grond van hun status als burger-in-wording toekomen. Tegelijkertijd blijft: een beschermende functie noodzakelijk, bij voorbeeld in het familierecht dat het functioneren van de ouderlijke macht controleert. Het is de vraag of die laatsite functie van het recht niet te veel dreigt te worden verwaarloosd door de aandacht op de rechtspositie van de minderjarige zelf.'
}

Het niet te onderschatten belang voor kinderen van het opgroeien onder

T.a.p., op p. 67.

54 Zie met betrekking tot DUTroux ook hoofdstuk 12 (par. 12.3.2).

55 Göran THERBORN, 'Child politics: dimensions and perspectives,' a.w., pp. 377-391, op pp. 384 en 385.

56 Carol VAN NINATTEN, "Het kind tussen recht en bescherming," in: dez. (red.), Kinderrechten in discussie, Amsterdam/Meppel 1993, pp. 124-142, op p. 139. 
de leiding en begeleiding van ouders die goed met hun macht weten om te gaan, of - moeten we daaraan toevoegen - léren om te gaan, drukt VAN NIJNATTEN zo uit: ${ }^{58}$

'De ervaring met mensen die hun macht positief gebruiken, verhoogt de kans dat kinderen later zwakkere medeburgers met hetzelfde respect zullen behandelen.'

\subsubsection{Een blinde vlek op de liberale retina}

Maar ook juristen hebben recht op verdediging. Kunnen hun eigenlijk wel verwijten worden gemaakt als moraalfilosofen hun zo weinig bouwstenen aanreiken waarvoor zij de specie mogen aanmaken? Niet alleen voor Immanuel KANT (1724-1804) zijn 'kinderen geen leden of participanten in het morele universum.' Maar dat 'is ook zo in het utilitair liberalisme van John Stuart MILL' (1806-1873). ${ }^{59}$ We zitten dan al ver in de negentiende eeuw. Van een slingerbeweging terug naar LOCKE is nog niets te merken. Maar - terug naar RAES: $:^{60}$

'Hedendaagse moraalfilosofen varen niet veel beter. Enerzijds geven zij blijk van een opvallende desinteresse voor het probleem van het ouderlijke paternalisme [de parentiarchie, jw], terwijl hun theorieën op een mensbeeld zijn gestoeld waarin kinderen impliciet worden uitgesloten. Zo is de centrale actor in RAWLS' rechtvaardigheidstheorie een persoon die als een "head of a family" delibereert. (...) Hij delibereert niet op grond van de eventualiteit zelf een kind te zijn. (...) RAWLS is meer begaan met het probleem van de legitimiteit in de verhoudingen tussen staat en burger dan met het probleem van de morele draagwijdte van verhoudingen tussen burgers en "hun" kinderen, mede omdat hij de privalatsfeer grotendeels tegen overheidsbemoeienis wenst af te schermen. (...)

Ook waar paternalisme tot onderwerp wordt genomen van moraalfilosofische reflectie, wordt het politieke paternalisme van de staat meer geproblematiseerd en grondiger behandeld dan het ouderlijk paternalisme. En waar het ouderlijk paternalisme aan de orde wordt gesteld, gebeurt dit vaag, te algemeen en weining overtuigend. Zo ontwikkelde Gerald DWORKIN een justificatie van het ouderlijk patermalisme op grond van een "ex post" instemmingsgedachte; de uitoefening van het ouderlijke gezag gebeurde legitiem indien het kind, eens de volwassenheid bereikt [is], te kennen geeft dat het juist werd witgeoefend. (...) Een dergelijke benadering leidt makkelijk tot een "thank-you"-justificatie van het ouderlijke gezag, waarbij kinderen hun ouders "dankbaar" zouden moeten zijn omdat ze bestaan. Dat heeft echter geen zin [aan]gezien een kind geen alternatief geboden wordt en iedere uitoefening van het ouderlijk gezag op die grond justificeerbaar wordt." 
RAES concludeert: ${ }^{61}$

"Deze veronachtzaming van de "moraal van het ouderlijk gezag" is niet onschuldig. (...) [Het is opmerkelijk dat moraalfilosofen] blijk geven van een grote desinteresse voor de morele status van kinderen binnen verhoudingen die worden gekenmerkt door een fundamentele machtsongelijkheid (...). In het beste geval wordt van de verantwoordelijken een paternalistische motivering gevergd, in het belang van het kind. Alsof het bestaan zèlf wan zekere, onbetwistbare afhankelijkheden kinderen, en mensen in het algemeen, tot volstrekt moreel onbekwame wezens zou maken en alsof aan het ouderlijk paternalisme geen morele grenzen èn richtlijnen behoren gesteld [te worden], die mede door de "wil van het kind" kunnen worden getrokken. Het lijkt wel alsof de (morele) rechten van de volwassene plotsklaps "uit de hemel komen gevallen" - zonder geleidelijke overgangen, zonder continuilteiten tussen de status van kind en die van volwassene. Dat wekt de suggestie dat het om radicaal àndere wezens gaat, het ene a-moreel, het andere moreel, het ene onmondig, het andere mondig, het ene object, het andere subject.'

\section{Kinderrechten in discussie}

Het zijn evenwel niet alleen de grote namen uit de geschiedenis van de moraalfilosofie, met inbegrip van de grote namen onder de huidige moraalfilosofen, die juristen niet van hun gebaande en platgetreden paden hebben gebracht en in een bos met nieuwe paradigma's aan het werk hebben gezet. Aan de door VAN NIJNATTEN uitgegeven bundel - Kinderrechten in discussie - waaruit hierboven tekstflarden van zijn hand zijn geciteerd, heeft ook een (rechts)filosoof een bijdrage geleverd. Het is teleurstellend dat deze in zijn - op zich boeiende - bijdrage niet verder komt dan af te sluiten "met een open vraag. ${ }^{62}$ Een open vraag waarachter vervolgens niet zozeer een vraagtreken als wel een waarschuwend uitroepteken wordt geplaatst: pas op met juridisering, pas op met rechtenbenaderingen. Dit gebeurt dan nadat de auteur ons eerst voor een 'vals' dilemma heeft gesteld: ${ }^{63}$

'Zonder er van uit te gaan dat er twee volledig elkaar uitsluitende soorten morele rationaliteit zijn, kunnen we op zijn minst accentverschillen ontdekken tussen een ethics of care enerzijds en een ethics of justice anderzijds (...). Wanneer een ethics of care misschien de meer geschikte conceptualisering van onze verhouding tot

T.a.p., op pp. 12 en 13.

62 Wibren VAN DER BURG, "Rechten van kinderen: enkele filosofische kanttekeningen," in: Carol VAN NINATTEN (red.), Kinderrechten in discussie, Amsterdam/ Meppel 1993, pp. 64-80, op p. 77.

63 T.a.p. Vgl. ook Selma SEVENHUIJSEN, 'Feministische ethiek en rechten van kinderen,' in: Kinderrechten in discussie, a.w., pp. 42-63, op p. 57; RAES, t.a.p., op p. 39 ('valse tegenstellingen'). 
kinderen inhoudt, dan is een rechtssysteem dat vooral op een ethics of justice is georiënteerd, minder geschikt om deze verhoudingen te reguleren. We hebben dus de keuze: of afzien van verdere juridisering, of proberen een rechtscultuur te ontwikkelen die meer recht doet aan een ethics of care-benadering.'

Alsof het ook hier niet om een èn-èn-aanpak zou moeten gaan: een operationalisering - en dus juridisering - van en vanuit rechtsbeginselen die een ethics of care (niet als tegenhanger van maar juist als aanvulling op een ethics of justice) als grondslag hebben. En deze derhalve, juridisch vorm gegeven, stipuleren - zo goed als zij stipuleren dat deze juridisch vorm gegeven wordt.

Wat dit betreft, biedt de ontwikkelingspsycholoog meer houvast en aanknopingspunten die - in dezelfde bundel - stelt: ${ }^{.4}$

"Mijn stelling luidt dat recht en zorg geen tegengestelde begrippen zijn. Zorg en gezag houden de ontwikkeling van kinderen tot autonome subjecten niet tegen. Integendeel, de motieven en valardigheden waarover elke burger moet beschikken voor de uitoefening van zijn of haar rechten, kunnen zich pas ontwikkelen onder de beschermende vleugels van zorgende volwassenen. Zonder meer roepen om gelijke rechten voor kinderen, gelijk aan die van volwassenen, impliceert een zelfstandigheid die kinderen miet aankunnen, en die daardoor in pseudo-gelijkheid ontaardt.'

Het recht staat voor de opgave de beste modaliteiten tot wetgeving en beleid te verheffen die 'de beschermende vleugels van zorgende volwassenen' over alle jonge leden van de maatschappij waarin dat recht zijn beschermende functie heeft te vervullen, kan doen uitstrekken.

Die opgave heeft het recht in onze zorgzame samenleving, in onze welvarende verzorgingsstaat, zo het er al een begin aan heeft gemaakt, nog verre van waargemaakt. De situatie is voor tienduizenden kinderen in ons land dermate schrijnend dat het recht het zich niet kan permitteren te wachten op de moraalfilosofie, te wachten tot moraalfilosofen de blinde vlek op de liberale retina' ${ }^{\prime 5}$ aan een grondig (zelf)onderzoek hebben onderworpen. En het recht - dat is geen ding, dat is geen abstractie. Het recht - dat zijn de juristen. Het zijn de juristen die, als moraalfilosofen van de daad, rechtsbeginselen en rechtsregels tot levend, werkbaar en werkzaam recht moeten maken.

64 Ed ELBERS, 'De verschuivende zone tussen zorg en zelfstandigheid; een ontwikkelingspsychologisch perspectief," in: Kinderrechten in discussie, a.w., pp. 81-101, op p. 82 .

65 Uit de titel die RAES een afdeling van zijn essay waaruit in deze paragraaf is geciteerd, heeft meegegeven: 'Hedendaagse moraalfilosofieën: kinderen als blinde vlek op de liberale retina" (t.a.p., op p. 9). 
Tegen de achtergrond van de hierboven geschetste filosofische en juridische stilte klinkt het bijna als muziek in de oren te vernemen dat in het internationale recht al in 1924 aandacht voor de rechten van het kind werd gevraagd. Muziek die echter meer van ruis wegkrijgt als we horen dat de Volkenbondsverklaring van dat jaar, bekend als de Verklaring van Genève - ook wel gepavoiseerd als 'Kinderhandvest van de Volkenbond'66 - geen enkele (morele) verplichting voor de staat bevat. Het 'Kinderhandvest' richt zich immers slechts tot 'men and women of all nations.' De lidstaten van de Volkenbond worden in een begeleidende tekst enkel uitgenodigd 'to be guided by its principles in the work of child welfare. ${ }^{67}$ Toch is hier, in dubbel opzicht, sprake van een mijlpaal: ${ }^{68}$

'Despite the historical diplomatic invisibility of children this instrument was the first human rights Declaration adopted by any inter-governmental organisation, and preceded the Universal Declaration of human rights by twenty-four years."

En eigenlijk in drievoudig opzicht, want niet alleen is hier sprake van de eerste mensenrechtenverklaring van een (intergouvernementele) internationale organisatie, en niet alleen betreft deze eerste mensenrechtenverklaring kinderen, maar ook is blijkens en krachtens de officiële titel van deze verklaring: Verklaring van de rechten van het kind, zij het dan tot deze titel beperkt, het concept 'rechten van het kind' geboren. ${ }^{69}$ Louter ruis is zij dus zeker niet.

Een volgende fase gaat het volkenrecht in in 1959, wanneer, op 20 november van dat jaar, een tweede, thans een vN-Verklaring van de rechten van het kind, het licht ziet. ${ }^{70}$ Met in tien beginselen verschillende

Geraldine VAN BUEREN in haar - overigens zonder de relevante internationaalrechtelijke data uitgegeven - International documents on children (Dord[r]echt etc. 1993, p. 3) geeft de woorden van - naar zich laat raden - de voorzitter van de Volkenbondsassemblée weer, die de indruk wekt de auctor intellectualis van deze pavoisering te zijn (mijn curs., jw): 'May I point out that the second resolu' tion contains the Declaration of Geneva, which forms what I may call a kind of children's charter: The Assembly's approval of the Declaration makes it, so to speak, the children's charter of the League. This is an important fact which I think calls for special notice." (Zie ook VAN BUEREN, The international law on the rights of the child, Dordrecht etc. 1995, p. 7.) VAN BUEREN, The international law on the rights of the child, t.a.p. VAN BUEREN, The international law on the rights of the child, a.w., p. 6 iff. Vgl. WAN BUEREN, a.w., p. 8. klaring van de rechten van het kind hebben aangenomen welke bijna volledig de 
(morele) verplichtingen, voor ouders, voor alle volwassenen, voor vrijwilligersorganisaties en voor plaatselijke en nationale overheden. Maar hoewel het kind (morele) rechten lijken te worden toegekend, blijft het toch voornamelijk object, zij het een object van bijzondere bescherming. Misschien dat daarom dit document - van de Verenigde Staten - geen "VNHandvest voor de rechten van het kind' mocht heten? ${ }^{71}$

De derde trede van het volkenrecht ${ }^{72}$ voor kinderen beklimt de wereldgemeenschap op 20 november 1989, wanneer het Verdrag inzake de rechten van het kind unaniem door de Algemene Vergadering van de Verenigde Naties wordt aangenomen ${ }^{73}$ - om iets meer dan negen maanden later in werking te treden, ${ }^{74}$ een werking die binnen luttele jaren

Verklaring van Geneve volgt (Nigel CANTWELL, "The origins, development and significance of the United Nations Convention on the rights of the child,' in: Sharon DETRICK (ed.), The United Nations Convention on the rights of the child; A guide to the "travaux préparatoires," Dordrecht etc. 1992, Ch. 1, pp. 19-30, op p. 19; voor de tekst van deze Verklaring zie a.w., bijlage II, pp. 641-642). Ik heb daarvan geen bevestiging kunnen vinden. Vermoedelijk betreft het een Verklaring van de Algemene Raad van de International Union for Child Welfare (vgl. Ph.E. VEERMAN, The rights of the child and the changing image of childhood, Dordrecht etc. 1992 , pp. 159/160-161 en 219 nt. 37).

Het gelijkheidsbeginsel uit de considerans wordt in de Verklaring van 1948 tot eerste beginsel verheven, en er wordt een nieuw beginsel toegevoegd: "The child must be cared for with due respect for the family as an entity.' (Curs. jw.) Een toevoeging die nauwelijks als een bijdrage aan het concept 'rechten van het kind' kan worden gezien. Voor het overige volgt de Verklaring in grote lijnen de tekst. van 1924 met hier en daar wat toevoegingen en wijzigingen. $\mathrm{Zij}$ behoort aldus meer tot de Volkenbonds- dan tot de (eerste) VN-fase van het kindervolkenrecht. Vgl. VERHELLEN, Jeugdbeschemingsrecht, Gent, editie 1996, p. 458.

72 De drie treden van het wolkenrecht is de titel van een genuchtmakend werkje van VAN VOLLENHOVEN uit 1918; vgl. P.H. KOOJMANS, 'How to handle the grotian heritage; GROTIUS and VAN VOLLENHOVEN' (Second Cormelis VAN VOLLENHOVEN memorial lecture), Netherlands International Law Review 1983/1, pp. 81-92. VAN VOLLENHOVENs dissertatie, uit 1898, heette: Omtrek en inhoud van het internationale recht. Een soortgelijk vernieuwende omtrek en inhoud van het internationale recht in de Trias pedagogica moet nog geschreven worden. Zie over VAN VOLLENHOVENS proefschrift W.J.M. VAN EYSINGA, Sparsa collecta, Leiden 1958 , pp. 204, 206, 220 en 345.

73 Res. AV $44 / 25$.

74. Op 26 januari 1990 is het VRK te New York voor ondertekening opengesteld (Trb. 1990, 46, p. 50 onder J.), 61 staten tekenen (Trb. 1990, 46, pp. 48-49; Trb. 1990,170, p. 1); op 3 augustus 1990 is de vereiste twintigste akte van ratificatie of toetreding binnen door de bekrachtiging/toetreding op die datum van Bangladesh, Benin en Soedan (Trb. 1990, 170, p. 30); ingevolge art. 49, lid 1 VRK treedt het Verdrag vervolgens op 2 september 1990 in werking. 
vrijwel de gehele statengemeenschap zal omvatten. ${ }^{75}$ Bijna alle (erkende) landen ter wereld zijn partij bij het Verdrag, met inbegrip van de (zo goed als) kinderloze ${ }^{76}$ staat Vaticaanstad. ${ }^{77}$ De Verenigde Staten moeten het Verdrag nog ratificeren, en staan dus nog op de drempel van de kring van verdragsstaten. ${ }^{78}$ Volledig buiten de familie van verdrags-

75 De wereld telt, de Cookeilanden - met minder dan 20 duizend inwoners - well, en Taiwan - met meer dan 20 miljoen inwoners - (en West-Sahara) niet meegeteld, 193 (erkende) staten. Per 6 juli 1997 (de Cookeilanden traden als laatste toe op 6 juni 1997: Tractatenblad 1998, 62, p. 6 onder F) zijn 191 staten partij.

76 Hoewel ik mij heb laten vertellen dat er in Vaticaanstad wel kinderen zijn, is het toch opmerkelijk dat hel Vaticaan partij bij het Verdrag inzake de rechten van het kind is geworden. Kennisneming van de travaux préparatoires voedt de verdenking dat dit om oneigenlijke redenen is gebeurd. SCHABAS beticht de "Holy See" ronduit van cynisme: '[1] ts cynical purpose in ratifying seems to be to enhance its credibility in insisting upon an anti-abortion interpretation of Article 6 of the Convention.' (William A. SCHABAS, 'Reservations to the Convention on the rights of the child,' $H R Q 1996 / 2$, pp. 472-491, op p. 479.) Als dit inderdaad de opzet van de Heilige Stoel zou zijn, dan heeft deze internationaalrechtelijk geen been om op te staan (vgl. J.C.M. WILLEMS, "Het vN-Kinderverdrag en het recht op abortus," NIB 1990, pp. 776-778; dez, "Van parentiarchie naar Vadertje Staat," Nemesis $1992 / 3$, pp. 8-23, op pp. $8 / 9$ en 22 nt. 68 ).

$77 \quad$ Zelfs de aanduiding "stad" lijkt niet geheel toepasselijk voor dit kleinste landje ter wereld, dat circa 800 inwoners (en slechts circa 400 staatsburgers) kent - omgerekend circa 1.800 per vierkante kilometer, waarmee het wel een van de dichtst bevolkte (stad)staten ter wereld is - na Macao, Monaco, Hong Kong en Singapore. Bovendien zijn er in Vaticaanstad ook nog eens enkele duizenden voornamelijk Italiaamse gast- c.q. grensarbeiders werkzaam. (Politiek memo; Landeneditie, Deventer 1996; Grote WINKLER PRINS Encyclopedie, negende druk.)

78 De Verenigde Staten hebben het VRK ondertekend op 16 februari 1995 (vgl. Cynthia Price COIEN, 'United States signs the Convention on the rights of the child,' International Journal of Children's Rights 1995/2, pp. 281-282). Ratificatie ligt niet in het verschiet. Vgl. THERBORN in Manitoring children's rights, t.a.p., op p. 385 (nt. 16), die dit sombere verschiet toeschrijft aan het Amerikaanse christelijke fundamentalisme, dat op dit punt het Iraanse moslim-fundamentalisme bijna rechts heeft ingehaald. Bijna - want Iran heeft het VRK onder een zodanig "jezuitisch' voorbehoud geratificeerd dat SCHABAS (t.a.p., op p. 478 i.f.) concludeert: 'Iran's reservation is so far reaching as to constitute a total absence of ratification."

Tot het moment van inwerkingtreding van het Verdrag voor de vs (30 dagen na ratificatie) is de gebondenheid van de vs aan het Verdrag beperkt tot de werking van art. 18 Weens Verdragenverdrag (niet handelen in strijd met de "geest" van het Verdrag). Voor zover kan worden betoogd dat de snelle en vrijwel universele ratificatie van/toetreding tot het Verdrag het verdragsrecht (althans de - niet door voorbehouden aangetaste en/of onaantastbare - bepalingen die kinderen beogen te beschermen tegen aantasting van hun lichamelijke en geestelijke integriteit/persoonswording) tot algemeen internationaal recht heeft gemaakt, voor zover het dat al niet was (gecodificeerde dan well 'instant' universele opinio juris 
staten staat alleen (het regeringsloze) Somalië.

Nederland, sinds het 'dure' Vrouwenverdrag behoedzamer dan ooit (want mensenrechten zijn mooi, maar wel graag gratis), behoorde tot de laatste landen waarvoor het Verdrag in werking is getreden. Sinds 8 maart 1995 geldt het Verdrag ook voor ons land, ${ }^{79}$ zodat we voortaan op 8 maart niet alleen internationale vrouwendag maar ook nationale kinderdag kunnen vieren. ${ }^{80}$

In hoeverre in dit Verdrag - een bindend instrument, met juridische rechten en verplichtingen - de geest van LOCKE waart, kan pas in hoofdstuk 10 blijken. Om toch alvast een voorproefje te geven, worden, ter illustratie, hier twee passages uit LOCKE gevolgd door twee bepalingen uit het Verdrag: ${ }^{81}$

\section{LOCKE (1689):}

'Kinderen, dat geef ik toe, worden niet geboren in deze volledige toestand van gelijkheid, hoewel zij ervoor geboren zijn. Hun ouders hebben een soort bewind en rechtsbevoegdheid over hen wanneer zij op de wereld komen, en nog enige tijd daarna, maar dit is slechts van tijdelijke aard. De banden van deze onderwerping zijn als de windsels waarin zij gewilkkeld zijn, en waarin zij worden gedragen in de zwakheid van hun eerste jeugd. Leeftijd en rede maken die losser naarmate zij opgroeien, tot zij ten slotte geheel wegvallen en een mens aan zijn eigen vrije beschikking overlaten.'

79 De goedkeuringswet (Rijkswet van 24 november 1994) van het Verdrag inzake de rechten van het kind is op 20 december 1994 in het Staatsblad verschenen ( $S t b$. 1994, nr. 862). Blijkens Tractatenblad 1995, nr. 92 vond ratificatie plaats op 6 februari 1995. Krachtens art. 49, lid 2 treedt het Verdrag voor de verdragspartij in werking 30 dagen na de ratificatie, derhalve is Nederland met ingang van 8 maart 1995 aan het Verdrag inzake de rechten van het kind (New York, 20 november 1989) gebonden.

80 De voorgestelde combinatie ligt meer voor de hand dan een simpel moeder-enkind-denken, of vrouwen-en-kinderen-cliche, zou doen bevroeden: aan de vrouwenbeweging is te danken dat we zoveel weten over de omvang en ernst van incest in Nederland; aan de vrouwenbeweging is te danken dat we zoveel weten over de omvang en ernst wan vrouwenmishandeling, en dus over de situatie van kinderen in veel, en veel te lang, veilig gewaande gezinnen in $\mathbb{N e d e r l a n d . ~ ( V g l . ~}$ Aleid VAN DEN BRINK en Jan JÜNGEN, "Thuisgeweld tegen vrouwen; het Meldpunt vrouwenopvang Amsterdam, 1991-1994; Tijdschrift voor Criminologie 1995/4, pp. 315-332, op p. 318.)

Voor het internationaalrechtelijke vrouwen-en-kinderen-cliche vgl. Bruce ABRAMSON, "The invisibility of children and adolescents; the need to monitor our rhetoric and our attitudes," in: Monitoring children's rights, a.w., pp. 393-402, op pp. 394-395.

81 LOCKE, Over het staatsbesturu, a.w., pp. 94 en 102 (\$55 resp. \$67); curs. niet overgenomen. 


\section{Art. 5 VRK (1989):}

De staten (...) eerbiedigen de verantwoordelijkheden, rechten en plichten van de ouders (...) [tot] het voorzien in passende leiding en begeleiding bij de uitoefening door het kind van de in dit Verdrag erkende rechten, op een wijze die verenigbaar is met de zich ontwikkelende vermogens van het kind.

Art. 14, lid 2 (juncto lid 1) VRK:

De staten (...) eerbiedigen de rechten en plichten van de ouders (...) om het kind te leiden in de uitoefening van zijn of haar recht [op vrijheid van gedachte, geweten en godsdienst] op een wijze die verenigbaar is met de zich ontwikkelende vermogens van het kind.

\section{LOCKE (1689):}

'De voeding en [opwoeding] van hun kinderen is een taak die ouders zozeer toevalt in het belang van hun kinderen dat niets hen ervan kan ontslaan deze uit te voeren. En hoewell de macht om hen te bevelen en te [kastijden] daarmee samengaat, heeft God toch (...) de beginselen van de menselijke natuur [met] zulk een tederheid [verweven] voor hun nakroost (...) dat er niet veel vrees hoeft te bestaan dat ouders hun macht met te veel hardheid zouden gebruiken. De overmaat is zelden aan de kant wan de strengheid, de sterke neiging der natuur trekt immers de andere kant op.'

Art. 19, lid 1 VRK (1989):

De staten (...) nemen alle passende wettelijke en bestuurlijke maatregelen en maatregelen op sociaal en opvoedkundig gebied om het kind te beschermen tegen alle vormen van lichamelijk of geestelijk geweld, letsel of misbruik, lichamelijke of geestelijke verwarlozing of nalatige behandeling, mishandeling of exploitatie, met inbegrip van sexueel misbrük, terwijl het kind onder de hoede is van de ouder(s), wettige woogd(en) of iemand anders die de zorg voor het kind heeft.

Het Verdrag inzake de rechten van het kind geldt intussen, zoals we zagen, behalve voor Somalië en de vs, voor alle landen van de wereld rijk en arm, ontwikkeld en onderontwikkeld, waaronder vele "staten van opluikende beschaving. ${ }^{, 82}$ Omdat deze studie niet over de problemen van kinderen in de derde wereld gaat, maar over die in het moderne, westerse en welvarende Nederland, is het goed hier BAARTMAN aan te halen, die met betrekking tot wat door velen in dit land nog wel als het minste probleem van kinderen wordt gezien: het feit dat zij door hun ouders geslagen worden - zo niet met reden dan toch met recht, immers de enige uitzondering die ons moderne rechtsstelsel erkent op het zonder toestem-

VAN VOLLENHOVEN (Ontrek en inhoud van het intemationale rech, diss. Leiden 1898 , p. 178) noemde Argentinië en Transvaal - maar dat was een eeuw geleden. 
ming inbreuk maken op eens anders lichamelijke integriteit -, het volgende heeft opgemerkt: ${ }^{33}$

'De discussie die ontstond over de vraag [naar aanleiding van een voorstel van DOEK "de regel in ons recht op te nemen dat het ouders niet is toegestaan hun kinderen te slaan ${ }^{84}$ ] naar het all of niet oirbare van het slaan van kinderen, zou

83 BAARTMAN, Opwoeden met alle geweld, a.w., p. 17.

84 J.E. DOEK, 'Preventie en overheidsbeleid,' in: Rom HAANSTRA e.a. (red.), Geweld tegen Kinderen; Opstellen over preventie van en hulpverlening bij kindemnishandeling, VKM Den Haag 1987, pp. 195-209, op p. 206; aangehaald door BAARTMAN, a.w., p. 15. DOEK haalde hierbij de (syllogistische) premissen van een Amerikaanse psycholoog aan: 'People are not for hitting. Children are people too' Zoals bij elk syllogisme is hier maar eên logische conclusie mogelijk. Deze conclusie is waar als de premissen waar zijn. De premisse 'children are people' - hoewel onomstotelijke ontologische waarheid - valt dan dadelijk als niet onomstreden maatschappelijke waarheid door de mand. Of liever: niet de premisse maar de maatschappij valt door de mand. Een maatschappij die de "opvatting over kinderen als "nog-niet"-mensen" (VERHELLEN, Verdrag inzake de rechten van het kind; Achtergronden, motieven, strategieën, hoofdlijnen, Leuven/Apeldoorn 1993, tweede druk, p. 11) nog (lang) niet door een opvatting over het kind als mens èn persoon-in-wording heeft vervangen. Een mens sla je niet, niet voor de broek, niet op de blote billen, en niet om de oren. Niet met een kleerhanger, niet met een matteklopper, en niet met de vlakke hand. En een persoon-in-wording sla je zeker niet, omdat dat diens persoonswording schaadt.

Niets toont beter aan hoe diep die beschadiging zit, en hoe ver zij reikt, dan de perverse 'ranselpedagogiek' (BAARTMAN, a.w., p. 90) die beschadigde opvoeders in het vooroorlogse Duitsland (en daarbuiten, en nog daarna) frisch und fröhlig als bittere maar zuiverende pil aan hun kinderen hebben doorgegeven (vgl. Frans HIDDEMA, Bnine terreur door zwatte pedagogie; Psychoanalytische aspecten van HTTLERs racistische nazidom, Rotterdam 1985, pp. 31-33, 'Het Duitse gezin'; Alice MILLER, In den beginne was er opvoeding, Bussum 1983 (derde druk), pp. 73-95, $165,180,183$, passim). Bitter voor het kind, maar zuiverend voor de opvoeder, want een pseudo-catharsis die tijdelijk het gemoed van de ranselende ouder verlichtte tot de volgende externalisatie van de ranselherhalingsdwang, was zijn loon. Het kind gaf altijd wel aanleiding. En een stok om het te slaan, is snel gevonden. Wie de roede spaarde ... deed toch vooral zichzelf te kort. En nog steeds .... moet de 'pedagogische tik' kunnen.

Met het "wie niet horen wil, moet aan den lijve voelen," heeft de Nederlandse maatschappij, na vele eeuwen pijnbank en lijfstraffen, grondig afigerekend. Waar art. 36 der burgerlijke en staatkundige grondregels van de Staatsregeling van 1798 de pijnbank afschafte "door de gantsche Republiek," waar openbare lijfstraffen werden afgeschaft in $1854 \mathrm{en}$ uiteindelijk in 1951 ook de in onbruik geraakte lijfstraf op het achterdeel met bullepees of rotting in de gevangenis in Leeuwarden uit ons recht verdween (J. REMMELINK, HAZEWINKEL-SURNGA's Inleiding tot de studie van het Nederlandse strafrecht, Arnhem 1995, veertiende druk, pp. $642 \mathrm{en}$ 646), is de ongeschiktheid van fysieke straffen "wegens hun vernederende, verbitterende en verruwende werking" (a.w., p. 646) al vele generaties communis opinio 
men misschien kunnen zien als een discussie over een bagatel. Vanuit een bepaald perspectief is het dat onk. Als we de omstandigheden van kinderen bezien die, zoals wij nu zeggen, vroeger op de meest onterende, brute en misdadige wijze in fabrieken gereduceerd werden tot produlktiemiddelen en die, als ze als radertjes in het fabricageproces onklaar geraakt waren, weer gemakkelijk door nieuwe konden worden vervangen, dan is het slaan van kinderen maar een bagatel. Als we weten dat in Brazilie jaarlijks honderden kinderen worden vermoord omdat ze als zwervertjes, als bedelaars, of gewoon als schoenpoetsers het straatbeell voor toeristen bederven of te veel van de criminele handel en wandel van volwassenen weten, wat maken we ons dan nog druk om "een pedagogische tik." En wie kan zich druk maken over het voor en tegen van een pedagogische tik alls hij de beelden ziet van verweesde en verworpen kinderen die wegkwijnen in gestichten in Roemenië? En lijkt het bij het zien van de soms gruwelijke, in veelkleurendruk afgebeelde letsels van kinderen die het gevolg zijn van ernstige mishandeling [door ouders of verzorgers, ${ }^{85}$ jw] niet beter onze aandacht daar maar op te richten? Toch is deze discussie geen bagatel. Elke cultuur en elk milieu kent, gegeven de socio-materiele en politieke omstandigheden, uiteraard grenzen voor wat er aan welzijn en ontplooiing voor zijn burgers, dus ook voor zijn jongste burgers, mogelijk is. Desondanks dient men niet een vraag naar het normatheve gehalte van het eigen handelen te verwaarlozen als voor die vraag in een andere cultuur nauwelijks nog plaats lijkt. Een discussie over het al of niet juiste

in dit land. 'In the Netherlands, people are not for hitting." Maar "in the Netherlands, children are people too" - dáár wil het gidslandje achter de hoge dijken nog niet aan.

85 Hoezeer zou het overigens als 'eye opener' kunnen werken dergelijke zeer confronterende beelden - van Nederlandse kinderen uit Nederlandse gezinnen dagelijks in Nederlandse kranten af te drukken en op Nederlandse televisie-uitzendingen te vertonen? Zie waartoe de mens in staat is: zie zijn kind" Hoe lang zou een permissieve maatschappij het zich dan nog kunnen permitteren de andere kant op te kijken? De kant waar zij zich, door haar lakeien en narren, de journalisten, op haar wenken bediend, kan vergapen aan rituele of pedofiele excessen waarbij de ouders als daders buiten beeld en aldus alle ouders buiten schot blijven.

Of vergis ik mij, en zal er enkel een nieuwe vorm van 'reality tv' ontstaan, die de 'reality' in de huiskamer van de buurman vertoont, dus per definitie nooit de "reality" van de eigen huiskamer? Het kind van de ander:" ziet en beeft! Of, rond de kersttijd: ziet en geeft! Met het gironummer van de VKM.

Misschien zouden we het toch eens moeten proberen. Hoewel ... ik geloof niet dat dit de gruwelbeelden zijn die we willen zien. Tal van verontwaardigde ingezonden brieven en boze telefoontjes naar de televisiestudio's zouden er spoedig een einde aan maken. Zodat Nederland weer om de haard van andere gruwelen dan die te dicht bij de eigen haard kan genieten. Want het journaille moet het natururlijk niet te bont maken. Ook een nar moet zijn plaats weten - en zal die weer schielijk innemen. Slaap zacht, lieve kijkbuiskindertjes.

En naturrlijk, er is al zo veel leed in de wereld. Ben ik mijns broeders hoeder? Laat staan de hoeder van diens kinderen? Misschien kan de staat iets doen mits hij van mijn privileges en privacy afblijft.... 
van het slaan van kinderen is even fundamenteel met betrekking tot de positie van een kind in de samenleving als een discussie over leerplicht of fabrieksarbeid van kinderen. Dat een kind onder een pedagogische tik minder gauw bezwijkt dan onder een 14-urige werkdag in een werkplaats, doet aan het principiële van deze discussie niet af. En al die gruwelijke letsels, in tv-uitzendingen soms op spectaculaire wijze getoond, horen bij het extreem van een glijdende schaal van geweld waar ook het alledaagse quasi-pedagogische geweld deel van uitmaakt. Dat dat alledaagse geweld minder sporen oplevert voor schokkende kleurenfoto's, doet daar niets aan af. Slaan van kinderen ontaardt maar al te vaak in mishandeling.'

Op deze plaats moet worden volstaan met op te merken dat Nederland in tegenstelling tot landen als Zweden (sinds 1979), Finland (sinds 1984), Denemarken (sinds 1986), Noorwegen (sinds 1987) en Oostenrijk (sinds 1989) - geen (burgerrechtelijk) verbod op het slaan van kinderen kent. ${ }^{86}$ BAARTMAN haalt de desbetreffende bepalingen uit het Zweedse en Deense familierecht aan: ${ }^{87}$

\section{Zweeds 'BW':}

"Kinderen hebben recht op zorg, weiligheid en een goede opvoeding. Kinderen dienen met respect voor hun persoon en hun individualiteit behandeld te worden en mogen niet onderworpen worden aan lichamelijke straffen of andere vernederende behandelingen."

\section{Deens 'BW':}

'De zorg van ouders impliceert de verplichting het kind te beschermen tegen fysiek en psychisch geweld en elke andere schadelijke handelwijze.'

En doet zelf een voorstel voor een bepaling, op te nemen in het Nederlandse $\mathrm{BW}:{ }^{88}$

Nederlands BW, voorstel-BAARTMAN:

"Kinderen hebben recht op eerbiediging van hun lichamelijke en hun psychische integriteit. Oudlers zullen zich daarom jegens hun kinderen onthouden van geweld.'

\section{Nederlands familierecht}

$\mathrm{Nu}$ we tot hier zijn gekomen, kan het geen kwaad kort te grasduinen in het Nederlandse familierecht. Wat bepaalt ons BW eigenlijk met betrek- 
king tot de rechten van kinderen en de verplichtingen van ouders op het stuk van de opvoeding en het ouderlijk gezag?

Tot november 1995 moesten we daarvoor te rade gaan bij de titel 'Ouderlijke macht,' afdeling 'De ouderlijke macht wat de persoon van het kind betreft." Deze afdeling besloeg 3 artikelen: art. 1:245 (verplichtingen van kinderen en ouders - in deze volgorde), art. 1:246 (gezamenlijke uitoefening ouderlijke macht; bij geschillen tussen de ouders beslist de rechter 'in het belang van het kind'), en art. 1:246a (kind terugeisen van pleegouders).

Art. 1:245 oud-BW bestond uit 2 leden. Lid 1 ('het vierde gebod') luidde aldus: Een kind, van welke leeftijd ook, is aan zijn ouders eerbied en ontzag verschuldigd. ${ }^{89}$ Lid 2 luidde: De ouders zijn verplicht hun minderjarige kinderen te verzorgen en op te voeden. Art. 1:246, lid 1 oud-Bw bepaalde: Gedurende hun huwelijk bezitten de ouders de ouderlijke macht over hun minderjarige kinderen. Door de jurisprudentie was deze bepaling al lang achterhaald. Maar voor de hele afdeling gold dat hier sprake was van 'volstrekt verouderde wetsbepalingen."90

Wat is er met ingang van november 1995 veranderd $?^{91}$ We slaan de wetten-editie van 1995/96 dicht en nemen de nieuwe wetteneditie, die van $1996 / 97$, ter hand. Het eerste dat opvalt, is dat de term ouderlijke macht blijkt te zijn vervangen door de term ouderlijk gezag: ${ }^{92}$

'In het verleden [dat wil zeggen: tot november 1995, jw] heeft de wet zich niet uitgelaten over de wijze waarop de ouders hun gezag moesten uitoefenen. $\mathrm{Zij}$ waren daarin vrij. Nu gaat art. 247 daar iets nader op in. Lid 1 stelt dat ouderlijk gezag de plicht en het recht omvat van de ouder zijn minderjarig kind te verzorgen en op te voeden. Lid 2 werkt dit verder uit. Onder werzorging en opvoeding worden mede verstaan de zorg en de verantwoordelijkheid voor het geestelijk en lichamelijk welzijn van het kind en het bevorderen van de ontwikkeling van zijn persoonlijkheid. Ouderlijk gezag omvat dus duidelijk meer dan alleen zorg dragen voor kleding, voeding en gezondheid."

Zie over deze bepaling en de volgorde tussen deze bepaling en die in het tweede lid: BAARTMAN, Opvoeden met alle geweld, a.w., pp. 20/21, alsook p. 44 nt. 3; zie ook dez. in GROEN/VAN MONTFOORT, t.a.p., op pp. 54/55. In zijn bijdrage in $O p$ gebaande paden? (t.a.p., op p. 24 i.f.) merkt hij nog op: 'Achting en loyaliteit kunnen niet worden opgedrongen of afgetroggeld [maar zijn] slechts dan bevorderlijk (...) voor de ontwikkeling van het kind indien ze berusten op verdiensten.' (Zinswolgorde door mij gewijzigd, jw.) ROOD-DE BOER in: VAN DER BURGHT/ROOD-DE BOER, Personen-en familierecht, Arnhem 1996 (tiende druk), p. 506.

91 Zie ook DOEK/VLAARDINGERBROEK, Jeugdrecht en jeugdhulpverleningsrecht, Den Haag 1996 (tweede druk), pp. 95 e.v.

92 ROOD-DE BOER, a.w., op p. 507 (curs. overgenomen). 
Inderdaad: de wet gewaagt niet alleen van een plicht tot verzorging, maar ook van een plicht tot opvoeding. Maar hoe duidelijk is die plicht? Wat wordt er door de wetgever onder verstaan? Hoe worden de uit die algemene plicht voortvloeiende bijzondere verplichtingen van de ouders en de daarmee corresponderende rechten van het kind ingevuld? Sluit zorg voor het geestelijk en lichamelijk welzijn van het kind het tuchtigingsrecht, de 'pedagogische tik,' nu wel of niet uit? Wat wordt er nu nader geregeld over de wijze waarop het gezag wordt uitgeoefend?

Vele vragen - geen antwoorden. We moeten gissen of en in hoeverre hier althans de schakelbepaling van art. 3:13 BW in verband met art. 1:247, lid 1 (ouderlijk gezag) en lid 2 (ouderlijke verantwoordelijkheid $)^{93}$ gelezen mag worden: ${ }^{94}$

Art. 3:13, lid 1 en 2 BW:

1. Degene aan wie een bevoegdheid toekomt, kan haar niet inroepen voor zover hij haar misbruikt.

2. Een bevoegdheid kan onder meer worden misbruikt door haar wit te oefenen met geen ander doel dan een ander te schaden of tnet een ander doel dan waarvoor zij is verleend of in geval men, in aanmerking nemende de onevenredigheid tussen het belang bij de uitoefening en het belang dat daardoor wordt geschaad, naar redelijkheid niet tot die uitoefening had kunnen komen.

We mogen niet aannemen dat hier het derde lid van art. 3:13 BW van toepassing is:

Art. 3:13, lid $3 \mathrm{BW}$ :

3. Uit de aard van een bevoegdheid kan voortvloeien dat zij niet kan worden misbruikt. 95

Art. 1:247, lid $1 \mathrm{BW}$ luidt: Het ouderlijk gezag omvat de pliclit en het recht van de ouder zijn minderjarig kind te verzorgen en op te voeden. Lid 2 van dit artikel bepaalt: Onder verzorging en opvoeding worden mede verstaan de zorg en de verantwoordelijkheid voor het geestelijk en lichamelijk welzijn van het kind en het bevorderen van de ontwikkeling van zijn persoonlijkheid. (Zie ook hierboven.)

94 Vgl. N.A. STEGERHOEK, De publieke kant wan het jeugdrecht, diss. Leiden, Zwolle 1995 , p. 8 i.f.

95 Uit art. 1:269, lid 1 aanhef en onder a BW kunnen we afleiden dat het concept misbruik van ouderlijk gezag in het burgerlijk recht wel bestaat. Art. 1:269 geeft de gronden voor ontzetting van het ouderlijk gezag: (a.) de ouder maakt misbruik van zijn gezag of verwaarloost de verzorging of opvoeding van zijn kind op grove wijze; (b.) slecht levensgedrag van de ouder of (c.) diens onherroepelijke veroordeling ter zake van misdrijven tegen of met het kind gepleegd, dan wel een onherroepelijke veroordeling tot twee jaar of langer vrijheidsstraf; (d.) ernstige veronachtzaming var de aanwijzingen van de gezinswoogdij-instelling of belemmering van een uithuisplaatsing; en (e.) het terugnemen of terugeisen van het kind terwijl gegronde vrees bestaat woor verwaarlozing van de belangen van het kind. 
Art. 1:266 BW bepaalt dat ongeschikte of onmachtige ouders van het ouderlijk gezag kunnen worden ontheven. Welke pedagogische kwaliteiten ouders moeten missen om ongeschikte opvoeders te zijn, bepaalt de wet niet. In hoeverre of in welke opzichten ouders te kort moeten schieten in de opvoeding van hun kind om onmachtige opvoeders te zijn, bepaalt de wet evenmin. Ontheffing is overigens, ingevolge art. 1:268, lid $1 \mathrm{BW}$, niet mogelijk indien de ouder zich daartegen verzet, behoudens een viertal uitzonderingen, genoemd in het tweede lid, waaronder (sub c) het geval van de ouder die (ernstig) geestelijk gestoord is. ${ }^{96}$

Tegenover dit alles staat dat sinds november 1995 wel de vanuit het perspectief van het mishandelde kind aanstootgevende ${ }^{97}$ bepaling van art. 1:245, lid 1 oud BW (Een kind, van welke leeftijd ook, is aan zijn ouders eerbied en ontzag verschuldigd) uit ons recht is geschrapt.

De - vanuit hetzelfde perspectief - niet minder wrange, immers als regel eerder een te late dan tijdige interventie suggererende grond voor de oTs (ondertoezichtstelling): bedreiging met zedelijke of lichamelijke ondergang (art. 1:254-oud BW), is evenwel nog niet volledig uit het BW verdwenen. Weliswaar luidt art. 1:254, lid $1 \mathrm{BW}$ thans:

Overigens is het commentaar veelzeggend dat ROOD-DE BOER (a.w., p. 531) ten aamzien van verwaarlozing geeft: 'Een liefdeloze, kille opvoeding is een nauwelijks te bewijzen grond voor ontzetting.' Als (enig) voorbeeld van misbruik van gezag noemt zij '[d]e moeder die haar" minderjarige dochter "uitleent" woor het vervaardigen van kinderporno' (a.w., p. 530 i.f.).

Ontzette ouders, die na de uithuisplaatsing van hun kinderen alleen zijn achtergebleven, kunnen overigens direct weer nieuwe kindjes maken: 'Noch een ontheffing noch een ontzetting hebben betrekking op toekomstige kinderen.' (ROOD-DE BOER, a.w., p. 530.)

96 'Een geestelijk gestoord iemand is waarschijnlijk niet de meest aangewezen opwoeder van kinderen,' merkt ROOD-DE BOER - laconiek? - op (a.w., p. 529). Iets meer begrip voor de positie van het kind bij gestoorde ouders vindt men in het reeds vermelde stuk van WINDELS, 'Social and educational assistance for children and their mild[ly] mental[ly] retarded parents," in: Monitoring children's rights, a.w., pp. 797-801. Men leze ook: P. REMMERSWAAL, F. VERHEIJ, "Transgenerationele dynamiek in symbiotische gezinnen,' im: Gestoonde ouders - gestoorde kinderen? Speciale uitgave van Kind en Adolescent; Tijdschrift voor pedagogïek, psychiatrie en psychologie 1991/3, pp. 176-184, en de overige bijdragen in dit themanummer.

Vgl. overigens ook art. 1:246 (juncto art. 1:245, lid 2) Bw: Onbevoegd tot het gezag [ouderlijk gezag dan well voogdii] zijn (...) zij wier geestvermogens zodanig zijn gestoord dat zij in de onmogelijkheid verkeren het gezag uit te oefenen (...).

97 Vgl. Alice MILLER over 'het vierde gebod' (zie haar hierboven opgesomde werken). Vgl. ook BAARTMAN hierboven. 
Indien een minderjarige zodanig opgroeit dat zijn zedelijke of geestelijke belangen of zijn gezondheid ernstig worden bedreigd, en andere middelen ter afwending van deze bedreiging hebben gefaald of, naar is te voorzien, zullen falen, kan de kinderrechter hem onder toezicht stellen van een gezinswoogdij-instelling (...).

Maar de bijna-fataal klinkende grond voorkoming van de zedelijke of lichamelijke ondergang' paraisseert nog steeds in art. 1:241, lid 2 (voorlopige toevertrouwing aan de Raad; in de toekomst: voorlopige voogdij ${ }^{98}$ ).

Vermeldenswaard is nog dat, met betrekking tot de (machtiging tot) uithuisplaatsing (MUP) ${ }^{99}$ art. 1:261 BW spreekt van: noodzakelijk in het belang van de verzorging en opvoeding van de minderjarige of tot onderzoek van diens geestelijke of lichamelijke gesteldheid.

Art. 1:249 BW geeft aan wat naar moderne(re) opvattingen als de plicht van het kind ten opzichte van de ouders (en overige gezinsleden) moet worden beschouwd: ${ }^{100}$

De minderjarige dient rekening te houden met de aan de ouder of voogd in het kader van de uitoefening van het gezag toekomende bevoegdheden, alsmede met de bellangen van de overige leden van het gezin waarvan hij dee: uitmaakt.

Art. 1:250 BW introduceert de bijzondere curator als figuur niet alleen in zaken het vermogen van het (vermogende) kind betreffende, maar ook in aangelegenheden betreffende diens verzorging en opvoeding. ${ }^{101}$

De zich ontwikkelende vermogens van het kind als belangrijk beginsel in het Verdrag inzake de rechten van het kind (we haalden de desbetreffende verdragsbepalingen hierboven al aan) zijn, voor wat de relatie ouder-kind betreft, in ons recht evenwel niet terug te vinden. Wel bepaalt art. 1:257, lid 3 BW dat de gezinsvoogdij-instelling rekening dient te houden met het leeftijds- en ontwikkelingsniveau van de minderjarige pupil, alsmede met diens bekwaamheid en behoefte zelfstandig te handelen en zijn leven naar eigen inzicht in te richten. Doch ontwerp-art. 247, lid $3 \mathrm{BW}$, luidende:

Bij de uitoefening van het gezag dient de ouder in toenemende mate, in aanmerking memende het leeftijds- en ontwikkelingsniveau van het kind, rekening te houden met diens mening over hem betreffende aangelegentheden, alsmede met diens toenemende bekwaamheid en behoefte zelfstandig te handelen en zijn leven naar eigen inzicht in te richten ..., 
... heeft de eindstreep niet gehaald. ${ }^{102}$ (Waarmee uiteraard niet art. 5 en art. 14, lid 2 van het Verdrag inzake de rechten van het kind zijn "weggestemd.')

Canonieke invulling van het ouderlijk gezag?

In 1987 verzuchtte I. JANSEN in een editorial - getiteld 'Invulling van het ouderlijk gezag?'- van het Tijdschrift voor familie- en jeugdrecht: ${ }^{103}$

[H]et gaat er bij mij] niet in dat het in de wet tot uitdrukking brengen wan wat onder verzorging en opvoeding moet worden begrepen - 6ók het bevorderen vam de ontwikkeling wan de persoonlijkheid van het kind - maar achterwege moet blijven. Dăt ouders rekening houden met de mening van het kind, aangelegenheden de uitoefening van het gezag betreffende, met het kind moeten bespreken, en ernaar dienen te streven om ter zake met hem of haar tot overeenstemming te komen (waarbij vooral telt de mate waarin de persoonlijkheid van het kind tot ontwikkeling is gekomen) is, behalve een goede pedagogische aanpak, immers ook nog geldend recht! (...)

Wat kan ons toch weerhouden te doen wat andere wetgevers reeds eerder hebben opgeschreven? (...) En om over te nemen hetgeen zelfs mondiaal ingang lijkt te vinden? Waardoor, als het gaat om de beoordeling van de uitoefening van het gezag ook door de rechter, vorenvermelde factoren meer expliciet in beschouwing kunnen worden genomen?'

Het voorafgaande overziend, moeten we concluderen dat de auteur, die namens Nederland actief was betrokken bij de totstandkoming van het Verdrag inzake de rechten van het kind, ${ }^{104}$ maar zeer ten dele bij de wetgever respons heeft gevonden. Het heeft er alle schijn van dat we in het canonieke recht meer houvast vinden dan in ons eigen Bw. Zo bepaalt canon 795 van de Codex Iuris Canonici, het Wetboek van canoniek recht $1987:^{105}$

102 Een confrontatie in het parlement is vermeden door het voorstel te schrappen: zie STEGERHOEK, a.w., p. 18; DOEK/VLAARDINGERBROEK, a.w., pp. 102/103.

De notitie Rechtspositie minderjarigen (Tweede Kamer 1989/1990), waarin opvoeding nog (enigszins) inhoudelijk werd omschreven, sprak van: "de mate waarim de persoonlijkheid van het kind is gerijpt.' Zie A.P. VAN DER LINDEN, 'Ouderlijk gezag en voogdij,' in: M.J.C. KOENS (red.), Het hedendaagse personen- en familierecht, Zwolle 1995, pp. 229-263, op p. 232.

103 I. JANSEN, 'Invulling van het ouderlijk gezag?' FJR 1987/8, p. 225 (curs. jw).

104 VI. Astrid DELISSEN, De rechten van het kind: na 10 jaar voorbereiding nu bij verdrag vastgesteld," NJCM-Bulletin 1990/5, pp. 566-575, op p. 569 (nt. 13).

105 Can. 795 - Cum vera educatio integram persequi debeat personae humanae formationem, spectantem ad finem eius ultimum et simul ad bonum commune societatum, pueri et iuvenes ita excolantur ut suas dores physicas, morales et intellectuales harmonice evolvere valeant, perfectionem responsabilitatis sensum libertatisque rectum usum acquirant et ad vitam socialem active participandam conformentur. 
Daar echte opvoeding ten doel moet hebben de integralle vorming van de menselijke persoon, gericht op zijn uiteindelijk doel en tegelijk op het algemeen welzijn van de maatschappij, moeten kinderen en jongeren zố gevormd worden dat zij hun fysieke, morele en intellectuele gaven harmonisch kunnen ontwikkelen, een dieper verantwoordelijkheidsgevoel en een juist gebruik van hun vrijheid verwerven en in staat gesteld worden aan het socialle leven actief deel the nemen.

Hoewel deze canon paraisseert in de titel over de katholieke opvoeding (De educatione catholica) zou hier tot op zekere hoogte van een katholiek in de eigenlijke betekenis van universeel ${ }^{106}$ opvoedingsdoel gesproken kunnen worden. Canon 1136 van de Codex laat hiervan de ouderlijke keerzijde zien: ${ }^{107}$

De ouders hebben de zeer ernstige plicht en als eersten het recht om, zo goed ze kunnen, zowell voor de fysieke, sociale en culturele als voor de morele en godsdienstige opvoeding van hun kinderen te zorgen.

Maar stop, en amen, we dreigen af te dwalen. We zouden slechts wat grasduinen in het Nederlandse familierecht. Dat hebben we voorlopig genoeg gedaan. De oogst is schraal. We keren op onze schreden terug naar de derde trede in het internationale kinderrecht.

Het Verdrag inzake de rechten van het kind: witzicht op persoonswording?

$\mathrm{Na}$ de afdaling in de vorige paragraaf naar de juridische situatie in $\mathrm{Ne}$ derland keren we thans terug naar de derde trede van het volkenrecht voor kinderen: het Verdrag inzake de rechten van het kind. Eenmaal op deze derde trede kijken we uit over een vergezicht waarin we het recht van het kind op persoonswording moeten zien te ontwaren. In het volgende hoofdstuk nemen we onze binocle - de dubbele veldkijker kerninhoud van kinderrechten - bij de hand. Het dubbele focus van die kerninhoud, het gelijkheids- en het ontplooiingsbeginsel - in de ruime zin van persoonswordings- en ontplooiingsbeginsel, die immers, zoals we al (even) zagen, in elkaars verlengde liggen -, wordt in dat hoofdstuk (hoofdstuk 6) nader onderzocht. Hoe scherper dit focus is, des te makkelijker zal het zijn in het hoofdstuk daarna het natuurrechtelijke landschap af te spie-

VAN DALE: '(eig.) algemeen, over de ganse aardbodem verspreid' (van het Griekse kat'holos $=$ over het geheel). Overigens betekent canoniek volgens VAN DALE ook 'voorbeeldig."

107 Can. 1136 - Parentes officium gravissimum et ius primarium habent prolis educationem tum physicam, socialem et culturalem, tum moralem et religiosam pro viribus curandi. 
den, op zoek naar sociaal-pedagogische rechten. In dat hoofdstuk (hoofdstuk 7) zal immers de sprong naar de sociaal-pedagogische rechten van het kind, de kernrechten van het kind in de Trias pedagogica, moeten worden gemaakt.

In dit hoofdstuk zijn we tot de ontdekking gekomen dat we niet stevig op de schouders van huidige en vroegere generaties filosofen en juristen kunnen staan. Sterker nog, we zullen van die schouders moeten afspringen en, bij de juridische en pedagogische stand van zaken die we aantreffen, zelf wat moeten proberen op te bouwen. Dit is wat we direct na het volgende hoofdstuk gaan doen. In de drie hoofdstukken daarna zal moeten blijken hoe stevig ons bouwsel juridisch en pedagogisch staat, en of we erin kunnen slagen het te verankeren in het Verdrag inzake de rechten van het kind. 
We besloten hoofdstuk 4 met de opmerking dat er genoeg bouwstenen waren aangedragen om (de idee van) grondbeginselen en kernrechten op de rechten van het kind te gaan toepassen. Na de lange (moraal)fillosofische en (rechts)historische aanloop in hoofdstuk 5 komen we dan nu toch aan het inlossen van die aankondiging toe. Dit betekent niet dat we rauwelijks de sprong wagen naar de kernrechten van het kind in de Trias pedagogica. In dit hoofdstuk gaan we aan de slag met de grondbeginselen, om in het volgende hoofdstuk tot de kernrechten te komen.

Om de draad te hervatten, breng ik in herinnering dat we wit de menselijke waardigheid in het algemeen en de waardigheid van het kind in het bijzonder een kerninhoud van de rechten van de mens, en dus naar we nog zullen zien: a fortiori - ook van de rechten van het kind, meenden te kunnen afleiden. Een kerninhoud bestaande uit twee, elkaar aanvullende en onderling versterkende grondbeginselen, namelijk het meer uitwendig gerichte (we zouden ook kunnen zeggen: 'horizontale') gelijkheidsbeginsel en het meer inwendig gerichte (ofwel: 'verticale') ontplooiingsbeginsel.

Over beide beginselen zullen in dit hoofdstuk enkele algemene en op het kind toegespitste opmerkingen worden gemaakt, die de sprong in het volgende hoofdstuk - naar de uit de beginselen voortvloeiende social-pedagogische rechten minder een sprong in het diepe moeten doen toeschijnen. Ter introductie en oriëntatie wordt eerst stilgestaan bij het onderscheid tussen algemene en speciale kinderrechten alsmede bij het veiligheids- en ontwikkelingsbelang van het kind.

Het hoofdstuk wordt afgesloten met enkele bespiegelingen over individuatie en (westers) individualisme. Onder het kopje "individuatie" wordt aandacht gevraagd voor het feit - voordat we naar de kernrechten van het kind in de Trias pedagogica overstappen - dat het kind niet tot de onbeduidendste actor in die trias behoort. Naarmate het kind opgroeit, gaat ouderlijke leiding over in begeleiding, en wordt gelijktijdig het aandeel van het kind in zijn eigen persoonswording groter. Daarbij heeft niet alleen de staat een bepaalde rol en bepaalde verplichtingen, ook de normen en waarden in de samenleving spelen op de achtergrond mee en bepalen de marges voor alle actoren in de trias. Dat laatste aspect komt, onder het kopje '(westers) individualisme,' aan het slot van dit hoofdstuk summier aan de orde. In hoofdstuk 7 worden bij de desbetref- 
fende sociaal-pedagogische rechten aan (westerse) maatschappelijke normen en waarden nadere bespiegelingen gewijd.

\title{
6.2
}

Algemene mensenrechten en speciale kinderrechten

Opnieuw laten we ons door een fillosoof bij de hand nemen, een filosoof die ook jurist is: VAN DER BURG. VAN DER BURG geeft aan: ${ }^{1}$

\begin{abstract}
'Rechten beschermen bepaalde belangen of waarden van mensen of groepen. In een politieke of morele theorie houdt dit in dat bepaalde aanspraken of claims een extra theoretisch gewicht of een bijzondere status krijgen. In een juridische rechtentheorie houdt dit in dat die aanspraken een speciale juridische status krijgen, waardoor ze beter beschermd worden.'
\end{abstract}

De auteur vervolgt:

\begin{abstract}
'We kunnen drie voorwaarden voor een dergelijke speciale status onderscheiden. Ten eerste dient er een specifieke grondslag te zijn. Deze wordt meestal gevonden in de belangen of in de intrinsieke waarde van de mens en in het bijzonder van diens autonomie.'
\end{abstract}

Een kind heeft een veiligheidsbelang en een ontwikkelingsbelang. Beide belangen zijn essentieel om tot een autonoom persoon - dat wil minimaal zeggen: tot een minimaal rationeel, moreel en authentiek persoon; en optimaal: tot een zo rationeel, moreel en authentiek mogelijk persoon - uit te kunnen groeien. We zouden dus kunnen zeggen: de grondslag voor de rechten van het kind in de zin zoals VAN DER BURG hierboven aangeeft, zijn dus tegelijkertijd zowel diens fundamentele belangen als de waarde van diens - wordende - autonomie.

We lezen verder:

'Sommige rechtentheorieën leggen alleen de nadruk op de belangen, andere alleen op de autonomie van mensen. Een gemengde theorie lijkt mij echter het beste verdedigbaar: rechten kunnen worden geconstrueerd zowel ter bescherming van bepaalde belangen als ter bescherming van bepaalde aspecten van de individuele autonomie.'

Juist omdat de meest fundamentele belangen van het kind met de intrinsieke waarde van het kind als mens en als persoon-in-wording zijn ver-

Wibren VAN DER BURG, 'Rechten van kinderen: enkele filosofische kanttekeningen," in: Carol VAN NINATTEN (red.), Kinderrechten in discussie, Amsterdam/ Meppel 1993, pp. 64-80, op p. 66. De hierna volgende citaten staan op pp. 66-67. 
vlochten, kunnen we ons hier alleen maar bij aansluiten. We luisteren nog naar de voorbeelden die de auteur geeft:

'Zo is een wezenlijk belang van mensen een goede huisvesting; het kan dus verdedigbaar zijn om een politiek recht op huisvesting te construeren. De vrije keuze en beleving van godsdienstige overtuigingen heeft daarentegen vooral te maken met de individuele autonomie; daarom kan een recht op vrijheid van godsdienst worden verdedigd.'

Hiermee zijn we er echter nog niet:

"Belangen of autonomie zijn nog niet een voldoendle voorwaarde om rechten te rechtvaardigen. Niet ieder belang, niet iedere vrijheid wordt door een recht beschermd. Een aanvullende voorwaarde is dat bescherming van dat specifieke belang of dat specifieke aspect van de autonomie bijzonder waardevol is voor het individu zelf of de gemeenschap.'

We spraken hierboven al van het veiligheids- en het ontwikkelingsbelang als de meest fundamentele belangen van het kind, belangen die vervlochten zijn met - ja, eigenlijk andere namen zijn voor - wat als het meest essentiële en fundamentele aspect van de autonomie moet worden gezien: de mogelijkheid om überhaupt tot althans een minimaal autonoom persoon uit te kunnen groeien. Ook aan VAN DER BURGs aanvullende voorwaarde lijkt dus voldaan. Te meer waar autonomie op zich niet alleen een belang en waarde van het individu zelf is, maar een maatschappelijk belang, een belang van de samenleving in haar geheel. Elke gezonde democratische samenleving heeft belang bij zo veel mogelijk personen die zo optimaal mogelijk persoon zijn.

Ook bij deze tweede voorwaarde geeft de auteur voorbeelden los van het kind:

"De vrijheid van meningsuiting en het recht op een behoorlijk strafproces [zijn niet alleen bijzonder waardevol voor het individu, maar] vertegenwoordigen ook een waarde voor de collectiviteit, resp. het goed functioneren van de politicke kanalen en de legitimiteit van de rechterlijke macht.'

Er is echter - in de optiek van de auteur - nog een derde voorwaarde:

${ }^{6}$ Een derde voorwaarde voor de erkenning van rechten ten slotte is dat het zinvol en effectief moet zijn om die bijzondere waarden door middel van rechten te beschermen.'

Hier waag ik het met de auteur van mening te verschillen. Het verknoopt zijn van fundamentele belangen met essentiële waarden betekent in mijn 
optiek, in mijn mensbeeld van de mens als met rechten bekleed en als zodanig bejegend persoon, hoe dan ook een vertaling in (fundamentele) rechten. Fundamentele rechten die het karakter dragen van rechtsbeginselen en op grond van dat karakter een operationalisering eisen die uiteraard zinvol en effectief moet zijn. Dit betekent, sprekend van kinderen, dat die operationalisering, ofwel juridisering, de specifieke ouder-kindcontext dient te verdisconteren, dat wil zeggen: rekening dient te houden met, uit dient te gaan van de specifieke aspecten die in die context bepalend zijn: de zorg-aspecten, de machtsaspecten, de ongelijkheidsaspecten, de afhankelijkheidsaspecten, de leidings- en begeleidingsaspecten, de disciplineringsaspecten, de ontwikkelingsaspecten, de losmakings- en verzelfstandigingsaspecten e tutti quanti.

Natuurlijk gaat het niet aan een bouwsel op te trekken op een particulier of eigenzinnig mensbeeld, een mensbeeld dat lang niet ieders mensbeeld hoeft te zijn. Maar nu roep ik WOLFSON te hulp: ${ }^{2}$

"What we need to know is whether or not rights and the related concepts and conventions, where properly applied, carry any real moral weight. We are especially interested in discovering anything about the nature of rights in general that might shed light on questions of children's rights. The relevant question then is whether or not this constellation of concepts is a significant addition to the moral life. Joel FEINBERG [Social philosophy (1973)] suggests a thought experiment which enables us to answer this question. We are told to imagine a world in which there are no rights. No matter how benevolent and possibly even devoted to duty everyone in it is, he says, such a world would be greatly "morally impoverished" because no one would feel deserwing of even decent treatment. Rather, inhabitants of this world would feel that they were at the mercy of the whims of everyone else and also feel humble gratitude for the smallest kindness. Imagining this world we can see that people would lack the dignity (and insurance) that come from considering oneself the moral equal of everyone else in the community. As FEINBERG puts it, "The harm to individual self-esteem and character development would be incallculable"."

\section{En even verderop voegt woLFSON daaraan toe: ${ }^{3}$}

'However, beyond being an addition to the moral life, moral rights seem to be a central and perhaps ineliminable part of morality itself.'

Susan WOLFSON, 'Children's rights: the theoretical underpinning of the "best interests of the child", in: Michael FREEMAN, Philip VEERMAN (eds.), The ideologies of children's rights, Dordrecht (etc.) 1992, pp. 7-27, op p. 8 (curs. sw). 
Maar als WOLFSON hier een mensbeeld lijkt te schragen, het beeld van de mens als redelijk en zedelijk en dus met rechten bekleed en als drager van rechten te bejegenen wezen, dan hoeft dit mensbeeld kinderen toch niet per se in te sluiten? Althans niet in de ouder-kind-relatie, de intieme, primair door zorg en vertedering ${ }^{4}$ beheerste relatie tussen vaders en moeders en het onder hun toegewijde leiding opgroeiende kroost? Op deze vraag laat ik FREEMAN antwoorden: ${ }^{5}$

"There are still those who argue that (...) it is not necessary to recognise as such children's rights. Where such arguments are put, they tend to employ one of two myths. One (...) idealises adult-child relations: it emphasises that adults (and parents in particular) thave the best interests of children at heart. Those who argue in this way, tend, like GOLDSTEIN, PREUD and SOLNIT (...), to adopt a laissez-faine attitude towards the family. Thus, the only right for children which GoLDSTEIN et al. would appear to accept, is the child's right to autonomous parents [i.e. ouders met een zo absoluut mogelijk recht op non-interventie, op 'family privacy'; niet te verwarren met het recht van het kind op zo autonoom mogelijke ouders in de zin van het recht van het kind op empowernent van zijn ouders, ${ }^{6}$ jw]. (...) It is somewhat unfortunate that in an age when so much abuse is being uncovered, that governments and writers should cling to the "cereal packet" [comflakes, jw] image of the family. The second myth (...) sees childhood as a golden age (...).'

\section{Ook de 'afmaker' zal ik aan FREEMAN overlaten:"7}

'Rights are important because possession of them is part of what is necessary to constitute personality. Those who lack rights are like slaves, means to others" ends, and [will] never [be] their own sovereigns."

We keren terug naar onze auteur. Wat zegt VAN DER BURG over zijn derde voorwaarde - de voorwaarde dat het zinvol en effectief moet zijn om waarden door middel van rechten te beschermen - in relatie tot kinderen? ${ }^{8}$

Een vertedering die wordt opgeroepen door het gelaat wan het kind, en die we ook zien bij (zoog)dieren ten aanzien van hun jongen - ja zelfs bij mensen ten aanzien van jonge poesjes, hondjes, beertjes, olifantjes enz. Uit deze vertedering vloeit de tederheid voor hun nakroost voort die volgens LOCKE door God in de beginselen van de menselijke natuur is geweven.

5 Michael FREEMAN, 'The limits of children's rights,' in: dez. en VEERMAN (eds.), The ideologies of children's rights, a.w., pp. 29-46, op p. 30. 
"Voor de morele en politicke theorie betekent [deze voorwaarde] dat een rechtendiscours de beste manier moet zijn om het denken over kinderen te conceptualiseren, waarbij de te verwachten uitwerking op het beleid en op collectief en individueel handelen meewegen. Voor de juridische theorie dient bovendien rekening te worden gehouden met allerlei positieve en negatieve effecten van juridische institutionalisering van kinderrechten."

Zoals we in het vorige hoofdstuk al zagen, ${ }^{9}$ is het voor VAN DER BURG niet de vraag hoe kinderrechten vorm moeten worden gegeven, maar of de belangen van kinderen überhaupt wel juridisch vorm moeten worden gegeven. De derde voorwaarde van deze auteur kan voor ons dan ook enkel een voorwaarde - en een belangrijke - zijn in de vraag, niet naar het of, maar naar het hoe van juridisering.

\section{Algemene en speciale rechten}

Toch nemen we hier nog geen afscheid van VAN DER BURG. Hij heeft nog meer te zeggen dat de opbouw van ons betoog dient: ${ }^{10}$

'Zoals gezegd [is], zijn er in hoofdzaak twee grondslagen voor rechten: belangen en autonomie. Er zijn geen bijzondere theoretische problemen om belangen als grondslag voor kinderrechten te construeren. Zoals ieder mens hebben kinderen belang bij goede huisvesting, goede voeding etc. De meeste rechten van volwassenen die te maken hebben met de bescherming van belangen, kunnen dan ook voor kinderen worden geconstrueerd. Vermogensrecht en erfrecht leveren tal van voorbeelden van ook al in het positieve recht [voor kinderen van "vermogende" ouders, $j w]$ erkende rechten.

Daarnaast hebben kinderen speciale belangen die samenhangen met het feit dat ze extra afhankelijk en nog miet volwassen zijn. Ze hebben belang bij een goede opvoeding en scholing en bij een goede en liefdevolle verzorging. Dit zijn bovendien voor kinderen zeer wezenlijke belangen: ze bepalen niet alleen of er een goede toekomst voor hen is weggelegd, maar zelfs of er überhaupt een toekomst voor hen is weggelegd. Deze specifieke belangen vau kinderen zouden de grondslag kunnen vormen voor speciale rechten.

De belangen waar we het hier over hebben, zijn niet alleen woor het kind zelf maar ook voor de gemeenschap van groot gewicht. De gemeenschap heeft er belang bij dat haar toekomstige [sic, jw] leden goed verzorgd en opgevoed worden.. Om die reden is het theoretisch mogelijk en verdedigbaar hun op basis van de algemene en van de specifieke belangen van kinderen bepaalde algemene en speciale rechten toe te kennen."

En, zo kunnen we daaraan toevoegen - al verhindert de derde voorwaarde van de auteur dat hij zelf dit fundamentele aspect kan zien -, wat op 
grond van deze gewichtige belangen theoretisch mogelijk en verdedigbaar is, moet op grond van de waarde en de waardigheid van het kind als mens en persoon-in-wording in theorie en praktijk verdedigd worden. Dat de auteur dit niet ziet, heeft behalve met de valkuil van zijn derde voorwaarde evenwel ook te maken met het systematisch buiten beeld laten van de derde actor in de Trias pedagogica: de overheid. Dit is des te opmerkelijker waar met name - doch zeker niet uitsluitend - de economische, sociale en culturele rechten een actieve overheid vergen, iets dat geen enkel filosofisch of juridisch auteur zou wagen of zelfs maar wensen te bestrijden.

Even afgezien van die Trias pedagogica, waar we later over komen te spreken, komt de auteur, we hebben dat in het citaat hierboven al geproefd, toch elke keer heel dicht in de buurt van een (kern)recht van het kind op veiligheid en ontwikkeling. Maar zoals een heel jong lid van de samenleving dat met sleutel en slot speelt, komt hij niet op het idee beide in elkaar te steken:

'Autonomie als grondslag voor rechten van kinderen is aanzienlijk problematischer. Kinderen zijn nu eenmaal nog niet autonoom, of nog slechts ten dele. Het is dan ook niet goed voorstelbaar dat een kind van acht jaar allerlei op een autonome status gebaseerde politieke rechten zou hebben, zoals het kiesrecht of de wrijheid van meningsuiting. Dit betekent dat het op het eerste gezicht moeilijk is om kinderrechten op autonomie te funderen. Hierbij passen twee kanttekeningen. Ten eerste is autonomie afhankelijk van de context. Kinderen kunnen wel degelijk in staat zijn tot bepaalde autonome keuzes in voor hen goed overzienbare kwesties. Een kind van twaalf kan misschien nog niet goed bepalen wie de premier wan Nederland moet worden [een recht dat overigens geen enkele Nederlander heeft, en dat een niet onaanzienlijk deel van de volwassen Nederlanders, als ze het wel zouden hebben, beslist niet beter zou uitoefenen dan menig twaalfjarige, jw], maar het is doorgaans wel goed in staat te zien bij welke van de twee ouders het na de scheiding wil blijven wonen. Voor dergelijke autonome keuzes is dlan ook een grondslag voor speciale rechten te vinden, bij voorbeeld het (inmiddels ook in het positieve recht erkende) recht om gehoord te worden over de toewijzing aan een van de ouders na echtscheiding. Voor een antwoord op de vraag vanaf welke leeftijd kinderen voldoende autonoom moeten worden geacht om bepaalde concrete rechten te krijgen, is overigens ontwikkelingspsychologische kennis noodzakelijk, maar niet voldoende (...). De normatieve vraag blijft immers welk kind men als uitgangspunt neemt: het meest voorlijke kind, het "gemiddelde" kind of juist de groep kinderen met een achterblijvende ontwikkeling.'

En nu spitsen we de oren:

"Ten tweede is een kind nog wel niet autonoom, maar het is wel de bedoeling dat het autonoom wordt. Dat word je niet wan de ene op de andere dag, maar het is een ontwikkelingsproces. Autonomie moet je leren, zoals je democratische participatie ook moet leren (..). Dat kun je leren door steeds meer de kans te krijgen 
om mee te beslissen of zelfstandig te beslissen, door steeds meer als (gedeeltelijk) autonoom persoon behandeld te worden. Men kan daarom een claim op ontwikkeling to autonoom persoon verdedigen die een angument vormt voor bij voorbeld medezeggenschap op scholen of thuis. De vraag hoever men hierin gaat, is een kwestie van afwegen tussen enerzijds de risico's van aan kinderen te vroeg een bepaalde verantwoordelijkheid te geven en anderzijds de wenselijkheid [lees: de rechtsplicht - naar de mate van de zich ontwikkelende vermogens van het kind, jw] van hen op te voeden tot steeds grotere verantwoordelijkheid.'

In het hierna volgende zal een 'claim op ontwikkeling tot autonoom persoon' worden verdedigd - tout court. Een claim, een kernrecht van het kind als basis van - in het Verdrag inzake de rechten van het kind vastgelegde - verplichtingen van ouders en overheid. Daartoe zal eerst een aantal speciale rechten, voortvloeiend uit het gelijkheids- (par. 6.4) en het ontplooiingsbeginsel (par. 6.5), en samenhangend met het veiligheids- en het ontwikkelingsbelang van het kind (par. 6.3), in kaart moeten worden gebracht (hoofdstuk 7).

\section{3}

Het veiligheids- en ontwikkelingsbelang van kinderen

VAN DER BURG sprak hierboven van speciale belangen die te maken hebben met het 'extra afhankelijk' en 'nog niet volwassen' zijn van kinderen. Het 'nog niet volwassen' zijn duidt op het belang van de ontwikkeling, op het ontwikkelingsbelang van het kind. Over dat ontwikkelingsbelang komen we nog nader te spreken onder het ontplooiingsbeginsel. Het 'extra afhankelijk' zijn duidt prima facie op het belang van veiligheid, op het veiligheidsbelang van het kind. Kinderen zijn immers in hoge en bijzondere mate kwetsbaar, kwetsbaar door hun fysieke zwakte en onvolgroeidheid, kwetsbaar zo mogelijk nog meer in psychische en ontwikkelingspsychologische zin: kinderen zijn totaal afhankelijk van hun ouders. Voor zorg, voeding, kleding, liefkozing, aandacht, bevestiging, steun, leiding, voor de ontwikkeling van eigenwaarde en zelfrespect, enz. enz. Uit deze - enuntiatieve - opsomming blijkt al hoezeer veiligheids- en ontwikkelingsbelang in elkaar overvloeien en eigenlijk niet goed van elkaar te scheiden zijn.

Kinderen kunnen om verschillende redenen niet veilig zijn bij hun ouders. Ouders kunnen door geweld of door een vijandige houding, of juist door zich in het geheel niet om hun kinderen te bekreunen en zich niets aan hen gelegen te laten liggen, misbruik maken van hun macht. Ouders kunnen door hun kinderen louter te gebruiken als object voor eigen emotionele of sexuele behoeftenbevrediging, misbruik maken van de totale afhankelijkheid van hun kinderen. In zijn totale afhankelijkheid is het kind onvoorwaardelijk loyaal ten opzichte van zijn ouders, en niet 
zelden zien we in misbruik-situaties die natuurlijke loyaliteit in pathologische hyperloyaliteit ${ }^{11}$ ontaarden, en zulks te meer naar mate het misbruik groter is. ${ }^{12}$ In zijn hyperloyaliteit neemt het misbruikte of afgewezen kind vaak ouderlijke rollen over, ontfermt het zich over de ouder, ziet het in diens machtsmisbruik ook onmacht en nood. Het onveilig gehechte, maar juist daardoor in dubbele bindingen met de ouder verknoopte, hyperloyale kind zal die ouder tegenover derden, en niet in de laatste plaats tegenover hulpverleners, in bescherming nemen. Zonder dat ik op deze plaats de hiermee gepaard gaande mechanismen en de hieraan verbonden valkuilen uitvoerig hoef te schetsen, zal duidelijk zijn dat het bij zijn ouders onveilige kind ook in zijn ontwikkeling gestoord zal raken, in zijn ontwikkeling zal worden geblokkeerd en beschadigd. In plaats van bij zijn ontwikkelingstaken te worden gesteund, verkeert het in de omgekeerde situatie alle ontwikkelingsenergie te moeten investeren in de bodemloze ouderlijke put - om zo een illusie van veiligheid en geborgenheid in stand te houden. Ook dit zij een illustratie van het gegeven dat veiligheids- en ontwikkelingsbelang in elkaars verlengde liggen, in elkaar overgaan, door elkaar heenlopen. Toch zou ik, om redenen van juridische terminologie en in zekere zin anomalie, over het veiligheidsbelang hier enkele opmerkingen willen maken.

\subsubsection{Lichamelijke en geestelijke integriteit}

Als we voor de rechten van het kind als juridisch vertrekpunt nemen het recht van het kind op lichamelijke en geestelijke integriteit, ${ }^{13}$ dan impli-

11 NICOLAI vermeldt hyperloyaliteit - loyaliteit tegen-beter-weten-in, parentificatie, verinnerlijking van de dader/identificatie met (lees: introjectie van) de agressor als één van de gevolgen van het incest-trauma (N.J. NICOLAI, "Incest als trauma: implicaties en consequenties voor de behandeling,' Tijdschrift voor Psychotherapie 1991/1, pp. 12-30, op p. 20). Hier wordt hyperloyaliteit als algemeen fenomeen in chronisch traumatiserende kindermishandelingssituaties bedoeld.

12 "Hoe rottiger de ouders, des te loyaler is het kind." Men dient kinderen tegen de gevolgen van dit soort loyaliteit jegens hun ouders te beschermen. Dit kan echter een dilemma in de hulpverlening opleveren, aangezien de kinderen zelf ook, of juist àls ze daat aan ten onder dreigen te gaan, in veel gevallen blijven kiezem voor de ouders." (S. DUKSTRA, F. SWETS-GRONERT, Dilemma's rond kindermishandeling; Een verkennend onderzoek naar signalering en melding, NcGV, Utrecht 1989, p. 19.)

13. Het recht op lichamelijke integriteit (onaantastbaarheid van het lichaam; art. 11 Grondwet) kent 'twee componenten':

- het recht te worden gevrijwaard van schendingen van en inbreuken op het lichaam door anderem;

- het recht zelf over het lichaam te beschikken.' (Zelfbeschikkingsrecht.) 
ceert dat dat we tussen lichamelijke en geestelijke aspecten van veiligheid moeten onderscheiden. De overgang tussen lichamelijke en geestelijke veiligheid is echter al even moeilijk te markeren als de overgang tussen (lichamelijke en geestelijke) veiligheid en ontwikkeling. Een kind dat op de vreemdste momenten op de wreedste afranselingen wordt getracteerd, wordt niet minder in zijn fysieke dan in zijn psychische veiligheid - en in zijn ontwikkeling - aangetast.

Om die reden is er wat voor te zeggen onder lichamelijke èn geestelijke veiligheid minimaal de afwezigheid van fysiek geweld te verstaan. Fysiek geweld - anders dan en voorbij de pedagogische tik "om de aandacht van het kind te richten ${ }^{14}$ - is in die opvatting een schending van de lichamelijke èn geestelijke integriteit van het kind. Zelfs botbreuken en brandwonden, door 'getergde' of 'overspannen' ouders toegebracht, helen, en hoewel zij soms littekens op het lichaam achterlaten, zijn de onzichtbare littekens op de ziel de echte en blijvende bewijzen van de schending van de - lichamelijke èn geestelijke - integriteit van het kind.

Hoewel ik hier niet opnieuw de discussie over een verbod op het slaan van kinderen wil aansnijden, ${ }^{15}$ is het goed ons te realiseren hoe fundamenteel minimaal de afwezigheid van fysiek geweld in elk samenlevingsverband, in elk intermenselijk verkeer is. Om dit - en daarmee de op dit vlak bestaande juridische, en in het bijzonder mensenrechtelijke anomalie, als het om geweld in de privésfeer, dat wil zeggen: geweld tegen vrouwen en geweld tegen kinderen, gaat - nog eens te onderstrepen, kan het nuttig zijn - zonder daar verder veel commentaar aan toe te voegen - het Vrouwenverdrag van 1979 en het Verdrag inzake de rechten van het kind van 1989 te plaatsen naast de Massachusetts Body of liberties uit ... 1641 (bijna 150 jaar vó́r de Franse Revolutie, precies 150 jaar vóór de Déclaration van Olympe DE GOUGES).

"Voor een inbreuk op de geestelijke integriteit kan (...) geen beroep worden gedaan op artikel 11, maar wel op artikel $10 \mathrm{Gw}$ [eerbiediging van de persoonlijke levenssfeer, $j w]$. In geval van aantasting van de lichamelijke integriteit staat zowel een beroep op artikel 11 als een beroep op artikel 10 woor de betrokkene open.' (P.W.C. AKKERMANS e.a., Grondrechten en grondrechtsbescheming in Nederland, Groningen/Heerlen 1988, p. 86.) Vgl. ook R. HOLTMAAT, T. LOENEN, Inleiding vroww en recht, Alphen aan den Rijn 1989, hoofdstuk 3, 'Lichamelijke en psychische integriteit en zelfbeschikking, pp. 47-64.

Onder geestelijke integriteit zouden zowel 'privacy' (eerbiediging van de persoonlijke levenssfeer) als "ontplooïng' (met inbegrip van 'persoonswording') kunnen worden begrepen. Hierover later meer. 
In laatstgenoemd juridisch instrument treffen we onder meer de volgende mensenrechtelijke bepalingen aan: ${ }^{16}$

Massachusetts Body of liberties, 1641:

(...)

[Artt. 1-17]

Art. 1. No mans life shall be taken away, (...) no mans person shall be arested, (...) unlesse it be by vertue or equitie of some expresse law of the Country (...). [Rule of law, rechtsstaatsbeginsel, legaliteitsbeginsel, jw.]

Art. 2. Every person within this Jurisdiction, whether Inhabitant or forreiner, shall enjoy the same justice and law, that is generall for the plantation, which we constitute and execute one towards another without partialitie or delay. [Gelijkheidsbeginsel, jw.]

Rites, Rules and Liberties concerning Juditiall proceedings [artt. 18-57]

Art. 46. For bodilie punishments we allow amongst us none that are inhumane, Barbarous or cruel.

Liberties more peculiarlie concerning the free men [artt. 58-78]

(...)

Liberties of Woemen [artt. 79-80]

Art. 80. Everie marryed woeman shall be free from bodilie correction or stripes by her husband, unlesse it be in his own defence upon her assa[u]lt. If there be any just cause of correction, complaint shall be made to Authoritie assembled in some Court, from which onely she shall receive it.

Liberties of Children [artt. 81-84]

Art. 83. If any parents shall wilfullie and unreasonably deny any childe timely or convenient mariage, or shall exercise any unnaturall severitie towards them, such childeren shall have free libertie to complaine to Authoritie for redresse.

Liberties of Servants [artt. 85-88]

Art. 85. If any servants shall flee from the Tiranny and crueltic of their masters to the howse of any freeman of the same Towne, they shall be there protected and susteyned till due order be taken for their relife. (...)

Art. 88. Servants that have served deligentlie and faithfully to the benefitt of their maisters seaven yeares, shall not be sent away emptie. (...)

Liberties of Forreiners and Strangers [artt. 89-91]

Art. 89. If any people of other Nations professing the true Christian Religion shall flee to us from the Tiranny or oppression of their persecutors, or from famyne, warres, or the like necessary and compulsarie cause, They shall be entertayned and succoured amongst us, according to that power and prudence God shall give us.

Bernard SCHWARTZ, The roots of the Bill of rights, New York 1971 (ed. 1980), vol. 1, pp. 71 i.f. -81 .

Zie over de Massachusetts Body of liberties ook Elizabeth PLECK, Domestic tyranny; The making of American social policy against family violence from colonial times to the present, New York/Oxford 1987, pp. 21 i.f.-27. 
Art. 91. There shall newer be any bond slaverie, villinage or Captivitie amongst us unles it be lawfull Captives taken in just warres, and such strangers as willingly selle themselves or are sold to us. (...)

Off the Bruite Creature [artt. 92-93]

Art. 92. No Man shall exercise any Tirranny or Crueltie towards any bruite Creature which are usuallie kept for man's use.

\section{Over de Massachusetts Body of liberties van 1641 is opgemerkt: ${ }^{17}$}

'When we bear in mind the date of its enactment, both the scope and specific provisions of the Body of Liberites are startling. Merely to provide for the liberties of women, children, serwants, aliens, and dumb animals, as well as those of free men, and to go as far as to outlaw slavery as well, was virtually unique in so early a code. In addition, to recognize that individual liberty depended, in the last resort, upon the courts, and to provide in detail for the rights of litigants and accused in judicial proceedings, was as far-seeing as it was unprecedented at that time."

Unprecedented - maar het voorbeeld lag er ... vanaf 1641. WIARDA ziet in de Massachusetts Body of liberties: ${ }^{18}$

'Een vrouwenrecht, kinder/jeugdrecht, arbeidsrecht, vreemdelingenrecht, waaraan de makers van ons $\mathbb{B W}$ [van] 1838 een voorbeeld hadden kunnen nemen; maar ... zij hebben zich gespiegeld aan de Franse Code civil/Code Napoléon!'

Een gemiste kans in het Nederland van 1838 - en in 1979 , op het internationale vlak? In het illustere forum waar unaniem ${ }^{19}$ tegenover het grote en het kleine kwaad van structureel patriarchaal onrecht mensenrechten $66 \mathrm{k}$ voor vrouwen werden gesteld?

\section{3 .2}

Huiselijk geweld

\section{Huiselijk geweld tegen vrouwen}

Kijken we naar het in 1979 door de Algemene Vergadering aangenomen Vrouwenverdrag, dan valt, na lezing en herlezing, op dat over domestic violence, huiselijk geweld, inzonderheid mannelijk geweld tegen vrouwen,

17 Bernard SCHWARTZ, The roots of the Bill of rights, a.w., p. 71.

18 J. WLARDA, 'Historisch overzicht over de juridische positie van kinderen,' in: $\mathbf{M}$. DE LANGEN e.a. (red.), Kinderen en recht; Opstellen over de positie van minderjarigen in het recht, Arnhem/Deventer 1989, pp. 1-11, op p. 7.

19 Res. AV 34/180 van 18 december 1979 werd aangenomen met 130 stemmen vóor, 0 tegen, en 10 onthoudingen (Noreen Burrows, The 1979 Convention on the elimination of all forms of discrimination against women,' Netherlands International Law Review 1985/3, pp. 419-460, op p. 419 nt. 1). 
in het Verdrag niets is opgenomen. Zij het dat het Vrouwencomite, het met het toezicht op de naleving van het Verdrag belaste verdragsorgaan, sedert 1992, na toepassing van enige juridische acribie dan wel acrobatiek, van mening is dat: ${ }^{20}$

20 M. VAN DEN BRINK, Het recht op lichamelijke integriteit en het Vrouweinverdrag;' NJCM-Bulletin 1993/6, pp. 660-673, op p. 670 (curs. overgenomen).

VAN DEN BRINK concludeert: [Het Vrouwencomite] is blijkens [zijn] Aanbevelingen van mening dat het recht op lichamelijke integriteit impliciet door het [V]erdrag beschermd wordt. De vraag is of thet Comite dit werkelijk denkt, of dat [het] probeert door een ruime interpretatie greep te krijgen op een wereldwijd probleem dat in andere mensenrechtenfora niet of nauwelijks aandacht krijgt.'

LOENEN verbaast zich erover dat het Vrouwenverdrag "geen algemene bepaling met betrekking tot geweld tegen vrouwen [kent], terwijl het Rassenverdag, waar[door] het toch is geinspireerd, wèl een specifieke bepaling kent die bet recht behelst op "bescherming door de staat tegen geweld of lichamelijk letsel, hetzij toegebracht door overheidsdienaren, hetzij door enige andere persoon, groep of instelling" [art. 5 sub b rVUR].' Over de ruim(hartig)e interpretatie van het Vrouwencomite verbaast zij zich minder: "[D] benadering van het [Vrouwencomite] is niet zo vreemd als men bedenkt dat ook in andere juridische kaders bepaalde vormen van geweld tegen vrouwen als seksediscriminatie zijn gekwalificeerd gezien het seksespecifieke karakter ervan.' (T. LOENEN, 'Het discriminatiebegrip, in: A.W. HERINGA e.a. (red.), Het vrouwenverdrag: een beeld van een werdrag ..., Antwerpen/Apeldoorn 1994, pp. 1-13, resp. op pp. 7 en 8.)

FOROER lijkt over alle juridische berwaren heen te stappen waar zij stelt: 'Artikel 16 [Vrouwenverdrag] beschermt de vrouw onder meer tegen geweld in het gezin.' Kennelijk acht zij de aanbevelingen van het Vrouwencomite dermate gezaghebbend dat deze een extensieve interpretatie van het Verdrag zonder meer rechtskracht verlenen. Dit is te meer opmerkelijk waar deze interpretatie natuurrechtelijk (verwijzend niet naar een algemene opinio juris maar naar een opinio necessitatis, een noodzakelijk-rechtsdenken) van aard is, een natwurrechtelijke toepassing, zou men kunnen zeggen, van het ut res magis valeat quam pereat-beginsel (vgl. bijv. Alfred verbross, Bruno SIMMA, Universelles Volkerrecht; Theorie und Praxis, Berlin 1976/1981, p. 393). In de woorden van FORDER: 'De bescherming tegen geweld is niet het hoofddoel van artikel 16 [Vrouwenverdrag], maar valt daar wel onder, omdat een vrouw tegen wie geweld gebruikt wordt, niet eens in staat zal zijn om de uit artike] 16 [Vrouwenverdrag] woortvloeiende rechten te genieten." (C.J. FORDER, 'In het gezinsleven: "Different but equal",' in: Het wrouwenverdrag: een beeld vant een verdrag ..., a.w., pp. 239-253, op p. 239.)

Zie verder ook Marjolein VAN DEN BRUNK, Aan den lijve; Over het Vrouwenverdrag en lichamelijke integriteit, Utrecht Papers on international, social and economic law, Universiteit Utrecht 1993. Zie voorts Lucy wILlEMS, 'Geweld tegen vrouwen: CEDAW-Algemene Aanbeveling nr. 19,' Actualiteitenkatern Nemesis 1995/5, pp. 26-30. Vgl. met betrekking tot 'geweld tegen vrouwen' eveneens de Verklaring inzake de uitbanning van geweld tegen vrouwen. (Declaration on the elimination of violence against women) van de Algemene Vergadering van de Verenigde Naties van 20 december 1993, Res. AV 48/104, en het Preliminary report submitted by the Special Rapporteur on violence against women, its causes and 
consequences, Ms. Radhika COOMARASWAMY, in accordance with Commission on Human Rights resolution $1994 / 45, \mathrm{E} / \mathrm{CN} 4 / 1995 / 42$ d.d. 22 november 1994 . Zie ook de door de Algemene Vergadering van de OAS op 9 juni 1994 aangenomen en inmiddels per 5 maart 1995 in werking getreden Inter-American Convention on the prevention, punishment and eradication of violence against women. Vgl. voor dit laatste Verdrag: Rebecca J. COOK (ed.), Human rights of women; $\mathrm{Na}$ tional and international perspectives, Philadelphia 1995 (third printing), passim (zie index).

Voor een analyse van geweld tegen vrouwen (domestic violence) als vorm van marteling die zou behoren te vallen onder het dwingendrechtelijke martelverbod ('Ultimately ... should be recognized as jus cogens'), zie Rhonda COPELON, "Intimate terror: understanding domestic violence as torture," in: Human rights of women, a.w., pp. 116-152 (op p. 144). Vgl. ook Catharine A. MACKINNON, 'On torture: a feminist perspective on human rights," in: Kathleen E. MAHONEX, Paul MAHONEY (eds.), Human rights in the twenty-first century; $A$ global challenge, Dordrecht (etc.) 1993, pp. 21-31. Zie voorts A.H.A. SOONS, Juridische vrouwenstudies en internationaal publiekrecht,' in: E.A. ALKEMA e.a. (red.), Lof der verscheidenheid; Rechtsgeleerden [sic, jw] over vrouw en recht, Zwolle 1993, pp. 191205, op pp. 201 en $202 / 203$.

COPELON merkt op: '[W] hen stripped of privatization, sexism, and sentimentalism, gender-based violence is no less grave than other forms of inhumane and subordinating official violence, which have been prohibited by treaty and customary law and recognized by the international community als jus cogens, or peremptory norms that bind universally and can never be violated.' En: 'As the horrifying parallels between torture and domestic violence are explored, perhaps the insistence that "human rights should begin at home" will take on a new urgency." (T.a.p., resp. op pp. 117 en 145.) Vanuit het perspectief van ernstig mishandelde vrouwen is het zeker geen holle retoriek of demogagie ten aanzien van de in bovenstaande bijdragen besproken casus van marteling te spreken. Dit geldt mijns inziens a fortiori met betrekking tot kindermishandeling indien (zoals bijvoorbeeld VAN DANTZIG met name ten aanzien van incest doet) opgevat als marteling vanuit het perspectief van het kind. Voor een kind geldt dat - juist doordat ouders zelden uit louter sadisme mishandelen, maar weeleer uit onmacht, wit een combinatie van liefde en (zelf)haat - de verwarring er alleen maar groter om is en de post-traumatische gevolgen dienovereenkonstig meer op die van ernstige vormen van moedwillige marteling kunnen lijken. Hier moet dan nog de verhoogde ontwikkelingspsychologische kwetsbaarheid en symbiotische afhankelijkheid van het kind worden bijgeteld, die de psychische impact van de mishandeling exponenticel verergeren.

Indien en voor zover thuiselijk geweld tegen vrouwen opgevat kan worden als exponent van een mannencultuur ('patriarchie'), kan huiselijk geweld tegen kinderen opgevat worden als exponent van een volwassenencultuur ('parentiarchie'). Indien en voor zover huiselijk geweld tegen vrouwen opgevat kan worden als marteling, namelijk in ernstige gevallen en in de context van structurele ('patriarchale') non-interventie (dat wil zeggen van structureel te kort schietende preventie, interventie en compensatie), kan huiselijk geweld tegen kinderen - in ernstige gevallen en in de context van structurele ("parentiarchale") non-interventie (struc- 
'Gender based violence may breach specific provisions of the Convention, regard" less of whether those provisions expressly mention violence."

En in 1989? In het hoge internationale forum waar tegenover het grote en het kleine kwaad van structureel adultocentrisch onrecht mensenrechten óók voor kinderen werden gesteld?

\section{Ouderlijk geweld tegen kinderen}

Ook in het Verdrag inzake de rechten van het kind schittert een verbod op het slaan van kinderen door afwezigheid. Waar ouderlijk slaan echter onmiskenbaar overgaat in kindermishandeling, is er evenwel althans art. 19 van het Verdrag, dat de staat opdraagt de hand van de mishandelende ouder tegen te houden.

Dit zal er meestal op neerkomen - althans in het gunstigste geval - dat de ouder wordt belet zijn kind ten tweeden, ten derden of ten zoveelsten male zodanig fysiek toe te takelen, en vanuit zulk een nefaste gezindheid ten opzichte van het kind, dat de autoriteiten hier de definitie van kindermishandeling van toepassing achten - en ingrijpen. In het ongunstigste geval is het kind ... al dood. Bij circa één op de duizend mishandelde kinderen is dat het geval. ${ }^{21}$ In die gevallen is de staat te laat. In Nederland minstens tachtig keer per jaar. Het excuus is bekend. De staat is God niet, die Abraham - wie waagt te oordelen: meer vervuld van godsvrucht dan van ouderliefde? - nog net op tijd bij de hand greep om hem ervan te weerhouden zijn zoon te doden.

Hoe het die zoon zelf te moede was, verhaall de bijbel niet. Abraham had zijn zoon behouden. En deze had het er toch maar mooi levend

tureel te kort schietende preventie, hulpverlening, interventie, rehabilitatie en compensatie) - met niet minder recht als marteling worden opgevat.

Ook GruYer e.a. (Frédérique GrUYer, Martine FAdIER-NISSE, Pierre SABOU$\mathbb{R I N}$, La violence impensable; Inceste et maltraitance, Paris 1991, 'La torture," pp. 91-92, op p. 91) stellen dat bepaalde vormen van kindermishandeling 'doivent, sans abus de terminologie, être qualifiés de tortures.' De auteurs zien de (structurele) parallel met marteling door staten in het bijzonder ook in het aspect van de ontkenning en de geheimhouding/loochening (het is er maar het is er niet, je ziet niet wat je ziet): 'Ce mécanisme de déni de l'abus de pouvoir intrafamilial peut être comparé à celui qui entre en jeu au niveau des états, à propos de la torture, ainsi que le démontre un rapport d'Amnesty International sur ce sujet: "La torture est clandestine et, tout en étant présente, elle ne doilt pas pouvoir être prouvee".' (A.w., p. 92.)

21 Amerikaans onderzoek komt uit op een percentage van 0,1 dat de mishandeling niet overleeft. Voor Nederland zou dat betekenen dat er jaarlijks 80 kinderen overlijden aan de gevolgen van kindermishandeling." (0/25, juni 1996, p. 9.) 
van afgebracht. ${ }^{22}$ Worden de gevoelens van Izaäk meestal, al een paar duizend jaar lang, volledig over het hoofd gezien - nergens blijkt van wanhoop, verdriet, woede, laat staan verzet, hij is in de meest verinnerlijkte zin slacht-offer -, KIERKEGAARD (of vergis ik mij?) lijkt wel heel erg ver te gaan in zijn poging de vader te idealiseren, en alle medegevoel naar Abraham te doen overhellen: ${ }^{23}$

Ik trof ooit een vermoedelijk $18 \mathrm{e}$ of $19 \mathrm{e}$ eeuwse gravure aan, voor de losse verkoop uit een antiquarisch boek gesneden (sic transil gloria libri - de gravure heb ik niettemin gekocht), waarop lzaäk als jonge knaap staat afgebeeld terwijl hij, zojuist van de slachtbank bevrijd, Abraham in de armen valt, terwijl deze de ogen ten hemel heeft opgeslagen. Veelzeggend voor het onbegrip voor de traumatische ervaring die de knaap zojuist heeft meegemaakt, is het onderschrift: "Zalig genot na zware beproeving.' MILLER theeft verschillende afbeeldingen van het offer van Abraham bekeken: nergens kijkt Abraham naar zijn zoon, zijn ogen zijn afgewend of ten hemel gericht terwijl hij met zijn linkerhand het gelaat van zijn zoon bedekt, naar wie hij met zijn rechterhand het mes opheft (Alice MLLER, De gemeden sleutel, De kindertijd en onze cultuur, Houten 1989, hoofdstuk 6: 'Wanneer Izaäk van het altaar afstapt,' pp. 129-136, op pp. 129/130). MILLER schrijft (a.w., p. 133 i.f.): 'Het weten van het offer van het kind is zo diep in ons verankerd dat de monsterachtigheid van thet verhaal van Abraham en Izaäk tot dusver nauwelijks lijkt te zijn opgevallen.' In mijn optiek is het niet zozeer het weten dat wil zeggen de vanzelfsprekendheid - wan het offer als wel het niet willen weten wan het lijden van het kind dat in dit bijbelverhaal, onbedoeld, wordt gesymboliseerd. Aldus opgevat, kan het lot van Izaäk als zinnebeeld dienen voor een eeuwenlang onvermogen zich te verplaatsen in de positie van het kind - om te beginnen in het kind in de volwassene. (Vgl. met betrekking tot 'het kind in de volwassene' bijwoorbeeld Gaby STROECKEN, Het miskende kind in onszelf, Leuven/ Amersfoort 1994. De auteur voegt een "ontwikkelingspsychologische dimensie" aan het werk van MILLER toe: a.w., p. 15.)

23 KIERKBGAARD, Dagboeknotities, aangehaald door R.H. STUTTERHEIM, 'Het kind van de rekening, in: M. DE LANGEN e.a. (red.), Kinderen en recht, a.w., pp. 353365, op p. 353; W.R. SCHOLTENS (red.), KIERKEGAARD; Dagboeknotities, een keuze, Baarn 1981 (derde druk), pp. 20-21; Sybren POLET (red.), Søren KIERKEGAARD; Dagboeken, Amsterdam 1993 (tweede druk), pp. 87-88 (1843, zonder datum).

STUTTERHENM wijst erop "[d]at wij de uitdrukking "het kind van de rekening zijn" ook en vooral gebruiken als volwassenen moeten boeten voor wat anderen misdreven hebben.' (T.a.p., curs. jw.) Het is niet vanzelfsprekend dat een volwassene het kind van de rekening is. Ten aanzien van een kind ligt dat anders. Hoewel juist de uitdrukking "het kind wan de rekening zijn" toch zou wijzen op een besef in onze cultuur (...) dat deze vorm van onrechtvaardigheid kinderen wordt aangedian, en dat dat onrecht zeer schrijnend is.' De traumatische essentie van het verhaal van Abraham en Izaäk heeft STUTTERHEIM beter begrepen dan KIERKEGAARD: 'Nog schrijnender wordt de sitwatie als het kind van de rekening zijn het gevolg is van diep geworteld geloof of idealen van de ouders. Het door KIERKEGAARD hierboven zo indringend beschreven drama rond Isaäk en Abraham is daar een voorbeeld van.' (T.a.p.) 
'Laat ons eens aannemen (wat niet in het [Oude "Testament], noch in de Koran verteld wordi), dat Isaäk wist dat zijn vader naar de berg Moria trok om hem daar te offeren, en dat een dichter die leeft in onze tijd, zou kunnen vertellen waarover er onderweg tussen deze twee gesproken was. (...)

Ik geloof dan dat Abraham eerst met al zijn vaderliefde Isaäk had aangekeken terwijl zijn eerbiedwaardig voorkomen en zijn vermorzeld hart zijn spreken nog veel indringender maakten, om vervolgens Isaäk te vermanen zijn noodlot met geduld te dragen, terwijll Isaäk half en half vermoeden kon dat zijn vader nog meer leed dan hijzelf. Maar dat hielp niets. Dan, denk ik, dat Abraham zich een ogenblik heeft afgewend en toen hij zich weer tot Isaäk wendde, was hij onherkenbaar geworden, met wilde ogen en met zijn eerbiedwaardige lokken als furiën rond zijn hoofd. Hij greep Isaäk, trok het mes en schreeuwde: "Als je denkt dat ik het om God doe, heb je het helemaal mis, ik ben een afgodendienaar en tintel van lust om je keel af te snijden. Stom kind, hoe kon je denken dat ik een vader ben, neen, moorden is mijn lust."

En Isaäk viel op de knieẽm en riep ten hemel: "Mijn God, ontferm U." Maar Abraham zei zwijgend tot zichzelf: "Laat het zo zijn, want het is beter dat hij denkt dat ik een onmens ben, dat hij me vervloekt, dan dat hij te weten komt dat God het is die dexe beproeving heeft opgelegd; want anders zou hij er zijn verstand bij verliezen en God wellicht gaan vervloeken".'

\section{De moraal van dit verhaal}

Mensen hebben, in een lang historisch proces, het recht gemaakt en vervolmaakt, instellingen in het leven geroepen en voorzieningen ontworpen, en blijven daarmee doende, om zichzelf en hun medemensen, eerst en vooral met betrekking tot hun lichamelijke en geestelijke integriteit, te beschermen waar en wanneer ook maar medemensen hen kwaad dreigen te doen, of waar hun medemensen - of God - hen te zwaar beproeven of in de steek laten. Voor vrouwen, en niet minder voor kinderen, gelden dezelfde beginselen - maar moeten deze, lijkt het soms, nog grotendeels tot recht worden gemaakt, tot instellingen en voorzieningen worden uitgebouwd. Wat sooNS ten aanzien van vrouwen heeft opgemerkt, is onverkort op kinderen van toepassing: ${ }^{24}$

'[Als] het internationaal recht onvoldoende de belangen van vrouwen behartigt, [is dat] niet zozeer door voor hen nadelig uitwerkende specifieke regels maar door het ontbreken van zulke regels. Voorstellen voor de vorming van nieuwe regels zullen moeten worden ontwikkeld. De normatieve structuur van het internationaal recht staat daaraan mijns inziens niet in de weg; het gaat om de politieke bereidheid van staten.'

A.H.A. SooNs, 'Juridische vrouwenstudies en internationaal publiekrecht,' in: Lof der verscheidenheid, a.w., pp. 191-205, op p. 201 i.f. 
Er lijkt een tweedeling in de maatschappij te zijn tussen gezinnen met kinderen die met alle zorg en liefde worden omringd, en aan de andere kant gezinnen waarin kinderen, door welke oorzaken en omstandigheden ook, ernstig te kort komen. Meer nog misschien dan op het onderscheid tussen gezinnen met ruime en die met krappe sociaal-economische mogelijkheden ziet het gelijkheidsbeginsel, toegepast in het rechtsgebied onder de vigeur van de Trias pedagogica, ${ }^{25}$ op het onderscheid tussen deze gezinnen, de gezinnen met de gekoesterde, goed verzorgde en liefdevol opgevoede, en de gezinnen met de verwaarloosde, misbruikte en mishandelde kinderen. De kinderen waar de ouders misschien niet om gevraagd hadden - de kinderen die ronduit ongewenst op de wereld zijn gezet (in de meest extreme gevallen na incest of verkrachting); de kinderen die 'per ongeluk' op de wereld zijn gezet (als 'Abfallprodukte des Koitus' ${ }^{26}$ ); en de kinderen die als iets vanzelfsprekends op de wereld zijn gezet, als iets wat erbij hoort of wat men doet om er zelf bij te horen, om mee te tellen in de maatschappij of in de kring van familie en bekenden -, en voor wie de ouders zelfs volgens minimale standaarden nooit hebben willen of kunnen zorgen. Maar even goed de kinderen in de gezinnen waar de ouders niet opgewassen zijn tegen de eisen van het ouderschap hoe vurig hun kinderen ook waren gewenst, en hoe langdurig zij misschien zelfs, met behulp van de modernste medische technieken, in de maak zijn geweest. De aanvankelijk vurig gewenste, maar vervolgens verworpen kinderen. Verworpen omdat zij toch meer lastig dan lief bleken, of omdat de medische technologie niet had gebracht wat men aan innerlijk of uiterlijk had verwacht. In al die gevallen betreft het evenwel kinderen die er zelf nooit om gevraagd hebben - laat staan met deze ouders als hun opvoeders - ter wereld te komen.

Hiermee doel ik op het geheel van regels en beginselen die het samenspel en de wisselwerking beheersen tussen kind, ouders en overheid. En dus bepaald niet alleen op het burgerrechtelijke familierecht. Misschien zouden we dit - functionele - rechtsgebied kinder- en gezinsrecht kunnen noemen.

Ernest BORNEMAN merkt in zijn boek Das Geschlechtsleben des Kindes; Beiträge zur Kindercnalyse und Sexualpädologie (München 1985, Taschenbuch-ed. 1988, pp. 132/133) op: 'So hat es sich beispielsweise gezeigt, daß die wachsende Anzahll von unchelichen Frühschwangerschaften und vorehelichen Abtreibungen im $\mathrm{Ju}_{\mathrm{u}}$ gendalter keineswegs das Produkt mangelnder Kenntnis der Verhütungsmittel ist, sondern das Resultat mangelnder Achtung vor dem Gebot, daß3 Kinder erwünscht seien und nicht als Abfallprodukte des Koitus gezeugt werden sollten. Nicht die Kenntnis der Verhütungsmittel ist wichtig, sondern das BewuBtsein der Pflicht, keine ungewollten Kinder in die Welt zu setzen.' 
Zowel de in liefde ontvangen en aanvaarde als de van meet af aan of na verloop van tijd verworpen kinderen, zowel de gekoesterde als de verwaarloosde en mishandelde kinderen hebben echter, zo wil de preambule van het Verdrag inzake de rechten van het kind het, gelijkelijk 'zonder onderscheid van welke aard ook' - het recht 'op te groeien in een gezinsomgeving, in een sfeer van geluk, liefde en begrip.' Waar wordt die sfeer echter meer aangetroffen dan in een gezin waarin een gewenst kind met alle liefde wordt omringd, waar minder dan in een gezin waarin een ongewenst kind wordt verworpen en afgewezen? Toch wordt in de tekst van het Verdrag, in art. 2, zonder clausulering of beperking bepaald:

Art. 2 VRK:

De staten die partij zijn bij dit Verdrag, eerbiedigen en waarborgen de in het Verdrag beschreven rechten woor ieder kind onder hun rechtsmacht zonder onderscheid van welke aard ook, ongeacht (...) geslacht, (...) maatschappelijke afkomst, welstand (...) of andere omstandigheid van het kind of van zijn (...) ouder (...).

Tot de rechten die zonder enig onderscheid moeten worden toegepast, behoort ook, en in de allereerste plaats, het recht van het kind op levensomstandigheden 'die toereikend [zijn] voor de lichamelijke, geestelijke, intellectuele, zedelijke en maatschappelijke ontwikkeling van het kind. ${ }^{27}$ Dat wil zeggen: het recht op instellingen, voorzieningen en diensten ter verzekering van pedagogische basisvoorwaarden. Weliswaar is dit recht niet als afzonderlijk recht beschreven, maar - zoals nog uitgebreid zal worden aangetoond - is dit recht, als kernrecht, in het Verdrag in te lezen, en vloeit het voort uit de samenhang tussen verschillende rechten die het Verdrag expliciet erkent. Hiermee is in alle scherpte ten opzichte van het soms schrille contrast met de maatschappelijke werkelijkheid de rechtsplicht van de overheid aangegeven het gelijkheidsbeginsel ook in het kinder- en gezinsrecht ${ }^{28}$ te waarborgen en te handhaven.

We zullen daar nu niet verder op ingaan. Op deze plaats beperken we ons tot de vraag wat in meer algemene zin onder het gelijkheidsbeginsel, toegepast op kinderen, dient te worden verstaan.

\section{4 .1}

Het gelijkheidsbeginsel

Het gelijkheidsbeginsel kan worden opgevat:

a.) als natuurrechtelijk beginsel van de gelijkwaardigheid van alle

28 Zie woor deze aanduiding hierboven. 
mensen (natuurrechtelijk in de zin van noodzakelijk-rechtelijk, op grond van een opinio juris sive necessitatis);

b.) als internationaalrechtelijk beginsel: zie (in het bijzonder) art. 26 IVBPR (zelfs dwingendrechtelijk, als beginsel van jus cogens, ten aanzien van onderscheid op grond van ethnische afstamming of natuurlijke pigmentatie);

c.) als staats- en bestuursrechtelijk beginsel (art. 1 Grondwet, het gelijkheidsbeginsel als algemeen beginsel van behoorlijk bestuur).

Als beginsel van internationaal en intern-nationaal recht kan de betekenis van het gelijkheidsbeginsel ten aanzien van kinderen als volgt worden aangeduid:

1. Gelijke gevallen (moeten) gelijk (behandeld worden): elk kind heeft recht op ... (met andere woorden: er zijn geen gedoemde, afgeschreven kinderen, bijvoorbeeld kinderen van 'asociale' of arme ouders).

2. Gelijke gevallen gelijk: elk kind heeft zo veel mogelijk gelijke rechten als volwassenen. Zo veel mogelijk wil zeggen: voor zover zulks, gezien de zich ontwikkelende vermogens van het kind, redelijk is en bevorderlijk voor de ontwikkeling. Met andere woorden: voor zover zulks niet in strijd is met het ontwikkelingsbelang van het kind c.q. voor zover aannemelijk is dat dat belang daardoor juist wordt gediend.

3. Ongelijke gevallen (moeten) ongelijk (behandeld worden) naar de mate van de ongelijkheid: omdat en voor zover het kind (de puber, de adolescent) nog niet 'volwassen' is, heeft het (hij/zij) recht op leiding en begeleiding bij de uitoefening van (onder meer) burgerlijke en politieke rechten (vgl. art. 5 en art. 14, lid 2 VRK), op een wijze die verenigbaar is met zijn/haar zich ontwikkelende vermogens.

4. Ongelijke gevallen ongelijk naar de mate van de ongelijkheid: extra/speciale beschermingsrechten voor zover vereist met het oog op minimale, c.q. voor zover gewenst met het oog op optimale persoonswording; voor zover met andere woorden in het (veiligheids- en ontwikkelings)belang van het kind.

Het persoon-in-wording (animal educandum - wat iets anders is dan tabula rasa) zijn van het kind impliceert de verhoogde kwetsbaarheid (totale veiligheids-, geborgenheids- en opvoedingsafhankelijkheid) van het kind, welke op zich als voldoende rechtvaardigingsgrondslag kan worden beschouwd voor de (extra dan wel speciale beschermings)rechten van het kind. De grotere kwetsbaarheid brengt op zich een grotere beschermwaardigheid met zich mee. Bij elke belangenafweging dient er extra aandacht te zijn voor het meest kwetsbare belang, dient het meest kwetsbare belang de doorslag te geven. Dit is de essentie van het gelijkheidsbeginsel in de betekenis: ongelijke gevallen ongelijk behandelen naar de mate der 
ongelijkheid. ${ }^{29}$ Ten overvloede wordt dit nog eens onderstreept door het (verdrags)vereiste bij elke belangenafweging het 'belang van het kind' voorop te stellen (vgl. art. 3, lid 1 en art. 18, lid 1 VRK), dus boven de al of niet egoïstische, 'adultocentrische' - belangen van volwassenen te laten prevaleren.

We volstaan hier met deze korte aanduiding. Verschillende aspecten zullen in de loop van het betoog nog terugkeren. Centraal staat hier de betekenis van het gelijkheidsbeginsel niet alleen als verbod van discriminatie, of als gebod tot gelijke behandeling van gelijke gevallen, maar ook, en niet minder, als gebod, opdracht, rechtsplicht tot ongelijke behandeling van ongelijke gevallen naar de mate van de ongelijkheid.

\subsubsection{De public/private dichotomie en het gelijkheidsbeginsel}

Zoals vrouwen hebben betoogd dat het niet handhaven van mensenrechten tot achter de voordeur, ja tot in de slaapkamer, schending van het gelijkheidsbeginsel is - een schending die, door de maatschappelijke dichotomie publiek-privé, ${ }^{30}$ en daarmee, valselijk, door het privacy-beginsel zou zijn gerechtvaardigd, een schending die haar overleverde aan willekeur en het recht van de sterkste, een schending die haar weerloos en rechteloos maakte zelfs in gevallen van mishandeling en verkrachting -, zo kan a fortiori, dat is: met nog meer recht en pertinentie, ten aanzien van kinderen, zoveel weerlozer en kwetsbaarder dan vrouwen, worden

Althans in de - mijns inziens enig juiste - materiële conceptie van het gelijkheidsbeginsel. Vgl. hierower R. HOLTMAAT, T. LOENEN, Inleiding wroww en recht, Alphen aan den Rijn 1989, pp. 24-25; T. LOENEN, 'Het discriminatiebegrip,' in: Het vrouwenverdrag: een beeld van een verdrag ..., a.w., pp. 1-13, op pp. 4 i.f. -6 ; J.E. GOLDSCHMIDT, "Staats- en bestuursrechtelijke aspecten van positieve actie," Preadvies NJV, in: Positieve discriminatie, Handelingen Nederlandse JuristenVereniging Zwolle 1989-1, pp. 57-117, op pp. 63 iff.-76; Jenny E. GOLDSCHMIDT, Mensenrechten: vrouwenrechten? Nieuwenhoflezing vil (4 juni 1994), Deventer 1995, pp. 10-12, 15, passim; Radhika COOMARASWAMY, "To bellow like a cow: women, ethnicity, and the discourse of rights,' in: Rebecca J. COOK (ed.), Human rights of women; National and intemational perspectives, Philadelphia 1995 (third printing), pp. 39-57, op pp. 46 i.f. -47 .

Zie echter voor de visie van het Europese Hof voor de rechten van de mens in de STUBBINGS-zaak de noot wan T. LOENEN, 'Seksueel kindermisbruik en verjaringstermijnen," NJCM-Bulletin 1997/3, pp. 287(294)-297, op pp. 296/297.

Zie bijvoorbeeld Celina ROMANY, 'State responsibility goes private; a feminist critique of the public/private distinction in international human rights law,' in: Hurnan rights of women, a.w., pp. 85-115, in het bijzonder op pp. 94 i.f.-96. Bij de bespreking van de staatsaansprakelijkheid in hoofdstuk 13 komen we nog op de zogenaamde public-private dichotomie terug. 
betoogd dat het gelijkheidsbeginsel eist dat juist achter de voordeur, ja tot in de slaapkamer, tot in het holst van de nacht, hun rechten moeten worden gewaarborgd.

Ter illustratie van de juridische merites van dit betoog diene het bepaalde in de Universele Verklaring en in het IVBPR. ${ }^{31}$

Art. 7 UV, eerste volzin:

Allen zijn gelijk voor de wet en hebben zonder onderscheid aanspraak op gelijke bescherming door de wet.

Art. 7 UV, tweede volzin:

Allen hebben aanspraak op gelijke bescherming tegen elke achterstelling in strijd met deze Verklaring en tegen elke ophitsing tot een dergelijke achterstelling.

Art. 26 IVBPR bepaalt, voor zoveel hier van belang (curs. jw):

Art. 26 IVBPR:

Allen zijn gelijk voor de wet en hebben zonder discriminatie aanspraak op gelijke bescherming door de wet. In dit verband (...) garandeert [de wet] een ieder gelijke en doematige bescherming tegen discriminatie op welke grond ook (...).

Onder achterstelling/discriminatie van kinderen in strijd met de UV en het IVBPR dient dan allereerst te worden begrepen minder bescherming door de wet en in de praktijk tegen schending van de lichamelijke en geestelijke integriteit in het gezin dan volwassenen, althans volwassen mannen, genieten (een fenomeen dat ten aanzien van vrouwen, zoals we zagen, als public-private dichotomie is gebrandmerkt). Dit terwijl juist art.

Vgl. Jakob Th. MÖLLER, 'Article 7,' in: Asbjørn EIDE e.a. (eds.), The Universal' Declaration of human rights; A commentary, Oslo(/Oxford) 1992, pp. 115-141, op pp. 128-133. Zie ook T. LOENEN, 'Het discriminatiebegrip," in: Het vrouwenverdrag: een beeld waw een verdrag ..., a.w., pp. 1-13, op pp. 10-11.

LOENEN acht het mogelijk "het hele Vrouwenverdrag in artikel 26 INBPR "in te lezen" ${ }^{n}$. Aldus kan 'de normstelling zoals neergelegd in het Vrowwenverdrag tot uitgangspunt word[en] genomen' bij de beantwoording van de vraag 'of er sprake is van discriminatie op grond van geslacht in strijd met artikel 26 IVBPR." (T.a.p., op p. 10 iff.) $\mathrm{Zij}$ beroept zich hierbij op een Algemeen commentaar van het Mensenrechtencomite (bedoeld zijn de General comments van het Comité d.d. 9 november 1989; als Annex 1 opgenomen in de bijdrage van Möller, t.a.p., op pp. 129-133). Langs deze lijn doorredenerend, zou men ook een kinderklachtrecht bij dat Comité kunnen construeren ten aanzien van discriminatoire schendingen van het Verdrag inzake de rechten van het kind (men denke aan tenachterstelling van bepaalde groepen kinderen, bijvoorbeeld in de vorm van onvoldoende c.q. ontoereikende positieve maatregelen ten aanzien van kinderen uit bepaalde 'a-sociale' c.q. 'pedagogisch zwakke' milieus). Dit Verdrag kent immers net zo min een individueel klachtrecht als het Vrouwenverdrag. 
25 , lid $2 \mathrm{UV}^{32}$ extra bescherming voor (moeders en) kinderen stipuleert.

Art. 25 UV:

1. Een ieder heeft recht op een levensstandaard die hoog genoeg is woor de gezondheid en het welzijn van zichzelf en zijn gezin, (...) alsmede het recht op [sociale voorzieningen].

2. Moeder en kind hebben recht op bijzondere zorg en bijstand. Alle kinderen (...) zullen dezelfde maatschappelijke bescherming genieten.

Dit is op tweeërlei wijze in strijd met het gelijkheidsbeginsel. Het gelijkheidsbeginsel als algemeen rechtsbeginsel en als beginsel van behoorlijk bestuur eist dat gelijke gevallen gelijk worden behandeld. Aangezien kinderen mensen zijn, hebben zij derhalve minimaal aanspraak op gelijke bescherming als volwassenen. Het gelijkheidsbeginsel eist evenwel eveneens dat ongelijke gevallen ongelijk worden behandeld naar de mate van hun ongelijkheid. Aangezien kinderen veel kwetsbaarder zijn en bovendien nog persoon-in-ontwikkeling eist het gelijkheidsbeginsell derhalve positieve of extra maatregelen. Dit kan ten overvloede worden afgeleid uit de eis van art. 26 IVBPR tot 'doelmatige bescherming.'

De Universele Verklaring bepaalt echter nog meer; in art. $6 \mathrm{UV}$ lezen we: $:^{33}$

\section{Art. 6 UV:}

Een ieder heeft, waar hij zich ook bevindt, het recht als persoon erkend te worden voor de wet.

Met andere woorden: óók als hij zich in de gevangenis bevindt, óók als hij zich in het gezin bevindt. Geen enkele institutie, noch de gevangenis, noch het gezin, staat boven de wet, kan een mens, van welk ras, geslacht of leeftijd ook, de mensenrechten ontzeggen door hem of haar als nonpersoon te ecarteren. BOGDAN ${ }^{34}$ merkt op:

Today there appears to be no State overtly accepting the traditional Roman law concept of slavery, degrading certain human beings to mere objects of law and denying them the status of persons before the law (in practice such treatment may

32 Vgl. Asbjorn ErDE, 'Article 25, in: The Universal Declaration of human rights, a.w., pp. 385-403, op p. 392 i.f.-393, 398-401. Vgl. ook WLLEMS, 'Kinderen in ons midden; enkele cultuurkritische notities naar aanleiding van artikel 25 van de Universele Verklaring en het Verdrag inzake de rechten van het kind,' Recht en kritiek 1994/4, pp. 322-339, op p. 322-323.

Curs. jw. Vgl. woor dit artikel Michael BoGDAN, 'Article 6," in: The Universal Declaration of human rights, a.w., pp. 111-113.

34 T.a.p.s op p. 112 (curs. jw). 
occur, however, even if it violates the llaw of the country in question). (...)

The importance of article 6 lies mainly in the field of (...) family law."

Vermoedelijk is men zich daar ook op 20 november 1959, en niet minder op 20 november 1989, en zeker - in Nederland - op 8 maart 1995 van bewust geweest. Of toch niet helemaal? Het gelijkheidsbeginsel paraisseert in elk geval prominent in beginsel 1 van de Verklaring van de rechten van het kind van 1959 (Every child without any exception whatsoever...), en in art. 2, direct na het definitie-artikel, van het Verdrag inzake de rechten van het kind (... each child ... without discrimination of any kind, irrespective of ...).

Wat ook de rechten zijn die we aan kinderen toekennen, of die kinderen impliciet en natuur-noodzakelijk hebben, die rechten hebben alle kinderen, zonder onderscheid, in het land waarin zij wonen, óok juist - binnen het gezin waarin hun wiegje staat of stond. ${ }^{35}$ En dit op grond van het gelijkheidsbeginsel, dat, zoals we al zagen, meer nog dan internationaal en intern-nationaal rechtsbeginsel natuurrechtelijk grondbeginsel van de rechten van de mens is.

\section{5}

\section{Kinderrechten en het ontplooiingsbeginsel}

Naast het gelijkheidsbeginsel is er nog een tweede natuurrechtelijk grondbeginsel, een beginsel dat we ontplooiingsbeginsel hebben gedoopt. Welk beginsel op zijn beurt in het verlengde ligt van wat we het persoonswordingsbeginsel genoemd hebben, zodat we ten aanzien van kinderen, en ook qua grote-mensenlogica, eigenlijk eerst met dat laatste beginsel zouden moeten beginnen. Juist omdat het persoonswordingsbeginsel in deze studie centraal staat, kan het echter verfrissend zijn vanuit de andere kant te vertrekken. We zouden namelijk kunnen stellen dat het persoonswordingsbeginsel het ontplooiingsbeginsel volledig overlapt, zij het dat niet helemaal duidelijk is - tenzij we alle mensenrechten onverkort op kinderen van alle leeftijden van toepassing zouden achten, quod non -

De werking in de privé-sfeer kan hier met nog meer recht en reden dan met betrekking tot het Vrouwenwerdrag tot object and purpose (vgl. artt. 18 en 19 Weens Verdragenverdrag), doel en wezen, zin en strekking van het Verdrag inzake de rechten van het kind worden gerekend. (Vgl. Liesbeth LINZAAD, "Het kussen van een kikker; de werkelijke betekenis van het Vrouwenverdrag,' Nemesis $1991 / 2$, pp. 5-17, op p. 13 1.k.) Voor het Verdrag inzake de rechten van het kind is hier niet een of andere ut res magis valeat quam pereat-constructie voor nodig: het Verdrag legt uitdrukkelijk verplichtingen op aan ouders, en niet alleen aanvulleade en vervangende pedagogische maar ook overige, rechtstreeks de gezinssfeer penetrerende verplichtingen aan de staat. 
vanaf welke leeftijd het ontplooiingsbeginsel vertrekt, terwijl dat van het persoonswordingsbeginsel een stuk duidelijker is, want persoonswording begint in de wieg, of eigenlijk al in de baarmoeder, in de "levende wieg onder het hart van moeder, ${ }^{36}$ zoals dat vroeger wijsneuzen werd wijsgemakkt. Wat kan er in meer algemene zin over het ontplooiingsbeginsel, ten aanzien van mensen in het algemeen en mensenkinderen in het bijzonder, worden gezegd?

\subsubsection{Het ontplooiingsbeginsel}

\section{Art. $22 u^{37}$ bepaalt:}

Een ieder heeft als lid van de gemeenschap recht op sociale zekerheid en heeft er aanspraak op dat door middel van nationale inspanning en internationale samenwerking, en overeenkomstig de organisatie en de hulpbronnen van de betreffende Staat, de economische, sociale en culturele rechten, dic onmisbaar zijn voor zijn waardigheid en voor de vrije ontplooiing van zijn persoonlijkheid, verwezenlijkt worden.

Art. 26, lid 2, eerste volzin, eerste gedeelte UV ${ }^{38}$ luidt:

Het onderwijs zal gericht zijn op de volle ontwikkeling van de menselijke persoonlijkheid (...).

Art. 29, lid 1 UV $^{39}$ luidt:

Een ieder heeft plichten jegens de geneenschap, zonder welke de vrije en volledige ontplooiing van zijn persoonlijkheid niet mogelijk is.

Art. $28 \mathrm{UV}^{40}$ ten slotte bepaalt:

36 Pastoor JJ.M. BRouwers, De tempel wan het gezin, Roermond/Maaseik, imprimatur J. KROON S.J. libr. censor, Trajecti ad Mosam [Maastricht] 1953, p. 436 r.k.

37 Vgl. Bård-Anders ANDREASSEN, 'Article 22,' in: The Universal Declaration of human rights, a.w., pp. 319-355, op pp. 343 en 352.

38 Vgl. Pentit ARAJÄRVI, 'Article 26,' in: The Universal Declaration of human rights, a.W., pp. $405-428$, op p. 409.

39 Vgl. Torkel OPSAHL, 'Articles 29 en 30, in: The Universal Declaration of human rights, a.w., pp. 449-470, op pp. 451 en 452 .

40 Vgl. Asbjorn EIDE, 'Article 28," in: The Universal Declaration of human rights, a.w., pp. 433-447. Op p. 446 i.f. merkt de auteur op (curs. jw): 'The recognition that the individual, each and every human being, is the subject of development and not a mere object, is a prerequisite for moving towards the goal outlined in article 28.' 
Een ieder heeft recht op het bestaan van een zodanige maatschappelijke en internationale orde dat de rechten en vrijheden in deze Verklaring genoemd, daarin ten volle kunnen worden verwezenlijkt.

Hoe deze bepalingen - inzonderheid de door mij gecursiveerde elementen - in verdragsartikelen terugkeren, zal hier en nu niet worden nagegaan. In een ander hoofdstuk (hoofdstuk 10) zal daaraan systematischer aandacht worden besteed. Het gaat op deze plaats om een eerste indruk van wat het ontplooiingsbeginsel zoal behelst en beoogt. Voor een enigszins nadere omschrijving gaan we te rade bij VAN BOVEN. Allereerst bepleit deze: ${ }^{41}$

[I]n matters of human rights, the main focus should not be the function of the State but rather the human existence and human personality on the individual and collective level.'

Om vervolgens, met verwijzing naar de artikelen 28 en 29 UV en de vijfde preambulaire overweging van IVESCR en IVBPR, in aansluiting op het woord 'collective,' op te merken: ${ }^{42}$

\begin{abstract}
'It is, after all, within the community that the individual can develop fully his personality, as is pointed out in article 29, para. 1, of the Universal Declaration. (....) It is, however, undeniable that the general orientation and outlook of the Universal Declaration of Human Rights is towards the individual person. (...) In fact, the Universal Declaration puts the individual and his personality on an elevated level in the national and international sphere. The basic idea is that every human being should have a full and equal chance to develop his personality, with due regard to the rights of others and to the community as a whole. (...) In this manner, human life in its manifold social relationships finds recognition and expression under the aegis of the promotion and protection of human rights.'
\end{abstract}

Voor we hierbij aansluiting zoeken, proberen we eerst ook het persoonswordingsbeginsel af te tasten.

\title{
6.5 .2
}

\section{Het persoonswordingsbeginsel}

Persoonswording ziet op de (optimale) ontwikkeling en ontplooiing, vanaf de baarmoeder-wieg tot het graf, van de rationaliteit, moraliteit en authenticiteit van mens en mensenkind. Dat wil zeggen: van de mens, die

Th.C. VAN BOVEN, 'Distinguishing criteria of human rights,' in: Karel VASAK, Philip ALSTON (eds.), The international dimensions of human rights, Westport, 
nu eenmaal als kind geboren is, en van het kind, dat, hoewel als mens geboren, op opvoeding is aangewezen om persoon te worden. Waakt het persoonswordingsbeginsel echter in de eerste plaats over het (jonge) kind, en specifiek over diens persoonswording, het ontplooiingsbeginsel bestrijkt, als grondslag van mensenrechten, in de meest brede zin de ontwikkeling en ontplooiing van in de eerste plaats de volwassene, en bij uitbreiding, voor zover mensenrechten ook onverkort voor kinderen gelden, dan wel in de mate dat zulks het geval is, ook die van de jonge mens, de jeugdige, het kind. Er zijn tussen beide beginselen dus slechts graduele verschillen, vandaar dat we al zeiden dat ze in elkaars verlengde liggen, of zelfs geacht kunnen worden elkaar te overlappen.

Hoe werd nu over de ontwikkeling en ontplooiing van het (jonge) kind op de eerste en tweede trede van het kindervolkenrecht gedacht? De Verklaring van Genève van 1924, de Volkenbond-Verklaring van de rechten van het kind, stelt voorop:

1. The child must be given the means requisite for its normal development, both materially and spiritually.

De vN-Verklaring van de rechten van het kind van 1959 wil:

\section{Principle 2.}

The child shall enjoy special protection, and shall be given opportunities and facilities, by law and by other means, to enable him to develop physically, mentalby, morally, spiritually and socially in a healthy and nomal mamer and in conditions of freedom and dignity. In the enactment of laws for this purpose, the best interests of the child shall be the paramount consideration.

Principle 6.

The child, for the full and hamonious development of his personality, needs love and understanding. He shall, wherever possible, grow up in the care and under the responsibility of his parents, and, in any case, in an atmosphere of affection and of moral and material security; a child of tender years shall not, save in exceptional circumstances, be separated from his mother. Society and the public authorities shall have the duty to extend particular care to children without a family and to those without adequate means of support. Payment of State and other assistance towards the maintenance of children of large families is desirable.

Principle 7.

The child is entitled to receive education (...). He shall be given an education which will promote his general culture, and enable him, on a basis of equal opportunity, to develop his abilities, his individual judgment, and his sense of moral and social responsibility and to become a useful member of society. (...)

Principle 9.

The child shall be protected against all forms of neglect, cruelty and exploitation. (...) The child shall (...) in no case be caused or permitted to engage in any occu- 
pation or employment which would prejudice his health or education, or interfere with his physical, mental or moral development.

Hoe in het bijzonder de gecursiveerde elementen op de derde trede van het kindervolkenrecht, in met name het Verdrag inzake de rechten van het kind, zijn gepositiveerd en uitgewerkt, zal nog uitgebreid onderwerp van onderzoek vormen. Bij beginsel 7 hierboven hebben we enkele passages weggelaten. Onder meer deze:

\section{Principle 7 (continued).}

(...) The best interests of the child shall be the guiding principle of those responsible for his education and guidance; that responsibility lies in the first place with his parents. (...)

Hoe fraai en overtuigend bovenstaande beginselen ook klinken, met name de laatste aangehaalde volzin legt bloot waar de schoen wringt. Het behoeft geen betoog dat aan de ouderlijke functie als intermediair voor de persoonswording van kinderen, hoezeer ook een historische vanzelfsprekendheid, hoezeer ook verdedigbaar vanuit de natuurlijke neiging tot tederheid voor het nakroost welke volgens LOCKE door God in de beginselen van de menselijke natuur is geweven, en hoezeer daarom wellicht ook te verkiezen boven elk denkbaar alternatief, niettemin ernstige bezwaren kleven. Om reeds op deze plaats, voor we komen te spreken over ouderlijke excessen in de hoofdstukken over kindermishandeling en de gevolgen daarvan (hoofdstuk 11 en 12), enig idee te krijgen van - en begrip voor - de menselijke problematiek die in dit verband, op het punt van de primaire ouderlijke verantwoordelijkheid voor de persoonswording van het kind, speelt, wenden we ons tot een tweetal psychologen: STUFKENS en SMAIL. Onze eerste auteur, STUFKENS, schrijft: ${ }^{43}$

"Veel ouders voelen automatisch aan wat een kind van hen vraagt en zijn in staat
adequat daarop in te gaan. Dat zijn de ouders die kunnen geven en doorgeven,
omdat ze zelf vroeger genoeg gehad hebben. Maar het omgekeerde is zeker ook
het geval: dat het kind op een of andere manier moet dienen ter reparatie, om op
te vullen wat de ouders te kort zijn gekomen of om te realiseren waar ze nalar
eigen idee zelf te kort zijn geschoten. En dat kan in velerlei varianten en ver-
mommingen worden gevraagd door de ouders en beantwoord door het kind. Dit
begint bij- en in sommige opzichten al vóor - de geboorte, het is vaak bepalend
voor de verdere ontwikkeling en kan ingrijpende gevolgen hebben, bij voorbeeld
voor het vermogen om fantasie en realiteit goed uit elkaar te houden. Of vader
en moeder juist voor die vroege perioden voldoende gevoelsgeëquipeerd zijn, het 
kind kunnen spiegelen, hun eigen rol kunnen onderkennen en oppakken, is van wezenlijk belang voor een positief zelfgevoel van het kind en voor wat hij of zij in de latere ontwikkelingsfasen en in de rest van het leven kan ontplooien.

\section{Onze tweede auteur, SMAI, voegt daaraan toe: ${ }^{44}$}

'Natuurlijk is het waar dat veel ouders zich nauw met hun kinderen verbonden woelen, maar die genegenheid is maar al te vaak afhankelijk van de anpassing van het kind aan de behoeften en verwachtingen van de ouders. Het onthouden ervan kan het kind op ieder moment in het kille isolement plaatsen dat zijn bestaan dreigt te vernietigen.

Veel ouders hebben zelf zo'n sterke behoefte aan de koesterende bevestiging waarvan ze weten dat ze die aan hun kinderen verschuldigd zijn, dat ze gewoon concurrenten worden. Sommige ouders zijn ook volstrekt niet voorbereid op de eisen die de kinderen aan hen stellen, vinden hun kroost vermoeiend en veeleisend en zijn niet in staat aan hun behoeften te voldoen."

'Dwang, variërend van het regelmatig onthouden van genegenheid tot regelrechte mishandeling, is een algemeen voorkomend kenmerk van de relatie tussen ouders en kinderen. Kinderen leren snel zich anders woor te doen om aan de verwachtingen te voldoen, om niet als het ware in de buitenste duisternis te worden geworpen."

'De mensen hebben meestal geen idee in welke mate ze werden gechanteerd, geprest, misvormd en onderworpen door de vele manieren waarop "liefde" en het onthouden ervan kan worden gebruikt. Voor de meeste mensen is hun ervaring nu eenmaal wat ze is, en zeker als kind konden ze niet weten dat het ook anders kon. Zelfs mensen wier jeugd een lange geschiedenis is van verwaarlozing en afwijzing (iets dat in onze wereld veel vaker voorkomt dan we graag denken), praten wak vol eerbied over hun ouders en vinden dat ze een viij normale en zelfs gelukkige jeugd hebben gehad. In het begin kunnen ze maar moeilijk het verband zien tussen hun gebrek aan zelfvertrouwen en gevoelens van nietswaardigheid aan de ene kant en hun jeugdervaringen aan de andere kant. We nemen meestal zonder meer aan dat wat met ouderliefde wordt bedoeld, datgene is wat we als kind van onze ouders ondervonden.'

'We moeten de liefde winnen van degenen die belangrijk voor ons zijn door bet object te worden dat zij willen dat we zijn." 
Teneinde wat tot nu toe over persoonswording en ontplooiing gezegd is, wat meer cachet en kleur te geven, veroorloof ik mij in deze paragraaf een klein 'filosofisch-psychologisch' voorschotje op wat in een ander hoofdstuk (hoofdstuk 9) nog - maar daar meer in pedagogische dan filosofische zin - over persoonswording gezegd moet worden. We kijken daartoe nog eens om naar de menselijke waardigheid die - via het gelijkheids- en het ontplooiingsbeginsel - tot mensenrechten heeft geleid, maar ook tot plichten van mensen tegenover elkaar, tegenover zichzelf, tegenover de samenleving, tegenover kinderen en tegenover de natuur.

\section{Mimesis, fairness, appetitus societatis}

Men kan zeggen: menselijke waardigheid kan slechts door het individu worden beleefd bij minimale rationaliteit, moraliteit en authenticiteit (lees hier: zelfrespect, eigenwaarde). Menselijke waardigheid impliceert zelfontplooiing in de zin van het streven naar optimale rationaliteit, moraliteit en authenticiteit als menselijke opdracht (noodzaak, lot, onderdeel der condition humaine) en menselijk ideaal (wezen der vrijheid, zelfbepaalde zin van het leven, essentie van the pursuit of happiness: het najagen van het goede, ware en schone). Opdracht en ideaal, lot en vrijheid: een schijnbare paradox, die wordt opgelost in en door de overwinning op de mimesis (GIRARD), ${ }^{45}$ het na-apen, de begeerte naar wat de ander heeft omdat de ander het heeft, de begeerte naar de bodem van de bodemloze put, of liever het dak van de dakloze hemel. Een overwinnen van zichzelf, welke de overwinning van de ratio is, die doet inzien dat niet na-apen maar de ontwikkeling van het natuurlijk vermogen tot zorgzaamheid en ontferming typisch menselijk zijn, bijdragen tot menselijke moraliteit en authenticiteit, en aldus tot menselijk, met inbegrip van het eigen, individueel geluk.

Zorgzaamheid en ontferming, empathie, de zorg voor de gemeenschap, ${ }^{46}$ in het bijzonder voor de zwakken in de gemeenschap, met een modernere term: solidariteit, kan slechts bloeien bij een zo groot moge-

Zie voor een korte kennismaking J.M.M. DE VALK, 'Het werk van René GIRARD," in René GIRARD, De zondebok, Kampen/Kapellen 1986, pp. 251-256. Vgl. ook A.W.M. MOOU, 'De blijwende waarde van het begrip zondebok' in: C. KELK e.a. (red.), Hamonie en tegenspraak; Gedragskundige en rechtsgeleerde opstellen over psychiatrie en strafrechtstoepassing, aangeboden wan F.H.L. BEYAERT, Arnhem 1990, pp. 213-223, op pp. 213-215.

46 Een zorg voor de gemeenschap die vóór-menselijk is: vgl. Frans DE WAAL, Good natured; The origins of right and wrong in humans and other animals, Cambridge/ London 1996, pp. 5, 7-27, passim. 
lijke eerlijkheid, faimess, dat wil - juridisch vertaald - zeggen: bij een zo ruim en zorgvuldig mogelijke toepassing van het gelijkheidsbeginsel. De mens is weliswaar tot alle kwaad in staat, maar ook geneigd tot zorg, en, van kindsbeen af, ${ }^{47}$ gehecht aan eerlijkheid, afhankelijk als hij is van sociale insluiting, opneming, opgenomen zijn in de gemeenschap. Dit is de kern van de moraal, en dus - via het natuurrecht - van het recht. Daarnaast ligt het in de natuur van elk levend wezen dat het wil groeien, zich ontplooien, ${ }^{48}$ vaak, ja juist tegen alle verdrukking in. Soms tijdelijk of een leven lang verkeerd gericht, niet zelden ook ergens onderweg egocentrisch geblokkeerd, en daarvoor weer compensatie zoekend in macht, wraak, status en bezit.

Hier ligt de diepere betekenis van wat in mensenrechtentaal "de menselijke waardigheid' is gaan heten. De menselijke waardigheid postuleert in de kern het gelijkheidsbeginsel zo goed als het recht op persoonswording en ontplooiing van elk mens c.q. van elk mensenkind. ${ }^{49}$

47 Vgl. Michael RUSE, 'Van nature goed,' bespr. van Frans DE WAAL, Good natured, in: Intermediair van 10 mei 1996, pp. 41 en 43 , op p. 43 l.k. i.f./tweede kol.

48 Dit ligt al ten grondslag aan ARISTOTELES' (natuurrechts)opvating van de mens

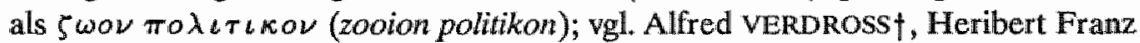
KOECK, Natural law: the tradition of universal reason and authority," in: R.St.J. MACDONALD, Douglas M. JOHNSTON, The structure and process of international law: Essays in legal philosophy, doctrine and theory, Dordrecht (etc.) 1986, pp. 1750, op pp. 17/18. De auteurs merken op (ta.p., op p. 18): "ARISTOTtE stresses that the real nature is the fully developed nature which has reached its final goal.' Ontplooiing behoort aldus tot de "primary aspirational ends" (Victor KRAFT; t.a.p.). Voor ontplooing als individu, ook los van de polis, is het concept van de inherente menselijke waardigheid nodig, door Thomas VAN AOUINO als volgt verwoord (t.a.p., op p. 19): dignitas humana, prout scilicet homo est naturaliter liber et propter seipsum existens (menselijke waardigheid [in de zin] dat de mens van nature vrij is en bestaat omwille van zichzelf). De op deze gedachte stoelende gewetenswrijheid kreeg, zoals we zagen, bij GROTIUs een juridische vertaling.

49. We zouden thans (onder verwijzing naar hoofdstuk 4, par. 4.2.3, en dit hoofdstuk, par. 6.4.1, en vooruitlopend op boek 4) de menselijke waardigheid kunnen veraanschouwelijken als in wieren gedeelde cirkel: de omtrek van de cirkel is het solidariteitsbeginsel, de horizontale diameter is het gelijkheidsbeginsel met als linkerstraal formele en als rechterstraal materiele gelijkheid, de verticale diameter is, van beneden naar boven, het persoonswordingsbeginsel dat op een willekeurig punt overgaat in het ontplooingsbeginsel. We zien dan vier kwadranten, waarvan in elk geval het kwadrant rechtsonder (de cirkelsector tussen persoonswording en materiele gelijkheid) vrijwel leeg is: er is in Nederland sprake van systemische sociaal-pedagogische discriminatie (zie hoofdstuk 13), welke moet worden uitgebannen door invulling van het kwadrant met SPS (een sociaal-pedagogisch steunstelsel: zie hoofdstuk 14). Volledige invulling - de jure en de facto - van alle kwadranten zou de cirkel doen opbollen tot een globe van menselijke waardigheid. Een even nastrevenswaardige als onbereikbare - natuurrechtelijke - globe, die 
Wanneer men onder natuurrecht verstaat de erkenning van de redelijke en zedelijke natuur van de mens als ultieme rechtsbron, waarbij 'redelijk' verwijst naar de uit het eerlijkheidsverlangen - het rechtsgevoel - voortspruitende eis der ratio tot redelijke belangenafweging (te midden van een veelheid van belangen), en 'zedelijk' naar de appetitus societatis, in de zin van de natuurlijke menselijke neiging tot zorgzaamheid (societatis custodia, gemeenschapszin ${ }^{50}$ ) en tot medelijden (ontferming, empathie, LEVINAS' gelaat ${ }^{51}$ ), dan is het bovenstaande natuurrechtelijk van

evenwel van een andere orde is dan de - utopische - globe van volmaakt menselijk geluk (vgl. Hans CROMBAG en Frank VAN DUN, De utopische verleiding, Amsterdam/Antwerpen 1997, pp. 255 i.f., 259, passim).

50 De societatis custodia is bij GRoTius grondslag van het natuurrecht, dat zelf weer 'cen gebod van de rechte rede [is], dat aangeeft dat een daad vamwege haar overeenstemming of strijdigheid met de redelijke en sociale natuur als zodanig moreel [geboden] dan wel moreel [laakbaar] is (...).' (De jure belli ac pacis 1.1.10:1; vert. EYPFINGER/VERMEULEN; de gecursiveerde woorden zijn door de vertalers toegevoegd; Hugo DE GROOT; Denken over oorlog en vrede, Baarn 1991, p. 64.) In het origineel: Ius naturale est dictatum rectae rationis indicans actui alicui ex eitus convenientia aut disconvenientia cum ipsa natura rationali inesse moralem turpitudinem aut necessitatem woralem (...).

VERDROSS/KOECK merken in dit verband op: 'GROTIUS follows the Aristotelian anthropology, enlarged by the Stoics, according to which man is by his very nature a social being, for he needs a society for his own development and fulfillment. However, it is "not any and every sort," but a peaceful and organized society according to the measure of his intelligence, with those who are of his own kind, to which human mature - according to GROTIUS - aspires. Consequently, the social nature of man is "the mother of the law of nature." This statement appears to be contradicted by another, namely, that the law of nature is "a dictate of right reason which points out that an act is or is not in conformity with rational nature." But both statements can be reconciled if we bear in mind that our social nature is rationall. Hence social nature can be interpreted by reason.' (VERDROSS 1 /KOECK, t.a.p., op pp. 24/25.)

De Stoicijnse filosofen hebben inmiddels van etholoog DE WAAL (zie hierboven) sociobiologisch gelijk gekregen. Redelijk c.q. redelijk en sociaal in GRoTuUs citaat is in het licht van moderne inzichten op te vatten als: sociaal, en dus moreel, waarbij de rede hulpmiddel is. Simpel gezegd: iets is (meer of minder) sociaal of a-sociaal. Dat kan een mens beredeneren en met anderen bespreken. En het vervolgens doen of laten.

51 Dat is: LEVINAS' 'ethiek van het gelaat,' het 'Dood mij niet' in het gelaat van de ander, welke "het naar autonomie strevende leven onder een heteronome wet stelt.' (R. LubBers, 'Het moderne kindbeeld,' in: Ad VAN DER LINDEN, Paul VLAARDINGERBROEK (red.), Met het oog op het belang van het kind; Opstellen aangeboden aan professor mr. Madzy ROOD-DE BOER ter gelegenheid van haar emeritaat, Deventer 1988 , pp. 1-12, op p. 4.)

LEVINAS: "De verschijning van het gellaat. Dat is mijn belangrijkste thema, mijn fundamentele stellingname. Het feit dat de andere mens van meet af aan deel 
aard. ${ }^{52}$ Inmiddels in verdragen gepositiveerd - maar nog niet voldoende genormativeerd, laat staan gerealiseerd - natuurrecht. ${ }^{53}$

\section{Mensenrechten - dierenrechten?}

Mensenrechten correleren met fundamentele (fysieke, psychische en sociale) behoeften (belangen en waarden) die inherent zijn aan het menszijn, aan de menselijke waardigheid (dat is: een persoon zijn, persoonlijkheid hebben; bij kinderen: persoon-in-wording zijn). In deze filosofische opvatting hebben dieren, bomen, planten, heeft de natuur geen natuurlijke rechten. ${ }^{54}$ Hetgeen niet impliceert dat mensen naar willekeur over dieren, bomen, planten, over de natuur kunnen beschikken. ${ }^{55}$ Die be-

uitmaakt van een geheel dat mijn gegevenheid uitmaakt [binnen] het gehele schouwspel van de werell. De andere mens nu doorbreekt als het ware dit geheel, juist door zijn verschijning als gelaat die niet enkel een beeldende (aanschouwelijke) vorm is maar die van meet af aan voor mij een engagement betekent, een appel, een bevel voor mij om mezelf te plaatsen in dienst van dit gelaat. De andere persoon te dienen die zich in dit gelaat aan mij aandient in al zijn naaktheid, zijn zonder verdediging zijn, zijn berooidheid. En tegelijkertijd is die verschijning een bevel. Het is dat wat ik het bevel van het aangezicht noem, en wat ik noem het woord van God in het aangezicht van de ander.' (France GUWY, Jij die mij aanziet"; Emmanuel LEVINAS, IKON, Hilversum 1986, p. 7.)

$52 \quad$ Zie ook hoofdstuk 3.

53 Vgll. het schema gebaseerd op EIDE/DRZEWICKI in hoofdstuk 3 (par. 3.5).

54 De vergelijking met hele jonge (en dus eveneens volledig van "grote mensen' afhankelijke) kinderen gaat niet op: deze hebben althans op latere leeftijd dieren nooit - een jus standi in judicio (denk aan het in rechte afdwingbaar recht op reparatie). Toch is het niet uitgesloten dat in de toekomst verplichtingen van de mens ten opzichte van dieren in de vorm van dierenrechten worden gejuridiseerd. Deze (quasi-)rechten zullen dan vermoedelijk in eerste instantie zijn gebaseerd op de door mensen ervaren negatieve epistemologie (cru gezegd: de selectieve sensitiviteit voor bepaalde zoogdiereny waarvan LABUSCHAGNE gewaagt (B.C. LABUSCHAGNE, "Wat maakt menselijke waardigheid tot menselijke waardigheid? Iets over de waarheidspretentie van mensenrechten,' Civis Mundi; Tijdschrift voor politieke filosofie en cultuur $1998 / 3$, pp. 122-130, op p. $130 \mathrm{nt} .18$ ). Wellicht zal er ooit - om te beginnen - een VN-verdrag tot stand komen inzake de bescherming van de rechten van alle niet humane hogere primaten - of zelfs direct van alle (of bepaalde?) niet humane zoogdieren.

Vgl. Gen. 1:26: God sprak: Laat ons dem mens maken als ons beeld, op ons gelijkend; hij heerse over de vissen der zee, de vogels in de lucht, de viervoetige dieren, en over heel de aarde met alles wat er op kruipt.

Vgl. ook (de ootmoedsexaltatie in) psalm 8:4-9 (Quoniam videbo wn lunam et stellas, quae tu fundasti): Als ik de hemelen zie, het werk uwer vingers, /De maan en de sterren, die Gij een plaats hebt bereid://Wat is dan een mens, dat Gij hem zoudt gedenken,/Een mensenkind, dat Gij acht op hem slaat?//Toch hebt Gij hem haast tot een godheid gemaakt,/Hem met glorie en luister gekroond.//Gij hebt hem gesteld over het werk uwer handen, /En alles aan zijn voeten gelegd:// 
schikkingsmacht is immers niet onbeperkt. Er is wetgeving om dieren, bomen, planten, de natuur te beschermen. Achtergrond daarvan kan zijn respect voor 'de schepping' en het verantwoordelijkheidsgevoel verbonden aan het 'rentmeesterschap' dan well doordrongenheid van de evolutionaire verbondenheid van alle leven op aarde ${ }^{56}$ en de bescheidenheid (zelfrelativering) die daar (onvermijdelijk?) uit voortvloeit. ${ }^{57}$

\section{6 \\ Individuatie en (westers) individualisme}

\section{Individuatie}

Het is moeilijk over persoonswording en ontplooiing te denken zonder dat het begrip individuatie naar boven komt. Onder individuatie versta ik het proces van identiteitsvinding en -ontwikkeling van (met name) de adolescent en (jong-)volwassene, ${ }^{58}$ het proces van ik-wording, van persoon(lijkheid)svorming van de mens. Dit proces - voluit: het proces van

Al de schapen en runderen,/En de beesten in het wild;//De vogels in de lucht en de vissen in zee, $/ \mathrm{Al}$ wat de paden der zeeën bewandelt.

6 C.q. het geloof/gevoelen dat de mens deel is van een kosmisch cyclisch proces in het algemeen en een aardse levenskringloop in het bijzonder. Een geloof/gevoelen (beleven/ervaren) dat de (wijze) mens brengt tot zowel zelfrelativering als respect voor alles wat groeit en bloeit, leeft, leven mogelijk maakt.

Vgl. Pouwel SLuRINK, 'Evolutieleer versterkt het moreel besef,' Forumpagina De Volkskrant van 7 december 1995, een bijdrage over creationisme en evolutionisme als ongelijkwaardige theorieën.

Persoonlijk neig ik meer naar de evolutionistische bescheidenheid dan naar de christelijke ootmoedsexallatie, omdat ik (doorleefde) bescheidenheid (zelfrelativering, kritische zelfreflectie) een grotere deugd acht dan godsvrucht; dat wil zeggen een deugd die in mijn ogen meer goed voor meer mensen bewerkstelligt. Natuurlijk kunnen beide deugden ook samengaan, en ieder van ons zal in zijn leven wel mensen hebben ontmoet die godswruchtig en toch bescheiden, of bescheiden en toch godsuruchtig zijn.

Van (separatie en) individuatie wordt ook al in wroegere ontwikkelingspsychologische leeftijdsstadia of levensfasen gesproken. In mijn optiek betreft het processen die zich op een steeds hoger niveau (mits er geen vroegere blokkades zijn opgetreden, in welk geval zich in het latere stadium de mogelijkheid van "herkansing' voordoet) in verschillende leeftijdsfasen herhalen. Ik verwijs hier naar de algemene ontwikkelingspsychologische (c.q. levensloop-)literatuur. Vgl. evenwel in het bijzonder: M.-L. VON FRANZ, 'Het individuatie-proces,' in: Carl G. JUNG, De mens en zijn symbolen (London 1964, Rotterdam 1966), ed. Amsterdam 1974, pp. 158-229; A. MARCOEN (red.), De middag van het leven; Ovengang en crisis, Leuven/Amersfoort 1992 (derde druk), hoofdstuk 1 en 2 (beide van MARCOEN); F.J. MÖNKS, A.M.P. KNOERS, Ontwikkelingspsychologie, Assen 1994 (9e druk), hoofdstuk 7 (van MARCOEN), pp. 258 e.v., op pp. 264/265; J.R. sCROGGS, Persoon en persoonlijkheid, deel 1, Rotterdam 1988, pp. 71-91. 
separatie en individuatie - wordt gekenmerkt door wat wel genoemd wordt 'oedipale problematiek.'

Oedipaal bezig ik hier, hoezeer het woord als een ode aan FREUD kan worden beschouwd, niet in de 'fantastische' betekenis die FREUD aan zijn Oedipuscomplex gaf, toen hij zijn Verleidingstheorie opgaf en - in zijn ongeloof aan en ontkenning c.q. verdringing van de vader-als-dader, niet in de laatste plaats van het (incest-?)daderschap van zijn eigen vader $^{59}$ - de perversiteit van de incestplegende vaders door de idee van het polymorf perverse kind ${ }^{60}$ verving. ${ }^{61}$ Met oedipaal doel ik op de verwikkelingen van het losmakings- en volwassenwordings- c.q. rijpingsproces. Verwikkelingen die samenhangen met de ambivalentie en innerlijke conflicten, de twijfels, het met zichzelf en de wereld overhoop liggen, waar het individuatie-proces mee gepaard gaat.

Ik doel dan met name op het uitageren van anachronistische (uit een andere tijd stammende en op de verkeerde personen geprojecteerde) gevoelens en de onbewuste reënscenering van vroege (in het bijzonder archaïsche/'pre-mnemoverbale') trauma's c.q. complicaties in de vroege moeder- (en/of vader-)kind-relatie, in het bijzonder in de partnerrelatie en in de partnerkeuze c.q. in verliefdheden (de herkansing - dat wil zeggen: de sleutel tot verwerking - in de herhalingsdwang). ${ }^{62}$ In deze - ik geef toe: enigszins eigenzinnige en vage - betekenis is individuatie een oedipaal gecompliceerd gebeuren (waarbij oedipale complicatie met andere woorden slaat op de sporen en spoken uit het "archaïsche' verleden

59 Zie hiervoor de uitgebreide noot in hoofdstuk 5 (par. 5.2.1 Een slok wan de Lethe').

60 In de tweede verhandeling ('De infantiele seksualiteit') van zijn Drie verhandelingen over de theorie wan de seksualiteit (1905; Sigmund FREUD - Nederlandse editie, Klinische beschouwingen I, Meppel/Amsterdam 1985, pp. 121/122), spreekt FREUD enerzijds van de polymorf perverse aanleg van het kind (en 'de gemiddelde ongecultiveerde vrouw'!), anderzij]ds stelt hij dat "een kind onder invloed van de verlleiding [d.i. sexueel misbruik door verwanten, jw] polymorf pervers kan worden.' Vgl, in dit verband ook de eerder aangehaalde bijdrage van BAARTMAN, "Onderkenning en miskenning van seksueel misbruik van kinderen," in: $O p g e$ baande paden? Utrecht 1995, pp. 13-27, op p. 22.

61 ISRAËLs heeft opgemerkt: 'De onverwacht hoge frequentie van seksueel misbruik, en vooral van vaders die zich vergrijpen aan hun eigen kinderen, leidt op zichzelf niet logisch dwingend tot herziening van de [Verleidings]theorie; deze hoge frequentie zou immers ook kunnen leiden tot herziening van de mening over de mate van fatsoen van keurig lijkende huisvaders." (Han ISRAELLS, Het geval FREUD; [Deel] 1. Scheppingsverhalen, Amsterdam 1993, p. 199.) Op deze aspecten wordt teruggekomen in de hoofdstukken over (de gevolgen van) kindermishandeling (bock 3 ). 
die in het proces noodzakelijkerwijze meespelen, op patronen die zijn te herleiden tot anachronistische angst, woede enzovoorts).

Hierboven (in par. 6.5.3) schreef ik: menselijke waardigheid impliceert zelfontplooiing in de zin van het streven naar optimale rationaliteit, moraliteit en authenticiteit als menselijke opdracht (noodzaak, lot, onderdeel der condition humaine) en menselijk ideaal (wezen der vrijheid, zelfbepaalde zin van het leven, essentie van the pursuit of happiness: het najagen van het goede, ware en schone). Welnu, naar mijn mening gaat het bij deze opdracht en dit ideaal om door overgave en inspanning het menselijke van de mens in zichzelf te verwezenlijken, ${ }^{63}$ gaat het, anders gezegd, bij 'het raadsel van de menselijke ontwikkeling ${ }^{364}$ enerzijds en bij (separatie/)individuatie - in de zin van het oedipaal complexe, met oedipale complicaties verweven, individuatie-proces - anderzijds in wezen om dezelfde zaken. Ik zou op deze plaats dan ook bij het individuatieproces, zoals ik dit (in min of meer JuNGiaanse ${ }^{65}$ zin) versta, enkele korte persoonlijke kanttekeningen willen maken.

Individuatie is niet een passief te ondergaan proces maar vaak ware Hercules-arbeid (trefwoorden: aan jezelf werken, rouwarbeid). Individuatie vereist echter allereerst de moed tot overgave, tot de sprong in het diepe, de stap in het duister (kwetsbaar durven zijn, op drift durven raken, los durven laten, vast durven pakken).

In zekere zin is individuatie een levenslang proces, met duidelijke 'pieken' (vaak beleefd als diepe dalen) in elke levensfase, zij het (in mijn visie) in het bijzonder in de adolescentie en vroege volwassenheid. Al zijn er - naast de vele nooit-bloeiers - ook talrijke laatbloeiers (denk aan de

ELDERS spreekt - onder verwijzing naar Dominique ZAHAN, Religion, spiritualité et pensée Africaines (Parijs 1970) - van spiritualiteit die enerzijds met religiositeit kan worden verbonden, doch die anderzijds 'wellicht het gevoel [is] dat de mens, zonder de hulp van de godheid, zoals wij geneigd zouden zijn te denken, maar eerder door een soms bewuste, vaak onbewuste inspanning, de mens[elijk]heid die hij in zichzelf meedraagt, moet verwezenlijken.' (Fons ELDERS, 'De verborgen kwaliteiten van een Afrikaanse wereldbeschouwing; een essay over de Dogon,' Rekenschap; Humanistisch tijdschrift voor wetenschap en culthur 1994/2, pp. 97105 , op p. 99 r.k.)

64 Mark RuCHARTZ, 'Pablo PICASSo: een latentie-tijd-loze? Psychobiografische kanttekeningen bij en psychodynamische overwegingen omtrent (zijn) creativiteit,' in: De Gids 1994/5, pp. 379-395, op p. 390 1.k. i.f.

65 Het woord oedipaal, dat voor sommigen synoniem is met freudiaans (denk aan de freudiaanse ofwell oedipale criminologie: W. DERKS, Zo waarlijk heipe mij FREUD almachtig: De invloed van de psychoanalyse op het strafrecht, Amsterdam 1986, p. 20), bezig ik dus juist in een jungiaanse zin. Vgl. over de individuatie bij JuNG, in het bijzonder ook de rol van animus en anima, vON FRANZ, "Het individuatieproces,' in: Carl G. JUNG, De mens en zijn symbolen, t.a.p. 
zogenaamde 'midlife crisis' van de man, een mijns inziens door de nog steeds bestaande vergaande arbeidsverdeling tussen mannen en vrouwen - mannen buitens-, vrouwen binnenshuis - veelal verlate crisis).

Een volledig geslaagde individuatie zal bovendien een illusie zijn: al of niet onder druk, in situaties van stress, zullen zelfs de besten onder ons nog wel onrijpe trekjes vertonen. In ons zit naast de volwassene ook altijd het kind, ook het gekwetste, het geminachte, het gemaltraiteerde kind. Vandaar: verwerken als opdracht, en overleven - dat wil zeggen: niet of niet voldoende verwerken maar daarentegen "gewoon" doorgaan (vaak een krampachtig en destructief doorbijten, in plaats van het voor individuatie noodzakelijke stilstaan, onderduiken, kopje-onder gaan) - als valkuil van het kwaad. Kwaad zichzelf en anderen, de naaste omgeving aangedaan, meestal onbewust, soms tegen beter weten in.

Individuatie geschiedt op basis van het onder ogen zien van zelfs de meest pijnlijke waarheid in de eigen geschiedenis en met betrekking tot de eigen vermogens. Individuatie houdt in de ontwikkeling van het empathische vermogen zich in (de positie van) een ander in te denken en in te leven. Individuatie heeft te maken met het veranderen - aan zichzelf en in de omgeving - van wat veranderd kan en moet worden, en het aanvaarden van wat niet veranderd kan worden. Individuatie leidt in die zin tot het overwinnen van frustraties, zowel interne als externe, meer van binnen of meer van buiten komende.

\section{Westers individualisme}

We zouden kunnen zeggen dat in het Westen individuatie een individualistische, door consumentisme en gebrek aan gemeenschapszin - aan collectief beleefde gemeenschappelijke normen en waarden en de sociale sanctionering en collectieve handhaving daarvan - bemoeilijkte aangelegenheid is. Dit in tegenstelling tot bijvoorbeeld (traditioneel) Afrika, waar de spirituele oriëntatie en de centrale positie van het concrete individu-in-de-gemeenschap tot een, wellicht andersoortiger, maar in elk geval harmonischer individuatie-proces leiden. ${ }^{66}$

Hiermee beweer ik iets over de verschillende omstandigheden, de andere - begunstigende of bemoeilijkende - culturele context van individuatie. Daarmee is uiteraard niets gezegd over de vraag of individuatie in

Dat dit proces duidelijk wordt gemarkeerd door initiatie-rituelen, waaronder het gruwelijke ritueel van de meisjesbesnijdenis, moet hier onaangeroerd blijven, maar is niet zonder betekenis. (Voor literatuur zie wILLEMS, "Van parentiarchie naar Vadertje Staat,' Nemesis 1992/3, pp. 8-23, op p. 23 nt. 76.) Overigens wordt het genitale-verminkingsritueel ook in Nederland gepraktizeerd (Cathy JOSEPH, 'Compassionate accountability (...),' Joumal of Psychohistory 1996, excerpt in: Violence and abuse abstracts 1996/4, nr. 1020, p. 271 l.k.). 
elk individueel geval beter slaagt, of per saldo, c.q. in kwantitatieve zin, hoger 'scoort' in de traditionele Afrikaanse samenleving, laat staan in het 'moderne' (verwesterde en verweesde) Afrika. Ik zal de laatste zijn om te verhullen dat het tegendeel van ons gebrek aan sociale controle: een al te strakke, rigide sociale controle, in welke cultuur ook, een nefaste invloed op het individuatie-proces kan hebben:

'Een eigen keuze van waarden en normen, vanuit een persoonlijke verhouding tot de wereld, is wolgens KIERKEGAARD noodzakelijk voor een menswaardig bestaan'

... lezen we bij VAN ACKER. ${ }^{67}$ Een menswaardig bestaan, een bestaan temidden van (voldoende) mensen die hun menselijkheid verwerkelijken, werkelijk en wár maken, impliceert aldus de ruimte voor zo'n eigen keuze en zo'n persoonlijke verhouding. Uiteraard in een mate die niet los kan worden gezien van het tijdsgewricht en de sociale en culturele context. IK vermoed dat in de (traditionele) Afrikaanse context de menselijkheid van de mens meer collectief en relationeel, en in elk geval minder individualistisch, wordt waargemaakt dan bij ons. SCHELTENS heeft opgemerkt: ${ }^{68}$

\begin{abstract}
"Het gebeurt wel eens dat een Afrikaan minachtend neerkijkt op de Westerse mensemrechten-idee. Hij zal dan verklaren dat in zijn geboorteland het Westerse individualisme gelukkig onbekend is en dat er een betere opvatting over de mensenrechten bestaat. Of de Westerse cultur niet te individualistisch is, is een vraag die ons ter harte moet gaan. Maar of de Afrikaanse solidariteit van die aard is dat ze de persoonlijke zelfstandigheid mogelijk maakt en toelaat, kan wel worden betwijfeld. De differentiatie in de cultuur, nodig om de mensenrechten te laten ontstaan, is er wellicht nog onbekend."
\end{abstract}

Met andere woorden: eerst (separatie en) individuatie, dan - mede met behulp van (het beroep op) mensenrechten - individualisering c.q. individualisme. Dat zou - met Afrika als meer of minder terecht voorbeeld de eerste conclusie uit deze woorden kunnen zijn.

De tweede conclusie is te lezen in de spiegel die ons hier wordt voorgehouden, in de vorm van een vraag die direct op het Westen terugslaat: is onze cultuur te individualistisch? En - waar we spreken over individuatieprocessen die zich in de gezinssfeer voltrekken - met welke gevolgen voor kinderen en voor het ouderschap? 
Het westerse ouderschap is in deze tijd - om DE GRAAF te parafraseren - even onbeteugeld als dat het door illusies en projecties gevleugeld is. ${ }^{69}$ Met ernstige teleurstellingen als gevolg. Oorzaak daarvan zou kunnen zijn 'te hoge verwachtingen in de strijd om het bestaan en te hoge individuatie als gevolg van sociale differentiatie. ${ }^{70}$ DE GRAAF vervolgt: ${ }^{71}$

'In extremis [in "extreme” gevallen, jw] zou dit gevleugelde ouderschap zelfs kunnen leiden tot vormen van kindermishandeling, uit teleurstelling omdat het kind niet beantwoordt aan de gestelde verwachtingen van emotionele nabijheid en kameraadschap.'

Kan individuatie te hoog zijn? Kan persoonswording, ontplooiing doorschieten in zulk een fnuikend en voor het kind nefast individualisme? $\mathrm{Me}$ dunkt dat ook hier van een verkeerd gericht, een egocentrisch geblokkeerd proces, hoezeer ook door de culturele context aangedreven, moet worden gesproken. Op de gestelde vragen is dan het antwoord respectievelijk nee en ja. Nee: individuatie als opdracht en ideaal kan nimmer te hoog zijn. Ja: individuatie, zelfontplooiing kan zodanig verkeerd gericht zijn, zo egocentrisch aangestuurd, dat de gevolgen voor kinderen zeer ernstig kunnen zijn. Dit is zeker iets wat wij in de westerse cultuur ter harte horen te nemen. ${ }^{72}$

BAARTMAN onderscheidt in dit verband ten aanzien van mishandelende ouders twee hoofdoorzaken: ${ }^{73}$

'De ene betreft de veelal overspannen verwachting van deze ouders dat het hebben van kinderen goed zal maken wat ze voorheen in hun relatie met hun ouders hebben gemist. Hoe hoger gespannen verwachtingen zijn en hoe meer een kind goed moet maken wat eertijds is nagelaten, hoe groter de kans is dat men in die verwachtingen zal worden teleurgesteld. Anders gezegd, er lijkt sprake van een voortdurende strijd rond de wraag wie er voor wie beschikbaar moet zijn: de ouders woor het kind of het kind voor de ouders. Op zich zijn spanningen op dit

Willibrord DE GRAAF, 'Gevleugeld of beteugeld ouderschap?" In: C. VAN NIJNATTEN (red.), Kinderrechten in discussie, Amsterdam/Meppel 1993, pp. 143-161.

70 G. KOOY (1957), geparafraseerd door DE GRAAF, t.a.p., op p. 154.

71 T.a.p., op p. 156; met een verwijzing naar BAARTMAN (1990).

72

Vgl. WLLLEMS, 'Kinderen in ons midden; enkele cultuurkritische notities naar aanleiding van artikel 25 van de Universele Verklaring en het Verdrag inzake de rechten van het kind," Recht en kritiek 1994/4, pp. 322-339.

73 Toegespitst, zoals hij stelt, op fysieke mishandeling en verwaarlozing: H. BAARTMAN, "Preventie van kindermishandeling en risicogezinnen," in: Gezinnen onder druk; Over veranderende ouder-kind relaties; hoe moeilijk/gewoon opvoeden kan zijin, Themadag Vrije Universiteit Amsterdam 23 november 1996 (samenvatting lezingen, pp. 11-13, op p. 11). 
punt geen ongewoon verschijnsel. (...) Mishandelende ouders lijken er echter bij woortduring op uit die strijd in hun voordeel te beslechten.

De andere hoofdoorzaak hangt samen met een zodanige stress in het lewen van alledag, dat deze eveneens een aanslag wormt op de beschikbaarheid van ouders voor hun kinderen.'

\title{
Persoonswording en individua(lisa)tie als 'westers concept'?
}

De spiegel die ons hierboven werd voorgehouden, heeft echter ook een andere kant. VISSER "T HOOFT laat daarvan een klein stukje zien: ${ }^{.74}$

\begin{abstract}
'Wat impliciet als onwaardig wordt beschouwd, is een zwaktepositie in het sociaal-economische bestel; en dat is, telkens, het te verbeteren lot van een bepaalde categorie. (...) Daarnaast leidt [het individuele differentiatie]proces (...) tot een individualisme waarvoor in hel individu niet zozeer de mens in het algemeen als wel de onvervangbare "persoonlijkheid" voorop komt te staan (de "persoon" wordt tot "persoonlijkheid")."
\end{abstract}

\section{En SIEGHART spiegelt even hard terug: ${ }^{75}$}

\begin{abstract}
"Another objection wich is sometimes heard is that "human rights" are an exclusively Western concept, whose "imposition" on the rest of the world constitutes a form of intellectual, political, or legal neo-colonialism or neo-imperialism. But that is in fact quite fallacious. Concepts of legitimacy, the justice of laws, the integrity and dignity of the individual, safeguards against arbitrary rule, freedom from oppression and persecution, individual participation in collective endeavours (including the government of the community), and the like are to be found in very similar form in every civilization throughout the world, and throughout history, whose aspirations have ever been recorded. Besides, the international instruments in which these concepts are now formulated have been freely negotiated, adopted, and ratified by many nations in all parts of the world, covering the entire spectrum of existing cultural, religious and political orientations."
\end{abstract}

Voor zover persoonswording (en ontplooiing) als achterliggend beginsel van het Verdrag inzake de rechten van het kind kan worden aangemerkt - en daar komen we nog uitgebreid over te spreken - is het ook immuun voor cultuurrelativistische kritiek, ${ }^{76}$ te meer waar het VRK als een nagenoeg universeel verdrag - en daarmee bijna als 'instant' internationaal gewoonterecht ${ }^{77}-$ kan worden beschouwd. Wat valt er op deze plaats

H.Ph. VISSER "T HOOFT, De menselijke waardigheid in traditie en actualiteit," Wijsgerig perspectief $1985-1986 / 5$, pp. 151-162, op p 157 l.k./r.k.

75 Paul sIEGHART, The international law of human rights, Oxford 1983, p. 15.

76 Zie SIEGHART, t.a.p.

77 Vgl. Geraldine VAN BUEREN, The international law on the rights of the child, Dordrecht (etc.) 1995, pp. 53 i.f. e.v. 
reeds over (persoonswording en) ontplooiing als fundamentele gepositiveerde internationaalrechtelijke waarden te zeggen? SZABO zegt dit: ${ }^{78}$

"The notion of human rights falls within the framework of constitutional law and international law, the purpose of which is to defend by institutionalized means the rights of human beings against abuses of power committed by the organs of the State and, at the same time, to promote the establishment of humane living conditions and the multidimessional development of the human personality.'

\section{En DAVIDSON schrijft: ${ }^{79}$}

'[T] phe phomenon known as human rights is connected not only with the protection of individuals from the exercise of state or governmental authority in certain areas of their lives, but $(\ldots)$ is also directed towards the creation of societal conditions by the state in which individuals may develop to their fullest potential. This description may reveal what human rights are intended to achicve [curs. SD] in a teleological sense (...)."

\section{Trias pedagogica}

Ik heb de opmerkingen in deze paragraaf niet in de laatste plaats gemaakt om aan te geven, en onszelf daarvan ook te doordringen, dat tot de drie actoren in de Trias pedagogica, waar we in het volgende hoofdstuk naar overstappen, niet alleen de staat c.q. de overheid en de ouder(s), maar zeer nadrukkelijk ook het opgroeiende kind zelf beuoort, dat naar de mate van zijn zich ontwikkelende vermogens een groter eigen aandeel in het proces van zijn eigen persoonswording krijgt. Duidelijk zij wel dat we dan vooral denken aan het kind op een leeftijd waarop we in het normale taalgebruik - in tegenstelling tot de verdragsrechtelijke terminologie ${ }^{80}$ - niet meer van kind maar van tiener, jeugdige of adolescent zouden spreken. Juist omdat in deze studie het nog (zeer) jonge kind expliciet of impliciet centraal staat, kan gemakkelijk over het hoofd worden gezien dat ook het kind, de minderjarige, actor is, niet alleen in toenemende mate, maar eerst en vooral als lid van de gemeenschap, als

Imre SZABO, 'Historical foundations of human rights and subsequent developments,' in: Karel VASAK; Philip ALSTON (eds.), The intemational dimensions of human rights, Westport, Ct./Paris 1982, vol. 1, pp. 11-40, op p. 11 (curs. jw); (gedeeltelijk) aangehaald door Scott DAVIDSON, Human rights, Buckingham/ Philadelphia 1993, p. 7.

79 DAVIDSON, Human rights, a.w., p. 24 (curs. jw).

80 Zie art. art. 1 VRK en vgl. over deze terminologie Bruce ABRAMSON, "The invisibility of children and adolescents; the need to monitor our rhetoric and our attitudes," in: Eugeen VERHELLEN (ed.), Monitoring children's rights, [Den Haag] (etc.) 1996 , pp. 393-402, op pp. 395 e.v. 
nieuwe staatsburger die van meet af aan is toegerust met het recht - en daardoor gedurende zijn of haar minderjarigheid wordt gedragen, gesteund en aangemoedigd - zodanig te worden opgevoed dat hij of zij in (zo snel mogelijk) toenemende mate actor kan zijn.

In het bovenstaande is hopelijk evenwel nog iets anders duidelijk geworden. Namelijk dat we bij de ouder als actor niet uitsluitend aan diens verantwoordelijkheden ten aanzien van de leiding en begeleiding van het kind bij zijn ontwikkelingstaken moeten denken, maar ook aan diens verantwoordelijkheden ten opzichte van de eigen ontwikkelingstaken. 


\section{KERNRECHTEN VAN HET KIND IN DE TRIAS PEDAGOGICA}

Vanuit de kerninhoud van kinderrechten, dat wil zeggen vanuit de grondgedachte, enerzijds, dat óok - en juist - de pedagogische rechten van het kind dienen te worden gedacht vanuit het gelijkheidsbeginsel en het ontplooiingsbeginsel en, anderzijds, dat binnen deze rechten kernrechten kunnen worden onderscheiden - korter gezegd: vanuit de grondgedachte dat vanuit beide grondbeginselen pedagogische kernrechten kunnen worden gedacht -, wordt in dit hoofdstuk een aantal fundamentele sociaalpedagogische rechten - dat wil zeggen rechten in de Trias pedagogica voorgesteld. Daaraan voorafgaand passeren enkele kinderrechtencatalogi - ter inspiratie - de revue. De voorgestelde fundamentele sociaal-pedagogische rechten zullen voorlopig als (natuurlijke) kernrechten van het kind worden aangeduid. Deze kernrechten worden in het slot van dit hoofdstuk nader in de Trias pedagogica, de juridisch-pedagogische driehoek kind-ouder-overheid, gesitueerd. Een en ander moet ons in staat stellen - aithans dat is de opzet - in een volgend hoofdstuk de bedoelde pedagogische 'driehoeks'-rechten met 'het belang van het kind' als rechtsbegrip te confronteren om allus de juridisch-pedagogische kern van dat begrip nader te kunnen bepalen.

In deze paragraaf worden enkele met het veiligheids- en ontwikkelingsbelang van het kind samenhangende en daaruit voortvloeiende sociaalpedagogische (natuurlijke) rechten ten tonele gevoerd, welke de mensenrechtelijke grondbeginselen gelijkheid en ontplooïng als gemeenschappelijke kerninhoud hebben.

Het veiligheids- en het ontwikkelingsbelang van het kind zijn dermate fundamenteel en essentieel voor diens persoonswording - dat wil zeggen: voor de evenwichtige uitgroei naar zelfstandigheid van het kind, het van animal educandum (op te voeden, uit de duisternis van angst en onwetendheid te leiden wezen) tot animal educatum (opgevoed, uit de duisternis van angst en onwetendheid geleid wezen) worden -, dat zij als fundamentele (natuurlijke) rechten van het kind kunnen en moeten worden beschouwd. We hebben al gezien dat het veiligheids- en het ontwikkelingsbelang in elkaars verlengde liggen, in elkaar overgaan, door elkaar 
heenlopen. We zouden evenwel kunnen zeggen dat bij het veiligheidsbelang het hoofdaccent op de eerbiediging van en zorg voor de lichamelijke integriteit van het kind ligt, en dat bij het ontwikkelingsbelang het hoofdaccent op de eerbiediging van en zorg voor de geestelijke integriteit van het kind ligt. Daarnaast en daarenboven bestaat het ontwikkelingsbelang uit een dubbel pedagogisch recht: het recht van het kind, van elk kind, op ontplooiing (geborgenheid, genegenheid, ondersteuning) en het recht van het kind, van elk kind, op leiding (toezicht, controle, disciplinering, opvoeding in enge zin).

Deze twee rechten, of liever dit dubbelrecht is dermate essentieel voor de opvoeding, voor de ontwikkeling van het kind, dat we ook zouden kunnen (be)redeneren dat schending ervan een aantasting van de geestelijke integriteit van het kind is. We doen in die opvatting de geestelijke - ofwel psychische - integriteit van het kind geweld aan wanneer we het niet respecteren in zijn vitale behoefte en existentiële nood aan leiding en ontplooiing, door het bieden van ruimte (warmte, ondersteuning) en het stellen van grenzen, dat wil zeggen: door disciplinering, opvoeding in enge zin, vanuit de basisveiligheid van onvoorwaardelijke genegenheid.

\section{Ouderijke basishouding en disciplinering}

Deze basisveiligheid is gelegen in de basishouding van onvoorwaardelijke toegenegenheid van de ouder ten opzichte van het kind: ${ }^{1}$

\footnotetext{
'Met de bekommernis, zorg, aandacht, respect die ouders hun kind betonen, zeggen ze met [en zonder, jw] zoveel woorden tegen een kind: jij mag er wezen, je bent éen van ons. In die veiligheid kan een kind zichzelf zijn en worden.'
}

Alleen binnen deze basisveiligheld kan disciplinering verantwoord geschieden. De ouderlijke basishouding is derhalve essentieel, want hoe vaak wordt fysieke mishandeling niet 'gerechtvaardigd' als uit de hand gelopen disciplinering. Zoals BAARTMAN schrijft: ${ }^{2}$

'Slaan kan de uiting zijn van een verwerping van het kind door de ouder, van het behandelen van een kind als eigen bezit, van een strijd tegen eigen impulsen die men bij het kind met geweld te liff gaat, van rivalisering met het kind in de voldoening van behoeften aan bevestiging. De ook in dergelijke situaties soms gehoorde argumenten dat men slaat omderwille van het welzijn van het kind en worpen kind,' in: Willem BERGER e.a. (red.), Geweld in relaties; Overwegingen en ervaringen, Baarn 1991, pp. 24-42, op p. 31. 
vanuit goed bedoelde pedagogische intenties, moeten gewantrouwd worden als maskerades en rationaliseringen van motieven - zij het niet altijd besefte - die van veel wezenlijker aard zijn. Als dergellijke grondig verstoorde attitudes de bron vormen van het geweld, dan is er reden om te spreken van kindermishandeling vanwege het zorgwekkende dat inherent is aan deze bronnen van geweld. Hier gaat het on meer dan om de schending van het recht van een kind op eerbiediging van zijn lichamelijke integriteit. Hier gaat het om een fundamentele schending van het recht van een kind op eerbiediging van zijn persoon en van het recht, dat specifiek een recht van kinderen is ten opzichte van hun opvoeders, het recht namelijk op die ondersteuning (die opvoeding) die de kansen op ontplooiing van zijn persoon-zijn optimaliseert.'

Ook psychische mishandeling - van uitschelden en vernederen tot emotionele chantage en maligne manipulaties - wordt wel als noodzakelijk of onvermijdelijk ter lering of disciplinering goedgepraat. Het 'wie niet horen wil, moet maar voelen' wordt dan niet letterlijk toegepast, maar het kind wordt op zijn ziel getrapt, in zijn wezen ontkend en aangetast. Ook hier is dan sprake van een verstoorde attitude, soms ook van een regelrecht vijandige of minachtende basishouding, welke door woorden, door zwijgen, door gebaren, door blikken, door niet te zien en niet te horen, kortom door te 'négeren' of te negéren, het kind veel dieper en duurzamer dan zelfs het meest hardhandige pak voor de broek verwondt.

Een ouder die daarentegen ondanks de basishouding van onvoorwaardelijke toegenegenheid zijn of haar kind slaat of uitscheldt, in onmacht, door een (plotseling) gebrek aan zelfbeheersing, maar die vervolgens het kind zijn of haar verontschuldigingen aanbiedt en het troost, loopt wellicht minder kans - zolang hier niet van een bestendig patroon van (onberekenbare) onmacht of een (onberekenbaar) gebrek aan zelfbeheersing sprake is (maar kumnen we dan nog wel van een basishouding van onvoorwaardelijke toegenegenheid spreken?) - bij zijn of haar kind trauma's te veroorzaken.

\section{Hoogste drieëenheid}

Aldus staat bovenaan in de kinderrechtenhiërarchie het respect voor de lichamelijke en geestelijke integriteit van het kind in de zin van de eerbiediging van en zorg voor de lichamelijke en geestelijke veiligheid en ontwikkeling van het kind. Als hoogste drieëenheid hebben we dan te pakken: het recht op fysieke veiligheid, het recht op ontplooiing en het recht op leiding.

Het recht op fysieke veiligheid omvat uiteraard meer dan het recht op onaantastbaarheid van het lichaam in de zin van vrijwaring tegen fysieke mishandeling en sexueel misbruik. Zoals het recht op ontplooiing en het recht op leiding naast vrijwaring tegen psychische en 
'pedagogische' mishandeling ${ }^{3}$ ook vrijwaring tegen psychische (emotionele, affectieve) en 'pedagogische' (cognitieve, morele) verwaarlozing ${ }^{4}$ impliceren, zo impliceert het recht op fysieke veiligheid naast vrijwaring tegen lichamelijke mishandeling en sexueel misbruik ook vrijwaring tegen lichamelijke verwaarlozing, en omvat dus mede het recht op koestering, dat wil zeggen het recht op lichamelijke en verbale liefkozing (vanuit de basishouding van affectie, dat is onvoorwaardelijke toegenegenheid ${ }^{5}$ ), en

Hieronder wordt in dit verband verstaan: excessieve en/of arbitraire vormen van disciplinering. Weliswaar kan dit ook als fysieke en/of psychische mishandeling worden gekwalificeerd, maar het accent ligt hier op disciplinering onder het mom van 'pedagogie' (dit wordt in de literatuur ook wel - zoals we in het volgende hoofdstuk zullen zien - als 'zwarte pedagogie' aangeduid).

Hiermee wordt in dit verband bedoeld: educatieve verwaarlozing (cognitief: het kind van school houden en/of niets/te weinig leren; moreel: het kind geen/onvoldoende waarden en normen bijbrengen) en 'eng-pedagogische' verwaarlozing: het kind niet/te weinig disciplineren, geen/onvoldoende (duidelijke) grenzen stellen, geen/onvoldoende zelfdiscipline bijbrengen. Vgl. voor dat laatste bijvoorbeeld John CLEESE, Robin SKYNNER, Hoe overleef ik mijn familie (oorspr. titel: Families and how to survive them, 1983; oorspr. Nederlandse vert.: Van je familie moet je 't hebben, 1986), Amsterdam 1995 (zesde druk), pp. 260-336 (passim), 411, 413; Alexander LOWEN, Leven zonder angst (1980), Cothen 1996 (derde druk), pp. $288 / 289$.

Deze basishouding is essentieel, want hoe vaak wordt incest niet 'gerechtvaardigd' als uit de hand gelopen liefkozing, terwijl de eraan ten grondslag liggende basishouding veeleer egocentrische wellust is, althans een egocentrische attitude waarbij onrijpe emotionele behoeften worden gesexualiseerd dan wel waarbij een gebrek aan sexuele zelfbeheersing op het kind wordt geprojecteerd: het kind als verleider en de (vader/)dader als slachtoffer (vgl. Frédérique GRUYER, Martine FADIER-NISSE, Pierre SABOURIN, La violence impensable; Inceste et maltraitance, Paris 1991, 'Le système de défense des abuseurs,' pp. 108-113).

Ten aanzien van zuigelingen wordt wel als rechtvaardiging gehoord dat het kind 'er toch geen weet of benul van heeft.' De (door de 'onwetendheid' of het 'onbenul' van het kind 'gerechtvaardigde') sexuele behoeftenbevrediging is dan uit de hand gelopen als de baby (bijna) in het ejaculaat is gestikt nadat de (vader/) dader van de zuigreflex wan het kind misbruik heeft gemaakt. Ik vraag mij in gemoede af of van het ondeugdelijke van ook deze zelfrechtvaardiging niet onder meer de verstikkingsangsten (suffocatio hysterica; slik- en stikangst) getuigen waaraan sommige volwassen vrouwen (en manmen), niet zelden om voor hen onverklaarbare redenen, lijden. De bijna gestikte baby's kunnen overigens, door zuurstofgebrek, hersenbeschadigingen oplopen, soms zodanig dat zij niet op latere leeftijd in de psychiatrie maar al heel snel in de zwakzinnigenzorg 'verdwijnen.' Over deze zaken is nog maar weinig bekend. Wel vermeldt bijwoorbeeld BLUME een "overactive gag reflex" (duidend op slik- en stikangst, vomitofobie?) bij incestslachtoffers (E. Sue BLUME, Secret survivors; Uncovering incest and its aftereffects in women, New York etc. 1990, pp. 197/198). DRAlJer wijst erop dat '[h]et documenteren van het trauma (...) het grootste probleem [is] bij chronische, extreme 
en/of geheime traumatisering binnen de familie.' Er is evenwel geen sprake van volledige 'infantiele amnesie voor het derde jaar': 'dat mensen geen autobiografische herinnering hebben aan de eerste paar levensjaren, de zogenaamde infantiele amnesie, is waar het traumatische ervaringen betreft, (...) maar ten dele juist (...). " Er zijn wel degelijk 'wormen van (impliciet) herimneren (...).' Herinneringen die in het lichaam zijn opgeslagen en die naar buiten treden in 'posttraumatisch spel' en gedrag en in 'traumaspecifieke angsten.' (Nel DRALJER, 'Herinneringen aan traumatische ervaringen in de kindertijd,' $M G v$ 1996/7-8, pp. 707-727, resp. op p. 711, curs. ND, en p. 716, met verwijzing naar [Lenore] TERR, [Unchained memories; True stories of traumatic memories, lost and found (1994), vertaald als Schokkende herinneringen," 7 Gevallen van traumaverwerking en geheugenverlies, Amsterdam/Antwerpen] 1994).

Volgens het Psychiatric Dictionary is 'suffocatio hysterica (...) often based on the unconscious rejection of incorporation phantasies of a sexual and/or aggressive nature.' (Robert I. CAMPBELL, Psychiatric Dictionary, New York/Oxford 1996 (seventh ed.), p. 694 l.k., s.v. "suffocatio hysterica.') Persoonlijik komt het mij echter niet onaannemelijk voor dat aan suffocatio 'hysterica' niet alleen 'verboden' fantasieën, dat wil zeggen intrapsychische (niet-posttraumatische innerlijke) conflicten, ten grondslag liggen, maar ook (en juist) heel rroege (pre-mnemoverbale, dat is pre-verbaliseerbare, vóórtalige, en dus niet talig geregistreerde maar wel in lichaams- of gedragstaal gecodeerde) oraal-sexuele trauma's (vgl. DRAIJER, t.a.p. op pp. 719/720, waar zij ook wijst op de mogelijkheid dat de herinnering in gedissocieerde vorm is geregistreerd).

Niet alleen ten aanzien van zuigelingen evenwel, doch ook ten aanzien van (veel) oudere kinderen maken (vaders/)daders anderen en zichzelf wijs dat het kind in zijn onschuld en onwetendheid miets kan hebben gemerkt, of alles wel weer snel zal vergeten. DRAIJER plaatst in haar proefschrift twee citaten (in het Engels) onder elkaar, het eerste uit NABOKOVs Lolita, het tweede uit een klassiek te noemen opstel van FERENCZI (Nel DRAINER, Seksuele traumatisering in de jeugd; Gevolgen op lange tennijn wan seksueel misbrük van meisjes door verwanten, ac. diss. Amsterdam 1990, p. [142]). In de desbetreffende Nederlandse vertalingen luiden deze citaten respectievelijk: 'En mijn kreunende mond, heren van de jury, raakte bijna haar naakte hals toen ik tegen haar linker bil de laatste druppel uitperste van de langste extase, ooit door man of monster gekend. Onmiddelijik daarna (alsof wij aan het vechten waren geweest en mijn greep nu verslapte), rolde ze van de divan en sprong rechtop (...). (...) Gode zij geprezen, ze had niets gemerkt!' (Vladimir NABOKOV, Lolita [1955], Amsterdam s.a., 21e druk, pp. 66/ 67.) "Wanneer het kind na zo"n aanslag [de sexuele handelingen van de (vader/) dader, jw] herstelt, voelt het zich ten prooi aan opperste verwarring en in feite reeds gespleten, onschuldig en schuldig tegelijk; zelfs zijn vertrouwen in wat zijn eigen zintuigen hem mededelen, is vernietigd.' (Sandor FERENCZI, 'Sprakkverwarring tussen de volwassenen en het kind (De taal van de tederheid en die van de hartstocht) [1933];' in: J.M. MASSON, Traumatische ervaring of fantasie; FREUDs rampzalige herziening van de verleidingstheorie, Amsterdam 1984, Appendix 2, pp. 182-193, op p. 188 if.) Een zin verder zegt FERENCZ: 'Bijna altijd doet de dader alsof er niets gebeurd is, zichzelf troostend met de gedachte: "Het is toch nog maar een kind, het weet nog niets, het zal alles weer vergeten".' (T.a.p., op pp. 
het recht op lichamelijke zorg - voeding, kleding, onderdak, medische (waaronder tandheelkundige) zorg, hygiëne (waaronder bewassing, baden en tanden poetsen) e tutti quanti.

Anders gezegd, het kind heeft eerst en vooral recht op optimale fysieke veiligheid (dat is op optimale lichamelijke liefkozing en op optimale lichamelijke zorg), op optimale ontplooiing en op optimale leiding; het kind heeft minimaal recht - als absolute bodem, te waarborgen met inzet van alle passende staatsmiddelen, waaronder in de ruimste mate financiële middelen - op vrijwaring tegen lichamelijke mishandeling en lichamelijke verwaarlozing, tegen psychische mishandeling en psychische verwaarlozing en tegen sexueel misbruik.

7.2 .1 Morele (natuurlijke) rechten

Tegen de achtergrond van het hierboven geschetste kunnen zo dadelijk enkele kernrechten worden geformuleerd die uit het recht op fysieke veiligheid (zorg en koestering), het recht op ontplooiing (warmte en ondersteuning) en het recht op leiding (toezicht en disciplinering) voortvloeien. Vooropgesteld zij dat het bij dit alles niet om rechten in juridische, dat wil zeggen in gepositiveerde zin, maar om natuurlijke rechten gaat, om wat bij RAES morele rechten heet: ${ }^{6}$

"In eerste instantie gaat het om morele rechten, die een zekere relationele ethiek normeren waarin het kind als subject wordt erkend dat recht heeft op bescher-

188/189.)

Dat de twaalfjarige Lolita een incestslachtoffer was, en geen perverse jongedame, zoals de 'mythe moderne de la nymphette' het wil, is door NABOKOV in 1975 nog eens benadrukt: volgens de auteur is de betekenis van zijn werk verdraaid (GRUYER e.a., a.w., pp. 111-112).

Vgl. voor de psychische gevolgen van sexuele en andere vormen van kindermishandeling hoofdstuk 12. Vgl. voor voorbeelden van zelfrechtvaardiging/verdediging door (pedofiele) daders, naast GRUYER e.a. (t.a.p.), ook A.E. BRODEUR, J.A. MONTELEONE, Child maltreatment: [vol. I] A clinical guide and reference, St. Louis (etc.) 1994, pp. 120-121.

BLLO en ORANJE maken melding van (zeldzame) orale afwijkingen ten gevolge van oro-genitaal misbruik van (heel jonge) kinderen, waaronder 'soms een achter in de keelholte gelocaliseerde seksueel overdraagbare aandoening, met name gonorroe of condylomata acuminata." (R.A.C. BLIO, A.P. ORANIE, Het ongehukshuidje; De huid op het raakwlak van kinderdermatologie en kindemmishandeling, Zwolle 1996, p. 48; vgl. ook a.w., pp. 91 en 104.)

6 Koen RAES, 'De morele betekenis van het vertoog over de rechten van het kind; naar een differentiele mens- en maatschappijopvatting, in: E. VERHELLEN e.a. (red.), Kinderrechtengids, Gent 1994 (losbladig), Deel 1 (Commentaren), 1.1 (Algemeen), RAES, pp. 1-47, op p. 42. 
ming van diens belangen en een recht op medezeggenschap (...) over beslissingen die het aanbelangen, en [dat] aanspraken kan laten gelden indien diens rechten met de voeten worden getreden. Of en hoe dergelijke rechten dienen [te worden] "gepositiveerd" is nog een andere vraag. De morele toelaatbaarheid van de "positivering" van een recht weronderstelt immers reeds een morele justificatie voor dwang (indien het recht niet wordt nageleefd) evenals een morele justificatie voor het recht van een actor (het kind zelf, diens "vertegenwoordiger," een welzijnswerker enz.) om een beroep te doen op dat gepositiveerde recht."

De dwang waarvan RAES gewaagt, in het bijzonder de handhaving van het recht van het kind op bescherming van zijn persoonlijke levenssfeer (zijn lichamelijke en geestelijke integriteit) en op (c.q. waaronder) borging van zijn minimale persoonswording in de vorm van aan zijn ouders c.q. in zijn gezin op te leggen vormen van pedagogische ondersteuning, komen we hieronder, onder de benaming integriteits- en persoonswordingsvindicatie of, kortweg, integriteitsactie), nog tegen. Toch is het goed ons van de mogelijkheid van dwang reeds op deze plaats rekenschap te geven.

Aangezien de samenleving als statelijke gemeenschap is georganiseerd, ligt het voor de hand, ja is het niet anders denkbaar dan dat de beleidsmatige verdediging en juridische bescherming van de rechten van kinderen, in het bijzonder van jonge kinderen, staatstaak is. De staat heeft het geweldsmonopolie, zoals dat heet, dat wil zeggen: alleen de staat beschikt over de sterke arm die normen afdwingbaar maakt, die de handhaving van normen in laatste instantie (en wellicht zelfs überhaupt) mogelijk maakt. Dat geldt ook voor de staat als defensor et protector liberum (kinderverdediger en -beschermer).

Ubi jus, ibi remedium. Waar een recht is, een rechtswaarborg, daar is een rechtsmiddel, een weg tot handhaving van het recht. Waar een rechtsmiddel, een rechtsweg is, daar is - in laatste instantie - dwang (en waar dwang is, daar is rechtsbescherming - en dus weer een rechtsmiddel; in dit geval een rechtsmiddel van ouders). Waar rechten van kinderen zijn, dienen er ook rechtsmiddelen van, dan wel dwingende rechtsregels ten behoeve van kinderen te zijn. Zoals RAES opmerkt: ${ }^{7}$

'Het is immers al te makkelijke retorick om het "ingrijpen middels dwingende rechtsregels" te contrasteren met het "rijk van de vrije wilsbeschikking." Dwingende rechtsregels worden niet ingesteld om de betrokkenen "afhankelij $\mathrm{k}^{\text {" }}$ te maken van een staatsapparaat, maar wel om hen een zekere onafhankelijkheid te verzekeren in maatschappelijke verhoudingen die anders al te makkelijk tot uitbuitingsverhoudingen kunnen verworden. Net zoals de "dwingende" regel van de gelijke rechten wan man en vrouw in het huwelijk - ongeacht de economische 
zelfstandigheid van de partners -, creëren de "dwingende" regels van het arbeidsrecht geen onvrijheid, maar willen zij juist een zekere vrijheid garanderen aan de partner die, omwille van een geheel aan maatschappelijke mechanismen, de grootste kans loopt om in een regime van totale contractuele wrijheid stelselmatig te worden uitgebuit."

\section{Evenzeer ...}

(...) is het immers te gemakkelijk om een kinderwereld die wordt gekenmerkt door spontane relaties van respect, liefde en zorgzaamheid, te contrasteren met de zakelijke wereld van het recht. Ook voor kinderen die [een] dergelijke leefwereld moeten ontberen, dienen minimale respectregels [te worden] verzekerd. (...) Waar slechts eén partij over alle handelingsalternatieven beschikt, zijn relaties nict "vrij" maar "onvrij." Slechts waar de handelingsalternatieven evenredig zijn verdeeld, kan men van vrijheid gewagen. Niet "vrijheid" maar "gelijke vrijheid" is de fundamentele morele waarde.'

Natuurlijk gaat het hier bij evenredigheid in handelingsalternatieven om een pedagogische evenredigheid, dat wil zeggen om een pedagogisch verantwoorde ${ }^{8}$ en voortdurend - ook politiek ${ }^{9}$ en eventueel in rechte ${ }^{10}-$ te verantwoorden evenredigheid. Op basis van een zodanig te verstane evenredigheid, als zo veel mogelijk te verwezenlijken moreel, mensenrechtelijk en rechtsstatelijk ideaal, kunnen we ons de vraag stellen: welke minimale respectregels zijn zoal denkbaar die het kind in toenemende mate de handelingsalternatieven kunnen bieden die bijdragen aan zijn evenwichtige uitgroei tot zelfstandig, verantwoordelijk staatsburger? En in het bijzonder, toegespitst op het jonge en zeer jonge kind, de vraag: welke minimale respectregels zijn zoal denkbaar die de staat als liberum

In wetenschappelijke zin, dat wil zeggen gebaseerd op pedagogische en ontwikkelingspsychologische inzichten en bevindingen. Vgl. voor de relatie ontwikkelingspsychologie en pedagogie en de (verschillende) rol van de ontwikkelingspsycholoog en de pedagoog: O. WAALDLK, 'Is voelen echt wel goed voor wie niet horen wil? Gedachten van een psycholoog over staffen,' in: K. BLANKMAN, L.C.M. STEGMANN (red.), Het recht of het belang van het kind, Assen/Maastricht 1989, pp. 30-40, op p. 32-33.

9 Dat wil zeggen ten opzichte van gekozen, vertegenwoordigende lichamen; dus de verantwoordingsplicht van bestuurders op centraal, regionaal en locaal niveau (bewindspersonen, Gedeputeerde Staten, burgemeester en wethouders) op elk moment dat er politieke beleidskeuzes zijn of worden gemaakt, al of niet in de vorm van regelgeving, of er om welke reden dan ook (achteraf) verantwoording wordt gevraagd.

10 Mogelijk in procedures door minderjarigen tegen hun ouders aangespanmen, althans zodra in Nederland minderjarigen een eigen rechtsingang hebben, doch wooral in (kind-en) gezinsrechtelijke (persoonswordingsvindicatie-)procedures (integriteitsacties) ter oplegging van opvoedingshulp. 
defensor et protector (kinderverdediger en -beschermer) in oplopende mate van appèl, rappel, drang en dwang handelingsalternatieven bieden om zijn aanvullende en vervangende pedagogische taak doeltreffend en doelmatig te kunnen uitoefenen?

\section{2 .2}

\section{Kinderrechtencatalogi}

De hierna (in par. 7.2.3) voor te stellen sociaal-pedagogische rechten zijn uiteraard niet bedoeld als het definitieve antwoord op beide bovenstaande vragen. Evenmin als een pretens laatste woord zijn zij evenwel het eerste woord dat op dit vlak is gesproken. Het feit dat - zoals RAES ons in hoofdstuk 5 heeft laten zien - er in het dominante morele (en rechtsfilosofische) vertoog noch voor kinderen noch voor het ouderlijk gezag veel plaats werd ingeruimd, wil niet zeggen dat er in minder dominante uithoeken van met name (rechts)politieke, (politiek-)ideologische dan wel (ontwikkelings-)psychologische aard nimmer rechten van kinderen en daarmee corresponderende (wettelijke) plichten van ouders, van volwassenen, van de gemeenschap en van de staat zijn voorgesteld. Hoe weinig daarvan tot de drie respectieve treden van het kindervolkenrecht mag zijn doorgedrongen, het feit dat er op elk van die drie treden toch zekere (rechts)beginselen te vinden zijn, die in de kiem specifieke plichten dan wel rechten bevatten, en op de derde trede zelfs een aantal algemene maar toch potentieel verreikende rechten van kinderen en verplichtingen van ouders en de overheid kan worden aangetroffen, betekent al dat er toch ergens enig voorwerk moet zijn verricht.

Uiteraard is het niet de bedoeling daarnaar hier een grondig onderzoek te doen. Verwezen kan worden naar de inventarisatie van kinderrechten(catalogi) die VEERMAN heeft gemaakt. ${ }^{11}$ Uit die inventarisatie zullen hier wel enkele voorbeelden worden aangehaald, welke enkel dienen ter illustratie - illustratie te verstaan in de zin niet van versierende maar van bezielende verluchtiging. Het behoeft immers geen betoog dat er onder die voorbeelden - niettegenstaande de aanwezigheid van tal van waardevolle gedachten en bouwstenen - niet zodanig of zoveel pertinente rechten, laat staan complete catalogi, te vinden zijn dat deze het doen van een eigen voorstel overbodig maken. Als dat het geval was, zou zo'n voorstel niet eens zijn beproefd. Wel dient hier te worden benadrukt dat de in de volgende paragraaf voor te stellen opsomming niet een doel op zich is - laat staan dat er de bedoeling achter zou zitten eerdere voorstellen te overtroefen - maar een hulpmiddel, een tussen-

Ph.E. VEERMAN, The rights of the child and the changing inage of childhood, International Studies in Human Rights vol. 18, Dordrecht (etc.) 1992. 
stap, om in het volgende hoofdstuk nader te kunnen bepalen wat de juridisch-pedagogische kern is van het rechtsbegrip/-beginsel 'het belang van het kind' (the best interests of the child), het belangrijkste juridische aanknopingspunt dat we hebben om tot de mensenrechtelijke verankering van het recht van het kind op (minimale c.q. optimale) persoonswording te kunnen geraken. De volgende catalogi en voorbeelden van rechten kunnen dan worden genoemd.

I. The Declaration of the rights of the child, proposed to Prolet' kult (Proletarkaja Kultura), Moskou 1918:12

1. Every child bom into the world has the right to live (...); the child's maintenance and development shall never be neglected; the child shall be provided with the means to cope with the trials of life. These conditions must be fulfilled irrespective of the social status of the child's parents.

2. The responsibility for providing suitable sanitary conditions to children resides with the parents, Society and the State. The role and extent of the responsibility of each of these components shall be detemined by law.

3. Every child, whatever his/her age, is a person in his/her own right. No child may, under any circumstances, be considered as the property of his/her parents, Society or the State.

4. Every child has the right to choose his/her nearest educators and to dissociate him/herself from his/her parents and leave them if they prove to be bad educators. The child has this right at every age; if such a move does take place, the State and Society must ensure that this does not result in a worsening of the child's material position.

5. Every child has the right to freely develop all of his/her inherent strenghts, capabilities and talents: the right to an education suited to his/her individuality. To this end, the child must unconditionally and at all ages be entrusted to educational institutions or training courses that guarantee optimal conditions for the harmonious development of all aspects of the child's nature and personality.

6. No child, at any age, shall be forced to attend an educational institution or training centre. (...)

7. Insofar as his/her abilities and talents permit, each child, from his/her earliest childhood, shall participate in social (public) educationall labour necessary for the good of the people as a whole. This labour, however, must not only not endanger the child's psychological health or hamper his/her spiritual growth, but it must be in full agreement with the complete system of his/her education and development. Participation in socially necessary educational work gives the child the opportunity to realise one of the most important rights of children: the right to feel that they are not parasites but active members and builders of life and that their lives. can have social worth, not only in the future, but also in the present.

8. With regard to freedom and rights, the child is, at all ages, viewed as equal to the adult person. If a right is not granted to a child, this may only be because the child does not have the necessary physical and spiritual capacity to use it. If, 
however, the child has the capacity, age may not stand in the way of realisation of the right.

9. The freedom consists of being allowed to do everything on the condition that it will not harm the plysical and spiritual development of the child or other people. Thus, no boundaries shall stand in the way of the child exercising his/her natural rights, other than those dictated by the laws of the child's own nomal physical and spinitual development, as well as the guarantee that other members of Society, too, are in a position to act on the same right.

10. Within their own peer groups, or in their relationships with the adults in their surroundings, children shall be expected to adhere to certain rules that forbid acts that are harmful to Society as a whole. (...)

11. Children must be granted the right to participate in the compilation of rules that will control their lives and their talents.

12. No one, neither parents nor Society nor the State, shall force a child to be instructed in any particular religion or to practice its rites. (...)

13. No child may be oppressed because of his/her convictions. (...)

14. Each child shall be allowed to express his/her opinions and thoughts whether in writing or verbally, just like adults. This right may only be restricted by dictates relating to the well-being of Society, in accordance with teachings of the child's educators and the limits of the child's understanding. All restrictions on this right shall be clearly determined by law.

15. Each child has the right to found, together with other children or adults, organisations, associations and the like, just like adults. Possible restrictions, dictated by the well-being of the child and his//Mer] momal physical and spiritual development, must be clearly determined by law.

16. No child may be deprived of his/her liberty or submitted to punishment. If a child has misbehaved or failed, he/she shall be rehabilitated with the help of appropriate educational institutions rather than by punishment and other repressive actions.

17. The State and Society shall employ every means possible to ensure that all the above mentioned rights of the child shall, in no way, be infringed upon; they shall protect these rights against all attempts to violate them, and force those who fail in their duty to the younger generation, to mend their ways.

\section{Commentaar}

Opmerkelijk in deze verklaring, die hierboven niet eens volledig is aangehaald, ${ }^{13}$ is de veronachtzaming, bijna verduistering van het fundamentele recht van het kind op leiding (met name in art. 6), dat de onmisbare wederhelft van het recht op ontplooiing is. We spraken hierboven al van een dubbelrecht; we zouden het nog sterker kunnen stellen: zonder leiding geen ontplooiing. Het recht op leiding omvat het recht op de verdiende straf (door GROTIUS - ten aanzien van volwassenen - het poenae meritum genoemd, het natuurrechtelijk grondbeginsel van de verdiende

Vrijwel alle weglatingen getuigen van mijn weinig progressieve gezindheid, waarvan degenen die het origineel raadplegen, zich vrijelijk kunnen vergewissen. 
straf $^{14}$ ) als ultimum remedium, uiterste (pedagogisch ${ }^{15}$ ) middel (anders: Prolet'kult, art. 16). Ook aan de kinderlijke loyaliteit en (pathologische)

Eên van de wijf grondbeginselen wan het natuurrecht in strikte zin, naast het - in senryü-vorm (voor het 'origineel' zie De jure belli ac pacis, Prol. 8 , aangehaald in hoofdstuk 3 , par. 3.3.1):

Handen thuis; ieder

hel zijne; je woord houden

fouten goedmaken.

Het natuurrecht in strikte zin kunnen we 'cultuurrechtelijk' omschrijven als - ik veroorloof mij weer de didactische (althans op college gebruikte) senryü-vorm:

Natuurrecht is in

beginselen gestolde

wijsheid wan eeuwer.

In een aan de 'postmoderne' cultuur aangepaste (inhoudelijke) omschrijving ligt het poenae meritum besloten:

Natuurrecht is: red

jezelf; eerlijk duurt het langst

misdaad wordt gestraft.

15 De straf als uiterste middel is pedagogisch binnen de grenzen van de noodzakelijke disciplinering. Slaan - met uitzondering van de pedagogisch tik 'om de aandacht van het kind te richten' (BAARTMAN, Opvoeden met alle geweld, a.w., p. 20) - valt buiten die grenzen. Het recht op straf komt tegemoet niet aan een masochistische (door FREUD veronderstelde) strafbehoefte (vgl. BAARTMAN, a.w., pp. 140-152; 'masochisme' of 'traumaverslaving' bij volwassenen dient veeleer alls reënscenering of herhalingsdwang verstaan te worden: Judith HERMAN, Trauma en herstel; De gevolgen van geweld - van mishandeling thuis tot politiek geweld, Amsterdam 1993, p. 149), maar aan het rechtsgevoel van het kind, dat op dit punt als in principe niet minder ontwikkeld mag worden beschouwd dan dat van de volwassene. Zonder strafdreiging en straftoediening - mits deze met praten en luisteren gepaard gaat - zou het kind net zo goed als de volwassene ten prooi vallen aan tegenstrijdige gevoelens, of aan gevoelloosheid, die de gewetensworming niet ten goede komen (zo deze überhaupt nog mogelijk zou zijn). Bovendien zou het afzweren van straf (zoals bij de zogenaamde anti-autoritaire opvoeding uit de zestiger jaren) kinderen aan gevaarlijke ouderlijke manipulaties en paradoxale situaties blootstellen. (Vgl. in dit verband O. WAALDIJK, "Is voelen echt wel goed voor wie niet horen wil? Gedachten van een psycholoog over staffen," in: K. BLANKMAN, L.C.M. STEGMANN (red.), Het recht of het belang vant het kind, Assen/Maastricht 1989, pp. 30-40, in het bijzonder op pp. 39-40.)

Het bij wijze wan 'straf' onthouden van liefde, of daarmee dreigen (de 'liefde-opvoorwaarde') is onpedagogisch - heeft met praten en luisteren niets van doen -, ja moet zelfs als een vorm van maligne manipulatieve psychische mishandeling worden beschouwd (hoe goed bedoeld vaak ook of uit onmacht of onwetendheid gepraktizeerd), omdat dit de genegenheid voor een kind voorwaardelijk maakt, en het daarmee afsnijdt van wat voor zijn psyche even onmisbaar is als lucht voor zijn lichaam (vgl. bijvoorbeeld Hans SEBALD, Lieve Mammie...; Gevolgen van verkeerd gericht moederschap op de ontwikkeling wan het kind, Utrecht/Antwerpen 1979, pp. 112 e.v., passim). 
hyperloyaliteit wordt volledig voorbijgegaan (Prolet'kult, art. 4).

Overige, met name in positieve zin opmerkelijke elementen, zijn hierboven gecursiveerd; zij worden hier niet nader becommentarieerd. Hetzelfde geldt voor de navolgende voorbeelden.

\section{The Children's charter of the International Council of Women (1922): \\ [Preambule:]}

This Charter is based on the principle that every child is born with the inalienable right to have the opportunity of full physical, mental and spiritual development. It is the privilege, no less than the duty of parents, to provide such opportunities for their children. In the event of parents not being able, for whatsoever reason, to discharge this duty, the community is bound to secure the fulfillment thereof. The provisions enumerated under the following headings are based on the recognition of this principle. ${ }^{17}$

\section{Pre-natal care}

3. Education of the general public regarding the responsibilities of persons about to marry, with the view of raising the standard of [mental? - jw] health and morals.

II. Care of mothers and children up to school age

5. Dental Clinics for mothers and children (...).

7. Preventoria, Convalescent and Holiday Homes for mothers and young children needing change of air, rest, and nourishing food.

9. Playgrounds and Play-rooms with specially trained Play Teachers, paid or voluntary, for young children.

III. Children of school age

4. Adequate salaries and pensions for teachers so that the teaching profession may attract the best type of young men and women (...).

10. Adequate Staff of School Physicians and School Nurses, who shall (...) visit the homes of the children to ensure the carrying out of physician's orders, and to assist and instruct the mothers in the care and feeding of their children.

13. Preventoria and Convalescent Homes under adequate supervision.

15. Compulsory education regarding the care of infants in all schools and Continuation schools.

19. Some State provision for the endowment and maintenance of needy mothers and children until the latter reach wage-earning age.

IV. Children in employment (...)

\section{Delinquent children}

5. In cases where parents are found unfit for the guardianship of their children, or are found guilty of cruelty, neglect and desertion, the State [is] to assume guardianship and to make such arrangements for the children's upbringing as may seem best, charging the parents for maintenance wherever possible.

VEERMAN, a.w., pp. 325-328; tekst in Appendix VII, pp. 439-443.

17 Een beginsel dat we samenvaltend kunnen 'vertalen' als het recht van het kind op optimale persoonswording: geboorterecht van elk mens(enkind) en gedeelde ouderlijke en maatschappelijke/statelijke opdracht en plicht. 
VT. Children's State Depantments

It is strongly advised that a State Depantment to watch over the interests of children from every point of view be established in every country. (...)

VII. International Conferences (...).

Nadat de latere Amerikaanse president HOOVER, op dat moment minister van Handel onder president HARDING, zich in 1922 in een speech voor de American Child Health Association had laten ontvallen:" ${ }^{18}$

'It should be the purpose of associations like yours to replace ten policemen with a single community nurse"

... besloot hij, eenmaal president, zelf maar een Witte-Huisconferentie te beleggen. Resultaat daarvan was:

III. The Children's charter of President HOOVER's White House Conference on Child health and protection (1930): ${ }^{19}$

xi. For every child such teaching and training as will prepare him for successful parenthood, home-making, and the rights of citizenship; and, for parents, supplementary training to lit them to deal wisely with the problems of parenthood.

Althans op deze bepaling, éen van de 19 die Hoovers Kinderhandvest beslaat, is de kwalificatie in de pers van die dagen - een 'string of platitudes ${ }^{20}$ - niet van toepassing te achten.

IV. Declaration of opportunities for children (Washington, 1942), adopted by the Eighth Pan American Child Congress:21

Family life (...)

(b) The State should take measures to assure the economic stability of the family. Health

(...) [I]t is necessary to safeguard the physical and mental health of the child from birth wntil the age at which he becones a contributing member of the community, for which the following are required:

(a) Adequate diet.

(b) Periodic medical and psychological supervision (...).

(c) Expert guidance in recreation.

(d) Adequate rest.

(e) Gudance in the proper formation of the personality, in all its aspects.

(f) Preparation for life in the community. 
V. The pledge to children (1950) van president TRUMANs MidCentury White House Conference on children and youth:22

To you, our children (...) we (...) make this pledge:

From your earliest infancy we give you our love, so that you may grow with trust in yourself and in others.

We will recognize your worth as a person and we will help you to strengthen your sense of belonging.

We will respect your right to be yourself and at the same time help you to understand the rights of others, so that you may experience co-operative living.

We will help you to develop initiative and imagination, so that you may have the opportunity freely to create.

We will encourage your curiosity and your pride in workmanship, so that you may have the satisfaction that comes from achievement.

We will provide the conditions for wholesome play that will add to your social experience, and to your happiness.

We will illustrate by precept and example the value of integrity and the importance of moral courage.

We will encourage you always to seek the tnith.

We will provide you with all opportunities possible to develop your own faith in God.

We will open the way for you to enjoy the arts and to use them for deepening your understanding of life.

We will work to rid ourselves of prejudice and discrimination, so that logether we may achieve a truly democratic society.

We will work to lift the standard of living and to improve our economic practices, so that you may have the material basis for a full life.

We will provide you with rewarding educational opportunities, so that you may develop your talents and contribute to a better world.

We will protect you against exploitation and undue hazards and help you grow in health and strength.

We will work to conserve and improve family life and, as needed, to provide foster care according to your inherent rights.

We will intensify our search for new knowledge in order to guide you more effectively as you develop your potentialities.

As you grow from child to youth to adult, establishing a family life of your own and accepting larger social responsibilities, we will work with you to improve conditions for all children and youth.

22 VEERMAN, a.w., pp. 250-254; tekst in Appendix XVI, pp. 461-462.

Overigens is dit dezelfde - of een bekeerde? - TRUMAN die twee atoombommen niet op het hoofd van de keizer en zijn criminele regering in Tokio of op hun militaire installaties heeft gegooid (hoewel dat - gezien de te verwachten "collaterale" schade - naar alle waarschijnlijkheid ook een oorlogsmisdrijf zou zijn geweest), maar op het hoofd van duizenden kinderen en volwassenen in de van meet af aan voor dat doel gespaarde steden Hirosjima en Nagasaki (zie B.V.A. RÖLING, Vredeswetenschap; Inleiding tot de polemologie, Utrecht/Antwerpen 1981, p. 259). Twee weggevaagde gave steden als 'aanschouwelijk onderwijs aan de Russen, met 100,000 dode Japanners als leermiddel.' (A.w., p. 263.) 
Aware that these promises to you cannot be fully met in a world at war, we ask you to join us in a firm dedication to the building of a world society based on freedom, justice and mutual respect. (...)

\section{Rights of children, formulated by the Joint Commission on} mental health of children (USA, 1969):23

Challenge for the 1970s

We believe that lives which are uprooted, thwarted, and denied the growth of their inherent capacities are mentally unhealthy, as are those determined by rigidity, conformity, deprivation, impulsivity, and hostility. Unfulfilled lives cost us twice - once in the loss of human resources, in the apathetic, unhappy, frustrated, and violent souls in our midst, and again in the loss of productivity to our society, and the economic costs of dependency. We believe that, if we are to optimize the mental health of our young and if we are to develop our human resources, every infant must be granted:

The right to be wanted, yet millions of unwanted children continue to be born - often with tragic consequences (...)

The right to be born healthy, yet (..).

The right to live in a heathy environment, yet (...).

The right to satisfaction of basic needs, yet $(. .$.$) .$

The right to continuous loving care, yet millions of our young never acquire the necessary motivation or intellectual and emotional skills required to cope effectively in our society because they do not receive consistent emotionally satisfying care. Society does litle to help parents. (...)

\section{The Draft Charter of children's rights of the British Magazine Where (1971): ${ }^{24}$}

1. All children have the right to protection from, and compensation for, the consequences of any inadequacies in their homes and backgrounds.

12. Children shall have freedom from physical assault, whether under the guise of punishment or in any other form. No person shall have the right to subject a child to such punishment as is intended to mentally or physically humiliate the child, or to reduce his self-respect. ${ }^{25}$

VEERMAN, a.w., pp. 359-362; tekst in Appendix XXI, pp. 470-472.

'Intended' minimaal te verstaan - in mijn optiek - als zich blootstellen aan de niet als denkbeeldig te verwaarlozen kans dat de bestraffing vernedering van het kind of beschadiging van zijn zelftespect ten gevolge heeft. Met andere woorden niet alleen het boze opzet maar ook het voorwaardelijke opzet van de ouder, het nemen van een pedagogisch onverantwoord risico bij de disciplinering, maakt de uitoefening van het ouderlijk tuchtigingsrecht wederrechtelijk (tot in principe strafbare mishandeling dan well belediging: artt. 300 e.v. resp. art. 266 WvStr) c.q. onrechtmatig (tot in principe burgerrechtelijke onrechtmatige daad wegens de inbreuk op de persoonlijke levenssfeer van het kind en de strijd met de zorgvuldigheid welke in het maatschappelijk verkeer ten aanzien van eens anders persoon, i.c. de persoon van het kind, betaamt: art. 6:162 BW). 
virr. The Children and youth bill of rights of the National Association of Social Workers (NASW) of the United States (1975): ${ }^{26}$

[Preambule:]

Historically, children have been considered as property. Early laws governing the relationship between parents and children relegated children to little more than chattel. Nineteenth-century reformers challenged this philosophy and initiated legislation to protect children from undue hardship and to provide for their more basic developmental needs. Despite legal advances made on their behalf, however, children too often have remained second-class citizens.

Ironically, legislation intended to protect the rights of children often has had the opposite effect. Lacking legal parity with adults, children frequently have, in the words of former Supreme Court Justice Abe FoRTAS, received "the worst of both worlds: ... neither the protection accorded to adults nor the solicitous care and regenerative treatment postulated for children."

It is essential that public social policy recognize children as individuals with rights, including the right to be part of a family. The well-being of children is advanced most frequently by public social policy that supports the well-being of the family. Children's needs as dependent persons requiring nurture must be reconciled with the protection of children's basis human rights and civil liberties. The guarantee of such protection should not deny children greater participation in society. In the past, basic rights extended for adults have not applied to children. This has resulted in circumstances of gross injustice and isolation. Children should not be kept infants until sudden adulthood. Rather, emancipation from dependence should be a gradual process from greater protection to greater participation and responsibility at key stages of maturity.

[Rights:]

The right to sound preparation for life.

Children are entitled to a good beginning. Such preparation is based on being wanted and cared for and should include adequate family planning to assist potential parents to decide [whether and, $j w]$ when it is best for them to have a child. (...)

The right to individuality. (...)

The right to a positive social identity. (...)

The right to a good parenting experience.

Every child has a right to continuous nurturing care and consistent parental controls and expectations. This right is based on the expectations that parents receive sufficient preparation and support in family living so that the family experience can be conducive to healthy development. (...)

The right to a healthy environment.

The child should have access to the following rights of all persons: freedom from want, adequate housing, safety, and security. Children should receive environmental supports conducive to health and development. Children should have freedom from pollution of air, water, and food. Provisions of recreational space and beautification of the environment are vital to aesthetic development and to a sense of respect for self, other persons, and the environment.

The right to health. (...) 
The right to a relevant education.

(...) Such education shall meet the standards of sufficient preparation for maturity, cmployment, parenthood, and citizenship in a changing and complex society. (..)

The right to participatory citizenship. (...)

The right to representation.

(...) Children and youths, within reasonable limits of age and personal competence, as is true [?] of the adult population, are entitled and able to be representatives of other minors. (...)

The right to legal status, legal protection, and legal redress. (...)

The right to services.

(...) A comprehensive, integrated system of services must be established for families with children and for children separated from their families.

The right to advocacy.

Children must have effective advocacy services to ensure that they will be guaranteed full benefit of the legal rights established by our society for the protection and well-being of all citizens, adult or children.

\section{Ten commandments for adults by Professor Leonhard FROESE (Marburg, West Germany, 1979): ${ }^{27}$}

i. Thou shalt regard the child as the highest good ever entrusted to you.

ii. Thou shalt not form the child in thine own image.

iii. Thou shalt give the child more freedom.

iv. Thou shalt respect the child's personality.

v. Thou shalt not use force against the child.

vi. Thou shalt not destroy the confidence of a child.

vii. Thou shalt protect the child against death.

viii. Thou shalt not tempt a child to lie.

ix. Thou shalt recognize what a child needs.

$x$. Thou shalt grant the child its own right..

$\mathrm{X}$. World Declaration on the survival, protection and development of children (World Summit for children, New York, 1990): ${ }^{28}$

1. We $\mathrm{e}^{29}$ have gathered at the World Summit for children to undertake a joint commitment and to make an urgent universal appeal - to give every child a better future.

VEERMAN, a.w., pp. 292-295; tekst in Appendix XXX, p. 497.

28 VEERMAN, a.w. pp. 209-216; tekst in Appendix XLIV, pp. 574-578. Zie ook het Plan of action for implementing the World Declaration on the survival, protection and development of children, opgenomen in Geraldine VAN BUEREN, International documents on children, Dord[r]echt (etc.) 1993, pp. 330-340.

De staatshoofden en regeringsleiders van 71 landen en regeringsvertegenwoordigers op ministersniveau van 88 andere landen (George $\mathrm{KENT}$, Children in the international political economy, New York etc. 1995, p. 142). Namens Nederland was dat minister PRONK (mondelinge mededeling Ministerie van Buitenlandse Zaken/DGPZ d.d. 28 nowember 1996). 
4. Each day, countless children around the world are exposed to dangers that hamper their growth and development. They suffer immensely as casualties of war and violence; as victims of racial discrimination (...); as refugees (...); as disabled; or as victims of neglect, cruelty and exploitation.

8. Together, our nations have the means and the knowlegde to protect the lives and to diminish enormously the suffering of children, to promote the full development of their human potential and to make them aware of their needs, rights and opportunities.

12. (no.) Girls must be given equal treatment and opportunities from the very beginning.

14. (...) The family, as a fundamental group and natural environment for the growth and well-being of children, should be given all necessary protection and assistance.

19. We ourselves hereby make a solemn commitment to give high priority to the rights of children, to their survival and to their protection and development.

20. (5) We will (...) support the efforts of parents (...) to nurture and care for children, from the earliest stages of childhood through adolescence. (...)

20. (7) We will work to ameliorate the plight of millions of children who live under especially difficult circumstances $-(. .$.$) the disabled and the abused, the$ socially disadvantaged and the exploited. (....)

Vanuit de kerninhoud van kinderrechten, dat wil zeggen met als algemeen vertrekpunt het gelijkheidsbeginsel en het ontplooiingsbeginsel, wordt in deze paragraaf een aantal fundamentele social-pedagogische rechten voorgesteld. Deze worden ingeleid door een korte (sub)paragraaf waarin een tweetal bijzondere uitgangspunten in herinnering wordt gebracht.

\subsubsection{1}

\section{Twee uitgangspunten}

Bij de samenstelling van onderstaande lijst van sociaal-pedagogische kernrechten is in het bijzonder uitgegaan van twee zaken. Ten eerste de gedachte dat rechten van het kind eo ipso betekent rechten in de Trias pedagogica, in de triade, de driehoek Kind-Ouder-Staat. Met andere woorden uitgegaan is en wordt van de (weliswaar eigensoortige maar niettemin) gemeenschappelijke opvoedingsverantwoordelijkheid van ouders en de staat. Hoezeer opvoeding ook primair ouderlijke verantwoordelijkheid is, het gegeven dat het kind op opvoeding is aangewezen om überhaupt, als zelfstandig staatsburger, mensenrechten te kunnen uitoefenen, impliceert een zware, zij het secundaire, dat wil zeggen aanvullende en desnoods vervangende pedagogische verantwoordelijkheid van de staat. Aanvullend: de staat is defensor liberum. Desnoods vervangend: de staat is protector liberum. Defensor et protector liberum - met bevoegdheden en handhavingsmiddelen die variëren van de fluwelen handschoen tot de 
sterke arm. Anders gezegd: in het Huis van de Opvoeding wonen niet alleen de ouders met hun kinderen, daar woont ook de gemeenschap, dat is: de staat. Dit impliceert, als het goed is, dat in het Huis van de Opvoeding noch kinderen noch ouders aan hun lot zijn overgelaten.

In de tweede plaats is uitgangspunt het veiligheids- en ontwikkelingsbelang van het kind, dat door de Vereniging van secretarissen van Raden voor de kinderbescherming - in het werkdocument Kinderbescherming: Maak het waar!!! - als volgt als fundamenteel recht van elk kind is geformuleerd: ${ }^{30}$

'Elk kind heeft een zelfstandig [c.q. individueel, jw] recht op een gezonde, evenwichtige ontwikkeling en uitgroei naar zelfstandigheid.'

Hierin zijn twee elementen van groot belang: het element 'evenwichtig,' dat het element 'gezond' geacht kan worden mede te omvatten; en het element 'ontwikkeling,' dat geacht kan worden het element 'uitgroei naar zelfstandigheid' mede te omvatten. We vertrekken dan vanuit een fundamenteel, een meta-kernrecht van het kind, van elk kind, op een evenwichtige ontwikkeling. Hieruit - dat wil zeggen uit de combinatie van beide uitgangspunten: 'gemeenschappelijke opvoedingsverantwoordelijkheid' en 'meta-kernrecht op evenwichtige ontwikkeling van elk kind' - vloeien sociaal-pedagogische kernrechten voort, waartegenover kern-verplichtingen van ouders en kern-verplichtingen van de overheid staan, respectievelijk die uit kern-verplichtingen van ouders en kern-verplichtingen van de overheid bestaan.

Ook ouderlijke (pedagogische) bevoegdheden ten opzichte van het kind en ouderlijke (pedagogische) claims ten opzichte van de overheid zijn afgeleid van de kernrechten van het kind, en betreffen dus nooit zelfstandige rechten, laat staan rechten die van een hogere orde zijn dan de kernrechten waarvan ze zijn afgeleid.

\subsubsection{Een dertien-puntenlijst}

De volgende dertien-puntenlijst van sociaal-pedagogische kernrechten van het kind kan thans worden voorgesteld. Hier en daar wordt een recht van een (korte of iets langere) toelichting voorzien. Aangezien het om kern-

Vgl. Jaap DOEK, "Van oude dogma's en dingen die voorbijgaan; de toekomst van onze justitiële jeugdbescherming met enige buitenlandse belichting," in: Afra GROEN en Adri VAN MONTFOORT (red.), Kinderen beschemen en jeugd hulp verlenen, Arnhem 1993, pp. 157-173, op p. 158 (en pp. 163-166); Herman BAARTMAN, 'Fysieke mishandeling van kinderen,' Tijdschrift voor Criminologie 1995/4, pp. 300-314, op p. 304. 
rechten gaat, dat wil zeggen om natuurlijke rechten met het karakter van fundamentele (rechts)beginselen, om 'levend,' deels geboren, deels nog baarmoederlijk recht, om jus constitutum, jus in statu nascendi, jus in statu pupillari en jus constituendum (positief recht, recht in wording, onrijp recht, wenselijk recht; ofwel hard recht, zacht recht, halfzacht recht en boterzacht recht), is het niet mogelijk - althans zonder tevens naar details, naar denkelijke concretising c.q. operationalisering, af te dalen -, maar ook niet nodig en gewenst alle gebruikte termen (bijvoorbeeld het begrip 'geweld') exact te definiëren; zij dienen naar het gewone, algemene, contemporaine - maar levende en zich dus voortdurend ontwikkelende - spraakgebruik te worden verstaan.

\section{Lichamelijke en geestelijke integriteit}

Het recht van het kind op respect van zijn ouders/opvoeders (hierna: ouders) voor zijn lichamelijke en geestelijke integriteit; waaronder het recht op vrijwaring van fysiek, sexueel en/of verbaal geweld ten opzichte van zijn persoon en het recht op vrijwaring getuige te zijn van fysiek, sexueel en/of verbaal geweld tussen zijn ouders; alsmede het recht op vrijwaring van elke vernederende of kleinerende behandeling of bejegening.

Tot dit recht behoort ook het recht op morele (en eventueel financiële) genoegdoening (als onderdelen van het recht op 'reparatie ${ }^{, 31}$ ) in geval van (ernstige) schendingen van de lichamelijke en geestelijke integriteit van het kind.

\section{Koestering}

Het recht van het kind op koestering door zijn ouders (dat is op lichamelijke en verbale liefkozing, op lijfelijk teder contact en op de prijzende en bewonderende taal der vertedering); waaronder het recht zijn aanhankelijkheid vrijelijk te kunnen tonen.

31. Reparatie wordt hier - in nawolging van het 'Final report' inzake restitutie, compensatie en rehabilitatie van slachtoffers van ernstige mensentechtenschendingen Van VAN BOVEN (Study concerning the right to restitution, compensation and rehabilitation for victims of gross violations of human rights and fundamental freedoms; Final report submitted by Mr. Theo VAN BOVEN, Special Rapporteur, Sub-Commission on Prewention of Discrimination and Protection of Minorities [van de] Commission on Human Rights, E/CN.4/Sub.2/1993/8 d.d. 2 juli 1993) - gebruikt als verzamelterm van de begrippen restitutie, compensatie, rehabilitatie, satisfactie (genoegdoening) en waarborgen voor niet-herhaling. Zie voor de toelichting en uitwerking van een en ander hoofdstuk 13 . 


\title{
3. Lichamelijke en geestelijke zorg en zorgvoorzieningen
}

Het recht van het kind op optimale lichamelijke en geestelijke zorg/verzorging door zijn ouders en op de best mogelijke lichamelijke en geestelijke gezondheidsvoorzieningen door de staat.

Het recht op lichamelijke zorg lijkt in Nederland, althans wat het aanbod aan pre-, peri- en postnatale medische (consultatie)voorzieningen betreft, verhoudingsgewijs ruimhartig geregeld. Het aanbod is evenwel veel te vrijblijvend. Van 'nurses who shall (...) visit the homes of the children to ensure the carrying out of physician's orders, and to assist and instruct the mothers in the care and feeding of their children' (International Council of Women, 1922) is in 'Nederland-vrijblijvendland' nog geen sprake. Dat een vrijblijvendland geen veilig land voor kinderen is, bewijzen de vaderlandse cohorten lichamelijk verwaarloosde kinderen. ${ }^{32}$

De geestelijke foetus-, zuigelingen- en peuterzorg staat evenwel nog niet eens in de kinderschoenen. Met betrekking tot prenatale zorg merkt BAARTMAN op: ${ }^{33}$

\begin{abstract}
"Zonder mensen te willen betuttelen, is het de moeite waard om vooral jonge ouders op gang te helpen. We hebben in Nederland een uilstekend systeem van prenatale zorg als het gaat om de medische aspecten, maar de sociale aspecten krijgen nog weinig aandacht. Zoals aanstaande moeders met een hoge bloeddruk een indicatie voor ziekenhuisopname krijgen, zo zou ouders met deplorabele persoonlijke omstandigheden standaard stevige begeleiding moeten worden aangeboden.'
\end{abstract}

Met de postnatale geestelijke zorg is het evenwel niet veel beter gesteld. Het heeft er alle schijn van dat op het punt van geestelijke gezondheidszorg in het algemeen nog veel weerstanden moeten worden overwonnen

In 1995 betrof het 9\% van de bij de BVA's gemelde gezinnen. (LSBVK, Jaarverslag 1995 , Bijlagen, p. vr.) Over de werkelijke aantallen is zeer weinig bekend. Volgens onderzoeken komt het echter vaker voor dan fysieke kindermishandeling. Gezien de welvaart in Nederland is het onaannemelijk dat hier lichamelijke verwaarlozing kan woorkomen zonder dat tegelijkertijd tevens minstens sprake is van pedagogische en emotionele verwaarlozing ('een systematisch tekort aan respectievelijk stimulering, regelgeving en handhaving en aan warmte en emotionele steun'). Verwaarlozing is in Nederland met andere woorden niet een (bittere) armoede- maar een mishandelingsfenomeen. Zie Suus VAN HEKKEN, 'Verwaarlozing: achtergronden, gevolgen en behandeling, in: H. BAARTMAN en A. VAN MONTFOORT (red.), Kindemishandeling, resultaten van multidisciplinair onderzoek, Utrecht 1992, pp. 166-185, op pp. 166-167.

33 Aangehaald door Arjen SCHREUDER in NRC Handelsblad van 5 oktober 1996, Z-bijl., p. 5, laatste kol. Vgl. ook BAARTMAN, Opvoeden kan zeer doen; Over oorzaken van kindermishandeling, hulpverlening en preventie, Utrecht 1996, p. 134. 
en ingesleten patronen moeten worden doorbroken. Zoals VAN DANTZIG stelde: ${ }^{34}$

“G]eestelijke hulp zou voor iedere Nederlander net zo vanzelfsprekend moeten zijn als een huisartsenconsult. (....) Bij [c.q. vanaf, jw] zijn geboorte valt een kind onder zuigelingenzorg, thuiszorg, inentingsprogramma's, schoolarts. De lichamelijke gezondheid wordt tot de puberteit intensief begeleid: preventief en curatief. Terwijl zoiets absoluut niet bestaat voor de geestelijke gezondheidszorg. En [dat] terwijl we weten hoeveel kinderen er mishandeld worden. Slachtoffer van incest zijn."

Over de gevolgen van deze anomalie - misschien moeten we zeggen: van deze 'medisch-psychisch'- of 'lichaam-geest'-dichotomie - had VAN DANTZIG zich al eerder uitgelaten, door TRIMBOS' woorden uit 1969 in herinnering te brengen: ${ }^{35}$

"Wat dat betekent, is door TRIMBOS in zijn inaugurale rede zo onder woorden gebracht: "... verreweg het allergrootste deel der psychische ongezondheid valt buiten het bereik der gezondheidssystemen. Het vormt een blijvende broedplaats voor nieuwe stoornissen, die van generatie op generatie wordt doorgegeven. [(...)] De economische gevolgen $[(\ldots)]$ voeren tot astronomische cijfers. De gevolgen voor het individu en diens milieu zijn onmeetbaar. Slechts de verbeelding laat toe de gevolgen te overzien van het psychisch gestoord zijn op de verknoeing van levens, het mislukken op school of in het arbeidsproces, op angsten en eemzaamheid, op onvrijheid, liefdesonmacht, op prestigehonger en onzinnig machtsmisbruik, op verslaving en sociaal-pathologische verschijnselen, op agressie, homicide, suicide, op intolerantie en discriminatie. Een onvoorstelbare en onmeetbare: hoeveelheid menselijk leed, die lang als [onvermijdelijke] "condition humaine" geaccepteerd werd, maar waaruan we thans de schakels in de kelen van oorzaak en gevolg beginnen te onderscheiden."

Dit gold dertig jaar geleden, het geldt vandaag nog net zo.'

34 In een interview in De Volkskrant wan 28 oktober 1995 ('Folio"), onder de kop: "Er is weel meer gekte dan je denkt".'

35 A. WAN DANTZIG, 'Persoonlijk lijden als publicke zorg; TrIMBOS-lezing 1991;' Maandblad Geestelijke volksgezondheid 1991/6, pp. 635-648, op pp. 645/646 (curs. jw); ook opgenomen in: dez., Is alles geoorloofd als God niet bestaat? Over geestelijke gezondheidszorg en maatschappij, Amsterdam/Meppel 1995, 'Persoonlijk lijden als publieke zorg, pp. 103-119, op p. 116.

Hoewel vermoedelijk in de war met TRIMBOS openbare les uit 1960 (Samen één, RU Utrecht) bedoelt VAN DANTZIG de rede wan TRIMBOS uit 1969 (Sociale evolutie en psychiatrie, EU Rotterdam, Bussum 1969, p. 14), die ten tijde van zijn lezing niet dertig maar (ruim) twintig jaar oud was. 


\section{Gelijke opvoeding}

Het recht van het kind op gelijke behandeling van broertjes en zusjes, waaronder in het bijzonder het recht van het kind op gelijke opvoeding van jongens en meisjes.

Dit laatste kernrecht is vooral - doch zeker niet uitsluitend - van belang ten aanzien van allochtone gezinnen. Met name kinderen uit zogenaamde macho-culturen (Latijns, Arabisch, Creools) verdienen bijzondere aandacht. De in deze culturen nog bestaande voorkeursbehandeling van jongetjes - die op grond van de ruime witleg die blijkens de travaux préparatoires van het Verdrag inzake de rechten van het kind aan het woord gezondheid dient te worden gegeven, net zo goed als meisjesbesnijdenis (GVM: genitale verminking van meisjes) onder de af te schaffen 'traditionele gebruiken die schadelijk zijn voor de gezondheid van kinderen' van art. 24 , lid 3 van het Verdrag valt ${ }^{36}$ - werkt een gebrekkige frustratie-tolerantie en impulscontrole en een kinderlijke 'bevoorrechtenarrogantie' in de hand die tot veel volwassen excessen aanleiding kunnen geven, waarvan onder meer bovengemiddelde vrouwenmishandeling ${ }^{37}$ doch ook (eveneens bovengemiddelde ${ }^{38}$ ) arbitraire en excessieve dis-

36 Vgl. Sharon DETRICK (ed.), The United Nations Convention on the rights of the child; A guide to the 'travaux préparatoires,' Dordrecht (etc.) 1992, p. 352.

37 Vgl. Aleid VAN DEN BRINK en Jan JÜNGEN, 'Thuisgeweld tegen vrouwen; het Meldpunt vrouwenopvang Amsterdam, 1991-1994,' Tijdschrift voor Criminologie $1995 / 4$, pp. 315-332, op pp. 317, 326 en 330-331.

38 HAARSMA En VAN HARTEN (Lennie HAARSMA en Trudy ZANDIJK-VAN HARTEN, Grenzen voorbij; Kindermishandeling in allochtone gezinnen, Amsterdam 1996, pp. 7-8) merken op dat er geen cijfers bekend zijn over het vó́rkomen van kindermishandeling in allochtone gezinnen (hetzelfde geldt overigens voor autochtone gezinnen). Doch, zo voegen zij daaraan toe: 'De aard van de bij de BVA's gemelde mishandeling laat wel duidelijke verschillen zien met autochtonen: relatief veel lichamelijke mishandeling, vooral in Turkse en Marokkaanse gezinnen." Uit het door hen gegeven overzicht van de meldingen wit het Jaarverslag 1994 van de LSBVK (Landelijke Stichting Bureaus Vertrouwensarts inzake Kindermishandeling) blijkt dat er minstens drie keer zo veel allochtone meldingen zijn als hun aandeel in de bevolking 'rechtvaardigt' (Turken, Marokkanen, Surinamers, Antillianen: $18 \%$ meldingen tegen circa $5,5 \%$ van het bevolkingstotaal). In het Jaarverslag. 1995 van de LSBVK (Utrecht 1996, Bijlagen, p. IX, tabel 14: 'Geboorteland van de ouders van de gemelde kinderen') is dit percentage gedaald tot 13 , nog altijd een oververtegenwoordiging van ruim een factor twee. Zells als men deze beslist niet zonder meer betrouwbare percentages voor verschillende meetbare en onmeetbare factoren zou pogen te corrigeren, blijft er altijd - uitgaande van een factor twee tot drie - sprake van een (meer of minder) significant verschil. Of er meer vaders dan moeders zijn die de handen los hebben zitten, vermelden de auteurs niet. En al evenmin hoeveel slaande moeders zelf worden geslagen. 
ciplinering van kinderen getuigen. ${ }^{39}$

Ongetwijfeld is de opvoeding tot mannelijke dominantie en machismo die in deze culturen nog bestaat, en uit onze cultuur hooguit sinds enkele generaties, en nog lang niet integraal is verdwenen, ooit functioneel geweest met het oog op het aankweken van een mannelijke (over-) moedscultus in de jacht of in de oorlog. ${ }^{40}$

Hier gaat, naar het mij voorkomt, de vergelijking op met op volwassen leeftijd averechts werkende en destructieve coping-mechanismen $^{41}$ ofwel survival-strategieë ${ }^{42}$ die, in al hun tragiek, uiterst functioneel waren ten tijde van de kinderlijke traumatisering. Het zijn de latere psychische 'trucendozen' of tactieken van survivors ${ }^{43}$ welke bijna een

Overigens kan het getuige (moeten) zijn van de ernstige of zeer ernstige mishandeling van hun moeder, wat minimaal duizend kinderen alleen al in Amsterdam jaarlijks overkonat (VAN DEN BRINK/JÜNGEN, t.a.p., op p. 331, onder 'Kinderen'), op zich al als een vorm van (psychische) kindermishandeling, en dus als een ernstige schending van de rechten van het kind, worden beschouwd. Dit los van wat de kinderen van gewelddadige vaders en mishandelde moeders aan thet eigen lijf aan geweld en misbruik ervaren. BAARTMAN schrijft: 'Mannen die herhaaldelijk hun vrouw sloegen, bleken [bij onderzoek] vaker kun kinderen te mishandelen dan andere mannen. Bij vrouwen die door hun mannen werden geslagen, bleek de groep die zich schuldig maakte aan kindermishandeling twee maal zo groot [als] bij vrouwen die niet het slachtoffer waren van vrouwenmishandeling." ( $O P$ voeden met alle geweld, a.w., p. 28.) Daar komt bij dat volgens onderzoek ruim driekwart 'wan de kinderen die door hun ouders fysiek mishandeld werden, zelf een broer of zus mishandelden' (t.a.p.). In een gezin waar de moeder geslagen wordt, kan het kind dus niet alleen zelf slaag verwachten, maar bovendien slaag uit vele hoeken. Daarvan leert het, en kinderen leren snel, niet dat mensen, in de eerste plaats het kind zelf, recht hebben op onaantastbaarheld van hun lichaam, maar dat de sterkste het recht heeft om te slaan (vgl. a.w., p. 29).

40 Zeer lezenswaard met betrekking tot dit en het verwante mannelijke maskeradethema is Fokke sIERKSMA, Religie, sexualiteit en agressie; Een cultuurpsychologische bijdrage tot de verklaring van de spanning tussen de sexen, Groningen 1979 (de wetenschappelijke versie, bezorgd door K.D. JENNER, van De roof van het vrouwengeheim).

41 Vgl. met betrekking tot 'coping' H.E.M. BAARTMAN, Opvoeden kan zeer doen, a.w., p. 102.

42 Vgl. met betrekking tot 'innerlijke overlevingsstrategieën' Nel DRAIJER, Sexueel misbruik van meisjes door verwanten; Een landelijk onderzoek naar de omvang, de aard, de gezinsachtergronden, de emotionele betekenis en de psychische en psychosomatische gevolgen, Mimisterie van Sociale Zaken en Werkgelegenheid, Den Haag 1988, p. 160 (pp. 153-160); Nel DRAIJER, Seksuele traumatisering in de jeugd; Gevolgen op lange termijn van seksueel misbruik van meisjes door verwanten, ac. diss. Amsterdam 1990, p. 220 (pp. 215-220).

43 '[T] victims of the Nazi Holocaust, survivors." Aldus GREEN (Richard GREEN, Sexual science and the law, Cambridge etc. 1992, p. 175; curs. RG). Een 'definitie' van 
geuzenbenaming zijn geworden voor wat in wezen overleefde - maar intussen vaak even gesofisticeerde als virulente - kinderlijke afweermechanismen zijn. Wat we hier op individueel niveau zien als voor zichzelf en omgeving schadelijke 'overlevingsstrategieën,' zien we met betrekking tot de voorkeursbehandeling van jongetjes (en de duistere keerzijde daarvan: de genitale verminking van meisjes) op collectief, cultureel niveau. Hoe functioneel wellicht ooit ook, het zijn in de actuele situatie en in deze tijd tragisch overleefde fenomenen.

Pas als die tragiek onder ogen kan worden gezien, is inzicht in de averechtse en destructieve werking mogelijk, en kan de rouwarbeid aanvangen. Vandaar dat een directe, confronterende benadering - op indivi-

surwivors die veel weg heeft van een sneer. Toch kunnen er bij het (modieuze) gebruik van het woord survivors wel kanttekeningen worden geplaatst.

Survivors zijn - in müjn 'kritische' definitie - voormalige slachtoffers van kindermishandeling (in het bijzonder van incest) die zich van hun ervaringen wel (degelijk) bewust zijn, maar deze nog niet of onvoldoende hebben verwerkt, terwijl die ervaringen soms net zozeer als 'rechtvaardiging' of verontschuldiging van 'wangedrag' worden gebruikt als sommige verdachten - of vaker: hun advocaten - dat doen in strafprocedures waar een beroep wordt gedaan op 'een moeilijke jeugd' - niet als verzachtende omstandigheid, maar bijna als materiele (ongeschreven) rechtvaardigings- of schulduitsluitingsgrond. De huiver of afkeer om het woord slachtoffer te gebruiken, leidt ertoe dat woormalige slachtoffers van kindermishandeling/incest die nog niet (eens) aan een bewustwordingsproces toe zijin (laat staan aan het verwerkingsproces waarin 'echte' survivors soms zelf zijn blijven steken) - en die dus geen survivors of overlevenden mogen heten -, worden aangeduid als non-sunivors of niet-overlevenden - alsof zij reeds dood en begraven zijn. (Vgl. bijv. Lane J. VELTKAMP, Thomas W. MLLER, Clinical handbook of child abuse and neglect, Madison, C. 1994, pp. 126-134; op p. 134 is zelfs sprake van een adult nonsurvivor die haar echtgenoot neerschoot, die, zo lezen we op p. 128 i.f., de aanval van de niet-overlevende gelukkig overleefde.)

Bijzonder tragisch is het wanneer prostitué zich als sturvivors betitelen terwijl zij hun pseudo- of nood-volwassenheid demonstreren door met meer of minder trots to verhalen hoe zij de aan hun jeugdervaringen overgehouden minachting voor mannen in klinkende munt weten om te zetten. Kenmelijk zonder in te zien hoezeer - maar waarom zouden zij daar ook een boodschap aan hebben? - een dergelijke naar twee kanten respectloze beroepshouding een niet weinig krachtige bijdrage levert aan de instandhouding van de patriarchale minachting voor vrouwen. Laat staan dat zij inzien - en daar zouden zij well een boodschap aan behoren te hebben - hoezeer juist in een patriarchale cultuur, die meer nog dan door mannelijke dominantie gekenmerkt wordt door mannelij|ke ambivalentie (de zogenaamde dubbele moraal), de prostitutie op zichzelf als een uiterst destructieve survival-strategie kan uitpakken. Ook los van het niet zelden gewelddadige milieu. Ook los van de verslavende werking van niet in de laatste plaats het 'snelle' geld. (Vgl. voor het aandeel van incestslachtoffers in de prostitutie hierna hoofdstuk 12, par. 12.3.2 onder Incest en prostitutie.) 
dueel dan wel collectief niveau - van zowell survival-tactieken als van traditional practices (traditionele gebruiken die schadelijk zijn voor de gezondheid van kinderen) slechts weerstand en actief of passief verzet zal oproepen. Hier dient eerst ruimte voor het onder ogen kunnen en durven zien van de vroege traumatisering en de vroege misleiding te worden geschapen. Dit vereist een ruimhartig werken op het brede vlak van sociaaleconomische en een omzichtig werken in de smalle marges van sociaalpsychologische randvoorwaarden.

\section{Ontplooiing}

Het recht van het kind op ontplooiing (op warmte, affectie, ruimte, ondersteuning, troost, bemoediging, verdiende complimenten, op morele en materiële geborgenheid).

Het verschil tussen (het recht op) ontplooiing en (het recht op) koestering zit in de meer lijfelijke kanten van dat laatste en de meer morele (en materiële) kanten van het eerste recht. Niettemin is hier overlap en is het verschil niet principieel. Het belang van het onderscheid blijkt evenwel wanneer we bijvoorbeeld overbeschermende ouders zien, die zeer wel tot koestering (van met name zeer jonge kinderen) in staat zijn, maar veel meer moeite hebben (met name wanneer kinderen opgroeien en zelfstandiger worden) met het bieden van ondersteuning, bemoediging en 'ruimte.'

\section{Leiding}

Het recht van het kind op leiding (op opvoeding in enge zin, op toezicht en controle, op realistische - niet te hoge en niet te lage - eisen en verwachtingen, op disciplinering, op het consequent stellen van consistente, begrijpelijke en duidelijke grenzen); waaronder het recht op verdiende ook in de uitoefening rechtvaardige, dus niet fysiek of verbaal gewelddadige, vernederende of kleinerende - straf, alsmede het recht op vrijwaring van overcontrole, overbescherming en betutteling.

\section{Begeleiding}

Het recht van het kind op begeleiding overeenkomstig de zich ontwikkelende vermogens van het kind. Dat wil zeggen het geleidelijk, begeleid, loslaten en meer ruimte en eigen verantwoordelijkheid geven.

Hoewel onderdeel van het recht op leiding wordt het hier als apart recht opgevoerd in verband met de nadruk op het aspect van de zich ontwikkelende vermogens van het kind, dat een van de dragende beginselen van het Verdrag inzake de rechten van het kind is. ${ }^{44}$ 
Tot dit recht behoren de beide hierna volgende rechten van het kind, welke gelden naar de mate van zijn zich ontwikkelende vermogens.

\section{Eigen mening, hoorrecht/eigen rechtsingang}

Het recht van het kind op een eigen mening (in en buiten het gezin); het recht van het kind gehoord en serieus genomen te worden in procedures die het kind aangaan (bijvoorbeeld bij echtscheiding, omgangsregelingen, pedagogische dwangmaatregelen ten aanzien van zijn ouders); het recht van het kind op een eigen rechtsingang en/of een curator ad litem.

\section{Gezinstaken}

Het recht van het kind op een zinvolle bijdrage aan gezinstaken en/of het gezinsinkomen.

Dit recht is om twee redenen van belang en als kernrecht te beschouwen. In de eerste plaats wordt aldus invulling gegeven aan de eigen verantwoordelijkheid van het kind. Verantwoordelijkheid wordt (aan)geleerd door verantwoordelijkheid te (laten) dragen. In de tweede plaats geeft een recht op werk c.q. op taken het kind de bevestiging dat het een eigen plaats in het gezin en daarbuiten heeft: het kind hoort erbij in deze maatschappij, heeft recht op actieve en volwaardige participatie in gezin en samenleving. Zoals de Riaad-richtlijnen van 1990 het uitdrukken. ${ }^{45}$

\section{Riaad-richtlijnen, fundamentele beginselen [art.] 3, tweede volzin:}

Young persons should have an active role and partnership within society and should not be considered as mere objects of socialization or control.

\section{Riaad-richtlijnen, [art.] 10, tweede volzin:}

Due respect should be given to the proper person[a]l development of children and young persons, and they should be accepted as full and equal partners in socialization and integration processes.

Een dergelijk 'partnership' begint bij eigen verantwoordelijkheden en dus eigen taken in c.q. ten behoeve van het gezin. De volgende overwegingen - en in grove lijnen geschetste maatschappelijke ontwikkelingen - spelen hierbij (mede) een rol.

In het Westen is het kind geen schakel meer in de generatie-keten (zoals bijvoorbeeld in Afrika), en aldus mede-drager en -instandhouder ('stam-houder' en 'steun-pilaar') van het gezin, maar met zijn geboorte begint het gezin, met zijn vertrek uit het gezin houdt het gezin - als opguidelines); Res. AV 45/112, Annex. Voor de tekst zie Geraldine VAN BUEREN, Intemational documents on children, Dord[r]echt (etc.) 1993, pp. 232-241. 
voedingsgemeenschap - op te bestaan. Het 'nucleaire' westerse gezin bestaat niet zelden slechts uit moeder met (en soms zonder) vader en baby c.q. kind, niet als kern, als nucleus, van een groter familie- of gemeenschaps-/stam-/clan-verband, maar als geätomiseerde (geïsoleerde) eenheid (LEACH). ${ }^{46}$ In dat - meer of minder geisoleerde - kerngezin is het kind ook geen steunpilaar meer, ${ }^{47}$ veeleer is het - omgekeerd - een economische last. Noch voor het gezinsinkomen noch voor gezinstaken is het kind (echt) nodig. Broertjes en zusjes om mee te helpen verzorgen, zijn er nog maar zelden. En voor allerlei huishoudelijke karweitjes zijn er steeds meer - en veel handiger - apparaten. ${ }^{48}$

Hoe belangrijk kinderen ook voor hun ouders (kunnen) zijn, het kind lijkt de boodschap mee te krijgen dat het niet echt belangrijk is voor en binnen het grotere familieverband en zelfs voor en binnen het gezin. Buiten het gezin lijkt het kind zelfs onverbloemd duidelijk te worden gemaakt dat ook de maatschappij niet echt op het kind zit te wachten. ${ }^{49}$ Dit gebeurt niet alleen pas op latere leeftijd als het kind beseft tot de "verloren generatie" te worden gerekend. Nee, van jongs af aan (b)lijkt het kind op straat niet welkom. Het publieke domein, dat ook het kind toebehoort, is immers bijna volledig in beslag genomen door volwassenen, die zich snel van A naar B moeten kunnen verplaatsen in hun niet minder milieu- dan kind-onvriendelijke vervoermiddelen. ${ }^{50}$

Tal van maatschappelijke ontwikkelingen ${ }^{51}$ lijken het kind dus

Vgl. Penelope L.EACH, Children first; What society must do - and is not doing - for children today, London 1994, pp. 7-9.

Vgl. dit bijvoorbeeld met oceanische culturen: Clifford R. O'DONNELL, "The right to a family environment in Pacific Island cultures,' Intemational Joumal of Chitdrens's Rights 1995/1, pp. 87-99, op pp. 91/92. Vgl. LEACH, a.w., p. 20 i.f.

49 Vgl. LEACH, a.w. pp. 25/26.

50 Vgl. M. BOUVERNE-DE BIE, 'De jeugdwelzijnsinterventie in het licht van het recht van kinderen op bijzondere bescherming en hulp, in: E. VERHELLEN, F. SPIESSCHAERT, L. CATTRIJSSE (red.), Rechten van kinderen; Een teksibundel van de Rijksuniversiteit Gent naar aanleiding van de UNO-Conventie woor de rechten van het kind, Antwerpen/Arnhem 1989, pp. 183-208, op p. 186 (aangehaald in hoofdstuk 8, par. 8.2.3).

51 Zie voor een uiteenzetting over dit thema Jens QvoRTrup, 'Het kind-zijn als sociaal verschijnsel; inleiding op een reeks nationale rapporten,' in: E. VERHELLEN e.a. (red.), Kinderrechtengids, Gent 1994 (losbladig), Deel 1 (Commentaren), 1.1 (Algemeen), OVORTRuP, pp. 1-37. Vgl. voorts: Martine SEGALEN, 'The indus" trial revolution: from prolletariat to bourgeoisie, in: André BURGUIERE e.a. (red.), A history of the family, Vol. II: The impact of modemity, Cambridge 1996 (vert. van Histoire de la famille, Parijs 1986), Ch. 9, pp. 377-415; Marc DSPAEPE, "De eeuw van het kind in historisch-pedagogisch perspectief," in: H. CAMMAER en E. VERHELLEN (red.), Onmondig en onwolwassen; De jonge mens in de eeuw van 
'uit te stoten' - zelfs binnen het eigen gezin. Zijn langdurige 'nog-niet' status maken zijn jeugd in plaats van tot een uitdagend wenkend tot een demoraliserend wijkend, ver voonitgeschoven en eindeloos uitgesteld later-als-je-groot-bent-land, ${ }^{52}$ in een maatschappij die zijn generatie bovendien met een achteloosheid die aan wreedheid grenst, als 'verloren' betitelt. Het gevoel nodig te zijn, een eigen taak, eigen verantwoordelijkheden - naar de mate van zijn zich ontwikkelende vermogens - te hebben, is evenwel fundamenteel voor het zelfrespect, en dus essentieel voor de persoonswording van het kind, betreft met andere woorden een basaal recht, een kernrecht van het kind. Vandaar het kernrecht van het kind op een zinvolle bijdrage aan gezinstaken en/of het gezinsinkomen, waardoor niet alleen een ouderlijke verantwoordelijkheid op het punt van zo vroeg mogelijke participatie van het kind in gezinstaken in het licht treedt, maar ook een maatschappelijke verantwoordelijkheid zichtbaar wordt zinvolle maatschappelijke taken voor kinderen en zinvol (betaald) werk voor adolescenten vanaf een bepaalde leeftijd te creëren (bijvoorbeeld vanaf 7 respectievelijk 14 jaar). Immers - om de Moskouse Verklaring van de rechten van het kind uit 1918 opnieuw aan te halen: ${ }^{53}$

Participation in socially necessary (...) work gives the child the opportunity to realise one of the most important rights of children: the right to feel that they are not parasites but active members and builders of life and that their lives can have social worth, not only in the future, but also in the present.

\section{Gelijke sociale omstandigheden en voorzieningen}

Het recht van het kind op sociaal-economische en sociaal-pedagogische omstandigheden en voorzieningen die het beginsel van de gelijke behandeling en gelijke rechten van alle kinderen niet in onredelijke en onbillijke mate schenden.

Uit dit recht vloeien de drie hierna volgende rechten voort.

het kind, Leuven/Amersfoort 1990, pp. 9-37; Eugeen VERHELLEN, "Naar een snel veranderend kindbeeld?' In: Onmondig en onvolwassen, a.w., pp. 53-73; Ph.E. VEERMAN, The rights of the child and the changing image of childhood, Dordrecht (etc.) 1992, 'To what extent did the image of childhood change?' Ch. 1, pp. 3-12 (kritisch ten aanzien van verHeLLENs geschiedbeeld: a.w., p. 10).

52 Vgl. in dit verband bijwoorbeeld Jacques CLAES, "Jeugd als moratorium," in: Onmondig en onvolwassen, a.w., pp. 39-51. Op p. 50 merkt CLAES op: 'Enigszins mag het moratorium jeugd well een schuilplaats zijn. Maar eigenlijk dient het een wachtplaats te wezen. Een wachtplaats moet zo [min mogelijk definitief] zijn. In een wachtplats wacht men op iets, anders wordt het wachten op GoDoT.' 


\section{Opvoedingsonderwijs}

Het recht van het kind op opvoedingsonderwijs, dat wil zeggen het recht van het kind op vakken als c.q. onderricht in relaties, ouderschap, huishouding, verzorging en opvoeding vanaf de basisschool; en het recht van het kind op ouderschapscursussen, -trainingen en -bijscholing voor zijn ouders.

Het kind kan niet alleen slachtoffer worden van in de maatschappij bestaande ernstige vormen van sociaal-economische ongelijkheid maar ook - dwars door alle rangen en standen heen - van ernstige vormen van sociaal-pedagogische ongelijkheid. Pedagogische kennis en vaardigheden zijn nu eenmaal geen aangeboren zaken. Hetzelfde geldt met betrekking tot kennis en (sociale) vaardigheden op relationeel vlak. Uiteraard is een goede opvoeding mede afhankelijk van een goede partnerkeuze en een goede relatie/een goed huwelijk. Hoewel dit zeker geen zaken zijn die louter op het gebied van kennis en vaardigheden liggen (er is bijvoorbeeld een gedocumenteerde samenhang tussen eigen onverwerkte jeugdervaringen en latere neurotische partnerkeuze en/of transgenerationele overdracht van de in de eigen jeugd opgelopen psychische schade $^{54}$ ), is het duidelijk dat een gebrek aan scholing en training van kinderen zelf en van hun ouders sommige ouders en kinderen op een ernstige en maatschappelijk onaanvaardbare pedagogische achterstand zet. Een achterstand die nog wordt vergroot en verscherpt door de hogere verwachtingen die in de moderne maatschappij bestaan, en de hogere eisen die ds huidige, alsmaar gecompliceerder wordende maatschappij stelt, ten aanzien van zowel relaties als de individuatie (het zelfstandig en mondig functioneren van individuen). ${ }^{55}$

Hierop wordt ingegaan in hoofdstuk 12.

55 Dat laatste brengt VAN DER MOST ertoe te wijzen op het tragische verschijnsel 'dat de eisen aan de individualisatie van het opgroeiende kind heden ten dage zo groot zijn, dat de verleiding machtig wordt om mee te gaan met de maatschappelijke tendens om je te handhaven in een slachtofferpositie.' (G.H.F. VAN DER MOST, 'Emoties van hulpverleners,' in: L.P.T. RAIMMAKERS e.a. (red.), Commissie Seksueel Misbruik van Jeugdigen, Handelen bij vermoeden van seksueel misbruik van kinderen en jeugdigen II; De richthijnen SMJ in de praklijk, Assen 1995, pp. 6467, op p. 66.) Het is mede dit tragisch fenomeen dat mijns inziens het belang van het kernrecht van het kind op "gezinstaken," op zo vroeg mogelijke actieve participatie van het kind binnen het gezin en binnen de maatschappij, onderstreept. Een meer of minder negatief zelfbeeld c.q. een gebrek aan zelfwertrouwen ten opzichte van de eisen van de maatschappij kan door actief mee-(moeten) doen worden overwonnen, doch komt door het aannemen van cen slachtofferrol enkel in een neerwaartse spiraal van toenemende zelfinvalid(is)ering (all of niet door middel van verslavingsgedrag). Jeugdwerkloosheid is in meer dan én opzicht een schandvlek voor de maatschappij. En in meer dan éen opzicht een ernstige schen- 
Ter verdere toelichting diene - en wordt hier volstaan met - een citaat van DERKSEN: 56

'De belangrijkste haalbare mogelijkheid is het beìnvloeden van de opvoedingspraktijken. (...) Geef elke burger tijdens zijn schoolcarrière een opleiding in de psychologie en pedagogiek van het opvoeden van kinderen. Binnen de kinder- en ontwikkelingspsychologie en pedagogiek is een hoeveelheid kennis en ervaring aanwezig die niet wordt overgedragen aan gewone mensen, terwijl deze mensen wel de opvoeders zijn van de nieuwe generatie. Iemand in deze tijd leren met een computer om te gaan en niet leren hoe je een kind opvoedt, is een frappante vorm van korte-termijndenken. Men richt zich wel op de productiviteit van zo iemand woor de arbeidsmarkt over laten we zeggen vijf of tien jaar, maar niet op hoe deze persoon over vijftien jaar weer cen volgend lid aan de gemeenschap helpt toevoegen. Het onderricht in kinderpsychologie en opvoedingsstrategieën zou al op de basisschool onderdeel van het lesprogramma kunnen gaan uitmaken en een vervolg krijgen op elke middelbare school.'

\section{Opvoedingsgeld}

Het recht van het kind op opvoedingsgeld voor zijn ouders; dat wil zeggen op een deels inkomensafhankelijk, deels inkomensonafhankelijk 'zorg- en opvoedingsloon' voor de verzorgende en opvoedende ouder(s). Een deel van dit loon zou kunnen bestaan uit coupons voor ouderschapscursussen, -trainingen, -werkboeken, ${ }^{57}$-scholings- en -verlofdagen; voor kinderopvang- en -oppasfaciliteiten; kortingen op bepaalde artikelen en boeken, educatieve en culturele voorstellingen, musea e tutti quanti.

Dit recht komt enigszins tegemoet aan enkele van de maatschappelijke ontwikkelingen die zijn genoemd in de toelichting bij kernrecht 9 (alsook bij kernrecht 11). Belangrijker nog dan de materiële betekenis (die voor een groot deel immers afhankelijk is van de vraag in hoeverre 'Erziehungsgeld' een substantiële financiële verbetering inhoudt ten opzichte van het bestaande Nederlandse systeem van kinderbijslag) acht ik evenwel de symbolische waarde, de verhoging van de status van het pedagogische en verzorgingswerk dat door ouders wordt verricht. En daarmee

dingen van de rechten wan het kind. Immers, meer nog dan het recht op arbeid is hier het recht op eigenwaarde (en dus op ontplooing) in het geding. Geldt dit al voor (tal van) volwassenen, voor jeugdigen geldt het a fortiori, in exponentieel versterkte mate.

56 J.J.L. DERKSEN, Handboek persoonlijkheidsstoomissen; Diagnostiek en behandeling wan de DSM-IV en ICD-10 persoonlijkheidsstoomissen, Utrecht 1993, pp. 256/257.

57 Om een voorbeeld te noemen: A. VAN LONDEN e.a., Vaardigheden voor ouders; Een werkboek met oefeningen en principes om het zelfbeeld wan uw kind te verbeteren, om goed te praten en te luisteren, om gedrag positief te beïnloeden en om gezond te denken in relatie tor problemen met kinderen, Amsterdam/Lisse 1990 (zevende druk). 
de verhoging van de status zowel van de vrouw als moeder en de 'vaderende/moederende' man als van het kind - en aldus de verhoging van het respect voor (de rechten van) vrouwen, huismannen en kinderen. Tegelijkertijd is het duidelijk dat deze status niet kan worden verhoogd door een symbolisch bedrag.

Een bijkomend - maar niet te veronachtzamen - voordeel van 'opvoedgeld' is de goed in deze tijd passende contractsgedachte: quid pro quo (er wordt wat gebracht en er wordt wat verwacht). Niet in de laatste plaats acht ik een voordeel van de term en een systeem van 'opvoedingsgeld' dat daarin tot uitdrukking komt de erkenning en waardering van de maatschappij voor hetgeen ouders investeren en presteren. Eigenlijk heb ik dat al gezegd, maar ik wil hier het belang onderstrepen van het contrast met de term en het systeem van kinderbijslag, waaraan - grof gezegd (maar zo wordt het wel vaak gedacht) - de kwalijke geur hangt van 'fokpremie ${ }^{58}, 59$ '

\section{Opvoedingsondersteuning}

Het recht van het kind op een glijdende schaal van opvoedingsondersteuning van zijn ouders en zijn gezin, met inbegrip van het recht van het kind op psychische empowerment van zijn ouders (en daarmee op het gezonder maken van de gezinshomeostase ${ }^{60}$ ).

58 Zo schrijft zekere Wilbert WAAL in het 'pamflet' Tegen kinderen (Uitgeverij Vriendenlust, Nijmegen 1983, vierde druk, p. 30): 'In Nederland heerst de merkwaardige situatie dat men per kind een bepaald geldsbedrag per maand uitgekeerd krijgt. En ieder kind dat men meer produceert, [levert] als extra bonus meer geld per maand [op]. Het is niet verbazingwekkend dat in het verleden vooral de katholieken hier een lleuke handel mee hebben opgezet.'

59 In hoofdstuk $14 \mathrm{zal}$ ik op deze zaken terugkomen. Wel wil ik hier vast kwijt dat naar mijn smakk geen exorbitante bedragen met een systeem van opvoedingsgeld hoeven te zijn gemoeid, terwijl ik er anderzijds van overtuigd ben dat een verhoging van de status van en het respect voor (vrouwen, huismannen en) kinderen niet alleen op zichzelf nastrevenswaardige en onwaardeerbare, niet te schatten en niet hoog genoeg te schatten zaken zijn, maar tevens, in samenhang met andere te nemen preventieve maatregelen, tot een vermindering van omvang en ernst van kindermishandeling, en aldus - als het is toegestaan (om met GROTIUS te spreken) nut of opportuniteit aan zulke gewichtige principiele voordelen toe te voegen - tot een vermindering van vandalisme en criminaliteit alsook tot een vermindering van het beroep op woorzieningen van lichamelijke en geestelijke gezondheid zal leiden: de maatschappij zal haar investering binnen êten of hooguit enkele generaties terugverdienen.

60 Zie voor de term (hyper)homeostase bijwoorbeeld Frédérique GRUYer, Martine FADIER-NISSE, Pierre SABOURIN, La violence impensable; Inceste et maltraitance, Paris 1991, pp. 82, 85-87, 121. 
BAARTMAN heeft opgemerkt: ${ }^{61}$

'De onderkenning dat veel volwassenen, opvoeders incluis, in emotioneel en seksueel opzicht onvolgroeid gebleven zijn, vormt een bedreiging voor het geloof in een veilige samenleving en vooral voor het geloof in een veilig gezin."

Aangezien we hier over kernrechten van het kind spreken, moeten we over dit - even magisch als mythisch, even bezwerend als verblindend maatschappelijk geloof heenstappen en de bedreiging van dit geloof door de confrontatie ervan met de werkelijkheid niet alleen voor lief nemen, maar zelfs als dure burgerplicht opvatten. Niet slechts omwille van de waarheid, die, hoe pijnlijk soms ook, ons even dierbaar als onze eigen kinderen behoort te zijn. Maar ook om ruimte te maken voor het geloof in een betere toekomst voor alle kinderen.

De onvolgroeidheid waarvan BAARTMAN spreekt, dient daarom gedacht vanuit de kernrechten van het kind - aanknopingspunt te zijn voor empowerment c.q. rehabilitatie van de desbetreffende opvoeders (ouders) in de vorm van therapie en (extra en speciale) trainingen en cursussen. Onder empowerment van ouders(/opvoeders) kan in dit verband worden verstaan: het vergroten van de draagkracht van ouders door het doen toenemen van hun individuele competentie en van hun vertrouwen in eigen kunnen/opvoedkundig handelen, en het verminderen van de draaglast van ouders door verbetering van de levensomstandigheden in materiële, sociale en pedagogische zin.

Dit alles vormt onderdeel van een glijdende schaal van opvoedingsondersteuning, welke oploopt:

a.) van vrijwillig (en laagdrempelig: vanuit een eerste lijn van gecombineerd lichamelijke en geestelijke pre-, peri- en postnatale zwangeren-, zuigelingen-, peuter- en kleuterzorg naar een brede waaier van medische en pedagogische voorzieningen);

b.) naar gedwongen (met deugdelijke rechtsbescherming): de integriteitsactie of persoonswordingsvindicatie door de staat, welke evenzeer een recht van het kind is.

Ter - summiere ${ }^{62}$ - toelichting diene het volgende. Een van de zwaarst denkbare verantwoordelijkheden, de verantwoordelijkheid voor de opvoeding van kinderen, legt de (westerse) maatschappij bijna uit-

BAARTMAN, 'Onderkenning en miskenning van seksueel misbruik van kinderen; enkele historische en actuele aspecten,' in: dez. (red.), Op gebaande paden? Ontwikkelingen in diagnostiek, hulpverlening en preventie met betrekking tot seksueel misbritk van kinderen, Utrecht 1995, pp. 13-27, op p. 25 sup. loc. 
sluitend in de handen van ouders (LEACH). ${ }^{63}$ Dat dit tot (structurele en ernstige) schending van de rechten van het kind moet leiden, kan geen verbazing wekken. ${ }^{64}$ LEACH: ${ }^{65}$

\begin{abstract}
"Since it is not acceptable for adults to hit each other, it cannot be acceptable for them to hit children. Children are people, first and foremost, and negative discrimination among people is unacceptable. But children are not yet adults. As young, vulnerable, developing people, they have special needs for nurturance and care, protection and education, and it is the meeting of these needs which serves as motivation, explanation or excuse for many discriminatory practices. It is from the crucial interface between children's universal and lifelong humanity and their special and temporary childishness that most social unjustice to children arises. Post-industrial Western countries make parents almost solely responsible for meeting the childish needs of their own offspring and in return they give parents almost total control over children's lives, vesting in them, by proxy, human rights that should belong to the children themselves.'
\end{abstract}

Het mag uit dit citaat duidelijk zijn dat er aan twee kanten iets dient te gebeuren - en gezien de ernst en de omvang van de schendingen waarvan we hier spreken, schendingen van kernrechten van het kind, dringend dient te gebeuren. Aan de ene kant dient de pedagogische (aanvullende) medeverantwoordelijkheid van de staat (dat wil zeggen: de taak van de staat als defensor liberum) veel meer uit de verf te komen. Ouders zijn niet alleen verantwoordelijk. Een staat die hen in de kou laat staan bij hun zware pedagogische plichten, schendt ook hun rechten.

Aan de andere kant dient het aanbod van de staat ook niet louter vrijblijvend te zijn. Ouderlijke almacht dient te worden beperkt in de mate dat ouders minder bereid of in staat zijn de kernrechten van het kind te respecteren. Deze beperking gebeurt door het opleggen van pedagogische hulp, van het verplichte huisbezoek tot de gedwongen uithuisplaatsing en alle mogelijke - geïndiceerde - varianten daartussenin, in situaties waar een hulpaanbod niet wordt geaccepteerd, niet wordt benut, of geen zin heeft. Aldus - dat wil zeggen: wanneer (de mogelijkheid, de dreiging van) 'dwang' niet meer dan de volgende 'logische' stap is, onderdeel van een duidelijk, geïntegreerd geheel van goede voorzieningen, één van de hoofdstukken in een consistent kinderrechtelijk verhaal - krijgt ook de taak van de staat als protector liberum een minder abrupte, fijner afgestemde en meer genuanceerde, minder 'ontmaskerende' en stigmatiserende, en niet in de laatste plaats ook minder arbitraire invulling. Hoe structureel en ernstig, hoe massief en massaal, hoe omvangrijk en ingrijpend deze schending is, zal worden (aan)getoond in hoofdstuk 12. 
Hoewel niemand zal beweren dat dit van vandaag op morgen uitgewerkt en gerealiseerd kan worden, dienen we wel ervan doordrongen te zijn dat 'rechten van het kind' - indien serieus en niet als paradijselijk vijgeblad van parentiarchale privacy-privileges opgevat - eo ipso betekent vermindering van de macht van ouders. Het recht van het kind op vermindering van de almacht van ouders zou zelfs het eerste recht van het kind kunnen worden genoemd. Het is evenwel een loos recht als niet de onmacht van ouders eveneens wordt verminderd. Het recht op empowerment van zijn ouders is daarom gelijkelijk het eerste recht van het kind. Vandaar, als onderdeel van het kernrecht van het kind op een glijdende schaal van opvoedingsondersteuning: het kernrecht van het kind op psychische empowerment van zijn ouders, zodat deze 'good enough'-ouders kunnen worden. Want niet 'goed-genoege' ouders ${ }^{66}$ geven hun kinderen het gevoel niet goed genoeg, of erger: niet de moeite waard te zijn.

Vgl. Bruno BeTtelHeIM, Niet volmaakt maar goed genoeg; Over het opvoeden van kinderen (oorspr. titel: A good enough parent: A book on child rearing, New York 1987), Amsterdam 1990.

Wat ik versta onder een oucler die goed genoeg, 'good enough' is, heb ik elders ('Kinderen in ons midden," Recht \& kritiek 1994/4, pp. 322-339, op p. 336 nt. 43) aan de hand van de volgende goede-ouder-dichotomieën pogen aan te geven: (goede) opvoeding bestaat wit affectie en zorg; zorg uit verzorging en opvoeding in enge zin; deze laatste uit structuur (regelmaat) en grenzen (regels); regels uit morele opvoeding (het bijbrengen van normen en waarden, de morele grenzen) en de 'regels van het huis'; deze laatste bestaan uit redelijke eisen, ofwel grenzen in enge $\operatorname{zin}_{\text {, }}$ en sancties; sancties wil zeggen: beloning en de verdiende straf (c.q. het onthouden van belloning).

Affectie (liefde, warmte, empathie) is het fundament van het Huis van de Opvoeding. Verzorging, structuur, grenzen en sancties/beloning zijn de vier muren. Het dak dient er door het kind (inmiddels puber/adolescent) zelf op te worden gezet - door, tijdens en na het loslaten door de opvoeders, de goede ouders.

Het recht van het kind op 'goed-genoege' ouders: dat zou de 2le eeuwse variant kunnen worden van Ellen KEY's 'eerste recht' van het kind, namelijk 'het recht zijn ouders verstandig te kiezen' (VEERMAN, The rights of the child and the changing image of childhood, a.w., p. 77 i.f.).

Ellen KEY publiceerde in 1900 een boek onder de titel De eeuw van het kind. Hierin haalt zij een toneelstuk aan waarin een oude man tot een jongeman zegt (VEERMAN, a.w., p. 78): "The next century will be the century of the child, just as this century has been the woman's century.' Die oude man sprak een eeuw yoor zijn beurt, wat de tweede helft van zijn uitspraak betreft. Over een eeuw weten onze achterkleinkinderen of dat ook voor de eerste helft geldt. De jongeman heeft zijn woorden echter voor zoete koek geslikt, want sinds KEY's boek wordt de twintigste eeuw 'sloganmatig' aangeduid als 'de eeuw van het kind' (vgl. A. VAN POUCKE, 'Woord vooraf,' in: Onmondig en onvolwassen, a.w., pp. 7.8, op p. 7 i.f.). 
Empowerment van ouders in zowel materiële als morele zin (opvoedingsgeld, opvoedingsscholing, opvoedingsvoorzieningen en -faciliteiten en opvoedingsondersteuning met inbegrip van vormen van individuele en gezinstherapie) en disempowerment van ouders in juridische zin (opgelegde opvoedingsondersteuning), kortom: onmachtsbestrijding en almachtsbeperking, dienen dus hand in hand te gaan.

\subsubsection{Een schema}

Het voorgaande kan als volgt (gedeeltelijk) in schema worden gebracht en worden geëxpliciteerd. Men lette op de onvermijdelijke overlap (alsmede op de onvermijdelijke onvolledigheid). Op een enkele plaats in het schema worden begrippen vermeld die in een later hoofdstuk nog moeten worden uitgewerkt.

A. Rechten van het kind $=$ (algemene) rechtsplichten van de ouders tegenover het kind:

A1. verantwoorde gezinsplanning en verantwoorde zwangerschap;

A2. verantwoorde verzorging en opvoeding;

A3. ter zake van ernstige fouten: erkenning en morele genoegdoening; in gevallen van kindermishandeling ook compensatie (financiële genoegdoening/schadeloosstelling). ${ }^{67}$

B. Rechten van het kind = (algemene) rechtsplichten van de staat tegenover het kind:

B1. krachtig en doeltreffend preventie-beleid, met name (doch niet uitsluitend) door opvoedingsgeld, opvoedingsonderwijs en (vrijwillige) opvoedingsondersteuning;

B2. aanvullende en desnoods vervangende verzorging en opvoeding door een glijdende schaal van (vrijwillige naar gedwongen) opvoedingsondersteuning (c.q. vervangende opvoeding);

B3. 'reparatie' (restitutie, compensatie, rehabilitatie, satisfactie en waarborgen voor niet-herhaling: de staat was nalatig).

C. Rechten van het kind = (algemene) rechten van kind èn ouders tegenover de staat:

c1. Pedagogisch Onderwijs (relaties-, zorg- en opvoedingsonderwijs vanaf de basisschool en volwassenen-ouderschapseducatie); C2. Pedagogisch Geld (zorg- en opvoedingsloon); 
c3. Pedagogische Ondersteuning (glijdende schaal van opvoedingsondersteuning).

D. Rechten van het kind = rechten van het kind tegenover de ouders:

I. Algemeen/basaal:

D1. gewenst ter wereld komen;

D2. prenatale zorgvuldigheid, waaronder het matigen of afzien van schadelijke/gevaarlijke medicijnen of drugs (medische giften), waaronder nicotine en alcohol ${ }^{6 \%}$;

D3. (materiële en morele) geborgenheid, dat is om te beginnen: voldoende psychische draagkracht en emotionele volwassenheid van de ouders, en zo nodig empowerment (bijvoorbeeld door psychotherapie) van de ouders, zodat deze het kind onvoorwaardelijke affectie kunnen geven en voldoende ruimte kunnen bieden en laten.

II. Specifiek/pedagogisch:

D4. leiding (disciplinering, grenzen stellen, opvoeden in 'enge' zin), met een zo min mogelijk autoritaire of permissieve, en zo veel mogelijk autoritatieve opvoedingsstij] $1^{69}$;

D5. begeleiding (rechten laten uitoefenen en verantwoordelijkheid laten dragen naar de mate van de zich ontwikkelende vermogens van het kind), hetgeen met zich brengt: een toenemend democratische opvoedingsstijl;

D6. uitleiding (leiding gaat steeds meer over in begeleiding, begeleiding gaat over in geleidelijke uitleiding, dat is de begeleiding in het losmakingsproces van de adolescent en het loslaten door de ouders). ${ }^{70}$

III. In geval van ernstige fouten of tekorten:

D7. erkenning en genoegdoening (in gevallen van kindermishandeling en incest ook financieel).

E. Rechten van het kind = rechten van het kind tegenover de staat:

E1. optimale medische en psychologische/psychiatrische en adequate sociaal-pedlagogische voorzieningen;

Vgl, in dit verband Judy F. ROSENBLITH, In the beginning; Development from conception to age two, Newbury Park (etc.) 1995, pp. 110-121.

69 Zie hiervoor hoofdstuk 11 (par. 11.3).

70 Leiding, begeleiding en uitleiding zijn niet te scheiden, omwille van de accentverschillen (die samenhangen met de toenemende leeftijd en rijpheid - en dus eigen-gerechtigdheid - van het kind) worden ze hier wel onderscheiden. Strikt genomen vallen begeleiding en uitleiding onder leiding. 
E2. kwalitatief hoogstaand onderwijs (waaronder ook relatie-, zorgen opvoedingsonderwijs, met inbegrip van, voor zover het daaraan in de thuissituatie heeft ontbroken, praktische huishoudelijke bijscholing/training, voor jongens en meisjes);

E3. overige ontplooiings- alsook speelfaciliteiten voor kinderen, waaronder het revindiceren (terugeisen van volwassenen, dat is gedeeltelijk autovrij maken) van het publieke domein, in het bijzonder van de binnensteden en van dorpskernen;

E4. in algemene zin: actieve en zorgvuldige verdediging en bescherming van de rechten van het kind, dat wil zeggen:

a.) pro-actieve persoonswordingsoptimalisatie;

b.) actieve en zorgvuldige persoonswordingsvindicatie;

c.) actieve en ruimhartige 'reparatie' (restitutie, compensatie, rehabilitatie, satisfactie en waarborgen voor niet-herhaling).

F. Rechten van het kind = dwang-bevoegdheden van de staat tegenover de ouders:

F1. Pedagogische Dwang (aan de ouders opgelegde vormen van opvoedingsondersteuning, pedagogische maatregelen van kinderbescherming);

F2. Pedagogische Rechtsbescherming van de ouders (mogelijkheid van bezwaar en beroep volgens de normale (bestuurs)procesrechtelijke waarborgen);

F3. recht van het kind (eventueel bijgestaan of vertegenwoordigd door een curator ad litem) gehoord en serieus genomen te worden in de desbetreffende rechtsgangen en procedures; vanaf een bepaalde leeftijd (in elk geval vanaf de leeftijd van 14 jaar) een eigen rechtsingang van het kind ter zake van zijn persoonswordingsvindicatie.

\section{Pedagogische dwang}

Onder pedagogische dwang wordt verstaan: de integriteits- en persoonswordingsvindicatie of, kortweg, de integriteitsactie van de staat als protector liberum, dat wil zeggen: de handhaving van het recht van het kind - ter bescherming van zijn persoonlijke levenssfeer (zijn lichamelijke en geestelijke integriteit) en/of ter behoeding en borging van zijn minimale persoonswording - op desnoods aan zijn ouders c.q. in zijn gezin opgelegde vormen van pedagogische ondersteuning (waaronder, indien en voor zover dat is geïndiceerd, de uithuisplaatsing van het kind dan wel de uithuisplaatsing van één of beide ouders, desnoods te handhaven door middel van een straat-, stad- of streekverbod of, in het uiterste geval, door gijzeling van de ouder). 
Bij wijze van geheugensteuntje kunnen de belangrijkste elementen uit bovenstaand schema in een acroniem worden samengevat: POGODè $=$ Pedagogisch(e) Onderwijs, Geld, Ondersteuning, Dwang èn Rechtsbescherming.

Rechten en actoren in de Trias pedagogica

In deze paragraaf worden nog enkele losse eindjes aan elkaar geknoopt met betrekking tot de rechten en de actoren in de Trias pedagogica. De rechten van het kind worden aldus nader in de Trias pedagogica gesitueerd.

\subsection{1}

Fundamentele kinderrechten in de Trias pedagogica

Hierboven werd als eerste van beide bijzondere uitgangspunten voor de dertien-puntenlijst van sociaal-pedagogische kernrechten genoemd de gedachte dat 'rechten van het kind' eo ipso betekent rechten in de Trias pedagogica, in de triade, de driehoek Kind-Ouder-Staat. In deze paragraaf staan we bij die gedachte nog even stil.

Gedurende zijn hele minderjarigheid staat het kind onder ouderlijk gezag (c.q. onder voogdij; art. 1:245 BW). Rechten van het kind zijn derhalve alleen al daardoor eo ipso rechten in de Trias pedagogica, rechten in de - vanuit een rechtsstatelijke en publiekrechtelijke ${ }^{71}$ optiek, qua checks and balances (bevoegdheidstoekenning en -verdeling, toezicht en verantwoording, handhaving en bescherming van de rechten van alle partijen), en vanuit een mensenrechtelijke optiek, qua bescherming van de rechten van de zwaksten, primitieve en ondoorzichtige - driehoeksrelatie kind-ouders-overheid.

71 Vgl. het in hoofdstuk 1 aangehaalde proefschrift van Nina STEGERHOEK, De publieke kant wan, het jeugdrecht; Publieke aspecten van het civiele jeugdrecht nader beschouwd (diss. Leiden), Zwolle 1995. Op p. 2 merkt de auteur op: 'Onheldere normen, een gebrekkig gewaarborgde normhandhaving, onduidellije procesverhoudingen en onevenwichtige rechtswaarborgen doen afbreuk aan een rechtsgebied: Om daar dadelijk aan toe te voegen: "Op het gebied van het kinderbeschermingsrecht heet het nog wel eens dat de spanning tussen normhandhaving en rechtsbescherming opgelost wordt in het criterium "het belang van de minderjarige".' Het belang van het kind als rechtsstatelijk oplosmiddel: is een beter pleidooi denkbaar dit 'belang' eindelijk eens door concrete rechten, rechten wan het kind, rechten in de Trias pedagogica, sociaal-pedagogische rechten, te vervangen? De vraag stellen, is haar beantwoorden; vandaar dat ik aan dit aspect niet meer dan een voetnoot wil wijden. In het volgende hoofdstuk komen we over het belang van het kind (the best interests of the child) dan ook slechts vanuit een mensenrechtelijke optiek te spreken. 
De Trias pedagogica kan in juridische zin het meest pregnant worden gedefinieerd aan de hand van de artt. 18 en 19 juncto art. 2 van het Verdrag inzake de rechten van het kind. Deze bepalingen luiden, voor zoveel hier van belang (curs. jw):

\section{Art. 2 VRK:}

1. De staten (...) eerbiedigen en waarborgen de in het Verdrag beschreven rechten voor ieder kind onder hun rechtsmacht zonder onderscheid van welke aard ook, ongeacht (...) huidskleur, geslacht, (...) maatschappelijke afkomst, welstand (...) of andere omstandigheid van het kind of van zijn (...) ouder (...).

2. De staten (...) nemen alle passende maatregelen om te waarborgen dat het kind wordt beschermd tegen alle wormen wan discriminatie (...) op grond van de omstandigheden (...) van de ouders (...) van het kind.

\section{Art. 18 VRK:}

1. De staten (...) doen alles wat in hun vermogen ligt, on de erkenning te verzekeren van het beginsel dat beide ouders de gezamenlijke verantwoordelijkheid dragen voor de opvoeding en de ontwikkeling van het kind. Ouders (...) hebben de primaire werantwoordelijkheid voor de opvoeding en de ontwikkeling van het kind. Het belang van het kind is hun allereerste zorg.

2. Ter waarborging en bevordering wan de in dit Verdrag beschreven rechten verlenen de staten (...) passende hulp en steun [assistance] aan ouders (...) bij de uitoefening van hun verantwoordelijkheden die de opvoeding van het kind betreffen, en waarborgen zij de ontwikkeling van instellingen, voorzieningen en diensten woor kinderzorg.

3. De staten (...) nemen alle passende maatregelen om te waarborgen dat kinderen van werkende ouders recht hebben op gebruikmaking van de diensten en voorzieningen voor kinder[opvang en kinder]zorg [child care] waarvoor zij in aanmerking komen.

\section{Art. 19 VRK:}

1. De staten (...) nemen alle passende wettelijke en bestuurlijke maatregelen en maatregelen op sociaal en opvoedkundig gebied om het kind te beschermen tegen alle vormen van lichamelijk of geestelijk geweld, letsel of misbruik, lichamelijke of geestelijke verwaarlozing of nalatige behandeling, mishandeling of exploitatie, met inbegrip van sexueel misbruik, terwijl het kind onder de hoede is van de ouder(s), wettige voogd(en) of iemand anders die de zorg voor het kind heeft.

2. Deze maatregelen ter bescherming dienen (...) doeltreffende [werkwijzen] te omvatten voor de invoering [het ingang doen vinden en vestigen] van sociale programma's om te voorzien in de nodige ondersteuning van het kind en van degenen die de zorg voor het kind hebben, alsmede [werkwijzen] woor andere vormen van voarkoming van, en woor opsporing, melding, verwijzing, onderzoek, behandeling en follow-up van gevallen van, kindermishandeling zoals hierboven beschreven, en, indien van toepassing, voor inschakeling van rechterlijke instanties.

Hoewel we in hoofdstuk 10 nog op deze en andere verdragsverplichtingen van de staat zullen terugkomen, is het van belang ons al in dit hoofd- 
stuk over natuurlijke rechten te beseffen dat deze rechten op zijn minst een verdragsrechtelijke grondslag hebben. Zoals we al opmerkten, kunnen sommige rechten geacht worden te behoren tot het jus constitutum (het positieve of geldende recht), andere tot het jus in statu nascendi of pupillari (soft law, recht in wording, nog niet uitgerijpt of uitgekristalliseerd recht), en weer andere tot het jus constituendum (wenselijk recht). Hun status varieert met andere woorden van die van hard recht, zacht recht en halfzacht recht tot die van boterzacht (moreel) recht. Wat die laatste categorie betreft, moet worden toegegeven dat er in de regel heel veel voor nodig is om iets van moreel recht tot positief recht te maken. Het is evenwel voorstelbaar dat het in het daglicht stellen van een (noodzakelijk) recht voldoende is on het bijna terstond te doen uitharden. Het schrille contrast met de maatschappelijke werkelijkheid doet dan als het ware een 'instant' opinio juris sive necessitatis ontstaan. Zoals boter snel hard kan worden als ze in de ijskast wordt gelegd, zo kan boterzacht recht - heel - soms ook snel hard worden - als het uit de ijskast wordt gehaald.

Wat er evenwel zij van de status van de diverse voorgestelde kernrechten, de pedagogische (mede)verantwoordelijkheid van de staat op zich is in geen geval boterzacht te noemen. We zagen al dat VAN DER BURG het toekennen van algemene en speciale rechten aan kinderen theoretisch mogelijk en verdedigbaar achtte: ${ }^{72}$

\footnotetext{
'De belangen waar we het hier over hebben, zijn niet alleen voor het kind zelf maar ook voor de gemeenschap van groot gewicht. De gemeenschap heeft er belang bij dat haar toekomstige [sic, jw] leden goed verzorgd en opgevoed worden. Om die reden is het theoretisch mogelijk en verdedigbaar hun op basis wan de algemene en van de specifieke belangen van kinderen bepaalde algemene en speciale rechten toe te kennen.'
}

Dat in de praktijk al ruim vóor de erkenning en formulering van algemene en speciale rechten van kinderen de samenleving, en dus de staat, een pedagogisch belang en (dus) pedagogische verantwoordelijkheid had, kan worden geillustreerd (meer wordt hier niet bedoeld) aan de hand van een tweetal uitspraken. In de enige uitspraak tot op heden met betrekking tot internationaal (privaat)recht en kinderen ${ }^{73}$ - de zogenaamde $B O L L$-zaak

Wibren VAN DER BURG, 'Rechten van kinderen: enkele filosofische kanttekeningen,' in: Carol VAN NIJNATTEN (red.), Kinderrechten in discussie, Amsterdam/ Meppel 1993, pp. 64-80, op p. 68.

Eugeen VERHELLEN, Jeugdbeschemingsrecht, Gent ed. 1996, p. 467. 
- overwoog het Internationale Gerechtshof in 1958: ${ }^{74}$

'Protective upbringing contributes to the protection of the child, but at the same time, and above all, it is designed to protect society against dangers resulting from improper upbringing, inadequate hygiene, or moral corruption of young people.'

In 1963 overwoog het Hooggerechtshof van Wisconsin in de KRITZIK versus KRITZIK-zaak:75

"In making his determinations as to what conditions of a divorce judgment would serve the interests of the children involved, the Trial Court does not function solely as an arbiter between two private parties. Rather, in his role as a Family Court, the Trial Court represents the interests of society in promoting the stability and best interests of the family. It is his task to determine what provisions and terms would best guarantee an opportunity for the children involved to grow to mature and responsible citizens, regardless of the desires of the respective parties. This power reflected a recognition that children inwolved in a divorce are always disadvantaged parties and that the law must take affirmative steps to protect their welfare.'

Klinkt in de laatste uitspraak al iets van een kentering in het juridisch denken over kinderen door, op de eerste is nog tot op grote hoogte van toepassing wat DOEK in een korte historische paragraaf als inleiding op een jeugdrechtelijk exposé optekende: ${ }^{76}$

"Afgezien van allerlei details kan men stellen dat eeuwenlang - ook in ons Nederlands recht - de aandacht van het recht voor het kind, de jeugdige persoon, zich beperkte tot zijn misdadigheid en zijn afstamming."

74 Case concerning the application of the Convention of 1902 governing the guardianship of infants (Netherlands vs. Sweden), Judgment of November 28th, 1958; ICJ Reports 1958, pp. 55-156, op p. 69 (curs. jw). Voor een korte samemwatting van de feiten, rechtsoverwegingen van het Hof en overige data zie J.J.G. SYATAUW, Decisions of the International Court of Justice; A digest, Leiden 1969 (tweede druk), pp. 95-100.

75 VEERMAN, The rights of the child and the changing image of childhood, a.w., pp. 333/334; Robert W. HANSEN, 'The role and rights of children in diworce actions,' Joumal of family law (University of Louisville School of Law) 1966, pp. 1-14, op p. 4 (curs. jw).

76 DOEK/VLAARDINGERBROEK, Jeugdrecht en jeugdhulpverleningsrecht, Den Haag 1996 (tweede druk), p. 21. 
Het denken in termen van criminaliteitspreventie - in heden ${ }^{77}$ en verleden - doet aan de pedagogische verantwoordelijkheid van de staat niets af, mits deze ook pedagogisch - gericht op persoonswording, ontplooiing en emancipatie (gelijkheidsbevordering door empowerment) - wordt vertaald, en niet louter repressief, hetzij in de richting van kinderen, hetzij in de richting van ouders, wordt opgepakt.

\subsubsection{Kernrechten van kinderen als fundamentele (rechts) begin- selen}

Hierboven stelden we dat het om kernrechten gaat, dat wil zeggen om (natuurlijke) rechten met het karakter van fundamentele (rechts)beginselen. Bij de betekenis van dat (rechts)karakter hebben we uitvoerig stilgestaan in hoofdstuk 3 ('Mensenrechten als rechtsbeginselen'). Op deze plaats willen we dat karakter nog eens benadrukken.

We kunnen VEERMAN ${ }^{78}$ nazeggen dat (mensen)rechten, in een meta- of supra-positieve betekenis ...

'(...) belong to man as part of his intrinsic nature, as much as his body, his mind, and his various powers.'

Tegelijk kunnen - met VEERMAN ${ }^{79}$ - mensenrechten, in een meer extra-, of liever pre-, para-, of peri-positieve betekenis, worden gedefinieerd als ...

'(...) those moral-political claims that, by contemporary consensus, every human being has, or is deemed to have, on his society and on his government, and that are considered indispenable for the development of the individual.'

Deze definitie parafraserend, zouden we de (sociaal-pedagogische kern-) rechten van het kind kunnen omschrijven als: ${ }^{80}$

'(...) those moral-political claims that, by contemporary consensus, every child has, or is deemed to have, on his parents, on his society and on his government, and that are considered indispenable for the development of the individual child."

77 Vgl. in dit verband het rapport van J. JUNGER-TAS, Jeugd en gezin; Preventie vanuit een justitieel perspectief, Den Haag (Ministerie van Justitie) 1996. (Over dit rapport komen we in hoofdstuk 13 en 14 nog te spreken).

78 VEERMAN, a.w., p. 23.

79 VEERMAN, a.w, p. 24.

80 Toevoegingen of veranderingen zijn gecursiveerd. 
Opgevat als (rechts)beginselen zijn deze claims eerst en vooral aanspraken op een bepaald beleid c.q. - afhankelijk van de diepte van de kloof tussen pays légal en pays réel - op min of meer radicale beleidsombuigingen. Zoals VERSCHUUREN in een opstel over beginselen in het milieurecht schreef: ${ }^{81}$

\begin{abstract}
'Beginselen bepalen ook de concrete beleidsdoelstellingen die verwezenlijkt moeten worden met het oog op een gewenste economische of sociale verbetering van de samenleving (of behoud van een gewenste status). Beleidsdoelstellingen zijn dus concrete doelstellingen ter verwezenlijking van achterliggende beginselen.'
\end{abstract}

Dit laat zich vrij eenvoudig vertalen - althans in abstracto - van het natuurlijk milieu (VERSCHUURENs onderwerp) naar het pedagogisch milieu, waar het in eerste en laatste instantie gaat om een pedagogico-sociaaleconomische klimaatverbetering: de reallocatie van menskracht, materiële hulpbronnen en geldstromen ten behoeve van kind en gezin.

De sociaal-pedagogische kernrechten van het kind, en in algemene, overkoepelende zin: diens recht op persoonswording, dienen daarbij - op politiek niveau en in het concrete geval - onder de werking te worden gesteld van het "voorzorgsbeginsel, inhoudende dat het ontbreken van wetenschappelijke zekerheid niet aan [sociaal-pedagogische] maatregelen in de weg mag staan. ${ }^{82}$ Welk beginsel mijns inziens beschouwd kan worden als een moderne variant van het oude (interpretatie)beginsel ut res magis valeat quam pereat. ${ }^{83}$ Gekozen moet dus worden voor die beleidsoplossingen en voor die oplossingen in het concrete geval die naar alle waarschijnlijkheid, althans met een redelijke mate van zekerheid, naar de huidige stand van de ontwikkelingspsychologische en pedagogische wetenschap, het recht op persoonswording van kinderen in het algemeen respectievelijk van het desbetreffende individuele kind het meeste dient.

81 Jonathan verSCHUUREN, 'Naar een codificatie van beginselen van het milieurecht,' Recht en kritiek 1995/4, pp. 421-445, op p. 423 (curs. JV).

82 VERSCHUUREN, t.a.p., op p. 424.

83 Als klassiek beginsel vergelijkbaar met het modern-internationaalrechtelijke 'principle of effectiveness'; vgl. voor een toepassingsvoorbeeld Loukis G. LOUCAIDES, Essays on the developing law of human rights, Dordrecht (etc) 1995, Ch. 6: 'Responsibility under the European Convention on Human Rights: objective or subjective test?' Pp. 141-156, op p. 144. 
Een korte opmerking nog over de drie actoren in de trias: kind, ouder(s), overheid.

De overheid treedt in de trias niet op in loco parentis, in de plaats van de ouder(s), dat wil zeggen als hulp-ouder, bij-ouder of super-ouder. Dat kan zij niet en dat past haar niet. Rechten van kinderen betekent echter wel dat, zolang een kind te jong is om voor zijn rechten op te komen en deze eventueel af te dwingen, de overheid optreedt namens het kind, controleert of, waarborgt dat de kernrechten van het kind niet worden geschonden. Met andere woorden: de staat is actor in loco liberum, zaakwaarnemer op de plaats van de kinderen. Namens de samenleving is de overheid zaakgelastigde ten aanzien van de pedagogische rechten van kinderen. Zo is gedwongen opvoedingshulp dan ook geen 'straf' voor ouders maar een recht van het kind. Zo kan een aan een ouder gedaan therapie-aanbod een rehabilitatie- of compensatierecht van een zelf als kind mishandelde ouder zijn, maar het is eerst en vooral een recht van zijn of haar kind, het recht van het kind op empowerment van zijn ouders, op zo autonoom, geïndividueerd mogelijke ouders.

De actoren kind en ouder in de trias zijn in supra-positieve zin gelijkwaardig maar noch feitelijk noch juridisch gelijk: hoe jonger het kind is, hoe groter dan ook de betekenis is van de derde actor: de overheid, dienares van het veiligheids- en ontwikkelingsbelang van het kind, en qualitate qua, dat wil zeggen: als dienares van dat belang, hoedster van het gezin.

\section{3 .4}

De Trias pedagogica en Gezinswaarden

Dat veiligheids- en ontwikkelingsbelang werd hierboven (in par. 7.2.3.1) als tweede uitgangspunt voor de dertien-puntenlijst genoemd, een belang waarop primair het persoonswordingsbeginsel ziet, in die paragraaf geprotojuridiseerd als meta-kernrecht op evenwichtige ontwikkeling van elk kind. Op grond van welke 'ruil,' van welke gentlemen's agreement, de derde actor in de Trias pedagogica, de staat, ten aanzien van dit metakernrecht verstek laat gaan, laten we ons uitleggen door OVORTRUP: ${ }^{84}$

Jens QVORTRUP, 'Het kind-zijn als social verschijnsel; inleiding op een reeks nationale rapporten,' in: E. VERHELLEN e.a. (red.), Kinderrechtengids, Gent 1994 (losbladig), Deel 1 (Commentaren), 1.1 (Algemeen), QVORTRuP, pp. 1-37, op p. 34. 


\begin{abstract}
'Er is zeker en vast een contradictie tussen apodictische uitspraken zoals "als een individu is het kind drager van alle fundamentele rechten gegarandeerd door constitutionele [en overige wetgeving]," en het feit dat voor kinderen een aanzienlijk deel van hun rechten toegewezen wordt aan ouders. "De autoriteit van ouders ... is een bundel rechten door de maatschappij aan de ouders toegekend in het eigen belang van het kind opdat zij in staat zouden zijn hun sociale taak tot een goed einde te brengen" (...). Die regeling is uiteraard van uiterst belang woor de maatschappij, die de verantwoordelijkheid van ouders in dat opzicht erkent, want "in ruil voor deze plichten moet de privacy van het gezin gerespecteerd worden en de integriteit [lees: de onschendbaarheid of immuniteit, jw] van het gezin ondersteund."

De "quid pro quo" uitwisseling tussen ouders en staat kent uiteraard [haar] grenzen als ouders hun taak verwaarlozen, maar de grenzen zijn ruim en tussenkomst wan de staat gebeurt normaal enkel in uitzonderlijke omstandigheden. Enkel in deze zeldzame gevallen worden de tegengestelde belangen tussen ouders en staat dus blootgelegd. De ongecontroleerde afhankelijkheid van kinderen van hun ouders prevaleert (....).
\end{abstract}

Zodra we de maatschappelijke mythe van het veilige gezin met de maatschappelijke werkelijkheid van tienduizenden Nederlandse kinderen confronteren, weten we, kunnen we weten, dat deze quid pro quo-accomodatie, wat er ook zjj van haar historische oorsprong en betekenis, ${ }^{85}$ en van haar voordeligheid voor op de korte termijn denkende beleidsmakers, in deze tijd niet voldoet. Bij te grote machtsverschillen, bij te grote eenzijdige afhankelijkheid past principieel geen gentlemen's agreement, of, moeten we in deze tijd zeggen, geen ladies' and gentlemen's agreement, geen 'dames en heren, doe uw best en maak het niet te bont.' Geen 'hier heeft $\mathrm{u}$ alle macht, maar houd uw vuile was zoveel mogelijk binnen.' Dat zijn geen boodschappen die passen in een rechtsstaat. Dit zijn geen signalen die een democratische overheid straffeloos naar haar mondige en onmondige burgers kan blijven uitzenden.

Neen, hier passen slechts wetten en een goed beleid. Wetten en beleidsmaatregelen die weliswaar het gezin steunen en beschermen, maar niet als magische of mythische entiteit, als geloofsartikel waar, zoals dat zo vaak gaat met geloof en goedgelovigheid, gemakkelijk en goedkoop politieke munt uit is te slaan, doch door uit te gaan van de rechten van individuele gezinsleden, kinderen voorop. Hoe belangrijk en beschermwaardig het gezin ook is, het is niet heilig. Als het niet veilig is, dienen er alternatieven te zijn, dienen kinderen in veiligheid te worden gebracht en hun rechten veilig te worden gesteld.

Bijzonder lezenswaard in dit verband is M. VAN DEN DUNGEN, "Het broeikaseffect: gezin en samenleving rond 2000,' in: Gezin; Tijdschrift voor primaire leefvormen 1989, pp. 164-180. 
Wet en beleid mogen geen ruimte laten voor een beroep op 'Privacy' of 'Gezinswaarden' dat zich niet zozeer bekreunt om de persoonlijke levenssfeer, de lichamelijke en geestelijke integriteit van kinderen, en om de voor kinderen fundamentele waarde van het veilige gezin, als wel bekommerd is om de teloorgang van parentiarchale privileges en bevreesd voor de ontmaskering van adultocentrische manipulaties die beter met de mantel der kinderliefde bedekt kunnen blijven. Wet en beleid dienen ruim baan te maken voor het zoeken naar oplossingen en het beproeven van alternatieven in situaties en gezinnen waar het recht van het kind op evenwichtige ontwikkeling in huiselijk geweld dreigt ten onder te gaan, in geweld tegen het kind dreigt te worden gesmoord.

Op indringende wijze wordt dit onder de aandacht gebracht door PLECK. Weliswaar beschrijft zij de Amerikaanse situatie, maar de verandering in het denken die nodig is om kinderen tot hun recht te laten komen, vergt het blootleggen en aanraken van zenuwen die bij Amerikanen niet zo wezenlijk anders lopen dan bij ons. We sluiten dit hoofdstuk af met een citaat uit PLECKs boek Domestic tyranny: ${ }^{86}$

'TThe family] is no longer viewed as a little kingdom but as an intimate grouping of individuals bound by affection and companionship. Children are seen as having rights to minimum standards of care and to physical and emotional safety. They are no longer expected to submit to parental commands with unquestioning obedience. Women have acquired a separate legal identity not subsumed by their husbands. (...) These changes, however, have not reduced family violence. Indeed, it may flourish as much in the context of disappointed hopes for warmth, support, and love as in a climate of authoritarianism. (...)

The history of social policy against family violence has been one of persistent, even inherent, conflict between protecting the victim and preserving the family, and the gradual development of alternatives withim and outside the family for victims of abuse. (...) In both the past and present, great faith has often been placed in therapeutic efforts to restore family harmony. In milder cases of abuse, this faith may be reasonable. However, the success of therapy should not be judged by whether the family unit is "preserved." The expectation that treatment should and will maintain the family often comes at the expense of victims who will be reinjured. It also diverts attention and resources from other approaches. (...) Although therapy may help in milder cases and criminalization in more serious ones, what is really needed is a variety of programs that increase or strengthen the alternatives to maintaining the family. Concern about abused children can be measured by the amount and quality of foster care available and the likelihood that a child can be placed permanently with adoptive parents. Efforts to help fantily violence from colonial times to the present, New York/Oxford 1987, pp. $201-203$. 
abused women or incest victims are only as good as the living conditions for single mothers and their children. (...)

Thus, a policy against family violence is only as far-reaching as the alternatives to the traditional family it makes available. The barrier to achieving this goal, however, is not only its monetary cost but also the challenge it represents to the Family Ideal. Most Americans support such abstractions as parent's rights, family autonomy, and domestic privacy, especially when these values are presented in opposition to the power of the state. In an era when almost every politician holds aloft the banner of "family values," an attack on the Family Ideal is unlikely to be popular. Yet it is precisely the family values that contemporary politicians so much affirm that permit, encourage, and serve to maintain domestic violence. The solution to family violence is not to appropriate this vacuous rhetoric - no matter how effective such a strategy has proven in the past - but to affirm the individual liberty of women and children within the nuclear family and legitimize and expand the alternatives to it." 



\section{Boek 2: Persoonswording}


'Aber noch immer kommt das Nachdenken über das Kind und seine Erziehung - und das heißt über seine Entwicklungsmöglichkeit - leicht in den Verdacht des Kindischen.'

M.J. LANGEVELD, Situdien zur Anthropologie des Kindes, Tübingen 1968, aangehaald door G.L.M. SNIK, Persoonswording en opvoeding, diss. Nijmegen, Kampen 1990 , p. 209 nt. 3. 


\section{PERSOONSWORDING EN HET BELANG VAN HET KIND}

\section{1}

\section{Inleiding: persoonswording en het belang van het kind}

In dit hoofdstuk wordt het 'belang van het kind' als juridische notie op zijn pedagogische inhoud, dat wil zeggen aan het veiligheids- en ontwikkelingsbelang van het kind getoetst. Aangezien noch in het Verdrag inzake de rechten van het kind, noch in soft law-instrumenten, noch in de jurisprudentie, noch in de doctrine een specifieke omschrijving van het belang van het kind (the best interests of the child) is te vinden, wordt als kern van dat belang - uitgegaan van het veiligheids- en ontwikkelingsbelang van het kind. De positief- en de natuurrechtelijke vertaling van het veiligheids- en ontwikkelingsbelang van het kind mogen hier worden gememoreerd. Veiligheids- en ontwikkelingsbelang kunnen positiefrechtelijk worden vertaald als respect voor de persoonlijke levenssfeer van het kind: de bescherming van zijn lichamelijke en geestelijke integriteit. En natuurrechtelijk als het recht van het kind op persoonswording, dat als paraplurecht kan gelden van de in het vorige hoofdstuk geformuleerde sociaal-pedagogische kernrechten van het kind. Kan 'persoonswording' (shorthand voor: het recht van het kind op minimale respectievelijk optimale persoonswording) als wezen en kern van het 'belang van het kind" worden beschouwd? En daarmee als meta-kernrecht ("natuurrechtelijk" rechtsbeginsel, supra-positief mensenrecht, natuurlijk kernrecht) van het kind worden aangemerkt?

Deze vragen (of eigenlijk deze dubbelvraag) liggen aan dit hoofdstuk ten grondslag en ook al worden zij pas aan het slot van dit hoofdstuk opgeworpen en daar, voor zover dat mogelijk is, beantwoord, zij lopen als een rode draad door dit hele hoofdstuk heen. Aangezien 'persoonswording' als pedagogisch criterium pas in het volgende hoofdstuk nader wordt geanalyseerd, is het nodig hier voorop te stellen dat het in dit hoofdstuk niet gaat om een omslachtige, meer of minder doorzichtige Etikettenschwindel. 'Persoonswording' heeft een bepaalde wijsgerig-antropologische/psychologische inhoud. Deze wordt in het volgende hoofdstuk, aan de hand van de drieslag: rationaliteit, moraliteit, authenticiteit, nader beschreven. 'Persoonswording' heeft tevens een bepaalde pedagogische strekking: de opvoeding van het kind tot een mens die adequaat kan handelen. Adequaat handelen impliceert minimaal drie kwalliteiten, namelijk minimale rationaliteit, minimale moraliteit en minimale authenticiteit. Zoals is aangegeven, zijn deze onderwerp van bestudering in thet volgen- 
de hoofdstuk. 'Persoonswording' als paraplurecht ten slotte verwijst naar een bundel rechten welke aan het kind toekomen dan wel dienen toe te komen. Aldus, zo wordt in dit hoofdstuk - waarbij de gedachte van persoonswording als paraplurecht centraal staat - betoogd, is "persoonswording' - hoe vaag nog op zich en zonder meer - meer richtinggevend en minder vrijblijvend dan het belang van het kind (the best interests of the child). Bevindt 'het belang van het kind' zich nog te veel in de sfeer van de gunst, de barmhartigheid en het burgerlijk - dat is parentiarchaal - fatsoen, 'persoonswording' daarentegen, althans zo wordt betoogd, bekleedt het kind met een meta-kernrecht, verhoogt dienovereenkomstig de morele status van het kind, en opent de weg naar juridisering, verhoogt dienovereenkomstig de juridische status van het kind, terwijl zij die weg markeert en belicht met een bundel deels positieve deels natuurlijke - dat is: te positiveren - sociaal-pedagogische kernrechten. Persoonswording, aldus beschouwd, is tegelijk pedagogische en juridische opdracht. Een opdracht die - vanuit een mensenrechtelijke optiek - de staat aansprakelijk maakt (zoals we in hoofdstuk 13 nader zullen onderzoeken) voor elke nalatigheid binnen de Trias pedagogica die toegerekend kan worden, direct of indirect, aan het niet ten volle, dat is met de ruimste inzet van zijn middelen, ${ }^{1}$ nakomen van zijn verplichtingen op grond van het Verdrag inzake de rechten van het kind.

\section{2}

\section{Het belang van het kind}

Deze paragraaf beoogt een impressie te geven van de betekenis van het 'belang van het kind' als juridische notie. Daartoe passeren een aantal internationaal- en buitenlandsrechtelijke en - aan de hand van het proefschrift van STEGERHOEK - een aantal Nederlandse jeugdrechtelijke auteurs kort de revue. Wat hebben al deze rechtsgeleerde auteurs over het belang van het kind te melden? We beginnen in eigen land.

\section{Nederland}

STEGERHOEK gaat in haar proefschrift in op de visies van zeven jeugdrechtelijke auteurs: DOEK, HERMANS, DE LANGEN, VAN NIJNATTEN, ROOD-DE BOER, DE RUITER en VAN TEEFFELEN. ${ }^{2}$ Van dit zevental staan we kort stil bij vier auteurs die zich over het belang van het kind hebben uitgelaten: DOEK, DE LANGEN, ROOD-DE BOER en DE RUITER.

1 Zie art. 4 Verdrag inzake de rechten van het kind.

2 N.A. STEGERHoEk, De publieke kant van het jeugdrecht; Publieke aspecten van het civiele jeugdrecht nader beschouwd, diss. Leiden, Zwolle 1995, p. 99. 
DOEK gaat uitdrukkelijk op zoek naar de centrale betekenis, de kerninhoud van het belang van het kind. Aansluiting zoekend bij de VNVerklaring van de rechten van het kind van 1959, formuleert hij - zo zagen we al in hoofdstuk 1 - 'het centrale belang van het kind' als volgt: ${ }^{3}$

\begin{abstract}
'We kunnen deze beginselen [uit de Verklaring van de rechten van het kind], die verder zijn uitgewerkt in de Conventie [imzake] de rechten van het kind, aldus samenvatten dat het kind bovenal recht heeft op een volledige en harmonische ontplooiing naar lichaam en geest. Dat recht zal het centrale beginsel moeten zijn bij de verzorging en opwoeding van een kind, warvoor de verantwoordelijkheid in de eerste plaats bij de ouders ligt (...).'
\end{abstract}

DE LANGEN ziet in het criterium 'het belang van het kind' zowel een voordeel als (grote) bezwaren. Als voordeel noemt zij het feit dat het criterium 'ruimte bied[t] aan rechtsontwikkeling en gewijzigde maatschappelijke en professionele inzichten. ${ }^{4}$ Hoewel STEGERHOEK het zo niet stelt, is het duidelijk dat dit voordeel, zeg maar: de grote elasticiteit, het gevolg is van de vaagheid, de bijna-nietszeggendheid van het criterium. Het belang van het kind is niet zo maar elastisch, het is - prima facie (moderner gezegd: at face value) - rekkelijk als rubber. De nadelen van dit caoutchouc-karakter ontgaan DE LANGEN niet. Bezwaarlijk is, in haar visie, dat het criterium 'voor velerlei interpretatie vatbaar [is], interpretatie afhankelijk van de discipline en de functionele relatie tot het kind, een bron van misverstanden, en een bron van voor de jeugdige onbegrijpelijk optreden. ${ }^{5}$ STEGERHOEK citeert de auteur (DE LANGEN, 1973): ${ }^{6}$

"Een begrip dat zo sterk afhankelijk is van subjectieve interpretatie, en waar de rechter die het hanteren moet, alles in kan leggen wat hij voor het kind nodig acht, en dat aan het kind kan opleggen, is thans [1973] geen redelijk en aanvaardbaar juridisch criterium meer."

OOk ROOD-DE BOER vraagt zich af wat nu "precies [wordt] bedoeld met de norm "in het belang van het kind":?

J.E. DOEK, 'Het belang van het kind en het recht,' in: J.B. WEENINK (red.), Het belang van het kind in het geding; Over opvoeding en kinderbescherning, Amsterdam 1990, pp. 73-92, op p. 75. Vgl. ook STEGERHOEK, a.w., pp. 102/103.

4 STEGERHOEK, a.w., p. 112.

5 T.a.p.

6 T.a.p.

7 STEGERHOEK, a.W., p. 117. 
In vroeger tijden werd hiermee gedoeld op een vermogensrechtelijk belang [het belang van het vermogende kind, jw]. Daarnaast was het voor het kind van belang om een wettige status te hebben [voor het recht geen bastaard te zijn, jw]. Vanaf het begin van de[ze] eeuw geldt het criterium ook als norm voor overheidshandelen, als (negatief gestelde) rechtvaardigingsgrond voor uitzonderlijk overheidsingrijpen in het gezin. Meer recent is het veeleer geworden tot een (positief gestelde) norm waaraan ieder handelen mett betrekking tot elk kind getoetst dient te worden.'

Een toetsingscriterium met als inhoud...? 'De auteur [ROOD-DE BOER, 1984] kiest zelf als uitgangspunt bij het bepalen [van] wat in het belang van het kind is, het zogenaamde welzijnsmodel: "met het oog op zijn gezondheid, veiligheid, opvoeding en rechtspositie. Dus met het oog op zijn geluk". ${ }^{8}$ Daarnaast pleit de auteur (ROOD-DE BOER, 1962, 1980) voor 'opneming van een algemeen artikel in de wet over het recht van kinderen op ontplooiing (....)."9

DE RUITER ten slotte, betoont zich een voorstander van 'open begrippen:' Al gaat hij 'niet in op de keerzijde, te weten: rechtsonzekerheid en een toeloop naar de rechtspraak. ${ }^{10}$ Desondanks bepleit de auteur (DE RUITER, 1972) 'nadere concretisering van [het criterium] "in het belang van het kind" op basis van systematisch onderzoek naar de maatstaven die rechters in de praktijk hebben aangelegd." ${ }^{11}$

Aan de zeven van STEGERHOEK voeg ik nog RUTTEN-ROOS toe, hoogleraar jeugdrecht in Leiden en raadsheer in het Hof Amsterdam, die we eveneens al in hoofdstuk 1 tegenkwamen, waar zij als volgt werd aangehaald: ${ }^{12}$

'Met het belang van het kind kan iedereen de kant uit die hij wil: de moedler naar het verbreken van het contact tussen kind en vader, de vader naar een omgangsregeling en de (kinder)rechter naar een ondertoezichtstelling omdat het kind in de strijd tussen de ouders in de verdrukking dreigt te raken.'

8 STEGERHOEK, a.w., pp. 117/118.

9 STEGERHOEK, a.w., p. 119 (curs. jw). Vgl. ook a.w., pp. 116 en 117.

10 STEGERHOEK, a.w., p. 123 (i.f.).

11 STEGERHoEK, a.w., p. 129. Vgl. ook a.w., p. 120. (Verderop zullen we DE RUITER opnieuw tegenkomen.)

12 A. RUTTEN-ROOS, "Kind en wetgever," in: Ted DE BOER e.a. (red.), De kant van het kind; Liber amiconum Prof. mr. Miek DE LANGEN, Arnhem 1992, pp. 291-299, op p. 298. 


\title{
Internationale auteurs
}

We openen de rij internationaal- en buitenlandsrechtelijke auteurs met HAMMARBERG, lid van het (verdrags)Comité inzake de rechten van het kind. Deze heeft opgemerkt: ${ }^{13}$

\begin{abstract}
"A major aspect of the philosophy behind the Convention [on the rights of the child] is that children, too, are equals; as human beings they have the same inherent value as grown-ups. (...) The idea that children have equal value may sound like a truism but is, in fact, a radical thought - not at all respected today. Children - especially when very young - are vulnerable, and need special support to be able to enjoy their rights in full. How can children be granted equal value and at the same time the necessary protection? Part of the answer lies in the principle of "the best interests of the child".'
\end{abstract}

Hierbij verwijst de auteur naar art. 3 , lid 1 van het Verdrag inzake de rechten van het kind. In de 'officiële' Nederlandse vertaling: ${ }^{14}$

\section{Art. 3, lid 1 VRK:}

Bij alle maatregelen betreffende kinderen, ongeacht of deze worden genomen door openbare of particuliere instellingen voor maatschappelijk welzijn of door rechterlijke instanties, bestuurlijke autoriteiten of wetgevende lichamen, vormen de belangen van het kind de eerste overweging.

Hetgeen een niet geheel juiste vertaling is van de (authentieke) Engelse tekst: ... the best interests of the child shall be a primary consideration. ${ }^{15}$ Art. 3, lid 1 VRK richt zich tot de derde actor in de Trias pedagogica: de staat, en al zijn organen en medewerkers, hetzij direct hetzij via particuliere instellingen (geheel of nagenoeg geheel) door de staat bezoldigd. Het belang van het kind (the best interests of the child) is voor deze organen - van wetgevende, bestuurlijke of rechterlijke aard - en medewerkers verbonden aan openbare of bijzondere lichamen of instellingen, met andere woorden een aanknopingspunt, eventueel zelfs een vertrekpunt, bij hun werkzaamheid, een soort meewegingsbeginsel dat het ook-menszijn van het kind - in de optiek van HAMMARBERG - verdisconteert, of

Thomas HAMMARBerg, 'Prelace," in: Bob FrankLIN (ed.), The handbook of children's rights; Comparative policy and practice, London/New York 1995, pp. ix-xiii, op $\mathrm{p}_{4}$ ix.

14 Tractatenblad 1990 , nr. 170 , pp. 6-29, op p. 8.

$15 \mathrm{Vgl}$. in verband met het gebruik van het lidwoord 'een'/ $a$ ' in plaats van 'de'/ the' in art. 3 , lid 1 VRK: Geraldine VAN BUEREN, The international law on the rights of the child, Dordrecht (etc.) 1995, pp. 46 en $48 / 49$. Vgl. ook Philip ALSTON, 'The best interests principle: towards a reconciliation of culture and human rights, in: dez. (ed.), The best interests of the child; Reconciling culture and human rights, Oxford 1994, pp. 1-25, op p. 12. 
liever: beoogt te verdisconteren. Ceteris paribus dient het belang van het kind boven de belangen van derden - de belangen van de organen en instellingen zelf, de belangen van de ouders - te prevaleren, telkens wanneer 'officiële' beslissingen worden genomen die het kind raken.

'Whenever official decisions are taken which affect children, their interests should be seen as important. The interests of the parents or the state should not be the all-important consideration. This is indeed one of the major messages of the Convention. ${ }^{.16}$

We zouden kunnen zeggen: het tweede lid van het 'over $U$, maar zonder $U^{\prime}$ - zwaarste vloek in de kerk van elke waarlijk democratische gemeente - wordt voor het kind, te jong voor inspraak en medezeggenschap, door de formule 'in het belang van het kind' vervangen. Een formule evenwel die zonder concrete inhoud eerder in brevier of missaal dan in een wetboek thuishoort.

Wat brengen andere buitenlandse auteurs over die inhoud, dan wel over het gebrek daaraan, te berde? Vanuit België doet MAES een poging. Alleerst merkt hij op: ${ }^{17}$

'Hoewel het VN-Verdrag [inzake de rechten van het kind] de notie "belang van het kind" benadrukt in [de] artikelen 9.1 [scheiding kind en ouders alleen in het belang van het kind]| en 9.3 [omgangsrecht van het kind tenzij dit in strijd is met het belang van het kind], 18.1 [belang van het kind is hoofdzorg van de ouders], 21 [adoptie alleen in het belang van het kind], 37c [kinderen in gevangenissen gescheiden van volwassenen tenzij dit niet in het belang van het kind wordt geacht], $40.2 \mathrm{~b}$ (iii) [kind berecht in aanwezigheid ouders tenzij dit niet in het belang van het kind wordt geacht] en bovenal in artikel 3.1. [belang van het kind eerste overweging voor wetgever, bestuur, rechter en particuliere instellingen], heeft het begrip zelf sedert het Verdrag - en dit is wel de merkwaardigste vaststelling een verandering ondergaan. Het "belang" situeert zich niet enkel meer in het bestrijden van schendingen van fundamentele mensenrechten (beschermen tegen; re-actief) - wat op zich, zeker wat kinderen betreft, broodnodig is als men ziet hoe ze bejegend en be-(mis-) handeld worden) -, maar tevens in het realiseren van verbeteringen van de levensomstandigheden van [jonge] mensen en het waarborgen van hun eigen beschikkingsrechten (pro-actief). De [verdrags]regelgever heeft in het Verdrag van 1989 reeds richtinggevende belangen aangeduid die het kind eigen zijn.'

17 Christian MAES, 'Rechten van het kind ... en verder' in: E. VERHELLEN e.a. (red.), Kinderrechtengids, Gent 1994 (losbladig), Deel I, Commentaren, 1.1 MAES, pp. 1-16, op p. 8. 
Om daar - cursief gezet - aan toe te voegen: ${ }^{18}$

\begin{abstract}
'Het wordt ondenkbaar dat een rechter zich niet door het Verdrag [inzake de rechten van het kind] zou laten leiden bij de invulling van het begrip "belang van het kind." Intellectuele eerlijkheid gebiedt hen de waarde van dit belang aan de hand van de verdragstekst te motiveren. Door hierbij, zoveel als mogelijk, aan het zelfbeschikkingsrecht [het kind-als-subject, jw] voorrang te verlenen boven het beschermingsrecht [het kind-als-object, jw], zal hij aan de wens tot meer respectvol omgaan met kinderen van de ondertekenaars van het Verdrag tegemoetkomen.'
\end{abstract}

Een veelbelovende opmaat die uitmondt in een (op het eerste gezicht) nogal teleurstellende, zich tot de (welwillende) rechter beperkende conclusie. Want meer dan een appèl aan die rechter, een appèl tot 'emancipatorische bezorgdheid, ${ }^{19}$ en in logische zin een petitio principii (want hoe moet dat dan bij het jonge en zeer jonge kind?) lijken deze woorden niet te bevatten. De rechter - hoe intellectueel eerlijk ook - zal het, tal van verdragsbepalingen ten spijt, die echter nergens het belang van het kind (the best interests of the child) concreet omschrijven, uiteindelijk (zolang de wetgever aan de verdragsverplichtingen geen pro-actieve handen en voeten - of liever 'body' - geeft) toch nog steeds moeten hebben van - wat WEXLER ${ }^{20}$ noemt - 'raw judicial intuition.' Om soms met wellicht meer geluk dan wijsheid tot een 'Solomonic judgement ${ }^{21}$ te geraken.

Maar, zo zou hier tegengeworpen kunnen worden, is het niet de weg van elk rechtsbeginsel dat het in de loop der jaren - in een rechtshistorisch proces, geleidelijk of met horten en stoten - handen, voeten èn tanden krijgt, en zo tegelijk ook zelf meer wordt afgebakend en duidelijker herkenbaar wordt? Zeker, en het gelijkheidsbeginsel van 1789 laat zien dat dit soms een proces van eeuwen kan zijn. Een emancipatorische onderstroom laat het recht lange tijd onberoerd om op een onverwacht moment het sluimerende rechtsbeginsel mee te sleuren op de toppen van hoog uitslaande emancipatie-golven. Het rechtsbeginsel blijkt "opeens" een dominant bestanddeel [te zijn] geworden in het westerse gedachtengoed $(\ldots . . .)^{, 22}$

T.a.p. (curs, niet overgenomen).

T.a.p. (i.f.).

Aangehaald door VAN BUEREN, a.w., p. 46 i.f. en p. 62 nt. 101.

ELSTER, aangehaald door VAN BUEREN, a.w., p. 47 en p. 62 nt. 104.

'Verwondering over het feit dat de juridische gelijkheid wan de vrouw' dit lot beschoren was, heeft Marjet GUNNING gebracht tot het schrijven van haar dissertatie over Gewaande rechten (M.J. GUNNING, Gewande rechten; Het denken over vrouwen en gelijkheid van Thomas VAN AQUINo tot de Bataafsche Constitutie, ac. diss. Utrecht, Zwolle 1991, p. 2). 
Als het gelijkheidsbeginsel, ten langen leste in 1983 ook in de Nederlandse Grondwet opduikend, bijna twee eeuwen nodig heeft gehad om zich het lot van de vrouw aan te trekken, wat mogen we dan verwachten van een pril beginsel als "het belang van het kind'? Zij het, als juridische notie, minder pril dan we misschien zouden denken. Want "het belang van het kind' dateert natuurlijk niet - alle (potentiële) vernieuwingen die het Verdrag inzake de rechten van het kind brengt, ten spijt pas van 1989. Hoe oud is eigenlijk het belang van het kind'? Het rechtsbegrip (nog geen rechtsbeginsel) van de 'best interests of the child' (het belang van het kind) is, althans in de Amerikaanse jurisprudentie, ${ }^{23}$ precies een eeuw ouder dan het Verdrag inzake de rechten van het kind, en precies een eeuw jonger dan het gelijkheidsbeginsel:

'The case most commonly credited for introducing the notion of the child's interests is an 1889 Kansan opinion, CHAPSKY v/ersus/ WOOD"...,

... meldt Ellis. ${ }^{24}$ Gaan we uit van 1889 als geboortejaar, dan is het inderdaad niet mogelijk van een pril begrip te spreken. Laten we niettemin geduldig, en van historisch besef vervuld, nog wat andere auteurs raadplegen - in binnen- en buitenland - om te zien wat na een eeuw rechtsontwikkeling de balans van dit beginsel, deze juridische notie is.

\subsubsection{Het bellang van het kind: een rechtsbeginsel?}

We gaan terug naar eigen land. Hebben daar buiten de kring van jeugdrechtsgeleerden geen kinderbelang-stemmen opgeklonken? We luisteren geduldig naar PESSERS, die het woord neemt over vader- en moederrech$\operatorname{ten}^{25}$

"Het familierecht is een strijdtoneel geworden tussen vaders en moeders. Waar eerst het huwelijk de Pax Matrimonialis garandeerde, daar veroorzaakt de onibinding van het huwelijksinstituut nu conflicten tussen de gezinslevens van moeders en de gezinslevens van vaders. En de staat blijft, gewoontegetrouw, der Dritte im Bunde.

23 Volgens VERHELLEN (Jeugdbeschemingsrecht, Gent (editie) 1996, pp. 466/467) zou in art. 7 van het Haags Voogdijverdrag van 1900/1902 waarschijnlijk voor het eerst in een (internationale?) wettekst de notie "belang van het kind" [zijn] geintroduceerd."

24 Jane ELLls, 'The best interests of the child,' in: Cynthia Price CoHEN; Howard A. DAVIDSON (eds.), Children's rights in America: UN Convention on the rights of the child compared with United States law, ABA, DCI-USA, s.l. 1990, pp. 3-18, op p. 3. Dorien PESSERS, 'Vaderrechten, moederrechten, verzorgersrechten,' redactioneel Nemesis 1987/1, pp. 1-2 (curs. DP). 
Ouderlijke macht was aanvankelijk uitsluitend vaderlijke macht, verbonden aan het huwelijk. De biologische onzekerheid over het vaderschap werd gecompenseerd met een juridische zekerheid: kinderen, staande huwelijk geboren, worden geacht van de echtgenoot te zijn. De vaderlijke macht was gebaseerd op een patriarchale en liberale ideologie. Als hoofd van de echtvereniging was de man heer en meester over zijn gezin en in zijn privé-sfeer mocht de staat niet treden. Pas in de loop van deze eeuw zijn vaders hun absolute macht kwijtgeraakt, aan moeders, met wie zij geleidelijk aan de ouderijike macht moesten gaan delen, en aan de staat, die via een gezinspolitiek, en met name via kinderbeschermingsmaatregelen, in de privé-sfeer ging interveniëren. Het familierecht bevat in het naamrecht nog een laatste restant patriarchaal positief recht. (...)

$[\mathrm{N}] \mathrm{u}$ het huwelijk in snel tempo wegvalt als juridische vaderschapsgarantie en statelijke beheerseenheid, wordt er in paniek gezocht naar een nieuwe rechtsgrond om de patriarchale dominantie en overheidsinterventie ten aanzien van verwantschapsbetrekkingen in stand te kunnen houden. Deze nieuwe rechtsgrond lijkt inmiddels te zijn gevonden in art. 8 van het Europese Mensenrechtenverdrag, dat onder meer de eerbiedliging van het private and family life garandeert. In dit artikel zien rechters en wetgever een mogelijkheid om kinderen terug te brengen onder de juridische invloedssfeer - in de vorm van gedeelde ouderlijke macht en omgangsrechten - van vaders en de staat. Het belang van het kind zou deze hypertro[f]iëring van art. 8 rechtvaardigen. De keerzijde hiervan is weer dat via het gezinsleven van vaders en via het belang van het kind dat door rechters en andere overheidsinstanties wordt getoetst, er inbreuk wordt gemaakt op het gezins- en privéleven van moeders.

Het belang van het kind is een van de beschaafdste, maar blijkens de praktijk ook een van de meest hypocriete beginselen van het recht. Buiten het familierecht heeft dit beginsel geen enkele betekenis en binnen het familierecht is het maar al te vaak een manipulatief en disciplinerend middel gebleken.

Het belang van het kind is in beginsel gediend met een vader, wiens betekenis voor het kind zal toenemen naar mate hij substantiëler bij de verzorging van het kind is betrokken. Het ligt daarom woor de hand de verzorging wan het kind als uitgangspunt te nemen voor de regeling van ouderrechten. Indien ouders deze verzorging daadwerkelijk delen (...), kunnen ook ouderrechten worden gedeeld. (...)

Het blijft overigens helemaal de vraag welk nut (behalve het patriarchale) wordt gediend met een verregaande regeling van relaties tussen ouders. Wanneer er tussen ouders een goede verstandhouding bestaat, zullen er geen problemen zijn. Wanneer er geen goede verstandhouding bestaat, zullen juridische regelingen geen effect hebben of een verdere verslechtering van de verstandhouding betekenen. Gedetailleerde rechtsregels zijn niet op hun plaats waar het een gevoelige en in beweging zijnde materie betreft.'

Hoewel PESSERS hier feilloos het gevaar blootlegt dat schuilt in een beginsel of rechtsbegrip dat vaagheid reeds in de vlag van zijn naam draagt - want wat is ruimer en nietszeggender, rekkelijker en kneedbaarder dan het 'belang' van een sprakeloze, stemloze, statusloze, rechteloze, machteloze? -, voert zij aan het slot van haar filippica het belang van het kind, dat zij even daarvoor als een van de beschaafdste beginselen van ons - 
helaas hypocriete patriarchale - recht, ogenschijnlijk aan de voordeur verwelkomde, weer snel - en stilletjes - door de matriarchale achterdeur af. Gedetailleerde rechtsregels zijn niet gewenst waar moeders en vaders grote-mensenruzies uitvechten - over het hoofd van het kind. Wie zal ontkennen dat de materie inderdaad zeer gevoelig is? En wie ziet de gevoeligheid van het als pion in ouderlijke ruzies heen en weer geschoven, zo al niet als wapen tegen de ander misbruikte kind? Het kind dat geen partij kan en wil - maar moet kiezen?

Neen, hier past geen vaag beginsel. Geen beginsel dat naar believen patriarchaal, matriarchaal, parentiarchaal kan worden om- en bijgebogen. Hier passen slechts gedetailleerde rechtsregels en een goed sociaal-pedagogisch beleid. Geen beginsel is eo ipso, van en door zichzelf, beschaafd. Beschaafd, en beschavend, is een beginsel naar de mate van zijn rechtsverfijning. Hooguit zouden de rechtsgenoten in een rechtssysteem dat na een eeuw nog aan die rechtsverfijning moet beginnen, zichzelf eerder dan beschaafd beschaamd kunnen voelen.

De zuiverste graadmeter van beschaving is de mate van rechtsverfijning ten aanzien van de omgang met de meest kwetsbaren en weerlozen in de samenleving; de mate waarin te hunnen opzichte de rechten van de sterksten zijn beknot. Niet lippendienst maar rechtsverfijning drukt op een beginsel het stempel van beschaving. Ten opzichte van kinderen is een criterium met zo weinig vastomlijnde inhoud dat polyvalentie en pluri-interpretabiliteit er bijna synoniem mee zijn, welhaast per definitie hypocriet. Ouders hebben vrijwel absolute fysieke en psychische macht over het jonge kind, dat als was is in hun handen, dat zij letterlijk kunnen maken en breken. Als dat kind beschermd moet worden tegen degeneratie of pervertering - door welke oorzaken of omstandigheden ook veroorzaakt - van de natuurlijke ouderlijke zorgzaamheid onder de vaan van een beginsel ten aanzien waarvan volwassenen bovendien 'de macht van de definitie" hebben, is het te meer duidelijk dat er voor juristen beschavingswerk te verrichten valt.

\section{Tegenvoeter}

Om het geduld met landgenoten niet tè zeer te beproeven, gaan we kort op bezoek bij enkele buitenlandse auteurs. Laten we maar meteen bij een tegenvoeter beginnen, een auteur uit Australië, bijna aan de andere

Selma SEVENHUUSEN, 'Feministische ethiek en rechten van kinderen,' in: Carol VAN NuINATTEN (red.), Kinderrechten in discussie, Amsterdam/Meppel 1993, pp. 42-63, op p. 56 . 
kant van Nederland. In het door hem geredigeerde boek The best interests of the child merkt deze auteur, ALSTON, op:27

'[A]lthough the [best interests] principle has often been recognized in international instruments, it has yet to acquire much specific content (...). (...) [However], there would seem to be three, rather different, roles which the formulation in Article 3(1) [of the Convention on the rights of the child] might play in the future in relation to children's rights. The first is in conjunction with other articles of the Convention in order to support, justify or clarify a particular approach to issues arising under the Convention. In this context, it is an aid to construction as well as an element which needs to be taken fully into account in implementing other rights. The second role is as a mediating principle which can assist in resolving conflicts between different rights where these arise within the overall framework of the Convention. The third role is (...) that "fi]n all matters not governed by positive rights in the Convention, Article 3(1) will be the basis for evaluating the laws and practices of the States parties".?

Hoewel we over de functie van het beginsel hiermee een stuk wijzer zijn geworden, zijn we nog steeds geen stap verder als het gaat om de inhoud, of althans de essentie ervan. Het lijkt intussen niet erg waarschijnlijk dat een beginsel waarvan de inhoud vaag is, en almaar in het midden blijft, de eraan toegedichte functies bij de rechtstoepassing waar zal kunnen maken.

Weer wat dichter bij huis laten we wOLF aan het woord. Vanuit het Max PLANCK Instituut in Heidelberg laat deze weten: ${ }^{28}$

"[T]he crucial question is, whether the "best interest" standard is presently regarded in view of the old concept of special protection, which is laid down in the Convention [on the rights of the child] as well, or the new concept of individual rights. The answer to be given to this question is of decisive importance for the legal standing of the "best interest" concept. (...) Should the second option prevail, the Convention would be open to new conceptual interpretation.'

Hier wordt gesteld dat het belang van het kind met meer recht rechtsbeginsel genoemd kan worden naarmate de inhoud van dit beginsel dichter bij het rechtenconcept ligt - het kind als subject en drager van rechten, van, zo voegen we thans toe, harde en gedetailleerde rechten, met andere woorden: rechten waar een duidelijke sociaal-pedagogische visie en een

Philip ALSTON, 'The best interests principle: towards a reconciliation of culture and human rights," in: dez. (ed.), The best interests of the child; Reconciling culture and human rights, Oxford 1994, pp. 1-25, resp. op pp. 4 en $15 / 16$.

Joachim WOLF, 'The concept of the "best interests" in terms of the UN Convention on the Rights of the Child,' in: Michael Freeman, Pbilip VEERMAN (eds.), The ideologies of children's rights, Dordrecht (etc.) 1992, pp. 125-133, op p. 128. 
stevig en consistent sociaal-pedagogisch beleid achter zit - dan bij het beschermingsconcept - het kind als object van bescherming, bescherming die meer gunst dan recht is, en niet zelden als wangunst wordt gevoeld: stigmatiserend voor ouders, en daardoor extra traumatiserend voor het kind.

WoLF laat ons niet gissen naar wat als de kerninhoud van het belang van kind dient te worden beschouwd: ${ }^{29}$

"As can be inferred from principle 2 of the 1959 Declaration, the "best interest" standard relates to opportunities and facilities to enable the child to develop physically, mentally, morally, spiritually and socially in a healthy and normal manner. That means that the concept of the "best interests" covers the all-round development of the child according to its abilities as a human person within a sound human environment.'

Een geluid dat we al bij DOEK hebben vernomen.

Gelukkig laat de auteur evenmin in het midden welk concept het rechten- of het traditionele beschermingsconcept -, mede gegeven deze kerninhoud, de sterkste papieren heeft: ${ }^{30}$

'The basic structure of the Convention [on the rights of the child] is that of a combination of the two elements, i.e. the rights of the child and the "best interest" standard. The one cannot be separated from the other. The interpretation of the Convention leads to the conclusion that the "best interest" standard exceeds traditional concepts of protection. It is open to new development and legal explanation.'

Bevestiging voor deze opvatting - het kind is subject in, door en in elk geval sinds het Verdrag inzake de rechten van het kind - vinden we ook bij een - Noordse - auteur naar wie al eerder is verwezen, EIDE: ${ }^{31}$

'The Convention on the Rights of the Child (...) is a wide-ranging elaboration of the protection of the child, but more importantly, it emphasizes the child as a separate and independent holder of (...) rights, not simply as an appendix to the family."

De vraag naar de juridische status van het beginsel/begrip kan nu ook worden beantwoord: ${ }^{32}$

T.a.p., op p. 126.

31 Asbjorn EIDE, 'Article 25,' in: dez. e.a. (eds.), The Universal Declaration of human rights: A commentary, Oslo(/Oxford) 1992, pp. 385-403, op p. 401 (curs. jw). 
"With the coming into force of the Convention on the Rights of the Child, the "best interests of the child" has become an international legal concept. For the first time, measures and procedural requirements of States which prescribe how they have to exercise their discretion in matters relating to the well-being of children, can be tested in terms of an international Convention."

Hierbij moet evenwel niet te vroeg worden gejuicht, want: $:^{33}$

"[O]ne may only speak to some extent of the "best interest" concept as a coherent legall concept shaped by contextual relations and different categories of individual human rights and State obligations. The restriction, using the phrase "to some extent," is still necessary because a legal concept as complicated as the "best interest" standard still needs time for further development."

Hieraan kan de opvatting van wOLFSON - uit Engeland, ook haar kwamen we eerder al tegen - worden toegevoegd: ${ }^{34}$

"TT] recently adopted United Nations Convention on the Rights of the Child, setting out international and national social and legal standards and guidelines, can rightly be seen as an attempt to articulate and enumerate the practical implications of the [best interest] standard.'

De vingerwijzing die deze laatste woorden bevatten, is dat, internationaalrechtelijk, mensenrechtelijk gezien, de kerninhoud van het belang van het kind in de bepalingen van het Verdrag ligt besloten, en daaruit vooropgesteld dat aan die bepalingen een duidelijke visie, al of niet in de travaux préparatoires, preambule of hoofdtekst verwoord, ten grondslag ligt, dan wel dat deze bepalingen van een duidelijke, of liever: eenduidige visie, blijk geven - kan worden afgeleid.

Volgens HAMMARBERG - met hem zijn we onze internationale tour d'horizon begonnen en met hem sluiten we dit onderdeel af - is dat laatste het geval: ${ }^{35}$

[T] he Convention [on the rights of the child] (...) is more than a dry document with some rules on how to behave. It has a vision. It expresses some basic values about the treatment of children, their protection and participation in society.'

WOLF, ta.p., op pp. 132/133 (curs. jw).

34 Susan WOLFSON, "Children's rights: the theoretical underpinning of the "best interests of the child", in: Michael FREEMAN, Philip VEERMAN (eds.), The ideologies of children's rights, Dordrecht (etc.) 1992 , pp. $7-27$, op p. 7.

hAMMARBERG, t.a.p., op p. ix (curs. overgenomen). 
Daarmee is de vraag beantwoord of het belang van het kind (the best interests of the child) een rechtsbeginsel is. Dat is het - internationaalrechtelijk gezien in elk geval sinds 1990, de inwerkingtreding van het Verdrag inzake de rechten van het kind, of althans sinds 1995, het jaar waarin het Verdrag vrijwel universele bijval verwierf..$^{36}$

Hoewel een nadere analyse van het Verdrag inzake de rechten van het kind vanuit en op een pedagogische kerninhoud ons staat te wachten in hoofdstuk 10 , nadat we eerst in hoofdstuk 9 die pedagogische kerninhoud nader hebben beschreven, ${ }^{37}$ is op deze plaats de vraag pertinent in hoeverre in de doctrine pedagogische inhoud aan het belang van het kind - ook los van het Verdrag - is gegeven. Het gaat hierbij niet om een inventarisatie of een overzicht. Immers, zoals WOLFSON (met een verwijzing naar GOLDSTEIN/FREUD/SOLNIT) opmerkt:.38

Dat de juridische status naar nationaal recht nog steeds omstreden is, blijke bijwoorbeeld, voor België, uit de woorden van SENAEVE, volgens wie 'de notie "belang van het kind" icn onrechte als algemeen rechtsbeginsel wordt beschouwd: het belang van het kind is 'leidmotief' voor rechterlijke beslissingen, waaraan 'het karakter van algemeen rechtsbeginsel ontzegd moet worden.'

Vanuit rechtsstatelijk oogpunt, vanuit het oogpunt van de bescherming van het kind èn vanuit het oogpunt van rechtsbescherming van ouders bijzonder zorgwekkend, is zijn conclusie: "De opgang die het "belang van het kind" gekend heeft, moet veeleer gezien worden als een typische uiting van de terugtred van de wetgever ten voordele van de rechter (...). Dit gebeurt door het aanwenden van blanco-normen of open begrippen, waarvan het wemelt in het hedendaagse familierecht (...). (...) Zeker is dat wanneer de rechtsregel zo vaag geformuleerd wordt, het niveau van de rechterlijke uitspraak nog meer dan in andere gevallen gedetermineerd wordt door de kwaliteit en de ingesteldheid van de magistraat die geroepen wordt om uitspraak te doen, en door de al dan niet bevredigende institutionele omkadering van het rechterlijke functioneren.' (P'. SENAEVE, 'Het belang van het kind in het Belgische familierecht, in: Ad VAN DER LINDEN, Paul VLAARDINGERBROEK (red.), Met het oog op het belang van het kind; Opstellen aangeboden aan professor mr. Madzy ROOD-DE BOER ter gelegenheid van haar emeritaat, Deventer 1988 , pp. 119-127, resp. op pp. 122, 126 en 127.)

37 Met andere woorden: in hoofdstuk 9 slijpen we de glazen van de (persoonswordings)bril waarmee we in hoofdstuk 10 naar het Verdrag gaan kijken. Is dit geen doorzichtige variant van de ervaringsregel dat je in een tekst ziet, wat je wil zien? Nee. De bril moet ons de dingen scherper laten zien, maar het is geen bril die ons kan laten zien wat er niet is. Wie, tot hier gekomen, meent nu het boek wel dicht te kunnen slaan, is dus voorbarig. Of, wat minder schoolmeesterachtig gezegd, slaat het boek om de verkeerde reden dicht. 
"There have been innumerable attempts to "pour content into the "best interests of the child?"

Hetgeen haar tot de radicale conclusie verleidt: ${ }^{39}$

'Even a cursory glance through the rellevant material relating to this standlard, yields the conclusion that there is such a diversity of opinion as to its meaning and content as to render the standard itself meaningless.'

In die conclusie heeft zij slechts gelijk in zoverre het onmogelijk zou zijn in 'het belang van het kind' een richtinggevende pedagogische kerninhoud te ontwaren. Het is de - nog te bewijzen - stelling van dit proefschrift dat zulks - op geleide van een minimaal pedagogisch criterium dat, op basis van diverse bepalingen van het Verdrag inzake de rechten van thet kind, als achterliggend beginsel van dat Verdrag kan worden beschouwd - wel degelijk mogelijk is. Op deze plaats gaat het er niet om bouwstenen voor dat bewijs aan te dragen, doch enkel om een indruk op te doen van de mate waarin en de wijze waarop het belang van het kind uberhaupt, ook los van het Verdrag, pedagogisch is gedacht.

Opnieuw kijken we eerst wat uitgebreider naar een Nederlandse auteur, of liever een auteurskoppel, om vervolgens een buitenlands kindervolkenrechtelijk handboek open te slaan.

\section{Nederland}

Het belang van het kind wordt 'sterk vanuit pedagogische intenties gedacht,' stellen HEINER en BARTELS in $1989 .^{40}$ De auteurs (beiden psychologen, doch publicerend in een juridisch tijdschrift) kiezen voor 'de ontwikkeling [van het kind] als centraal perspectief' in hun voorstel 'voor een inhoudelijk nadere omschrijving' van het begrip het belang van het kind. ${ }^{41} \mathrm{Zij}$ omschrijven het belang van het kind dan als volgt: ${ }^{42}$

'Het belang van het kind is het belang van zijn ontwikkeling, van in de gegeven omstandigheden zo gunstig mogelijke ontwikkelingskansen, van in de gegeven omstandigheden zo gunstig mogelijke condities voor die ontwikkeling."

T.a.p.

40 J. HEINER, A.A.J. BARTELS, 'Jeugdstrafrecht en het belang van het kind: het belang van het kind nader omschreven,' FJR (Tijdschrift voor familie-en jeugdrecht) $1989 / 3$, pp. $59-67$, op p. 59.

41 T.a.p., resp. op p. 61 r.k. if. en p. 59.

42 T.a.p., op pp. $61 / 62$ (curs. niet overgenomen). 
En stellen: ${ }^{43}$

"Een kind kan zich volgens eigen aanleg en mogelijkheden ontwikkelen en de vereiste sociale competentic en emotionele draagkracht werwerven, wanneer voorzien wordt in een aantal basale behoeften, wanneer voldaan wordt aan een aantal basale voorwaarden. Deze behoeften en voorwaarden zijn blijkens sociaalwetenschappelijk onderzoek alsook volgens de geldende theoretische inzichten de volgende.'

Waarbij zij de volgende opsomming geven (waarbij onder kind ook de jongere wordt begrepen $\left.{ }^{44}\right)::^{45}$ (1.) adequate verzorging; (2.) een veilige fysieke omgeving; (3.) continuïteit en stabiliteit; (4.) interesse in het kind ('in zijn belevenissen en leefwereld, en in zijn persoon'); (5.) respect ('[d]e behoeften, wensen en verlangens van het kind worden serieus genomen'); (6.) geborgenheid, steun en begrip (bij c.q. van 'tenminste één volwassene, ${ }^{46}$ bij voorkeur de verzorger(s)'); (7.) een ondersteunende, flexibele structuur; (8.) veiligheid; (9.) voldoende adequate voorbeelden; (10.) educatie ('scholing en opleiding'; 'de gelegenheid tot ontplooiing van talenten als muzikale, kunstzinnige of sportieve aanleg'); (11.) omgang met leeftijdgenoten; (12.) kennis over en contact met het eigen verleden.

T.a.p., op p. 62 l.k. if.

T.a.p., op pp. 62-63.

46 Anders: BEYAERT, die van mening is dat een kind recht heeft op twee ouders (F.H.L. BEYAERT, 'Het kind, de jeugdige in het recht,' in: Ted DE BOER e.a. (red.), De kant wan het kind; Liber amiconum Prof. mr. Miek DE LANGEN, Armhem. 1992, pp. 175-181, op p. 180). Ik zou dat willen clausuleren tot: twee elkaar respecterende ouders (vgl. J.C.M. WILLEMS, 'Van parentiarchie naar Vadertje Staat; Over 't verwekken, mishandelen en beschermen van kinderen,' Nemesis $1992 / 3$, pp. 8-23, op pp. $11 / 12$ en p. 20 nt. 52-54). Dat laatste beweert BEYAERT in feite ook als hij] stelt (t.a.p.): 'Ik meen slechts dat kinderen in een duurzame respecten liefdevolle hetero-relatie de beste kansen hebben.' Ik denk dat een kind inderdaad beter af is met 'een "redelijke andere" ouder' (t.a.p., i.f.), en daar dan ook recht op zou horen te hebben. Of die andere ouder van het andere geslacht behoort te zijn, lijkt mij meer voor betwisting vatbaar. De opvatting van BEYAERT lijkt evenwel te zijn ingegeven door bevreesdheid dat het voorbeeld van bewust manloze "elite"-vrouwen' die evenwel 'vadersubstituties' hebben geregeld, wordt nagevolgd door vrouwen die zich - in vivo of in vitro (dat wil zeggen: met of zonder coitus) - laten bevruchten om een kind te nemen 'zoals een pop voor het raam of op de bank' (t.a.p.). 
De behoefte aan/voorwaarde van continuiteit en stabiliteit (3.) splitsen de auteurs uit ${ }^{47}$ naar continuiteit en stabiliteit (a.) met betrekking tot de levensomstandigheden:

'De omgeving verandert niet onvoorzien en plotseling. Optredende veranderingen komen niet onaangekondigd. Het is het kind duidelijk waarom verandering geschiedt. Het kind ervaart dat met zijn wensen bij veranderingen zoveel mogelijk rekening gehouden wordt. Het kind heeft binnen de grenzen van het redelijke de mogelijkheid zelf veranderingen te initiëren.'

Continuïteit en stabiliteit (b.) met betrekking tot de verzorging:

'Een verzorger blijft zo lang voor het kind zorgen dat er voldoende hechting kan optreden. Bij het wisselen van verzorger(s) gaat de overgang niet abrupt.'

En (c.) inzake de voortzetting van een gunstige ontwikkeling:

'Het indien mogelijk voortzetten van gunstige of potentieel gunstige voorwaarden voor ontwikkeling, zoals het niet afbreken van een gunstige relatie met significante figuren uit de omgeving, van werk of een opleiding.'

Een ondersteunende, flexibele structuur (7.), aangepast aan het kind, schrijven zij, houdt onder andere in: ${ }^{48}$

'a. Een zekere regelmaat in het leven van alledag; b. Aanmoediging en stimulering; $c$. Het stellen van realistische eisen; d. Het stellen van grenzen en het geven van regels; e. Het geven van inzicht [in] en argumenten voor de gestelde eisen, grenzen en regels, dat wil zeggen voor de gehanteerde flexibele structuur; [en] f. Het voldoende ruimte laten aan het kind voor eigen wensen, en voldoende vrijheid voor eigen initiatief en experimenteren, alsook de mogelijkheid om over de structuur te (leren) onderhandelen; g. Het kind krijgt niet meer verantwoordelijkheid te dragen dan het aankan, en ervaart binnen die begrenzing de gevolgen van zijn gedrag. Het leert daardoor die gevolgen voorzien en anticiperen, en zijn gedrag afwegen en afstemmen op de situatie en mogelijkheden.'

Onder veiligheid (8.) stellen de auteurs: $:^{49}$

'Dit is een zeer basale ontwikkelings- en levensbehoefte en -voorwaarde. Indien aan de genoemde behoeften en voorwaarden ([hierboven] $1 \mathrm{t} / \mathrm{m}$ 7) is voldaan, wordt in de veiligheidsbehoefte voorzien. Afgezien van de in de punten $1 \mathrm{t} / \mathrm{m} 7$ 
beschreven voorwaarden, kan de minimale behoefte aan veiligheid ook omschreven worden als: de behoefte aan een volwassene die overzicht en structuur brengt in het leven wan het kind, wiens aanwezigheid angstreducerend werkt, die continuiteit en stabiliteit bewerkstelligt en die het kind voldoende ruimte laat voor eigen wensen.'

Met voldoende adequate voorbeelden (9.) bedoelen zij: ${ }^{50}$

'Het kind komt in contact met andere kinderen en volwassenen van wie het gedrag, optreden en normen kan overnemen en zich eigen maken, die voor hem nu en waarschijnlijk later van belang zijn.'

Onder kennis over en contact met het eigen verleden (12.) verstaan $\mathrm{zij}^{51}$ zowel:
'a. Een zo eerlijk en waarheidsgetrouw mogelijk verhaal over de eigen afkomst op een leeftijd dat het kind daaraan toe is, en zo nodig hulp bij het verwerken en integreren daarvan in de eigen levensgeschiedenis, het zelfbeeld en de identiteit.'

Alsook:

b. Contact met de biologische ouders of significante figuren uit het eigen verleden en zonodig opvang en begeleiding daarbij, indien het kind dit wenst, indien mogelijk, indien en voor zover het kind eraan toe is, en indien dit niet uitdrukkelijk ongewenst wordt geacht."

Met betrekking tot de hierboven opgesomde (twaalf) condities stellen de auteurs: ${ }^{52}$

\begin{abstract}
'De voorwaarden vullen elkaar aan, vervulling van de ene voorwaarde kan tot op zekere hoogte tekortschietende vervulling van een andere compenseren. Wanneer echter aan deze behoeften van het kind op ernstige wijze in onvoldoende mate tegemoet gekomen wordt, zo blijkt uit empirisch onderzoek, verwerft het kind of de jongere onvoldoende sociale competentie. Dat wil zeggen het leert niet de vaardigheden, het zelfvertrouwen en de emotionele draagkracht om zich te handhaven. De ontwikkeling verloopt dan problematisch en er ontstaat een grote kans op psychologische en/of psychosociale problemen, gedragsproblemen en eventueel antisociaal gedrag waaronder delinquentie.'
\end{abstract}

In een noot voegen zij hieraan toe: ${ }^{53}$ 
'Delinquentie ontstaat uiteraard niet alleen door een ongunstig verlopen ontwikkeling, maar ook door maatschappelijke factoren. Deze factoren werken echter vooral negatief bij jongeren met een al ongunstig verlopen ontwikkeling. Direct en indirect is daarom de bijdrage van zo'n [ongunstig verlopen] ontwikkeling aan antisociaal gedrag relatief groot. (...).".

\section{Tot slot, althans voor zover hier van belang, merken zij op..$^{54}$}

'Indien aan én of meer van de hier genoemde voorwaarden gedurende langere tijd in de ontwikkeling van het kind of de jongere onvoldoende wordt tegemoet gekomen, spreekt men van risicofactoren met betrekking tot de ontwikkeling. De predicerende waarde van een groot aantal risicofactoren is al in verschillende studies gebleken.'

De hier gegeven invulling van het belang van het kind blijkt een ontwikkelingspsychologische/pedagogische vertaling op hoofdpunten van het (veiligheids- en) onwikkelingsbelang van het kind te betreffen. In feite is het de meest gedetailleerde, actuele en adequate invulling die ik in de literatuur ben tegengekomen (hetgeen moge rechtvaardigen dat zij hier in extenso is weergegeven). ${ }^{55}$

T.a.p., op p. $631 . \mathrm{k}$.

55 Zelf stellen de auteurs in een noot: 'De formulering van de condities hier zal iemand met kennis wan en ervaring met kinderen en jeugdigen niet volledig nieuw of onverwacht voorkomen. Wat er nieuw aan is, is de onderlinge samenhang waarin ze gepresenteerd worden, en het feit dat ze gesteund worden door empirisch onderzoek.' (T.a.p., op p. 62 nt. 38.) Ook is het niet de eerste keer dat (mede) vanuit psychologische (althans psychoanalytische) hoek naar invulling en concretisering van 'het belang van het kind' wordt gestreefd. De auteurs zeggen hierover: 'Met deze inhoudelijk nadere omschrijving wordt in zekere zin de draad weer opgenomen van GOLDSTEIN e.a. [Joseph GOLDSTEIN, Anna FREUD, Albert SOLNTT, Beyond the best interests of the child (1973); Before the best interests of the child (1979); vertalingen/bewerkingen: De toverformule: in het belang van het kind (1979); Wanneer de toverformule: criteria voor overheidsinterventie in het belang van het kind (1984)] (...)." (T.a.p., op p. 62 mt. 33.)

Overigens betekent dit opnemen van de draad niet dat wordt voortgeborduurd op GOLDSTEIN c.s., wier werk m.i. als gedateerd, zo niet als achterhaald moet worden beschouwd (vgl. Doret DE RUYTER, Met recht ingrijpend; Een pedagogisch criterium voor het opleggen van hulp, ac. diss. VU Amsterdam, s.l. 1993, pp. 69-72; Douglas BARNETT, Jody Todd MANLY, Dante CICCHETT, "Defining child maltreatment: the interface between policy and research,' in: Dante CICCHETTr, Sheree L. TOTH (eds.), Child abuse, child development, and social policy, Advances in applied developmental psychology, vol. 8, Norwood, New Jersey 1993, pp. 7-73, op p. 14; Ross A. THOMPSON, 'Developmental research and legal policy: toward a two-way street,' in: a.w., pp. 75-115, op pp. 80,82 en 88). 


\section{Kindervolkenrecht}

We zouden ook een buitenlands kindervolkenrechtelijk 'handboek' openslaan. Zijn nationale (wat uiteraard iets anders is dan nationaalrechtelijke) geluiden, zoals we die hierboven tegenkwamen, doorgedrongen tot (de derde trede van) het kindervolkenrecht? In haar The international law on the rights of the child merkt VAN BUEREN op. ${ }^{.6}$

'The Convention's approach strengthens the Declaration of the Rights of the Child [of] 1959 which applies the best interests holistically in relation to the development of the child.'

Deze constatering maakt haar niet blind voor het feit dat ...

'(...) the world lacks (...) a philosopher's stone which can be utilised to determine what is truly in the child's best interests. ${ }^{.57}$

Daarom bepleit zij, als ik haar goed begrepen heb, en niet (erg veel) meer in haar - zo dadelijk aan te halen - woorden lees dan zij heeft bedoeld, twee zaken. In de eerste plaats zouden er (internationale of regionale) richtlijnen moeten komen die aangeven uit welke elementen in de in deze studie gehanteerde terminologie: uit welke (sociaal-pedagogische) kernrechten - het belang van het kind bestaat. Of op zijn minst welke gedragingen, houdingen of omstandigheden in elk geval als schadelijk voor het kind moeten worden beschouwd. Met andere woorden: er zou (op internationaal of regionaal niveau) een positieve en/of negatieve lijst, een lijst van protectieve en van risico-factoren, dienen te worden samengesteld. Tegelijk zouden er richtlijnen moeten worden uitgevaardigd met betrekking tot de gewenste regeling van de bevoegdhedenverdeling (waaronder toezicht en rechtsbescherming) tussen overheidsorganen en ouders/opvoeders. In haar eigen woorden. ${ }^{58}$

'The new approach to the best interests of the child importantly takes into consideration the equality rights of children and thus has the potential to remove some of the past tyrannies imposed by the application of the best interests of the child. It is, however rare for actions by adults not [to] be argued in the language of best interests. Hence, in order to minimise the degree of subjectivity and to help ensure a consistency of expectations, it would be in the best interests of children if regional and international bodies were in [the] future to indicate not only the elements which they [regard] as consistent with the child's best interests,

Geraldine VAN BUEREN, The international law on the rights of the child, Dordrecht (etc.) 1995, p. 47.

57 A.w., p. 49.

58 T.a.p. (curs. jw), en p. 63 nt, 127 . 
but also guidance as to how to assess the power relations between the relevant decision-makers. (...) Perhaps [however] we ought to be honest and realise that although the best interests is the desired standard, in reality are applying what we perceive as the better interests of the child or at least the less harmful. (Instead of best interests "least detrimental" (...).)'

In de tweede plaats bepleit zij het belang van het kind te hanteren als paraplu- c.q. interpretatiebeginsel, en wel in combinatie met het tweede paraplu- en interpretatiebeginsel dat zij in en met betrekking tot het Verdrag inzake de rechten van het kind onderscheidt: het beginsel van de zich ontwikkelende vermogens van het kind: $:^{59}$

"Less harm is also likely to arise if the new approach to the best interests of the child is applied together with the second principle of interpretation, that of the evolving capacities of the child. The evolving capacities of the child stems from the acknowledgement that childhood is not a single, fixed, universal experience. Children are not adults in miniature. At different stages in their lives children require different degrees of protection, provision, prevention and participation. If the international law on the rights of the child is to be effective, it must be able to respond to these developments. In other words the international legal protection of the rights of the child is not accomplished simply by inserting the word "child" into every article which codifies a human right. It requires that the evolving nature of childhood is also considered to enable children gradually to take responsibility for different areas of their own lives. (...)

The evolving capacities of the child and the best interests of the child are umbrella principles underlining the exercise of all the rights in the Convention.'

\section{Grundnorm}

Wat er van deze opvatting over en met betrekking tot het Verdrag inzake de rechten van het kind zij (in hoofdstuk 10 keren we ernaar terug), de bijzondere bescherming van het ontwikkelingsbelang van het kind acht VAN BUEREN Grundnorm van het kindervolkenrecht. Een kindervolkenrechtelijke Grundnorm die de vaagheid van het belang van het kind er op zich niet minder op maakt - al worden verschillende aspecten van die Grundnorm in en door het Verdrag inzake de rechten van het kind gecodificeerd: ${ }^{60}$

'(...) [S]tates have accorded children special protection. It is the [G]rundnom of the international law on the rights of the child. The principle is codified in the Declaration of the Rights of the Child [of] 1959 [Principle 2]: "The child shall enjoy special protection and shall be given opportunities and facilities, by law and [by] other means, [to enable him] to develop physically, mentally, morally, spirim 
wally and socially in a healthy and normal manner and in conditions of freedom and dignity $(. .$.$) ." It is a principle which underlies much of the international and$ regional protection of children's rights including article 10(3) of the International Covenant on Economic, Social and Cultural Rights and article 24(1) of the International Covenant on Civil and Political Rights and is reflected in many national constitutions. However, although as a principle it is widely, if not universally accepted, because of its lack of precision detailed codification of aspects of the special protection was required. Hence many articles in the Convention on the Rights of the Child enshrine facets of this [G]rundnom."

\section{Grondwettelijke verankering}

Voor wat de grondwettelijke verankering van de Grundnorm betreft, verwijst VAN BUEREN naar de constituties van Costa Rica, Cuba, Egypte, Noord-Korea en Portugal. ${ }^{61} \mathrm{Om}$ aan haar lijst toch ook een rijk land toe te voegen, zou gewezen kunnen worden op art. 6, lid 2 en lid 4 van de Duitse Grondwet:

(2) Pflege und Erziehung der Kinder sind das natürliche Recht der Eltern und die zuvörderst ihnen obliegende Pflicht. Über ihre Betätigung wacht die staatliche Gemeinschaft.

(4) Jede Mutter hat Anspruch auf den Schutz und die Fürsorge der Gemeinschaft.

Zij het dat de verantwoordelijkheid van de staat ten aanzien van de ontwikkeling van kinderen hier een indirecte is. Weliswaar waakt de (Duitse) staat over de plichtsbetrachting van de ouders ter zake van de verzorging en opvoeding van kinderen, doch een uitdrukkelijke bijzondere beschermingsplicht van de staat ten aanzien van het ontwikkelingsbelang van kinderen is in art. $6 \mathrm{GG}$ (Grundgesetz) niet te lezen. Bijzondere bescherming geniet wel de moeder - en met haar, indirect, haar kind. Hetgeen uiteraard ver verwijderd is van een zelfstandige aanspraak van het kind jegens de staat.

In de Nederlandse Grondwet is de kindervolkenrechtelijke grondnorm niet terug te vinden. In het hoofdstuk over grondrechten (hoofdstuk 1) komt het hele woord kind niet voor. Zelfs het onderwijsartikel regelt primair de rechten van volwassenen: het geven van onderwijs. ${ }^{62}$ Toch heeft DE RUITER, die spreekt van de 'afwezigheid van het kind in de

62 Vgl. L.F.M. BEsSELINK, "Een kwestie van mondigheid: burgerschap voor jeugdigen?" In: M. DE LANGEN e.a. (red.), Kinderen en recht; Opstellen over de positie wan minderjarigen in het recht, Arnhem/Deventer 1989, pp. 100-114, op pp. 100/ 101. 
Grondwet, ${ }^{, 63}$ niet volledig gelijk. In hoofdstuk 2 (Regering) krijgt het oudste kind voorrang bij de troonopvolging (art. 25 Grondwet), en het ongeboren kind wordt als reeds geboren aangemerkt als de troon vacant is (art 26 Grondwet). Ten slotte komen kinderen c.q. minderjarigen voor in art. 28, lid 2, art. 34 en art. 37, lid 1 Grondwet. Het betreft hier evenwel in alle gevallen koningskinderen. Gewone kinderen komen inderdaad in de Nederlandse Grondwet niet voor.

\section{2 .3}

Het belang van het kind: een tussenbalans

In bovenstaande geluiden, hoe variërend in toon en klank, en hoe weinig eenstemmig ook, lijken toch twee melodische lijnen te kunnen worden ontwaard. De juridische lijn lijkt het rechtsbegrip (dat wil zeggen: het in het recht voorkomend begrip) 'het belang van het kind' (the best interests of the child) allengs te verheffen tot de status van fundamenteel rechtsbeginsel (alomvattend paraplu- en interpretatiebeginsel). De pedagogische lijn lijkt steeds meer aansluiting te zoeken bij het (veiligheids- en) ontwikkelingsbelang, de ontwikkelingskansen, de ontplooiings- ofwel persoonswordingsoptimalisatie van het kind (het belang van het kind als persoonswordingsbeginsel). Toch is grote voorzichtigheid geboden, zowel waar het de bepaling van de juridische status, als waar het de peiling van de pedagogische inhoud betreft.

In verdrags- of andere internationale instrumenten, in rechtspraak noch doctrine (voor zover we dat in de literatuur, en in het bijzonder in een recent kindervolkenrechtelijk handboek konden nagaan) is een expliciete omschrijving te vinden van inhoud of zelfs maar strekking van het belang van het kind. Al kwamen we in Nederland bij HEINER en BARTELS een betrekkelijk uitgewerkte poging tegen de pedagogische inhoud van het belang van het kind te schetsen. Hoewel bewierookt als 'een van de beschaafdste beginselen van het recht' (PESSERS, hierboven aange-

Job DE RUTER, 'Het kind en de grondrechten,' in: Afra GROEN en Adri VAN MONTFOORT (red.), Kinderen beschermen en jeugd hulp werlenen, Arnhem 1993, pp. $175-192$, op p. 180 i.f.

In zijn 'Voorwoord' bij dit boek staat Jan LEIJTEN erbij stil dat DE RUITER spreekt van het kind en de grondrechten, en niet van het kind en zijn grondrechten (a.w., pp. v-x, op pp. wiii/ix). LEITEN beschrijft hoe hij, "nog maar kort advocaat,' met een kwalijke worm van oneigenlijk gebruik van thet belang van het kind" werd geconfronteerd. Dat was evenwel in de tijd dat "onrecht leren verdragen zonder tegenspraak' als 'goed voor de opvoeding" werd beschouwd (t.a.p., resp. op pp. v-y/vi). Dat (expliciete) grondrechten van het kind goed voor de opvoeding zijn, is een gedachte die - ten onrechte - net zo modieus lijkt als LEIJTENS relaas - ten onrechte - achterhaald. 
haald), "[e]en van de belangrijkste beginselen van onze rechtsorde” (opnieuw PESSERs), ${ }^{64}$ blijkt het belang van het kind, als de wierook is opgetrokken, niet veel meer om het lijfje te hebben dan een beroep op volwassenen wat gevoeliger ten aanzien van de behoeften van kinderen te zijn, en wat minder egoïstisch. ${ }^{65}$ En het is nog maar de vraag of het zelfs die intentie waarmaakt, of dus niet BOUVERNE-DE BIE moet worden nagezegd, die het belang van het kind, als uitkomst van enkele behartigenswaardige constateringen, een mythe heeft genoemd: ${ }^{66}$

"[Het belang van het kind] is een weinig concreet, en moeilijk te concretiseren begrip. (...) Het "belang van het kind" concretiseert zich naarmate het in overeenstemming gebracht kan worden met het belang van andere kinderen en volwassenen, en naarmate het ingepast kan worden in de wederzijdse afhankelijkheidsverhoudingen die mensen, en groepen van mensen, met elkaar vormen op sociaalcultureell, economisch en politiek vlak. Het "bellang van het kind" is [met andere woorden] een contextgebonden begrip.

Deze vaststelling van contextgebondenheid lost het concretiseringsprobleem niet op (...). Evenmin geeft de vaststelling van contextgebondenheid enige aanwijzing over de al dan niet werkbaarheid c.q. [de] strategische waarde van het begrip. Een filosofisch en historisch doordenken wan wat "kinderen" zijn, en van wat hun belangen en rechten zijn, leidt tot confronterende vaststellingen. Er is in eerste instantie de vaststelling dat we de vraag naar wat we concreet weten over kinderen, nog maar weinig kunnen beantwoorden, ondermeer omdat de hiertoe ontwikkelde concepten veelal te statisch zijn, en te weinig zelf-reflexief, en niet in het minst omdat de ervaringen van kinderen zelf nauwelijks in het ondlerzoek betrokken werden. In de tweede plaats is er de vaststelling dat desondanks het begrip strategisch zeer belangrijk is, en legitimerend werkt zowel naar acties die de

Tamara TROTMAN, Kornelie vos, "Het recht op hoor en wederhoor wordt nergens meer geschonden dan binnen de traditionele rechtswetenschap; interview met Dorien PESSERS, Ars Aequi 1991/1, pp. 27-35, op p. 32 1.k. (aangehaald door WLLLEMS, 'Van parentiarchie naar Vadertje Staat,' Nemesis $1992 / 3$, pp. 8-23, op p. 10 l.k.).

"The ultimate message is that adults have to be more sensitive to the needs of children and less selfish in meeting those needs, which, in formal language, becomes the best interests rule of Article 3." (Bruce ABRAMSON, "The invisibility of children and adolescents; the need to monitor our rhetoric and our attitudes,' in: Eugeen verHELLEN (ed.), Monitoring chitdren's rights, [Den Haag] etc. 1996, pp. 393-402, op pp. 398/399.)

66 M. BOUVERNE-DE BIE, 'De jeugdwelzijnsinterventie in het licht van het recht van kinderen op bijzondere bescherming en hulp,' in: $\mathbb{E}$. VERHELLEN, F. SPIESSCHAERT, L. CATTRJSSE (red.), Rechten van kinderen; Een tekstbundel wan de Rijksuniversiteit Gent naar aanleiding van de UNO-Conventie voor de rechten van het kind, Antwerpen/Arnhem 1989, pp. 183-208, op pp. 185-186; aan het slot ook aangehaald door Christian MAES, 'Rechten van het kind ... en verder,' in: E. vERHELLEN e.a. (red.), Kinderrechtengids, Gent 1994 (losbladig), Deel I, Commentaren, 1.1 MAES, pp. 1-16, op p. 7 . 
ontplooiingskansen (...) bevorderen, als naar interventies die "in het belang van het kind" volwassenen macht geven over kinderen, zonder dat de vraag wanneer en tot waar kan (c.q. moet) opgetreden worden, voldoende gesteld wordt. Dit laatste geldt [bijwoorbeeld] in situaties van kindermishandeling, op het microvlak wanneer het kind geschaad wordt door toedoen en/of nalatigheid van zijn opvoeders. Het uit zich evenwel ook in [bijvoorbeeld] doorgedreven vormen van interventionisme vanuit de institutionele jeugdbescherming en in het macrosociaal gezien geen rekening houden met kinderen; de verkeersproblematiek, en algemeen gezien onze ruimtelij.ke ordening, is hiervan een vaak aangehaald, doch nog steeds tekenend voorbeeld. In die zin is het "hoogste belang wan het kind" in niet onbelangrijke mate een mythe, [dat wil zeggen] "in psychologische en sociologische zin functies vervullend en als zodanig reëel, maar niet die aanspraken waarmakend, en dus: een mythe" [HUPE, 1984].'

Kan men, wanneer men deze woorden op zich laat inwerken, of wanneer men kijkt naar de rechtspraktijk, praktisch/juridisch-technisch gezien, de auteurs ongelijk geven die bestrijden dat - in hun nationale recht - het belang van het kind een rechtsbeginsel is? ${ }^{67}$ Want wat kan de juridische status zijn van een beginsel dat, van zijn fraaie vlag ontdaan, niet meer blijkt in te houden dan een appèl aan de machtigen rekening te houden met de belangen van de rechteloze, de statusloze, de machteloze bij uitstek: het jonge kind? Wat kan de juridische status zijn van een beginsel dat, n'en déplaise de goede bedoelingen, intellectuele eerlijkheid en deskundigheid van rechters en hulpverleners, door het nationale recht met niet meer waarborgen wordt aangekleed dan de schaamlap van een appèl aan de disgenoten grootmoedig de bedelaar de kruimels te gunnen die

67 Voor (neerlandofoon) België kwamen we al SENAEVE tegen (P. SENAEVE, 'Het belang van het kind in het Belgische familierecht; in: Met het oog op het belang van het kind, a.w., pp. 119-127, in het bijzonder op pp. 122 en 126-127). Voor België's wederhelft kan naar RIGAUX worden verwezen: '[L]'interêt de l'enfant est aujourd'hui le maitre-mot du droit des relations familiales. Ill est excellent que cet intêrêt inspire le législateur. II est moins satisfaisant que ce dernier habilite le juge à prononcer sur les droits subjectifs des citoyens en fonction d'une directive imprécise.' (F. RIGAUX, aangehaald door MAES, Kinderrechtengids, ta.p.)

In Nederland spreekt FRANKEN (H. FRANKEN, 'Het belang van thet kind voor wetgeving en bestuur,' in: Met het oog op het belang van het kind, a.w., pp. 27-42, op p. 38) van een "super" vaag beginsel, dat gelukkig vaak als rechtsbeginsel wordt gehanteerd zowel in de zin van bescherming als van waarborg van recht.' Hij voegt daaraan toe: 'Het verdient echter steeds, juist om manipulatie en discriminatie te voorkomen, te worden uitgesplitst of gespecificcerd, want het belang van. het kind is even ruim als het belang van de mens."

Dat laatste kan natuurlijk niet waar zijn. Het kind deelt met de volwassen mens het algemene belang van de ontplooiing. Het kind onderscheidt zich van de volwassen mens in en door het specifieke belang van de persoonswording. Het belang van het kind moet dus, logisch gezien, juist die persoonswording betreffen. 
van de tafel zijn gevallen? Of, wat minder gechargeerd: wat kan de juridische status zijn van een beginsel dat, blijkens de nationale rechtspraktijk, niet meer behelst dan een min of meer vrijblijvend appèl aan volwassenen - omstanders en buitenstaanders, vrije buren en burgers; ouders en opvoeders, eerstverantwoordelijken; beroepshalve verantwoordelijken, onder wie gezagsdragers en medewerkers, rechtstreeks of via particuliere instellingen bezoldigd door het staatsapparaat - om om te kijken, omlaag te kijken, achter de gordijnen te kijken om het kind in nood te zien en te hurken om het bij te staan?

BOUVERNE-DE BIE legt de vinger op de zere wonde als zij, bijna terloops, verwijst naar een appèl dat aan de concretisering van het belang van het kind, aan operationalisering en rechtsverfijning, dient vooraf te gaan, en waarmee deze dient gepaard te gaan: het appèl aan de volwassene om vanuit de zelf-reflectie ten aanzien van het kind dat hij of zij is geweest (en vaak tot ver in de volwassenheid meer is gebleven dan menigeen aan zichzelf wil toegeven), zich in maatschappelijke (en dus ook juridische, rechtsvormende, rechtspolitieke) zin om het kind te bekreunen, zich in het kind in te leven en zich over het kind te ontfermen. Waar is dit laatste - tweeledige - appèl indringender verwoord dan in en met welke tekst is tweeduizend jaar lang minder gedaan dan met Mattheüs 18:1-6: ${ }^{68}$

Op dat ogenblik kwamen de discipelen bij Jezus en vroegen: "Wie is wel de grootste in het Koninkrijk der hemelen?' En Hij riep een kind tot zich, plaatste dat in hun midden, en zeide: 'Voorwaar, Ik zeg u, wanneer gij $u$ niet bekeert en wordt als de kinderen, zult gij het Koninkrijk der hemelen voorzeker niet binnengaan. Wie nu zichzelf gering zal achten als dit kind, die is de grootste in het Koninkrijk der hernelen. En een ieder die zulk een kind ontvangt in Mijn naam, ontvangt Mij. Maar een ieder die één dezer kleinen, die in Mij geloven, verleidt, het zou beter voor hem zijn, dat een molensteen om zijn hals ware gehangen en hij verzwolgen ware in de diepte der zee.'

De ondermaanse werkelijkheid laat evenwel iets anders zien. In het belang van het kind als juridisch brandpunt van het maatschappelijk welzijn van kinderen balt zich samen wat HAMMARBERG, lid van het Comité inzake de rechten van het kind, in meer algemene zin opmerkte: ${ }^{69}$

Zie ook Marcus 9:42; Lucas 17:2; nieuwe vert. NBG. Curs. jw; vgl. met betrekking tot deze cursivering Fokke SIERKSMA, Religie, sexualiteit en agressie; Een cultuurpsychologische bijdrage tot de verklaring van de spanning tussen de sexen, Groningen 1979, p. 228.

Thomas HAMmarberG, 'Preface,' in: Bob FRANKLIN (ed.), The handbook of children's rights; Comparative policy and practice, London/New York 1995, pp. ixxiii, op p. ix. 
'We know that few areas have been so riddled by political hypocrisy as children's rights and wellare."

Ergens tussen deze twee uitersten van nieuw-testamentisch appèl en nationaal en internationaal politiek farizeïsme bevindt zich het internationaalrechtelijke, het mensenrechtelijke rechtsbeginsel van het belang van het kind (the best interests of the child). Kan een benadering vanuit het belang bij uitstek waarin en waardoor een kind zich van de volwassene onderscheidt, het (veiligheids- en) ontwikkelingsbelang, het persoonswordingsbelang, tussen zoveel dissonantie en wanklanken de toon zetten, of op zijn minst de juiste snaar raken?

Het belang van het kind is, naar geldend (nationaal) recht, wat volwassenen in het belang van het kind achten (het kind als object). Persoonswording, of liever: het recht van het kind op persoonswording (het sociaal-pedagogisch geoperationaliseerde veiligheids- en ontwikkelingsbelang van het kind), vertrekt vanuit het kind (het kind als subject). ${ }^{70}$ Het belang van het kind kan, in een bepaald geval, op zijn best weliswaar samenvallen met 'persoonswording' maar kan even goed, in een concreet geval, op zijn slechts een 'pia fraus'-beginsel blijken.

Om een voorbeeld te noemen: de ouders (of de hulpverleners ${ }^{71}$ ) achten het in het belang van het kind dat het kind geen hulp krijgt/thuis blijft ondanks de ernstige bedreiging van de persoonswording van het kind die van hen uitgaat. Zij interpreteren het belang van het kind dan vermoedelijk meer in termen van de instandhouding van het gezinssysteem - de rigide maar precaire homeostase waarvan de doorbreking in de ogen van zowel leken als hulpverleners soms traumatiserender lijkt dan het oorspronkelijke trauma, ${ }^{72}$ of liever de voorstelling die zij zich daarvan, met name in gevallen van chronische traumatisering, kunnen maken - dan in termen van ontwikkelingspsychologische/pedagogische

Met betrekking tot het kind als subject (dan wel object) zie ook: Marieke KronEMAN, 'De pedagogische opvattingen van de Raad voor het Jeugdbeleid, Jengd \& Samenleving 1996/4, pp. 162-168, op pp. 163 en 164-165. Een citaat (op p. 165 1.k.): 'Opvallend is dat in de adviezen over de onder-kindrelatie de Raad niets doet met de opvatting "het kind als subject".' Dit ondanks het uitgangspunt wan de Raad: 'mensenrechten gelden voor jeugdigen' (t.a.p., r.k.).

71 Doordat in de hulpverlening te veel nadruk ligt op het weer bijeen brengen van het gezin (...). De hulpverlening is te veel gericht op het [gezins]systeem en daarna houdt het op.' (Peter SCHOOF, ex-directeur VKM, aangehaald door Veronique HUUBREGTS, "Peter SCHOOF: "Kinderen een stem en een gezicht geven", VKMagazine $10 / 2$, pp. 1-3, op p. 2 l.k.)

72 Vgl. Frédérique GRUYeR, Martine FADrer-NISSE, Pierre SABOURIN, La wiolence impensable; Inceste et maltraitance, Paris 1991, "Le secret familial," pp. 98-102, op p. 100. De auteurs spreken hier van een 'erreur d'interprétation." 
behoeften/noden. Om deze laatste te kumnen beoordelen zal de hulpverlener c.q. de rechter niet alleen naar het korte-termijn-belang van het kind $^{73}$ maar ook - expliciet - naar zijn toekomstkansen moeten kijken: wat valt daarover naar de huidige stand van de (ortho)pedagogische, ontwikkelingspsychologische en psychopathologische kennis te zeggen?

De wettelijk gewaarborgde aandacht voor zijn toekomst-, dat wil zeggen: zijn persoonswordingskansen, maakt het kind tot een rechtssubject in het heden, niet in de laatste plaats omdat het als drager van rechten in de toekomst rehabilitatie en compensatie kan claimen als er met zijn belangen kortzichtig of ondeskundig omgesprongen is. Met de mogelijkheid van een claim dienen volwassenen (ouders, de staat) dus te allen tijde rekening te houden. De preventieve werking, de noodzaak tot zorgvuldigheid, die hiervan uitgaat, is duidelijk. Respect moet soms worden afgedwongen. Niets dwingt meer respect af dan het vooruitzicht van een claim, de wetenschap niet alleen dat de ander ook zijn of haar rechten heeft, maar deze vroeger of later zal opeisen, of verhaal zal zoeken, zodat met hem of haar ondanks alle - tijdelijke - weerloosheid niet te spotten valt.

Is het nationale recht nog ver van deze en dergelijke wettelijke waarborgen verwijderd, met het Verdrag inzake de rechten van het kind heeft 'de politiek' (zoals we in hoofdstuk 10 nog zullen zien) om met MAES te spreken, 'het Trojaanse paard binnengehaald. ${ }^{74}$ Vooralsnog moet echter BOUVERNE-DE BIE worden toegegeven: het belang van het kind is mythe; mythe omdat en voor zover het zijn pedagogische/ontwikkelingspsychologische aanspraken niet waarmaakt.

\section{Het kind als machtsobject}

Door schadelijke traditionele pedagogische praktijken ('de roede niet sparen $^{75}$ : het slaan van kinderen; maar ook het vernederen van kinde-

Zoals KOENS stelt: 'Niet ontkend kan worden dat bij het nemen van beslissingen ten aanzien van de persoon van de minderjarige vooral de status quo en de korte termijn situatie bepalend zijn voor de oordeelsvorming van de rechter." (M.J.C. KOENS, 'Het belang van het kind in het vreemdelingenrecht,' in: Met het oog op het belang wan het kind, a.w., pp. 255-265, op p. 256 i.f.; vgl. ook p. 265 if.) MAES, Kinderrechtengids, t.a.p., op p. 15 iff.

75 'Maak aan uw kinderen duidelijk, hoe goed en nodig de bestraffingen woor hen zujn en hoe nuttig voor hun ziel. De Heere gebiedt de ouders immers de roede te gebruiken en te bestraffen. (....) Die zijn roede inhoudt, haat zijn zoon; maar die hem liefheeft, zoekt hem vroeg met tuchtiging, Spr. 13:24 (...). Aldus regel 125 van Jacobus KOELMANs De plichten der ouders in kinderen voor God op te voeden, herschreven door C. BREGMAN, Houten 1994 (vierde druk; eerste druk 1982; oorspronkelijke editie Amsterdam 1679), pp. 90/91.

GREVEN (Philip GREVEN, Spare the child; The religious roots of punishment and 
ren, door schreeuwen, uitschelden, afwijzen/verwerpen/liefde onthouden) - praktijken die evengoed als meisjesbesnijdenis en voorkeursbehandeling van jongetjes onder de werking van art. 24, lid 3 van het Verdrag inzake de rechten van het kind ('traditionele gebruiken die schadelijk zijn voor de gezondheid van kinderen') zouden kunnen worden gebracht - wordt een kind niet als subject gezien maar als object, i.c. object van de vrijheids- c.q. privacyrechten van zijn of haar ouders. Wat tussen volwassenen ondenkbaar is (gelukkig in toenemende mate ook binnen het huwelijk, in de relatie man-vrouw): schending van de lichamelijke en geestelijke integriteit, wordt tussen ouders en kinderen met de mantel der 'liefde' bedekt. Waar de vrouw als mannelijk en echtelijk object ter botviering van lust of onlust door het feminisme in de ban is gedaan, is het kind als machtsobject nog steeds niet echt uit de taboesfeer geraakt. Dat wil zeggen: wel steeds meer als lustobject (de maatschappelijke ontdekking van 'incest,' van sexuele kindermishandeling), maar nog steeds niet, nog lang niet als onlustobject (fysieke en emotionele mishandeling als gevolg van ouderlijke onmacht en frustraties).

\section{Misbruik van een vaag criterium}

Laten we eens wat scherper inzoomen op het Nederlandse intern-nationaalrechtelijke belang van het kind, "het centrale begrip van ons jeugdrecht. ${ }^{76}$ DE RUITER wijst op de verschillende juridische contexten waarin we (het belang van) het kind tegenkomen: ${ }^{77}$

'Wij komen de minderjarige tegen:

[1.] als individu, dat zijn belang bij mogelijkheden voor ontplooiing vastgelegd ziet onder meer in de onderwijswetgeving (leerplicht) en arbeidswetgeving (verbod op arbeid beneden een zekere leeftijd) ...'

Als individu, met andere woorden, vanaf de schoolleeftijd c.q. vanaf de leeftijd dat kinderarbeid mogelijk zou zijn. Ontplooiing ziet hier dus niet op het jonge en zeer jonge kind.

the psychological impact of physical abuse, New York 1992, p. 54) vraagt zich af waarom het slaan van kinderen eeuwenlang 'christelijk' is genoemd terwijl dit nergens in het Evangelie wordt verkondigd en men zich buiten de oud-testamentische spreuken en vermaningen slechts op een passus bij de anonieme auteur (niet Paulus, die zelf de roede heeft gevoeld: 2 Korintiërs 11:24-25) van Hebreeën (12:5-11) kan beroepen.

76 Job DE RUTER, 'Het kind en de grondrechten,' in: Kinderen beschernen en jeugd hulp verlenen, t.a.p., op p. 176 i.f.

T.a.p., op pp. 177-178 (curs. jw). 
[2.] als afstammeling (...); [als] eerstegraads bloedverwant in de neerdalende lijn ..."

... dat wil zeggen: als wettig of gewettigd kind (mantelkind, erkend kind) dan wel buitenechtelijk kind (voorheen: bastaard, dat is speelkind of overwonnen - in overspel of bloedschande geteeld - kind). ${ }^{78}$ Het belang van het kind is hier 'het belang van het kind bij een wettige afstamming (...) of wel - moderner - bij een afstammingsrelatie met zijn moeder en zijn vader. ${ }^{79}$

[33.] als kind onder gezag van zijn ouder(s); hier geldt als voorondersteld belang, als premisse, dat het in het belang van het kind is, dat het wordt opgevoed door en in het gezinsverband van zijn eigen ouder(s);

[4.] als kind indien tussen de ouders moet worden gekozen; met name na echtscheiding kan de vraag actueel zijn wèlke ouder het best met het gezag over het kind kan worden belast; de ouders staan (in beginsel) gelijk en het belang van het kind moet de doorslag geven aan de hand van een beoordeling van datgene wat elk der ouders het kind te bieden heeft, en wat dit kind in het bijzonder nodig heeft;

[5.] als kind dat beschermd moet worden tegen disfunctionerende ouders; hier moeten zó zwaarwegende belangen van het kind aanwezig zijn, dat zij een inbreuk op de ouderlijke gezagspositie, en dus op het hiervoor omschreven vooronderstelde belang van het kind bij opvoeding door de eigen ouders, rechtvaardigen, zodat er plaats is voor een beschermende maatregel als ondertoezichtstelling of ontheffing dan wel ontzetting van het gezag; de zwaarte van dit belang komt tot uitdrukking in de formulering van de gronden voor de verschillende maatregelen, zoals misbruik van het gezag en gevaar voor zedelijke of lichamelijke ondergang. van het kind (...), waarbij zij aangetekend dat het hier geen automatisme betreft, en dat ook bij het aanwezig zijn der gronden nog eens afzonderlijk moet worden beoordeeld of de maatregel in het belang van het kind is ...'

Hier lijkt te staan dat een met geestelijke of lichamelijke ondergang bedreigd kind van de ondergang kan/moet worden gered voor zover dat in zijn belang is. Wellicht moet hierbij worden gedacht aan het gevaar dat door een maatregel de ondergang enkel wordt bespoedigd. Bijvoorbeeld doordat de hulpverlening die de staat te bieden heeft, nog rampzaliger is dan de ellende waar het kind al in leeft. (Dat dit laatste geen louter theoretische mogelijkheid is, zal geen krantelezer ontgaan, en is bekend bij al degenen die weet hebben van de mate van parentificatie van sommige hulpverleners. Deskundigheidsbevordering en verbetering van inter- 
visie en supervisie zouden op dit vlak als kernrechten van het 'beschermde' kind, het kinderbeschermingskind, kunnen worden geformuleerd ${ }^{80}$ )

'[6.] als onmondige in het rechtsverkeer; hier gaat de wet uit van de aanname dat het minderjarige kind nog niet in staat is zelfstandig aan het rechtsverkeer deel te nemen, en dat het dus in zijn belang moet worden vertegenwoordigd (...), waarbij zich echter voortdurend de spanning voordoet of er (...) ruimte is voor erkenning van de geleidelijk toenemende bekwaamheid van het kind (...); intussen is hier naast het belang van de minderjarige mede aan de orde het belang van het maatschappelijk verkeer en wel in het bijzonder het belang van degene die met de minderjarige handelt.'

\section{DE RUTTER trekt hieruit de conclusie: ${ }^{81}$}

'(..) dat "het belang van het kind" niet maar een algemene weergave is van ons streven om het beste te zoeken voor het kind, maar dat het een functie heeft ter fundering èn bepaling van de rechten die aan het kind toekomen, zoals het recht op ontplooiing, recht op gezinsleven met de eigen ouders, recht op bescherming, recht op deelname aan het maatschappelijk verkeer."

Hoewel DE RUTER het recht op onplooiing dus met zoveel woorden als recht noemt, ${ }^{82}$ en hoewel onder het recht op gezinsleven (family life) toch ook moet worden verstaan het recht op eerbiediging van de persoonlijke levenssfeer van het kind, dat wil zeggen op eerbiediging binnen het gezin van zijn lichamelijke en geestelijke integriteit (met andere woorden: het recht op een zinnig en zindelijk gezinsleven), kan uit zijn opsomming niettemin worden afgeleid dat het recht van het kind op ontplooiing als recht van in het bijzonder het jonge en zeer jonge kind, zo het al een 'recht' is, een negatief recht is: de overheid kan (waar wordt gezegd: moet?) ingrijpen niet om die ontplooiing te bevorderen maar om het kind van het tegendeel van ontplooiing: de geestelijke of lichamelijke ondergang, te redden. Voor zover deze interpretatie juist is, is zij ver verwijderd van de boodschap - in de vorm van verplichtingen voor ouders en de staat - die het Verdrag inzake de rechten van het kind lijkt te bevatten.

80 Zo ergens, dan is hier de staatsaansprakelijkheid direct in het geding: ex art. 3 , lid 3 VRK. Zue J.C.M. WILLEMS, "Kinderen zijn niet automatisch veilig bij hun ouders," Tijdschrift voor Jeugdhulpverlening en Jeugdwerk 1993/11, pp. 18-22, op p. $19 \mathrm{r.k}$.

81 T.a.p., op p. 178.

82 Ook KoENS (in: Met het oog op het belang van het kind, t.a.p., op p. 256) spreekt van een 'recht op ontplooiing.' Het belang van het kind zou niet alleen op bescherming zien, maar ook worden gehanteerd met het oog op dit 'recht' (t.a.p.). 
Het belang van het kind - 'voor alle duidelijkheid zij het nog eens gezegd - (...) betekent in de strafrechtelijke context het belang van de opvoeding van het kind, of het opvoedingsbelang.' Aldus - zonder aarzeling of reserve - BARTELS. ${ }^{83}$ Het belang van het kind is het "opvoedkundig belang,' stelt ook DE KONING, althans als we het hebben over 'het individuele kind' in 'ons familie- en jeugdrecht uit Boek 1 BW. ${ }^{34}$ Toch lijkt het belang van het kind hier een slag anders te liggen. Een scherp oog van hulpverlener en rechter voor het opvoedkundig belang van het individuele kind dat min of meer toevallig in de kinderbeschermingsmolen is beland, moet er voor waken dat civielrechtelijke kinderbescherming niet in de praktijk ouderbescherming wordt. Anders dan in het jeugdstrafrecht immers is in het civiele recht pedagogisch handelen sluitstuk, zo niet sluitpost, maar niet vertrekpunt, officieel uitgangspunt van overheidsbeleid. FRANKEN spreekt dan ook van het belang van het kind als een 'beschermingsbeginsel' in het civiele recht - bescherming, zouden we kunnen zeggen, tegen ouders die het te bont maken. Terwijl we "[i]n het jeugdstrafrecht (...) een zware nadruk op het pedagogische karakter' van het belang van het kind vinden: 'Niet het strafbare feit, maar de persoon van het kind staat voorop. Straf en maatregel staan in het teken van de opvoeding. 85

Wat er van het precieze onderscheid tussen civiel- en strafrecht zij, tezamen genomen, globaal intern-nationaalrechtelijk beschouwd, bestaat het belang van het kind dus uit een protegendum, een beschermingsbeginsel, en een educandum, een pedagogisch beginsel; het is zowel een 'maatstaf voor pedagogisch als voor juridisch handelen. ${ }^{, 86} \mathrm{Zij}$ het met verspringende accenten, met wisselende betekenissen, met verschuivende perspectieven in verschillende rechtsgebieden.

We laten dit verder voor wat het is. Het wordt namelijk tijd het educandum, de pedagogische dimensie wat nader in ogenschouw te nemen. In deze paragraaf spitsen we ons toe op het pedagogisch belang van het kind, het belang van het mensenkind persoon te worden. Daartoe brengen we door middel van (betrekkelijk uitvoerige) citaten van DIELE-

83 J.A.C. BARTELS, 'Het belang van het kind in het jeugdstrafrecht, of "de evolutie van een rechtsbegrip", in: Met het oog op het belang van het kind, a.w., pp. 225240 , op p. 228.

84 S.J.M. DE KONING, 'Jeugdbeleid en het belang van het kind,' in: Met het oog op het belang van het kind, a.w., pp. 13-26, op p. 13.

85 H. FRANKEN, 'Het belang van het kind voor wetgeving en bestuur,' in: Met het oog op het belang van het kind, a.w., pp. $27-42$, op p. 28.

86 FRANKEN, t.a.p. 
MAN en SPAN (samenstellers van en auteurs in Pedagogiek van de levensloop) eerst 'het spanningsveld van de pedagogiek' in beeld en daarna 'het jonge kind in het gezin.' Hieraan voegen we een citaat over 'Zwarte pedagogie' toe, dat ons ook de keerzijde laat zien: het (thans historisch?) gevaar van 'pedagogisch' misbruik, dat wil zeggen kindermishandeling onder het mom van opvoeden, waarbij enkele kanttekeningen worden geplaatst. Met deze wetenschap gewapend, proberen we vervolgens, aan het slot van dit hoofdstuk, enkele conclusies te formuleren met betrekking tot persoonswording als recht van het kind c.q. het recht van het kind op persoonswording in relatie tot 'het belang van het kind.'

Het kind als animal educandum: persoonswording als (universeel) opvoedingsdoel

Het spanningsveld van de pedagogiek

Onder het hoofd 'Het spanningsveld van de pedagogiek' schrijven DIELEMAN en SPAN: $:^{87}$

"Het kind is een animal educandum (een dier dat opgevoed moet worden), schreef ooit de in 1990 overleden pedagoog en ontwikkelingspsycholoog LANGEVELD. In deze twee woorden is in een notedop het spanningsveld aangegeven waarin de pedagogiek zich beweegt. Aan de ene kant is er de biologische uitrusting waarmee het kind ter wereld komt [animal], aan de andere kant is er de mogelijkheid tot humane ontwikkeling [educandum].

Die mogelijkheid verwezenlijkt zich echter niet vanzelf. Alleen door deel te hebben aan menselijke communicatie kan het kind zijn in aanleg gegeven mens-zijn ontplooien [dat is: persoon worden, jw]. De weinige curieuze gevallen waarin kinderen zijn opgegroeid zonder verzorging door mensen ("wolfskinderen") laten zien dat essentiële menselijke eigenschappen als spraak en rechtopgaande gang niet tot ontwikkeling komen als kinderen niet deel witmaken van een mensengemeenschap. Alleen door meedoen leert het kind de taal, de regels en de conventies die het in staat stellen te participeren in een menselijke wereld. (...)

Bewust of onbewust streven opvoeders doelen na. Hun handelen is intentioneel. Het feit dat het kind is aangewezen op opwoeding, geldt daarom voor alle culturen. Opvoeding is universeel. Weliswaar worden jonge kinderen op uiteenlopende wijzen binnengeleid in verschillende leefwerelden en wereldbeelden, maar dat betekent nog niet dat de voorwaarden waaronder humane ontwikkeling en persoonswording plaatswinden, fundamenteel van elkaar verschillen. Elke (sub)cultuur kent bijvoorbeeld normen waaraan kinderen moeten leren te voldoen. In onze van humanisme en christendom doortrokken samenleving is het centrale

A.J. DIELEMAN, P. SPAN, 'Inleiding: de pedagogiek en het animal educandum,' in: dez. (red.), Pedagogiek van de levensloop, Amersfoort/Leuven, ou Heerlen 1992, pp. $15-27$, op pp. $15-17$. 
doel de persoonswording met de daaraan ten grondslag liggende waarden van individualiteit, socialiteit en normbesef.

De opdracht to opvoeding aanvaarden ouders meestal zonder veel nadenken. Ze weten zich verantwoordelijk, ook al wordt dit heel verschillend gemotiveerd, en ze leggen normen aan over wat goed en slecht is voor de ontwikkeling van een kind. Het zijn deze - veelal weinig beredeneerde - verantwoordelijkheidsgevoelens die ten grondslag liggen aan het opwoedend handelen. Per definitie is dit handelen waardegeladen; het kan nimmer neutraal zijn.

Dat een kind zich op menselijke wijze ontwikkelt en een persoon wordt, is dus geen "natuurlijk" proces, maar [is] bepaald door menselijk handelen. (...)

De vraag naar het opvoedingsdoel is in dit verband uiteraard van het grootse belang. Veel moderne, ook Nederlandse, pedagogen omschrijven persoonswording als zelfstandigwording van het individu. LANGEVELD, bijwoorbeeld, benadrukt de zelfverantwoordelijke zelfbepaling (...). (...) De pedagogiek is, kortom, geinteresseerd in datgene wat de ontwikkeling tot zelfstandigheid van de "persoon in wording" bevordert.

Dit betekent echter niet dat zelfstandigheidsopvoeding overal dezelfde invulling krijgt of moet krijgen. Het gaat hier eerder om een (abstract) structuurbegrip waarvan de concrete inhoud, al naar gelang de (sub)cultuur waarin het kind opgroeit, kan verschillen. (Denk bijwoorbeeld aan de verschillen in politieke en religieuze levensovertuigingen.) (...)

De voortdurende waarden- en normenreflectie, die gepaard gaat met een praktische gerichtheid, onderscheidt de pedagogiek van haar directe nabuur: de ontwikkelingspsychologie. In tegenstelling tot deze aanverwante discipline bezit zij, als het over de opvoeding gaat, een uitgebreide traditie van bezinning en betekenisonderzoek (hermeneutiek). De pedagogiek doet meer dan alleen onderzoeken hoe de opvoeding in haar werk gaat. Toch is de pedagogiek sterk aangewezen op de kennis die de ontwikkelingspsychologie biedt. Deze discipline onderzoekt de menselijke ontwikkelingsmogelijkheden (...).'

\section{Het jonge kind in het gezin}

Onder het hoofd 'Het jonge kind in het gezin' schrijven de auteurs - na te hebben aangegeven dat het traditionele gezin zijn monopolie verliest, allengs meer vrouwen buitenshuis werken en de individualisering alsmaar voortschrijdt: $: 88$

'Sommige pedagogen zetten nog steeds vraagtekens achter het buitenshuis werken van moeders. $Z$ ij twijfelen eraan of de moeder de eerste levensjaren van een kind well kan worden gemist. Anderen zien hierin nauwelijks risico's mits er sprake is van een goede vervanging, en zij wijzen liever op de positieve keerzijde, namelijk op de psychologische winst die werken vrouwen oplevert, en waarvan het kind meeprofiteert. Liever enkele uren na gedane arbeid een opgewekte en aandachtige speelkameraad dan de hele dag door een irritabele en depressieve moeder, zo houden ze de twijfelaars voor. 
In het licht van deze discussie is onderzoek naar de betekenis van de moederkind-relatie en naar de vervangingsmogelijkheden van enorm pedagogisch gewicht.

Terwijl het debat hierover voortduurt, toont ontwikkelingspsychologisch onderzoek steeds overtuigender aan hoe belangrijk de voorschoolse jaren (derde en vierde levensjaar) uit pedagogisch oogpunt zijn. Dat de kwaliteit van de fysieke en sociale omgeving invloed uitoefent op de emotionele en cognitieve ontwikkeling van peuters en kleuters, wist men al langer. Voldoende stimulatie, afwisseling in de omgeving en affectieve ondersteuning zijn onmisbare voorwaarden voor een gunstige intellectuele en sociale groei. Een kind dat onvoldoende exploratiemogelijkheden heeft, de aanmoediging van volwassenen mist en weinig genegenheid krijgt, doet het gemiddeld slechter dan een kind dat dit allemaal wel heeft. Dit zijn alom bekende en geaccepteerde onderzoeksresultaten, waarop een heel verzorgings- en begeleidingsnetwerk is gebouwd. Denk maar cens aan de consultatiebureaus, de intellectuele stimuleringsprogramma"s voor peuters en kleuters, de ontwikkelingstesten enzovoort.

Dat echter de eerste twee levensjaren eenzelfde functie vervullen, krijgt minder aandacht. Men spreekt eerder van "babyverzorging" dan van "baby-opvoeding." Bij zuigelingen denken we in de eerste plaats aan op tijd voeden, verschonen en laten slapen dan aan cognitieve of sociale ontwikkelingsspelletjes. Toch hebben baby's ook behoefte aan intellectuele stimulatie en menselijke omgang. Het psychologisch baby-onderzoek heeft het laatste decennium een grote vlucht genomen, en laat zien dat baby's geen passieve organismen zijn maar sociale wezens, die bijna onmiddellijk ma de geboorte, hoe primitief ook, actief reageren op hun verzorgers. Er is dus eigenlijk al direct sprake van een tweerichtingsverkeer in de relatie tussen baby en verzorger, kortom van interactie. Daarom is ook in de opvoedkunde meer alandacht gekomen voor het contact van de primaire verzorgers met de zuigeling.

De wijze waarop de baby, en later de peuter, aan zijn directe verzorgers is gehecht, is van het grootste belang in het kader van de vroege ontwikkeling. Dit laatste was all langer bekend ait onderzoek van de Britse psycholoog John BOWLBY. Ontwikkelingsstoornissen bij kinderen die langdurig van hun ouders waren gescheiden, zetten hem op het spoor van de psychologische betekenis van een goede hechting tussen moeder en kind. (...) Vanuit veiligheid en geborgenheid moeten kinderen de gelegenheid hebben de directe wereld om hen heen fysiek en sociaal uit te proberen. Op die manier leren $z e$ de materiële eigenschappen van objecten kennen en leren ze met andere kinderen en volwassenen omgaan.'

\section{'Zwarte pedagogie"}

Om het pedagogisch belang van het kind ook vanuit de pathologie (ziekelijke vormen van omgaan met kinderen onder het mom van opvoeding), dat is vanuit de zogenaamde 'zwarte pedagogiek' te benaderen, halen we hier nog GÖRTZEN aan: ${ }^{89}$

89 R. GÖRTZEN, "Onderdrukking en bevrijding van het kind," in: B. SPIIBCKER e.a. (red.), Theoretische pedagogiek, Meppel/Amsterdam 1982, pp. 151-176, op pp. $153 / 154$. 
"De aanduiding "zwarte pedagogiek" verwijst naar dat pedagogisch denken en handelen dat gericht is op de onderwerping van het kind door volwassenen. Onder het mom dat het om zijn bestwil geschiedt, wordt het kind gemanipuleerd, mishandeld en bedrogen. (...) Zonder zich daarvan bewust te zijn, creëren de ouders een totalitaire opvoeding, die, alle toewijding en liefdesblijken ten spijt, het eigen leven en de eigenwaarde van het kind aantast. (...)

De "zwarte pedagogiek" is niet van recente datum. De sporen ervan vindt men al in het Oude Testament, met name in het vierde gebod, dat kinderen dwingt tot idealisering van de ouders en verdringing van hun vroegkinderlijke traumatiseringen (...). Ook oudtestamentische opvoedingsspreuken als "Tuchtig je kind, opdat het je (niet: heml) goed gaat," verraden de aanwezigheid van beginselen der "zwarte pedagogiek." Hoe kinderen en jeugdigen toen en in de eeuwen daarna geleden hebben aan hun kinderlewen, valt nauwelijks meer te achterhalen. Desondanks kan uit de pedagogische geschiedschrijwing (...) worden afgelezen dat "de geschiedenis van de kindsheid een nachtmerrie is, waaruit wij nu pas ontwaken." (DEMAUSE ...).'

Hoe wijdverbreid deze 'pedagogische' pathologie in het verleden was, of heden ten dage nog is, kan hier in het midden blijven. Zeker is dat er over de geschiedenis ook minder nachtmerrie-achtig wordt gedacht. Zo stelt NOORDAM in zijn Historische pedagogiek van Nederland: 90

\footnotetext{
'De kinderen groeiden in grote vrijheid op en maakten al vroeg aanspraak op een zeker respect bij de volwassenen. Dat gold ook voor de meisjes, die vroeger wel bestemd waren voor een huiselijke functie, maar waarvan verwacht werd dat ze deze zelfstandig zouden vervullen. De kinderen ontwikkelden zich tengevolge hiervan over het algemeen rustiger dan elders, ze werden minder geslagen en ook minder hard, infanticide en te vondelling leggen zijn betrekkelijk zeldzaam gebleven.'
}

Een zeker respect als regel waarop de historische praktijk waarschijnlijk niet minder talrijke - en niet minder ernstige of zelfs gruwelijke - uitzonderingen te zien zal hebben gegeven dan wat we, als we daar oog voor hebben, anno 1998 aan uitzonderingen op respectregels voor kinderen dagelijks om ons heen kunnen waarnemen. Een zeker historisch respect dat we enigszins kunnen navoelen bij lezing van Betje WolfFs Proeve over de opvoeding aan de Nederlandsche moeders uit $1780:^{91}$

90 N.F. NOORDAM, Historische pedagogiek van Nederland; Een inleiding, Nijkerk 1979 , p. 110.

91 Betje wolfF, Proeve over de opvoeding, aan de Nederlandsche moeders (1780), tweede druk, heruitgave met een inleiding van H.C. DE wOLF, Meppel/Amsterdam 1977 , pp. 56 resp. 76 . Zie over woLFF (en opvoeding zoals het was en worden moet): Wouter POLS, Moderne pedagogische gedachten in de achttiende eeuw, in: dez. e.a. (red.), Opvoeding zoals het is, Amersfoort/Leuven 1989, pp. 113-143. 
'Een Kind is goed van vertrouwen - Het is oprecht, en nog nimmer bedrogen zynde, denkt het niet eens dat er zo iets is, 't welk wy bedrog noemen.

Een Kind veinst niet - Zyn ziel is altoos in zyne oogen; alle zyne aandoeningen tintelen in zyme levendige trekjes. Hoe! zou het veinzen? Het veinzen is immers een bedekzel? en weet het Kind dat 'er iets te bedekken is?'

'Meent gy een Kind door vrees te verbeteren? Ik geloof dat dit het ware middel niet zy! Vrees maakt kleine huichelaars, en werre van een gebrek wegtenemen, dryft gy dat naar binnen, daar het zich verbergt, om, ter gelegener tyd, met woede, los te barsten.

ô Verduistert den dageraad der lieve kindschheid niet! Angst, en vrees zyn de vergiftigers van harten die nog geene zorgen behooren te kennen; die nimmer moesten zuchten dan om betreurde en vergevene misslagen.'

Aan deze alleszins respectvolle woorden doet uiteraard niet af dat in menig hoeksteen van de samenleving kinderen zijn - en nog dagelijks worden - verpletterd, ingevolge het bijbelwoord bij Lucas 20:17-18:

Maar Hij zag hen aan en zeide: 'Wat betekent dan dit, dat er geschreven is [Psalm 118:22]: "De steen dien de bouwlieden afgekeurd hadden, deze is tot een hoeksteen geworden"? Een ieder die op dien steen valt, zal verpletterd worden; en op wien hij valt, dien zal hij vermorzelen. ${ }^{92}$

\subsection{2}

Het pedagogisch belang van het kind: persoonswording als Grundnorm (meta-kernrecht)

We maken opnieuw de balans op. En wel door de volgende omschrijving, of liever aanduiding, typering, van het belang van het kind (the best interests of the child) te beproeven. Het belang van het kind is een (internationaalrechtelijk) rechtsbeginsel c.q. een (intern-nationaalrechtelijk) rechtsbegrip waarin de opvoedingsverantwoordelijkheid van de gemeenschap, dat wil zeggen de primaire opvoedingsverantwoordelijkheid van ouders en de secundaire - aanvullende (ondersteunende) en desnoods vervangende (aan ouders ontnomen) - opvoedingsverantwoordelijkheid van de staat, tot uitdrukking komt. Die opvoedingsverantwoordelijkheid is het spiegelbeeld van het recht van het kind op persoonswording als kinder(volken)rechtelijke Grundnorm; een Grundnorm die op haar beurt het spiegelbeeld van die opvoedingsverantwoordelijkheid is. Met andere

'Het is weer mode om te spreken over het gezin als "hoeksteen van de samenleving." Dat lijkt een bijbelser beeldspraak dan het is: met het woord "hoeksteen" werd in de bijbel nooit het gezin bedoeld. De letterlijke hantering van een tekst als de bovenstaande zou al helemaal slecht in zo"n pleidooi passen.' (Henk VAN SETTEN, In de schoot wan het gezin; Opvoeding in Nederlandse gezinnen in de twintigste eeuw, Nijmegen 1987, p. 7.) 
woorden: zet men opvoedingsverantwoordelijkheid voor de spiegel, dan ziet men persoonswording. Zet men persoonswording voor de spiegel, dan ziet men opvoedingsverantwoordelijkheid.

Met een variant op LEVINAS zouden we kunnen zeggen: in het gelaat van het kind spiegelt zich de opvoedingsverantwoordelijkheid van de gemeenschap. In het gelaat van het kind leest de maatschappij het gebod: voed mij goed (genoeg) op! Voed mij op tot (optimaal) persoon! In een maatschappij die ouders de primaire opvoedingsverantwoordelijkheid toekent, wordt dat: help mijn ouders mij goed (genoeg) op te voeden!

De juridische vertaling van dat gebod is het belang van het kind (the best interests of the child) als een tegelijk overkoepelend en alomvattend beginsel. De vertaling is evenwel (nog) een gebrekkige. Gezien de geringe mate, de bijna afwezigheid van intern-nationaalrechtelijke juridisering, van uitwerking in diverse rechtsbeginselen, in bijzondere (grond-) rechten van het kind, is het belang van het kind, intern-nationaalrechtelijk gezien, een 'super-vaag' beginsel: niet duidelijk is wat het overkoepelt en wat het omvat. Hier moet het spiegelbeeld van de opvoedingsverantwoordelijkheid die het beoogt uit te drukken, namelijk het recht van het kind op persoonswording, te hulp worden geroepen.

Vanuit een grondrechtelijke (dat is rechtsstatelijke) optiek is het recht van het kind op persoonswording het voertuig waarmee het kind in de rechtsstaat zou kunnen worden geïncorporeerd, althans geïntroduceerd. Het belang van het kind als (rechts)beginsel heeft daarmee niet afgedaan. Men zou kunnen hopen dat het belang van het kind een fiets is die door het recht op persoonswording een hulpmotor heeft gekregen. En op zijn minst een fiets waarvan men, na achterop gesprongen te zijn, niet meer maar moet afwachten waar hij je afzet. Wat rechtvaardigt deze hoop?

Op de eerste plaats zijn dat ontwikkelingen in de maatschappij, en dus, op meer of minder grote afstand, in het recht. Ontwikkelingen die niettemin snel kunnen gaan, en waarbij soms rechtsontwikkelingen zelfs voorop lijken te lopen. COHEN heeft geschreven: ${ }^{93}$

'Until the latter part of this century the image of the child as person, separate from the family, with rights of his or her own, was totally missing from the writings of philosophers and/or social scientists. Neither the child saving movement of the nineteenth century nor the child labor movement of the early twentieth centu-

93 Cynthia Price COHEN, "The relevance of theories of natural law and legal positivism, in: Michael FREEMAN, Philip VEERMAN (eds.), The ideologies of children's rights, Dordrecht (etc.) 1992, pp. 53-70, op p. 59 (zie voor de betekenis van de term 'individual personality' pp. $67 / 68$ nt. 46 ). 
ry focused on the child as an individual human being. It took almost another half century before child advocates gave any serious consideration to the idea that the child might be entitled to civil and political rights or what might be termed the child's rights of "individual personality".

\section{Even daarvoor had zij opgemerkt: $:^{94}$}

"Compared to human rights in general, public interest in children"s rights is a relatively recent phenomenon, confined to the latter part of the twentieth century. Early sources of children's rights advocacy can be found in the classical stories of mid-19th century rescues undertaken by the Society for the Prevention of Cruelty to Animals to save children from the hands of abusive adults. ${ }^{95}$

Also well known are the activities of "child savers" who established orphanages, schools for handicapped children and created special juvenile justice procedures. Overall, however, the history of childhood is not very attractive. At worst, children were treated as chattel and were abandoned, shipped off to sea or sent into factories. At best, children were treated as inferior beings to be given protection by their parents, other adults and the state.

The writings of phillosophers, while less factual than [those] of historians, merely serve to support the thesis that children were not looked upon as individuals. Most philosophical writings about children were intermingled with theories of the familly."

\section{Des te meer verbaast - en verblijdt - haar conclusie $:^{96}$}

"While not going so far as to guarantee the child's right to vote, the Convention [on the rights of the child, 1989] backed by the world community [near universal ratification by $1995, j w]$, has come down squarely on the side of the child's right to dignity, respect and to rights of "individual personaliry".'

In de tweede plaats kan hoop worden geput uit het sequeel dat een Grundnorm - als subjectief recht ge(her)formuleerd, als (meta-)kernrecht van het kind opgevat -, als een logische staart met zich meedraagt. In dit verband kunnen de dertien sociaal-pedagogische kernrechten van het kind die in het vorige hoofdstuk werden geformuleerd, in herinnering worden gebracht. Wat er ook zij van hun min of meer natuurrechtelijke dan wel min of meer positiefrechtelijke status, zij vormen een samenstel van beginselen die verwijzen naar maatschappelijke verantwoordelijkheden waarin 'persoonswording' als recht van het kind wordt gespiegeld.

95 'Stories' die soms mythische vormen hebben aangenomen, met alle mystificatie vandien, zoals het beroemde verhaal van de zaak van Mary Ellen wit 1874 (zie BAARTMAN, Opvoeden kan zeer doen, Utrecht 1996, p. 15). 
Dit is geen spel van woorden, geen terminologische wisseltruc, geen meer of minder doorzichtige Etikettenschwindel. 'Persoonswording' heeft een bepaalde wijsgerig-antropologische/psychologische inhoud. In het volgende hoofdstuk wordt deze, aan de hand van de drieslag: rationaliteit, moraliteit, authenticiteit, nader beschreven. 'Persoonswording' heeft tevens een bepaalde pedagogische strekking: de opvoeding van het kind tot een mens die adequaat kan handelen. Adequaat handelen impliceert minimaal drie kwaliteiten, namelijk minimale rationaliteit, minimale moraliteit en minimale authenticiteit: de bodem van de drieslag die onderwerp van bestudering is in het volgende hoofdstuk. 'Persoonswording' als paraplurecht ten slotte verwijst naar een bundel rechten welke aan het kind toekomen dan wel dienen toe te komen. Aldus is 'persoonswording' - hoe vaag nog op zich en zonder meer - meer richtinggevend en minder vrijblijvend dan het belang van het kind (the best interests of the child). Zoals we in par. 8.1 al aangaven, bevindt 'het belang van het kind' zich nog te veel in de sfeer van de gunst, de barmhartigheid en het burgerlijk - dat is parentiarchaal - fatsoen. 'Persoonswording' als rechtsbeginsel/ paraplurecht - dat is: het recht van het kind op optimale persoonswording - daarentegen bekleedt het kind met een meta-kernrecht, verhoogt dienovereenkomstig de morele status van het kind, en opent de weg naar juridisering, verhoogt dienovereenkomstig de (allengs te concretiseren) juridische status van het kind, terwijl dit recht(sbeginsel) die weg markeert en belicht met een bundel deels positieve deels natuurlijke - dat is: te positiveren - sociaal-pedagogische kernrechten.

Persoonswording, aldus beschouwd, is tegelijk pedagogische en juridische opdracht. Een opdracht die - vanuit een mensenrechtelijke optiek - de staat aansprakelijk maakt (zoals we in hoofdstuk 13 nader zullen onderzoeken) voor elke nalatigheid binnen de Trias pedagogica die toegerekend kan worden, direct of indirect, aan het niet ten volle, dat is met de ruimste inzet van zijn middelen, ${ }^{97}$ nakomen van zijn verplichtingen op grond van het Verdrag inzake de rechten van het kind.

Nog anders gezegd: het recht op persoonswording (als paraplurecht) perkt zowel de beleidsruimte van de overheid als de rechterlijke beslissingsmarges (het freies Ermessen, de margin of appreciation) in die 'het belang van het kind' onvermijdelijk biedt. De rol van 'private opvattingen ${ }^{\text {'98 }}$ wordt teruggedrongen: overheid en rechter moeten 'kleur be-

98 'Immers, hoe minder concreet de grond, hoe groter de marge voor private opvattingen van rechters en hulpverleners (...).' (D.J. DE RUYTER, 'Onder pedagogisch toezicht; een pedagogisch voorstel voor een nadere omschrijving van de ondertoezichtstelling," FJR 1994/9, pp. 202-206, op p. 202 1.k.) 
kennen.' Beslissingen en motiveringen worden daardoor toetsbaarder. Dit is op zich al winst. Want het kind heeft geen bellang bij een min of meer arbitrair ingrijpen in zijn gezin net voor het (echt) te laat is, of als het (eigenlijk) al te laat is. Toch is dat wat het belang van het kind als civielrechtelijk beschermingsbeginsel laat zien: een (alleen al door de afwezigheid in Nederland van een meldplicht of meldcode) flagrante schending van het gelijkheidsbeginsel, van het ontplooiingsbeginsel, van het veiligheids- en ontwikkelingsbelang van het kind, dat is van het persoonswordingsbeginsel, wat wil zeggen van het recht van het kind op persoonswording als fundamenteel rechtsbeginsel.

Persoonswording-als-rechtsbeginsel zoekt/geeft direct(er) aansluiting bij de idee van het kind-als-subject dat, zoals we nog zullen zien, aan het Verdrag inzake de rechten van het kind ten grondslag ligt c.q. in dat Verdrag besloten ligt.

Voorop dient hierbij te staan dat het recht van het kind op (minimale/optimale) persoonswording een pro-actief overheidsbeleid vergt, en dus een uitbreiding/verfijning van het bestaande wettelijke en institutionele instrumentarium. Aan uitbreiding/verfijning van het bestaande wettelijke en institutionele instrumentarium gaat in het bijzonder de ontwikkeling van een diagnostisch apparaat vooraf (zeg maar: het praktisch uitwoerbaar maken van aanwezige pedagogische en ontwikkelingspsychologische kennis). Deze ontwikkeling is gebaat bij een pedagogisch valabel criterium ('het recht op persoonswording') dat tevens als valide algemeen rechtsbeginsel c.q. fundamenteel mensenrecht kan worden aangemerkt. De ontwikkeling van een diagnostisch apparaat maakt het pedagogisch criterium operationeel; juridisering - institutionele inkadering (in hoofdstuk 14 nader aangeduid als het drie-echelonsmodel) van het diagnostisch apparaat en vertaling van een en ander in wetgeving en beleid - maakt het rechtsbeginsel als fundamenteel recht van het kind operationeel. ${ }^{\text {99 }}$

Bij de ontwikkeling van een diagnostisch apparaat kunnen mijns inziens in positieve termen geformuleerde criteria (die aangeven wat voor een evenwichtige ontwikkeling van het kind nodig is) zoals die van HEINER en BARTELS (vgl. HElNER/BARTELS, t.a.p., op p. $63 \mathrm{r.k}$ ) wan groot nut zijn. Niettemin lijken mij met het oog op juridusering (dat wil zeggen ter beantwoording van de vraag: wanneer ingrijpen/hulp opleggen?) in negatieve termen geformuleerde criteria (dic aangeven wat voor een evenwichtige ontwikkeling van het kind schadelijk is) van minstens even groot nut. Zulke criteria, criteria inzake kindermishandeling (definities van en criteria voor de verschillende subtypen van kindermishandeling met aanduiding van gradaties per subtype), zijn ontwikkeld door BARNETT e.a. (Douglas BARNETT, Jody Todd MANLY, Dante CICCHETT, 'Defining child maltreatment: the interface between policy and research,' in: Dante CICCHETT; Sheree L. TOTH (eds.), Child abuse, child development, and social policy, Advances in applied developmental psychology, vol. 8, Norwood, New Jersey 1993, pp. 7-73, 'Appen- 
Uiteraard - en ten overvloede - wordt in dit verband onder juridisering niet louter verstaan meer - en vroegere - gezinsinterventie, maar ook en vooral 'empowerment' in de vorm van meer (materiële en immateriële) opvoedingshulp en -steun, opvoedingsscholing en -training, alsook uitgebreide rehabilitatie- en reïntegratieprogramma's voor kinderen zowel als voor volwassenen/ouders (zie de dertien sociaal-pedagogische kernrechten). En dit alles niet vanuit een dwang-, maar in de eerste plaats vanuit een contracts- (een quid pro quo-)gedachte (er wordt wat gebracht en er wordt wat verwacht), waarbij dwang altijd laatste middel is, dwangmiddel waartegen deugdelijke rechtsmiddelen openstaan (in de zin van een goed geregelde rechtsbescherming tegen de overheid). In essentie gaat het bij juridisering immers om de rechtsverfijning van - dat wil zeggen: het handen en voeten geven aan - het beginsel 'het belang van het kind.' Juridisering van gezinsverhoudingen betekent in dit verband: meer recht omwille van minder onrecht in het gezin.

\section{4}

\section{Persoonswording als het ultieme belang van het kind}

VAN DER PLOEG stelt in zijn dissertatie Opvoeding en politiek in de overleg-democratie (1995): $:^{100}$

'De ratio van de pedagogische verantwoordelijkheid wan de oudere voor de jongere generatie is de onwaarschijnlijkheid dat kinderen zonder bijstand voldoende zullen leren. Omdat leren van fundamenteel belang is, kan het gelden als "basic need." Het leren is niet alleen in het belang van het kind zelf, maar is bovendien van algemeen belang. Hierom is er iets voor te zeggen om opwoding niet alleen als mensenrecht, maar ook als mensenplicht te begrijpen.'

dix: Maltreatment subtype definitions and severity ratings," op pp. 51-73, 'System for quantifying child protective service records; subtype definitions and severity scales, op pp. 54-73). In hoofdstuk 11 besteden we aandacht aan deze criteria. Zij zijn in extenso opgenomen in bijlage III.

We zouden (alvast) kunnen zeggen: de criteria van HEINER en BARTELS geven aan wat in het belang van het kind is met het oog op diens recht op (optimale) persoonswording; de criteria van BARNETT c.s. geven aan wat schending oplevert van het recht van het kind op minimale persoonswording. Deze laatste criteria zijn met andere woorden een uitwerking, een specificatie van wat HEINER en BARTELS aanduiden als het 'op ernstige wijze in onvoldoende mate' tegemoet komen aan de (ontwikkelings)behoeften van het kind (zie hierboven par. 8.2.2). Piet VAN DER PLOEG, Opvoeding en politiek in de overleg-democratie; Democratische verdeling en nornering wan pedagogische autoriteit, diss. Utrecht, Baarn 1995 , pp. 154/155. 
Wat de auteur in dit verband onder 'leren' verstaat, kan hier gevoeglijk in het midden blijven. Duidelijk is immers en in elk geval dat de pedagogische verantwoordelijkheid, opvoeding als fundamenteel (kleine-)mensenrecht en - alleen al daarom, dat wil zeggen: in mijn optiek ook los van enig algemeen belang - als basale (grote-)mensenplicht, verder gaat dan het 'schoolse' leren. ${ }^{101}$ Zoals we zagen bij DIELEMAN en SPAN: ${ }^{102}$

'[O]ntwikkelingspsychologisch onderzoek [toont] steeds overtuigender aan hoe belangrijk de voorschoolse jaren (derde en vierde levensjaar) uit pedagogisch oogpunt zijn. (...) Dat echter de eerste twee levensjaren eenzelfde functie vervullen, krijgt minder aandacht. Men spreekt eerder van "baby-verzorging" dan van "babyopvoeding".'

Met andere woorden: de pedagogische verantwoordelijkheid van de oudere voor de jongere generatie, dat wil zeggen: de opvoedingsverantwoordelijkheid van ouders, van de samenleving, van de staat, begint bij de geboorte - en eigenlijk al eerder, dat wil zeggen: op zijn minst negen maanden vóór de geboorte. We zullen het woord 'leren' bij VAN DER PLOEG dan ook vervangen door het in deze studie gehanteerde begrip 'persoonswording' c.q. een persoon worden.

Kan 'persoonswording' (shorthand voor het in het volgende hoofdstuk uit te werken recht van het kind op minimale respectievelijk optimale persoonswording) als wezen en kern van het 'belang van het kind" als het belang van het kind bij uitstek, als het ultieme belang van het kind - worden beschouwd? En daarmee - natuurrechtelijk vertaald - als meta-kernrecht ('natuurrechtelijk' rechtsbeginsel, supra-positief mensenrecht, natuurlijk kernrecht) van het kind worden aangemerkt? In aansluiting op wat in dit verband al in de vorige paragraaf is gesteld, kan op deze plaats het volgende antwoord op deze (dubbel)vraag worden geformuleerd.

Het concept 'rechten van het kind' ziet op de waardigheid c.q. integriteit èn de ontwikkeling van het kind, dat wil zeggen: op diens persoonswording. Immers: het kind wordt wel als mens maar niet als persoon geboren, het ontwikkelt zich tot persoon. Als mens is de rechtengrondslag van het kind de menselijke waardigheid, de integriteit van de menselijke persoon. Als persoon in wording is de rechten-grondslag van het kind, dat wil zeggen: de grondslag van de rechten van het kind, tevens het fundamentele beginsel 'het belang van het kind' - als belang, wel te

101 Voor zover VAN DER PLOEG zulks van mening zou zijn (vgl. in dit verband zijn dissertatie op de pp. 24 en 265 e.v.), kan hij hierin dan ook allerminst worden gevolgd.

102 DIELEMAN en SPAN, t.a.p., op p. 19 (curs. jw). 
verstaan, van ontwikkelingspsychologische en pedagogische aard. Het belang van het kind is in deze optiek primair een ontwikkelingspsychologisch en pedagogisch, en op basis dáárvan, dat wil zeggen op basis van wat de psychologie en de pedagogiek te melden hebben, een juridisch te operationaliseren begrip.

Een kind dat niet langer een object van bescherming is "in the same way as animals are objects of laws forbidding cruelty to animals' (BOGDAN), ${ }^{103}$ maar subject van rechten, is minimaal gerechtigd zijn ouders als primair en de staat als secundair opvoedingsverantwoordelijken aan te spreken, ${ }^{104}$ mochten zij in hun respectieve plichten ter zake van zijn persoonswording te kort zijn geschoten. Vooropgesteld dat deze plichten voldoende zijn geëxpliciteerd, en dus zijn recht op persoonswording voldoende is geoperationaliseerd.

Zolang een zodanige operationalisering niet heeft plaats gevonden, ligt misbruik van een vaag criterium als het belang van het kind op de loer. Misbruik in de zin van een toepassing of uitlegging van het beginsel die juist tegen het veiligheids- c.q. ontwikkelingsbelang van het kind ingaat, of waarbij in feite de rechten van ouders, of eén van beide ouders, ten koste van het veiligheids- c.q. ontwikkelingsbelang van het kind worden gesauveerd. Een dergelijk misbruik kan slechts het hoofd worden geboden door een richtinggevende (zij het zonder verdere operationaliseringen c.q. indicatoren nog steeds vage) inkleuring met een universeel pedagogisch criterium, dat daartoe als recht/rechtsbeginsel wordt vertaald: het recht van het kind op minimale/optimale persoonswording. Tevens impliceert zo'n pedagogisch-juridische inkleuring dat een begin, een pedagogisch en juridisch begin, gemaakt kan worden met de rechtsverfijning - dat is de uitwerking in wetgeving en beleid - van dat recht/ rechtsbeginsel.

'Persoonswording' respectievelijk het recht op minimale c.q. optimale persoonswording gaan we in de twee nu volgende hoofdstukken nader bekijken.

103 Michael BogDAN, 'Article 6,' in: Asbjørn EIDE c.a. (eds.), The Universal Declaration of human rights; A commentary, Oslo(/Oxford) 1992, pp. 111-113, op p. 112.

104 Ter zake van rehabilitatie en/of compensatie: zie de artt. 18 en 19 juncto art. 39 VRK. 


\section{PERSOONSWORDING ALS PEDAGOGISCH CRITERIUM}

'Persoonswording' heeft een bepaalde wijsgerig-antropologische/psychologische inhoud en een bepaalde pedagogische strekking, stelden we in het vorige hoofdstuk: 'persoonswording" ziet op de opvoeding van het kind tot een mens die adequaat kan handelen. In dit hoofdstuk wordt dit, aan de hand van de drieslag: rationaliteit, moraliteit, authenticiteit, nader beschreven. In het vorige hoofdstuk spraken we ook van 'persoonswording' als paraplurecht, dat wil zeggen als een begrip of beginsel dat verwijst naar een bundel rechten welke aan het kind toekomen dan wel dienen toe te komen. De desbetreffende rechten hebben we in hoofdstuk 7 sociaal-pedagogische kernrechten gedoopt. In dat hoofdstuk respectievelijk in hoofdstuk 8 hebben we die kernrechten nader in de Trias pedagogica, de juridisch-pedagogische driehoek kind-ouder-overheid, gesitueerd en aan 'het belang van het kind' als rechtsbegrip/rechtsbeginsel gerelateerd. In hoofdstuk 8 werd tevens gesteld dat een herformulering van het belang van het kind (the best interests of the child) als subjectief recht van het kind, namelijk als meta-kernrecht van het kind op 'persoonswording' - 'persoonswording' dat een aantal sociaal-pedagogische kernrechten omvat - meer richtinggevend zou zijn dan het blote "belang van het kind.'

Hoewel we over de (idealiter) te verwachten merites van het begrip c.q. beginsel 'persoonswording' als meta-kernrecht vanuit een oogpunt van wenselijk recht (de jure constituendo) al iets gezegd hebben, wordt pas in het volgende hoofdstuk nader op de juridische status ervan ingegaan (de mogelijke verankering in het jus constifutum). Voor we die status kunnen navorsen, is het namelijk nodig eerst 'persoonswording' als pedagogisch (gezins)interventie-criterium, zoals voorgesteld door $\mathrm{DE}$ RUYTER, te beschrijven en op basis van de drieslag rationaliteit, moraliteit en authenticiteit nader in ogenschouw te nemen.

Aan dit hoofdstuk liggen dan ook de volgende vragen ten grondslag. Wat is de betekenis van persoonswording als pedagogisch criterium? Welke bezwaren zijn (c.q. kunnen) er tegen dit criterium, als pedagogisch gezinsinterventie-criterium, (worden) ingebracht? Wat kan de functie van het criterium zijn gezien de huidige (Nederlandse) interventie-praktijk? Dient een en ander te leiden tot wijzigingen c.q. toespitsingen van het 
criterium, en zo ja welke? In welke bredere maatschappelijke en rechtspolitieke context dient het criterium te worden gezien?

'Over een criterium voor het ingrijpen in gezinnen wordt door juristen gediscussieerd,'

Aldus de openingszin van DE RUYTER (1995a). ${ }^{1}$ In het vorige hoofdstuk hebben we tijdens onze speurtocht naar het belang van het kind (the best interests of the child) enkele groene en rijpe vruchten van die discussie geplukt. Een vrucht die we al in hoofdstuk 5 tegenkwamen, mag op deze plaats worden gememoreerd: in Nederland heeft de discussie van juristen ertoe geleid dat sinds eind 1995 niet langer "bedreiging met zedelijke of lichamelijke ondergang' grond voor ondertoezichtstelling is (art. 1:254oud $\mathrm{BW}$ ), doch is art. 1:254, lid $1 \mathrm{BW}$ komen te luiden:

Indien een minderjarige zodanig opgroeit dat zijn zedelijke of geestelijke belangen of zijn gezondheid ernstig worden bedreigd, en andere middelen ter afwending van deze bedreiging hebben gefaald of, naar is te voorzien, zullen falen, kan de kinderrechter hem onder toezicht stellen van een gezinsvoogdij-instelling (...).

In datzelfde hoofdstuk $5 \mathrm{kwamen}$ we tot de ontdekking dat moraalfilosofen weinig bouwstenen hebben aangereikt om het juridische discours van

D.J. DE RUYTER, 'Het recht on persoon te worden: een criterium voor het opleggen van pedagogische hulp, ${ }^{3}$ in: dez. en P.A. DE RUYTER (red.), Opvoedingshulp geboden; Pedagogische criteria voor het opleggen van hulp, theoretisch en praktisch bezien, Utrecht 1995, pp. 15-27, op p. 15. Hierna: DE RUYTER (1995a). Dit opstel kan als een (geactualiseerde) samenvatting worden beschouwd van haar proefschrift: Doret DE RUYTER, Met recht ingrijpend; Een pedagogisch criterium woor het opleggen wan hulp, diss. VU Amsterdam, s.l. 1993. Hierna: DE RUYTER (1993). Verwezen wordt voorts naar c.q. gewezen wordt voorts op: D.J. DE RUYTER, 'Onder pedagogisch toezicht; een pedagogisch voorstel voor een nadere omschrijving van de ondertoezichtstelling,' FJR (Tijdschrift voor familie- en jeugdrechi) $1994 / 9$, pp. 202-206 ("een samenvatting van een aantal delen van de dissertatie”), hierna: DE RUYTER (1994); D.J. DE RUYTER, B. SPIECKER en P.A. DE RUYTER, 'Verplichte opvoedingshulp; introductie op een thema, in: Opvoedingshulp geboden, a.w., pp. 9-14 (1995b); D.J. DE RUYTER, 'Een nieuw pedagogisch criterium? Reacties op de commentaren van de auteurs,' in: Opvoedingshulp geboden, a.w., pp. 117-122 (1995c); Doret DE RUYTER, 'Pedagogische onzin? Een beschouwing over argumenten om in gezinnen in te grijpen," in: Gezinnen onder druk; Over veranderende ouder-kind relaties; hoe moeilijk/gewoon opvoeden kan ziju, Themadag Vrije Universiteit Amsterdam 23 november 1996 (samenwatting lezingen, pp. 14-15), hierna: DE RUYTER (1996). 
een stevig natuurrechtelijk (of in moderne termen: mensenrechtelijk) fundament te kunnen voorzien. Gaat het evenwel - zoals in dit hoofdstuk - om de pedagogische onderbouwing van (kandidaat-)juridische criteria, dan dienen juristen hun oren te luisteren te leggen bij orthopedagogen. We luisteren naar de tweede volzin van DE RUYTER. ${ }^{2}$

'Interventie in gezinnen behoort ook tot het debat van orthopedagogen, maar zij mengen zich tot op heden niet in de discussie ower het criterium dat daaraan ten grondslag zou moeten liggen."

Vermoedelijk roeren orthopedagogen niet graag in de pot waarin juristen 'de privacy van het gezin' en 'het belang van het kind' laten pruttelen en borrelen, in de hoop dat lang genoeg koken, en de toevoeging van snuifjes 'vroom bedrog' en goede bedoelingen, wel tot verteerbare kost zal leiden. Aan een pot waarin zulke gewichtige zaken als 'de privacy van het gezin' en 'het belang van het kind' tot een maatschappelijk aanvaardbaar mengsel worden verhit, brandt men al licht de vingers. Juristen zijn hier de chef-koks, die niet alleen midden in de maatschappij, maar ook het dichtst bij de politiek staan. Zouden orthopedagogen zich dan moeten aanmatigen eens anders vakbroeders hoeder te zijn? Waarom zouden juist zij zich geroepen moeten voelen juristen te ontmaskeren als maatschappelijke alchimisten die al of niet tegen beter weten in de hoeksteen van de 'privacy' pogen om te smelten tot het goud van het 'belang van het kind'? Als nolens volens de status quo dienende tovenaarsleerlingen die de rechter pogen te assisteren bij het toepassen van magische wetsformules? $?^{3}$ Pas op, dit alles is een (duister) vermoeden van mijzelf. $D E$ RUYTER laat zich er (wijselijk) niet over uit. Zij stelt, in en na de derde volzin: ${ }^{4}$

'Tk meen dat het nodig is dat vanuit een pedagogisch perspectief ecn criterium voor het opleggen van pedagogische hulp wordt geformuleerd. Vanuit een pedagogisch perspectief een interventie-criterium formuleren, betekent dat het criterium betrekking heeft op gezinssituaties waarin om pedagogische redenen moet

DE RUYTER (1995a), t.a.p.

3 Het is inderdlaad "prudenter" (zij het minder opportuun met het oog op het belang van het kind) die ontmaskering aan juristen zelf over te laten. Zoals bijwoorbeeld aan DOEK (vgl. J.E. DOEK, 'Ondertoezichtstelling en het belang van het kind: een toverformule in het kwadraal?' In: Ad VAN DER LINDEN, Paul VLAARDINGERBROEK (red.), Met het oog op het belang van het kind; Opstellen aangeboden aan professor mr. Madzy ROOD-DE BOER ter gelegenheid van haar emeritaat, Deventer 1988, pp. 97-107). 
worden ingegrepen teneinde pedagogische hulpverlening aan een gezin op te leggen.

Ingrijpen vanwege pedagogische redenen, betekent dat er wordt verwezen naar specifieke opvoedingsdoelen die, indien de ontwikkeling van het kind daartoe stagneert, het opleggen van pedagogische hulp rechtvaardigen [c.q. daartoe nopen, jw]. ${ }^{5}$ De pedagogische hulp die kan worden opgelegd, kan uiteenlopen van thuishulp aan het gezin, ambulante hulpverlening aan een of meer gezinsleden tot residentiële hulpverlening.'

Hoewel de Nederlandse wet maatregelen kent waarmee pedagogische hulp kan worden opgelegd (in het bijzonder, doch niet uitsluitend, de ondertoezichtstelling), zijn de toepasselijke criteria 'zeer vaag geformuleerd. ${ }^{6}$ De auteur is evenwel van mening dat ...

'(...) vaagheid juist in het familierecht zorgelijk is, omdat er nauwelijks overeenstemming is over welk ouderlijk gedrag inadequaat of niet passend is. Bij afwezigheid van duidelijke criteria moeten rechters (en degenen die hen adviseren) een subjectief oordeel vellen, dat soms alleen gebaseerd is op hun eigen opvattingen over de factoren die belangrijk zijn voor een gezonde ontwikkeling van het kind. Zonder een duidelijke wettelijke regel en sociale en morele norm is er een grote kans dat gelijke zaken verschillend behandeld zullen worden. Een preciezer geformuleerd criterium zal de invloed van de persoonlijke opvattingen van zowel degene die overweegt voor te stellen om pedagogische hulp op te leggen, als degene die beslist of deze hulp moet worden opgelegd, verkleinen. ${ }^{7}$

\section{Vier voorwaarden}

Zij vervolgt: ${ }^{8}$

'Een criterium op grond waarvan besloten wordt om in een gezin in te grijpen teneinde pedagogische hulpverlening op te leggen, moet aan verschillende eisen voldoen. Er kunnen mijns inziens vier voorwaarden worden onderscheiden.

$5 \quad$ Rechtvaardigen als inbreuk op de 'privacy van het gezin' (de rechten van ouders). De rechten van het kind nopen tot het opleggen van hulp indien het gedrag van de ouders niet langer door 'het belang van het kind' wordt gerechtvaardigd. Zoals wanneer ouders ten onrechte vrijwillige hulpverlening weigeren of nolens volens frustreren. De ouderlijke autonomie ('souvereiniteit in eigen gezin') is er immers niet omwille van zichzelf doch in het belang van het kind (souvereiniteit 'rechtvaardigt' geen mensenrechtenschending). Schending van de rechten van het kind noopt tot interventie (overheidsbemoeienis), non-interventie is op zich een schending van de rechten van het kind.

6 DE RUYTER (1995a), op p. 16.

7 DE RUYTER (1995a), t.a.p. Zij parafraseert hier MELTON en THOMPSON (1987). Voor het Engelse origineel zie DE RUYTER (1993), pp. 105/106.

8 DE RUYTER (1995a), op pp. 17-19. De vier voorwaarden zijn het ingedikte zevental van DE RUYTER (1993), pp. 105-109. 
[1.] De eerste voorwaarde luidt dat het criterium niet te vaag moet zijn geformuleerd. Deze [voorwaarde] is in de eerste plaats gebaseerd op het zojuist genoemde argument dat de invloed van particuliere opvattingen van beslissers zoveel mogelijk moet worden beperkt. Een tweede reden om het criterium zo precies mogelijk te formuleren, is het streven de kans op onterechte interventie of onterechte non-interventie door hulpverleners en rechters in het gezin zo klein mogelijk te houden.

[2.] De tweede voorwaarde is dat het criterium in minimale termen geformuleerd moet worden. Deze voorwaarde is gebaseerd op twee redenen. In de eerste plaats moet interventie in het bellang van het kind zijn. (...) Dit betekent echter niet veel. Immers, hat begrip 'belang' is zo vaag dat weliswaar iedereen stelt dat het bellang van het kind moet worden gediend, maar dat er geen eenduidige opvatting is wat het belang van het kind nu precies inhoudt, en er uiteenlopende opvattingen zijn op welke wijze dit gediend wordt. In de praktijk van de hulpverlening en rechtspraak wordt per geval afgewogen of ingrijpen het belang van het kind dient. Het is echter ook wenselijk in de formulering van het criterium rekening te houden met deze eis. Dit impliceert dat het criterium zo geformuleerd moet worden dat het gebruilk ervan vrijwel zeker het belang van het kind dient. Wat in het belang van het kind is, is niet zonder meer duidelijk. Dit moet dus nader worden omschreven. In het geval van interventie in gezinnen betekent dit mijns inziens op zijn minst dat de opbrengst van het ingrijpen de schade van deze ingreep overtreft. Meer specifiek betekent dit in het geval van pedagogische interventie dat voor het kind de geboden pedagogische hulpverlening opweegt tegen het ingrijpende karakter van de interventie. Dit leidt mijns inziens tot de voorwaarde dat het criterium in minimale termen geformuleerd moet worden. In het geval van een pedagogisch criterium betekent dit dat er minimale opvoedingsdoelen worden opgenomen die tot de fundamentele belangen van kinderen kunnen worden gerekend. Indien ouders zodanig handelen dat deze minimale opvoedingsdoelen in gevaar komen, kunnen we veronderstellem dat hulpverlening (...) [lees: adequate hulpverlening, $\left.{ }^{9} \mathrm{jw}\right]$ een verbetering impliceert.

Hiermee bedoel ik hulpverlening door deskundige, dat is goed opgeleide en zorgvuldig op 'parentificatie' gescreende hulpverleners, wier deskundigheid bovendien wordt bevorderd en bewaakt door intensieve collegiale intervisie en duidelijke hiërarchische supervisie (dat wil zeggen: duidelijk is wie aan wie waarover verantwoording moet afleggen). Onder 'parentificatie' versta ik in dit verband: zich onvoldoende in het kind kunnen verplaatsen, althans onvoldoende de positie van het kind kiezend, ten gevolge van een onvoldoende verwerkt hebben van eigen jeugdervaringen. De hulpverlener die zich vroeger, als kind, over de eigen ouders moest ontfermen (rol-omkering), c.q. zich in en vanuit de kinderlijke noodsituatie te zeer met zijn of haar ouders identificeerde, is later bij de beroepsuitoefening veelal loyaler ten opzichte van ouders dan ten opzichte van het te beschermen kind. (Althans als betrokkene geen inzicht heeft in de desbetreffende mechanismen, en de autobiografische achtergrond erwan, of aan een zeker inzicht geen beroepsmatige consequenties kan of wil verbinden.)

Op dit punt meen ik DE RUYTER te moeten corrigeren die in het door mij weggelaten (hier gecursiveerde) gedeelte opmerkt: '(...) dat hulpverlening, in ieder geval in Nederland, vrijwel zeker een verbetering impliceert." Ik ben van de des- 
In de tweede plaats moet het criterium in minimale termen worden geformuleerd omdat private waarden en normen, opvattingen en levensovertuigingen niet mogen domineren in het criterium. Dit volgt uit de opvatting dat aan ouders een grote mate van autonomie [souwereiniteit in eigen gezin, jw] in de opvoeding van hun kinderen moet worden toegekend, en daarmee samenhangend dat de staat niet bevoegd is een private opvoedingsinhoud van de ouders af te dwingen. In onze [ten aanzien van volwassenen, jw] liberale samenleving heeft de overheid niet het gezag om inhoudelijk te bepalen tot welke volwassenen de ouders hun kinderen moeten opwoeden en op welke wijze zij dat moeten doen. Wel heeft de overheid in een dergelijke samenleving het recht en de plicht in te grijpen als iemand specifieke schade wordt berokkend. De overheid wordt niet geheel de zeggenschap over de personen in een gezin ontnomen, maar deze zeggenschap is secundair. Gewoonlijk bepalen de ouders zelf wat er in hun gezin gebeurt, wat er acceptabel is, en wat er wordt bestraft. Hun soevereiniteit kan echter worden ingeperkt wanneer de grenzen worden overtreden die in wetten door de overheid zijn opgesteld. Indien nu de ontwikkeling van het kind tot een minimaal opvocdingsdoel stagneert door het handelen [of nalaten] van de ouders, kunnen we stellen dat het kind schade wordt berokkend op grond waarvan de overheid mag [c.q. moet, jw] ingrijpen. De minimale grens [qua] opvoedingsdoel betreft, zoals ik straks duidelijk zal maken, de condities waaronder het kind kan uitgroeien tot een minimale persoon. Wanneer het criterium in minimale termen gesteld wordt, wordt de vrijheid van ouders om hun kinderen op een bepaalde wijze op te voeden, zo groot mogelijk gehouden, en wordt er rekening gehouden met de pluriformiteit van opvoedingsstijlen en concepties van het goede leven.

[3.] De derde voorwaarde die aan een dergelijk criterium gesteld moet worden, hangt samen met de zojuist gestelde eis dat in het criterium verwezen moet wor-

kundigheid - in bovenbedoelde zin - van de hulpverlening in Nederland, met zijn 'private' gezinswoogdij-instellingen, heel wat minder zeker dan DE RUYTER. Vgl. op dit punt J. DOEK, 'Een andere tussenbalans,' FJR (Tijdschrift voor familie- en jeugdrecht) $1991 / 5$, p. 97. In dit 'editorial' stelt DOEK (naar aanleiding van de World Summit for Children in september 1990): '(...) [D]e vele berichten over kindermishandeling en -verwaarlozing doen (soms ernstig) twijfelen aan de kwaliteit van de "protection and development" van kinderen in Nederland. (...) Wat ik [in diverse rapporten] node heb gemist, was o.a. de verbetering van de kwaliteit in de ambulante jeugdhulpverlening, meer in het bijzonder in de ambulante gezinswoogdij. Maar dat was ongetwijfeld te duur. Zojuist heeft de regering de uitkomsten van haar tussenbalans bekend gemaakt, en gevreesd moet worden dat er nog veel meer "te duur" zal blijken te zijn in de sfeer van "protection" en "development" van kinderen." Na enkele plechtige verklaringen van de World Summit te hebben aangehaald, vraagt DoEK zich af (curs. ID): 'Wordt inderdaad geprobeerd hogere prioriteit aan het welzijn van kinderen te geven? Wordt inderdaad iedere (mogelijke) poging ondernomen om te verzekeren dat de programma's voor de bescherming en ontwikkeling van kinderen in ons land worden beschermd tegen het geweld van de cijferaars van het Ministerie van Financiën en het Centraal Plan Bureau? De "World declaration" zegt het zo treffend: "The well-being of children requires political action at the highest level. We are determined to take that action".' 
den naar fundamentele belangen van het kind. Deze [voorwaarde] luidt [daarom] dat het criterium in termen van een recht van het kind geformuleerd moet worden. Hierbij spelen verschillende overwegingen een rol, die samenhangen met de opvatting dat de belangen van kinderen beter verdedigd kunnen worden wanneer zij rechten hebben dan wanneer de ouders [uitsluitend door de staat] aangesproken kunnen worden op het feit dat zij bepaalde [wettelijke] plichten verzuimen. Ten eerste geeft een recht de rechtendrager de positie waarin hij een gerechtvaardigde claim kan maken, niet slechts een werzoek of een appel ten opzichte van de plichtendrager (...). Het toekennen van een recht geeft de rechtendrager het surplus van een [juridische] claim boven het [morele] appèl dat hij kan doen wanneer iemand anders een plicht heeft. ${ }^{10}$ Ten tweede kunnen we er meer zeker van zijn dat we daadwerkelijk het belang van kinderen op het oog hebben, en niet dat van anderen (...). Een belang beschrijwen in termen van een recht van een persoon in plaats van een plicht van een ander, dwingt ons tot het in ogenschouw nemen van de positie en de belangen van de rechtendrager. Zo is het niet vreemd te zeggen: "Kinderen moeten worden opgevoed tot eerzame burgers van de samenleving, die hard werken en uit de bijstand blijwen." Anderzijds zal men niet zo snel zeggen: "Kinderen hebben het recht opgevoed te worden tot eerzame burgers van de samenleving, die hard werken en uit de bijstand blijven," tenzij men het idee heeft dat dit een belang van het kind betreft. Ten derde zijn kinderen door hun eigen rechten minder afhankelijk van de opvatting van volwassenen dat kinderen bepaalde fundamente belangen hebben, en van het feit dat wolwassenen zich moeten herinneren dat zij bepaalde plichten hebben. [Er dreigt immers ook de claim van het kind op reparatie, de ouderlijke immuniteit kan als het ware door het kind zelf worden opgeheven, $j w]$.

[4.] De vierde voorwaarde luidt dat in het criterium gerefereerd moet worden aan het handelen [of nalaten] van ouders. Omdat gezocht wordt naar een pedagogisch criterium, moet verwezen worden naar een specifiek soort handelen [of nalaten] van ouders, namelijk dat handelen [of nalaten] dat negatieve consequenties heeft voor de [evenwichtige, $j w$ ] ontwikkeling van het kind. In het criterium staat het belang van het kind centraal, maar de schade die aan het belang van het kind wordt toegebracht, moet samenhangen met het doen en laten van de ouders. Dit

10 Strikt juridisch, althans privaatrechtelijk gezien, lijkt mij dit niet (geheel) juist. Een onrechtmatige-daadsactie kan worden ingesteld niet alleen ter zake van een inbreuk op mijn recht maar ook ter zake van de schending van een wettelijke plicht van de dader (art. 6:162, lid 2. Bw). Tenzij men zou aannemen (hetgeen tegen de achtergrond van de traditionele ouderlijke 'immumiteit' minder uitzonderlijk ware dan men op het eerste gezicht wellicht zou menen) dat de geschonden norm (een wettelijk omschreven ouderlijke plicht) niet strekt tot bescherming tegen de schade zoals het kind die aan zijn ontwikkeling ("persoonswording") lijdt of (inmiddels volwassen) heeft geleden (de zogenaamde Schutznom, art.. 6:163 BW). Betreft het louter verdragsplichten, dan speelt de (niet geringe) complicatie in hoeverre de (Nederlandse) rechter bereid is de desbetreffende plicht als een (correlerend) rechitstreeks (en horizontaal) werkend recht van de klager op te vatten en toe te passen. Wat hier verder van zij, niet valt te ontkennen dal een recht de rechtendrager een betere (start-)rechtspositie geeft, al was het maar door het (psychologische) aspect van de 'socio-juridische' status. 
(...) omdat met het opleggen van pedagogische hulpwerlening beoogd wordt een opwoeding zoveel mogelijk te verbeteren. Indien de schade aan de ontwikkeling van thet kind niet samenhangt met het handelen [of nalaten] van de ouders, dan is het niet zinvol om pedagogische hulp op te leggen.'

\section{Samengevat}

We vatten (in eigen woorden/termen) samen: (1.) het criterium moet (juridisch en pedagogisch) zo precies mogelijk zijn; (2.) als ('liberaal,' dat is neutraal) interventie-criterium moet het een minimum-criterium zijn (een minimaal opvoedingsdoel moet in gevaar zijn, de condities waaronder het kind kan uitgroeien tot een minimale persoon, zijn niet of onvoldoende aanwezig); (3.) het criterium is een (fundamenteel) recht van het kind; (4.) als Trias-criterium stelt het overheidsbemoeienis tegenover pedagogisch schadelijk handelen of nalaten van ouders (handelen of nalaten dat schade berokkent aan de evenwichtige ontwikkeling van het kind).

Met andere woorden (en nu nemen we alle voorwaarden bijeen): (3.) het (basis)recht van het kind op (1.) 'persoonswording' (zie hierna) impliceert (4.) rechtswaarborgen voor overheidsbemoeienis met het gezin ter waarborging van (2.) een minimaal opvoedingsdoel.

\section{Optimum en minimum}

We voegen op deze plaats ook alvast iets toe: het recht van het kind op persoonswording kan worden uitgesplitst in een optimum en een minimum. Als minimum spreken we dan van het recht van het kind op minimale persoonswording: het interventie-criterium van DE RUYTER. Als optimum spreken we van het recht van het kind op optimale persoonswording, hetgeen impliceert: overheidsinspanningen en -voorzieningen ter bevordering van een optimaal opvoedingsdoel.

Gaat het bij het recht van het kind op minimale persoonswording om een 'waarborging' door de overheid, om een resultaatsverplichting (althans om een verplichting die daar dicht tegenaan ligt, die in de burt komt van een resultaatsverplichting), bij het recht van het kind op optimale persoonswording gaat het om een 'bevordering' door de overheid, met andere woorden om een (uiterste) inspanningsverplichting. Wat dit inhoudt, kunnen we (tentatief) afleiden uit art. 4 van het Verdrag inzake de rechten van het kind.

Art. 4 VRK:

De staten (...) nemen alle passende wettelijke, bestuurlijke en andere maatregelen om de in dit Verdrag erkende rechten te verwezenlijken. Ten aanzien van economische, sociale en culturele rechten nemen de staten (...) deze maatregelen in de ruimste mate waarin de hun ter beschikking staande middelen dit toelaten en, indien nodig, in het kader van internationale samenwerking. 
De eerste volzin van dat artikel kan van toepassing worden geacht op de minimum-verplichting: de staten nemen alle passende wettelijke, bestuurlijke en andere maatregelen. Dat wil zeggen: ongeacht de kosten. De enige beperking is dat de maatregelen passend moeten zijn, dat wil zeggen: het doel (de waarborging van minimale persoonswording) redelijkerwijze moeten kunnen dienen.

De tweede volzin van artikel $4 \mathrm{kan}$ van toepassing worden geacht op de optimum-verplichting: de staten nemen alle passende wettelijke, bestuurlijke en andere maatregelen in de nuimste mate waarin de hun ter beschikking staande middelen dit toelaten. Met andere woorden hier is een zekere budgettaire afweging mogelijk, welke in ontwikkelingslanden uiteraard anders uitvalt dan in een (puissant) rijk land als Nederland. Vandaar dat de slotwoorden van de tweede volzin, met het oog op die ontwikkelingslanden (dat wil zeggen: met het oog op ontwikkelingshulp), luiden: en, indien nodig, in het kader van internationale samenwerking.

Met deze toevoeging lopen we evenwel vooruit zowel op wat 'persoonswording' nu eigenlijk inhoudt (par. 9.3), als op de strekking en inhoud van de staatsaansprakelijkheid (hoofdstuk 13). We houden dus even de pas in, en kijken om ons heen: wat is een "persoon"?

Persoon = "een mens die adequaat kan handelen" en de drieslag rationaliteit, moraliteit, authenticiteit

DE RUYTER beloofde ons duidelijk te zullen maken welke miminale grens (qua opvoedingsdoel) wordt bedoeld met 'de condities waaronder het kind kan uitgroeien tot een minimale persoon.' We geven haar weer snel het woord: ${ }^{11}$

In de meeste dominante pedagogische theorieën wordt het doel van opvoeding omschreven als de persoonswording van het kind. Kinderen worden als mens of [lees: èn, jw] als persoon-in-wording geboren, en ontwikkelen zich door opvoeding tot persoon.'

Voor alle - terminologische - duidelijkheid val ik DE RUYTER hier even in de rede. Een kind wordt als mens geboren. Een mens wordt als persoon-in-wording geboren. Juridisch is een mens een persoon. Pedagogisch wordt een mens een persoon, namelijk door opvoeding. Anders gezegd: een mens wordt als mens geboren, net als een paard als paard. Maar een mens wordt - door opvoeding - een persoon: de ruiter. En het gaat om de combinatie: de tot persoon opgevoede mens die zichzelf ment, die zijn 
eigen leven (zoveel mogelijk) in handen neemt, de zelfbewuste equipe van lichaam en geest.

In welke mate een mens daarin slaagt (dat wil zeggen: erin slaagt de daarmee samenhangende ontwikkelingstaken tot een goed einde te brengen), is afhankelijk van drie factoren (CAMMAER). ${ }^{12}$ Drie factoren brengen een mens tot waar hij zich op een bepaald moment bevindt. Factor 1: aanleg (het paard - i.c. van de 'soort mens'). Factor 2: opvoeding (de stal, zowel in de zin van 'nest' - de ouders, de overige gezinsleden - als het wijdere milieu, en de invloeden die daarvan uitgaan). Factor 3: de persoon zelf (de ruiter); respectievelijk: de persoon-in-wording, de ruiter-in-spe (en wel naar de mate van zijn zich ontwikkelende vermogens). Drie factoren in de globale verhouding $1: 1: 1 .^{13}$ Alle drie

12 Vgl. H. CAMMAER, Menselijke levensloop: genetische psychologie, Leuven/Amersfoort 1990 (vierde druk), p. 9.

CAMMAER definieert genetische psychologie als 'de studie van de mens in zijn groei.' (In andere termen: ontwikkelingspsychologie opgevat als levensloop-psychologie.) En voegt daaraan toe: Men vraagt zich [in deze discipline] af op welke wijze de mens in de loop van zijn leven tegelijkertijd eén en hetzelfde individu is en tevens op elke leeftijd als anders wordt ervaren in vergelijking met vroegere of volgende perioden in eigen leven. Dit individueel anders-zijn verloopt op vergelijkbare wijze bij andere individuen van dezelfde leeftijd: de overeenkomsten die bestaan tussen leefijdgenoten zijn ook voorwerp van de genetische psychologie." Hij merkt dan op: "Wij nemen vanaf het begin aan dat de menselijke levensloop, met daarin de groeiende individuele eigenheid en de vergelijkbaarheid met leeftijdgenoten, door drie factoren wordt bepaald: 1. Aanleg: als individu behoren tot de "soort mens" (..); 2. Milieu (...); 3. Zelfbepaling" in staat zijn zichzelf te kennem, het eigen leven te richten en te bepalen, er zin aan te geven.'

Het bellang van deze laatste factor doet hem de aanduiding genetische (dat is: wordings-) psychologie prefereren boven de aanduiding ontwikkelingspsychologie (a.w., pp. 9/10): 'De zelfbepaling lijkt moeilijker te verbinden met de term "ontwikkelingspsychologie" die in het Nederlands vaak gebruikt wordt ter aanduiding van dit vakgebied: het woord "ontwikkeling" verwijst in zijn oorsprong naar het loswikkelen en ontrollen van een boekenrol, wat suggereert dat alles reeds geschreven staat en men er alleen maar moet voor zorgen dat het op tijd en stond leesbaar is. Dit leidt te gemakkelijk tot een opvatting waarbij het individu slechts hoeft te groeilen, te ontluiken, te ontplooien, terwijl de opvoeding zorgt voor een geschikt milieu, vooral door het afweren van mogelijke beschadiging of geforceerde groei." Opvoeden is uiteraard veel meer dan dat: het is een actief en interactief proces. (In zekere zin voeden de kinderen ook de ouders op - tot ouders.)

13 Hiermee wordt uitsluitend bedoeld dat het om een èn-èn-èn-combinatie gaat. Het is niet mogelijk (in abstracto) uitspraken te doen over het exacte aandeel van elk van de drie factoren nature, nurure en 'self' - laat staan tot achter de komma (in de zin van $3 \times 33,33 \%$ ). 
dus van in principe ${ }^{14}$ gelijk gewicht.

Het gevoel dat men niet alleen het lastdier, paard of zelfs ezel, maar ook de ruiter van zijn eigen leven is, dat gevoel kan een mens in laatste instantie alleen zichzelf geven (soms door eerst heel veel ballast overboord te gooien). Voor sommige mensen, of voor alle mensen in sommige fasen van het leven, lijkt het bijna onvoorstelbaar dat men ooit (weer) de ruiter zou kunnen zijn die, stevig in het zadel, de teugels strak in handen, zich één weet met het paard, éen bonk kracht en vitaliteit. Voor ons allen evenwel is te allen tijde de mythologische centaur (het paardmens waarvoor mensen ooit de eerste ruiters aanzagen) een even onbereikbaar (lichaam en geest als volmaakte twee-eenheid) als nastrevenswaardig (hoog te paard gezeten goed in je vel zitten) ideaal.

Om met een korte typering te besluiten: een persoon worden is iemand worden, in individuele - niet (zozeer) in maatschappelijke (aanzien) - zin. Niet omdat men anders 'niemand' blijft, maar omdat men anders 'niemand' wordt. (En iemand worden is vaak hard werken - niet zelden dwars door angsten heen.)

Ik onderbrak DE RUYTER langer dan mijn bedoeling was (al heb $i k$, ondanks de schijn van het tegendeel, nog niet één grassprietje voor haar voeten weggemaaid): ${ }^{15}$

"Het begrip "persoon" is echter nog te vaag en vereist nadere invulling. Ik omschrijf een persoon als een mens die adequaat kan handelen (...). Adequaat han-

14 Iemand die gehandicapt of 'mismaakt' geboren is, of die een zeer traumatische jeugd heeft gehad, zal over dit 'principe' uiteraard anders denken dan iemand die gezond van lijf en leden en met dierbare herinneringen aan een warm nest in het leven staat. Het 'principe' kan evenwel zo worden verstaan dat (grosso modo en ceteris paribus) het aandeel van de zelfbepaling (factor 3) groter is (om iets van het leven te maken) naar mate er ernstiger tekorten zijn ten aanzien van de factoren 1 en 2. Maar uiteraard kan 'zellbepaling' niet alle tekorten (defecten) compenseren of weer goedmaken. (Net zo goed overigens als een ernstig gebrek aan 'zelfbepaling" alle goeds van de factoren 1 en 2 teniet kan doen.) Met een aantal zaken zal men moeten leren leven. En sommige zaken zijn nooit meer goed te maken. Het 'principe' is dan te zeer scheefgetrokken, te zeer uit zijn lood geraakt. Hier komen mij de versregels in gedachten:

Gesprekken over onze jongensdagen

kan deze man nog altijd niet verdragen:

een heel stuk tijd, voor mij zo onbezorgd,

is door zijn vader uit hem weggeslagen.

(Willem WILMINK, 'Vriendje van vroeger,' VKM, kaartenserie Kunstenaars tegen kindermishandeling, Den Haag s.a.) 
delen impliceert minimaal drie kwaliteiten, namelijk minimale rationaliteit, minimale moraliteit en minimale authenticiteit.

Wanneer gesteld wordt dat het doel van de opvoeding de persoonswording van het kind is, dan moet het opvoeden ten minste gekenmerkt worden door een begeleiding van de ontwikkeling en de instandhouding van de onderscheiden minimale kwaliteiten van het handelen wan een persoon.

Er kunnen drie vormen van schadelijk handelen onderscheiden worden die een stagnatie in de persoonswording van het kind of een beschadiging van een eigenschap van de minimale persoon tot gevolg kunnen hebben. In de eerste plaats zal de persoonswording stagneren wanneer de ouders niet opwoeden. Wanneer er in het geheel geen sprake is van opvoeding, zal het kind zich niet tot een persoon kunnen ontwikkelen, omdat deze ontwikkeling afhankelijk is van opvoeding. In de tweede plaats kunnen ouders het kind misbruiken. Hun handelen wordt dan gekenmerkt door het nastreven van eigen doelen in plaats van doelen die met de ontwikkeling van het kind verbonden zijn. Dit kan consequenties hebben voor zowel het werwerven als het behoud van minimale rationaliteit, minimale moraliteit en minimale authenticiteit. In de derde plaats kan het opvoeden van ouders inadequat zijn. Dit kan de ontwikkeling van het kind tot minimale rationaliteit, minimale moraliteit en minimale authenticiteit doen stagneren of deze eigenschappen beschadigen. Wanneer de ouders bijvoorbeeld zelf irrationeel zijn, zal het opvoeden van het kind tot een minimaal rationeel persoon ernstig verzwaard worden of onmogelijk zijn."

Een kind is een mens die moet worden opgevoed tot een persoon. Een persoon is een mens die (zodanig is opgevoed dat hij of zij) adequaat kan handelen. Daartoe dient die mens over drie kwaliteiten te beschikken die alle drie in elk geval op een minimum-niveau aanwezig moeten zijn, namelijk minimale rationaliteit, minimale moraliteit en minimale authenticiteit. ${ }^{16}$ In dit verband c.q. over deze kwaliteiten merken DE RUYTER c.s. op: ${ }^{17}$

"Er kunnen twee niveaus van handelen worden onderscheiden. Het eerste niveau wan handelen is het niveau van het zelfstandig handelen. (..) Een hoger niveau van handelen is bet autonome handelen. (..) Kenmerkend voor het autonome handelen is dat een persoon weet dat regels veranderbare conventies zijn die het

Vgl. voor hel 'filosofische' persoonsbegrip ook Ger SNIK, Persoonswording en opvoeding diss. Nijmegen, Kampen 1990, pp. 228 e.v., 239 e.v., 281 e.v. en 384 e.v. Opmerkelijk is wat SNIK als (voorlopig) standpunt formuleert met betrekking tot persoonswording/ontwikkeling en identiteit (a.w., pp. 393 i.f.-394): 'De identiteit van het "ding" dat zich gedurende de ontwikkeling van zygote tot seniel ontwikkelt, is zelf veranderlijk. (....) De identiteit van het ding dat verandert, verandert met deze veranderingen. (...) [D]e persoonswording van een mens [is] geen "ens per se" maar een "ens successivum" (...). (...) De identiteit van een mens c.q. persoon wordt vastgelegd in een verhaal dat hij over zichzelf vertelt en dat anderen over hem vertellen.'

DE RUYTER (1995b), op pp. 13-14. 
samenleven structureren. De persoon onderwerpt die regels aan reflectie en zo nodig aan kritiek in het licht van principes. Autonomie is geen inhoudelijk maar een formeel opvoedingsdoel. Dat wil zeggen, het opvoedingstoel wordt niet geformuleerd in bepaalde (inhoudelijke) regels, maar er wordt gesteld dat de persoon kritisch kan nadenken ower de regels en dat hij die regels modificeent indien dat gezien de veranderende omstandigheden nodig is. Om redelijk goed mee te kunnen doen in een samenleving moet een persoon wel zelfstandig kunnen handelen. Het hogere niveau is een ideaal en in die zin nastrevenswaardig, maar het is niet een niveau dat we van iedereen mogen verwachten. (...)

[H]et opvoedingsdoel [kan] in termen van kwaliteiten van handelen worden gedefinieerd (...). Dit betreft de kenmerken wan handelen die noodzakelijk zijn om het handelen adequat te noemen. Een aantal auteurs onderscheidt drie kwaliteiten aan het handelen (...). Het eerste criterium is de rationaliteit van het handelen. Een handeling is rationeel wanneer een persoon gestelde doelen weet te realiseren. Het tweede criterium is de moraliteit van het handelen. Indien een persoon in woldoende mate rekening houdt met zowel de belangen van anderen als die van zichzelf, dan is zijn handelen moreel. Het derde criterium is de authenticiteit van het handelen. Indien een persoon zich in voldoende mate identificeert met zijn handelen, dat handelen berkent en erkent als zijn eigen handelen, dan is zijn handelen authentiek.

De kwaliteitscriteria voor handelen gelden zowel op het niveau van zelfstandig handelen als op het niveau van autonoom handelen. De criteria verschillen op deze niveaus well inhoudelijk van elkaar. [Bij] DE RUYTER [1995a] worden de criteria op het eerste niveau besproken."

We lopen in de hierna volgende (sub)paragrafen de drie bedoelde (minimale) kwaliteiten c.q. (sub)criteria afzonderlijk - kort - langs. Bij één van de drie (minimale moraliteit) gaan we met DE RUYTER in discussie.

Minimale rationaliteit (cognilieve vaardigheden)

Minimale rationaliteit zou ik het catchword willen meegeven van (minimale) cognitieve vaardigheden. DE RUYTER geeft van minimale rationaliteit de volgende uitleg en omschrijving, welke zij met een voorbeeld van (waarschijnlijk) schadelijk handelen van ouders illustreert: ${ }^{18}$

"Minimale rationaliteit is het niveau van rationaliteit dat van ieder mens verwacht wordt. Iemand die niet over minimaal rationele kwaliteiten beschikt, zullen we irrationeel noemen (...). De minimaal rationele persoon moet over de volgende eigenschappen beschikken (...):

a. Hij moet alternatieven in de werkelijkheid kunnen onderkennen. Dit impliceert dat hij de werkelijkheid reëel moet kunnen interpreteren. Dat wil zeggen dat hij oog heeft voor de relevante kenmerken van de situatie. 
b. Hij moet in staat zijn de alternatieven voor zijn gedrag af te wegen. Daarbij moet het gewicht dat de persoon aan bepaalde alternatieven geeft, kunnen worden beïvloed door relevante informatie.

c. Hij moet in staat zijn een beslissing te nemen (indien er meerdere alternatieven zijn). Hetgeen hij kiest, moet zoveel mogelijk in overeenstemming zijn met de redenen die hij als doorslaggevend beschowwt, en zoveel mogelijk passen in de sinuatie waarin hij moet beslissen.

d. Hij moet zijn beslissingen in zijn doen en laten tot uitdrukking kunnen brengen. Dit houdt in dat er sprake is van een consistentie tussen zijn beslissing en zijn gedrag.

Niemand zal onder alle omstandigheden woldoen aan deze kenmerken. Dit betekent echter niet dat iedereen irrationeel is. Slechts indien mensen voortdurend of langdurig irrationele beslissingen nemen, zijn zij irrationele personen. Eveneens moet het irrationeel handelen overheersend zijn, en niet beperkt zijn tot een bepaald gebied [zoals bij sommige vormen van neurotisch handelen, ${ }^{19}$ jw], om te kunnen spreken van een irrationeel persoon.

De opvoeding van ouders heeft een negatieve inwloed op de ontwikkeling van het kind tot een minimaal rationeel persoon indien ouders voortdurend tegenstrijdig reageren op het handelen wan het kind. Het kind leert niet zijn alternatieven af te wegen en op grond daarvan beslissingen te nemen, omdat de wereld onvoorspelbaar is geworden. Als een kind immers niet weet of [het] een aail over zijn bol krijgt of een fikse klap wanneer het zijn vader een compliment geeft, dan is het voor het kind niet mogelijk om te beslissen wat het zal doen, omdat de overweging [wat het zou moeten doen] onmogelijk is geworden. Hierdoor leert het kind niet minimaal rationeel te handelen."

\section{3 .2}

Minimale moraliteit (gewetensvorming)

Minimale moraliteit zou ik het catchword willen meegeven van (minimale) gewetensworming. DE RUYTER geeft van minimale moraliteit de volgende uitleg en omschrijving, welke zij wederom met een voorbeeld van (naar alle waarschijnlijkheid) schadelijk handelen van ouders illustreert: ${ }^{20}$

'Een minimaal moreel persoon kan worden omschreven als een persoon die minimale morele regels volgt. (...) Minimale morele regels kunnen worden om-

19 Hierbij kan gedacht worden aan fobieën of dwanghandelingen maar ook aan vormen van verslavingsgedrag die in een consumentistische maatschappij zelden of nooit psychopathologisch worden geduid. DE RUYTER (1993, pp. 114/115) geeft hiervan een 'hoogstaand' voorbeeld: 'Temand die zich bijwoorbeeld flink in de schulden steekt om de door hem geliefde kunst te kopen, terwijl hij zich steeds voorneemt niet meer naar veilingen te gaan om zichzelf [niet] in de verleiding te brengen, is in dit opzicht irrationeel, maar is geen irrationeel persoon indien hij op andere terreinen wel minimaal rationcel is.' DE RUYTER (1995a), op p. 21. Vgl. ook DE RUYTER (1993), pp. 116-118. 
schreven als die regels die noodzakelijk zijn voor het bestaan van een [democratische $\left.^{21} \mathrm{jw}\right]$ samenleving. Het zijn regels die een leefbaar bestaan voor alle mensen in een samenleving garanderen, en [die] dus in het belang [zijn] van alle leden van die samenleving (...). Tot de minimale morele regels kunnen we rekenen: anderen niet doden of mishandelen, anderen niet bedriegen, niet stelen, en het bieden van hulp aan personen in nood met wie we geconfronteerd worden, indien dit geen grote negatieve consequenties heeft (...).

Evenals bij minimale rationaliteit kunnen we een aantal kwaliteiten onderscheiden waaraan de minimaal morele persoon moet voldoen.

a. Een minimaal moreel persoon wordt geacht over het vermogen te beschikken de minimale morele regels van de samenleving te volgen. Dit betekent dat hij in staat is de yoor de situatie relevante morele regels toe te passen.

b. Hij is intrinsiek gemotiveerd om de minimale morele regels van de samenleving te volgen.

c. Hij ervaart schuldgevoelens wanneer hij de regels overtreedt en er geen rechtvaardigende redenen zijn om de minimalle regels niet na te komen.

d. Hij zal afkeuring ervaren wanneer anderen blijk geven van een gebrek aan deze motivatie.

e. Een minimaal moreel persoon vertrouwt erop dat anderen de minimalle morele regels volgen.

Een voorbeeld van schadelijk handelen dat de ontwikkeling van het kind tot een minimaal moreel persoon negatief beïnloedt, zijn ouders die hun kind aanzetten andere kinderen te mishandelen."

\section{Discussie}

De ontwikkeling van de moraliteit is - op basis van het werk van PIAGET - vooral onderzocht door KOHLBERG. KOHLBERG onderscheidt diverse stadia in de ontwikkeling van de moraliteit, namelijk preconventionele (oriëntatie op straf en beloning), conventionele (oriëntatie op af- en goedkeuring, op law and order), en postconventionele (sociaal-contractoriëntatie, oriëntatie op universele beginselen) stadia. Een postconventioneel niveau van moreel redeneren wordt door slechts weinigen bereikt. ${ }^{22}$ DE RUYTER laat zich er niet over uit op welk (structureel) moreel niveau een minimaal moreel persoon redeneert. Een minimaal moreel persoon volgt minimale morele regels. In haar dissertatie voert zij

21 I $k$ woeg het woord democratisch toe omdat de morele regels die DE RUYrTER noemt: anderen niet doden of mishandelen, anderen niet bedriegen, niet stelen, en het bieden van hulp aan personen in nood, bijwoorbeeld in nazi-Duitsland, toch een (hoog) georganiseerde en zelfs goed geöliede samenleving, niet golden ten aanzien van Joden, zigeuners, gehandicapten enz. Uit haar verdere omschrijving blijkt dat DE RUYTER in feite ook een democratische samenleving (leefbaar voor alle mensen'; mijn curs.) bedoelt.

Vgl. F.J. MÖNKS, A.M.P. KNOERS, Ontwikkelingspsychologie, Assen 1994 (negende druk), pp. 149-154 en 246-252, in het bijzonder op pp. 247-249. 
een maximaal moreel persoon op: een (heilige?) persoon die maximale morele regels volgt. Hierbij merkt zij op: $:^{23}$

'Iemand wordt eveneens maximaal moreel genoemd wanneer hij op een hoog moreel niveau redeneert, bijvoorbeeld op het post-conventionele niveau van KOHLBERG (1981)."

Het gaat haar niet om het (structurele) redeneer-niveau maar om de aard (waarmee zij, naar ik aanneem, bedoelt: het morele gehalte) van de gevolgde regels (minimaal-'modaal'-maximaal). Zij kijkt daarbij (als ik haar goed heb begrepen) niet naar iemands morele structuur, maar naar hoe iemand moreel functioneert. De minimale regels niet mishandelen, niet stelen, niet bedriegen en mensen in nood helpen worden in onze samenleving echter op betrekkelijk grote schaal overtreden (geweld in het gezin, uitkerings- en belastingfraude, winkeldiefstallen en inbraken, relationele ontrouw, doorrijden na aanrijdingen, niet melden van kindermishandeling waarvan men weet of een ernstig vermoeden heeft of zelfs getuige is ${ }^{24}$ ). Kennelijk zijn veel mensen niet of onvoldoende intrinsiek gemotiveerd deze minimale regels te volgen. De dominante materialistische culturur en de talrijke verleidingen in de moderne permissieve (laissez faire, laissez passer ofwel 'moet kunnen') maatschappij geven dan de doorslag. En wel in de verkeerde richting: de extrinsieke 'pakkans' is immers tamelijk klein.

Een voldoende intrinsieke motivatie (mate van verinnerlijking van normen) vereist mijns inziens evenwel een vrij hoog (conventioneel tot postconventioneel) moreel niveau (vanaf een 'law and order'- tot aan een

DE RUYTER (1993), p. 116.

24 In Nederland blijken mensen, met inbegrip van degenen die beroepshalve met kinderen te maken hebben, in overwegende mate de andere kant op te kijken als ouders hun kind mishandelen: 'Nog het minst wordt gemeld door personen uit de sociale omgeving van het kind. Slechts in één op de vijf gevallen wordt daadwerkelijk ergens aan de bel getrokken. Van de personen die beroepshalve met kinderen werken (de zgn. beroepsbeoefenaren zoals leerkrachten, peuterspeelzaalleidsters en huisartsen), gaat $27 \%$ nooit over tot een melding, hoewel ze frequent vermoeden dat een kind thuis mishandeld wordt. Van de personen die een hulpverleningsrelatie met het kind of het gezin hebben, zegt 19\% nooit te melden.' Uit: WERKGROEP MELDPUNT KINDERMISHANDELING, Het melden van vermoedens van kindermishandeling; Samenvatting van een onderzoek naar ervaringen en wensen van potentiële melders, Roermond, juni 1996, p. 5. (Het integrale onderzoeksverslag is van de hand van Agnes VAN BURIK en Mireille GELDORP. De Werkgroep meldpunt kindermishandeling is eind 1994 ingesteld door de staatssecretarissen van vws en Justitie.) 
sociaal-contract-oriëntatie of zellfs een oriëntatie op universele beginselen). Iets wat, zoals we zagen, voor hoipolloi niet is weggelegd. Het lijkt mij evenwel te ver gaan een relatief groot gedeelte van de bevolking als sub-minimaal morele (en dus sub-minimale) personen te diskwalificeren: zij allen zouden als het ware voor heropvoeding (door de staat!) in aanmerking komen c.q. een claim hebben op reparatie (rehabilitatie en compensatie). Tenzij ik DE RUYTERs premissen verkeerd heb begrepen, of daaruit de verkeerde conclusies heb getrokken, zou ik dan ook willen bepleiten een minimale morele persoon te omschrijven in termen van KOHLBERGs morele ontwikkelingsstadia, bijvoorbeeld als iemand wiens gewetensvorming onder een conventioneel of zelfs pre-conventioneel niveau is blijven steken. Uit onderzoek is immers bekend dat iemand met een relatief hoge morele structuur toch (kortere of langere tijd) op een laag/lager moreel niveau kan functioneren. ${ }^{25}$

\subsubsection{Minimale authenticiteit (identiteitsontwikkeling)}

Minimale authenticiteit zou ik het catchword willen meegeven van (minimale) identiteitsontwikkeling. Naar mijn indruk is het niet in de laatste plaats (althans qua omvang) de identiteitsontwikkeling, als buitenste schil, die schade lijdt door een ongunstig opvoedingsklimaat. ${ }^{26}$ DE RUYTER

Vgl. MÖNKS/KNOERS, a.w., pp. 152/153.

26 Deze indruk kan in zoverre (ernstig) vertekend zijn dat mensen met identiteitsproblematiek (zich uitend in verslavingsproblemen, relatieproblemen, insufficiëntiegevoelens, sociale fobieën, psychosomatisering, eenzaamheid e.d.m.) nadrukkelijker in de geestelijke gezondheidszorg aanwezig zijn dan subminimaal rationele of subminimaal morele personen (waarvan kan worden aangenomen dat zij de stap naar hulpverlening niet kunnen respectievelijk willen zetten). Zolang (minimale) rationaliteit, moraliteit en authenticiteit niet helder geoperationaliseerd zijn, heeft dit alles natuurlijk wel enigszins (zacht uitgedrukt) het karakter wan koffiedik kijken.

Ook het beeld van schillen, dat ik hier invoer, is in zoverre 'onwetenschappelijk' dat de ontwikkeling van rationaliteit, moraliteit en authenticiteit wel te onderscheiden maar niet van elkaar los te denken zijn. 'De cognitieve ontwikkeling wordt gezien als een logisch noodzakelijke - maar niet voldoende - voorwaarde voor de ontwikkeling van sociale cognitie, terwijl de ontwikkeling van de sociale cognitie als logisch noodzakelijke, maar niet voldoende voorwaarde voor de ontwikkeling van het normbesef gezien wordt.' (MÖNKS/KNOERS, a.w., p. 249; vgl. ook H.E.M. BAARTMAN, "Moreel van huis uit?' In: J.W. sTEUTEL (red.), Morele opvoeding; Theoretisch-en historisch-pedagogische opstellen, Meppel/Amsterdam 1984, pp. 89-115, op pp. 99/100.) Autonoom moreel gedrag ('integriteit') is niet goed denkbaar zonder (boven-minimale) authenticiteit (wgl. MÖNKS/KNOERS, a.w., p. 250; BAARTMAN, t.a.p., op p. 107). Mits men zich hierwan terdege rekenschap geeft, kan het beeld wellicht nuttig zijn van de ontwikkeling van het kind als appel met 
geeft van minimale authenticiteit de volgende uitleg en omschrijving, welke zij eveneens met een voorbeeld van schadelijk handelen van ouders illustreert: ${ }^{27}$

"Authenticiteit wordt gekenmerkt door een overeenstemming tussen het handelen van de persoon en zijn zelfbeeld (...). Iemand is minimaal authentiek indien er wel sprake is van deze overeenstemming, maar wanneer de kennis van de persoon over zichzelf nier kritisch of volledig bereflecteerd is. Alvorens ik de kenmerken van de minimalle authentieke persoon beschrijf, zal ik eerst nader uitleggen wat bedoeld wordt met het zelfbeeld van de persoon.

Aan de concepten die betrekking hebben op het "zelf" van personen worden verschillende inhouden en interpretaties gegeven (...). Voor de witleg van minimale authenticiteit zijn vier concepten van belang, namelijk zelfbeeld, zelfwaardering, zelfideaal en zelfrespect. Het zelfbeeld van een persoon bestaat uit een groot aantal voorstellingen van de persoon over zichzelf. Deze betreffen onder andere fysieke eigenschappen, vaardigheden, sociale eigenschappen, psychische kenmerken en zijn overtuigingen. Het zelfbeeld omvat niet alleen de kennis die de persoon van zichzelf heeft, maar ook het oordeel dat de persoon daarover heeft: zijn zelfwaardering. Zo spreken we over een negatief zelfbeeld wanneer een persoon zijn zelfbeeld negatief beoordeelt, en over een positief zelfbeeld wanneer hij dit positief waardeert. In dit llaatste geval zeggen we dat de persoon beschikt over zelfrespect.

Naast een zelfbeeld hebben personen ook zelfidealen. Zelfidealen zijn voorstellingen van de persoon ten aanzien van eigenschappen, vaardigheden, opvattingen die hij voor zichzelf nastrevenswaardig acht. Deze zelfidealen zijn van invloed op de waardering die de persoon voor zichzelf heeft.

Een persoon is minimaal authentiek wanneer hij beschikt over de volgende twee disposities:

a. Hij kan zich met zijn handelen identificeren. Hij herkent dat zijn handelen een uitdrukking is van zijn zelfbeeld, dat is gedefinieerd als zijn kennis van en waardering voor zichzelf [welke laatste] mede beinvloed wordt door zijn zelfideaal.

b. Hij onderschrijft zijn handelen. Hij erkent dat zijn handelen een uitdrukking is van zijn zellbeeld.

Het meest duidelijke voorbeeld van schadelijk handelen van ouders dat negatieve consequenties heeft voor de ontwikkeling tot een authentiek persoon, is seksueel misbruik. In verslagen van misbruikte meisjes kunnen we lezen dat vooral hun zelfrespect verdwijnt, en dat zij geen zelfbeeld weten te ontwikkelen of dit verliezen. Een citaat uit De straf op zwijgen is levenslang (1983): "Ik kreeg een steeds groter minderwaardigheidsgevoel, kon geen nee meer zeggen, voelde me voor alles verantwoordelijk. Mijn eigenwaarde was nihil. (...) Ik moet de weg terug op zoek naar wie ik ben (...)." [Een ander citaat:] "(...) [A]ls het even fijn geweest is,

als klokhuis de rationaliteit, als vruchtvlees de moraliteit en als schil de authenticiteit. Het is dan maar net hoe diep de ouders, door hun beschadigend gedrag ten opzichte van het kind, die appel stukbijten. DE RUYTER (1995a), op pp. 21-22. Vgl. ook DE RUYTER (1993), pp. 118-121. 
dan is het daarna nog of ik het stuk moet maken, dat ik het allemaal niet verdien, dat het niet kan, ik ben niets waard". 28

\subsection{Criterium-DE RUYTER: toevoeging en toespitsing}

$\mathrm{Na}$ deze toelichting van (minimale) persoonswording - de ontwikkeling van het kind tot (minimaal) rationeel, moreel en authentiek persoon - als (minimaal) opvoedingsdoel, is al iets duidelijker geworden welke miminale grens (qua opvoedingsdoel) DE RUYTER bedoelt met 'de condities waaronder het kind kan uitgroeien tot een minimale persoon.' In elk geval in abstracto: 29

'De minimale grens, dat wil zeggen de grens die wanneer deze wordt overschreden, allijd moet leiden tot ingrijpen, is dat ouders [hun kind] zo opvoeden en zich [ten opzichte van het kind] zo gedragen dat het kind in staat is zich te ontwikkelen tot een persoon die normaal kan functioneren, anders gezegd tot een minimale persoon. Een persoon die in staat is normaal na te denken, die zich houdt aan minimale morele regells, en die in staat is iets van zichzelf aan anderen te laten zien.'

Aldus komt haar interventie-criterium (in 'eerste termijn') te luiden: $:^{30}$

'Pedagogische hulpveriening moet aan een gezin worden opgelegd indien het recht van een kind om zich te ontwikkelen tot een minimaal rationeel, minimaal moreel of minimaal authentiek persoon wordt geschonden, of indien zijn minimale rationaViteit, minimale moraliteit of minimale authenticiteit wordt beschadigd door het handelen [dat is: door toedoen of nalaten, ${ }^{31} \mathrm{jw}$ ] van zijn ouders.'

\section{Toevoeging}

In "tweede termijn" ${ }^{32}$ voegt DE RUYTER hieraan (de voorwaarden) toe ....

'(...) dat adequate hulpverlening is geboden doch heeft gefaald, en dat adequate hulpverlening voorhanden is om aan het gezin of het kind op te leggen.'

VERENIGING TEGEN SEKSUELE KINDERMISHANDELING BINNEN HET GEZIN, De straf op zwijgen is levenslang; Over seksuele kindermishandeling binnen het gezin, Amsterdam 1988 (vierde druk), pp. 36, 37 en 41.

29 DE RUYTER (1996), Op p. 15.

30 DE RUYTER (1995a), op p. 22 (curs. DdR). Dit is een door haarzelf enigszins aangepaste versie van de omschrijving in haar proefschrift (DE RUYTER (1993), p. 125): DE RUYTER (1995a), op pp. 26/27 nt. 1. Als reactie op haar critici voegt zij daaraan in 'tweede termijn' nog een element toe (zie direct hierna).

32 DE RUYTER (1995c), op p. 122. 
In deze toevoeging (hier prima facie genomen, bij de motivering c.q. bedoeling van DE RUYTER staan we zo dadelijk stil) zitten twee uiterst belangrijke waarborgen besloten. In de eerste plaats de waarborg dat de staat altijd eerst een hulpaanbod doet vóór er met dwangmaatregelen wordt gedreigd en vóór er dwangmaatregelen worden opgelegd. In een rechtsstaat kloppen we in de regel eerst op de deur voordat we (in)kijkoperaties verrichten. De overheid in een democratie dient burgers/ouders niet a priori te wantrouwen. VAN DER PLOEG ${ }^{33}$ noemt dit (laatste) in zijn proefschrift een eis van politieke bescheidenheid. Hoewel deze bescheidenheid nimmer zo ver mag gaan, dat kinderen in de kou blijven staan, kan zij wel worden gezien als een uitvloeisel van het subsidiariteitsbeginsel: ${ }^{34}$ waar het mindere/lichtere $\mathrm{kan} /$ is geïndiceerd, mag het meerdere/zwaardere niet worden opgelegd. Dit lijkt mij tevens en volkomen in overeenstemming met het vertrouwensbeginsel, pedagogisch-democratisch te verstaan: de overheid dient bij elke volgende stap in het hulpscenario uit te gaan van de goede trouw, dat is de goede wil en de inzet van de ouders/opvoeders. Uiteraard stelt dit alles hoge eisen aan de deskundigheid en integriteit van hulpverleners, en dus aan zaken als intervisie en supervisie; 'randwoorwaarden' waarop de overheid direct heeft toe te zien.

In de tweede plaats (en in nauwe samenhang met de vorige waarborg) bevat de toevoeging de waarborg dat het hulpaanbod van de staat - en a fortiori ook de door de staat opgelegde hulp - adequaat is. Het element 'adequate hulpverlening' is van eminent belang met het oog op de privacy-bescherming van kind en ouders/gezin (art. 16 VRK, art. 8 EVRM): het gezin, kind en ouders dienen te worden beschermd tegen bemoeienis/interventie door ongeschikte (incompetente, geparentificeerde, slecht opgeleide, afgebrande enz., enz..) hulpverleners (art. 3, lid 3 VRK). Zowel de deugdelijkheid en de kwaliteit van de hulpverlening/hulpverleners als het voorhanden zijn van adequate (geschikte, toereikende, voor elk gezin dat het nodig heeft bereikbare) hulpverlening vallen onder de staatsaansprakelijkheid (art. 3, lid 3 VRK, respectievelijk - zoals we nog zullen zien - art. 3, lid 2 VRK, art. 4 VRK juncto het recht op persoonswording' als achterliggend beginsel van het Verdrag, en art. 19 VRK). Ik zall hierna evenwel betogen dat deze tweede waarborg - die als een

Piet VAN DER PLOEG, Opvoeding en politiek in de overleg-democratie; Democratische verdeling en nomering van pedagogische autoriteit, diss. Utrecht, Baarn 1995, p. 271 en passim.

34 Zoals ook in de wet (art. 1:254 BW) neergelegd; vgl. M.J.C. KOENS, Jeugdigen in de knel; Maatregelen van jeugdbescherming in de toekomst, inaugurele rede Maastricht, Deventer 1994, p. 33 i.f. 
rechtsstatelijke vanzelfsprekendheid hoort te gelden - in het criterium niet thuishoort.

Zelf stelt DE RUYTER met betrekking tot de toevoeging aan haar criterium: $:^{35}$

'In de formulering van mijn criterium heb ik als premisse[n] aangenomen dat tot het moment van ingrijpen de hulpwerlening adequaat is geweest, en dat na de interventie geschikte hulp aangeboden kan worden. BuLLeNs ${ }^{36}$ laat zien dat dit geen premisse[n] zijn waar men zonder meer van uit mag gaan (...). Het is noodzakelijk dat de hulpverlener ook [de] hand in eigen boezem steekt. (....) Moet dit dan ook worden opgenomen in het criterium? In de herziene formulering van de [ondertoezichtstelling; art. 1:254, lid $1 \mathrm{BW}$ ] wordt wel een dergelijke eis opgenomen: alle middelen ter afwending van de bedreiging hebben gefaald of, naar is te woorzien, zullen falen. Deze toevoeging lijkt mij juist.'

DE RUYTER ziet hierbij wel een probleem: ${ }^{37}$

'Er dreigt dan echter een ander probleem, namelijk een te grote terughoudendheid in het nemen van [noodzakelijke, jw] ingrijpende beslissingen, bijwoorbeeld het uit huis plaatsen van kinderen om het kind residentiële hulp te bieden. Dit is onterecht [en mijns inziens onrechtmatig, jw] indien dit wel noodzakelijk zou zijn. Indien een vorm van residentiële hulpverlening geindiceerd is, maar er eerst langdurig ambulante hulpverlening wordt aangeboden omdat dit minder ingrijpend is, kan dit het belang van het kind en van de ouders juist schaden.'

Dit probleem acht ik evenwel niet onoverkomelijk. Een hulpverlener die iets anders doet dan wat noodzakelijk (en mogelijk) is, maakt immers een (kunst)fout, waarvoor hij of zij, en/of de instelling bij welke hij of zij werkzaam is (c.q. de staat), aansprakelijk is/zijn. Met andere woorden, het betreft hier niet een principieel, maar een praktisch probleem: de bevordering en bewaking van deskundigheid en kwaliteit binnen de hulpverlening.

\section{Toespitsing van de toevoeging}

Toch zou ik willen bepleiten, tegen de achtergrond van het praktische (maar daarom niet minder dringende) probleem van de hulpverlening, en ter verduidelijking van de rechtspositie van de ouders dienaangaande, de

DE RUYTER (1995c), op p. 120.

36 R.A.R. BULlENS, "Aandachtspunten bij de beslissing om een kind uit huis te plaatsen: tombola of methodiek?' In: Opvoedingshulp geboden, a.w., pp. 67-80. DE RUYTER (1995c), op pp. 120/121. 
toevoeging van DE RUYTER iets meer toe te spitsen. ${ }^{38}$ Het criterium zou dan als volgt kunnen komen te luiden (de toevoeging inclusief mijn toespitsing is gecursiveerd):

Pedagogische hulpverlening moet aan een gezin worden opgelegd indien het recht van een kind om zich te ontwikkelen tot een minimaal rationeel, minimaal moreel of minimaal authentiek persoon wordt geschonden, dan wel indien zijn minimale rationaliteit, minimale moraliteit of minimale authenticiteit wordt beschadigd, door toedoen of nalaten van zijn ouders, terwijl adequate hulpverlening aam het gezin of het kind is aangeboden doch door de ouders is geweigerd, dan wel adequate hulpverlening anderszins door de ouders onmogelijk is gemaakt of is tegengewerkt, fenzij in redelijkheid niet kan worden verwacht dat de ouders in staat of bereid zijn een adequat hulpaanbod te aanvaarden en /of daaraan op zinvolle wijze mee te werken.

\section{Staatsaansprakelijkheid}

Het tweede lid van de toevoeging van DE RUYTER (de voorwaarde 'dat adequate hulpverlening voorhanden is om aan het gezin of het kind op te leggen') is hierbij weggelaten, omdat een eventueel tekort aan hulpverleners of aan pleeggezinnen of plaatsgebrek in c.q. wachtlijsten voor ambulante of (semi-)residentiële zorginstellingen wel de staatsaansprakelijkheid activeert, doch niet a priori in een criterium thuishoort dat beoogt een fundamenteel recht van het kind veilig te stellen. Ten aanzien van (zeer) fundamentele rechten en waarden (kernrechten) heeft de overheid er immers maar voor te zorgen dat zij haar zaken op orde heeft. In geen geval kan een te kort schieten daarin de gedupeerden worden tegengeworpen. En al helemaal niet in een (wettelijk) criterium dat een minimum-grens, een absolute bodem legt onder primaire humane belangen op het punt wan veiligheid en ontwikkeling.

Wat bouder gesteld: het tweede lid van de toevoeging van $\mathrm{DE}$ RUYTER zou het criterium tot een 'clawback clause' (FLINTERMAN/ANKU$\mathrm{MAH})^{39}$ maken: de andere hand neemt terug wat de ene zojuist heeft

Althans wat het eerste lid van die toevoeging betreft (cle voorwaarde "dat adequate hulpverlening is geboden doch heeft gefaald'). Over het tweede lid (de voorwaarde "dat adequate hulpverlening voorhanden is om aan het gezin of het kind op te leggen') kom ik zo dadelijk te spreken.

39 "While the African Charter [het Afrikaans Handvest inzake de rechten van de mens en de rechten wan volken] contains a relatively large number of protected rights, many are significantly weakened by the inclusion of "clawback" clauses which appear to permit states to act with a great deal of discretion in limiting theoretically protected rights. While such permissible limitations are common to all international human rights instruments - very few human rights are considered to be absolute - the scope of limitations in the African Charter is much broader than that found in other instruments." (Cees FLINTERMAN, Evelyn ANKU- 
gegeven. Het geeft geen pas dergelijke clausules op te nemen in de wetboeken van een rijk land. In een welvarend land als Nederland zou een 'sorry, adequate hulpverlening is nu even niet voorhanden' beschamender behoren te zijn dan een 'sorry, voedsel en water zijn op, probeert $U$ het volgende maand nog eens' in een Sahel-land.

\subsection{Criterium-DE RUYTER: toetsing en bezwaren}

In deze paragraaf laten we allereerst DE RUYTER verslag doen van haar toetsing van het criterium aan de door haar geformuleerde voorwaarden (par. 9.5.1). Tegen het criterium is in de literatuur een aantal bezwaren ingebracht. De meeste hiervan zijn door DE RUYTER afdoende beantwoord. ${ }^{40}$ In wisselende gedaanten keert één bezwaar evenwel bij diverse auteurs terug. Op dit belangrijkste naar voren gebrachte bezwaar gaan we nader in (par. 9.5.2).

\subsubsection{Toetsing van de woorwaarden}

In paragraaf 9.2 werden als voorwaarden waaraan een pedagogisch interventie-criterium dient te voldoen, (in eigen woorden/termen samengevat) genoemd: (1.) het criterium moet (juridisch en pedagogisch) zo precies mogelijk zijn; (2.) als ('liberaal,' dat is neutraal) interventie-criterium. moet het een minimum-criterium zijn (een minimaal opvoedingsdoel moet in gevaar zijn, de condities waaronder het kind kan uitgroeien tot een minimale persoon, zijn niet of onvoldoende aanwezig); (3.) het criterium is een (fundamenteel) recht van het kind; (4.) als Trias-criterium stelt het overheidsbemoeienis tegenover pedagogisch schadelijk handelen of nalaten van ouders (handelen of nalaten dat schade berokkent aan de evenwichtige ontwikkeling van het kind). In dit verband stelt DE RUYTER: $:^{41}$

MAH, 'The African Charter on human and peoples' rights," in: Hurst HANNUM (ed.), Guide to international human rights practice, Philadelphia 1992, tweede druk, pp. 159-169, op pp. 165/166.)

Vgl. voor de term 'clawback clauses' - in de (meer) algemene zin van 'limitations' - (ook) Theodor MERON, Human rights and humanitarian noms as customary law, Oxford 1989, p. 94.

40 Zie DE RUYTTER (1995c). Verschillende bezwaren lijken op misverstanden te berusten. Mot name wordt geen of onvoldoende onderscheid gemaakt tussen het criterium-DE RUYTER en (wenselijke) geoperationaliseerde (sub)criteria (duagnostisch apparaat en juridisering), al of niet voor specifieke (doel)groepen. Een ander misverstand betreft het verzuin onderscheid te maken lussen pedagogische en eventuele andere redenen (medische, ethische) om in een gezin in te grijpen. DE RUXTER (1994), op pp. 205-206. Vgl. ook DE RUYTER (1993), pp. 125-130. 
'Ik heb een aantal woorwaarden geformuleerd waaraan het criterium moet voldoen. [1.] Wat betreft de eerste woorwaarde, kan gesteld worden dat het criterium is geformuleerd in tamelijk precieze termen. In het criterium zelf wordt geexpliciteerd wat bedoeld wordt met de term "persoon." Het criterium is duidelijk omdat in het criterium de pedagogische doelen die in het geval van een bedreiging een woldoende voorwaarde voor interventie vormen, worden beschreven.

[2.] Aan de woorwaarde dat in het criterium [geen] specifieke waarden en normen mogen domineren, is eveneens voldaan. De beschreven eigenschappen waarover de minimaal rationele, morele en authentieke persoon moet beschikken, zijn niet gebonden aan een bepaalde conceptie van het goede leven. We kunnen zelfs stelllen dat de eigenschappen noodzakelijk zijn om [überhaupt, jw] een conceptie van het goede leven te [kunnen] hebben en te [kunnen] praktizeren. ${ }^{42}$

[4.] Conform de voorwaarde wordt in het criterium verwezen naar het handelen van de ouders dat de schade aan het kind moet hebben veroorzaakt. Er wordt niet uitgewerkt welk doen en laten van de ouders nu precies beoogd [lees: bedoeld, jw] wordt. Voor de formulering van het criterium is dit echter niet noodzakelijk. Well is het woor de praktijk van het [aanbieden en desnoods, jw] opleggen van hulpverlening noodzakelijk dat inzicht verkregen wordt in de schade die bepaald handelen kan hebben voor kinderen. ${ }^{43}$

[3. Bij de voorwaarde dat het ingrijpen in het gezin op grond van het criterium in het belang van het kind moet zijn, wil ik uitgebreider stilstaan. In het door mij geformuleerde criterinm is het belang van het kind als uitgangspunt genomen. Niet alleen wordt interventie verbonden aan schade die aan het kind wordt toegebracht, maar ook wordt het criterium geformuleerd in termen van een recht van het kind. Wanneer er gesproken wordt over het recht van het kind om zich tot een persoon te ontwikkelen, dan wordt daarmee uitgedrukt dat het kind een fundamenteel belang heeft om zich in ieder geval te ontwikkelen tot een minimaal persoon. Een schending van dit recht betekent een schade aan een fundamenteel belang wan het kind en interventie wordt op grond daarvan verondersteld in zijn belang te zijn. Maar zijn de onderscheiden kenmerken van de persoon te begrijpen als belangen?

Voordat deze wrag kan worden beantwoord, is het noodzakelijk te verhelderen wat bedoeld wordt met het begrip "belang." Algemeen aanvaard is dat een belang een woordeel woor de bezitter van het belang met zich meebrengt. Er is echter een verschil in interpretatie van dit voordeel [GRIFIN 1990]. De interpretatie die ik zou willen volgen, is de zogenaamde geinformeerde-wensentheorie. Volgens deze theorie bestaan belangen van mensen in de wensen die zij hebben wanneer zij de situatie, de toekomst, de inhoud en de consequenties van de wensen over-

42 SNIK lijkt dit nog scherper te formuleren als hij stelt: "Een staat die het neutraliteitsprincipe serieus neemt, dient het recht van het kind op een open toekomst (...) serieus te nemen, en voor het kind op te komen als dit recht [door verregaande ouderlijke indoctrinatie, jw] geschonden wordt:' (G.L.M. SNIK, 'Staatsbemoeiing, opvoedingsvrijheid, persoonsideaal,' in: Opvoedingshulp geboden, a.w., pp. 93-104, op p. 102 i.f.)

43 Zie voor een uitgewerkte classificatie van schadelijk ouderlijk handelen de in de bijlagen opgenomen criteria van CICCHETT/TorH. Hierop komen we nog terug. 
zien. Alleen indien een wens aan deze vereiste[n] voldoet, kunnen we de wens een belang noemen. Zijn de door mij genoemde kenmerken van de persoon nu kwaliteiten die een kind, c.q. een vervangende volwassene voor hem, zou wensen? Minimale rationaliteit is om de volgende redenen in het belang van de persoon. Ten eerste is het een noodzakelijke voorwaarde om onze doelstellingen te realiseren, om onze levensplannen te ontwikkelen en uit te kunnen voeren. Indien iemand niet minimaal rationeel is, $k$ an hij niet plannen, zal hij doelen niet adequaat nastreven of alternatieven verkiezen die niet rationeel zijn. Ten tweede staat het kind dat buiten de regelpatronen staat, nog machteloos in de regel-geleide maatschappij. Door het leren van vaardigheden wordt de machteloosheid en afhankelijkheid van het kind werminderd en worden diens ontplooingskansen wergroot [DUNTrER 1983]. Minimale rationaliteit is dus tevens een belang vanwege het feit dat een irrationeel persoon niet in staat is een zelfstandig bestaan te leiden en daarmee dus afhankelijk is van het plichtsbesef of de zorg van anderen.

Minimale moraliteit is in het belang van personen omdat zij verbonden zijn met anderen en altijd in relatie tot anderen staan. We kunnen dan stellen dat het in het belang van personen [is] dat zij zich aan de minimale morele regels houden omdat er negatieve sancties staan op het overtreden van deze regels. Hun belang wordt door deze sancties ernstig geschaad, zeker wanneer de ultieme consequentie is dat zij worden uitgestoten uit hun samenleving of wanneer anderen met hen geen relatie meer aangaan. Anderen zullen zich niet zonder meer aan hen durven toe te vertrouwen, waardoor zij een geisoleerde positie in zullen nemen. Het is dus in het belang van het kind om opgevoed te worden tot een minimaal morele persoon. Een volwassene zou ook kunneu proberen zich voor te doen als een minimaal moreel persoon en de regels [kumnen] overtreden wanneer hem dit zijns inziens voordeel biedt. Het is echter de vraag of iemand voldoende in staat is anderen [voortdurend, jw] het idee te geven dat hij een minimaal moreel persoon is zonder dit ook daadwerkelijk te zijn. Iemand die daartoe wel in staat zou zijn, moet bijna een getalenteerde duivel [een uitzonderlijk innemende en intelligente psychopaat, jw] zijn. En aangezien vrijwel niemand dit is, moet een opvoeder, indien hij het belang van zijn kind op het oog heeft, morele principes en sterke gevollens inprenten waarop het kind kan terugvallen [HARE 1981].

Minimale authenticiteit is tenslotte ook in het belang van personen. BONNETT [1978] verdedigt zeer krachtig de wenselijkheid van de ontwikkeling van authenticiteit: "[T]o deny its desirability is to deny so fundamental an aspect of "human nature' that is just seems perverse." Volgens de filosoof RAwLS [1972] wordt zelfrespect door iedere rationele persoon gewenst. Hij stelt dat "(...) without it nothing may seem worth doing. All desire and activity becomes empty and vain, and we sink into apathy and cynicism." [En:] "It is clearly rational for men to secure their self-respect. A sense of their own worth is necessary if they are to pursue their conception of the good with zest and to delight in its fulfillment. Self-respect is not so much a part of any rational plan of life as the sense that one"s plan is worth carrying out"."

\section{Filosofische rechtvaardiging}

Bij de uitgebreide filosofische rechtvaardiging die DE RUYTER geeft voor haar criterium (aan de hand van de filosofen HARE en RAWLS) staan we 
hier niet stil. ${ }^{44}$ Slechts de conclusie van deze exercitie wordt hier weergegeven: ${ }^{45}$

'Alle belangen [de, vaak tegenstrijdige belangen van kinderen, ouders en de samenleving] overziende, kunnen we (...) tot slechts én conclusie komen, namelijk dat wanneer de belangen van de partijen onpartijdig worden gewogen, het criterium het welzijn van de betrokken partijen al met al maximaliseert. In de meeste situaties worden immers de belangen van alle betrokkenen gediend als er wordt ingegrepen op grond van het criterium. In het bijzondere geval dat de ouders wel een belang hebben om hulpverlening te weigeren, wegen de belangen van het kind en de samenleving zowel afzonderlijk, doch zeker gezamenlijk, zwaarder dan het belang van de ouders. In de eerste plaats overtreft het belang van het kind dat van de ouders: het opleggen van hulp heeft voor de ouders minder negatieve consequenties dan het nalaten daarvan woor het kind. In de tweede plaats overstijgt het belang dat de leden van de samenleving hebben bij een ontwikkeling van het kind tot minimaal moreel [rationeel en authentiek, jw] persoon het belang van de ouders. Ik durf zelfs te beweren dat de ontwikkeling van het kind tot een minimaal persoon ook in het belang is van de ouders, omdat het ook in hun belang is dat de samenleving leefbaar is [c.q. dat hun kind niet levenslang van hen afhankelijk is of hen anderszins tot last of bron van zorg is, jw].'

Als voorbeeld van een ouderlijk belang dat door interventie wordt geschaad, noemt DE RUYTER een mogelijk belang van ouders 'hun kind op [te] voeden tot een bekwame delinquent' om zich zo te 'verrijken met de opbrengst van de acties van hun kind. ${ }^{36}$ Een ander voorbeeld zou zijn ouders die hun kind exploiteren voor pornografische doeleinden of in de prostitutie (of welke andere vorm van economische en/of sexuele exploitatie ook). Dit zijn evenwel belangen die door de ouders niet tegen interventie kunnen worden ingebracht op grond van de regel dat niemand zich in rechte op eigen schandelijkheid kan beroepen (nemo suam turpitudinem allegans auditur).

\section{5 .2}

\section{(Mogelijke) bezwaren}

Tegen het criterium van DE RUYTER zijn zowel door haarzelf als in de literatuur (mogelijke) bezwaren geformuleerd. DE RUYTER heeft deze of geanticipeerd, en dus reeds in haar proefschrift (of latere bijdragen) beantwoord, (en/) of heeft daarop later gereageerd. Het belangrijkste bezwal is dat het criterium (nog) te abstract is. Zonder nadere operatio- 
nalisering is het - in de woorden van $\mathrm{KOENS}^{47}$ - nog maar de vraag ...

((..) of voor diegenen die met dit criterium moeten werken in de rechtspraktijk dit woorstel [het criterium-DE RUYTER, jw] qua concreetheid en duidelijkheid als een verbetering zal worden ervaren vergeleken bij de huidige wettelijke criteria."

Bij dit (hoofd)bezwaar - en het antwoord c.q. de repliek van DE RUYTER - staan we in deze (sub)paragraaf stil.

\section{Correctie-KOENS}

In zijn oratie brengt KOENS een drietal bezwaren tegen het criterium van DE RUYTER naar voren. ${ }^{48} \mathrm{Al}$ in haar 'samenvatting, ${ }^{49}$ gaat DE RUYTER op deze bezwaren in. Alleen het tweede bezwaar acht zij pertinent. Zij merkt hierover op: ${ }^{50}$

'Ten tweede windt KOENS het een bezwaar dat in het criterium "niet [wordt] uitgewerkt welk doen en laten van de ouders nu precies als schadelijk voor het kind moet worden aangemerkt. Dit maakt het voor justitiabelen moeilijk te voorzien in welke gevallen zij een dergelijke ingrijpende overheidsinterventie [opgelegde vormen van pedagogische hulpverlening, jw] mogen verwachten." (....) Eerder heb ik hierover gezegd dat dit voor de formulering van het criterium niet noodzakelijk is, maar dat het voor de praktijk van het [aanbieden en desnoods, jw] opleggen van hulpverlening essentieel is dat inzicht wordt verkregen in de schade die bepaald handelen kan hebben voor kinderen (...) ${ }^{51}$ Dit standpunt zon ik wat willen bijstellen. Ik zou willen voorstellen dat in de toelichting op de wet het handelen van ouders wordt geconcretiseerd. Overigens zij opgemerkt dat dit handelen nooit een voldoende voorwaarde is om in bet gezin in te grijpen. De (dreigende) schade aan het kind is tevens een noodzakelijke voorwaarde."

De correctie-KOENS die DE RUYTER hier aanbrengt, gaat naar mijn smaak niet ver genoeg. (Alleen al) vanuit een oogpunt van rechtsbescherming hoort de uitwerking van het criterium niet in een (Memorie van) toelichting thuis doch in de wet zelf. In hoofdstuk 8 hebben we tamelijk uitvoerig stilgestaan bij de positieve criteria (criteria die aangeven wat

47 M.J.C. KOENS, Jeugdigen in de knel; Matregelen wan jeugdbescheming in de toekonst, inaugurele rede Maastricht, Deventer 1994, p. 21. KOENS, a.w., pp. 20-21. (Voor de door KOENS zelf gedane voorstellen en zijn uitgangspunten daarbij zie hoofdstuk 1, par. 1.1.1.)

49 DE RUYTER (1995a), op pp. 22 i.f. 23.

50 DE RUYTER (1995a), op p. 23.

51 Vgl. DE RUYTER (1993), p. 126; DE RUYTER (1994), op p. 205 r.k. (hierboven aangehaald, par. 9.5.1, toetsing voorwaarde 4). Dat DE RUYTER (1994) nog nict aan KOENS" oratic refereert, heeft wellicht te maken met het feit dat haar bijdrage is gepresenteerd als lezing op de dag dat KOENS zijn oratie hield. 
voor een evenwichtige ontwikkeling van het kind nodig is) van HEINER en BARTELS. ${ }^{52}$ Daar is toen opgemerkt dat met het oog op juridisering (dat wil zeggen ter beantwoording van de vraag: wanneer ingrijpen/hulp opleggen?) negatieve criteria (criteria die aangeven wat voor een evenwichtige ontwikkeling van het kind schadelijk is) van minstens even groot nut zijn. Zulke criteria, criteria inzake kindermishandeling (definities van en criteria voor de verschillende subtypen van kindermishandeling met aanduiding van gradaties per subtype), zijn ontwikkeld door BARNETT e.a. (CICCHETTI/TOTH 1993). ${ }^{53}$ Hun criteria zijn in extenso (in Nederlandse vertaling) opgenomen in bijlage III. In hoofdstuk 11 besteden we hier nader aandacht aan. De criteria van BARNETT c.s. zijn dermate concreet en specifiek dat zij mijns inziens op zijn minst een goed vertrekpunt vormen voor juridisering (de wettelijke uitwerking ${ }^{54}$ van DE RUYTERs crite-

52 J. HEINER, A.A.J. BARTELS, 'Jeugdstrafrecht en het belang van het kind: het belang van het kind nader omschreven," FJR (Tijdschrift voor familie- en jeugdrecht) $1989 / 3$, pp. 59-67, uitgebreid aangehaald in hoofdstuk 8, par. 8.2.2.

53 Douglas BARNETT, Jody Todd MANLY, Dante CICCHETTI, 'Defining child maltreatment: the interface between policy and research,' in: Dante CICCHETTI; Sheree L. TOTH (eds.), Child abuse, child development, and social policy, Advances in applied developmental psychology, vol. 8, Norwood, New Jersey 1993, pp. 7-73, "Appendix: Maltreatment subtype definitions and severity ratings,' op pp. 51-73, 'System for quantifying child protective service records; subtype definitions and severity scales, op pp. 54-73.

54 Het is van belang te benadrukken dat het hierbij om de witwerking van DE RUYTERs criterium gaat. Het gevaar ligt immers altijd op de loer dat subcriteria van het hoofdcriterium worden losgezongen en een eigen leven gaan leiden - met alle valse positieven ('gezinnen waarin door de overheid ten onrechte niet wordt ingegrepen'; DE RUYTER (1993), p. 69) vandien, doordat niet meer per analogiam maar a contrario wordt geredeneerd (het schadelijk ouderlijk handelen valt niet helemaal onder het specifieke subcriterium, dus niet ingrijpen, in plaats van: ingrijpen vloeit bij analoge toepassing van suberiteria direct voort wit het hoofdcriterium). Bij de toepassing van een glijdende-schaalscenario (waarbij naar een zwaar middel als de uithuisplaatsing alleen wordt gegrepen als residentiële hulpverlening aan het kind geindiceerd, en dus noodzakelijk is, terwijl allerlei vormen wan vrijwillige hulpverlening aan het gezin gefaald hebben dan wel onmogelijk of zinloos zijn) wegen valse negatiewen (gezinnen 'waarin door de overheid ten onrechte is ingegrepen'; DE RUYTER, t.a.p.) tegen valse positieven op. Dit geldt te meer wanneer in een goede rechtsbescherming van de ouders is voorzien. $Z \mathrm{Zj}$ kunnen zich dan prima, bijgestaan door advocaten, tegen een (dreigende) onterechte ingreep verzetten. Het (jonge) kind is niet in staat (heeft geen benul) of bij machte (ten gevolge van loyaliteitsproblemen of regelrechte ouderlijke pressie) om - omgekeerd - de overheid om een ingreep te verzoeken. Zeker waar het om een minimaal (en minimalistisch uitgewerkt) criterium gaat, is de schade voor het kind bij niet ingrijpen disproportioneel te achten zowel ten opzichte van de (gepercipieerde) belangen van de ouders bij non-interventie als ten opzichte van de 
rium). Aldus zou kunnen worden voldaan aan het (hoofd-)bezwaar van KOENS, een bezwaar dat we in verschillende vormen ook bij andere auteurs tegenkomen.

Van deze auteurs is VAN DER PLOEG wellicht het scherpst in zijn kritiek. Hij stelt na lezing van het criterium 'even perplex' te zijn geweest. ${ }^{55} \mathrm{Na}$ tot 'bezinning' te zijn gekomen, concludeert hij niettemin: ${ }^{56}$

"Afgezien van het feit dat hulpverleners niet of nauwelijks werken met begrippen als rationaliteit, moraliteit en authenticiteil, draagt ook de toevoeging "minimale" niet bij tot de door de onderzoekster zelf zo nadrukkelijk nagestreefde precisie."

Wat VAN DER PLOEG hier verwoordt, is evenwel in essentie hetzelfde wat we beluisterd hebben bij KOENS, en wat we ook kunnen beluisteren bij andere critici: vanuit een praktische gerichtheid of met het oog op de (rechts)praktijk achten zij het criterium te abstract (ROELOFS, VAN NIFTRIK, VAN MONTFOORT, BULLENS). ${ }^{57}$ Het ligt evenwel voor de hand dat het criterium, indien in praktische termen geoperationaliseerd, ook tot bij- of herscholing van (juristen en) hulpverleners zal leiden, hetgeen aanvankelijke onbekend-maakt-onbemind-reacties snel kan doen wegebben. Zelf antwoordt DE RUYTER haar critici als volgt: ${ }^{58}$

'VAN NIFTRIK, VAN MONIFOORT en BULLENS stellen terecht dat een operationalisering van het criterium voor de praktijk noodzakelijk is. Ook deel ik het commentaar van VAN MONTFOORT dat met een specifieker criterium alleen de praktijk van de kinderbescherming niet verbeterd wordt. Dit had ik ook reeds in mijn dissertatie gesteld. ${ }^{59}$ Een meer effectieve en efficiënte samenwerking tussen

schade die door onterecht ingrijpen kan wordlen toegebracht aan het kind, waarbij overigens de rechtsplicht bestaat tot reparatie/rehabilitatie (en wellicht compensatie aan de ouders). Uiteraard is reparatie/rehabilitatie direct volgend op een onterechte interventie veell minder omvangrijk en ingrijpend dan de reparatie/ rehabilitatie die nodig is wanneer op (veel) latere leeftijd blijkt dat ten onrechte niet is ingegrepen.

55 Jan VAN DER PLOEG, bespreking diss. DE RUYTER (1993), Jeugd en samenleving $1995 / 4$, pp. $230-231$, op p. 230 r.k.

56 T.a.p., op p. 231 r.k.

57 Vgl. DE RUYTER (1995c), op pp. 117-120.

58 DE RUYTER (1995c), op p. 122.

Al op p. 4 van haar proefschrift schrijft DE RUYTER: Het doel van deze dissertatie is de verbetering van de interventiepraktijk in Nederland door een criterium te formuleren dat aangeeft onder welke omstandigheden terecht in het gezin wordt ingegrepen teneinde pedagogische hulpverlening op te leggen. Hiermee is dus voor eén facet gekozen om de praktijk van interventie in het gezin te verbeteren. Maar is dit nu het juiste middel? Uiteraard is de formulering van een criterium voor interventie niet voldoende om de gehele interventiepraktijk te verbeteren. 
hulpverlenende instanties, betere meldpunten, grotere alertheid [en meer morele moed en burgerzin, $\left.{ }^{60} \mathrm{jw}\right]$ van buren, familieleden, etc. zijn evenzeer noodzakelijk. Wel ben ik van mening dat eerst het pedlagogisch criterium geformuleerd moet worden, onder andere omdat zo'n criterium noodzakelijkerwijze voorafgaat aan de ontwikkeling van een diagnostisch apparaat.'

\section{Dit laatste sluit dan fraai aan bij de woorden van KOENs.61}

"Het paard moet niet achter de jeugdbeschermingswagen gespannen worden. Eerst dienen fundamentele rechtsvragen over het doel, het karakter, de inhoud en de grenzen van de overheidsinterventie beantwoord te worden (....).'

In hoeverre is op deze plaats een (voorlopige) beantwoording van deze fundamentele rechtsvragen mogelijk? We kunnen (en moeten) daarover in het bestek van deze (sub)paragraaf kort zijn.

1. Doel: het veilig stellen van de minimale persoonswording van het kind (zie criterium-DE RUYTER).

2. Karakter: en wel volgens een glijdende-schaalscenario, waarbij die vormen van hulp worden aangeboden, en desnoods opgelegd, die zijn geindiceerd; doch (extreme uitzonderingen daargelaten) steeds op basis van een ondubbelzinnige poging de ouders tot (zelf)inzicht (en inkeer) te brengen (wat waarschijnlijk in het merendeel van de gevallen zal betekenen: aandacht besteden aan het gekwetste kind in de ouder zelf).

3. Inhoud: die vormen van hulp die zijn geïndiceerd, variërend van (bijvoorbeeld) oudercursussen tot residentiële vormen van hulpverlening.

Een effectievere en efficiëntere samenwerkïng tussen hulpwerlenende instanties, betere meldpunten, grotere alertheid van buren, familieleden, etc. zijn evenzeer noodzakelijk. I $\mathrm{k}$ ben er echter van owertuigd dat een vernieuwd criterium wel een eerste belangrijke stap voorwaarts is, die bijvoorbeeld noodzakelijkerwijze voorafgaat aan de ontwikkeling van een diagnostisch apparaat."

60 Zo lezen we in de Beleidsbrief kindemishandeling unt 1990 (met op het omslag de fraaie lewze: Het is niet de vragg of het kan, mar weten dat het moet) van de bewindslieden D'ANCONA, SIMONS en KOSTO: 'Onze samenleving is zo ingericht dat het wel en wee van kinderen is opgedragen aan hun opvoeders. Bij vermoedens omtrent ontsporingen wan de kant van opvoeders jegens aan hen toevertrouwde kinderen reageert de omgeving vaak te laat. Het is een dilemma waarbij wij aantekenen dat wij [minister en staatssecretarissen, $j w$ ] als politiek aangesprokenen len politiek èn juridisch/internationalrechtelijk (mede)werantwoordelijken! $-j w]$ vinden dat diegenen die dichtbij mogelijke slachtoffers staan, óbk een taak, zo miet een burgerplicht hebben bij aanhoudende vermoedens niet te zwijgen.' (Tweede Kamer, vergaderjaar 1990-1991, 21 938, nrs. 1-2, 4 december 1990, p. 4; curs. jw.)

61 KOENS, Jeugdigen in de knel, a.w., p. 17. 
4. Grenzen: hier moet, voor wat de ondergrens betreft (de overheid moet in elk geval ingrijpen omwille van de fysieke en ontwikkelingspsychologische veiligheid van het kind), verwezen worden naar de operationalisering en juridisering van het criterium-DE RUYTER aan de hand van (bijvoorbeeld) de criteria van BARNETT c.s. (zie hoofdstuk 11 en bijlage III); voor wat de bovengrens betreft (hoe ver mag de overheid gaan? welke randvoorwaarden en waarborgen zijn van toepassing? hoe pakt men dit soort - zeer gevoelige - zaken het meest doeltreffend en doelmatig aan?), moet verwezen worden naar de institutionele inkadering van een en ander (de geïntegreerde preventieve benadering volgens het drieechelonsmodel), die aan de orde komt in hoofdstuk 14.

\title{
9.6
}

\section{Uitleiding}

Niet kan worden ontkend dat de (centrale) kritiek van diverse auteurs: het criterium is (nog) te abstract, een kern van waarheid bevat. Een (kern van) waarheid die - dat mogen we intussen niet vergeten - direct verband houdt met een andere waarheid, het feit namelijk dat buiten de pedagogie en de ontwikkelingspsychologie het denken over het kind nog (steeds) in de kinderschoenen staat. Schoenen die filosofen, onder wie ook en zelfs wijsgerig antropologen, en, in hun voetspoor, juristen ${ }^{62}$ niet pasten, en die door hen nog steeds een aantal maten te klein worden geacht. Zo haalt SNIK in een voetnoot in zijn proefschrift VAN PEURSEN en KORTHALS aan: ${ }^{63}$

\begin{abstract}
"Wanneer men vanuit een andere planeet kennis zou nemen van aardse wijsgerige boeken over het menselijk denken, dan zou men niet spoedig te weten komen dat er ook zoiets als kinderen bestaal[t]. (..) Dit gaat ook op in de hedendaagse wijsbegeerte. Slechts zeer zelden komt [men] bij existentie-filosofen en analytici een verwijzing naar het kind tegen; men zou zelfs kunnen menen dat dergelijke filosofen nooit kinderen hebben, of zelf nooil kind geweest zijn." (WAN PEURSEN [1974/75].) "Wanneer men zich op de hoogte stelt van traditionele filosolieèn, dan krijgt men de indruk dat mensen direct als volwassenen geboren worden." (KORTHALS [1983].)
\end{abstract}

In een andere voetnoot merkt SNIK op: $:^{64}$

62 Voor wie wijsgerige antropologie, als onderdeel van het vak rechtsfilosofie, deel uitmaakt(e) van het (basis-)curriculum, wat in elk geval in mijn studietijd (nog) gold voor de KU Nijmegen.

63 G.L.M. SNIK, Persoonswording en opvoeding, diss. Nijmegen, Kampen 1990, p. 209 nt. 2.

A.w.y. p. 209 nt. 4. 
"Dat de categorie "ontwikkeling" zelfs genegeerd is en wordt in de wijsgerige antropologie wekt natuurlijk wel werbazing. "Auch im anthropologischen Denken im engeren Sinne zeigt sich der Gedanke kaum, daß der Mensch als Kind anfängt." (LANGEVELD [1968].) "De meeste theoretici van het subject lijken ervan uit te gaan dat de mens als volwassene ter wereld komt en dan andere mensen toevalligerwijs tegenkomt." (KORTHALS [1983].) Ook in deze tak van de filosofie houdt men zich met "de mens in het algemeen" bezig, en wordt ontkend dat de kindheid [sic, jw] een modus van het mens-zijn is met een eigen positieve waarde en betekenis. "Eher (...) noch spricht [der Philosoph] davon, daB der Mensch die Tatsache des Kindseins überwinden muB. (...) Man ist anscheinend erst ein "vollstä̈ndiger' Mensch, wenn man kein Kind mehr ist." (LANGEvELD [1968].) (...) De betekenis van intersubjectieve relaties in en voor het functioneren en de ontwikkeling van mensen [wordt] (...) veronachtzaamd [KORTHALS]. LANGEVELD merkt op dat de tendens om in de wijsgerige antropologie de volwassene centraal te stellen, gepaard gaat met een negatieve waardering van de kindertijd. De kindertijd is een periode waarvoor men zich schaamt. "Die Pädagogik vertritt eine Grunddeterminante des Menschlichen, an die der Erwachsene nicht gerne erinnert wird: das Schwache, Hilflose, dem man die Treue zu halten hat; [das, mil dem man verbunden ist, weil man es ins Leben gerufen hat, oder das zumindestens nicht die Gelegenheit hatte, um seine Existenz zu bitten. ${ }^{65}$ ] Das Kind stört den Erwachsenen, es ist nicht von Wichtigkeit." (...)"

'De kindertijd is een periode waarvoor men zich schaamt.' Een schaamte die kennelijk maar zelden tot nader (zelf)onderzoek leidt. Waarbij zich dan toch snel de vraag zou opdringen: waarom zou men zich voor de kindertijd schamen, tenzij men als kind beschaamd is gemaakt? En wie anders dan volwassenen, dan de oudlers, kunnen een kind beschaamd maken? (En wie anders kan daarmee in het reine komen, dan de latere volwassene - die liever een slok van de Lethe neemt.) Maar dit terzijde. SNIK vervolgt zijn noot met te constateren: ${ }^{66}$

\footnotetext{
'Tussen het negeren/vergeten van de kindertijd en de negatieve waardering van de kindertijd is een vicieuze cirkel. "Volwassenen die zich schamen voor het kinderlijke, vergeten hun kindsheid, en omdat ze die vergeten zijn, hebben ze er geen waardering voor." (FORTMANN [1971].)"
}

Naar mijn gevoelen is de omvang en de historische betekenis van deze andere waarheid, de waarheid van het vergeten van de eigen kindertijd, nog maar nauwelijks tot het collectieve bewustzijn van de mensheid doorgedrongen. Voor zover de indruk juist is dat we aan de dageraad staan

65 De tekst tussen haken, door SNIK weggelaten, is direct overgenomen uit het origineel: Martinus J. LANGEveld, Studien zur Anthropologie des Kindes, Tübingen 1968 (derde druk), p. 8. 
van het vanuit het zelf-kind-geweest-zijn en het-kind-in-onszelf nadenken over het kind - over zijn positie en zijn rechten in gezin en samenleving -, is het niet zo heel verwonderlijk dat denkers die uit de ochtendschemer te voorschijn treden, worden onthaald met (tegen)argumenten die teruggrijpen op bekende, oude en vertrouwde noties en begrippen. We kunnen mijns inziens dan ook veilig concluderen dat DE RUYTER een criterium heeft voorgesteld dat - hoe 'schemerig' nog op zich - bijna een generatie verder is dan 'het belang van het kind.'

En wel alleen al om deze twee redenen. In de eerste plaats is het als recht van het kind geformuleerd - en daarmee mensenrechtelijk vertaald, op het niveau van de (fundamentele) rechten van de mensen getild. In de tweede plaats is de eis tot operationalisering, tot uitwerking in pedagogische en juridische categorieën, sub-criteria en sub-rechten en -plichten, als het ware in het criterium ingebakken (inherent als deze is aan het karakter van - mensenrechtelijk - rechtsbeginsel). Ook dit geeft het een duidelijke voorsprong op 'het belang van het kind,' waarvan het caoutchouc-karakter soms zelfs wordt bejubeld, ${ }^{67}$ doch onder welke noemer - in de woorden van BULLENS - 'ook vaak ouderbelangen uitgevochten worden, hetgeen niet "in het belang van het kind" is. ${ }^{.68}$

DE RUYTER stelt: ${ }^{69}$

'Ik ben van mening dat, ondanks [bepaalde] procedurele garanties, een meer specifieke wetgeving noodzakelijk is. De bescherming van [zwakke, weerloze, en de rechtsbescherming van alle, $j w]$ rechtssubjecten kan niet ver genoeg gaan, en hoe specifieker de wet, hoe duidelijker het is voor ouders en kinderen wanneer er in hun gezin kan worden ingegrepen.'

Namelijk (althans kennelijk) door juristen die 'open' of 'vage begrippen' prima vinden passen in de gereedschapskist van de rechter, zoals DE RUTTER (vgl. N.A. STEGERHOEK, De publieke kant van het jeugdrecht; Publieke aspecten wan het civiele jeugdrecht nader beschoutd, diss. Leiden, Zwolle 1995, p. 123) en VAN MONTFOORT (A.J. VAN MONTFOORT, 'Criteria onder druk der omstandigheden; besluitvorming over gedwongen hulpverlening aan gezinnen,' in: Opvoedingshulp geboden, a.w., pp. 53-65, op p. 55). VAN MONTFOORT wordt door DE RUYTER op dit punt als volgt van repliek gediend (DE RUYTER (1995c), op p. 120): 'Dat, zOals VAN MONIFOORT (...) stelt, de regering van mening is dat de rechter vertrouwd is met vage begrippen die moeten worden toegepast, is een interessante opmerking, maar een beroep op autoriteit geldt binnen de wetenschap nog steeds niet als een adequate rechtvaardiging.' R.A.R. BULLENS, 'Aandachtspunten bij de beslissing om een kind uit huis te plaatsen: tombola of methodiek?' In: Opvoedingshulp geboder, a.w., pp. 67-80, op p. $80 \mathrm{nt} .2$. DE RUYTER (1995c), op p. 120. 
Wie deze (dubbele) stelling onderschrijft, kan de mensenrechtelijke vertaling en (potentiële) aanscherping van 'het belang van het kind,' mits inderdaad gevolgd door adequate en voortschrijdende operationalisering, institutionele verankering en (dus) juridisering, enkel toejuichen.

Toch kan er een in psychologisch opzicht belangrijk bezwaar tegen het criterium-DE RUYTER worden ingebracht, een bezwaar dat nergens in de literatuur wordt genoemd. Het bezwaar namelijk dat een in minimale termen geformuleerd criterium noopt tot het uitwerken van minimale standaarden, tot expliciete omschrijvingen van schadelijk ouderlijk handelen, en wel in het bijzonder tot criteria inzake kindermishandeling, omschrijvingen en criteria die het bestaan van wreedheden ten aanzien van kinderen blootlegt op een wijze die maatschappelijk en politiek ongemak en afweer kan veroorzaken. Iets wat met 'het belang van het kind" niet het geval is. Men zou zelfs kunnen stellen dat 'het belang van het kind' - zeker in combinatie met de notie van natuurlijke ouderliefde ${ }^{70}$ - veel onrecht en wreedheden ten aanzien van kinderen verhult en toedekt. Minimale criteria trekken dan een sluier weg, en leggen zo op een directe, confronterende wijze structurele tekorten en misstanden bloot. Anderzijds zou in die confrontatie - mits zij niet uit de weg wordt gegaan - wel eens de grootste winst van het voorstel van DE RUYTER kunnen blijken te liggen.

Natuurlijke ouderliefde ('natural love'), LoCKE's natururlijke ouderlijke tendermess, is een 'instinctual phenomenon, grounded in human nature' en bezit als zodanig een 'speciall, enduring, timeless and culture-free quality." Echter: "If it is assumed that all parents love their children as a fact of nature, then it becomes very difficult to read evidence in a way which is inconsistent with this assumption.' (Robert DINGWALL, John EEKELAAR, Topsy MURRAY, The protection of children; State intervention and family life, Oxford/New York 1985, Chapter 4, "The rule of optimism,' pp. 79-102, op pp. 86 en 87.) 


\title{
PERSOONSWORDING EN HET VERDRAG IN- ZAKE DE RECHTEN VAN HET KIND
}

10.1

\author{
Inleiding: persoonswording en het Verdrag inzake de rech- \\ ten van het kind
}

In het vorige hoofdstuk hebben we 'persoonswording' als pedagogisch criterium onder de loep genomen. In pedagogische zin spreken we van een persoon als er sprake is van (minimaal) drie minimale kwaliteiten: minimale rationaliteit, minimale moraliteit en minimale authenticiteit. Een kind dat tot minder dan een minimaal persoon is opgevoed, staat zodanig gehandicapt in het leven, is zodanig misvormd geraakt en gemaakt, dat van een ernstige schending van zijn fundamentele rechten moet worden gesproken. Deze fundamentele rechten vatten we samen onder de paraplu: het recht van het kind op minimale persoonswording. Het recht van het kind op minimale persoonswording is tweeledig; het omvat zowel het recht van het kind zich (minimaal) tot een minimaal (rationeel, moreel en authentiek) persoon te ontwikkelen, als het recht van het kind op vrijwaring van beschadiging van zijn minimaal persoonzijn (dat wil zeggen van zijn minimale rationaliteit, moraliteit en/of authenticiteit). Schending van één van beide rechten verplicht de overheid tot interventie. Het recht van het kind op een minimum aan kwaliteiten, een minimum dat het kind, eenmaal volwassen, in staat moet stellen tot het genot en de zelfstandige uitoefening van zijn mensenrechten, behelst aldus de plicht van de overheid dit minimum te waarborgen (preventief hulpaanbod) en bij bedreiging ervan te interveniëren (hulpaanbod/hulpoplegging). Dit is de essentie van wat we het interventie-criterium van DE RUYTER hebben genoemd.

Het kind heeft echter recht op meer dan een minimum en de overheid is tot meer dan het minimale verplicht. We zouden het minimum een psychisch overlevingspakket kunnen noemen, de smalste basis waarop ontplooiing tot volwaardig lid van de samenleving mogelijk is. Maar de samenleving zou niet ver komen, en snel in verval raken, als haar leden niet meer dan dit minimum in hun ransel hadden. Elk individu en de samenleving in haar geheel is zozeer gebaat bij een bovenminimale geestelijke bagage als startkapitaal van elke nieuwe volwassene, dat we een recht van het kind op optimale persoonswording hebben voorgesteld, behelzende de plicht van de staat zich tot het uiterste in te spannen dit optimum binnen het bereik van al zijn minderjarige burgers te brengen. Een comprehensief (veelomvattend, breed en diep vertakt) stel- 
sel van Sociaal-Pedagogische Steun en een daarin ingebed hulpaanbod dient elke ouder in staat te stellen zelf de voorwaarden voor een optimum aan rationaliteit, moraliteit en authenticiteit van zijn kind in het leven te roepen. Een zelfstandig te maximaliseren optimum dat het psychisch werkkapitaal wan de jonge volwassene is waarmee deze naar de mate van zijn of haar individuele ambities en talenten een bijdrage aan de samenleving kan (en naar verwachting zal) leveren.

In dit hoofdstuk gaan we allereerst naar het optimum-recht op zoek. Is er in het Verdrag inzake de rechten van het kind, en eventueel in andere instrumenten, een beginsel of recht van het kind vastgelegd dat overeenkomt met - of althans in de buurt komt van - wat hierboven het recht van het kind op optimale persoonswording is genoemd? Uiteraard met inbegrip van de corresponderende (uiterste) inspanningsverplichting van de staat. Pas als we daarover meer duidelijkheid en zekerheid hebben verkregen, tasten we het kindervolkenrecht verder af, op zoek naar een recht van het kind op minimalle persoonswording - met inbegrip van een corresponderende (resultaats)verplichting van de staat.

Het optimum-recht (het recht van het kind op optimale persoonswording) zullen we aanduiden als de welzijnsrechten van het kind. Het minimum-recht (het recht van het kind op minimale persoonswording) zullen we aanduiden als de beschermingsrechten van het kind. Daarnaast zullen we onderscheiden de zelfbepalingsrechten van het kind, met dien verstande dat zelfbepaling niet los kan worden gedacht van de ontwikkeling van minimale, en al helemaal niet van de ontwikkeling van optimale kwaliteiten.

We beginnen met een onderzoek van het Verdrag inzake de rechten van het kind, en meer in het bijzonder een onderzoek van de vraag in welke mate de drie genoemde categorieën in dat Verdrag zijn terug te vinden. Daarbij gaan we in eerste instantie (dat wil zeggen vóor we van 'optimum' naar 'minimum' overstappen) uit van de tweedeling: persoonin-wording en persoon-in-wording. Bij persoon-in-wording gaat het om de bescherming en het welzijn van het kind (kind als 'object/subject' ofwel 'kind-als-object'), bij persoon-in-wording gaat het om de zelfbepaling van het kind (kind als 'subject/subject' ofwel 'kind-als-subject').

10.2

Het Verdrag inzake de rechten van het kind

Zoals we al in hoofdstuk 5 zagen (in par. 5.3) is het Verdrag inzake de rechten van het kind op 20 november 1989 unaniem door de Algemene Vergadering van de Verenigde Naties aangenomen, ${ }^{1}$ en iets meer dan 
negen maanden later, op 2 september 1990 , in werking getreden. ${ }^{2} \mathrm{Na}$ ommekomst van zeven jaar (begin 1997) was vrijwel de gehele statengemeenschap partij bij het Verdrag. Buiten de kring van verdragsstaten stonden toen nog slechts twee rijke landen (de Verenigde Staten en Zwitserland, die het Verdrag wel al hadden ondertekend $\left.{ }^{4}\right)$, een ministaat (de Cookeilanden') en een 'failed state' (Somalië). Alleen de vs en Somalië zijn nog steeds geen partij. Waarschijnlijk zal dit feit nog geruime tijd een van de weinige zaken zijn die beide landen verbindt.

Nederland, één van de hekkesluiters, is sinds 8 maart 1995 aan het Verdrag gebonden. ${ }^{6}$ De staten die partij zijn bij het Verdrag, vertegenwoordigen circa $95 \%$ van de wereldbevolking. Ratificatie door de vs zou dit percentage op bijna 100 brengen.

Aan de totstandkoming van het Verdrag is gedurende tien jaar gewerkt (vanaf 1979, het internationale jaar van het kind) door een door de

2 Op 26 januari 1990 werd het VRK te New York voor ondertekening opengesteld, op 3 augustus 1990 was de vereiste twintigste akte van ratificatie of toetreding binnen; ingevolge art. 49, lid 1 VRK trad het Verdrag vervolgens op 2 september 1990 in werking.

3 Zie de lijst van 189 staten die op 24 januari 1997 het Verdrag hadden ondertekend en geratificeerd c.q. tot het Verdrag waren toegetreden, in UN doc. CRC/ C/62 d.d. 3 maart 1997, Annex 1, pp. 51-56.

4 De Verenigde Staten op 16 februari 1995 (vgl. Cynthia Price COHEN, 'United States signs the Convention on the rights of the child,' International Journal of Children's Rights 1995/2, pp. 281-282). Ratificatie door de vs ligt niet in het verschiet. Ratificatie door Zwitserland zou slechts een kwestie van tijd blijken (ratificatic vond plaats op 24 februari 1997: Tractatenblad 1998, 62, p. 1 onder E). Vgl. met betrekking tot Zwitserlands 'tardiness': Marie-Françoise LÜCKER-BABEL e.a., 'Pre-surveillance of children's rights,' in: Eugeen VERHELLEN (ed.), Monitoring children's rights, [Den Haag] (etc.) 1996, pp. 517-523, op pp. 517/518.

5 Toegetreden op 6 juni 1997: Tractatenblad 1998, 62, p. 6 onder $F$.

6 Ratificatie vond plaats op 6 februari 1995; ingevolge art. 49, lid 2 vRK trad het Verdrag vervolgens op 8 maart 1995 voor Nederland in werking.

In de lijst van staten die op 24 januari 1997 het Verdrag hadden ondertekend en geratificeerd c.q. tot het Verdrag waren toegetreden, in UN doc. $\mathrm{CRC} / \mathrm{C} / 62 \mathrm{~d}$.d. 3 maart 1997, Annex I, pp. 51-56, staan bij elk land ook de data van ondertekening, ratificatie c.q. toetreding en inwerkingtreding vermeld; abusievelijk (volgens mijn rekenmethode) paraisseert bij Nederland 7 maart 1995 in plaats van 8 maart 1995 als datum van inwerkingtreding. De exacte datum is in het bijzonder van belang met betrekking tot de fatale termijnen voor de Nederlandse statenrapporten. Overeenkomstig opgemeld abuis (althans als ik goed heb geteld) vermeldt UN doc. CRC/C/57 d.d. 31 oktober 1996 (Annex III, CRC/C/54, pp. 57-67, op p. 66) als uiterste datum waarop ingevolge art. 44 , lid 1 onder a VRK het eerste Nederlandse statenrapport bij het Comite inzake de rechten van het kind binnen dient te zijn, 6 maart 1997 in plaats van 7 maart 1997. (Overigens is het eerste Nederlandse rapport gedateerd 'April 1997.') 
VN-Mensenrechtencommissie ingestelde Open werkgroep ${ }^{7}$ onder voorzitterschap van de Pool LOPATKA. Landen uit alle continenten alsook inter-en non-gouvernementele organisaties particeerden in de voorbereiding van het Verdrag. ${ }^{8}$

Het initiatief tot de opstelling van een kinderrechtenverdrag kwam van Polen. Passend in het klimaat van de koude oorlog ondervond dit initiatief verre van een warm westers onthaal. ${ }^{9}$ Niettemin is er tijdens het gehele voorbereidingsproces - van 1979 tot 1989 - slechts én keer een stemming nodig geweest: door verzet van de Verenigde Staten was geen consensus mogelijk over de wijze van financiering van het Comitê

Dit betekent dat de werkgroep openstond voor deelname (met spreek- doch zonder stemrecht) door staten die niet vertegenwoordigd waren in de VN-Mensenrechtencommissie, of die zelfs geen lid waren van de VN (zoals Vaticaanstad en Zwitserland), alsook door IGO's en NGO's (inter- respectievelijk non-gouvernementele organisaties). De NGO's vormden sinds 1983 een NGO Ad hoc Group, die in 1989 een vijftigtal leden telde, waarvan het secretariaat werd gevoerd door DCI (Defence for Children International).

8 Vgl. Bea VAN DEN BERGH, Recht op recht(en)? Kinderen als maatschappelijke groep, Centrum voor Bevolkings- en Gezinsstudiën, Ministerie van de Vlaamse Gemeenschap, Departement WVC, Administratie Gezin en Maatschappelijk Welzijn, Brussel 1994, p. 8. Zie ook - uitgebreider - Geraldine VAN BUEREN, The international law on the rights of the child, Dordrecht (etc.) 1995, pp. 13-15; Nigel CANTWELL, "The origins, development and significance of the United Nations Convention on the rights of the child,' in: Sharon DETRICK (ed.), The United Nations Convention on the rights of the child; 'A guide to the 'travaux préparatoires,' Dordrecht (etc.) 1992, pp. 19-30, op pp. 20-25; Cynthia Price COHEN, "The role of nongovernmental organisations in the drafting of the Convention on the rights of the child,' HRQ 1990/1, pp. 137-147; Astrid J.M. DELISSEN, 'De rechten van het kind: na 10 jaar voorbereiding nu bij verdrag geregeld,' NJCM-Bulletin 1990/5, pp. 566-575; Lawrence I. LEBLANC, The Convention on the rights of the child; United Nations lawmaking on human rights, Lincoln/London 1995, pp. 16-45; Ph.E. VEERMAN, The rights of the child and the changing image of childhood, Dordrecht (etc.) 1992, pp. 181-184; Eugeen VERHELLEN, Verdrag inzake de rechten van het kind; Achtergronden, motieven, sitrategieën, hoofdlijnen, Leuven/Apeldoorn 1993 (tweede druk), pp. 83-87; Marian KOREN, Tell mel The right of the child to information, diss. Amsterdam, Den Haag 1996, pp. 168-171.

Vgl. met betrekking tot de instelling/samenstelling van de Open werkgroep en de rol van NGO's in het bijzonder LEBLANC, a.w., pp. 27 en 40-45; VEERM.AN, a.w., pp. 182-183; VERHELIEN, a.w., pp. 84-85; COHEN, t.a.p., op pp. 139-141; CANTWELL, t.a.p., op pp. $21 / 22$ en 24-25. Zie in het bijzonder met betrekking tot de rol van NGO's ook Cynthia Price COHEN, 'The United Nations Convention on the rights of the child: involvement of NGO's,' in: Th. VAN BOVEN, C. FLINTERMAN, F. GRÜNFELD, R. HUT (eds.), The legitimacy of the United Nations: towards an enhanced legal status of non-state actors, SIM Special 19, Utrecht 1997, pp. 169184. 
inzake de rechten van het kind. ${ }^{10}$ Uiteindelijk zouden, qua participatiegraad, westerse, en pas op de tweede plaats Oost-Europese staten - op (soms grote) afstand gevolgd door andere geopolitieke regio's - de belangrijkste opstellers van het Verdrag blijken. ${ }^{11}$

Het Verdrag bestaat uit een preambule (met 13 preambulaire overwegingen) en drie delen. Het materiële deel I beslaat 41 artikelen: een definitie-artikel (kind is mens van 0 tot 18 jaar: ${ }^{12}$ art. 1 ), een savings clause ('meest-gunstige-bepaling-clausule,' dat wil zeggen de hoogste standaard geldt: art. 41) en daartussenin 39 bepalingen die rechten van kinderen en/of verplichtingen van staten en/of bevoegdheden en verplichtingen van ouders bevatten. Deel II betreft de bekendmaking (art. 42) en het toezichtsmechanisme (artt. 43-45), inhoudende een statenrapportageverplichting (binnen twee jaar en vervolgens om de vijf jaar) aan een verdragsorgaan (het Comité inzake de rechten van het kind), dat 'suggesties en algemene aanbevelingen' (art. 45 onder d) kan doen. Deel IIr (artt. 4654) bevat regels van formeel (sluiting, bekrachtiging, toetreding, voorbehouden, inwerkingtreding, registratie) en materieel (wijziging, opzegging) tractatenrecht. ${ }^{13}$

\section{Bijna-universele gelding: Scylla en Charybdis}

De snelle bijna universele bekrachtiging van (c.q. toetreding $\operatorname{tot}^{14}$ ) het

Vgl. LEBLANC, a.w., pp. 26 en 220-223. LEBLANC, a.w., pp. 31-37.

12 Art. 1 vRK spreekt van een mens onder de 18 jaar, doch het Verdrag heeft de ondergrens bij de geboorte willen leggen. Dit betekent niet dat het kind geen recht zow hebben op prenatalle zorg en zorgvuldigheid (althans dat onder het Verdrag een dergelijk recht niet zou kunnen worden geconstrueerd). Schending van dat recht kan immers in principe tot latere reparatie/compensatie leiden. Slechts heeft men bij de opstelling van het Verdrag het recht op leven niet tot de prenatale fase willen oprekken. In overeenstemming met algemeen internationaall recht is dit een (omstreden) zaak die (daarom) binnen de 'domestic jurisdiction' van elk land valt. (Vgl. J.C.M. WILLEMS, "Het VN-Kinderverdrag en het recht op abortus,' $N J B$ 1990, pp. 776-778; dez., 'Van parentiarchie naar Vadertje Staat,' Nemesis $1992 / 3$, pp. 8-23, op pp. 8/9 en 22 nt. 68.) Zeer lezenswaard met betrekking tot (kindermishandeling en) de abortuskwestie (althans voor wie zich niet laat afschrikken door de onverwrikte toonzetting) is Alice MILLER, De muur vant zwijgen; De waarheid van de feiten, Houten 1990, pp. 146-152 ('Voor de bescherming van het geleefde en geboren leven').

13 Vgl. voor dit onderscheid A.M. STUYT, Formeel tractatenrecht; Overzicht aan de hand van de Nederlandse praktijk, Den Haag 1966, p. 22.

14 Een verdrag kan na voorafgaande ondertekening worden aanvaard door ratificatie (ofwel bekrachtiging), en zonder voorafgaande ondertekening door toetreding (vgl, STUYT, a.w., p. 63; P.H. KOOIJMANS, Intemationaal publiekrecht in vogelwlucht, ed. Groningen 1996, p. 97 i.f.). Verdragen worden veelal onder voorbe- 
Verdrag inzake de rechten van het kind is dermate uniek dat zij bijna om een verklaring smeekt. Op die smeekbede ingaan, vereist een laveren tussen de Scylla van verlammend cynisme en de Charybdis van ontwapenende naïviteit. Kortom een stuurmanskunst die mij zozeer ontbreekt dat ik mij ertoe zal beperken die Scylla en Charybdis, zoals ik die zie opdoemen, in grove lijnen te schetsen.

De Scylla. De situatie van kinderen in alle landen van de wereld, ${ }^{15}$ niet in de laatste plaats de rijke landen, in het gezin, waar, onder de vleugels van het recht op privacy, de meest fundamentele mensenrechten aan ouderlijke prerogatieven en willekeur ondergeschikt zijn - met levenslange beschadiging voor miljoenen kinderen (alleen al in Nederland tienduizenden per jaar) als gevolg, beschadiging die in veel gevallen voorkomen had kunnen worden als overheden aan die prerogatieven en willekeur in sociaal-pedagogische zin paal en perk hadden gesteld -, die situatie is tegelijk zo anomisch en abominabel dat de snelheid waarmee bijna alle staten van de wereld partij bij het Verdrag inzake de rechten van het kind zijn geworden, met enige kwaadaardigheid geduid zou kunnen worden als uiting van een al of niet bewuste internationale gretigheid voor die situatie een schaamlap te vinden. Ratificatie met andere woorden als 'a token gesture."16

En zelfs als men nationaal, in het bijzonder in de rijke landen, voor die situatie, de situatie van kinderen in het gezin, geen oog heeft want niets maakt blinder, individueel en collectief, dan wat men niet wil $z_{i e n}{ }^{17}$-, dan zijn er in tal van minder rijke staten wel andere situaties

houd van ratificatie gesloten. De ondertekening behelst dan niet meer (en minder) dan de verplichting zin en strekking (betekenis en bedoeling, doel en wezen) van het verdrag niet te frustreren (art. 18 Weens Verdragenverdrag), dat wil zeggen het verdrag naar zijn geest te respecteren, totdat het - door en na de ratificatie - ook naar de letter verbindend wordt (dat is in werking treedt). Een dergelijk voorbehoud wordt gemaakt om democratische staten in staat te stellen het huiswerk van de regering aan het nationale parlement ter (uitdrukkelijke of stilzwijgende) goedkeuring voor te leggen (vgl. KOOIJMANs, a.w., pp. 94 en 96). Vergelijk de 11e preambulaire overweging van het Verdrag inzake de rechten van het kind (curs. jw): 'Erkennende dat er, in alle landen van de wereld, kinderen zijn die in uitzonderlijk moeilijke omstandigheden leven, en dat deze kinderen bijzondere aandacht behoeven (...).'

16 Michael FREEMAN, 'Beyond conventions - towards empowerment,' in: Maud DROOGLEEVER FORTUYN, Miek DE LANGEN (eds.), Towards the realization of human rights of children; Lectures given at the second International Conference on Children's Ombudswork, DCI-Netherlands, Amsterdam 1992, pp. 19-39, op p. 27.

En niets leidt bij confrontatie met werkelijkheid of waarheid tot hardnekkiger kronkels. Vgl. voor een voorbeeld Herman BAARTMAN, 'Onderkenning en miskenning van seksueel misbruik van kinderen; enkele historische en actuele aspecten,' in: dez. (red.), Op gebaande paden? Ontwikkelingen in diagnostiek, hulpverle- 
zo schrijnend voor kinderen dat men deze het liefst zo spoedig mogelijk met een mondiale schaamlap zou willen bedekken. Reden genoeg om het Verdrag te omhelzen, en eer te behalen aan het geduldige papier waarop het geschreven staat, in plaats van aan de kinderen over wie het gaat en voor wie het is bedoeld. Of, anders gezegd, reden genoeg om mee te deinen op de golven van internationale politieke goodwill ten aanzien van kinderen, ${ }^{18}$ met de reservatio mentalis, het stilzwijgende voorbehoud, dat het volwassen thuisfront, als de golven zijn weggeëbd, andere prioriteiten - 'geef ons BARABBAS in plaats van die kindervriend!' 19 - zal stellen. ${ }^{20}$ Ratificatie met andere woorden als staaltje van internationaal 'regelgevend escapisme ${ }^{21}$ met binnenlandse 'rookgordijnen' en 'kluitjes-in-hetriet' achter de hand of in het verschiet voor kritische vragenstellers die de vrome (en niet meer dan dat) bedoelingen hebben misverstaan. ${ }^{22}$

Trouwens, hoeveel en hoe kritische vragenstellers heeft de staat eigenlijk te duchten nu, zoals DOEK terecht opmerkt, 'de implementatie van de rechten van het kind zich' - DOEK schrijft 'vaak,' maar we kunnen even goed zeggen 'in principe': kinderen staan immers in principe onder ouderlijk gezag - 'afspeelt in een driehoeksverhouding van kind-ouders-

ning en preventie met betrekking tot seksueel misbruik van kinderen, Utrecht 1995, pp. 13-27, op p. 24, met verwijzing naar (David) HECHLER, The battle and the backlash; The child sexual abuse war (Lexington etc. 1988, p. 126; voor voCAL bij BAARTMAN lees: de Coalition of Concerned Citizens; zie a.w., p. 125).

18 Zoals KOREN in haar proefschrift opmerkt: 'There seems to be a taboo on being opposed to all well-meaning initiatives which have to do with children. This has also its effect when one weighs the value of the acceptance of a convention on children's rights. Such acceptance says little about substantive implementation in reality.' (Marian KOREN, Tell me! The right of the child to information, diss. Amsterdam, Den Haag 1996, p. 169.)

19 Vgl. Mattheüs 27:11-26; Marcus 15:1-15; Lucas 23:13-25; Johannes 18:33-40.

20 De staat, zo merkt DoEK op, 'wekt niet zelden de indruk dat op zorg voor minderjarigen vooral gemakkelijk - dat is zonder al te veel negatieve gevolgen in electorale zin - kan worden bezuinigd." (J.E. DOEK, "De ratificatie van het Verdrag inzake de rechten van het kind; enige beschouwingen over de mogelijke gevolgen voor de Nederlandse rechtspraktijk,' NICM-Bulletin 1995/1, pp. 10-21, op p. 12.) Bezuinigingen in plaats van de vereiste en noodzakelijke investeringen: met de stilzwijgende instemming van het electoraat (waar, zoals bekend, kinderen niet toe behoren).

21 Nico SCHrIJver, 'Collectieve mensenrechten: rookgordijnen of extra cement voor het universele bouwwerk van de rechten van de mens?' In: dez. e.a. (red.), Mensenrechten, voor armen weggelegd? Evert VERMEER Stichting, Amsterdam 1989, pp. 148-171, op p. 170.

22 Vgl. voor voorbeelden van mogelijke KIR-antwoorden (staatkundig acroniem voor Kluitje-In-'t-Riet) - en de parlementaire (on)tevredenheid daarover - in de Nederlandse kamerstukken (goedkeuringswet VRK): DOEK, t.a.p., op pp. 13-14 nt. $12-16$. 
staat. ${ }^{23}$ Die driehoeksverhouding wordt immers nog steeds gedomineerd door de maatschappelijke en juridische mythe van 'het veronderstelde samenvallen van de belangen van ouders en kinderen, door Donna GOMIEN "a legal fiction" genoemd. ${ }^{24}$

De Charbydis. Of zouden staten oprecht bedoeld hebben nationaal en internationaal kosten noch moeiten te sparen de verdragsverplichtingen naar letter en geest na te leven? Zowel in eigen huis orde op zaken te stellen als in andere, minder bedeelde landen hun goede diensten aan te bieden en met goede gaven klaar te staan? Goede trouw wordt in het recht voorondersteld. En 'elk in werking getreden verdrag verbindt de partijen en moet door hen te goeder trouw ten uitvoer worden gelegd. ${ }^{, 25}$

Op de Scylla loopt men gemakkelijk te pletter en de Charybdis is een draaikolk waarin men voorgoed verdwijnt. Een jurist zal echter eerder (te) sceptisch zijn dan naïef, achterdocht is voor hem of haar beroepshalve een grotere valkuil dan argeloosheid. Omdat voor de interpretatie van een verdrag de bedoeling van staten niet geheel zonder betekenis is, ${ }^{26}$ staan we daarom kort stil bij de gematigd-sceptische opmerkingen van TOMAŠEVSKI. In haar (zeer kritische) bespreking van LEBLANCs boek, waarnaar hierboven al enkele malen werd verwezen, stelt deze: ${ }^{27}$

\footnotetext{
'LEBLANC attributes the Convention's attractiveness to States to the fact that "[v]irtually everywhere in the world, children are perceived to be vulnerable to the most serious forms of human rights abuse" (p. xii). Additional factors, such as the possibility that children's inability to claim and enforce their proclaimed rights may have facilitated its acceptance, or the eternal misconception of children's needs equalling children's rights and thus avoiding conflict-prone human rights dilemmas, are not explored. Indeed, distinctions between children's rights and children's needs are blurred in LEBLANCs book, thus undermining the core features of human rights.'
}

Wat TOMAŠEVSKI hier aan de kaak lijkt te stellen, is het - zodra het om de rechten van het kind gaat - veronachtzamen of verbloemen van het juridische postulaat dat het bij mensenrechten om effectieve c.q. te effec-

DOEK, t.a.p., op p. 11.

24 DOEK, t.a.p.

25 Art. 26 Weens Verdragenverdrag: pacta sunt servanda.

26 Zo bepaalt art. 31, lid 4 Weens Verdragenverdrag: "Een term dient in een bijzondere betekenis verstaan te worden als vaststaat dat dit de bedoeling van de partijen is geweest.' En art. 32 noemt als aanvullend middel van uitlegging 'de omstandigheden waaronder het verdrag is gesloten.'

27 Katarina TOMASEVSKI, bespreking van LEBLANCs The Convention on the rights of the child; United Nations lawmaking on human rights, Lincoln/London 1995, NQHR 1996/1 ('Book reviews'), pp. 111-115, op p. 111. 
tueren rechten gaat, niet om mooie woorden, goede bedoelingen, fooien of gunsten. Schrijvers over de (mensen)rechten van het kind lijken soms volledig het feit te ignoreren dat de fundamentele behoeften/belangen van kinderen - in het bijzonder het basale, centrale, primordiale persoonswordingsbelang van het kind als conditio sine qua non voor de uitoefening van de rechten van de mens, ja als conditio sine qua non voor menselijke ontplooiing en de ervaring aan zichzelf en ten opzichte van de medemens van de menselijke waardigheid - verre van volledig zijn geoperationaliseerd en gejuridiseerd. Vaker schijnen deze schrijvers stilzwijgend uit te gaan van de fictie dat het met betrekking tot kinderen in vergelijkbare mate om gepositiveerde en gedetailleerde rechten zou gaan als dat ten aanzien van de behoeften/belangen van volwassenen het geval is. Slechts de handhaving van die rechten zou in sommige landen - ten gevolge van armoede en onderontwikkeling - ernstig te kort schieten. Over de rechten van het kind kan evenwel niet zinvol geschreven worden zonder explicitatie van het postulaat van rechtsverfijning. Veel schrijvers bevinden zich evenwel in een vicieuze cirkel die slechts door rechtsverfijning zelf lijkt te kunnen worden doorbroken. Pas bij serieuze en stelselmatige rechtsverfijning treedt immers duidelijk aan het licht dat (zoals TOMAŠEVSKI stelt ${ }^{28}$ ) ...

'(...) similarly to the rights of women, rights of the child reach deeply into the private sphere and challenge relations within the family, between parents and children. Governments, the usual target of safeguards against abuse of power, are in this area granted powers to insist on changes within the family and society. This stretches human rights far beyond their "traditional" role and necessarily generates conceptual problems, evidenced in the large number and wide scope of reservations, but as yet unsolved.'

In hoeverre is er ten aanzien van het Verdrag inzake de rechten van het kind sprake van 'reservations' (voorbehouden) die het postulaat van rechtsverfijning in zoverre ondermijnen dat van een juridisch instrument, althans van een verdrag dat de aanduiding 'rechten van het kind' met recht en reden in zijn titel draagt, niet meer kan worden gesproken? Anders gezegd: in hoeverre heeft TOMAŠEVSKI, als het om het Verdrag inzake de rechten van het kind gaat, met haar laatste hierboven aangehaalde woorden gelijk? Hoewel deze vraag zich slechts voorlopig laat beantwoorden zolang we de inhoud van het Verdrag niet nader hebben geanalyseerd, besteden we aan het vraagstuk van de voorbehouden - nu TOMAŠEVSKI ons die handschoen heeft toegeworpen - op deze plaats toch enige aandacht. 


\section{Voorbehouden}

TOMASEVSKI heeft in zoverre gelijk dat er inderdaad verregaande (althans potentieel verregaande) 'reservations' (voorbehouden, al of niet in de vermomming van interpretatieve verklaringen) zijn gemaakt door verschillende niet-westerse (islamitische) alsook door enkele westerse staten (Andorra, Liechtenstein, Nederland, welk laatste land in de vorm van een verklaring). ${ }^{29}$ Deze voorbehouden, die het nationale recht in algemene en vage zin voorrang willen verlenen boven het internationale, zijn mijns inziens regelrecht in strijd met de grondslag - ik zou bijna zeggen: met 'zin en strekking' - van het verdragenrecht. ${ }^{30}$

Vgl, met betrekking tot (het rechtskarakter van) deze en andere gemaakte voorbehouden: William A. SCHABAS, 'Reservations to the Convention on the rights of the child,' HRQ $1996 / 2$, pp. 472-491.

Vgl voor wat de Nederlandse 'verklaring' betreft, bijlage I (Verdrag inzake de rechten van het kind) bij art. 22 (beschenming van (alleenstaande) minderjarige asielzoekers). In de in de desbetreffende noot vermellde Tractatenbladen vindt men ook de voorbehouden(/verklaringen) van Liechtenstein en Andorra respectievelijk de door Nederland (de pot verwijt de ketel ...) tegen deze voorbehouden gemaakte bezwaren, te weten resp. Trb. 1996, 188, p. 6 nt. 5 en 6 , en Trb. 1997, 83, pp. $3 / 4$ (nog eens herhaald in Trb. 1998, 62, p. 4 nt. 2). De (hier gewraakte) Nederlandse verklaring luidt (voor zover hier van belang; curs. $j w$ ): "With regard to article 22 of the Convention, the Government of the Kingdom of the Netherlands declares (...) that it is of the opinion that the obligation imposed under the terms of this article does not prevent the submission of a request for admission from being made subject to certain conditions, failure to meet such conditions resulting in inadmissibility (...)."

Zie hierna in de hoofdtekst voor (de tekst van) het Nederlandse bezwaar (dezelfde pot maar nog zwartere ketels) tegen de voorbelhouden van enkele nietchristelijke staten.

30 LIJNZAAD drukt hetzelfde net andersom uit: 'Acting in contravention of general rules of treaty law is contrary to the object and purpose of any treaty.' (Liesbeth LIJNZAAD, Reservations to UN-Human [sic, jw] rights treaties: Ratify and nim? Diss. Maastricht, Dordrecht etc. 1994, p. 363.) Tot die 'general rules' rekent zij kennelijk het lex scripta-beginsel (a.w., pp. 363/364), dat eist dat een partij het contract niet op losse schroeven zet door de inhoud der verbintenis of de aard van zijn gebondenheid in nevelen te hullen. In mijn optiek wordt hier de bijl gezet aan het pacta sumt servanda. En daarmee aan de natuurrechtelijke grondslag van het hele internationale recht. Een voorbehoud dat op elk willekeurig moment een streep kan zetten door een internationalrechtelijke verplichting onder verwijzing naar de (zojuist gewijzigde) nationale wetgeving of (zojuist door religieuze exegese tot klaarheid gebrachte) beginselen van nationaal recht, is een clawback clause met wel heel grote klauwen. Een dergelijke clausule ontneemt het rechtskarakter aan het internationale recht, maakt het tot instrument van nationale en internationale politiek. En zet daarmee de klok terug naar de volkenrechtelijke middeleeuwen na GRoTIUS.

Naar mijn mening zou ten aanzien van traitës-lois, zoals mensenrechtenverdragen, 
Voorbehouden mogen niet in strijd zijn met 'object and purpose' (zin en strekking, doel en wezen) van het verdrag. De verplichting zin en strekking van het verdrag niet te frustreren, dat wil zeggen het verdrag naar zijn geest te respecteren, ${ }^{31}$ geldt niet alleen ten aanzien van ondertekende maar nog niet geratificeerde c.q. in werking getreden verdragen (art. 18 Weens Verdragenverdrag), maar ook ten aanzien van het maken van voorbehouden (art. 19 aanhef en onder $c$ Weens Verdragenverdrag). Het feit dat men, gezien de statenpraktijk, de zin-en-strekking-clausule tot de juridische 'zalvende bepalingen's2 zou kunnen rekenen, maakt haar nog niet geheel betekenisloos. Een mensenrechtenconventie wordt immers in haar hart getroffen door 'reservations indicating the prevalence of national legislation in favour of [dat wil niet zeggen ten faveure, maar ten detrimente van, $j w]$ the Convention. ${ }^{33}$ De westerse $\operatorname{staten}^{34}$ hebben

die rechtstreeks raken aan de (rechts)positie van burgers, zelfs een verzwaarde 'zin-en-strekking'-test dienen te gelden, overeenkomstig het strafrechtelijke lex certa-beginsel (Bestimmtheitsgebot). Bij vage bepalingen c.q. voorbehouden dient dan het beginsel in dubio pro reo (of liever: in dubio pro civibus) c.q. het contra proferentem-beginsel te worden toegepast (dat wil zeggen interpretatie ten nadele van de partij die van de zelf gecreëerde vaagheid wil profiteren).

31 Deze formulering maakt de verplichting niet tot een positieve (vgl. LiJNZAAD, a.w., p. 363). Het getuigt immers niet van respect, noch voor het internationale (verdragen)recht, noch voor zijn (toekomstige) verdragspartners, het verdrag ais verdrag ('the treaty qua treaty') dan wel de inhoud van het verdrag ('the content of the treaty') te ondermijnen (LIJNZAAD, t.a.p.) door de 'raison d"être' ervan (LINZAAD, a.w., p. 59) te negeren en aldus te saboteren. Met als bedoeld of onbedoeld gevolg dat het verdrag - en en passant het verdragenrecht - tot in zijn kern wordt aangetast.

32 De term is van SOUDIJ, die hem overigens in een geheel andere context hanteert, namelijk met betrekking tot de eerste bepaling van de NIP-code (de beroepscode van het Nederlands Instituut van Psychologen), volgens welke de zorgvuldige psycholoog dient te handelen 'naar de inhoud en de geest van de beroepscode.' (K.A. soudiN, Psychologen en beroepsethiek, Lisse 1995, p. 97.) Een jurist zal met deze bepaling minder moeite hebben omdat voor hem of haar de 'analogische' benadering in beginsel meer voor de hand ligt dan een uitleg en toepassing naar de letter ('a contrario'), los van de 'geest' die waart in systeem, context, geschiedenis en teleologie. Kernachtig is dit verwoord in art. 31, lid 1 Weens Verdragenverdrag: "Een verdrag moet te goeder trouw worden uitgelegd overeenkomstig de gewone betekenis van de termen van het Verdrag in hun context en in het licht van wezen en doel van het Verdrag.' Ook bij de uitlegging dient de geest van het verdrag te worden gerespecteerd. Een geest die zich bij toekenning van directe werking door de nationale rechter laat materialiseren in jurisprudentie.

33 LIJNZAAD, a.w., p. 364.

34 Zweden, Noorwegen, Denemarken, Portugal, Duitsland, Oostenrijk, België, Italië, Ierland, Nederland, maar ook de "nieuwe westerse" staten 'Tjechoslowakije (later 
dan ook juist tegen zulke clawback-voorbehouden ${ }^{35}$ bezwaar gemaakt. Zo luidt - in bewoordingen die aan duidelijkheid niets te wensen overlaten - het bezwaar van Nederland: $:^{36}$

'De aanvaarding [door ratificatie, jw] door het Koninkrijk der Nederlanden geschiedde onder (...) het volgende bezwaar: (...)

"With regard to the reservations made by Djibouti, Indonesia, Pakistan, the Syrian Arab Republic and Iran upon ratification:

The Government of the Kingdom of the Netherlands considers that such reservations, which seek to limit the responsibilities of the reserving State under the Convention by invoking general principles of national law, may raise doubts as to the commitment of these States to the object and purpose of the Convention and,

de Slowaakse republiek) en Finland.

35 Zo luidt het voorbehoud van Djibouti (Tractatenblad 1995, nr. 92, p. 9 nt. 5): [Le Gouvernement de la République de Djibouti ne se considérera pas] liée [sic, jw] par les dispositions ou articles incompatibles avec sa religion, et ses valeurs traditionnelles.' Indonesië verklaart zijn grondwet ten aanzien van de rechten van het kind tot het hoogste recht (Trb. 1990, nr. 170, p. 32 nt. 5). Iran behoudt zich het recht voor bepalingen of artikelen van het Verdrag die niet verenigbaar zijn met islamilische wetten en de van kracht zijnde mationale wetgeving, niet toe te passen (Trb. 1995, nr. 92, p. 20 nt. 35). Pakistan maakt het voorbehoud dat "[p]rovisions of the Convention shall be interpreted in the light of the principle of Islamic laws and values ${ }^{*}$ (Trb. 1995, nr. 92, p. 7 nt. 2). Syrië heeft voorbehouden bij de verdragsbepalingen die niet in overeenstemming zijn met de Syrische wetgeving en met de islamitische sharia-beginselen (Trb. 1995, nr. 92, p. 17 nt. 32). Aldus maken verschillende landen het internationale recht ondergeschikt aan nationale moraaltheologie. Volgens RUTTEN zijn mamelijk "[r]echtswetenschap en moraaltheologie (...) in de Isllam in beginsel eén.' (Susan RUTTEN, Moslims in de Nederlandse rechtspraak, Kampen 1988, p. 18.) En wat is in die landen het verschil tussen moraaltheologie en politiek? Hoewel hetzelfde ook gezegd c.q. gevraagd zou kunnen worden met betrekking tot de staat Vaticaanstad - die bij ratificatie de verklaring heeft afgelegd niet van plan te zijn "to prescind in any way from its specific mission which is of a religious and moral character" (Trb. 1990 , nr. 170, pp. 31/32 nt. 1) - , is er evenwel dit verschil dat Vaticaanstad geen rechtsmacht over (ouders en) kinderen uitoefent, en dus zijn moraaltheologie (die de indruk wekt woornamelijk sexueel van aard te zijn) niet dwingend kan opleggen, terwijl in de overige 'clawback-staten' de pretens exclusieve binnenlandse rechtsmacht zich over tientallen duizenden of zelfs miljoenen kinderen uitstrekt. Ontwikkelingshulp ten behoeve van deze kinderen, waarvoor het Verdrag in een rechtsbasis voorziet (vgl. art. 4 , art. 17 sub b, art. 23 , lid 4, art. 24 , lid 4, art. 28 , lid 3 VRK), wordt aldus losgekoppeld van mensenrechtelijke interventie ten aanzien van kinderen. Althans, dat zou één van de (mogelijke) bedoelingen van de clawback-staten kunnen zijn.

36 Tractatenblad 1995, nr. 92, pp. 20-21 nt. 37, op p. 20 (aanhef) en p. 21 (onder 'Bezwaar'). Overigens volgt het Nederlandse bezwaar bijna woordelijk het bezwaar van Zweden tegen het voorbehoud van Indonesië (vgl. Trb. 1995, nr. 92 , p. 6 nt. 1). 
moreover, contribute to undermining the basis of international treaty law. It is in the common interest of States that treaties to which they have chosen to become parties, should be respected, as to object and purpose, by all parties. The Government of the Kingdom of the Netherlands therefore objects to these reservations. This objection does not constitute an obstacle to the entry into force of the Convention between the Kingdom of the Netherlands and the aforementioned States"."

Afgezien van de kennelijk zeer omstreden algemene clawback-voorbehouden van met name islamitische staten, zijn er evenwel nauwelijks of geen (en zeker geen verreikende) bijzondere voorbehouden gemaakt - hetzij door westerse ${ }^{37}$ hetzij door niet-westerse staten - bij bepalingen van het Verdrag die zulke voor een adequaat functioneren van de Trias pedagogica essentiële rechten c.q. verplichtingen bevatten ${ }^{38}$ als art. 2 (gelijkheidsbeginsel), art. 3 (het belang van het kind, toezicht op ouders en hulpverleners), art. 4 (resultaats- respectievelijk uiterste-inspanningsverplichtingen van de staat), art. 5 (bevoegdheden en plichten van de ouders ter zake van leiding en begeleiding naar de mate van de zich ontwikke-

37 Wat Nederland betreft: ons land heeft voorbehouden gemaakt bij de artt. 26, 37 en 40 van het Verdrag (Trb. 1995, 92, pp. 20-21 nt. 37; vgl. ook Stb. 1994, 862). Deze voorbehouden betreffen het sociale (zekerheids)recht (geen zelfstandig recht op uitkeringen voor minderjarigen) en het straf- en strafprocesrecht (toepassing van volwassenenstrafrecht mogelijk vanaf 16 -jarige leeftijd; kleine vergrijpen kunnen worden berecht zonder advocaat en zonder mogelijkheid van hoger beroep). Wat men ook van deze voorbehouden mag denken, niet kan worden gezegd dat zij de sociaal-pedagogische kernrechten van het (jonge) kind raken. Deze constatering doet niet af aan het feit dat ernstige juridische (niet alleen juridisch-technische maar, afhankelijk van de concrete gevolgen voor de persoonswording van met name alleenstaande minderjarige asielzoekers, ook juridischethische) bezwaren kunnen worden ingebracht tegen de 'verklaring' die Nederland heeft afgelegd met betrekking tot art. 22 VRK (zie hierboven en bijlage I). Anders (althans ogenschijnlijk) KOREN (Marian KOREN, Tell me! The right of the child to information, diss. Amsterdam, Den Haag 1996, p. 231 bij nt. 88), die de indruk wekt (zonder nadere specificatie of argumentatie) als zouden staten door middel van voorbehouden en verklaringen ouderlijke rechten zoveel mogelijk hebben willen sauveren. Wellicht wreekt zich (ook) hier evenwell het gebruik van de term 'rechten' ('the rights of parents'; vgl, het voorbehoud van de Heilige Stoel) in plaats van - al naar gelang hetgeen bedoeld is - hetzij 'bevoegdheden' ("parental authority'; vgl. de verklaringen van Polen, Singapore en Kiribati) hetzij 'prerogatieven' (traditionele 'rechten'/praktijken). Uiteraard maakt het nogal wat verschil of men bevoegdheden wil 'sauveren,' om ouders in staat te stellen hun verantwoordelijkheden waar te maken, dan wel prerogatieven, om alles zo veel mogelijk bij het oude te laten. Het is ook mogelijk dat KOREN vooral de burgerlijke rechten op het oog heeft gehad, in het bijzonder art. 1.4 (de zeer gevoelig liggende godsdienstvrijheid; vgl. a.w., pp. 312-323). 
lende vermogens van het kind), art. 6, lid 2 (waarborging van de ontwikkeling van het kind), art. 9 (scheiding van kind en ouders alleen indien noodzakelijk in geval van mishandeling of verwaarlozing van het kind), art. 12 (de visie van het kind, hoorrecht), art. 16 (bescherming van de lichamelijke en geestelijke integriteit van het kind), art. 18 (primaire opvoedingsverantwoordelijkheid van beide ouders, secundaire opvoedingsverantwoordelijkheid van de staat in de vorm van sociaal-pedagogische voorzieningen), art. $19^{39}$ (bijzondere bescherming tegen kindermishandeling met name door brede opvoedingsondersteunings- en preventie-programma's, gezinsinspectie, meldingsregeling, gezinsonderzoek, verwijzing, behandeling, follow-up en, zo nodig, juridische interventie), art. 20 (verzwaarde zorgverplichting van de staat bij uithuisplaatsing, pleeggezinplaatsing e.d.m.), art. 24 (gezondheidszorg, waaronder pre- en postnatale bemoeienis met moeders; afschaffing van schadelijke 'opvoedkundige' praktijken), art. 25 (periodieke evaluatie bij uithuisplaatsing), art. 27 (levensstandaard die toereikend is voor de algemene ontwikkeling van het kind), artt. 34-36 (bescherming tegen sexueel misbruik en andere vormen van exploitatie), art. 37 (vrijwaring van onmenselijke of vernederende behandeling of bestraffing), en art. 39 (reparatie/rehabilitatie). ${ }^{40}$

Waar het de sociaal-pedagogische essentie (en potentie) van het Verdrag betreft, heeft TOMAšEVSKI dus veel minder gelijk. Deze is niet of nauwelijks door voorbehouden aangetast. Op deze plaats zullen we in het midden laten of hieraan vooral onnadenkendheid (in de zin van thet zal zo'n vaart niet lopen') of overmoed van staten (in de zin van 'de formuleringen zijn vaag en vrijblijvend, de verplichtingen hooguit program-

Ten aamzien van art. 19 (en art. 37) VRK is slechts een interpretatieve verklaring afgellegd door Singapore, welke in het bijzonder ziet op de toepassing van lijfstraffen (vgl. UN doc. CRC/C/2/Rev.5 d.d. 30 juli 1996, pp. 30/31; overigens niet terug te vinden in de index op p. 54; Trb. 1996, 188, p. 9).

40 Vgl. Alastair BISSETT-JOHNSON, "What dit States really agree to? - Qualifications of signatories to the United Nations Convention on the rights of the child," The Intemational Joumal of Children's Rights (IJCR) 1994/4, pp. 399-411, op pp. 401409 (Table I) en p. 411. (Table 3). De tabellen geven de stand van zaken weer per ultimo 1992. Op dat moment waren 127 staten partij bij het Verdrag (t.a.p., op p. 399 nt. 2). Tractatenblad 1990, nr. 170, en 1995, nr. 92 vermelden de staten die partij zijn geworden tot aan de Nederlandse ratificatie d.d. 6 februari 1995. Bestudering van de in de tractatenbladen weergegeven voorbehouden leidt niet tot een andere dan de in de tekst gegeven (algemene) conclusie. (Vgl. ook UN doc. $\mathrm{CRC} / \mathrm{C} / 2 /$ Rev. 5 d.d. 30 juli 1996 , pp. 10-55, voor een volledig overzicht van alle gemaakte voorbehouden, verklaringen, bezwaren e.t.q. per 30 juni 1996.) Zie voor een 'macroscopisch' overzicht Lawrence J. LEBLANC, 'Reservations to the Convention on the rights of the child: a macroscopic view of state practice, IJCR 1996/4, pp. 357-381. 
matorisch en adhortatief van aard') ten grondslag ligt. Want wat daar ook van zij, het postulaat van rechtsverfijning - sociaal-pedagogische rechtsverfijning binnen de Trias pedagogica -, een postulaat dat inherent is aan de notie 'rechten van het kind," is, los van de exacte inhoud van de verdragsverplichtingen, door aard of tal van voorbehouden bij het Verdrag inzake de rechten van het kind niet geëcarteerd.

Met betrekking tot die 'exacte' inhoud - die we zo dadelijk nader gaan bekijken - beschikken we over een pedagogisch criterium: het recht van het kind op (minimale) persoonswording, dat we met des te meer recht als lux interpretum, ${ }^{41}$ als uitleg-sleutel, mogen gebruiken naarmate aannemelijk zal blijken dat het recht van het kind op (minimale respectievelijk optimale) persoonswording' ook als fundamenteel achterliggend beginsel van het Verdrag inzake de rechten van het kind kan worden beschouwd.

Op het eerste gezicht is er geen reden eraan te twijfelen dat we die sleutel in het Verdrag zelf zullen vinden. Het hanteren ervan zal ons in staat stellen de steven te wenden en Scylla en Charybdis achter ons te laten. Een universeel geldend verdrag is daarbij het vaartuig waarin we zeil kunnen zetten naar de horizon waarachter operationalisering van de rechten van het kind opdoemt. Over de zeewaardigheid van het schip hoeven we ons, als we CANTWELL mogen geloven, geen zorgen te maken: ${ }^{42}$

'By its genesis, scope, content and very existence, this Convention ranks as a landmark in efforts on behalf of children. (...)

There is a well known general rule that the greater the awareness of rights, the more chance there is of securing respect for them. Trying to make known and explain an incomplete set of provisions to be found in a disparate selection of instruments, is not likely to be effective. Through the Convention, the human rights of the child are clear, coherent and comprehensive. That is a pre-condition for their being respected.'

Hoe 'clear, coherent and comprehensive' de rechten in het Verdrag inzake de rechten van het kind zijn, zal gaande de reis moeten blijken.

42. Nigel CANTwELL, "The origins, development and significance of the United Nations Convention on the rights of the child,' in: Sharon DETRICK (ed.), The United Nations Convention on the rights of the child; A guide to the travaux préparatoires,' Dordrecht (etc.) 1992, pp. 19-30, op pp. 27 en $29 / 30$. 


\section{De 6 P's uit het Verdrag}

We keren terug naar de inhoud van het Verdrag. Het Verdrag inzake de rechten van het kind bevat zowel economische, sociale en culturele ('esocul'-) als burgerlijke en politieke ('bupo'-), alsook humanitair(rechtelijk)e rechten (rechten die van toepassing zijn in situaties van gewapend conflict $\left.^{43}\right) .^{44}$ De klassieke ('bupo'-) en sociale ('esocul'-)rechten worden in het internationale recht in toenemende mate als 'universal, indivisible and interdependent and interrelated' gezien. ${ }^{45}$ Het Verdrag inzake de rechten van het kind, waarin, zoals gezegd, burgerlijke, sociale, politieke èn humanitaire rechten (art. 38 VRK) - voor het eerst in een internationaal verdrag - samenvloeien, illustreert dat de humanitaire rechten niet buiten deze ontwikkeling staan. ${ }^{46}$

Deze laatste categorie overigens in nogal teleurstellende mate. De leeftijdsgrens van 15 jaar die het Verdrag (in art. 38, lid 2) bevat voor het onder de wapenen mogen komen wan kinderen, verdraagt zich blijkens de verklaringen van sommige staten niet met zin en strekking van het Verdrag (vgl. LEBL.ANC, a.w., pp. 148-156, op pp. 153/154). Art. 38 blijft zelfs onder de norm van art. 4, lid 3 onder c van Additioneel Protocol II bij de Verdragen van Genève. Een protocol bij het Verdrag inzake de rechten van het kind om deelname van kinderen aan gewapende conflicten uit te sluiten, is inmiddels in de maak. Zie Rachel BRETT, 'Child soldiers: law, politics and practice,' The Intemational Joumal of Children's Rights 1996/2 (Special issue 'Children in armed conflict'), pp. 115-128, op pp. 117-118 en $123-128$.

44 Vgl. VAN BUEREN, The intemational law on the rights of the child, a.w., p. 16. Het Verdrag inzake de rechten van het kind brengt niet alleen bestaande standaarden in één instrument bijeen maar creëert tevens - aldus VAN BUEREN zowel nieuwe rechten van het kind als nieuwe verplichtingen op het punt van voorzieningen ten behoeve van kinderen en met betrekking tot hun bescherming. Vgl. World Conference on Human Rights: Vienna Declaration and Programme of Action, UN doc. A/conf157/23, part I, par. 5; 25 juni 1993 (opgenomen in: Gudmundur ALFREDSSON, Katarina TOMASEVSKI (eds.), A thematic guide to documents on the human rights of women; Global and regional standards adopted by intergovemmental onganizations, intemational non-governmental organizations and professional associations, The Raoul WALLENBERG Institute Human Rights Guides vol. 1, Den Haag etc. 1995, pp. 20-25; citaat op p. 21). Vgl. met betrekking tot de 'unity and indivisibility of human rights' Fons COOMANS, 'Economic, social and cultural rights,' in: dez., Economic, social and culturat rights; Marlies GALENKAMP, Collective rights, Reports commissioned by the Advisory Committee on Human Rights and Foreign Policy of the Netherlands, SIM Special 16, Utrecht 1995, pp. 3-51, op pp. 4-6.

46 In dit verband kan ook gewezen worden op de benoeming en het mandaat van de Special Rapporteur on the Protection of Children in Ammed Conflict (UN doc. A/ res $/ 48 / 157,20$ dec. 1993), mevrouw Graca MACHEL. Alsook op de Declaration of Minimum Humanitarian Standards, de zogenaamde Turku-Declaration, van 2 dec. 1990, opgesteld door een groep van internationale deskundigen (UN doc. $\mathrm{E} / \mathrm{CN} .4 /$ Sub.2/1991/55; AIIL 1991/2, pp. 375-381), welke is gebaseerd op een combinatie 
Nu klassieke en sociale mensenrechten - in vredes-dan wel in oorlogstijd - steeds meer hun onderscheidende karakter verliezen (alle drie categorieën vergen immers een actief optreden van de overheid, en niet louter een 'respecteren' in passieve zin, terwijl er steeds meer oog voor is dat zij elkaar onderling aanvullen en versterken en geen enkele categorie zelfstandige betekenis heeft), ligt het voor de hand naar andere, meer zinvolle indelingen te zoeken. Met betrekking tot het Verdrag inzake de rechten van het kind hebben sommige auteurs hierbij een grote creativiteit aan de dag gelegd. Een in de literaturur inmiddels veelvuldig gehanteerde indeling is die in de zogenaamde 3 P's (provision, protection, participation). ${ }^{47}$ Hieraan kunnen evenwel gemakkelijk nog 3 (of zelfs 4 ) P's worden toegevoegd. We kunnen alsdan onderscheiden:

- Provisionaire rechten: materiële (basis-)aanspraken (zoals gezonde voeding, lichamelijke en geestelijke gezondheidszorg, onderwijs, speelvoorzieningen, sociaal-pedagogische voorzieningen);

- Protectionele rechten: daadwerkelijke, effectieve bescherming van de lichamelijke en geestelijke integriteit (met inbegrip van de persoonswording);

- Participatoire (waaronder Politieke) rechten: ${ }^{48}$ 'erbij horen,' gehoord worden, meetellen, een stem hebben: hoorrecht, het hebben van een eigen rechtsingang, recht op gezinstaken, kiesrecht;

- Preventie-rechten: aanspraken (meer specifiek) gericht op het voorkomen van beschadiging van de persoonswording (Pedagogisch Onderwijs, opvoed-Geld, Opvoedingsondersteuning);

- Pedagogische rechten: recht op leiding en begeleiding bij de persoonswording naar de mate van de zich ontwikkelende vermogens van het kind, recht op pedagogische interventie (persoonswordingsvindicatie);

- Punitieve rechten: ${ }^{49}$ door het strafrecht gehandhaafde/te handhaven

van humanitair recht en mensenrechten. Vgl ook Allan ROSAS, Monika SANDVIK, 'Armed conflicts,' in: Asbjørn EIDE, Catarina KRAUSE, Allan ROSAs (eds.), Economic, social and' cultural rights; A textbook, Dordrecht (etc.) 1995, pp. 341-352, op p. 342, waar de auteurs stil staan bij 'the fact that humanitarian law has increasingly become related to human rights law.'

47 LEBLANC (a.w., p xviii) schrijft de 3 p's-classificatie toe aan HAMMARBERG. Vgl. Thomas HAMMARBERG, 'The UN Convention on the rights of the child - and how to make it work,' HRQ $1990 / 1$, pp. 97-105, op p. 100.

48. HAMMARBERG is van oordeel dat commentatoren 'somewhat simplistically' spreken van een "participation element in the CRC." (Thomas HAMMARBERG, "Children,' in: Asbjorn EIDE, Catarina KRAUSE, Allan ROSAS (eds.), Economic, social and cultural rights; A textbook, Dordrecht etc. 1995, pp. 289-307, op p. 292.)

Hiermee is het Verdrag inzake de rechten van het kind - anders dan het Vrouwen- en met name het Rassenverdrag - bepaald niet kwistig. Slechts art. 32, lid 2 sub c VRK (arbeidsrechtelijke bescherming van het kind ook strafrechtelijk te 
rechten (vrijwaring van mishandeling, verwaarlozing, geestelijke kwelling en sexueel misbruik; vrijwaring van economische en sexuele exploitatie; vrijwaring van verlating bij hulpbehoevendheid/recht op melding; vrijwaring van slechte hulpverlening/kunstfouten; vrijwaring van lijfstraffen).

Het zou een boeiende exercitie zijn de verdragsartikelen over deze zes (à zeven) P's te verdelen (vooropgesteld dat daarbij een retrograde P-woord: overlap, ons niet al te zeer parten speelt) om te bezien hoe vol of (vrijwel) leeg de zes categorieën zijn. In het kader van deze studie zullen we ons echter houden aan de driedeling in welzijnsrechten (optimumrechten), beschermingsrechten (minimum-rechten) en zelfbepalingsrechten (kind-als-subject-rechten), waarbij ad libitum een nadere P-classificering kan worden aangebracht.

Voor we daartoe overgaan, is het nuttig te vermelden dat VERHELLEN $^{50}$ zowel een traditionele indeling geeft, namelijk een indeling in (1) civiele ofwel burgerlijke rechten (waaronder de 'integriteitsrechten'), (2) politieke (ofwel burger- en burgerschaps ${ }^{51}$ ) rechten, (3) economische rechten, (4) sociale rechten en (5) culturele rechten; als een indeling in doelstellingen: (1) zelfbeschikkingsrechten, (2) beschermingsrechten en (3) specifieke rechten (niet te verwarren met het hierboven gemaakte onderscheid tussen welzijnsrechten, beschermingsrechten en zelfbepalingsrechten); alsook de $3 P^{\prime} s$-indeling.

waarborgen) kan tot de punitieve rechten worden gerekend. Vgl. daarentegen art. 4 aanhef en onder a en b IVUR en art. 2 aanhef en onder b VUDV. Vgl. aok cuDV-aanbeveling 19 (1992), waarin gesproken wordt van '(...) effective legal measures, including penal sanctions (...)." Zie Andrew BYRNES, "Women, feminism and international human rights law - methodological myopia, fundamental flaws or meaningful marginalisation?" In: The Australian Year Book of Intemational Law 1992, pp. 205-240, op p. 239, nt. 101. Zie ook Lucy WILLEMS, 'Geweld tegen vrouwen: CEDAW-Algemene Aanbeveling nr. 19,' Actualiteitenkatern Nemesis $1995 / 5$, pp. $26-30$, op p. 29 r.k. (i.f.).

50 VERHELLEN, Verdrag inzake de rechten wan het kind, a.w., pp. $90-92$ (derde druk, 1997, pp. 96-98).

51 De - steeds meer burgerrecht krijgende - vertaling van civil and political rights door burgerrechten en politieke rechten (in plaats van door burgerlijke en politieke rechten) is m.i. zowel onvolledig als tautologisch. Burgerlijke rechten zien (van oorsprong) meer op individuele vrijheden in de rechtsstaat ("afweerrechten"); politieke rechten (burger- en burgerschapsrechten) zien (van oorsprong) meer op participatie in de democratie (vgl. Manfred NOWAK, UNO-Pakt über bürgerliche und politische Rechte und Fakultativprotokoll; CCPR-Kommentar, Kehl etc. 1989, pp. xwi, 357, 471 en 477). In deze opvatting staat de vertaling 'burgerrechten en politieke rechten' gelijk aan de aanduiding van '(vrije) vogels en pluimvee' als "kippen en pluimvee." 
VAN BUEREN hanteert een 4 P's-indeling. ${ }^{52} \mathrm{Zij}$ splitst protection in prevention en protection om de unieke en speciale betekenis van preventieve rechten/beschermingsbepalingen in het Verdrag te benadrukken. Volledigheidshalve vermeld ik ook nog de indeling van LEBLANC, ${ }^{53}$ die - in navolging van DONNELLY en HOWARD (1988) - survival rights, membership rights, protection rights en empowerment rights onderscheidt. ${ }^{54}$ DOEK, ten slotte, merkt op: $:^{5}$

'Kortom, het Verdrag [inzake de rechten van het kind] biedt het kind recht op de 3 P's Provision, Protection en Participation op een wijze (dat will zeggen met verduidelijking, explicitering) die niet in andere mensenrechtenverdragen is te vinden.'

10.2.1

Het kind als persoon-in-wording: welzijns-en beschermingsbepalingen in het Verdrag inzake de rechten van het kind

Twee zaken zijn van fundamenteel belang bij het speuren naar "persoonswording' in het Verdrag inzake de rechten van het kind. In de eerste plaats is dat de vraag naar het juridisch beschermingsgehalte van het Verdrag, de rechtswaarborgen die het bevat ten aanzien van het veiligheids- en ontwikkelingsbelang van het kind (bij voorkeur geformuleerd als zo concreet en gedetailleerd mogelijke verplichtingen van de staat en van ouders, althans verplichtingen die zo duidelijk mogelijk doel en middelen aangeven). In de tweede plaats is dat de vraag in hoeverre het Verdrag het kind ook als rechtssubject ziet, dat wil (om te beginnen) zeggen in hoeverre de fundamentele (pedagogische) belangen van het kind ook als subjectieve rechten van het kind zijn geformuleerd. 'Persoonswording' - zowel als optimum (zo rationeel, moreel, authentiek mogelijk: het ideaal van de redelijke, sociale en echte mens) als als minimum (gezinsinterventiecriterium) - is immers als recht van het kind geformuleerd. Anders gesteld: hoe materialiseert het Verdrag de beschermingsgedachte en de rechtengedachte?

Geraldine VAN BUEREN, The international law on the rights of the child, a.w., p. 15. LEBLANC, a.w., pp. xviii-xix.

54 Vgl. Jack DONNELLY, Rhoda E. HOWARD, 'Assessing national human rights performance: a theoretical framework, $H R Q 1988 / 2$, pp. 214-248, op pp. 214/215. J.E. DOEK, 'De ratificatie van het Verdrag inzake de rechten van het kind; enige beschouwingen over de mogelijke gevolgen voor de Nederlandse rechtspraktijk," NJCM-Bulletin $1995 / 1$, pp. 10-21, op p. 13 (curs. jw). 
Ter beantwoording van die vraag, gaan we bij onze speurtocht allereerst uit van de tweedeling: persoon-in-wording en persoon-in-wording. Bij persoon-in-wording (kind als kind en kind als 'persoon to be') ligt het hoofdaccent op de bescherming en het welzijn van het kind: kind als object van ouderlijke en/of statelijke verplichtingen, kind als 'voorwerp' van ouderlijke en collectieve zorg. Bij persoon-in-wording (kind als mens/ latere volwassene, kind als 'would be persoon') ligt het hoofdaccent op de zelfbepaling van het kind: kind als subject van rechten, kind als 'autonome' rechtendrager, kind als mens met (algemene en speciale) rechten. Uiteraard kan bij een (heel) jong kind nog nauwelijks of slechts in beperkte mate van 'zelfbepaling' sprake zijn. Zodra een bepaling evenwel als subjectief recht van het kind is geformuleerd, bestaat er in principe de mogelijkheid dat het kind vroeger of later een claim op reparatie doet gelden. In zoverre is er dan toch sprake van een (aanvankelijk sluimerend) element van zelfbepaling, van een persoon-in-wording, met het hoofdaccent op persóón - ons 'voorwerp' van onderzoek in de volgende (sub)paragraaf. In de onderhavige (sub-)paragraaf gaan we op zoek naar de persoon-in-wording in het Verdrag inzake de rechten van het kind.

Om een inzichtelijk en (dus) zo volledig mogelijk beeld te geven, passeren in beide subparagrafen alle (materiële) bepalingen van het Verdrag de revue. Bepalingen in de eerste subparagraaf keren slechts dan in de tweede subparagraaf terug indien er in de desbetreffende bepaling (artikel of artikellid) tevens of mede van een recht van het kind of van rechten van het kind sprake is.

\section{Preambulaire overwegingen}

Van de dertien preambulaire overwegingen zien er negen direct of zijdelings op het welzijn en/of de bescherming van het kind. Zij worden hieronder weergegeven, waarbij de relevante termen of passus zijn gecursiveerd.

[5.] Ervan overtuigd dat aan het gezin, als de kern van de samenleving en de natuurlijke omgeving voor de onplooiing en het welzijh van al haar leden en wan kinderen in het bijzonder, de nodige bescherming en bijstand dient te worden verleend zodat het zijn verantwoordelijkheden binnen de gemeenschap volledig kan dragen;

[6.] Erkennende dat het kind voor de volledige en hamonische ontplooiing van zijn persoonlijkheid dient op te groeien in een gezinsomgeving, in een sfeer van geluk, liefde en begrip;

[7.] Overwegende dat het kind volledig dient te worden voorbereid op het leiden van een zelfstandig leven in de samenleving, en dient te worden opgevoed in de geest wan de in het Handvest van de Verenigde Naties verkondigde idealen, en 
in het bijzonder in de geest van vrede, waardigheid, verdraagzaamheid, vrijheid, gelijkheid en solidariteit ${ }^{56}$;

[8.] Indachtig [het feit] dat de noodzaak wan het verlenen van bijzondere zong aan het kind is vermeld in de Verklaring van Geneve van de rechten van het kind van 1924 en in de Verklaring van de rechten van het kind aangenomen door de Algemene Vergadering op 20 november 1959, en is erkend in de Universele Verklaring wan de rechten van de mens, in het Internationaal Verdrag inzake burgerlijke en politieke rechten (met name in de artikelen 23 en 24 ), in het Internationaal Verdrag inzake economische, sociale en culturele rechten (met name in artikel 10) en in de statuten en desbetreffende akten van gespecialiseerde organisaties en internationale organisaties die zich bezighouden met het welzijn van kinderen;

[9.] Indachtig [het feit] dat, zoals aangegeven in de Verklaring van de rechten van het kind [van 1959], 'het kind op grond van zijn lichamelijke en geestelijke onrijpheid bijzondere waarborgen en zorg behoeft, met inbegrip van geèigende wettelijke bescherming zowel vóór als na zijn geboorte $e^{57}$;

Deze preambulaire overweging brengt antï-racisme, tolerantie ('gelijkheid"/"waardigheid'/"verdraagzaamheid"), anti-militarisme ("Vrede'), gemeenschapszin en mensenrechten ("vrijheid, gelijkheid en solidariteit") binnen het domein van de staatspedagogische (persoonswordings-) verantwoordelijkheid.

57 Behoudens het recht van de vrouw op zwangerschapsonderbreking als intentnationaalrechtelijke aangelegenheid. (Vgl. J.C.M. WILLEMS, 'Het VN-Kinderverdrag en het recht op abortus," NJB 1990, pp. 776-778.) HAMMARBERG merkt in dit verband op: "There are, however, several other aspects [other than abortion] of the protection and development of the unborn child which can be discussed on the basis of the CRC [such as] (...) health care for pregnant women. (...) It is important to encourage pregnant women to avoid the use of alcohol, drugs, and smoking. When tackling these problems it may not matter much whether action is based on a right to protection for the unborn child or the right of the born child to have a healthy beginning." (Thomas HAMMARBERo, "Children," in: Asbjorn EIDE, Catarina KRAUSE, Allan ROSAS (eds.), Economic, social and cultural rights; A textbook, Dordrecht etc. 1995, pp. 289-307, op p. 293.) Dat laatste is in zoverre juist dat ook een prenatale persoonswordingsvindicatie zeer wel denkbaar is. Weliswaar kan alleen een geboren kind (te gelegener tijd) een zelfstandige reparatie-claim uitoefenen, maar dat sluit op zich niet wit dat ook een foetus als rechtendrager zou kunnen worden aangemerkt. In een dergelijke conceptie (en daar wringt toch enigszins de theoretische schoen) zou de foetus dan wel het recht op overleven en ontwikkeling (survival and development) maar niet het recht op leven hebben (althans in landen waar de wrouw een meer of minder geclausuleerd recht op abortus heeft). Ik geef er dan ook de voorkeur aan foetale mishandeling (bijvoorbeeld door drug-, alcohol- of nicotine-misbruik), wegens de beschadiging van de ontwikkelingskansen van het kind, als een (prenatale) schending van de rechten van het kind, in het bijzonder van het recht van het kind op (optimale) persoonswording, te beschouwen. Ook hier is sprake van een misbruik van bevoegdheden. Het behoeft immers geen betoog dat het adagium dat wie het meerdere mag, ook het mindere is toegestaan, uitzondering lijdt ten aanzien van het 'jus vitae necisque' van de zwangere vrouw ten opzichte wan de vrucht. Uiter- 
[10.] Herinnerende aan de bepalingen van [a.] de Verklaring inzake sociale en juridische beginselen betreffende de bescherning en het welzijn vas kinderen, in het bijzonder met betrekking tot plaatsing in een pleeggezin en adoptie, zowel nationaal als internationaal; [b.] de Standaard minimumregels van de Verenigde Naties voor de toepassing van het [straf]recht op jongeren (de Pekingregels); en [c.] de Verklaring inzake de bescherming van vrouwen en kinderen in noodsituaties en gewapende conflicten;

[11.] Erkennende dat er, in alle landen van de wereld, kinderen zijn die in uitzonderlijk moeilijke omstandigheden leven, en dat deze kinderen bijzondere aandacht behoeven;

[12.] Op passende wijze rekening houdend met het belang van de tradities en culturele waarden van elk volk voor de bescherming en de harmonische ontwikkeling wan het kind;

[13.] Het belang erkennende van internationale samenwerking ter verbetering van de levessomstandigheden van kinderen in elk land, in het bijzonder in de ontwikkelingslanden. (...).

aard kan niet worden aangenomen dat het recht op abortus op een (a fortiori-) recht op foetale mishandeling aanspraak zou geven. En hoewel (om hetzelfde anders te zeggen) het recht op abortus - onder zekere temporele voorwaarden voorrang heeft boven het recht op leven (althans in alle onder meer om die reden modern c.q. geëmancipeerd geachte rechtsstelsels), heeft het (zelf)beschikkingsrecht van de vrouw geen voorrang boven het recht van het kind op (optimale) persoonswording (althans niet in een rechtsstelsel dat de aanduiding modern of geëmancipeerd ook enigermate verdient). Overigens acht ik een rechtsstelsel pas echt modern en geëmancipeerd als het zodanige sociaal-pedagogische voorzieningen kent - waaronder goede ouderschapswoorlichting en -vorming, geavanceerde vormen wan opvoedingsondersteuning en witgebreide pleeggezinszorg dat abortus daardoor in veel minder gevallen dan thans de enige "uitweg" lijkt. Dat lijkt mij per definitie een rechtsstelsel waar voldoende waarborgen voor verantwoord ouderschap bestaan, en waar door volwassenen meer claims op sociaalpedagogische voorzieningen worden gelegd dan op - desnoods of desgewenst met geavanceerde medische technieken geproduceerde - kinderen.

PIERS (Maria W. PIERS, Kindermishandeling en kindenmoord, Utrecht/Antwerpen 1980, p. 113) noemt het feit 'dat er tegenwoordig universele overeenstemming bestaat dat elk kind dat geboren wordt, het recht heeft om te leven' een 'werkelijke prestatie van deze eeuw.' Wellicht dat een volgende eeuw een soortgelijke prestatie levert met betrekking tot het foetale leven. Het moet echter uitgesloten worden geacht dat een dergelijke prestatie mogelijk is zonder het totstandbrengen van een uitgebreid stelsel van sociaal-pedagogische voorzieningen in de eeuw die voor ons ligt, zonder beschavingswerk binnen en rondom het gezin, zonder operationalisering van 'de rechten van het kind' - en dus van de plichten van volwassenen, van ouders en van de samenleving in haar geheel. Ik kan mij dan ook geen zinnige en zindelijke anti-abortus-lobby voorstellen die niet tegelijk een lobby vór de rechten van het kind is, en die ijvert voor de verwerkelijking van die rechten niet in de wolgende eeuw maar liefst nog in de luttele tijd die ons rest in de 'eeuw van het kind' die ten einde loopt. 


\section{Artikelen}

De volgende verdragsbepalingen regarderen in het bijzonder het welzijn en/of de bescherming van het kind (in het bijzonder relevante termen of passus zijn gecursiveerd):

- art. 2, lid 2 VRK: bescherming van het kind tegen discriminatie verband houdend met de sociale omstandigheden of politieke opvattingen van de ouders (het kind mag niet het slachtoffer worden van de sociale positie e.d. van de ouders ${ }^{58}$;

- art. 3, lid 1 VRK: het belang van het kind als leidend (verticaal, horizontaal en diagonaal ${ }^{59}$ ) welzijns- en beschermingsbeginsel, niet alleen voor (openbare en particuliere instellingen van) kinderbescherming en hulpverlening, maar ook voor rechter, bestuur èn wetgever (op centraal èn decentraal niveau);

- art. 3, lid 2 VRK: bescherming en zorg met het oog op het welzijn van het kind als algemene staatsplicht; de staat houdt daarbij rekening met bevoegdheden en plichten van de ouders (dat wil zeggen: de staat respecteert de bevoegdheden van ouders en ziet 'op afstand'60 toe op de naleving van ouderlijke verplichtingen: secundaire opvoedingsverantwoordelijkheid van de staat);

- art. 3, lid 3 VRK: bescherming/welzijn van kind en gezin in dier voege dat staten kwaliteit van en toezicht op hulpverlening en kinderbescherming waarborgen, in het bijzonder met betrekking tot het aantal personeelsleden en hun geschiktheid;

- art. 5 VRK: bescherming/welzijn van het kind in dier voege dat de ou-

Hieruit zou indirect (dat wil zeggen in samenhang met andere verdragswerplichtingen) een verplichting tot positieve discriminatic (voorkeursbehandeling, extra sociaal-pedagogische voorzieningen en financieel-pedagogische middelen ten behoeve) van kinderen/gezinnen in achterstandssituaties kunnen worden afgeleid. Verticaal in de relatie staat/overheid-kind; horizontaal: in de relatie particuliere instelling/met zorg belaste particulier-kind; diagonaal: in de relatie staat/overheid-ouders. Voor de horizontale werking (werking tussen burgers onderling) van 'het belang van het kind' in de (verticale) relatie ouders-kind zie art. 18, lid 1. Onder "toezicht op afstand" wordt in dic verband verstaan het recht en de plicht van de staat ouders/opvoeders te adviseren, te waarschuwen en aan te moedigen. Hieronder dient ook te worden begrepen het recht en de plicht van de stat opvoedingshulp aan te bieden. Deze laatste rechtsplicht stoelt mede op art. $1.8 \mathrm{en}$ art. $19 \mathrm{VRK}$. Het recht en de plicht van de staat te interveniëren (opvoedingshulp op te leggen) berust in het bijzonder op art. 19, Jid 2 VRK. Overigens is aanknopingspunt voor het aanbieden c.q. opleggen van opvoedingshulp niet ouderlijk plichtsverzuim of tekortschieten maar de (dreigende) schending van de rechten van het kind. Het kind dient (ten opzichte van andere kinderen) een 'faire kans' en een 'faire start' te krijgen, en van de ouders mag (en moet) daarbij een positieve en constructieve opstelling worden verwacht. 
ders verantwoordelijk zijn voor de leiding en begeleiding van het kind, in overeenstemming met diens zich ontwikkelende vermogens, bij de uitoefening door het kind van zijn rechten ${ }^{61}$; de staten respecteren de ouderlijke bevoegdheden en plichten op dit punt (zien met andere woorden 'op afstand' toe op de ouderlijke plichtsbetrachting);

- art. 6, lid 2 VRK: bescherming/welzijn van het kind in dier voege dat de staten in de ruimst mogelijke mate de overlevings- ${ }^{62}$ en ontwikkelingskansen (persoonswordingsoptimalisatie) ${ }^{63}$ van het kind waarborgen;

- art. 8, lid 2 VRK: bescherming en bijstand om de identiteit van het kind te herstellen (bij 'verduistering van staat'/wegmaken of achterhouden van afstammingsgegevens $\left.{ }^{64}\right)$;

61 Geven ouders geen deugdelijke leiding en begeleiding, en maken zij bijvoorbeeld inbreuk op het recht van het kind op privacy (art. 5 juncto art. 16 VRK), dan maken zij zich schuldig 'aan willekeurig en dus onrechmatig gedrag.' (J.E. DOEK, 'De ratificatie van het Verdrag inzake de rechten van het kind; enige beschouwingen over de mogelijke gevolgen voor de Nederlandse rechtspraktijk,' NJCM-Bullein 1995/1, pp. 10-21, op pp. 16/17; curs. jw.)

62 De term 'overleven' (survival) heeft 'a special meaning within the United Nations context, especially for [the WHO] and UNICEF. "Survival" include[s] growth monitoring, oral rehydration and disease control, breastfeeding immunization, child spacing [geboortenspreiding, jw], food, and female literacy' (UN doc. E/CN.4/ $1989 / 48$, p. 17, par. 88). HAMMARBERG merkt in dit verband op: "The word "survival" [in art. 6, lid 2 VRK] (...) originates in a proposal by UNICEF. The purpose was to introduce a dynamic aspect to the right to life [art. 6, lid 1 VRK], including the need for preventive action such as immunization.' (Thomas HAMMARBERG, 'Children,' in: Economic, social and cultural rights, a.w., pp. 289-307, op p. 292.)

63 Met betrekking tot ontwikkeling (development) stelt HAMMARBERG (t.a.p.y op p. 292 i.f.): "The term "development" adds a qualitative dimension to [art. 6]. It relates to the individual child and should be interpreted in a broad sense, referring not only to physical health, but also to mental, emotional, cognitive, social and cultural development.' Dat wil dus zeggen: ontwikkeling in de zin van (optimale) persoonswording.

Even verder voegt hij hieraan toe (HAMMARBERG, t.a.p., op p. 293): "Modern chill psychology has made clear how important the first days, weeks and months are for the future development of the child. This should also be considered in the implementation of Article 6 . Is is essential that the child from the very beginning has a possibility to relate to and communicate fully with the mother and/or another adult. Do all parents know these fundamental facts? Are they given a chance to be with their children? Recent surveys in several industrialized countries indicate that parent education is unsatisfactory and that time for children is a scarce commodity. Day-care centres, nursery and ordinary schools are other critical social environments for children in which it should be possible for children to develop their personalities."

64 Een problematiek die vroeger vooral speelde bij afstand/adoptie en thans (en in de nabije toekomst) vooral bij geanonimiseerde voortplantingsmethoden. Zie hierna par. 10.2 .2 onder art. 8 , lid $1 \mathrm{VRK}$. 
- art. 9, lid 1, tweede volzin VRK: scheiding van kind en ouders (alleen) indien noodzakelijk in geval van mishandeling of verwaarlozing van het kind (bescherming van het kind tegen de ouders desnoods door uithuisplaatsing van kind of ouder/ouders);

- art. 11 (lid 1 en 2) VRK: bescherming tegen (door maatregelen, waaronder verdragen, ter bestrijding van) internationale kinderontvoering; - art. 14, lid 2 VRK: bescherming/welzijn van het kind in dier voege dat de staten de ouderlijke bevoegdheden en plichten respecteren ("op afstand' toezien op de ouderlijke plichtsbetrachting) ter zake van de leiding en begeleiding van het kind, in overeenstemming met diens zich ontwikkelende vermogens, bij de uitoefening door het kind van zijn recht op vrijheid van gedachte, geweten en godsdienst;

- art. 17 VRK: bescherming/welzijn van het kind in de vorm van toegang tot informatie die bijdraagt aan de persoonswording/persoonlijkheidsvorming (het 'sociale, psychische en morele welzijn' en de 'lichamelijke en geestelijke gezondheid') van het kind; bescherming van het kind tegen (voor de persoonswording) schadelijke informatie ${ }^{65}$;

- art. 18, lid 1 VRK: bescherming/welzijn van het kind door het (doen) respecteren van het beginsel dat beide ouders gezamenlijk verantwoordelijk zijn voor de opvoeding en de ontwikkeling (persoonswording) van het kind; ouders hebben de primaire verantwoordelijkheid voor de opvoeding en de ontwikkeling (de persoonswording) van het kind; hun voornaamste zorg is het belang van het kind (als welzijnsbeginsel: de optimale persoonswording van hun kind);

- art. 18, lid 2 VRK: bescherming/welzijn van het kind in de vorm van (a.) passende bijstand aan ouders bij de uitoefening van hun pedagogische verantwoordelijkheden (uit te werken op basis van kernrechten als opvoedingsgeld en opvoedingsondersteuning) en (b.) ontwikkeling (en uitbouw) van (sociaal-pedagogische) instellingen, voorzieningen en diensten (voor kinderzorg);

- art. 18, lid 3 VRK: bescherming/welzijn van het kind in de vorm van kinderopvang-/kinderzorgvoorzieningen voor werkende ouders;

- art. 19 (lid 1 en 2) VRK: bijzondere bescherming tegen kindermishandeling (waaronder incest) met name door brede opvoedingsondersteuningsen preventie-programma's, gezinsinspectie, meldingsregeling, gezinsonder-

KOREN spreekt van het recht van het kind op informatie, aan welk recht zij haar boeiende proefschrift heeft gewijd: Marian KOREN, Tell me! The right of the child to information, diss. Amsterdam, Den Haag 1996. Uit haar overzicht op p. 212 blijkt niet alleen hoeveel verwijzingen het Verdrag inzake de rechten van het kind naar het recht op informatie bevat, doch ook hoeveel verschillende actoren een plicht tot informeren hebben (staat, ouders, media, partijen bij adoptie, vluclatelingenorganisaties, rijke landen ten opzichte van ontwikkelingslanden). 
zoek, verwijzing, behandeling, follow-up en, zo nodig, juridische interventie;

- art. 20, lid 2 en 3 VRK: bijzondere bescherming van en zorg voor kinderen die tijdelijk of blijvend niet bij hun ouders kunnen of in hun eigen belang mogen wonen, zoals pleeggezinplaatsing enz., rekening houdend met de wenselijkheid van continuiteit in de opvoeding;

- art. 21 VRK: bescherming van het kind bij adoptie: adoptie moet in de eerste plaats in het belang van het kind zijn; materiële (wettelijke) en procedurele waarborgen; inlichting, advisering en instemming van betrokkenen; interlandelijke adoptie als ultimum remedium;

- art. 22 VRK: bescherming en humanitaire bijstand van minderjarige asielzoekers en kinderen die vluchteling zijn; opsporen van de ouders; - art. 23, lid 1 VRK: bescherming/welzijn van het gehandicapte kind ('een volwaardig en behoorlijk leven') met verzekering van de waardigheid van het kind en bevordering van zijn zelfstandigheid en actieve deelneming aan het gemeenschapsleven;

- art. 23, lid 3 VRK: bescherming/welzijn door (gratis) bijstand die toegang tot onderwijs, revalidatie enz. van het gehandicapte kind verzekert met het oog op zijn integratie, persoonlijke, culturele en intellectuele ontwikkeling (dat is met het oog op de optimale persoonswording van het gehandicapte kind);

- art. 23, lid 4 vRK: bescherming/welzijn door middel van internationale samenwerking/informatie-uitwisseling op medisch, psychologisch en (beroeps)onderwijskundig gebied (met name ten behoeve van gehandicapte kinderen in ontwikkelingslanden);

- art. 24, lid 2 sub a VRK: bescherming van het kind in de vorm van maatregelen ter vermindering van baby- en kindersterfte $e^{66}$;

- art. 24, lid 2 sub b vRK: bescherming/welzijn van het kind in de vorm van medische voorzieningen, ontwikkeling/uitbouw eerste-lijnsgezondheidszorg (c.q. consultatievoorzieningen);

- art. 24, lid 2 sub c VRK: bescherming/welzijn van het kind in de vorm

Voor Nederland ligt het belang van dit onderdeel in het verlengde van art. 19. In welvarende landen als Nederland is infanticide door ouders immers een belangrijkere doodsoorzaak dan gebrekkige medische voorzieningen. $\mathrm{Vgl}$. in dit verband F.H.L. BEYAERT, 'Strafwetgeving en de crime passionnel, dodingen in het gezin en toch weer de vader, in: A. LADAN e.a. (red.), De betekenis van de vader; Psychoanalytische visies op het vaderschap, Meppel/Amsterdam 1985, pp. 102-122; vgl. over de hier besproken rapprochement crisis (pp. 113-118) ook dez., "Partneren kinderdodingen,' Justitiele Verkenningen 1986/4, pp. 445-457, op pp. 453-454 en 456. Voor sterftecijfers zie J. VAN KAMPEN (red.), De staat van jeugdig Nederland" 1996; Een sociale kaant van de jeugd van Nederland, Werkdocument 1 Stichting Jeugdinformatie Nederland (Utrecht), Delft [1996], p. 63. 
van gezonde voeding, zuiver drinkwater, bestrijding van milieuverontreiniging (rookvrije en uitlaatgasarme lucht ${ }^{67}$;

- art. 24, lid 2 sub d VRK: bescherming/welzijn van de vrucht en het geboren kind door het waarborgen van pre- en postnatale gezondheidszorg voor moeders ${ }^{68}$;

- art. 24, lid 2 sub e VRK: bescherming/welzijn in de vorm van voorlichting/scholing/ondersteuning voor ouders en kinderen met betrekking tot gezondheid, voeding, borstvoeding, hygiëne, sanitaire voorzieningen en het voorkomen van ongevallen;

- art. 24, lid 2 sub f VRK: bescherming/welzijn van het kind in de vorm van preventieve gezondheidszorg, begeleiding van ouders (met het oog op het recht van het kind op de best mogelijke gezondheid ${ }^{69}$ ) en voorzieningen voor en voorlichting over gezinsplanning ${ }^{70}$;

FREEMAN doet enkele suggesties ter operationalisering van dit onderdeel: "There is evidence of an association between respiratory illnesses in children and the amounts of pollution in the areas where they live. Much more could be done to tackle smoking now that the evidence of the effects of passive smoking is incontestable. Smoking could be banned in public places. Cigarette advertising could be stopped, including sponsorship of sporting and other events. Taxation on tobacco products could be vastly increased. More could be done to discourage smoking by children. The right to a smoke-free environment must "trump" the socalled freedon of smokers to destroy themselves and others." (Michael FREEMAN, 'Children's rights in a land of rites,' in: Bob FRANKLIN (ed.), The handbook of children"s rights; Comparative policy and practice, London/New York 1995, pp. 7085 , op pp. $81 / 82$.)

Naar mijn mening zou cen rookverbod niet alleen dienen te gelden voor publieke ruimtes c.q. de publieke ruimte maar tevens voor alle particuliere ruimtes waar zich kinderen ophouden. Bovendien zou de publieke aandacht zich evenzeer op andere vormen van milieuverontreiniging dienen te richten waarvoor kinderen bijzonder kwetsbaar zijn, zoals de luchtvervuiling, geluidsoverlast en speelhinder (zo niet -verhindering) door het verkeer, in het bijzonder in binnensteden en dorpskernen.

68 Foetale mishandeling/verwaarlozing door zwangere vrouwen kan mijns inziens met een beroep op deze bepaling (mede in verband met preambulaire overweging 9 juncto art. 6, lid 2: zie hierboven) onder de werking van art. 19 (dat wil zeggen: desnoods juridische interventie, dus - in laatste instantie - opgelegde hulpverlening/behandeling) worden gebracht.

69 Gezien de ruime ("holistische') opvatting van gezondheid (namelijk lichamelijk, geestelijk en qua ontwikkeling: zie hierna par. 10.2 .2 onder art. 24, lid 1 VRK) kan worden verdedigd/aangenomen dat het hier niet alleen om medische doch ook om psychologische/pedagogische begeleiding van ouders gaat.

70 Vaticaanstad heeft hierbij het voorbehoud gemaakt dat gezinsplanning in deze bepaling in zijn optiek alleen zict op natuurlijke methoden van gezinsplanning (Trb. 1990, nr, 170, p. 31 nt. 1 onder a). Gezien het weinig natuurlijke karakter van de hier bedoelde methoden (periodieke onthouding/geslachtsverkeer rond de 
- art. 24, lid 3 VRK: bescherming van het kind (met name het meisje) tegen schadelijke culturele praktijken, in het bijzonder genitale verminking van meisjes en het voortrekken van jongetjes bij de opvoeding (bij toekomstige dynamische interpretatie wellicht ook tegen schadelijke pedagogische praktijken zoals het slaan, anders dan de 'pedagogische tik,' en het 'ter correctie' vernederen van kinderen ${ }^{71}$ );

menstruatie, de kerk vóór het Agnus Deil verlaten) kan de vraag worden opgeworpen of dit voorbehoud nilet zin en strekking, of liever: elke inhoud, aan de bepaling ontneemt.

71 Praktijken die - althans wat het slaan van kinderen betreft - in verschillende (met name de Scandinavische) landen reeds verboden zijn (in Zweden al sinds 1979 - en met iobegrip van het wernederen van kinderen). Vgl. Peter NEWELL, 'Respecting children's right to physical integrity,' in: Bob FRANKLIN (ed.), The handbook of children's rights; Comparative policy and practice, London/New York 1995, pp. 215-226, op pp. 215 en 218-221; alsook Michael FREEMAN, "Children's rights in a land of rites,' in: a.w., pp. 70-85, op pp. 75-76.

NEWELL acht het slaan van kinderen in strijd met art. 19 juncto art. 2 VRK (t.a.p., op p. 222). Art. 2 (gelijkheidsbeginsel/discriminatieverbod) shit zijns inziens een beroep op religieuze of culturele rechtvaardigingen uit (p. 222 iff.). Op p. 216 brengt hij het gelijkheidsbeginsel/discriminatieverbod nog op een andere wijze in stelling" het slaan van kinderen "discriminates against children because of their greater physical [and psychological and social, jw] vulnerability and the imperatives of their growth and development.'

Ook FREEMAN beroept zich op art. 19 VRK. Hij merkt op (t.a.p., op p. 75): 'Article $19(\ldots)$ goes beyond abuse in its narrow and accepted sense. It pledges States to protect children from "all forms of physical (...) violence".' Engeland, 'land of rites' (in plaats van 'rights"), zal het Zweedse voorbeeld dan ook dienen te volgen. FREEMAN (t.a.p., op p. 76): "There is probably no more significant step that could be taken to advance both the status and protection of children than to outlaw the practice of physical punishment. Much child abuse is, we know, punishment which has gone awfully wrong."

De ruime UNICEF-definitie van 'survival and development' en de 'holistische" wHO-delinitie van gezondheid - mede omwattende de geestelijke gezondheid en de gezonde ontwikkeling van het kind tot persoon - impliceren mijns inziens dat de omschrijving 'traditional practices prejudicial to the health of children' in de toekomst ook kan worden toegepast op traditionele praktijken als het disciplineren van kinderen met behulp van mensonwaardige methoden, zoals het slaan met de blote hand of zelfs met woorwerpen, die - ook in tal wan westerse landen thans nog niet allom als kindonwaardig worden beschouwd. Ook hier zullen we zien dat het niet zozeer de letter van her Verdrag van 1989 is als wel de lading en potentie ervan bij een dynamische interpretatie en toepassing vanuit een heldere kijk op het recht en het belang van het kind met betrekking tot zijn persoonswording, welke de vergelijking rechtvaardigt met het dynamiet in het gelijkheidsbeginsel van 1789 . Zij het dat dit laatste pas met ernstige vertraging tot een explosie binnen maatschappelijke en gezinsverhoudingen - althans op het punt van de man-vrouw relatie - heeft geleid. 
- art. 24, lid 4 VRK: bescherming/welzijn van kinderen in ontwikkelingslanden door middel van internationale samenwerking (zodat ook daar de verwezenlijking van het recht van het kind op de best mogelijke gezondheid en de beste gezondheidsvoorzieningen steeds dichterbij kan worden gebracht);

- art. 27, lid 2 VRK: bescherming/welzijn van het kind door diens ouders primair verantwoordelijk te stellen ter zake van de levensstandaard/levensomstandigheden die nodig is/zijn voor de lichamelijke, geestelijke, intellectuele, zedelijke en maatschappelijke ontwikkeling van het kind (diens optimale persoonswording);

- art. 27, lid 3 VRK: bescherming/welzijn van het kind in de vorm van materiële bijstand en ondersteuning aan ouders (secundaire financiële/ materiële verantwoordelijkheid van de staat), met name wat betreft voeding, kleding en huisvesting, ter verwezenlijking van het recht van het kind op een toereikende levensstandaard met het oog op de ontwikkeling (optimale persoonswording) van het kind;

- art. 28, lid 2 VRK: bescherming van het kind tegen slaan op school: handhaving van de discipline op scholen dient verenigbaar te zijn met de menselijke waardigheid van het kind en in overeenstemming met het Verdrag (met andere woorden mag de lichamelijke en geestelijke integriteit van het kind niet schenden);

- art. 28, lid 3 VRK: bescherming/welzijn van het kind door internationale samenwerking op onderwijskundig gebied, in het bijzonder ter bestrijding en uitbanning van onwetendheid en analfabetisme (met name ten behoeve van kinderen in ontwikkelingslanden);

- art. 29, lid 1 VRK: bescherming/welzijn van het kind door het stellen en bewaken door de staat van (welomschreven) onderwijsdoelen: het onderwijs aan het kind dient te zijn gericht op (a.) de zo volledig mogelijke ontplooiing van de persoonlijkheid, talenten en geestelijke en lichamelijke vermogens van het kind (optimale persoonswording); (b.) het bijbrengen van eerbied voor de mensenrechten en de beginselen van het Handvest van de Verenigde Naties; (c.) het bijbrengen van eerbied voor de ouders, ${ }^{72}$ voor de eigen cultuur en voor andere culturen; (d.) de voorbereiding van het kind op een verantwoord leven in een vrije samenleving

Eerbied niet in de 'absolute' zin van het Vierde Gebod (Alice MLLER), maar eerbied voor en loyalliteit ten opzichte van de ouders die 'bevorderlijk zijn voor de ontwikkeling van het kind,' dat wil zeggen: die "berusten op verdiensten." Immers: 'Achting en loyaliteit kunnen niet worden opgedrongen of afgetroggeld.' (Herman BAARTMAN, 'Onderkenning en miskenning van seksueel misbruik van kinderen; enkele historische en actuele aspecten," in: dez. (red.), Op gebaande paden? Ontwikkelingen in diagnostiek, hulpwerlening en preventie met betrekking for seksueel misbrikk van kinderen, Utrecht 1995, pp. 13-27, op p. 24 i.f.) 
(boven-minimale persoonswording), in de geest van (democratische idealen als) vrede, verdraagzaamheid, gelijkheid van man en vrouw, vriendschap tussen alle volken en ethnische groepen; (e.) het bijbrengen van eerbied voor het milieu;

- art. 29, lid 2 VRK: bescherming/welzijn van het kind door het respecteren van de vrijheid van onderwijs, binnen de grenzen van de onderwijsdoelen van lid 1 , en door het bewaken van de door de staat vastgestelde onderwijskundige minimumnormen waaraan onderwijsinstellingen dienen te voldoen;

- art. 32, lid 2 VRK: bescherming van het kind tegen economische uitbuiting door middel van het voorschrijven van minimumleeftijden voor het verrichten van betaalde arbeid en het geven van voorschriften voor de regeling van werktijden en arbeidsvoorwaarden, een en ander te handhaven door punitieve en andere maatregelen (het stellen van straffen en boetes op overtredingen door ouders en/of werkgevers);

- art. 33 VRK: bescherming van het kind tegen (schadelijke) illegale drugs $^{73}$;

- art. 34 VRK: bescherming van het kind tegen sexuele exploitatie en sexueel misbruik, in het bijzonder door middel van (nationale en internationale, bi- en multilaterale) maatregellen ter voorkoming van (a.) aanzetting of dwang tot deelname aan onwettige sexuele activiteiten (beter: aanzetting tot deelname aan sexuele handelingen vóor de wettige minimumleeftijd of dwang tot deelname aan welke sexuele handelingen dan ook), (b.) kinderprostitutie en (c.) kinderpornografie;

- art. 35 VRK: bescherming van het kind tegen kinderhandel;

- art. 36 VRK: bescherming tegen alle overige vormen van uitbuiting/exploitatie die schadelijk zijn voor enig aspect van het welzijn van het kind (dus voor diens optimale persoonswording);

- art. 38 VRK: bescherming van het kind bij gewapende conflicten door het (doen) respecteren van het humanitaire (oorlogs)recht van toepassing op kinderen; geen kindsoldaten van 14 jaar of jonger;

- art. 39 VRK: bescherming/welzijn van het kind door bevordering van de rehabilitatie (lichamelijk en geestelijk herstel en maatschappelijke herintegratie) van slachtoffers van welke vorm ook van verwaarlozing, exploitatie of mishandeling, van foltering of welke andere vorm ook van wrede, onmenselijke of onterende (vernederende) behandeling of bestraffing, of

Bescherming tegen schadelijke legale drugs (alcohol en nicotine) kan onder de werking van art. 24 worden gebracht. Hetzelfde geldt/gelde, zoals we hierboven ten aanzien van 'smoking' zagen (FREEMAN), voor de bescherming van het kind tegen misbruik van illegale drugs en/of legale genotmiddelen/medische giften (alcohol, nicotine) door ouders/opvoeders. 
van gewapende conflicten; rehabilitatie vindt plaats in een omgeving die bevorderlijk is voor de gezondheid, het zelfrespect en de waardigheid van het kind;

- art. 40, lid 3 VRK: strafvorderlijke bescherming/welzijn door minimumleeftijd voor strafbaar handelen en buitengerechtelijke oplossingen (alternatieve afdoening);

- art. 40, lid 4 VRK: bescherming/welzijn in de vorm van een verscheidenheid van regelingen/alternatieven, jeugdreclassering, pleegzorg enz. zodat het welzijn van het kind niet wordt geschaad;

- art. 41 VRK: bescherming/welzijn door de regel dat de voor het kind meest gunstige - nationale of internationale - (beschermings- c.q. welzijns)bepaling geldt (zogenaamde savings clause). ${ }^{74}$

Hieraan zouden nog de volgende (formele) verdragsbepalingen kunnen worden toegevoegd (hoewel zij niet alleen het kind als object van bescherming, maar ook de bescherming van de rechten van het kind regarderen):

- art. 42 VRK: bescherming/welzijn van het kind door algemene bekendmaking van het Verdrag inzake de rechten van het kind;

- art. 43 VRK: bescherming/welzijn van het kind door voortgangsbewaking door het (verdrags-)Comité voor de rechten van het kind;

- art. 44 VRK: bescherming/welzijn van het kind door statenrapportage aan het Comité en algemene beschikbaarheid van de statenrapporten (staten dienen verslag uit te brengen zowel over de door hen genomen maatregelen ter uitvoering/operationalisering van de rechten van het kind als over de resultaten van die maatregelen, de in de desbetreffende staat geboekte vooruitgang);

- art. 45 VRK: bescherming/welzijn van het kind door samenwerking van het Comité met zowell inter- als non-gouvernementele organisaties ('andere bevoegde instellingen'); de mogelijkheid de Secretaris-Generaal van de $\mathrm{VN}$ onderzoek naar specifieke kinderrechtelijke thema's te laten verrichten; en de bevoegdheid van het Comité aan staten suggesties en algemene aanbevelingen te doen.

10.2 .2

Het kind als persoon-in-wording: de zelfbepalingsrechten in het Verdrag inzake de rechten van het kind

In deze (sub)paragraaf zoeken we naar de persoon-in-wording. Rechten dat wil zeggen de rechtenconceptie ofwel de 'rights approach' - komen in het Verdrag inzake de rechten van het kind bovenop bescherming - 'wel-

Ten aanzien van bepalingen die rechten bevatten, is de sowings clause ook als recht van het kind te beschouwen: zie hierna par. 10.2.2. 
farism. ${ }^{75}$ Niet alleen worden in het Verdrag inzake de rechten van het kind algemene mensenrechten ten aanzien van het kind herbevestigd en toegespitst, ook worden aan het kind nieuwe (speciale) rechten toegekend. In verschillende gevallen wordt daarbij, zo zal in deze (sub)paragraaf blijken, bescherming opgetild naar het rechtenniveau.

\section{Preambulaire overwegingen}

Vier preambulaire overwegingen plaatsen het Verdrag inzake de rechten van het kind in de context van de algemene mensenrechten(verdragen) of voeren het kind direct op als rechtendrager. Deze vier zijn hieronder weergegeven, waarbij de relevante termen of passus worden gecursiveerd.

[1.] Overwegende dat, in overeenstemming met de in het Handwest van de Verenigde Naties verkondigde beginselen, erkenning van de inherente [aan het mens zijn verbonden] waardigheid en de gelijke en onvervreemdbare rechten van alle leden wan de mensengeneenschap de grondslag is voor vrijheid, gerechtigheid en vrede in de wereld;

[2.] Indachtig [het feit] dat de volkeren van de Verenigde Naties in het Handwest hun vertrouwen in de fundamentele rechten van de mens en in de waardigheid en de waarde van het individu opnieuw hebben bevestigd, en hebben besloten sociale vooruitgang en een hogere levensstandaard in grotere vrijheid te bevorderen;

[3.] Erkennende dat de Verenigde Naties in de Universele Verklaring van de rechten van de mens en in de internationale verdragen inzake de rechten van de mens hebben verkondigd en zijn overeengekomen dat een ieder recht heeft op alle rechten en vrijheden die daarin worden beschreven, zonder onderscheid van welke aard ook, zoals naar ras, huidskleur, geslacht, taal, godsdienst, politieke of andere overtuiging, nationale of sociale afkomst, eigendom, geboorte of andere status;

Vgl. Joachim woLf, "The concept of the "best interests" in terms of the UN Convention on the Rights of the Child," in: Michael FrEeMAN, Philip VEERMAN (eds.), The ideologies of children's rights, Dordrecht (etc.) 1992, pp. 125-133, op pp. 128-129; Cynthia Price COHEN, "The relevance of theories of natural law and legal positivism,' in: The ideologies of children's rights, a.w., pp. 53-70, op pp. 59 en $67 / 68$ nt. 46; Eugeen VERHELLEN, Verdrag inzake de rechten wan het kind; Achtergronden, motieven, strategieër, hoofdlijnen, Leuven/Apeldoorn 1993 (tweede druk), pp. 33-36, 48-53, 70, 77/78; Bea VAN DEN BERGH, Recht op recht(en)? Kinderen als maatschappelijke groep, Centrum voor Bevolkings- en Gezinsstudiën, Ministerie van de Vlaamse Gemeenschap, Departement WVC, Administratie Gezin en Maatschappelijk Welzijn, Brussel 1994, pp. 52-55.

Vgl. met betrekking tot een 'right-centred approach' van esocul-rechten: Asbjørn EIOE, Allan ROSAS, 'Economic, social and cultural rights: a universal challenge,' in: Asbjørn EIDE, Catarina KRAUSE, Allan ROSAS (eds.), Economic, social and cultural rights: A textbook, Dordrecht (etc.) 1995, pp. 15-19, op pp. 17/18. 
[4.] Eraan herimerende dat de Verenigde Naties in de Universele Verklaring van de rechten van de mens hebben werkondigd dat kinderen rech hebben op bijzondere zorg en bijstand (...).

\section{Artikelen}

Evenals in de Nederlandse Grondwet, waar het gelijkheidsbeginsel troon, scepter en kroon der democratie - als eerste grondrecht wordt opgevoerd, vinden we ook in het Verdrag inzake de rechten van het kind als eerste mensenrecht van het kind het recht op gelijke behandeling, met op de situatie van het kind toegespitste verboden discriminatie-gronden. Direct na definitie-artikel 1 bepaalt art. 2, lid 1 VRK dat de rechten in het Verdrag door de staten worden geëerbiedigd en gewaarborgd voor elk kind zonder discriminatie van welke aard ook, ongeacht huidskleur, geslacht, sociale komaf, welstand of enige andere omstandigheid van kind of ou$\operatorname{der}(\mathrm{s}){ }^{76}$

Het belang van deze bepaling kan moeilijk worden onderschat in een land waar juist de kinderen voor wie de rechten van het kind zijn bedoeld, als 'wegwerpkinderen' worden weggeschreven: ${ }^{.7}$

'Ik vraag me weleens af of het echte probleem van de kinderbescherming niet hierin bestaat dat kinderen niet te beschermen zijn, behalve dan door hun ouders. Doen die dat niet, dan is er weinig meer te redden en krijg je wat een collega

Evenals art. 14 EVRM - en anders dan art. 1 Grondwet en art. 26 IVBPR - betreft art. 2, lid 1 VRK dus een connex (een onzelfstandig, alleen inroepbaar in verband met andere rechten in het Verdrag) recht. Aangezien het recht van het kind op persoonswording (c.q. de sociaal-pedagogische rechten van het kind) verknoopt is (zijn) met c.q. zich oplost (oplossen) in verschillende rechten van het kind in het Verdrag, is dit verschil in het kader van deze studie niet van belang. Wordt lid 1 van art. 2 gelezen in verband met het tweede lid, dan zou uit dat verband overigens een zelfstandig recht op gelijke behandeling/discriminatieverbod kunnen worden afgeleid waarmee elk overheidshandelen of door de overheid niet geredresseerd en/of gerepareerd/gecompenseerd handelen van derden in strijd zou komen dat niet of onvoldoende rekening houdt met de sociale omstandigheden van de ouders/het gezin. Hierbij kan in het bijzonder worden gedacht aan het schrijnende fenomeen van het de facto afschrijven van kinderen uit zogenaamde a-sociale milieus door de hulpverlening, door leetkrachten en door de politie, die aan zulke gezinnen hun handen niet willen branden (en die zich vaak ook niet of te weinig 'gedekt,' beschermd en toegerust weten door de staat). We worden hier geconfronteerd met wat als een ernstige - zo niet de grootste - aanfluiting van het gelijkheidsbeginsel (en dus de democratie) en van de rechten van het kind (en dus de rechtsstaat) moet worden beschouwd.

77 Paul SCHNABEL, 'Kind en gevaar,' bespr. van Adri VAN MONTTO[O]RT, Her topje van de ijsberg; Kinderbescherming en de bestrijding pan kindermishandeling in sociaal-juridisch perspectief (diss. vU Amsterdam, Utrecht 1994), NRC Handelsblad van 11 mei 1994. 
eens "wegwerpkinderen" noemde, in de dubbele zin van het woord: ze zijn zelf verworpen en ze zullen alles verwerpen, ook en juist hulpverlening die bedoeld is om hen te "recyclen." Heropwoeding bestaat niet."

Een comprehensief sociaal-pedagogisch preventiebeleid en een actieve en gerichte benadering van kinderen en gezinnen in risicovolle omstandigheden vloeit, in het licht van dit citaat, direct uit het gelijkheidsbeginsel als eerste mensenrecht van het kind voort. Los van verdragsverplichtingen geldt hierbij - net zoals met betrekking tot de gelijke behandeling van mannen en vrouwen, waarin Nederland nooit gidsland is geweest ${ }^{78}$ - dat de kosten voor de baat uitgaan. Los van de kosten hebben "wegwerpkinderen' rechten - op reparatie en op sociaal-pedagogische voorzieningen ten behoeve - straks - van hun ouderrol. Hùn kinderen hebben immers het recht - onder het Verdrag inzake de rechten van het kind - nooit 'wegwerpkinderen' te worden.

Ook de volgende verdragsbepalingen regarderen in het bijzonder (de) rechten van het kind (termen of passus die in het bijzonder relevant zijn, zijn gecursiveerd):

- art. 4 VRK: de staten zijn verplicht de in het Verdrag erkende rechten te verwezenlijken, waarbij zij geen enkel wetgevend of beleidsinstrument onbeproefd mogen laten; maatregelen ten behoeve van 'esocul'-rechten (dat wil zeggen: 'dure' rechten) dienen zij te nemen naar de ruimste mate die de overheidsmiddelen toestaan, waarbij een beroep op internationale samenwerking (dat wil zeggen: ontwikkelingshulp) kan worden gedaan; - art. 5 VRK: de ouders zijn primair verantwoordelijk voor de leiding en begeleiding van het kind - in overeenstemming met diens zich ontwikkelende vermogens - bij de uitoefening door het kind van zijn rechten; de staten zijn secundair verantwoordelijk: zij zien (op afstand) toe op de ouderlijke plichtsbetrachting ten aanzien van de rechten van het kind; - art. 6, lid 1 VRK: het recht van het (geboren) kind op leven ${ }^{79}$;

- art. 7, lid 1 (en lid 2) VRK: het recht van het kind op een naam; het

78 Er gaapt in het algemeen een kloof tussen het beeld in Nederland - bij de politilek zowel als de gemiddelde burger - van het rechtsstatelijk/mensenrechtelijk gehalte van onze samenleving enerzijds en de maatschappelijke en politieke Nederlandse werkelijkheid op een aantal fronten anderzijds. Op het front van de gelijke behandeling van mannen en vrouwen zag Nederland zich echter voor wel heel bijzondere 'verrassingen' gesteld. Vgl. hierover Pieter VAN DIJK, 'The Universal Declaration of human rights; its significance in the year 1988,' in: The Universal Declaration of human rights: Its significance in 1988, Report of the Matastricht/Utrecht workshop (...) on the occasion of the 40th anniversary of the Universal Declaration, SIM Special 9, pp. 27-33, op pp. 31-33.

79 Zie met betrekking tot de voorrang van het recht van de vrouw op abortus in het nationale recht van verschillende staten de vorige subparagraaf. 
recht van het kind op een nationaliteit; het recht van het kind voor zover mogelijk (dat is naar de volle maat van het mogelijke) zijn ouders te kennen; het recht van het kind voor zover mogelijk (dat is naar de volle maat van het mogelijke) door zijn ouders te worden verzorgd;

- art. 8, lid 1 VRK: het recht van het kind op behoud van zijn identiteit, dat wil zeggen: het recht van het kind niet van zijn identiteit, met inbegrip van naam, nationaliteit en familiebetrekkingen, te worden beroofd ${ }^{80}$;

80 Het recht van het kind op behoud van zijn identiteit is verro van volledig in het nationale recht geoperationaliseerd - of zelfs maar erkend. Terecht merkt DE LANGEN in haar preadvies voor de NJV op dat het de voorkeur verdient om in het afstammingsrecht uit te gaan van het waarheidsbeginsel' en dat 'de waarheid haar rechten heeft.' $\mathrm{Zij}$ vervolgt: 'Dat wil ook zeggen dat zoveel mogelijk voorkomen dient te worden dat deze identiteit niet te achterhalen valt, zoals bij inseminatie met zaad van anonieme donoren of bij andere voortplantingstechnieken waarbij de afkomst in het duister blijft. Zorgelijk is dat de regering - evenals vele auteurs en instanties, vooral vit de medische hoek - dit recht van het kind niet laat prevaleren en kinderen op wil zadelen met twee soorten donoren. bekende en anonieme, alsof een kind kan kiezen of het door middel van zaad van een al of niet anonieme donor verwekt wil worden. De privacybescherming van de donor en de verwachting dat er bij opheffing van de anonimiteit minder donoren beschikbaar zullen zijn, kunnen toch niet als serieuze argumenten beschouwd worden? Er kan niet van een evenwichtige afweging van belangen gesproken worden, wanneer aan een recht van een donor, die een bewuste keuze kan maken, meer waarde wordt gehecht dan aan het recht van het produkt van dit alles: het kind, dat niet eens zou mogen weten van wie het afstamt." (M. DE LANGEN, "De betekenis van artikel 8 EVRM voor het familierecht,' Preadvies NW, Artikel 8 EVRM, Handelingen Nederlandse Juristen-Vereniging 1990-I, Zwolle [1990-1], pp. 85-183, op pp. 104/105 resp. 107/108.)

RUTGERS VAN DER LOEFF schrijft in een ingezonden reactie in het Tijdschrift voor Familie- en Jeugdrecht: 'In haar interessante artikel "KI in de USA en in Nederland" (FJR 1988 afl. 2) concludeert Mevr[ouw] BROEKHUUSEN-MOLENAAR dat zij vóór handhaving van strikte anonimiteit is [ten aanzien van] KI met sperma van een ander dan de echtgenoot van de moeder. Schrijlster is er dus voor dat een redelijk groot aantal kinderen de mogelijkheid wordt onthouden iets aan de weet te komen omtrent hun biologische vader. Het komt mij voor dat de gemiddelde jeugdige het daar vroeg of laat erg moeilijk mee zal krijgen. Hoe moeilijk is niet door juristen te overzien maar wel door gekwalificeerde psychiaters en psychologen in te schatten. Ouders die een kind willen dat zij met deze problematiek belasten, denken in de eerste plaats aan hun eigen wensen en maken, aldus handelende, zich schuldig aan een vorm van misbruik van de ouderlijke macht; en dat op zodanige wijze dat hun ontzetting uit die ouderlijke macht in overweging zou kunnen worden genomen. De vrees van Mevr[ouw] BROEKHUUSEN dat het doorbreken van die anonimiteit de KI-markt zal doen instorten, roept bij mij de vraag op wat de karakter-structuur is van mannen die met hun sperma kinderen geboren willen laten worden met wier bestaan zij nooit willen worden geconfronteerd. [Een vraag die men wellicht ook kan stellen met betrekking tot 
de mannen dic hun vrouw alleen met anoniem sperma willen laten insemineren, jw]. MCVr[OUW] BROEKHUUSEN vreest voor de emotionele stress die zo'n confrontatie woor hen en hun gezin zou oproepen, maar is de emotionele stress die door die anonimiteit geheel onschuldig bij hun kinderen wordt opgeroepen, niet véel erger? Degene die als donor die stress niet aan wil, zie van zijn donorschap af. Tegen wettelijke aanspraken op alimentatie en erfenis van zijn nageslacht dient de donor uiteraard wel wolledig te worden beschermd. (...) Concluderend acht ik het anonieme donorschap iets dat moet worden verboden, al moet [het] duidelijk zijn dat alleen het kind het recht heeft om te weten wie zijn biologische vader is. Zijn wettige ouders of anderen komt dat recht zeker niet toe:' (M. RUTGERS VAN DER LOEFF, 'Reactie: de anonieme donor;' FJR 1988/4, p. 91.)

Vgl. ook J.E. DOEK, "Het recht van het kind op identiteit," in: P.C.Th.M. VAN EEUWLK, J.H.A. VAN LOON (red.), Identiteitsproblemen bij adoptiekinderen, Amsterdam/Lisse 1989, pp. 47-61. De auteur merkt op (t.a.p., op p. 56 i.f.): Maximale informatie over zijn herkomst is (...) van groot belang zoals algemeen wordt erkend." DOEK spreekt weliswaar over het geadopteerde kind maar met betrekking tot het recht op identiteit is dit geen principieel andere categorie. We zouden in dit verband kunnen spreken van 'de adoptie-effecten van de moderne procreatie-technieken.' Al bedoelde de auteur van deze woorden (R.A.C. HOKSBERGEN, 'De psychologie van adoptie,' in: dez. e.a., Interlandelijke adoptie, Publikatie 15 wan de Rechtskundige Afdeling van het THIMgenootschap, Zwolle 1990, pp. 1-15, op p. 14) daar iets anders mee.

Voor opheffing van donor-anonimiteit wegens strijd met het belang van het kind - overigens zonder verwijzing naar (art. 8 van) het (door Nederland destijds al ondertekende) Verdrag inzake de rechten van het kind - pleit ook D.M. FERNHOUT, Rechtsuragen rond in vitro fertilisatie en embryo-transfer, Arnhem 1992, pp. 53-56. De auteur merkt op, verwijzend naar de waarborg van de menselijke waardigheid in de Duitse Grondwet (a.w., p. 55): 'Indien een mens in de kern van zijn bestaan wordt aangetast, is er (...) sprake van schending van de "Menschenwürde." Dit is naar mijn mening inderdaad het geval wanneer men iemand bewust de kennis omtrent zijn genetische afkomst onthoudt." Deze opvatting - die door mij wordt gedeeld - impliceert dat niet alleen in Duitsland, op basis van de Duitse Grondwet, maar ook in Nederland op basis van de 'Menschenwürdegarantie? die ten grondslag ligt aan alle mensentechtenverdragen, in het algemeen en op basis wan (art. 8 van) het Verdrag inzake de rechten van het kind in het bijzonder anonimiteit van de donor ongeoorloofd moet worden geacht. Hieraan kan de schending van andere verdragsbepalingen (c.q. -beginselen) worden toegevoegd omdat en in zover de persoonswording wordt geschaad door het opgroeien met een Gezinsgeheim, zoals ik elders heb betoogd (WLLEMS, 'Van parentiarchie naar Vadertje Staat; over 't verwekken, mishandelen en beschermen van kinderen,' Nemesis $1992 / 3$, pp. 8-23, op p. 8).

HAMMERSTEIN spreekt van 'het oergevoel van een mens te willen weten van wie hij afstamt.' Ook zij bepleit de opheffing van de anonimiteit. (W.C.E. HAMMERSTEIN-SCHOONDERWOERD, 'De problematiek rond kunstmatige inseminatie met donorsperma, in vitro fertilisatie en draagmoederschap, gezien vamuit het personen- en familierecht,' in: dez. e.a., Kunstmatige voortplanting; Recht en ethiek, Publikatie 14 van de Rechtskundige Afdeling van het THIMgenootschap, Zwolle 
- art. 9, lid 1, eerste volzin VRK: het recht van het kind niet van zijn ouders te worden gescheiden tegen hun (lees: $z_{i j n}{ }^{81}$ ) wil tenzij dat in het belang van het kind is (dat wil zeggen: scheiding van kind en ouder(s) is alleen mogelijk krachtens een plaatsingsbeslissing in geval van gescheiden levende ouders dan wel indien uithuisplaatsing van ouder(s) of kind een noodzakelijke vorm van - onder rechterlijke toetsing - op te leggen hulp is in geval van 'mishandeling of verwaarlozing van het kind door de ouders,' met andere woorden in geval van een handelen of nalaten door de ouders waardoor de minimale persoonswording van het kind wordt bedreigd);

- art. 9, lid 2 VRK: het recht van het kind in (uithuis-)plaatsingsprocedures te worden gehoord;

- art. 9, lid 3 VRK: het recht van het kind bij (echt)scheiding van ouders/ indien gescheiden van ouders op omgang met beide ouders tenzij zulks strijdig is met het belang van het kind (hier te verstaan als het veiligheidsen ontwikkelingsbelang van het kind, het belang van zijn maximale veiligheid en optimale persoonswording $)^{82}$;

1989, pp. 23-46, op p. 32.)

Zie met betrekking tot art. 8 , lid 1 VRK in verband met in vitro fertilisatie: VAN BUEREN, The international law on the rights of the child, a.w., pp. 118-120, op p. 119; Marian KOREN, Tell me! The right of the child to information, diss. Amsterdam, Den Haag 1996, pp. 295-306, op p. 297.

Zie voor wetgevingsontwikkelingen in Nederland de brief van de staatssecretaris van Justitie en de minister van vwS over 'de verdere gang van zaken met het wetswoorstel donorgegevens kunstmatige inseminatie': Kamerstukken 1I 1997/98, 23207 , Regels voor de bewaring, het beheer en de verstrekking van gegevens van donoren bij kunstmatige donorinseminatie (Wet donorgegevens kunstmatige inseminatie), nr. 9 (Brief d.d. 27 oktober 1997).

81 M.i. dient art. 9 , lid 1 in samenhang met het tweede lid juncto art. 12 zo te worden gelezen dat 'hun' alleen slaat op de ouders van het (zeer) jonge kind en dat ten aanzien van het oudere kind (bijwoorbeeld vanaf de leeftijd van 6 of 7 jaar) voor 'hun' gelezen moet worden: zijn. Het gaat hier immers om een recht van het kind, los van de - in het tweede lid benadrukte - rechtsbescherming van alle betrokkenen, onder wie de ouders. VAN BUEREN (The intemational law on the rights of the child, a.w., p. 80 ) is van mening dat het bezittelijk voornaamwoord hun in 'tegen hun wil' in het licht van het fundamentele verdrags(interpretatie-) beginsel van de zich ontwikkelende vermogens van het kind 'ought to refer to the will both of the parents and of the child.".

82. Dit is zo te verstaan dat een omgangsrecht - hoewel in beginsel in het belang van de persoonswording van het kind - aan de ouder (en het kind) moet worden geweigerd indien er ernstige twijfels bestaan omtrent de integriteit - in sexuele of andere zin (hiertussen bestaat geen principieel of zwaarwegend onderscheid) van hetzij de vader hetzij de moeder (onder integriteit wordt in dit verband verstaan: de mogelijkheid zich in het kind te verplaatsen en met zijn belangen rekening te houden, dat will zeggen de mogelijkheid zich over het kind te ontfermen 
- art. 9, lid 4 VRK: het recht van het kind op informatie over de verblijfplaats van een gearresteerde ouder, tenzij dit schadelijk is voor het welzijn van het kind ${ }^{83}$;

- art. 10, (lid 1 en) lid 2 VRK: transnationale bewegingsvrijheid met het oog op gezinshereniging (de desbetreffende aanvragen worden door de staat 'met welwillendheid, menselijkheid en spoed' behandeld); het recht van het kind op transnationale omgang met zijn ouder(s), en met het oog daarop het recht van kind of ouder(s) het land te verlaten en het recht naar zijn eigen land terug te keren;

- art. 12, lid 1 VRK: het recht van het kind dat in staat is zijn eigen mening te vormen, die mening vrijelijk te uiten in alle aangelegenheden die het kind betreffen; het recht van het kind op respect voor zijn mening in dier voege dat aan zijn mening 'passend belang' wordt gehecht in overeenstemming met leeftijd en rijpheid van het kind;

- art. 12, lid 2 VRK: het recht van het kind gehoord te worden, recht-

en het voldoende veiligheid en aandacht te bieden). Indien het risico bestaat dat het kind sexueel en/of emotioneel (als pion in de strijd tussen de ouders) zou kunnen worden misbruikt, dan is dat als een ernstigere bedreiging voor zijn (optimale) persoonswording te beschouwen dan het (tijdelijk) niet toestaan van omgang (uiteraard periodiek te evalueren). Naar mijn mening doet dit risico zich woor telkens wanneer moet worden aangenomen dat de ouders (of én van hen beiden) het scheidingsproces nog onvoldoende hebben verwerkt (in dier voege dat zij vijandig tegenover elkaar staan). Het gevaar is dan niet denkbeeldig dat hett omgangsrecht het kind tot pion maakt van ontvang-ouder, zend-ouder of beide ouders: het kind raakt bekneld tussen twee vuren op een leeftijd dat en in een situatie waarin het bijzonder kwetsbaar is voor manipulatie en corrumpering. Een onvoldoende verwerkt hebben van de scheiding moet worden voorondersteld (behoudens tegenbewijs) in alle gevallen dat de ouders er niet in slagen zelf een omgangsregeling tot stand te brengen. Met andere woorden: bij elk aan de rechter voorgelegd verzoek om omgang met een kind dient de bewijslast dat omgang in het belang van het kind is (diens persoonswording dient) op de aanvrager te rusten. Bij verzet van de andere ouder zal deze bewijslast bijzonder zwaar zijn. Het kennelijk tussen de ouders bestaande conflict geldt immers als presumptie van schadelijkheid van omgang voor de persoonswording. De rechter zou de ouders na ommekomst van een afkoelingsperiode van bijvoorbeeld drie maanden de kans moeten geven zelf een omgangsregeling te treffen. Hierbij zou de ouders - met het oog op het principielle belang van omgang voor het kind - professionele bemiddeling moeten worden aangeboden. Deze bemiddeling dient - evenals andere vormen van ouderbegeleiding (opwoedingsondersteuning) - als een recht van het kind te worden gezien (het recht van het kind op echtscheidings- en omgangsbemiddeling).

83 Het mag opmerkelijk genoemd worden dat de verdragsgever zelfs een elementair en (in een rechtsstaat) voor de hand liggend recht als het recht te weten waar een ouder in hechtenis wordt gehouden, onder de persoonswordingstoets ("tenzij schadelijk voor het welzijn van het kind') heeft gebracht. 
streeks of door tussenkomst van een vertegenwoordiger (curator litis, "procesvoogd"84 of 'kinderadvocaat') of een 'daarvoor geschikte instelling' (kinderombudsman?);

- art. 13 (lid 1 en 2) VRK: het recht van het kind op vrijheid van meningsuiting, waaronder het recht van het kind inlichtingen en denkbeelden te vergaren, te ontvangen en door te geven in welke vorm dan ook en van en naar welk land dan ook, en slechts onderworpen aan wettelijke beperkingen die noodzakelijk zijn voor de eerbiediging van de rechten of de goede naam van anderen of ter bescherming van de nationale veiligheid of van de openbare orde, de volksgezondheid of de goede zeden; - art. 14, lid 1 juncto lid 2, en lid 3 VRK: het recht van het kind op vrijheid van gedachte, geweten en godsdienst; het recht van het kind op leiding en begeleiding - in overeenstemming met zijn zich ontwikkelende vermogens - door zijn ouders bij de uitoefening van dit recht ${ }^{85}$; het recht van het kind zijn godsdienst of levensovertuiging tot uiting te brengen, welk recht slechts kan worden onderworpen aan wettelijke beperkingen die noodzakelijk zijn ter bescherming van de openbare veiligheid, de openbare orde, de volksgezondheid of de goede zeden, of van de fundamentele rechten en vrijheden van anderen;

- art. 15 (lid 1 en 2) VRK: het recht van het kind op vrijheid van vereniging en het recht van het kind op vrijheid van vreedzame vergadering; deze rechten zijn slechts onderworpen aan wettelijke beperkingen die in een democratische samenleving noodzakelijk zijn ter bescherming van de nationale of de openbare veiligheid, de openbare orde, de volksgezondheid of de goede zeden, of van de rechten en vrijheden van anderen; - art. 16 (lid 1 en 2) VRK: het recht van het kind op privacy; het recht van het kind op bescherming tegen willekeurige of onrechtmatige aantasting van zijn privacy (dat wil zeggen van zijn lichamelijke en geestelijke

Deze term wordi bepleit door J.E. DOEK, 'De ratificatie van het Verdrag inzake de rechten van het kind; enige beschouwingen over de mogelijke gevolgen voor de Nederlandse rechtspraktijk," NJCM-Bulletin 1995/1, pp. 10-21, op p. 18. COOMANS (A.P.M. COOMANS, De intemationale bescheming wan het recht op onderwijs, diss. Maastricht, Leiden 1992, p. 155; curs. AC) merkt terecht op: 'De bepaling gaat niet uit van de rechten van ouders de zedelijke en godsdienstige opvoeding van hun kinderen te verzekeren volgens hun eigen overtuigingen zoals in andere verdragen. De bepaling stelt daarentegen de uitoefening van het recht door het kind zelf centraal onder begeleiding van de ouders (...). Die begeleiding dient in overeenstemming te zijn met de zich ontwikkelende vermogens van het kind, dat wil onder andere zeggen met de groeiende zelfstandigheid van het kind.' Vgl. ook zijn beschouwing met betrekking tot de betekenis van art. 41. VRK voor de vraag welke bepaling (in VRK, IVBPR of IVESCR) als de meest gunstige moet worden beschouwd 'aangaande de zedelijke en godsdlienstige opvoeding en onderwij]zing] van kinderen,' a.w., op p. 156. 
integriteit, privéleven, gezinsleven, woning/kamer, correspondentie/dagboeken, eer of goede naam);

- art. 18, lid 2 VRK: teneinde de rechten van het kind te waarborgen en te bevorderen verschaffen de staten ouders passende bijstand en waarborgen zij de ontwikkeling van sociaal-pedagogische voorzieningen;

- art. 18, lid 3 VRK: teneinde het recht van het kind van werkende ouders op gebruikmaking van kinderopvang-/kinderzorgvoorzieningen te waarborgen, nemen staten alle geschikte maatregelen;

- art. 20, lid 1 VRK: het recht van het kind op bijzondere bescherming en bijstand van staatswege indien het tijdelijk of blijvend buiten het gezin moet verblijven;

- art. 22, lid 1 VRK: bescherming en humanitaire bijstand van minderjarige asielzoekers en kinderen die vluchteling zijn, bij het genot van de rechten van het kind in dit Verdrag en in andere mensenrechten- en humanitaire verdragen;

- art. 23, lid 2 VRK: het recht van het gehandicapte kind op bijzondere zorg; bijstand voor kind en ouders/verzorgers;

- art. 24, lid 1 VRK: het recht van het kind op de best mogelijke gezondheid en op gezondheidszorgvoorzieningen, toegankelijk voor alle kinderen (met inbegrip van voorzieningen voor geestelijke gezondheidszorg ${ }^{86}$ );

VAN BUEREN (The international law on the rights of the child, a.w., pp. 297-298) vermeldt dat de Constitutie van de Wereldgezondheidsorganisatie (1946) gezondheid definieert als 'a state of complete physical, mental and social well-being.' In de Verklaring van Alma-Ata van 1978 wordt dit herbevestigd. Gezondheid is 'not merely the absence of disease or inlirmity.' Een goede gezondheid dient individuen in staat te stellen, zo leest VAN BUEREN in de Verklaring, 'to develop to the maximum of their physical and mental potential.' In de opvatting van de auteur is deze Verklaring - en daarmee de 'holistische' benadering van gezondheid - omgezet in bindend internationaal recht in art. 24 VRK (a.w., Pp. 297 en 301). $Z$ ij verwijst hierbij ook naar art. 12 , lid 1 IVESCR, dat spreekt van het recht van een ieder op een zo goed mogelijke lichamelijke en geestelijke gezondheid (a.w. p. 298). De 'gezondle ontwikkeling van het kind' in art. 12, lid 2 sub a IVESCR moet dan ook, zo mogen we concluderen, geacht worden op meer te doelen dan enkel de gezonde lichamelijke ontwikkeling van het kind.

Niettemin onderkent VAN BUEREN (a.w., p. 298) dat staten sare only beginning to discover the "true extent of mental illness and emotional disturbances in children" [WESTMAN]."

Vgl. ook Katarina TOMASEVSKI, 'Health rights,' in: Asbjørn EIDE, Catarina KRAUSE, Allan ROSAS (eds.), Economic, social and cultural rights; $A$ textbook, Dordrecht (etc.) 1995, pp. 125-142, op pp. 128-129 en 134-135.

Overigens luidde de oorspronkelijke redactie van het huidige art. 24 , lid 1 VRK aldus (vgl. Sharon DETRICK (ed.), The United Nations Convention on the rights of the child; A guide to the "travanu preparatoires," Dordrecht etc. 1992, p. 344; curs. jw): 'It is recognized that the child shall be entitled to benefit from the highest 
- art. 24, lid 1 juncto art. 39 VRK: het recht van het kind op rehabilitatie (lichamelijk en geestelijk herstel en maatschappelijke herintegratie) in geval van (onder meer) kindermishandeling; herstel en herintegratie vinden plaats in een omgeving die bevorderlijk is voor de gezondheid, het zelfrespect en de waardigheid van het kind;

- art. 25 VRK: het recht van het kind op periodieke evaluatie bij uithuisplaatsing met het oog op de lichamelijke of geestelijke gezondheid van het kind (dat is bij uithuisplaatsing om medische, pedagogische en/of therapeutische redenen);

- art. 26 (lid 1 en 2) VRK: het recht van het kind op sociale zekerheid (staten dienen de algehele verwezenlijking van dit recht te bewerkstelligen);

- art. 27, lid 1 VRK: het recht van het kind op een toereikende levensstandaard met het oog op zijn lichamelijke, geestelijke, intellectuele, zedelijke en maatschappelijke ontwikkeling (dat is met het oog op de optimale persoonswording van het kind);

- art. 28, lid 1 VRK: het recht van het kind op (verplicht en kosteloos) onderwijs ${ }^{87}$;

- art. 30 VRK: het recht van het kind dat tot een minderheidsgroep be-

attainable standard of health care for his physical mental and moral development, and also, in the case of need, from medical and rehabilitation facilities.' Aldus de basic working text' aangenomen in 1980. In een Canadees voorstel ingebracht in 1983 was het woord 'moral' verwangen door 'social' (t.a.p.). Gezondheid omvat in deze redactie dus expliciet ook de geestelijke gezondheid, dat wil zeggen de gezonde lichamelijke, geestelijke en morele/sociale ontwikkeling van het kind. In deze redactie zou een witdrukkelijke sPS-plicht (plicht tot opbouw van een sociaalpedagogisch steunstelsel) van de staat te lezen zijn, die nu moet worden afgeleid uit een combinatic van artikelen, waaronder art. 24 , maar ook art. 6 (vgl. DETRICK, a.w., p. 123; curs. jw: "realize the full development of his or her personality, both from the material and spiritual points of view'), en in het bijzonder art. 19 en art. 39. In 1985 werd de Canadese redactie geherformuleerd tot een recht van het kind (DETRICK, a.w., p. 345; curs. jw): 'The States Parties to the present Convention recognize the right of the child to the highest attainable standard of health care and, in case of need, to medical and rehabilitation facilities." Om redenen die DETRICK niet vermeldi (enkel van tekst-economische aard?), was de formule for his physical, mental and social development' - kennelijk - uit de ontwerptekst verdwenen.

VAN BUEREN (a.w, pp. 256) wijst erop dat het recht op onderwijs ook ouders toekomt. We zouden het recht van het kind op opvoedingsonderwijs van zijn ouders dan ook mede op art. 28 kunnen baseren. Met andere woorden het recht van het kind op opvoedingsonderwijs van zijn ouders hoeft niet uitsluitend als een uitwerking of uitvloeisel van diverse verdragsbepalingen (zoals art. 3 , lid 2 ; art. 5; art. 6, lid 2; art. 14, lid 2; art. 18, lid 1 en 2 en, in het bijzonder, art. 19, lid 2) te worden gezien. 
hoort, de eigen cultuur van de groep te beleven, de eigen godsdienst te belijden en ernaar te leven, en de eigen taal te spreken;

- art. 31 (lid 1 en 2) VRK: het recht van het kind op vrije tijd, rust, spel, recreatie passend bij de leeftijd van het kind; het recht van het kind op deelneming aan het culturele en artistieke leven;

- art. 32, lid 1 VRK: het recht van het kind op bescherming tegen economische uitbuiting en tegen gevaarlijke of voor de persoonswording schadelijke kinderarbeid (het verrichten van werk dat naar alle waarschijnlijkheid gevaarlijk is of de opvoeding van het kind zal hinderen, of schadelijk zal zijn voor de gezondheid of de lichamelijke, geestelijke, intellectuele, zedelijke of maatschappelijke ontwikkeling van het kind);

- art. 37 VRK: martelverbod; vrijwaring van wrede, onmenselijke of onterende/vernederende behandeling of bestraffing; geen doodstraf of levenslang 'levenslang'; habeas corpus; humane behandeling tijdens detentie van het kind met eerbied voor de waardigheid inherent aan de menselijke persoon, waarbij rekening wordt gehouden met de behoeften van een persoon van zijn leeftijd; detentie gescheiden van volwassenen tenzij het in het belang van het kind wordt geacht dit niet te doen; recht op contact en correspondentie met en bezoeken van familie; recht op rechtsbijstand, recht op een rechter (rechtsbescherming), recht op een onverwijlde beslissing;

- art. 40, lid 1 VRK: het recht van het kind op een strafvorderlijke behandeling die geen afbreuk doet aan het gevoel van waardigheid en eigenwaarde van het kind, en waarbij rekening wordt gehouden met de leeftijd van het kind;

- art. 40, lid 2 VRK: nulla poena-beginsel, onschuldpresumptie, mededeling van de beschuldiging, rechtsbijstand, onafhankelijke rechter, aanwezigheid van ouders tenzij dit wordt geacht niet in het belang van het kind te zijn, met name gezien zijn leeftijd, processuele waarborgen, hoger beroep, gratis tolk, privacy-bescherming;

- art. 41 VRK: recht op het nationaal- of internationaalrechtelijk beste/ sterkste recht (saving clause).

In deze paragraaf vegen we allereerst de belangrijkste verdragsbepalingen op een hoop waarvan (bovenminimale c.q.) optimale persoonswording geacht kan worden zin en strekking te vormen, doel en wezen uit te maken (par. 10.3.1). Vervolgens maken we een kort horizon-verruimend optimaal-persoonswordingsuitstapje naar andere internationaal- en in het bijzonder kindervolkenrechtelijke instrumenten (par. 10.3.2). En ten slotte staan we stil bij een jurisprudentieel precedent dat ons een juridisch 
aanknopingspunt biedt om optimale persoonswording als achterliggend rechtsbeginsel van het Verdrag inzake de rechten van het kind te kunnen betitelen (par. 10.3.3).

\subsubsection{Optimale persoonswording in het Verdrag}

Uit het gelijkheidsbeginsel in art. 2, lid 1 juncto lid 2 VRK in verband met in het bijzonder (a.) de volgende rechten van het kind:

- het recht op bescherming van zijn lichamelijke en geestelijke integriteit (art. 16 VRK juncto art. 8 EVRM en art. 17 IVBPR);

- het recht op de best mogelijke lichamelijke en geestelijke gezondheid (art. 24, lid 1 VRK);

- het recht op rehabilitatie (lichamelijk en geestelijk herstel en maatschappelijke herintegratie) in geval van (onder meer) kindermishandeling (art. 24, lid 1 juncto art. 39 VRK);

- het recht op een toereikende levensstandaard met het oog op zijn lichamelijke, geestelijke, intellectuele, zedelijke en maatschappelijke ontwikkeling (art. 27, lid 1 VRK);

- het recht op onderwijs (art. 28, lid 1 VRK);

- het recht op vrije tijd, rust, spel en recreatie (art. 31, lid 1 VRK);

- het recht op deelneming aan het culturele en artistieke leven (art. 31, lid 2 VRK);

- het recht op bescherming tegen economische uitbuiting en tegen het verrichten van werk dat de opvoeding van het kind hindert of schadelijk is voor de gezondheid of de lichamelijke, geestelijke, intellectuele, zedelijke of maatschappelijke ontwikkeling van het kind (art. 32, lid 1 VRK);

- het recht op vrijwaring van wrede, onmenselijke of onterende/ vernederende behandeling of bestraffing (art. 37 VRK juncto art. 3 EVRM en art. 7 IVBPR);

alsmede in verband met in het bijzonder (b.) de volgende verplichtingen van de staat:

- het hanteren van 'het belang van het kind' als leidend sociaalpedagogisch beginsel door wetgever en bestuur en als leidend pedagogisch beginsel in individuele gevallen door bestuur en rechter (art. 3, lid 1 VRK);

- het verzekeren van de bescherming en de zorg die nodig zijn voor het welzijn van het kind met inachtneming van de bevoegdheden en de plichten van de ouders (in het kader van de secundaire - aanvullende, ondersteunende en desnoods geheel of gedeeltelijk vervangende - opvoedingsverantwoordelijkheid van de staat: art. 3, lid 2 VRK); 
- het uitoefenen van 'toezicht op afstand' ten aanzien van de pedagogische plicht van ouders tot het geven van leiding en begeleiding aan hun kinderen in overeenstemming met de zich ontwikkelende vermogens van het kind (art. 5 VRK);

- het in de ruimst mogelijke mate waarborgen van de lichamelijke en geestelijke ontwikkelingskansen van het kind (art. 6, lid 2 VRK); - het waarborgen van de toegangelijkheid van informatie die bijdraagt aan het sociale, psychische en morele welzijn en de lichamelijke en geestelijke gezondheid van het kind (art. 17 VRK); met inbegrip van:

- het stimuleren van richtlijnen ter bescherming van het kind tegen informatie die en materiaal dat schadelijk is voor zijn welzijn (art. 17 onder e VRK);

- het doen respecteren van het beginsel dat beide ouders gezamenlijk verantwoordelijk zijn voor de opvoeding en de ontwikkeling van het kind (art. 18, lid 1, eerste volzin VRK);

- het uitoefenen van 'toezicht op afstand' op de primaire opvoedingsverantwoordelijkheid van ouders, in het bijzonder op de plicht van ouders steeds het (veiligheids- en ontwikkelings)belang van het kind voorop te stellen (art. 18, lid 1, tweede en derde volzin VRK);

- het verlenen van passende bijstand aan ouders bij de uitoefening van hun verantwoordelijkheden die de opvoeding van het kind betreffen (art. 18, lid 2 VRK);

- het waarborgen van de ontwikkeling van (sociaal-pedagogische) instellingen, voorzieningen en diensten voor kinderzorg (art. 18, lid 2 VRK);

- het waarborgen van het recht van het kind van werkende ouders op gebruikmaking van diensten en voorzieningen voor kinderopvang/-zorg (art. 18, lid $3 \mathrm{VRK})^{88}$;

- het nemen van alle passende wettelijke en bestuurlijke maatregelen en maatregelen op sociaal en pedagogisch gebied om het kind te beschermen tegen alle vormen van lichamelijk of geestelijk geweld, letsel of misbruik, lichamelijke of geestelijke verwaarlozing of nalatige behandeling, mishandeling of uitbuiting, met inbegrip van sexueel misbruik, terwijl het kind onder de hoede is

Vgl. in dit verband ook art. 11, lid 2 aanhef en onder $c$ van het Verdrag inzake de uitbanning van alle vormen van discriminatie van vrouwen, waarin sprake is van 'het opzetten en ontwikkelen van een netwerk van faciliteiten voor kinderopvang.' 
van de ouder(s), wettige voogd(en) of iemand anders die de zorg voor het kind heeft (art. 19, lid 1 VRK);

- het (aanstalten maken om te) voorzien in sociale opvoedingsondersteunings- en preventie-programma's, in procedures voor opsporing van gevallen van kindermishandeling ('gezinsinspectie'), in een meldingsregeling, in procedures voor gezinsonderzoek, verwijzing, behandeling, follow-up en, waar nodig, voor inschakeling van rechterlijke instanties (art. 19, lid 2 VRK);

- het waarborgen van gezinsvervangende zorg, zoals pleeggezinplaatsing of plaatsing in geschikte instellingen voor kinderzorg, voor elk kind dat gedurende kortere of langere tijd het verblijf in het gezin van oorsprong moet missen (art. $20 \mathrm{VRK}$ );

- het nemen van maatregelen ter vermindering van baby- en kindersterfte (waaronder infanticide; art. 24, lid 2 sub a VRK);

- het nemen van maatregelen ter waarborging van de verlening van medische hulp en (ook geestelijke) gezondheidszorg aan alle kinderen, met nadruk op de ontwikkeling van de eerste-lijnsgezondheidszorg (art. 24, lid 2 sub b VRK);

- het nemen van maatregelen ter bestrijding van (onder meer) slechte voeding en milieuverontreiniging (art. 24, lid 2 sub c VRK); - het nemen van maatregelen ter waarborging van pre- en postnatale gezondheidszorg voor moeders (art. 24, lid 2 sub d VRK); - het nemen van maatregelen ter waarborging van de beschikbaarheid voor alle geledingen van de samenleving, met name voor ouders en kinderen, van gezondheids-, voedings- en veiligheidsvoorlichting en -scholing c.q. -ondersteuning (art. 24, lid 2 sub e VRK); - het nemen van maatregelen ter ontwikkeling van preventieve gezondheidszorg, begeleiding voor ouders en voorzieningen voor en voorlichting over gezinsplanning (art. 24, lid 2 sub f VRK); - het voorzien in programma's voor materiële bijstand en ondersteuning aan ouders ('opvoedingsgeld'), met name wat betreft voeding, kleding en huisvesting, ter verwezenlijking van het recht van het kind op een toereikende levensstandaard met het oog op zijn lichamelijke, geestelijke, intellectuele, zedelijke en maatschappelijke ontwikkeling (art. 27, lid 3 VRK);

- het stellen en bewaken van (welomschreven) onderwijsdoelen: het onderwijs aan het kind dient te zijn gericht op (a.) de zo volledig mogelijke ontplooiing van de persoonlijkheid, talenten en geestelijke en lichamelijke vermogens van het kind; (...) (d.) de voorbereiding van het kind op een verantwoord leven in een vrije samenleving in de geest van (democratische idealen als) vrede, ver- 
draagzaamheid, gelijkheid van man en vrouw, vriendschap tussen alle volken en ethnische groepen; (e.) het bijbrengen van eerbied voor het milieu (art. 29, lid 1 VRK);

- het beschermen van het kind tegen alle vormen van uitbuiting die schadelijk zijn voor enig aspect van het welzijn van het kind (art. 36 VRK);

kan worden afgeleid dat - in de woorden van DE RUYTER ${ }^{89}$ - op de staat de algemene en fundamentele (verdrags)verplichting rust ...

"(...) om het kind een faire kans te geven zijn mogelijkheden te maximaliseren en (....) zorg te dragen dat het kind niet zoveel mist in zijn jeugd dat het onevenredig zou worden benadeeld aan het begin van zijn volwassen leven in vergelijking met andere kinderen."

Deze algemene en fundamentele rechtsplicht (verdragsrechtelijke bodemverplichting) van de staat zullen we hierna - in juridische zin - aanduiden als het recht van het kind (dat is van elk kind) op optimale persoonswording. Op grond van art. 4 VRK betreft dit recht een uiterste-inspanningsverplichting van de staat (dit uiteraard los van de verdragsbepalingen die specifieke te waarborgen rechten van het kind betreffen).

Deze bodemverplichting (basale uiterste-inspanningsverplichting) kan ook worden omschreven als de verplichting van de staat (wetgever, overheid, rechter, lagere overheden) alles in het werk te stellen dat elk kind als boven-minimaal, dat wil zeggen als (afhankelijk van de nationale omstandigheden zoveel mogelijk) meer dan minimaal rationeel, moreel en authentiek persoon, de volwassenen-maatschappij betreedt.

\subsubsection{Optimale persoonswording in andere instrumenten}

Buiten het Verdrag inzake de rechten van het kind kan de in de vorige subparagraaf deels gededuceerde deels geïnduceerde (dat is geconstrueerde) algemene en fundamentele rechtsplicht van de staat alles in het werk te stellen dat elk kind als (zoveel mogelijk) boven-minimaal persoon de volwassenen-maatschappij betreedt - c.q. het (verdragsrechtelijke) recht van het kind op optimale persoonswording - geadstrueerd worden aan de hand van de volgende instrumenten (termen of passus die in het bijzonder relevant zijn, zijn gecursiveerd; de aangehaalde bepalingen zijn enuntiatief en illustratief, niet limitatief en peremptoir bedoeld): 
1. De Verklaring van de rechten van het kind van 1924 (de Verklaring van Genève/Volkenbondverklaring): ${ }^{90}$

Beginsel 1. The child must be given the means requisite for its nomal development, both materially and spiritually.

\section{De Verklaring van de rechten van het kind van 1959 (de vN-Verkla- ring): ${ }^{91}$}

Beginsel 2. The child shall enjoy special protection, and shall be given opportunities and facilities, by law and by other means, to enable him to develop physically, mentally, morally, spiritually and socially in a healthy and normal manner and in conditions of freedom and dignity. In the enactment of laws for this purpose, the best interests of the chill shall be the paramount consideration.

Beginsel 6. The child, for the full and harmonious development of his personality, needs love and understanding. He shall, wherever possible, grow up in the care and under the responsibility of his parents, and, in any case, in an atmosphere of affection and of moral and material security; a child of tender years shall not, save in exceptional circumstances, be separated from his mother. Society and the public authorities shall have the duty to extend particular care to children without a family and to those without adequate means of support. Payment of State and other assistance towards the maintenance of children of large families is desirable.

Beginsel 7. [Education]. (...) [TJo develop his abilities, his individual judgment, and his sense of moral and social responsibility (...).

90 Vgl. Geraldine VAN BUEREN (ed.), Intemational doctments an children, Dord[r]echt (etc.) 1993, p. 3; Sharon DETRick (ed.), The United Nations Convention on the rights of the child; A guide to the 'travaux preparatoires,' Dordrecht (etc.) 1992, p. 641; Ph.E. VEERMAN, The rights of the child and the changing image of childhood, Dordrecht (etc.) 1992, p. 444; Marian KOREN, Tell me! The right of the child to infornation, diss. Amsterdam, Den Haag 1996, p. 511.

91 VAN BUEREN, a.w., pp. 4-6; DETRICK, a.w., pp. 642-644; VERRMAN, a.w., pp. 465467; KOREN, a.w., pp. 511-512.

Op p. 511 heeft KOREN een niet bestaande VN-verklaring van de rechten van het kind van 1948 ingelast, die zij wermoedelijk van DETRICK, a.w., pp. 641-642, heeft overgenomen. Volgens CANTWELL zou de Algemene Vergadering van de VN in 1948 een Verklaring van de rechten van het kind hebben aangenomen welke bijna volledig de Verklaring van Genève volgt (Nigel CANTWELL, "The origins, devellopment and significance of the United Nations Convention on the rights of the child," in: DETRICK, a.w., Ch. 1, pp. 19-30, op p. 19). Daarvan is evenwel geen bevestiging te vinden. Vermoedelijk betreft het een Verklaring van de Algemene Raad van de International Union for Child Welfare (vgl. Ph.E. VEERMAN* The rights of the child and the changing image of childhood, Dordrecht etc. 1992, pp. $159 / 160-161$ en 219 nt. 37 ). 
Beginsel 9. [Exploitation]. (...) The child shall (...) in no case be caused or permitted to engage in any occupation or employment which would prejudice his health or education, or interfere with his physical, mental or moral development.

\section{De Universele Verklaring van de rechten van de mens (10 december 1948): ${ }^{92}$}

Art. 26 , lid 2. Education shall be directed to the full development of the human personality (...).

4. Het Internationaal Verdrag inzake economische, sociale en culturele rechten (IVESCR, 1966/1976/1979 $)$ :

Art. 10 onder 1. De groatst mogelijke bescherming en bijstand dient te worden verleend aan het gezin, dat de natuurlijke en fundamentele kern van de maatschappij vormt, in het bijzonder bij de stichting daanan en zolang het de verantwoording draagt voor de zorg voor en opvoeding van kinderen (...). (...)

Art. 10 onder 2. Aan moeders dient bijzondere bescherning te worden verleend gedurende een redelijke periode wóor en na de geboorte van hun kind. (...)

Art. 10 onder 3. Bijzondere maatregellen ter bescherming van en ter verlening van bijstand aan kinderen en jeugdige personen dienen te worden genomen zonder enigerlei discriminatie ter zake van afstamming of anderszins. (..) Tewerkstelling van [kinderen en jeugdige] personen voor het verrichten van arbeid die schadelijk is voor hun zedelijk of lichamelijk welzijn, levensgevaar oplevert, dan wel groot gevaar inhoudt dat hun nomale ontwikkeling zal worden geremd, dient strafbaar te zijn bij de wet. (...)

Art. 12, lid 1 en 2, aanhef en sub a. De staten (...) erkennen het recht van een ieder op een zo goed mogelijke lichamelijke en geestelijke gezondheid. De door de staten (...) te nemen maatregelen ter volledige verwezenlijking van dit recht omvatten onder meer die welke nodig zijn on te komen tot (...) een gezonde ontwikkeling wan het kind.

Art. 13, lid 1. The States parties (...) agree that education shall be directed to the full development of the human personality and the sense of its dignity (...).

5. Het Verdrag inzake de uitbanning van alle vormen van discriminatie van vrouwen (Vrouwenverdrag, 1979/1981/1991):

92 Vgl. Pentti ARAJÄnv, 'Article 26,' in: The Universal Declaration of human rights, a.W., pp. 405-428, op p. 409 .

93 De jaartallen betreffen respectievelijk het jaar van de totstandkoming van het verdrag (dit kan het jaar zijn waarin het verdrag is gesloten c.q. ondertekend dan wel het jaar waarin het verdrag is aangenomen door een orgaan van een internationale organisatie, meestal de Algemene Vergadering van de VN, waarop het verdrag woor ondertekening wordt opengesteld); het jaar van de inwerkingtreding van het verdrag (nadat het vereiste aantal ratificaties binnen is); en het jaar van de inwerkingtreding voor Nederland. 
Art. 5 aanhef en sub b. State parties shall take all appropriate measures (...) [t]o ensure that family education includes (...) the recognition of the common responsibility of men and women in the upbringing and development of their children, it being understood that the interest of the children is the primortial consideration in all cases.

Art. 16, lid 1 aanhef en sub $d$ [en f]. State parties shall take all appropriate measures to eliminate discrimination against women in all matters relating to marriage and family relations and in particular sthall ensure, on a basis of equality of men and women (...) [t] he same rights and responsibilities as parents, irrespective of their marital status, in matters relating to their children; in all cases the interests of the children shall be paramount. [Sub f dezelfde slotzin.]

6. Het Internationaal Verdrag ter bescherming van de rechten van migranten (Migrantenverdrag, 1990): ${ }^{94}$

Art. 30. Each child of a migrant worker shall have the basic right of access to education on the basis of equality of treatment with nationals of the State concerned. (...)

7. Het herzien Europees Sociaal Handvest (ESH, 1961/1965/1980; herzien ESH, 1996): ${ }^{95}$

Art. 17. The right of children and young persons to social, legal and economic protection.

With a view to ensuring the effective exercise of the right of children and young persons to grow up in an environment which encourages the full development of their personality and of their physical and mental capacities, the Parties undertake either directly or in cooperation with public and private organisations, to take all appropriate and necessary measures designed: (...)

a. to ensure that children and young persons, taking account of the rights and duties of their parents, have the care, the assistance, the education and the train-

94 Zie over het Migrantenverdrag (International Convention on the protection of the rights of all migrant workers and nembers of their families): Shirley HUNE, Jan NIESSEN, 'The first UN Convention on Migrant Workers,' Netherlands Quarterly of Human Rights 1991/2, pp. 130-141; dez., "Ratifying the UN Migrant Workers Convention: current difficulties and prospects, NQHR 1994/4, pp. 393-404. De tekst van het Verdrag is opgenomen in NQHR 1991/2, pp. 203-232.

Zie COUNCIL OF EUROPE, The family - onganisation and protection within the European Social Charter, Human rights, Social Charter monographs 1, [Straatsburg] 1995, pp. 8 en 73; COUNCIL OF EUROPE, Children and adolescents - protection within the European Social Charter, Human rights, Social Charter monographs 3, 1996, pp. 7 en 87/88. De volledige tekst is te vinden in NQHR 1996/3, Appendix II (Revised Social Charter), pp. 341-359. Zie ook C.J. STAAL, 'Het herziene Europees Sociaal Handvest,' NJCM-Bulletin 1997/3, pp. 349-380 (tekst op pp. 359-380). 
ing they need, in particular by providing for the establishment or maintenance of institutions and services sufficient and adequate for this purpose;

b. to protect children and young persons against negligence, violence or exploitation;

c. to provide protection and special aid from the state for children and young persons temporarily or definitively deprived of their family"s support; (...).

8. De American Declaration of the rights and duties of man (2 mei 1948): ${ }^{96}$

Art. XXIX. It is the duty of the individual so to conduct himself in relation to others that each and every one may fully form and develop his personality.

\section{Het Protocol van San Salvador van 1988 (Additioneel Protocol bij de} Amerikaanse Conventie voor de rechten van de mens, het Pact van San José, 1969/1978): $:^{97}$

Art. 13, lid 2 (eerste volzin). The states parties to this Protocol agree that education should be directed towards the full development of the human personality and human dignity (...).

Art. 15, lid 3 sub c. To adopt special measures for the protection of adolescents in order to ensure the full development of their physical, intellectual and moral capacities.

10. Het Afrikaans Handvest inzake de rechten en het welzijn van het kind (African Charter on the rights and welfare of the child, $1990^{98}$ ): ${ }^{99}$

Preambule (vierde overweging). (...) [T]he full and harmonious development of his personality (...).

(Vijlde owerweging). (...) [T] he child, due to the needs of his physical and mental development, requires particular care with regard to health, physical, mental, moral and social development (...).

Art. 11 [Education], lid 2 sub a. (...) [T] he promotion and development of the child's personality, talents and mental and physical abilities to their fullest potential.

Art. 21, lid 1. States (...) shall take all appropriate measures to abolish customs and practices harmful to the welfare, nomal growth and development of the child

96 Ian BROWNLIE (ed.), Basic documents on humain rights, Oxford 1981 (tweede druk), pp. 381-387.

97 De tekst is opgenomen in NQHR 1992/2, pp. 232-242. Vgl. ook VAN BUEREN, a.W., pp. 73 en 71 (de artt. 15 en 16 van het Protocol van San Salvador heeft VAN BUEREN abusievelijk opgenomen onder het Pact van San José).

98 Per 1 januari 1998 nog slechts door 8 (OAE-)staten geratificeerd; nog niet in werking getreden.

99 VAN BUEREN, a.w., pp. 33-48; VEERMAN, a.w., pp. 579-597. 
and in particular (...) those customs and practices discriminatory to the child on the grounds of sex or other status.

\section{De Recommendation on parental responsibilities ${ }^{100}$ van de $\mathbb{R a a d}$}

"Het doel van deze aanbeveling, die op 28 februari 1984 werd aanvaard door het Comite van Ministers van de Raad van Europa, is de persoonlijkheid wan het kind in zijh ontwikkeling via een witeenzetting van de grondbeginselen van de parental responsibilities te benadrukken. "Beoogd wordt verder te bevorderen dat het kind in het recht niet wordt beschouwd als object van bescherming, maar als drager van rechten en plichten die ook in de wet hun erkenning vinden" [WORTMANN]. In de viteenzetting van de juridische rol wan de ouders is de positie van het kind, zijn persoonlijkheid en welzijn in het geding. (...) In (...) de Toelichting bij deze Recommendation worden de nationale wetgevers uitgenodigd: "to consider children no longer as [objects] protected by the law but as holders of legally recognised rights. In this way emphasis is placed on the development of the personality of the child and his material and moral well-being, in a legal situation of full equality between the parents. Such an approach is in accord with the dignity of the child and the role of parents."

Blijkens beginsel 1 onder a is het begrip "parental responsibilities" een verzamelbegrip van plichten en bevoegdheden die ouders hebben om het morele en materiële welzijn van hun kind te verzekeren, in het bijzonder door zorg te dragen voor de persoon/swording] van het kind, door het onderhouden van persoonlijke betrekkingen met het kind en door te voorzien in zijn opvoeding, zijn levensonderhoud, de vertegenwoordiging van het kind in rechte, alsmede het bewind over het vermogen van het kind. In de Toelichting wordt dit nader uitgelegd: "Parents are given the task to educate, legally represent, maintain etc. their children. In order to do so they exercise powers to carry out duties in the interest of the child." (...)

De term "parental responsibilities" geeft (...) de huidige opvatting weer dat "parents are, on a basis of equality between the parents and in consultation with their children, given the task to educate, legally represent, maintain etc. their children. In order to do so they exercise powers to carry out duties in the interests of the child and not because of an authority wich is conferred on them in their own interests." (...) De term ouderlijk gezag geeft in tegenstelling tot de term ouderlijke macht naar huidige juridische opvattingen weer dat ouders verantwoordelijk zijn voor de verzorging en opvoeding van hun minderjarige kinderen en te dien einde ouderlijk gezag hebben. Het ouderlijk gezag dient naar redelijkheid en. billijkheid en met inachtneming van de rechten en bevoegdheden van de kinderen te worden nitgeoefend [DOEK e.a.].'

Aldus M.L.C.C. DE BRUIN-L̈̈CKERS, EVRM, minderjarigheid en ouderlijk gezag, diss. Leiden, Zwolle 1994, pp. 103/104 en 105 (curs. jw).

Vgl. ook M.I.C. KOENS, Jeugdigen in de knel, i.o. Maastricht, Deventer 1994, pp. 29-30; A.P. VAN DER LINDEN, 'Ouderlijk gezag en voogdij,' in: M.J.C. KOENS (red.), Het hedendaagse personen-en familierecht, Zwolle 1995, pp. 229-263, op pp. $229 / 230$. 
van Europa $a^{101}(1984):^{102}$

Principle 1 (sub a). Parental responsibilities are a collection of duties and powers which aim at ensuring the moral and material welfare of the child, in particular by taking care of the person of the child, by maintaining personal relationships with him and by providing for his education, his maintenance, his legal representation and the administration of his property.

Principle 3. (...) [C]hildren (...) should be consulted if their degree of maturity with regard to the decision [of the competent authority, affecting their essential interests] so permits.

Principle 4. When the persons having parental responsibilities exercise them in a way which is detrimental to the essential interests of the child, the competent authority should take, of its own motion or on application, any appropriate measures.

Principle 8. (...) The parent with whom the child does not live, should have at least the possibility of maintaining personal relationships with the child, unless such relationships would be seriously hamfal to the interests of the child. ${ }^{103}$

12. De WHo en UNICEF Declaration of Alma-Ata (1978): ${ }^{104}$

The International Conference on primary health care (...) strongly reaffirms that health, which is a state of complete physical, mental and social wellbeing, and not merely the absence of disease or infirmity, is a fundamental human right (...).

13. De UN Standard minimum rules for the administration of juvenile justice (Beijing rules, 1985): ${ }^{105}$

101 De Raad van Europa heeft aan de wieg gestaan van verschillende studies, documenten en aanbevelingen inzake kinderen. Het 'Childhood Policies'-project van de Raad van Europa (1992-1995) heeft geleid tot een bundeling van deze teksten, welke als basis kan dienen voor de European Strategy for Children (Aanbeveling 1286 (1996) van de Parlementaire Vergadering): COUNCIL of EUROPE, The rights of the child; A European perspective, Strasbourg 1996. Vgl. hierover Ferran CASAS, 'The Childhood Policies Project of the Council of Europe, in: Eugeen VERHELLEN (ed.), Understanding children's rights; Collected papers presented at the first Intemational interdisciplinary course on children's rights, Gent 1996, pp. 215-221. Zie voor een overzicht van Europese (Raad van Europa èn Europese Unie) kinderrechtelijke 'regelgeving' Eugeen WERHELLEN, 'Children's rights in Europe,' in: Understanding children's rights, a.w., pp. 515-540, op pp. 526-533.

102 VAN BUEREN, a.w., pp. 116-118; The Raoul WALLENBERG Institute Human Rights Guides vol. 1, a.w., pp. 232-233 (gedeeltelijk); COUNCIL OF EUROPE, The rights of the child, a.w., pp. 322-324.

103 Dus niet: if (and only if) such relationships are in the interest of the child (voor zover omgang in het belang van het kind is/kan worden geacht).

104 VAN BUEREN, a.w., pp. 313-316.

105 VAN BUEREN, a.w., pp. 199-216. 
General principles 1.2. Member states shall endeavour to develop conditions that will ensure for the juvenile a meaningful life in the community, which (...) will foster a process of personal development and education (...).

14. De UN Declaration on social and legal principles relating to the protection and welfare of children, with special reference to foster placement and adoption, nationally and internationally (1986): $:^{106}$

Article 5. In all matters relating to the placement of a child outside the care of the child's own parents, the best interests of the child, particularly his of her need for affection and right to security and continuing care, should be the paramount consideration.

Article 9. The need of a foster or an adopted child to know about his or her background should be recognized by persons responsible for the child's care unless this is contrary to the child's best interests.

\section{De UN Guidelines for the prevention of juvenile delinquency (Riyadh} guidelines, 1990): 107

The General Assembly,

Mindfill of the large number of young persons (...) who are abandoned, neglected, abused, exposed to drug abuse, in marginal circumstances, and who are in general at social risk (...).

\section{Fundamental principles.}

2. The successful prevention of juvenile delinquency requires efforts on the part of the entire society to ensure the hannonious development of adolescents, with respect for and promotion of their personality from early childhood.

3. (...) $[A]$ child-centred orientation should be pursued. Young persons should have an active role and partmership within society and should not be considered as mere objects of socialization or control.

4. (...) [T] The well-being of young persons from early childhood should be the focus of any preventive programme.

IV. Socialization processes.

A. Fanily.

11. Every society should place a high priority on the needs and well-being of the family and of all its members.

12. (...) The society has a responsibility to assist the family in providüng care and protection and in ensuring the physical and mental well-being of children. Adequate arrangements including day-care should be provided.

13. Governments should establish policies that are conducive to the bringing up of children in stable and settled family environments. Families in need of assistance in the resolution of conditions of instability or conllict should be provided with requisite services. 
14. Where a stable and settled family environment is lacking and when community efforts to assist parents in this regard have falled and the extended family cannot fulfill this role, alternative placements, inciuding foster care and adoption, should be considered. Such placements should replicate, to the extent possible, a stable and settled family environment, while, at the same time establishing a sense of permanency for children, thus avoiding problems associated with 'foster drift."

16. Measures should be taken and programmes developed to provide families with the opportunity to leam about parental roles and obligations as regards child development and child care, promoting positive parent-child relationships, sensitizing parents to the problems of children and young persons and encouraging their involvement in family and community-based activities.

\section{B. Educational.}

21. Education systems should (...) devote particular attention to the following:

(b.) Promotion and development of the personality, talents and mental and physical abilities of young people to their fullest potential,

(d.) Undertaking activities that foster a sense of identity with and of belonging to the school and the community;

(g.) Provision of positive emotional support to young persons and the absence of psychological maltreatment;

(h.) Avoidance of harsh disciplinary measures, particularly corporal punishment.

26. Schools should serve as resource and referral centres for the provision of medical, counselling and other services to young persons, particularly those with special needs and suffering from abuse, neglect, victimization and exploitation.

\section{Community.}

32. Community-based services and programmes (....) which offer appropriate counselling and guidance to young persons and their families should be developed, or strengthened where they exist.

35. A range of services and helping measures should be provided to deal with the difficulties experienced by young persons in the transition to adulthood. (...)

D. Mass media.

43. (...) [M]inimize (...) violence portrayed (...).

V. Social policy.

46. The institutionalization of young persons should be a measure of last resort and for the minimum necessary period, and the best interests of the young person should be of paramount intportance. Criteria authorizing formal intervention of this type should be strictly defined and limited to the following situations:

(a.) where the child or young person has suffered harm that has been inflicted by the parents or guardians;

(b.) where the child or young person has been sexually, physically or emotionally abused by the parents or guardians;

(c.) where the child or young person has been neglected, abandoned or exploited by the parents or guardians;

(d.) where the child or young person is threatened by physical or moral danger due to the behaviour of the parents or guardians; and

(e.) where a serious physical or psychological danger to the child or young person has manifested itself in his or her own behaviour and neither the 
parents, guardians or the juvenile him or herself nor non-residential community services can meet the danger by means other than institutionalization.

49. Scientific information should be disseminated to the professional community and to the public at large about the sort of behaviour or situation which indicates or may result in physical and psychological victimization, harm and abuse, as well as exploitation of young persons.

51. Governments should begin or continue to explore, develop and implement policies, measures and strategies (...) to prevent domestic violence against and affecting young persons and to ensure fair treatment to these victims of domestic violence.

VI. Legislation and juvenile justice administration.

54. No child or young person should be subjected to harsh or degrading correction or punishment measured at home, in schools or in any other institution.

57. [Instelling ombudsman].

VII. Research (...).

60. [Coôrdinatie tussen instellingen].

16. De Vienna Declaration and Programme of Action, adopted by the World Conference on Human Rights (Wenen, 1993): ${ }^{108}$

Par. 21. The World Conference (...) urges universal ratification of the Convention [on the Rights of the Child] by 1995 and its effective implementation by states parties through the adoption of all the necessary legislative, administrative and other measures and the allocation to the maximum extent of the available resources. In all actions concerming children, non-discrimination and the best interest of the child should be primary considerations and the views of the child given due weight.

17. De rapportage-richtlijnen van het Comite inzake de rechten van het kind (1991): $:^{109}$

'De bepalingen van het Verdrag w[o]rden gegroepeerd onder [acht] rubrieken, waarbij gelijk belang gehecht wordt aam alle door het Verdrag erkende rechten. [1.] Algemene implementatiemaatregelen

[De staten informeren het Comite omtrent de door hen genomen] maatregelen om de nationale wetgeving en beleidsvoering in overeenstemming te brengen met de bepalingen van het Verdrag (...). (...)

108 Opgenomen in NQHR 1993/3, pp. 346-368 (The rights of the child: par. 45-53, t.a.p.y op pp. 361-362); The Raoul WALLENBERG Institute Human Rights Guides vol. 1, a.w., pp. 20-25 (gedeeltelijk).

109 General guidelines regarding the form and content of initial reports to be submitted by states parties under article 44, paragraph 1 (a), of the Convention, UN doc. CRC/C/5 (1991); 'officieuze vertaling' (in het Vlaams) in E. VERHELLEN e.a. (red.), Kinderrechtengids, Gent 1994 (losbladig), Deel 2 (Regelgeving), 2.1.B, pp. 14-19, op pp. 15-19, par. 8-23. 


\section{[2.] Definitie van het kind}

[De staten verschaffen informatie omtrent] wettelijke minimum-leefitijen [met betrekking tot onder anderel juridisch of medisch advies zonder toestemming van de ouders, (...) leerplicht, (...) tewerkstelling, (...) sexuele betrekkingen, huwelijk, (...) legerdienst, (...) strafrechtelijke aansprakelijkheid, (...) consumptie van alcohol of andere substanties walarvan het gebruik is gereglementeerd.

[3.] Algemene beginselen

[De staten verschaffen informatie omtrent de implementatie van de volgende werdragsbeginselen:]

(a.) Non-discriminatie (art. 2);

(b.) Het belang van het kind (art. 3);

(c.) Het recht op leven, overieven en ontwikkeling (art. 6);

(d.) Respect voor de mening van het kind (art. 12).

(...)

[4.] Bungerlijke rechten en vrijheden

[De staten verschaffen informatie omtrent de implementatie van de volgende burgerlijke rechten en vrijheden:]

(a.) Naam en nationaliteit (art. 7);

(b.) Behoud van identiteit (art. 8);

(c.) Vrijheid van meningsuiting (art. 13);

(d.) Toegang tot passende informatie (art. 17);

(e.) Vrijheid van gedachte, geweten en godsdienst (art. 14);

(f.) Vrijheid van vereniging en van vreedzame vergadering (art. 15);

(g.) Bescherming van de privacy (art. 16);

(h.) Het recht niet onderworpen te worden aan foltering of aan andere wrede, onmenselijke of onterende behandeling of bestraffing (art. 37 (a)).

[5.] Het gezinsmilieu en alternatieve zorg

[De staten verschaffen informatie omtrent de implementatie van de volgende bepalingen, in het bijzonder met het oog op de beginselen 'het belang van het kind' en 'respect voor de mening van het kind':]

(a.) De ouderijke begeleiding (art. 5);

(b.) De ouderlijke verantwoordelijkheden (art. 18, lid 1 en 2) ${ }^{110}$;

(c.) Van de ouders gescheiden worden (art. 9);

(d.) Gezinshereniging (art. 10);

(e.) Verhaal van uitkeringen tot onderhoud van het kind (art. 27, lid 4);

(f.) Kinderen die het gezinsmilieu moeten missen (art. 20);

(g.) Adoptie (art. 21);

(h.) Ongeoorloofde overbrenging en het niet doen terugkeren (art. 11);

(i.) Mishandeling en verwaarlozing (art. 19), met inbegrip van lichamelijk en geestelijk herstel en herintegratie in de maatschappij (art. 39);

(j.) Periodieke evaluatie van plaatsing (art. 25).

Daarenboven [verschaffen de staten informatie ontrent] het aantal kinderen per jaar binmen de periode van rapportage in elk van de volgende groepen, uitgesplitst per leeftijdsgroep, geslacht, etnische of nationale achtergrond en stedelijk

110 De verwijzing naar beide leden van art. 18 impliceert dat het Comité niet alleen doelt op de primaire ouderlijke opvoedingswerantwoordelijkheid (lid 1), maar ook op de secundaire statelijke opwoedingsverantwoordelijkheid (lid 2). 
of landelijk milieu: thuisloze kinderen, mishandelde of verwaarloosde kinderen die onder voogdij zijn geplaatst, kinderen geplaatst in pleeggezimen, kinderen geplaatst via adoptie (...).

[De staat verschaffe] aanvullende statistische informatie en indicatoren (...) in verband met kinderen die in deze rubriek worden behandeld.

[6.] Gezondheid en welzijn

[De staten verschaffen informatie omtrent de implementatie van de volgende bepalingen:]

(a.) Overleven en ontwikkeling (art. 6, lid 2);

(b.) Gehandicapte kinderen (art. 23);

(c.) Gezondheid en gezondheidszorg (art. 24);

(d.) Sociale zekerheid en diensten en voorzieningen voor kinderopvang/-zorg (art. 26 en art. 18, lid 3);

(e.) Levensstandaard (art. 27, lid 1, 2 en 3). ${ }^{111}$

[De staat verschaffe] aanvullende statistische informatie en indicatoren (...) in verband met kinderen die in deze rubriek worden behandeld.

[7.] Onderwijs, vrije tijd en culturele activiteiten

[De staten verschaffen informatie omtrent de implementatie van de volgende bepalingen:]

(a.) Onderwijs (...) (art. 28);

(b.) Doelstellingen van het onderwijs (art. 29);

(c.) Vrije tijd, recreatieve bezigheden en culturele activiteiten (art. 31).

[De staat verschaffe] aanvullende statistische informatie en indicatoren (...) in verband met kinderen die in deze rubriek worden behandeld.

[8.] Bïzondere beschermingsmaatregelen

[De staten verschaffen informatie omtrent de implementatie van de volgende bepalingem:]

(a.) Kinderen in noodsituaties: (i) Vluchtelingenkinderen (art. 22); (ii) Kinderen in gewapende conflicten (art. 38), met inbegrip van lichamelijk en geestelijk herstel en herintegratie in de maatschappij (art. 39);

(b.) Kinderen die in aanvaring komen met de wet: (i) Het systeem van de jeugdbescherming (art. 40); (ii) Kinderen die van hun vrijheid beroofd zijn (...) (art. 37 (b), (c) en (d)); (iii) De bestraffing van jongeren (...) (art. 37 (a) [tweede volzin]); (iv) Lichamelijk en geestelijk herstel en herintegratie in de maatschappij (art. 39);

(c.) Kinderen in situaties van exploitatie, met inbegrip van lichamelijk en greestelijk herstel en herintegratie in de maatschappij (art. 39): (i) Economische exploitatie, met inbegrip van kinderarbeid (art. 32); (ii) Drugmisbruik (art. 33); (iii) Sexuele exploitatie en sexueel misbruik (art. 34); (iv) Andere vormen van exploitatie (art. 36); (v) Verkoop, handel en ontvoering (art. 35);

(d.) Kinderen die to een minderheid (...) behoren (art. 30).

[De staat verschaffe] aanwullende statistische informatie en indicatoren (....) in verband met kinderen die in deze rubriek worden behandeld."

111 Ook hier impliceert de verwijzing naar de artikelleden dat zowel op de primaire ouderlijke als op de secundaire statelijke verantwoordelijkheid inzake persoonswordingsoptimalisatie wordt gedoeld. 
Zonder nader op de betekenis van deze richtlijnen in te gaan, ${ }^{112}$ is het van belang naar voren te halen dat het Comité inzake de rechten van het kind $^{113}$ vier fundamentele verdragsbeginselen onderscheidt en daarbij verwijst naar: ${ }^{114}$ (1.) art. 2 , lid 1 VRK (non-discriminatie); (2.) art. 3 , lid 1 VRK (het belang van het kind); (3.) art. 6, lid 2 VRK (overleven en ontwikkeling); en (4.) art. 12, lid 1 VRK (de mening van het kind). We herkennen hierin zowel het gelijkheidsbeginsel als de tot het "persoonswordingsbeginsel' te rekenen beginselen van het veiligheids- en ontwikkelingsbelang van het kind en het beginsel van de zich ontwikkelende vermogens van het kind (respect voor de mening van het kind 'in accordance with the age and maturity of the child'). Het persoonswordingsbeginsel met andere woorden als de combinatie van bescherming (welfarism) en rechten (rights approach).

Op deze plaats kan ook de opvatting van VAN BUEREN in herinnering worden gebracht, ${ }^{115}$ die bepleit het belang van het kind te hanteren als paraplu- c.q. interpretatiebeginsel, en wel in combinatie met het tweede paraplu- en interpretatiebeginsel dat zij in en met betrekking tot het Verdrag inzake de rechten van het kind onderscheidt: het beginsel van de zich ontwikkelende vermogens van het kind. ${ }^{116}$

10.3.3 Optimale persoonswording als achterliggend rechtsbeginsel van het Verdrag inzake de rechten wan het kind

Zorgvuldige lezing van de bepalingen van het Verdrag inzake de rechten van het kind, zowel de bepalingen op zich als in hun onderling verband

112 Vgl. daarover Lawrence J. LEBLANC, The Convention on the rights of the child; United Nations lawmaking on human rights, Lincoln/London 1995, pp. 244-249; Johan VANDE LANOTTE, Geert GOEDERTIER, 'Monitoring human rights: formal and procedural aspects, in: Eugeen VERHELLEN (ed.), Monitoring children's rights, [Den Haag] (etc.) 1996, pp. 73-111, op pp. 87-100; Eugeen VERHELLEN, Verdrag inzake de rechten yan het kind; Achtergronden, motieven, strategieën, hoofdlijnen, Leuven/Apeldoorn 1993 (tweede druk), pp. 106-113; Geraldine VAN BUEREN, The international law on the rights of the child, Dordrecht (etc.) 1995, pp. 390 e.v.

113 Vgl. voor de (holistische) benadering van het Comite inzake de rechten van het kind van de (diverse) verdragsbepalingen ook par. 10.5 (Addendum).

114 Zie hierover Thomas HAMMARBERG, "Children,' in: Asbjørn EIDE e.a. (eds.), Economic, social and cultural rights; $A$ textbook, Dordrecht (etc.) 1995, pp. 289 307, op pp. 291-294. Zie ook dez., 'Preface,' in: Bob FRANKLIN (ed.), The handbook of children's rights; Comparative policy and practice, London/New York 1995, pp. ix-xiii, op pp. ix-xi.

115 Zie hoofdstuk 8, par. 8.2.2 (onder Kindervolkenrecht).

116 Geraldine VAN BUEREN, The intemational law on the rights of the child, a.w., resp. pp. $49 / 50$ en 51 . 
en in het licht van de door het Comite inzake de rechten van het kind onderscheiden verdragsbeginselen van non-discriminatie en persoonswording (het belang van het kind, overleven en ontwikkeling, de mening c.q. de zich ontwikkelende vermogens van het kind), laat bepaald niet de indruk achter van een onevenwichtig instrument dat ten onrechte onder de vlag van 'rechten van het kind' vaart, hetzij door lichtvaardig van rechten te spreken, hetzij door onvoldoende tot uitdrukking te brengen dat 'rechten van kinderen' een zorgvuldig uitbalanceren vergt van ouderlijke en statelijke verplichtingen. In de mate dat deze conclusie kan worden gedeeld - en zowel qua statenpraktijk als qua nationale uitvoeringsregelgeving als qua nationale en internationale jurisprudentie is het nog te vroeg om hier andere dan zeer voorzichtige bewoordingen te hanteren -, is het pleidooi terecht en pertinent het recht van elk kind op optimale persoonswording - dat wil zeggen het recht van elk kind op die sociaalpedagogische diensten, instellingen en voorzieningen die het in staat stellen de volwassenen-maatschappij te betreden als een, gezien zijn aanleg, talenten en ambities, zo rationeel, moreel en authentiek mogelijk persoon - als achterliggend sociaal-pedagogisch kernbeginsel van het Verdrag inzake de rechten van het kind aan te merken. Een uitgebalanceerd evenwicht van rechten en verplichtingen in de Trias pedagogica is van dat kernbeginsel eerste kinderrechtelijk en rechtspolitiek postulaat. Voor het bereiken van dat evenwicht - op zich tegelijk rechtsstatelijke en mensenrechtelijke eis en rechtsstatelijk en mensenrechtelijk ideaal - zijn aanzienlijke investeringen nodig in opvoedingsscholing en materiële en immateriële opvoedingsondersteuning, waarbij kan worden aangeknoopt bij diverse bepalingen in het Verdrag inzake de rechten van het kind. Zo al niet moet worden geconcludeerd dat deze bepalingen indirect tot dergelijke investeringen nopen of daar zelfs direct toe verplichten. Bij het recht van het kind op minimale persoonswording komen we hierop terug.

Op deze plaats rest ons nog de vraag naar de juridische significantie van de notie 'achterliggend' (respectievelijk 'in te lezen') rechtsbeginsel. Ter beantwoording van deze vraag kan aansluiting worden gezocht bij de Nederlandse jurisprudentie. Op 15 april 1994 namelijk wees de Nederlandse Hoge Raad het zogenaamde Valkenhorst-arrest. ${ }^{117}$ In de onderhavige zaak ...

117 Nederlandse Jurisprudentie 1994, 608; Rechtspraak wan de Week 1994, 94c; Nederlands Juristenblad-katern 1994, pp. 230-231, nr. 94C; NJCM-Bulletin 1994/6, pp. 652-658, met noot L.F.M. VERHEY ('Valkenhorst: het recht op afstammingskennis als persoonlijkheidsrecht'). Opgenomen in T. BARKHUYSEN e.(v.)a., 'Overzicht van Nederlandse jurisprudentie met betrekking tot het internationale recht inzake de rechten van de mens over 1994,' NICM-Bulletin 1995/8, pp. 1023-1069, op p. 1052 . 
'(...) ging het om de vraag of een instelling (Valkenhorst) gehouden is "De R." (als buitenechtelijk kind in 1935 in die instelling geboren) op haar verzoek bekend te maken met de indertijd door haar moeder aan de leiding van "Moederheil" - zoals die instelling destijds heette - verstrekte gegevens omtrent haar vader $(\ldots . .)^{1118}$

\section{In zijn arrest overwoog de Hoge Raad: ${ }^{19}$}

"(...) Uitgangspunt voor de beoordeling van het [cassatie]middel is dat het aan grondrechten als het recht op respect voor het privéleven, het recht op vrijheid van gedachte, geweten en godsdienst en het recht op vrijheid van meningsuiting ten grondslag liggende algemene persoonlijkheidsrecht mede omvat het recht om te weten van welke ouders men afstamt. Dit recht heeft ook infernationaal erkenning gevonden in art. 7 van het - door Nederland nog niet geratificeerde - Verdrag inzake de rechten van het kind van 20 november 1989.'

Saillant detail is dat Nederland ten tijde van 's Hogen Raads arrest, zoals de Raad zelf opmerkt, nog niet aan het Verdrag inzake de rechten van het kind was gebonden. In zijn noot bij een ander arrest (die evenwel voor een groot deel aan het Valkenhorst-arrest is gewijd) merkt HERINGA op: ${ }^{120}$

'De aan grondrechten ten grondslag liggende algemene rechtsbeginselen dienen (...) in aanmerking te worden genomen en bepalen dan mede, tezamen met andere in het geding zijnde belangen en beginselen, de uitkomst.'

Het Valkenhorst-arrest, zo vervolgt HERINGA zijn noot ...

'(...) laat zien hoe spannend de ontdekkingstocht, ingezet door de Hoge Raad, naar "achterliggende" (of misschien beter: ten grondslag liggende) algemene

118 KOOPMANS' Compendium van het staatsrecht, Deventer 1994 (zevende druk), p. 291.

Een andere hoofdrolspeelster in de Valkenhorst-jurisprudentie (Hof Den Bosch 18 september 1991, NJ 1991, 796), MARIECLAIRE, voor de burgerlijke stand M.J. ROOVERs, inmiddels volgens de indertijd vervalste registers bijna 70 jaar, is in haar speurtocht naar haar verduisterde staat nog steeds geen stap verder gekomen. Zie Ingrid HARMS, "Moederheil; een kind betwist haar eigen staat," Vrij Nederland 8 februari 1997, pp. 20-22. Haar relaas is een indringend getuigenis van de respectloosheid waarmee met de afstamming van (ongewenste) kinderen werd - en ten aanzien wan (zér gewenste) zaaddonor-kinderen overigens nog steeds wordt - omgesprongen.

119 T.a.p. (curs. jw).

120 A.W. HERINGA, "Toepassing gelijkheidsbeginsel in thet arbeidsrecht," NJCM-Bulletïn $1994 / 6$, pp. 644-651, op p. 648 onder 1. 
rechtsbeginselen kan zijn. (...) De zoektocht onvat (...) niet alleen de herleiding van een specifiek grondrecht tot het aan dat recht ten grondslag liggende beginsel, maar ook, nog verder, het speuren naar gemeenschappelijke achtergronden. Die rechtsvinding en -worming doet denken aan de Amerikaanse zaak Griswold v[ersus] Connecticut (1965), waarin het Amerikaanse Hooggerechtshof het - niet in de [Amerikaanse Constitutie] als zodanig opgenomen - recht op privacy leest in de wel opgenomen rechten. En zoals later bleek, met werstrekkende gevolgen, waar dat recht en die uitspraak de grondslag bleek voor de grondrechtelijke fundering van een recht op abortus. Ik citeer uit de opinie van rechter DOUGLAS, die de meerderheidsopinie van het Hof schreef: "(...) [T] hat specific guarantees in the Bill of Rights have penumbras, formed by emanations from those guarantees that help give them life and substance".,"121

'Nog duidelijker' evenwel acht HERINGA 'de verwantschap met de Duitse rechtspraak,' waarbij hij de conclusie van advocaat-generaal KOOPMANS aanhaalt: $^{122}$

'Een belangwekkende redenering is te vinden in een arrest van het Duitse Bundesverfassungsgericht uit 1989 (...), waarin het recht van het kind op kennis van de eigen afstamming wordt afgeleid uit door het Grundgesetz beschermde waarden, namelijk het recht op vrije ontplooiing van de persoonlijkheid in combinatie met de menselijke waardigheid (respectievelijk artikel 2, lid 1 en artikel 1, lid 1 [GG für die Bundesrepublik Deutschland]). Deze beide grondrechten waarborgen ieder individu, aldus het gerecht, "einen autonomen Bereich privater Lebensgestaltung, in dem er seine Individualität entwickeln und wahren kann." Die individualiteit [c.q. identiteit, $j w$ ] is echter nauw verbonden met de kennis van haar constitutieve elementen, waartoe de afstamming moet worden gerekend. De afstamming vervult in de ogen van het gerecht een dubbele rol: enerzijds legt zij de genetische uitrusting van het individu vast en helpt zij zo diens persoonlijkheid te vormen; anderzijds bekleedt zij in het bewustzijn van het individu een sleutelpositie voor het begrip van zichzelf en van de eigen persoonlijkheid.'

\section{Het woord van KOOPMANS overnemend, vervolgt de auteur: ${ }^{123}$}

'In het arrest inzake Valkenhorst volgt de Hoge Raad de lijn dat ter nadere bepaling of een recht als geformuleerd in het geding is, acht geslagen wordt op het bepaalde dienaangaande in internationale verdragen. (...) Een op dusdanige wijze acht slaan op andere internationale teksten, waarbij op systematische wijze gezocht wordt naar erkende rechtsbeginselen, is ook te vinden in de jurisprudentie van het [Europees Hof voor de Rechten van de Mens]. (...)

Zoals ook al bleek uit [Hoge Raad] 7 mei 1993 (...) [De rechtstreekse werking van sociale grondrechten], kan deze benadering met zich brengen dat het criterium van de een ieder verbindendheid minder een barrière wordt. Immers wat

T.a.p., op p. 651, respectievelijk onder 6,7 en 8 (curs. jw). 
toen gebeurde, is dat het tot dan toe (nog) niet als een ieder verbindend beschouwde recht op gelijke beloning als neergelegd in artikel 7 IVESCR ingelezen [werd] in een andere well een ieder verbindende verdragsbepaling (toen: art. 26 IVBPR). (...) Het gaat er dus steeds om, wanneer men van doen heeft met een niet rechtstreeks werkende verdragsbepaling respectievelijk met een recht dat in Grondwet of verdrag nog niet als zodanig is neergelegd, te zoeken naar (...) een redenering langs welke betoogd kan worden dat er sprake is wan een recht dat ten grondslag ligt aan/te herkennen is in wel gecodificeerde rechten.

De vraag die in de geschetste benadering natuurlijk opkomt, is (...) hoever gegaan wordt in de ontwikkeling (ontdekking) van "nieuwe" rechten."

De beantwoording van die slotvraag vergt een blik in de bekende glazen bol. Maar ook een blik in de spiegel. Want juristen zijn meesters in het manipuleren van die bol. Daarmee is niet gezegd dat zij rechtsgeleerde trucjes uithalen: dat zij het recht vinden dat zij eerst vormen. Wel dat zij een belangrijke bijdrage kunnen leveren aan de rechtsontwikkeling, aan rechtsvorming en -vinding, door op bestaande regels en beginselen een specifiek licht te werpen. Hetzij, in meer technische of rechtskundige zin, vanuit de eigen discipline, hetzij met gebruikmaking van de bevindingen in andere disciplines. Dan wel beide, door vanuit de bevindingen in andere disciplines iets achter bestaande regels en beginselen te zoeken, of daar iets in te lezen (zoals hierboven A-G KOOPMANS, althans het Bundesverfassungsgericht, lijkt te doen, in casu in de vorm van ontwikkelingspsychologisch geschraagde juridische analogie). ${ }^{124}$

Of juristen met hun beroep op rechten die voortvloeien uit beginselen achter beginselen succes hebben, hangt niet af van foefjes, maar

$124 \mathrm{Zij}$ het dan dat de inzichten uit andere disciplines soms uiterst langzaam doordringen. 'The importance of children's knowledge of their identity and background has been known for 20 years, yet how many countries' laws reflect this?' Vraagt BISSETI'-JOHNSON zich af, verwijzend naar TRISELIOTIS" In search of onigins wit 1973 (Alastair BISSETT-JOHNSON, "What dit States really agree to? Qualifications of signatories to the United Nations Convention on the rights of the child," The Intemational Joumal of Children's Rights 1994/4, pp. 399-411, op p. 400 en $i b$. nt. 8). HOKSBERGEN (R.A.C. HOKSBERGEN, De invloed van het verleden op de identiteitsbeleving, in: P.C.Th.M. VAN EEUWIJ, J.H.A. VAN LOON (red.), Identiteitsproblemen bij adoptiekinderem, Amsterdam/Lisse 1989, pp. 30-44, op pp. 36/37) grijpt nog verder terug en verwijst naar JAMES' The principles of psychology uit 1890 , een eeuw voor het recht van het kind op afstammingskennis door de inwerkingtreding van het Verdrag inzake de rechten van het kind rechtskracht verwierf.

Overigens hebben sommige staten een expliciet voorbehoud gemaakt c.q. interpretatieve verklaringen afgelegd bij art. 7 (lid 1) VRK, zoals Polen ten aanzien van adoptie-kinderen, Tsjechië ten aanzien van adoptie- en kunstmatige inseminatiekinderen en Luxemburg ten aanzien van 'anonieme geboorten' (vgl. UN doc. CRC/C/2/Rev.5 d.d. 30 juli 1996, pp. 10-55, resp. op pp. 29, 16/17 en 24). 
van de kracht van hun argumenten. In laatste instantie is dat de (overtuigings)kracht van en in de rechtsbeginselen zelf, toegepast in een bepaalde maatschappelijke context en in het licht van nieuwe wetenschappelijke inzichten. Rechtsbeginselen - al of niet in mensenrechtelijke vermomming - die per slot van rekening niets meer of minder zijn dan het gemeenschappelijk erfdeel der mensheid. Erfdeel waarover de mensheid, en in het bijzonder de (beginselgerichte) jurist, te waken heeft. Erfdeel waarmee de mensheid, en in het bijzonder de (beginselgeleide) jurist, te woekeren heeft.

In dit licht zou met betrekking tot de vraag of en in hoeverre het recht van het kind op (optimale) persoonswording als achterliggend beginsel van het Verdrag inzake de rechten van het kind kan worden beschouwd c.q. op basis van de erkende verdragsbeginselen en diverse verdragsbepalingen in het Verdrag kan worden ingelezen - om aldus als paraplu-recht voor verschillende sociaal-pedagogische kernrechten c.q. de positieve verdragsrechten van het kind te kunnen functioneren -, wellicht gevoeglijk, nu we tot hier zijn gekomen, kunnen worden volstaan met een terugverwijzing naar wat in vorige hoofdstukken over 'persoonswording' is geschreven en wat in dit hoofdstuk aan en over verdragsbeginselen en -bepalingen naar voren is gebracht. Immers, niet mag uit het oog worden verloren dat het recht van elk kind op (optimale) persoonswording uiteindelijk is te herleiden tot de mensenrechtelijke (en eigenlijk algemeen juridische) Grundnorm van de menselijke waardigheid, waaronder begrepen de Grundnorm van het respect voor (de menselijke waardigheid van) het kind, welke Grundnorm uiteenvalt in het gelijkheids- en het ontplooiingsbeginsel, dat wil met betrekking tot het zich tot persoon te ontplooien kind, het kind als persoon-in-wording zeggen: het persoonswordingsbeginsel, persoonswordingsoptimalisatie als recht van elk kind. Toch voegen we op deze plaats twee opmerkingen toe.

\section{Interpretatiekader}

In de eerste plaats is dat de opmerking dat voor de idee van 'optimale persoonswording' als aan het Verdrag inzake de rechten van het kind ten grondslag liggend beginsel, ook steun kan worden gevonden in de literatuur. En wel bij DOEK. Deze merkt immers op: $:^{125}$

'Al jaren wordt door Nederland - via de overheid en via particuliere organisaties - een groot aantal [internationale] projecten en programma's gesteund die bijbeschouwingen over de mogelijke gevolgen voor de Nederlandse rechtspraktijk,' NJCM-Bulletin 1995/1, pp. 10-21, op p. 20 (curs. jw). 
dragen aan het welzijn van kinderen. Dat is prachtig en moet vooral zo blijven. Maar de aandacht voor kinderen in het Nederlandse beleid zall nadrukkelijker moeten worden gevoed door de aan het [VRK] ten grondslag liggende idee, namelijk dat kinderen burgers zijn die [rechtens, jw] aanspraak kunnen maken op Provision, Protection en Participation, en geen voorwerpen die men met name in een verkiezingstijd op de arm neeml of over de bol aait voor het front van fotografen.'

Even daarvoor had DOEK met betrekking tot art. 14 VRK (het recht van het kind op vrijheid van gedachte, geweten en godsdienst) gesteld: ${ }^{126}$

"De Nederlandse regering heeft ten aanzien van dit artikel [bij de ratificatie wan het Verdrag, jw] een interpretatieve verklaring [quasi-voorbehoud, $j w$ ] afgegeven. In die verklaring wordt gestipuleerd dat artikel 14 mede onvat de vrijheid van het kind een door hem- of haarzelf gekozen godsdienst of levensovertuiging te hebben of te aanvaarden zodra het kind daartoe, gelet op zijn of haar leeftijd of rijpheid, in staat is. Het CDA en klein rechts vond het afleggen van die verklaring niet nodig. Een motie [de molie-KOEKKOEk] met het verzoek die verklaring niet af te leggen, werd echter verworpen.

De conclusie dient mijns inziens dan ook te zijn dat [in Nederland, jw] gerechtelijke actie van de ouders om het kind in godsdienstig gareel te krijgen c.q. te houden, geen succes zal hebben (behoudens uiteraard andere argumenten c.q. omstandigheden, bijvoorbeeld: het lidmaatschap [van sekte of kerkgenootschap, jw] vormt een ernstige bedreiging van de hamonische ontwikkeling van het kind).'

Andere argumenten c.q. omstandigheden die dus de doorslag geven, door DOEK samengevat onder de noemer: 'ernstige bedreiging van de harmonische ontwikkeling van het kind.'

Uit de combinatie van beide voorgaande passages kan mijns inziens worden afgeleid: a.) dat DOEK de idee van een aan het Verdrag inzake de rechten van het kind ten grondslag liggend rechtsgoed - i.c. (de idee van) het kind als subject van rechten met betrekking tot voorzieningen, (speciale) bescherming en 'eigen aandeel'/deelname - omhelst; en b.) dat DOEK dit rechtsgoed nader c.q. tevens aanduidt als 'de harmonische ontwikkeling van het kind.' Hierbij kan worden betrokken dat DOEK in ander verband heeft gesteld: $:^{127}$

"We kunnen deze beginselen [beginsel 2, 6 en 7 uit de VN-Verklaring van de rechten van het kind van 1959 , jw], die verder zijn uitgewerkt in de Conventie van [het Verdrag inzake] de rechten van het kind, aldus samenvatten dat het kind

127 J.E. DOEK, 'Het belang van het kind en het recht,' in: J.B. WEENINK (red.), Het belang van het kind in het geding Over opvoeding en kinderbescherming, Amsterdam 1990, pp. 73-92, op p. 75 (curs. jw). 
bovenal recht heeft op een volledige en harmonische ontplooing naar hichaam en geest. Dat recht zal het centrale beginsel moeten zijn bij de verzorging en opvoeding van een kind, waarvoor de verantwoordelijkheid in de eerste plaats bij de ouders ligt (...).

Weliswaar spreekt DOEK van harmonische ontwikkeling" - c.q. van volledige en harmonische ontplooiing” - maar dit kan niet anders dan als praktisch synoniem ${ }^{\mathbb{1 2 8}}$ met (in onze terminologie) 'optimale persoonswording" worden beschouwd.

In dit verband kan ook worden gewezen op het werkdocument Kinderbescherming: Maak het waar!!! van de Raden voor de kinderbescherming uit november 1991, volgens hetwelk elk kind - zoals we al eerder zagen ${ }^{129}$ - "een zelfstandig recht [heeft] op een gezonde, evenwichtige ontwikkeling en uitgroei naar zelfstandigheid. ${ }^{, 130}$ Met andere woorden: een subjectief optimaal-persoonswordingsrecht. Met betrekking tot dit rapport schrijft DOEK: ${ }^{131}$

\begin{abstract}
'De titel van het werkdocument zou beter hebben kunnen luiden: Overheid: maak het waar!!! Het is de owerheid die haar kerntaak ten aanzien van kinderen waar moet maken: het verstrekken van zorg en bescherming aan kinderen die dat behoeven. Dit betekent in de eerste plaats dat zij de beste voorwaarden moet scheppen om de primaire verantwoordelijkheid van ouders voor zorg en bescherming van hun kind tot [haar] recht te laten komen, bijvoorbeeld door het aanbieden van een gevarieerd en toereikend pakket van opvoeding-ondersteunende voorzieningen $(. .$.$) ."$
\end{abstract}

Uit DOEKs toepassing van het (doorslaggevende) argument (dus hoger beginsel) van 'harmonische ontwikkeling' (in onze terminologie: 'optimale persoonswording') met betrekking tot art. 14 VRK kan evenwel niet alleen worden afgeleid dat 'optimale persoonswording' als een aan het Verdrag inzake de rechten van het kind ten grondslag liggend beginsel kan worden beschouwd, doch tevens als een beginsel dat voor dat Verdrag een dwin-

128 Zij het uiteraard afgezien van de specifieke betekenis die 'persoonswording' als pedagogisch en juridisch (sociaal-pedagogisch) te operationaliseren - pedagogisch interventie-criterium heeft.

129 Zie hoofdstuk 7, par. 7.2.3.1.

130 Aldus geparafraseerd door Jacquellien SOETENHORST-DE SAVORNIN LOHMAN, 'De armslag van de uitvoerend werker op het raakvlak tussen hulp en recht,' in: Afra GROEN en Adri WAN MONTFOORT (red.), Kinderen beschermen en jeugd hulp verlenen, Arnhem 1993, pp. 127-145, op p. 135.

131 Jaap DOEK, 'Van oude dogma's en dingen die woorbijgaan; de toekomst van onze justitiële jeugdbescherming met enige buitenlandse belichting, in: Afra GROEN en Adri VAN MONTFOORT (red.), Kinderen beschemen en jeugd hulp verlenen, Arnhem 1993, pp. 157-173, op p. 165. 
gend of op zijn minst dringend interpretatiekader biedt. Anders gezegd: het recht van het kind op (optimale) persoonswording is (te beschouwen als) tegelijk achterliggend, dragend èn leidend beginsel van het Verdrag inzake de rechten van het kind.

Het recht van het kind op (optimale) persoonswording als achterliggend, dragend en leidend beginsel van het Verdrag inzake de rechten van het kind maakt in het bijzonder - althans in de specifieke nationale context - 'creatief-grammaticale interpretatie' van verdragsbepalingen mogelijk. Van 'creatief-grammaticale' uitleg van bepalingen is sprake indien men in voorkomend geval met het oog op een sociaal-adequate wetstoepassing '(...) in de wettekst méér leest dan er letterlijk staat." ${ }^{, 132}$ Meer concreet op het Verdrag inzake de rechten van het kind toegespitst, zou dit kunnen betekenen dat de sociaal-pedagogische rechten en verplichtingen in het Verdrag niet minimalistisch ('a contrario') worden 'afgeknepen,' maar ruimhartig ('per analogiam') 'naar boven worden afgerond.'

Een dergelijke creatief-grammaticale interpretatie - ik zou bijna zeggen: verdrags- c.q. persoonswordingsconforme attitude - doet niet alleen in algemene zin meer recht aan zin en strekking van het Verdrag: optimale persoonswording; maar is in het bijzonder van belang bij de operationalisering en juridisering van (minimale c.q. optimale) persoonswording in de vorm van opvoedingsscholing, opvoedgeld en - generaalen speciaal-preventieve alsook repressieve - vormen van opvoedingsondersteuning, dat wil zeggen het actief benaderen van (risico)gezinnen en het aanbieden dan wel opleggen van hulp in het concrete geval.

\section{Minimale persoonswording}

In de tweede plaats voegen we de opmerking toe dat voor de idee van 'optimale persoonswording' als achterliggend, dragend en leidend beginsel van het Verdrag inzake de rechten van het kind extra argumenten kunnen worden ontleend aan en rondom het (kern)recht van het kind op minimale persoonswording. Een en ander moge blijken in de nu volgende paragraaf.

\subsection{Het recht van het kind op minimale persoonswording}

Het pleidooi om de betrekkelijk vage rechtsnotie van 'het belang van het kind' in verband met andere noties, beginselen en rechten in het Verdrag inzake de rechten van het kind te vervangen door, althans te vangen 
onder een meer in pedagogische zin richting gevend (rechts)beginsel: het recht van het kind op persoonswording, alsmede om dat beginsel te beschouwen als een achterliggend rechtsbeginsel van het Verdrag c.q. een in het Verdrag in te lezen rechtsbeginsel, lijkt niet alleen gewettigd gezien de pluri-interpretabiliteit van het belang van het kind (the best interests of the child) in het recht. Evenzeer - en in verband daarmee - is dat het geval met het oog op de kloof die gaapt tussen enerzijds het concept van het kind-als-subject dat in het Verdrag, blijkens aard en hoeveelheid van de erin opgenomen rechten van het kind, tot uitdrukking komt, en anderzijds de feitelijke situatie van het kind in het gezin, de situatie van minimaal tachtigduizend kinderen in Nederland wier grondrechten op lichamelijke en geestelijke integriteit en op een gezonde en evenwichtige ontwikkeling jaarlijks op flagrante wijze worden geschonden. Het concept van het kind-als-subject wil immers zeggen: (1) het kind als drager van, ook tegenover de ouders te handhaven rechten, in het bijzonder op (a) bescherming door de staat tegen die ouders; en (2) het kind als subject van aanspraken op de overheid krachtens (b) de verdragsrechtelijke primaire plicht van de staat kind en ouders (het gezin) alle benodigde hulp en steun te verlenen, alsmede (c) krachtens de secundaire opvoedingsverantwoordelijkheid van de staat. Dit concept is in het Verdrag inzake de rechten van het kind in verschillende bepalingen uitgewerkt.

Hoewel het Verdrag reeds bij oppervlakkige beschouwing - $a$ prima vista - voldoende aanknopingspunten biedt tussen 'optimum' en 'minimum' te differentiëren en (blote) beschermings- van (beschermingsen) welzijnsrechten te onderscheiden, zal de lezer een dergelijke, weinig nieuwe inzichten opleverende exercitie hier worden bespaard. Wat minimale persoonswording als interventie-criterium betreft: dadelijk uit art. 19 (juncto art. 4) VRK vloeit de verplichting van de overheid voort adequate opvoedingshulp aan te bieden en desnoods op te leggen als door toedoen of nalaten van de ouders de lichamelijke of geestelijke integriteit c.q. de lichamelijke en geestelijke ontwikkeling van het kind wordt geschaad of bedreigd. Voor de goede orde zij opgemerkt dat deze verplichting verder gaat dan de nationaalrechtelijke (famillierechtelijke) rechtsplicht waarvan VON BRUCKEN FOCK gewaagt, namelijk 'de verplichting van de overheid om een jeugdbeschermingsmaatregel uit te lokken als de fysieke of psychische integriteit van het kind gevaar loopt. ${ }^{533}$ In art. 19, lid 2 wordt immers ook over preventie-programma's gesproken. De preventie-verplichtingen van de overheid kunnen daarenboven direct of indirect ook uit andere verdragsbepalingen worden afgeleid. 
Hoe valt nu (het recht van het kind op) minimale persoonswording in juridische zin te verstaan? Een kind dat tot minder dan een minimaal persoon is opgevoed, staat zodanig gehandicapt in het leven, is zodanig misvormd geraakt en gemaakt, dat van een ernstige schending van zijn fundamentele rechten moet worden gesproken. In het Verdrag vinden we een waaier van fundamentele rechten die we zouden kunnen samenvatten onder de juridische noemer: het recht van het kind op minimale persoonswording. Dit is één juridische benaderingswijze.

Een tweede benaderingswijze vertrekt vanuit de pendant van elk recht van het kind: de verplichtingen van ouders en/of de staat. We beperken ons hier tot de verplichtingen van de staat. Het recht van het kind op minimale persoonswording is vanuit de staatsaansprakelijkheid gezien tweeledig. Het omvat zowel het - door de staat te waarborgen - recht van het kind zich tot een minimaal (rationeel, moreel en authentiek) persoon te ontwikkelen, als het - door de staat te waarborgen - recht van het kind op vrijwaring van beschadiging van zijn minimaal persoonzijn (dat wil zeggen van zijn minimale rationaliteit, moraliteit en/of authenticiteit). Schending van één van beide rechten door zijn ouders verplicht de overheid dan ook tot interventie in het gezin. Het recht van het kind op een minimum aan kwaliteiten, een minimum dat het kind, eenmaal volwassen, in staat moet stellen tot het genot en de zelfstandige uitoefening van zijn mensenrechten, behelst dus de plicht van de overheid dit minimum te waarborgen. En wel in dubbele zin: het minimum moet kunnen worden bereikt, en terugval tot onder het minimum moet met alle mogelijke middelen worden tegengegaan. Daartoe dient de staat in het uiterste geval, dat wil zeggen bij met andere middelen niet te keren bedreiging van het minimum, juridisch in het gezin te interveniëren. Deze verplichting vergt in elk geval algemene preventie- en steunprogramma's, een adequaat hulpaanbod in het concrete geval en, desnoods, hulpoplegging. Dit is de essentie van wat we in het vorige hoofdstuk het interventie-criterium van DE RUYTER hebben genoemd. ${ }^{134}$ Dit criterium stoelt immers op de volgende vooronderstelling: ${ }^{135}$

'De premisse waarop het criterium is gebaseerd, is dat persoon-zijn een bijzonder belang is van de mens, op grond waarvan kan worden gesteld dat kinderen het recht hebben om persoon te worden, en daarmee recht hebben op opvoeding.

134 Vgl. ook de sociaal-pedagogische kernrechten ('POGODèR') in hoofdstuk 7, welke onder de paraplu van (minimale respectievelijk optimale) persoonswording als basisrecht vallen.

135. Doret DE RUYTER, Met recht ingrijpend, diss. 1993, p. 109 en ib. nt. 66 (curs. overgenomen). 
Het recht om persoon te worden omvat meer dan het recht op opvoeding. Er zijn ook andere handelingen die voor het kind kunnen worden afgedwongen op grond van zijn recht om persoon te worden. Deze kunnen beschouwd worden als voorwaarden voor de opvoeding en de persoonswording.'

Verschillende verdragsbepalingen, doch in het bijzonder, zoals we al zagen, art. 19 juncto art. 4 VRK regarderen de hier bedoelde afdwingbare rechten ${ }^{136}$ c.q. verplichtingen van de staat.

Een derde benaderingswijze vertrekt vanuit de tegengestelde richting, dat wil zeggen vanuit het sequeel van een te waarborgen recht: het recht op reparatie (herstel, compensatie, rehabilitatie) indien de waarborgfunctie van het recht niet is waargemaakt, dat wil zeggen: indien de staat heeft gefaald. Vertrokken wordt dus vanuit de situatie dat in principe compenseerbare, redresseerbare of substitueerbare pedagogische tekorten ${ }^{137}$ ertoe hebben geleid dat een achttienjarige mens sub-minimaal in het leven staat. Voor dit sequeel dienen we naar aanknopingspunten te zoeken zowel binnen (vgl. art. $39 \mathrm{VRK}$ ) als buiten het Verdrag inzake de rechten van het kind. ${ }^{138}$ Waar deze benaderingswijze toe leidt (kort gezegd: tot welke geschonden rechten de pathologie kan worden herleid), kan hier niet worden uitgewerkt. ${ }^{139}$ Wel zal thans kort worden stilge-

136 Art. 19, lid 1. VRK dient in werband gelezen te worden met algemene fundamentele rechten als het recht op respect voor de lichamelijke en geestelijke integriteit en het recht op vrijwaring van wrede of vernederende behandeling of bestraffing (art. 3 EVRM), dat als jus cogens (dwingend volkenrecht) wordt beschouwd. In die zin kan gesproken worden van het recht van het kind op bescherming tegen alle vormen wan lichamelijk en geestelijk geweld in het gezin als afdwingbaar recht. (Zie ook par. 10.4.2 en par. 10.4.3.)

137 Compenseerbaar: door opvoedingsondersteuning die de oudlerlijke tekorten aanvult. Redresseerbaar: door opvoedingsscholing en -ondersteuning die de ouders pedagogisch competent maakt (de ouderlijke tekorten hersteli). Substitueerbaar: door te voorzien in vervangende vormen van opvoeding buiten het gezin, bijvoorbeeld door pleeggezinplaatsing of andere (gezinsvervangende) opvoedingswijzen.

138 Vgl. in algemene zin: Study concerning the right to restitution, compensation and rehabilitation for victims of gross violations of human rights and fundamental freedoms; Final report submitted by Mr. Theo VAN BOVEN, Special Rapporteur, SubCommission on Prevention of Discrimination and Protection of Minorities [van de] Commission on Human Rights, E/CN.4/Sub.2/1993/8 d.d. 2 juli 1993.

139 Uiteraard zal hier een grote mate van overlap met de eerste benaderingswijze optreden, doch niet kan worden uitgesloten dat geheel nieuwe rechten, als nitvloeisel van bestaande rechten of beginselen, waarvan de nieuwe betekenis nog niet of onvoldoende bekend was, moeten/kunnen worden ge(re)construeerd. Het meest vruchtbaar zal ongetwijfeld een 'holistische' benadering, een combinatie van de drie benaderingswijzen zijn (de derde benaderingswijze is overigens een psycho-juridische). Zij gaat evenwel het bestek van deze studie, althans van dit hoofdstuk te buiten. 
staan bij de overwegingen die deze benaderingswijze schragen (overwegingen, kort gezegd, betreffende pathogenese en therapie).

We zouden het persoons(wordings)minimum een psychisch overlevingspakket kunnen noemen, de smalste basis waarop ontplooiing tot volwaardig lid van de samenleving mogelijk is. Hierbij dienen we ons te realiseren dat mensen die minder dan dit minimum van huis uit hebben meegekregen - doordat hun ouders hun niet meer konden bieden en de staat en de gemeenschap die ouders als opvoeders, en dus die kinderen als mensen en als personen in wording aan hun lot overliet - , in hun jeugd in vergelijking tot andere kinderen zoveel zijn te kort gekomen, en dat hun door hun ouders en door de gemeenschap zoveel is te kort gedaan, dat we per definitie met getraumatiseerde mensen te maken hebben. Hun recht op reparatie is dan ook in de eerste plaats een recht op trauma-verwerking. Trauma-verwerking op basis van erkenning door (zo mogelijk) de ouders en (in elk geval) door de gemeenschap dat hun te kort is gedaan, en in welke opzichten hun te kort is gedaan.

Het betreft met andere woorden mensen die in hun jeugd een last te dragen hebben gekregen, die de draagkracht van menige volwassene te boven zou zijn gegaan. Hetzij doordat zij te vroeg en te zwaar met de problemen, behoeftes, conflicten, stoornissen, enzovoorts van hun ouders zijn opgezadeld. Hetzij doordat zij als kind in hun omgeving geen enkel begrip, aanmoediging, uitdaging, bewondering, verwondering, troost, kortom: geen respect en geen grenzen ondervonden. En meestal natuurlijk door een combinatie van beide: een teveel aan problemen en conflicten; een tekort aan leiding en affectie. Teveel van het goede of ronduit het slechte is hun in hun jeugd door de strot geduwd, terwijl zij in andere opzichten zijn uitgehongerd. En er was niemand die het zag of in de gaten had, niemand die liet zien dat het anders kon, niemand die een helpende hand toestak, niemand die een pleister plakte. Er was - in de woorden van MILLER ${ }^{140}$ - geen helpende getuige. Eerder zullen omstanders, vrienden, familie er immers op wijzen dat een plant te weinig licht of te veel water krijgt, of een hond te weinig aandacht en te veel voer, dan dat zij zich met de opvoeding van een kind zullen bemoeien. Zelfs slaapkamergeheimen lijken (tegenwoordig) minder heilig dan wat er tussen ouders en kinderen gebeurt.

Door de bovenmenselijke last die deze mensen als kind te dragen hadden, zijn zij geblokkeerd geraakt in hun ontwikkeling tot minimaal persoon. Die blokkering geeft hun trauma's een tragische dimensie. Het betreft veelal mensen die zich als kind - vanuit hun kinderlijke nood meer over hun ouders hebben ontfermd dan dat dezen of derden zich 
ooit over hen hebben ontfermd. Het hierdoor onstane patroon van (doorlopend of beurtelings) te veel of (van de weeromstuit) te weinig geven en te weinig of te veel nemen, zetten zij, indien zij hun trauma's onvoldoende kunnen verwerken en er niet in slagen geblokkeerde ontwikkelingstaken alsnog tot een bevredigende oplossing te brengen, hun hele leven voort. Tragischer nog, zij geven het door aan, brengen het over op hun eigen kinderen. Want hoewel dat patroon niet in de genen zit, en dus niet erfelijk is, zit het wel tussen de oren, en is het transgenerationeel. Alweer ruim een decennium geleden schreef BEYAERT: ${ }^{141}$

'Opvallend is dat ouders die kinderen mishandelen of doden, in hun jeugd vaak zelf mishandeld zijn. Dat suggereert ten minste een samenhang die bij de wetenschappelijke stand van zaken van 1986 niet meer kan worden afgedaan met een gedachte aan erfelijkheid alleén (...). Een uit de praktijk van het forensisch onderzoek meest voor de hand liggende hypothese is de navolgende. Mishandelde kinderen zullen, eenmaal ouder[s] geworden (en clat dan veelal onder sociaal ongelukkige of zelfs miserabele omstandigheden), aan zichzelf èn hun kind de allerhoogste eisen stellen wat betreft "het gelukkig zijn." "Mijn kind moet nooit meemaken wat ik heb meegemaakt," is een uitspraak die men veelvuldig hoort. Kennelijk kan de mishandelende ouder die zelf vroeger mishandeld is, naar zijn eigen idee "nooit goed genoeg" zijn. Bij moeders die hum kinderen mishandelen of doden, komt daar dan bij dat juist zij de veel te hooggespannen verwachtingen gefrustreerd zien door de zich op die leeftijd verzelfstandigende peuter - die bovendien lang niet altijd voldloet aan het hooggestemde ideaal van het gezonde en gelukkige kind. Voor sommige vrouwen is de komst van een volgend kind de oplossing van de als symbiotisch wurgend ervaren verstrengeling. Voor andere vrouwen, gevangen blijwend in de symbiose met hun kind, leidt de verzelfstandiging van het kind tot de woedeuitbarstingen [c.q. de wanhoopsgevoelens waarvan het kind het slachtoffer wordt, jw]. De scheurende wijze waarop sommige van die kinderen hun verzelfstandiging dan vorm (moeten) geven, draagt daar uiteraard toe bij.'

Het is deze tragische vicieuze cirkel, deze tragische spiraal van geweld, die ons ervan doordringt dat het recht op reparatie van deze ouders, naast en in samenhang met hun recht op trauma-verwerking, mede omvat, en moet omvatten, een recht op begeleiding bij het aanpakken van geblokkeerde ontwikkelingstaken - dwars door alle angsten, obsessies, insufficiëntiegevoelens, sociale handicaps, enzovoorts heen. Hun recht op reparatie behelst aldus, naast het recht op erkenning, het recht op een

F.H.L. BEYAERT, 'Partner- en kinderdodingen,' Justitiele Verkenningen 1986/4, pp. 445-457, op pp. $452 / 453$ (curs. jw).

Op het aspect van de transgenerationaliteit komen we nog terug in de volgende hoofdstukken. De in deze subparagraaf geschetste overwegingen kunnen als een prehuderen daarop worden beschouwd. 
therapeutisch proces. Een therapeutisch proces dat gericht is - in de mate van het mogelijke ${ }^{142}$ - op verwerking en op 'heropvoeding,' of misschien beter: zelfopvoeding, tot (boven-minimaal en hopelijk) optimaal persoon. (Daarnaast maken uiteraard ook compensatie, in de zin van materiële schadeloosstelling althans genoegdoening, en rehabilitatie, in de zin van sociale reïntegratie, deel van dit recht uit.) Hun kinderen hebben gelijkelijk een - zelfstandig - recht op reparatie van hun ouders omdat dat de belangrijkste, zo niet de enige waarborg is dat de transgenerationele cyclus wordt doorbroken.

Niet mag en kan worden verhuld dat een therapeutisch proces een (soms uiterst) pijnlijk proces is, waarbij decompensatie altijd op de loer ligt, met andere woorden een proces is dat alleen onder zeer deskundige leiding kan en mag verlopen. Geen bevalling zo zwaar - lijkt het soms als die van de waarheid van het eigen leven. Het moge vreemd klinken een recht op een dergelijk pijnlijk proces te formuleren. Bedacht moet evenwel worden dat het alternatief is dat de pijn die het kind is aangedaan, het hele leven wordt meegedragen - en aan de eigen kinderen, ondanks en vaak juist door de beste (bewuste ${ }^{143}$ ) bedoelingen, wordt doorgegeven.

Het recht van het kind op minimale persoonswording kan aldus zowel door een waaier van fundamentele rechten van het kind, als door zijn pendant: de verplichtingen van de staat op het punt van algemene preventie en het in het concrete geval aanbieden en desnoods opleggen van opvoedingsondersteuning, alsook door zijn sequeel, het recht van de volwassen 'survivor' op reparatie c.q. het recht van diens kind(eren) op reparatie van zijn/hun ouder(s), (nader) juridisch in kaart worden gebracht. In de hierna volgende (sub)paragrafen staan we respectievelijk (kort) stil bij (minimale persoonswording als) het recht van het kind op een buitenstaander (par. 10.4.1), minimale persoonswording als quasiresultaatsverplichting van de staat (par. 10.4.2) en minimale persoonswording als primordiaal en absoluut kernrecht van het kind (par. 10.4.3). Daarbij worden - in omgekeerde volgorde - aspecten van de drie hierboven vermelde benaderingswijzen nog eens summier belicht. We stelden in dit hoofdstuk dat het recht van het kind op (optimale) persoonswording als achterliggend - mede in de zin van dragend en leidend - beginsel van het Verdrag inzake de rechten van het kind kan worden beschouwd. Dit

142. Soms valt er natuurlijk nicts meer te 'repareren' - en dus te verwerken -, is er door de ouders domweg te veel kapot gemaakt. Er rest dan slechts compensatie en begeleiding bij reïntegratie (sociale aanpassing/vaardigheden, reclassering). Vgl. P.C. KUIPER, Nieuwe neurosenleer, Deventer 1984 (achtste druk), pp. 26-27: reactievorming (zie bijlage IV bij dit proefschrift) als 'kwellende vorm van liefde'; de overbezorgde moeder die haar kind kwelt met haar goede bedoelingen. 
recht c.q. (rechts)beginsel - 'optimale persoonswording' - hebben we een bodemverplichting van de staat genoemd. Ter afsluiting van dit hoofdstuk tasten we, in de drie hierna volgende subparagrafen, nog eenmaal het minimum, dat is de bodem van deze (bodem)verplichting af.

\subsubsection{Minimale persoonswording als het recht van het kind op een buitenstaander}

De ramificaties van het recht van het kind op minimale persoonswording kunnen het treffendst worden voorgesteld aan de hand van de uitspraak van DE RUYTER Sr., dat het kind recht heeft op "buitenstaanders die oog hebben voor de stagnatie' in de opvoeding, dat wil zeggen: 'recht heeft op een buitenstaander die het gezin in de gaten houdt. ${ }^{144}$ Immers: ${ }^{145}$

'Een stagnerende opvoeding vanuit de pedagogische hulpverlener gezien, is "cen zodanig ontregelde opvoeding dat er sprake is van een (dreigende) schade voor de persoonswording van het kind" (...). De uitspraak dat het kind recht heeft op een buitenstaander die het gezin in de gaten houdt, moet (...) worden geinterpreteerd als: hulpverlening is noodzakelijk wanneer er sprake is van (dreigende) schade aan de persoonswording van het kind, en de ouders dit niet herkennen of erkennen."

We zouden - meer in de trant van MILLER - kunnen spreken van het recht van het kind op een helpende getuige. ${ }^{146}$

Ouders die niet herkennen wat de effecten van hun gedrag zijn, kunnen tot inzicht worden gebracht. Het opleggen van hulpverlening is dan uiteraard niet nodig. Door de herkenning en het nieuw verworven inzicht kan vrijwillige hulp snel effectief zijn. Hulpoplegging is pas aan de orde als ouders niet kunnen of willen inzien wat zij aanrichten en/of (vooralsnog) niet bij machte zijn adequater te handelen. De in stilte voor de rechten van het slachtoffer opkomende getuige wordt dan een juridisch actieve getuige, een getuige die de rechten van het slachtoffer vindiceert.

Het recht van het kind op een buitenstaander, op een helpende getuige, is in het Verdrag inzake de rechten van het kind te vinden in

144 P.A. DE RUYTER (1987), aangehalald door D. DE RUYTER (diss. 1993), p. 25.

145 D. DE RUYTER, t.a.p. (curs. jw; de aanhaling binnen de aanhaling is evencens van DE RUYTER ST.).

146 Vgl. (bijv.) Alice MLLer, Het drama wan het begaafde kind; Op zoek naar het ware zelf, Houten 1995 (achttiende druk), p. 29 i.f; Zelfkennis in ballingschap; De verdringing wan de kindertijd, tor welke prijs? Houten 1989, p. 148; De muur van zwijgen; De waarheid van de feiten, Houten 1990, pp. 11 i.f. $43,61$. 
art. 5. Op de bodem van het verdragsrechtelijke persoonswordingsbeginsel vinden we, in een tussenzin, de volgende parel:

De staten (...) eerbiedigen de verantwoordelijkheden, rechten ${ }^{147}$ en plichten van de ouders of, indien van toepassing, van de leden van de familie in mimere zin [the extended fanily] of de gerneenschap [community] al naar gelang het plaatselijk gebruik (...).

Het plaatselijk gebruik volgens welke de leden van de 'extended family' of zelfs van de 'community" ${ }^{\text {148 }}$ zich medeverantwoordelijk weten voor de opvoeding van het kind, zich met de opvoeding van het kind bemoeien en zich over het kind ontfermen, is evenwel in welvarende landen al enkele generaties terug een stille dood gestorven. De helpende getuige is nog maar zelden een oom, oma, nicht, oudere broer, tante of buurman, tandarts, dominee, pastoor, juf of schoolmeester, akela, hopman of andere kindervriend. Afgaand op de kranten (en helaas ook op de statistieken), zouden we in (mannelijke) familieleden en buurtgenoten zelfs eerder potentiële 'incest'-plegers dan helpende getuigen behoren te zien. Zoals op zoveel terreinen die voorheen door patriarchaat en patronaat werden bestreken, en we kunnen dat betreuren of niet, dienen we in onze welvarende wereld voor de buitenstaander die als helpende getuige van het kind optreedt, te kijken naar de staat.

\subsubsection{Minimale persoonswording als quasi-resultaatsverplichting}

Gaat het bij het recht van het kind op optimale persoonswording om een 'bevordering' door de overheid, met andere woorden om een (uiterste) inspanningsverplichting, bij de bodem van dat recht: het recht van het kind op minimale persoonswording, gaat het om een 'waarborging' door de overheid, om een resultaatsverplichting, althans om een verplichting

147 Voor (ouderlijke) 'rechten' lees: bevoegdheden. Ingestemd wordt hier met de opvatting van de UK Law Commission uit 1982 dat "to talk of "parental rights" is not only inaccurate as a matter of juristic analysis but also a misleading use of ordinary language.' (Geraldine VAN BUEREN, The international law on the rights of the child, Dordrecht etc. 1995, p. 108 nt. 44.) Anders dan tegenover de onder hun gezag staande minderjarige kinderen kunnen ouders, als ouders, natuurlijk wel rechten hebben tegenover de staat.

148 Voor de betekenis van de 'extended family' en de 'community' voor de opvoeding van kinderen in Afrika(anse gemeenschappen) zie VAN BUEREN, a.w., p. 68. Vgl. met betrekking tot de invoeging van de desbetreffende tussenzin bij de tweede lezing, en de betekenis daarvan voor het hele Verdrag, VAN BUEREN, a.w., p. 71. Vgl. ook Sharon DETRICK (ed.), The United Nations Convention on the rights of the child; A guide to the 'travaux preparatoires," Dordrecht (etc.) 1992, p. 161. 
die daar dicht tegenaan ligt, die in de buurt komt van een resultaatsverplichting. Deze laatste nuancering dient te worden aangebracht omdat de verdragsverplichtingen ook hier voornamelijk jus constituendum betreffen, zij het - wel te verstaan - in de letterlijke zin van: te nemen juridische (en beleids)maatregelen. Jus constituendum met andere woorden als weliswaar geldend doch (in de nationale rechtsorde) verder te verfijnen, nog te operationaliseren (internationaal) recht.

Op grond van art. 4, eerste volzin juncto art. 19, art. 37 en art. 39 VRK betreft het recht van het kind op minimale persoonswording daarom wat we thans zullen noemen een quasi-resultaatsverplichting van de staat. Daarmee bedoelen we dat zolang het resultaat van minimale persoonswording niet is bereikt, zolang dus een kind door welke pedagogische (met zijn opvoeding of gebrek daaraan verband houdende) oorzaken of omstandigheden ook niet is uitgegroeid tot een minimaal rationeel, moreel en authentiek persoon, op de staat verplichtingen blijven rusten tot reparatie. Deze verplichtingen lopen door tot in de volwassenheid, en omvatten in principe mede de mogelijkheid van gedwongen behandeling indien de subminimale persoon vervalt in crimineel gedrag ten opzichte van kinderen dan wel in (anderszins) roekeloos gedrag (men denke aan extreme vormen van verslaving aan niet illegale middelen of zaken) dat tot onverantwoord ouderschap zou kunnen leiden (gedwongen daderbehandeling/ouderbehandeling).

In de allereerste plaats houdt deze quasi-resultaatsverplichting evenwel in dat, ongeacht de kosten (art. 4 VRK), ${ }^{149}$ een comprehensief sociaal-pedagogisch stelsel wordt opgezet waarmee op doeltreffende wijze kan worden voldaan aan inzonderheid de verplichtingen van de staat onder art. 18, lid 2 juncto art. 27, lid 3 (materiële en opvoedingsondersteuning aan ouders, sociaal-pedagogische instellingen, diensten en voorzieningen); art. 19, lid 2 (sociale opvoedingsondersteunings- en preventieprogramma's, procedures voor opsporing van gevallen van kindermishandeling, meldingsregeling, procedures voor gezinsonderzoek, verwijzing, behandeling, follow-up en inschakeling van rechterlijke instanties); art. 24, lid 2 juncto art. 6, lid 2 (ontwikkeling eerstelijnszorg met het oog op een gezonde ontwikkeling en de geestelijke gezondheid van het kind); art. 28 , lid 1 juncto art. 29, lid 1 aanhef en onder a en d en art. 18 (opvoedingsonderwijs voor kinderen en voor ouders); en art. 39 VRK (maatregelen voor herstel en rehabilitatie van slachtoffers van kindermishandeling).

Hoewel het recht van het kind op minimale persoonswording wortelt in een aantal fundamentele mensenrechten/rechten van het kind/ verdragsbeginselen (respect voor de lichamelijke en geestelijke integriteit; 
vrijwaring van wrede of vernederende behandeling of bestraffing; recht van het kind op de best mogelijke lichamelijke en geestelijke gezondheid; 'overleven en ontwikkeling'/"het belang van het kind'/'de zich ontwikkelende vermogens van het kind'), wil de term 'quasi-resultaatsverplichting' niettemin elk element of verwijt van 'wishful thinking' - van te hooggespannen verwachtingen ${ }^{150}$ ten aanzien van de naleving van de verdragsverplichtingen tot rechtsverfijning en operationalisering (hoe gemakkelijk kunnen staten zich immers niet achter ouderlijke 'rechten' verschuilen en dus talmen of stilzitten?) - uitsluiten c.q. de pas afsnijden. Uiteraard schuilt daarin het gevaar van roomser te zijn dan de paus. Opnieuw lijken we voor de (cynische) Scylla (Heilige Stoel) en de (naïeve) Charybdis ('whisful thinking') te dobberen. Deze keer wenden we de steven met HAMMARBERG aan het roer.

$\mathrm{Na}$ zijn '"three P's": provision, protection, and participation' te hebben geïtroduceerd, merkt deze op: ${ }^{151}$

"The Convention is stronger on the first two aspects - provision for basic needs and protection - than on rights relating to participation. The UNICEF-concept of "child survival" is included and the concreteness of some of the protective norms [is] almost surprising. (...) A major step forward was the ban on female circumcision, described in the Convention as "traditional practices prejudicial to the health of children."

The respect for the wishes of children themselves is much clearer than in the two declarations [of 1924 and 1959]. When courts, welfare institutions, or administrative authorities deal with children, the child's interest should be the main consideration, and the child's opinion should be given careful consideration. In discipline matters, the dignity of the child should be respected.'

\section{Om dan te vervolgen: ${ }^{152}$}

'Hidden behind these formulations is the tension between parents' [traditional prerogatives] and children's [fundamental] rights. Of course, these do coincide in most cases. But it would be naive, and in fact a denial of the whole concept of children's rights, to assume that there could never be a conflict between the two. Our sad experience is that most of the physical and sexual abuse against children [is] committed in a family context. (...)

The triangular relationship between the child, the [parents], and the state was of course a sensitive problem during the drafting. (...) However (...) some delegations in the working group seemed not to have been fully aware of the delicacy of

150 Vgl. evenwel ook hierna par. 10.5 (Addendum).

151 Thomas HAMMARBERG, "The UN Convention on the rights of the child - and how to make it work,' $H R Q 1990 / 1$, pp. 97-105, op p. 100 .

152 HAMMARBERG, ta.p., op pp. 100-101 (de toevoegingen/toespitsingen tussen vierkante haken zijn van mij). 
the problem. In fact, a delegate from the Federal Republic of Germany tried towards the end to get a "minor" change in the whole Convention. He wanted every mention of the right of the child to be substituted with a statement on parents" rights and responsibilities. Had that torpedo been fired at an early stage of the drafting, we would probably not [have been] in a position to have the text be quickly adopted.'

In hoeverre deze "reactionaire' poging van de $\mathrm{BRD}^{153}$ kan worden toegeschreven aan op slag van twaalven wakker geschrokken parentiarchen - wier aandacht vervolgens meer uitging naar de stuiptrekkingen van een stervende broederstaat,$-{ }^{154}$ kan slechts voorwerp zijn van pure speculatie. Feit is dat het kind als drager van rechten ook binnen de beslotenheid van het gezin, dat wil zeggen het kind als zelfstandig rechtssubject in de Trias pedagogica, alfa en omega van het Verdrag inzake de rechten van het kind is. Ja, ontkenning van het concept van het kind als in zijn eigen recht staand subject zou het hart uit het Verdrag snijden, zou - in verdragenrechtelijke termen ${ }^{155}$ - zin en betekenis eraan ontnemen, bedoeling en strekking ervan tenietdoen.

Jus vigilantibus scriptum: het recht is voor de wakkeren geschreven. Maar niet mag voetstoots worden aangenomen dat het door slapenden is gemaakt. ${ }^{156}$ Massaal en met volle bewustheid, zo niet van alle denkbare en ondenkbare implicaties dan toch op zijn minst van hun ernstige verantwoordelijkheden, hebben staten het Verdrag inzake de rechten van het kind omarmd. Elke suggestie door een staat van het tegendeel met de bedoeling de werking van het Verdrag te frustreren of de naleving van zijn verplichtingen op te schorten of te traineren, alsook elk voorbehoud of elke exceptie met die intentie, zou in strijd zijn niet alleen met de comitas gentium, met internationaal fatsoen, doch ook met het pacta sunt servanda, de goede trouw die wordt geëist door art. 26 Weens Verdragenverdrag.

153 Vgl. ook DETRICK (ed.), The United Nations Convention on the rights of the child; A guide to the 'travaux préparatoires,' a.w., pp. 159-160.

154 Deze broederstaat, de voormalige DDR, heeft het Verdrag inzake de rechten van het kind op 2 oktober 1990 ondertekend om de volgende dag, 3 oktober 1990, in de BRD op te gaan.

155 Vgl. art. 18 (aanhef) en art. 19 (alamhef en) onder c Weens Verdragenverdrag..

156 Overigens wekt lezing van de travaux preparatoires niet de indruk dat dit het geval zou zijn geweest bij de opstelling van het Verdrag inzake de rechten van het kind. Zo wordt in de sessie van 1988 uitdrukkelijk gesproken van "the delicate balance between the rights of children and the correlative rights [lees: bevoegdheden, jw] of parents' in art. 5 ontwerp-VRK. Hierbij wordt ook verwezen naar (huidig) art. 18 VRK. Zie The United Nations Convention on the rights of the child; A guide to the 'travaux préparatoires,' a.w., p. 159, par. 30 (curs. jw). 
10.4.3 Conclusie: minimale persoonswording als primordiaal en absoluut kernrecht van het kind

Het belang van het kind is als familierechtelijke rechtsnotie zo vaag en onzeker dat het onwillekeurig het adagium in herinnering roept: misera est servitus ubi jus est vagum aut incertum. Vrij vertaald: miserabel is het lot van het kind waar het recht vaag is of onzeker. Het belang van het kind, the best interests of the child, evenwel, zoals neergelegd en uitgewerkt in het Verdrag inzake de rechten van het kind, zou ons bijna doen uitroepen: gelukkig is het kind dat in een land geboren wordt waar dat Verdrag serieus wordt genomen, en waar ter naleving van de verdragsverplichtingen, conform hetgeen het Verdrag eist, kosten noch moeiten worden gespaard.

Zie hier wat - in het licht van het recht van het kind op optimale persoonswording als achterliggend, dragend en leidend beginsel van het Verdrag - wellicht als samenvatting van dit hoofdstuk, en de in dit hoofdstuk gegeven overzichten en rubriceringen van verdragsbepalingen, zou kunnen gelden. Welke samenvatting zou echter kunnen worden gegeven van het recht van het kind op minimale persoonswording - anders dan bij wege van verwijzing naar de bodem van de bodemverplichting die 'optimale persoonswording" voor de staat is? De te waarborgen bodem, boven welke het recht van het kind op (optimale) persoonswording uiterste statelijke inspanningsverplichting is.

Misschien kan de volgende samenvatting (of misschien beter: recapitulerende typering) worden beproefd.

(1.) Het recht van het kind op minimale persoonswording is een recht dat bijna als harder, als fundamenteler moet worden beschouwd dan art. 3 EVRM (het recht op vrijwaring van wrede, onmenselijke of vernederende behandeling of bestraffing), dat tot het jus cogens (dwingend volkenrecht) wordt gerekend. Niettemin is het meeromvattend dan art. 3 EVRM (c.q. art. 7 IVBPR en art. 37 onder a, eerste volzin VRK) in dier voege dat, bovenop - of misschien beter: onder of achter - het in art. 3 EVRM bepaalde, het recht van het kind op respect voor zijn lichamelijke en geestelijke integriteit, het recht van het kind op de best mogelijke lichamelijke en geestelijke gezondheid, het recht van het (mishandelde) kind op herstel en reïntegratie, alsmede, in onderlinge samenhang, de beginselen overleven en ontwikkeling, het belang van het kind en de zich ontwikkelende vermogens van het kind, en de daarmee verband houdende c.q. de daaronder ressorterende rechten, er - tot het minimum aanvullend - deel van uitmaken.

(2.) Als (bijna- of quasi-)resultaatsverplichting van de staat ziet het recht van het kind op minimale persoonswording op de ontwikkeling van 
een comprehensief sociaal-pedagogisch stelsel waarmee op doeltreffende wijze kan worden voldaan aan de verplichtingen van de staat tot materiële en opvoedingsondersteuning aan ouders, het opzetten van c.q. voorzien in sociaal-pedagogische instellingen, diensten en voorzieningen, sociale opvoedingsondersteunings- en preventie-programma's, procedures voor opsporing van gevallen van kindermishandeling, een meldingsregeling, procedures voor gezinsonderzoek, verwijzing, behandeling, follow-up en juridische interventie (hulpoplegging), de ontwikkeling van eerstelijnszorg met het oog op een gezonde ontwikkeling en de geestelijke gezondheid van het kind, opvoedingsonderwijs voor kinderen en voor ouders, en maatregelen voor herstel en reïntegratie van slachtoffers van kindermishandeling. En dit alles - gezien art. 4 VRK - ongeacht de daaraan verbonden kosten.

(3.) Immers, weliswaar verplicht de tweede volzin van artikel 4 de staten tot het nemen van alle passende (dat wil zeggen: alle adequa$t e^{157}$ ) wettelijke, bestuurlijke en andere maatregelen in de nimste mate waarin de hun ter beschikking staande middelen dit toelaten. Met andere woorden, laat deze tweede volzin staten de ruimte voor een zekere budgettaire afweging (een afweging die in ontwikkelingslanden uiteraard anders uitvalt dan in een puissant rijk land als Nederland). Doch deze (beperkte) discretionaire ruimte geldt slechts de 'esocul'- (economische, sociale en culturele) rechten in het Verdrag. Bij minimale persoonswording gaat het evenwel in essentie om absolute c.q. kernrechten als respect voor de lichamelijke en geestelijke integriteit, (mede in de zin van) vrijwaring van wrede of vernederende behandeling of bestraffing, en 'overleven en ontwikkeling' (lees: lichamelijke en geestelijke veiligheid en ontwikkeling). Betoogd kan worden dat het basale, centrale, primordiale persoonswordingsbelang van het kind - ook al vergt de waarborging van dat belang kostbare investeringen en ook al zijn daarbij 'esocul'-rechten mede in het geding, zich zozeer in deze kernrechten oplost, daarmee zozeer onlosmakelijk is verbonden dat, althans waar het de minimale persoonswording betreft, dit met deze kernrechten op één lijn moet worden gesteld. $^{158}$

157 Vgl. Louise MULDER, 'Recht voor één is geen recht voor allen; emancipatiereclyten voor zwarte, migranten- en wluchtelingenvrouwen,' Nemesis 1997/1, pp. 4-12, op p. 12 .

158 Vgl. in dit verband The Maastricht guidelines on violations of economic, social and cultural rights (NQHR 1997/2, Appendix II, pp. 244-252, op pp. 247/248), opgesteld door een internationale groep van deskundigen in januari 1997 ter uitwerking van The Limburg principles on the implementation of the International Covenant on Economic, Social and Cultural Rights (UN doc. E/CN.4/1987/17, Annex; opgenomen in $H R Q 1987 / 2$, pp. 122-135, en, recentelijker, in: A.P.M. COOMANS, 
(4.) Deze redenering is plausibel ook al kan worden tegengeworpen, en niet worden ontkend, dat de grenzen van en tussen minimum en optimum (in het bijzonder het gebied waar subminimaal in minimaal en minimaal in boven-minimaal overgaat) niet scherp kunnen worden getrokken (en zeker niet zolang minimale persoonswording als kernrecht nog onvoldoende is geoperationaliseerd). Echter, de (nog) bestaande, en deels blijvende, inherente vaagheid van deze grenzen doet aan bovenstaande redenering niets af. De staat kan gezien de waarborgfunctie van minimale persoonswording immers geen enkel risico nemen dat hij te laag inzet.

Bovendien kan - (zij het) tegen de achtergrond van de herhaalde internationale bevestiging van de eenheid en ondeelbaarheid van alle mensenrechten ${ }^{159}$ - worden betoogd dat het recht van het kind op minimale persoonswording (anders dan het recht van het kind op optimale persoonswording voor zover dat recht de waarborging van minimale persoonswording overstijgt) in essentie een (democratisch) burgerschapsrecht is, namelijk als voorwaarde ('pre-condition') voor de uitoefening, binnen een (democratische) rechtsgemeenschap, van burgerlijke, politieke en andere (economische, sociale, culturele) mensenrechten. Minimale persoonswording kan tegelijk gerekend worden tot de harde kern van 'civil rights,' de (rechtsstaats)burgerlijke vrijheden van niet alleen volwassenen in de publieke, maar ook van (vrouwen en) kinderen in de private sfeer. Als de woorden van KOREN hierop mogen worden toegepast: ${ }^{160}$

A.W. HERINGA, I. WESTENDORP (red.), De toenemende betekenis wan economische, sociale en culturele mensenrechten, Leiden 1994, pp. 153-167), par. 9, Minimum core obligations: "Violations of the Covenant occur when a State fails to satisfy what the Committee on Economic, Social and Cultural Rights has referred to as "a minimum core obligation to ensure the satisfaction of, at the very least, minimum essential levels of each of the rights [...]. Thus, for example, a state party in which any significant number of individuals is deprived of essential foodstuffs, of essential primary health care, of basic shelter and housing, or of the most basic forms of education is, prima facie, violating the Covenant." Such minimum core obligations apply irrespective of the availability of resources of the country concened or any other factors and difficulties.' (Curs. jw.) Vgl. ook hierna par. 10.5 (Addendum).

159 Zie hierover - zeer uitgesproken - Cees FLINTERMAN, 'The protection of economic, social and cultural rights and the European Convention on human rights," in: Rick LAWSON, Matthijs DE BLOIS (eds.), The dynamics of the protection of human rights in Europe; Essays in honour of Henry G. SCHERMERS, vol. III, Dordrecht (etc.) 1994, pp. 165-174, op p. 165. Marian KOREN, Tell me! The right of the child to information, diss. Amsterdam, Den Haag 1996, p. 233. 
"The international protection of children's civil rights now touches the core of family life."

\section{Conclusie}

Met betrekking tot deze paragraaf (par. 10.4) kan, als toevoeging aan bovenstaande recapitulatie, de volgende samenvattende conclusie worden gegeven.

(5.) Het recht van het kind op minimale persoonswording betreft het basale, centrale, primordiale persoonswordingsbelang van het kind als conditio sine qua non voor de uitoefening van de rechten van de mens, ja als conditio sine qua non voor menselijke ontplooiing en de ervaring aan zichzelf en ten opzichte van de medemens van de menselijke waardigheid. Een kind dat tot minder dan een minimaal persoon is opgevoed, staat zodanig gehandicapt in het leven, is zodanig misvormd geraakt en gemaakt, dat van een ernstige schending van zijn fundamentele rechten, van een ernstige schending van de rechten van de mens, moet worden gesproken. Het is zodanig wreed een sub-minimaal persoon de maatschappij in te sturen, dat minimale persoonswording als kindervolkenrechtelijke bodem van art. 3 EVRM moet worden beschouwd. Om die reden kan en moet het recht van het kind op minimale persoonswording als primordiaal en absoluut kernrecht van het kind worden aangemerkt. Primordiaal omdat het aan de uitoefening en het genot van de rechten van de mens voorafgaat. Absoluut omdat de staat geen financiële of andere 'overmachts'-argumenten kan (althans mag) aanvoeren om van het recht te derogeren en minder te doen dan waartoe het recht de staat verplicht.

In het bijzonder kan de staat niet aanvoeren dat het opzetten van preventie-programma's en/of het aanbieden of opleggen van opvoedingshulp bepaalde sociale groepen zou stigmatiseren respectievelijk een onevenredige inbreuk zou maken op de 'rechten' van de ouders uit zulke groepen. Ook voor de kinderen uit zulke groepen is het recht op minimale persoonswording een primordiaal en absoluut recht. Tegen 'welwillende verwaarlozing' van zulke groepen verzet zich het gelijkheidsbeginsel in de zin van art. 1 van de Universele Verklaring van de rechten van de mens. Dat wil zeggen: het recht van elk kind op minimale (respectievelijk optimale) persoonswording. BAARTMAN heeft dit ooit zo uitgedrukt: ${ }^{161}$

'Zoals prof. dr. BAARTMAN in zijn toespraak bij de première van de film "Johan" zei: "Het is éen ding om in een film te laten zien hoe gemakkelijk grootbrengen kan ontaarden in kleineren. Het is een ander ding om ouders te helpen het an- 
ders te doen." In dit kader pleit prof. BAARTMAN ervoor dat aanstaande ouders gratis de mogelijkheid wordt geboden om zich door cursussen en individuele begeleiding voor te bereiden op het ouderschap. Met name zou dit moeten gelden voor die groepen ouders waarvan uit onderzoek is gebleken dat ze meer risico's lopen problemen te krijgen in de relatie met hun kinderen. Het gaat dan om ouders die erg onzeker zijn, slechte jeugdervaringen hebben, weinig sociale contacten, geen of een weinig steunende partmer hebben, en die vaak geen notie hebben wat het betekent een kind op te voeden of juist zeer overspannen verwachtingen hierover koesteren. Over het nogal eens gehoorde bezwaar dat men op die manier bepaalde risicogroepen zou stigmatiseren, zegt BAARTMAN: "Als dit onethisch zou zijn, hoe ethisch is het dan om af te wachten of de bange voorgevoelens uitkomen? ${ }^{\text {n' }}$

Deze woorden kunnen als inleiding worden beschouwd op wat in hoofdstuk 12 aan de orde komt: de gevolgen van kindermishandeling - voor individu en samenleving - wanneer niet of te laat ingegrepen wordt. Alsmede, om te beginnen, de omvang van dat niet of te laat ingrijpen in ons land. De omvang en de gevolgen van het structurele afwachten, het stelselmatig passief toekijken - of liever: de andere kant opkijken - van de maatschappij, tot het fout loopt met (ouders en) kinderen.

De vraag hoe ethisch dat is, lost zich op in de vraag of en in hoeverre zulks juridisch - internationaalrechtelijk, mensenrechtelijk - is te verantwoorden. Met andere woorden in de centrale vraagstelling van hoofdstuk 13, waaraan nog, ter completering van dit (juridische) hoofdstuk, de volgende internationaal-/mensenrechtelijke overwegingen en ontwikkelingen voorafgaan.

10.5

Addendum: De opvatting van het Comité inzake de rechten van het kind ${ }^{162}$

Tot hier toe is ten aanzien van de aard van de verdragsverplichtingen onze aandacht in het bijzonder uitgegaan naar de letter en de geest (optimale persoonswording als causa finalis) van de diverse bepalingen van het Verdrag inzake de rechten van het kind. Wellicht nog belangrijker dan de tekst van de verdragsbepalingen an sich - zowel vanuit een minimale handhavingsoptiek op korte termijn als met het oog op (optimale

162 Zie ook het Post scriptum bij het 'Woord vooraf en dankwoord,' waarin wordt gewezen op de uitgebreide, artikelsgewijze weergave van de opvattingen van het Comite in het UNICEF-Implementation handbook for the Convention on the rights of the child. Daarnaast kan hier (ten overvloede) nog worden gewezen op Marta SANTOS PAIS, 'The Convention on the rights of the child,' in: Manual on human rights reporting under six major intemational human rights instruments, United Nations, Geneva 1997, pp. 393-504. 
persoonswording als) hun causa finalis, en dus vanuit een handhavingsoptiek op langere termijn - is evenwel de wijze waarop het Comité inzake de rechten van het kind, als toezichthoudend orgaan, deze bepalingen hanteert en interpreteert. Hierover verschaft MIJNARENDS belangwekkende inlichtingen: ${ }^{163}$

'Het [Verdrag inzake de rechten van het kind/VRK] stimuleert een holistische en multidisciplinaire benadering van de verdragsrechten. ${ }^{164}$ Het [Verdrag] omvat zowel burger[lijke] en politieke [d.i. klassieke] rechten als sociale, economische en culturelle [d.i. sociale] rechten omdat [alle] noodzakelijk worden geacht voor de "full and harmonious development of the personality [optimale persoonswording, jw] (...) of the child." (...) Deze holistische benadering heeft echter implicaties voor het implementatieproces. De meeste sociale rechten houden immers een overheidsopdracht in en zijn - in tegenstelling tot de klassieke rechten - niet rechtstreeks afdwingbaar [dat wil zeggen dat de rechter er slechts sporadisch directe werking aan toekent, dat is: aan toetst, jw]. De art[t]. 2 en 4 [van het Verdrag] bieden echter uitkomst.

Wat betreft art. 2 stelt het Comité dat elke lidstaat een tweeledige implementatieverantwoordelijkheid heeft: (1) [hij, d.i. de staat] dient een bepaald doel te verwezenlijken, namelijk te eerbiedigen en te waarborgen dat ieder kind [dat] zich binnen de jurisdictie [rechtsmacht] van de [staat] (...) bevindt, (2) zonder discriminatie [onderscheid op welke grond ook] op alle verdragsrechten aanspraak kan maken (...). Ongeacht de status [lees: het rechtskarakter, jw] van het verdragsrecht veronderstelt het Comité dát negatieve onthoudingsplichten alsmede positieve maatregelen noodzakelijk zijn om een kind in concreto van zijn verdragsrechten te laten genieten. Eerbiediging [curs. jw] heeft weliswaar een negatieve [d.i. onthoudings-]connotatie maar het Comité verwijst voor de uitleg van dit begrip naar de implicaties van het MARCKX-arrest waaruit mag worden afgeleid dat het principe van effectiviteit [principle of effectiveness: ut res magis valeat quam pereat, $\mathrm{jw}]$ met zich mee kan brengen dat door een lidstaat positieve maatregelen moeten worden genomen om een recht te effectueren, Waarborgen [curs. jw] omvat ver-

163 Isabeth MUNARENDS, 'De Nederlandse rapportage-verplichting in het licht van het (...) Verdrag inzake de rechten van het kind,' FJR 1997/1, pp. 10-18, op pp. 11 (vanaf 1.k. i.f.)-12 (curs. IM tenzij anders aangegeven; de niet altijd precieze en heldere schrijfstijl van de auteur maakt het noodzakelijk veelvuldig met teksthaken te werken teneinde de bedoeling van de auteur zoveel mogelijk te doen uitkomen).

164 Vermoedelijk bedoelt de auteur hier - in elliptische zin - te spreken van de toepassing of benadering van het Verdrag door het Comité inzake de rechten van het kind. CANTWELL spreekt in dit verband van de "holistic approach to child welfare and development that is fundamental to the proper implementation of the Convention.' (Nigel CANTWELL, 'The role of UNICEF in the implementation of the Convention on the rights of the child,', in: Eugeen VERHELLEN (ed.), Understanding children's rights; Collected papers presented at the first International interdisciplinary course on children's rights, Gent 1996, pp. 385-387, op p. 385; curs. jw.) 
dergaande verplichtingen, namelijk [de verplichting] om al die maatregelen te nemen die het kind in staat stellen zijn verdragsrechten te effectueren.

Ook art. 4 [VRK] biedt uitkomst. Voor het Comité is dit artikel een graadmeter ter bepaling van de politieke wil van lidstaten het [Verdrag] als pro-actief instrument te gebruiken. Art. 4 [lees: het Comite (op basis van art. 4 juncto art. 2)? -jw] benadrukt dat, vanwege de ondeelbaarheid en onderlinge verwevenheid van de verdragsrechten [in het bijzonder in het licht van en met het oog op de optimale persoonswording van het kind, jw], [vanwege] het gegeven dat vele rechten zowel "klassieke" als "sociale" componenten bevatten, en [vanwege] het voorschrift dat elk kind gelijkelijk van alle verdragsrechten moet genieten (art. 2), de nationale overheid tenminste implementatieverplichtingen op twee niveaus heeft: 1. Samenwerking met de private sector (...). De ondeelbaarheid van de verdragsbepalingen maakt het mogelijk een effectieve interactie te initiëren tussen de verschillende [nationale] sectoren en instanties [departementen! -jw] zowel wat betreft het bepalen wan een implementatiebeleid alsmede wat betreft het opzetten van [verantwoord-ouderschaps-]campagnes, training [ouderschapsonderricht en deskundigheidsbevordering van hulpverleners, $\mathrm{jw}$ ] en technical assistance [ouderschapsondersteunings-/sociaal-pedagogische, jw] programma's. (...)

2. Hoewel het begrip "available resources" [in art. 4 VRK] zich direct richt tot de implementatie van [lees: betrekking heeft op] de economische, sociale en culturele rechten, interpreteen het Comite dit begrip zodanig dat het ook op de andere [klassieke/burgerlijke] kinderrechten betrekking heeft [curs. jw]. Wat betreft de implementatie van de in art. 4 genoemde [klassieke èn sociale] rechten, legt het Comité de bewijslast bij de nationale overheid [de staten] aan te tonen dat de budgetbesteding plaats vindt "to the maximum extent of their available resources." Recessie als argument [rechtvaardiging of verontschuldiging] voor in gebreke blijwen, wordt van de hand gewezen en van rijkere landen wordt een groter aandeel van het bruto nationaal product verwacht bij de besteding aan sociale [sociaal-pedagogische, jw] doeleinden dan van armere landen. Dat is nu juist de interpretatieruimte [lees: naar de mate van rijkdom van het land afnemende discretionaire ruimte, $j w$ ] die het begrip [de bewoordingeri] "to fine maximini sacia of their available resources" biedt.

De - van oorsprong - klassieke rechten vallen (indirect) echter ook onder deze implementatieplicht nu het Comite bepaalt dat het begrip "resources" niet langer beperkt geïnterpreteerd wordt [als] beschikbare financiële middelen die de overheid investeert, maar (...) ook [als] menselijk potentieel [door] de organisatie van een samenleving (op micro-niveau) daarin te betrekken. (...) Door het begrip "available resources" direct te koppelen aan de gevolgen van de financiële budgettbesteding, in het bijzonder aan [in het licht van] het gelijkheidsbeginsel (...), wordt het onderscheid in implementatie tussen "klassieke" [verticale onthouding/ horizontale waarborging, rechtstreekse werking, jw] en niet-klassieke [inspanning, niet in rechte inroepbaar/afdwingbaar, jw] kinderrechten niet langer houdbaar.'

Het behoeft geen betoog dat de hier gereweleerde praxis van het Comité de aan het slot van dit hoofdstuk gereleveerde theorie over de ondeelbaarheid van klassieke en sociale rechten bevestigt en onderstreept. Die theorie wordt met andere woorden door het Comité tot implementatiepraktijk gemaakt. Duidelijk en onmiskenbaar treedt hierdoor de - in de 
praktijk - eerder vloeiende dan scherpe overgang aan het licht tussen (quasi-)resultaats- en (uiterste) inspanningsverplichtingen.

Een en ander versterkt - afgezien van mogelijke theoretische implicaties, en complicaties, voor de bepaling van de staatsaansprakelijkheid, welke onderwerp van nadere analyse is in hoofdstuk 13 - het praktische belang van een 'glijdende-schaal-scenario' - vertrekkend vanuit een breed hulpverleningsaanbod onder een wijde sociaal-pedagogische paraplu - op het punt van het aanbieden en opleggen van opvoedingshulp, zoals dat in hoofdstuk 14 (ten aanzien van de verantwoordelijkheden van de staat c.q. de overheid) nader zal worden bepleit.

Voor we evenwel (staats)aansprakelijkheid en (overheids)verantwoordelijkheden onder de loep kunnen nemen, in het licht van de ernst - qua omvang en gevolgen (of sequelae) - van kindermishandeling, is het nodig eerst het fenomeen kindermishandeling zelf nader te beschouwen. Hetgeen we gaan doen in het nu volgende hoofdstuk. 



\section{Boek 3: Kindermishandeling}


'Wij groeien op in een gezin, in een familie en ons innerlijk blijft een familie.'

$$
\text { P.C. KUIPER, Nieuwe neurosenleer, Deventer 1984, p. } 15 \text { (if.). }
$$

'Toen ik een kind was, sprak ik als een kind, was ik gezind als een kind, overleide ik als een kind; maar wanneer ik een man geworden ben, zoo heb ik te niet gedaan hetgeen eens kinds was.'

1 Cor. 13:11 (Statenvertalling). 


KINDERMISHANDELING ALS SCHENDING
VAN HET RECHT VAN HET KIND OP MINI-
MALE PERSOONSWORDING

11.11

\author{
Inleiding: kindermishandeling als schending van het recht \\ van het kind op minimale persoonswording
}

\title{
Algemene inleiding
}

Kinderen kunnen door hun ouders emotioneel, fysiek en/of sexueel worden gemaltraiteerd (mishandeld/misbruikt en/of verwaarloosd). ${ }^{1}$ Het

1 Maltraiteren c.q. maltraitering wordt hiter gebezigd als vertaling van het Engelse maltreatment, dat meeromvattend is dan het Nederlandse mishandeling (vgl. H.E.M. BAARTMAN, Opvoeden kan zeer doen; Over oonaken van kindemishandeling, hulpverlening en preventie, Utrecht 1996, p. 89). Maltraiteren is "verkeerd [be]handelen,' en wordt in die zin hier gehanteerd als verzamelterm voor mishandelen, misbruiken en verwaarlozen in lichamelijke (fysieke), sexuele of emotionele (psychische c.q. affectieve) zin als vormen van ouderlijk geweld ten opzichte van kinderen. De term '(ouderlijk) geweld' wordt hier dus eveneens - anders dan bij BAARTMAN (vgl. H.E.M. BAARTMAN, 'Schuld, herstel en overleven; aspecten van hulpverlening inzake kindermishandeling,' in: D.J. DE RUYTER en P.A. DE RUYTER (red.), Opvoedingshulp geboden; Pedagogische criteria voor het opleggen van hulp, theoretisch en praktisch bezien, Utrecht 1995, pp. 83-91, op pp. 83/84) als overkoepelend begrip gezien. Genoemde auteur acht "verwaarlozing geen gewelddadig handelen' (t.a.p., op p. 84). In het (straf)recht zijn bepaalde vormen van nalaten (nalatig handelen) evenwel wel degelijk 'gewelddadig': men spreekt dan van oneigenlijke of onzuivere omissiedelicten (delicta commissiva per omissionem). Zo maakt een moeder zich schuldig aan het geweldsdelict doodslag (een ander opzettelijk van het leven beroven, art. $287 \mathrm{WwSr}$ ) indien zij haar kind niet voedt (J. REMMELINK, HAZEWINKEL-SURINGA's Inteiding tot de studie van het Nederlandse strafrecht, Arnhem 1995, 14e druk, p. 119). Ook in de literatuur over kindermishandeling wordt verwaarlozing tot geweld gerekend (zie Michael LEWIS, 'What can child development tell us about child abuse?' In: Kevin BRowNE e.a. (eds.), Early prediction and prevention of child abuse, Chichester etc. 1993, pp. 3-12, op pp. 3/4).

Elders spreekt BAARTMAN overigens van 'geweld met de handen op de rug'; hij doelt dan op emotioneel geweld als 'terroriseren, verwerpen of kleineren' ( $O p^{\text {- }}$ voeden kan zeer doen, a.w., p. 33). Ook hier geldt mijns inziens dat vormen van verwaarlozing, zoals affectieve verwaarlozing die een verwerping van het kind impliceert of ten gevolge heeft, en zelfs sexuele verwaarlozing (te kort schieten in de sexuele opvoeding van het kind) voor zover dit het kind op (chronisch) traumatiserende wijze overlevert aan angsten rondom (zijn) sexualiteit, als gewelddadig (ouderlijk geweld, ouderlijke overweldiging of verplettering van het kind) kunnen worden aangemerkt. Gewell is - vanuit de optiek van het slachtoffer - 
schort die ouders dan aan voldoende pedagogisch besef. ${ }^{2}$ In hun eigen geschiedenis hebben zij niet het niveau van (ontwikkelingspsychologische, pedagogische, relationele en zelf-)kennis en gevoeligheden (eigenwaarde, verantwoordelijkheidsbesef, empathie, realiteitsbesef, ambivalentie- en frustratietolerantie) opgebouwd die hen in staat stelt 'goed-genoege' ouders te zijn. ${ }^{3}$ De sociale en emotionele leeromgeving waarin zij zijn opgegroeid, heeft hen met andere woorden onvoldoende of inadequaat op het ouderschap voorbereid. Niet zelden is hun leef- en leeromgeving dermate te kort geschoten, dat zij als ouders "hun kinderen zozeer nodig hebben om zelf iemand te zijn, dat het kind niet de ruimte krijgt om iemand te [worden]. ${ }^{4}$

In het ergste geval zijn zij zelf als kind gemaltraiteerd, en zitten zij gevangen in een vicieus, transgenerationeel "pechvogelschap. ${ }^{5}$ De kloof tussen het televisie-beeld van het gelukkige comflakes-gezin en hun dagelijkse ervaring van isolement, eenzaamheid, teleurgestelde verwachtingen en hulpeloosheid kan zelfs zo groot worden, dat zij - in een vlaag van machteloze woede, meegezogen in een mateloze wrok of aan uitzichtloze wanhoop ten prooi - overgaan tot vernietiging van wat hun het meest

een vorm van wreedheid, van ongevoeligheid voor de pijin en de kwetsbaarheid van een ander, die zowel uit een doen als een nalaten kan blijken, die zich zowel als mishandeling of misbruik als als verwaarlozing kan aandienen.

(Onder meer) uit een oogpunt van pedagogische hulpverlening - zowel generaal preventief bezien: het actief benaderen van (risico)gezinnen, als in concrete gevallen (speciaal preventief: het aanbieden van hulp aan een bepaald gezin, en repressief: het opleggen van hulp aan een bepaald gezin) - kan het uiteraard van belang zijn tussen de diverse vormen (en dus ook tussen mishandeling en verwaarlozing) te differentiëren (vgl. Opvoeden kan zeer doen, a.w., p. 45). Met betrekking tot werwaarlozing laat zich dan ook de variant cognitieve verwoarlozing (waar bovenvermelde sexuele verwaarlozing onder zou kunnen worden gebracht) onderscheiden, alsook 'pedagogische' verwaarlozing in de zin van ouderlijk te kort schieten in het leiding geven aan (en disciplineren van) het kind (vgl. Opvoeden kan zeer doen, a.w., p. 90). Overigens zou in beginsel elk ouderlijk plichtsverzuim als pedagogische (taak)verwaarlozing kunnen worden aangeduid.

2. Vgl. voor deze term BAARTMAN, Opwoeden kan zeer doen, a.w., pp. 44 e.v., op pp. $48 / 49$.

3 Vgl. Opvoeden kan zeer doen, a.w., pp. 45, 46, 47 i.f., 52, 53, 79 .

4 Opvoeden kan zeer doen, a.w., p. 79.

5 Deze term ontleen ik aan N. JÖRG, C. KELK, Strafrecht met mate, [Arnhem] 1996 (negende druk), p. 77. Volgens de auteurs heeft de victimologie 'ons geleerd dat sommige mensen "victim-prone" zijn; een soort "pechvogelschap" bezitten om slachtoffer van een delict te worden.' Enigszins gechargeerd (dat wil zeggen geabstraheerd van het element 'verwerking') op kindermishandeling toegepast, zou dit kunnen worden vertaald met: eenmaal een slachtoffer, altijd een slachtoffer! Vgl ook BAARTMAN, Opvoeden kan zeer doen, a.w., p. 43 (het Mattheüseffect). 
dierbaar is: hun kinderen. En net zoals zelfvernietiging zich beweegt tussen de uitersten van destructieve verslaving, psychische zelf-devaluatie en zelf-sabotage of relationele uitlevering aan deze en zelfmoord aan gene zijde, kan de vernietiging van het kind zich bewegen tussen vormen van emotionele of fysieke maltraitering en 'plotselinge' kindermoord.

De excessen die het nieuws halen, worden politiek bezworen als 'tragische incidenten.' De link met een te kort schietende leeromgeving in heden en verleden wordt zelden of nooit gelegd. En zo blijft de maatschappij haar eigen uitgeslotenen en wraakroependen, gemarginaliseerden en criminelen, vervolgers en zondebokken, kortom: slachtoffers en daders voortbrengen. ${ }^{6} \mathrm{Zo}$ houdt, om bij het onderwerp van deze studie te blijven, de maatschappij een situatie van ernstige en structurele mensenrechtenschendingen - van grootschalige schending in publiekrechtelijk vrijgestelde privé-structuren ${ }^{7}$ van primordiale (zowel onvoorwaardelijke

Vgl. Alice MILLER, Gij zult niet merken; Tachtig jaar psychoanalyse, Weesp 1983 (derde druk, Houten 1988), p. 303: "Wat heeft het voor zin "maatschappijkritiek" te oefenen als wij als analytici de kennis omtrent de manier waarop de wreedheid in de maatschappij ontstaat en wordt doorgegeven, vóór ons houden of er zelfs niet van willen horen, om alsjeblieft maar niemand schuldgevoelens te bezorgen?' Met 'publiekrechtelijk vrijgestelde privéstructuren" wordt gedoeld op het politicojuridische ontzag voor het privacy-recht (en bijgevolg de relatieve onaantastbaarheid van de privésfeer ten aanzien van de uitoefening van ouderlijke bevoegdheden en de vervulling van ouderlijke verplichtingen) ten koste van sociaal-pedagogische wetgeving en matregelen ter ondersteuning en (desnoods opgelegde) begeleiding van ouders met het oog op de bescherming van de rechten van kinderen (hierna ook well als publiekrechtelijk "ouderschapslibertinisme' aangeduid).

In dit verband kan worden gewezen op twee auteurs. In de eerste plaats wOLLESWINKEL (Ria WOLLESWINKEL, Gevangen in moederschap; Gedetineerde vrouwen en het recht op family life, diss. Maastricht, Deventer 1997, pp. 230-232). WOLLESWINKEL onderscheidt 'twee politieke reacties": "een liberale, die overheidsbemoeienis altijd gevaarlijk vindt en de privesfeer een groot daartegen te beschermen goed.' En 'een sociale, die veel meer nadruk legt op ongelijke ontwikkelingskansen van kinderen, omdat die sterk bepaald zijn door het nest waarin ze geboren worden.' Zij merkt daarbij op dat de 'liberale invalshoek' aansluit 'bij de klassiekjuridische benadering.' Daarentegen is de 'sociale invalshoek (...) betrekkelijk nieuw in het juridisch systeem. Die wordt ook veelal van buiten aangevoerd door rechtssociologen en metajuristen."

Wat er (precies) van dat laatste zij, het lijkt nauwelijks voor discussic vatbaar dat de liberale/klassiekjuridische geestesgesteldheid tot op heden bijzonder succesvol is geweest in het buiten de verzorgingsstaat houden van sociaal-pedagogisch welzijn. Dit brengt ons op de tweede auteur, "T HART (A.C. "T HART, "Spanning en overspanning van de rechtshandhaving,' in: Strafrecht en beleid; Essays, Leuven (/Zwolle) 1983, pp. 377-411, op p. 400). Volgens 'T HART wordt de verzorgingsstaat (onder meer) gekenmerkt door 'het politieke compromiskarakter tussen liberalisme en socialisme en de juridisering van de sociale zorg welke verschuift 
als voorwaarden-scheppende) rechten van het kind - in stand.

Terwijl tien gevallen van mishandeling in gevangenissen zouden wijzen op structurele tekorten in het toezicht op het gevangeniswezen, worden tienduizenden gevallen van kindermishandeling per jaar in $\mathrm{Ne}$ derland nog steeds niet gezien als symptoom van structurele tekorten in het sociaal-pedagogisch vangnet rondom kind en gezin in dit land. Noch door journalisten, de mensen van het woord; noch door activisten, de mensen van de daad; noch door fillosofen, de mensen van de kritische gedachte. Om met MILLER te spreken: ${ }^{8}$

van gunst naar recht.' In een verzorgingsstaat als de onze, welke - alle bureaucratische (bezuinigings-)dehumanisering ten spijt - nog verre van afgebroken is, zou men ook ten aanzien van het sociaal-pedagogisch welzijn van ouders en kinderen een toenadering van de liberale/klassiekjuridische en sociale(/metajuridische) denkwijze - en bijgewolg de juridisering van sociaal-pedagogische zorg, een opschuiven van (incidentele) gunst naar (structureel) recht - verwachten. Hier lijkt het liberale/klassiekjuridische denken evenwel zijn laatste verdedigingsbastion van de tegenstelling individu-staat te hebben betrokken. Een tegenstelling die evenwel ten diepste op een misvatting berust. Elders (in zijn noot bij Hoge Raad 10 april 1984, Nederlandse Jurisprudentie 1984, 612, 'Jodiumhoudend broodzout,' op p. 2150 l.k./r.k.) spreekt "T HART onomwonden van een "ideologische bevangenheid' die diegenen parten speelt die denken 'in termen van polariteit tussen de individuele rechtssubjecten en de staat, waarbij de eersten - als het ware woórgegeven - de laatste zouden hebben gemaakt." Hij stelt hierover: 'De theoretische kernvraag is in hoeverre de door recht en staat vooronderstelde [volwassen, dat is meerderjarige, $j w]$ mens zèlf een creatie is van dat recht en van die staat. De (...) vraag tot hoever de staat kan ingrijpen in het private domein van het individuele rechtssubject, gaat aan de kwintessens wan de theoretische problematiek voorbij door haar ideologische bevangenheid: $2 i j$ gaat immers uit van een vermeende evidentie dat het individu als "natuurgegeven" vooraf zou gaan aan de staat en die zou hebben gemaakt, zonder de wisselwerking te analyseren waarin staat - en nog breder: cultuur - en individu elkaar hebben geconstitueerd."

Van alle bevangenheid ontdaan, kan de liberale invalshoek tot geen andere uitkomst leiden - zou men denken - dan de sociale: de afweging van rechten en belangen waarbij het persoonswordingsbelang/-beginsel de (mensenrechtelijke, verdragsrechtelijke en publiekrechtelijke - dat is het algemeen belang clienende) doorslag geeft.

Tegenover de 'tendens tot dereguleren' zal mijns inziens dan ook in toenemende mate komen te staan 'de ontwikkeling van veelomvattende positieve verplichtingen voor de staat in het belang van het kind' - om de (slot)woorden van FORDER te bezigen (Caroline FORDER, Legal establishment of the parent-child relationship: Constitutional principles in Dutch, English and German law, having regard to the European Convention for the protection of human rights and fundamental freedoms and other applicable international instrments, diss. Maastricht 1995, 'Samenvatting, pp. 557-570, op p. 570).

Alice MILLER, Gij zult niet merken, a.w., p. 310.

Natuurlijk kan niet worden uitgesloten - en MLLER zou de eerste zijn om dat te 
'Er zijn nu eenmaal dingen op deze wereld die het denken wan de filosofen (de gelukkigen) nog niet hebben beroerd.'

\section{Vraagstelling}

Wanneer spreken we van kindermishandeling en waardoor wordt kindermishandeling 'veroorzaakt' (dat is: gekenmerkt')? Welk verband kan worden gelegd tussen kindermishandeling en het recht van het kind op (minimale) persoonswording? Welke opvoedingsstijlen staan met dit recht op gespannen voet? Dat zijn de centrale vragen waarop in dit hoofdstuk antwoorden worden beproefd. De in deze inleiding zijdelings opgeworpen vragen omtrent de gevolgen van kindermishandeling voor individu, huwelijk (partnerkeuze en nageslacht ${ }^{10}$ ) en maatschappij, en de aansprakelijkheid en verantwoordelijkheden van staat en samenleving, komen in volgende hoofdstukken aan de orde.

\section{2}

\section{Definities, vormen en 'oorzaken' van kindermishandeling}

In deze paragraaf kijken we eerst naar de 'oorzaken' van kindermishandeling (par. 11.2.1), in het bijzonder de vraag of en hoe kindermishandeling van generatie op generatie wordt doorgegeven. Vervolgens passeren de te onderscheiden vormen en enkele definities van kindermishandeling de revue (par. 11.2.2). In de derde en laatste subparagraaf (par. 11.2.3) staan we stil bij een specifieke benadering van kindermishandelirg: de ontwikkelingspsychopathologische benadering van BARNETT c.s.

\subsubsection{De nemo plus-regel en transgenerationaliteit}

Een grondregel in het recht luidt: nemo dat quod non habet, niemand kan geven wat hij zelf niet in huis heeft (beter bekend in de variant: nemo plus juris transferre potest quam ipse habet, niemand kan meer rechten overdragen dan hij zelf heeft). We zullen dit de nemo plus-regel noemen.

erkennen - dat (sommige) filosofen zo'n ongelukkige jeugd hebben gehad dat zij elke gedachte daaraan of reflectie daaromtrent hebben moeten afweren omdat dat te veel angst zou hebben opgeroepen (niet alle filosofen zijn morele helden). Niettemin is de bevinding van KOREN illustratief (niet meer dan dat) dat in een filosofische faculteitsbibliotheek (zij vermeldt wijselijk niet welke) de titels over rechten van kinderen waren ondergebracht bij die over rechten van dieren en door de laatste in aanial werden overtroffen (Marian KOREN, Tell me! The right of the child to information, diss. Amsterdam, Den Haag 1996, p. 186 nt. 175).

9 Vgl. BAARTMAN, Opvoeden kan zeer doen, a.w., p. 91.

10 Het aspect van de transgenerationaliteit komt reeds in de volgende paragraaf aan de orde. 
Een andere grondregel in het recht luidt: nemo ultra posse obligatur (of tenetur), niemand is gehouden meer te doen dan hij kan. We zullen dit de nemo ultra-regel noemen. De nemo ultra-regel zal in het hierna volgende enkele malen in zijn oorspronkelijke juridische betekenis terugkeren. De nemo plus-regel daarentegen wordt in dit hoofdstuk, min of meer losgezongen van zijn juridische oorsprong, vooral als sociaal-pedagogische metafoor - zo men wil: als quasi-juridische hyperbool - gehanteerd. Hoewel beeldspraak de werkelijkheid niet alleen kan verhelderen, maar ook geweld kan aandoen, omdat zij deze 'ver-tekent' en in die zin zowel accentueert als reduceert, zij hier, wellicht ten overvloede, opgemerkt dat wij het 'nemo plus-beeld' in de relatie ouders-kinderen enkel betrekken op (gemiddelde) pedagogische kwaliteiten ten aanzien van in het bijzonder (zeer) jonge kinderen: kinderen op een leeftijd waarop het element 'zelfbepaling' niet of nauwelijks een rol speelt.

Welnu, omdat ouders hun kinderen - nogmaals: in pedagogische zin - niet meer kunnen geven dan zij zelf van huis uit hebben meegekregen en later hebben bijgeleerd (nemo plus-regel); omdat ouders ook niet kunnen worden verplicht meer te geven dan zij in huis hebben (want niemand is tot het onmogelijke gehouden: nemo ultra-regel); en omdat vanaf 1924 - mannen en vrouwen van alle naties hebben erkend dat de mensheid aan het kind het beste verschuldigd is dat zij kan geven, ${ }^{11}$ hebben staten een aanvullende, ondersteunende en desnoods vervangende opvoedingsverantwoordelijkheid op zich genomen, die in 1989 - in het Verdrag inzake de rechten van het kind - is uitgewerkt in tal van rechten van het kind en verplichtingen van staten, verplichtingen die kunnen worden samengevat onder de noemers: materiële en immateriële opvoedingsondersteuning, opvoedingsscholing en persoonswordingsvindicatie (desnoods door juridische interventie te waarborgen minimale persoonswording).

The Declaration of Geneva 1924: By the present Declaration of the rights of the child (...) men and women of all nations, recognizing that mankind owes to the child the best that it has to give, declare and accept it as their duty that (...) [t]he child must be given the means requisite for its normal development, both materially and spiritually (...).

The UN Declaration of the rights of the child 1959: (...) Whereas mankind owes to the child the best it has to give, [n] ow therefore, the General Assembly proclaims this Declaration of the rights of the child (...), and calls upon parents, upon men and women as individuals and upon voluntary organizations, local authorities and national governments to recognize these rights and strive for their observance by legislative and other measures (...). 


\section{Nemo plus}

In deze (sub)paragraaf gaan we allereerst de nemo plus-regel nader in psycho(patho)logische en pedagogische zin analyseren. Uitgangspunt daarbij is de fictie (het rechtsvermoeden, behoudens tegenbewijs) dat ouders die zelf geen (boven-)minimaal persoon zijn, hun kind(eren) niet zonder meer tot een (boven-)minimaal persoon kunnen opvoeden.

Pedagogische essentie van de nemo plus-regel is dat niemand meer rationaliteit, moraliteit en authenticiteit (echtheid, eigenwaarde) kan uiten overdragen, en pedagogische vaardigheden kan uitoefenen, ${ }^{12}$ dan hij of zij zelf heeft meegekregen, van de eigen ouders en leefomgeving, door scholing of andere aanvulling van de staat, door zelfstudie en zelfontwikkeling. Zelfontwikkeling onder meer met behulp van psychotherapie, als vorm van reparatie door de staat in geval van maltraitering (door pedagogische tekorten veroorzaakte subminimale persoonswording) in de eigen jeugd, dan wel als vorm van opvoedingsondersteuning in geval van boven-minimaal doch (ernstig) sub-optimaal (pril) ouderschap.

'Kindermishandeling,' schrijft BAARTMAN, ${ }_{*}^{13}$ en wij zullen dat begrip later in dit hoofdstuk herdefiniëren als de schending van het recht van het kind op minimale persoonswording ...

"(...) is gewelddadig [met inbegrip van verwaarlozend, ${ }^{14} \mathrm{jw}$ ] gedrag dat de ontwikkeling van rationeel, moreel en authentiek handelen van het kind schaadt, en dat berust op een verstoorde gezindheid [bij] en /of gebrekkige competentie van de opvoeder.'

Die 'verstoorde gezindheid' wijst op een tekort aan moraliteit (en vermoedelijk ook aan authenticiteit; tezamen genomen: aan integriteit) bij de ouder/opvoeder; 'gebrekkige competentie' wijst op een tekort aan rationaliteit van de ouder/opvoeder. Welnu, de aanvullende opvoedingsverantwoordelijkheid van de staat bestaat in dit verband - naast en in nauwe samenhang met 'hulp tot herstel of woorkoming van (verdere) beschadiging van het kind' - in ...

"(...) een verbetering van de rationaliteit, en een verandering van de moraliteit van de opvoeder." 15

Vgl. BAARTMAN, Opvoeden kan zeer doen, a.w., p. 74.

H.E.M. BAARTMAN, 'Schuld, herstel en overleven; aspecten van hulpverlening inzake kindermishandeling, in: D.J. DE RUYTER en P.A. DE RUYTER (red.), Opwoedingshulp geboden; Pedagogische criteria voor het opleggen van hulp, theoretisch en praktisch bezien, Utrecht 1995, pp. 83-91, op p. 85 (curs. toegevoegd).

4 Zie par. 11.1 hierboven (noot 1).

15 BAARTMAN in: Opvoedingshulp geboden, ta.p. 


\section{Transgenerationaliteit}

Bij maltraiterende ouders dient eerste vraag te zijn: in hoeverre is hier sprake van niet verwerkte eigen jeugdproblematiek? ${ }^{16}$ Met andere woorden, de eerste vraag betreft de zogenaamde transgenerationaliteit: het van generatie op generatie doorgeven van niet verwerkte (jeugd)trauma's. Hulp voor kind èn ouders is hier geboden wegens de nemo plus-regel: niemand kan (en soms - ten dele - ook: wil) meer uit- en overdragen dan hij-/zijzelf in zijn/haar jeugd heeft meegekregen en later heeft 'bijgeleerd.' Kan en soms ook wil: we stuiten hier op onmacht en/of het afgunst-motief (we komen daar later op terug).

Dit betekent (uiteraard steeds behoudens latere verwerking en 'bijscholing'): je kunt je kind niet meer of beter leiden/begeleiden dan naar de mate dat je je eigen ontwikkelingstaken tot een goede oplossing hebt gebracht. Nogmaals: niemand kan meer overdragen dan hij-/zijzelf in huis heeft; heeft men onvoldoende pedagogische bagage/competentie, dan kan daarvan de oorzaak zijn de combinatie van traumatische jeugdervaringen c.q. ernstige pedagogische tekortkomingen in de eigen jeugd en het zelf later niet of onvoldoende verwerkt en/of 'bijgespijkerd' hebben daarvan. Met andere woorden: de eigen ontwikkelingstaken zijn niet tot een goede oplossing gebracht ten gevolge van traumatische jeugdervaringen/pedagogische tekortdoeningen die men niet/onvoldoende heeft kunnen/willen verwerken/'bijwerken.'

Hierbij dient de kanttekening te worden gemaakt dat tussen traumatische jeugdervaringen en ernstige pedagogische tekortkomingen geen principieel, doch hooguit een gradueel onderscheid kan worden gemaakt. Dit ligt voor de hand: het kind is een op opvoeding aangewezen, pedagogisch hongerig wezen. De nood van het kind is in de kern ontwikkelingsnood, nood die samenhangt met, terug te voeren is tot, uitstraalt naar de natuur- en cultuurnoodzakelijkheid van zijn ontwikkeling tot persoon. Wanneer in het hiernavolgende sprake is van (jeugd)trauma"s dienen deze altijd in de ontwikkelingscontext te worden gedacht, mogen deze niet los van, niet buiten de ontwikkelingsdimensie worden gezien. Anders zou men deze traumatisaties plat slaan (twee-dimensionaal maken) tot het leed en de pijn die nu eenmaal bij het leven hoort, en die de mens hetzij vroeg hetzij laat in het leven kan treffen. Minder dramatisch gezegd: men zou er de ontwikkelingspsychologische en pedagogische angel uit halen.

We keren terug naar ons onderwerp. Wanneer kan men zeggen dat een ouder de eigen ontwikkelingstaken tot een goede oplossing heeft gebracht? De eigen ontwikkelingstaken tot een goede oplossing hebben 
gebracht, wil - voor een ouder - zeggen: (1.) voldoende ambivalentie- en frustratietolerantie hebben opgebouwd (tegenstrijdige gevoelens kunnen hanteren, tegenslagen en teleurstellingen aankunnen, door een en ander niet in paniek raken of zijn/haar zelfbeheersing verliezen en zich dan op het kind afreageren); (2.) voldoende discipline hebben aangeleerd/zelfdiscipline hebben aangekweekt (structuur hebben om structuur te kunnen bieden; grenzen hebben om grenzen te kunnen trekken, om op consequente wijze leiding te kunnen geven); en (3.) voldoende empathische vermogens hebben verworven (zich voldoende kunnen inleven in anderen, waarvoor in de regel enige levenservaring vereist zal zijn: men heeft zich - door schade en schande - een zekere levenswijsheid en menselijkheid eigen gemaakt) om zich over een kind te kunnen ontfermen.

Daarenboven dient men zich voldoende ontwikkelingspsychologische en pedagogische kennis te hebben eigen gemaakt (onderwijs, ouderschapscursussen) om een kind te kunnen opvoeden; dóordenkend vanuit de rechten van het kind: om een kind te mógen opvoeden.

Een en ander wordt door BAARTMAN, vanuit het begrip pedagogisch besef, aldus verwoord: ${ }^{17}$

'Het gaat hierbij om zaken als verwachtingen, sensitiviteit, empathie en kenuis van de ontwikkeling wan kinderen."

Bij verwachtingen gaat het niet alleen om (volwassen) verwachtingen omtrent (kinderlijke) vaardigheden, intelligentie en dergelijke meer, doch ook om ...

'(...) wat men van zijn kind voor zichzelf verwacht, om dat wat men aan bijdragen verwacht van het kind aan het eigen goede leven.'

Een nauw met verwachtingen verweven aspect van pedagogisch besef is de ouderlijke beleving: ervaart men de zorg voor het kind (enkel) als een last? Is het kind geliefd en voelt men zich door het kind geliefd, of juist miskend? Beleeft de opvoeder plezier aan het kind als kind en aan de groei van het kind als persoon in ontwikkeling? Of is er voornamelijk sprake van ergernis ${ }^{18}$

Onder sensitiviteit (c.q. empathie ${ }^{19}$ ) verstaat BAARTMAN ...

De drie hierna volgende korte citaten staan in Opvoeden kan zeer doen, a.w., resp. op pp. 52,52 iff. en 53 .

19 Zie voor de precieze relatie tussen sensitiviteit en empathie a.w., pp. 61/62. 
'(..) het aanwoelen en weet hebben van alsmede het rekening houden met de behoeften, emoties en belevingen van het kind.'

Ook het thema disciplineren, dat BAARTMAN aan zijn bespreking toevoegt, zou men onder sensitiviteit kunnen rekenen.

In hoeverre kan nu gezegd worden dat een gebrekkige oplossing van de eigen ontwikkelingstaken ten gevolge van een onvoldoende verwerkt hebben van vroege traumatisaties c.q. irreële of anderszins dysfunctionele ouderlijke verwachtingen, een haperende ouderlijke beleving en/ of gemankeerde ouderlijke sensitiviteit en disciplinering te herleiden zijn tot transgenerationele patronen?

De stelling wordt hier verdedigd dat transgenerationaliteit bijna een psychische (c.q. sociaal-psychologische) wetmatigheid is te noemen nu verwerking in de huidige maatschappelijke context van 'ouderschapslibertinisme' (kort gezegd: publiekrechtelijk vrijgesteld, of beter: verwaarloosd ouderschap) eerder uitzondering dan regel lijkt. ${ }^{20}$ Ter adstructie

20 Hiermee is niet gezegd of bedoeld dat er een direct, 'automatisch' verband zou bestaan tussen mishandeld zijn en mishandelen. Een misbruikt/verwaarloosd kind is niet gedoemd een misbruikende/verwaarlozende ouder te worden. Vandaar mijn centraal stellen van de verwerking van jeugdtrauma's en mijn overtuiging dat de herhalingsketen (in de herhaling ligt immers voor wie zijn gedrag onder ogen wil zien, ook een kans) kan worden doorbroken: ja, dat compensation (erkenning en recht-doen) en rehabilitation (herstel en herintegratie: vgl. art. 39 VRK) van child-en adult-survivors tot de belangrijkste preventieve maatregelen gerekend dienen te worden. Voor een kritiek op de 'unqualified acceptance of the intergenerational hypothesis' zie Joan KAUFMAN, Edward ZIGLER, "The intergenerational transmission of child abuse, in: Dante CICCHETT, Vicki CARISON (eds.), Child maltreatment; Theory and research on the causes and consequences of child abuse and weglect, Cambridge (etc.) 1989, pp. 129-150. Zonder aandacht voor de protectieve en compenserende factoren die het verwerkingsproces begunstigen, en de risico-factoren die het verwerkingsproces belemmeren, is de "intergenerational hypothesis" een 'intergenerational myth' die - zo merken beide onderzoekers op - onschuldige slachtoffers ten onrechte stigmatiseert.

Toch zullen lang niet alle sunvivors erin slagen zonder deskundige psychische hulp hun problemen te overwinnen, althans onder controle te krijgen, zodat de meesten, die die hulp moeten ontberen of nooit aan een hulpvraag toekomen - en met name degenen bij wie het ontbreken van een hulpvraag juist een symptoom van hun (invaliderende persoonlijkheids)stoornis is -, hun omgeving, en in het bijzonder hun (jonge, zich vormende) kinderen, daarmee blijven belasten. Dit zou wel eens kunnen betekenen dat de bestrijding van het maatschappelijke taboe op psychische problemen en psychische hulp als de allerhoogste prioriteit in de geestelijke volksgezondheid moet worden beschouwd.

Wat daarvan zij, dat wil zeggen: los van de vraag wat hulp op individueel niveau vermag, en wat er ook zij van de intergenerationele transmissiehypothese op individueel niveau, zij is zeker geen mythe op maatschappelijk niveau. In de 
woorden van Willard GAYLIN ([Adam and Eve and Pinocchio:] On being and becoming human, New York 1990; pbk. ed. 1991, pp. 151, 152 en 154): "Children who are sufficiently deprived of warmth and attention will obviously enter adult life with different expectations from the environment and a different image of their place in that environment. Our capacity as adults to trust, our ability to be caring to our own children or to others in general, our openness or lack thereof, our level of paranoia, our optimism or cynicism, our level of generosity, empathy, compassion, and understanding will all be shaped by those early lessons about the nature of the human contract learned when we ourselves were children. When the deprivation of caring is severe enough, either the survival of the small human being will be imperiled or the nature of its "humanity" will be diminished. (...) We must remember that whatever increments of deprivation wisit on the next generation, will be compounded by their [the next generation's, jw] inability to give to the succeding generation, for which they are responsible. (...)

In summary, to be human is not necessarily to be always good. (...) To be human is ultimately to have "a good heart." To be human is to be able to take the nur. turing that was given us in childhood and, with a peculiar kind of linear justice, reciprocate by giving selfless nurturing to our children and beyond that to all of the helpless, infantile, and dependent in our community."

De (maatschappelijke en dus) politieke desinteresse voor het "dilemma van de intergenera[tiona]liteit" wordt door Gé HAANS in Kinderen voor onze rekening; Een casuistische werkenning wan het (gezins)voogdijwerk (Utrecht 1992, pp. 178179; curs. jw) aldus aan de kaak gesteld: "Wie lang genoeg werkzaam is in een gezinsvoogdij-instelling weet dat de kans reëel is dat de problemen zich een generatie later gaan herhalen. (...) Deze intergenerationele problematiek, de vicieuze cirkel waarin sommige gezinnen/individuen gevangen raken, komt binnen het (gezins) voogdijwerk relatief vaak voor. (...) Feit is, blijkens ervaring, dat het gezinnen en jongeren betreft die functioneren in de marge van de samenleving. (...) Vaak zijn het jongeren met essentiële hiaten in hun ontwikkeling; ernstig affectief werwaarloosd, langdurig misbruikt of mishandeld. (...) Het is ontmoedigend wanneer je als (gezins) voogd erachter komt dat de kinderen van jouw ex-pupil hetzelfde is overkomen als jouw pupil destijds. Dat [zijn/haar] zoon of dochter ook seksueel [is] misbruikt, mishandeld of ernstig werwaarloosd (...). Ofschoon de schuldvraag in dit verband niet zo relevant is, heb ik me altijd verbaasd over de politieke desinteresse voor deze schaduwkant van anze beschaving. (...) Nog dagelijks spelen er zich binnen de gezinsvoogdij hemelschreiende taferelen af (...). (...) Kinderbescherming is geworden tot een vorm van armoedezorg. De rekening wordt in de wolgende generatie gepresenteerd.'

Nogmaals: een wet van Meden en Perzen hoeft trans- of intergenerationaliteit niet te zijn: àls de cycle of violence kan worden doorbroken. Michael RUTTER ('Intergenerational continuities and discontinuties in serious parenting difficulties, ${ }^{\prime}$ in het hierboven aangehaalde Child maltreatment, pp. 317-348, op p. 344) concludeert: 'There is very little that is unalterable even with respect to the sequelae of severe and prolonged maltreatment in childhood. Good experiences as late as early adult life can make an important difference in outcome. However, it would be misleading to see such experiences as a matter of chance or good luck. In part, later experiences arise as a result of earlier circumstances, but also indi- 
van deze stelling laten we eerst een auteur aan het woord over het werk van Alice MLLer: ${ }^{21}$

\begin{abstract}
"Als psycho-analytica wijst zij [Alice MTLLER, jw] vooral op het feit dat ouders, ondanks bewuste pogingen het tegendeel te doen, onbewust de tragedie van hun vroegkinderlijke ervaringen doorgeven aan hun kinderen. De opvoeding vormt wolgens haar dan ook bij uitstek bet terrein waarop de "innerlijke vijand eindelijk aan de buitenkant kan worden vervolgd" (...). Door middel van het pedagogisch handelen, het belangnijkste vehikel voor het doorgeven van de eigen neurosen, tasten ouders aan wat in henzelf is aangetast: een creatief leven, het recht op een eigen toekomst, humaniteit. Opvoeding, zo concludeert MLLER, is in feite niet primair een behoefte van het kind maar van de ouder.

Deze gedachte is overigens niet nieuw. Reeds Wilhelm REICH wees in zijn opstel "Der Erziehungszwang und seine Ursache" (1926/27) op het feit dat uit de noodzaak om traumatische gebeurtenissen wit de eigen kindertijd te reproduceren (herhalingsdwang) een opvoedingsdwang ontstaat, een dwang om zich op kinderen te wreken en hen te gebruiken voor de bevrediging van eigen behoeften en verlangens.'
\end{abstract}

Met betrekking tot het centrale thema van MLLERs werk (en daarmee haar visie op transgenerationaliteit, zoals onder andere uitgewerkt in Du sollst nicht merken, 1981) schrijft BAARTMAN in Opvoeden met alle geweld: 22

'Daarin [in Gij zult niet merken, jw] werkt [Alice MLLLER] de stelling uit dat kinderen vervreemden van zichzelf als hen door opvoeders impliciet het recht ontzegd wordt op het gewoel door hun ouders gekrenkt en gekwetst te zijn, een vervreemding die zich later wreekt als ze zelf in de positie zijn om kinderen op te

viduals can do much to shape their lives, and it is the possibility of this positive action to break cycles of transmitted deprivation that provides the opportunity for preventive and therapeutic interventions."

Tot slot Margaret uit Christine DINSMORE's From surviving to thriving; Incest, fentinism, and recovery (New York 1991, p. 170): 'I have done a tremendous amount of work on myself in therapy (...). I have opportunities to abuse my kid, but I don't and won't. The buck stops here ...'

21 René GÖRTZEN, 'Alice MILLER, "Zwarte pedagogiek" en psychoanalyse,' Internediair 20 augustus 1984 , pp. 9, 11 en 13, op p. 11 1.k.

22 H.E.M. BAARTMAN, Opvoeden met alle geweld; Hardnekkige gewoontes en hardhandige opvoeders, Utrecht 1993, p. 88.

De auteur noemt zijn boek een pleidooi voor 'een voorzichtiger hanteren van de eigen almacht door opvoeders (a.w., p. 14 i.f.; curs. jw). We zouden de ondertitel evenwel ook kunnen omdraaien: hardhandige gewoontes (het slaan van kinderen als traditionele 'pedagogische' praktijk) en - ten gevolge van eigen traumatisaties - hardnekkige opvoeders. Het wordt dan duidelijk(er) dat er ook iets aan de (posttraumatische) onmacht van opwoeders zal moeten veranderen. 
voeden. Als een kind zijn woede en zijn krenking niet voelen mag, kunnen de appels die daarna gegeven worden, zeer zuur zijn.'

In Opvoeden kan zeer doen haalt BAARTMAN opnieuw MILLER aan (Am Anfang war Erziehung, 1980):.23

\begin{abstract}
"Wie nooit zijn situatie als slachtoffer heeft kunnen beleven, omdat hij is opgegroeid in de idleologie van moed en zelfbeheersing, loopt gemakkelijk het gevaar zich op de volgende generatie te wreken voor zijn onbewust gebleven situatie yan slachtoffer. Wie echter na een periode van toorn kan rouwen ower deze situatie, kan ook rouwen over de slachtoffers die zijn ouders zijn geweest, en zal zijn eigen kinderen niet meer vervolgen. Het vermogen tot roww zal hem binding geven met zijn kinderen.'
\end{abstract}

Transgenerationaliteit in verband met (massale schending van) de rechten van het kind wil kennelijk zeggen: te weinig ouders hebben de kans gehad en de tijd genomen voor een rouwproces. Dit brengt ons op de vraag: wat is rouwen? Op deze vraag kan het volgende antwoord worden beproefd. Rouwen is de waarheid van de eigen jeugd onder ogen zien. ${ }^{24}$ Woede en verdriet toelaten omtrent wat afgenomen en niet gegeven is. Onder ogen zien wat de gevolgen van dat tekort in het eigen leven zijn geweest, en hoe men door en vanuit dat tekort zichzelf en anderen te kort heeft gedaan. Met zichzelf in het reine komen. ${ }^{25}$ Aan dat tekort werken. Kortom: rouwen is zware arbeid, en rouwen is, méér dan 'mens durf te leven': mens durf te lijden.

Tegelijk is rouwen een proces waarbij, zeker in geval van vroege en ernstige c.q. chronische traumatisaties, deskundige begeleiding nodig is. ${ }^{26}$ Het is bijna onmogelijk geheel wit zichzelf tot inzicht in oorzaken

23 Opwoeden kan zeer doen, a.w., p. 83 (gedeeltelijk nogmaals aangehaald op p. 159). De passage is uit MILLERs In den beginne was er opvoeding (Am Anfang war Erziehung, 1980; vert. 1983, p. 257), niet uit MLLLEs Gij zult niel merken (Du sollst. nich merken, 1981; vert. 1983): alleen de laatste titel wordt in de literatuurlijst van Opwoeden kan zeer doen (a.w., p. 241) vermeld. (Curs. overgenomen uit MLLLER.)

24 Zoals VAN DANTZIG het eens witdrukte (in een interview in De Volkskrant van 28 oktober 1995, 'Folio,' onder de kop: "Er is veel meer gekte dan je denkt"'): 'Psychotherapie beoogt niet mensen gelukkig te maken, maar mensen de waarheid van hun situatie te laten beleven. En die waarheid is vaak verdrietig."

25 Therapie is: de neurotische schuld vervangen door reele schuld. Want we zijn minder schuldig dan we ons - vanuit ons verleden - vaak voelen, maar tegelijk ook minder onschuldig - in het hier en nu - dan we soms denken (vgl. Alice Miller, Het drama van het begaafde kind, Houten 1995, 18e druk, p. 47).

26 Zo acht MILLER FREUDs vervanging van de verleidingstheorie (kindertraumatheorie) door de oedipus-theorie (kinderdrift- en -fantasie-theorie) het gevolg van 
en gevolgen te komen, tot op de bodem te gaan van de overweldigende angsten die dit oproept, op het juiste moment de confrontatie met ouders aan te gaan, niet in woede of verdriet te blijven steken, en - niet in de laatste plaats - de kloof te overbruggen tussen verworven inzicht en het opbrengen van de moed daarnaar te handelen. Het kost bloed, zweet en tranen datgene wat in vroege levensfasen verkeerd geprogrammeerd is, en wat zoveel vitale bestanden heeft aangetast, op te sporen, te 'wissen' en een nieuw levensprogramma te ontwerpen. De mens is een te angstig dier om dit geheel op eigen kracht te kunnen volbrengen. Hij heeft een deskundige, spiegelende getuige bij zijn verwerkingsproces nodig - al is en blijft hij zijn eigen heelmeester. En ook hier geldt: zachte heelmeesters maken stinkende wonden.

Met veel minder woorden drukt BAARTMAN de relatie tussen rouw en transgenerationaliteit aldus uit: ${ }^{27}$

'Dit opmaken van een balans, de woede om wat ouders eertijds aanrichtten, de rouw om wat gemist is en niet meer is ongedaan te maken, dit nemen van een verlies zonder blijvend ambivalent omzien in wrok, lijken belangrijke voorwaarden om te kunmen ingaan op de aanspraken die [de eigen] kinderen nu hebben. Wie [daarentegen] met alle geweld het verleden toe wil stoppen en ongedaan wil maken, loopt kans [in het] nu met alle geweld van zijn kinderen te eisen wat hij vroeger bij zijn ouders te kort kwam."

Wellicht meer algemeen bekend dan de hierboven aangeduide posttraumatische transgenerationaliteit is de sociaal-economische transgenerationaliteit. Hierover laten we VAN BUEREN aan het woord: ${ }^{28}$

het feit dat hij tijdens zijn zelfanalyse niet beschikte over een 'empathische, begeleidende en niet-veroordellende persoon' (Alice MILLER, Gij zult niet merken; Tachig jaar psychoanalyse, Weesp 1983, nt. pp. 224-225, op p. 225; vgl. ook a.w., pp. 114-125, alsook pp. 63-68), zodat hij de eigen vroege trauma's niet (volledig) kon beleven. Toen de angst te groot werd, zocht hij de bedriegelijke vertroosting van de Lethe. De professionele vertroosting van degenen die in allerlei verdrukking zijn (2 Kor. 1:3-4), was daardoor voor hem niet mogelijk. De oedipus-theorie moest zozeer zijn eigen nood "oplossen" dat zij tot dogma, en haar verkondiger tot paus der psycho-analyse werd. Een paus die meer dan én vroegere discipel excommuniceerde (vgl. Phyllis GrossKURTH, The secret ring; FREUD's inner cirle and the politics of psychoanalysis, Reading, Mass. etc. 1991).

27 H. BAARTMAN, "Transgenerationele aspecten van kindermishandeling," in: P.B. DEFARES, J.D. VAN DER PLOEG (red.), Agressie; Determinanten, signalering en interwentie, Assen/Maastricht 1991, pp. 150-161, op p. 159.

28. Geraldine VAN BUEREN, The international law on the rights of the child, Dordrecht (etc.) 1995 , p. 263 i.f. (curs. jw). 
"Child labour is in danger of becoming institutionalised in a number of states because it is regarded as a "significant factor" in their national economies, "although no authorities would say so openly." Carpets, for example, provide Pakistan with [a large amount] in foreign currency and it is children who have made Pakistan [one of] the (...) major carpet producer[s] in the world. Child labour also forms part of a generational chain, as exploited children become illiterate adults who in turn have to send their own children to work to help support their families.'

Onder andere dankzij de eerste kinderwetten - ten tijde van de 'sociale kwestie' - komt sociaal-economische transgenerationaliteit in deze mate in ons land niet meer voor. Er is echter geen reden aan te nemen dat de posttraumatische variant in ons land - ten gevolge van de 'pedagogische kwestie': de combinatie van publiekrechtelijk ouderschapslibertinisme (het gebrek aan sociaal-pedagogische 'kinderwetten') en massale private kindermishandeling - in ook maar enigszins vergelijkbare mate aan betekenis heeft ingeboet.

Transgenerationaliteit is niet alleen een (posttraumatisch) fenomeen met intrapsychische momenten, het kan ook gezien worden als een 'doodgewoon' (cognitief) leerproces, een 'niet beter weten.' Zoals met betrekking tot het slaan van kinderen ('hardhandige gewoontes'). OpnieuW BAARTMAN: ${ }^{29}$

'Kinderen zijn dus nogal eens in de situatie waarin ze thuis beurtelings slachtoffer en getuige zijn van geweld, en eventueel ook pleger. Wat veel kinderen op deze wijze leren, is dat er een verband bestaat tussen genegenheid en geweld, dat er ogenschijnlijk een moreel recht is om een ander te slaan (...). Hier is nog aan toe te voegen dat kinderen op deze wijze ook leren dat het recht om te slaan vooral een recht is van degene die sterk is en macht heeft. Een dergelijk leerproces is veelal niet zonder gevolgen voor de wijze waarop men later zelf met kinderen omgaat. Ouders die hun kinderen mishandelen, zijn als kind meer fysiek geslagen dan andere ouders $(\ldots .$.$) .'$

\section{Het afgunst-motief}

Hierboven was sprake van onmacht ${ }^{30}$ en/of het afgunst-motief. Het intrapsychische moment van de afgunst wordt ook wel als een 'zich wre-

BAARTMAN, Opvoeden met alle geweld, a.w., p. 29.

30 Onmacht die veelal samenhangt met diepe frustratie, dat wil (in het bijzonder) zeggen de gefrustreerde (niet geslaagde) oplossing van eigen (vroege) ontwikkelingstaken en/of de gefrustreerde (niet geslaagde) werwerking van eigen (wroege) trauma's (een en ander met name in verband met onveilige gehechtheidsrelaties). 
ken' aangeduid, ${ }^{31}$ of "persoonlijk motief ${ }^{32}$ genoemd. Een typerende uitspraak in dit verband is die van de incest-moeder in de Bolderkar-zaak. Aan het woord is een maatschappelijk werkster, een gezinsbegeleidster, in dienst van De Bolderkar: ${ }^{33}$

\footnotetext{
"Voor een maatschappelijk werker is die beslissing [om om bescherming van het kind, en dus om optreden, on een maatregel te vragen, jw] moeilijker; [wij] staan in principe aan de kani van de ouders. Je voelt je dus in dit soort situaties als een verrader van de ouders. Maar er is een punt waarop je ziet dat ouders - sommige ouders - de emoties van een kind niet zien, niet kunnen zien of niet willen zien. De moeder van het kind dat [lees: de peuter die, jw] driemaal per week door haar vader wordt geneukt, en die zegt: "Het is toch zo weer voorbij." En: "Een kind moet toch wel vaker iets doen dat het niet leuk vindt?"
}

Die moeder zegt in feite: 'Wij moesten vroeger als kind ook wel dingen doen die we minder leuk vonden.' Dat zij zelf soortgelijke dingen moet hebben doorstaan, lijkt mij de meest plausibele verklaring voor haar totale gebrek aan empathie met haar kind. (Of we zouden moeten aannemen dat zij louter ten gevolge van een aangeboren defect een gevaarlijke psychopate is. Gevaarlijk voor haar kind is zij zeker.)

Overigens kun je je afvragen wat de - traumatische (is zij zelf als kind in een misbruik-/mishandelingssituatie wellicht geparentificeerd geraakt?) of opleidingstechnische (wat heeft zij eigenlijk geleerd op de sociale academie?) - achtergrond is van een maatschappelijk werkster die wel gewaagt van het gevoel de daders te verraden op het moment dat zij voor het slachtoffer kiest, maar niet van een gevoel van verraad ten opzichte wan het slachtoffer zolang zij niet naar buiten om optreden woor het kind vraagt. Maar dit terzijde. ${ }^{34}$

In de trant van MILLER kan men spreken van 'de wraak van ziekgemaakte kinderen.' Zo ook BAARTMAN (aangehaald in Dagblad de Limburger van 22 juni 1996, onder de kop: "Begeleiding, middel tegen kindermishandeling'): 'Die verwerking is belangrijk. Allến dan zullen ze zich niet wreken op hun eigen kinderen.' Alexander LowEN, Leven zonder angst, [Amsterdam] 1996 (derde druk), p. 243: 'Dergelijk gedrag van de kant van de ouder heeft dikwijls een persoonlijk motief. De ouder verafschuwt het idee dat zijn kind beter af is dan hij was. "Waarom zou jij het beter hebben dan ik het had?" Dat is een onuitgesproken gevoel dat veel [te kort gedane, jw] ouders ten opzichte van hun kinderen hebben.'

Ursula DEN TEX, 'De Bolderkar: "Ik wist dat ik kon vragen: word je vastgebonden? Maar aan het idee van afplakken van monden was ik nog niet toe"," Vrij Nederiand 29 april 1989, pp. 3-4 (op p. 4 onder de kop: 'De kinderrechter: "De zorg van De Bolderkar om de kinderen is in alle gevallen terecht geweest"'), op p. 3 r.k. (curs. jw).

Het is niet uitgesloten dat hier sprake is van 'parentificatie.' In de volgende subparagraaf komen we daar nog kort op terug. 
Afgunst- of wraakmotief heeft niet altijd geheel en al terecht een connotatie van bewust (opzettelijk of zelfs boosaardig) handelen: niet verwerkte trauma's leiden immers hun eigen leven. Onthullend in haar directheid en onverbloemdheid is niettemin de verklaring die (Afrikaanse of Arabische) moeders geven als hun gevraagd wordt waarom zij hun dochters laten besnijden (hetgeen men kan rekenen tot de meer rituele varianten van uiterst schadelijke 'pedagogische' praktijken, om die reden ook wel genitale verminking van meisjes genoemd): ${ }^{35}$

'If I submitted to this and bore it, then so shall those who follow.'

Het afgunst-motief als menselijk, al te menselijk motief, dat wil zeggen als leidraad en lijdensdraad in de conditio humana, vindt men fraai verwoord bij Maya ANGELOU: ${ }^{36}$

'Terugkijkend realiseer ik me dat de strelingen van de vrouwen eerder sensueel waren dan seksueel. Omdat ze me aanmoedigden, maakten ze deel uit van mijn dans. Omdat ze van hun eigen jeugd hadden genoten, benijdden ze mij de mijne niet.

Veel volwassenen tonen zich ongeduldig met jongeren. Ze willen niet alleen dat ze volwassen worden, maar ook dat ze oud worden en wel onmiddellijk. Ze staan klaar met berispingen, kritiek en vermaningen: "Hou je mond." - "Ga zitten." "Waarom zit je altijd zo te draaien?" - "Hou je gemak."

Of het nu bewust gebeurt of niet, die vermaningen komen woort uit een sterk ongenoegen over het leven en spijt over een werspilde jeugd.'

35 Jacqueline SMTTH, Hermine VAN DER WEIDE, Visies en discussies [rond] genitale verminking van meisjes; Een inventarisatie in intemational perspectief, DCI Afd. Nederland, Amsterdam 1992, p. 20; Jacqueline sMrTH, Visions and discussions on genital mutilation of girls; An intemational survey, The Hague/Amsterdam 1995, pp. 16 en 29 nt. 45 . Uit het citaat kan worden afgeleid dat het motief tot op zekere hoogte wel degelijk bewust is.

REYNERS trekt de vergellijking met incest:" "De gebeurtenis speelt zich af in familiekring, met medeweten van verwanten, die ooit hetzelfde hebben meegemaakt en die, in een soort haat-liefdeverhouding, de volgende generatie een dergelijke behandeling niet willen besparen.' (M.M.J. REYNERS, Het besnijden van meisjes; Een leven lang leed en pin, Amsterdam 1993, p. 40 if.) Even verder merkt hij op (a.w., pp. 51/52): 'Dat men het zelf heeft ondergaan, lijkt in het proces van voortdurende herhaling mede een rol te spelen: de moeder accepteert niet dat haar dochter meer of beter zal zijn dan zij zelf, wat zij heeft moeten doorstaan, zal haar dochter niet bespaard blijven. Een trieste vicieuze cirkel van pijn, van geslacht tot geslacht.'

36 Maya ANGELoU, 'Sensuele aanmoediging,' uit: De reis zou licht zijn, Breda 1994 , pp. $[85]-88$, op p. 88 . 
Niet zelden worden deze vermaningen, of zelfs fysieke afranselingen, aanhoudende vernederingen en rituele verminkingen ${ }^{37}$ zoals baby-besnijdenissen gerechtvaardigd met de bekende ouderlijke versie van het belang van het kind: zijn of haar bestwil ${ }^{38}$ Alleen van incestplegers accepteren we de (zelf)rechtvaardiging niet (meer) dat zij zouden bekreunen om de sexuele opvoeding van hun kind.

In haar boeiende analyse van leven en werken van Franz KAFKA, die (naar ik, op geleide van de aan te halen auteur, aanneem ${ }^{39}$ ) als kind

Met opzet noem ik fysieke afranselingen, aanhoudende wernederingen en rituele verminkingen in één adem. Art. 24, lid 3 VRK beoogt de afschaffing van traditionele praktijken die de gezondheid van het kind schaden. Blijkens de travaux preparatoires (vgl. Sharon DETRICK (ed.), The United Nations Convention on the rights of the child; A guide to the 'travaux préparatoires,' Dordrecht etc. 1992, pp. 343-359, op p. 352; SMITH/VAN DER WEIDE, a.w., pp. 51 en 84; c.q. SMITH, a.w., pp. 43 en 57) wordt hiermee - naast onder meer op de voorkeurbehandeling van jongetjes bij voeding en opvoeding in veel landen - in het bijzonder gedoeld op de besnijdenis van meisjes, een praktijk die gezien de ernstige gevolgen voor de lichamelijke en geestelijke gezondheid van de slachtoffers ook wel (sinds het eindrapport van WARZAZI aan de Sub-commissie van de Commissie voor de rechten van de mens uit 1991: SMTTH, a.w., pp. 57/58; SMITH/VAN DER WEIDE, a.w., p. 86) wordt aangeduid als genitale verminking van meisjes (afgekort: GVM of in het Engels FGM: Female Genital Mutilation). Hoewel krachtens dit artikel grote delen van Afrika en het Arabisch schiereiland, maar ook delen van Azië, Australië en Latijns-Amerika in het beklaagdenbankje zitten (vgl. REYNERS, a.w., pp. 4550; SMITH/VAN DER WEIDE, a.w., pp. 13-14 en [224]; c.q. SMITH, a.w., pp. 11 en [217]), zou het niet ongepast zijn schadelijke pedagogische praktijken - zoals het bijbels geïnspireerde 'de roede niet sparen' (vgl. BAARTMAN, Opvoeden met alle geweld, a.w., passim; bijv. 'ranselpedagogiek': onder meer pp. 12 en 90; Philip GREVEN, Spare the child; The religious roots of punishment and the psychological impact of physical abuse, New York 1992, pp. 46-54) -, die in het Westen onder de vlag en vrijbrief van de "privacy" in stand worden gehouden, zo al niet worden aangemoedigd, onder de werking van dit artikel te brengen. En het aldus niet te beperken tot schadelijke pedagogische praktijken in niet-westerse culturen, in de meer rituele variant van genitale verminking van meisjes. Vgl. de Engelse vertaling van MILLERs Am Anfang war Eriehung (1980): For your own good; Hidden cruelty in child-rearing and the roots of violence [op de omslag: For your own good; The roots of violence in child-rearing] (New York 1983, London 1983, 1987).

39 Anders dan BAARTMAN (Herman BAARTMAN, 'KAFKA's brief aan zijn vader; over het opgroeien als verworpen kind,' in: Willem BERGER e.a. (red.), Geweld in relaties; Overwegingen en ervaringen, Baarn 1991, pp. 24-42, op pp. 27/28) aarzel ik niet, op geleide van MLLERs analyse, KAFKA's jeugd als mishandeling te kwalificeren. Voor de kwalificatie '(zeer) ernstige emotionele mishandeling' verwijs ik naar de definitie (hierna par. 11.2.3) en criteria (opgenomen in bijlage III) van BARNETT C.S. 
In haar De mum van zwijgen (Abbruch der Schweigemaner, 1990) citeert MILLER witvoerig uit de Klaagliederen van JEREMLA (zesde eeuw voor Christus). Hetgeen zij als volgt toelicht: 'Net als in het geval van KAFKA's werken wilde ik hier het mishandelde kind aan het woord laten komen, en daarom heb ik de symbolische verhulling in de historische zinspelingen, dat wil zeggen: de censuur van de verdringing, weggelaten.' (De muur wan zwijgen; de waarheid van de feiten, Houten 1990 , p. 126.) Behalve verhulde zinspelingen bevatten de Klaggliederen evenwel nog iets anders: naast verhulde verwijten openlijke zelfverwijten. Zij laten zien hoe de profeet, lees: het kind, zichzelf beschuldigt omdat het onmogelijk is God, lees: de ouders, verwijten te maken. Wat BAARTMAN noemt: [M] ]jn vader kan niet slecht zijn, dus moet ik wel slecht zïjn.' (T.a.p., op p. 39.)

IK neem slechts enkele versen uit de Klaggliederen van MILLER over (a.w., pp. 120 en 123-125; Klaagliederen $1: 12-14 ; 1: 18 ; 3: 27-33 ; 3: 42-44 ; 3: 47 ; 3: 49-50 ; 3: 55-56$; 5:21-22):

Raakt het $u$ niet, gij allen die voorbijgaat? Aanschouwt en ziet of er een sman is als de smant die mij werd aangedaan, waarmee de Heer mij in konmer dompelde ten dage van zijn brandende toom. Vanuit den hoge zond Hij viur; tot in mijn gebeente deed Hij het zinken; Hij spreidde een net voor mijn voeten en deed mij deinzen achterwaants; Hij deed mij verbijsterd staan, ellendig de ganse dag. $Z$ waar weegt het juk van mijn overtredingen, door zijn hand ineengevlochten; zij liggen op mijn hals, het heeft mijn kracht doen struikelen; de Heer heeft mij overgegeven in de macht van hen tegenover wie ik niet staande kon blijven. (....)

Hij, de Heer, is rechtvaardig, want tegen zijn woord ben ik weerspannig geweest. Hoort toch, al gij volken, en ziet mijn smant (...). (...)

Goed is het voor de man dat hij een juk in zijn jeugd draagt.

Hij zitte eenzaam en zwijge stil, als Hij het hem heeft opgelegd.

Hij drukke zijn mond in het stof, misschien is er hoop.

Hij biede de wang aan wie hem slaat, hij worde verzadigd van smaad.

Want niet voor eeuwig verstoot de Heer.

Want na de kastijding ontfermt Hij zich naar de grootheid van zijn gunstbewijzen.

Immers niet wan harte verdrukt en bedroeft Hij de mensenkinderen. (...)

Wij hebben overtreden en zijn weerspannig geweest - Gij hebt niet vergeven.

Gij hebt $U$ in toorn gehuld, Gij hebt ons vervolgd, ons meedogenloos gedood.

Gij hebt $U$ gehuld in een wolk ondoordringbaar voor het gebed. (...)

Schrik en strik zijn over ons gekomen, werderf en breuk. (...)

Mijn oog baadt in tranen, zonder ophouden, zonder verpozen,

Totdat de Heer neerziet en neerschouwt uit de hemel. (...)

Ik roep Uw naam aan, o Heer, uit het onderste van de put. 
(zeer) ernstig emotioneel is mishandeld, houdt MILLER ons voor: $:^{40}$

'Wij hebben, net als bij onze patiënten, de keus om op grond van [KAFKA's] brieven te spreken wan KAFKA's "narcistische aard," zijn "frustratie-intolerantie," zijn "ik-zwakte," zijn vreesachtigheid, hypochondrie, zijn fobieën, psychosomatische stoornissen en dergelijke, of wij zoeken en winden in KAFKA's leven en werken mededelingen over het leven dat deze mens alls kind heeft gehad; met andere woorden: wij kunnen ook zijn symptomen niet beschouwen als onhebbelijkheden of karakterfouten, maar als de zichtbare schakels van een onzichtbare keten."

Een onzichtbare keten ... het is wat DANIELI - met betrekking tot het tot in de derde en volgende generaties doorgeven van holocaust-trauma's ${ }^{41}$

\author{
Gij hoort mijn stem: verberg Uw oor niet voor mijn zuchten, mijn \\ hulpgeschrei. (...) \\ Breng ons, Heer, tot $U$ weder, dan zullen wij wederkeren. Vernieuw \\ onze dagen gelijk van ouds! \\ Of zoudt Gij ons geheel en al verwerpen? Zoudt Gij al te zwaar \\ tegen ons toomen?
}

Wie in deze woorden de nood van het kind in de profeet hoort, en tot zich laat doordringen, zal niet snel meer het woord 'jeremiëren' in de mond nemen. MILLER drukt deze nood, en het transgenerationele ervan, als volgt uit (a.w., resp. pp. 126 en 127): 'Het [kind] beeft van pijn, maar het klampt zich steeds vast aan de gedachte dat de marteling slechts een reactie is op zijn schuld; dat het uit liefde getuchtigd is. Zijn eigen schuld is zijn enige troost!' Maar wij 'begrijpen' wel de ouders maar niet het mishandelde kind omdat we eraan voorbij gaan 'dat het kind, precies zoals JEREMIA het zesentwintighonderd jaar geleden heeft uitgesproken, zelfs voor de wreedste en gewelddadigste ouders liefde en aanhankelijkheid voelt omdat het wacht en hoopt op het wonder, op de verlossing. Voor die illusie moet het betalen met de gevaarlijke blindheid waardoor het later vasthoudt aan zijn recht zijn eigen kinderen eveneens wreed te mogen behandellen - juist omdat het zijn tolerantie tegenover zijn ouders nooit in twijfel heeft getrokken.' BAARTMAN haalt SHENGOLD ['Child abuse and deprivation: soul murder,' 1979] aan: 'Only the mental image of a good parent can help the child deal with the terrifying intensity of fear and rage which is the effect of the tormenting experiences. (...) So the bad has to be registered as good.'

Alice MILLER, Gij zult niet merken; Tachtig jaar psychoanalyse, Weesp 1983 (derde druk, Houten 1988), 'Het lijden van Franz KAFKA,' pp. 247-310, op p. 279. Als op volwassen leeftijd opgelopen traumatisaties zulke langdurige transgenerationele gevolgen hebben, hoe moet het dan niet gaan met traumatisaties die in de vormende jaren zijn opgelopen? Zoals MILLER opmerkt: "Uit de onderzoekingen naar de tweede generatie na de holocaust kan een analyticus ook het een en ander leren over het ontstaan van narcistische stoornissen, perversies, dwangneurosen en andere ziekten. De trauma's van de ouders, die niet verwerkt zijn omdat ze al te gruwelijk waren, veranderen in de "neurotische ellende" van hun kinderen. Wanneer men dit heeft kunnen aantonen aan de hand van de bekende massale traumatisaties van de ouders op volwassen leeftijd, dan geldt dit inzicht 
- noemt "the transmission of pathological intergenerational processes to (...) succeeding generations. ${ }^{42}$ De transgenerationele cycle of violence als posttraumatische cycle of pain, als slachtoffer-dader-slachtoffer-cyclus ad infinitum. Dat wil zeggen: totdat de cirkel door verwerking kan worden doorbroken. Totdat éen slachtoffer niet langer zwijgt, zijn of haar pijn niet 'pedagogisch' uitageert, maar onderzoekt en uitspreekt. Oorzaken en gevolgen durft te benoemen. Woorden vindt voor woede en verdriet, voor schaamte en spijt. Zonder hulp - desnoods met enige aandrang in het belang van het kind' opgelegd - is dat evenwel slechts weinigen gegeven. Sommigen kunnen niet spreken al zouden zij misschien willen. Anderen willen niet spreken al zouden zij misschien kunnen. DANIELI haalt BETTELHEIM aan: ${ }^{43}$

"What cannot be talked about can also not be put to rest; and if it is not, the wounds continue to fester from generation to generation.'

Doordat de ouder is verinnerlijkt, de vervolgende ouder een deel van het zelf is geworden (een ziek deel of een deel van een ziek, dat is versplinterd zelf), zal men eerder de eigen ouders de ergste wreedheden - hardvochtigheid, onverschilligheid - 'vergeven' dan zijn eigen kind, zelfs als weerloze en onwetende zuigeling, de kleinste 'misstap' toestaan. De eigen (verinnerlijkte) ouder moet 'good parent' blijven, en dus wordt het eigen kind: 'bad child." ${ }^{44}$ Zondebok van (eigen) vlees en bloed.

In het zwakke zal men de eigen zwakheid vervolgen. Door het zwakke te vervolgen zal men pogen zich van de eigen vervolgers te bevrijden. Sed frustra. Tevergeefs. IJdele wreedheid en wrede tragiek. Zoals BAARTMAN schrijft: het kind wordt vervolgd met verwachtingen die het niet kan, maar ook niet mag inwilligen. Het kind kan het nooit goed doen, maar mag het ook nooit goed doen ...

mijns inziens eens te meer voor de trauma's die ouders hebben opgelopen in hun kinderjaren en puberteit.' (Gij zult niet merken, a.w., p. 201.)

2 Yael DANIEL, 'Preliminary reflections from a psychological perspective,' in: Th. VAN BOVEN, C. FLINTERMAN, F. GRÜNFELD, I. WESTENDORP (eds.) "Seminar on the right to restitution, compensation and rehabilitation for victims of gross violations of human rights and fundamental freedoms, SIM (Studie- en Informatiecentrum Mensenrechten) Special 12, Utrecht 1992, pp. 196-213, op p. 198 nt. 1.

43 Bruno BETTELhEIM, t.a.p., op p. 198. Eveneens aangehaald door MILLER, Gij zult niet merken, a.w., pp. $187 / 188$.

44 Vgl. BAARTMAN, Opwoeden kan zeer doen, a.w., pp. 82/83, waar na de valkuil van verwijten en verwachtingen van KAFKA's vader wordt geconcludeerd (a.w., p. 83): 'Zijn eigen ouders valt men niet hard, zijn kinderen wel, als waren het de ouders met wie nog wat te vereffenen valt.' 
"(...) omdat het het voorwerp moet blijven van een wrok die wortelt in de eigen jeugd van de opvoeder, [die] daarmee het zaad zaai[t] woor de wrok van een volgende generatie. 45

We concluderen: ouders zijn soms zo wreed tegenover hun 'eigen vlees en bloed' dat een verklaring daarvoor in de eerste plaats moet worden gezocht in verdrongen - 'vergeten en vergeven' - wreedheid henzelf als kind aangedaan. De psychische wetten zijn bekend, maar wie maakt zich sterk die wetten met de rechten van het kind te verbinden? De Bolderkar-onderzoekscommissie haalde in haar rapport Roland SUMMIT aan: ${ }^{46}$

\footnotetext{
"What makes the issues so difficult is not their power but their paradox. Most of us are survivors of childhood. We are intimidated and embarrassed by the shadows of our past. (...) Who can dare slip back to experience the feelings and vulnerabilities of a dependent child? (...) Child advocacy is not only not reasonable, it is not professional. (...)
}

\section{Begin en einde van de tunnel}

Het Bolderkar-rapport drukt ons met de neus op het 'incest'-probleem, het sexuele misbruik van kinderen binnen het gezin, dat de afgelopen jaren veel pennen in beweging heeft gebracht. We zullen enkele auteurs aan het woord laten die zich over deze problematiek hebben uitgesproken, en daar de visie van enkele andere auteurs aan toevoegen. Hun conclusies laten zich veelal direct vertalen naar het (bredere) thema dat hier aan de orde is: (het doorbreken van) de transgenerationaliteit met betrekking tot alle vormen van het maltraiteren van kinderen door hun ouders. Als eerste geven we MILLER het woord. In haar 'Nawoord' (1983) stelt deze: ${ }^{47}$

45 Herman BAARTMAN, "KAFKA's brief aan zijn vader; over het opgroeien als verworpen kind,' in: Geweld in relaties, t.a.p., op pp. 32 i.f. en 33/34; citat op p. 34.

46 H. BAARTMAN, O. VAN DER BAAN-SLOOTWEG, C. RÜMKE, Onderzoek en hulpverlening door het medisch kleuterdagverblijf 'De Bolderkar' inzake seksueel misbruik, Rapport uitgebracht aan de geneeskundige inspectie van de volksgezondheid voor Zuid-Holland, april 1989, p. [1] (curs. overgenomen). De aangehaalde passage begint aldus: 'Child sexual abuse is an intensely controversial, deeply divisive subject. (...) Each question becomes a dispute and every answer an insult. Here, in the midst of the flowering of 20 th-century reason and scientific enlightenment, is a neglected relic of mythic and superstitious issues allmost untouched by mainstream adult consciousness. (....)

47 Gij zult niet merken, Houten 1988 (derde druk), pp. 320-327, op p. 321; vgl. ook 'De dochters zwijgen niet meer' (1982), a.w., pp. 313-319, op pp. 318/319. 
'De informatie van de media over de dagelijkse, reèle seksuele mishandelingen van kinderen raakt (...) slechts een klein deel van het probleem; het effect van dergelijke gebeurtenissen op ons coëxisteren en op de volgende generatie, evenals de vraag hoe de daar ontstane schade te herstellen is, wordt daardoor immers nict geraakt. (...) [We zullen ons moeten afvragen:] "Hoe ontwikkelen dergelijke kinderen zich als volwassene en hoe vergaat het hun als ze zelf ouders zijn geworden?" Of anders geformuleerd: "Wat is de betekenis van het feit dat tachtig procent van de vrouwelijke drugverslaafden en zeventig procent van de prostituées seksweel misbruikte kinderen zijn geweest?"

\section{In 'De dochters zwijgen niet meer' (1982) stelt zij: ${ }^{48}$}

'Omdat de psychische moord [op het misbruikte kind, jw] niet volledig kan slagen, blijven de afgekapselde gevoelens hangen in het onbewuste w waar ze pas actief worden wanneer het kind als volwassene een partner ontmoet die het zonder angst dergelijke gevoelens kan aandoen. Als zo iets bij de partner onmogelijk blijkt, bijwoorbeeld omdat hij op dergelijke emotionele uitbarstingen met overeenkomstige ervaringen kan reageren [met andere woorden: beide partners zitten in dezelfde - en elkaars - val; op grond van de ('traumatofiele') herhalingsdwang ligt dit zelfs voor de hand, jw], dan zal dat in elk geval zonder mankeren lukken bij het eigen kind.'

\section{Als tweede VAN DANTZIG; deze schreef in $1990:^{49}$}

"Kort geleden bleek uit het onderzoek van Nel DRAJJER dat $6 \%$ van alle meisjes een ernstige vorm van incest moet ondergaan. Nederland kent honderdduizenden ermstige alcoholisten, met hun gezinnen en familic - er is geen einde aan de ellende waar de [geestelijke gezondheidszorg] mee te maken heeft. En toch slaagt de maatschappij erin dit alles marginaal te houden, is het bericht over tienduizenden gemartelde meisjes na een paar weken weer vergeten, is er nauwelijks een serieus anti-alcoholbeleid (...). Kortom: in de geestelijke gezondheid[szorg] bestaan toestanden die in de somatische gezondheid[szorg] geen moment getolereerd zouden worden, maar waaraan wij gewend zijn, zoals men in de derde wereld gewend is aan armoede. (...) Maar het is de mens niet gegeven nergens in te geloven, en dan vind ik geloof aan het verminderen van individueel lijden nog niet hell slechtste om te hebben."

En in $1991:^{50}$

48 Gij zult niet merken, Houten 1988 (derde druk), pp. 313-319, op pp. 316/317.

49 A. WAN DANTZIG, 'Afscheid' ('Buiten de orde'), Maandblad Geestelijke volksgezondheid $1990 / 1$, pp. 106-108, op pp. $107 / 108$ resp. p. 108 r.k.

50 A. VAN DANTZIG, 'Persoonlijk lijden als publieke zorg (2); Antwoord [aan Jos DRÖES】," Maandblad Geestelijke volksgezondheid 1991/9, pp. 962-964, op pp. 963 . 964. 
"Ik meen (...) dat (...) milsstanden, zoals incest en neurose, bestreden moeten worden binnen het kader van onze democratische welvaartsstaat (...). (...) Waar ik het over heb, is (...) die innerlijke gesteldheid die men neurose noemt, en die het onmogelijk maakt om "gewoon" ongelukkig te zijn (wat zich bijwoorbeeld laat herkennen aan kunnen huilen en troost kunnen zoeken en aanvaarden), en die veroorzalkt wordt doordat men dingen meegemaakt heeft, in de "leefwereld," die alle verdriet grondeloos maakt en troost onbestaanbaar. Voor mij is psychotherapie dan ook geen "groei- en zelfverwerkelijkingsideologie" (...) maar echt een therapie, dus een poging om een storing, een kwaal, noem het zoals u wilt, te verheipen. De psychotherapie en de [geestelijke gezondheidszorg] worden door mij niet uit een ideaal van een beter lewen, maar uit het lijden gelegitimeerd. Dat kan door individuen te behandelen. Maar het kan ook helpen de aan die individuen gewonnen inzichten maatschappelijk relevant te maken. (...) Ik vind het (...) paternalistisch en professioneel onverantwoord om mensen onbehandeld te laten op grond van een eigen maatschappij-opvatting. Ik meen dat (...) mensen, die maar éen keer leven, een kans moeten krijgen dat zo goed mogelijk te doen, onder andere door hun neurose te werhelpen.

Is dat een ideologie? Ja, voor zover het een politieke stellingname is. Nee, voor zover dat standpunt zich legitimeert uit het lijden (...) en niet uit een alomvattend idee over het goede, ware en schone.'

\section{GRUYER C.s. schrijven: ${ }^{51}$}

'Sans sombrer dans le désespoir ou le cynisme, nous devons accepter que le monde autour de nous ne soit pas aussi bon, aussi humanitaire que nous le souhaiterions. Dans ce cas, accepter cette réalité est la condition du changement."

'Depuis toujours, les conséquences des abus sexuels ont étế minimisées, par la société dans son ensemble et par les professionnels de la protection de la jeunesse, dont les responsabilités sont très lourdes lorsqu'ill faut prendre en charge ces enfants sacrifíes. Parfois, les victimes elles-mêmes tentent de rendre leur passé plus supportable en se fabriquant une version idéalisée de leur histoire.

Nous devons constater que, dans la majorité des cas, l'inceste est un assassinat psychique."

'Il faut enfin mentionner, parmi les conséquences majeures des abus sexuels, leur reproduction sur la génération suivante (...).

'La maltraitance et les abus sexuels compromettent gravement l'avenir des enfants. Pour la societé, le coût de leurs conséquences est considérable. Il est donc essentiel de nous donner tous les moyens nécessaires à la prévention de la prostitution enfantine, de la delinquance, de la toxicomanie, du suicide et de toutes les malladies psychiques et physiques causées par les abus sexuels et la maltraitance." 
WEEDA stelt: 52

'MPS [de meervoudige persoonlijkheidsstoornis of dissociatieve identiteitsstoornis; maar hier kunnen verscheidene andere (persoonlijkheids)stoornissen worden ingevuld, $\mathrm{jw}$ is een bellangrijk sociaal verschijnsel, het houdt de samenleving een spiegel voor. In alle zelfgenoegzaamheid over de liefde [van] en [de] superieure opvoeding door ouders die het beste met hun kinderen voorhebben, kan niet voorkomen worden dat een aanzienlijk deel van deze kinderen domweg vernield wordt voor het leven. De macht van ouders en anderen zal aan banden gelegd moeten worden. We zijn het ons nageslacht verschuldigd."

DE WIT schrijfit: ${ }^{53}$

'De overheid moet de voorwaarden scheppen voor de vrijheid en de ontplooiing van haar burgers. In dit geval ligt het voor de hand dat een ouderschapscursus wordt ingesteld, die even vanzelfsprekend deel gaat uitmaken van het leven als de zwangerschapsgymnastiek en het consultatiebureau. (...) Het is kortom de hoogste tijd dat de overheid sturend gaat optreden ten opzichte van wat zich in dle hoeksteen van de samenleving afspeelt. Om ouders en betaalde opvoeders maar te laten aanmodderen met beschadigende sekse-stereotypen [en andere, (nog) ergere handicaps, jw], geeft geen pas. We laten mensen ook niet het wiel uitvinden als het gaat om hygiëne of het verschil tussen mijn en dijn.'

FRENCH voegt daar aan toe: ${ }^{54}$

'In plaats van het grootste deel van het nationale budget te spenderen aan legers en wapentuig (...) [voor Nederland kan men hier naar believen andere 'overheidsverspillingen' invullen, jw], zou de regering het grootste deel van de middelen die we produceren, dienen te besteden aan de ondersteuning van hen die de kinderen opvoeden. En ook moet aan ieder kind een veilige en gezonde plek om te leven, behoorlijk voedsel, medische hulp, scholing en werk worden gegarandeerd.'

In een kinderdagverblijf treft men uiteraard niet enkel sexueel misbruikte kinderen aan, maar bijvoorbeeld ook 'gewoon' verwaarloosde kinderen. NAGEL: $:^{55}$

Iteke WEEDA, 'Meer persoonlijkheden in é́n lichaam; MPS: een "creatieve oplossing" van de geest om te overleven,' Opzij april 1992, pp. 80-83, op p. 83 r.k.

53 Bernadette DE WTr, 'Ouders en tuttebollen," Forumpagina De Volkskrant van 3 februari 1992.

54 Marilyn FRENCH, 'De verbeten oorlog van mannen tegen vrouwen, ${ }^{\text {Forompagina }}$ De Volkskrant van 7 juli 1992.

55 W.H. NAGEL, 'Het probleem van het problecm, 'in: L.G. MOOR e.a. (red.), Grenzen van de jeugd, [Nijmegen] 1981, pp. 5-7, op p. 7. 
'Een uitermate deskundige wertelde iets over het werk in een kinderdagverblijf (1/2-6 jaar) waarheen kinderen verwezen werden met moeilijkheden die beslist moesten worden opgelost voor zij naar een peuterklas of een lagere school kunnen. Er waren kinderen bij die niet konden eten, die niet zindelijk werden of op andere manieren lastig waren, kinderen met chronische snotneuzen of [die] last hadden van vlooien en luizen. Evengoed, in deze universiteitsstad, kinderen van dagloners als van academici. Ons werd verteld dat deze kinderen voor zij werden toegelaten, "onderzocht" werden. Een vraag aan de spreker was of de ouders ook "onderzocht" werden. Dat bleek niet zozeer het geval te zijn, die omstandigheden waren wel bij de maatschappelijk werkster bekend. $\mathrm{Ik}$ geloof echter dat onderzoek naar ouders heel vaak leerzamer zal zijn dan onderzoek naar hun kinderen.'

\title{
Bij JONKER-DE PUTTER komt het recht van het kind op een buitenstaan-
} der om de hoek kijken, naast en bovenop het recht van het kind op een vaderende moeder en een moederende vader: ${ }^{56}$

\begin{abstract}
'Kinderen zullen altijd minder machtig blijven, maar volgens het feministische model wordt zowel van mannen als van vrouwen werwacht dat zij zich verantwoordelijk volen voor het kind (...). Kinderen hebben recht op de bescherming van zowel ouders als buttenstaanders. Op grond van zijn studie over de internalisatietheorie van CHODOROW en de analyse van 120 onderzoeken naar de verschillen in opwoeding van jongens en meisjes meent DUINDAM te kunnen voorspellen dat gedeeld ouderschap de in onze maatschappij bestaande vrouwenhaat zal doen afinemen. De ambivalentie van meisjes en jongens ten opzichte van vrouwen zal verminderen. (...) DUINDAM bepleit niet alleen gedeeld ouderschap van een vader en moeder, maar is ook voorstander van het betrekken van én of meer andere volwassenen in de zorg woor het kind (...).'
\end{abstract}

SCHOEMAKER poogt achter het fenomeen sexuele kindermishandeling te kijken: ${ }^{57}$

'De collectieve ontkenning van een zo grootschalig fenomeen alls sexueel misbruik moet naar mijn mening een fundamentele rol spelen bij het in stand houden van de sociale ordening van onze samenleving. Deze ordening wordt op microniveau weerspiegeld in de structuur van het gezin. Generaliserend gesteld, vindt misbruik veelal plaats binnen de context van het gezin, zijn de misbruikers veelal (bloed-) verwanten, en ligt de gemiddelde leeftijd waarop het misbruik start, rond het negende jaar (...). Het ontkennen van het op grote schaal voorkomen van sexueel misbruik binnen het gezin, betekent dat de mythe van "het gelukkige gezin" in stand gehouden kan worden. Alice MILLER beschrijft in haar boek Gij zult niet

Ineke JONKER-DE PUTTER, Als je kind misbruikt is; Moeders van seksueel misbruikte kinderen, diss. [1992], Amsterdam 1991, p. 40 (curs. jw).

57 Beatrix SCHOEMAKER, Niet gehoord en niet gezien; Verwerking wan seauele trauma's bij vrouwen en mannen, diss. Utrecht, Amsterdam/Lisse 1991, p. 12 (curs. jw). 
merken de andere kant van de hoeksteen van onze samenleving: "Het kind is door zijn hulpeloosheid een bron van machtsgevoel voor de onzekere volwassene en bovendien in veel gevallen diens dierbaarste sexobject." (MILLER, 1983 [p. 12].) $\mathrm{Zij}$ maakt duidelijk hoe ouders hun eigen onzekerheden, verlangens en behoeften op hun kinderen projecteren, en hoe kinderen op hun beurt zo goed mogelijk aan het verlangde beeld zullen proberen te voldoen. Zij ziet dit als een algemeen kenmenk van onze opvoedingspraktijken; sexueel misbruik is hier slechts éen van de consequenties van.'

Als voorlaatste een auteur - FROMAN - die, hoewel schrijvend over een (op het eerste gezicht) geheel andere problematiek: de nucleaire overbewapening, ${ }^{58}$ de noodzaak en aard of soort van verandering die bij bovenstaande auteurs is te beluisteren, in een perspectief plaatst dat ons niet alleen het beklemmende begin maar ook het wenkende einde van de tunnel laat zien: ${ }^{59}$

"'[F]ragmented identities and stunted psychic development [men leze grosso modo: met onverwerkte traumatisaties samenhangende identiteitsversplintering en ontwikkelingsstoornissen, jw] pose the underlying problems that must be overcome to generate the attitudinal, value, and institutional changes that can enable our species to survive, and to survive with dignity" (...). Overcoming fragmentation would allow individuals - and, hence, accountable governments - to bridge gaps between "us" and "them," between rich and poor, between this and future generations, between the human and the other species, and between the rational and the empathetic.'

In haar voorwoord bij de Engelse vertaling van Am Anfang war Erziehung (For your own good, London 1987, pp. vii-xii, op pp. vii/viii) schrijft de Pools-Zwitserse auteur, Alice MILLER: 'Since the end of World War II, I have been haunted by the question of what could make a person conceive the plan of gassing millions of human beings to death and of how it could then be possible for millions of others to acclaim him and assist in carrying out this plan. (...) [T] he terrifying stockpiling of nuclear weapons worldwide raises the same question in an even more acute form: namely, what could motivate a person to misuse power in such a way as to cause, completely without scruples and with the use of beguiling ideologies, the destruction of humanity, an act that is altogether conceivable today? It can hardly be considered an idle academic exercise when somebody attempts to expose the roots of an unbounded and insatiable hatred like HITLER's; an investigation of this sort is a matter of life and death for all of us, since it is easier today than ever before for us to fall victim to such hatred."

59 Michael B.G. FROMAN, bespreking van Burns H. WESTON (ed.), Alternative securi1y; Living without nuclear deterrence (1990), in American Joumal of Intemational Law 1992/1, pp. 205-207, op pp. 206/207; het citaat in het citaat is van Robert JOHANSEN, auteur in het besproken werk. 


\title{
De afsluiting is eveneens aan MILLER. Haar eerste woorden sluiten direct op FROMANs laatste woorden aan: ${ }^{60}$
}

\begin{abstract}
'Kinderen die men respecteert, leren respect. Kinderen die men dient, leren dienen, leren de zwakkere dienen. Kinderen die men liefheeft zoals ze zijn, leren ook verdraagzaamheid. Op die basis ontstaan hun eigen idealen, die nooit anders dan menselijk kunnen zijn omdat ze voortkomen uit de ervaring van liefde."
\end{abstract}

\section{Haar slotwoorden nopen ons terug te keren naar het begin van FROMANS tunnel (het belang van zijn woorden rechtvaardigt wellicht een iets langer citaat): ${ }^{61}$}

"Ik geef toe dat de geschiedenis weinig reden tot optimisme en hoop op verandering geeft. Vierhonderd jaar geleden heeft Michel DE MONTAIGNE al geschreven over de opvoeding van kinderen met een respect voor de kinderlijke waardigheid dat onze tegenwoordige opvoeders in de praktijk nog lang niet hebben bereikt; en meer dan tweeduizend jaar geleden nam sOCRATES al een houding aan tegenover het psychische waarbij onze wetenschappelijke psychologie ver achterblijft. De omvang van het kwaad en de bereidheid tot bijgeloof lijken constant in deze wereld, en niet te beïnloeden door nieuwe inzichten. Daarom kan nauwelijks iets worden ingebracht tegen de rechtmatigheid van deze pessimistische argumentatie, behalve dat alle mogelijke slimme en ingewikkelde systeemtheorieën op het gebied van psychotherapie en psychoanalyse deze situatie 6ók niet zullen wijzigen. Wat zouden wij zeggen als wij een gewonde, iemand die door een auto was aangereden, naar het zickenhuis brachten en de artsen zich bij hun medisch onderzoek lieten hinderen door de automobilist, omdat deze haast heeft zijn onschuld te bewijzen? Soms voel ik me in een vergelijkbare situatie als ik van analytici te horen krijg dat mijn boeken de ouders schuldgevoelens zouden kunnen bezorgen. Ik heb toch zelf geschreven dat nergens ter wereld een moeder bestaat die een kind alles kan geven wat het nodig heeft, en ik heb ook geprobeerd wit te leggen waarom zo'n moeder niet kan bestaan. Dat bevrijd ons analytici echter niet van die andere vraag, namelijk welke woorwaarden een kind nodig heeft om later niet neurotisch of psychotisch te worden, al was het maar om te begrijpen waardoor onze patiënten ziek zijn geworden. Als men op deze vragen reageert met een verdediging van de moeders, is dat een expressie van schuldgevoelens die geworteld zijn in de eigen (meestal religieuze [het vierde gebod, jw]) opwoeding en vandaaruit verklaarbaar zijn, maar die niemand helpen omdat ze het rouwproces belemmeren (...). Wij kunnen het lijden van kinderen niet ongedaan maken, met beschuldiging noch met verdlediging van de ouders, maar wij zouden misschien kunnen helpen toekomstig lijden te voorkomen als wij niet de waarheid hoefden te verloochenen, op grond van de behoefte ons zelf of onze ouders te verdedigen. Die warheid is dat de neurosen van onze tijd niet ontstaan door driftmatige tekorten en conflicten, maar door zware narcistische traumatisaties (bijwoorbeeld vernederingen, krenkingen, seksueel misbruik en onder meer het kleineren van 
het lijden van het kind), gecombineerd met de noodzaak die traumatisaties te verdringen [het vierde gebod: Gij zult niet merken, jw]. Zulke traumatisaties Ireden des te vaker op naarmate het publiek minder weet van hun betekenis, hun pathogeen effect en de draagwijdte voor de gehele maatschappij. Alleen dit inzicht, en niet alleen meer vrije tijd voor moeders [ouders, jw], kan helpen het begrip voor het kind te verruimen en het, voor zover de moeder [ouder, jw] daartoe in staat is, meelevend te begeleiden. Dat inzicht zouden moeders [ouders, $j w$ ] kunnen krijgen van psychoanalytici, als die niet ten onrechte medelijden voor de moeders [ouders, jw] koesterden. Ik noem dat ten onrechte omdat men, door de mensen de waarheid te onthouden en deze te versluieren, anderen ertoe brengt opnieuw schuldig te worden, zich opnieuw te verstrikken in onopzettelijke wreedheden, en dat komt erop neer dat men de mensen in de val laat lopew. Dan is het toch zinvoller de mensen de ogen te openen voor de waarheid?'

\section{2 .2}

\section{Definities en vormen van kindermishandeling}

"Met uilzondering van de politie en militaire organisaties is het gezin wellicht de meest gewelddadige sociale groep in onze samenleving (...). Dit gegeven zien wij niet graag onder ogen. Uit onderzoek weten we dat verhoudingsgewijs incest het misdrijf is waarvan het kleinste percentage, namelijk $1 \%$, aan het licht komt (...). We weten ook dat de mishandelde kinderen pas "ontdekt" werden toen in medische vakbladen over de hele wereld publikaties over het "battered child syndrome" verschenen waren.'

Aldus BEYAERT. ${ }^{62}$ In de literatuur over kindermishandeling is 1962 het annus memorabilis, het 'heuglijke' jaar waarin het verschijnsel kindermishandeling - aangeduid als 'battered child syndrome' - door de Amerikaanse kinderarts KEMPE c.s. werd herondekt. ${ }^{63}$ Behalve het jaartal 1962 en de naam KEMPE wordt nog een derde element tot de verplichte examenstof gerekend: de typering van kindermishandeling als 'sociaal con-

F.H.L. BEYAERT, "Strafwetgeving en de crime passionnel, dodingen in het gezin en toch weer de vader, ${ }^{\prime}$ in: A. LADAN e.a. (red.), De betekenis van de vader; Psychoanalytische visies op het vaderschap, Meppel/Amsterdam 1985, pp. 102-122, op p. 102.

Volgens BAARTMAN was het STRAUS die van het gezin heeft gezegd: [N]aast een bron van weldadigheid is het gezin ook het meest gewelddadige instituut in onze samenleving, behalve de politie en het leger in oorlogstijd." (H. BAARTMAN, 'Kindermishandeling en botsende belangen,' in: J.B. WEENINK (red.), Het belang van het kind in het geding; Over opvoeding en kinderbeschemming, Amsterdam 1990, pp. 59-72, op p. 67.) In het rijtje pollitie, gezin en leger in oorlogstijd komt mij de eerste groep als gewelddadig instituut vreemder voor dan de tweede. KEMPE zelf houdt het op 1960: zie de 'Preface to the third edition' van Ray E. HELFER, Ruth S. KEMPE (eds.), The battered child, Chicago/London 1988 (vierde druk), pp. xix-xx, op p. xix. 
struct. ${ }^{94}$ Daarmee wordt bedoeld dat de definities van kindermishandeling veranderen met de maatschappelijke of wetenschappelijke mode van het moment, met abstractere woorden: cultureel en historisch zijn bepaald. In par. 11.2.2.1-2 lichten we dit kort toe. Waarna we nader op vormen en definities van kindermishandeling ingaan (par. 11.2.2.3-4).

\title{
11.2.2.1 Kindermishandeling als 'sociaal construct"
}

\section{Over de constructie van maltraitering lezen we bij McGILLIVRAY: ${ }^{65}$}

\begin{abstract}
"Child abuse, however defined, has for centuries cycled between discovery and invisibility, panic and indifference. It has been moralized, bureaucratized, scientized, medicalized, legalized [gejuridiseerd, jw], politicized and criminalized. Different forms of abuse have been discovered, denounced and forgotten. Definitions of abuse - the nature and intentionality of the conduct, the degree of harm, the requisite child-adult relationship - vary to the point that the term "child abuse" has no inherent medical or legal meaning. Its ambit for child protection purposes is contained by statute and defined by policy. It otherwise carries the meaning ascribed by its user.

Exposure to the elements, exposure to immorality, physical and emotional neglect, corporal punishment, physical and emotional abuse, incest, sexual assault, sexual exploitation, fetal damage, transracial or transcultural adoption, ritual or satanic abuse: all have been labeled child abuse. Explanations range from social deviance to individual pathology; circumstantial wariants such as divorce or alcoholism; systemic factors such as economic stress or racism; to ecological or multivariate models; and all the way back again. Remedies have ranged from the individual to the systemic: lecturing and tutoring, apprehension or institutionalization of the child, criminal actions against parents, public education, poverty relief, daycare and improvement of social and educational facilities, visionary calls for massive social reform or revolution. The politics of abuse have ranged from moral entrepreneurship, through bureaucratic expansionism and expansion of expert prestige, to the promotion of tribal, feminist, conservative, fundamentalist and medical interests."
\end{abstract}

$\mathrm{Na}$ deze inleiding over westerse (lees Amerikaanse) constructie (en deen reconstructie) onderscheidt de auteur een vijftal historische sociale constructen van kindermishandeling. Als eerste het morele construct: ${ }^{66}$

Vgl. BAARTMAN, Opwoeden kan zeer doen, a.w., hoofdstuk 1, pp. 11-30; Marian ROELOFS, Kindermishandeling en hulpverlening; De aampak van lichannelijke kindermishandeling door het BUREAU VERTROUWENSARTS, (diss.) Amsterdam 1996, pp. $12-28$.

Anne McGILLIVRAY, 'Reconstructing child abuse: Western definition and nonwestern experience,' in: Michael FREEMAN, Philip VEERMAN (eds.), The ideologies of children's rights, Dordrecht (etc.) 1992, pp. 213-236, op p. 226. 


\section{'The moral construct: cruelty to children}

Although what we now view as child abuse has always been publicly visible, so strong was the ideology of the private and so little done in any concerted fashion that even its public face was rendered invisible. Its private face, intrafamilial abuse, was denied by the 18th century Enlightenment portrayal of the affectivelybonded family and the 19 th century idealization of the middle-class patriarchal family. Child abuse as we know it, did not exist: it had not been socially constructed. The new wealth of the 19 th century middle classes, a rising social and feminist conscience and a general belief in the betterment of humanity engendered private action on behalf of visibly afflicted children. These moral crusades for child welfare resulted in the formal involvement of the state in child welfare. The prototype of child abuse, cruelty to children, emerged in the $1870 s$. (...)

In de kwart eeuw daarna, zo beschrijft MCGILLIVRAY, werd kindermishandeling opgevat ('geconstrueerd') als een moreel probleem dat werd toegeschreven aan ('gelocaliseerd' in) de 'dierlijkheid' van mannen en vermeende ('gepercipieerde') tekorten van moeders uit de lagere klassen. Deze constructie ging niet gepaard met enige conceptie van eigen belangen van kinderen: "children remained the property and subordinates of their parents.' Een antwoord op het probleem werd onder meer gezocht in liefdadigheid, morele kruistochten en de ontwikkeling van 'male-run agencies staffed by volunteer women.' Er kwam wetgeving tot stand die uithuisplaatsing van kinderen mogelijk maakte en vervolging van ouders verplicht stelde. Dat laatste (strafvervolging van ouders) verdween snel uit beeld. Al ras werd kindermishandeling weer 'geprivatiseerd' - 'but this time the agencies were in there too,"

In het eerste decennium van deze eeuw, zo vervolgt de auteur, verschenen professionele maatschappelijke werk(st)ers op het toneel. Een wetenschappelijke kijk op gezinswerk deed daarmee zijn intrede. Het tweede construct, het wetenschappelijke, werd aldus een feit:67

\section{'The scientific construct: hygiene and psychopathy}

(..) The agencies were now the designated experts in child abuse management. Child abuse was reconstructed as neglect; moral hygiene was reconstructed as physical and mental hygiene; abusive men were no longer brutes, criminals or deviants but were to be pitied, as poverty or unemployment excused their bad behaviour. Co-incident with the fall of feminism, [child] abuse became a buried sub-category of neglect and the sex offender became a stranger rather than at parent or stepfather or uncle, and the property of psychiatry rather than the law. Intrafamilial sexual abuse, by far the largest category of sexual abuse cases, was reconstructed as sexual delinquency: girls who had been abused, were "sex offenders" under juvenile delinquency legislation. Psychiatry was introduced into the agency roster of remedies in the 1940 s and 50 s; the goal of therapy, as with all 
agency remedies since the $1910 \mathrm{~s}$, was to keep the family together regardless of the cost to women and children. Public awareness of child abuse was once again effectively nil. Child abuse did not exist.'

We naderen nu het jaar 1962, de geboorte van het derde construct, het medische: 68

\section{"The medical construct" the battered child syndrome}

The silence was broken in 1962 with the publication of "The battered child syndrome," a designation chosen by the authors as less incriminating, more coolly medical, than "child abuse." The "syndrome" consisted of patterned repeated physical injury to children, "probably" inflicted by parents. The moral panic surrounding the battered child inaugurated the present era in child abuse construction. The primary actors were members of the medical profession: pediatric radiologists, whose research orientation freed them from patient confidentiality concerns, published their findings and thereby achieved professional prestige (...). The medical univariate construct of child abuse, premised on a parental psychopathy model, dominated child abuse theory for close to a decade. The family was again identified as the source of the problem and the locus of treatment and, as the relationship of offender and victim fit the social work family orientation, child welfare legislation was rewritten to strengthen agency mandates.'

Maar het zou niet lang duren of de artsen moesten plaats maken voor de sociale wetenschappers - en daarmee voor het vierde construct, het ecologische: ${ }^{69}$

\section{'The ecological construct: child' abuse"}

The new activism of sociologists involved in child abuse intervention and treatment resulted in a proliferation of research as well as law reform. The environmental orientation of sociology led to the displacement of the univariate medical model with a multivariate ecological model. Child abuse was reconstructed as a complex of predisposing factors requiring a complex of responses (...). (...) Theorists and reformers were obsessed with definitional issues. (...) Backlash to perceived overintervention in the family, which challenged strongly-held values of autonomy and privacy, coalesced into vocal lobby groups. (...) Increasing dissatisfaction with the agency model and its family focus sparked searches for new explanations and new controls. It was into this environment that the feminist rediscovery of sexual abuse fell.'

De tweede feministische golf spoelt ook over de ecologisten heen: child abuse wordt sexual abuse, het vijfde (en vooralsnog laatste) construct: $^{70}$ 


\section{'The political construct: sexual abuse}

Sexual abuse as constructed in the late 1970 s and 80 s is a highly gendered issue: the aggressor is male, the victim usually female and the context home and familycentred relationships. The root cause is patriarchy and its control of the private. Child abuse, always a locus of political expediency, became overtly politicized. With thousands of children disclosing sexual abuse year after year as a result of programs designed to encourage victim complaint, and a public who now believes them; and a proliferation of studies indicating high levels of sexual victimization, this construct has received strong empirical support. Despite the fact that the victims of a single homosexual pedophile may number in the hundreds, meaning that male victims numerically may equal female victims, the construct remains little challenged. ${ }^{71}$ Incest - sexual intercourse within a proseribed range of blood relationships - has been popularly reconstructed as any sexual contact with a child in any relationship of trust. Sexual abuse is constructed as classless and pervasive. For now, child abuse is sexual abuse and sexual abuse is crime.

Several results flow from this construct. (...) [P]rotection policy is shifting from a social welfare focus on the family to the direct and immediate interests of the child victim. This focus both reflects and magnifies public awareness of children's rights. (...) Neglect, emotional or psychological abuse and physical abuse have sunk in public visibility. (...)'

In aansluiting op MCGILLIVRAY's historisch exposé laten we DINGWALL c.s. aan het woord met betrekking tot twee historische - (groten)deels nog steeds actuele - fenomenen: cultureel relativisme en 'natural love,' die ons terugbrengen bij het aspect van de transgenerationaliteit - nu in (relatie tot) de hulpverlening.

\subsubsection{Cultureel relativisme en 'natural love'}

\section{In zijn voorwoord bij het boek van DINGWALL c.s. merkt GELLES op: ${ }^{72}$}

"Twenty [inmiddels ruim dertig, jw] years ago, when the first scholarly articles on child abuse were being published, and when the very topic of child abuse was being discovered by physicians, lawyers, and the lay public, the abuse of children was thought to be both rare and caused by mental defects in the perpetrators. Two decades of research have demonstrated that both views mere misconceptions. Child abuse is not rare, and mental illness [psychische stoornissen, jw] and

Het aantal (met name zér jonge) jongetjes dat het slachtoffer wordt van sexueel misbruik binnen het gezin is ten opzichte van het aantal meisjes overigens bepaald niet verwaarloosbaar te achten. Aangenomen wordt wel dat één op de vier of vijf incestslachtoffers mannelijk is (zie voor cijfers hoofdstuk 12).

72 Richard J. GELLES, 'Foreword,' in: Robert DINGWALL, John EEKELAAR, Topsy MURRAY, The protection of children; State intervention and family life, Oxford/ New York 1985, pp. vii-viii. 
character disorders [persoonlijkheidsstoornissen, jw] explain no more than 10 per cent of the instances of abuse.

In the course of scientifically establishing the extent of abuse, an important problem arose, which, to the best of my knowledge, was not identified or addressed by anyone until this volume was prepared by Robert DINGWALL, John EEKELAAR, and Topsy MURRAY. The problem is the discrepancy between the number of officially validated instances of child maltreatment and incidence estimates obtained through social surveys. (...) Official reports of child maltreatment significantly and consistently underestimate the actual extent of abuse and neglect of children. (...) The private and intimate nature of the family as a modern institution means that most abuse and neglect takes place behind closed doors, in the privacy of the home. The official detection of maltreatment nearly always requires a report, an assessment of the condition of the child, an inquest into how that condition arose, and, often, an assessment of family history. This entire process, whether in the United Kingdom, United States, or many other countries, is conducted under what DINGWALL, EEKELAAR, and MURRAY call "the rule of optimism," where clinical staff are required to think the best of parents."

De auteurs ontdekten twee 'institutionalised devices,' namelijk 'cultural relativism' (cultureel relativisme - als rechtvaardigingsgrond) en 'natural love' (natuurlijke ouderliefde - als verontschuldigingsgrond), die tezamen als rechtvaardiging respectievelijk verontschuldiging functioneerden om aan kindermishandeling niets (of te weinig en te laat) te doen, en die 'front-line workers' in staat stelden ouderlijk gedrag met een roze bril te bekijken ('optimistic reading'). ${ }^{73}$ 'Cultural relativism' ....

'(...) is an agency [kinderbeschermingsinstellings-, jw] justifucation. Justifications concede that, in some sense, the ascription of deviance [afwijkend ouderlijk gedrag, lees: ouderlijk wangedrag, ouderlijke wanprestatie, jw] is correct but that, in practice, the observed conduct is permitted or required by the particular circumstances. (...) [T] his amounts to saying that the mistreatment of a child was somehow unavoidable. The acts complained of are not abusive or neglectful but positive attempts to comply with alternative normative standards that would allow them to be recognized as appropriate parental behaviour.

The term "cultural relativism" is used here to denote an intellectual position that all cultures are equally valid ways of formulating relationships between human beings and between human beings and the material world, together with the possible political corollary that members of one culture have no right to criticize members of another by importing their own standards of judgement.'

'Natural love' - LOCKE's natuurlijke ouderlijke tenderness - is een 'instinctual phenomenon, grounded in human nature' en bezit als zodanig

The protection of children, a.w., Chapter 4, 'The rule of optimism," pp. 79-102, citaat op p. 82. 
een 'special, enduring, timeless and culture-free quality. ${ }^{74}$ SCHOEMAN drukt dit zo uit: ${ }^{75}$

'[P]arents' natural affections for their offspring and their infants" needs make for something like a preestablished harmony of interests.'

'Natural parent-child love' krijgt echter de werking van 'excuse' door een ander bijna even 'natural phenomenon'.76

"If it is assumed that all parents love their children as a fact of nature, then it becomes very difficult to read evidence in a way which is inconsistent with this assumption."

DINGWALL c.s. stellen: 77

"Cultural relativism has no internal limit to its theorizing. It is indefinitely extendable, so that any small group or articulate individual can find their own theories being elevated to the status of a culture and turned into a justification. What may seem like eccentricities or perversions are ellevated into valid cultural statements. (...) Tout comprendre c'est tout pardonner. (...) When parental love is defined as a natural fact, any challenge constitutes its objects as deficient in their humanity. (...)

These two devices [cultureel relativisme en natuurlijke ouderliefde, jw] allow the front-line workers [kinderbeschermers/jeugdhulpverleners, jw], despite substantial evidence to the contrary, to reconstitute families as having some integrity and personal worth through which some gains can be made, however slight.'

Zoals ook in andere mensenrechtendiscussies offert het culturele relativisme mensen - i.c. kinderen - op aan een ideologie, een gouvernementele of juist een anti-gouvernementele, een burgerlijke of juist een antiburgerlijke ideologie. Niet dat het hier haat-ideologieën zou betreffen: integendeel vaak. Maar er is een ideologische verblinding - waarbij het ideologische gedachtengoed veelal niet meer is dan een intellectualistische (pseudo-intellectuele) verpakking ${ }^{78}$ - die het onmogelijk maakt dat

74 DINGWALL c.s., t.a.p., op pp. 86 en 87.

75 SCHOEMAN (1980), aangehaald door DE RUYTER (1993) " p. 138. DE RUYTER beschouwt SCHOEMANs argument als een 'naturalistische drogreden' (t.a.p.).

76 DINGWALL c.s., t.a.p., op p. 87.

77 DINGWALL c.s., t.a.p., op pp. 89 en 90.

78 Een rationalisatie (vgl. bijlage rv bij dit proefschrift) wan niet verwerkte - en dus niet geïntegreerde - (diepe) frustratie of (vroege) traumatisatie, in het bijzonder (bij hulpverleners) parentificatie. 
de slachtoffers worden gezien. Dat zulke ideologische verpakkingen niet worden doorgeprikt - door omstanders, buitenstaanders of zelfs (voormalige) slachtoffers -, heeft wellicht iets te maken met de mimetische aard van de mens (meeloper, nabootser, zie GIRARD). Maar vermoedelijk ligt hieraan toch mede, althans in sommige gevallen, ${ }^{79}$ ten grondslag de onmogelijkheid van de hulpverlener zich te ontfermen over het gekwetste kind in hem- of haarzelf. De ideologische verpakking verhult het niet mogen zien van de eigen afgepakte jeugd; de ideologische verblinding stelt het zelf (vroeger) door de ouders verworpen zijn in een zwarte schaduw. ${ }^{80}$

Transgenerationaliteit is aldus niet alleen een kwestie van het 'blindelings' doorgeven van leed van genetische generatie op generatie (staatszorg ex art. 3, lid 2 VRK), maar ook van generatie hulpverleners op generatie pupillen (staatszorg ex art. 3 , lid 3 vRK). Men voelt niet wat men kinderen aandoet (door niet in te grijpen en de ouders te verontschuldigen), doordat men als kind niet heeft mogen voelen wat dat kind door de eigen ouders werd aangedaan. ${ }^{81}$

\subsubsection{Definities en vormen}

$\mathrm{Na}$ deze inleidende bespiegelingen aan de hand van enkele auteurs, kan thans, in twee varianten, een gangbare definitie van kindermishandeling worden weergegeven. ${ }^{82}$ Als eerste variant vermeld ik die van de Raad voor het jeugdbeleid (1988), zoals overgenomen in de Beleidsbrief kindermishandeling (1990) en de Memorie van toelichting bij het goedkeurings-

79 In deze gevallen zou men kunnen spreken van een neurotische beroepskeuze c.q. van een 'geparentificeerd" zijn van de betrokken hulpverleners. Uiteraard kunnen deze gevallen - en hun mogelijke relatieve gewicht - niet los worden gezien van de maatschappelijke context (zie J.C.M. WLLEMS, 'Kinderen zijn niet automatisch veilig bij hun ouders,' Tijdschrift voor Jeugdhulpverlening en Jeugdwerk november 1993, themanummer 'Rechten voor [lees: van, jw] kinderen," pp. 18-22).

80 Vgl. ook Herman BAARTMAN, 'Onderkenming en miskenning van seksueel misbruik van kinderen; enkele historische en actuele aspecten,' in: dez. (red.), OP gebaande paden? Ontwikkelingen in diagnostiek, hulpverlening en preventie met betrekking tot seksueel misbnik wan kinderen, Utrecht 1995 , pp. 13-27, op p. 26.

81 'Parentificatie' zou aldus niet alleen als individueel probleem (c.q. als én van de vele problemen waarmee de hulpwerlening heeft te kampen), maar ook als cultureel fenomeen - als transgenerationele schakel in cen grotere sociaal-historische en -psychologische keten, als radertje, met andere woorden, in de geschiedenis van het lijden van het kind - kunnen worden bestudeerd. Op deze plaats wordt het enkel als zodanig aangestipt. Vgl. BAARTMAN, Opvoeden kan zeer doen, a.w., p. 88. 
wetsontwerp van het Verdrag inzake de rechten van het kind (1992): ${ }^{83}$

'Kindermishandeling is elke vorm van voor het kind bedreigende en gewelddadige $^{84}$ interactie van fysieke, psychische of sexuele aard die de opvoeders het kind in de afhankelijkheidsrelatie actief of passief opdringen waardoor emstige schade wordt berokkend aan het kind in de vorm van fysiek letsel en/of psychische stoomissen.'

De variant van de BVA's (Bureaus Vertrouwensarts) vervolgens luidt: ${ }^{85}$

'Kindermishandeling is elke vorm van lichamelijke en/of emotionele geweldpleging of verwaarlozing die kinderen niet door toeval of per ongeluk, doch door toedoen of malaten van ouders of andere verzorgers overkomt, en waarbij geestelijke en/of lichamelijke schade of afwijkingen ontstaan dan wel dreigen te ontstaan."

Deze definitie omvat de vijf algemeen onderscheiden vormen van kindermishandeling:

1. lichamelijke (fysieke) mishandeling;

2. psychische (geestelijke, emotionele) mishandeling (emotioneel misbruik);

3. lichamelijke (fysieke) verwaarlozing;

4. psychische (emotionele, affectieve) verwaarlozing; en:

5. sexueel misbruik (sexuele kindermishandeling, 'incest') ${ }^{86}$

Beleidsbrief kindermishandeling, Kamerstukken II 1990/91, 21 938, nrs. 1-2, p. 9; Goedkeuring van het op 20 november 1989 te New York tot stand gekomen Ver-

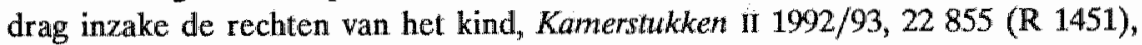
nr. 3, pp. $28 / 29$ (curs. jw).

84 Onder 'gewelddadig' zij te verstaan: ten koste van de ander eigen belangen of behoeften doordrukkend of voorop stellend. Deze omschrijwing brengt de overlap aan het licht tussen gewelddadigheid en egocentrisme, waarbij de eerste term in heviger mate de connotatie heeft van schadelijkheid en hardwochtigheid/onverschilligheid.

85 Overgenomen uit: Marian ROELOFs, 'Ernstige of minder ernstige kindermishandeling? De opvattingen van de Bureaus Vertrouwensartsen,' in: Maandblad Geestelijke volksgezondheid $1991 / 1$, pp. 18-33, op p. 18 (curs. jw).

Zie voor enige literatuur: John BRIERE e.a. (eds.), The APSAC LAmerican Professional Society on the Abuse of Children $/$ handbook on child maltreatment, Thousand Oaks (etc.) 1996, pp. 1-99; A.E. BRODEUR, J.A. MONTELEONE, Child maltreatment; [vol. 1] A clinical guide and reference, St. Louis (etc.) 1994, pp. 27-111 (radiology, injuries, burns), 113-190 (sexual abuse), 191-215 (MPD), 217-227 (poisoning), 229-240 (Munchausen syndrome by proxy), $241-257$ (neglect and abandoument), 259-283 (emotional abuse); Lane J. VELTKAMP, Thomas W. MILLER, Clinical handbook of child abuse and neglect, Madison, Ct. 1994, pp. 7-39; Doug- 
Deze vijf vormen zullen we thans aan de hand van enkele citaten summier pogen te typeren (bij de laatste staan we - mede gezien de overvloed aan recente 'incest'-literatuur - wat uitgebreider stil). Omdat het in deze studie niet om individuele diagnostiek en therapie/hulpverlening aan kind of gezin in concreto gaat, maar om maatschappelijk - en dus rechtens - relevante oorzaken en gevolgen van kindermishandeling (rechten van het kind, staatsaansprakelijkheid/staatsverantwoordelijkheden), stellen wij hier het door kindermishandeling veroorzaakte psychotrauma (en zijn transgenerationele aspecten) centraal. Voor ons is kindermishandeling, kort gezegd en grosso modo, een vorm van (chronische) traumatisering van kinderen in het gezin, dat wil zeggen door hun ouders; ouders die ten gevolge van hun eigen ontwikkelingsgeschiedenis, dat wil zeggen vanuit een eigen pedagogisch tekort, onvoldoende pedagogisch besef hebben 'meegekregen' om hun kind zonder meer tot een (boven-) minimaal persoon te kunnen opvoeden. Met andere woorden: wij gaan uit van de - door onderzoek bevestigde ${ }^{87}$ - (ervarings)regel (en gaan niet in op de uitzonderingen) dat kinderen actuele maar hun ouders historische slachtoffers zijn van ernstige schendingen van de rechten van het kind. Dit impliceert tevens dat we geen aandacht besteden aan actuele omstandigheden (van socio-materiële aard dan wel andere uitwendige stress-factoren) die de draagkracht van overigens betrekkelijk stabiele (pedagogisch goed genoege) ouders dermate kunnen belasten dat hun kinderen daarvan het kind van de rekening worden (veelal zal dan immers sprake zijn van een 'teruggrijpen' op c.q. terugval in 'primitieve' althans inadequate afweermechanismen c.q. coping-stijlen, ${ }^{88}$ welke op hun beurt veel zo niet alles te maken hebben met de eigen voorgeschiedenis).

Samenvattend: we gaan in juridische c.q. sociaal-pedagogische zin uit van de nemo plus- en nemo ultra-regel (en dus van - in principe staatsaansprakelijkheid c.q. staatsverantwoordelijkheden ter zake van adequate aanvullende, ondersteunende en desnoods vervangende sociaalpedagogische voorzieningen, instellingen en diensten); en in sociaal-psychologische zin van de transgenerationaliteit van niet verwerkte psychotrauma's.

las J. BESHAROV, Recognizing child abuse, New York (etc.) 1990, pp. 66-133; Marjan MICHIELS, 'Hoe ideaal en hoe veilig zijn de privé-ruimten van gezin en omgeving voor kind en jeugdige?’ In: H. CAMMAER en E. VERHELLEN (red.), Onmondig en onvolwassen; De jonge mens in de eeuw van het kind, Leuven/Amersfoort 1990, pp. 107-120, op pp. 111-119.

87 Vgl. bijwoorbeeld BAARTMAN, Opvoeden kan zeer doen, a.w., pp. 96-136, 189 i.f., 229-231.

Zie hiervoor bijlage IV bij dit proefschrift. 
Omdat in de literatuur veelal gesproken wordt van een trans- of intergenerationele hypothese, welke als zodanig niet onomstreden is, zij hier (nogmaals) onderstreept dat wij met 'transgenerationaliteit' als sociaal-psychologische wetmatigheid bedoelen aan te geven dat het in onze opvatting in eerste en laatste instantie gaat om een sociaal-politiek en cultureel fenomeen (hierboven, in par. 11.2.1, als publiekrechtelijk ouderschapslibertinisme aangeduid). Zoals BUCHANAN opmerkt: ${ }^{89}$

\footnotetext{
"Given the difficulties and differences in research methodology, it is not surprising that the rates of intergenerational transmission of child maltreatment range from $1 \%$ to nearly $100 \%$ (...). (...)

Intrafamilial research suggests that the majority of those parents who were abused as children will not repeat the patterns. However, research does suggest that having been abused is a significant risk factor for later parenting. There is a growing consensus that problably around one third of abused children will repeat the patterns of their childhood. These intrafamial studies need, however, to be seen in the wider socio-political and cultural context.'
}

We spraken zojuist van de transgenerationaliteit van niet verwerkte psychotrauma's. Ook het element 'psychotrauma' verdient enige toelichting. Het begrip wordt in deze studie gehanteerd als verzamelterm voor elke door de ouders in de opvoedingsrelatie teweeggebrachte beschadiging van de geestelijke gezondheid en aantasting van het psychisch welzijn van het kind als persoon in ontwikkeling - dat wil zeggen: elke bedreiging (schending ex ante, gevaarzetting) of beschadiging (schending ex post) van minimale rationaliteit, moraliteit of authenticiteit -, die op langere termijn nadelige psychische en psychosociale effecten (sequelae) heeft van zodanige ernst en omvang dat deze sequelae als psychische stoornis (in het bijzonder maar niet noodzakelijk als persoonlijkheidsstoornis c.q. gestoorde persoonlijkheidstrekken met een achterliggende meer of minder ernstige - neurotische, borderline, psychotische - structurele psychopathologie) classificeerbaar zijn..$^{90}$

Met andere woorden (en iets eenvoudiger gezegd): het gaat in de kern om emotionele beschadigingen, door ouderlijk ${ }^{91}$ te kort schieten -

89 Ann BUCHANAN, Cycles of child maltreatment; Facts, fallacies and interventions, Chichester (etc.) 1996, pp. 32 en 35 (curs. jw).

90 De meer diagnostische of psychiatrische aspecten komen (summier) aan de orde in hoofdstuk $12 . \mathrm{Vgl}$. ook bijlage $\mathrm{V}$ bij dit proefschrift.

91 Eigenlijk zou ik liever zeggen: door pedagogisch te kort schieten, hetgeen niet alleen het te kort schieten van ouders, maar ook een maatschappelijk te kort schieten, het te kort schieten van de statelijke waarborging, bescherming en handhaving (vindicatie) van de (kern)rechten van het kind is. De nemo plus-en nemo ultra-regel impliceren dat ouderlijk te kort schieten los staat wan de schuldwraag. 
in welke vorm dan ook - veroorzaakt, die leiden tot ontwikkelingspsychopathologie. We verduidelijken dit aan de hand van THOMPSON: ${ }^{92}$

'A considerable research literature now attests to the fact that children who consistently experience insensitive, unresponsive, and unhelpful parental care, often show long-term consequences, including impaired peer relations, diminished self-esteem, and behavioral problems at home and school. When these studies are considered together with research on the etiology of childhood psychological disorders, as well as the literature on the causes and consequences of child maltreatment, there is rather convincing evidence that the quality of parental care that children recieve, has important consequences for their mental health and psychologicall well-being (...).'

Tegen deze achtergrond, tegen de achtergrond dus van de idee van het niet verwerkte psychotrauma als oorzaak van een pedagogisch tekort en het pedagogisch tekort als (potentiële) oorzaak van nieuwe psychotrauma's (van herhaald - 'transgenerationeel" - pedagogisch falen), zullen we thans de vijf vormen van kindermishandeling, aan de hand van enkele kernachtige (zij het niet noodzakelijk korte) citaten, in kaart pogen te brengen. Het gaat daarbij niet om een systematisch of zelfs maar schematisch overzicht, laat staan om een gedetailleerd nalopen van allerlei onderzoeksbevindingen, doch om het belichten van enkele saillante punten in het 'maltraiterings-landschap,' punten die eruit springen tegen bovenbedoelde achtergrond. Om die reden keren we na afloop direct naar het aspect van het pedagogisch tekort (tekort aan pedagogisch besef) terug (en wel in de laatste subparagraaf, par. 11.2.2.4).

Aangezien we het psychotrauma centraal stellen, lijkt het nuttig om te beginnen met psychische kindermishandeling.

\section{Psychische kindermishandeling}

Even voor de zojuist aangehaalde passus merkt THOMPSON op: $:^{93}$

Met andere woorden: er kan onder omstandigheden c.q. tot op zekere hoogte sprake zijn van posttraumatische (intergenerationele) ontoerekeningsvatbaarheid en/of een verontschuldigbaar 'niet weten' (niet verwijtbaar gebrek aan ontwikkelingspsychologische en pedagogische kennis en pedagogische vaardigheden ten gevolge van inadequate of afwezige pedagogische scholing).

Ross A. THOMPSON, 'Developmental research and legall policy: toward a two-way street,' in: Dante CICCHETT, Sheree L. TOTH (eds.), Child abuse, child development, and social policy, Adwances in applied developmental psychology, vol. 8, Norwood, New Jersey 1993, pp. 75-115, op p. 90. 
'The parental behaviors that constitute psychological maltreatment are varied: they can include "rejecting," "degrading," "isolating," or "exploiting" the child (...), "psychologically unavailabe caregiving" (....), "ignoring," "corrupting," or "terrorizing" children (...), or "any communication pattern" that may potentially damage the child psychologically, especially by undermining the child's resolution of important developmental tasks (...). According to some commentators, psychological maltreatment is also involved in prejudice and racism, living in dangerous environments, families with substance abuse problems, and the child's exposure to "negative and limiting models" (...) in certain social environments (...). From this perspective, psychological maltreatment is not only extensively involved in other foms of child abuse, but it is also the most prevalent and destructive form of child maltreatment (...).'

Voor de nadere uitwerking van het bovenstaande gaan we opnieuw bij BAARTMAN te rade: ${ }^{94}$

'Het belang van het begrip psychische kindermishandeling is tweeledig. In de eerste plaats kan het begrip psychische kindermishandeling in de hulpverlening het oog scherpen voor tekenen die wijzen op een ernstig verstoorde opvoedingsrelatie. (...) Ten tweede is dit begrip meer in het algemeen van belang ter stimulering van een kritische bezinning op vaak al te vanzelfsprekend gehanteerde opvoedingspraktijken. (...) In verband hiermee biedt het begrip een eigen entree voor de stelselmatig noodzakelijke bezinning op rechten van kinderen en op het respect dat opvoeders aan kinderen verschuldigd zijn."

"Het merkwaardige is dat het zo moeilijk is om psychische kindermishandeling te definiëren, juist omdat het bij psychische kindermishandeling gaat om dat wat de kern is van elke vorm van kindermishandeling. Bij psychische kindermishandeling hebben we niet te maken met de spectaculaire en overigens soms ook gruwzame franje van agressie en seksualiteit. Deze kern is dat men, op wat voor wijze ook, als opvoeder een kind zijn gevoel van velligheid, zelfvertrouwen en zelfwaardering afneemt, dan well dit niet ontwikkelt. Het is deze beschadiging die het meest cruciale gevolg is van elke vorm van kindermishandeling.'

"Tk zou psychische kindermishandeling als volgt willen omschrijven: van psychische kindermishandeling is sprake als een opvoeder, zonder de lichamelijke integriteit van een kind te schenden, actief en stelselmatig een kind zijn gevoel van veiligheid, zelfvertrouwen en zelfwaardering ontmeem, dan wel deze gevoelens niet helpt ontwikkelen."

Voor alle duidelijkheid: 'actief,' dus emotionele verwaarlozing valt buiten deze definitie ${ }^{95}$; 'stelselmatig,' dus geen incidentele gebeurtenissen"; VKMagazine $1990 / 1$, pp. $1-4$, op p. 2 m.k.-r.k. 
'veiligheid ontnemen,' bijvoorbeeld door onberekenbaarheid van de ouder(s), door onvoorspelbaarheid van zijn (hun) gedrag.

De auteur onderscheidt als sub-vormen van psychische kindermishandeling: kleineren (degrading), verwerpen (rejecting) en terroriseren: ${ }^{97}$

'Een analyse van vormen van psychische kindermishandeling leverde (...) met betrekking tot de vraag: "waarom doet iemand zo iets?" het volgende op:

[kleineren:]

- men accepteert "het kleine" van het kind niet wegens eigen ambivalenties ten aanzien van het beeld waar men zelf aan moet beantwoorden [gespletenheid/ dubbelheid: frustratie (geen integratie) en (dus) projectie ten aanzien van het 'good me' en het 'bad me,' idealiseren van het ene, demoniseren van het andere kind, jw];

- men accepteert "het grote" van het kind niet wegens eigen ambivalenties met betrekking tot zijn eigen zelfwaardering [gespletenheid/dubbelheid: minderwaardigheidscomplex en arrogantie (meerderwaardigheidsgevoelens/-waan als minderwaardigheidscompensatie, jw];

[verwerpen:]

- men erkent en accepteert het kind niet omdat de vraag die het kind is, beleefd wordt als een overvragen [gespletenheid/dubbelheid: geen plaats en geen tijd hebben/maken voor het kind, 'misschien omdat men zelf nooit een plaats had in thet bestaan van anderen,' jw];

[terroriseren:]

- men terroriseert het kind omdat men bang is voor de mondigheid en zelfstandigheid van het kind [gespletenheid/dubbelheid: gemeenheid en manipulatie, 'dreiging met verlating of verstoting,' 'het gevangen houden van het kind in een extreme afhankelijkheidspositie,' jw].'

CLEMENS SCHRÖNER spreekt in haar proefschrift Psychische kindermishandeling uit 1956 van 'iets gemeens,' 'een procrustisch element,' en van 'kwellust. ${ }^{98}$ Met 'de term het procrustisch element (afgeleid van PROCRUSTES)' bedoelt zij aan te geven 'dat er b.v. van een kind dingen worden gevergd waarvan men kan weten dat het er niet aan kan voldoen." 99 Over de kwellust van PROCRUSTES lezen we bij KLEIJNTJENS en KNIPPENBERG: $:^{100}$

'De beruchtste booswicht van die tijd was DAMASTES. Hij was gevreesd om de bijzondere wreedheid waarmee hij de voorbijgangers behandelde, en ontleende

T.a.p., op p. 3 l.k.

97 T.a.p. op p. 4 r.k. (curs. jw).

98 B.L.F. CLEMENS SCHRÖNER, Psychische kindermishandeling, diss. Leiden, Den Haag [1956] 1957, pp. 117/118.

A.W., p. 7 i.f...

100 J. KLEINTJENS S.J., H.H. KNIPPENBERG, Van goden en helden; Mythen en sagen van Grieken, Romeinen en Germanen, Groningen 1965 (19e druk), p. 108. 
hieraan de bijnaam van PROKRUSTES (d.i. nit-rekker). Hij had namelijk twee ijzeren bedden, een kort en een lang. De kleine mensen die hij ving, werden op het lange bed gebonden en dan rekte hij met koorden hun ledematen uit totdat zij de lengte van het bed hadden. De groten legde hij op het kleine bed. Wat van hun benen daarbuiten uitstak, hieuw hij onmeedogend af met een bijl."

BAARTMAN laat zien welke (soort) ambivalenties, minderwaardigheidsgevoelens, angsten, gevoelens van overvraagd worden die de ouders vanuit hun eigen ontwikkelingsgeschiedenis 'inbrengen' in de opvoedingsrelatie, aan het procrustisch element, ik zou bijna zeggen: de procrustische dwang, ten grondslag liggen. Een dwang die nimmer is gecorrigeerd. Een dwang die in de opvoedingsrelatie straffeloos kan worden uitgeleefd.

\section{Affectieve verwaarlozing}

Psychische, emotionele en affectieve verwaarlozing worden hier als synoniem beschouwd. We geven geen definitie maar een typering, zo men wil: een impressie, niet van het fenomeen zelf maar van zijn gevolgen. Of liever, we laten dat VAN EPEN doen: ${ }^{101}$

'Om te beginnen hebben [emotioneel verwaarloosde] mensen grote moeilijkheden met het leggen van contacten met medemensen. Hun leven is vaak een patroon van telkens weer opnieuw aangeknoopte banden met mensen welke banden na enige tijd weer verbroken worden. Typisch hierbij is dat de niet-verwaarloosde medemens zich in het contact met de verwaarloosde vaak gebruikt voelt. Hij krijgt de indruk dat hij "leeggezogen" wordt, het is alsof hij telkens zijn liefdesdan wel vriendschapsgevoelens aan de verwaarloosde medemens moet bewijzen. De verwaarloosde mens gelooft van zichzelf niet dat hij of zij in staat is tot het ontvangen van liefde, genegenheid en vriendschap. De verwaarloosde mens heeft dan ook de neiging, als zich toch een band met enig medemens voordoet, deze band op zijn soliditeit te beproeven, waarbij onbewust de volgende redenering wordt gevolgd: als hij of zij werkelijk van mij houdt, dan moet hij ook nog van me houden als ik dit of dat doe. De niet-verwaarloosde medemens mot bewijzen dat hij van de verwaarloosde blijft houden, ook al wordt hij door hem op soms onvoorstelbare wijze bejegend.

Daar op den duur gezonde mensen een dergelijke relatie niet volhouden, krijgt de verwaarloosde mens altijd gelijk: "Zie je wel, in feite houdt hij niet van me." Niet zelden tracht de verwaarloosde mens zijn vroegere vriend of vriendin na verbreking van de relatie op malafide, chanterende wijze terug te winnen (...).

De manier waarop de verwaarloosde mens als beschreven met zijn medemensen omgaat, wordt wel testing to the limits genoemd.

Bij de verwaarloosde mens is voorts sprake van een ernstige gevoelsdeficiëntie, welke gevoelsdeficièntie door de patiënt zelf beleefd wordt. Verwaarloosde mensen hebben vaak goed van zichzelf in de gaten dat zij in feite niet in staat zijn

101 J.H. VAN EPEN, Drugverslaving en alcoholisme, Amsterdam/Brussel 1983 (derde druk), pp. 18-19. 
duurzame banden met medemensen te onderhouden, werkelijke liefde of genegenheid te voelen, tederheid te ervaren, enz. Als gevolg van deze gevoelsdeficiëntie kan een ware "prikkel-honger" ontstaan, waarbij de patiënt tracht zichzelf door het toedienen van sterke prikkels gevoelens te doen ervaren.

Niet zelden bestaat een voorkeur voor vormen van riskant gedrag, waarbij gespeeld wordt op de grens van de dood. Dit "spel met de dood" is min of meer typisch voor de verwaarloosde mens, die immers zichzelf als waardeloos beleeft, als gevolg waarvan hij bijna voortdurend latent of manifest suïcidaal is.

Uit het bovenstaande kan afgeleid worden, dat drugverslaving de emotioneel verwaarloosde jonge mens op het lijf geschreven is.'

\title{
3. Lichamelijke kindermishandeling
}

In haar proefschrift (uit 1996) geeft ROELOFS een eigen definitie van lichamelijke kindermishandeling: ${ }^{102}$

\begin{abstract}
"Lichamelijke kindermishandeling is het bij herhaling fysiek veroorzaken van pijn of verwondingen bij het kind door ouders of verzorgers, waarbij het meestal gaat om overmatige, vaak cultureel ter discussie staande lichamelijke bestraffing van het kind door de opvoeder, waarbij het op medische, pedagogische en psychologische gronden aannemelijk is dat de lichamelijke en/of geestelijke ontwikkeling van het betreffende kind hierdoor wordt geschaad.'
\end{abstract}

Ook hier lichten we het psychische element, de psychische schade voor de ontwikkeling, het psychotrauma eruit. Waar het ók bij fysieke kindermishandeling om gaat is de psychische schade (nást de eventuele fysieke schade) die het kind oploopt. Anderzijds dient bij lichamelijke kindermishandeling het aspect van de excessieve tuchtiging, het (door)slaan - uit onmacht of wegens andere (achterliggende) motieven - nader belicht te worden. Beide punten: de psychische impact van fysiek geweld en het hellendle vlak van slaan naar doorslaan, keren herhaaldelijk in de literatuur terug. Wat het eerste punt betreft, zes jaar vóor 'KEMPE' merkte CLEMENS SCHRÖNER al op: $:^{103}$

'Binnen het begrip kindermishandeling staan lichamelijke en niet-lichamelijke mishandelingen als gelijksoortige handelingen op eén lijn: de ene opvoeder zal zijn machtswellust [c.q. onmacht, jw] voornamelijk botvieren in lichamelijke, de ander[e] in niet-lichamelijke handelingen, doch beide[n] kunnen psychische krenkingen veroorzaken. Het essentiële is gelegen in de mogelijkheid van psychische schade tengevolge van de gemene [verstoorde, jw] intentie van iemand bij wie het kind zich veilig zou moeten kunnen voelen.'

Marian ROELOFS, Kindermishandeling en hulpverlening; De aanpak van lichamelijke kindermishandeling door het BUREAU VERTROUWENSARTS, (diss.) Amsterdam 1996, p. 29 (curs. niet overgenomen). 
Bij BAARTMAN (1991) vinden we de volgende algemene typering van kindermishandeling: ${ }^{104}$

'Kindermishandeling impliceert een beschadiging in de verhouding tussen opvoeder en kind. Daarbij is enerzijds de mishandeling zelf voor die verhouding beschadigend van aard, en geldt anderzijds dat mishandeling te zien is als een exponent, als een manifestatie van een beschadiging in die verhouding. Deze beschadigde verhouding is fundamenteler dan het gewelddadige gebeuren op zich en fundamenteler dus ook voor de inwloed ervan op het leven van een volgende generatie. (...) De kern van kindermishandeling is dat een kind zijn bestaan ontnomen wordt en dat het tegen de verdrukking in, tegen de kleinering in, groot moet zien te worden.'

Elders treffen we met betrekking tot het slaan van kinderen de volgende uitweiding aan (BAARTMAN 1993): ${ }^{105}$

"Slaan kan de uiting zijn van een verwerping van het kind door de ouder, van het behandelen van een kind als eigen bezit, van een strijd tegen eigen impulsen die men bij het kind met geweld te lijf gaat, van rivalisering met het kind in de voldoening van behoeften aan bevestiging. De ook in dergelijke situaties soms gehoorde argumenten dat men slaat omderwille van het welzijn van het kind en vanuit goed bedoelde pedagogische intenties, moeten gewantrouwd worden als maskerades en rationaliseringen van motieven - zij het niet altijd besefte - die van veel wezenlijker aard zijn [dat wil zeggen die heel diep zitten; vergelijk hiervoor het afgunst-motief met zijn verwijzing naar eigen onverwerkte traumatische jeugdervaringen, $\mathrm{jw}]$. Als dergelijke grondig verstoorde attitudes de bron vormen van het geweld, dan is er reden om te spreken van kindermishandeling vanwege het zorgwekkende dat inherent is aan deze bronnen van geweld. Hier gaat het om meer dan om de schending van het recht van een kind op eerbiediging van $z$ jijn lichamelijke integriteit. Hier gaat het om een fundamentele schending van het recht van een kind op eerbiediging van zijn persoon en van het recht, dat specifiek een recht van kinderen is ten opzichte van hun opvoeders, het recht namelijk op die ondersteuning (die opvoeding) die de kansen op ontplooiing van zijn persoon-zijn optimaliseert.'

ROELOFS staat stil bij het tweede punt, het hellende vlak tussen fysieke disciplinering en kindermishandeling: ${ }^{106}$

'Het toepassen van fysieke straffen in de opvoeding wordt in brede kringen geaccepteerd. (...) [Onderzoekers] stelden vast dat lichamelijke mishandeling vaak het resultaat is van uit de hand gelopen lichamelijke disciplinering. Soms zijn de

Herman BAARTMAN, 'KAFKA's brief aan zijn vader; over het opgroelen als verworpen kind,' in: Geweld in relaties, t.a.p., op pp. 30/31.

ROELOFS, a.w., pp. 19/20. 
verwondingen het niet bedoelde en niet voorziene resultaat van die lichamelijke straf omdat de ouders niet weten of niet beseffen wat de fysieke gevolgen van geweld voor het kind kunnen zijn. Soms zijn ze het resultaat van het verliezen van de zelfbeheersing van de ouder. (...)

Weinig kinderen zullen de volwassenheid bereiken zonder door hun ouders lichamelijk gestraft te zijn."

Of ouderlijke disciplinering nu 'uit de hand loopt' door onbenul of door een gebrek aan zelfbeheersing, in beide gevallen is uiteraard bij de desbetreffende ouders sprake van een (ernstig) pedagogisch tekort. Toch moet, gezien de frequentie en dus het relatieve gemak waarmee disciplinering van kinderen in mishandeling ontaardt, het nog steeds bijna vanzelfsprekende karakter in onze cultuur van lichamelijke - en andere vernederende - straffen voor kinderen bepaald zorgwekkend worden genoemd. Deze bijzonder verontrustende en sociaal-pedagogisch schadelijke vanzelfsprekendheid kan vermoedelijk niet beter worden geïllustreerd dan door de retorische vraag aan te halen van een bekende Leidse hoogleraar in de ... mensenrechten: ${ }^{107}$

'Worden de rechten van ouders en onderwijzers niet al te sterk beknot als een kind geen enkele vernederende bestraffing mag ondergaan?"

\section{Lichamelijke verwaarlozing}

Ook hier geven we geen definitie maar een (vergelijkende) impressie van de gevolgen (BAARTMAN 1996): ${ }^{108}$

'Onderzoek naar gevolgen wan verwaarlozing heeft laten zien dat deze voor een deel anders zijn dan in geval van andere vormen van kindermishandeling. (...) Fysiek mishandelde kinderen worden over het algemeen minder aan hun lot overgelaten en moeten meer op hun hoede zijn. Wellicht dat daardoor fysiek mishandelde kinderen beter in staat zijn tot differentiatie in het onderkennen van emoties bij anderen dan verwaarloosde kinderen (...). Fysiek mishandelde kinderen hebben de neiging de schuld voor de mishandeling bij zichzelf te leggen. De onderkenning ouders te hebben die niet beschikbaar zijn, zou wel eens desastreuzer kunnen uitwerken dan de veronderstelling zelf schuldig te zijn aan het wangedrag wan ouders (...). (...) Resultaten van [longitudinaal] onderzoek (...) suggereren dat verwaarlozing ernstiger gevolgen heeft dan fysieke mishandeling. (...) Studenten die als kind verwaarloosd waren, makkten meer melding van angsten, depressiviteit, somatisering en paranoia dan studenten die fysiek mishandeld waren."

H.G. SCHERMERS, 'Lijfstraffen op school,' in: Ex Iure; Veentien opstellen bij het veertiende lustrum van Societas Iuridica GROTIUS en de vierhonderdenvijfde geboortedag van GROTIUS, Arnhem 1987, pp. 169-179, op p. 173.

108 BAARTMAN, Opvoeden kan zeer doen, a.w, pp. 88-94 ('Mishandeling en verwaarlozing'), op pp. 93/94. 


\title{
5. Sexuele kindermishandeling
}

Zoals al is opgemerkt, zullen we bij deze vorm van kindermishandeling wat uitgebreider stilstaan. Meer dan door de hausse aan recente literatuur over dit onderwerp lijkt dit gerechtvaardigd door de inzichten - ook, bij uitbreiding en doordenking, ten aanzien van de andere vormen van kindermishandeling - die deze (al lang niet meer louter feministisch georiënteerde) literatuur oplevert.

Incest, sexueel misbruik van kinderen binnen het gezin of sexuele kindermishandeling worden hier door elkaar gebruikt, ongeacht of éen van de ouders pleger is, beide ouders daders zijn (hetzij als pleger, doen pleger, medepleger of uitlokker), of één van de ouders dader en de andere ouder medeplichtige. Incest komt veelal voor in een context van affectieve verwaarlozing en ook hier is het psychotrauma het belangrijkste element. De volgende citaten kunnen een en ander verduidelijken.

\section{VAN DEN BOOGAARD: 109}

\begin{abstract}
"Essentieel voor kindermishandeling is dat het gebeurt in sociaal isolement, in de oester van het gezin, met een kind dat meestal geen mogelijkheden heeft zijn eigen behandeling te toetsen aan die in andere gezinnen. Kindermishandeling is niet die incidentele tik, een pak op je donder krijgen of de hardhandige vader in bijvoorbeeld Turkse en Marokkaanse gezinnen, die het normbesef desnoods met riem of zweep bijbrengt terwijl moeder de troostende roll speelt," aldus [Th.] SIJBESMA [arts, coördinator van het Bureau Vertrouwensartsen inzake kindermishandeling te Utrecht]. "Nee, essentieel is die enorme verlatenheid, de cenzaamheid van het kind. Dat spreekt nog het meest bij seksuele mishandeling, je wordt ten diepste aangetast en je weet niet wat het is "t". $^{\text {, }}$
\end{abstract}

\section{RITSEMA: ${ }^{110}$}

"Incest lijkt me een uiterste worm van lichamelijke en geestelijke mishandeling. Dat zou betekenen dat veel gedragingen die minder erg, maar toch nog afschuwelijk genoeg zijn, ook op het repertoire van de ouders woorkomen. Als ze voor incest al geen remmingen hebben, waarom dan wel voor schoppen, vernederen, opsluiten en bedreigen?'

\section{Nogmaals VAN DEN BOGAARD: ${ }^{111}$}

R. VAN DEN BOOGAARD, 'Ouders moeten kind niet als bezit zien; meer meldingen over mishandeling niet alleen gevolg bekendheid vertrouwensarts,' $N R C$ Handelsblad 29 augustus 1989, p. 2. 
"Het essentiële verschil tussen seksuele en andere vormen van mishandeling ligt volgens SIJBESMA wooral in de incidentie: "[E]en keer slaan overkomt bijna iedere ouder wel eens, maar je hoeft maar én keer met je dochter naar bed te gaan, en het kwaad is al aangericht"'

BAARTMAN $(1990):^{112}$

'Incestueus misbruik als een eenmalig gebeuren is van een andere orde dan lichamelijk of geestelijk geweld (verwaarlozing kan per definitie niet eenmalig zijn). Bepaalde vormen van geweld liggen nog ergens op een continuum van straffen en mishandeling en zijn als het ware vervormingen van bepaalde tamelijk algemene vormen van disciplinering. Het aanspreken van een kind echter als een seksuele partner staat volstrekt haaks op de opvoedingsrelatie, waardoor op zijn minst de vader, die de man voorheen was voor het kind, niet meer de man is die de vader daarna is voor het kind. Seksueel misbruik is naar zijn aard een breuk in de relatie opvoeder-kind."

Zowel DRAIJER als SCHOEMAKER benadrukken dat incest veelal voorkomt in een context van affectieve verwaarlozing. SCHOEMAKER: ${ }^{113}$

'In de presentatie [door incest-survivors, jw] van [psychosomatische] klachten zien we de veelzijdige en veelvuldige effecten van een onderliggend onverwerkt sexueel trauma, veelal ontstaan in een sociale context van affectieve verwaarlozing.'

\section{DRAIJER: $:^{114}$}

'De ernstiger pathologie die vrouwen laten zien, heeft valk te maken met het feit dat de seksuele mishandeling gepaard ging met affectieve verwaarlozing.'

AAN DE STEGGE laat Inge aan het woord, de dochter wier vader een omgangsregeling ${ }^{115}$ eiste met het kind dat hij bij haar had verwekt: ${ }^{116}$

112 H. BAARTMAN, 'De betekenis van het begrip psychische kindermishandeling, VKMagazine $1990 / 1$, pp. 1-4, op p. 3 l.k.

113 Beatrix SCHOEMAKER, Niet gehoord en niet gezien; Verwerking wan senuele trauma's bij vrouwen en mannen, diss. Utrecht, Amsterdam/Lisse 1991, p. 15 (curs. jw).

114 Nel DRAIJER, aangehaald door M. VAN AKEN, 'Vrouwenhulpverlening in de intramurale psychiatrie,' Slangengodin december 1989, pp. 42-44, op p. 43 l.k. Vgl. ook Nel DRAIJER, Seksuele traumatisering in de jetugd; Gevolgen op lange termijn wan seksueel misbruik van meisjes door verwanten, diss. Amsterdam 1990, pp. 263-264. Affectieve verwaarlozing was binnen de misbruikgroep min of meer een vast gegeven' (a.w., p. 264).

De (groot)vader had cassatie aangetekend tegen de bijzondere voorwaarde van het Hof Arnhem bij zijn veroordeling wegens ontucht, dat hij "gedurende twee 
'Dit soort mensen is zo slim. Ze weten precies tot hoever ze kunnen gaan met mensen die ze onder de duim hebben. Want voordat een vader zoiets kan doen met zijn kind, is daar veel aan vooraf gegaan. Een kind dat geborgenheid kent en vertrouwen, zal zijn mond opendoen als het met incest wordt geconfronteerd. Dat zal sneller naar iemand toegaan, dat is niet voortdurend bezig met zich schuldig voelen. Het is nooit in mijn hoofd opgekomen naar iemand toe te stappen. Ik was altijd op mijn hoede. Dat mijn vader raar deed, lag aan mij. Dus kon ik dat maar beter tegen niemand zeggen.'

Zijn sexuele contacten tussen ouders en kinderen alleen al door de rolverwarring en (potentiële) rolomkering 'per definitie' schadelijk ${ }^{117}$ dus nog afgezien van bijkomende fenomenen als affectieve verwaarlozing of juist 'verwenning' (corrumpering, 'prinsesjesincest ${ }^{\text {'11 }}$ ), de geheimhouding (het gezinsgeheim), manipulatie, chantage en wat dies meer zij - in hoeverre geldt dat nu ook voor sexuele contacten, binnen of buiten het gezin, met anderen dan de ouders op jonge leeftijd? ROELOFS geeft een aantal 'criteria voor schadevrije seksuele opvoeding' (lees: sexuele handelingen): ${ }^{119}$

'De volgende criteria lijken redellijk.

- De seksuele handelingen moeten binnen de belevingswereld van het kind pas-

jaar geen contact mocht zoeken met zijn dochter en haar kind.' De bloedschenmige (groot)vader achtte hierdoor zijn recht op gezinsleven met zijn (klein)kind geschonden. (Nora HOLTRUST, 'Commentaar,' Opzij september 1989, p. 25 1.k.) De cassatieschrifturur van zijn advocaat (G. SPONG) is afgedrukt in Nemesis 1989/ 4 , pp. $148-150$.

116 Jolanda AAN DE STEGGE, "Het zal je pa maar wezen", het relaas van het meisje dat een kind kreeg van haar vader,' Opzij september 1989, pp. 23-25, op p. 23 r.k. Van de huisarts kreeg Inge te horen: 'Ik kan je niet helpen want ik heb dit nog nooit eerder meegemaakt.' (T.a.p., op p. 24 1.k.) Over de advocaat van haar vader zegt Inge: 'Als een bulldozer is zijn advocaat, mr. SPONG, over me heen gedenderd.' (T.a.p., op p. 24 r.k.)

117 Zie ook BAARTMANs "Openingslezing: macht en onmacht bij incestueus misbruik van kinderen,' in: dez. e.a., Incest en hulpverlening, Amersfoort/Leuven 1990, pp. 12-22, op p. 18.

118 Zie C.K. JONKER-DE PUTTER, R.A.R. BULLENS, 'Machtsverhoudingen en seksueel geweld,' in: Atti NOORDHOF (red.), Signaten van incest, Amsterdam/Lisse 1988, pp. 11-28, op p. 21. Vgl. ook Nel DRAIJER, Sexueel misbruik van meisjes door verwanten; Een landelijk onderzoek naar de omvang, de aard, de gezinsachtergronden, de emotionele betekenis en de psychische en psychosomatische gevolgen, Den Haag 1988, pp. 132 en 135/136.

119 Gerard ROELOFS, 'Gezinstherapie,' in: Carla VAN LICHTENBURCHT e.a. (red.), Verder na incest; Hulpverlening bij het verwerken van incestervaringen, Baarn 1986 (tweede druk), pp. 70-77, op p. 77. 
sen, geen grote intensiteit hebben en geen competitie veroorzaken binnen het gezin.

- Het kind moet een gevoel van veiligheid hebben en - wanneer het dat wil zonder repercussies een einde aan de handelingen kunnen maken. Als het seksuele gedrag uitsluitend in dienst staat van de behoeftebevrediging van vader, broer, enzovoort, is dat schadelijk voor het kind.

- Vrijwillige toestemming van een kind is op zich nog niet voldoende. Het kind mag door het seksuele contact niet in problemen komen, op het moment zelf niet en ook later niet (de late gevolgen). Een verbod om erover te praten, is schadelijk. Ook schadelijk is als een kind er wel over praat, maar niet opgewassen is tegen de sterk negatieve reacties uit de buitenwereld (bijwoorbeeld op school)."

Zelfs deze zeer 'liberale' criteria (vader is bijvoorbeeld niet per definitie buiten beeld) sluiten mijns inziens elk ongelijkwaardig sexueel contact dat wil zeggen: elk contact in afhankelijkheidsverhoudingen en/of elk contact waarbij sprake is van relatief grote leeftijdsverschillen - met kinderen uit. In elke verhouding tussen jonge en oudere kinderen en (jonge) kinderen en volwassenen dient men van het rechtsvermoeden van een afhankelijkheidsverhouding uit te gaan. ${ }^{120}$

Dit brengt ons op de vraag wat nu precies - in, achter of bovenop 'het sexuele' - incest tot een bijzondere vorm van kindermishandeling maakt? In 1956 schreef CLEMENS SCHRÖNER: ${ }^{121}$

"Tot kindermishandeling zou gerekend kunnen worden sexueel wangedrag, dat uit machtswellust wordt gepleegd, zoals dikwijls geschiedt in gevallen van incest. Ofschoon dit wangedrag in vele gevallen alle elementen zou bevatten die aan kindermishandeling inhaerent geacht worden, zie ik dit soort gedragingen als een afzonderlijke categorie, omdat hierwoor een extra element, het sexuele, vereist is. Vanwege de zeer speciale problematiek hiervan laat ik dit wangedrag in deze studie buiten beschouwing."

Ruim een generatie later, in de tweede helft van de tachtiger jaren, is er over zowel de gemeenschappelijke als de specifieke aspecten van incest in relatie tot andere vormen van kindermishandeling iets meer bekend. We halen - ten behoeve in het bijzonder van de uitsluitend juridisch geschoolde lezer - uitgebreid JONKER-DE PUTTER en BULLENS (1988) aan: $^{122}$

120 Vgl. ook Diana E.H. RUSSELL, The secret trauma; Incest in the lives of girls and women, New York 1986, Ch. 3 ('Can incest be nonabusive?'), pp. 38-55, op p. 55.

121. CLEMENS SCHRÖNER, Psychische kindemishandeling, a.w., p. 9.

122 C.K. JONKER-DE PUTTER, R.A.R. BULLENS, 'Machtswerhoudingen en seksueel geweld, in: Signalen van incest, a.w., op pp. 21-25 (curs. jw). 


\section{"Macht en afhankelijkheid in het gezin}

Ouders hebben het opwoedingsgezag. Kinderen worden geboren in een staat van natuurlijke hulpbehoevendheid en zijn dus afhankelijk. Opvoedingsgezag dat niet gericht is op het laten verwerven van autonomie door het kind, verwordt tot macht. Macht die gaat stollen, die er is om zichzelfs wil: machtsmisbruik. Een kind dat daarmee te maken krijgt, zal afhankelijk blijven: afhankelijk van zijn/ haar afhankelijkheid. Men zou dit een onderworpen kind kunnen noemen: er is geen keuze-vrijheid meer om te bepalen wat je zelf wilt.

De incestdader is in onwoldoende mate gericht op de ontwikkeling van een kind. Hij opereert voornamelijk vanuit zijn eigen behoeften, dringt deze op aan het kind. Het kind wordt zodoende opgezadeld met volwassen seksuele wensen, waar het qua ontwikkeling totaal nog niet aan toe is. Binnen de incestueuze relatie wordt het kind op ontoelaatbare wijze overprikkeld met niet fasetypische seksuele impulsen van buitenaf. In seksueel opzicht worden deze kinderen nood-rijp gemaakt, hetgeen niet verward mag worden met vroeg-rijp. Aan de fasespecifieke sociaal-emotionele ontwikkeling, zoals het onbekommerd allerlei ervaringen kunnen opdoen in sociale contacten met leeftijdsgenootjes, komen deze kinderen dan ook nauwelijks toe. (...)

Vanuit een pedagogisch perspectief gezien, zal duidelijk zijn dat incestslachtoffers een ernstige verstoring in de opbouw van hun emotionele ontwikkeling kunnen doormaken. Deze verstoring kan levenslang durende gevolgen hebben voor het persoonlijke en relationele functioneren. Ogenschijnlijk adequat functionerende volwassen slachtoffers krijgen vroeger of later te maken met het grote ontwikkelingsgat uit hun kindertijd: een verstoorde en/of gestagneerde ontwikkeling. Enerzijds doordat ze niet onbekommerd kind konden zijn en anderzijds door het feit dat ze al zo vroeg allerlei volwassen emoties moesten tonen en/of doormaken.

Naast de bekende gevoelens van schuld en schamte kunnen slachtoffers zich ook bewust worden van het overtrokken verantwoordelijkheidsgevoel, de grote mate van onzekerheid en het lage zelfbeeld, welke alle een belangrijke rol in hun emotionele huishouding spelen. Iemand die door een machtiger persoon wordt belaagd, probeert zich in te leven in de persoon van zijn tegenstander, teneinde een verklaring te vinden voor de aanwallen en tevens een strategie hiertegen te ontwikkelen. Dat inleven in de persoon van de tegenstander kan leiden tot identificatie met de agressor (....).

Een volwassene kan deze daderidentificatie in therapie kwijtraken, maar een kind neemt tijdens de groei de daderidentificatie op in haar of zijn eigen persoonlijkheid (...) [het misbruik gaat in elke hersencel zitten, jw]. Een kind staat open voor allerlei indrukken van buitenaf, kan minder differentiëren en zichzelf afgrenzen. De misleiding waaraan een misbruikt en mishandeld kind zelf was onderworpen, kan zij of hij later op anderen toepassen, intussen bij herhaling zelf aan nieuwe misleiding ten prooi vallend. Dit patroon wordt uitstekend zichtbaar in de film "The last Emperor," waarin de effecten van psychische kindermishandeling op beklemmende wijze zijn uitgebeeld. Verschillende keren zegt de misleide kind-keizer: "You are liars, all of you." (...)"

\section{'De pathologie van de venweverheid'}

Geweldpleging betekent grensoverschrijding bij het slachtoffer. In het geval van incest komt daarbij als uiterste grensoverschrijding de seksuele mishandeling, die 
in de meeste gevallen geschiedt door één of meer mannen die deel uitmaken van de leefsfeer van de kinderen.

Kenmerkend voor incestgezinnen is daarnaast het ontbreken van duidelijke grenzen tussen de gezinsleden onderling. We noemen dit de pathologie van de verwevenheid, waarbij het woord pathologie de mate van rigiditeit (stolling) van het verschijnsel "grenzeloosheid" aangeefit. Vaak gaat het om kluwengezinnen, die nauwelijks de individuatie-processen toelaten die nodig zijn voor de verdere uitgroei van de persoon (...).

Paradoxaal gesproken zijn genoemde kluwengezinnen tegelijkertijd ook los-zandgezinnen vanwege het grote geheim, dat als een splijtzwam tussen de gezinsleden onderling fungeert. In de meeste incestgezinnen is de communicatie verstoord geraakt. De incestdader heeft er zo'n groot belang bij dat zijn geheim bewaard blift, dat hij met alle macht gaat beinvloeden wat er gezegd en verzwegen wordt. Hij construeert een kader van misleidingen. Hij drijft een wig tussen de moeder en haar kind. (...)

Terugkomend op het kluwenachtige van de incestgezinnen, zou dat in pedagogische termen vertaald het volgende beeld kunnen opleveren: het ontbreekt de betrokkenen aan voldoende mate van eigenheid. Grenzen zijn vervaagd. Het kind kan geen rechten doen gelden op iets eigens. Zelfs op de wc en op de badkamer is zij dikwijls niet veilig. De dader overschrijdt ook haar grenzen voor lief-zijn.

Het grenzeloos kluwenachtige en los-zand-achtige worden weerspiegeld in het kind zelf. Men kan zich nauwelijks voorstellen in welke mate een verkracht kind in de intimiteit van haar verkrachter wordt ingezogen, met hem versmelt tot éen persoon, hoezeer ze hem ook haat of van hem walgt. Tegelijkertijd wordt ze door hem afgewezen als persoonlijkheid. Dat proces verloopt razendsnel, is in enkele seconden voltooid. Het maakt dat de gebeurtenis in haar hersens gekerfd staat en dat zij haar verkrachter moeilijk van zich af kan schudden.'

De auteurs spraken over de 'nood-rijpheid' van het kind. Al in 1933 bracht FERENCZI de pseudo- of nood-volwassenheid die het gevolg is van de beschadiging van de persoonswording, als volgt onder woorden: ${ }^{123}$

'Het seksueel geschonden kind kan onder druk van zijn traumatische nood plotseling alle toekomstige vermogens tot ontwikkeling brengen die in aanleg in hem aanwezig zijn (...), alsmede alle gevoelens van een volwassen persoon. Hier kan men gerust spreken van traumatische (pathologische) progressie of vroegrijpheid, als tegendeel van het bekende begrip regressie. De gedachte dringt zich op aan het snelle rijp en zoet worden van vruchten die door de snavel van een vogel beschadigd zijn, of aan de vroegrijpheid van wormstekig ooft. Een shock kan tot gevolg hebben dat een deel van de persoonlijkheid plotseling tot wasdom komt, niet slechts emotioneel maar ook intellectueel. (...) Angst voor de ongeremde en daardoor zo goed als krankzinnige volwassene maakt van het kind als het ware

123 Sandor FERENCZI, 'Spraakverwarring tussen de volwassenen en het kind (De taal van de tederheid en die van de hartstocht) [1933], in: J.M. MAsson, Traumatische ervaring of fantasie; FREUDs rampzalige herziening van de verleidingstheorie, Amsterdam 1984, Appendix 2, pp. 182-193, op p. 191 (curs. overgenomen). 
een psychiater; en om dat te worden en zich te beschermen tegen de gevaren die uitgaam van mensen zonder zelfbeheersing, moet het eerst weten hoe het zich volledig met hen kan vereenzelvigen. Het is schier ongelooflijk hoeveel wij eigenlijk van onze wijze kinderen, de neurotici, kunnen leren."

De 'ontdekking' van sexuele kindermishandeling wordt wel toegeschreven aan FREUD, ${ }^{124}$ die honderd jaar geleden, in 1896 , schreef: ${ }^{125}$

[V]eel talrijker [zijn de] gevallen waarin een volwassene die het kind verzorgt (...) helaas maar al te vaak (...) een naaste bloedverwant [voetnoot: In een brief aan FLIESS ((...) uit 1897) maakt FREUD melding van het feit dat bij vrouwelijke patiënten altijd de vader als verleider figureert. (...)] - het kind in het seksuele verkeer inwijdde en er een werkellijke - ook in psychisch opzicht ontwikkelde liefdeswerhouding mee onderhield, vaak jarenlang. (...)

Van personen die niet aarzelen hun seksuele behoeften aan kinderen te bevredigen, kan men niet verwachten dat zij zich druk zullen maken om nuances in de wijze waarop die bevrediging haar beslag krijgt (...). Alle merkwaardige omstandigheden waaronder het ongelijke paar zijn liefdesrelatie onderhoudt - enerzijds de volwassene die zich niet kan onttrekken aan zijn deel in de wederzijdse afhankelijkheid zoals een seksuele relatie die noodzakelijkerwijs schept, maar die tegelijkertijd is toegerust met alle autoriteit en het recht tot kastijding, en terwille van de ongeremde bevrediging van zijn grillen de ene rol met de andere afwisselt; anderzijds het kind dat in zijn hulpeloosheid aan deze willekeur is overgeleverd, voortijdig tot alle mogelijke gevoeligheden wordt gewekt en aan alle mogelijke teleurstellingen blootgesteld, en dat bij het uitwoeren van de hem opgedragen seksuele handelingen vaak wordt onderbroken door zijn gebrekkige beheersing

124 Overigens niet (geheel) terecht. DRAIJER vermeldt in haar dissertatie dle (voor-) studies van TOULMOUCHE (1856), TARDIEU (1860), BERNARD (1886), JANET $(1889,1893)$ en BREUER en FREUD (1893-1895). Wel zijn de laatsten (BREUER en FREUD) de eersten die een psychologische theorie formuleerden over de psychopathologische invloed van traumata en de relatie legden tussen incestervaringen en psychosomatische klachten ('hysterie'): Nel DRAUER, Seksuele traumatisering in de jeugd; Gevolgen op lange temijn wan seksueel misbruik van meisjes door verwanten, ac. diss. Amsterdam 1990, resp. pp. 21-22, 46 en 63/64.

Alice MILLER, die zich in Gij zult niet merken (1981, vert. 1983) nadrukkelijk distantieert van FREUDs latere driftheorie (1897/1906), draagt niettemin haar boek aan FREUD op (in 1981 viel FREuDs 125e geboortedag). Zij schrijft: "Aan zijn ontdekking van de geschiedenis van de kindertijd die leeft in het onbewuste van de volwassene, en aan die van het fenomeen van de verdringing dank ik mijn instrumentarium, dat niet weg te denken is uit mijn wijze van zoeken en vragen.' (A.w. p. 7 i.f.)

125 Sigmund FREUD, Over de etiologie van de hysterie (1896), Sigmund FREUD; Nederlandse editie, Klinische beschouwingen I, Meppel/Amsterdam 1985, resp. pp. 31 en 38-39. Vgl. over deze ontdekking (de verleidings- ofwel incesttraumatheorie) en FREUDs snelle herroeping ervan (de slok van de Lethe): MILLER, Gij zult niet merken, a.w., pp. 114-125. 
van de natuurlijke behoeften [FREUD heeft het over kinderen wanaf drie, vier of zelfs twee jaar; vgl. a.w., p. 35 i.f., jw] - al deze groteske maar niet minder tragische wanverhoudingen komen bij de verdere ontwikkeling van het individu en van zijn neurose tot uitdrukking in een enorm aantal blijvende effecten, die grondig onderzock zouden verdienen."

\section{Child sexual abuse accommodation syndrome}

Terug naar de onderzoeksbevindingen van eind tachtiger jaren van de twintigste eeuw. Bij DE JONG (1987) lezen we (en ook hier zij ten behoeve van de uitsluitend juridisch geschoolde lezer een tamelijk omvangrijk citaat toegestaan): ${ }^{.26}$

'Een kind reageert sterk op zijn directe omgeving en moet dat ook wel, want het is in de meest primaire levensbehoeften van deze omgeving afhankelijk. Deze afhankelijkheid brengt voor het kind mee dat het altijd kwetsbaar is. Het moet maar afwachten of anderen op een integere wijze met deze kwetsbaarheid omgaan. Voeding, veiligheid, wrijheid en liefde zijn ingrediënten waarmee deze afhankelijkheid en kwetsbaarbeid kunnen worden omgezet in zelfstandigheid en onschendbaarheid. Een kind moet zich voortdurend aanpassen aan de situatie die door zijn ouders of verzorgers wordt gecreëerd. (...)

Seksueel misbruik binnen het gezin is meestal niet een eenmalige gebeurtenis. Vaak worden de grenzen op seksueel gebied door de pleger steeds verder verlegd en telkens volgen opnieuw intimidatie, alkopen met cadeautjes en dreigen met geweld. Voor het slachtoffer is er maar én manier om te overleven en dat is niet alleen te accepteren, maar ook actief erbij betrokken te raken. Alleen op deze wijze krijgt het slachtoffer aandacht en affectie. Het is een subtiel spel van in de val lopen en niet meer terug kunnen. (...)

Het kind heeft vreemd genoeg de macht om het gezin te vernietigen, maar ook de verantwoordelijkheid om het gezin bij elkaar te houden, en het nemen van deze verantwoordelijkheid betekent dat het kind zich altruïstisch op zal moeten stellen en veel wan moeders rol over zal moeten nemen. Het kind loopt ook in deze val en zal zich moeten aanpassen om ermee te kunnen leven. Deze fase kan heel wat jaren duren en meestal begint hier pas in de puberteit verandering in te komen.

In de puberteit komt het slachtoffer in verzet tegen de macht van vader en ontslaat de wens een eigen leven te gaan leiden. Het gedrag op basis van de overlevingsmechanismen geeft veelvuldig ruzie en conflicten. De angst bij de pleger dat het geheim wordt verteld, neemt toe en de dreiging met geweld wordt groter. Dit kan tot gevolg hebben dat de boosheid en de wil om uit de dwangbuis van overmacht te ontsnappen, het slachtoffer ertoe brengen met het geheim naar buiten te treden. Dit grote geheim pas na zovele jaren en in zo'n conflictueuze gezinssituatie vertellen, komt niet erg overtuigend over. De buitenwereld zal geneigd

126 Willem N. DE JONG, 'Seksueel misbruik van kinderen binnen het gezin: werken aan de crisis," in: Gerben BRUINSMA e.a. (red.), Vrouw en criminaliteit; Vrouwen als plegers en slachtoffers van criminaliteit, Meppel/Amsterdam 1987, pp. 128-140, op pp. $135-136$ (curs. jw). 
zijn begrip te tonen voor de ouders, die bet zo moeilijk hebben met hun rebellerende dochter. Zoals we al eerder hebben gezien, wordt het acting out-gedrag van het slachtoffer vaak als afwijkend gezien in plaats van als normaal [namelijk als signaal, jw] voor die situatie. Het moment om het geheim te verklappen, had niet ongelukkiger gekozen kunnen worden! Deze reactie van de omgeving doet het slachtoffer begrijpen dat er buiten het gezin geen steun te verwachten valt, zij raakt in de war en gaat twijfelen.

In de chaos na het vertellen van het geheim is er bij het slachtoffer een mengeling van boosheid, schuldgevoel en verwarrende verantwoordelijkheidsgevoelens. Alles wat voorspeld was, dreigt uit te komen: vader noemt haar een leugenaar en laat haar vallen, moeder gelooft haar niet, raakt in paniek en wordt woedend, het gezin dreigt uit elkaar te vallen en jongere broertjes en zusjes worden bedreigd in hun veiligheid. Opnieuw draagt het slachtoffer de verantwoording voor het vernietigen of het sparen van het gezin. Ambivalente schuldgevoelens en de reactie van de omgeving doen haar besluiten haar uitspraken te verzachten of ongedaan te maken. Het slachtoffer trekt zich al of niet terug in de relatieve veiligheid van het gezin en wordt zo voor de tweede keer slachtoffer. Deze vijf voor seksueel misbruik typische reacties: geheimhouding, hulpeloosheid, in de val zitten en aanpassing, het late naar buiten treden met het geheim op een conflictueuze, niet overtuigende manier en terugtrekking van verklaringen, worden door SuMMrT tezamen het "Child Sexual Abuse Accommodation Syndrome" genoemd (...)."

\title{
Even daarvoor merkte de auteur op: ${ }^{127}$
}

\begin{abstract}
"Seksueel misbruik lijkt een worm van mishandeling te zijn waarin alle andere vormen zijn wervat: een soort uiterste, het laatste taboe, het faillissement van het gezin en een bedreiging voor de samenleving. De reactie hierop is ondoordacht, onbeheerst en hard. Het moet een gezinsgeheim blijven en er mag niet over worden gepraat. Het is juist daarom dat slachtoffers zo vroeg slachtoffertjes worden en wo lang slachtoffer blijven [immers: hoe vroeger het misbruik begint, hoe totaler de macht van de pleger over het kind is en blijft, jw]. Er is een blokkade voor het opvangen van signalen die het slachtoffer uitzendt. Zelfs binnen het gezin worden de signalen niet opgevangen (conflictwermijding). De samenleving reageert zoals een moeder in een conflictvermijdend gezin reageert en beïnvloedt zo de aard, de ernst en de duur van het seksuele misbruik!'
\end{abstract}

De samenleving als conflictvermijdende moeder, die haar kind in vredesnaam opoffert: daarvan lijkt niet alleen bij incest sprake ....

\section{Definities van sexueel misbruik}

We geven thans enkele definities van sexueel misbruik weer. De definitie uit het bekende onderzoek van DRAIJER (1988) luidt: ${ }^{128}$ 
'Onder seksueel misbruik van meisjes door verwanten verstaan we:

seksuele contacten van familieleden of huisgenoten met een meisje onder de 16 jaar, die plaatsvinden tegen haar zin, of zonder dat zij - als gevolg van lichamelijk of relationeel overwicht, emotionele druk, of van dwang of geweld - het gevoel heeft (gehad) de seksuele contacten te kunnen weigeren.

Onder "seksuele contacten" verstaan we alle daadwerkelijke seksuele aanrakingen - van het aanraken of doen aanraken van borsten en genitaliēn, kussen met seksuele bedoelingen tot en met geslachtsgemeenschap (vaginaal, oraal of rectaal, of het binnendringen met voorwerpen of vingers, vaginaal of rectaal). Niet onder deze definitie vallen het aandringen op seksueel contact of het vertonen of doen vertonen van genitaliën.

Onder "verwanten" verstaan we het sociale verband wan familieleden of personen die de rol van familieleden vervullen. Dat wil zeggen dat de term verwanten niet in de strikte biologische zin van "bloedverwanten" gebruikt wordt, maar in de emotionele en sociale betekenis.'

De definitie van haar Amerikaanse "voorgangster"129 RUSSELL (1986) luidt: ${ }^{130}$

'The definition of incestuous abuse in our survey was any kind of exploitive sexual contact or attempted contact that occurred between relatives, no matter how distant the relationship, before the victim turned eighteen years old. Experiences involving sexual contact with a relative that were wanted and with a peer were regarded as nonexploitive and hence nonabusive.'

'A peer relationship was defined as one in which the age difference between the participants was less than five years.'

Uiteraard hangen de gehanteerde definities ten nauwste samen met de 'geturfde' omvang van het verschijnsel (waarover meer in hoofdstuk 12). We laten nog twee met definities worstelende auteurs aan het woord. PLATVOET en DUBBINK (1988) schrijven: ${ }^{131}$

'Het ontbreken van een eenduidige definitie is op zichzelf niet zo verwonderlijk. De problematiek wordt, zeker als het om kinderen gaat, in verhouding tot andere sociale problemen nog maar sinds kort erkend en bestudeerd. De erkenning van het feit dat volwassenen, bewust of onbewust, ernstige schade aanrichten door het

de psychische en psychosomatische gevolgen, Ministerie van Sociale Zaken en Werkgelegenheid, Den Haag 1988, p. 70 (curs. ND).

129 Vgl. Judith Lewis HERMAN, Trauma en herstel; De gevolgen van geweld - van mishandeling thuis tot politiek geweld, Amsterdam 1993, pp. 47/48.

130 Diana E.H. RUSSELL, The secret trauma; Incest in the lives of girls and women, New York 1986, resp. pp. 41 en 59.

131 Anna PLATVOET, Anneke DUBBINK, Incest: hun zorg, jouw zorg, Orthovisies 30, Groningen 1988, pp. 15-17. 
seksueel misbruiken van een kind, is er nog maar sinds kort; het onderwerp zit bij velen nog in de taboesfeer.

Deze erkenning de nog heersende taboes en de daarmee gepaard gaande emoties ten aanzien van kindermishandeling in de vorm van incest, impliceren een zoeken naar de juiste taal en betekenissen.

(...) Bij de formulering van de door ons te gebruiken definitie stonden twee elementen, die in vrijwel alle recente omschrijvingen terug te vinden zijn, centraal. Seksuele kindermishandeling wordt steeds madrukkelijker geplaatst tegen de achtergrond van de ongelijkwaardige machtsrelatie tussen het kind en de volwassene in de gezinssituatie en er wordt in toenemende mate minder nadruk gelegd op de objectieve, concrete imformatie en meer op de subjectieve beleving van het kind zelf. We gebruiken de term "incest," "seksueel misbruik" of "seksuele mishandeling" in dit boek in de volgende betekenis. De situatie speelt zich af tussen de ouder(s), of volwassene(n) die tot het gezinswerband gerekend kan worden, en het kind, waarbij het kind zich niet in staat voelt om zich aan de gebeurtemissen te onttrekken, vanwege het fysieke en/of psychische overwicht van de volwassene. Daarbij benoemen we al die ervaringen als incest waarbij door het kind wordt aangegeven dat het er fysiek en/of psychisch onder geleden heeft."

\title{
De definitie van WOELINGA (1988) ten slotte luidt: ${ }^{132}$
}

\begin{abstract}
'Seksueel misbruik van kinderen in het gezin definiëren wij als: misbnuik van macht en van vertrowwen door een ouder gezins- of familielid ten opzichte van het kind in de vorm van seksuele handelingen of pogingen daantoe, meestal onder drik wan geheimhouding.'
\end{abstract}

\section{Reacties op (het sexuele van) sexuele kindermishandeling}

Over incest wordt al geruime tijd meer gesproken en geschreven (we zinspeelden er al enkele malen op) dan over andere vormen van kindermishandeling. Om een beeld te krijgen van het hoe en waarom van het verschil in maatschappelijke reacties op sexuele kindermishandeling enerzijds en fysieke en psychische kindermishandeling anderzijds, lichten we weer enkele passages uit de literatuur. Uit het uitgebreide aanbod kiezen we twee bespiegelingen van BAARTMAN. Om te beginnen uit VKMagazine, het tijdschrift over kindermishandeling van de VKM (de Vereniging tegen Kindermishandeling, sinds 1995 de stichting Voorkoming van Kindermishandeling): ${ }^{133}$

Heleen WOELINGA, Seksuel misbruik van kinderen in het gezin; Signalering en opvang, Meppel/Amsterdam 1988, p. 14. 


\section{'Het taboe}

(...) Minder invoelbaar zijn seksuele emoties ten opzichte van eigen kinderen, laat staan het toegeven daaraan. In het algemeen geldt dat in onze cultuur seksualiteit met veel taboes omgeven is, alle seksuele revoluties ten spijt, en dat seksualiteit in de verhouding tussen ouders en kinderen verboden gebied is. Ook de onderkenning van seksualiteitsbelevingen van kinderen is voor de meeste volwassenen een moeilije aangelegenheid, terwijl we toch in West-Europa episodes gekend hebben waarin men met seksualiteit in de verhouding tussen volwassenen en kinderen heel wat vrijmoediger omging (men leze hiervoor VAN USSELs Geschicdenis wan het seksuele probleem). (...)

Op seksualiteit in de verhouding tussen ouders en kinderen, en dan met name op geslachtsverkeer, rust in elke cultuur een zeer zwaar taboe. We kunnen gissen [naar] de herkomst van dit taboe, maar feit is dat de doorbreking ervan angst en agressie [en jaloezie? -jw] oproept. (...)

(...) ROSENFELD laat zien (...) hoe diep geworteld het verbod op seksueel verkeer tussen ouders en kinderen is, en dat hel misschien juist ook de onwrikbaarheid van deze worteling is die het ons welhaast onmogelijk maakt de gedachte onder ogen te zien dat een verbod impliciet verwijst naar de mogelijkheid van overtreding, anders gezegd, naar de mogelijkheid dat er naast daadwerkelijke overtreders ook potentiële overtreders zijn, namelijk wijzelf. (...)

Seksualiteit kent meer emoties dan alleen tederheid; het is een sluis die voor meerdere emoties de weg vrij kan maken, zoals bijwoorbeeld voor geweld en sensaties van macht. De mate waarin men in staat is te onderkennen voor zichzelf dat ook de de eigen seksualiteitsbeleving op zijn minst complexer is dan pure tederheid en intimiteit, is bepalend voor de mate waarin men in staat is om te gaan met andermans complexiteit inzake seksualiteit.'

\section{'De machisongelijkheid}

(...) Samenvattend kunnen we zeggem: in situaties van seksueel misbruik van kinderen hebben we te maken met drie patronen:

- [op maatschappelijk, structureel niveau, jw] de machtsongelijkheid tussen mannen en vrouwen;

- [op individueel, intrapsychisch niveau] miswormingen in de seksuele identiteitsontwikkeling van sommige mannen;

- [op maatschappelijk en gezinsniveau] de machtsongelijkheid tussen ouders en kinderen [het kind als bezit, als object van de emotionele en seksuele behoeften van zijn ouders/vader, jw]. (...)

$[\mathrm{H}]$ oe speelt deze machtsongelijkheid een rol? (...) Culturele opvattingen dragen er zeker toe bij dat bij sommige mannen de opvatting ontstaat dat zij slechts dàn van betekenis zijn als ze seksueel onweerstaanbaar gebleken zijn. Er hebben dan echter twee verengingen plaatsgevonden.

- De eerste verenging is die waarin de hang naar bevestiging in het seksuele de hang naar andere vormen van bevestiging overwoekerd heeft.

- De tweede verenging bestaat hierin dat de verbondenheid met een ander alleen maar beleefd kan worden - of bij uitstek gezocht wordt - in het domein van het seksuele.

Als dergelijke verengingen in de loop van een ontwikkelingsproces plaatsvinden, dan is dat het gevolg van twee factoren: 
1.) een van kindsaf gevoede onzekerheid of men er werkelijk voor een ander wel toe doet, en:

2.) de gereedliggende en vaak ook direct voorgeleefde patronen in onze maatschappij voor jongens en mannen om hun behoefte aan eigenwaarde uit te leven in hun seksueel onweerstaanbaar zijn.

Deze twee factoren vormen een patroon dat er bovendien in vele gevallen de oorzaak van kan zijn dat er een soort verslavingsproces optreedt, waardoor gegeven andere factoren - eenmaal opgetreden misbruik jaren kan blijven voortduren. (...)

De trieste werkelijkheid is dat een kind vaak jarenlang het geheim bewaart, omdat het, door zichzelf schuldig te rekenen aan het gebeuren, de illusie in stand kan houden dat het goede ouders heeft. Met een citaat van FAIRBAIRN: "Better a sinner in a world ruled by the Lord, than a saint in a world ruled by the devil."

Bij dit voortduren van het seksueel misbruik speelt met name de machtsongelijkheid tussen ouder en kind een rol: het kind is voor zijn bestaansgarantie, naarmate het jonger is, volstrekt afhankelijk van zijn bevestiging door zijn ouders.'

\section{'Sancties [de dader, jw]}

(...) Duidelijk is dat, gegeven onder meer de sterkte van de emoties die door seksueel geweld worden opgeroepen, het vinden van een evenwicht tussen [het 'compassie-model' ('begrijpen') en het 'controle-model' ('ingrijpen')] vaak moeilijker is bij seksueel misbruik dan bij fysieke mishandeling. ROSENFELD \& NEWBERGER geven in dit verband een aantal richtlijnen (...). Ze zijn van toepassing zowel voor situaties van seksueel misbruik als voor situaties van fysieke mishandeling.

a. Is het geweld/misbruik incidenteel of chronisch? (...)

b. Is er sprake van gevoelens van schuld bij de dader of niet? (...)

c. Is de positie van ouders tegenover de maatschappij geïsoleerd of niet? (...)

d. Is de ouder het kind goed of slecht gezind? (...)

e. Is de ouder in staat het kind te zien als iemand met een eigen persoonlijkheid en rechten? Hoe meer een kind een verlengstuk is van de ouder, hoe symbiotischer en diffuser de relatie met het kind, hoe meer reden voor ingrijpen.

f. Heeft de ouder een evenwichtige persoonlijkheidsstructuur? Hoe sterker en evenwichtiger de persoonlijkheidsstructuur en daarmee ook hoe beter hij/zij opgewassen is tegen stress, hoe minder reden om in te grijpen.

Uiteraard geldt dat beslissingen gebaseerd moeten zijn op elk van deze aspecten tezamen."

Naar aanleiding van een rechterlijke uitspraak in een zaak waarin door de verdediging bezwaren waren geopperd tegen de zogenaamde 'poppenmethode' bij het verhoor van kinderen, schreef BAARTMAN in De Volkskrant: ${ }^{134}$

"Het Hof in Den Haag heeft [op 30 januari 1990, jw] een man vrijgesproken die was beschuldigd van het seksueel misbruiken van een of meer van zijn kinderen, 
nadat hij eerst door de rechibank in Alkmaar en dlaarna in hoger beroep door het Hof in Amsterdam hiervoor veroordeeld was. Een deel van de bewijsvoering waarop men zich in Alkmaar en in Amsterdam heeft gebaseerd, vormde de informatie die de betrokken kinderen over het vermoede gebeuren hebben gegeven. De kinderen hebben hun verhaal gedaan in een gesprek met een orthopedagoge, die bij dit gesprek gebruik heeft gemaakt van de zogeheten anatomisch correcte poppen.

Het Hof in Den Haag heeft [zijn arrest] niet gemotiveerd en geen verband gelegd met de wijze waarop met de kinderen het gesprek is gevoerd. Niettemin wordt allerwegen de conclusie getrokken dat het Hof het gebruik van anatomisch correcte poppen heeft afgewezen. Telkenmale blijkt weer hoe hardnekkig het miswerstand is rond deze poppen. (...)

Deze poppen zijn niet meer dan een hulpmiddel bij een gesprek met een kind. (...) Het is van tweeën een. Ofwel we nemen een kind als potentiële getuige serieus en helpen het om zijn verhaal over dat wat mogelijk gebeurd is, zo eenduidig mogelijk te doen, ook als het mogelijkerwijs niet alleen getuige maar ook slachtoffer is. Ofwel we vermijden alle risico's die het luisteren naar een minder mondige getuige met zich meebrengt, en ontzeggen daarmee kinderen dus ook het recht om voor zichzelf bescherming en hulp te vragen.

Ik kan mij soms niet aan de indruk onttrekken dat een deel van de weerstand tegen het gebruik van de anatomisch correcte poppen voortkomt uit de algemene weerstand om het bestaan van incestueus misbruik van kinderen als probleem serieus te nemen. De wijze waarop de samenleving als geheel op dit probleem reageert, is zeer dubbelhartig.

Enerzijds is er de op zich niet onbegrijpelijke neiging om, wegens de verontrusling die de berichten over dit probleem oproepen, de ernst en de omvang ervan te relativeren. Nu kan relativeren op zich geen kwaad, maar soms loopt dit uit [op] bagatelliseren. Het probleem wordt dan bijwoorbeeld weggemoffeld achter termen als heksenjacht of massahysterie.

Anderzijds wordt over volwassenen die kinderen gebruiken voor hun eigen seksuele behoeften, geoordeeld als over de meest abjecte mensensoort. In deze incriminerende benadering, waarin het moreel verwerpelijke van het gedrag de boventoon voert, lijkt het seksucel misbruik maken van een kind van een heel andere orde te zijn dan andere, eveneens bijzonder schadelijke manieren van omgaan met een kind, zoals ernstige verwaarlozing, dagelijks grof lichamelijk geweld of dagelijkse vernederingen.

Overspannen behoeften aan respect, aan macht, aan gezag, overtrokken angst het kind niet meer de baas te kunnen, of weerstand om voor een kind beschikbaar te moeten zijn, kunnen ouders ertoe brengen dat ze stelselmatig geweld gebruiken of stelselmatig een kind verwerpen.

We hebben intussen geleerd om de mogelijkheid van geweld of verwaarlozing in te passen in onze beelden over opvoeden. We hebben er ook ruimschoots de tijd voor gehad. In vergelijking met geweld en verwaarlozing zijn de verhalen over incestueus misbruik nog betrekkelijk nieuw. Toch zullen we ook onder ogen moeten zien, dat ouder-kind-relaties evenzeer vertroebeld kunnen worden door seksuele behoeften van ouders.

Dit lukt alleen maar als we ons willen realiseren, dat ouder zijn en volwassen zijn geenszins identiek hoeven te zijn. En als er één domein is waarin kinderlijkheid 
en onvolwassenheid van volwassenen zichtbaar worden, ook of soms juist in hun omgang met kinderen, dan is dat het domein van de seksualiteit.

Zolang we er niet in slagen ook deze vertroebeling van de betrekking van een ouder tot zijn kind als een reële mogelijkheid onder ogen te zien, zolang zal, denk ik, geen middel deugen om een kind dat intussen wel van deze mogelijkheid weet heeft, zijn verhaal te laten doen.'

\title{
11.2.2.4 Pedagogisch besef
}

In het voorafgaande zijn de vijf vormen van kindermishandeling verre van gedetailleerd, doch al evenmin systematisch of zelfs maar schematisch, in kaart gebracht. Met behulp van verschillende gidsen is slechts gepoogd een aantal markante punten in het - zeer brede - landschap te belichten. Dit tegen de achtergrond van de idee van het niet verwerkte psychotrauma als oorzaak van een pedagogisch tekort en het pedagogisch tekort als (potentiële) oorzaak van nieuwe psychotrauma's. Met andere woorden tegen de achtergrond van een zo al niet op individueel en gezinsniveau dan doch in elk geval in collectieve en maatschappelijke zin cyclisch proces, een proces dat - zolang het niet door het serieus nemen van de (kern)rechten van het kind doorbroken wordt - zichzelf in stand houdt. In Amerika wordt dit cyclisch proces wel aangeduid met het acroniem WAR: the World of Abnormal Rearing.

Over deze WAR schrijft HELFER, de 'uitvinder' ervan, althans degene die het acroniem heeft geïntroduceerd: ${ }^{135}$

\begin{abstract}
"A few years ago the concept of the "world of abnormal rearing" (WAR) was proposed [HELFER 1974]. This was devised in order to better understand what occurs when one's childhood does not provide a very favorable environment in which to learn basic interpersonal skills. Adults who are victims of the WAR, truly have "missed out on childhood," that is, missed learning many of those basic skills necessary to interact with others. (...) Referring to WAR children or adults from the WAR, does not imply that all, or even most, were physically beaten. For every adult who was actually beaten as a child, there are probably scores who look back at their childhoods and say, "I wasn"t beaten [too badly, jw], but it was really a bad experience." Some WAR children are beaten, some are sexually molested, others are ignored, some are belittled, some find themselves so controlled that they cannot function outside of their homes, and so on. This WAR is hell, no matter how it manifests itself. (...) This WAR is a never-ending cycle, passing from one generation to another.'
\end{abstract}

135 Ray E. HELFER, 'The developmentall basis of child abuse and neglect: an epidemiological approach,' in: dez. en Ruth S. KEMPE (eds.), The battered child, Chicago/London 1988 (vierde druk), pp. 60-80, op pp. 70-71. 
We keren thans nog eenmaal kort naar het aspect van het pedagogisch tekort, het ouderlijk tekort aan pedagogisch besef (waarvan we aan het begin van dit hoofdstuk spraken), terug. In Opvoeden kan zeer doen komt BAARTMAN, na BELSKY's ecologische verklaringsmodel (uit 1984) te hebben behandeld, tot de volgende slotsom: ${ }^{136}$

'BELSKY's ecologische verklaringsmodel laat zien dat contextuele factoren [de partnerrelatie, het sociaal netwerk, werk, kindkenmerken, $j w]$ weliswaar van invloed zijn op het handelen van opvoeders maar dat kenmerken van de ouders [de persoonlijkheid als resultante van de eigen ontwikkelingsgeschiedenis, jw] werken als een filter waar deze invloeden doorheen moeten. Daarnaast maakt het duidelijk dat deze factoren mede een product van die kenmerken zijn.'

Aan BELSKY's model voegt BAARTMAN vervolgens de dimensie 'pedagogisch besef' toe. Binnen deze dimensie komt de pedagogische ouder-kindrelatie als het ware in een transgenerationeel perspectief te staan. Immers: $:^{137}$

'In wezen (...) gaat het (...) om ouders die niet geslaagd zijn in een rouwproces. (...) [B]enadrukt [moet worden] dat het niet slagen in de emotionele verwerking van traumatische ervaringen in de jeugd ouders parten speelt in hun relatie met hun kind.'

In navolging van KOHLBERGs theorie over morele (ontwikkelings)niveaus onderscheidt NEWBERGER verschillende niveaus van pedagogisch besef. BAARTMAN geeft deze niveaus als volgt weer: ${ }^{138}$

"Het eerste is het niveau van de "egocentrische oriëntatie." "De ouder ziet het kind als een projectie van zijn eigen ervaringen en geeft zijn rol als ouder gestalte louter op basis van zijn eigen wensen en behoeften."

Het tweede niveau is dat van de "conventionele oriëntatie." "Het kind wordt begrepen op basis van algemene opvattingen over kinderen en op basis van algemene verklaringen van hun gedrag, welke stoelen op argumenten van traditie, cultuur of gezag."

Het derde niveau duidt [NEWBERGER] aan als een "subjectief-individualistische oriëntatie." "De ouder heeft oog voor de uniciteit van het kind en begrijpt diens gedrag binnen de context van de eigen relatie met het kind. De ouderrol krijgt

136 Opvoeden kan zeer doen, a.w., p. 43.

137 Opvoeden kan zeer doen, a.w., p. 160.

138 Opwoeden kan zeer doen, a.w., p. 50.

Vgl. ook (met voorbeelden) Peggy S. PEARL, "Emotional abuse," in: A.E. BRoDEUR, J.A. MONTELEONE, Child maltreatment; [vol. 1] A clinical guide and reference, St. Louis (etc.) 1994, pp. 259-283, op pp. 271-272 (Table 15-13). 
gestalte op basis van het zicht hebben op en het tegemoet komen aan de behoeften van het kind."

Het vierde niveau tenslotte is dat van een "interactieve orientatie." "De ouder begrijpt het kind als een complex en veranderend psychologisch zelf. Ouder en kind groeien beiden in hun rol, en de ouder onderkent dat relatie en rol niet alleen gebaseerd zijn op het voldoen aan de behoeften van het kind maar ook op het zoeken naar een evenwicht tussen het op verantwoorde wijze honoreren van de eigen behoeften en die van het kind".'

We zouden thans kunnen concluderen: in een adequate definitie van kindermishandeling zou de persoon van de ouder, dat wil zeggen: diens pedagogisch besef, een cruciaal element dienen te zijn. Is die persoon dat wil zeggen: is de persoonlijkheid van de ouder en daarmee (grosso modo) diens pedagogisch besef - voldoende ontwikkeld, zodat zij als buffer functioneert in geval van stress of frustraties, of is die persoon in zijn eigen ontwikkelingstaken geblokkeerd, zodat reeds bij geringe stress of (nieuwe) frustraties het kind de dupe, het kind van de rekening van het kind in de ouder - anders gezegd: het kind van de transgenerationele rekening - wordt? ${ }^{139}$

Hoewel we hier niet zullen proberen een dergelijke adequate definitie (adequaat vanuit het oogpunt van staatsaansprakelijkheid/staatsverantwoordelijkheden) van kindermishandeling te formuleren, laten we een en ander wel uitmonden in de vraag naar de juridische betekenis van de relatie tussen enerzijds het recht van het kind op (minimale c.q. optimale) persoonswording en anderzijds te kort schietend (c.q. een te laag niveau van) ouderlijk pedagogisch besef als sequeel van een tekort in de persoonswording van de ouder. Voor we nader op deze (juridiserings-) vraag ingaan, stellen we eerst een benadering van kindermishandeling aan de orde die goede perspectieven lijkt te bieden voor de operationalisering van het recht van het kind op minimale persoonswording, opgevat als lijst van criteria van schendingen of beschadigingen van minimale rationaliteit, moraliteit en authenticiteit, en als zodanig als lijst van criteria voor gezinsinterventie.

De ontwikkelingspsychopathologische benadering van BARNETT c.s.

In het voorafgaande hebben we uitgebreid stilgestaan bij definiëring en definities van kindermishandeling, per variant of subtype. We hebben opgemerkt dat en gezien hoe het publiekrechtelijk ouderschapslibertinisme

Vgl. Opvoeden kan zeer doen, a.w., pp. 31, 37, 44 e.v., 85-86, 110, 115, 137-138, 140,150 en 160. 
in combinatie met de onverbiddelijke pedagogische en juridische logica van nemo plus- en nemo ultra-regel tot ernstige en structurele schending van het recht van het kind op minimale c.q. optimale persoonswording leidt. Schending van het recht van het kind op minimale persoonswording is, zo concludeerden we in hoofdstuk 10 , schending van het fundament van (kern)inhoud en betekenis - van art. 3 EVRM, het dwingendrechtelijke verbod van (het structureel in stand houden en laten voortbestaan van) onmenselijke en mensonwaardige behandeling.

Het maltraiteren van kinderen, emotioneel, fysiek en/of sexueel, door doen of nalaten van ouders - libertinistisch ${ }^{140}$ aan hun transgenerationele lot overgelaten door staat en maatschappij - zullen we thans herdefiniëren als schending van het recht van het kind op minimale persoonswording. Strekking (in de zin van causa finalis) van dit recht is: de operationalisering van de rechtsplicht van de staat (door zijn organen en in samenwerking met bijzondere instellingen uit te oefenen) tot interventie in het gezin, met andere woorden: de formulering van criteria voor het opleggen van hulp aan kind en gezin in pedagogische nood.

Een dergelijke operationalisering is het antwoord, of liever het begin van een antwoord, vanuit de erkenning van de inherente menselijke waardigheid en de gelijke en onvervreemdbare rechten van het kind, op het historische onrecht van het prijsgeven van kinderen aan ouderlijke onmacht en almacht. Aan het einde van de twintigste eeuw zijn we aanbeland bij het keerpunt in de geschiedenis van het menselijk lijden, het lijden van kinderen en ouders, dat er geen excuus meer is in de trant van 'we wisten het niet, en al hadden we het geweten, wat hadden we in Gods naam kunnen doen?' Een volgende generatie mag over deze niet boekstaven: 'Sie haben schrecklich viel geschrieben, aber sie haben nichts getan.'

Bij die operationalisering gaat het erom, per subtype van kindermishandeling, zo concreet mogelijk de vormen van ouderlijk (wan)gedrag te benoemen, bij voorkeur gerubriceerd naar de mate van schadelijkheid voor de ontwikkeling van het kind. Gerubriceerd, met andere woorden, naar de graad van gevaar voor het ontstaan van ontwikkelingspsychopathologie. Een zodanige graduele classificatie doet immers direct in het oog springen niet alleen dàt er een alarmfase is ingetreden, maar ook welke alarmfase is ingetreden. Zodat onverwijld adequate hulp aan kind

140 Onder libertinisme zij (in algemene zin) te verstaan: een (negatief en positie) vrijheidsdenken dat weinig of niets op heeft of van doen heeft met gelijkheid en solidariteit en veel, zo niet alles, met het recht van de (sociaal-economisch en/of sociaal-emotioneel) sterkste. 
en gezin kan worden aangeboden (zo dat nog niet was geschied), en desnoods kan worden opgelegd.

De hier bedoelde ontwikkelingspsychopathologische benadering en classificatie vinden we bij BARNETT c.s.

\section{Striking a balance}

BARNETT, MANLY en CICCHETTI merken op: ${ }^{141}$

'In prior centuries, the law grouped children with other parental possessions. Under this condition, public interference into parenting violated the right to manage private property.

Current opposition to governmental definitions and policies to combat child abuse and neglect continues over whether the government has the right to dictate parenting practices. Albert SOLNIT (...), for example, warned that few would elect to live in a community where parental infractions were broadly defined and strictly enforced. In fact, the novelist Kurt vONNEGUT (...) has satirized one such society. In the futuristic society portrayed by vONNEGUT in one of his short stories, children routinely sue their parents for what the children perceive to be their parents' shortcomings. In reality, however, no democracy represents either extreme. Striking a balance along this continuum of public jurisdiction over parenting represents a continual challenge to the modern world.'

Het behoeft geen betoog dat bij het streven naar een dergelijk evenwicht een genuanceerde en tegelijk zo eenduidig mogelijke omschrijving van (vormen en graden) van kindermishandeling cruciaal is. De auteurs staan in dit verband een integratieve benadering voor, een benadering die de sterke elementen van diverse theorieën en onderzoeksbevindingen incorporeert. Daarbij mag het doel van de definitie (hierboven als causa finalis aangeduid) niet uit het oog worden verloren. ${ }^{142}$ De auteurs stellen: ${ }^{143}$

"Although some have argued that mo single definition can meet all purposes (...), we believe that consensus may be reached by concentrating on the shared underlying purposes across disciplines. Common to each aim is the affirmative goal of promoting children's physical and psychological well-being through the identification and eradication of detrimental childrearing practice, and the promotion of supportive, sensitive parenting.'

Douglas BARNETT, Jody Todd MANLY, Dante CICCHETT, "Defining child maltreatment: the interface between policy and research," in: Dante CICCHETT; Sheree L. TOTH (eds.), Child abuse, child development, and social policy, Advances in applied developmental psychology, wol. 8, Norwood, New Jersey 1993, pp. 7-73, op p. 13 . 
De auteurs vervolgen: $:^{144}$

"We place our multisystems, integrated approach to definition within a developmental psychopathology perspective (..). Developmental psychopathology is a broad macroparadigm whose tenets include a recognition for the necessity of multiple perspectives, including cross-culturall and multidisciplinary work (...). (...) Consummate to understanding the multifaceted nature of the causes and consequences of maltreatment is the recognition of the developmental aspects of child abuse and neglect. Each of the components inwolved in child maltreatment, the enviromment, the parent, and the child, are transacting over time (...). Because more is known about child development than about adult and environmental development, ontological factors influencing maltreatment become most readily apparent when considering the child's contribution. For example, we know that children"s needs change as they mature. The need for autonomy expresses itself differently for a toddler than for a school-aged child or for an adolescent. The same is true of other child needs such as those for attachment, acceptance, and positive regard. As these developmental child needs change, so must parental supports. Caregivers must be able to adapt to the growth of their children. And in this sense, the parental acts that are judged to be unacceptable by society change as a function of the child's age. Moreover, the types of parental acts that can enhance development, or that can result in psychollogical harm to children, also change over the course of development. (...) Consequently, parental acts must be viewed within the context of particular concerns at specific developmental stages (...). (...)

In addition, the consequences of child maltreatment manifest themselves differently according to the child's developmental level. Consequently, the criteria for documenting psychological harm will necessarily vary with the age of the child. (...) [T] mental issues that are most salient at the time of assessment. For example, attachment in infancy, self- and language development in toddlerhood, and peer relations in middle childhood represent the central emotional and social tasks that children must master during the developmental course. Child abuse and neglect have been shown to undermine the negotiation of these stage salient issues (...).

In addition to the child component, each of the elements in the systemic picture of maltreatment is constantly in flux. We have already noted that parental acts have to change in accord with the child's growth. In addition, parents are developing cognitively, socially, and emotionally (...). Moreover, the family system is constantly in transition as new siblings are born, and as parental relationships and supports change (...). Finally, the extrafamilial environment also should not be viewed as static, since neighborhoods and economies also go through transformations (....).' 


\title{
Classificatiesysteem
}

BARNETT c.s. presenteren vervolgens een classificatiesysteem waarover zij opmerken: ${ }^{145}$

\begin{abstract}
'We focus on dimensions that may influence the impact that maltreatment has on children and families, and therefore, that will affect provision of the most appropriate intervention and treatment methods. The goal for our classification system was to quantify dimensions of maltreatment so that they could be examined systematically, in order to explore empirically the relationships of these variables to etiology, sequelae, and treatment methods.'
\end{abstract}

De volgende dimensies (in DSM-termen zouden we wellicht kunnen spreken van 'assen' ${ }^{146}$ ) worden onderscheiden: ${ }^{147}$

A. Subtypen. Als subtypen van kindermishandeling zijn in de taxonomie opgenomen: ${ }^{148}$ 1.) fysieke verwaarlozing/gebrek aan zorg; 2.) fysieke verwaarlozing/gebrek aan toezicht; 3.) lichamelijke mishandeling; 4.) sexueel misbruik; 5.) emotionele maltraitering (mishandeling en/of verwaarlozing); 6.) morele corrumpering en schoolverzuim.

B. Graden. De (vijf) ernst-categorieën lopen op van licht, matig, ernstig en zeer ernstig tot bijna-fataal. ${ }^{149}$ Deze ernst-schalen betreffen de aard van het ouderlijk (wan)gedrag, niet noodzakelijkerwijs de sequelae voor het kind. ${ }^{150}$

C. Frequentie/chroniciteit. De frequentie betreft het aantal keren dat een kind is mishandeld of misbruikt ('incidenten' die eenmalig, soms, vaak, herhaaldelijk plaatsvinden); bij chroniciteit gaat het om bestendige patronen als voortdurende of onderliggende kilheid, afwijzing, vijandigheid, negativiteit).

D. Ontwikkelingsstadium. Zoals uit bovenstaande citaten al bleek, is de ontwikkelingsfase van het kind zowel wat de impact als wat de sequelae betreft, cruciaal.

E. Scheiding van ouders en kind/uithuisplaatsingen. Deze kunnen noodzakelijk zijn, hetzij in het kader van de meest geschikte vorm van hulpverlening, hetzij omdat hulpverlening aan de ouders geen zin heeft of onmogelijk is (zodat pleeggezinplaatsing is geïndiceerd). In beide gevallen zijn er uiteraard voor het kind naast de positieve ook negatieve (bij-)

T.a.p., op p. 29 i.f.

Vgl. bijlage $v$ ('Persoonlijkheidsstoornissen') bij dit proefschrift.

T.a.p., op pp. $32-44$.

T.a.p., op p. 34.

T.a.p., op p. 52 . De benaming van de vijf schalen of graden is van mij (jw).

T.a.p., op pp. $39 / 40$ en 52 . 
effecten, welke in het meer-assige systeem dienen te worden verdisconteerd.

F. Dader. Betreft het de moeder (vooralsnog meestal de primaire verzorger van het kind), de vader of een ander gezinslid?

Ter verduidelijking worden hierna enkele voorbeelden gegeven uit de categorie emotionele maltraitering (de volledige classificatie is opgenomen in bijlage $\mathrm{mr}$ bij dit proefschrift ${ }^{151}$ ). Bij emotionele maltraitering gaat het meestal om een in extreme mate frustreren van de emotionele basisbehoeften van een kind, waartoe ook ouderlijke ongevoeligheid voor het onwikkelingsniveau van het kind dient te worden gerekend. ${ }^{152}$ Deze basisbehoeften betreffen onder meer: ${ }^{153}$

1. Psychologische veiligheid en geborgenheid: de behoefte aan een gezinsklimaat dat vrij is van excessieve vijandigheid en gewelddadigheid alsmede de behoefte aan een beschikbare en stabiele hechtingsfiguur.

2. Aanvaarding en respect: de behoefte aan positieve bejegening (welwillende blik) en de afwezigheid van een excessief negatieve of onrealistische beoordeling van het kind, gezien diens ontwikkelingsfase.

3. Autonomie, passend bij de leeftijd van het kind: de behoefte de omgeving te onderzoeken en contacten te leggen buiten het gezin (met name met vriendjes/leeftijdsgenootjes) en de behoefte aan individuatie zonder verlies van ouderlijke aanvaarding en binnen de door de ouders gestelde grenzen en geboden structuur, voor zover daarbij geen verantwoordelijkheden worden opgelegd die niet passen bij de ontwikkelingsfase en geen onnodige beperkingen worden gesteld.

De volgende voorbeelden uit de vijf ernstgraden kunnen als illustratie dienen (het complete overzicht vindt men in de bijlagen): ${ }^{154}$

1. Lichte vormen van emotionele maltraitering:

Bijvoorbeeld: de ouder ondermijnt de relatie van het kind met belangrijke anderen (maakt bijvoorbeeld herhaaldelijk minachtende opmerkingen over de andere ouder); de ouder kleineert het kind vaak of maakt het belachelijk (noemt het kind dom, een femel, een slapjanus); de ouder veronachtzaamt of negeert het aandacht vragen van het kind (reageert niet op het huilen van de baby of op de pogingen tot contact van een ouder kind); de ouder disciplineert het kind door middel van intimidatie of bangmakerij.

151 BARNETT e.a., ta.p., 'Appendix: Maltreatment subtype definitions and severity ratings,' op pp. 51-73, 'System for quantifying child protective service records, subtype definitions and severity scales,' op pp. 54-73.

152 T.a.p., op p. 67.

153 T.a.p.

154 Vgl. BARNETT e.a., t.a.p., op pp. 68-71. (De voorbeelden tussen haakjes zijn niet steeds letterlijk van de auteurs overgenomen.) 
2. Matige vormen van emotionele maltraitering:

Bijvoorbeeld: de ouder staat geen vriendschappen met leeftijdgenootjes toe; rol-omkering (het kind wordt verantwoordelijk gesteld voor en wordt geacht tegemoet te komen aan de emotionele noden van de ouder); de ouder dwarsboomt de zich ontwikkelende gevoelens van rijpheid en verantwoordelijkheid van het kind (infantiliseert het kind); de ouder verwerpt, veronachtzaamt of is zich niet bewust van de behoefte van het kind aan genegenheid en respect (positieve en liefdevolle interactie ontbreekt chronisch); de ouder stelt het kind bloot aan extreme, zij het niet gewelddadige huwelijksconflicten.

3. Emstige vormen van emotionele maltraitering:

Bijvoorbeeld: de ouder geeft de kinderen de schuld van huwelijks- of familieconflicten ('de kinderen zijn de oorzaak van de echtelijke ruzies'); de ouder stelt het kind ongepaste of excessieve eisen en brengt aldus een gevoel van ontoereikendheid en tekortschieten bij het kind teweeg (het kind is verantwoordelijk voor het sussen en beslechten van de ouderlijke ruzies); de ouder stelt het kind bloot aan extreem, onberekenbaar en/of ongepast gedrag (geweldpleging tegenover gezinsleden, gewelddadige driftbuien, hysterische uitvallen, hysterisch-dwangmatig/fobisch gedrag); de ouder legt een patroon van negativiteit en vijandigheid aan de dag tegenover het kind ('het kind is egoïstisch, denkt altijd alleen aan zichzelf, doet altijd alleen zijn eigen zin, heeft altijd bijbedoelingen' enzovoorts).

4. Zeer ernstige vormen van emotionele maltraitering:

Bijvoorbeeld: de ouder dreigt het kind met zelfmoord of verlating (weglopen met medeneming van het huishoudgeld); het kind wordt langdurig opgesloten en geïsoleerd; de ouder vertelt het kind dat het naar de tuchtschool moet omdat het zo slecht is.

5. Bijna-fatale vormen van emotionele maltraitering:

Bijvoorbeeld: de moeder (de primaire verzorger) verlaat het gezin (met jonge kinderen) een etmaal of langer zonder enige indicatie of en wanneer zij zal terugkeren of waar zij kan worden bereikt; de moeder prent het (jonge) kind in dat het de nagel aan haar doodkist is.

\section{Bruikbaarheid}

Hoewel dit classificatiesysteem zich nog in de praktijk moet bewijzen, en de bruikbaarheid ervan nog nader moet worden onderzocht, wordt het hier voorgesteld als eerste handvat voor de operationalisering (en dus juridisering) van het recht van het kind op minimale persoonswording. 
In het voorgaande is herhaaldelijk de nadruk gelegd op de secundaire opvoedingsverantwoordelijkheid van de staat, of, juister gezegd, zijn staat en maatschappij medeverantwoordelijk gesteld voor het bestaan en voortbestaan van pedagogische praktijken - zo men wil: van sociaal-pedagogische wantoestanden - die als grootschalige kindermishandeling c.q. als grootschalige schending van het recht van het kind op minimale persoonswording kunnen worden gekwalificeerd. Deze grootschalige schending blijkt grosso modo terug te voeren op een - dienovereenkomstig grootschalig tekort aan pedagogisch besef bij ouders, welk tekort op zijn beurt ten nauwste samenhangt met het te kort schieten van staat en maatschappij ten aanzien van de verdrags- en mensenrechtelijke plicht tot het voorzien in adequaat toegeruste sociaal-pedagogische instellingen en in adequate sociaal-pedagogische voorzieningen en diensten.

Het achterliggend sociaal-politiek en cultureel fenomeen van het publiekrechtelijk ouderschapslibertinisme - ook wel aangeduid als 'privacy-cultuur' (en eerder in deze studie als parentiarchie) - geeft aan deze grootschaligheid ook een structurele dimensie, maakt de ernstige schending in zekere zin systematisch, sluit haar op, legt haar vast in een 'systeem.' Een systeem van collectieve sociaal-pedagogische nalatigheid, van collectieve sociale ouderschapsverwaarlozing.

Zo tekent zich aan het eind van het millennium een 'pedagogische kwestie' af die lijkt voort te vloeien uit een gedateerd 'maatschappelijk contract.' Een sociaal contract dat hoognodig aan herziening toe is, of liever dat dient te worden verrijkt met sociaal-pedagogische clausules, verzegeld met zilveren sociaal-pedagogische koorden.

Omvang en ernst van en aansprakelijkheid voor voorkoombare, verzachtbare en herstelbare vormen van lijden van het kind; rechten, verplichtingen en verantwoordelijkheden ten aanzien van het doorbreken van transgenerationele processen; verplichtingen, bevoegdheden en verantwoordelijkheden ter zake van het bemiddelen in en beëindigen van de WAR (de World of Abnormal Rearing, die de wereld-in-oorlog van de verworpen kinderen is) - met als uiteindelijk doel, en geen doel dat menselijk lijden wil verminderen, kan hoog genoeg gegrepen zijn: haar uitbanning en verwijzing naar de tragische ruïnes van de geschiedenis der pedagogiek -, het zijn zaken die nog terugkomen in de volgende hoofdstukken en daar onderwerp van nadere studie zijn.

Wat er verder dan ook van zij, we mogen bij al deze aspecten die nadrukkelijk samenhangen met de secundaire opvoedingsverantwoordelijkheid van de staat, intussen niet uit het oog verliezen dat de primaire opvoedingsverantwoordelijkheid bij de ouders berust. Zinvolle uitspraken 
over kwalitatieve aspecten, wenselijkheden en onwenselijkheden ten aanzien van eerstgenoemde zijn niet mogelijk zonder enige kennis over kwalitatieve aspecten, gekoppeld aan globale vormen en varianten ("stijlen'), van laatstgenoemde. Tegen deze achtergrond zal in dit hoofdstuk, volledigheidshalve, thans nog iets over opvoedingsstijlen van ouders/primaire opvoeders in relatie tot (minimale) persoonswording worden gezegd.

\title{
11.3.1 Ouderlijke opvoedingsstijlen
}

De staat van jeugdig Nederland 1996 bevat de volgende gegevens: ${ }^{155}$

\author{
'Problematische gezinssituatie \\ 135.000 jeugdigen wonen in gezinnen met een niet warme opvoedings- \\ stijl; \\ 210.000 leerlingen van 12-19 jaar zijn niet graag thuis; \\ 250.000 kinderen tot 18 jaar hebben te maken met alcoholverslaafde \\ ouders; \\ 8.000 kinderen hebben te maken met harddrugverslaafde ouders; \\ 13.220 meldingen van kindermishandeling in 1993 bij de bureaus Ver- \\ trouwensartsen (100\% meer dan 1990); \\ 20.853 jeugdigen tot 18 jaar zijn in 1994 onder een maatregel van kin- \\ derbescherming (25\% meer dan 1990).'
}

\begin{abstract}
'Probleemgedrag jeugdige
Probleemgedrag kan worden onderscheiden in emotionele problemen en gedragsproblemen. In de literatuur wordt er van uitgegaan dat meisjes in sterkere mate te kampen hebben met emotionele problemen en jongens met gedragsproblemen.

- Emotionele problemen

Ruim $20 \%$ van de leerlingen van 12-19 jaar heeft een laag zelfbeeld;

$12 \%$ van de leerlingen woelt zich vaak eenzaam;

$12 \%$ van de jongeren tussen 12-20 jaar zegt geen vriend(in) te hebben;

$2,5 \%$ van de leerlingen voelt zich zeer gedeprimeerd;

$5,5 \%$ van de leerlingen zegt een poging tot zelfdoding te hebben gedaan.

- Gedragsproblemen
\end{abstract}

Bijna 12\% van de leerlingen van 12-19 jaar drinkt per matand meer dan 40 glazen alcoholhoudende dranken;

4\% van de leerlingen gebruikt regelmatig softdrugs;

nog geen $1 \%$ van de leerlingen gebruikt regelmatig harddrugs;

2,6\% van de leerlingen vindt zichzelf een regelmatige gokker;

6 a 7.000 jongeren zijn dakloos en/of zwervend;

$3,8 \%$ van de $12-18$ jarigen komt wegens een delict in aanraking met de politie;

155 J. VAN KAMPEN (red.), De staut van jeugdig Nederland 1996; Een sociale kaart vart de jeugd" van Nederland, Werkdocument 1 Stichting Jeugdinformatie Nederland (Utrecht), Delft [1996], p. 17. 
$66 \%$ wan de jeugd van 12-18 jaar zegt zich wel eens aan een delict schuldig te maken;

$2,1 \%$ van de jeugd van $12-18$ jaar is al aan cen criminele carrière begonnen.'

In bovenstaande cijfers en percentages zitten, zo mag men aannemen, de minimaal 80.000 gevallen van kindermishandeling per jaar in Nederland voor een groot gedeelte verstopt. Wat gaat er schuil achter een cijfer van 135.000 jeugdigen ( 1 op de 16 kinderen onder de 12 jaar) ${ }^{156}$ wier ouders een niet warme opvoedingsstijl hebben?

\section{Warmte en toezicht}

Zoals we al vaker in deze studie opmerkten, heeft het kind een veiligheidsbelang en een ontwikkelingsbelang. Beide zijn dermate fundamenteel en essentieel voor de persoonswording dat zij als fundamentele rechten van het kind kunnen/moeten worden beschouwd. Het ontwikkelingsbelang bestaat uit een dubbel pedagogisch recht: het recht van het kind op warmte (geborgenheid, affectie, ruimte, ondersteuning, ontplooiing) en het recht van het kind op leiding (toezicht, controle, grenzen, disciplinering/opvoeding in enge zin). Niet alleen een gebrek aan warmte en affectie, ook een gebrek aan leiding en disciplinering is kindonwaardig: een miskenning van de fundamentele rechten van het kind, een miskenning van het recht van het kind hier-en-nu kind te zijn èn van de huidige en toekomstige ontplooiingskansen van het kind. ${ }^{157}$

Anders gezegd, en tegelijk samengevat: vanuit het (universele) opvoedingsdoel van de (optimale althans boven-minimale) persoonswording van het kind (adequaat kunnen handelen/functioneren, dat is op basis van boven-minimale rationaliteit, moraliteit en authenticiteit) kunnen twee basisrechten worden onderscheiden:

- het recht van het kind op warmte (affectie en ontplooiing);

- het recht van het kind op toezicht (leiding en disciplinering).

Afhankelijk van (het niveau van) hun pedagogisch besef komen ouders in hoge (optimale) of in geringe (minder dan optimale of zelfs minder dan minimale) mate aan beide rechten tegemoet. In parallelle zin onderscheidt MCMARTIN 'parenting dimensions of nurturance (warm versus cold) and control (setting firm limits versus not setting limits). ${ }^{158}$ Hij concludeert: 'Parenting style is one of the key elements in the soil

Vgl. a.w., pp. 41, 79 en 145.

157 Vgl. ook Marieke KRoNEMAN, 'De pedagogische opvattingen in de adviezen van de Raad voor het Jeugdbeleid,' Jeugd en samenleving 1996/4, pp. 162-168, op pp. 166-167.

158 Jim McMARTIN, Personality psychology; A student-centered approach, Thousand Oaks (etc.) 1995 , pp. 57-68, op pp. $57 / 58$. 
of personality development., 159

Liever dan van een warme of koude c.q. kille opvoedingsstijl zou ik willen spreken van een warm of koud/kil opvoedingsklimaat. Trefwoorden voor een warm klimaat zijn: acceptatie, emotionele steun en betrokkenheid, ${ }^{160}$ hetgeen ik samenvattend aanduid met de term responsiviteit. Een warm klimaat is responsief, een kil klimaat is niet responsief; een warm opvoedingsklimaat is een gezond klimaat; een koud klimaat acht ik ongezond (ziekmakend). De term opvoedingsstijl nu reserveer ik voor de modus van ouderlijk toezicht (of gebrek daaraan). ${ }^{161}$

In de literatuur worden vier stijlen onderscheiden, een autoritaire (hardvochtige), een permissieve (toegeeflijke), een autoritatieve (consequente, doch toenemend democratische) en een afwezige of indifferente (onverschillige) stijl. ${ }^{162}$ De combinatie van stijl en klimaat levert dan op, in schema (in de derde kolom zijn de trefwoorden geplaatst waarmee mogelijke - dus niet noodzakelijkenwijs optredende c.q. onvermijdelijke gevolgen/gevaren kunnen worden getypeerd ${ }^{163}$ ):

a.) autoritair

b.) permissief

c.) autoritatief

d.) indifferent niet responsief + hardvochtig

responsief, maar (te) toegeeflijk

responsief

+ consequent

niet responsief + onverschillig $\rightarrow$ kluwengezin (ambivalentie, symbiose)

$\rightarrow$ problemen met discipline, met frustratietolerantie en impulscontrole

$\rightarrow$ gezonde persoonswording

$\rightarrow$ los-zandgezin (gremzenloos $\rightarrow$ grensoverschrijdingen $\rightarrow$ antisociaal).

159 A.w. p. 68.

160 E.M. SCHOLTE en L. SONTAG, Opwoeding en ontwikkeling; Een literatuuronderzoek naar de samenhang tussen opwoedingsgedrag wan primaire opwoerders en de ontwikkeling van jeugdigen, PCoJ-werkdocument nr. 7, Utrecht januari 1992, p. 27.

161 Vgl. Maurice VAN LIESHOUT, 'Nederlandse ouders zijn opvoedingsoptimisten; het onderzoek Opvoeden in Nederland,' 0/25; Tijdschrift over jeugd juni 1996/1, pp. 10-17, op p. 13 m.k. Zie ook Martine F. DELFos, Kinderen in ontwikkeling; Stoornissen en belemmeringen, Lisse 1996, pp. 132-135.

DELFOS geeft een twee-assig schema, t.a.p., op p. 133; op p. 134 stelt zij een drieassig model voor: as $I_{n}^{\prime \prime}$ afwijzing versus liefde; as II: autonomie versus controle; as III: individueel versus groepsgericht. Alleen al het twee-assig model leidt tot maar liefst veertien verschillende opwoedingsstijlen: vrijlatend, democratisch, coöperatief, accepterend, al te toegeeflijk, bezorgd/toegeeflijk, overbezorgd, bezitterig, autoritair/dictatoriaal, veeleisend/tegenstrijdig, afwijzend, verwaarlozend, onwerschillig en afstandelijk. Vgl. MCMARTIN, a.w., p. 58; SCHOLTE/SONTAG, a.w., p. 26. Vgl. MCMARTTN, a.w. p. 59 . 
Een niet responsief klimaat duidt op affectieve verwaarlozing. Binnen dit (kille, ziekmakende) klimaat duidt een autoritaïre stijl op een vorm van toezicht die wordt gekenmerkt door enerzijds overcontrole en anderzijds arbitraire grenzen. Affectieve verwaarlozing en overcontrole gaan hier hand in hand, zoals ook bleek in het incest-onderzoek van DRAIJER. ${ }^{164}$ Daarnaast is er de indifferente variant: er is geen of weinig controle, er zijn geen of weinig grenzen. In een gezond (responsief) klimaat passen zowel de permissieve stijl, waarin er geen duidelijke grenzen zijn - hetgeen als een ernstige risicofactor moet worden beschouwd ${ }^{165}-$, als de autoritatieve stijl, waarin de ouders duidelijke grenzen aangeven en deze consequent handhaven, zij het dat geleidelijk aan de teugels worden gevierd (vandaar dat deze stijl - mijns inziens nogal misleidend en onterecht - ook wel de 'democratische' stijl wordt genoemd ${ }^{166}$ ).

Uitgaande van de genoemde vier opvoedingsstijlen: 'een autoritaire, een permissieve, een "afwezige" en een autoritatieve (ook wel democratische genoemd),' concluderen SCHOLTE en SONTAG dat de laatste stijl 'de beste ontwikkelingsprognose' geeft. Autoritatief ...

"(...) opgevoede kinderen hebben een hoge mate van controle over hun impulsen agressie-huishouding, ze zijn in staat verantwoordelijkheid te dragen en zijn in hoge mate zelfstandig. Verder beschikken deze kinderen over een positief zelfbeeld en zijn ze sociaal en cognitief vaardig. ${ }^{\text {.67 }}$

Nel DRAIJER merkt in haar proefschrift (Seksuele traumatisering in de jeugd; Gevolgen op lange termijn van seksuel misbrulk van meisjes door verwanten, Amsterdam 1990, p. 277) op: [D]e ernst van de latere psychische problemen bij seksueel misbruik door verwanten is in grote lijnen vergelijkbaar met die bij affectieve verwaarlozing. Affectieve verwaarlozing duidt zij aan als: '[w]einig ouderlijke ondersteuning en emotionele koestering enerzijds en veel controle en onvrijheid anderzijds' (a.w., p. 179). Een nadere omschrijving (op p. 272; curs. jw) luidt: "Affectieve verwaarlozing" dient (...) niet in de meest letterlijk[e] zin te worden opgevat - zoals bij kinderen waar niet naar omgekeken is, die verlaten of verstoten zijn - maar meer in termen van een gebrek aan persoonlijke aandacht, respect en gentegenheid in combinatie met veel controle." Op p. 190 gewaagt zij van een incest-gezinsdynamiek van 'een conflictueus huwelijk tussen de ouders, een labiele, vaak zieke moeder, een overcontrolerende vader (...).' Op p. 195 van 'een klimaat van "affectionless control," van veel controle en weinig affectie.' Op p. 279 van "[g]ebrek aan warmte en een teveel aan betutteling of controle." Vgl. met betrekking tot risicofactoren (en beschermende of protectieve factoren) DELFOS, a.w., pp. 135-147.

166 Iets beter zou zijn: democratiserende stijl. En helemaal goed: autoritatief-democratiserende stijl (mooier: gezagsvol-democratiserende stijl).

167 Overgenomen uit de bespreking van SCHOLTE/SONTAG door Jo HERMANNS in Jeugd en samenleving 1994/2, pp. 115-117, op p. 115 r.k. 
Kinderen hebben zowel recht op een 'affectief klimaat' van 'warmte, veiligheid, geborgenheid, ondersteuning' alsook recht op redelijke eisen, op beloning en op de verdiende straf ("invoelende redelijkheid in het stellen van eisen, het geven van beloningen en het straffen'). Bij een autoritatieve opvoedingsstijl scoren de opvoeders hoog op deze twee 'hoofddimensies in opvoedergedrag,' slagen zij er met andere woorden in hoge mate in beide rechten te verwezenlijken. ${ }^{168}$ Met de voorspoedige ontwikkeling van kinderen als gevolg. We zouden dus kunnen zeggen dat bij een autoritatieve opvoedingsstijl de rechten van het kind het beste zijn gewaarborgd. ${ }^{169}$

MCMARTIN acht alleen de autoritatieve opvoedingsstijl gunstig, de andere drie stijlen daarentegen have been found to detrimentally affect children in various ways. ${ }^{170}$

\section{3 .2}

\section{De autoritatieve opvoedingsstijl als recht van het kind?}

DELFOS merkt op dat opvoedingsstijlen "over het algemeen intergenerationeel en cultureel worden overgedragen., ${ }^{171}$ Dit wijst er all op dat er een verband moet worden gelegd tussen ouderlijke opvoedingsstijlen en het uit de eigen ontwikkelingsgeschiedenis 'meegekregen' pedagogisch besef. Aannemelijk is dat niet alleen voor het bereikte niveau van pedagogisch besef, maar ook voor de gehanteerde opvoedingsstijl de eigen ontwikkelingsgeschiedenis cruciaal is. Hierboven zinspeelden we daar al op (door de zinsnede 'in parallelle zin' in de vorige subparagraaf).

Hoewel het te ver zou voeren op deze plaats nader op dit verband in te gaan, kan wel worden opgemerkt dat de autoritatieve opvoedingsstijl zoveel vóór heeft op andere opvoedingsstijlen, c.q. dat andere opvoedingsstijlen dermate schadelijk zijn in verhouding tot de autoritatieve opvoedingsstijl, dat er van een 'recht' van het kind op een autoritatieve opvoedingsstijl gesproken zou kunnen/moeten worden.

168 De woorden tussen aanhalingstekens zijn overgenomen van HERMANNS, t.a.p.

169 BAARTMAN stelt een autoritaire tegenover een inductieve opvoedingsstijl (Opvoeden met alle geweld, a.w., p. 40), welke laatste de kenmerken van de autoritatieve stijl vertoont: In Opvoeden kan zeer doen (a.w., p. 51; curs. jw) verwijst hij naar onderzoek waarin een verband werd vastgesteld 'tussen het niveau van pedagogisch besef en de kwaliteit van het pedagogisch handelen in die zin dat ouders die op een hoger niveau van pedagogisch besef redeneren, meer ondersteunend zijn en meer op een autoritatieve wijze controle uitoefenen dan ouders die op een lager niveau redeneren.'

170 MCMARTTN, a.w., p. 59.

171 DELFOS, a.w., p. 132 (curs. MD). 
De vraag wordt dan hoe ouders ertoe kunnen worden gebracht hun opvoedingsstijl in autoritatieve zin bij- of om te buigen? Met andere woorden: onder de vigeur van welke verdragsrechten c.q. sociaal-pedagogische kernrechten zou zulks onder de persoonswordingsparaplu kunnen worden gebracht? Dit brengt ons in positiefrechtelijke zin terug naar (onder meer) de artt. 2, 5, 18 en 27 van het Verdrag inzake de rechten van het kind (zie het vorige hoofdstuk), en in natuurrechtelijke zin naar het recht van het kind op sociaal-economische en sociaal-pedagogische omstandigheden en voorzieningen die het beginsel van de gelijke behandeling en gelijke rechten van alle kinderen niet in onredelijke en onbillijke mate schenden. Uit dit kernrecht, zo zagen we in hoofdstuk 7, vloeien drie rechten voort: opvoedingsonderwijs, opvoedingsgeld en opvoedingsondersteuning. Het is dit trio dat ook hier uitkomst moet brengen en soelaas moet bieden. ${ }^{172}$

Kindermishandeling als bedreiging of beschadiging van minimale rationaliteit, moraliteit of authenticiteit

Hierboven (in par. 11.2.3) werd kindermishandeling - tegen de achtergrond van het recht van het kind op (optimale c.q. minimale) persoonswording als achterliggend rechtsbeginsel van het Verdrag inzake de rechten van het kind (hoofdstuk 10) en met het oog op een bepleite operationalisering van dat beginsel aan de hand van de criteria van BARNETT c.s. - geherdefinieerd als schending van het recht van het kind op minimale persoonswording. Eerder al (in par. 11.2.2.3) werd een link gelegd tussen kindermishandeling en het begrip psychotrauma. Dit begrip werd geïntroduceerd als verzamelterm voor elke door de ouders - door een doen of nalaten van emotionele, fysieke en/of sexuele aard - in de opvoedingsrelatie teweeggebrachte beschadiging van de geestelijke gezondheid en/of aantasting van het psychisch welzijn van het kind als persoon in ontwikkeling, die op langere termijn nadelige psychische en psychosociale effecten heeft van zodanige ernst en omvang dat deze als psychische stoornis clas-

172

Erg ver hïerbij - althans in de ogen van HERMANNS - lijken SCHOLTE en SONTAG te gaan, die van mening zijn dat hun onderzocksresultaten "van nut kunnen zijn bij het vroegtijdig onderkennen van "risicovol (incompetent) opvoedingsgedrag", en voorstellen 'het primaire opvoedingsmilieu van het kind hierop te screenen. Een opvoedingstraining voor de incompetente ouder ligt dan voor de hand en wordt ook door de auteurs bepleit. Om dit alles technisch beter te laten verlopen, stellen ze voor een "bruikbaar onderzoeksinstrument te ontwerpen waarmee "(on)bekwaam opvoedingsgedrag van primaire opvoeders" betrouwbaar en valide in kaart kan worden gebracht".' (HERMANNS, t.a.p., op p. $1161 . \mathrm{k}_{*}$; curs. jw.) 
sificeerbaar zijn. De combinatie van dit begrip met het recht van het kind op minimale persoonswording maakt het mogelijk kindermishandeling (de schending van dit minimum-recht) te omschrijven als elke bedreiging of beschadiging van minimale rationaliteit, moraliteit of authenticiteit met de hierboven aangeduide effecten.

Om hier nog een tweede (of derde) link te leggen: op basis van een (al eerder aangehaalde) uitspraak van BAARTMAN kunnen deze effecten (de sequelae van kindermishandeling op langere termijn) worden toegeschreven aan een verstoorde gezindheid en/of gebrekkige competentie van de kant van de opvoeder: ${ }^{173}$

\footnotetext{
'Kindermishandeling is gewelddadig [met inbegrip van verwaarlozend, ${ }^{174} \mathrm{jw}$ ] gedrag dat de ontwikkeling van rationeel, moreel en authentiek handelen van het kind schaadt, en dat berust op een verstoorde gezindheid [bij] en/of gebrekkige competentie van de opvoeder.'
}

Een verstoorde gezindheid c.q. gebrekkige competentie van de kant de opvoeder wijst in beginsel - gezien wat we weten en gezegd hebben over transgenerationaliteit - op een pedagogisch deficit of defect in de voorgeschiedenis van de de ouder. Omdat betrokkene ouder is, dat wil zeggen: met het oog op het recht van zijn of haar kind op (optimale c.q. minimale) persoonswording, dient dit deficit te worden aangevuld c.q. dit defect te worden gerepareerd (nemo plus, nemo ultra: de statelijke suppletieen/of reparatieplicht welke voortvloeit uit de verdrags- en mensenrechtelijke secundaire opvoedingsverantwoordelijkheid van de staat).

In dit hoofdstuk (par. 11.2.2.1) hebben we ook stilgestaan bij de sociale constructie van kindermishandeling. We zagen dat MCGILLIVRAY vijf historische constructen onderscheidde: een moreel, een wetenschappelijk, een medisch, een ecologisch en - als voorlopig laatste - een politiek construct. Met een schok brak in de zeventiger jaren het collectieve besef door van de achterstelling van vrouwen. De doorbraak van het gevoel dat vrouwen zich eeuwenlang hadden laten misleiden door de mannelijke maskerade, de sublimatie - of liever hyper-compensatie - van het mannelijk tekort (SIERKSMA), ${ }^{175}$ dreef de private 'war of the sexes' huis-

173 H.E.M. BAARTMAN, 'Schuld, herstel en overleven; aspecten van hulpverlening inzake kindermishandeling, in: D.J. DE RUYITER en P.A. DE RUYTER (red.), Opvoedingshulp geboden; Pedagogische criteria voor het opleggen van hulp, theoretisch en praktisch bezien, Utrecht 1995, pp. 83-91, op p. 85.

174 Zie par. 11.1 hierboven (noot 1).

175 Fokke SIERKSMA, Religie, sexualiteil en agressie; Een cultuurpsychologische bijdrage tot de verklaring van de spanning tussen de sexen, Groningen 1979 (door K.D. JENNER bewerkte versie van $D e$ roof van het vrouwengeheim), p. 234. 
en slaapkamers uit en de straat op: het persoonlijke werd politiek. En kindermishandeling werd incest, om dat tot in de negentiger jaren te blijven. Niet alleen de vrouw maar ook het meisje, en al spoedig ook het jongetje, bleken slachtoffer van inbreuken op de lichamelijke en geestelijke integriteit, inbreuken 'behind closed doors' ${ }^{176}$ die publiekelijk aan de kaak werden gesteld. Niet alleen gelauwerde oorlogsveteranen maar ook eeuwenlang weggemoffelde en tot zwijgen gebrachte vrouwen en kinderen bleken te lijden aan posttraumatische stoornissen (HERMAN). ${ }^{177}$

En al even spoedig bleek niet alleen de, ten gevolge van het Grote Machtsverschil tussen mannen en vrouwen weinig gesublimeerde, mannelijke sexuele drift de oorzaak te zijn. Toen de feministische golven waren weggeëbd, bleek op het strand meer dan incest alleen als schending van de rechten van het kind te zijn aangespoeld. De rechten van het kind zelf werden er gevonden. Kindermishandeling kreeg een eigen artikel in een internationaal verdrag. We schrijven 1989. MCGILLIVRAY schrijft: ${ }^{178}$

"The challenge of cross-cultural study has yielded a definition of child abuse which embraces both emic [internal, jw] and etic [external, jw] perspectives and roots control in cultural beliefs. Child abuse, as defined by KORBIN and FINKELHOR, is not just any harm which befalls children: it is harm resulting from human action which is "proscribed, proximate and preventable." (...)

Although endemic to the human species, [child abuse] is wasteful of human resources and offensive to human values. As KORBIN and FINKELHOR point out, child abuse is "a powerful concept that can be the basis for strong international action" to improve the status of all children. The Convention on the Rights of the Child may the the focus of such action.'

Met deze woorden, onder het hoofd 'transculturele reconstructie,' besluit de auteur haar historisch exposé. In haar conclusie voegt zij hieraan toe: $:^{179}$

"The suffering of children is intolerable: for the child and for the child become adult; for the compassionate and for those who count the social cost of generations of dropouts, runaways, the impaired, the dysfunctional. An adequate theory of children's rights will embrace the hard case of child abuse. It will be based on factual information about how children are treated and provide a framework for

176 Titel van het boek van Murray A. straus e.a., Behind closed doors; Violence in the American family, Garden City, N.Y. 1980; Newbury Park (etc.) 1981.

177 Judith Lewis HERMAN, Trauma en herstel; De gevolgen van geweld - wan mishandeling thuis tot politiek geweld, Amsterdam 1993, p. 45.

178 Anne McGILLIVRAY, 'Reconstructing child abuse: Western definition and nonwestern experience," in: Michael FREEMAN, Philip VEERMAN (eds.), The ideologies of children's rights, Dordrecht (etc.) 1992, pp. 213-236, op p. 229 (curs. jw). MCGILIIVRAY, t.a.p., pp. 230-231 (curs. jw). 
consideration of how children ought to be treated. It will deal with the fact of children's changing dependence. It will cut through the ideologies of privacy and parental rights. It will distinguish the preservation of adult supremacy from the child's need for intimacy, protection and nurrure. The suffering of children at the hands of the family is the hard case for the law. (...)

Child abuse is a recent construct which has grown out of what may be a uniquely Western experience. Definition and response have been shaped by Western institutions and sensibilities and influenced by rapidly changing notions of children's rights. Although the construct may be inapplicable to other types of societies, there is increasing evidence that the range of behaviours variously defined as child abuse, occurs in every society, modern, modernizing or untouched. They may mot be locally recognized as such; where they are, controls vary widely. From a Western point of view, developing nations reflect our own child abuse history. This history of rediscovery accompanied by the rapid evolution and devolution of theory, model and policy is more than just a lesson in the making of a social problem. It demonstrates the difficulty of seeing what we do not want to see. The Western lesson is instructive for countries which do not acknowledge the existence of child abuse or attribute it to politically expedient causes, just as Western nations have done for much of their history.

The goal of raising healthy children to fully functional adulthood, whatever the sociospecific mode of childrearing, is universal. Setting broad international standards, such as those contained in the UN Convention on the Rights of the Child, is for this reason appropriate. The Convention is highly reflective of the Western construct of child abuse. It is expected that states whose culture and ethos is decidedly non-Western will not only adopt this particular view of injury to children but will also take effective action. To resolve the problem of variable social construction and find universality, we need to explore the folklore surrounding the treatment of children: the inarticulate beliefs, culturally-defined responses, social conventions and pretentions, formalistic manifestations of state concern. In so doing, we move from the conventional to the challenging and from acquiescence to revolution.'

Het cultureel relativisme - op macro- en micro-niveau (par. 11.2.2.2) heeft ons lang zand in de ogen gestrooid, zodat we niet goed konden zien wat we misschien ook wel niet wilden zien, of maar liever niet al te goed zagen. De ouderlijke (zelf)rechtvaardiging lijkt op de culturele - in de woorden van KORBIN: ${ }^{180}$

'The refrain, "This is how we do things in our culture or community," deceptively resonates to the refrain from abusive parents, "This is how I was raised and this is how I will raise my children".'

180 Jill E. KORBIN, 'Child abuse and neglect: the cultural context,' in: Ray $\mathbb{E}$. HELFER, Ruth S. KEMPE (eds.), The battered child, Chicago/London 1988 (vierde druk), pp. 23-41, op p. 31 . 
Het deceptieve, het bedrieglijke, schuilt in wat we weten over de transgenerationele verminkingen van ouderliefde, over het afgunstmotief als verwoester van 'natural love' (par. 11.2.1 en 11.2.2.2). De tijd is aangebroken het politieke construct achter ons te laten en ruim baan te maken voor het verdrags-, het mensenrechtelijke construct. De cyclus van gemankeerde liefde, van pedagogische tekorten en defecten, van emotioneel en fysiek geweld dat opvoedt tot emotioneel en fysiek geweld, die vicieuze cirkel moet worden doorbroken in de naam van de rechten van het kind. De 'WAR' (HELFER) moet stoppen:" ${ }^{.81}$

\section{'And on and on it goes entity, functioning in the extremes, than to: \\ Mute his senses. \\ Fail to teach him how to get his needs met. \\ Teach him he is responsible for the actions of others. \\ Give him little practice in problem solving. \\ Convince him he cannot trust others.}

The abused child continues, around and around, learning fewer and fewer skills of interaction. He is "out of towch" with the world about him; control over his life is lost, actually never gained. What better way to train a child to become a non-

Show him day after day that feelings and actions are one and the same.

The results! (...) The WAR [World of Abnormal Rearing] has convinced its victims that they are "no damn good," unable to help others, have minimal skills for finding and keeping real, close friends, much less a suitable mate, and are easily discouraged and depressed (...). At that point in their young adult lives, they may enter the "I think I'll have a family" route as a solution to their loneliness. 182 Some bypass this option and go on to work or school, trying to cope as best as they can, using what few skills they have learned in their childhood. Some make it, many do not.

Considerable work can be done to facilitate their breaking out of this cycle (...). Even more can be achieved if the cycle is interrupted before its damage has been too severe."

WILLIAMS legt de vinger op de maatschappelijke en wetenschappelijke Wond: ${ }^{183}$

181 Ray E. HELFER, 'The developmental basis of child abuse and neglect: an epidemiological approach, in: dez. en Ruth S. KEMPE (eds.), The battered child, Chicago/London 1988 (vierde druk), pp. 60-80, op p. 79.

182 Vgl. ook recent onderzoek waaruit blijkt dat tienerouders eerder in hun jeugd vaak mishandeld of verwaarloosd zijn (Joumal of Adolescence 1998; Wilma volLEBERGH, 'Tienerouders hebben vaak problematische achtergrond,' $0 / 25$; Tijdschrift over jeugd oktober 1998, 'Onderzoek,' p. 52).

183 James J. WILLIAMS, 'The cycle of abuse,' in: A.E. BRODEUR, J.A. MONTELEONE, Child maltreatment; [vol. I] A clinical guide and reference, St. Louis (etc.) 1994, pp. 285-307, op pp. 285-286. 
'Relatively scant societal attention and resources have been directed to the study of human violence. While societal awareness of interpersonal violence has been raised by various groups who have come forward and identified it in their own lives, children are largely a silent group. To this list of sufferers must be added children who are themselves abusers. ${ }^{184}$ Our ideas about human violence are flawed when they ignone child maltreatment and its links to human violence. (...) Family violence and neglect should be among the most preventable of situations. (...)

Family violence is not entirely mysterious. To a large degree, it is predictable and understandable. When unchecked, its costs reach far beyond the tragedy of individual families. To the immediate costs of therapy are added the social costs of school failure, substance abuse, impaired parenting, psychiatric hospitalization, and criminal violence. These costs are more substantial for the victims but ultimately affect us all. (...) Revelations that children are battered or denied the necessities of life, evoke contradictory and complex mixtures of denial and horror, disgust and fascination from the professions, media, and the public. (...)

The home retains its aura of privacy for citizens in our society, making welldesigned studies of family violence difficult to pursue. Yet the home is where aggressive interactions begin.'

Het lijkt niet ongepast dit hoofdstuk met een - in dubbele zin vermanend - citaat van KEMPE te besluiten: ${ }^{185}$

'Nobody can predict human behaviour, although all of us try to do so; and all of us do make serious mistakes, generally on the side of undue optimism for the child's future in his home.'

184 Hierbij kan behalve aan bijvoorbeeld de oudere broer die het jongere zusje misbruikt, mishandelt of pest, ook gedacht worden aan het (fysiek en verbaal gewelddadig) pesten van kinderen buiten het eigen gezin.

185 C. Henry KEMPE, 'Foreword,' in: Ray E. HELFER, Ruth S. KEMPE (eds.), The battered child, Chicago/London 1988 (vierde druk), pp. xiii-xv, op p. xiii. 
In dit hoofdstuk staan drie vragen centraal. In de eerste plaats de vraag: wat is er bekend omtrent de omvang van het fenomeen kindermishandeling? De vraag naar de cijfers en de percentages. In de tweede plaats de vraag naar de sequelae: wat is er bekend omtrent de ernst van het fenomeen kindermishandeling? Deze tweede vraag kan worden uitgesplitst in de vraag naar de gevolgen voor het individu: de psychische en psychosociale sequelae. En de vraag naar de gevolgen - de 'kosten' - voor de maatschappij: de sociale en economische sequelae.

Bij de eerste categorie gevolgen - die voor het individu - horen vragen als: welke prijs betaalt het slachtoffer? In hoeverre betekent kindermishandeling dat het slachtoffer "voor het leven beschadigd" ${ }^{1}$ is? In hoeverre is de 'survivor' gedoemd zijn of haar hele leven slachtoffer te

Vgl. de titel van Ben RENSENs Kindermishandeling: woor het leven beschadigd, Utrecht 1990.

$2 \quad$ Letterlijk: de 'overlevende." Dat wil (hier) zeggen: degene die zich well bewust is in zijn of haar jeugd misbruikt, mishandeld en/of verwaarloosd te zijn, maar die nog steeds in zoverre slachtoffer is dat hij of zij nog niet met zichzelf in het reine is, rijn of haar verwerkingsproces nog niet tot een bevredigende oplossing, of zelfs nog niet op gang heeft gebracht. De waarheid van de eigen traumatische jeugd heeft men dan wel (even) onder ogen gezien, maar men is nog niet klaar met of zelfs blijwen steken in het (her)beleven van woede en verdriet en/of het handelen naar nieuw verworven inzichten. Met andere woorden: het voltooien van het rouwproces en het tot een oplossing brengen van gestagneerde ontwikkelingstaken is (nog) niet mogelijk gebleken.

De term 'survivor' wordt vooral gehanteerd door incest-slachtoffers. FORWARD/ BUCK merkt hierover op: 'Tk weet dat er therapeuten en incest-cliënten zijn die liever de term overlevende [survivor, jw] van incest dan slachtoffer van incest gebruiken en dat is uitstekend. Maar ik vind slachtoffer van incest een nawweuriger beschrijving van de individuele ervaringen. Ik sta natuurlijk open voor de taalkundige poging de pijn te verzachten, zolang het woord overlevende maar niet wordt gebruikt om te ontkennen hoeveel werk er moet worden gedaan.' (Susan ForWARD, Craig BUCK, Eindelijk je eigen leven leiden; Loskomen van een beschadigde jeugd, Utrecht/Antwerpen 1990, p. 231.) Dit laatste wordt ook benadrukt door BASS en DAVIS: 'Healing from child sexual abuse takes years of commitment and dedication. But if you are willing to work hard, if you are determined to make 
blijven van de 'coping'-mechanismen ${ }^{3}$ die hem of haar in staat hebben gesteld een traumatische jeugd te overleven? ${ }^{4}$ Slachtoffer van de daaruit voortgekomen psycho-sociale strategieën, emotionele valkuilen en (anti-) sociale tactieken?' ? $^{5}$ Slachtoffer van diep in de cerebrale 'hardware' - in het psychische levensontwerp, het 'intern werkmodel' - ingesleten fnuikende en tragische patronen? Slachtoffer van een scheefgegroeide, een vervormde, 'dysmorfe" persoonlijkheid? ${ }^{6}$ Slachtoffer van 'neurotische"

lasting changes in your life, if you are able to find good resources and skilled support, you can not only heal but thrive. We believe in miracles and hard work." (Ellen BASS, Laura DAVIS, The courage to heal; A guide for women surviwors of child sexual abuse, New York 1988, p. 20 iffo)

3 Zie voor een lijst van afweermechanismen c.q. coping-stijlen bijlage IV bij dit proefschrift. Vgl. met betrekking tot 'coping' voorts H.E.M. BAARTMAN, Opvoeden kan zeer doen, Utrecht 1996, p. 102. Eén van de daar aangehaalde omschrijvingen van 'coping' is: 'efforts, both action-oriented and intrapsychic, to manage (i.e., master, tolerate, reduce, minimize) environmental and internal demands, and conflicts among them, which tax or exceed a person's resources." Met andere woorden: het betreft fenomenen die optreden wanneer de draaglast de draagkracht owerschrijdt.

4 Vgl. met betrekking tot "innerlijke overlevingsstrategieën” (ook) Nel DRAIJER, Sexael misbruik wan meisjes door verwanten; Een landelijk onderzoek naar de omvang, de aard, de gezinsachtergronden, de emotionele betekenis en de psychische en psychosomatische gevolgen, Ministerie van Sociale Zaken en Werkgelegenheid, Den Haag 1988, p. 160 (pp. 153-160); Nel DRAJJER, Seksuele traumatisering in de jeugd; Gevolgen op lange temijn wan seksueel misbruik van meisjes door verwanten, diss. Amsterdam 1990, p. 220 (pp. 215-220).

5 Eén van deze valkuilen is het presenteren van oude, openstaande emotionele rekeningen niet aan de eigen ouders maar aan andere volwassenen, die men daardoor van zich vervreemdt, zodat degenen die in deze kuil vallen, 'van feitelijk beschikbare steun niet weten te profiteren." (Herman BAARTMAN, "KAFKA's brief aan zijn vader; over het opgroeien als verworpen kind, in: Willem BERGER e.a. (red.), Geweld in relaties, Baarn 1991, pp. 24-42, op p. 37.)

6 Onder een 'dysmorfe" persoonlijkheid versta ik een persoonlijkheid met dysmorfe (miswormde, mismaakte) trekken, zoals de achterdochtige en rancuneuze trekken die we vinden bij de paranoïde persoonlijkheid, de leugenachtige en roekeloze trekken van de anti-sociale ('psychopathische') persoonlijkheid, de onbetrouwbare en impulsieve trekken van de borderline-persoonlijkheid, de onechte en manipulatieve trekken van de theatrale ('hysterische') persoonlijkheid, de arrogante en gevoelloze trekken van de narcistische persoonlijkheid, de negatiwistische trekken van de passief-agressieve en de depressieve persoonlijkheid, enzovoort. (Vgl. de Diagnostic and Statistical Manual of mental disorders; Fourth edition/DSM-IV, American Psychiatric Association, Washington 1994, pp. 629-673 en 732-735; De ICD-10 classificatie van psychische stoomissen en gedragsstoomissen, World Health Organization/Nederlandse Vereniging voor Psychiatrie, Lisse 1994, pp. 222-232.) 
partnerkeuze - met alle relatie-ellende vandien'; van 'neurotische' beroepskeuze, met alle schade en schande die dat veroorzaakt? Slachtoffer van het onvermogen 'zichzelf te vinden, 'iemand' te worden, slachtoffer daarom van uitwendige symbolen waaraan de schijn van identiteit kan worden ontleend, zoals geld, bezit, (twee) kinderen, macht, verslavingen in velerlei gedaanten en varianten?

Slachtoffer van daders wier fysiek en/of psychisch geweld, manipulaties, geestelijke terreur, emotionele chantage e tutti quanti zozeer zijn verinnerlijkt, met wie men daardoor zozeer is verknoopt, ${ }^{8}$ dat men er nooit meer in slaagt zich uit hun greep, of uit de greep van de introjecties, hun altijd en alom op de loer liggende spoken en monsters, te bevrijden? Slachtoffer van multipele revictimisering, van "traumaverslaving," de doem steeds opnieuw slachtoffer te worden? Slachtoffer van de doem dader te worden, steeds opnieuw, slachtoffer van misbruikverslaving, van herhaalde recidive? Slachtoffer van de doem tot herhaling van slachtoffer- en/of daderpatronen, de herhalingsdwang, de dwang die voortvloeit uit de combinatie van verkeerde programmering en de macht van de verkeerde gewoonte? Slachtoffer zodoende van het transgenerationele noodlot tot in het derde, vierde, zevende vervloekte - althans ongezegende geslacht?

De tweede categorie sequelae - de maatschappelijke (c.q. sociaaleconomische) gevolgen - draait, in het verlengde van de eerste, om de vraag: in hoeverre zijn vandalisme (materieel en psychisch: pesten) en criminaliteit, verslaving aan legale en illegale (allang niet meer genots-) middelen, menselijk en maatschappelijk kapitaal vernietigende psychische en psychiatrische stoornissen - variërend van verlammende en invaliderende depressies, dissociaties, fobieën, dwanghandelingen en -gedachten, tobberijen, vreetbuien, magerzucht, slapeloosheid, paniekaanvallen, sexuele en relatiestoornissen, drift-explosies, kleptomanie, pyromanie, pathologisch gokken, psycho-somatische klachten enzovoorts, enzovoorts tot

KUIPER spreekt van 'sadomasochistische relatie[s], waaraan gewoonlijk weel beleefd wordt - never a dull moment -, weliswaar voornamelijk ellende.' Een andere kwalificatie is partner-verslaving ("love-addiction'), waarover KUIPER opmerkt: '[H]et kan niet worden ontkend dat mensen in giftigheid ten opzichte van de ander soms niet onderdoen voor alcohol en heroinc." (P.C. KUIPER, Nieuwe neurosenleer, Deventer 1984, achtste druk, resp. pp. 190 en 217.)

Vgl. voor het proces van 'verknoping' tussen slachtoffer en dader (in de literatuur ook wel aangeduid als traumatic bonding, traumatische verbondenheid of hechting): N.J. NICOLAI, Incest als trauma: implicaties en consequenties voor de behandeling, Tijdschrift voor Psychotherapie 1991/1, pp. 12-30, op p. 20.

Vgl. Judith Lewis HERMAN, Trauma en herstel; De gevolgen van geweld - wan mishandeling thwis tot politiek geweld, Amsterdam 1993, p. 149. 
aan borderline-, narcistische, theatrale, anti-sociale, paranoïde, passiefagressieve enzovoorts persoonlijkheidsstoornissen, en de vlucht, wanneer vluchten niet meer kan, in allerlei psychosen - toe te schrijven aan kindermishandeling?

In de derde plaats is er de vraag naar het incidentele dan wel structurele karakter van het fenomeen kindermishandeling. In meer juridische termen: de vraag of kindermishandeling - in elk individueel geval onmiskenbaar een ernstige, ja flagrante schending van de rechten van het kind - op maatschappelijk vlak, mede gezien de ormvang ervan, de grootschaligheid, kan - en dan ook moet - worden aangemerkt als ernstige en systematische mensenrechtenschending? Systematisch niet in de zin van een actief kinderen vervolgende maatschappij en overheid. Maar systematisch in de zin van een passief toekijkende samenleving, die de overheid heeft die zij 'verdient'?

12.2

Kindermishandeling als ernstige mensenrechtenschending (1): de cijfers

Met betrekking tot de vraag naar de omvang van kindermishandeling in Nederland kijken we in de eerste plaats naar de bijdrage van NOORDHOEK-VAN DER STAAY over 'Definiëring, prevalentie en incidentie van kindermishandeling. ${ }^{10}$ Daarnaast maken we in het bijzonder gebruik van het VKM Info 'Kindermishandeling in getallen' (hierna: VKM Info) uit $1996 .^{11}$

\section{2 .1}

Defimiëring, prevalentie en incidentie

\section{Definiëring}

Het is evident dat de omvang van een te meten verschijnsel direct afhankelijk is van de definitie die men van het verschijnsel heeft of geeft. We hebben in het vorige hoofdstuk gezien hoe moeilijk het is een adequate definitie van kindermishandeling te geven. Dit betekent dat cijfers altijd

10 Jacquelien NOORDHOEK-VAN DER STAAY, 'Definiëring, prevalentie en incidentie van kindermishandeling,' in: H. BAARTMAN en A. VAN MONTFOORT (red.), Kindermishandeling resultaten van multidisciplinair onderzoek, Utrecht $1992, \mathrm{pp} .40-$ 53 (op pp. 47-51).

11 A. WOLZAK, "Kundermishandeling in getallen," VKM Info, (Stichting) Voorkoming van Kindermishandeling/VKM (met ingang van 1997 ondergebracht bij het Nederlands Instituut voor Zorg en Welzijn/NIZW te Utrecht), februari 1996.

In 1998 verscheen een tweede (herziene) druk, die evenwel (behoudens enkele cijfers van de Raad voor de Kinderbescherming over 1996) nauwelijks of geen nieuwe gegevens of (herziene) cijfers(/extrapolaties) bevat. 
met de nodige argwaan moeten worden bekeken, en dat hoe dan ook een voorzichtig hanteren en presenteren van cijfers geboden is. In dit verband lijkt het met name raadzaam, althans waar het globale cijfers betreft, cijfers die een indicatie willen geven van de omvang van alle vormen van kindermishandeling bij elkaar (per jaar of per leeftijdsgroep), steeds van bodem-cijfers (tenminste zoveel per jaar of tenminste zoveel in deze groep) of band-cijfers (tussen zo- en zoveel) uit te gaan. NOORDHOEKVAN DER STAAY schrijft: ${ }^{12}$

'Op dit moment wordt in Nederland in het algemeen onder kindermishandeling verstaan: fysieke mishandeling en verwaarlozing, psychische mishandeling en verwaarlozing en seksueel misbruik (...). Fysieke mishandeling kan betekenen: slaan (met voorwerpen), schoppen, branden (met vuur of heet water), blootstellen aan extreme kou, krachtig door elkaar schudden ([baby] shaking) en laten vallen. Fysieke verwaarlozing komt tot uiting in zaken zoals: onthouden van medische zorg en voeding, slechte hygiëne, onvoldoende slaap, niet adequaat gekleed gaan en veel zonder toezicht alleen zijn. We kunnen spreken van psychische mishandeling wanneer een kind afgewezen, gekleineerd, geterroriseerd, geisoleerd, gecorrumpeerd of geexpploiteerd wordt (...). Van psychische verwaarlozing is sprake wanneer het kind onvoldoende koestering, stimulans, gevoel van veiligheid en geborgenheid ervaart. Seksueel misbruik ten slotte omvat al die handelingen waarbij de lichamelijke (en de psychische) intimiteit van het kind geschonden wordt, van gluren naar en bespieden van het kind tot betasting en penetratie. Deze indeling wordt ook door de Bureaus Vertrouwensarts inzake Kindermishandeling [BVA's] gebruikt bij de registratie van meldingen van kindermishandeling.'

De in het vorige hoofdstuk vermelde definitie van kindermishandeling van de BVA's zullen we hier niet herhalen. De auteur merkt op: $:^{13}$

'Een goede begripsomschrijving (...) [en] een heldere formulering [kunnen] ons enige zekerheid verschaffen dat we "allemaal weten dat we over hetzelfde praten," zowel binnen een bepaalde beroepsgroep als tussen beroepsgroepen onderling. Voorwaarde is dan wel dat een bepaalde definitie als werkbaar uitgangspunt geaccepteerd is en op een heldere wijze geoperationaliseerd is. (...) Een definitie kan echter nog zo nauwkeurig omschreven zijn, zij is toch altijd onderhevig aan interpretaties. (...)

Een en ander betekent dat er een grijs gebied is van handelingen, al dan niet voorzien van het predikaat "opvoedkundig," waarover op z'n zachtst gezegd verschil van mening en van interpretatie blijkt te bestaan.'

Behalve het probleem van de definiëring is er de vraag wàt de cijfers bedoelen aan te geven en uit welk type onderzoek zij voortkomen. De 
auteur behandelt dit onder het kopje 'prevalentie en incidentie,' dat wij hier zullen overnemen.

\title{
Prevalentie en incidentie
}

NOORDHOEK-VAN DER STAAY merkt op: ${ }^{14}$

\begin{abstract}
'We kunnen op twee manieren aangeven in welke mate kindermishandeling v66rkomt. Er zijn op de eerste plaats cijfers over de incidentie van dit verschijnsel, waarmee het totale aantal personen bedoeld wordt dat binnen een bepaalde periode slachtoffer van mishandeling wordt. Het gaat dan meestal om een periode van een jaar.

Daarnaast zijn er cijfers die de prevalentie weergeven, waarbij het gaat om het aantal gevallen van kindermishandeling binnen een bepaalde populatie (bijvoorbeeld een instelling of een leeftijdscategorie) (...).
\end{abstract}

Zij vervolgt: $:^{15}$

'Er zijn in Nederland geen cijfers beschikbaar die de incidentie van kindermishandeling weergeven. Wel zijn er cijfers voorhanden van het aantal meldingen dat per jaar gedaan wordt bij de Bureaus Vertrouwensarts inzake Kindermishandeling. Deze geven echter geen beeld van de incidentie van kindermishandeling in Nederland; er worden ook meldingen gedaan bij de Raden voor de Kinderbescherming, bij de politie en bij hulpverleningsinstellingen. Bij deze laatste instanties wordt echter niet of niet systematisch geregistreerd welke zaken onder de noemer kindermishandeling worden gemeld (...). En dan is er natuurlijk nog het aantal zaken dat nimmer ter ore van genoemde instanties komt.'

In Nederland is er noch een wettelijke meldplicht ter zake van kindermishandeling, noch een (grote) meldingsbereidheid bij het publiek ${ }^{16}$ of bij 'professionals.' Zo meldt de Werkgroep meldpunt kindermishandeling (naar haar voorzitter ook wel de werkgroep-HERMANNS genoemd): $:^{17}$

14 T.a.p., op pp. $47 / 48$ (curs. overgenomen).

15 T.a.p., op p. 48 (curs. jw).

16 Een typerend citaat in dit verband: 'Er belt ook een onderhoudsmonteur wan het gasbedrijf, die in de huishoudens waar hij komt meer ziel dan hem lief is. "Een keer ben ik er tussen gesprongen toen een ventje van twee door zijn dronken vader in ellkaar getrapt werd," wertelt hij. Dat kwam hem op een reprimande van zijn werkgever te staan. Hij moest zich er buiten houden. Ook zijn vrouw zegt dat. "Maar ik voel dat toch anders," houdt hij vol.' (Michaja LANGELAAN, "Kundermishandeling: de 06-lijn,' Maandblad Geestelijke volksgezondheid 1992/6, pp. 661669 , op p. 666 1.k.)

17 WERKGROEP MELDPUNT KINDERMISHANDELING, Het melden van vermoedens van kindermishandeling; Samenvatting wan een onderzoek naar ervaringen en wensen van potentiële melders, Roermond, juni 1996 , p. 5 . 
Nog het minst wordt gemeld door personen uit de sociale omgeving van het kind. Slechts in én op de vijf gevallen wordt daadwerkelijk ergens aan de bell getrokken. Van de personen die beroepshalve met kinderen werken (de zgn. beroepsbeofenaren zoals leerkrachten, peuterspeelzaalleidsters en huisartsen), gaat $27 \%$ nooit over tot een melding, hoewel ze frequent vermoeden dat een kind thuis mishandeld wordt. Van de personen die een hulpverleningsrelatie met het kind of het gezin hebben, zegt $19 \%$ nooit te melden."

Hoewel er tegen een meldplicht zeker bezwaren zijn in te brengen, is het helaas zo dat in een 'privacy-gevoelige' cultuur als de Nederlandse de zwaksten in de samenleving, dat zijn de zwaksten achter de gesloten deuren, de eerste en ergste slachtoffers zijn. ${ }^{18}$ Het zijn (jonge en met

18 Als bezwaren tegen een meldplicht noemt VAN UNEN: 1.) het aantal valse meldingen (kinderen die ten onrechte worden gemeld; een nadeel dat - moreel gezien - in het niet valt tegen de aantallen kinderen die ten onrechte niet worden gemeld, en dus ook niet kunnen worden beschermd; al kan men juridisch het een uiteraard niet tegen het ander wegstrepen); en 2.) het gebrek aan (politieke wil) fondsen (te voteren) om aan meldingen een verantwoord vervolg te kunnen geven (in mijn ogen hooguit een tijdelijk nadeel: in een democratie - vrije pers, publieke opinie, actiegroepen - zal het immers op den duur niet mogelijk zijn politieke verantwoordelijkheden te laten liggen en een onmenselijke/onrechtvaardige/ ondoelmatige status quo te handhaven). Zie Alice VAN UNEN, "Meldingssystemen inzake kindermishandeling in Europa en Amerika," Tijdschrift voor de rechten van het kind 1997/1, pp. 6-9, op p. 9 r.k.; dez., Melden van kindermishandeling over de grens; Een onderzoek naar meldingssystemen inzake kindermishandeling in Noorden West-Europa en de Verenigde Staten van Amerika, Nederlands Instituut voor Zorg en Welzijn/Nrzw, Utrecht (maart) 1997, pp. 68/69.

Vgl. ook Gail L. ZELLMAN, Kathleen C. FALLER, 'Reporting of child maltreatment,' in: John BRERE e.a. (eds.), The APSAC [American Professional Society on the Abuse of Children] handbook on child maltreatment, Thousand Oaks (etc.) 1996, pp. 359-381, op p. 377 1.k., waar (in een citaat) 'the "can't afford" argument against child welfare programs' wordt gehekeld ('lack of seriousness') onder verwijzing naar '[t]he $\$ 150-500$ billion savings and loan crisis": "The public money to make the S\&L depositors whole was forthcoming with no debate at all ....' Het citaat vervolgt: 'Until we change our notions of how desirable adequate child welfare programs are, the public purse, which opens so easily and lavishly for other purposes, will not be available for them."

Groot voordeel van het Amerikaanse systeem van verplichte meldingen is de enorme toename van het aantal gevallen van kindermishandeling dat onder de aandacht van de autoriteiten (en het publiek) komt. VAN UNEN zegt hierover (Tijdschrift voor de rechten van het kind, t.a.p.y op p. 7 r.k.): 'Door het feit dat probleemgezinnen onder de aandacht van de kinderbeschermingsinstanties worden gebracht, worden kinderen in nood beter beschermd. Bovendien heeft het professionals gedwongen zichzelf te trainen en te onderwijzen over kindermishandeling en is het voor hen een stok achter de deur gevallen van mishandeling te melden, zelfs als zuj dat moeilijk vinden.' 
name zeer jonge) kinderen voor wie het gelag het hardste is in 'Nederland-vrijblijvendland.' Waarschijnlijk is in ons land het aantal zaken dat ter ore van instanties komt, dan ook slechts het zichtbare topje van de beruchte ijsberg. Zoals bekend is, bevindt een ijsberg zich voor 80 tot $85 \%$ onder water, slechts 15 tot $20 \%$ vertoont zich aan het oppervlak. ${ }^{19}$ In het voorwoord van zijn proefschrift Het topje van de ijsberg; Kinderbescherming en de bestrijding van kindermishandeling in sociaal-juridisch perspectief, merkt VAN MONTFOORT op: ${ }^{20}$

'Ongetwijfeld is ook nu nog het leed dat bekend wordt bij allerlei instanties,
slechts een deel van wat zich in het gezin afspeelt. De vertegenwoordigers van
wat ik de beweging tegen kindermishandeling zal noemen, gebruiken hiervoor
vaak de uitdrukking dat wat we nu weten, niet meer is dan het topje van de
ijsberg.'

Hoe groot is dit topje, welke aantallen betreffen de zichtbare "15 tot $20 \%$ ' - althans het stukje, het topje van het topje van die '15 tot $20 \%$ " dat bij de BVA's (Bureaus Vertrouwensarts) wordt geregistreerd? NOORDHOEK-VAN DER STAAY vervolgt: ${ }^{21}$

'Bij de Bureaus Vertrouwensarts inzake Kindermishandeling werden in 1991 9.807 meldingen van kindermishandeling geregistreerd (dit betreft zowel de meldingen ter activiteit als de meldingen ter advies), waarvan $21 \%$ niet verifieerbaar bleek. Als oorzaak voor het niet verifieerbaar blijken van deze zaken wordt aangegeven dat bij het inwinnen van informatie met betrekking tot het gezin onvoldoende gegevens binnenkomen om te kunnen vaststellen of er werkelijk sprake is van mishandeling.

Over de aard van de mishandeling kan worden opgemerkt dat het in $40 \%$ wan de geverifieerde meldingen ging om emotionele mishandeling/verwaarlozing; $9 \%$ had betrekking op lichamelijke verwaarlozing; in $22 \%$ op lichamelijke mishandeling; $18 \%$ op seksueel misbruik en $11 \%$ op overige vormen (...).'

Om hier wat recentere cijfers aan toe te voegen: in 1992 werd de tienduizend-grens gepasseerd, er werden 11.466 meldingen geregistreerd; in 1993 waren dat er 13.220; in 1994: 13.946; in 1995: 14.175. In acht jaar tijds is

19 De tafelvormige antarctische ijsberg is voor circa $80 \%$ ondergedompeld, de kiesvormige arctische (of Groenlandse) ijsberg bevindt zich voor circa $85 \%$ onder water.

20 A. VAN MONTFOORT, Het topje van de ijsberg; Kinderbescherming en de bestrijding van kindernishandeling in sociaal-juridisch perspectief, ac. diss. vU Amsterdam, Utrecht 1994, p. 11.

21 NOORDHOEK-VAN DER STAAY, $t_{n}$ a.p. 
het aantal meldingen bij de BVA"s bijna verdubbeld, van 7.429 in 1988 tot 14.175 in $1995 .{ }^{22}$

Per 1 januari 1996 zijn de landelijke steuntaken van de LSBVK (Landelijke Stichting Bureaus Vertrouwensarts inzake Kindermishandeling) overgedragen aan het bij het NIZW (Nederlands Instituut voor Zorg en Welzijn te Utrecht) ondergebrachte LSMK (Landelijk Steunpunt Melden van Kindermishandeling). De BVA's zijn aan provinciaal of regionaal werkende instellingen overgedragen. De LSBVK zelf is in liquidatie gebracht. Een en ander zou een verklaring kunnen zijn voor de relatief geringe stijging in 1995 ten opzichte van vorige jaren. ${ }^{23}$

Van de 6.851 meldingen ter activiteit (6.851 gezinnen met 10.432 mishandelde kinderen) in 1995 betrof het in $36 \%$ van de gezinnen emotionele maltraitering (psychisch geweld: $16 \%$; affectieve verwaarlozing: $20 \%$ ); in $9 \%$ van de gezinnen ging het om lichamelijke verwaarlozing; in $25 \%$ om lichamelijke mishandeling; in $18 \%$ om sexueel misbruik (en overige: $\left.12 \%{ }^{24}\right)^{25}$ Deze percentages moeten met de nodige voorzichtigheid worden gehanteerd. Zo merkt BAARTMAN op dat er ...

'(...) goede redenen [zijn] om aan te nemen dat het werkelijke aandeel van lichamelijke verwaarlozing op het geheel vele malen groter is dan $[9 \%](\ldots) .{ }^{26}$

Daarnaast moet met het volgende rekening worden gehouden: ${ }^{27}$

'Over het algemeen zal er sprake zijn van een combinatie van verschillende vormen van mishandeling. De meest prominente vorm wordt geregistreerd.'

Het is niet onaannemelijk dat niet zelden 'sex' ('incest') alls het meest prominente zal worden betiteld (althans door de omgeving en/of het slachtoffer), terwijl er daarnaast - en veelal: daarmee verweven - even ernstige, zo niet ernstiger zaken spelen. Hetzelfde kan vermoed worden met betrekking tot slaag of andere vormen van fysiek geweld. In de kern

LSBVK (Landelijke Stichting Bureaus Vertrouwensarts inzake Kindermishandeling), Jaarverslag 1995, Utrecht 1996, Bijlagen, p. ini, tabel 4.

23 B. SAMSOM, Jaanverslag 1995 LSBKK, p. 37.

24 "Onder de categorie "overig" vallen onder meer baby's van drugsverslaafde moeders die vaak uit voorzorg al voor de geboorte gemeld worden." (VKM Info, p. [1] r.k.)

25 LSBVk, Jaarverslag 1995, Bijlagen, pp. ii, vi en vii, tabel 2, 6 en 7.

26 Herman BAARTMAN, "Omvang, oorzaken, hulpverlening en preventie inzake kindermishandeling; inzichten vanuit de research voor praktijk en beleid op het terrein van kindermishandeling,' Gezin; Tijdschrift voor primaire leefvomen 1990/ 2, pp. 76-87, op pp. $77 / 78$. 
gaat het immers (zo zagen we in het vorige hoofdstuk) om de (on)pedagogische houding van de ouder(s), en dat is per definitie een psychologisch, een emotioneel gegeven. Hoewel psychische maltraitering (psychotraumatisering, ontwikkelingsschade, 'persoonswordingsbeschadiging') de rode draad is die door alle vormen van kindermishandeling loopt, ${ }^{28}$ is het veelal gemakkelijker een schending van de lichamelijke integriteit te identificeren - en in zekere zin als 'hoofdschuldige' te benoemen - dan een schending (de onderliggende chronische of herhaalde schending) van de geestelijke integriteit. ${ }^{29}$

Ten aanzien van de gemelde kinderen ligt de verhouding tussen jongens en meisjes globaal gelijk, met uitzondering van sexueel misbruik: hier wordt op elke drie meisjes één jongen gemeld. ${ }^{30}$ Voor de goede orde: in totaal betrof $46 \%$ van de gemelde kinderen jongens, $54 \%$ meisjes. ${ }^{31}$ Meisjes zijn vooral oververtegenwoordigd in de categorie vanaf 12 jaar, veelal als slachtoffer van sexueel misbruik. ${ }^{32}$

Wat de leeftijden van de gemelde kinderen betreft: $53 \%$ valt in de categorie van 0 tot 9 jaar, $45 \%$ in de categorie van 9 tot 18 jaar (2\% is na de melding 18 geworden, of het betreft geestelijk gehandicapten). ${ }^{33}$ Slechts $12 \%$ betreft kinderen van 0 tot en met 2 jaar: vermoedelijk gaat het hier evenwel om de grootste - en in elk geval om de gevaarlijkste ijsberg met het kleinste zichtbare topje. ${ }^{34}$ In totaal gaat het om ruim

28 Vgl. James GARBARINO, 'Future directions,' in: Robert T. AMMERMAN, Michel HERSEN (eds.), Children at risk; An evaluation of factors contributing to child abuse and neglect, New York/London 1990, pp. 291-298, op p. 297.

29 In een onderzoek in het Sophia Kinderziekenhuis te Rotterdam ging het in 40\% van de meldingen om (vermoedens van) sexueel misbruik, $35 \%$ emotionele verwaarlozing, $33 \%$ lichamelijke mishandeling, $16 \%$ lichamelijke verwaarlozing en $10 \%$ emotionele mishandeling. In deze telling (onder 204 kinderen, waarvan $30 \%$ onder de 3 jaar) is kennelijk alles geturfd (met andere woorden is niet geregistreerd op basis van de meest prominente vorm), aangezien het totaal boven de $100 \%$ uitkomt. Het percentage van 40 voor (vermoedens van) sexueel misbruik (bij ruim $30 \%$ baby's en peuters) is opmerkelijk te noemen. Zie eindrapport Kindemishandeling, een probleem voor het ziekemhuis, besproken door Charlotte JANSE en Roland AARSEN, VKMagazine 1997/1, pp. 1-3, op p. 2 l.k. Zie ook het eindverslag zelf (van dezelfde auteurs; s.l.e.a.), pp. 28 en 34 i.f.

$30 \quad$ LSBVK, Jaarverslag 1995, Bijlagen, p. wii, tabel 9.

31. LSBVK, Jaarverslag 1995, Bijlagen, p. vii, tabel 8 en 9.

32 Vgl. ook VKM Info, p. [1] r.k.

33 LSBVK, Jaarverslag 1995, Bijlagen, p. vii, tabel 7.

34 Vgl. VKM Info, p. [1] r.k. De eerste twee levensjaren worden gerekend tot de 'high-risk-of-abuse' jaren van een kinderleven. Zie Murray A. strAuS, Glenda K. KANTOR, 'Stress and child abuse,' in: Ray E. HELFER, Ruth S. KEMPE (eds.), The battered child, Chicago/London 1988 (vierde druk), pp. 42-59, op p. 50. 


\subsection{0 mishandelde kinderen..$^{35}$}

De grootste alertheid/meldingsbereidheid bestaat in (het werkgebied) Lelystad ( 1 melding per 150 kinderen: $0,67 \%$ ) en Utrecht ( 1 op de 180: 0,56\%); de geringste in Breda (1 op de 340: 0,29\%) en Maastricht ( 1 op de 300: 0,33\%). Landelijk ligt het gemiddelde op 1 melding per 260 kinderen $(0,38 \%)$. De landelijke rangorde qua alertheid/meldingsbereidheid ziet er als volgt uit: Lelystad $(0,67 \%)$, Utrecht $(0,56 \%)$, Leeuwarden $(0,43 \%)$, Rotterdam $(0,4 \%)$, Alkmaar-Amsterdam, Arnhem en Groningen $(0,37 \%)$, Zwolle $(0,36 \%)$, Den Haag $(0,34 \%)$, Maastricht $(0,33 \%)$, Breda $(0,29 \%){ }^{36}$ Deze percentages betreffen kinderen van nul tot twintig jaar. ${ }^{37}$

Van de gemelde gezinnen gaat het in de helft van de gevallen om een twee-, in een kwart van de gevallen om een éen-oudergezin. ${ }^{38}$ Dit betekent een forse oververtegenwoordiging van de laatste categorie (de helft in plaats van één zevende). ${ }^{39}$ Dat een twee-ouder(gezins)systeem zich beter van de buitenwereld kan afschermen (c.q. dat een éenoudersysteem zich meer in een glazen huisje bevindt), kan hiervan slechts een deel van de verklaring zijn. Het kan immers ook zo zijn dat éénoudersystemen door de bank genomen niet alleen sociaal en sociaal-economisch, maar ook sociaal-pedagogisch kwetsbaarder zijn (er is, vanuit de optiek van het kind, geen 'corrigerende' andere ouder ${ }^{40}$ ). Anderzijds kan een verhoogde sociaal-pedagogische kwetsbaarheid ook worden vermoed ten aanzien van twee-oudersystemen met (te) jonge ouders (in wier materiële en immateriële, inzonderheid sociaal-emotionele behoeften niet of nauwelijks is voorzien). ${ }^{41}$

LSBVK, Jaarverslag 1995, Bijlagen, p. vii, tabel 7 (10.432 kinderen waarvan 251 bowen de 18 jaar).

36 Vgl. LSBVK, Jaarverslag 1995, Bijlagen, p. v, tabel 5.

37 LSBVK, Jaarverslag 1995, Bijlagen, p. v.

38 LSBVK, Jaarverslag 1995, Bijlagen, p. ix, tabel 13.

39 Immers: '85\% van de minderjarige jeugd van Nederland groeit op in een gezin met twee gehuwde ouders, $13 \%$ woont in een cenoudergezin en $1,5 \%$ woont bij ongehuwd samenwonende ouders." Zie J. VAN KAMPEN (red,), De staat van jeugdig Nederland 1996; Een sociale kart wan de jeugd van Nederland, Werkdocument 1 Stichting Jeugdinformatie Nederland (Utrecht), Delft [1996], p. 13.

Vgl. bij BEYAERT het recht van het kind op 'een "redelijke andere" ouder" (F.H.L. BEYAERT, 'Het kind, de jeugdige in het recht,' in: Ted DE BOER e.a. (red.), De kant wan het kind; Liber amiconm Prof. mr. Miek DE LANGEN, Arnhem 1992, pp. 175-181, op p. 180).

41 Vgl. in dit verband H.E.M. BAARTMAN, Opwoeden kan zeer doen, Utrecht 1996, p. 116. 
Wat de plegers van kindermishandeling betreft: vrouwen doen niet voor mannen onder ( 49 respectievelijk $51 \%$ ). ${ }^{42}$ BEYAERT noemt kindermishandeling ...

'(...) en kinderdoding, met name van kleine kinderen, (...) het enige delict dat meer door vrouwen (moeders) wordt gepleegd dan door mannen (vaders). ${ }^{43}$

Hetgeen hij voor een gedeelte toeschrijft aan het fenomeen van de "afwezige vader': ${ }^{44}$

"De "afwezige vader" die zou hebben kunnen interveniëren in een escalerende moeder-peuterrelatie, blijkt meestal juist door zijn afwezigheid aan deze tragische calamiteiten een aandeel te leveren.'

Wat daarvan verder ook zij, over het geheel genomen, dus gekeken naar alle leeftijdcategorieën van kinderen en alle vormen van kindermishandeling, houden de geslachten elkaar evenwel bijna volledig in evenwicht. Mannen zijn wel oververtegenwoordigd als plegers van sexueel misbruik; vrouwen zijn echter oververtegenwoordigd bij lichamelijke verwaarlozing en psychische maltraitering. ${ }^{45}$

Pedagogisch besef is kennelijk niet iets dat in de (vrouwelijke) genen zit ('nature'), maar iets dat door mannen èn vrouwen moet worden verworven, afhankelijk van de waarde die de maatschappij daaraan hecht ('culture'), en uiteraard van de mate waarin mannen èn vrouwen erin slagen hun eigen (traumatische) jeugdervaringen te verwerken (wat op zijn beurt eveneens afhankelijk is van de waarde die de maatschappij dáaraan hecht, en dus van sociale steun, steun van de omgeving; opnieuw dus: 'culture' - in casu het doorbreken van een transgenerationele 'cultuur').

Enkele percentages kunnen hier ter verfijning worden vermeld. ${ }^{46}$ In het geval van één pleger $(60 \%)$ is dit in $20 \%$ van de gevallen de vader en in $29 \%$ van de gevallen de moeder (de overige $11 \%$ bestaat voor $4 \%$ uit stiefvaders; voor $3 \%$ uit broers, opa's, ooms of neven; voor $4 \%$ uit mannen buiten de familiekring en voor minder dan $1 \%$ uit stiefmoeders of vriendinnen van de vader). De man-vrouw verhouding ligt hier dus

43 F.H.L. BEYAERT, 'Strafwetgeving en de crime passionmel, dodingen in bet gezin en toch weer de vader,' in: A. LADAN e.a. (red.), De betekenis van de vader; Psychoanalytische wisies op het vaderschap, Meppel/Amsterdam 1985, pp. 102-122, op pp. $103 / 104$.

44 BEYAERT, t.a.p., op p. 104.

45 VKM Info, p. [1] r.k. if.

46 LSBVK, Jaarversiag 1995, Bijlagen, p. viii, tabel 11. 
praktisch gelijk ( $<31 \%$ versus $>29 \%$, waarbij het bij de $7 \%$ mannelijke niet-vaderfiguren vermoedelijk voornamelijk om 'incest' zal gaan). In het geval van twee plegers (40\%) zijn dit in $29 \%$ van de gevallen vader en moeder beiden/tezamen (de resterende $11 \%$ bestaat voor $4 \%$ uit moeder tezamen met haar vriend of de stiefvader; voor $1 \%$ uit vader tezamen met zijn vriendin of de stiefmoeder; en voor $6 \%$ uit andere combinaties). De man-wrouw verhouding ligt hier per definitie gelijk, ervan uitgaande dat bij homosexuele c.q. gelijkgeslachtelijke combinaties mishandelende man-man- en vrouw-vrouw-relaties gelijk opgaan.

Wanneer worden meldingen afgesloten of, anders gezegd, hoe zit het met de afgesloten meldingen? Van de 4.201 in 1995 afgesloten meldingen is in $10 \%$ van de gevallen de mishandeling gestopt; $14 \%$ is niet geverifieerd (wegens thet ontbreken van informatie, ${ }^{47}$ ); in $9 \%$ bleek van mishandeling geen sprake; in 3 gevallen is het kind na mishandeling overleden. $^{48}$ De overige meldingen ${ }^{49}$ zijn overgedragen $(55 \%)$ - naar ik aanneem aan de hulpverlening -, of aan de Raad voor de Kinderbescherming gemeld ( $7 \%$, waarvan $3 \%$ door de BVA's zelf, $4 \%$ door anderen); $5 \%$ valt in de categorie 'anders.' Niet duidelijk is of deze laatste categorie de 'hopeloze,' letterlijk afgeschreven gevallen betreft. ${ }^{50}$

47 VKM Info, p. [1] r.k. Niet duidelijk is of hieraan stilzwijgen van de omgeving, onbekendheid in de omgering van het kind met mishandelingssymptomen of -signalen, onbekendheid van het gezin in de omgeving (het kind is na confrontatie van de ouders van school gehaald en naar een andere school gestuurd, men is snel van huisarts veranderd, het gezin is verhuisd enz. enz.), of de onmogelijkheid het gezinssysteem binnen te komen (het hyperhomeostatische systeem heeft zich hermetisch gesloten) debet ${ }^{4}$.

Vgl. ook Gail L. ZELLMAN, Kathleen C. FALLER, 'Reporting of child maitreatment," in: John BRUERE c.a. (eds.), The APSAC (American Professional Society on the Abuse of Children] handbook on child malteatment, Thousand Oaks (etc.) 1996, pp. 359-381, op p. 375 l.k.

48 In 1994 was er "in veertien gevallen sprake van een overleden kind.' (VKM Info, p. [4] 1.k.) Zie ook hierna.

49 Zie LSBVK, Jaarverslag 1995, Bijlagen, p. xuii, tabel 18.

50 Indien dit zo zou zijn, zouden de BVA's zich hier lelijk in de kaart laten kijken: mijns inziens is het afleggen van een dossier zonder dat er voor adequate (voortgezette) hulpverlening is gezorgd (voor zover daarvan uiteraard in het desbetreffende geval sprake is), een strafbaar feit. Art. 255 WwStr bepaalt: Hij die opzettelijk iemand tot wiens onderhoud, verpleging of verzorging hij krachtens wet of overeenkomst verplicht is, in een hulpeloze toestand brengt of laat, wordt gestraft met gevangenisstraf van ten hoogste twee jaren (...). Art. 257 WwStr voegt hieraan toe: Lid 1: Indien een der in de artikelen 255 en 256 omschreven feiten zwaar lichamelijk letsel ten gevolge heeft, wordt de schuldige gestraft met gevangenisstraf van ten hoogste zeven jaren en zes maanden (...). Lid 2: Indien een van deze feiten de dood ten gevolge heeft, wordt hij gestraft met gevangenisstraf van ten 
De meldingen bij de BVA's noemde ik hierboven het topje van het topje van de ijsberg. Er wordt immers ook gemeld bij de Raden voor de Kinderbescherming, bij de politie en bij hulpverleningsinstellingen. Hoe bevreemdend het wellicht ook mag klinken: ${ }^{51}$

'Uit de categorieên zoals die binnen de registratie van de Raden gehamteerd worden, is geen totaalcijfer te achterhalen over het aantal meldingen van kindermishandeling dat daar binnenkomt.'

Uit dossieronderzoek van VAN MONTFOORT (Kindermishandeling en Justitie 1993$)^{52}$ kan evenwel afgeleid worden dat er ...

'(...) naar schatting jaarlijks tussen de 5.000 en 6.000 meldingen van kindermishandeling binnenkomen, waarbij het zou gaan om in totaal 8.000 à 9.000 minderjarigen.' 53

Dit betrof evenwel de jaren 1987-1990: $:^{54}$

'Een stijging van het aantal meldingen zoals die bij de BVA's te zien is, zou ook kunnen gelden voor de Raden. Wellicht zou de schatting daarom momenteel hoger moeten uitvallen.'

hoogste negen jaren (...).

Vgl. voor het afschrijwen van mishandelde kinderen door de BVA'S: Marian ROELoPs, Kindermishandeling en hulpverlening; De aanpak wan lichamelijke kindermishandeling door het BUREAU VERTROUWENSARTS, [diss. VU] Amsterdam 1996, p. 197 (curs. jw): 'In bijna eenderde van het totaal kwam een hermelding voor [dat wil zeggen: na hulpverlening en afsluiting van het dossier, jw]. Dit grote aantal hermeldingen heeft ons verbaasd. Voor een decl van deze gevallen was de hermelding geen verrassing voor het BVA, want bij de voorgaande afsluiting was al bekend dat de mishandeling nog doorging. Blijkbaar zag het BVA in die gevallen geen mogelijkheden meer tot verbetering en wellicht was men daarom van mening dat de energie van de hulpverleners effectiever in andere zaken kon worden geinvesteerd."

51 VKM Info, p. [2] 1.k.

52 Adri WAN MONTFOORT, Kindermishandeling en Justiti; Een empinisch onderaek naar de afhandeling door de Raad voor de Kinderbescherming, de poitie en het Openbaar Ministerie van meldingen van kindermishandeling en seksueel misbruik, Amsterdam 1993.

53 VKM Info, p. [2] l.k. Vgl. VAN MONTFOORT, a.w., p. 148.

Marieke BRUGGEMAN-KLUVERS en Adri VAN MONTFOORT, Kindemtishandeling: de weg naar het meldpunt, Amsterdam 1994, p. 54, melden: 'Uit onderzoek bij de Raden kan worden afgeleid dat ruim $70 \%$ van de meldingen bij de Raden in de categorie "klachten over de opvoeding" gerekend kan worden onder het ruime begrip kindermishandeling (...)."

VKM Info, t.a.p. 
Uit hetzelfde dossieronderzoek bleek dat in de vermelde periode van vier jaar bij zes van de destijds 159 politiekorpsen 1.079 meldingen van kindermishandeling waren binnengekomen..$^{55}$ Dit cijfer is evenwel niet eenvoudig om te rekenen c.q. te extrapoleren. Niettemin concludeert VAN MONTFOORT: ${ }^{.56}$

'Uitgaande van de aantallen meldingen die we hebben aangetroffen, gaat het naar onze mening jaarlijks (...) om tenminste enkele duizenden meldingen van kindermishandeling-in-ruime-zin.'

Onder dat laatste wordt verstaan: 'seksueel misbruik, kindermishandeling en andere voor kinderen bedreigende opvoedingssituaties. ${ }^{57}$

Samenvattend: een kleine $15.000^{58}$ meldingen per jaar bij de $\mathrm{Bu}-$ reaus Vertrouwensarts; 5.000 a 6.000 meldingen bij de Raden voor de Kinderbescherming, enkele duizenden meldingen bij de politie (over meldingen bij de hulpverlening zijn mij geen gegevens bekend). Bij de meldingen ter activiteit (bijna 7.000 meldingen/gezinnen) bij de BVA's betrof het ruim 10.000 kinderen. Bij de Raden ging het om 8.000 a 9.000 kinderen. Bij de politie moeten we ruwweg schatten dat het om een paar of enkele duizenden kinderen zal gaan. Een voorzichtige schatting (rekening houdend met mogelijke overlap) wijst dan in de richting van 20.000 gemelde kinderen per jaar. Dit aantal betreft derhalve het - meer of minder duidelijk - zichtbare topje van de ijsberg.

\section{Kindermishandeling als doodsoorzaak}

Niet minder verbazingwekkend dan het ontbreken van eenduidige registratie bij de Raden voor de Kinderbescherming is het ontbreken van kindermishandeling als doodsoorzaak in de statistieken van het CBS. In het VKM Info lezen we: ${ }^{59}$

'Het is onbekend hoeveel kinderen in Nederland per jaar aan de gevolgen van kindermishandeling overlijden. Uit de statistieken betreffende doodsoorzaken van onder meer het CBS zijn hierover geen gegevens te achterhalen.'

VKM Info, t.a.p.

56 VAN MONTFOORT, a.w., p. 154.

57 VAN MONTFOORT, t.a.p. (curs. jw).

58 In 1997 waren het er 14.650 (tweede druk "VKM Info': A. WOLZAK, "Kindermishandeling in getallen,' brochure NIZW/Infocentrum Kindermishandeling, Utrecht 1998, p. $1 \mathrm{r} . \mathrm{k}$.). 
Het Info vervolgt: $: 00$

'(...) Amerikaans onderzoek meldt dat een percentage van $0,1 \%$ van de mishandelde kinderen aan de gewolgen is owerleden. Voor Nederland zou dit betekenen dat per jaar minstens 50 [80, jw] kinderen overlijden aan de gevolgen van kindermishandeling.'

In het tweede interimrapport van Werkgroep meldpunt kindermishandeling (werkgroep-HERMANNS) wordt opgemerkt: ${ }^{61}$

[D]e Werkgroep [is] er door deskundigen op gewezen dat er "een onbekend zwart cijfer" bestaat met betrekking tot die gevallen waar kindermishandeling het overlijden van het kind tot gevolg heeft. De registratiegegevens uit 1995 [over 1994 ? - jw] van de bureaus vertrouwensarts in Nederland bevatten 14 van dergelijke gevallen. Extrapolerend vanuit de Noord-Amerikaanse situatic is men het er in Nederland doorgaans over eens dat een aantal van 50 [80, jw] in Nederland een minimumschatting is. Het verschil tussen het [geregistreerde] aantal fatale gevallen van kindermishandeling en de veel hogere minimumschatting vindt zijn oorzaak in het feit dat artsen bij het vaststellen van de doodsoorzaak van het kind er soms woor kiezen een natuurlijke doodsoorzaak op te geven. En dat is ten onrechte als kindermishandeling evident aanwezig is of meer is dan een vaag vermoeden. Het is ook ten onrechte omdat het kind er (...) op moet kunnen rekenen dat [ook na zijn dood] iemand voor zijn rechten opkomt."

Gezien de aanwezigheid van vooraanstaande juristen in de Werkgroep (mrs. ROOD-DE BOER en BENDER) ${ }^{62}$ moeten we aannemen dat de woorden 'ten onrechte' (in plaats van de woorden 'onrechtmatig' en/of 'wederrechtelijk') in het rapport bewust zijn gekozen.

Van de minimumschatting waarvan het rapport gewaagt, (b)lijkt ook SCHNABEL uit te gaan: ${ }^{63}$

'Gemiddeld overlijdt er in Nederland elke week [minimaal elke vier à vijf dagen, jw] een kind aan de gevolgen van kindermishandeling. Dat is het einde van een

60 T.a.p.

61. WERKGROEP MELDPUNT KINDERMISHANDELING, Advies- en meldpunten kindermishandeling, Roermond, januari 1997, p. 25.

62 Voor de samenstelling van de Werkgroep zie bijlage 1 van het rapport, a.w., p. 33. Behalve de genoemde juristen-leden maken ook adviserende juristen-leden (op woordracht van het Ministerie van Justitie) van de Werkgroep deell uit.

63 Paul SCHNABEL, 'Voorwoord,' in: Sietske DUKSTRA e.a., Kindemishandeling: van signaal naar hulp $I_{;}$Hulpverlenen en samenwerken, Nederlands centrum Geestelijke volksgezondheid/NcGv, Utrecht 1990 , pp. ix-x, op p. ix. 
bestaan dat woor vele duizenden andere kinderen niet de dood, maar toch nauwelijks een leven betekent. Preventie van kindermishandeling beschermt niet alleen het kind als kind, maar ook de volwassene die uit het kind zal groeien. Een kind dat mishandeld wordt door wie hem zou moeten beschermen en liefhebben, draagt dat trauma de rest van zijn leven met zich mee, soms niet eens meer bewust als herinnering, maar vaak wel als onvermogen om zich bij anderen veilig te woelen of zelf anderen veiligheid te kunnen bieden."

RENSEN vermeldt dat alleen al in Vlaanderen het aantal nieuwe gevallen van kindermishandeling per jaar op 25.000 wordt geschat; alsook dat kindermishandeling in Vlaanderen de op één na belangrijkste doodsoorzaak bij jonge kinderen is. ${ }^{64}$ In Amerika zou mishandeling de belangrijkste doodsoorzaak zijn van kinderen tussen de zes en twaalf maanden, en oorzaak van overlijden van $5 \%$ van alle minderjarigen ${ }^{65}$ (naar ik aanneem suïcidepercentages ten gevolge of in verband met mishandeling daaronder niet begrepen).

Betreft het hier gegevens over het overlijden van kinderen als gevolg van mishandeling door ouders/opvoeders, over kinderdoding (het opzettelijk en in voorkomend geval ook met voorbedachten rade zijn of haar eigen kind of kinderen van het leven beroven) is nog minder bekend. Nederland werd begin 1997 opgeschrikt door een 'golf' van gevallen van ouders die hun kinderen om het leven brachten. ${ }^{66}$

\section{Onderrapportage}

We nemen NOORDHOEK-VAN DER STAAY weer ter hand, en pakken dus de incidentie-/prevalentiedraad weer op: ${ }^{67}$

"Er zijn dus geen Nederllandse incidentie-onderzoeken voorhanden. Well zijn er Nederlandse prevalentie-onderzoeken die één of enkele vormen van kindermishandeling tot onderwerp hebben. Er zijn drie typen prevalentic-onderzoek te onderscheiden. Het eerste type is het onderzoek van retrospectieve aard, waarvan het bekendste voorbeeld dat van DRAIJER [Sexueel misbruik van meisjes door

Ben RENSEN, Kindermishandeling: voor het leven beschadigd, Utrecht 1990, p. 58.

65 RENSEN, a.w., p. 55.

Het zou hier om sterk-symbiotische verhoudingen gaan (naar ik vermoed in combinatie met hyperhomeostatische situaties, die geen verandering of verlies velen), waarbij kinderen niet enkel het verlengstuk maar het volledig (geestelijk) bezit van hun ouders zijn. Deze symbiose (en de daaraan gepaard gaande hyperhomeostase) 'vindt zijn oorsprong waarschijnlijk in de eigen kindertijd van de ouder (...), [in] een gemis aan een eigen leven (...) [dat] zou zijn ontstaan doordat de ouder vroeger als kind veel te kort is gekomen.' (BAARTMAN, aangehaald door Adrie WOLZAK, 'Kinderdoding,' VKMagazine juni 1997, pp. 8-9, op p. 8 r.k.) NOORDHOEK-VAN DER STAAY, t.a.p., op pp. $48-49$ (curs. jw). 
verwanten $\left.{ }^{68}\right]$ is. In een retrospectief onderzoek wordt nagegaan in welke mate er sprake is geweest van kindermishandeling in de jeugd van volwassen respondenten. Zo werd in het onderzoek van DRAIJER nagegaan in welke mate er sprake was van seksueel misbruik in de jeugd van volwassen vrouwen. Een belangrijk nadeel van retrospectief onderzoek is de mogelijkheid dat gebeurtenissen vertekend zijn, in het bijzonder wanneer het onderzoek traumatische gebeurtenissen tot onderwerp heeft. Zo kunnen traumatische ervaringen verdrongen zijn, vergeten of ontkend. Daar staat tegenover dat men in de methode van onderzoek wel rekening kan houden met dergelijke vertekeningen (...).

Bij een tweede type prevalentie-onderzoek gaat het om de mate waarin kindermishandeling daadwerkelijk vóórkomt bij een gemiddelde groep kinderen; er wordt dus niet teruggegaan naar vroegere ervaringen. Een groot nadeel van dit type onderzoek is gelegen in de praktische en de ethische bezwaren die eraan kleven; het ondervragen van kinderen is alleen toelaatbaar voor zover het een hulpverleningssituatie betreft (...). Dat betekent dat aan ouders of verzorgers gevraagd moet worden of hun kinderen ervaringen met betrekking tot mishandeling hebben.

Bij het derde en laatste type onderzoek gaat het om een specifieke groep mensen, bijvoorbeeld zij die in aanraking zijn gekomen met de hulpverlening (...). We hebben in dit type onderzoek altijd te maken met een selecte onderzoekspopulatie, waarvan de onderzoeksresultaten niet of nauwelijks generaliseerbaar zijn.'

Met betrekking tot retrospectieve prevalentie-onderzoeken (zoals het grote incest-onderzoek van DRAIJER) wijst de auteur terecht op het risico van onderrapportage: traumatische ervaringen zijn niet zelden verdrongen en 'vergeten,' dat wil zeggen: worden ontkend, zijn niet (bewust) gekend, of beide (worden tegelijk geweten en niet geweten). ${ }^{69}$ SCHNABEL doelde daar al op in het hierboven aangehaalde citaat.

\section{2 .2}

Cijfers

Op basis van verschillende (typen) prevalentie-onderzoeken kunnen diverse cijfers worden gepresenteerd. Om te beginnen worden hier enkele cijfers uit het incest-onderzoek van DRAIJER vermeld: ${ }^{70}$

Nel DRAUER, Sexueel misbnik van meisjes door verwanten; Een landelijk onderzoek naar de omvang, de aard, de gezinsachtergronden, de emotionele betekenis en de psychische en psychosomatische gevolgen, Ministerie van Sociale Zaken en Werkgelegenheid, Den Haag 1988.

In de volgende paragraaf komen we op de cognitieve 'logica van het vergeten van kindermishandeling' terug aan de hand van de verraadstraumatheorie van FREYD (Jennifer J. FREYD, Betrayal trauma; The logic of forgetting childhood abuse, Cambridge, Mass./London 1996).

70 Herman BAARTMAN, 'Omvang, oorzaken, hulpverlening en preventie inzake kindermishandeling; inzichten vanuit de research voor praktijk en beleid op het 
'DRALERs data leidden tot de schatting dat $15,6 \%$ van de wrouwen vór de leeftijd van 16 jaar het slachtoffer is geweest van enigerlei wijze van sexueel misbruik door verwanten; [een percentage dat] overeenkom[t] met vergelijkbaar onderzoek van RUSSELL in Los Angeles (1986). $Z$ ij [DRAUER] heeft becijferd dat tussen de 102.000 en de 144,000 meisjes van de huidige groep meisjes onder de 16 jaar ernstige ervaringen van incestueus misbruik heeft meegemaakt of nog zal meemaken."

Met andere woorden: van de ruwweg 1,4 à 1,5 miljoen meisjes van 0 tot 16 die op dit moment in Nederland wonen, is c.q. wordt tussen de $7 \%$ en de $10 \%$ slachtoffer van (zeer) ernstige, dat wil zeggen traumatiserende incestervaringen. ${ }^{71}$ In de woorden van VAN DANTZIG: ${ }^{72}$

'Ongeveer de helft $[44,4 \%$, jw] van alle meisjes onder de zestien jaar die door verwanten zijn misbruikt, zijn ernstig tot zeer ernstig misbruikt: frequent, langdurig, geterroriseerd. Dat is aan de lage kant geschat. (DRAUER [1988] geeft aan dat een deel van de ergst mishandelde vrouwen niet geantwoord heeft (prostituées, druggebruiksters (en vrouwen in een psychiatrische inrichting, ${ }^{73}$ jw]).) Vijf procent $[44,4 \times 15,6 \%=6,9 \%$, jw] van alle vrouwen dus, van alle meisjes

terrein van kindermishandeling," Gezin; Tijdschrift voor primaire leefvormen $1990 /$ 2, pp. 76-87, op p. 78 I.k. (i.f.). Vgl. ook NOORDHOEK-VAN DER STAAY, t.a.p., op p. 49 ; J.C.M. WILLEMS, 'Ouderbescherming en kinderbescherming: wordt het geen tijd voor een meldplicht?' Nederlands Juristenblad 1990, pp. 1243-1247, op pp. 1246/1247; Nel DRAIJER, Sexteel misbruik van meisjes door verwanten; Een landelijk onderzoek naar de omvang de aard, de gezinsachtergronden, de emotionele betekenis en de psychische en psychosomatische gevolgen, Ministerie van Sociale Zaken en Werkgelegenheid, Den Haag 1988, pp. 91-93 en 349; Nel DRALER, Een lege plek in mijn geheugen; Seksueel misbruik van meisjes door verwanten, Ministerie van Sociale Zaken en Werkgelegenheid, Den Haag 1988, pp. 22-24.

Zie ook Gail L. ZELLLMAN, Kathleen C. FALLER, 'Reporting of child maltreatment," in: John BRERE e.a. (eds.), The APSAC [American Professional Society on the Abuse of Children] handbook on child maltreatment, Thousand Oaks (etc.) 1996, pp. 359-381, op pp. 369/370, voor een opsomming van Amerikaanse studies, waaronder die van RuSSELL in de San Francisco-area.

71 Vgl. voor een overzicht van het aantal jeugdigen per 1 januari 1994, uitgesplitst naar geslacht en leeftijdsgroep, De staat van jeugdig Nedertand 1996, a.w., p. 41, tabel 2-1. Het aantal meisjes van 0 tot 16 bedraagt circa $16 / 18 \times 1,64$ miljoen $=$ 1,45 miljoen.

72 A. VAN DANIZIG, 'DRAIJER, Nel - Sexueel misbruik van meisjes door verwanten; of: Incest: hoe is het mogelijk, Gezin; Tijdschrift voor primaire leefiomen 1989/4, pp. 235-238, op p. 235 l.k. (ook opgenomen in: A. VAN DANTZIG, Psychotherapie - een vak apart; Opstellen ower mogelijkheden en grenzen van psychotherapie, Meppel/Amsterdam 1990, pp. 160-167; citaat op p. 160). 
[zijn ernstig tot zeer ernstig misbruikt, ${ }^{74} \mathrm{jw}$ ]. In absolute getallen: DRALER vermeldt $(. . .)^{75}$ dat van de groep meisjes die op 1 januari 1981 [lees: 1986 , jw] zestien [lees: vijftien, jw] jaar of jonger [onder de zestien dus, jw] was, 231.276 [gebaseerd op CBS-cijfers, jw], laten we zeggen tweehonderdduizend, enig [van licht tot zeer ernstig, jw] seksueel misbruik mee heeft moeten maken [of nog mee zal maken, jw]. Wanneer dus de helft van dat misbruik ernstig tot zeer ernstig was, spreken we over minstens honderdduizend meisjes ${ }^{76}$ van wie we mogen aannemen dat ze regelmatig lichamelijk en geestelijk gemarteld worden [dan wel gemarteld zijn of nog gemarteld zullen worden, jw].'

De mannenemancipatie is in Nederland nog niet zo ver voortgeschreden dat er ook een vergelijkbaar onderzoek is verricht naar het sexuele misbruik van jongens. Extrapolaties van buitenlands onderzoek - dat percentages oplevert van $2,5 \%$ tot $8,7 \%$ van alle jongens ${ }^{77}$ - naar Nederlandse cijfers, levert aantallen op van 43.000 tot 150.000 jongens van 0 tot 18 die door zowel verwanten als niet-verwanten sexueel zijn c.q. nog zullen worden misbruikt. ${ }^{78}$

74 DRAUER gewaagt van $6,8 \%$. Zij stelt 'dat weliswaar én op de zes à zeven vrouwen $[15,6 \%]$ met seksuele toenaderingen door een familielid te maken heeft, maar dat minimaal één op de vijftien als kind met een ernstige en tratumatiserende vorm van misbruik te maken heeft.' (DRAIJER 1988, a.w., p. 151.)

75 DRAIJER 1988, a.w., p. 93 (verwijzing van VAN DANTZIG).

76 DRAUIER (vgl. a.w., pp. 349, 339, 97 en 143) hanteert een ondergrens van $6,8 \%$ (ernstig tot zeer ernstig misbruik door verwanten) en een bovengrens van $9,7 \%$ (misbruik door verwanten gepaard aan meervoudig misbruik door andere daders). Passen we deze percentages toe op de ruwweg 1,5 miljoen meisjes van 0 tot 16, dan levert dat absolute aantallen slachtoffers (bestaande en toekomstige) op van tussen de 102.000 en 145.000 meisjes. De door VAN DANTZIG genoemde 231.276 meisjes moeten met 44,4\% (DRAIJER 1988, a.w., p. 143) vermenigvuldigd worden; de uitkomst is dan 102.686 meisjes (als ondergrens dus).

77 VKM Info, p. [3] 1.k. (i.f.). Zie voor cen 'overzicht van incidentie- en prevalentiecijfers in de literatuur' Ron VAN OUTSEM, Seksueel misbruik van jongens, Amsterdam 1992, pp. 165-170. VAN OUTSEM spreekt van 2 a $8 \%$ van de mannelijke bevolking die sexueel misbruikt is vór het zestiende jaar; het percentage mannelijke slachtoffers van alle sexueel misbruikte kinderen ligt, zo stelt hij, "ergens tussen de $15 \%$ en $30 \%$ ' (a.w., p. 32). Zie ook Gail L. ZELLMAN, Kathleen C. FALLER, 'Reporting of child maltreatment,' in: The APSAC handbook on child maltreatment, a.w., pp. 359-381, op p. 369 r.k., waar de auteurs gewagen van percentages tussen de 3 en de 30.

Vgl. voorts Mic HUNTER, Abused boys; The neglected victims of sexual abuse, Lexington, Mass./Toronto 1990, pp. 25-43.

78 Uitgaande van 1,7 miljoen minderjarige jongens (De stat van jeugdig Nederland" 1996, a.w., p. 41, tabel 2-1). Graan we-om vergelijking met meisjes tot en met 15 mogelijk te maken - uit van 1,5 miljoen jongens onder de $16(16 / 18 \times 1,7$ miljoen), dan komen de aantallen te liggen turssen respectievelijk 37.000 en 130.000 jongens. Bij meisjes kwamen we uit op circa 100.000 gevallen van emstig tot zeer 


\section{Fysiek geweld}

Extrapolerend uit een Amerikaans onderzoek (STRAUS e.a., Behind closed doors; Violence in the American family, 1980), dat tot een schatting leidde van jaarlijks circa 3\% van de kinderen tussen 3 en 17 jaar [dat] thuis het slachtoffer is van lichamelijk geweld,' komt BAARTMAN 'zeer ruw geschat' op een totaal van bijna 100.000 kinderen in Nederland in de categorie van 0 tot 17 (18?) jaar die jaarlijks het slachtoffer zijn van (ernstig) lichamelijk geweld (3\% van 3,3 miljoen minderjarige kinderen volgens mijn becijfering). ${ }^{79}$ NOORDHOEK-VAN DER STAAY, die naar hetzelfde onderzoek verwijst, spreekt van 'jaarlijks ongeveer $3,6 \%$ van de kinderen tussen 3 en 17 jaar [dat] thuis het slachtoffer is van ernstig fysiek geweld. ${ }^{.80}$ Voor de goede orde: het betreft een schatting die gebaseerd is op ondervraging van de ouders (een voorbeeld van het tweede door haar gememoreerde type prevalentie-onderzoek). $\mathrm{Zij}$ voegt daaraan toe: ${ }^{81}$

'Naar alle waarschijnlijkheid zou dit percentage hoger geweest zijn wanneer de onderzoekers niet als ondergrens de leeftijd van 3 jaar gehanteerd hadden. Daarnaast beperkten zij zich in hun onderzoek tot twee-oudergezinnen.'

ernstig misbruik door verwanten.

79 BAARTMAN, "Omvang, oorzaken, hulpverlening en preventie inzake kindermishandeling,' Gezin 1990/2, pp. 76-87, op p. 78 1.k./r.k. Vgl. ook ZELLMAN/FALLER, "Reporting of child maltreatment," in: The APSAC handbook on child maltreatment, a.w., pp. 359-381., op p. 369 1.k.

Het $V K M$ Info, p. [2] r.k. (i.f.), spreekt van 1,9\% van de gezinnen waarin, blijkens het onderhavige onderzoek, 'het gebruikte geweld onder de noemer kindermishandeling' viel. In Nederland woont $99,5 \%$ van de kinderen in gezinsverband; in elk gezin wonen gemiddeld 1,8 kinderen (De staat van jeugdig Nederland 1996, a.w., pp. 13 en 71-72). Geëxtrapoleerd naar Nederlandse cijfers zou dit betekenen: $1,9 \% \times 99,5 \% \times 1,8$ kind per gezin $\times 3,3$ miljoen kinderen $=$ ruim 112.000 fysiek mishandelde Nederlandse kinderen. Voor de goede orde: het betreft extrapolaties op basis van een onderzoek dat zich beperkte tot twee-oudergezinnen met kinderen in de leeftijd van 3 tot 17 jaar, waarbij een strenge definitie van fysicke kindermishandeling werd gehanteerd.

NOORDHOEK-VAN DER STAAY, t.a.p., op p. 50. Vgl. ook Murray A. STRAUS, Glenda K. KANTOR, 'Stress and child abuse,' in:" Ray E. HELFER, Ruth S. KEMPE (eds.), The battered child, Chicago/London 1988 (vierde druk), pp. 42-59, op pp. 48-50. Tot de items behoorden aanvankelijk: 'kicked, bit, punched; hit with an object; "beat up" child; used a knife or gun.' Omdat "hit with an object' ook bepaalde vormen van 'disciplinering" kan omvatten (met de 'traditional strap, cane, or paddle') is dit item er vervolgens uitgelaten (t.a.p., op p. 49). T.a.p. Vgl. ook STRAUS/KANTOR, t.a.p., op p. 50. 
De eerste twee levensjaren worden gerekend tot de "high-risk-of-abuse" jaren van een kinderleven. ${ }^{82}$ Daarnaast zagen we al dat bij de meldingen bij de BVA's kinderen uit én-oudergezinnen oververtegenwoordigd zijn (waarbij een grotere sociaal-pedagogische kwetsbaarheid werd vermoed). Zelfs als men ernstig fysiek geweld waarvan ouders toegeven dat zij dat jegens hun kinderen, in de leeftijd van 3 tot en met 16 jaar, gepleegd hebben, niet (onder alle omstandigheden) tot lichamelijke kindermishandeling zou willen rekenen, ${ }_{9}^{83}$ dan nog lijkt het plausibel dat een extrapolatie voor Nederland, welke ook kinderen van 0 tot 3 (en van 17 jaar) omvat, ruimschoots boven de 100.000 kinderen uitkomt ( $>3,6 \%$ van 3,3 miljoen is bijna 120.000 kinderen). Tenzij ...

Tenzij men uiteraard (gegronde) reden(en) heeft aan te nemen dat Nederlandse ouders door de bank genomen minder gewelddadig zijn jegens hun kroost dan Amerikaanse. Iets wat we natuurlijk graag geloven, ook al weten we dat fysiek geweld veel, zo niet alles te maken heeft met pedagogische onmacht (nemo plus!) - en juist daardoor zo schadelijk is voor het kind. En redenen om aan te nemen dat Nederlandse ouders beter met pedagogische onmacht kunnen omgaan dan Amerikaanse, of in dat opzicht sociaal beter worden gesteund en begeleid (dankzij een effectief sociaal-pedagogisch vangnet, wat natuurlijk nog iets anders is dan een wettelijke meldplicht), hebben we niet.

\section{Psychiatrische patiënten en criminelen}

Als voorbeelden van het derde door NOORDHOEK-VAN DER STAAY gememoreerde type prevalentie-onderzoek (onderzoek onder specifieke groepen, bijvoorbeeld onder kinderen of volwassenen die in aanraking zijn gekomen met de hulpverlening of met justitie) kan een viertal studies genoemd worden. Allereerst een onderzoek van NOORDHOEK-VAN DER STAAY zelf binnen de hulpverlening aan kinderen, te weten ...

'(...) een studie naar de mate waarin kindermishandeling vóorkomt in de levensgeschiedenis van kinderen die verblijven in Medische Kleuterdagverblijven (voor kinderen van 1,5 tot 7 jaar), Medische Kindertehuizen (voor kinderen tot 16 jaar) en instellingen voor Kinder- en Jeugdpsychiatrie (voor kinderen tot 18 jaar) (NOORDHOEK-VAN DER STAAY [De prevalentie van kindermishandeling bij kinderen met sociale, gedrags- en emotionele problematiek, VU Amsterdam 1992, jw]). Het onderzoek richt zich op drie vormen van kindermishandeling, te weten lichamelijke mishandeling, lichamelijke verwaarlozing en seksueel misbruik. Het aantal kinderen waarover gegevens is verkregen, bedraagt 2.690 , van wie $67,5 \%$ mannelijk is en $32,5 \%$ vrouwelijk. Lichamelijke mishandeling werd bij $11,7 \%$ van de

83 Vgl. BAARTMAN, Gezin 1990/2, t.a.p., op p. 78 r.k. 
kinderen vastgesteld, bij 9,1\% bestond hieromtrent een vermoeden. Bij 13,2\% van de kinderen werd lichamelijke verwaarlozing vastgesteld en bij $5,2 \%$ van de kinderen bestond hierover een vermoeden. Tot slot de cijfers met betrekking tot seksueel misbruik: bij $2,9 \%$ van de populatie werd dit zonder twijfel vastgesteld en bij 6,8\% van de kinderen bestond hierover een vermoeden. ${ }^{34}$

In totaal werd in $34,9 \%$ (ruim één derde) van de gevallen kindermishandeling vastgesteld of vermoed. ${ }^{85}$

Het $V K M$ Info vermeldt nog drie andere studies, welke zijn verricht binnen de hulpverlening aan volwassenen: ${ }^{86}$

'Onderzoek van N. NICOLAI in een crisisafdeling van het Algemeen Psychiatrisch Ziekenhuis te Bloemendaal bracht aan het licht dat een derde van de patiënten in hun jeugd seksueel misbruikt is: vier op de tien vrouwen en twee op de tien mannen. ${ }^{87}$ Ook in het Algemeen Psychiatrisch Ziekenhuis in Endegeest werd een onderzoek uitgevoerd. Daar vond M. VAN EGMOND dat $29 \%$ van de vrouwelijke en $12 \%$ van de mannelijke patiënten [bewezen] of vermoedelijk seksueel misbruikt is. ${ }^{88}$

De VAN MESDAG-kliniek is een inrichting voor personen die voor een misdrijf veroordeeld zijn en aan wie een behandeling is opgelegd. Een onderzoek van $H$. VAN MARLE meldt dat vier op de vijf van de daar behandelde delinquenten in zijn jeugd emotioneel verwaarloosd is. Een op de vijf is als kind seksueel misbruikt. Bij meer dan de helft was de gerinssituatie zo ernstig dat ingrijpen van buitenaf noodzakelijk [onvermijdelijk? -jw] was. ${ }^{39}$

84 NOORDHOEK-VAN DER STAAY, t.a.p., op p. 50.

85 VKM Info, p. [3] r.k. Optelling leidt tot een aandeel van bijna de helft (48,9\%): kennelijk is er niet op hoofdvormen geregistreerd. Vgl. ook het onderzoeksverslag zelf (vU, Faculteit der Psychologie en Pedagogische Wetenschappen, Vakgroep Kinder- en jeugdpsychologie, Sectie Speciale pedagogiek, december 1992), p. 23.

86 VKM Info, p. [3] r.k. (i.f.).

87 Vgl. Nelleke NICOLAI, 'Seksueel müsbruik en psychiatrische stoornissen; een orienterend onderzoek op een gesloten afdeling van een psychiatrisch ziekenhuis,' Maandblad Geestelijke volksgezondheid/MGv 1990/9, pp. 908-923 (op p. 917).

Zie ook dez., 'Noodkreet; over de behandeling van personen met een voorgeschiedenis van seksuele en fysieke kindermishandeling, $M G v 1993 / 9$, pp. 939-943, op p. 942 l.k., waar de auteur opmerkt: '[O]nder verschillende populaties van psychiatrische patiënten wordt het percentage van hen die als kind of later mishandeld en misbruikt zijn, geschat van dertig tot tachtig (...).'

88 Vgl. Marjan VAN EGMOND e.a., 'De plaats van seksuele kindermishandeling in de psychiatrie; een onderzoek onder hulpverleners in een APZ,' Maandblad Geestelijke volksgezondheid/MGv 1992/12, pp. 1344-1354 (op p. 1346).

89 Vgl. H.J.C. VAN MARLE, Een gesloten systeen; Een psychoanalytisch kader voor de verpleging en behandeling van TBS-gestelden, diss. Utrecht, Arnhem 1995, p. 198. Zie ook dez., Motivatie in de klinisch forensisch psychiatrische behandeling, in: R.V. SCHWARZ, D.H. LINSZEN (red.), Persoonlijkheidsstoomissen; Diagnostiek, behandeling, beleid, Amsterdam/Lisse 1991, pp. 87-96, op p. 89. 
Daarnaast kan in dit verband het recente onderzoek van DERKS e.a. vermeld worden..$^{90}$ De auteurs onderzochten de relatie tussen onveilige gehechtheid in de kinderjaren en later (gewelddadig) crimineel gedrag. Hun steekproef omvatte 40 autochtone mannelijke ter beschikking gestelden die waren opgenomen in de VAN DER HOEVEN-kliniek of de POMPEkliniek in verband met ernstige gewelds- of sexuele delicten. Uit hun belangwekkende onderzoeksverslag zal in de volgende paragraaf (par. 12.3.2) uitgebreid worden geciteerd. Op deze plaats volstaan we met de weergave van één van de onderzoeksbevindingen: ${ }^{11}$

'Bezien tegen de verdeling van zo'n 50 à $65 \%$ veilig gehechten die veelal onder "normale" volwassenen wordt aangetroffen, ${ }^{92}$ is in onze steekproef van ter beschikking gestelden het aantal van 38 patiënten ( $95 \%$ ) met een classificatie van onveilige gehechtheid opvallend. Hieruit kan echter niet zomaar geconcludeerd worden dat er een rechtstreeks verband bestaat tussen gewelddadig gedrag en onveilige gehechtheid. Omdat de frequentieverdeling niet sterk afwijkt van die bij andere [niet criminele/gewelddadige, $j w$ ] psychiatrische patiënten [bij wie niet zozeer persoonlijkheidsstoornissen als wel psychiatrische symptoomstoornissen worden gediagnostiseerd, jw], doen de uitkomsten eerder een verband tussen een brede range van psychische problemen en onveilige gehechtheid vermoeden dan tussen gewelddadig gedrag en onveilige gehechtheid. (...)

Van de 38 patiënten in ons onderzoek met een classificatie van onveilige gehechtheid, vallen er tien in de categorie van het onverwerkte trauma en elf in de gedesorganiseerde categorie. Binnen de steekproef hebben vooral deze laatsten een problematische levensloop gehad met grote discontinuïteit in de opvoeding en met ernstige gedragsproblemen op jonge leeftijd. Veel patiënten kwamen in de onverwerkt-trauma-categorie terecht omdat zij nog steeds beheerst worden door vroegere trauma's in de vorm van fysieke mishandeling en/of seksueel misbruik."

90 Frans DERKS, Martien PHILIPSE en Rien VAN IJZENDOORN, "De betekenis van BOWLBY's gehechtheidstheorie in de beoordeling en behandeling van ter beschikking gestelden,' Tijdschrift voor Criminologie/TvCr 1997/1, pp. 42-55.

91 T.a.p., op pp. $49-50$.

92 Dit percentage is op zich al opmerkelijk. Indien een derde tot de helft van alle volwassenen onveilig gehecht is, dan is het evident dat een sociaal-pedagogisch vangnet dat in principe voor alle kinderen een veilige(r) gehechtheid mogelijk maakt (dat wil zeggen: hun recht op minimale persoonswording realiseert), niet alleen een belangrijke bijdrage levert aan de preventie van kindermishandeling, maar ook aan de preventie van psychische stoornissen en van criminaliteit, en clus aan de preventie van ernstig menselijk lijden voor miljoenen Nederlanders, alsmede aan de besparing van vele miljarden op de uitgaven aan somatische en psychische gezondheidszorgvoorzieningen, arbeidsongeschiktheids- en andere sociale uitkeringen en misdaadbestrijding. Dit mag een sweeping statement lijken, maar het is veeleer een open deur waar de samenleving en de overheid, die geacht wordt die samenleving te leiden, zuinig met de schaarse middelen om te gaan, en de rechten van de zwakken te beschermen, met een wijde boog omheen lopen. 
We hebben hierboven enkele percentages gezien (en extrapolaties beproefd) ten aanzien van sexueel misbruik en fysiek geweld. Cijfers over emotionele maltraitering en fysieke verwaarlozing zijn nog moeilijker te reconstrueren. ${ }^{93}$ Onderzoek naar deze categorieën betreft immers vooralsnog klinische populaties (kinderen of volwassenen in de hulpverlening/ psychiatrie). ${ }^{94}$ Dit maakt dat het ook moeilijk is een betrouwbaar percentage voor het fenomeen kindermishandeling in zijn geheel te geven. Toch zijn er wel indicaties te geven, gebaseerd op onderzoek in de Vs, waar immers een meldplicht bestaat. ${ }^{95}$

Hoewel RENSEN een percentage van 2 tot 4 noemt, ${ }^{96}$ op basis waarvan het in Nederland zou gaan om jaarlijks 66.000 tot 132.000 kinderen, ${ }^{97}$ gaat de VKM uit van een - geschat - percentage van $1,6 .^{98} \mathrm{De}$ VKM schat de ondergrens voor kindermishandeling - op basis van Amerikaans onderzoek waarbij een 'redelijk strenge' definitie van kindermishandeling werd gehanteerd - op 1,6\% van alle kinderen (ruwweg 1 kind op de 60). In Nederland zou het dan minimaal gaan om 1/60 van circa 3,3 miljoen minderjarige kinderen, ${ }^{99}$ om minimaal 55.000 kinderen per jaar dus.

Het Amerikaanse onderzoek waaraan (kennelijk) wordt gerefereerd, is de zogenaamde National Incidence Study (NIS-II), welke werd voltooid in 1986 (US Department of Health and Human Services 1988). Volgens deze studie (zo schrijven TOTH en CICCHETTI) ${ }^{100} \ldots$

93 Vgl. NOORDHOEK-VAN DER STAAY, t.a.p., op p. 49; BAARTMAN, 'Omvang, oorzaken, hulpwerlening en prewentie inzake kindermishandeling, Gezin 1990/2, pp. 76* 87, op pp. 77/78; VKM Info, resp. p. [3] l.k. (psychische kindermishandeling en verwaarlozing) en p. [2] r.k. i.f. (lichamelijke verwaarlozing).

94 Vgl. ZELLMAN/FALLER, 'Reporting of child maltreatment,' in: The APSAC handbook on child maltreatment, a.w., pp. 359-381, op pp. 368/369.

95 Zie over de meldingsplicht in de VS: Seth C. KALICHMAN, Mandated reporting of suspected child abuse; Ethics, law and policy, American Psychological Association/APA, Washington 1993.

96 Ben RENSEN, Kindermishandeling: voor het leven beschadigd, Utrecht 1990, p. 55.

97 Elders noemt RENSEN een aantal van 150.000 kinderen, op basis van een percentage van 3 (hetgeen dan toch zou moeten zijn 4,55): Ben RENSEN, "Rechten van kinderen tussen dokters, ouders en culturem: de dagelijkse praktijk,' Tijdschrift voor de rechten van het kind december 1994, pp. 13-14, op p. 14 1.k.

98 VKM Info, p. [2] r.k.

99 Per 1 januari 1994 waren er in Nederland 3.362 .929 minderjarigen (De staat van jeugdig Nederland 1996, a.w., p. 41, tabel 2-1).

100 Sheree $\mathbb{L}$. TOTH, Dante CICCHETT, 'Child maltreatment: where do we go from here in our treatment of victims?' In: Dante CICCHETT, Sheree L. TOTH (eds.), Child abuse, child development, and social policy, Advances in applied develop- 
'(...) approximately 16.3 children per 1,000 were victims of abuse or neglect, a figure suggesting that over 1 million children were maltreated in that year. When the definition of maltreatment was expanded to include children at risk for maltreatment who may not yet have suffered harm, estimates rose to over 1//2 million cases nationwide. Even if the more conservative definition of maltreatment that requires demonstrable harm to the child is adhered to, the 1986 study reflects a $67 \%$ increase over the incidence rate obtained in NIS-I, which was completed in 1980 (United States Department of Health and Human Services 1981). Additionally, a review of official nationwide statistics on child protective service reports reveals a preponderance of child victims in the 0 to 5-year age group, especially with regard to severe forms of physical abuse (American Humane Associations 1988).'

Omrekening van deze aantallen (één respectievelijk anderhalf miljoen kinderen per jaar) naar Nederlandse cijfers (3,3/61,3 miljoen kinderen $=5,4 \%$ ) levert op 54.000 respectievelijk 81.000 Nederlandse kinderen per jaar. In de Amerikaanse studie zelf ${ }^{101}$ wordt met betrekking tot de 'expanded' definitie een percentage van 2,52 genoemd. Dit zou voor Nederland betekenen: meer dan 83.000 kinderen. Dit laatste percentage moet realistischer worden geacht dan het 'conservative' percentage van 1,63. De Amerikaanse studie (NIS-II) zegt hier zelf over: ${ }^{102}$

'[I]n order to respond to serious criticisms of the original definitions, the NIS-II also implemented revised versions of these standards. As a result of this strategy, the present study generated two sets of national estimates - one set based on original definitions (...), and a supplementary set of estimates using the revised NIS-II standards."

De eerste - ernstig bekritiseerde - definitie leverde, zoals we zagen, het percentage 1,63 op. De tweede herziene definitie dus het percentage 2,52. Het VKM spreekt van 'tenminste 50.000 kinderen' die in ons land 'per jaar het slachtoffer zijn van mishandeling. ${ }^{103}$ Het gaat daarmee veiligheidshalve nog onder de bodem zitten van de laagste Amerikaanse extrapolatie $(1,6 \%)$. Wellicht had het VKM er beter aan gedaan voor Nederland te spreken van 'tenminste 80.000 kinderen,' uitgaande van de meer

mental psychology, vol. 8, Norwood, New Jersey 1993, pp. 399-437, op pp. 399 400. (Vgl. ook ZELLMAN/FALLER, 'Reporting of child maltreatment,' in: The APSAC handbook on child maltreatment, a.w., pp. 359-381, op pp. 363 sqq.; Patricia sCHENE, 'Child abuse and neglect policy,' in: a.w., pp. 385-397, op p. 394.)

101 Study findings: Study of national incidence and prevalence of child abuse and neglect, us Department of Health and Human Services 1988, p. xiii.

102 Study findings: Study of national incidence and prevalence of child abuse and neglect, a.w., p. 2-6.

103 VKM Info, p. [2] r.k., p. [4] 1.k. 
realistische (en in elk geval meer bij de gangbare Nederlandse definitie aansluitende) definitie van kindermishandeling van de NIS-II $(2,5 \%)$, waarbij het overigens nog steeds om 'underestimates' gaat. ${ }^{104}$

Het zal mij niet verbazen indien uit toekomstig Nederlands onderzoek voor ons land een percentage rolt dat heel wat dichter bij de 2,5 of zelfs (RENSENs) 3\% ligt (circa 100.000 kinderen per jaar) dan bij de 1,6\% (de minimaal 50.000 kinderen per jaar van de VKM). Zijn er op dit moment echter helemaal geen Nederlandse cijfers, geen cijfers van eigen bodem bekend?

De staat van jeugdig Nederland 1996 vermeldt dat $6 \%$ van de kinderen tot 12 jaar (dat is $6 \%$ van ruim $21 / 4$ miljoen kinderen, ofwel ten minste 135.000 kinderen) in Nederland opgroeien in een gezin waarin sprake is van een niet warm opvoedingsklimaat. ${ }^{105}$ Dit betekent dat de betrokken gezinnen in principe een risico-groep vormen voor kindermishandeling. ${ }^{106}$ Geëxtrapoleerd voor alle kinderen zou het gaan om 3,3 miljoen $\times 6 \%$, ofwel bijna 200.000 kinderen die zich in een pedagogische gevarenzone bevinden. Daarnaast wordt geschat dat in Nederland ...

'(...) 250.000 kinderen opgroeien in een gezin waarin zich alcoholproblemen voordoen. Onderzoek wijst uit dat deze kinderen vaak gedragsproblemen vertonen. Zij zijn vaker dan anderen hyper-actief, ongezeggelijk, anti-sociaal en kennen hun grenzen niet (...). (..)

Het aantal kinderen van drugverslaafde ouders werd tweede helft tachtiger jaren geschat op 5.000 [tot] 8.000. Onlangs is vanuit de gezondheidszorg aandacht gevraagd voor het toenemend aantal bij hun geboorte (...) drugverslaafde baby's. Hun juiste antal is niet bekend, maar medisch specialisten gaan uit van minimaal 1.000 baby's per jaar (...). ${ }^{107}$

De staat van jeugdig Nederland 1996 vervolgt: ${ }^{108}$

'De werkelijke onvang wan de [kindermishandelings]problematiek laat zich raden. Zo gaat de Vereniging tegen Kindermishandeling [stichting Voorkoming van

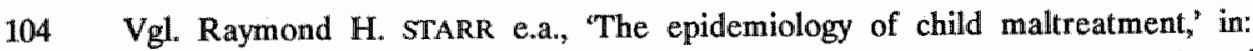
Robert T. AMMERMAN, Michel HERSEN (eds.), Children at risk; An evaluation of factors contributing to child abuse and neglect, New York/London 1990, pp. 23-53, op p. 36 .

105 De staat van jeugdig Nederland 1996, a.w., p. 79; op p. 145 geschat op 135.000 kinderen (onder de twallf). Warmte staat hier tegenover vijandigheid; vgl. José PEETERS, Claartje WOLDRINGH, Kinderen: van privé-zorg naar overheidsbeleid, Instituut voor Toegepaste Sociale wetenschappen/rrs (Nijmegen), Utrecht 1994, p. 89.

106 De staat van jeugdig Nederland 1996, a.W., p. 145.

107 T.a.p.

108 A.w., pp. 146/147. 
Kindermishandeling] uit van [ten minste, dat is: als (absoluut) bodemcijfer, $j w]$ 55.000 mishandelde kinderen. Het kan echter zijn dat ook dit [bodem]cijfer veel te laag is. Onderzoek onder scholieren van het voortgezet onderwijs, dat in 1992 is uitgevoerd, maakt melding van opzettelijke lichamelijke mishandeling bij $8,5 \%$ van de leerlingen en bij 1,9\% van seksueel misbruik door familieleden. Omgezet in absolute cijfers komen deze percentages neer op 93.000 jeugdigen van 12-18 jaar die te maken hebben (gehad) met lichamelijke mishandeling en 21.000 jeugdigen van deze leeftijd met seksueel misbruik (...).

Het is een gegeven dat de gevolgen van mishandeling zeer traumatisch kunnen zijn, zeker als dat kinderen betreft. Naast lichamelijke schade is er vaak ook psychische schade. Die uit zich dan in emotionele en gedragsproblemen, in leerproblemen en relatieproblemen.'

Voorts wordt gemeld: $:^{109}$

'Op basis van probleemsituaties van jeugdigen in voorzieningen is een schatting gemaakt van de prevalentie van problemen onder de jeugd tot 19 jaar. Geschat wordt dat 173.900 jeugdigen $[4,57 \%$ ] tot 1.9 jaar kampen met problemen van psychopathologische aard; $53.000[1,39 \%]$ hebben te maken met ontwikkelingsstoornissen en bij 100.400 jeugdigen $[2,64 \%]$ is de problematiek meer psychosociaal van aard. Dat komt bij elkaar neer op een prevalentie van $8,6 \%$ [Volksgezondheid Toekomst Verkenningen 1994].'

Een prevalentie van $8,6 \%$ bij 3,3 miljoen minderjarigen betekent dat het gaat om zo'n 284.000 kinderen die te kampen hebben of te kampen zullen krijgen met psychische c.q. ontwikkelingsproblematiek. De (in 1996 opgeheven) Raad voor het Jeugdbeleid spreekt van 'zo'n 10 aे $15 \%$ van de jeugd" met 'ernstige of meervoudige problemen': ${ }^{110}$

'In Nederland heeft zo'n 10 à $15 \%$ van de jeugd ernstige of meervoudige problemen. Dat varieert van gedrags- of sociaal-emotionele problemen tot school- en leerproblemen. Vooral deze jeugdigen lopen het gevaar "uit te vallen," zoals dat in beleidsjargon heet. Concreet gaat het dan bijwoorbeeld om jeugdigen-met-problemen die op school niet mee kunnen komen, in het speciaal onderwijs terechtkomen, uithuisgeplaatst worden, weglopen, of gaan zwerven. Velen van hen hebben vaak al diverse vormen van hulpverlening achter de rug, die ze al dan niet voortijdig verlaten hebben.'

Elders lezen we (BAKKER e.a.): $:^{11}$

109 A.w., pp. 155/156.

110 RAAD VOOR HET JEUGDBELEID, Aanval op uitval; Advies over de bestrijding van uitval van jeugdigen, Utrecht 1994, p. 7.

111 Kees BAKKER, Tom TER BOGT, Mieke DE WAAL, Opgroeien in Nederland, Amersfoort 1993, pp. 79 resp. 83. 
'Het rapport Jeugd in oniwikkeling, dat [in opdracht van de Wetenschappelijke Ralad voor het Regeringsbeleid] onder redactie van de psycholoog DIEKSTRA (1992) verscheen, en dat ook de jongeren boven de 12 jaar in haar beschouwing opneemt, typeert maar liefst 15 tot $30 \%$ van alle jongeren alls een "verliesgeneratie." Het schokkend hoge percentage wordt weliswaar genuanceerd door te stellen dat de schatting lager uit zou komen wanneer men die beperkt tot de jeugdigen met ernstige problemen, maar ến op de vijf jeugdigen moeten we volgens DIEKSTRA en de zijnen toch well beschouwen als "bedreigde jeugd." Van een vijfde deel van de vaderlandse jeugd kan men volgens then verwachten dat het later moeite zal hebben om zich maatschappelijk te handhaven.

In opdracht van het Nederlandse Centrum voor Geestelijke Volksgezondheid bestudeerden Rob BUL en Andrế VAN GAGELDONK de literatuur over jeugdigen met problemen en [zij maakten] daarbij [wel] een onderscheid tussen gematigde en ernstige problematiek. BIJL [kwam] in Aanleiding fot zorg [1991] (...) tot de conclusie dat gegevens over het vór rkomen van problematiek bij kinderen en jeugdigen in Nederland grotendeels ontbreken. Echter: "Ondanks alle verschillen in meetmethoden en onderzoeksopzet, blijken onderzoekingen steeds weer aan te geven dat gematigde of ernstige psychiatrische stoornissen voorkomen bij 14 tot $20 \%$ van alle kinderen en jeugdigen. De prevalentie (het op enig moment vórkomen) van emstige psychiatrische problematiek bedraagt $7 \%(\ldots) .{ }^{\prime \prime}(. .$.

Wanneer jeugdigen in problemen raken, heeft dat volgens de op dit moment toonaangevende pedagogen en ontwikkelingspsychologen vrijwel altijd oorzaken die op het gezin zijn terug te voeren. $\mathrm{Nu}$ is het opvoeden er volgens deze zelfde deskundigen ook niet eenvoudiger op geworden en krijgen opvoeders bij hun heikele taak bovendien onvoldoende steun."

Achter de verschillende genoemde percentages gaan enkele honderdduizendend kinderen in Nederland schuil.

Keren we terug naar De staat van jeugdig Nederland 1996, dan kunnen - bijna tot slot - nog cijfers worden vermeld met betrekking tot jeugdcriminaliteit: ${ }^{112}$

'Onderzoek wijst uit dat $2,1 \%$ van de jeugdigen van deze leeftijdscategorie [12-18 jaar; ruim 1 miljoen] tot de (...) groep behoort [wan jeugdigen die all aan een echte criminele carrière zijn begonnen]. In totaal zijn dat circa 23.000 jongeren. In meerderheid betreft het jongens. Er zijn aanwijzingen dat bij deze groep jongeren psychiatrische problemen zevenmaal vaker voorkomen dan bij de normale populatie (FERWERDA [e.a., $\mathrm{TvCr}$ 1995/2]).'

Helemaal tot slot, en vóor we een balans zullen proberen op te maken: aan al dit cijfermateriaal zouden nog kunnen worden toegevoegd de minimaal duizend kinderen alleen al in Amsterdam die jaarlijks getuige 
zijn van de ernstige of zeer ernstige mishandeling van hun moeder, ${ }^{13}$ hetgeen, los van wat de kinderen van gewelddadige vaders en mishandelde moeders direct aan geweld en misbruik overkomt, ${ }^{114}$ op zich al een vorm van kindermishandeling kan worden genoemd (in de vakliteratuur aangeduid als child-witnessed domestic violence ${ }^{115}$ ).

\section{Balans}

We zullen pogen een 'balans' op te maken. Zoals we zagen, werden van alle kinderen in Nederland (circa 3,3 miljoen) er in 1995 iets meer dan 10.000 bij de BVA's gemeld ( $0,3 \%$ ofwel circa 1 kind op de 330$)$. Van alle mishandelde kinderen (met als laagste bodemgetal: 50.000 ) derhalve minder dan één vijfde. De (ijsberg-)ratio 1:5 tussen gemelde en niet gemelde gevallen van kindermishandeling wordt ook in de Verenigde Staten aangehouden. ${ }^{116}$ In dat land bestaat evenwel, zoals al eerder gezegd is, een

113 Aleid VAN DEN BRINK en Jan JÜNGEN, 'Thuisgeweld tegen vrouwen; het Meldpunt vrouwenopvang Amsterdam, 1991-1994," Tijdschrift voor Criminologie 1995/4, pp. 315-332, op p. 331 (onder 'Kinderen').

Het gaat om 700 nieuwe gevallen per jaar van Amsterdamse vrouwen met gemiddeld één à twee kinderen (t.a.p.y op pp. 321, 327, 328). Grofweg geëxtrapoleerd naar het landelijke aantal van 15.000 aanmeldingen per jaar (t.a.p., op p. 327), verminderd met een kwart 'recidiverende' aanvragen (t.a.p., op p. 328) en vermenigvuldigd met 1 à 2 kinderen, zou het om jaarlijks tussen de 12.000 en 20.000 kinderen in Nederland gaan die in een gezin opgroeien waarin het geweld tegen de moeder dermate ernstig is dat deze zich tot de vrouwenopvang wendt (en net niet ernstig genoeg dat dit voor haar onmogellijk of voor haar of haar kinderen te gevaarlijk is). Om welk gedeelte van het totale aantal kinderen met gewelddadige vaders/vaderfiguren het hier gaat, is niet te zeggen. Majorie KAANDORP e.a. (eds.), Intemational yearbook of children's rights 1995, Defence for Children International, Amsterdam 1996, p. 27, spreken abusievelijk van 200.000 kinderen in Nederland. De werkelijkheid zal, voor heel Nederland - inclusief de gezinnen waarin vrouwen, door betere economische of sociale omstandigheden, andere mogelijkheden hebben dan een beroep op vrouwenopvang, of juist in zulke extreme omstandigheden verkeren dat zelfs die weg voor hen is afgesloten -, echter vermoedelijk geen grote factor daarmee verschillen.

114 BROWNE en HERBERT merken op: 'The most important fact for prediction and prevention is that the various forms of family violence do not occur in isolation. If spouse abuse occurs, then there is a very high probability that child abuse is also occurring, and vice versa.' (Kevin BROWNE, Martin HERBERT, Preventing family violence, Chichester etc. 1997, p. 18.)

115 Zie onder de gelijknamige rubriek in Violence and abuse abstracts (vanaf 1995/2). Vgl. ook Ola W. BARNETr e.a., Family violence across the lifespan; An introduction, Thousand Oaks (etc.) 1997, Chapter 6: 'Children exposed to marital violence."

116 Zie Sietske DIJKSTRA, F. SWETS-GRONERT, Dilemma's rond kindermishandeling; Een verkennend onderzoek naar signalering en melding, Nederlands centrum Gees- 
meldplicht, welke moet worden afgezet tegen de geringe meldingsbereidheid in Nederland (werkgroep-HERMANNS). Bovendien dienen aan de ruim 10.000 kinderen die in 1995 bij de BVA's zijn gemeld, nog de kinderen te worden toegevoegd, die bij de Raden voor de Kinderbescherming, bij de politie en bij hulpverleningsinstanties zijn gemeld (verrekend met eventuele overlap). Wanneer we het totale aantal gemelde kinderen voorzichtig op 20.000 per jaar schatten en daar de ijsberg-ratio 1:5 op loslaten, dan komen we - heel grof geschat dus - uit op 100.000 kinderen (RENSENs 3\%). Hetzelfde percentage (3\%) dat we in een (geheel ander) Amerikaans onderzoek (STRAus e.a., Behind closed doors), tegenkwamen voor alleen al fysieke kindermishandeling (ernstig lichamelijk geweld), en dat BAARTMAN eveneens tot de 'ruwe schatting' van (bijna) 100.000 kinderen in Nederland bracht.

In Amerika werden in 1993 over 3 miljoen kinderen (4,9\%) rapporten opgemaakt wegens vermoedens van kindermishandeling. Omgerekend naar Nederlandse aantallen zou dat hier op 162.000 rapporten neerkomen $\left(3,3 / 61,3\right.$ ofwel $5,4 \%$ van 3 miljoen). ${ }^{117}$ Als we aannemen dat in de helft van de gevallen kindermishandeling (nog) niet kan worden aangetoond, ${ }^{118}$ dan spreken we toch nog over zo'n 80.000 kinderen. Hetzelfde aantal dat extrapolatie van het tweede $N I S-I I$ percentage $(2,5 \%)$ oplevert (de helft van 4,9\%).

In de Amerikaanse rapportages gaat het in $44 \%$ van de (bewezen of vermoedelijke) gevallen om verwaarlozing, $24 \%$ om fysieke verwondingen, $15 \%$ om sexueel misbruik en $6 \%$ om emotionele maltraitering (overige: $11 \%) .{ }^{119}$ Een vrij stabiele verdeling. ${ }^{120}$ Bij de BVA's waren deze

telijke volksgezondheid/NcGv, Utrecht 1989, p. 4; Lane J. VELTKAMP, Thomas W. MILLER, Clinical handbook of child abuse and neglect, Madison, Ct. 1994, p. 8. RENSEN (Kindermishandeling: voor het teven beschadigd, a.w., p. 55) spreekt van de helft. Het betreft dan vermoedelijk het percentage gevallen dat bij professionals bekend is en niettemin niet is gemeld (vgl. ZELLMAN/FALLER, 'Reporting of child maltreatment,' in: The APSAC handbook on child maltreatment, a.w., pp. 359-381, op p. 363).

117 ZELLMAN/FALLER, 'Reporting of child maltreatment,' in: The APSAC handbook on child maltreatment, a.w., pp. 359-381, op p. 361 r.k. (i.f.).

118 ZELLMAN/FALLER, t.a.p., op p. 374 r.k., noemen een substantiation-percentage van $53(43 \%$ in $1980,53 \%$ in 1986 , hetgeen vermoedelijk een stijgende lijn aangeeft; t.a.p.). Hier staan de - ondanks de meldplicht - niet gemelde gevallen tegenover: "[M]ost investigators do agree that reported cases are only the "tip of the child abuse iceberg"' (Raymond H. STARR e.a., "The epidemiology of child maltreatment,' in: Robert T. AMMERMAN, Michel HERSEN (eds.), Children at risk; An evaluation of factors contributing to child abuse and neglect, New York/London 1990 , pp. 23-53, op p. 29). ZELLMAN/FALIER, t.a.p., op pp. 361/362. T.a.p., op p. 362 l.k. 
percentages in 1995 respectievelijk $9 \%, 25 \%, 18 \%, 36 \%$ en $12 \%$ (zoals we hierboven, in par. 12.2.2, al vermeldden). ${ }^{121}$ Uiteraard is dit niet meer dan een globale indicatie dat er in Nederland minder (fysiek) wordt verwaarloosd en meer emotioneel wordt gemaltraiteerd (verwaarloosd/ mishandeld). ${ }^{122}$

Spreken we over kindermishandeling in ruime zin, dus met inbegrip van voor kinderen bedreigende opvoedingssituaties die (nog net) niet als kindermishandeling worden beschouwd, of niet als zodanig worden geregistreerd, dan moeten we aannemen dat ook deze 80.000 kinderen een ondergrens zijn.

Resumerend. Zeer voorzichtig geschat bedraagt de zichtbare top van de ijsberg - de gemelde ' 15 à $20 \%$ ' - ten minste 20.000 kinderen (ruim 10.000 kinderen die gemeld worden bij de BVA's ${ }^{123}$; 8 a 9.000 kinderen die gemeld worden bij de Raden voor de Kinderbescherming ${ }^{124}$; enkele duizenden kinderen die gemeld worden bij de politie ${ }^{125}$ ): 20.000 van de 3,3 miljoen minderjarigen in Nederland $(0,6 \%)$. De volledige ijsberg moet geschat worden op minimaal 80.000 kinderen per jaar, maar dat zou ook alleen al het gedeelte onder water kunnen zijn $(2,5 \%)$. Per saldo moet dus worden aangenomen dat 'tenminste 50.000' mishandelde kinderen per jaar (het VKM-aantal) voor Nederland een absoluut en (te) 'conservatief' bodemcijfer betreft.

Concluderend. Al met al bevinden vele tienduizenden, en misschien wel enkele honderdduizenden kinderen in ons land zich op zijn minst in een geestelijke gevarenzone, variërend van mishandelings- en andere ernstig bedreigende opvoedingssituaties tot aan situaties waarin hun persoonswordingskansen - zacht uitgedrukt - ver achterblijven bij die van het 'modale' Nederlandse kind. Bij hun 'evenwichtige ontwikkeling en uitgroei tot zelfstandige staatsburgers' kunnen op zijn voorzichtigst grote vraagtekens worden geplaatst. Zij behoren tot de sociaal-pedagogische minima van ons land. Minima voor wie geen adequaat vangnet bestaat. Minima voor wie geen vakbond het opneemt. Minima die voor het grootste gedeelte onzichtbaar zijn.

121 LSBVK, Jaarverslag 1995, Bijlagen, p. vi, tabel 6.

122 Vgl. met betrekking tot (lichamelijke, emotionele, normatieve en educatieve) verwaarlozing (en gebrek aan structuur en toezicht) het recente PEWA-rapport van de hand van Mariska KROMHOUT, Verwaarloosde kinderen; Opvattingen uit het veld, Leiden 1996. Vgl. (in algemene zin) ook J.E. RINK, Pedagogische verwaarlozing en orthopedagogiek, Leuwen/Apeldoorn 1995.

123 LSBVK, Jaarverslag 1995, Bijlagen, p. vii, tabel 7 (10.432 kinderen waarvan 251 boven de 18 jaar).

124 VAN MONTFOORT, Kindermishandeling en Justitie, a.w., p. 148.

125 VAN MONTFOORT, a.w., p. 154. 
Zelfs als we ons beperken tot de sociaal-pedagogisch zwaksten in de samenleving, de gezinnen met de kinderen van wie zelfs de minimale persoonswording gevaar loopt, de verwaarloosde, de mishandelde en de misbruikte kinderen, lijkt het beeld van de ijsberg bepaald niet overdreven. Met gevoel voor understatement concludeert NOORDHOEK-VAN DER STAAY dan ook dat het fenomeen kindermishandeling een niet ongewoon maatschappelijk verschijnsel is' en dat de cijfers ons zeggen 'dat de problematiek rond kindermishandeling geen uitzonderlijk fenomeen is., ${ }^{126}$ Een conclusie die evenwel nauwelijks tot het grote publiek - en dus tot de politiek - lijkt te zijn doorgedrongen.

Het leed dat achter de cijfers schuilgaat, laat zich (nog) moeilijker meten. In de volgende paragraaf staan we bij dat leed, de sequelae van kindermishandeling, stil. Juist daarom lijkt het gepast deze paragraaf met en over cijfers en percentages af te sluiten met een waarschuwend citaat van RENSEN: ${ }^{127}$

'Individueel menselijk leed is gezien de uiterst subjectieve manier van beleven niet te meten. Het wantrouwen, het ondermijnde gevoel van eigenwaarde, de jarenlange depressies die elke kleur uit het bestaan halen, de voortdurend terugkerende angstwekkende beelden, het zich voortslepen door het leven om anderen niet wederom te beschamen, de suïcidepogingen en de schaamte achteraf, het iedere keer weer vernederd worden door in de slachtofferrol gedrongen te worden. De neerbuigendheid van "de anderen" die het niet meemaakten, die in onze maatschappij aan de touwtjes trekken, die met hun macht je wederom vermederen door het niet te kunnen, willen en durven geloven, die je niet serieus nemen .... Wie heeft de illusie dat te kunnen meten? De kale cijfers van de epidemiologie zijn niet in staat de diepgang te beschrijven, hoogstens de omvang."

12.3

Kindermishandeling als ernstige mensenrechtenschending (2): de gevolgen

In deze paragraaf staat de vraag naar de sequelae centraal: wat is er bekend omtrent de ernst van het fenomeen kindermishandeling? Deze vraag kan worden uitgesplitst in de vraag naar de gevolgen voor het individu: de psychische en psycho-sociale (sociaal-emotionele) sequelae. En de vraag naar de gevolgen - de 'kosten' - voor de maatschappij: de sociaal-economische sequelae. Hoewel er tussen beide vragen een nauw verband bestaat - de schade aan en in het individu zal immers steeds direct of indirect, vroeg of laat, op de maatschappij worden afgewenteld, uiteindelijk en in enigerlei vorm krijgt de maatschappij de rekening ge- 
presenteerd, met rente op rente, voor hetgeen zij in principe had kunnen voorkomen of in zijn gevolgen had kunnen verzachten -, zullen we deze toch in twee aparte subparagrafen aan de orde stellen. Om herhalingen zoveel mogelijk te vermijden, zullen we de tweede vraag opvatten als een verbijzondering c.q. een afgeleide van de eerste, en daarenboven slechts enkele krenten uit de maatschappelijke mik pikken.

\subsection{1}

De psychische en psycho-sociale gevolgen

Met betrekking tot de eerste categorie gevolgen, die voor het individu, kan gewezen worden op een overvloed aan empirische literatuur. ${ }^{128}$ Omdat het ons in deze paragraaf - na de cijferparade in de vorige (par. 12.2) - niet zozeer te doen is om 'empirie' als wel om het schetsen van een beeld, een verhalend verduidelijken van 'oorzaak-en-gevolg' (meer in het bijzonder: oorzaken-en-gevolgen-door-de-generaties-heen), zullen we hier een aantal meer klinisch-fenomenologisch geörienteerde auteurs aan het woord laten.

\section{Trauma en herstel}

We beginnen met enkele (langere) achter elkaar geplaatste tekstfragmenten uit het hoofdstuk 'Kindermishandeling' van Judith HERMANs Trauma en herstel (Trauma and recovery, 1992), waarin de auteur laat zien hoe sexueel en ander geweld de persoonswording (persoonlijkheidsontwikkeling) van het kind ondermijnt: ${ }^{129}$

'Herhaalde traumatische gebeurtenissen op volwassen leeftijd hollen de structuur van de reeds gevormde persoonlijkheid uit, maar herhaalde traumatische gebeurtenissen in de kindertijd vormen en vervormen de persoonlijkheid. Het kind dat gevangen zit in een omgeving waar van mishandeling sprake is, krijgt met enorme aanpassingsmoeilijkheden te maken. [Het] moet op een of andere manier het gevoel blijven houden dat [het] kan vertrouwen op mensen die onbetrouwbaar

128 Vgl. bijvoorbeeld de diverse bijdragen in Part III ('The developmentall consequences of child maltreatment') van Dante CICCHETT, Vicki CARLSON (eds.), Child maltreatment, Theory and research on the causes and consequences of child abuse and neglect, Cambridge (etc.) 1989, pp. 375-721. Vgl. (bijvoorbeeld) ook R.K. OATES, The spectrum of child abuse; Assessment, treatment, and prevention, Basic Principles into Practice series, vol. 8, New York 1996, Ch. 6, pp. 118-136; Gail E. WYATT, Gloria J. POWELL (edsw), Lasting effects of child sexual abuse, Newbury Park (etc.) 1989. Voor literatuuroverzichten vgl. (diverse rubrieken in) Violence and abuse abstracts, vol. 1 (1995) tot heden.

129 Judith Lewis HERMAN, Trauma en herstel, De gevolgen van geweld - van mishandeling thuis tot politiek geweld, Amsterdam 1993, hfd. 5: 'Kindermishandeling,' pp. 129-152, op pp. 129, 131, 133, 135-136, 137, 147 en 150 (curs. jw). 
zijn, dat [het] veilig is in een onveilige situatie, dat [het] controle heeft over een situatie die angstaanjagend onvoorspelbaar is en dat [het] over macht beschikt in een toestand van hulpeloosheid. Aangezien [het] nivet woor zichzelf kan zorgen en zichzelf niet kan beschermen, moet [het] het ontbreken van zorg en bescherming van de kant van volwassenen compenseren door het enige middel waarover [het] beschikt, namelijk een onvolgroeid stelsel van psychische afweermechanismen.

De pathologische omgeving waarin kindermishandeling plaatsvindt, dwingt tot de ontwikkeling van uitzonderlijke vermogens die zowel creatief als destructief van aard zijn. Een dergelijke omgeving stimuleert de ontwikkeling van een abnormale bewustzijnstoestand, waarin het gewone verband tussen geest en lichaam, werkelijkheid en verbeelding, kennis en geheugen, verbroken is. Door zo'n verandering wan het bewustzijn kan een zeer groot aantal uiteenlopende symptomen ontstaan, somatische zowel als psychische. Deze syptomen verhullen hun oorsprong, maar onthullen die eveneens: ze spreken in versluierde taal van geheimen die te vreselijk zijn voor woorden. (...)

Chronische mishandeling en chronisch misbruik van kinderen vindt plaats in een gezinsklimaat van allesoverbeersende angst waarin de normale, op zorg en verzorging gebaseerde relaties grondig zijn verstoord. De overlevenden [lees: degenen die hun traumatische jeugdervaringen in meer- of mindere mate hebben verwerkt, jw beschrijwen een kenmerkend patroon van totalitaire controle, die wordt afgedwongen door geweld en doodsbedreigingen [c.q. bedreigingen met verlating of verstoting (uithuisplaatsing), jw], het willekeurig opleggen van onbenullige regels, incidentele [materiële of conditioneel-emotionele, jw] beloningen en het vernietigen [c.q. verpesten, feitelijk onmogelijk maken, $j w$ ] van alle concurrerende relaties [onder meer] door middel van isolement, geheimhouding en verraad.'

Bijvoorbeeld: het kind wordt uitgenodigd de ouder iets toe te vertrouwen, doch alles wat het kind aan de ouder toevertrouwt, wordt in de eerste de beste conflictsituatie door de ouder genadeloos tegen het kind gebruikt. $\mathrm{Er}$ is met andere woorden niet alleen sprake van een situatie van willekeur, maar ook van volstrekte rechteloosheid. We lezen verder:

"Meer nog dan bij volwassenen ontwikkelt zich bij kinderen die in een dergelijke sfeer van heerszucht opgroeien, een pathologische band met degenen die hen mishandelen en verwaarlozen, een band die ze zelfs ten koste van hun eigen wel$z_{i j j} n_{*}$ hun eigen [zich geestelijk - dat wil zeggen: biopsychologisch - ontwikkelende, jw] realiteit en hun eigen [zich ontwikkelende gewoels-]leven in stand trachten te houden. (...)

De aanpassing aan deze sfeer van voortdurend gevaar vereist een toestand van voortdurende alertheid. Mishandelde en misbruikte kinderen leren buitengewoon goed te letten op tekenen die hen waarschuwen dat ze een aanval kunnen verwachten. Ze voelen de gemoedstoestand van degenen die hen mishandelen, haarfijn aan. Ze ontdekken hoe ze een subtiele verandering in gelaatsuitdrukking, stem en lichaamstaal kunnen herkennen als een blijk van boosheid, seksuele opwinding, dronkenschap of [dader-]dissociatie. (...)"

Wat betekent dit voor de ontwikkelingstaken van het kind? 
"In deze sfeer van grondig, verstoorde relaties staat het kind bij [zijn] ontwikkeling voor een zware taak. [Het] moet op de een of andere manier een primaire band aangaan met verzorgers die gevaarlijk zijn of [het] (...) verwaarlozen. [Het] moet het gevoel krijgen dat [het] verzorgers die niet betrouwbaar zijn, toch kan vertrouwen en dat [het] veilig bij hen is, ondanks de blijken van het tegendeel. [Het] moet [zijn] zelfgevoel ontwikkelen in relatie tot mensen die hulpeloos, onverschillig of wreed zujn. [Het] moet [zijn] lichaamsfuncties leren reguleren in een omgeving waarin [zijn] lichaam ter beschikking staat van de behoeften van anderen en [het] moet zichzelf leren troosten in een omgeving die geen troosit biedt. [Het] moet initiatief leren nemen in een omgeving die van [het kind] vereist dat [het] zich volledig schikt naar de will van degene die [het] mishandelt. En tot slot moet [het] [zijn] vermogen tot intimiteit ontwikkelen in een omgeving waarin alle intieme relaties gecorrumpeerd zijn, en een eigen identiteit verwerven in een omgeving waarin [het] wordt beschouwd als een [(lust)object, een last, een verlengstuk, een nul, of nog minder, jw].'

\section{En wat voor de existentiële taak waarvoor het kind gesteld is (waarbij we uiteraard de ontwikkelingsdimensie niet kunnen wegdenken):}

'De existentiële taak van het mishandelde of misbruikte kind is al even zwaar. Ofschoon [het] merkt dat [het] onderworpen is aan een genadeloze machtsuitoefening, moet [het] op de een of andere manier een gevoel van hoop en zinvolheid levend houden. Het alternatiel is volslagen wanhoop, iets wat geen enkel kind kan verdragen. Om vertrouwen in [zijn] ouders te kunnen blijwen stellen, moet [het] [zijn] eerste en meest voor de hand liggende conclusie, namelijk dat er iets vreselijk mis met hen is, verwerpen. [Het] zal [zijn] uiterste best doen om een verklaring te verzinnen die [zijn] ouders van alle blaam en verantwoordelijkheid zuivert. De psychische aanpassing van het mishandelde kind is volledig gericht op het fundamentele doel om [zijn] primaire band met [zijn] ouders te handhaven, ook al blijkt dagelijks dat die [hem] kwaad willen doen of hulpeloos en onverschillig. zijn. Voor de verwezenlijking van dit doel neemt het kind [zijn] toevlucht tot allerlei psychische afweermechanismen. Met behulp daarvan wordt de mishandeling afgegrendeld wan het bewustzijn en het geheugen, zodat het net is alsof er in werkelijkheid niets is gebeurd, of [wordt de mishandeling] gebagatelliseerd, gerationaliseerd en goedgepraat, zodat het net is alsof er niet echt van mishandeling sprake is. Het kind kan niet daadwerkelijk aan de ondraaglijke realiteit ontsnappen of die veranderen, en verandert de werkelijkheid daarom in [zijn] geest. (...) Daarvoor staa[t] [het] een aantal middelen ter beschikking: ontkenning zonder meer, het (...) onderdrukken van gedachten, of allerlei dissociatieve reacties. (...) Uit onderzoek is gebleken dat er een verband bestaat tussen de ernst van de mishandeling en de mate waarin het kind vertrouwd is met dissociatie. (...) Deze kinderen leren hoe ze hevige pijn kunnen negeren, hoe ze hun herinneringen kunnen verbergen door middel van complexe vormen van geheugenverlies, hoe ze hun tijds-, plaats- en persoonlijkheidsbesef kunnen wijzigen en hoe ze hallucinaties of een toestand van bezetenheid kunnen opwekken. (...)

In extreme gevallen (...) is dissociatie niet alleen meer een afweermechanisme dat bijdraagt tot de aanpassing [aan een overweldigende situatie, jw], maar wordt het een wezenlijk kenmerk van de persoonlijkheidsstructuur. Het onstaan van persoon- 
lijkheidsfragmenten, of alters, als gevolg wan zeer ernstige trauma's bij kinderen is door talrijke onderzoekingen bevestigd. (...)

Veel mishandelde kinderen koesteren de hoop dat ze zich aam hun lot zullen kunnen onttrekken als ze eenmaal volwassen zijn. Maar een persoonlijkheid die in een omgeving van dwang wordt gevormd, is niet goed aangepast aan de volwassenheid. [Het slachtoffer] blijft wezenlijke problemen houden op het gebied van basisvertrouwen, autonomie en initiatief. (....) "Herhaling is de zwijgende taal van het mishandelde kind." (...)

Ofschoon het merendeel van de slachtoffers zelf niet [actief of direct, jw] gaat mishandelen, is er duidelijk een minderheid die dat wel doet. Trauma's schijnen de stereotiepe kenmerken van mannen en vrouwen te versterken: mannen die als kind mishandeld zijn, reageren hun agressie waker af op anderen, terwijl vrouwen vaker het slachtoffer van anderen worden of zichzelf letsel toebrengen."

Wat niet een minderheid doet, maar wat onbewust gebeurt (afgezien van de situaties waarin het 'afgunstmotief' bewust is) in alle gevallen waarin trauma's niet of onvoldoende zijn verwerkt, is de intergenerationele overdracht van de onveilige gehechtheid - ook als het daarbij ogenschijnlijk niet (of nog niet) tot mishandeling van het eigen kind komt, maar - van de weeromstuit - tot bijvoorbeeld die 'gevaarlijke variant van (...) "suboptimaal ouderschap" (...)' die - in de woorden van TAVECCHIO ${ }^{130}$ bestaat in ...

"(...) het bieden van overdreven bescherming, ook bekend als "overprotectie" of "smothering." WEISFELT [Nestgeuren, 1996] beschrijft dergelijke excessieve symbiotische relaties in het hoofdstuk "Wurgen in liefde".".

Dat dit gebeurt in alle gevallen waarin de traumatisering in de jeugd niet of onvoldoende is verwerkt, dat wil zeggen: in de regel, als wet(matigheid), ligt voor de hand: niemand kan iets anders, laat staan méér overdragen dan hij of zij in huis heeft (nemo plus als logische evidentie en tegelijk als ontwikkelingspsychologische c.q. psychodynamische 'wet'). Nogmaals TAVECCHIO: ${ }^{131}$

"Uit empirisch onderzoek komt duiclelijk naar voren dat de aard van de vroege gehechtheidsrelatie van kinderen met hun ouders lang doorwerkt en niet alleen van invloed is op de latere ontwikkeling, maar ook mede bepalend is voor de kwaliteit wan hun eigen ouderschap."

130 Louis TAVECCrro, bespreking van Piet WEISFELT, Nestgeuren; Over de betekenis van de ouder-kindrelatie in een mensenleven (Baarn 1996), in: 0/25; Tijdschrift over jeugd 1996/5, pp. 51-52, op p. 52 r.k.

131 TAVECCHIO, bespreking van WEISFELTs Nestgeuren, t.a.p., op p. $521 . \mathrm{k}$. 
Mede bepalend, zouden we kunnen zeggen, voor het (niveau van) ouderlijk pedagogisch besef, zoals beschreven door BAARTMAN in Opvoeden kan zeer doen (zie het vorige hoofdstuk, in het bijzonder par. 11.2.1 en par. 11.2.2.5).

\section{BOWLBY's gehechtheidstheorie}

De wet(matigheid) van de intergenerationele overdracht van (veilige dan wel onveilige) gehechtheidsrelaties brengt ons op een tweede reeks tekstfragmenten, overgenomen uit de belangwekkende studie van DERKS e.a., die we in de vorige paragraaf al tegenkwamen (par. 12.2.2 onder Psychiatrische patiënten en criminelen). Gezien de 'verhalende' opzet van deze paragraaf zij een uitgebreid citeren uit deze studie toegestaan. De auteurs leiden hun bijdrage als volgt in: ${ }^{132}$

"Delinquenten die ten tijde van hun delict leden aan een "ziekelijke stoornis of gebrekkige ontwikkeling van de geestesvermogens" kunnen volgens het Nederlandse recht een terbeschikkingstelling met bevel tot verpleging opgelegd krijgen. De verpleging is erop gericht de maatschappij te beveiligen en de patiënt te motiveren tot deelname aan een (psychiatrische) behandeling die er op termijn toe moet leiden dat hij/zij zonder onaanvaardbare risico's voor anderen weer in de samenleving kan terugkeren. Een terbeschikkingstelling kan alleen worden opgelegd indien het om een ernstig (gewelds)delict gaat, waarbij de rechter een verhoogd gevaar voor herhaling constateert wegens een op het moment van het misdrijf aanwezige stoornis. (...)

Voor de psychische problematiek die we bij ter beschikking gestelden vaak aantreffen, zijn in de loop van de tijd verschillende benamingen in zwang geweest. Oorspronkelijk gebruikte men bij voorkeur de generieke term "psychopathie," maar tegenwoordig onderscheidt men een aantal verschillende "persoonlijkheidsstoornissen." In de psychiatrie duidt men hiermee duurzame en starre patronen van afwijkende gedragingen en imnerlijke ervaringen aan, die subjectief lijden of [lees: en/of, ${ }^{133} \mathrm{jw}$ ] beperkingen in het sociaal en beroepsmatig functioneren

132 Frans DERKS, Martien PHILIPSE en Rien VAN UZENDOORN, 'De betekenis van BOWLBY's gehechtheidstheorie in de beoordeling en behandeling van ter beschikking gestelden,' Tijdschrift woor Criminologie/TVCr 1997/1, pp. 42-55, op pp. 42-43 (curs. zowel overgenomen als aangebracht).

133 Van subjectief lijden is lang niet altijd sprake, het is voornamelijk de omgeving die lijdt, en dat geldt niet alleen voor de persoonlijkheidsstoornissen uit het 'antisociale' B-cluster (de anti-sociale, de borderline-, de narcistische en de theatrale persoonlijkheidsstoornis). Er is immers (veel) meer egosyntonie dan -dystonie: 'Patiënten met een persoonlijkheidsstoornis storen anderen meer dan zichzelf. (...) Iemand met een persoonlijkheidsstoornis lijdt niet zozeer in zichzelf en om zichzelf, zoals een patiënt met een neurose, maar dór zichzelf zonder dit in te zien. Het gedrag is "ego-syntoon," wat betekent dat ze problemen en fouten bij de anderen leggen en niet bij zichzelf. Deze egosyntonie is niet altijd absoluut. De persoonlijkheidstrekken kunnen ook in mindere of in meerdere mate "ego- 
veroorzaken. Men geeft ermee aan dat de patiënt niet aan een acute psychiatrische ziekte lijdt, maar dat sprake is van een al in de vroege kinderjaren begonnen scheefgroei van de persoonlijkheid, die de normale omgang met andere mensen ernstig verstoort. Bij ter beschikking gestelden is dit concreet in een delict tot uitdrukking gekomen. (...)

Volgens FELDBRUGGE (1986) kwalificeren behandelaars de verstoorde interactiepatronen van ter beschikking gestelden vaak als contactvemijing of contactambivalentie. Onder contactvermijding verstaan zij dat ze er niet in slagen een therapeutische relatie met de patiënt tot stand te brengen. Bij contactambivallentie komt wel een relatie tot stand, maar maakt de patiënt daar misbruik van om zijn eigen wensen en behoeften te bevredigen zonder dat de behandeling er baat bij heeft. FELDBRUGGE vond aanwijzingen dal deze patronen in de omgang met behandelaars en medepatiënten een herhaling zijn van vroegere interactiepatronen tussen de patiënten en hun opvoeders.

Op grond van de overeenkomsten tussen contactvermijding/-ambivalentie en de begrippen die ontwikkeld werden binnen de "gehechtheids" se kinderpsychiater John BOWLBY (...) werd bij een veertigtal ter beschikking gestelden onderzocht of deze theorie een nieuw licht kan werpen op de persoonlijkheidsstoornissen die we bij hen aantreffen. De verwachting was dat dit inzicht zou kunnen verschaffen in de sociale interactiepatronen vór en tijdens de behandeling, die verband houden met de kans op delictherhaling [recidive]. Zijn dit misschien inadequate interactiepatronen (dysfunctioneel gehechtheidsgedrag) waarvan de basis al in de kinderjaren is gelegd, en die op latere leeftijd tot een persoonlijkheidsstoornis zijn uitgegroeid? Zo ja, bestaat er dan bij volwassen ter beschikking gestelden, net als bij kinderen, een verband tussen gehechtheid en [geëxternaliseerde] gedragsproblemen zoals agressie, impulsiviteit en criminaliteit? En levert dit vóor en tijdens de behandeling aanwijzingen op voor de beoordeling van de kans op recidive?

Deze vragen leidden tot het onderzoek waarvan wij in dit artikel verslag doen."

De auteurs presenteren vervolgens eerst BOWLBY's gehechtheidstheorie. Gezien het belang van deze theorie voor het sociaal-pedagogische fenomeen van de intergenerationele overdracht van (veilige dan well onveilige) gehechtheidsrelaties ${ }^{134}$ wordt zij hier in extenso weergegeven in de - klare - bewoordingen van de auteurs: ${ }^{135}$

dystoon" zijn en de betrokkene kan niet in staat zijn deze te veranderen ondanks grote inspanning.' Aldus G.J. ZWANIKKEN e.a. (red.), Psychiatrie, Utrecht 1990, p. 290. (Zie ook bijlage $v$ bij dit proefschrift.)

134 Vgl. met betrekking tot (het bellang van en studies over) hechting ook Judy $F$. ROSENBLITH, In the beginning; Development from conception to age two, Newbury Park (etc.) 1995, Chapter 12 ('Social development of the infant'), pp. 456-500, op pp. 458-477, alsmede Chapter 13 ('Influence of environment: deprivation and enrichment'), pp. 502-540. Zie ook J.E. DE BOER, 'Infantpsychiatrie,' in: dez. (red.), Infantpsychiatrie I; De gezonde en verstoorde ontwikkeling van de vroege ouder-kind relatie, Assen/Maastricht 1991, pp. 3-22. 
"Volgens BOWLBY vertonen kinderen al op jonge leeftijd gedrag waarmee zij de afstand tot hun opvoeders reguleren. Kinderen hebben behoefte aan een persoon die de veilige basis verschaft vanwaaruit zij hun omgeving exploreren en naar wie zij kunnen terugvluchten wanneer ze daar iets tegenkomen dat hen beangstigt. Door waar te nemen hoe anderen op hun angst reageren, vormen zij zich een blauwdruk - een zogenaamd "intern werkmodel" - van de relaties met hun opvoeders. Deze blauwdruk vormt in principe het basispatroon waarop in de volwassenheid hun omgang met anderen zal gaan berusten."

We staan TAVECCHIO toe de auteurs hier een kort moment te onderbreken. De bespreker van WEISFELTs Nestgeuren wijst op het verband tussen 'herhalingen van [gehechtheids]relaties uit het verleden' en het "driegeneratiemodel" van NAGY, ${ }^{, 136}$ en merkt op: ${ }^{137}$

'De belangrijke theoreticus NAGY staat centraal in het hoofdstuk over loyaliteit, met als natuurlijk vertrekpunt de loyaliteit tussen ouders en kinderen, een vorm van zogenaamde verticale loyaliteit. Als deze verticale loyaliteit ernstig verstoord of misvormd is, heeft dat grote consequenties voor de horizontale loyaliteit zoals die zich ontwikkelt tussen gelijken: vrienden, collega"s of partners.'

DERKS c.s. vervolgen:" ${ }^{138}$

'Bij kinderen onderscheidde men in eerste instantie drie basispatronen, namelijk ến veilig patroon en twee onveilige. De beide onveilige patronen worden aangeduid met de termen angstig-vernijdend en angstig-ambivalent. Omdat in onder-

136 Vgl. Over NAGY (uit te spreken als 'nodjz'): Ammy VAN HEUSDEN en ElseMarie VAN DEN EERENBEEMT, Ivan BOSZORMENYT-NAGY en zijn visie op individuele en gezinstherapie; Balans in beweging, Haarlem 1988 (derde druk; in de vierde druk van 1990 zijn hoofd- en subtitel omgedraaid); Annelies ONDERWAATER, De theorie van NAGY; De onverbrekelijke band tussen ouders en kinderen (oorspr. titel: De onverbrekelijke band tussen ouders en kinderen; Over de denkbeelden van Iwan BosZORMENYT-NAGY en Heim STIERLIN), Lisse 1995 (vierde druk); H.E.M. BAARTMAN, Opvoeden kan zeer doen; Over oorzaken van kindermishandeling, huipverlening en preventie, Utrecht 1996, pp. (67 en) 82-84 (waar ook een verband wordt gelegd met de theorie van Alice MILLER).

137 TAVECCHIO, bespreking van WEISFELTS Nestgeuren, t.a.p., op p. 52 I.k.

138 DERKS e.a., t.a.p., op pp. 44-45 (curs. zowel overgenomen als aangebracht). Vgl. met betrekking tot de in deze passage onderscheiden gehechtheidspatronen $c, q$. -typen ook Sheree L. TOTH, Dante CICCHETTI, 'Child maltreatment: where do we go from here in our treatment of victims?' In: Dante CICCHETT, Sheree L. TOTH (eds.), Child abuse, child development, and social policy, Advances in applied developmental psychology, vol. 8, Norwood, New Jersey 1993, pp. 399-437, op p. 402 . 
zoek bleek dat sommige kinderen een inconsistent onveilig patroon van vermijding èn ambivalentie lieten zien, werd later het gedesonganiseerde patroon toegevoegd.

Veilig gehechte kinderen wertrouwen erop dat hun opvoeder beschikbaar is en adequaat reageert wanneer ze behoefte hebben aan bescherming of troost bijvoorbeeld knuffelen en geruststellen. Onveilig gehechte kinderen daarentegen hebben geleerd dat ze daarop maar beter niet kunnen vertrouwen. Ouders van angstig-vermijdende kinderen blijken signalen van ongenoegen, pijn of angst vaak niet op te merken of er afwijzend op te reageren. Daarnaast hebben deze ouders een aversie tegen lichamelijk contact met hun kind.'

Een aversie die zo tegennatuurlijk is dat zij zelf een ernstig-traumatische oorsprong moet hebben, dan wel geacht moet worden voort te komen uit de combinatie van een ernstig (posttraumatisch) tekort aan pedagogisch besef en een ernstig gewetensconflict, bijvoorbeeld omdat het kind volstrekt ongewenst was en men het niettemin geboren heeft laten worden (respectievelijk niet heeft afgestaan). Maar dit terzijde. We lezen verder:

'Opvoeders van angstig-ambivalente kinderen hebben hiermee geen moeite, maar ze reageren niet consistent op angstsignalen: ze gaan er de ene keer wel op in en de andere keer niet. Kort gezegd: het angstig-vermijdende kind heeft geleerd dat het van anderen geen hulp hoeft te verwachten; het angstig-ambivalente kind heeft geleerd dat nooit valt te voorspellen hoe de ander zal reageren op zijn hulpvraag. Wanneer zich een beangstigende situatie voordoet, zal een veilig gehecht kind contact met zijn opvoeder zoeken en zich laten geruststellen. Een. angstig-vermijdlend kind zoekt geen contact; een angstig-ambivalent kind zoekt via omwegen wel contact maar de geruststelling lukt niet.

Deze basishoudingen vormen de kern van hun interne werkmodellen, en dus in theorie ook van hun relaties met anderen in de volwassenheid."

Met andere (NAGY-iaanse) woorden: deze interne werkmodellen zijn de latere vertaling van verticale naar horizontale loyaliteit, de latere herhaling van verticale in horizontale (hyper- en/of dys-)loyaliteit. Dus, om enkele (aan)verwante termen te gebruiken: er is bij onveilige gehechtheid in het latere leven veelal sprake van hetzij (internaliserende) hyperloyaliteit/symbiose/co-dependency/scheidingsangst/vastklampen/emotioneel 'masochisme'; hetzij van (externaliserende) dysloyaliteit/onbetrouwbaarheid/pseudo-onafhankelijkheid/bindingsangst/aantrekken-en-afstoten/ emotioneel 'kannibalisme'; hetzij van combinaties: de persoon in kwestie is hyperloyaal (dweperig, sentimenteel) ten opzichte van sommige personen of in sommige situaties (zoals bijvoorbeeld sommige incestslachtoffers ten opzichte van hun vader/dader), en dysloyaal (hardvochtig, onverschillig) ten opzichte van andere personen of in andere situaties (zoals bijvoorbeeld sommige incestslachtoffers ten opzichte van hun partner en/ 
of hun kinderen). ${ }^{139}$ Kort gezegd: in latere (intieme maar ook werk-) relaties laat men een spoor van vernielingen achter, waarbij betrokkene veelal zijn of haar eigen ergste slachtoffer is. Tenzij deze erin is geslaagd zijn of haar kinderen tot de grootste slachtoffers te maken. We lezen weer verder:

"Voor volwassenen werden in eerste instantie de drie voor kinderen ontwikkelde categorieën (veilig, vermijdend, ambivalent) overgenomen, maar later werden er twee toegevoegd. Mensen bij wie op volwassen leeftijd blijkt dat zij vroegere [aanwijsbare/achterhaalbare, jw] traumatisering nog niet goed verwerkt hebben (bijwoorbeeld het overlijden van een gehechtheidsfiguur, seksueel misbruik of fysieke mishandeling [op niet te vroege leeftijd, jw]) worden ingedeeld in een onverwerkt-trauma-categorie. Daarnaast werd er, net als voor kinderen, een gedesorganiseerde categorie ontwikkeld voor mensen met een inconsistente mix van verschillende werkmodellen. - [Noot:] Bij volwassenen hanteert men binnen de gehechtheidstheorie andere namen voor deze categorieën dan bij kinderen. Autonoom [dat is: relatiebekwaam, competent en autonoom, jw] bij volwassenen correspondeert met veilig bij kinderen; gereserveerd correspondcert met angstig-vermijdend, en verstrikt correspondeert met angstig-ambivalent. (...) Binnen de relatie met hun opvoeders heeft het gehechtheidsgedrag van jonge kinderen een adaptieve functie: door zich aan te passen aan de gehechtheidsstrategie van hun opvoeders leren kinderen uit ervaring hoe ze de afstand tot andere mensen zodanig kunnen reguleren dat ze zich daar prettig en vertrouwd bij voelen. Ze ontwikkelen een verwachtings- en gedragspatroon dat met deze interactie correspondeert. Een patroon dat binnen een gegeven ouder/kind-relatie adaptief is, kan echter op latere leeftijd en in andere relaties gemakkelijk dysfunctioneel worden (...). Een peuter die heeft geleerd dat hij bij pijn of angst beter niet de aandacht van zijn moeder kan trekken (bijwoorbeeld omdat ze hem dan altijd afwijst), zal later misschien steeds de kleuterjuf afweren als ze hem wil helpen, of hij zal vervelend doen tegen een leeftijdgenootje dat met hem wil spelen. Reageren de juf of het andere kind hier negatief op (bijwoorbeeld door hem te negeren), dan bevestigt en versterkt dat het onveilige werkmodel. Dit kan er op zijn beurt weer toe leiden dat het kind op een negatieve manier om aandacht gaat vragen. Onderzoek heeft inderdaad aangetoond dat kinderen bij wie als baby een onveilig werkmodel werd vastgesteld, op kleuter- en lagere-school-

139 Vgl. in dit verband bijvoorbeeld Ingrid FOEKEN, 'Inbreuk en uitbreken; loyaliteitsverandering door confrontaties van slachtoffers met daders van seksueel misbruik en andere familieleden,' in: Elly SINGER en Margreet WEGELIN (red.), De familieband verbroken? Opstellen over gezinsgeweld, autonomie en loyaliteit, Utrecht 1991, pp. 38-52, op p. 47: 'Leven met een gezinsgeheim is als rondspartelen in een vissekom en steeds dezelfde destructieve patronen herhalen. Besef van een andere, vrijere wereld is nauwelijks voor te stellen. Slachtoffers van trauma's zoeken later nogal eens troost en liefde bij mensen die op de dader lijken of nog steeds bij de dader zelf! (...) Diepe twijfel en almachtsfantasieën dat het gezin uit elkaar zou vallen bij onthulling, weerhouden haar zich te bevrijden uit die beperkende vissekom.' 
leeftijd gedragsproblemen gingen vertonen, die onder meer tot uiting kwamen in agressief optreden tegen leeftijdsgenoten. Bij veilig gehechte kinderen kwamen dergelijke gedragsproblemen veel minder vaak voor (...). De laatste jaren is er steeds meer onderzoek beschikbaar gekomen over samenhangen tussen onveilige gehechtheid en verschillende vormen van psychopathologie in de jeugd en op latere leeftijd."

Dit brengt ons op de vraag in hoeverre vormen van veilige dan wel onveilige gehechtheid, van gezonde dan wel verstoorde loyaliteit, van adequate dan wel dysfunctionele (averechtse) interne werkmodellen, een 'tweede natuur' kunnen worden, dat wil zeggen doorwerken in de karaktervorming, in de persoonswording, de persoonlijkheidsontwikkeling, en aldus leiden tot hetzij een (in principe) evenwichtige en gezonde, hetzij een scheef gegroeide, een 'dysmorfe' persoonlijkheid. De auteurs stellen deze vraag aan de orde onder het kopje 'Onveilige gehechtheid en persoonlijkheidsstoornissen': 140

"In een aantal studies bij volwassenen zijn aanwijzingen gevonden voor een samenhang tussen angstig-vermijdende gehechtheid en externaliserende problematiek (zoals bijvoorbeeld boosheid en agressie) en tussen angstig-ambivalente gehechtheid en internaliserende problematiek (waartoe bijvoorbeeld angst en depressie behoren), maar in een ander onderzoek kregen deze uitkomsten geen bevestiging (...). Op theoretische en empirische gronden mogen we verwachten verbanden tussen gehechtheid en persoonlijkheidsstoornissen aan te treffen. Zo is beargumenteerd dat gehechtheidsproblematiek ten grondslag ligt aan de borderline-persoonlijkheidsstoornis (...). FONAGY (1993) vond inderdaad een verband tussen borderline-problematiek (die zich kenmerkt door een instabiliteit in zelfbeeld en sociale relaties) en angstig-ambivalente gehechtheid. Ook voor andere persoonlijkheidsstoornissen zijn vanuit de gehechtheidstheorie verklaringsmodellen ontwikkeld, met name voor de afhankelijke (...), de ontwijkende (...) en de antisociale persoonlijkheidsstoornis (...) [uit respectievelijk het internaliserende, sociaal-angstige $\mathrm{C}$-cluster en het externaliserende, antisociale B-cluster van de $D S M-N$, jw]. BOWLBY (1988) was van mening dat aan persoonlijkheidsstoornissen vaak een selectief "vergeten" van traumatische jeugdervaringen ten grondslag ligt en volgens WEST \& SHELDON-KELLER (1992) is dysfunctionele gehechtheid een centraal kenmerk van vrijwel alle persoonlijkheidsstoornissen. Op grond van deze literatuur mogen we verwachten bij mensen met persoonlijkheidsstoornissen, en dus ook bij ter beschikking gestelden, relatief vaak een onveilig werkmodel van gehechtheid aan te treffen.'

Onder het kopje 'Onveilige gehechtheid en crimineel gedrag' vervolgen $\mathrm{zij}^{141}$ 
"Vórdat BOWLBY zijn gehechtheidstheorie ontwikkelde, deed hij onderzoek onder jeugdige delinquenten waaruit hij concludeerde dat een aantal van hen zich had ontwikkeld tot "affectionless psychopaths" nadat zij er in hun vroege jeugd niet in waren geslaagd (of niet de kans hadden gekregen [niet in staat waren gesteld, jw]) een affectieve relatie met hun moeder aan te gaan (BOWLBY 1944, 1951). Volgens hem richt de agressie van kinderen die mishandeld of misbruikt werden, zich voornamelijk tegen degenen met wie zij [later, als partner of ouder, jw] de meest hechte band hebben (BOWLBY 1988). Later heeft MAWSON (1980) een theoretisch model opgesteld waarin agressie en interpersoonlijk geweld worden opgevat als het [latere, jw] resultaat van gefrustreerde pogingen [wan het jonge kind, $j w]$ gehechtheidsrelaties aan te gaan.

Binnen de criminologie is bekend dat gezinsachtergronden een grote rol spelen bij het ontwikkelen van crimineel gedrag. Vooral in de sociale-"bindingen"-theorie van HIRSCHI (1969; WEERMAN 1995, [TV Cr] 1996) wordt expliciet ingegaan op de rol die de gehechtheid tussen ouders en kind hierbij speelt. Wetenschappelijk bezien vormt dit thema zelfs een van de hoekstenen van de theorie, maar in de praktijk is men de moeilijkheden die zich bij de operationalisatie bleken voor te doen, veelal uit de weg gegaan door zich te concentreren op de andere theoretische kernbegrippen ("commitment,' 'involvement' en 'betiefs'), of door 'attachment" [gehechtheid] voornamelijk vanuit een a-theoretische of sociologische optiek te bezien en niet wanuit een psychologisch-pedagogische invalshoek à la BOWLBY [zoals WEERMAN, TvCr 1996/1]. (...) LEEUW e.a. (1987) (...) wijzen erop dat gehechtheid niet gelijk is aan binding, maar dat het ontwikkelen van een veilig werkmodel van gehechtheid eerder een voorwaarde is om op volwassen leeftijd bevredigende bindingen te kunnen aangaan. De empirische toetsing van deze veronderstelling werd medio jaren tachtig echter nog belemmerd door het ontbreken van betrouwbare en gevalideerde methoden om de interne werkmodellen van gehechtheid bij jeugdigen en volwassenen vast te stellen. De ontwikkeling van het Gehechtheids-Biografisch Interview (GBI) heeft daar inmiddels verandering in gebracht.'

\section{De auteurs beschrijven vervolgens dit GBI. Daarbij merken zij op: ${ }^{142}$}

'(...) [G] evraagd [wordt] naar beschrijvingen van de vroegere relatic met de ouders en specifieke herinneringen daarbij, naar de huidige relatie, en naar reacties op traumatische ervaringen in de jeugd. (...) Het gaat niet om [overeenkomsten en] verschillen in wat men tijdens de jeugd heeft meegemaakt, maar [om] hoe men daar op latere leeftijd op terugblikt en in hoeverre die ervaringen iemands verdere bestaan zijn blijven kleuren. Het is dus geenszins zo dat mensen met een veilig werkmodel van gehechtheid per definitie een gelukkiger en minder problematische jeugd hebben gehad dan degenen met een onveilig werkmodel. Waar het om gaat is hoe eventuele negatieve enaringen verwerkt zijn in de levensgeschiedenis en of men een manier heeft gevonden om er evenwichig mee om te gaan." 
In het kort komt de GBI-methode erop neer, aldus de auteurs: ${ }^{143}$

\begin{abstract}
'(...) dat volwassenen die [ex tunc of ex nunc, d.i. van jongs af aan of na latere reparatie/verwerking, $j w]$ als veilig gehecht worden geclassificeerd, in staat zijn een helder en genuanceerd beeld van hun relaties met vroegere gehechtheidsfiguren over te brengen en begrip/acceptatic te tonen woor wat ze als kind mogelijk te kort zijn gekomen. Voor de angstig-vermijdende categorie geldt als karakteristiek dat de geïnterviewde de relaties met vroegere gehechtheidsfiguren idealiseen, maar niet in staat is dit met voorbeelden te illustreren vanwege het ontbreken van concrete herinneringen aan de jeugdjaren. $\mathrm{Zij}$ benadrukken hun onafhankelijkheid en minimaliseren de invloed van vroegere ervaringen op hun persoonlijkheid. Kenmerkend voor de angstig-ambivalente gehechtheid is de incoherentie en boosheid waarmee iemand vertelt over vroegere gehechtheidsrelaties. In hun vroegere ervaringen treffen we vaak [ouderlijke] overbezorgdheid en rolomkering aan. Mensen bij wie onverwerkt trauma op de voorgrond staat, taten in het GBI zien hoe het vroegere trauma hun belevingen en gedachten is blijven bepalen tot op de dag van vandaag. Dit kan onder andere blijken uit incoherenties in het denken en spreken over het trauma. Tot de gedesorganiseerde categorie worden mensen gerekend die in hun werkmodel een inconsistent basispatroon laten zien (bijvoorbeeld tegelijkertijd idealiseren en boosheid).'
\end{abstract}

\title{
Ten aanzien van de resultaten van hun onderzoek onder ter beschikking gestelden merken de auteur op: ${ }^{144}$
}

"Wat het plegen van delicten betreft, zien we dat de criminele carrière van de patiënten bij wie onverwerkt trauma domineert, vaak al is begonnen tussen het zesde en twaalfde levensjaar. Bij de patiënten met een angstig-ambivalent of gedesorganiseerd werkmodel gebeurde dit tussen twaalf en achttien jaar, en bij degenen met een angstig-kermijdend werkmodel pas daarna. (...) De angstig-ambivalente patiënten en degenen met een gedesorganiseerd werkmodel hebben meer geweld gebruikt tijdens hun delicten; hun slachtoffers werden vaker gedood of raakten ernstig verwond. Bij de angstig-ambivalente patiënten waren deze delicten bovendien vaker seksueel van aard. (...)

De meest robuuste onderzoeksuitkomst is dat we onder autochtone ter beschikking gestelden wrijwel geen personen aantreffen met een veilig werkmodel van gehechtheid. Het merendeel behoort tot het type met anverwerkt tratuma of tot het gedesorganiseerde type. Deze mensen kampen wanaf jonge leeftijd met een fundamentele en onopgeloste problematiek die diep heeft ingewerkt op hun persconlijkheid en levensloop. (...) Hun persoonlijkheidsontwikkeling is al op zeer jonge leeftijd op een bijzondere manier verstoord geraakt, waardoor zij in toenemende mate problemen kregen in de omgang met andere mensen. Vanuit diagnostisch oogpunt lijkt het dan ook zinvol de aard van de verstoring gehechtheidstheoretisch te bezien. Wel roept dit de vraag op waarom de stoornis bij deze patiënten tot zo ernstig crimineel gedrag heeft geleid dat een terbeschikkingstelling nodig 
werd bevonden en bij andere psychiatrische patiënten niet. Een antwoord op deze wraag kan misschien gevonden worden in het relatief hoge aantal patiënten in de gedesonganiseerde categorie of bij wie een onverwerkt trauma in de vorn wan fysieke mishandeling en/of seksueel misbruik een rol speelt. Hier lijken ter beschikking gestelden immers af te wijken van andere psychiatrische patiënten. In een aantal gevallen is misschien de preoccupatie met het eigen wroegere slachtofferschap verantwoordelijk voor het agressieve, antisocialle acting-out-gedrag dat tot de veroordeling heeft geleid en dat een verhoogd recidive-risico inhoudt. In andere gevallen kan ditzelfde gelden voor de inconsistentie in het interne werkmodel van gehechtheid.'

\title{
Wel relativeren de auteurs hun onderzoeksbevindingen: ${ }^{145}$
}

\begin{abstract}
'Het hier gerapporteerde onderzoek heeft plaatsgevonden binnen een zeer specifieke populatie, waardoor de (...) generaliseerbaarheid beperkt is. Desalniettemin kan onze bevinding ten aanzien van verbanden tussen persoonlijkheidspathologie en onveilige gehechtheid beschouwd worden als richtingwijzend voor verder onderzoek naar de pedagogische en ontwikkelingspsychologische grondslagen van ernstig crimineel gedrag. (...)

De gehechtheidstheorie kan ons meer inzicht verschaffen in de ontwikkelingspsychologische en gezinspedagogische achtergronden van ernstige criminaliteit, in de aard van de psychische problematiek bij ter beschikking gestelden , en in de behandelingsresultaten die bij deze uitzonderlijke populatie te behalen zijn. De maatschappelijke relevantie hiervan is evident.'
\end{abstract}

\section{De verraadstraumatheorie}

Een derde lap 'verhalende' tekst ontlenen we aan (Jennifer) FREYD. Haar 'verraadstraumatheorie' drukt ons met de neus op de cognitieve 'logica van het vergeten van kindermishandeling.' ${ }^{146}$ Uit hoofdstuk 7 van FREYDs Betrayal trauma; The logic of forgetting childhood abuse cite-

T.a.p., op p. 53 (curs. jw).

146 Vgl. met betrekking tot deze (geheugen)problematiek ook Onno VAN DER HART, Kees VAN DER VELDEN, 'Over het waarheidsgehalte van traumatische herinneringen,' in: Onno VAN DER HART (red.), Trauma, dissociatie en hypnose; Handboek, Lisse 1995 (derde druk), pp. 415-437; Nel DRAUER, 'Herinneringen aan traumatische ervaringen in de kindertijd," $M G v 1996 / 7-8_{*}$ pp. 707-727, met verwijzing naar [Lenore] TERR, [Unchained memories; Thue stories of tranmatic memories, lost and found (1994), vertaald als Schokkende herinneringen; 7 Gevallen wan traumaverwerking en geheugenverlies, Amsterdam] 1994; Onno VAN DER HART, Ellert NUENHUIS, 'Dissociatieve amnesie woor traumatische ervaringen,' $M G v$ 1996/7-8, pp. 728-747.

Zie (in meer allgemene zin) ook G.S. KUIPERS e.a., 'Op zoek naar dissociatieve stoornissen; de ervaringen in het psychiatrisch ziekenhuis Reinier VAN ARKEL,, $M G v 1996 / 11$, pp. 1153-1166, dat met name onthullend is voor de aangetroffen frequentie. 
ren we enkele (om de verhaallijn niet te zeer te verstoren: langere) passages. ${ }^{147}$ Allereerst kijken we echter naar haar omschrijving en introductie van 'betrayal trauma": ${ }^{148}$

'Betrayal is the violation of implicit or explicit trust. The closer and more necessary the relationship, the greater the degree of betrayal. Extensive betrayal is traumatic. Much of what is traumatic to human beings involves some degree of betrayal.

Betrayal trauma theory posits that under certain conditions, betrayals necessitate a "betrayal blindness" in which the betrayed person does not have conscious awareness, or memory, of the betrayal. A theory of psychological response to trauma, betrayal trauma [theory] builds from the belief that the degree to which a trauma involves betrayal by another person significantly influences the traumatized individual's cognitive encoding of the experience of trauma, the accessibility of the event to awaremess, and the psychological as well as behavioral responses. (...) Betrayal trauma theory does not directly address the issue of veracity of recovered memories of abuse or trauma. Instead, it asks the basic question: "If a child is abused and betrayed, what would we expect to happen to the information about that abuse and betrayal?" From a logical analysis of developmental pressures and cognitive architecture, we can expect cognitive information blockage under certain conditions (like sexual abuse by a parent), which will create various types of betrayal blindness and traumatic amnesia."

\section{Hoewel de polsstok van deze introductie zeer kort is, springen we direct} naar het slothoofdstuk van FREYDs boek: ${ }^{149}$

"Humans are social beings, fundamentally dependent on relationships, alliances, and trust. Betrayal violates the basic ethic of human relationships, and though we are skilled at recognizing betrayal when it occurs, this ability may be stifled for the greater goal of survival. A child sexually abused by an adult who has power and authority over that child, is in a bind. That child needs to trust his or her parents and caregivers. Child sexual abuse perpetrated by a trusted caregiver is therefore a prime example of the kind of event that can create information blockage in the mind of the victim. To know is to put oneself in danger. To not know is to align with the caregiver and ensure survival. Some degree of amnesia or unawareness of the abuse is thus a natural reaction to childhood sexual abuse. Forgetting occurs not for the reduction of suffering but to stay alive. (...)

To forget and to later remember are everyday aspects of human experience. Various degrees of amnesia, various times of onset, and various consequences can be understood in terms of what we currently know about memory and attention. Knowledge is multi-stranded. We can simultaneously not know and know about a betrayal. This knowing is often what cognitive psychologists call "implicit knowlbridge, Mass./London 1996, Chapter 7 ('Creating connections'), pp. 163-196. 
edge" or "implicit memory." While experiencing a complex traumatic event such as sexual abuse, multiple mental mechanisms are activated in the person's brain to process the information and determine responses. Many of those mechanisms operate outside of conscious awareness. (...) The survivor of childhood sexual abuse who "forgets" and "does not know" about the abuse may have implicit memory and knowledge of the events that surface in other ways: specific phobias, learned behaviors, a self-perception of being a "bad girl" or "bad boy." (...)

Betrayal trauma also is consistent with difficulties with trust, either in the form of too great a willingness to trust or an inability to trust, also a common result of child abuse (BROWNE and FINKELHOR 1986). (...)

With dissociations between different memory stores for the same event and the blockage of information about current reality to some processing units, a firm foundation for assessing reality using all available internal sources of knowledge cannot be laid (see HERMAN 1992; KLUFT 1990; VAN DER KOLK 1987). This lack of integration is likely to produce alterations in consciousness, dissociated states, and problems such as depersonalization - feeling detached from one's own body. (...) With the "everydlay pleasures, sensations, and comforts of human embodiment" denied to the survivor of childhood sexual abuse, and with other human mental capacities attenuated or dissociated from consciousness, it is no wonder that depression is such a common experience for abuse survivors (BROWNE and FINKELHOR 1986). With sensory and affective memories missing episodic interpretation, and with reduced connectivity between different sorts of memory systems, we would also expect to see inexplicable mood states, hallucinations, flashbacks, nightmares, and bodily sensations that are easily interpreted as physical illness or somatization (VAN DER KOLK 1987). Those experiencing betrayal trauma are also likely to exhibit specific learned behaviors. For instance, a child who has been beaten repeatedly may learn to flinch or to manipulate the timing of another person's aggressive tendencies. Similarly, a child who has been sexually abused, may learn degrading sexual behaviors demanded by the perperrator. Without conscious interpretation, the trauma survivor has no way of knowing the source of his or her behavior. Sadly, this may be especially true for behaviors learned during infancy and childhood and later expressed during parenting (SEAY, ALEXANDER and HARLOW ['Maternal behavior of socially deprived rhesus monkeys'] 1964)."

\section{Van bijzonder belang voor ons onderwerp is hetgeen FREYD in haar slot- hoofdstuk opmerkt met betrekking tot 'The issue of children's rights': 150}

\footnotetext{
"In The little prince, Antoine DE SAINT-EXUPÉRY observed: "All grown-ups were once children - although few of them remember it." Although at some intuitive level we all know the struggle and joy of childhood, for most of us, coming of age involves a disconnection from that childhood - a kind of culturally induced dissociation. The concept of the "inner child" that has emerged in popular culture, is easy to ridicule (...). Yet ridicule is often a response of those in power when they have little to say in defense of a challenge to the status quo (...).
} 
Western civilization has been moving slowly toward acceptance of children as human beings, worthy of human rights. This movement had been something like that of a wide, bending, slowly running river. Recently, however, that lazy river has suddenly become fast-moving and full of rapids. Carried along, we slam against the rocks, we get caught in swirling eddies. The river is taken us to a recognition of children's needs and rights, and we have entered particularly challenging waters. In addition, unlike other human rights struggles, the primary oppressed group in this case - children - cannot lead the movement. Instead, adults must take the lead.

The struggle for the freedom, dignity, and rights of children is also a struggle for the liberation of the human spirit in adults. If we free our children, they may mature into freer adults, living more fully, with more of an opportunity to fulfill their potential, thus making the world a better place for all. At the same time, by accepting the continuity between our adult selves and our childhood histories, we may help free the human spirit in ourselves and others. In this way, when we promote children's rights we are promoting our own freedom.

Although the concept of the inner child is easy to ridicule, it represents a profound change in society's understanding of human nature. Instead of perceiving adolescence as an abrupt transformation, producing adults who have left childhood in the past, we are increasingly perceiving the continuity of human experience from birth to old age. Although our needs change as we grow older, each of us represents the totality of our experiences, including those in our childhood. To be aware of this continuity decreases dissociation from childhood memories of self and thus promotes internal healing. To be aware of this continuity also leads us to realize that children deserve human rights too, and thus awareness of the continuity also promotes external action."

\section{Vermelding verdient hier ook wat FREYD suggereert met betrekking tot dader-dissociatie en de intergenerationele overdracht van dissociatieve toestanden: ${ }^{151}$}

"I have focused on childhood sexual abuse by a caregiver as the type of betrayal trauma most likely to lead to amnesia for the betrayal. Childhood sexual abuse by a caregiver is especially likely to contain the situational factors that make amnesia both adaptive (to maintain necessary attachment) and possible (it is kept secret, it is never discussed, alternative realities are presented). A possible additional factor that awaits future investigation, is the relationship between sexual behavior and the likelihood of altered states of consciousness we may call "trance." We may be particularly vulnerable to entering dissociated states while engaged in sexual activity. This may help explain why otherwise inexplicable ritualized behaviors and fetishes are so often associated with sex. In addition, trance states may be somewhat contagious. Trance may beget trance. If an adult who is sexually abusing a child, enters a dissociated state, that altered state of consciousness

151 FREYD, Betrayal trauma, a.w, p. 188.

Vgl. over deze fenomenen ook Frits BRUNSMA, Incesthulpwerlening; Diagnostiek, opvang en behandeling van incest, Utrecht 1994, pp. 194-195 (en 199). 
may be instrumental in inducing an altered state of consciousness in the child victim as well.

However, even if sexual abuse is the most likely sort of betrayal trauma to induce amnesia, it is not the only sort of trauma likely to have this effect."

\section{De auteur besluit haar betoog aldus: $:^{152}$}

'Unawareness, not knowing, forgetting, dissociating - being less than fully connected internally - may be adaptive if the external situation is such that aware-

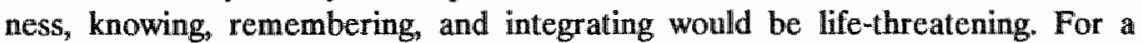
child dependent on abusive caregivers, lack of internal conmection can help maintain some sort of external connection to necessary others. (...)

Blindness and lack of connectedness, whether truly needed or not, are ultimately tragic solutions to life. These adaptations keep us from knowing ourselves and others fully. We end up fragmented both internally and externally - impoverished spiritually and socially. We have learned this is the way to survive, a sort of minimum strategy. It may seem like a good solution when we are limited by the immediate context, but it seriously constrains human potential. (...)

Survivors of childhood sexual abuse and betrayal trauma have learned to cope by being disconnected internally so as to manage a minimal kind of external connection. But with adult freedom and responsibility come the potential to break silence, to use voice and language to promote internal integration, deeper external connection, and social transformation.'

\section{Brede range van posttraumatische psychopathologie (sequelae)}

Het voorafgaande zou wellicht de onjuiste indruk kunnen wekken dat elke (ernstige) bedreiging of beschadiging van de persoonswording van het kind in het latere leven tot een of andere (sociaal-angstige dan wel antisociale) persoonlijkheidsstoornis leidt. Deze conclusie is evenwel voorbarig (en dus zonder meer onjuist) om twee redenen. In de eerste plaats vullen de sequelae van kindermishandeling een weidse horizon van psychische, psychosomatische en psycho-sociale problematiek, in de literatuur treffend aangeduid als traumaspectrum. ${ }^{153}$ DERKS e.a. spreken op dit punt (zoals we zagen in de vorige paragraaf) van "een verband tussen een brede range van psychische problemen en onveilige gehechtheid.154

FREYD, Betrayal trauma, a.w., pp. 195-196.

Vgl. Nelleke NICOLAI, 'Seksueel misbruik en psychiatrische stoornissen; aen orienterend onderzoek op een gesloten afdeling van een psychiatrisch ziekenhuis," Maandblad Geestelijke walksgezondheid/MGv 1990/9, pp. 908-923, op p. 920; Onno VAN DER HART, Wybrand OP DEN VELDE, 'Posttraumatische stoornissen,' in: Onno VAN DER HART (red.), Trauma, dissociatie en hypnose; Handboek, Lisse 1995 (derde druk), pp. 103-143, op p. 103.

Frans DERKS, Martien PHILIPSE en Rien VAN IJZENDOORN, 'De betekenis van BOWLBY's gehechtheidstheorie in de beoordeling en behandeling van ter beschikking gestelden,' Tijdschrift woor Criminologie/TvCr 1997/1, pp. 42-55, op (p)p. 
Een brede 'range' overigens zowel qua symptomatologie als qua omvang, dat wil zeggen qua aantal 'patiënten.' Zo noemt JOHNSON alleen al incest "common enough to have profound public health consequences.' 155

In de tweede plaats is het bepaald geen wet van Meden en Perzen dat kindermishandeling levenslange beschadigingen ten gevolge heeft. Hoezeer traumatische jeugdervaringen onder negatieve (sociaal-)pedagogische condities ook kunnen leiden tot coping-gedrag dat - in de vorm van pathologische ('gestoorde') persoonlijkheidstrekken - een "pantser $^{156}$ of zelfs een tweede natuur van de 'survivor' wordt, er is, naast nature (aanleg) en nurture (omgeving/opvoeding), altijd nog het element van de zelfbepaling, dat wil zeggen de mogelijkheid - althans in principe (een principe dat in zeer ernstige gevallen uiteraard meer theoretisch dan reëel is) - deze ervaringen te verwerken door het onder ogen zien van wat door ouders (en de maatschappij die hen en hun kinderen aan hun lot overliet) is afgepakt, niet gegeven en kapotgemaakt, door het volvoe-

(49/)50 (curs. jw).

155 Stephen M. JOHNSON, Character styles, New York/London 1994, p. 232.

156 Met betrekking tot dit 'pantser' merken KLEBER c.s. op: 'Traumatische ervaringen uit de kindertijd blijven in "gestolde" vorm bestaan en worden tot een pantser tegen angst en agressie, maar tegelijk ook tot een keurslijf.' (R.J. KLEBER e.a., Traumatische ervaringen, gevolgen en verwerking, Lisse 1986 - zie in het bijzonder hoofdstuk 8, 'Gevolgen van langdurige extreme situaties: het concentratiekampsyndroom,' en hoofdstuk 11, par. 3, 'Ervaringen in de jeugd en persoonlijkheidseigenschappen,' resp. pp. 135-154 en 210-214; citaat op p. 210.)

Een tweede citaat (in een citaat; t.a.p.): "'Soms zijn de pantsers harnassen, belemmeringen, verlammingen, soms ook moeten ze eerder vergeleken worden met gelei, blubber, lijm, kauwgom, zoals al te grote hoffelijkheid, terughouding, verlegenheid, constante ironie, bescheidenheid en andere deugden die een natuurlijke en ongedwongen houding vervangen." Wij zien in deze beschrijving weer de al eerder genoemde incompetentie en rigiditeit.'

Een incompetentie - zo zou ik daaraan willen toevoegen - die door veel ambitie en (eenzijdig) uiterlijk succes kan worden overdekt, doch die zich vooral wreekt op het interpersoonlijke vlak, op het punt van empathie (en dus collegialiteit). Het zijn rond de ingekapselde weke, onzekere kern - maar lang niet altijd ook aan de (meer of minder geforceerd-aardige) buitenkant - harde, (vooral) voor het oog competente personen. In de wetenschap komt men hen tegen als het type meer of minder minzame netwerkers die veel van anderen afschrijven doch die zelden op originele gedachten worden betrapt. Het type dat in 1737 door de ten onrechte voor positivist versleten jurist VAN BYNKERSHOEK is vereeuwigd in een uit niet meer dan drie woorden bestaande sneer aan het adres van ZOUCHE (die zijn opinies te veel van GROTIUS zou afschrijven en een bepaald vraagstuk behandelde zonder - naar zijn gewoonte - zelf een standpunt in te nemen): 'Hanc quaestionem tractat zoucheus (...), ipse, pro more suo, nihil definiens.' (Quaestionum juris publici libri duo, 1737; zie Kinji AKASHI, Comelius VAN BYNKERSHOEK: His role in the history of international law, Den Haag etc. 1998, p. 146 nt. 84.) 
ren van de rouwarbeid die de (zware) tol van die pijnlijke waarheid is, en door het (alsnog) tot een bevredigende oplossing brengen van gestagneerde ontwikkelingstaken. Hoe moeilijk - concedo - dat alles ook is in een maatschappij die kindermishandeling - de dramatische ontwikkelingspsychologische en pedagogische bedreiging van (vele) tienduizenden kinderen per jaar - niet of nauwelijks als maatschappelijk probleem ziet, laat staan oog heeft voor de pijn en de prijs van rehabilitatie.

Zó moeilijk dat we misschien moeten concluderen dat zulks vooralsnog bijna uitsluitend voor de zeer moedigen, ${ }^{157}$ en onder hen dan nog slechts voor de 'vrijgestelden' is weggelegd, de mensen die zich de 'luxe' - qua tijd, geld en sociale verplichtingen (werk! kinderen!) - van een verwerkingsproces kunnen veroorloven. ${ }^{158}$

Hoewel het een en ander bekend is over protectieve factoren, ${ }^{159}$ factoren die onder meer geacht kunnen worden het verwerkingsproces te begunstigen, weten we evenwel nog erg weinig over wat door mij hierboven het element van de zelfbepaling is genoemd. ${ }^{160}$ Met des te meer

157 Daarmee doel ik niet op morele helden, doch enkel op mensen wie de confrontatie met pijnlijke waarheden in heden of verleden niet meer afschrikt dan het (verder) afglijden in diepe (neurotische en/of verslavings)ellende. Voor zover die keuze hen althans helder voor ogen staat, hetgeen zonder helpende getuige niet altijd het geval is. (Vgl. Alice MLLer, Het drama van het begaafde kind, Houten $1995,18 \mathrm{e}$ druk, p. 24 i.f.)

158 Zoals SHENGOLD opmerkt: '(...) Most of the people I have treated were able to survive their childhood experiences with considerable intactness, and even with what seems to be some psychic strengths brought out by the need to deal with and transcend the early overstimulations and deprivations (...). But my patients are a few individuals, not only healthy enough but successful and wealthy enough to sustain a psychoanalysis.' (Leonard SHENGOLD, Soul murder; The effects of childhood abuse and depriwation, New Haven/London 1989, p. 310.)

159 Vgl. Han GROENENDAAL e.a. (red.), Protectieve factoren in de ontwikkeling wan kinderen en adolescenten, Lisse 1987; Rita VUYK, Opgroeien onder moeilijke gezinsomstandigheden, Amersfoort/Leuven 1987 (tweede druk); Anne-Marieke DEN HAAN, Monique KAVELAARS, Preventie vam seksueel misbruik van kinderen, deel 1 , LOP (Landelijk Ondersteuningspunt Preventie), Utrecht [1988], pp. 43-50; M.M.J. VAN OOYEN-HOUBEN, E.G.M.J. BERBEN, 'Protectieve factoren; een paradigmatische ommezwaai of nieuwe kleren van de keizer?’ Justitiele Verkenningen 1988/8 (Gezin, opvoeding en criminaliteit"), pp. 90-117.

160 Zelfreflectie en zelfdiscipline lijken hierbij belangrijke ingrediënten, maar dit brengt ons slechts in een vicieuze cirkel, want ook het daartoe vereiste invoelend vermogen (empathie) en doorzettingsvermogen en zelfbeheersing ("wilskracht, 'karakter') zijn geen (louter) aangeboren zaken: zij dienen in geval van (sociaal-) pedagogische (ouderlijke/maatschappelijke) tekorten door zelfopvoeding c.q. zelfheropvoeding (in en na ont-dekkende psychotherapie) te worden aangekweekt, waartoe weer minimale voorwaarden in nature en murture aanwezig dienen te zijn, enzovoorts. Vgl. in dit verband Daniel GOLEMAN, Emotionele intelligentie; Emo- 
nadruk dient hier dan ook op de woorden van NICOLAI te worden gewezen: ${ }^{161}$

'Een] andere vraag betreft de factoren die het individu in staat stellen ondanks de trauma's goed te blijven functioneren. (...) Naast de theorieën over de effecten van trauma's is een theorie over wat het individu in staat heeft gesteld te overleven, minstens zo belangrijk.'

Zeker, mits daarbij althans niet uitsluitend wordt gedacht aan "psychiatrische research (...) gericht (...) op het aspect van meer of minder adequate overlevingsstrategieën, ${ }^{162}$ doch ó6k aan onderzoek naar (meer of minder) adequate verwerkingsstrategieën. ${ }^{163}$ Op het belang van onderzoek op dit gebied wijst ook CICCHETTI: ${ }^{164}$

"We do think that all maltreated children will "pay a price" for their misfortune, though we believe that, through therapy and/or adaptive re-representation ['herkansing' in de herhaling(sdwang), jw] of their experiences, many maltreated children will go on [eventually (vroeger of - meer waarschijnlijk - later), jw] to lead productive lives. Obviously, these speculations can only be confirmed through rigorous longitudinal investigations.'

ties als sleutel tot succes, Amsterdam/Antwerpen 1996, pp. 381-383 ('Karakter, moraal en democratische bekwaamheden'); en Hans VAN EPEN, Sichets voor een nieuwe psychiatrie, Houten/Deurne 1990, pp. 173-175 ('Ontdekkende en confronterende therapie').

Als er eén lering is die we wit deze vicieuze cirkel kunnen trekken, dan is het wel dat we de emotionele opvoeding van kinderen niet uitsluitend aan het toeval (de toevallige ouders) kunnen overlaten (GOLEMAN, a.w.* p. 18)..

161 Nelleke NICOLAI, 'Seksueel misbruik en psychiatrische stoornissen;, een oriënterend onderzoek op een gesloten afdeling van een psychiatrisch ziekenhuis," $M G v 1990 / 9$, pp. 908-923, op p. 921.

162 T.a.p.

163 Met betrekking tot de daartoe vereiste onderzoeksmethode merkt A.D. DE GROOT evenwel op: '[O]p het grondig retrospectief ondervragen van een persoon over wat hijzelf te melden heeft over zijn psychische ervaringen, denkwijzen en gevoelens, [rust] nog steeds een behavioristisch taboe. Althans, it is not done met name niet in de zuiver-wetenschappelijke sector.' Uit: Karen HAMERLYNCK, Claudia BELLINI, De stand van zaken: 15 jaar psychologie,' Psychologie aprill 1997, pp. 16-23, op pp. 19-21 ('Adriaan DE GROOT: "Psychologen meten te veell en denken te weinig"'; citaat op p. 21 r.k.).

164 Dante ciCCHErT, "How research on child maltreatment has informed the study of chill development: perspectives from developmental psychopathology,' in: dez. en Vicki CARuSON (eds.), Child maltreatment; Theory and research on the causes and consequences of child abuse and reglect, Cambridge (etc.) 1989, pp. 377-431, op p. 419 iff. 
Min of meer bij wijze van recapitulatie laten we aan het slot van deze paragraaf een viertal (vrouwelijke) auteurs de revue passeren die met betrekking tot beide of éen van beide zojuist genoemde thema's (range van sequelae en verwerking) behartenswaardige dingen hebben opgemerkt: NICOLAI, DRAIJER, SCHOEMAKER en MILLER. Hoewel veel van wat deze auteurs naar voren brengen, althans op hoofdlijnen ruimer kan worden opgevat, dienen we ons wel te realiseren dat zij specifiek over incest (sexuele kindermishandeling) schrijven.

\section{Traumatisering en revictimisering}

Wat de psychische/psycho-sociale sequelae betreft, kunnen we twee aspecten eruit lichten: (de impact van) de traumatisering, dat wil zeggen: de posttraumatische symptomatologie, en (het fenomeen van) de revictimisering, de zogenaamde 'herhalingsdwang.' Om met het eerste te beginnen. In haar bijdrage over het incest-trauma in het Tijdschrift voor Psychotherapie (1991) ${ }^{165}$ onderscheidt de eerste hierboven genoemde onderzoekster, NICOLAl, symptomen van de eerste orde (posttraumatische reacties), van de tweede orde (vermijdingsgedrag, dissociatieve reacties, niet goed kunnen uiten van woede en boosheid), en van de derde orde (alcohol- en drugsmisbruik, automutilatie, explosies, chronisch schuldgevoel, schaamtegevoel). ${ }^{166}$ Als gevolgen van het incest-trauma noemt zij voorts de narcistische fantasie (grootheidsfantasieën); hyperloyaliteit (loyaliteit tegen-beter-weten-in, parentificatie, verinnerlijking van de dader/identificatie met - lees: introjectie van - de agressor als compenserende strategie of overlevingsstrategie), en in verband daarmee het proces van 'verknoping' tussen slachtoffer en dader (in de literatuur ook wel aangeduid als traumatic bonding, traumatische verbondenheid of hechting); de (gevoeligheid voor) verdraaiing en vervorming van de werkelijkheid; alsmede de vervorming van de persoonlijkheidsontwikkeling van het slachtoffer. ${ }^{167}$

165 N.J. (Nelleke) NICOLAI, Incest als trauma: implicaties en consequenties voor de behandeling,' Tijdschrift voor Psychotherapie 1991/1, pp. 12-30.

Vgl. ook Nel DRAlJER, Seksuele traumatisering in de jeugd; Gevolgen op lange temijn van seksueel misbruik van meisjes door verwanten, diss. Amsterdam 1990, en haar (mede) daarop gebaseerde bijdrage 'Psychische en psychosomatische gevolgen van seksueel misbruik en fysieke mishandeling' in H. BAARTMAN, A. VAN MONTFOORT (red.), Kindermishandeling; Resultaten van multidisciplinair onderzoek, Utrecht 1992, pp. 54-72; alsmede Nel DRAIJER, 'Trauma, persoonlijkheidsstoornissen en andere psychiatrische diagnoses, ${ }^{\prime} M G v 1996 / 11$, pp. 11341152 .

166 T.a.p., op pp. 17-18.

167 T.a.p., op pp. 19-21 en 27. 
Behalve op de centrale betekenis van schaamte en schuld wijst zij ook op het fenomeen van de omgekeerde wereld, bij haar: 'de cognitieve omkering van waarden' (ten gevolge van cognitieve verwarring en hersenspoeling bij het misbruikte kind, een 'proces van woorden die nooit met feiten kloppen, en feiten die niet mogen bestaan'), en 'de collusie van de vermijding' (de loochening van de ernst van het gebeurde door slachtoffer èn hulpverlener/omgeving). ${ }^{168}$ Schuldgevoelens - 'die schaamte moeten afweren en een illusie van controle in stand moeten houden' ziet zij als onbewuste grootheidsfantasieën - die 'op hun beurt de verwerking van het trauma [verhinderen]. ${ }^{, 169}$

Hoe boeiend een verder gaande traumaspectrum-analyse ook zou zijn, voor ons onderwerp is het van belang steeds zo veel mogelijk een helicopter-view in te nemen, dat wil zeggen de grote (psycho-mensenrechtelijke c.q. sociaal-pedagogische) lijnen vast te houden en de (persoonswordings)context niet uit het oog te verliezen. We 'charteren' daartoe de tweede hierboven genoemde onderzoekster, DRAIJER: ${ }^{170}$

'Op grond van mijn onderzoeks- en diagnostische ervaring acht ik de essentie in de trauma-anamnese de taxatie van de plaats en de ernst van de traumatisering in de totale context van de persoonlijkheidsontwikkeling. Traumatisering speelt namelijk niet altijd een centrale rol in de ontwikkeling van de stoornis. Soms betreft het incidenten, die "ingekapseld" zijn. Soms wordt seksueel misbruik door een patiënt naar voren geschoven bij wijze van afweer; de achtergrond van de problemen ligt dan bijvoorbeeld veel vroeger. Er is een diffuus en ongrijpbaar onbehagen over de jeugd en men zoekt een stok om de hond te slaan [bijwoorbeeld wegens een onbegrepen onveilige gehechtheidsrelatie, jw]. Soms echter gaat het om chronische traumatisering: onmacht en pijn in relaties met belangrijke anderen, zodlat deze ervaringen een bepalende invloed hebben op de ontwikkeling van de persoonlijkheid. De context is dus belangrijk: Hoe waren de hechtingsrelaties voorafgaand aan de traumatische ervaringen? Heeft de betrokkene als kind enige mate van koestering ondervonden? Is er (mede als gevolg daarvan) enige egostructuur aanwezig, noodzakelijk om traumatische herinneringen te kunnen integreren? Zijn er in de kinderjaren van de patiënt (andere) hechtingsfiguren geweest die het in hen gestelde vertrouwen niet beschaamden?'

Het tweede door ons eruit gelichte aspect, revictimisering, of liever (in meer algemene zin): de herhalingsdwang, keert terug bij diverse auteurs, en onder diverse benamingen zoals (traumatische) herhalingsdwang, herhalingstendens, herhaling van gedragspatronen, herhalingsgedrag of "uit-

T.a.p., op pp. 21 en 25.

169 T.a.p., op p. 27.

170 Nel DRAIJER, "Trauma, persoonlijkheidsstoornissen en andere psychiatrische diagnoses," MGv 1996/11, pp. 1134-1152, op p. 1147. 
ageren' (acting-out), (neurotische) enscenering en enactment of re-enactment. ${ }^{171}$ Deze termen verwijzen soms meer naar de actieve variant (externaliserende herhaling van verinnerlijkte daderpatronen: 'uitageren'), soms meer naar de passieve variant (internaliserende herhaling van ingesleten/'aangeleerde' slachtofferpatronen: 'enscenering'). De term herhalingsdwang op zich is neutraal. Hij kan zowel actieve als passieve, externaliserende dan wel internaliserende varianten betreffen; of de gemengde variant, wanneer zowel dader- als slachtofferpatronen in het gedragsrepertoire voorkomen. Hetgeen niet zelden bij (voormalige) slachtoffers ('survivors') het geval is, die dan zowel opnieuw slachtoffer van hun omgeving worden als in hun omgeving slachtoffers maken: daders worden, bijvoorbeeld ten opzichte van partners, kinderen, collega's.

Hier komen tevens de horizontale en de verticale varianten in beeld: de relationele respectievelijk de transgenerationele herhalingsdwang; de herhalingsdwang in relaties, ten opzichte van vrienden, collega's, partners (actief en/of passief). En die ten opzichte van de eigen kinderen (aanvankelijk meestal actief, later soms ook passief, wanneer ouders slachtoffers van hun oudere kinderen worden), en die ten opzichte van de eigen ouders (passief maar soms, vroeger of later, ook actief).

Al verschillende malen is in het bijzonder gewezen op de verticale variant, die tussen ouders en kinderen, de transgenerationele tragiek van de herhalingsdwang als posttraumatisch fenomeen, een tragische circulariteit die slechts door verwerking kan worden doorbroken. Kenmerkend voor alle varianten is evenwel de tragiek van het gevangen zitten in circulaire processen, in destructieve patronen.

Om zelf niet in herhalingsgedrag te vervallen, zullen we hier het aspect van de herhalingsdwang slechts zijdelings belichten onder het hierna volgende hoofdje 'verwerking.'

171 Vgl. bijvoorbeeld NICOLAI, t.a.p.y op p. 24; H. VAN MARLE, "Motivatie in de klinisch forensisch psychiatrische behandeling,' in: R.V. SCHWARZ, D.H. LINSZEN (red.), Persoonlijkheidsstoomissen; Diagnostiek, behandeling, beleid, Amsterdam/ Lisse 1991, pp. 87-96, op p. 88; Sietske DIJkstra, 'Perpetuum mobile? De overdracht van geweld betwist,' TVCr 1995/4, pp. 346-359, op p. 353; Nel DRAIJER, 'Trauma, persoonlijkheidsstoornissen en andere psychiatrische diagnoses, $M G \nu$ $1996 / 11$, pp. $1134-1152$, op p. 1148 i.f.

Zie met betrekking tot revictimisering c.q. herhalingsgedrag in het bijzonder $\mathrm{Nel}$ DRALJER, Sexueel misbruik van meisjes door verwanten; Een landelijk onderzoek noar de omvang, de aard, de gezinsachtergronden, de emotionele betekenis en de psychische en psychosomatische gevolgen, Ministerie van Sociale Zaken en Werkgelegenheid, Den Haag 1988, pp. 104-107. 


\section{Verwerking}

In de herhalingsdwang ligt - ondanks alle tragiek, en hoe vreemd het wellicht ook mag klinken - als het ware ook een element van 'herkansing' besloten. ${ }^{172}$ De herhalingsdwang maakt patronen zichtbaar (zij het soms pas na lange tijd of in therapie), en inzicht in die patronen maakt het mogelijk deze te doorbreken, ermee af te rekenen. Dat wil zeggen: het verwerkingsproces op gang te brengen. Het element van de herkansing, de herkansing in de herhalingsdwang, brengt ons (opnieuw) bij het thema verwerking. Ter 'apotheosering' van dit thema wenden we ons tot de derde onderzoekster, SCHOEMAKER. ${ }^{173}$ Allereerst halen we echter haar (algemene) definitie van een (psycho)trauma aan: ${ }^{174}$

'Een psychotrauma kan worden aangeduid als een geestelijke verwonding die ontstaat wanneer een mens door een schokkende of stressvolle gebeurtenis zodanig is getroffen dat hij of zij innerlijk, geheel of gedeeltelijk, in machteloze afsluiting, in machteloos verdriet en in machteloze angst en woede is vast blijven zitten, zonder dat hij of zij het ervaren van dat rampzalige gebeuren heeft kunnen verwerken'

$\mathrm{Na}$ het diep ingrijpende (traumatiserende) gebeuren strijden ontkenning en herbeleving veelal om de voorrang, alvorens er van verwerking sprake kan zijn. Ontkenning (inhibitie) kan verstarren tot inadequaat vermijdingsgedrag (zoals bijwoorbeeld drugs- of alcoholmisbruik en riskant herhalingsgedrag'). Maar ook de verwerking kan pathologisch verlopen. Zij kan geblokkeerd raken (gestagneerde verwerking, veelal met psychosomatische klachten), en onvoltooid blijven, hetgeen zich uit in onvermogen tot handelen en liefhebben en in karaktervervormingen (gestoorde trekken, persoonlijkheidsstoornissen). ${ }^{175}$ SCHOEMAKER schrijft: ${ }^{176}$

Vgl. hiervoor (in enigszins ander verband) STIBANE, die opmerkt: 'Deze "herkansing" geldt inderdaad voor het oplossen van oude ontwikkelingsconflicten, echter al minder voor het veranderen van vast ingesleten karaktertrekken en niet voor echte tekorten in de persoonlijkheidsstructuur, veroorzaakt door echte tekorten (affectief-pedagogisch) in de vroege ontwikkelingsfasen.' (K.W.U.F. STIBANE, "De ontwikkeling van het identiteitsgevoel vanuit kinderpsychiatrisch perspectief," in: P.C.Th.M. VAN EEUWIK, J.H.A. VAN LOON (red.), Identiteitsproblemen bij adoptiekinderen, Amsterdam/Lisse 1989, pp. 17-29, op p. 25.)

173 Beatrix SCHOEMAKER, Niet gehoord en niet gezien; Verwerking van sexuele trauma's bij wrouwen en mannen, diss. Utrecht, Amsterdam/Lisse 1991.

174 SCHOEMAKER, a.w., p. 18 (curs. jw).

175 SCHOEMAKER, a.w., pp. 17-30 ('Algemene traumatheorie'); zie in het bijzonder het verhelderende schema op p. 22.

176 SCHOEMAKER, a.w., p. 119. 
'De tegenovergestelde pool van inhibitie (ontkenning) is confrontatie, ofwel herbeleving. Confrontatie verwijst naar het actieve denken en/of praten over de traumatiserende ervaringen, alsmede het erkennen van relevante emoties. Door de confrontatie met het (sexuele) trauma aan te gaan, kan het proces van assimileren en betekenis geven op gang worden gebracht. De psychologische confrontering van trauma's doet de effecten van ontkenning teniet, op zowel fysiologisch als cognitief niveau (...).'

Dit geldt niet alleen met betrekking tot sexuele trauma's. En ook bij 'incest' moeten we verder kijken dan het sexuele. Immers, afgezien, van het feit dat 'de' incest op zich een affectief en pedagogisch verraad is, is er vaak sprake van verwaarlozende opvoedingssituaties voorafgaande aan, en neurotiserende (geheimhouding) en corrumperende (selectieve verwenning) opvoedingssituaties rondom en volgend op 'de' incest. SCHOEMAKER schrijft in dit verband: ${ }^{177}$

'In de presentatie [door incest-survivors, jw] van [psychosomatische] klachten zien we de veelzijdige en veelvuldige effecten van een onderliggend onverwerkt sexueel trauma, veelal ontstaan in een sociale context van affectieve verwacrlozing.'

En: 178

'De interpretatie van mijn onderzoeksgegevens pleit ervoor om sexuele trauma's meer te zien in het licht van de emotionele verwaarlozing van kinderen. De socialle omgeving die gekenmerkt wordt door emotionele verwaarlozing, lijkt voorwaardescheppend te werken voor een tragische scriptworming en de daaruit voortvloeiende levensstijl. De traumatiserende sexuele ervaringen worden eerder gezien als de bevestiging, de sluitsteen, van deze tragische scriptvorming dan als de oorzaak ervan."

Overigens is vroege emotionele/affectieve verwaarlozing op zichzelf 'als een vorm van ernstige traumatisering op te vatten.' SCHOEMAKER citeert hierbij uitgebreid VAN DER HART (e.a.): ${ }^{179}$

'Bij traumatische ervaringen wordt doorgaans aan concrete en specifieke gebeurtenissen gedacht. Moeilijker om voor te stellen als traumatische ervaring is het voortdurend verkeren in bedreigende omstandigheden, zoals een kind dat zich

177 Niet gehoord en niet gezien, a.w., p. 15 (curs. jw).

178 Niet gehoord en niet gezien, a.w., p. 126.

179 T.a.p. Het citaat is afkomstig uit Onno VAN DER MART (red.), Trauma, dissociatie en hypnose, Amsterdam/Lisse 1991 (p. 351). Wij halen hier de desbetreffende passage aan uit de derde druk: Onno VAN DER HART e.a., "Trauma-behandeling en de persoon van de therapeut," in: Onno VAN DER HART (red.), Trauma, dissociatie en hypnose; Handboek, Lisse 1995 (derde druk), pp. 439-456, op p. 441. 
continu bedreigd voelt door verbaal en[/of, jw] fysiek geweld van de ouders, of door de frequente ruzies tussen die ouders (...). (...) Nog moeilijker is het om vroege emotionele verwaarlozing (...) als een vorm van ernstige traumatisering op te vatten. Er zijn geen schokkende gebeurtenissen die in het oog springen. Het gaat hierbij juist om wat er niet is gebeurd, om wat ontbreekt terwijl het voor een gezonde ontwikkeling noodzakelijk was. (...)

Het is ons in de behandeling van mensen met Type 2 trauma ${ }^{180}$ opgevallen dat vroege emotionele verwaarlozing niet minder traumatiserend is dan seksueel misbruik en fysick geweld op zeer jonge leeftijd. Het is een extreme vorm van emotionele mishandeling, die de slachtoffers hiervan waarschijnlijk ook meer kwetsbaar maakt voor seksueel misbruik zoals incest. Vroege emotionele verwaarlozing is beter te begrijpen met behulp van een vergelijking. Het is als eenzame opsluiting, maar dan in een emotionele zin. Buiten het verwaarloosde kind gaat het leven $z^{\prime} n$ gang. De noodzakelijke erkenning van z'n bestaan en persoonlijke aandacht worden het kind continu onthouden, terwijl het verlangen daarnaar als een "uitgeholde, ondragelijke pijn" (...) altijd gevoeld wordt. Eén van de gevolgen is dat het hele leven - niet slechts bepaalde situaties die aan een concreet trauma doen denken - blijvend als onveilig en bedreigend wordt ervaren. Vroege emotionele verwaarlozing zal meer aandacht moeten krijgen in de studie en behandeling van chronische traumatisering (Type 2 trauma).'

Veel symptomen van incest-survivors (bij wie de verwerking - gezien onze definitie van survivors ${ }^{181}$ - geblokkeerd is geraakt of onvoltooid is gebleven) zijn met andere woorden niet zozeer aan de incest op zich toe te schrijven als wel - aldus VAN EPEN - "aan de neurotiserende of verwaarlozende opvoedingssituaties waarbinnen de incestsituatie zich kon ontwikkelen. ${ }^{182}$

Hoe ernstig de traumatisering van incest- en andere kindermishandelings- en verwaarlozingsslachtoffers echter ook mag zijn, dit betekent niet dat verwerking in het algemeen (vrijwel) onmogelijk is. Ook ernstige en gecompliceerde, (niet te) vroege en/of chronische trauma's kunnen in principe worden verwerkt. Terecht wijst SCHOEMAKER op een in dit verband veel gemaakte denkfout: ${ }^{183}$

'Er is sprake van een min of meer monocausale lineaire redenering: "als je sexueel bent misbruikt in je jeugd, dan ben je beschadigd en zal het je bijna per defi-

'Type 2 trauma betreft herhaalde en vaak ook langdurige traumatisering, zoals die zich onder meer bij incest, kindermishandeling en -verwaarlozing kan voordoen." (T.a.p., op p. 440.)

181 Zie in het bijzonder hierboven par. 12.1.

182 Hans VAN EPEN, Schets voor een nieuwe psychiatrie, Houten/Deurne 1990, p. 78 (onder 'De late gevolgen van incest'). Voor het onderscheid tussen verwaarlozingsen neurotische toestandsbeelden - ten gevolge van respectievelijk 'een te weinig' en 'een te veel' - zie a.w., pp. $7-8$ (onder 'Neurose en emotionele verwaarlozing'). Niet gehoond en niet gezien, a.w., p. 14 (curs. BS). 
nitie slecht gaan." Deze lineaire redenering wordt dan onderbouwd door aan te geven dat de betrokkenen er ook lange tijd na het misbruik slecht aan toe zijn. Aan het verwerkingsproces, dat het integreren van de traumatische ervaringen in het eerdere leven tot doel heeft, wordt voorbijgegaan. Ook wordt voorbijgegaan aan de socialle context waarbinnen het sexuele trauma zich heeft afgespeeld: de gezinssituatie vóbr, tijdens en na het misbruik, de aanwezigheid van steunende anderen, en dergelijke. De gehanteerde redenering is in wezen stigmatiserend en weinig hoopvol. $\mathrm{Ze}$ biedt geen ruimte voor het verwerkingsproces en de integratie van de traumatisch beleefde sexuele ervaringen, en dus geen ruimte voor verandering. Juist deze redenering maakt en bevestigt de slachtoffer-identiteit waar vele betrokkenen mee worstelen. Het is een fatalistische zienswijze [die] geen recht [doet] aan de realiteit en de mogelijkheden van de betrokken individuen.'

Opnieuw wordt het tijd voor het innemen van een helicopter-view. Op de impact van (in casu) sexueel misbruik (juist) op de persoonswording/persoonlijkheidsontwikkeling wijst ook de vierde onderzoekster, MILLER: ${ }^{184}$

'Het ligt zeer voor de hand dat een kind dat heel vroeg misbruikt is voor de behoeften van een volwassene of een oudere broer of zuster, zijn leven lang het basisgevoel houdt dat het te veel heeft moeten afstaan. (...)

Dat het seksuele misbruik van het kind moet leiden tot stoornissen in zijn latere seksuele leven, zal de gemiddelde leek zich zonder moeite kunnen voorstellen. (...) De gevolgen van seksueel misbruik beperken zich echter niet uitsluitend tot problemen in het seksuele leven: zij belemmeren de ontwikkeling van het zelf en de vorming van een autonoom karakter. De redenen kan men als volgt samenvatten:

(1.) De situatie van machtelloos uitgeleverd zijn aan de geliefde persoon, de moeder of de vader, creëert een zeer vroege koppeling van liefde en haat.

(2.) Aangezien de woede jegens de geliefde persoon vanwege het dreigement met onthouding van liefde niet uitgesproken en dus ook niet doorleefd kan worden, blijft de ambivalentie, de koppeling van liefde en haat, een belangrijk kermmerk wan de latere objectrelaties. Veel van deze mensen kunnen zich totaal niet voorstellen dat liefde zonder verdriet en opofferingen, zonder angst om misbruikt te worden, zonder vernederingen en krenkingen, zelfs maar tot de mogelijkheden behoort.

(3.) Omdat het feit van het misbruik omwille van de overleving moet worden verdrongen, moet ook alle kennis die de censuur van deze verdringing zou opheffen, uit alle macht worden afgeweerd, wat ten slotte leidt tot een weraming van de persoonlijkheid en een verlies van de levende wortels, bijwoorbeeld in de vorm van een depressie.

(4.) De gevolgen van een trauma zijn echter door de verdringing nitet uit de weg geruind, maar juist bezegeld. Omdat het onmogelijk is zich het trauma te herinneren, het onder woorden te brengen (dat wil zeggen: de voormalige gevoelens 
mee te delen aan een begelleidende persoon die erin gelooft), ontstaat de noodzaak van articulatie door middel van de herhalingsdwang.

(5.) De vroeger beleefde, maar niet meer te herinneren situatie van uitgeleverdzijn en misbruikt-worden door het geliefde object wordt voorgezet in de passieve of in de actieve rol, of beurtelings in beide rollen.

(6.) Een van de eenvoudigste en volstrekt ongemerkte vormen van voortzetting van de actieve rol is het misbruik wan de eigen kinderen woor de eigen behoeften, die des te dringender en ongecontrolleerder zijn naarmate het eigen voormalige trauma dieper is verdrongen.'

Dit laatste punt verwijst naar de (actieve) transgenerationele herhalingsdwang. We sluiten deze paragraaf af met een citaat van MILLER dat verwijst naar de (passieve) relationele herhalingsdwang: ${ }^{185}$

"Met de zekerheid van een slaapwandelaar zal de patiënt mensen zoeken die net als zijn ouders (zij het ook om andere redenen) niet in staat zijn hem te begrijpen. En juist tegenover zulke mensen zal hij - door de herhalingsdwang - alle mogelijke moeite doen om zich verstaanbaar te maken, dat wil zeggen: het onmo* gelijke toch mogelijk te maken.'

\subsubsection{De maatschappelijke gevolgen}

De tweede categorie sequelae - de maatschappelijke c.q. sociaal-economische gevolgen - draait om de vraag (schreven we in par. 12.1): in hoeverre zijn zaken als vandalisme, pesten, criminaliteit, verslavingen en (andere) zowel menselijk als maatschappelijk kapitaal vernietigende psychische en psychiatrische stoornissen toe te schrijven aan kindermishandeling?

Een vraag die op haar beurt, meer direct, de economische vraag oproept: welke schadepost levert dit alles op voor de maatschappij, in termen van kosten voor medische en GGZ-(geestelijke gezondheidszorg-) voorzieningen, kosten van criminaliteit en vandalisme, kosten in verband met en in de vorm van verknoeid of verknoeiend arbeidsvermogen en gederfde levensvreugde voor slachtoffers èn hun omgeving, en niet in de laatste plaats de kosten van een verminderd of verminkt pedagogisch besef: de prijs die wordt betaald door de volgende generatie?

We weten inmiddels dat het eerder regel dan uitzondering is dat gevangenissen en psychiatrische inrichtingen worden bevolkt door mannen en vrouwen die in hun jeugd zijn getraumatiseerd door in het bijzonder fysieke mishandeling, sexueel misbruik en emotionele verwaarlozing.

Alice MILLER, Het drama van het begaafde kind; Een studie over het nancisme, Bussum 1983 (vijfde druk), p. 84 (vgl. ook de achttiende, geheel herziene druk, Houten 1995, p. 106 i.f.). 
'Gevangenissen' en 'psychiatrische inrichtingen' zijn evenwel slechts de (zichtbare) polen van een continuum van externaliserend (anti-sociaal) en internaliserend (sociaal-angstig) gedrag. ${ }^{186}$ Tussen die polen bevinden zich miljoenen Nederlanders die jaarlijks kampen met ernstige psychische problemen: ${ }^{187}$

\begin{abstract}
"Volgens een schatting van het RIVM [Rijksinstituut voor Volksgezondheid en Milieuhygiëne] heeft jaarlijks liefst een kwart van de Nederlandse bevolking te kampen met een ernstig geestelijk gezondheidsprableem. Dat zou neerkomen op 3,75 miljoen mensen, wan wie [tot op heden, jw] slechts een beperkt deel daadwerkelijk hulp zoekt. Hier ligt een potentiële markt van geweldige omvang (...).'
\end{abstract}

Hoeveel van die problemen hadden kunnen worden voorkomen, of zouden minder ernstig zijn geweest, indien relatiestoornissen in gezinnen eerder waren gesignaleerd, gemeld, onderzocht, verwezen, behandeld en na-behandeld (art. 19, lid 2 VRK)? Hoeveel Nederlanders zouden nìet tot die 'potentiële markt van geweldige omvang' - een markt die binnen één generatie de hele GGZ ernstig kan ontwrichten ${ }^{188}$ - hebben behoord indien hun ouders een sociaal-pedagogisch ondersteuningsaanbod hadden gekregen? Meer erkenning en waardering - sociaal, moreel en financieel - hadden ondervonden voor de zware eisen van het ouderschap? Meer begrip hadden ontmoet voor de ballast die zij uit hun eigen jeugd meetorsten? Meer sociale en overheidscontrole hadden ervaren waar onmacht, onkunde of onwil in het spel waren? Hoewel globale antwoorden op deze vragen zich gemakkelijk laten raden, kunnen we naar precieze antwoorden louter gissen. Niettemin dringt het beeld zich krachtig op dat - in visserstermen gesproken - het uitwerpen van een sociaal-pedagogische spiering door de huidige generatie toekomstige generaties in staat zal stellen vele vette - dat wil zeggen geestelijk gezonde - kabeljauwen binnen te halen.

Hoe beter dit beeld in de (nabije) toekomst wetenschappelijk zal (kunnen) worden onderbouwd, en binnen en buiten de wetenschap zal worden uitgedragen, des te gretiger - zo mag men, op basis van onze koopmenslievende volksaard, verwachten - zal de (onmenselijke) prijs van de 'privacy' (in libertinistische, parentiarchale zin) worden ingeruild voor de (menswaardige) prijs voor de rechten van het kind. Voor het zover is, moet het tot de eerste plicht van pedagogen, ontwikkelingspsy-

Vgl. met betrekking tot de dichotomie externaliseren-internaliseren hoofdsuk 14, par. 14.3.2.1.

187 Marcel METZE, De staat van Nederiand - op weg naar 2000, Nijmegen 1996, 'Gezondheid," pp. 39-54, op p. 54 r.k. 
chologen, psychiaters, psychopathologen, criminologen, victimologen en beoefenaren van het jeugd- en familierecht en de rechten van de mens worden gerekend de verbanden in kaart te brengen tussen een 'deplorabele jeugd' en een 'beperkt pedagogisch besef' en tussen een beperkt pedagogisch besef en kindermishandeling: een deplorabele jeugd voor weer een generatie (BAARTMAN, Opvoeden kan zeer doen); tussen onveilige gehechtheid en psychopathologie en tussen psychopathologie (persoonlijkheidspathologie) en (gewelds)criminaliteit (DERKS e.a.); tussen de schending van de rechten van het kind en de schending van rechten, normer en waarden in de maatschappij door als kind geschonden volwassenen; tussen publiekrechtelijk ouderschapslibertinisme en de prijs van de privacy: de ernstige en grootschalige schending van de fundamentele rechten en in het bijzonder de persoonswording - van het kind. Waarbij we nog de economen te hulp zouden kunnen roepen om die prijs in harde guldens te berekenen (zodat met veelcijferige getallen tot achter de komma kan worden aangetoond dat ook hier korte-termijn-denken 'penny-wise and pound-foolish' is).

Het is duidelijk dat dit alles te veel hooi is voor de vork van deze paragraaf, zelfs als we angstvallig zouden proberen alle overlap met de vorige paragraaf te vermijden - iets dat, gezien de samenhang tussen psychische/psycho-sociale (sociaal-emotionele) en maatschappelijke (sociaaleconomische) gevolgen, bijna ondoenlijk is. Een samenhang die niet in de laatste plaats hierin bestaat (zo schreven we in par. 12.3) dat de schade aan en in het individu direct of indirect, vroeg of laat, op de maatschappij zal worden afgewenteld. Uiteindelijk en in enigerlei vorm krijgt de maatschappij de rekening gepresenteerd, met rente op rente, voor hetgeen zij in principe had kunnen woorkomen of in zijn gevolgen had kunnen verzachten.

Deze en dergelijke meer economische aspecten zullen we evenwel laten voor wat ze zijn. Ook de meer sociologische aspecten gaan onze bevoegdheid (verre) te buiten. Bij wijze van (schamel) compromis staan we in deze paragraaf daarom kort stil bij slechts twee onderwerpen die als verbijzondering kunnen worden gezien van de aan het slot van de vorige paragraaf aan de orde gestelde revictimisering of herhalingsdwang: 'incest en prostitutie' en 'criminaliteit.' Onder het laatste kopje kijken we zowel naar het kleine (vermogenscriminaliteit; 'het kleine onrecht') als naar het grote kwaad (misdaden tegen de mensheid: 'het geval HITLER'; met een - terloopse - verwijzing naar misdaden tegen het kind: 'het geval DUTRoUX'). We sluiten deze paragraaf af met (een citaat uit) het belangwekkende rapport Jeugd en gezin van JUNGER-TAS, onder (inmiddels) sub-kopje 'criminaliteit (3).' 


\section{Psychische en maatschappelijke gevolgen: een overzicht}

Om te beginnen geven we - duidelijkheidshalve - in zes rubrieken een korte opsomming van de (gecombineerde) psychische en maatschappelijke gevolgen (c.q. potentiële gevolgen) van kindermishandeling. Waarbij - wellicht ten overvloede - de kanttekening zij gemaakt dat men de zaken uiteraard niet kan omkeren: indien morgen kindermishandeling als maatschappelijk probleem is verdwenen, wil dat niet zeggen dat overmorgen alle hier opgesomde kwalen de wereld (althans Nederland) uit zijn. Het eerste punt van onderstaande opsomming was het (hoofd)onderwerp van de vorige paragraaf. De punten 2 en 3 worden hieronder (in omgekeerde volgorde) nader toegelicht. De punten 4 en 5 zijn eveneens, zij het zijdelings, in de vorige paragraaf aan de orde geweest. Punt 6 is aan het eind van de vorige paragraaf (opnieuw) (in algemene zin) nadrukkelijk aan de orde gesteld. Voor wat de reeds behandelde punten betreft, kan deze opsomming als een korte samenvatting worden beschouwd. De bedoelde zes rubrieken zijn:

1. De ernstige psych(iatr)ische problematiek waarmee 'survivors' (en/of hun omgeving) worstelen, een traumaspectrum dat in beginsel de hele psychiatrische diagnostiek omvat: ${ }^{189}$ stemmingsstoornissen (depressies, dysthymie, cyclothymie, manisch-depressieve stoornissen, premenstruele-dysforie-stoornis); angststoornissen, waaronder de paniekstoornis (met of zonder agorafobie), specifieke fobieën (bijvoorbeeld angst voor katten, onweer, bloed, tunnels, harde geluiden), de sociale fobie (socialeangststoornis, bijvoorbeeld ten aanzien van het aanknopen van gesprekken, spreken met autoriteitsfiguren, feestjes bijwonen), dwanggedachten of dwanghandelingen ('smetvrees'), PTSS (post-traumatische stress-stoornis); psychosomatische verschijnselen, waaronder (psychogene) lichamelijke klachten en pijn, maar ook conversie-verschijnselen, obsessieve dysmorfofobie en hypochondrie; MPS c.q. DIS (de meervoudige-persoonlijkheidsstoornis, in $D S M-I V$ dissociatieve identiteitsstoornis geheten) en andere dissociatieve stoornissen; sexuele stoornissen (van dyspareunie en vaginisme tot parafilieën zoals pedofilie); eetstoornissen (anorexia nervosa, boulimie, vreetbuien-stoornis); slaapstoornissen (slapeloosheid, inslaap- of doorslaapproblemen, overmatige slaperigheid, narcolepsie, nachtmerries, pavor nocturnus, slaapwandelen); zelfbeheersingsstoornissen, zoals de (gewelddadige of vandalistische) explosieve stoornis, kleptomanie, pyromanie, gokverslaving; aanpassingsstoornissen; afhankelijke, dwangmatige, ontwijkende, theatrale, narcistische, anti-sociale, borderlineenzovoorts persoonlijkheidsstoornissen; psychotische stoornissen (met 
wanen of hallucinaties, onsamenhangende spraak, sterk chaotisch of katatoon gedrag), waaronder waanstoornissen (zoals grootheidswaan of achtervolgingswaan of de waanachtige dysmorfofobie), de folie à deux, de post partum psychose enzovoorts; en niet te vergeten de aan (overmatig gebruik c.q. misbruik van) sedativa, anxiolytica, alcohol, drugs of nicotine gebonden stoornissen.

2. Diffuus ressentiment, onverschilligheid jegens mensen en regels, (zelf)haat en (uiteindelijk) criminaliteit (SCHUYT; zie hieronder).

3. Prostitutie (voor wat het aandeel van incest-/emotionele-verwaarlozingsslachtoffers betreft; zie hieronder).

liteit.

4. Zelfdestructiviteit, zelf-sabotage, automutilatie ${ }^{190}$ en suïcida-

5. Verslavingen in de brede zin des woords: drugsverslaving en alcoholisme, nicotinisme/rookverslaving, partnerverslaving, gokverslaving, sexverslaving, enzovoorts enzovoorts (niet als psychiatrisch - zie onder 1 - maar als maatschappelijk probleem beschouwd).

6. Relationele en transgenerationele herhalingsdwang: het steeds weer verzeild raken in destructieve relaties en situaties, het 'afreageren' op partners en kinderen, het doorgeven van de eigen ellende aan de volgende generatie, omdat de gevolgen van kindermishandeling voor een deel - en waarschijnlijk (zolang de verwerking van jeugdtrauma's, voor zover deze mogelijk is, slechts voor een meer of minder vrijgestelde 'elite' is weggelegd) voor een groot deel - óók de oorzaken van kindermishandeling zijn. De zogenaamde (inter- of) transgenerationele cycle of violence (beter wellicht: transgenerationele onveilige-gehechtheidscyclus c.q. transgenerationele traumatiseringscyclus), de keten van oorzaak en gevolg van menselijk lijden, die evenwel geen menselijke noodlotsketen is, maar een keten die doorbroken zou kunnen worden àls 'verwerking' op de politieke agenda zou staan, àls - nu de omvang en de ernst van kindermishandeling (in het bijzonder van incest) in grote lijnen in kaart zijn gebracht zulks ó́k zou gebeuren met betrekking tot de maatschappelijke kosten. Dat wil (dus) zeggen: àls wij de prijs van de privacy, van het zo lang mogelijk privé houden van beschadigende gezins- (en relatie-)patronen waarbij in het bijzonder de fundamentele rechten van het kind op het spel staan -, in volle omvang onder ogen zouden (durven) zien.

190 Voor zover ik heb kunnen nagaan in de DSM- $I V$ slechts vermeld bij de borderline-persoonlijkheidsstoornis; zie evenwel Robert J. CAMPBELL, Psychiatric Dictionary, New York/Oxford 1996 (seventh ed.), pp. 657-658 s.v. "self-mutilation"; alsook Hans VAN EPEN, Schets voor een nieuwe psychiatrie, Houten/Deurne 1990, pp. $79-80$. 
Zoals al is aangegeven, nemen we de punten 2 en 3 uit deze opsomming - in omgekeerde volgorde - nader onder de loep.

\section{Incest en prostitutie}

Incest-survivors zijn in de prostitutie oververtegenwoordigd. ${ }^{191}$ Zózeer dat sommigen aan ' $[\mathrm{h}]$ et hoge aantal prostituées met incestervaringen' de conclusie verbinden 'dat de keuze voor prostitutie nooit vrijwillig kan zijn' (DE JONG 1988). ${ }^{192}$ Ook wordt bij incest-survivors in 'het vak' een ernstigere mate van (herhaalde) victimisatie (mishandeling, dwang) en geringere arbeidssatisfactie gerapporteerd (VANWESENBEECK 1995). ${ }^{193}$

Wat is de betekenis van het significant hogere aandeel incestslachtoffers onder prostituées? Waarbij we 'incest' waarschijnlijk in de kern moeten verstaan als emotionele verwaarlozing (gevolgd door later sexueel misbruik), of emotionele verwaarlozing zelfs op de voorgrond

VANWESENBEECK (Ine VANWESENBEECK, "Wat hebben ze nou aan een verdrietige hoer?" Een onderzoek naar zelfredzaamheid bij prostituees, $M G v 1990 / 3$, pp. 235-249, op p. 237) rapporteert een percentage van 39,3\% onder prostituées (tegen 15,6\% van alle vrowwen in het onderzoek van DRAIJER). In andere studies c.q. door andere auteurs worden echter weer heel andere percentages genoend. DE JONG (Harry DE JONG, 'Prostitutie: een vorm van seksueel geweld?' In: Eelco DAMEN en Nico VAN OOSTEN (red.), Mannelijkheid en seksueel geweld, Deventer 1988, pp. 82-91, op pp. 83/84) noemt een percentage van 80 (bij een onderzoek onder 30 straatprostituees met een voorgeschiedenis van ernstig sexueel misbruik of fysieke mishandeling). MILLER (Alice MILLER, Gij zult niet merken, Houten 1988, p. 321) noemt een percentage van 70. GREEN (Richard GREEN, Sexaal science and the law, Cambridge etc. 1992, pp. 174 en 295 nt. 174) vermeldt (en kritiseert) een onderzoek uit 1977 (gepubliceerd in de American Joumal of Psychiatry) waarin een percentage van 55 wordt gerapporteerd. BOUTEL.LIER (J.C.J. BOUTELLIER, 'Prostitutie en moraal,' Justitiële Verkenningen 1987/1, themanummer 'Prostitutie," pp. 7-35, op p. 33 nt. 10) verwijst naar een Canadees onderzoek waarin vermoedelijk zo'n ruime sexueel-misbruik-definitie is gehanteerd (resultaat: $50 \%$ van alle vrouwen) dat daarmee mijns inziens geen zinnige/zindelijke uitspraken zijn te doen (DRAUER 1988 constateerde ongewenste sexuele ervaringen bij $33 \%$ van de vrouwen onder de $16 ; 7 \%$ was ernstig tot zeer ernstig sexueel misbruikt door verwanten). Overigens laat BOUTELLIER ruimte voor de mogelijkheid dat prostitutees meer dan gemiddeld in de categorie 'ernstig misbruilkt" vallen. SANDERSON (Christiane SANDERSON, Counselling adult survivors of child sexual abuse, London/Bristol 1995, tweede druk, pp. 77/78) maakt gewag van een onderzoek dat aangaf dat prostitutees gemiddeld op jongere leeftijd waren misbruikt, waarbij vaker sprake was van fysiek geweld.

192 Harry DE JONG, 'Prostitutie: een vorm van seksueel geweld?' In: Eelco DAMEN en Nico VAN OOSTEN (red.), Mannelijkheid en seksueel geweld, Deventer 1988 , pp. $82-91$, op p. 83 i.f.

193 Ine VANWESENBEECK, 'Geluk en ongeluk in de prostitutie,' MGV 1995/10, pp. 1043-1057, op pp. 1049-1050. 
moeten schuiven (zodat incest in voorkomend geval een subtype wordt), zoals RENSEN lijkt te suggereren: ${ }^{194}$

\begin{abstract}
'Als men de lichamelijke [verwaarlozing] en emotionele [maltraitering] samen neemt, komt dit het meest voor ([45\% van de meldingen bij de BVA's in 1995; tegen $25 \%$ lichamelijke mishandeling en $18 \%$ sexueel misbruik, jw]). Dit is enigszins vreemd als men ziet met hoeveel ophef er over seksueel misbruik geschreven wordt en hoe weinig over verwaarlozing [en emotionele maltraitering]. Verwaarlozing wordt verwaarloosd, en misbruik wordt misbruikt, en dat terwijl verwaarlozing even erge gevolgen kan hebben. Een werwaarloosd kind is niet meer in staat om diepe relaties aan te gaan. Veel verwaarloosde jongens belanden via criminalisering [sic, jw] uiteindelijk in de gevangenis. Verwaarloosde meisjes zijn vaak levenslang wanhopig op zoek naar affectie van wie dam ook en belanden zodoende in de prostitutie, of ze verwaarlozen of mishandelen hun eigen kind omdat dit niet genoeg kan geven, of ze compenseren hun tekort door een onverzadigbare behoefte aan materiële welstand. Een bodemloos bestaan ...."
\end{abstract}

\title{
Of zoals GREEN laat weten: ${ }^{195}$
}

"The path to prostitution starts with a dysfunctional family and usually includes incest, rape, neglectful parents, abandonment. That leads to a lack of education and skills, an inability to cope with the pressures of a daily job, drug addiction, alcoholism, abusive relationships.'

Verwaarlozende ouders en verlating (lees: onveilige gehechtheid), incest en verkrachting (door niet-verwanten): deze volgorde lijkt de chronologisch juiste. Het is vermoedelijk ook de juiste volgorde voor wat de impact, de ernst van de sequelae betreft. Misschien moeten we de vraag dan ook iets anders formuleren: wat is de betekenis van het relatief grote aandeel emotionele-verwaarlozings- (waaronder incest-)slachtoffers onder prostituées?

Een antwoord op deze, ik zou bijna zeggen gewetensvraag - voor 'hoerenlopers' niet minder dan voor feministen die strijden voor 'hoerenrechten, ${ }^{196}$ voor de sexindustrie niet minder dan voor de maatschappij

194 Ben RENSEN, Kindermishandeling: voor het leven beschadigd, Utrecht 1990, p. 57.

195 Los Angeles Tines, 'Magdalene: Rehabilitation Project,' aangehaald door Richard GREEN, Sextal science and the law, Cambridge (etc.) 1992, p. 189.

196 De roep om 'hoerenrechten' lijkt in Nederland het toonaangevende feministische geluid. Internationaal (althans in de vs) is het feminisme meer verdeeld: In feminist literature there is a deep schism regarding consensual prostitution so deep that the subject is largely avoided or finessed by the leading writers.' Aldus Anthony D"AMATO, 'Letter from the chair, Human Rights Interest Group,' ASIL/HRIG Newsletter $1994 / 4$, p. 1. Zo stelt RASKIN: '[I]I en est parmi elles [les prostituées] qui s'en sortent saines et sauves, enrichies, et qui se justifient d'une 
in haar geheel - zal, en kan, hier niet worden beproefd. Wel lijkt in het kader van deze studie de volgende kanttekening op haar plaats.

Optimale persoonswording betekent de ontwikkeling tot optimale rationaliteit, moraliteit en authenticiteit. Zonder - met name - minimale authenticiteit is er in het latere leven niet zelden sprake van revictimisering, waarvan de prostitutie - naast en niet zelden in combinatie met verslavingsgedrag - één van de meest in het oog springende voorbeelden is. Men heeft onvoldoende basisvertrouwen, zelfvertrouwen, zelfrespect, eigenwaarde van huis uit meegekregen (hoezeer ook achter een pantser of masker verborgen of overschreeuwd) en lijkt zichzelf daarvoor het hele verdere leven te straffen. Soms lichamelijk: denk aan automutilatie, verslaving aan medische giften (met name aan nicotine, zo niet het meest suïcidale dan toch het meest verbreide medische gif), verslaving aan gewelddadige partners ('love is a battlefield'). Vaak psychisch: 'traumatofilie' - een lelijk woord voor wat het 'opzoeken' van ellende lijkt, niet zelden in 'kannibalistische' relaties (waarin de geliefden elkaar psychisch uitvreten, schijnbaar onderbroken door emotionele verzoeningen, waarbij soms 'liefdesbaby's' als zoenoffer dienen - om al snel zondebok te worden). Soms 'psychosomatisch': denk aan hypochondrie, psychosomatische decompensatie, het 'opzoeken' van ongelukken (accident proneness ${ }^{197}$ ), of ander riskant, risico-zoekend gedrag. Zulks geschiedt, zo lijkt het, naar het Mattheüs-woord (Matthëus 13:12):

'Want wie [basisvertrouwen, jw] heeft, hem zal gegeven worden, en hij zal in overvloed hebben; maar wie niet heeft, hem zal ontnomen worden ook wat hij heeft.'

Men spreekt daarom wel van het 'Mattheüs-effect': de gelukkigen worden steeds gelukkiger, de ongelukkigen steeds ongelukkiger. 'Geluk en ongeluk stapelen zich op' (VANWESENBEECK). ${ }^{198}$ Over het 'sneeuwbaleffect'

manière que ne désavotieraient pas des fabricants ou des commerçants d'armes: "Si je ne le fais pas, c'est quelqu'un d'autre qui le fera à ma place". (Brigitte RASKIN, 'Prostitution et société patriarcale,' Déviance et Société 1986/3, pp. 289291, slotzin.) Vgl in het bijzonder ook Alice MiLLER, Gij zult niet merken; Tachtig jaar psychoanalyse, Houten 1988 (derde druk), pp. 83/84.

197 Vgl. Robert J. CAMPBELL, Psychiatric Dictionary, New York/Oxford 1996 (seventh ed.), pp. 563/564 s.v. "proneness, accident."

198 Ine VANWESENBEECK, 'Geluk en ongeluk in de prostitutie,' MGv 1995/10, pp. 1043-1057, op p. 1053.

Over het 'Matthew Effect' van het Verdrag inzake de rechten van het kind vgl. Göran THERBORN, 'Child politics; dimensions and perspectives,' Childhood 1996/ 1 , PP. 29-44, op p. 40 ('the more misery there is, the less laws count'). 
(zOals VANWESENBEECK het zelf noemt ${ }^{199}$ ) van psychische ellende zegt KUIPER::200

\begin{abstract}
'Ondoelmatig gebruik van afweermechanismen leidt tot symptoomvorming $\mathrm{en}_{\text {, }}$ wat minstens even ernstig is, tot neurotische manoeuvres en relaties, zeer tot schade van ontplooiing en levensvervulling, en veel verdriet veroorzakend voor de ander en voor zichzelf. Angst verdragen en doorworstelen is het enige wat op den duur uitkomst biedt.'
\end{abstract}

Elders stelt deze auteur dan ook (en deze woorden zouden kapitaal moeten worden gezet): ${ }^{201}$

'Onze taak is niet elkaar aan te moedigen het rouwproces af te sluiten doch elkaar aan te moedigen om er mee aan te vangen, geen licht kan ooil dagen wanneer we niet de waarheid onder ogen zien $(. .$.$) .'$

Om terug te keren tot de prostitutie: het is niet relevant of iemand een (traumatisch) verwaarlozings- en/of incest-verleden heeft, maar of het (chronische) trauma al of niet is verwerkt en, voor zover dat niet het geval is, in hoeverre de keuze voor 'het vak' door het niet op gang gekomen of niet voltooide (c.q. gestagneerde) verwerkingsproces is bepaald. Het onderkennen van het element van de 'herhalingsdwang' in de prostitutie lijkt mij dan ook vruchtbaarder dan het benoemen van prostitutie als 'overlevingsstrategie. ${ }^{202}$ Althans voor zover dat laatste de (quasi-

199 VANWESENBEECK, t.a.p.

200 P.C. KUIPER, Nieuwe neurosenleer, Deventer 1984, p. 271.

201 P.C. KUIPER, Ker heen; Verslag van een depressie, "s-Gravenhage 1988, pp. 17/18.

202 Prostitutie opgevat als 'overlevingsstrategie' lijkt veelleer een complex van afweermechanismen die de 'sturvivor' afhouden van of blokkeren in de verwerking. Afweermechanismen zijn psychische mechanismen die het mogelijk maken overweldigende emoties aan te passen aan de psychische draagkracht van het individu. Deze mechanismen - de 'aanpassing' uit het traumatische verleden - kunnen, zoals we al eerder zagen, een tweede natuur worden, verharden tot 'onaangepaste,' inadequate overlevingsmechanismen, in het post-traumatische heden. De mechanismen keren zich tegen het voormalige slachtoffer, krijgen een averechts, destructief effect. Of keren zich vooral tegen derden. Een opmerkelijk voorbeeld van dat latatste trof ik aan in De Volksknant van 22 november 1993 (op p. 4, onder de kop: 'Rechteloosheid prostituée oorzaak uitbuiting'). M. WuERS van de Stichting tegen Vrouwenhandel stelt volgens dat bericht: 'Sommige slachtoffers [van vrouwenhandel] passen niet in het beeld dat we vaak hebben van vrouwen die de dupe worden van een malafide pooier. Enkelen zijn zeer mondig geworden of zijn in het uiterste geval zelf overgegaan tot vrowwenhandel als een soort overlevingsstrategie.' 
heroïsche) connotatie heeft een levensloop als noodlot te zien dat men 'vrijwillig' tot (pseudo-volwassen) deugd heeft gemaakt. ${ }^{203}$

\section{Criminaliteit (1): $\quad$ het kleine onrecht}

Van prostitutie naar criminaliteit hoeft geen grote stap te zijn. Hetzelfde geldt helaas ook voor de samenhang, de causale correlatie, niet alleen tussen (bepaalde - niet adequaat verwerkte - vormen van) kindermishandeling (incest/emotionele verwaarlozing) en prostitutie, maar minstens evenzeer die tussen (niet adequaat verwerkte vormen van) kindermishandeling (schending en beschadiging van minimale rationaliteit, moraliteit of authenticiteit c.q. onveilige gehechtheid) en criminaliteit.

Aan SCHUYT ontleen ik de aanduiding 'het kleine onrecht. ${ }^{204}$ Dat 'kleine' slaat op de micro-wereld (in de eerste plaats het gezin) waarin het onrecht is geschied - tegenover het macro-onrecht in de grote wereld. Micro- plus macro-onrecht ('maatschappelijke ongelijkheid') kunnen leiden - aldus SCHUYT - hetzij tot verzet hetzij 'via dynamische psychische processen tot maatschappelijk en persoonlijk ressentiment; tot haat jegens anderen (...) en ten slotte ook tot zelfhaat.' Dit ressentiment kan op zijn beurt - via 'de omweg van de onverschilligheid': 'onverschilligheid jegens anderen, ouders en ouderen, jegens persoonlijke bezittingen van anderen, jegens de persoonlijke integriteit van anderen en natuurlijk ook onverschilligheid jegens regels en regelovertredingen' - weer leiden tot criminaliteit. Criminaliteit (en in het algemeen onfatsoen en wangedrag) die juist door het tot onverschilligheid omgevormde ressentiment zo'n 'lelijk en grimmig' gezicht heeft (hebben). SCHUYT concludeert:

'De verwaarlozing van dit kleine onrecht - zowel in de maatschappij als in wetenschappelijke theorieën - stelt de maatschappij telkens weer voor nieuwe verrassingen en problemen, zoals in dit geval de omvang van de vermogenscriminaliteit (ongeveer 75 procent van alle delicten en ongeveer voor 80 procent gepleegd door jongeren).'

\section{RUTENFRANS vraagt zich af: ${ }^{205}$}

'Is het zo dat slecht gedrag, dat wil zeggen gedrag dat anderen schade berokkent en tot slachtoffer maakt (...), het eigen welzijn kan bevorderen?'

Vgl. in dit verband ook Jennifer FREYD, Betrayal trauna; The logic of forgetting childhood abuse, a.w., Chapter 7 ('Creating connections'), pp. 163-196, op pp. $172 / 173-176$. 
Dat will zeggen: anders dan als herkansing in de herhalingsdwang c.q. als tijdelijke opluchting of korte-termijn uitlaatklep voor spanningen; dus in de vorm van de secundaire winst (de 'ziektewinst"206) van "maladaptive or misdirected coping." ${ }^{207}$ De auteur laat ons niet lang op zijn - op het eerste gehoor wellicht wat moralistisch klinkend - antwoord wachten:

'Het antwoord op die vraag moet volgens mij ontkennend luiden. (...) Mensen die zich met regelmaat overgeven aan crimineel gedrag, beheersen zichzelf onvoldoende en zijn, in een grotere mate dan anderen, de slaaf van hun hartstochten. Kan men hun nog de dierlijke vreugde van de ongeremde overgave toeschrijven, van menselijk geluk, dat slechts kan bloeien op een basis van zelfbeheersing en zelfbeperking, kan geen sprake zijn.

Deze opvatting van de crimineel als slaaf en als ongelukkige wordt gestaafd door tal van onderzoeksresultaten. $Z o$ is er de bekende samenhang tussen criminaliteit enerzijds en het gebruik van gezondheidsondermijnende en verslavende stoffen als tabak, alcohol en drugs anderzijds (...). Hieraan verwant is het gegeven dat ernstige (verkeers)ongevallen en ernstige ziektes meer voorkomen onder "delinquenten" dan onder "niet-delinquenten" (...). (...) [E]veneens [blijkt] een samenhang [te bestaan] tussen delinquent gedrag enerzijds en maagklachten, depressies en suïcidale gedachten anderzijds.

Dat laatste hoeft geen verbazing te wekken. De grondlegger van de sociologische criminologie, Emile DURKHEIM, constateerde al dat, op macro-niveau, het zelfmoord- en het criminaliteitscijfer nauw samenhangen. Een stijging in deze beide cijfers beschouwde hij als de uitdrukking van een en dezelfde onderliggende $p a$ thologie: een verstoring van het controle-niveau in de betreffende samenleving of cultuur (...). En waar pathologie is, is geen vrije keuze. (...)

Crimineel gedrag geeft blijk van onvrijheid en irrationaliteit en is sterk verbonden met indicatoren van ongeluk [met andere woorden: duidt op pathologie, jw] (...).'

\section{In meer algemene zin merkt KOHUT op: $:^{208}$}

Vgl, voor dit - omstreden - begrip H.G.M. RoOLMANS, 'Stoornissen met bijzondere somatische klachten en verschijnselen,' in: W. VANDEREYCKEN e.a. (red.), Handboek psychopathologie, deel 1, Houten/Antwerpen 1990, hfd. 8, pp. 256-274, op p. 267.

207 Aan de zesde editie van Robert J. CAMPBELLs Psychiatric Dictionary, New York/ Oxford 1989, p. 375 1.k. (s.v. 'instinct, death,' pp. 374-375; curs. jw) ontleen ik: 'FReUD's hypotheses about the death instinct [Thanatos, jw] have by no means achieved universal acceptance in psychoanalytic circles, and many feel that although destructiveness may accompany any response pattern, it is not an instinct or drive in itself but is rather a "maladaptive or misdirected expression of the single instinct to live" [i.e. of Eros, jw]."

208 Heinz KOHUT, aangehaald door P.P. GOUDENA, 'Adaptatie, individuatie en het ontstaan van het zelf;' in: C.H.C.J. VAN NIJNATTEN (red.), Psychodynamische ontwikkelingsmodellen, Meppel/Amsterdam 1992, pp. 82-102, op p. 82. 
'Ik geloof dat de menselijke destructiviteit als psychologisch fenomeen secundair is; dat deze oorspronkelijk ontstaat als gevolg van het onvermogen van de zelfobject-omgeving [ouders/opvoeders, jw] om aan de behoefte van het kind aan optimale - niet aan maximale, dat moet benadrukt worden - empathische reacties tegemoet te komen.'

Criminaliteit (2): $\quad$ misdaden tegen de mensheid en misdaden tegen het kind (psychopathie of kindermishandeling?)

Van SCHUYTs (kleine) vermogenscriminaliteit en RUTENFRANS' ongelukkige crimineel is het weer wèl een grote stap - een op het eerste gezicht in veler ogen wellicht ongeoorloofde of ongepaste stap - naar misdaden tegen de mensheid: KOHUTs menselijke destructiviteit op een schaal van Adolf HITLER. Of zelfs naar 'misdaden tegen het kind,' zoals onlangs in België gepleegd door Marc DUTROUX.

Toch kan het ons inzicht verdiepen, al moet daartoe ongetwijfeld de nodige afkeer en afweer worden overwonnen, ook hier een (sociaal-) pedagogisch en (ontwikkelings)psycho(patho)logisch ontleedmes te hanteren. Om de kans te verkleinen dat we onszelf in de vingers snijden, is het verstandig kort stil te staan bij een specifieke persoonlijkheidsstoornis, die vroeger werd (en nog wel wordt) aangeduid als psychopathie.

Voor een beknopte beschrijving van psychopathie (in de DSM-IV de anti-sociale persoonlijkheidsstoornis), waarin niet alleen gedragskenmerken (zoals in de DSM-IV) maar ook affectieve en interpersoonlijke kenmerken zijn verwerkt, verwijs ik naar VERHEUL. ${ }^{209}$ Aan zijn bijdrage ontleen ik het volgende.

Aan de hand van de herziene versie van de Psychopathy Checklist van Robert HARE (de PCL-R) kunnen de (gedrags-, affectieve en interpersoonlijke) kenmerken bij psychopathie in twaalf categorieën worden ondergebracht: 1.) glibberigheid en oppervlakkige charme; 2.) egocentrisme en grootheidsfantasieën; 3.) onvermogen tot gevoelens van wroeging of schuld; 4.) gebrek aan empathie; 5.) neiging tot liegen en manipuleren; 6.) gevoelsarmoede; 7.) impulsiviteit; 8.) gebrekkige impulscontrole; 9.) sensatielust; 10.) gebrek aan verantwoordelijkheidsgevoel; 11.) gedragsproblemen tijdens de jeugd (hierbij kunnen drie in belangrijke mate genetisch bepaalde psychische stoornissen bij kinderen een rol spelen: de concentratiestoornis met hyperactiviteit (ADHD), de oppositioneel-opstandige gedragsstoornis en de gedragsstoornis-tijdens-de-vroegeadolescentie); 12.) volwassen antisociaal gedrag. ${ }^{210}$

209 Roel verHeuL, 'Het masker van de psychopaat,' Psychologie september 1996, pp. 31-35.

210 'Het masker van de psychopaat,' t.a.p., op p. 32. 
Hoewel de auteur vermeldt dat intelligente psychopaten kunnen opklimmen tot de top van het bedrijfsleven en in de politiek soms massaal worden vereerd ('Adolf HITLER en Saddam HUSSEIN spreken in dat opzicht wellicht het meest tot de verbeelding ${ }^{211}$ ), gaat het in zijn opvatting bij psychopathie om een continuum: ergens op dit continuum hebben wij allemaal een plaats, maar pas voorbij een bepaald punt kan van psychopathie worden gesproken. ${ }^{212}$

Bijzonder zorgwekkend is de ongevoeligheid van de psychopaat voor behandeling: ${ }^{213}$

'Er bestaan zelfs aanwijzingen dat behandelde psychopaten sneller in hun oude [criminele/gewetenloze, jw] patroon terugvallen dan onbehandelde psychopaten.'

Buiten de extreme gevallen (extreem in de mate als het syndroom van DowN, voorheen 'mongolisme,' dat is ten aanzien van de intelligentie), waarbij een enkelvoudige, mogelijkerwijs genetische oorzaak aannemelijk is, speelt bij de genese van psychopathie een combinatie van genetische èn omgevingsfactoren een rol. Tot deze laatste kunnen worden gerekend: 'frequente ruzies tussen de ouders, gezinssituatie of opvoedingsstijl' van de ouders; voorts: 'fysiek geweld thuis, emotionele verwaarlozing, vijandigheid in de buurt, slechte leraren en weinig orde op school. ${ }^{214}$

Alice MILLER nu laat zien dat ook bij een vermoedelijk extreme psychopaat als Adolf HITLER omgevingsfactoren, in het bijzonder zijn gezinssituatie en de opvoedingsstijl van zijn vader, een cruciale rol in zijn monster-wording moeten hebben gespeeld. ${ }^{215}$ MILLER schrijft:.216

'On te begrijpen hoe zo'n levenslange, onverzadigbare haat als waardoor Adolf HTTLER werd bezeten, kan ontstaan, moet men (...) het vertrouwde terrein van de drifttheorie [FREUDs. Thanatos, jw] verlaten en zich openstellen voor de vraag wat zich afspeelt in een kind dat enerzijds door zijn ouders vernederd en veracht wordt en aan de andere kant verplicht is de persoon die hem dat aandoet, te respecteren, lief te hebben en zijn pijn onder geen beding te uiten."

En even verder: $:^{217}$

'Het masker van de psychopaat,' t.a.p., op p. 34 r.k. 'Het masker van de psychopaat,' t.a.p., op p. $351 . \mathrm{k}$.

'Het masker van de psychopaat,' t.a.p., op p. 35 i.f. $140-189$.

216 In den beginne was er opvoeding, a.w., p. 142. 
'Laten we eens proberen ons het volgende voor te stellen: een jood gaat de straat op, bijwoorbeeld om naar de melkboer te gaan, en daar wordt hij overvallen door een man met een SA-band om zijn arm, een man die het recht heeft alles met hem te doen wat hij wil, wat zijn fantasie hem maar ingeeft en wat zijn onbewuste op zo'n moment nodig heeft. Op dat alles heeft de jood geen enkele in* vloed - evenmin als vroeger het kind Adolf. Wanneer de jood zich verzet, kan en mag hij worden doodgetrapt, net als destijds de elfjarige Adolf toen hij samen met drie vriendjes uit vertwijfeling was weggelopen om op een zelfgebouwd vlot de rivier af te zakken en te vinchten woor het geweld wan zijn vader. Alleen al omdat hij gedacht had aan vlucht, werd hij halfdood geslagen (...). Ook de jood heeft nu geen kans om te wuchten, alle wegen zijn afgesloten en leiden naar de dood, zoals de spoorrails in Treblinka en Auschwitz gewoon ophielden, daar hield het leven op. Zo voelt zich immers ieder kind dat dagelijks geslagen wordt en om de gedachte aan vlucht bijna is vermoord."

Twee externe factoren verklaren waarom HITLER zijn (verdrongen ${ }^{218}$ respectievelijk onverwerkte) jeugdervaringen kon uitageren in de massacultus van zijn persoon, de massa-cultus van de jodenhaat en de massale Duitse judeocide. De eerste factor was de hardvochtige, wrede Duitse opvoeding in die tijd. MILLER: $:^{219}$

"HTLERs grote en enthousiaste schare aanhangers bewees dat zij een zelfde structuur vertoonden als hij, dat wil zeggen: op dezellde manier waren opgevoed.'

HIDDEMA stelt in dit verband: 220

'Hij [HTTLER] was én van de staatslieden van wie LASSWELL [in Psychopathology and politics] opmerkt dat zij dikwijls hun verdrongen impulsen gebruiken om deze te projecteren en te rationaliseren tot nationaal beleid. "Alleen wanneer de structuur van een leider samenvalt met individuele structuren van brede lagen van de bevolking, kan een leider geschiedenis maken" [REICH, The mass psychology of fascism]."

En verderop: $:^{221}$

218 'Uit dexe tijd is mij weinig bijgebleven," schrijft HITLER in Mein Kampf (aangehaald door Frans HIDDEMA, Bnine terreur door zwarte pedagogie; Psychoanalywische aspecten van HITLERs racistische nazidom, Rotterdam 1985, p. 12).

219 In den beginne was er opvoeding, a.w., p. 165.

220 Frans HIDDEMA, Bnine terreur door zwarte pedagogie; Psychoanalytische aspecten van HTLERs racistische nazidom, Rotterdam 1985 , p. 9.

221 Bruine terreur door zwarte pedagogie, a.w., p. 77 ('Epiloog'); zie ook pp. 31-40 ('Opvoedingspatronen'). 
'Het nazidom kan inhoudelijk vooral gezien worden als verlengstuk van zijn [HITLERs] zieke gedachten- en gevoelswereld, die hij door zijn demagogische en organisatorische gaven massaal kon overbrengen op het Duitse wolk, dat hiervoor ontvankelijk bleek op grond van een gelijksoortige karakterontwikkeling. Verdrongen haat, schuldgevoel en vergeldingsdrang waren hierbij van grote betekenis; gevolens die onder invloed van zwarte pedagogie en de sociaal-economische situatie in het toenmalige Duitsland tot abnormale proporties waren versterkt. EINSTiEINs wens: "Mütter in der ganzen Welt sind verpflichtet die Samen des Friedens in die Seelen ihrer Kinder zu säen," kan pas worden vervuld als moeders hiertoe emotioneel in staat zijn."

De tweede factor was het eeuwenoude Europese antisemitisme - en de politieke bruikbaarheid daarvan voor machthebbers - in combinatie dus met de verdrongen haat van hardvochtig, wreed opgevoede kinderen. MILLER::222

'Onder de Europese volkeren bestaat [bestond? -jw] waarschijnlijk geen hechtere onderlinge band dan het antisemitisme. Dit is van oudsher een betrouwbaar manipulatiemiddel van de overheid en kan kennelijk zeer uiteenlopende belangen voortreffelijk camoufleren, zodat ook onderling zeer vijandige groeperingen het eens kunnen worden over gevaarlijkheid of laagheid van de joden. Als volwassene wist HITLER dat, en hij heeft zelfs eens tegen RAUSCHNING gezegd: "Als de joden niet bestonden, moesten ze worden uitgevonden."

Waardoor kan het antisemitisme zich voortdurend vernieuwen? Dat is niet zo'n moeilijke vraag. Men haat de jood niet omdat hij dit of dat doet of is. Alles wat joden zijn of doen, kan men ook bij andere volkeren winden. Men haat de joden omdat men een ongeoorloofde haat in zijn hart draagt en deze maar al te graag wil legitimeren. Het joodse volk is voor een dergelijke legitimatie buitengewoon geschikt. Omdat joden al tweeduizend jaar werden vervolgd door de hoogste kerkelijke en wereldlijke autoriteiten, hoefde men zich nooit te schamen voor jodenhaat, zelfs niet wanneer men met zeer strenge morele beginselen was opgevoed en zich voor het overige moest schamen voor de meest naturlijke gemoedsbewegingen (...), Een kind dat opgroeit binnen het pantser van te vroeg opgelegde deugden, zal graag zijn toevlucht zoeken bij de enige toegestane vitlaatklep, het zal antisemitisme (dat wil zeggen zijn recht op haat) zelf "zoeken" en het zijn leven lang behouden."

Thans, aan het eind van de twintigste eeuw, zien we hoe jongeren om het even welke uitlaatklep vinden - drugs, vandalisme, pesten, maar ók die van het antisemitisme, racisme en rechtsextremisme, waarbij ernstig geweld soms niet wordt geschuwd -, niet of niet meer zo massaal vanwege het pantser waarvan MILLER gewaagt, maar vermoedelijk veeleer vanwege de schrijnende innerlijke leegte van het emotioneel verwaarloosd zijn of de diffuse woede ten gevolge van het niet opgevoed, gemanipu- 
leerd, well 'verwend' maar niet begrepen zijn. 'Verwend' tussen aanhalingstekens, want - in de woorden van HIDDEMA: ${ }^{223}$

'Verwenning hangt nauw samen met overbezorgdheid. Het is geen uiting van bewuste tolerantie, maar van affectieve verwaarlozing; het is owergecompenseerde zorg, waarbij gift tot gif wordt.'

Waarbij niet mag worden verhuld dat tal van jongeren behalve slachtoffer van emotionele verwaarlozing ook nog eens slachtoffer of op zijn minst getuige zijn van ernstig fysiek relationeel geweld. Op deze plaats is het misschien nuttig de woorden van LEWIS e.a. in herinnering te roepen. ${ }^{224}$

\begin{abstract}
'Abuse alone does not usually create violent youngsters. It would seem that abuse, family violence, and neuropsychiatric vulnerabilities in the child together engender violence. Unfortunately, this combination of factors is prevalent in our society today.

The recognition that extraordinary violence is often, perhaps usually, the result, at least in part, of having been the victim of extreme abuse, raises theoretical, moral, and legal questions. (...) $)^{, 225}$
\end{abstract}

Si parva licet componere magnis. Maar is het wel toegestaan het huidige 'kleine' met het historische 'grote' te vergelijken? Ofwel, om naar HITLER terug te keren: is het wel geoorloofd, of gepast, een dergelijke massamoordenaar als schrikwekkend voorbeeld van de gevolgen van kinder-

Brine terreur door zwarte pedagogie, a.w., p. 36.

Vgl. ook DSM-TV (Beknopte handleiding, p. 356; curs. jw), V 61.20 ( $\mathrm{z}$ 63.8): 'cen patroon van een verstoorde interactic (...) tussen ouder en kind (bijvoorbeeld werstoorde communicatie, overprotectie, inadequate discipline) (...). ${ }^{2}$

Dorothy $O$. LEWIS e.a., 'Child abuse, delinquency, and violent criminality, in: Dante CICCHETT, Vicki CARLSON (eds.), Child maltrearment; Theory and reseanch on the causes and consequences of child abuse and neglect, Cambridge (etc.) 1989, pp. 707-721, op p. 718 .

225 Het citaat gaat als volgt verder (t.a.p., op pp. 718/719): 'We know that probably everyone, under certain circumstances, is capable of violence. The question is, simply, what kinds of stresses on what kinds of vulnerabilities and for what duration of time make violent behavior a probability - even a centainty - rather than an unlikely possibility? This basic theoretical question raises a moral and, therefore, legal question. To what extent is a violenty abused individual responsible for his or her own violent behaviors? We know that human beings are remarkably resilient; however, this is compromised when the centrall nervous system is disordered by virtue of injury, psychosis, retardation, or the myriad of other factors

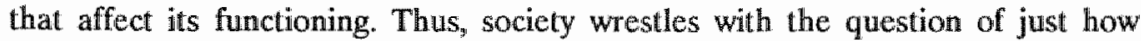
much control the physically and mentally traumatized individual has over the expression of rage. It is at this cynosure of psychology, medicine, morality, and law that research on the relationship of abuse to violence must focus." 
mishandeling ten tonele te voeren? Worden - helaas - sommige psychopaten - zoals bijvoorbeeld (vermoedelijk) ook de Belgische kinderverkrachter en -moordenaar Marc DUTROUX? - niet 'gewoon' als monster geboren? Een laatste citaat van MILLER:226

\begin{abstract}
'Toch zou ik me kunnen voorstellen dat ook mensen die zich wèl hebben beziggehouden met het onbewuste, wantrouwend of ontzet reageren op mijn poging HITLERs optreden vanuit zijn kindertijd te begrijpen, omdat zij niets met deze "onmenselijke geschiedenis" te maken willen hebben. Daar moet ik tegenin brengen dat wij toch niet mogen aannemen dat onze lieve Heer plotseling het idee heeft gekregen een "necrofiel monster" naar de aarde te sturen, ongeveer in de zin van Erich FROMM die [HIrtLERs ouders niet heeft kunnen/willen doorzien/ doorgronden en daarom, jw] het volgende heeft geschreven: "Hoe is het te verklaren dat deze beide goedbedoelende, stabiele, zeer nomale en bepaald niet destructieve mensen het latere monster Adolf HITLER op de wereld hebben gezet?" (n...)
\end{abstract}

Ook BASTIAANS komt het niet ongeoorloofd of ongepast - en misschien zelfs gewenst en noodzakelijk - voor naar HITLERs jeugd te verwijzen, voor zover dat althans mag worden afgeleid uit de spiegel die hij ons voorhoudt: 227

\footnotetext{
'Wat HITLER de wereld aandeed, is langzamerhand wel voldoende bekend. Veel minder is bekend dat hij hiertoe kwam op grond van een persoonlijk getraumatiseerd-zijn.

Ook is in het algemeen veel te weinig bekend dat kinderen die in hun jeugd verwaarloosd, gepijnigd en getraumatiseerd worden, een grote kans lopen in hun latere leven of als slachtoffer te blijven functioneren, of zich te gaan gedragen als personen die, uit wraak over wat henzelf overkwam, slachtoffers maken, vaak zonder enige beperking.'
}

Uit wraak, maar een wraak die niet bewust is, of liever 'verplaatst' - en daardoor vaak bodemloos, als het ware tegen de hele wereld gericht, onder de werking van het mechanisme van het idealiseren, het noodgedwongen, uit nood geboren 'ontzien' van de ouders. Nogmaals HIDDEMA: ${ }^{228}$

226 In den beginne was er opvoeding, a, $\mathrm{w}_{\text {, }}$ pp. 170/171 (curs. overgenomen). Vgl. ook haar bespreking van de lustmoordenaar van jongetjes Jürgen BARTSCH, a.w., pp. 190-226, op p. 195.

227 J. BASTLAANS, 'Voorwoord,' in: HDDEMA, Bruine terreur door zwarte pedagogie, a.w., pp. 7-8, op p. 7 .

228 Brime terreur door zwarte pedagogie, a.w., pp. $74 / 75$. 
${ }^{8}$ De wolwassene weet vaak niet de werkelijke reden waarom hij zich tot het nazisme aangetrokken voelt. Hij rationaliseert dit, bijwoorbeeld met de gedachte dat deze ideologie een betere toekomst mogelijk zou maken. De sterke wens tot wraak en vergelding voor het hem als kind aangedane leed die tij in het nazidom kon meebeleven, is hem onbekend."

Nazisme in bovenstaand citaat kan vervangen worden door elk '-isme' dat in zijn diepste kern als haat-, angst- en/of afgunstideologie kan worden ontmaskerd. Ook vandalisme, zinloze daden zonder ideologie, of misschien moeten we zeggen: de ideologie van de daad, de destructieve daad, kan tot deze '-ismen' worden gerekend, alsook, wellicht, het nihilisme en negativisme dat tot uitdrukking komt in criminaliteit, in steeds gewelddadiger vormen van criminaliteit van steeds jongere jeugdigen en zelfs kinderen. Zo was enige tijd geleden in de krant te lezen (in een bericht dat toevallig uit Duitsland afkomstig is, maar soortgelijke geluiden worden ook in Nederland vernomen $\left.{ }^{229}\right): 230$

\footnotetext{
${ }^{6}$ BONN - Het afgelopen half jaar is de kinder- en jeugdcriminaliteit in Duitsland met meer dan tien procent gestegen. De voorzitter van de grootste Duitse politievakbond, Hermann LuTz, spreekt van een alarmerende situatie.

Minstens zo zorgwekkend vindt LUTZ het verschijnsel dat steeds jongere kinderen crimineel actief zijn. De politie kijkt er niet meer van op als ze tien-, elfjarigen in de kraag grijpt. Bovendien signaleert LUTZ dat ook de allerjongsten met steeds meer bruut geweld optreden. Hij vindt die ontwikkeling een bewijs van verloedering en verruwing van de samenleving. LUTZ vreest de komende jaren ook een stijging van het aantal drugsdoden onder minderjarigen.

Hij vindt dat de politie niet voor alles verantwoordelijk kan worden gesteld. De politievakbondswoorzitter vindt dat de ouders zich meer met hun kroost moeten bezighouden om definitieve ontsporingen te woorkomen.'
}

Maar waar ouders te kort schieten, komt de - secundaire - opvoedingsverantwoordelijkheid van de staat om de hoek kijken, zoals (onder meer) vastgelegd in het Verdrag inzake de rechten van het kind. En waar de staat - internationaalrechtelijk - te kort schiet, is de kwestie aan de orde van de staatsaansprakelijkheid. Een kwestie die we hier zullen laten rusten: zij staat centraal in het volgende hoofdstuk.

\section{Criminaliteit (3): jeugd en gezin}

Tot besluit daarom nog een korte 'helicoptervlucht' over de criminele gevolgen, of liever: de criminogene effecten, van falend ouderschap, van

229 Zie hoofdstuk 14, par. 14.3.2.

230 Dagblad de Limburger van 2 september 1996, p. 9, onder de kop: "Criminaliteit Duitse jeugd alarmerend". 
wanopvoeding, van het niet waar kunnen maken van de primaire, de ouderlijke opvoedingsverantwoordelijkheid (waarbij we uiteraard steeds de secundaire, de statelijke opvoedingsverantwoordelijkheid in het achterhoofd houden). We vertrekken op het teken van MÖNKS en KNOERS. ${ }^{231}$ Een onderzoeksgegeven waar we niet omheen kunnen, is immers, zo doceren zij ...

'(...) dat de opvoedingsstijl van de ouders van centrale betekenis is. Wanneer iemand accepterende, warmwoelende ouders heeft, moet dat beschouwd worden als de beste voorwaarde om een goed functionerend geweten te ontwikkelen.'

Wat we vervolgens onder ons voorbij zien trekken, is helder beschreven in het rapport Jeugd en gezin, in opdracht van de Directie Beleid van het Ministerie van Justitie geschreven door JUNGER-TAS:232

( $(. .).[\mathrm{H}] \mathrm{et}$ meeste dielinquente gedrag [komt voor] in twee-ouder gezinnen waar de ouders voortdurend met elkaar in conflict zijn, met name als die conflicten met geweld gepaard gaan. Dat is ook het geval in gebroken gezinnen waar de moeder weinig affectie voor haar kinderen koestert. Weinig delinquentie komt voor in harmonieuze, volledige gezinnen en in érn-ouder gezinnen met warme, affectueuse moeders (...). (...)

Een gebrekkig toezicht op kinderen is eén van de sterkste voorspellers van criminaliteit (....). Slecht opvoedingsgedrag van ouders, in termen van toezicht en disciplinering, alsook criminaliteit van de ouders en van broers en zusters wormen bellangrijke oorzaken voor dellinquent gedrag (...). Opvallend is dat kinderen, als hun ouders hun te weinig structuur en discipline bieden, van mening zijn dat hun ouders te weinig om then geven (...). (...)

Een andere factor die in verband staat met delinquentie, is inconsistente disciplinering, dikwijls gepaard gaande met harde, gewelddadige disciplineringsmethoden, zoals schelden, bedreigen, slaan en schoppen. (...) Verder is het zo dat zowel te weinig controle en disciplinering als juist extreem veel controle en discipline samenhangen met een grotere frequentie van delinquent gedrag. Te vaak, te streng en te hard straffen met gebruik van geweld lijkt delinquent gedrag zelfs te stimuleren (...).

Naast het controle-aspect is de kwaliteit van de relatie tussen ouders en kind van groot belang. In de eerste plaats blijken emotionele aspecten een rol te spelen: sterke negatieve gevoelens van het kind ten aanzien van zijn ouders hangen samen met crimineel gedrag. De belangrijkste elementen in dit verband zijn:

- acceptatie, respect en vertrouwen in het kind;

- goede communicatie tussen ouders en kind met betrekking tot gevoelens, gedachten en problemen;

231 F.J. MÖNKS, A.M.P. KNOERS, Ontwikkelingspsychologie, Assen 1994 (negende druk), pp. 153/154.

232 Josine JUNGER-TAS, Jeugd en gezin;" Prewentie vanuit een justitieel perspectief, Den Haag (Ministerie van Justitie) juni 1996, pp. 25-26, $(22,27)$ en 30-31. 
- de houding van ouders ten opzichte van [de] vrienden van het kind; en

- de afwezigheid van conflicten zowel tussen ouders onderling alls tussen ouders en kinderen.

Opmerkelijk is dat geen van deze factoren verband houd[t] met de structuur van hel gezin [gezinsgrootte, én-ouder gezin, buitenshuis werkende moeder, jw]. (...) In dit opzicht blijkt de interne gezinsdynamick aanzienlijk belangrijker dan de gezinsstructuur. (...)

(...) [M]en [kan] zich afvragen wat de sterkste invloed heeft op het gedrag van het kind: structurele achtergrondfactoren [slechte behwizing, witkeringsafhankelijkheid, armoede, allochtone status, alcoholisme van ouders e.d.m., jw] of interne gezinsfactoren. Bovendien dringt de bekende "mature [aanleg] of nurture [milieu]" vraag zich op: zijn het bepaalde risico-kenmerken van het kind [temperament, impulsiwiteit, (lage) intelligentie, concentratie-/hyperactiviteitsstoornis, jw] die de doorslag geven? Of spelen gezinsinwloeden de belangrijkste rol? (...)

In de eerste plaats blijkt dat gezinsfactoren de krachtigste voorspellers van later delinquent gedrag zijn. In essentie zijn dit de mate wan toezicht, de mate en kwaliteit van discipline en de affectieve band tussen ouders en kind.

In de tweede plaats blijkt dat structurele achtergrondfactoren niet een rechtstreeks werband met criminaliteit vormen, maar opereren via gezinsprocessen (...). Deze factoren faciliteren of bemoeilijken het goed functioneren van het gezin. (...) Hoewel (...) opvoedingsfactoren en gezinsprocessen van doorslaggevend belang zijn bij het ontstaan van delinquent gedrag, spelen (...) ook kindfactoren een belangrijke rol. Dit zijn voornamelijk impulsief en storend" gedrag, moeilijk te disciplineren en vroegtijdig anti-sociaal gedrag. (...) Het probleem is echter dat er in de opvoeding altijd sprake is van interactie tussen kindfactoren en ouderfactoren. (...) [Daarnaast] blijken structurele achtergrondfactoren van sterkere invloed te zijn op de opvoedingsstijl van ouders dan kindkenmerken. (...) [R]isicofactoren in het kind vormen [echter] wel een belangrijke, maar zeker niet de enige verklaring van latere criminaliteit. Ouderfactoren zijn bepalender voor de ontwikkeling van delinquent gedrag dan kindfactoren (...). Daarom zal een goed preventiebeleid niet kunnen wolstaan met maatregelen die uitsluitend of het kind [buiten het gezin, jw] zijn gericht. De rol van het gezin is dermate doorslaggevend dat dit er altijd bij betrokken zal dienen te worden, wil men blijwende resultaten boeken.'

De hier aangehaalde onderzoeksbevindingen bepalen uiteraard in sterke mate de aansprakelijkheid èn de verantwoordelijkheden van de staat c.q. de overheid op het punt van de morele ontwikkeling, de uitgroei tot minimaal c.q. optimaal moreel persoon, van het kind. Het eerste aspect de staatsaansprakelijkheid - staat centraal, we zeiden het al, in het volgende hoofdstuk, hoofdstuk 13 . Het tweede aspect - de verantwoordelijkheden van de overheid - stellen we aan de orde in hoofdstuk 14 , het slothoofdstuk van deze studie.

De vragen naar en omtrent de omvang (par. 12.2) en de ernst (par. 12.3) van de schending van het recht van het kind op (minimale) persoonswording zijn hiermee beantwoord. Althans, onze poging daartoe sluiten we hiermee af. De gevolgtrekking uit beide paragrafen kan geen mildere zijn dan dat kindermishandeling in Nederland een grootschalig 
en ernstig maatschappelijk fenomeen is: een grootschalige schending van fundamentele rechten van het kind en in die zin een ernstige mensenrechtenschending. Rest ons nog (de beantwoording van) de vraag naar het systematische karakter van deze schending.

12.4 Kindermishandeling als passief-systematische mensenrech-
tenschending: culturele en structurele ouderschapswerwaar-
lozing als passief-systematische kinderrechtenschending

Over de derde en laatste centrale vraag van dit hoofdstuk - de vraag naar het incidentele dan wel structurele karakter van het fenomeen kindermishandeling - kunnen we korter zijn dan over de beide vorige centrale vragen, de vragen naar respectievelijk de omvang en de ernst (sequelae) van dit fenomeen. Het antwoord op de derde vraag vloeit in feite direct voort uit hetgeen hierboven naar aanleiding van de beide eerste vragen is behandeld en gesteld. We zouden, tot hier gekomen, dan ook bijna kunnen zeggen: de vraag stellen, is haar beantwoorden.

Om dat laatste te illustreren, zullen we, alvorens het (morele/ natuurrechtelijke en mensenrechtelijke/rechtspolitieke) antwoord op de laatste centrale vraag van dit hoofdstuk weer te geven, eerst de vraag zodanig stellen, zodanig onder woordlen proberen te brengen, dat haar beantwoording daarin besloten ligt. Onze - enuntiatieve en suggestieve vraagstelling zou er dan als volgt uit kunnen zien.

Moet kindermishandeling - als maatschappelijk fenomeen - op het conto worden geschreven van het noodlot, de tragiek van het menselijk leven in het aardse tranendal? Betreft het met andere woorden een min of meer toevallige samenloop van omstandigheden die - afhankelijk van sociaal-economische factoren - dan weer meer en dan weer minder snel zal optreden; aan niet meer dan de wisselvalligheid van hoog- of laagconjunctuur onderhevig? Kortom, valt kindermishandeling onder de categorie onvermijdelijke rampen die elke samenleving treffen? Iets van alle tijden tot op het laatst der dagen? Een optelsom van tragische incidenten die, zo goed als tal van andere grotere of kleinere, meer of minder frequent voorvallende natuurrampen, inherent zijn aan de condition humaine?

Of moet kindermishandeling op het conto worden geschreven van het menselijk tekort? Een tekort dat cultureel, structureel en principieel is verankerd, maar dat juist daardoor cultureel, structureel en principieel omkeerbaar is? lets dat door toekomstige generaties, die een effectief sociaal-pedagogisch vangnet zullen hebben opgericht, slechts als een rimpeling in de oceaan van menselijke wreedheid en kortzichtigheid zal worden beschouwd, een tragische maar transitoire episode in de vroege 
beschavingsgeschiedenis van homo sapiens sapiens, iets dat weliswaar nog moest worden overwonnen in de Genocidale (twintigste) Eeuw, maar dat im Grunde genommen, vanuit het perspectief van het derde millennium, niet meer is geweest dan een socio-evolutionaire kinderziekte, een primitief maatschappelijk ouderschapskwaaltje sub specie aeternitatis?

Met andere - en nu meer juridische - woorden: moet, in het hier en nu, kindermishandeling - in elk individueel geval onmiskenbaar een ernstige, ja flagrante schending van de rechten van het kind - op maatschappelijk vlak, mede gezien de omvang ervan, de grootschaligheid, worden aangemerkt als emstige en systematische mensenrechtenschending? Systematisch niet in de zin van een actief kinderen vervolgende maatschappij en overheid. Maar systematisch in de zin van een passief toekijkende samenleving, die de overheid heeft die zij "verdient"? Of juister (maar tegelijk demaskerender) gezegd: de overheid die zij - bijna letterlijk - verkiest? Democratisch verkiest - door middel van het 'algemene' kiesrecht, dat is het kiesrecht van volwassenen?

Wat er zij van (het demasqué door) beide laatste vragen, staat en samenleving kunnen - hoezeer ook 'democratisch' gelegitimeerd (c.q. democratisch 'gelegitimeerd') - hun morele en mensenrechtelijke verantwoordelijkheden niet ontlopen. Immers, zoals de 'preambule' van het (voor-)Ontwerp-Europees (EG-/EU-)Handvest inzake rechten van het kind (aangenomen door het Europees Parlement bij resolutie van 8 juli 1992) stelt, in zowel postulerende als appellerende zin, en de artikelen 8 , 11 en 37 van het Ontwerp-Handvest (par. 8.8, 8.11 en 8.37 van de desbetreffende parlementaire resolutie) vervolgens (her)bevestigen: ${ }^{233}$

\section{'The European Parliament, (...)}

A. whereas every individual's childhood and family and social background to a great extent determine his or her subsequent life as an adult,

European Charter of rights of the child, European Parliament, Res. A3-0172/92 (8 juli 1992), opgenomen in: Eugeen VERHELLEN (ed.), Monitoring children's rights, [Den Haag] (etc.) 1996, Appendix 3, pp. 923-930, op pp. 924, 925, 926 en 929 (curs. jw). Deze resolutie van het Europees Parlement (de gekozen volksvertegenwoordiging wan de Europese Gemeenschap/EG) is niet bindend, en het is maar de vraag of de EG ooit een bindende tekst zal uitvaardigen. (Bijvoorbeeld een EG-verordening of -richtlijn ex art. $189 \mathrm{EG}$-verdrag? Of een door de lidstaten verplicht te ratificeren verdragstekst, al of niet in de vorm van een Protocol bij het EVRM, een verdrag c.q. Protocol waartoe de EG vervolgens ook zelf zou kunnen toetreden?)

Zie over het EG-'Charter' de (naar eigen zeggen) auteur ervan: Juan Maria BANDRÉS MOLET, 'Towards a European law on children; the European Charter of rights of the child,' in: Monitoring children's rights, a.w., pp. 159-164. 
B. stressing in particular the fundamental role of the family and its stability in ensuring the harmonious and balanced development of the child,

C. Whereas children constitute one of the most vilnerable sections of the population, whose specific needs must be satisfied and safeguarded,

D. whereas many international texts have recognized that these needs give rise to a number of rights for [of, jw] children which in turn entail obligations for parents, the State and society in general, (...)

8. Calls on the [Etropean] Commission to submit, on the one hand, specific proposals for appropriate actions in favour of a policy on the family, and on the other [hand], a draft Community Charter of rights of the child, containing a minimum of basic principles (...):

8.8 (...) If the parents or persons responsible for the child are not in a position to ensure his survival and development, the State must guarawtee him the necessary protection and care (...) and take steps to encourage and facilitate the provision of this care by individuals or famillies willing [and capable, jw] to do so, or, if this is not possible, via direct intervention by the authorities.

8.11 (...) The State must provide parents with appropriate assistance to fulfill their responsibilities, in the form of social institutions, services and facilities. (...) 8.37 (...) Children's education must, as well as preparing them for working life, also encourage the development of their personality and promote respect for human rights and the national cultural differences of other countries or regions and the eradication of racism and xenophobia. (...)'

Niet in de laatste plaats dient echter gewezen te worden op hetgeen wordt (her)bevestigd in art. 19 van het Ontwerp-Handvest (par. 8.19 van de resolutie): ${ }^{234}$

'8.19 Every child has the right to physical and moral integrity. Where a child is. subjected to torture or to inhuman, cruel or degrading treatment by any public or private person, such treatment shall be considered an especially aggravating circumstance. The Member States [of the European Community] shall give special protection to any child who suffers torture, ill-treatment, brutality or exploitation at the hands of members of his family or the persons responsible for looking after him. Furthermore, the Member States shall ensure that such children continue their education and that they receive suitable treatment to facilitate their reintegration into society.'

234 Monitoring children's rights, t.a.p., op p. 927 (curs. jw).

Jacqueline SMTTH, Visions and discussions on genital mutilation of girls; An international survey, The Hague/Amsterdam 1995, pp. 47-48, op p. 48 (curs. jw; bronvermelding op p. 51 nt. 45), geeft een afwijkende tekst: 'Every child has the right to physical, and moral integrity. No child shall be subjected to torture, inhuman, cruel or degrading treatment by any public or private person.' Te meer waar zij (op p. 47) ook spreekt van een Draft European c.q. Community Charter on the rights of the child (curs. van mij), vermoed ik dat het hier om een 'lapsus' gaat. 
De schending van dit recht - het recht van het kind op lichamelijke en geestelijke integriteit, op vrijwaring van en bescherming tegen 'torture, illtreatment, brutality or exploitation at the hands of members of his family' voert in haar kielzog de schending van het recht van het kind op minimale persoonswording, sterker nog: die schending is er de crux van, de wrede kern die we aanduiden als kindermishandeling.

De schaal waarop dit fundamentele recht wordt geschonden, en de ernst van de individuele en maatschappelijke gevolgen daarvan, zoals deze, gezien het maatschappelijk stilzwijgen en statelijk stilzitten, klaarblijkelijk zijn ingebed in culturele ('parentiarchale') patronen en zowel private als publiekrechtelijke structuren, kortom: het zowel massale als massieve karakter van deze schending, voeren tot de morele en rechtspolitieke - tot de natuurrechtelijk-mensenrechtelijke - conclusie die we thans als expliciet antwoord op onze vraagstelling weergeven: grootschalige kindermishandeling, zoals deze ten onzent plaatsvindt als op de koop toe genomen sequeel van maatschappelijk en publiekrechtelijk ouderschapslibertinisme, dat wil zeggen: van culturele en structurele maatschappelijke en publiekrechtelijke ouderschapsverwaarlozing ...

'(...) not only constitutes a gross violation of human rights (...) but is also [a] particularly serious offense to human dignity. ${ }^{* 35}$

In rond Nederlands: de grootschalige kindermishandeling in ons lai.d, als sequeel en uitdrukking van ernstige en stelselmatige ouderschapsverwaarlozing, dat is van de ernstige en systematische sociaal-pedagogische nalatigheid van staat en samenleving, is niet alleen een grove mensenrechtenschending, maar ook een bijzonder grove aanslag op de menselijke waardigheid.

$\mathrm{Nu}$ is evenwel een 'grove' schending (gross violation) nog niet hetzelfde - althans niet noodzakelijk of per definitie hetzelfde - als een 'systematische' schending (systematic violation). In de woorden van REIDY e.a.: 236

235 Naar UNHCR Executive Committee, Conclusion 73 (XLIV), Refugee protection and sexual violence, $199[2] 3$.

236 Aisling REDY' e.a., "Gross violations of human rights: invoking the European Convention on human rights in the case of Turkey,'NQHR 1997/2, pp. 161-173, op p. 162 (curs. jw).

KAMMINGA gebruikt de tern "ernstige en systematische mensenrechtenschendingen' (gross and systematic violations) als 'shorthand' voor 'officially inspired practices' van marteling enzovoorts (Menno T. KAMMINGA, 'Is the European Convention on human rights sufficiently equipped to cope with gross and systematic violations?' NQHR 1994/2, pp. 153-164, op p. 154; curs. jw). 
'A pattern of systematic and gross violation[s] of human rights does not occur in a vacum or as a result simply of negligence or default on the part of governmental authorities. Rather such a pattern requires the sanction of the State at some level."

De term 'gross violation' (grove mensenrechtenschending) in onze conclusie vertalen we hier daarom met: ernstige en passief-systematische, zo men wil: permissief-systematische (mensenrechten)schending. Juist het stilzitten en stilzwijgen, zo men wil: de stilzwijgende instemming, het stilzwijgend 'gedogen' - niet in de zin van door de vingers zien maar in de zin van de andere kant opkijken, het stelselmatig niet willen zien van omvang en ernst - van staat en samenleving, en in verband daarmee en ten gevolge daarvan de systematische, dat wil zeggen: cultureel bepaalde en structureel verankerde ouderschapsverwaarlozing, is de essentie van de ernstige rechtsinbreuk, van de ernstige aanslag op de menselijke waardigheil. Anders geformuleerd: een historisch gegroeid en onder de vlag van het grondrecht van de privacy gecultiveerd ouderschapslibertinisme ${ }^{237}$ heeft in zo ernstige mate en op zo grote schaal geleid tot een schending van de fundamentele rechten van het kind - in het bijzonder het recht van het kind op (optimale) persoonswording als achterliggend, dragend en leidend beginsel van het Verdrag inzake de rechten van het kind - dat in de huidige maatschappelijke en juridische context ouderschapsverwaarlozing als permissief-systematische mensenrechtenschending moet worden opgevat.

Deze permissief-c.q. passief-systematische mensenrechtenschending zal voortduren zolang in ons land een effectief sociaal-pedagogisch vangnet ontbreekt, zolang staat en samenleving niet actief betrokken raken bij de opbouw van een sociaal-pedagogisch stelsel, waarin de 'infrastructuur' waarvan - in onderstaand citaat - DIRKSE (in een advies van de Raad voor het Jeugdbeleid) gewaagt, nog maar één van de hoekstenen vormt,

Vgl. ook de definitie wan MEDINA (Cecilia MEDINA QUIROGA, The battle of human rights; Gross, systematic violations and the Inter-American System, Dordrecht etc. 1988, p. 16; curs. jw): 'Gross, systematic violations of human rights are those violations, instrumental to the achievement of governmental policies, [that are] perpetrated in such a quantity and in such a manner as to create a sicuation in which the rights to life, to personal integrity or to personal liberty of the population as a whole or of one or more sectors of the population of a country are continuously infringed or threatened.' (In hoofdstuk 13 komen we op deze definitie terug.)

237 Libertinisme hebben we eerder aangeduid als een privaat vrijheidsdenken dat te weinig respect heeft voor de natuur- en mensenrechtelijke grondbeginselen en idealen van gelijkheid en solidariteit en te veel woor de 'natuurlijke' vrijheid van de (sociaal-economisch en sociaal-emotioneel) sterkste. 
en waarschijnlijk niet eens de eerste hoeksteen die (door een minister woor Kind en Gezin?) moet worden gelegd: ${ }^{238}$

'De voorwaarden voor een verantwoord ouderschap kunnen aanzienlijk worden verbeterd, zodat we als samenleving beter op de kleintjes gaan letten. Dit is een zaak van hoog moreel belang. Want een beschaafde samenleving zorgt ervoor dat er geen kinderen verloren gaan voor de toekomst. Verbetering van de sociaaleconomische omstandigheden is een inspanningsverplichting die alle energie vraagt. Maar niet vergeten moet worden een infrastructuur te ontwikkelen die vroegtijdige signalering en melding van kindermishandeling en misbruik van kinderen mogelijk maakt.'

Kindermishandeling (opgevat) als 'gross violation of human rights," als ernstige en passief-systematische mensenrechtenschending, is het moreel/ natuurrechtelijk gededuceerde en tegelijk mensenrechtelijk/rechtspolitiek gepostuleerde antwoord op de derde centrale vraag van dit hoofdstuk. Met andere woorden: de titel van dit hoofdstuk bedoelt niet alleen de lading ervan te dekken, maar is tevens de morele en rechtspolitieke conclusie ervan.

Op de internationaalrechtelijke pertinentie van deze conclusie gaan we in het volgende, op de internationaalrechtelijke implicaties ervan in het daarop volgende hoofdstuk, het laatste van deze studie, in. We doelen dan op de mensenrechtelijke sequelae voor staat en samenleving van wat zich pregnant laat samenvatten in het gezegde van GAYLIN: ${ }^{239}$

'The newborn human infant is totally incapable of survival and must be tended to constantly and completely. But he must be more than physically tended to. What happens in that first year will determine whether he grows into a person who loves and is lovable, who has emotions and relationships, who is capable of altruism and hope. And though all of these attributes are biologically rooted in our nature, they will fail to develop unless they are psychologically and sociologically encouraged in that early year of dependency and extended helplessness.'

De mensenrechtelijke sequelae, zo zouden we kunnen zeggen, op het vlak van preventie en vroege interventie (provision/prevention, protection; hier in sociaal-pedagogische zin: opvoedingsondersteuning/persoonswordingsvindicatie, opvoedingsonderwijs/ouderschapscursussen, opvoedings-

238 D.G. DIRKSE (voorzitter Raadscommissie kindermishandeling), 'Voorwoord,' in: RAAD VOOR HET JEUGDBELEID, Kindermishandeling vermeldenswaard; Advies over de aanpak wan kindermishandeling: preventie, hulpverlening en rechtstoepassing, Ministerie van Welzijn, Volksgezondheid en Cultuur, Rijswijk 1988.

239 Willard GAYLIN, Adam and Eve and Pinocchio: On being and becoming human, New York 1990, p. 132. 
geld/voorwaardelijk verstrekte ouderschapssubsidie). Maar we doelen evenzeer op de mensenrechtelijke sequelae op het vlak van reparatie (reparation/participation), dat is van rehabilitatie/sociale herintegratie en compensatie (hier: geestelijk herstel/revalidatie/resocialisatie respectievelijk erkenning/genoegdoening/schadeloosstelling). Deze zijn van niet minder belang, al was het slechts met het oog op het doorbreken van transgenerationele patronen.

Beide categorieën sequelae vergen evenwel, om te beginnen, het tot het publieke domein rekenen van veel van wat tot op heden - in de in het recht en (dus) in de politiek nog steeds dominante 'klassiekjuridische benadering" (WOLLESWINKEL) ${ }^{240}$ - onder de dekmantel van de privacy valt. Op het punt van preventie en vroege interventie zal dit zich vermoedelijk niet minder doen gevoelen - en dus in beginsel (afhankelijk van hoe een en ander door 'de politiek' wordt opgepakt en in het vat wordt gegoten) niet minder weerstanden oproepen - dan op het punt van rehabilitatie en compensatie (reparatie). Waar gezinsgeheimen ${ }^{241} \mathrm{nu}$ immers slechts incidenteel sneuvelen, doordat voormalige slachtoffers het zwijgen doorbreken, zal straks het overheidsbeleid op het terrein van de geestelijke volksgezondheid onder meer op 'fact-finding, ${ }^{, 42}$ op waar-

240 Ria WOLLESWINKEL, Gevangen in moederschap; Gedetimeerde vrouwen en het recht op family life, diss. Maastricht, Deventer 1997, p. 232.

De auteur onderscheidt "twee politieke reacties": "een liberale, die overheidsbemoeienis altijd gevaarlijk vindt en de privesfeer een groot daartegen te beschermen goed." En 'een sociale, die veel meer nadruk legt op ongelijke ontwikkelingskansen van kinderen, omdat die sterk bepaald zijin door het nest waarin ze geboren worden.' $\mathrm{Zij}$ merkt vervolgens op dat de 'liberale invalshoek' aansluit 'bij de klassiekjuridische benadering.' Daarentegen is de 'sociale invalshoek (...) betrekkelijk nicuw in het juridisch systeem. Die wordt ook veelal van buiten aangevoerd door rechtssociologen en metajuristen." (A.w., pp. 230-232.)

Het mag duidelijk zijn dat in deze studie - op mensenrechtelijke grondslag, inzonderheid op de grondslag van het Verdrag inzake de rechten van het kind - de 'sociale invalshoek' als juridisch dwingend wordt beschouwd. Over de 'socialle' benadering schrijft wOLLESWINKEL nog (a.w., pp. 231/232): "Als vorm van sociale politiek wordt binnen deze stroming gepleit voor meer overheidsbemoeienis in de voorwaardenscheppende sfeer voor àlle ouders en hun kinderen (...). Voor kinderen is het van belang nieuwe sociale netwerken te ontdekken.' In het vervolg van deze studie zal nog worden betoogd dat deze "sociale politiek" direct uit de verdragsverplichtingen onder het VRK voortvloeit, en zullen tevens de vereiste 'sociale netwerken' nader worden ingevuld.

241 Vgl. met betrekking tot de schadelijkheid van ('gesloten') gezinsgeheimen L. PINCUS, Chr. DARE, Gezinsgeheimen; Achtergronden van persoonlijke betrekkingen en individueel gedrag, Rotterdam 1980.

Vgl. voor deze term B.G. RAMCHARAN (ed.), Intemational law and fact-finding in the field of human rights, Den Haag (etc.) 1982. 
heidsvinding, gericht moeten zijn. Slachtoffers en soul survivors ${ }^{243}$ ('psycho-overlevenden') hebben immers, al was het slechts met het oog op hun genezingsproces, recht op erkenning, en dus recht op de waarheid. In de woorden van VAN BOVEN: ${ }^{244}$

'[Reparation] also implies that the truth be revealed and that responsibilities be clearly established.'

En in de door VAN BOVEN ten behoeve van (vaststelling in) de Mensenrechtencommissie van de VN opgestelde Basic principles and guidelines on the right to reparation for victims of [gross] violations of human rights and international humanitarian law (revised draft) lezen we (in par. 15): ${ }^{245}$

'Satisfaction and guarantees of non-repetition shall be provided, including, as necessary: (...) Verification of the facts and full and public disclosure of the truth.'

Steeds meer zal het Mattheüs-effect aldus plaats moeten maken voor het Marcus-effect (Marcus 4:22-23): $:^{246}$

Want niets is verborgen, of het moet worden geopenbaard; en niets is geheim, of het komt aan het licht. Zo iemand oren heeft om te horen, hij hore"

243 De term ontleen ik aan J. Patrick GANNON, Soul survivors; A new beginning for adults abused as children, New York (etc.) 1989.

244 Theo VAN BOVEN, "The right to restitution, compensation and rehabilitation for victims of gross violations of human rights and fundamental freedoms,' in: Gudmundur ALFREDSSON, Peter MACALISTER-SMTTH (eds.), The living law of nations; Essays on refugees, minorities, indigenous peoples and the human rights of other vulnerable groups; in memony of Alle GRAHL-MADSEN, Kehl (etc.) 1996, pp. 339354, op p. 354 .

245 E/CN.4/1997/104 d.d. 16 januari 1997, Appendix, pp. 3-5, op p. 5.

246 Vgl. ook Carol POSTON, Karen LISON, Incest overleven; Ervaringen van slachtoffers en therapeutische hulp, Utrechl/Antwerpen 1990, p. 13. 

Boek 4: Staatsaansprakelijkheid 
'Het is schoon, grijsaards te verzorgen, en hen zachtkens tot hun einde te geleiden; het is goed, dat men ongeneeslijke zieken verpleegt en hun leed verzacht; maar het is beter, het is nuttiger voor de maatschappij, zich de kinderen aan te trekken: want zij hebben een toekomst waarvan wij de leidslieden en de weldoeners kunnen zijn.'

Maxime DU CAMP, La charité privée à Paris, 1885; aangehaald door J.A. LEVY, P.H. HUGENHOLTZ Jr., A.J. RETHAAN MACARE, Th. NOLEN (rapporteur), in opdracht van de MAATSCHAPPI TOT NUT VAN 'T ALGEMEEN, Het vraagstuk van de verzorging der verwaarloosde kinderen, [Amsterdam 1898], p. 5 (openingscitaat).

'[M]eer en meer [komt men] tot het besef dat tot beteugeling van de baldadigheid, losbandigheid en criminaliteit der jeugd meer heil moet worden verwacht van de praeventieve werking eener goede opvoeding dan van het ingrijpen van den strafrechter.'

Memorie van Toelichting (1898) bij het Ontwerp van wet tot wijziging en aanvulling van de bepallingen in het Burgerlijk Wetboek omtrent de vaderlijke macht en de voogdij en daarmede samenhangende artikelen (ontwerp CORT VAN DER LINDEN), weergegeven door A.D.W. DE VRIES, F.J.G. VAN TRICHT, Geschiedenis der wet op de ouderlijke macht en de woogdij ( 6 februan 1901, Staatsblad no. 62); Verzameling van Regeeringsontwerpen, gewisselde stukken, gevoerde beraadslagingen, enz, met enkele korte kanteekeningen en register, Groningen 1903, Deel 1, p. 10.

'De bewering wordt wel eens vernomen, dat de Nederlanders over het algemeen meer tijd noodig hebben dan andere volkeren om zich nieuwe denkbeelden eigen te maken en tot de overtuiging te komen, dat het bestaande verkeerd en verandering dus geboden is.'

A.D.W. DE VRUES en F.J.G. VAN TRICHT, Geschiedenis der wet op de ouderlijke macht en de voogdij (...), Groningen 1903, Deel 1, 'Inleiding,' pp. 1-8, op p. 2. 


\section{STAATSAANSPRAKELIJKHEID EN SYSTEMISCHE SOCIAAL-PEDAGOGISCHE DISCRIMINATIE}

13.1

Inleiding: staatsaansprakelijkheid en systemische sociaalpedagogische discriminatie

In dit hoofdstuk staat in de eerste plaats het volkenrechtelijke leerstuk van de staatsaansprakelijkheid, toegespitst op grove mensenrechtenschendingen, centraal. Onder grove mensenrechtenschendingen verstaan we in dit hoofdstuk: schendingen van fundamentele c.q. kernrechten, welke op grote schaal plaatsvinden. Onder fundamentele c.q. kernrechten verstaan we hier in het bijzonder: rechten die de veiligheid van de persoon en de bescherming van diens lichamelijke en geestelijke integriteit betreffen. Toegespitst op kinderen zijn dat rechten die beogen te waarborgen en te bevorderen dat het kind als bovenminimaal persoon de volwassenheid betreedt, dat wil zeggen als persoon die, ernstige aangeboren afwijkingen daargelaten (in welk geval specifieke rechten van toepassing zijn), over voldoende rationaliteit, moraliteit en authenticiteit beschikt om in beginsel tot de vrije en zelfstandige uitoefening en het gave genot van de rechten van de mens in staat te zijn.

Een tweede centrale plaats is in dit hoofdstuk ingeruimd voor wat we kortheidshalve aanduiden als systemische sociaal-pedagogische discriminatie. Hoewel deze op het eerste gezicht wellicht enigszins cryptische aanduiding in de desbetreffende paragraaf nader zal worden toegelicht, is het van belang op deze plaats althans het bestanddeel 'systemisch' te definiëren. Onder 'systemisch" wordt hier verstaan: betrekking hebbend op de gehele maatschappij, dat wil zeggen op het publieke zowel als op het private leven, op instituties zowel als op gewoontes en tradities, op openbare lichamen (bestuurlijke, vertegenwoordigende, rechtsprekende) zowel als op particuliere instellingen, op oudere zowel als op jongere generaties, op het openlijke zowel als op het heimelijke, op het uiterlijke zowel als op het verinnerlijkte. Systemische discriminatie is met andere woorden discriminatie waarvan de hele maatschappij doordesemd is, en wel zozeer - al zo lang en zo diepgaand - dat zonder speciale bril, zonder bril die een extra dimensie toevoegt en zichtbaar maakt, niemand in die maatschappij van discriminatie zou spreken. In dit hoofdstuk heet die bril: sociaal-pedagogische grondrechten. De dimensie die hij in het bijzonder waarneembaar maakt, is - binnen de meer algemene dimensie van het grote (doch stille) onrecht dat (jonge) kinderen en/door (jonge) 
ouders wordt aangedaan - die van de categorie menselijk (vooral kinderlijk doch ook ouderlijk) lijden die gekenmerkt wordt door de menselijke (ouderlijke en kinderlijke) tragiek dat dit lijden van generatie op generatie wordt doorgegeven; de dimensie die wij daarom aanduiden met de term transgenerationaliteit.

Voor alle duidelijkheid: transgenerationaliteit wil niet zeggen dat als kind mishandelde ouders gedoemd zijn hun eigen kinderen te mishandelen. Wat het (in de kern) wel wil zeggen, is dit. Op grond van wat bekend is over de intergenerationele overdracht van gehechtheid, moet worden aangenomen dat als kind onveilig gehechte c.q. (chronisch) getraumatiseerde ouders hun eigen kind in affectieve en pedagogische zin niet (volledig) kunnen meegeven wat dat kind, ontwikkelingspsychologisch gezien, nodig heeft (nemo plus-regel). Het schort hun (in meer of minder ernstige mate) aan pedagogisch besef (BAARTMAN). Althans zolang zij er niet in geslaagd zijn hun jeugdervaringen op adequate wijze te verwerken. Dit laatste begrip (verwerking c.q. rouwarbeid) impliceert dat zij emotioneel contact hebben kunnen maken met het te kort gekomen 'kind in henzelf' (het kind dat zij eens waren) en, op basis van dat intrapsychische contact, 'achterstallige' ontwikkelingstaken alsnog tot een bevredigende oplossing hebben kunnen brengen. Aangezien verwerking (als individuele aangelegenheid en verantwoordelijkheid - uiteraard altijd naar de mate van het individueel mogelijke) in een (maatschappelijk en rechts)systeem waarin primaire (originaire) ouderlijke opvoedingsverantwoordelijkheid de facto neerkomt op (vrijwel) exclusieve ouderlijke opvoedingsverantwoordelijkheid, eerder (hoge) uitzondering dan (algemene) regel is, kunnen we transgenerationaliteit - in de meer collectieve en dus (enigszins) globale zin die toereikend is voor dit hoofdstuk - kort omschrijven als het maatschappelijke (c.q. sociaal-pedagogische) fenomeen dat (posttraumatische) sociaal-emotionele/pedagogische deprivatie, in enigerlei vorm, en behoudens individuele (vooralsnog incidentele) verwerking (reparatie), per saldo en grosso modo aan de volgende generatie wordt doorgegeven. Met alle ontwikkelingspsychopathologische gevolgen voor die generatie - en alle sociale en economische gevolgen voor de samenleving in haar geheel (uitval, uitsluiting, criminaliteit) - vandien. Transgenerationaliteit is, in meer scherpe (overdrachtelijke) bewoordingen, de benaming van een diepe maatschappelijke kloof $^{1}$ die in haar spe-

Hoewel 'hard werken' (en studeren) ertoe kan leiden, en ertoe heeft geleid dat, althans in de Nederlandse situatie van na 1945, sociaal-economische transgenerationaliteit wordt (en op grote schaal is) doorbroken, is de Nederlandse sociaalpedagogische situatie van dien aard dat 'hard ver-werken' (zich op het ouderschap voorbereiden om te beginnen door de eigen jeugd te 'bestuderen' en zich te onderwerpen aan de 'discipline' van de rouwarbeid) niet wordt gestimuleerd, 
lonken en krochten het - ten principale vermijdbare - lijden van kinderen (en ouders) verborgen houdt. Een maatschappelijke kloof waarvoor we een collectieve blinde vlek schijnen te hebben, waardoor we haar niet zien, ondanks het feit dat er jaarlijks in ons land tienduizenden kinderen in verdwijnen, om er vroeger of later als psycho-sociaal gehandicapten, als verslaafden, of zelfs als criminelen, ${ }^{2}$ weer uit te kruipen. Of om er nooit meer uit te kruipen, hetgeen in Nederland elk jaar tussen de vijftig tot honderd kinderen overkomt. ${ }^{3}$ Ongeveer eén op de duizend mishandelde kinderen laat in die maatschappelijke kloof het leven. ${ }^{4}$

Uit het verband c.q. de overlapping tussen beide centrale onderwerpen van dit hoofdstuk - staatsaansprakelijkheid ter zake van de grootschalige schending van fundamentele mensenrechten van kinderen (c.q. van sociaal-pedagogische grondrechten) enerzijds en systemische sociaalpedagogische discriminatie (dat is het systemisch discriminatoire karakter van die schending) anderzijds - worden ten slotte, onder de aanduiding 'staatstransgenerationaliteitsaansprakelijkheid' (par. 13.3.3, afgerond in par. 13.4), enkele deels juridische (als opinio juris sive necessitatis in de zin van deductief-positiefrechtelijke), deels rechtspolitieke (als jus constituendum in de zin van te operationaliseren rechtsbeginselen/mensenrechten) conclusies getrokken (c.q. - voor het slothoofdstuk - aangekondigd). Conclusies waarmee, naar mag worden verwacht, het de profundis clamavi (uit de diepte roep ik tot $\mathrm{U})^{5}$ vanuit de kloof hoorbaar gemaakt, en tegelijk

laat staan tot ouderlijke (pedagogische) verantwoordelijkheid - en dus tot secundaire, (pedagogisch) ondersteunende en faciliterende verantwoordelijkheid van de staat - wordt gerekend. Anders gezegd: er is wel een sociaal-economisch beleid en een sociaal-economisch vangnet, maar er is geen social-pedagogisch beleid, laat staan een sociaal-pedagogisch vangnet. Wat dat betreft, bestaan er nog 'vooroorlogse' discriminatoire patronen (wie voor een sociaal-emotioneel/pedagogisch dubbelfje geboren is ...) met zodanig ernstige discriminatoire gevolgen (... wordt nooit een kwartje) dat van een maatschappelijke kloof kan worden gesproken: een (diepe) sociaal-emotionele/pedagogische kloof (met overigens, gezien de aanslag op de lichamelijke en geestelijke gezondheidszorg en het justitie-apparaat en de directe en indirecte vernietiging van menselijk en maatschappelijk kapitaal, zeer grote sociaal-economische consequenties).

2. Zie (naast hoofdstuk 12) ook hierna hoofdstuk 14, par. 14.3.2.1 (Externaliseren/ internaliseren).

3 Vgll. het Eindrapport van de WERKGROEP MELDPUNT RINDERMISHANDELING (commissie-HERMANNS), Advies-en meldpunten kindermishandeling, Roermond, oktober 1997 , p. 52 (onderzoek fataal verlopende kindermishandeling): Michaja LANGELAAN, 'Kindermishandeling' (interview met Jo HERMANNS), NRC Handelsblad 18 oktober 1997 ("Wetenschap \& Onderwijs," p. 4).

4 Zie hoofdstuk 12, par. 12.2.1 (onder Kindermishandeling als doodsoorzaak).

5 De profundis clamavi ad te, Domine! Domine, exaudi vocem meam. Fiant aures tuae intendentes in vocem deprecationis meae: Uit de diepte roep ik tot $\mathrm{U}$, Heer! 
de mogelijke reactie van een lavabo manus meas (ik was mijn handen in onschuld $)^{6}$ van de staat de pas afgesneden wordt.

\section{2}

\section{Staatsaansprakelijkheid en de tria onera paedagogica}

In deze pararagraaf kijken we in algemene zin naar de staatsaansprakelijkheid ter zake van (grove) mensenrechtenschendingen en staan we in het bijzonder stil bij de tria onera paedagogica van de staat, de drie trappen (letterlijk: de drie dure plichten of lasten) van staatsaansprakelijkheid met betrekking tot de rechten van het kind, dat wil zeggen in de Trias paedagogica (de constitutionele driehoeksverhouding kind-oudersstaat); te weten: preventie (provision), (vroege) interventie (protection) en reparatie (in het bijzonder rehabilitatie en compensatie), ter bevordering van sociale herintegratie (dat is van participation). We spreken hierbij van drie 'trappen' omdat de drie verdragsrechtelijke $P$ 's van het Verdrag inzake de rechten van het kind (Provision, Protection en Participation) in elkaars verlengde liggen. Dat wil zeggen: vroege interventie en rehabilitatie/participatie zijn ingebed, respectievelijk dienen als ingebed te worden beschouwd, in een groter geheel van sociaal-pedagogische (educatief/ informatieve, materieel/financiële en counselend/begeleidende) voorzieningen, instellingen en diensten (zie hoofdstuk 10), en worden op basis daarvan - dat is: binnen een algemeen sociaal-pedagogisch kader, voortvloeiend, bij wijze van spreken, uit een Algemeen Sociaal-Pedagogische Kader- (of Raam-)Wet - gewaarborgd. Met andere woorden: de drie

Heer, hoor mijn klagen; Laat Uw oren toch luisteren naar mijn bidden en smeken. (Psalm 129 [130]:1-2.) Het Latijn is overgenomen uit het Officium parnm beatae Mariae Vinginis et Officium defunctorum, ed. Einsiedeln/Köln [imprimatur] 1959, pp. 181-182, op p. 181 .

6 Lavabo inter innocentes manus meas: ik was mijn handen in onschuld (Psalm 25 [26]:6). Vgl. ook Matth. 27:24 (... Lavit manus coram populo, dicens: Innocens ego sum a sanguine iusti huius .... ... hij waste zijn handen ten aanschowwen van het volk, en sprak: Ik ben onschuldig aan het bloed van deze rechtwaardige ....). De psalmregel (gevolgd door vs. 6-12) wordt uitgesproken bij de liturgische handwassing na de ritus van de offerande in de R.K.-eredienst (Latijnse mis), in de plechtige mis na de bewieroking van de offergaven, het altaar en de priester. In het versgedeelte bij Mattheüs is PILATUS aan het woord. De erop volgende twee versen (27:25-26) luiden: 'Heel het volk antwoordde: Zijn bloed kome over ons en over onze kinderen. Toen liet PILATUS BARABBAS vrij, maar Jezus liet hij geselen, en [hij]] gaf Hem over om te worden gekruisigd."

Zie voor het Latijn respectievelijk de onveranderlijke gebeden van de heilige misviering in een parochiemissaal on het Novum Testamentum Latine; Textum Vaticarum (...) [1906/1952], Württembergische Bibelanstalt, Stuttgart 1971 (editio undecirna). 
trappen vormen geen aparte eilanden, maar één persoonswordings-'raket." Althans in een goed functionerende, verdragsconforme (dat is: persoonswording optimaliserende) Trias pedagogica.

Deze paragraaf bestaat uit twee subparagrafen. In par. 13.2.1 wordt een korte uiteenzetting gegeven over staatsaansprakelijkheid als internationaal-/mensenrechtelijk leerstuk. Vanuit een volkenrechtshistorisch (grotiaans) kader worden enkele lijnen getrokken naar de moderne volkenrechtelijke doctrine op dit punt. In par. 13.2.2 worden vervolgens de drie algemene aansprakelijkheids-onera van de staat (preventie, interventie, reparatie) toegespitst op de (grove) schending van de rechten van het kind.

\subsubsection{Staatsaansprakelijkheid en 'allermensenrecht"}

Het suum cuique (ieder het zijne) als dwingende eis van gerechtigheid, ${ }^{7}$ ofwel mandatoir natuurrecht in enge zin - in tegenstelling zowel tot het permissieve natuurrecht ('Freies Ermessen') als tot de dwingende eisen

Voor een moderne variant van de hier bedoelde regelethiek (alsmede voor het verschill tussen deze vorm van ethiek en bestaansethiek) zie Jacques GRASTE, 'Ethiek als kritische reflectie: de Ethica van ARISTOTELES, Maandblad Geestelijke volksgezondheid $1998 / 5$, pp. 474-489, op pp. 474-475. GRASTE ontleent aan VAN ASPEREN (1988) het volgende rijtje van (grotendeels grotiaanse) regel-ethische beginselen (ta.p., op p. 475): "het respecteren van de individuele autonomie van een persoon, het afzien van geweld, het respecteren van elkaars bezit, het naleven van contracten en het spreken van de waarheid.'

Het is nuttig deze regelethiek te bezien in het licht van hetgeen CROMBAG en VAN DUN opmerken (Hans CROMBAG en Frank VAN DUN, De utopische werleiding, Amsterdam/Antwerpen 1997, pp. 28/29; zie ook a.w., pp. 70-71, 127 en 195196 over resp. 'de idee van het recht,' 'de natuurlijke rechten' en 'het objectieve natuurrecht"): "Rechtvaardigheid dunkt ons de minst fantastische, minst utopische oplossing. Zij bedient zich van vertrouwde juridische figuren als eigendom, contract en persoonlijke aansprakelijkheid, die geen goede pers hebben onder utopisten. $Z i j$ veronderstelt geen bovennatuurlijke of metafysische kennis of andere vermogens, slechts het vermogen van mensen om elkaar als soortgenoten en daarom gelijken, en tegelijkertijd als anderen en daarom zelfstandige en wrije mensen, te herkennen. Operationalisering van rechtwaardigheid vereist slechts een externe controle op het gedrag van mensen, om na te gaan of ieder van hen zich well aan het zijne houdt en zich niet eenzijdig meester maakt van anderen of van wat hun toebehoort. De organisatie van rechtvaardigheid is geen bovenmenselijke opgave, omdat het immers niet onredelijk lijkt dat ieder er tenminste in zoverre aan zal willen meewerken als zijn/haar eigen recht daardoor gewrijwaard [gewaarborgd, jw] wordt:"

Dit proefschrift is niet meer en niet minder dan een pleidooi ook kinderen - als mensen en als personen-in-wording - op te nemen in het hier kernachtig beschreven - in essentie grotiaanse - "poldermodel' van rechtvaardigheid. 
van het gezonde verstand (prudentia ${ }^{8}$ ), van redelijkheid en billijkheid (aequitas) dan wel van menselijkheid (humanitas ${ }^{9}$ ), gedrieën ${ }^{10}$ : mandatoir (doch naar positief recht veelal sanctieloos) natuurrecht in ruime zin -, kent, als historisch monument van het (grotiaanse) natuur- en vol-

Wellicht vergelijkbaar met VAN BYNKERSHOEKs ratio: zie Kinji AKASH, Comelius VAN BYNKERSHOEK: His role in the history of intemational law, Den Haag (etc.) 1998, pp. 71, 78-80 en 178-179.

9 Vgl. daarentegen VAN BYNKERSHOEKs opmerking (aangehaald door AKASH, Comelius VAN BYNKERSHOEK, a.W., p. 53 nt. 55): 'alia est humanitatis, alia juris regula."

10 Men kan zich dit wellicht het beste als drie concentrische cirkels voorstellen. De binnenste cirkell is dan het mandatoire natuurrecht in enge zin (de natuurlijke kerniechten, zo men wil: de geboorterechten van een in een georganiseerde maatschappij ter wereld gekomen mens, alsmede, per analogiam, de natuurlijke kernrechten van staten, te weten: zelfverdediging, self help en bestraffing/humanitaire interventie/collectieve dwangactie). Daarom heen laat zich de cirkel trekken van het mandatoire natuurrecht in ruime zin, naar moderne terminologie vertaald: een verplichtend (niet vrijblijvend), dat is in beginsel (c.q. op basis van fundamentele rechtsbeginselen, in het bijzonder mensenrechten) bindend soft law. Een soft law, met andere woorden, dat, woor zover het kan worden geacht voort te vloeien uit de eisen van het gezond verstand c.q. van het algemeen rechtsbewustzijn (opinio necessitatis), van redelijkheid en billijkheid dan wel van menselijkheid, op geleide van die (rechts)beginselen de (positieve) rechtssfeer binnentreedt. Als buitenste cirkel is er dan het permissieve natuurrecht, een zeer grote (men zou kunnen zeggen: met de mate van maatschappelijke organisatie uitdijende) cirkel waarbinnen moreel indifferente (dat wil zeggen niet tegelijk binnen de andere cirkels vallende) praktische of utiliteitsoverwegingen ruim baan krijgen. Met andere woorden een in meer technische zim vrije ruimte voor individuen dan wel staten. Een ruimte die met positief recht (menselijk c.q. statelijk wils-rechi) kan worden opgevuld zolang dat positieve recht het mandatoire natuurrecht (als sociaal - dat is uit de sociale natuur van de mens, zijn gemeenschapszin en gemeenschapsafhankelijkheid voortvloeiend en door sociale interactie, door bescha* vingsprocessen, dat is door de culturele evolutie van de mens gestuurde - rede recht) niet schendt. Net zo goed als op zijn beurt dat mandatoire natuurrecht geheel of gedeeltelijk kan worden - en waarschijnlijk in toenemende mate zal worden - gepositiveerd. Let wel: menselijk gedrag, waaronder het doen en laten van staten, kan naar permissief natuurrecht vrijstaan, het bevindt zich nooit aan 'gene zijde" van het recht, dat is buiten de (natuur)rechtssfeer. Recht, in welke zin of worm dan ook, van goddelijke geboden tot sociale codes en tribale mores, is dan wel niet per definitie het kenmerk van het goede, ware en schone, het is well, bijna per definitie, het kenmerk van menselijke beschaving, van menselijke samenlevingsvormen. Anders gezegd: de drie concentrische cirkels vullen bet rechts-heelal.

Vgl. voor GROTIUS' - met het bovenstaande niet c.q. niet geheel samenvallende 'concept of law': TANAKA Tadashi, "GROTUUS' concept of law," in: ONUMA Yasuaki (ed.), A nomative approach to war: Peace, war, and justice in Hugo GRoTUS, Oxford 1993, pp. 32-56, in het bijzonder op pp. 39-40. 
kenrecht, de volgende vier (eigenlijk vijf) hoekstenen: de eerbiediging van wat een ander toekomt of toebehoort, dat wil zeggen zowell respect voor eens anders lijf, eerbaarheid (lichamelijke en geestelijke integriteit) en goed (aliéni abstinentia) als een restitutie-verplichting in geval van ongerechtvaardigde toeëigening of verrijking (restitutio); de verplichting tot het - te goeder trouw (bona fide) - nakomen van zijn beloften (pacta sunt servanda); de verplichting tot billijke straftoemeting (poenae meritum); en, voor ons onderwerp van dadelijk belang: de verplichting tot herstel van door schuld (dat wil zeggen door eigen toedoen of nalaten) veroorzaakte schade (damni culpa dati reparatio). ${ }^{11}$ Het zijn deze vier (c.q. vijf) postulaten van elementaire gerechtigheid - zo men wil: juridische axioma's die in een beschavingsproces van eeuwen zijn neergeslagen (gepositiveerd, gejuridiseerd, geoperationaliseerd $)^{12}$ in ordonnanties, wetboeken, constituties en verdragen die welke vorm van menselijk samenleven dan ook - gezinnen, stammen, steden, staten, de statengemeenschap - vit de oorspronkelijke amorele - en dus wrede - natuurtoestand beogen te verheffen tot - uiteindelijk - een ideale toestand (zo men wil: een goddelijke, dat is een door God c.q. het goddelijke in de mens 'gewilde' orde) waarin het recht van de sterkste is vervangen door de rule of law, dat is een toestand van vrede en veiligheid voor allen ( $z o$ men wil: een toestand zonder geweld waarin de rechten van de mens ten volle zijn verwezenlijkt). Het behoeft hier geen nader betoog dat wij in dat beschavingsproces van eeuwen, zo niet van millennia, in dat rechtscultureel evolutionair proces als 'natuurlijke' (etiamsi daremus!) ${ }^{13}$ menselijke opdracht, eerder aan het begin dan aan het einde staan.

GRoTuUs, De jure belli ac pacis (1625), Prol. 8 (en 9-10). Vgl. (C.M. WHULEMs, "Hugo DE GROoT en het volkenrecht,' Wijgerig perspectief 1982/1983, nr. 3, pp. 66-70, ap p. 67 r.k. Zie ook B.P. VERMEULEN, G.A. VAN DER WAL; "GROTUS, AOUNAS and HOBBES; grotian natural law between lex aeterna and natural rights," Grotiana New Series vol, 16-17, 1995-1996, pp. 55-83, op p. 80 .

In die zin zijn GROTUS' (a priori) axioma's als de cultuurrechtelijke (a posteriori) grondslagen te beschouwen van vrijwel alle positiefrechteligle stelsels: vgl. FURUKAWA Terumi, 'Punishment, in: ONuMA Yasuaki (ed.), A nomative approach to war: Peace, war, and justice in Hugo Grotus, Oxford 1993, pp. 221-243, op p. 240 (tekst en) nt. 84.

13 Etiamsi daremus ... non esse Deum ... (indien wij - voor GroTrus per impossibile - zowel Gods bestaan als Zijn bestier zouden loochenen): GRoTrus, De jure belli ac pacis (1625), Prol. 11. Vgl. J.C.M. WILLEMS, 'Hugo DE GROOT en het volkenrecht, Wijggerig perspectief 1982-1983/3, pp. 66-70, op p. $67 \mathrm{r.k}$; dez., 'GroTus als filosoof,' Algemeen Nederlands Tijdschrift voor Wijsbegeerte 1983/1, pp. 49-55, op pp. 51 en 54 nt. 16. Voor een uitgebreide beschouwing zie Leonard BESSELINK, 'The impious hypothesis [etiamsi daremus] revisited," Grotiana New Series vol. 9, 1988, pp. 3-63. 
Helemaal aan de wieg van dat beschavingsproces, voor zover het het volkenrecht betreft, staat Hugo DE GROOT. ${ }^{14}$ Bij hem lezen we: ${ }^{15}$

14 Hiermee is niet in algemene zin gezegd dat GRoTIus "de' vader van het (natuurrechtelijk gefundeerde) volkenrecht is. $\mathbb{R}$ ond de wieg staan meerdere vaders. Een prominente plaats bij de wieg komt Gromus evenwell stellig toe omdat en voor zover de herleving van natuurrechtelijke elementen in het moderne volkenrecht ik doel op de (her) codificatie van de MARTENS-clausule (daterend van 1899), met haar verwijzing naar de beginselen der menselijkheid en de eisen wan het openbare rechtsbewustzijn, in art. 1, lid 2 van Additioneel Protocol I (1977) bij de Verdragen van Geneve van 1949; de opname (in 1920) van algemene rechtsbeginselen als bron van volkenrecht in art. 38 van hel Statuut van het Permanente Hof van Internationale Justitie, thans art. 38 , lid 1 onder c Statuut van het Internationaal Gerechtshof; de introductic (in 1969) van de lex superior-regel (regelhièrarchie) in het volkenrecht door plaatsing boven de andere volkenrechtsbronnen (formeel alleen boven verdragen) van een jus cogens-categorie (dwingend volkenrecht) in art. 53 van het Weens Verdragenverdrag; de vermelding (in 1970) van erga omnes-verplichtingen door het Internationaal Gerechtshof in de Barcelona Traction-zaak (Case conceming the Barcelona Traction, Light and Power Company, Limited, Second phase, par. 33 en 34); equity (justice') als natuurrechtelijke bron van volkenrecht (vgl. Peter MALANCZUK, AKEHURST's Modem introduction to international law, London/New York 1997, seventh ed. (AKERURST/ MALANCZUK), pp. 55-56), althans (naar mijn smaak) voor zover equity als het voertuig kan worden beschouwd waarmee fundamentele morele/natuurrechtelijke beginselen, opgenomen in soft law-instrumenten, de (positiefrechtelijke) rechtssfeer worden binnengeleid; (de opwatting van) mensenrechten als algemene $j u s$ naturale-rechtsbeginselen alsmede, in verband daarmee, universaliteit als onderliggend beginsell dáárvan (vgl. de dissenting opinion wan rechter TANAKA in de South West Africa cases (Second phase), International Gerechtshof 1966; zie Ian BROWNLIE (ed.), Basic documents on human rights, Oxford 1981 (second ed.), pp. 441-470, op pp. 452 sqq.); en, last but not least, staatsaansprakelijkheid erga ommes, dat is enga de internationale gemeenschap gezien als een 'society of mankind rather than of states' (humana societas), waarover hierna meer - direct in verband kan worden gebracht met de 'grotian tradition in international law' (zie Hersch LAUTERPACHT, "The grotian tradition in international law,' in: The British Yearbook of International Law 1946, pp. 1-53; herdrukt in: E. LAUTERPACHT (ed.), Intemational law, being the collected papers of Hersch LAUTERPACHT, wol. 2, Cambridge etc. 1975, pp. 307-365; vgl. ook ONUMA Yasuaki, 'Conclusion: law' dancing to the accompaniment of love and calculation," in: dez. (ed.), A normative approach to war, a.w., pp. 333-370, op p. 362).

Een promimente plaats die, hoewel de vader nooit zeker is, op vaderschap van het (natuur- en) volkenrecht, althans in elke aanvaardbare betekenis van BEDERMANs woorden, neerkomt (David J. BEDERMAN, 'Reception of the classical tradition in international law: GROTIUS' De jure belli ac pacis," in: Grotiana New Series 19951996, pp. 3-34, op p. 34 i.f.): 'GRoTrus not only created a new discipline and gave it content, he achieved a rational intellect which would direct the course of internationall relations, from his time to ours."

Zie evenwel ook ONUMA c.s., a.w.w. pp. 1, 4, 30/31, 56 en 358/359. (Met betrek- 
'I. Hierboven hebben wij gezegd dat hetgeen aan ons verschuldigd is, drie bronnen kan hebben: pactio (overeenkomst), maleficium ("[wan]daad"), lex (de wet). Over pactiones is reeds voldoende gehandeld. Laat ons nu komen tot hetgeen ons uit malefichum naar de natuur verschuldigd is. Maleficium noemen wij in dit verband elke culpa ("fout") - hetzij in handelen, hetzij in niet handelen bestaande die strijdt met hetgeen de mensen behoren te doen, hetzij in het algemeen, hetzij op grond van een bepaalde hoedanigheid. Uit een dergelijke culpa ontstaat naar de natuur een verbintenis indien daardoor dammum (schade) is toegebracht, [dat wil zeggen] een verbintenis tot vergoeding daarvan.

11.1 Het woord dammum, wellicht afgeleid van demere (Latijnse term voor "wegnemen"), is "to ellatton" (Griekse term voor "het minder zijin"), [dat wil zeggen] het geval dat iemand minder heeft dan het zijne; dit zijne kan hem toekomen hetzij alleen uil de natuur, hetzij doordat daar nog een menselijk handelen bijkomt, zoals bij eigendom of overeenkomst, hetzij uit de wet. Naar de natuur kan de mens als het zijne beschouwen [natura homini suum est]: zijn leven - wel te verstaan niet om het te vernietigen maar om het te beschermen -, zijn lichaam, zijn ledematen, zijn goede naam, zijn eer, zijn vrijheid om [binnen de grenzen van het fatsoen ${ }^{16}$ I te doen en te laten wat hij wil."

In deze omschrijving van het natuurrechtelijk suum (het zijne) van de mens kan de essentie van natuurlijke rechten ('natural rights'), ${ }^{17}$ dat is (wat wij noemen) mensenrechten, worden gelezen: recht op leven, zij het onder de verplichting dat leven te koesteren (ad custodiendum), en met ontkenning van een recht op zelfbeschikking in de zin van een recht zijn leven te verwoesten, laat staan te beëindigen (non ad perdendum), op

king tot de 20-eeuwse herleving van GROTIUS' bellum justum-doctrine, vgl. a.w., pp. $97-98$ nt. 137.)

15 H. GROTIUS, De jure belli ac pacis, 1625, II.17.1-2:1; vertaling overgenomen wit R. FEENSTRA, Vergelding en vergoeding; Enkele grepen uit de geschiedenis van de onrechmatige daad, Deventer 1982 , p. 37.

16 In het oorspronkelijke Latijn (GRoTTus, De jure belli ac pacis, 11.17.2:1) staat: Natura homini suum est vita, non quidem ad perdendum, sed ad custodiendum, corpus, membra, fama, honor, actiones propriae.' (Myjn curs., jw.) De vertaling is ontleend aan R. FEENSTRA, Vergelding en vergoeding ( $a_{*}$, p. 37). De woorden 'binnen de grenzen van het fatsoen' zijn door mij toegevoegd omdat FEENSTRA (en/of Margreet AIXSMANN: uit het "Voorwoord" blijkt niet ondubbelzinnig wie van beiden de (hoofd)vertaler is) de dubbele betekenis van propriae (zowel 'eigen' als "juist, gepast') niet heeft (heeft/hebben) verdisconteerd.

Wat proprium, gepast, is, verwijst in mijn opvatting owerigens niet naar burgermansfatsoen maar naar (burgerlijk) fatsoen in de zin wan empathie en integriteit. Beter is het daarom wellicht in dit geval te spreken van: binnen de grenzen van. (natuur)recht en moraal.

17 Vgl. B.P. VERMEULEN, G.A. VAN DER WAl, "GROTIUS, AQUINAS and HOBBes; grotian natural law between lex aeterna and natural rights," Grotiana New Series vol. 16-17, 1995-1996, pp. 55-83, op pp. 80-81. De auteurs spreken in dit verband van een "decisive break with the past" door GROTIUS (t.a.p., op p. 81). 
lichamelijke en geestelijke integriteit, op vrijheid (zij het binnen de grenzen van moraal en fatsoen), dat is op positieve vrijheid (dat is niet de wrijheid om alleen gelaten te worden, wij zouden zeggen: privacy, maar de wrijheid om te doen en te laten wat, te gaan en te staan waar men wil, wij zouden zeggen: zelfbepaling of ontplooiing). Dit evenwel terzijde.

Over de in het zojuist aangehaalde fragment verwoorde juridische visie omtrent schadevergoeding schrijft FEENSTRA: ${ }^{18}$

'De gedachte dat in het algemeen elk delict of elke onrechtmatige handeling naast eventuele strafrechtelijke gevolgen - tot een verbintenis tot schadevergoeding aan de tegenpartij moet leiden, vindt [haar] oorsprong bij de 16e eeuwse natuurrechtelijke/moraal-theologische schrijvers (leer van de "restitutio"). Zij wordt voor het eerst duidelijk in een systeem uitgewerkt door DE GROOT. In zijn De jure belli ac pacis heeft hij het beginsel als een regel van natuurrecht beschreven (zie [bovenstaande] tekst (...)); deze passage heeft grote invloed op de Europese rechtswetenschap gehad en heeft uiteindelijk geleid tot de formulering van artt. 1382-1383 Code civil, die aan artt. 1401-1402 [huidig art. 6:162 Burgerlijk Wetboek] ten grondslag ligt. In zijn Inleidinge tot de Hollandsche Rechtsgeleerdheid Igeschreven in Loevesteinse gevangenschap (1619-1621), dus vóór De jure belli ac pacis (1625), doch eerst in 1631 gepubliceerd, jw] heeft DE GROOT deze gedachte voor het Hollandse recht van zijn tijd als volgt geformuleerd: wanneer iemand tegen zijn wil door eens anders "misdaed" schade heeft geleden, ontstaat daaruit "schuld van vergoeding"."

\section{FEENSTRA vervolgt: ${ }^{19}$}

"DE GROOT omschrijft "misdaed" als "een doen ofte laten, zijnde uit zich zelve ofte door eenige wet ongeoorloft" (...). De tegenstelling tussen hetgeen "wit zich zelve" en hetgeen "door eenige wet" ongeoorloofd is, komt ongeveer overeen met het tegenwoordig wel gemaakte onderscheid tussen onrechtmatig en onwetmatig. Als voorbeelden van ongeoorloofd "uit zich zelve" noemt DE GROOT "iemand het zijne ontnemen, iemand schade of hinder toebrengen, zijn woord niet houden, zijn ambtsplicht niet vervullen en voorts al hetgeen strijdig is met de redelijkheid"; deze [de redelijkheid, jw] kan afgeleid worden uit en wordt bekrachtigd door het natuurrecht [het mandatoire natuurrecht in ruime $\left.\mathrm{zin},{ }^{20} \mathrm{jw}\right](. .$.$) .'$

Hoe is dit eeuwenoude natuurrechtelijke gedachtengoed - de leer van de restitutio (of reparatio) - uitgewerkt in de moderne internationaalrechte-

18 R. FEENSTRA, Vergelding en vergoeding; Enkele grepen uit de geschiedenis wan de onrechtmatige daad, Deventer 1982, p. 4 (curs. jw).

19 T.a.p.

20 Vgl. ten onzent, dat is in ons privaatrecht, de jurisprudentiële afleiding en bekrachtiging van met de maatschappelijke zorgvuldigheid (art. 6:162, lid 2 Bw) strijdige normen: de rechter als natuurrechtspreker. 


\section{lijke doctrine van de staatsaansprakelijkheid? Bij KOOUMANS lezen we hierover - ter introductie - het volgende: ${ }^{21}$}

"Wanneer een staat een internationaalrechtelijke verplichting [dat is een verplichting die niet langer tot de domestic jurisdiction wan de staat behoort, geen zuiver bimenlandse aangelegenheid meer is, in het bijzonder doordat zij is opgenomen in een verdrag waarbij de staat partij is, jw] geschonden heeft, is die statat daarvoor aansprakelijk. Zulk een schending kan bestaan zowel uit een handelen als wit een malaten. (...)

Een staat is echter een abstractie, die niet zelf handelt of nalaat. Wanneer kunnen we dan van staatsaansprakelijkheid spreken? Naast het feit dat er een schending van een internationaalrechtelijke verplichting is geweest, moeten we derhalve weten of die schending aan de staat kan worden toegerekend. Schending van een volkenrechtelijke verplichting en toerekenbaarheid daarvan aan de staat wormen derhalve de beide constituerende elementen van staatsaansprakelijkheid. Dat is de kern (art. 3) van de ontwerp-artikelen inzake staatsaansprakelijkheid, zoals die zijn opgesteld door de VN-Comnissie voor Internationaal Recht; (...) deze ontwerp-artikelen beogen het [internationale] gewoonterecht te codificeren.

In het ontwerp komt uitwoerig de vraag aan de orde wanneer handelen of nalaten toegerekend kan worden aan de staat. Dit geldt in de eerste plaats voor handelingen (waaronder in het vervolg ook nalaten wordt begrepen) van staatsorganen, of deze nu behoren tot de wetgevende, de uitvoerende of de rechterlijke macht. (...) [D]e staat [kan] zich niet (...) onttrekken aan zijn internationale aansprakelijkheid door zich te beroepen op het feit dat hij aldus behoorde te handelen op grond van een nationale wet (art. 4) dan wel dat hij geen inwloed kan uitoefenen op de opstelling van de onafhankelijke rechter. Ook wetgever en rechter zijn orgaan van de staat. De plaats van het orgaan in het staatsbestel is irrelevant (....). Bepalend is slechts of [betrokkenen: een politieagent, een minister, een gezinsvoogd, een kinderrechter, $j w]$ gehandeld hebben in de uitoefening van hun functie, of zij dus in de hoedanigheid van orgaan van de staat zijn opgetreden (artt. 5 en 6). (...) Slechts voor datgene wat staatsorganen buiten functie verrichten, is de staat niet aansprakelijk. Dan worden zij gelijkgesteld met particulieren en voor handelingen van particulieren kan de staat niet aangesproken worden (art. 11, lid 1). Met betrekking tot deze stelling moet evenwel de nodige voorzichtigheid worden betracht. Want door niet op te treden tegen handelingen van particulieren, kan een staat zijn eigen verplichtingen schenden (art. 11, lid 2 juncto art. 23). (....) Slechts als de staat kan aantonen dat [schadelijke handelingen wan particulieren hebben] plaatsgevonden in weerwil wan alle maatregelen die redelijkerwijs van hem konden worden verwacht, zal hij [daarvoor] niet aansprakelijk kunnen worden gesteld. Deze zorgvuldigheidsplicht van de staat wordt ook wel aangeduid met de begrippen "due diligence" of "due care"." de druk), pp. 112-113. 


\title{
Met betrekking tot het element culpa (dat we bij GROTIUS tegenkwamen) merkt BROWNLIE op: ${ }^{22}$
}

\begin{abstract}
The term culpa is used to describe types of blameworthiness [verwijtbaarheid/ vermijdbaarheid] based upon reasonable foreseeability, or foresight without desire of consequences (recklessness, culpa lata). Although culpa is not a general condition of liability, it may play an important role in certain contexts. Thus where the loss complained of [damnum] results from acts of individuals not employed by the state [bijvoorbeeld ouders, jw] (...), the responsibility of the state will depend on an unlawful omission [i.c. tot het waarmaken door de staat van zijn secundaire opvoedingsverantwoordelijkheid, jw]. In this type of case questions of knowledge may be relevant in establishing the omission or, more properly, responsibility for failure to act. This type of relevance is not necessarily related to the culpa principle. However, tribunals [denk hierbij niet alleen aan nationale of internationale rechtsprekende organen, maar ook aan het Comite inzake de rechten van het kind, jw] may set standards of "due diligence" and the like, in respect of the activities, or failures to act, of particular organs of state [i.c. in het bijzonder de regering/de wetgever, jw]. (...) [S]ince looking for specific evidence of a lack of proper care on the part of state organs is often a fruitless task, the issue becomes [in effect] one of causation [causaal verband tussen nalatigheid en schade, $j w]$."
\end{abstract}

We zullen dit (grotiaanse) ${ }^{23}$ element (culpa, en de gradaties daarvan, dat is culpa en dolus) verderop in dit hoofdstuk, onder de noemer (gebrek aan) goede trouw, betrekken op het epitheton 'systematisch' in 'ernstige en systematische mensenrechtenschendingen.' Aan het element culpa (c.q. causaliteit of causaal verband), welke zich in feite oplost in de onrechtmatigheid (met andere woorden ongeacht de vraag of c.q. in hoeverre een moreel verwijt kan worden gemaakt), zal evenwel geen nadere juridische analyse worden gewijd. ${ }^{24}$

22 Ian BRownL1E, Principles of public international law, Oxford 1990 (fourth ed.), p. 440 (curs. jw).

23 Vgl. BRowNLIE, a.w., p. 438. Vgl. ook ONUMA Yasuaki, "War," in: dez. (ed.), A nomative approach to war, a.w., pp. 57-121, op pp. 88-50.

We volstaan ermee BROWNLE's algemene conclusie te onderschrijven dat objectieve - dat is van culpa geabstraheerde - aansprakelijkheid eerder een algemeen beginsel ("de regell) in het internationale recht is (en de grotiaanse culpa-doctrine de uitzondering). En wel om zeer vallabele, namelijk praktische redenen (dat will zeggen om redenen van 'effectiveness': ut res magis valeat quam pereat), immers: 'Objective responsibility (...) provides a better basis for maintaining good standards in international relations and for effectively upholding the principle of reparation.' (BROWNLIE, a.W., p. 439.) Met een knipoog naar art. 6:162, lid 3 BW zouden we hier kunnen spreken van aansprakelijkheid (of liever toerekening) krachtens de in het internationale verkeer geldende opvattingen.

Juridische argumentatie op basis van 'effectiveness' (overwegingen van 'common sense' c.q. 'practicality and utility') is overigens - soms als a posteriori-onderbou- 
Na deze 'inleidende schermutselingen' is het zaak wat gedetailleerder op enkele aspecten van 'mensenrechtelijke' staatsaansprakelijkheid in te gaan. We doen dit aan de hand van het 'Final report' inzake restitutie, compensatie en rehabilitatie van slachtoffers van ernstige mensenrechtenschendingen uit 1993 dat VAN BOVEN als Speciale rapporteur schreef ten behoeven van de Sub-Commission on Prevention of Discrimination and Protection of Minorities van de VN-Mensenrechtencommissie. In deze studie merkt VAN BOVEN op:.$^{25}$

"IIt is generally accepted by authoritative opinion that States do not only have the
duty to respect internationally recognized human rights but also the duty to ensure
these rights, which may imply an obligation to ensure compliance with interna-
tional obligations by private persons and an obligation to prevent violations. If
Governments fail to apply due diligence in responding adequately to or in structur-
ally preventing human rights violations, they are legally and morally responsible."

Voor we op de door mij gecursiveerde elementen ('due diligence in responding adequately to or in structurally preventing') kunnen ingaan, dient eerst een meer technische volkenrechtelijke vraag te worden besproken, de vraag namelijk tegenover wie de staat aansprakelijk is indien hij, in algemene zin, te kort schiet in de naleving van zijn verplichting adequate maatregelen te nemen ter zake van het - structureel - voorkomen en bestrijden van grove ${ }^{26}$ mensenrechtenschendingen? Voor GROTIUS zou dit waarschijnlijk een minder moeilijke vraag zijn dan voor de moderne volkenrechtsjurist. Althans wanneer we ervan uitgaan - wat we zonder grote aarzeling mogen doen - dat GROTIUS (ook) deze vraag vanuit zijn algemene volkenrechtsconceptie zou beantwoorden. We citeren eerst uit VAN VOLLENHOVENS The framework of GROTIUS' book De jure belli ac pacis (1625) uit 1931 - met uitgebreide verwijzingen naar andere (meer recente) literatuur - om op basis daarvan een (summiere) naar onze tijd ver-

wing of versterking van natuurrechtelijke regels en beginselen, veelal als adstructie van 'dwingende' eisen van menselijkheid (beteugeling van oorlogsgeweld) verre van vreemd aan GRoTHUS' denken (vgl. ONUMA Yasuaki, 'Conclusion,' in: dez. (ed.), A nomative approach to war, a.w., pp. 333-370, op pp. 333-334, 340341, 355-357).

25 Study concerning the right to restitution, compensation and rehabilitation for victims of gross wiolations of human rights and fundamental freedoms; Final report submitted by Mr. Theo VAN BOVEN, Special Rapporteur, Sub-Commission on Prevention of Discrimination and Protection of Minorities [van de] Commission on Human Rights, E/CN.4/Sub.2/1993/8 d.d. 2 juli 1993, p. 16, par. 41 (curs. deels overgenomen, deels aangebracht).

26 Ernstige doch niet noodzakelijk ook systematische mensenrechtenschendingen: vgl. VAN BOVEN, Study conceming the right to restitution (...), a.w., p. 59 nt. 1. 
taalde grotiaanse volkenrechtsconceptie te beproeven (onder het kopje Allermensenrecht). Waarna we spoorslags terugkeren naar de studie van VAN BOVEN.

\section{VAN VOLLENHOVEN}

Over GROTIUS' volkenrechtsconceptie schrijft VAN VOLLENHOVEN in de Verhandelingen van de Koninklijke (Nederlandse) Akademie van Wetenschappen (1931):27

'The highest of human associations on earth is the society or family of mankind rather than: the family of nations -, embracing all human beings. The society of mankind is indicated [in De jure praedae ${ }^{28}$ and De jure belli ac pacis] by the fo]lowing names: communis societas generis humani, communis illa ex humano genere constans societas, humana societas, magna illa communitas, magna illa universitas, maior illa gentitum societas, mutua gentium inter se societas [and magna illa generis humani societas, magna humani generis societas, ${ }^{29}$ jw]. In his book of 1604 [De jure praedae] he styled it moreover illa mundi civitas, societas onbis. It is not a super-state, but a natural association of its own specific type. (.... $)^{30}$

27 C. VAN VOLLENHOVEN, The framework of GROTJus' book De jure belli ac pacis (1625), Verhandelingen der Koninklijke Akademie van Wetenschappen te Amsterdam, Afdeeling Letterkunde, Nieuwe Reeks, deel XXX, no. 4, Amsterdam 1931, pp. 11-12, par. 11-12.

28 De jure praedae (Verhandeling over het recht op buit) is geschreven tussen 1603 en 1606 (VAN VOLLENHOVEN spreekt van het boek van 1604). Eén (bewerkt) hoofdstuk hieruit (het twaalfde) verscheen in 1609 onder de titel Mare liberum (De vrije zee). Volledige uitgave van De jure praedae liet op zich wachten tot 1868 (ed. HAMAKER, Den Haag); de Nederlandse vertaling: Verhandeling over het recht op buit, verscheen in 1934 (ed. DAMSTE, Leiden); de Engelse: Commentary on the law of prize and booty, in 1950 (ed. BROWN SCOTT/WILLLAMS, Oxford). De jure praedae wordt als 'een eerste aanzet tot het grote werk van 1625, De jure belli ac pacis' beschouwd. Maar dan toch vooral als het werk van de advocaat-jurist, 'de pleitbezorger van de zaak van de Republiek' (en weldra gedoodverfd opvolger van VAN OLDENBARNEVELT), in tegenstelling tot De jure belli ac pacis, dat het werk is van de rechter-jurist, vico's generis humani jurisconsultus: 'de rechtsgeleerde van de mensheid.' (A.C. EYFFINGER, B.P. VERMEULEN, (red.), Hugo DE GROOT: Denken over oorlog en vrede, Geschiedenis van de wijsbegeerte in Nederland, deel 8, Baarn 1991, 'Inleiding,' pp. 11-40, op pp. 11-13 en 34 nt. 9.)

29 Vgl. W.J.M. VAN EYSINGA, Gids voor DE GROOTs De jure belli ac pacis, Leiden 1945, resp. pp. 1 en 2.

30 Vgl. ook H. FORTUIN, De natuurrechtelijke grondslagen van DE GROOTs volkenrecht, Den Haag 1946, pp. 193-196. Alsmede, meer recent: A.M. STUYT, 'GROTIUS: Vader des volkenrechts?' Samenvatting van een voordracht in het Verslag van de Algemene Ledenvergadering juni 1983, Mededelingen van de Nederlandse Vereniging voor Internationaal Recht $\mathrm{nr} .88$, Deventer 1984, pp. 1-7, op pp. 3-4; Benedict KINGSBURY, Adam ROBERTs, 'Introduction: grotian thought in interna- 
tional relations, in: Hedley BULL, Benedict KINGSBURY, Adam ROBERTS (eds.), Hugo GROTIUS and international relations, Oxford 1990, pp. 1-64, op pp. 5-15; Hedley BULL, "The importance of GROTTUS in the study of international relations,' in: a.w., pp. 65-93, op pp. 71-75; Peter HAGGENMACHER, 'GROTIUs and GENTIL: a reassessment of Thomas E. HOLLAND's inaugural lecture,' in: a.w., pp. 133-176, op p. 172 i.f: R.J. VINCENT, 'GROTIUS, human rights and intervention,' in: a.w., pp. 241-256, op pp. 241-242 en 252-254; Hidemi SUGANAMI, "GROTTUS and international equality, in: a.w., pp. 221-240, op pp. 223-225, 229/230, 236/237 en 237/238. Voorts: J. WIERSMA, "The grotian moment: the "pièce de résistance" in BONHOEFFER's letters and papers from prison,' Grotiana New Series vol. 12-13, 1991-1992, pp. 62-77, op p. 72; Karl-Heinz ZIEGLER, 'GROTIUS topical, or the import of antiquity into the international law of Europe,' Grotiana New Series vol. 12-13, 1991-1992, pp. 78-87, op p. 86; TANAKA Tadashi, 'GROTIUS' method: with special reference to [the] Prolegomena,' in: ONUMA Yasuaki (ed.), A normative approach to war: Peace, war, and justice in Hugo GROTIUS, Oxford 1993, pp. 11-31, op pp. 17 (nt. 29) en 19; dez., 'GROTIUS' concept of law,' in: a.w., pp. 32-56, op p. 44; ONUMA Yasuaki, 'War,' in: a.W., pp. 57-121, op pp. 108 en 117; YANAGIHARA Masaharu, 'Dominium and imperium,' in: a.w., pp. 147-173, op pp. 157/158 (nt. 65); ONUMA Yasuaki, 'Agreement,' in: a.w., pp. 174-220, op p. 209; FURUKAWA Terumi, 'Punishment,' in: a.w., pp. 221-243, op pp. 235/236; KIMURA Makoto, 'Agreements between nations: treaties and good faith with enemies,' in: a.w., pp. 308-332, op p. 328 i.f.; ONUMA Yasuaki, 'Conclusion: law dancing to the accompaniment of love and calculation,' in: a.w., pp. 333-370, op pp. 337 en 360; Martin VAN GELDEREN, 'The challenge of colonialism: GROTIUS and VITORIA on natural law and international relations,' Grotiana New Series vol. 14-15, 1993-1994, pp. 337, op pp. 11-12 en 35-37; David J. BEDERMAN, 'Reception of the classical tradition in international law: GROTIUS' De jure belli ac pacis,' in: Grotiana New Series vol. 16-17, 1995-1996, pp. 3-34, op pp. 7/8 en 32; B.P. VERMEULEN, G.A. VAN DER WAL, "GROTTUS, AQUINAS and HOBBES; grotian natural law between lex aeterna and natural rights,' Grotiana New Series vol. 16-17, 1995-1996, pp. 55-83, op pp. $75 / 76$

Vgl. ten slotte C.G. ROELOFSEN, "GROTUS and the "grotian heritage" in international law and international relations; the quatercentenary and its aftermath (circa 1980-1990),' Grotiana New Series vol. 11, 1990, pp. 6-28, op p. 8, waar de anteur bepleit de vormgeving van een internationale gemeenschap ('the shaping of an international community'; beter: 'international society"; zie de caveat van Georg SCHWARZENBERGER, 'The GROTIUS factor in international law and relations: a functional approach,' in: Hugo GROTIUS and intemational relations, a.w., pp. 301312 , op pp. 309/310) als het centralle thema in de werken van DE GROOT (niet alleen diens internationaalrechtelijke maar ook de theologische, historische, politiek-theoretische en literaire werken) te beschouwen.

Zolang er geen "full-scale modern biography" van GroTIuS bestaat, zo lijkt ROELOFSEN te beweren (t.a.p., op pp. 7/8), is dit een veiliger en vruchtbaarder weg dan een "return to the simple consideration of "Gromus the Father of International Law".' De auteur moet worden toegegeven dat dat laatste (beschouwingen over GROTIUS' geestelijke vaderschap) hooguit het resultaat, maar niet een zinvol vertrekpunt (als zodanig inderdaad 'question mal posée'; KINGSBURY/ROBERTS, 
In GROTrUs' view the counterpart of this society of mankind is a generall law of mankind, just as the counterpart of a state lies in its municipal law [and rule of law, jw]. If this correlative law either disappeared or were ignored, all security would wane.'

Dat GROTIUS in dit opzicht een universalist was, ${ }^{31}$ moge blijken uit het

ta.p., op p. 2 i.f.) van de door hem - terecht - bepleite speurtocht kan zijn. (Vgl. ook ONUMA Yasuaki, 'Introduction,' in: A nomative approach to war, a.w., pp. 1-10, op p. 1.)

31 Zie over GRoTIUS' stoische universalisme (en het ermee samenhangende morele parallellisme tussen individu/gezin(shoofd) en staat/heersers): EYFFINGER/VERMEULEN, Denken over oorlog en vrede, t.a.p., op pp. 23 (en 38 nt. 118) en 26-27; PORTUN, De natuwrechtetijke grondslagen wan DE GROOTs walkenrecht, a.w., pp. 163-226. Zie over GRoTIUS' 'universality of international society': BULL in Hugo GROTIUS and international relations, t.a.p., op pp. $80-83$.

ONUMA evenwel beschouwt GROTUU' universalisme als een Eurocentrische projectie, "nothing but the egocentric illusion of universalism prevalent in the West" (ONUMA in A nomative approach to war, a.w., pp. 4/5; zie ook pp. 6/7, 83/84 en de Appendix: 'Eurocentrism in the history of international law,' a.w, pp. 371-386; vgl. ook de bijval die ONUMA op dit punt oogst van recensent Edward GORDON in de American Joumal of Intemational Law 1995/2, pp. 461-463, op p. 463 r.k.). Daarmee lijkt hij zich te scharen in de kring van auteurs (zoals RöLING? - zie hierna) en (niet-westerse) staten die GRoTrus (wensen te) zien als 'een exponent van het kolonialisme' (STUYT, 'GROTIUS: Vader des volkenrechts?' t.a.p., op p. 6). Wat daar ook van zij (we komen er zo dadelijk op terug), het feit dat de uniwersaliteitsgedachte in GROTus' tijd, en tot op zekere hoogte tot op de dag van vandaag, gekleurd is door blanke vooroordelen, doet mijns inziens niets af aan de radicale essentie en revolutionaire betekenis ervan. Sterker nog: door het aan de kaak stellen van zulke vooroordelen, ja juist door zijn ontmaskering als illusie dat wil zeggen: als lege huls, stoïsch-grotiaans gevuld vanuit een christelijk-humanistisch referentiekader (vgl. FURUKAWA's beklag in zijn bijdrage, 'Punishment,' in A nomative approach to war, a.w., pp. 221-243, op p. 236, tekst en nt. 64; an ONUMA zelf op pp. 84 en 108 nt. 171) of, ergerlijker, modicus omkleed met gratuite westerse dikdoenerij -, wordt het universalisme, als boodschap van insluiting, versterkt.

Dat hiermee, dat wil zeggen met de radicale strekking van GROTIUS" jus fiumanae societatis, niets te veel is gezegd, kan worden geillustreerd aan de hand van SIUYTs woorden (ca.p., op pp. 5-6): "Het Stoicijnse, door DE GROOT opnieuw verdedigde jus humanae societatis heeft vooral na de tweede wereldoorlog een opmerkelijke herlewing te zien gegeven. In de eerste plaats op hel gebied van het internationale strafrecht [Neurenberg]. (...) Vervolgens hebben de American Declaration of the rights and duties of man, mei 1948, en de Universele Verklaring van de rechten van de mens, aangenomen door de Algemene Vergadering van de Verenigde Naties (met onthouding van de toenmalige Oostblok-landen) op 10 december 1948 , een nieuw wereldwijd tijdperk van de rechten van de mens ingeluid, geheel in de geest van GRoTuUs" jus humanae societatis. En tenslotte is er een nieuwe ontwikkeling gaande rondom het beginsel van "het gemeenschap- 
pelijk erfdeel der mensheid" [art. 11 Maanverdrag 1979; art. 136 juncto art. 140, lid 1 Zeerechtverdrag 1982]. Fijntjes voegt de auteur daar nog aan toe (t.a.p., op p. 6): 'In de Derde wereld schaart men zich gaarne - het klinkt paradoxaal achter de hier ontvouwde visie van DE GROOT, doch zonder hem te noemen."

Als voorbeeld van de werking van het jus humanae societatis bij GRoTIUs zelf kan gewezen worden op De jure belli ac pacis II.25.8:2-4 (in de KELSEY-vertaling uit The Classics of Intemational Law, Oxford/London 1925, p. 584): 'If (...) the wrong is obvious [si manifesta sit injuria], in case some [despotic ruler] should inflict upon his subjects such treatment as no one is warranted in inflicting, the exercise of the right vested in human society [jus humanae societatis] is not precluded. (...) If, further, it should be granted that even in extreme need [in summa necessitate] subjects cannot justifiably take up arms (..), nevertheless it will not Collow that others may not take up arms on their behalf. (...) Hence, (...) [third parties] may make war upon one who (...) oppresses his own [people] (...); a procedure which is often connected with the protection of innocent persons [defensio innocentium].' Waarbij GRomUs opmerkt dat het misbruik dat van dit humana societas-recht (humanitaire interventie) wordt gemaakt (maar al te bekend, zegt hij, uit de oude en nieuwe geschiedenis), wanneer het als dekmantel dient voor eigenbelang (alièni cupriditas), aan zijn gelding niet in de weg staat: iets houdt niet op recht te zijn als kwaadwilligen er mee aan de haal gaan. Waaraan hij laconiek toevoegt: navigant et piratae, ferro ununtur et latrones (wij bevaren de zee en smeden het ijzer, al maken van het ijzer rovers, van de zee piraten misbruik).

Als voorbeeld van manifest onrecht (manifesta injuria, wij zouden zeggen: van ernstige en systematische mensenrechtenschendingen) dat humanitaire interventie wettigt, noemt GROTIUs de vervolging van christenen. Dit heeft bij GREWE (Epochen der Volkerrechtsgeschichte 1984) tot de denigrerende (en in het licht van GROTrus ${ }^{*}$ angstvallige pogingen godsdienstgeschillen buiten het bellum justumbegrip te houden, van zijn ontkenning van de rechtmatigheid van een oorlog die heidenen tot het christendom wil bekeren, kortom zowel van de door hem betrachte secularisatie als van het feit dat voor GROTUS wolkenrecht, als allermensenrecht, dat is natuur- en volkenrecht, nu juist niet een jus Europaeum christianum is, mijns inziens onjuiste) interpretatie geleid die helaas is overgenomen in het voor studenten bedoelde boek van AKEHURST/MALANCZUK (Modem introduction to intemational law), a.w., p. 19 (vgl. ook ONUMA, a.w., Pp. 108 en 117). Hetgeen ons terugbrengt bij de smet van Eurocentrisme. Zie in verband daarmee nog ROELOFSEN, "GROTIUS and the "grotian heritage" (...),' t.a.p., op p. 10, waar de auteur opmerkt dat GROTIUS woor de ene internationaalrechtelijke jurist nog steeds "an authority to be invoked" is, en voor de andere 'one of the bad influences - indeed the bad one - which go on fashioning legal thinking in a European, i.e. "imperialistic" cultural mould.' Waaraan hij, op p. 14, sprekend over RÖLINGs 'rejection of the "grotian tradition" (p. 13 iff.), toevoegt: "In attacking GROTIUS, RÖLING was really stating once more his own dissent with what he perceived as the conservative, even obsolete traits in a still Western-dominated international legal system. In so far as this criticism was aimed at Gromus as a protagonist of European colonialism, it was (...) beside the mark, since GROTIUS did not develop a theory of colonialism. RöLING does not take into account that in GRoTiUs' time, jw] Western European (i.e. Dutch and English) collonialism was 
only in its initial, mercantile stage. (...) This consideration should have diverted ROLING's attack on "colonialism" from GRoTrus and could conceivably have led him to accuse [18th-] and [19th-]century positivists of having in fact perverted classic [stoic-grotian, jw] universalism (...)."

Hier moeten we, on GRoTTus meer recht te doen, toch op (althans) drie plaatsen in De jure belli ac pacis wijzen. Allereerst op II.20.48 (it): "Dat men niet gerechtigd is de oorlog te verklaren aan hen die het christelijk geloof niet willen aanvalarden." Zie hierover EYFTINGER/VERMEULEN, t.a.p., op pp. $23 / 24$ en $39 \mathrm{nt}$. 130, waar de auteurs opmerken: '[A]ldus stelt DE GROOT ook de meestal onder dit mom gevoerde koloniale oorlogen onder kritiek.' In de tweede plaats II.20.41, waar GROT7Us, ter adstructie van zijn waarschuwing dat wat bij vele (Europese) staten gebruik is, daarom nog geen natuurrecht is, PLUTARCHUS aanhaalt (KELSEY-vertalling, p. 507): "To wish to impose civilizaton upon uncivilized peoples is a pretext which may serve to conceal greed for what is another's.' En tensllotte II.22.9 (in de KELSEY-vertaling, p. 550): 'Equally shameless is it to claim for oneself by right of discovery what is held by another, even though the occupant may be wicked, may hold wrong views about God, or may be dull of wit. For discovery applies to those things which belong to no one." Met andere woorden: het is onrechtmatig - en zelfs schandelijk (improbum) - onder het mom van ontdekking ('terra nullius") het land van 'barbaren," "heidenen" of "wilden' te veroveren (vgl. ONUMA, a.w., pp. 81 sqq.).

Er schuilt nogal wat iromie in de constatering dat RöLING in feite zeer 'grotiaans' was in zijn verwerping van wat ONUMA (a.w., p. 109 i.f.) het "absurd" maxim fiat justitia, nut coelum [fiat justitia et pereat mundus]' noemt. Kort gezegd: in een wereld met kernwapens gaat vrede boven recht (zie B.V.A. RÔLING, Volkenrecht en vrede, Deventer 1985 , derde druk, pp. 21 e.v.). Ter illustratie van GRoTIUS' standpunt kan gewezen kan worden op De jure belli ac pacis III.25.3 (tit.): "Peace should be accepled even at a loss, especially by Christians"; en II.24.6: "Right reason teaches us that life [when a whole people is threatened with destruction] is of greater value than liberty [i.e. the right of self-determination, jw]. (...) The slaughter of a people (...) ought to be considered as the greatest possible evil.' In deze zin is ook slavernij voor Gromus een 'lesser evil' (II.24.6:2; KELSEY-vertaling, p. 573 i.f.): "And so God Himself reckons it as a benefit that He does not destroy men but casts them into slavery.' (Vgl. over GroTius' opvattingen over slavernij: ONUMA c.s., a.w., pp. 29 i.f., 143 tekst en nt. 118,150 nt. $29,210,267-268,289 /$ 290.) Zoals OUNMA opmerkt (a.w., p. 109 i.f.): "Justice for GRorrus is nothing other than justice within the framework of common sense (...)." Haaks op 'common sense' staan bloedvergieten en geweld. In een voetnoot concludeert ONUMA dan ook (a.w., p. 9 nt. 11): 'One might say that in locating the notion of justice at the centre of his system, GRoTuUs sought to overcome structural violence [systemische schending van mensenrechten, $j w]$. But when he was forced to make the ultimate decision between "justice" and "(negative) peace" [afwezigheid van fysiek geweld en bloedvergieten, jw], he did not hesitate to choose the latter." Waar ONUMA direct op laat volgen: "Yet, it might be said that for GROTUS the very act of choosing peace constituted justice."

RöLING had echter geen (open) oog (en oor) woor deze en andere aspecten van GROTIUS' bellum justum-doctrine (het is op zijn minst opmerkelijk dat ROELOF- 
SEN, t.a.p., op p. 14 bovenaan, RÖLING hierin zelfs bij lijkt te vallen), welke door GROTIUS van theologie tot recht gemaakte doctrine bij hem doordrenkt was van elementen die geweldgebruik, en de daaraan inherente escalatie, moesten voorkomen - zoals bijwoorbeeld het spes boni exitus-element, de vrijwaring van deelname aan 'hopeloos' geweldgebruik, in een op zich rechtmatige alliantie-oorlog, dat is (naar het heden vertaald) collectieve zelfverdediging of collectieve humanitaire interventie (IBP II.25.4; vgl. over dit element als aanzet voom een ethische discussie: I.C.M. WILLEMS, "GROTIUS and the atomic weapon: the nuclear weapon-discussion in the light of the theory of "just war" with Hugo DE GROOT" Grotiana New Series vol. 2, 1981, pp. 103-114, op pp. 104, 107, 108, 112); of het recht en de plicht van de individuele burger en militair bevelen niet op te volgen indien hij in gewreten overtuigd was van of zelfs maar twijfelde an de rechtmatigheid van geweldgebruik: ongehoorzaamheid is immers een minder kwaad dan doodslag, laat staan het afslachten van wele onschuldigen (JBP II.26.3:1, 5; 11.26.4:4-5; II.26.4:5-7; II.26.5; 1.4.1:3; 1.3.9:1; II.14.12:2; II.23.2; II.23.5-6; III.10.3-4; vgl. Ben VERMEULEN, 'GROTUUS on conscience and military orders,' Grotiama New Series vol. 6, 1985, pp. 3-19, op pp. 13-16; ONUMA, a.w., p. 112) -, of in het algemeen voor de progressieve elementen van de 'grotian tradition.' GRoTTUs' - of liever De jure belli ac pacis' - complexe, gelaagde normatieve structuur (ONUMA, a.W., pp. 340-341; zie ook p. 77 tekst en nt. 71 , en passim) stond immers in dienst van slechts én ideaal: het voorkomen van bloedvergieten door de beperking van oorlogsgronden (causae belli) en de beteugeling van (oorlogs)geweld (zoals door ONUMA C.s. nog eens op overtuigende wijze wordt aangetoond). De zorg voor de vrede als basisvoorwaarde voor elke menselijke vooruitgang kon voor GROTIUS, in GROTUS' tijd - dertigjarige en tachtigjarige oorlog! vandaar zijn (with the wisdom of hindsight conservatieve doch in een tijd van gruwelijke godsdienstburgeroorlogen niet al te verbazende) bijna-ontkenning (in JBP 1.4.8-14; vgl. ONUMA c.s., a.w., pp. 101-105, 108, 117, 143-144, alsook p. 9 tekst en nt. 12) van een recht op opstand aan onderdrukte volken of groepen -, geen andere vorm krijgen dan deze: het wit de kast halen van alle denkbare juridische en meta-juridische (aan de klassicken, aan de bijbel, aan de menselijke 'psychologie,' dat is aan 's mensen ten gronde sociale en redelijke natuur ontleende) argumenten die de oorlog als statelijke vrijbrief moesten uitbannen, die geweldgebruik moesten woorstellen als - uitersire - middel van rechtshandhaving en als niets anders dan dăt. Een middel bovendien waarvan vin boni, goede mannen, in het bijzonder christenen, liever af zouden zien (JBP III.25.3), en in het onverhoopte gebruik waarvan zij zich tal van beperkingen (temperamenta) zouden opleggen. In GROTIUs' eigen woorden (JBP III.25.2 iff; vert. EYFFINGER/VERMEULEN): "Geweld is iets dierlijks, dat in de oorlog het meest naar voren treedt. Daarom dienen wij er des te nawwlettender op toe te zien dat de oorlog door humaniteit gematigd wordt, om te voorkomen dat wij door al te zeer de dieren na te volgen onze menselijke waardigheid verliezen.'

Het is jammer dat dit alles woor een groot volkenrechtsjurist als RÖLING een gesloten boek was (zie ook Herman DE LANGE, 'GROTUS en de internationale betrekkingen: historisch of actueel?" Transaktie $1992 / 2$, pp. 182-189, op p. 184, waar DE LANGE zover gaat te beweren dat RÖLING GROTJUS zag als 'een theoreticus van de machtspolitiek zoals Henry KISSINGER" - iets dat in het licht van 
volgende (VAN VOLLENHOVEN 1931).32

GROTUS' consequente verwerping wan raison d'état volstrekt onbegrijpelijk is). Volgens ROELOFSEN was RÖLINGs kritiek misplaatst: hij rekende, bij wijze van gechargeerd - spreken, de uitvinder van het wiel het grote aantal verkeersslachtoffers aan, in plaats van de automobilisten, of 'het' automobilisme. Zoals ROELOFSEN zelf het - zo niet milder dan toch minder direct - uitdrukt (t.a.p., op p. 14 i.f.): '[E]ven if you reject "history," it is advisable to be aware of what it is you are rejecting."

Vgl. ook KINGSBURY/ROBERTS, ta.p., op p. 47, waar, behalve het verwijt van anachronistisch projecteren ('developments after [GROTIUs"] works were written"), tevens, voorzichtig, wordt gesuggereerd dat RÖLING grotiaanse hoofd-en bijzaken verwart. Hoe relevant is het immers of GRomus wellicht te veel - tijdgebonden/ intern-nationale (nogmaals; in een tijd van bloedige godsdienstburgeroorlogen) concessies maakte 'in seeking to articulate the principles of law which governed [the realities of power in international relations]?' Alsof dat laatste, en niets anders, althans in (volkenrechts-/ideeën-) historisch perspectief, niet the crucial issue ${ }^{3}$ is (vgl. t.a.p., nt. 166; zie ook DE LANGE, t.a.p., op pp. 185 e.v.).

Wie 'hoofd- en bijzaken' niet onderscheidt, loopt het risico Gromus op ten hoop te gooien met de piratae et latrones, piraten en rovers, machtigen en hun vleiers, die van (weelal uit het verband gerukte) delen van GroTiUs' complexe, gelaagde normatieve stelsel - waarmee hij op unieke wijze zijn 'very considerable expertise in international relations ${ }^{\wedge}$ wist te verzoenen met zijn 'dogmatic conviction of the supremacy of the law in this, as in any sphere of human activity' (vgl. KINGSBURY/ROBERTS, t.a.p., op p. 47 nt. 166) - misbruik maakten. Een (altijd mogelijk doch niet altijd even gemakkelijk) misbruik (welk sprekender voorbeeld dan de bijbel?) dat zorgvuldige en onbevangen lezing te meer de voorkeur doet verdienen boven welke vorm van wetenschappelijk ostracisme ook die geesteskinderen met het badwater weggooit. Welk weerwoord is er dan nog, buiten de barvloek? Meer concreet: een wereld met kernwapens wordt niet veiliger door grote denkers uit het verleden naar de schroothoop van de geschiedenis te verwijzen (vgl. voor de wijze war ni. 21). Ten aanzien van GROTIUS is er zelfs reden aan te nemen dat eerder het tegendeel het geval is. Want net zo min als de blote macht van wapenen en de stompe macht wan de haat mag de historische kracht wan ideeën worden onderschat. Internationaal recht en internationale betrekkingen zijn in laatste instantie niet uitsluitend een zaak van macht en machtspolitiek, doch mede van doctrine en ideeën, wan rechtsbeginselen en rechtsbewustzijn zoals deze worm krijgen in het juridisch forum en de publieke opinie (vgl. ook ONUMA, a.w., p. 8). Een jurist die die gedachte loslaat, ondermijnt de - universele - idee van recht zelf; in plaats van die idee, desnoods aan haar eigen haren, uit het moeras omhoog te trekken. De mens is immers niet voor niets, zo leert ons GROTnus èn de moderne evolutionaire psychologie (vgl. Robert WRIGHT, DARWNs geweten; Evolutionaire psychologie en het dagelijks leven, Amsterdam 1997; Matt RIDLEY, De oorsprong van de monaal, Amsterdam/Antwerpen 1997), een moreel, dat is een ten gronde sociaal en redelijk dier. In theologische termen: van alle schepselen het schepsel Gode meest dierbaar (Deo carissimum animal), zoals de slotwoorden van De jure belli ac pacis thet willen. 
"A community of all Christian states [Orbis Christianus] might even be conceived, as an inner circle of the society of mankind. (...) GROTIUS, however, disapproved of all racial discriminations between nations, whether of barbarian as against civilized nations, or of colored as against white nations, or of non-Christian as against Christian nations. (...) He advocated treaties with non-Christian peoples, took his materials and arguments from all groups of nations alike (...), considered injustice towards heathens as he considered injustice towards Christian peoples; (...) the law he advocated verily is a universal law, not one for the Christian part of the world only.'

Immers, in GROTIUS' eigen woorden.: ${ }^{33}$

'[E]t historia sacra (...) nos docet ab iisdem primis parentibus ortos homines omnes (...): Ook de bijbelse geschiedenis leert ons dat alle mensen van dezelfde voorouders afstammen.'

In het onderdeel over het jus ad bellum: het recht - of zelfs de 'dure' plicht $^{34}$ - in het uiterste geval het volkenrecht (in de zin van het recht van de humani generis societas) ${ }^{35}$ door middel van militaire dwangacties te handhaven, schrijft VAN VOLLENHOVEN: ${ }^{36}$

'It followed for GROTIUs from the existence of a society of mankind (humani generis societas) that nations and individuals [princes or rulers, $\mathrm{j} w$ ] are entitled to

VAN VOLLENHOVEN, The framework of GROTIUS" book, a.w., pp. 8-9, par. 9-10.

De jure belli ac pacis, Prol. 14 (VAN VOLLENHOVEN, a.w., p. 10 nt. 2).

De vraag in hoeverre een mens verplicht is zijn medemens, een volk een ander volk tegen onrecht te verdedigen (homo hominem, populus populum ab injuria defendere) komt aan de orde in De jure belli ac pacis II.25.7. Deze verplichting bestaat slechts voor zover er geen onevenredig groot gevaar is voor eigen leven of belangen. Vgl. ook II.25.4: er is geen militaire bijstandsverplichting voor een bondgenoot (in een verdedigings- of bestraffings-/humanitaire interventie-alliantie) als er geen goede afloop valt te verwachten (si nulla spes sit boni exitus). Een bondgenootschap wordt immers opgericht omwille van enig nut of iets goeds, niet om een groot kwaad over zich af te roepen (boni enim non mali causa societas contrahitur).

Veeleer dan staten een verplichting tot bestraffing [lees: humanitaire interventie, jw] op te leggen, stelt GROTIUs hen onder verdenking: 'Ten slotte dient dit nog vermeld, en ik zeg het voor eens en voor goed om het daarna niet meer te herhalen, dat oorlogen die ondermomen worden met het doel te straffen, onder de verdenking staan van onrechtmatigheid, tenzij de te bestraffen misdaden [lees: mensenrechtenschendingen, $\mathrm{jw}$ ] afgrijselijk en zonneklaar [atrocissima et manifestissima; men leze: ernstig en systematisch] zijn of er een bijkomende andere [rechtmatige, jw] reden voor is.' (JBP II.20.43:3; vert. EYFIINGER/VERMEULEN.) 
support an "innocent" nation against international injustice. The society of mankind - to lend the conception a modern form - has a right to protect human beings, its members. But they are not merely authorized to support an "innocent" nation against international injustice, it is ewen recommendable for them to do so. His book of 1604 [De jure praedae], which often speaks of this type of assistance, in one place called it: "to realize that one is fighting for the law of nations" (pro jure gentium pugnare).'

Als één van de bewijsplaatsen haalt VAN VOLLENHOVEN De jure belli ac pacis 11.25 .6 aan: $^{37}$

'The final and most wide-reaching cause for undertaking wars on behalf of others is the mutual tie of kinship among men [hominum inter se conjunctio], which of itself affords sufficient ground for rendering assistance (...).'

\section{Allermensenrecht}

Is het mogelijk GROTIUs' volkenrechtsconceptie, in het bijzonder zijn opvatting van het recht van de humani generis societas, te vertalen naar deze tijd - zodanig dat de eerder opgeworpen 'technische' vraag (waar we zo dadelijk, onder het volgende kopje, naar terugkeren) in een nieuw (zij het uiteraard vooralsnog 'speculatief') licht kan worden geplaatst? We wagen op deze plaats, alvast een voorschot nemend op aan het eind van dit hoofdstuk aan de conclusies toe te voegen beschouwingen, de volgende poging. Het recht van de humani generis societas, korter: het humana societas-recht (jus humanae societatis), ofwel allermensenrecht, ${ }^{38}$ kan, vanuit een modern perspectief, ${ }^{39}$ worden bezien in de dimensie van het

VAN VOLLENHOVEN, a.w., p. 84 (nt. 2). KELSEY-vertaling, p. 582.

38 Als theoretisch construct waaraan een 'universalist/cosmopolitan moral [international relations] theory" ten grondslag ligt, dat is een morele theorie (over internationale betrekkingen) volgens welke 'all human beings belong to the same moral realm (...); ; volgens welke 'we are all members of one global community or society (...).' (Nigel DowER, 'Human rights and international relations,' The International Joumal of Human Rights 1997/1, pp. 86-111, op p. 87.)

De auteur concludeert (t.a.p., op p. 109 i.f.): "The increasing tendency to talk of human rights is one of the main manifestations of the increasing acceptance [in international political discourse, $j w]$ of a universalist/cosmopolitan moral framework.' Waaraan hij toevoegt (t.a.p., op p. 110): 'The creation of a better world depends, I believe, in large part on [futher, $\mathrm{jw}]$ developing this cosmopolitan [Stoic-grotian, jw] consciousness.'

39 Vgl. in dit verband van al eerder aangehaalde literatuur met name ook KINGSBURY/ROBERTS, 'Introduction: grotian thought in international relations,' in: Hugo GROTIUS and international relations, t.a.p., op pp. 6-15; BULL, "The importance of GRoTrus in the study of international relations,' in: id., t.a.p., op pp. 8387; VINCENT, 'GROTIUS, human rights and intervention,' in: id., t.a.p., op pp. 241 - 
natuurlijk-positieve mensenrechtenrecht en in de dimensie van het positieve volkenrecht. Met opzet spreek ik van dimensies omdat het geen dichotomie betreft: het volkenrecht overlapt (grotendeels) het mensenrechtenrecht, maar terwijl in de volkenrechtsdimensie de wil van staten allesoverheersend is (zij het niet altijd en uiteindelijk niet: aan het natuurrechtelijke - zo men wil: pre-positieve - pacta sunt servanda hangt uiteindelijk alle wilsovereenstemmingsrecht op), ${ }^{40}$ is in de mensenrechtendimensie de menselijke waardigheid Grundnorm. Deze Grundnorm, de menselijke waardigheid, bestaat uit de drieëenheid gelijkheid, vrijheid - in de negatieve zin van privacy ('the right to be let alone') èn in de positieve zin van zelfbepaling en ontplooiing -, en solidariteit. Sollidariteit, of, om in evolutionair-psychologische termen te spreken: wederkerig altruïsme, ${ }^{41} \mathrm{kan}$ als de basis worden beschouwd waarop mensen, of wellicht historisch juister: gezinshoofden (GROTIUS' favoriete pater famili$a s)^{42}$ zich in grotere verbanden, en uiteindelijk in staten hebben georganiseerd. Solidariteit is immers in het lange-termijnbelang van allen, ook al gaat het tegen de korte-termijnbelangen van de sterksten in. Toenemende gelijkheid (sociale insluiting) en vrijheid (ontplooiing, emancipatie) zijn dan het historisch-logische gevolg.

Om dit met DARWIN (The descent of man, 1871) naar de - inmiddels hopelijk zeer nabije toekomst - te extrapoleren: ${ }^{43}$

'Als de menselijke beschaving voortschrijdt en kleine stammen in grotere gemeenschappen worden verenigd, zal de eenvoudigste rede elk individu vertellen dat hij zijn sociale instincten en sympathieën tot alle leden van dezelfde natie zou moeten uitbreiden, ook al kent hij ze niet persoonlijk. Als dit punt eenmaal is bereikt, belet nog slechts een kunstmatige barrière hem om zijn sympathieën tot de mensen van alle naties en rassen uit te breiden.'

Zoals het (van oorsprong stoüsche) ${ }^{44}$ denkbeeld van het allermensen-

$242,252-254$ en in het bijzonder 255/256; WIERSMA, "The grotian moment: the "pièce de résistance" in BONHOEFFER's letters and papers from prison,' Grotiana New Series vol. 12-13, 1991-1992, t.a.p., op p. 72; VAN GELDEREN, "The challenge of colonialism: GROTIUS and VTTORIA on natural law and international relations," Grotiana New Series vol. 14-15, 1993-1994, t.a.p., op pp. 11-12 en 35-37.

$40 \quad$ Vgl. EYFIINGER/VERMEULEN, Denken over oorlog en vrede, t.a.p., op p. 29.

41. Vgl. Robert WRIGHT, DARWINs geweten; Evolutionaire psychologie en het dagelijks leven (oorspr. titel: The moral animal 1994), Amsterdam 1997, pp. 204-225.

42 Vgl. ONUMA c.s. in A normative approach to war, a.w., pp. 60/61, 120 nt. $206 \mathrm{en}$ $336(-337)$ nt. 5 ; zie ook pp. 2/3, 33 i.f., 106, 128, 156-157, 171-172, 210, 290. Zie WRIGHT, DARWTNS geweten, a.w., foto-onderschrift tegenover p. 321 en p. 394.

44 Zie wan al eerder aangehaalde literatuur in het bijzonder ForTUIN, De natuurrechtelijke grondslagen van DE GROOTs volkenrecht, a.w., pp. 106-122, passim; 
recht door GROTIUS met het volkenrecht is verbonden, ${ }^{45}$ zo is dat ook het geval met GROTIUS' opvatting over de menselijke solidariteit, de sociale instincten van de mens, bij GROTIUS smakelijker: appetitus societatis, die volgens hem immers leidde tot een zorg voor de gemeenschap, de societatis custodia, die in zijn natuur- en volkenrechtsleer de bron van het natuurrecht is. ${ }^{46}$ Hoewel beschouwd als 'pre-modern' (VERMEULEN/ VAN DER WAL) ${ }^{47}$ doet deze visie eerder 'post-modern' (of liever: postpostmodern) aan. Immers, 'post-moderne' evolutionair-psychologische (genetisch gecodeerde) fenomenen als zelfbehoud/zelfbedrog (egoïsme, kortzichtig eigenbelang), ${ }^{48}$ verwantschapsselectie/broederliefde, ${ }^{49}$ 'oog om oog'/wederkerig altruïsme, ${ }^{50}$ sociale hiërarchie/vriendschap (coalities, statusjacht) ${ }^{51} \mathrm{en}$, in het verlengde daarvan ('de afstelling van de genetische knoppen'), ${ }^{52}$ het ontwikkelingspsychologische fenomeen van de gewetensvorming door angst voor (ouderlijke) afwijzing (schuldgevoelens) en/of voor uitstoting uit de (leeftijd-/lotgenoten)groep (schaamte), ${ }^{53}$

STUYT, "GROTIUS: Vader des volkenrechts?" t.a.p., op pp. 3-5; BEDERMAN, 'Reception of the classical tradition in international law: GROTIUs' De jure belli ac pacis," in: Grotiana New Series 1995-1996, t.a.p., op pp. 5-9; zie ook Arthur EYFFINGER, "Europe in the balance: an appraisall of the Westphalian system," Netherlands Intemational Law Review 1998/2, pp. 161-187, op pp. 172/173 en 186.

In de woorden van BEDERMAN ('Reception of the classical tradition in international law: GRoTIus' De jure belli ac pacis,' in: Grotiana New Series 1995-1996, t.a.p., op p. 34): "[N]o known writer of that period [classical antiquity] - not even CICERO - had undertaken the task that GROTIUS had assigned for himself. This was the creation of a self-sustaining, artificial reason [namelijk de humana societas c.q. het jus humanae societatis, het allermensenrecht, jw] for international law that could bridge the gap between moral right (natural law) and State practice (custom).'

46 De jure belli ac pacis, Prolegomena par. 8 (men leze echter ten minste par. 5-25). Vgl. VERMEULEN/VAN DER WAL, "GROTIUS, AQUINAS and HOBBES; grotian natural law between lex aetema and natural rights,' Grotiana New Series vol. 16-17, 1995-1996, t.a.p., op p. 75, waar de auteurs opmerken (curs. jw): "The source of natural law must therefore be located in the necessity of maintaining society, not only motivated by self-interest, but also inspired by an innate sociableness, a "naturall social bond and kinship" (....).' VERMEULEN/VAN DER WAL, t.a.p., op pp. (58 en) 76/77. Zie WRIGHT, DARWTNS geweten, a.w., resp. pp. 46, 49-50, passim, en 280-304, 344346, 392-393. WRIGHT, DARWINs geweten, a.w., pp. 169-195, 197, 216, 387, 393-397, passim. WRIGHT, DARWINs geweten, a.w., pp. 204-225, passim. WRIGHT, DARWINs geweten, a.w., resp. pp. 245-279 en 204-225; passim.

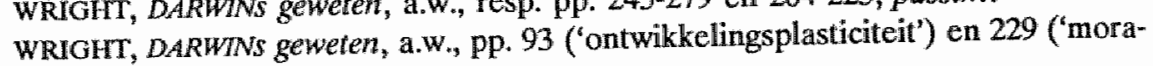
liteitsknoppen'). 
welke uiteindelijk de enige betrouwbare pijlers voor een theorie over 'de aard van de mens' kunnen zijn, vinden we in GROTIUs' 'pre-moderne' mensbeeld eerder terug dan in het '(post)moderne' HOBBESiaanse beeld van de mens als wolf voor zijn medemens (homo homini lupus) en de natuurtoestand als die van een oorlog van allen tegen allen (bellum omnium contra omnes). ${ }^{54}$

Vgl. VERMEULEN/VAN DER WAL, t.a.p. Vgl. ook FORTUIN, a.W., p. 114 i.f.: 'Tegen CARNEADES en met CICERO neemt DE GROOT stelling tegen de opvatting, als zouden de menschen slechts gedreven worden tot hetgeen hun van mut is [dat wil zeggen: door louter egoisme, jw]. Reeds zijn Mare liberum [1609] vangt in dezen geest aan: "Error est non minus vetus quam pestilens (...)".'

De door FoRTUIN (in het Latijn) aangehaalde passage verdient het wat uitgebreider (en in de huidige internationale wetenschapstaal) te worden weergegeven:

'The delusion is as old as it is detestable with which many men, especially those who by their wealth and power exercise the greatest influence, persuade themselves, or as I rather believe, try to persuade themselves, that justice and injustice are distinguished the one from the other not by their own nature, but in some fashion merely by the opinion and the custom of mankind. Those men therefore think that both the laws and the semblance of equity were devised for the sole purpose of repressing the dissensions and rebellions of those persons born in a subordinate position, affirming meanwhile that they themselves, being placed in a high position, ought to dispense all justice in accordance with their own good pleasure, and that their pleasure ought to be bounded only by their own view of what is expedient. This opinion, absurd and unnatural as it clearly is, has gained considerable currency; but this should by no means occasion surprise, inasmuch as there has to be taken into consideration not only the common frailty of the human race by which we pursue not only vices and their purveyors, but also the arts of flatterers, to whom power is always exposed.

But, on the other hand, there have stood forth in every age independent and wise and devout men able to root out this false doctrine from the minds of the simple, and to convict its advocates of shamelessness. For they showed that God was the founder and ruler of the universe, and especially that being the Father of all mankind, $\mathrm{He}$ had not separated human beings, as He had the rest of living things, into different species and various divisions, but had willed them to be of one race and to be known by one name; that furthermore He had given them the same origin, the same structural organism, the ability to look each other in the face, language too, and other means of communication, in order that they all might recognize their natural social bond and kinship." (Hugonis GROTI Mare liberum, sive de jure quod Batavis competit ad Indicana commercia dissertatio; The freedom of the seas or the right which belongs to the Dutch to take pat in the East Indian trade; A dissertation by Hugo GROTIUS, translated with a revision of the Latin text of 1633 by Ralph VAN DEMAN MAGOFFIN; edited with an introductory note by James Brown SCOTT, Carnegie Endowment for International Peace, Division of International Law, New York, London etc. 1916, ['Woord vooraf'] 'Ad principes populosque liberos orbis Christiani'/'To the rulers and to the free and independent nations of Christendom,' pp. 1-6, op pp. 1-2.) 
Ter illustratie mogen de volgende passus uit De Jure belli ac pacis (1625) dienen.

\section{Egoïsme/eigenbelang}

Bij GROTIUS vinden we geen naïeve of eenzijdige sociabiliteit: eigenbelang mag worden gediend mits de rechten van anderen niet worden geschonden: $:^{55}$

"Het is dan ook niet in strijd met het wezen van de maatschappij om voor zichzelf te zorgen en het eigen belang te dienen, zolang daarmee het recht van de ander maar niet wordt aangetast. (Non est ergo contra societatis naturam sibi prospicere, atque consulere, dum ius alienum non tollatur.)'

\section{Broederliefde, wederkerig altrü̈sme}

Men vergelijke GROTIUS' woorden met die van DARWIN, welke hierboven werden aangehaald: ${ }^{56}$

'Terecht menen zij die over de plichten van de mens geschreven hebben [CICERO, De officiis], dat niets een mens meer tot nut is dan de medemens (nihil esse homini utilius homine altero). Er zijn dan ook banden van de meest uiteenlopende aard tussen mensen, die vitnodigen tot wederzijdse steun. Immers, zo komen bloedverwanten elkaar te hulp en roepen buren en burgers onderling elkaars steun in. Maar al zouden de overige banden ontbreken, dan volstaat nog de gemeenschappelijke menselijke natuur. De mens immers is niets menselijks vreemd (ab homine enim nihil humani alienum est).'

\section{Geweten(sworming)/moraal}

Bij GROTIUS is het individuele geweten de primaire kenbron van het natuurrecht. ${ }^{57}$ GROTIUS' definitie van het natuurrecht ${ }^{58}$ laat zich bijna

JBP I.2.1:6 (vert. EYFFINGER/VERMEULEN; curs, jw). Vgl. EYTFINGER/VERMEULEN, Denken over oorlog en vrede, ta.p., op p(p). (25/)26; VERMEULEN/VAN DER WAL, t.a.p., op pp. 79-80. Zie (echter) ook ONUMA c.s., a.w., pp. 15, 26, 36-37, 47$48,56,64-66,144,240,349$.

$J B P$ 1.5.2:1-2 (vert. EYFTINGER/VERMEULEN; curs. jw). Vgl. ook VERMEULEN/ VAN DER WAL t.a.p., op p. 75 (met tal van andere bewijsplaatsen). Zie voorts FORTUIN, a.w., pp. 46 ("de mensch [is] tot samenleven geboren": MARCUS AURELIUS [121-180]), 74 ("de mensch [is] van nature sociabel': kerkvaders), 157-158 ("de natuurlijke eigenaardigheid, die den mensch door God is ingeschapen, de liefde tot zich zelf en de zucht naar gezelligheid"; "de sociabele en redelijke natuur van den mensch': GROTIUS).

VERMEULEN, 'GROTTUS on conscience and military orders,' Grotiana New Series vol. 6, 1985, t.a.p, op p. 13. Vgl. ook WIERSMA, "The grotian moment: the "piece de résistance" in BONHOEFFER's letters and papers from prison,' Grotiana New Series vol. 12-13, 1991-1992, t.a.p., op p. 63. 
lezen als een definitie van het goede geweten. ${ }^{59}$ Het geweten (wij weten thans: hoe flexibel in aanleg ook, ja juist door zijn flexibele aanleg) ${ }^{60}$ doet een constant beroep op het gezonde verstand (recta ratio) en de sociale behoeften (sociabiliteit) van de mens, twee eigenschappen waarin onze soort zich onderscheidt van andere dieren: GROTIUS' mens is een (1) met rede begiftigd, (2) sociaal (3) dier (in die volgorde). Een wezen dat, hoe primair-egoïstisch ook, verlangt naar 'een geregeld, vreedzaam en op zijn intelligentie afgestemd samenleven met zijn soortgenoten. ${ }^{.61}$ Juist en mede omdat dat zijn eigenbelang dient. Hetgeen we secundair egoïsme, of welbegrepen eigenbelang mogen noemen. ${ }^{62}$

In tegenstelling tot dat laatste kan op primair (HoBBEsiaans) egoïsme geen morele (c.q. natuurrechts)leer - althans geen leer die de wereld rationeler en socialer, minder 'dierlijk' (dat is: humaner) wil maken, ${ }^{63}$ die, in utili(tari)stische zin (John Stuart MILL), ${ }^{64}$ meer goed voor

'Het natuurrecht is een gebod van de rechte rede [dictatum rectae rationis] dat aangeeft dat een daad vanwege haar overeenstemming of strijdigheid met de redelijke $e n$ sociale natuur ['s mensen rationele gemeenschapszin c.q. wederkerig altruïsme, $\mathrm{jw}$ ] als zodanig moreel laakbaar dan wel moreel geboden is [inesse moralem turpitudinem aut necessitatem moralem], en dientengevolge [consequenter] verboden dan wel geboden wordt door God, de schepper van de natuur.' (JBP 1.1.10:1; vert. EYFFINGER/VERMEULEN; curs. jw.) Overigens worden in deze definitie de woorden cum natura rationali gebezigd;" iets verderop, in 1.1.12:1, paraisseren de woorden cum natura rationali ac sociali.

59 VERMEULEN, "GROTUUS on conscience and military orders,' t.a.p, op p. 15.

60 Vgl. WRIGHT, DARWTNs geweten, a.w., pp. 229 e.v.

61 JBP Prolegomena par. 6 (vert. EYFFINGER/VERMEULEN).

62 Zo is groepsegoïsme - ook op internationaal niveau - zo vaak zelfbedrog omdat het te veel primait (korte-termijn-) en te weinig secundair (lange-termijn-)egoistisch is. Vgl. ook JBP Proll. 18 (en 22).

63 Waarmee ik niet wil zeggen dat de mens niet zo waak lupus, wolf, is voor zijn medemens (of een calculerende/frauderende burger tegenover de overheid) dat tal van rechtsregels niet meer zijn (of lijken) dan 'gejuridiseerd wantrouwen.' En daarmee net zo banaal als het (menselijk samen)leven zelf vaak $66 \mathrm{k}$ is (c.q. lijkt). Rechtsbeginselen (natuurrechtelijke dan wel reeds/tevens gecodificeerde) zijn mijns inziens echter steeds te herleiden tot de appetitus societatis. Hun zin en strekking is immers 'de bekrachtiging van maatschappelijk belangrijk geachte waarden." Een bekrachting (dat is operationalisering, juridisering) die nimmer verhevener of banaler is dan het leven zelf. (Aanhalingen uit Carl ALEXANDER, bespr. van VAN DER BURG/IPPEL (red.), De Siamese tweeling; Recht en moraal in de biomedische praktijk (1994), in: Recht en kritiek 1997/3, pp. 267-277, op p. 273 r.k.) Anders gezegd: het recht is een sociaal (beschavings)fenomeen dat - onder meer - de anti-sociale lupus wil beteugelen, en in laatste instantie tot de (sociale) orde wil roepen; om zo - dat is: mede daardoor - de sociale appetijt voor steeds meer mensen te doen toenemen. 
meer mensen wil bewerkstelligen, en tegelijk (GROTIUS), in deontologische zin, Gode ${ }^{65}$ welgevallig is - worden gestoeld: ${ }^{66}$

'Een leer die de mens zijn medeleven met de medemens afneemt (doctrina quae hominem hominibus insociabilem facit), kan op den duur niet tot voordeel strekken - en is gehaat in de ogen van God.'

\section{Vervangen we de religieuze toon in deze melodie door een genetisch-bio-} logische (waardoor de muziek niet plotsklaps materialistisch wordt, ${ }^{67}$

Vgl. voor MILLs 'veroordeling van de naturalistische drogreden' (waarden ontlenen aan de evolutie) en zijn en DARWINs (en WRIGHTs) ethiek (waarden - het vermeerderen van geluk, lees: het verminderen van lijden en geweld in de wereld, het vermeerderen van vrijheid, gelijkheid en solidariteit - verdedigen met gebruikmaking van evolutionaire inzichten in de aard van de mens): WRIGHT, DARWINS geweten, a.w., pp. 350 (i.f.) -365 .

Het utili(tari)sme opgevat als de leer die zo veel mogelijk mensen in staat wil stellen het lijden in hun leven te verminderen voor zichzelf en hun omgeving (meestal positief geformuleerd: het bewerkstelligen van zo veel mogelijk geluk voor zo veel mogelijk mensen), kan voor deze studie vertaald worden als de leer (of het ideaal) van de persoonswordingsoptimalisatie-maximalisatie, dat wil zeggen: de maximalisatie (bewerkstelliging voor zo veel mogelijk mensen/kinderen) van optimalle persoonswording; nog anders: de maximalisatie van universele optimale rationaliteit, moraliteit en authenticiteit (dat is de maximalisatie niet alleen van universele lichamelijke maar ook van universele geestelijke gezondheid).

Of men God nu beschouwt als het - transcendente en immanente-Opperwezen, dat zich bekommert om de menselijke aangelegenheden (JBP Prol. 11, II.20.4546); als (ten hoogste) een zeker witwendig intelligent beginsel (vgl. voor de term, niet voor de betekenis, Prol. 7), een beginsel althans, woor het menselijk verstand niet te bevatten dan wel door het menselijk verstand nog niet begrepen, dat tegelijk Alpha ('oerknal': Niets is Alles) en Omega ('homeopathische eindsoep': Alles is Niets) van het Heelal, dat is van tijd/toeval en materie/energie, maar geen letter, zelfs geen jota daartussenin, is; dan well (all of niet in samenhang met het voorgaande) als menselijke projectie van het goede/goddelijke (sociale en rationele) in de mens, en dus als de opdracht in en aan de mens het beste in zichzelf na te streven, dat is goed te doen aan anderen, in het bijzonder door goed te doen waar hij of zij - ten goede - goed in is, en dat steeds te verbeteren (waardoor en waarbij een mens zich immers ook goed voelt en tegelijk iets voor een ander, of voor anderen, betekent). JBP III.25.1:3 (vert. EYFFINGER/VERMEULEN; curs. jw).

Het (mijns inziens onontkoombare) feit dat het bewustzijn en de vrije wil zijn terug te voeren tot hersenactiviteiten (mentale representaties), wil nog niet zeggen dat zij dus niet meer zijn dan dàt, dan biologie, materie-energie.

Als men - zoals WRIGHT (DARWNs geweten, a.w., p. 371; maar zie ook a.w., pp. 379-380, alsmede pp. 229 en 365) - de vrije wil een begoocheling ('illusie') acht, moet men dat mijns inziens ook doen ten aanzien van het mentale fenomeen van de ontdubbeling (het 'zelf' als subject en als object: ik/me) dat we zellfbewustzijn 
zij het wellicht in veler oren minder sonoor), dan blijkt de conclusie niet langer houdbaar dat GROTIUS' mensbeeld hem tot een pre-moderne denker maakt (in tegenstelling tot de moderne - doch in het licht van evolutionair-psychologische inzichten juist pre-moderne - denker HOBBES). We zullen RIDLEY (1997) de vertolker laten zijn van huidige genetischbiologische/evolutionair-psychologische inzichten omtrent de aard van de mens, zodat de lezer(es) die zelf aan GROTIUs" visie kan toetsen: ${ }^{68}$

'De menselijke geest is gevormd door zelfzuchtige genen, maar hij is gevormd om sociaal, betrouwbaar en coöperatief te zijn. (...) Mensen hebben sociale instincten. $\mathrm{Ze}$ komen ter wereld, toegerust met de aanleg om te leren hoe ze samen kunnen werken, hoe ze betrouwbaarheid kunnen onderscheiden van bedrog, hoe ze zelf betrouwbaar kunnen zijn, hoe ze een goede reputatie opbouwen, hoe ze goederen en informatie kunnen uitwisselen en thoe ze tot arbeidsdeling kunnen komen. In dat opzicht staan we alleen [althans op aarde, jw]. Geen enkele andere soort heeft zich tot dusver op deze evolutionaire weg begeven, want geen enkele andere soort heeft ooit een echt geïntegreerde samenleving gevormd, anders dan via de inteeltverhoudingen van een grote familie zoals een mierenkolonie. We danken ons succes als soort aan onze sociale instincten (...). (...) De menselijke samenleving en de menselijke geest zijn samen geëvolueerd, en daarbij heeft de een bepaalde ontwikkelingen in de ander versterkt en [vice versa]. Deze instinctieve coöperativiteit is (...) kenmerkend voor de mensheid en onderscheidt ons van alle andere dieren. (...)

[Echter:] hoewel we misschien het mentale vermogen bezitten om een functionele [rechtvaardige, jw] samenleving te vormen, blijkt overduidelijk dat we er niet [nog

noemen (wat WrIGHr ook lijkt te doen als hij spreekt van de illusie 'dat we ons gedrag "bewust" controleren'; in feite gaat het dan echter toch over de 'vrije wil'; zie a.w., p. 292).

Wat de vrije wil betreft: zelf ben ik van mening dat men niet tegelijk de vrije wil (c.q. het element van de zelfbepaling, naast en in principe gelijkwaardig aan de factoren genen/erfelijkheid en opvoeding/omgeving) kan ontkennen (biologisch determinisme, dat is: reductie tot biochemische processen) en kan èrkennen dat de mens (in potentie dan wel in essentie) een moreel dier is, een wezen dat - in grotiaanse termen en collectief gezien - streeft naar een vorm van zorgzaam samenleven (van steeds grotere verbanden en uiteindelijk van de grote gemeenschap van het menselijk geslacht, magna illa humani generis societas) welke in overeenstemming is met zijn verstandelijke vermogens (waarbij implicite maatschappelijk onrecht wordt opgevat als een aanfluiting van het menselijk verstand). Liever dan van een begoocheling (WRIGHTs 'illusie') spreek ik daarom van mentale representaties. Ook zonder (het geloof in c.q. de kunstgreep van) 'goddelijke imblazing' kan een mentale representatie de vitalle kracht worden toegedicht zich aan haar eigen haren omhoog te trekken. Een (menselijk) vermogen dat - en dus een vrije wil die - evenwel onmiskenbaar afneemt met de mate van (door jeugdervaringen of anderszins veroorzaakte) psychopathologie (denk aan 'ego-zwakte'). Matt RIDLEY, De aorsprong van de moraal, Amsterdam/Antwerpen 1997 (oorspr. titel The origins of virtue 1996), pp. 225-226 (curs. jw). 
steeds niet, jw] in slagen dat [vermogen] naar behoren te gebruiken. Onze samenlevingen worden geplaagd door oorlogen, geweld, diefstal, onenigheid en ongelijkwaardigheid. (*..)

Als we begrijpen hoe de evolutie ervoor gezorgd heeft dat mensen in staat zijn tot maatschappelijk vertrouwen, moeten we toch zeker het ontbreken ervan kunnen verhelpen. Door welke menselijke instituties wordt vertrouwen geschapen en door welke wordi het ondermijnd?'

Voor GROTIUS is de weg van rede en vrede ${ }^{69}$ (van sociale redelijkheid/ redelijke sociabiliteit en voorkoming, beperking en reparatie van geweld) de weg van het recht en de weg van het recht de weg van rede en vrede, al kan die weg in deze onvolmaakte wereld niet altijd een rechte weg zijn. Soms moet, om lijden te verminderen, een omweg worden gemaakt, moet van twee kwaden het minste kwaad als het goede worden gekozen. $^{70}$

Evolutionair-psychologen zouden thans zeggen: het wederkerig altruïsme (do ut des, quid pro quo, oog om oog) is de bron van de moraal. Dankzij de evolutie van het wederkerig altruïsme is de mens - n'en déplaise zijn primaire zelfzucht, wellustigheid, hebzucht (verzamelwoede) en hang naar status (met alle manipulaties, roddel en opportunistische coalities die een hogere plaats in de sociale hiërarchie moeten bewerkstelligen) een moreel - redelijk (en) sociaal - dier, in potentie zelfs een universalistisch moreel dier, die zijn gemeenschapszin uitbreidt tot de gehele menselijke soort. ${ }^{71}$

Is aldus - met GROTIUS - het allermensenrecht in de im Grunde sociale (en redelijke) natuur van de (met rede begiftigde) mens te funderen - een natuur die evenwel zeer flexibel is en zich aan 'sociale' omstan-

Zoals hij in een brief aan CRELLIUS schreef (10 mei 1631; Engelse vert. van het Latijnse orig. in: Herbert F. WRIGHT, 'Some less known works of Hugo GROTIUS, Bibliotheca Visseriana VII, Leiden 1928, pp. 131-238, op p. 208 (vgl. ook ONUMA, a.w., p. 57 nt. 1)." "In my books De jure belli ac pacis I had this particularly in view, namely, that $I$ might abate, as far as in me lay, that fierceness, unworthy not only of Christians, but even of men, for undertaking and prosecuting wars at whim - a fierceness which today I see waxing strong to the evil of so many peoples. (...)

70 Vgl. bijvoorbeeld $D e$ jure belli ac pacis 11.26 .45 . Bij twijfel aan de rechtmatigheid van de toepassing of methoden van geweld is ongehoorzaamheid (passief verzet) ten aanzien wan geweldgebruik het minste kwaad, en daarom vrij van zonde. Mocht een staat er niet in slagen ziyn onderdanen (burgers en militairen) van de rechimatigheid te overtuigen, dan kan hij hen wel extra belastingen opleggen maar geen dienstplicht, met name niet als er genoeg anderen zijn die willen dienen. Dienstweigering is dan net zo vrij van schuld als het stelen van geld van een gewetenloze woekeraar in geval van extreme armoede (JBP II.26.5:1). Vgl, WRIGHT, DARWINs geweten, a.w., p. 394. 
digheden evengoed aanpast als aan 'anti-sociale' (en aldus te meer noopt de eerste te bevorderen, de laatste te bestrijden) -, zo kan dit recht, het jus humanae societatis, als overkoepelende aanduiding van beide hierboven genoemde dimensies: de dimensie van het natuurlijk-positieve mensenrechtenrecht en de dimensie van het positieve volkenrecht worden gezien. Hoewel, zoals gezegd is, zelf geen dichotomie, kunnen beide dimensies op hun beurt wel in dichotomieën worden uitgesplitst.

De dimensie van het natuurlijk-positieve mensenrechtenrecht kan dan worden uitgesplitst in een categorie kernrechten ${ }^{72}$ (in het bijzonder - met het oog op deze studie - fundamentele of minimale persoonswordingsrechten) en in een categorie overige mensenrechten (secundaire en tertiaire - waaronder ouderlijke - rechten). De dimensie van het positieve volkenrecht kan worden uitgesplitst in een categorie positief-natuurlijk volkenrecht (algemene rechtsbeginselen, ${ }^{73}$ jus cogens-regels en -beginselen, ${ }^{74}$ erga omnes-verplichtingen, ${ }^{75}$ beginselen van menselijkheid en de eisen van het openbare rechtsbewustzijn ${ }^{76}$ ) en in een categorie positief-volitief volkenrecht (verdrags- en internationaal gewoonterecht). ${ }^{7}$

72 Een categorie kernrechten met als 'harde' kern: mensenrechten en humanitairrechtelijke beginselen met een jus cogens-/erga omnes-karakter (vgl. hierna), zoals het genocideverbod, het slavernijverbod, het martelverbod, het rassendiscriminatieverbod, het oorlogsrechtelijke discriminatie-gebod (de verplichting geen blinde wapens te gebruiken, wapens die geen onderscheid kunnen maken tussen de burgerbevolking en militaire doelen) en het verbod wapens te gebruiken die onnodig leed veroorzaken (vgl. voor het jus cogens-karakter van beide laatste de verklaring van president BEDJAOUI bij het kernwapenadvies van het Internationaal Gerechtshof; Human Rights Law Joumal 1996/7-10, pp. 269-272, op p. 271, par. 21). En dit in tegenstelling tot jus cogens-/erga omnes-regels/beginselen die zien op internationale betrekkingen, de relatie tussen staten, zoals het agressie-verbod, het verbod van kolonialisme en de jus cogens-verplichting 'of all states to co-operate in the suppression of genocide' (Yougindra KHUSHALANI, Dignity and honour of women as basic and fundamental human rights, Den Haag etc. 1982, p. 142). Art. 38, lid 1 onder c Statuut International Gerechtshof. Vgl. de dissenting opinion van rechter TANAKA in de South West Africa cases (second phase), IGH 1966; zie Ian BRoWNLIE (ed.), Basic documents on human rights, Oxford 1981 (second ed.), pp. 441-470, op pp. 452 sqq. (zie hierna).

74 Art. 53 Weens Verdragenverdrag (1969).

75 Barcelona Traction-zaak (Case concerning the Barcelona Traction, Light and Power Company, Limited, Second phase, IGH 1970), par. 33 en 34.

76 DE MARTENS-clausule (1899), laatstelijk art. 1, lid 2 Additioneel Protocol I (1977) bij de Verdragen van Genève van 1949.

77 Vgl. ten aanzien van de drie bronnen van het internationale recht in art. 38 van het Statuut van het Internationale Gerechtshof: verdrag, gewoonte en rechtsbeginselen, rechter TANAKA, dissenting opinion, t.a.p., op p. 456: 'From a positivistic, voluntaristic viewpoint, first the convention, and next the custom, is considered important, and general principles occupy merely a supplementary position. On 
the contrary, if take the supra-national objective viewpoint, the general principles would come first and the two others would follow them. If we accept the fact that convention and custom are generally the manifestation and concretization of already existing general principles, we are inclined to attribute to this third source of internationall law the primary position vis-d-vis the other two."

In de opvatting van TANAKA, die door mij wordt gedeeld en die ten grondslag ligt aan deze studie, zijn aan sommige rechtsbeginselen, in het bijzonder de rechten van de mens, 'natural law elements (...) inherent' (t.a.p., op p. 454). Internationaalrechtelijke rechtsbeginselen hebben in zijjn visie of een jus gentium-karakter: hun praktisch juridisch nut is bewezen gedurende vele eeuwen en zij komen bijgevolg voor in (nagenoeg) alle rechtsstelsels, of een jus naturale-karakter: zij overstijgen de wil van staten (hebben dan ook een jus cogens-karakter) omdat zij diep geworteld zijn 'in the conscience of mankind and of any reasonable man' (t.a.p.). Blijkens de travaux préparatoires is art. 38 Statuut IGH (oorspronkelijk ontworpen voor het Permanente Hof van Internationale Justitie en ondertekend in 1920) het resultaat van een compromis dat de verwerping inhoudt wan de positivistische doctrine ( $t .$. a.p., op pp. 454/455). Natuurrechtelijke rechtsbeginselen (in het bijzonder de rechten van de mens) behoren dan ook een belangrijke rol te spelen in filling in gaps in the positive sources in order to avoid nonliquet decisions' (t.a.p.).

Daarnaast en daarenboven evenwel dienen zij steeds de toetssteen van het positieve recht te zijn. Wellicht ligt hier ook het belangrijkste praktische verschil tussen natuurrechtsdenken en rechtspositivisme. Zijn (gecodificeerde) rechtsbeginselen voor het rechtspositivisme slechts een marginaal fenomeen (aanvulling, hulpmiddel bij interpretatie), in het moderne natuurrechtsdenken (c.q. cultuurrechtsdenken, dat is de natuurrechtsconceptie waarbij aan a posteriori-bewijs een belangrijkere plaats toekomt dan aan a prori-'bewijs' (zoals feitelijk bij GRoTIUs; vgl. EYFFINGER/VERMEULEN, Denken over oorlog en wrede, t.a.p., op pp. 21-23), dan well de mogelijkheid van dat laatste wordt ontkend; kortom waarbij het waardenrealisme wordt gerelativeerd, er wel eeuwenoude maar geen eeuwige en eeuwig-onveranderlijke waarden zijn) staan rechtsbeginselen centraal: als rechts(vindings)bron die 'non liquets' witsluit, èn als kritische toetssteen.

Aangezien vrijwel alle rechtsbeginselen zijn gecodificeerd (dan well in bestaande rechtsbeginselen kunnen worden ingelezen, zoals het recht op persoonswording), lijkt het belangrijkste theoretische verschil tussen rechtspositivisme en naturur-/ cultuurrechtsdenken (het al of niet erkennen van de band tussen moraal c.q. rechtvaardigheid en recht) thans minder relevant. Dat op het eerste gezicht louter theoretische verschillen (iemands houding of gezindheid ten opzichte van de idee van recht) toch belangrijke praktische consequenties kunnen hebben, blijkt wel uil het advies wan het Internationaal Gerechtshof inzake de rechtmatigheid van kernwapens, dat uitloopt op een non liquet (the Court cannot conclude definitively whether the threat or use of nuclear weapons would be lawful or unlawful in an extreme circumstance of self-defence, in which the very survival of a State would be at stake; Legality of the threat or use of nuclear weapons, ICJ, Advisory opinion, 8 July 1996, par. 105 sub 2E, tweede volzin; HRLJ 1996/7-10, pp. 253-269, op p. 269 1.k. iff.) dat een juridische bres slaat in een vrijwel volledige onrechtmatigverklaring (waar dan de stoplap van de ontwapeningsonderhandelingsresultaats- 
Tegen deze achtergrond is staatsaansprakelijkheid ter zake van mensenrechtenschendingen beter te plaatsen, namelijk als inbreuk op het allermensenrecht, dat tegelijk het fundament is van en zich welft over het (algemene) volkenrecht (als mede omvattende het mensenrechtenrecht). Aangezien het allermensenrecht (als theoretisch construct) kan worden bezien in dimensies die niet uitsluitend uit volitief (statelijk wilsovereenstemmings)recht bestaan - Grundnorm van de ene dimensie is immers de menselijke waardigheid, Grundnorm van de andere dimensie het pacta sunt servanda, Grundnorm van beide dimensies, en daarmee van het allermensenrecht zelf, de societatis custodia, de rationele gemeenschapszin en -zorg, als (sociaal-psycho)logisch sequeel van de appetitus societatis, de redelijk(e en) sociale menselijke ("gezelligheids"-/'gezelschaps'-)natuur (op grond waarvan mensen vreedzaam willen samenleven, als betrouwbaar persoon, dat is: respectvol, behandeld willen worden, ${ }^{78}$ en dus de menselijke - intern-nationale en internationale - samenleving zo vreedzaam en respectvol mogelijk willen inrichten) -, kan het voorgaande tevens worden gezien als een (hoogst noodzakelijke) nuancering van wat KOOIJMANS noemt "het dominante beginsel dat een staat internationaal slechts verplicht wordt krachtens zijn toestemming. ${ }^{79}$ Een nuancering die als volgt is verwoord door rechter BEDJAOUI: ${ }^{80}$

verplichting in wordt geduwd). Het advies kan als een treffende illustratie worden beschouwd van de dominante positie van het rechtspositivisme in het internationale recht (vgl. AKEHURST/MALANCZUK, a.w., pp. 15-17 en 32; alsook pp. 50 en 348/349; Richard A. FALK, 'Nuclear weapons, international law and the World Court: a historic encounter,' Editorial comment, American Joumal of Intemational Law 1997/1, pp. 64-75, op pp. 66, 68, 70-73), dat wil zeggen van de (gezien de ontwikkelingsfase van het internationale recht op zich begrijpelijke) aarzeling van de internationaalrechtelijke jurist (gecodificeerde en wrijwel universeel aanvaarde) rechtsbeginselen (fundamentele mensenrechten, elementaire humanitairrechtelijke beginselen, jus cogens, enga omnes-verplichtingen) centraal te stellen en kritisch toe te passen (FALK, t.a.p., op p. 66) - ook tegen de wil en korte-termijnbelangen van machtige staten en hun bondgenoten in.

78 Vgl. over de psycho-evolutionaire ontwikkeling hiervan WRIGHT, DARWNS geweten, a.w., pp. 282 e.v., 290 e.v.; RIDLEY, De oorsprong van de moraal, a.w., p. 225. We zouden kunnen zeggen: om de indruk van betrouwbaarheid te wekken, en zo te kunnen ruilen en handelen, dus om morele (een redelijke en socialle) indruk te maken en zo respect af te dwingen, teneinde als mens te overleven, hogerop te komen (in de statushièrarchie) en sex te hebben (zich voort te planten), is de neocortex nodig als orgaan dat de projectie (mentale representatie) die we het zell noemen, mogelijk maakt.

79 P.H. KOOUMANS, Intemationaal publiekrecht in vogelvlucht, Groningen 1996 (zesde druk), p. 29.

80 Verklaring wan president BEDJAOUt bij het kernwapenadvies van het Internationaal Gerechtshof (1996); Human Rights Law Joumal/HRLJ 1996/7-10, pp. 269- 
"Despite the still limited emergence of "supra-nationalism," the progress made in terms of the institutionalization, not to say integration and "globalization," of international society cannot be denied. Witness the proliferation of international organizations, the gradual substitution of an international law of co-operation for the traditional international law of co-existence, [and] the emergence of the concept of "intemational community" (...). A testimony to all these developments is provided by the place which international law now accords to concepts such as obligations erga omnes, rules of jus cogens, or the common heritage of mankind. The resolutely positivist, voluntarist approach to international law which still held sway at the beginning of the century (...) has been replaced by an objective conception of international law, a law more readily seen as the reflection of a collective juridical conscience and as a response to the social necessities of States organized as a community.'

Op het belang van deze nuancering (en daarmee van het construct van het allermensenrecht) voor de conclusies van dit hoofdstuk komen we na het trekken van die conclusies, dus aan het eind van dit hoofdstuk, terug. ${ }^{81}$

\section{VAN BOVEN}

We keren - spoorslags, hadden we beloofd - terug naar de vraag tegenover wie de staat aansprakelijk is. Anno 1993 lezen we daarover bij VAN BOVEN wat VAN VOLLENHOVEN wellicht een 'terugkeer naar GROTIUS' zou noemen, doch wat in elk geval als het evolutionair-logisch sequeel van GROTIUS' conceptie kan worden opgevat: ${ }^{82}$

"The question now arises towards whom States are responsible when they breach their human rights obligations under international law. In traditional international law the offending State carries responsibility for its conduct vis- $\alpha$-vis the injured State at the inter-State level. This means in terms of human rights that it is at matter of State responsibility if a State causes injury to a national of another State inasmuch as the offending State violates internationally recognized human rights which the State is bound to respect and ensure with respect to all persons. In traditional intermational law the subject who has suffered the injury is not the individual person, or for that matter a group of persons, but the State of which the person or the group of persons is [a] or are national(s). It is in this perspective that States may claim reparation from the offending State but the victims themselves have no standing to bring international claims."

272, op p. 270 , par. 13 (curs. overgenomen).

Aan deze verklaring dient een bijzonder gewicht te worden toegekend aangerien BEDJAOUI als president de doorslaggevende voorzittersstem gaf bij het staken van de stemmen (zeven tegen zeven) bij de 'non liquet'-uitspraak van het Hof. Zie in het bijzonder par. 13.4.2 onder De taak varl de jurist.

82 VAN BOVEN, Study conceming the right to restitution (...), a.w., p. 16, par. 42 (curs. jw). 
VAN BOVEN verwijst vervolgens naar het werk van de ILC (International Law Commission). Ingevolge art. 40, lid 2 onder e (iii) van de ILC-ontwerp-artikelen inzake staatsaansprakelijkheid ${ }^{83}$ is in geval van schending van een mensenrechtelijke verplichting door een staat elke andere staat die partij is bij het desbetreffende mensenrechtenverdrag, als gelaedeerde staat ('injured State') aan te merken. ${ }^{84}$

Hieruit kan worden afgeleid dat, ongeacht de nationaliteit van de slachtoffers, elke andere verdragsstaat als gelaedeerde partij voor die slachtoffers in het strijdperk kan treden. Dit betekent dat Nederland in geval van nalatigheid of onzorgvuldigheid (tekort aan due diligence) ter zake van de naleving van verplichtingen onder het Verdrag inzake de rechten van het kind ter verantwoording kan worden geroepen door 190 'gelaedeerde' staten, dat wil zeggen door op twee na - Somalië en de Verenigde Staten $^{85}$ - alle staten van de wereld (met inbegrip van, orm maar enkele te noemen: Vaticaanstad, China, Indonesië, Brazilië, Suriname, België, Rwanda, Irak, Kiribati, Mali, Papoea Nieuw-Guinea, Turkije, Bosnië-Herzegowina, Cambodja, Libië, Saoedi-Arabië, Cuba, NoordKorea, Frankrijk, Mongolië, Micronesië ...). Het Verdrag inzake de rechten van het kind kent inmiddels immers - ruim zeven jaar na zijn aanvaarding door de Algemene Vergadering van de Verenigde Naties - 191 aangesloten staten. 86 Daarmee is het niet alleen - formeel, uitwendig het meest succesvolle verdrag uit de wereldgeschiedenis, doch tevens een uniek bijna-universeel verdrag. Slechts het geen partij zijn van Somalië en de Verenigde Staten (bien étonnés de se trouver ensemble?) belet het pre-

83 Zie evenwel het caveat van MALANCZUK (Peter MALANCZUK, AKEHURST's Modem introduction to intemational law, London/New York 1997, seventh ed., p. 272 iff.) ten aanzien van de juridische status van het onderhavige deel van de ILC-ontwerpcode (vgl. Report of the Intemational Law Commission on the wark of its farty" eighth session, UN doc. A/51/10 (1996); zie hierover: Robert ROSENSTOCK, "The forty-eighth session of the International Law Commission,' American Joumal of Intemational Law/AJIL. 1997/2, pp. 365-374).

84 Vgl. VAN BOVEN, Study concening the right to restitution (...), a.w., p. 17, par. 43.

85 De vs (die het Verdrag op 16 februari 1995 heeft ondertekend) en Somalië zouden zich natuurlijk wel op de quasi-universele gelding van het Verdrag kunnen beroepen om te betogen dat diverse verplichtingen onder het Verdrag de status van internationaal gewoonterecht moet worden toegekend. En op basis daarvan Nederland op de vingers kunnen tikken. Daarmee zouden zij dan wel gewoonterechtelijke binding óok voor zichzelf erkennen. Zodat Nederland dadelijk met het vingertje zou kumnen terugwijzen. Zie ook hierna (Barcelona Traction-zaak).

Zwitserland ratificeerde als $190 \mathrm{e}$ staat het Verdrag op 24 februari 1997 (hetgeen betekent dat het Verdrag voor Zwitserland op 26 maart 1997 in werking is getreden); de Cookeilanden traden op 6 juni 1997 als $191 \mathrm{e}$ staat tot het Verdrag toe (zie Tractatenblad 1998, nr. 62, pp. 1 en 6). 
dikaat universeel onverkort op het Verdrag van toepassing te achten.

We kunnen hierin, dat wil zeggen in de opvattingen van de $\mathrm{LC}_{\text {, }}$ een ontwikkeling in de richting van voortschrijdende collectivisering ontwaren. Zo rekent art. 40 , lid 3 van de ILC-ontwerp-code 'all other States,' alle andere staten: de gehele statengemeenschap met andere woorden, ${ }^{87}$ tot 'injured State' in geval van internationale misdrijven (zoals - ingevolge art. 19, lid 3 onder c - slavernij en genocide). VAN BOVEN stelt in dit verband: 88

"The identification of collective aspects of State responsibility as evidenced in the drafting work of the International Law Commission is in consonance with the growing trend in international human rights law that State responsibility under multilateral human rights treaties or under customary law of human rights is not only due to the "injured State" but to the community of nations. This was also the underlying principle in the opinion of the European Commission of Human Rights when it held that a State party to the European Convention on Humarn Rights claiming a violation of the Convention is not enforcing its own rights, or the rights of its nationals, but vindicating the public order of Europe (...).'

'[H]et rechtsbelang van de statengemeenschap als geheel is aangetast,' schrijft KOOUMANS in navolging van het Internationaal Gerechtshof (Barcelona Traction-zaak), ${ }^{89}$ in geval van de schending van verplichtingen die de staat heeft tegenover alle andere staten: erga omnes-verplichtingen. We zouden kunnen zeggen: internationaal-constitutionele verplichtingen. Hieronder worden (ook) regels van dwingend recht (jus cogens) gerekend, 'al houden,' aldus nogmaals KOOMMANS, 'de begrippen dwingend recht en enga omnes-verplichtingen niet per definitie hetzelfde in. ${ }^{90}$

Zoals we al eerder zagen, wordt door gezaghebbende auteurs (gezaghebbend in de zin van art. 38, lid 1 onder d van het Statuut van

87 Uiteraard laat 'aansprakelijkheid tegenover de statengemeenschap' zich niet zonder meer vertalen als 'aansprakelijkheid tegenover de humana societas,' dat is: in de allermensenrechtsorde. Statengemeenschap (society of states) en allermensenrechtsorde (society of mankind) vallen - overigens ook bij GROTIUS - niet samen. De laatste hebben we als theoretisch construct voorgesteld dat kan worden bezien, c.q. hetwelk 'zichtbaar' wordt, in twee dimensies van 'internationale rechtsorde': een volkenrechtelijke en een mensenrechtelijke. VAN BOVEN, Study concerning the right to restitution (...), a.w., p. 17, par. 44 (curs. jw).

89 KOOLMANS, Internationaal publiekrecht in vogelwlucht, a.w., p. 142 iff.

90 KoOIJMANS, t.a.p. (Vgl. in dit verband ook MALANCZUK/AKEHURST, Modern introduction to international law, a.w., pp. 57-60; BROWNLIE, Principles of public international law, a.w., pp. 512-515; en Henry J. STEINER, Philip ALSTON (eds.), Intemational human rights in context; Law, politics, morals, Oxford 1996, p. 147 onder $n$ en $o$.) 
het Internationaal Gerechtshof) het verbod van onmenselijke en vernederende behandeling en bestraffing (vgl. art. 3 EVRM, art. 7 IVBPR, art. 37 onder a, eerste volzin juncto art. 19 VRK), welk verbod we de (positiefrechtelijke) bodembepaling van het (kern)recht van het kind op minimale persoonswording hebben genoemd, als norm van dwingend volkenrecht (jus cogens), in de zin van art. 53 van het Verdrag van Wenen inzake het verdragenrecht (Weens Verdragenverdrag), aangemerkt. ${ }^{91}$ Alleen hartstochtelijke rechtspositivisten wachten in dezen nog op een uitspraak van het Internationaal Gerechtshof. Uiteraard heeft de staat ten aanzien van onmenselijke behandeling (c.q. kindermishandeling) door particulieren (c.q. ouders) ook een (uiterste) due diligence-verplichting.

Ook VAN BOVEN haalt de Barcelona Traction-zaak aan: $:^{92}$

'The underlying principle that State responsibility under multilateral human rights treaties entails obligations wis-à-vis the collectivity or community of nations that are bound to respect and ensure the rights enshrined in those treaties, may also be considered applicable when the obligations derive from customary international law of human rights, in conformity with the language of the Barcelona Traction Judgment of the Internationall Court of Justice, where the Court declared that all States have the right to vindicate erga omnes obligations. As the Court stated: "(...) an essential distinction should be drawn between [the] obligations of a State towards the international contmunity as a whole [curs. $\mathrm{jw}$, and those arising vis-dvis another State in the field of diplomatic protection. ${ }^{93}$ By their very nature the former are the concern of all States. In view of the importance of the rights involved, all States can be held to have a legal interest in their protection; they are obligations enga omnes. Such obligations derive, for example, in contemporary international law, from the outlawing of acts of aggression, and of genocide, [as] also from the principles and rules concerning the basic rights of the human person [curs. jw], including protection from slavery and racial discrimination. Some of the corresponding rights of protection have entered into the body of general international law (...); others are conferred by international instruments of a universal or quasi-universal character."

It can be concluded that when a State breaches an obligation erga ommes, it injures the international legal and public order as a whole and consequently every

91 MURPHY gewaagt zelfs van een 'general consensus today' welke 'torture' (art. 5 Universele Verklaring, art. 7 rVBPR) tot de internationale misdrijven rekent: John F. MURPHY, 'International crimes,' in: Chr.C. JOYNER, The United Nations and international law, Cambrigde 1997, pp. 362-381, op p. 371.

92 VAN BOVEN, Study concerning the right to restitution (...), a.w., pp. 17/18, par. 44 (vervolg).

93 Diplomatieke bescherming is het opkomen - uit eigen recht - doar de staat voor zijn onderdanen in den vreemde (uit hoofde van staatsaansprakelijkheid ter zake van de behandeling van vreemdelingen), zoals hierboven door VAN BOVEN beschreven (a.w., par. 42). (Vgl. ook KOOUMANS, a.w., pp. 114-117; MALANCZUK/ AKEHURST, a.w., pp. 256-269.) 
State may have a right and an interest to bring an action against the offending State."

'The international legal and public order as a whole': ziedlaar wat GROTIUS verstond onder 'internationaal' recht: het recht van magna illa generis humani societas. Het handhaven van die allermensenrechtsorde, dat wil zeggen: het opkomen tegen grove mensenrechtenschendingen, schendingen van mensenrechtelijke erga omnes-verplichtingen, schendingen met name op grote schaal - van 'the basic rights of the human person," is het recht (en de grotiaanse plicht) ${ }^{94}$ van elke staat. Om de woorden van rechter JESSUP (separate opinion, South West Africa-zaken, 1962) ${ }^{95}$ te gebruiken: bij de bescherming van 'general interests of mankind' hebben alle staten een rechtsbelang. Dit geldt te meer waar het gaat om de bescherming van de 'sacred trust of civilization'96 par excellence: the basic rights of the human person, de fundamentele of kernrechten van de mens, (in het bijzonder) de rechten die de veiligheid van de persoon en de bescherming van diens lichamelijke en geestelijke integriteit betreffen (rechten die we ten aanzien van kinderen fundamentele of minimale persoonswordingsrechten genoemd hebben). VAN BOVEN concludeert: ${ }^{97}$

'It may therefore be assumed that the concept of State responsibility for breaches of internationally recognized human rights standards has legal implications with

Vgl. in dit verband echter (naast de verplichtingen woor staten welke kunnen voortwloeien wit het optreden van de Veiligheidsraad van de Verenigde Naties onder hoofdstuk vII van het Handvest van de VN) ook art. 53 aanhef en onder d (iuncto art. 19, lid 2 en lid 3 aanhef en onder c) van de ILC-draft articles on State responsibility.

Art. 19, lid 2 en lid 3 aanhef en onder c luidt:

2. An internationally wrongful act which results from the breach by a State of an international obligation so essential for the protection of fundamental interests of the international community that its breach is recognized as a crime by that community as a whole constitutes an international crime.

3. Subject to paragraph 2 , and on the basis of the rules of international law in force, an international crime may result, inter alia, from:

c. a serious breach on a widespread scale of an international obligation of essential importance for safeguarding the human being [curs. jw], such as those prohibiting slavery, genocide and apartheid.

Art. 53 aanhef en onder d luidt (curs. jw):

An international crime committed by a State entails an obligation for every other State: (...) d. to cooperate with other States in the application of measures designed to eliminate the consequences of the crime. 
respect to the "injured State" in the traditional sense [diplomatic protection -jw] and, as the case may be, all other States participating in a legal order created by a multilateral human rights treaty - to the extent that rights and interests of all these participating States may be "injured" - and with respect to the entire international community, in particular when the offending State has breached human rights obligations which are of an enga omnes character.'

Een logische vervolg-vraag betreft het jus standi in judicio (in ruime zin: zijn recht kunnen halen, tot zijn - internationale - recht kunnen komen) van het individu. ${ }^{98}$ VAN BOVEN vervolgt: ${ }^{99}$

\begin{abstract}
'Another aspect of the question [towards whom States are responsible] is whether State responsibility not only comes into play with respect to States participating in the international legal order but also more directly with respect to persons within the jurisdiction of the offending State whenever these persons are the victims of violations of internationally recognized human rights committed [by commission or omission, jw] by that State. As regards human rights treaty law, the InterAmerican Court [of Human Rights] left no doubt that the American Convention on Human Rights envisages essentially the protection of individuals and that State responsibility prevails in their interest. In an advisory opinion the InterAmerican Court held: "(...) modern human rights treaties in general, and the American Convention in particular, are not multilateral treaties of the traditional type concluded to accomplish the reciprocal exchange of rights for the mutual benefit of the contracting States. Their object and purpose is the protection of the basic rights of individual human beings, irrespective of their nationality, both against the State of their nationality and all other contracting States. In concluding these human rights treaties, the States can be deemed to submit themselves to a legal order within which they, for the common good, assume various obligations, not in relation to other States, but towards all individuals within their jurisdiction (....)."

It may therefore be stated that the obligations resulting from State responsibility for breaches of international human rights law entail corresponding rights on the part of individual persons and groups of persons who are under the jurisdiction of the offending State and who are victims of those breaches. The principal right these victims are entitled to under international law, is the right to effective remedies and just reparations.'
\end{abstract}

Dit brengt ons bij het onderwerp van onze tweede (sub)paragraaf: de tria onera paedagogica (de drie dure plichten c.q. trappen van staatsaanspra-

In strikte zin gaat het hier om 'procedurele middelen' van het individu. Vgl. in dit verband de interventie van VAN BOVEN in de NVR: Mededelingen van de Nederlandse Vereniging voor Internationaal Recht 116 (Verslag van de Algemene Ledenvergadering, bespreking der preadviezen van M.T. KAMMINGA en L.A.D. KEUS, Stadsaansprakelijkheid jegens individuen: beginselen en procedures), Deventer 1998, pp. 4-6, op p. 5 . 
kelijkheid met betrekking tot de rechten van het kind, dat is in de Trias paedagogica).

\section{2 .2}

De tria onera paedagogica: preventie, interventie, reparatie

Staatsaansprakelijkheid kan - evenals de privaatrechtelijke onrechtmatige daad (ten onzent: art. 6:162 BW) ${ }^{100}$ - worden opgevat als een medaille, dat wil zeggen als een voorwerp of onderwerp met twee kanten. Aan de ene kant vinden we de onrechtmatigheid (de rechtsinbreuk) en de toerekenbaarheid daarvan, aan de andere kant de verplichting tot schadevergoeding. Over deze keerzijde van de medaille ${ }^{101}-$ en de gelaagdheid

100 Art. 6:162 BW luidt:

1. Hij die jegens een ander een onrechtmatige daad pleegt, welke hem kan worden toegerekend, is verplicht de schade die de ander dientengevolge lijdt, te vergoeden.

2 . Als onrechtmatige daad worden aangemerkt een inbreuk op een recht en een doen of nalaten in strijd met een wettelijke plicht of met hetgeen volgens ongeschreven recht in het maatschappelijk verkeer betaamt, een en ander behoudens de aanwezigheid van een rechtwaardigingsgrond.

3. Een onrechtmatige daad kan aan de dader worden toegerekend, indien zij te wijten is aan zijn schuld of aan een oorzaak welke krachtens de wet of de in het verkeer geldende opvattingen voor zijn rekening komt.

101 Strikt genomen is alleen de verplichting tot reparatie rechtsgevolg, namelijk van de schending van de verplichting tot (tijdige en adequate) interventie (tijdig opleggen van adequate opvoedingshulp/-maatregelen); of liever van de schending van de verplichting tot (adequate) preventie (adequate opvoedingsvoorbereiding, -begeleiding/-bewaking en -ondersteuning). Alle drie kunnen evenwel zowel als primaire verplichtingen van de staat onder het Verdrag inzake de rechten van het kind worden beschouwd (als constitutionele kernverplichtingen in de Trias pedagogica, welke in verschillende verdragsbepalingen hun rechtsgrond hebben), doch evenzeer worden opgevat - uitgaande van de huidige situatie waarin er sprake is van langjarige, hardnekkige en bijzonder omwangrijke schendingen van elementaire persoonswordingsrechten met vrijwel de gehele maatschappij, de overheid incluis, als toeschouwer - als vallende onder reparatie in ruime zin, bij wijze van rechtsherstel, als genoegdoening zou men kunnen zeggen, aan allen die in Nederland als kind door hun ouders(/opvoeders) mishandeld(/verwaarloosd/misbruikt) zijn zonder daarvoor ooit op enigerlei wijze te zijn gecompenseerd (of zelfs maar publicke erkenning te hebben ondervonden), en aan alle kinderen die op dit moment mishandeld worden, terwijl de maatschappij (nog steeds, hoe lang nog?) de andere kant opkijkt.

Vgl. voor dat 'de andere kant opkijken' ten overvloede nog het Eindrapport van de WERKGROEP MELDPUNT KINDERMISHANDELING (commissie-HERMANNS), Advies - en meldpunten kindermishandeling, Roermond, oktober 1997, p. 13: 'Slechts $23 \%$ van de Nederlandse bevolking die in hun sociale omgeving kindermishandeling signaleert of vermoedt, neemt contact op met enig meldpunt. Van de beroepsbeoefenaren [zij die beroepshalve met kinderen omgaan of te maken 
daarvan in drie dure plichten - gaat deze subparagraaf. Na de uitsplitsing in drie onera gaan we over naar de toespitsing op de Trias pedagogica. Daarmee wordt de schets afgerond (schets in de zin van kenschets en voorstudie doch bepaald niet van synopsis) van staatsaansprakelijkheid als kindervolkenrechtelijke 'leer van de restitutio.'

We lezen eerst nog maar eens verder bij VAN BOVEN: ${ }^{102}$

"Under international law, a State that has violated a legal obligation is required to terminate the violation and to make reparation, including in appropriate circumstances restitution or compensation for loss or injury. As noted in the previous paragraphs, the injured subject to whom the reparation is due, may be a State directly injured, a collectivity of States - in particular in the case of breach of obligations erga omnes - and/or an individual person or group of persons who are victims of breaches of internationally recognized human rights.'

Opnieuw verwijst VAN BOVEN vervolgens naar de ILC-code, en wel (bij aangepaste, doorlopende nummering) naar de volgende 'draft articles': art. 41 (cessation of wrongful conduct); art. 42 (reparation ten behoeve van de 'injured state'), te weten: art. 43 (restitution in kind, ofwel restitutio in integrum); art. 44 (compensation); art. 45 (satisfaction: verontschuldigingen, symbolische schadevergoeding, disciplinaire c.q. strafmaatregelen tegen functionarissen of particulieren); art. 46 (assurances and guarantees of non-repetition, plechtige beloftes en waarborgen dat het niet meer zal gebeuren). ${ }^{103}$ VAN BOVEN merkt hierover op: ${ }^{104}$

'These draft articles (...) were mainly drawn up in the perspective of inter-State relations and therefore not primarily aimed at the relation between States and individuals. (...) Nevertheless, these articles (...) contain elements that are also most pertinent in the context of the present study."

hebben, jw] laat ongeveer $35 \%$ na contact op te nemen.' Hetgeen, let wel, zowel te maken heeft met angst voor problemen met de - wettelijk naar verhouding zeer goed beschermde en afgeschermde - ouders als met twijfel of, gezien de huidige, in het licht van de omvang en ernst van de problematiek volstrekt inadequate voorzieningen, "een melding voor het kind veel uitmaakt" (t.a.p.), of zelfs wel in het belang van het kind is! In zoverre die twijfel gegrond is (en er geen sprake is van bijkomende laksheid of gemakzuctt, van burgerlijke apathie of beroepsmatige geblaseerdheid ten koste van medemensen), kan reparatie in ruime zin (adequate preventie, interventie en reparatie) zelfs opgevat worden als vorm wan rechtsherstel door de overheid niet alleen namens doch ook ten opzichte van de hele Nederlandse samenleving.

102 VAN BOVEN, Shdy conceming the right to restitution (...), a.w., p. 19, par. 46.

103 VAN BOVEN, a.w., p. 19, par. 47. (Vgl. ook KOOLJMANS, a.w., p. 121; MALANCZUK/AKEHURST, a.w., pp. 269-271.)

104 T.a.p. (par. 47 vervolg). 
Dit laatste is met name het geval indien een link wordt gelegd met belangrijke internationale jurisprudentie op dit vlak, afkomstig van het Mensenrechtencomité onder het Internationaal Verdrag inzake burgerlijke en politieke rechten en het Inter-Amerikaanse Hof onder de Amerikaanse Conventie voor de rechten van de mens. VAN BOVEN verwijst in het bijzonder naar de VELASQUEZ RODRIGUEZ-zaak ...

'(...) where the [Inter-American] Court stated: "The State has a legal duty to take reasonable steps to prevent human rights violations and to use the means at its disposal to carry out a serious investigation of violations committed within its jurisdiction, to identify those responsible, to impose the appropriate punishment and to ensure the victim compensation. ${ }^{\text {,105 }}$

\subsubsection{Grove schendingen van mensenrechten van kinderen}

Voordat we terugkomen op de drie gecursiveerde begrippen ${ }^{106}$ uit de VELASQUEZ RODRIGUEZ-zaak - zeg maar: preventie, (gezins)onderzoek, (opvoedings)compensatie -, en een verband leggen met de (artikelen 41 tot en met 46 uit de) ILC-ontwerp-code, gaan we eerst nader in op het tweede element uit de titel van VAN BOVENs Study concerning the right to restitution, compensation and rehabilitation for victims of gross violations of human rights and fundamental freedoms, namelijk het element 'grove' (gross) mensenrechtenschendingen. Het doel van VAN BOVENS studie was, voor zover mogelijk, te komen tot basic principles and guidelines with respect to the right to restitution, compensation and rehabilitation for

VAN BOVEN, a.w., p. 20 , par. 49 (curs. jw).

106 Een vierde begrip: punishment, bestraffing, hebben we niet gecursiveerd, hoewel het strafrecht (niet alleen vanuit de maatschappij gezien maar ook in de beleving van de - bekennende - dader) zeker een rol kan spelen in de rehabilitatie van de dader/ouder (en daarmee in de compensatie van het slachtoffer/kind). Vanuit een oogpunt van voorkoming van recidive is rehabilitatie in de vorm van (strafrechtelijk ingekaderde) dadertherapic ongetwijfeld doeltreffender dan 'blote' strafoplegging (en reclassering). Het zal evenwel steeds van de concrete omstandigheden van het geval afhangen welke daderbenadering (strafrechtelijk, strafrechtelijk/therapeutisch, bestuurs-familierechtelijk, zo men wil: gezinsbestuursrechtelijk, gezinsbestuursrechtelijk/therapeutisch) in het (leeftijds-, ontwikkelingsen persoonlijkheidsafhankelijk) persoonswordingsbelang van het kind (het in dezen doorslaggevende criterium) is, zodat er hier niet apart aandacht aan wordt besteed en het gehele probleem van het strafrecht onder (opvoedings) compensatie wordi gerekend (waaraan het in elk geval tot de meerderjarigheid van het slachtoffer ondergeschikt is).

Voor de goede orde: aan een vijffe begrip: identificatie van de dader ("identify those responsible'), wordt hier geheel voorbijgegaan omdat mèt de diagnose pedagogische tekorten de 'dader' (namelijk de falende opvoeder) gegeven is. 
victims of gross violations of human rights and fundamental freedoms. ${ }^{107}$ Over de (uiteindelijk opgestelde) 'basic principles and guidelines' komen we zo dadelijk te spreken. Over het element 'gross violations' merkt de Speciale rapporteur in zijn studie op: ${ }^{108}$

\begin{abstract}
"No agreed definition exists of the term "gross violations of human rights." It appears that the word "gross" qualifies the term "violations" and indicates the serious character of the violations but that the word "gross" is also related to the type of human right that is being violated.'
\end{abstract}

In een noot gewaagt de auteur van de definitie van 'gross, systematic violations of human rights' van MEDINA OUIROGA. Aangezien zijn onderzoeksmandaat zich niet uitstrekt tot het bestanddeel 'systematic,' beperkt de auteur zich ertoe met betrekking tot deze definitie vast te stellen: ${ }^{109}$

'[T]he proposed definition by Cecilia MEDINA is not fully applicable for present purposes. What should, however, be retained from the formula suggested by Cecilia MEDINA are such elements as the type of rights involved and the character of violations. As regards the type of rights involved, she mentions in particular the rights to life, to personal integrity or to personal liberty."

Is het element 'type of rights' hiermee duidelijk (het gaat om rechten welker schending ernstig lichamelijk en/of geestelijk lijden teweegbrengt: 'de profundis clamavi'), allerminst duidelijk is waarop het element 'character of violations" ziet. We kunnen daarbij immers denken aan verschillende zaken zoals: de mate van (actieve c.q. directe) betrokkenheid van de overheid; (de ernst van) de gevolgen (lange-termijn-sequelae) voor de slachtoffers; (de ernst van) de gevolgen (moreel en economisch) voor de maatschappij in haar geheel (mate van morele aantasting/corrumpering van de samenleving, omvang van schade/kapitaalvernietiging voor huidige en toekomstige generaties); de mate van geïnstitutionaliseerd, cultureel 'gedoogd' of zelfs 'vanzelfsprekend' zijn van de schendingen (waarbij de houding van de overheid er een is van 'lavabo manus meas'). Het element 'character of violations' zou echter ook (louter of voornamelijk) kunnen zien op de omvang, de grootschaligheid van de schendingen, ongeacht of met hooguit zijdelings belang voor wat we ons daarbij aan oorzaken en/of gevolgen kunnen voorstellen.

Teneinde te pogen hierin toch enige klaarheid te brengen, zullen we - niet gehinderd door enigerlei mandaat dat ons noopt tot ruimtelijke 
beperkingen (althans het station gepasseerd hebbend dat een bladzijde meer of minder er nog toe doet) - op deze plaats de definitie van MEDINA OURROGA aanhalen: ${ }^{110}$

'Gross, systematic violations of human rights are those violations, instrumental to the achievement of governmental policies, [that are] perpetrated in such a quantity and in such a manner as to create a situation in which the rights to life, to personal integrity or to personal liberty of the population as a whole or of one or more sectors of the population of a country are continuously infringed or threatened.'

Passen we deze definitie toe op de grootschalige schending van fundamentele rechten van het kind, dat wil zeggen op het fenomeen kindermishandeling in Nederland, dan zien we dat in elk geval het bestanddeel 'instrumental to the achievement of governmental policies' niet zonder meer op de Nederlandse situatie kan worden toegepast. Dit bestanddeel lijkt immers een element van kwade trouw (en zelfs van boos opzet) te bevatten, waarvan in Nederland geen sprake is (nog afgezien van het feit dat goede trouw altijd moet worden voorondersteld). Slechts indien in Nederland een bezuinigingsbeleid zou worden gevoerd dat haaks staat op de verplichtingen onder het Verdrag inzake de rechten van het kind (dat wil zeggen: de overheid doet minder waar zij gehouden is meer te doen, bijvoorbeeld door bezuinigingen op de kinderbescherming, de jeugdhulpverlening, op opvoedingsondersteuning, ouderschapscursussen en andere sociaal-pedagogische diensten, instellingen en voorzieningen, alsmede op wetenschappelijk onderzoek daarnaar), zou getwijfeld kunnen worden aan de goede trouw van de Nederlandse overheid. Aan de 'instrumentaliteit' van het bezuinigingsbeleid worden dan de fundamentele rechten van het kind - in passieve zin (dat is: door nalatigheid) - ondergeschikt gemaakt. Vandaar dat er mijns inziens, zelfs als een zekere mate van overheidsbetrokkenheid kan worden vastgesteld (dat wil zeggen: een financieel, politiek of ander korte-termijnbelang van de overheid bij handhaving van de status quo), hooguit van passief-systematische schending kan worden gesproken (zoals we dat in hoofdstuk 12 ook in pre- of praeter-juridische zin hebben gedaan).

Zonder op deze plaats evenwel op de eindconclusie van dit hoofdstuk te willen vooruitlopen, wil ik hier wel stilstaan bij het element 'overheidsbetrokkenheid' - in actieve en/of directe zin - dat ik in het bestanddeel 'systematisch' meen te moeten inlezen. Zo zagen we al (in een noot in de slotparagraaf van hoofdstuk 12) dat KAMMINGA de term 'ern- 
stige en systematische mensenrechtenschendingen' (gross and systematic violations) als 'shorthand' gebruikt voor 'officially inspired practices' (van marteling enzovoorts). ${ }^{11}$ Als we nu het element 'actieve en/of directe overheidsbetrokkenheid' eruit lichten als het aspect dat een meerwaarde (sit venia verbo) geeft aan het bestanddeel 'systematisch' boven het bestanddeel 'grof,' dan zouden we kunnen voorstellen de (dis)kwalificatie 'ernstige en systematische mensenrechtenschending(en)' te reserveren voor situaties waarin een dergelijke betrokkenheid ook kan worden aangetoond. En voor alle overige situaties ons te beperken tot de (dis) kwallficatie 'ernstige' of 'grove' mensenrechtenschending(en). Is er van een passieve c.q. indirecte betrokkenheid van de overheid sprake (bijvoorbeeld in situaties waarin ernstige mensenrechtenschendingen in culturele praktijken, tradities en gewoontes, al of niet gesanctioneerd door religieuze of ideologische leerstellingen of opvattingen, geïnstitutionaliseerd zijn en in structurele zin door de overheid 'gedoogd' worden), waarbij de overheid wel lippendienst bewijst aan de voorkoming en bestrijding van de schendingen en (symbool-)wetgeving uitvaardigt, doch slechts in incidentele (excessieve) gevallen of willekeurig (zonder systematische aanpak op basis van in structurele, wettelijk geregelde voorzieningen, instellingen en diensten vertaald effectief en efficiënt beleid) tegen schendingen optreedt, dan zou de (dis)kwalificatie 'ernstige en passief-systematische mensenrechtenschending(en)' van toepassing kunnen zijn.

In het laatste geval zouden we kunnen zeggen: er is niet - althans niet in actieve en/of directe zin - sprake van een 'State policy,' maar wel van een - door de staat 'gedoogd,' niet als 'official policy,' op grond van een officieel (beleden) gedoogbeleid, maar ten gevolge van een (traditioneel, historisch gegroeid/cultureel 'verklaarbaar') de facto-beleid van niet structureel en adequaat bestrijden, dat is van stelselmatig niet doen wat men onder de gegeven omstandigheden vermag en behoort te doen 'consistent pattern,' van een bestendig patroon van 'gross violations of internationally recognized human rights.' Deze laatste bestanddelen ontlenen we aan de Restatement (Third) of the foreign relations law of the United States van het American Law Institute (ALI, 1987). ${ }^{112}$ De desbetreffende paragraaf $(\$ 702)$ luidt, voor zover hier van belang: ${ }^{113}$

111 Menno T. KAMMINGA, 'Is the European Convention on human rights sufficiently equipped to cope with gross and systematic violations,' Netherlands Quarterly of Human Rights/NQHR 1994/2, pp. 153-164, op p. 154 (curs. jw).

112 Zie STEINER/ALSTON, Intemational human rights in context, a.w, pp. 145-147; VAN BOVEN, Study concerning the right to restitution (...), a.w., p. 7, par. 11; vgl. ook Oscar SCHACHTER, Intemational law in theory and practice, Dordrecht (ete.) 1991, pp. 211 en 338.

113 Zie Intemational human rights in context, a.w., p. 145 (curs. jw). 
'Customary intemational law of human rights

A state violates international law if, as a matter of state policy, it practices, encourages, or condones:

(d) torture or other cruel, inhuman, or degrading treatment or punishment,

(g) a consistent pattern of gross violations of internationally recognized human rights."

Het ALI op zijn beurt heeft het bestanddeel 'bestendig patroon' overgenomen ${ }^{114}$ uit resolutie 1503 (XLVIII) van de ECOSOC, de Economische en Sociale Raad van de VN, uit $1970 .{ }^{115}$ Resolutie 1503 gewaagt van 'a constistent pattern of gross and reliably attested violations of human rights. ${ }^{.16}$ Dat overigens niet alleen in de literatuur maar ook in internationaalrechtelijke (hulp)bronnen de gebezigde terminologie niet eenduidig, en zelfs op het eerste gezicht verwarrend is, moge blijken uit een andere ontwerp-code van de ILC, de - in 1996 in tweede lezing aanvaarde - Draft Code of Crimes against the peace and security of mankind. ${ }^{117}$ In deze code wordt gesproken van 'systematic or mass violations of human rights. ${ }^{118}$ Hier worden 'systematisch' en 'grootschalig' op één lijn gesteld, weliswaar niet in de zin dat grootschalige mensenrechtenschendingen eo ipso systematische mensenrechtenschendingen zouden zijn, doch wel ten aanzien van de rechtsgevolgen. ${ }^{119}$

114 Zie SCHACHTER, Intemational law in theory and practice, a.w., pp. 338 en 356 nt. 24.

115 Zie over deze resolutie en de erin vervatte zogenaamde confidentiële procedure: Th.C. VAN BOVEN, "Internationale instrumenten en procedures ter bevordering en bescherming van de rechten van de mens,' in: P. VAN DIJK e.a., Rechten wan de mens in mundiaal en Europees perspectief, Nijmegen (Ars Aequi Libri) 1991 (vierde druk), pp. 41-81, op pp. 76-79.

116 De tekst van de resolutie is te vinden in P. VAN DLKK e.a., Internationale regelingen, mensenrechten, Lelystad 1993, pp. 96-97; Intemational law, human rights, 1998 (third ed.), pp. 87-88.

117 Vgl. VAN BOWEN, Study concerning the right to restitution (..), a.w., p. 6, par. 9. Zie voor de laatste stand van zaken ROSENSTOCK, t.a.p. (AJIL 1997/2), op pp. 365-370.

118 Curs. toegevoegd. Vgl. hierover ook MURPHY, 'International crimes,' in: The United Nations and intemational law, t.a.p., op p. 366.

119. Iets soortgelijks treffen we aan in art. 10 van het Ontwerp-Facultatief protocol bij het Vrouwenverdrag (CEDAW), dat de (vertrouwelijke) onderzoeksprocedure regelt. In lid 1 van dit artikel wordt gesproken van 'ernstige of systematische schending" (mijn curs.). Ingevolge art. 10 krijgt het verdragscomité onder het Vrouwenverdrag (CEDAW of Vrouwencomité) bepaalde bevoegdheden (waarbij men zich overigens niet te veel moet voorstellen) wanneer het betrouwbare inlichtingen ontvangt 'indicating a serious or systematic violation by a State party to the protocol of rights set forth in the Convention or of a failure to give effect to obligations set forth in the Convention' (de tekst van het ontwerp-Protocol is 
Voor beide categorieën eist de ontwerp-code dat de schendingen - crimes against humanity genaamd - hebben plaatsgevonden op instigatie of onder leiding van de overheid of van enige organisatie of groep. Zijn de schendingen 'systematic,' dan is het optreden van de overheid of de particuliere groep "part of a broader plan or policy." ligheid is - blijkens het commentaar bij de code ${ }^{121}$ - sprake indien het optreden van overheid of particuliere organisatie of groep is ...

(....) directed against a multiplicity of victims [and/or? -jw] the cumulative effect of a series of inhumane acts or the singular effect of an inhumane act of extraordinary magnitude.'

opgenomen in Nemesis 1997/4, pp. 150-152; curs. jw). In een eerder ontwerp (aangenomen tijdens een deskundigenbijeenkomst in Maastricht in 1994) werd (in art. 11, lid 1) gesproken van 'a serious or systematic violation by a State party of rights set forth in the Convention, or a serious or systematic failure by a State party to give effect to its obligations under the Convention' (de tekst van het Maastrichtse 'voor-ontwerp' is opgenomen in Nemesis 1995/1, pp. 8-11; curs. jw). Art. 10 van het Ontwerp-Facultatief protocol is kennelijk geinspireerd door art. 20 vam het Folterverdrag (Anti-martelverdrag of CAT), waarin een onderzoeksprocedure is neergelegd in geval het desbetreffende verdragscomité (CAT of Foltercomité) 'receives reliable information which appears to it to contain well-founded indications that torture is being systematically practised in the territory of a State Party' (curs. jw).

Over het verschil tussen beide (en over de mogelijke betekenis van de gehanteerde terminologie) wordt helaas niets medegedeeld in het begeleidende commentaar in Nemesis' 'Aanhangige zaken' (Ineke BOEREFIN, Cees FLINTERMAN, 'Het Facultatief protocol bij het VN-Vrouwenverdrag,' Nemesis 1997/4, pp. 146149, op p. 149 1.k.). Hetzelfde geldt woor het begeleidende commentaar bij de Maastrichtse versie (Cees FLINTERMAN, 'Het recht tot klagen; totstandkoming van een Facultatief protocol bij het Vrouwenverdrag,' Nemesis 1995/1, pp. 5-7, op p. 7 1.k.).

Het verschil zou gelegen kunnen zijn in, of onder meer te maken kunnen hebben met de expliciete verwijzing in art. 1 Folterverdrag (dat de folterdefinitie bevat) naar een 'public official or other person acting in an official capacity'; met andere woorden in c.q. met het feit dat het Folterverdrag ziet op handelingen die direct aan de staat zijn toe te rekenen: op state action, waarvan in het bijzonder politieke gevangenem, en niet op state inaction, waarvan in het bijzonder vrouwen en kinderen het slachtoffer zijn. Zo merkt ROTH op: 'It is a human rights violation for a state to commit even a single act of torture (...). But a single act of domestic violence is not a human rights violation unless the state can be said through its systematic inaction to have condoned the violence.' (Kenneth ROTH, 'Domestic violence as an international human rights issue,' in: Rebecca J. COOK (ed.), $\mathrm{Hu}$ man rights of women; National and intemational perspectives, Philadelphia 1995 (third printing), pp. 326-339, op p. 331 i.f; curs. jw.) ROSENSTOCK, t.a.p. (AIIL 1997/2), op p. 368.

121 Aangehaald door ROSENSTOCK, t.a.p. 
Als we de hier genoemde elementen combineren (in het midden latend of zij alternatief dan wel cumulatief zijn bedoeld), dus: een veelheid van slachtoffers en/of het cumulatieve effect van een reeks onmenselijke handelingen of het bijzondere effect van een onmenselijke (be)handeling van buitengewone grootte (psychologisch vertaald: de sequelae van chronische traumatisering dan wel van een eenmalig buitengewoon ernstig psychotrauma), dan lijken we hier op een omschrijving te stoten die het bestanddeel 'grootschalig' niet alleen op het element 'massaal' doch ook op het element 'ernstig lijden' betrekt.

Hoewel wij verderop in dit hoofdstuk een verband zullen leggen tussen geïnstitutionaliseerde (systemische) gezinsdiscriminatie (de - door het Mattheüs-effect versterkte - structurele tenachterstelling van transgenerationeel getraumatiseerde ouders en kinderen) en sociaal-pedagogische nalatigheid van de overheid (leidende tot een bestendig patroon van 'gross violations of internationally recognized human rights'), zullen wij daar niet opnieuw (elementen van) de definitie van crimes against humanity bij betrekken. We volstaan die definitie hier weer te geven. Het betreft art. 18 (Crimes against humanity) van de ILC-ontwerp-code inzake misdrijven tegen de vrede en veiligheid van de mensheid: ${ }^{122}$

A crime against humanity means any of the following acts, when committed in a systematic manner or on a large scale and instigated or directed by a Government or by any organization or group:
(a) murder;
(b) extermination;
(c) torture;
(d) enslavement;
(e) persecution on political, racial, religious or ethnic grounds;
(f) institutionalised discrimination on racial, ethnic or religious grounds involving the violation of fundamental human rights and freedoms and resulting in seriously disadvantaging a part of the population;
(g) arbitrary deportation or forcible transfer of population;
(h) arbitrary imprisonment;
(i) forced disappearance of persons;
(j) rape, enforced prostitution and other forms of sexual abuse;
(k) other inhumane acts which severely damage physical or mental integ- rity, health or human dignity, such as mutilation and severe bodily harm.

Een voorzichtige balans opmakend, zou ik willen bepleiten de term 'gross violations,' ernstige (of grove) mensenrechtenschendingen, te hanteren in de betekenis van grootschalige (of massale) schendingen van fundamentele c.q. kernrechten van de mens, waaronder in het bijzonder dienen te 
worden verstaan: rechten die de veiligheid van de persoon ${ }^{123}$ en de bescherming van diens lichamelijke en geestelijke integriteit betreffen. ${ }^{124}$ Het bestanddeel 'systematisch' kan mijns inziens pas worden toegevoegd als er sprake is van een aantoonbaar (gedoog)beleid van de overheid, dat wil zeggen van aantoonbare actieve en/of directe overheidsbetrokkenheid. En dus van een element van kwade trouw, mala fides, oplopend van onbewuste schuld (onnadenkendheid, bijvoorbeeld van een 'braaf' bezuinigende of deregulerende overheid) tot bewuste schuld (nonchalance, bijvoorbeeld ten aanzien van de rechten en belangen van 'zwijgende' minderheden) en voorwaardelijk of kansopzet (verregaande onverschilligheid: de overheid neemt de gevolgen voor bepaalde groepen voor lief of op de koop toe), en, van kwaad tot erger komend, van een motief dat, hoewel niet op de gevolgen gericht, wel een zekerheids- of noodzakelijkheidsbewustzijn ten aanzien van het intreden van die gevolgen inhoudt (bijvoorbeeld de overheid wil met haar bezuinigings- of dereguleringsbeleid bepaalde groepen niet treffen, maar zij is zich er terdege van bewust, of moet dat zijn, dat zonder het nemen van positieve maatregelen kwalijke gevolgen voor die groepen niet uit kunnen blijven), tot, in het meest verdorven geval, dolus malus (boos opzet): het op de kwade gevolgen gerichte motief (de totalitaire of terroriserende overheid die bepaalde groepen vervolgt). ${ }^{125}$

Overigens past hierbij de kanttekening dat goede trouw ten aanzien van een abstractie als de staat toch altijd (in meerdere of mindere mate) moet worden geobjectiveerd (of basis van de formule: 'zou een redelijk denkende overheid in de gegeven omstandigheden/bij afweging van alle in aanmerking komende belangen zo hebben kunnen handelen'). Bovendien past hierbij de relativering dat er een grijs gebied is tussen vormen van nalatigheid waarbij nog wel en waarbij niet meer (in positieve of negatieve zin) aan de goede trouw van een overheid kan worden

123 Art. 3 Universele Verklaring, art. 9, lid 1, eerste wolzin IVBPR. Vgl. voor de opvatting - onder verwijzing naar jurisprudentie van het Mensenrechtencomite (in DELGADO PAEZ vs. Columbia) - dat 'the right to security of the person" in art.9, lid 1, eerste volzin IVBPR ook kan worden gelezen buiten het verband van 'arrest or detention" (art. 9, lid 1, tweede volzin): Courtney W. HOWLAND, "The challenge of religious fundamentalism to the liberty and equality rights of women: an analysis under the United Nations Charter,' Columbia Joumal of Transnational Law 1997/2, pp. 271-377, op (pp. $368 / 369$ en) p. 369 nt. 418.

124 Dit kan gezien worden tegen de achtergrond wan de algemene opmerking in de studie van VAN BOVEN (Study concerning the right to restitution (...), allw, p. 8, par. 16 if.) dat "the parameters of the present study are shaped by the notion of serious damages and grave injuries to human dignity [and] to the physical and moral integrity of the human person (...).'

125 Vgl. N. JÖRG, C. KELK, Strafrecht met mate, s.l. 1996 (9e druk), pp. 99-100. 
getwijfeld. SPIJKERBOER en VERMEULEN lijken dit tot de uiterste consequentie door te trekken wanneer zij opmerken::26

'Zo gaat het bij de beoordeling of een staat al dan niet conform mensenrechtenstandaarden handelt, niet om de subjectieve goede trouw van die staat, maar [om de vraag] of dat handelen objectief gezien aan die standaarden voldoet.'

Beklemtoond moet daarom (nogmaals) worden dat een (voorzichtig) hanteren van het begrip goede trouw hier uitsluitend met betrekking tot het bestanddeel systematisch wordt bepleit.

\section{Recapitulerend}

Om de hierboven bepleite (en in dit hoofdstuk gehanteerde) terminologie nog eens te recapituleren (c.q. de puntjes op de $i$ te zetten):

a.) ernstige (of grove) ${ }^{127}$ mensenrechtenschending(en): (1) grootschalige (of massale) schending(en) van (2) kernrechten (the basic rights of the human person': de fundamentele of kernrechten van de mens (in het bijzonder de rechten die de veiligheid van de persoon en de bescherming van diens lichamelijke en geestelijke integriteit betreffen);

b.) systematische (stelselmatige) mensenrechtenschending(en): er is sprake van aantoonbare actieve en/of directe overheidsbetrokkenheid; we zouden kunnen zeggen: de schendingen zijn tot systeem verheven;

c.) passief-systematische (quasi- of semi-stelselmatige) mensenrechtenschending(en): er is sprake van een bestendig patroon van schendingen dat de overheid de facto en grosso modo in stand houdt (passieve c.q. indirecte overheidsbetrokkenheid/'sociaal-culturele medeplichtigheid'): de overheid is laks, afzijdig, niet actief genoeg of schiet anderszins ten opzichte van massieve (systemische) sociale patronen en culturele praktijken (rechtswidrige Tradition, dat is: de privacy-cultuur) structureel te kort ter zake van een adequate naleving van verdragsverplichtingen; we zouden kunnen zeggen: de schendingen zijn tot (privacy-)systeem verworden.

Ernstig èn passief-systematisch zijn dan die 'gedoogde' massale en massieve schendingen die gepaard gaan met ernstig lijden van zeer velen.

126 T.P. SPLKERBOER, B.P. VERMEULEN, Muchtelingenrecht; Serie Migratierecht III, NCB Utrecht 1995 , p. 148.

127 Een variant zou zijn de term grove mensenrechtenschending(en) te reserveren voor niet-grootschalige schendingen van kernrechten, schendingen van kernrechten die geen massaal karakter hebben; met andere woorden waarbij in een land (bijvoorbeeld) enkele tientallen ernstig (waaronder chronisch) getraumatiseerde slachtoffers per jaar zijn betrokken, maar geen tienduizenden (zoals in Nederland bij kindermishandeling). Emstige mensenrechtenschendingen (zoals kindermishandeling in Nederland) zijn dan grove en grootschalige mensenrechtenschendingen. 


\title{
13.2.2.2 Preventie, interventie, reparatie in de Trias pedagogica
}

We hebben de draad van ons betoog laten vallen bij de International Law Commission (de artikelen 41-46 uit de ILC-ontwerp-code inzake staatsaansprakelijkheid) en bij het Inter-Amerikaanse Hof in de VELASQUEZ RODRIGUEZ-zaak, waarbij we de uitkomst van VAN BOVENs Study concerning the right to [reparation], de (uiteindelijk opgestelde) basic principles and guidelines' van de auteur, in het vooruitzicht stelden. We pakken de draad op het laatstgenoemde punt weer op.

In de door VAN BOVEN, op basis van zijn studie en commentaren daarop, ${ }^{128}$ ten behoeve van (vaststelling in) de Mensenrechtencommissie van de VN (en vervolgens, gezien de normale gang van zaken, aanvaarding en afkondiging door de Algemene Vergadering van de vN) opgestelde Basic principles and guidelines on the right to reparation for victims of [gross] $]^{129}$ violations of human rights and international humanitarian law (revised draft, 1997) ${ }^{130}$ lezen we: $:^{131}$

\begin{abstract}
'The obligation to respect and to ensure respect for human rights and international humanitarian law includes the duty: to prevent violations, to investigate violations, to take appropriate action against the violators, and to afford remedies and reparation to victims. Particular attention must be paid to the prevention of gross violations of human rights and international humanitarian law and to the duty to prosecute and punish perpetrators of crimes under international law.'
\end{abstract}

We lopen de diverse hier genoemde (door mij gecursiveerde) verplichtingen (kort) langs.

128 Vgl. E/CN.4/1997/104 d.d. 16 januari 1997, p. 2, Annex (d.d. 13 januari 1997): Note prepared by the former Special rapporteur of the Sub-Commission, mr. Theo VAN BOWEN (...), par. 1.

129 Tekst tussen teksthaken kan, zo stelt de voormalige Speciale rapporteur voor, worden geschrapt (E/CN.4/1997/104, ta.p., par. 2).

130 Inmiddels ook gepubliceerd door de INTERNATIONAL COMMISSION OF JURISTS, The right to reparation for victims of human rights violations (...); A compilation of essential documents (...), Geneva (januari) 1998, pp. 7-11.

De Draft is inmiddels door de Mensenrechtencommissie doorgeleid naar de (nieuwe) Secretaris-Generaal van de VN (Kofi ANNAN) met het verzoek 'alle leden wan de VN te vragen hun visie kenbaar te maken' (zie M.C. CASTERMANSHOLLEMAN, 'De 53e zitting van de VN-Commissie voor de rechten van de mens," NJCM-Bulletin 1997/5, pp. 661-668, op p. 665).

131 E/CN.4/1997/104 d.d. 16 januari 1997, Appendix, pp. 3-5, op p. 3, par. 2 (curs. jw; oorspr. curs. niet overgenomen). 


\title{
1. Preventie: $\quad$ The duty to prevent (in het bijzonder met betrekking tot 'gross violations')
} MERON merkt op: $:^{132}$

\begin{abstract}
Although contemporary human rights law focuses on the duty of governments to respect the human rights of individuals, human rights violations committed by one private person against another (...) cannot be placed outside the ambit of human rights law if that law is ever to gain significant effectiveness. The [International Court of Justice] acknowledged this reality when, in a different context, it deplored "[t]he frequency with which at the present time the principles of international law ... are set at naught by individuals or groups of individuals ... [United States diplomatic and consular staff in Tehran (USA vs. Iran) 1980]." Because the purpose of human rights law is to protect human dignity, and because some essential human rights are often breached by private persons, the obligation of states to observe and ensure respect for human rights and to prevent violations cannot be confined to restrictions upon governmental powers but must extend to at least some private "interferences" with human rights. States should exercise due diligence to prevent violations by non-governmental actors; the standard of care required would depend on the character and the importance of the norm protected."
\end{abstract}

\section{Dit brengt ons terug bij de VELASQUEZ RODRIGUEZ-zaak. Elders heeft VAN BOVEN over deze zaak opgemerkt (VAN BOVEN 1991): ${ }^{133}$}

"Under international law there is clearly a duty on the part of states to prevent violations of human rights. The most forceful legal opinion on this matter can be found in the judgment of the Inter-American Court of Human Rights in the VELASQUEZ RODRIGUEZ case, dated 29 July 1988. (..) In a judgment which will go into the books as a landmark legal opinion on state responsibility with regard to violations of human rights, the Inter-American Court also addressed the duty of states to prevent violations of human rights.....) It is clear from the Court's judgment (...) that the duty to prevent implies a wide range of measures with a view to forestalling, or at least limiting, breaches of human rights standards. (...) It is assumed that the responsibility of the state is involved insofar as acts or omissions can be attributed to the state and for that matter the state is under a duty to prevent. But in its landmark decision the Inter-American Court went still a step further. It stated: "An illegal act which violates human rights and which is initially not directly imputable to a State (for example, because it is the act of a private person (...)) can lead to international responsibility of the State, not be-

132 Theodor MERON, Human rights and humanitarian noms as customary law, Oxford 1989, pp. 162-164 (curs. jw).

133 'Theo VAN BOVEN, 'Prevention of human rights violations,' in: Asbjørn EIDE, Jan HELGESEN (eds.), The future of human rights protection in a changing world; Fifty years since the Four freedoms address; Essays in honour of Torkel OPSAHL, Oslo 1991, pp. 183-196, op pp. 191-193 (curs. zowel overgenomen als aangebracht). 
cause of the act itself, but because of the lack of due diligence to prevent the violation (...) or to respond to it as required by the Convention". 134

\section{VAN BOVEN vervolgt: ${ }^{135}$}

'While the duty to prevent must be considered an integral part of human rights law in general, a review of international human rights instruments reveals that the duty to prevent and more generally the preventive approach, is an explicit and prominent element of human rights policy and strategy. (...) Perusal of (...) various documents makes it evident that the duty to prevent is most clearly and explicitly expressed with a view to precluding gross violations of human rights and serious breaches of human rights and humanitarian standards.

The means, methods and measures which form part of the preventive approach, and which states have undertaken to implement on the basis of their acceptance of international instruments, constitute a wide range of modalities of preventive action. They include: legislative measures, including (...) regular review, control, inspection and reporting; remedies, compensation and rehabilitation; information and education; social measures, development assistance; and international coordination and co-operation. (...) In sum, a wariety of preventive devices commends [itself]. They form an indispensable component of any human rights strategy, in particular in connection with wide-ranging policies aimed at suppressing and combatting grave offences and evil practices which threaten human life and human dignity."

Hoewel van 'remedies, compensation and rehabilitation' zeker ook preventieve werking uitgaat - en er daarom (ook in dit opzicht) ${ }^{136}$ onmiskenbaar sprake is van een 'close link between the obligaton to prevent

134 Aldus getuigt deze untspraak - in de woorden van CLAPHAM (Andrew CLAPHAM, Human rights in the private sphere, Oxford 1993, pp. $352 / 353$, op p. 352 iff.) - van "a shift in emphasis away from (...) the search for "guilty state actors" towards protection and reparation for those who suffer violations of their human rights as such.' En dus iri de richting van een 'achter de broek zitten' van 'afzijdige,' dat wil zeggen nalatige 'state actors.' CLAPHAM bepleit een dergelijke 'victim-orientated approach' ook voor de Straatsburgse 'machinerie' onder het EVRM en wijst op EVRIGENIS' voorstel van 'ecologische aansprakelijkheid,' welk concept 'presumes a responsibility on the part of the State for all abuses within its jurisdiction' (a.w., pp. $353 / 354$ en 183 ).

Deze laatste woorden betreffen de derde van CLAPHAMs "general conclusions"; we wijzen hier ook nog op de tweede (a.w., p. 353 onder 2): 'By suggesting that the State may violate human rights norms by its failure to tackle a situation involving "private" interference with human rights, the application of human rights in the private sphere admits the importance of "positive" liberty and not just the "negative" liberty of freedom from state interference."

135 T.a.p., op pp. 193-194.

136 Dat is: reparatic als preventie. Al eerder stuitten we op preventie als reparatie. 
and the obligation to restore' (VAN BOVEN 1996) ${ }^{137}$ - zullen we deze (onder de noemer 'reparation') zo dadelijk apart laten terugkeren. Opnieuw dient namelijk eerst een 'technische' vraag te worden afgedaan. Immers: kan de (inter-)Amerikaanse VELASQUEZ RODRIGUEZ-zaak ook buiten de Amerikaanse regio - en dan in beginsel ook op Nederland (het Europese deel van het Koninkrijk) - worden toegepast?

MERON stelt in dit verband met betrekking tot de jurisprudentie van het Inter-Amerikaanse Hof: ${ }^{138}$

'Because of the similarity of Article 1 of the American Convention [on human rights $]^{139}$ to Article 2 of the Political Covenant [IVBPR $]^{140}$ and, in this context, to Artile 1 of the European Convention [on human rights], ${ }^{141}$ the jurisprudence of the [Inter-]American Court is of general importance for the international law of human rights. It demonstrates that this evolving law aims at the prevention of violations of human rights by private or unofficial actors or groups within the state and that punishment is a necessary component of an effective policy of prevention. (...)

The "to respect and to ensure to all individuals" clause of Article 2(1) of the Political Covenant implies the duty of states to ensure compliance by private persons with some of the Covenant's norms, or, at a minimum, to adopt measures "against private interference with enjoyment of the rights ...." This interpretation

137 Theo VAN BOVEN, 'The right to restitution, compensation and rehabilitation for victims of gross violations of human rights and fundamental freedoms,' in: Gudmundur AlFREDSSON, Peter MACALISTER-SMTTH (eds.), The living law of nations; Essays on refugees, minorities, indigenous peoples and the human rights of other wulnerable groups; in memory of Atle GRAHL-MADSEN, Kehl (etc.) 1996, pp. 339354 , op p. 354.

138 MERON, Human rights and humanitarian norms as customary law, a.w., pp. 164 . 165 .

139 Luidende (curs. jw): 1. The States Parties to this Convention undertake to respect the rights and freedoms recognised herein and to ensure to all persons subject to their jurisdiction the free and full exercise of those rights and freedoms, without any discrimination for reasons of race, colour, sex, language, religion, political or other opimion, national or social origin, economic status, birth or any other social condition.

2. For the purposes of this Convention, 'person' means every human being.

De Amerikaanse mensenrechtenconventie (San Jose 1969) is opgenomen in Internationale regelingen, mensenrechten, a.w., pp. 176-192; Intemational law, human rights, 1998 (third ed.), pp. 220-234.

140 Luidende (curs. jw): 1. Each State Party to the present Covenant undertakes to respect and to ensure to all individuals within its territory and subject to its jurisdiction the rights recognized in the present Covenant, without distinction of any kind, such as race, colour, sex, language, religion, political or other opinion, national or social origith, property, birth or other status. 2. (...)

141 Luidende (curs. jw): The High Contracting Parties shall ensure to everyone within their jurisdiction the rights and freedoms defined in Section I of this Convention. 
is supported by the practice of the Inter-American Court of Human Rights in application of Article 1 of the American Convention [on] Human Rights and of the European Commission and Court of Human Rights in application of Article 1 of the European Convention (...) and other provisions of the European Convention on Human Rights.'

Waarmee we van de formele (technische) kant meteen weer terug zijn bij de materiële kant van de zaak: de 'merits' (inhoud en kern) van de VELASQUEZ RODRIGUEZ-jurisprudentie. MERON vat deze als volgt samen: ${ }^{.142}$

'In its judgment in the VELASQVEZ RODR/GUEZ case, the Inter-American Court (...) stated that the obligation to ensure the free and full exercise of the rights recognized in the Convention to every person subject to its jurisdiction implies the duty of every state to organize the govemmental apparatus in such a way that this goal could be juridically ensured. States must, therefore, prevent, investigate, and punish any violation of such rights, and, if possible, attempt to restore the right violated and provide for compensation.'

Voordat we van preventie overstappen naar de andere hier aangehaalde aspecten ('investigate and punish' respectievelijk 'restore the right violated and provide for compensation'), dient ter afronding van dit onderdeel met enige nadruk gewezen te worden op de volgende woorden uit de Study van VAN BOVEN: ${ }^{143}$

'[I]t is clear that the preventive approach should receive due priority and emphasis because an ounce of prevention is more effective than a pound of cure.'

In laaglandse koopmanstermen vertaald: een dubbeltje uitgegeven aan het dempen van de put zet meer zoden aan de dijk dan een gulden besteed aan het redden van het kalf.

2. Interventie: $\quad$ The duty to investigate and to take appropriate action; The duty to prosecute and punish perpetrators (of crimes under international law)

Direct na de eerste hierboven aangehaalde passus van MERON vervolgt de auteur: $:^{144}$

MERON, Human rights and humanitarian noms as customary law, a.w., pp. 165/ 166 (curs. jw).

143 Study conceming the right to restitution (...), a.w., p. 37, par. 88.

144 MERON, Human rights and humanitarian norms as customary law, a.w., p. 164. 


\begin{abstract}
'When prevention faills, states should resort to criminall proceedings against the perpetrator of human rights violations and should ensure that their internal law provides the victim with effective civill remedies against the responsible private actor.'
\end{abstract}

In moderne strafrechtstheorieën wordt het toemeten van de verdiende straf (poenae meritum ${ }^{145}$ als één van de hoekstenen ${ }^{146}$ van GROTIUS' natuur- en volkenrechtsleer) wel (eenzijdig) gerechtvaardigd onder de labels generale of speciale preventie: afschrikking van derden of van recidive door de dader zelf. Zo modern is dat overigens niet: al vele eeuwen vór GROTIUS leerde SENECA, in navolging van PLATO: nemo prudens punit quia peccatum, sed ne peccetur (een verstandig mens straft niet omdat er gezondigd is, maar opdat er niet gezondigd worde). ${ }^{147}$ MERON zei het hen hierboven na: 'punishment is a necessary component

145 Met als drie doelen (vgl. JBP II.20.6):

1.) rehabilitatie ('reclassering') van de dader (hetgeen, zoals ik al eerder aangaf, mijns inziens in de huidige omstandigheden eerder behandeling, psychotherapie, dan straf zal vergen);

2.) voorbeeldfunctie (ne peccetur): affschrikking (a) van de dader (voorkoming van recidive, speciale preventie); en/of (b) van anderen (generale preventic);

3.) genoegdoening aan het slachtoffer/de maatschappij (vergelding: quia peccatum); waarbij ik zo vrij ben (ten aanzien van de huidige omstandigheden) aan te tekenen dat bij een geldboete en/of werkstraf de grens tussen vergelding-alsgenoegdoening en vergelding-als-wraak minder snel zal worden overschreden dan bij een vrijheidsstraf.

146. Om deze nog even kort in herinnering te brengen:

1.a.) respect/non-agressie: zich niet vergrijpen aan/respect voor wat van een ander is; welk gebod geldt sinds mensen (c.q. volken) eigendom - en bij uitbreiding: het huwelijk, slavernij, souvereine staten - hebben ingesteld (JBP 1.1.10:4; 11.20.43:1); met andere woorden: respect/gewelidverbod ten aanzien van eens anders lijf, eer (lichamelijke en geestelijke integriteit) en goed/grondgebied (politieke onafhankelijkheid, territoriale integriteit);

1b.) restitutie (suum cuique: ieder het zijne): de verplichting tot teruggave van wat ons niet toebehoort (onrechtmatige toeeigening) of toekomt (ongerechtvaardigde verrijking);

2.) trouw aan het gegeven woord (pacta sunt servanda): de verplichting tot het nakomen van beloften (met inbegrip wan bona fides: te goeder trouw naleven van afspraken, contracten, verdragen);

3.) genoegdoening/reparatie: het vergoeden van schade door schuld veroorzaakt;

4.) billijke straftoemeting (poenae meritum): het toepassen van de verdiende straf door wie (de staat/staten die) zich niet aan soortgelijke misdrijven of even ernstige misdadigheid heeft/hebben schuldig gemaakt (JBP II.20.7:1).

J. REMMELINK, HAZEWINKEL-SURINGA's Inleiding tot de studie van het Nederlandse strafrecht, Arnhem 1995 (14e druk), p. 894. 
of an effective policy of prevention. ${ }^{.148}$

Dit behoeft 'punishment' evenwel niet altijd te zijn, zeker niet als strafbaarstelling en strafvervolging als panacee, als alleenzaligmakend, worden gezien. Ook het gezegde van HORATIUs: quid leges sine moribus (wat baten wetten zonder goede zeden, dat is zonder moreel fond) bevat een belangrijke kern van waarheid. Wanneer culturele patronen moeten worden doorbroken, wanneer een mentaliteitsverandering moet worden bewerkstelligd, is het strafrecht eerder een sluitstuk, de 'kroon' op een ontwikkeling die begint met het problematiseren van ongewenst gedrag, het benaderen van een sociale problematiek met en vanuit een breed instrumentarium en programma van 'social engineering,' maatschappelijk 'opbouw-werk.'

Dit alles doet uiteraard niet af, wanneer wij deze overwegingen betrekken op de strafbare feiten die ouders plegen jegens hun kinderen ten onzent (de jure maar meer nog de facto): (zeer) ernstige tot (bijna) fatale vormen van fysieke mishandeling en fysieke verwaarlozing en ernstige vormen van sexueel misbruik -, aan de wenselijkheid (en mettertijd noodzakelijkheid) in het Wetboek van Strafrecht ook die gedragingen te incorporeren welke thans niet of nauwelijks onder een wettelijke delictsomschrijving zijn te subsumeren, doch die voor kinderen buitengemeen schadelijk zijn. Voor een summiere 'proeve' op dit vlak zij verwezen naar de bijlagen (bijlage II juncto III) bij dit proefschrift. Omdat de problematiek van kindermishandeling (vooralsnog en waarschijnlijk nog geduiende verschillende generaties) een andere aanpak vergt dan een (primair) strafrechtelijke, volsta ik met deze verwijzing (waarbij ik de enigszins schamele doch niet onbelangrijke kanttekening maak over dermate weinig strafrechtstechnische expertise te beschikken dat de in de 'proeve' in de bijlagen opgenomen bepalingen niet anders dan als 'voorbeeld-strafbepalingen,' zoals zij ook zijn aangeduid, dus louter ter illustratie, mogen worden gelezen).

Dit betekent dat we aan de 'duty to prosecute and punish perpetrators' geen aandacht zullen besteden. Voor zover zou kunnen worden betoogd (we laten dat hier verder in het midden) dat deze plicht, in algemene (gewoonterechtelijke) zin, alleen geldt in geval van 'crimes under international law, ${ }^{149}$ kan worden volstaan met te wijzen op het feit dat mishandelende ouders bezwaarlijk als een 'organisatie' of 'groep' kunnen

148 MERON, Human rights and humanitarian norms as customary law, a.w., p. 164 (i.f.) (hiervoor aangehaald).

149 Voor een uitgebreid expose over deze materie (althans over de diverse hiermee samenhangende rechtsvragen) zie Naomi ROHT-ARRLAZA, 'State responsibility to investigate and prosecute grave human rights violations in international law," Califomia Law Review 1990/2, pp. [449]451-513, op pp. 462-505. 
worden gezien en alleen al om die reden niet onder de termen van art. 18 (Crimes against humanity) van de ILC-ontwerp-code inzake misdrijven tegen de vrede en veiligheid van de mensheid kunnen worden gebracht, ook al is kindermishandeling in Nederland een grootschalig fenomeen en ook al spreekt dit artikel (dat we in de vorige subparagraaf volledig hebben aangehaald) van inhumane acts which severely damage physical or mental integrity, health or human dignity (...).'

Op de 'duty to investigate and to take appropriate action' komen we (zijdelings) terug in paragraaf 13.4.1, waarin we de feitelijke bescherming die de staat het mishandelde kind biedt, toetsen aan de verplichtingen van de staat onder het Verdrag inzake de rechten van het kind.

\section{Reparatie (1): The duty to afford reparation}

We refereerden zojuist aan het poenae meritum als één van de vier hoekstenen van GROTIUS' natuur- en volkenrechtsleer. Aan het begin van dit hoofdstuk stonden we stil bij een andere hoeksteen: de verplichting tot herstel van door eigen schuld (dat wil zeggen door toedoen of nalaten) veroorzaakte schade (damni culpa dati reparatio). In 1928 was de wereldrechtsorde zover ontwikkeld dat de voorganger van het huidige Internationale Gerechtshof, het Permanente Hof van Internationale Justitie (1922-1946), ${ }^{150}$ kon opmerken (in de Chorzów Factory-zaak, aangehaald doOr VAN BOVEN 1996): $:^{151}$

'[I]t is a principle of international law, and even a general conception of law, that any breach of an engagement invo[lv]es an obligation to make reparation. (...) [R]eparation is the indispensable complement of a failure to apply a convention, and there is no necessity for this to be statedl in the convention itself.'

Zoals we al zagen, hanteert de ILC-ontwerp-code inzake staatsaansprakelijkheid reparatie als verzamelterm van de begrippen restitutie, compensatie, satisfactie (genoegdoening) en waarborgen voor niet-herhaling. Restitutie (restitution in kind), zo bepaalt art. 43 van de code, is ...

150 Niet te verwarren met het Permanente Hof van Arbitrage (1900 tot heden), waarvoor in Den Haag het Vredespaleis zou worden gebouwd. Vgl. Arthur EYPFINGER, The Peace Palace; Residence for justice, domicile of learning (1913-1988), Wormer 1988, pp. 129 sqq., 145 sqq.; dez., The International Coun of Justice 19461996, The Hague (etc.) 1996, pp. 50 sqq., $74 s q q$.

151 VAN BOWEN, The right to restitution, compensation and rehabilitation for victims of gross violations of human rights and fundamental freedoms,' in: The living low of nations, a.w., pp. 339-354, op p. 350 . 
(...) the re-establisment of the situation which existed before the wrongful act was committed (...).

Compensatie (compensation) treedt voor restitutie in de plaats (bijvoorbeeld wanneer restitutio in integrum, herstel in de oorspronkelijke toestand, niet mogelijk is), en omvat dan, ingevolge art. 44 , lid $2 \ldots$

(...) any economically assessable damage (...), and may include interest and, where appropriate, loss of profits.

Genoegdoening (satisfaction) is in het bijzonder van belang met betrekking tot morele schade, en kan, zo bepaalt art. 45 , lid 2 , de volgende vormen aannemen:

(a) an apology [verontschuldigingen];

(b) nominal damages [symbolische schadevergoeding];

(c) in cases of gross infringement (...) damages reflecting the gravity of the infringement [boetes];

(d) in cases where the internationally wrongful act arose from the serious misconduct of officials or from criminal conduct of officials or private parties, disciplinary action against, or punishment of, those responsible [disciplinaire c.q. strafmaatregelen tegen functionarissen of particulieren; curs, $j w]$.

Over waarborgen voor niet-herhaling wordt gesproken in art. 46 van de ontwerp-code (assurances and guarantees of non-repetition). Hiermee worden bedoeld formele verzekeringen en materiële waarborgen van de kant van de staat dat geen herhaling van het gebeurde zal plaatsvinden.

In VAN BOVENs op (grove) mensenrechtenschendingen toegesneden Basic principles and guidelines on the right to reparation for victims of [gross] violations of human rights and international humanitarian law is reparatie de verzamelterm voor de begrippen restitutie, compensatie, rehabilitatie, satisfactie en waarborgen voor niet-herhaling. Voor ons onderwerp (kort gezegd 'reparatie van kindermishandeling') zijn van direct belang: compensatie, rehabilitatie en satisfactie (in de Basic principles and guidelines in één adem genoemd met waarborgen voor niet-herhaling). Over compensatie wordt bepaald (c.q. voorgesteld): ${ }^{152}$

'Compensation shall be provided for any economically assessable damage resulting from violations of human rights (...), such as:

(a) Physical or mental harm, including pain, suffering and emotional distress;

(b) Lost opportunities including education; 
(c) Material damages and loss of earnings, including loss of earning potential;

(d) Harm to reputation or dignity;

(e) Costs required for legal or expert assistance, medicines and medical services.'

Met betrekking tot rehabilitatie lezen we: ${ }^{153}$

'Rehabilitation shall be provided and will include medical and psychological care as well as legal and social services.'

En ten aanzien van satisfactie en waarborgen voor niet-herhaling: ${ }^{154}$

'Satisfaction and guarantees of non-repetition shall be provided, including, as necessary:

(a) Cessation of continuing violations ${ }^{155}$;

(b) Verification of the facts and full and public disclosure of the truth ${ }^{156}$;

(c) An official declaration or a judicial decision restoring the dignity, reputation and legal rights of the victim and/or of persons closely connected with the victim; (d) Apology, including public acknowledgement of the facts and acceptance of responsibility;

(e) Judicial or administrative sanctions against persons responsible for the violations;

(f) Commemorations and paying tribute to the victims;

(g) Inclusion in human rights training and in history or school textbooks of an accurate account of the violations committed in the field of human rights and international humanitarian law;

(h) Preventing the recurrence of violations by such means as: (...) Conducting and strenghtening, on a priority and continued basis, human rights training to all sectors of society, in particular to (...) law enforcement officials.'

Aangezien onder 'human rights training' ook kan en moet worden verstaan onderricht en vorming in de rechten van het kind, mogen - te meer waar er gesproken wordt van 'all sectors of society' - de laatste woorden, bij uitbreiding, als volgt worden gelezen: 'in particular to law enforcement officials, to professionals working with children, and to parents.'

Hoewel art. 39 van het Verdrag inzake de rechten van het kind expliciet op reparatie van kindermishandeling ziet ("physical and psycho-

VAN BOVEN, Basic principles and guidelines, t.a.p.y op p. 5, par. 14. VAN BOVEN, Basic principles and guidelines, t.a.p., op p. 5, par. 15.

Vgl. art. 41 van de ILC-ontwerp-code inzake staatsaansprakelijkheid (cessation of wrongful conduct): A State whose conduct constitutes an internationally wrongful act having a continuing character is under the obligation to cease that conduct, without prejudice to the responsibility it has already incurred.

Een voorwaarde die we aan het slot van hoofdstuk 12 in verband brachten met een - verhoopt - Marcus-effect. 
logical recovery and social reintegration of a child victim of any form of neglect, exploitation, or abuse, torture or any other form of cruel, inhuman or degrading treatment or punishment'), dienen we toch de Basic principles and guidelines hierbij te betrekken, niet alleen ter 'inkleuring" van de termen 'recovery' en 'social reintegration,' doch met name met het oog op 'adult survivors,' inmiddels meerderjarig geworden slachtoffers van kindermishandeling, die immers niet meer vallen onder de definitie van kind in art. 1 VRK, en mitsdien niet onder de termen van (art. 39 van) het Verdrag. ${ }^{157}$

In dit verband kan het nuttig zijn enige nadere (algemene c.q. softof semi- dan wel pre- of proto-gewoonterechtelijke) duidelijkheid te krijgen over het begrip slachtoffer (victim). Daartoe zullen we te rade gaan bij de Declaration of basic principles of justice for victims of crime and abuse of power. ${ }^{158}$ In deze VN-Verklaring vinden we, in art./par. 1-2, de volgende omschrijving van 'victims of crime':

1. 'Victims' means persons who, individually or collectively, have suffered harm, including physical or mental injury, emotional suffering, economic loss or substantial impairment of their fundamental rights, through acts or omissions that are in violation of criminal laws operative within Member States, including those laws proscribing criminal abuse of power.

2. A person may be considered a victim, under this Declaration, regardless of whether the perpetrator is identified, apprehended, prosecuted or convicted and regardless of the familial relationship between the perpetrator and the victim. 'The term 'victim' also includes, where appropriate, the immediate family or dependants of the direct victim [partner en/of kind(eren) in geval van (im)materiële schade en in het bijzonder van indirecte traumatisering/traumabesmetting ${ }^{159}$ : tweede-plan-slachtoffers, jw] and persons who have suffered harm in intervening

157 Hetgeen niet betekent dat zij geen compensatic (zouden) kunnen claimen voor het feit dat de staat hun als minderjarigen geen hulp/reparatie heeft geboden. In dit verband kunnen de Basic principles and guidelines de onrechtmatigheid (maatschappelijke onzorgvuldigheid) van de statelijke nalatigheid in de zin van art. 6:162 $\mathrm{BW}$ inkleuren, en in die (indirecte) zin een recht op reparatie (althans compensatie) voor de volwassen survivor in het leven roepen.

158 Resolutie 40/34 van de Algemene Vergadering van de VN d.d. 29 november 1985, opgenomen in Human rights; A compilation of international instruments, Centre for Human Rights Geneva, New York 1988, pp. 262-265.

159 Onder traumabesmetting (irauma-infectie) verstaan wjj het oplopen van psychische (c.q. psychosomatische) schade in en door de nawwe relatie of band die men heeft met een (ernstig) getraumatiseerd persoon, ook als deze persoon zich van de oorspronkelijke traumatisering (c.q. het oorspronkelijke trauma) niet of slechts ten dele bewust is en niet zozeer zelf lijdt (althans in zijn of haar eigen beleving) als wel zijn of haar omgeving aan of liever onder de posttraumatische gevolgen (in het bijzonder de onaangepaste overlevingsstrategieën ofwel destructieve/ant" sociale coping-mechanismen) doet lijden. 
to assist victims in distress or to prevent victimization [derde-plan-slachtoffers, onder wie, in geval van indirecte traumatisering/traumabesmetting, hulpverleners, jww].

Alsmede, in art./par. 18-19, de volgende omschrijving van victims of abuse of power:

18. 'Victims' means persons who, individually or collectively, have suffered harm, including physical or mental injury, emotional suffering, economic loss or substantial impairment of their fundamental rights, through acts or omissions that do not yet constitute violations of national criminal laws but of internationally recognized norms relating to human rights.

Deze laatste omschrijving gaat met de volgende adhortatie gepaard:

19. States should consider incorporating into the national law norms proscribing abuses of power [zoals het met fysiek of psychisch geweld disciplineren van kinderen, $\mathrm{jw}$ ] and providing remedies to victims of such abuses. In particular, such remedies should include restitution and/or compensation, and necessary material, medical, psychological and social assistance and support.

Sommige slachtoffers van kindermishandeling worden in hun latere leven opnieuw slachtoffer van 'domestic violence.' Met name (internaliserende) vrouwelijke 'adult survivors' lopen, zolang zij hun jeugdervaringen niet adequaat hebben verwerkt, of daar zelfs nog niet eens mee naar buiten zijn gekomen (Marcus-effect), als gevolg van de werking van het mechanisme van de herhalingsdwang (c.q. het Mattheüs-effect) het risico zich door hun (externaliserende) partners te laten misbruiken en mishandelen. of anders geformuleerd: ten gevolge van een posttraumatische 'neurotische' partnerkeuze - en onder invloed van posttraumatische minderwaardigheidsgevoelens - komen zij opnieuw in misbruik- en mishandelingssituaties en -relaties terecht. In dit verband is het daarom van belang te wijzen op een drietal mensenrechtelijke instrumenten (een $\mathrm{VN}$-verklaring, een regionaal verdrag en een algemene aanbeveling van een verdragsorgaan) over 'violence against women.' Instrumenten waarvan ook een reflexwerking zou kunnen uitgaan (kort gezegd: een interpretatieve inkleurings- en aanscherpingsinvloed) ten aanzien van het bredere 'issue' van 'domestic violence' en dus van (reparatie van) kindermishandeling als onderdeel daarvan. Bovendien verwijzen de instrumenten expliciet naar kinderen of zijn zij ook op meisjes van toepassing.

In de eerste plaats wijzen we op de VN-Verklaring inzake de uitbanning van geweld tegen vrouwen (Declaration on the elimination of violence against women) uit (eind) 1993. De artikelen 1 en 2 van deze Ver- 
klaring geven een omschrijving en aanduiding van wat onder violence against women' dient te worden verstaan: ${ }^{160}$

Article 1.

For the purposes of this Declaration, the term violence against women means any act of gender-based violence that results in, or is likely to result in physical, sexual or psychological harm or suffering to women, including threats of such acts, coercion or arbitrary deprivation of liberty, whether occurring in public or in priwate iffe.

Article 2.

Violence against women shall be understood to encompass, but not be limited to, the following:

(a) physical, sexual and psychological violence occurring in the family, including battering, sexual abuse of female children in the household, dowry-related violence, marital rape, female genital mutilation and other traditional practices harmful to women, non-spousal viollence and violence related to exploitation;

(b) (...)

(c) physical, sexual and psychological violence perpetrated or condoned by the State, wherever it occurs.

Art. 4 aanhef en onder $g$ van de Verklaring bepaalt vervolgens:

Article 4.

States should condemn violence against women and should not invoke any custom, tradition or religious consideration to avoid their obligations with respect to its elimination. States should pursue by all appropriate means and without delay a policy of eliminating violence against women and, to this end, should:

(...)

(g) work to ensure, to the maximum axtent feasible in the light of their available resources (...) that women subjected to violence and, where appropriate, their children have specialized assistance, such as rehabilitation, assistance in child care and maintenance, treatment, counselling health and social services, facilities and programmes, as well as suppon structures, and should take all other appropriate measures to promote their safety and physical and psychological rehabilitation.

In de tweede plaats kan hier worden vermeld de Inter-Amerikaanse Conventie inzake de voorkoming, bestraffing en uitroeiing van geweld tegen vrouwen (Inter-American Convention on the prevention, punishment and eradication of violence against women), aangenomen door de Organisatie

160 Resolutie 48/104 van de Algemene Vergadering van de VN d.d. 20 december 1993, opgenomen in Gudmundur ALFREDSSON, Katarina TOMASEVSKI (eds.), A thematic guide to documents on the human rights of women, Global and regional standards adopted by intergovernmental organizations, international non-governmental onganizations and professional associations, The Raoul WALLENBERG Institute Human Rights Guides vol. 1, Den Haag (etc.) 1995, pp. 318-322 (curs. jw). 
van Amerikaanse Staten in juni 1994 (Verdrag van Belém do Pará, in werking getreden in maart 1995). ${ }^{161}$ Hoewel ik niet durf uit te sluiten dat (Latijns-)Amerikaanse mannen gemiddeld gewelddadiger zijn jegens hun vrouwen (en dochters) dan Europese (of Aziatische of Afrikaanse), zijn mij geen gegevens bekend dat in Amerika geweld tegen vrouwen een (substantieel) groter of structureel ander probleem vormt dan in Europa (of andere continentale regio's). Niettemin is dit regionale verdrag (vooralsnog?) het enige dat zich specifiek richt op (huiselijk en ander) geweld tegen vrouwen, op "violence in both the public and private spheres' (art. 3). In hoofdstuk III van dit 'Anti-publiek-en-privé-geweldverdrag' (Duties of the States, artt. 7-9) lezen we: $:^{162}$

\section{Article 7}

The States parties condemn all forms of violence against women and agree to pursue, by all appropriate means and without delay, policies to prevent, punish and eradicate such violence and undertake to:

(g) establish the necessary legal and administrative mechanisms to ensure that women subjected to violence have effective access to restitution, reparations or other just and effective remedies (...).

Article 8

The States parties agree to undertake progressively specific measures, including programs:

(d) to provide appropriate specialized services for women who have been subjected to violence, through public and private sector agencies, including shelters, counselling services for all family members where appropriate, and care and custody of the affected children;

(e) to promote and support governmental and private sector education designed to raise the awareness of the public with respect to the problems of and remedies for violence against women;

(f) to provide women who are subjected to violence access to effective readjustment and training programs to enable them to fully participate in public, private and social life;

(h) to ensure research and the gathering of statistics and other relevant information relating to the causes, consequences and frequency of violence against women, in order to assess the effectiveness of measures to prevent, punish and eradicate violence against women and to formulate and implement the necessary changes (...).

De term eradication (uitroeiing) c.q. eradicate (uitroeien) in titel en corpus van dit moedige verdrag - waar in de titel van andere verdragen, zo-

161 Opgenomen in $A$ thematic guide to documents on the human rights of women, a.w., pp. 324-328; P. VAN DIUK e.a. (eds.), Intemational law, human rights, Lelystad 1998 (third revised ed.), pp. 246-249.

162 A thematic guide (...), t.a.p., op pp. 326-327; Intemational law, human rights, t.a.p., op pp. $247-248$ (curs. jw). 
als het Rassenverdrag of het Vrouwenverdrag, 'slechts' de term elimination (uitbanning) paraisseert -, zou bijna doen verzuchten: als diverse ten dele nog ontwikkelingslanden het ideaal omarmen en handen en voeten geven mannen zozeer te beschaven dat geweld tegen vrouwen als structureel sociaal probleem niet meer voorkomt, met wortel en tak is uitgeroeid, wordt het dan geen tijd, hoogste tijd, dat rijke landen, die ooit pretendeerden in die andere landen de beschaving te brengen - de beschaving niet in (wapen-)technologische $\operatorname{zin}^{163}$ maar de beschaving van de christelijke naastenliefde -, het ideaal omarmen en handen en voeten geven mannen èn vrouwen zozeer te beschaven dat geweld tegen kinderen als structureel sociaal probleem niet meer voorkomt, met wortel ('causes': door preventie) en tak ('consequences": door interventie en reparatie) wordt uitgeroeid? Uiteraard begint elk beschavingsproces met het onder ogen zien dat er een sociaal probleem bestáat. De geschiedenis leert helaas dat daarvoor eerst een krachtige pressiegroep van mondige slachtoffers en buitengeslotenen nodig is. De ergste slachtoffers maken nooit deel van zo'n pressiegroep uit. Zij zijn letterlijk met stomheid geslagen en zo tot zwijgen gebracht. ${ }^{164}$ Slachtoffers die om andere redenen niet

163 Ter relativering van đeze pretentie mag een Japanse diplomaat, door RöLING aan het woord gelaten, ten tonele worden gevoerd. RÖLING geeft aan hoe, ma de uitnodiging aan Turkije in 1856 "to participate in the public law and concert of Europe,' het 'niet langer mogelijk [was] om nog te spreken van "Christelijke Naties".' Men sprak sindsdien van de 'Beschaafde Naties.' Tot deze groep 'wordt Japan toegelaten als het in een succesvolle oorlog China heeft verslagen.' RÖLING vervolgt: 'De directe aanleiding tot Japans bimnentreden in de volkengemeenschap kan erop duiden dat de eis van "beschaving" vóor alles betrof de capaciteit om een oorlog te woeren met technisch behoorlijk toegeruste troepenmacht. Een. Japans diplomaat ontging deze samenhang niet toen hij constateerde: "We show ourselves at least your equalls in scientific butchery, and at once we are admitted to your council tables as civilized men".' (B.V.A. RöLING, 'Europees volkenrecht of wereldvolkenrecht?' (1958), opgenomen in: Volkenrecht en vrede, Deventer 1985, derde druk, pp. 203-225, op pp. 208/209.)

164 VAN BOVEN laat zijn Study voorafgaan door een Prologue welke bestaat uit de volgende woorden wit de Birthright of man: 'The groans and cries to be heard in these pages are never uttered by the most wretched victims. These, throughout the ages, have been mute. Wherever human rights are completely trampled underfoot, silence and immobility prevail, leaving no trace in history; for history records only the words and deeds of those who are capable, to however slight a degree, of ruling their own lives, or at least trying to do so. There have been there still are - multitudes of men, women and children who, as a result of poverty, terror or lies, have been made to forget their inherent dignity, or to give up the efforts to secure recognition of that dignity by others. They are silent. The lot of the victim who complains and is heard is already a better one.' (Rene MAHEU, "Preface" (1968), in: Jeanne HERSCH (ed.), Birthright of man; A selection of texts (...), UNESCO, Parijs 1969, pp. [7-10], op pp. [9/10]; VAN BOVEN, Study conceming 
mondig zijn, horen we echter evenmin. Door toedoen of nalaten van hun ouders gemaltraiteerde kinderen hebben het ongeluk tot beide categorieën te behoren. Slechts volwassenen, 'adult survivors," die in de spiegel van hun eigen jeugd durven (en kunnen) kijken (mens kijk: zie het kind $!^{165}$ ), zouden zo'n pressiegroep kunnen vormen .... Maar nu laten we ons in onze verzuchting over het "Anti-publiek-en-privé-geweldverdrag' meeslepen, en dwalen af.

In 1992 kwam het Comité inzake de uitbanning van vrouwendiscriminatie (CEDAW, het verdragsorgaan onder het Vrouwenverdrag) met Algemene aanbeveling $19,{ }^{166}$ welke hier als derde mensenrechtelijk instrument wordt opgevoerd. Strikt genomen is een algemene aanbeveling van een verdragsorgaan (zoals in casu ex art. 21, lid 1 Vrouwenverdrag) geen instrument (ervan uitgaande dat instrumenten alleen afkomstig kunnen zijn van staten of organen van internationale organisaties), maar de gezaghebbende (dynamische) uitleg die in deze aanbeveling wordt gegeven, rechtvaardigt wellicht, in de onderhavige context, haar aanduiding als instrument.

Algemene aanbeveling 19 bevat om te beginnen (in par. 9, slotzin) een belangrijke uitspraak met betrekking tot het onderwerp van dit hele hoofdstuk, staatsaansprakelijkheid:

the right to restitution (...), a.w., p. 3.)

165 Als het geoorloofd is deze woordspeling op het Ecce homo (Joh. 19:5) te bezigen. Bij Johannes lezen we (Joh. 19:1-5): Toen liet Pilatus Jezus geselen. En de soldaten vlochten een kroon van doornen, en zetten ze Hem op het hoofd; ze wierpen Hem een purperen mantel om, traden op Hem toe, en zeiden: Wees gegroet, Koning der Joden. En ze sloegen Hem in het gelaat. Nu kwam Pilatus weer naar buiten, en sprak tot hen: Ziet, ik breng Hem u naar buiten, om u te doen weten, dat ik volstrekt geen schuld in Hem vind. Jezus kwam dus naar buiten, met de doornenkroon en de purperen mantel. En hij sprak tot hen: Ziet den mens .... (In het Latijn: Et dicit eis: Ecce homo.)

Het ecce homo-motief (Christus met de doornenkroon en de purperen mantel) verschijnt in de late middeleeuwen in de christelijke kunst (afzonderlijk of in de passiecyclus). Het is verwant aan de imago Pietatis-figuur (Man van Smarten), de afbeelding van Christus met de traumata in handen, voeten en zijde en met de doornenkroon op het neerhangende hoofd. Ook de term Pietà (Nood Gods: het van het kruis afgenomen lichaam van Christus over de schoot van Maria) wordt hiervoor wel gebruikt (zoals bijvoorbeeld in het Museo Nazionale in Lucca, waar het houten beeld van de Man van Smarten van Matteo cIVTrALI als Pietd wordt aangeduid).

Opgenomen in $A$ thematic guide to documents on the thuman rights of women, a.W., pp. 313-318. Zie ook Lucy WILLEMS, 'Geweld tegen vrouwen: CEDAW-Algemene aanbeveling nr. 19,' Actualiteitenkatern Nemesis 1995/5, pp. 26-30 (tekst op pp. 27-30; curs. in aan te halen passus van mij, jw). Vgl. woorts VAN BOVEN, Study concening the right to restitution (...), a.w., pp. 29-30, par. 65-66. 
'Under general international law and specific human rights covenants, States may also be responsible for private acts if they fail to act with due diligence to prevent violations of rights or to investigate and punish acts of violence, and for providing compensation."

Deze laatste term brengt ons bij het onderdeel waarop we hadden ingezoomd: reparatie. Hierover zegt de Algemene aanbeveling van het Vrouwencomité (in par. 23 juncto par. 24 onder $a, i, k$ en $r$ ):

'23. Family violence is one of the most insidious forms of violence against women. It is prevalent in all societies. Within familly relationships women of all ages are subjected to violence of all kinds, including battering, rape, other forms of sexual assault, mental and other forms of violence, which are perpetuated by traditional attitudes. (...)

24. In light of these comments, the Committee on the Elimination of Discrimination Against Women recommends:

(a) States parties should take appropriate and effective measures to overcome all forms of gender-based violence, whether by public or private act.

(i) Effective complaints procedures and remedies, including compensation, should be provided.

(k) States parties should establish or support services for victims of family violence (...), including refuges, specially trained health workers, rehabilitation and counselling.

(r) Measures that are necessary to overcome family violence should include:

i. criminal penalties where necessary and civil remedies in case of domestic violence;

iii. services to ensure the safety and security of victims of family violence, including refuges, counselling and rehabilitation programmes;

iv. rehabilitation programmes for perpetrators of domestic violence;

w. support services for families where incest or sexual abuse has occurred."

\section{Reparatie (2): $\quad$ The duty to afford remedies}

In hierboven aangehaalde instrumenten (art./par. 19 van de Declaration of basic principles of justice for victims of crime and abuse of power; art. 7 onder $g$ en art. 8 onder e van het Anti-(publiek- en privé-)geweldtegen-vrouwenverdrag; par. 24 onder i en r (i) CEDAW-Algemene aanbeveling 19) was sprake van 'remedies' in de ruime (materiële) zin van rechtsherstel (the mechanisms of justice). We kunnen dit begrip ook in enge (formele) zin opvatten als rechtsmiddelen (een rechtsingang). Over dat laatste bepalen de Basic principles and guidelines: ${ }^{167}$

VAN BOVEN, Basic principles and guidelines on the right to reparation (...), t.a.p., op p. 3, par. 4-5 (curs. jw; add./corr. curs. niet overgenomen). Vgl. ook t.a.p., op pp. $3 / 4$, par. $6-11$. 
'Every State shall ensure that adequate legal or other appropriate remedies are availabe to any person claiming that his or her human rights have been violated. The right to a remedy against violations of human rights and humanitarian norms includes the right to access to national and any available international procedures for their protection.

The legal system of every State shall provide for prompt and effective disciplinary, administrative, civil and criminal procedures so as to ensure readily accessible and adequate redress, and protection form intimidation and retaliation.

Every State shall provide for universal jurisdiction over gross violations of human rights and international humanitarian law which constitute crimes under international law,"

Eén raket:

Preventie, interventie, reparatie: samenvloeiling in de Trias pedagogica

Hoewel we de drie staatsaansprakelijkheidsplichten, die we nu in algemene zin zijn langsgelopen, hier en daar al direct op de rechten van het kind - dat wil zeggen op die rechten die beogen te waarborgen en te bevorderen dat het kind als bovenminimaal persoon de volwassenheid betreedt, als persoon, met andere woorden, die (ernstige aangeboren afwijkingen daargelaten, in welk geval specifieke rechten van toepassing zijn), over voldoende rationaliteit, moraliteit en authenticiteit beschikt om in beginsel tot de vrije en zelfstandige uitoefening en het gave genot van de rechten van de mens in staat te zijn - hebben toegespitst, is het van belang, tot hier gekomen, nogmaals het specifieke karakter van de Trias pedagogica (de constitutionele - zo men wil: staats-familierechtelijke of gezinsstaatsrechtelijke - driehoeksverhouding kind-ouders-staat) te benadrukken. In de Trias pedagogica, als onder het familierecht, jeugdrecht en aanverwante rechtsgebieden liggende, en op haar beurt aan de mensenrechten(verdragen) c.q. het mensenrechtenrecht, in het bijzonder (het Verdrag inzake) de rechten van het kind c.q. het kindervolkenrecht opgehangen triangulaire structuur, vloeien de drie staatsaansprakelijkheidsplichten samen tot één nieuwe constellatie. Zij vormen de in elkaar geschoven, zo nodig ná elkaar te ontsteken trappen van én sociaal-pedagogische raket: de persoonswordingsraket. We brengen hier (nogmaals) in herinnering dat het recht van het kind op (optimale) persoonswording (zoals we zagen in hoofdstuk 10) het dragende en leidende beginsel van het Verdrag inzake de rechten van het kind, dat is van het positieve kindervolkenrecht, is.

Om dit, duidelijkheidshalve, ook anders te formuleren: net zoals de drie verdragsrechtelijke $P$ 's (de $P$ 's van Provision, Protection en Participation) van het Verdrag inzake de rechten van het kind - dat wil zeggen: de verdragsrechten die zijn te classificeren c.q. te kwalificeren als preventie (sociaal-pedagogische provision), (vroege) interventie (protection) en reparatie (in het bijzonder rehabilitatie en compensatie), ter bevorde- 
ring van sociale herintegratie (dat is van participation) - in elkaars verlengde liggen, zo zijn, vanuit een oogpunt van staatsaansprakelijkheid: de keerzijde van één en dezelfde medaille, vroege interventie en rehabilitatie/participatie ingebed, respectievelijk dienen even noodzakelijkerwijze als ingebed te worden beschouwd, in een groter geheel van sociaalpedagogische (educatief/informatieve, materieel/financiële en counselend/begeleidende) voorzieningen, instellingen en diensten (ook hiervoor: zie hoofdstuk 10). Minder moeilijk gezegd: binnen een algemeen-preventief sociaal-pedagogisch kader (kort gezegd: het structureel aanbieden van opvoedingshulp) - voortvloeiend, bij wijze van (voor de beurt) spreken, uit een Algemene Wet Gezinsbestuursrecht of, voor wie dat te futuristisch klinkt: een Algemeen Sociaal-Pedagogische Kader- (of Raam-)Wet - dienen vroege interventie (het desnoods opleggen van opvoedingshulp) en rehabilitatie/participatie (persoonswordingsreparatie en het zo - veel - mogelijk bevorderen van gezonde gezinspatronen) te worden gewaarborgd. En om het ook makkelijk te zeggen: de drie trappen vormen geen aparte (de-parte-mentale) eilanden, maar één persoonswordingsraket. Althans in een goed functionerende, verdragsconforme (en dus persoonswording optimaliserende) Trias pedagogica.

\subsubsection{Compensatie: kindermishandeling voor de rechter}

Voor volwassen 'survivors' van kindermishandeling heeft 'reparatie' een andere betekenis dan ten aanzien van minderjarigen. Zij zijn met de intrede van de meerderjarigheid immers buiten de Trias pedagogica getreden. Pas wanneer zij zelf ouder (wensen te) worden, treden zij de trias weer binnen. Het gaat het bestek van deze studie te buiten te onderzoeken wat zoal onder reparatie (compensatie/rehabilitatie) voor slachtoffers die buiten de trias vallen, zou kunnen worden verstaan. Een recht op kosteloze therapie? Een uitkering uit het Schadefonds geweldsmisdrijven? Een recht op publieke erkenning - compleet met een nationaal monument voor het Mishandelde Kind, op te richten vóor het ministerie van Kind en Gezin, en uiteraard een jaarlijkse dag van het Mishandelde Kind, op 20 november? Of 28 december? Of een echte nationale dag: op 5 december? (Zodat die oud-Hollandse dag niet van de nationale kalender verdwijnt tegen de tijd dat de Kerstman de functie van Sinterklaas volledig heeft overgenomen.)

Het klinkt als exotische toekomstmuziek, met name in het licht van het volgende. Opmerkelijk is immers dat tot nu toe 'survivors' van kindermishandeling binnen het gezin, en dan nog (vrijwel) uitsluitend incestslachtoffers, wel - met stijgende kans op succes - compensatie (ver- 
vangende erkenning, ${ }^{168}$ financiële genoegdoening, vergoeding van kosten voor herste], van studievertraging, van gemiste inkomenskansen en gederfde levensvreugde) hebben gezocht door hun ouders, doch (nog) niet door de staat (als secundair opvoedingsverantwoordelijke, als borg voor minimale persoonswording; uitgaande van boven-minimale persoonswording als geboorterecht) voor de burgerlijke rechter te dagen (uitwinning van de staat met zijnerzijds, afhankelijk van de wederzijdse mate van ouderlijk en statelijk wanpresteren ter zake van bedoeld geboorterecht, al of niet dan wel gedeeltelijk verhaal op ouders). ${ }^{169}$

$\mathrm{Nu}$ moet worden toegegeven dat het aanspreken van de staat ter zake van (ernstige) nalatigheid ten aanzien van feiten die hebben plaatsgevonden vóor de inwerkingtreding voor ons land van het Verdrag inzake de rechten van het kind (1995), ook bijzonder moeilijk (zij het althans ten aanzien van extreme gevallen mijns inziens niet per definitie onmogelijk $^{170}$ is. Waarschijnlijk is dit - het met succes aansprakelijk stellen van de staat - pas voor de generatie die thans in de wieg ligt, weggelegd. En zelfs als haar tijd gekomen is, in 2013, zullen procedures tegen de staat vermoedelijk nog geruime tijd eerder uitzondering dan regel zijn. Al kan, gezien de ontwikkelingen rond andere mensenrechtenverdragen, als de kogel eenmaal door de kerk is, gevoeglijk een sneeuwbal-effect worden voorspeld als de staat niet tijdig zijn verdragsverplichtingen (in structurele zin) au sérieut neemt. Het zou dan, al met al, wel eens om meer dan - ja een veelvoud van - de gevreesde miljarden-claim (een bedrag van zeven miljard gulden werd indertijd genoemd) van vrouwen op grond van het gelijkheidsbeginsel en het Burgerlijke-en-politieke-rechten-

168 Directe erkenning door ouders zou wellicht in vele gevallen (vervangende) voor de rechter afgedwongen erkenning in de vorm van financiële compensatie overbodig maken. Directe erkenning door ouders zal echter veelal pas mogelijk zijn na en door reparatie van die ouders zelf. Immers: een mens kan pas zien dat hij een beul is (geweest) als men hem heeft laten zien wat hem tot beul heeft gemakt (dat is: wie zijn beulen waren).

169 Omgekeerd zouden ook ouders in deze visie de staat kunnen aanspreken en bij hem (geheel of gedeeltelijk) verhaal zoeken indien zij tot schadevergoeding zijn veroordeeld.

170 Niet sinds vandaag of gisteren kan de staat geacht worden gehouden te zijn zich meer dan welwillende doch volstrekt ontoereikende inspanningen te getroosten ook minderjarigen tegen onmenselijke behandeling en bestraffing te beschermen. Al zal het ook hier voor juridische actievoerders een kwestie van lange adem van frappez toujours le juge - worden. De eerste survivor moet zich echter nog melden die zich tot juridisch activist ontpopt. Zo vanzelfsprekend is het kennelijk dat ouders, als eerst-verantwoordelijken, ook als enig-verantwoordelijken (en daarmee in zekere zin als "zondebok") worden beschouwd. 
verdrag kunnen gaan. ${ }^{171}$ Hoe lang zal, over twee à drie decennia, de burgerlijke rechter - of tegen die tijd wellicht de gezinsbestuursrechter tientallen, of misschien wel honderden (en, bij extrapolatie van huidige kindermishandelingscijfers, potentieel duizenden), jaarlijkse omvangrijke, in sommige gevallen, gezien huidige ontwikkelingen (we komen daar zo dadelijk op), ongetwijfeld miljoenen-claims, kunnen tegenhouden?

Wat daar - te zijner tijd - ook van zij, gezegd moet hier worden dat met betrekking tot het aanspreken van ouders (in het bijzonder van wellustige vaders en stiefvaders), incestslachtoffers de civielrechtelijke spits hebben afgebeten. Bij de rechter vinden zij inmiddels een open oor. Het is onmiskenbaar dat over incest niet alleen meer wordt gesproken en geschreven maar - vooral - ook meer wordt geprocedeerd dan over andere vormen van kindermishandeling. Terwijl steeds meer (voormalige) slachtoffers van incest erkenning van het hun aangedane onrecht zoeken èn vinden - niet zelden in relatief aanzienlijke schadebedragen uitgedrukt $^{172}$ - bij de burgerlijke rechter, komt het evenwel nog slechts sporadisch voor dat een slachtoffer van fysieke (laat staan emotionele) mis-

171 Zie Jacqueline PARLEVLIET, 'Nederland in rep en roer door witspraken van het Mensenrechtencomite; Nemesis 1988/2, pp. 79-81; dez. en Malva DRIESSEN, 'Internationale escapades?' Nedertands Juristenblad 1988, p. 357.

Vgl. Mynke WARNINK, Schadevergoeding bij seksueel misbruik; Een jurisprudentieonderzoek nat de civielrechtelijke schadevergoeding aan slachtoffers van seksueel misbruik, Ars Aequi Libri, Nijmegen 1995, pp. 57 en 82-101.

Uiteraard is de belangrijkste vorm van genoegdoening: erkenning van het gebeurde, en de gevolgen ervan voor het kind(/de dochter), door de dader(/vader). Een dader die blijft ontkennen (en aldus weigert enige verantwoordelijkheid te nemen), vergroot de (psychische) schade voor het slachtoffer. Hetgeen tot uitdrukking komt in (de hoogte van) het te vergoeden schadebedrag ( $z$ ie a.w., pp. 41/42 en vgl. Rechtbank Maastricht 14 juni 1990, NJ 1993, 130; a.W., pp. 100-101, nr. 54; Rechtbank Alkmaar 4 jamuari 1996, Actualiteitenkatern Nemesis 1996/4, Rechtspraak nr. 587).

Zo overwoog Hof Amsterdam 2 november 1995 (Actualiteitenkatern Nemesis 1996/2, Rechtspraak nr. 556, onder 'Omvang van de schadevergoeding'): "Het aan [de dochter] toekomende bedrag aan schadevergoeding dient door de rechter te worden vastgesteld naar billijkheid, rekening houdende met alle omstandigheden van het geval, waarbij onder meer de volgende aspecten van belang zijn: (...) 7. de houding van de pleger van het sexueel misbruik nadien (...). (...) Ad 7: Hoewel voor [de vader] pleit dat hij in elk geval een gedeelte van het door hem gepleegde sexueel misbruik heeft erkend, hetgeen op de verwerking van het slachitofer een gunstige invloed kan hebben, moet helaas worden geconstateerd dat hij kennelijk de ernst daarwan nog steeds niet of nauwelijks inziet, waar hij immers zich ook thans nog beroept op een wederzjijdse liefdesrelatie, als gevolg waarvan hem geen of nauwelijks verwijt zou treffen. (...). Alle omstandigheden in aanmerking genomen, is het Hof van oordeel dat het door de Rechtbank vastgestelde bedrag van f 20.000 aan immateriele schadevergoeding juist is." 
handeling de weg naar de rechter vindt. Het enige mij bekende geval uit de Nederlandse rechtspraak mag hier daarom niet onvermeld blijven: ${ }^{173}$

"Arr.-Rechtbank Utrecht; 5 april 1989 (...); (BW art. 1401 [huidig art. 6:162]). [Zoon, eiser, tegen vader en moeder, gedaagden]

2. Vasistaande feiten

a. Eiser is op 12 december 1963 geboren wit het huwelijk van gedaagden als een van een tweeling;

b. eiser leed aan een aangeboren hartafwijking, waarvoor hij zeer geruime tijd in ziekenhuizen is behandeld;

c. in november 1967 verbleef eiser sinds enige maanden weer bij zijn ouders;

d. hij was destijds 's nachts nog niet zindelijk;

e. op dinsdagmorgen 7 november 1967 constateerde zijn moeder dat hij weer in zijn bed geplast had;

f. zijn moeder heeft hem, ondat zij erg kwaad was, onder een ijskoude douche gehouden en vervolgens in een plastic badje, gevuld met koud water, buiten op het balkon van hun flat neergezet;

g. zijn vader heeft dit gezien en heeft niet ingegrepen;

h. eiser is door de kou bewusteloos geraakt en zijn vader heeft hem, toen hij dit zag, naar binnen gehaald en zeer dicht bij de gashaard, die op de hoogste stand was gezet, gehouden;

i. zijn vader constateerde na enige tijd dat het lichaam van eiser brandblaren ging vertonen; hij heeft margarine gesmeerd op die blaren en is weer met eiser op schoot voor de haard gaan zitten, nu op een afstand van $\pm 50 \mathrm{~cm}$;

j. de huisarts van gedaagden heeft eiser naar "De Lichtenberg" gebracht, waar hij in praktisch succomberende toestand werd opgenomen (brief van de kinderarts ZWAAN van 15 februari 1968), diep in shock en comateus met zwellingen in het gezicht, een gescheurde bovenlip, twee ontbrekende snijtanden in de bovenkaak en vele brandwonden; (...).

3. De wordering

3.1. Eiser stelt dat gedaagden hem ernstig hebben mishandeld en dat hij daardoor blijvend letsel heeft opgelopen. Hij wijst op de vele operaties die hij heeft moeten ondergaan in verband met de littekens van de brandwonden.

3.2 Eiser stelt voorts dat gedaagden hem sedertdien geen genegenheid hebben getoond.

3.3 Hij stelt als gevolg hiervan veel pijn en verdriet te hebben geleden, terwijl deze voorgeschiedenis ook van invloed is geweest op zijn arbeidsongeschiktheid.

3.4 Hij begroot de door hem geleden materiële en immateriële schade op $f 100,000$ en hij vordert betaling van dit bedrag in termijnen van $f 500$ per maand.

173 Rechtbank Utrecht 5 april 1989 (Mrs. DE KONING-BEU, NUNNIKHOVEN, DE GROOT-VAN DUKEN), Nederlandse Jurisprudentie 1990, nr. 183.

Vgl. over dit vonnis - in het bijzonder met betrekking tol de vraag van de ouderlijke "immuniteit" (parental immunity) in het (burgerlijke) recht - A.M.L. BROEKHUIJSEN-MOLENAAR, "Onrechtmatige daad in de relatie ouder-kind," in: Als een goed huiswader; Opstellen aangeboden aan J.H. NIEUWENHUIS, Deventer 1992, pp. 133-148. 


\section{Het verweer}

4.1 Gedaagden voeren als verweer aan dat zij in 1967 beiden in overspannen toestand verkeerden en dat zij in die tijd niet opgewassen waren tegen hun taak als verzorgers en opvoeders van eiser. Zij wijzen erop dat zij daarom ook korte tijd later zijn ontheven van de ouderlijke macht. (...)

4.3 Gedaagden wijzen er voorts op dat de wet een aantal maatregelen kent die worden toegepast wanneer ouders te kort schieten in hun taak tot verzorging en opvoeding van hun minderjarige kinderen, en dat er daarnaast geen plaats is voor een vordering op grond van art. $1401 \mathrm{BW}$. (...)

\section{De beoordeling}

5.1 De Rechtbank is van oordeel dat de wet in geval van tekortschieten van ouders in hun opvoedkundige taak een aantal specifieke maatregelen kent en dat er naast die sancties [sic, jw] in beginsel geen plaats is voor een vordering uit onrechtmatige daad.

5.2 Indien zich evenwel de uitzonderlijke $\left[\right.$ sic $\left._{*} \mathrm{jw}\right]$ situatie voordoet dat de gedragingen waarop de vordering tegen de ouders is gebaseerd, ook ten opzichte van een derde in emstige mate [curs. van de rechters] onzorgvuldig zouden zijn, komt: aan het kind terzake van die gedragingen ook tegen zijn eigen ouders een vordering uit onrechtmatige daad toe. De aansprakelijkheid van de ouders is dan niet uitsluitend gebaseerd op gedragingen die opleveren een tekortkoming bij het verwullen van hun opvoedkundige en verzorgende taak jegens hun kinderen.

5.3 Het handelen en nalaten van gedaagden op de fatale datum van 7 november 1967 omvat mede gedragingen als bedoeld onder 5.2, waardoor het leven van eiser zelfs in gevaar is gebracht. Gedaagden zijn in beginsel verplicht de dientengevolge door eiser geleden schade te vergoeden.

5.4 Gedaagden hebben echter aangevoerd dat zij destijds niet toerekeningsvatbaar waren en in ernstig overspannen toestand verkeerden.

5.5 (...) Een dergelijk beroep kan alleen slagen wanneer gedlaagden zich niet bewust zouden zijn geweest van hun handelen of nalaten, hetgeen i.c. niet is gesteld of gebleken.

5.6 Uit de stukken blijkt bovendien dat gedaagden in de weken woorafgaand aan de fatale datum al grote moeite hadden met de verzorging van eiser, dat buitenstaanders hun hulp en steun hebben aangeboden Imaar heeft niemand iets gemeld, of zou de Raad woor de Kinderbescherming het hebben laten afweten? jw], maar dat zij geweigerd hebben daar gebruik van te maken.

5.7 De Rechtbank verwerpt daarom het beroep van gedaagden op alwezigheid van schuld. (...)

5.10 Onder deze omstandigheden is de Rechtbank van oordeel dat gedaagden aan eiser behoren te betalen als schadevergoeding wegens immateriële schade een bedrag van $f 2.400$, te betalen in termijnen van $f 200$ per maand.

5.11 De proceskosten zullen worden gecompenseerd [ten laste van elk der partijen gebracht c.q. gelaten, jw] op grond wan de familierelatie [sic jw] tussen partijen.'

De toegekende schadevergoeding staat in geen verhouding tot inmiddels gangbare 'incest-tarieven,' die al gauw een factor tien hoger liggen dan 
het hier toegewezen bedrag. ${ }^{174}$ In 1987 - twee jaar vór het hier aangehaalde vonnis - werd in een incestzaak $f 10.000$ smartegeld toegewezen, met veroordeling van de vader in de proceskosten. ${ }^{175}$ In 1996 werd aan een als kind sexueel misbruikte man een bedrag van $f 50.000$ toegewezen als voorschot op materiële en immateriële schade, met veroordeling van zijn stiefvader in de proceskosten; in 1997 werd deze man, in de bodemprocedure, schadeloos gesteld à raison van een schadesom van ver over de $f 1$ miljoen, waarvan iets minder dan $f \mathbb{1}$ miljoen wegens verlies van verdiencapaciteit (en $f 35.000$ smartegeld). ${ }^{176}$

We zullen ons hier niet wagen aan speculaties of een en ander met sexuele blikvernauwing (sexuele delinquenten die als zondebok de woestijn van collectieve ouderlijke èn maatschappelijke schuld in worden gejaagd), de mythe van de moederliefde (alsof vrouwelijke misdadigheid, het geweld en de terreur van moeders, binnen het gezin net zo onaanzienlijk is als daarbuiten, waar mannen de criminele dienst uitmaken), de vaderloze maatschappij (de sociaal-psychologische eclips van de vader), 'politiek correcte' man-vrouw verhoudingen in het algemeen, of nog andere maatschappelijke euvels te maken heeft. Wel mag worden opgemerkt dat de hierboven geconstateerde discrepantie als illustratief kan worden beschouwd voor de lange weg die niet alleen door (voormalige) slachtoffers van andere dan sexuele vormen van kindermishandeling, maar ook door de maatschappij in haar geheel nog is te gaan.

Een weg die, voor zover hij al is gebaand, nog nauwelijk van verlichting is voorzien. ${ }^{177}$ Voor we kunnen bepalen in hoeverre de staat (ook) daarvoor aansprakelijk is, moet die weg eerst worden gewezen. Hetgeen ons brengt bij de volgende paragraaf.

174 Vgl. WARNINK, Schadevergoeding bij seksueel misbruik, t.a.p., vanaf p. 95 i.f. Zie ook Actualiteitenkatern Nemesis 1996/2, Rechtspraak nr. 556 (Hof Amsterdam. 2 november 1995) voor wegingsfactoren bij smartegeldtoewijzing (i. $c_{*}$ ad $/ 20.000$ ).

175 Rechtbank Den Haag 25 maart 1987; WARNINK, a.w., pp. 91-92, nr. 43.

176 Actualiteitenkatern Nemesis 1996/6, Rechtspraak nr. 630 (Rechispraak Nemesis/ $R N 1996,630)$; id. 1997/5, Rechtbank Leeuwarden 2 juli $1997, R N 1997,786$.

177 Gebaand, om precies te zijn, door beleidsplannen en uitvoeringswetgeving ten aanzien van in het bijzonder de artikelen $2-6,9,12,16,18-20,24-25,27,37$ (a) en 39 van het Verdrag inzake de rechten van het kind. En verlicht door een actief overheidsbeleid ter zake van art. 42 van het Verdrag, dat brede bekendmaking wan zijn inhoud en strekking voorschrijft, in dit verband toegespitst op de betekenis en bedoeling van - en de overheidsplannen met betrekking tot - voornoemde artikelen. 


\section{3 Systemische sociaal-pedagogische discriminatie}

$\mathrm{Na}$ het uitlichten van enkele (algemeen volkenrechtelijke) aspecten van staatsaansprakelijkheid ter zake van grove mensenrechtenschendingen gaan we thans over naar het tweede onderwerp dat, zo beloofden we in de inleidende paragraaf, een centrale plaats in dit hoofdstuk zou krijgen (dat wil zeggen tweede hoofdonderwerp, tweede centrale thema vór het trekken van conclusies zou zijn): systemische sociaal-pedagogische discriminatie. Een belofte die we in korter bestek zullen trachten in te lossen.

In de eerste subparagraaf (par. 13.3.1) nemen we het begrip 'systemische discriminatie' onder de loep. In de tweede subparagraaf (par. 13.3.2) stellen we de systemisch-discriminatoire schending van sociaalpedagogische grondrechten in het licht. In de derde subparagraaf (par. 13.3.3) vatten we de bevindingen van de vorige en deze paragraaf (par. 13.2 en 13.3.1-2) samen onder de term 'staats-transgenerationaliteitsaansprakelijkheid' en geven hiervan een schematische weergave. (De conclusies van die bevindingen, in het licht van het schema, volgen dan in par. 13.4.)

\section{3 .1}

Systemische discriminatie

Om de geur van chimerische begripsvorming geen kans van beklijving te geven, hebben we al dadelijk in de inleidende paragraaf (par. 13.1) een omschrijving van het adjectief 'systemisch' gegeven. Onder systemisch zeiden we te verstaan: betrekking hebbend op de gehele maatschappij, dat wil zeggen op het publieke zowel als op het private leven, op instituties zowel als op gewoontes en tradities, op openbare lichamen (bestuurlijke, vertegenwoordigende, rechtsprekende) zowel als op particuliere instellingen, op oudere zowel als op jongere generaties, op het openlijke zowel als op het heimelijke, op het uiterlijke zowel als op het verinnerlijkte. Systemische discriminatie, zo voegden we toe, is met andere woorden discriminatie waarvan de hele maatschappij doordesemd is, en wel zozeer al zo lang en zo diepgaand - dat zonder speciale bril, zonder bril die een extra dimensie toevoegt en zichtbaar maakt, niemand in die maatschappij van discriminatie zou spreken.

Voordat we die speciale bril gaan opzetten, de bril van de sociaalpedagogische grondrechten van hoofdstuk 7 , althans voor zover deze als de directe uitwerking van het recht van het kind op optimale persoonswording als achterliggend, dragend en leidend beginsel van het Verdrag inzake de rechten van het kind (hoofdstuk 10) kunnen worden beschouwd en (derhalve) besloten liggen in diverse verdragsbepalingen (we zouden, enigszins elliptisch, ook kunnen zeggen: de trias-dimensionale persoons- 
wordingsbril van het Kinderrechtenverdrag), is het nodig beide elementen van het begrip systemische discriminatie nader toe te lichten c.q. te analyseren. Allereerst dient het adjectief 'systemisch' te worden afgebakend (voor zover mogelijk) van het adjectief 'systematisch.' Als springplank daarvoor gebruiken we een fragment van een internationale tekst waarin beide termen (na/naast elkaar) voorkomen. In het Platform for action, aangenomen door de Vierde VN-Wereldvrouwenconferentie in Peking (1995) lezen we: ${ }^{178}$

'If the goal of full realization of human rights for all is to be achieved, international human rights instruments must be applied in such a way as to take more clearly into consideration the systematic and systemic nature of discrimination against women that gender analysis has clearly indicated.'

Als we 'women' vervangen door 'transgenerationeel beschadigde ouders en kinderen' in de hoop dat de woorden 'deze studie' (of liever: de in de hoofdstukken 11 en 12 aangehaalde literatuur) voor de woorden 'gender analysis' kunnen worden gesubstitueerd, komen we in de burt van wat in deze paragraaf wordt betoogd. Met dien verstande dat wij in deze studie niet van systematische doch van passief-systematische mensenrechtenschendingen spreken (vgl. hoofdstuk 12, par. 12.4), welke in het verlengde liggen van en verweven zijn met het fenomeen van systemische discriminatie. Anders gezegd: de (al vaker gereleveerde en in dit hoofdstuk nader te adstrueren) passieve (dat is sociaal-pedagogisch structureel te kort schietende) overheidsrol en het passieve (stelselmatig met zalf en pleisters achter de transgenerationele feiten aanhollende, met de mantel van marginale en marginaliserende overheidszorg de ware aard en omvang van de problematiek bedekkende) overheidsaandeel zijn onderdeel van systemische discriminatie als maatschappelijk totaal-fenomeen, ${ }^{179}$ staan tot dit fenomeen in wisselwerking en houden het duurzaam in stand.

178 Aangehaald door J.C. HES, C.E. VAN VLEUTEN, Het Vrouwenverdag in de Nederlandse rechisorde, Den Haag 1996, p. 179 i.f. (juncto p. 119 nt. 232; curs. jw). Voor het origineel zie: The Beijing Declaration and the Platform for action, UN, New York 1996, pp. 121-133 (par. 210-233: 'Human rights of women'), op p. 124 (par. 222). Par. 210 noemt mensenrechten het geboorterecht van elk mens, en de bescherming en bevordering ervan de eerste verantwoordelijkheild van regeringen. GROENMAN c.s. spreken met betrekking tot vrouwendiscriminatie van een "totall phenomenom" (...) dat zich als complex en structureel probleem in alle onderdelen van het menselijke bestaan voordoet." (L.S. GROENMAN e.a., Het Vrouwenverdrag in Nederland anno 1997; Verslag van de commissie voor de eerste nationale rapportage over de implementatie in Nederland van het $/ \mathrm{VN}$-J Verdrag tegen discriminatie van vrouwen, Den Haag 1997, p. 28.) 
In de tweede plaats dienen we een adequate juridische definitie van discriminatie te geven. Op basis van de algemene discriminatie-definitie van art. 90 quater Wetboek van Strafrecht (welke afgeleid is van de definitie van rassendiscriminatie van art. 1 Internationaal Verdrag inzake de uitbanning van alle vormen van rassendiscriminatie) ${ }^{180}$ in verband met de definitie van vrouwendiscriminatie in art. 1 van het Verdrag inzake de uitbanning van alle vormen van discriminatie van vrouwen, ${ }^{181}$ stellen we de volgende definitie voor. ${ }^{182}$

Onder discriminatie of discrimineren wordt verstaan elke worm van onderscheid, witsluiting of beperking die ten doel heeft of ten gewolge kan hebben dat de erkenning, het genot of de uitoefening op voet van gellykheid van de rechten wan de mens en de fundamentele vitheden op politiek, economisch, social of cultureel terrein, op het terrein van de burgenligke rechten of welk ander gebied dan ook wordt teniet gedaan of angetast.

\section{Publiek/privé}

De woorden '[op] welk ander gebied dan ook' maken ten overvloede duidelijk dat het discriminatieverbod zich ook uitstrekt tot de privésfeer. ${ }^{183}$ Op deze plaats is het nuttig het begrip 'privésfeer' door GROENMAN c.s. te laten verduidelijken: ${ }^{184}$

'Er bestaat veel verwaring over het begrip privesfeer of priveleven en over de vaag in hoeverre de overheid daarin zou mogen of moeten ingrijpen op grond van verdragswerplichtingen en de grondrechten.

In de eerste plats kan het onderscheid worden gebruikt on het verschil en de grens aan te geven tussen de staatssfeer en de burgerligke samenteving. Bij dit onderscheid gaat het om het verschil tussen overheidsactoren en niet-overheidsactoren.

In de tweede plaats kan het onderscheid worden gebruikt om het verschil en de grens aan te geven tussen de markt en het gezin. Onder de markt wordt dan het

180 Zie C.F. PATTIPAWAE, A.C. POSSEl, C.A. TAZEla.AR, 'Begrippen en definities," in: C.F. PATTIPAWAE, C.A. TAZELAAR (red.), Met recht discriminatie bestrijden, Een juridische handleiding bij de bestrijding van discriminatie op grond van ras en mationaliteit, Utrecht/Deventer 1997 (tweede druk), pp. 3-14, op p. 3.

181 Vgl. HES/VAN VLEUTEN, a.w., pp. 32-34.

182 De gecursiveerde woorden vestigen de aandacht op het feit dat ook de zogenaamde indirecte discriminatie onder het discriminatiebegrip valt (vgl. PATTIPAWAE e.a., t.a.p., op pp. 3-5 en 10-14; GROENMAN e.a., a.w., pp. 55-59).

PATTTPAWAE c.s. onderscheiden naast directe en indirecte discriminatie ook incidentele of stnucturele discriminatie: 'Bij structurele discriminatie gaat het om een vast gedragspatroon of gevestigde praktijk, waarvan de discriminatoire effecten niet altijd direct herkenbaar hoeven te zijn.' (T.a.p., op p. 10; curs. jw.) Vgl. HES/VAN VLEUTEN, a.w., pp. 36/37; GROENMAN e.a., a.w., pp. 28-31. GROENMAN e.a., a.w., pp. 28-29. 
openbare productieve leven of de wereld van de betaalde arbeid en de handel verstaan. Het gezin staat voor de private affectieve levens van mensen, de leefwereld thuis, of de persoonlijke levenssfeer.

Dat het [Vrouwen]verdrag zich ook richt op niet-overheidsactoren - door het beginsel van non-discriminatie niet alleen voor de overheid zelf te laten gelden, maar ook woor horizontale verhoudingen - is niet omstreden. Verschillende verdragsartikelen en sommige algemene aanbevelingen van het [Vrouwen(verdrags-) comite] hebben zonder meer betrekking op de verhoudingen en verantwoordelijkheden binnen het gezin.

De discussie gaat over de vraag in hoeverre de overheid bij de uitvoering van het Verdrag mag ingrijpen in de "private affectieve levens" van haar onderdanen. Met andere woorden: kan de Nederlandse overheid gevolg geven aan deze verdragsnormen zonder daarbij in botsing te komen met de grondwettelijke bescherming van het priveleven?

De Nederlandse overheid heeft een toenemende invloed op het priveleven van haar onderdanen door middel van allerlei wetgeving en voorzieningen (...) die diep ingrijpen [in] het gezinslewen van mensen.

De grenzen tussen waar de overheid zich wel en niet mee mag bemoeien, zijn in het verleden vaak op ideologische gronden getrokken. Het kwam er veelal op neer dat vooral de belangen van mannen in de patriarchale samenleving werden ontzien.'

Waaraan wij kunnen toevoegen - de (onvoltooid) verleden tijd van de patriarchale samenleving naar de tegenwoordige tijd van de parentiarchale samenleving omzettend:

De grenzen tussen waar de overheid zich wel en niet mee mag bemoeien, worden nog steeds op ideologische gronden getrokken. Het komt er veelal op neer dat vooral de belangen van ouders in de parentiarchale samenleving worden ontzien.

Voor deze toevoeging (of liever inlassing: we keren zo dadelijk naar GROENMAN c.s. terug) laten we wat hierover in eerdere hoofdstukken is gezegd, samenvatten door FORDER: ${ }^{185}$

'Waarom hebben ouders eigenlijk zoveel rechten?

(...) WALSH [1991] identificeert twee rechtvaardigingen voor de bescherming van de rechten van ouders en degenen die voor de kinderen zorgen. De eerste is daarin gelegen dat de ouders en de anderen die kinderen verzorgen, een eigen belang hebben om hun kinderen naar eigen goeddunken op te voeden. Aldus wordt uitdrukking gegeven aan de autonomie van de ouders "Deze rechtvaardiging voor ouderlijke rechten vindt brede erkenning in de nationale rechtsstelsels. De tweede rechtvaardiging ziet op de bescherming van de rechten van ouders en anderen die kinderen verzorgen, vamuit het oogpunt van het belang van het kind. 
Deze visie gaat ervan uit dat de ouders [in beginsel, jw] het beste in staat zijn de belangen van hun kinderen te behartigen, en dat hun (of anderen die kinderen verzorgen) om die reden rechten [lees: bevoegdheden, jw] worden toegekend [en plichten worden opgelegd, $j w]$. In de eerste visie is de uttoefening van de rechten door de ouders ook dan gerechtvaardigd als de belangen van het kind hierdoor miet worden bevorderd. In de tweede visie vindt de uitoefening van de ouderlijke rechten haar grens in het belang van het kind. ${ }^{186}$ (...)

SEYMOUR [1992] heeft naar aanleiding van een studie van het Australische recht gesuggereerd dat er in het rechtsstelsel elementen zijn die tegemoet komen aan het belang dat ouders erbij hebben dat hun kinderen opgroeien tot de door hen gewilde "soort mensen." (...) DE GRAAF [1993] heeft erop gewezen dat dit fenomeen in Nederland feitelijk aanwezig is, soms met zeer ongunstige psychologische effecten voor kinderen.'

FORDER concludeert: $:^{187}$

'Het beeld van het gezin dat ik zojuist heb geschetst, botst met het Kinder[rechten]verdrag, niet alleen met de hoofdlijnen ervan (artikelen 3 [secundaire opvoedingsverantwoordelijkheid van de staat] en 5 [primaire opwoedingsverantwoordelijkheid, dat is bevoegdheden èn plichten, van ouders in het belang van het kind]), maar ook met een groot antal specifieke door het Verdrag gewaarborgde rechten.'

Haar slotconclusie luidt: ${ }^{188}$

${ }^{6}$ De euforie over de gevolgen van het Kinder[rechten]verdrag is inmiddels geluwd. Juist waar het gaat om de grondbeginselen zijn de vooruitzichten van de toepassing van dit verdrag in Nederland op dit moment niet optimaal.'

Aan deze slotconclusie, getrokken na het langslopen van parlementaire discussies op het gebied van het Nederlandse familierecht, mogen we ge-

186 Enkele kolommen eerder had FORDER (t.a.p., op p. 138 L.k.), in navolging van EEKELAAR (1986), het belang van het kind opgesplitst in drie soorten rechten, namelijk die welke basic interests, die welke development interests, en die welke autonorry interests betreffen. In deze studie (die overigens vooral het jonge en zeer jonge kind voor ogen heeft, zodlat relatief weinig aandacht aan 'autonomy interests' is besteed) zijn deze drie onder én noemer gebracht en als ontwikkelingsbelang (c.q. persoonswordingsbelang) van het kind aangeduid: in ontwikkelingspsychologische zin heeft het kind, in relatie tot zijn zich ontwikkelende vermogens wisselende basale fysieke, emotionele en geestelijke behoeften, behoefte aan leiding en begeleiding (waaronder disciplinering) bij zijn ontwikkelingstaken, en in toenemende mate behoefte aan zelfstandigheid en eigen verantwoordelijkheid, totdat in de adolescentie het (laatste) losmakingsproces is geslaagd. FORDER, t.a.p. (p. 141 l.k.). 
voeglijk de bevestiging van het (door de studies van SEYMOUR en DE GRAAF gerezen) vermoeden verbinden dat de tweede door de auteur gememoreerde rechtvaardiging voor ouderlijke rechten: ouderlijke "rechten" in het primaire belang van het kind, in Nederland (dat is bij de Nederlandse politieke en juridische elite) niet dominant, en verre van algemeen gangbaar is. Dit in tegenstelling tot de eerste rechtvaardiging: ouderlijke rechten in het primaire belang van ouders, en de daaronder liggende en daarmee verknoopte parentiarchale ideologie (voor zover 'ideologie' niet een te mooi woord is voor het ogenschijnlijk gedachteloos of clichématig vasthouden aan een 'politiek-folkloristische' familierechtelijke status quo).

Het vanzelfsprekende, ongenuanceerde gebruik van de term 'ouderlijke rechten' (in plaats van ouderlijke bevoegdheden, verantwoordelijkheden en verplichtingen, alsmede aanspraken jegens de overheid) sprak men in de middeleeuwen zo ook niet over "heerlijke rechten'? illustreert op zich al dat het predikaat parentiarchaal voor onze samenleving - wat onder die vlag ook de precieze lading moge zijn ${ }^{189}$ - onevenredig nijpender en actueler is dan het (zij het nog niet volledig historische) predikaat patriarchaal. SACHS, rechter in het Constitutionele Hof van Zuid-Afrika, ${ }^{190}$ weet dit treffend te typeren als hij enerzijds spreekt van ...

"(...) the obnoxious term "marital rights" which until recently was used in relation to sexual activity between spouses (...)'

189 Hieronder kom ik daar - aan de hand van FREEMAN - nog op terug.

190 Een rechter die waakt over een unieke Grondwet: art. 28 (juncto art. 7, lid 2) van de Zuidafrikaanse Constitutie erkent het door de staat te waarborgen recht van het kind op (onder andere) gezinszorg of ouderlijke zorg dan wel passende verwangende zorg alsmede op bescherming tegen mishandeling, verwaarlozing, misbruik of vernedering. Ook gewaagt het artikell wan de fysieke èn geestelijke gezondheid en de intellectuele, morele en sociale ontwikkeling van het kind. Het belang van het kind is beslissend in alles wat het kind regardeert. Zie hierover: Pierre DE vOS, 'Introduction to South Africa's 1996 Bill of rights, ${ }^{*}$ NQHR 1997/2, pp. 225-243; Julia SLOTH-NIELSEN, "The contribution of children"s rights to the reconstruction of society: some implications of the constitutionalisation of children's rights in South Africa," IJCR 1996/4, pp. 323-344; Michael FREEMAN, The moral status of children; Essays on the rights of the child, Den Haag 1997, pp. 3, (107), 389.

Uiteraard is constitutionalisering van de rechten van het kind (in combinatie met een rechterlijk toetsingsrecht, volgens Marbury $v$. Madison the very essence of judicial duty') niet meer - maar ook niet minder - dan de eerste nationale stap, een stap die in Nederland nog moet worden gezet, op weg naar beëindiging van transgenerationele 'Apartheid: de systemische tweedeling tussen de 'welopgevoede' kinderen en de kinderen van het Mattheüs-effect, ter maatschappelijke dood gedoemd tot in het derde geslacht. 
... de voltooid verleden tijd van de sexuele huwelijksrechten van de man in een slechts in de definitie gelijkwaardige verbintenis tussen 'man ende wijf tot een gemeen leven, medebrengende een wettelick gebruick van malkanders lichaem, ${ }^{191}$ en anderzijds opmerkt: ${ }^{192}$

'I think it is inappropriate to speak of rights in relation to a child, as though a child were an object or a species of property in terms of which rights could be exercised. A parent has responsibilities and powers in terms of a relationship with a child; the child has claims on the parent.'

Maar genoeg hierover. We keren terug naar GROENMANs grenzen van de (patriarchale) privacy: ${ }^{193}$

'De vrouwenbeweging heeft de [patriarchale privacy-]grenzen de laatste decennia ter discussie gesteld. Door bijvoorbeeld geweld en verkrachting binnen het gezin en de consequenties van economische afhankelijkheid van vrouwen en kinderen aan de orde te stellen, werden verhoudingen binnen het gezin een openbare aangelegenheid. De groei van de kinderopvang, de toenemende politieke belangstelling voor de onbetaalde zorgarbeid en de huidige discussie over de juridisering van onbetaalde zorgarbeid laten zien dat er grote verschuivingen hebben plaatsgevonden in het denken over de grenzen tussen de publieke en privésfeer.

191 Hugo DE GROOT, Inleidinge tot de Hollandsche rechtsgeleerdheid (1631, ed. Leiden 1952), 1.5:1 (Institutiones Jüis Hollandici: 'mutuus corporis usus'; vgl. over DE GROOTs definitie: L.J. VAN APELDOORN, Geschiedenis van het Nederlandsche huwelijksrecht wóór de invoering van de Fransche wetgeving, Amsterdam 1925, p. 9). In par. 1.3:8, tweede volzin had DE GROOT evenwel al aangegeven: 'Daer en boven alzoo doorgaens der wijven geslacht, als kouder ende vochtiger [Irst. Iur. Holl.: 'foeminarum sexus magis frigidus (...) et humidus'], minder bequaemheid heeft tot zaken, verstand vereisschende, als 't geslacht der mannen, zoo is het mannelick gheslacht genoegzaem aengeboren eenige opperheid over de wijven. Want het wijste komt altijd toe te gebieden.'

Overigens laat (Rainer) KNUBMANN in zijn De man, een vergissing der natuur (Utrecht/Antwerpen 1983, pp. 49-50), juist zien dat de man $1 \%$ meer bloed (8\% tegen de vrouw 7\%) heeft, dus 'vochtiger' is, en een minder gunstige warmtehuisbouding heeft, dus 'kouder' is. Gelukkig kent de (k)oude sappenleer geen aanhangers meer. Vgl, over de vrouw als een 'vergissing van de natuur' wegens 'haar "teveel aan vocht" en haar "ondertemperatuur"' bij Thomas VAN AQUINO (gestorven in 1274, doch sedert een eeuw 'eerste leermeester van de Catholica' en 'patroon van alle katholieke universiteiten en scholen'): Karlheinz DESCHNER, $D e$ kerk en haar knis; Geschiedenis van de seksualiteit in het Christendom, Amsterdam 1978, p. 221 (op p. 222 gewaagt hij van 'kinderen met een groter watergehalte, te weten meisjes,' ten gevolge van 'de "vochtige zuidenwind" (venti australes)').

192 Albie SACHS, 'Human rights in the twenty first century: real dichotomies, false antagonisms,' paper presented to conference of the Canadian Institute for Judicial Administration, Halifax april 1997 (nog niet gepubliceerd). GROENMAN e.a., a.w., pp. 29/30. 
De wijze waarop deze grenzen tot stand kwamen en komen, heeft onder meer te maken met de mate waarin een bepaald probleem als een "natuurlijk" gegeven wordt gezien. Daardoor lijkt het of de overheid er geen invloed op kan uitoefenen."

Ik ben zo vrij de rest van het betoog, waar van toepassing, door middel van teksthaken direct naar het Verdrag inzake de rechten van het kind te vertalen: ${ }^{194}$

'Juist in verband met de [hoofd]doelstelling [van het Kinderrechtenverdrag: de optimale persoonswording van elk kind binnen de rechtsmacht van de staat] is het van belang dat de overheid onderkent dat er in dit opzicht geen "natuurlijkheid" bestaat, en dat de grenzen tussen wat privé of publiek "is" (of zou [moeten] zijn), sociaal en cultureel zijn bepaald. Het Verdrag [inzake de rechten van het kind] bevat, via de normstelling in [de artikelen 3, 5, 19 enz., enz.] een zwaarwegende opdracht aan de overheid deze grenzen voortdurend ter discussie te stellen. (...)

De begrenzing van de overheidsbemoeienis met het priveleven ligt in de klassieke grondrechten. Deze grondrechten hebben hun oorsprong in de bescherming tegen de macht van de overheid ter voorkoming van machtsmisbruik en van een te grote invloed op individuele keuzen en wijzen van leven. De sociale grondrechten hebben aan de beschermende en terughoudende rol van de overheid een extra dimensie toegevoegd, namelijk die van ondersteuning van het individu bij de eigen ontplooiing.

Door de toenemende verwevenheid van de klassieke en de sociale grondrechten is de tegenstelling tussen de publieke en de privésfeer veel minder scherp komen te liggen. Dat will echter zeker niet zeggen dat het grondrecht van "bescherming van het privéleven" in de klassieke betekenis wan afscherming tegen overheidsbemoeienis geen betekenis meer zou toekomen.

Het voeren van een beleid ter verbetering van de positie van vrouwen [en kinderen] en het witwaardigen van antidiscriminatiewetgeving [waaronder sociaal-pedagogische wetgeving] - ook wanneer daarbij normen worden gesteld die ingrijpen in het privéleven van mensen - behoeft op zichzelf niet in strijd met deze grondwettelijke bescherming te komen. Pas wanneer de overheid in haar controlerend optreden daarbij bepaalde grenzen overschrijdt, kan van strijdigheid sprake zijn.

Een andere grens aan de overheidsbemoeienis met het privéleven heeft te maken met de principiële discussie over de (on)wenselijkheid van een steeds verdergaande juridisering van het menselijk samenleven. (...) Hierover lijkt in zoverre consensus te bestaan dat de verschuiving van de grens tussen publiek en privéleven niet zover mag gaan dat publieke normen en publieke verwachtingen het gehele persoonlijke leven gaan bepalen.'

Dat laatste laat zich moeilijker naar (de opvoeding van) kinderen vertalen. Door het nemen (c.q. geboren laten worden dan wel niet afstaan) van kinderen hebben ouders immers een (internationaal-)publiekrech- 
telijk genormeerde taak op zich genomen. Een taak overigens die - door de onmiddellijke en volledige verwevenheid van het leven van het kind, vanaf of zelfs al vóór zijn geboorte, met dat van de ouders - ook zonder die normering hun gehele persoonlijke leven bepaalt. ${ }^{195}$ Het belang van het kind, en in elk geval het recht van het kind, van elk kind, op bovenminimale persoonswording, prevaleert daarbij boven elk gevoelen - hoezeer geworteld in geloof en traditie, die ten enenmale voor fundamentele(re) mensenrechten moeten wijken, dan wel van idiosyncratische ${ }^{196}$ aard ook - van aantasting van de privacy door overheidsbegeleiding en -bewaking (mits uiteraard niet willekeurig of met schending van enig ander beginsel van behoorlijk bestuur uitgeoefend) van de primaire ouderlijke opvoedingsverantwoordelijkheid.

\section{Trias pedagogica}

We vatten samen. Wat voor het Vrouwenverdrag geldt, geldt $a$ fortiori voor het Verdrag inzake de rechten van het kind, namelijk dat de werking ervan in de private sfeer [niet enkel onvermijdelijk is maar, verre van een noodzakelijk kwaad te zijn] "zelfs tot doel en strekking van het verdrag" moet worden gerekend. ${ }^{197}$ De Trias pedagogica betreft per definitie de (structurele, stelselmatige) bemoeienis van de staat, in zijn (natuur- - zo men wil: sociaal-contractuele - en verdragsrechtelijke) hoedanigheid van verdediger en beschermer van het kind, met de gezins(privé)sfeer. De desbetreffende bepalingen in het Kinderrechtenverdrag zijn niet zozeer "doorbraakbepalingen" ${ }^{198}$ als wel expliciete en tamelijk

195 Een verwevenheid die niet zelden zo zwar (transgenerationeel) belast is, dat onthouding van opvoedingsondersteuning (en in het algemeen opvoedingsonderwijs/-voorlichting en -subsidiëring) door de overheid óok ten aanzien van ouders als een ernstige mensenrechtenschending moet worden beschouwd.

196 Idiosyncratisch kan het privacy-beleven genoemd worden wanneer de roep om vrijheid, vrijheid in de negatieve zin wan 'the right to be let alone' - waartoe reeds in 1890 het recht op privacy werd herleid (vgl. KOOPMANS" Compendium van het staatsrecht, Deventer 1994, pp. 312/313) -, vooral lijkt ingegeven door de deels angstige deels zelfgenoegzame wens alleen gelaten te worden met de eigen (ouderlijke) onmacht en een slecht (pedagogisch) geweten in een maatschappij waarin ouderlijke 'natuurlijke' zelfverzekerdheid eerste parentiarchaal dogma is (een dogma met de sociale plicht de vuile was niet buiten te hangen als eerste sequeell).

197 T. LOENEN, 'Het discriminatiebegrip," in: A.W. HERINGA, J. HES, L. LLNZAAD (red.), Het wrouwenverdrag: een beeld van een verdrag ...., Antwerpen/Apeldoorn 1994, pp. 1-13, op p. 2 (met aanbaling van LJNZAAD, Nemesis 1991).

198 '[B]epalingen die een doorbraak naar de privé-sfeer inhouden': Liesbeth LIJNZAAD, "Het kussen van een kikker; de werkelijke bettekenis van het Vrouwenverdrag,' Nemesis 1991/2, pp. 5-17, op p. 12 r.k. i.f.

Volgens LUNZAAD (t.a.p., op p. 13 1.k) zijn de doorbraakbepalingen van het 
gedetailleerde - dat wil zeggen naar doel (de optimale persoonswording van elk kind) en globale middelen (opvoedingsbegeleiding en -bewaking, ouderschapsvoorlichting en -ondersteuning) afgebakende - opdrachten aan de staat de gecodificeerde rechten en beginselen door wetgeving en (sociaal-pedagogisch) beleid te operationaliseren.

Dat daarbij de parentiarchale ideologie ${ }^{199}$ moet worden doorbroken, dat de parentiarchale mens etwas ist das überwunden werden muss (zoals dat, althans in Nederland, grosso modo ook is geschied met de patriarchale $\operatorname{man}^{200}$ ), om te beginnen in de wetenschap ${ }^{201}$ en in de politiek, is een andere zaak. Een zaak die beter niet als doel op zich, doch als te verwachten bijeffect van het voortvarend en te goeder trouw voldoen aan de verdragsrechtelijke opdrachten kan worden beschouwd.

\section{Materiële gelijkheid}

Met inachtneming van de zowel publieke als private strekking en betekenis van het kindervolkenrechtelijke - dat is sociaal-pedagogische -

Vrouwenverdrag weliswaar "ambitieus" maar is het nog maar "de vraag of het internationale recht in staat is deze taak [bedoeld is: de taak van de ambitieuze doorbraakbepalingen, $j w]$ te vervullen.' Dit lijkt mij een misleidende reificatie van het recht. Het zijn immers de juristen, politici, rechters, instellingen, organisaties, burgers die het recht, dat wil zeggen: rechten en beginsellen, moeten operationaliseren, inroepen, toepassen, kortom: 'hard' maken. Niet 'het' recht bezielt het recht, maar de politieke wil, dat is de ambitie en de goede trouw van de rechtsgenoten gevolg te geven aan de verbindende opdracht die in rechten en beginselen besloten ligt.

199 In essentie kan parentiarchie worden getypeerd als de ideologie die de ouderkind-relatie niet opvat en voorstelt in termen van ouderlijke verantwoordelijkheden maar als een bundel van ouderlijke rechten (vgl. IREEMAN, The moral stanus of children, a.w., p. 166). Ouderlijke rechten op staatsonthouding (laissez faire, laissez passer) in de gezinsprivésfeer alsmede ouderlijke (semi-)bezitsrechten ten aanzien van hun kinderen, dat wil zeggen de kinderen onder hun (ouderlijke) rechtsmacht. Of zelfs het recht van nog-niet-ouders op medische ingrepen om ouders te worden, een 'gezondheidsrecht' van volwassenen op kunstmatig voortgebrachte kinderen, met inbegrip van het recht de (biologische) identiteit van die kinderen te verduisteren/te verzwijgen (vgl. over dat laatste FREEMAN, a.w., pp. 185-212: "The rights of the artificially procreated child").

200 Niet te verwarren met de macho met de grote mond on het kleine hartje, die zorgtaken beneden de mannelijke waardigheid acht teneinde aan huishoudelijke klussen te ontsnappen (en achter wie een vrouw, gewillig, berustend of onder protest, met stoffer en blik, maald en draad, vaatdoek en schone broek klaarstaat).

201 Vgl. woor enkele voorbeelden van parentiarchale wetenschapsbeoefening (GOLDSTEIN/FREUD/SOLNTT, 1973, 1979; WARDLE, 1996) en een summiere kritiek daarop: FREEMAN, The moral status of children, a.w., 'Afterword,' pp. 389-396, op pp.

392-393. 
discriminatieverbod dient de hierboven voorgestelde definitie te worden bezien in het licht van art. 26 van het Burgerlijke-en-politieke-rechtenverdrag (IVBPR):

\begin{abstract}
Allen zijn gelijk voor de wet en hebben zonder discriminatie aanspraak op gelijke bescherming door de wet. In dit verband verbiedt de wet discriminatie van welke aard ook en garandeert een ieder gelijke en doelmatige bescherming tegen discriminatie op welke grond ook, zoals ras, huidskleur, geslacht, taal, godsdienst, politieke of andere overtuigingen, nationalle of maatschappelijke afkomst, eigendom, geboorte of andere status.
\end{abstract}

Deze bepaling wijst veel indringender (blijkens de door mij gecursiveerde woorden) in de richting van een materiële (niet louter formele) invulling van het discriminatieverbod dan het (te) korte en (minder?) krachtige art. 1 van de Nederlandse Grondwet: ${ }^{202}$

Allen die zich in Nederland bevinden, worden in gelijke gevallen gelijk behandeld. Discriminatie wegens godsdienst, levensovertuiging, politieke gezindheid, ras, geslacht of op welke grond dan ook, is niet toegestaan.

Reeds eerder, in hoofdstuk 6 (par. 6.4.1), hebben wij een materiële gelijkheidsbenadering bepleit: gelijke behandeling wil niet alleen zeggen dat gelijke gevallen gelijk, maar ook dat ongelijke gevallen ongelijk worden behandeld naar de mate van hun ongelijkheid. ${ }^{203} \mathrm{De}$ materiële benadering impliceert dat positieve maatregelen (positieve actie, voorkeursbehandeling, speciale rechten) geen (positieve) discriminatie zijn maar (materiële) discriminatiebestrijding. Immers: ${ }^{204}$

'De invulling van het discriminatieconcept volgens de materiële gelijkheidsnorm betekent (...) dat positief rekening moet worden gehouden met verschillen. Dit impliceert een (sociaal) beleid met als doel de realisatie van materiële gelijkheid.'

In dit verband wordt ook wel gesproken van de klassieke component (trefwoorden: gelijkheid voor de wet, vrijheid, onthouding) respectievelijk

202 Uit de parlementaire behandeling leiden HES en VAN VLEUTEN af dat met het discriminatieverbod van art. 1 Grondwet (in werking getreden in 1983) 'ook materiële gelijkheid wordt nagestreefd,' welke (regerings)opvatting zij ook van toepassing achten op het Vrouwenwerdrag (HES/VAN VLEUTEN, a.w., pp. 80/81). Zie HES/VAN VLEUTEN, a.w., pp. 34-36. Vgl. ook LOENEN in Het vrouwenverdrag: een beeld van een verdrag ..., t.a..p., op pp. 4 i.f. -6 ; vgl. voor de/een (formele) gelijkheidsbenadering van het Europees Hof voor de rechten van de mens de noot van (Titia) LOENEN büj de STUBBINGS-zaak (1996): 'Seksueel kindermisbruik en verjaringstermijnen,' NJCM-Bulletin 1997/3, pp. 287-297, op pp. 296/297. HES/VAN VLEUTEN, a.w., p. 217. 
de sociale component van het gelijkheidsbeginsel, welke laatste noopt tot positieve maatregelen (onder meer ter bescherming in horizontale relaties). ${ }^{205}$ Aldus wordt recht gedaan aan (maatschappelijke situaties van) de facto ongelijkheid, en wordt het veronachtzamen van (maatschappelijke situaties van) de facto ongelijkheid tot de facto (dat is systemische c.q. passief-systematische) discriminatie. Althans voor zover dat veronachtzamen, het niet actief doorbreken van patronen, neerkomt op het in stand houden en structureel dan wel duurzaam bestendigen van de facto ongelijkheid.

Na het langslopen van de elementen 'systemisch' en 'discriminatie' dient thans het element 'sociaal-pedagogisch' nader in het licht te worden gesteld.

13.3.2

De systemisch-discriminatoire schending van sociaal-pedagogische grondrechten

Daartoe nemen we de speciale bril ter hand waarvan hierboven sprake was, en poetsen de brilleglazen op. Al wrijvende ontdoen we de volgende sociaal-pedagogische grondrechten van het kind van het stof en de aanslag van verschillende hoofdstukken:

\section{Lichamelijke en geestelijke integriteit}

Het recht van het kind op respect van zijn ouders/opvoeders (kortheidshalve: ouders) voor zijn lichamelijke en geestelijke integriteit; waaronder het recht op vrijwaring van fysiek, sexueel en/of verbaal geweld ten opzichte van zijn persoon en het recht op vrijwaring getuige te zijn van fysiek, sexueel en/of verbaal geweld tussen zijn ouders; alsmede het recht op vrijwaring van elke vernederende of kleinerende behandeling of bejegening. Tot dit recht behoort ook het recht op morele (en eventueel financiële) genoegdoening (als onderdelen van het recht op 'reparatie') in geval van (ernstige) schendingen van de lichamelijke en geestelijke integriteit van het kind.

\section{Koestering}

Het recht van het kind op koestering door zijn ouders (dat is op lichamelijke en verbale liefkozing, op lijfelijk teder contact en op de prijzende en bewonderende taal der vertedering); waaronder het recht zijn aanhankelijkheid vrijelijk te kunnen tonen.

3. Lichamelijke en geestelijke zorg en zorgvoorzieningen

Het recht van het kind op optimale lichamelijke en geestelijke zorg/verzorging door zijn ouders en op de best mogelijke lichamelijke en geestelijke gezondheidsvoorzieningen door de staat. 


\section{Gelijke opvoeding}

Het recht van het kind op gelijke behandeling van broertjes en zusjes, waaronder in het bijzonder het recht van het kind op gelijke opvoeding van jongens en meisjes (geen bevoorrechting van een bepaald geslacht of 'voortrekken' van een bepaald kind).

\section{Ontplooiing}

Het recht van het kind op ontplooiing (op warmte, affectie, ruimte, ondersteuning, troost, bemoediging, verdiende complimenten, op morele en materiële geborgenheid).

\section{Leiding}

Het recht van het kind op leiding (op opvoeding in enge zin, op toezicht en controle, op realistische - niet te hoge en niet te lage - eisen en verwachtingen, op disciplinering, op het consequent stellen van consistente, begrijpelijke en duidelijke grenzen); waaronder het recht op verdiende ook in de uitoefening rechtvaardige, dus niet fysiek of verbaal gewelddadige, vernederende of kleinerende - straf, alsmede het recht op vrijwaring van overcontrole, overbescherming en betutteling.

\section{Begeleiding}

Het recht van het kind op begeleiding overeenkomstig de zich ontwikkelende vermogens van het kind. Dat wil zeggen het geleidelijk, begeleid, loslaten en meer ruimte en eigen verantwoordelijkheid geven. Tot dit recht behoren de beide hierna volgende rechten van het kind, welke gelden naar de mate van zijn zich ontwikkelende vermogens.

8. Eigen mening, hoorrecht/eigen rechtsingang

Het recht van het kind op een eigen mening (in en buiten het gezin); het recht van het kind gehoord en serieus genomen te worden in procedures die het kind aangaan (bijvoorbeell bij echtscheiding, omgangsregelingen, pedagogische dwangmaatregelen ten aanzien van zijn ouders); het recht van het kind op een eigen rechtsingang en/of een curator ad litem.

\section{Gezinstaken}

Het recht van het kind op een zinvolle bijdrage aan gezinstaken en/of het gezinsinkomen. Dit recht is om twee redenen van belang en als kernrecht te beschouwen. In de eerste plaats wordt aldus invulling gegeven aan de eigen verantwoordelijkheid van het kind. Verantwoordelijkheid wordt (aan)geleerd door verantwoordelijkheid te (laten) dragen. In de tweede plaats geeft een recht op werk c.q. op taken het kind de bevestiging dat het een eigen plaats in het gezin en daarbuiten heeft: het kind hoort erbij in deze maatschappij, heeft recht op actieve en volwaardige participatie in gezin en samenleving.

\section{Gelijke sociale omstandigheden en voorzieningen}

Het recht van het kind op sociaal-economische en sociaal-pedagogische omstandigheden en voorzieningen die het beginsel van de gelijke behan- 
deling en gelijke rechten van alle kinderen niet in onredelijke en onbillijke mate schenden (met andere woorden: die systemisch-discriminatoire parentiarchale patronen substantieel doorbreken). Uit dit recht vloeien de drie hierna volgende rechten voort.

\section{Opvoedingsonderwijs}

Het recht van het kind op opvoedingsonderwijs, dat wil zeggen het recht van het kind op vakken als c.q. onderricht in relaties, ouderschap, huishouding, verzorging en opvoeding vanaf de basisschool; en het recht van het kind op ouderschapscursussen, -trainingen en -bijscholing voor zijn ouders.

\section{Opvoedingsgeld}

Het recht van het kind op opvoedingsgeld voor zijn ouders; dat wil zeggen op een (deels inkomensafhankelijk, deels inkomensonafhankelijk) 'zorg-en opvoedingsloon' voor de verzorgende en opvoedende ouder(s).

\section{Opvoedingsondersteuning}

Het recht van het kind op een glijdende schaal van opvoedingsondersteuning van zijn ouders en zijn gezin, met inbegrip van het recht van het kind op psychische empowerment van zijn ouders (en daarmee op het gezonder maken van de gezinshomeostase). Dit alles vormt onderdeel van een glijdende schaal van opvoedingsondersteuning, ${ }^{206}$ welke oploopt:

a.) van vrijwillig (en laagdrempelig: vanuit een eerste lijn van gecombineerd lichamelijke en geestelijke pre-, peri- en postnatale zwangeren-, zuigelingen-, peuter- en kleuterzorg naar een brede waaier van medische en pedagogische voorzieningen);

b.) naar gedwongen (met deugdelijke rechtsbescherming): de integriteitsactie of persoonswordingsvindicatie door de staat, welke evenzeer een recht van het kind is.

\section{Transgenerationaliteit}

Bovenstaande sociaal-pedagogische grondrechten of kernrechten betreffen de kerninhoud ${ }^{207}$ van de primaire en secundaire opvoedingsverantwoordelijkheid van ouders respectievelijk de staat zoals deze tot uitdrukking komt in verschillende (preambulaire overwegingen en) bepalingen van het Verdrag inzake de rechten van het kind (zie hoofdstuk 10) als constitutie van de Trias pedagogica, dat wil zeggen als juridische draagconstructie van het persoonswordingsbeginsel, als (verdrags)staatsrechtelijk raamwerk ter (gezins)bestuursrechtelijke operationalisering van het recht van het kind op optimale persoonswording, dat op zijn beurt de 
ontwikkelingspsychologische/pedagogische vertaling is van "het belang van het kind' (zie hoofdstuk 8 en 9).

We zetten de brill, de trias-dimensionale persoonswordingsbril van het Kinderrechtenverdrag, op onze neus. Voor onze ogen opent zich de afgrond van menselijk leed, van het lijden van kinderen, die transgenerationaliteit heet: de verborgen maatschappelijke kloof die we al omschreven in de inleidende paragraaf, de sociaal-pedagogische 'apartheid' tussen 'welopgevoede' kinderen en de kinderen van het Mattheüs-effect. Wat we zien is, meer juridisch en als zodanig minder dramatisch c.q. direct gezegd, een grootschalige (ernstige en passief-systematische) schending van sociaal-pedagogische grondrechten welke - ten gevolge van bestendige parentiarchale patronen - op systemisch-discriminatoire wijze kinderen van transgenerationeel (in hun eigen jeugd/in hun eigen ontwikkeling) beschadigde en dientengevolge (collectief gezien) sociaal-emotioneel/ pedagogisch gedepriveerde ouders onevenredig zwaar treft.

ALEXANDER noemt drie criteria aan welke moet zijn voldaan om een claim tot een moreel recht (dat is een nog niet gepositiveerd, een nog niet door het positieve recht erkend recht) te maken: ${ }^{208}$

'(...) het moet gaan om [1] een dringende behoefte [2] die gerelateerd is aan de menselijke waardigheid en [3] waarvan de verwezenlijking vereist is om een ontoelaatbare ongelijkheid op te heffen.'

Teneinde de ontoelaatbare - immers ten principale vermijdbare en in principe doorbreekbare - maatschappelijke ongelijkheid van (het maatschappelijke c.q. sociaal-pedagogische fenomeen van) de transgenerationaliteit (van generatie op generatie doorgegeven sociaal-emotionele/ pedagogische deprivatie) op te heffen, en tegelijk recht te doen aan de persoonswording van het kind als ontwikkelingspsychologische/pedagogische levensbehoefte en uitvloeisel van de waardigheid van het kind als op opvoeding aangewezen mens - en derhalve van de waardigheid van de mens in het algemeen -, is het niet nodig een moreel recht in te roepen, of zelfs maar te wijzen op het 'revolutionaire' Verdrag inzake de rechten van het kind. Al in het Burgerlijke-en-politieke-rechtenverdrag is te lezen (art. 24, lid 1 IVBPR):

Elk kind heeft, zonder onderscheid naar ras, huidskleur, geslacht, taal, godsdienst, nationale of maatschappelijke afkomst, eigendom of geboorte [sociaal-economische status, jw], recht op die beschermende maatregelen van de zijde van het ge- 
zin waartoe het behoort, de gemeenschap en de Staat welke in verband met zijn minderjarigheid [lees: (bovenminimale) persoonswording, jw] noodzakelijk zijn.

Mijn toevoeging/vertaling '(bovenminimale) persoonswording' is gerechtvaardigd blijkens de 'general comments' van het Mensenrechtencomité met betrekking tot art. 24 IVBPR van 5 april $1989^{209.210}$

'[T]ous les enfants, sans aucune discrimination, ont le droit de recevoir de leur famille, de la société et de l'Etat la protection qu'exige leur état de mineur. L'application de cette disposition nécessite l'adoption par les Etats de mesures speciales. (...)

[T]outes les mesures possibles devraient être prises pour (...) éviter que [les enfants] ne soient victimes d'actes de violence ou de traitement cruels ou inhumains (...). (...)

[L]a société, les institutions et l'Etat doivent aider la famille à assurer la protection de l'enfant, et l'Etat doit intervenir dans le cas où les [parents] et la famille manquent gravement à leurs devoirs, maltraitent l'enfant ou le négligent.'

Hetgeen ons terugvoert naar de vraag van de staatsaansprakelijkheid.

\section{3 .3}

Staats-transgenerationaliteitsaansprakelijkheid

We beginnen deze paragraaf met een sprookje, of liever een hypothese. Stel: elk jaar vallen in Nederland tienduizenden kinderen ten prooi aan een kwaadaardig virus dat al vóór de geboorte tot in de adolescentie de ontwikkeling en de werking van (de verbindingen in) de hersenen aantast. Slachtoffers die niet tijdig geholpen worden, bereiken niet het niveau van rationaliteit, moraliteit en authenticiteit dat nodig is om in de maatschappij mee te komen, laat staan dat zij op belangrijke levensgebieden als geestelijk gezond en mondig burger zouden kunnen functioneren.

Het virus is al eeuwenoud, maar pas sinds het in 1962 door de Amerikaanse dokter KEMPE wetenschappelijk is benoemd en beschreven, wordt er min of meer systematisch onderzoek naar gedaan. Al snel ontdekt men dat het virus in veel gevallen van generatie op generatie wordt

209 De dag waarop de Rechtbank Utrecht het vonnis wees dat uitgebreid is aangehaald in par. 13.2.2.3.

210 Overgenomen uit Marc BossuYT, 'The International Covenant on civil and political rights and children,' in: Eugeen VERHELLEN (ed.), Understanding children's rights; Collected papers presented at the first Intemational interdisciplinary course on children's rights, Gent 1996, pp. 303-308, op p. 305; voor de Engelse versie zie Manfred NOWAK, UNO-Pakt über büngerliche und politische Rechte und Fakultativprotokoll; CCPR-Kommentar, Kehl (etc.) 1989, pp. 893-895 ('General Comment 17/35 (Rechte des Kindes)'). 
doorgegeven als men er niet in slaagt de werking ervan te neutraliseren. Hoewel men vermoedt dat het virus al bestaat vanaf Kain en Abel, wier ouders nooit hebben kunnen verwerken omwille van een onnozele appel onder verwensingen en vervloekingen met vlammend zwaard uit het paradijs te zijn verdreven ${ }^{211}$ - zoals een kind dat de buitensporige toorn van

211 Welke therapeut had hen immers tot het inzicht kunnen brengen dat zij het slachtoffer waren van een armhartige priesterprojectie. Althans in de interpretatie van NIETZSCHE, De antichrist (1888, ed. Amsterdam 1978, par. 48-49, pp. 79-82). Een interpretatie die op onovertroffen literaire wijze steun vindt (of slechts lijkt te vinden?) in DOSTOIEvSKI's grandioze Christus en de grootinquisiteur wit De gebroeders KARAMAZOV (1879-1880, Ned. vert. 1995, pp. 326-350).

Vóórdat Ivan zijn broer Aljosja zijn poëem De grootinquisiteur voordraagt, zegt hij over het lijden van kinderen - en ik haal zijn woorden hier, bij wijze van literair tegenwicht, aan omdat zij in de aard van de mens lijken te zoeken (vgl. niettemin mijn cursiveringen) wat in deze studie primair (en prozaisch) als transgenerationeel fenomeen, dat will zeggen: als (tragisch) sequeel van niet of onvoldoende (beseft, laat staan) verwerkt oud zeer, wordt geschetst (Fjodor DostoJEVSKI, De gebroeders KARAMAZOV, vert. Marko FONDSE, s.l. 1995, pp. 319-320): 'Ik heb een heel uitgebreid dossier over Russische kinderen, Aljosja. Een vader en moeder, "allerrespectabelste mensen uit de ambtenarenstand, ontwikkeld en welopgevoed [dat is gedrild? -jw (mijn curs.)]," hadden een geweldige hekel aan hun vijfarig dochtertje gekregen. Zie je, ik wil je nogmaals met nadruk verzekeren dat deze zucht tot het mishandelen van kinderen, maar dan ook alleen van kinderen, een speciale eigenschap van heel wat mensen is. Tegen alle andere vertegenwoordigers van de menselijke soort gedragen deze zelfde beulen zich juist voorkomend en zachtmoedig zoals dat ontwikkelde en humane Europeanen betaamt, maar ze doen niets liever dan kinderen kwellen en in die zin houden ze zelfs van die kinderen. Het is juist de weerloosheid van die wezentjes die deze kwelgeesten aantrekt, het engelachtige vertrouwen van een kind dat geen enkele kant uit kan en bij niemand anders zijn toevlucht kan zoeken. (...) Natuurlijk zit er in ieder mens zo'n beest gekooid dat uitbreekt bij een aanval van woede (...). Die ontwikkelde ouders onderwierpen dat vijfjarige dochtertje aan alle denkbare mishandelingen. Ze sloegen, beukten en trapten haar zonder zelf te weten waarom [curs. van mij, jw] en weranderden haar lijfje in éen grote bont en blauwe plek. Ten slotte bereikten ze het hoogst denkbare raffinement: toen het vroor dat het kraakte, sloten ze het kind op in [de] plee omdat het 's nachts niet had gevraagd om eruit te mogen (alsof zo'n vijfjarig wurm dat de diepe slaap der onschuldigen slaapt, dat op die leeftijd al kan leren), en om diezelfde reden smeerden ze haar hele gezichtje onder de uitwerpselen en dwongen ze haar die uitwerpselen op te eten. En het was de moeder, de moeder die het kind daartoe dwong! En die moeder kon slapen terwijl de hele nacht het gesteun van die arme opgesloten stumperd weerklonk uit dat smerige hok! Kun jij er met je verstand bij dat zo'n klein schepseltje, dat nog niet eens kan begrijpen wat er met haar gebeurt, daar in dat weerzinwekkende hok in het donker en in de kou met haar kleine knuistjes tegen het bont en blauw geslagen borstje slaat en bloedige zachtmoedige tranen schreit tot "Onze Lieve Heertje" om haar te helpen. Begrijp jij iets van zo'tn absurditeit, mijn vriend en mijn broer, mijn vrome kleine novice van God, begrijp jij 
zijn ouders niet begrijpt, daarom zelf een vreselijke misstap of tekortkoming verzint en daarmee zijn hele leven worstelt -, is het duidelijk dat het virus niets met de erfzonde of met erfelijke belasting te maken heeft, niets met enige bijbelse vervloeking tot in het zoveelste geslacht noch met slechte genen, maar heel veel, zo niet alles, met de mate waarin psychotrauma's (kunnen) worden verwerkt.

In 1989 is men zover dat men, op internationaal niveau, weet dat alleen een cocktail van medicijnen soelaas biedt. De hoofdingrediënten van die cocktail zijn derivaten van de middelen Opvoedingsondersteuning, Opvoedingsonderwijs en Opvoedingsgeld. Overigens experimenteert men al sinds het begin van de eeuw met vaccins en met verplichte vaccinatie, 'maatregelen van kinderbescherming' genaamd. Tegen het einde van de eeuw valt evenwel niet meer te ontkomen an de conclusie dat alleen algemene vaccinatie met een zo compleet en hoogwaardig mogelijke cocktail, gevolgd door intensieve en zelfs blijvende nabehandeling in ernstige gevallen, de werking van het virus structureel en duurzaam kan neutraliseren.

De kosten van een dergelijke operatie, de daarmee gepaard gaande gezinsonderzoeken en de oprichting en instandhouding van daarvoor noodzakelijke instellingen, programma's en voorzieningen zijn weliswaar zeer hoog, maar hetzelfde geldt voor de verwachte terugverdien-effecten op middellange en lange termijn. Bovendien wordt in toenemende mate door juristen betoogd dat de overheid tot deze operatie verplicht is op grond van internationaal erkende en beschermde mensenrechten, zoals het recht op een zo goed mogelijke gezondheid, op bescherming van de lichamelijke en geestelijke integriteit, op sociaal-emotionele, economische en culturele ontplooiing, op reparatie en rehabilitatie en, in samenhang met deze en andere van toepassing zijnde rechten, op gelijke behandeling.

Stel vervolgens dat de Nederlandse staat in 1995 partij wordt bij een verdrag waarin alle toepasselijke rechten zijn opgesomd, compleet met de soort maatregelen en de budgettaire prioriteit die vereist is om tot de verwerkelijking ervan te komen. Stel ten slotte dat twee jaar later in Nederland nog niets is veranderd en Nederland in zijn rapportage aan

waarom deze absurditeit zo nodig deel moet uitmaken van de schepping? Zonder die absurditeit, zeggen ze dan, zou het bestaan van de mens op aarde geen zin hebben, want dan zou hij het verschil tussen goed en kwaad niet leren onderscheiden. Maar waarom moeten we dat zo nodig, als dat de prijs is dic ervoor betaald moet worden? Dan verzinkt toch immers alle kennis van de wereld in het niet bij de traantjes die dat kindje tot "Onze Lieve Heertje" schreit. Ik heb het niet over het lijden van de grote mensen, die hebben de appel gegeten, en laat ze voor mijn part naar de hel lopen, maar die kinderen!" 
het verdragscomite op dit punt niets substantieels in het vooruitzicht stelt.

Vraag voor juristen: is het dan te vroeg, of eigenlijk al te laat, om te concluderen dat Nederland zich schuldig maakt aan grove - ernstige en passief-systematische - schending van de rechten van de mens? Een diplomatiek antwoord zou zijn dat het voor die conclusie in elk geval hoog tijd is. In de volgende paragraaf (par. 13.3.4) zullen we voor dat diplomatieke antwoord enkele juridische argumenten aandragen. Althans indien we het woord 'virus' in onze hypothese vervangen door het woord 'kindermishandeling' (c.q. het woord/de woorden '[het] fenomeen [kindermishandeling]'). Of beter nog door de aanduiding: schending van het recht van het kind op minimale persoonswording (zie hoofdstuk 11).

Dat laatste geeft al aan dat het weliswaar om een zeer fundamenteel recht gaat, een kernrecht, maar tegelijk een recht dat het karakter van rechtsbeginsel heeft (dat wil zeggen: dat nog nader juridisch moet worden geoperationaliseerd), en bovendien berust op een in het Verdrag inzake de rechten van het kind ingelezen rechtsbeginsel, namelijk het recht van het kind op optimale persoonswording. Om die reden is enige juridische bescheidenheid, en dus een diplomatiek antwoord op zijn plaats. (Al staan diplomaten niet bekend om een beduidend grotere bescheidenheid dan wetenschappers, of zelfs dan juristen.)

Voordat we enkele (nadere) juridische overwegingen en feitelijke (c.q. politieke) illustraties aan het oordeel 'grove - ernstige en passiefsystematische - schending van de rechten van de mens' wijden, dat wil zeggen voor we naar de volgende paragraaf overstappen, geven we - om onnodige herhalingen van wat in voorafgaande hoofdstukken is gezegd, zo veel mogelijk te voorkomen - in een schema weer hoe staatstransgenerationaliteitsaansprakelijkheid kan worden voorgesteld (zie volgende pagina).

\section{Toelichting bij het schema}

De staat is in sociaal-pedagogisch verzuim indien niet in structurele zin de transgenerationele mishandelingscyclus wordt doorbroken. Aan de verplichtingen onder (in het bijzonder art. 18, lid 2 en art. 19 juncto art. 39 van) het Verdrag inzake de rechten van het kind is alsdan, in structurele c.q. substantiële zin, niet voldaan. Staatsaansprakelijkheid treedt in. Deze staatstransgenerationaliteitsaansprakelijkheid is op de volgende pagina schematisch weergegeven. $^{212}$

Het schema is onder meer gebaseerd op H.E.M. BAARTMAN, "Als mishandelde kinderen ouder[s] worden,' Tijdschrift woor Orthopedagogiek 1996, pp. 417-431; Sietske DIrkSTRA, "In gesprek over kindermishandeling; groepshulpverlening aan volwassenen,' VKMagazine juni 1997, pp. 6-7; Sandra VISSER, 'Trauma en ouder- 


\section{SCHEMATISCHE VOORSTELLING STAATS- TRANSGENERATTONALITEITSAANSPRAKELIJKHEID}

In de jeugd ernstig te kort gekomen ( $\rightarrow$ ontwikkelingspsychopathologie); diverse criteria kindermishandeling (vormen/gradaties classificatie BARNETT c.s.: zie infra bijlage IIr) zijn van toepassing

4i

psychotraumas's/psycho-sociale problemen (min of meer beseft OUD ZEER van de survivor"; diverse afweermechanismen/ coping stijlen zijn van toepassing: zie bijlage IV) - herhalingsdwang/re-ensceneringen: 'herkansing' in de herhaling van (oude) interactiepatronen

\section{$\downarrow$}

ROUWARBEID, evt. m.b.v. psychotherapie ( = zich ontfermen over 'het verworpen kind in zichzelf' + ontwikkelingstaken alsnog tot een oplossing brengen)

$\downarrow$

geslaagde VERWERKING/psychocicatrisatie (het eigen kind hoeft niet meer vanuit de eigen nood te kort te worden gedaan)

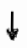

TRANSGENERATIONELE CIRKEL (doorgeven/rondzingen van trauma's) DOORBROKEN

optimale persoonswording in principe mogelijk (bij naleving alle VRK-verplichtingen) (onbeseft) OUD ZEER van de ouder $(\rightarrow$ wantrouwen; kwetsbaar gevoel van eigenwaarde: timide/heetgebakerd; te veel/weinig verantwoordelijkheid nemen/rekening houden met anderen; rigiditeit; enzaamheid/isolement enz.)

$\downarrow$

VERWERKING niet op gang gebracht/niet geslaagd ( $G E E N$ geestelijk herstel - reparatie/rehabilitatie - in het kader van opvoedingsonderstewning $\rightarrow$ broze draagkracht/snelle overbelasting/chronische spanningen; onzekerheid/geen steun zoeken/"vijandigheid"

$\downarrow$

gemankeerd PEDAGOGISCH BESEF (wringen/rondzingen oud zeer $\rightarrow$ ) irrec̈le/ongepaste verwachtingen jegens en negatieve beleving van het kind

$\downarrow$

het eigen kind komt ernstig te kort (NAS/maltraitering: beschadiging/ bedreiging minimale persoonswording)

TRANSGENERATIONELE CIRKEL (circulair slachtoffer-/daderschap) VOORTGEZET

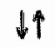

art. $18(2), 19+39$ VRK niet vervuld $\rightarrow$ STAATSAANSPRAKELIJKHEID

schap; over hoe het verleden kan "rondzingen" in het heden," Maandblad Geestelijke volksgezondheid/MGv 1997/6, pp. 633-646; R.K. OATES, The spectrum of child abuse; Assessment, treatment, and prevention, Basic Principles into Practice series, vol. 8, New York 1996, pp. 28-31 (in het bijzonder p. 30). 


\section{(Vervolg toelichting bij het schema)}

Een in het schema geïntroduceerde term en dito acroniem verdienen nog uitleg. De term psychocicatrisatie in het schema wil aanduiden dat verwerking wel geslaagd maar nooit volledig kan zijn: bij geslaagde verwerking zijn wonden (psychotraumata) tot littekens (psychocicatrices) geworden. Het acroniem NAS staat voor: Negatieve Affectieve Stijl, welke volgens VISSER wordt gekenmerkt door "een hoge mate van kritiek, overbetrokkenheid en schuld-inducerende opmerkingen. ${ }^{213}$

\section{4 \\ Staatsaansprakelijkheid en overheidsverantwoordelijk- heden}

In en door (de toelichting bij) bovenstaand schema zijn gewoonte- en verdragsrechtelijke overwegingen bijeengebracht in het begrip (en de nog nader te adstrueren - conclusie): staatstransgenerationaliteitsaansprakelijkheid. Verdragsrechtelijke door een directe verwijzing naar het Verdrag inzake de rechten van het kind. Gewoonterechtelijke (of liever: algemeen volkenrechtelijke $)^{214}$ door de indirecte verwijzing naar het grove (ernstige en passief-systematische) karakter van de desbetreffende mensenrechtenschendingen, namelijk door het bezigen van de termen 'substantieel' en 'structureel.' Beide categorieën keren in deze paragraaf terug.

We brengen in herinnering dat de laatste categorie, de algemeen volkenrechtelijke overwegingen, in par. 13.2 uitgebreid zijn behandeld onder de vlag 'reparatie.' Over de 'reparatie' van mishandelde kinderen merkt CICCHETTI (1989) op: $:^{215}$

"We do think that all maltreated children will "pay a price" for their misfortune, though we believe that, through therapy and/or adaptive re-representation [herkansing in de herhaling(sdwang), jw] of their experiences, many maltreated children will go on [eventually (vroeger of - meer waarschijnlijk - later), jw] to lead productive lives. Obviouslly, these speculations can only be confirmed through rigorous longitudinal investigations."

213 Sandra VISSER, "Trauma en ouderschap; over hoe het verleden kan "rondzingen" in het heden,' $M G \nu 1997 / 6$, pp. 633-646, op p. 642.

214 Vgl. Peter MALANCZUK, AKEHURST'S Modern introduction to intemational law, London/New York 1997, seventh ed. (AKEHURST/MALANCZUK), pp. 220/221.

215 Dante CICCHETT, 'How research on child maltreatment has informed the study of child development: perspectives from developmental psychopathology,' in: dez. en Vicki CARLSON (eds.), Child maltreatment; Theory and research on the causes and consequences of child abuse and neglect, Cambridge (etc.) 1989, pp. 377-431, op p. 419 i.f. 
Met de "reparatie" van mishandelde kinderen - voor zover deze niet geschiedt door middel van herhalingsfenomenen ten koste van het eigen kroost - staat of valt het doorbreken van transgenerationaliteit ${ }^{216}$; 'rig-

216 Uiteraard is er ook nog een andere 'oplossing." Transgenerationaliteit stopt immers ook als 'niet-gerepareerde' getraumatiseerden zich niet meer voortplanten. Het is niet uitgesloten dat een langdurig proces van reparatie, vanuit een groot verantwoordelijkheidsgevoel, tot uitstel en uiteindelijk afstel van het 'nemen' van kinderen leidt. Anderzijds hebben we gezien dat hoofdkenmerk van niet-reparatie (dat is het niet of onvoldoende verwerkt hebben van trauma's) is de neiging de rekening naar de volgende generatie door te schuiven, welke in sociale zin een wetmatigheid kan worden genoemd. Met andere woorden: de wetmatigheid van het (ondoordacht) 'nemen' van kinderen vanuit een onbewuste nood ('herhalingsdwang") die de cirkel van geweld sluit (onmacht c.q. "afgunst-motief). Anders gezegd: hoe groter (bij ernstige traumatisering, waar men niet zomaar of vanzelf overheen groeit; dus: hoe langduriger èn verder gevorderd) de reparatie, hoe geringer - vermoedelijk - de kans dat men kinderen neemt (dat is: nog aan het nemen van kinderen toekomt). Anderzijds: hoe geringer de reparatie (opnieuw: bij ernstige traumatisering), hoe groter - waarschijnlijk - de kans dat men wèl (en zéér vroeg, bij wijze van pseudo-reparatie, dat is vanuit de herhalingsdwang) kinderen neemt (men denke hierbij onder meer aan het fenomeen van de traumatische vroeg- ofwel noodrijpheid/pseudo-volwassenheid: het ouderschap verschaft immers maatschappelijke/familiale status en compenseert aldus innerlijke traumatische onzekerheid).

Een 'oplossing" in de richting van beperking van de voortplantingsvrijheid ("reproductieve rechten," in het bijzonder het fundamentele recht een gezin te stichten), bijwoorbeeld door het invoeren van een verplicht ouderschapsexamen (net zo lang te herkansen tot men hetzij geslaagd is, hetzij de vruchtbare leeftijd is gepasseerd: een vorm van juridische sterilisatie), wordt in deze studie evenwel niet bepleit, of zelfs maar in overweging genomen, omdat zij de duivel met Beëlzebub zou uitdrijven (Matth. 12:27). Om dit aan de hand van een voorbeeld te verduidelijken. Een verbod op nachtarbeid van vrouwen zou vrouwen minder blootstellen aan het gevaar van nachtelijke mannelijke (sexuele) agressie tijdens het woonwerk-verkeer. Deze oplossing woor het probleem is evenwel een groter kwaad dan het probleem zelf (vanuit de moderne - jurisprudentieel verankerde: ik verwijs naar de STOECKEL-zaak uit 1991 van het EG-Hof van Justitie - optiek dat een dergelijk verbod de kans op deelname van vrouwen aan het arbeidsproces discriminatoir beknot), dat met een minder kwaad (beperking van de bewegingsvrijheid/auto-mobiliteit van vrouwen) of zelís een goed (gratis en veilig vervoer) kan worden opgelost, door immers werkneemsters 's nachts wan bedrijfswege te vervoeren (hetgeen een positieve maatregel is op basis van het materiële gelijkheidsbeginsel). Zo is het aanbieden en desnoods opleggen van opvoedingshulp ter uitdrijving van het kwaad van de transgenerationaliteit een geringer kwaad (beperking van de privacy c.q. van ouderlijke 'rechten'/privileges) of zelfs een goed (gratis deskundige hulp en begeleiding) dan een beperking van de voortplantingsvrijheid. Dit nog afgezien van het feit dat een serieuze (althans consequente) implementatic van een dergelijke beperking hetzij tot totale controle van de privacy (Vrij-Veiligheidsdienst? Condoom-Politie?), hetzij tot gedwongen sterilisa- 
orous longitudinal investigations' naar de levensloop van gemaltraiteerde individuen zullen aan deze sociaal-psychologische wet slechts a posterioribewijs kunnen toevoegen.

De overstap van individuele naar mensenrechtelijke 'reparatie' (in de ruime zin van preventie, interventie en rehabilitatie) maken we aan de hand van ROMANY:217

"Human rights discourse is a powerful tool within international law to condemn those state acts and omissions that infringe core and basic notions of civility and citizenship. "To assert that a particular social claim is a human right, is to vest it emotionally and morally with an especially high order of legitimacy" [BILDER 1969]." Violence [and especially child abuse, $\mathrm{jw}$ ] is an egregious form of such an infringement of the core and basic notions of civility and citizenship. Violence assaults life, dignity, and personal integrity.'

Geweld tegen kinderen - kindermishandeling - is behalve een aanslag op hun leven(svreugde), hun waardigheid en hun persoonlijke integriteit, een

ties, gedwongen anti-conceptieve medicatie dan wel een abortus- of afstandsplicht zou moeten leiden, terwijl implementatie van opvoedingshulp - mits deze als niet-stigmatiserend algemeen aanbod, ondersteund met algemeen en speciaal schools en buitenschools opvoedingsonderwijs alsmede met aan opvoedingssubsidiëring gelieerde zowel algemene als individueel afgestemde voorwaarden en afspraken, aan de man/vrouw wordt gebracht - in beginsel rechtmatig, volstrekt practicabel en relatief eenvoudig is (terwijl de weliswaar grote investeringen zichzelf terugverdienen en niet opwegen of zelfs in het niet vallen tegen de economische, sociale en psychologische kosten van transgenerationaliteit).

Bovendien kan opvoedingshulp die in het bijzonder getraumisecrden ten goede komt, als een vorm van rechtsherstel (juridische reparatie) worden gezien. Hetgeen van welke beperking van de voortplantingsvrijheid ook allerminst kan worden gezegd. We zouden ook kunnen zeggen: opvoedingshulp (in de ruime zin van Opvoedingshulp, Opvoedingsgeld en Opvoedingsonderwijs) versterkt het Marcuseffect (taboe-doorbreking, doorbreking van het zwijgen, psychische reparatie, geestelijke volksgezondheid; naar Marcus 4:22; Lucas 8:17); voortplantingsbeperking versterkt het Mattheüs-effect (stigmatisering, psycho-sociale Verelendung, zelfdestructie/zelfsabotage, psychopathologie; naar Matth. 13:12; Lucas 8:18), en verhoogt behalve individuele ook maatschappelijke pathologie. De pathologie van een maatschappij die toestaat dat veler licht van generatie op generatie onder de korenmaat wordt gezet (Matth. 5:15; Marcus 4:21; Lucas 8:16, 11:33), zou dan vervangen worden door de pathologie van een maatschappij die, in het belang van een niet-pathologisch nageslacht, de lichten die onder de korenmaat zijn gezet, niet verheft maar uitdooft.

217 Celina ROMANY, 'State responsibility goes private: a feminist critique of the public/private distinction in international human rights law, in: Rebecca J. COOK (ed.), Human rights of women; National and intemational perspectives, Philadelphia 1995 (third printing), pp. 85-115, op p. 85. 
aanslag van opvoeders - maar niet minder van zwijgende omstanders en van een meer privacy- dan law-abiding maatschappij - op de (minimale) persoonswording van kinderen. Van de andere zijde benaderd: tot de 'core and basic notions' van beschaving en burgerzin behoort niet in de laatste plaats 'het belang van het kind' zoals dat juridisch gestalte heeft gekregen in het Verdrag inzake de rechten van het kind en meer in het bijzonder in het recht van het kind op optimale persoonswording, dat in deze studie - op basis van een contextuele analyse van het wikkend ${ }^{218}$ (preambulaire) en beschikkend (dispositieve) deel (diverse materiële bepalingen) van dat Verdrag (zie hoofdstuk 10) - aan het licht is gebracht als achterliggend, dragend en leidend beginsel ervan.

In hoeverre kunnen nu - om de hamvraag van deze paragraaf te verwoorden - aan het internationale recht argumenten worden ontleend om (in de terminologie van ROMANY) de Nederlandse 'omissions' te veroordelen ter zake van het nemen van adequate wetgevende en andere maatregelen waardoor de optimale persoonswording van kinderen in dit land structureel zou worden bevorderd en hun minimale persoonswording structureel zou worden veilig gesteld?

Dat er, gezien de omvang van kindermishandeling in Nederland en de gevolgen ervan, sprake is van een ernstige schending van fundamentele rechten van het kind, behoeft, na hetgeen daarover te berde is gebracht in het vorige hoofdstuk, in dit hoofdstuk (eigenlijk) geen nader betoog. Wat het structurele - het passief-systematische - karakter van die schending betreft: de omissions c.q. het gebrek aan due diligence van de staat (met andere woorden: de aspecten die staatsaansprakelijkheid vestigen), wordt in deze paragraaf de lijn gevolgd dat, omdat en in zoverre er ten

218 Wikkend - op zich niet bindind - maar rechtens relevant krachtens art. 31 (lid 2, aanhef, juncto lid 1) van het Weens Verdragenverdrag en in de zin van de woorden van rechter ANZILoTT (dissenting opinion bij de Advisory opinion uit 1932 van het Permanente Hof van Internationale Justitie aangaande 'Interpretation of the 1919 Convention concerning employment of women during the night"): "[I] do not see how it is possible to say that an article of a convention is clear until the subject and aim ['object and purpose" in de huidige terminologie, jw] of the convention have been ascertained, for the article only assumes its true import in this convention and in relation thereto." (PCIJ, Series $A / B$, no. 50, p. 383; translation.) Rechtens relevant met andere woorden niet in abstract-objectieve (strict grammaticale) maar in teleologisch-objectieve interpretatieve zin: de termen van het verdrag in hun context (dat is preambule en artikelen in hun onderling verband) en in het licht van (uit preambule en verdragssamenhang af te leiden) zin en strekking ('object and purpose') van het verdrag, zoals art. 31 wVV het will (en dus enigszins - anders dan KOOIJMANS, Intemationaal publiekrecht in vogelvlucht, a.w. (ed. 1996), p. 100, doceert). 
aanzien van vrouwen sprake is van (in de woorden van ROMANY) ${ }^{219} \ldots$

'(...) a systematic failure on the part of the state to institute the political and legal protections necessary to ensure the basic rights of life, integrity, and dignity (...)'

... zulks a fortiori dient te worden geconcludeerd ten aanzien van kinderen. Met betrekking tot vrouwen ${ }^{220}$ merkt ROMANY op: $:^{221}$

'Women are everyday subjects of a system of familial terror that includes diverse modalities of violence. Yet the human rights discourse of protection has not been available to women.'

Wat er verder zij van de positie van vrouwen in veel staten, met betrekking tot kinderen in Nederland lijkt een 'human rights discourse of protection' vooral af te ketsen op traditionele (verzuilings-religieuze, zo men wil: historisch-christelijke) culturele normen op het punt van ouderlijke opvoedingsvrijheid. In dit verband is het zinvol de woorden van AN-NA'IM in herinnering te brengen: ${ }^{222}$

'States are responsible for bringing their domestic law and practice into conformity with their obligations under international law to protect and promote human rights. This responsibility applies not only to laws enacted by formal legislative organs of the state but also to those attributed to religious and customary sources or sanction, regardless of the manner of their "enactment" or articulation and/or implementation. In other words, every state has the responsibility to remove any inconsistency between international human rights law binding on it, on the one

219 ROMANY, "State responsibility goes private (...)," t.a.p., op pp. 85/86.

220. Een kleine greep uit de overvloedige (hier niet aangehaalde) literatuur: Charlotte BUNCH, 'Women's rights as human rights: toward a re-vision of human rights,' Human Rights Quarterly 1990/4, pp. 486-498; Rebecca J. COOK, 'Accountability in international law for violations of women's rights by non-state actors,' in: Dorinda G. DALLMEYER (ed.), Reconceiving reality: Women and intemational law', ASIL, Washington 1993, pp. 93-116; Hilary CHARLESWORTH, Christine CHINKIN, 'The gender of jus cogens,' Human Rights Quarterly 1993/1, pp. 63-76; Jenny E. GOLDSCHMIDT, Mensenrechten: vrouwenrechten? Nieuwenhoflezing VIII (4 juni 1994), Deventer 1995; Titia LOENEN, 'Rethinking sex equality as a human right," Netherlands Quarterly of Human Rights 1994/3, pp. 253-270; Anne GALLAGHER, 'Ending the marginalization: strategies for incorporating women into the United Nations human rights system,' Human Rights Quanterly 1997/2, pp. 283-333.

221 ROMANX, 'State responsibility goes private (...), t.a.p., op p. 85.

222 Abdullahi Ahmed AN-NA'TM, 'State responsibility under international human rights law to change religious and customary laws," in: Rebecca J. COoK (ed.), Human rights of women; National and intemational perspectives, Philadelphia 1995 (third printing), pp. 167-188, op p. 167. 
hand, and religious and customary "laws"223 operating within the territory of that state, on the other. This responsibility is fully consistent with the principle of state sovereignty in international law, since it does not purport to force any state to assume legal obligations against its will. It simply seeks to ensure that states effectively fulfill legal obligations they have already assumed under international law.'

Toch zou men kunnen (veronder)stellen dat de nalatigheid - in de zin van lack of due diligence, 224 - van de Nederlandse politiek (dat is de Nederlandse wetgever: regering en Staten-Generaal, het constitutioneel onschendbare staatshoofd q.q. uiteraard niet meegerekend) c.q. van de Nederlandse overheid (in het bijzonder de rijksoverheid als centraal en hoogste bestuursorgaan van de staat) hoofdzakelijk hierin bestaat dat zij (de politiek, de overheid) of hij (de wetgever) voor bedoelde traditionele (van oorsprong religieuze) culturele normen te zeer het hoofd buigt in plaats van deze het hoofd te bieden. Principiële redenen kunnen hier niet in het geding zijn. Anders had men uiteraard de diverse mensenrechtenverdragen, en in het bijzonder het Verdrag inzake de rechten van het kind, niet ondertekend, goedgekeurd en geratificeerd. Althans niet zonder religieuze c.q. parentiarchale voorbehouden (voor zover zulks natuurlijk te goeder trouw mogelijk zou zijn geweest en niet direct in strijd met doel en strekking van het Verdrag). Aangezien ook 'onkunde' uitgesioten moet worden geacht, althans niet voetstoots mag worden aangenomen, lijkt hier veeleer van een politieke traagheid of gemakzucht sprake te zijn. Een traagheid of gemakzucht die - goede wil en goede bedoelingen ten spijt - staatsaansprakelijkheid juist eerder in het leven lijkt te roepen.

In deze paragraaf zetten we, na onze lange rondreis langs allerlei historische (GROTIUs' allermensenrecht), moderne (VAN BOVENS reparation-Study; systemische discriminatie) en neologische (staatstransgenerationaliteitsaansprakelijkheid) 'bezienswaardigheden' op het nog nauwelijks ontgonnen terrein van staatsaansprakelijkheid ter zake van handelingen van privé-personen, ${ }^{225}$ de puntjes op de $i$ door het trekken van enkele deductieve (uit onze exploraties afgeleide) conclusies in de eerste sub-

223 Aanhalingstekens van mij, jw; vgl. de auteur, ta.p., op p. $185 \mathrm{nt} .1$.

224 Theodor MERON, Human rights and humanitarian noms as customary law, $\mathrm{Ox}$ ford 1989 , p. 171.

225 Een (buiten "vrouwenstudies') nauwelijks ontgonnen terrein dat zelf weer de (verscholen) achtertuin is van - wat in een preadvies heet (M.T. KAMMINGA, "Volkenrechtelijke aansprakelijkheid van de staat jegens het individu," Mededelingen van de Nederlandse Vereniging voor Internationaal Recht 115, Deventer 1997, pp. 5-49, op p. 9) - het 'onontgonnen terrein' van volkenrechtelijke aansprakelijkheid van de staat jegens het individu, een 'onderwerp" waaraan, aldus de preadviseur (KAMMINGA, t.a.p.), "gemakkelijk een serie proefschriften [kan] worden gewijd." 
paragraaf (par. 13.4.1), waarna we stilstaan bij het dominante internationaalrechtelijke positivisme ${ }^{226}$ in de tweede subparagraaf (par. 13.4.2) om staatsaansprakelijkheid (state responsibility) niet zozeer te relativeren als wel te relateren aan overheidsverantwoordelijkheden (state accountability): de grijze zone van de derde subparagraaf (par. 13.4.3).

\subsubsection{Staatsaansprakelijkheid: enkele deductieve conclusies}

Bij staatsaansprakelijkheid, schrijft KEUs in zijn preadvies voor de Nederlandse Vereniging voor International Recht (NVIR 1997):227

('..) gaat het om secundaire regels, die toepassing vinden als Staten hun primaire verplichtingen niet nakomen. (...) De [primaire regels] zijn de internationaalrechtelijke gedragsnormen, terwijl de [secundaire regels] aan de [primaire regels] dienstbaar zjin, onder meer als "rules of adjudication," die, eenvoudig gezegd, in acties en sancties voorzien.'

Dit onderscheid, gemaakt aan het begin van zijn uiteenzetting, keert aan het eind ervan terug, wanneer de auteur opmerkt: ${ }^{228}$

'Tussen primaire en secundaire regels bestaat een nauw verband. (...) [Zij] zijn (...) sterk aan elkaar verknocht. $\mathrm{Z}_{\mathrm{jj}}$ vormen tezamen eén en hetzelfde rechtssysteem."

In dit hoofdstuk zijn wij vertrokken vanuit secundaire (reparatie-)regels die we hebben bezien, waar van toepassing, in het licht van de primaire (trias-)regels (in het bijzonder de sociaal-pedagogische grondrechten) van het Verdrag inzake de rechten van het kind, zoals wij deze hebben geconstrueerd in hoofdstuk 7 en hebben gereconstrueerd, ingedeeld en uitgelicht in hoofdstuk 10. De interactie tussen beide categorieën, en daarmee de wederzijdse spiegelingsfunctie tussen algemeen volkenrechtelijke en verdragsrechtelijke aspecten (voor zover deze laatste geen op zichzelf

226 Zeg maar: de beperkte tolerantie van het internationaalrechtelijke forum ten opzichte van exploratief-deductieve conclusies. (Hoewel ik deze tolerantie niet op de proef zal stellen door mijn conclusies, zoals KAMMINGA, ta.p., een 'uitdaging aan de lezer' te noemen 'om de schrijwer te betrappen op valkuilen waarin hij is getwimeld.')

227 L.A.D. KEUS, 'Acties van het individu wegens schendingen van het internationale recht door staten; een bekmopt onderzoek naar drie rechtsniveaus,' Mededelingen van de Nederlandse Vereniging voor Intemationaal Recht 115, Deventer 1997, pp. 51-126, op p. 58 i.f. (tekst en nt. 9). 
staand, specifiek en exclusief zogenaamd "self contained regime, men), is daarbij ons impliciete uitgangspunt geweest. Het was ons immers te doen om een exploratie, waarbij elke weerkaatsing meer licht kan werpen op voor ons onderwerp relevante doch donkere uithoeken. Thans gaan we evenwel expliciet over tot het aanwijzen van enkele primaire gedragsnormen, waaraan wij het feitelijke gedrag (daden c.q. tekortkomingen) en de houding (woorden, beloften) van de Nederlandse staat (wetgever, politiek, rijksoverheid) toetsen. Uiteraard is het niet de bedoeling hierbij 'rechtertje' te spelen. Waar het ons in deze (sub)paragraaf om gaat is een illustratie, een adstructie, van de (dis)kwalificatie "ernstige en passief-systematische mensenrechtenschendingen.' En zulks vanuit het volle besef dat met betrekking tot staatsaansprakelijkheid ter zake van (grootschalige) schendingen van (fundamentele) rechten van het kind in privé-verhoudingen doctrine en jurisprudentie vrijwel, zo niet geheel, ontbreken.

Mede daarom staan we niet stil bij mogelijke (theoretische) onderscheidingen van staatsaansprakelijkheid (men denke hierbij aan volkenrechtelijke equivalenten of varianten van privaatrechtelijke figuren als schuld- en risico-aansprakelijkheid en vermoede aansprakelijkheid met mogelijkheid van disculpatie: fault responsibility, liability), ${ }^{230}$ doch geven - mèt een door KEUS aangehaalde auteur - 'de voorkeur aan een onderscheid naar de inhoud van de betrokken primaire norm. ${ }^{\text {,231 }}$ Kortom we onderscheiden, vóór we tot (marginale) toetsing overgaan, tussen inspannings- en resultaatswerplichtingen.

LOUCAIDES merkt op dat internationaalrechtelijke verplichtingen hetzij inspanningsverplichtingen (obligations of means, obligations of con$d u c t$ ), hetzij resultaatsverplichtingen (obligations of result) zijn - waarbij hij verwijst naar art. 20 en art. 21 van de ILC-Draft articles on State responsibility: $:^{232}$

Art. 20 (Breach of an international obligation requiring the adoption of a particular course of conduct)

There is a breach by a State of an international obligation requiring it to adopt a particular course of conduct when the conduct of that State is not in conformity

229 Vgl. Peter MALANCZUK, AKEHURST's Modern introduction to international law, London/New York 1997, seventh ed. (AKEHURST/MALANCZUK), p. 221.

230 Vgl. in dit verband ook CLAPHAMs 'ecologische aansprakelijkheid' ('ecological liability"), waarnaar we al eerder verwezen (CLAPHAM, Human rights in the private sphere, a.w., pp. 183 en 354).

231 KEUS, preadvies NVIR 1997, t.a.p., op p. 59 nt. 11.

232 Loukis $\mathrm{G}$. LOUCAIDES, Essays on the developing law of human rights, Dordrecht (etc.) 1995, Ch. 6" 'Responsibility under the European Convention on Human Rights: objective or subjective test?' Pp. 141-156, op pp. 145/146. 
with that required of it by that obligation.

Art. 21 (Breach of an intemationat obligation requiring the achievement of a specified result)

1. There is a breach by a State of an international obligation requiring it to achieve, by means of its own choice, a specified result if, by the conduct adopted, the State does not achieve the result required of it by that obligation.

2. When the conduct of the State has created a situation not in conformity with the result required of it by an international obligation, but the obligation allows that this or [an] equivalent result may nevertheless be achieved by subsequent conduct of the State, there is a breach of the obligation only if the State also fails by its subsequent conduct to achieve the result required of it by that obligation.

In de in deze studie ontvouwde visie omvat het recht van het kind op persoonswording - als (ontwikkelingspsychologische en pedagogische) aanscherping van het (veiligheids- en ontwikkelings)belang van het kind (the best interests of the child) - zowel inspannings- als resultaatsverplichtingen.

Het kind heeft recht op optimale persoonswording (met als juridisch draagvlak het integrale Verdrag inzake de rechten van het kind): op de staat rust (ex art. 4 VRK: 'maximum extent') een uiterste inspanningsverplichting dit recht, onder meer door middel van een adequaat stelsel van sociaal-pedagogische voorzieningen, instellingen en diensten, voor elk kind onder zijn rechtsmacht tot gelding te brengen.

Het kind heeft recht op minimale persoonswording (met als ultiem juridisch draagvlak art. 3 EVRM, het dwingendrechtelijk verbod van onmenselijke of vernederende behandeling of bestraffing): de staat staat, door middel van een adequaat stelsel van sociaal-pedagogische voorzieningen, instellingen en diensten, garant dat aan minimale pedagogische basisvoorwaarden wordt voldaan (hetgeen we, voorzichtigheidshalve, een quasi-resultaatsverplichting hebben genoemd).

Dit laatste (minimum-)recht impliceert dat het kind, of een pro infante optredende instantie, zoals een AMK (Advies- en Meldpunt Kindermishandeling) ${ }^{233}$ als opvolger van de BVA's (Bureaus Vertrouwensarts), een (sociaal-pedagogisch geëquipeerd) Consultatiebureau of de Raad voor de kinderbescherming, deze basisvoorwaarden rechtens kan afdwingen. Uiterste consequentie van dit minimum-recht is ook dat het meerderjarige (ex-)slachtoffer, althans een pro victima optredende instantie, bijvoorbeeld de VKM (Stichting Voorkoming van Kindermishandeling

Vgl. hierover de special Advies- en Meldpunten Kindermishandeling van VKMagazine (Tijdschrift over kindermishandeling) 1997/4, naar aanleiding van het Eindadvies van de Werkgroep Meldpunt Kindermishandeling (Werkgroep of commisSie HERMANNS). 
c.q. een met deze Stichting gelieerd Proefprocessenfonds Kind \& Recht), het RIAGG, de Sociale Dienst, in rechte compensatie en rehabilitatie van de staat (der Nederlanden) kan vorderen. ${ }^{234}$

Om de woorden van SIMON (die sprak over uitzetting en uitlevering van asielzoekers, voor wier rechtspositie art. 3 EVRM eveneens als onderste bodem fungeert) naar dit minimum-recht te vertalen: ${ }^{235}$

'De conclusie is dat, als vaststaat dat door [het niet opleggen van pedagogische hulp, en aldus de uitlevering van het kind aan ouders met een volstrekt ontoereikend pedagogisch besef, jw] de Staat betrokkene blootstelt [aan] een behandeling of situatie die als onmenselijk moet worden gekwalificeerd, [niet ingrijpen c.q. bedoelde uitlevering, jw] in strijd komt met het verbod van art. 3 EVRM (...).'

Uiteraard kan, uitgaande van een intrinsieke, niet van 'volwassenheid' afhankelijke opvatting van menselijke waardigheid (welke de uiteindelijke bestaansgrond van het Verdrag inzake de rechten van het kind is), niet als niet onmenselijk ten aanzien van een kind worden beschouwd, wat wel als zodanig ten aanzien van een volwassene zou worden gekwalificeerd. Sterker nog: het recht van het kind op minimale persoonswording noopt de kring van wat nog als menselijk kan worden beschouwd, veel enger te trekken. Steeds moeten ook de mogelijke gevolgen op langere termijn voor (de persoonswording van) het kind in de afweging worden betrokken.

Met afweging wordt hier niet bedoeld wat gemeenlijk onder belangenafweging wordt verstaan: de afweging van in beginsel gelijkwaardige particuliere belangen, doch de (ontwikkelingspsychologische en pedagogische) afweging van de mogelijkheden van het kind om in de toekomst van zijn vrijheid (de rechten van de mens in brede zin) te kunnen genieten - waarvoor minimale rationaliteit, moraliteit en authenticiteit noodzakelijk zijn -, tegen de (in beginsel tijdelijke) beperking van de vrijheid van de ouders (privacy, primaire opvoedingsverantwoordelijkheid) in het

Vanuit een oogpunt van compensatie/rehabilitatie is het wellicht doeltreffender in geval van schending van het recht van het kind op minimale persoonswording ten opzichte van de subminimale persoon in kwestie wit te gaan van een tekortkoming in de nakoming van een resultaatsverplichting (rechtsvermoeden). Met andere woorden: nu het resultaat op c.q. vanaf 18 -jarige leeftijd niet blijkt te zijn bereikt (er is bij betrokkene sprake van ernstige criminaliteit, anti-socialiteit, destructiviteit/neuroticisme/depressiviteit c.q. een ernstig gebrek aan eigenwaarde/ernstige identiteitsproblemen, kortom van ernstige psychopathologie), is er eo ipso sprake van staatsaansprakelijkheid en dus van een claim tot compensatie/rehabilitatie (behoudens tegenbewijs/disculpatie).

235 H.J. SIMON, 'Onmenselijke behandeling en asiel,' Nederland's Juristenblad 1990, pp. 1437-1446, op p. 1440 r.k. (curs. van de auteur). 
hier en nu. Een moeilijke afweging, waarbij evenwel de verwachting ten aanzien van de ontwikkelingskansen van het kind rechtens de doorslag behoort te geven (art. 3, lid 1 en art. 18, lid 1, derde volzin VRK).

Het behoeft geen betoog dat de beperking van de vrijheid van de ouders aan strikte voorwaarden (rechtswaarborgen en rechtsbescherming) dient te zijn gebonden: ${ }^{236}$

'Dit vereiste vloeit voort uit het principe van de democratische rechtsstaat, op grond waarvan de individuele vrijheid de regel is, terwijl de beperking van die vrijheid de uitzondering vormt, die een zware legitimatie behoeft.'

Die (zware) legitimatie is evenwel gelegen in de rechten van het kind, in het recht van het kind op minimale persoonswording. Zijn bescherming is minstens evenzeer een vereiste dat voortvloeit uit 'het principe van de democratische rechtsstaat' nu zijn mogelijkheden om in de toekomst van zijn vrijheid te kunnen genieten, staan of vallen met zijn bescherming tegen het misbruik of oneigenlijk gebruik van de vrijheid van zijn ouders.

Een cruciale term bij de (uiterste) inspannings- en (quasi-)resultaatsverplichtingen van de staat ten aanzien van de persoonswording van de kinderen onder zijn rechtsmacht, is (het vereiste van) een adequaat stelsel van sociaal-pedagogische voorzieningen, instellingen en diensten. In dit hoofdstuk gaat het hierbij niet om wenselijkheden of desiderata (daarop wordt voortgeborduurd in hoofdstuk 14), maar om datgene wat voor (minimale c.q. optimale) persoonswording noodzakelijk en geschikt (ofwel doeltreffend en doelmatig) is. Op deze term past de sleutelformule in het Verdrag inzake de rechten van het kind dat de staat gehouden is (alle) passende (wetgevende en beleids-/sociale en opvoedkundige) maatregelen te treffen (vgl. art. 2 , lid 2; art. 3, lid 2; art. 4, eerste volzin; art. 18, lid 3; art. 19, lid 1; art. 21 onder d; art. 22 , lid 1; art. 24 lid 2 en 3; art. 27, lid 3 en 4 ; art. 28, lid 2; artt. 33-35 en art. 39, eerste volzin VRK). Voor de betekenis en reikwijdte van het begrip 'alle passende maatregelen,' dat ook in het Vrouwenverdrag (VuDV: Verdrag inzake de uitbanning van alle vormen van discriminatie van vrouwen, New York 1979) voorkomt, kan worden aangesloten bij de visie van de Rapportagecommissie [VN-]Verdrag tegen discriminatie van vrouwen (Commissie voor de eerste nationale rapportage over de implementatie in Nederland van het Internationaal [sic] Verdrag tegen discriminatie van vrouwen, onder voor-

T.P. SPUKERBOER, B.P. VERMEULEN, Vhuchtelingenrecht; Serie Migratierecht In, NCB Utrecht 1995, p. 461. 
zitterschap van GROENMAN), verwoord in het rapport Het Vrouwenverdrag in Nederland anno 1997:237

'Het gaat, kort gezegd, om een breed scala van maatregelen die door het Verdrag worden voorgeschreven, en die ter uitvoering [van] het Verdrag ook genomen moeten worden zodra [curs. jw] op grond van objectieve gegevens aannemelijk [curs. jw] is dat zij noodzakelijk [curs. auteurs] zijn voor een optimaal resultaat.'

'Aannemelijk (...) noodzakelijk' zullen we vertalen met: geschikt en (bijgevolg in beginsel) noodzakelijk. Over wat in ons kader - dat will zeggen in sociaal-pedagogische zin (en) met betrekking tot de minimale persoonswording van kinderen - 'op grond van objectieve gegevens' geschikt en (bijgevolg in beginsel) noodzakelijk is, gaan we te rade bij BAARTMAN (1997). ${ }^{238}$ Volgens deze auteur maakt de research 'twee dingen duidelijk: ${ }^{239}$

'1. Er zijn gezinnen waar jonge ouders in bijzonder moeilijke omstandigheden een begin maken met het opvoeden van een kind. De kans op het optreden van verwaarlozing of fysieke mishandeling in deze gezinnen is groter dan in andere gezinnen.'

Het komt mij voor dat gezond verstand (bij afwezigheid van research) volstaat om te concluderen dat dit niet fundamenteel anders zal zijn ten aanzien van affectieve verwaarlozing en psychische mishandeling (die immers in de kern als de ondergrond of de aangroei van elke vorm van kindermishandeling kunnen worden beschouwd). De auteur vervolgt:

'Dit zou een reden kunnen zijn om aan deze gezinnen vroegtijdig hulp en ondersteuning te bieden. Daar staat echter tegenover dat een voorspelling omtrent het verloop van de kwaliteit van het opvoeden in deze gezinnen een zeer grote marge van onzekerheid kent. Het is dus allerminst zeker dat mishandeling of verwaarlozing zich zullen gaan voordoen. Aan die onzekerheid zou het argument te ont-

237 L.S. GROENMAN e.a., Het Vrouwenverdrag in Nederland anno 1997; Verslag van de commissie voor de eerste nationale rapportage over de implementatie in Nederland van het $[$ WN-JVerdrag tegen discriminatie van vrouwen, Den Haag 1997, p. 48.

238 H.E.M. BAARTMAN, 'Kindermishandeling en risicogezinnen; een patstelling in preventie?" In: dez. e.a., Gezinnen onder dnik; Over veranderende ouder-kind relaties, Kampen 1997 , pp. $80-107$ (in enigszins aangepaste vorm onder de titel 'Risicogezinnen en predictie en preventie van kindermishandeling' ook verschenen in Tijdschrift woor Orthopedagogiek 1997/6, pp. 245-257).

Hierna wolgende citaten (curs. jw) uit: BAARTMAN (1997), t.a.p., op pp. 80 (i.f.)81 (i.f.). 
lenen zijn om niets te doen en af te wachten met het bieden van hulp tot do nood daadwerkelijk aan de man [lees: aan het kind, jw] is.'

Edoch, de research maakt nog een tweede ding duidelijk:

2. In de tweede plaats is het zo dat het overgrote deel van de gezinnen waar kinderen worden mishandeld of verwaarloosd, gezinnen zijn waar in bijzonder moeilijke omstandigheden een start is gemaakt met het opvoeden. Terugblikkend [slaakt men] dan ook vaak de verzuchting (...): was er maar eerder hulp geboden, dan had het misschien zo ver niet hoeven komen,'

Dit leidt in de (kinderbeschermings)praktijk tot een patstelling:

"Vooraf lijken er redenen voor het bieden van preventieve hulp maar het is onzeker hoe de toekomst er zonder die hulp uit zal zien, en achteraf lijkt het verleden voldoende reden te hebben geboden woor vroegtijdige hulp.'

Hier voegt de auteur nog een derde overweging aan toe:

'Hier komt nog bij dat (...) interventie minder resultaat heeft naarmate de verwaarlozing en de mishandeling alsmede de problemen die eraan ten grondslag liggen, langer hebben voortgeduurd."

\section{Hetgeen hem tot de volgende bevinding voert:}

'Het resultaat van deze patstelling is dat we buitengewoon veel investeren in curatie - met overigens beperkt effect - [chargerend gezegd: in palliatie, jw] en zeer weinig in preventie. COHN \& DARO (1987) trokken de volgende conclusie uit hun onderzoek naar de effecten van hulpwerlening aan ouders die hun kinderen mishandelen: "If research findings are to be of any use in setting policies, the results of a decade of evaluative research [dus vanal 1977 , jw] on treatment programmes suggest that putting all resources into interwention after the fact does not make sense $(\ldots)^{n}$,

Geschikt en noodzakelijk zijn derhalve preventieve ("vroegtijdig hulp en ondersteuning"), in tegenstelling tot palliatieve ('intervention after the fact') maatregelen. Art. 19, lid 2 VRK (mijn cursivering) rekent dan ook tot de (wettelijke en beleidsmatige sociaal-pedagogische) 'maatregelen ter bescherning': 'sociale programma's om te voorzien in de nodige ondersteuning van het kind en van degenen die de zorg voor het kind hebben, alsmede (...) andere vormen van voorkoming van (...) kindermishandeling.' Dit brengt ons direct bij de vraag: hoe zijn gezinnen die de nodige ondersteuning behoeven, ofwel risico-gezinnen: 'gezinnen waar jonge ouders in 
bijzonder moeilijke omstandigheden een begin maken met het opvoeden van een kind,' te screenen?

Het antwoord op deze vraag zal laten zien dat, net zoals optimale persoonswording in het verlengde ligt van minimale persoonswording en derhalve uiterste inspannings- en quasi-resultaatsverplichtingen in elkaar overvloeien -, (juridische) interventie (het opleggen van hulp, indien nog nodig) in het verlengde behoort te liggen van (sociaal-pedagogische) preventie (het aanbieden van hulp). Met andere woorden: dat met een algemeen ondersteuningsaanbod aan alle (aanstaande/jonge) ouders dient te worden begonnen om vandaaruit, dus vanuit een sociaal-pedagogische eerstelijn, risico-indicatoren in kaart te brengen en gezinnen waarin zich deze indicatoren voordoen, naar een sociaal-pedagogische tweedelijn en eventueel derdelijn te verwijzen. Tevens zullen we zien dat deze indicatoren, althans de niet-materiële (de materiële zijn eenvoudig te ondervangen door een reële opvoedingssubsidiëring), voor een belangrijk deel in het transgenerationele vlak liggen. Met andere woorden: tweede- en derdelijnspreventie zullen grotendeels een reparatoir karakter hebben: ook primaire en secundaire regels vloeien in elkaar over. Dit overwegend reparatoire karakter versterkt als het ware in het kwadraat, gezien de ermee verweven systemisch discriminatoire aspecten, de wetgevende, financiële en beleidsprioriteiten waarmee staatsaansprakelijkheid op dit vlak het hoofd dient te worden geboden.

Een en ander zullen we illustreren en voor zoveel mogelijk demonstreren voor wat de sociaal-pedagogische aspecten betreft, aan de hand van BAARTMAN en voor wat de juridische aspecten betreft, aan de hand van GROENMAN c.s. Waanna we krachtig het beeld zullen moeten wegdrukken dat zelfs een marginale toetsing eigenlijk overbodig is om ons ervan te doordringen hoezeer de staat (de overheid, de politiek, maar ook: de samenleving, de volwassenen) - ondanks alles wat thans reeds denkbaar, haalbaar en mogelijk is - de voor een transgenerationeel dubbeltje geboren kinderen in ons land, als waren dezen rechteloos, in de kou laat staan.

Allereerst verdient de term 'risico-indicator' enige toelichting. BAARTMAN $^{240}$ omschrijft deze als ...

(...) een kenmerk of een variabele waarvan is aangetoond dat hij een verband vertoont met de aanwezighteid van een sociaal probleem."

En verduidelijkt:

240 Hierna volgende citaten (curs. jw) hit: BAARTMAN (1997), t.a.p., op p. 83. 
'Het gaat hierbij om niet meer dan een comelationeel verband. Zo zou de jonge leeftijd van een moeder opgevat kunnen worden als een risico-indicator voor opvoedingsproblemen, waarbij duidelijk zal zijn dat leeftijd niet cen causale factor is. Overigens, jonge leeftijd blijkt slechts dan een relevante risico-indicator te zijn als deze gepaard gaat met een lage sociaal-economische positie (...)."

\section{Risicofactoren daarentegen wijzen wel op causaliteit:}

"Van een risicofactor is sprake als het gaat om een variabele waarvan is aangetoond dat deze een verklaring vormt voor de toename van het risico op een psychosociaal probleem. Een risicofactor is dus ook een risico-indicator, maar niet elke risico-indicator is een risicofactor.'

Wil men de causaliteit in het midden laten, dan is het dus veiliger zich te 'bedienen van de term risico-indicator.' BAARTMAN vervolgt zijn betoog aldus: $:^{241}$

'Dat preventie van kindermishandeling belangrijk is, behoeft in het algemeen weinig betoog; niettemin will ik enkele redenen noemen. De belangrijkste reden is dat met effectieve primaire preventie [in het algemeen: voorkoming van nieuwe gevallen; in het bijzonder: preventie gericht op risicogroepen (CAPLAN, 1964), jw] ernstig leed van veel kinderen kan worden woorkomen, leed dat niet alleen hun bestaan als kind tekent, maar veelal ook hun bestaan als hun jeugd - en de mishandeling - inmiddels woorbij] is. Dit leed heeft als regel [bij subminimale persoonswording per definitie, jw] ernstige gevolgen voor de ontwikkeling van het kind. Mishandelde en verwaarloosde kinderen vertonen veelal problemen op het gebied van contacten met leeftijdsgenoten (...) en op het gebied van hun cognitieve ontwikkeling (...). Er is bij hen meer sprake van depressiviteit (...) en van suicidaliteit (...), van antisociaal gedrag (...) en van angst, woede en agressie (...). Ook is gebleken dat persoonlijk en maatschappelijk dysfunctioneren op latere leeftijd vaak samenhangen - onder meer althans [en uiteraard alleen in geval van niet-reparatie, jw] - met het als kind mishandeld zijn (...). Zo geldt dat de kans dat iemand die als kind mishandeld is, zijn eigen kinderen mishandelt, aanmerkelijk groter is dan in geval iemand als kind niet is mishandeld [maar wellicht andere traumatische (jeugd)ervaringen, die niet of net niet onder de gehanteerde definitie van kindermishandeling vallen of niet als (vorm van) kindermishandeling zijn herkend, niet of onvoldoende heeft kunnen verwerken, jw] (...). Dus zowel het actuele leed als de gevolgen ervan op kortere en langere termijn vormen voldoende reden voor het onderschrijven van het belang van primaire preventie.'

\section{Daar komt echter nog een bijzonder schrijnend fenomeen bij:}


'Daarbij komt nog dat mishandeling, indien het eenmaal een patroon is gaan vormen in de opvoeding, een zeer hardnekkig verschijnsel is. Uit een onderzoek van ROELOFS (1996) naar effecten van interventie in geval van fysieke mishandeling bleek dat in eén op de drie meldingen van mishandeling bij een Bureau Vertrouwensarts na verloop van tijd opnieuw een melding gedaan wordt. Een evaluatieonderzoek van hulp aan gezinnen waar sprake was van fysieke mishandeling, liet zien dat in een derde van de gevallen de mishandeling doorging tijdens de periode van de hulpverlening en dat in 50 procent van de gevallen bij afsiuiting van de hulp de kans op herhaling reëel werd geacht (...). In een ander onderzoek (...) bleek [dat] er in bijna 67 procent van de gezinnen ondanks hulpverlening sprake was van recidivisme ( 25 procent van de gezinnen had gedurende meer dan drie jaar hulp gehad)."

Waaraan de auteur de conclusie verbindt:

'Gelet op deze recidivecijfers lijkt de veronderstelling gewettigd dat het moeilijker is om een negatieve interactiespiraal tussen ouders en kinderen te doorbreken naarmate deze langer heeft geduurd."

Interventies anders dan het laatste middel van de uithuisplaatsing (het losscheuren van een, na een langdurig inkankeringsproces, traumatisch aan zijn ouders verknoopt kind op hoop van zegen die de flarden mee doet helen met de oorspronkelijke, ingekapselde wonden) bieden geen garantie voor niet-herhaling. Of anders gezegd: tegen de tijd dat het kalf (bijna) verdronken is, is de put van (gezins)ellende bodemloos, en dus niet meer te dempen. Interventie die niet - als vroege interventie - in het verlengde ligt van preventie, met andere woorden: hulpoplegging die niet direct voortvloeit uit een in een (zeer) vroeg stadium gedaan (doch door welke oorzaken of omstandigheden ook mislukt) aanbod van hulp, is water in de zee dragen. Zoals de auteur het vragenderwijs formuleert: ${ }^{242}$

"Maar als mishandeling in veel gevallen de resultante is van een al langer slepend proces van problemen, spanningen, ${ }_{\text {, }}$ conflicten en teleurstellingen, rijst uiteraard de vraag of het wenselijk is om eerder aan deze problemen iets te doen [alvorens ze zo escaleren].'

Hoezeer handelen naar deze wenselijkheid, in abstracto, ook vanuit het belang - en de rechten - van het kind kan worden gelegitimeerd, staatsaansprakelijkheid met betrekking tot het geen gehoor geven aan deze wenselijkheid - de wenselijkheid van (een adequaat stelsel van) primaire preventie - treedt eerst in als - en zodra - is aangetoond dat, in concreto, primaire preventie (als geïnstitutionaliseerde ouderschapsondersteu- 
ning) een geschikt en (bijgevolg in beginsel) noodzakelijk middell is ter bescherming van kinderen. Dit brengt ons terug bij de vraag van de mogelijkheid en modaliteit van het screenen van risico-gezinnen. Opnieuw reiken we naar de hand van BAARTMAN: 243

'Er bestaan geen standaardcriteria ter aanduiding van een risicogezin. Dergelijke criteria variëren met de aard van het risico. Maar ook als het gaat om het risico op mishandeling, zijn er geen standaardcriteria. Bij de operationalisering [in de research, jw] van het begrip risicogezin wordt gebruik gemaakt van risico-indicatoren die afkomstig zijn uit retrospectief onderzoek dan wel berusten op klinische ervaring. (...) Naast (...) demografische en economische variabelen zijn er criteria die samenhangen met de beschikbaarheid van sociale steun, de kwaliteit van de eigen jeugd, een problematische voorgeschiedenis van de moeder onder meer in termen van psychiatrische problemen, de beleving van de zwangerschap, verwachtingen en gevoelens ten aanzien van het kind, pedagogische vaardigheden, mate van stressvolle omstandigheden, eerdere vermoedens van kindermishandeling (bij moeders die reeds een kind hadden).'

Als centrale conclusie uit de research omtrent de predictieve betekenis van deze en dergelijke risico-indicatoren (let wel: bij moeders) die de auteur vermeldt, noem ik die van VIETZE e.a. (1991): $:^{244}$

'[T]he mother's childhood development and experience may be the most powerful precursor of child maltreatment (...). Most of the evidence points to an accumulation of circumstances resident in the mother and her living conditions that conspire to interrupt the normal caregiving functions.'

\section{De auteur concludeert: ${ }^{245}$}

"Het besproken onderzoek maakt duidelijk dat een succeswolle screening op risico's op kindermishandeling verre van eenvoudig is. (...) Uit het prospectieve onderzoek bleek dat het vooral de combinatie is van kenmerken van de persoon van de opvoeder (diens voorgeschiedenis en de beleving van zijn betrekking tot zijn kind [dat is: diens meer of minder traumatische jeugdervaringen en de mate van verwerking/reparatie daarvan, ofwel diems vorming, vervorming, misworming en mate van hervorming, die zijn houding en beleving bepalen, jw]) en de [daarvan wel te onderscheiden doch niet te scheiden, jw] mate waarin iemand een plaats heeft binnen cen sociaal netwerk en daarbimnen de mogelijkheid heeft voor het ontvangen van steun, die de kwaliteit van het opvoeden bepalen.'

\section{Echter:}


$[B] \mathrm{ij}$ een eventuele screening van risicogezinnen (...) gaat het er niet primair om de kans op een succesvolle voorspelling van kindermishandeling te vergroten, maar de kans te vergroten dat men die gezinnen selecteert waar de kans op ernstige opwoedingsproblemen (die zich onder meer kunnen manifesteren in mishandeling) in hoge mate aanwezig is.'

De gevolgtrekking uit deze constatering met betrekking tot het belang en de vorm - de geschiktheid en de noodzakelijkheid - van primaire preventie (dat is: als algemeen hulp- en ondersteuningsaanbod met tweedeen derdelijnsvertakkingen) is deze:

'Zo goed als dat geldt voor criminaliteit (IUNGER-TAS 1996), zo geldt ook voor kindermishandeling dat het nagenoeg niet met zekerheid kan worden voorspeld. Ik (...) refereer (...) aan een toespraak die de minister van Justitie [in oktober 1996] hield over preventie van jeugdcriminaliteit. Ik citeer: "Een algemeen aanbod. [van ondersteuning, $\mathrm{HB}$ ] aan risicogroepen maakt de predictievraag ondergeschikt aan een breder belang, zowel van het kind en de ouders als van de gemeenschap. Een dergelijk aanbod kan op basis van vrijwilligheid [basis, met het oog op staatsaansprakelijkheid, op te vatten als uitgangspunt, en in elk geval niet als dekmantel voor vrijblijvendheid, $j w]$ worden toegesneden op de eigen behoeften van de betrokkenen. (...) Vanuit het oogpunt van criminaliteitspreventie gaat het daarbij om de selectie van de doelgroep, de gebruikte methoden en de mogelijkheid om met enige drang [drang tegen de achtergrond, nogmaals: met het oog op staatsaansprakelijkheid, van de gedachte dat de staat in laatste instantie een diwanggemeenschap is die, onder rechtswaarborgen, over dwangmiddelen beschikt, jw] mensen tot het aanvaarden van ondersteuning aan te zetten"."

Waarbij (tussen haakjes) overigens ook de zilveren koorden van - onder op het individuele (gezins)geval toegesneden voorwaarden te verstrekken - opvoedingssubsidiëring een zinvolle rol kunnen vervullen, zo al niet moet worden aangenomen dat het subsidiariteitsbeginsel (kort gezegd: het mindere middel moet beproefd worden vór het zwaardere; ook, juist hier, als pedagogische wet: beloning is effectiever dan straf) daartoe verplicht. (BAARTMAN vervolgt:)

'Opgetekend uit de mond van een minister van Justitie zijn dit zeer belangwekkende uitspraken. Hier [lees: haar (?) -jw] gaat het weliswaar om preventie van criminaliteit, maar de probleemstelling is exact dezelfde als bij preventie van kindermishandeling. In beide gevallen gaat het om twee kernwragen. De ene vraag luidt: zijn we op de hoogte van risico-indicatoren. De tweede vraag luidt: is het te legitimeren om risicogroepen een aanbod van ondersteuning te doen, eventueel [lees: desnoods, dat is in laatste instantic, jw] met enige drang [lees: dwang, jw]. Het antwoord op de eerste vraag luidt in beide gevallen: we kennen ze in grote lijn, maar kunnen er geen trefzekere voorspelling aan verbinden [een constatering die we in de sociale wetenschappen wel vaker doen overigens].' 
Wat hierna volgt, is van cruciaal belang om tot een (voorlopig) oordeel inzake staatsaansprakelijkheid te komen (een 'finaal' oordeel, voor zover mogelijk, ligt buiten het bestek van deze subparagraaf), al zullen aan de hand van GROENMAN c.s. nog nadere juridische overwegingen kunnen en moeten worden toegevoegd:

'Het antwoord op de tweede vraag hangt deels samen met het antwoord op de eerste, maar is ook een politieke aangelegenheid. Omdat we geen trefzekere voorspelling kunnen doen, [lijken] we een belangrijke legitimeringsbasis [te missen]. Dat we die voorspelling niet kunnen doen, hangt voor een deel hiermee samen dat het verloop van (de kwaliteil van) het opvoeden mede afhangt van factoren die op het moment van de voorspelling nog onbekend zijn. De politieke vraag is dan of we menen gerechtigd te zijn door ondersteuning het verloop van dit ontwikkelingsproces te beinvloeden. Daartoe dient ten minste aan vier randvoorwaarden te zijn voldaan: ${ }^{246}$

1. Een aanbod van preventieve hulp moet gedaan worden op basis van vrijwilligheid.

2. Dit aanbod mag niet stigmatiserend zijn (in geval van preventie van kindermishandeling betekent dat, dat het niet gaat om preventie van kindermishandeling, maar om ondersteuning bij een verzwaarde start van het opvoeden).

3. Er dient sprake te zijn van een publisk gedeelde opvatting [a.] dat het opvoeden van kinderen weliswaar primair, maar niet alleen een zaak van ouders is, en [b]. dat de gemeenschap de plicht heeft de primair verantwoordelijke opvoeders de middelen te verschaffen die nodig zijn om hun verantwoordelijkheid waar te kunnen maken.

4. En tenslotte het publiek gedeelde en politiek onderschreven besef dat rechten van ouders zijn afgeleid van hun plichten, en dat hun plichten gebaseerd zijn op rechten van kinderen.'

Veiligheidshalve plaats ik bij deze vier randvoorwaarden direct enkele korte kanttekeningen:

Ad 1. Zoals ik tussen teksthaken bij de aangehaalde woorden van de minister reeds aangaf, is vrijwilligheid iets anders dan vrijblijvendheid. In concreto betekent dit dat de weigering van een aanbod onder (door de rechter - aan ontwikkelingspsychologische/pedagogische minimumnormen en algemene beginselen van behoorlijk gezinsrecht - te toetsen) omstandigheden tot het opleggen van hulp kan leiden (hetgeen ook thans mogelijk is, ook al gebeurt dit nog steeds eerder arbitrair en achteraf (incidenteel en 'repressief') dan stelselmatig en vroegtijdig (preventief), krachtens maatregelen van kinderbescherming).

246 De hierna volgende opsomming is overgenomen uit: BAARTMAN, 'Risicogezinnen en predictie en preventie van kindermishandeling,' Tijdschrift voor Orhopedagogiek 1997/6, pp. 245-257, op p. 256 l.k. 
Ad 2 (a). Een (niet algemeen en dus) stigmatiserend aanbod zou systemisch discriminatoire patronen, die men nu juist rechtens (zoals we nog nader zullen zien) verplicht is te bestrijden, juist bestendigen. Anders gezegd: 247 'toch al kwetsbare ouders' (transgenerationeel beschadigde en dus, zacht gezegd, niet van zelfvertrouwen overlopende mensen) direct als risico-ouders benaderen, betekent hun bij voorbaat 'een brevet van onvermogen' uitreiken (in politieke termen: een motie van wantrouwen aan de broek/jurk hangen), hetgeen diep ingewortelde culturele (parentiarchale) weerstanden (onder het mom van 'absolutistische' privacy- en ouderrechten) eerder zal vergroten dan doorbreken. Daarenboven doet een niet-algemeen (en dus stigmatiserend) aanbod ernstig afbreuk aan de (wel te onderscheiden doch niet scherp te scheiden dubbele) rechtsplicht van de staat niet alleen tot bewaking van het recht van het kind op minimale doch ook tot bevordering van het recht van het kind op optimale persoonswording (eigenlijk: tot bewaking van 'minimale persoonswording' vanuit en binnen het sociaal-pedagogische kader van bevordering van 'optimale persoonswording'). Met andere woorden: het zou een kunstmatige en bovendien averechts werkende scheiding van dit dubbelrecht bewerkstelligen (men denke aan wat we hierboven, aan het slot van par. 13.2.2.2, hebben opgemerkt over preventie, interventie en reparatie als drietrapspersoonswordingsraket).

Ad 2 (b). Ondersteuning bij een verzwaarde start van het opvoeden is niet alleen een (reparatie-)recht van ouders, maar tevens en vooral een recht van het kind, dat niet alleen kan worden gelegitimeerd op basis van het Verdrag inzake de rechten van het kind, maar in dat Verdrag als algemene opvoedingsondersteuningsverplichting van de staat ligt verankerd, zowel krachtens de secundaire opvoedingsverantwoordelijkheid van de staat die grondslag van (de Trias pedagogica van) het Verdrag is, alsook krachtens expliciete verdragsbepalingen.

Ad 3 en 4. Ook deze twee (politieke/maatschappelijke) randvoorwaarden zijn in Nederland, sinds de inwerkingtreding van het Verdrag inzake de rechten van het kind, dus sedert 8 maart 1995, geldend recht. Hetgeen evenwel nog niet betekent dat zij ook als zodanig in brede (politieke en maatschappelijke) lagen worden gevoeld en beleefd. Vandaar het grote belang van art. 42 van het Verdrag: de verplichting van de staat de beginselen en de bepalingen van het Verdrag algemeen bekend te maken, zowel aan volwassenen als aan kinderen. (Uiteraard ligt hier ook een zeer belangrijke opdracht voor de rechtswetenschap en voor mensenrechtenorganisaties, waaronder niet in de laatste plaats wetenschappelijke 
instituten en maatschappelijke organisaties die zeggen op te komen voor, in theoretische dan wel praktische zin, de rechten van het kind.)

Van niet minder belang voor het opmaken van de balans van staatsaansprakelijkheid is ten slotte het volgende (kinderrechten)vertoog van BAARTMAN (dat we hier zonder onderbrekingen opnemen):248

'[H]et zou (...) wel eens kunnen [zijn] dat men als het gaat om de bestrijding van criminaliteit, eerder bereid is tot preventieve interventies in het gezin dan in geval van bestrijding van kindermishandeling. Criminaliteit vormt immers primair een bedreiging voor het welzijn van de samenleving, kindermishandeling is primair een bedreiging voor het welzijn van het kind. Vergeten wordt dan overigens dat met een bedreiging van het belang van kinderen ook het belang van de samenleving in het geding is.

De terughoudendheid om aan jonge risicogezinnen waar zich (nog) geen evidente problemen rond kinderen voordoen, hulp te bieden, berust waarschijnlijk op twee overwegingen. De ene is dat de wijze waarop deze gezinnen zich ontwikkelen, niet precies voorspeld kan worden. Dat is op zich juist. Daar zijn echter twee argumenten tegen in te brengen. In de eerste plaats is er, zoals uit de besproken research bleek, wel sprake van een verhoogd risico. En zonder te twisten over de vraag hoe hoog "hoog" dan moet zijn alvorens preventieve interventies verdedigbaar zijn, kunnen we wel vaststellen dat verwaarlozing en mishandeling bijzonder ernstige verschijnselen zijn. Anders gezegd, de hoogte van een risico is niet alleen een kwantitatieve maar zeker ook een kwalitatieve kwestie. ${ }^{249}$ In de tweede plaats zij opgemerkt dat in gevallen waarin we menen wel te mogen of zelfs te moeten ingrijpen, bijvoorbeeld door een kind uit huis te plaatsen, we evenmin met zekerheid kunnen voorspellen hoe het kind zich met die ingreep, noch hoe het zich zonder die ingreep, zal ontwikkelen.

De tweede overweging is deze, een overweging die een belangrijke basis vormt voor ons hele systeem van jeugdhulpverlening en jeugdbescherming. Men laat zich van buitenaf pas dan in met het functioneren van ouders als opvoeders als [deze] het min of meer evident af laten weten. Het [parentiarchale, jw] "recht" [mijn aanhalingstekens, $j w]$ van ouders om zo lang mogelijk verschoond te blijven van bemoeienis met de wijze waarop ze hun verantwoordelijkheid als opvoeder vormgeven, leidt er in de praktijk toe dat rechten van kinderen al lang [en in zeer ernstige zo niet bijna onherstelbare mate, jw] in de knel zijn alvorens die rechten gehonoreerd [althans geactiveerd, jw] worden. Men bedenke hier echter dat men met het doen van een [niet stigmatiserend, jw] aanbod van steun of hulp de rechten van ouders miet beknot. Hoe groter de marges van onzekerheid - en bij het doen van een voorspelling hoe een jong risicogezin zich ontwikkelt, zijn de marges groot - hoe minder ingrijpend een interventie zal behoren te zijn. Het [structureel, dat is geîntegreerd-geïnstitutionaliseerd, en vroegtijdig, $j w]$ doen van een aanbod van hulp in de sfeer van vrijwilligheid is heel wat minder ingrijpend dan

248 'Risicogezinnen en predictie en preventie van kindermishandeling,' ta.p., op pp. 256 r.k.-257 (curs. jw).

249 De maatschappij kan, cru gezegd, een tamelijk verhoogd risico verdragen dat goederen, maar nauwelijks een verhoogd risico dat kinderen worden vernield. 
het [rauwelijks, dat is incidenteel/arbitrair en achteraf/"repressief," jw] opleggen van hulp in het kader van een maatregel van kinderbescherming.

Cruciaal is of men het [parentiarchale, jw] "recht" [mijn aanhalingstekens, jw] van ouders zo lang mogelijk van externe bemoeienissen gevrijwaard te blijwen, laat prevaleren boven het recht van kinderen op een zo optimaal mogelijke ontplooiing in situaties waar de kansen daarop beperkt zijn. Omdat echter [niet-parentiarchalle, (doch) uit hun primaire opvoedingsverantwoordelijkheid voortvloeiende, jw] rechten van ouders [dus ouderlijke bevoegdheden ten opzichte van kinderen en claims ten opzichte van de (secundair verantwoordelijke) staat, jw] uiteindelijk gebaseerd zijn op rechten van kinderen, valt het te verdedigen ouders een [niet stigmatiserend, dus tweedelijns-, jw] aanbod van hulp te doen als er sprake is van een verhoogd risico dat de rechten van een kind geschaad zullen gaan worden.'

We nemen thans de toegestoken hand van (de commissie-)GroENMAN om te bezien in hoeverre de rechtsontwikkelingen (overigens met name op papier, dat wil zeggen in de doctrine, zij het mede op basis van de 'jurisprudentie' wan het Vrouwencomité) ten aanzien van het Vrouwenverdrag zich laten vertalen naar het Verdrag inzake de rechten van het kind. De beste, althans meest efficiënte wijze om dit te doen, lijkt te zijn dat we mutatis mutandis - dat wil zeggen: waar mogelijk en van toepassing beide verdragen, de (hoofd)subjecten van beide verdragen (vrouwen respectievelijk kinderen) ${ }^{250}$ en de objecten van beide verdragen (uitbanning van discriminatie van vrouwen respectievelijk optimale persoonswording van kinderen in het bijzonder door uitbanning van transgenerationeel traumatiserende en andere minimale persoonswording bedreigende patronen en factoren in het gezin en in de maatschappij) tussen teksthaken substituerend - enkele voor de bepaling van staatsaansprakelijkheid relevante juridische overwegingen aanhalen uit het (al eerder ingeroepen) rapport Het Vrouwenverdrag in Nederland anno 1997: $:^{251}$

'Het Verdrag [inzake de rechten van het kind] geeft geen blauwdruk van een ideale ["kindvriendelijke"] samenleving, maar schrijft [in art. 19, lid 2] een groot aantal maatregelen voor ter uitbanning van [transgenerationeel traumatiserende en andere minimale persoonswording bedreigende patronen en factorem in het

250 Men zou ook mannen als subjecten van het Vrouwenverdrag kunnen zien, namelijk als (in het bijzonder) dragers van verplichtingen, en volwassenen, dat wil zeggen (aanstaande) ouders, als subjecten van het Kinderrechtenverdrag, namelijk als dragers van bevoegdheden ten opzichte van hun kinderen, van verplichtingen ten opzichte van hun kinderen en de gemeenschap/de stat en van rechten (in het bijzonder materièle en immateriële sociaal-pedagogische claims) ten opzichte van de overheid.

251 L.S. GROENMAN e.a., Het Vrouwerwerdrag in Nederland anno 1997; Verslag van de commissie voor de eerste nationale rapportage over de implementatie in Nederland van het [VN-JVerdrag tegen discriminatie van vrouwen, a.w., p. 12. 
gezin en in de maatschappij]. Het Verdrag en de daaraan gekoppelde internationale [mensenrechtelijke] ideeenontwikkeling dienen leidraad te zijn voor het nationale [kind- en gezins]beleid èn zij kunnen dienen als inspiratiebron.

Een en ander vereist echter wel een eenduidige en samenhangende visie op de betekenis van het Verdrag. Is die er niet, dan ontbreekt ook het kader om te toetsen of de Nederlandse overheid voldoet aan de verdragsverplichtingen."

Het spreekt vanzelf dat deze studie op zijn minst de pretentie heeft, met alle bescheidenheid die past bij het betreden van 'terra incognita, ${ }^{, 252}$ een dergelijke 'eenduidige en samenhangende visie' op hoofdlijnen te presenteren. Dit is gebeurd door zowel de (historische en filosofische) achtergrond en de (juridische en psychologische) grondslagen van het Verdrag inzake de rechten van het kind te onderzoeken als het object ervan (zoals hierboven kort aangeduid) vanuit verschillende deel-disciplines (ontwikkelingspsychologie, pedagogie, psychopathologie) uitvoerig te schetsen en juridisch (waaronder enigermate volkenrechtshistorisch en -theoretisch) te onderbouwen. $\mathrm{Zij}$ het dat hierbij de kanttekening past dat dit uiteraard niet anders kon geschieden dan door uitgebreid uit diverse bronnen te putten en diverse auteurs meer of minder uitgebreid aan het woord te laten (waarbij een meer volledige integratie van het materiaal, nu het landschap enigszins in kaart is gebracht, aan andere tijden en aan andere auteurs wordt overgelaten).

We lopen verder aan GROENMANs hand:253

'De eigen intenties en reeds gekozen doelstellingen van de overheid zijn de maatstaf, niet [zoals het zou moeten zijn, jw] de strekking van het Verdrag of de precieze betekenis van de afzonderlijke verdragsartikelen. (...)

De doelstelling van het Verdrag is [de optimale persoonswording wan kinderen in het bijzonder door uitbanning van transgenerationeel trawmatiserende en andere minimale persoonswording bedreigende patronen en factoren in het gexin en in de maatschappij]. Dit is een opdracht tot handelen. (...) De Preambule [c.q. het integrale Verdrag] gaat ervan uit dat [sociaal-pedagogische nalatigheid ten aanzien van kinderen, in het bijzonder het verzaken van de secundaire opvoedingsverantwoordelijkheid van de staat] een schending is van de beginselen van gelijke behandeling en van de menselijke waardigheid, en de toename van de welvaart van maatschappij en gezin belemmert. (...)

Teneinde een beter zicht te kunnen krijgen op de inhoud van de verplichtingen die het Verdrag met zich meebrengt, is het wenselijk de doelstelling onder te verdelen in drie subdoelstellingen. Deze kunnen worden afgeleid uit de [diverse verdragsbepalingen, afzonderlijk en in onderlinge samenhang, alsmede in verband met de preambulaire overwegingen beschouwd]. De drie [elkaar overlappende] subdoelstellingen zijn: 
1. [Optimale persoonswording van alle kinderen onder de rechtsmacht van de staat, in het bijzonder door uitbanning van minimale persoonswording bedreigende patronen en factoren in het gezin en in de maatschappij.]

2. [Sociaal-pedagogische steun (opvoedingsscholing en materielle en immaterielle opwoedingsondersteuning) als grondslag en sluitstuk van de Trias pedagogica.]

3. Witbanning van alle vormen van transgenerationele systemische discriminatie door (a.) doorbreking van traditionele (parentiarchale) patronen en (b.) uitbanning vast transgenerationeel traumatiserende patronen en factoren in het gezin en in de maatschappij.]"

De derde subdoelstelling valt onder dezelfde rubriek als het object (en doel) van het Vrouwenverdrag: uitbanning van discriminatie. Gaat het bij het Vrouwenverdrag om uitbanning van discriminatie van vrouwen, bij het Verdrag inzake de rechten van het kind gaat het om uitbanning van sociaal-pedagogische discriminatie, dat is sociaal-pedagogische nalatigheid die een onevenredig nadelig effect heeft voor een bepaalde achtergestelde en kwetsbare groep: transgenerationeel getraumatiseerde/traumatiserende ouders en kinderen (c.q. sociaal-emotioneel/pedagogisch gedepriveerde/depriverende ouders en kinderen). Verschillende juridische overwegingen uit het rapport-GROENMAN kunnen dan ook - mutatis mutandis - van toepassing worden geacht ten aanzien van deze groep: ${ }^{254}$

'Het komt voor dat een [ongedifferentieerde/"neutrale'] juridische regeling [met betrekking tot gezinnen en kinderen] - als gevolg van bestaande maatschappelijke verschillen tussen [pedagogisch 'gezonde' en pedagogisch 'gehandicapte' ouders] - een onevenredig nadelig effect heeft voor [de laatste groep en hum kinderen]. Dan is er sprake van indirecte discriminatie, tenzij er objectieve rechtvaardigingsgronden zijn aan te voeren. Van een objectieve rechtvaardigingsgrond kan alleen sprake zijn (1) wanneer het doel van de desbetreffende regeling [a.] in zichzelf niet discriminerend [c.q. stigmatiserend, $j \mathrm{w}$ ] is en [b.] van voldoende zwaarwegend belang is [hetgeen bij de doelstelling van minimale/optimale persoonswording zonder meer het geval is, jw], en (2) wanneer de gekozen middelen geschikt en noodzakelijk zijn om dat doel daadwerkelijk te bereiken [hetgeen van het huidige stelsel van gezins- en kinderbescherming, waarbij jaarlijks tienduizenden ouders en kinderen van de regen in de drup komen of tussen wal en schip vallen, bepaald niet kan worden gezegd, $\mathrm{jw}$. Het is onomstreden dat het discriminatieverbod in het Verdrag [art. 2, lid 1] ook betrekking heeft op indirecte discriminatie."

De indirecte sociaal-pedagogische discriminatie in Nederland is als volgt door HAANS onder woorden gebracht: ${ }^{255}$

Het Vrouwenverdrag in Nederland anno 1997, a.w., pp. 22/23.

Gé HAANS, Kinderen voor onze rekening: Een castistische verkenning van het (gezins) voogdijwerk, Utrecht 1992, pp. $178-179$ (curs. jw); reeds eerder aangehaald in een noot in hoofdstuk 11. 
"Wie lang genoeg werkzaam is in een gezinsvoogdij-instelling weet dat de kans reëel is dat de problemen zich een generatie later gaan herhalen. (...) Deze intergenerationele problematiek, de vicieuze cirkel waarin sommige gezinnen/individuen gevangen raken, komt binnen het (gezins) voogdijwerk relatief vaak voor. (...) Feit is, blijkens ervaring, dat het gezinnen en jongeren betreft die functioneren in de marge van de samenleving. (...) Vaak zijn het jongeren met essentièle hiaten in hun ontwikkeling; ernstig affectief verwaarloosd, langdurig misbruikt of mishandeld. (...) Het is ontmoedigend wanneer je als (gexins)voogd erachter komt dat de kinderen van jouw ex-pupil hetzelfde is overkomen als jouw pupil destijds. Dat [zijn/haar] zoon of dochter ook seksueel [is] misbruikt, mishandeld of ernstig verwaarloosd (...). Ofschoon de schuldvraag in dit verband niet zo relevant is, heb ik me altijd verbaasd over de politieke desinteresse voor deze schaduwkant van onze beschaving. (...) Nog dagelijks spelen er zich binnen de gezinswoogdij hemelschreiende taferelen af (...). (...) Kinderbescheming is geworden tot een vorm wan armoedezorg. De rekening wordt in de volgende generatie gepresenteerd.'

\section{GROENMAN C.S. vervolgen: ${ }^{256}$}

'De opdracht tot gelijke behandeling door de overheid beperkt zich niet alleen tot wetgevingsactiviteiten. Onder deze subdoelstelling valt ook het uitbannen van directe en indirecte discriminatie die ontstaat door feitelijk handelen [of nalaten, jw] van de overheid of door overheidsbeschikkingen die op het individuele geval zijn gericht [of nalaten in het concrete geval te beschikken, jw]. (...)

Het Verdrag schrijft voor dat de owerheild [onder overheid worden hier ook de lagere overheden verstaan (...)] verantwoordelijk is voor het daadwerkelijk realiseren van sociale, burgerlijke, economische, culturele en politieke mensenrechten van [kinderen; (art. 2 en 4 VRK)]. Het non-discriminatiebeginsel van het Verdrag houdt meer in dan een garantie dat [ouders en kinderen] door de wetgever, het openbaar bestuur en de rechtspraak gelijk worden behandeld (de klassieke component van het gelijkheidsbeginsel). Het houdt ook in dat de overheid alles in het werk stelt om aan discriminat[oire patronen en factoren] in de samenleving en aan feitelijk bestaande ongelijkheden tussen [pedagogisch voldoende en pedagogisch onvoldoende geëquipeerde ouders] een einde te maken (de sociale component van het gelijkheidsbeginsel). (...) Dit betekent onder meer het ontwikkelen van beleid, het opzetten en instandhouden van een [ouderschaps]ondersteuningsstructuur en een "national machinery" (...), en het uitvoeren van [persoonswordings-]effectrapportages (...)."

Over de betekenis en het belang van (het desideratum van) persoonswordingseffectrapportages komen we te spreken in hoofdstuk 14. Onder een 'national machinery' verstaat het rapport, in navolging van Algemene aanbeveling 6 (1988) van het Vrouwencomite: 257

Het Vrowwenverdrag in Nederland anno 1997, a.w., pp. 23 en $23 / 24$.

Het Vrowwenverdrag in Nederland anno 1997, a.w., Pp. 63 (i.f.) en 64/65; voor de tekst wan de General recommendations zie a.w., pp. 159-181. (Algemene aanbeve- 
'(...) een infrastructuur (...) op rijksniveau (...) voor de verwezenlijking van de verdragsverplichtingen. (...) Deze "national machinery" dient op hoog niveau binnen de overheid gepositioneerd te zijn en de beschikking te hebben over voldoende bronnen, "commitment" en gezag om te adviseren over het overheidsbeleid en de gevolgen daarvan voor [de persoonswording wan kinderen]. Het is noodzakelijk, zo leert de praktijk, dat een dergelijke "national machinery" wordt aangehaakt bij de bestaande politieke en bestuurlijke structuren. De "national machinery" heeft als taken:

- advisering over de invloed van bet regeringsbeleid op [(de pedagogische situatie van) ouders en kinderen, dat is op de Trias pedagogica];

- bewaking ("monitoring") van de samenhang [van het sociaal-pedagogisch beleid op diverse terreinen];

- hulp bij de beleidswoorbereiding en het ontwikkelen van effectieve strategieën en matregelen;

- periodicke rapportage van de wijze waarop de adviezen wan het [Kinderrechtencomite] ter harte zijn genomen [en van de wijze waarop aan het Comité zal worden gerapporteerd].'

Gezien het onmiskenbaar en onevenredig ernstiger en kwetsbaarder karakter van de menselijke conditie van ouders en kinderen in sociaal-pedagogische achterstandssituaties ten opzichte van de sociaal-economische positie van vrouwen in Nederland in het algemeen, kan het bovenstaande mijns inziens met betrekking tot het Verdrag inzake de rechten van het kind enkel vertaald worden (vertaald hier in politieke zin: we beroepen ons immers op een op zich niet bindende aanbeveling, hoe gezaghebbend en 'spiegelend' ook, van een verdragscomité onder een ander verdrag) in de instelling van een ministerie van Kind en Gezin, althans de aanstelling van een coördinerend bewindspersoon, bij voorkeur de minister-president zelf (die dan minister van Algemene, Kind- en Gezinszaken wordt), die toeziet op het gehele nationale 'persoonswordingsbeleid,' dadelijk bij de eerste kabinetsformatie na de inwerkingtreding van het Verdrag. (Wij willen dat hier gezegd hebben, hoewel dit voorstel strikt genomen thuishoort in hoofdstuk 14.)

We lezen (en substitueren) verder: ${ }^{258}$

'De huidige [parentiarchale] ideologie [houdt sociaal-pedagogisch discriminatoire patronen in stand]. Deze ideologie dient ontmaskerd te worden en de daaruit voortvloeiende [transgenerationele] uitshitingsmechanismen [Mattheüs-effecten] dienen effectief bestreden te worden. (...)

Gevestigde of dominante [absolutistische] opvattingen over [de opvoedingsvrijheid en privacy-rechten van ouders] en over wat typisch [een taak van de ouders] en typisch [géén taak van de overheid] zou zijn, zijn diep doorgedrongen in het ge-

ling 6: pp. 160/161).

258 Het Vroumenwerdrag in Nederland anno 1997, a.w., pp. 24-25. 
hele maatschappelijke, economische, sociale, culturele, politieke en persoonlijke leven van mensen. (...) De op [ouderlijke privileges/ouderschapslibertinisme] en [staatsonthouding/ouderschapsverwaarlozing] gebaseerde structurering van het menselijk leven [met zijn onevenredig nadelige effecten voor transgenerationeel getraumatiseerde ouders en hun kinderen] wordt ook wel aangeduid met de termen structurele discriminatie, institutionele discriminatie of systeemdiscriminatie [in deze studie/dit hoofdstuk: systemische discriminatie].'

We borduren, met de rapportagecommissie, nog even op dit thema voort, zij het dat we er hier, ten overvloede doch nadrukkelijk, op wijzen dat onze exercitie de extrapolatie betreft van juridische overwegingen aangaande de (achtergestelde) positie en de rechten van (in beginsel weerbare en mondige) vrouwen (het althans in psychische zin sterke geslacht) naar de situatie van grootschalige en grove mensenrechtenschendingen ten aanzien van (weerloze en onmondige) kinderen (zuigelingen, peuters, kleuters, vijf-, zesjarigen) - met als doel de aansprakelijkheid van de rijksoverheid ${ }^{259}$ ten aanzien van (het voortduren en bestendigen van) die situatie in beeld te brengen. De commissie-GROENMAN: ${ }^{260}$

"In de literatuur wordt geregeld gesproken over de programmatische opzet van het Verdrag. Naar de opvatting van de rapportagecommissie bestaat het programma van het Verdrag uit de uitwerking en realisatie van de drie hierboven [genoemde] subdoelstellingen.

De [verdragsbepalingen] zullen - los van hun zelfstandige betekenis - vc oral in onderlinge samenhang optimaal effect sorteren. Immers, het realiseren van [optimale persoonswording] en het woeren van een [sociaal-pedagogisch] beleid kunnen niet effectief bijdragen aan de bestrijding van alle vormen van [transgenerationele] discriminatie wanneer [persoonswordings-]onderdrukkende en [transgenerationeel getraumatiseerden-]uitsluitende ideologieèn niet tevens ter discussie worden gesteld. Wanneer [de derde] subdoelstelling wordt veronachtzaamd, zul-

259 De staat is verantwoordelijk en aansprakelijk met al zujn organen en instellingen (ook particuliere: zie art. 3, lid 1 en 3 VRK). Evenwel, zoals het rapport-GRoENMAN terecht opmerkt (Het Vrouwenverdrag in Nederland anno 1997, a.w., p. 40): 'De rijksoverheid kan haar zorg voor de uitvoering van het Verdrag op vele wijzen vormgeven, onder andere door een deel daarvan concreet in handen te geven van lagere overheden [provincie, gemeente, $j w$ ] of overheidsorganen [provinciale en/of gemeentelijke bestuursorganen, jw], [alsmede - politiek niet verantwoordelijke - kinderrechters en particuliere (gezins)woogdij-instellingen ${ }_{y}$ jw]. Dit neemt niet weg dat de rijksoverheid als eerste verantwoordelijk is en blijft vanwege het feit dat de rijksoverheid optreedt voor Nederland als verdragsluitende staat. Zo zal de rijksoverheid onder alle omstandigheden de voortgang moeten bewaken, een infrastructuur voor een passende uitvoering in stand moeten houden, moeten sturen en coördineren, en verslag moeten doen aan het [Comite inzake de rechten van het kind.].'

260 Het Wrouwenverdrag in Nederland anno 1997, a.w., pp. 26-27 (curs. jw). 
len uitsluitingsmechanismen ten aanzien van [sociaal-pedagogisch achtergestelden] blijven bestaan.

Anderzijds is weinig effect te verwachten van aandacht voor [transgenerationele discriminatie] wanneer dit niet wordt ondersteund door concrete [sociaal-pedagogische』matregelen.

[Een en ander] betekent dat de overheid niet kan ophouden bij de eerste twee subdoelstellingen, maar dat een fundamentele verandering van de samenleving noodzakelijk is: een verandering van [parentiarchale] opvattingen, waarden en structuren op grond van het [persoonswordings]perspectief.'

Hieraan zou $\mathrm{ik}$ - ter afsluiting van dit thema - de kanttekening willen verbinden dat de drie kinderrechtelijke subdoelstellingen een integraal ('totaal'-)beleid vergen. Net als statelijke souvereiniteit (het beginsel van niet-inmenging in interne aangelegenheden: art. 2, lid 7 Handvest vN) zijn 'ouder-rechten' (parentiarchaal c.q. absolutistisch opgevatte opvoedingsvrijheid en privacy-rechten) immers een relatief begrip. Hoe meer mensenrechten c.q. kinderrechten gecodificeerd en geoperationaliseerd worden, hoe meer statelijke respectievelijk ouderlijke souvereiniteit ipso jure inkrimpt - en deze inkrimping sluipenderwijs oude vanzelfsprekendheden ('souvereiniteit in eigen kring') door nieuwe ('kinderen hebben ook mensenrechten') vervangt. Met andere woorden: het codificeren, constitutionaliseren en - vooral - operationaliseren van de (sociaal-pedagogische grond-)rechten van het kind is de veiligste en snelste weg om parentiarchale patronen te doorbreken, terwijl een frontale aanval op parentiarchale tradities en (voor)oordelen (anders dan binnen het eigen overheidsapparaat, om te beginnen het ministerie van Algemene, Kinden Gezinszaken) waarschijnlijk slechts extra weerstanden zal oproepen en aldus averechts zal werken. Ook hier geldt: de meest efficiënte is de juridisch verplichte weg.

Anderzijds kunnen en mogen we de ogen niet sluiten voor het feit dat transgenerationele systemische discriminatie volstrekt onzichtbaar blijft zolang we haar niet willen zien. Alsook (voorzijde van dezelfde vastgeroeste medaille) dat parentiarchale patronen - allengs in grotere tegenstelling tot patriarchale/sexistische (en zeker tot racistische en 'klassistische') patronen - nog steeds (en zonder actief overheidsbeleid, ondersteund door publiekscampagnes, ${ }^{261}$ waarschijnlijk nog lange tijd) een

GROENMAN c.s. (Het Vrouwenverdrag in Nederland anno 1997, a.w., p. 74) gewagen behalve van voorlichtingscampagnes dic zijn doorgegaan, ook van de afgeblazen anti-patriarchale campagne Een beetje vent strijkt zijn eigen overhemd. Het wachten is op een anti-parentiarchale campagne als Een beetje ouder houdt $z^{\prime} n$ handen thuis. Of cen voorlichtingscampagne van de Raden voor de kinderbescherming: Ouders geeft Uw kind geen dreun, wij staan klaar met hulp en steun. Wie zich van zulke campagnes een voorstelling kan maken, heeft begrepen welke 
zeer hoge mate van "natuurlijke" vanzelfsprekendheid kennen. Om (mutatis mutandis) met BYRNES te spreken: ${ }^{262}$

'Quite simply, if you are not looking for something (or at least aware that it might exist), then your chances of finding it are significantly reduced. The importance of being aware that [transgenerational trauma] may be significant, asking what the position of [pedagogically deprived parents and children] is, and whether that is reflected in universal norms and taken into account in designing responses to social problems, has been demonstrated time and again. However, in the area of human rights abuses it appears that too often this [extra-legal, jw] dimension of a situation may not be explored thoroughly [or may not be explored at all, jw] (....).

aardverschuiving het Verdrag inzake de rechten van het kind in petto heeft. Tegelijk zal hij/zij beseffen hoe urgent dergelijke campagnes zijn. Meer nog wellicht dan ten aanzien van het slaan van kinderen geldt zulks ten aanzien van verbaal geweld (Een beetje ouder let op z'n woorden). Ik denk hier in het bijzonder aan een campagne ter werspreiding van de Tien Verboden, de tien dingen die men een kind nooilt zegt (Psychological Reports 1997; zie Psychologie oktober 1997, p. 13 r.k.):

Verbod 1. Gij zult Uw kind niet afwijzen door te zeggen:

'Van jou kast niemand houden."

Verbod 2. Gij zult Uw kind niet neerhalen door te zeggen:

'Wat ben jij toch stom!"

Verbod 3. Gij zult Uw kind niet tot perfectie drijwen door te zeggen:

'Hoe komt het nou dat je slechts tweede werd?'

Verbod 4. Gij zult Uw kind niet verdoemen door te zeggen:

"Het wordt nooit wat met joul"

Verbod 5. Gij zult Uw kind niet negatief vergelijken door te zeggen:

Waarom lijk je niet wat meer op je broer?"'

Verbod 6. Gij zult $U_{w}$ kind niet tot zondebok maken door te zeggen:

'Het is jouw schuld dat wij gaan scheiden.'

Verbod 7. Gij zult Uw kind niet beschamen door te zeggen:

'Kijk eens hoe kinderachtig Jantje nog doet."

Verbod 8. Gij zult Uw kind niet uitschelden: 'Hujter"' "Hoer"'

Verbod 9. Gij zult Uw kind niet bedreigen: 'Ik sta je nog eens tot moes/'

Verbod 10. Gij zult UW kind niet emotioneel chanteren (op zijn schuldgevoel werken) door te zeggen:

'Hoe kan je dat nou doen, na alles wat ik voor jou gedaan heb?'

262 Andrew BYRNES, 'Women, feminism and international human rights law - methodological myopia, fundamental flaws or meaningful marginalisation?' In: The Australian Year Book of Intemational Law 1992, pp. 205-240, op p. 212.

Het cital is ook te vinden in J.C. HES, C.E. VAN VLEUTEN, Het Vrouwenverdrag in de Nederlandse rechtsorde; Onderzoek verricht in opdracht van het Ministerie van Sociale Zaken en Werkgelegenheid door de vakgroep Publiekrecht van de IUniversiteit Maastricht], Den Haag 1996, p. 177 (overigens zonder traceerbare bronvermelding). 
Dit brengt ons - down to earth - op de vraag: hoeveel tijd kan de overheid rechtens worden gegund met het keren van het tij? Meer concreet komt dit neer op de vraag waar we de juridische grens moeten trekken tussen de (onmogelijke) aansprakelijkheid voor wat gisteren bereikt had moeten zijn, en de (mogelijke) aansprakelijkheid voor wat niet kan worden uitgesteld - met een beroep op de complexiteit en hardnekkigheid van de materie in relatie tot het geleidelijkheidskarakter van de verdragsverplichtingen die ook in andere landen nog niet enzovoorts enzovoorts tot de feestdag van de heilige Juttemis volgens de Griekse kalender. We sluiten met deze vraag onze gehele 'vertaalslag' af: ${ }^{263}$

'Uit de steeds terugkerende zinsnede dat alle passende maatregelen genomen dienen te worden, volgt in de eerste plaats datt er een [maximale] inzet [art. 4 VRK: "maximum extent'] geëist wordt, en in de tweede plaats dat er sprake moet zijn wan matregelen die het beoogde effect [grof gezegd: 'Kinderen beschermen'] sorteren [en in elk geval - grosso modo de huidige kinderbeschermingspraktijk niet - per (nadelig) saldo - (nog meer) frustreren, jw]. (...)

De verdragsstaten zijn gehouden een aantoonbare vooruitgang te boeken bij de verwezenlijking van het Verdrag (...). (...) De mogelijkheid van verwezenlijking moet beoordeeld worden per verdragsbepaling, en met het oog op de onderlinge samenhang van de verdragsverplichtingen. Daarover is uiteraard wel enig verschil van inzicht mogelijk, maar in zijn algemeenheid liggen or in het Verdrag duidelijke politieke opdrachten die met gepaste zorgvuldigheid en met gepaste spoed aangevat moeten worden.

In ieder geval is een begin van verwezenlijking noodzakelijk. De overheid dient de eerste [wetgevings- en beleids]stappen gezet te hebben op de weg van uitwoering van de verschillende verdragsverplichtingen [dat is op de weg van optimale persoonswording]. Verder dient de minimumnorm [minimale persoonswording: de veiligheid en de lichamelijke en geestelijke integriteit van kinderen, de wrijwaring van onmenselijke en vernederende behandeling en bestraffingl, die de kern van de afzonderlijke bepalingen uitmaakt, vanaf het begin gewaarborgd te zijn. Dexe beide vereisten [uiterste inspannings- en quasi-resultaatsverplichtingen] zijn in rechte toetsbaar en de Nederlandse Staat kan daarop in een internationaal forum, zoals het Mensenrechtencomite [onder het Burgerlijke-en-politieke-rechtenverdrag: zie art. 24 (juncto art. 26) IVBPR, waarin de bepalingen van het Verdrag inzake de rechten van het kind kunnen worden ingelezen $\left.{ }^{264}\right]$ of $[z i j$

Het Vrouwerverdrag in Nederland anno 1997, a.w., pp. 34 en 37-38.

264 Zoals het Vrouwenverdrag kan worden ingelezen in art. 26 IVBPR: Het Vrowwenverdrag in Nederland anno 1997, a.w., p. 42 nt. 57.

Art. 24, lid 1 rVBPR luidt (curs. jw): Elk kind heeft, zonder onderscheid (...), recht op die beschermende maatregelen van de zijde van het gezin waartoe het behoort, de gemeenschap en de Staat waarop het in verband met zijn minderjarigheid recht heeft [in het - authentieke - Engels: as are required by his status as a minor, dat is in onze terminologie: die met het oog op zijn persoonswording noodzakelijk zijn]. 
het niet direct door individuen/kinderen en slechts indirect door groepen/NGO's (art. 45 VRK: "andere bevoegde instellingen"), jw] het [Comite inzake de rechten van het kind] worden aangesproken. (...)

Een beroep op schaarse middelen om de verwezenlijking van bepaalde verplichtingen te temporiseren of na te laten, gaat na de [inwerkingtreding] van het Verdrag niet meer op [zie art. 4 VRK]. Een verdragsstaat kan aangesproken worden op de matregelen die hij gezien zijn economische positie had kunnen nemen."

Hetgeen in - inmiddels weer booming - Nederland geen enkele geschikte maatregel uitsluit. De 'maximum extent'-verplichting van art. 4 VRK laat met name geen als financieel verpakt parentiarchaal excuus toe: een excuus, met de hand op de knip, dat bestaande patronen niet doorbreekt maar in stand houdt - ten detrimente van de subjecten van het Verdrag inzake de rechten van het kind, ten detrimente van een beschaafde Trias pedagogica, ten detrimente van de gelijkwaardigheid van elke mens en de gelijke menselijke waardigheid van elk kind. Doch evenmin een excuus dat, met de hand op het hart van de vele zorgen en de goede bedoelingen, naar morgen vooruitschuift wat vandaag had kunnen - en dus moeten - worden gedaan, al was het maar om de persoonswording van één enkel mensenkind veilig te stellen.

Een mensenkind evenwel dat ooit - opgestaan na het Eli, Eli, lamá sabachtáni $i^{265}$-, met behulp van maatschappelijke organisaties en (proefprocessen)fondsen, reeds opgericht en nog op te richten, de weg

Art. 26 IVBPR Iuidt (curs. jw): Allen zijn gellik voor de wet en hebben zonder discriminatie aanspraak op gelijke bescherming door de wet. In dit verband verbiedt de wet discriminatie van welke aard ook en garandeent een ieder gelijke en doelmatige bescherming tegen discriminatie op welke grond ook (...).

265 Lieve Mammie, lieve Pappie ... mijn God, mijn God, waarom hebt Gij mij verlaten? (Matth. 27:46.)

Vgl. ook psailm 22 (21): 'Deus, Deus meus, réspice in me: quare me dereliquisti? (...) Deus meus, clamábo per diem, et non exáudies: et nocte, et non ad insipièntiam mihi."

'Mijn God, mijn God,/waarom hebt gij mij verlaten,/ver van mijn roepen om uitkomst,/ver van mijn schreien om hulp./Bij dag roep ik, mijn God - gij blifft zwijgen,/bij nacht - en ik word niet gestild./ (...) Gij deed mij de moederschoot witgaan,/aan haar borst hebt gij mij gevlijd;/ù viel ik toe, nauwelijks geboren,/van mijn oorsprong af zijt gij mijn God./O, blijf dan niet verre van mij:/nu is mij wat dreigde, genaderd;/en er is geen mens die mij helpt.'

(Psalmus 21 uit: Memoriale rifuum (...) in minoribus ecclesiis (...), Rome etc. 1920, pp. 41-42, op p. 41; respectievelijk psalm 22 ('Uitgeleverd'), vers $2-3$ en 10-12, uit: De psalmen, uit het Hebreeuws vertaald door Ida G.M. GERIARDT en Marie H. VAN DER ZEYDE, Katholieke Bijbelstichting/Nederlands Bijbelgenootschap, Wageningen 1972 , pp. 46-48, op p. 46.) 
naar de rechter en, direct of indirect, internationale fora ${ }^{206}$ zal weten te vinden: want de staat die, en het land dat niet horen wil, moet (leren) voelen. Voelen in overdrachtelijke zin: in 's lands eer en portemonnee. Ook dat is een pedagogische wet.

\section{Toetsing aan de hand van getuige-deskundigenverklaringen}

Wij hebben een marginale toetsing voorgesteld, en een marginale toetsing vórgesteld als zijnde voldoende om staatsaansprakelijkheid in beginsel (meer beogen wij niet en meer past ons niet) vast te stellen. Staatsaansprakelijkheid, het zij nogmaals herhaald, ter zake van ernstige en passiefsystematische (systemische) mensenrechtenschendingen. Het vermoeden zal inmiddels gerezen zijn dat met 'passief' niet alleen bedoeld wordt dat de overheid stilzit (nalatig is), doch ook dat zij haar verdragsverplichtingen onder het Verdrag inzake de rechten van het kind 'negatief-actief' (door negatieve of averechtse handelingen) schendt. Dat wil zeggen dat de overheid actief is in het verkeerde te doen: incidentele palliatie ofwel 'intervention after the fact' (doekjes voor het bloeden die even stelpen maar niet helpen). Anderzijds is zij dermate passief in het goede te laten (structurele primaire preventie ofwel het onverwijld uitvoeren van de drie subdoelstellingen van het Verdrag inzake de rechten van het kind), dat er van actieve medeplichtigheid aan de instandhouding van grootschalige en grove mensenrechtenschendingen gesproken zou kunnen worden. Die (incriminerende) weg willen wij evenwel niet bewandelen - om redenen die al eerder zijn aangegeven en die in de volgende (sub)paragraaf nader uit de doeken worden gedaan. Wat wij thans wèl doen is: onze (feitelijke en juridische) beweringen aan de hand van enkele voorbeelden illustreren. Wij roepen daartoe een zevental (juridische en andere) getuige-deskundigen op, met wie wij, ter versnelling en verlevendiging, maar vooral ter verduidelijking en aanscherping van het betoog, in dialoog treden. Vóór we deze samenspraak aangaan, luisteren we naar de (aan)klacht van BAARTMAN (1996): ${ }^{267}$

"Met (...) [primaire] preventie [gericht op risicogroepen] zijn zeer goede ervaringen opgedaan in New York, beschreven door OLDS e.a. (1986). Het ging hierbij om een zeer intensieve en vroegtijdige vorm van hulp die reeds prenataal startte aan alleenstaande, arme, jonge aanstaande moeders, welke aanwijsbaar leidde tot

266 Direct: het Mensenrechtencomité onder het IVBPR voor zover het Verdrag inzake de rechten van thet kind in art. 24 juncto art. 26 IVBPR is in te lezen; indirect (via NGo's): het Comité inzake de rechten van het kind.

267 H.E.M. BAARTMAN, Primaire preventie van kindermishandeling: onbegonnen werk?' Nederlands Tijdschift voor Opvoeding, Vorming en Onderwijs/NTOVO 1996/1, pp. 17-33, op pp. 27/28. 
minder opvoedingsproblemen en minder fysieke mishandeling en verwaarlozing en tot meer plezier over en weer in het contact tussen moeder en kind. (...)

Deze vorm van preventie is in ons land een zo goed als verwaarloosd werkterrein. Dit hangt mede samen met de verkokering van prenatale en zuigelingenzorg enerzijds en de jeugdhulpverlening anderzijds. Prenatale zorg en zuigelingenzorg zijn in hoofdzaak van medische en verpleegkundige aard, en als men zich al prenataal zorgen maakt omtrent het functioneren straks alls moeder en omtrent de context waarin ze dat worm moet geven, wacht men meestal met het bieden van hulp tot het kalf verdronken is. In vroegtijdige ondersteuning van en hulpverlening aan risicogezinnen wordt nauwelijks geïnvesteerd, terwijl dat juist zeer veel leed en zeer veel geld zou kunnen besparen.'

\section{De eerste getuige-deskundige (BOGERS 1993): ${ }^{268}$}

'[D]e diverse instanties die aangewezen zijn om voor minderjarigen op te komen, [zijn] overbelast (...) De gezinswoogden hebben een te hoge caseload, De Raden [voor de kinderbescherming] zijn bedolven onder een hoeveelheid wettelijke taken waardoor voor de kerntaak [kinderbescherming, jw] te weinig tijd over is, terwijl de opvangvoorzieningen voor minderjarigen niet adequaat zijn of geheel ontbreken."

\section{Voor welke problemen staan de Raden? Wat kan de Raad doen?}

'[I]k [zal] (...) een aantal minderjarigen de revue [laten] passeren van wie om wat voor reden ook het fundamentele recht op een gezonde en evenwichtige ontwikkeling en witgroei naar zelfstandigheid is geschaad. Deze minderjarigen zijn in aanraking gekomen met de Raad, die dit fundamentele recht voor hen behoort te waarborgen.'

\section{Wie is Uw eerste minderjarige?}

"Het meisje Naima - Naima is een Marokkaans meisje van veertien, dat al haar hele leven in Nederland woont. Als driejarige wordt ze in het ziekenhuis opgenomen met ernstige verwondingen, die wijzen op lichamelijke mishandeling. De kinderarts van het ziekenhuis meldt de zaak bij de Raad. Het daarop volgende onderzoek door de Raad brengt weinig aan het licht. De ouders zeggen van geen mishandeling te weten en wijten de verwondingen aan een ongeluk: ze is van de trap gevallen. Als er al sprake zou zijn van mishandeling, dan waren hiervoor niet

Thea BOGERS, 'De rechten van beschermde kinderen; een visie vanuit de praktijk van de kinderbescherming,' in: Carol VAN NUNATTEN (red.), Kinderrechten in discussie, Amsterdam/Meppel 1993, pp. 162-175, respectievelijk op pp. 166 en 167-174. (A.w., p. 175 nt. 2: 'De beschreven situaties zijn gebaseerd op de werkelijkheid. De namen e.d. zijn zodanig aangepast dat de privacy van betrokkenen is gewaarborgd.') 
de ouders aansprakelijk, maar één van de familieleden met wie ze in huis woonden. De Raad geeft de ouders het voordeel van de twiiffel ..."

\section{Levert de Raad de driejarige dan niet uit naar een situatie waarin het niet denkbeeldige risico bestaat dat zij onmenselijk wordt behandeld?}

"... als ze beloven het grootouderlijke huis te verlaten en zelfstandig te gaan wonen. Daarna is het jaren stil rond Naima.

Elf jaar later meldt het Bureau Vertrouwensarts, in eerste instantie anoniem, het volgende. Diverse instanties, zoals school en ziekenhuis, hebben het vermoeden dat Naima geestelijk en lichamelijk wordt mishandeld. Ze vertoont suícidaal gedrag, plast nog in haar bed en wordt op zeer willekeurige momenten van school gehouden. Ze heeft een vriendinnetje in vertrouwen genomen en zo wordt een lerares van school op de hoogte gesteld. Naima wordt al mishandeld zolang ze zich kan herinneren. Ze wordt door haar beide ouders geslagen met een bezemsteel, met een riem, aan haar haren getrokken of met woorwerpen naar haar hoofd gegooid. Ze heeft diverse littekens op haar lichaam. Dit vindt ze echter niet het ergste. Ze heeft het gevoel dat haar ouders niet van haar houden, dat ze een ongewenst kind is. Ze moet als oudste meisje het hele huishouden doen en voor haar broertjes en zusjes zorgen. Het Bureau Vertrouwensarts roept alle betrokken instanties bijeen voor een zogenaamd casusoverleg. De Raad wordt hierbij als toehoorder uitgenodigd. Al snel blijkt dat iedereen van de ernst van de situatie is doordrongen, maar dat geen enkele hulpverlenende instantie actie durft te ondernemen. Van de politie en van Naima zelf heeft men vernomen dat de vader vuurwapengevaarlijk is. Bovendien zou ingrijpen in de situatie betekenen dat Naima alle banden met haar familie zou moeten verbreken omdat ze "de vuile was heeft buiten gehangen." De hulpverlening durft hiervoor niet de verantwoordelijkheid te nemen. Ze willen slechts iets doen als Naima zelf een daad stelt, bijwoorbeeld weglopen van huis."

Dat meent U niet! Dat is toch een eis die men onmogelijk aan een ernstig getraumatiseerd persoon, aan een puber, aan een allochtoon meisje kan stellen? Wat doet de Raad?

"Vanaf dat moment is alle hoop gevestigd op de Raad. Wanneer de Raad de vraag stelt wie van de instanties als officiële melder wil optreden, is het stil. Uit angst voor represailles van de ouders durft geen enkele instantie dit aan. De Raad vindt dat er met ingrijpen niet langer gewacht kan worden en brengt alles in gereedheid om Naima toe te vertrouwen aan de Raad. De Officier van Justitie geeft toestemming, met Naima wordt gesproken, een gastgezin wordt gevonden en met de ouders vindt een gesprek plaats op het politiebureau. Op dit moment zit Naima in een behandelingstehuis voor meisjes, op een voor haar ouders onbekend adres. Ze heeft aangifte gedaan bij de politie van mishandeling door haar ouders en ze verwondert zich dat ze belangrijk genoeg is om zoveel mensen speciaal voor haar bezig te laten zijn.' 


\title{
Wat is Uw conclusie?
}

\begin{abstract}
'Het ingrijpen moest met zoveel rechtswaarborgen omkleed worden dat het belang van Naima in het gedrang is gekomen. Althans, de situatie heeft te lang kunnen voortbestaan terwijl de hulpverlening op de hoogte was. (...)

Naima heeft recht op de zorg van de overheid. Die heeft de plicht haar te beschermen tegen de inbreuk die haar ouders maken op haar fundamentele recht op een gezonde en evenwichtige ontwikkeling. (...) Of het uiteindelijke ingrijpen door de Raad en de beslissing om Naima vit huis te plaatsen, juist is geweest, zal pas na jaren blijken.'
\end{abstract}

Maar wie blijft haar volgen na haar meerderjarigheid? Zal de maatschappij ooit weten hoe het maar haar is afgelopen? Zal er ooit iemand ter verantwoording worden geroepen? Een raadsmedewerker, een hulpverlener, een vertrouwensarts, een minister!? Wie is Uw tweede minderjarige?

'Baby Jill en haar dngverslaafde ouders - De ouders van Jill zijn al jarenlang verslaafd aan heroine. Verschillende pogingen tot afkicken hebben geen resultaat gehad. Door de allesowerheersende behoefte aan drugs worden hun twee kinderen Maria en Stefan van twee en vier jaar verwaarloosd. Ze zijn vaak alleen thuis, krijgen onvoldoende te eten en de elektriciteit in huis is afgesloten omdat de rekening niet is betaald. Op een gegeven moment schakelt de politie de Raad in omdat beide ouders op het politiebureau worden vastgehouden op verdenking van diefstal en het dealen van drugs. De kinderen worden toevertrouwd aan de Raad en later volgt een ondertoezichtstelling met uithuisplaatsing van de kinderen in een pleeggezin. Tijdens de afronding van het onderzoek is de moeder opnieuw zwanger. De Raad gaat ervan uit dat zijn verantwoordelijkheid ophoudt op het moment dat een gezinsvoogd is benoemd en gaat voorbij aan het feit van de nieuwe zwangerschap."

\section{Logisch - een kind heeft in dit land toch pas fundamentele rechten vanaf} zijn geboorte?

'De gezinsvoogd, die bang is dat het druggebruik van moeder schade toebrengt aan de ongeboren vrucht, nemt contact op met het Consultatie[bureau] voor Alcohol en Drugs (CAD). De ouders zeggen hun medewerking toe om af te kicken en gaan deelnemen aan het methadonprogramma wan het CAD. Hierbij gaan ze akkoord met verplichte urinecontroles. Verder wordt de wijkverpleging. erbij betrokken om te zorgen dat de babykamer op orde is op het moment dat de baby zich aandient. De Raad wordt in dit stadium niet bij de zaak betrokken omdlat de hulpverleners bang zijn dat de ouders dan zullen afhaken. De ouders lijken in eerste instantie zeer gemotiveerd, maar naarmate de zwangerschap vordert, gaan ze weer drugs gebruiken. Als Jill in het ziekenthuis wordt geboren, heeft ze lichte ontwenningsverschijnselen. Met de ouders wordt afgesproken dat ze Jill mee naar huis mogen nemen als ze zich gedurende een maand aan het methadonprogramma houden, op vaste tijden urine laten controleren, de baby in het ziekenhwis komen verzorgen en als de babykamer op orde is. Alle hulpverle- 
ners zijn zeer betrokken bij de ouders. Omdat ze de voorgeschiedenis kennen, gunnen ze het deze ouders dat ze voor dit kind wel zelf mogen zorgen."

Maar een kind is toch geen pop? Als het eenmaal geboren is, is het een mens met fundamentele mensenrechten. Gaat $U$ door.

'Ondanks het feit dat de ouders zich niet aan de verplichte urinecontroles houden, zodat niet is gegarandeerd dat ze niet bijgebruiken, beloven de hulpverleners de ouders dat het kind mee naar huis mag. Nog steeds is de Raad niet op de hoogte gesteld. De middag vóordat het kind uit het ziekenhuis wordt ontslagen, belt de gezinswoogd de Raad met de vraag of de hulpverlening in deze een goede beslissing heeft genomen? De raadsmedewerker, die de gebeurtenissen met de twee oudere kinderen nog vers in het geheugen lig[gen], is verbaasd dat er pas in dit stadium om advies wordt gevraagd. Na intern overleg besluit de Raad dat het voor Jill te riskant is als ze de volgende ochtend naar huis zou gaan. Vooral de weigering van de urinecontroles en de recente gebeurtenissen met de twee oudere kinderen geven de doorslag. Het hulpverlenersteam is het hier niet mee eens omdat ze hun belofte aan de ouders niet willen schenden. De Raad vraagt echter een voorlopige ondertoezichtstelling bij de kinderrechter met een uithuisplaatsing in een gastgezin. Jill wordt door medewerkers van de $\mathbb{R}$ aad de volgende ochtend uit het ziekenhuis opgehaald. De ouders zijn niet op het afgesproken tijdstip aanwezig, zodat [hun] niet direct medegedeeld kan worden dat ze hun kind niet naar huis mogen meenemen. Later op de dag worden de ouders door de Raad thuis bezocht om ze op de hoogte te stellen en ze de beschikking voorlopige ondertoezichtstelling uit te reiken. De ouders zijn verdrietig en boos en zullen met hun advocaat overleggen wat te doen. Ze voelen zich bedrogen door de hulpverleners. De uitleg dat dit geen beslissing van de hulpverlening is maar van de Raad, gesanctioneerd door de kinderrechter, komt niet over.

De Raad volgt gedurende drie maanden de situatie bij de ouders om te bezien of het verantwoord is dat Jill naar huis gaat. Als ze niet naar huis kan, zal aan de kinderrechter een definitieve ondertoezichtstelling en voortzetting van de uithuisplaatsing worden gevraagd. Helaas is dit laatste nodig geweest. De ouders vervielen in hun oude verslavingsgedrag, waardoor ze niet in staat waren voor hun kinderen te zorgen. Volgens de ouders waren ze weer gaan gebruiken omdat de Raad hun kind had "afgepakt." Op dit moment verblijven alle drie kinderen in én pleeggezin, waar de ouders wekelijks op bezoek komen. Het laatste bericht is dat moeder opnieuw zwanger is.'

\section{Kunt U tot een conclusie komen?}

'De ouders wilden de kans hebben te bewijzen dat ze ondanks hun verslavingsgedrag toch voor dit kind konden zorgen, terwijl het kind behoefte heeft aan een liefdevolle verzorging en opvoeding."

Aan liefde ja, en aan genoeg eten. Aan toezicht. En aan reinheid, rust en regelmaat. Of is dat inmiddels achterhaald? 
'De hulpverlening heeft in deze zaak het verlangen van de ouders om zelf voor hun kind te willen zorgen, laten prevaleren boven het belang van het pasgeboren kind. Op het laatste moment wilden de bulpverleners [de gezinsvoogd, jw] hun [zijn] beslissing gefiatteerd zien door de Raad. Door in zo'n laat stadium de Raad in te schakelen, werd het ingrijpen van de Raad bijna per definitie onzorgvuldig.'

\section{Ten opzichte van de ouders bedoelt U?}

'[H]oe kan de Raad in een dergelijke situatie voldoen aan de eis van artikel 8, lid 2 EVRM dat een beslissing voorzienbaar moet zijn? In dit geval zou het beter zijn geweest als de hulpwerlening de Raad van begin af aan had betrokken bij het opstellen van het hulpverleningsplan. Dan was het voor de ouders duidelijk geweest wat er zou gebeuren als zij de afspraken niet zouden nakomen. Dan zou de hulpverlening zich als belangenbehartiger van het kind hebben opgesteld en zouden er geen valse verwachtingen zijn gewekt bij de ouders.'

$U$ bedoelt dat de hulpverlening niet bekend is met de doorslaggevende betekenis van het belang van het kind? Misschien kan de Raad uittreksels uit het Verdrag inzake de rechten van het kind verspreiden onder hulpverleningsinstellingen. Of ligt dat te gevoelig? Enfin, U mag nog één minderjarige ten tonele voeren. $U$ begrijpt dat wij het kort moeten houden. We hoeven hier vandaag niet te bewijzen dat het hele Nederlandse stelsel van kinderbescherming failliet is. Bovendien zitten nog zes andere getuige-deskundigen op hun beurt te wachten. Wie is Uw derde, en laatste, minderjarige?

'Walter de pendelende puber - Walter is acht jaar als zijn ouders gaan scheiden. Het liefste zou hij bij zijn vader gaan wonen, maar ondat deze buitenshuis werkt, kan dit niet. Hij blijft bij zijn moeder en haar nieuwe vriend wonen en gaat in de weekeinden naar zijn vader. Zodra hij twaalf is, zo wordt hem beloofd, mag hij zelf kiezen waar hij gaat wonen. Moeder, die zich schuldig voelt dat ze bij haar man is weggegaan en is gaan samenwonen met een ander, verwent Walter erg. In de weekeinden bij vader gelden strengere regels. Tegen de tijd dat Walter twaalf is, wil hij na een weekend bij vader, niet meer terug naar huis. Vader gaat akkoord zolang hij zich maar aan de regels houdt. Dit gaat een tijdje goed totdat Walter met zijn vader ruzie krijgt omdat hij spijbelt. Walter vindt zijn vader veel te streng en loopt weg naar de moeder, die hem met open armen ontwangt en minder zwaar tilt aan zijn regelmatige schoolverzuim. Walter heeft ook de gokautomaten ontdekt en weet zijn moeder voortdurend geld afhandig te maken. $\mathrm{Na}$ korte tijd blijkt dat hij geld steelt van huisgenoten en na een flinke ruzie hierover vertrekt hij wederom naar de vader. Hij mag terugkomen maar dan moet hij wel naar school. Ze kiezen de kappersopleiding, die Walter altijd al heeft willen doen. Enthousiast begint hij hieraan, maar de gokautomaten blijven trekken. Spijbelen volgt. Vader neemt contact op met een adviesbureau voor jongeren en ouders en met het $C A D$ in verband met Walters gokverslaving. Walter heeft twee gesprekken met deze instanties en laat het dan verder afweten. Hij is inmiddels zestien jaar en is in contact gekomen met een jeugdbende die "spannende" dingen 
doet, zoals tasjes roven, auto's kraken en mensen in elkaar slaan. De vader kan de verantwoordelijkheid voor Walter niet meer aan en in overleg met het adviesbureau wordt Walter in een begeleid kamertrainingsproject geplaatst. Hier kan hij leren zelfstandig te wonen en voor zichzelf te zorgen. Walter is blij met deze oplossing, maar merkt al snel dat hij zich hier ook aan regels behoort te houden. Op tijd thuis zijn en overdag een zinvolle tijdsbesteding hebben, zijn een paar van die regels. Walter komt 's nachts steeds vaker niet thuis en het kamertrainingscentrum staat op het punt hem op strat te zetten. De vader heeft de politie verzocht zjjn zoon op te sporen en terug te brengen naar het kamertrainingscentrum wanneer hij een week lang spoorloos is. De politie, die Walter al regelmatig heeft opgespoord, gaat niet actief op zoek. Ten einde raad komt de vader op het spreekuur van de Raad. Hij weet niet meer wat te doen en voelt dat het met zijn zoon de verkeerde kant op gaat. De vrijwillige hulpverlening zegt hem niet meer te kunnen helpen nu Walter niet meer wil meewerken. De Raad legt de vader uit dat er een onderzock zal worden gestart en eventueel een ondertoezichtstelling zal worden gevraagd. Op dit moment is het echter erg druk, maar de zaak zal met voorrang worden behandeld. Opgelucht dat er in ieder geval iets gaat gebeuren, verlaat de vader het kantoor van de Raad. In verband met drukke werkzaamheden kan pas na zes weken met het onderzoek worden gestart. Op het moment dat de maatschappelijk werker van de Raad bij de vader op bezoek is voor een eerste gesprek, komt de politie aan de deur. Ze vertellen dat Walter is opgepakt op verdenking van zware mishandeling [de dood ten gevolge hebbend], doodslag [dan wel] moord op een bejaarde vrouw. Hierbij zijn tevens een viertal jongens betrokken van cen bij de politie bekende jeugdbende. Voor de vader stort de wereld in. Hij is wanhopig en woedend dat de Raad niet eerder heeft ingegrepen. Hij geeft de Raad de schuld dat de loekomst van zijn jongen is verwoest.

Op de Raad heerst verslagenheid. Was dit te voorkomen geweest? Is de situatie zo verkeerd ingeschat? Waarom bestaat er nog steeds geen crisisteam dat in spoedzaken direct kan optreden?"

\section{Un conclusie graag.}

[H]et [is] nodig dat opvoeders met liefdevolle aandacht en betrokkenheid hun kinderen passende grenzen stellen. Wanneer ouders hiertoe niet in staat zijn, is het de plicht wan de maatschappij de minderjarige te begeleiden naar zijn volwassenheid. Hiervoor is een geëigende hulpwerlening nodig, die het niet zonder meer laat afweten op een moment dat de minderjarige niet meer wil meewerken. Zeker niet in dit geval, waar juist het vaste patroon was dat Walter afhaakte op het moment dat er eisen aan hem werden gesteld. De hulpverlening had dit moeten doorzien en een passende plaats voor Walter moeten zoeken."

De Raad zal toch bekend zijn met art. 3, lid 3 van het Verdrag inzake de rechten van het kind, dat waarborgen eist voor de geschiktheid van en het toezicht op jeugdhulpverleners en kinderbeschermers. In dit geval is er een dode gevallen, een oude vrouw kwam op gruwelijke wijze aan haar einde. Maar de Raad zal ongetwijfeld aan de bel hebben getrokken bij de minister .... Bij welke, vraagt U? Ach ..., wilt U een papieren zakdoekje? Alstublieft, 
gaat U maar zitten. Het woord is aan de tweede getuige-deskandige (VAN NIJNATTEN 1996): ${ }^{269}$

"Als het kind ervaart dat degenen die van hem houden, hun macht in zijn belang aanwenden, ontwikkelt het vertrouwen in regels. Als het tegelijkertijd wordt aangespoord de eigen belangen af te wegen tegen die van anderen, durft het een kritische houding ten opzichte van autoriteiten aan te nemen. Ouderlijk gezag is de koppeling van formele en fysieke macht en ouderlijke liefde. De (psychologische) gezagsdispositie (de in de persoonlijkheid van het kind verankerde capaciteit en gevoeligheid om regels te zien als de mogelijkheid om eigen belangen en die van derden goed af te wegen: VAN NLNATTEN, [Het gezicht van gezag] 1995) komt voort uit een combinatie van liefde en macht. Er kunnen problemen ontstaan door een teveel aan macht en [een] tekort aan liefde, of een teveel aan liefde en een tekort aan macht.'

Ik hoor het al, een ontwikkelingspsycholoog. De vorige getuige-deskundige heeft een aantal klanten van de kinderbescherming opgevoerd. Kunt $U$ ons iets vertellen over de psychische make up van kinderbeschermingskinderen?

'Kinderbeschermingskinderen hebben vaak een fundamenteel wantrouwen in regels en zijn niet in staat zich stap voor stap te bevrijden van de principes die aan het gezag ten grondslag liggen (...). Zij hebben lak aan afspraken omdat deze uit eigenbelang werden gemaakt of systematisch niet werden nagekomen.'

Eigenbelang van ... niet werden nagekomen door qua 'liefde-en-macht' dysfunctionerende ouders ....

'Ze verschuilen zich achter een barrière van valse presentaties.'

Valse ... de kinderen? U bedoelt onechte? Overaangepaste, onaangepaste, en in die zin ongepaste.

'Het is moeilijk tot hun psychologische kern door te dringen. Ze koesteren archaïsche fantasieën over de goede ouder die hen komt redden uit de ellende in het kindertehuis. Zelfs als zij in het kader van een maatregel van kinderbescherming uit huis zijn geplaatst, blijven zij hun ouders als de echte gezagsfiguren in hun leven beschouwen (...). In symptoomigedrag maken zij kenbaar dat het niet goed met hen gaat en laten zij de onbewuste hoop doorklinken dat de omgeving zich met hen zal bemoeien (...). De jarenlange gezagsloze of gezagsmisbruikende situatie heeft nu geleid tot zichtbare pathologie bij het kind en tot een maatregel van kinderbescherming.'

269 C. VAN NINATTEN, 'Gedragsgestoord en gezagsgestoord; de verhouding tussen kinderbescherming en gezin,' Justitielle Verkenningen 1996/6 ('Preventief ingrijpen in het gezin'), pp. 74-84, respectievelijk op pp. 76-77, 78-79, 81 en 82 . 
Kennelijk is in deze gevallen van 'zichtbare pathologie' de interventie, het aanbieden en desnoods opleggen van opvoedingshulp, véél te laat gekomen. Het lijkt mij, als leek, dat de problematiek dan al zo is geëscaleerd, zo gecompliceerd is geworden dat van de gezinsvoogd het onmogelijke wordt verwacht. Aan hem, of haar, als eenvoudig maatschappelijk werker, worden eisen gesteld waaraan een psychotherapeut of psychiater pas na een jarenlange zware opleiding kan voldoen. Zie ik dat goed?

\begin{abstract}
'De problematiek van ouders en kinderen stelt hoge eisen aan de persoon van de gezinswoogd. Hij moet enerzijds dichtbij en vertrouwd zijn en anderzijds ruimte geven zodat kinderen hun weggestopte fantasieën kunnen projecteren. Is de gezinsvoogd iemand [op wie] je boos durft te worden en met wie je je kinderlijke hoop durft te delen? De hoop op verbetering lijkt bij de meeste kinderbeschermingskinderen ver weggestopt. Hun toekomstverwachtingen hebben vaak een megalomaan karakter: ze hopen op veranderingen tegen beter weten in, zijn niet realistisch in hun vermogen om te veranderen en zijn belust op macht. Dit zijn echter ook ongecontroleerde pogingen om het kwaad te bezweren. Het is de taak van de (gezins) voogd deze signalen op te vangen en woedereacties te zien als de projectie van jarenlange opgekropte haat en teleurstelling. Dan wordt voorkomen dat de boosheid als een persoonlijke aantijging wordt gezien en in de tegenoverdracht nieuwe schade veroorzaakt. Dat vereist geduld en tolerantie. In die zin worden aan de (gezins)voogd overeenkomstige eisen gesteld als aan de therapeut, zonder echter dat van een therapeutische behandeling sprake is."
\end{abstract}

\title{
Dat dacht ik al. Gaat U door.
}

'De kinderbescherming staat voor de dubbele taak een mieuwe gezagsrelatie op te bouwen en de negatieve gevolgen van het falend ouderlijk gezag goed te maken. Van jongeren wordt verwacht dat zij het belang van regels en afspraken in de gaten hebben, en dat zij een onafhankelijke kritische houding ten aanzien daarvan kunnen aannemen. De jongeren die in de kinderbescherming terecht komen, zijn echter gestoord in hun gezags[dispositionele] ontwikkeling. Deze stoornis komt niet alleen in aanmerking voor herstel, maar belemmert tevens de vorming van een nieuwe gezagsrelatie. Deze jongeren staan negatief tegenover "het" gezag, zijn in hun hart teleurgesteld in hun ouders maar staan negatieve opmerkingen over hen niet toe. $\mathrm{Ze}$ zien niet in waarom ze zouden moeten luisteren naar iemand die ze nauwelijks kennen.'

Met iemand bedoelt $U$ de gezinsvoogd, die pas in hun leven komt nadat er al zoveel is kapot gemaakt, macht en liefde tussen ouder en kind al zo'n gordiaanse knoop zijn geworden. Die dubbele taak waarvan $U$ sprak, lijkt mij sisyfusarbeid. Is dit alles?

"Voorts heeft de (gezins)voogd te maken met ouders die hun ouderlijke gezagstaak niet naar behoren konden uitvoeren en die zich door de interventie vaak in hun ouderlijke eer voelen gekrenkt.' 
Daar komt na $U$ een stigmatiseringsdeskundige over te spreken. Is er nog meer?
'Tegelijkertijd beschikt de (gezins)voogd niet over hetzelfde (pedagogische) in- strumentarium als waarover de ouders beschikken. De intensiteit van de profes- sionele gezagsrelatie is aanmerkelijk minder dan die van de ouder-kind-relatie. Recentelijk werd berekend dat de gemiddelde gezinsvoogd niet meer dan twee uur per maand tijd heeft voor direct contact met de cliënt.'

\title{
Twee uur per maand!?
}

'Deze tijd moet dan nog verdeeld worden over diverse familieleden.'

\section{Uw conclusie?}
'Hoe kan een gezinsvoogd in die korte tijd repareren wat jaar in jaar uit is misge- gaan?'

De vraag stellen is haar beantwoorden!

'De helft van de ondertoezichtstellingen eindigt omdat de pupil meerderjarig wordt, en gezinswoogden vinden verdere hulpverlening vaak geïndiceerd (...).'

Gezinsvoogden moeten toch wel massaal burn out-verschijnselen vertonen? Of zijn ze net zo geparentificeerd als hun pupillen? Vergeet $U$ die laatste vraag. Is er iets bekend over de arbeidssatisfactie van gezinsvoogden?

"[Ondanks het hiervoor gezegde] vindt $40 \%$ van de onderzochte gezinswoogden dat zij hun doelen volledig bereikten en nog eens $40 \%$ gedeeltelijk.'

Zo...l?

\begin{abstract}
'Het is moeilijk vast te stellen hoe hoog gezinsvoogden hun doelen stelden. Er is voldoende aanleiding te veronderstellen dat de kinderbeschermingsproblematiek van dien aard is dat slechts bescheiden doelen kunnen worden verwezenlijkt. Wat jarenlang scheef is gegroeid, kan meestal niet in enkele jaren hersteld worden. Het is natuurlijk de vraag of de kinderbescherming (...) in staat kan worden geacht haar pedagogische gezagstaak naar behoren te vervullen (...). (...) Dat pedagogisch gezag tijd en geld kost, behoeft niet te worden verheeld.'
\end{abstract}

Het paard van de kinderbescherming niet achter, maar vóór de ouderlijke wagen spannen, is goedkoper dan genezen. Zo genezen al mogelijk is. Is dat ook Uw conclusie? 
'Elke persoon maakt een ontwikkelingsproces door alvorens over zichzelf meester te worden. Daarbij is enige vorm van sociale controle onontbeerlijk. Het wegvallen daarvan stelt soms te hoge eisen aan kinderen. De liberalisering kent een uiterste grens. Vormen van sociale controle blijven voorwaarde voor het voortbestaan van de disciplinaire samenleving (...). Primaire socialisatiekaders die door de opkomst van de verzorgingsstaat in verval zijn geraakt, blijken soms onvoldoende in staat hun opwoedende rol te vervullen. Criminaliteit is het waarschijnlijke gevolg wan een overheid die minder controleert en minder zorgzaam is."

\section{Zou U iets concreter kunnen worden?}

'Ook (gezins)woogden zijn meer gaan vertrouwen op het zelfcontrolerend vermogen van hun kinderen, en het is de vraag of dat op zijn plaats is voor kinderbeschermingskinderen. (...) De medewerkers van de kinderbescherming hebben een totaal andere pedagogische stijl dan de ouders van deze kinderen. (...) Maar vaak hebben de jongeren niet geleerd met de hun toegestane vrijheid om te gaan en komen zij in een machtspositie terecht die zij niet (nog niet) aankunnen.'

\section{Waar wilt U naartoe?}

"Machtsgelijkheid mag dan een sterk ideaal zijn in onze gemeenschap, het blijft iets dat mensen moeten leren hanteren. Dat geldt voor kinderen die dat van hun ouders en andere opvoeders leren, en dat geldt voor ouders die met de kinderbescherming in aanraking komen en (opnieuw) moeten leren hun ouderlijke verantwoordelijkheden te dragen. De staat blijft machtiger dan de ouders en trekt de witerste grenzen waarbinnen ouders zich bewegen. Bij een gezagsvolle opvoeding tot sociale verantwoordelijkheid hoort regelmatige controle $(. .$.$) , zowel van ouders$ als van de overheid.'

Wilt $U$ beweren dat binnen de kinderbescherming en de gezinsvoogdij het maatschappelijke gelijkheidsideaal op volstrekt onprofessionele wijze is doorgeschoten? Dat dáár de problemen liggen?

'Het streven naar machtsgelijkheid is (...) illusoir omdat het voorbij gaat aan de machtspositie van de overheid. Voor veel medewerkers in de kinderbescherming is dat het grote probleem. Hun gelijkheidsideaal is soms zo sterk dat zij hun macht en de daarbij behorende verantwoordelijkheid niet durven of willen nemen. Dat kan ertoe leiden dat kinderen aan hun ouderlijk lot worden overgelaten."

Het onpedagogisch hanteren van het maatschappelijke gelijkheidsideaal heeft tot gevolg dat kinderen buiten de boot van het maatschappelijke gelijkheidsideaal vallen. Zit dat zo! Mag ik dan concluderen dat de kinderbescherming, en de gezinsvoogdij, in laatste instantie het instrument is, zich laat ge- 
bruiken als het instrument, door middel waanan de maatschappij de kinderen uit sociaal-pedagogisch zwakke milieus, de kinderen van ouders met een zwak, veelal transgenerationeel gebrekkig ontwikkeld pedagogisch besef, welwillend afschrijft? Klaar staand met de pot zalf, en de rol eilketten, voor de gevallen waar zijzelf, en de maatschappij die zij dient, niet omheen kan? Riep daar iemand iets ... stilte! ... over stigmatiseren? Ah, de derde getuigedeskundige. $U$ spreekt, begrijp ik, namens een internationaal gezelschap, dat onderzoek heeft gedaan in Engeland, Nederland en Spanje (COLTON e.a. 1997). ${ }^{270}$ Uw bevindingen vloeien voort uit een ...

"(...) empirical stady of the relationship between stigma and child welfare services in three European Union countries.'

Ik noemde ze al. En welke zijn die bevindingen?

'If the cost of using social welfare services is a set of ideological messages which question the user's worth (...), ...'

Als schandvlek voor de parentiarchie, bijvoorbeeld. Nee, ik berijd mijn geliefkoosd stokpaardje, gaat $U$ door.

'... then such services will emerge as more stigmatizing than a less developed service which is provided as a symbol of a society's investment in its own inclusiveness and future human capital.'

Dat lijkt mij, with all due respect, een open deur. Kunt u enkele concrete conclusies aangeven? Waaraan moeten voorzieningen voor ouders en kinderen voldoen om niet stigmatiserend te zijn, om mensen die zich toch al buitengesloten en uitgezonderd, de mindere, de gebeten hond voelen, niet nog eens extra in dat gevoel te versterken?

'First, services must be sensitive to particularities. Actions which disperse stigma in one locality may intensify it in another. Home visiting, for example, which has been identified as symbolic of solidarity and engagement in the British context (...), is clearly to be avoided in the Netherlands. Similarly, issues of daycare in Spain emerge as holding a particular local significance which, unless addressed with sensitivity, add to a sense of disqualification.

270 Matthew COLTON e.a. (Wales), Evert SCHOLTE (Leiden), Ferran CASAS (Barcelona), Margaret WILLLAMS (Calgary), "Child welfare and stigma; principles into practice,' Childhood 1997/3, pp. 265-283, op pp. 265 en 281-282. 
Second, increasingly intrusive intervention is strongly associated with increased perception of stigma. Services which assist families to prevent problems from arising or becoming unmanageable are far preferred by users to those designed to solve difficulties which have already passed the user's own capacity to address. Measures which assist families to extend and improve their own coping mechamisms, and thus find their own solutions to child welfare problems, are preferable to those which require reliance upon the services of others. Prevention rather than cure emerges as a powerful message for service providers whose aim is to enhance rather than undercut the positive experience of users.

Third, when intervention is required, then minimalism is best. In particular, a major stigmatic divide separates those services which are provided within the family and those which lead to separation. This perception extends almost equally to all extrafamilial courses of action, fostering as well as residential care. Child welfare services in all three countries have shifted decisively towards substitute family arrangements for children and young people who experience severe difficulties while living at home. The strong sense of stigma which families of origin experience may not have been appreciated with equal force by service providers. Fourth, across the range of services, stigma is more potently a part of the experience of those receiving compulsory service than of those who accept service voluntarily. The taint of stigma clings to compulsory service even when the content may be valued. Services that wish to avoid stigmatizing associations therefore need to redouble their efforts to support voluntary participation wherever possible.

Finally, and overarching all these considerations, users consider least stigmatizing and most empowering those services which are delivered in a way that emphasizes the human quality of social work encounters. The communication of an authentic interest in the lives and circumstances of service users is most closely associated in the minds of recipients with an experience that is free form contamination or disgrace. When this is reinforced by a professional attitude among service providers which comprises cooperation, understanding and respect for service users, greatly enhanced levels of satisfaction on the part of users follow; and this, in turn, is associated with their own active involvement in child welfare services."

Kortom: let op traditionele gevoeligheden, en verder: zo veel mogelijk preventie; zo veel mogelijk empowerment van ouders; 'minimalisme,' dus een glijdende schaal die met het lichtst mogelijke middel begint; zo weinig mogelijk uithuisplaatsing (dat wil zeggen: het niet zo ver laten komen dat uithuisplaatsing nog de enige mogelijkheid is!); zo veel mogelijk vrijwilligheid (dat wil dus zeggen: zo vroeg mogelijk erbij zijn, als mensen nog voor raad en daad openstaan, niet al zoveel pijnlijke dingen te verbergen" hebben!); en zo veel mogelijk een professionele respectvolle attitude. Het lijkt mij dat hier aspecten van professionele cultuur binnen organisaties en de organisatorische overall structuur van voorzieningen dooreen lopen. Hoe goed de cultuur, de professionele attitude en de intenties binnen instellingen ook mogen zijn, hoe zit het met de globale structuur - waarbinnen die cultuur moet gedijen, of waarbinnen die cultuur wordt gesmoord? Tegen welke politieke mu- 
ren lopen we dáár op in Nederland - wel genoemd het Koninkrijk van de On-Verenigde Departementen? De vierde getuige-deskundige graag (DOEK/ VLAARDINGERBROEK 1996): ${ }^{271}$

'Het streven naar meer samenhang tussen de justitiële jeugdbescherming (waarvoor Justitie primair verantwoordelijk is) en de (vrijwillige) jeugdhulpverlening (ressorterend onder WVC, thans. VWS) bestaat al ruim twintig jaar. Tot nu toe heeft het echter weinig concrete resultaten afgedwongen.

De Taskforce Doelmatigheid, Effectiviteit en Financiering Jeugdhulpverlening (voorzitter, mevr. E. TER VELD, voormalig staatssecretaris van Sociale Zaken) schetst in haar rapport [Plaats maken; Op weg naar goede jeugdzorg, Ministerie van WVC, 1994] dat en hoezeer jeugdhulpverlening, jeugdbescherming en jeugdgezondheidszorg een verbrokkeld, onoverzichtelijk en verre van efficiënt geheel van voorzieningen vormen. De Taskforce stelt onder andere voor per regio Bureaus voor Jeugdzorg op te richten. Deze bureaus zouden moeten worden gevormd door de huidige (gezins)voogdij-instellingen, de adviesbureaus voor ouders en minderjarigen, de jeugdafdelingen van RLAGG's, de JAC's en de Raden voor de kinderbescherming. Deze bureaus zouden een eerstelijnsfunctie moeten vervullen (a la de huisarts in de gezondheidszorg) en tevens moeten functioneren als meldpost voor klachten over problemen met opvoedingssituaties (bijvoorbeeld kindermishandeling) en als instantie die een maatregel kan vragen, individuele hulpverlening coördineert en zonodig gezag over minderjarigen uitoefent. Daarnaast wordt geadviseerd de verdere ontwikkeling van zogenaamde multifunctionele organisaties, dlat wil zeggen organisaties met een gevarieerd aanbod van ambulante hulpverlening, te bevorderen.

Deze en andere voorstellen van de Taskforce zijn de meest ingrijpende die de afgelopen jaren zijn gedaan. Tevens zijn het de enige die zeer concreet aangeven wat er nodig is om een eind te maken aan de al twintig jaar durende "kringloop" van voorstellen en rapporten. Wil daaraan werkelijk een eind komen, dan is een duidelijke politieke keuze nodig, zoals de Taskforce terecht opmerkt. Als de politiek een goede integrale en efficiënte jeugdzorg wil, dan moet dat op korte termijn worden besloten, aldus de Taskforce. De conclusie van de afgelopen twintig jaar is dat die politieke wil kennelijk ontbreekt of woor zover zij er wel is, de politiek er niet in slaagt daaraan concrete uitwoering te geven.

De reorganisatie van de Raden, resulterend in een strakke centrale regie vanuit het Ministerie van Justitie zal (met kennelijke instemming van het parlement) niet bijdragen aan doorbreking van bestaande en verkokerde verhoudingen. Te verwachten valt dat er ook de komende jaren weer veel over de wenselijke samenhang tussen jeugdbescherming, jeugdhulpverlening en jeugdgezondheidszorg zal worden geschreven en gedebatteerd. Stevige politieke besluiten vallen er niet te verwachten. En de voorstellen van de Taskforce zullen als utopisch worden bijgezet bij de vele die haar voorafgingen. Is dat erg? Ja dat is erg voor al die minderjarigen wier opvoeding en verzorging problematisch verloopt en die of te laat worden opgemerkt of die met hun ouders van het ene professionele kastje naar de volgende bureaucratische muur worden verwezen. Uitcraard met de

271 J.E. DOEK, P. VLAARDINGERBROEK, Jeugdrech en jeugdhulpverleningsrecht, Den Haag 1996 (tweede druk), pp. 273/274-275. 
beste bedoelingen en aan de thand van zorgvuldige intake criteria, maar wel vaak zonder voor de ouders en minderjarige bevredigend resultaat. Een jeugdzorg die op een efficiènte en doeltreffende wijze - en tijdig - reageert op de hulpbehoefte van ouders en kinderen zou in het licht van het Verdrag [inzake] de rechten van het kind meer dan een utopie moeten zijn. De Taskforce heeft een duidelijke weg gewezen, nu de politieke wil nog.'

Maar is de politiek voor de verwezenlijking van noodzakelijke structurele veranderingen op haar beurt niet weer afhankelijk van de cultuur. In dit verband de (mag ik het woord weer laten vallen) parentiarchale cultuur, het uitsluitend voor sociaal-pedagogisch bevoorrechte ouders gunstige dominante klimaat in de Nederlandse samenleving. Een dominante cultuur die dank zij stigmatiseringsmechanismen (versterkt door transgenerationele fenomenen, zoals een geringe eigenwaarde wan ouders, die tot een extra gevoeligheid voor stigmatisering leiden) kennelijk zo stevig in het zadel zit dat de slachtoffers ervan haar beste verdedigers lijken.

Divide et impera, heette dat bij de Romeinen. Verdeel-en-heers-mechanismen. Niet als bewuste strategie, maar als sociale repressie in stand houdend, verinnerlijkend en aldus versterkend bij-effect van een dominante cultuur. We associëren dat vaak met het functioneren van oligarchieën, het optreden van regenten. Misschien hadden de regenten uit de (slaven)handelsrepubliek van de Verenigde Nederlanden weinig alternatieven om het volk en de Oranjes op afstand te houden. Daar mogen de historici over oordelen tegen de tijd dat we over Johan VAN OLDENBARNEVELT, Jan DE WITT en de Bataafse Opstand, en de rol van de Oranjes, aan onpartijdige geschiedschrijving toe zijn. Maar in deze tijd? In een democratie! We mogen toch niet aannemen dat in een democratie de politiek de gevangene is van het heersende culturele klimaat? Een willoos werktuig van sociaal-culturele krachten? Wij willen het tegendeel geloven! Als de politiek verdragen onderschrijft die nieuwe morele en juridische bakens witzetten, geeft zij daarmee uiting aan moreel leiderschap; kan zij, moet zij, durft zij elk cultureel klimaat trotseren dat van die nieuwe bakens niet horen wil.

Zijn er in Nederland, in weerwil van het dominante culturele klimaat, ja dwars tegen dat klimaat in, politieke aanzetten te bespeuren voor een overall gezinsbeleid? Wil de vijfde getuige-deskundige naar voren komen (JUNGER-TAS 1996):.272

"Een gezinsbeleid dat - mede - door de overheid gestimuleerd en ondersteund wordt, wekt in Nederland grote huiver en stuit op talrijke bezwaren. De overheid heeft zich niet met de privésfeer te bemoeien en al helemaal niet met de wijze ningen 1996/6 ('Preventief ingrijpen in het gezin'), pp. 17-37, op pp. 17-18. 
waarop we onze kinderen opvoeden. Een gezinsbeleid waaraan dan ook nog van justitiezijde steun wordt gegeven, lijkt wel een zeer hachelijke zaak. Justitie grijpt immers alleen in bij kinderen en gezinnen wanneer er al grote brokken gemaakt zijn en dan is dit ingrijpen bovendien met talloze waarborgen omkleed."

Waarborgen voor ouders, wel te verstaan. Rechtswaarborgen dus.

"Het probleem van justitieel ingrijpen is evenwel dat het eerst plaatsvindt nadat er ernstige moeilijkheden zijn opgetreden hetzij binnen het gezin - waarbij men kan denken aan (seksuele) kindermishandeling en verwaarlozing - hetzij met betrekking tot delinquent gedrag van de kinderen. Daarbij blijkt steeds weer dat met ingrijpen, wanneer de situatie eenmaal ernstig uit de hand is gelopen, weinig succes op de lange termijn wordt geboekt."

Een bekend geluid, dat we eerder hebben gehoord. Uw invalshoek is, dacht $i k$, jeugdcriminaliteit?

'Ernstig crimineel gedrag komt meestal eerst voor vanaf het veertiende, vijftiende jaar. Adolescenten die een aantal successen boeken op het criminele pad, zijn al helemaal niet gemakkelijk van hun - vooralsnog belonende -- levenswijze af te brengen. Bovendien is de plasticiteit en beinvloedbaarheid van de mens het groatst bij jonge kinderen tussen zo'm twee en acht jaar en ze neemt met de jaren af om plaats te maken voor een zekere rigiditeit (...). Ingrijpen op latere leeftijd heeft dan ook veelal slechts kortdurende effecten.

Het ligt daarom voor de hand te zoeken maar vroegtijdige preventiemaatregielen, die met meer succes zouden kunnen worden aangewend zowel voor de kinderen als voor hun ouders."

Dat is ons inmiddels duidelijk. Dank U. Misschien kan de zesde getuige-deskundige enkele juridische conclusies trekken, enkele verdragsrechtelijke en feitelijke draadjes aan elkaar knopen, als medewerker beleidsontwikkeling bij de kinderbescherming, vóór we de staat aan het woord laten (VELDKAMP 1997): ${ }^{273}$

'De consequenties van de invoering van het Verdrag [inzake de rechten van het kind] lijken niet te zijn doorgedrongen; niet tot de Staat en niet tot zijn burgers. De eerste tekenen daarvan waren zichtbaar in de Memorie van Toelichting bij de wet tot goedkeuring van het Verdrag. In plaats van het bestaande te toetsen aan het wenselijke [heeft de regering] het Verdrag zodanig vertaald dat het bestaande daarin onder te brengen is. Wat mij betreft, een omkering van zaken en een ge-

Ton VELDKAMP, Nog te vroeg voor een feestje! De doorwerking van het (...) Verdrag inzake de rechten van het kind in de jeugdbescherming, Tijdschrift voor de rechten wan het kind december 1997, pp. 4-6. 
miste kans om de draagwijdte van het Verdrag goed onder ogen te zien en daaruit uitdagingen voor de toekomst te destilleren. (...)

Het Verdrag verplicht op consequente wijze vooral tot het voorkomen van situaties die bedreigend zijn voor hel kind. Het roept de samenleving op tot het scheppen van de voorwaarden die nodig zijn voor een volledige en harmonische ontplooing van het kind.'

\section{Voor optimale persoonswording, om een technische term te gebruiken.}

'Van de samenleving wordt dus geen afwachtende houding verwacht, maar een actieve opstelling. Deze dient niet te zijn gefundeerd op een behoefte aan bemoeizucht of bevoogding, maar op een besef van medewerantwoordelijkheid uit respect voor het kind en zijn gezin.'

Optimale persoonswording vergt een actief en innoverend beleid. Niet meer van hetzelfde. Maar anders. En beter. Met een overheid die voorop loopt, die haar verantwoordelijkheid neemt ....

'Het dragen van (mede)verantwoordelijkheid is een actief gebeuren en vereist initiatief en inspanningen van allen aan wie het Verdrag verantwoordelijkheid heeft toegekend. Dat zijn in de eerste plaats de ouders ([art. 18, lid 1 VRK]). Wanneer deze niet in staat zijn op eigen kracht het gewenste ontplooiingsklimaat te bewerkstelligen, hebben anderen de verplichting daarbij gevraagd of ongevraagd bescherming en bijstand te bieden. Die verplichting richt zich tot iedere volwassene; in het bijzonder tot degenen die beroepsmatig bij kind en gezin zijn betrokken. De overheid is van deze verplichting niet vrijgesteld. Zij kan zich daarvan deels kwijten door de ontwikkeling van instellingen, voorzieningen en diensten voor kinderzorg te waarborgen, en voor het resterende deel door de rechten van kinderen te waarborgen, zonodig met juridische middelen ([art. 18, lid 2, art. 19, art. 39 VRK])."

De Trias pedagogica? De ouders rond het kind en de staat met zijn instellingen, voorzieningen en diensten, en sterke arm, achter de ouders?

"Het Verdrag schetst een samenhangend stelsel wan verantwoordelijkheden, die elkaar aanvullen en ondersteunen. Een stelsell van soepel in elkaar grijpende tandwielen, gericht op het scheppen van de vereiste basisvoorwaarden voor een volledige en harmonische ontplooiing van het kind. Kinderen zijn in belangrijke mate afhankelijk van het inzicht en de bereidheid van hun ouders om van de geboden voorzieningen gebruik te (...) maken."

Daar is ouderschapsvoorlichting voor nodig, publiekscampagnes, postbus 51 . Ouders geeft Uw kind geen dreun, wij staan klaar met hulp en steun!! Ouderschapsondericht, op school. Jong geleerd is oud gedaan. Ouderschaps- 
vormingswerk in de buurten. Ouderschapsfolders en -informatie bij de huisarts en natuurlijk op de consultatiebureaus....

"Tot op grote hoogte zijn ouders vrij hun eigen weg te kiezen; een vrijheid die ook door het Verdrag wordt erkend en gerespecteerd. De grens van de vrijheid wordt bereikt wanneer het kind wordt verhinderd de voorzieningen te benutten die voor zijn ontplooiing noodzakelijk zijn.'

Wanneer de aangeboden hulp wordt geweigerd terwijl die hulp voor het kind noodzakelijk is?

'(...) [W] anneer ouders hun opvoedingsverantwoordelijkheid niet volledig kunnen dragen of in strijd met de rechten van het kind aanwenden. Op die momenten verwacht het Verdrag van anderen dat zij bun eigen verantwoordelijkheid nemen en kind en gezin helpen en bescherming bieden.'

Door het aanbieden - het vroegtijdig aanbieden, het in tweede lijn aanbieden, het in derde lijn aanbieden - en desnoods (doen) opleggen van hulp. $U$ schetst de door het recht, het Verdrag, verlangde situatie. Wat is de praktijk?

'In de praktijk zien we dat het stelsel van in elkaar overvloeiende verantwoordelijkheden niet goed functioneert. De tandwielen zijn aanwezig maar grijpen niet soepel in elkaar. In plaats daarvan zien we rigide gescheiden verantwoordelijkheden. Binnen de afgeperkte gebieden blijken de als samenhangend bedoelde verantwoordelijkheden elk een zelfstandig bestaan te leiden. Verantwoordelijkheden die bovendien door eenieder naar eigen goeddunken worden ingekleurd.'

$U$ schetst een stuurloos en ongecoördineerd geheel. Is er dan geen centraal beleid? Geen centrale sturing? Geen centrale controle?

'Wanneer de ontwikkeling van het kind gevaar loopt, is het niet vanzelfsprekend dat de hulp en bescherming worden geboden waarop het kind aanspraak heeft. Ook bij degenen die beroepsmatig bij kind en gezin betrokken zijn, treffen we een terughoudende opstelling aan waar het de inmenging in opvoedingsaangelegenheden betreft. Onbekendheid met het Verdrag speelt hierbij zeker een rol. Daarnaast lijkt angst voor afwerende reacties van ouders de zorg voor het kind te overheersen en naar de achtergrond te drukken. Zolang het bieden van hulp en bescherming geen vanzelfsprekende zaak is, is het kind overgeleverd aan het toeval.'

Overgeleverd aan het toeval? Dat lijkt mij het toppunt van stuurloosheid, het toppunt van rechteloosheid, het toppunt van onrechtsstatelijkheid. Of valt het uiteindelijk allemaal wel mee? 
"De tandwielen in het stelsel van verantwoordelijkheden knarsen opnieuw wanneer de bedreiging voor de ontwikkeling van het kind ernstige vormen gaat aannemen, zoals in het geval van kindermishandeling, sexueel misbruilk of ernstige verwathoxing."

Bij bedreiging van de minimale persoonswording - om weer een vakterm te laten vallen.

'In die situaties kan de vraag zich voordoen of overheidsinterventie noodzakelijk is om het gevaar te keren en de verdere ontwikkeling wan het kind in goede banen te leiden. Die vraag dient met "ja" te worden beantwoord wanneer de veiligheid, gezondheid en ontwikkeling van het kind in gevaar zijn en er langs andere weg geen adequate bescherming mogelijk is.'

Wat verlangt - eist - het Verdrag in die gevallen?

'Het Verdrag verplicht de Staat alie wettelijke en bestuurlijke maatregelen te nemen om het kind te beschermen tegen gewelld ([art. 19, lid 1 VRK]). Deze maatregelen dienen ook doeltreffende procedures te omvatten voor melding [(art. 19, lid 2 VRK)]. Een dergelijke procedure ontbreekt in Nederland.'

Een dergelijke procedure ontbreekt in Nederland? Ontbreekt geheel?

'Het melden van ernstige schendingen van rechten van het kind is een vrijblijvende zaak, die aan ieders vrije interpretatie wordt overgelaten. Hierdoor wordt vele kinderen ten onrechte bescherming onthouden.'

Het komt mij voor dat deze constatering alléén al volstaat om staatsaansprakelijkheid vast te stellen. In een situatie van grootschalige en grove mensenrechtenschendingen is dit toch het toppunt van gebrek aan due diligence, due care. Zoals dat in de internationaalrechtelijke literatuur heet. Is hier sprake van hetzelfde gebrek aan beleid, sturing en controle dat $U$ zoëven schetste?

"Wanneer het gaat om melden, is het bedreigde kind opnieuw aan toevalligheden overgeleverd. Weer zien we grote aarzelingen, zowel bij burgers als professionals, en opnieuw is angst de regerende vorst."

Een koninkrijk van onverenigde departementen, geregeerd door angst? Dat gelooft $U$ toch zelf niet!?

'Melden wordt dikwijls gezien als klikken of verraad." 
Is niet melden dan géén verraad? Verraad van het kind. Een verraad ook van zichzelf. Want een goed en wijs mens ziet het kind in zichzelf en zichzelf in alle kinderen ... als ik even filosofisch mag worden.

'[De] problemen van het kind [worden] dikwijls schromelijk onderschat en het probleemoplossend vermogen van ouders hogelijk overschat.'

Een al even filosofisch antwoord. Zijn er niet meer alledaagse verklaringen?

"De problemen rond het melden houden deels verband met het negatieve beeld dat de samenleving van de jeugdbescherming heeft.'

Dat lijkt mij een vicieuze cirkel: als er geen centraal beleid, geen centrale sturing, geen centrale controle is, moeten er in de praktijk wel rampen gebeuren, die niet aan positieve beeldvorming zullen bijdragen.

'Dat beeld is verklaarbaar. Vanuit de historie is het instituut omgeven met een kwalijke geur van repressie. Vroeger manifesteerde de jeugdbescherming zich vooral als bestrijder van ouderlijk wangedrag. De wet- en regelgeving waarvan de jeugdbescherming zich bedient, ademt nog steeds de sfeer van repressie uit."

Waarom wordt er toch steeds gesproken van jeugdbescherming in plaats van kinderbescherming - alsof we ons alleen bekreunen om jeugd, schooljeugd, tieners, en niet om ongeborenen, pasgeborenen, peuters, kleuters, vijf-, zes-, zevenjarigen. Alsof we alleen maar iets doen als het kind al wat ouder is. Als het zelf zijn mond open kan doen en we er niet meer omheen kunnen. Alsof de ontwikkeling, de persoonswording van een kind, niet al vóor zijn geboorte begint, en niet pas als het naar school gaat. Alsof we per definitie pas iets doen als het al te laat, véél te laat, is .... Alsof een kind pas Nederlands staatsburger wordt als het de schoolpoort binnenwandelt, en niet als het ter wereld komt. Jeugdbescherming, jeugd .... Wie het over zijn jeugd heeft, denkt toch niet aan zijn baby-en peutertijd; wie herinnert zich die nou! Maar ... jeugdbescherming hanteert $U$ natuurlijk als nieuwe wettelijke term? De laatste jaren is er toch veel vernieuwend wetgevingswerk verricht?

\footnotetext{
"Nog steeds moet gebruik worden gemaakt van oude wettelijke formuleringen waarin de morele veroordeling van ouders doorklinkt. Dat verdraagt zich miet met het respect voor ouders waartoe het Verdrag oproept. Het is ook mijn overtuiging dat het wettelijk instrumentarium niet aan de eisen wan deze tijd voldoet en op meerdere punten strijd oplevert met het Verdrag. Neem de maatregel van ondertoezichtstelling."
} 
$U$ komi nu met een oud en eerbiedwaardig instituut - de ondertoezichtstelling - waar eveneens het stof van overheidsnalatigheid bij wijze van spreken duimdik bovenop ligt. Moet ik het zo zien?

'Deze hoogbejaarde viert dit jaar zijn 75 e verjaardag. Sommigen zien hierin een aanleiding voor een feestelijke herdenking.'

\title{
Dat is fraai. Dus tien jaar na mijn pensionering ben ik hoogbejaard!
}

'Het juridisch gevolg van de ondertoezichtstelling is een beperking van het ouderlijk gezag, het afnemen van een stukje gezag van de ouders.'

Dat kan terecht zijn. De vraag is enerzijds of het effectief is. En anderzijds of het niet onnodig stigmatiserend is. Mensen in hun transgenerationele hokje, in een marginaal hoekje van de samenleving houdt.

\begin{abstract}
"Een beperking van het gezag laat zich niet rijmen met de in het Verdrag gestelde verplichting dat ouders nu juist van passende bijstand moeten worden voorzien ([art. 18, lid 2 VRK]). Het bieden van bijstand heeft de betekenis van "het actief toevoegen van datgene wat ontbreekt": een ondersteuning en versterking van de aanwezige ouderlijke verantwoordelijkheid; niet een ontkrachting of beperking ervan. In mijn optick moet dat "toevoegen" aanzienlijk meer inhouden dan "het geven van aanwijzingen" door de gezinsvoogd. Aanwijzingen die nota bene door de ouders moeten worden opgevolgd, terwijl zij degenen zijn die vanwege een gemis aan benodigde vaardigheden of het uitblijven van passende hulp bij het opvoeden van hun kinderen zijn vastgelopen. Het is bovendien een illusie te veronderstellen dat ernstige gezins- en opvoedingsmoeilijkheden met aanwijzingen zouden zijn te verhelpen.'
\end{abstract}

$U$ neemt dit te serieus. Volgens een vorige getuige-deskundige heeft de gemiddelde gezinsvoogd maar twee uur per maand tijd voor direct contact met een gezin. Ik heb hier een rapport wan het Ministerie van Justitie waarin zelfs wordt gesproken van éen uur of zelfs een half uur per maand per cliënt. ${ }^{274}$ Maar laten we het houden op twee uur per gezin. Binnen dat tijdsbestek, zo stel ik me dat voor ... uiteraard laat ik mijn fantasie de vrije loop..., moet

274 H.B. FERWERDA e.a., Signalen woor toekomstig crimineel gedrag; Een onderzoek thar de signaalwaarde van kinderdelinquentie en probleemgedrag op basis van casestudies van emstig criminele jongeren, Ministerie van Justitie, Den Haag (december) 1996, p. 67 1.k. (tekst en nt. 31): 'In het geval van een ors heeft de gezinsvoogd (met een caseload van rond de dertig jongeren) hooguit ến uur per maand de tijd om aan de jongere te besteden. (Er zijn zelfs schattingen die spreken over 1,5 uur per drie maanden per cliënt.) [Bij ernstige] problematiek mag er nauwelijks iets verwacht worden van dergelijke hulpverleningscontacten.' 
de begroeting plaatsvinden, moeten praktische zaken worden besproken en zo mogelijk geregeld, moet met de gezinsleden, vaak uiteraard ook apart, worden bijgepraat - liefst op therapeutisch niveau -, moet de situatie worden geanalyseerd, moeten aanwijzingen worden gegeven, en moet en passant worden nagegaan of de aanwijzingen van een maand geleden wat hebben uitgehaald ... of überhaupt zijn opgevolgd.

'Het opvolgen van aanwijzingen leidt hooguit tot oppervlakkige aanpassingen, zeker wanneer er een zekere dreiging in de lucht hangt, en vrijwel nimmer tot intrinsieke gedragsveranderingen. Bescherming en bijstand, in de betekenis van het Verdrag, houden inspanningsverplichtingen in voor degenen die beroepsmatig bij kind en gezin zijn betrokken.'

Een inspanningsverplichting is iets anders dan het geven van zinloze, zo niet onzinnige aanwijzingen. Maar kan men die overbelaste en (therapeutisch) ondergeschoolde gezinsvoogden iets verwijten? De staat geeft hun per 'casus' twee uur per maand de tijd voor contact met het gezin, en daarna moeten ze nog achter hun bureau rapporten schrijven ....

'Het wordt hoog tijd dat de kinderbeschermings- ...'

Nu zegt U het goed!

‘... -maatregelen grondig worden gereviseerd en in overeenstemming worden gebracht met de strekking van het Verdrag. De praktijk vereist een gevarieerd pakket van juridische maatregelen waarmee bevoegdheden en verplichtingen worden geschapen om voor kinderen beschermend te kunnen handelen. Niet in de plaats van de ouderlijke verantwoordelijkheid maar als aanvulling daarop."

Is dat Uw belangrijkste juridische conclusie?

'De eerste uitdaging is ervoor te zorgen dat het Verdrag binnen de Nederlandse samenleving werkelijk tot leven komt. Dat is geen eenmalig gebeuren, maar een permanent proces. Hier ligt een belangrijke verantwoordelijkheid voor de overheid. De Staat is op grond van het Verdrag ook verplicht de beginselen en bepalingen op passende en doeltreffende wijze bekend te maken ([art. 42 VRK]).'

Op de TV heb ik nog niets zien aangekondigd wat in de buurt komt van Uw conclusies. Ook niet in de Staatscourant trouwens. Een meldplicht, althans een einde aan de vaderlandse vrijblijvendheid (over Vadertje Staat gesproken ...); de bezem door het wettelijk instrumentarium van de kinderbescherming. Dat is nogal wat. Maar zelfs van publiekscampagnes om ouders op hun primaire opvoedingsverantwoordelijkheid - en op de rechten van kinderen - te wijzen, geen spoor. Laat staan campagnes waarin wordt uitgelegd 
hoe de overheid haar secundaire opvoedingsverantwoordelijkheid vorm denkt te geven. Opnieuw een verdragsschending!? Maar dan toch niet de grootste?

'Daarnaast is het van groot belang dat gewerkt wordt aan een andere mentaliteit onder degenen die beroepsmatig bij kinderen en gezinnen zijn betrokken. $\mathrm{Z}_{i j}$ moeten ervan doordrongen raken dat het kind altijd op de eerste plaats dient te komen."

Hier zijn art. 3, lid 1 (het belang van het kind) en art. 3, lid 3 (toezicht op de professionaliteit van hulpverleners en kinderbeschermers) in het geding. Schort het aan deskundigheid - of vooral aan leiding, aan regievoering door de rijksoverheid? Wat moet er gebeuren?

'Beroepsopleidingen kunnen hierbij behulpzaam zijn. Tegelijkertijd zou gewerkt kunnen worden aan de totstandkoming van op de praktijk van beroepsgroepen toegesneden richtlijnen, waarmee invulling wordt gegeven aan de verplichtingen uit het Verdrag."

Maar hoe zit het dan met het centrale beleid, de centrale sturing, de centrale controle? Kortom, wat moet er gebeuren door de politiek?

'Ook voor de wetgever valt er nog wel wat te doen. Gedacht kam worden aan wetgeving die het gebruik van geweld in de opvoeding verbiedt (lart. 19 VRK in de interpretatie van het Comite inzake de rechten van het kind $\left.{ }^{275}\right]$ ), ...'

Een wettelijk verbod op het slaan van kinderen. Gepaard aan een publiekscampagne onder het motto Een beetje ouder houdt z'n handen thuis!! Maar dan toch zeker ook een wettelijk verbod op het gebruik van verbaal geweld in de opvoeding, op het bedreigen, beschamen, vernederen en uitschelden van kinderen? Een gelijktijdige publiekscampagne onder het motto Een beetje ouder let op z'n woorden .... Ik onderbrak $U$....

'... aan een regeling voor het melden van voor het kind bedreigende opvoedingssituaties, en aan een herziening van de maatregelen van kinderbescherming.'

$U$ ziet de toekomst optimistisch tegemoet?

'Wellicht geeft het volgende rapport aan [het Comite inzake de rechten van het kind], over vijf jaar, aanleiding voor dat feestje.'

Zie hoofdstuk 14, par. 14.5.2.3 onder Lessoort I: het goede voorbeeld (ad 6). 
Dan bent $U$ in elk geval nog niet hoogbejaard. In hoeverre $U w$ optimisme gerechtvaardigd is, zullen we snel weten - althans kunnen bevroeden. Audi et alteram partem. Het wordt tijd de staat zelf aan het woord te laten. Vóor de zevende, en laatste, getuige-deskundige. Een kwestie van omgekeerde préséance: het hoogste woord komt het laatste. Welaan, wat heeft de staat gerapporteerd aan het Comité inzake de rechten van het kind in zijn eerste rapport, ex art. 44, lid 1 aanhef en onder a van het Verdrag? Het woord is aan de vertegenwoordiger van de staat. Ah, ik begrijp dat $U$ om redenen van chronologie eerst wilt citeren uit de Beleidsbrief kindermishandeling, vervolgens uit de Memorie van Toelichting bij het goedkeuringswetsontwerp van het Verdrag inzake de rechten van het kind, ten derde uit de Notitie gezin, en pas als laatste uit het rapport aan het Comité inzake de rechten van het kind. Ga Uw gang.

(1.) De Beleidsbrief kindermishandeling (1990)::276

\begin{abstract}
'Kindermishandeling is een afschuwelijke ervaring. Deze ervaring wordt nog erger als kinderen, om welke reden dan ook, geen kans zien de hulp te krijgen die ze behoeven. Terecht wordt verlangd dat degenen die zich inzetten voor preventie en hulpverlening naar vermogen alles doen om binnen de grenzen van professionele zorgvuldigheid kindermishandeling terug te dringen.

Kindermishandeling mag echter niet terug gebracht worden tot een individueel probleem van slachtoffer en dader. Het gaat hier om een maatschappelijk probleem waarin sociaal-economische factoren, opvattingen over macht, gezag, privacy, familierelaties en geweld in de samenleving een rol spelen.

In de samenleving bestaat er eensgezindheid dat kindermishandeling veroordeeld en zoveel mogelijk voorkomen moet worden. Dat dit niet alleen voor Nederland geldt, bleek nog onlangs uit de unanieme aanvaarding van het VN-Verdrag inzake de rechten van het kind op 20 nowember 1989 . (...)

De ernst van de problematiek brengt met zich mee dat de samenleving de politiek aanspoort om de inspanningen op dit gebied te intensiveren."
\end{abstract}

Het recht, het Verdrag, al bijna een jaar vóor de Beleidsbrief door Nederland ondertekend, niet als scepter en zwaard voor de overheid, maar als stok voor de burger om de overheid mee achter de vodden te zitten? Natuurlijk, waarom niet. Gaat $U$ verder.

'De stijging van het aantal meldingen met betrekking tot kindermishandeling in de afgelopen jaren vormt aanleiding voor de regering zich - opnieuw - te bezinnen op het gevoerde overheidsbeleid terzake. (...)

276 Brief van de minister van WVC en de staatssecretarissen van WVC en van Justitie d.d. 4 december 1990: Beleidsbrief kindermishandeling (Het is niet de uraag of het kan, maar' weten dat het moer), Kamerstukken II 1990/91, 21 938, nr. 2, pp. 3, 8, 11,12 i.f., $18,22,24$ en 28 . 
Het feit dat vele factoren oorzaak kunnen zijn van kindermishandeling kan leiden tot gevoelens van machteloosheid met betrekking tot mogelijkheden voor preventie ervan. Een menswaardige samenlewing vereist echter een niet aflatende inzet om kindermishandeling te voorkomen. (...) Het is de verantwoordelijkheid van de overheid hier voorwaarden toe te scheppen. (...)

Een op eventuele risicocategorieên onder de bevolking afgestemde publieksbenadering wijzen wij af. Er is onvoldoende steun, zo blijkt uit de adviezen, voor de aanname van het bestaan van aanwijsbare risicocategorieẽn. ${ }^{277}(.$.

Een meldingsplicht lijkt ons op dit moment niet de aangewezen weg (...).

In elk arrondissement is een Raad voor de kinderbescherming gevestigd. De Raad heeft een aantal wettelijke taken. Zo dient de Raad daar op te treden waar de rechten van een minderjarige op een evenwichtige uitgroei naar volwassenheid ernstig in het gedrang komen."

In elk geval vanaf (eind) 1990 erkent de staat dus het recht, het recht, van het kind op optimale c.q. minimale persoonswording - zoals uitgewerkt in het (begin 1990) door de staat ondertekende Verdrag inzake de rechten van het kind. Waarvan akte!

'In dat verband komt de Raad veel in aanraking met zogenaamde verzorgings- en opvoedingsproblematiek, waaronder kindermishandeling. De medewerkers dienen te beschikken over juridische, ontwikkelingspsychologische en sociaal-maatschappelijke kennis, ervaring en deskundigheid .....

Kunt $U$ aangeven wat er in de Beleidsbrief concreet wordt voorgesteld? Althans wat de uitgangspunten van de aangekondigde herbezinning op het beleid zijn?

'Het voorkómen van kindermishandeling vereist veranderingen in het functioneren van de maatschappij, gemeenschappen, gezinnen en individuen. Dil is niet van vandaag op morgen gerealiseerd."

Niet van vandaag op morgen ... schetst de Beleidsbrief nog een wijder perspectief?

'Het is een probleem met ongewenste maatschappelijke gevolgen waarbij een wissel wordt getrokken op de toekomst. De slachtoffers van wandaag zijn immers de opvoeders van morgen. Dit vergt ook een mentaliteitsverandering. Die is niet op korte termijn te realiseren ....'

Anders, althans genuanceerder: BAARTMAN (H.E.M. BAARTMAN, 'Kindermishandeling en risicogezinnen; een patstelling in preventie?' In: dez. e.a., Gezinnen onder druk, a.w., pp. 80-107; dez., "Primaire preventie van kindermishandeling: onbegonnen werk?' NTOVO 1996, pp. 17-33), die deze passage uit de beleidsbrief op de korrell neemt (t.a.p., op p. 80 ; resp. t.a.p., op p. 26). 
Niet op korte termijn .... Dat is zo. Is er al een begin gemaakt? Zijn er plannen voor .... Enfin, in elk geval lijkt de overheid hier oog te hebben voor de transgenerationele aspecten. Het daget in den oosten. Gaat $U$ verder.

(2.) De Memorie van Toelichting bij het wetsontwerp Goedkeuring van het op 20 november 1989 te New York tot stand gekomen Verdrag inzake de rechten van het kind (1992): 278

[ $[\mathrm{H}]$ et tweede lid van artikel 18 [van het Verdrag inzake de rechten van het kind] [handelt] over het waarborgen dat ouders hun verantwoordelijkheden inzake de opvoeding van kinderen kunnen waarmaken. In het kader van het preventiebeleid worden opvoedingsondersteunende projecten en voorzieningen, zoals instellingen voor spel- en opvoedingsvoorlichting, ontwikkeld en gestimuleerd. (...)

Er worden maatregelen getroffen op het punt van opvoedingsvoorlichting, stimulering van vroegtijdige onderkenning door beroepsbeoefenaren, netwerkontwikkeling, specifieke aandacht voor het onderwerp kindermishandeling in de opleidingen van beroepsbeoefenaren, onderzoek naar risicofactoren, opvoedingsondersteuning, sociale en materiële steun aan gezinnen. (...)

Het eerste lid [van art. 19 Verdrag inzake de rechten van het kind] spreekt van het bieden van bescherming tegen elke vorm van lichamelijk geweld.'

Niet alleen van lichamelijk geweld. Ook van geestelijk geweld, sexueel geweld. Bescherming tegen alle vormen van geweld, alle vormen van kindermishandeling, waaronder lichamelijke en geestelijke, emotionele, affectieve verwaarlozing. Of bedoelt $U$ te zeggen dat de regering het sláán van kinderen wil verbieden?

"Uit de onderhandelingen bij de totstandkoming van het Verdrag inzake de rechten van het kind blijkt niet dat een opvoedkundig "pak voor de broek" ook onder deze bepaling zou moeten vallen. Ook de bewoordingen van het Verdrag geven geen aanleiding om ook tegen een lichte opvoedkundige tik, waaruit geen lichamelijk of geestelijk letsel voortvloeit, bescherming te moeten bieden.'

Restrictieve interpretatie heet dit. Enge uitleg. Heeft de regering wel eens gehoord van dynamische interpretatie? De rechter wel!

278 Kamerstukken II $1992 / 93,22855$ (R 1451), nr. 3, pp. 28 en 29-30.

Vgl. ook de overige parlementaire stukken: Kamerstukken II 1992/93, 1993/94, 22855 (R 1451); Handelingen II 1993/94, pp. 5548-5567, 5703-5725, 5728-5733, 5777-5778, 5782-5791; Kamerstukken I 1993/94, 22.855 (R 1451), nr. 408; 1994/95, 22855 (R 1451), nrs. 22, 22a; Handelingen I 1994/95, p. 116. Zie ook Staatsblad 1994 , nr. 862 (Rijkswet van 24 november 1994, houdende goedkeuring van het op 20 november 1989 te New York tot stand gekomen Verdrag inzake de rechten van het kind). 
"Het tweede lid geeft een opsomming van mogelijk in het kader van het eerste lid te nemen maatregelen.'

Mógelijk te nemen maatregelen!? U bedoelt: alle mogelijke maatregelen die geschikt en doelmatig zijn. Gaat $U$ verder.

(3.) De (kabinets-)Notitie gezin (1996): ${ }^{279}$

"In aansluiting op de definitie die het Nationaal Comite voor het Jaar van het Gezin heeft vastgesteld, kiest het kabinet ervoor het gezin te omschrijven als elk leefuerband van één of meer volwassenen die verantwoordelijkheid dragen voor de verzonging en opvoeding van één of meer kinderen. Deze definitie geeft de kermfunctie van het gezin aan, namelijk de opvoeding en verzorging van kinderen. Met opvoeding wordt hier bedoeld het bieden van geborgenheid, veiligheid en behaaglijkheid, kortom nestwarmte, maar ook socialisering, de overdracht van waarden en normen, de zorg voor gezondheid, onderwijs en educatie, de voorbereiding op maatschappelijke functies en de bescherming van de lichamelijke integriteit,"

Nestwarmte, bescherming van de lichamelijke integriteit: dat komt al aardig in de buurt van een verbod op het slaan van kinderen. Of wilt $U$ daar niet naar toe?

'In het Nederlandse overheidsbeleid wordt op een groot aantal terreinen aandacht geschonken aan de maatschappelijke positie en de functies van thet gezin. Gezamenlijk vormen deze inspanningen een impliciet gezinsbeleid, waarvoor het gehele kabinet zich verantwoordelijk acht.'

\section{Een impliciet beleid?}

'Het gezin neemt in de visie van het kabinet wanwege de opvoeding van kinderen een bijzondere positie in. Het scheppen van optimale voorwaarden voor de opvoedingstaak van het gezin krijgt in het beleid daarom bijzondere aandacht."

\section{Impliciet?}

'Het kabinet acht het vooral van belang de cumulatieve gevolgen van beleid op deelterreinen voor mensen in gezinssituaties in hun onderlinge verband te beschouwen."

Impliciet?

279 Notitie gezin; De maatschappelijke positie van het gezin, Rijswijk 1996, respectievelijk pp. $5-6,8-9,20,22,12$ en 23 . 
'Nederland kent dus geen specifiek gezinsbeleid vanuit een afzonderlijke beleidseenheid binnen de overheidsorganisatie en evenmin een gezinsminister, zoals in een aantal Europese landen het geval is.'

Dus expliciet geen expliciet gezinsbeleid. Het kabinet is zich er natuurlijk wel expliciet van bewust dat het staat voor een situatie van grootschalige en ernstige mensenrechtenschendingen ... in één van de rijkste landen ter wereld. Een nationale ramp noemen ze kindermishandeling in de Verenigde Staten (US Advisory Board on Child Abuse and Neglect 1990). En in Nederland? Een land waarin de politiek de mond vol heeft van mensenrechten en buitenlands beleid .... Een land waarin burger en overheid met enige gretigheid met de vinger wijzen naar landen waar het met de mensenrechten minder nauw wordt genomen .... Een nationaal schandaal zouden we het hier moeten noemen. Expliciet! Gaat $U$ verder.

'Waar de positie van het gezin aan de orde komt, zijn respect voor de persoonlijke levenssfeer, respect voor de bereidheid van mensen om te investeren in verantwoordelijkheid en zorg voor elkaar en respect voor het vermogen om zèlf oplossingen te vinden, de belangrijkste uitgangspunten van het kabinet. Nog sterker dan op andere terreinen het geval is, beschouwt het kabinet ontwikkelingen in de gezinssfeer als een zaak en verantwoordelijkheid wan burgers zelf,'

Gaat U dat aan Naima vertellen? Aan baby Jill, als ze wat groter is? Aan de vader van Walter?

'Het stichten en instandhouden van een gezin en het opvoeden en bescherming bieden aan kinderen zijn primair verantwoordelijkheden van de ouders.'

Juist primair! En wie is secundair verantwoordelijk? En hoe?

"Dat vraagt van de ouders grote investeringen in persoonlijk en materieel opzicht. De omvangrijke persoonlijke inzet die mensen elkaar willen bieden, is onvervangbaar.'

Dit lijken eerder woorden uit de kerstboodschap van de koningin. De taal van een zondagskind, dat het met zijn ouders zeer getroffen heeft. Een gezinsbeleid gaat over iets anders. Kunt U ter zake komen!

'Voor de legitimatie van de betrokkenheid van de overheid bij het gezin onderscheidt het kabinet twee gronden. Een adequate opvoeding en verzorging van kinderen is een essentiële voorwaarde voor de kwaliteit van leven en voor continuiteit en ontwikkeling van de samenleving. Investeren in het gezin is derhalve investeren in de toekomst. Dat gemeenschappelijk belang vormt een aangrijpingspunt voor betrokkenheid van de overheid bij het gezin.' 
We zitten weer op dezelfde golflengte. Mijn excuses voor mijn ongeduld. $U$ begrijpt, het dossier wordt zo dik .... Rijk gedocumenteerd, zegt U? Dank U. Bijzonder hoffelijk. Gaar $U$ verder.

"Het tweede aangrijpingspunt is de zorgplicht van de overheid voor zwakkeren en het recht van kinderen op veiligheid, gezondheid en een goede opvoeding. Dit recht is vastgelegd in de Grondwet en in internationale verdragen.'

De enige kinderen in de Nederlandse Grondwet zijn de niet dood ter wereld komende wettige nakomelingen van Koning Willem I, Prins van Oranje-Nassau, waarvan een vrouw zwanger is op het ogenblik van het overlijden van de Koning (art. 26 Grondwet). Het ongeboren kind van koninklijken bloede. Voor gewone kinderen, in Nederland geboren kinderen, of hier woonachtig, moeten we naar het Verdrag inzake de rechten van het kind. Maar goed, dat $U$ erkent dat er een internationaalrechtelijk recht van het kind-ongeacht de kleur van zijn bloed en andere toevallige omstandigheden - op een goede opvoeding bestaat, een recht van het kind, zij het nog te constitutionaliseren, op optimale persoonswording, om de wetenschappelijke paraplu-term te gebruiken, brengt ons een stap in de goede richting. Gaat $U$-vooral-verder.

'De overheid dient enerzijds de vrijheden van burgers te waarborgen, zoals de vrijheid van inrichting van het privéleven. Anderzijds heeft zij de plicht om vrijheden te beperken als dat noodzakelijk is in het belang van degenen waarvoor de overheid in het bijzonder de verantwoordelijkheid draagt, of als dat in het belang is van de samenleving als geheel.'

$U$ ziet vrijheid kennelijk slechts als een negatief begrip: het recht op privacy, op een persoonlijke levenssfeer, als recht op niet-inmenging. Vrijheid heeft echter ook een positieve inhoud: het recht op persoonlijke ontplooiing. Dient de overheid nu niet juist de vrijheid - de positieve vrijheid - van mensen te vergroten: door hen te ondersteunen bij hun opvoedingstaak, bij het verwerken en waar nodig verwerven van hetgeen zij in hun eigen jeugd, in hun eigen ontwikkeling, te kort zijn gekomen? $U$ had het net over de Grondwet. Art. 22, lid 3 van de Grondwet legt de overheid de verplichting op voorwaarden te scheppen voor maatschappelijke ontplooiing. Valt daar niet mede onder - in het licht van het Verdrag inzake de rechten van het kind - social-emotionele, sociaal-pedagogische ontplooiing? Toename in plaats van beperking van persoonlijke vrijheid, toename in plaats van beperking, ten aanzien van de eigen kinderen, van pedagogische opties en mogelijkheden?

'Wanneer de kernfuncties van het gezin niet worden vervuld en wanneer daardoor de rechten van kinderen worden bedreigd of aangetast, moeten kinderen 
verzekerd kunnen zijn van bescherming en ondersteuning of behartiging van hum belangen door de overheid.

Waar zonder maatregelen grote ongelijkheid zou ontstaan in ontplooiingskansen van gezinnen en gezinsleden, ligt een verantwoordelijkheid voor de overheid om die kansen te vergroten."

Het is vandaag nog niet gesteld. $U$ bent de eerste, en gelukkig niet de geringste: grote sociaal-pedagogische ongelijkheid dient voorkomen te worden, en uiteraard: bestaande emstige sociaal-pedagogische ongelijkheid dient bestreden te worden. Ziet de overheid ook de diepere oorzaken - de root causes van ernstige sociaal-pedagogische ongelijkheid? En daarmee van kindermishandeling? Onderkent zij dat hier sprake is van systemische transgenerationele discriminatie? En heeft zij - op basis van die inzichten - een actieplan, een plan de campagne?

"Waar door (...) geweld of andere problemen binnen het gezin de veiligheid van gezinsleden in het geding is, is begeleiding of hulpverlening aan de orde en, indien dat noodzakelijk blijkt, sanctionerend ingrijpen."

$U$ bent weer terug bij staatsinmenging, bij interventie met de sterke arm. Verwacht $U$ niet meer heil van vroegtijdige ondersteuning en begeleiding, met speciale zorg en aandacht voor risico-situaties, dan van ingrijpen achteraf? $I k$ wil $U$ uiteraard geen woorden in de mond leggen ....

'Overheidsingrijpen is niet alleen een kwestie van bescherming van zwakkeren; het is op langere termijn ook van belang voor het behoud van de welvaart.'

Dat is preventie ook. En bovendien op een manier die niet alleen veel leed, maar ook veel kosten bespaart. Als ik alle getuige-deskundigen vandaag tenminste goed begrepen heb. Of bedoelt $U$ met ingrijpen ook preventieve maatregelen? Kunt $U$ misschien samenvatten wat volgens het kabinet de sociaalpedagogische taak wan de overheid zoal inhoudt?

'De taak van de overheid omvat:

- het scheppen van voorwaarden waarbinnen het gezin zelf zijn kernfunctie van opvoeden en verzorgen kan vervullen (onder andere de sociale zekerheid);

- het ondersteunen en begeleiden van gezinnen bij het vervullen van die kernfunctie. Dit betreft algemene ondersteuning en begeleiding (onder andere regulier onderwijs, consultatiebureaus) en specifieke ondersteuning en begeleiding (opvoedingsondersteuning, speciaal onderwijs, jeugdhulpverlening, enzovoort);

- actief ingrijpen waar de kernfunctie ernstig wordt bedreigd, met name wanneer de rechten en ontwikkelingsmogelijkheden van het kind in het gedrang komen (onder andere justitiële maatregelen).' 
$U$ beschrijft nu wat wordt verstaan onder de trits Opvoedingsgeld, Opvoedingsonderwijs en Opvoedingsondersteuning, tot en met de persoonswordingsvindicatie. Ervan uitgaande althans dat $U$ met sociale zekerheid bedoelt materiële sociaal-pedagogische zekerheid: financiële en fiscale regelingen gekoppeld aan ouderschap, niet aan kostwinnerschap of wat dies meer zij. Wat ik evenwel mis, is de glijdende schaal, de schakels tussen het preventief aanbieden van hulp en hulp-oplegging. Er gaapt een gat tussen vrijwilligheid (vrijblijvendheid?) en dwang. Met andere woorden, wat ik mis, is de precieze samenhang tussen eerstelijns-, tweedelijns- en derdelijnszorg, en hoe deze overgaat in justitieel ingrijpen. Laat ik het anders zeggen: wat ik mis, deerlijk mis, is de overall structuur en de centrale regie: de organisatorische beginselen en hoofdlijnen, de uitgewerkte visie op en het concrete raamwerk van de Trias pedagogica. Of maai ik nu het gras voor $U_{w}$ voeten weg?

'Niet alle ouders zijn in staat hun kinderen een veilige en evenwichtige opwoeding te geven. Ernstige problemen van uiteenlopende aard kunnen de overheid noodzaken in de gezinssituatic in te grijpen, in het belang van het kind of de ouder. Het kabinet is van mening dat de overheid primair de belangen dient te bewaken van degene die bescherming nodig heeft. Het belang van de privacy van het gezin is daaraan ondergeschikt.'

$U$ bedoelt het goed, maar begrijpt mij niet helemaal.

'In de opvoeding gaat het primair om het belang van het kind, in afgeleide zin om het belang van de ouders, maar ook om het belang van de gemeenschap. Met name dit laatste perspectief verdient een nadrukkelijke accentuering binnen het kader wan een hernieuwde aandacht ....'

Is er nagedacht over het hoe van preventie, van primaire preventie, van het screenen van risicogezinnen? Of studeert het kabinet daar nog op?

'Voorbeelden van algemene, faciliterende en voorwaardenscheppende beieidsmaatregelen zijn ook te vinden binnen het onderwijsbeleid, het arbeidsbeleid, het sociale-zekerheidsbeleid, de kinderopvang en het algemene jeugdbeleid. (...) Samenvattend constateert het kabinet dat het beleid van bijna alle sectoren bijdraagt aan het scheppen van voorwaarden voor het functioneren ....

Dit heeft geen zin. Gaat $U$ verder met Uw laatste document.

(4.) Het Nederlandse statenrapport aan het Comité inzake de rechten van het kind (1997): ${ }^{280}$

280 Implementation of the Convention on the rights of the child, The Netherlands, April 1997 (s.l. [Ministerie wan Buitenlandse Zaken], par. 121. 
In the autumn of 1996 the Netherlands Government published a paper on its family policy

Dit lijkt mij een herhaling van zetten. De vertegenwoordiger van de staat wordt bedankt voor de mooie door hem aangehaalde woorden. We hebben vandaag evenwel ook veel aangehoord over de daden, en de daadkracht van de staat. Wat daarvan zij, niet de staat heeft in dezen het laatste woord, doch de internationale gemeenschap. Wij roepen de zevende en laatste getuige-deskundige op (VAN BOVEN 1991): ${ }^{281}$

\begin{abstract}
"Any human rights policy worthy of its name cannot content itself with merely reacting to violations of human rights. All human rights policies and strategies should also address the problem of preventing violations of human rights. The recognition that human rights violations are more effectively tackled by coming to grips with the root causes of the violations rather than dealing exclusively with symptoms has become an increasingly accepted notion in the international community.'
\end{abstract}

Kort en krachtig. Opnieuw: preventie. Een preventieve aanpak die begint bij de - transgenerationele - root causes. Natuurlijk ook curatie. Maar geen Kurieren am Symptom, ofwel palliatie: pappen en nat houden, in incidentele individuele crepeergevallen de zweren omzwachtelen zonder de maatschappelijke ziekte zelf structureel aan te pakken. En als we het dan over een structurele aanpak hebben, vooral: na en naast woorden óók daden, eindelijk eens daden, daden die zoden aan de dijk zetten.

Wij hadden beloofd geen rechtertje te zullen spelen. Wij zien ook af van een requisitoir, dat al snel trekken zou vertonen van een meer retorisch dan juridisch 'J'accuse. ${ }^{282}$ We laten de woorden en daden van de overheid derhalve voor zich spreken. De indiener van de aanklacht mag het slotpletdooi houden (BAARTMAN, Opvoeden kan zeer doen).:283

'In het kader vam pre- en perinatale zorg is er een mentaliteit waarbinnen het volstrekt vanzelfsprekend gevonden wordt moeders en kinderen te onderzoeken op de aanwezigheid van risico's die de [lichamelijke, jw] gezondheid van moeder en kind bedreigen. Even vanzelfsprekend zou het moeten zijn om aandacht te besteden aan risico's die adequaat ouderschap bedreigen. Het aanbieden van hulp

281. Theo VAN BOVEN, "General course on human rights," in: The protection of human rights in Europe, Collected Courses of the Academy of European Law, Vol. IV, Book 2, 1993, The Hague (etc.) 1995, pp. 1-106, op p. 31.

282 Vgl. met betrekking tot het gevaar van 'rhetorical exercises' door 'legal scholars': Leora BILSKY, Naming and re-categorization in the law; child abuse as slavery,'

The International Joumal of Children's Rights $1997 / 2$, pp. 147-176.

H.E.M. BAARTMAN, Opvoeden kan zeer doen, Utrecht 1996, p. 231.. 
en sleun aan jonge risicogezinnen [(aanstaande) ouders met een deplorabel pedagogisch besef/een deplorabele (niet verwerkte) jeugd, en in (nauw) verband daarmee levend in sociaal isolement met een gebrek aan sociale steun, jw] dient te gebeuren in een context waar gebruikmaking van een aanbod van steun en hulp tot de [maatschappelijke, sociaal-pedagogische, jw] mogelijkheden behoort van alle [aanstaande] en jonge ouders, zoals dat ook het geval is met medische preen perinatale voorzieningen. Het is in dit opzicht (...) van tweeèn [én]. Ofwel wij] creëren een dergelijk pakket van [sociaal-pedagogische, jw] woorzieningen [een sociaal-pedagogisch vangnet als onderdeel van een sociaal-pedagogisch stelsel, jw], ofwel we wachten af met het bieden van hulp en het [eventueel] treffen (...) van vrij ingrijpende juridische maatregelen tot het evident is dat een kind mishandeld of verwaarloosd wordt. De ervaringen die elders, met name in de VS, opgedaan zijn met het bieden van vormen [van] vroegtijdige hulp, hebben laten zien dat hiermee veel ellende te voorkomen is.'

\section{Conclusie}

Van tweeën één? Neen! De keuze die BAARTMAN ons schijnbaar laat, bestaat - juridisch/mensenrechtelijk bezien - niet. Zoals VAN BOVEN (1991, 1996) overtuigend heeft aangetoond en bij herhaling benadrukt, is de preventieve benadering geen vrijblijvend alternatief, maar een mensenrechtelijk verplichtende, een - zo kunnen we daar onder verwijzing naar het Verdrag inzake de rechten van het kind aan toevoegen - verdragsrechtelijk dringende en zelfs dwingende weg. Het roer van het schip van staat moet dus om: de vaarweg van de - arbitraire, marginale en marginaliserende - palliatie moet worden verlaten en afgesloten; de vaarweg van de - structurele, eerste-, tweede- en derdelijns sociaal-pedagogische - preventieve benadering moet worden gevolgd.

Onder eerstelijns dient (grosso modo) te worden verstaan: een algeheel aanbod aan alle (jonge en aanstaande) ouders, geïntegreerd in (thans nog uitsluitend of voornamelijk medisch geöriënteerde en gerichte) eerstelijns voorzieningen (provision). Onder tweedelijns dient te worden verstaan: een specifiek aanbod in risico-situaties (via de eerstelijn 'gescreend') volgens een glijdende schaal van bemoeizorg die desnoods oploopt tot het opleggen van hulp (protection). Onder derdelijns dient (inzonderheid) te worden verstaan: reparatie van transgenerationeel beschadigde (jonge en aanstaande) ouders zodat zij en hun kinderen uit hun sociale/sociaal-emotionele isolement, uit hun marginale sociaal-pedagogische positie geraken (participation/rehabilitation).

Om het (ontwikkelings)belang van het kind, of liever het recht van het kind op (optimale respectievelijk minimale) persoonswording, en de daartoe in een rechtsstaat, geconfronteerd met een situatie van grove en grootschalige (ernstige en passief-systematische) mensenrechtenschendingen (te weten kindermishandeling met de omvang en ernst waartoe het Nederlandse privacy-systeem heeft geleid), noodzakelijke structuele en 
geïntegreerde preventieve benadering van opvoedingsproblematiek in kort en bondig Engels weer te geven, hoeven we slechts vóór de titel van een 'basic working paper' van ALSTON: Development and the rule of law: Prevention versus cure as a human rights strategy, het woordje 'child' te plaatsen en ìn die titel het woordje 'cure' te vervangen door 'palliation,' want 'cure,' genezing, is een te mooi woord voor Kurieren am Symptom; we krijgen dan: Child development and the rule of law: Prevention versus palliation as a human rights strategy! ${ }^{284}$

Child development and the rule of law: Prevention versus palliation as a human rights strategy! Persoonswording in de Rechtsstaat: Preventie versus Palliatie als Mensenrechtelijke Strategie! Zulks is de vaarroute die wij als kindvriendelijke samenleving, als zichzelf serieus nemende rechtsstaat, als (nog altijd) sociale verzorgingsstaat èn als (hoe lang nog?) mensenrechtelijk gidsland hebben te gaan. Op straffe van collectieve maatschappelijke, op straffe van staatsaansprakelijkheid.

\subsubsection{Staatsaansprakelijkheid en het dominante positivisme}

'I must retrace my steps (...)'

In $D e$ jure belli ac pacis worden we verrast met de volgende passage:285

'Ik moet hier op mijn schreden terugkeren en bijna alles weer terugnemen wat ik eerder aan de oorlogvoerenden leek toe te kennen, maar wat ik feitelijk niet toegekend heb. Toen ik namelijk mijn uiteenzetting over dit gedeelte van het volkenrecht inzette, heb ik al betoogd dat er veel zaken zijn die de naam hebben tot het recht te behoren, of althans toegestaan te zijn, omdat zij straffeloos gedaan kunnen worden, deels ook [door]dat de rechtbanken met de macht van hun gezag hun instemming aan deze handelingen verleenden. Intussen wijken deze zaken af van de zuivere norm - of deze nu gelegen is in het [natuur]recht in strikte zin of in een [ruimer natuurrechtelijk] voorschrift dat andere deugden opleggen - of dienen tenminste op nog verhevener [morele, christelijke, humanitaire, $j w]$ gronden, en met groter bijval van rechtgeaarde mannen, achterwege gelaten te worden.'

GROTIUS schreef deze woorden na de 'positivistische' behandeling van het strikte (en wrede) oorlogsgewoonterecht. Om vervolgens over te stap-

Philip ALSTON, Development and the nule of law: Prevention versus cure as a human rights strategy, International Commission of Jurists, Conference on 'Development and the rule of law' (The Hague 1981), s.l.e.a.

285 GROTTUS, De jure belli ac pacis (1625) III.10.1:1 (vert. EYFFINGER/VERMEULEN). In de KELSEY-versie: 'I must retrace my steps, and must deprive those who wage war of nearly all the privileges which I seemed to grant, yet did not grant to them. (...) 
pen op de temperamenta ("maningen tot matiging"), zoals deze worden voorgeschreven door het mandatoire natuurrecht in strikte (de vier c.q. vijf rechtspostulaten) of ruime zin ('soft law') of door 'de aan de christelijke caritas en de klassieke magnanimitas (grootmoedigheid) ontleende morele beginselen': 'de hogere humanitaire beginselen,' de eisen van 'de humanitaire gerechtigheid. ${ }^{286}$ Voor ons geldt bijna het omgekeerde. Vertrokken vanuit het construct van het allermensenrecht en indachtig de geleidelijke verzachting van de absoluutheid en exclusiviteit van het traditionele rechtspositivisme in het internationale recht, hebben wij de staat 'veroordeeld' wegens onvoldoende handhaving van fundamentele rechten van het kind, welke dienden te worden gelezen in samenhang met het meta-recht van het kind op optimale persoonswording, als achterliggend beginsel van het Verdrag inzake de rechten van het kind, en in het licht van een rechtsstatelijke visie op dat Verdrag als constitutie van de Trias pedagogica.

Hoewel wij uiteraard hopen zowel de juridische gefundeerdheid van dat (meta-)beginsel als van die (meta-)visie aannemelijk te hebben gemaakt, in juridisch-betogende zin te hebben 'bewezen' in de voorafgaande hoofdstukken, past ons uiteraard de academische bescheidenheid dat wij geen rechter zijn en geen wetgever, en buiten onze argumenten geen vonnissen of wetten kunnen tonen die dat beginsel en die visie expliciet tot uitgangspunt nemen, toepassen en uitwerken. ${ }^{287}$ Het is in die zin dat wij moeten terugkeren op onze schreden - zonder evenwel bijna alles terug te nemen wat wij tot nu toe - in voorlopige en voorwaardelijke zin doch soms in deductief-stellige termen - hebben geconcludeerd. Vandaar dat wij de vorige (sub)paragraaf (in) de titel (de woorden) meegaven: enkele deductieve conclusies. Dat zijn conclusies die - hoe onontkoombaar logisch ook - nog niet daarom juridisch onontkoombaar zijn. Uiteindelijk, zo zal de rechtswetenschapper zeggen, is het allemaal een kwestie van interpretatie. En zoals AKEHURST/MALANCZUK terecht opmerken: $:^{288}$

'Interpretation is an art, not a science."

Vgl. over deze juridische systematiek en techniek EYFANGER/VERMEULEN, Denken over oorlog en wrede, a.w., pp. 18 i.f.-21; ONUMA, A normative approach to war, a.w., pp. 344-346.

287 Al Ijkt het Comte inzake de rechten van het kind zich wel een (heel) eind in 'onze' richting te bewegen: zie hoofdstuk 14, par. 14.52 .3 (onder Lessoort 1: het goede woorbeld).

288 AKEHURST/MALANCZUK, Modem introduction to intemationai law, a.w., p. 365. 
Over de creatieve rechtsgeleerde, of beter wellicht: de geleerde rechtskunstenaar GROTIUS, schreef BEDERMAN:289

"GROTUU knew that he had to refashion the international history of antiquity and to place it in a durable construct that would provide neutral sources for legitimate rules of State conduct. The vehicle for this transformation of the classical experience was (...) CrCERo's notion of the humani generis societas. By emphasizing a body of law for a "society of mankind, rather than of states" [BASDEVANT 1904] GROTIUs could inject a moral element of natural law as a counterweight to what were (sometimes) regressive State practices which formed the basis of the customary and "voluntary" law of nations. (...)

While the material that GRoTrus used for De jure belli ac pacis was classical or classicist, bis scholarship was thoroughly and unmistakably modern. Superbly read, GROTIUS had the depth of knowlegde to collect vast amounts of material and to organize it in rational, and novel, ways. Throughout De jure belli ac pacis there is a dramatic tension in the ways that GRorrus used classical sources. (...) GROTIUS thus embodied the modern ambivalence of legal scholarship. He sought to balance the legitimacy of law as descriptive science with its power as social theory. GROTIUS' dilemma is ours today as international law scholars: divining rules which are descriptive of how States really behave and, yet, are also binding on States irrespective of their will.'

'To balance the legitimacy of law as descriptive science with its power as social theory': treffend wordt in deze woorden de positie van de jurist als evenwichtskunstenaar gevangen, een positie die van alle tijden is. Zoals ook blijkt uit de niet minder toepasselijke woorden van LOBEL: $:^{290}$

"Robert COVER once described the world of law as "constituted by a tension between reality and vision." COVER metaphorically pictured law as a bridge connecting the world that is with an imagined alternative of what ought to be. From this perspective, a legal scholar must navigate the tension between is and ought, between reality and dreams, between our "reach" and our "grasp," as the poet Robert BROWNING put it."

Het recht is een brug (dat wil zeggen vervult een brugfunctie) tussen de wereld zoals zij is, en de wereld zoals zij behoort te zijn. De jurist evenwel die in het hier en nu een brug te ver gaat, maakt een kunstfout. Hem of haar treft de blaam recht met moraal, met ideaal, met wenselijkheid te

David J. BEDERMAN, "Reception of the classical tradition in international law: GROTUS" De jure belli ac pacis,' in: Grotiana New Series 1995-1996, pp. 3-34, op pp. 32, 33 en 34. (Vgl. ook Karl-Heinz ZIEGLER, "GRoTIUS topicall, or the import of antiquity into the international law of Europe,' Grotiana New Series 1991-1992, pp. $78-87$, op pp. 82 en 86. )

290 Jules LOBEL, boekbespreking in American Joumal of International Law 1997/3, pp. 556-558, op p. 556 1.k. 
hebben verward. Maar hetzelfde geldt voor de jurist die niet over de brug komt, die, aan de veilige kant van de brug, op de vaste oever van een regelgerichte en regelgeleide beoefening van rechtswetenschap, recht met feiten, de gegeven werkelijkheid, de status quo vereenzelvigt. Ook hij (of zij) maakt een kunstfout. Al lijkt het eerder regel dan uitzondering dat in dat laatste geval het juridisch forum klaarstaat met de mantel van de vakbroederliefde. Sterker nog, terwijl de jurist die een brug te ver gaat, daarop door het forum van vakbroeders zwaar wordt afgerekend, lijkt het alsof in het geval van de jurist die niet over de brug komt, in het geheel niet wordt gezien dat er van een kunstfout sprake is.

Legisme in het moderne jasje van een regelgericht en regelgeleid (de facto-)positivisme ${ }^{291}$ - misschien kan ik beter zeggen: neo-legisme -, waarbij voor de macht van het gezag van de rechter soms nog dieper, nog vanzelfsprekender wordt gebogen dan voor het machtswoord van de wetgever, kan, zo lijkt het, ongemerkt en ongestraft de nodige rechtsgeleerde potjes breken. Te meer waar het schuilgaat onder een modieus - of met een modewoord: 'postmodern' - cynisme. Het bevredigt dan ook in beduidende mate het rechtsgevoel wanneer dat eerste ('neo-legisme,' opgevat als de beroepshouding: recht is wat - volgens de rechter - in de wet staat) wordt toegeschreven aan een 'gebrek aan zicht op de realiteit'

291 Vgl. voor een 'regelgericht model van het recht' in tegenstelling tot een 'principeen ideaalgericht model van het recht' Carl ALEXANDER, bespr. van VAN DER BURG/IPPEL (red.), De Siamese tweeling; Recht en moraal in de biomedische praktijk (1994), in: Recht en kritiek 1997/3, pp. 267-277, op p. 268 1.k. (en p. 276 1.k.). Vgll. voor een bredere (zij het nogal pessimistische) cultuurkritiek in dit verband Hans CROMBAG en Frank VAN DUN, De utopische verleiding, Amsterdam/Antwerpen 1997, pp. 257/258: 'De hedendaagse ontkenning van de natuurrechtelijke ethiek neemt de vorm aan van een legalistische ethiek - een ethiek van de [calculerende? -jw] burger - die nog slechts weinig belang hecht aan het onderscheid tussen recht en onrecht, maar des te meer aan het onderscheid tussen legaliteit en illegaliteit. Dit houdt niet alleen in dat er geen ethisch stigma meer kleeft aan manipulatie van anderen, door misleiding of het gebruik van geweld, zolang dit maar krachtens of binnen de perken van de wet geschiedt. Het houdt ook in dat rechtmatig handelen slechts aanvaardbaar is als het door de wet wordt gedoogd. De wet zelf is daarbij aan geen natuurrechtelijk beginsel gebonden. Burgers leven immers niet als mensen in de natuurrechtelijke [rechts]orde, maar als creaturen van de wet in een door de wet geschapen ['neo-legistische," jw] orde."

Hoewell aan deze scherpzinnige cultuurkritiek een kern van waarheid niet kan worden ontzegd, bekruipt de(ze) lezer toch enigszins het gevoel dat de auteurs zijn bezweken voor de "Cultuurpessimistische Verleiding." Er zijn immers genoeg tekenen - de belofte voor de toekomst van de mensheid van het Verdrag inzake de rechten van het kind is er niet het geringste van - die een zekere natuurrechtelijke hoop lijken te rechtvaardigen. 
(VAN DUN), ${ }^{292}$ en dat laatste (een beroeps- of zelfs levenshouding van 'postmodern' cynisme) wordt ontmaskerd als 'pragmatisme' (DIERX) 293 of, nog scherper, als 'decadent scepticisme' (ROZEMOND). ${ }^{294}$

Is dit de toestand van de vaderlandse rechtsbeoefening (althans vanuit de beginselgerichte en beginselgeleide visie vanwaaruit deze studie geschreven is), voor het internationale recht komt daar nog de loodzware erfenis bij van wat AKEHURST/MALANCZUK (het 'mainstream thinking' of de 'dominant philosophy' van) de 'positivist doctrine of international law ${ }^{295}$ noemt: een erfenis die een beginselgerichte en beginselgeleide beoefening van het internationale recht nauwelijks enige speelruimte laat, en de beginselgerichte en beginselgeleide beoefenaar van rechtswetenschap al helemaal het gevoel geeft een danser op het slappe koord te zijn. Eên misstap en hij (of zij) bijt niet slechts in het zand, doch verdwijnt voorgoed in het land waarvan men hem (of haar) verwijt het recht te hebben beschreven: Utopia. ${ }^{296}$

292 In de woorden van HERRAETS in een interview met VAN DUN: zie hierna onder De taak van de jurist.

293 Janny DIERX, 'Pragmatische en symbolische mensenrechten,' Nemesis ('Recht uit het hart') $1997 / 5$, p. 182 (i.f.).

294 Klaas ROZEMOND, 'De toekomst van de kritische rechtstheorie,' Redactioneel Recht \& kritiek 1997/3, pp. 197-205, op p. 200.

295 AKEHURST/MALANCZUK, Modem introduction to intemational law, a.w., Index (met verwijzing naar onder meer p. 32).

296 Utopia is evenwel thet land waar men normaal gesproken pas belandt nadat men niet én doch wele bruggen te ver is gesprongen. In de woorden van CROMBAG/ VAN DUN (De utopische verleiding, a.w., p. 16): 'Wij houden het voor waarschijnlijk dat juist het utopische karakter van veel voorstellen tot oplossing van samenlevingsproblemen in de weg staat aan oplossingen, die weliswaar minder spectaculair en allesomvattend zijn dan de utopische recepten, maar zich door hun pragmatische oogmerk en hun beperkte omvang beter lenen voor een proefondervindelijke toetsing."

Het vele bruggen te ver willen springen, met andere woorden: het aandragen van utopische, in een groots systeem gevangen oplossingen, roept overigens het 'megalomane' (posttraumatisch magische en manische) denken in herinnering van het kinderbeschermingskind van WAN NIJNATTEN (zie de vorige subparagraaf: par. 13.4.1. onder Toetsing aan de hand van getuige-deskundigenverklaringen). Wellicht zou het onthullend zijn eens een onderzoek in te stellen naar de (niet werwerkte) jeugd(trauma's) van grote utopische systeembouwers.

Tegenover Utopia ligt evenwel Pantopia, de alomtegenwoordige werkelijkheid van de jurist aan de veilige kant van de brug. Hem en zijn geestverwanten maken CROMBAG en VAN DUN (a.w., p. 129) het - even terechte - verwijt dat zij 'dikwijls te veel overlaten aan het vrije spel der psychologische krachten en aldus problemen op hun beloop laten waarvan de oplossing of verzachting binnen ons bereik ligt." 
De taak van de jurist

Toch willen wij hier staande houden dat het de taak is van de jurist, op welke plaats en in welke tijd hij of zij zich ook bevindt, door middel van interpretatie, presentatie van argumenten en deductie vanuit en kritische reflectie in het licht van algemene (rechts)beginselen de oevers te verbinden, de kloof te overbruggen, althans aan die verbinding, die overbrugging een steentje bij te dragen, tussen de wereld zoals zij is, op de plaats waar en in de tijd waarin hij of zij haar aantreft, en de wereld zoals zij behoort te zijn, in zijn of haar (natuur-, dat is mensenrechtelijke) visie op waar de mensheid, of althans de gemeenschap waartoe hij of zij behoort, zich naartoe zal hebben te bewegen teneinde menselijk lijden, teneinde onrecht, teneinde misbruik van publieke en particuliere macht te verzachten en te voorkomen.

Wij onderschrijven dan ook met kracht de visie van VAN DUN dat het de taak is van de jurist recht en onrecht te onderscheiden met dezelfde mate van verantwoordelijkheid die de arts draagt ten aanzien van het verschil tussen gezondheid en ziekte: ${ }^{297}$

\footnotetext{
${ }^{{ }^{H}}$ Het eerste argument dat [rechten-] studenten gebruiken, is: het is $z \mathrm{O}$, want $\mathrm{zo}$ staat het in de wet. Voor mij ligt de scheidslijn niet tussen wettig en niet-wettig, maar tussen recht en onrecht. Wetten kunnen net zo goed onrechtmatig zijn als andere teksten. Het zou dus nuttig zijn juristen op hun verantwoordelijkheid als jurist te wijzen: bij jullie moet het gaan om het onderscheid recht en onrecht, zoals een geneesheer verantwoordelijkheid draagt ten opzichte van gezondheid en ziekte"."
}

Uiteraard is met het hier betoogde niet gezegd dat er geen (beroepsmatig in acht te nemen) onderscheid zou bestaan tussen recht en moraal. Ontkend wordt slechts dat tussen beide een principieel, een wetenschappelijk/filosofisch houdbaar, laat staan een absoluut onderscheid zou bestaan. Daarmee dient zich de vraag aan van de precieze verhouding tussen recht en moraal. MEUWISSEN merkt in dit verband op: ${ }^{298}$

297 Jacques HERRAETs, "Aardse paradijzen, niet te genieten!" Interview met rechtsfilosoof Frank VAN DUN, Continu-UM (Kwartaablad van de Universiteit Maastricht) $1998 / 1$, pp. $31-34$, op p. 34 .

$\mathrm{Na}$ de aangehaalde woorden vervolgt de interviewer: 'Veell juristen zien zich graag als gidsen in het oerwoud van regels en procedures, maar wat hun werk te maken heeft met het onderscheid tussen recht en onrecht, zien ze niet. Volgens VAN DUN heeft dat te maken met het gebrek aan zicht op de realiteit: "Ze zijn van mening dat recht en onrecht puur conventionele zaken zijn: het recht is zo omdat het zo wordt toegepast"."

298 D.H.M. MEUWISSEN, Grondslagen van rechtsfilosofie, Deventer 1997, pp. 158-163 ('Polaire structuur van het recht'), respectievelijk op pp. 158/159 en 160. 
'Er is wel betoogd dat het recht een polaire structuur vertoont, dat wil zeggen dat het in zich een spanning bevat tussen de rechtsidee (inhoud) aan de ene kant en vorm (formele structuur) aan de andere kant. Deze benadering spreekt ons aan en we zeggen dan ook dat aan de ene kant de rechtsidee staat (de inhoud of het doel van het recht) en aan de andere kant het juridisch instrumentarium (wetgeving, rechtspraak) staal met behulp waarvan de rechtsidee kan worden verwerkelijkt. Dit houdt in dat het positieve recht mér is dan hetgeen we in wetten of arresten kunnen lezen. Deze positiefrechtelijke verschijnselen zijn uitdrukking van een bovenpositief beginsel. Daaraan ontleent het positieve recht zijn "rechtszin." Daarin ligt ook het criterium waarmee de kwaliteit van het recht kan worden beoordeeld. (...)

We hebben al gezien dat het kenmerkend is voor het rechtspositivisme (KELSEN, HART) het recht in zijn geheel tot [de formele pool, jw] te reduceren. De andere [de materiële pool, $j w]$ word $[t]$ "genegeerd" of buiten het positieve recht gehouden (ze word[t] als het ware "buitengesloten"), met het veelal rampzalige gevolg dat ze zich toch - via een omweg - la[at] gelden. (...)."

Rechtspositivisten pogen moraal en recht, bij definitie, waterdicht af te scheiden, sed frustra (in dwaling, tevergeefs). In het natuur-, of zo men wil cultuurrechtsdenken daarentegen, is de ethiek het onderliggende, het 'het geheel dragende beginsel. ${ }^{299}$ Aldus wordt (in de woorden van de auteur) ${ }^{300}$...

'(...) tot uitdrukking gebracht dat aan het recht ook een ethische zijde aanwezig is. Er gelden in dit opzicht bepaalde normen of beginselen, welke voor het recht inhoudelijk relevant zijn. (...) Daarmee wordt gesteld dat recht en ethiek niet scherp van elkaar mogen worden gescheiden (al vallen recht en ethiek zeker niet samen)."

Wij zouden het natuurrecht willen voorstellen als membraan (semipermeabele wand) tussen moraal (gerechtigheid/rechtvaardigheid/rechtsidee) en (volken)recht. Door het relatieve gewicht (overdruk) van morele beginselen is het membraan meer of minder doorlaatbaar. Door zelfs maar een minimale membraan-werking (osmose) tussen moraal en recht te erkennen, wordt de rechtsidee gered voor het volkenrecht. Wij bepleiten dus een membraneuze voorstelling van natuur- en volkenrecht (ter adstructie van de osmotische werking tussen recht en moraal).

Aangezien het woord natuurrecht evenwel een beladen, zo niet belaste term is voor veel rechtswetenschappers (voor het woord cultuurrecht geldt dat vermoedelijk in mindere mate, doch daar staat tegenover dat slechts weinigen met die term vertrouwd zijn), stellen wij voor dit 
woord te vervangen door het woord (rechts) beginselen (waaronder fundamentele mensenrechten een bijzondere plaats innemen) ${ }^{301}$ In een beginselgerichte en beginselgeleide visie spelen (rechts)beginselen niet alleen een grote rol, zij zijn tevens het (chirurgisch) instrument waarmee moraal en ideaal tot het recht kunnen doordringen, afhankelijk van het relatieve gewicht van de moreel-ideële argumenten en de kracht van de moreeljuridische argumentatie. $\mathrm{Bij}$ een regelgerichte en regelgeleide attitude zal aan (rechts)beginselen die niet enigermate zijn gejuridiseerd/geoperationaliseerd, nauwelijks of geen betekenis of gewicht (kunnen) worden toegekend. In een positivistische optiek is dit zelfs per definitie onmogelijk. Maar ook bij een niet strikt- of formeel-positivistisch regelgerichte en regelgeleide beroepshouding ("neo-legisme') komt men door het nauwe beroepsfocus (op de regel in plaats van op het beginsel) aan (binnenjuridische) moreel-kritische reflectie niet toe. (En toegegeven moet worden dat dit binnen sommige technisch hoogontwikkelde rechtsgebieden ook zelden nodig zal zijn, te meer niet waar de positivist - of neo-legist binnen zo'n gebied slechts, zij het tot op ontzagwekkende diepte, enkele super-specialistische vierkante centimeters bezet.)

In dit licht willen wij het specifieke karakter zien van het (natuurlijk-positieve) mensenrechtenrecht (in het bijzonder met betrekking tot de rechten van het kind: het kindervolkenrecht) als recent tot ontwikkeling en bloei gekomen dimensie van het grotiaanse allermensenrecht, naast en dwars door de traditionele dimensie van het (positief-natuurlijke/-volitieve) volkenrecht. VAN BOVEN heeft onlangs, refererend aan de oratie van HIRSCH BALLIN, de term 'het recht der wereldburgers' laten vallen. De geest van wat wij onder 'allermensenrecht' verstaan, is fraai gevangen in de volgende passage, die wij hier aanhalen enerzijds om niet te hoeven volstaan met enkel een verwijzing naar wat wij over dat recht te berde brachten in paragraaf 13.2.1, anderzijds omdat zij uitmondt in de polariteit van ideaal en werkelijkheid die het onderwerp van deze (sub-) paragraaf is, een polariteit die in onze visie inherent is aan het recht, een polariteit waarvan de jurist zich steeds rekenschap dient te geven. In de eerste MULTATULr-lezing (1996) sprak VAN BOVEN de woorden: ${ }^{302}$

In zijn mooie Tilburgse oratie van begin maart 1995, getiteld Wereldburgers: personen in het intemationale recht, grijpt HIRSCF BALLIN terug op het oude jus gentium als een recht dat over de grenzen heenreikt en dat een inspiratiebron is woor het jus gentium van onze tijden, het recht dat aan mensen toekomt niet in

302 Theo VAN BOVEN, 'De ontmoeting met de ander,' in dez. en Hugh LEWIN, Natie, migratie, integratie, Eerste MulTATUli-lezing (Breda), Den Bosch 1996, pp. 8-26, op pp. $20,21 / 22$ en $23 / 24$. 
hun hoedanigheid van staatsburgers maar qua mensen of, zo men wil, qua wereldburgers. (...)

Er wordt thans algemeen erkend dat er dwingende normen van recht bestaan, genoemd jus cogens, die staten niet naar believen opzij kunnen zetten; [ermee strijdige afspraken mogen zij, op straffe van nietigheid, niet maken]. Het betreft hier dwingende voorschriften als het verbod van volkerenmoord, het verbod van agressie, het recht op zelfbeschikking van volken, het verbod van slavernij en soortgelijke voor de mensheid fundamentele rechtsnormen. Deze normen staan boven de staten, perken de soevereiniteit van staten als hoogste rechtsmacht in, en rechtvaardigen, in geval van schending van die normen, ingrijpen vanwege de internationale gemeenschap. Natuurlijk bestaan er ook verdragen en afspraken die eveneens de soevereiniteit wan staten inperken, maar deze verdragen en afspraken berusten op expliciete aanvaarding door staten en niet per se op boven de staten verheven normen. Evenwel, naarmate staten op steeds grotere schaal verdragen en afspraken expliciet aawvaarden, rechtsnormen bevattend welke essentieel zijn voor de bescherming van de fundamentele belangen van de internationale gemeenschap, bijvoorbeeld op het gebied van mensenrechten (...), breidt het moderne jus gentium zich uit en daarmee de plicht van gezagsdragers en machthebbers om zich te verantwoorden, nationaal en internationaal. (...)

De zojuist aangeduide ontwikkeling naar erkenning van normen van recht en gerechtigheid die boven de staten (...) uitreiken, (...) vertegenwoordigt een visie die niet verwerkelijkt kan worden zonder de inzet van vele mensen en organisaties, nationaal en internationaal. In de afgelopen decennia zijn tal van organisaties en groeperingen in alle continenten van de grond gekomen die opkomen voor de rechten van mensen, vrouwen, kinderen (...). In het verleden [VAN BOVEN, Opdat mensen tot hun recht komen, DOM HELDER CAMARA-lezing, 1984] heb ik deze organisaties en groeperingen wel eens betiteld met de [term] "derde macht," ter onderscheiding van de "eerste macht," [namelijk] regeringen, en van de "tweedle macht," [namelijk] de transnationale ondernemingen.. Langs dezelfide lijnen heeft de Zwitser Marc NERFIN ervoor gepleit de Algemene Vergadering der Verenigde Naties uit drie kamers te laten bestaan: "une chambre des princes" (regeringen), "une chambre des commerçants" (ondernemingen) en, als derde kamer, "une chambre des citoyens" (de derde macht). Het is juist deze derde macht die affiniteit vertoont met het recht der wereldburgers en die de eerste en de tweede macht moet blijven pousseren. De machten van ideatal en van werkelijkheid hebben elkaar nodig."

\section{De huidige stand van het internationale recht}

Keren wij ons evenwel om, weg van deze woorden, staan wij voor een ogenblik met de rug naar de toekomst, maar turen wij evenmin in de geschiedenis, in de voltooid verleden tijd, kijken wij niet verder dan tot de einder van het hier en nu - en dat is op deze plaats, in dit hoofdstuk, onze plicht, al is het niet onze gehele plicht -, dan moeten wij constateren dat, naar de huidige stand van het internationale recht, krachtens de dominante positivistische volkenrechtsdoctrine, het een kunstfout zou zijn te beweren dat de Nederlandse staat zich ten aanzien van kinderen schuldig maakt aan (ernstige en) systematische mensenrechtenschendingen. Het 
heeft, strikt juridisch gesproken, weinig zin ons hier aan een voorspelling te wagen op welk moment in de toekomst het geen brug te ver zal zijn de staat die zijn verplichtingen onder het Verdrag inzake dle rechten van het kind niet veel serieuzer neemt en een veel centralere plaats geeft in zijn (gezins)beleid dan thans het geval is, wèl met (positief) recht dat verwijt te maken.

Groot juridisch-feitelijk (rechtssociologisch) probleem daarbij is immers dat 'het belang van het kind' nog steeds, ondanks alle richtinggevende verdragsbepalingen, te zeer als een emotioneel/moreel geladen (als moreel gevoeld) begrip - zo men wil als morele metafoor - in plaats van als moreel/juridisch operationeel beginsel (dat is als rechtsbeginsel) wordt ervaren en gehanteerd. ${ }^{303}$ Het is (mede) om die reden dat wij hebben gepoogd 'het belang van het kind' - dat is het veiligheids- en het ontwikkelingsbelang van het kind - te vertalen in (het rechtsbeginsel van) het recht van het kind op optimale persoonswording.

Tweede groot juridisch-feitelijk (rechtspsychologisch/-sociologisch) probleem is de parentiarchale lading van het privacy-beginsel, waardoor privacy wordt ervaren als louter negatief (klassiek) rechtsbeginsel, ziende op negatieve vrijheid in de vorm van een staatsvrije (en 'medeburgersvrije') sfeer (het 'individualistische "right to be let alone"'), 304 in plaats van als tevens positief (sociaal, in casu sociaal-pedagogisch) beginsel: als recht op positieve vrijheid, op ontplooiing (cognitief, cultureel, sociaalemotioneel), op geestelijke gezondheid(szorg), op persoonlijke groei, ${ }^{305}$ op optimale persoonswording (die immers niet ophoudt op achttienjarige leeftijd). ${ }^{306}$ Pas wanneer privacy wordt gezien als klassiek èn sociaal be-

303 Vgl. ALEXANDER, bespreking van De Siamese tweeling; Recht en moraal in de biomedische praktijk (1994), in: Recht en kritiek 1997/3, t.a.p., op p. 268 r.k.

304 (Vgl.) ALEXANDER, t.a.p., op p. 273 l.k.

305 Dat wil zeggen op de essentiële sociale randwoorwaarden om - door hard werken - in het reine te komen met de trauma's, de angsten en de frustraties van het leven. Met andere woorden het gaat bij 'persoonlijke groei' juist niet om, ja bijna om het tegendeel van 'de utopische notie wan bevrijding als gewaarborgde bevrediging van iedere behoefte en wens' (CROMBAG en VAN DUN, De utopische verleiding, a.w., p. 174).

306 Een variant op vrijheid als ruim, mede-positief begrip, komen we tegen bij VAN BOVEN (Th.C. VAN BOVEN, De volkenrechrelijke bescheming van de godsdienstvrijheid, diss. Leiden, Assen 1967, p. 82; curs. jw), die tot étn van de (minimaal) vier rechten die vallen onder 'het begrip rechten van de mens in het Handvest [van de VN],' rekent (naast het recht op leven, het recht op godsdienst- en gewetenswrijheid en 'het recht op gelijkheid voor de wet en om gewrijwaard te zijn van discriminatie'): 'het recht op vrijheid, inclusief het recht op de integriteit van de persoon.' Opmerkelijk is dat het Handvest ten aanzien van dit recht (evenals ten aanzien van het recht op leven en het techt op godsdienst- en gewetenswrijheid) 
ginsel, ziende op negatieve èn positieve vrijheid, komt de horizontale betekenis en werking ervan, de betekenis en werking in de onderlinge verhoudingen tussen burgers, mannen en vrouwen, ouders en kinderen, duidelijk in beeld. Dan rijzen vanzelf vragen als (om ALEXANDER te parafraseren): ${ }^{307}$ wat te doen bij botsing van de (ontplooiings)vrijheid van de ouder(s) en het (persoonswordings)recht van het kind? En: $:^{308}$

'[H]oe weegt de rechter de verschillende vrijheidssferen tegen elkaar af; kan een derde iemands "vrijheid tot" invullen ....'

Tussen mannen en vrouwen zal hier, evenals tussen auto- en allochtonen, afgezien van te redresseren achterstandssituaties en te repareren historisch onrecht, sprake zijn van afweging van in beginsel gelijkwaardige belangen. Tussen ouders en kinderen zal het concrete antwoord op de aangehaalde vragen gevonden moeten worden enerzijds door de persoonswording van het kind voorrang te geven (art. 3, lid 1 juncto art. 18, lid 1 VRK), anderzijds door voorrang te geven aan de ouderlijke opvoedingsverantwoordelijkheid boven een te vroege of te ver gaande vrijheidsdrang van het (oudere) kind (art. 5 en art. 14, lid 2 VRK).

Doch ook in de verticale relatie, de verhouding overheid-ouders, of liever de verhouding tussen overheid en ouders-en-kinderen, zet privacy als klassiek-sociaal beginsel bepaalde verdonkeremaande, verduisterde zaken in het volle licht, zaken die 'het recht om alleen gelaten te worden' aanvullen met rechten op actieve overheidsbemoeienis, actieve overheidszorg in de sociaal-pedagogische sfeer.

Wat er verder van beide (juridisch-feitelijke) problemen - en hun mogelijke 'oplossingen' - zij, het relatieve stilzitten - met inbegrip van het (veel) te laat en averechts (stigmatiserend) actief worden (palliatief Kurieren am Symptom ofwel ex post-interventionisme) - van de overheid, van de staat, tegenover een (zéér) omvangrijke en (buitengewoon) ernstige mensenrechtelijke problematiek als kindermishandeling, kan, met name in het licht van de systemisch (sociaal-pedagogisch/transgenerationeel) discriminatoire dimensie daarvan, wel reeds thans - en moet dan ook - als een ernstige en passief-systematische mensenrechtenschending worden ge(dis)kwalificeerd. Verre van een brug te ver te zijn, wekt het verbazing dat het juridisch forum deze brug niet al lang heeft veroverd en

enkel declaratoir is: het recht op vrijheid/integriteit van de persoon was al geldend recht (dat wil zeggen: maakte reeds 'deel uit van het algemene volkenrecht') vór het Handvest, dat overigens wel constitutieve betekenis heeft ten aanzien van het gelijkheidsrecht (a.w., pp. 82/83). 
in groten getale overschreden. Toekomstige generaties zullen zich hierover waarschijnlijk net zozeer verbazen als over de decennia-lange juridische zwijgzaamheid ten aanzien van de nucleaire (over)bewapening. Troost kan worden geput uit het feit dat, toen die zwijgzaamheid eenmaal was doorbroken, een stroom van publicaties het licht zag, welke het advies van het Internationaal Gerechtshof (mede) heeft mogelijk gemaakt, waarin de Wereldrechter de algemene onrechtmatigheid van het dreigen met of gebruiken van kernwapens uitspreekt - met slechts een (diplomatiek?) non liquet voor een extreme uitzonderingstoestand, voor welke de rechtmatigheid of onrechtmatigheid in het midden wordt gelaten. ${ }^{309}$

We herhalen onze conclusie: ook in juridische zin kunnen, en bijgevolg moeten we stellen, dat kindermishandeling in Nederland een ernstige en passief-systematische mensenrechtenschending is, waarvoor de staat zijn aansprakelijkheid niet kan ontgaan. Immers tot GROTIUS' vier hoekstenen (c.q. vijf rechtspostulaten) behoorde 606 , en zeker niet in de

309 ICI, Legality of the threat or use of nuclear weapons, Advisory opinion 8 julli 1996, par. 105 sub 2E; HRLJ 1996/7-10, pp. 253-269, op p. 269 1.k.

STELLING noemt het advies van het Hof 'van buitengewoon groot belang': 'Het Hof concludeerde dat het dreigen met en het gebruik van kernwapens in het algemeen in strijd is met (....) de beginselen en regels van humanitair recht. Met. dit oordeel heeft het Internationaal Gerechtshof de bodem weggeslagen onder de zienswijze van de nucleaire mogendheden en hun bondgenoten. Die zienswijze, dat kernwapens in voorkomend geval als rechtmatig geweldsmiddel kunnen worden gebruikt, werd door het Hof van tafel geveegd. Uitdrukkelijk heeft het Hof in zijn rechtsoverwegingen aangegeven dat geen van de staten die de rechtmatigheid van het gebruik van kernwapens in bepaalde omstandigheden bepleitten, heeft aangegeven wat de precieze omstandigheden zijn die zulk gebruik zouden rechtwaardigen."

Niet onbelangrijk met het oog op zijn rechtsherstel als voormalig officier-jurist is zijn volgende conclusie: "Het oordeel van het Internationaal Gerechtshof is van grote politieke en juridische betekenis. Politiek, omdat het oordeel duidelijk maakt dat staten niet gerechtigd zijn vast te houden aan een rol voor kernwapens in hun buitenlandse politiek en hun militair-strategische plannen. Juridisch, omdat het oordeel op ondubbelzinnige wijze aangeeft dat het gebruik van kernwapens in beginsel onrechtmatig is. Dit betekent dat in procedures waarin een beroep wordt gedaan op de onrechtmatigheid van het gebruik van kerwapens, de vermeende rechtmatigheid dient te worden bewezen. Met andere woorden: er is een omkering van de bewijslast ten nadele van de regeringen die de rechtmatigheid van het gebruik van kernwapens bepleiten. Dergelijke procedures zijn en worden in diverse landen gevoerd, waaronder (...) Nederland." (M.J.F. STELLING, "Woord vooraf,' in: N.M.P. STEINNEN, M.J.F. STELLING (red.), Rechmatigheid van kemwapens? De rechtmatigheid van de bedreiging met of het gebruik van kemwapens; uitspraak van het International Gerechtsh of van 8 juli 1996; vert. L.J. REINDERS en B.J. VERHEIJ, Stichting Tribunaal voor de Vrede, [Amsterdam] 1998, pp. 7-8.) 
laatste plaats: de verplichting tot het - te goeder trouw (bona fides) nakomen van zijn beloften (pacta sunt servanda). Een hoeksteen die thans hoofdpijler, ja fundament van het verdragenrecht en het (Weens) Verdragenverdrag (art. $26 \mathrm{WVV}$ ) is. Te goeder trouw, bona fide, dat wil zeggen (art. $4 \mathrm{VRK}$ ): met inzet van alle (kennis, financiële en andere) middelen die de staat ter beschikking staan.

In de nu volgende (slot-sub)paragraaf passeren nog enkele juridische overwegingen en instrumenten die in dit verband van belang zijn, de revue alvorens we deze gehele paragraaf (par. 13.4) met een eindconclusie pogen af te sluiten.

\subsubsection{Staatsaansprakelijkheid en overheidsverantwoordelijkhe- den: een grijze zone}

Het rechtsgebied van de internationale mensenrechten kent verschillende grijze zones. Eén daarvan, die paalt aan de status (ofwel rechtskracht) van mensenrechtelijke instrumenten, is als volgt door VAN BOVEN gekenschetst: ${ }^{310}$

[N]o clear divisions exist between legal instruments (treaties) in the field of human rights and political (policy) human rights documents. All these texts serve the purpose of setting out norms and of establishing accountability on the part of the States concerned.'

Een andere betreft het onderscheid tussen de door de auteur genoemde term accountability en de term (state) responsibility, tussen staatsaansprakelijkheid en (staats)verantwoordelijkheid. Ook hier stuiten we op een gebrek aan juridische duidelijkheid. Zoals de auteur elders, in een boekbespreking, stelde: $:^{311}$

'(...) [KAMMINGA] correctly observes that " $[\mathrm{t}]$ he notion of inter-state accountability for violations of human rights has nowhere been formally enshrined as a concept of general international law." It appears, therefore, that this notion of accountability lacks sufficient precision so as it make it legally operational.'

310 Theo VAN BOVEN, 'General course on human rights,' in: The protection of human rights in Europe, Collected Courses of the Academy of European Law, Vol. N, Book 2, 1993, The Hague (etc.) 1995, pp. 1-106, op p. 36.

311 Theo VAN BOVEN, bespr. van Menno T. KAMMINGA, Inter-state acconntability for violations of human rights (1992; diss. Leiden 1990), Human Rights Quarterly $1992 / 4$, pp. $561-567$, op p. 562 . 
De besproken auteur zegt zelf over deze notie (KAMMINGA 1990): ${ }^{312}$

"[A]ccountability for violations of human rights is not restricted to "acts contrary to international law" but extends also to acts contrary to (non-binding) international human rights standards.'

Hetgeen ons weer terugbrengt bij de grijze zone van de status, de rechtskracht, de precieze juridische verbindendheid van mensenrechtelijke instrumenten, een grijze zone die met de weke term 'soft law' de hardheaded jurist tot kloek wijken nodigt. Waarbij hij echter (niemand minder dan) SIMMA op zijn pad vindt: ${ }^{313}$

"(...) I consider it not really state of the art jurisprudentially to regard "soft law" as "legally non-binding," especially in a field like international human rights where the use of "soft law" for defining the precise content of hard law is more the rule than the exception.'

In deze subparagraaf wagen wij ons in het grijze gebied tussen (juridische) staatsaansprakelijkheid en (rechtspolitieke) staatsverantwoordelijkheid - ofwel overheidsverantwoordelijkheden -, niet zozeer 'inter-state' als wel ten opzichte van individuen, burgers, ouders en kinderen. Zonder over deze laatste - de modaliteiten van staatsverantwoordelijkheid - uit te weiden (dat gebeurt in hoofdstuk 14), willen we nog enkele (normen uit diverse) instrumenten langslopen. Daarmee wordt enerzijds beoogd de (positiefrechtelijke) hardheid dan wel zachtheid van onze conclusie aangaande (staatsaansprakelijkheid ter zake van) ernstige en passief-systematische mensenrechtenschendingen zowel te nuanceren als meer reliëf te geven, en anderzijds een beeld te schetsen van de (proto- en praeterjuridische) invulling die in diverse instrumenten reeds aan de (persoonswordings)rechten van het kind, en dus aan overheidsverantwoordelijkheden ten opzichte van (ouders en) kinderen, is gegeven.

Een en ander willen we inleiden met enkele (nadere) juridische overwegingen. Om te beginnen zouden we een parallel willen trekken tussen raciale en transgenerationele (c.q. sociaal-pedagogische) syste-

312 Menno T. KAMMINGA, Inter-state accountability for violations of human rights, diss. Leiden 1990 , p. 193.

313 Bruno sIMMA, 'International human rights and general international law: a comparative analysis,' in: The protection of human rights in Europe, Collected Courses of the Academy of European Law, Vol. IV, Book 2, 1993, The Hague (etc.) 1995, pp. $153-236$, op pp. $234 / 235$. 
mische discriminatie-structuren. Met betrekking tot de eerste categorie heeft VAN BOVEN opgemerkt: ${ }^{314}$

"Victims of racial discrimination are entitled, individually and collectively, to effective measures of profection as well as to remedies and, as the case may be, to affirmative action in the economic, social and political fields in order to repair and to make up for the adverse and often degrading and disgraceful situation in which they find themselves.'

Wij zouden dit willen vertalen naar slachtoffers van kindermishandeling. Affirmative action (positieve maatregelen, voorrangs- of voorkeursbeleid) is een antwoord op discriminatoire patronen, op historisch onrecht, en is als zodanig bepleit (en wordt gepraktizeerd) ten aanzien niet alleen van kleurlingen/zwarten/allochtonen (lees: natuurlijk-gepigmenteerden) doch ook ten aanzien van vrouwen. ${ }^{315}$ Beide categorieën worden immers geconfronteerd met wat VAN BOVEN, even verderop in zijn bijdrage, "structures with built-in forms of discrimination' noemt. ${ }^{316}$

Wij zouden hier op de parallel willen wijzen met in niet mindere mate aanwezige en hardnekkige 'structures with built-in forms of child abuse,' op structureel, systemisch ingebouwde vormen van kindermishandeling, dat wil zeggen ingebouwd en ingebakken in de stelselmatige politieke en feitelijke onverschilligheid en nalatigheid van overheid en samenleving ten aanzien van pedagogische ouder-kind-verhoudingen in het algemeen en ten aanzien van (transgenerationeel) sociaal-pedagogisch gedepriveerden in het bijzonder. We doelen dan - met het begrip systemisch - op (de ideologie en praktijk van) de privacy-cultuur, in internationaalrechtelijke 'feministische' literatuur wel aangeduid als 'publiekprivé-dichotomie.' Eén van de (vele) auteurs op dit gebied willen we op deze plaats aanhalen (CASS 1992): $:^{317}$

"It is clear that the alleged dichotomy between private and public, between the privacy of the family and the public domain of the state and its instrumentalities,

314 Theo VAN BOVEN, 'Combating racial discrimination in the world and in Europe,' Netherlands Quarterly of Human Rights 1993/2, pp. 163-172, op p. 165 (curs. jw).

315 Nog steeds lezenswaardig in dit verband: Derek L. PHILLIPS, "De rectificatie van onrechtvaardigheid; het geval van Surinamers en Antillianen in Nederland," Beleid en Maatschappij 1982, pp. 129-137; dez., 'Voorkeursbehandeling voor vrouwen: enige sociologische en morele overwegingen," De Gids 1979/1, pp. 3-27 (ook te vimden in: dez, De naakte Nederlander, Amsterdam 1985, pp. 134-169; 253-262).

316 VAN BOVEN, t.a.p., op p. 166.

317 Bettina CASS, 'The limits of the public/private dichotomy (...),' in: Philip ALSTON e.a. (eds.), Children, rights and the law, Oxford 1992, pp. 140-147, respectievelijk op pp. 141, 142 en $142 / 143$. 
is challenged fundamentally when the principle of "protecting the best interests of the child" is interposed between these two apparent polarities. (...) One of the possible interpretations of the Convention [on the Rights of the Child] (...), is its fundamental questioning of the family/state dichotomy (...).(...)

What the Convention does is firstly to question the public/private dichotomy; secondly, and even more fundamentally, to disaggregate the rights of children from the rights of "families," to constitute children as independent actors with rights vis-d-vis their parents and wis-d-vis the state. (...) [T] he so-called "right to privacy" (...) is no more than a protection of patriarchal rights to maintain rellations of inequality and dominance under the guise of family inviolability.'

Wij zouden hier de volgende kanttekening bij willen maken. Het Verdrag inzake de rechten van het kind staat haaks op de 'gewoonterechtelijke' onverschilligheid en nalatigheid die inherent is aan de privacy-cultuur en die deze cultuur tot een privacy-systeem heeft gemaakt. In die zin is het Verdrag een (intrinsieke, 'holistisch-totale') oorlogsverklaring aan die cultuur en dat systeem. Dit achten wij geen mogelijke ('one of the possible interpretations') doch een noodzakelijke en onvermijdelijke uitleg van het Verdrag. Onder de werking van het principe van effectiviteit (principle of effectiveness, de interpretatiemaxime ut res magis valeat quam pereat) is geen andere uitleg mogelijk. Elke andere uitleg zou immers afbreuk doen aan inhoud en strekking, bedoeling en betekenis van het Verdrag. De traditie, de culturele gewoonte, de maatschappelijke praxis, de interne statenpraktijk moet hier wijken voor de ratio van het Verdrag, de ratio van de rechten van het kind: optimale persoonswording. Om met paus Gregorius vIr (1021-1085) te spreken: ${ }^{318}$

'Indien $U$ wellicht wilt tegenwerpen dat er een hiermede strijdige regel van gewoonterecht bestaat, dient men te bedenken dat de Heer zegt: "Ik ben [de weg,] de waarheid en het leven" [Joh. 14:6]. Hij heeft niet gezegd: "Ik ben de gewoonte," maar de waarheid. En natuurlijk dient (om een zin van de zalige Cyprianus te gebruiken) iedere gewoonte, hoe oud en hoe wijd verspreid ze ook is, bij de waarheid ten achter te worden gesteld, en een gebruik dat in strijd is met de waarheid, dient te worden afgeschaft."

De auteur aan wie ik dit ontleen, voegt aan deze woordlen toe (ZWALVE 1993): $:^{319}$

'Zo introduceerde het canonieke recht de regel dat een slechte gewoonte geen recht maakt: pravum usum ratio vincat, "de rede prevaleert boven de gewoonte"

318 Aangehaald door W.J. ZWALVE, Hoofdstukkern uit de geschiedenis van het Europese privaatrecht, deel I (Inleiding en zakenrecht), Groningen 1993, p. 36. 
[letterlijk: de rede prevalere boven de slechte gewoonte, jw]. Door op deze wijze het gewoonterecht ondergeschikt te maken aan de rede [dat wil zeggen: aan het rechtsbeginsel van de redelijkheid en billijkheid, jw], onderstreepte het canonieke recht het allesoverheersend belang van het natuurrecht, dat volgens de canoniekrechtelijke bronnenleer de primaire rechtsbron is (....)."

Zonder een beroep te doen op het natuurrecht, kunnen wij direct naar de ratio, de raison d'être van het Verdrag inzake de rechten van het kind, verwijzen. Bovendien behoeft het geen betoog dat ten aanzien van de publiek-privé-dichotomie, ofwel de privacy-cultuur c.q. het privacy-systeem, niet van gewoonterecht sprake is doch slechts van een - slechte gewoonte, een de facto statelijke onthoudingspraktijk. Geen rechtsregel, ook geen gewoonterechtsregel noopt of noodt de staat een situatie van grove mensenrechtenschendingen, van - om de terminologie van het Verdrag van Amsterdam te bezigen ${ }^{320}$ - 'een ernstige en aanhoudende schending van fundamentele rechten en vrijheden,' in stand te houden. Ook niet, juist niet als deze situatie de meest weerlozen in de samenleving, jonge en zeer jonge kinderen, betreft. Ook niet, juist niet als het een categorie betreft wier leden, noch nationaal noch voor het Europees Parlement, een stem kunnen uitbrengen.

We noteren - in het licht zowel van Nederlands verdragsverplichtingen als van een situatie in Nederland van ernstige en aanhoudende schending van fundamentele rechten - het volgende: Er is een statelijk tekort aan due diligence, aan due care met betrekking tot de persoonswording van het kind; en wel een ernstig tekort: er is sprake van een bestendig patroon van onvoldoende/ontoereikende/inadequate steun aan en toezicht op opvoeders van (jonge) kinderen; een ernstig tekort zowel in het recht (wat het juridisch statuut betreft) als in de praktijk (die palliatief, marginaal en marginaliserend is). Op grote schaal is er (feitelijk) geen effectieve bescherming terwijl verschillende maatregelen mogelijk en denkbaar zijn, zowel. in algemeen-preventieve zin, als met betrekking tot risicogroepen/-situaties, als met betrekking tot reparatie/rehabilitatie (secundaire/tertiaire preventie). ${ }^{321}$

320 Vgl. R. BARENTs, 'Het Verdrag van Amsterdam: een eerste indruk,' Nederlands Juristenblad 1997 , pp. 1261-1268, op p. 1263 l.k.

321 We vermelden het slechts in een voetnoot: van een recht op reparatie van volwassen 'survivors' (voormalige slachtoffers van kindermishandeling) is in Nederland, bij mijn weten, nog nooit iets vernomen. Hier kan evenwel van secundaire staatsaansprakelijkheid sprake zijn. Om de woorden van VTTÁNYI (B.K.J. VTTÁNYI, Intemationale aansprakelijkheid van staten voor hun rechtsbedeling, Afscheidscollege KU Nijmegen 1983, p. 12) te gebruiken: 'De bron van de [zogenaamde] indirecte of secundaire aansprakelijkheid is de passieve houding der autoriteiten ten opzichte van het naleven der volkenrechtelijke verplichting die het verschaffen 
We noteren - in het licht zowel van Nederlands verdragsverplichtingen als van een situatie in Nederland van ernstige en aanhoudende schending van fundamentele rechten - tevens dit: Er is onvoldoende toezicht op (de bekwaamheid en de werkomstandigheden van) hulpverleners/kinderbeschermers; onvoldoende capaciteit(suitbreiding) en deskundigheid(sbevordering); onvoldoende richting en leiding ten aanzien van interventie (in de ruime zin van het gericht aanbieden en zo nodig opleggen van opvoedingshulp). Er is (nog steeds) geen wettelijke meldplicht, of althans een niet-vrijblijvende, tot niets verplichtende meldcode (met het juridisch statuut en de rechtswaarborgen die daarbij horen).

Dit alles terwijl art. 4 wan het Verdrag inzake de rechten van het kind een zeer hoge, een bijna maximale ${ }^{322}$ standard of care ${ }^{323}$ aanlegt. Dit alles terwijl bepaalde (transgenerationeel kwetsbare) groepen hiervan in onevenredige mate de dupe zijn. Om die reden is er sprake van (systemische) schending van het gelijkheids- en het ontplooiingsbeginsel (dat is het positieve vrijheidsbeginsel als emancipatie-, en meer specifiek als per-

van reparatie voorschrijft aan [degenen, jw] op wier rechten door particuliere personen inbreuk werd gemaakt.'

Aldus opgevat impliceert kindermishandeling niet alleen een 'cyclus van geweld' (althans een 'cyclus van onveilige gehechtheidsrelaties') maar ook een 'cyclus van staatsaansprakelijkheid.'

322 We kunnen zelfs spreken van een maximale standaard als we in aanmerking nemen dat het hier om kernrechten gaat met een gemengd klassiek en sociaal karakter. Voor wat dat laatste betreft, verwijzen we naar de opvattingen van het Comite inzake de rechten van het kind, die - in de woorden van MIJNARENDS uitgebreid zijn weergegeven in de slot-('addendum'-)paragraaf van hoofdstuk 10 . Voor wat het budget-onafhankelijke (en in die zin maximaal verplichtende) karakter van (bodem- of minimale) kernverplichtingen betreft, verwijzen we naar par. 9 (Minimum core obligations) van The Maastricht guidelines on violations of economic, social and cultural rights (NJCM-Bulletin 1997/5, pp. 569-576; NQHR 1997/2, Appendix I., pp. 244-252), waarvan de slotzin luidt: '(.... [M]inimum core obligations apply irrespective of the availability of resources of the country concerned or any other factors and difficulties."

$\mathrm{Vgl}$. in dit verband ook par. 15 (Violations through acts of omission) van de Maastricht guidelines, in het bijzonder onder (e): "The failure to utilize the maximum of available resources towards the full realization of the Covenant.'

In het licht van art. 4 van het Verdrag inzake de rechten van het kind en de opvattingen dienaangaande van het Comité kan worden gesteld dat de Maastricht guidelines (althans de hier aangehaalde paragrafen) a fortiori op dat Verdrag van toepassing zijn.

Vgl. Theodor MERON, Human rights and humanitarian noms as customary law, Oxford 1989, p. 164 (aangehaald in par. 13.2.2.2). Vgl. ook a.w., pp. 169 (principle of effectiveness in verband met 'private action') en 171 ("the critical question," namelijk, voor zoveel hier van belang: heeft de staat al of niet geschikte preventiemaatregellen genomen?). 
soonswordingsbeginsel). Om die reden verdient Nederland het - om met KO te spreken - 'aan de schandpaal van het recht te worden genageld' wegens het niet voldoen aan zijn verplichtingen. ${ }^{324}$ Verplichtingen - op grond van verdragen en het algemene volkenrecht - ter zake van het respecteren en bevorderen van fundamentele mensenrechten, rechten die elk mens beogen te vrijwaren van onmenselijk door mensen toegebracht lijden. SACHS heeft opgemerkt: ${ }^{325}$

"Torture is the greatest violation of human rights. It is intended to subjugate the human being by the infliction of pain, to humiliate, degrade and to strip the victim of any sense of dignity or rights. International instruments rightly give high priority to the prohibition of torture or cruel, inhuman or degrading punishment or treatment. Yet, the prohibitions in these instruments refer only to torture practised by agents of the state acting in the name of public authority. They do not refer to the systematic torture of human beings which takes place on a massive scale in all societies in the private sphere. Torture in the home, like torture in police cells, stems from inequality of power and subordination. It involves forms of abuse that have their origin not simply in the particular psychology of certain authoritarian individuals, but from features embedded in our societies and our cultures. ${ }^{326}(\mathrm{~m} .$.$) Yet our legal culture defines the issue as one of ordinary$ criminal law, not of human rights. The mischief to be combatted is seen to be that of personal misconduct, not of violation of internationally accepted standards. The state is left off the hook, because its involvement is one of abrogation [rechtsontkrachting, jw] rather than of perpetration [rechtsverkrachting, jw].'

\section{We haalden (in een noot) reeds ROTH aan: $:^{327}$}

'It is a human rights violation for a state to commit even a single act of torture (...). But a single act of domestic violence is not a human rights violation unless the state can be said through its systematic inaction to have condoned the violence.'

Met andere woorden: de staat is aansprakelijk indien er een verband kan worden gelegd tussen het 'incident' en de stelselmatige niet-handhaving -

324 Ko Swan Sik, De verplichting in het volkenrecht, i.o. Rotterdam 1990, Den Haag 1991, p. 11.

325. Albie SACHS, 'Human rights in the twenty first century: real dichotomies, false antagonisms, paper presented to conference of the Canadian Institute for Judicial Administration, Halifax april 1997.

326 Zoals de maatschappelijke tolerantie ten aanzien wan het in plaats van verwerken afreageren van frustraties.

327 Kenneth ROTH, 'Domestic violence as an international human rights issue," in: Rebecea J. COOK (ed.), Human rights of women; National and intemational perspectives, Philadelphia 1995 (third printing), pp. 326-339, op p. 331 i.f. (curs. jw). 
en aldus ontkrachting - van de (fundamentele) rechten van het kind.

Nunc illud addamus (nu voegen we dit toe - om met GROTIUS te spreken) ${ }^{328}$ : onder 'systematic inaction' (stelselmatige niet-handhaving van fundamentele rechten, stelselmatige rechtsontkrachting) dient ook (indirect) discriminatoire "inaction" te worden begrepen. ${ }^{329}$ Onder 'systematic inaction" verstaan we in dit verband: het gezien de verdragsverplichtingen onder het Verdrag inzake de rechten van het kind en de situatie van ernstige en aanhoudende schending van fundamentele rechten van kinderen structureel te weinig en te laat in actie komen, meer in het bijzonder: het structurele tekort aan (niet-vrijblijvende) primaire preventie (met name aan opvoedingshulp die terechtkomt waar zij het meeste nodig is). Welnu, het effect van deze 'inaction' is discriminatoir: stelselmatige 'inaction' (lees: palliatie in plaats van preventie) dupeert, marginaliseert en stigmatiseert transgenerationeel beschadig(en)de ouders en kinderen in onevenredige mate en - behoudens 'toevallige' individuele reparatie, waardoor de 'cyclus van geweld" (of liever: de cyclus van onveilige gehechtheid) wordt doorbroken - over een reeks van generaties. Zoals we zagen: een tekort aan sociaal-pedagogische voorzieningen is door het fenomeen van de transgenerationaliteit (welhaast) per definitie sociaal-pedagogische discriminatie.

Met betrekking tot de hierdoor in het leven geroepen aansprakelijkheid en de verantwoordelijkheid van de staat kunnen we het Platform for action, aangenomen door de Vierde VN-Wereldvrouwenconferentie in Peking (1995), door middel van teksthaken op (de rechten van) kinderen toespitsen: ${ }^{330}$

"The gap between the existence of rights and their effective enjoyment derives from a lack of commitment by Governments to promoting and protecting those rights and the failure of Governments to inform women and men [parents and parents to be, adults and children] alike about them. (...)

Unless the human rights of [children], as defined by [the Convention on the rights of the child], are fully recognized and effectively protected, applied, implemented and enforced in national law as well as in national practice in family, civil,

Nunc illud addamus ne tunc quidem teneri socium si nulla spes sit boni exitus. (We kunnen nu dit [beginsel] toevoegen, dat er geen bondgenootschappelijke verplichting bestaat als er geen enkele hoop is op een goede afloop.) GROTIUS, De jure belli ac pacis II.25.4 (vgl. J.C.M. WILLEMS, "GROTIUs and the atomic weapon: the nuclear weapon-discussion in the light of the theory of "just war" with Hugo DE GROOT, "Grotiana, New Series, vol. 2, 1981, pp. 103-114, op p. 104 ad nt. 6).

329 Vgl. ROTH, t.a.p., op pp. 333-335.

330 The Beijing Declaration and the Platfom for action, UN, New York 1996, pp. 121133, op pp. 122-123, par. 217-218 (curs. jw). 
penal, labour and commercial codes and administrative rules and regulations, they will exist in name only.'

Lijnrecht tegenover het hier gestelde constateren we: een structureel tekort c.q. structurele nalatigheid op het vlak van publiekscampagnes, een structureel tekort c.q. structurele nalatigheid op het vlak van opvoedingsonderwijs aan jongeren (de volgende generatie opvoeders), een structureel tekort c.q. structurele nalatigheid op het vlak van (niet vrijblijvende) opvoedingsondersteuning, een structureel tekort c.q. structurele nalatigheid op het vlak van de zorg voor risicogezinnen, een structureel tekort c.q. structurele nalatigheid op het vlak van de hulpverlening aan kind en gezin (reparatie/rehabilitatie/psychotherapie op de plaatsen waar deze het hardst nodig is), een structureel tekort c.q. structurele nalatigheid op het vlak van de genoegdoening aan meerderjarige (voormalige) slachtoffers ('survivors') van kindermishandeling (compensatie/rehabilitatie). ${ }^{331}$ Alsmede een structureel tekort c.q. structurele nalatigheid ter zake van een juridisch statuut (en de rechtswaarborgen die daarbij horen) op het punt van het melden van vermoedens van kindermishandeling. ${ }^{332}$

Hierboven zeiden we (par. 13.3.3, par. 13.4.2) dat we in juridische zin (wat betreft 'harde' conclusies met betrekking tot staatsaansprakelijkheid) bescheiden moesten zijn (althans diplomatiek). Om twee redenen mogen we echter ook weer niet te bescheiden zijn. De eerste reden is als volgt door VAN BOVEN onder woorden gebracht: ${ }^{333}$

'[T] he whole human rights endeavour may be said to be built on the foundation of care and love for children and respect for their rights.'

De tweede reden ligt in het (groene) hart van de grijze zone waarin we ons in deze subparagraaf bevinden. We doelen op internationale en vooral Europese instrumenten die de plichten en verantwoordelijkheden van individuen, gemeenschappen, samenlevingen en staten, inzonderheid wetgevers en overheden, zoals deze voortvloeien uit mensenrechtelijke

331 Vgl. in dit verband H.E.M. BAARTMAN, 'Primaire preventie van kindermishandeling: onbegonnen werk?' Nederlands Tijdschrift voor Opvoeding Vorming en Ondenvijs/NTOVO 1996, pp. 17-33, op p. 30 ('Conclusie').

332 Vgl. in dit verband Adrie Wol,ZAK, 'Een herkenbaar meldpunt,' VKMagazine $1997 / 4$, pp. 1-3 (alsook de andere bijdragen in dit themanummer).

333 Theo VAN BOVEN, 'Children's rights; address at the opening meeting of the International Forum on the rights of the child' (Boedapest 1979), opgenomen in: Hans THOOLEN (ed.), People matter; Views on international human rights policy by Theo VAN BOVEN, Director of the United Nations Division of Human Rights 1977-1982, Amsterdam 1982, pp. 157-164, op p. 157. 
rechtsbeginselen, nader uitwerken - proto- en praeter-juridiseren - en cachet geven. Op wereldschaal lichten we er één document uit: de vNDeclaration on the right to development (1986), welke zowel ziet op de ontwikkeling van volken als op de ontplooiing van individuen. We beperken ons tot art. 1 , lid 1 en art. 2, lid 2 van de Verklaring: ${ }^{334}$

1.1 The right to development is an inalienable human right by virtue of which every human person and all peoples are entitled to participate in, contribute to, and enjoy economic, social, cultural and political development, in which all human rights and fundamental freedoms can be fully realized.

2.2 All human beings have a responsibility for development, individually and collectively, taking into account the need for full respect for their human rights and fundamental freedoms as well as their duties to the community, which alone can ensure the free and complete fulfillment of the human being, and they should therefore promote and protect an appropriate political, social and economic order for [human and social, jw】 development.

Meer specifiek voor de rechten van (en dus plichten en verantwoordelijkheden tegenover) kinderen, en dichter bij huis, zijn de talrijke juridische documenten, afkomstig van de Raad van Europa, die aan- en inscherping beogen van en reflexief (indirect, via rechtsbeginselen of -regels, bindend) en reflectief (deductief of subsumptief bindend als opinio necessitatis) invulling en inkleuring geven aan (de implementatie van) de rechten van het kind; documenten - aangenomen vóor en na de inwerkingtreding voor de lidstaten van de Raad van Europa van het (VN-)Verdrag inzake de rechten van het kind - waarin in verschillende bewoordingen en met wisselende accenten wat wij het recht van het kind op optimale persoonswording hebben gedoopt, als constitutionele grondslag van de Trias pedagogica en als dragend beginsel van diverse sociaal-pedagogische grondrechten in die trias, wordt benadrukt. Om ons tot enkele graantjes (uit recente en 'historische' documenten) te beperken: ${ }^{335}$

'Recommendation 1286 (1996) of the Parliamentay Assembly of the Council of Europe on a European strategy for children

6. The Assembly recommends that the Committee of Ministers urge the member states of the Council of Europe:

i. (....) to implement the [United Nations Convention on the rights of the child in the letter and the spirit by reviewing and adapting their legislative and regulatory provisions; (...).

334 Declaration on the right to development, Algemene Vergadering resolutie $41 / 128$ van 4 december 1986 (opgenomen in: Human rights; $A$ compilation of international instmoments, New York 1988, pp. 403-408; curs. jw). COUNCIL OF EUROPE, The rights of the child; $A$ European perspective, Straatsburg 1996, pp. $9-12$ (voor de eerste tekst; curs. jw). 
7. The Assembly also recommends that the Committee of Ministers invite the states grouped together in the Council of Europe to make children's rights a political priority by:

i. adopting at national and local level a proactive childhood policy which seeks full implementation of the Convention on the rights of the child, which will consider the best interests of the child as a guiding principle of all action and which will anticipate situations instead of trying to deal with emengencies or problems that have already arisen; (...)

v. ensuring, especially at policy-making level, that the interests and needs of children are always duly considered and taken into account, for example by introducing practices such as the "child impact statement, ${ }^{436}$ which offers a way of determining the probable impact on children of any proposed legislative, regulatory or other measures in whatever field (...);

vi. investing in children and giving them budgetary priority $(. .) ;.(.$.$) .$

8. The Committee of Ministers should strongly urge these states:

i. to guarantee, through explicit recognition in their constitutional texts or domestic law, children's (...) rights, as enshrined in the United Nations Convention on the rights of the child; (...)

iii. to inform children and also their parents of their [children's, jw] rights by widely publicising and disseminating the text of the Convention on the rights of the child (...) and by introducing education on children's rights and [parental? -jw] responsibilities into the school curriculum from primary level onwards;

iv. to encourage the media (...) to promote children's right to a healthy and balanced development (...), to eliminate violence and to illustrate positive social values;

v. to inform children about the means and remedies available to them in the event of violation of their fundamental rights and, for example, to extend the provision of free help-lines, specialist advocates and child friendly judicial and administrative systems which recognise the claims of individual children for protection against all forms of abuse;

vi. to provide specific training in children's rights for all professionals who come into contact with children, including teachers, the various members of the judicial authorities, social workers, etc.;

vii. to enable the views of children to be heard in all decision-making which affects them, and to enable them to participate actively, responsibly and in a manner appropriate to their capacity, at all levels of society - in the family, in local communities, in schools and other institutions, in judicial hearings and in national government ${ }^{337}$;

viii. (...) to reconsider the age at which young people can wote; (...)

xi. to emphasise to parents (...) that in a civilized society responsibilities. and obligations go hand in hand with rights and privileges.'

336 Vgl. de in hoofdstuk 14 voor te stellen Persoonswordings-Effect-Rapportage.

337 Een minderjarige als een van de staatssecretarissen op het Ministerie van Kind en Gezin? En na drie generaties vrouwen achtereenvolgens drie minderjarige prinsjes of prinsesjes als staatshoofd? Of op zijn minst een adviesraad - een Commissie van Advies inzake Kinderwolkenrechtelijke vraagstukken - (mede) samengesteld uit kinderen? 
Ook meer 'historische' teksten blijken (althans voor Nederland) een hoge actualiteitswaarde te hebben: $:^{338}$

\section{"Recommendation 561 (1969) on the protection of minors against ill-treatment \\ The Assembly,}

1. Having learned with disquiet that a serious number of children suffer or die each year from what pediatricians call the "beaten child syndrome"; (..)

5. Considering that in some countries the social services and the competent private organisations are prevented by lack of funds and often by lack of co-ordination from effectively combating cruelty to children; (...)

8. Considering that effective measures against cruelty to children ought essentially to involve preventive action in the social field - together with help and treatment for parents where necessary,

9. Recommends that the Committee of Ministers invite member governments:

a. to take all necessary measures to ersure that the competent ministeries and departments are aware of the gravity and extent of the problem of children subject to physical or mental cruelty;" (...)

$d$. to require the administrative authority and the social services to give their attention at the earliest opportunity to cases of maltreatment brought to their notice, by regular supervision of the family in question and by ensuring that the child receives proper care;

e. to provide the social services with the necessary funds and personnel to enable them to take proper care of maltreated children and also to keep a watch on parents liable to commit such cruelty; (...).

Niet minder opmerkelijk (althans voor Nederland en Nederlands langdurige en aanhoudende stilzitten, omissions en lack of due diligence) is het volgende document, dat een uitgewerkte aanbeveling bevat met betrekking tot Opvoedingsgeld, de Europese invulling van een (inmiddels universee $^{339}$ ) sociaal-pedagogisch grondrecht, welke alweer even oud is als de huidige lichting afstuderende juristen: ${ }^{340}$

"Recommendation 751 (1975) on the position and responsibility of parents in the modem family and their support by society

The Assembly,

2. Assured that society has not only a humanitarian duty but also a vital economic and social interest in ensuring that standards in the care of young children are preserved and improved; (...)

339 Dat wil zeggen een door (afgezien van de 'failed state' Somalië) alle (naar men placht te zeggen: beschaafde) staten onderschreven en - met uitzondering van de Verenigde Staten van Amerika - ook formeel bekrachtigd rechtsbeginsel.

The rights of the child, a.w., pp. $49-53$ (curs. jw). 
9. Considering that [the] upbringing of children must be not purely a matter of physical shelter and care, but should be continually aiming at their long-term emotional, intellectual and social needs;

10. Affirming its belief that the complex needs of children in their first years of life - and in particular their need for a stable personal relationship with an adult - are with few exceptions most effectively met through the personal care of a parent; (...)

12. Affirming its bellief that governments should pursue family policies which (...), regardless of income levels, grant the children a secure growth environment and encourage their emotional, intellectual, cultural and social development; (...)

14. Recommends that the Committee of Ministers (...) transmit to member governments the [following] proposals (...) [Appendix]:

a. To establish a family responsibility allowance, payable to households in which there are children under the age of three or requiring special care and:

i. not more than one of the two parents is in paid employment, or

ii. there is only one parent.

b. The rate of the allowance specified under $a$ shall be fixed at at least $50 \%$ of the national minimum wage (...). The allowance shall be fixed at at least twice this amount [100\% of the national minimum wage, jw] for category a.ii where the beneficiary is not in employment.

c. This allowance is not taxable.

Het behoeft geen betoog dat een substantiële (opvoedings)verantwoordelijkheidsuitkering ouders moreel aanspreekbaar maakt in geval van ouderlijk plichtsverzuim of plichtsverzaking. Een morele aanspreekbaarheid die juridisch zodanig in het vat kan worden gegoten dat de staat zijn secundaire opvoedingsverantwoordelijkheid (in de aangehaalde tekst aangeduid als tegelijk humanitaire plicht en vitaal economisch en sociaal belang) optimaal kan waarmaken. Hetgeen ons brengt op een derde pre-(VN-) Conventie-document (tevens het laatste dat we hier zullen aanhalen), waarin de Raadgevende Vergadering, dertien jaar later, opnieuw de Europese alarmbel luidt: ${ }^{341}$

'Recommendation 1071 (1988) on child welfare - providing institutional care for infants and children

The Assembly,

1. Considering that (...) all children should have the right to care provisions which complement the care they receive in their own families;

2. Having noted the development of alarming family trends, namely the rise in the number of illegitimate children, single-parent families and divorces;

3. Noting that inadequate provision of [complementaire, jw] institutional child care is partly responsible for the increase in juvenile delinquency, and that the risks of a breakdown in the social relations between parents and children are now very great; 
4. Considering that the principles of equal opportunities cannot be respected while excessive disparities in the material conditions of [complementaire, sociaal-pedagogische, jw] child care persist;

5. Wishing to see recognition given to the enormous efforts made by those professionally involved in the care of young children to encourage development of their full potential;

6. Noting that physical and mental well-being is essential for satisfactory child development;

7. Drawing attention to the cost to society of inadequately providing for the care of young children;

8. Recognising the right of all children to care provisions which complement those made by their own families, the duration of such additional care to be assessed in relation to the specific needs of the children;

9. Recommends that the Committee of Ministers invite the governments of member states:

a. to set up (...) a permanent body to:

i. assess and monitor progress with the decompartmentalisation of services and government departments dealing with child welfare;

ii. promote the introduction in every country of a specific policy for child care in and outside the family; (...)

$b$. to make plans to set up administrations (ministries or departments) which could one day propose guidelines for common action on the care of young children, the training of child-care staff and the harmonisation of their status in order to provide conditions that enable families to raise their children properly; (..)

d. to increase the sums devoted by each government to research on early childhood, and to all public campaigns about children organised by official associations which have undertaken the task to protect children's rights in society; (...)

$f$. to urge local, regional and national authorities to reconsider budgetary priorities, in order to lay down guidelines for a policy on the care of young children at their respective levels; (...)

$i$. to break down barriers between the various local, regional or national services or administrations responsible for particular aspects of child welfare (health, environment, architecture, care provisions, protection of mothers, etc.);

$j$. to support financially innovative forms of child care which take account of children's specific physical and psychological needs;

$k$. to set up an information programme for parents and child-care staff on children's specific needs and the appropriate care conditions for the development of their full porential $(\ldots) ;(.$.$) .'$

De status en het gezag van deze documenten (hun rechtskracht op zich en hun rechtswerking, die niet verder reikt dan het reflexieve of reflectieve rechtskarakter van het aanbevolene) geeft al aan dat we ons hier in een overgangszone bevinden, een grijze zone tussen staatsaansprakelijkheid en overheidsverantwoordelijkheden. Niettemin verbaast het in niet geringe mate hoezeer een rijk land als Nederland van deze (en soortgelijke) teksten een arsenaal dode letters heeft gemaakt, hoezeer deze aanbevelingen aan Nederlandse dovemans oren zijn gericht. We verbazen 
ons over de kracht van het nationale dogma, dat wij daarachter vermoeden; over de heiligheid waarmee in Nederland in dat dogma wordt geloofd, het dogma namelijk dat bij ons, in aperte tegenstelling tot landen als België, Rwanda, Frankrijk, Turkije, Indonesië, China ... met zijn onmenselijke één-kind-beleid, en natuurlijk Amerika ... het land overigens waar kindermishandeling als nationale ramp, 'national emergency,' wordt opgevat en benaderd, ${ }^{342}$ ja in tegenstelling tot de rest van de wereld, alles zo goed geregeld is. We verbazen ons met VAN BOVEN over ...

'(...) de halfhartigheid (...) van vele spraakmakers - ook in Nederland - om verplichtingen op het gebied wan de rechten van de mens eerder op anderen te betrekken dan op de eigen samenleving. ${ }^{, 343}$

We zetten ons echter over onze verbazing heen en pogen thans met de noodzakelijke distantie onze eindconclusie te formuleren.

\section{Eindconclusie}

Staatsaansprakelijkheid kan niet los worden gezien van transgenerationaliteit, en transgenerationaliteit kan niet los worden gezien van het vraagstuk van de 'reparatie' van ouders. Dit betekent dat staatsaansprakelijkheid staat of valt met wat ik zou willen noemen: reparatoire opvoedingsondersteuning. Let wel dat het hierbij gaat om preventie van kindermishandeling, dus om voorkoming van de noodzaak van latere reparatie van kinderen. Kortom, men begrijpe goed dat het bij reparatoire opvoedingsondersteuning gaat om doorbreking van transgenerationaliteit, en dus om

342 us Advisory Board on Child Abuse and Neglect 1990. Vgl. Howard A. DAVIDSON, "Orphanages" or child abuse prevention?' The International Joumal of Children's Rights $1995 / 2$, pp. 283-291, op p. 285.

343 Theo VAN BOVEN, "Nogmaals het IVUR en de strijd tegen rassendiscriminatie," LBR-Bulletin 1997/2, pp. 25-27, op p. 27 1.k.

VAN BOVEN verwijst vervolgens naar de Nederlandse parlementaire behandeling van zowel EVRM als IVUR woor 'frappante staaltjes" van de door hem gelaakte geestesgesteldheid. Even daarvoor trok hij een treffende parallel die zich gemakkelijk naar deze geestesgesteldheid laat doortrekken. Gezien haar relevantie voor ons onderwerp geven wij deze parallel hier weer (t.a.p., op p. 26 r.k.): 'Evenzeer als internationale teksten (verdragen en verklaringen) in toenemende en klemmende mate een optreden van de overheid eisen ter bestrijding van geweld in particuliere relaties tegen kinderen en tegen vrouwen - in weerwil van waarden als het recht op privacy en het recht op gezinsleven -, zo vergt het rvur van de overheid dat mensen beschermo worden tegen racistische haatzaaierij, in weerwil van het recht op wrije meningsuiting. Dat is de plicht en de verantwoordelijkheid van een attente overheid. (...) [V]olgens de normen van het internationale recht vormen deze verplichtingen van de overheid een onderdeel van de staatsaansprakelijkheid." 
actieve omkering (in plaats van passieve instandhouding) van systemischdiscriminatoire patronen.

Wordt deze reparatoire opvoedingsondersteuning doelmatig en doeltreffend aangepakt, dan voldoet de staat in principe aan zijn (uiterste) inspannings- en (quasi-)resultaatsverplichtingen ten aanzien van de (optimale c.q. minimale) persoonswording van de kinderen onder zijn rechtsmacht. Worden niet-gerepareerde of anderszins pedagogisch 'gehandicapte' ouders en hun kinderen niet doelmatig en doeltreffend van opvoedingsbegeleiding en -bewaking voorzien - of juister gezegd: is er geen adequaat stelsel van eerstelijns sociaal-pedagogische voorzieningen dat voor alle (aanstaande en jonge) ouders toegankelijk is (waarbij men concreet zou kunnen denken aan pedagogisch adequaat toegeruste consultatiebureaus), doch dat tweede- en derdelijnsvoorzieningen kent voor ouders met een gemankeerd pedagogisch besef, waarbij in laatste instantie, met rechtswaarborgen omkleed, opvoedingshulp kan worden opgelegd -, dan is de staat in beginsel aansprakelijk voor de gevolgen, zowel, bij voldoende gekwalificeerde schendingen van zijn verdragsverplichtingen (waarbij bovendien sprake is van een direct causaal verband tussen de geschonden rechten van betrokkenen, de merkelijke psychische schade c.q. sociaal-emotionele ontwikkelingsachterstanden die dezen hebben opgelopen, en de materiële en immateriële schade die daarvan weer het gevolg is), in juridisch-technische zin ten aanzien van gemaltraiteerde kinderen c.q. subminimaal persoon geworden volwassenen, als in juridisch-politieke zin ten aanzien van de samenleving in haar geheel en zelfs ten opzichte van de gehele mensheid, nu het gaat om fundamentele mensenrechten, neergelegd in een (vrijwel) universeel aanvaard verdrag, bij welker handhaving - gezien het onvoorstelbare humane potentieel dat daarbij op het spel staat en de immense vernietigingskrachten die niet verwerkte collectieve c.q. systemische traumatiseringen in de geschiedenis hebben ontketend (met de ochlo- en mediocratische nazi-tyrannie als Europees genocidaal dieptepunt) - in beginsel elk lid van de mensengemeenschap belang heeft.

Op basis van verschillende gegevens en feiten moeten we constateren dat in Nederland van bovenbedoeld adequaat stelsel geen sprake is: zelfs de contouren daarvan, in de vorm van concrete (kind-en-gezins- c.q. sociaal-pedagogische) beleids- en (uitvoerings)wetgevingsplannen, zijn niet te onderscheiden. De conclusie kan dan ook geen andere zijn dan dat Nederland, in de gegeven omstandigheden, niet alleen in morele en politieke doch ook in juridische zin, bij systematische uitleg, qua inhoud en strekking, van zijn algemeen mensenrechtelijke en specifieke verdragsverplichtingen onder het Verdrag inzake de rechten van het kind, verantwoordelijk is voor de ernstige en passief-systematische schending van de 
sociaal-pedagogische grondrechten van het kind en het gezin waartoe het behoort, op materiële en immateriële vormen van opvoedingsondersteuning c.q. op opvoedingsbegeleiding en -bewaking (opvoedingsonderwijs, opvoedingsgeld, adequate desnoods opgelegde opvoedingshulp) en meer in het bijzonder verantwoordelijk is voor en aansprakelijk is ter zake van de ernstige en passief-systematische schending van de fundamentele persoonswordingsrechten (veiligheidsrechten, integriteitsrechten, ontwikkelingsrechten) van jaarlijks tienduizenden kinderen onder zijn rechtsmacht.

Om het bovenstaande in de - meer leesbare - woorden van een klinisch psychologe weer te geven (DRAIJER 1997):

"Sommige ouders zijn in staat en bereid om hun kind als een min of meer zelfstandig individu te bezien dat hun steun en bescherming nodig heeft als voorwaarde om vandlaaruit te opereren. Zij zien hun kind als losstaand van zichzelf en kunnen van zijn zelfstandigheid, zijn volstrekte eigenheid genieten. Zij kunnen het kind steunen als het een moeilijke periode doormaakt of ingewikkelde ervaringen opdoet, en [het] de vrijheid geven als het op eigen benen wil staan.

Andere ouders houden [ook, jw] veel van hun kinderen maar zien hun kinderen - veelal zonder dat zij zich dat bewust zijn - als een onderdeel van zichzelf. Hetzij als bron van steun bij hun eigen wankel innerlijk evenwicht, hetzij als bron van trots bij hun eigen gebrekkige zelfgevoel, hetzij als mikpunt van agressie bij het ontbreken van voldoende innerlijke veiligheid om agressief te zijn tegen anderen in de buitenwereld, hetzij als bron wan seksuele gratificatie bij het ontbreken van voldoende innerlijke veiligheid om "zichzelf te zijn" - waar seks toch voor staat - in de aanwezigheid van een volwassen partner. Vaak zijn die ouders zelf gekwetst in hur kindertijd.

Als ouders hun kinderen onbewust vooral als verlengstuk van zichzelf zien, hebben zij geen oog voor de persoon die het kind is, voor de eigen wensen en verlangens, de eigen talenten, de volstrekte eigenheid van het kind. Uiteindelijk is dat waar kinderen [op de lange duur, jw] het meest onder lijden: onder dit niet "gezien" zijn. (...)

Bij de diagnostiek en behandeling van [gemaltraiteerde, mis-behandelde, jw] kinderen is het taxeren van de draagkracht en beschikbaarheid van ouders dan ook een van de belangrijkste stappen. In hoeverre is het mogelijk de ouders te mobiliseren [om] de steun te bieden die het kind nodig heeft om de ingewikkelde en vaak angstaanjagende ervaringen van het [emotioneel, emotioneel/sexueel of emotioneel/fysiek, jw] misbruik te boven te komen? Wat zijn hun eigen zorgen en angsten? (...) Hebben zij zelf wellicht belastende erwaringen gehad, waardoor ze niet wrij kunnen luisteren en horen wat hun kind hun vertelt, omdat ze niet herin-

344 N. DRAIJER, "Is seksueel misbruik van kinderen altijd erg? Over de noodzaak van differentiatie," in: H. BAARTMAN e.a., Gezinnen onder druk; Over veranderende ouder-kind relaties, Kampen 1997, pp. 63-79, op pp. $74-75$ (curs. jw).

Hoewel DRAInER over sexueel misbruik schrijft, zijn haar woorden veelal wit te breiden tot andere vormen van mis(be)handeling, hetgeen in de aangehaalde passages door middell van teksthaken gebeurt. 
nerd willen worden aan hun eigen belastende ervaringen? In hoeverre kunnen ze stilstaan, letteriijk, buj de ervaringen van hun kind? Het is pijnlijk om te merken [doch wolledig te verwachten, $j w$ ] dat moeders [en vaders, $j w]$ soms identieke ervaringen hebben meegemaakt als hun dochters [en zonen, jw] nu; helaas komt dit naar verhouding vaak voor. Zelfs als [traumatische ervaringen, jw] buiten het gezin [hebben] plaatsgevonden, zijn de ouders vaak zo gepreoccupeerd door hun eigen problemen dat ze aan hun kind geen adequate opvang kunnen bieden. Eén van de mogelijkheden is dan om eigen zorg of behandeling te regelen voor het kind."

En gelijktijdig de draagkracht en het pedagogisch besef van de ouders, door reparatoire ondersteuning en interventies, te vergroten. Zoals de auteur besluit: ${ }^{345}$

'De grote uitdaging voor de toekomst ligt dan ook in het verbeteren van deze ondersteunende kwaliteit van het ouderschap.'

Aan die uitdaging te werken is dure rechtsplicht van staat en samenleving. Die uitdaging gedurig uit de weg te (blijven) gaan, maakt staat en samenleving verantwoordelijk, en de staat aansprakelijk, ter zake van (de instandhouding van) grove mensenrechtenschendingen in één van de rijkste en meest sociaal ontwikkelde landen ter wereld. Een mensenrechtelijk gidsland dat in eigen land, door systematisch niet de kant van het kind op te kijken, de weg kwijt lijkt te zijn.

\section{5}

\section{En niemand bood hulp}

Op wie zijn meer dan op kinderen, 6ók kinderen in ons land, tienduizenden kinderen in ons land, de woorden van Prediker 4:1 van toepassing:

\section{Verdnkkingen in het leven}

Dan weer beschouwde ik alle verdrukkingen,

Die er onder de zon voorkomen:

Ik zag de tranen der verdrukten, en niemand gaf troost;

De onderdrukkers pleegden geweld, en niemand bood hulp.

En niemand bood hulp. Zelfs God in de hemel niet. De vrome woorden: Introibo ad altare Dei, ad Deum qui laetificat iuventutem meam (ik zal opgaan naar het altaar van God, naar God die mijn jeugd verblijdt), ${ }^{346}$

346 Onveranderlijke gebeden van de heilige miswiering; gebeden aan de voet van het altaar (Psalm 43:4); te vinden in een parochiemissaal. 
zijn holle woorden voor vele tienduizenden kinderen in dit land. En niemand bood hulp. In die vier woorden ligt de essentie van transgenerationaliteit, de essentie van systemische sociaal-pedagogische discriminatie, en daarmee de essentie van staatsaansprakelijkheid besloten.

In een samenleving die een reeks van gevallen van kinderdoding door ouders ${ }^{347}$ afdoet als tragische incidenten, die niet ziet dat kinderdoding het uiterste is op een continuum van sociaal-pedagogische nalatigheid, en die daarom niet met een structureel antwoord komt, in die samenleving zijn er méér dan de gedode kinderen voor wie ook de twee volgende verzen van Prediker kunnen worden gedeclameerd (Prediker $4: 2-3)$ :

Daarom prees ik de doden gelukkig, reeds lang ontslapen,

Boven hen die nog in leven zijn.

En gelukkiger nog dan hen beiden

$Z i j$ die nog niet hebben bestaan:

Want zij zagen nog niet het boze gedoe,

Dat er plaats heeft onder de zon.

Het past een jurist niet te prediken. Hij zou allicht van demagogie worden beticht. Het past hem beter, sprekend over kinderdoding, hardop de tekst te lezen van art. 19 van het Verdrag inzake de rechten van het kind. Zolang dat artikel niet naar de letter en de geest wordt nageleefd, houdt hij de ogen droog. Pas als de oorlog-door-nalatigheid tegen kinderen zal zijn verdwenen, zal hij met de dichter willen zeggen: ${ }^{348}$

'Kom vanavond met verhalen

boe de oorlog is verdwenen, en therhaal ze honderd malen:

alle malen zal ik wenen."

Zie Adrie wOLZAK, 'Kinderdoding,' VKMagazine; Tijdschrift over kindermishandeling juni 1997 (1997/2), pp. 8-9.

348 Leo VROMAN, 'Vrede' (slotcouplet), uit: Uit slaapwandelen (1957), opgenomen in: dez., Neenbaar; Een keuze uit de gedichten, Amsterdam 1991, pp. 42-43, op p. 43. (Het eerste couplet eindigt met bijna dezelfde versregels: Komt een duif van honderd pond, / een olijboom in zijn kiauwen, / bij mijn oren met zijn mond / vol wan koren zoete wrouwen, / vol van kirrende verhalen / hoe de oorlog is verdwenen / en herhaall ze honderd malen: / alle malen zal ik wenen.) 


\section{PERSOONSWORDING EN MODALITEITEN VAN STAATSVERANTWOORDELIJKHEID}

\section{1}

\section{Inleiding: over de opbouw van dit hoofdstuk}

$\mathrm{Na}$ de uitgebreide juridische beschouwingen en conclusies van het vorige hoofdstuk besluiten we deze studie, in dit hoofdstuk, met enkele meer rechtspolitieke (c.q. meta-juridische) overwegingen en toevoegingen, doch bovenal met een min of meer samenvattende en schetsmatige weergave van diverse deels juridische deels rechtspolitieke c.q. voornamelijk rechtspolitieke voorstellen en conclusies uit eerdere hoofdstukken. Kortom: met overwegingen en gedachten de lege ferenda (over te maken wetten) zonder directe of expliciete koppeling aan de lex lata (de geldende wet). Hierbij moet uiteraard dadelijk de kanttekening worden geplaatst dat het jus constituendum in dit hoofdstuk geen wenselijk recht in de zin van een gedroomd recht is, doch daarentegen, letterlijk uit het Latijn: het te stellen recht, het recht dat tot stand moet worden gebracht, recht (en beleid) dat logisch, zo niet noodzakelijk en onvermijdelijk (opinio necessitatis) uit de juridische beschouwingen in deze studie ten aanzien van het Verdrag inzake de rechten van het kind voortvloeit. Of, nog anders gezegd: recht (en beleid) dat de fundamentele rechtsbeginselen van het Verdrag beoogt te operationaliseren, handen en voeten te geven, hard te maken.

Met name vanwege het (groten)deels samenvattende karakter van dit hoofdstuk is gekozen voor een enigszins afwijkende opbouw, een indeling namelijk in tamelijk gedetailleerde, doch soms (zeer) korte paragrafen en subparagrafen, die op hun beurt ook weer zijn onderverdeeld, zodat een doorzichtig raamwerk ontstaat, om in biologische termen te spreken: een zo compleet mogelijk skelet zonder vlees en spieren, welke laatste immers in andere hoofdstukken liggen opgetast of uitgestald en daar zijn ontleed. Voor wat de inhoudelijke opbouw van dit hoofdstuk betreft: aan het begin van elke paragraaf (par. 14.2 tot en met par. 14.6) zal kort de opbouw (de te behandelen onderwerpen) van de desbetreffende paragraaf worden geschetst. Wat de (hoofd)onderwerpen van deze (vijf) paragrafen betreft: par. 14.2 gaat in op begrippen uit de titel van dit hoofdstuk (alsmede op enkele daarmee nauw samenhangende begrippen uit deze studie); par. 14.3 gaat over SPS: (stelselmatige) sociaal-pedagogische steun als geïntegreerde preventieve benadering (volgens een geünificeerd anti-escalatoir en niet-stigmatiserend preventief-interveniërendreparatoir model); par. 14.4 poogt inhoud te geven aan de notie respect voor kinderen; par. 14.5 zet de Trias pedagogica in de constitutioneel-ope- 
rationele steigers; en par. 14.6 wil vorm en (diepere) betekenis geven aan de (rechts)notie rehabilitatie. Het hoofdstuk, en het boek, wordt afgesloten met een slotparagraaf (par. 14.7) waarin een nieuwe interpretatie wordt beproefd van het verhaal van Kaiin en Abel: de eerste en tegelijk de eerste transgenerationeel getraumatiseerde kinderen uit de (bijbelse) geschiedenis van de mensheid.

Persoonswording en modaliteiten van staatsverantwoordelijkheid

Deze paragraaf bestaat uit vijf subparagrafen waarin achtereenvolgens kort wordt stilgestaan bij enkele sleutelbegrippen uit deze studie, te weten: (persoon en) persoonswording, ontwikkeling(sbelang) van het kind, het recht van het kind op optimale persoonswording, de (sociaal-)pedagogische kwestie en, als laatste, staatsaansprakelijkheid/overheidsverantwoordelijkheden.

\subsubsection{Persoon en persoonswording: minimale en optimale ratio- naliteit, moraliteit en authenticiteit}

In deze eerste subparagraaf scheren we in vogelvlucht over enkele grotere en kleinere thema's (zowel verband houdend met terminologie als met 'mens- en wereldbeeld') rond het centrale begrip in deze studie: persoonswording.

\section{Mentale representaties}

In materialistische (evolutionair-psychologische) zin is de mens een biologische 'machine' die bestaat en functioneert bij de gratie van de mentale representaties (mijns inziens minder juist: 'illusies ${ }^{11}$ ) van een 'zelf' en een

1 Zie bijwoorbeeld ten aanzien van de 'vrije wil' WRIGHT (DARWINs geweten, 1997, p. 371), met wie we in discussie traden in (een noot in) hoofdstuk 13 (par. 13.2.1, Allermensennecht).

Vgl. ook Stephen HAWKING, Het heelai; Verleden en toekomst war ruinte \& tijd, Amsterdam 1997 (21e druk), p. 207 r.k., waar de auteur opmerkt: 'U kunt natuurlijk aanvoeren dat een vrije will altijd een illusie is. Als er werkelijk een volledige geünificeerde theorie bestaat die alles beheerst, bepaalt ze vermoedelijk ook al uw handelingen. Maar dat gaat op een manier in zijn werk die voor een complex wezen als een mens onmogelijk van tevoren berekend kan worden. We kunnen zeggen dat de mens over een vrije wil beschikt omdat we niet kunnen voorspellen hoe een mens zal handelen.' 
'vrije wil."2 In spiritualistische (theologische/filosofische) zin kan men deze 'goddelijke inblazingen' noemen. ${ }^{3}$ Gebruikmaking van deze representaties in de vorm van zelfreflectie en introspectie ${ }^{4}$ maakt de mens tot een unieke morele 'biologische machine,' tot (aldus WRIGHT) 'het enige morele dier."5

Het 'morele dier' (animal morale) mens duiden wij in deze studie (vanuit een ontwikkelingspsychologisch-pedagogische invalshoek) aan als een (meer of minder) rationeel, moreel en authentiek persoon (in wording) ${ }^{6}$ Hieraan doet niet toe of af dat ook 'de persoonlijkheid, de basis van onze identiteit,' een constructie van onze hersenen, een mentale representatie, is: "Onze hersenen maken wie wij zijn. ${ }^{7}$ Die hersenen zijn evenwel niet een louter aangeboren gegeven.

\section{Het brein en individuatie}

Aan het begin van hoofdstuk 12 (in par. 12.1) vroegen we ons af in hoeverre mishandelde kinderen 'voor het leven beschadigd" zijn ten gevolge van (vroeg en daardoor) diep in de cerebrale 'hardware' ingesleten patronen en van de (destructieve) herhalingsdwang die samenhangt met hun vroege 'verkeerde programmering.' Hoe volstrekt ontoereikend deze en dergelijke beeldspraak ook moge zijn in relatie tot de hersenen, de meest

In meer algemene zin merkt BERGSMA op: Neurowetenschappers gaan er steeds meer van uit dat alle geestelijke processen, dus ook het bewustzijn en de vrije wil producten zijn van de hersenen." (Ad BERGSMA, Het brein; Ons innerlijk univer sum, Utrecht 1997, derde druk, p. 32.)

CROMBAG en VAN DUN (Hans CROMBAG en Frank VAN DUN, De utopische verlei ding, Amsterdam/Antwerpen 1997, p. 50) wijzen terecht op het nauwe verbanc tussen taal en bewustzijn: 'Er zijn goede redenen on aan te nemen dat het zelf bewustzijn van mensen pas tot ontwikkeling is gekomen nadat en doordat zij taa hadden verworven. (...) Als dit een juiste woorstelling van zaken is, dan is zell bewustzijn en het besef van het eigen lot [en de gedachte van het in eigen han nemen van dat lot: de vrije wil, jw] dat daarvan de kern vormt, een recente on! wikkeling op de evolutionaire tijdschaal." Wellicht moeten we taal zien als ce - recent - "godsgeschenk." Maar dan zijn we weer terug bij het 'godsgeschenl van de radicale contingentie.

En bijgevolg empathie: 'Dankzij het bewustzijn weet iemand wat hij zelf voelt $\mathrm{e}$ denkt en daarom wordt het voor hem gemakkelijker om zich te verplaatsen i anderen." (BERGSMA, Het brein, a.w., p. 32 i.f.) Gemakkelijker, maar op zich ni gemakkelijk: voor zelfreflectie en introspectie is morele moed nodig (wilskrach vrije wil). WRIGHT, a.w., p. 365. Zie ook hierna onder Het dynamische persoonsbegrip: de mens als persoon i porentie. BERGSMA, Het brein, a.w., p. 131 i.f. (curs. overgenomen). 
complexe stof die tot nu toe in het heelal is aangetroffen, ${ }^{8}$ zij geeft wel aan waar de schoen wringt. Een mensenkind wordt namelijk, om het geboortekanaal te kunnen passeren, feitelijk als foetus geboren. ${ }^{9} \mathrm{Er}$ is geen sprake van dat het kind kort na de geboorte, zoals we elders in de natuur zien, op zijn benen staat en ronddartelt. Daartoe zou een schedelomvang nodig zijn die baring onmogelijk zou maken. ${ }^{10} \mathrm{Na}$ de geboorte ontwikkelen de hersenen zich razendsnel, de 'bedrading' - het netwerk van myriaden verbindingen tussen de honderd miljard zenuwcellen in het babybrein - wordt fijner en fijner. Bij BERGSMA lezen we: ${ }^{11}$

'Het brein van een pasgeborene kan feitelijk nog niet zoveel, maar heeft wel de potentie om tot een machtig informatieverwerkend systeem uit te groeien. Daarvoor blijkt een intensieve wisselwerking met een gevarieerde en stimulerende omgeving noodzakelijk. De activiteit die deze wisselwerking in de zenuwcellen oproept, maakt het voor het brein mogelijk de onderlinge verbindingen tussen de zenuwcellen fijn af te stellen. (...) Vroege stimulatie is letterlijk van levensbelang voor de ontwikkeling van het brein. Het brein heeft op jeugdige leeftijd een grote mate van flexibiliteit. De "bedrading" van de hersenen wordt aangepast aan de hand van vroege ervaringen (...).'

Vroege (traumatische) ervaringen vormen en vervormen niet alleen uiteindelijk - de persoonlijkheid (HERMAN), ${ }^{12}$ zij vormen en vervormen van meet af aan het menselijk brein.

De mens is (minder uniek in het dierenrijk) ook een sociaal dier (kuddedier, animal sociale). Dankzij het bewustzijn is hij zich evenwel letterlijk - van zichzelf bewust, zodat hij zich van een ander, de ander,

En n.m.m. gezien de onoverbrugbare afstanden in tijd en ruimte in het heelal tussen theoretisch wellicht mogelijke (doch uitgaande van radicale contingentic niet erg waarschijnlijke) beschavingen op basis van kansberekening ooit zal worden aangetroffen: de mens is met zijn hersenen in het heelal in elke redelijke zin alleen. En het is slechts én van de vele illustraties van de - mijns inziens grotendeels posttraumatische - gekte van de mens dat hij naar contacten met buitenaardse beschavingen zoekt en daar kapitalen in 'investeert' die zoveel beter zouden kunnen worden besteed aan het voorkomen van (vroege jeugd)trauma's, geïnvesteerd in een minder gekke toekomst voor het menselijk geslacht.

9 Pas na drie maanden verliest de baby zijn foetale kenmerken (VAN TOL-GEERDINK in Jaarboek ontwikkelingspsychologie, orthopedagogie en kinderpsychiatrie 2 (1996-1997), aangehaald in de bespr. van Lidwien GEERTJENS in MGv 1997/4, pp. 432-435, op p. 434 1.k. i.f.).

10 Vgl. Willard GAYLN, Adam and Eve and Pinocchio: On being and becoming hwman, New York 1990, pp. 130-131.

11 Ad BERGSMA, Het brein; Ons innerlijk universum, Utrecht 1997 (derde druk), p. 10 .

12 Judith HERMAN, Trauma en herstel (1993): zie par. 12.3.1. 
kan onderscheiden (ik-ander differentiatie). Dit stelt hem vervolgens in staat zich in de ander te verplaatsen (empathie), om aldus in de menselijke, humane zin van het woord een animal sociale, een moreel 'kuddedier,' een politiek dier, een uniek sociaal wezen, een persoon te worden. Het bewustzijn èn de moraal kunnen dan ook - in wisselwerking met en dankzij de taal - worden gezien als een evolutionaire vervolmaking van de appetitus societatis van de mens als kuddedier. ${ }^{13}$

Het opmerkelijke is dan: hoe meer een mens is geïndividueerd (separatie-individuatie), hoe meer hij zich heeft losgemaakt van oorspronkelijke banden en een eigen (zelfstandige) persoonlijkheid heeft ontwikkeld, des te groter zal zijn empathie, zijn vermogen zich in anderen te verplaatsen, zijn. Hoe beter de individuatie is geslaagd, des te socialer (en dus niet: des te individualistischer in de zin van egocentrischer) zal een mens zijn (egocentrisme duidt immers op het niet tot een goede oplossing gebracht hebben van ontwikkelingstaken, op een niet geslaagde individuatie, op een niet goed verwerkt hebben van negatieve/traumatische ervaringen, kortom op een in emotionele zin niet rijpe, niet volwassen persoonlijkheid).

Ernstige bedreiging of beschadiging van de sociaal-emotionele ontwikkeling van het kind leidt (grosso modo) tot sociaal-angstig of anti-sociaal gedrag en uiteindelijk tot een sociaal-angstig of een anti-sociaal persoon. Ontwikkelingstaken, waarvan de taken rond het losmakingsproces, de individuatie, niet de geringste zijn, stagneren of raken geblokkeerd. Hoe vroeger in het leven deze bedreiging of beschadiging plaatsvindt, des te diepere sporen laat zij in de 'bedrading' van de hersenen na. En des te moeilijker zal een 'omkabeling,' een persoonlijkheidsverandering zijn. ${ }^{14}$

De enorme psychotrauma-gevoeligheid (psychische vulnerabiliteit) van het menselijk brein/zenuwstelsel, in het bijzonder in zijn (vroege',

Vgl. BEROSMA, Het brein, a.w., p. 32 (i.f.).

De term appetitus societatis (sociale "appetijt": gemeenschapszin; $\circ i \kappa \epsilon \iota \omega 0 \iota 5$ ) i van GROTTUS, De jure belli ac pacis (1625), Prol. 6.

Vgl. in dit verband ook Judy F. ROSENBLTH, In the beginning; Development fron conception to age two, Newbury Park (etc.) 1995, Chapter 13 (Influence of er vironment: deprivation and enrichment'), pp. 502-540. Alsmede het belangwel kende hoofdstuk 'Trauma en emotionele herscholing' uit Daniel GoLEMANs Emc tionele intelligentie; Enoties als sleutel tot succes, Amsterdam/Antwerpen 1994 pp. 271-290. Zie voorts B.C.L. TOUWEN, De neurologische ontwikkeling van 0 to 3 jaar,' in: J.E. DE BOER (red.), Infantpsychiatrie $11 ;$ De gezonde en verstoor ontwikkeling van het zeer jonge kind, Assen 1993, pp. 71-80, op pp. 74-75; J.A. VA HoOFF, "Wat studies aan [sic] primaten ons kunnen leren over de invloed van c sociale omgeving op de moeder-kind relatie,' in: J.E. DE BOER (red.), Infantps chiatrie I; De gezonde en verstoorde ontwikkeling van de vroege ouder-kind relat Assen/Maastricht 1991, pp. 40-55. 
ontwikkelingsfase, betekent dat - uit een oogpunt van voorkoming en beperking van menselijk lijden, individueel en collectief, van geweld (geweld in het gezin, vreemdelingenhaat, groepsagressie, geweldscriminaliteit, vandalisme, burgeroorlog, oorlog, genocide en andere ernstige en systematische mensenrechtenschendingen) en van kapitaalvernietiging, zowel van menselijk kapitaal als van schaarse gemeenschapsmiddelen het voorkomen van traumatisering in de jeugd en het verlichten van de gevolgen (snelle therapie/rehabilitatie) in geval van traumatisering allerhoogste maatschappelijke, nationaal- en internationaal-politieke en mensenrechtelijke/mensenrechtsactivistische prioriteit verdient. Immers, in de woorden van PERRY: ${ }^{15}$

"The brain is what makes us human, and the experiences of childhood sculpt the brain. Deprivation, terror, physical assault, sexual exploitation and abuse, and emotional abuse affect the biology of the developing brain in a permanent negative way."

\section{Bevordering en bewaking van persoonswording: handelen naar inzicht} PERRY moet evenwel op één punt worden gecorrigeerd. Inderdaad boetseren jeugdervaringen onze hersenen. ${ }^{16}$ Maar het zijn niet onze herse-

15 Bruce D. PERRY, Maltreated children; Experience, brain development, and the next generation, London (aangekondigd).

16 Vgl. ook Daniel GolEMAN, Emotionele intelligentie, a.w., pp. 303-308. De auteur merkt op (a.w., resp. pp. 303, 306 en 307-308): 'Ervaring, met name ervaring in de kindertijd, geeft vorm aan het brein. (...) [D]oorslaggevende ervaringen [zijn] onder andere de betrouwbaarheid van de ouders en hun ontvankelijkheid voor de behoeften van het kind, de kansen en begelleiding die een kind krijgt bij het leren omgaan met zijn eigen ontreddering en het beheersen vau zijn impulsen, en de oefening in empathie. Evenzo drukken verwaarlozing of mishandeling, gebrek aan aandacht van een onverschillige of door zichzelf in beslag genomen ouder en fysieke straffen hun stempel op het emotionele schakelsysteem. (...) De enorme schaal waarop neurale circuits in de kindertijd worm gegeven en gesnoeid worden, kan een onderliggende reden zijn dat vroege emotionele ontberingen en trauma's zulke blijwende en indringende gevolgen hebben voor de volwassenheid. Het zou ook kunnen verklaren waarom het vaak zo lang kan duren voordat psychotherapie een aantal van deze patronen beïnloedt - en waarom (...) deze patronen meestal zelfs na de therapie blijven bestaan als fundamentele beheptheden, hoewel bekleed met nieuwe inzichten en opnieuw geleerde responsen. (...) Elk leerproces impliceert een verandering in de hersenen, een versterking van synaptische verbindingen. (...) Psychotherapie is in zekere zin voor een groot deel een bijscholing op gebieden die eerder in het leven een knauw kregen of zich in het geheel niet ontwikkelden.' Om ten slotte te verzuchten (a.w., p. 308): 'De vraag is dan ook waarom we er niet alles aan doen om die behoefte aan therapie te vermijden door de kinderen meteen de zorg en begeleiding te geven waarmee ze fundamentele emotionele vaardigheden kunnen ontwikkelen.' 
nen, het is het gebruik ervan - op geleide van onze emoties ${ }^{17}$ - dat ons tot mensen maakt. Het - maatschappelijk - inzetten van onze hersenen, op geleide van onze empathie, om vroege hersenbeschadigingen en -vervormingen te voorkomen, en dus als samenleving de persoonswording van kinderen als groep en van elk kind afzonderlijk te bevorderen en te bewaken, maakt ons bovendien tot sociale èn verstandige mensen. Tot mensen wie ook de mensenrechten van kinderen nauw aan het hart liggen. Tot mensen die - om te beginnen - inzicht hebben in de tragiek van mishandelende ouders en mishandelde kinderen. Om - vervolgens - naar dat inzicht te handelen. Een inzicht dat als volgt door BAARTMAN is verwoord: ${ }^{18}$

'Via drie perspectieven, dat van de gehechtheidstheorie, de object-relatietheorie en de theorie inzake loyaliteit, is de tragiek zichtbaar te maken van mishandelende ouders (en hun kinderen). Het is de tragick van geen weg weten met tegenstrijdige ervaringen, van het telkens herhalen van wat men juist wenst te vermijden als gevolg van de pogingen het te vermijden. Een negatief werkmodel, een "bad me," dat men, hoe pijnlijk het ook is, nolens volens in stand houdt, door vanuit dat model zodanig vorm te geven aan relaties dat het telkens weer bevestigd wordt. Het gevangen zitten in ambivalenties omdat het doorbreken daarvan woede vergt, die weer schuld oproept. Het beter willen doen dan de eigen ou-

17 Vgl. met betrekking tot de emoties als 'co-agent' (in plaats van antipode, zoals

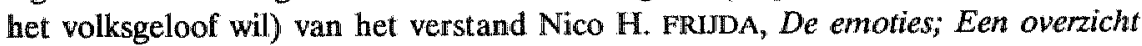
wan onderzoek en theorie (1986), Amsterdam 1993.

Dit wil uiteraard niet zeggen dat er niet ook 'onaangepaste' emoties kunnen zijn zoals bijwoorbeeld de ('overaangepaste') 'emoties die steunen op verouderde hechtingsrelaties' (FRJJDA, a.W., p. 494): anachronismen die in stand blijven door het niet verwerken en bewerken van de traumatische c.q. negatieve (averechtse) aspecten van die ver-ouder-de/verinnerlijkte relaties. (Althans in mijn interpretatie, FRIJDA onthoudt zich hier van een antwoord op de waarom-vraag: a.w., p. 495.) Zo merkt GOLEMAN op (Emotionele intelligentie, a.w., pp. 199/200): 'Veel, misschien wel de meeste emotionele responsen die in een huwelijk zo gemakkelijk in gang gezet worden, vinden hun oorsprong in de tijd dat we kind waren. (...) Zo worden we automatisch geinstrueerd in bepaalde emotionele gewoonten (...), ook al hebben we gezworen dat we ons niet zo zouden gedragen alls onze ouders.' Uiteraard is dit geen noodlot, al 'verdwijnt geen enkele van deze emotionele gewoonten van de ene dag op de andere; daar is op zijn minst doorzettingsvermogen en waakzaamheid voor nodig." Deze 'relationeles emotionelle gewoonten kunnen met des te meer reden anachronismen genoemd worden naarmate ze voortspruiten uit wat GOLEMAN noent 'emotioneel onbekwame ouderschapsstijlen." Hiertoe rekent hij: "[hjet totaal negeren van gevoelens," "[t]e "laissez-faire" zijn" en 'Injeerbuigend zijn, geen respect hebben voor hoe het kind zich voelt.' ('Het gezin als laboratorium," a.w., pp. 257-270, op p. 259.)

H.E.M. BAARTMAN, Opvoeden kan zeer doen; Over oorzaken van kindermishandeling, hulpverlening en preventie, Utrecht 1996, p. 83. 
ders, maar zich op voorhand reeds (opnieuw) uitgebuit woelen. Ergernis om een kind omdat het een kind is, dat wil zeggen iemand van wie men terecht minder verwachten "mag." Bovendien, de wens het beter te doen dan de eigen ouders, laat staan het uitvoering geven daaraan, kan al ervaren worden als een vorm van dysloyaliteit aan de eigen ouders, en dus kan de eigen (afgetroggelde) loyaliteit maken dat men zijn eigen pogingen het beter te doen, vervolgens zelf boycot [posttraumatische zelf-sabotage, jw].'

\section{Het dynamische persoonsbegrip: de mens als persoon in potentie}

We repten zoëven van het bevorderen en bewaken van de persoonswording van kinderen (als maatschappelijke verantwoordelijkheid). Duidelijk zij dat in deze studie een dynamisch persoonsbegrip wordt gehanteerd: het kind wordt als mens, maar de mens wordt niet als persoon geboren; de mens is 'niet per definitie een persoon, maar is persoon in potentie' (DE RUYTER). ${ }^{19}$ Eveneens aan DE RUYTER ontlenen we de hierboven al aangestipte trits rationaliteit, moraliteit \& authenticiteit waarmee in deze studie het minimum dan wel optimum van de persoonswording van (mens en) kind wordt aangegeven (zie hoofdstuk 9). Een onderscheid dat we in juridisch-pedagogische zin hebben doorgetrokken: dreigt subminimale persoonswording, dat is subminimale rationaliteit, moraliteit en/of authenticiteit (lees: is het kernrecht van het kind op minimale persoonswording in gevaar), dan is het opleggen van opvoedingshulp aan het gezin onontkoombaar, doch opvoedingshulp dient steeds (en al veel eerder) te worden aangeboden omdat en in zoverre deze optimale rationaliteit, moraliteit en authenticiteit, kortom optimale persoonswording - als fundamenteel recht van het kind - bevordert.

14.2.2

Ontwikkeling van het kind: leiding en begeleiding bij de ontplooiing naar bovenminimale rationaliteit, moraliteit en authenticiteit als kernrecht

Het kind is voor zijn ontwikkeling en uitgroei naar zelfstandigheid, dat is om persoon te worden, op opvoeding aangewezen: op leiding en begeleiding bij zijn ontplooiing naar optimale, en ten minste minimale rationali-

Doret DE RUYTER, Met recht ingrijpend, diss. VU Amsterdam 1993, p. 111.

Dit in afwijking van de juridische terminologie met betrekking tot persoon en persconlijkheid. Vgl. bijwoorbeeld V.M. SMTrS, 'De persoon,' in: M.J.C. KOENS (red.), Het hedendaagse personen-en familierecht, Zwolle 1995, pp. 15-70, op p. 16 ("Door de geboorte ontstaat de persoonlijkheid'); op p. 18 ('Het einde van de persoonlijkheid'). Persoonlijkheid (dus de persoon geworden mens) ontstaat in onze visie/terminologie pas na de geboorte; kan tijdens het leven gestoord raken en misschien wel zodanig dat zij al voor de dood heeft opgehouden te bestaan (denk aan de demente mens die voor zijn omgeving onherkenbaar geworden is). 
teit, moraliteit en authenticiteit. Opvoeding tot (boven-)minimaal persoon is met andere woorden net zo goed een "basic need" - en daarmee een kernrecht - van het kind als zijn of haar recht op leven en overleven, op lichamelijke en geestelijke integriteit en vrijwaring van wrede of vernederende behandeling of bestraffing.

Betoogd/bepleit is (a) het (minimum-)recht van het kind op minimale persoonswording tot de kernrechten (van de mens) te rekenen c.q. aan de reeks kernrechten (zie hoofdstuk 4) toe te voegen (aanhakend bij art. 25, lid 2 van de Universele Verklaring van de rechten van de mens), c.q. dat het recht van het kind op minimale persoonswording als kernrecht van het kind moet worden beschouwd. En (b) dat ten aanzien van dit recht een beroep op het beperkt-zijn van overheidsfinanciën rechtens niet door de beugel kan: er is een rechtsplicht tot reallocatie van middelen zonder welke Nederland staatsaansprakelijkheid niet kan ontlopen.

Het mag duidelijk zijn dat tegen kern-rechten van kinderen, met als binnenste kern het recht op integriteit van de persoon (VAN DIJK 1994; zie hoofdstuk 4, par. 4.3.2, no. 6) en de vrijwaring van wrede of vernederende behandeling of bestraffing ( $i b .$, no. 8 ), niet door ouders met succes een beroep kan worden gedaan op minder fundamentele rechten (tertiaire of derde-categorierechten) als het recht op eerbiediging van de privacy (ib., no. 36), het recht te huwen en een gezin te stichten (ib., no. 42), of het recht op vrije keuze van opvoeding en onderwijs (ib., no. 44). Of anders, wellicht beter, gezegd: een beroep op deze zogenaamde derde-categorierechten rechtvaardigt niet dat de overheid stilzit met betrekking tot het stellen van wettelijke beperkingen aan deze rechten, dan wel het scherper toezien op en beter handhaven van bestaande beperkingen, ter betere bescherming van de (kern)rechten van het kind. Een dergelijk stilzitten zou - gezien de transgenerationeel marginaliserende effecten - een vorm van discriminatie kunnen worden genoemd: sociaal-pedagogische nalatigheid bestendigt systemüsch stigmatiserend-selectieve patronen (sociaal-emotionele/-economische Verelendung door het Mattheüs-effect), ${ }^{20}$ met als uiterste consequentie: kinderbescherming als vorm van armoedezorg, waarvoor de rekening telkens in de volgende generatie wordt gepresenteerd (HAANS). ${ }^{21}$ In de huidige bedeling is (en heet) maatregelhulp ondertoezichtstelling: "een (dreigende) breuk tussen gezin en samenleving"

Het Mattheüs-effect kan slechts door reparatie (psychisch herstel/rehabilitatie) worden doorbroken. Zolang reparatie niet op grote schaal plaatsvindt, is het Mattheüs-effect in feite synoniem met sociaal-emotionele/-economische Verelendung als maatschappelijk fenomeen.

Gë HAANS, Kinderen voor onze rekening; Een caswistische verkenning van het (gezins) voogdijwerk, Utrecht 1992, p. 179 if. (aangehaald in hoofdstuk 13, par. 13.4.1). 
(HAANS), ${ }^{22}$ discriminatoir stigma op transgenerationeel trauma. Vandaar: staatstransgenerationaliteitsaansprakelijkheid.

Kindermishandeling is (in hoofdstuk 11) in juridische zin geherdefinieerd als schending van het (kern)recht van het kind op minimale persoonswording (bedreiging of beschadiging van minimale rationaliteit, moraliteit en/of authenticiteit).

14.2.3

Het 'belang van het kind' als pedagogisch recht: het recht van het kind op optimale persoonswording

Grondslag van de rechten van de mens is de menselijke waardigheid, welke noopt tot respect voor de persoonlijke integriteit van elke mens. Grondslag van de rechten van het kind is, kort aangeduid, waardigheid/ integriteit èn ontwikkeling. Immers (nogmaals): het kind wordt wel als mens maar niet als persoon geboren, het ontwikkelt zich, door opvoeding, tot persoon. Als mens is de rechten-grondslag van het kind menselijke waardigheid/integriteit, als persoon-in-wording tevens het fundamentele beginsel 'het belang van het kind': een belang van ontwikkelingspsychologische/pedagogische aard. Het 'belang van het kind' is dus primair een (ontwikkelingspsychologisch en) pedagogisch, en pas daarna, in het verlengde daarvan, een juridisch te operationaliseren begrip (zie hoofdstuk 8). Bepleit is daarom 'het belang van het kind' om te zetten in het fundamentele rechtsbeginsel: het recht van het kind op optimale persoonswording. Betoogd is (in hoofdstuk 10) dat dit recht als achterliggend, dragend en leidend beginsel van het Verdrag inzake de rechten van het kind kan worden beschouwd. Het verenigt in zich de door het Comité inzake de rechten van het kind (krachtens de door het Comité in 1996 aangenomen Algemene richtlijnen voor statenrapporten) gehanteerde algemene (verdrags)beginselen: non-discriminatie (het recht van elk kind...), het belang van het kind, (over)leven \& ontwikkeling (van met name het jonge en zeer jonge kind) en respect voor de mening van het (zich ontwikkelende) kind (c.q. de jongere).

Het recht van het kind (van elk kind) op optimale persoonswording als fundamenteel rechtsbeginsel is echter tevens een fundamenteel mensenrecht, een fundamenteel, zo niet - naast het recht op (over)leven het meest fundamentele recht van het kind (vandaar art. 6, lid 2 VRK: het recht van het kind op overleven èn ontwikkeling). Het recht van het kind op optimale persoonswording als fundamenteel rechtsbeginsel, mensenrecht en recht van het kind brengt veel duidelijker dan - zo niet bijna in tegenstelling tot - de (rechts)notie 'het bellang van het kind' tot uitdruk- 
king wat als volgt door FRANKLIN, in een bijdrage geschreven in zijn hoedanigheid van voorzitter van de British Association for the Prevention and Study of Child Abuse and Neglect, is verwoord: $:^{23}$

\begin{abstract}
"What is needed is for all countries, including our own, to accept the overriding importance of the growth and development of children to their full potential [i.e. optimale persoonswording, jw] and of the need to make this a conscious goal. Each country should then accept certain responsibilities - to examine the ways in which this goal can be achieved, to examine those attitudes and practices which hinder the achievement of this goal and to renew, in the context of their own society and culture, the priority to be given to the achievement of this goal.'
\end{abstract}

Waaraan hij de bittere woorden toevoegde:

"Yet many children will continue to have as raw a deal in the [Western, jw] world of the eighties [and nineties, jw] as children have ever had ....'

Het Verdrag inzake de rechten van het kind maakt evenwel dat wij zijn pessimisme niet (willen) delen:

'As to life in the world to come this receives diminishing attention as the decades pass.'

14.2.4

De sociaal-pedagogische kwestie: een natuurlijk en verdragsrecht op een evenwichtige en geweldloze opvoeding. zonder effectief recht op opvoedingsbegeleiding en -bewaking als grove mensenrechtenschending

Omvang (minimaal 50.000 c.q. 80.000 kinderen per jaar bij zeer enge c.q. enge definitie/extrapolatie) ${ }^{24}$ en ernst - qua kinderleed, qua seque-

A.W. FRANKLIN (1982), aangehaald in Robert DINGWALL, John EEKELAAR, Topsy MURRAY, The protection of children; State intervention and family life, Oxford/ New York 1985, p. 211. (Hierna volgende twee citaten: t.a.p.)

24 Het betreft hier (minimale) incidentie-cijfers (zie hoofdstuk 12, par. 12.2.1), ofwel (jaarlijkse) bodemcijfers. Een prevalentie-percentage van 3 ( 3 op de 100 minderjarigen) voor ernstige tot zeer ernstige en (bijna-)fatale vormen van kindermishandeling, en van 10 ( 1 op de 10 minderjarigen) voor (lichte tot) matige èn ernstige tot zeer ernstige/(bijna-)fatale vormen van kindermishandeling komt mij in Nederland als niet onwaarschijnlijk, en zelfs niet als bovengrens voor (vgl, hoofdstuk 12, par. 12.2.2-3). Zie voor wat onder lichte, matige, ernstige, zeer ernstige en (bijna-)fatale vormen van kindermishandeling moet worden verstaan, bijlage III (Criteria kindermishandeling). Voor de goede orde: ook bij lichte vormen gaat het (gezien de definitie van kindermishandeling) om te verwachten (aanneme- 
lae (langdurige/levenslange psycho-sociale gevolgen voor het individu) en qua (materiële en immateriële) kosten voor naaste (gezins-/werk-) omgeving en de samenleving in haar geheel - van kindermishandeling in Nederland rechtvaardigen - nópen tot - de kwalificatie ernstige (grove en grootschalige) mensenrechtenschendingen. Zijn deze in beginsel (c.q. in het gros van de gevallen) aan de staat toe te rekenen? (Presumptie van, dat is 'ecologische') staatsaansprakelijkheid, puur en simpel, is hierin gelegen dat de staat, in de huidige bedeling, minimale persoonswording (als verdragsrechtelijke quasi-resultaatsverplichting) structureel niet kan waarborgen. Niet kan en - grosso modo - niet wil. Om met de Commissie Seksueel Misbruik van Jeugdigen te spreken: ${ }^{25}$

\begin{abstract}
'Rechten van ouders kunnen ook beperkt worden, maar in Nederland bestaat aan de kant van de overheid grote terughoudendheid ten aanzien van het beperken of overnemen van de verantwoordelijkheid van ouders. Alleen als ouders in verregaande mate hun plichten ten aanzien van hun kinderen verzaken of misbruik maken van hun ouderlijke macht, kan hiertoe worden [lees: wordt hiertoe in incidentele gevallen, jw] overgegaan.'
\end{abstract}

Hoe talrijk die incidentele gevallen (in absolute cijfers) ook zijn - en hoezeer ook bekend is dat zij hooguit het (te-late-interventie-)topje van het (te-weinig-gemelde) topje van de (kindermishandelings)ijsberg betreffen -, kennelijk slaagt de staat erin de werkelijke omvang van kindermishandeling in Nederland voor zichzelf en de maatschappij verborgen te houden. Zo wordt dadelijk aan het begin van de beleidsbrief Naar een solide basis; Opvoedingsondersteuning en ontwikkelingsstimulering als bijdrage aan het voorkomen van maatschappelijke uitval en jeugdcriminaliteit (gedateerd 8 april 1998), opgemerkt: ${ }^{26}$

'Ons land kent een voor grote groepen goed toegankelijk stelsel van onderwijs, zorg en welzijn. Problemen van en met jongeren blijven binnen de perken, al zijn er ook incidenten die ons zorgen baren.'

Hier wordt de hele ijsberg tot 'incident' verklaard. Het verbaast dan niet meer dat de investeringen voor de in het vooruitzicht gestelde 'solide

lijke/waarschijnlijke) schade aan de psycho-sociale ontwikkeling van het kind, met (ernstige) psychische stoornissen (behoudens verwerking) tot (ver) in de volwassenheid als gevolg.

25 COMMISSIE SEKSUEEL MISBRUIK VAN JEUGDIGEN, Handelen bij vermoeden van seksueel misbruik van kinderen en jeugdigen I; Richtlijnen voor beroepsbeoefenaren, Assen 1994, p. 88 (curs. jw).

26 Kamerstukken II 1997/98,25980, Opvoedingsondersteuning en ontwikkelingsstimulering, nr. 1, p. 3 . 
basis" in 1998 de somma van $f 1,6$ miljoen belopen ${ }^{27}$ : omgerekend ten hoogste 20 gulden per in dat jaar mishandeld kind. Alleen UNICEF beweert kinderlevens te kunnen redden voor nog minder geld.

Een andere variant van het wegmoffelen, onzichtbaar houden, van een humanitaire catastrofe (catastofe niet in de zin van natuurramp maar van door mensen veroorzaakte en in stand gehouden vernietiging van menselijk en maatschappelijk kapitaal, een vernietiging die voor de direct betrokkenen, en vaak ook hun omgeving, met ernstig en langdurig lijden gepaard gaat) treffen we aan in de Rapportage jeugd 1997 van het Sociaal en Cultureel Planbureau, waarin de omvang van die catastrofe als volgt wordt afgezwakt: ${ }^{28}$

'Uit de registratie van de LSBVK blijkt dat jaarlijks minstens 10.000 jeugdigen slachtoffer zijn van kindermishandeling.'

Wat de auteurs in hun 'Slotbeschouwing"29 niet vermelden, is dat uit aanvullend cijfermateriaal (zoals dat lacuneus en summier elders in de Rapportage wordt gepresenteerd ${ }^{30}$ ) en andere onderzoeksgegevens afgeleid kan worden dat dit aantal gemakkelijk met een factor vijf tot tien kan worden vermenigvuldigd. En dan is er nog steeds sprake van een bodemcijfer.

'Persoonswording in de Rechtsstaat: Preventie versus Palliatie als Mensenrechtelijke Strategie!' Die boodschap heeft de staat duidelijk nog niet bereikt. Terwijl er toch verschillende roependen in de woestijn zijn, zoals HERMANNS: ${ }^{31}$

'Verschillende voorzieningen en maatschappelijke verhoudingen kunnen een bijdrage leveren aan een effectieve preventie (...). Men kan denken aan preventieve [lichamelijke èn geestelijke, jw] gezondheidszorg, opwoedingswriendelijke woon- en leefomgevingen, woorbereiding van mensen op hun taak als opvoeders, versterking wan de maatschappelijke medeverantwoordelijkheid voor kinderen, het bieden van materiële en financiële bestaanszekerheid en levenskwaliteit aan ouders en kinderen. Om dergelijke veranderingen maatschappelijk en politiek te realiseren, zal echter de positie van het kind en diens opvoeding in de samenleving meer gewaar-

Naar een solide basis, p. 17.

28 M. BEKER, C.J. MAAS, Rapponage jeugd 1997, scP Rijswijk, Den Haag (april) 1998, p. 161 i.f.

29 A.w., pp. 161-170.

30 A.W., pp. 28-30.

31 Jo HERMANNS, "Preventie als voorkeursstrategie,' Comenius; Wetenschappelijk forum voor opvoeding onderwijs en cultuur 1998/1 ('Criminaliteitspreventie en opvoedingsondersteuning ${ }^{9}$ ), pp. 65-76, op pp. $72-73$ (curs. jw). 
deerd moeten worden. Thans lijkt het er op dat het kind en diens opvoeding sluitposten zijn. (...)

Van veel vormen van ernstige jeugdproblematiek is inmiddels duidelijk dat er een samenhang is met de risicocumulatie in de eerste levensjaren. ( $m$. Een meer fundamentele en bredere aanpak van preventie lijkt alleen al om praktische redenen aan te bevelen. (...) Een van de factorem die van buiten af [zijn] te beinvloeden, is sociale ondersteuning. Daar waar sociale ondersteuning aan opvoeders op een georganiseerde wijze wordt verstrekt of aangeboden, spreken we over professionele opvoedingsondersteuning. In de praktijk betekent dit het versterken van de sociale cohesie rond gezinnen, het opbouwen van persoonlijke sociale netwerken in en rond gezinnen en het invullen van lacunes aan informele opvoedingsondersteuning door professionele of professioneel georganiseerde opvoedingsondersteuning.'

Het zijn ware en wijze woorden die evenwel prompt lijken af te ketsen op de dikke muren van het vaderlandse privacy-systeem. Tegenover de door HERMANNS duidelijk gewezen weg staat de schrille Nederlandse werkelijkheid, onder velen aan de kaak gesteld door VAN DER LINDEN. Deze gaat daarbij zelfs zo ver de (feitelijke en juridische) scheiding in ons land tussen Ouderlijke Autonomie ('rechten van ouders'/'de verantwoordelijkheid van ouders'/'ouderlijke macht') en de Staat te vergelijken met de (bijna even sacrosancte althans strikte) scheiding tussen Kerk en Staat. $^{32}$ Een scheiding - dat wil zeggen een geesteshouding, een mentaliteit - die nog versterkt lijkt door de post-communistische (ten onzent: 'postmoderne' of 'paarse') economische waan van de dag: ${ }^{33}$

'The focus on economic growth tends to marginalise care for the weak and the poor. The current attitude is that parents must solve their own problems and government should not interfere. This attitude is in direct conflict with human rights; and those human rights are children's rights too (...).'

Het (ouderlijk) recht op privacy ('family life'), aldus VAN DER LINDEN ...

(...) should be used, not misused. It should not serve to turn autonomy of the family into an absolute autonomy. ${ }^{34}$

Adriaan VAN DER LINDEN (RU Utrecht), 'Change in acceptance of child (care and) protection measures in the Netherlands,' Paper presented at the 9th World Conference of the International Society of Family Law, Durban, South Africa 1997 (nog niet gepubliceerd; 'The autonomy of parental authority, inleiding/ openingswoorden).

33 VAN DER LINDEN, t.a.p. ("Conclusion").

34 T.a.p. $\left(\right.$ i.f. $\left.f_{\mathrm{n}}\right)$. 
Deze ontwikkeling, deze geesteshouding is niet slechts in algemene zin of qua gevolgen ('neveneffecten') in strijd met de rechten van de mens en de rechten van het kind. De verdrags- en mensenrechtelijke (kindervolkenrechtelijke) secundaire opvoedingsverantwoordelijkheid van de staat wordt door deze traditionele (men zou bijna zeggen: pseudo-religieuze) grondhouding (de Nederlandse 'dominee'), door deze (nauwelijks) verborgen sociaal-economische agenda (de Nederlandse 'koopman' - penny wise op de korte, pound foolish op de lange termijn) tot een wassen neus gemaakt. Overheidsinterventie (met een - veel te - groot woord Kinderbescherming genaamd) wordt aldus tot een doekje voor het bloeden, is en blijft symptoombestrijding, een marginaal (in de marge van de samenleving gehouden) en marginaliserend (systemisch-discriminatoir/stigmatiserend) beleid van too little en (per definitie) too late.

Het Nederlandse 'poldermodel' is niet alleen 'ongeschikt voor gezinsbeleid ${ }^{35}$ : het staat haaks op het kindervolkenrecht, is met het recht van het kind, van elk kind, op optimale persoonswording onverenigbaar. Vanuit het perspectief van verdrags- en (algemeen) mensenrechtelijke verplichtingen en in het licht van een situatie van grove en grootschalige mensenrechtenschendingen ten aanzien van kinderen - in Nederland zo goed als in andere welvarende landen -, komt het Nederlandse poldermodel, waarvan het voornaamste dogma lijkt dat de overheid het treffen van sociaal-economische (en dus ook sociaal-pedagogische c.q. gezins-) maatregelen in beginsel onderwerpt aan overeenstemming, en bij voorkeur consensus, tussen de 'sociale partners' (organisaties van werkgevers en werknemers), omdat en voor zover het leidt tot een (gezins)onthoudingsbeleid en het ontlopen van (secundaire opvoedings)verantwoordelijkheden ${ }^{36}$ - en hier houdt in principe de vergelijking met andere welvarende landen op -, neer op het per saldo niet beschermen van de allerzwaksten in de samenleving, het verzaken van de voornaamste plicht, ja de bestaansreden van elke overheid. Het - van sociaal-liberaal (tolerant èn de zwakkeren beschermend, een stem gevend) tot antisociaal-libertinistisch (permissief en de zwaksten aan hun lot overlatend) verworden ${ }^{37}$

Maurice VAN LIESHOUT, "'Poldermodel ongeschikt voor gezinsbeleid"; zes stellingen over gezin en opvoeding in Nederland,' 0/25 (Tijdschrift over jeugd) aprill 1998, pp. 14-19.

36 Zie in dit verband Margriet WANDERS, 'Zorg en opvoeding als politiek probleem; gezinsbeleid bij de overheid en de vier grote partijen,' 0/25 (Tijdschrift over jeugd) april 1998, pp. 8-13; Mieke DE WAAL, 'Van zorgzaamheid naar waakzaamheid,' in: dez. e.a., Gezinnen gezien, Assen 1998, pp. 39-49.

37 WANDERS (t.a.p., op p. 10 l.k.) concludeert: '[I]n het gevoerde beleid viert het poldermodel hoogtij. Een terughoudende overheid schept "randvoorwaarden." Sociale partners en gezinnen [lees: ouders, jw] zelf zijn verantwoordelijk voor de 
- poldermodel is, zacht gezegd, als vloeken in de kindervolkenrechtelijke kerk.

De staat handelt evenwel niet tegen de wil van het volk in: de politiek (wetgever en bestuurlijke overheid) doet niet wat zij maximaal kan omdat zij daartoe niet het duidelijke mandaat van de kiezer, op basis van een brede roep uit de samenleving, heeft. Slechts internationaalrechtelijke (bij zwijgen van de natie en zwichten van de rechter niet meer dan papieren) verplichtingen 'dwingen' haar daartoe. Gevolg: tegenover een natuurlijk en verdragsrecht op een evenwichtige en geweldloze opvoeding voor elk kind in Nederland staat geen effectief recht op opvoedingsbegeleiding (en -bewaking) van elk gezin in Nederland dat daarvoor in aanmerking komt. De politieke wil om radicaal in te grijpen ontbreekt, maar in de maatschappij (zie de zwijgende of nietszeggende partijprogramma's) ontbreekt even radicaal het inzicht in enerzijds de omvang, de ernst èn de kosten van kindermishandeling en anderzijds de mogelijkheden die er op dit moment wel en deugdelijk zijn, volstrekt haalbaar en betaalbaar, om een adequaat SPS-systeem (een geïntegreerd anti-escalatoir en niet-

invulling daarvan. Hier[door] is de collectieve verantwoordelijkheid voor de zorg kleiner dan in de periode van het kostwinnersideaal [de periode van 1945 tot begin zeventiger jaren (t.a.p., op p. 8, eerste alinea)] (...)."

Om de mate van polderlandse onkunde (waaronder mensenrechtelijk en sociaalpedagogisch benul) en/of onwil (en impliciet het niveau van morele ontwikkeling?) te illustreren, zij het toegestaan hier éen politica te citeren (t.a.p., op p. 13 1.k.): 'De houding van de [vier grote politieke] partijen [PvdA, VVD, D66, CDA] bij probleemsituaties in gezinnen is vergelijkbaar met die bij de combinatie van arbeid en zorg. De VVD is terughoudend; het gezin is priveterrein. Monique DE VRIES [VVD]: "Ingrijpen? Alleen in uitzonderingsgevallen. Je kunt niet overal maar binnenbanjeren on te kijken of ze [bedoeld zijn: (jonge) kinderen, jw] wel genoeg verse groente krijgen".' Aangezien dit gezegd wordt door een persoon die gerekend moet worden tot de elite van onze representatieve (en dus tot op zekere hoogte - en afgezien van het formeel-democratische'/ochlocratische fenomeen van racistische volksvertegenwoordigers - meritocratische) democratic,

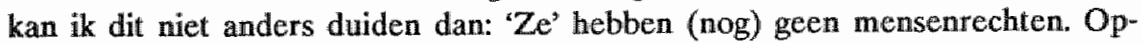
voedingsondersteuning is 'binnenbanjeren.' En kindermishandeling is n(i)et zo erg als 'niet genoeg verse groente.' Ik versta de boodschap zo: aan een gebrek aan verse groente ga je (heus) niet dood. En aan kindermishandeling (meestal) ook niet. En inderdaad: aan kindermishandeling gaan in Nederland 'slechts" (minimaal) tachtig kinderen per jaar dood, "slechts" eên op de duizend mishandelde en (waarschijnilik/meestal) voor het leven beschadigde vrij en gelijk in rechten geboren burgers van onze rechtsstaat. Latere zelfmoordgevallen uiteraard niet meegerekend. En evenmin de gevallen wan zelfmoord-op-termijn door verslavingsen ander risico-zoekend gedrag. $\mathrm{Zij}$ verdwijnen achter de wijde polder-horizon, evenals de slachtoffers van de slachtoffers-die-daders-worden. Zij verdwijnen, om GEZELLE na te dromen, hoger dan politieke ogen dragen, wijder dan polderwinden jagen. 
stigmatiserend stelsel van sociaal-pedagogische voorzieningen, instellingen en diensten) in het leven te roepen.

Omdat elk kind een verdragsrechtelijk recht heeft, bekleed is met het fundamentele mensenrecht op te groeien tot een optimaal persoon, omdat elk kind een verdragsrechtelijk recht heeft, bekleed is met het fundamentele mensenrecht op waarborging van zijn minimale persoonswording, omdat dit minimum en dit optimum respectievelijk als dwingendrechtelijke garantie (als bodem van het verbod op onmenselijke bejegening) en uiterste-inspanningsverplichting van de staat aan het Verdrag inzake de rechten van het kind ten grondslag liggen, daarom kan en moet gesteld worden dat het Verdrag inzake de rechten van het kind de staat verplicht tot een actieve, en zelfs activistische opstelling met betrekking tot 'de pedagogische kwestie,' dat wil zeggen de staat verplicht een einde te maken aan de libertinistische pedagogische wetteloosheid, de huidige sociaal-pedagogische anarchie, de staat verplicht, positief geformuleerd, sociaal-pedagogisch orde op zaken te stellen.

De 'paedagogische quaestie' (c.q. de sociaal-pedagogische kwestie) kan, voor wat haar oorzaak en essentie betreft, als volgt kort worden getypeerd. Iemand die van zijn vak houdt, is enkel daarom nog geen goed vakman. Daar is op zijn minst een jarenlange opleiding en training aan voorafgegaan. Iemand die van zijn kinderen houdt, is enkel daarom nog geen goede opvoeder. Te meer niet omdat er geen enkele opleiding en training, èn structurele reparatie van hetgeen in de eigen jeugd mogelijkerwijs is misgegaan en mis-gedaan, aan is voorafgegaan.

Geen staat zou een rechtsstaat mogen heten waar - anders dan incidenteel en vrijblijvend, en enkel of voornamelijk weggelegd voor een sociaal-pedagogisch reeds mondige en in die zin bevoorrechte klasse opleiding, training (ouderschapsvorming, opvoedingsonderwijs), begeleiding, ondersteuning (opvoedingsondersteuning, opvoedingsloon), materieel en moreel, politiek en sociaal, in wetgeving en beleid, voor ouders niet bestaan, waar er voor ouders geen sociaal-pedagogisch vangnet is. Geen staat kan een rechtsstaat heten waar jaarlijks tienduizenden kinderen aan sociaal-pedagogisch libertinisme worden opgeofferd - tot schade van henzelf, hun partners, hun latere kinderen, en de hele maatschappij. Geen staat heet een rechtsstaat waar fundamentele mensenrechten op grote schaal worden geschonden terwijl de natie toekijkt, de andere kant opkijkt, de gordijnen sluit, wel uitkijkt zich met de buren te bemoeien. Geen staat mag een rechtsstaat heten waar fundamentele mensenrechten van kinderen op grote schaal worden verwaarloosd en veronachtzaamd.

Door partij te worden bij het Verdrag inzake de rechten van het kind houden staten de schijn hoog rechtsstaten te zijn, houdt Nederland de schijn hoog een rechtsstaat te zijn. Maar pas de effectieve naleving 
van het Verdrag kan hen tot rechtsstaten maken. Enkel sociaal-pedagogisch activisme van overheid en samenleving, politiek en publiek, kan in Nederland de kloof tussen schijn en werkelijkheid, tussen pays légal en pays réel, tussen papieren (internationaalrechtelijke) ${ }^{38}$ rechtsstatelijkheid en feitelijke (nationale) grove, grootschalige en passief-systematische mensenrechtenschendingen ${ }^{39}$ overbruggen. Waarom zou Nederland niet hierin gidsland zijn?

Een gidsland, om te beginnen, in het doorbreken van traditionele attitudes, in het breken van de macht der historische gewoonte. Wat dit voor de samenleving, voor volwassenen, voor ouders in wezen betekent, kan eenvoudig worden geillustreerd door de positie van vrouwen (c.q. zin en strekking van het Vrouwenverdrag) met de situatie van kinderen (c.q. betekenis en bedoeling van het Kinderrechtenverdrag) te vergelijken. Om wrouwen te incorporeren in de rechtsstaat moesten, en moeten, mannen een stuk(je) opschuiven; om kinderen een plaats te geven in de rechtsstaat moeten volwassenen een stuk(je) opschuiven: zij zullen afstand moeten (leren) doen van de vanzelfsprekendheid niet alleen van het op de wereld zetten maar ook van het opvoeden van kinderen. Met name dat laatste zal minder binnen de staatsvrije sfeer komen te liggen dan vele generaties gewend zijn geweest - en soms in ernstige mate aan den lijve hebben ondervonden.

Om een variant van een ooit door mij gepubliceerde (Recht en kritiek 1994/4, p. 322 , doch ter plaatse verminkt weergegeven) senryü te gebruiken:

\section{Kinderrechten in}

een verdrag: moole woorden

op geschept papier....

Voor dat verdrag, het Verdrag inzake de rechten wan het kind, voor de rechten in dat Verdrag geldt wat voor mensentechten in het algemeen geldt: 'Les droits de l'homme ne s"apprennent pas par coeur, ils se pratiquent ou ils meurent." (Guy AURENCHE, aangehaald door Chr. MAES, 'Rechten van het kind ... en verder,' in: E. VERHELLEN e.a. (red.), Kinderrechtengids, Gent 1994 (losbladig), Deel I, Commentaren, 1.1 MAES, pp. 1-16, op p. 15.) Hetgeen uiteraard ook positiever (in de zin van de halflege fles die door levenskunstenaars voor halfvol wordt aangezien) kan worden verwoord: 'Menschenrechte streben nach ihrer Erfüllung, zu einer ihnen dienenden Politik.' (Ludger KünHARDT, Die Universalität der Menschenrechte, Bonn 1991, p. 13.)

Passief-systematisch, immers (kort gezegd) de staat die geweld (fysiek, emotioneel, sexueel) tegen kinderen niet effectief bestrijdt (omdat hij zich niet dan na ernstige escalatie van problemen met de privacy van gezinnen wil bemoeien), pleegt zelf - indirect, structureel of passief - geweld tegen kinderen.

In die zin is Kinderbescherming in Nederland, omdat en in zoverre zij voor (late) Palliatie in plaats van voor (vroegtijdige) Preventie staat, eerder een gewelddadig dan een weldadig instituut. 

van cen kind = en gezinsvriendelijke samenleving

In dit hoofdstuk gaan we, in het grijze gebied tussen staatsaansprakelijkheid (state responsibility) en staatsverantwoordelijkheid (accountability), dat wil zeggen tussen algemeen-internationaalrechtelijke staatsaansprakelijkheid ter zake van ernstige mensenrechtenschendingen en specifieke rechtspolitieke overheidswerantwoordelijkheden met betrekking tot (ruim geformuleerde) verdragsverplichtingen, of anders gezegd in het juridische schaduwland van het recht van het kind op optimale persoonswording, op zoek naar wetgeving en beleidsmaatregelen die adequaat uitvoering geven aan de internationaalrechtelijke verplichtingen ex (in het bijzonder) art. 2, lid 1; art. 3 ; art. 6, lid 2; art. 9; art. 18, lid 2; art. 19, lid 2; art. 20; art. 24, lid 2 aanhef en onder e en f, en lid 3; art. 25; art. 27, lid 1 en 3; art. 29, lid 1 aanhef en onder b en d; art. 32, lid 1; art. 33 juncto (voor wat betreft alcohol en nicotine) art. 36; art. 34; art. 37 aanhef en onder a, eerste volzin; art. 39 ; en art. 42 van het Verdrag inzake de rechten van het kind. Ons streven is niet meer en niet minder dan het geven van een blauwdruk van een verdragsconforme kind- en gezinsvriendelijke samenleving. In de hierna volgende paragrafen van dit hoofdstuk wordt die blauwdruk, worden de contouren van zo'n samenleving geschetst (en op onderdelen nader toegelicht).

14.3

Sociaal-Pedagogische Steun als geïntegreerde preventieve benadering

Ter inleiding op deze paragraaf (her)introduceren we de afkorting SPS, drie letters die staan voor zowel Sociaal-Pedagogische Steun als SociaalPedagogisch Stelsel. Met beide wordt gedoeld op stelselmatige sociaal-pedagogische steun, dat wil zeggen op sociaal-pedagogische voorzieningen, instellingen en diensten opgericht en ingericht volgens het model van de glijdende schaal. Dit model wordt in subparagraaf 14.3.3 ingeluid om in een andere (sub)paragraaf (par. 14.5.2.2.1) te worden uitgewerkt (drieechelonsmodel). In deze paragraaf gaat het ons vooral om déze gedachte: het belang - of liever de noodzaak - van een geïntegreerde preventieve benadering. Via twee zij-ingangen pogen we deze gedachte voor het voetlicht te brengen: de linkeringang van 'monitoring parenting' (par. 14.3.1) en de rechteringang van preventie van (jeugd)criminaliteit (par. 14.3.2). 


\subsubsection{Monitoring parenting als schrikbeeld}

\section{Mensenrechtenschending}

Art. 3, lid 3 (kort gezegd: geschiktheid van en toezicht op jeugdhulpverleners en kinderbeschermers) en het bepaalde in (onder meer) art. 3, lid 2, art. 18, lid 2 en art. 19, lid 1 (kort, en enigszins pregnant, gezegd: zorg voor, competentie van en toezicht op ouders/opvoeders) van het Verdrag inzake de rechten van het kind impliceren dat de zorg voor en de bescherming van kinderen niet langer vallen binnen de domestic jurisdiction, niet langer enkel een binnenlandse aangelegenheid zijn, een - internationaalrechtelijk - rechtsvrij gebied, waarop staten hun gang kunnen gaan respectievelijk ouders (c.q. opvoeders) en particuliere organisaties hun gang kunnen láten gaan. Kan kindermishandeling (het in ernstige mate te kort schieten in de zorg voor en de bescherming van kinderen door ouders of in instellingen, door overbelaste, onvoldoende toegeruste of gewoon ongeschikte hulpverleners) al sinds jaar en dag als mensenrechtenschending gebrandmerkt worden - als schending immers van fundamentele algemene mensenrechten, zoals het recht op persoonlijke veiligheid en integriteit (met als bodem vrijwaring van onmenselijke en vernederende behandeling en bestraffing) - in elk geval sinds de inwerkingtreding van het Verdrag inzake de rechten van het kind kan ook statelijke nalatigheid en onzorgvuldigheid ten aanzien van de secundaire (aanvullende en desnoods vervangende) opvoedingsverantwoordelijkheid van de overheid als mensenrechtenschending worden ge(dis) kwalificeerd.

Om dit ook anders te formuleren (en ons weer tot ouders te beperken): behoorden tot voor kort dysfunctionele ouders (buiten de incidenteel ter kennis van de overheid gekomen gevallen van ernstige tot en met fatale fysieke mishandeling/verwaarlozing of sexueel misbruik) tot de vele risico-factoren in het (kinder)leven waarmee de wereld van het recht principieel geen bemoeienis had, tegenwoordig (voor Nederland in elk geval sinds 8 maart 1995) zijn dysfunctionele ouders (f)actoren waar het (internationale) recht iets over te zeggen heeft, inzoverre kinderen recht hebben op bescherming tegen dysfunctionele, hun persoonswording bedreigende of beschadigende ouders (en deze laatsten tegen zichzelf voor zover het hun hoedanigheid van ouders betreft, dat wil zeggen hun kinderen raakt).

Uit het recht van het kind op optimale (waaronder begrepen minimale) persoonswording, zoals dat ten grondslag ligt aan en zijn uitwerking vindt in het Verdrag inzake de rechten van het kind, vloeit als corresponderende plicht van de verdragsstaat voort het door wetgevende en andere maatregelen bewerkstelligen van alle vormen van preventie, tijdige signalering, melding en vroege interventie die effectief (doeltreffend) 
en efficiënt (doelmatig) zijn. Daarnaast - of liever: in verband daarmee dient er adequate hulpverlening woor kind en gezin te zijn, en dient het kind reparatie (therapie) en de survivor (het meerderjarige slachtoffer) morele (erkenning en rehabilitatie, waaronder desgewenst therapie) en financiële compensatie (van symbolische genoegdoening tot en met zo volledig mogelijke schadeloosstelling) te worden geboden.

\section{Monitoring parenting}

Bovenstaand mensenrechtelijk verhaal (verhaal in dubbele betekenis) roept bij velen niet het in principe positieve beeld van maatschappelijke bemoeizorg ${ }^{40}$ op (een nieuw maternalisme: 'Moedertje Maatschappij'), doch daarentegen het uiterst negatieve beeld, ja bijna schrikbeeld van een bemoeizuchtige overheid (ouderwets paternalisme: 'Vadertje Staat'). Wij zullen op deze plaats niet herkauwen welke parentiarchale eigenaardigheden en 'onaardigheden' - onder de vaan van privacy - daarachter schuilgaan. In hoofdstuk 13 hebben wij benadrukt dat privacy te zeer wordt ervaren als louter negatief rechtsbeginsel, ziende op negatieve vrijheid in de vorm van een staatsvrije (en 'medeburgersvrije') sfeer (het individualistische 'right to be let alone'), in plaats van als tevens positief beginsel: als recht op positieve vrijheid, op ontplooiing, op geestelijke gezondheid, op 'persoonlijke groei,' op optimale persoonswording. Daarmee willen en mogen wij evenwel opgemeld schrikbeeld - en het daarachter opdoemende spookbeeld van 'staatspedagogiek' ${ }^{41}$ - niet wegwuiven. Op deze plaats willen wij daarom kort aandacht besteden aan wat in de literatuur monitoring parenting is genoemd: een (consequent en grootscheeps) stelsel van ouderschapsinspectie, let wel: als (uit onmacht geboren) alternatief voor het huidige - met 'Kinderbescherming' aangeklede en met 'Jeugdhulpverlening' opgeklopte - stelsel van (substantiële) overheidsonthouding ${ }^{42}$ (en dus kinderverzaking). ${ }^{43}$

De term ontleen ik aan Paul KUYpers en Jos VAN DER LANS, Naat een modern patemalisme; Over de noodzaak van sociaal beleid, Amsterdam (De Balie) 1994, pp. 35 e.v. Zie inmiddels ook de (eerder aangehaalde) beleidsbrief 'Naar een solide basis," Kamerstukken II 1997/98, 25 980, Opvoedingsondersteuning en ontwikkelingsstimulering, nr. 1., p. 15.

Een term die ik ontleen aan het opstel van Philip KOHNSTAMM, 'Staatspedagogiek of persoonlijkheidspedagogiek (1919),' in: dez., Persoon en samenleving; Opstellen over opvoeding en democratie, Meppel/Amsterdam 1981, pp. 89-120.

Een onthoudingspolitiek die als volgt is verwoord door LEACH (Penelope LEACH, Children first; What society must do - and is not doing - for children today, London 1994, p. 6): 'Outside the Nordic nations, where children's care is regarded as a joint responsibility of parents and the state, Western governments leave responsibility for children to their natural families as a matter of individualist, laissezfaire principle - and economics. Responsibility for children brings parents con- 
Onder het kopje 'ouderschapsinspectie' (monitoring parenting) merkt VAN DER PLOEG in zijn dissertatie Opvoeding en politiek in de overleg-democratie (1995) op: $:^{44}$

[Gezins-]Inspectie levert meer op naarmate men zich minder aan de privacy van de ouders gelegen lat liggen. Signalering en preventie [van kindermishandeling c.q. van escalatie van opvoedingsproblemen, jw] zijn slechts mogelijk als de inspectie de vorm krijgt van regelmatige onaangekondigde bezocken bij elk gezin thuis en gesprekken met de gezinsleden afzonderlijk. Zo'n systeem zou een gigantische investering betekenen en een immens administratief apparaat met grote hoeveelheden functionarissen, enzovoorts.'

Een praktisch probleem met principiële kanten: de inspecterende bureaucratie kan zo log worden dat bij haar doorzichtigheid, controleerbaarheid, betrouwbaarheid en (bijgevolg) doelmatigheid en rechtvaardigheid steeds meer vraagtekens zullen worden geplaatst. Naast dit gemengd praktischprincipiële bezwaar werpt de auteur ook het (in zijn visie) puur principiële bezwaar op van de aantasting van de (negatieve) privacy van de ouders (over de positieve privacy in de zin van de persoonswording van kinderen spreekt hij niet ${ }^{45}$ ).

siderable rights [bevoegdheden: kind als rechtssubject, versus - i.c. - macht: kind als machtsobject] ower them; indeed many' social institutions reflect a view of children as parents' personal possessions [kind als eigendom] rather than as members of society in their own right [kind als staatsbunger]."

Consequentie van deze onthoudingspolitiek is dat enerzijds goed ouderschap niet wordt gewaardeerd, althans geen maatschappelijke erkenning krijgt, en dat anderzijds slecht (alchans 'asociaal') ouderschap leidt tot maatschappelijke stigmatisering met behulp van het - in de huidige bedeling per definitie te laat komende en te weinig kunnende - "onthoudingsapparaat" Kinderbescherming.

Een ander alternatief: de 'ouderschapsvergunning" (licensing parents): "de invoerïng van een vergunningenstelsel voor ouderschap" (zie Piet VAN DER PLOEG, Opvoeding en politiek in de overleg-democratie; Democratische verdeling en normering van pedagogische autoriteit, diss. Utrecht, Baarn 1995, pp. 266-268; aanhaling op p. 266), laten we hier buiten beschouwing. Meer nog dan monitoring parenting schiet het zijn doel volledig voorbij. Het is een te grof (dus ondoelmatig) middel, dat bovendien direct ingrijpt op (zoiets 'onbeheersbaars' als) de voortplantingsvrijheid. Om die reden heeft het geen zin morele voordelen (vanuit een persoonswordingsoptiek) en bezwaren (vanuit een privacy-optiek) hier op een rijtje te zetten (om dan het minste van twee kwaden: grootschalige kindermishandeling of grove privacy-schending, te kiezen). Ook aan meer 'banale' zaken als politieke haalbaarheid en maatschappelijke aanvaardbaarheid hoeven we dus geen woorden vuil te maken. verstaat: 'kinderen bijstaan in hun leren' (a.w., p. 144). Zie ook a.w., pp. 154/155: 
Echter: monitoring parenting hoeft niet per se als synoniem met 'ouderschapsinspectie' ('regelmatige onaangekondigde bezoeken bij elk gezin thuis en gesprekken met de gezinsleden afzonderlijk') te worden opgevat (concedo: een kwalijke - en dus ook onwerkbare - vorm van statelijk wantrouwen ten opzichte van ouders, ${ }^{46}$ waarbij spontane oprispingen van statelijke kritiek op calculerende burgers in het niet vallen). Er is wel degelijk een derde weg, een weg tussen de onmacht van het huidige stelsel en de 'almacht" van monitoring parenting in de hierboven aangehaalde zin: de weg van opvoedingsbegeleiding en -bewaking.

\section{Tertium datur: de derde weg}

Monitoring parenting kan ook worden opgevat als SPS-aanbod: financieel (opvoedingsbijslag of ouderschapsloon); medisch (de huidige consultatiebureaus); pedlagogisch (opvoedingscursussen, pedagogische vaardigheidstrainingen, opvoedingsadviezen en opvoedingsondersteuning via sociaalpedagogische uitbouw van consultatiebureaus en opbouw van schoolmaatschappelijk werk); psychologisch (therapie-aanbod aan in hun jeugd te kort gedane of te kort gekomen ouders met het oog op hun empowerment als mens en ouder, op vergroting van hun eigenwaarde, hun sociaalemotionele vaardigheden, hun pedagogisch besef).

Allerlei modaliteiten en varianten zijn hierbij denkbaar om binnen een ruim eerste kader van vrijwilligheid - een en ander niet te laten ontaarden in vrijblijvendheid, waardoor juist degenen die hulp het meest nodig hebben, opnieuw buiten de boot zouden vallen, en degenen die de weg toch wel weten te vinden, extra worden bevoordeeld. Zo zou er ten aanzien van de sociaal-pedagogisch opgetuigde consultatiebureaus een wettelijke opkomstplicht (periodieke verschijnplicht) kunnen worden ingevoerd als 'contraprestatie' voor de opvoedingsbijslag (die bijvoorbeeld op het bureau wordt uitgekeerd). Dit dient de generale preventie (er gaat immers de boodschap, het sociale consigne van uit: opvoeden is niet vanzelfsprekend maar wordt door de gemeenschap moreel en materieel gewaardeerd en, in de vorm van randvoorwaarden, bewaakt), maar maakt uiteraard ook snelle(re) signalering van opvoedproblemen mogelijk. Even vanzelfsprekend als thans het vragen naar en adviseren over de lichamelijke gezondheid van het kind dient - zo spoedig mogelijk - te worden

leren als 'basic need' betekent dat 'opvoeding niet alleen als mensenrecht, maar ook als mensenplicht [zij] te begrijpen.' Aan VAN DER PLOEGs 'onbetwistbare waarde van bezonnenheid' (a.w., p. 155) gaat iets heel basaals vooraf: de onbetwistbare waarde van een goede hechting tussen moeder(vader) en zuigeling, peuter, kleuter: het 'voorschoolse' kind.

Vgl. VAN DER PLOEG, a.w., p. 271. 
het vragen naar en adviseren over het psychisch welbevinden in het gezin en opvoedingsaspecten.

Een tweede modaliteit om vrijblijvendheid (en dus kapitaalvernietiging) te voorkomen, zou inspectie of huisbezoek kunnen zijn, maar - let wel - pas ingeval de ouders bijvoorbeeld niet verschijnen op het (medisch en pedagogisch) consultatie-spreekuur of het kind niet komt opdagen op crèche, (medisch/pedagogisch) dagverblijf of school. Pas dan volgt (na rappel) inspectie thuis (SPI: Sociaal-Pedagogische Inspectie, door SPID: Sociaal-Pedagogische Inspectie-Dienst) met, indien nodig, een concreet en specifiek hulpaanbod. Dat laatste - een op de gezinssituatie toegesneden hulpaanbod in geval van pedagogische nood c.q. dreigende escalatie van problemen - kan uiteraard, bij wèl verschijnen op het consultatiespreekuur, ook direct worden gedaan door de consultatie-pedagoog die (ernstige) opvoedproblemen constateert.

Pas bij weigering (of - al dan niet bewuste - 'sabotage') van opvoedhulp kan (en moet) het opleggen van hulp worden overwogen (glijdende-schaalscenario). We betreden dan het tweede, strikte kader van justitiële maatregelen (van hulp en steun). Pas op dit moment speelt de vraag van de (ouderlijke) rechtsbescherming (bezwaar bij SPID en beroep bij gezinsrechter).

Gesteld kan worden dat bij een dergelijke 'privacy-bewuste' invulling van 'monitoring parenting' de staat in principe voldoet aan zijn rechtsplicht onder het Verdrag inzake de rechten van het kind (art. 19 VRK juncto het recht op optimale/minimale persoonswording). Vooralsnog vormt ouderlijke privacy evenwel - als statelijk alibi voor een onthoudingspolitiek (non pòssumus, non debémus, non vólumus: wij kunnen het niet, wij hoeven het niet, wij willen het niet) ${ }^{47}$ - een gracht met dubbele wallen rond het gezin: privacy-rechten maken het gezin tot een ware 'zone of secrecy. ${ }^{48}$ Het aanpakken van (nefaste) gezinsstructuren houdt

Dat wil zeggen: wij kunnen het niet, en als wij het (al) kunnen, dan boeven wij het niet, en als wij het (al) moeten, dan willen wij het niet. (Vgl. het antwoord van paus Clemens VII op het echtscheidingsverzoek van Hendrik viII.)

Dexe aanduiding lijkt mij bij nader inzien adequater dan de term 'totale institutie' die ik in het verleden hanteerde (WILLEMS, "Van parentiarchie naar Vadertje Staat; over 't verwekken, mishandelen en beschermen van kinderen,' Nemesis $1992 / 3$, pp. 8-23, op p. 11 l.k.). In een totale institutie, zoals de gevangenis, gelden nog bepaalde reglementen, zijn er rechten naast plichten, en is er rechtsbescherming. De totale willekeur waaraan kinderen in het dysfunctionele gezin (kunnen) worden blootgesteld, heeft meer weg van slavernij, horigheid, dwangarbeid, foltering, onmenselijke/vernederende behandeling/bestraffing, doorlopende schending van het recht op persoonlijke veiligheid en het recht op privacy (respectievelijk artt. 4, 5, 3, 8 EVRM; 8, 7, 9, 17 rVBPR). Voor wie dit ten aanzien van (kleine) kinderen te grote kwalificaties vindt, draag ik als voorbeeld ter toet- 
dan ook allereerst in het aanpakken - en om te beginnen het ter discussie stellen - van maatschappelijke structuren vanuit de radicale opvatting dat kinderen, ook en met name de jongsten onder hen, in een rechtsstaat minimaal dezelfde bescherming genieten tegen schending van hun privacy - dat wil zeggen: van hun fysieke en psychische integriteit (waaronder hun minimale persoonswording) - als volwassenen, de stemgerechtigde leden van de maatschappij. En zulks zonder onderscheid naar afkomst, buurt, rang of stand.

\section{3 .2}

\section{Preventie van kindermishandeling is preventie van (jeugd-) criminaliteit}

Tot de sociaal-emotionele sequelae (lange-termijn gevolgen) van kindermishandeling behoren niet alleen uiteenlopende psychische problemen van slachtoffers (c.q. 'survivors') maar ook problemen die zij - in het verlengde daarvan - veroorzaken voor hun omgeving. Dit laatste kan variëren van de last die partners, kinderen, collegae hebben van de angsten, onzekerheden, zeg maar: de neurosen van slachtoffers, tot en met meer of minder ernstige vormen van uitgeageerde innerlijke problematiek: de situatie dat de omgeving meer (b)lijkt te lijden onder de gedragsproblemen van slachtoffers/survivors dan zijzelf. Ernstige vormen van ver-uiterlijkte problematiek brengen jongeren - dat wil zeggen: nog steeds voornamelijk jongens (13:2), en naar het lijkt op steeds jongere leeftijd eerst in de grijze zone van de randcriminaliteit en vervolgens in land van de uitgestotenen bij uitstek: dat van de echte (jeugd)criminaliteit. ${ }^{49}$

sing ến casus aan, nee én brief slechts, enkele met de hand geschreven regels van een kind, afgedrukt in Jim GolDBERG, Raised by wolves, New York 1995, p. [270] (en door mij als volgt vertaald):

"Ik ben gestoord, als kind mishandeld. Ze knijpen me de keel dicht en slaan me. Ze spelen met mijn penis. Ik heb een probleem met mensen. $k k$ ben geen nomaal kind. Soms voel ik me een klein kind in een groot lichaam. Ik zou de wereld willen opblazen. Ik will mijn eigen weg gaan. Ik wil naar niemand luisteren. Mijn moeder en vader moesten me niet. Ze sloegen met een hamer naar $m$ 'n been - hersenbeschadiging. Er is geen liefde in mijn leven. Alles zit hartstikke fout! Ik zuig mannen af voor geld. Woor mij geen kerstfeest ([dit jaar]). Misschien word ik [komend] jaar groot, trouw ik en krijg ik drie kinderen. Ik hoop dat mijn leven dan op orde is. - Robert FOWLKES (...)" 
Hoewel dit al als voldoende 'bewijs' van de stelling die in de titel van deze (sub)paragraaf is vervat, kan worden beschouwd, willen we in deze (sub)paragraaf zowel het zojuist beweerde nader adstrueren (par. 14.3.2.1) als stilstaan (zij het toch ingehouden-stampvoetend) bij een reactie op justitiële voorstellen die deze (bewezen) stelling tot uitgangspunt namen (par. 14.3.2.2).

\subsubsection{Externaliseren/internaliseren}

Bij kinderen spreken we van gedragsstoornissen; het zou prematuur zijn bij hen de specifiekere classificaties voor volwassenen, in het bijzonder waar het as-II-psychopathologie betreft (de persoonlijkheidsstoornissen), toe te (willen) passen. ${ }^{50}$ Problemen waarmee kinderen, hetzij primair vanuit hun aanleg, hetzij primair vanuit hun opvoedingssituatie, te kampen hebben, kunnen door hen naar buiten dan wel naar binnen gericht worden. We spreken dan van externaliseren respectievelijk internaliseren. Bij meisjes komt vooral het laatste voor, bij jongens vooral het eerste. Meisjes zijn dientengevolge gemiddeld vaker 'sociaal-angstig,' jongens gemiddeld vaker 'anti-sociaal.'

Ten behoeve van een helder begrip van in het bijzonder de dichotomie externaliseren-internaliseren in verband met gedragsmoeilijkheden van kinderen (als latere mogelijk 'gestoorde' volwassenen) gaan we te rade bij DELFOS, die onlangs een belangwekkend biopsychologisch model voor gedragsstoornissen heeft geïntroduceerd. De auteur schrijft hierover: $:^{51}$

basis van casestudies van emstig criminele jongeren, Ministerie van Justitie, Den Haag (december) 1996; Sociaal en Cultureel Planbureau, Rapportage jeugd 1997, Den Haag 1998 (NRC Handelsblad van 17 april 1998, p. 6: 'SCP: jeugdcriminaliteit harder, verdachten jonger'); Juliaan VAN ACKER, Jeugdcriminaliteit" Feiten en mythen over een beperkt probleem, Houten/Diegem 1998.

50 Vgl. (voor een recente studie op dit gebied) R.E. ABRAHAM, Het ontwikkelingsprofiel; Een psychodynamische diagnose van de persoonlijkheid, Assen 1997, p. 13 (waar de auteur onder meer opmerkt: 'Het gedrag van de volwassene wordt getypeerd door de mate waarin hij de bij zijn leeftijd passende gedragspatronen heeft ontwikkeld en de mate waarin zijn gedrag bepaald wordt door "vroege" patronen. In principe heeft iedere volwassene kenmerken van het kind dat hij is geweest.") Zie ook bijlage $\mathrm{V}$ (Persoonlijkheidsstoornissen).

51 Martine F. DELFos, Kinderen en gedragsproblemen; Een bio-psychologisch model met richtijnen voor diagnostiek en behandeling, Lisse 1997, "Inleiding," pp. 15-21 (curs. zowel overgenomen als aangebracht). Vgl. (onder meer) ook de hoofdstukken 8 ('Seksueel misbruik en kindermishandeling') en 9 ('Opvoeding: beschermende en risicofactoren voor de ontwikkeling') uit DELFOS" Kinderen in ontwikkeling; Stoornissen en belemmeringen, Lisse 1996, pp. 115-147. 
"Agressiestoornissen en angststoornissen zijn twee uitingsvormen van "gedragsstoornissen" bij kinderen en jeugdigen. Wanneer deze stoormissen bij volwassenen voorkomen, noemen we deze niet "gedragsstoornissen" maar wordt de problematiek fijnmaziger beschreven (voor angst bijvoorbeeld de benoeming van specifieke angststoornissen zoals agorafobie of sociale fobie) of in termen van persoonlijkheidsstoornissem (bijwoorbeeld anti-sociale persoonlijkheid[sstoomis]). (...) [1]n [de Nederlandse uitgave van] de $D S M-I V$, de meest gebruikte internationale classificatie voor psychische stoornissen, worden de "conduct disorders" met "gedragsstoornissen" vertaald. (...) [I]n dit boek [zullen we】 de "conduct disorders" onder de overkoepelende term gedragsmoeilikheden laten vallen. We introduceren een nieuw begrippenstelsel dat gebruik maakt van bekende terminologie, en die de verschillen in problematiek in een overkoepelend kader zet. Zo proberen we recht te doen aan de aard en de oorsprong van de problematiek in aanleg, omgeving [in het bijzonder opvoeding, jw] of rijping van het centrale zenwwstelsel. We zullen zien dat binnen de conduct disorders, die we onder de term gedragsmoeilijkheden rangschikken, twee soorten onderscheiden worden: de gedragsstoornis, die vooral vanuit aanleg ontstaat, en het gedragsprobleem, dat vooral als gevolg van de inwloed van de angeving [in het bijzonder de opvoeding, jw] ontstaat. (...) Gedurende lange tijd werden onder "gedragsstoornissen" (gedragsmoeilijkheden) alleen die gedragingen verstaan waarbij de betrokkene in conflict kwam met zijn of haar omgeving: de agressieve, naar buiten gerichte vorm. [Daarmee] worden echter alleen de maatschappelijk problematische gedragingen bedoeld [zo]als agressie, stelen of brandstichten. ACHENBACH [1978] laat de groep gedragingen waarbij geen sprake is wan agressie maar van extreme verlegenheid en angst, ook onder "gedragsstoornissen" (gedragsmoeilijkheden) vallen. Hij spreekt over een geëxternaliseerde - naar buiten gerichte, agressieve - vorm en een geïntemaliseerde - naar binnen gerichte, angstige - vorm. (...)

Voor het scheppen van duidelijkheid beginnen we de groep gedragingen, [de geëxternaliseerde] "conduct disorders" en [de geïnternaliseerde] angststoornissen in het algemeen, samen te vatten onder de term gedragsmoeilijkheden, als overkoepelend begrip. Daarbinnen maken we dan onderscheid tussen gedragsstoomissen en gedragsproblemen. De stoornissen worden voornamelijk gestuurd vanuit de aanleg van het kind, de problemen vooral [vanuit] de omgeving. In het eerste geval hebben we te maken met een stoomis ten opzichte van de normale ontwikkeling ..."

... waar ouders meer of minder adequaat pedagogisch op inspelen (c.q. 'nemo plus' - op in kùnen spelen); waarbij in het meest onopvoedkundige geval van een vorm van kindermishandeling sprake kan zijn ...

'... in het tweede geval met een belemmering van deze ontwikkeling ...'

... waarin de ouders in directe zin een negatieve pedagogische rol speler (wanopvoeding), waarbij in de ergste gevallen van (een vorm van) kinder mishandeling sprake is. 
(...) Bij beide vormen [stoornis en belemmering] zullem we een onderscheid maken tussen agressief, geärtemaliseerd [anti-sociaal] gedrag en angstig, geintemaliseerd [sociaal-angstig] gedrag. (...)

Naast de gedragsmoeilijkheden behandelen we ADHD [Attention-Deficit/Hyperactivity Disorder, de aandachtstekortsstoornis met hyperactiviteit (welke term overigens niet duidt op een tekort aan aandacht voor het kind maar op concentraticproblemen van het kind; vandaar dat wellicht de vertaling concentratiestoomis met hyperactiviteit duidelijker ware), jw], waarbij eveneens sprake is van een aanlegproblematiek zoals bij de gedragssioonis, maar (...) van een geheel andere orde. Bij ADHD hebben we te maken met een vertraagde of beperkte rijping van het centrale zenuwstelsel; bij de gedragsstoomis met een afwijking van het centralle zenuwstelsel. (...)

Het maken van een onderscheid tussen aanleg [nature] en omgeving [nurture] is een hachelijke zaak. Niet voor niets wordt het vaak niet gemaakt of wordt een extreem standpunt ingenomen waarbij alles op aanleg wordt geschoven of, net zo extreem, alles aan de omgeving [in het bijzonder de opvoeding, dus aan de ouders, jw] wordt toegeschreven. De continue interactie tussen beide aspecten maakt de zaak er bovendien niet eenvoudiger op. (...) Problematiek die vooral in aanleg gegeven is, kan via de hulpverlening niet wezenlijk veranderd worden; mensen [ouders en kinderen, jw] kunnen alleen leren [ondersteund vanuit een sociaal-pedagogisch netwerk, jw] er optimaal mee te leven [dat is: het beste ervan te maken, jw]. Een probleem [lees: geèxternaliseerd, anti-sociaal, dan wel geinternaliseerd, sociaal-angstig probleemgedrag, $j w]$ dat vanuit de omgeving ontstaan is, zou in principe om te buigen zijn [in geval van een effectief sociaal-pedagogisch stelsel, jw] en de hulpverlening kan er in dat geval op gericht zijn de omgeving te veranderen of de gevolgen van de invloed wan de omgeving te behandelen fen het kind uit de omgeving te halen indien en voor zover deze niet veranderbaar/behandelbaar is, jw]. Voor een juiste hulpverlening [ouderschapsondersteuning en/ of therapie, $j w]$ is het gemaakte onderscheid daarom van essentieel belang. (...) Binnen de hulpverlening aan kinderen en jongeren zijn gedragsmoeilijkheden de meest voorkomende hulpvraag. De meeste aanmeldingen betreffen jongens met gedragsmoeilijkheden en wel de agressieve, naar buiten gerichte vorm. (...)

Veel psychiatrische stoornissen komen in het algemeen meer bij jongens dan bij meisjes voor [als jongen geboren worden, is een risico-factor (DELFOs 1996); biopsychologisch zijn jongens het zwakke geslacht, jw]. De [anti-sociale] worm van gedragsproblematiek die meestal bij jongens voorkomt, veroorzaakt last voor hun omgeving en is van daaruit vaker aanleiding tot het doen van een beroep op de hulpverlening. De voor meisjes typisch [sociaal-]angstige vorm is naar binnen gericht en veroorzaakt meer last voor henzelf. (...) Gezien de last die jongens kunnen veroorzaken, zullen ze eerder tijdens hun jeugd aangemeld worden dan meisjes. De gedragsmoeilijkheden bij meisjes zullen eerder leiden tot aanmeldingen door henzelf wanneer ze volwassen zijn.'

Het mag duidelijk zijn dat een effectief sociaal-pedagogisch netwerk veel problemen die primair met de aanleg samenhangen, kan ondervangen door (vormen van) ondersteuning van de ouders bij hun extra zware opvoedingstaak. Anderzijds mag niet worden onderschat hoe diep problemen die primair met de opvoedingssituatie samenhangen, op het zich 
ontwikkelende brein en zenuwstelsel van het (jonge) kind kunnen inwerken. Met - bij afwezigheid van een adequaat sociaal-pedagogisch stelsel - ernstige, langdurige en soms zelfs blijvende cerebro-psychische schade als gevolg. Schade - puur economisch gezien bestaande uit, direct of indirect verband houdend met en direct of indirect voortkomend uit vernietigd menselijk kapitaal - die altijd op de maatschappij wordt afgewenteld: hetzij in de vorm van gederfde maatschappelijke winst (uitval), hetzij in de vorm van ziektekosten (in de lichamelijke zowel als in de geestelijke gezondheidszorg), hetzij in de vorm van criminaliteit (de prijs van de uitsluiting en de kosten van opsluiting). Meestal in een combinatie van die vormen. Soms in alle drie vormen.

\subsubsection{Als het kalf verdronken is}

Ter (nadere) adstructie van de stelling die in de titel van paragraaf 14.3.2 is vervat, kunnen we (ook) verwijzen naar het lange citaat uit de nota Jeugd en gezin van JUNGER-TAS in hoofdstuk $12 .{ }^{52}$ Op deze plaats beperken we ons tot een reactie op haar voorstellen, van de hand van Justitieonderzoekster BOL, welke we (vanuit de grondgedachte van de noodzaak van een geïntegreerde preventieve benadering) van doorlopend commentaar voorzien.

Privésfeer is heilig, persoonswording niet? BOL stelt: ${ }^{53}$

"Naar mijn mening is er geen rechtsgrond woor een op preventie gerichte bemoei. enis met burgers of hun gezinnen [lees: ouders/opwoeders en/of kinderen, jw zolang de genoemde emstige moeilijkheden [hetzij binnen het gezin, hetzij me betrekking tot delinquent gedrag van kinderen; JUNGER-TAS, JV 1996/6] zich nie daadwerkelijk voordoen.'

Josine JUNGER-TAS, Jeugd en gezin; Preventie vanuit een justitieel perspectief, De Haag (Ministerie van Justitie, Directie Belleid) juni 1996; aangehaald in hoofdstu. 12, aan het slot van par. 12.3.2 (onder het kopje. Criminaliteit (3): jeugd en gezin? Een bewerking van de nota verscheen in Justitiële Verkenningen: J. JUNGER-TA: "Gezinsbeleid vanuit een justitieel perspectief;" Justitiële Verkenningen 1996/ ('Preventief ingrijpen in het gezin'), pp. 17-37; hieruit is geciteerd in hoofdstuk 1: par. 13.4.1 (onder het kopje Toetsing aan de hand van getuige-deskundigenverklk ringen). Zie inmiddels ook Josine JUNGer-TAS, 'Predictie van criminaliteit en pr ventief ingrijpen,' Comenius; Wetenschappelijk forum voor opvoeding, onderwijs e culturu 1998/1 ('Criminaliteitspreventie en opvoedingsondersteuning'), pp. 28-4' M.W. BOL, 'Preventief ingrijpen: rechtsgrond is heilig, ondergrens niet,' react ('Journaal') in Justitiële Verkenningen 1996/8, pp. 93-96, op p. 93 1.k. (curs. jw). 
In haar uitwerking van dit standpunt beperkt BOL zich tot de (primaire, secundaire en tertiaire) preventietaken van het ministerie van Justitie (bij BOL 'justitie') - met andere woorden: het is haar niet te doen om staatsaansprakelijkheid/overheidsverantwoordelijkheden maar om "territoriumafbakening.' Bovendien gaat zij aan de (kern)rechten van het kind c.q. het Verdrag inzake de rechten van het kind volledig voorbij. De onderbouwing (of liever adstructie) van haar standpunt wordt hieronder weergegeven, waarbij ik mijn kritische (op punten enigszins gechargeerde) commentaar - vragenderwijs - tussen vierkante teksthaken heb geplaatst. Onder het kopje 'Primaire preventie' stelt BOL.: ${ }^{54}$

'Het creëren van gunstige sociale omstandigheden woor jeugdigen in het algemeen [optimale sociaal-pedagogische voorzieningen? - jw] ligt voornamelijk op de weg van andere departementen. (...) Wel (...) kan [Justitie] meedenken en adviseren over de wijze waarop scholen en gezinsondersteunende instanties zouden kunnen bijdragen aan de normatieve disciplinering van kinderen.'

Ook al zou Nederland een bureaucratische statenbond zijn, een republiek van onafhankelijke departementen, dan nog kan aan deze adstructie geen argument ter ontkenning van staatsaansprakelijkheid worden ontleend. Integendeel, in het licht van het Verdrag inzake de rechten van het kind kan zij als veelzeggend worden beschouwd ten aanzien van de afwerende en bezwerende minimalistische houding van de staat (hierboven 'onthoudingspolitiek' gedoopt) ten opzichte van zijn mensenrechtelijke verplichtingen. Onder het kopje 'Secundaire preventie' vervolgt BOL:.55

'Bij secundaire preventie gaat het om het vroegtijdig interveniëren in de levens van individuen of groepen [sic, jw] die in "criminogene" omstandigheden [omstandigheden waarin de persoonswording van kinderen op meer of minder criminele wijze wordt bedreigd? -jw] verkeren. (...) Maar hoeveel drang of dwang is gerechtvaardigd als er van vrijwillige deelname [aan preventie-programma's] geen sprake is? Op dit punt dient een uiterst zorgvuldige afweging [tussen de kernrechten van het kind en tertiaire ouderlijke rechten? -jwl te worden gemaakt. Voor drang of dwang is geen legitimatie [buiten het Verdrag inzake de rechten van het kind? - jw] zolang er slechts sprake is van verontrustende omstandigheden zonder dat de gevreesde gedragsproblemen zich (al) hebben gemanifesteerd [lees: her kalf al verdronken is? -jw]. Mw. JUNGER-TAS stelt voor om aan bepaalde groepen ouders stimuleringspremies aan te bieden en om op andere groepen een zekere drang uit te oefenen teneinde hen te bewegen tot deelname aan zo'n [preventic-]programma. Naar mijn mening gaan deze voorstellen net iets te ver. Ook waar het secundaire preventie betreft, past justitie een zekere terughoudendheid,

T.a.p., op pp. 93/94 (curs. deels aangebracht, deels overgenomen). 
met name ten aanzien van groepen in de samenleving waarvan sommige zich wellicht toch al snel gestigmatiseerd voelen."

Bepaalde groepen - lees gezinnen - die "zich wellicht toch al snel gestigmatiseerd voelen,' dienen extra aan hun lot te worden overgelaten. Zodat de kinderen in die gezinnen het stigma aan hun kinderen zullen kunnen doorgeven, en die weer aan hun kinderen, net zolang totdat de maatschappij de internationaalrechtelijke rechtsgrond(en) die BOL niet ziet, tot nationaal recht heeft "getransformeerd" en in het nationale recht heeft geoperationaliseerd. Net zolang totdat de staat zijn internationaalrechtelijke verplichtingen onder het Verdrag inzake de rechten van het kind naar de letter en de geest naleeft. Of gaat het voorstel dat de staat dat dóét, althans daar aanstalten toe maakt, een proces van sociaal-pedagogisch beleid en sociaal-pedagogische wetgeving op gang brengt, ook 'net iets te ver'?

\section{Interventie geslaagd, patiënt overleden}

Niet afwijzend staat BOL ten opzichte van tertiaire preventie: justitiële interventie als (aanvankelijk nog beheersbare en in principe oplosbare) opvoedingsproblemen tot (niet of nauwelijks meer te corrigeren, te repareren) ernstige gedragsproblemen hebben geleid. ${ }^{.6}$

"Is men het er over eens dat van ernstige gedragsproblemen moet worden gesproken [met andere woorden: vindt ieder weldenkend mens dat het kalf verdronken is? -jw], dan kan de interventie worden omschreven als tertiaire preventie. (...) Justitiële dwang is hierbij] in principe gerechtvaardigd [op basis van het principe: baat het niet (meer), erger schaden kan het niet (meer)? -jw] en vaak geïndiceerd."

Geïndiceerd op basis van de justitiële diagnose: de rechtsorde is (dool het criminele kind!) geschokt. Volgt de justitiële therapie: het mes erin Met als voorspelbaar resultaat: de zwaardmacht van de overheid heef gezegevierd, maar aan (de persoonswording van) de minderjarige val nauwelijks nog iets te redden. Ofwel: interventie geslaagd, patiënt over leden.

Een integrale aanpak en een glijdende schaal van ouder schapsondersteuning (inluiding/intermezzo)

De patiënt overlijdt echter niet terstond, hij sterft een langzame door TOMAŠEVSKI heeft deze 'justitiële dood' - de dood in de pot van de or 
dertoezichtstelling van ouders, de dood in de put van de (in de huidige bedeling vroeger of later onvermijdelijke) uithuisplaatsing van kinderenvan de volgende aankondiging voorzien: ${ }^{57}$

[T] postulates of the primacy of the family, especially parents, and legitimacy of governmental powers to intervene, ultimately to take a child away from parents, in the name of the child's best interest. This is conceptually the most far-reaching development of human rights because it places the State, traditionally the target of safeguards against abuse of power, into the position of guarantor against abuse of power by parents. The issue is far from rhetorical because the practice of many countries shows that a child who was "saved" from parental abuse ends up in an institution resembling a prison rather than a surrogate family."

Wij pretenderen dat het concept van een integrale aanpak volgens het model van een glijdende schaal zodanige conceptuele harmonie kan brengen dat TOMAŠEVSKI's tegenstrijdige postulaten althans enigermate kunnen worden verzoend. Dit concept of model, een geïntegreerde preventieve benadering volgens een glijdende-schaal-aanpak, presenteren wij - in (sub)paragraaf 14.5.2.2.1 - als een geünificeerd anti-escalatoir en niet-stigmatiserend preventief-interveniërend-reparatoir raamwerk. In deze (sub)paragraaf gaan we - om onze (niet geringe) pretentie stevige grond onder de voeten te geven - te rade bij diverse deskundigen, die ons raamwerk als het ware inluiden. Dit 'inluiden' dient tegelijkertijd een tweede doel: de in deze subparagraaf aangehaalde ontwikkelingspsychologische en pedagogische uiteenzettingen (waarop de eveneens aangehaalde 'inluidende' sociaal-pedagogische opinies zijn gebaseerd) brengen in kort bestek enkele elementen bijeen die als samenvattingen en -voegingen kunnen worden opgevat van verschillende in eerdere hoofdstukken behandelde onderwerpen. Deze dubbele doelstelling mag rechtvaardigen dat er in deze paragraaf, in het bijzonder ten behoeve van de (wel juridisch doch) niet (tevens) psychologisch/pedagogisch geschoolde lezer(es), wat uitgebreider wordt geciteerd. Voor andere lezers kan deze paragraaf (groten)deels als een (synoptisch) intermezzo worden beschouwd, waarbij ik op deze plaats wel graag wijs op het (aangenaam) verrassende feit dat in deze paragraaf (vrijwel) volledig uit een juridisch tijdschrift kan worden geput. Bedoelde (resumerende) uiteenzettingen en ('inluidende') opinies lichten wij hier en daar kort toe hetzij door middel van teksthaken hetzij

Katarina TOMASEESKI, bespreking van LEBLANCS The Convention on the rights of the child, United Nations lawmaking on human rights (Lincoln/London 1995), in: NQHR 1996/1 ('Book reviews'), pp. 111-115, op p. 113 i.f. 
door middel van korte onderbrekingen van het betoog. Ter inleiding op de reeks citaten diene het volgende.

'Het kind heeft een fundamenteel recht op optimale persoonswording' betekent: de staat spant zich tot het uiterste in voor optimale sociaal-pedagogische voorzieningen. Dat wil (onder andere) zeggen:

- voor ouderschapsscholing, -advisering, -ondersteuning, -begeleiding enzovoorts, kortom: voor een sociaal-pedagogisch apparaat dat adequaat is uitgerust, dat adequaat functioneert en dat adequaat wordt gecontroleerd; - voor hulpverlening aan kind en gezin, dat is voor een kinderbeschermingsapparaat dat adequaat (met inbegrip van rechtsmiddelen) is uitgerust, dat adequaat functioneert en dat adequaat wordt gecontroleerd.

In onze visie zijn beide apparaten (per definitie) volledig geïntegreerd, het eerste in het laatste en het laatste in het eerste. Dit éne socilaal-pedagogische kinderbeschermingsapparaat - deze sine qua non van een modern, althans zinnig en zindelijk gezinsbeleid - duiden wij aan met SPS.

\section{De eerste deskundige}

Bij GOUDENA lezen we:: 58

'De afgelopen vijftien jaar heeft zich op het gebied van onderzoek van de problematische ontwikkeling van kinderen een discipline gevormd die aangeduid wordt met de term "ontwikkelingspsychopathologie" (..). In de ontwikkelingspsychopathologie wordt het verband tussen normale en gestoorde ontwikkeling bestudeerd. Een centraal begrip is in dat verband "ontwikkelingsopgave" [of ontwikkelingstaak, jw]. Met ontwikkelingsopgave wordt een thema aangeduid dat voor het kind in een bepaalde periode van zijn of haar leven verschijnt en dat door het kind beheerst moet worden wil het kind zich optimaal verder ontwikkelen. Een voorbeeld van een ontwikkelingsopgave is "het aangaan van een veilige gehechtheidsrelatie met de opvoeder." Deze opgave speelt vanaf het einde van het eerste levensjaar. Over deze ontwikkelingsopgave is veel onderzoek gedaan, dat het belang van het hebben van een goede relatie met minimaal én opvoeder onderstreept. Een ander voorbeeld van een ontwikkelingsopgave is "omgaan met leeftijdsgenoten." Uit een groot aantal onderzoeken (...) blijkt dat kinderen die deze opgave niet goed leren beheersen, hetgeen bijvoorbeeld naar voren kan komen uit het feit dat zij door leeftijdsgenoten verworpen worden, een verhoogde kans op latere problemen hebben. (...)

Hoe kan een kind nu optimaal een ontwikkelingsopgave leren beheersen? Daarvoor is de hulp van opvoeders nodig. Complementair an ontwikkelingsopgave kunnen wij het begrip "opvoedingsopgave" [of opvoedingstaak, jw] onderscheiden. Met opvoedingsopgave bedoelen wij die pedagogische activiteiten en voorzieningen (curs. jw). 
die het kind helpen een ontwikkelingsopgave te leren beheersen. Het door een kind aangaan van een veilige gehechtheidsrelatie met een opvoeder wordt bevorderd wanneer de opvoeder sensitief reageert op de signalen van het kind, dat wil zeggen de uiteenlopende behoeften van het kind alert opmerkt en daarop gepast reageert. Een opvoeder die het kiad geen aandacht geeft, verwaarloost of mishandelt, maakt het voor het betreffende kind vrijwel onmogelijk een veilige gehechtheidsrelatie met de opvoeder aan te gaan. Het leren omgaan met leeftijdsgenoten wordt voor het kind gemakkelijker wanneer het kind in een democratisch opvoedingsmilieu opgroeit en wanneer de opvoeders voor het kind mogelijkheden verschaffen om constructief met leeftijdsgenoten om te gaan. Een autoritair opvoedingsklimaat, waarin fysieke straffen regel zijm, of sociaal isolement van het gezin hebben daarentegen een negatieve uitwerking. (...) Kinderen kunnen in hum ontwikkeling bedreigd worden [indien er sprake is van (meerdere) risicofactoren, jw], maar tijdens bedreiging kan er ook bescherming zijn [bij aanwezigheid van protectieve factoren, jw]. (...).'

Naast opvoeders(kenmerken) zijn er echter, vooral naarmate het kind ouder wordt, meerdere ontwikkelingsdeterminanten: ${ }^{59}$

'Hoewel opvoeders een belangrijke rol spelen in het leven van kinderen, zijn zij bepaald niet de enigen die de ontwikkeling van het kind beïnloeden. Op een wat abstracter niveau kunnen we de volgende "determinanten" van de ontwikkeling van kinderen onderscheiden: [1.] opvoeding [ouders, leerkrachten, grootouders, beroepsopvoeders]; [2.] opvoederskenmerken [persoonlijkheidskenmerken van de opvoeder, opvoedingskwaliteiten/pedagogisch besef, jw]; [3.] gezinskenmerken [gezinsklimaat, gezinssamenstelling, socio-economische status van het gezin]; [4.] omgevingsfactoren [de buurt, sociale contacten buitenshuis]; [5.] schoolkenmerken [organisatie, aantal leerlingen, kwaliteit van het onderwijs]; en [6.] kindkenmerken [temperamentstype, intelligentieniveau, aanwezigheid van psychopathologie]. [Bovenstaande] determinanten doen zowel afzonderlijk als in samenhang hun invloed op de ontwikkeling van kinderen gelden. Binnen elk van deze zes clusters kunnen wij bedreigende [risico-] en beschermende [protectieve] factorem lokaliseren. Met "bedreigend" worden die factoren bedoeld die een negatief effect op de ontwikkeling van kinderen hebben. Als "beschermend" worden die factoren omschreven die het effect van bedreigende factoren verminderen of te niet doen. (...)

Met name de rol van "verwerpende en dwingende gezinsinteracties" lijkt (in negatieve zin) van belang te zijn. Bovendien is het zo dat bij de aanwezigheid van meerdere bedreigende factoren het negatieve effect sterker toeneemt dan de som der afzonderlijke effecten. (...)

Beschermende factoren hebben betrekking op die factoren die een tegenwicht bieden tegen bedreiging. Op het niveau wan kindkenmerken is "intelligentie" een voorbeeld van een beschermende factor.' 
Althans voor zover (een relatief grote) intelligentie een kind in staat stelt zich de positie van betrekkelijke buitenstaander aan te meten en voor zover het die zelf-marginalisering binnen (en buiten) het gezin vroeger of later weet te compenseren met het vinden van een 'mentor' in de buitenwereld, aan wie het zich emotioneel en intellectueel kan 'optrekken. ${ }^{60}$ Maar laten we bij de les blijven: ${ }^{61}$

"Op gezinsniveau is het voor het kind van belang met minimaal één ouder een goede relatie te hebben. (...) Op het niveau van de omgeving kan sociale steun een beschermende factor zijn. (...) Ook de school kan voor kinderen met een problematische gezinsachtergrond een beschermende werking hebben (...).'

Evenwel met alle risico's vandien voor een eenzijdige cognitieve (intellectuele) ontwikkeling - terwijl het 'slimste jongetje van de klas' ten opzichte van leeftijdsgenootjes een onaangepast (emotioneel en later neurotisch infantiel) buitenbeentje blijft. De auteur waarschuwt overigens terecht dat we het hier over 'kansuitspraken' hebben ...

In een besprekingsartikel van RUBINs Het onverwoestbare kind (Nederlandse vert. 1997) spreekt RIJNAARTS in dit verband van 'marginaliteit" en 'adopteerbaarheid': Met marginaliteit bedoelt [RUBIN] dat een kind zich al jong terugtrekt in de marge van het gezin vanuit het gevoel dat het er niet thuis hoort, alsof de ooievaar het bij het verkeerde adres heeft afgeleverd. (...) RUBIN omschrijft adopteerbaarheid als het vermogen mensen aan te trekken die je willen helpen en van wie je iets kunt leren, het vermogen ook om te zien wat anderen je te bieden hebben en er gebruik van te maken. (...) Kinderen die deze gave bezitten, herkennen een potentiële "mentor" wanneer die hun pad kruist.' (José RUNAARTS, 'Het onverwoestbare kind, Opzij juni 1997, pp. 10 en 13-15, op p. 13 l.k.)

In dit artikel trekt RINAARTS ten strijde tegen 'de heersende opinie' ten aanzien van de transgenerationaliteit van traumatische jeugdervaringen (volgens RIJNAARTS een 'mythe' (t.a.p., op p. 14 r.k. i.f.) - overigens zonder één keer het woord 'verwerking' of 'rouwarbeid' te noemen. Het is evenwel met name dit laatste aspect (rouwarbeid en het aanpakken van niet volvoerde ontwikkelingsopgaven) dat - meer nog dan intelligentie - "moed, dapperheid, flinkheid" (taa.p., op p. 13 r.k.) vereist. Waarbij niet uitgesloten kan worden geacht dat die moed als de kinderlijke marginaliteit, en dus (eventuele 'mentoren' ten spijt) het isolement en de eenzaamheid in het latere leven (in de adolescentie en vroege volwassenheid) maar ver genoeg zijn doorgeschoten - minstens even veel met persoonlijke nood en ellende (de moed der wanhoop in, door en na cen vereenzamingsproces) als met wilskracht en doorzettingsvermogen te maken heeft.

Vgl. ook het (meer genuanceerde en informatieve) besprekingsartikel van Judith SCHEEPSTRA in Psychologie juli/augustus 1997, pp. 58-60. 
(...) en niet over de voorspelling van de levensloop van een kind. (...) [O]ver de processen die bij bedreiging en bescherming op individueel niveau werkzaam zijn, [is] vrijwel niets bekend. ${ }^{962}$

Met betrekking tot preventieve activiteiten leidt een en ander de auteur tot de volgende overwegingen: ${ }^{63}$

"In deze bijdrage beperken we ons tot de preventie van psychosociale problemen van kinderen. Dat zijn problemen waarvan we aannemen dat deze in hoge mate bepaald of versterkt worden door omgevingsfactoren, met name door opvoeding en onderwijs. Een gangbare indeling van deze problemen is die in internaliserende, externaliserende en gemengde problematiek. Internaliserende problematiek betreft bijwoorbeeld angst en depressie, externaliserende problematiek onder andere hyperactiviteit en gedragsstoornissen, en gemengde problematiek verwijst naar bijwoorbeeld seksuele problemen.

De zes determinanten van de kinderlijke ontwikkeling en de begrippen "bedreiging" en "bescherming" die hiervoor werden besproken, bieden, tezamen met de begrippen "ontwikkelingsopgaven" en "opvoedingsopgaven" het kader van waaruit over preventic nagedacht kan worden. Daarbij is het van belang een onderscheid te maken tussen primaire en secundaire preventie. Met primaire preventie doelt men op het voorkómen dat problemen tot ontwikkeling komen; met secundaire preventie op het vroegtijdig opsporen en behandelen van problemen.

Laten we dit preventiekader eens concretiseren aan de hand van de problematiek gedragsstoornissen (...). (...) Met welke ontwikkelingsopgaven hangen (...) [het] ontstaan en verloop van gedragsstoornissen samen? In de literatuur over dit onderwerp komen de volgende ontwikkelingsopgaven aan de orde: veilige gehechtheid, impulscontrole en internalisatie van maatschappelijke regels, decentratie (het je kunnen verplaatsen in het gezichtspunt van een ander) en constructief omgaan met leeftijdsgenoten (...). Redenerend vanuit het geschetste kader houdt dit in dat men in het bijzonder nastreeft dat kinderen veilig gehecht zijn, hun impulsen goed leren beheersen en zich maatschappelijke regels eigen maken, zich in een ander kunnen verplaatsen, en goed met leeftijdsgenoten om kunnen gaan. Factoren die de ontwikkeling van kinderen in dit opzicht bedreigen, zal men trachten te elimineren.

Die eliminatie zal echter niet altijd mogelijk of eenvoudig zijn. Op het niveau van "kind" doemen al de eerste problemen op. De oververtegenwoordiging van jongens in de categorie kinderen met gedragsstoornissen is alleen via sekse-wijziging

62 GOUDENA, t.a.p. Vgl ook de klacht van A.D. DE GROOT: 'TO]p het grondig retrospectief onderwragen van een persoon over wat hijzelf te melden heeft over zijn psychische ervaringen, denkwijzen en gevoelens, [rust] nog steeds een behavioristisch taboe. Althans, it is not done - met name niet in de zuiver-wetenschappelijke sector.' (Aangehaald door Karen HAMERLYNCK, Claudia BELLINI, 'De stand van zaken: 15 jaar psychologie," Psychologie april 1997, pp. 16-23, op p. 21 r.k.) Een klacht die we al eerder aanhaalden in hoofdstuk 12, par. 12.3.1 onder Brede range van posttraumatische psychopathologie (sequelae). GOUDENA, t.a.p., op pp. $42-44$ (curs. PG). 
te beïnvloeden, en moeilijk temperament lijkt evenmin een kandidaat voor eliminatie. Bedreigende factoren op het niveau van opwoeders en gezin lijken een geschikter doelwit voor preventieve activiteiten. (...)

Bij secundaire preventie van gedragsstoornissen gaat het om het vroegtijdig onderkennen wan dit type problematiek en daarop aansluitende interventies. Bij onderkenning kan men denken aan het vaststellen van die gedragingen van kinderen die onder de noemer "overtreden van sociale regels" vallen. Men kan echter vanuit een ontwikkelingsperspectief ook alert zijn op het niet goed beheersen van de eerder genoemde ontwikkelingsopgaven en, aansluitend daarop, op het te kort schieten van opvoedingsvaardigheden bij de ouders. Veilige gehechtheid kan een aandachtspunt zijn op het consultatiebureau. Impulscontrole, het zich voegen naar maatschappelijke regels en het constructief omgaan met leeftijdgenoten kunnen in de schoolcontext aandacht krijgen. (...)'

We zijn hier op een cruciaal punt aangeland. Onder het kopje 'Overheidsbemoeienis en preventie' vervolgt de auteur: ${ }^{64}$

'Bij het uitstippelen van een overheidsstrategie op het gebied van preventie van psychosociale problemen bij kinderen spelen twee met elkaar verbonden vragen een rol. In de eerste plaats betreft dit de afweging of men bepaalde preventieactiviteiten zonder meer [en niet vrijblijvend, jw] aanbiedt [aan alle (aanstaande) ouders, $\mathrm{jw}$ w] of slechts op verzoek verstrekt. Zo worden "echtparen die een buitenlands kind willen adopteren," verplicht om voorafgaand aan adoptie een cursus over dit onderwerp te volgen. De achterliggende gedachte is uiteraard om de risico's na adoptie te verminderen.'

Hierbij (bij adoptie van buitenlandse kinderen) is sprake van een dwingend (niet vrijblijvend) aanbod. Is het gewenst een zodanig aanbod (tot het volgen van een ouderschapscursus) uit te breiden tot alle aanstaande (c.q. prille) ouders(/pleegouders/adoptief-ouders)? De auteur. ${ }^{65}$

'Dit leidt ons naar het tweede vraagstuk: welke sociaal-politieke [sociaal-pedagogische, jw] uitgangspunten hanteert men bij preventie van psychosociale problemen? (...) Een sociaal-politieke overweging om preventie van psychosociale problematiek in het algemeen na te streven, zou kunnen zijn dat men het welbevinden van kinderen [lees: hun (optimale) persoonswording, jw] als centrale doelstelling van preventieve activiteiten beschouwt.'

We naderen de ontknoping. Onder de 'Slotopmerkingen' van de auteur lezen we: ${ }^{66}$ 
"Met betrekking tot sociaal-politieke afwegingen is het van belang dat bij het denken over preventie als minimum-optie respect woor de rechten van het kind gehanteerd wordt. (...) Het rechten-aspect kan echter nog [heel wat] werder [dan thans geschiedt, jw] doordacht worden. In het door de Veremigde Naties opgestelde Verdrag inzake de rechten van het kind, dat in 1990 in werking trad Ivoor Nederland in 1995, jw], wordt een drietal categorieen met betrekking tot rechten [van kinderen] onderscheiden: [sociaal-pedagogische] voorzieningen [ter bevordering van optimale persoonswording, jw] (...); bescherming [tegen aantasting van lichamelijke en geestelijke integriteit/minimale persoonswording, jw] (..); en participatie [naar de mate van de zich ontwikkelende vermogens van het kind, jw] (...). Het zou de moeite waard zijn om in de Nederlandse situatie na te gaan in hoeverre de rechten van kinderen binnen de domeinen opvoeding/gezin, school en omgeving [sociaal-pedagogische steun, jw] voldoende gewaarborgd zijn. (....)

Rechten van kinderen, belangen van kinderen en het wellbevinden [de (optimale) persoonswording, jw] van kinderen zijn verre van toevallig met elkaar verbonden. Op het terrein van de preventie van psychosociale problemen van kinderen lijkt die gedachte (...) een geschikte [zo niet dwingende, jw] leidraad woor overheidsbemoeienis.'

\section{De tweede deskundige}

In één van bovenstaande citaten was sprake van internaliserende, externaliserende en gemengde problematiek. De volgende deskundige bij wie we (als voorzichtige, zorgvuldige en leergierige juristen) te rade gaan: SLOT, gaat nader op externaliserende problematiek, op anti-sociaal gedrag dus, in. Antisociaal gedrag omschrijft deze auteur als ...

(...) een variëteit van meer of minder ernstige, al dan niet strafbare vormen van agressief en aanstootgevend gedrag die kunnen resulteren in geestelijk of lichamelijk lijden van anderen. ${ }^{267}$

Met betrekking tot de primaire ouderlijke (opvoedings)verantwoordelijkheid ten aanzien van het antisociaal gedrag van hun kind, merkt de auteur op: ${ }^{68}$

'De ouders van kinderen met antisociall gedrag worden vaak gezien als medeverantwoordelijk voor het ontstaan van de problemen. De literatur geeft hier ook well aanleiding toe. In hun overzichtsstudie naar de predictoren van delin quent gedrag noemen wILSON en HOWELL (1995) de volgende ouderkenmerken: - inadequate prenatale ouderlijke zorg [bijwoorbeeld ten gevolge van verslavingsen/of relatieproblematiek, ongewenste zwangerschap, onverwerkte jeugdproblesociaal gedrag," Justitielle Verkenningen 1996/6 ('Preventief ingrijpen in het gezin'), pp. $50-62$, op p. 50 . 
matiek, of "domweg" een gebrek aan kennis en socialle en/of sociaal-pedagogische steun, jw];

- afwijzing wan het kind [grove respectloosheid voor het kind als persoon en voor zijn rechten, ontkenning van de rechtssubjectiviteit van het kind, jw];

- inadequaat toezicht op en onvoldoende aandacht voor het kind [dat wellicht ten gevolge van aangeboren problematiek juist extra toezicht en aandacht behoeft: grove respectloosheid voor het kind als persoon-in-wording, jw];

- inconsistente discipline [grove 'rechtsonzekerheid" en dus onveiligheid voor het kind, jw];

- echtelijke ruzies en fysiek geweld [growe onredelijkheid en rechteloosheid welke zeer bedreigend zijn voor het kind, jw];

- mishandeling van het kind [grove en systematische schending van de meest fundamentele (integriteits- en persoonswordings)rechten van het kind, jw].'

Uiteraard zijn - afgezien nog van de secundaire (sociaal-pedagogische) verantwoordelijkheid van de (afwezige en nalatige) staat - niet alleen de ouders "de schuld": 69

"Het is bekend dat bepaalde eigenschappen en gedragingen van het kind kunnen bijdragen tot de ontwikkeling van antisociaal gedrag. Een moeilijk temperament van het kind dat zich bijvoorbeeld uit in [concentratie]stoornissen en [hyperactiviteit], is een aanzienlijke risicofactor en hetzelfde geldt voor een geringe intelligentie (...). Daarnaast maken kinderen in ongunstige gezinssituaties zich soms gedragingen eigen die op de korte termijn voor het kind voordelen bieden maar die op de langere termijn het kind in een negatieve uitzonderingspositie kunnen brengen. Het basismechanisme is negatieve versterking (...). (...)

Maatschappelijke factoren zijn evenzeer van belang. WAHLER (1980) stelde vast dat moeders die een geïsoleerd bestaan leiddem, een groot risico liepen om in problematische ouder-kind interacties terecht te komen. (...) In verschillende onderzoeken is de negatieve invloed van antisociale vrienden aangetoond.'

Echter: ${ }^{70}$

"Rusico-kenmerken van ouders of kinderen al of niet gecombineerd met risico's in de omgeving leiden niet onvermijdelijk tot de ontwikkeling van antisociaal gedrag. Uit onderzoek van WERNER (199[5]) blijkt dat protectieve factoren - dat zijn bepaalde positieve aspecten in de omgeving en gunstige persoonlijkheidskenmerken van kinderen zoals een goed humeur - de negatieve invloeden kunnen neutralise$\operatorname{ren}\left({ }_{n+w}\right)$."

Waaraan de auteur toevoegt: ${ }^{71}$

69 SLOT, t.a.p.; op p. 51 (curs. NS).

70 SLOT, t.a.p. op p. 52.

71 SLoT, t.a.p. 
"Van belang zijn ook vaardigheidstekorten en ontwikkelingsachterstanden bij het kind. Kinderen die onvoldoende vaardigheden leren om de voor hen aan de orde zijnde ontwikkelingstaken te vervullen, zajn minder goed voorbereid voor de volgende fasen in hun leven en lopen risico deviant gedrag te ontwikkelen (...). Voorbeelden van ontwikkelingstaken voor kinderen zijn: het rekening houden mett anderen, het vergroten van de onafhankelijkheid ten opzichte van ouders/opvoeders, het participeren in het basisonderwijs, het aanknopen en onderhouden van (vriendschappelijke) contacten met leeftijdsgenoten, het nemen van deel-verantwoordelijkheden in huis en voor broertjes en zusjes, zelfstandig gebruik van de basale infrastructurele voorzieningen in de samenleving en het maken van keuzes met betrekking tot de eigen veiligheid en gezondheid.

Voor adolescenten gelden weer andere ontwikkelingstaken [zoals]: (...) het accepteren van autoriteit en het binnen geldende regels en codes opkomen voor eigen belang[en] (*...).

Ook het ontwikkelingsniveau van ouders [dat wil zeggem: het niveau van onderlijk pedagogisch besef (dat is in de eerste plaats: het vanuit de eigen jeugdervaringen en levensgeschiedenis in meerdere of mindere mate geslaagd zijn in de oplossing van de eigen ontwikkelingstaken), jw] is van belang, en de vraag [in] hoeverre zij de taken aankunnen die voor hun levensfase kenmerkend zijn [afhankelijk dus van de vraag in hoeverre zij erin zijn geslaagd eerdere ontwikkelingstaken te vervullen, jw], geldt ook voor hen.'

Met andere woorden: de vraag in hoeverre ouders hun opvoedingsopgaven aankunnen, hangt in de eerste plaats af van de vraag in hoeverre zij hun eigen ontwikkelingsopgaven (alsnog) hebben volvoerd. Uiteraard is dit iets waar sociaal-pedagogische preventie op kan en moet inspelen. Zelf zegt de auteur daar dit over: ${ }^{2}$

'Ouders van kinderen met antisociaal gedrag hebben meerdere gezichten. Soms lijken ze op daders, vooral wanneer blijkt dat ze hun kinderen mishandelen en verwaarlozen. Ouders blijken soms ook slachtoffer te zijn van uilzonderlijk negatieve omstandigheden of van gebeurtenissen in hun jeugd die hun persoonlijkheid negatief beïnvloed hebben. Soms zijn ouders letterlijk het slachtoffer van het antisociale gedrag van hun kinderen. Diezelfde ouders zijn echter ook de opvoeders van de kinderen (...).

De laatste jaren is er bijzonder veel onderzoek gepubliceerd over de wijze waarop ouders, in al die verschillende rollen, van invloed kunnen zijn op de ontwikkeling van hun kind. Het blijkt dat verschillende onderzoekstradities en disciplines nader tot elkaar komen: moderne modellen over de ontwikkeling van antisociaal gedrag zijn gebaseerd op (ontwikkelings)psychologische, biologische, psychiatrische en criminologische uitgangspunten. Dit biedt veel aanknopingspunten voor hulpverlening en preventie.' 


\title{
Reacties
}

Vóor we stilstaan bij enkele reacties op bovenstaande (en andere) bijdragen (uit het themanummer 'Preventief ingrijpen in het gezin' van Justitiële Verkenningen), wijzen we eerst op de opmerking van GRAPENDAAL (uit hetzelfde themanummer): ${ }^{73}$

\begin{abstract}
"Waar we cerder tot de conclusie kwamen dat het vooral omgevings- en gezinsfactoren [in tegenstelling tot erfelijke/genetische factoren, jw] zijn die de morele ontwikkeling van kinderen bepalen, is de vraag gewettigd in hoeverre ouders/ verzorgers (ook strafrechtelijk) aangesproken moeten kunnen worden op het ontbreken wan de juiste voorwaarden waaronder een kind opgroeit."
\end{abstract}

De tussen haakjes geplaatste woorden - '(ook strafrechtelijk)' - bieden ons de kans nog eens nadrukkelijk te wijzen op het in deze studie ingenomen en verdedigde standpunt dat het strafrecht dient te worden gezien als een sluitstuk (zie ook bijlage II bij deze studie). Aan strafbaarstelling van (c.q. strafvervolging ter zake van) ouderlijk/pedagogisch wangedrag c.q. ouderlijke/pedagogische nalatigheid (feiten die ook thans reeds tot strafvervolging aanleiding kunnen geven, uiteraard daargelaten) gaan in principe enkele essentiële zaken vooraf, namelijk het tot stand brengen en in stand houden van een adequaat sociaal-pedagogisch netwerk (zie in dit verband ook par. 14.4.3.1.4: 'Nieuwe delictsomschrijvingen'). De zowel principiële als opportuniteitsgrond hiervan mag duidelijk zijn: een overheid die zelf in ernstige mate (sociaal-)pedagogisch nalatig is - zich immers ten aanzien van (ouders en) kinderen schuldig maakt, en houdt, aan ernstige en passief-systematische mensenrechtenschendingen en (c.q. in de vorm van) systemische (indirecte, transgenerationele) sociaal-pedagogische discriminatie -, is (zacht gezegd) niet geloofwaardig als zij het strafrecht als sociaal-pedagogisch instrument inzet en ouders/opvoeders (al te actief) vervolgt ter zake van pedagogisch wangedrag/pedagogische nalatigheid.

Verschillende auteurs hebben op de hierboven aangehaalde bijdragen (uit het themanummer 'Preventief ingrijpen in het gezin' van Justitiële Verkenningen) gereageerd (ELDERING, NIJBOER, SLOT en VAN AKEN). We laten hen achtereenvolgens aan het woord. Als eerste ELDERING, die opmerkt: $^{74}$

M. GRAPENDAAL, 'Over criminaliteit en kattekwaad,' Iustitiële Verkenningen 1996/ 6 ('Preventief ingrijpen in het gezin'), pp. 85-100, op pp. 99/100.

L. ELDERING, 'Van doelgroepenbeleid naar ouderondersteuning, reactie ('Journaal") in Justitielte Verkenningen 1996/9, pp. $78-83$, op p. 78 1.k./r.k. 
'Er worden verschillende verklaringen aangevoerd voor de marginalisering en delinquentie van jongeren. Veel onderzoek wijst op de rol van de ouders in dit proces. Het ontbreken van direct toezicht op het doen en laten van kinderen en conflicten binnen de familie zijn goede voorspellers van delinquentie (...). Ook uit kwalitatief onderzoek onder allochtone gezinnen blijkt dat langdurige conflicten binnen het gezin tot psycho-sociale problemen en marginalisering van kinderen kunnen leiden (...)"

De auteur presenteert vervolgens "enkele stellingen met betrekking tot ondersteuning van ouders van probleemkinderen en -jongeren." 75 De belangrijkste stelling(name) van de auteur is in dit verband dat ondersteuning in gezinnen met 'jongeren die met de politie in aanraking zijn gekomen, (...) ondersteuning op maat' moet zijn en dat deze 'niet vrijblijvend' Kan zijn: ${ }^{76}$

'Nagegaan moet worden welke aangrijpingspunten in het gezin aanwezig zijn voor ondersteuning (ouders, oudere broers of zussen of andere familieleden) en op basis van de zwakke en sterke punten [in het gezin] wordt per gezin een plan gemaakt."

Uiteraard betreft het hier secundaire preventie (c.q. interventie): het kwaad is immers al geschied. Het 'plan' (van aanpak) is dan ook een directe, namens de samenleving opgelegde reactie op het antisociale gedrag van de jongere.

Ook NIJBOER gaat in zijn reactie in op (vroegtijdige) interventie. Hij wijst allereerst op het belang van 'gezinsculturele factoren':"7

'Het gaat dan om factoren die ook uit de literatuur bekend zijn:

- De (emotionele) band tussen ouders en kinderen en - daarmee samenhangend - toezicht en controle; bijvoorbeeld de vraag of de ouders over het algemeen weten waar hun kinderen zich bevinden.

- Voorspelbaarheid in de opvoeding (vergelijkbaar met het begrip rechtszekerheid): weten kinderen hoe hun ouders zullen reageren, worden [de ouders] boos zonder duidelijke reden?

- [Gezonde a]fhankelijkheid van de ouders: het bij problemen hulp vragen van ouders, bij belangrijke beslissingen overleggen met ouders en hun oordeel daarbij betrekken."

77 J. NLBBOER, 'Achter de feiten aanhollen; het dilemma van justitiële preventie in het gezin,' reactie ('Journaal') in Justitiele Verkenningen 1996/9, pp. 84-89, op p. $841 . \mathrm{k} . / \mathrm{r} . \mathrm{k}$. 
De auteur benadrukt dat het 'justitiële aangrijpingspunt' in de eerste (en laatste) plaats de 'gezonde ontwikkeling van kinderen' - dus hun (optimale) persoonswording - hoort te zijn. Dit lijkt haaks te staan op het traditionele justitieperspectief van handhaving en naleving - niet van handhaving en naleving van de rechten van het kind (op welk terrein nog geen traditie bestaat), maar handhaving en naleving in de zin van 'bestrijding van overlast en delinquent gedrag' (en dus een Kurieren am Symptom, in rond Nederlands: dweilen met de kraan open). De auteur vreest in dit verband -- verwijzend naar de drugsproblematiek - een geleidelijke "verschuiving (...) van een volksgezondheidsperspectief naar een justitieperspectief in opgemelde zin. ${ }^{78}$ Volksgezondheidsperspectief in dit kader in het bijzonder als persoonswordingsperspectief te verstaan. Met betrekking tot het aspect (justitiële) 'dwang' merkt de auteur op: ${ }^{79}$

'Justitielle dwang is uiteraard niet ongewoon en over het algemeen roept dat ook niet zoveel problemen op. (...) Waar het om draait, is dat dwang gelegitimeerd moet worden, en het criterium dat daarbij vooral een rol zou moeten spelen, is de directe causaliteit [evenredigheid? -jw] tussen het gedrag dat afgedwongen wordt, en het doel dat daarmee beoogd wordt. (...)

Dwang, bij afwezigheid van motivatie, zorgt [evenwel] voor lijdelijk verzet. Daar komt nog bij dat de stigmatiserende werking van een afgedwongen [opvoedingsondersteunings]programma veel groter zal zijn dan die van een programma op [in principe, jw] vrijwillige basis. (...) Mijns inziens moet vrijwilligheid voorop staan. Motivatie is allijd de crux.'

Hij voegt daaraan toe: $:^{80}$

'Ik denk dat in die gevallen waarin sprake is van een grotere [sociaal-pedagogische, jw] kwetsbaarheid, ouders/opvoeders naast allerhande praktische tips toch vooral behoefte hebben aan morele ondersteuning. (...) Ouders hebben moed nodig om te reageren op ongewenst gedrag [van hun opgroeiende kinderen], terwijl veel ouders langzamerhand juist de moed verliezen. (...)

[Sociaal-pedagogiscly] kwetsbare ouders [hebben] vooral behoefte (...) aan sociale steun. Om [hen] te kunnen bereiken, moet echter wel de sociale afstand tussen ouders en hulpverlening worden overbrugd. Daarvoor is een medium nodig.'

Een medium dat in deze studie bij herhaling is aangeduid als sociaalpedagogisch stelsel of netwerk c.q. waarop (mede) werd gedoeld met de term sociaal-pedagogische steun (SPS als 'instituut," dat is als faciliteren- 
de, drempelverlagende infrastructuur). De auteur besluit overigens met (in algemene zin) op te merken dat ...

'(...) er met de nodige creativiteit heel veel te doen is zonder dat er sprake hoeft te zijn van ongewenste dwang. ${ }^{.81}$

SLOT, de derde reagerende auteur (hierboven onze tweede deskundige), is van mening dat ...

'(...) de risicofactoren die in algemene zin iets zeggen over het ontstaan van criminaliteit, niet altijd de beste aangrijpingspunten zijn om kinderen te bereiken die het risico lopen crimineel te worden. ${ }^{82}$

Hij wijst erop dat het van het aantal risicofactoren afhangt of een kind zich in antisociale richting zal ontwikkelen: welke risicofactor daarbij doorslaggevend is (en dus het aangrijpingspunt voor interventie zou moeten vormen), is net zo min te bepalen als de druppel welke de emmer uiteindelijk zal doen overlopen. Bovendien is de menselijke plasticiteit ('het menselijk vermogen tot adaptatie') bijzonder groot: het is onvoorspelbaar wanneer de rek eruit is. In de woorden van de auteur: $:^{83}$

'Deviante ontwikkelingen zijn niet onherroepelijk. Met behulp van specifieke competenties bij ouders en kinderen, en beschermende factoren in de omgeving [sociaal-pedagogische steun, $\mathrm{jw}$ ] kunnen bepaalde negatieve invloeden onschadelijk gemaakt worden.'

\section{Waarop hij direct laat volgen: ${ }^{84}$}

"Men zou er eens bij moeten stilstaan dat de veelgehoorde klacht dat criminollogen en ontwikkelingspsychologen er niet in slagen criminaliteit te voorspellen, een miskenning inhoudt van een heel vitaal en positief kenmerk van de menselijke ontwikkeling, namelijk het vermogen om tegen de stroom van allerlei ongunstige invloeden in, te komen tot positieve adaptieve patronen.'

Blijft de vraag: ${ }^{85}$

NIJBOER, t.a.p., op p. 89 i.f.

82 N.W. SLOT, "Preventie en behandeling van jeugdcriminaliteit," reactie ("Journaal') in Justitiële Verkenningen 1996/9, pp. 90-94, op p. $901 . \mathrm{k}$. i.f.

83 SLOT, t.a.p., op p. 90 r.k.

84 SLOT, t.a.p.y op pp. 90/91.

85 SLOT, t.a.p., op p. 91 l.k. 
'Als de [algemene, jw] risicofactoren dan niet de beste aangrijpingspunten zijn om kinderen te bereiken die het risico lopen crimineel gedrag te ontwikkelen, welke factoren zijn dat dan wel?'

Ter beantwoording van deze vraag verwijst de auteur naar onderzoek volgens hetwelk ...

'(...) crimineel gedrag bijzonder stabiel is over de tijd. De beste predictor van antisociaal gedrag is het antisociale gedrag in een eerdere ontwikkelingsfase. Dit impliceert dat men jongeren die grote kans lopen om een antisociale carrière te ontwikkelen, op het spoor kan komen door te kijken naar mogelijke uitingen van antisociaal gedrag op eerdere leeftijd.'

\section{De ouders van deze kinderen worden dan benaderd ...}

(...) niet (...) omdat ze allochtoon zouden zijn, omdat ze wellicht in een achterstandswijk wonen, of omdat er bij hen thuis misschien problemen zijn, maar de ouders worden benaderd op grond van concrete observaties met betrekking tot hun kind."

Observaties - gedaan op het (peuter-)consultatiebureau, in de crèche ('kindergarten') of op de lagere school - op basis waarvan 'een interventie [wordt] aangeboden. ${ }^{86}$

Op deze plaats is het nuttig even een ander recent geluid te laten horen (BROWNE \& HERBERT 1997): ${ }^{87}$

'According to research, delinquent and disturbed children are significantly more likely to have been referred for child abuse and neglect than non-delinquents (...). In fact, is has been suggested that childhood maltreatment and/or witnessing violence [in the family, jw] as a child may be a primary cause of delinquency in adolescence (...), although the majority of maltreated children do not become delinquent (...).'

Met deze wetenschap in gedachten (kort gezegd: criminele adolescenten hebben in de regel een geschiedenis van maltraitering/geweldservaringen, maar de meerderheid van gemaltraiteerde kinderen externaliseert niet in criminele $\operatorname{zin}^{88}$ ) begrijpen we beter het belang van SLOTs opmerking om

SLOT, t.a.p.s op p. 91 r.k.

87 Kevin BROWNE, Martin HERBERT, Preventing family violence, Chichester (etc.) 1997, p. 246.

Hetzij doordat zij (overwegend) internaliseren(/somatiseren/psychiatriseren: medisch/psychisch 'gehandicapten' worden), hetzij doordat zij weliswaar antisociale(/theatrale/borderline-) doch (net) geen criminele 'survivor-strategieën' ont- 
ook (primair-preventieve) opvoedingsondersteunings- en stimuleringsprogramma's niet aan 'risicogroepen' (let wel: hier in de - grove en discriminatoire - zin van gezinnen in auto- en/of allochtone achterstandsbuurten) aan te bieden, maar aan bredere categorieën ouders (SLOT noemt als voorbeeld: 'alle ouders van leerlingen op bepaalde scholen'), waarbij om de lijn van SLOT door te trekken - in geval van concrete (op observaties gebaseerde) risicofactoren verdergaande programma's worden aangeboden; verdergaand onder andere in deze zin: ${ }^{89}$

'Ik kan me bijvoorbeeld goed voorstellen dat er meer dan tot nu toe aandacht wordt besteed aan opvoedingsvaardigheden zoals "monitoring" en consequente directieve begeleiding."

Hetgeen kan gebeuren in het kader van aan risico(buurt)-gezinnen aangeboden ouderschapscursussen en -trainingen. Welke op hun beurt in individuele gevallen (waar de problematiek meer met onmacht te maken blijkt te hebben dan met onkunde) aanleiding kunnen geven tot het aanbieden van meer specifieke 'interventies' (hulp op maat) - om de lijn nog verder door te trekken. Dit is wat wij verstaan onder bezig zijn met een glijdende schaal, al zouden wij met dat bezig zijn in een veel eerder stadium dan de schoolleeftijd willen beginnen (bij voorkeur al in het stadium van de zwangerschap). SLoT zelf vervolgt: ${ }^{90}$

'We weten redelijk goed wat we ouders en kinderen zouden moeten bieden. Maar het grote probleem is om tot een continu kwalitatief verantwoord aanbod te komen."

Een - groot - probleem dat mijns inziens is te herleiden tot een - even groot - gebrek aan politieke wil en (wetgevende, beleidsmatige en financiële) daadkracht. En dus aan een - minstens even groot - gebrek de verplichtingen onder het Verdrag inzake de rechten van het kind - en dus het kind - serieus te nemen. Een - ernstige - tekortkoming in de nakoming van hetgeen men het kind verdragsrechtelijk en moreel ('het beste wat de mensheid heeft te bieden'! $!^{91}$ ) verschuldigd is.

wikkelen, hetzij doordat zij hun ervaringen te boven weten te komen, al of niet met deskundige (therapeutische) hulp en/of (al of niet na een 'herhalingsdwang* matige' periode met destructieve relaties) dank zij een ondersteunende (tolerante en tegelijk grenzen stellende) partmer.

89 SLOT, t.a.p., op p. 91 r.k. (i.f.).

90 sLoT, ta.p., op p. 92 r.k.

91 '[M]ankind owes to the child the best [that] it has to give': preambule Verklaring van Genève (1924) en VN-Verklaring van de rechten van het kind (1959). 
Maar - vóór we politiserend, juridiserend en moraliserend "afdwalen" - terug naar SLOT: ${ }^{.2}$

"Als een interventie ertoe leidt dat het opklimmen in een criminele carrière wordt vertraagd, scheelt dat de samenleving veel geld en verdriet, maar wat misschien nog belangrijker is: de ontwikkelingskansen van de jongere in kwestie blijven aamwezig. Voor jongeren die een antisociaal ontwikkelingstraject doorlopen, geldt een kritiek niveau. Voor jongeren die boven dat niveau komen, is een terugkeer naar een normale ontwikkeling bijna niet mogelijk. Dat niveau 『dat point of no retum, jw] wordt bereikt als jongeren hun contact met de primaire opvoeders en opvoedende instanties in de matschappij verloren hebben, wanneer zij niet in staat zijn de ontwikkelingstaken te vervullen die nodig zijn om de volwassen levensfase aan te vangen, en wanneer zij worden gekenmerkt door een gedragsrepertoire dat wordt gecontroleerd door reinforcers (beloningen) die thans - maar ook later - niet met wettige middelen te verkrijgen zijn.

Van jongeren die onder dit niveau blijven, mag worden verwacht dat ze gemakkelijker uit de criminaliteit stappen rond hun zeventiende of achttiende jaar. De jongeren boven het [kritieke] niveau zijn waarschijnlijk degenen die een "volwassen" [aanhalingstekens van mij, jw] criminele carrière op zullen vatten.'

Behalve op bovenstaand 'vertragingsmodel' wijst de auteur nog op een tweede interventie-perspectief: het 'chronic care model': ${ }^{93}$

'Er zijn gezinnen en jongeren die dermate te maken hebben met een cumulatie van risicofactoren dat een veel langere begeleiding noodzakelijk is. Deze begeleiding hoeft niet zo intensief te zijn maar wel zeer langdurig, of misschien wel altijd. Het is merkwaardig dat het in de somatische zorg geaccepteerd is dat iemand chronisch afhankelijk is van medicatie - denk aan insuline of apparatuur, denk aan de pacenaker - maar dat we daar bij de behandeling van antisociaal gedrag niet aan willen."

Voor antisociaal (externaliserend) gedrag kan men, moet men in het bovenstaande (mutatis mutandis) natuurlijk ook gemengd ('sexualiserend') en internaliserend - 'zelfsaboterend' of 'zelf-invaliderend' - gedrag lezen. Ook, juist voor wie louter economisch denkt, zou het naïef zijn te veronderstellen dat daar - buiten het criminele circuit - de schade voor de maatschappij wel zal meevallen. Degene die gevoelig(er) is voor morele argumenten, bedenke dat het richten van alle aandacht op (externaliserende) slachtoffers-die-daders-worden niet te rechtvaardigen is, noch in algemeen-ethische zin noch ten opzichte van (internaliserende) slachtoffers-die-slachtoffers-blijven - en juist daardoor minder (publieke) overlast en minder (zichtbaar) lijden voor anderen veroorzaken. 


\section{De derde deskundige}

VAN AKEN - de (vierde en) laatste in de pen geklommen auteur, die we evenwel onder een apart tussenkopje als 'derde deskundige' opvoeren om recht te doen zowel aan het aantal als aan de sociaal-pedagogische (lees: rechtspolitieke) relevantie van zijn hier aangehaalde opmerkingen - bepleit (ter preventie van jeugdcriminaliteit) een 'meer-settingen- en meer-facetten-beleid.' Hoewel hij op het eerste gezicht van een minder optimistisch humaan plasticiteitsbeeld lijkt uit te gaan, sluiten zijn opmerkingen bijna naadloos op die van SLOT aan: ${ }^{94}$

'De harde kern van daders wordt al op zeer jonge leeftijd gekenmerkt door bepaalde temperaments- of persoonlijkheidskenmerken. Het betreft hier basale karakteristieken van een persoon [sterke prikkelbaarheid, impulsiviteit, extraversie, laag IQ]. Deze temperaments- of persoonlijkheidskenmerken hebben een sterke genetische en biologische (neuropsychologische) component (...), worden onder invloed van omgevingsfactoren in de eerste levensjanen vaak aanzienlijk versterkt [komen in een negatieve spiraal, jw], en kennen vervolgens een zeer hoge stabiliteit (...). Het is onwaarschijnlijk dat een interventie (in welke vorm dan ook) na de leeftijd van ongeveer drie jaar in staat is deze basale persoonlijkheidskenmerken nog wezenlijk te veranderen. Wat wel veranderd kan worden, is of deze persoonlijkheidskenmerken zich manifesteren in antisociaal of crimineel gedrag, of in acceptabel gedrag, met andere woorden de manier waarop persoonlijkheid met de omgeving interacteert. Hiervoor zijn echter gedurende de gehele levensloop, in meerdere sociale settings, langs meer sporen gerichte begeleidingsactiviteiten nodig. $\mathrm{Er}$ is dan in zekere zin geen sprake meer van preventie: het gaat om interventie."

De auteur stelt met nadruk dat criminaliteit of agressie niet aangeboren (c.q. genetisch of biologisch bepaald) zijn: ${ }^{95}$

'Duidelijk is alleen dat aangeboren temperament ${ }^{96}$ of persoonlijkheid[stype, jw] een zware risicofactor is voor de ontwikkeling van agressie en criminaliteit, maar

M.A.G. WAN AKEN, 'Een meer-settingen- en meer-facetten-beleid ter preventie van jeugdcriminaliteit," reactie ('Journal') in Justitièle Verkenningen 1996/9, pp. 95-103, op p. $951 . k . /$ r.k. (curs. jw).

95 VAN AKEN, tua.p., op p. 96 nt. 1 (curs. jw).

96 Owerigens is het mijns inziens nog maar de vraag of temperament (louter) is aangeboren (genetisch bepaald) dan wel (mede) onder invloed staat van - al of niet in principe 'corrigeerbare' - omgevingsfactoren tijdens de zwangerschap van de moeder. Het lijkt mij a annemelijk dat de stemming en de levensstijl van de moeder tijdens de zwangerschap niet alleen van (meer of minder) inwloed zijn op de gezondheid en de intellectuele capaciteiten maar ook op het temperament van het kind. Mij zijn hierover evenwel geen onderzoeksgegevens bekend (en het is ook maar de vraag of de wetenschap hierover ooit ondubbelzinnige uitspraken kan doen: hoe kunnen we het weten, is ook hier: hoe kunnen we het meten). 
altijd in interactie met omgevingsfactoren (in thet begin het gezin, later ook de school enzovoort). Het gaat erom hoe temperaments- en persoonlijkheidsfactoren met de omgeving interacteren.'

\title{
Anders gezegd: ${ }^{97}$
}

'In welk soort gedrag[spatroon, jw] persoonlijkheidskenmerken zich [zullen, jw] manifesteren, hangt in sterke mate af van de [vroege, $j w]$ interactie tussen de persoon en zijn/haar [sociaal-pedagogische, jw] omgeving.'

Op drie verschillende manieren kan 'persoonlijkheid" met de omgeving interacteren: ${ }^{98}$

\begin{abstract}
'Allereerst is [er] sprake van reactieve interactie: verschillende mensen ervaren en interpreteren hun omgeving verschillend. Zo zijn bijwoorbeeld agressieve kinderen eerder geneigd om ambigue signalen van leeftijdgenoten te duiden als vijandig (...). Ten tweede is er sprake van evocatieve interactie: verschillende mensen lokken [onbewust, jw] verschillende reacties van hun omgeving uit. Zo kan moeilijk gedrag op zeer jonge leeftijd reacties uitlokken die dit gedrag juist versterken (...). Ten derde is er sprake van (prolactiewe interactie: verschillende mensen kiezen/creëren andere omgevingen voor zichzelf. Zo lijken personen met anti-sociaal gedlrag eerder partners met soortgelijk gedrag uit te zoeken (...) ['soort zoekt soort, jw]."
\end{abstract}

\section{De auteur merkt op:99}

'Omdat de persoonlijkheid redelijk stabiel is, duikt hij telkens in de levensloop weer op, bij elke overgang naar nieuwe sociale settings. Kinderen "nemen hun persoonlijkheid mee" naar nieuwe settings, zoals de school, buitenschoolse activiteiten, en ook later naar de werkgever [interactive continuity ofwel interactieve patronen, jw].'

De auteur zegt het niet, maar de goede verstaander kan zelf concluderen dat een inadequaat reactief (werkelijkheid en perceptie liggen te ver uiteen), evocatief (men lokt steeds de verkeerde reacties uit, waardoor een negatieve spiraal ontstaat), dan wel proactief (men zoekt steeds de verkeerde vrienden, waarbij een 'krabbenmand-effect' optreedt: ontsnappen uit 'het milieu' is vrijwel onmogelijk) interactiepratroon self-defeating is (averechts werkend, zichzelf-saboterend, zelf-destructief). Bij kinderen 
met een 'moeilijk' temperament is dan ook blijvende waakzaamheid en zorgzaamheid geboden (de auteur weer aan het woord): $:^{100}$

"Zelfs als kinderen met een "high risk"-temperament in de eerste jaren in cen "goed" gezinsklimaat zijn opgegroeid, zodat ze niet in een negatieve spiraal zijn geraakt, blijven ze toch kwetsbaar bij elke nieuwe "ontwikkelingstaak," ook (en met name) die buiten het ["goede"] gezin."

De auteur verbindt hieraan de conclusie dat ...

(...) men voor deze kinderen in die nieuwe sociale settings bedacht moet zijn op de noodzaak van interventies. Het gaat hierbij om interventies die in het algemeen al van belang zijn, maar voor kinderen met een moeilijk temperament of moeilijke persoonlijkheidskenmerken in het bijzonder. ${ }^{101}$

\section{Deze conclusie werkt de auteur in drie punten uit. ${ }^{102}$ Ten eerste:}

'In de voorschoolse periode gaat het nog om eén setting [het meer of minder 'goede' (pedagogisch adequate) gezin, jw], maar als zich na de schoolintrede agressieproblemen en storend gedrag voordoen, dienen school èn gezin in de interventie betrokken te worden, zoveel mogelijk vanuit een gezamenlijk belang [het (ontwikkelings)belang van het kind, jw]. Interventie in én setting [met name alleen de school bij een minder adequaat gezin, jw] blijft zonder resultaat, zeker wanneer school en gezin conflicten hebben over de (wijze van) interventie.'

Ten tweede:

'In de basisschool dient werstorend of negatief gedrag door kinderen [daadwerkelijk en daadkrachtig, jw] aangepakt te worden. Uit onderzoek (...) blijkt dat met name verworpen/agressieve kinderen een grotere kans lopen op later antisociaal en crimineel gedrag. Onderzoek naar de stabiliteit van antisociaal gedrag (...) heeft bovendien aangetoond dat kinderen die dergelijk gedrag vertonen, vaak al in een zeer vroeg stadium te herkennen zijn (...).

Betrokkenheid van een kind dat wór school thuis agressieproblemen theeft gehad, als dader bij pesterijen is een duidelijke aanwijzing voor de noodzaak van interventie op school. (...)'

Ten derde:

Te denken valt ook aan initiatieven bij de overgang van school naar een beroepscarrière. Jongeren die ondanks alle [gezins- en school-]interventies tot dan toe 
nog steeds problematische persoonlijkheidskenmerken hebben, hebben hierbij extra begeleiding nodig, die hen leert om zonder agressieproblemen met leiding en collega's om te gaan en zich aan te passen aan de eisen van een werkplek [zodat ook hùn recht op sociaal-economische participatic kan worden waargemaakt, jw]. Te denken is hier bijvoorbeeld aan het Duitse duale systeem, waarbij jongeren die niet verder studeren, voor een groot deel in een soort leerlingwezen terechtkomen. In dit leerlingwezen zou een begeleiding van de sociaal-emotionele ontwikkeling kunnen worden ingepast.'

\section{De auteur vat samen: 103}

'Voor jongeren bij wie problematisch sociaal gedrag sterk verankerd lijkt in de persoonlijkheid, is een continue begeleiding over meerdere settings heen (in eerste instantie gezin en school) en vanuit meerdere settings tegelijkertijd een noodzakelijke voorwaarde."

Wat wij in deze studie steeds benadrukt hebben: de noodzaak van een adequaat sociaal-pedagogisch stelsel als (conceptueel) antwoord op de (theoretische en praktische) vragen die opgeroepen worden door slechts bij oppervlakkige of vooringenomen beschouwing tegenstrijdige aan het Verdrag inzake de rechten van het kind ten grondslag liggende en daarin tot uitdrukking gebrachte beginselen, te weten het fundamentele recht van het kind op optimale persoonswording, de primaire ouderlijke en de secundaire statelijke/gemeenschappelijke opvoedingsverantwoordelijkheid, wordt door de auteur als volgt "geprefigureerd': 104

[V]roegtijdige signalering zou (....) gevolgd moeten worden door een systeem van laagdrempelige doorwerwijzing. Het gaat erom dat problemen vanaf zeer jonge leefijd herkenbaar en benoembaar moeten zijn voor ouders en hulpverleners, bijwoorbeeld wanneer een zuigeling "ontroostbaar" is, een peuter "onhandelbaar," of wanneer er sprake is van escalerende agressie thuis (bijwoorbeeld tussen siblings [(ontwikkelings)psychologische vakterm voor: broertjes en zusjes, jw], of op school. Op zeer jonge leeftijd (rond de geboorte) kan deze signallering plaatsvinden door kruisbureaus, huisarts, of vroedvrouw. In deze fase vormen, thaast gedragssignalen [van de neonatus, jw], ouder-en gezinsfactoren de voornaamste indicatoren. Men zou hier kunnen spreken van "risicomoeders" of "risicogezinnen," waarbij (cumulatieve) risicofactoren bijvoorbeeld zijn: alleenstaand, geisoleerd, verslaald, mishandeld of met een anderszins belast [niet (adequaat) verwerkt, $j w$ ] verleden, financiële problemen, geweld in het gezin, oudere probleemkinderen, allochtoon [en met gering (westers) cultureel kapitaal, ${ }^{105}$ jw] enzovoort."

103 VAN AKEN, t.a.p., op p. 97 l.k. $/$ r.k.

104 VAN AKEN, ta.p., op p. 98 1.k. (curs. jw).

105 Vgl. in dit verband T.V.M. PELS, 'Preventie in Marokkaanse gezinnen; het spanningsveld tussen vraag en aanbod," Justitiële Verkenningen 1996/6 ('Preventief 
Het is bepaald niet zo dat de auteur in een 'prefiguratie' blijft steken: ${ }^{106}$

'Interventies zouden zich kunnen richten op de aanpak van dergelijke [risico-] factoren, zoals aanpak van gezondheids- of financiële problemen, het helpen opbouwen van een sociaal ondersteuningsnetwerk, enzovoort. Interventies op dit moment [lees: op dit niveau, jw] moeten zich niet per se richten op de opvoederkind-interactie, maar eerder op de wortel van het probleem: het "verlichten" wan de situatie voor de opvoeder.'

In SPS-termen: op dit niveau, het niveau van de pedagogische randvoorwaarden, zou 'opvoedingsgeld' al veel soelaas bieden, mits gekoppeld aan laagdrempelige medische en sociaal-pedagogische voorzieningen, die brede en algemene materiële, praktische, adviserende èn morele steun bieden. Vandaaruit kan, indien noodzakelijk, eenvoudig naar een hoger - specifieker en specialistischer - ondersteuningsniveau worden doorgeschakeld. In de 'prefiguratie' van de auteur: ${ }^{107}$

'Later gaan ook het gedrag en de ontwikkeling van het kind bij de signalering een rol spelen. In de eerste twee levensjaren kan "moeilijk" gedrag van kinderen (bijvoorbeeld overmatig huilen en conduct disorders) een risicofactor zijn, zeker in combinatie met bepaalde gezinskenmerken. (...) [G]evoelens van overbelasting en incompetentie [ontoereikendheid, jw] bij de opvoeders [bleken] goede indicatoren te zijn voor problemen in de ouder-kind-relatie die voorlopers kunnen zijn van later probleemgedrag. Voor dergelijke overbelaste ouders zou een laagdrempelige doorwerwijzing naar een ontwikkelingspsycholoog of pedagoog van belang zijn. Vaak is in dit stadium een relatief weinig intensieve of korte begeleiding al voldoende om verbetering te bewerkstelligen. Een belangrijke rol kan hiervoor weggelegd zijn voor de consultatiebureaus, die via een medische hoek makkelijk ingang vinden.

Op dit moment is een dergelijke laagdrempelige voorziening er op het gebied van opvoedingshulp niet, en is de stap tussen consultatiebureau en Riaggs voor deze problematiek te groot en bovendien te drastisch voor veel ouders. Koppeling van een eerstelijnswoorziening op het gebied van een dergelijke opvoedingshulp aan de consultatiebureaus kan een soort opwoedingsbegeleiding geven. (... $)^{\prime}$

ingrijpen in het gezin'), pp. 63-73, op pp. 67-68. Naast een 'tekort aan cultureel kapitaal' onderscheidt de auteur nog andere specificke ('etnisch-culturelle') risicofactoren" (t.a.p., op p. 63): cen "gezagsvacuüm" in het gezin; 'vrees voor culturele vervreemding' en 'discriminerende reacties' (van 'uitgescholden worden' en 'negatieve beeldworming' tot uitsluiting - in het bijzonder op de arbeidsmarkt - en neo-racisme, bij de auteur: "etnocentrisme") van autochtone zijde (t.a.p., op pp. 64-67 en 68-69).

106 VAN AKEN, t.a.p., op p. 98 l.k./r.k.

107 VAN AKEN, t.a.p., op p. 98 r.k. 
Op het niveau van de school, dat wil zeggen ...

(...) [o]p lagere-schoolleeftijd is te denken aan (...) [anti-]pestprojecten, waarbij eveneens gedragsproblemen van pesters (met name zij die ook in de thuissituatie agressieproblemen hebben) vroeg gesignaleerd kunnen worden, en met programma's geprobeerd kan worden de peer-relaties [omgang met leeftijdsgenoten, jw] van deze groep kinderen te verbeteren. Ook kan gedacht worden aan projecten die tot doel hebben risicoleerlingen te signaleren en deze jongeren en hun ouders, in goede samenspraak met de school, een interventie [een niet vrijblijvende cursus of training, therapie of opvoedingsondersteuning, jw] aan te bieden., 108

Met betrekking tot 'schoolprojecten ter preventie van jeugdcriminaliteit' - zo merkt de auteur in een noot op - bedenke men ...

(....) dat morele ontwikkeling, ofwel de ontwikkeling van pro-sociaal gedrag, mogelijk een keerzijde vormt van de ontwikkeling van anti-sociaal gedrag., 109

Inadequate morele opvoeding (van meer of minder moeilijk opvoedbare kinderen/jongeren) is echter niet slechts de achterzijde van antisocialiteit: de ontwikkeling van minimale moraliteit, en dus de minimale persoonswording als mensenrechtelijke quasi-resultaatsverplichting van de staat, is hier in het geding. Ook hieraan kan een argument worden ontleend dat het nooit bij schoolprojecten alleen kan blijven: er dient altijd tevens naar het gezin te worden gekeken en desnoods in het gezin te worden geïntervenieerd (in eerste instantie door middel van een niet vrijblijvend begeleidings- en ondersteuningsaanbod).

Ten overvloede (althans voor wie hem tot dusverre goed gevolgd heeft) merkt de auteur nog op: ${ }^{110}$

\footnotetext{
"Ervaringen (...) tonen (...) aan dat er [bijwoorbeeld] een groep moeders is die wel degelijk voldoende opvoedingspotentieel [een in principe adequaat niveau van pedagogisch besef, jw] heeft, maar die onder druk van omstandigheden niet in staat is dit potentieel aan te wenden. Voor deze groep is het verlichten van de omstandigheden een betere interventie dan het geven van een oudertraining, en is het eerste zelfs een noodzakelijke voorwaarde om het tweede te doen slagen.'
}

Van niet minder belang is zijn opmerking dat - van justitiezijde - niet eenzijdig de nadruk gelegd moet worden op het 'controle-element in de opvoeding: ${ }^{\text {111 }}$ 
'Gesuggereerd wordt dat gebrekkig toezicht en controle één van de sterkste voorspellers wan delinquentie is. Hoewel op sommige plaatsen [in het rapport Jetugd' en gezin van JUNGER-TAS ${ }^{112}$ ] wel aandacht wordt besteed aan het belang van de affectieve relatie tussen opvoeder en kind, lijkt men bij het ontwerpen van interventies toch meer te kiezen voor een "harde lijn": op [op] sociale leerprincipes gebaseerd[e wijze] moeten ouders vooral toezicht vitoefenen, sturen, en belonen en straffen.'

Evenwel: ${ }^{113}$

'(...) in meerdere opvoedings- of ontwikkelingsmodellen wordt benadrukt dat controle alléén niet werkt. De relationele component, ofwel een warme emotionele ondersteuningsrelatie, blijk $[\mathrm{t}$ ] gedurende de gehele levensloop van belang [niet alleen woor de lichamelijke en geestelijke gezondheid ${ }^{114}$ maar ook, jw] voor het overbrengen van normen en waarden. (...) Aversieve ['liefdeloze,' jw] controle [in het bijzonder de combinatie affectieve verwaarlozing en overcontrole, jw] roept tegenagressie [of passief verzet, passieve agressie, jw] op, en is in veel studies de beste versterker van een agressieve persoonlijkheid gebleken.'

112 Uit dit rapport is uitvoerig geciteerd in hoof dstuk 12 (aan het slot van par. 12.3.2) van deze studie. Vgl. ook hiervoor par. 14.3.2.2 en hoofdstuk 13, par. 13.4.1 (onder Toetsing aan de hand van getuige-deskundigenverklaringen).

113 WAN AKEN, t.a.p., op pp. 99/100.

114 Vgl. voor de (causale?) relatie tussen (gebrek aan) ouderliefde en latere fysieke gezondheid(sproblemen) het onderzoek van RUSSEK en SCHWARTZ gepresenteerd tijdens de 55th Annual Scientific Meeting van de American Psychosomatic Society, maart 1997, vermeld in Psychologie juni 1997, p. 11 ('Ouders moet je met zorg kiezen"). Volgens dit bericht blijken vijftigers die als student hadden aangegeven dat hun ouders geen warme opvoedingstijl hadden ("weinig liefde en zorg boden'), aanmerkelijk meer ( 84 tegen $37 \%$ ) gediagnostiseerde ziekten te hebben (zoals een maagzweer of hoge bloeddruk) dan vijftigers die als student hun ouders in alle opzichten positief beoordeelden. Het bericht concludeert: 'Ouderlijke liefde bespaart de gezondheidszorg flink wat geld.' Let wel: we hebben het dan alleen nog maar over de lichamelijke gezondheidszorg.

De titel van het bericht: 'Ouders moet je met zorg kiezen,' kan om meer dan éen reden en op meer dan één manier worden opgevat als de vitdrukking en benadrukking van een cruciale maatschappelijke verantwoordelijkheid - een verantwoordelijkheid ten opzichte van (toekomstige) kinderen en tegenover de maatschappij in haar geheel. De pendant van het recht van het kind op "goed genoege" ouders is immers de maatschappelijke plicht de secundaire opvoedingsverantwoordelijkheid van de staat ten volle waar te maken. Uiteraard is het de primaire verantwoordelijkheid van (aanstaande) ouders zichzelf met zorg te kiezen, dat will zeggen: zorgvuldig en na een grondig zelfonderzoek te kiezen voor het ouderschap, maar het is de (complementaire) verantwoordelijkheid van staat en samenleving hen met zorg te begeleiden en te ondersteunen, waar en zolang dat zinvol (dat is: in het - directe en onmiskenbare - belang van de persoonswording van hun kind) is. 
Aversieve controle lijkt mij eveneens de beste voorspeller van een passief-agressieve (ofwel negativistische) persoonlijkheid(sstoornis) c.q. van de ontwikkeling van passief-agressieve (en obsessief-compulsieve) persoonlijkheidstrekken. ${ }^{115}$ Maar laten we de uitleg van VAN AKEN (ver-) volgen: ${ }^{116}$

IIn talloze correlationele studies (...) worden twee dimensies van opvoedingsstijlen onderscheiden in samenhang met maten [gradaties? -jw] van het functioneren van kinderen, enerzijds een controledimensie en anderzijds een responsiviteit- of warmtedimensie. Bij ouders die hoog scoren op de controledimensie, kan een onderscheid gemaakt worden tussen autoritatieve ouders, die een hoge controle combineren met een warme, affectieve relatie, en cutoritaire ouders, die een hoge controle combineren met een koele, afstandelijke relatie. In meerdere opzichten blijkt een autoritatieve opvoedingstijl gunstiger voor de ontwikkeling van het kind dan een autoritaire. Dit blijkt bijvoorbeeld op het gebied van schoolprestaties, maar ook bij de ontwikkeling van emotionele autonomie tijdens de adolescentie.

In autoritatieve gezinnen zijn grenzen flexibel en open voor discussie, en worden de belangen van het kind gerespecteerd (ook al nemen de ouders toch de uiteindelijke beslissing). In autoritaire gezinnen worden grenzen strikt en zonder discussie vastgehouden, waardoor de adolescent niet de gelegenheid krijgt te oefenen met het verwerven van autonomie en vrijheid. Uiteindelijk loopt in dit soort [rigide of zelfs hyperhomeostatische, $\mathrm{jw}$ ] gezinnen het proces van autonomieverwerving [losmaking, late separatie-individuatie, $j w]$ vaak uit in rebellie en conflicten [dan wel in internaliserende psychische/psychiatrische problematiek, jw].'

De auteur gaat verder: ${ }^{117}$

'Ook op jonge leeftijd is het belang van warme emotionele ondersteuning aangetoond, niet alleen als belangrijke dimensie in de opvoeding an sich, maar ook als belangrijke voorwaarde voor het werken van controle. Aan controle of toezicht door opvoeders waarmee kinderen geen emotioneel ondersteunende relatie hebben, laten kinderen zich weinig gelegen liggen; deze controle lijkt weinig effect te hebben en kan zelfs averechts werken.'

Er kunnen in dit verband vier componenten worden onderscheiden, aldus de auteur, ${ }^{118}$ namelijk...

115 Vgl. bijlage $v$ bij deze studie (Persoonlijkheidsstoomissen). Vgl. ook J.J.L. DERK-

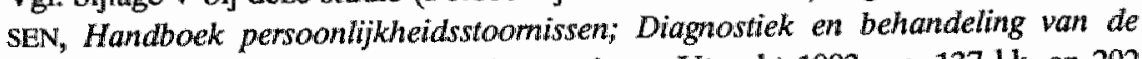
DSM-IV en ICD-10 persoonlijkheidsstoomissen, Utrecht 1993, pp. 137 l.k. en 202 l.k. 
(...) emotionele ondersteuning, respect voor autonomic, het bieden van structuur, en het geven van kwalitatief goede informatie. De eerste component blijkt in de ontwikkeling als vroegste component in de opvoeder-kind-relatie van belang te zijn, en blijft gedurende de rest van de ontwikkeling de basis, voor het effect van de andere componenten. De vier componenten bleken (...) ook goed aan ouders uit te leggen en te trainen.'

De auteur vat nog eens samen: ${ }^{19}$

\begin{abstract}
'Van belang is (...) goed in het oog te houden dat kinderen gedurende hun ontwikkeling functioneren in meerdere sociale settings. Een effectief preventiebeleid moet zich dan ook niet alleen richten op gezinsfactoren in de vroege ontwikkeling [voor de goede orde: wat op dit ogenblik in Nederland in structurele, sociaalpedagogische zin (nog steeds) niet gebeurt, jw], maar moet tevens oog hebben voor hernieuwde problemen en bijbehorende interventies in andere sociale settings. Goede en tijdige signalering van [externaliserend èn internaliserend, jw] probleemgedrag, en laagdrempelige mogelijkheden tot ondersteuning zijn daarbij onontbeerlijk.'
\end{abstract}

In de beschouwingen van VAN AKEN kan onmiskenbaar meer gelezen worden dan een voorafschaduwing van de in dit boek bepleite SPS-pijlers 'Opvoedingsgeld' en 'Opvoedingsondersteuning' (naast de derde pijler: 'Opvoedingsonderwijs'). Hoeveel meer blijke in de paragrafen waarin deze pijlers worden behandleld.

De stelling vervat in de titel van deze paragraaf, wordt toegelicht en verdedigd in drie subparagrafen, en wel aan de hand van drie substellingen. In par. 14.4.1 brengen we een eerdere koppeling in herinnering tussen het kernrecht van het kind op minimale persoonswording en 'het recht van het kind op een buitenstaander.' In par. 14.4 .2 verwijzen we kort naar het concept van sociaal-pedagogische voorzieningen als secundaire statelijke aanvulling van primaire ouderlijke opvoedingsverantwoordelijkheid. In par. 14.4 .3 beginnen we met te wijzen op de grote vrijheden (in bestuursrechtelijke termen: de ruime discretionaire bevoegdheden) van ouders enerzijds en de kernrechten (in staatsrechtelijke termen: de sociaalpedagogische grondrechten) van kinderen anderzijds. Respect voor ouderschap (het serieus nemen van de secundaire opvoedingsverantwoordelijkheid) en respectvol ouderschap (het serieus nemen van de primaire opvoedingsverantwoordelijkheid) zijn communicerende vaten, zo stellen we, 
die gezamenlijk kunnen leiden tot (meer) respect voor kinderen. Vervolgens geven we aan met behulp van welke formele en materiële elementen - via respect voor ouderschap - respect voor (de rechten van) kinderen van lege huls tot (een begin van) maatschappelijke werkelijkheid zou kunnen worden gemaakt. De formele elementen passeren kort de revue (in par. 14.4.3.1), de materiële elementen worden door middel van twee oer-Hollandse spreekwoorden 'kort en krachtig' ingeleid en aangekondigd (in par. 14.4.3.2) om in de volgende (hoofd)paragraaf (par. 14.5) te worden uitgewerkt.

14.4.1

Respect voor kinderen: bevordering van optimale, waarborging van minimale persoonswording (het recht van het kind op een buitenstaander)

De titel van deze subparagraaf bevat opnieuw een stelling: respect voor kinderen betekent - hoe dan ook - bevordering van optimale en waarborging van minimale persoonswording als (morele en rechts)plicht van staat en samenleving. Op deze plaats brengen we in herinnering dat het (kern)recht van het kind op minimale persoonswording betekent dat het kind - hoe dan ook - recht heeft op een (deskundige) buitenstaander. We herhalen de uitspraak van DE RUYTER Sr. uit hoofdstuk 10 (par. 10.4.1), dat het kind recht heeft op "buitenstaanders die oog hebben voor de stagnatie' in de opvoeding, dat wil zeggen: 'recht heeft op een buitenstaander die het gezin in de gaten houdt. ${ }^{, 20}$ DE RUYTER Jr. lichtte dit aldus toe: ${ }^{121}$

"Een stagnerende opvoeding vanuit de pedagogische hulpverlener gezien, is "een zodanig ontregelde opvoeding dat er sprake is van een (dreigende) schade voor de persoonswording van het kind" (...). De uitspraak dat het kind recht heeft op een buitenstaander die het gezin in de gaten houdt, moet (...) worden geinterpreteerd als: hulpwerlening is noodzakelijk wanneer er sprake is van (dreigende) schade aan de persoonswording van het kind, en de ouders dit niet herkennen of erkennen.'

Het minimum-recht van het kind op een (deskundige) buitenstaander heeft alleen betekenis binnen en kan alleen worden gewaarborgd door middel van een adequaat stelsel van sociaal-pedagogische voorzieningen. 

voorzieningen

Wederom een stelling: respect voor ouderschap betekent om te beginnen. morele en substantiële maatschappelijke waardering voor en - waar nodig en voor zover nodig - ondersteuning van ouders ten aanzien van de (niet zelden zware) opvoedingstaken die vallen onder hun primaire opvoedingsverantwoordelijkheid. Waardering en ondersteuning die gestalte krijgen in een Trias pedagogica (een constitutionele sociaal-pedagogische driehoeksverhouding tussen ouders, kinderen en de staat) waarin diverse sociaal-pedagogische voorzieningen, instellingen en diensten de hoekstenen zijn van een adequaat sociaal-pedagogisch overheidsapparaat, de instrumenten van een adequaat sociaal-pedagogisch gezinsbeleid.

Het concept van de Trias pedagogica c.q. van een adequaat stelsel van sociaal-pedagogische voorzieningen, instellingen en diensten symboliseert en materialiseert de secundaire opvoedingsverantwoordelijkheid van staat en samenleving. We brengen in herinnering dat de secundaire statelijke opvoedingsverantwoordelijkheid een rechtsplicht is ex (in het bijzonder) art. 18, lid 2 van het Verdrag inzake de rechten van het kind:

Art. 18, lid 2 VRK:

Om de toepassing van de in dit Verdrag genoemde rechten te waarborgen en te bevorderen, verlenen de Staten die partij zijn, passende bijstand aan ouders (...) bij de uitoefening van hun verantwoordelijkheden die de opvoeding van het kind betreffen, en waarborgen zij de ontwikkeling van instellingen, voorzieningen en diensten voor kinderzorg.

De primaire ouderlijke opvoedingsverantwoordelijkheid is in art. 18 , lid 1 van het Verdrag aldus vastgelegd:

Art. 18, lid 1, tweede en derde volzin VRK:

Ouders (...) hebben de eerste verantwoordelijkheid voor de opvoeding en de ontwikkeling van het kind. Het belang van het kind is hun allereerste zorg.

We voegen aan deze mondiale - vrijwel universeel bekrachtigde - rechtsopvatting op deze plaats een Europees mensenrechtelijk geluid toe: ${ }^{122}$

'The [Childhood Policies] Project [of the Council of Europe (1992-1995)] was based on the following principles: (...)

4. Children should grow up in a family environment which is the natural environment for their full and hamonious development and wellbeing. 
5. Acknowledging that changes in family life mean that there is a need for increasing societal and social responsibility for children, which in turn means an increased need for services such as consultation centres for parents and children, child daycare services, and proper arrangements facilitating the reconciliation of family responsibilities and working life. (...)'

\section{Respect voor ouderschap: formele en materiële elementen}

Onze derde substelling luidt: maatschappelijk respect voor ouderschap leidt tot respectvol ouderschap. Respect voor ouderschap (lees: morele en materiële invulling en operationalisering van secundaire opvoedingsverantwoordelijkheid) en respectvol ouderschap (lees: primaire opvoedingsverantwoordelijkheid die wordt vorm gegeven op basis van het belang van het kind' als allereerste ouderlijke zorg) zijn communicerende vaten. Naarmate respect voor ouderschap meer is gematerialiseerd, er meer waardering en ondersteuning is ten aanzien van de ouderlijke opgave tot persoonswordingsoptimalisering van hun kind(eren), in die mate zal het ouders gemakkelijker vallen hun opgave waar te maken en zo nodig daarbij hulp en steun te zoeken en te aanvaarden. Respect voor ouderschap en respectvol ouderschap gaan aldus hand in hand en leiden gezamenlijk tot (meer) respect voor kinderen, voor de rechten van kinderen, voor de rechtssubjectiviteit, dat wil zeggen: voor het mens-zijn en de mensenrechten van kinderen; mensenrechten èn kinderrechten van kinderen als leden van het menselijk geslacht èn als personen-in-wording.

De primaire ouderlijke opvoedingsverantwoordelijkheid bestaat uit een pakket bevoegdheden en verplichtingen, waarvan de bevordering en waarborging van de kernrechten - in staatsrechtelijke termen, in de terminologie van de Trias pedagogica: de sociaall-pedagogische grondrechten - van kinderen in de eerste plaats afhankelijk is. Het behoeft geen betoog dat - met het oog op fundamentele vrijheden van (jong- c.q. bijna-) volwassenen op het gebied van gezinsvorming, gezinsleven, onderwijs(in-) richting en godsdienstkeuze/levensovertuiging - de (in bestuursrechtelijke termen: discretionaire) bevoegdheden van ouders zeer ruim zijn. Het ligt ook voor de hand dat bij zwaarwegende verplichtingen ruime discretie, ruime bevoegdheden horen. Niettemin is en blijft het object van het pakket ouderlijke bevoegdheden en verplichtingen de bundel sociaal-pedagogische grondrechten van het kind. De bestanddelen 'sociaal' en 'grond-' (rechten) geven al aan dat de samenleving zich hiermee bemoeien mag en zich hiermee te bemoeien heeft (sociaal-pedagogische bemoeizorg). De verwijzing naar staats- en bestuursrechtelijke terminologie doet daar als het ware nog een schepje bovenop: welke privacy-aspecten ouderschap ook aankleven, ouderlijke macht is in eerste en laatste instantie een functie binnen de Trias pedagogica, en als zodanig een publieke functie. 
De Nederlandse wetgever zal door dit geluid niet zijn verrast. Al een eeuw geleden - in 1898 - werd hem, in de Memorie van Toelichting bij het Ontwerp van wet tot wijziging en aanvulling van de bepalingen in het Burgerlijk Wetboek omtrent de vaderlijke macht en de voogdij en daarmede samenhangende artikelen (ontwerp CORT VAN DER LINDEN), voorgehouden: ${ }^{123}$

'De uitdrukking vaderlijke magt is vervangen door ouderlijk gezag. Met de Staatscommissie is de ondergeteekende van oordeel dat van een vaderlijke macht, gelijk de patria potestas der Romeinen "in het belang en ten behoeve van den vader gegeven," naar onze rechtsbegrippen geen sprake meer kan zijn. De macht die de ouders uitoefenen, is hun gegeven "in het belang van ouders en kinderen beiden, ja in dat der geheele maatschappij." Deze macht is, gelijk iedere publieke functie, tegelijk recht en verplichting.'

Voor de Nederlandse samenleving als geheel ligt dat evenwel misschien toch een slag anders. De vraag kan immers worden gesteld of de cultuuromslag wel werkelijk heeft plaatsgevonden die - eveneens alweer (bijna) een eeuw geleden - besloten leek te liggen in de wet van 6 februari 1901:.124

"In onmacht en teleurstelling vindt de wet van 6 Februari 1901 (Staatsblad no. 62) haren oorsprong. Onmacht en teleurstelling van hen, die zich de schoone taak hebben gesteld het kind te behoeden woor den nadeeligen invloed waaraan het is blootgesteld, wanneer de door de natuur aangewezen verzorger en opvoedler zijne plichten als zoodanig verwaarloost en, met een beroep op de wetten des lands, zich verzet tegen elken inbreuk op zijn recht om zijn eigen kind naar willekeur te verzorgen en op te voeden of niet te werzorgen en te verwaarlozen.'

In elk geval in de zestiger jaren van deze eeuw was van de hierboven bedoelde cultuuromslag in ons land nog maar weinig te bespeuren, ter illustratie waarvan onderstaande brief moge dienen van N.N. aan haar vader: ${ }^{125}$

'Als halverwege de jaren zestig een leger hulpverleners onze straat was binnengebanjerd om mij te redden (warar ik zo intens naar verlangde: haal me alsjeblieft

123 Weergegeven door A.D.W. DE VRIES, F.J.G. VAN TRICHT, Geschiedenis der wet op de ouderlijke macht en de voogdij (6 februari 1901, Staatsblad no. 62); Verzameling van Regeeringsontwerpen, gewisselde stukken, gevoerde beraadslagingen, enz, met enkele korte kantteekeningen en register, Groningen 1903, Deel 1, p. 75.

124 DE VRIES/VAN TRICHT, Geschiedenis der wet op de ouderlijke macht en de woogdij (...), a.w., 'Inleiding,' pp. 1-8, op p. 1. N.N., 'Vader,' De Volkskrant van 25 janwari 1990, p. 15 ('Geachte redactie'). 
weg hier geef me alsjeblieft een lief en warm nest), hadden mijn ouders ze er in vijf minuten weer uitgeknikkerd. $\mathrm{Ze}$ staan bekend als zeer fatsoenlijke, intelligente en goed opgeleide burgers. Zo beleefd en voorkomend, geld en goederen woor hun kinderen, een vriendelijk woord voor iedereen, enzovoort.'

Méér dan illustratief zijn de conclusies die KOMEN trekt uit haar vergelijkend onderzoek naar kinderbeschermingsdossiers uit de jaren zestig, zeventig en tachtig-negentig: ${ }^{126}$

'Anders dan we zouden werwachten op grond van de literatuur, werd incest in de jaren zestig-dossiers wèl gezien en vormde het relatief vaker een reden voor het opleggen van kinderbeschermingsmaatregelen dan in de meer recente periode. De incestzaken uit de jaren zestig geven echter geen aandacht aan het ontstaan van eventuele trauma's bij de slachtoffers als gevolg van het misbruik. De slachtoffers konden rekenen op weinig compassie. (....) In de kinderbeschermingsdossiers uit de jaren zeventig steeg het percentage meldingen wan incest, maar onder kinderbeschermers overheerste toch ongeloof, ontkenning en bagatellisering van thet probleem. (...) De recente aandacht voor seksueel misbruik bracht toch minder verandering dan verwacht. Incest werd in de jaren tachtig en negentig weliswaar vaker gesignaleerd, maar dit betekende niet dat er ook effectiever tegen werd opgetreden. (...) Vergeleken met de jaren zeventig werd er well eerder ingegrepen, maar niet vergeleken met de jaren zestig. In zaken waarin volgens kinderbeschermers werkelijk sprake was van incest en met het probleem ook allerminst leek te onderschatten, werd vaker dan vroeger hulpeloos en terughoudend gereageerd. Als de positie van de melder (moeder of kind) in het gezin extreem zwak was, dan was het optreden van de kinderbescherming navenant. Uit mijn onderzoek blijkt vooral bij misbruik van weerloze kinderen eerder een toegenomen beduchtheid voor te snel en te streng optreden dan voor te traag optreden.'

126 Mieke KOMEN, "De blinde vlek voor incest, vroeger en nu," MGv 1998/3, pp. 240255, op pp. 252-253.

Vgl. (van dezelfde auteur) ook: (Mieke KOMEN), 'Kindermishandeling en sociale verandering,' Tijdschrift voor Criminologie 1998/1, pp. 39-58, waarin zij (met betrekking tot lichamelijke kindermishandeling) concludeert (t.a.p., op p. 57): "Net als het grote publiek maakten kinderbeschermers in de recente periode meer ophef over gebruik van geweld in de opvoeding en toonden zij er minder begrip voor. Opvallend daarentegen was dat zij bij ernstige geweldpleging weinig deden. In gevallen waarin kinderen daadwerkelijk werden mishandeld, lieten kinderbeschermers juist een grotere hulpeloosheid zien. $\mathrm{Zij}$ maakten zich weliswaar sneller zorgen dan voorheen, maar zij konden deze bezorgdheid door de toegenomen macht van de ouders in de hulpverleningsrelatie niet altijd omzetten in daden. Daarvoor hadden zij de medewerking nodig van cliënten - van én van de ouders of van het [oudere, jw] kind. In vergelijking met vroeger toonden de betrokken professionals een grotere terughoudendheid in hun optreden tegen het gebruik van ernstig geweld in de opwoeding. (...) De woorden en de gevoelens veranderden veel sterker dan de daden.' 
Dat ook in de jaren negentig van een (werkelijke) cultuuromslag nog geen sprake is, zal grif worden erkend door wie KOMENs vermoeden met betrekking tot de maatschappelijke context van de terughoudendheid van kinderbeschermers (die de Kinderbescherming bijna eerder tot een maatschappelijk instituut voor Ouderbescherming maakt) deelt: ${ }^{127}$

'Dit [de beduchtheid voor tijdig en effectief optreden bij misbruik wan weerloze kinderen - en navenant machtige ouders, $j w]$ heeft misschien iets te maken met het paradoxale feit dat publieke kritiek op en procedures tegen kinderbeschermers die met ernstige vermoedens van seksueel misbruik niets hebben gedaan, zeldzaam zijn.'

Sinds 1995 evenwel, gedenkwaardig jaar waarin Nederland de volle last der verplichtingen onder het Verdrag inzake de rechten van het kind op zich nam, kijkt ten aanzien van die cultuuromslag de internationale gemeenschap mee, kijken de Verenigde Naties mee, kijkt de Raad van Europa mee en kijken tal van non-gouvernementele organisaties (nee, nog niet Amnesty International ${ }^{128}$ ) mee over de Nederlandse schouder die

127 T.a.p., op p. 253 i.f.

128 Al heeft binnen Amnesty International sinds kort een opmerkelijke doorbraak (zij het vooralsnog beperkt tot vrouwenrechten) plaatsgevonden. In het Jaarboek 1998 van Amnesty International lezen we in de openingsbijdrage "Alle mensenrechten voor iedereen' onder het kopje 'Vrouwenrechten' (AMNESTY INTERNATIONAL, Jaanboek 1998, Amsterdam [1998], pp. 7-24, op pp. 19-20; aanhallingen op p. 20): 'Doctrines over privésfeer en bescherming [lees: afscherming, jw] van het gezin, die in zowel internationale als nationale wetten zijn opgenomen, hebben [de] kunstmatige scheidslijn tussen "persoonlijke" en "openbare" domeinen versterkt. Dit onderscheid heeft geleid tot een van de meest voorkomende misvattingen op het gebied van de mensenrechten, en een die Amnesty International heeft beïnvloed. Staten zijn uitsluitend verantwoordelijk gehouden woor schendingen die zich voordoen in het "openbare" domein, maar niet voor schendingen die zich voordoen in de "privésfeer." Als gevolg hiervan was er onvoldoende oog en bezorgdheid voor veel schendingen van vrouwenrechten. [En is er nog steeds onvoldoende oog en bezorgdheid voor veel schendingen van de rechten van het kind, jw.] Zo omvat de interpretatie van het recht om gevrijwaard te zijn van marteling niet het geweld tegen vrouwen [en kinderen, jw] binnen het gezin (zoals huiselijk geweld) en geweld tegen wrouwen [en in het bijzonder meisjes, jw] binnen een gemeenschap (zoals vrouwen- [lees: meisjes]besnijdenis). Bovendien biedt [de jure bood, jw] de weronderstelling dat de maatschappelijke positie van vrouwen [en kinderen] voortkomt uit onschendbare sociale en culturele tradities staten de mogelijkheid om de verantwoordelijkheid voor schending van vrouwen- [en kinder]rechten van de hand te wijzen.'

En onder het kopje 'Uitbreiding wan de [staats]verantwoordelijkheid: passiviteit van regeringen" (t.a.p., op p. 21) lezen we: "De hoop op "een wereld vrij van vrees" (de belofte waarop de Universele Verklaring uitzicht biedit), blijft ijdel zolang 
zich onder die verplichtingen heeft gezet.

In deze (sub)paragraaf gaan we op zoek naar structurele elementen, formele zowel als materiële, die de verdragsrechtelijke cultuuromslag zowell bevorderen als tot uitdrukking brengen. Langs de gulden verdragsrechtelijke weg van respect voor ouderschap kijken we uit naar voorstellen en ideeën die ertoe kunnen bijdragen respect voor de rechten van kinderen van lege huls, van loze taal, van vroom bedrog - nee, zonder beschuldigend crescendo: van politieke slogan waarachter grove en grootschalige, passief-systematische mensenrechtenschendingen worden verstopt - tot maatschappelijke werkelijkheid te maken. Langs de koninklijke verdragsweg plukken we een ruiker formele elementen in subparagraaf 14.4.3.1; aan de materiële elementen ruiken we in subparagraaf 14.4.3.2, doch deze laten we staan voor de volgende (hoofd)paragraaf (par. 14.5). Uitgangspunt voor beide categorieën is dat rechten van kinderen, in het bijzonder en in elk geval de sociaal-pedagogische grondrechten, de kernrechten van kinderen, hun pendant vinden in gedeelde ouderlijke en maatschappelijke zorgen en verantwoordelijkheden. Om in de termen van een ander verdrag, het net iets oudere Vrouwenverdrag (1979, voor Nederland in werking getreden in 1991), te spreken: ${ }^{129}$

praktijken als (...) kinderslavernij, [meisjes]besnijdenis, geweld in de huiselijke kring (...) straflieloos doorgaan. Deze schendingen eisen aandacht omdat ze in de hedendaagse wereld wijdverspreid zijn en een verwoestend effect hebben op de minderbevoorrechten. Onlangs ontwikkelde internationale normen op het gebied van de mensenrechten bevestigen de verantwoordelijkheid van regeringen om dergelijke schendingen te voorkomen en te bestraffen als zij thuis of in de gemeenschap worden begaan door "privépersonen."

Als de staat nalaat zijn burgers te beschermen tegen onrecht door anderen, deelt hij de verantwoordelijkheid met degenen die het onrecht plegen. Ruimere verantwoordelijkheid woor de bescherming van de mensenrechten betekent niet alleen aandacht voor wat regeringen doen, maar ook voor wat zij nalaten ter bevordering van de mensenrechten en ter voorkoming van schendingen.

In het verleden heeft Amnesty International aan dergelijk "privégeweld" uitsluitend aandacht geschonken wanneer er duidelijke aanwijzingen waren dat er sprake was van medeplichtigheid of stilzwijgende instemming van de regering (...). Tijdens de Internationale Algemene Vergadering van 1997 ging de organisatie akkoord met het ontwikkelen van een breder kader voor het aanpakken van schendingen door "niet-overheidsdaders" en met het ontwikkelen van haar deskundigheid op dit gebied door het uitwoeren van een aantal proefprojecten.'

Het wachten is op het moment dat Amnesty International ook kindermishandeling in westerse landen opneemt in haar actieprogramma's en daarmee ook deze steen licht uit de westerse en in het bijzonder Nederlandse "muur van stilzwijgen" ('Werken met internationale organisaties (...), ' a.w., pp. 41-54, op p. 53).

Slot $13 \mathrm{e}$ (op twee na laatste) preambulaire overweging Vrouwenverdrag (curs. jw). In het authentieke Engels: '(...) aware that (...) the upbringing of children 
VUDV (CEDAW), preambule [13]

De Staten die partij zijn bij dit Verdrag, (...) beseffend (...) dat de verantwoordelijkheid voor de opvoeding van kinderen door manten, wrowwen en samenleving als geheel gezamenlijk moet worden gedragen (...).

14.4.3.1

Secundaire opvoedingswerantwoordelijkheid: formele elementen

Onder formele elementen van secundaire opvoedingsverantwoordelijkheid verstaan we die voorstellen en ideeën die niet direct verbonden zijn met de inhoudelijke invulling, het vruchtvlees van de Trias pedagogica (dat wil zeggen: met de trits Opvoedingsondersteuning, Opvoedingsonderwijs en Opvoedingsgeld), doch die, als het ware als schillen rondom de trias (en de trits), in de sfeer liggen van 'kinderrechtelijke opvoeding' van volwassenen door middel van voorlichting en wetgeving. Om concrete voorbeelden te noemen:

- in de voorlichtingssfeer: publiekscampagnes van de overheid, bewustwordingscampagnes van maatschappelijke groeperingen en instellingen, actie- en programma(speer)punten van politieke partijen;

- in de wetgevingssfeer: civielrechtelijke verboden op het slaan van kinderen en op het gebruik van emotioneel (psychisch) en in het bijzonder verbaal geweld in de opvoeding, alsmede - als buitenste schil, als 'ruwe' bolster - nieuwe strafrechtelijke bepalingen (a.) ter zake van fysiek en/of psychisch grensoverschrijdend gedrag door ouders (kinderkwelling, kindermishandeling), (b.) als onderdeel van de sanctiemaatregelen die het sluitstuk vormen van een systeem van ouderschapsondersteuning (SPS), dan wel (c.) ingeval kinderkwelling of kindermishandeling door meldingsplichtigen ten onrechte niet worden gemeld (kinderverlating).

\subsection{Publiekscampagnes, politieke programma's}

\section{In 1885 schreef DU CAMP in La charité privée à Paris: $:^{130}$}

'Il est beau d'adopter les vieillards et de les conduire en paix jusqu'au seuil de l'éternité; il est bien de soigner les maux incurables et d'en adoucir la souffrance; mais il est mieux, il est plus utile au groupe humain dans lequel la destinée nous a vus naître, de récolter les enfants, car ils gardent en eux un avenir dont on peut se rendre le maître et le bienfaiteur."

requires a sharing of responsibility between men and women and society as a whole (...).'

130 Maxime DU CAMP, La charité privée à Paris, Paris 1885, p. 525. 
Dertien jaar later, in 1898 , werden deze woorden, fraai vertaald, aangehaald in een rapport met de titel Het vraagstuk van de verzorging der verwaarloosde kinderen, geschreven in opdracht van de Maatschappij tot nut van "t algemeen: ${ }^{131}$

\begin{abstract}
"Het is schoon, grijsaards te verzorgen, en hen zachtkens tot hun einde te geleiden; het is goed, dat men ongeneeslijke zieken verpleegt en hun leed verzacht; maar het is beter, het is nuttiger voor de maatschappij, zich de kinderen aan te trekken: want zij hebben een toekomst waarvan wij de leidslieden en de weldoeners kunnen zijn.'
\end{abstract}

Honderd jaar later, eind januari 1998, schrijft VAN DER GROEN in NRC Handelsblad: ${ }^{132}$

\begin{abstract}
'De Amerikaanse wetenschapsfilosoof KUHN heeft in zijn kritiek op de leer van Karl POPPER gesteld dat we met elkaar als groep onbewust overeenkomen binnen welk kader, door hem paradigma genoemd, een discussie gevoerd wordt. De deelnemers aan zo'n discussie, onverschillig of dit wetenschappers, politici of journalisten zijn, zijn geconditioneerd om zich binnen de lijnen van dit paradigma voort te bewegen, totdat de informatiewaarde hiervan dermate gekelderd is dat een breuk optreedt. Hierna neemt een nieuw paradigma de plaats van het oude in.'
\end{abstract}

Al een eeuw, al minstens een eeuw, loopt elke aandacht die men vraagt voor het vraagstuk van de mishandelde kinderen stuk op het privacyparadigma. Wetenschappers, politici, journalisten, boeren, burgers en buitenlui: allen bewegen zich, al een eeuw lang, binnen dit paradigma, binnen dit denk- en handelkader waarvan de informatiewaarde is gekelderd tot het meest bedenkelijke niveau dat men zich in een rechtsstaat kan voorstellen: de ontkenning, het weg-rationaliseren, het niet kunnen en willen zien van een situatie van grove en grootschalige mensenrechtenschendingen. Voor juristen, zelfs juristen die niet voorbijgaan aan het Verdrag inzake de rechten van het kind, is de juridische invalshoek per definitie de invalshoek van het bestaande recht zoals dat door rechters wordt gesanctioneerd en gesanctificeerd: de invalshoek van het privacyparadigma. Rechten van kinderen zijn slechts toeters en bellen die aan dat paradigma worden opgehangen, waarmee dat paradigma, paradoxaal

131 J.A. LEVY, P.H. HUGENHOLTZ Jr., A.J. RETHAAN MACARÉ, Th. NOLEN (rapporteur), Het vraagstuk wan de verzonging der verwaarloosde kinderen, [Amsterdam 1898; in opdracht van de Maatschappij tot nut wan 't algemeen], p. 5 (openingscitaat).

132 Bob VAN DER GROEN, "Ambtelijk ontslagrecht blokkeert democratie," opiniepagina NRC Handelsblad van 28 januari 1998 (naar aanleiding van de kwestie sORGDRAGER-DOCTERS VAN LEEUWEN, doch deze aanleiding doet hier niet ter zake). 
maar punctueel: wetenschappelijk, politiek, journalistiek, juridisch en maatschappelijk verantwoord, wordt opgetuigd - niet afgebroken.

In deze studie zijn we dit paradigma onder diverse benamingen tegengekomen: parentiarchie, ouderschapsilbertinisme, privacy-cultuur, privacy-systeem, publiekrechtelijk vrijgestelde privestructuren, de publiek/ privé- (public/private-)dichotomie. De maatschappelijke fenomenen van kindermishandeling en privacy-paradigma tezamen hebben we aangeduid als de pedagogische kwestie (c.q. de social-pedagogische kwestie) en de overheidsreactie op en -houding ten aanzien van die kwestie als onthoudings- c.q. non pòssumus-politiek: hooguit een goed bedoeld beleid tot Kurieren am Symptom, tot palliatie in plaats van preventie. Het fenomeen kindermishandeling tegen de achtergrond van het privacy-paradigma hebben we gekwalificeerd als ernstige en passief-systematische mensenrechtenschending; een kwalificatie die eo ipso scheuren veroorzaakt in, die desnoods als stormram kan fungeren - 'in naam van Oranje, doe open die poort' - tegen de muren van dat dysinformatieve paradigma. Een kwalificatie die, mits luid en vaak genoeg verkondigd, zodat zij werkelijk tot de hoofden en harten van mensen doordringt, die muren, gelijk de muren van Jericho, vanzelf zal doen omvallen. Zoals ons Jozua 6:20 belooft:

Nu begon het volk te juichen, en blies men op de bazuinen; en zodra het volk het bazuingeschal hoorde, schreeuwde het uit alle macht. De stadsmuur stortte in, en het volk stormde naar boven, de stad in, iedereen recht voor zich uit. (...)

Als antwoord op de pedagogische kwestie hebben wij evenwel (nog) geen politiek bazuingeschal voorgesteld, doch hebben wij als begin van een oplossing een rechtsstatelijke gedachte aangedragen: hebben wij de suggestie gedaan het Verdrag inzake de rechten van het kind als constitutie van de Trias pedagogica op te vatten, met SPS, een adequaat sociaalpedagogisch stelsel, als kind- en gezinsvriendelijk bouwwerk bovenop dat constitutionele fundament. Thans stellen wij - al hebben wij daar al eerder en bij herhaling, in allerlei bewoordingen, op gehamerd - als nieuw paradigma, ter vervanging van het oude, het persoonswordingsparadigma voor, en daarmee het motto: zonder SPS geen rechtsstaat! ${ }^{133}$

In een rechtsstaat wordt de primaire ouderlijke opvoedingsverantwoordelijkheid met secundaire elementen aangevuld - niet ex post facto

133 Een motto dat wij, zodra wij, als gidsland, binnenslands onze zaakjes op orde hebben, voor ons grote buitenland, voor wat betreft 'mensenrechten en buitenlands beleid,' ook kunnen omkeren: geen rechtsstaat zonder sPS! Geen eakele zichzelf (en - dus - de mensenrechten) respecterende rechtsstaat kan het stellen zonder SPS. Kijk naar ons. En vice versa: zonder SPS mag geen (ontwikkelings-) land zich rechtsstaat noemen. 
en ex abrupto, als donderslag die sommige gezinnen treft ná het feit van de mishandeling, maar $a b$ ovo en in continuo, preventief en trapsgewijs. Aangevuld met secundaire elementen die, hoe kan het anders, beginnen met publieksvoorlichting en bewustwording. Wij doen op deze plaats, exempli causa, bij wijze van voorbeeld en zonder enige pretentie van volledigheid of 'alleenzaligmakendheid' enkele - summier toegelichte suggesties voor acties en campagnes aan de hand.

Een kind is geen pop. Het heeft rechten - nèt als U!

Publiekscampagnes van de overheid die het privacy-paradigma (in het bijzonder het parentiarchaal bezitsdenken) willen doorbreken of relativeren door het kind voor te stellen als rechtssubject, als drager van fundamentele rechten zoals het recht op lichamelijke en geestelijke integriteit, zouden kunnen worden gevoerd onder de vlag: Een kind is geen pop. Het heeft rechten - nèt als U!

Uw buurkind is ook een mens. Niet uitstellen: het Meldpunt bellen!

Zodra er een adequaat sociaal-pedagogisch stelsel is opgericht, met een volwaardig juridisch statuut voor Advies- en Meldpunten inzake Kindermishandeling (zie hierna par, 14.5.2.1), althans zodra de hulpverlening op een behoorlijk niveau is gebracht, zowel in kwalitatieve als in kwantitatieve zin, zodat adequaat op meldingen gereageerd kan worden, zou van overheidswege een publiekscampagne van start kunnen gaan onder de vlag: Uw buurkind is ook een mens. Niet uitstellen: het Meldpunt bellen! Een tekst die wat dwingender zou kunnen worden gemaakt (bijvoorbeeld door vermelding in kleiner corps van een waarschuwing of strafdreiging ter zake van verlating van hulpbehoevenden) zodra er een (algemene) meldplicht ter zake van kindermishandeling in ons land wordt ingevoerd (zie eveneens par. 14.5.2.1 alsook hierna par. 14.4.3.1.4).

\section{Ouders, geeft $U_{w}$ kind geen dreun, wij staan klaar met hulp en steun!}

Onder dezelfde restrictie(s) als hierboven zouden adequaat sociaal-peda. gogisch toegeruste Raden voor de kinderbescherming - die tegen die tijd vanuit een primair zorgdragend en secundair justitieel (dat is primair per. soonswordingsoptimaliserend en secundair persoonswordingsvindicatoir perspectief, wellicht beter in Raden voor Kind \& Gezin kunnen worder omgedoopt - campagnes kunnen voeren onder de vlag of in de trant van Ouders, geeft Uw kind geen dreun, wij staan klaar met hulp en steun!

De dubbele boodschap is duidelijk: laat pedagogische onmach niet uit de hand lopen, vraag hulp voordat je je zelfbeheersing verliest es met geweld uiting aan onlust geeft. En: vraag hulp, want die hulp is er Echte hulp, dat wil zeggen onmiddellijke, geschikte en, als het nodig is 
intensieve hulp, hulp die (dus) niet begint met het afpakken van je kind.

\section{Ouders, eis hulp! Vecht vóór - niet tegen Uw kind!}

Teneinde het proces van kwalitatieve en kwantitatieve verbetering van de (jeugd)hulpverlening, ingekaderd in een goed geolied sociaal-pedagogisch stelsel, te versnellen, zouden (van overheidswege gesubsidieerde) maatschappelijke organisaties en groeperingen (bewustwordings)campagnes kunnen voeren in de trant van: Ouders, eis hulp! Vecht vóór - niet tegen Uw kind! Ook hier een dubbele boodschap: ouder, je hebt recht op hulp, je staat er niet alleen voor, hebt het recht er niet alleen voor te staan. Een recht dat geen kreet is maar is vastgelegd in een kind- en gezinsvriendelijk verdrag: het Verdrag inzake de rechten van het kind. En: eis dat recht op, eis die hulp, ga de straat op, maak het persoonlijke politiek, in plaats van thuis te blijven en onlust en onmacht op je kind af te reageren (waar je later, wellicht de rest van je leven, de wrange vruchten van plukt). Tevens: organiseer je als ouders, maak een politieke vuist, eis een kind- en gezinsvriendelijk gezinsbeleid, eis structurele hervormingen in een achterhaald, ziekmakend apparaat, laat je niet langer gebruiken in een (inter-departementaal) politiek spel van verdeel-en-heers. Heel concreet: schop niet tegen de Raden, het welwillende instrument van justitiële non possumus-politiek, maar schop tegen de hoogst verantwoordelijken: de regering, die zichzelf, het parlement, het volk èn het Comité inzake de rechten van het kind een rad voor de ogen draait ${ }^{134}$; het parlement, dat de regering haar gang laat gaan; en de politieke partijen, van links tot rechts, van regeringspartijen tot oppositiepartijen, die het te druk hebben om na te denken over een verdragsconform kind- en gezinsbeleid. Richt desnoods een nieuwe politieke partij op, een partij die zich sterk maakt voor een sociaal-pedagogisch steunbeleid, een SPS-partij.

134 Vgl. Sharon DETRICK, Jaap DOEK, Isabeth MIJNARENDS, 'Slotbeschouwing' Tijdschrift poor Familie- en Jeugdrecht 1998/1 (special over het Verdrag inzake de rechten van het kind), pp. 26-27. De auteurs merken op (t.a.p., op p. 26 1.k.): 'De functie van rapportageplicht moet ernstig worden betwijfeld als landen met een voorbeeldfunctie en voortrekkersrol zo weinig interne zelfreflectie ten aanzien wan hun eigen rechtssysteem kunnen opbrengen en elke vorm van analyse achterwege laten."

Vgl. ook Jacqueline SMITH, 'Rapportageverplichting onder het [VRK],' FJR 1998/ 1 , pp. $2-6$, op p. 5 r.k; , en A.A.W. VAN UNEN, 'Part v: Family environment and alternative care,' FJR $1998 / 1$, pp. $15-18$, op pp. 15 r.k.-17. Zie ook E.P. VON BRUCKEN FOCK, "Blijft het [VRK] statisch kinderrecht?' FJR 1998/1, p. 1 (editorial). Deze laatste auteur merkt, enigszins zalvend, op: 'De ervaring leert dat het jaren duurt voordat een verdrag als het onderhavige zich in de rechtscultuur van een land een eigen plaats heeft verworven. De wetenschap zal, evenals dat op vele andere terreinen van het recht het geval is, het voortouw moeten nemen.' 
Opvoedingsproblemen? gezinsproblemen? verwerkingsproblemen? bedenk en onthoud: Spreken is zilver, zwijgen is Fout!

Daarnaast zouden bovenbedoelde organisaties en groeperingen hun aandacht kunnen richten op het Marcus-effect (zie het slot van hoofdstuk 12), op de positieve invloed van praten over problemen - althans als adequate hulp paraat staat -, in tegenstelling tot de negatieve neerwaartse spiraal van geheimhouding: het Matthëus-effect (het sneeuwbaleffect van psychische ellende door het herhalingsdwangmechanisme). Een negatieve spiraal die alleen door praten, door in het gesprek met (al of niet professionele, afhankelijk van de ernst van de onderliggende problematiek) vertrouwenspersonen verworven inzicht in ('vroege') patronen (ontstaan in de jeugd en 'mee-resonerend' in het latere leven) en door handelen naar dat inzicht kan worden doorbroken. Door praten, en nog eens praten 66k over gezinsgeheimen, geheimen die toch niet geheim kunnen blijven. Zoals het spreekwoord zegt: geheim van één weet God alleen, geheim van twee wordt licht gemeen, geheim van drie weet iedereen. Het geheim van twee (kind en v/dader/ouder) komt vroeger of later uit (Marcus 4:22-23):

Want niets is verborgen, of het moet worden geopenbaard; en niets is geheim, of het komt aan het licht. Zo iemand oren heeft om te horen, hij hore!

Het geheim van drie (kind en beide ouders of kind en één ouder en een ander gezinslid of een latere partner) wordt vroeg of laat van de daken geschreeuwd (Lucas 12:1-3):

Vooreerst, wacht u voor het zuurdeeg der farizeeën, dat is voor huichelarij. Want niets is bedekt, dat miet ontdekt, niets verborgen, dat niet bekend zal worden. Alles dus wat gij spreekt in de duisternis, zal in het licht worden gehoord; en wat gij in kelders in het oor hebt gefluisterd, zal van de daken worden verkondigd.

Dit alles kan men maar beter voor zijn door gezinsgeheimen zo vroeg mogelijk aan zorgdragende instanties voor te leggen: Opvoedingsproblemen? gezinsproblemen? verwerkingsproblemen? bedenk en onthoud: Spreken is zilver, zwijgen is Fout!

\section{Bent $U$ nooit kind geweest? Of heeft $U$ nooit kind mogen zijn?}

In de derde plaats zouden maatschappelijke organisaties en groeperingen meer confronterende bewustwordingscampagnes kunnen voeren in de trant van: Bent $U$ nooit kind geweest? Of heeft $U$ nooit kind mogen zijn? Campagnes die volwassenen uitnodigen het (gekwetste, verworpen) kind in zichzelf te zien, en zichzelf in andere (mishandelde, misbruikte, verwaarloosde) kinderen. 


\section{Voor gezinnen zorgen: vandaag niet morgen!}

Van cruciaal belang is uiteraard om de doorbreking van het honderdjarige privacy-paradigma, of liever het nieuwe sPS-paradigma, en nog liever SPS zelf, op de politieke agenda te krijgen. Ik doe enkele suggesties aan de hand voor vliegende vaandels en bazuingeschal welke op wervende wijze actie- en beleidsspeerpunten in de programma's en propaganda van politieke partijen van links tot rechts zouden kunnen begeleiden. Om te beginnen - ere wie ere toekomt - voor het $\mathrm{CDA},{ }^{135}$ dat zich sinds enige tijd (met stilzwijgende steun, mogen we aannemen, van klein rechts), vanuit de onwennige en ook wel ondankbare rol van (christelijke) oppositiepartij tegenover een kabinet gevormd en gesteund door drie zich tot een bisschoppelijke kleur vermengd hebbende partijen, als pro-gezinspartij poogt te profileren: Een groen geluid. Voor gezinnen zorgen: vandaag niet morgen!

\section{Nederland: rechtsstaat. Ook voor kinderen!}

Een SPS-beleid zou door de VVD (en D66?) gepropageerd kunnen worden onder het liberale vaandel: Nederland: rechtsstaat. Ook voor kinderen! Een meer economisch vaandel zou natuurlijk ook mogelijk zijn door te wijzen op de kapitaalvernietiging van het huidige non-(possumus-)beleid en de kapitale winsten, in menselijke, maatschappelijke en economische zin, die op termijn zijn te verwachten van een SPS-beleid.

Vgl. de korte analyse van de concept-verkiezingsprogramma's van Maurice VAN LIESHOUT, "Meeste aandacht voor jeugd in CDA-programma," 0/25; Tijdschrift over jeugd december 1997 (rubriek Nieuws), pp. 5-6, walarin de 'coördinerend bewindspersoon [lees: -vrouw, jw] voor jeugdbeleid, [VVD-]staatssecretaris Erica TERPSTRA," aldus wordt aangehaald (t.a.p., op p. 5, eerste kolom; curs. jw): 'Eén van de grootste [verkiezings] thema's is hoe we uitsluiting wan bepaalde jongeren voorkomen en hoe we bereiken dat er jeugdinclusief beleid wordt gevoend (...)." Niet haar partij doch het CDA bepleit evenwel voor een volgend kabinet "een minister voor gezinsbeleid (...) met een eigen budget' en (althans) 'extra geld voor opvoedingsondersteuning' (t.a.p., eerste/tweede kolom).

DE WAAL schetst hoe het zover met het CDA is kunnen komen (Mieke DE WAAL, "Van zorgzaamheid naar waakzaamheid,' in: dez. e.a., Gezinnen gezien, Assen 1998, pp. 39-49, op p. 40): 'Sinds de Algemene Politicke Beschouwingen van 1995 [jaar van de inwerkingtreding voor Nederland van het Verdrag inzake de rechten van het kind! -jw] was CDA-fractievoorzitter HEERMA de meest invloedrijke pleitbezorger voor aandacht voor het gezin. Hij betoogde: "Als je ziet dat gezinnen verbrokkelen en desintegreren, moeten we die opvoeders gaan ondersteunen. Of moeten we soms alles gaan investeren in RLAGG's, jeugdgevangenissen en echtscheidingsadvocaten?" Het liefst had HEERMA direct de benoeming van een aparte gezinsminister gezien, maar dat leverde hem slechts hilariteit in het kabinet op.' 
Een land zonder mishandelde kinderen vóór 2010: elk jaar 10.000 mishandelde kinderen minder! Het kan! Het moet! We gaan ervoor!

Sociaal 'angehauchte' partijen als de PvdA en GroenLinks (en D66?) zouden wellicht meer voelen voor concrete sociale eindtermen, bijvoorbeeld voor de actieleus: Een land zonder mishandelde kinderen vóór 2010: elk jaar 10.000 mishandelde kinderen minder! Het kan! Het moet! We gaan ervoor! Een leus die niet alleen lijkt aan te sluiten bij de ('post-')moderne ideologie van het pragmatisme doch die - oneindig belangrijker - ons aanspoort vol (goede) moed toe te werken en toe te leven naar een ideaal dat, hoe hoog gegrepen ook, wij aan onszelf, als schakels in de keten van generaties, als kinderen van ouders, als ouders van kinderen, als kinderen van kinderen van kinderen, verplicht zijn na te streven, het ideaal namelijk, kort en krachtig verwoord door DONNELLY, ${ }^{136}$ dat ...

\section{'(...) it shouldn't hurt to be a child.'}

Inderdaad: it shouldn't hurt so much for so many for so long. Inderdaad: we staan erbij en kijken er (liever niet) naar. Niet omdat we slechte of wrede, gevoelloze of onverschillige mensen zijn, maar omdat we gevangen zitten, al honderd jaar lang, in een paradigma. Omdat we elkaar, sociale dieren die we zijn - l'homme est né pour la société -, al meer dan een eeuw, al langer dan de eeuw van het kind, aan dat paradigma vastgeketend houden - l'homme est né libre, et partout il est dans les fers. Een paradigma dat gepaard gaat met grove en grootschalige mensenrechtenschendingen, die te pijnlijk zijn, te confronterend, te compromitterend om aan te zien, om onder ogen te zien. De pijn van kinderen is te pijnlijk voor volwassenen die zich wentelen in hun paradigmatische onmacht. We zullen die pijn, de pijn van tienduizenden kinderen elk jaar in dit land, de blijvende pijn, de knagende pijn, echter in alle openheid, tegen alle weer. standen in, moeten láten zien, namens hen uit moeten schreeuwen. $I$ hurts so much for so many for so long. We moeten dat doen, de juristen de mensenrechtenactivisten, de kinderbeschermers, de jeugdhulpverle ners, de pedagogen, de ontwikkelingspsychologen, de huisartsen, de ver trouwensartsen, leraren, psychiaters, psychotherapeuten, reclasseringswer kers, inrichtingswerkers, ouders, scholieren, studenten, wij allen die e weet van hebben, niet uit sensatiezucht, uit wanhoop, of uit wrok, maa omdat de menselijke conditie er - geluk bij een ongeluk - een is die tra gedie paart aan hoop - l'homme est un apprenti, la douleur est son maitr

Anne C. DONNELLY, 'Foreword,' in: R.K. OATES, The spectrum of child abus Assessment, treatment, and prevention, Basic Principles into Practice series, vol. New York 1996, pp. vii-ix, op p. ix if. 
Een nieuw paradigma kondigt zich aan. Om met VAN VOLLENHOVEN (1918) te spreken: ${ }^{137}$

'Het wolkenrecht van GROTIUS [lees: het kindervolkenrecht, jw] staat aan de deur, en het klopt. [H]onderd jaar heeft men het laten kloppen. Nu wordt het ons te machtig. Het slot is nog niet om, maar de grendels zijn al weggeschoven."

De grendels zijn weggeschoven door de (vrijwel) universele ratificatie van het Verdrag inzake de rechten van het kind. De nationale sleutel van het slot houden we zelf in de hand. Maar hoor, het kloppen van het kindervolkenrecht op de vaderlandse deur is al bonken geworden, het bonken van een opgesloten, niet meer wanhopig maar opstandig kind. Een kind dat onder mensen van goede wil steeds meer bondgenoten vindt. Zijn we zo wijs, zo menslievend het slot om te draaien vóór de stormram van de mensenrechten wordt aangesleept? 'In naam van Oranje ....'

Of heeft het kleine Nederland - land van ERASMUS, van Hugo DE GROOT, van Jan DE WTTT - het te druk met mensenrechtenschendingen in zijn voormalige koloniën en zijn grote, boze buitenland? Te druk met de rechten van kinderen in andere landen: ${ }^{138}$

"Ten slotte presenteert de regering ons land in internationale fora als pleitbezorger voor aandacht voor de rechten van kinderen.'

Zullen de woorden van Lucas, hierboven aangehaald, eerlang over ons allen komen:

Vooreerst, wacht $\mathrm{u}$ voor het zuurdeeg der farizeeën, dat is voor huichelarij. Want niets is bedekt, dat niet ontdekt, niets verborgen, dat niet bekend zal worden.

Zullen wij het Comité inzake de rechten van het kind ook over vijf jaar een dik rapport sturen met de boodschap dat ...

(...) [h]et huidige beleid en de huidige wetgeving (...) voldoen aan de eisen die door het [V]erdrag worden gesteld. ${ }^{139}$

137 C. VAN VOLLENHOVEN, De drie treden van het volkenrecht (1918), Den Haag 1935 (derde druk), p. 61 i.f.

138 Kamerstukken II 1993/94, 22855 (R 1451), Goedkeuring van het op 20 november 1989 te New York tot stand gekomen Verdrag inzake de rechten van het kind, nr. 6 (Nota naar aanleiding van het verslag), p. 5.

139 Kamerstukken II 1993/94, 22855 (R 1451), nr. 6 (Nota naar aanleiding van het verslag), p. 4. Het geciteerde is weliswaar van oudere datum dan het rapport van de regering aan het Verdragscomité, matar zoals VON BRUCKEN FOCK (editorial 
Of is tegen die tijd het privacy-paradigma dood en begraven, zodat een dergelijke verwaten rapportage het Comité slechts de reactie zal ontlokken: ${ }^{140}$

Wee $U$, schriftgeleerden en farizeeërs, gij huichelaars, die gelijk zijt aan witgepleisterde graven, welke van buiten schoon schijnen, maar van binnen vol zijn van doodsbeenderen en allerlei onreinheid.

\subsection{Een wettelijk verbod op het slaan van kinderen}

\section{Culturele praktijken}

SMITH en VAN DER WEIDE stellen in hun boek Visies en discussies rond genitale verminking van meisjes: ${ }^{141}$

'Een van de belangrijkste aspecten bij het bepalen of een culturele praktijk [lees: genitale verminking van meisjes; vul aan: het slaan van kinderen, $j w]$ als een schending van mensenrechten aan te merken is, is de mate waarin onschuldige mensen [lees: kinderen, jw] gewond [lees: getraumatiseerd, jw] worden of gedood als resultaat van die praktijk.'

Er zijn landen waar men de culturele praktijk van de genitale verminking van meisjes ('meisjesbesnijdenis') poogt af te schaffen - iets waartoe art. 24 , lid 3 van het Verdrag inzake de rechten van het kind verdragsstaten verplicht. Er zijn landen waar men de culturele praktijk van het slaan van kinderen, het traditionele $j u s$ castigandi ${ }^{142}$ (anders dan en voorbij de pedagogische tik op de vingers 'om de aandacht van het kind te richten $^{\text {,143 }}$ ), poogt af te schaffen - iets waartoe art. 24, lid 3 juncto art. 19, lid 1 van het Verdrag inzake de rechten van het kind verdragsstaten zo al niet verplicht dan toch opwekt (zie voor de opvattingen van het Comité inzake de rechten van het kind op dit punt hierna par. 14.5.2.3). Over

FJR 1998/1, t.a.p.) terecht over de Nederlandse rapportage opmerkt: 'Blijkens de 413 paragrafen tellende droge, langdradige, soms plichtmatig ogende maar vooral ook kritiekloze opsomming geeft de Nederlandse Regering zichzelf kennelijk een hoog rapportcijfer. Slechts op éen enkele plaats (par. 34) wordt de vraag opgeworpen - welke vraag overigens onmiddellijk bevestigend wordt beantwoord - of het Nederlandse recht voldoet aan de vereisten van het [VRK].'

140 Mattheüs 23:27.

141 Jacqueline SMTTH, Hermine VAN DER WEIDE, Visies en discussies omtrent [rond] genitale verminking van meisjes; Een inventarisatie in intemationaal perspectief, DCI Afdeling Nederland, Amsterdam 1992, p. 32.

142 Vgl. J. DE BOER, 'De pedagogische tik' (besprekingsartikel van H.E.M. BAARTMAN, Opvoeden met alle geweld), Nederlands Juristenblad 1994, pp. $389-390$ (met 'toegift' op p. 542), op p. $3891 \mathrm{k}$.

143 H.E.M. BAARTMAN, Opvoeden met alle geweld, Utrecht 1993, p(p). (19/)20. 
deze laatste landen, de landen waarin lijfstraffen ook voor kinderen zijn afgeschaft, merkt OATES op: ${ }^{144}$

\begin{abstract}
'The experience of the Scandinavian countries and Austria, where parents by law are not allowed to hit their children, suggests that societies do not break down when parents stop hitting their children. However, it must be realized that the intention of the Scandinavian legislation was education rather than punishment [of parents, jw]. Along with the legislation, there was an education campaign, helping parents to learn more acceptable methods of discipline. The legislation was not meant to punish parents, but to aim for a generation of children to grow up without the experience of being hit, so that they may in turn be less aggressive and violent in their dealings with other adults and with their own children.'
\end{abstract}

Hoewel het op zich geen schande is dat andere landen ons zijn voorgegaan, is het meer dan jammer dat we met betrekking tot het slaan van kinderen onze humanitaire voorsprong van gemiddeld meer dan een eeuw ${ }^{145}$ op de Scandinavische landen Finland, Noorwegen en Zweden zo laks hebben prijsgegeven: ${ }^{146}$

'In many countries, corporal punishment has not been allowed in schools for several generations, and the fabric of their societies has not disintegrated.

For example, corporal punishment in schools was abolished in the Netherlands (1820), Italy (1860), Belgium (1867), France (1881), Finland (1890), Norway (1936), Sweden (1958), Switzerland (1970), and England (1986).'

\title{
OATES houdt ons voor: $:^{147}$
}

'Adults do not like to be hit in public and our society does not condone the use of physical means by adults to settle their differences. Instead, adults thrive on praise and positive reinforcements. These principles also hold true for children.'

\section{Een beetje ouder houdt zijn handen thuis!}

Wij bepleiten een civielrechtelijk (c.q. 'gezinsbestuursrechtelijk') verbod op het slaan van kinderen. ${ }^{148}$ Wij zijn ons bewust van de reactie van

144 R.K. OATES, The spectrum of child abuse; Assessment, treatment, and prevention, Basic Principles into Practice series, vol. 8, New York 1996, p. 24.

Welke godwrezende kenner van onze volksaard zei ook al weer dat hij op de dag van het Laatste Oordeel naar ons land zou vluchten omdat daar alles een halve eeuw later gebeurt?

146 OATES, a.w., p. 26.

147 T.a.p.

148 Zoals eerder bepleit door DOEK (1987) en DE BOER (1992); zie J. DE BOER, 'Het slaan van kinderen,' in: Ted DE BOER e.a. (red.), De kant wan het kind; Liber amiconum Prof. mr. Miek DE LANGEN, Arnhem 1992, pp. 137-145, op p. 144 
sceptici (en zijn dat niet per definitie alle goede juristen?) dat op 'symboolwetgeving' niemand - en zeker geen kind - zit te wachten. Wij antwoorden hen als volgt. Wie een wettelijk verbod op het slaan van kinderen afwijst omdat het voornamelijk symbolische waarde zou hebben, miskent niet alleen in algemene zin het civiliserende belang - en dus de humaniserende werking - van symbolen (met andere woorden: de mijlpaalfunctie van 'symboolwetgeving' als sociaal-cultureel omslagpunt en de moreel-juridische bakenfunctie voor de toekomst), maar ziet in het bijzonder de vormende en educatieve waarde over het hoofd die een dergelijk verbod heeft voor ouders. Wij bepleiten een verbod op het slaan van kinderen met andere woorden in het bijzonder omwille van de opvoedende waarde ervan voor opvoeders, welke waarde vooral gekapitaliseerd zal worden indien introductie van het verbod met zorgvuldige voorlichtingscampagnes gepaard gaat. Campagnes in de trant van: Een beetje ouder houdt zijn handen thuis! Waarbij voor pedagogisch verantwoorde alternatieven voor de 'opvoedkundige tik' (in de excessieve zin van het 'opvoedkundig "pak voor de broek"149 - of erger) verwezen kan worden naar ouderschapscursussen, bijvoorbeeld te volgen via het kruiswerk.

\subsection{Een wettelijk verbod op (verbaal) geweld tegen kinderen}

DOEK bepleit ...

'(..) het opnemen in het Burgerlijk Wetboek van de regel dat het ouders niet is toegestaan in de opvoeding en verzorging van hun kinderen (geestelijk of lichamelijk) geweld te gebruiken. ${ }^{\text {150 }}$

En hij vervolgt: ${ }^{151}$

'De discussie over dit voorstel wordt ten onrechte verengd tot een verbod op het slaan van kinderen en leidt vrijwel altijd tot publieke commotie. Het is een weinig vruchtbare verenging [die] (...) - welbewust? - de aandacht af[leidt] van het wezenlijke punt: dient het recht van het kind op preventie niet te resulteren in de plicht van de ouders zich wan geweld in de opvoeding te onthouden? Waarom kan

(nt. 39 juncto p. 140 nt. 18); zie ook de hierna volgende paragraaf.

Kamerstukken II 1992/93, 22855 (R 1451), Goedkeuring van het op 20 november 1989 te New York tot stand gekomen Verdrag inzake de rechten van het kind, nr. 3 (Memorie van Toelichting), p(p). (29/)30 (ook aangehaald in hoofdstuk 13, par. 13.4.1 onder Toetsing aan de hand van getuige-deskundigenverklaringen).

Jaap DOEK, 'Kindermishandeling: recht op en/of dwang tot preventie,' VKMagazine $[1995 / / 3$ (special 'Primaire preventie van kindermishandeling'), pp. 18-21, op p. 20 r.k. (curs. jw). 
die regel wel in verscheidene andere Europese landen worden ingevoerd en niet in het onze? Dat het afdwingen van de naleving beperkt mogelijk is, lijkt mij geen beslissend argument. Ondanks die beperking kan die regel wel degelijk haar invloed doen gelden, onder andere omdat [h]ij het aanknopingspunt kan zijn voor intensieve en doorgaande voorlichting over het vermijden van geweld in de opvoeding.'

Een concreet voorstel voor een wetsbepaling met bovenstaande strekking, op te nemen in het Nederlandse BW, kwamen we in hoofdstuk 5 (par. 5.4) tegen van de hand van BAARTMAN: ${ }^{152}$

'Kinderen hebben recht op eerbiediging van hun lichamelijke en hun psychische integriteit. Ouders zullen zich daarom jegens hun kinderen onthouden van geweld.'

Een beetje ouder let op $z^{\prime} n$ woorden!

Wij onderschrijven volledig voornoemde voorstellen (en de toelichting erop). Daarnaast bepleiten wij een expliciet verbod op het gebruik van verbaal geweld in de opvoeding, op het bedreigen, beschamen, vernederen en uitschelden van kinderen. Introductie van een dergelijk verbod zou gepaard kunnen gaan aan een campagne (met als motto: Een beetje ouder let op $z^{\prime} n$ woorden!) ter verspreiding van de Tien Verboden, de tien dingen die men een kind nooit zegt (die wij in een vorig hoofdstuk al in een noot vermeldden): ${ }^{153}$

VERBOD 1. Gij zult Uw kind niet afwijzen door te zeggen: 'Van jou kan niemand houden.'

VERBOD 2. Gij zult Uw kind niet neerhalen door te zeggen: 'Wat ben jij toch stom!"

VERBOD 3. Gij zult Uw kind niet tot perfectionisme drijven door te zeggen: 'Hoe komt het nou dat je slechts tweede werd?'

VERBOD 4. Gij zult Uw kind niet verdoemen door te zeggen: 'Het wordt nooit wat met jou!"

VERBOD 5. Gij zult Uw kind niet negatief vergelijken door te zeggen: 'Waarom lijk je niet wat meer op je broer?!'

VERBOD 6. Gij zult Uw kind niet tot zondebok maken door te zeggen: 'Het is jouw schuld dat wij gaan scheiden.'

VERBOD 7. Gij zult Uw kind niet beschamen door te zeggen: 'Kijk eens hoe kinderachtig Jantje nog doet."

H.E.M. BAARTMAN, Opwoeden met alle geweld: hardnekkige gewoontes en hardhandige opvoeders, Utrecht 1993, p. 21.

153 Psychological Reports 1997; zie Psychologie oktober 1997, p. 13 r.k. (eerder aangehaald in par. 13.4.1). 
VERBOD 8. Gij zult Uw kind niet uitschelden: 'Hufter!' 'Trut!' 'Zak!' 'Hoer!'

VERBOD 9. Gij zult Uw kind niet fysiek bedreigen: 'Ik sla je nog eens tot moes!"

VERBOD 10. Gij zult Uw kind niet emotioneel chanteren (op zijn schuldgevoel werken) door te zeggen: 'Hoe kan je dat nou doen, na alles wat ik voor jou gedaan heb?'

\subsection{Nieuwe delictsomschrijvingen}

Nieuwe delictsomschrijvingen (c.q. toespitsing en aanscherping van bestaande delictsomschrijvingen) - in het huidige Wetboek van Strafrecht dan wel in een nieuw eenentwintigste-eeuws 'gezinsbestuursrechtelijk' Wetboek van Gezinsrecht - kunnen drie categorieën betreffen:

(a.) crimineel misbruik van c.q. criminele nalatigheid met betrekking tot de primaire ouderlijke opvoedingsverantwoordelijkheid, te weten. fysiek, sexueel en/of psychisch grensoverschrijdend gedrag door ouders/ opvoeders (kinderkwelling, kindermishandeling, kindermisbruik, kinderverkrachting) en fysieke en/of psychische verwaarlozing (kinderverwaarlozing, voortdurende/herhaaldelijke ouderlijke zorgeloosheid en/of liefdeloosheid c.q. pedagogische onverschilligheid);

(b.) 'trias-criminaliteit': strafwaardig gedrag van ouders/opvoeders met betrekking tot de secundaire statelijke opvoedingsverantwoordelijkheid (als laatste categorie van de sanctiemaatregelen die het sluitstuk vormen van een systeem van ouderschapsondersteuning/sPS);

(c.) 'omstanders-criminaliteit': strafwaardig gedrag met betrekking tot het niet te hulp schieten van kinderen, in het bijzonder met betrekking tot het (ten onrechte) niet melden van gevallen van kinderkwelling, kindermishandeling, kindermisbruik, kinderverkrachting of kinderverwaarlozing door meldingsplichtigen (kinderverlating).

Ad (a.) In bijlage II bij deze studie vindt men voorbeeld-strafbepalingen ter zake van grensoverschrijdend/nalatig gedrag door ouders, waarbij gebruik is gemaakt (c.q. voor nadere uitwerking kan worden gemakkt) van de in bijlage III opgenomen criteria voor kindermishandeling uit CICCHETTI/TOTH.

Voor de goede orde: fysiek grensoverschrijdend gedrag door ouders jegens hun kinderen kan thans reeds worden vervolgd op grond van artt. 300(-303) juncto 304 aanhef en onder $1^{\circ}$ Wetboek van Strafrecht (mishandeling begaan tegen zijn kind). Sexueel grensoverschrijdend gedrag door ouders jegens hun kinderen ('incest') is strafbaar krachtens art. 249, lid 1 Wetboek van Strafrecht (er kunnen evenwel ook andere bepalingen uit de titel 'misdrijven tegen de zeden' van toepassing zijn). 
Theoretisch zou psychisch grensoverschrijdend gedrag door ouders jegens hun kinderen gebracht kunnen worden onder art. 300, lid 1 juncto lid 4 Wetboek van Strafrecht (opzettelijke benadeling van de gezondheid: gezondheid te verstaan als mede omvattende geestelijke gezondheid en/of gezonde/harmonische geestelijke/psycho-sociale/sociaal-emotionele ontwikkeling). Een voorstel van een expliciete strafbepaling ter zake van psychisch grensoverschrijdend gedrag door ouders jegens hun kinderen is reeds in 1956 beproefd door CLEMENS SCHRÖNER. ${ }^{154}$ Volgens VAN MONTFOORT en DOEK is dit voorstel 'weinig omstreden, maar heeft [het] evenmin veel navolging gekregen'155 (met andere woorden: het is doodgezwegen). Dezelfde auteurs merken op dat (fysieke) verwaarlozing van kinderen door hun ouders "kan vallen onder de bepalingen over "verlating van hulpbehoevenden" (artt. 255-260 [Wetboek van Strafrecht]).,156 Affectieve/emotionele verwaarlozing, hoewel moreel en ontwikkelingspsycho(patho)logisch gezien een zeer ernstige misdaad (als er - voorwaardelijk of erger - opzet in het spel is), valt in principe buiten het bereik van de strafwet.

Ad (b.) Hierbij kan men bijvoorbeeld denken aan misbruik van opvoedingsloon, opzettelijk boycotten van opvoedingscursussen of opzettelijke en herhaaldelijke sabotage van opvoedingshulp (dat wil zeggen het geval dat geaccepteerde dan wel opgelegde opvoedingshulp opzettelijk en herhaaldelijk wordt tegengewerkt).

Voor de goede orde: tot de categorie 'trias'-sanctiemaatregelen, strafrechtelijk of anderszins ('gezinsbestuursrechtelijk'), behoort nadrukkelijk niet de belangrijkste maatregel in een systeem van ouderschapsondersteuning (SPS): de persoonswordingsvindicatie. Deze maatregel (van hulp en steun) vindt zijn (ultieme) grondslag immers niet in (strafbaar of anderszins onrechtmatig) gedrag van ouders, maar in de rechten van het kind: in het kernrecht van het kind op minimale persoonswording (zie hierna par. 14.5.2.2.2). Hetzelfde geldt in het bijzonder ook voor de gedwongen uithuisplaatsing van een kind: deze maatregel wordt uitsluitend

B.L.F. CLEMENS SCHRÖNER, Psychische kindermishandeling, diss. Leiden (1956), Den Haag 1957, pp. 270-277 (zie voor de tekst bijlage 1I; vgl. ook hoofdstuk 11, par. 11.2.2.3).

Onder de concept-delictsomschrijving van CLEMENS SCHRÖNER valt ook de specifieke deelnemingsvorm van het "klikken"' ("verslag [doen] van slecht gedrag van het kind') van de ene ouder dat voor de andere ouder de aanleiding is om het kind kwellend te bejegenen (a.w., p. 273).

Adri VAN MONTFOORT en Jaap DOEK, "Kindermishandeling en het strafrecht,' in: H. BAARTMAN, A. VAN MONTFOORT (red.), Kindermishandeling: resultaten van multidisciplinair onderzoek, Utrecht 1992, pp. 263-278, op p. 264. 
opgelegd op grond dat geschikte hulp ter waarborging van de minimale persoonswording van een kind op een andere manier niet mogelijk is (zie eveneens par. 14.5.2.2.2).

Ad (c.) In bijlage II bij deze studie treft men ook een voorbeeldstrafbepaling aan ter zake van het in hulpeloze toestand brengen of laten van een kind. Wij volstaan op deze plaats met een verwijzing naar par. 14.5.2.1 (wettelijke meldplicht).

\section{4 .3 .2}

\section{Secundaire opvoedingsverantwoordelijkheid: materiële elementen}

Onder materiële elementen van secundaire opvoedingsverantwoordelijkheid verstaan we voorstellen en ideeën die inhoudelijk invulling (pogen te) geven aan de wezenstrekken van de Trias pedagogica, dat wil zeggen: aan de trits Opvoedingsonderwijs-Opvoedingsondersteuning-Opvoedingsgeld (met als binnenste kern, als klokhuis, Opvoedingsondersteuning). Gestuurd en gesticht door de logica en wijsheid van twee spreekwoorden leiden we deze trits kort in.

Voorkomen is beter dan genezen, doch de kost gaat voor de baat uit VAN DANTZIG drukt ons met de neus op een apert voorbeeld van staatsaansprakelijkheid: grove verdrags- en mensenrechtenschending door de persistente nalatigheid van de staat hulpverleners adequate sociaal-pedagogische (persoonswordingsoptimaliserende) middelen en juridische (persoonswordingsvindicatoire) instrumenten te verschaffen - een nalatigheid die deze hulpverleners huns ondanks tot 'kampbewakers' maakt, tot medeplichtigen aan de 'marteling' van kinderen: ${ }^{157}$

"In "Hulpverlening bij seksueel misbruik aan jonge kinderen en hun ouders" [bespr. werk, hfd. 12, pp. 218-228] bespreekt Francien LAMERS-WINKELMAN de mogelijkheden en onmogelijkheden van therapie. Schrijnend vond ik hoe ze beschreef dat de hulpverlening soms maanden moet toezien hoe het [sexuele] misbruik verder gaat [a.w., p. 221.]: "(...) binnen MKD's (Medisch Kinderdagverblijf, AVD) bijvoorbeeld kan men geconfronteerd worden met jonge misbruikte kinderen die aan het eind van de dag weigeren naar huis te gaan, zich hevig verzetten als ze toch in de taxi moeten. Het vergt moed en "eelt op de ziel" om een kind te kunnen antwoorden dat ook jij niet weet wanneer "dat akelige" voorbij zal zijn. Op het "waarom" van het kind kan geen antwoord gegeven worden en het is een zware opgave om week in week uit te moeten zien hoe een kind meer en meer beschadigd wordt. De ervaring leert dat het over het algemeen geruime tijd (en-

A. VAN DANTZIG, bespr. van H. BAARTMAN, A. VAN MONTFOORT (red.), Kindermishandeling, resultaten van multidisciplinair onderzoek, Utrecht 1992 , in: $M G v$ $1993 / 12$, pp. 1384-1389, op p. 1387. 
kele maanden) vergt on de situatie voor een kind veiliger te maken." Het zal wel, maar hoe is het godsmogelijk.

De auteur schenkt verder veel belang aan "protectieve factoren, die aspecten van het leven van het kind die bevorderen dat het niet ten onder gaat aan de deprivatie. $\mathrm{Zij}$ heeft daar ongetwijfeld gelijk in, maar ik vraag me af of daarbij kan horen dat een kind maandenlang dag in dag uit teruggestuurd wordt naar de marteling.'

Van de moderne Nederlandse rechtsstaat kunnen en moeten andere dan welwillende doch marginale - een-beetje-meer-van-hetzelfde maar in wezen, qua achterliggende grondhouding (kort gezegd: 'bescherming' van het kind versus rechten van het kind; 'bescherming' die bovendien ten principale halt hield voor patri-, halt houdt voor parentiarchale privacy), nog steeds 'negentiende-eeuwse' - zaken worden verwacht en geëist. De illusie dat er al genoeg wordt gedaan of dat zelfs - post-modern pseudopragmatisme ten top! - nog bezuinigd kan worden, vormt op dit moment in ons land wel de grootste bedreiging voor de verwerkelijking van het recht van elk kind op optimale persoonswording. In de slotzin van hun studie Preventing family violence roepen BROWNE en HERBERT als volgt tot meer maatschappelijke en politieke werkelijkheidszin op: ${ }^{158}$

'Perhaps, in order to prevent family violence, child abuse and neglect, we have to first challenge the unrealistic expectations of service managers, politicians, policy makers and society in general of what limited resource[s] can achieve. We must inform them of the consequences of underestimating the irvestment required in the prevention of family violence, child abuse and neglect for the next generation and future society.'

\section{Eerder in hun boek stelden $z$ ij: ${ }^{159}$}

"The costs of family violence to the individual and society as a whole are immense. (...) Thus, it is possible to justify putting resources into the prevention of family violence, not only from a philanthropic [and legal/human rights, jw》 viewpoint but also from an economic one. Furthermore, the notion that a variety of negative life experiences or "life events" may adversely affect psychological wellbeing and precipitate psychiatric disorder is well established (...) and there are many papers on the impact of child abuse on adult mental health (...). (...) The cost of psychiatric morbidity is immense. (...) [G]iven the cost and extent of psychological disorder, a preventative approach has received less attention than would be expected.' 


\section{De trits Opvoedingsonderwijs-Opvoedingsondersteuning-Opvoedingsgeld}

Tegen de achtergrond van alles wat wij tot dusverre in deze studie betoogd hebben, kunnen uit bovenstaande citaten de volgende stellingen worden gedestilleerd:

- de (integrale) preventieve benadering is geen utopische, maar een realistische (commonsensical, dat is nuchtere en redelijke) en, mensenrechtelijk gezien, onvermijdelijke optie (voor de constitutionalisering en operationalisering van deze benadering zie de volgende paragraaf);

- het huidige (symptoom-)beleid is mensonterend ten aanzien van kinderen ('teruggestuurd naar de marteling'), onmenselijk ten aanzien van hulpverleners/kinderbeschermers ("eelt op de ziel"') en onverantwoord ten aanzien van ouders, die immers - op de rechtsgrondslag van art. 18, lid 2 juncto art. 9, lid 1 van het Verdrag inzake de rechten van het kind (kort gezegd: vroegtijdige opvoedingsondersteuning met het oog op voorkoming van scheiding van kind en ouders) - tegen zichzelf, dat is in hun ouderschap, beschermd behoren te worden ${ }^{160}$;

- het huidige (non possumus-)beleid ondermijnt de rechtsstaat intrinsiek (door het sluipende morele gif van aanhoudende ernstige en passief-systematische mensenrechtenschendingen) en inherent (onder meer door het connexe morele en materiële, deels openlijke en deels verborgen gif van jeugdcriminaliteit en verslaving) ${ }^{161}$;

- het huidige (ex post-interventie-)beleid komt neer op vernietiging van menselijk, maatschappelijk en economisch kapitaal;

- een ander beleid, een niet-hapsnap maar structureel en integraal preventiebeleid vergt investeringen in deze generatie waarvan de vruchten

160 Vgl. als antwoord op deze mensonterende, onmenselijke en onverantwoorde situatie de roep om 'regionale centra' waarvoor al in 1989 op het Groningse incestcongres werd gepleit (Herman BAARTMAN, 'Enkele slotconclusies: macht en onmacht van hulpverlening en justitie,' in: dez. e.a., Incest en hulpverlening, Amersfoort/Leuven 1990 , pp. 68-77, op p. 68).

161 Hiermee is niet bedoeld dat het (justitieel kinderbeschermings-)beleid criminogeen is - zoals mijns inziens wel het (justitiële) 'war on drugs'-beleid (zie J.C.M. WILLEMS, 'Heroïne, mythen en juristen,' Delikt en Delinkwent 1984/10, pp. 955959, op pp. 956/957; dez., 'Recht en rechter in de "dyas politica"; enkele gedachten over internationaal recht, juridisch activisme en de rolperceptie van de rechter vanuit staatsrechtelijk perspectief en met het oog op de rechtshulp aan vreemdelingen,' in: 'T. HOOGENBOOM e.a. (red.), Sociale advocatuur en de rechten van de mens, Ars Aequi Libri, Nijmegen 1989, pp. 114-145, op pp. 114 en 126 nt. 4) en verslaving(sgedrag) veroorzaakt, doch dat het haaks staat op zinvolle (zinnige en zindelijke, lees: structurele en geïntegreerde) preventie, met (toenemende) jeugdcriminaliteit en verslaving (in brede zin, dus niet alleen aan illegale genotmiddelen) als 'connexe' problematiek (zie ook hoofdstuk 12, par. 12.3.2). 
pas geplukt worden in de volgende generatie(s), met andere woorden: lang, lang, lang na de zittingsduur van welk kabinet ook.

Zolang we echter niet echt durven kiezen, niet voor de toekomst willen kiezen, houden we de situatie in stand die door de Parlementaire Vergadering van de Raad van Europa aldus is geschetst: ${ }^{162}$

'(...) The Assembly notes that the rights of the child are still far from being a reality in our own rich and developed continent of Europe and that children are often the first victims of armed conflicts, economic recession, poverty, and in particular budgetary constraints."

Dit laatste - kinderen het slachtoffer laten worden van budgettaire politiek, meer specifiek: (zelfs) de (minimale) persoonswording van kinderen ondergeschikt maken aan een bezuinigingsbeleid - gaat zozeer in tegen de verdragsverplichtingen onder het VRK (art. 4 in de interpretatie van het Comité inzake de rechten van het kind: zie hoofdstuk 10, par. 10.5; zie ook hierna par. 14.5.2.3), dat - zo ergens - hier staatsaansprakelijkheid in het leven wordt geroepen.

Om staatsaansprakelijkheid te keren, dienen we tegenover het huidige een ander beleid, een nieuwe benadering te stellen. Deze benadering is die van de preventieve trits Opvoedingsonderwijs-Opvoedingsondersteuning-Opvoedingsgeld. Een trits die we in de nu volgende paragraaf eerst in het constitutionele kader van de Trias pedagogica plaatsen en vervolgens vanuit dat kader op hoofdlijnen pogen te operationaliseren. Aldus bewandelen we de weg van sociaal-pedagogische grondrechten naar een sociaal-pedagogisch beleid, wandelen we weg van staatsaansprakelijkheid, op weg naar wáárgemaakte overheidsverantwoordelijkheden en een ten aanzien van ouderschap en kinderen verantwoordelijke staat en samenleving.

De Trias pedagogica als constitutionele grondslag

Waar het in deze paragraaf in essentie over gaat, kan het beste worden verteld door DAVIDSON, (voormalig) voorzitter van de Amerikaanse Raad van Advies inzake Kindermishandeling en Verwaarlozing: ${ }^{163}$

162 Aanbeveling 1286 (1996) van de Parlementaire Vergadering van de Raad van Europa inzake een Europese strategie voor kinderen; COUNCIL OF EUROPE, The rights of the child, aw., pp. 9-12, op p. 9, par. 3 (curs. jw).

Howard A. DAVIDSON, "Orphanages" or child abuse prevention?' The Intemational Joumal of Children's Rights 1995/2, pp. 283-291, op p. 285 (curs. jw, tenzij anders aangegeven). 
"[In 1990], the US Advisory Board on Child Abuse and Neglect (...) categorized child abuse in America as constituting "a national emengency." The Board meant to send a strong warning message to the American public and its politicall leaders. The Board said that every year, hundreds of thousands of American children are being starved and abandoned, burned and severely beaten, raped and sodomized, berated and belittled - that the system of responding to such abuse is dysfunctional and in danger of collapse, and that as taxpayers Americans are spending billions of dollars on programs that deal with the consequences of the failure to prevent child abuse. High on the list of such consequences is violent, criminal behavior.

That 1990 report of the Board called protection of children from abuse a "matter of national survival." [In 1992] (...) the Advisory Board stated that the child protection emergency that it had proclaimed [two years] earlier had "clearly deepened in all parts of the nation."

In the 1992 report, the Board asserted that much of the price Americans pay in fear of violence is attributable to child abuse and child neglect. It further maintained that "adult violence against children leads to childhood terror; childhood terror leads to teenage anger; and teenage anger too often ieads to adult rage, both destructive towards others and self-destructive." The Board then proposed that an effective and adequately funded child maltreatment prevention program must be at the heart of any [curs. HD] national, state, or local crime prevention program.'

\section{Daarnaast bepleit de auteur (achtereenvolgens): $:^{164}$}

- 'Hitting children, even in the name of discipline and correction, needs to become socially unacceptable in this country, just as excessive drinking for pregnant women or smoking in the workplace are no longer acceptable in America. (...) Newspapers, television, the schools, churches and synagogues, all should be providing information to parents on non-violent child rearing, as well as firm messages on why that is so important.'

- "[E]ssential to any crime prevention program [are] policies aimed at stopping child abuse and neglect. Spending on child abuse prevention, historically among the most underfunded of all services, must be substantially enhanced. (...)

Strengthening families should be the national goal, especially since it is known that being raised by strangers (in "orphanages" or group homes) is, for most children, a very poor substitute. However, more diligence is needed in terminating parent-child relationships with chilldren subjected to the most extreme forms of abuse, neglect, or abandonment. (...)

Child protection front-line work should be on a par with police and firefighting as an essential, visible, and respected public safety service. (...)

[C] hildren wrongfully removed from home, or kids endangered by decisions to return them to or leave them in abusive environments, need a special Ombudsman Office for help, where complaints will be heard and fairly resolved. Lawsuits alone cannot solve these problems.'

DAVIDSON, t.a.p., respectievelijk op pp. 287-288, 289-290 en 290-291 (curs. jw, tenzij anders aangegeven). 
- 'The title of the 1993 US Advisory Board on Child Abuse and Neglect report was Creating Caring Communities: A Bheprint for a New National Strategy for the Protection of Children. It is this idea - the creation of caring conmunities - that is the key concept behind ending the cycle of violence that extends from child abuse in the home to violence in society-at-large. Violence is too often found today in family life as well as in institutions, such as schools and prisons, that often fail to respect the human dignity and potential of those they serve. (...) It must become as easy for a parent to pick up the telephone and get help before [curs. HD] abusing a child as it is now for a neighbor to phone in a report of child abuse after it has occurred."

Omdat dat laatste - buren die kindermishandeling melden om hulpverlening op gang te brengen - in Nederland nog verre van gewoon is, besteden we in deze paragraaf, behalve aan de diverse door DAVIDSON aangeroerde (en nog enkele andere) elementen, ook (summier) aandacht aan de wenselijkheid of noodzaak van een wettelijke meldplicht.

\section{5 .1}

Constitutionalisering van sociaal-pedagogische grond rechten

De beste manier om de maatschappij en de politiek ontvankelijk te maken voor informatie over de kosten op korte en de baten op lange termijn van voorkoming van kindermishandeling, lijkt vooralsnog het aan de kaak stellen van de ernstige en passief-systematische mensenrechtenschendingen die wij onder onze ogen in Nederland laten gebeuren en door ons stilzitten en stilzwijgen in stand houden. De beste manier om dit stilzitten en stilzwijgen te doorbreken, lijkt vooralsnog het hameren op het recht van elk kind op optimale persoonswording als achterliggend, dragend en leidend beginsel van het Verdrag inzake de rechten van het kind; ja, het hameren op dit Verdrag zelf als waarborg ener wijze constitutie ${ }^{165}$ ten aanzien van de inrichting en toerusting van de Trias pedagogica in de moderne rechtsstaat. Een rechtsstaat die een eeuw na de 'sociale kwestie' wordt geconfronteerd met een 'sociaal-pedagogische kwestie" die in niet mindere mate de principiële bereidheid en morele moed vergt het staatsbestel en binnen dat bestel vigerende waarden op hun grondslagen te onderzoeken en deze tegen het licht te houden zowel van nieuwe - meta-juridische en interdisciplinaire - inzichten als van nieuwe instellingen waarvan de contouren zich aftekenen in een pre- en

"In 1813 werd (...) [d]e nationale "soevereiniteit" (..) aangeboden aan de zoon van stadhouder Willem V. De Prins aanvaardde de soevereiniteit in zijn Proclamatie van 2 december 1813 "onder waarborging eener wijze Constitutie, welke Uwe vrijheid tegen volgende mogelijke misbruiken verzekert".' (KOOPMANS' Compendium van het staatsrecht, Deventer 1994, zevende druk, p. 80.) 
peri-juridisch, een 'natuurrechtelijk' ofwel grotiaans schaduwland. ${ }^{166} \mathrm{Al}-$ dus kan een bijdrage worden geleverd aan moderne civiliseringsprocessen en beschavingsoffensieven ${ }^{167}$ waarbij mensenrechten, waaronder niet in de laatste of zelfs in de eerste plaats de (kern)rechten van kinderen, aan de basis staan.

Behelst de waarborg ener wijze constitutie, de constitutie van een beschaafde rechtsstaat, nu de constitutionalisering van de (kern)rechten van kinderen, van sociaal-pedagogische (grond)rechten? Wij zijn nadrukkelijk van mening van wel. Ook al moeten nog veel van deze elementaire rechten geoperationaliseerd worden, dat is op zich geen argument met constitutionalisering te wachten tot al die rechten in wetten zijn uitgewerkt. Ook mensenrechtenverdragen worden geratificeerd vóórdat de wetgeving en de beleids(in)richting die zij van morele tot juridische plicht verheffen, al tot in de puntjes geregeld en in orde zijn. Ook onze Grondwet kent het fenomeen van de organieke wet die in het vooruitzicht wordt gesteld. Al eerder gewaagden wij van een nieuw eenentwintigsteeeuws 'gezinsbestuursrechtelijk' Wetboek van Gezinsrecht, een organieke wet, gevorderd door grondwetsbepalingen in een nieuw sociaal-pedagogisch grondwetshoofdstuk waarin de Trias pedagogica wordt verankerd en afgebakend. ${ }^{168}$

Wuiven wij nu echter niet al te gemakkelijk (reële en serieuze) praktische bezwaren weg met een variant van de bekende retorische tegenvraag: 'waarom niet?' De vraag 'waarom wèl' - waarom grondrechten, waarom constitutionele rechten? - hebben wij daarmee nog niet beantwoord. Ons tegelijk principiële en praktische, zo men wil 'poëtische' en

Vgl. P.H. KOOLMANS, "How to handle the grotian heritage; GROTus and VAN VOLLENHOVEN' (Second Cormelis VAN VOLLENHOVEN memorial lecture), Netherlands Intemational Law Review 1983/1, pp. 81-92, op pp. 90 e.v.; met verwijzing naar R. FALK, 'Introduction: The grotian quest,' in: Ch.S. EDWARDS, Hugo GROTrus: the miracle of Holland; A study in political and legal thought, Chicago 1981, pp. xiii-xxi; herdrukt in: Richard FALK e.a. (eds.), International law; A contemporary perspective, Boulder/London 1985, pp. 36-42 ('The grotian quest'), overgenomen uit: The end of world order; Essays on momative international relations, New York/London 1983, pp. 25-32.

167 Vgl. Natan SZNAIDER, 'Compassion and control; children in civil society,' Childhood $1997 / 2$, pp. 223-240, op pp. 224/225 en 236 .

168 Wij wijzen met betrekking tot de (fundamentele) publiekrechtelijke kanten óók van het civiele jeugdrecht opnieuw op het belangwekkende proefschrift van STEGERHOEK (N.A. STEGERHOEK, De publieke kant wan het jeugdrecht; Publieke aspecten van het civiele jeugdrecht nader beschouwd, diss. Leiden, Zwolle 1995), dat wij in deze studie op verschillende plaatsen (in de hoofdstukken $1,5,7,8$ en 9) hebben aangehaald. 
prozaïsche antwoord op die vraag is het antwoord dat FREEMAN gaf toen hij zich - überhaupt - de vraag stelde: 'But why rights?' 169

'It is significant that some of the best restatements of the case for rights have come from minority scholars, like (...) CRENSHAW, or from those arguing the case of the excluded, like (...) MINOW. For CRENSHAW, as also for (...) HUNT, adopting a rights-based discourse is a vehicle in which social movements can enter a debate into the validity of the dominant ideology as part of a counter-hegemonic strategy. For HUNT, "rights ... have the capacity to be ellements of emancipation, but they are neither a perfect nor [an] exclusive vehicle for the emancipation. [They] can only be operative as constituents of a strategy for social transformation as they become part of an emergent common sense [zoals 'gecodificeerd" in het Verdrag inzake de rechten van het kind, jw] and are articulated within social practices [hetgeen ten aanzien van de sociaal-pedagogische rechten van het kind nog slechts schoorvoetend het geval is, jw]."

Where the law has been silent, this has all too often meant not an absence of power, but the absence of a means to challenge private power: often the power of husbands and fathers [and mothers, jw]. (...)

[Women's and children's r]ights are entitlements; they are trumps [DWORKIN, Taking rights seriously]; they are valuable commodities. But they are also, we now learn, weapons to undermine power. (...) A rights strategy is one way in which the hitherto excluded can be included, within the community and within the political structure.'

Laten we het in onze eigen woorden proberen te zeggen, althans samen te ballen. Verdragsrechten zijn mooi, maar waar het gaat om enerzijds de uitval en uitsluiting van bepaalde (transgenerationeel pedagogisch gedepriveerde) kinderen, jongeren, (jong)volwassenen en anderzijds een even massieve als virulente conventie als die van het privacy-paradigma, met andere woorden waar het gaat om de botsing van kernrechten van kinderen en traditionele rechten/privileges van ouders/volwassenen, daar is enerzijds tegelijk symbolische (in de zin van voorbeeld-ige) en solide (dus grondwettelijke) verankering en anderzijds zorgvuldige (dus organieke) afbakening uiterst wenselijk zo niet noodzakelijk. Bepleit wordt daarom de kernrechten van het (jonge) kind op te nemen in (een gezinsrechtelijk hoofdstuk in) de Grondwet en aldus tot sociaal-pedagogische grondrechten te maken. We brengen de dertien kernrechten uit hoofdstuk 7 kort in herinnering:

\section{Lichamelijke en geestelijke integriteit;}

2. Koestering;

Michael FREEMAN, 'The moral status of children,' in: Eugeen VERHELLEN (ed.), Understanding children's rights; Collected papers presented at the first International interdisciplinary course on children's rights, Gent 1996, pp. 9-23, op pp. 16-18 (citaat op pp. 17 i.f. -18 ). 
3. Lichamelijke en geestelijke zorg en zorgvoorzieningen;

4. Gelijke opvoeding (van broertjes en zusjes, gelijke behandeling van jongens en meisjes);

5. Ontplooüing (waaronder ontwikkelingsstimulering ${ }^{170}$ );

6. Leiding en

7. Begeleiding;

8. Eigen mening, hoorrecht/eigen rechtsingang;

9. Gezinstaken (participatie binnen als voorbereiding op participatie buiten het gezin);

10. Gelijke sociale omstandigheden en voorzieningen: het recht van het kind op sociaal-economische en sociaal-pedagogische omstandigheden en voorzieningen die het beginsel van gelijke behandeling en gelijke rechten van alle kinderen niet in onredelijke en onbillijke mate schenden (met andere woorden: die systemisch-discriminatoire patronen substantieel doorbreken); uit welk recht(sbeginsel) drie rechten voortvloeien:

11 (10a). Opvoedingsonderwijs: het recht van het kind op opvoedingsonderwijs, dat wil zeggen het recht van het kind op vakken als c.q. onderricht in relaties, ouderschap, huishouding, verzorging en opvoeding vanaf de basisschool; en het recht van het kind op ouderschapscursussen, -trainingen en -bijscholing voor zijn ouders;

$12(10 b)$. Opvoedingsgeld: het recht van het kind op opvoedingsgeld voor zijn ouders; dat wil zeggen op een (deels inkomensafhankelijk, deels inkomensonafhankelijk) 'zorg- en opvoedingsloon' voor de verzorgende en opvoedende ouder(s);

$13(10 \mathrm{c})$. Opvoedingsondersteuning: het recht van het kind op een glijdende schaal van opvoedingsondersteuning van zijn ouders en zijn gezin, met inbegrip van het recht van het kind op sociaal-emotionele empowerment van zijn ouders; welke glijdende schaal oploopt van vrijwillig en laagdrempelig - vanuit een eerste lijn van gecombineerd lichamelijke en geestelijke pre-, peri- en postnatale zwangeren-, zuigelingen-, peuteren kleuterzorg naar een brede tweede- en derdelijns waaier van psychomedische en pedagogische voorzieningen in psycho-medisch/pedagogische risicosituaties - naar gedwongen (met deugdelijke rechtsbescherming): de integriteitsactie of persoonswordingsvindicatie door de staat, welke evenzeer een recht van het kind is.

Bovenstaande sociaal-pedagogische grondrechten of kernrechten betreffen de kerninhoud van de primaire en secundaire opvoedingsver-

Een begrip dat ik hier toevoeg naar aanleiding van de studie van Ina BAKKER e.a., $O+O=O^{2}$; Naar een samenhangend beleid en aanbod van opvoedingsondersteuning en ontwikkelingsstimulering woar kinderen en ouders in risicosituaties, NIZW, Utrecht 1997 (zie voor de omschrijving: a.w., p. 11). 
antwoordelijkheid van ouders respectievelijk de staat zoals deze tot uitdrukking komt in verschillende (preambulaire overwegingen en) bepalingen van het Verdrag inzake de rechten, gezien in het licht van het fundamentele (meta-)recht van het kind op optimale persoonswording, dat op zijn beurt de ontwikkelingspsychologische/pedagogische vertaling is van (in het bijzonder) het (verdrags)beginsel van 'het belang van het kind' (the best interests of the child).

\section{5 .2}

Operationalisering van Opvoedingsondersteuning, Opvoedingsonderwijs en Opvoedingsgeld

Ouderschap is niet alleen een zaak van individuele maar ook van collectieve verantwoordelijkheid: ouderschap is iets dat moet worden geleerd, dat moet worden begeleid en dat moet worden bewaakt. ${ }^{171}$ In die zin zijn ouderschapsvorming (Opvoedingsonderwijs), aan minimale voorwaarden gebonden ouderschapssubsidiëring (Opvoedingsgeld) en ouderschapsc.q. gezinsbescherming (Opvoedingsondersteuning volgens een glijdende schaal van aangeboden tot en met - desnoods - opgelegde hulp), hoewel op het eerste gezicht rechten van (aanstaande) ouders, in wezen de meest basale rechten van het kind. In deze (sub)paragraaf passeren - in een zevental sub(sub)paragrafen - enkele voorstellen en gedachten de revue die deze basale rechten pogen te operationaliseren. Als aanloop naar die voorstellen confronteren we - onder het hierna volgende cursieve kopje - het belang van een integrale aanpak met de (begrijpelijke) huiver voor een nieuw paternalisme.

Op weg naar een sociaal-pedagogisch beleid

KUYPERS en VAN DER LANS stellen in hun (Witte-boorden-)pamflet Naar een modern paternalisme (1994): ${ }^{172}$

"De normatieve onmaatschappelijkheidsbestrijder uit de jaren vijftig en de dram" merig gepolitiseerde welzijnswerker uit de jaren zeventig hebben de laatste vijftien jaar definitief plaats gemaakt voor een professioneel handelende werker die

171. Gezien de frequentie waarmee en de mate waarin opvoeden niet goed gaat, komt ons de stelling die HERMANNS betrekt (Io HERMANNS, 'Preventie als voorkeursstrategie," Comenius; Wetenschappelijk fonum voor opvoeding onderwijs en cultuur 1998/1, 'Criminaliteitspreventie en opvoedingsondersteuning,' pp. 65-76, op p. 66), 'dat opvoeden meestal. vanzelf gaat,' nogal gratuit voor - om niet te zeggen kwetsend ten aanzien van honderdduizenden mishandelde kinderen en survivors.

172 Paul KUYPERs en Jos VAN DER LANS, Naar een modem paternalisme; Over de noodzaak van sociaal beleid (pamflet De Balie, Witte-boordenreeks), Amsterdam 1994, pp. $36 / 37$. 
zichzelf (en zijn opvattingen) op afstand wist te houden van de klant, die dan ook niet langer gezien werd. als a-social of onderdrukt maar vooral als cen in potentie autonoom individu dat door omstandigheden tijdelijk ontspoord was en - uit vrije en op basis van bewezen motivatic - bijgestaan moest worden.

Inmiddels zijn de keerzijden van dit proces steeds duidelijker geworden. Bij de professionals en hun professionele organisaties hebben non-directiviteit en de vrees cliënten afhankelijk te maken, ertoe geleid dat men zich verschanst achter professionele attitudes, een kantooruren-mentaliteit en een grote terughoudendheid als het erom gaat de cliënt in zijn eigen omgexing op te zoeken. Voor wat betreft de cliënten, kan gezegd worden dat het beeld van autonoom handelende maar door omstandigheden ontspoorde individuen in de maatschappelijke werkelijkheid feitelijk weinig zegt. Mensen kunnen worden meegezogen in processen van vereenzaming, verloedering en uitstoting waar ze zelf nict of nauwelijks meer op kunnen reflecteren. Daar ligt niet zozeer een professioneel dilemma of er wel of niet directief moet worden opgetreden, daar ligt de maatschappelijke verantwoordelijkheid - misschien wel een beschavingsopdracht - om een helpende hand te bieden."

\section{Onder het kopje Naar een nieuw paternalisme vervolgen de auteurs: ${ }^{173}$}

"Maar wat betekent dat nu concreet? Betekent dat - zo zullen de sceptici al snel tegenwerpen - dat de wat moedeloos achter zijn geraniums turende oudere buurtbewoner door hyperactieve moderne beschavingsmissionarissen naar een bejaardensoos moet worden gesleurd? Aan dit type - weinig met de werkelijkheid uitstaande - karikaturen is in de discussie over welzijnswerk en hulpverlening in dit land nooit gebrek geweest. Wees gerust; wij pleiten niet voor het massaal sleuren met mensen. Onze boodschap is simpeler: wij pleiten voor een professionele invulling van een gegeven dat wij tot de kern van de Nederlandse verzorgingsstaat blijven rekenen - het uitgangspunt dat niemand aan zijn lot wordt overgelaten. En dat betekent inderdaad bemoeien, opzoeken, meegaan, aanbellen, regelen en sturen en niet (professioneel) wachten tot het te laat is. Dat is een houding die al snel versleten zal worden als een nieuw soort paternalisme - het zij zo. Het is het soort paternalisme waar het in onze ogen het afgelopen decennium tezeer aan heeft ontbroken. Elke vorm van zorg heeft iets van paternalisme - en zolang het niet die morele beladenheid krijgt uit de jaren vijftig of de politieke drammerigheid van de jaren zeventig, zien wij niet in wat er Cout anan is.

Een nieuw paternalisme is bovendien her beste wapen tegen de neiging tot afwachten en vrijblijvendheid waar hulpverleners en sociaal werkers zich nog steeds gemakzuchtig in verschansen.'

MALMBERG haalt in zijn bijdrage "Overheid en gezin: een spannende relatie' (1996) beide 'pamflet'-schrijvers aan. ${ }^{174}$ 'Het uitgangspunt moet

M.J.J.M. MALMBERG, 'Overheid en gezin; een spannende relatie,'Justitiele Verkenningen 1996/6 ('Preventief ingrijpen in het gezin'), pp. 8-16, op p. 12. 
zijn dat niemand,' zo zegt hij hen na - niemand, dus óok, zo voegen wij toe, geen kind en geen ouder ...

'(...) aan zijn lot wordt overgelaten. Er moet bemoeizorg ontstaan: verantwoordelijkheid nemen, opzoeken (...) en een nadrukkelijk aanspreken van burgers op hun eigen vermogen."

Onder het (omineuze) kopje Wie voor een dubbeltje geboren is ... vervolgt hij: $:^{175}$

'Algemeen is dat alle landen een beleid met betrekking tot de bescherming van kinderen en jongeren voeren. Zeer verschillend zijn echter de opvattingen met betrekking tot de ondersteuning van gezinnen. Er is in die zin zeker geen sprake van een evenwichtige benadering tussen kinderbescherming en gezinsondersteuning. (...)

Hoewel het zeker niet de bedoeling van mijn betoog is om een pessimistische visie over de gezinnen en de opvoeding in Nederland uit te dragen, lukt het ons toch niet goed om de moeilijkst bereikbare gezinnen echt te bereiken. (...)

Het lastige van de situatie is dat [zij] wraagt om een aanpak die zowel rekening houdt met een beleidsintegrerende aanpak als aandacht moet geven aan de intergenerationele aspecten van het vraagstuk. Het lastige van het vraagstuk is dat het (...) om een categoriale benadering èn om een specifieke benadering behoort te gaan. Het lastige van de aanpak is dat het èn om "bemoeizorg" moet gaan èn om een aanpak mèt de betrokkenen.'

Het (SPS-)antwoord op deze lastige zaken wordt in de hierna volgende subparagrafen toegelicht. De auteur zoekt ook zelf een oplossing, wijst op een uitweg: ${ }^{176}$

"Men kan niet van de overheid verwachten dat zij een oplossing kan aanbieden voor ernstige vraagstukken alls incest, kindermishandeling en sociale uitsluiting als niet tegelijkertijd aangegeven wordt wat de verantwoordelijkheid van de instellingen en de burgers zelf moet zijn. Burgers en instellingen horen te signaleren wat er in gezinnen mis kan gaan, horen mee te praten over normen en waarden die in het maatschappelijk verkeer [ten opzichte van kinderen, jw] aan de orde zijn, horen mee te bepalen hoever een overheid kan en moet gaan bij de bescherming van kinderen en gezinnen in dit land.

In mijn visie kan het niet zo zijn dat we de relatie burgers-instellingen-overheid met betrekking tot de inbreng in de opvoeding van kinderen zo impliciet, zo onduidelijk laten als [z]ij nu is. (...) Gezinsbeleid, jeugdbeleid, sociaal beleid [lees: sociaal-pedagogisch beleid, jwl maken betekent veel nadrukkelijker kiezen dan thans het geval is en deze keuzes ook in wetgeving en beleidsstukken verwoorden.' 
De richting voor een oplossing, de uitweg die de auteur wijst, maken wij tot de onze: gezamenlijk op weg naar een gedurfd expliciet sociaal-pedagogisch beleid.

\section{5 .2 .1}

\section{Een wettelijke meldplicht en een juridisch statuut voor meldpunten}

\section{Stelling}

Het feit dat de invoering van een (algemene) wettelijke meldplicht ter zake van kindermishandeling pas maatschappelijk verantwoord kan geschieden als eerst (procedures voor) verwijzing, [gezins]onderzoek, behandeling en nazorg" effectief geregeld zijn (art. 19, lid 2 VRK), betekent niet dat een meldplicht voor Nederland wegens het ontbreken in ons land van een dergelijke effectieve regeling, althans van de voor een effectieve regeling noodzakelijke institutionele sociaal-pedagogische infrastructuur, moet worden afgewezen, maar dat aan het effectief regelen van deze zaken in het kader van de invoering van een wettelijke meldplicht en van andere effectieve procedures voor 'signallering' alsmede voor 'het opstellen van sociale programma's om de noodzakelijke hulp te verlenen aan het kind en aan zijn verzorgers, alsook voor andere vormen van preventie' (ibidem) de hoogste politieke, juridische en financiële prioriteit (art. 4 juncto art. 2, lid 1 VRK) moet worden toegekend.

\section{Kinderverlating}

Wij bepleiten met bovenstaande stelling(name) in abstracto een algemene (dat is in beginsel voor iedereen - bijvoorbeeld vanaf de leeftijd van zestien jaar ${ }^{177}$ - geldende) wettelijke meldplicht om éến principiëlè têdên: het niet in gang (doen) brengen van hulpverlening in het geval dat men een ernstig vermoeden heeft dat een kind (en gezin) in (geestelijke) nood is (zijn), levert ons inziens een incriminerend (laakbaar niet slechts in de zin van immoreel, dat is: belastend voor het eigen geweten, maar in strafwaardige mate) feit op, het feit namelijk van kinderverlating: een kind in hulpeloze toestand laten, c.q. de verlating van hulpbehoevenden (zie bijlage II bij deze studie). Met opzet en met nadruk zeggen wij: in abstracio: een meldplicht kan en mag ons inziens niet worden bepleit los van een (preventieve benadering binnen een) geünificeerd sociaal-pedagogisch stelsel, zoals dat in deze paragraaf (nader) wordt ontvouwd. ling (Werkgroep of commissie HERMANNS), Roermond (oktober) 1997. 


\section{Niet uitstellen: het AMK bellen!}

Over enige tijd zullen in elke provincie en grootstedelijke regio AMK's (Advies- en Meldpunten inzake Kindermishandeling) van start gaan. ${ }^{178}$ Een (algemene) meldplicht dient onderdeel te zijn van een juridisch statuut voor deze AMK's. In dat statuut dienen bevoegdheden en verplichtingen van de meldpunten alsmede de noodzakelijke rechtswaarborgen met betrekking tot de melding van vermoedens van kindermishandeling wettelijk geregeld te zijn. Aangezien Nederland vooralsnog niet rijp (gemaakt) lijkt voor een wettelijke meldplicht, bepleiten wij in dit verband intensieve publiekscampagnes, niet alleen om professionals en leken, waaronder niet in de laatste plaats (pedagogisch gedepriveerde) ouders, met de nieuwe AMK's bekend te maken, doch ook om te wijzen op (sociaal-pedagogische) hulp als (mensen)recht en melden als (burger)plicht: 'Niet uitstellen: het AMK bellen!' Dit laatste is mede ingegeven door het feit dat op dit moment ...

'(...) [s]lechts $23 \%$ van de Nederlandse bevolking die in hun sociale omgewing kindermishandeling signaleert of vermoedt, (...) contact op[neemt] met enig meldpunt. Van de beroepsbeoefenaren [zij die beroepshalve met kinderen omgaan of te maken hebben, jw] laat ongeveer $35 \%$ na contact op te nemen. ${ }^{, 179}$

De noodzaak van publiekscampagnes ter voorbereiding op en (te zijner tijd) begeleiding van de invoering van een algemene meldplicht lijkt hiermee evident: ruim driekwart van de bevolking maakt zich nolens volens schuldig aan kinderverlating. Zelfs van mensen aan wier deskundige zorgen kinderen zijn toevertrouwd of die althans mede aan kinderen hun brood verdienen, geeft meer dan een derde niet thuis als kind en gezin in nood verkeren. Bij zulke hoge percentages leken en professionals die niet melden, dient de overheid het als een plicht te beschouwen op dit punt een mentaliteitsverandering te bewerkstelligen. Niet wel valt echter in te zien dat dit uitsluitend met gebruikmaking van 'Postbus 51' mogelijk is. Een mentaliteitsverandering is slechts te verwachten indien het niet bij woorden en beelden blijft, maar de overheid ook het goede voorbeeld geeft, een duidelijke politieke daad stelt door gebruikmaking van het instrument bij uitstek van de politiek: de wet in formele zin. De invoering

178 Vgl. hierover de special Advies- en Meldpunten Kindermishandeling van VKMagazine (Tijdschrift over kindermishandeling) 1997/4, naar aanleiding van het Eindadvies van de Werkgroep Meldpunt Kindermishandeling (Werkgroep of commissie HERMANNS).

179 Eindrapport van de Werkgroep Meldpunt Kindermishandeling (commissie-HERMANNS), Advies-en meldpunten kindermishandeling, Roermond, oktober 1997 , p. 13. 
van een wettelijke meldplicht, ingekaderd in een op ondersteuning - dat is in de eerste plaats op aanvullende en pas in de laatste plaats op vervangende opvoeding - gericht sociaal-pedagogisch stelsel, lijkt daarvoor de aangewezen weg. ${ }^{180}$

180 Voor enige literatuur verwijzen wij naar Jaap $\mathbb{E}$. DOEK, "Child abuse and neglect: Article 19 CRC, The Intemational Joumal of Children's Rights 1994/1, pp. 88-95 (guidelines op pp. 94/95); dez., 'Kindermishandeling, beroepsgeheim, privacy en inzage van vertrouwelijke gegevens,' in: H. BAARTMAN, A. VAN MONTFOORT (red.), Kindermishandeling: resultaten van multidisciplinair anderzoek, Uttecht 1992, pp. 279-300; dez., 'Van oude dogma's en dingen die voorbijgaan; de toekomst van onze justitiele jeugdbescherming met enige buitenlandse belichting, in: Afra GROEN en Adri VAN MONTFOORT (red.), Kinderen beschemen en jeugd hulp verlenen, Arnhem 1993, pp. 157-173 ('Eén bureau voor kinderbescherming": pp. 170-172); dez., "Meldingsplicht, ja of nee?' In: H. BAARTMAN e.a., Incest en hulpverlening, Amersfoort/Leuven 1990, pp. 274-279 (vgl. ook W. KLOOSTERMAN, 'De stand wan zaken bij politie en justitie, ' a.w., pp. 246-253, op p. 252, alsook het 'Voorwoord" van H. D'ANCONA, pp. [9-10], op p. [9]); dez., 'Preventie en overheidsbeleid,' in: R. HAANSTRA e.a. (red.), Geweld tegen kinderen; Opstellen over preventie van en hulpwerlening bij kindermishandeling, VKM, Den Haag 1987, pp. 195-209, op pp. 206/207; Joan DOUGHTY, "Verschillen in de aanpak van kindermishandeling: een kwestie van cultuur?' VKMagazine 1990/2, pp. 8-10; Alice VAN UNEN, 'Meldingssystemen inzake kindermishandeling in Europa en Amerika,' Tijdschrift woor de rechten van het kind 1997/1, pp. 6-9; dez., Melden van kindermishandeling over de grens; Een onderzoek naar meldingssystemen inzake kindermishandeling in Noord-en West-Europa en de Verenigde Staten van Amerika, Nederlands Instituut voor Zorg en Welzijn/NIZw, Utrecht (maart) 1997; Seth C. KALICHMAN, Mandated reporting of suspected child abuse; Ethics, law and policy, APA, Washington 1993; Gail L. ZELLMAN, Kathleen C. FALLER, 'Reporting of child maltreatment,' in: John BRIERE e.a. (eds.), The APSAC (American Professional Society on the Abuse of Children $/$ handbook an child maltreatment, Thousand Oaks (etc) 1996, pp, 359-381; RAAD VOOR HET JEUGDBELEID, Kindermishandeling vermeldenswaard; Advies over de aanpak wan kindermishandeling: preventie, hulpwertening en rechtstoepassing, Ministerie van WVC, Rijswijk 1988, pp. 86-91; Sietske DUKSTRA, Frea SWETS-GRONERT, Dilemma's nond kindermishandeling; Een verkennend onderzoek naar signalering en melding, Utrecht 1989; Willie LANGELAND e.a., Kindermishandeling: van signaal naar hulp I; Signaleren en melden, Utrecht 1990; Sietske DUKSTRA e.a., Kindermishandeling: van signaal naar hulp II; Hulpwerlenen en samenwerken, Utrecht 1990; DIJKSTRA en LANGELAND, 'Het melden van kindermishandeling; in: GROEN en VAN MONTFOORT (1993), a.w., pp. 59-78; Marieke BRUGGEMANN-KLUVERS, Adri VAN MONTFOORT, Kindemishandeling* de weg naar het meldpunt, Amsterdam 1994; Commissie Seksueel Misbruik van Jeugdigen, Handelen bij vernoeden van seksueel misbruik van kinderen en jeugdigen I, Richtlijnen voor beroepsbeoefenaren, Assen 1994, pp. 77 80; M.A.J. VAN BIJSTERVELDT, 'Verslag van de workshop juridische aspecten,' in: L.P.T. RALMA.Kers e.a. (red.), Commissie Seksueel Misbruik van Jeugdigen, Handelen bij vermoeden van seksueel misbruik van kinderen en jeugdigen $I I ; D e$ richtiijnen SMJ in de praktijk, Assen 1995, pp. 77-79; J.H.S. vAN HERTEN, 'Juri- 
14.5.2.2 Ouderschapsondersteuning en Persoonswordingswindicatie in plaats van Ondertoezichtstelling

\section{Bij FIJN lezen we met betrekking tot de ots (ondertoezichtstelling): ${ }^{181}$}

"Het civielrechtelijk ingrijpen, in de vorm van met name een ondertoezichtstelling (ots), kan in principe even ingrijpend zujn als het strafrechtelijke, even niet-vrijblijvend, even sterk op concrete gedragsverandering gericht. Het is eerder de veel voorkomende wijze van uitvoering van de ondertoezichtstelling, de interpretatie als hulpverlening met alle attributen vandien (horizontaal, non-directief, instemming van de cliënt zoekend, gezag verhullend, afstandelijk) die ter discussie gesteld zou moeten worden. De ondertoezichtstelling valt te interpreteren als een wijze van leiding geven aan ouders en jeugdigen in vastgelopen of inadequate opvoedingssituaties teneinde deze situaties te verbeteren. Daarbij is een meer verticalle benadering aan de orde, een gezagswolle houding en werkwijze, een directieve en voortvarende aampak, en een zorgvuldige afweging op welke momenten wel en welke juist niet de instemming van het cliëntsysteem (jeugdige en/of ouders) verworven moet worden.'

dische aspecten van kindermishandeling,' NJB 1986, pp. 251-253; reacties en naschrift, pp. 525-528; J.C.M. WILLEMS, "Ouderbescherming en kinderbescherming: wordt het geen tijd voor een meldplicht?' NJB 1990, pp. 1243-1247; reacties op pp. 1637-1640; J. oOST, 'Kindermishandeling: meldingsplicht ja of nee,' Algemeen Politieblad januari 1987, pp. 11-12; S. CORNELISSE, Naar een wettelijke meldingsplicht in geval van kindermishandeling?' FJR 1987/8, pp. 232-238; verslagen van de studiedag 'Kindermishandeling: meldingsplicht, ja of nee?' op 21 november 1986 te Utrecht van VAN MONTFOORT, "Kindermishandeling en meldingsplicht," MGv 1987, pp. 191-194, en van Klaas KoOJMAN, 'Symposium over meldingsplicht bij kindermishandeling,' VKMagazine 1987/1, pp. 4-5; J.J. PrETERSE, reactie op VAN MONTFOORT, De ongrijpbare werkwijze van de Bureaus Vertrouwensarts,' MGv 1988 (pp. 980-986), pp. 1360-1362 (vgl. ook de reactie van H.A.A. MOURTS op pp. 1250-1252 en het 'Antwoord' van VAN MONTFOorT op pp. 1362-1363 resp. 1252-1253). Vgl. tot slot in meer algemene zin ook de vergelijkende bundel onder redactie van Neil GILBERT, Combatting child abuse; Intemational perspectives and trends, New York/Oxford 1997, waarin (de meldingssystemen van) negen landen worden ondergebracht in drie rubrieken: op (bescherming van) het kind gericht, met of zonder meldplicht (de vs, Canada en Engeland), op (hulpverlening aan) het gezin (de ouders) gericht mèt (Zweden, Denemarken en Finland) en zonder meldplicht (België, Nederland en Duitsland). De bijdrage over Nederland is van de hand van BAARTMAN en ROELOFS (Marian A.S. RoELOFs, Herman E.M. BAARTMAN, 'The Netherlands: Responding to abuse - compassion or control?' A.w., pp. 192-211). H.J.R. FIJ, 'Effectief ingrijpen onder de grens van het strafrecht voor jeugdigen,' reactie ('Journaal') in Justitiële Verkenningen 1996/8, pp. 97-98, op pp. 97 r.k.-98 (curs. jw). 
Het bovenstaande kunnen we bezien tegen de achtergrond van de visie (en kritiek) van VAN NIJNATTEN, die - in een eerder aangehaalde bijdrage $^{182}-$ de stelling verdedigt dat ...

'(...) de democratisering van gezagsrelaties een einde kent omdat elk kind opnieuw controle behoeft en moet leren gezag van macht te onderscheiden.'

Deze (en dergelijke) kritiek richt zich evenwel tegen het hoe van de ots, niet tegen het instituut zelf. Wat er met dat hoe (nog meer) mis is, kan men lezen in de (in gematigde en soms verhullende ${ }^{183}$ toon gezette) studie van MERTENS: Gezinsvoogden aan het werk (De uitvoering van de ondertoezichtstelling in 1993). ${ }^{184}$ Hierboven is al gewezen op bemoeizorg, op het nieuwe paternalisme dat althans de kritiek op non-directiviteit en 'professionele' vrijblijvendheid en afstandelijkheid (ten koste van kind en gezin) zou moeten ondervangen. Het behoeft op deze plaats evenwel geen (nieuw) betoog meer dat onze kritiek zich veeleer richt tegen het instituut ots zelf, of liever tegen het $e x$ post-stelsel, het non possumus-systeem waarvan dat instituut de exponent en het instrument is. In de beide hierna volgende (sub)paragrafen stellen wij tegenover dat non possumus-instrument drie sociaal-pedagogische echelons en de (éne) maatregel van hulp en steun.

14.5.2.2.1 Ouderschapsondersteuning: het aambieden van hulp en steun in drie echelons

In deze (sub)paragraaf willen we enkele grote lijnen uitzetten, enkele wegwijzers plaatsen. Deze studie pretendeert hooguit een blauwdruk van (kindervolkenrechtelijke) grondslagen te geven, niet een in zich in wishful detail-denken vertakkend operationeel program. Het uitstippelen van

C. VAN NIJNATTEN, 'Gedragsgestoord en gezagsgestoord; de verhouding tussen kinderbescherming en gezin,' Justitiële Verkenningen 1996/6 ('Preventief ingrijpen in het gezin'), pp. 74-84, op pp. 74/75. Zie ook hoofdstuk 13, par. 13.4.1 (onder Toetsing aan de hand van getuige-deskundigenverklaringen).

Vgl. de kritische bespreking van Kees SCHAEPMAN, "Naar 15.000 Nederlandse [door de rechter onder toezicht van gezinsvoogden gestelde, jw] kinderen wordt nauwelijks nog omgekeken," Vrij Nederland 17 februari 1996, pp. 18-19, op p. 18, tweede kolom (midden), waar de auteur als voorbeeld van verhullend taalgebruik de passage aanhaalt: 'Vooralsnog ontbreekt op methodisch gebied een coherent kader dat gezinswoogden aangereikt wordt om hun eigen wijze van interpreteren en handelen te toetsen [bespr. werk, pp. $9 / 10, \mathrm{jw}$ ].' Volgens de auteur staat hier: 'ze [de gezinswoogden, jw] doen maar wat.'

N.M. MERTENS, Gezinsvoogden aan het werk; De uitvoering wan de ondertoezichtstelling in 1993, woDC-rapport 149, Arnhem 1996. 
concrete plannen, het vergaand operationaliseren van uitgangspunten, het proto-juridiseren van rechtsbeginselen door het voorleggen van kant en klare wetsvoorstellen is luchtfietserij zolang niet eerst de teerling is geworpen, de Rubicon is overschreden van de preventieve benadering. De preventieve benadering in de eerste plaats als mensenrechtelijk voorschrift (we brengen de woorden van VAN BOVEN in herinnering): ${ }^{185}$

"While the duty to prevent must be considered an integral part of human rights law in general, a review of international human rights instruments reveals that the duty to prevent and more generally the preventive approach, is an explicit and prominent element of human rights policy and strategy.'

In de tweede plaats als maatschappelijk voorschrift - in de woorden van HELFER: ${ }^{186}$

'Preventing a phenomenon that occurs at least a million [voor Nederland: minimaal $50.000 / 80.000, \mathrm{jw}]$ times each year, that adversely affects children's physical growth and emotional development, and that eats away at the very foundation of our society - the family - is a goal that must always be before us.'

In de derde plaats als wetenschappelijk voorschrift - in de zin van PETERS" en MCMAHONs woorden: ${ }^{187}$

"A long tradition of research in the behavioral and social sciences exists describing myriad etiological factors that contribute to the manifestation of childhood and adolescent problems. Also, there exists an extensive literature concerning a variety of treatment approaches to child and adolescent psychological and social problems (...). However, despite whatever successes (...) treatment interventions may have with seriously disordered children, there is a growing recognition that there are simply not enough individuals trained in these procedures to make a significant impact on the prevalence of these disorders (...). Consequently there has been increased interest in the past decade in approaches to these major social and emotional disorders in children that are designed to prevent the onset of disorder or to deal with problematic behaviors when they first appear.'

185 Theo VAN BOVEN, "Prevention of human rights violations," in: Asbjorn EIDE, Jan HELGESEN (eds.), The future of human rights protection in a changing world; Fifty years since the Four freedoms address; Essays in honour of Torkel OPSAHL, Oslo 1991, pp. 183-196, op p. 193 (curs. jw).

186 Ray E. HeLFER, 'An overview of prevention,' in: dez. en Ruth S. KEMPE (eds.), The battered child, Chicago/London 1988 (vierde druk), pp. 425-433, op p. 425.

187 Ray DeV. PETERS, Robert J. MCMAHON, 'Preface,' in: dez. (eds.), Preventing childhood disorders, substance abuse, and delinquency, Thousand Oaks (etc.) 1996, p. ix. 
De titels van de hoofdstukken in het werk dat met de hier aangehaalde woorden wordt gepresenteerd, spreken boekdelen; om slechts enkele te noemen: Promoting Development and Preventing Disorder: The Better Beginnings, Better Futures Project; Improving Availability, Utilization, and Cost Efficacy of Parent Training Programs (...); Parental Engagement in Interventions for Children at Risk for Conduct Disorder; The Strengthening Families Program for the Prevention of Delinquency and Drug Use.

In de vierde plaats (kan gewezen worden op de preventieve benadering) als doelmatigheidswoorschrift - indachtig de oude (eveneens al eerder aangehaalde) wijsheid verwoord door VAN BOVEN: ${ }^{188}$

'[I]t is clear that the preventive approach should receive due priority and emphasis because an ounce of prevention is more effective than a pound of cure.'

En in de vijfde plaats, zoals we op de vingers van één hand kumnen natellen, als economisch (en godsdienstig?) voorschrift - zoals betoogd door DOEK:. ${ }^{189}$

'Voorkomen is beter dan genezen. Deze versleten Hollandse wijsheid behoeft nauwelijks toelichting. Iedereen gelooft erin. Zelfs politici laten weinig gelegenheden onbenut om het grote belang van preventie te belijden. Maar helaas weten veel politici niet meer dat geloof en daad onlosmakelijk bij elkaar horen (een gevolg van afnemende godsdienstigheid?). De omvang van preventieve acties en maatregelen blijft ver achter bij de omvang van het geloof in preventie. Ook hier lijkt te gelden: de geest is gewillig maar het vlees is zwak.

"Voorkomen is goedkoper dan genezen." Ook die "wijsheid" lijkt een grote aanhang te hebben. Voor zover men in deze wijsheid gelooft, laat men echter vaak na dit geloof met harde cijfers te onderbouwen of toe te lichten. Laat ik een (te?) eenvoudig voorbeeld geven. Drie drugverslaafde vrouwen zijn opnieuw zwanger. De zorg over hun eerste kind is hun ontnomen omdat er sprake was van ernstige verwaarlozing en fysieke mishandeling (ook door hun aan drugs verslaafde partners). De kinderen zijn inmiddels in een tehuis opgenomen waar zij intensieve behandeling krijgen in de hoop dat zij althans zover herstellen dat pleeggezinplaatsing en weilicht adoptie mogelijk wordt. $\mathrm{Zij}$ verblijwen nu ruim een jaar in het tehuis en het behandelplan mikt op plaatsing in een pleeggezin binnen een jaar. Totale verblijfsduur tweeëneenhalf jaar per kind. Kosten per dag $\pm f 200$,

188 Study concerning the right to restitution, compensation and rehabilitation for victims of gross violations of human rights and fundamental freedoms; Final report submitted by Mr. Theo VAN BOVEN, Special Rapporteur, Sub-Commission on Prevention of Discrimination and Protection of Minorities [van de] Commission on Human Rights, E/CN.4/Sub.2/1993/8 d.d. 2 juli 1993, p. 37, par. 88.

Jaap DOEK, 'Kindermishandeling: recht op en/of dwang tot preventie,' VKMagazine [1995]/3 (special 'Primaire preventie van kindermishandeling'), pp. 18-21, op p. 18. 
zodat de totale kosten voor de drie kinderen na tweeëneenhalf jaar [bijna vijfeneenhalve tom] belopen. Wat te doen ten aanzien van de drie aanstaande kinderem? Zal deze kinderen eenzelfde toekomst beschoren zijn of kunnen we dit voorkomen? Er is vrij veel onderzoek gedaan dat aannemelijk maakt dat intensieve hulp aan huis succesvol kan zijn in het voorkomen van kindermishandeling. De drie vrouwen krijgen vanaf de geboorte van hun kind die hulp aangeboden. [Deze] wordt gedurende twee jaar gegeven door twee terzake getrainde en ervaren maatschappelijk werkers. De kosten daarvan belopen [drie ton]. Deze intensieve hulp gedurende de eerste twee cruciale levensjaren wan deze kinderen is in termen van preventie veel effectiever dan de genezing (?) achteraf. Bovendien is hij veel goedkoper. Waarom doen wij dat soort dingen niet op een systematische manier ten behoeve van ouders van wie wij weten dat zij een ernstig risico voor hun kinderen vormen?"

\title{
De auteur laat het niet bij een eenvoudige prijsvergelijking: ${ }^{190}$
}

\begin{abstract}
'Om (...) preventie tot stand te brengen, is een veelheid aan algemene en bijzondere maatregelen nodig, waarvan de essentie kan worden teruggebracht tot een opmerking van Ray HELFER: "If you want to prevent something bad (child abuse) yow need to support something good (families)." Maar hoe moeilijk deze op het oog eenvoudige opdracht is, wordt uiteengezet door KRUGMAN (1995). Hij wijst onder andere op de noodzaak van structurele veranderingen en van een aanzienlijke uitbreiding van het aanbod van elementaire, primaire hulpverlening.'
\end{abstract}

Op grond van het Verdrag inzake de rechten van het kind heeft het kind, aldus DOEK, niettemin 'recht op preventie,' recht dus op structurele veranderingen en recht op een aanzienlijke uitbreiding van het aanbod van elementaire, primaire (maar ook meer gespecialiseerde) hulpverlening. De overheid dient dit recht, het recht van het kind op preventie, met passende maatregelen, dat wil (onder meer) zeggen met (vroegtijdig) aanvullende en (tijdig) vervangende opvoeding, te ondersteunen. ${ }^{191}$ Desnoods door middel van het Recht, door 'dwang tot preventie': ${ }^{192}$

'Het optreden van de overheid dient in de eerste plaats niet dwingend maar vooral voorwaardenscheppend te zijn. Ik herinner aan de plicht van de overheid (art. 18 [VRK]) om ouders bij de verzorging en opvoeding te voorzien van "appropriate assistance." Die bijstand is bijwoorbeeld passend als de drugverslaafde moeders uit mijn voorbeeld [hierboven] worden voorzien van incensieve hulp aan huis als beschreven. Een voorziening die mijns inziens te weinig wordt aangeboden, hoewel zij goedkoper is en effectiever lijkt dan de meer klassieke reactie van uithuisplaatsing. $(. .$. 
Maar deze voorwaardenscheppende plicht van de overheid betekent niet dat zij zich geheel behoort te onthouden van enigerlei meer dwingend voorschrift. $\mathrm{Zij}$ kan aangeven welke (minimum-)normen ouders naar haar mening in acht dienen te nemen bij de verzorging en opvoeding. Bovendien zal zij alle passende maatregelen moeten nemen om de naleving ervan te bevorderen. Niet in de eerste plaats door het nemen van sanctie[maatregelen] in geval van niet-naleving (...), maar vooral door goede voorlichting, informatie etcetera (zachte dwang).'

Aan 'goede voorlichting" (waaronder de prenatale DOEK-cursus met postnatale terugkom-dagen) besteden we (enige) aandacht in par. 14.5.2.3. Op het aspect van de dwang - dwang, via de rechter, in geval de minimale persoonswording van het kind niet op een andere manier kan worden gewaarborgd omdat de ouder(s) niet (langer) bereid of in staat is (zijn) van het (gevarieerde en deskundige) hulpaanbod gebruik te maken komen we terug in de volgende subparagraaf (par. 14.5.2.2.2). In onze voorstelling gaan aan dwang (in de hier bedoelde zin van de persoonswordingsvindicatie) immers (in principe, dat wil zeggen extreme situaties daargelaten) drie etappes, drie echelons vooraf.

\section{Het eerste echelon: het BAARTMAN-gesprek}

Het eerste echelon van (post-conventionele, dat is: na de inwerkingtreding, in 1995, voor Nederland van het Verdrag inzake de rechten van het kind) opvoedingsondersteuning trekt de cirkel van te bereiken personen rond alle aanstaande en jonge ouders. In de woorden van de bedenker van dit voorstel (BAARTMAN 1996): ${ }^{193}$

'Elke jonge of aanstaande ouder krijgt eenzelfde aanbod, te weten een gesprek over de op handen zijnde of prille opvoedingssituatie. In dat gesprek, waarin ook systematisch, eventueel ondersteund met een vragenlijst, aandacht wordt besteed aan de vier genoemde factoren [(steun bij) verwerking van een eventuele moeilijke jeugd; (nivean van) eigen pedagogisch besef; sociaal netwerk/isolemen;; (gebrek aan) socialle steun, jw], gaat het om de vraag hoe men het (gaan) opvoeden beleeft. Tijdens het gesprek kan blijken dat de ouders en de interviewer enigerlei vorm van hulp gewenst vinden. In dat geval zal als tweede stap een systematischer onderzoek plaats moeten vinden op basis waarvan duidelijk kan worden wat de gewenste vorm van hulp is. Op zo'n manier worden alle ouders op gelijke wijze benaderd en zal men niet, zoals in een situatie waar de een wel en de ander niet zo'n aanbod krijgt, hoeven denken dat men in de ogen van de ander een probleemgeval is.'

193 H.E.M. BAARTMAN, Opvoeden kan zeer doen; Over oarzaken van kindemishandeling, hulpuerlening en preventie, Utrecht 1996, pp. 132-135 ('Screening op de wenselij.kheid van hulp"), op p. 134. 
Het eerste echelon (het 'BAARTMAN-gesprek') is met andere woorden een niet-stigmatiserende zeef ter screening van risico-situaties c.q. -gezinnen: ${ }^{194}$

\begin{abstract}
"Als screening op een dergelijke wijze plaats vindt, wordt er niet gescreend op het risico op kindermishandeling, zelfs niet op het risico op meer of minder ernstige opvoedingsproblemen. Er worden geen predicties gedaan. Er wordt gescreend op de behoefte aan stewn bij het opvoeden. En men zal daarbij extra alert en wellicht in het doen van een aanbod ook extra actief zijn, als het gaat om jonge ouders voor wie weinig bronnen van steun beschikbaar zijn, die weinig contacten hebben, die blijk geven van een beperkt pedagogisch besef, en voor wie het hebben van een kind de mogelijkheid is om af te kunnen rekenen met een verleden dat hun weinig heeft geboden.'
\end{abstract}

De screening van risico-gezinnen ${ }^{195}$ geschiedt aldus in twee stappen. Laten we proberen ons dit cruciale aspect van de preventieve benadering zo concreet en praktisch mogelijk voor te stellen (zonder ons uiteraard in details te verliezen). We gaan dan uit van een politieke ontwakings- en activeringstijd die loopt tot vijf jaar na de inwerkingtreding voor Nederland van het Verdrag inzake de rechten van het kind, dus tot het jaar 2000 (de eerste postconventionele voorfase). We nemen vervolgens aan dat de beleidsmatige, wetgevende en organisatorische voorbereiding van een en ander opnieuw vijf jaar in beslag neemt, dus van 2000 tot 2005 (de tweede postconventionele voorfase), en dat wordt voorzien in een overgangsperiode van wederom vijf jaar, van 2005 tot 2010 (de derde postconventionele voorfase). Alsdan kan - als eerste stap - met ingang van het jaar 2005 aan alle aanstaande ouders, direct bij vaststelling van de zwangerschap door de (zieken)huisarts, door deze een uitnodiging worden overgelegd voor een Consultatiebureau-bezoek binnen een termijn van bijvoorbeeld zes weken.

Deze uitnodiging betreft - naast eventuele (para)medische - drie sociaal-pedagogische zaken. In de eerste plaats de uitreiking van een Opvoedings(voorbereidings)geld-formulier, in te vullen door de voorziene hoofdverzorger of -verzorgster van het kind waarvan men in (hopelijk) blijde verwachting verkeert (zie par. 14.5.2.4). In de tweede plaats de intekening op de (van incentives voorziene) prenatale DOEK-cursus (zie par. 14.5.2.3). ${ }^{196}$ En in de derde plaats het voeren van het hierboven

BAARTMAN, a.w., pp. 134/135.

195 Zie met betrekking tot (het begrip) risico-gezin(nen) ook het worige hoofdstuk, par. 13.4.1.

Het betreft hier een algemene cursus, niet te verwarren met de DOEK-cursus 'Drugverslaafde Ouders En hun Kinderen' (vgl. daarover Hanneke LAFEBER, 'Evaluatie van de DOEK-methodiek; de effecten van een training voor hulpver- 
beschreven BAARTMAN-gesprek (met een daartoe speciaal opgeleid maatschappelijk werk(st)er). In de overgangsperiode, dus van 2005 tot 2010 , wordt deze uitnodiging tevens gedaan aan alle jonge ouders, dat wil zeggen ouders waarvan het jongste kind (bijvoorbeeld, afhankelijk van de logistieke mogelijkheden) onder de vijf jaar is, waarbij in elk geval een BAARTMAN-gesprek wordt gevoerd.

Het BAARTMAN-gesprek op het Consultatiebureau wordt korte tijd na de geboorte van het kind (zeg maar tussen zes en negen maanden na het eerste gesprek) en vervolgens in beginsel (afhankelijk van bepaalde indicaties of door de jonge ouders uitgesproken zorgen) één keer per jaar herhaald tot het kind de Consultatiebureau-leeftijd is ontstegen en onder de supervisie van de (analoog medisch-ontwikkelingspsychologisch/pedagogisch geïntegreerde) Schoolgezondheidszorg valt: ${ }^{197}$

'Gebleken is dat de kwalificatie van een gezin op het moment van de geboorte van een kind - hetzij als hoog-, hetzij als laag-risico-gezin - na werloop van tijd soms herzien moet worden (...). De reden hiervan is dat er zich in de loop van de tijd transactie-effecten voordoen in de verhouding tussen ouders en kind, in combinatie met contextuele factoren, die ten tijde van de geboorte [c.q. aan het begin van de zwangerschap, jw] niet voorspeld kunnen worden. Daarom zal bovengenoemde screening niet slechts pre- of perinataal moeten plaatswinden, maar gedurende de eerste levensjaren van een kind op gezette tijden herhaald moeten worden.'

Geeft het BAARTMAN-(vervolg)gesprek daartoe aanleiding, dan kan - als tweede stap - een nader onderzoek(sgesprek), (met c.q.) onder supervisie van een consultatiebureau-pedagoog, volgen dat duidelijkheid moet verschaffen over 'de gewenste vorm van hulp.' Dit brengt ons bij het tweede echelon.

Het tweede echelon: het hulpaanbod bij moeilijke gezinsomstandigheden Het tweede echelon van opvoedingsondersteuning in het post-conventionele tijdperk trekt de cirkel van te bereiken personen aanmerkelijk nauwer, namelijk rond alle jonge en aanstaande ouders die in moeilijke gezinsomstandigheden verkeren, die zelf moeilijke gezinsomstandigheden verwachten en/of ten aanzien van wie men redelijkerwijs moet aannemen dat hun aanstaande kind zonder hulp in moeilijke gezinsomstandigheden zal moeten opgroeien. Het tweede echelon betreft derhalve het aanbieden van hulp bij aanwezigheid van risico-factoren, variërend van prak-

leners van drugverslaafde ouders en hun kinderen en multi-problem gezinnen,' Systeemtherapie 1995/2, pp. 88-97). 
tische en eenvoudige thuishulp (voor het waarborgen van structuur en het opdoen van elementaire verzorgings- en opvoedingsvaardigheden) tot en met (tactvolle, soepele en verantwoorde) doorgeleiding naar het derde echelon: een combinatie van (individuele en/of partnerrelatie-/gezins-) therapie en intensieve (ouder- c.q. gezins)begeleiding onder verantwoordelijkheid van een (pre-, peri- en/of postnatale, vrijwillige dan wel door de rechter aangewezen) gezinscoach. (Voor de goede orde: het onderscheid tussen het tweede en derde echelon is meer praktisch en economisch van aard; deze echelons hebben derhalve eerder een gradueel dan een principieel ander karakter.) Op dit punt (dat wil zeggen op het doorgangspunt van het eerste naar het tweede en eventueel derde echelon) scheidt onze weg zich van die van BAARTMAN: ${ }^{198}$

\begin{abstract}
'Gesprek en aanbod hebben principieel een vrijblijvend karakter. Maar dat hoeft niet weg te nemen dat in sommige gevallen de zin van zo'n aanbod wat indringender - niet opdringerig - beklemtoond kan worden. We weten immers wat belangrijke risico-indicatoren zijn. Dit moet, ook zonder dat we op grond van die indicatoren met zekerheid de toekomst kunnen voorspellen, voldoende zijn om op de aanwezigheid van die indicatoren attent te zijn en waar nodig betrokken ouders er attent op te maken.'
\end{abstract}

Ons principiêle uitgangspunt is een ander, is en blijft het (post)conventionele recht van het kind op optimale persoonswording c.q. het kernrecht van het kind op minimale persoonswording. Dit fundamentele c.q. kernrecht verdraagt zich ten enenmale niet met vrijblijvendheid als uitgangspunt. Doch wel, en deugdelijk, met vrijwilligheid. Dat wil zeggen: vrijwilligheid-in-verantwoordelijkheid. Het is niet uitgesloten dat wij daarmee in de praktijk, als het in een wetenschappelijke studie is toegestaan te turen in de glazen bol voorbij het jaar 2005 , niet ver van de aangehaalde auteur zullen blijken te zitten. Toch mag niet worden weggemoffeld dat vrijwilligheid (opgevat als vrijwilligheid-in-verantwoordelijkheid, als vrijheid-in-gebondenheid) in plaats van vrijblijvendheid (opgevat als tot niets verplichtend privilege) als principieel uitgangspunt tot belangrijke praktische verschillen kan leiden.

Parentiarchale vrijblijvendheid, ouderschapslibertinisme, het preconventionele privacy-paradigma is, van rechtswege, onttroond en te kijk gezet door het Verdrag inzake de rechten van het kind. ${ }^{199}$ Vrijblijvend-

198 BAARTMAN, t.a.p.

199 We zijn het in dit verband dan ook bepaald niet eens met SGRrTTA (Giovanni B. SGRTTA, 'Inconsistencies: childhood on the economic and political agenda,' Childhood $1997 / 4$, pp. $375-404$, op p. 378) voor zover deze aan 'the sheer fact that the adoption of the Convention has not [yet, mijn toevoeging, jw] altered the 
heid-als-uitgangspunt, hoe indringend het 'om eigen bestwil' ook wordt beklemtoond, plaatst dit juridisch acquis terug op een hellend vlak, verlamt het verdragspotentieel in plaats van het te mobiliseren. Vrijblijvendheid is te licht bevonden voor de weegschaal van Vrouwe Justitia sinds daar, op 20 november 1989 , ook het kind op is geplaatst. Vrijblijvendheid zal ook in de praktijk van het recht, om de inmiddels vrijwel universeel verstoorde balans te herstellen, plaats moeten maken voor vrijwilligheidin-verantwoordelijkheid.

Niet voor niets investeert de maatschappij - con amore zodra de nationale schande van ernstige en passief-systematische mensenrechtenschendingen door de samenleving niet meer te dragen en door politici niet meer te verkopen valt, en volwassenen, uit burgerzin en welbegrepen eigenbelang, de stemmen in de weegschaal werpen die kinderen niet kunnen uitbrengen: daar is geen glazen bol doch enkel historisch besef en enig psychologisch inzicht voor nodig - grote bedragen in het BAARTMAN-gesprek, in opvoedingsgeld, in opvoedingscursussen, -trainingen en -onderwijs, in allerlei vormen van opvoedingshulp en in de belangrijke figuur (we komen haar zo dadelijk tegen) van de - noch bevoogdende noch voor het direct aanspreken van ouders weglopende - gezinscoach. Daar mag wel degelijk wat tegenover staan en wat aan vastzitten: het (geleidelijk, dat is begeleid) nemen van verantwoordelijkheid door ouders en, bij pertinent weigeren of de absolute onmogelijkheid daarvan, dan wel bij het (stelselmatig, althans herhaaldelijk) schenden van afspraken, het (tijdelijk) overnemen van bepaalde of alle opvoedingsverantwoordelijkheden, het - via de (gezins)rechter en op basis van door de rechter toe te passen wettelijke minimum-normen en algemene beginselen van behoorlijk gezinsrecht (zie par. 14.5.2.2.2) - 'glijden' van aangeboden in opgelegde hulp. En zulks in beginsel (dat is: afgezien van van meet af aan aperte gevallen van onwil of onvermogen) en in laatste instantie (dat wil zeggen: na toetsing door de rechter aan de minimum-normen en de

existing systems of rights of the nations that have ratified it,' de conclusie lijkt te verbinden dat het Verdrag niet meer inhoudt dan 'an expression of political impotence, rhetoric and status quo.' Die conclusie is alleen juist als men - mèt de goedkeurende/ratificerende politici? - de privacy-paradigma-oogkleppen op heeft èn houdt. Het recht van het kind op optimale persoonswording als causa finalis van het Verdrag is echter een mensenrechtelijke tijdbom die, zoals dat nu eenmaal met (ver)nieuwe(nde) verdragsrechten gaat, nog wel enige tijd doortikt voor zij 'the existing systems of rights' opblaast. Is het met de emancipatie van de wrouw, dat wil zeggen met de (ver)nieuwe(nde) codificatie en toepassing van het gelijkheidsbeginsel, niet ook zo gegaan? (Al is 'opblazen' natuurlijk een term die beter past op een historische tijdschaal dan bij het - terechte - ongeduld van betrokkenen.) 
algemene beginselen en vaststelling van de bedreiging van de minimale persoonswording) op de even simpele als heldere (rechts)grond dat (met de consultatiebureau-pedagoog c.q. de gezinscoach) vrijwillig (dat wil zeggen op basis van verworven en/of aanvaarde inzichten) gemaakte afspraken (bij herhaling) niet zijn nagekomen.

Kortom: vrijwilligheid (en duidelijkheid) voorop, maar - zoals ook het kind (in de ouder) moet leren - er zijn grenzen! Wettelijk vastgestelde pedagogische grenzen, wettelijke minimum-normen. Immers, als kinderen rechtssubjecten zijn, en dus fundamentele rechten hebben ten aanzien van hun lichamelijke en geestelijke integriteit, alsmede minimale rechten ten aanzien van hun verzorging en opvoeding, dan betekent dat dat de samenleving - met het oog op en in het licht van wettelijk vastgelegde minimale waarborgen respectievelijk criteria - bepaalde risico's niet kan nemen, bepaalde risico-factoren moet ondervangen. Naar beste vermogen, op basis van zorgvuldige procedures (niet in de laatste plaats ook wat de geschiktheid van en het toezicht op hulpverleners betreft), en na alle middelen te hebben beproefd - zoals wij ook BAARTMANs woorden moeten verstaan - (aanstaande) ouders te motiveren en vrijwilligheid te stimuleren.

Klaarstaan met een hulpaanbod en daarbij niet terugschrikken voor een volhardende opstelling - voor 'bemoeizorg' - betekent evenwel niet dat gelijkwaardigheid en respect, grondslagen van onze liberale democratie en onze sociale rechtsstaat, aan het 'nieuwe paternalisme' mogen worden opgeofferd. Integendeel, het stimuleren van vrijwilligheid kan en mag slechts geschieden vanuit de grondhouding en de grondgedachte dat (de volwassene in) iedere ouder het beste wil voor zijn kind en dat alle hulp als doel heeft: de ouder in staat stellen (een 'goed-genoege') ouder te zijn, dat wil zeggen: transgenerationele tekorten (de ouder in de ouder c.q. de ouder die men 'herbeleeft' in het eigen kind) te overwinnen in het belang van het kind. Of, nog anders (en wellicht beter) gezegd: de ouder in staat stellen oog te krijgen voor en zich te ontfermen over het kind in hemzelf ${ }^{200}$ en (al)dus (straks) oog te krijgen voor en zich te

200 Uiteraard is dit (het kind in jezelf) een metafoor. Met zich onifermen over het kind in jezelf wordt niet bedoeld dat we zouden moeten proberen het verleden met. terugwerkende kracht te veranderen of ongedaan te maken. Dat is 'gewoon onzinnig.' Wat bedoeld wordt, is dat we (dat is: de zich ontfermende volwassene, 'het wolwassen gedeelte van [onze] persoonlijkheid') moeten 'teruggaan en voelen.' Dat wil zeggen: teruggaan naar "het kind dat we waren"” (willen weten, onder ogen willen zien: wat is er met dat kind gebeurd? Was hat man dir, du ames Kind, getan?) en toegang zoeken tot de "staat van bewustzijn (...) waarin de oude pijn gevoeld wordt.' Immers: 'Dat is de enige manier waarop genezing [verwerking, jw] kan plaatsvinden.' En dus integratie van 'het kind' en de volwassene tot 
ontfermen over het eigen (op komst zijnde) kind.

Deze grondhouding en grondgedachte zijn niet enkel in het belang van een werkbare atmosfeer binnen het tweede (en derde) echelon, doch bepalen ook de werkzaamheid van de aangeboden hulp. De - in wezen

stand kan komen. (Aanhalingen wit: Jean [C.] JENSON, Op weg naar je ware zelf; Een stap voor stap gids om schadelijke gevolgen van onze opvoeding te boven te komen; Met een woord wooraf van Alice MTLLER, Houten 1998 (tweede druk), pp. 133-134 nt. 1, op p. 134, resp. 'Woord vooraf door Alice MILLER,' pp. 11-14, op p. 11. Vgl ook de bespreking van Ingeborg N. BOSCH in $M G v 1998 / 3$, pp. 318-321, op p. 320 .)

Het kind in jezelf staat voor (posttraumatische) verinnerlijkte c.q. verdrongen/ weggestopte (deel)aspecten (van de persoon) en de daarmee samenhangende psychische overlevingsmechanismen (historische aanpassingsmechanismen) die (omdat en in zoverre ze inmiddels achterhaald/inadequaat/niet meer aangepast zijn) maken dat 'we het [onverwerkte, jw] verleden telkens opnieuw creëren in het heden' (BOSCH, t.a.p., op p. 319 l.k.), dat wil zeggen: maken dat we onvrij, namelijk herhalingsdwangmatig, en dus beperkt/gehandicapt in het leven staan. Immers, op onwillekeurige momenten (ten gevolge van bepaalde 'triggers" waarvan we ons pas bewust zijn/worden in, door en na rouwarbeid) verschuift het volwassen bewustzijn naar (posttraumatische) 'kindbewustzijnsinhouden" (BOSCH, t.a.p., op p. 319 r.k.), reageren we dus (bij wijze van spreken) primitief (en handelen we zelf-destructief).

Voor de goede orde: rouwarbeid is 'verdrietswerk' (vgl. JENSON, a.w., pp. 42-43) dat (onder meer) bestaat in (a.) het blootleggen van 'de emotionele waarheid van de eigen kindertijd'; (b.) het voelen, beleven van die waarheid als (zich ontfermende) volwassene; (c.) "disidentificatie": het lijden aan het verleden naar het verleden leiden; (d.) 'zelfobservatie'/kritische zelfreflectie: ontdekken en leren herkennen van de triggers (c.q. van gedragspatronen/zich herhalende patronen en 'kinderbelevingen': vgl. JENSON, a.w., pp. 19, 113 en 60-63); en (e.) zelf-reëducatie: miet voltooide ontwikkelingstaken alsnog tot een goede oplossing brengen, ofwel: handelen naar inzicht, dóen (vgl. voor a-d: BOSCH, t.a.p. op pp. 319 r.k./ 320 ll.k.).

Zich ontfermen over het kind in jezelf is niet alleen een individuele (en transgenerationele) maar ook een maatschappelijke verantwoordelijkheid, staat niet alleen voor een therapeutische (en kinderrechtelijke) maar ook voor een politieke opdracht. Erkenning van omvang en ernst van kindermishandeling, (h)erkenning van kindermishandeling als grove en grootschalige mensenrechtenschending staat of valt ermee. Zoals JENSON (a.w., p. 32) opmerkt: 'Als we toegeven dat kindermishandeling op grote schaal voorkomt, vormt dat een bedreiging voor de ontkenning van onze jeugdervaringen." Welnu, naarmate meer volwassenen erin slagen de individuele ontkenning (verdringing, bagatellisering) van (traumatische) jeugdervaringen te doorbreken, zal de basis voor de maatschappelijke ontkenning van kindermishandeling verder afbrokkelen. Het persoonlijke is dus ook hier (bedoeld of niet) politiek. 
optimistische doch geenszins naïeve - filosofie ${ }^{201}$ die eraan ten grondslag ligt, is aldus door MLLER verwoord: ${ }^{202}$

'Die JuNGsche Lehre vom Schatten und die Vorstellung, das Böse sei die Kehrseite des Guten, dienen dem Ziel, die Realität des Bösen zu leugnen. Doch das Böse ist real. Es ist nicht angeboren, sondern erworben, und es ist niemals die Kehrseite des Guten, sondern dessen Zerstörer. (...). Es ist nicht wahr, daß das Böse, Destruktive, Perverse notwendig zur menschlichen Existenz gehört, auch wenn dies immer wieder behauptet wird. Es ist aber wahr, daß das Böse ständig neu produziert [wird] und mit ihm ein Meer won Leid für Millionen geschaffen wird, das ebenfalls vermeidbar wäre. Wenn einst die aus der Verdrängung der Kindheit entstandene Ignoranz aufgehoben sein wird und die Menschheit erwacht ist, kann sie diese Produktion des Bösen einstellen.'

De werkzaamheid van alle drie echelons impliceert intussen twee meer 'praktische' zaken. In de eerste plaats een organisatorische (zowel structurele als culturele) integratie van vrijwillige hulpverlening, justitiële bescherming en geestelijke gezondheidszorg' ten behoeve van zowel kinderen en jeugdigen (DOEK) ${ }^{203}$ als (jong)volwassenen. En in de tweede plaats een professionele heroriëntering en omschakeling van consultatiebureaus (en schoolgezondheidszorg) van een uitsluitend of voornamelijk medisch naar een medisch-(ontwikkelings)psychologisch/pedagogisch ofwel een lichamelijk-en-geestelijk (mens sana in corpore sano) gezondheidsbegrip. Een heroriëntering waarvan het uiteindelijke - bredere doel aldus, kort en krachtig, door VAN DANTZIG (1997) is verwoord: ${ }^{204}$

'Men mag niet rusten voor de geestelijke gezondheidszorg evenwaardig aan de lichamelijke gezondheidszorg is geworden. ${ }^{205}$

201 Een filosofie die ik dan ook niet in de laatste plaats zou willen voorhouden aan niet klinische psychologen, met name auteurs - hoe kan het anders in deze onvolmaakt maakbare en bij afwezigheid of ontstentenis wan morele elites volmaakt onmaakbare wereld - wier pennevruchten soms een vleugje meer naar weerstand dan naar wetenschap smaken. Zie voor de wijze waarop eén (of enkelen?) van hen van repliek wordt (worden) gediend: Nel DRAIJER, "Hervonden misdrijwen" eenzijdig bekeken,' MGV 1997/12, pp. 1249-1256.

202 Alice MILLER, Das verbannte Wissen, Frankfurt am Main 1988 (tweede druk), pp. $182-183$.

203 DOEK, 'Kindermishandeling: recht op en/of dwang tot preventie,' t.a.p., op p. 19 r.k.

204 A. VAN DANTZIG, 'Enkele opmerkingen over zorgvernieuwing,' $M G v 1997 / 11$, pp. 1132-1134, op p. 1134.

205 Waaraan hij in een latere bijdrage 'toevoegt' (Andries VAN DANTZIG, geïnterviewd door Paul SCHNABEL, "Net als het lichaam moeten we het gevoelsleven onder het regime van de wetenschap stellen"; NFGV ereprijs 1998 voor dr. A. VAN 
En om van gezondheid dan ook maar meteen een medische/(ontwikkelings)psychologische/pedagogische definitie te geven (RISPENS en VAN TUIJ 1994): $:^{206}$

'Gezondheid wordt niet langer gedefinieerd als de afwezigheid van ziekte, maar positief geformuleerd in termen van vrijheid, autonomie, zelfverwerkelijking en ontplooiing. Bovendien vat men gezondheid niet op als een (relatief stabiele) eigenschap van een persoon, maar als de uitkomst van een interactie tussen persoon en omgeving. Gezondheid houdt in het vermogen zich aan te passen en het kunnen bewaren van het evenwicht tussen de eigen mogelijkheden en de eisen van de omgeving.'

Volgens recent onderzoek van RYFF en SINGER ${ }^{207}$ zorgen zes factoren voor geestelijke gezondheid:

1. 'zelfacceptatie' (vrij vertaald: van jezelf houden);

2. 'voldoende positieve relaties met anderen' (zeg maar: vrienden hebben - en liefst natuurlijk een goede partnerrelatie);

3. autonomie: 'bepaalt zelf wat er met het eigen leven gebeurt en is onafhankelijk' (dus: je niet door anderen laten leven, emotioneel op eigen benen staan);

4. controle: 'gevoel van controle over de omgeving' (het gevoel dat je zelf de touwtjes in handen hebt, en dus niet aan de omstandigheden bent overgeleverd en min of meer machteloos in het leven staat);

5. persoonlijke groei: je capaciteiten/talenten ten volle benutten; waaraan ik zou willen toevoegen: het leven zien als een permanent leerproces (zeg maar: permanente zelf-opvoeding als grondhouding, ook al is het natuurlijk lang niet altijd mogelijk je capaciteiten/talenten 'ten volle' te benutten: er moeten in het leven, en in het dagelijkse werk, nu eenmaal ook tal van meer of minder nuttige klussen worden geklaard);

DANTZIO; een interview,' $M G v$ 1998/10, pp. 927-943, op p. 942 i.f.): '[lk ben] misschien wat meer geneigd de oplossing te zoeken in een verwetenschappelijking van ons dagelijks en persoonlijk leven, wat niet meer wil zeggen dan dat ik de voorkeur geef aan op feiten gebaseerde oplossingen boven magische oplossingen. Dat is niet eng, voor wat betreft ons lichaam willen we allang niet anders meer, en het betekent eerder minder dan meer Big Brother-achtige toestanden.'

206 J. RISPENS, C. VAN TUIJ, 'Preventie van psychosociale problemen bij kinderen en jeugdigen: begripsbepaling en context, hoofdstuk 1 in: J. RISPENS, P.P. GOUDENA, J.J.M. GROENENDAAL, Preventie van psychosociale problemen bij kinderen en jeugdigen, Houten/Zaventem 1994, pp. 13-27, op p. 14.

207 Carol RYFF, Burton SINGER, Psychotherapy and psychosomatics 1996, pp. 14-23; gesignalleerd in Psychologie september 1996, p. 6 (onder de kop: 'Geestelijk gezond'). 
6. doelgerichtheid ('heeft het gevoel dat het leven zin heeft en streeft naar bepaalde doelen'); ik zou zeggen: doelen in het leven hebben, dat wil zeggen zin aan het leven geven (onder andere) door jezelf doelen te stellen. ${ }^{208}$

208 Het is verrassend deze 'empirische' elementen (en in het bijzonder het basiselement zelfacceptatie/van jezelf houden) te leggen naast de 'deugden' (de voorwaarden voor, of liever: het 'zoeken naar de juiste toestand of houding' voor 'optimaal functioneren') in de aristotelische bestaansethiek, zoals kort, en boeiend, uiteengezet door GRASTE (Jacques GRASTE, 'Ethiek als kritische reflectie: de Ethica van ARISTOTELES,' Maandblad Geesielijke volksgezondheid 1998/5, pp. 474489; aanhalingen op p. 481). Eén van de door GRASTE behandelde deugden/ voorwaarden voor optimaal functioneren is philia pros heauton: 'vriendschap voor zichzelf.' GRASTE stelt hierover (t.a.p, op pp. 483-484): 'Het is voor ARISTOTELES vanzelfsprekend dat de houding die je ten opzichte van jezelf inneemt, positief is. Deze positieve houding zou je de basis van geestelijke gezondheid kunnen noemen. ARISTOTELES beschrijft deze houding in verband met philia, vriendschap en liefde, en begint het [des]betreffende hoofdstuk met de stelling dat "de vriendschappelijke houding ten opzichte van vrienden (...) is afgeleid van de gevoelens van vriendschap die een mens voor zichzelf heeft" (...). (...) De tegenovergestelde vorm beschrijft ARISTOTELES als het "oneens" en in conflict met zichzelf zijn. Zo iemand kiest voor dingen dic aangenaam en lustvol zijn terwijl hij weet dat dit niet goed voor hem is. Dergelijke mensen zoeken elkaar op en ontvluchten zichzelf, want: "Wanneer ze namelijk op zichzelf zijn, hebben ze te veel confronterende herinneringen (...), maar wanneer ze in gezelschap van anderen zijin, vergeten ze dit. En omdat ze zelf niets hebben dat de moeite van het liefhebben waard is, ervaren ze geen enkel gevoel van liefde voor zichzelf. Zulke mensen vinden bij zichzelf dus ook geen (echte) vreugde of verdriet" (...). De ziel van dergelijke mensen verkeert in een tweespalt: wanneer ze niet krijgen wat ze begeren of waar ze behoefte aan hebben, voelen ze zich ongelukkig, maar wanneer ze het wel hebben, is het ook niet goed. (...) ARISTOTELES schenkt in zijn Ethica veel aandacht aan dit verschijnsel, dat hij akrasia noemt. Hij bedoelt hiermee een gebrek aan zelfintegratie en aan een sturend beginsel, een gebrek aan meesterschap over zichzelf (enkrateia). (...) Iemand die positief staat ten opzichte [van] zichzelf, kent een dergelijke gespletenheid niet. Hij houdt van zichzelf zonder dat er sprake is van zelfzucht. Bij de meeste mensen is echter sprake van een vorm van eigenliefde waarbij het alleen maar om het eigenbelang gaat. $\mathrm{Zij}_{\mathrm{ij}} \mathrm{ijn}$ uit op zoveel mogelijk geld, bezit en genot. En, zegt ARISTOTELES, "zij maken zich om deze dingen druk in de veronderstelling dat het om het belangrijkste gaat" (...). (...) Deze vorm van eigenliefde is niet goed. Iemand met de juiste vorm van zelfliefde doet juist goede dingen omdat hij dit graag doet, en niet om zichzelf te bevoorrechten. Verder geeft hij gehoor aan het meest soevereine deel in zichzelf, en dat is het denkende deel, de logos. Hieronder verstaat ARusToTELES zowel het praktisch inzicht als het nadenken, reflecteren, en het bewusizijn: "Wie dus dat deel van zichzelf liefheeft en dit ter wille is, is bij uitstek een vriend van zichzelf" $(\ldots)$. 
We vermelden deze zes factoren om de kloof zichtbaar te maken tussen dit gezondheidsideaal en de situatie van veel ouders (zelfs van veel niet transgenerationeel gedepriveerde ouders), van veel jeugdigen en dus van (de som der delen:) de maatschappij in haar geheel. Aldus maken we de spanning voelbaar die onder fatsoenlijke mensen nodig is om oplossingen te bereiken (VAN DANTZIG 1996): $:^{209}$

\begin{abstract}
'Ervan uitgaande dat gezondheidszorg bedoelt lijden te verminderen, bestaat er (...) een probleem wat betreft geesteljjk lijden: daar bestaan toestanden die in de somatiek niet meer geduld worden. Waar ik in de eerste plaats voor pleit, is erkenning van dat probleem als een centraal probleem van de gezondheidszorg. Dat is moeilijk een probleem erkennen zonder ook een oplossing in het vizier te hebben. Maar ik meen dat het nodig is met die spanning te leven, want alleen op die manier kan men gaan denken aan oplossingen die zullen leiden, niet tot een geestelijk gezonde samenleving, want ik weet ook niet wat dat is, maar tot een samenleving waarin het geestelijk lijden geleidelijk zal afnemen.

Daarvoor is misschien meer psychotherapie nodig, maar dat is zeker niet het enige en misschien niet eens het belangrijkste. (...) In [het] beleid zal vooral aandacht gegeven motten worden aan manieren om lijden te voorkomen. Het is toch niet onredelijk om bijwoorbeeld te proberen incest en mishandeling niet te laten duren van de kleutertijd tot aan de volwassenheid.'
\end{abstract}

Preventie is belangrijker dan curatie, dus ook belangrijker dan psychotherapie. Waar therapie evenwel nodig is, is deze op zich ook weer een vorm van preventie. Een geslaagde therapie betekent immers geen nieuw lijden of althans minder lijden voor betrokkene en zijn omgeving. Een geslaagde therapie doorbreekt (per definitie) de transgenerationele keten van mishandeling, misbruik en verwaarlozing. Soms is psychotherapie zo al niet de enige dan toch in elk geval een heel belangrijke manier om lijden, ernstig lijden van kinderen, te voorkomen: namelijk in ons derde echelon.

Het derde echelon: de gezinscoach

Het derde echelon van (post-conventionele) opvoedingsondersteuning trekt de binnenste cirkel van te bereiken personen rond die aanstaande (en prille) ouders die, wegens de aanwezigheid van ernstige en/of meervoudige (cumulatieve) risico-factoren, vanuit het tweede echelon zijn doorverwezen ter fine van een combinatie van therapeutische hulp en intensieve en/of langdurige (ouder- c.q. gezins)begeleiding onder verantwoordelijkheid van een gezinscoach.

A. VAN DANTZIG, 'Alle dagen psychologie? (2)* $M G v 1996 / 11$, pp. 1183-1184, op p. 1184. 
De gezinscoach is, in onze voorstelling - en in tegenstelling tot de huidige 'ouders onder toezicht stellende" gezinsvoogd (alleen de terminologie komt al bijna neer op het vragen om escalatie en problemen) -, tegelijk een deskundig supervisor van het (overall-)hulpplan en de vertrouwenspersoon van het gezin, dat wil zeggen: degene die met de ouders (en eventuele andere gezinsleden) duidelijke afspraken maakt en dezen daar ook direct op aanspreekt. Hij of zij kan - bijvoorbeeld bij ernstige verslavingsproblematiek (drugs, allcohol, vanuit een medisch-gift-optiek in de toekomst waarschijnlijk ook nicotine ${ }^{210}$ ), bij psychiatrische (psychotische en psychopathische c.q. cluster A en B persoonlijkheidsstoornissen) problematiek of bij zwakbegaafdheid) - al prenataal worden ingeschakeld, hetzij op verzoek van de aanstaande ouders (c.q. de gravida), hetzij op vordering van de consultatiebureau-pedagoog (of de Raad voor de kinderbescherming, bijvoorbeeld na melding bij een Advies- en Meldpunt door de arts die de zwangerschap heeft vastgesteld) en aanwijzing door de (gezins)rechter, die daarbij weer de wettelijke minimum-normen hanteert. (Het lijkt niet raadzaam een vrijwillige gezinscoach dit vorderingsrecht te geven: hij of zij dient de zaak over te dragen aan de consultatiebureau-pedagoog c.q. de Raad indien hij/zij tot de conclusie komt dat voortzetting van vrijwillige hulpverlening geen zin heeft.)

Behalve als prenatale mentor ventris ${ }^{211}$ en postnatale mentor familiae zou de figuur van de gezinscoach ook kunnen worden ingezet als mentor divortii in geval van (dreigende) ernstige (omgangs)problemen bij echtscheiding en als mentor ad litem in geval van gecompliceerde en (dreigend) escalerende (hoog oplopende c.q. uit de hand lopende) juridische procedures waarin het belang van het kind in het geding is. Bij (tijdelijke) afwezigheid van beide ouders zou zelfs gedacht kunnen worden aan de figuur van de inwonende gezinscoach (mentor domesticus of, indien men hier de vrouwelijke variant mentrix wil gebruiken: mentrix domestica).

210 Vergelijk bijwoorbeeld de onlangs (wolgens een 'flits'-bericht in Dagblad de Limburger van 31 maart 1998) gestarte campagne: "Roken? Niet waar dè Kleine bij is."

211 Letterlijk: buikgids. De spreekwijs 'Baas in eigen buik" kan geacht worden te slaan op het recht op (vroege) abortus doch niet op het 'spelen' met de vrucht door "schadelijke "gewoontes" [als] drinken [en] roken' (DOEK, 'Kindermishandeling: recht op en/of dwang tot preventie," t.a.p., op p. 20 r.k., "Tot besluit'). Het betreft hier immers risico's voor (de gezonde ontwikkeling van) het kind die de samenleving niet kan en, op grond van het Verdrag inzake de rechten van het kind, niet mag nemen. 
In al deze gedaanten zijn op de gezinscoach onverkort de basisprincipes van coaching van toepassing, zoals uitgewerkt door VERHOEVEN En VAN VLERKEN:.12

1. zelfsturing (je kunt een paard wel naar het water leiden, maar het niet laten drinken'), en daarbij vertrekken vanuit 'de ervaringen en percepties van de gecoachte,' het coachingsproces beginnen vanuit de 'situatie waarin de gecoachte zit en zijn definitie van de werkelijkheid';

2. evenwaardigheid: 'coach en gecoachte zijn partners die beiden hun eigen specifieke inbreng hebben om de resultaten van de gecoachte [geco-achte! -jw] te verbeteren'; let wel: ook hier gaat het om een uitgangspunt: de (kennis- c.q. gezags)hiërarchie in de relatie (in het bijzonder) in geval van een door de rechter aangewezen coach hoeft (en behoort) niet te worden geloochend (zie ook beginsel 6 en 7);

3. bewustzijn, leidend tot inzicht ('iemand die zich niet bewust is van wat hij doet, kan ook niet reflecteren op zijn handelen') en groei ('en zonder die reflectie kan hij zijn handellen niet systematisch verbeteren');

4. verantwoordelijkheid nemen ('bewustzijn zonder verantwoordelijkheid te nemen leidt alleen maar tot [een afhankelijke opstelling en dus tot negatieve] kritiek en in extremo tot machteloosheid');

5 . vertrouwen in potenties van mensen;

6. gestrengheid: 'coaching is niet soft: je maakt heldere afspraken met elkaar en daar spreek je elkaar op aan; en als de basisafspraak niet meer klopt en je komt er ook niet uit door die hernieuwd te maken, dan is het "over en sluiten"; coaching betekent het einde van (...) "pappen en nathouden"' (vgl. ook de volgende subparagraaf);

7. resultaatgerichtheid: de coach heeft geen 'terughoudende counselende rol; coaching is gericht op ontwikkeling van individuen en [gezinnen], maar wel met het oog op prestatieverbetering.'

14.5.2.2.2 Persoonswordingsvindicatie: het opleggen van hulp en steun als raad en daad niet baat (de maatregel van hulp en steun)

'Over en sluiten': dat is de stap waarvoor in de regel in het derde echelon de gezinscoach (als mentor/mentrix ventris, mentor/mentrix familiae, mentor/mentrix divortii, mentor/mentrix ad litem of mentor/mentrix domesticus/-ca) en in extreme c.q. urgente situaties in het tweede echelon de consultatiebureau-pedagoog dan wel, bij later optredende extreme c.q.

212 Willem VERHOEVEN en Anita VAN VLERKEN, "De basisprincipes van coaching," in: Jan DE RUIJTER (red.), De docent als coach, Baarn 1997, pp. 19-32, op pp. 20-29 (de interpunctie van aanhalingen is aangepast). 
urgente (bijvoorbeeld snel en ernstig escalerende echtscheidings)problematiek, hetzij de schoolpedagoog, hetzij de Advies- en Meldpunt-pedagoog hetzij de Raad voor de kinderbescherming verantwoordelijk is in alle gevallen dat, om welke redenen of door welke oorzaken ook, een hulpaanbod geen zin (meer) heeft, kort gezegd: raad en daad niet baat. Met het zetten van die stap treedt een nieuwe fase in: de fase waarin - na tussenkomst van de (gezins)rechter - hulp wordt opgelegd omdat anders minimale verzorgings- en opvoedingscondities niet (meer) kunnen worden gewaarborgd c.q. de minimale persoonswording van een kind/kinderen wordt bedreigd. Voor de (gezins)rechter moet aannemelijk zijn dat het gezin in (chronisch) traumatiserend vaarwater terecht zal komen of daar niet uit zal komen, met alle (levenslange) gevolgen vandien, als bepaalde of alle ouderlijke opvoedingsverantwoordelijkheden niet (tijdelijk) worden overgenomen, dat is: als geen in beginsel geschikte hulp wordt opgelegd. Uiteraard dient (op grond van art. 3, lid 1 VRK) in geval van twijfel door de rechter voor het persoonswordingsbelang van het kind, en niet voor de pretense belangen van ouders te worden gekozen - conform het adagium in dubio pro infimo: bij twijfel dient voor de geringste (de zwakste, de meest kwetsbare partij) te worden gekozen, c.q. in dubio contra parentes: bij twijfel moet beslist worden tegen de eis van de ouder(s) in; met andere woorden: de persoonswording van het kind, niet de ouder(s) krijgt (krijgen) het voordeel van de twijfel. ${ }^{213}$

Ook hier kan die hulp variëren van eenvoudige en praktische hulp aan huis tot en met al of niet (semi-)residentiële derde-echelon-varianten. Als residentiële hulp geïndiceerd is of blijkt, hetzij voor éen of beide ouders, hetzij voor één of meer kinderen, hetzij voor het hele gezin, dan is voor (niet vrijwillige) uithuisplaatsing van het desbetreffende gezinslid/ gezinsleden c.q. (in geval beide ouders voor langere of onbepaalde tijd zullen moeten worden opgenomen) pleeggezinplaatsing van het kind/de kinderen of (bij korter durende residentiële behandeling van beide ouders) de benoeming van een inwonende gezinscoach (mentor domesticus of mentrix domestica) een aparte rechterlijke machtiging nodig.

Zijn dit niet te ver gaande juridische (gezinsverhoudingen "juridiserende') voorstellen? FINKELHOR heeft opgemerkt:"14

'The opening up of the problem of family violence can count as one of the major accomplishments of sociall science in the last generation.'

213 Op dit ogenblik zijn de woordenboeken juridisch Latijn nog nïet met deze adagia verrijkt.

214 David FINKELHOR, 'Foreword,' in: Kevin BROWNE, Martin HERBERT, Preventing family violence, Chichester (etc.) 1997, pp. xv-xvi, op p. xv. 
Het wekt niet weinig verbazing dat de grote juridische en rechtspolitieke draagwijdte van deze sociaal-wetenschappelijke prestatie van de eerste orde, een prestatie die niet van gisteren op vandaag is tot stand gebracht, nog nauwelijks door juristen wordt beseft. ${ }^{215}$ Alsof de rechtsstaat alleen met de rechten van (gevaarlijke) ${ }^{216}$ verdachten en de vrijheid van pro-

215 Met uitzondering van juristen die zich bewegen binnen het kader van vrouwenstudies ("vrouw en recht"). Vgl. bijwoorbeeld het recente proefschrift van LUNNEMANN (Katinka D. LUNNEMANN, Vrowwenmishandeling strafrechtelijk afgedaan; Strafrechtelijke regulering van mannelijk geweld tegen vrouwen in de privésfeer, diss. Maastricht, Dewenter 1996), dat evenwel (zoals de titel aangeeft) beperkt is tot strafrechtsbescherming.

216. Wat de voor kun kinderen gevaarlijke categorie van incestplegers betreft, wijs ik in dit verband gaarne op de volgende woorden van BAARTMAN (H.E.M. BAARTMAN, 'Seksueel misbruik: een betrouwbaar antwoord?' In: L.P.T. RAUMAKERS e.a. (red.), Commissie Seksueel Misbruik van Jeugdigen, Handelen bij vermoeden van seksueel misbruik van kinderen en jeugdigen II; De richtlijnen SMJ in de praktijk, Assen 1995, pp. 122-130, op p. 129): 'De angst voor de gevolgen van een inadequat verhoren wan een kind is in de wijze waarop hij wordt geformuleerd, wrij eenzijdig. Men vreest dat daardoor mensen ontenecht veroordeeld worden. In dit verband zij terzijde opgemerkt dat uit onderzoek van VAN MONTFOORT ([Kindermishandeling en justitie] 1993) is gebleken dat niet meer dan ongeveer $22 \%$ van alle aangiften van seksueel misbruik tot een strafrechtelijke veroordeling leidt. De zorg dat door een inadequaat verhoor iemand juridisch gezien misschien terecht maar met het oog op het belang van het kind ten onrechte niet veroordeeld wordt, of minstens dat daardoor seksueel misbruik dat daadwerkelijk heeft plaats gevonden, niet overtuigend bewezen kan worden - met alle ellende voor het kind van dien - is veel geringer.'

Vgl ook Mick SALET, die een interview met Hans CROMBAG en Harald MERCKELBACH (auteurs van Hervonden herinneringen en andere misverstanden) in Dagblad de Limburger van 29 april 1996 de ironische titel meegaf: "Mag je een baby nog knuffelen?' En P.T. Mus, die zich in een ingezonden brief in De Observant van 9 mei 1996 afvraagt waarom de "kruistocht" van genoemde auteurs zich tegen de 'hervonden herimnering' zelf richt. Kritick niet op het fenomeen an sich maar op het eventueel onprofessioneel omgaan daarmee, door therapeuten dan wel door rechters, zou inderdaad meer yoor de hand liggen. En in elk geval wetenschappelijker, althans serieuzer overkomen. Men proeft in geschriften als deze toch een snufje te veel weerstand en (dus) een vleugie te weinig wetenschap, dat will zeggen: wetenschap die zo onbevangen is dat zij ook kinderen omvat of althans niet tussen haakjes - en daarmee buiten de rechtsstaat - plaatst.

Ik zou tot slot nog willen wijzen op de woorden van BOUTELLIER naar aanleiding van de zogenaamde 'Bolderkar-affaire" (J.C.J. BOUTELLIER, 'Seksueel misbruik wan kinderen,' Justitiele Verkenningen 1989/6, pp. 8-33, op p. 9): 'Wanneer het om concrete gevallen gaat, verandert (...) de toon. In de berichtgeving over de Bolderkar-affaire lijken de onvangscijfers te zijn vergeten en overheerst de scepsis. Men kan eenwoudigweg niet geloven dat het waar is en verplaatst zich in het standpunt van de beschuldigde ouders."

Steeds opnieuw stuiten we op het - niet alleen vanuit het perspectief van rechts- 
paganda en partijvorming van (ongevaarlijke?) xenofoben en demagogen te maken heeft. Alsof mensenrechten alleen betrekking hebben op autoritaire regeringen en politieke gevangenen, de rechten van het kind alleen op straatkinderen (ver weg) en kinderen die (dichterbij) door pedofielen 'van straat' worden gehaald. Alsof, om bij de academische leest te blijven, de uitvinding van het wiel in alle disciplines tot nieuwe paradigma's leidt behalve in het recht (dat altijd al rond - of krom? - was).

Intussen staan de ontwikkelingen niet stil. BROWNE en HERBERT schrijven (onder het kopje 'Prevention starts with parents'): ${ }^{217}$

'WOLFE ([Child Abuse Review] 1993) observes that there have been promising developments in early interventions which address parental competency and family support in order to promote more positive parental knowledge, attitudes, skills and behaviour. He claims that personalized programmes such as home visits over a period of 1 to 3 years stand out as the most successful interventions in achieving desired outcomes in terms of fewer child injuries, emergency room visits and reports to protective agencies.

A number of countries in the world have statutory government sponsored home visitation schemes, usually using health professionals such as community nurses. (...) It has been emphasized (...) that community nursing services (...) could be used to prevent child abuse and neglect at a primary and secondary level through the promotion of positive parenting. (...) Thus, the Department of Health Research Programme on Child Protection (... [1995]) concludes that an effective system of child protection needs to be complemented and balanced by well-targeted family support services. However, few countries have systematically used home visitation practices in this way and even fewer have evaluated the effectiveness of home visits on the incidence and prevalence of child maltreatment. An exception has been the work of David OLDS and his colleagues in the USA. They have shown that "Nurse Home Visitation Schemes" (a) have lasting effects in the promotion of positive qualities of parenting (...); (b) improve the development of socially disadvantaged mothers and their children (...); and (c) save on government spending in relation to these families both in the short and long term (...)."

Toch is het niet zo dat er onder juristen geen enkele vernieuwingsdrang te bespeuren valt. Afgezien van DOEK, die, zoals we zagen en nog zullen zien, ook buiten het (ex post-)interventie-paradigma treedt (doch die zelfs met geluiden over een meldplicht of een familierechtelijk geweldverbod sinds jaar en dag Neêrlands vox clamantis in deserto juridico is), heeft recentelijk bijvoorbeeld KOENS nieuwe (justitiële) voorstellen gelanceerd.

staat en (rechts)wetenschap - dubieuze fenomeen van het volwassen hemd dat nader is dan de (vergeten of verdrongen) kinderlijke rok. 
KOENS' maatregel van hulp en steun

KOENS bepleit in zijn oratie 'een nieuw stelsel van maatregelen van [kinder]bescherming., ${ }^{218}$ Binnen dat stelsel ziet hij plaats voor twee (voor zoveel hier van belang) sociaal-pedagogische (hoofd)maatregelen, ${ }^{219}$ waarvan de ene ('de maatregel van hulp en steun') prima facie overeenkomt met wat wij (in algemene zin) persoonswordingsvindicatie (voluit integriteits- en persoonswordingsvindicatie en kortweg integriteitsactie) hebben gedoopt, en de andere (de 'gedwongen uithuisplaatsing") gelijkenis vertoont met de machtiging waarvan wij hierboven spraken. Belangrijk principieel en organisatorisch verschil is uiteraard dat onze maatregel en machtiging zijn ingekaderd binnen SPS: zij betreffen een geheel andere context - namelijk de context van de glijdende schaal die in principe (dat wil zeggen extreme situaties daargelaten) begint met een (geschikt) aanbod en met (heldere) afspraken - dan die waarin KOENS schrijft.

We herhalen en benadrukken dat de SPS-context geïntegreerd en geünificeerd is: er is, onder de regie van één minister (zie par. 14.5.2.7), afgerekend met het huidige ("verdeel-het-geld-zuinig-en-heers'- en dus 'pappen-en-nathouden'-)systeem ${ }^{220}$ van (het langs elkaar heen werken

218. M.J.C. KOENS, Jeugdigen in de knel; Maatregelen van jeugdbescheming in de toekomst, inaugurele rede Maastricht, Deventer 1994, p. 37. (De uitgangspunten voor dat stelsel bekeken we in hoofdstuk 1, par. 1.1.1.)

219 KoENS, a.w., pp. 38-40 resp. 41-44. Voor hetgeen de auteur ten aanzien van beide maatregelen samenvattend stelt, zij eveneens verwezen naar hoofdstuk 1 (par. 1.1.1.).

220 Een systeem dat steevast leidt tot Competentie-Competitie ofwel stammenoorlogen, binnen de GGZ aan de kaak gesteld door VAN DANTZIG (in de weergave van Paul SCHNABEL, "(...) NFGV ereprijs 1998 voor dr. A. VAN DANTZIG; een interview,' MGv 1998/10, pp. 927-943, op pp. 935/936): 'De huidige discussie over de beperking van het domein van de geestelijke gezondheidszorg is het jammerlijke gevolg van een strijd om de middelen bimnen de geestelijke gezondheidszorg, die door de politiek en de financiers zo kort gehouden wordt dat men de hulpvraag niet meer kan beantwoorden [exit reparatie, intrede secundaire staatsaansprakelijkheid, jw]. (...) We worden in de geestelijke gezondheidszorg nu tegen elkaar uitgespeeld en we voeren zelf de ideologische ammunitie aan om de strijd te woeren (...). We maken van de ons van buiten opgelegde armoede een punt van eigen overtuiging. (...) Als het gaat om een afweging tussen psychotherapie [de behandeling van in het bijzonder geinternaliseerde c.q. 'neurotische' problematiek, jw] en sociale psychiatrie, wint de sociale psychiatrie het. Dat is niet omdat die patiënten erger ziek zijn - wie zal dat bepalen? - maar omdat hun problemen zich in de publieke sfeer afspelen en dus minder gemakkelijk genegeerd kunnen worden. (...) [W]at de politiek niet wil oplossen door voldoende geld ter beschikking te stellen, moet nu de Riagg zelf intern oplossen. Inmiddels bevinden ook de psychiatrische ziekenhuizen zich in die situatie en zien we bij hen hetzelfde mechanisme optreden. De domeindiscussie is een ideologisering van de discussie over een gebrek aan middelen, meer niet.' 
van en het afschuiven van verantwoordelijkheden door) 'aparte koninkrijkjes met eigen regels en financiering' (DOEK). ${ }^{221}$ We herhalen en benadrukken dat SPS de principiële vertaling en structurele en consequente invulling is van de mensenrechtelijk vereiste (en in het Verdrag inzake de rechten van het kind nader gestipuleerde) preventieve benadering. En wel volgens een (drie-echelons)model dat werkt met een niet-stigmatiserende en anti-escalatoire glijdende schaal. Niet-stigmatiserend door de methode van het BAARTMAN-gesprek ter screening van risico-gezinnen. En anti-escalatoir doordat in een zo vroeg mogelijk stadium, bij voorkeur prenataal (dat wil zeggen in een zo vroeg mogelijk stadium van de zwangerschap), gescreend wordt op wetenschappelijk gevalideerde risico-indicatoren, waarna een geschikt hulpaanbod-op-maat wordt gedaan (binnen het brede sociaal-pedagogische kader van een algemeen niet vrijblijvend ouderschapskundig cursusaanbod en een algemeen niet onvoorwaardelijk uit te betalen opvoedingsloon).

En dit alles vóór- en niet nádat ernstige opvoedingsproblemen zijn ontstaan en (jarenlang) de kans hebben gekregen te escaleren, dat wil zeggen te leiden tot de psychologisch wetmatige verharding van (de ontkenning van) problemen en (dus) de bijna-onoplosbaarheid ervan doordat confrontatie (als zij al geschiedt) geschiedt in een stadium dat het gezin al te veel te 'verbergen' heeft (en ook voor zichzelf heeft weggestopt). Waarbij een negatief versterkend (verder verhardend en in elk geval niet deëscalerend) effect optreedt door het gebruikte confrontatiemiddel, namelijk een alleen al in de (vooroorlogse) benaming stigmatiserend instrument: de 'infamerende' ondertoezichtstelling.

\section{Persoonswordingsvindicatie}

Onder 'onze' persoonswordingsvindicatoire matregel van hulp en steun dient dan te worden verstaan: het na een mislukt hulpaanbod c.q. (bij herhaling of in ernstige mate) mislukte afspraken door de (gezins)rechter - na toetsing aan wettelijke minimum-normen en aan algemene beginselen van behoorlijk gezinsrecht en vaststelling van de bedreiging van de minimale persoonswording - opleggen van geschikte hulp aan ouder(s) en/of kind(eren), al of niet in combinatie met een rechterlijke machtiging tot plaatsing van betrokkene(n) in een residentiële instelling (waaronder bijvoorbeeld een sociaal-therapeutische inrichting voor incestdaderbehandeling, een instelling voor intramurale afkick-therapie of voor andere vormen van intramurale ouder-, kind- en/of gezinsbehandeling), voor zoveel nodig met gelijktijdige machtiging tot inwoning van een gezinscoach c.q. 
tot plaatsing van een kind/kinderen in een pleeggezin, zulks met het oog op zo spoedig mogelijke verantwoorde terugkeer van het desbetreffende gezinslid/de desbetreffende gezinsleden in het gezin.

Uitsluitend in uitzonderlijke gevallen waarin het op voorhand duidelijk is dat het aanbieden en/of opleggen van hulp niet in het persoonswordingsbelang van het kind is (bijvoorbeeld doordat ouders, door welke oorzaken of omstandigheden ook, een onmiddellijk en vermoedelijk permanent of zeer langdurig dreigend fysiek, psychisch of moreel gevaar zijn voor zichzelf en/of het kind), ${ }^{222}$ vindt persoonswordingsvindicatie plaats door de plaatsing van een kind voor onbepaalde duur in een alternatieve of vervangende gezinssituatie.

\section{Rechtswaarborgen: minimum-normen en algemene beginselen van behoorlijk gezinsrecht}

KOENS onderscheidt drie rechtswaarborgen ten aanzien van 'overheidsinterventie in de ouderlijke opvoedings- en verzorgingsautonomie' (lees: ten aanzien van de primaire ouderlijke opvoedingsverantwoordelijkheid), rechtswaarborgen gelegen in art. 8, lid 2 EVRM: $:^{23}$

1. de maatregel(en) moet(en) met voldoende concreetheid wettelijk zijn omschreven ('Willen ouders en kinderen [hier zal bedoeld zijn: jeugdigen/jongeren, jw] de gevolgen van hun gedragingen kunnen overzien, dan behoren zij in de wet te kunnen lezen waaraan zij zich te houden hebben');

2. er dient sprake te zijn van een legitiem doel;

3. aan het noodzakelijkheids- ('dringende maatschappelijke noodzakelijkheid') en evenredigheidsvereiste (juiste verhouding tussen doel en middelen) dient te zijn voldaan, hetgeen (óók) betekent:

3a. er is voldaan aan het effectiviteitsvereiste ('de overheidsinterventie moet een positief effect hebben op de verdere ontwikkeling van het kind');

3b. er is voldaan aan het subsidiariteitsvereiste, hetgeen betekent:

"a) geen gedwongen hulpverlening als hetzelfde resultaat bereikt kan worden met wrijwillige hulpwerlening;

b) geen uithuisplaatsing als een ambulante maatregel volstaat;

c) geen gedwongen uithuisplaatsing als ouders en kind op vrijwillige basis mee willen werken aan de uithuisplaatsing;

222 Men denke hierbij aan zeer gewelddadige (psychopathische) of ernstig psychiatrisch gestoorde (psychotische) ouders (c.q. ouders met ernstige persoonlijkheidsstoornissen wit het A- of B-cluster), aan zwakzinnige ouders of aan (niet ernstig gestoorde) zwaar criminele ouders. 
d) geen langere duur van de ingreep dan vereist is om het beoogde doel te bereiker;

e) geen ontneming van het gezag als een zelfde resultaat kan worden bereikt met een minder ver gaande overheidsingreep."

De waarborgen onder 3 spreken voor zich; wij hebben deze vertaald en ingebouwd in onze glijdende schaal, welke (in principe en principieel) begint met een aanbod van geschikte hulp-op-maat. Dat geschikte hulp of het nu praktische steun betreft in de vorm van eenvoudige adviezen, enkele gesprekken, een cursus, hulp in de huishouding, kinderopvang, oppas dan wel, aan de andere kant van het SPS-spectrum, specialistische intramurale zorg, een plaats in een tehuis of instelling - te allen tijde voorhanden dient te zijn, is de eerste waarborg die SPS biedt, een waarborg die in juridische zin besloten ligt in art. 4 van het Verdrag inzake de rechten van het kind. Het is overigens juist op dit punt dat de politiek door haar lakse opstelling vuile handen heeft en een national sociaalpedagogisch rampenplan de hoogste prioriteit verdient.

Waarborg 2, het legitieme doel, luidt in onze terminologie: het persoonswordingsbelang van het kind c.q. het recht van het kind op minimale persoonswording. Met betrekking tot dat persoonswordingsbelang c.q. minimum-recht, en dit brengt ons meteen naar waarborg 1 , hebben wij in hoofdstuk 8 (par. 8.2.2) tamelijk uitvoerig stilgestaan bij de positieve criteria (criteria die aangeven wat voor een evenwichtige ontwikkeling van het kind nodig is) van HEINER en BARTELS (de do's), en hebben wij in hoofdstuk 9 (par. 9.5.2) gewezen op de negatieve criteria (de don'ts) ontwikkeld door BARNETT e.a. (definities van en criteria voor de verschillende subtypen van kindermishandeling met aanduiding van gradaties per subtype). Wij volstaan hier (opnieuw) met een verwijzing naar de bijlagen bij deze studie: de criteria van BARNETT c.s. (c.q. CICCHETTI/TOTH) zijn in extenso (en in vertaling) opgenomen in bijlage III. Een combinatie van beide, dus van do's and don'ts, zou wellicht tot een catalogus van minimum-normen kunnen leiden, een set richtlijnen, waarop de rechter zich kan c.q. moet baseren. In voortdurende wisselwerking met de rechtspraktijk zou aldus een genuanceerde doch niet tot verstarring leidende concretisering en operationalisering van minimale persoonswording als interventie-criterium tot stand kunnen komen en tot verdere (progressieve) ontwikkeling worden gebracht (waarborg 1). Toch lijkt ons een belangrijkere waarborg gelegen in het volgende.

In de eerste plaats wordt binnen SPS in principe en principieel gewerkt op basis van met (aanstaande) ouders vrijwillig (dat wil zeggen op basis van verworven en/of aanvaarde inzichten) gemaakte afspraken. Wij zien hierin een belangrijke, zij het vooral psychologische waarborg. Het maken van afspraken betekent immers dat ouders daarop ook kun- 
nen worden aangesproken en daaraan kunnen worden gehouden. Wat is duidelijker en concreter dan een afspraak die (niet) is nagekomen? En waarvan men weet dat de nakoming eventueel - na toetsing aan minimum-criteria - voor de rechter kan worden afgedwongen? Wij volstaan op deze plaats met het vermelden van dit uitgangspunt; op verschillende plaatsen in deze studie legden wij ook het verband tussen het maken van afspraken en eventwele voorwaarden te verbinden aan (de uitkering van) opvoedingsgeld: wij komen daarop terug in par. 14.5.2.4.

In de tweede plaats bepleiten wij de ontwikkeling - parallel aan de algemene beginselen van behoorlijk bestuur, toegepast door de bestuursrechter - van algemene beginselen van behoorlijk gezinsrecht, toe te passen door de (al eerder door ons geopperde) gezins(bestuurs)rechter (een kinderrechter zou ons inziens alleen in het strafrecht nog een rol kunnen vervullen). Bij die ontwikkeling kunnen zowel de hierboven bedoelde do's and don'ts alsook de sociaal-pedagogische grondrechten waarvan al eerder (en vaker) sprake was, een nuttige rol vervullen. Aldus wordt de Trias pedagogica niet alleen beheerst en begrensd door constitutionele normen maar ook door rechtsbeginselen die tot de standaardgereedschapskist behoren van de rechter, beginselen die jurisprudentiële verfijning van '(on)behoorlijk ouderschap' mogelijk maken en rechterlijke controle op '(on)behoorlijk (gezins)bestuur' effectief.

\section{Rechtsbescherming}

Uiteraard betekent het aanbieden (met op de achtergrond de impliciete dreiging van rechterlijke oplegging) en (het aanzeggen van) het vorderen van de oplegging van hulp voor de rechter (of bijvoorbeeld het verbinden van voorwaarden aan de uitkering van opvoedingsgeld en het verminderen of stopzetten van die uitkering, het intrekken van bepaalde sociaalpedagogische voorzieningen wegens het niet nakomen van afspraken, het laten zakken voor een oudercursus, het administratief beboeten van het uitdelen van onpedagogische tikken, of wat een creatieve wetgever of toekomstig minister van Sociaal-Pedagogische Zaken verder nog maar bedenken kan): het uitoefenen van pedagogische macht door hulpverleners/ de staat. Daarmee is het risico van machtsmisbruik gegeven (handelen in strijd met de beginselen van behoorlijk bestuur/behoorlijk gezinsrecht), en de noodzaak van rechtsbescherming (het openstaan van bezwaar en beroep) van gezinsleden/ouders vastgesteld. Machtsmisbruik kan daardoor deels worden geredresseerd.

Machtsmisbruik voorkómen kan niet, wel kan het vóórkomen van machtsmisbruik worden tegengegaan/gemitigeerd door het werken met een glijdende-schaalscenario: van snelle en gemakkelijk toegankelijke vrijwillige opvoedingshulp (cursussen en ouderbegeleiding) bij consultatie- 
bureaus en scholen/schoolartsen (drempelverlagend één-loket-aanbod, dat wil zeggen: één loket vanaf de zwangerschap tot aan de schoolleeftijd en éên loket vanaf de schoolleeftijd), via vrijwillige vormen van thuishulpverlening, (semi-)residentiële hulpverlening aan het gezin en (semi-) residentiële hulpverlening ten behoeve van het aangemelde kind/de kinderen en/of één of beide ouders, naar de verplichte vormen van cursussen, ouderbegeleiding, thuishulpverlening, enzovoorts. Het opleggen van hulpverlening is dan immers niet een donderslag bij heldere hemel, maar het (psycho)logisch sequeel van herhaaldelijk mislukte afspraken en mislukte pogingen. Een sequeel dat, naar de mate van de kwaliteit van de voorafgegane hulp, minder als een overval, laat staan als een ontmaskering zal worden gezien. Terwijl ook bij dat sequeel, net zo goed als in de vrijwillige fase, naar een verfijnd en gevarieerd instrumentarium, en niet naar de botte bijl wordt gegrepen.

De goede wil van ouders dient in het recht net zo zeer te worden voorondersteld als de feilbaarheid en niet-alwetendheid van de staat: adequate rechtsbescherming op dit punt is altijd geboden, rechtsbescherming die baat vindt bij heldere afspraken, duidelijke wettelijke criteria (minimum-waarborgen/-normen) en deugdelijke beginselen van behoorlijk gezinsrecht. Steeds staat echter voorop: het recht van kind èn ouders op (voldoende capaciteit en kwaliteit van de) hulpverlening in het persoonswordingsbelang van het kind..224

Zie voor meer discussie hoofdstuk 9, par. 9.4 (Criterium-DE RUYTER: toevoeging en toespitsing) en par. 9.5 (Criterium-DE RUYTER: toetsing en bezwaren). Vgl. in dit verband ook de discussie ten alanzien van het "voorzorgsbeginsel" in hooldstuk 7, par. 7.3.2. Op deze plaats wijzen wij met betrekking tot dit beginsel nog op de (zoals altijd) wijze woorden van VAN DANTZIG (weergegeven door Paul SCHNABEL, '(...) NFGV ereprijs 1998 voor dr. A. VAN DANTZIG; een interview' MGV 1998/10, pp. 927-943, op p. 932): 'De lichamelijke gezondheidszorg heeft [haar] effectiviteit ook pas gaandeweg verworven, maar als je effectiviteit vooraf als uitsluitende voorwaarde voor het handelen stelt, dan kom je natuurlijk nooit verdier. Kijk maar naar kanker (...). (...) [Er is] niemand die voorstelt de strijd maar op te geven en te accepteren dat we aan kanker niets kunnen doen. Integendeel, iedereen beseft dat het een heel moeilijk probleem is en iedereen vindt dus ook dat we nog harder ons best moeten doen er een antwoord op te vinden. Waarom doen we bij psychische problemen niet hetzelfde? We beschikken in Nederland inmiddels over een heel goed ontwikkelde geestelijke gezondheidszorg, maar er is altijd te weinig geld en naarmate de problemen [en in het bijzonder de oorzaken, jw] meer zichtbaar worden, is er altijd de neiging er eerder minder dan meer geld voor beschikbaar te stellen [door VAN DANTZIG eerder als 'ontkenning" geduid: t.a.p., op p. 930, jw]. Toch zou dat laatste moeten en daarbij zouden we ook veel meer bereid moeten zijn te accepteren dat het geld vaak experimenteel ingezet zal worden, in situaties dus waarin we niet met zekerheid kunnen zeggen dat het ook helpt wat we doen.' 


\subsection{Ouderschapsondersteuning: het eind van de eeuw van het interventionisme}

In zijn boek Children in the international political economy merkt KENT, schrijvend over wereldwijde kindersterfte, op: ${ }^{225}$

'If we consider not only the clinical factors but also the social context we would see that almost all deaths of small children are due to some form of abuse or neglect, whether by the immediate family or by society at large.'

Staten zijn - individueel ('poor countries ... do have money') en collectief (art. 6 juncto art. 4, tweede volzin, tweede nevenschikking VRK) ${ }^{226}-$ verantwoordelijk voor de medisch-technisch onnodige dood van jaarlijks minimaal 10.000 .000 kinderen onder de vijf jaar. ${ }^{227}$ In het begin van deze eeuw was ook in Nedlerland sprake van een enorme medisch-technisch onnodige kinder- althans zuigelingensterfte. In 1992 oreert HERMANNS hierover: ${ }^{228}$

'De zuigelingensterfte bedroeg in sommige regio's enkele tientallen procenten. Medisch-technisch gezien was dat onnodig. De samenleving stelde in die tijd echter andere prioriteiten dan tegenwoordig. In een industriestad in het zuiden des lands kwam een groep verontruste burgers in actie toen daar in 1907 de zuigelingensterfte opliep tot vijftig procent. Ze organiseerde inzamelingsacties onder de burgerij en vroeg het gemeentebestuur en Provinciale Staten om een financiële bijdrage. Men wilde met het gekregen geld een melkkeuken openen, tijdens huisbezoeken ouders voorlichten over voeding en verzorging, en een consultatiebureau oprichten dat de gezondheid van de kinderen zou bewaken (...). De archiewen van de daartoe opgerichte Vereeniging Pro Infantibus laten zien dat, ondanks inzet van tientallen vrijwilligers en een sterke politieke lobby [!], het stervende jonge kind niet erg aansprak. Zo wordt de volgende reactie van de burgerij op een collecte beschreven: "Och, zo zeggen er velen, dit is een uitkomst voor de arme menschen; als de kinderen sterven, dan zijn deze gelukkig [in de hemel? -jw], en de ouders van een grooten last ontslagen." Typerend is ook de discussie in de Provinciale Staten, die geen subsidie toekenden. Bij het bespreken van dit

225 George KENT, Children in the international political economy, New York (etc.) 1995 , p. 34.

226 Kort weergegeven: de staat erkent het recht op leven en waarborgt het overleven van het kind mede in het kader van internationale samenwerking.

227 Het verschil tussen vermijdbare en niet vermijdbare kindersterfte was in 1991 ruim elf miljoen: 'about 89 percent of the total number of deaths of children under five were "unnecessary" or excessive." (KENT, t.a.p.)

228 J.M.A. HERMANNS, Het sociale kapitaal van jonge kinderen, inaugurele oratie Amsterdam 1992, Utrecht 1995 (tweede druk), p. 3. 
punt staat als argument vóór de subsidie in de notulen: "Wel wordt door dat college subsidie verleend voor de veredeling van het varkensras." (...)."

De tijden veranderen, maar veranderen wij in wezen ook? De auteur vervolgt: 229

'Er is de afgelopen tachtig jaar veel veranderd. Het leven van het pasgeboren of zelfs ongeboren kind, van de zuigeling en de peuter is zeer in waarde gestegen. De medische preventieve en curatieve zorg voor alle kinderen is sterk ontwikkeld. Het jonge kind is in ons land [!] zijn leven inmiddels zeker. Maar hoe staat het met de kwaliteit van zijn opwoeding?

Het is mede van de kwaliteit van die opvoeding (en in veel grotere mate dan van onderwijs conform art. 29 , lid 1 sub b en d VRK ${ }^{230}$ afhankelijk of het kind later oog heeft voor het lot van kinderen in andere, in arme, in onderontwikkelde landen. En voor het lot van kinderen in eigen land? Voor de (sociaal-)pedagogisch-technisch onnodige mishandeling van jaarlijks enkele tienduizenden kinderen in ons hoog-ontwikkelde Nederland? Ondanks vele vrijwilligers en sociaal bewogen beroepsbeoefenaren is er van een sterke politieke lobby die zich hun lot aantrekt, die zich sterk maakt voor 'de kwaliteit van het kinderlijk bestaan' (DE WINTER), ${ }^{231}$ aan het eind van de eeuw van het kind hoegenaamd niets ${ }^{232}$ te bespeuren. HERMANNS schetst hoe het zo ver met ons is kunnen komen, in welk (kinderbeschermings-)'systeem' - en mensenrechtelijk vacuüm - wij in de loop van deze eeuw opgesloten zijn geraakt: ${ }^{233}$

'Pas rond 1900 vonden maatschappelijke ontwikkelingen plaats die een aandacht voor opvoeding mogelijk maakten die in de geschiedenis van westerse landen ongekend was (...). De eeuw van het kind was volgens velen aangebroken (...). Ook de overheid zag voor zichzelf een aantal taken. Kinderarbeid werd verboden, de leerplicht werd ingesteld en het werd mogelijk onders uit de ouderlijke macht te ontzetten of te ontheffen. De overheid stelde niet alleen regels, maar ging ook

\section{HERMANNS, t.a.p.}

230 Kort weergegeven: het bijbrengen van eerbied voor de rechten van de mens en de voorbereiding van het kind op een verantwoord maatschappelijk leven in de geest van verdraagzaamheid, vriendschap tussen volken en bevolkingsgroepen enzovoorts.

231 Aangehaald door HERMANNS, i.o., p. 6.

232 Al zijn er lichtpuntjes, zoals de eerste Nederlandse wethouder gezinszaken in Nijkerk, die in NRC Handelsblad van 4 april 1998 opmerkt: 'Er zijn zeker mensen die vinden dat we ons ergens mee bemoeien waar we niets mee te maken hebben. Maar wij blijven van oordeel dat het goed is dat ouders worden geholpen bij de opvoeding."

233 HERMANNS, i.o., pp. 3/4-5 (curs. jw). 
geld vitgeven aan de opwoeding. Zo ontwikkelde zich gesubsidieerd onderwijs, hulpverlening, kinderbescherming en vorming. (...) Het accent lag daarbij vooral op het schoolkind en de puber. Het jonge kind (van nul tot vier jaar) moest iets langer wachten op zijn maatschappelijke ontdekking. Door vele pedagogen (...) werd al v6or het begin van onze eeuw het belang van de eerste levensjaren woor de verdere levensloop benadrukt. Deze visie leidde evenwel nauwelijks tot het scheppen van maatschappelijke voorzieningen die konden bijdragen aan een [verantwoorde, $j w]$ opvoeding van het jonge kind. (...) Het gezin, dat wil zeggen de (liefst biologische) ouders en vooral de moeder, werd voor jonge kinderen gezien als de beste maatschappelijke voorziening. Vrouwen werden hierdoor teruggedrongen tot het gebied van de verzorging en opvoeding van kinderen. Het traditionele gezinsmodel van een buitenshuis werkende vader en een voor de kinderen zorgende moeder werd tot exclusief opvoedingsinstituut verheven. Het idealiseren van het gezin ging zelfs zover dat het vragen van advies of hulp bij het opvoeden nauwelijks mogelijk was. Het hebben van problemen met zeer jonge kinderen werd een taboe. Men kon vrijwel uitsluitend terecht bij de artsen, bij wie men toch al moest zijn voor de licharnelijke zorg. Deze artsen, werkend in consultatiebureaus, propageerden met name de drie R's: rust, reinheid en regelmaat. Veel verder ging de hulp bij het opvoedlen niet.

Pas als het gezin er volledig en bewijsbaar een potje van maakte, stond de samenleving klaar: als duidelijk was dat het kind in het gezin met "lichamelijke en geestelijke ondergang werd bedreigd," werd er rigoureus ingegrepen. Het kind werd "beschermd." Als men in de eerste helft van deze eeuw over het verwaarloosde kind sprak, werd niet bedoeld dat deze kinderen te kort gekomen waren, maar dat ze in moreel en maatschappelijk opzicht ontspoorden in criminaliteit of andere ongewenste gedragingen (....). Er werd een systeem gecreëerd dat corrigerend optrad ten opzichte van ouders en/of kinderen: de kinderbescherming. (...) De dominante politieke en maatschappelijke opvatting bleef lange tijd [en is tot op vandaag, jw] dat een systeem voor hulp aan jonge kinderen er in essentie op gericht moet zijn de verzorging en opvoeding over te nemen als het gezin daartoe niet goed in staat is.. (...) Het maatschappelijke erfgoed woor de huidige ouders van jonge kinderen vertoont (...) nog [steeds, jw] te veel kenmerken van deze voorgeschiedenis.

Op het gebied van de opvoeding van het jonge kind is de maatschappelijke voorzieningenstructuur nog steeds beperkt. Het gezin wordt geacht deze opvoeding zelf vorm en inhoud te geven. Veel hulp mogen ze niet vragen en ook niet verwachten. In het bijzonder wan moeders wordt nog steeds verwacht dat ze onbetaald opvoedingsarbeid verrichten. Aan die opvoedingsarbeid worden bovendien hoge eisen gesteld. Kinderen moeten zo gekoesterd en onderwezen worden dat ze op vierjarige leeftijd als leergierige kant en klare scholiertjes worden afgeleverd. Ze moeten daarbij van hun moeder voldoende emotionele basiszekerheid hebben meegekregen om zonder psychische problemen volwassen te kunnen worden. Ook nu is het nog zo dat pas als het gezin duidelijk in zijn taak te kort schiet, de samenleving in actie komt [ex post-interventionisme, jw]. Op deze principes is een systeem van jeugdhulpverlening gebaseerd dat moeilijk veranderbaar is gebleken. (...) Het geld wordt volgens hetzelfde [interventionische, jw] stramien uitgegeven: meer dan negentig procent van het budget wordt in typen vam hulpverlening gestoken die de opvoeding van ouders overnemen. De rest wordt uitgegeven aan ambulant werk en preventief werk. 
Het is dan ook geen wonder dat de term jeugdhulpwerlening bij ouders eerder angst dan hoop losmaakt. (...) Beschreven [is] hier "het systeem, met zijn historische wortels en structurele eigenschappen, waarin de werkers zitten opgesloten [met de maatschappij en de politiek als cipiers, jw]. (...) De onevenwichtigheid van het hulpaanbod is (...) evident. Een wezenlijk kenmerk blijft "afwachten tot het fout gaat"."

En als het fout gaat, gaat het goed fout, want als het fout gaat met een (jong) kind, gaat het fout voor een mensenleven, voor mensen die dat leven kruisen, en voor een volgende generatie. Tenzij een wonder geschiedt. Het wonder van de wetende getuige (MILLER), ${ }^{234}$ de helpende buitenstaander (DE RUYTER) (235 $^{235}$ nog wonderbaarlijker, het wonder van de verwerking op eigen kracht. Wonderen die soms gebeuren, niet dankzij maar ondanks de maatschappij waarin we kinderen laten leven. Het excuus is bekend, en is vaker gehoord: we hebben het niet geweten, en hadden we het geweten, wat hadden we kunnen doen? Wel, we weten het nu, en we kunnen wat doen, heel veel zelfs: de eeuw van het interventionisme achter ons laten en ruim baan maken voor de eeuw van de rechten van het kind. Tegen een prijs die ons allen verrijkt: ${ }^{236}$

'Er zijn op dit moment in Nederland ongeveer 900.000 kinderen jonger dan vier jaar. (...) Deze kinderen zijn bezig fundamentele conclusies te trekken over hoe mensen zijn en wat ze zelf zijn. Deze conclusies zullen voortdurend een rol spelen wanneer ze op oudere leeftijd en in andere situaties met mensen te maken krijgen. Het investeren in de opvoeding van deze jonge kinderen is daarom maatschappelijk gezien zeer de moeite waard.

(....) [E]r [is] meer dan voldoende wetenschappelijke en praktische kennis voorhanden (...) om (...) opvoedingsondersteuning inhoud te geven. We gaan uit van een transactioneel model. Dus er is ook een andere kant. Iedereen die regelmatig met jonge kinderen omgaat, kent deze andere kant. Het jonge kind confronteert ons door zijn manier van reageren, zijn openheid en directheid steeds opnieuw op wezenlijke menselijke waarden, zoals eerlijkheid, wederkerigheid, nieuwsgierigheid, creativiteit en emotionaliteit. Het jonge kind investeert voortdurend in ons. [T]oenemende maatschappelijke aandacht voor het jonge kind zal daarom ongetwijfeld een bijdrage leveren aan een beter bestaan voor ons allen.'

Voor de goede orde: onder 'opvoedingsondersteuning' verstaat de auteur (bijna) hetzelfde als wat wij in deze paragraaf met 'ouderschapsonder-

Alice MILLER, Zelfkennis in ballingschap; De verdringing van de kindertijd, tot welke prijs? Houten 1989, pp. 144 e.v. (en 167); dez., Het drama van het begaafde kind, Houten 1995 (18e druk), p. 29 (i.f.). Zie ook hoofdstuk 10, par. 10.4.1. En vgl. BAARTMAN, Opvoeden kan zeer doen, a.w., pp. 159/160.

236 HERMANNS, i.o., p. 27. 
steuning" hebben bedoeld: ${ }^{237}$ 'al die activiteiten die specifiek tot doel hebben de opvoedingssituatie van kinderen te verbeteren'; waaraan we evenwel de woorden zouden willen toevoegen: en voor ouders te verlichten.

\section{5 .2 .3}

\section{Opvoedingsonderwijs: jong geleerd is oud gedaan, maar men is nooit te oud om iets te leren}

Drie soorten lessen willen we bepleiten in deze subparagraaf: lessoort 1: het goede voorbeeld (opvoedkundige lessen voor de politiek); lessoort 2 * onderwijs aan kinderen als de toekomstige generatie opvoeders; en lessoort 3: (algemene en speciale) ouderschaps(deficiëntie-)cursussen. Deze laatste lessoort hangt deels samen met de tweede, deels met ouderschapsondersteuning/hulpverlening: de bepleite algemene cursus moet de huidige onderwijsachterstand ondervangen totdat deze over een generatie is ingehaald; speciale cursussen zijn eigenlijk stukjes die horen te worden gelegd in een uitgekiende hulpverleningspuzzel.

\section{Lessoort 1: het goede voorbeeld}

De politiek, die door haar lakse opstelling en grove nalatigheid (vandaar: ernstige en passief-systematische mensenrechtenschendingen) vuile handen heeft - en met die vuile handen het blazoen van de staat internationaalrechtelijk besmeurt -, kan dat blazoen niet beter oppoetsen dan door het bestuderen en (mutatis mutandis) navolgen van goede buitenlandse voorbeelden - waarmee ook binnenslands het goede voorbeeld wordt gegeven. Gedacht kan hier in de eerste plaats worden aan buitenlandse lessen met betrekking tot een meldplicht (zie de vele literatuurverwijzingen aan het slot van par. 14.5.2.1) en het daaraan vastgeknoopte stelsel van follow $u p$-voorzieningen en preventieve maatregelen, als integrerend onderdeel van een breder - en breed gedragen - expliciet nationaal gezinsbeleid. Zeker niet de laatste of geringste buitenlandse les die de vaderlandse politiek ter harte zou kunnen nemen, is die van FREEMAN: ${ }^{238}$

[ $\mathbb{N}]$ othing is a clearer statement of the position that children occupy in society, a clearer badge of childhood, than the fact that children alone, of all people in society, can be hit with impunity. There is probably no more significant step that could be taken to advance both the status and protection of children than to outlaw the practice of physical punishment. Much child abuse is, we know, punish-

238 Michael FREEMAN, 'Children's rights in a land of rites," in: Bob FRANKLIN (ed.), The handbook of children's rights;" Comparative policy and practice, London/New York 1995 , pp. $70-85$, op p. 76. 
ment which [h]as gone awfully wrong. Sweden goes even further; their Parenthood and Guardianship Code outlaws "other humiliating treatment" as well."

Een ander buitenlands voorbeeld is Finland, waar ouders van kinderen onder de vier jaar de wettelijke keus hebben ('absolute statutory right") tussen dagopvang voor hun kind ('municipal day care") of opvoedingsgeld (home care allowance': zorgvergoeding). ${ }^{239}$ Doch ook aan Indonesië, met zijn 'mass parent education programme' (BKB), ${ }^{240}$ kunnen wij ons spiegelen.

Naast deze en (vele) andere buitenlandse lessen is er bovendien en bovenal het in enkele jaren tijd tot een indrukwekkende omvang uitgegroeide internationale lespakket van het Comité inzake de rechten van het kind, door HODGKIN en NEWELL in opdracht van UNICEF in een lijvig kindervolkenrechtelijk cursusboek - het Implementation handbook for the Convention on the rights of the child - ondergebracht. ${ }^{241} \mathrm{De}$ (gezaghebbende doch in strikte zin niet bindende) ${ }^{242}$ uitleg die het Comite geeft

239 Implementation handbook for the Convention on the rights of the child (zie hierna), p. 232 L.k. ('Government support for parenting').

240 "Indonesia launched a programme "BKB" to "empower poor mothers and communities with knowledge and skills allowing them to interact with and provide mental stimulation for the very young child, i.e. the 0-3 year-old child. (...) Close to 1.3 million mothers in some 18,500 villages have been trained in the programme. (...) [T] he Indonesian approach to early child development is unique in a number of ways. Firstly, it focuses on the 0-3 year-old children rather than the 3-6 yearold children. Secondly, it aims at educating mothers and communities in early child stimulation thus avoiding expensive solutions such as institutions. Thirdly, it is implemented entirely through NGOs and women's group[s] and thus is very much seen as 'belonging' to the community. Fourthly, it has successfully combined parental monitoring of physical and mental growth via the introduction of a unique chill growth and development chart based on milestones in Indonesian child development. And fifthly, in 1991, President SOEHARTO elevated the BKB programme to a 'National Monument' thus giving it the highest status and importance possible in Indonesia." (...)" (Implementation handbook for the Convention on the rights of the child - zie hierna -, p. $228 \mathrm{l.k}$.)

241 Implementation handbook for the Convention on the rights of the child, prepared for UNICEF by Rachel HODGKIN and Peter NEWELL, New York/Genève 1998.

242 Vgl. art. 45, aanhef en onder d VRk. Vgl. voor de werkwijze/bevoegdheden van het Comité: Jacqueline SMITH, 'Rapportageverplichting onder het [VRK]," FJR 1998/1, pp. 2-6, op pp. 3-5. Vgl. met betrekking tot het rechtskarakter (de juridische 'status') van de opvattingen/uitleg van het Comité de interventie van (Th.C.) VAN BOVEN (Mededelingen van de Nederlandse Vereniging voor Intemationaal Recht 116, Verslag van de Algemene Ledenvergadering, bespreking der preadviezen van M.T. KAMMINGA en L.A.D. KEUS, Staatsaansprakelijkheid jegens individuen: beginselen en procedures, Deventer 1998, pp. 4-6, op pp. 5/6): "Wat de aard van (...) besluiten en uitspraken [van toezichthoudende organen op het gebied van 
aan diverse verdragsbepalingen, betreft evenwel meer dan een in voorkomend geval al of niet te volgen goed voorbeeld. De politiek wordt hier niet alleen getracteerd op broodnodige kindervolkenrechtelijke educatie maar ook geconfronteerd met een kindervolkenrechtelijke marsroute en de niet op Nederlandse dijken afketsende klaroenstoten die de aanbevelingen $^{243}$ van een verdragsorgaan met een vrijwel universeel mandaat, en dito verantwoordelijkheid ten opzichte van kinderen, ${ }^{244}$ het karakter geven van een marsbevel. Vanwege hun gemeenschappelijke juridische noemer en dringende rechtspolitieke strekking stellen we hier enkele lessen uit het UNICEF-handboek in het gelid (sommige vallen onder reeds aan de orde gestelde, andere onder nog te behandelen voorstellen). Met het oog op die noemer en strekking citeren we eerst de aanhef van het voorwoord: ${ }^{245}$

'The nearly universal ratification of the Convention on the rights of the child is a remarkable achievement. The fact that virtually every country in the world has committed itself to a code of binding obligations towards its children gives us tremendous hope for the future and puts children's rights at the cutting edge of

de rechten van de mens] betreft, lijkt het te ongenuanceerd om uitsluitend een onderscheid te maken tussen bindend en niet-bindend. (...) Ik ben geneigd (...) meer waarde toe te kennen aan het gezag van het toezichthoudende comité, aan follow-up controle en aan de bereidheid wan staten zich naar besluiten en uitspraken te richten.'

243 Op dit moment zijn deze nog nict rechtstreeks tot Nederland gericht: naar verwachting zal het Comité pas in de loop van 1999 toekomen an de bespreking van het eerste Nederlandse statenrapport (vgl. SMrTH, 'Rapportageverplichting onder het [VRK],' t.a.p., op p. 5 r.k. i.f.). Dit laat evenwel het feit onverlet dat Nederland allang lering had kunnen trekken uit de aanbevelingen en suggesties (ex art. 45, aanhef en onder $d$ VRK) gericht aan andere (rijke) staten.

Overigens is er van het Nederlandse - te laat ingediende - (regerings)rappor slechts een Engelstalige ('gestencilde') versie, na verkregen toestemming van hei ministerie van Buitenlandse Zaken, beschikbaar, hetgeen op gespannen voet lijki te staan met de eis van 'algemene beschikbaarheid' ex art. 44, lid 6 VRK (med, gezien in verband met art. $42 \mathrm{VRK}$ ). Ook in formele (procedurele) zin is Neder land maar moeilijk een mensenrechtelijk gidsland te noemen.

244 De leden van het Comité achten zich 'solely accountable to the children of th world' (Implementation handbook for the Convention on the rights of the chila a.w., chairpersons' 'Preface,' p. xi). Niettemin strekt deze verantwoordelijkhei zich niet uit tot gebieden waar het Comité geen bevoegdheid heeft, dus: Ameri kaanse en Somalische kinderen uitgezonderd. (Wat uiteraard niet afdoet aan d verantwoordelijkheid van de wereldgemeenschap, dat wil zeggen zowel van de $\mathrm{V}$ : - en organisaties als UNICEF of regionale organisaties - als van individuele states ten opzichte van deze kinderen.)

245 Carol BELLAMY, 'Foreword,' Implementation handbook for the Convention on th rights of the child, a.w., p. ix. 
the globall struggle for human rights. It also places a tremendous responsibility on governments and civil society to live up to these commitments.'

\section{Rights of the child in constitutions}

De eerste les (van de zeven die wij uit de 'cursus' hebben gelicht) betreft de constitutionalisering van (fundamentele) rechten van het kind: ${ }^{246}$

'Because of children's physical, emotional and economic dependence on adults, they may deserve special measures of protection within the constitution; and because the future prosperity of the State depends on them, it is also in the State's interest to accord them special constitutional rights.'

\section{A 'comprehensive national strategy' for children}

De tweede les betreft een expliciet en overkoepelend nationaal kind- c.q. jeugdbeleid (kinderen- en jongerenbeleid): ${ }^{247}$

"The Committee on the rights of the child, often quoting the principle of "first call for children," promoted at the World Summit for Children, has emphasized that children must be accorded a high, or higher, priority. In stressing the need for a comprehensive approach to the implementation of children's rights, the Committee has frequently promoted the need for a national policy or plan of action reflecting not only the World Summit goals but also the implementation of the whole Convention. (...)

[Ter attentie van Pakistan:] "The Committee encourages the State Party to undertake a thorough review of its national plan of action on children. It is recommended that the goals of the plan should be achieved, measurably, within a specific timeframe, and that the Convention on the rights of the child be fully integrated into the plan".

\section{Budgeting and budgetary analysis}

De derde opvoedkundige les voor de politiek betreft onder meer de wijze waarop kinderen het slachtoffer worden gemaakt van bezuinigingen: ${ }^{248}$

'Ter attentie van Nieuw Zeeland:] "The Committee also suggests that the State Party undertake a study on the impact on children and their families of the economic reform process that has been ongoing during the last severall years in terms of its impact on government budgetary resources available for support services, as well as on the impact of unemployment and changed conditions of employment on children, young persons and their families. Conclusions from such a study could be a useful starting point for developing a comprehensive strategy for future action"."

Implementation handbook, a.w., pp. 63-64. 
[Ter attentie van Zweden:] "(...) [T] he Government should ensure that spending cuts carried out by municipalities are effected with due regard for the best interests of children, particularly those from the most vulnerable groups (...)"'

[Ter attentie van Engeland:] "With respect to article 4 of the Convention, the Committee is concerned about the adequacy of measures taken to ensure the implementation of economic, social and cultural rights to the maximum extent of available resources. It appears to the Committee that insufficient expenditure is allocated to the social sector both within the State Party and within the context of international development aid; the Committee wonders whether sufficient consideration has been given to the enjoyment of fundamental rights by children belonging to the most vulnerable groups in society".'

\section{Effective coordination/permanent government mechanisms}

De vierde internationale les betreft de effectieve, structurele en permanente coördinatie van het nationale kind-(en gezins)beleid - voor zover een staat zo'n beleid (expliciet) kent: ${ }^{249}$

[Ter attentie van Mauritius:] "The Committee recommends that the State Party strengthen coordination between the various governmental mechanisms involved in children's rights, at both the national and local levels, with a view to developing a comprehensive policy on children and ensuring effective evaluation of the implementation of the Convention in the country".'

"[Ter attentie van de Filippijnen:] "Coordination between the various governmental agencies involved in the implementation of the Convention and its monitoring should be ensured, and efforts should be made towards closer cooperation with nongovernmental organizations".'

'TTer attentie van Argentinië:] "The Committee is concerned that sufficient administrative and other measures seem not to have been taken to facilitate an effective coordination of the implementation of the Convention on local, regional and national levels"."

"TTer attentie van Chili:] "(...) an overall national mechanism be set up with the mandate to assure continuing supervision and evaluation throughout the country of the implementation of the Convention, which is particularly important within the context of the realization by the Government of the decentralization programme"."

"[Ter attentie van Canada:] "The Committee is concerned that sufficient attention has not been paid to the establishment of a permanent monitoring mechanism 
that will enable an effective system of implementation of the Convention in all parts of the country. (.... $)^{\text {m? }}$

[Ter attentie van Denemarken:] "The Committee is encouraged to note the existence of the Government's Children's Committee, and the Inter-Ministerial Committee on Children which is composed of civil servants from 16 ministries".

\section{Child impact analysis}

De vijfde (rechtspolitieke) les betreft wat wij straks (in par. 14.5.2.5) zullen aanduiden als persoonswordingseffectrapportage (PER): ${ }^{250}$

"The Committee on the rights of the child has emphasized that article 3(1) [the best interests of the child as a guiding principle in the application of the Convention; lees: het recht van elk kind op optimale persoonswording als dragend en leidend beginsel, $\left.{ }^{251} \mathrm{jw}\right]$ is fundamental to the overall duty to undertake all appropriate measures to implement the Convention for all [!] children under article 4 [ensuring that the maximum extent of resources are made available for chilldren's programmes]. (...) Where a plan of action [om te beginnen (de hoofdlijnen van) het nationale kind- en gezinsbeleid, jw] is proposed, the "best interests" principle [lees: het recht van elk kind op optimale persoonswording, jw] should be fully integrated. Integration of the principle must imply the development of mechanisms to assess the impact of government actions on children and to incorporate the results of the assessment in policy development (...). (...)

In relation to the vital issue of resource allocation, the best interests principle demands first that within the overall central government budget, and regional and local budgets, there be an adequate allocation for children (...). There must therefore be sufficient analyses of relevant budgets to determine the proportion and amount allocated to children. In considering priorities in resource allocation, both between and within services at the national and local level, best interests must be a primary consideration. The non-discrimination principle is also important (...) [since it] allows for positive discrimination - that is, affirmative action - on behalf of particularly disadvantaged or vulnerable groups of children. Thus, the setting

Implementation handbook, a.w., pp. 41-43.

251 Hoewel deze in de onderhavige studie werdedigde ontwikkelingspsychologische en (sociaal-)pedagogische concretising van 'het belang van kind' uiteraard niet van het Comité afkomstig is, is het van belang hier in herinnering te brengen dat het Comité 'het belang van het kind' tot éen wan de vier algemene verdragsbeginselen rekent, tezamen met non-discriminatie, overleven en ontwikkeling, en respect voor de mening (en dus de zich ontwikkelende vermogens) van het kind (c.q. hoorrecht) - welke alle vier in "het recht van elk kind op optimale persoonswording' besloten liggen. Zo hebben leden van het Comité bij de behandeling van statenrapporten te kennen gegeven dat het belang van het kind als 'both broader and deeper than the issue of custody in divorce cases' moet worden beschouwd en, meer in het algemeen, "should not be viewed merely legalistically" (Implementation handbook, a.w., p. 42 r.k.). 
of priorities and targeting within resource allocation is vital to reducing 【sociaalpedagogische, $\mathrm{jw}$ ] discrimination in overall impllementation. (....)

Similarly, the impact on children of economic adjustment policies and budgetary cuts must be considered in the light of the best interests principle and other basic principles. (...)

The best interests principle should guide the deliberations of parliaments as well as the policies of governments: [ter attentie van Frankrijk:] "The Committee also welcomes the decision taken by the Government to submit an annual report to the Parliamentary Assemblies on the implementation of the Convention and on its policies in relation to the situation of children in the world. This procedure will contribute to emphasizing the importance of the principle of the best interests of the child, which is a primary consideration to be taken into account in all actions concerning children, including those undertaken by legislative bodies".'

Op dit laatste fenomeen - periodieke rapportages aan het parlement komen we terug in par. 14.5.2.6 ('kinder-KALSBEEKrapportage'). Bij het belang dat het Comité hecht aan de 'persoonswordingseffectrapportage' (child impact analysis), staan we nog kort stil in par. 14.5.2.5, waar we tot een op de Nederlandse EER (emancipatie-effectrapportage) geënte (nadere) invulling overgaan.

6. The child's right to protection from corporal punishment/traditional practices involving violence and/or prejudicial to health

De zesde politiek-opvoedkundige (ofwel sociaal-pedagogische) les van het Comité tilt de hierboven gememoreerde (buitenlandse) les van FREEMAN op juridisch bindend (dat wil zeggen minimaal soft law-)niveau: ${ }^{252}$

'The Committee on the rights of the child has indicated that the Convention on the rights of the child requires a review of legislation to ensure that no level of violence to children is condoned. In particular, the Committee has emphasized that corporal punishment in the family, or in schools and other institutions, or in the penal system is incompatible with the Convention. (...)

The specific reference to protecting children from traditional practices comes in article 24(3), which obliges States to "take all effective and appropriate measures with a view to abolishing traditional practices prejudicial to the health of children" (...). But traditional practices also need to be reviewed to determine whether they involve any form of physical or mental wiolence from which children must be protected under article 19.'

Niettemin heeft het Comité hierbij niet zozeer juridisch afdwingbare verboden als wel een mentaliteitsverandering voor ogen: ${ }^{253}$ 
The Committee has stressed that both legislative and educational measures are needed to change attitudes and practice. It has commended States Parties that have implemented a clear prohibition of corporal punishment within the family as well as in institutions (including Austria, Sweden, Norway, Finland and Cyprus). And it has stressed that the purpose is educational rather than punitive and that such reforms tend to lead to less rather than more prosecutions of parents, because of the change in attitudes that they promote. (...)

[Ter attentie van Spanje:] "(...) [T] he Committee expresses concern at whe wording of article 154 of the Spanish Civil Code which provides that parents 'may administer punishment to their children reasonably and in moderation,' which may be interpreted to allow for actions in contradiction with article 19 of the Convention. (...) [T] The Committee encourages the Spanish authorities to pursue the law reform to ensure full compliance of the domestic legislation with the provisions of the Convention. (....)"

[Ter attentie van Engeland: ${ }^{254}$ "The Committee is disturbed about the reports

254 Inmiddels heeft ook de Europese Commissie voor de rechten van de mens in A tegen het Verenigd Koninkrijk (Application No. 25599/94; rapport van de Commissie d.d. 18 september 1997) Engeland (pedagogisch) op de vingers getikt: '37. In its COSTELLO-ROBERTs judgment (...), the Court [het Europese Hof voor de rechten van de mens] recalled that it had already held that corporal punishment may constitute an assault on a person's dignity and physical integrity as protected under Article 3 [EVRM]. However, the Court also recalled that, in order for punishment to be "degrading" and in breach of Article 3, the humiliation or debasement involved must attain a particular level of severity and must in any event be other than that usual element of humiliation inherent in any punishment: (...).

"40. The Government place emphasis on the fact that the caning of the applicant was not administered in school or by public authorities but in the applicant's home by his stepfather and thus lacked the element of "institutionalised violence" (...). While it is true that the punishment was administered privately at home, rather than in the institutional setting of a school, this fact cannot in the view of the Commission be determinative. (...) [T]he injuries inflicted on the applicant (in this case, a young boy) are unacceptable "whoever were to inflict the punishment, be it parent or teacher" (...).

"41. The Commission accordingly considers that (...) the corporal punishment inflicted on the applicant caused him significant physical injury, pain and humiliation which attained such a level of seriousness that it constituted degrading treatment or punishment within the meaning of Article 3 of the Convention.

42. The question remains whether the State may be held responsible for such treatment or punishment, administered as it was not by an agent of the State or by a teacher but by the applicant's stepfather.

'45. The Commission recalls (...) that it has previously held that, even in the absence of any direct responsibility for the acts of a private individual under Article 3 of the Convention, State responsibility may nevertheless be engaged through the obligation imposed by Article 1 of the Convention "to secure ... the rights and freedoms defined in Section 1 of this Convention." (...) [T] he Commission [has previously] held (...) that "the United Kingdom was responsible under the Con- 
it has received on the physical and sexual abuse of children. In this conmection, the Committee is worried about the national legal provisions dealing with reasonable chastisement within the family. The imprecise nature of the expression of reasonable chastisement [maar vergelijk ook het "pak woor de broek" van de Nederlandse regering: zie (het slot van) par. 14.4.3.1.2, jw] (...) may pave the way for it to be interpreted in a subjective and arbitrary manner. Thus, the Committee is concerned that legislative and other measures relating to the physical integrity of children do not appear to be compatible with the provisions and principles of the Convention, including those of its articles 3,19 and 37. (...) The Committee is (...) of the opinion that additional efforts are required to overcome the problem of violence in society. The Committee recommends that physical punishment of children in families be prohibited in the light of the provisions set out in articles 3 and 19 of the Convention. In connection with the child's right to physical integrity as recognized by the Convention, namely in its articles $19,28,29$ and 37 , and in the light of the best interests of the child, the Committee suggests that the State Party consider the possibility of undertaking additional education campaings. Such measures would help to change societal attitudes towards the use of

vention, Articles 1, 3 and 8 of which having imposed a positive obligation on High Contracting Parties to ensure a legal system which provides adequate protection for children's physical and emotional integrity" (...). (...)

'48. (...) In order that a State may be held responsible it must in the view of the Commission be shown that the domestic legal system (...) fails to provide practical and effective protection of the rights guaranteed by Article 3 (...).

'49. In determining whether such protection is provided, the Commission attaches importance to the international recognition of the need for the protection against all forms of physical ill-treatment of children, who by reason of their age and vulnerability are not capable of protecting themselves. The Commission has had particular regard to the UN Convention of the rights of the child (...). The Commission notes that by Article 19 of the UN Convention, States are enjoined to take all appropriate measures "to protect the child from all forms of physical or mental violence, injury or abuse."

'52. (...) In this connection, the Commission notes that, in its concluding observations of 15 February 1995 on the initial report of the United Kingdom, the UN Committee on the rights of the child expressed concern about the national legal provisions dealing with reasonable chastisement within the family, observing that the "imprecise nature of the expression of reasonable chastisement may pave the way for it to be interpreted in a subjective and arbitrary manner" (...). (...)

'55. The Commission, accordingly, finds that the domestic law failed to provide the applicant with adequate and effective protection against corporal punishment which was in the circumstances of the case degrading within the meaning of Article 3 of the Convention and that the applicant was a victim of treatment or punishment contrary to Article 3 of the Convention for which the United Kingdom must be hell responsible. (...)'

Inmidldels (we schrijven een jaar later) heeft ook het Europese Hof zich over deze zaak gebogen en Engeland veroordeeld tot betaling van $f 30.000$ smartegeld en $f 60.000$ voor proceskosten (NRC Handelsblad 24 september 1998, p. 5, onder de kop: 'Britse ouder mag niet slaan'). 
physical punishment in the family and foster the acceptance of the legal prohibition of the physical punishment of children"."

In (weliswaar) ander verband (maar daarom niet minder pertinent) stelt het Implementation handbook onomwonden: $:^{255}$

"That such legislation might be, at the end of the day, unenforceable is not the point. Law has an important educational function as well."

\title{
7. Protective and preventive measures: art. 19(2)
}

De zevende en laatste hier aan de politiek voorgehouden les betreft de 'non-exhaustive list of measures that States should take to protect children and to prevent violence' in art. 19, lid $2 \mathrm{VRK}^{256}$ Ook hier geeft Zweden het goede voorbeeld: ${ }^{257}$

'Preventing abuse in Sweden: Swedlen's Initial Report notes: "The best protection against the abuse of children is, of course, to make it easier for parents to be good parents, and in this way to prevent the child being neglected and abused ${ }^{\mathrm{H}}$.'

\section{Elders in het Implementation handbook lezen we:258}

\begin{abstract}
'Most nations of the world have a history of laws and customs that assumes parental "ownership" of children - an assumption that parental rights over children could be exercised for the benefit of the parents alone. These laws and customs are now being rethought in many parts of the world. The Convention requires that current legal principles of parental rights be translated into principles of parental responsibilities - the responsibilities of parents to act in the best interests of their children. (...) Any breach of [the child's] rights [under the Convention] (including failure to respect [and promote] children's evolving capacities) is likely to be contrary to the child's bests interests. (...) The State (...) has a duty to advise and educate parents about their responsibilities."
\end{abstract}

\section{En op weer een andere plaats: ${ }^{259}$}

'There exists a growing recognition of the importance of early child development within the family for the prevention of violence and other forms of crime, both in childhood [adolescence, jw] and later life. This recognition provides further moti-

255 Implementation handbook, a.w., p. 359 1.k.

256 Implementation handbook, a.w., p. 247 e.v.

257 Implementation handbook, a.w., p. $2481 . \mathrm{k}$.

258 Implementation handbook, a.w., pp. $227 / 228$ (curs. jw).

259 Implementation handbook, a.w., p. 81 ('Preparation for parenthood'; curs. jw). 
vation for developing comprehensive support and education programmes for parenting and preparation for parenthood.'

Lessoort 2: onderwijs aan kinderen als de toekomstige generatie opvoeders Veranderde maatschappelijke inzichten en omstandigheden vergen dat in toenemende mate in het onderwijs aandacht wordt besteed aan de sociaal-emotionele ontwikkeling van kinderen en een vroegtijdige voorbereiding op de zware verantwoordelijkheid van het moderne ouderschap. In dit kader verdient het aanbeveling kinderkennis (kinder- en ontwikkelingspsychologie) en ouderkunde (pedagogiek, kennis van opvoedingsstijlen en -strategieën) als verplichte vakken in te voeren vanaf de basisschool; op de middelbare school dienen daar de vakken zelfkennis (psychologie, in het bijzonder persoonlijkheidsleer en psychopathologie) en relatiekunde (toegepaste psychologische kennis en vaardigheden) aan te worden toegevoegd. Daarnaast dienen kinderen van jongs af aan wegwijs te worden gemaakt in de SPS-filosofie, -methoden en -technieken, dat wil zeggen in de (grond-/kern)rechten van kinderen en in de voorzieningen, instellingen en diensten die van die rechten het sequeel zijn.

We onderbouwen dit pleidooi met twee korte citaten. Het eerste is van DERKSEN:260

'De belangrijkste haalbare mogelijkheid is het beïnvloeden van de opvoedingspraktijken. (...) Geef elke burger tijdens zijn schoolcarrière een opleiding in de psychologie en pedagogiek van het opvoeden van kinderen. Binnen de kinder- en ontwikkelingspsychologie en pedagogiek is een hoeveelheid kennis en ervaring aanwezig die niet wordt overgedragen aan gewone mensen, terwijl deze mensen wel de opvoeders zijn van de nieuwe generatie. Iemand in deze tijd leren met een computer om te gaan en niet leren hoe je een kind opvoedt, is een frappante vorm van korte-termijndenken. Men richt zich wel op de productiviteit van zo iemand voor de arbeidsmarkt over laten we zeggen vijf of tien jaar, maar niet op hoe deze persoon over vijftien jaar weer een volgend lid aan de gemeenschap helpt toevoegen. Het onderricht in kinderpsychologie en opvoedingsstrategieën zou al op de basisschool onderdeel van het lesprogramma kunnen gaan uitmaken en een vervolg krijgen op elke middelbare school.'

Het tweede van BAARTMAN: ${ }^{261}$

260 J.J.L. DERKSEN, Handboek persoonlijkheidsstoomissen; Diagnostiek en behandeling van de DSM-IV en ICD-10 persoonlijkheidsstoomissen, Utrecht 1993, pp. 256/257 (eerder aangehaald in hoofdstuk 7, par. 7.2.3.2).

H.E.M. BAARTMAN, 'Primaire preventie van kindermishandeling: onbegonnen werk?' Nederlands Tijdschrift voor Opvoeding, Vorming en Onderwijs/NTOVO 1996, pp. 17-33, op p. 29. 
'Primaire preventie [van kindermishandeling] kan (...) om twee verschillende redenen op kinderen en jongeren gericht zijn. Men kan ze benaderen als potentiele slachtoffers of als de volgende generatie volwassenen en opvoeders. (...) Er valt naar het mij voorkont, meer te verwachten van onderwijs waar in het kind benaderd wordt als potentiële opvoeder dan als potentieel slachtoffer. Ervan uitgaande dat hef overgrote deel van de scholieren later kinderen zal opvoeden, zou, met name in het voortgezet onderwijs, aandacht besteed moeten worden aan die toekomstige taak. Op de agenda van dat onderdeel van het curriculum horen dan thema's als man-vrouw-relaties, opvoeding en ontwikkeling van kinderen, instituties en werkwijzen van zorg- en hulpwerlening voor gezinnen en opvoeders.'

\title{
Lessoort 3: ouderschaps(deficiëntie-)cursussen
}

BAARTMAN maakt het belangrijke onderscheid tussen 'gemeenzaamheidsproblematiek' en 'kundigheidsproblematiek.' Met kundigheid wordt bedoeld 'kennis en vaardigheden' in 'technische' zin: ${ }^{262}$

\begin{abstract}
'Het opwoeden van een kind vergt kennis van zaken en vaardigheden. Hierbij is te denken aan kennis van de ontwikkeling van kinderen, kennis van het effect van pedagogische praktijken als disciplineren en aan vaardigheden als communiceren, conflicthantering, "problemsolving," verzorging, het vormgeven aan een dagritme en het gecontroleerd omgaan met eigen gevoelens in de interactie met het kind."
\end{abstract}

Kundigheidsproblematiek duidt op een 'technisch' tekort in het 'perspectief nemen,' de eerste dimensie van pedagogisch besef, waarbij het gaat om 'het adequate van de perceptie van de ouder van het gedrag van het kind. ${ }^{263}$ Bij gemeenzaamheid gaat het, in 'relationele' zin, 'om de verhouding tussen de mate waarin men recht doet aan de ander en de mate waarin men recht doet aan zichzelf. ${ }^{264}$ Gemeenzaamheidsproblematiek duidt dan ook op een te grote, niet hanteerbare (en vaak verwrongen) ...

'(...) spanning tussen het verlangen naar een goed leven voor zichzelf en de plicht zorg te dragen voor het goede leven van het kind., 265

We zijn hier aanbeland bij de tweede, de morele dimensie van pedagogisch besef: ${ }^{266}$ de 'pedagogische grondhouding (...) van recht doen en zich recht laten doen op basis van het primaat van het belang van het kind.' Ik heb 'technisch' en 'relationeel' tussen aanhalingstekens geplaatst: het is duidelijk dat beide wel te onderscheiden maar niet (altijd) te schei-

262 BAARTMAN, Opvoeden kan zeer doen, a.w., (p)p. (71/)72.

263 BAARTMAN, a.w., resp. pp. 228 en 154.

264 BAARTMAN, a.w., p. 72 (zie onder meer ook pp. 76/77, 79, 154, 176 en 183),

265 A.W. p. 228 (na het midden).

266 A.w., p. 228 (boven het midden). 
den zijn. Bij mishandelende ouders zijn 'technische' aspecten geïnfecteerd door 'relationele,' en deze op hun beurt (vaak) door 'geesten uit het verleden": ${ }^{267}$ niet verwerkte aspecten uit de eigen vroege 'relatiegeschiedenis" (dat wil zeggen: niet of onvoldoende verwerkte traumatiserende/op den duur traumatische ervaringen in en/of niet of inadequaat opgeheven ontwikkelingsblokkades en alsnog opgeloste ontwikkelingstaken in verband met de relatie die men als kind had met de eigen ouders). Bij deze ouders hangt kundigheidsproblematiek ...

'(...) minstens voor een deel [samen] met de overspannen wens dat het kind bijdraagt aan het eigen goede leven van de ouders. Deze overspannen wens kan voor een deel hiermee samenhangen dat de actuele leefomstandigheden, zoals partnerconflicten en armoede, ouders niet bieden wat ze van het leven verwachten. Voor een belangrijk deel echter wortelt [de]ze in een [vroege, jw] relatiegeschiedenis waarin men [de ouder, jw] als kind niet tot zijn recht [is] kunnen komen. Het gevolg daarvan kan zijn dat. men dan alsnog verhaal gaat halen bij zijn kinderen. De kans zijn eigen kinderen te kort te doen, is dan des te groter naarmate het besef zelf tekortgedaan te zijn, diffuser en ambivalenter is."

Een belangrijk sleutelwoord in dit verband is sensitiviteit: ${ }^{269}$

\begin{abstract}
'Van sensitiviteit yoor eigen behoeften en gevoelens en sensitiviteit voor de behoeften van anderen, i.c. het kind, is onvoldoende sprake bij mishandelende ouders. Uit onderzoek naar trangenerationele aspecten van kindermishandeling en onveilige hechting is gebleken dat dit gebrek aan sensitiviteit in sterke mate samenhangt met het afweren van herinneringen aan en gevoelens over het te kort gedaan zijn in de eigen jeugd. De claims van het eigen kind roepen herinneringen op aan de onvoldane claims die men als kind had. Hoe meer deze herinneringen als bedreigend ervaren worden, hoe minder open men staat zowel woor de claims van het kind als voor de gevoelens van het zelf te kort gedaan zijn. Sterker nog, voldoen aan de claims van het kind kan maken dat men het gevoel heeft zichzelf te kort te doen.'
\end{abstract}

Kortom bij kindermishandeling gaat het "doorgaans primair (...) om een gebrek aan gemeenzaamheid. ${ }^{270} \mathrm{Er}$ is (immers) een gebrek aan (intrapsychische ruimte voor relationeel/sociaal) 'engagement': ${ }^{271}$

'[B] ij mishandelende ouders zijn de claims van het kind structureel ondergeschikt aan die van de ouder. Niet permanent, dat is in slechts uitzonderlijke gevallen zo,

Zie a.w., pp. 155 i.f. e.v., respectievelijk p. 79.

268 A.w., p. 228 i.f.

269 A.w., p. 155 (zie ook p. 79).

270 A.w., p. 177 (zie ook pp. 183/184 en 224).

271 A.w., pp. 83/84 (curs jw). 
maar structureel. (...) Maar ook bij mishandelende ouders is er in het algemeen sprake van de wens en de bereidheid het belang, van het kind te dienen. En uiteraard wordt er ook aan die wens uitvoering gegeven. Maar dan blijkt dat mishandeling ook een opvoedingsprobleem is in de zin van een engagementsprobleem. Omdat, in het licht van de eigen voorgeschiedenis, de wens het belang van een kind te dienen, ook de mogelijkheid biedt met een verleden af te rekenen, wordt een sterke mate van afhankelijkheid ten opzichte van het kind ingebouwd. Immers, aan de waardering door het kind wordt dan zeer zwaar getild [dankbaar moet het zijn, nederig en klein, jw]. Bovendien, men moet het, om als opvoeder te kunnen slagen, dan ook maar treffen met een kind [het kind moet, cru gezegd, voldoende intelligent en vooral gevoelig - in MILLERs terminologie "begaafd" 272 - zijn om langdurig emotioneel te kunnen worden uitgebuit, jw]. (...) Deze afhankelijke houding werkt door in de technische dimensie van het handelen: het opvoeden wordt beleefd als een zware opgave, het kind als moeilijk, en men is overgevoelig voor wat er niet goed gaat. (...) Het kind, zo wordt het beleefd, werkt niet mee aan de realisering van de eigen goede voornemens [met name het voornemen het beter/anders te doen dan de eigen 'foute' ouders, jw], en dit veronderstelde niet meewerken wordt dan vervolgens geinterpreteerd als tegenwerken. Daarnaast [leidt] de hoog gespannen wens een goede ouder te zijn [althans een betere dan de eigen ouder(s), jw], (...) er gemakkelijk toe dat men het kind veel [verkeerde, oneigenlijke, jw] ruimte geeft, overpermissief is. (...) Permissiviteit kan maken dat een kind, bij gebrek aan regels en controle, zich gaat misdragen, hetgeen door de ouder wordt ervaren als een nieuw bewijs - en na verloop van tijd ook terecht soms - voor de interpretatie van het gedrag van het kind. Dit kan leiden tot een omslag in de permissiviteit. Niet alleen dat de teugels worden aangetrokken [op de verkeerde c.q. op willekeurige momenten, jw], maar de frustratie die zich heeft opgestapeld, kan maken dat de aanvankelijke allocentrische houding, een houding waarin men zich [voor zijn emotionele huishouding, de instandhouding van een broos emotioneel evenwicht, het overeind houden van een kwetsbaar (en dus afgeschermd of onbereikbaar ingekapseld) zelfgevoel, jw] van het kind afhankelijk heeft gemaakt, omslaat in een autocentrische [de knop gaat om: het kind wordt van het ene moment op het andere afgewezen, psychisch verstoten: de ouderliefde blijkt nu onontkoombaar van meet af aan voorwaardelijk te zijn geweest - maar ... had ook niet anders dan voorwaardelijk kùnnen zijn, gezien de vele voorwaarden die in de eigen jeugd van de ouder niet waren vervuld, jw]. De eigen gevoelens en verlangens [lees: toenemende irritaties en frustraties, jw] worden bepalend, met het kind wordt geen rekening meer gehouden, en men koelt zijn woede [niet in Den Haag, maar op het kind, jw].'

Als wij praten over cursussen voor ouders, dienen we ons dus terdege rekenschap te geven van de vraag of in een bepaald geval een gebrek aan kundigheid (kennis en vaardigheden) niet een gebrek aan gemeenzaamheid (in het bijzonder de na- en weergalm van oud zeer) verhult. Om het wellicht enigszins gechargeerd te zeggen: werken aan kundigheid zonder 
oog voor onderliggende gemeenzaamheidsproblematiek heeft op zijn best geen effect. In wezen stuiten we hier op een algemeen probleem met betrekking tot het aanbieden van hulp. Zonder oog voor gemeenzaamheidsproblematiek (zeg maar: voor nog openstaande rekeningen uit de eigen jeugd) is de kans groot dat een aanbod wordt geweigerd of niet werkt. De ouder zal slechts versterkt worden in het diep wortelende doch aan de oppervlakte diffuse gevoel dat de wereld voor hem of haar onrechtvaardig is, en geesten uit het verleden, met voorop hand in hand het minderwaardigheidsduiveltje en het ambivalentiespook, zullen hun destructieve dansje maken met de nä̈eve feeën van de goede bedoelingen, de feeën in de inborst van de (geparentificeerde althans persoonswordingsgevaarlijke althans eenzijdig opgeleide) maatschappelijk werk(st)er of hulpverle(e)n(st)er. ${ }^{273}$

Ook hier ligt de sleutel voor een oplossing naar onze mening in het werken met de drie SPS-echelons. Voor het eerste echelon bepleiten wij de algemene DOEK-cursus (in principe als prenatale cursus met postnatale terugkom-dagen). Althans zolang lessoort 2 nog niet de eerste generatie (cognitief en sociaal-emotioneel) op het ouderschap voorbereide scholieren heeft afgeleverd. Voor het tweede echelon bepleiten wij (kort gezegd) kundigheidsbevorderingscursussen met gemeenzaamheidsmodules, en voor het derde echelon (eveneens kort gezegd) gemeenzaamheidsbevorderingstrainingen met kundigheidsmodules. Met name in het derde echelon zal de grens tussen trainingen ('onderwijs') en hulpverlening ('ondersteuning') overigens niet scherp getrokken kunnen worden. En misschien is het ook maar beter alle speciale ouderschapscursussen te zien als specifieke vormen van hulpverlening, waarbij bijvoorbeeld overwegende gemeenzaamheidsproblematiek met een kundigheidscursus en overwegende kundigheidsproblematiek met (al of niet in cursusvorm of -verband gegeven) gemeenzaamheidstrainingen kan worden ondersteund.

\section{A. Echelon I: de algemene DOEK-cursus}

DOEK bepleit het volgende: ${ }^{274}$

'De overheid zou als regel kunnen stellen dat elke aanstaande ouder een cursus "ouderschapskunde" volgt. Het is uiteraard niet te verwachten dat zo'n cursus tot perfect ouderschap leidt. Niemand ziet enig probleem in de eis dat men, om deel te mogen nemen aan het gemotoriseerd verkeer, een bepaalde proeve van bekwaamheid aflegt. Ik stel niet voor dat men, om actief te mogen deelnemen aan het opwoedingsverkeer (en ook daarin vallen regelmatig slachtoffers), een proeve

Vgl. (gemuanceerder en voorzichtiger) BAARTMAN, a.w., p. 183.

274 DOEK, 'Kindermishandeling: recht op en/of dwang tot preventie,' t.a.p., op p. 20 1.K./T.k. 
van bekwaamheid moet afleggen. Maar het minste wat men zou kunnen doen, is zich op die deelname serieus en zorgvuldig woor te bereiden. Men zou kunnen denken aan een cursus met "terugkom-dagen" als het kind er eenmaal is. Een naief voorstel? Wat echt naief is - om niet te zeggen gevaariijk [naief] - is de gedachte dat een ieder die kinderen kan verwekken [of] baren, ook in staat is die kinderen op een adequate wijze te verzorgen en op te voeden. Het recht van het kind op preventie schept voor ouders de plicht zich op hun taak goed voor te bereiden. De overheid zou dit in bovenbedoelde regel met zachte dwang kunnen bevorderen.'

Wij sluiten ons bij dit pleidooi aan en plaatsen het dadelijk binnen het eerste SPS-echelon. Als (tweede ${ }^{275}$ ) vast onderdeel van het BAARTMANgesprek vindt de adstructie van en (gratis) intekening op de - van incentives (waaronder nuttige goederen voor de baby-uitzet en andere 'premies') voorziene - prenatale DOEK-cursus met postnatale terugkom-dagen plaats. Bijkomend voordeel van deze constructie is dat eventueel later optredende risico-factoren ook tijdens de cursus of de terugkomdagen aan het licht kunnen komen en desgewenst tot een onmiddellijk hulpaanbod kunnen leiden.

\section{B. Echelon 2 en 3: speciale ouderschaps(deficiëntie-)cursussen/trainingen} Voor het tweede echelon is het nog denkbaar zonder verdere hulpverlening kundigheidsbevorderende cursussen aan te bieden (kennis- en vaardigheden-deficiëntiecursussen), namelijk in gevallen waarin weliswaar aanwezige risico-factoren vooralsnog geen 'zwaarder geschut' vergen. Toch verdient het in het algemeen aanbeveling daarin wat ik gemakshalve maar gemeenzaamheidsdeficiëntiemodules noem, op te nemen (bijvoorbeeld in de vorm van enkele trainingen of trainingsdagen met individuele aandacht).

In het derde echelon is kundigheid(sbevordering) ondergeschikt aan gemeenzaamheid(sbevordering): therapeutisch reparatiewerk zal hier eerst ruimte voor kundigheidsbevordering moeten creëren. Dit reparatiewerk behoeft niet per se te bestaan in inzichtgevende psychotherapie. Althans niet in de visie van BAARTMAN: ${ }^{276}$

'[D]e sensitiviteit [van ouders] voor een kind [is] geringer (...) naarmate er (...) meer sprake is van afgeweerd verlangen bij de ouders tegen de achtergrond van een voorgeschiedenis waarin ouders als kind sterk tekortgekomen zijn. Dit leid[t] tot de conclusie dat het werken aan verhoging van sensitiviteit voor een kind in deze situaties volgen moet op of in elk geval gecombineerd moet worden met

275 Voor het eerste onderdeel zie de hierna volgende subparagraaf. Het derde onderdeel is het eigenlijke gesprek. 
verhoging van sensitiviteit voor eigen gevoelens en verlangens. Dil betekent niet dat ik pleit voor vormen van inzichtgevende psychotherapie. Niet dat deze niet zinvol zouden zijn, maar we hebben het hier over hulp aan ouders bij opvoedingsproblemen, en niet over individuele problemen van volwassenen."

Als ik hier de auteur voor een ogenblik mag onderbreken: zeker bij ernstige ('derdegraads"-)problematiek zijn beide (opvoedingsproblemen en psychische problemen van ouders) niet te scheiden (immers waarschijnlijk pas in en door therapie te ontrafelen), maar de auteur moet worden toegegeven dat de invalshoek, zo men wil de 'entree,' inderdaad een andere is. Daar staat dan weer tegenover dat het feit dat men iemand door de voordeur binnenleidt, niet betekent dat men hem niet door de achterdeur zou mogen uitlaten ${ }^{27}$ - mits hij uiteraard die deur als een beter (en in elk geval niet als een slechter) mens verlaat. Gelukkig betreft het hier niet een alles-of-niets-situatie, er is een tussenweg (een zijdeur?): ${ }^{278}$

\begin{abstract}
'Het betekent wel dat ik er voor pleit om in deze hulp bij opvoedingsproblemen plaats in te ruimen voor het bieden van hulp aan ouders bij het verwerken van en het omgaan met dat oude zeer, dat hen parten speelt in de verhouding tot hun kinderen. Daarbij dient te worden uitgegaan van de actuele verhouding tussen ouder en kind en de spanningen daarin. Te gemakkelijk wordt soms gezegd dat een beroep op het reflectieve vermogen van mishandelende ouders weinig zinvol is omdat dat slechts in beperkte mate aanwezig is. Het gaat niet om reflectie op zich maar om het zodanig leggen van verbindingen tussen de beleving van het ouderschap, de beleving van het kind en de beleving van de eigen jeugd dat ouders (...) in staat zijn tot een adequater perspectief nemen als het gaat om gedrag en emoties van hun kinderen en tot het consequenter worm geven aan hun verantwoordelijkheid als opvoeder, (...) de twee kernelementen van pedagogisch besef."
\end{abstract}

Hiermee zijn we echter van het onderwijspad afgestapt en zitten we midden in het veld van ('derdegraads'-)hulpverlening - die uiteraard met in cursusvorm aangeboden (gemeenzaamheids)trainingen (met kundigheidsmodules) gepaard kan gaan. Mits er maar sprake is van op het gezin c.q. individuele gezinsleden toegesneden hulp-op-maat. En mits - zo voegen we daar nog maar eens ex abundanti cautela (tot vervelens toe overbodig) aan toe - het geheel is ingebed in (een postinterventionistisch) SPS, is voorzien van, met andere (en in enigszins ander verband gebezigde) woorden, "een hechte juridische en institutionele verankering., 279

277 Althans niet volgens de katholieke etiquette waarin ik (door paters Jezuĩeten) ben opgevoed.

278. BAARTMAN, ta.p.

279 BAARTMAN, Opvoeden kan zeer doen, a.w., p. 185. 
Sequeel van die verankering is dat alle onder lessoort 3 aan te bieden ouderschapscursussen in principe ook kunnen worden opgelegd, namelijk ter pre- of postnatale persoonswordingsvindicatie. Sanctionering van een en ander zou onder meer kunnen geschieden in het kader van de voorziening die aan de orde komt in de nu volgende subparagraaf: de derde en laatste poot van de Trias-trits $O$ (pvoedingsondersteuning) + $\mathrm{O}$ (pvoedingsonderwijs) $+\mathrm{O}$ (pvoedingsgeld).

\subsubsection{Ouderschapsloon}

Als (eerste ${ }^{280}$ ) vast onderdeel van het BAARTMAN-gesprek vindt, op het consultatiebureau, de uitreiking plaats van een Opvoedings(voorbereidings)geld-formulier, in te vullen door de voorziene hoofdverzorger of -verzorgster van het op komst zijnde kind (die over een eigen bank- of girorekening dient te beschikken). Tegen de tijd dat dit trias-onderdeel kan worden geïmplementeerd, is het nieuwe Nederlandse naamrecht misschien wel zover ingeburgerd dat de voorziene hoofdverzorger of -verzorgster van het op komst zijnde kind ook degene is wiens of wier familienaam het kind zal gaan dragen. (Eigenlijk is het een eis van historische en actuele gerechtigheid ten opzichte van moeders, de belangrijkste opvoeders van nieuwe burgers maar zelf, moreel en materieel, tweederangsburgers, dat ook dat laatste in het naamrecht wordt vastgelegd.)

De boodschap achter opvoedingsgeld (c.q. ouderschapsloon of opvoedloon) is tweeërlei. In de eerste plaats: de gemeenschap investeert in de persoonswording, en dus in de opvoeding van kinderen, vanaf het moment dat zij zich aandienen. Twee: de gemeenschap erkent en waardeert de enorme investering die gevraagd wordt van de verzorgende ouder(s) c.q. van de hoofdverzorger en hoofdopvoeder van het kind, die zijn en/of haar carrière daarvoor (gedeeltelijk) moet(en) opgeven of althans gedurende de eerste levensjaren van het kind moet(en) onderbreken.

Het heeft weinig zin, en gaat in elk geval mijn bevoegdheid en belangstelling te boven, hier uit te weiden over mogelijke modaliteiten en diverse financiële en fiscale 'details' (zoals de hoogte, de wijze en mate van inkomensafhankelijkheid, de fiscale vrijstelling e.t.q.) van opvoedloon. Bij drie aspecten zullen we evenwel kort stilstaan.

\section{Ouderschapsbeginsel in plaats van kostwinnersbeginsel}

Ook indien opvoedloon niet (veel) méér zou gaan kosten dan het huidige systeem van kinderbijslag (een term die hopelijk al vroeg in de nader 
ijlende eeuw een olijke rechts- en cultuurhistorische klank zal krijgen) in combinatie met de huidige kosten van bijstand aan (alleenstaande) ouders, is het van belang te onderstrepen dat opvoedloon - anders (c.q. op consequentere wijze) dan het huidige kostwinnersstelsel - een inkomensoverdracht teweeg dient te brengen van volwassenen zonder opvoedverantwoordelijkheid naar volwassenen met opvoedverantwoordelijkheid. Met andere woorden: opvoedloon impliceert dat het ouderschapsbeginsel het (fiscale) kostwinnersbeginsel vervangt. Tegelijk zal de goede lezer(es) een andere implicatie hebben ontwaard: opvoedloon haalt alle moeders (met opvoedverantwoordelijkheid) uit de bijstand.

\section{Het huidige stelsel verdraagt zich niet met het Verdrag}

Het is, strikt genomen, in dit hoofdstuk niet aan de orde, maar de (dubbele) vraag van RENSEN ...

"Vinden we dat er in Nederland aan het VN-Verdrag [inzake de rechten van het kind] als "minimum" standaard ruimschoots voldaan wordt? Of vinden we dat we onze kinderen maar voor half geld en onder de vier jaar gratis moeten opwoeden? 281

... doet ons al op de klompen aanvoelen dat ons kostwinners-, kinderbijslag- en moeders-in-de-bijstandsstelsel op gespannen voet staat met zo niet de letter dan toch de (persoonswordings)geest van het Verdrag. ${ }^{282}$

281 Ben RENSEN, 'Rechten van kinderen tussen dokters, ouders en culturen: de dagelijkse praktijk,' Tijdschrift woor de rechten wan het kind (DCI-Nederland) 1994/4, pp. 13-14, op p. 13.

282 Ook ten aanzien van art. 27, lid 1 juncto lid 3 VRK (de secundaire verantwoordelijkheid van de staat - in overeenstemming met de nationale omstandigheden en met de middelen die de staat ten dienste staan - ten aanzien van de waarborging van het recht van elk kind op een levensstandaard die toereikend is voor zijn lichamelijke, geestelijke, intellectuele, zedelijke en maatschappelijke ontwikkeling) geldt immers de 'maximum extent'-verplichting van art. 4: 'The primary responsibility of parents (...) to meet the child's [developmentall] needs reflects the principles stated in article $3(2)$, article 5 and article 18 . Where provision for the child's development is concerned under article 27 [para 2], parental responsibility is expressly qualified by the proviso "within their abilities and financial capacities." This is an important reminder that, where parents lack the requisite skills or resources, the State must assist the parents in meeting their responsibilities, including the provision of material assistance (...). (...) When parents are unable to ensure an [developmentally] adequate standard of living for their child, the State should step in. Article 27 [para 3] also puts explicit qualifications on the State's obligations - "in accordance with national conditions and within their means." These words reflect a general nervousness of governments about financial commitments and control over government expenditure (including wealthy govern- 
Ook hier drukt DOEK de vinger in enkele wonde plekken: ${ }^{283}$

'Ook in andere opzichten mag worden betwijfeld of de overheid wel voldoet aan haar plicht te zorgen voor passende - en preventieve - ondersteuning. Men denke in dit verband aan de financiële problemen van bijstandsmoeders en de problemen van alleenstaande ouders om passende (en betaalbare) opvang (dag: opvang voor peuters, buitenschoolse opvang) voor hun kinderen te vinden."

\section{Het Sociaal-Pedagogisch Contract en Gezinsafspraken}

In hoofdstuk 13 (par. 13.4.3) verwezen we naar een aanbeveling van de Parlementaire Vergadering van de Raad van Europa uit $1975,{ }^{284}$ die een uitgewerkte aanbeveling bevat met betrekking tot opvoedingsgeld. We overwogen daarbij dat een substantiële (en expliciete) opvoedverantwoordelijkheidsvergoeding ouders moreel aanspreekbaar maakt in geval van ouderlijk plichtsverzuim of plichtsverzaking. Een morele aanspreekbaarheid die juridisch zodanig in het vat kan worden gegoten, zo stelden we, dat de staat zijn secundaire opvoedingsverantwoordelijkheid optimaal kan waarmaken. Een geschikte modaliteit daartoe lijkt ons het sociaalpedagogisch contract met (in voorkomend geval) gezinsafspraken. Met andere woorden: opvoedloon wordt uitbetaald op grond van een contract dat, eventueel al tijdens of direct na afloop van het BAARTMAN-gesprek, door de (aanstaande) ouders wordt ondertekend. (We gaan ervan uit dat de wettelijke bedenktijd voor ouders samenvalt met de abortusbedenktijd: zij hebben per slot de uitnodiging voor het BAARTMAN-gesprek bij de arts die de zwangerschap heeft vastgesteld, in ontvangst mogen nemen.)

In dat contract staan de sociaal-pedagogische grondrechten van het kind vermeld, met daaraan toegevoegd alle (relevante) bepalingen uit organieke (gezins)wetten en uitvoerende regelgeving, met inbegrip van alle voorzieningen waarop ouders aanspraak (kunnen) maken. Een en

ments - it was the United States delegate who introduced the phrase "in accordance with national conditions" and the United Kingdom delegate, "within their means" (...). However, it is doubtful whether these qualifications dilute the overarching obligation to meet the economic rights of the child "to the maximum extent of .... available resources" under article 4. "Available" surely implies "in accordance with national conditions and within ... means." Certainly, no country has yet argued to the Committee [on the rights of the child] that the provisions of article 4 do not apply to rights under article 27.' (Implementation handbook for the Convention on the rights of the child, a.w., pp. $358 / 359$; curs. jw.)

283 DOEK, 'Kindermishandeling: recht op en/of dwang tot preventie,' t.a.p., op p. 20 I.k. (midden).

284 Recommendation 751 (1975) on the position and responsibility of parents in the modern family and their support by society, opgenomen in: COUNCIL OF EUROPE, The rights of the child; A European perspective, Straatsburg 1996, pp. 49-53. 
ander uiteraard met duidelijke toelichting, adressen enzovoorts. Het contract bevat bovendien een clausule waarin op de mogelijkheid van het in voorkomend geval, in het bijzonder bij doorverwijzing naar het tweede of derde echelon - maken van gezinsafspraken wordt gewezen, alsmede een soort boetebeding waarin mogelijke korting op of intrekking van opvoedloon of eventuele andere sancties worden aangekondigd indien gezinsafspraken zonder goede reden niet worden nageleefd.

Uiteraard is er geen sprake van contractsvrijheid in privaatrechtelijke zin omdat het gaat om het juridiseren van een zware morele en constitutionele (burger)plicht, die men echter vrijelijk kan ontgaan door geen kinderen te nemen (of daarvan afstand te doen). Anderzijds is niet uit te sluiten, en zelfs zeer gewenst, dat in de toekomst ouderorganisaties met de overheid collectieve contracten sluiten en binnen zekere (kinderrechtelijke) marges onderhandelingsruimte hebben. Ook kan gedacht worden aan een tripartite sociaal-pedagogische SER, dus een SPR (te acronimiseren tot SOPER, of KIGER: Kind- en gezinsraad), waarin de minister van Kind en Gezin overlegt en onderhandelt met vertegenwoordigers van zowel ouderorganisaties als kinderrechten- en jongerenorganisaties (een sociaal-pedagogisch 'poldermodel ${ }^{285}$ ). Voor de (quasi-) contractsvorm ${ }^{286}$ wordt hier evenwel gekozen vanwege de belangrijke psychologische voordelen daarvan (zelfbinding althans persoonlijke betrokkenheid en commitment: het contract als tweede 'huwelijksboekje"; afspraken als coachingsinstrument èn als heldere grondslag voor maatregelen en rechtsbescherming; en heel praktisch: het contract als sociaal-pedagogisch 'spoorboekje').

Vgl. daarentegen voor het huidige 'libertinistische' sociaal-economische poldermodel hierboven par. 14.2.4.

Voor een parallel kan worden verwezen naar het inburgeringscontract voor immigranten. Het CDA bepleit opvoedingsondersteuning vast onderdeel van dit contract te maken (zie Maurice VAN LIESHOUT, "Meeste aandacht voor jeugd in CDA-programma, 0/25; Tijdschrift over jeugd december 1997, rubriek Nieuws, pp. 5-6, op p. 5, derde/vierde kolom). Maar uiteraard zijn niet alle allochtone gezinnen risico-gezinnen - en zijn vele autochtone gezinnen dat wel. Ook wil deze partij (aldus VAN LIESHOUT, ta.p., vierde kolom) de 'zogenaamde mentorprojecten die moeten voorkomen dat allochtone jongeren maatschappelijk afhaken,' financieel ondersteunen. Ook hiervoor geldt dat er meer jongeren c.q. gezinnen zijn die een mentor (gezinscoach) kunnen gebruiken c.q. hard nodig hebben. Sociaal-pedagogisch gelijke - dat wil zeggen gelijkelijk (generaties lang) gedepriveerde - gevallen moeten gelijk worden behandeld - ongeacht huidskleur, ethnische afstamming of geloofsovertuiging. En gelijk behandeld wil zeggen: na screening via het BAARTMAN-gesprek ondersteund met hulp-op-maat. 


\title{
14.5.2.5 Persoonswordings-Effect-Rapportage
}

De term 'effectrapportage' is in Nederland vooralsnog voornamelijk het tweede en derde lid van een samenstelling die hetzij begint met 'milieu' hetzij met 'emancipatie' (welk laatste eerste lid een verkorting is van 'vrouwenemancipatie" - hoewel het toch niet uitgesloten is dat mannen en uiterst aannemelijk is dat kinderen en jongeren zich als nulde lid zouden willen laten lezen). Over de idee achter milieu-effectrapportage lezen we bij ALEXANDER: 287

\begin{abstract}
'Enerzijds maakt het inzicht dat de objecten (de dieren, de natuur ...) intrinsieke waarde toekomt, steeds meer opgang. Correcter gesteld, gaat het om het inzicht dat de waarde van de objecten niet louter instrumenteel in functie van de mens kan vastgesteld worden, wil men tenminste miet in een destructieve neerwaartse spiraal terecht komen. De vraag blijft echter wie de dingen [en de kinderen, jonge kinderen, jw] voorspraak verleent. Anderzijds zijn er de wetenschapssociologische inzichten over de wijze waarop wetenschappen met onzekerheden omgaan. Wetenschappelijke bedrijvigheid (...) verloopt via [publicatie-, jw]technischwetenschappelijke netwerken. In die netwerken belichamen feiten wat collectief wordt verduurzaamd [wat paradigmatisch wordt, jw] in een context van controversen. Het feit [het paradigma, jw] dat verondersteld wordt de werkelijkheid over de natuur weer te geven, is slechts een construct. Maar als [eenmaal erkend wordt dat, jw] elk feit aan de oorsprong argument, project of controverse is, als [ingezien en erkend wordt dat] elke aanspraak op wetenschappelijke waarheid verbonden is aan de handeling, gebeurtenis en/of macht die haar mogelijk gemaakt heeft, dan is de [democratische, jw] weg geëffend om de macht die wetenschappers witoefenen, onderhevig te maken aan de politiek-juridische bemiddeling zoals die geldend is [ten aanzien van] alle maatschappelijke machten. De idee dat [aldus c.q. dientengevolge, jw] voorzien wordt in fora [deel uitmakend van beleidsinstrumenten of besluitvormingsprocessen, jw] waar (...) ethische en wetenschappelijke onzekerheid [zoals bijwoorbeeld met betrekking tot wat sociaal-pedagogisch verantwoord is, jw] (...) uitgesproken kan worden, is vrij recent. Diezelfde idee ligt bijwoorbeeld ook ten grondslag aan de milieu-effectenrapportage, die op metaforische wijze de natuur een stem geeft in het besluitvormingsproces.'
\end{abstract}

Jonge en heel jonge kinderen op metaforische wijze een stem geven in politieke besluitvormingsprocessen: ziedaar wat 'persoonswordingseffectrapportage" beoogt. Voor oudere kinderen, ofwel jongeren, is uiteraard niet een metaforisch instrument nodig doch directe (vormen van) participatie - om te beginnen het verlenen van (actief en passief) kiesrecht op een leeftijd waarop jeugdigen door de van uitstel tot afstel opgeschorte

287 Carl ALEXANDER, bespr. van VAN DER BURG/IPPEL (red.), De Siamese tweeling; Recht en moraal in de biomedische praktijk (1994), in: Recht en kritiek 1997/3, pp. $267-277$, op pp. $274 / 275$. 
ingroel in de samenleving nog niet apathisch ten aanzien van de (geendaden-maar-woorden-jpolitiek zijn geworden. ${ }^{288}$ Ofschoon 'kinderemancipatie' en 'persoonswording' begrippen zijn die elkaar gedeeltelijk overlappen, kiezen wij niet voor de term "kinderemancipatie-effectrapportage" omdat deze te lang zou zijn, doch omdat hij primair een politieke (participatoire) connotatie heeft, terwijl persoonswordingseffectrapportage (PER) de ontwikkelingspsychologische en (sociaal-)pedagogische klank en kleur heeft die in deze studie in diverse toonaarden en schakeringen is geschetst. Wij hechten evenwel niet zózeer aan de term persoonswording dat wij niet ook termen als opvoedingseffectrapportage (OER), gezinseffectrapportage (GER) of kind- en gezinseffectrapportage (KeGER) een snelle inburgering zouden willen toewensen. Hoewel Amerikaanse (althans Engelstalige) begrippen in de Nederlandse samenleving nog het snelste ingang lijken te vinden, geven wij toch aan persoonswordingseffectrapportage (PER) de voorkeur boven 'child impact analysis' (CIA), welke laatste term we aantreffen (en al aantroffen: zie hierboven par. 14.5.2.3) in het UNICEF-Implementation handbook for the Convention on the rights of the child: 289

"The Committee [on the rights of the child] has looked for processes which ensure that children's interests are considered in policy formulation, and has begun to propose that States should adopt a comprehensive system of "child impact assessment" (...). (...)

[Ter attentie van Myanmar (Birma):] "(...) [T] he Committee suggests that the 'child impact' of decisions taken by the authorities be assessed on an ongoing basis." (...)

[Ter attentie van Nieuw Zeeland:] "The Committee notes with interest the recently established procedure of the State Party to have an evaluation of the impact on children of all proposed legislation affecting children that is submitted to the Cabinet. It welcomes such a child impact analysis as part of the legislative process." (....)."

De tijden zijn nu eenmaal veranderd: op achttienjarige leeftijd is eventueel sluimerende politieke belangstelling en burgerzin allang overgegaan in relatieproblematick (of zelfs in impulsproblematiek - het geen maat weten - ten aanzien van legale en illegale recreatieve middelen). Kiesrecht zou daarom al op vijftienjarige leeftijd (voor jongens, het psychisch zwakkere en later rijpe) en veertienjarige leeftijd (voor meisjes, het psychisch sterkere en eerder rijpe geslacht) moeten worden verleend. Het vervolgens oprichten van een jongerenpartij zou het politieke landschap - en in elk geval de beschamende mensenrechtensituatie van kinderen - in Nederland aanmerkelijk kunnen veranderen. Implementation thandbook for the Convention on the rights of the child, a.w., pp. 66-67 ("Child impact analysis'; curs. jw). 


\title{
(Vrouwen-)emancipatie-effectrapportage (EER) wordt door VERLOO en ROGGEBAND omschreven als: 290
}

\begin{abstract}
'(...) een onderzoek dat uitgevoerd wordt naar beleidswoornemens en waarin nagegaan wordt wat de effecten zouden kunnen zijn van bepaald beleid voor de structureel ongelijke machtsverhoudingen tussen de seksen [vertaal: de (groten-) deels transgenerationeel bepaalde (en in zoverre) structureel ongelijke persoonswordingskansen tussen kinderen uit sociaal-emotioneel/pedagogisch adequate en sociaal-emotioneel/pedagogisch gedepriveerde (zogenaamde risico-)gezinnen, jw]. Effectrapportages zijn een vorm van ex-ante evaluaties: vó́r de uitvoering van beleid wordt in een dergelijke evaluatie in kaart gebracht wat de potentiële en waarschijnlijke effecten van beleid zullen zijn. Een emancipatie-effectrapportage is een hulpmiddel bij de besluitvorming. Door de emancipatie-effectrapportage kan vóor tot de uitvoering van beleid besloten wordt, duidelijkheid verkregen worden over de mogelijke effecten van beleid op [persoonswordings(optimaliserings)-, opvoedings(stimulerings)-, gezins(versterkings)- en bijgevolg kinder-] emancipatieprocessen. Voor het ontwikkelen van de emancipatie-effectrapportage is aangesloten bij ervaringen met de milieu-effectrapportage, waarin plannen en initiatieven worden onderzocht op mogelijke milieu-effecten.'
\end{abstract}

De invoering (in 1992) ${ }^{291}$ van het beleidsinstrument van de EER voor vrouwen - stemhebbende leden van de samenleving - makt een pleidooi voor de invoering van een kinder-EER: de persoonswordingseffectrapportage voor kinderen - de stemlozen, gelijk een lam stemloos is voor wie het scheert (Handelingen 8:32) - overbodig. Althans in morele zin, en voor wie de bijbel in het politieke vaandel voert. Doch ook een omstandig juridisch pleidooi is overbodig nu het Comité inzake de rechten van het kind duidelijk de weg heeft gewezen. Althans aan wie de mensenrechten in het politieke vaandel voert.

\section{5 .2 .6}

Kinder-KALSBEEKrapportage

In februari 1997 verscheen het Verslag van de commissie voor de eerste nationale rapportage over de implementatie in Nederland van het Verdrag tegen discriminatie van vrouwen (rapport-GROENMAN). In dit verslag is de eerste Nationale Implementatie Rapportage VN-Vrouwenverdrag (NIRV), naar de initiatiefneemster ook wel KALSBEEKrapportage genaamd, ${ }^{292}$

Mieke VERLOO en Conny ROGGEBAND, Emancipatie-effectrapportage: theoretisch kader, methodiek en voorbeeldrapportages, Ministerie van szW, Den Haag 1994, p. 3. VERLOO en ROGGEBAND, a.W., "Voorwoord." Vgl. A.A.M. MATTIISSEN, "Bestrijding van vrouwendiscriminatie; het onbekende VN-Verdrag,'Justitiele Verkenningen 1997/9, pp. 20-34, op pp. 21-23 ('De KALSBEEKrapportage'), (meer in het bijzonder) op p. 21 i.f. 
neergelegd. Het betreft hier een staatsrechtelijk novum (en mondiaal unicum): de regering is wettelijk verplicht tot periodieke verslaglegging aan het parlement over de uitvoering van een verdrag vóórdat zij rapporteert aan het desbetreffende verdragscomité. ${ }^{293}$ In de woorden van de staatssecretaris van SZW (WALLAGE) en de minister van Buitenlandse Zaken (KOOIMMANS): ${ }^{294}$

'De wettelijke verplichting voor de regering tot periodieke verslaglegging aan de Staten-Generaal over de uitvoering van het [Verdrag] is een novum bij de Nederlandse implementatie van mensenrechtenverdragen: tot nu toe is altijd volstaan met rapportage aan verdragsorganen. Daardoor is de Nederlandse discussie over de nationale naleving van mensenrechtenverdragen grotendeels beperkt gebleven tot de kring van gespecialiseerde organisaties.'

In het voorwoord van de (in hoofdstuk 13 uitgebreid aangehaalde) eerste KALSBEEKrapportage, het GROENMAN-rapport, lezen we:295

'Dit rapport beoogt antwoord te geven op de vraag waartoe het $V N$-Verdrag inzake de uitbanning van alle vormen van discriminatie van vrouwen de Nederlandse overheid verplicht, en in welke mate en op welke wijze de overheid aan deze verplichtingen voldoet. Het rapport, gesehreven door een commissie van onafhankelijke deskundigen, is tot stand gekomen op verzoek van minister MELKERT van

293 MATTUSSEN, t.a.p., op p. 22 (bovenaan). Zie ook Kamerstukken II 1992/93, 18950 (R 1281), Goedkeuring van het Verdrag inzake de uitbanning van alle vormen van discriminatie van vrouwen (New York, 18 december 1979), nr. 13 (Brief van de staatssecretaris van Sociale Zaken en Werkgelegenheid en van de minister van Buitenlandse Zaken d.d. 18 december 1992), p. 2 (i.f.), waar de betrokken bewindspersonen (TER VELD en VAN DEN BROEK) opmerken: 'De indieners van het amendement kozen voor een vierjarige verslagperiode, opdat de Staten-Generaal zich telkens éśn jaar vóór de rapportage aan het [Vrouwencomité] aan de hand van het verslag aan het parlement een oordeel kunnen vormen over het nationale beleid tot implementatie van het Verdrag.' Voor het Verdrag inzake de rechten. van het kind zou in dit licht met een vijfjarige verslagperiode kunnen worden volstaan (vgl. art. 18, lid 1 aanhef en onder b Vrouwenverdrag met art. 44, lid 1 aanhef en onder $b$ VRK). Gezien de ernst en de omvang van de (kindermishandelings- en gezins)problematiek verdient een frequentere (voortgangs)verslaglegging aan het parlement uiteraard de voorkeur.

294 Kamerstukken II 1993/94, 18950 (R 1281), Goedkeuring van het Verdrag inzake de uitbanning van alle vormen van discriminatie van vrouwen (New York, 18 december 1979), nr. 14 (Brief van de staatssecretaris van Sociale Zaken en Werkgelegenheid en de minister van Buitenlandse Zaken d.d. 3 maart 1994), pp. 2/3.

295 L.S. GROENMAN, 'Voorwoord,' in: dez. e.a., Het Vrouwenverdrag in Nederland anno 1997; Verslag van de commissie voor de eerste nationale rapportage over de implementatie in Nederland van het [VN-JVerdrag tegen discriminatie van vrouwen, Den Haag 1997, pp. 7-8, op p. 7. 
Sociale Zaken en Werkgelegenheid, tevens belast met de coördinatie van het [vrouwen]emancipatiebeleid. Hij gaf hiermee uitvoering aan een bepaling in de goedkeuringswet die een periodieke rapportage aan de Staten-Generaal voorschrijft. (...) Het initiatief van de Tweede Kamer om bij amendement ${ }^{296}$-KALSBEEK e.a. in de goedkeuringswet op het Verdrag de verplichting tot een vierjaarlijkse rapportage aan het parlement op te nemen, is in onze opvatting een nuttig besluit geweest. De periodieke presentatie van een overzicht van de uitwoering van het Verdrag kan immers de discussie inspireren en uiteindelijk leiden tot de situatie waarin Nederland geheel en al naar letter en geest voldoet aan de verdragsverplichtingen. De stand van zaken anno 1997 , die in deze rapportage wordt beschreven en van aanbevelingen voorzien, toont aan dat die situatie namelijk nog lang niet is gerealiseerd. Implementatie van het Verdrag vraagt permanente aandacht en operationalisering van beleid om met alle passende maatregelen op zo kort mogelijke termijn te kunnen voldoen aan de resultaatsverplichtingen ${ }^{297}$ van het Verdrag.'

Hierboven (in par. 14.5.2.3) waren we getuige van het strelen door het Comité inzake de rechten van het kind van de veren van de Gallische haan: 298

"[Ter attentie van Frankrijk:] "The Committee also welcomes the decision taken by the Government to submit an annual report to the Parliamentary Assemblies on the implementation of the Convention and on its policies in relation to the situation of children in the world. (...)".'

Het zal nog wel enige politieke dressuur vergen vóor het Comité de $\mathrm{Ne}$ derlandse leeuw kan aaien. Frankrijk ligt drie marsorders op Nederland vó́r: de Franse regering rapporteert jaarlijks aan het parlement over de uitvoering van het Verdrag; de Franse regering rapporteert niet alleen over de kinderen in Frankrijk maar ook over haar ontwikkelingsinspan-

296 Een amendement op een goedkeuringswet (een wet in formele zin, ex art. 81 Grondwet, die niet tevens wet in materiële zin is, doch inhoudelijk een besluit van de formele wetgever - van algemene strekking) is slechts mogelijk voor zover het, zoals in casu, niet de verdragstekst betreft, welke immers - als vollkenrechtelijke overeenkomst - niet door nationale parlementen kan worden geamendeerd.

297 Op p. 137 van het Verslag lezen we: 'De hoofddoelstelling van het Verdrag houdt een opdracht tot handelen in die meer een resultaatsverplichting dan een inspanningsverplichting impliceert." Hier zij in herinnering gebracht dat wij met betrekking tot het Verdrag inzake de rechten van het kind onderscheid hebben gemaakt tussen het recht van het kind op optimale persoonswording als ('hoofddoelstelling' en) uiterste inspanningsverplichting van het Verdrag, en minimale persoonswording als quasi-resultaatsverplichting.

298 Implementation handbook for the Convention on the rights of the child, a.w., p. 43 l.k. 
ningen ten aanzien van kinderen in andere (francofone en/of arme) landen; de Franse regering rapporteert over ... kinderen.

Wat is er mis gegaan tijdens de goedkeuring van het Verdrag inzake de rechten van het kind in het Nederlandse parlement? Waar waren de partijen van de indieners van het KALSBEEK-amendement? Waar waren de partijen die w6́6r het KALSBEEK-amendement stemden? We zullen de pijn en gêne niet uit de weg gaan die de poging tot het beantwoorden van deze vragen aan het stellen ervan toevoegt.

Vrouwen hoeven niet meer te zwijgen in de kerk (zie hoofdstuk 1, par. 1.1.1), zij moeten spreken in het parlement. Maar zij zwegen - tezamen met de heren van de parlementaire schepping - bij de behandeling van het goedkeuringswetsontwerp voor het Verdrag inzake de rechten van het kind. ${ }^{299}$ De partijen van de indieners van het KALSBEEK-

299 Ingediende amendementen betroffen enkel de door Nederland te maken voorbehouden ter zake van het detineren van minderjarigen tezamen met volwassenen (aangenomen) en de zelfstandige sociale zekerheid voor kinderen (verworpen): Kamerstukken II 1993/94, 22855 (R 1451), Goedkeuring van het op 20 november 1989 te New York tot stand gekomen Verdrag inzake de rechten van het kind, nrs. 9 (en 16), 10 (en 15) en 11 (en 13); Handelingen 11, pp. (84-)5777-8 (30 juni 1994). Bij de mondelinge behandeling (Handelingen $\mathrm{II}$, pp. (84-)5708 r.k.-5710 en 5715; 30 juni 1994) is door mevrouw VAN DER BURG (PvdA) nog wel gerefereerd aan het KALSBEEK-amendement, doch in tweede termijn heeft zij zich neergelegd bij de KIR-toezeggingen van de minister (KOSTO). Voor de goede orde: KIR is het staatkundig acroniem voor Kluitje-In-'t-Riet. In haar eigen woorden (t.a.p., op p. 5715 , eerste kolom i.f-middenkolom): 'De minister zegt dat hij de rapportage [aan het Comite inzake de rechten van het kind; dus niet een aparte nationale rapportage, zoals de Nationale Implementatie Rapportage $\mathrm{VN}$-Vrouwenverdrag (NIRV); met andere woorden het betreft hier een standaardprocedure, géćn Nationale Implementatie Rapportage VN-Kinderrechtenverdrag (NIRK), jw] naar de Kamer zal sturen en dat verder (....) de betrokken organisaties in het land [de VKM? -jw], de NGO's [DCl? -jw], bij de voorbereiding hun inbreng kunnen leveren [zodat de staat nog wat voet- en pepernoten heeft, jw]. Ik ben blij met deze toezeggingen $[s i c, j w]$. Wij kunnen vervolgens over de rapportage debatteren. De eerste rapportage zal over twee jaar plaatsvinden. Ik verzoek de minister op tijd te rapporteren, zodat wij de mogelijkheid hebben een debat te voeren. Als dit leidt tot opmerkingen, kunnen deze nog worden meegenomen. Ik heb nog overwogen voor te stellen dit in [de] goedkeuringswet vast te leggen. De minister heeft echter een nadrukkelijke toezegging gedaan op dit punt, dus misschien is dat niet nodig. Ik denk daar nog even over na. [Op deze plaats in de Handelingen ho6rt men de afgevaardigde denken, men léest:] Ik denk dat de toezegging voldoende is. (...) Ik hoop dat op deze laatste dag voor het zomerreces de Kamer haar goedkeuring geeft aan dit zeer belangwekkende verdrag (...). Het uiteindelijke doel is dat een bijdrage wordt geleverd aan de verbetering van de situatie van kinderen in ons land, maar met name in het buitenland!' (Curs. jw.)

Overigens was al in de (regerings-) Nota naar aanleiding van het (parlementaire 
amendement (PvdA, D66 en VVD: paars avant la couleur) ${ }^{300}$ vergaten hun achterban, de kiesgerechtigde vrouwen in Nederland, niet. Met uitzondering van klein-rechts (SGP, GPV en RPF) stemden alle politieke partijen vór het KALSBEEK-amendement. ${ }^{301} \mathrm{Zij}_{\mathrm{ij}}$ vergaten hun achterban, de kiesgerechtigde vrouwen in Nederland, niet. Maar bij de behandeling van het goedkeuringswetsontwerp voor het Verdrag inzake de rechten van het kind vergaten zij ... ook de kinderen niet. Kinderen zijn niet de achterban van politieke partijen.

Deze politieke werkelijkheid, dit hardvochtige en onverschillige pays réel van de dyas publico-privata (staat en volwassenen), hoezeer ook in strijd met de mensenrechtelijke (door en op basis van het Verdrag geconstrueerde en gepostuleerde) rechtswerkelijkheid, het pays légal van de Trias pedagogica (staat, ouders/volwassenen èn kinderen), legt een grote verantwoordelijkheid op (de nationale afdelingen van) non-gouvernementele organisaties. Gelukkig is er op dit punt wel sprake van een novum met betrekking tot het Verdrag inzake de rechten van het kind, een internationaalrechtelijk unicum: ${ }^{302}$

'NGO's [(inter)nationale non-gouvernementele organisaties] hebben bij uitstek de mogelijkheid het Comité [inzake de rechten van het kind] te wijzen op lacunes,

commissie-)verslag d.d. 6 december 1993 (Kamerstukken II 1993/94, 22 855, nr. 6, p. 39 onderaan) te lezen: "Conform de bestaande praktijk zal deze rapportage [aan het Comité] in interdepartementale samenwerking [dus nooit op tijd klaar? -jw] worden opgesteld. In het rapport zal de regering verantwoording afleggen over het gevoerde beleid. De tekst zal ter beschikking worden gesteld aan het Parlement en diverse maatschappelijke organisaties, die deze verantwoording kunnen toetsen.'

300 Het amendement is ondertekend door KALSBEEK-JASPERSE (PvdA), GROENMAN D66 en WEISGLAS (VVD): Kamerstukken II 1989/90, 18950 (R 1281), Goedkeuring van het Verdrag inzake de uitbanning van alle vormen van discriminatie van vrouwen (New York, 18 december 1979), nr. 11.

301 Handelingen II, p. 87-4979 (5 juli 1990). In de Eerste Kamer werd het goedkeuringswetsvoorstel (dus inclusief het amendement) zonder beraadslaging en zonder stemming aangenomen. Door de SGP werd een stemverklaring afgelegd, waarin deze partij te kennen gaf dat haar tegenstem niet mocht worden verstaan als een stem vór discriminatie van vrouwen: de bezwaren van de partij richtten zich 'met name tegen de doorwerking van het verdrag in de private sfeer' ... (Handelingen I, p. 35-1300; 2 juli 1991).

302 Isabeth MIJNARENDS, 'De Nederlandse rapportage-verplichting in het licht van het (...) Verdrag inzake de rechten van het kind,' F/R 1997/1, pp. 10-18, op p. 15 r.k. Vgl. ook Johan VANDE LANOTTE, Geert GOEDERTIER, 'Monitoring human rights: formal and procedural aspects,' in: Eugeen VERHELLEN (ed.), Monitoring children's rights, Den Haag (etc.) 1996, pp. 73-111, op pp. 81-102 (in het bijzonder op pp. 97/98). 
gebreken en onjuistheden in het regeringsrapport. Deze mogelijkheid ${ }^{303}$ is absoluu $^{304}$ een unicum in het arsenaal van internationale mensenrechten[instrumenten], die [voor het overige, dus op het Verdrag inzake de rechten van het kind na] een dergelijk mechanisme ontberen. De vergelijking met het gebrekkig functioneren van mensenrechtenverdragen met ook alleen een rapportageverplichting [lees: de vergelijking met andere mensenrechtenverdragen zonder individueel klachtrecht, die het moeten stellen met een gebrekkig functionerende rapportageverplichting, jw] gaat dan ook niet op, nu het [VRK] als enig mensenrechtenverdrag een extra waarborg biedt alle relevante informatie aan het Comité te doen toekomen.'

\subsubsection{Beleidsintegratie en -coördinatie: de (Eerste) Minister voor} Kind en Gezin

De aanwezigheid van (jonge) kinderen in een land, die (voornamelijk) opgroeien in gezinnen, moet aanknopingspunt van beleid en wetgeving zijn. Gezien de departementale verkokering in Nederland is dit alleen mogelijk (haalbaar/reëel) als er een apart ministerie is, of op zijn minst een minister(-president) belast met de coördinatie van het nationale kind- en gezinsbeleid.

Het eerste lid van deze stelling vloeit direct voort uit het Verdrag inzake de rechten van het kind, dat uitgaat van de juridisch en beleidsmatig daadwerkelijk en doeltreffend geoperationaliseerde secundaire opvoedingsverantwoordelijkheid van de staat, en (dus) op de staat de verplichting legt "to assist, advise and educate parents" ${ }^{305}$ met betrekking

303 Ex art. 45 onder a, tweede volzin VRK, waarin wordt gesproken van 'andere bevoegde instellingen die [het Comité] passend acht."

304 Een kleine relativering is hier wel op haar plaats: 'Betreffende andere verdragen is de praktijk gegroeid dat niet-gouvernementele organisaties commentaar geven op de rapporten en dit commentaar ook ter hand stellen van de leden van de toezichthoudende comités, die daar vervolgens gebruik van maken als het Koninkrijksrapport aan de orde komt.' (Kamerstukken II 1993/94, 22855 (R 1451), Goedkeuring van het op 20 november 1989 te New York tot stand gekomen Verdrag inzake de rechten van het kind, nr. 6, Nota naar aanleiding van het verslag d.d. 6 december 1993, p. 39 i.f.; curs. jw.)

Vgl. ook Jacqueline SMITH, 'Rapportageverplichting onder het [VRK],' FJR 1998/ 1 , pp. 2-6, op pp. $3 / 4$.

305 Art. 18, lid 2 VRK; Implementation handbook, a.w., p. 228 1.k. (zie ook p. 228 r.k., ter attentie van Tunesië) en p. 232 1.k. (ter attentie van Italië). Zie ook p. 232 r.k., waar wordt opgemerkt dat algemene voorzieningen ('universal services': algemeen toegankelijke/laagdrempelige sociaal-pedagogische voorzieningen, instellingen en diensten; 'and non-means-tested financial benefits': inkomensonafhankelijk opvoedingsgeld) 'often the most effective form of prevention' zijn, 'in that families at risk are mot deterred from receiving the provision because of the stigma attached, or because of ignorance, or because of complications in claiming it." 
tot de primaire ouderlijke opvoedingsverantwoordelijkheid. Ter adstructie van het tweede lid van deze stelling moge op deze plaats (maar zie ook op verschillende andere plaatsen in dit en in het vorige hoofdstuk) de vertwijfeling van DOEK volstaan: ${ }^{306}$

'[D]e territoir-drift van het ministerie van Justitie vormt geen bijdrage aan het recht van het kind op preventic (om het zo vriendelijk mogelijk te zeggen).'

Onze eerste voorkeur gaat derhalve uit naar een minister van SociaalPedagogische Zaken (c.q. van Kind en Gezin) met een eigen budget uit de algemene middelen (hetgeen inkomensoverdracht van kinderlozen naar opvoedingsverantwoordelijken impliceert) en met bevoegdheden op alle terreinen die kind en gezin raken - hetgeen dus minimaal betekent: volledige integratie van kinderbescherming, jeugdhulpverlening en lichamelijke en geestelijke (jeugd)gezondheidszorg (die thans vallen onder diverse ministeries, met name Justitie, vws en Onderwijs). Wij bevinden ons hier in goed gezelschap: ook het CDA wil in een volgend kabinet een minister voor gezinsbeleid met een eigen budget. ${ }^{307}$ En naar we mogen aannemen niet alleen voor de 85 à $90 \%$ van de gezinnen waarmee het redelijk tot goed gaat in Nederland, maar ook voor de probleemgezinnen en de risicogezinnen, waarin een half miljoen kinderen opgroeien - of maar moeten zien op te groeien (zie hierna par. 14.5.3).

Primair pleiten wij dus voor een minister voor alle gezinnen en voor alle kinderen, een minister die bovendien niet aarzelt een beroep te doen op de solidariteit van twee-auto-gezinnen met één-ouder-gezinnen en van mensen zonder kinderen met kinderen die opgroeien in bijzonder moeilijke gezinsomstandigheden. Subsidiair (als eventuele overgangsoplossing) pleiten wij ervoor de minister-president te belasten met de coör-

306 DOEK, 'Kindermishandeling: recht op en/of dwang tot preventie,' t.a.p., op p. 19 r.k. (midden).

307 Zie Maurice VAN LIESHOUT, "Meeste aandacht voor jeugd in CDA-programma," 0/25; Tijdschrift over jeugd december 1997 (rubriek Nieuws), pp. 5-6, op p. $51 . \mathrm{k}$. (i.f.).

De Socialistische Partij (SP) bepleit (primair een minister en secundair) een staatssecretaris voor 'Kinderen en Jongeren' (c.q. voor jeugdzaken). De SP is de enige politieke partij die "een rapport over de positie van de Nederlandse jeugd heeft uitgebracht': Alles Kids? Pleitnota voor gelijke kansen. Deze partij is van mening dat 'er alle reden is om jeugd de hoogste politieke prioriteit te geven' en 'zet zich [daarbij] sterk af tegen het consumentisme en de groeiende individualisering die Paars op zijn geweten zou hebben, maar komt zelf nauwelijks met nieuwe beleidswoorstellen op het niet-materiële vlak.' (Maurice VAN LIESHOUT, "SP wil staatssecretaris voor jeugdzaken," 0/25; Tijdschrift over jeugd' maart 1998, rubriek Nieuws, p. 6.) 
dinatie van het integrale kind-en gezinsbeleid. ${ }^{308}$

Laat er over de mensenrechtelijke crux van deze voorstellen geen misverstand bestaan: het recht van het kind op 'provision, prevention and protection" impliceert het recht op een zo effectief mogelijk - dus per definitie niet verkokerd en bij voorkeur supra-departementaal - overheidsbeleid. Dat wil zeggen: op een overheid die op basis van een slagvaardig integraal (centraal, regionaal en locaal) beleid (aanstaande en jonge) ouders actief benadert om - door middel van een breed scala van algemene voorzieningen en (via de algemene sluis van het BAARTMANgesprek) individueel toegesneden hulp-op-maat - (ernstige) opvoedingsproblemen (en dus ook justitiële maatregelen) zoveel mogelijk te voorkómen. De opdracht daartoe en het mandaat daarvoor heeft de overheid al dik drie jaar op zak: het Verdrag inzake de rechten van het kind, dat op 8 maart 1995 voor Nederland in werking trad.

\subsubsection{De trits en de trias: witzicht en uitleiding}

Ter afsluiting van deze paragraaf (par. 14.5) over de Trias-trits $O$ (pvoedingsondersteuning) $+\mathrm{O}$ (pvoedingsonderwijs) $+\mathrm{O}$ (pvoedingsgeld) zetten we aan de hand van de studie $O+O=O^{2}$ ("een inventarisende studie naar de mogelijkheden voor een integrale aampak van opvoedingsondersteuning en ontwikkelingsstimulering aan gezinnen en jeugdigen in meervoudige-risicosituaties') nog eens enkele feiten en cijfers uit het welvarende welzijnslland Nederland op een rijtje: ${ }^{309}$

"Met een minderheid van de kinderen gaat het niet goed. Volgens schatting is bij zo"n 10 i $15 \%$ van de jeugdigen [van de circa 3,5 miljoen minderjarigen, dus tussen de 350.000 en ruim een half miljoen kinderen! -jw] sprake van psychosociale problemen, zoals schooluitval, psychische problemen, gedragsproblematiek, [problematisch] alcohol- of drugsgebruik en criminaliteit. De omvang van pedagogische problemen in gezinnen wordt eveneens op zo'n 10 a $15 \%$ geschat. Een kleine groep gezinnen heeft te maken met een opeenstapeling van financiële, pedagogische, sociale en maatschappelijke problemen. Over deze gezinnen is minder bekend. Er zijn weinig studies verricht naar opgroeien en opvoeden in groepen aan de onderkant van de samenleving, met uitzondering van studies naar

308 De pvdA wil een coördinerend minister voor het millenniumprobleem, meldt Dagblad de Limburger van 2 maart 1998 op de voorpagina, doch daarmee wordt, zo blijkt al snel uit het bericht, iets anders bedoeld dan de stoute proclamatie van het millennium van het kind.

309 Ina BAKKER e.a., $O+O=O^{2}$; Naar een samenhangend beleid en aanbod wan opvoedingsondersteuning en onwikkelingsstimulering voor kinderen en ouders in risicosituaties, NIzw, Utrecht 1997, pp. (6), 16/17, 18, 19, 20 en 22 (curs. overgenomen). 
(intergenerationele) gevolgen van werkloosheid voor gezinnen en de school-en beroepsprestaties van de kinderen (...). (...)

De opvoeding en ontwikkeling van kinderen is de verantwoordelijkheid van het primaire leefmillieu [let wel: hier wordt de feitelijke, niet de juridische/mensenrechtelijke situatie weergegeven, $j w]$. Een aantal kinderen groeit op in gezinnen met ernstige en langdurige maatschappelijke, psychosociale of relationele problemen. Zo woont $4 \%$ van de jeugdigen [circa 140.000 kinderen, jw] in gezinnen waar een niet-warme opvoedingsstijl heerst, en heeft bijna $8 \%$ [circa 280.000 kinderen, jw] [een] alcoholverslaafde ouder(s) (...). (...)

In 1993 verkeerden zo"n 270.000 gezinnen met kinderen van 0-17 jaar in de laagste welvaartsgroep. Dat is iets meer dan $15 \%$ van het totale aantal gezinshuishoudens met kinderen; 95.000 één- en twee-oudergezinnen met kinderen jonger dan 18 jaar verkeerden zelfs langdurig in een situatie met een laag inkomen; dat is iets meer dan 5\% van alle gezinnen met kinderen tussen 0 en 18 jaar. Cijfers over het aantal kinderen dat deel uitmaakt van deze gezinnen, zijn niet beschikbaar. Maar als we ervan uitgaan dat het aantal kinderen in deze gezinnen ongeveer gelijk is aan het landelijk gemiddelde, dan impliceert dit dat tussen de 200.000 en 600.000 kinderen (5-15\% van 4 miljoen kinderen [175.000-525.000 van 3,5 miljoen kínderen, jw]) jonger dan 18 jaar opgroeien in permanente armoede, respectievelijk te maken hebben met materieel moeilijke gezinsomstandigheden (...) [voor de juridische/mensenrechtelijke situatie zie art. 27, lid 3 VRK, jw]. Een onderzoek van de GGD in Breda wijst uit dat $35 \%$ van de gezinnen die drie jaar of langer van een uitkering moeten rondkomen, wordt bedreigd in hun gezondheid [voor de juridische/mensenrechtelijke situatie zie art. 24 VRK, jw]. Dit betreft $6 \%$ van de basisschoolkinderen in Breda. Het ontbreekt hun aan goede voeding [art. 24, lid 2 onder $\mathrm{c}$ en art. 27, lid 3 VRK], voldoende kleding [art. 27, lid 3 VRK], voldoende sociale contacten [art. 18, lid 2 VRK] en sen gezonde leefomgeving [art. 24, lid 1 en lid 2 onder $c$ en $f$ VRK]. Tien procent van de basisschoolkinderen kan niet op een (sport)club [voor de juridische/mensenrechtelijke situatie zie art. 31 VRK, jw]. (...)

[Sociaal-pedagogisch gedepriveerde m] eisjes hebben over het algemeen meer last van zogenaamd internaliserend probleemgedrag (neurotisch en geremd) en [sociaal-pedagogisch gedepriveerde] jongens van externaliserend probleemgedrag (lastig en sociaal ongewenst) (...). Externaliserend probleemgedrag trekt over het algemeen meer aandacht dan internaliserend probleemgedrag. Het is zichtbaarder en het levert overlast op voor de omgeving. Tot voor kort werden sociaal teruggetrokken en niet-assertief gedrag als lichte problematick opgevat, die vanzelf wel overgaat. Uit een longitudinale studie (...) kwam echter naar voren dat beide typen gedragsproblemen tamelijk stabiel zijn. (...)

Psychische problematiek waarbij sterfte een duidelijke rol speelt, zijn suicide, anorexia nervosa en kindermishandeling. $(\ldots)[\mathrm{H}]$ et aantal geslaagde suïcides per jaar onder 15- tot 24-jarigen [wordt geschat] op 330, ofwel 14 geslaagde zelfdodingen per 100.000 jongeren in die leeftijdscategorie. Bij anorexia nervosa overlijdt $11 \%$ van de patiënten (...) en het aantal kinderen dat jaarlijks sterft ten gevolge van [kinder]mishandeling, wordt op 120 geschat, terwijl een iets grotere groep blijvende hersenbeschadiging oploopt (....).'

Voor de schatting van het cijfer mishandelde/verwaarloosde kinderen (minimaal 50.000 per jaar volgens de te lage/voorzichtige extrapolatie 
van de VKM en minimaal 80.000 per jaar volgens de extrapolatie in deze studie), die voor een deel binnen, voor een deel buiten de hierboven vermelde cijfers vallen, verwijzen we naar hoofdstuk 12 (voor de juridische/ mensenrechtelijke situatie zie art. 19 VRK).

Vanuit dit Pays Bas réel moeten we op weg naar het Pays Bas légal. Een weg die is geblokkeerd zolang niet het mensenrechtelijk inzicht doorbreekt dat, zoals FURSTENBERG het, in de openingszin van zijn bijdrage 'State-family alliances and children's welfare,' verwoordt: ${ }^{310}$

"Modern states and the family are jointly responsible for cultivating the potential of children (...).

Een gedeelde verantwoordelijkheid die voor beide partijen - de moderne staat en de aanstaande ouders - aanvangt vór de geboorte van het kind. Doch het dagen van dit inzicht is nog maar het begin. Om zijn (mede-) verantwoordelijkheid waar te kunnen maken, dient de moderne staat bovendien van de illusie te worden bevrijd dat hij kan volstaan met omtrekkende bewegingen rond het gezin en een beleid van marginale preventie en Kurieren am Symptom: een beleid van welwillende ouderschapsverwaarlozing en het 'op de privacy-koop toe' in de steek laten van kinderen. Kinderen: de hoop van elke natie op een betere toekomst voor alle wereldburgers - onder wie kinderen.

Vooralsnog functioneert "privacy" als alibi voor de overheid om de status quo niet te verstoren door de deur open te zetten voor andere dan gevestigde, stemhebbende belangen. Kinderen zijn dus altijd in het nadeel, worden niet gehoord. Want welke democratische overheid luistert naar stemmen die geen stemmen opleveren? Tenzij hun belangen samenvallen met de belangen van anderen die wel gehoord worden. Zoals sinds kort en in de marge vrouwen, die carrière en gezin willen - en grotendeels moeten - zien te combineren.

Het - op de keper beschouwd - maatschappelijk en statelijk in de steek laten van kinderen kan als een moderne - passieve - vorm van wreedheid worden gekwalificeerd. Zoals meer dan een eeuw geleden, in 1883, de oprichter van de New York Society for the Prevention of Cruelty to Children (tevens de raadsman van de - oudere - American Society for the Prevention of Cruelty to Animals ${ }^{311}$ ) $\mathrm{zei}^{312}$

310 Frank F. FURSTENBERG $\mathbf{J r}_{\mathrm{r}}$, 'State-family alliances and children's welfare; a research agenda, , Childhood $1997 / 2$, pp. 183-192, op p. 183.

311 Ik neem aan dat hij de raadsman is van wie BAARTMAN gewaagt, in de beruchte zaak van Mary Ellen uit 1874 (BAARTMAN, Opvoeden kan zeer doen, a.w., p. 15). Naar aanleiding van deze zaak werd de New York Society for the Prevention of Cruelty to Children opgericht in 1875 . De American Society for the Prevention of 
'Cruelty to children produces mental and physical disease, and the prevention of such cruelty is a matter, therefore, of grave public importance (GERRY, 1883 $(\ldots))$.'

En zoals in deze eeuw OATES lat horen: ${ }^{313}$

'Prevention of child abuse is likely to be cost-effective, reducing death, injury, and psychological disturbance. It should also enhance the development, and subsequent parenting skills of many children who may have otherwise been at risk for perpetuating abuse in the next generation."

En, zo vervolgt de auteur: ${ }^{314}$

'Preventing a proportion of abuse will also free resources for more effective management of children and families who escape the preventive net."

\section{De auteur makt zich evenwel geen illusies: ${ }^{315}$}

'Just as child abuse is a complex problem, so too is prevention. Clearly multiple strategies are required. Areas that need to be addressed, include societal attitudes toward the following:

- violence [handen thuis: geen maatschappelijke tolerantie voor lichamelijk geweld waar en tegen wie ook gepleegd; verbieden van gewelddadige, agressieve en mensonterende vormen van 'sport' (zoals boksen en erger); geen geweld op televisie vór 8 uur's avonds, jw];

- family violence [verbieden van het slaan van kinderen en aanleren van meer adequate en effecticve disciplineringsmethoden, jw];

- alcohol and drug abuse [geen maatschappelijke tolerantie voor alcohol en drugs (waaronder nicotine) in combinatie met zwangerschap en ouderschap, jw];

- poverty [opvoedingsgeld! -jw];

- education of the media [wetgeving die de verantwoordelijkheden vastlegt van alle media die zich ook of mede tot kinderen richten, jw];

(....)

- enhancing competence and child-rearing skills of families [opvoedingsondersteuning en opvoedingsonderwijs! -jw];

- public education about abuse prevention [publiekscampagnes over sociaal-pedagogische instellingen, voorzieningen en programma's, waaronder rehabilitatie-

312 Elbridge GERRY, 'Cruelty to children,' North American Review 1883, aangehaald door Natan SZNAIDER, "Compassion and control; children in civil society," Childhood 1997/2, pp. 223-240, op p. 232 (en p. 234).

313 R.K. OATES, The spectnum of child abuse; Assessment, treatment, and prevention, Basic Principles into Practice series, vol. 8, New York 1996, p. 139 i.f. 
programma's (erkenning, lotgenotengroepen, counseling), behandelprogramma's (therapie, daderbehandeling) en voorwaarden voor compensatie uit een schadefonds; verhogen meldingsbereidheid bij beroepsgroepen en publiek en invoeren meldplicht voor iedereen die weet heeft of een ernstig vermoeden van kindermishandeling, jw];

- enhancing self-esteem of parents and children [opvoedingsondersteuning; reparatie/rehabilitatie! $-\mathrm{jw}$;

(...)

- development of family and community support networks [algemeen toegankelijke (laagdrempelige) sociaal-pedagogische voorzieningen, instellingen en diensten; saciaal-pedagogisch netwerk op buurtniveau! -jw];

- parent education about child development [opvoedingsonderwijs! -jw];

- treatment of parents with personality disorders [reparatie/rehabilitatie! -jw].'

\section{De auteur concludeert.: ${ }^{316}$}

'Although child abuse may never be eliminated, we do know enough about prevention to be able to reduce its incidence if there is a public, political, and professional will to do so. We also understand enough about treatment to ensure that for those cases where prevention has not been possible, treatment can be provided at a level of quality that will have long-lasting beneficial effect.'

Dit alles begint met, en staat of valt met ...

'(...) a caring society that provides opportunities for parents in circumstances of stress and poverty to receive assistance in their child-rearing. ${ }^{, 317}$

En dus met instellingen, voorzieningen en programma's ...

'(...) to enhance parenting skills of new mothers and fathers. The thought is that by targeting a large group, those within that group who are at risk of abusive behavior, will be assisted and thus the risk of abuse will be reduced. Primary preventive programs have an advantage of not stigmatizing any particular group as being "at risk." There are also helpful fringe benefits such as the value to all parents of being helped with their parenting skills. ${ }^{, 318}$

\subsection{Rehabilitatie en reparatie}

In hoofdstuk 13 (par. 13.2.2.3) constateerden we dat ten aanzien van re. paratie (c.q. rehabilitatie) een onderscheid moet worden gemaakt tusser minderjarige slachtoffers van kindermishandeling en volwassen 'survivors,

A.w., pp. 154-155 (curs. jw).

317 A.w., p. 154.

318 A.w., pp. 144/145. 
zowel wat de inhoud en betekenis van 'reparatie' betreft als in juridische zin. Juridisch gezien valt de eerste groep immers volledig onder de werking van art. 39 van het Verdrag inzake de rechten van het kind, terwijl de tweede groep hetzij valt onder het algemene volkenrecht op dit punt, hetzij onder andere bepalingen van het Verdrag, indien zij namelijk (aanstaande) ouders zijn en in die hoedanigheid aanspraak maken op reparatoire opvoedingsondersteuning. Wat het algemene volkenrecht betreft, citeerden we uitvoerig uit de Study concerning the right to restitution, compensation and rehabilitation for victims of gross violations of human rights and fundamental freedoms van VAN BOVEN, speciale rapporteur van de Subcommissie inzake preventie van discriminatie en bescherming van minderheden van de vN-Mensenrechtencommissie, en de op basis van die studie en commentaren door VAN BOVEN opgestelde Basic principles and guidelines on the right to reparation for victims of (gross) violations of human rights and international humanitarian law. ${ }^{319}$ De laatste van deze beginselen en richtlijnen luidt (voor zover hier van belang): ${ }^{320}$

"Satisfaction and guarantees of non-repetition shall be provided, including, as necessary:

(a) Cessation of continuing violations;

(b) Verification of the facts and full and public disclosure of the truth ${ }^{321}$;

(c) An official declaration or a judicial decision restoring the dignity, reputation and legal rights of the victim and/or of persons closely connected with the victim;

(d) Apology, including public acknowledgement of the facts and acceptance of responsibility;

(e) Judicial or administrative sanctions against persons responsible for the violations;

(f) Commemorations and paying tribute to the victims;

(g) Inclusion in human rights training and in history or school textbooks of an accurate account of the violations committed in the field of human rights (...);

(h) Preventing the recurrence of violations by such means as: (...) [c]londucting and strenghtening, on a priority and continued basis, human rights training to all sectors of society (...).'

In de desbetreffende paragraaf constateerden we ook dat het het bestek van deze studie te buiten zou gaan te onderzoeken wat zoal onder reparatie (compensatie/rehabilitatie) voor slachtoffers die buiten de trias (pedagogica) vallen, zou kunnen worden verstaan. We suggereerden dat

Inmiddels in drie talen gepubliceerd door de International Commission of Jurists: The right to reparation for victims of human rights violations (...), Geneve 1998. Beginsel/richtlijn 15, a.w., pp. 10-11 (zie ook hoofdstuk 13, par. 13.2.2.2).

Een voorwaarde die we aan het slot van hoofdstuk 12 in verband brachten met een - verhoopt - Marcus-effect. 
te denken ware aan een recht op kosteloze therapie (met inbegrip, zo voegen we hier toe, van faciliteiten voor lotgenotengroepen en gratis counseling), een uitkering uit het Schadefonds geweldsmisdrijven en een recht op publieke erkenning, bestaande uit (onder meer) een nationaal monument voor het Mishandelde Kind (op te richten vóor het ministerie van Kind en Gezin), en een jaarlijkse dag van het Mishandelde Kind (bijvoorbeeld op 20 november, of 28 december, of een echte nationale dag: op 5 december).

In dit hoofdstuk en op deze plaats is het passend de hierboven gesuggereerde, het individuele verwerkingsproces faciliterende sociale voorstellen uitdrukkelijk te bepleiten. ${ }^{322}$ Een nadere toelichting op deze voorstellen lijkt ons echter minder zinvol dan het nog eens (kort en vanuit een andere invalshoek) naar voren halen van drie elementen die er ten nauwste mee samenhangen en die als een rode draad door deze studie lopen: transgenerationaliteit, verwerking en zelfbepaling.

\section{Transgenerationaliteit}

Uiteraard - het zij hier nogmaals herhaald - wil transgenerationaliteit niet zeggen dat als kind mishandelde ouders gedoemd zijn hun eigen kinderen te mishandelen. De wetmatigheid die in het begrip transgenerationaliteit besloten ligt, althans zoals dat begrip in deze studie is gehanteerd, is veel subtieler en complexer van aard. Sleutels voor het bevatten van deze subtiliteit en complexiteit, zijn de in deze studie gebruikte begrippen nemo plus-regel, pedagogisch besef en (mate van) verwerking. Dat eerste begrip duidt (hier kort gezegd) op het volgende. Op grond van wat bekend is over de intergenerationele overdracht van gehechtheid, moet worden aangenomen dat als kind onveilig gehechte c.q. (chronisch) getraumatiseerde ouders hun kind in affectieve en pedagogische zin niet (volledig) kunnen meegeven wat dat kind, ontwikkelingspsychologisch gezien, nodig heeft ('nemo plus'). Het schort hun aan wat we, in navolging van BAARTMAN, genoemd hebben pedagogisch besef. Dat wil zeggen: tenzij zij erin geslaagd zijn hun jeugdervaringen op adequate wijze te verwerken. Dit laatste begrip impliceert dat zij emotioneel contact hebben kunnen maken met het te kort gekomen kind in henzelf en, op basis van dat intrapsychische contact, 'achterstallige' ontwikkelingstaken alsnog tot een bevredigende oplossing hebben kunnen brengen.

Om ook in meer spirituele zin recht te doen aan wat hier in technische termen wordt samengevat, komen we zo dadelijk op het begrip

322. Vgl. in dit verband ook Judith Lewis HERMAN, Trauma en herstel; De gevolgen

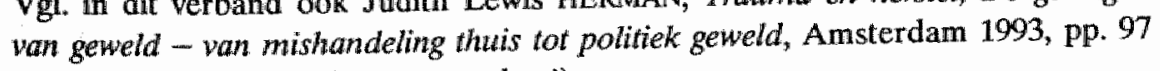
(i.f.) e.v. ('De rol van de gemeenschap'). 
verwerking terug. Op deze plaats zij erop gewezen dat ook kinderen die niet zijn mishandeld volgens de gangbare definities van fysieke mishandeling, verwaarlozing en sexueel misbruik, ouders kunnen hebben gehad wier eigen (onbewuste) nood - alle goede bedoelingen en voornemens ten spijt, en ook al deden zij hun uiterste best, en getroostten zij zich daarbij vele opofferingen, hun kinderen goed te verzorgen en op te voeden - tot gevolg had dat hun kinderen door een emotionele hel zijn gegaan of in een emotionele woestijn hebben gewoond. Ook kinderen die niet zijn geslagen en niet zijn verkracht, en die in materiële zin niets te kort zijn gekomen, kunnen ernstig, en soms levenslang, zijn verwond. Soms is kindermishandeling niet meer dan het op de wereld zetten van een kind - een kind dat men te weinig te bieden heeft, door welke oorzaken of omstandigheden ook, om het, zonder steun of hulp, minimaal verantwoord naar de volwassenheid te kunnen begeleiden. Voor zover die oorzaken (mede) in de jeugd van de ouder liggen (of hebben gelegen), vallen zij evenwel in beginsel, dat wil - steeds - zeggen: behoudens verwerking, onder het begrip transgenerationaliteit.

\section{Verwerking}

Op verschillende plaatsen in deze studie hebben wij gewezen op het belang van de verwerking van traumatische jeugdervaringen, in het bijzonder met het oog op de doorbreking van transgenerationele processen, met andere woorden met het oog op het recht van het kind op optimale persoonswording. Een recht dat bestaat uit een interacterend geheel van verplichtingen van ouders, staat, omgeving van het kind èn het kind zelf - dat wil zeggen: naar de mate van zijn zich ontwikkelende vermogens. In deze paragraaf staan wij nog eenmaal stil bij dit cruciale, hoogst persoonlijke aspect van rehabilitatie en reparatie.

Donum fac remissionis (wil het woord vergeving spreken) ) $^{323}$

Verwerking zouden wij op deze plaats, enigszins impressionistisch, willen typeren als een, vaak jarenlang, soms een leven lang, eerder in golven dan in fasen verlopend proces, waarbij om te beginnen vroege fantasieën die de kinderlijke hoop op redding, op verlossing, op opstanding uit de emotionele dood uitdrukken, om de voorrang vechten met de al even archaische schuldgevoelens van het kind dat om te overleven wel geloven moest dat het hem aangedane onrecht aan hemzelf te wijten was ... schadelijke gevolgen van onze opvoeding te boven te komen; Met een woord vooraf van Alice MILLER, Houten 1998 (tweede druk), pp. 177 en 234 i.f.-235. 
Tuba, minum spargens sonum

Per sepullcra negionum,

Coget omnes ante thronum.

Rex tremendae majestatis,

Qui salvandos salvas gratis,

Salva me, fons piëtatis.

Ingemisco, tamquam reüs:

Culpa nubet vulitus meüs:

Supplicanti pance, Deis.
Wondere trompetrumoeren: zullen al de graven noeren, al die dood zijn troonwaars voeren.

Koning schrikbaar en grootmachtig. bron van goedheid, nederslachtig bid ik $U$, wees mij indachtig?

"k Zucht als een ter dood verwezen, maar mijn schaamrood schuldig wezen hoopt op uw barmhartig wezen.

... waarna, dat will zeggen na bewerking waarvan, nu eens gevoelens van verontwaardiging en vertwijfeling elkaar afwisselen ...

Recordáre, Jesu piè,

Quod sum causa tuae viae:

Ne me perdas illa dië.

Qui Mariam absolvisti,

Et latrónem exaudisti,

Mihi quoque spem dedisti.

Quid sum miser tunc dichüns?

Quem patrörum rogatürus,

Cum vix justus sit secürus?
Jesu, wil toch wel gedenken: als Gij mij kwaant 't leven schenken, was 't on me op die dag te krenken?

Werd Maria 't eeuwig leven, werd de moord'naar hoop gegeven, hopen durf ik ook, en beven.

Wie zal dan toch mijn verweer zijn, wat mijn voorsprake of begeer zijn, als de goeden zelfs verveerd zijn?

... en dan weer de tweestrijd tussen loskomende woede en de zucht naar vergelding zich onstuitbaar opdringt ...

Quantus tremor est futhirus, Quando judex est ventinus, Cuncta stricte discussúns!

Liber scriptus proferétur, In quo totum continetur, Unde mundus judicëtur.

Juder engo cum sedebit, Quidquid latet, apparébit: Nil inúltum remanébir.
Welk een gruwel 'n zal 't niet wezen, als de Rechter, opgerezen, it goê zal uit het kwade lezen!

't Zal een boek te voorschijn komen, waarin "t al staat opgenomen, dat het oordeel Gods moet schromen,

Als de Rechte; neengezeten, al 't werdoken kwaad zal weten, straffen ende niets vergeten.

... om vervolgens, na veel verdriet, weer te wijken voor ogenschijnlijk onuitroeibare schuldgevoelens en schuldbeladen verwijten die de bitterzoete hoop op erkenning van onrecht en pijn en de onsterfelijke hoop op verzoening amper kunnen verhullen ... op verzoening met ouders vóór zij 
er niet meer zijn, met ouders die nog levend al dood zijn, die eenmaal dood zijnd voortleven ...

Juste judex ultionis,

Donum fac remissionis

Ante dient rationis.

Mors stupébit et natüra,

Cum resürget creatúra,

Judicànti responsura.

Pië Jesu Dómine,

Dona eis rêquiem.

Amer.
Schoon 't uw recht zij wan te wreken, wil mij vrij van zonden spreken, eer die dag komt aan te breken.

Stom zal staan de Dood en "Leven, als de doden antwoond geven, staan, en voor de Rechter beven.

Zoete Here Jesu mijn, laat ze in rust en wrede zijn, in alle eeuwer. Amen. 324

Mihi quoque spem dedisti (hopen durf ik ook ... en léven)

Verwerking (die helaas niet altijd, en in zeer ernstige gevallen alleen bij uitzondering mogelijk is - welke reparatoire steun ook wordt geboden) heeft veel, en in laatste instantie alles, te maken met een derde rode draad: zelfbepaling. Mèt de zich ontwikkelende (niet geblokkeerde) vermogens van het kind neemt ook het element van de zelfbepaling toe, een element dat de uiteindelijke doorslag geeft, tenzij het volledig is gebroken, ontsnapping uit de herhalingsdwang mogelijk te maken, en wel door die herhalingsdwang om te buigen naar een (aanvankelijk niet minder wel anders - pijnlijke) herkansingsdrang. Met betrekking tot dit element permitteren we ons op deze plaats een laatste korte opmerking.

We leven weliswaar maar éen keer, maar wat we van dat leven maken, bepaalt ieder voor zichzelf. $\mathrm{Al}$ is het tragisch dat pogingen pijn en angst te vermijden (waarbij mensen zich soms, 'gevangen' in hun jeugd, in de gekste bochten wringen), veelal alleen maar meer pijn en angst veroorzaken - blijvende en zeurende pijn, veelvormige en duistere angst. Geen bevalling zo zwaar, lijkt het soms, als die van de waarheid van het eigen leven. Wie zou die pijn niet willen ontlopen? Maar tegen (w)elke prijs?

324 Dies irae (twaalfde/dertiende eeuw), sequentia uit de liturgie der overledenen (de uitvaartmis) c.q. de mis op Allerzielen ( 2 november); vertaling van Guido GEZELLE (overgenomen uit een parochiemissaal). De (drieregelige) coupletten van het Dies irae zijn anders gerangschikt; het eerste, tiende en de zes voorlaatste coupletten ontbreken hier. Het Dies irae, in de oorspronkelijke volgorde, 'roept (...) het beeld op van de ziel die op het laatste oordeel terecht staat voor God.' Het eerste couplet kondigt de apocalyps, het Laatste Oordeel, allus aan:

Dies irae, dies illa,

Solvet saecium in favilla:

Teste David cum Sibylla.
Kwade dag, die al de dagen

eens lijk asse weg zult vagen, zo 't Sibille en David zagen. 
In hoofdstuk 13 hebben we uitgebreid stilgestaan bij het stoïsche concept van het allermensenrecht als grondslag en overkoepeling van GROTIUs" natuur- en volkenrecht: een universalistische volkenrechtsvisie waarmee ten nauwste samenhing de opvatting van een moreel-juridisch parallellisme tussen individu en staat, volgens LAUTERPACHT één van de hoofdkenmerken van de grotiaanse traditie in het internationale recht. ${ }^{325} \mathrm{Nu}$ wijst ONUMA er evenwel op dat GROTIUS' theoretische parallellisme uitgaat van een ander individu-concept dan het (individualistische) huidige. Wanneer GROTIUS het over privati, private personen ('individuen') heeft, heeft hij eigenlijk families, gezinnen, of liever het gezinshoofd, de pater familias, in gedachten: de heerser, de staatsman wordt zogezegd de morele verantwoordelijkheid van een goed huisvader voorgehouden (een opvatting die, zoals bekend is, nogal afwijkt van die van MACCHIAVELLI). In ONUMA's eigen woorden: ${ }^{326}$

'Whereas the modern concept of the individual assumes individuals stripped of both the authority to rule others [wife, children, slaves, jw] and the legitimate means of violence [jus castigandi, the right to punish physically, $\mathrm{jw}$ ], the term privatus [private person, individual, $\mathrm{jw}$ ] as used by GRoniUs assumes a head of a household [pater familias, jw] (...) vested with both.'

Wijkt GRoTrus' individu-concept echter wel zo sterk af van het huidige als ONUMA met zoveel stelligheid beweert? Zolang immers (weliswaar niet alleen de man maar - meer dan dubbel zo erg - beide) ouders hun kinderen mogen slaan, althans met gebruikmaking van een zekere mate van fysiek geweld, door toediening van - in de woorden van de Nederlandse regering - "een opvoedkundig "pak voor de broek"'327 mogen disciplineren, zolang met andere woorden ouders bekleed zijn niet alleen met ouderlijk gezag over hun kinderen - een ouderlijk gezag dat overigens slechts in theorie aan de 'rule of law' onderhevig is -, maar ook met een ouderlijk tuchtigingsrecht, is het nog maar de vraag in hoeverre het

325 Hersch LAUTERPACHT, 'The grotian tradition in international law,' (The British Yearbook of Intemational Law 1946, herdrukt) in: E. LAUTERPACHT (ed.), International law, being the collected papers of Hersch LAUTERPACHT, vol. 2, Cambridge (etc.) 1975 , pp. 307-365, op pp. 336-340.

326 ONUMA Yasuaki, "Conclusion: law dancing to the accompaniment of love and calculation,' in: dez. (ed.), A normative approach to war: Peace, war, and justice in HugO GROTIUS, Oxford 1993, pp. 333-370, op p. 336 i.f.

327 Kamerstukken II 1992/93, 22855 (R 1451), Goedkeuring van het op 20 november 1989 te New York tot stand gekomen Verdrag inzake de rechten van het kind, nr. 3 (Memorie van Toelichting), pp. 29/30. 
moderne 'concept of the individual' ook van toepassing is in relatie tot - zoals een reclame-slogan het wil - de belangrijkste mensen van de wereld: kinderen. Waar ONUMA GROTIUS zelfs een zekere regressie naar een Romeinsrechtelijk pater familias-begrip verwijt, ${ }^{328}$ lijkt ons eindtwintigste-eeuwse pater et mater familias-begrip nog ver van wat ONUMA de moderne opvatting van het individu acht, verwijderd.

Bij ONUMA's opvatting kan echter nog een ander vraagteken worden geplaatst. Een - uiterst - modern (ogend) individu-concept komen we in de wereldliteratuur immers al tegen bijna anderhalve eeuw vóór GROTIUS' De jure belli ac pacis (1625). Waar mooier is de 'moderne' opvatting van het individu - let wel: niet in relatie tot het kind dat wèl individu, persoon, individueel persoon moet worden - verwoord dan, vijfhonderd jaar geleden, in de rede Over de menselijke waardigheid, PICO DELLA MIRANDOLA's (1463-1494) De hominis dignitate uit 1487, waarin God de eerste mens aldus toespreekt: ${ }^{329}$

\begin{abstract}
"WU HEBBEN U, O ADAM, geen bepaalde woonplaats, geen eigen aangezicht, geen enkele speciale taak gegeven, opdat ge die woonplaats, dat aangezicht en die taak die ge verkiest, verwerven en bezitten zult naar uw eigen wil en wens. Voor alle andere wezens is de natuur vastomlijnd en binnen de door Ons voorgeschreven wetten beperkt. Gij zult die voor uzelf bepalen, door geen grenzen belemmerd, naar eigen vrije wil, waaraan Ik u heb toevertrouwd. Ik heb u midden in het heelal gezet, opdat ge van daaruil gemakkelijker alles rondom u zien kunt wat er in de wereld is. En We hebben u niet hemels of aards, niet sterfelijk of onsterfelijk gemaakt, opdat ge als een vrij en soeverein kunstenaar uzelf boetseert en modelleert in de vorm die ge verkiest. Het staat u vrij naar het lagere, het dierenrijk te ontaarden; maar ge kunt u ook verheffen naar het hogere, het goddlelijk rijk door eigen wilsbeschikking."
\end{abstract}

Ook hier zijn echter, een half millennium later, nog steeds grote vraagtekens op zijn plaats. Hoe vrij en soeverein is immers de mens, met welke middelen toegerust een levenskunstenaar te worden, die gebukt gaat onder de last van een jeugd waarin hem alles is onthouden wat voor en volgens volwassenen de vanzelfsprekende parafernalia der menselijke waardigheid zijn: respect, zorg, lichamelijke en geestelijke integriteit,

328 ONUMA, a.w., pp. $336(-337)$ nt. 5 en 120 ntt. 206 (op p. 60 i.f. lijkt de auteur zichzelf evenwel tegen te spreken waar hij opmerkt dat GROTIUs' opvatting gedeeld werd door 'many of his contemporary thinkers').

329 Giovanni PICO DELLA MIRANDOLA E CONCORDLA, Over de menselijke waardigheid (vert. J. HEMELIRIJK), Arnhem 1968, pp. 11-12.

Zie ook B.P. VERMEULEN, G.A. VAN DER WAl, 'GROTTUS, AQUINAS and HOBBES; Grotian natural law between lex aeterna and natural rights,' Grotiana New Series 1995-1996, pp. 55-83, op p. 64. 
kortom: geen willekeur en onverschilligheid maar rechten? Gebukt onder de onvrijheid, bekneld in de dwangbuis van een psychopathologie die schade veroorzaakt - tegen beter willen in - aan zijn geliefden, aan collega's, aan de maatschappij en, transgenerationeel en exponentieel, aan zijn kinderen. Schade aan hemzelf en alles wat een gezond mens dierbaar zou zijn: de parafernalia der menselijke waardigheid, de rechten van de mens.

De mens die niet in staat gesteld of geweest is traumatische jeugdervaringen naar de mate van het mogelijke te verwerken, kan de pijn, mag de pijn niet voelen, hem als kind aangedaan. De menselijke gave van de empathie is bij hem daardoor vergiftigd. Hoe kan wie geen toegang heeft tot zijn eigen pijn, de pijn van anderen na-voelen, mee-voelen? En wat is empathie anders dan juist dat: het vermogen de pijn van anderen te voelen, aan te voelen, in te voelen. Een vermogen dat voor niet weinigen slechts bestaat bij de gratie van de ervaring, de herbeleving, van de pijn van het gekwetste kind in henzelf. Hoe kan van wie deze genade - de genade van de (gedoseerde) pijn van de herbeleving, en het inzicht en de groei, de herwonnen levenslust en levenskracht, de geestelijke gezondheid en vrijheid, die daaruit voortkomen, wat wij verwerking noemen; een genade die een recht, een recht op verwerking, althans op therapie, en desnoods levenslange begeleiding, zou moeten zijn -, hoe kan van wie deze genade, dit recht, niet deelachtig is geworden, worden verlangd dat hij zich ontfermt over zijn kinderen, dat hij hun troost biedt, en zo de pijn voelt die niet gevoeld kan, niet gevoeld mag worden?

God heeft geen kinderen geschapen. De mens is niet als kind door Hem in het paradijs gezet. God heeft Adam, en Eva, been van zijn gebeente, vlees van zijn vlees, ${ }^{330}$ als volwassenen geschapen. ${ }^{331} \mathrm{En}$ hen vervolgens als onwaardigen - en ten aanzien van goed en kwaad niet meer onwetenden - uit het paradijs verdreven. ${ }^{332}$ Nog bidden wij: $:^{333}$

330 Genesis 2:23.

331 Man en vrouw schiep Hij hen (Genesis 1:27); de man vit kleiaarde (Genesis 2:7), de vrouw uit een rib van de man (Genesis 2:21-22).

332 CROMBAG en VAN DUN (Hans CROMBAG en Frank VAN DUN, De utopische verlei-

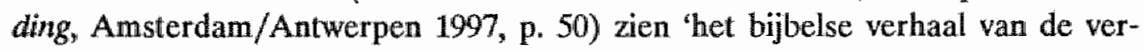
jaging uit het paradijs (...) als cen metafoor van de prijs van de bewustwording." Deze opvatting heeft mij op de gedachte gebracht van een mogelijke lezing van dit bijbelverhaal als Oer-Individuatie-mythe. Zij het van een zeer traumatisch verlopen, blijkens de transgenerationele gevolgen mislukte individuatie. Kennelijk was de paradijselijke homeostase te symbiotisch en de goddelijke Vader zelf te bang voor 'veelheid en verscheidenheid' (a.w., p. 51) om een gelukte individuatie bij het eerste mensenpaar mogelijk te maken. Uiteindelijk moet elk mensenkind echter het Ouderlijk paradijs (wat niet per se hetzelfde is als het ouderlijk huis) verlaten - of desnoods daaruit worden verjaagd (vgl. ook a.w., pp. 191/192) " 
Domine, non sum dignus .... Heer, ik ben niet waardig .... (Want ik heb gezondigd in gedachten, woorden en werken .... Mea culpa, mea culpa, mea maxima culpa ....) De verstoting uit het aards paradijs, ${ }^{334}$ gepaard gaande met vervloekingen en bedreigingen ${ }^{335}$ - in smarten zult ge kinderen baren, ${ }^{336}$ in het zweet wws aanschijns zult ge uw brood eten -, de ultieme afwijzing door een Almachtige Vader, ${ }^{337}$ was niet alleen het eerste psychotrauma van de mens, maar ook een psychotrauma van de eerste orde, het oer-psychotrauma dat zes bijbelse millennia, tot in het zevenmaal zeven maal zevende geslacht is doorgegeven. ${ }^{338}$

333 Zowel de priester als de gelovigen zeggen bij de communie driemaal, terwijl zij zich telkens op de borst kloppen: Domine, non sum dighus, ut intres sub tectum meum: sed tantum dic verbo, et sanabitur anima mea. (Heer, ik ben niet waardig dat Gij tot mij komt; maar spreek slechts één woord, en mijn ziel zal genezen.) Tot de gebeden aan de voet van het altaar behoort de schuldbelijdenis. De gelovigen bidden het Confiteor: Confiteor Deo omnipotenti (...) quia peccavi nimis cogitatione, verbo et opere: mea culpa, mea culpa, mea maxima culpa. (Ik belijd voor de almachtige God (...) dat ik zeer gezondigd heb met gedachten, woorden en werken: door mijn schuld, door mijn schuld, door mijn allengrootste schuld.) (Parachiemissaal, onveranderlijke gebeden van de heilige misviering.)

334 Genesis 3:22-24.

335 Genesis 3:14-19.

336 Er was nog een tweede tot de vrouw gerichte verwensing: naar uw man zal uw begeente uitgaan, en hij zal over u heersen (Gen. 3:16). Sinds 1979 (voor Nederland sinds 1991) lijkt althans het tweede gedeelte van die vloek door de beloften van het Verdrag inzake de uitbanning van alle vormen van discriminatie van vrouwen doorbroken.

337 Credo in unum Deum, Patrem ommipotentem .... Ik geloof in de éne God: de almachtige Vader .... (Credo of Geloofsbelijdenis; Parochiemissaal, onveranderlijke gebeden van de heilige misviering.)

338 Zelfs aan generaties natuurrechtsdenkers. Is het voluntarisme, de natuurrechtsleer volgens wellke aan de - arbitraire, slechts door de openbaring kenbare - goddelijke will (met als theologisch extreem de leer wan de predestinatie), en niet aan de goddelijke rede, kenbaar - be-rede-neerbaar - voor het autonome menselijke verstand (rationalisme), het primat toekomt (zie B.P. VERMEULEN, 'God, wil en rede in Hugo DE GROOTs natuurrecht,' Wijsgerig perspectief 1982-1983, pp. 54-59; Leonard BESSELINK, 'The impious hypothesis \etiamsi daremus \revisited,' Grotiana New Series vol. 9, 1988, pp. 3-63, op pp. 3/4, 8-9, 36/37, 45-46, 46/47 en $62-63$; A.C. EIJFFINGER, B.P. VERMEULEN, 'Inleiding," in dez. (red.), Hugo DE GROOT; Denken over oorlog en vrede, Baarn 1991, pp. 11-40, op pp. 24-25; B.P. VERMEULEN, G.A. VAN DER WAL, "GROTIUS, AQUINAS and HOBBES; grotian natural law between lex aeterna and natural rights,' Grotiana New Series vol. 16-17, 1995-1996, pp. 55-83, op pp. 71-72), niet een projectie van de ouderlijke willekeur op God? Een projectie met andere woorden van in hun jeugd aan volstrekte ouderlijke willekeur overgeleverde volwassenen? Als ouders "well haast een soort goden" zijn (De jure belli ac pacis, Prol. 14, slotzin: quasi Dii quidam sunt parentes), is de goedheid van wrede, almachtige ouders een afspiegeling van de oneindige goed- 
Zich met de door zijn ouders, huns ondanks, in hem geplante onwaardigheid geen raad wetend, en onder invloed daarvan niet opgewassen tegen de afwijzing van zijn offer door God, doodde het eerste mensenkind, Kaïn, zijn broer Abel, wiens offer wel was aanvaard. ${ }^{339} \mathrm{Zo}$ betaalde Abel de prijs van het oer-trauma met zijn leven, zijn broer met het Kaïnsteken van broedermoordenaar, een zwerver en vluchteling op aarde, verbannen uit het aanschijn van God. ${ }^{340}$ Trauma was op trauma gestapeld. Zevenmaal zeven maal zeven generaties slachtoffers zouden volgen. Het lot van de mens als zesduizendjarig ${ }^{341}$ transgenerationeel noodlot. 'Wij hebben u, o Adam, o Seth, o Enos, o Kenan, o Mahalalel, o Jered, o Henoch, o Methusalem, o Lamech, o Noach ....'

Ja zelfs na Noach, nadat het water van de zondvloed niet alleen de onwaardige mens maar ook de redeloze dieren had verdelgd, ging dat door. De zondvloed als uiterste straf van een Almachtige, doch teleur-

heid (dogma) van een wrede (mysterie, 'hogere bedoelingen'), almachtige God (vgl. de beproeving van Abraham die een beproeving voor Izaäk was).

Genesis 4:1-8.

340 Genesis 4:13-16.

341 Volgens Matthëus 1:17 zijn er van Abraham tot David 14 generaties en van David tot de Messias tweemaal 14 (42 in totaal dus). Historisch kan evenwel worden gereconstrueerd dat tussen Abraham en Christus ongeveer 2000 jaar liggen (bij benadering 1000 jaar tot koning David en nog eens zo'n 1000 jaar na hem). Dat zijn, uitgaande van tijdvakken van 18 jaar tussen geboorten, 111 generaties. Maar het is geenszins uitgesloten dat deze 111 generaties 42 stamvaders omspannen, die dan gemiddeld 48 jaar zijn geworden (vóór David 72 jaar, na David 36 jaar). Uiteraard is het onmogelijk de tijdspanne tussen Adam en Abraham te reconstrueren. Volgens de genealogie van Genesis zijn er tien generaties van Adam tot en met Noë (Gen. 5:3-32; 9:28), en nog eens tien na Noë tot en met Abraham (Gen. 11:10-27 en $32 ; 25 ; 7$ ). Het gemiddelde tijdsverloop tussen de geboorten van de 20 genoemde stamvaders, die zelf wonderbaarlijk hoge leeftijden bereikten (waarbij de 969-jarige Methusalem de kroon spant: Gen. 5:27), is evenwel bijna 100 jaar. Aangezien zij meerdere zonen en dochters kregen, kennelijk tot op hoge leeftijd (Gen. 5:4, 7, 10, 13, 16, 19, 22, 26, 30; 11:11, 13, 15, 17, 19, 21, 23, 25), zijn er verschillende generaties tussen de stamvaders. Gaan we - om religieuze, althans niet wetenschappelijke redenen - uit van de bijbelse tijdspanne van (20 stamvaders $x$ gemiddeld 100 jaar $=$ ) ongeveer 2000 jaar tussen Adam en Abraham, dan zijn er circa $(3 \times 2000=) 6000$ jaar verlopen $(2 \times 2000$ jaar v6or en 2000 jaar na Christus) tussen de eerste mens en de kinderen die vandaag (of morgen) geboren worden. Gedeeld door tijdvakken van 18 jaar tussen geboorten zijn dat 333, ofwel (10 minder dan) zevenmaal zeven maal zeven generaties. (Vgl. voor deze gegevens ook $A B C$ van de bijbel, vert. W. VAN OPZEELAND, Amsterdam/ Brussel 1992, pp. [8], [22], 270, 286; Mysteries van de bijbel, vert. J.C. CONSTANT, Amsterdam/Brussel 1990, pp. 40 en 46-47.) Overigens begint de Joodse jaartelling in 3760 vóiór Christus; in 2000 zijn we dus nog ruim twee eeuwen verwijderd van het Joodse zevende millennium. 
gestelde Vader ${ }^{342}$ maakte aan het van geslacht op geslacht doorgeven van trauma's, aan de vloek van het oer-trauma geen eind. In het teken van Gods verbond, ${ }^{343}$ zou Noach al spoedig zijn zoon, die de schaamte van zijn vader had gezien, straffen door ... diens zoon, zijn onschuldige kleinzoon (Kanaän), èn zijn nakomelingen (de Kanaänieten), te vervloeken. ${ }^{344}$ 'Wij hebben u, o Sem, o Arpachsad, o Selah, o Heber, o Peleg, o Rehu, o Serug, o Nachor, o Terah, o Abraham ....'

Transgenerationele vloek wordt op transgenerationele vloek gestapeld. In verschillende oud-testamentische boeken keren ze terug: kinderen die moeten boeten voor de fouten van hun ouders, ${ }^{345}$ transgenerationele vloeken tot in het derde en vierde geslacht. ${ }^{346}$ 'Bij u en uw nakomelingen zullen die vervloekingen voor altijd een teken en een waarschuwing zijn.. ${ }^{347}$ Als dan God van Abraham het slacht-offer van zijn zoon eist, want welke keus heeft een godvrezend man, en Abraham Izaäk offert - ook al bleef diens leven gespaard -, is, Gods zegening van Abrahams nageslacht ten spijt, ${ }^{348}$ enkel een nieuw gruweltrauma geregen in de keten der geslachten, die loopt tot de komst van de Christus.

Maar zie, de oud-testamentische transgenerationaliteit blijkt zelfs hardnekkiger ${ }^{349}$ dan de blijde boodschap van Jezus: Laat de kinderen

342 En Jahweh sprak: Ik zal den mens, dien Ik geschapen heb, van de aarde verdelgen; zowel den mens als de viervoetige dieren, de kruipende dieren en de vogels in de lucht; want het spijt Mij, dat $1 \mathrm{k}$ ze gemaakt heb. (Genesis 6:7.)

343 Genesis 9:12-17.

344 Genesis 9:20-25.

345 Met als bijbels dieptepunt de bestraffing van de Amalekieten (1 Samuël 15:3): Ruk dus uit en sla de Amalekieten neer en wijd alles wat hun toebehoort aan de vernietiging; spaar hen niet, maar dood iedereen, mannen en vrouwen, kinderen en zuigelingen (...).

De banvloek als uitroeing heeft hier duidelijk nog geen plaats gemaakt voor de banvloek als uitsluiting. Vgl. Numeri 21:3 en Deuteronomium 7:2, 13:13-16, 20:1617 met Psalm 109:9-10, 12 (al lijkt er slechts sprake van uitstel van executie: zie vers 13).

346 Exodus 20:5, 34:7; Numeri 14:18; Deuteronomium 5:9.

347 Deuteronomium 28:46 (Willibrordvertaling). Zie ook vers 59.

348 Genesis 22:1-18 (zie ook hoofdstuk 6, par. 6.3 .2 onder Ouderiijk geweld tegen kinderen).

349 Zo vermeldt VAN STERKENBURG (P.G.J. VAN STERKENBURG, Woeken, s.l. [Sdu/ Standaard] 1997, p. 14) dat omstreeks 900 in de kathedraal van Reims 'de volgende formule aanwezig [was]: "In de naam van de Heer (...) en het gezag dat van Godswege (...) toegekend is aan bisschoppen (...). Mogen zij vervloekt zijn in de stad en op de velden. Mogen hun huizen en hun beenderen vervloekt zijn. Mogen hun nazaten (...) vervloekt zijn. (.... $)^{\text {Hy }}$ Een formulier dat kennelijk is ontleend aan het oude testament (Deuteronomium 28:16 e.v.) en ver afstaat van het nieuw-testamentische (vgl. echter ook Leviticus 19:18 en Spreuken 25:21) gebod: Zegent hen die u vervolgen; zegent ze, en vervloekt ze niet (Romeinen 12:14). 
tot Mij komen. ${ }^{350}$ Een blijde boodschap die de opdracht aan volwassenen behelst: laat de kinderen tot hun recht komen. Laat elk kind in uw midden tot zijn recht komen. De nieuw-testamentische opdracht aan de samenleving van mensen, en aan de over hen gestelde overheden: Zie het kind! Zie het lijden van een kind! Doch tevergeefs. Nog is de tijd niet rijp die opdracht in wetten, verdragen of verbonden vast te leggen, in de harten van mensen te griffen, ${ }^{351}$ tot hoeksteen en toets van menselijke beschaving, en dus van overheidsbeleid te maken.

Het is, zevenmaal zeven maal zeven geslachten later, aan ons, aan deze generatie volwassenen - aan alle volwassenen, aan de hele maatschappij, niet alleen aan de ouders - de wording tot PICO DELLA MIRANDOLA's individu, de individu-atie, de persoonswording van het kind te bewaken. Het Verdrag inzake de rechten van het kind maakt alle volwassenen ten opzichte van alle kinderen, maakt alle Adams en Eva's ten opzichte van alle Kaïns en Abels, en hun naamloze zussen, ${ }^{352}$ tot huns broeders hoeders. ${ }^{353}$

Om verstandige hoeders te zijn ten aanzien van de persoonswording van kinderen, om als samenleving de persoonswording van het kind te kunnen bewaken op een wijze die recht doet aan alle betrokkenen, is - binnen een algemeen sociaal-pedagogisch stelsel, met als pilaren opvoedingsonderwijs, opvoedingsgeld en opvoedingsondersteuning; opvoedingsondersteuning in een eerste lijn, een tweede lijn en een derde lijn in het bijzonder nodig dat wij ouders, jonge ouders, aanstaande ouders, in staat stellen in contact te komen met het kind in henzelf, en hen extra steunen en begeleiden als het kind in de ouder een verworpen, een afge-

En zelfs: Zegent die u vloeken; bidt voor wie u lasteren. Wie u op de ene wang slaat, keer hem ook de andere toe (Lucas 6:28-29). Vermoedelijk gingen de bisschoppen in Reims uit van de gedachte dat er pas in het hemels paradijs geen enkele vervloeking meer zal zijn (Openbaring/Apokalyps 22:3).

Mattheüs 19:13-15, Marcus 10:13-16, Lucas 18:15-17.

Het lijkt zelfs alsof Christus de zaken omkeert: niet het kind verdient straf (voor de fouten van zijn ouders), maar strafwardig is de volwassene die het kind misbruikt: $[W]$ ie én van deze kleinen, die op Mij vertrouwen, ten val brengt, het zou beter voor hem zijn dat een molensteen om zijn hals ware gehangen en hij verzwolgen ware in de diepte der zee.' (Mattheüs 18:6; zie ook Marcus 9:41, Lucas 17:2.)

351 Enkele jaren na Jezus' woorden geschiedde het dat '[h]eel het volk [PILATUS] antwoordde: Zijn [Christus'] bloed kome over ons en over onze kinderen.' (Matth. $27: 25$; curs. jw.)

352 Slechts Naäma wordt genoemd, zus van een van de nazaten van Kaïn (Genesis 4:17-22)

353 Nu sprak Jahweh tot Kain: Waar is Abel, uw broer? Hij zeide: Ik weet het niet; ben ik mijns broeders hoeder? (Genesis 4:9.) 
wezen, een onbegrepen, een vernederd, een geminacht, een gemanipuleerd, een misbruikt, een misleid, een verwaarloosd, een verlaten, een geslagen, een achtergesteld, een betutteld, een vereenzaamd, een gedrild, een gekortwiekt, een gepest, een uitgebuit, een getergd, een overbelast, een overvraagd, een ondervraagd, een ongevraagd en ongewenst, kortom een gekwetst kind blijkt te zijn. Omwille van deze ouders zelf - uit naam van hun recht op rehabilitatie. Maar evenzeer, en meer nog, omwille van de belangrijkste mensen van de wereld, б́6k, ja juist voor ouders, voor alle ouders: hun kinderen. Uit naam van het recht van het kind, van elk kind, óok in Nederland, niet in de laatste plaats in Nederland, van alle welvarende sociale rechtsstaten toch niet in de laatste plaats in Nederland, op persoonswording.

Vijfhonderd jaar na PICO DELLA MIRANDOLA, begenadigde zoon van de graaf van CONCORDIA, naakt de ochtendschemer, nadert de dag dat wij kunnen, dat wij mogen, dat wij zullen zeggen: "WIJ HEBBEN U, O ABEL, met alle sociaal-pedagogische zorg omringd, opdat ge als een vrij en soeverein kunstenaar uw lot in eigen hand kunt nemen. Opdat, tussen menselijk tranendal en tuin van Eden, uw lot geen transgenerationeel noodlot meer zal zijn.'

Wij hebben u, o Abel .... O, Kaïn .... 
HET RECHT VAN HET KIND OP OPTIMALE PERSOONSWORDING is - when all is said and done...

'(...) een uitdaging voor de samenleving om de noodzakelijke voorwaarden te scheppen waarbinnen alle kinderen gelijkelijk kunnen krijgen waar ze recht op hebben: een verzorging en opvoeding door hun (sociale) ouders die hen in staat stelt hun persoonlijkheid op een harmonische wijze te ontplooien. Daardoor zullen zij niet alleen kunnen bijdragen aan een humane samenleving maar wordt tevens een basis gelegd voor een gezonde ontwikkeling van hun kinderen, zodat deze minder behoefte zullen hebben aan een kinderbeschermende interventie met inschakeling van de kinderrechter, zoals thans helaas nog het geval is.'

Theo KOENS, 'De civiele kinderrechter; verleden, heden en toekomst,' in: [Johan BAC en Ad VAN DER LINDEN (red.)], De kinderrechter 75 jaar: Reden tot vreugde/? Deventer 1998, pp. 21-45, op p. 45, besluit (curs. jw).

'Het nieuwe Particulier Initiatief bestaat uit de protagonisten [van de beweging] voor de rechten van het kind (...). (...) Dit nieuwe Particulier Initiatief moet de motor zijn achter de implementatie van het Verdrag [inzake de] rechten [van het] kind: zo nodig [door] procedures aan [te] spannen bij de Europese rechter, waardoor het beroemde artikel 8 EVRM [wanneer het Verdrag inzake de rechten van het kind door de Europese rechter in dat artikel wordt ingelezen, jw], het recht op gezinsleven, de invulling krijgt die het moet hebben: het recht van kinderen op een gezinsleven waarin zij zich het best kunnen ontwikkelen.'

Jacquelien DE SAVORNIN LOHMAN, 'Kind in het geding; kinderbescherming tussen traditie en vernieuwing;' in: Th.N.M. SCHUYT en M. STEKETEE, Zorgethiek: Ruimte binnen regels, Utrecht 1998, pp. 21-39, op p. 36. 


\section{SAMENVATTING ${ }^{1}$}

'Ouders die een kind mishandelen of seksueel misbruiken, zijn meestal geen gehukkige of blije mensen die greep op hun eigen leven hebben. Ze vertonen geen groot scala van gevoelens, omdat ze zelf uit gevoelsarme gezinnen komen. Het is triest te bedenken dat ongezonde en ongelukkige patronen en verwachtingen generaties lang doorgegeven kaunen worden, maar het is bemoedigend te weten dat de kringloop doorbroken kan worden als we aan deze patronen de nodige aandacht schenken.'

(Eliana GIL) $^{2}$

\section{Kindervolkenrecht}

In deze studie wordt - op een breed fundament van sociaal-wetenschappelijke (in het bijzonder psychologische en juridische) bevindingen en citaten - een mensenrechtelijke analyse gegeven van grondslag en strekking van het Verdrag inzake de rechten van het kind, met als doel te komen tot in het licht van die grondslag en strekking adequate rechtspolitieke voorstellen en richtlijnen ter operationalisering van de verdragsrechtelijke secundaire (aanvullende en desnoods geheel of gedeeltelijk vervangende) opvoedingsverantwoordelijkheid van de staat.

Hoewel psychologie - in het bijzonder ontwikkelingspsychologie en (ontwikkelings)psychopathologie - en pedagogiek in deze studie een bepalende rol spelen, is dit werk toch eerst en vooral het verslag, in vier boeken, van een zoektocht naar grondslag en geest van het kindervolkenrecht, en als zodanig een beschrijving, vanuit mensenrechtelijke optiek of liever: vanuit een optiek van mensenrechten als rechtsbeginselen -, van (recente) aanvang en (prille) voortgang van dat (in neologische zin) nieuwe rechtsgebied. Kindervolkenrecht is het rechtsgebied, de internationale (universele) rechten van het kind betreffende, dat de omtrek en inhoud van de secundaire opvoedingsverantwoordelijkheid van staten in kaart wil brengen. Het vertrekt daarbij vanuit (het fundamentele rechtsbeginsel van) het recht van het kind op optimale persoonswording (dat is het opgevoed worden tot optimale rationaliteit, moraliteit en authenticiteit), en heeft als bodem het kernrecht van het kind op minimale persoonswording (het geheel van sociaal-pedagogische waarborgen tegen kindermishandeling in de vijf varianten fysieke of lichamelijke mishande-

1 Deze samenvatting is een bewerking van Jan wLLEMS, 'Kindermishandeling als ernstige mensenrechtenschending,' VKMagazine (Tijdschrift over kindermishandeling) $1997 / 2$, pp. $4-5$.

2 Eliana GL, Samen de pün te boven; Een boek voor de partners van mensen die als kind werden mishandeld of misbruikt, Houten 1993, p. 111. 
ling, fysieke of lichamelijke verwaarlozing, psychische of emotionele mishandeling, psychische of emotionele/affectieve verwaarlozing en 'incest'/ sexueel misbruik/sexuele kindermishandeling). Het kindervolkenrecht beoogt de sociaal-pedagogische operationalisering van de persoonswordingsrechten van het kind. In het bijzonder stelt het zich ten doel de juridisering (nationaal-constitutionele verankering en vastlegging/uitwerking in nationale wetgeving en beleid) van de Trias pedagogica (de rechtsstatelijke driehoeksverhouding staat-ouders-kinderen).

Internationaalrechtelijke constitutie van die trias is het Verdrag inzake de rechten van het kind. Het recht van het kind op optimale persoonswording is de kindervolkenrechtelijke term voor het ontwikkelingspsychologische/pedagogische belang van het kind als achterliggend, dragend en leidend beginsel van dat Verdrag.

\section{Universele kinderrechten}

Het Verdrag inzake de rechten van het kind (VRK) is op 20 november 1989 unaniem door de Algemene Vergadering van de Verenigde Naties aangenomen, en iets meer dan negen maanden later, op 2 september 1990 , in werking getreden. Het Verdrag geldt inmiddels voor vrijwel de gehele statengemeenschap. Slechts twee staten zijn nog geen partij (Somalië en de Verenigde Staten). Nederland, één van de hekkesluiters, is sinds 8 maart 1995 aan het Verdrag gebonden. De staten die partij zijn bij het Verdrag, vertegenwoordigen circa $95 \%$ van de wereldbevolking. Ratificatie door de vs zou dit percentage op bijna 100 brengen. Omdat de vs het Verdrag wel al heeft ondertekend, is het niet ver van de waarheid te spreken van een universeel Verdrag, althans van universele kinderrechten.

\section{Kindermishandeling}

Hamvraag in deze studie is: hoe verhouden zich de (universele) kinderrechten in het VRK tot het (universele) fenomeen kindermishandeling, toegespitst op de Nederlandse situatie? Om deze vraag te kunnen beantwoorden, zijn twee zaken onderzocht. In de eerste plaats het rechtskarakter van de verdragsbepalingen. Dat wil zeggen: gaat het voornamelijk om inspanningsverplichtingen, of gaat het (ook) om resultaatsverplichtingen? In de tweede plaats: de omvang en ernst (sequelae) van het fenomeen kindermishandeling in Nederland.

Om met dat laatste te beginnen. Op basis van diverse onderzoekingen (Amerikaanse zowel als Nederlandse) kan - grosso modo - gesteld worden dat elk jaar minimaal $2,5 \%$ van de minderjarigen valt onder wat wij in Nederland onder kindermishandeling verstaan. Het gaat dan om ten minste 80.000 kinderen per jaar. $\mathrm{Zij}$ behoren tot de veel grotere 
categorie kinderen die zich bevinden in (ernstig) bedreigende opvoedingssituaties. Bijvoorbeeld kinderen met alcoholistische, depressieve, psychotische, zwakbegaafde, gewelddadige of doorlopend ruziende ouders, of kinderen die (anderszins) opgroeien in gezinnen met een niet warme opvoedingsstijl. Niet zelden gaat het dan om een cumulatie van problemen die in de kern te maken hebben met ernstige persoonlijke beperkingen van ouders welke gepaard gaan met een liefdeloze of zeer ambivalente houding ten opzichte van het kind. Op basis văn wat we inmiddels weten over de ernstige tot zeer ernstige ontwikkelingspsycho(patho)logische (sociaal-emotionele), sociaal-economische (uitval en criminaliteit) en sociaal-pedagogische gevolgen van kindermishandeling (veelal tränsgenenerationeel: de sociaal-emotionele/pedagogische gevolgen, bij niet-rehabilitatie, voor de volgende generatie), kan bovendien gesteld worden dat kindermishandeling niet alleen een grootschalig maar ook een rampzalig maatschappelijk fenomeen is. Rampzalig alleen al qua vernietiging van menselijk en maatschappelijk 'kapitaal.'

Betekent dit nu ook dat in Nederland op grote schaal en op grove wijze de verplichtingen onder het VRK worden geschonden?

\section{Ernstige en systematische mensenrechtenschending?}

Geheel los van het Verdrag kan worden gesteld dat kindermishandeling een schending is van het recht van elk mens op lichamelijke en geestelijke integriteit en op vrijwaring van onmenselijke en vernederende behandeling of bestraffing. Beide rechten gelden ook in privé-verhoudingen, dus tussen vaders en moeders en tussen ouders en kinderen. De Nederlandse overheid dient deze rechten zo veel mogelijk te waarborgen. Ingeval van massale schending (zoals bij kindermishandeling) is zij daarbij gehouden tot een (structurele) preventieve benadering (VAN BOVEN). Is zij daarin op grove (stelselmatig-'medeplichtige') wijze nalatig, dan betekent dit dat er in Nederland sprake is van een situatie van ernstige en systematische mensenrechtenschendingen (theoretisch zou dat de Verenigde Naties het recht geven in Nederland op enigerlei wijze te interveniëren).

De Nederlandse overheid is evenwel ook gehouden de privacy van haar burgers zo veel mogelijk te respecteren. Het plaatsen van een politie-agent, of desnoods een hulpverlener, in elke huis- en slaapkamer zou - zelfs als daarmee elke vorm van (vrouwen-en) kindermishandeling kon worden voorkomen - vermoedelijk door (nationale en internationale) rechters als een in een democratie te ver gaande inbreuk op de privacy worden beschouwd. De vraag is dan of er geen andere positieve (met name preventieve) maatregelen mogelijk zijn. En in hoeverre het VRK tot het nemen van verschillende positieve (preventieve) maatregelen verplicht. 
Positieve (preventieve) maatregelen

Voorop dient te worden gesteld dat het VRK voor een rijk land als Nederland nauwelijks of geen ruimte laat voor een financieel verweer tegen het nemen van maatregelen die als zinvol zijn te beschouwen. De vraag wordt dan: welke - desnoods verstrekkende en kostbare - (positieve) maatregelen zijn (in de eerste plaats vanuit een preventieve optiek) als zinvol te beschouwen? En hoe actief of nalatig is de Nederlandse overheid in het uitvoeren van thans reeds denkbare maatregelen en het verrichten van onderzoek naar nieuwe of betere maatregelen?

Twee wegen zijn thans denkbaar. Het VRK kan artikelsgewijze op zinvolle (positieve/preventieve) maatregelen worden uitgevlooid. Of het VRK kan op zijn grondslag en strekking worden onderzocht, om in het licht daarvan de bepalingen - en de naleving ervan - aan een kritisch onderzoek te onderwerpen. De eerste weg is weinig vruchtbaar. Uitspraken met de strekking dat het Verdrag feitelijk niet meer is dan een multiinterpretabele intentieverklaring, lijken vooral afkomstig van juristen die op die weg enige 'positivistische' (regelgerichte en regelgeleide) schreden hebben gezet. De tweede (beginselgerichte en beginselgeleide) weg lijkt meer lonend, al is ook hij niet zonder valkuilen, en bovendien nog grotendeels ongebaand. Van de poging die weg te bewandelen, is deze studie het verslag.

\section{Trias pedagogica}

Men zou het VRK kunnen opvatten als een mensenrechtelijke grondwet, als de internationaalrechtelijke constitutie van de Trias pedagogica. Van die trias maken deel uit het kind, de ouders en de staat. Grondnorm van die constitutie is het recht van het kind op persoonswording (DE RUYTER). Dat will zeggen: het recht van elk kind op een evenwichtige ontwikkeling en uitgroei tot zelfstandig staatsburger (een formulering ontleend aan de Raden voor de kinderbescherming). Een meer inhoudelijke (ontwikkelingspsychologische/pedagogische) formulering zou zijn: het recht van het kind, van elk kind, op te groeien in een veilige en stabiele omgeving met volwassenen die affectie tonen en leiding geven naar de mate van de zich ontwikkelende vermogens van het kind. ${ }^{3}$

Dit fundamentele recht kan men uitsplitsen in een optimum en een minimum. Het recht van het kind op optimale persoonswording (op-

Deze formulering kan als een samenvatting worden beschouwd van enkele in deze studie omschreven sociaal-pedagogische grondrechten. Gedeeltelijk is zij ontleend an Sven E. OLSSON HORT, "Sweden: Toward a deresidualization of Swedlish child welfare policy and practice?' In: Neil GILBERT (ed.), Combatting child abuse; Intemational perspectives and trends, New York/Oxford 1997, pp. 105-124, op p. 121. 
timalle ontwikkeling, optimale ontplooiing, optimale voorbereiding op een tolerant en vredelievend burgerschap) kan worden beschouwd als achterliggend, dragend en leidend beginsel van het VRK. Ter bevordering van dit recht berusten op de staat diverse (uiterste-)inspanningsverplichtingen. Het recht van het kind op minimale persoonswording (het ontwikkelen van minimale kwaliteiten en capaciteiten ten aanzien van rationaliteit, moraliteit en authenticiteit, zonder welke men ernstig is beknot in het genot en de uitoefening van de rechten van de mens) moet als een quasiresultaatsverplichting worden beschouwd. Dat wil zeggen dat de staat in beginsel heeft in te staan voor de minimale persoonswording van elk kind onder zijn rechtsmacht. Kindermishandeling is per definitie een schending van dit minimum-recht. Dit minimum is tegelijk de bodem van het recht van elk mens op vrijwaring van onmenselijke en vernederende behandeling of bestraffing, dat algemeen als een norm van dwingend volkenrecht (jus cogens) wordt aangemerkt.

Krachtens de trias-constitutie - en in overeenstemming met geldend recht - berust de primaire (originaire) opvoedingsverantwoordelijkheid bij de ouders, en de secundaire opvoedingsverantwoordelijkheid bij de staat. Dit betekent dat op de staat de algemene verplichting rust een tekort aan pedagogisch besef (BAARTMAN) bij de ouders te compenseren. Deze algemene verplichting kan worden geconstrueerd op basis van - en is uitgewerkt in - de diverse verdragsverplichtingen van het VRK, elk op zich en in hun onderling verband beschouwd.

Een tekort aan pedagogisch besef bij de ouders houdt vaak verband met tekorten in de opvoeding van de ouders zelf. In thet ergste geval zijn zij zelf in hun jeugd mishandeld (deplorabele jeugd), en zijn zij later nooit in de gelegenheid gesteld/geweest hun jeugdervaringen adequaat te verwerken (leidende tot transgenerationalisering: transgenerationele traumatisering/sociaal-emotionele beschadiging). Maar een tekort aan pedagogisch besef bij de ouders kan ook te maken hebben met tekorten in heden en verleden met betrekking tot ouderschapsonderwijs in Nederland (zowel op lagere en middelbare scholen als aan volwassenen in de vorm van ouderschapscursussen en dergelijke meer). Daarnaast (en daarmee verweven) kunnen vele andere factoren een rol spelen: zeer jeugdige leeftijd van de ouder(s), gebrekkige geestelijke vermogens, verslavingen, ernstige psychische (of zelfs psychiatrische) problemen, criminele levenswandel, een lichamelijk of geestelijk gehandicapt kind of een kind met ernstige gedragsmoeilijkheden, weinig of geen sociale steun, sociaal isolement, ontoereikende financiële middelen enzovoorts. Al deze zaken dienen op adequate wijze door de staat te worden gecompenseerd (door middel van opvoedingsondersteuning, opvoedingsonderwijs en opvoedingsgeld). 


\section{Sociaal-pedagogisch vangnet}

De pedagogische compensatieplicht van de staat (krachtens diens secundaire opvoedingsverantwoordelijkheid) kan op zijn beurt worden vertaald in de algemene verplichting tot de opbouw en instandhouding van een (preventief) sociaal-pedagogisch stelsel, dat om te beginnen een sociaalpedagogisch vangnet moet bieden aan de (veelal ten gevolge van transgenerationalisering) pedagogisch meest kansarme en kwetsbare gezinnen in Nederland. Dit stelsel wordt geschraagd door drie zuilen: (vroegtijdige) opvoedingsondersteuning (volgens een glijdende-schaal- c.q. drie-echelonsmodel), opvoedingsonderwijs (op scholen en voor ouders) en opvoedingsgeld. Met name dat laatste maakt het mogelijk op (semi-)contractuele basis afspraken met ouders te maken, bijvoorbeeld door aan opvoedingsgeld (ouderschapssubsidie) van geval tot geval concrete voorwaarden te verbinden.

Dit (semi-)contractuele (en dus in beginsel vrijwillige) uitgangspunt laat onverlet dat de staat in laatste instantie over dwangmiddelen beschikt. Sociaal-pedagogisch dwangmiddel bij uitstek is de persoonswordingsvindicatie: het door de rechter doen opleggen van opvoedingshulp indien het aanbieden van hulp evident geen zin (meer) heeft of een in principe geschikt hulpaanbod niet wordt aanvaard, terwijl de minimale persoonswording van het kind wordt bedreigd c.q. zou kunnen worden bedreigd (bij aanwezigheid van een cumulatie van risico-indicatoren, waaronder in het bijzonder een niet verwerkte deplorabele jeugd). Uiteraard hoort daar een uitgebreid stelsel van rechtsbescherming (mogelijkheden van bezwaar en beroep) bij, alsmede duidelijke rechtswaarborgen in de vorm van wettelijk vastgelegde operationele ontwikkelingspsychologische/pedagogische minimum-normen en de mogelijkheid van rechterlijke toetsing aan algemene beginselen van behoorlijk (gezins)bestuur.

Op dit punt zitten we overigens in het grensgebied tussen staatsaansprakelijkheid en overheidsverantwoordelijkheden. Staatsaansprakelijkheid ziet op de schending van internationaalrechtelijke verplichtingen (inadequate naleving c.q. gebrek aan due diligence). 'Overheidsverantwoordelijkheden' ziet op de meest opportune - de in de Nederlandse context meest geschikte - naleving en invulling van verdrags- en andere juridische verplichtingen.

Omvang en ernst van het fenomeen kindermishandeling in Nederland enerzijds (kort gezegd: het komt te veel voor met te verstrekkende gevolgen voor individu en samenleving) en anderzijds het feit dat er aan dit ernstige maatschappelijke kwaad structureel te weinig en te laat wat wordt gedlaan (ongecoördineerd incidenteel ex post-interventionisme met stigmatiserende, escalatoire en dus averechtse effecten, dat haaks staat op het kindervolkenrechtelijk vereiste van een - in hoofdstuk 14 van deze 
studie op hoofdlijnen uitgewerkte - geïntegreerde structurele preventieve benadering), nopen tot de conclusie dat op dit moment in ons land zeer veel schort aan wat zelfs maar de contouren van een sociaal-pedagogisch vangnet zouden kunnen worden genoemd. Veel meer is hier mogelijk dan thans geschiedt. En met name veel meer in structurele, wettelijk geregelde en ontwikkelingspsychologisch/pedagogisch geoperationaliseerde zin. Wat we doen, blijft verre ten achter bij wat we weten dat in ontwikkelingspsychologische en sociaal-pedagogische zin nodig, wenselijk en mogelijk is.

In dit licht kan worden gesteld dat in Nederland sprake is van een zodanig sociaal-pedagogisch te kort schieten, een zodanige sociaal-pedagogische nalatigheid van de kant van de Nederlandse overheid, dat hier de (dis)kwalificatie ernstige en passief-systematische mensenrechtenschending van toepassing is. De kloof tussen wat we doen, en wat we weten en kunnen (voorkomen), dreigt zo groot te worden dat aan het eind van de eeuw van het kind van een nieuwe, een tweede sociale quaestie: de sociaal-pedagogische kwestie, sprake lijkt.

\section{Sociaal-pedagogische kwestie}

Het wordt tijd dat staat en samenleving actief worden om iets aan deze sociaal-pedagogische kwestie te doen. Ook al hoeven we - mede gezien wat er in de landen om ons heen (niet) gebeurt - vooralsnog niet bang te zijn voor bemoeienis van de Verenigde Naties, er is anderzijds geen enkele reden onszelf als mensenrechtelijk gidsland te beschouwen. Althans niet als het gaat om het in een rijk land en in een rechtsstaat meest fundamentele recht van een kind: het recht op optimale persoonswording als grondrecht voor elk kind in Nederland - ongeacht afstamming, huidskleur, geslacht of niveau van ouderlijk pedagogisch besef.

Zoals alle ernstige mensenrechtelijke situaties kunnen we ook de sociaal-pedagogische kwestie in het (historische) perspectief van (nationale) 'beschavingsarbeid" zien. ${ }^{4}$ Als we kijken naar enerzijds de omvang

Waar in deze studie wordt gesproken van of over beschaving (c.q. beschaven of civiliseren of samenstellingen met beschaving, zoals beschavingsproces, beschavingsarbeid of -werk, beschavingsoffensief, beschavingsopdracht), wordt gedoeld op de civilisatie-theorie van (Norbert) ELLAs, de theorie volgens welke, kort en simpel gezegd en voor zover hier van belang, op basis van en in wisselwerking met een proces wan collectieve norm-aanvaarding en -verimnerlijking, een samenleving beschaafder, "in de zin van minder gewelddadig is, in de mate dat er minder gebieden zijn waar de staat zijn invloed niet of onvoldoende kan doen gelden. Toegepast op deze studie: het ingang doen vinden van normen betreffende een minder gewelddadige/meer respectvolle omgang met (wrouwen en) kinderen (binnen het gezin) dient hand in hand te gaan met een grotere rol van de overheid. 
en ernst van kindermishandeling in Nederland en anderzijds naar zowel de sociaal-pedagogische rechteloosheid van (jonge) kinderen en (jonge) ouders in ons land als naar de politieke en maatschappelijke 'arbeidsschuwheid' (ook, ja juist lijkt het soms, bij morele elites, die bevangen lijken door het privacy-paradigma) ten aanzien van de detransgenerationalisering van de Nederlandse samenleving (bestrijding van transgenerationele sociaal-emotionele/pedagogische deprivatie c.q. van systemische sociaal-pedagogische discriminatie), dan moeten we constateren dat onze democratische nationale cultuur, onze geavanceerde westerse beschaving vliesdun is. Onze houding en inspanningen ten opzichte van de meest weerlozen in ons midden - tienduizenden gemaltraiteerde kinderen, en vooral de jongsten onder hen die door beide ouders worden mishandeld, verwaarloosd en misbruikt (KOMEN) - zijn nog ver verwijderd van wat van een decent society zou kunnen worden verwacht.

Op dit moment zien we echter, bij toegenomen norm-ontwikkeling en norm-verwachting op dit gebied, nog geen daarmee overeenkomende nieuwe staatsinvloed. Vgl. voor deze theorie in verband met de socialisatie (individuele ontwikkeling van zelfcontrole/zelfbeheersing, internalisering/verinnerlijking van normen) c.q. de morele persoonswording in en door de gezinsopvoeding van kinderen/jongeren in een tijd van afnemende sociale controle ('selectieve decivilisering'): Nico WILTERDINK, 'Zelfcontrole en civilisatie; GOTTFREDSON \& HIRSCHI en ELIAS vergeleken," Tijdschrift voor Criminologie 1998/2, pp. 139-150. Zie meer specifiek ook Mieke KOMEN, 'Gevaarlijke kinderen; veranderingen in de aard en aanpak van jeugdcriminaliteit, 1960-1995,' Amsterdams Sociologisch Tijdschrift 1997/3-4, pp. 496-526, welke bijdrage het beeld verder aanscherpt dat de (transgenerationele) maatschappelijke kloof tussen een welopgevoede (op basis van een veilige hechting met een ouderfiguur/binding met het gezin gesocialiseerde/tot bovenminimaal moreel persoon opgegroeide) meerderheid en een door 'het toeval' opgevoede onder-kaste van "in de steek gelaten" jongeren in hopeloze situaties' (KOMEN, t.a.p.y op p. 521) alsmaar dieper wordt. Anders gezegd: de civilisatietheorie in combinatie met ontwikkelingspsychologische en pedagogische inzichten en sociologische verschijnselen en veranderingen maakt duidelijk dat en hoe de sociaal-pedagogische tweedeling in de maatschappij steeds meer zichtbaar en voelbaar wordt nu immers de traditionele staatsonthouding met betrekking tot de gezinsopvoeding wordt geconfronteerd met de (onomkeerbare) tanende sociale controle door particulieren en niet-overheidsorganisaties en de (navenant) 'toegenomen tolerantie' van overheidsinstellingen als politie, justitie en de kinderbescherming (KOMEN, t.a.p., op pp. 520-521). Er lijken minder hindernissen op de weg van misdaad en geweld te liggen voor de slachtoffers van een niet door de gemeenschap gecompenseerd (transgenerationeel) tekort aan ouderlijk pedagogisch besef. Een traditioneel (en tragisch) tekort dat evenwel in de vorm van ernstige jeugdcriminaliteit steeds meer aan de oppervlakte komt, zodat het steeds duidelijker tot ons doordringt dat de maatschappij de jeugd krijgt die zij verdient. (Zie ook bijlage VII bij dit proefschrift: 'Opvoedingsviijheid en persoonswording: waar staat de staat?') 


\title{
SUMMARY ${ }^{1}$ \\ Who will educate the educators? Child abuse and the right of the child to become a person ${ }^{2}$
}

\begin{abstract}
'Abusive parents for the most part are indivicluals who are not happy, exciled, and feeling in control of their own destinies. They cannot model a full range of feelings because they frequently come from emotionally empty families themselves. It is sad to think that unhealthy and unhappy patterns and expectations can be passed down from generation to genteration, but it's encouraging to know that giving these patterns care and attention [before parents undertake their child-rearing responsibilities and by offering them assistance in their child-rearing responsibilities, jw] can result in breaking the cycle of abuse.'

(Eliana GL) $)^{3}$
\end{abstract}

\section{The children's law of nations}

This study, which is founded on a broad basis of research findings and quotations from the social sciences (especially psychology and law), presents a human rights law analysis of the foundation and purpose of the UN-Convention on the rights of the child (CRC), with a view to formulating - in the light of that foundation and purpose - adequate legal-political proposals and guidelines which put into operation the Convention's subsidiary (complementary and, if necessary, partially or totally surrogatory) responsibility of the state to educate.

Although psychology, especially developmental psychology and (developmental) psychopathology, as well as educational specialists, play a central part in this study, the present work gives, above all, an account, in four parts (four 'books'), of the search for the foundation and spirit of the children's law of nations, and as such a description, from a human rights law perspective - or rather from a perspective of human rights as legal principles -, of the recent origin and early development of this neologism. The children's law of nations, then, is the field of law, regarding the international (universal) rights of the child, which attempts to map the objectives and extent of the subsidiary responsibility of the state to educate. The children's law of nations departs from the fundamental legal

1 This summary is an adaptation and elaboration of $\mathbf{J}$ an WILLEMS, "Kindermishandeling als ernstige mensenrechtenschending [Child abuse as a gross violation of human rights]," VKMagazine (Tijdschrift over kindemishandeling [Joumal of child abusef) $1997 / 2$, pp. $^{4}-5$.

2 The author's translation from the Dutch has been revised by Caroline FORDER.

3 Eliana GL, Outgrowing the pain together; $A$ book for spouses and partners of adults abused as children, New York 1992, pp. 123/124. 
principle of the right of the child to become an optimal person (i.e. the right of the child to be brought up to optimal rationality, morality, and authenticity). The core right of the child to become (more than) a minimal person (i.e. the whole of socio-educational guarantees against child abuse, in the five variants of child physical abuse, child physical neglect, child emotional abuse, child emotional neglect, and child sexual abuse) is the foundation of the children's law of nations. The children's law of nations endeavours to make the optimal/minimal rights of the child to become a person socio-educationally operational. More specifically, it intends the juridification (incorporation in national constitutions and elaboration in national laws and policies) of the Trias pedagogica (the rule of law in the triangular relationship between the state, parents, and children).

The CRC is the international legal constitution of the Trias pedagogica. The right of the child to become an optimal person is the children's law of nations term for the developmental-psychological/educational best interests of the child as underlying, founding, and guiding principle of the CRC.

\section{The universal rights of the child}

The CRC was adopted unanimously on November 20, 1989 by the UNGeneral Assembly. After a little more than nine months, on September 2, 1990 , it entered into force. The CRC is by now binding on almost the entire community of states. Only two states (the 'failed state' Somalia and the Us) are not yet parties. The Netherlands, one of the last states in the world to join the CRC, is bound by the CRC since March 8, 1995.

The states parties to the CRC represent approximately $95 \%$ of the world's population. Ratification of the CRC by the US would bring this close to $100 \%$. Since the us has already signed the CRC, it is not far from the truth to speak of a universal convention, or at least of universal rights of the child.

\section{Child abuse}

A key question in this study is: how do the universal rights of the child in the CRC relate to the universal phenomenon of child abuse, especially with regard to the Dutch situation? In order to answer this question, two matters have been investigated. In the first place, the legal character of the provisions of the CRC is scrutinized, i.e. are they obligations of conduct or are they also obligations of result? In the second place, the scope and gravity (sequelae: psycho- and socio(patho)logical long term effects) of the phenomenon of child abuse in the Netherlands has been examined. 
To start with the latter. On the basis of several research findings (both American and Dutch), it can be stated that - roughly speaking each year at least $2.5 \%$ of all minors experience what in the Netherlands is considered to constitute child abuse. We are talking, then, about at least 80,000 children every year in the Netherlands. They belong to the much larger category of children who find themselves in seriously threatening educational situations. For instance, one can think of children with alcoholic, depressive, psychotic, retarded, violent or continuously quarrelling parents, or children who grow up in families with an educational style which, for other reasons, is lacking in emotional warmth. Often, there exists in these families a cumulation of socio-emotional and socioeconomic problems which have basically to do with serious personal limitations of the parents concerned which go hand in hand with an unloving or very ambivalent attitude towards the child. On the basis of the present state of knowledge of the serious-to-very-serious developmental psycho(patho)logical (socio-emotional), socio(patho)logical (socio-economic: persons who drop out, criminality), and socio-pedagogical (pedagogically dysfunctional families), including transgenerational consequences of child abuse (the socio-emotional/-economic/-educational consequences, in case of non-rehabilitation, for the next generation), it can moreover be stated that child abuse is not only an enormous, but also a disastrous, social phenomenon. Disastrous, if only because of the inherent destruction of human and social 'capital.'

Does all of this mean that in the Netherlands the state's obligations under the $\mathrm{CRC}$, together constituting the secondary (subsidiary) educational responsibility of the (Dutch) state, are violated on a large scale and in a gross manner?

\section{Gross and systematic violations of human rights?}

Apart from the CRC, it can be stated that child abuse constitutes a violation of the right of every human being to physical and mental integrity and the right not to be subjected to cruel, inhuman or degrading treatment or punishment. Both rights also apply to private relation(ship)s, as between fathers and mothers and between parents and children. The Dutch authorities are under an obligation to guarantee these rights. In case of massive violations, such as is the case with child abuse, they are moreover obliged under general human rights law to structurally adopt a preventive approach (VAN BOVEN). Gross negligence in this, amounting to complicity in the form of systematically 'condoning,' would mean that in the Netherlands a situation of gross and systematic violations of human rights exists. Theoretically, this would give the UN the right to intervene in the Netherlands in one way or another. 
However, Dutch authorities are also under an obligation to respect as much as possible the privacy and the family life of the population. Positioning a police officer or social worker in every living room or bedroom - even if this were apt to prevent all forms of abuse in the family would probably be considered, by national and international judges alike, to be too great an intrusion in a democratic society on one's privacy. The question then arises whether there are no other positive preventive measures which could be taken. And to what extent does the CRC oblige states to adopt various kinds of positive preventive measures?

\section{Positive (preventive) measures}

It should be made clear from the outset that the CRC does not leave much scope for rich states such as the Netherlands to raise objections of a financial nature against the adoption of any kind of measures which can be considered to be effective. The question, then, is: which - if necessary, far-reaching and costly - positive measures can be considered to be effective, first and foremost from a preventive perspective? Furthermore, how active or negligent does the Dutch government appear to be, either regarding the adoption of measures which are already conceivable and the execution of research on the implementation of new and better measures?

Two different paths may now be followed. The first one is to examine the CRC article by article for possibly useful positive/preventive measures. The second path is to examine the CRC for its foundation and purpose, with a view to critically investigating its provisions - and their observance - in the light of the legally and psychologically/educationally clarified and specified foundation and purpose of the Convention. The first path is not very fruitful. Comments to the effect that the $\mathrm{CRC}$ is, in the final analysis, little more than a declaration of intent, capable of supporting a multitude of interpretations, seem to emanate chiefly from lawyers who have made a few 'positivistic' (rule-orientated and rule-guided) moves along that path. The second (principle-orientated and principleguided) path appears to be more rewarding, although it does have its pitfalls and, on top of that, is by and large untrodden. This study gives an account of the attempt to clear that path.

\section{Trias pedagogica}

One might take the $\mathrm{CRC}$ as a human rights law constitution, as the international legal constitution of the Trias pedagogica. To this Trias belong the child, the parents, and the state. The basic principle of the Trias-constitution is the right of the child to become a person (DE RUYTER). That 
is the right of each child to a harmonious development and preparation to live an individual life in society (cf. $\mathrm{CRC}$, preambular para 6-7). To put this in more technical (developmental-psychological/pedagogical) terms: the right of the child, of each child, to grow up in a safe and stable environment with adults who show affection and give guidance in a manner consistent with the evolving capacities of the child. ${ }^{4}$

This fundamental right can be split up into an optimum and a minimum. The right of the child to become an optimal person (optimal development as a child, optimal development of one's personality/talents/ abilities, optimal preparation for responsible life in a free society ${ }^{5}$ ) can be considered as the underlying, founding, and guiding principle of the CRC. In order to promote that right, the state is under an 'obligation of maximum means,' i.e. the obligations of conduct to which the state is subjected, oblige the state to take measures to the maximum extent of its available resources. ${ }^{6}$ The right of the child to become more than a minimal person (which entails the development of - at least - minimal qualities and abilities with regard to rationality, morality, and authenticity, without which one is seriously limited in the enjoyment and exercise of human rights) should be considered as an obligation of quasi-result. That means that the state has to guarantee in principle (i.e. barring highly exceptional situations) that each child under its jurisdiction becomes more than a minimal person. Child abuse is by definition a violation of this minimum-right. This minimum is at the same time the basis of the right of every human being not to be subjected to cruel, inhuman or degrading treatment or punishment, which is generally regarded as a peremptory norm of general international law (jus cogens). ${ }^{7}$

Under the Trias-constitution, and in accordance with positive law, the primary educational responsibility rests with the parents, and the secondary (subsidiary) educational responsibility with the state. That means that the state is under a general obligation to compensate for a lack of parental awareness (NEWBERGER/BAARTMAN) in families. This general obligation can be construed on the basis of various provisions of the $\mathrm{CRC}$,

See for this formulation: Sven E OLSSON HORT, 'Sweden: Toward a deresidualization of Swedish child welfare policy and practice?" In: Neil GLBERT (ed.), Combatting child abuse; Intemational perspectives and trends, New York/Oxford 1997, pp. 105-124, at p. 121; cf. also article 5 and article 14, para 2 CRC.

This formulation is shorthand for some of the socio-pedagogical constitutional rights, elaborated in this study.

$5 \quad C$. article 6, para 2, and article 29 , para 1 sub a and sub d CRC.

$6 C$. article 4 and article 6 , para 2 CRC.

$7 \quad C f$. article 53 of the Vienna Convention on the law of treaties. 
taken on their own and viewed in their context (and in the light of the preambular paragraphs). ${ }^{8}$

A lack of parental awareness often is related to serious shortcomings in the ways the parents were raised themselves. At worst, parents lacking parental awareness have been abused as children and have never had the opportunity to adequately outgrow their childhood pain (which can manifest itself as fear, anger, ambivalence, lability, loss of confidence, destructive coping mechanisms, re-enacting, over- or underreacting). This may lead to transgenerationalization (transgenerational traumatization/ socio-emotional damage). However, a lack of parental awareness may also have to do with shortcomings, in the past and in the present, with regard to education of parents in the Netherlands (both in primary and secondary schools and adult education in such forms as parent training, parent courses, family life education). In addition to this, and closely interwoven with it, many other factors may play a role, such as: very young age of parent(s), low intelligence, abuse of legal and illegal drugs, serious psychological or even psychiatric problems, criminal conduct, a physically or mentally disabled child or a child with serious conduct disorders, little or no social support, social isolation and poverty. All these factors have to be adequately compensated for by the state (by means of educational support to families, parent education, and financial assistance/educational pay). ${ }^{9}$

\section{Socio-pedagogical safety net}

The pedagogico-compensatory obligation of the state (by virtue of the state's secondary educational responsibility) can subsequently be translated into the general obligation to set up and support a (preventive) socio-pedagogical system which, in the first place, should offer a sociopedagogical safety net to the pedagogically most disadvantaged and vulnerable families in the Netherlands. (Such disadvantage is often the result of transgenerationalization.) This socio-pedagogical system consists of three foundations: early educational support to young parents (on a sliding preventive scale, this represents a three-echelons screening-model), parent education, both during school education, and later, for parents, and educational pay. The latter, specifically, enables semi-contractual agreements to be made with parents, e.g. by granting educational pay under specific conditions.

$9 \quad \mathrm{Cf}$. CRC, preambular para 5 , article 18 , para 2 , article 27 , para 1 and 3 , as well as article 5: (positive, active) respect for the responsibilitics, rights (qualifications) and duties of parents. 
This semi-contractual (and therefore, in principle, voluntary) point of departure leaves the state's ultimate coercive powers intact. Sociopedagogical coercion in optima forma is the state's vindication of the core right of the child to become more than a minimal person (vindication of minimal personality). Vindication of minimal personality takes place when educational services are imposed by a court of family law. Child protection agencies have to take a matter to court when it is obvious that offering educational support is of no use, or is no longer of any use, or when an essentially adequate offer is rejected, whilst at the same time the child's chance of achieving a development which is at least at or above the minimum is or may be endangered. (Such circumstances represent a case of cumulation of risk indicators, among which most prominently the lack of possibilities for the parents concerned to outgrow a pedagogically deprived youth.) It goes without saying that this requires an elaborate system of legal protection, which must include family-administrative proceedings, as well as material legal guarantees in the form of legally established operational developmental-psychological/pedagogical minimumrules and the possibility of judicial examination for compatibility of vindication requests (and general agency interference) with both socio-pedagogical constitutional rights and general principles of good family-administrative law.

At this point, we find ourselves on the borderline between state responsibility and government accountability. State responsibility bears upon the violation of international obligations (inadequate observance or lack of due diligence). Government accountability bears upon the most expedient - having regard to the Dutch situation - implementation of treaty and other international obligations.

The scope and gravity of the phenomenon of child abuse in the Netherlands on the one hand (to put it briefly: it occurs too frequently with excessively far-reaching consequences for individuals and society at large), and, on the other hand, the fact that this social evil is met with agency reactions which are structurally 'too little too late' (unco-ordinated incidental ex post-interventionism with stigmatizing, escalatory and thus counterproductive effects, as opposed to children's law of nations demands for an integrated structural preventive approach, as outlined in the final chapter of this study), prompt us to the conclusion that, at this moment, in this country, even the contours of a socio-pedagogical safety net (let alone a comprehensive socio-pedagogical system) are not evident. Much more can and should be done. I mean particularly that more can be done in a structural, legislative, and developmental-psychologically/ pedagogically operational sense. What we do, falls far short of what we 
know to be developmental-psychologically and socio-pedagogically necessary, desirable, and possible.

In the light of the foregoing, it can be stated that in the Netherlands a situation exists of such grave socio-pedagogical negligence on the part of the Dutch government, that the qualification 'gross and passivesystematic violations of human rights' applies here. The gap between what we do and what we know we can do, and can prevent, threatens to become so large that, towards the end of the century of the child (KEY), a new, a second social question: the socio-pedagogical question, presents itself.

\section{The socio-pedagogical question}

It is high time for state and society to be more active in doing something about this socio-pedagogical question. Although we need not, for the time being, be afraid - in view of what happens (and does not happen) in countries around us - of UN-intervention, there is no ground to view ourselves as a model state regarding the safeguarding of human rights. Not, at any rate, as far as the most fundamental right of the child, in a wealthy democracy, is concerned: the right to become an optimal person as a constitutional right of each child in the Netherlands - irrespective of race, colour, sex, social status, or level of parental awareness.

Just like other serious human rights situations, the socio-pedagogical question can be seen in the historical perspective of national civilizing work. ${ }^{10}$ If we look, on the one hand, at the scope and gravity of child abuse in the Netherlands, and, on the other hand, at both the socio-pedagogical lack of rights of young children and young parents in this country and the political and social 'workshyness' (also, and especially, it seems, among moral elites, caught up as they are in the privacy paradigm) with regard to the detransgenerationalization of Dutch society (the elimination of transgenerational socio-emotional/pedagogical deprivation and of structural socio-pedagogical discrimination), then we cannot but conclude that our democratic national culture, our advanced Western civilization, is no more than a thin veneer. Our attitudes and efforts towards the most defenceless in our midst - tens of thousands of abused children, and especially the youngest amongst them who are abused by both parents are a long way removed from what could be expected of a decent society. 


\section{BIJLAGE I}

\section{Verdrag inzake de rechten van het kind}

New York (Algemene Vergadering van de Verenigde Naties) 20 november 1989 (Tractatenblad 1990, 46; 1990, 170; 1995, 92; 1996, 188; 1997, 83; 1998, 62) (opengesteld voor ondertekening en ondertekening door het Koninkrijk der Nederlanden: 26 januari 1990; inwerkingtreding: 2 september 1990; inwerkingtreding voor Nederland: 8 maart 1995, voor de Nederlandse Antillen: 16 januani 1998) ${ }^{1}$

\section{PREAMBULE [Preambulaire overwegingen]}

De Staten die partij zijn bij dit Verdrag [hierna: de staten $(\ldots)^{2}$ ],

[1.] Overwegende dat, in overeenstemming met de in het Handvest van de Verenigde Naties verkondigde beginselen, erkenning van de inherente [aan het mens-zijn verbonden] waardigheid en de gelijke en onvervreemdbare rechten van alle leden van de mensengemeenschap de grondslag is voor vrijheid, gerechtigheid en vrede in de wereld;

[2.] Indachtig [het feit] dat de volkeren van de Verenigde Naties in het Handvest hun vertrouwen in de fundamentele rechten van de mens en in de waardigheid en de waarde van [het individu] opnieuw hebben bevestigd, en hebben besloten sociale vooruitgang en een hogere levensstandaard in groter[e] vrijheid te bevorderen;

[3.] Erkennende dat de Verenigde Naties in de Universele Verklaring van de rechten van de mens en in de internationale verdragen inzake de rechten van de mens hebben verkondigd en zijn overeengekomen dat een ieder recht heeft op alle rechten en vrijheden die daarin worden beschreven, zonder onderscheid van welke aard ook, zoals naar ras, huidskleur, geslacht, taal, gods-

De hierna volgende Nederlandse vertaling van het Verdrag is overgenomen uit Tractatenblad 1990, nr. 170, pp. 6-29. Aangezien deze 'officiële' Nederlandse vertaling niet authentiek is (vgl. art. $54 \mathrm{VRK}$ ), zijn, ter verduidelijking van de tekst/vertaling, toevoegingen en kleine aanpassingen (met uitzondering van kleine aanpassingen in interpunctie, hoofdlettergebuik en gebruik van elk/ieder) tussen vierkante teksthaken geplaatst. Eveneens zijn tussen teksthaken bij de preambule, de delen en de artikelen cursieve kopjes toegevoegd (welke zijn 'ingekleurd' door de duidingen in dit proefschrift en/of de interpretaties van het Comite inzake de rechten van het kind zoals beschreven in het UNICEF-Implementation handbook for the Convention on the rights of the child); de vier door het Comite inzake de rechten van het kind gehanteerde algemene beginselen zijn daarbij in hoofdletters weergegeven. Omdat kind onzijdig is, is de (hypercorrecte) zijn of haar-vorm niet overgenomen.

2 Met uitzondering van (vooralsnog) de vs, die het Verdrag nog niet heeft geratificeerd (na ondertekening op 16 februari 1995), en (regeringsloos) Somalië zijn immers alle (erkende) staten (191 van de 193) partij bij het Verdrag. 
dienst, politieke of andere overtuiging, nationale of sociale afkomst, eigendom, geboorte of andere status;

[4.] Eraan herinnerende dat de Verenigde Naties in de Universele Verklaring van de rechten van de mens hebben verkondigd dat kinderen recht hebben op bijzondere zorg en bijstand;

[5.] Ervan overtuigd dat aan het gezin, als de kern van de samenleving en de natuurlijke omgeving voor de onplooiing en het welzijn van al haar leden en van kinderen in het bijzonder, de nodige bescherming en bijstand dient te worden verleend [zo]dat het zijn verantwoordelijkheden binnen de gemeenschap volledig kan dragen;

[6.] Erkennende dat het kind voor de volledige en harmonische ontplooiing van zijn persoonlijkheid dient op te groeien in een gezinsomgeving, in een sfeer van geluk, liefde en begrup;

[7.] Overwegende dat het kind volledig dient te worden voorbereid op het leiden van een zelfstandig leven in de samenleving, en dient te worden opgevoed in de geest van de in het Handvest van de Verenigde Naties verkondigde idealen, en in het bijzonder in de geest van vrede, [respect voor de menselijke] waardigheid, verdraagzaamheid, vrijheid, gelijkheid en solidariteit;

[8.] Indachtig [het feit] dat de noodzaak van het verlenen van bijzondere zorg aan het kind is vermeld in de [Volkenbond-]Verklaring van Genève [van] de rechten van het kind van 1924 en in de Verklaring van de rechten van het kind aangenomen door de Algemene Vergadering [van de Verenigde Naties] op 20 november 1959, en is erkend in de Universele Verklaring van de rechten van de mens, in het Internationaal Verdrag inzake burger[lijke] en politieke rechten (met name in de artikelen 23 en 24), in het Internationaal Verdrag inzake economische, sociale en culturele rechten (met name in artikel 10) en in de statuten en desbetreffende akten van gespecialiseerde organisaties en internationale organisaties die zich bezighouden met het welzijn van kinderen;

[9.] Indachtig [het feit] dat, zoals aangegeven in de Verklaring van de rechten van het kind [van 1959], 'het kind op grond van zijn lichamelijke en geestelijke onrijpheid bijzondere [waarborgen] en zorg behoeft, met inbegrip van geëigende wettelijke bescherming, zowel vóór als na zijn geboorte' ${ }^{3}$;

3 De 'reproductieve wrijheid" van de zwangere vrouw is, gezien vanuit (het Verdrag inzake) de rechten van het kind, beperkt tot het recht op abortus, binnen de grenzen door het nationale recht gesteld; voor het overige geldt ook hier, blijkens deze preambulaire overweging in verband met diverse verdragsbepalingen, een secundaire (aanvullende en ondersteunende) zorgverantwoordelijkheid (inclusief, bij misbruik van de vrijheid ten nadele van de ontwikkelingskansen van de vrucht in een mate die de postnatale minimale persoonswording bedreigt, de mogelijkheid van c.q. verplichting tot het opleggen van hulp) van de staat.

Voor de goede orde: aan het internationale recht (het 'vrouwenvolkenrecht") zijn wel argumenten ten faveure van een (intern-nationaalrechtelijk beperkt) recht op abortus te ontlenen, doch (vooralsnog, deze preambulaire overweging ten spijt) geen argumenten ten faveure van een recht op leven van het ongeboren kind. 
[10.] Herinnerende aan de bepalingen van [a.] de Verklaring inzake sociale en juridische beginselen betreffende de bescherming en het welzijn van kinderen in het bijzonder met betrekking tot platsing in een pleeggezin en [nationale en internationale] adoptie (...); [b.] de Standaard minimumregels van de Verenigde Naties voor de toepassing van het [straf]recht op jongeren (de Beijingregels); en [c.] de Verklaring inzake de bescherming van vrouwen en kinderen in noodsituaties en gewapende conflicten;

[11.] Erkennende dat er, in alle landen van de wereld, kinderen zijn die in uitzonderlijk moeilijke omstandigheden leven, en dat deze kinderen bijzondere aandacht behoeven;

[12.] Op passende wijze rekening houdend met het belang van de tradities en culturele waarde[n van] elk volk [voor] de bescherming en de harmonische ontwikkeling van het kind ${ }^{4}$;

[13.] Het belang erkennende van internationale [ontwikkelings]samenwerking ter verbetering van de levensomstandigheden van kinderen in elk land, in het bijzonder in de ontwikkelingslanden;

zijn het volgende overeengekomen:

\section{DEEL I [Materiële bepalingen]}

Artikel 1 [Definitie kind]

Voor de toepassing van dit Verdrag wordt onder een kind verstaan ieder mens jonger dan achttien jaar, tenzij volgens het op het kind van toepassing zijnde recht de meerderjarigheid eerder wordt bereikt.

Artikel 2 [1. Gelijkheidsbeginsel/NON-DISCRMINATIE; 2. anti-discriminatiebeleid ter zake van de gezinsomstandigheden/positie enz. van de ouders]

1. De staten (...) eerbiedigen en waarborgen de in het Verdrag beschreven rechten voor ieder kind onder hun rechts[macht] zonder discriminatie van welke aard ook, ongeacht ras, huidskleur, geslacht, taal, godsdienst, politieke of andere overtuiging, nationale, ethnische of maatschappelijke afkomst, welstand, handicap, geboorte of andere omstandigheid van het kind of van zijn ouder of wettige voogd.

2. De staten (...) nemen alle passende maatregelen om te waarborgen dat het kind wordt beschermd tegen alle vormen van discriminatie of bestraffing op grond van de omstandigheden of de activiteiten van, de meningen geuit door, of de overtuigingen van de ouders, wettige voogden of familieleden van het kind.

4 Met uitzondering van schadelijke traditionele gebruiken (zie art. 24, lid 3 VRk), zoals (blijkens de travaux préparatoires in het bijzonder) genitale verminking van meisjes en voorkeursbehandeling van jongetjes. 
Artikel 3 [1. HET (ontwikkelings) BELANG VAN HET KIND als algemeen beginsel; 2 secundaire opvoedingsverantwoordelijkheid van de staat; 3. kwalitatieve en kwantitatieve toerusting van en toezicht op instellingen van kinderbescherming en jeugdhulpverlening/geschiktheid van en toezicht op kinderbeschermers/jeugdhulpverleners]

1. Bij alle [handelingen] betreffende kinderen, ongeacht of deze worden [verricht] door openbare of particuliere instellingen voor maatschappelijk welzijn of door rechterlijke instanties, bestuurlijke autoriteiten of wetgevende lichamen, vorm[t] [het belang] van het kind [een] eerste overweging.

2. De staten (...) verbinden zich ertoe het kind te verzekeren van de bescherming en de zorg die nodig zijn voor zijn welzijn, rekening houdend met de [bevoegdheden] en plichten van zijn ouders, wettige voogden of anderen die wettelijk verantwoordelijk voor het kind zijn, en nemen hiertoe alle passende wettelijke en bestuurlijke maatregelen.

3. De staten (...) waarborgen dat de instellingen, diensten en voorzieningen die verantwoordelijk zijn voor de zorg voor of de bescherming van kinderen, voldoen aan de door de bevoegde autoriteiten vastgestelde normen, met name ten aanzien van de veiligheid, de gezondheid, het aantal personeelsleden en hun geschiktheid, alsmede bevoegd toezicht.

Artikel 4 [Op maximaal resultaat gericht (kind)beleid met inzet van maximale financiële middelen; internationale ontwikkelingssamenwerking]

[1e] De staten (...) nemen alle passende wettelijke, bestuurlijke en andere maatregelen om de in dit Verdrag erkende rechten te verwezenlijken. [2e] Ten aanzien van economische, sociale en culturele [lees: geld eisende] rechten nemen de staten (...) deze maatregelen in de ruimste mate [maximum extent] waarin de hun ter beschikking staande middelen dit toelaten en, indien nodig, in het kader van internationale [ontwikkelings]samenwerking.

Artikel 5 [Primaire ouderlijke opvoedingsverantwoordelijkheid: verplichting ouders tot leiding en begeleiding naar de mate van de zich ontwikkelende vermogens van het (opgroeiende) kind] De staten (...) eerbiedigen de verantwoordelijkheden, [bevoegdheden] en plichten van de ouders of, indien van toepassing, van de leden van de familie in ruimere zin [extended family] of de gemeenschap [community] al naar gelang het plaatselijk gebruik, van wettige voogden of anderen die wettelijk verantwoordelijk zijn voor het kind, [ter zake van] het [bieden van] passende leiding en begeleiding bij de uitoefening door het kind van de in dit Verdrag erkende rechten, op een wijze die verenigbaar is met [en recht doet aan] de zich ontwikkelende vermogens van het kind.

Artikel 6 [Recht op (OVER) LEVEN EN (optimale) ONTWIKKELING]

1. De staten (...) erkennen dat ieder kind het inherente recht [het geboorterecht] op leven heeft. 
2. De staten (...) waarborgen in de ruimst mogelijke mate [maximum extent] de mogelijkheden tot overleven en de ontwikkeling van het kind.
Artikel 7 [1. Inschrijving, recht op naam, recht op mationaliteit, recht zijn ouders te kennen (afstammingskennis), recht door zijn ouders te worden verzorgd ('recht op biologische ouders'; recht op empowerment van zijn ouders); 2 . plicht van de staat deze rechten te waarborgen/in het nationale recht vorm en inhoud te geven]

1. Het kind wordt onmiddellijk na de geboorte ingeschreven en heeft vanaf de geboorte het recht op een naam, het recht een nationaliteit te verwerven en, voor zover mogelijk, het recht zijn ouders te kennen en door then te worden verzorgd. ${ }^{5}$

2. De staten (...) waarborgen de verwezenlijking van deze rechten in overeenstemming met [op de wijze voorzien in] hun nationale recht en [overeenkornstig] hun verplichtingen krachtens de desbetreffende internationale akten op dit gebied, in het bijzonder wanneer het kind anders staatloos zou zijn.

\section{Artikel 8 [1. Recht op behoud van identiteit (afstammingszeker- heid): de staat mag niet meewerken aan 'verduistering van staat'; 2. (inspannings)verplichtingen van de staat ter zake van herstel van identiteit: 'recht op waarheid' door de staat wettelijk vorm en in- houd te geven]}

1. De staten (...) verbinden zich tot eerbiediging van het recht van het kind zijn identiteit te behouden, met inbegrip van nationaliteit, naam en familiebetrekkingen zoals wettelijk erkend, zonder onrechtmatige inmenging.

2. Wanneer een kind op niet rechtmatige wijze wordt beroofd van enige of alle bestanddelen van zijn identiteit, verlenen de staten (...) passende bijstand en bescherming, teneinde zijn identiteit snel te herstellen.

In het recht van het kind door zijn ouders te worden verzorgd, bij uitbreiding (c.q. in verband met art. 5, art. 9, lid 1, art. 18 , lid 1 en art. 27 , lid 2 ): het recht van het kind door zijn ouders te worden opgevoed, dient - in verband met art. 3, art. 18 , lid 2, art. 19, art. 20, art. 27, lid 3, art. 39 en art. 40, lid 4 - ingelezen te worden het recht van het kind op empowerment van zijn ouders, met andere woorden het recht van het kind op met name preventieve opvoedingsondersteuning van zijn ouders (waaronder begrepen een zodanig - en zodanig vroegtijdig aanbod van hulp aan het gezin dat ouders in staat worden gesteld hun pedagogisch besef tijdig te verbeteren en eventuele traumatische eigen jeugdervaringen adequaat te verwerken).

In deze studie wordt betoogd dat het recht van het kind op empowerment van zijn ouders betekent "het recht van het kind" op een sociaal-pedagogische infrastructuur met een sociaal-pedagogisch vangnet voor risico-gezinnen op basis van prenatale screening (door middel van het BAARTMAN-gesprek) op risico-indicatoren. 
Artikel 9 [1. Scheiding ouders en kind alleen in het (ontwikkelings)belang van het kind/in geval van kindermishandeling/verwaarlozing; 2. hoorrecht; 3. omgangsrecht van het kind voor zover niet in strijd met zijn (ontwikkelings) belang; 4. informatieplicht wan de staat bij detentie ouder/kind]

1. [1e] De staten (...) waarborgen dat een kind niet wordt gescheiden van zijn ouders tegen [zijn/] hun wil, tenzij de bevoegde autoriteiten, onder voorbehoud van de mogelijkheid van rechterlijke toetsing, in overeenstemming met het toepasselijke recht en de toepasselijke procedures, beslissen dat deze scheiding noodzakelijk is in het belang van het kind. [2e] Een dergelijke beslissing kan noodzakelijk zijn in een bepaald geval, zoals wanneer er sprake is van [mishandeling/]misbruik of verwaarlozing van het kind door de ouders, of wanneer de ouders gescheiden leven en er een beslissing moet worden genomen ten aanzien van de verblijfplaats van het kind. ${ }^{6}$

2. In procedures ingevolge het eerste lid van dit artikel dienen alle betrokken partijen de gelegenheid te krijgen aan de procedures deel te nemen en hun standpunten naar voren te brengen.

3. De staten (...) eerbiedigen het recht van het kind dat van een ouder of beide ouders is gescheiden, op regelmatige basis persoonlijke betrekkingen en rechtstreeks contact met beide ouders te onderhouden, tenzij dit in strijd is met het belang van het kind.

4. [1e] Indien een dergelijke scheiding voortvloeit uit een maatregel genomen door [de] staat (...), zoals de inhechtenisneming, gevangenneming, verbanning, deportatie, of uit een maatregel het overlijden ten gevolge hebbend (met inbegrip van overlijden, door welke oorzaak ook, terwijl de betrokkene door de staat in bewaring wordt gehouden) van éen ouder of beide ouders of van het kind, verstrekt die staat, op verzoek, aan de ouders, aan het kind of, indien van toepassing, aan een ander familielid van het kind de noodzakelijke inlichtingen over waar het afwezige lid van het gezin zich bevindt of waar de afwezige leden van het gezin zich bevinden, tenzij het verstrekken van die inlichtingen het welzijn van het kind zou schaden. [2e] De staten (...) waarborgen voorts dat het indienen van een dergelijk verzoek op zich geen nadelige gevolgen heeft voor de betrokkene( $\mathrm{n})$.

Artikel 10 [1. Gezinshereniging; 2. transnationale bewegingsvrijheid

bij scheiding]

1. [1e] In overeenstemming met de verplichting van de [staat] (...) krachtens artikel 9, eerste lid, worden aanvragen van een kind of van zijn ouders om een staat (...) voor gezinshereniging binnen te gaan of te verlaten, door de [staat]

In het recht van ouders en kind in beginsel niet van elkaar te worden gescheiden (dit artikellid in verband met art. 5, art. 7, lid 1, art. 18, lid 1 en art. 27, lid 2), dient - in verband met art. 3 , art. 18, lid 2 , art. 19 , art. 20 , art. 27 , lid 3 , art. 39 en art. 40 , lid 4 - ingelezen te worden het recht van het kind op empowerment van zijn ouders (zic voor de betekenis daarvan de vorige noot). 
(...) met welwillendheid, menselijkheid en spoed behandeld. [2e] De staten (...) waarborgen voorts dat het indienen van een dergelijke aanvraag geen nadelige gevolgen heeft voor de aanvragers en hun familieleden.

2. [1e] Een kind van wie de ouders in verschillende staten verblijven, heeft het recht op regelmatige basis, behalve in uitzonderlijke omstandigheden, persoonlijke betrekkingen en rechtstreekse contacten met beide ouders te onderhouden. [2e] Hiertoe, en in overeenstemming met de verplichting van de [staat] (...) krachtens artikel 9, [eerste ${ }^{7}$ ] lid, eerbiedigen de staten (...) het recht van het kind en van zijn ouders welk land ook, met inbegrip van het eigen land, te verlaten, en het eigen land binnen te gaan. [3e] Het recht welk land ook te verlaten, is slechts onderworpen aan de beperkingen die bij de wet zijn voorzien en die nodig zijn ter bescherming van de nationale veiligheid, de openbare orde, de volksgezondheid of de goede zeden, of van de rechten en vrijheden van anderen, en verenigbaar zijn met de andere in dit Verdrag erkende rechten.

\section{Artikel 11 [(Intemationale) bestrijding van kinderontwoering]}

1. De staten (...) nemen maatregelen ter bestrijding van de ongeoorloofde overbrenging van kinderen naar en het niet doen terugkeren van kinderen uit het buitenland.

2. Hiertoe bevorderen de staten (...) het sluiten van bilaterale of multilaterale overeenkomsten of het toetreden tot bestaande overeenkomsten.

\section{Artikel 12 [1. (Pro-actief) RESPECT WOOR DE MENING VAN HET KIND;}

2. hoorrecht $]$

1. De staten (...) verzekeren het kind dat in staat is zijn eigen mening te vormen, het recht die mening vrijelijk te uiten in alle aangelegenheden die het kind betreffen, waarbij aan de mening van het kind passend belang wordt gehecht in overeenstemming met zijn leeftijd en rijpheid.

2. Hiertoe wordt het kind met name in de gelegenheid gesteld te worden gehoord in elke gerechtelijke en bestuurlijke procedure die het kind betreft, hetzij rechtstreeks, hetzij door tussenkomst van een vertegenwoordiger of een daarvoor geschikte instelling, op een wijze die verenigbaar is met de procedureregels van het nationale recht.

\section{Artikel 13 [1. Vrijheid van meningsuiting, recht op informatieverga- ring; 2. wettelijke beperkingen/doelcriteria (rechten van anderen, goede zeden)]}

1. Het kind heeft het recht op vrijheid van meningsuiting; dit recht omvat mede de vrijheid inlichtingen en denkbeelden wan welke aard ook te vergaren, te ontvangen en door te geven, ongeacht landsgrenzen, hetzij mondeling, hetzij in

7 Zie de correctie met betrekking tot Tractatenblad 1990, nr. 46 in Trb. 1990, nr. 170, p. 1, welke correctie niet is doorgevoerd in de Nederlandse vertaling in hetzelfde Trb. Zie (echter) ook Trb. 1997, nr. 83, pp. 1 en 2 onder resp. B en C. 
geschreven of gedrukte vorm, in de vorm van kunst, of met behulp van andere media naar zijn keuze.

2. De uitoefening van dit recht kan aan bepaalde beperkingen worden gebonden, doch alleen aan de beperkingen die bij de wet zijn voorzien en die nodig zijn:

a. voor de eerbiediging van de rechten of de goede naam van anderen; of

b. ter bescherming van de nationale veiligheid of van de openbare orde, de volksgezondheid of de goede zeden.

\section{Artikel $14^{8}$ [1. Vrijheid van gedachte, geweten en godsdienst; 2. bevoegdheden en plichten ouders tot leiding overeenkomstig de zich ontwikkelende vermogens van het kind; 3. wettelijke beperkin- gen/doelcriteria]}

1. De staten (...) eerbiedigen het recht van het kind op vrijheid van gedachte, geweten en godsdienst.

2. De staten (...) eerbiedigen de [bevoegdheden] en plichten van de ouders en, indien van toepassing, van de wettige voogden, om het kind te leiden in de uitoefening van zijn recht op een wijze die verenigbaar is met [en recht doet aan] de zich ontwikkelende vermogens van het kind.

3. De vrijheid van een ieder zijn [of haar] godsdienst of levensovertuiging tot uiting te brengen, kan slechts in die mate worden beperkt als wordt voorgeschreven door de wet en noodzakelijk is ter bescherming van de openbare veiligheid, de openbare orde, de volksgezondheid of de goede zeden, of van de fundamentele rechten en vrijheden van anderen.

\section{Artikel 15 [1. Vrijheid van vereniging en vergadering; 2. wettelijke} beperkingen/doelcriteria]

1. De staten (...) erkennen de rechten van het kind op vrijheid van vereniging en vrijheid van vreedzame vergadering.

2. De uitoefening van deze rechten kan aan geen andere beperkingen worden onderworpen dan die welke in overeenstemming met de wet worden opgelegd en die in een democratische samenleving geboden zijn in het belang van de nationale veiligheid of de openbare veiligheid, de openbare orde, de bescherming van de volksgezondheid of de goede zeden, of de bescherming van de rechten en vrijheden van anderen.

Ten aanzien van dit artikel heeft Nederland de volgende (interpretatieve) verklaring afgelegd (Tractatenblad 1995, nr. 92, pp. 20-21 nt. 37): 'It is the understanding of the Government of the Kingdom of the Netherlands that article 14 of the Convention is in accordance with the provisions of article 18 of the [ICCPR] and that this article shall include the freedom of a child to have or adopt a religion or belief of his or her choice as soon as the child is capable of making such choice in view of his or her age or maturity.' 
Artikel 16 [1. Recht op privacy, wrijwaring van aantasting van geestelijke integriteit; 2. recht op wettelijke bescherming]

1. Geen enkel kind mag [door zijn ouders of derden] worden onderworpen aan willekeurige of onrechtmatige inmenging in zijn priveleven, in zijn gezinsleven [omgang met ouder(s) en familieleden], zijn woning [ouderlijke woning/kamer van het kind] of zijn correspondentie, noch aan enige onrechtmatige aantasting van zijn eer en goede naam [psychische integriteit].

2. Het kind heeft recht op bescherming door de wet tegen zodanige inmenging of aantasting [door ouders of derden].

Artikel 17 [Recht op informatie, beleid ten aanzien van de media e.d, internationale ontwikkelingssamenwerking, kinderboeken, taalminderheden, richtlijnen inzake bescherming tegen schadelijk materiaal]

[1e] De staten (...) erkennen de belangrijke functie van de massamedia en waarborgen dat het kind toegang heeft tot informatie en materiaal uit een verscheidenheid van nationale en internationale bronnen, in het bijzonder informatie en materiaal gericht op het bevorderen van zijn sociale, psychische en morele welzijn en zijn lichamelijke en geestelijke gezondheid. [2e] Hiertoe dienen de staten (...):

a. de massamedia aan te moedigen informatie en materiaal te verspreiden die tot sociaal en cultureel nut zijn voor het kind en in overeenstemming zijn met de strekking van artikel 29 ;

b. internationale [ontwikkelings]samenwerking aan te moedigen bij de vervaardiging, uitwisseling en verspreiding van dergelijke informatie en materiaal uit een verscheidenheid van culturele, nationale en internationale bronnen;

c. de vervaardiging en verspreiding van kinderboeken aan te moedigen;

d. de massamedia aan te moedigen in het bijzonder rekening te houden met de behoeften op het gebied van de taal van het kind dat tot een minderheid of tot de oorspronkelijke bevolking behoort;

e. de ontwikkeling aan te moedigen van passende richtlijnen voor de bescherming van het kind tegen informatie en materiaal die schadelijk zijn voor zijn welzijn, indachtig de bepalingen van de artikelen 13 en 18.

Artikel $18[1$. Primaire opvoedingsverantwoordelijkheid wan de ouders: beide ouders gezamenlijk verantwoordelijk, belang van het kind hoogste ouderlijke plicht; 2. secundaire opvoedingsverantwoordelijkheid van de staat: (algemene) sociaal-pedagogische voorzieningen en (gerichte) opvoedingsondersteuning voor ouders; 3. recht op kinderopvang van kinderen van werkende ouders]

1. [1e] De staten (...) doen alles wat in hun vermogen ligt om de erkenning te verzekeren van het beginsel dat beide ouders de gezamenlijke verantwoordelijkheid dragen voor de opvoeding en de ontwikkeling van het kind. [2e] Ouders of, al naar gelang het geval, wettige voogden hebben de eerste verantwoordelijkheid voor de opvoeding en de ontwikkeling van het kind. [3e] Het belang van het kind is hun allereerste zorg. 
2. Om de toepassing van de in dit Verdrag genoemde rechten te waarborgen en te bevorderen, verlenen de staten (...) passende [ondersteuning] aan ouders en wettige voogden bij de uitoefening van hun verantwoordelijkheden die de opvoeding van het kind betreffen, en waarborgen zij de ontwikkeling van instellingen, voorzieningen en diensten voor kinderzorg.

3. De staten (...) nemen alle passende maatregelen om te waarborgen dat kinderen van werkende ouders recht hebben op gebruikmaking van diensten en voorzieningen voor kinderzorg waarvoor zij in aanmerking komen.

\section{Artikel $19[1$. Secundaire opvoedingsverantwoordelijkheid van de staat: bescherming tegen kindermishandeling (preventie, interventie, reparatie); 2. opvoedingsondersteuning en andere (preventieve) sociaal-pedagogische maatregelen (waaronder 'opvoedingsonder- wijs'); signalering, melding, verwijzing, onderzoek, behandeling, fol- low-up; inschakeling van de rechter]}

1. De staten (...) nemen alle passende wettelijke en bestuurlijke maatregelen en maatregelen op sociaal en opvoedkundig gebied om het kind te beschermen tegen alle vormen van lichamelijk of geestelijk geweld, letsel of misbruik, lichamelijke of geestelijke verwaarlozing of nalatige behandeling, mishandeling of exploitatie, met inbegrip van sexueel misbruik, terwijl het kind onder de hoede is van de ouder(s), wettige voogd(en) of iemand anders die de zorg voor het kind heeft.

2. Deze maatregelen ter bescherming dienen, indien van toepassing, doeltreffende [werkwijzen] te omvatten voor de invoering [het ingang doen vinden en vestigen] van sociale programma's om te voorzien in de nodige ondersteuning van het kind en van degenen die de zorg voor het kind hebben, alsmede [werkwijzen] voor andere vormen van voorkoming van, en voor opsporing, melding, verwijzing, onderzoek, behandeling en follow-up van gevallen van, kindermishandeling zoals hierboven beschreven, en, indien van toepassing, voor inschakeling van rechterlijke instanties.

\section{Artikel 20 [1. Recht op bijzondere bescherming en bijstand van kind buiten of zonder gezin/ouders; 2. (secundaire opvoedingsver- antwoordelijkheid van de staat:) vervangende zorg (en opvoeding); 3. zoals pleeggezinplaatsing of (desnoods) plaatsing in een instel- ling; continuiteit in de opvoeding]}

1. Een kind dat tijdelijk of blijvend het verblijf in het gezin waartoe het behoort, moet missen, of dat men in [het belang van het kind] niet kan toestaan in het gezin te blijven, heeft recht op bijzondere bescherming en bijstand van staatswege.

2. De staten (...) waarborgen, in overeenstemming met [op de wijze(n) voorzien in] hun nationale recht, een andere vorm van zorg voor dat kind.

3. [1e] Deze zorg kan, onder andere, plaatsing in een pleeggezin omvatten, kafalah volgens het islamitische recht, adoptie, of, indien noodzakelijk, plaatsing in geschikte instellingen voor kinderzorg. [2e] Bij het overwegen van oplossingen wordt op passende wijze rekening gehouden met de wenselijkheid van con- 
tinuïteit in de opvoeding van het kind en met de ethnische, godsdienstige en culturele achtergrond van het kind en met zijn achtergrond wat betreft de taal.

\section{Artikel 21 [Adoptie in het belang van het kind; procedurele waar-}

borgen, instemming betrokkenen; interlandelijke adoptie]

De staten (...) die de methode van adoptie erkennen en/of toestaan, waarborgen dat het belang van het kind daarbij de voornaamste overweging is, en:

a. waarborgen dat de adoptie van een kind slechts wordt toegestaan mits daartoe bevoegde autoriteiten, in overeenstemming met de van toepassing zijnde wetten en procedures en op grond van alle van belang zijnde en betrouwbare gegevens, bepalen dat de adoptie kan worden toegestaan gelet op de verhoudingen van het kind met zijn ouders, familieleden en wettige voogden, en mits, [voor zover] vereist, de betrokkenen, na volledig te zijn ingelicht, op grond van de adviezen die noodzakelijk worden geacht, daarmee hebben ingestemd;

b. erkennen dat interlandelijke adoptie kan worden overwogen als [alternatieve] oplossing voor de zorg voor het kind indien het kind niet [binnenslands] in een pleeg- of adoptiegezin kan worden geplaatst en op geen enkele andere passende wijze kan worden verzorgd in het land van zijn herkomst;

c. verzekeren dat voor het kind dat bij een interlandelijke adoptie is betrokken, waarborgen en [maatstaven] gelden die gelijkwaardig zijn aan die welke bestaan bij adoptie in het eigen land;

d. nemen alle passende maatregelen om te waarborgen dat [bij] interlandelijke adoptie de plaatsing niet leidt tot ongepast geldelijk voordeel voor de betrokkenen;

e. bevorderen, wanneer passend, de verwezenlijking van de doeleinden van dit artikel door het aangaan van bilaterale of multilaterale regelingen of overeenkomsten, en spannen zich in om, in het kader daarvan, te waarborgen dat de plaatsing van het kind in een ander land wordt uitgevoerd door bevoegde autoriteiten of instellingen.

\section{Artikel $22^{9}$ [1. Positieve maatregelen ter zake van de rechten van}

Ten aanzien van dit artikel heeft Nederland de volgende (interpretatieve) verklaring afgelegd (Trb, 1995, nr. 92, t.a.p.): 'With regard to article 22 of the Convention, the Government of the Kingdom of the Netherlands declares:

a) that it understands the term "refugee" in paragraph 1 of this article as having the same meaning as in article 1 of the Convention relating to the Status of Refugees of $28 \mathrm{July} 1951^{;}$, and

b) that it is of the opinion that the obligation imposed under the terms of this article does not prevent

- the submission of a request for admission from being made subject to certain conditions, failure to meet such conditions resulting in inadmissibility;

- the referral of a request for admission to a third State, in the event that such a State is considered to be primarily responsible for dealing with the request for asylum.'

Voor zover het verklaarde onder $b$, eerste gedachtenstreepje, beoogt, in algemene 
(al of niet alleenstaande) minderjarige asielzoekers/vluchtelingenkinderen; 2. samenwerking met $W N$, IGO's en NGO's met het oog op gezinshereniging: alleenstaande minderjarige asielzoekers/vluchtelingenkinderen dezelfde (hoge) bescherming als andere kinderen buiten of zonder gezin/ouders]

1. De staten (...) nemen passende maatregelen om te waarborgen dat een kind dat de vluchtelingenstatus wil verkrijgen of dat in overeenstemming met het toepasselijke internationale of nationale recht en de toepasselijke procedures als vluchteling wordt beschouwd, ongeacht of het al dan niet door zijn ouders of door iemand anders wordt begeleid, passende bescherming en humanitaire bijstand krijgt bij het genot van de van toepassing zijnde rechten beschreven in dit Verdrag en in andere internationale akten inzake de rechten van de mens of humanitaire akten waarbij de bedoelde staten partij zijn.

2. [1e] Hiertoe verlenen de staten (...), naar zij passend achten, hun medewerking aan alle inspanningen van de Verenigde Naties en andere bevoegde intergouvernementele organisaties of niet-gouvernementele organisaties die met de Verenigde Naties samenwerken, om dat kind te beschermen en bij te staan en de ouders of andere gezinsleden op te sporen van een kind dat vluchteling is, teneinde de nodige inlichtingen te verkrijgen voor hereniging van het kind met het gezin waartoe het behoort. [2e] In gevallen waarin geen ouders of andere familieleden kunnen worden gevonden, wordt aan het kind dezelfde bescherming verleend als aan ieder ander kind dat om welke reden ook blijvend of tijdelijk het leven in een gezin moet ontberen, zoals beschreven in dit Verdrag.

\section{Artikel 23 [1-3. Rechten van en (gratis) bijstand voor gehandicapte}

kinderen; 4. internationale (ontwikkelings)samenwerking]

1. De staten (...) erkennen dat een geestelijk of lichamelijk gehandicapt kind een volwaardig en behoorlijk leven dient te hebben, in omstandigheden die de waardigheid van het kind verzekeren, zijn zelfstandigheid bevorderen en zijn actieve deelneming aan het gemeenschapsleven vergemakkelijken.

2. De staten (...) erkennen het recht van het gehandicapte kind op bijzondere zorg, en stimuleren en waarborgen dat aan het daarvoor in aanmerking komende kind en degenen die verantwoordelijk zijn voor zijn verzorging, afhankelijk van de beschikbare middelen, de bijstand wordt verleend die is aangevraagd en

en vage zin, bepaalde c.q. nog (nader) te bepalen (restrictieve) nationaalrechtelijke voorwaarden boven 'object and' purpose' van het Verdrag - de optimale persoonswording van alle kinderen onder de rechtsmacht van de staat en (dus) in het bijzonder passende bescherming van en humanitaire bijstand voor minderjarige asielzoekers - te laten prevaleren, dan wel zulks ten gevolge heeft of kan hebben, kan daartegen hetzelfde, althans cen soortgelijk bezwaar worden ingebracht als de bezwaren welke Nederland heeft gemaakt tegen diverse verklaringen en/of voorbehouden van andere landen met eenzelfde strekking (vgl. bijvoorbeeld $T$ th. 1996 , nr. 188 , onder E nt. 5 , p. 6 , voor het voorbehoud van Liechtenstein met betrekking tot art. 7, en het Nederlandse bezwaar daartegen: Trb. 1997, nr. 83, onder E nt. 2, op pp. 3/4; Trb. 1998, nr. 62, onder E nt. 2, p. 4). 
die passend is gezien de gesteldheid van het kind en de omstandigheden van de ouders of anderen die voor het kind zorgen.

3. [1e] [Gezien] de bijzondere behoeften van het gehandicapte kind dient de in overeenstemming met het tweede lid [van dit artikel] geboden bijstand [waar] mogelijk gratis te worden verleend, rekening houdend met de financiële middelen van de ouders of anderen die voor het kind zorgen. [2e] Deze bijstand dient erop gericht te zijn te waarborgen dat het gehandicapte kind daadwerkelijk toegang heeft tot onderwijs, opleiding[en], voorzieningen voor gezondheidszorg en revalidatie, voorbereiding voor een beroep en recreatiemogelijkheden op een wijze die ertoe bijdraagt dat het kind een zo volledig mogelijke integratie in de maatschappij en persoonlijke ontwikkeling bereikt, met inbegrip van zijn culturele en intellectuele ontwikkeling.

4. [1e] De staten (...) bevorderen, in de geest van internationale samenwerking, de uitwisseling van passende informatie op het gebied van preventieve gezondheidszorg en van medische en psychologische behandeling van en [de] behandeling van functionele stoornissen bij gehandicapte kinderen, met inbegrip van de verspreiding van en de toegang tot informatie betreffende revalidatiemethoden, onderwijs en beroepsopleidingen, met als doel de staten (...) in staat te stellen hun vermogens en vaardigheden te verbeteren en hun ervaring op deze gebieden te verruimen. [2e] Wat dit betreft, wordt in het bijzonder rekening gehouden met de behoeften van ontwikkelingslanden.

Artikel 24 [1. Recht op de best mogelijke gezondheid(szorg), recht op toegang tot voorzieningen voor ieder kind; 2. eerstelijnszorg, milieuverontreiniging, pre- en postnatale zorg moeders, onderwijs/ voorlichting volwassenen/ouders en kinderen, borstvoeding, preventieve zorg/begeleiding van ouders, gezinsplanning, e.d.m.; 3. bestrijding van schadelijke traditionele gebruiken en praktijken; 4. internationale (ontwikkelings) samenwerking]

1. [1e] De staten (...) erkennen het recht van het kind op het genot van de grootst mogelijke mate van gezondheid en op voorzieningen voor de behandeling van ziekte en het herstel van de gezondheid. [2e] De staten (...) streven ernaar te waarborgen dat geen enkel kind zijn recht op toegang tot deze voorzieningen voor gezondheidszorg wordt onthouden.

2. De staten (...) streven de volledige verwezenlijking van dit recht na en nemen passende maatregelen, met name:

a. om baby- en kindersterfte te verminderen;

b. om de verlening van de nodige medische hulp en gezondheidszorg aan alle kinderen te waarborgen, met nadruk op de ontwikkeling van eerstelijnsgezondheidszorg;

c. om ziekte, ondervoeding en slechte voeding te bestrijden, mede binnen het kader van de eerstelijnsgezondheidszorg, door onder andere het toepassen van gemakkelijk beschikbare technologie en door het voorzien in voedsel met voldoende voedingswaarde en zuiver drinkwater, de gevaren en risico's van milieuverontreiniging in aanmerking nemend; 
d. om passende pre- en postnatale gezondheidszorg voor moeders te waarborgen;

e. om te waarborgen dat alle geledingen van de samenleving, met name ouders en kinderen, worden voorgelicht over, toegang hebben tot onderwijs over en worden gesteund in het gebruik van de fundamentele kennis van de gezondheid van en de voeding van kinderen, de voordelen van borstvoeding, hygiëne en sanitaire voorzieningen en het voorkomen van ongevallen;

f. om preventieve gezondheidszorg, begeleiding voor ouders en voorzieningen voor en voorlichting over gezinsplanning te ontwikkelen.

3. De staten (...) nemen alle doeltreffende en passende maatregelen teneinde traditionele gebruiken die schadelijk zijn voor de gezondheid van kinderen af te schaffen. ${ }^{10}$

4. [1e] De staten (...) verbinden zich ertoe internationale samenwerking te bevorderen en aan te moedigen teneinde geleidelijk de algehele verwezenlijking van het in dit artikel erkende recht te bewerkstelligen. [2e] Wat dit betreft, wordt in het bijzonder rekening gehouden met de behoeften van ontwikkelingslanden.

\section{Artikel 25 [Recht van het kind op periodieke evaluatie bij uithuis- plaatsing]}

De staten (...) erkennen het recht van een kind dat door de bevoegde autoriteiten uit huis is geplatst ter verzorging, bescherming of behandeling in verband met zijn lichamelijke of geestelijke gezondheid, op een periodieke evaluatie van de behandeling die het kind krijgt, en van alle andere omstandigheden die verband houden met zijn plaatsing.

\section{Artikel $26^{11}$ [1. Recht van het kind op sociale zekerheid/sociale verzekeringen; 2 . uitkeringen (mede) afhankelijk van situatie onder- houdsplichtigen]}

1. De staten (...) erkennen voor ieder kind het recht de voordelen te genieten van voorzieningen voor sociale zekerheid, met inbegrip van sociale verzekering,

Het Comité inzake de rechten van het kind vestigt in dit verband, naast in de travaux préparatoires reeds aan de orde gestelde traditionele gebruiken en praktijken (in het bijzonder genitale verminking van meisjes en voorkeursbehandeling van jongetjes), ook de aandacht op bepaalde 'vormen van kindermishandeling in het gezin,' waarbij gedacht moet worden aan 'forms of discipline which are violent and/or prejudicial to health." Het slaan van kinderen als (traditionele) pedagogische praktijk ('corporal punishment') acht het Comité in strijd met in het bijzonder art. 3, 19 en 37 van het Verdrag. (Zie Implementation handbook for the Convention on the rights of the child, UNICEF 1998, resp. pp. 336 r.k., (335/)336 en 242-245.)

11 Bij dit artikel heeft Nederland het volgende voorbehoud gemaakt (Trb. 1995, nr. 92, t.a.p.): "The Kingdom of the Netherlands accepts the provisions of article 26 of the Convention with the reservation that these provisions shall not imply an independent entitlement of children to social security, including social insurance.' 
en nemen de nodige maatregelen om de algehele verwezenlijking van dit recht te bewerkstelligen in overeenstemming met [op de wijze(n) voorzien in] hun nationale recht.

2. De voordelen dienen, [voor zover] van toepassing, te worden verleend, waarbij rekening wordt gehouden met de middelen en de omstandigheden van het kind en de personen die verantwoordelijk zijn voor zijn onderhoud, alsmede elke andere overweging die van belang is voor de beoordeling van een verzoek daartoe dat door of namens het kind wordt ingediend.

\section{Artikel 27 [1. Recht op levensstandaard/levensomstandigheden die toereikend/nodig is/zijn voor de ontwikkeling(/persoonswording) van het kind; 2. primaire financiële opvoedingsverantwoordelijkheid ouders; 3. secundaire verantwoordelijkheid van de staat/"opvoe- dingsgeld' (programma's voor materiële bijstand en ondersteuning); 4. (primaire verantwoordelijkheid ouders/secundaire verantwoorde- lijkheid van de staat:) verhaalsplicht van de staat, nationaal en transnationaal/internationale samenwerking]}

1. De staten (...) erkennen het recht van ieder kind op een levensstandaard die toereikend is voor de lichamelijke, geestelijke, intellectuele, zedelijke en maatschappelijke ontwikkeling van het kind.

2. De ouder(s) of anderen die verantwoordelijk zijn voor het kind, hebben de primaire verantwoordelijkheid voor het waarborgen, naar vermogen en binnen de grenzen van hun financiële mogelijkheden, van de levensomstandigheden die nodig zijn voor de ontwikkeling van het kind.

3. De staten (... ) nemen, in overeenstemming met de nationale omstandigheden en met de middelen die hun ten dienste staan, passende maatregelen om ouders en anderen die verantwoordelijk zijn voor het kind, te helpen dit recht te verwezenlijken, en voorzien, [waar dlaaraan behoefte] bestaat, in programma's voor materiële bijstand en ondersteuning, met name wat betreft voeding, kleding en huisvesting.

4. [1e] De staten (...) nemen alle passende maatregelen om het verhaal te waarborgen van uitkeringen tot onderhoud van het kind [op] de [niet-verzorgende] [ouder/] ouders of andere personen die de financiële verantwoordelijkheid voor het kind dragen, zowel binnen de staat (...) als vanuit het buitenland. [2e] Met name voor gevallen waarin degene die de financiële verantwoordelijkheid voor het kind draagt, in een andere staat woont dan die van het kind, bevorderen de staten (...) de toetreding tot internationale overeenkomsten of het sluiten van dergelijke overeenkomsten, alsmede het treffen van andere passende regelingen.

Artikel 28 [1. Recht op onderwijs: leerplicht, gratis onderwijs/studiefinanciering, school- en beroepskeuzebegeleiding, beleid tegen schoolverzuim en vroegtijdige schoolverlating; 2 . menswaardige en verdragsconforme schooldiscipline; 3. internationale ontwikkelings- 
samenwerking (en samenwerking met betrekking tot onder meer modeme onderwijsmethoden)]

1. De staten (...) erkennen het recht van het kind op onderwijs, en teneinde dit recht geleidelijk en op basis van gelijke kansen te verwezenlijken, verbinden zij zich er met name toe:

a. primair onderwijs verplicht te stellen en voor iedereen gratis beschikbaar te stellen;

b. de ontwikkeling van verschillende vormen van voortgezet onderwijs aan te moedigen, met inbegrip van algemeen onderwijs en beroepsonderwijs; deze vormen voor ieder kind beschikbaar te stellen en toegankelijk te maken; en passende maatregelen te nemen zoals de invoering van gratis onderwijs en het bieden van financiële bijstand [waar] noodzakelijk;

c. met behulp van alle passende middelen hoger onderwijs toegankelijk te maken voor een ieder naar gelang zijn [of haar] capaciteiten;

d. informatie over en begeleiding bij onderwijs- en beroepskeuze voor alle kinderen beschikbaar te stellen en toegankelijk te maken;

e. maatregelen te nemen om regelmatig schoolbezoek te bevorderen en het aantal kinderen dat de school vroegtijdig verlaat, te verminderen.

2. De staten (...) nemen alle passende maatregelen om te verzekeren dat de wijze van handhaving van de discipline op scholen verenigbaar is met de menselijke waardigheid van het kind en in overeenstemming is met dit Verdrag.

3. [1e] De staten (...) bevorderen en stimuleren internationale samenwerking in aangelegenheden die verband houden met onderwijs, met name teneinde [a.] bij te dragen tot de uitbanning van onwetendheid en analfabetisme in de gehele wereld en [b.] de toegankelijkheid van wetenschappelijke en technische kennis en moderne onderwijsmethoden te vergroten. [2e] In dit opzicht wordt met name rekening gehouden met de behoeften van de ontwikkelingslanden.

Artikel 29 [1. Onderwijsdoelstellingen: optimale persoonswording; eerbied voor mensenrechten en beginselen Verenigde Naties; eerbied voor (eerbied verdienende) ouders, eigen cultuur, nationale waarden en andere culturen; vrijheid-in-verantwoordelijkheid, tolerantie, gelijkheid man en vrouw, xenofilie, irenofilie; eerbied voor het milieu; 2. vrijheid van oprichting en leiding (richting en inrichting) van scholen gebonden aan kwalitatieve normen (de onderwijsdoelstellingen en deugdelijkheidseisen)]

1. De staten (...) komen overeen dat het onderwijs aan het kind dient te zijn gericht op:

a. de zo volledig mogelijke ontplooiing van de persoonlijkheid, talenten en geestelijke en lichamelijke vermogens van het kind;

b. het bijbrengen van eerbied voor de rechten van de mens en de fundamentele vrijheden, en voor de in het Handvest van de Verenigde Naties vastgelegde beginselen;

c. het bijbrengen van eerbied voor de ouders van het kind, voor zijn eigen culturele identiteit, taal en waarden, voor de nationale waarden van het land waar 
het kind woont, het land waar het is geboren, en voor andere beschavingen dan de zijne;

d. de voorbereiding van het kind op een verantwoord leven in een vrije samen. leving, in de geest van begrip, vrede, verdraagzaamheid, gelijkheid van geslachten, en vriendschap tussen alle volken, ethnische, nationalle en godsdienstige groepen en personen behorend tot de oorspronkelijke bevolking;

e. het bijbrengen van eerbied voor de natuurlijke omgeving.

2. Geen enkel gedeelte van dit artikel of van artikel 28 mag zo worden uitgelegd dat het de vrijheid aantast van individuele personen en rechtspersonen [om] onderwijsinstellingen op te richten en daaraan leiding te geven, evenwel altijd met inachtneming van de in het eerste lid van dit artikel vervatte beginselen, en van het vereiste dat het aan die instellingen gegeven onderwijs voldoet aan de door de staat vastgestelde minimumnormen.

\section{Artikel 30 [Minderheden-kinderen]}

In die staten waarin ethnische of godsdienstige minderheden, taalminderheden of personen behorend tot de oorspronkelijke bevolking voorkomen, wordt het kind dat daartoe behoort, niet het recht ontzegd tezamen met andere leden van zijn groep zijn cultuur te beleven, zijn eigen godsdienst te belijden en ernaar te leven, of zich van zijn eigen taal te bedienen.

Artikel 31 [1. Recht op rust, vrije tijd, spel en recreatie; recht op deelneming aan kunst en cultuur; 2. positieve maatregelen, creëren van geschikte en gelijke kansenl

1. De staten (...) erkennen het recht van het kind op rust en vrije tijd, op deelneming aan spel en recreatieve bezigheden passend bij de leeftijd van het kind, en op vrije deelneming aan het culturele en artistieke leven.

2. De staten (...) eerbiedigen het recht van het kind volledig deel te nemen aan het culturele en artistieke leven, bevorderen de verwezenlijking van dit recht, en stimuleren het bieden van passende en voor ieder gelijke kansen op culturele, artistieke en recreatieve bezigheden en vrijetijdsbesteding.

\section{Artikel 32 [1. Recht op bescherming tegen economische exploitatie en gevaarlijke, voor de opvoeding niet bevorderlijke of voor de ge- zondheid, de lichamelijke ontwikkeling of de persoonswording scha- delijke kinderarbeid; 2. positieve maatregelen, arbeidsrechtelijke en strafrechtelijke bescherming]}

1. De staten (...) erkennen het recht van het kind te worden beschermd tegen economische exploitatie en tegen het verrichten van werk dat naar alle waarschijnlijkheid gevaarlijk is of de opvoeding van het kind zal hinderen, of schadelijk zal zijn voor de gezondheid of de lichamelijke, geestelijke, intellectuele, zedelijke of maatschappelijke ontwikkeling van het kind.

2. [1e] De staten (...) nemen wettelijke, bestuurlijke en sociale maatregelen en maatregelen op onderwijsterrein om de toepassing van dit artikel te waarborgen. [2e] Hiertoe, en de desbetreffende bepalingen van andere internationale akten in acht nemend, verbinden de staten (...) zich er in het bijzonder toe: 
a. een minimumleeftijd of minimumleeftijden voor toelating tot betaald werk voor te schrijven;

b. voorschriften te geven voor een passende regeling van werktijden en arbeidsvoorwaarden;

c. passende straffen of andere maatregelen voor te schrijven ter waarborging van de daadwerkelijke uitvoering van dit artikel.

\section{Artikel 33 [Bescherming tegen illegale drugs en tegen inschakeling}

bij productie en handel]

De staten (...) nemen alle passende maatregelen, met inbegrip van wettelijke, bestuurlijke en sociale maatregelen en maatregelen op onderwijsterrein, om kinderen te beschermen tegen het illegale gebruik van verdovende middelen en psychotrope stoffen zoals omschreven in de desbetreffende internationale verdragen, en om inschakeling van kinderen bij de illegale productie van en de sluikhandel in deze middelen en stoffen te voorkomen.

Artikel 34 [Nationaal en internationaal beleid tegen sexuele exploitatie, sexueel misbruik, kinderprostitutie en kinderpornografie]

[1e] De staten (...) verbinden zich ertoe het kind te beschermen tegen alle vormen van sexuele exploitatie en sexueel misbruik. [2e] Hiertoe nemen de staten (...) met name alle passende nationale, bilaterale en multilaterale maatregelen om te voorkomen dat:

a. een kind ertoe wordt aangespoord of gedwongen deel te nemen aan onwettige sexuele activiteiten;

b. kinderen worden geexploiteerd in de prostitutie of andere onwettige sexuele praktijken;

c. kinderen worden geëxploiteerd in pornografische voorstellingen en pornografisch materiaal.

\section{Artikel 35 [Bestrijding kinderhandel]}

De staten (...) nemen alle passende nationale, bilaterale en multilaterale maatregelen ter voorkoming van de ontvoering of de verkoop van of van de handel in kinderen voor welk doel ook of in welke vorm ook.

Artikel 36 [Bescherming tegen alle (overige) vormen van exploita-

tie]

De staten $(. .$.$) beschermen het kind tegen alle andere vormen van exploitatie$ die schadelijk zijn voor enig aspect van het welzijn van het kind.

Artikel $37^{12}$ [Vrijwaring van wrede, onmenselijke of vernederende

Bij dit artikel heeft Nederland het volgende voorbehoud gemaakt (Trb. 1995, nr. 92, t.a.p.): 'The Kingdom of the Netherlands accepts the provisions of article 37 (c) of the Convention with the reservation that these provisions shall not prevent the application of adult penal law to children of sixteen years and older, 
behandeling of bestraffing; geen doodstraf of levenslange gevangenisstraf; geen onrechtmatige vrijheidsheroving; arrestatie, inverzekeringstelling enz. als witerste middel; menselijke behandeling, rekening houden met leeftijd; gescheiden van volwassenen voor zover in het belang van het kind, recht op contact met familie; recht op onverwijlde rechts- en andere bijstand, recht op rechtsmiddelen, recht op onverwijlde beslissing]

De staten (...) waarborgen dat:

a. [1e] geen enkel kind wordt onderworpen aan foltering of aan een andere wrede, onmenselijke of [vernederende] behandeling of bestraffing. [2e] Doodstraf noch levenslange gevangenisstraf zonder de mogelijkheid van vrijlating wordt opgelegd voor strafbare feiten gepleegd door personen jonger dan achttien jaar;

b. [1e] geen enkel kind op onwettige of willekeurige wijze van zijn vrijheid wordt beroofd. [2e] De aanhouding, inhechtenisneming of gevangenneming van een kind geschiedt overeenkomstig de wet en wordt slechts gehanteerd als uiterste maatregel en voor de kortst mogelijke passende duur;

c. [1e] ieder kind dat van zijn vrijheid is beroofd, wordt behandeld met menselijkheid en met eerbied voor de waardigheid inherent aan de menselijke persoon, en zodanig dat rekening wordt gehouden met de behoeften van een persoon van zijn leeftijd. [2e] Met name wordt ieder kind dat van zijn vrijheid is beroofd, gescheiden van volwassenen tenzij het in het belang van het kind wordt geacht dit niet te doen, en heeft ieder kind het recht contact met zijn familie te onderhouden door middel van correspondentie en bezoeken, behalve in uitzonderlijke omstandigheden;

d. ieder kind dat van zijn vrijheid is beroofd, het recht heeft onverwijld te beschikken over juridische en andere passende bijstand, alsmede het recht de wettigheid van zijn vrijheidsberoving te betwisten ten overstaan van een rechter of een andere bevoegde, onafhankelijke en onpartijdige autoriteit, en op een onverwijlde beslissing ten aanzien van dat beroep.

\section{Artikel $38^{13}[1$. Respecteren humanitaire rechten van kinderen in}

provided that certain criteria laid down by law have been met.'

Ten aanzien van dit artikel heeft Nederland de volgende (rechtspolitieke/interpretatieve) verklaring afgelegd (Trb. 1995, nr. 92, t.a.p.): 'With regard to article 38 of the Convention, the Government of the Kingdom of the Netherlands declares that it is of the opinion that States should not be allowed to involve children directly or indirectly in hostilities and that the minimum age for the recruitment or incorporation of children in the armed forces should be above fifteen years.

In times of armed conflict, provisions shall prevail that are most conducive to guaranteeing the protection of children under international law, as referred to in article 41 of the Convention.'

Het Comité inzake de rechten wan het kind heeft een ontwerp-Facultatief protocol voorgesteld met de strekking dat minderjarigen niet aan vijandelijkheden deelmemen en dat geen minderjarigen in de strijdkrachten worden opgenomen of 
oorlogssituaties; 2-3. kindsoldaten alleen vanaf vijftien jaar; 4. bescherming en verzorging van kinderen in oorlogssituaties]

1. De staten (...) verbinden zich ertoe eerbied te hebben voor en de eerbiediging te waarborgen van tijdens gewapende conflicten op hen van toepassing zijnde regels van internationaal humanitair recht die betrekking hebben op kinderen.

2. De staten (...) nemen alle uitvoerbare maatregelen om te waarborgen dat personen jonger dan vijftien jaar niet rechtstreeks deelnemen aan vijandelijkheden.

3. [1e] De staten (...) onthouden zich ervan personen jonger dan vijftien jaar in hun strijdkrachten op te nemen op in te lijven. [2e] Bij het opnemen of inlijven van personen die de leeftijd van vijftien jaar hebben bereikt maar [nog] niet de leeftijd van achttien jaar, streven de staten (...) ernaar voorrang te geven aan diegenen die het oudste zijn.

4. In overeenstemming met hun verplichtingen krachtens het internationale humanitaire recht om de burgerbevolking te beschermen in gewapende conflicten, nemen de staten (...) alle uitvoerbare maatregelen ter waarborging van de bescherming en de verzorging van kinderen die worden getroffen door een gewapend conflict.

Artikel 39 [(Secundaire opvoedingsverantwoordelijkheid van de staat:) reparatie (herstel/rehabilitatie); herstel/rehabilitatie in een positieve (gezondheid, zelfrespect en eigenwaarde bevorderende) omgeving]

[1e] De staten (...) nemen alle passende maatregelen ter bevordering van het lichamelijk en geestelijk herstel en de herintegratie in de maatschappij van een kind dat het slachtoffer is van: welke vorm ook van verwaarlozing, exploitatie of misbruik; foltering of welke andere vorm ook van wrede, onmenseliijke of [vernederende] behandeling of bestraffing; of gewapende conflicten. [2e] Dit herstel en deze herintegratie vinden plaats in een omgeving die bevorderlijk is voor de gezondheid, het zelfrespect en de waardigheid van het kind.

Artikel $40^{14}[1-3$. Waarborgen jeugdstraf(proces)recht; 4. (secundaire opvoedingsverantwoordelijkheid van de staat:) zorg, begeleiding en toezicht, pleegzorg, programma's voor onderwijs en beroepsopleiding en andere alternatieven voor institutionele zorg]

1. De staten (...) erkennen het recht van ieder kind dat wordt verdacht van,

ingeliffl (zie Implementation handbook for the Convention on the rights of the child, UNICEF 1998, pp. 517 en 523-525).

Bij dit artikel heeft Nederland het volgende voorbehoud gemaakt (Trb. 1995, nr. 92, t.a.p.): "The Kingdom of the Netherlands accepts the provisions of article 40 of the Convention with the reservation that cases involving minor offences may be tried without the presence of legal assistance and that with respect to such offences the position remains that no provision is made in all cases for a review of the facts or of any measures imposed as a consequence.' 
vervolgd wegens of veroordleeld ter zake van het begaan van een strafbaar feit, op een wijze van behandeling die geen afbreuk doet aan het gevoel van waardigheid en eigenwaarde van het kind, die de eerbied van het kind voor de rechten van de mens en de fundamentele vrijheden van anderen vergroot, en waarbij rekening wordt gehouden met de leeftijd van het kind en met de wenselijkheid van het bevorderen van de herintegratie van het kind en van de aanvaarding door het kind van een opbouwende rol in de samenleving.

2. Hiertoe, en met inachtneming van de desbetreffende bepalingen van internationale akten, waarborgen de staten (...) met name dat:

a. geen enkel kind wordt verdacht van, vervolgd wegens of veroordeeld ter zake van het begaan van een strafbaar feit op grond van enig handelen of nalaten dat niet volgens het nationale of internationale recht verboden was op het tijdstip van het handelen of nalaten;

b. ieder kind dat wordt verdacht van of vervolgd wegens het begaan van een strafbaar feit, tenminste de volgende garanties heeft:

(i) dat het voor onschuldig wordt gehouden tot zijn schuld volgens de wet is bewezen;

(ii) dat het onverwijld en rechtstreeks in kennis wordt gesteld van de tegen [zijn persoon] ingebrachte beschuldigingen, indien van toepassing door tussenkomst van zijn ouders of wettige voogd[en], en dat het juridische of andere passende bijstand krijgt in de voorbereiding en het voeren van zijn verdediging;

(iii) dat de [zaak] zonder vertraging wordt beslist door een bevoegde, onafhankelijke en onpartijdige autoriteit of rechterlijke instantie in een eerlijke behandeling overeenkomstig de wet, in aanwezigheid van een rechtskundige of anderszins deskundige raadsman of -vrouw, en, tenzij dit wordt geacht niet in het belang van het kind te zijn, met name gezien zijn leeftijd of omstandigheden, in aanwezigheid van zijn ouders of wettige voogden;

(iv) dat het er niet toe wordt gedwongen een getuigenis af te leggen of schuld te bekennen; dat het getuigen à charge kan ondervragen of doen ondervragen en dat het de deelneming en ondervraging van getuigen à décharge op gelijke voorwaarden kan doen geschieden;

(v) indien het schuldig wordt geacht aan het begaan van een strafbaar feit, dat dit oordeel en elke maatregel die dientengevolge wordt opgelegd, opnieuw wordt beoordeeld door een hogere bevoegde, onafhankelijke en onpartijdige autoriteit of rechterlijke instantie overeenkomstig de wet;

(vi) dat het kind kosteloze bijstand krijgt van een tolk indien het de gebruikte taal niet verstaat of spreekt;

(vii) dat zijn privéleven volledig wordt geëerbiedigd tijdens alle stadia van het proces.

3. De staten (...) streven ernaar de totstandkoming te bevorderen van wetten, procedures, autoriteiten en instellingen die in het bijzonder bedoeld zijn voor kinderen die worden verdacht van, vervolgd wegens of veroordeeld ter zake van het begaan van een strafbaar feit, en, in het bijzonder:

a. de vaststelling van een minimumleeftijd onder welke kinderen niet in staat worden geacht een strafbaar feit te begaan; 
b. de invoering, wanneer passend en wenselijk, van maatregelen voor de handelwijze ten aanzien van deze kinderen zonder dat men zijn toevlucht neemt tot gerechtelijke stappen, mits de rechten wan de mens en de wettelijke garanties volledig worden geëerbiedigd.

4. Een verscheidenheid van regelingen, zoals rechterlijke bevelen yoor zorg, begeleiding en toezicht; adviezen; jeugdreclassering; pleegzorg; programma's voor onderwijs en beroepsopleiding en andere alternatieven voor institutionele zorg, dient beschikbaar te zijn om te verzekeren dat de handelwijze ten aanzien van kinderen hun welzijn niet schaadt en in de juiste verhouding staat zowel tot hun omstandigheden als tot het strafbare feit.

\section{Artikel 41 [Meest gunstige nationale of internationale bepaling geldt]}

Geen enkele bepaling van dit Verdrag tast bepalingen aan die meer bijdragen tot de verwezenlijking van de rechten van het kind en die zijn vervat in:

a. het recht van een staat (...); of

b. het in die staat geldende internationale recht.

\section{DEEL II [Bekendmaking en implementatie]}

\section{Artikel 42 [Effectieve nationale bekendmaking rechten van het \\ kind aan alle ingezetenen]}

De staten (...) verbinden zich ertoe de beginselen en de bepalingen van dit Verdrag op passende en doeltreffende wijze algemeen bekend te maken, zowel aan volwassenen als aan kinderen.

\section{Artikel 43 [Comitê inzake de rechten van het kind]}

1. Ter beoordeling van de voortgang die de staten (...) boeken bij het nakomen van de in dit Verdrag aangegane verplichtingen, wordt een Comité [inzake] de rechten van het kind ingesteld, dat de hieronder te noemen functies uitoefent. 2. [1e] Het Comité bestaat uit tien [na amendering: achttien ${ }^{15}$ ] deskundigen van hoog zedelijk aanzien en met erkende bekwaamheid op het gebied dat dit Verdrag bestrijkt. [2e] De leden van het Comité [treden op in hun persoonlijke hoedanigheid; zij] worden door de staten (...) gekozen uit hun [burgers] (...), waarbij aandacht wordt geschonken aan een evenredige geografische verdeling, alsmede aan de vertegenwoordiging van de voornaamste rechtsstelsels.

3. [-12.] (...).

Artikel 44 [1. Rapportage door staten aan Comité binnen twee jaar en vervolgens om de vijf jaar; 2. rapportage-voorschriften: relevante factoren, problemen, voldoende gegevens; 3, uitwoerig eerste

Zie Implementation handbook for the Convention on the rights of the child, 1998, p. 571; Trb. 1996, nr. 188 en 1997, nr. 83 onder J; voor Nederland aanvaard op 4 december 1996. 
rapport; 4. nadere inlichtingen; 5. rappontage Comité aan Ecosoc;

6. algemene beschikbaarheid van staten-rapporten]

1. De staten (...) nemen de verplichting op zich aan het Comite, door tussenkomst van de Secretaris-Generaal van de Verenigde Naties, verslag uit te brengen over de door hen genomen maatregelen die uitvoering geven aan de in dit Verdrag erkende rechten, alsmede over de vooruitgang die is geboekt ten aanzien van het genot van die rechten:

a. binnen twee jaar na de inwerkingtreding van het Verdrag voor de betrokken staat (...);

b. vervolgens elke vijf jaar.

2. [1e] In de krachtens dit artikel opgestelde rapporten dienen de factoren en eventuele moeilijkheden te worden aangegeven die van invloed zijn op de nakoming van de verplichtingen krachtens dit Verdrag. [2e] De rapporten bevatten ook voldoende gegevens om het Comité een goed inzicht te verschaffen in de toepassing van het Verdrag in het desbetreffende land.

3. Een staat (...) die een uitvoerig eerste rapport aan het Comité heeft overgelegd, behoeft in de volgende rapporten die deze staat in overeenstemming met het eerste lid [aanhef en onder] b [van dit artikel] overlegt, basisgegevens die eerder zijn verstrekt, niet te herhalen.

4. Het Comité kan staten (...) verzoeken om nadere gegevens die verband houden met de toepassing van het Verdrag.

5. Het Comité legt aan de Algemene Vergadering, door tussenkomst van de Economische en Sociale Raad, elke twee jaar rapporten over aangaande zijn werkzaamheden.

6. De staten (...) dragen er zorg voor dat hun rapporten algemeen beschikbaar zijn in hun land.

\section{Artikel $45[$ Rol IGO'S/UNCEF/VN en NGO's; onderzoek naar specifie-}

ke thema's; suggesties en algemene aanbevelingen van het Comite]

Teneinde de daadwerkelijke toepassing van het Verdrag te bevorderen en internationale [ontwikkeling]samenwerking op het gebied dat het Verdrag bestrijkt, aan te moedigen:

a. [1e] hebben de gespecialiseerde organisaties, het Kinderfonds van de Verenigde Naties en andere organen van de Verenigde Naties het recht vertegenwoordigd te zijn bij het overleg over de toepassing van die bepalingen van dit Verdrag welke binnen de werkingssfeer van hun mandaat vallen. [2e] Het Comité kan de gespecialiseerde organisaties, het Kinderfonds van de Verenigde Naties en andere bevoegde instellingen die [het] passend acht, uitnodigen deskundig advies te geven over de toepassing van het Verdrag op gebieden die binnen de werkingssfeer van hun onderscheiden mandaten vallen. [3e] Het Comité kan de gespecialiseerde organisaties, het Kinderfonds van de Verenigde Naties en andere organen van de Verenigde Naties uitnodigen rapporten over te leggen over de toepassing van het Verdrag op gebieden waarop zij werkzaam zijn;

b. doet het Comité, naar [het] passend acht, aan de gespecialiseerde organisaties, het Kinderfonds van de Verenigde Naties en andere bevoegde instellingen 
alle rapporten van staten (...) toekomen die een verzoek bevatten om, of waaruit een behoefte blijkt aan technisch advies of technische ondersteuning, vergezeld van eventuele opmerkingen en suggesties van het Comité aangaande deze verzoeken of deze gebleken behoefte[n];

c. kan het Comité aan de Algemene Vergadering aanbevelen de Secretaris-Generaal te verzoeken namens het Comite onderzoeken te doen naar specifieke thema's die verband houden met de rechten van het kind;

d. [1e] kan het Comité suggesties en algemene aanbevelingen doen gebaseerd op de ingevolge de artikelen 44 en 45 van dit Verdrag ontvangen gegevens. [2e] Deze suggesties en algemene aanbevelingen worden aan elke betrokken staat (...) toegezonden, en medegedeeld aan de Algemene Vergadering, vergezeld van eventuele commentaren van de staten (...).

DEEL III [Slotbepalingen]

Artikel 46 [Ondertekening]

Dit Verdrag staat open voor ondertekening door alle staten.

Artikel 47 [Ratificatie en deponering]

[1e] Dit Verdrag dient te worden bekrachtigd. [2e] De akten van bekrachtiging worden nedergelegd bij de Secretaris-Generaal van de Verenigde Naties.

Artikel 48 [Toetreding en deponering]

[1e] Dit Verdrag blijft open voor toetreding door elke staat. [2e] De akten van toetreding worden nedergelegd bij de Secretaris-Generaal van de Verenigde Naties.

Artikel 49 [1. Inwerkingtreding van het Verdrag; 2. inwerkingtreding voor elke staat]

1. Dit Verdrag treedt in werking op de dertigste dag die volgt op de datum van nederlegging bij de Secretaris-Generaal van de Verenigde Naties van de twintigste akte van bekrachtiging of toetreding.

2. Voor elke staat die dit Verdrag bekrachtigt of ertoe toetreedt na de nederlegging van de twintigste akte van bekrachtiging of toetreding, treedt het Verdrag in werking op de dertigste dag na de nederlegging door die staat van zijn akte van bekrachtiging of toetreding.

\section{Artikel 50 [Amendering]}

1. [1e] Elke staat (...) kan een wijziging voorstellen en deze indienen bij de Secretaris-Generaal van de Verenigde Naties. [2e] De Secretaris-Generaal deelt de voorgestelde wijziging vervolgens mede aan de staten (...) met het verzoek hem te berichten of zij een conferentie van staten (...) verlangen teneinde de voorstellen te bestuderen en in stemming te brengen. [3e] Indien, binnen vier maanden na de datum van deze mededeling, tenminste een derde van de staten (...) een dergelijke conferentie verlangt, roept de Secretaris-Generaal de [conferentie] onder auspiciën van de Verenigde Naties bijeen. [4e] Elke wijziging 
die door een meerderheid van de ter conferentie aanwezige staten (...) die hun stem uitbrengen, wordt aangenomen, wordt ter goedkeuring voorgelegd aan de Algemene Vergadering.

2. Een wijziging die in overeenstemming met het eerste lid van dit artikel wordt aangenomen, treedt in werking wanneer zij is goedgekeurd door de Algemene Vergadering van de Verenigde Naties en is aanvaard door een meerderheid van twee derde van de staten (...).

3. Wanneer een wijziging in werking treedt, is zij bindend voor de staten (...) die haar hebben aanvaard, terwijl de andere staten (...) gebonden zullen blijven door de bepalingen van dit Verdrag en door elke voorgaande wijziging die zij hebben aanvaard.

\section{Artikel 51 [Voorbehouden]}

1. De Secretaris-Generaal van de Verenigde Naties ontvangt de teksten van de voorbehouden die de staten op het tijdstip van bekrachtiging of toetreding maken, en stuurt deze rond aan alle staten.

2. Een voorbehoud dat niet verenigbaar is met [zin] en strekking van dit Verdrag is niet toegestaan.

3. [1e] Een voorbehoud kan te allen tijde worden ingetrokken door een daartoe strekkende mededeling gericht aan de Secretaris-Generaal van de Verenigde Naties, die vervolgens alle staten hiervan in kennis stelt. [2e] Deze mededeling wordt van kracht op de datum van ontvangst door de Secretaris-Generaal.

Artikel 52 [Opzegging]

[1e] Een staat (...) kan dit Verdrag opzeggen door een schriftelijke mededeling aan de Secretaris-Generaal van de Verenigde Naties. [2e] De opzegging wordt van kracht één jaar na de datum van ontvangst van de mededeling door de Secretaris-Generaal.

\section{Artikel 53 [Depositaris]}

De Secretaris-Generaal van de Verenigde Naties wordt aangewezen als de depositaris van dit Verdrag.

\section{Artikel 54 [Depot origineel; zes authentieke teksten]}

Het oorspronkelijke exemplaar van dit Verdrag, waarvan de Arabische, de Chinese, de Engelse, de Franse, de Russische en de Spaanse tekst gelijkelijk authentiek zijn, wordt nedergelegd bij de Secretaris-Generatal van de Verenigde Naties.

TEN BLIJKE WAARVAN de ondertekenende gevolmachtigden, daartoe behoorlijk gemachtigd door hun onderscheiden regeringen, dit Verdrag hebben ondertekend. 


\section{BIJLAGE II}

\section{Voorbeeld-strafbepalingen kindermishandeling}

(Misdrijven en overtredingen tegen de persoonswording van het kind)

\section{Ten geleide}

Onderstaande 'voorbeeld-strafbepalingen' zijn louter bedoeld als illustratie met betrekking tot de staatsaansprakelijkheid ter zake van strafrechtelijk optreden in geval van ernstige en systematische mensenrechtenschendingen. Het betreft met andere woorden geen voorstel van ontwerpstrafbepalingen (laat staan een strafwetstechnisch en strafvorderlijk doorgelicht en strafrechtelijk afgewogen voorstel), doch enkel een eerste discussie-aanzet (en dus een voor discussie vatbare aanzet) over hoe het Wetboek van Strafrecht zou kunnen worden uitgebreid met nieuwe delictsomschrijvingen als onderdeel van de sanctiemaatregelen die het sluitstuk vormen van een sociaal-pedagogisch stelsel (SPS). Het strafrecht fungeert daarbij als hulpverleningsstok achter de deur (men denke aan $\mathrm{v} /$ daderbehandeling bij incest), doch heeft in de meer ernstige gevallen ook een zoen- en gerechtigheidsfunctie (quia peccatum; poenae meritum). Hoezeer immers ook moet worden voorkomen dat strafrecht een stigma op ouderlijke onmacht drukt, mag anderzijds niet uit het oog worden verloren dat ouders zich soms zó 'misdragen en daarbij door de samenleving gestelde grenzen dermate [overschrijden], dat daarop niet via een "gewone" kinderbeschermingsmaatregel kan worden gereageerd. ${ }^{1}$ Niet alleen de gezinsbestuursrechtelijke persoonswordingsvindicatie, maar onder omstandigheden ook de strafrechtelijke reactie op ernstig onrecht is een recht van het kind. Ook het recht van het kind op melding heeft, bij ernstige schending, een pendant: strafbare kinderverlating.

\section{Kindermishandeling}

Analoog aan art. $254 \mathrm{WvSr}$ (dierenmishandeling) en art. $300 \mathrm{WvSr}$ (mishandeling):

1. Met gevangenisstraf van ten hoogste $\mathrm{x}$ maanden/jaren of geldboete van de $x^{*}$ categorie wordt gestraft:

$1^{\circ}$ hij die, zonder redelijk doel of met overschrijding van hetgeen ter bereiking van zodanig doel toelaatbaar is, opzettelijk een minderjarige lichamelijke of geestelijke pijn of lichamelijk of geestelijk letsel veroorzaakt of de lichamelijke of geestelijke gezondheid en/of de persoonswording van een minderjarige benadeelt;

In een andere context: Carla VAN WAMELEN, 'De ontzetting uit het ouderlijk gezag: afschaffen of reanimeren?' Editorial FJR 1998/5, p. 101. 
$2^{\circ}$ hij die, zonder redelijk doel of met overschrijding van hetgeen ter bereiking van zodanig doel toelaatbaar is, opzettelijk aan een minderjarige die geheel of ten dele onder zijn toezicht staat, of aan een minderjarige tot wiens verzorging en/of opvoeding hij werplicht is, de nodige verzorging en/of opvoeding onthoudt.

2. Indien het feit zwaar lichamelijk letsel, een ernstig psycho-trauma en/of cen ernstige beschadiging of langdurige blokkering of stoornis van de persoonswording ten gevolge heeft, wordt de schuldige gestraft met gevangenisstraf van ten hoogste $x$ jaren of geldboete van de $x^{e}$ categorie.

3. Indien het feit de dood, de zelfdoding of blijvende opname in een psychiatrische of zwakzinnigeninrichting ten gevolge heeft, wordt hij gestraft met gevangenisstraf van ten hoogste $x$ jaren of geldboete van de $x^{e}$ categorie.

4. Indien tijdens het plegen van hel misdrijf nog geen $x$ jaren zijn verlopen sedert een vroegere veroordeling van de schuldige wegens én der strafbare feiten omschreven in dit artikel of in artikel 455 onherroepelijk is geworden, kan gevangenisstaf van ten hoogste $\mathrm{x}$ jaar/jaren of geldboete van de $\mathrm{x}^{e}$ categorie worden opgellegd.

5. De in de voorgaande leden bepaalde gevangenisstraffen kumnen met een derde worden verhoogd ten aanzien van de schuldige die het misdrijf begat tegen zijn minderjarig kind.

6. Bij veroordeling wegens éen der in dit artikel omschreven misdrijwen kan ontzetting van de in artikel 28 vermelde rechten alsmede ontzetting uit de ouderlijke macht worden uitgesproken.

\section{Kinderkwelling}

Analoog aan art. 455 WvSr (dierenkwelling) en art. 453 WvSr (openbare dronkenschap):

1. Met hechtenis van ten hoogste $x$ weken/maanden of geldboete van de $x^{e}$ categorie wordt gestraft:

$1^{\circ}$ hij die nodeloos een minderjarige pijn of letsel veroorzaakt, nodeloos een minderjarige kwelt of nodeloos de gezondheid en/of de persoonswording van een minderjarige benadeelt;

$2^{\circ}$ hij die nodeloos aan een minderjarige die geheel of ten dele onder zijn toezicht staat, of aan een minderjarige tot wiens verzorging en/of opvoeding hij verplicht is, de nodlige verzorging en/of opvoeding onthoudt.

2. Tot de in het voorgaande lid strafbaar gestelde feiten worden in elk geval gerekend: (....).

Hier zouden de criteria in CICCHETT/TOTH (zie hierna bijlage III) met de ernstfactoren 1 en 2 ('lichte' en 'matige' vormen van kindermishandeling) kunnen worden ingevoegd. De criteria met de ernstfactoren 3 tot en met 5 (ernstige tot en met fatale vormen van kindermishandeling) zouden eventueel ( $x$ abundanti cautela) onder het hierboven in algemene termen omschreven misdrijf kindermishandeling kunnen worden gebracht.

3. Indien tijdens het plegen van de overtreding nog geen $x$ jaren zijn verlopen sedert een vroegere veroordeling van de schuldige wegens een der strafbare fei- 
ten omschreven in dit artikel of in artikel 254 onherroepelijk is geworden, kan hechtenis wan ten hoogste $\mathrm{x}$ weken/maanden of geldboete van de $\mathrm{x}^{e}$ categorie worden opgelegd.

4. Bij tweede herhaling binnen een jaar nadat de eerste veroordeling wegens herhaling onherroepelijk geworden is, wordt hechtenis van ten hoogste $\mathrm{x}$ weken/ maanden of geldboete van de $x^{\varepsilon}$ categorie opgelegd.

5. Bij derde of volgende herhalingen gepleegd telkens binnen een jaar nadat de laatste veroordeling wegens tweede of volgende herhaling onherroepelijk geworden is, wordt hechtenis opgelegd van ten hoogste $\mathrm{x}$ weken/maanden of geldboete van de $x^{e}$ categorie en kan de schuldige daarenboven, zo hij tot leren in stalat is, tot plaatsing in een rijksheropvoedingsinrichtïng [rijksjeugdverwerkingsinrichting] worden veroordeeld woor ten hoogste een jaar. In geval van herhaling van overtreding na te zijn geplaatst geworden in een rijksheropvoedingsinrichting [rijksjeugdverwerkingsinrichting], vangt de termijn van een jaar, bedoeld in de vorige zinsnede, aan op de dag van het ontslag uit de rijksheropvoedingsinrichting [rijksjeugdverwerkingsinrichting].

6. Zo de schuldige niet tot leren maar wel tot werken in staat is, kan hij, voor dezelfde duur en met dezelfde termijnbepaling, tot plaatsing in een rijkswerkinrichting worden veroordeeld.

7. Zo de schuldige niet tot leren bereid of in staat is, kan ontzetting uit de ouderlijke macht worden uitgesproken.

\section{Kinderverlating}

\section{Art. 255 WvSr (kind in hulpeloze toestand brengen of laten):}

Hij die opzettelijk iemand tot wiens onderhoud, verpleging [ontferming/bescherming] of verzorging hij krachtens wet of overeenkomst verplicht is, in een hulpeloze toestand brengt of laat, wordt gestraft met gevangenisstraf van ten hoogste twee jaren of geldboete van de vierde categorie.

- juncto artt. 257, 258, 260 juncto 28 , lid 1 onder 4e (strafverzwarende omstandigheden/ontzetting van rechten) - ware wellicht van toepassing te achten op kinderbeschermers/(jeugd)hulpverleners die 'niets doen,' en op ouders in bepaalde ernstige gevallen van kindermishandeling.

2. Wijziging/uitbreiding art. $450 \mathrm{WvSr}$ (verlating hulpbehoevenden/verzaking meldplicht):

Hij die, getuige van de lichamelijke of geestelijke mishandeling of verwaarlozing of het sexuele misbruik van een kind, of kennis dragende van het gevaar waarin een kind ten gevolge van lichamelijke of geestelijke mishandeling of verwaarlozing of sexueel misbruik verkeert, nalaat het kind die hulp te verlienen of te verschaffen die hij hem, zonder gevaar voor zichzelf of anderen redelijkerwijs te kunnen duchten, verlenen of verschaffen kan, en/of nalaat hiervan onverwijld bij de politie en/of kinderbeschermingsautoriteiten melding te doen, wordt gestraft met hechtenis van ten hoogste drie maanden of geldboete van de tweede categorile. 


\section{Toevoeging in WvSr van misdrijf van art. 450:}

Hij die, getuige van de lichamelijke of geestelijke mishandeling of verwatarlozing of het sexuele misbruik van een kind, of kennis dragende van het gevaar waarin een kind ten gevolge van lichamelijke of geestelijke mishandeling of verwaarlozing of sexueel misbruik verkeert, nalat het kind die hulp te verlenen of te verschaffen die hij hem, zonder gevaar voor zichzelf of anderen redelijkerwijs te kunnen duchten, verlenen of verschaffen $\mathrm{kan}$, en/of nalaat hiervan onverwijld bij de politic en/of kinderbeschermingsautoriteiten melding te doen, wordt, indien de dood van het kind volgt, gestraft met gevangenisstraf van ten hoogste $x$ jaren of geldboete van de $x^{e}$ categorie.

\section{Psychische kindermishandeling}

Voorstel van een strafbepaling 'psychische kindermishandeling' (dissertatie CLEMENS SCHRÖNER 1956): ${ }^{2}$

"Hij die een aan zijn zorg, opleiding of waakzaamheid toevertrouwde minderjarige met misbruik van het uit die verhouding voortvloeiend overwicht herhaaldelijk of bij woortduring opzettelijk kwellend bejegent, of opzettelijk niet naar vermogen verhindert dat deze minderjarige aldus kwellend wordt bejegend door een ander aan wiens zorg, opleiding of waakzaamheid het kind mede is toevertrouwd, wordt, indien daarvan ernstig gevaar voor de geestelijke gezondheid van het kind is te duchten, gestraft met gevangenisstraf van ten hoogste 5 jaren.' 


\section{BIJLAGE III \\ Criteria kindermishandeling \\ (Definities en gradaties per subtype)}

\section{Typering}

Operationalisering kindermishandeling (schending van het kernrecht van het kind op minimale persoonswording) in zes vormen met elk vijf ernstfactoren; definities per vorm, criteria en voorbeelden per ernstfactor. ${ }^{1}$

\section{Bron/vertaling}

In deze studie is afwisselend verwezen naar de criteria van (beter: in) CICCHETTI/TOTH dan wel van BARNETT e.a. ${ }^{2}$ De verantwoordelijkheid voor de vertaling van deze criteria (uit het Engels) berust bij de auteur. ${ }^{3}$

\section{Subtypen (vormen van kindermishandeling)}

A. Lichamelijke mishandeling;

B. Sexueel misbruik (sexuele kindermishandeling);

C. Lichamelijke verwaarlozing: onvoldoende fysieke zorg (met betrekking tot de lichamelijke en geestelijke gezondheid);

D. Fysieke verwaarlozing: onvoldoende fysiek toezicht;

E. Emotionele maltraitering: psychische mishandeling, emotioneel misbruilk, affectieve verwaarlozing en normatieve/pedagogische verwaarlozing (onvoldoende grenzen, structuur, disciplinering);

F. Normatieve en educatieve maltraitering (morele corrumpering en schoolverzuim).

Vgl. woor een nadere toelichting hoofdstuk 11, par. 11.2.3.

2 Douglas BARNETT, Jody Todd MANLY, Dante CICCHETT, 'Defining child maltreatment: the interface between policy and research, in: Dante CICCHETTI, Sheree L. TOTH (eds.), Child abuse, child development, and social policy, Advances in applied developmental psychology, vol. 8, Norwood, New Jersey 1993 , pp. 7-73, "Appendix: Maltreatment subtype definitions and severity ratings," op pp. 51-73, "System for quantifying child protective service records; subtype definitions and severity scales,' op pp. 54-73.

Cursiveringen in het origineel zijn weggelaten; toevoegingen of aanpassingen/ inkortingen zijn tussen [teksthaken] geplaatst; weglatingen zijn op de gebruikelijke wijze - aldus: (...) - aangegeven. Soms (met name bij de voorbeelden) is tamelijk vrij vertaald; de interpunctic is aangepast. 


\section{Gradaties (ernstfactoren)}

Vanuit een ontwikkelingsperspectief, ${ }^{4}$ dat is (naar de terminologie van deze studie vertaald) vanuit een oogpunt van (gemiddeld te verwachten) bedreiging van de minimale persoonswording (ontwikkeling van minimale rationaliteit, moraliteit en authenticiteit), lopen deze als volgt op:

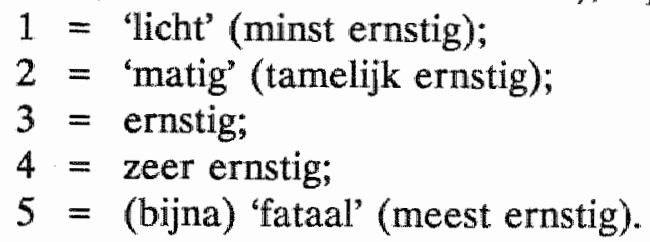

\section{A. Lichamelijke mishandeling ${ }^{5}$}

\section{Definitie}

Van lichamelijke [kinder]mishandeling is sprake wanneer de verzorger of opvoeder van het kind c.q. degene die voor het kind verantwoordelijk is [hierna kortheidshalve: de ouder], het kind lichamelijk verwondt anders dan ten gevolge van een ongeluk. Onder verwonden wordt niet verstaan het (doen) verrichten van door culturele tradities voorgeschreven lichamelijke ingrepen zoals de besnijdenis [van jongetjes ${ }^{6}$ ] en het aanbrengen van gaatjes in het oor. (...)

Een kind opsluiten of vastbinden valt onder emotionele malıraitering. Als het kind daarbij evenwel verwondingen oploopt (bijvoorbeeld door touw veroorzaakte brandplekken), vallen die verwondingen onder lichamelijke mishandeling en het opsluiten of vastbinden onder emotionele maltraitering. (...) Lichamelijke verwondingen die direct samenhangen

Het betreft, strikt genomen, een ontwikkelingspsychopathologische benadering waarbij volledigheidshalve behalve naar (de subtypen en) de gradaties ook moet worden gekeken naar (de relatie tot) de dimensies: frequentie/chroniciteit van de gewraakte handelingen/tekortkomingen; ontwikkelingsfase/leeftijd van het kind; scheilding van kind en ouder(figur) of uithuisplaatsing van het kind; en pleger van de gewraakte handelingen/nalatigheden (moeder/vader, stiefmoeder/-vader/ ander ouderfiguur, ander familielid, oppas/vriend, wreemde/onbekende): zie BARNETT e.a., t.a.p., op (met name) pp. 23-24, 32-44 en 51-52. Gemakshalve is evenwel in deze bijlage van deze dimensies geabstraheerd. Uiteraard betekent dit te meer dat de ernstfactoren met de nodige woorzichtigheid dienen te worden gehanteerd. Bij nadere juridische operationalisering (dat wil zeggen bij de afweging of opvoedingshulp moet worden opgelegd) zal die voorzichtigheid nopen tot wooropstelling van het ontwikkelings-, dat is persoonswordingsbelang van het kind.

5 Vgl. DSM-IV, v 61.21 (z 61.6).

6 De besnijdenis (genitale verminking) van meisjes valt naar Nederlands recht onder strafbare mishandeling. 
met sexuele handelingen (bijvoorbeeld vaginale of rectale scheurtjes), vallen onder sexueel misbruik. Verwondingen ten gevolge van pogingen het kind te dwingen tot [het dulden van of deelnemen aan] sexuele handelingen (bijvoorbeeld slaag of brandplekken), vallen zowel onder lichamelijke mishandeling als onder sexueel misbruik.

\section{Gradaties (criteria en voorbeelden)}

\section{1. ('Licht')}

- De ouder heeft tijdens een afstraffing op het lichaam van het kind niet ernstige vlekken toegebracht; er zijn geen vlekken op het hoofd of op de nek.

- De ouder heeft het kind geslagen; er zijn geen verdere aanwijzingen.

- Het kind heeft niet aan een ongeluk te wijten verwondingen opgelopen; er zijn onvoldoende details om de juiste ernstfactor te bepalen.

- De ouder heeft het kind geslagen met de vlakke hand of met een voorwerp dat meestal alleen niet ernstige plekken nalaat (bijvoorbeeld een roe, een zachte riem, een liniaal of een plat voorwerp); het kind heeft plekken op of lager dan de schouders.

\section{Voorbeelden}

- Het kind hield een blauwe plek op de arm over na met de vlakke hand geslagen te zijn.

- Niet ernstige blauwe plekken op het achterwerk van het kind [bleven zichtbaar] na een afstraffing met een riem.

\section{2. ('Matig")}

- De ouder heeft bij enige afstraffing op het lichaam van het kind vele of vrij ernstige plekken toegebracht [het kind is 'voor straf' bont en blauw geslagen].

- De ouder heeft het kind geslagen met een voorwerp dat meestal vrij ernstige plekken nalaat (bijvoorbeeld een haarborstel, een riem met gesp, een electrisch snoer), of heeft het kind geschopt of met de volle vuist gestompt met achterlating van plekken op het lichaam van het kind lager dan de nek.

\section{Voorbeelden}

- Het kind had striemen op de rug na met een haarborstel geslagen te zijn.

- Het kind zat onder de rode vlekken na met een electrisch snoer te zijn geslagen. 


\section{3. (Ernstig)}

- De ouder heeft vlekken teweeggebracht op het hoofd, het gezicht of de nek van het kind (bijvoorbeeld een blauw oog).

- De ouder heeft het kind dermate ruw behandeld dat ernstige blauwe plekken of niet ernstige verwondingen ontstonden (de huid was opengescheurd waarbij bijvoorbeeld hechtingen nodig waren of eenvoudige medische behandeling).

- De ouder heeft niet ernstige brandwonden (bijwoorbeeld met een sigaret) op het lichaam van het kind veroorzaakt.

\section{Voorbeelden}

- De hand van de ouder stond in de nek van het kind nadat dit was vastgegrepen.

- Het kind had een blauw oog na in het gezicht gestompt te zijn.

- Kleine ronde brandplekken op de handen van het kind bleken met sigaretten te zijn toegebracht.

\section{4. (Zeer ernstig)}

- De ouder heeft het kind geslagen met een voorwerp (bijvoorbeeld een honkbalknuppel of een telefoontoestel) dat meestal ernstige verwondingen veroorzaakt (bijvoorbeeld vrij ernstige verscheuringen, tweedegraads verbrandingen, botbreuken of hersenschudding), of heeft het kind tegen de muur gegooid, zonder dat de opgelopen verwondingen tot ziekenhuisopname leidden (...).

- De ouder heeft het kind pogen te verstikken of te smoren zonder dat eerste hulp noodzakelijk was.

- De ouder heeft ernstige (tweedegraads) brandwonden op het lichaam van het kind veroorzaakt zonder dat ziekenhuisopname noodzakelijk was.

- De ouder heeft verwondingen toegebracht die in een ziekenhuis moesten worden behandeld, bijvoorbeeld op de eerstehulpafdeling, maar die niet tot een ziekenhuisopname van 24 uur of langer leidden (bijvoorbeeld voor hechtingen, vanwege breuken of vrij ernstige verstuikingen).

\section{Voorbeelden}

- Het kind was geslagen met een plank met spijkers; het had blauwe plekken en snijwonden.

- Het kind werd van de trap gegooid en brak een arm.

- De ouder had het kind ernstige brandwonden toegebracht; het werd behandeld op de eerstehulpafdeling. 


\section{5. ('Fataal')}

- De ouder heeft het kind een verwonding toegebracht die tot ziekenhuisopname leidt (bijwoorbeeld ernstige en/of meervoudige brandwonden, inwendige verwondingen) en/of tot blijvende fysieke schade of tot verminking of misvorming (bijvoorbeeld [afstraffingen] die resulteren in hersenbeschadiging, zware littekens, kreupelheid).

- De ouder heeft het kind een dodelijke verwonding toegebracht.

\section{Voorbeelden}

- Het kind werd in brand gestoken met zware brandwonden en blijvende misvorming als gevolg.

- Het kind verbleef een week in het ziekenhuis wegens inwendige verwondingen en tekenen van het door-elkaar-geschudde-baby-syndroom.

\section{B. Sexueel misbruik ${ }^{7}$}

\section{Definitie}

Van sexueel misbruik [sexuele kindermishandeling] is sprake wanneer de verzorger of opvoeder van het kind [hierna kortheidshalve: de ouder] of iemand anders die voor het kind verantwoordelijk is, sexueel contact met het kind heeft, of poogt te hebben, ter bevrediging van de sexuele gevoelens van de betrokken volwassene en/of uit geldelijk gewin. Bij sexueel misbruik verwijst ouder of 'verantwoordelijke volwassene' naar enig gezinslid of [huis]vriend die een [vertrouwens]band met het kind heeft of in een gezagsrelatie tot het kind staat (bijvoorbeeld de oppas). (...)

De sexuele handelingen met het kind kunnen onder fysieke of psychische dwang plaatsvinden. Uit de ouder ernstige dreigementen, dan is er zowel van emotionele maltraitering als van sexueel misbruik sprake. Zoals onder lichamelijke mishandeling is aangegeven, vallen lichamelijke verwondingen die direct samenhangen met sexuele handelingen (bijvoorbeeld vaginale of rectale scheurtjes), onder sexueel misbruik. Verwondingen ten gevolge van pogingen het kind te dwingen tot sexuele handelingen (bijvoorbeeld slaag of brandplekken), vallen zowel onder lichamelijke mishandeling als onder sexueel misbruik.

Vgl. DSM-IV, v 61.21 (Z 61.4). Vgl. ook noot 15 (sexuele verwaarlozing, affectieffysieke verwaarlozing). 


\section{Gradaties (criteria en voorbeelden)}

\section{1. ('Licht')}

- De ouder stelt het kind bloot aan expliciete sexuele prikkelingen of handelingen zonder dat hij of zij het kind er direct bij betrekt.

\section{Voorbeelden}

- De ouder laat het kind pornografisch materiaal zien.

- De ouder belet niet dat het kind getuige is van sexuele handelingen.

- De ouder praat in het bijzijn van het kind expliciet over sex zonder pedagogische bedoelingen, bijvoorbeeld over de sexuele activiteiten of fantasieën van de ouder(s); het kind kan dit vrijelijk aanhoren.

\section{2. ('Matig')}

- De ouder vraagt het kind rechtstreeks om sexueel contact.

- De ouder toont zijn of haar geslachtsdelen aan het kind om aan zijn of haar gerief te komen of met de bedoeling het kind sexueel te prikkelen.

\section{Voorbeelden}

- De ouder vraagt het kind om een sexuele relatie aan te gaan zonder dat het tot lichamelijk contact komt.

- De ouder vraagt het kind toe te kijken terwijl hij zich masturbeert.

\section{3. (Ernstig)}

- De ouder betrekt het kind bij wederzijdse sexuele aanrakingen of laat zich om aan zijn gerief te komen, door het kind aanraken.

- De ouder raakt het kind aan om aan zijn gerief te komen.

\section{Voorbeelden}

- De ouder streelt het kind totdat hij klaar komt.

- De ouder betrekt het kind bij wederzijdse masturbatie.

\section{4. (Zeer emstig)}

- De ouder probeert sexueel bij het kind binnen te dringen of dringt daadwerkelijk bij het kind binnen; dit omvat coïtus, orale sex, anale sex of andere vormen van [penetratie ${ }^{8}$.

In het origineel is sprake van 'sodomie.' Als overkoepelend begrip voor 'onnacuurlijke' en 'tegennatuurlijke' handelingen vallen hier allerlei sexuele variaties en varianten onder waarvan een rangschikking, voorzien van Latijnse nomenclatuur, is te vinden (de vrucht, zo laat zich denken, van vele eeuwen sollicitatio bij de biecht) in de katholieke moraaltheologie. Zie bijwoorbeeld J. STELZENBERGER, Zedenleer van het Koninkrijk Gods (oorspr. titel: Lehrbuch der Moratheologie; 


\section{Voorbeelden}

- De ouder valt het kind sexueel lastig.

- De ouder heeft sexuele gemeenschap met het kind of onderneemt pogingen daartoe.

- Het kind heeft een geslachtsziekte; [het kind is nog zeer jong en] er zijn geen gegevens over sexuele contacten bekend.

- Een moeder heeft orale sex met haar zoon.

\section{5. ('Fataal')}

- De ouder heeft onder dwang gemeenschap met het kind of dringt onder dwang op andere wijze sexueel bij het kind binnen. Dwang omvat het vasthouden, vast doen houden of vastbinden van het kind teneinde het sexueel te benaderen. Dwang omvat tevens het gebruik van wapens, fysiek geweld en fysieke overweldiging van het kind met de uitdrukkelijke bedoeling om zich aan het kind sexueel te bevredigen. [Zie ook onder de definitie van lichamelijke mishandeling.]

- De ouder prostitueert het kind; hieronder valt ook het gebruiken of uitbesteden van het kind voor pornografische doeleinden, alsmede het toestemming geven aan en aanmoedigen of dwingen van het kind tot het verrichten of ondergaan van sexuele handelingen met c.q. van derden.

\section{Voorbeelden}

- De ouder bindt het kind vast op het bed en verkracht het kind. (...)

- De ouder houdt het kind onder schot en verkracht het anaal. ${ }^{9}$

- De ouder dwingt het kind mee te doen aan opnames voor kinderpornografische films.

Die Sittlichkeitslehre der Königsherrschaft Gottes), (imprimatur) Brugge 1962, pp. 262-266. Op p. 266 leest men onder 'sodomie' (in enge of eigenlijke zin): 'Hieronder verstaat men een onnatuurlijke geslachtelijke omgang tussen man en vrouw extra vas naturale id est extra vaginam (in anum, in os, inter mamillas, inter bracchia, inter crura). (...) Vaak wordt het woord sodomie (...) gebruikt voor bestialiteit (sodomia ratione generis) en homosexualiteit (sodonia ratione sexus). Verder gebruikt men dikwijls de uitdrukking sodomia perfecta voor homosexualiteit en sodomia imperfecta voor de concubitus van personen van verschillend geslacht in wase indebito. Om de zaak zuiver te stellen moet men het woord sodomie slechts in de laatste betekenis gebruiken." In casu gaat het om de combinatie van incestus (als zonde van onkuisheid en 'zwaar vergrijp tegen de heilige banden van piëteit': a.w., p. 264 sub 4) en sodomia (als sexuele perversiteit in perfecte dan wel imperfecte zin). (Vgl. met betrekking tot de sollicitatio het kritische werk van Karlheinz DESCHNER, De kerk en haar knuis; Geschiedenis van de seksualiteit in het Christendom, Amsterdam 1978, pp. 206-208.)

In het origineel is sprake van 'sodomie bedrijven': zie daartoe de vorige noot. 
- Op uitnodiging van de ouder hebben andere volwassenen sexuele omgang met het kind.

\section{Lichamelijke verwaarlozing: onvoldoende fysieke $\mathrm{zorg}^{10}$}

\section{Definitie}

Van lichamelijke verwaarlozing/onvoldoende fysieke zorg is sprake wanneer de verzorger of opvoeder van het kind c.q. degene die voor het kind verantwoordelijk is [hierna kortheidshalve: de ouder], niet in staat of bereid is tot het verschaffen van minimale zorg ten aanzien van de lichamelijke noden van het kind. Bij gezinnen onder de armoedegrens is er alleen sprake van lichamelijke verwaarlozing als niet of onvoldoende wordt voorzien in de lichamelijke noden van het kind ten gevolge van de onmacht of onwil van de ouder(s) gebruik te maken van maatschappelijke voorzieningen [zoals bijstand en aanvullende of andere voorzieningen] voor het welzijn van kinderen. (...)

Onvoldoende fysieke zorg betreft het niet of onvoldoende voorzien in de lichamelijke noden van het kind op één of meer van de volgende gebieden:

a. [voeding] - het kind geschikt voedsel geven;

b. [kleding] - zorgen voor schone, aan de weersomstandigheden aangepaste en niet te ruim of te strak zittende kleding;

c. [onderdak] - zorgen voor geschikt onderdak;

d. [bezoek aan arts, tandarts en psycholoog/psychiater] - zorgen voor geschikte medische, tandheelkundige en geestelijke gezondheidszorg;

e. [hygiëne] - zorgen voor voldoende hygiëne.

\section{Gradaties (criteria en voorbeelden)}

\section{Toelichting/waarschuwing}

[Ook hier geldt dat de ernstfactoren op gemiddelde bedreigingen van de persoonswording zien en derhalve in individuele gevallen soms (met het oog op de vraag of in een bepaald gezin opvoedingshulp moet worden opgelegd) naar beneden of boven dienen te worden bijgesteld. ${ }^{11}$ ]

\section{1. ('Licht')}

- De ouder zorgt niet dat er eten in huis is voor de vaste maaltijden; het kind (onder de 10 jaar) moet vaak zijn eigen eten klaarmaken en/of mist geregeld maaltijden door ouderlijke nalatigheid.

Zie ook noot 4 (ernstfactoren relateren aan diverse dimensies). 
- De ouder zorgt niet voor kleren die voldoende schoon zijn en die het kind vrijlaten in zijn bewegingen (bijvoorbeeld de kleren zijn zoveel maten te klein dat het kind zich niet vrij kan bewegen, of zoveel maten te groot dat het kind geregeld struikelt of moeite heeft de kleren aan of op te houden).

- De ouder zorgt niet voor een schoon huis; afval wordt niet verwijderd, de afwas zit vol korsten, de vloeren en andere oppervlakken zijn smerig; er hangt in huis een onaangename, doordringende geur, afkomstig van afval en vuil.

- De ouder heeft verschillende afspraken voor het kind met arts of tandarts laten lopen (...); het kind krijgt niet alle vereiste inentingen (...).

- De ouder houdt een licht gedragsprobleem waar [bevoegde derden] op hebben gewezen, niet in de gaten (bijvoorbeeld het kind vertoont bepaalde gedragssymptomen zonder dat zijn sociaal functioneren of zijn schoolprestaties er ernstig onder lijden).

- De ouder zorgt niet dat het kind schoon is; het kind wordt onregelmatig gebaad, de haren worden zelden gewassen; het kind poetst bijna nooit zijn tanden, er is sprake van tandbederf of tandverkleuring.

\section{Voorbeelden}

- Een kind van 9 jaar kookt verschillende keren per week omdat de ouders slapen [ten gevolge van nachtdiensten, dronkenschap enzovoorts].

- Het kind heeft altijd kleren aan die veel te strak zitten.

- De ouder ondertekent geen schoolrapporten waarin melding wordt gemakkt van gedragsproblemen.

- Het kind is vuil en krabt geregeld op zijn hoofd met klittend haar.

- De kleren van het kind zijn vuil en stinken naar urine.

\section{2. ('Matig')}

- De ouder zorgt niet altijd dat er eten in huis is; vaak is er geen eten in huis en twee tot drie keer per week worden achtereen twee of meer maaltijden overgeslagen; de ouder geeft het kind 24 uur niets te eten.

- De ouder zorgt niet dat het kind kleren draagt die in overeenstemming zijn met de weersomstandigheden (het kind draagt bijvoorbeeld dunne kleding in de winter).

- De ouder beseft terdege dat het huis vol kakkerlakken en ander ongedierte zit, maar doet er niets aan.

- De ouder zorgt niet voor geschikte slaapgelegenheid voor het kind (er zijn bijvoorbeeld geen bedden of matrassen, of de matrassen zijn vuil en klam van urine of ander vocht dat schimmelvorming bevordert).

- De ouder zorgt er niet voor dat doktersadvies voor de behandeling van een niet ernstige ziekte of infectie stipt worden opgevolgd (voorgeschre- 
ven medicijnen voor een lichte infectie worden bijvoorbeeld niet toegediend, chronisch haarluis wordt niet behandeld).

- De ouder verschoont niet regelmatig de luiers van de baby; vaak heeft de baby urenlang vuile luiers aan, de baby heeft luiereczeem.

\section{Voorbeelden}

- Dagenlang loopt een kind bij licht vriesweer naar school in een dun jasje en zonder muts of handschoentjes.

- Een maatschappelijk werkster kwam een aantal keren op bezoek terwijl er geen eten was, de kinderen vertellen dat zij twee of drie keer per week tussen de middag niet eten [en] zonder warm eten naar bed gaan.

- Bij het kind is een oorinfectie vastgesteld, maar de ouder dient de voorgeschreven antibiotica niet consequent toe.

\section{3. (Emstig)}

- De ouder zorgt niet voor regelmatige maaltijden, maaltijden worden stelselmatig overgeslagen; vier keer of vaker per week krijgt het kind tenminste twee keer achter elkaar niets te eten.

- De ouder zorgt niet dat het gezin kan rekenen op vast onderdak; hij/zij doet bijvoorbeeld geen moeite om bijstand of huursubsidie te krijgen of te behouden met als gevolg dat [doordat de huur niet tijdig is betaald] het gezin het huis uit moet of zeven dagen of langer het recht op een uitkering verliest.

- De ouder raadpleegt geen dokter of volgt doktersadvies niet op bij tamelijk ernstige gezondheidsklachten (het kind heeft bijvoorbeeld hartklachten maar de ouder veronachtzaamt voorzorgsmaatregelen, of er wordt niets gedaan aan een nogal verhoogd loodgehalte in het bloed), of de ouder speelt zelf voor dokter (de ouder geeft het kind bijvoorbeeld, zonder doktersadvies, een kalmerend middel om het onder controle te houden).

- De ouder zorgt er niet voor dat therapie wordt afgemaakt die het kind of het gezin ondergaat wegens psychische of gedragsproblemen van het kind, terwijl deze problemen de omgang van het kind met leeftijdgenootjes of zijn schoolprestaties nadelig beïnvloeden.

- De ouder doet niets aan een ongezonde woonsituatie, geregeld blijven voedselresten of afval liggen, er zijn ratten of het huis zit vol ongedierte zonder dat daar iets aan wordt gedaan.

- De aanstaande moeder brengt de gezondheid van haar ongeboren kind in gevaar door alcohol- of drugsgebruik ${ }^{12}$ tijdens de zwangerschap, ${ }^{13}$ er 
zijn geen aantoonbare foetale alcohol- of drugssymptomen [ontwenningsverschijnselen].

\section{Voorbeelden}

- De kinderen krijgen vaak niet te eten; de afgelopen maanden zijn gemiddeld vier keer per week twee maaltijden achter elkaar overgeslagen.

- Het gezin is het huis uit gezet omdat de ouder zich niet aan de uitkeringsvoorwaarden hield en ook geen andere regelingen trof om de huur te betalen; het gezin had twee weken geen vast onderdak.

- De [moeder] was tijdens de zwangerschap verschillende keren dronken.

- Het kind komt op school met een ontstoken wond; ondanks aanwijzingen van de schoolarts blijft de wond etteren.

- Een maatschappelijk werker treft bij elk huisbezoek een janboel aan; keukentafel, gootsteen en aanrecht zijn bedekt met vuile vaat en voedselresten; ratten snuffelen in kapotte vuilniszakken bij de voordeur.

- Het kind is in therapie wegens ernstige emotionele problemen, de ouder heeft het kind al zes weken niet meer naar de therapie gestuurd.

\section{4. (Zeer ernstig)}

- De ouder heeft niet voor geschikt onderdak gezorgd (bijvoorbeeld voor voldoende verwarming tijdens de winter; of het gezin woont in een auto omdat er niet actief naar een huis is gezocht); langdurig verandert er niets.

- De ouder verwaarloost het huishouden zodanig dat er een extreem ongezonde woonsituatie is ontstaan (in de woonkamer ligt urine en ontlasting).

- De ouder zoekt geen medische hulp of houdt zich niet aan medische aanwijzingen bij mogelijk levensgevaarlijke ziekte of verwonding van het kind (het kind wordt bijwoorbeeld niet naar de eerste hulp gebracht bij een ernstige bloeding, derdegraads verbranding of schedelbreuk [ongeacht of deze door de ouder zelf is veroorzaakt]).

- De ouder geeft het kind zo slecht te eten dat het kind niet aankomt, of niet normaal groeit zonder dat daarvoor natuurlijke oorzaken zijn aan te wijzen.

13 Let wel dat het hier niet gaat om schending van 'rechten van de foetus' maar om prenatale schending van de (gezonde-ontwikkelings)rechten van het kind (het kind is immers - per juridische definitie - pas rechtssubject bij de geboorte; vandaar dat er geen prenataal recht op leven bestaat). Met andere woorden: alcohol-, nicotine- en/of drugsgebruik tijdens de zwangerschap is in beginsel een enstige schending van het kernrecht van het kind op minimale persoonswording (zie echter ook onder 'Fataal'). 


\section{Voorbeelden}

- De kinderen wonen in een onverwarmd huis omdat de ouders niet voor verwarming hebben gezorgd; in de winter kwamen de kinderen met bevriezingsverschijnselen naar school.

- Het kind was door een auto overreden en liep daarbij een botbreuk en ernstige snijwonden en kneuzingen op; op school klaagt het kind over pijn en zegt dat de ouders hem niet naar het ziekenhuis wilden brengen.

\section{5. ('Fataal')}

- De ouder geeft het kind zo slecht te eten of verzorgt het kind dermate slecht dat dit ernstige lichamelijke gevolgen heeft, zoals gewichtsverlies bij een zuigeling, ernstige ondervoeding of kunstmatige wegkwijning (nonorganic failure-to-thrive).

- De [moeder] heeft tijdens de zwangerschap misbruik van alcohol of drugs gemaakt in een mate die heeft geleid tot de geboorte van een kind met foetaal alcoholsyndroom of met ontwenningsverschijnselen. ${ }^{14}$

- De ouder heeft de gezondheidstoestand van het kind zo grof verwaarloosd dat het kind is overleden of blijvend invalide is doordat het geen of niet tijdig medische hulp kreeg (bijvoorbeeld bij ondervoeding of uitdroging).

- De ouder zoekt geen deskundige hulp voor levensgevaarlijke emotionele problemen van het kind (bijvoorbeeld bij zelfmoordpogingen of pogingen tot doodslag).

\section{Voorbeelden}

- Het kind wordt geboren met heroïneverslaving.

- Een arts constateert dat het kind ernstig ondervoed is.

- De ouder wordt ervan in kennis gesteld dat het kind zelfmoordgedachten heeft geuit, doch onderneemt niets om de veiligheid van het kind te verzekeren. 


\section{Fysieke verwaarlozing: onvoldoende fysiek toezicht ${ }^{15}$}

\section{Definitie}

(...) Van fysieke verwaarlozing/onvoldoende fysiek toezicht is sprake wanneer de verzorger of opvoeder van het kind c.q. degene die voor het kind verantwoordelijk is [hierna kortheidshalve: de ouder], geen geschikte voorzorgsmaatregelen neemt om de veiligheid van het kind binnens- en buitenshuis te verzekeren overeenkomstig de aard en de ontwikkeling van het kind. Tot het onvoldoende verzekeren van de veiligheid van het kind door de ouder wordt zowel gerekend toestaan dat het kind wordt blootgesteld aan gevaarlijke situaties (bijwoorbeeld goedvinden dat het kind op onveilige plaatsen speelt, goedvinden dat het kind met iemand meegaat van wie bekend is dat hij gewelddadig is), als nalaten zich vooraf op de hoogte te stellen van situaties die gevaarlijk voor het kind zouden kunnen zijn (bijvoorbeeld niet informeren naar de achtergrond of geschiktheid van de oppas, niet informeren naar waar het kind uithangt).

Op vier gebieden kunnen ouders de fysieke veiligheid van hun kinderen in gevaar brengen:

a.) Toezicht - nalaten maatregelen te nemen om er voor te zorgen dat het kind zich op veilige wijze bezighoudt. Aangezien de kans op ongelukken stijgt met het aantal uren dat het kind zonder toezicht wordt gelaten, liggen de ernstfactoren op dit vlak hoger naar gelang de duur van het ontoereikende toezicht. [Waarschuwing: Uiteraard zijn de aangegeven periodes per ernstfactor betrekkelijk: de criteria dienen ook hier dus voorzichtig - dat wil zeggen: voorzichtig vanuit het persoonswordingsbelang van het kind - te worden gehanteerd. ${ }^{16}$ ]

b.) Omgeving - nalaten te verzekeren dat het kind op een veilige plaats speelt. Een onhygiënische of anderszins ongezonde (woon)omgeving valt onder lichamelijke verwaarlozing/onvoldoende fysieke zorg. Bij

Onvoldoende normatief toezicht - gebrek aan structuur en disciplinering (stellen van duidelijke grenzen) - valt onder emotionele maltraitering (E).

Al met al zouden de volgende (elkaar deels overlappende) vormen van verwaarlozing kunnen worden onderscheiden: lichamelijke verwaarlozing (gebrek aan fysieke zorg) (C); fysieke verwaarlozing (gebrek aan fysiek toezicht) (D); affectieve (of emotionele) verwaarlozing (E); normatieve verwaarlozing (gebrek aan grenzen/ normen-en-waarden) (E/F); pedagogische verwaarlozing (gebrek aan structuur en disciplinering) (E); cognitieve verwaarlozing (gebrek aan geestelijke stimulering) (E/F); educatieve verwaarlozing (F); sexuele verwaarlozing (kind niet voorlichten, sexuele gevoelens/problemen van puber/adolescent negeren) (E); affectief-fysieke verwaarlozing (kind nooit aanhalen of knuffelen) (E).

Vgl. ook de onderscheiding gemaakt in de PEWA-studie Verwaarloosde kinderen: opwattingen uit het veld, vermeld in 0/25 (Tijdschrift over jeugd) 1997/1, pp. 57-58. Zie ook noot 4 (ernstfactoren relateren aan diverse dimensies). 
de onderhavige vorm (fysieke verwaarlozing/onvoldoende fysiek toezicht) gaat het om een omgeving, zowel binnens- als buitenshuis, die direct fysiek gevaar voor het kind oplevert, zoals de aanwezigheid van glasscherven, onbeveiligde stopcontacten of electrische bedrading, giftige chemicaliën en [in de vs of bij politieagenten in Nederland] vuurwapens.

c.) Vervangende zorg - niet zorgen voor oppas of opvang bij afwezigheid, ziekte of ernstige overspannenheid van de ouder. Onvoldoende vervangende zorg omvat ook gevallen waarin er niet voor noodzakelijk extra toezicht wordt gezorgd, gevallen waarin ouders zich er niet van vergewissen dat oppassers ook in staat zijn voldoende toezicht op het kind uit te oefenen, gevallen waarin ouders de veiligheid van het kind niet voldoende in de gaten kunnen houden omdat zij beneveld zijn door alcohol of drugs, en het geval dat ouders psychiatrische problemen hebben die het zeer onwaarschijnlijk maken dat zij tot voldoende toezicht op hun kinderen in staat zijn (zoals wanen of hallucinaties).

d.) Ontwikkelingsniveau van het kind - geen rekening houden met het ontwikkelingsniveau van het kind bij het zorgen voor passend toezicht ter verzekering van zijn veiligheid. [In het algemeen hangt het ontwikkelingsniveau van het kind samen met zijn leeftijd. Hoe jonger het kind, hoe meer en intensiever toezicht noodzakelijk is.] Ook kinderen met een achtergrond van gevaarlijk, impulsief of 'onvolwassen' gedrag vergen [meer en] intensiever toezicht. [Gebrekkig toezicht leidt in deze gevallen tot een hogere ernstfactor, zulks ter discretie van de beoordelaar.] (...)

Kortom [de ernstfactoren hangen samen met] de tijd dat het kind zonder toezicht was, de mate van gevaar in de directe omgeving, de aanwezigheid, geschiktheid en feitelijke mogelijkheden van oppassers en het ontwikkelingsniveau van het kind, welke verschillen in elk individueel geval.

\section{Gradaties (criteria en voorbeelden)}

\section{1. ('Licht')}

- De ouder oefent onvoldoende toezicht uit of regelt onvoldoende vervangend toezicht gedurende korte tijd (bijvoorbeeld minder dan drie uur), er is geen directe bron van gevaar in de omgeving van het kind.

\section{Voorbeelden}

- Een kind van acht jaar wordt dagelijks enkele uren alleengelaten.

- Kinderen onder de zes spelen zonder toezicht buiten of worden 's middags overgelaten aan de zorg van een kind van acht. (...) (Met betrekking tot het kind van acht is van emotionele maltraitering sprake voor zover 
het [geregeld/chronisch] met een te grote verantwoordelijkheid wordt belast.)

- Kinderen worden overgelaten aan de zorg van een oppas met twijfelachtige geschiktheid (bijvoorbeeld een kind onder de twaalf of een licht invalide bejaarde).

\section{2. (Matig")}

- De ouder oefent geen toezicht uit of regelt onvoldoende vervangend toezicht gedurende langere tijd (ongeveer drie tot acht uur), er is geen directe bron van gevaar in de omgeving van het kind.

- De ouder oefent gedurende korte tijd (minder dan drie uur) geen toezicht uit terwijl de kinderen spelen op een onveilige plaats.

Een kind met problematisch gedrag (impulsief, hyperactief enzovoorts) krijgt onvoldoende toezicht.

\section{Voorbeelden}

- Het kind wordt overdag geregeld alleengelaten zonder dat er een ouder of oppas in de buurt is.

- Een kind van acht moet enkele uren op de baby passen. (...)

- Een kind mag zonder toezicht spelen op een onveilige plaats (bijvoorbeeld op een plek waar glasscherven liggen, of in een kelder of garage waar chemicaliën staan, electrisch gereedschap of een oude ijskast).

- Een kind krijgt weinig toezicht en veroorzaakt problemen met de buren.

\section{3. (Ernstig)}

- De ouder oefent geruime tijd (bijvoorbeeld ongeveer acht tot tien uur) onvoldoende toezicht uit.

- De ouder laat het kind langere tijd (ongeveer drie tot acht uur) spelen op een onveilige plaats.

\section{Voorbeelden}

- Het kind is 's nachts alleen thuis (gedurende zo'n acht tot tien uur).

- Een kind van zes moet na school alleen buiten blijven: de deur zit op slot, de ouder komt pas 's avonds thuis.

- Het kind wordt langere tijd overgelaten aan de zorg van een niet betrouwbare oppas (bijwoorbeeld iemand die drinkt of nooit oplet, of de ouder maakt zich niet druk om de betrouwbaarheid van de oppas).

\section{4. (Zeer ernstig)}

- De ouder oefent langdurig geen toezicht uit (bijvoorbeeld 's avonds en 's nachts of andere perioden van ongeveer 10 tot 12 uur aaneen).

- De ouder laat het kind spelen op een zeer gevaarlijke plaats (er is een 
grote kans dat het kind zal worden overreden, uit een raam valt, zich verbrandt of verdrinkt).

- De ouder oefent [kortere of langere tijd] geen toezicht wit over een kind dat geregeld destructief of gevaarlijk gedrag vertoont (zoals brandstichting, zelfmoordpogingen).

\section{Voorbeelden}

- Een kind van lagere-schoolleeftijd wordt 's nachts alleengelaten.

- Het kind mag spelen langs de snelweg of op het dak van een vervallen gebouw of onbewoonbaar verklaarde woning.

- Het kind mag meegaan met een ouder die gewelddadig jegens kinderen is (geweest), die kinderen sexueel (heeft) misbruikt, of aan wie een contactverbod is opgelegd.

\section{5. ('Fataal')}

- De ouder oefent langer dan een half etmaal onvoldoende toezicht uit.

- De ouder brengt het kind in een levensgevaarlijke situatie of neemt geen maatregelen om te voorkomen dat het kind in een levensgevaarlijke situatie belandt.

\section{Voorbeelden}

- Een peuter wordt 24 uur alleengelaten.

- Het kind wordt het huis uit gejaagd zonder dat er elders onderdak is geregeld.

- De ouder [in de Vs, of een Nederlandse politieagent] bewaart een geladen vuurwapen op een plaats waar het kind bij kan.

- Een peuter speelt zonder toezicht bij een zwembad. (Dit wordt voor een peuter levensgevaarlijk geacht wegens het hoge aantal verdrinkingen op deze leeftijd.)

\section{E. Emotionele maltraitering (pathogene zorg) ${ }^{17}$}

\section{Definitie}

[Bij wijze van definitie wordt hieronder allereerst aangegeven wat de essentie van emotionele maltraitering is; dit is bij deze vorm van bijzonder belang omdat emotionele maltraitering als substraat van alle vormen van

17 Emotionele maltraitering wordt als verzamelterm gebruikt voor zowel psychische mishandeling/emotioneel misbruik en affectieve verwaarlozing als normatieve/ pedagogische verwaarlozing (onwoldoende grenzen, onvoldoende structuur, onwoldoende/geen disciplinering). Zie voor dat laatste de volgende noot. Zie voor de (deel)term pathogene zorg noot 20 . 
kindermishandeling kan worden beschouwd (1). Mede met het oog daarop worden vervolgens enkele afbakeningscriteria ten opzichte van andere subtypen vermeld (2).]

\section{Emotionele basisbehoeften}

In toenemende mate is men het erover eens dat vrijwel alle vormen van mishandeling, misbruik en verwaarlozing negatieve emotionele/psychologische boodschappen overbrengen naar de slachtoffers ervan. Dientengevolge kan elke vorm van maltraitering (mishandeling, misbruik en verwaarlozing) als emotionele maltraitering worden beschouwd. [Toch wordt emotionele maltraitering als aparte categorie vermeld.] De meeste gevallen die tot deze categorie behoren, worden gekenmerkt door de aanhoudende of extreme frustratie van elementaire emotionele behoeften van het kind. Hieronder valt ook het handelen of nalaten van ouders waarvan de schadelijkheid gelegen is in de ongevoeligheid voor het ontwikkelingsniveau van het kind [te veel of te weinig van het kind vragen of verwachten, het kind overbelasten of juist betuttelen]. De elementaire emotionele behoeften [emotionele basisbehoeften] van het kind bestaan uit, doch zijn niet beperkt tot:

a.) Psychische veiligheid en geborgenheid - de behoefte aan een gezinsomgeving zonder excessieve vijandigheid en geweld, alsmede [in de allereerste plaats] de behoefte aan een beschikbare en stabiele hechtingsfiguur. Het gaat hierbij dus niet om een fysiek veilige omgeving, zoals bij de vorige categorie (fysieke verwaarlozing/onvoldoende toezicht), maar om een veilig gezinsklimaat, om interpersoonlijke veiligheid. (...)

b.) Acceptatie en respect (in zijn waarde gelaten worden, op de juiste waarde geschat worden/ - de behoefte aan positieve bejegening (aan een 'welwillende blik') en de afwezigheid van een excessief negatieve of onrealistische beoordeling van het kind, gezien zijn ontwikkelingsniveau.

c.) Toenemende autonomie en duidelijke grenzen [ruimte/begeleiding en leiding/disciplinering/ - de behoefte de omgeving te onderzoeken en contacten te leggen buiten het gezin, en de behoefte aan individuatie [geleidelijke/gefaseerde losmaking en zelfstandigwording] zonder verlies van ouderlijke acceptatie en binnen de door de ouders gestelde grenzen en geboden structuur, voor zover daarbij geen verantwoordelijkheden worden opgelegd die niet passen bij de ontwikkelingsfase noch onnodige beperkingen worden gesteld. ${ }^{18}$

Het bieden van structuur, het op basis daarvan stellen van grenzen, en het als gevolg daarvan c.q. in verband daarmee disciplineren van het kind betreft een emotionele basisbehoefte van het kind welke bij niet-vervulling kan worden gerangschikt onder de sub-subvorm normatieve/pedagogische verwaarlozing. Deze 


\section{Afbakening/overlapping}

Sommige handelingen/nalatigheden vallen uitsluitend onder emotionele maltraitering, andere vallen zowel onder emotionele maltraitering als onder andere vormen van kindermishandeling. In onduidelijke (overlappings)gevallen kunnen de volgende afbakeningscriteria dienst doen:

a.) Een grijs gebied tussen emotionele maltraitering en lichamelijke mishandeling betreft het opsluiten of vastbinden van een kind. Omdat opsluiten of vastbinden [emotionele basisbehoeften] van het kind ondermijnt, rekenen we het tot emotionele maltraitering. Als het evenwel tot verwondingen leidt (bijvoorbeeld door touw veroorzaakte brandplekken), valt het geheel onder zowel emotionele maltraitering als lichamelijke mishandeling.

b.) Een tweede grijs gebied betreft bedreigingen met de dood [of met verminking of verwonding]. Als ouders kinderen angst aanjagen door het uiten van bedreigingen of het maken van dreigende gebaren, valt dat onder emotionele maltraitering. Brengen zij het kind daadwerkelijk verwondingen toe, dan is er sprake van lichamelijke mishandeling.

c.) Als er aanwijzingen zijn dat het kind fysiek bedreigd is of dat er psychische dwang is uitgeoefend teneinde sexuele betrekkingen met het kind aan te gaan, is er sprake van zowel sexueel misbruik als emotionele maltraitering $(\ldots .)^{19}$

variant is niet expliciet onder de (vijf) onderstaande ernst-categorieën uitgesplitst. De van toepassing zijnde ernstfactor (in de regel vermoedelijk ernstig tot zeer ernstig) zal van geval tot geval moeten worden beoordeeld, afhankelijk van de concrete (gezins)omstandigheden, de duur, leeftijd en aard van het kind, en de mate van aan- of afwezigheid van protectieve factoren zoals veerkracht c.q. wilskracht, intelligentie, "helpende [i.c. bijsturende] getuige” (MLLER) en zo meer. $\mathrm{Vgl}$. voor meer inzicht in (de gevolgen van) normatieve/pedagogische verwaarlozing bijwoorbeeld John CLEESE, Robin SKYNNER, Hoe overleef ik mijn familie (oorspr. titel: Families and how to survive them, 1983; oorspr. Nederlandse vertaling: Van je familie moet je 't hebben, 1986), Amsterdam 1995 (zesde druk), pp. 260-336 (passim), 411, 413. Ik wijs ook op het gezegde bij LOWEN (Alexander LOWEN, Leven zander angst (1980), Cothen 1996 (derde druk), pp. 288/289) dat '[w]e beginnen in te zien dat het kind-gerichte gezin [het gezin dat aan kinderen geen eisen/grenzen stelt, waarin kinderen worden "werwend, $\mathrm{jw}$ ] geen individuen voortbrengt die een sterk en zeker besef van het zelf hebben. Het is een paradox van het leven dat vrijheid afhankelijk is van begrenzingen en structuur.'

(Vgl ook DSM-IV, V 61.20 (z 63.8): "inadequate discipline.")

19 Sexueel misbruik vindt veelal plaats tegen een achtergrond van affecticve verwaarlozing (ORAIJER); door 'bijkomende' omstandigheden (valse/geveinsde aandacht, misleiding, emotionele chantage/manipulatie, beloningen/voortrekken, geheimhouding/"bondjes," rol-omkering, omkering van waarden/hypocrisie, omkering van de waarheid/ricksichtslose ontkenning c.q. blaming the victim, en wat incestplegers verder nog maar in hun 'trucendoos' hebben) is sexueel misbruik 
d.) Het is van groot belang te onderscheiden tussen emotionele maltraitering en lichamelijke/fysieke verwaarlozing in gevallen van verlating. Als een ouder een kind verlaat, maar toezicht en verzorging heeft geregeld (de ouder laat het kind bijvoorbeeld achter bij familie zonder adres achter te laten), is dat emotionele maltraitering. Als het kind echter volledig alleen wordt achtergelaten, zonder dat er iets geregeld is qua toezicht en verzorging, dan is er sprake van èn lichamelijke verwaarlozing (onvoldoende fysieke zorg) èn fysieke verwaarlozing (onvoldoende fysiek toezicht) èn emotionele maltraitering.

e.) Als een jong kind voor een nog jonger kind moet zorgen zonder dat er (voldoende) toezicht van een ouder is, dan is er niet alleen sprake van fysieke verwaarlozing/onvoldoende fysiek toezicht ten aanzien van beide kinderen dan wel van het jongste kind, maar ook van emotionele maltraitering ten aanzien van het kind dat met een te grote verantwoordelijkheid wordt belast.

\section{Gradaties (criteria en voorbeelden)}

\section{1. ('Licht')}

- De verzorger of opvoeder [hierna kortheidshalve: de ouder] verwacht of eist geregeld dat het kind te veel [of te weinig] verantwoordelijkheid draagt (bijvoorbeeld dat een kind van schoolgaande leeftijd de belangrijkste verzorger van de jongere kinderen is (...)).

- De ouder ondermijnt de relatie van het kind met belangrijke anderen (maakt bijvoorbeeld herhaaldelijk minachtende opmerkingen over de andere ouder).

- De ouder kleineert het kind vaak of maakt het belachelijk (noemt het kind 'dom,' 'een femel,' 'een slapjanus').

- De ouder veronachtzaamt of negeert het aandacht vragen van het kind (de ouder reageert bijvoorbeeld in het algemeen niet op het huilen van de baby of op de pogingen tot contact van een ouder kind).

- De ouder disciplineert het kind door middel van intimidatie of bangmakerij.

wellicht in de eerste plaats, althans in de kern emotionele maltraitering. Vgl. NICOLAI in hoofdstuk 12, par. 12.3.1 (onder Traumatisering en revictimisering). Zie ook hoofdstuk 11, par. 11.2.2.3 (vanaf 5. Sexuele kindemishandeling). Sexueel misbruik kan met andere woorden beter gekwalificeerd worden als psycho-sexuele mishandeling (veelal) na affectieve verwaarlozing (beide: emotionele maltraitering) en (veelal) in combinatie met morele corrumpering (sexueel-normatieve maltraitering). 


\section{Voorbeelden}

- De ouder verwacht dat haar zoon van 10 jaar de verantwoordelijkheid op zich neemt voor de verzorging van de baby.

- De ouder laat de baby langdurig huilen in de wieg terwijl zij aan het telefoneren is.

- De ouder toont geen belangstelling voor de prestaties van het kind.

\section{2. ('Matig')}

- De ouder staat geen vriendschappen met leeftijdgenootjes toe [klasgenootjes van het kind mogen bijvoorbeeld nooit thuis komen spelen of zijn niet welkom].

- De ouder manoeuvreert het kind in een rol-omkering [het kind wordt verantwoordelijk gesteld voor en wordt geacht tegemoet te komen aan de emotionele noden van de ouder].

- De ouder dwarsboomt de zich ontwikkelende gevoelens van rijpheid en verantwoordelijkheid van het kind [klein houden, infantiliseren].

- De ouder verwerpt, veronachtzaamt of is zich niet bewust van de behoefte van het kind aan genegenheid en respect [positieve en liefdevolle interactie ontbreekt bijvoorbeeld chronisch]. ${ }^{20}$

- De ouder stelt het kind bloot aan extreme, zij het niet gewelddadige huwelijksconflicten.

20 Vgl. DSM-IV, 313.89 sub C, Pathogene zorg (ad 1): 'Pathogene zorg zoals blijkt wit ten minste één van de volgende: 1 . aanhoudende veronachtzaming van de basale emotionele behoeften van het kind aan troost, aanmoediging en affectie; 2. aanhoudende veronachtzaming van de basale lichamelijke behoeften van het kind; 3. herhaald wisselen van de vaste verzorger, hetgeen de vorming van een stabiele hechting verhindert (bijwoorbeeld frequent veranderen van pleegzorg).'

Pathogene (psychisch-ziekmakende, tot ontwikkelingspsychopathologie leidende) zorg in de betekenis van aanhoudende (passieve dan wel actieve) veronachtzaming (niet aanwoelen, negeren, frustreren, manipuleren) van (de) emotionelle basisbehoeften van het kind kan als de quintessens (zo al niet als synoniem) van emotionele maltraitering worden beschouwd (zie Definitie (1)). Wellicht verdient deze term zelfs de voorkeur boven emotionele malltraitering. In elk geval wordt het verschijnsel dat een kind ernstig/langdurig emotioneel wordt beschadigd door (fysiek) zeer zorgzame (overbeschermende/neurotische) ouders, meer recht gedaan door de term pathogene zorg te bezigen: zorg namelijk dic, hoe goed bedoeld ook, ontwikkelingspsychopathogeen is. Juist bij zeer zorgzame maltraiterende ouders is het immers aannemelijk dat het vooral eigen niet verwerkte jeugdervaringen zijn die het hun onmogelijk maken - althans bij afwezigheid van op verwerking van eigen jeugdervaringen gerichte opvoedingsondersteuning - (alle) emotionele basisbehoeften wan het kind aan te voelen. 


\section{Voorbeelden}

- De ouder is in extreme mate passief en is niet in staat tegemoet te komen aan de behoefte aan aandacht van het kind; voor zover er interactie is, is deze van de kant van de ouder hardvochtig en kritisch.

- De ouder wil dat het kind na school thuis blijft omdat de ouder eenzaam is en behoefte heeft aan gezelschap.

- De ouder schreeuwt geregeld tegen de andere ouder, gilt of is grof en beledigend jegens de andere ouder in aanwezigheid van het kind.

- De ouder maant een kind van vier jaar luiers te blijven dragen hoewel het kind fysiek en psychisch in staat is het toilet te gebruiken.

\section{3. (Ernstig)}

- De ouder geeft de kinderen de schuld van huwelijks- of gezinsconflicten ['de kinderen zijn de oorzaak van de (chronische) echtelijke ruzies/van de (dreigende) echtscheiding"].

- De ouder stelt het kind ongepaste of excessieve eisen en brengt aldus een gevoel van ontoereikendheid en tekortschieten bij het kind teweeg [het kind is bijvoorbeeld verantwoordelijk voor het sussen en beslechten van de ouderlijke ruzies (excessief en ongepast) maar wordt tegelijk geacht partij te kiezen voor één van beide ouders/de dominante ouder/ beide ouders (ongepast)].

- De ouder dreigt op ernstige en overtuigende wijze het kind (fysiek) te verwonden.

- De ouder betitelt het kind op minachtende wijze (noemt het kind een 'slet' of een 'hoer' [bijwoorbeeld na het eerst sexueel misbruikt te hebben] of 'waardeloos' [bijvoorbeeld na teleurstellingen wegens ongepaste verwachtingen].

- De ouder bindt het kind vast aan handen en voeten gedurende enkele uren (bijvoorbeeld ongeveer 2 tot 5 uur), het kind wordt niet alleen achtergelaten.

- De ouder stelt het kind bloot aan extreem, onberekenbaar en/of ongepast gedrag [zoals geweldpleging tegenover gezinsleden, gewelddadige driftbuien/explosies, hysterische uitvallen en ander ernstig neurotisch, psychotisch of paranoïde gedrag dat voor het kind angstaanjagend is].

- De ouder legt een patroon van [geprojecteerde] negativiteit en vijandigheid aan de dag tegenover het kind [voegt het kind geregeld toe dat het niets kan, niet deugt, altijd alleen aan zichzelf denkt, altijd alleen zijn eigen zin doet, altijd bijbedoelingen heeft enzovoorts].

\section{Voorbeelden}

- De ouder schreeuwt en vloekt constant tegen de kinderen en geeft hen scheldnamen. 
- De ouder verwerpt de kinderen, zij worden voortdurend afgewezen.

- De ouder dreigde het kind dat hij het uit het raam zou gooien.

\section{4. (Zeer ernstig)}

- De ouder dreigt het kind met zelfmoord of verlating [de moeder loopt weg met medeneming van het huishoudgeld, de vader maant de kinderen moeder op te sporen en terug te halen].

- De ouder laat het kind getuige zijn van extreem geweld tegen de andere ouder waarbij de laatste ernstige verwondingen oploopt.

- De ouder geeft het kind de schuld van de zelfmoord of dood van een gezinslid.

- Het kind wordt opgesloten en geïsoleerd (bijvoorbeeld in zijn kamer) gedurende vijf à acht uur.

- De ouder bindt het kind helemaal vast of sluit het kind op in een enge ruimte (het kind wordt bijvoorbeeld vastgebonden aan een stoel of opgesloten in een doos) gedurende minder dan twee uur (het kind is volledig of bijna volledig beperkt in zijn bewegingsvrijheid en/of de temperatuur, ventilatie of verlichting zijn zeer ongunstig of worden zeer ongunstig gemaakt).

\section{Voorbeelden}

- De kinderen waren getuige van een handgemeen tussen de ouders, de moeder werd door de vader belaagd en moest in het ziekenhuis worden opgenomen.

- De ouder sluit het kind voor straf tien uur op in de kelder.

- De ouder dreigt het kind dat het naar de tuchtschool moet omdat het niet deugt.

\section{5. ('Fataal')}

- De ouder doet een zelfmoordpoging in bijzijn van het kind.

- De ouder poogt het kind te doden of dreigt het kind te zullen vermoorden zonder dat het kind daadwerkelijk gewond raakt.

- De moeder [de primaire verzorger] verlaat het gezin een etmaal of langer zonder enige aanwijzing of en wanneer zij zal terugkeren of waar zij kan worden bereikt [zie ook Definitie (2) onder d].

- De ouder bindt het kind strak vast of sluit het op in een enge ruimte gedurende meer dan twee uur (het kind wordt bijvoorbeeld strak vastgebonden aan een stoel of opgesloten in een kist).

- De ouder sluit het kind langdurig (bijvoorbeeld langer dan acht uur) op in een enge ruimte (bijvoorbeeld in een kast of in een kruipgat). 


\section{Voorbeelden}

- De ouder ketent het kind met behulp van een halsband twee dagen lang vast aan de muur.

- De moeder liet de kinderen twee weken bij oma achter zonder iets te zeggen over waar zij zou zijn en wanneer (en of) zij zou terugkeren.

- Om het kind schrik in te boezemen, jaagt de ouder het kind op met de auto; het kind liep geen (fysieke) verwondingen op.

- In bijzijn van de kinderen nam de ouder een overdosis slaappillen in, de ouder vertelde de kinderen dat het leven met hen ondraaglijk was.

\section{F. Normatieve en educatieve maltraitering (morele corrumpering en schoolverzuim) $)^{2 \Perp}$}

\section{Definitie}

Van normatieve dan wel educatieve maltraitering is sprake wanneer de verzorger of opvoeder van het kind c.q. degene die voor het kind verantwoordelijk is [hiema kortheidshalve: de ouder], gedrag vertoont waaruit blijkt dat hij of zij niet in staat of bereid is tot minimale bekommernis omtrent de socialisering van het kind [normatieve maltraitering/morele corrumpering], met inbegrip van de zorg voor geschikt onderwijs voor het kind [educatieve maltraitering/schoolverzuim]. De ouder stelt het kind bloot aan of betrekt het kind bij illegale activiteiten of andere handelingen of feitelijkheden die delinquentie of antisociaal gedrag bij het kind uitlokken of bevorderen; respectievelijk ziet er niet op toe dat het kind regelmatig naar school gaat.

\section{Gradaties (criteria en voorbeelden)}

\section{1. ('Licht')}

- [Morele corrumpering, hierna MC:] De ouder laat het kind activiteiten van en voor volwassenen bijwonen (het kind heeft hiervoor niet de wettige leeftijd bereikt).

- [Schoolverzuim, hierna SV:] De ouder houdt het kind vaak thuis zonder dat er sprake is van ziekte of sterfgevallen in het gezin of andere noodsituaties; het kind is minder dan $15 \%$ van de tijd afwezig.

\section{Voorbeelden}

- [MC:] De ouder neemt het kind mee naar drinkgelagen of naar gelegenheden voor volwassenen die duidelijk niet voor het hele gezin zijn bedoeld. 
- [sv:] De ouder staat toe dat het kind zonder opgaaf van redenen 25 schooldagen in een jaar mist.

\section{2. (Matig')}

- [MC:] De ouder laat zich in met illegale activiteiten met medeweten van het kind (bijvoorbeeld winkeldiefstal of heling waar het kind bij is). - [sv:] De ouder staat toe dat het kind spijbelt gedurende 15 tot $25 \%$ van de tijd.

\section{Voorbeelden}

- [MC:] De ouder verkoopt drugs in bijzijn van het kind.

- [sV:] De ouder houdt het kind thuis om op de jongere kinderen te passen; het kind mist in zeven weken tijds negen schooldagen.

\section{3. (Ernstig)}

- [MC:] De ouder is ervan op de hoogte dat het kind zich inlaat met illegale activiteiten maar grijpt niet in (staat bijvoorbeeld vandalisme, winkeldiefstal, alcoholgebruik toe).

- [sv:] De ouder houdt het kind vaak of langdurig van school of is ervan op de hoogte dat het kind vaak of langdurig spijbelt zonder in te grijpen ( 25 tot $50 \%$ van de tijd per jaar, of tot zestien schooldagen achtereen).

\section{Voorbeelden}

- [MC:] De ouder is verteld dat het kind winkeldiefstallen pleegt maar doet er niets aan.

- [sv:] Het kind is drie weken niet op school verschenen zonder dat het ziek was.

\section{4. (Zeer ernstig)}

- [MC:] De ouder laat het kind strafbare feiten plegen of daaraan deelnemen (het kind wordt bijvoorbeeld aangezet tot winkeldiefstal, of het krijgt drugs); volwassenen moedigen [met instemming van de ouder] het kind aan tot deelname aan strafbare feiten of dwingen het daartoe.

- [sv:] De ouder houdt het kind geregeld langdurig (meer dan 50\% van de tijd in een bepaalde periode of langer dan drie weken [zestien schooldagen] achtereen) van school, zonder het kind van school te nemen.

\section{Voorbeelden}

- [MC:] De [niet behoeftige/hongerende] ouder zet het kind aan tot diefstal van etenswaren uit de supermarkt.

- [sv:] Het gezin is verschillende keren verhuisd en elke keer heeft het 
kind langdurig de school verzuimd, in totaal heeft het een half schooljaar gemist.

\section{5. ('Fataal')}

- [MC:] De ouder laat het kind deelnemen aan ernstige misdrijven (gewapende diefstallen, gijzeling [resp. artt. 312 en 282a WvStr]).

- [SV:] De ouder zet een kind onder de zestien aan de school te verlaten of stuurt het kind in het geheel niet naar school.

\section{Voorbeelden}

- [MC:] Het kind woont in een drugspand dat door de ouders wordt gerund; het kind wordt ingeschakeld bij de verkoop van drugs en heeft deelgenomen aan conflicten met andere drugsdealers die met wapens werden uitgevochten.

- [SV:] De ouder stuurt het kind niet naar school, het kind krijgt geen enkel onderricht. 
BLJLAGE IV

\section{Lijst van afweermechanismen en coping-stijlen ${ }^{1}$}

(Beschadigde persoonswording en aanpassing/onaangepastheid)

'Het is de angst die zelfkennis onmogelijk maakt."

Glossarium van (27) afweermechanismen of afweertechnieken c.q. copingstijlen (ook wel aangeduid als survival- of overlevingsstrategieën of -tactieken).

\section{Ten geleide}

Het gaat hierbij om de vraag: hoe gaat men (vanuit zijn jeugdervaringen en levensgeschiedenis) om met emotionele conflicten en innerlijke of van buiten komende stress-veroorzakende factoren (wanneer de draaglast de draagkracht dreigt te overschrijden)? Respectievelijk om de vraag: welke oorspronkelijke (kinderlijke ${ }^{3}$ ) afweermechanismen zijn een tweede natuur geworden, in de vorm van meer of minder aangepaste coping-stijlen (c.q. zijn tot meer of minder neurotische karaktertrekken verhard)?

Ontleend aan de Diagnostic and Statistical Manual of mental disorders; Founth edition/DSM-IV, American Psychiatric Association, Washington 1994, pp. (751-753 en) 755-757. Mijn vertaling van termen en (met name) omschrijvingen wijken op onderdelen af van die van de $D S M-N$. In een aantal gevallen zijn duidelijkheidshalve voorbeelden toegevoegd, meestal (vrijwel woordelijk) ontleend aan P.C. KUIPER, Nieuwe neurosenleer, Deventer 1984 (achtste druk), pp. 24-39.

2 En aldus mensen doet 'lijden aan zichzelP (KUIPER, a.w., resp. Pp. 33 en 271).

3 'Afweermechanismen worden gestimuleerd in de opvoedingssituatie." Immers: 'De afweer wordt gemobiliseerd door angst, angst voor het eigen strenge geweten [dat is: de geintrojecteerde 'sadistische' ouders, jw], woor de driften en de daaraan verbonden gevoelens. (...) [A]ngst heeft centrale betekenis voor de symptoomvorming en de karakterdeformatie [subminimale persoonswording, jw].' (KUIPER, Nieuwe neurosenleer, a.w., p. 29.)

'Bij de bestudering en behandeling van de neurotische patiënt [iemand dic 'ondoelmatig en overmatig gebruik van afweermechanismen' maakt, jw] moeten we altijd ons het kind voor ogen houden (...). (...) Het is goed de fundamentele betekenis van de angst, angst voor het driftleven, angsit voor de dreigingen wan het geweten, geworteld in de vroegere angst voor de ouders, voortdurend in gedlachten te houden.' (KuIPER, a.w., p. 42 [en p. 90]; curs. jw.)

'Tenslotte wil ik nogmaals wijzen op de betekenis van de angst voor neurotische symptoomvorming, karakterdeformaties, manoeuvres en relaties. Alle dienen om de angst af te weren, die verbonden is met ervaringen uit de kindertijd.' (KUIPER, a.w. p. 48.) 


\section{Glossarium}

* = (zeer) aangepast (adequaat/constructief)

** $=$ (op den duur) meer of minder onaangepast (inadequaat/destructief)

1. " acting-out of uit-ageren: geen 'woorden' (reflectie en praten), maar (destructieve) 'daden': een (wanhoops)daad stellen; handelen (trauma's actief herhalen, 'turning passive into active ${ }^{94}$ ) in plaats van (kunnen) herinneren (en bewerken);

2. "affiliatie: hulp en steun zoeken bij anderen; problemen met anderen delen zonder deze anderen in de schoenen te schuiven;

3. *altruïsme: (de aandacht verleggen naar) toewijding aan de nood van anderen (doch zonder 'zelfopoffering')

4. *anticipatie: mogelijke problemen 'voorvoelen' (emotioneel voorbewerken) en bij voorbaat naar realistische alternatieve reacties of oplossingen (wijzen van hanteren) zoeken;

5. *autistische fantasie: excessief dagdromen in plaats van praten en doen (werken aan probleem-oplossing);

6. * devaluatie (ontwaarding): toedichten van overdreven negatieve eigenschappen aan zichzelf of aan anderen;

7. ** dissociatie: uiteenvallen van bewustzijn, geheugen en andere functies (soms ook in de betekenis van isolatie ${ }^{6}$ );

8. "humor: de lach in de traan, ironie (mits het ware zelf niet achter een pantser van "geestigheid" schuil gaat);

9. **idealiseren: toedichten van overdreven positieve eigenschappen aan anderen;

10. * *intellectualiseren: verwarrende gevoelens eronder (of klein) houden door excessief abstract te denken of te generaliseren;

11. **isolatie (van affect en inhoud): loskoppelen van gevoel en verstand; bij (het praten over) pijnlijke herinneringen of gebeurtenissen niets

Dit herhalen (herhalingsdwang) of doorgeven (" $[\mathrm{e}]$ indeloos moet dan het geledene anderen worden aangedaan') onderscheide men van het inhalen van hetgeen men als kind te kort gekomen is "in de omkering, bijwoorbeeld door narcistische identificatie: de eenzame man die al zijn liefde op zijn windhonden richt, zichzelf verbeeldend van even oude adel te zijn als zij (KuIPER, Nieuwe neurosenleer, a.w., p. 36).

5 Onwillekeurig dringen zich hier de treffende woorden van KuIPER op: 'Het dilemma dat je je zelf nooit kan vinden dan door jezelf te verliezen, vraagt om een oplossing langs een schïnbare omweg: geen werkzaamheid aan je zelf. Als je werkelijk kunt ingaan op het beroep dat er van je medemens uitgaal, dan verdampen zonder dat je er iets aan doet, al die giftige ik-nevels vanzelf.' (P.C. KUIPER, Ver heen; Verslag van een depressie, 's-Gravenhage 1988, p. 146.)

6 'Vgll. Robert J. CAMPBELL, Psychiatric Dictionay, New York/Oxford 1996 (seventh ed.), pp. 209 en 382 resp. s.v. 'dissociation' en s.y. 'isolation.' 
voelen ('de knop omdraaien'; op de 'automatische piloot" verder gaan; vgl. ook splitting en devalueren/idealiseren);

12. * "loochening ${ }^{7}$ of ongedaan-maken (undoing): 'magisch' ontkennen van gedachten; gevoelens of daden; doen en (bezwerend/symbolisch) 'ongedaan' maken ${ }^{8}$;

13. * *mnipotentie: zichzelf superieur wanen en/of zich superieur (alsof men erboven staat) gedragen (bijvoorbeeld door machismo);

14. "onderdrukking (suppression): bewust vermijden aan nare/ver velende dingen te denken (bijvoorbeeld afleiding zoeken om preoccupatie te vermijden; een emotionele/stressvolle situatie door bepaalde tactieken of technieken hanteerbaar houden: bewuste compensatie voor zover geen 'vlucht' in activiteiten, met andere woorden voor zover doelmatig in het kader van een 'gedoseerde' verwerking);

$15 .{ }^{*}$ ontkenning (denial): weigeren nare/vervelende dingen te erkennen (weigeren de werkelijkheid onder ogen te zien in weerwil van feiten en bewijzen, bijvoorbeeld het malligne karakter van een ziekte, het maligne karakter van zijn levenspartner, of de gevaren van nucleaire bewapening ${ }^{9}$;

16. * passieve agressie: indirect en niet assertief zijn agressie uiten; uiterlijke aanpassing en bedekt verzet, heimelijke wrok of vijandigheid; stiekem zijn gang gaan, stiekem obstructie plegen - ook als dit niet (langer) door de omstandigheden (autoritaire ouders of agressieve bazen) geboden is (bijvoorbeeld door temig treuzelen zich tergend aan de ander onderwerpen);

17. * "projectie: ten onrechte toedichten van eigen onaanvaardbare gevoelens, gedachten en neigingen aan anderen; in anderen (menen te) ontdekken wat men niet in zichzelf kan waarnemen (bijwoorbeeld in het potentieel gevaarlijke - doch nog steeds, onder het mom van democratische vrijheden gedoogde - geval van vreemdelingenhaat ${ }^{10}$ );

7 Loochening wordt veelal gehanteerd als synoniem van ontkenning (bijwoorbeeld bij KUIPER, Nieuwe neurosenleer, a.w., p. 33). Hier geldt het als wan omtkenning te onderscheiden alternatief voor 'ongedaan-maken' (wndoing).

8 Het niet waar kunnen/willen hebben en tegelijk weten-en-niet-weten dat hierin frappeert, kan men ook bij andere afweermechanismen aantreffen.

9 De drie voorbeelden zijn van KUIPER, Nieuwe neurosenleer, a.w., $\mathrm{p}_{\text {. }} 33$ i.f.

10 KUIPER (Nieuwe neurosenteer, a.w., pp. 28/29): "Rassenhaat is het gevolg van het projectie-mechanisme. Anderen zijn slecht, gemeen, losbandig, hyperseksueel, vies en wat niet al. De samenhang in de groep ['ons soort mensen," jw] wordt hechter, maar tot welke prijs ['eigen volk eerst,' jw]! Vijandige verhoudingen tussen volkeren zijn niet zelden het gevolg van een consequente collectieve achtervolgingswaan, tot stand gekomen door projectie." 
18. "* projectieve identificatie: de eigen (anders onaanvaardbare) gevoelens etc. worden als een terechte reactie gezien op ten onrechte aan de ander toegedichte of eerst (onbewust) bij de ander geïnduceerde affecten (c.q. geprovoceerde houdingen/gedragingen/uitingen);

19. "queruleren (help-rejecting complaining): klagen en ogenschijnlijk om hulp en advies vragen, waarna deze worden verworpen, als uiting van verborgen (verboden) vijandigheid of verwijten;

20. " rationalisatie: zijn ware motieven voor zichzelf (en anderen) verbergen en weg-redeneren door middel van uitgebreide geruststellende of goed in zijn straatje passende maar onjuiste verklaringen;

21. * "reactievorming": gevoelens etc. overdekken door het tegendeel, steeds met risico van doorbrak van de overdekte gevoelens (bijvoorbeeld vijandigheid door zelfopoffering, ambivalentie/agressie/ ergernis door overbezorgdheid: kwellende vormen van liefde; men kan hier ook denken aan de activiteiten van de zedenprediker ${ }^{12}$ );

22. ** splijting (splitting): compartimenteren (in aparte hokjes plaatsen) van tegenstrijdige belevingen; ambivalente gevoelens niet kunnen verdragen/gelijktijdig ervaren, positieve en negatieve eigenschappen/ kanten niet in één beeld kunnen integreren, waardoor zelf en anderen (al of niet afwisselend) hetzij worden geïdealiseerd hetzij gedemoniseerd (ambitendency); evenwichtige/genuanceerde opvattingen/verwachtingen uitsluiten (zwart-wit-denken: iets of iemand is of volledig goed of volledig slecht, machtig of waardeloos, aardig of boosaardig etc.);

23. "sublimatie: negatieve (onaangepaste) gevoelens en neigingen worden omgezet in sociaal aanvaardbaar gedrag (bijvoorbeeld agressie of frustratie 'weg'-sporten of 'weg'-schrijven en -dichten; uiteraard voor zover een en ander geen vlucht in activiteiten is, die zelfreflectie in de weg staat, met andere woorden voor zover een en ander conflictvrij is ${ }^{13}$ );

11 Hieronder zou men wellicht ook 'identificatie met de agressor' (KUIPER, Nieuwe neurosenleer, a.w., pp. 35/36) kunnen rekenen.

12 "Voortdurend leest hij anderen de les over hun seksuele wangedrag; hij is aldus voortdurend met de [voor hem al of niet om celibataire tredenen verboden, $\mathrm{jw}$ ] seksualiteit bezig.' (KUIPER, Nieuwe neurosenleer, a.w., p. 27.)

In dit verband zij ook gewezen op de uitspraak wan MILLER: 'Veel mensen vinden het (...) eenwoudiger medicijnen in te nemen, te roken, alcohol te drinken, te preken, anderen op te voeden, te behandelen, oorlogen voor te bereiden dan zich bloot te stellen aan de eigen pijnlijke walarheid.' (Alice MILLER, Zelfkennis in ballingschap; De verdringing van de kindertijd, tot welke prijs? Houten 1989, p. 127.) Men bedenke evenwel dat het hier niet om bewuste processen of keuzes gaat, doch om onbewuste vormen van compensatie (vgl. KUIPER, a.w., pp. 27/28 en 36). Anders spreken we van pseudo-sublimatie (Nietwwe neurosenteer, a.w., p. 38). 
24. **verdringing (repression): uit het bewustzijn bannen van verwarrende (nare) ervaringen, gedachten of verlangens (de verdrongen neiging valt op door haar - veellal storende - afwezigheid $)^{14}$;

25. * verplaatsing of verschuiving (displacement): het richten van gevoelens of reacties op een ander (minder bedreigend) object (bijvoorbeeld opgekropte woede uitleven op een ander, zwakker persoon, frustraties afreageren op een kind, of op 'de buitenlanders': de moed der zwakken, pantoffelheldenmoed; of uitleven op de eigen persoon, zelf-sabotage, depressie, suïcide); ook wel 'affect-substitutie' (bijvoorbeeld haat voor/ afkeer van een persoon door angst voor iets of iemand anders ${ }^{15}$ );

26. "zelfexpressie (self-assertion): gevoelens en gedachten direct, op niet dwingende of manipulatieve wijze, uiten;

27. ${ }^{*}$ zelfreflectie (self-observation): reflecteren over zijn gevoelens, gedachten, motieven en gedrag, en naar het aldus verworven (zelf-)inzicht handelen.

Tal van andere (neurotische) afweermechanismen zijn de 'hulptroepen' van de verdringing als basis-afweermechanisme (Nieuwe neurosenleer, a.w. pp. 25, 39 en 163). Hoeveel en welke hulptroepen worden ingeroepen, hangt af van de specifieke "hiërarchie van de afweer" welke 'kenmerkend [is] voor iemands persoonlijkheidsstructuur' (a.w., p. 39; curs. jw). Vgl. de 'Defensive functioning scalle" van de DSMIV (Diagnostic and Statistical Manual, a.w., pp. 751-753), welke uitga.at van 'defense levels,' Ter adstructie wan de (psycho-genetische, dat is ontwikkelingspsychologische, met ontwikkelingsstadia samenhangende) 'hiërarchie van de afweer' zou men op het (afweer)fenomeen van de regressie kunnen wijzen (Nieuwe neurosenleer, a.w., pp. 18, 33 i.f. $-35,165-166$ ). Een boeiende adstructie wan dat fenomeen is de (neurotische) verliefdheid: terug in de troostende baarmoeder is niet mogelijk en dan is verliefdheid een gelukzalige - zij het niet zelden al na korte tijid rampzalige - tweede 'keus' (a.w., pp. 89-92). Vgl. Robert J. CAMPBELL, Psychiatric Dictionary, New York/Oxford 1996 (seventh ed.), p. 208 s.v. 'displacement.' 


\title{
BIJLAGE V \\ Persoonlijkheidsstoornissen
}

(Verminkte persoonswording en maligne ontwikkelingspsychopathologie)

Wellicht de meest maligne vorm, in psycho-sociale zin, van ontwikkelingspsychopathologie, van vervorming en verminking van de persoonswording, zowel voor wat betreft de ontwikkeling van rationaliteit (cognitieve stijl), als van moraliteit (gedragsregulering), als van authenticiteit (identiteit), zijn de persoonlijkheidsstoornissen (en dan vooral die uit het zogenaamde B-cluster: de antisociale, de theatrale, de borderline- en de narcistische persoonlijkheidsstoornissen). In deze bijlage worden ter adstructie van dat maligne karakter enkele passages uit de psychiatrische literatuur aangehaald. Om te beginnen uit de Beknopte psychiatrie van GRIEZ: ${ }^{1}$

\begin{abstract}
Meestal zal de last niet in eerste instantie door betrokkene zelf ervaren worden, maar zullen de problemen voortkomen uit interactie met anderen. Pathologische trekken zoals bijwoorbeeld overdreven impulsiviteit, agressiviteit en egocentrisme zijn dan eerder een last voor de omstaanders dan voor betrokkene. (...) Meestal ervaart de persoon met een persoonlijkheidsstoornis wel zeer bewust de moeilijkheden die het gevolg zijn van zijn problematiek, maar hij mist het inzicht en attribueert de oorzaak ervan aan omstandigheden buiten zichzelf. Er is weinig zelfkritiek: per definitie zou de zelfkritick neerkomen op het op het spel zetten van de eigen identiteit. (...) Bij mensen met een persoonlijkheidsstoornis werkt het hele gedragsrepertoire het aanpassingsvermogen tegen en in geval van moeilijkheden is hun reactie meestal probleem-genererend in plaats van probleemoplossend. (...) Daarom hebben mensen met een persoonlijkheidsstoornis niet één of enkele duidelijk verwoorde symptomen of klachten, maar wel talloze grieven over allerlei onbevredigende situaties."
\end{abstract}

\section{ZWANIKKEN e.a. schetsen het ziektebeeld aldus: ${ }^{2}$}

"[O]naangepast gedrag als levenswijze, een starre, weinig beweeglijke manier van hanteren van situaties; een patroon van chronische en levenslange persoonlijke problemen; een verscheidenheid van sociale, persoonlijke en lichamelijke problemen en externalisatie van problemen: anderen en situaties de schuld geven, geen eigen aandeel kunnen zien. Zij lijden, in tegenstelling tot de neurotische mens, alleen onder wat anderen of omstandigheden "'hen aandoen".' 


\section{SCHIPPERS merkt op: $:^{3}$}

'Een persoonlijkheidsstoornis kan woor een persoon [als in het verhaal van Broer Konijn, die in de doornenstruiken geboren en getogen was] een doornenstruik betekenen. Pijnlijk en beperkend maar tegelijk veilig en vertrouwd. De wereld erbuiten is misschien aantrekkelijk en fraai, maar ook vol gevaar en het aangaan van het nieuwe en niet-wertrouwde roept angst op."

Niettegenstaande de opvatting dat "persoonlijkheidsstoornissen in wezen niet te behandelen zijn, enkel te beheersen' (DE MEY), ${ }^{4}$ mag de mogelijkheid van een 'persoonlijkheidsverandering' (VAN KALMTHOUT) ${ }^{5}$ - en daarmee van een ontwikkelingsgang van een gestoorde naar een 'volwassen' identiteit - niet worden uitgesloten. Laatst genoemde auteur spreekt van de 'thematiek van het afsterven van de oude persoonlijkheid en het geboren worden van een nieuwe.' En vervolgt: ${ }^{6}$

'Ik twijfel er niet aan dat ook in de psychotherapie dergelijke grote veranderingen voorkomen. Hoe vaak dat het geval is, weten we niet, en evenmin waar ze aan toegeschreven moeten worden. Niet zelden lijkt een diepgaande crisis te leiden tot zo'n verandering. Een dergelijke crisis kan bijwoorbeeld veroorzaakt worden door een lewensbedreigende zilekte (LESHAN [Cancer as a tuming point, New York] 1989), dreigend ontslag op het werk, een wastgelopen relatie, seksueel misbruik of andere vormen van geweld. In zo'n situatie staan cliënt en hulpverlener voor de keuze of ze de crisis toedekken of de verschrikkingen ervan durven te beleven. In termen van LESHAN is het de keuze voor een keerpunt of voor een terugkeer in het oude patroon. Alleen in het eerste geval kan er sprake zijn van een persoonlijkheidsverandering. Crisissen komen ook buiten de psychotherapie voor en ook daarbij treden vaak ingrijpende veranderingen op.'

\section{VAN KALMTHOUT merkt nog op:?}

'Echte verandering heeft te maken met in beweging zijn, of in technische termen, in-proces-zijn. Zolang dat het geval is, kan gesproken worden van een in principe

3 G.M. SCHIPPERS, 'Cognitieve therapie bij persoonlijkheidsstoornissen,' in: C.P.F. VAN DER STAAK, C.A.L. HOOGDUIN (red.), Diagnostiek en behandeling wan de persoonlijkheidsstoomis, Nijmegen 1990, pp. 59-66, op p. 59.

4 H.R.A. DE MEY, "Eens een persoonlijkheidsstoornis ... altijd een persoonlijkheidsstoornis,' in: a.w., pp. 49-58, op p. 49. DE MEY (t.a.p., op p. 56): 'Persoonlijkheidisstoornissen zijn (...) niet lichtwaardig op te vatten als gedrags patronen die we well even veranderen. (...) Persoonlijkheidsstoormissen (...) zijn (...) erg weerbarstig tegen verandering."

5 M.A. VAN KALMTHOUT, "Psychotherapeutische mogelijkheden bij "persoonlijkheidisstoornissen",' in: a.w., pp. 39-47, op pp. 43-46. 
gezonde situatie, terwijl fixatie als pathologie omschreven moet worden. Niet de problemen, klachten of symptomen zijn voor dit laatste het criterium, maar of er afwezigheid van beweging en verandering is."

Geen enkele confrontatie, geen enkele crisis en geen enkele psychotherapie kan, aldus VAN KALMTHOUT: ${ }^{8}$

'(...) garanderen (..) dat er ook daadwerkelijke veranderingen optreden, laat staan opheffing van de gespletenheid in de persoon. (...) Well wijst het begrip persoonlijkheidsverandering naar een bijzondere menselijke mogelijkheid die zich zowel binnen als buiten de psychotherapie kan voordoen."

Een ander aspect betreft de - meer of minder vloeiende - overgang van de 'normale' persoonlijkheid naar de persoonlijkheidsstoornis. VAN DEN BRINK spreekt in dit verband van een 'overlap tussen pathologie en normaliteit." En DE JONGHE stelt - aan de hand van voorbeelden uit COUPERUS' Eline VERE (1889): ${ }^{10}$

"De genoemde kenmerken zal men wellicht, zij het slechts in beperkte mate, bij zichzelf of bij een buurman, hoe gezond ook, herkennen. (...) Deze kenmerken zijn niet op zichzelf pathologisch. Het feit dat zij, zoals bij Eline, in sterke mate aanwerig zijn ("onaangepast," "constant," "krampachtig") maakt dat zij als pathologisch worden opgevat."

Hij doet dit onder het kopje 'Een continuum tussen normaliteit en as-II[dat is persoonlijkheids-, jw] pathologie. ${ }^{11}$ Daarnaast onderstreept deze auteur de relatie tussen structurele (c.q. ontwikkelings-) en descriptieve (DSM-)pathologie, en bepleit hij op basis daarvan de aanvulling van de (horizontale) DSM-as (as II) met een verticale (structurele c.q. ontwikkelings)as, 'die de ernst van de pathologie aangeeft,' en 'waarvan de ene

VAN KALMTHOUT, t.a.p., op p. 46. Vgl. met betrekking tot (de mogelijkheden en onmogelijkheden van) de behandeling van persoonlijkheidsstoornissen (ook) J.J.L. DERKSEN, Handboek persoonlijkheidsstoomissen; Diagnostiek en behandeling van de DSM-IV en ICD-10 persoonlijkheidsstoomissen, Utrecht 1993, pp. 174-182.

9 W. VAN DEN BRINK, 'Leugens, misvattingen en potenties; DSM-III en DSM-III-R persoonlijkheidsstoornissen, "in: R.V. SCHWARZ, D.H. LINSZEN (red.), Persoonlijkheidsstoomissen;, Diagnostiek, behandeling beleid, Amsterdam/Lisse 1991, pp. 2131 , op p. 28 .

10 F. DE JONGHE, 'Descriptieve en structurele persoonlijkheidspathologie,' in: a.w., pp. 33-48, op pp. 38-39 (curs. jw).

11 Vgl. in dit verband evenwel ook DERKSEN, Handboek persoonlijkheidsstoomissen, a.w., pp. 175/176, waar de kanttekening wordt gemaakt "dat de stelling dat persoonlijkheidspathologie en normaliteit op eenzelfde dimensie liggen, niet opgaat voor alle persoonlijkheidsstoornissen.' 
pool de utopische normaliteit (oftewel volwassenheid) voorstelt en de andere de psychose,' ${ }^{12}$ met daartussenin de karakterneurotische pathologie, de ontwikkelingspsychopathie en de borderline-pathologie. ${ }^{13}$

KERNBERG onderscheidt in dit verband drie organisatieniveaus van het ego: de neurotische persoonlijkheidsorganisatie, de borderlinepersoonlijkheidsorganisatie en de psychotische persoonlijkheidsorganisatie. ${ }^{14}$ KERNBERG merkt op: ${ }^{15}$

'Underlying all my work is the conviction that the psychopathology of personality is determined by the psychic structures erected under the impact of affective experiences with significant early objects [lees: de ouders/opvoeders, $j w$ ]. This conviction is expressed in my emphasis on the need to integrate a diagnostic system. based upon description of behavior [lees: de $D S M-I V, \mathrm{jw}$ ] with a psychodynamic approach centered on psychic structure formation. (...)

$[\mathrm{M}] \mathrm{y}$ focus is on (...) structured aggression in the form of chronic hatred and secondary defenses against this hatred. The interplay among identity diffusion, reality testing, and treatment stalemates is explored through the entire spectrum of personality disorders from neurotic through borderline and psychotic organizations.'

In de (descriptief opgezette) DSM-IV (APA 1994), ${ }^{16}$ de opvolger van de $D S M-I I I-R$ (1987), wordt een dozijn persoonlijkheidsstoornissen onderscheiden, ondergebracht in drie clusters en een restcategorie. Tot het (de werkelijkheid ontvluchtende, 'psychotische') A-cluster behoren de paranoïde persoonlijkheidsstoornis (typering: te waakzame persoonlijkheidsstijl; trefwoorden: achterdochtig, rancuneus) en de schizoïde en schizotypische persoonlijkheidsstoornissen (respectievelijk te eenzelvig en te excentriek).

Tot het (externaliserende, anti-sociale) B-cluster behoren de antisociale (eufemistisch: te avontuurlijke) persoonlijkheidsstoornis (trefwoorden: onverantwoordelijk, leugenachtig, roekeloos, gewetenloos); de borderline-persoonlijkheidsstoornis (het te wispelturige 'kantje-boordkarakter" op de grens van neurose en psychose; trefwoorden: instabiel qua zelfbeeld, affecten en relaties: anderen beurtelings idealiserend/verafgodend

T.a.p., op pp. 45 resp. 44.

13 Zie hiervoor de bijdrage van $H$. VAN MARLE, 'Motivatie in de klinisch forensisch psychiatrische behandeling,' in: SCHWARZ/LINSZEN, a.w., pp. 87-96, op p. 90. Zie DERKSEN, Handboek persoonlijkheidsstoomissen, a.w , pp. 36-38 en 107 e.v., op p. 108 r.k.

Otto F. KERNBERG, Aggression in personality disorders and perversions, New Haven/London 1992, pp. vii-viii.

16 Diagnostic and Statistical Manual of mental disorders; Fourth edition/DSM-IV, American Psychiatric Association, Washington 1994, pp. 629-673 en 732-735. 
en demoniserend/kleinerend); de theatrale (te dramatische) persoonlijkheidsstoornis (trefwoorden: onecht, oppervlakkig, buitensporig aandacht vragend, erotiserend), en de narcistische (te zelfbewuste) persoonlijkheidsstoornis (belangrijkste trefwoorden: grootheidsgevoelens, gebrek aan empathie).

Tot het (internaliserende, sociaal-angstige, 'neurotische') C-cluster behoren de ontwijkende (te gevoelige) persoonlijkheidsstoornis; de afhankelijke (te aanhankelijke) persoonlijkheidsstoornis, en de obsessief-compulsieve persoonlijkheidsstoornis (te gewetensvol, dwangmatig).

Tot slot zou nog een ' $D$-cluster' kunnen worden onderscheiden, een restcategorie waarin zowel gemengde persoonlijkheidsstoornissen als de in de appendix bij de $D S M-I V$ opgenomen depressieve en passief-agressieve (negativistische) persoonlijkheidsstoornissen kunnen worden ondergebracht. Daarnaast kunnen (onder meer) nog worden onderscheiden de 'masochistische' (te dienstbare, zelfondermijnende) en de 'sadistische' (te agressieve) persoonlijkheidsstoornis, die waren opgenomen in appendix $\mathrm{A}$ van de $D S M-I I I-R$, alsmede de (psycho-)infantiele persoonlijkheidsstoornis. ${ }^{17}$ Men vergelijke tevens de waslijst aan ICD-10 (International Classification of Diseases and related health problems, Tiende Revisie, WHO 1992) persoonlijkheidsstoornissen. ${ }^{18}$

Persoonlijkheidsstoornissen liggen niet zelden ten grondslag aan (gewelds)delicten, verslavingen en relationele en gezinsproblematiek, zoals DERKSEN opmerkt in zijn (al eerder aangehaalde) Handboek persoonlijkheidsstoomissen: ${ }^{19}$

'Mensen met een persoonlijkheidsstoornis zijn in veel gevallen moeilijke mensen voor hun gezins- en familieleden, voor hun werkgevers en voor de hulpverleners (...). $\mathrm{Zij}$ zien de wereld en niet zichzelf als uit de pas lopend. Een gevolg hiervan is dat zij niet worden begrepen en dit proces stimuleert hun deviatie.

De studie van persoonlijkheidsstoornissen kan in potentie een belangrijke bijdrage leveren aan de geestelijke wolksgezondheid en aan het maatschappelijk welbevinden. Tenslotte liggen er veelal persoonlijkheidsstoornissen ten grondslag aan die dingen waar we tegenwoordig veel last van ondervinden: geweldsdelicten en andere misdrijven, misbruik en afhankelijkheid van een groot aantal middelen, zelfdodingen, relatie- en gezinsproblemen. Darrel REGIER, directeur onderzoek van het Amerikaanse National Institute of Mental Health, vindt dat, zodra we de

17 Vgl. DERKSEN, Handboek persoonlijkheidsstoomissen, a.w., pp. 38 l.k., 108 r.k., 136 l.k., 202 r.k. Vgl. over het 'onrijpe' ('infantiele') karakter ook Johan CULLBERG, Modeme psychiatrie, Baarn [1990] (tweede druk), pp. 143-145.

De ICD-10 classificatie van psychische stoomissen en gedragsstoomissen, World Health Organization/Nederlandse Vereniging voor Psychiatrie, Lisse 1994, pp. 222-232 (vgl. ook de index op pp. 367-368 s.v. persoonlijkheidsstoornis). 
etiologie begrijpen en succesvolle behandelingen hebben woor "malar" twee typen persoonlijkheidsstoornissen, de bordertine- en de antisociale [persoonlijkheidsstoornis], de voordelen voor de [betrokken] individuen en de samenleving als geheel niet meer in getallen zijn uit te drukken $(\ldots)$."

Deze voorspelling lokt de verwoording van een andere voorspelling uit, de verwachting namelijk dat een effectief sociaal-pedagogisch vangnet dat de verslimmering en verstarring van ontwikkelingsproblematiek tot persoonlijkheidsstoornissen voorkomt, zichzelf veelvaldig terugverdient. Ook hier geldt niettemin dat de kost voor de baat uitgaat. De kosten ten behoeve van de kernrechten van het kind zullen de maatschappij in de toekomst evenwel thans nog nauwelijks voorstelbare winsten opleveren - in immateriële èn materiële zin. Het vergt geen glazen bol, doch slechts inzicht in de in deze paragraaf door diverse auteurs beschreven processen, om deze voorspelling te kunnen doen.

Een tweede citaat uit DERKSENs Handboek diene in dit verband ter illustratie van deze voorspelling, en plaatst deze tegelijk in een bredere (sociaal-pedagogische) context: ${ }^{20}$

"De condities tijdens de kinderjaren worden door praktisch alle richtingen binnen het veld van de psychopathologie als relevant voor de persoonlijkheidsontwikkeling beschouwd. Onder de dekmantel van deze ruime aanduiding vallen heel verschillende processen.

[1] De opvoeding en verzorging van zuigeling, baby, peuter en kleuter vallen er onder. Het is wellicht overbodig op te merken dat de opvoeding volgens geheel verschillende stijlen kan plaatsvinden. Die stijlen hangen samen met de persoondijkheden van de ouders (...).'

Ook hier kan worden teruggehaald wat we in deze studie opmerkten over ouderlijk pedagogisch besef als resultante van de ouderlijke voorgeschiedenis; dat wil zeggen de eigen meer of minder traumatische, door meer of minder veilige gehechtheid gekenmerkte persoonswordings- c.q. persoonlijkheidsontwikkelingsgeschiedenis van de ouders, en wat zij vanuit die geschiedenis en latere verwerking en vorming/scholing aan pedagogisch besef hebben meegekregen (opvoeding/scholing) c.q. verworven (zelfbepaling/vorming). We onderbraken DERKSEN:

'[2a] De trauma's die van buitenaf invloed kunnen uitoefenen op het proces van opvoeding en verzorging horen eveneens bij genoemde condities. Hierbij kan men denken aan ziekenhuisopname van de moeder tijdens de vroege kindertijd, een ongeval, een ramp in de vorm van een oorlog etcetera. Afhankelijk van de precieze aard van het trauma, de leeftijd van het kind en de wijze waarop met de ge- 
beurtenis in relatie tot het kind is omgegaan [ook hier dus: afhankelijk van ouderlijk pedagogisch besef, jw] krijgt deze verstoring [haar] invloed op de ontwikkeling van de persoon.

[2b] Trauma's kunnen daarnaast ook door de ouders of gezinsleden zelf worden gecreeterd. Inmiddlels is op basis van empirisch onderzoek herhaaldelijk gewezen op de rol van verwaarlozing, fysiek en seksueel misbruik van het jonge kind bij het ontstaan van met name de borderline- en de antisociale persoonlijkheidsstoornis. Meer generaliserend kunnen we opmerken dat trauma's die van buitenaf de verzorging verstoren [en door de ouders niet adequaat (kunnen) worden tegemoet getreden of door de ouders worden verwaarloosd, jw] of worden veroorzaakt door het gedrag van de ouders, schade van structurele aard kunnen achterlaten indien ze het kind op zeer jonge leeftijd treffen. Bij structurele schade moeten we dan denken aan aantasting van de ego-structuur. In deze gevallen moeten we er rekening mee houden dat er eerder van een defect dan van een conflict in de persoonlijkheidsstructuur sprake zal zijn. Het resultaat hiervan zien we terug in persoonlijkheidsstoornissen van het cluster-A of cluster-B type, functionerend op borderline- of psychotisch niveau. In mindere mate geldt dit voor een persoonlijkheidsstoornis uit het C-cluster [functionerend op neurotisch niveau, jw].

[3] De relatievorming tussen het kind en de verzorgers speelt voorts een belangrijke rol. In de meer klinische literatuur over de genese van de borderline-persoonlijkheidsstoornis wordt een verstoring van het separatie-individuatieproces door veel auteurs als hoofdoorzaak aangewezen. Vanuit de theorie van de objectrelaties gezien, worden de vroegkinderlijke relaties door het opgroeiende kind verinnerlijkt: wat in aanvang tussen het kind en de ouders bestond, bestaat later binnen de volwassene. Meer concreet gezegd: zoals vroeger de ouders met het kind spraken, zo prat de volwassene nu met zichzelf.'

Een ouderlijk gesprek dat pedagogisch adequaat was getoonzet, of waarin pedagogische onmacht werd overschreeuwd. Een kinderlijk innerlijk gesprek waarin desgelijks - tot ver in de volwassenheid - zuivere of valse tonen de muziek bepalen.

"[4] Voorts vallen onder dit aspect ook de gevoels- en fantasieprocessen van het kind zelf. De perceptie van het kleine kind wordt in hoge mate gestuurd vanuit deze processen en van deze perceptie gaat weer een bepaalde invloed uit op de psychologische ontwikkeling.'

Doch ook hier: processen die plaatsvinden binnen een pedagogisch adequaat dan wel tekortschietend kader, en daarmee in wisselwerking staan. We rijgen nog enkele zinnen uit DERKSENs Handboek aaneen.: ${ }^{21}$

"In studies naar de gezinsachtergrond van borderline-patiënten komen fysiek en seksueel misbruik frequent naar voren. (...) 
In het geval van de borderine-stoornis is inmiddels door onderzoek weel bekend over fysieke en psychische mishandeling en seksueel misbruik. (...)

Volgens onderzoek van HERMAN c.\$. (1989) is $81 \%$ van de volwassen borderlinepatiënten in hun kindertijd getraumatiseerd door fysiek of seksueel misbruik of doordat ze getuige waren van ernstig geweld. (...)

De meeste clinici kunnen het er over eens zijn dat een factor van berckenis voor een gestoorde persoonlijkheid van het borderline-, narcistische of antisociale type is gelegen in de kindertijd. (...) In deze vroege ervaringen treden de eerste verstoringen in de psychologische ontwikkeling op die verwolgens versterkt of verzwakt, gecompenseerd of niet gecompenseerd worden door de ontwikkelingen die hierop volgen."

\section{Waaraan we tot slot een kort citaat van VERHEUL toevoegen: ${ }^{22}$}

'[E]motionele verwaarlozing en lichamelijk en seksueel geweld [zijn] sterke risicofactoren voor het ontstaan van de borderline- en de antisociale persoonlijkheidsstoornis. Zo ontwikkelen kinderen die al vroeg en langdurig te maken krijgen met incest of andere vormen van geweld en dwang, vaak ernstige borderline-pathologie zoals impulsiviteit [gebrekkige impulscontrole, verslavingen e.d., jw], zelfverminkingen [automutilatie, jw] en dissociatie-verschijnselen.'

Een waarschuwend woord is hier wellicht nog op zijn plaats. Mensen met persoonlijkheidsstoornissen uit het 'anti-sociale' B-cluster (de borderline-, antisociale, narcistische of theatrale persoonlijkheidsstoornissen) zijn niet per definitie criminelen, of gedoemd dat te worden, in de morele of strafrechtelijke zin van het woord. Voor een lichtend voorbeeld verwijs ik naar VAN REE, de psychiater-psychotherapeut die bij zichzelf een antisociale persoonlijkheidsstoornis met kenmerken van een borderline- en een theatrale persoonlijkheidsstoornis diagnostiseerde (gepaard aan onder meer de volgende as-I-pathologie: nicotine- en alcohol-afhankelijkheid, sexuele dysfunctie en hypochondrie). ${ }^{23}$ In zijn "Ten geleide' bij VAN REE's Mijn zelfonderzoek schrijft VAN DANTZIG:24

'Hij] [VAN REE] is vaak niet makkelijk geweest, niet voor anderen, maar ook niet voor zichzelf. Dat laatste blijkt ook het feit dat hij dit boek geschreven heeft. Een poging tot zelfanalyse zoals VAN INEE in dit boek aangaat, is niet alleen een groot werk, het moet ook angstaanjagend geweest zijn om de verlegenheid en schaamte te overwinnen zoals voor ons allen nodig zou zijn om, zoals VAN REE zo duidelijk probeert, voor de waarheid over zichzelf uit te komen.'

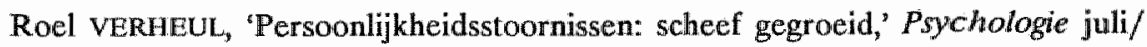
augustus 1995 , pp. $54-58$, op p. 58 l.k.

23 Frank VAN REE, Mijn zelfonderzoek: een tenugblik; Frank VAN REE over het belang van leertherapie, Lisse 1996, pp. 95-106.

A. VAN DANTZIG, "Ten geleide," a.w., p. 9. 


\section{BIJLAGE VI \\ Persoonlijkheidsstijlen \\ (Omgeving/opvoeding en ontwikkeling van stijl en stoornis)}

Hierboven (in bijlage $v$ ) viel de term persoonlijkheidsstijl (deze zou bij de paranoïde persoonlijkheidsstoornis te waakzaam zijn). Deze term, mijn vertaling van character styles, ontleen ik aan JOHNSON. ${ }^{1}$ We zouden hier van een etiologische variant van de DSM-IV kunnen spreken. Waar de $D S M-I V$ gedragingen (c.q. trekken) beschrijft ten behoeve van een diagnostisch (of liever: een categoriserings)systeem, ${ }^{2}$ presenteert JOHNSON een structureel ontwikkelingscontinuum ${ }^{3}$ ten behoeve van een karakterologisch systeem, een persoonlijkheidsleer gebaseerd op structurele aanpassingen in kritische ontwikkelingsperioden (hechting, ik-ander differentiatie, individuatie). ${ }^{4}$ In de woorden van de auteur: ${ }^{5}$

"What developmental theory and research have given us is an increasingly broad yet increasingly precise description of human nature. This particularly includes the kinds of needs humans must have met and the kinds of environments that must be provided to achieve human potential. Similarly, observations of children in development tell us what happens when these needs are chronically frustrated or when the needed environments are not provided. (...) [T] he theories suggest what to look for and posit the most central relationships between early environment and resulting development.

I [have] always found the most fascinating application of this basic knowledge to involve answering the (...) question: "Why are we so crazy?" It's obvious that were it not for our craziness, there would be so much less suffering and destruction in the world. Humans solve problems far better than any other life-form but our craziness interferes profoundly with that process at every level. It is in the family, the workplace, and the politics of humankind that we see the colossal waste and pain of our proclivity for destructive dysfunctionality. (...)

Now (...), [t]he studies of human development or human nature fit very nicely with the descriptions of the patterns of human craziness. Furthermore, these patterns don't just occur in the most severe forms of mental illness. Such patterns are clearly documented in normal populations and in less severely pathological

1 Stephen M. JoHNSON, Character styles, New York/London 1994.

2 Vgl. J.E. DE BOER, 'Infantpsychiatrie,' in: dez. (red.), Infantpsychiatrie I; De gezonde en verstoorde ontwikkeling van de vroege ouder-kind relatie, Assen/Maastricht 1991, pp. 3-22, op p. 9.

3 Vgl. hiervoor zowel Table 1, op pp. 12-13, als Table 2, op p. 20, van Character styles.

4 JOHNSON, Character styles, a.w., pp. 17-18 en 12-13 (Table 1).

5 JOHNSON, a.w., pp. xvi-xvii (curs. zowel overgenomen als aangebracht). 
groups. I believe there are several useful continua of human dysfunction from the most to the least severe, which reflect quintessential building blocks of human nature. I believe I've found seven such building blocks around which personality and psychopathology are organized. There may be more.

Critical to any individual's adjustment on any of these continua is interaction. That interaction is between the individual, with his changing but basic needs, and the changing environment's ability to meet them. Such interaction makes personality and produces psychopathology. In an era when our most basic science, particle physics, asserts that matter itself is made of interaction, we are ripe to understand and experience our personality and our personal pathology as the product of interaction.

The interactional perspective in psychiatry is far from new. [Since 1952] (...) object relations theory (...) emphasizes the role of the parent-child relationship in the development of personality and psychopathology. (...) What is necessary [however] for a more profound understanding of [human nature] is the integration of developmental process, interactional determinants, and characterological syndromes."

JOHNSON introduceert vervolgens een 'persoonlijkheidsontwikkelingstheorie': een (eclectische ${ }^{6}$ ) ontwikkelingspsychologische (etiologische) persoonlijkheidsleer, rond de persoonlijkheidsthema's hechting en bonding, 'de ontwikkeling van het zelf' en 'het zelf in het systeem.' Op basis daarvan komt hij tot zeven persoonlijkheidsstijlen (c.q., in de ergste mate: persoonlijkheidsstoornissen): 1.) die van het (eigenlijk) gehate kind: de schizoïde ervaring ten gevolge van de frustratie van veiligheid ${ }^{7} ; 2$.) die van het verlaten kind: de symbiotische terugtrekking ten gevolge van de frustratie van basale behoeften ${ }^{8}$; 3 .) die van het bezette kind: de symbiotische persoonlijkheid als 'product' van grensoverschrijdingen (het niet respecteren van grenzen) ${ }^{9}$; 4.) die van het gebruikte kind: de narcistische ervaring ten gevolge van de frustratie van eigenwaarde ${ }^{10}$; 5.) die van het verslagen kind: sociaal 'masochisme' en patronen van zelf-sabotage ten gevolge van de frustratie van vrijheid ${ }^{11} ; 6$.) die van het misbruikte kind: hysterische afweer en de theatrale persoonlijkheid ten gevolge van de

Vgl. a.w., p. xix if.

7 Character styles, a.w., pp. 21-27 en 73-99 (zie in het bijzonder Table 3 ad Etiological constellation/parenting (style), p. 26).

8 Character styles, a.w., pp. 27-34 en 100-128 (zie in het bijzonder Table 4 ad Etiological constellation/parenting (style), pp. 33-34, op p. 33).

9 Character styles, a.w., pp. 35-41 en 129-154 (zie in het bijzonder Table 6 ad Etiological constellation/parenting (style), pp. 39-40, op p. 39).

10 Character styles, a.w., pp. $41-47$ en 155-191 (zie in het bijzonder Table 7 ad Etiological constellation/parenting (style), pp. 45-46, op p. 45).

11 Character styles, a.w., pp. 47-53 en 192-229 (zie in het bijzonder Table 8 ad Etiological constellation/parenting (style), pp. 51-52, op p. 51). 
frustratie van liefde als onderscheiden van $\operatorname{sex}^{12} ; 7$.) die van het gedrilde kind: de dwangmatige persoonlijkheid ten gevolge van de frustratie van 'oedipale' ontwikkelingstaken ${ }^{13}$; welke frustratie optreedt door ...

"(...) over-controlling, rigid, rule-bound, and exacting parenting, which disallows spontaneity and flexibility in socialization and moral development. ${ }^{, 14}$

Voor de goede orde: buiten JoHNSONs model valt alle persoonlijkheidspathologie met (overwegend of ten dele) organische of genetische oorzaak: psychosen, bipolaire en antisociale (socio- of psychopathische) stoornissen en autisme. ${ }^{15}$ Hij presenteert met andere woorden een "functioneell" model ...

'(...) meaning that it covers that which can be attributed to environmental as opposed to organic or genetic causes. ${ }^{\text {,16 }}$

In de zeven genoemde persoonlijkheidsstijlen herkennen we - à outrance (dat wil zeggen aan het gestoorde einde van het continuum): ${ }^{17}$ de schizoïde, schizotypische en ontwijkende ${ }^{18}$ persoonlijkheidsstoornissen (ad 1); de afhankelijke persoonlijkheidsstoornis (ad 2); de borderline- en afhankelijke persoonlijkheidsstoornissen (ad 3); de narcistische persoonlijkheidsstoornis (ad 4); de 'masochistische' persoonlijkheidsstoornis (ad 5); de theatrale persoonlijkheidsstoornis (ad 6); en de obsessief-compulsieve persoonlijkheidsstoornis (ad 7).

12 Character styles, a.w., pp. 54-61 en 230-265 (zie in het bijzonder Table 9 ad Etiological constellation/parenting (style), pp. 59-60, op p. 59). Character styles, a.w., pp. 61-70 en 266-290 (zie in het bijzonder Table 10 ad Etiological constellation/parenting (style), pp. 68-69, op p. 68).

14 JOHNSON, Character styles, a.w., p. 271 (iff.).

15 JOHNSON, a.w., pp. $18 / 19$.

16 JOHNSON, a.w., p. 18 i.f.

17 JOHNSON, a.w., pp. 12-13 (Table 1 r.k.).

18 Op het continuum persoonlijkheidsstijl-karakterneurose-persoonlijkheidsstoornis plaatst JoHNSON deze stoornis onder de karakterneurose (t.a.p.). 


\section{BLILAGE VII}

Opvoedingsvrijheid en persoonswording: waar staat de staat? (Het doorbreken van het privacy-paradigma)

'Kindervolkenrecht is het rechtsgebied, de internationale (universele) rechten van het kind betreffende, dat de omtrek en inhoud van de secundaire opvoedingsverantwoordelijkheid van staten in kaart wil brengen.' Zo staat er in (de samenvatting van) dit boek te lezen. Wat betekent dit, in gewoon Nederlands, met betrekking tot enerzijds de opvoedingsvrijheid van ouders en anderzijds de plaats van de overheid? De sleutel voor het antwoord op deze vraag ligt besloten in de term 'de rechten van het kind.' De opvoedingsvrijheid van ouders en overheidsbemoeienis dan wel -onthouding ten aanzien van het gezin worden namelijk door die rechten, de rechten van het kind, beperkt. In hoofdstuk 14 wordt betoogd dat de overheid deze rechten, in het bijzonder - of liever in de kern - het recht van het kind op (optimale) persoonswording, dient te waarborgen door:

1. een integraal kind- en gezinsbeleid (trefwoorden: structurelle preventieve benadering, algemene sociaal-pedagogische infrastructuur, sociaal-pedagogisch vangnet voor risico-gezinnen; pijlers: opvoedingsonderwijs, opvoedingsondersteuning, opvoedingsgeld);

2. een beleid van (op risico-gezinnen) toegespitste opvoedingsondersteuning (screening op basis van risico-indicatoren in een drie-echelonsmodel; trefwoorden: vroegtijdig/prenataal, niet-stigmatiserend, antiescalatoir);

3. een beleid gericht op het centraal stellen van de vraag (bij een cumulatie van risico-indicatoren): hoe en in hoeverre zijn de eigen (traumatische/pedagogisch-deficiënte) jeugdervaringen van de (aanstaande) ouders verwerkt/gerepareerd? En het op basis van het antwoord op die vraag en de eigen wensen van (aanstaande) ouders doen van een passend ondersteuningsaanbod.

4. een algemeen (voorlichtings)beleid gericht op het doorbreken van het privacy-paradigma.

Bij dat laatste staan we in deze bijlage nog kort stil. Wat wordt bedoeld met 'het doorbreken van het privacy-paradigma"? In essentie dit: het doorprikken van de mythe van de staatsvrije sfeer als het om opvoeding, of liever: om de ontwikkeling, de persoonswording van kinderen, gaat. Een drietal (aangepaste) citaten bij één auteur mag volstaan om dit toe te lichten (het derde citaat wordt door een korte conclusie ingeleid), waarna - in en door een vierde (in tweeën geknipt) citaat - de horizon achter de doorgeprikte mythe wordt getoond. 
"[E]en staatsvrije sfeer vind ik (...) "een aanmatigend woord." (...) [Hoe licht wordt niet] "[h]et spook van de verderfelijke overheidsinvloed (...) opgeroepen, een overheid die zich van elke inmenging dient te onthouden, doch [die] tezelfdertijd wel als financiële melkkoe mag, neen moet optreden".

'In zijn Groninger rede heeft DONNER gesteld dat het recht op een adequate grondwetsbepaling één van de meest fundamentele grondrechten vormt. Geldt dit niet voor (....) [het recht van het kind op optimale persoonswording, en dus voor de secundaire opvoedingsverantwoordelijkheid van de staat als stut en staf voor de ouderlijke opvoedings]vrijheid (...)? Of draagt de vraag naar een meer moderne invulling van die vrijheid per se de smaad van [haar] nieuwigheid? ${ }^{2}$

Concluderend: de secundaire opvoedingsverantwoordelijkheid van de staat/overheid beweegt zich op de 'rechten'-as van (sub)minimale naar optimale persoonswording van kinderen, (mede) afhankelijk van het niveau van pedagogisch besef van de desbetreffende ouder(s), en op basis van wettelijke waarborgen voor kinderen en voor ouders. $\mathrm{Zij}$ beweegt zich niet op de "mythische" as van ouderlijke opvoedingsvrijheid naar staatsopvoeding, al of niet in de vorm van een opvoedingsmonopolie van de staat, welke in plaats van de voorwaarden voor vrijheid te scheppen, het hart uit elke vrijheid zou snijden. Om ten aanzien van deze mythische as met THORBECKE te spreken: ${ }^{3}$

"De "buitensporigheid dezer leer" (van het [opvoedings]monopolie van de staat) heeft nu, aldus THORBECKE, "uit louter ontkennend beginsel eene algemeene individuele vrijheid doen inroepen," ondersteund door betogen over de voorrang van de ouderlijke macht (...). "Zelfs mannen van een niet gewoon doorzigt hebben zich in de bekrompenheid dezer [ouderlijke monopolie-]leer laten vangen, om de dwingelandij der andere te ontduiken".'

Wat met deze (aangepaste) citaten in negatieve zin dan wel vragenderwijs ten aanzien van opvoedingsvrijheid is aangeduid, is als volgt als positief antwoord uit de mond van (psychiater) VAN DANTZIG opgetekend: ${ }^{4}$

CRINS, met aanhaling van resp. SCHELFHOUT en PEPER (zoals aangehaald door VAN KREVELD): F.C.L.M. CRIJNS, "De herziening van artikel 208 [huidig art. 23] van de Grondwet: het loon van de angst?' In: A.K. KOEKKOEK e.a. (red.), Grondrechten; Commentaar op hoofdstuk 1 van de herziene Grondwet (zogenaamde JEUKENSbundel), Ars Aequi Libri, Nijmegen 1982, pp. 439-505, op p. 485 (bij nt. 256-257).

2 (Naar) CRINS, t.a.p., op p. 505.

3 (Naar) CRLINS, t.a.p., op pp. 486/487.

4 Monic SLINGERLAND, "VAN DANTZIG wil staatssecretaris geestelijke gezondheidszorg,' Trouw van 6 juni 1998, p. 9. 
"Volgens VAN DANTZIG is er, in werhouding tot de schade, maar weinig aandacht voor problemen in opvoeding, huwelijk [en] gezin, en vergen die een structurele aanpak. (...) "(...) Het gaat erom, met een centraal beleid, de schade zo klein mogelijk te houden. Dat kan alleen als naast het bestrijden van de witwassen er ook een beleid komt tot bevordering van de geestelijke gezondheid [en in het bijzonder van de persoonswording, jw]. Het is onvolledig in dit geval wan preventie te spreken. [Geestelijke gezondheidszorg c.q. eem (centraal en structureel) algemeen sociaal-pedagogisch beleid, jw] is niet alleen een kwestie van het voorkómen van beschadiging, net zomin als leesonderwijs het voorkomen van analfabetisme is."

VAN DANTZIG is voorstander van overheidszorg op het gebied van opvoeding en huwelijk, terreinen die in de Nederlandse democratie als privé beschouwd worden. De weerstand tegen ingrijpen in en controle van hogerhand op opvoeding en huwelijk is groot. Dat hoeft volgens de psychiater geen reden [te] zijn om af the zien van hulp bij huwelijk of ouderschap. "(...) [D]e verantwoording voor de opwoeding is zo groot dat het niet billijk is dit over te laten aan willekeurig twee mensen die daar geen enkele opleiding voor gekregen hebben." VAN DANTZIG noemt het gezin "iets kostbaars, maar vaak ook een structuur die de problemen verbergt."

Het is een kwestie van wennen, maar wennen gaat snel. "Neem de seksuele voorlichting. In mijn tijd was het ondenkbaar dat daar op school over gesproken werd. Nu is het vreemd als het niet gebeurt," zegt VAN DANTZIG. Zo zou het ook moeten gaan met lessen met-elkaar-omgaan, lessen in invoelingsvermogen, of het voeren van een gesprek. Lessen voor kinderen en docenten, want VAN DANTZIG denkt ook aan het signaleren van mishandeling en emotionele verwaarlozing en aan een meldpunt voor stille kinderen. Het gaat erom tot een cultuur te komen waarin het gewoon is dat de gemeenschap helpt bij het grootbrengen van kinderen.'

Dat laatste - hulp van de gemeenschap - geldt dan in het bijzonder als er sprake is van discontinuiteit: ${ }^{5}$ als de natuurlijke stroom van geven en nemen (in die volgorde) tussen de generaties is doorbroken door kindermishandeling, verwaarlozing, incest. Ouders met zulke "discontinuïteitservaringen' - ouders die als kind hebben moeten geven in plaats van dat hun gegeven werd, en die tengevolge daarvan in hun latere leven hebben moeten ervaren dat hun ook het weinige aan eigenwaarde dat zij hadden, nog ontnomen werd (Mattheüs-effect) -, verdienen extra en gerichte steun bij de opvoeding. Wat in het bijzonder wil zeggen: steun gericht op verwerking van de eigen jeugdervaringen, op het leren omgaan met discontinuilteitspijn, -ambivalentie en -vragen ('hoe kan ik mijn kind geven wat ik zelf nooit kreeg?').

We onderbraken VAN DANTZIG, die de horizon verbreedt tot opvoedingslessen voor de democratie:

Vgl. Phily ELST, 'Van afgewezen dochter naar liefdevolle moeder,' Psychologie juni 1998 , pp. 20 en 22 , op p. 22. 
"Alle orthodoxe gemeenschappen geven kinderen les in de regels. Dat geldt voor de marxistische gemeenschap, voor de orthodox protestantse, voor de katholieke. Maar hoe zit het met de democratie? Krijgen kinderen wel les in de regels daar$\operatorname{van} ?^{6}(\ldots)^{\text {n }}$

Volgens VAN DANTZIG heeft in elk maatschappelijk systeem de gemeenschap - de overheid of de kerk - een aandeel in de opvoeding van het kind tot lid van de gemeenschap waarvan het deel gaat uitmaken, behalve in de democratie. "De democratie is het hoogtepunt van de beschaving. De democratie verdient het daarom dat kinderen opgevoed worden in het besef wan die waarde en in de regels die gevolgd moeten worden om die democratische gemeenschap gezond te maken en te houden. Hett is niet voldoende volwassenen aan te sporen te komen tot een civil society. Waarden worden in de kindertijd verworven en daar moet actief aan gewerkt worden."

VAN DANTZIGs voorstel voor een centraler beleid voor geestelijke gezondheid is wel afgedaan als utopisch. "[D]at heeft men ook eeuwenlang gedacht van gezondheidszorg, onderwijs en basisvoorzieningen. Die zijn er wèl gekomen".'

Zolang opvoedingsvrijheid gekleed gaat in het privacy-paradigma, is het de vrijheid, de vrijheid-zonder-overheidsverantwoordelijkheid, die onderdrukt. De utopie van het recht dat bevrijdt, is in de geschiedenis evenwel vaker een voertuig van menselijke beschaving en vooruitgang gebleken. ${ }^{7}$

Zoals voorgeschreven door art. 29, lid 1 aanhef en onder b-e van het Verdrag inzake de rechten van het kind.

7 Utopie niet in de zin van het magische en megallomane denken dat we tegenkomen bij op (zeer) jonge leeftijd ernstig getraumatiseerde (kinderbeschermings-) kinderen (VAN NUNATTEN), en andere "fantasten" die nooit volwassen worden, doch in de zin van een beginselgericht en beginselgeleid natuurrechtsdenken, dat wil zeggen een denken over recht in termen van rechtvaardigheid, gelijkheid en menselijke waardigheid, dat is: inclusiviteit (waarvoor nodig is solidariteit), emancipatie en positieve vrijheid (ofwel optimale persoonswording en ontplooiing). Vgl. voor de on-utopische utopie van het recht Hans CROMBAG en Frank VAN DuN, De uropische werleiding, Amsterdam/Antwerpen 1997, pp. 28/29, 43-44, 46, $70-71,127-129,194-197,233-234,249,257 / 258$ en 259 . 


\section{BIJLAGE VIII}

\section{Korte omschrijving van enkele in deze studie gehanteerde sa- menhangende termen}

\section{Ernstige en passief-systematische mensenrechtenschendingen:}

Ernstig = grof en grootschalig.

Grof = leidende tot ernstig lijden (het gaat om de schending van kernrechten). Grootschalig $=$ zeer velen zijn het slachtoffer (in de eerste en ergste plaats kinderen, in afgeleide zin ook ouders).

Passief-systematisch = de overheid is passief ten opzichte van het privacy-systeem; dat wil zeggen de overheid houdt de maatschappelijke privacy-cultuur (= parentiarchie) in stand en maakt deze daardoor tot een statelijk privacy-systeem, waar zij vervolgens weer passief tegenover staat; het privacy-systeem op zijn beurt houdt een situatie van transgenerationele discriminatie in stand $(=$ sociaal-pedagogische kwestie).

Transgenerationele discriminatie $=$ de sociaal-pedagogisch zwaksten in de samenleving aan hun (transgenerationele) lot overlaten, zodat onveilige gehechtheidsrelaties en chronische traumatisering (en daarmee ontwikkelingspsychopathologie c.q. een gebrek aan pedagogisch besef) in principe (dat wil zeggen behoudens toevallige verwerking in individuele gevallen) van generatie op generatie worden doorgegeven.

Aan hun (transgenerationele) lot overlaten = niets doen (staatsonthouding) of ten hoogste onderwerpen aan een systeem van ex post-interventionisme.

Ex past-interventionisme $=$ in plaats van een structurele preventieve benadering van opvoedingsproblematiek pas ingrijpen als problemen zijn geëscaleerd (tot overlast voor de maatschappij hebben geleid); ex post-interventionisme (grofweg de huidige ondertoezichtstelling) als systeem houdt transgenerationele discriminatie in stand en is bovendien stigmatiserend.

Preventieve benadering = integraal kind-en-gezinsbeleid ter effectuering van de kernrechten van het kind binnen de Trias pedagogica.

Trias pedagogica $=$ de constitutionele - dat wil zeggen op de grondslag van sociaal-pedagogische grondrechten en ter effectuering van een die grondrechten waarborgend sociaal-pedagogisch stelsel gejuridiseerde - driehoeksverhouding Kind-Ouders-Staat.

Sociaal-pedagogisch stelsel $=$ kind-en-gezinsstelsel met sociale vangnetfunctie op basis van algemene sociaal-pedagogische voorzieningen en in het bijzonder Opvoedingsonderwijs, Opvoedingsgeld en Opvoedingsondersteuning (met inbegrip van maatregelhulp/persoonswordingsvindicatie). 
Opvoedingsonderwijs = sociaal-emotionele/relationele/ontwikkelingspsychologische/pedagogische schoolvakken voor kinderen en cursussen/trainingen voor ouders.

Opvoedingsgeld = verzorgings- en opvoedingsloon op eventueel deels (semi-) contractuele basis (dat is met op het individuele geval toegespitste afspraken); opvoedingsgeld impliceert dat de huidige kinderbijslag verdwijnt en dat het kostwinnersbeginsel plaats maakt voor het ouderschapsbeginsel.

Opvoedingsondersteuning = het na het (pre- of perinataal) screenen van opvoedkundige risico-situaties aanbieden en desnoods, bij wanprestatie of onvermogen, opleggen van hulp-op-maat aan kind en gezin (geïntegreerde preventieve opvoedingsbegeleiding en repressieve - dat is krachtens maatregelhulp opvoedingsbewaking).

Opleggen van hulp-op-maat = het na een mislukt ondersteuningsaanbod door de (gezins)rechter (doen) opleggen van geschikte hulp (als juridische actie: persoonswordingsvindicatie $=$ het veilig stellen van de minimale persoonswording van een kind); een en ander omringd met deugdelijke (gezinsbestuursrechtelijke) rechtswaarborgen in de vorm van zorgvuldige procedures en rechterlijke toetsing aan operationele ontwikkelingspsycho(patho)logische/pedagogische minimum-normen (onder andere kindermishandelingscriteria) en aan algemene beginselen van behoorlijk (gezins)bestuur.

Screenen = het op niet-stigmatiserende wijze, dat wil zeggen: op basis van het drie-echelonsmodel, in kaart brengen van opvoedkundige risico-situaties.

Opvoedkundige risico-situaties = situaties die, blijkens een cumulatie van bekende (wetenschappelijk gevalideerde) risico-indicatoren, een ernstige bedreiging inhouden voor de evenwichtige ontwikkeling van een kind.

Drie-echelonsmodel $=$ BAARTMAN-gesprek voor alle anstaande of prille ouders met, bij aanwezigheid van (een cumulatie van) risico-factoren, doorverwijzing naar een tweede en eventueel (bij ernstige problematiek) derde echelon.

\section{Massale en massieve kinderrechtenschendingen:}

Massaal = grootschalig $($ minimaal 80.000 mishandelde $/$ misbruikte $/$ verwaarloosde kinderen in Nederland per jaar, van wie er minimaal 80 per jaar aan de gevolgen overlijden).

Massief $=$ systemisch, samenhangend met het privacy-systeem, en met gevolgen voor individu en samenleving die het privacy-systeem (in het bijzonder marginalisering, stigmatisering en transgenerationele discriminatie) verder versterken of in stand houden (stigmatisering maakt van de slachtoffers de felste verdedigers van het privacy-/staatsonthoudingssysteem en bestendigt aldus staatsonthouding als ouderlijk privilege $=$ publiek/privé-dichotomie $=$ ouderschapslibertinisme). 
Massale en massieve kinderrechtenschendingen leiden tot grove en grootschalige transgenerationele discriminatie en daarmee tot staatstransgenerationaliteitsaansprakelijkheid.

Staatstransgenerationaliteitsaansprakelijkheid $=$ de internationale aansprakelijkheid van de staat ter zake van het niet (adequaat) voldoen aan zijn sociaalpedagogische verplichtingen (onder het Verdrag inzake de rechten van het kind) ten opzichte van ouders en kinderen (en de daaruit voortvloeiende schendingen van de persoonswordingsrechten van kinderen) in het licht van een voortdurende situatie van grove en grootschalige schendingen van fundamentele mensenrechten (mishandeling, verwaarlozing en misbruik - en dus traumatisering en ontwikkelingspsychopathologisering - van ten minste 80.000 kinderen in Nederland per jaar) alsmede van een voortdurende situatie van systemische sociaal-pedagogische (transgenerationele) discriminatie. 
'Verdraagzaamheid is niet onbegrensd of onvoorwaardelijk. (...) Overschrijden we zekere [tolerantie-]grenzen, dan wordt onze verdraagzaamheid onverschilligheid. Door de ander niet te hinderen in zijn afwijkend gedrag, worden we medeplichtig. Ook kan onze passiviteit tot gevolg hebben dat anderen lijden. Ik kan, met andere woorden, eventueel verdraagzaam zijn ten aanzien van het geweld dat mij wordt aangedaan, maar niet ten aanzien van geweld dat anderen wordt aangedaan.'

Juliaan VAN ACKER, Jeugdcriminaliteit: Feiten en mythen over een beperkt probleem, Houten/Diegem 1998, p. 26.

'Maar ik blijf het onbegrijpelijk vinden dat we het gewoon vinden dat één geval van gekke-koeienziekte of varkenspest voldoende aanleiding kan zijn om ongeveer een hele veestapel te slachten, terwijl we tegelijkertijd passief accepteren dat elk jaar enkele tientallen kinderen door hun ouders doodgeslagen worden.'

Andries VAN DANTZIG, in gesprek met Paul sCHNABEL, een interview in: $M G v 1998 / 10$, pp. 927-943, op p. 932. 


\section{LIJST VAN AANGEHAALDE LITERATUU ${ }^{1}$}

\begin{tabular}{|c|c|}
\hline$A J L$ & American Joumal of Intemational Law \\
\hline ASIL & American Society of International Law \\
\hline $\mathrm{DCl}$ & Defence for Children International \\
\hline FJR & Tijdschrift voor familie- en jeugdrecht \\
\hline$H R L J$ & Human Rights Law Joumal \\
\hline$H R Q$ & Human Rights Quarterly \\
\hline IICR & Intemational Joumal of Children's Rights \\
\hline$L B R-B$ ulletin & $\begin{array}{l}\text { uitgave van het } L \text { andelijk Bureau ter } \\
\text { bestrijding van } R \text { assendiscriminatie }\end{array}$ \\
\hline$M G v$ & Maandblad Geestelijke volksgezondheid \\
\hline $\mathrm{NcGN}$ & Nederlands centrum Geestelijke volksgezondheid \\
\hline$N I L R$ & Netherlands Intemational Law Review \\
\hline $\mathrm{NIZW}$ & Nederlands Instituut voor Zorg en Welzijn \\
\hline$N J B$ & Nederlands Juristenblad \\
\hline NJCM-Bulletin & $\begin{array}{l}\text { Nederlands Tijdschrift voor de Mensenrechten } \\
\text { (uitgave van het Nederlands Juristen Comité } \\
\text { voor de Mensenrechten) }\end{array}$ \\
\hline$N Q H R$ & Netheriands Quanterly of Human Rights \\
\hline SIM & $\begin{array}{l}\text { Studie- en Informatiecentrum Mensenrechten } \\
\text { (Netherlands Institute of Human Rights) }\end{array}$ \\
\hline $\mathrm{TvCr}$ & Tijdschrift voor Criminologie \\
\hline VKM (VKMagazine) & $\begin{array}{l}\text { (uitgave van NIZW/)Voorkoming van Kinder- } \\
\text { Mishandeling }\end{array}$ \\
\hline
\end{tabular}

ABRAHAM, R.E., Het ontwikkelingsprofiel; Een psychodynamische diagnose van de persoonlijkheid, Assen 1997

ABRAMSON, Bruce, "The invisibility of children and adolescents; the need to monitor our rhetoric and our attitudes,' in: Eugeen verHeLlEN (ed.), Monitoring children's rights, Den Haag (etc.) 1996, pp. 393-402

ACKER, J. vAN, De menselijke mens, Utrecht 1994

ACKER, Juliaan VAN, Jeugdcriminaliteit: Feiten en mythen over een beperkt probleem, Houten/Diegem 1998

AKASHI, Kinji, Cornelius VAN BYNKERSHOEK: His role in the history of international law, Den Haag (etc.) 1998

1 Umlautsvormen zijn gealfabetiseerd als stond er vocaal + e. Een apostrof in een naam is alfabetisch genegeerd. Namen met voorvoegsel(s) zijn gealfabetiseerd na gelijkluidende namen zonder voorvoegsel(s). 
AKEN, M.A.G. VAN, 'Een meer-settingen- en meer-facetten-beleid ter preventie van jeugdcriminaliteit,' reactie ('Journaal') in Justitiële Verkenningen 1996/9, pp. $95 \cdot 103$

AKKERMANS, P.W.C., e.a., Grondrechten en grondrechtsbescherming in Nederland, Groningen/Heerlen 1988

ALBACH, Francine, frevDS verleidingstheorie; Incest, trauma en hysterie, diss. Universiteit van Amsterdam, Middelburg 1993

ALEXANDER, Carl, bespr. van VAN DER BURG/IPPEL (red.), De Siamese tweeling; Recht en moraal in de biomedische praktijk (1994), in: Recht en kritiek 1997/ 3, pp. $267-277$

ALFREDSSON, Gudmundur; Katarina TOMASEVVSKI (eds.), A thematic guide to documents on the human rights of women; Global and regional standards adopted by intergovernmental organizations, international non-governmental organizations and professional associations, The Raoul walleNBERg Institute Human Rights Guides, vol. 1, Den Haag (etc.) 1995

ALKEMA, E.A., 'Voorwoord: tweehonderd jaar rechten van de mens in Nederland 1795-1995,' in: F.H. VAN DER BURG, H. BOELS, Tweehonderd jaar rechten van de mens in Nederland, Leiden 1994, pp. 1-2

Ausron, Philip, Development and the rule of law: Prevention versus cure as a human rights strategy, International Commission of Jurists, Conference on 'Development and the rule of law' (The Hague 1981), s.le.a.

ALSTON, Philip, 'The best interests principle: towards a reconciliation of culture and human rights;' in: dez. (ed.), The best interests of the child; Reconciling culture and human rights, Oxford 1994, pp. 1-25

AMERICAN PSYCHIATRIC ASSOCLATION, Beknopte handleiding bij de diagnostische criteria van de DSM-III-R (vert. G.A.S. KOSTER VAN GROOS), Amsterdam/ Lisse 1989 (tweede druk)

AMERTCAN PSYCHIATRIC ASSOCLATION, Diagnostic and Statistical Manual of mental disorders; Fourth edition/DSM-IV, Washington 1994

AMERICAN PSYCHIATRIC ASSOCIATION/Nederlandse Vereniging voor Psychiatrie, Beknopte handleiding bij de diagnostische criteria van de DSM-IV, Lisse 1995 AMNESTY INTERNATIONAL, Jaarboek 1998, Amsterdam [1998]

ANDREASSEN, Bărd-Anders, 'Article 22,' in: Asbjørn EIDE e.a. (eds.), The Universal Declaration of human rights; A commentary, Oslo(/Oxford) 1992, pp. 319-355

ANGELOU, Maya, 'Sensuele aanmoediging,' uit: De reis zou licht zijn, Breda 1994, pp. [85]-88

AN-NA'IM, Abdullahi Ahmed, 'State responsibility under international human rights law to change religious and customary laws,' in: Rebecca J. Cook. (ed.), Human rights of women; National and international perspectives, Philadelphia 1995 (third printing), pp. 167-188

APELDOORN, L.J. VAN, Geschiedenis van het Nederlandsche huwelijksrecht vórr de invoering van de Fransche wetgeving, Amsterdam 1925

ARajärvi, Pentti, 'Article 26,' in: Asbjørn eide e.a. (eds.), The Universal Declaration of human rights; A commentary, Oslo(/Oxford) 1992, pp. 405-428 
BaArtman, H.E.M., 'Moreel van huis uit?' In: J.W. Steutel (red.), Morele opvoeding: Theoretisch-en historisch-pedagogische opstellen, Meppel/Amsterdam 1984, pp. 89-115

BAARTMAN, H., 'Reacties op mishandeling en seksueel misbruik van kinderen,' VKMagazine $1987 / 3$, pp. 6-8

BAARTMAN, H.; O. VAN DER BAAN-SLOOTWEG, C. RÜMKE, Onderzoek en hulpverlening door het medisch kleuterdagverblijf 'De Bolderkar' inzake seksueel misbruik, Rapport uitgebracht aan de geneeskundige inspectie van de volksgezondheid voor Zuid-Holland (Den Haag), april 1989

BAARTMAN, Herman, 'Openingslezing: macht en onmacht bij incestueus misbruik van kinderen," in: dez. e.a., Incest en hulpverlening, Amersfoort/Leuven 1990, pp. 12-22

BAARTMAN, Herman, 'Enkele slotconclusies: macht en onmacht van hulpverlening en justitie,' in: dez. e.a., Incest en hulpverlening, Amersfoort/Leuven 1990, pp. 68-77

BAARTMAN, H., 'Kindermishandeling en botsende belangen,' in: J.B. WEENINK (red.), Het belang van het kind in het geding; Over opvoeding en kinderbescherming, Amsterdam 1990, pp. 59-72

BAARTMAN, Herman, 'Omvang, oorzaken, hulpverlening en preventie inzake kindermishandeling; inzichten vanuit de research voor praktijk en beleid op het terrein van kindermishandeling,' Gezin; Tijdschrift voor primaire leefvormen $1990 / 2$, pp. $76-87$

BAARTMAN, H., 'De betekenis van het begrip psychische kindermishandeling,' VKMagazine 1990/1, pp. 1-4

BAARTMAN, H., toespraak filmpremière, aangehaald door Joke NICAISE, 'Johan een terugblik,' VKMagazine $1990 / 1$, p. 8

BAARTMAN, H., 'Verwarring over poppenmethode zeer hardnekkig," Forumpagina De Volkskrant 13 februari 1990

baARTMAN, Herman, 'KAFKA's brief aan zijn vader; over het opgroeien als verworpen kind,' in: Willem BERGER e.a. (red.), Geweld in relaties; Overwegingen en ervaringen, Baarn 1991, pp. 24-42

BAARTMAN, H., 'Transgenerationele aspecten van kindermishandeling,' in: P.B. DEFARES, J.D. VAN DER Ploeg (red.), Agressie; Determinanten, signalering en interventie, Assen/Maastricht 1991, pp. 150-161

BaARTMAN, Herman, 'Geweld in het gezin,' in: dez. en A. VAN MONTFOORT (red.), Kindermishandeling, resultaten van multidisciplinair onderzoek, Utrecht 1992, pp. 15-39

BAARTMAN, H.E.M., Opvoeden met alle geweld: Hardnekkige gewoontes en hardhandige opvoeders, Utrecht 1993

BAARTMAN, Herman, 'Wie zijn kind liefheeft ...; over slaag, geweld en mishandeling,' in: Afra GROEN en Adri VAN MONTFOORT (red.), Kinderen beschermen en jeugd hulp verlenen, Arnhem 1993, pp. 37-58

BAARTMaN, Herman, 'Onderkenning en miskenning van seksueel misbruik van kinderen; enkele historische en actuele aspecten,' in: dez. (red.), Op gebaan- 
de paden? Ontwikkelingen in diagnostiek, hulpverlening en preventie met betrekking tot seksueel misbruik van kinderen, Utrecht 1995, pp. 13-27

BAARTMAN, H.E.M., 'Seksueel misbruik: een betrouwbaar antwoord?' In: L.P.T. RalmMakers e.a. (red.), Commissie Seksueel Misbruik van Jeugdigen, Handelen bij vermoeden van seksueel misbruik van kinderen en jeugdigen II; De richtlijnen SMJ in de praktijk, Assen 1995, pp. 122-130

BAARTMAN, H.E.M., "Schuld, herstel en overleven; aspecten van hulpverlening inzake kindermishandeling,' in: D.J. DE RUYTER en P.A. DE RUYTER (red.), Opvoedingshulp geboden; Pedagogische criteria voor het opleggen van hulp, theoretisch en praktisch bezien, Utrecht 1995, pp. 83-91

BAARTMAN, Herman, 'Fysieke mishandeling van kinderen,' TvCr 1995/4, pp. 300314

BAARTMAN, H.E.M., Opvoeden kan zeer doen; Over oorzaken van kindermishandeling, hulpverlening en preventie, Utrecht 1996

BAARTMAN, H.E.M., 'Primaire preventie van kindermishandeling: onbegonnen werk?' Nederlands Tijdschrift voor Opvoeding, Vorming en Onderwijs 1996/1, pp. 17-33

BA.ARTMAN, H.E.M., 'Als mishandelde kinderen ouder[s] worden,' Tijdschrift voor Orthopedagogiek 1996, pp. 417-431

BAARTMAN, H., aangehaald in Dagblad de Limburger 22 juni 1996, onder de kop: 'Begeleiding, middel tegen kindermishandeling'

BAARTMAN, H., aangehaald door Arjen SCHREUdER, 'Bij een vuist past geen fluwelen handschoen (...), ${ }^{\prime}$ NRC Handelsblad 5 oktober 1996, Z-bijlage, p. 5

BAARTMAN, H., 'Preventie van kindermishandeling en risicogezinnen,' in: Gezinnen onder druk; Over veranderende ouder-kind relaties; hoe moeilijk/gewoon opvoeden kan zijn, Themadag Vrije Universiteit Amsterdam 23 november 1996 (samenvatting lezingen), pp. 11-13

BAARTMAN, H.E.M., 'Kindermishandeling en risicogezinnen; een patstelling in preventie?' In: dez. e.a., Gezinnen onder druk; Over veranderende ouder-kind relaties, Kampen 1997, pp. 80-107

BAARTMAN, H.E.M., 'Risicogezinnen en predictie en preventie van kindermishandeling,' Tijdschrift voor Orthopedagogiek 1997, pp. 245-257

BaDran, Hoda, 'Foreword,' in: Geraldine van Bueren, The intemational law on the rights of the child, Dordrecht (etc.) 1995, pp. xw-xvi

BAEHR, P.R., Mensenrechten, Meppel/Amsterdam 1989

BAKKER, Ina, e.a., $O+O=O^{2}$; Naar een samenhangend beleid en aanbod van opvoedingsondersteuning en ontwikkelingsstimulering voor kinderen en ouders in risicosituaties, NIzw, Utrecht 1997

BAKkER, Kees; Tom TER BOGT, Mieke DE WAAL, Opgroeien in Nederland, Amersfoort 1993

BANDRÉS MOLET, Juan Maria, "Towards a European law on children; the European Charter of rights of the child,' in: Eugeen verheulen (ed.), Monitoring children's rights, Den Haag (etc.) 1996, pp. 159-164

BARENTS, R.; L.J. BRINKHORST, Grondlijnen van Europees recht, Alphen aan den Rijn 1994 (zesde druk) 
BARENTS, R., 'Het Verdrag van Amsterdam: een eerste indruk,' NJB' 1997, pp. $1261-1268$

BARKIUYSEN, T., e.(v.)a., "Overzicht van Nederlandse jurisprudentie met betrekking tot het internationale recht inzake de rechten van de mens over 1994," NJCM-Bulletin 1995/8, pp. 1023-1069

BarnetT, Douglas; Jody Todd Manly, Dante cicchetT, 'Defining child maltreatment: the interface between policy and research,' in: Dante cICcHETr, Sheree L. TOTH (eds.), Child abuse, child development, and social policy, Advances in applied developmental psychology, vol. 8, Norwood, New Jersey 1993, pp. 7-73

BARNETr, Ola W., e.a., Family violence across the lifespan; An introduction, Thousand Oaks (etc.) 1997

BARTELS, J.A.C., 'Het belang van het kind in het jeugdstrafrecht, of "de evolutie van een rechtsbegrip",' in: Ad VAN DER LINDEN, Paul VLAARDINGERRROEK (red.), Met het oog op het belang van het kind; Opstellen aangeboden aan (...) Madzy ROOD-DE BOER (...), Deventer 1988, pp. 225-240

BASIC PRINCIPLES AND GUIDELINES on the right to reparation for victims of [gross] violations of human rights and international humanitarian law, E/CN.4/1997/ 104, 16 januari 1997, Appendix, pp. 3-5; INTERNATIONAL COMMISSION OF JURISTS, The right to reparation for victims of human rights violations (...);A compilation of essential documents (...), Geneva (januari) 1998, pp. 7-11

BASS, Ellen; Laura DAVIS, The courage to heal; $A$ guide for women survivors of child sexual abuse, New York 1988

BASTIAANS, J., 'Voorwoord,' in: Frans HIDDEMA, Bruine terreur door zwarte pedagogie; Psychoanalytische aspecten van FITLERs racistische nazidom, Rotterdam 1985, pp. 7-8

BAX, C.J., e.a. (red.), Universaliteit van grondrechten, Mededelingen van het Juridisch Instituut van de Erasmus Universiteit Rotterdam 48, 1989

BEDERMAN, David J., 'Reception of the classical tradition in international law: GRoTrus' De jure belli ac pacis,' in: Grotiana, New Series, vol. 16-17, 19951996, pp. 3-34

BEIJING DECLARATION and the Platform for action, (THE), Fourth World Conference on Women, Beijing, China, 4-15 September 1995, UN, New York 1996 BELEIDSBRIEF KINDERMISHANDEIING; Het is niet de vraag of het kan, maar weten dat het moet (D'ANCONA, SIMONS, KOSTO), Tweede Kamer der Staten-Generaal, vergaderjaar 1990-1991, 21 938, nrs. 1-2, (Den Haag) 4 december 1990 BELLAMY, Carol, 'Foreword,' in: Implementation handbook for the Convention on the rights of the child, prepared for UNICEF by Rachel HODGKIN and Peter NEWEL, New York/Genève 1998, p. ix

Bellekom, Th.L., e.a., KoopMans' Compendium van het staatsrecht, Deventer 1994 (zevende druk)

BERGH, Bea VAN DEN, Recht op recht(en)? Kinderen als maatschappelijke groep, Centrum voor Bevolkings- en Gezinsstudiën, Ministerie van de Vlaamse Gemeenschap, Departement wvc, Administratie Gezin en Maatschappelijk Welzijn, Brussel 1994 
BERGSMA, Ad, Het brein; Ons innerlijk universum, Utrecht 1997 (derde druk) BESHARov, Douglas J., Recognizing child abuse, New York (etc.) 1990 BEsSELINK, Leonard, 'The impious hypothesis [etiamsi daremus] revisited,' Grotiana, New Series, vol. 9, 1988, pp. 3-63

BEsSELINK, L.F.M., 'Een kwestie van mondigheid: burgerschap voor jeugdigen?'

In: M. DE LANGEN e.a. (red.), Kinderen en recht; Opstellen over de positie van minderjarigen in het recht, Arnhem/Deventer 1989, pp. 100-114

BETTELHEIM, Bruno, Niet volmaakt maar goed genoeg; Over het opvoeden van kinderen (oorspr. titel: A good enough parent: $A$ book on child rearing, New York 1987), Amsterdam 1990

BEYAERT, F.H.L., "Strafwetgeving en de crime passionnel, dodingen in het gezin en toch weer de vader,' in: A. LADAN e.a. (red.), De betekenis van de vader; Psychoanalytische visies op het vaderschap, Meppel/Amsterdam 1985, pp. 102-122

BEYAERT, F.H.L., 'Partner- en kinderdodingen,' Justitiële Verkenningen 1986/4 ('Intrafamiliale agressie'), pp. 445-457

BEYAERT, F.H.L., 'Het kind, de jeugdige in het recht,' in: Ted DE BOER e.a. (red.), De kant van het kind; Liber amicorum (...) Miek DE LANGEN, Arnhem 1992, pp. 175-181

BUSTERVELDT, M.A.J. VAN, 'Verslag van de workshop juridische aspecten,' in: L.P.T. Raimmakers e.a. (red.), Commissie Seksueel Misbruik van Jeugdigen, Handelen bij vermoeden van seksueel misbruik van kinderen en jeugdigen II; De richtlijnen SMJ in de praktijk, Assen 1995, pp. $77-79$

BILO, R.A.C.; A.P. ORANJE, Het ongelukshuidje; De huid op het raakvlak van kinderdermatologie en kindermishandeling, Zwolle 1996

BILSKY, Leora, 'Naming and re-categorization in the law; child abuse as slavery,' IJCR 1997/2, pp. 147-176

BISSETT-JOHNSON, Alastair, 'What dit States really agree to? - Qualifications of signatories to the United Nations Convention on the rights of the child,' IJCR $1994 / 4$, pp. $399-411$

BLuME, E. Sue, Secret sunivors; Uncovering incest and its aftereffects in women, New York (etc.) 1990

воввіо, Norberto, The age of rights, Cambridge 1996

Boexhorst, M.G., 'Artikel 94,' in: P.W.C. AKKERMANS en A.K. koEkKoek (red.), De Grondwet; Een artikelsgewijs commentaar, Zwolle 1992 (tweede druk), pp. $873-887$

BOER, J. DE, 'Het slaan van kinderen,' in: Ted DE BOER e.a. (red.), De kant van het kind; Liber amicorum (...) Miek DE LANGEN, Arnhem 1992, pp. 137-145 BOER, J. DE, 'De pedagogische tik' (besprekingsartikel van H.E.M. BAARTMAN, Opvoeden met alle geweld, Utrecht 1993), NJB 1994, pp. 389-390 (met 'toegift" op p. 542)

BOER, J.E. DE, 'Infantpsychiatrie,' in: dez. (red.), Infantpsychiatrie I; De gezonde en verstoorde ontwikkeling van de vroege ouder-kind relatie, Assen/Maastricht 1991, pp. 3-22 
boerefin, Ineke; Cees flinterman, "Het Facultatief protocol bij het VN-Vrouwenverdrag,' Nemesis 1997/4, pp. 146-149

BoGdan, Michael, 'Article 6,' in: Asbjørn eme e.a. (eds.), The Universal Declaration of human rights; $A$ commentary, Oslo(/Oxford) 1992, pp. 111-113

BOGERS, Thea, 'De rechten van beschermde kinderen; een visie vanuit de praktijk van de kinderbescherming,' in: Carol VAN NUNATIEN (red.), Kinderrechten in discussie, Amsterdam/Meppel 1993, pp. 162-175

BOL, M.W., 'Preventief ingrijpen: rechtsgrond is heilig, ondergrens niet,' reactie ('Journaal') in Justitièle Verkenningen 1996/8, pp. $93-96$

BOOGAARD, R. VAN DEN, 'Ouders moeten kind niet als bezit zien; meer meldingen over mishandeling niet alleen gevolg bekendheid vertrouwensarts,' $N R C$ Handelsblad 29 augustus 1989, p. 2

BORNEMAN, Ernest, Das Geschlechtsleben des Kindes; Beiträge zur Kinderanalyse und Sexualpädologie, München 1985, Taschenbuch-ed. 1988

BOSCH, Ingeborg N., bespr. van Jean JENSON, Op weg naar je ware zelf (Houten 1998), in: $M G v 1998 / 3$, pp. 318-321

BossuyT, Marc, 'The International Covenant on civil and political rights and children,' in: Eugeen verHeLleN (ed.), Understanding children's rights; Collected papers presented at the first International interdisciplinary course on children's rights, Gent 1996, pp. 303-308

BOUTELLIER, J.C.J., 'Prostitutie en moraal,' Justitiële Verkenningen 1987/1 ('Prostitutie'), pp. 7-35

BOUTELLIER, J.C.J., 'Seksueel misbruik van kinderen,' Justitiële Verkenningen 1989/6 ('Seksuele kindermishandeling en Justitie'), pp. 8-33

BOUVERNE-DE BIE, M., 'De jeugdwelzijnsinterventie in het licht van het recht van kinderen op bijzondere bescherming en hulp,' in: E. vERHELLEN, F. SPIESSCHAERT, L. CATTRISSE (red.), Rechten van kinderen; Een tekstbundel van de Rijksuniversiteit Gent naar aanleiding van de UNO-Conventie voor de rechten van het kind, Antwerpen/Arnhem 1989, pp. 183-208

BOVEN, Th.C. VAN, De volkenrechtelijke bescherming van de godsdienstvrijheid, [diss. Leiden], Assen 1967

BOVEN, Theo VAN, 'Children's rights; address at the opening meeting of the International Forum on the rights of the child' (Boedapest 1979), opgenomen in: Hans THOOLEN (ed.), People matter; Views on international human rights policy by Theo VAN BOVEN, Director of the United Nations Division of Human Rights 1977-1982, Amsterdam 1982, pp. 157-164

BOVEN, Theodoor C. VAN, 'Distinguishing criteria of human rights,' in: Karel VASAK, Philip ALSTON (eds.), The international dimensions of human rights, Westport (Ct.)/Paris 1982, vol. 1, pp. 43-59

BOVEN, Th.C. VAN, Opdat mensen tot hun recht komen, (Tweede) DOM HeLder CAMARA-lezing (30 mei 1984), vu Amsterdam 1984

BOVEN, Theo VAN, 'The Déclaration des droits de l'homme et du citoyen of 1789 and its influence on the Constitutions,' in: E.H. HoNDIUs, G.J.W. STEENHOFF (eds.), Netherlands reports to the thirteenth International Congress of Comparative Law, Montreal 1990, Den Haag 1990, pp. 363-373 
BOVEN, Th.C. VAN, 'Internationale instrumenten en procedures ter bevordering en bescherming van de rechten van de mens,' in: P. VAN DUK e.a., Rechten van de mens in mundiaal en Europees perspectief, Ars Aequi Libri, Nijmegen 1991 (vierde druk), pp. 41-81

BOVEN, Theo WAN, 'Prevention of human rights violations,' in: Asbjørn EIDE, Jan HELGESEN (eds.), The future of human rights protection in a changing world; Fifty years since the Four freedoms address; Essays in honour of Torkel opSAHL, Oslo 1991, pp. 183-196

BOVEN, Theo VAN, bespr. van Menno T. KAMMINGA, Inter-state accountability for violations of human rights (1992; diss. Leiden 1990), in: HRQ 1992/4, pp. 561.567

BOVEN, Theo VAN, Study concerning the right to restitution, compensation and rehabilitation for victims of gross violations of human rights and fundamental freedoms; Final report submitted by Mr. Theo VAN Boven, Special Rapporteur, Sub-Commission on Prevention of Discrimination and Protection of Minorities [of the] Commission on Human Rights, E/CN.4/Sub.2/1993/8, 2 juli 1993

BOVEN, 'Theo VAN, 'Combating racial discrimination in the world and in Europe,' NQHR 1993/2, pp. 163-172

BOVEN, Theo VAN, 'General course on human rights,' in: The protection of human rights in Europe, Collected Courses of the Academy of European Law, vol. Iv, book 2, 1993, The Hague (etc.) 1995, pp. 1-106

BOVEN, Theo vaN, 'De ontmoeting met de ander,' in dez. en Hugh LewiN, Natie, migratie, integratie, Eerste multatul-lezing (Breda, 19 april 1996), Den Bosch 1996, pp. 8-26

BOVEN, Theo VAN, 'The right to restitution, compensation and rehabilitation for victims of gross violations of human rights and fundamental freedoms,' in: Gudmundur alfredsSON, Peter MACALISTER-SMTTH (eds.), The living law of nations; Essays on refugees, minorities, indigenous peoples and the human rights of other vuinerable groups; in memory of Atle GRAHL-MADSEN, Kehl (etc.) 1996, pp. 339-354

BOVEN, Theo VAN, 'Nogmaals het IVUR en de strijd tegen rassendiscriminatie,' LBR-Bulletin $1997 / 2$, pp. $25-27$

BOVEN, Theo VAN, interventie, Mededelingen van de Nederlandse Vereniging voor Internationaal Recht 116 (Verslag van de Algemene Ledenvergadering, bespreking der preadviezen van M.T. KAMMINGA en L.A.D. Keus, Staatsaansprakelijkheid jegens individuen: beginselen en procedures), Deventer 1998, pp. 4-6

BRAND, Ed; Ewald vervaEt, 'Kaspar HAuSEr, een gewoon mensenkind?' Psychologie juli 1991, pp. 32-34

BRANDS-BOTTEMA, G.W., 'Recht in de opvoedingsrelatie,' in: A.R.J. GROOT en H.J.L.M. VAN DE LUYTGAARDEN (red.), Zonder meer recht, Zwolle 1993, pp. 49-94

BREDBro, Gerbrand Adriaensz, Moortje (Amsterdam 1615), Het Nationale Toneel Den Haag, Amsterdam 1993 
BRETT, Rachel, 'Child soldiers: law, politics and practice,' IJCR 1996/2 (special issue 'Children in armed conflict'), pp. 115-128

BRIERE, John, e.a. (eds.), The APSAC [American Professional Society on the Abuse of ChildrenJ handbook on child maltreatment, Thousand Oaks (etc.) 1996

BRINK, Aleid VAN DEN; Jan JüNGEN, 'Thuisgeweld tegen vrouwen; het Meldpunt vrouwenopvang Amsterdam, 1991-1994,' TvCr 1995/4, pp. 315-332

BRINK, M. VAN DEN, 'Het recht op lichamelijke integriteit en het Vrouwenverdrag,' NJCM-Bulletin 1993/6, pp. 660-673

BRINK, Marjolein VAN DEN, Aan den lijve; Over het Vrouwenverdrag en lichamelijke integriteit, Utrecht papers on international, social and economic law, Universiteit Utrecht 1993

BRINK, W. VAN DEN, 'Leugens, misvattingen en potenties; DSM-III en DSM-III-R persoonlijkheidsstoornissen,' in: R.V. schwarz, D.H. LINSZEN (red.), Persoonlijkheidsstoornissen; Diagnostiek, behandeling, beleid, Amsterdam/Lisse 1991, pp. 21-31

Brodeur, A.E.; J.A. MONTEleOne, Child maltreatment; [vol. 1] A clinical guide and reference, St. Louis (etc.) 1994

BROEKHUIJSEN-MOLENAAR, A.M.L., "Onrechtmatige daad in de relatie ouderkind,' in: [Carel sroLker, Lodewijk VALK (red.)], Als een goed huisvader; Opstellen aangeboden aan J.H. NIEUWENHUIS, Deventer 1992, pp. 133-148

BRoUWERS, J.J.M., De tempel van het gezin, Roermond/Maaseik, imprimatur J. KROON S.J., libr. censor, Trajecti ad Mosam [Maastricht] 1953

BRoWne, Kevin; Martin HerBert, Preventing family violence, Chichester (etc.) 1997

BRownue, Ian (ed.), Basic documents on human rights, Oxford 1981 (tweede druk)

BRoWNLIE, Ian, Principles of public international law, Oxford 1990 (fourth ed.) BRUCKEN FOCK, E.P. VON, 'Familieleven en familierecht,' NICM-Bulletin 1996/1 (speciaal nummer 45 Jaar EVRM 1950-1995), pp. 147-169

BRUCKEN FOCK, E.P. vON, "Blijft het [Verdrag inzake de rechten van het kind] statisch kinderrecht?' Editorial FJR 1998/1, p. 1

BRUGGEMAN-KLUvERs, Marieke; Adri vAN MONTFOORT, Kindermishandeling: de weg naar het meldpunt, Amsterdam 1994

BrugaER, Winfried, 'The image of the person in the human rights concept,' $H R Q 1996 / 3$, pp. 594-611

BRUIN-LÜCKERS, M.L.C.C. DE, EVRM, minderjarigheid en ouderlijk gezag, diss. Leiden, Zwolle 1994

BRUINSMA, Frits, Incesthulpverlening; Diagnostiek, opvang en behandeling van incest, Utrecht 1994

BUChanan, Ann, Cycles of child maltreatment; Facts, fallacies and interventions, Chichester (etc.) 1996

BUEREN, Geraldine VAN (ed.), International documents on children, Dord[r]echt (etc.) 1993 
BUEREN, Geraldine VAN, The international law on the rights of the child, Dordrecht (etc.) 1995

BULl, Hedley, 'The importance of Grotrus in the study of international relations,' in: dez., Benedict kingsbury, Adam roberts (eds.), Hugo grotius and international relations, Oxford 1990, pp. 65-93

BULLENS, R.A.R., 'Aandachtspunten bij de beslissing om een kind uit huis te plaatsen: tombola of methodiek?' In: D.J. DE RUYTER, P.A. DE RUYTER (red.), Opvoedingshulp geboden; Pedagogische criteria voor het opleggen van hulp, theoretisch en praktisch bezien, Utrecht 1995, pp. 67-80

BunCH, Charlotte, 'Women's rights as human rights: toward a re-vision of human rights,' HRQ $1990 / 4$, pp. 486-498

BURG, F.H. VAN DER; H. BOELS, Tweehonderd jaar rechten van de mens in Nederland, Leiden 1994

BURG, Wibren VAN DER, 'Rechten van kinderen: enkele filosofische kanttekeningen,' in: Carol van nunatTen (red.), Kinderrechten in discussie, Amsterdam/ Meppell 1993, pp. 64-80

Burgers, Jan Herman, 'The road to San Francisco: the revival of the human rights idea in the twentieth century,' HRQ 1992/4, pp. 447-477

BURGHT, Gr. VAN DER; M. ROOD-DE BOER, Personen-en familierecht, PITLo-serie deel 1, Arnhem 1996 (tiende druk)

BURMAN, Erica, 'Local, global or globalized? Child development and international child rights legislation,' Childhood 1996/1, pp. 45-66

Burrows, Noreen, 'The 1979 Convention on the elimination of all forms of discrimination against women,' NILR 1985/3, pp. 419-460

BYRNES, Andrew, 'Women, feminism and international human rights law methodological myopia, fundamental flaws or meaningful marginalisation?' In: The Australian Yearbook of International Law 1992, pp. 205-240

CAmmaER, H., Menselijke levensloop: genetische psychologie, Leuven/Amersfoort 1990 (vierde druk)

CAMP, Maxime DU, La charité privée à Paris, Paris 1885

CAmpiell, Robert J., Psychiatric Dictionary, New York/Oxford 1989 (sixth ed.), 1996 (seventh ed.)

CANTwELL, Nigel, 'The origins, development and significance of the United Nations Convention on the rights of the child,' in: Sharon DETrick (ed.), The United Nations Convention on the rights of the child; $A$ guide to the 'travaux préparatoires,' Dordrecht (etc.) 1992, Chapter 1, pp. 19-30

CANTWELL, Nigel, 'Monitoring: back to basic questions,' in: Eugeen verHelleN (ed.), Monitoring children's rights, Den Haag (etc.) 1996, pp. 67-72

CANTwELL, Nigel, 'The role of UNICEF in the implementation of the Convention on the rights of the child,' in: Eugeen VERHELLEN (ed.), Understanding children's rights," Collected papers presented at the first International interdisciplinary course on children's rights, Gent 1996, pp. 385-387

CAPPELAere, Geert, 'Possible Optional protocols to the Un Convention on the rights of the child: improving or undermining the Convention and its moni- 
toring? The case of child prostitution, child pornography and sale of children,' in: Eugeen veruellen (ed.), Monitoring children's rights, Den Haag (etc.) 1996, pp. 403-430

CASAS, Ferran, 'The Childhood Policies Project of the Council of Europe,' in: Eugeen VERHELLEN (ed.), Understanding children's rights; Collected papers presented at the first International interdisciplinary course on children's rights, Gent 1996, pp. 215-221

CASs, Bettina, 'The limits of the public/private dichotomy (...),' in: Philip ALSTON

e.a. (eds.), Children, rights and the law, Oxford 1992, pp. 140-147

CASSESE, Antonio, International law in a divided world, Oxford 1988

CASSESE, Antonio, Human rights in a changing world, Cambridge 1990

CASTERMANS-HOLLEMAN, M.C., 'De 53e zitting van de VN-Commissie voor de rechten van de mens,' $N J C M$-Bulletin 1997/5, pp. 661-668

CHARLesworth, Hilary; Christine CHINKIN, 'The gender of jus cogens,' $H R Q$ 1993/1, pp. 63-76

CICCHETTI, Dante; Vicki CARISON (eds.), Child maltreatment; Theory and research on the causes and consequences of child abuse and neglect, Cambridge (etc.) 1989

CICCHETrI, Dante, 'How research on child maltreatment has informed the study of child development: perspectives from developmental psychopathology,' in: dez. en Vicki CARLSON (eds.), Child maltreatment; Theory and research on the causes and consequences of child abuse and neglect, Cambridge (etc.) 1989, pp. $377-431$

CICcHETTI, Dante; Sheree L. TOTH (eds.), Child abuse, child development, and social policy, Advances in applied developmental psychology, vol. 8, Norwood, New Jersey 1993 (zie BARNETT e.a.)

CLAES, Jacques, 'Jeugd als moratorium,' in: H. CAMMAER en E. VERHELLEN (red.), Onmondig en onvolwassen; De jonge mens in de eeuw van het kind, Leuven/ Amersfoort 1990, pp. 39-51

CLAPHAM, Andrew, Human rights in the private sphere, Oxford 1993

CLEESE, John; Robin SKYNNER, Hoe overleef ik mijn familie (oorspr. titel: Families and how to survive them, 1983; oorspr. Nederlandse vert.: Van je familie moet je 't hebben, 1986), Amsterdam 1995 (zesde druk)

CLEMENS SCHRÖNER, B.L.F., Psychische kindermishandeling, diss. Leiden 1956, Den Haag 1957

CLITEur, P.B., 'Macht en vrijheid; een reflexie over het werk van S.W. couwENBERG,' in: S.W. COUWENBERG, Geschiedenis als noodlot; Over de historiciteit van het menselijk bestaan en het machtsmotief als primaire drijfkracht; Met een bijdrage van P.B. clirteur, Kampen/Kapellen 1995, pp. 117-140

Curreur, P.B., 'De Verklaring van de rechten van de mens en van de burger zijn de mensenrechten "af"?' NJCM-Bulletin 1995/7, pp. 882-892

CODEX IURIS CANONICI (1983), Wetboek van canoniek recht, Latijns-Nederlandse uitgave, Brussel/Hilversum 1987

COHEN, Cynthia Price, "The role of nongovernmental organisations in the drafting of the Convention on the rights of the child,' HRQ 1990/1, pp. 137-147 
CoHen, Cynthia Price, "The relevance of theories of natural law and legal positivism,' in: Michael freeman, Philip veERMAN (eds.), The ideologies of children's rights, Dordrecht (etc.) 1992, pp. 53-70

COHEN, Cynthia Price, "United States signs the Convention on the rights of the child," IJCR 1995/2, pp. 281-282

COHEN, Cynthia Price, 'The United Nations Convention on the rights of the child: involvement of NGo's [nongovernmental organizations],' in: Theo C. VAN BOVEN, Cees Flinterman, Fred GRUNFELD, Rita hut (eds.), The legitimacy of the United Nations: towards an enhanced legal status of non-state actors, sim Special 19, Utrecht 1997, pp. 169-184

COLTon, Matthew, e.a. (Wales); Evert scholte (Leiden), Ferran CAsas (Barcelona), Margaret willuams (Calgary), 'Child welfare and stigma; principles into practice," Childhood 1997/3, pp. 265-283

COMMISSIE SEKSUEEL MISBRUIK VAN JEUGDIGEN, Handelen bij vermoeden wan seksueel misbruik van kinderen en jeugdigen I; Richtlijnen voor beroepsbeoefenaren, Assen 1994

COMMISSIE SEKSUERL MISBRUIK VAN JEUGDIGEN (red. L.P.T. RAIJMAKERS e.a.), Handelen bij vermoeden wan seksueel misbruik van kinderen en jeugdigen II; De richtlijnen $S M J$ in de praktijk, Assen 1995

CONSTANT, Jac.C. (vert./bewerking), Mysteries van de bijbel, Amsterdam/Brussel 1990

cook, Rebecca J., 'Accountability in international law for violations of women's rights by non-state actors,' in: Dorinda G. DALlmEYer (ed.), Reconceiving reality: Women and international law, ASIL, Washington 1993, pp. 93-116

cook, Rebecca J. (ed.), Human rights of women; National and international perspectives, Philadelphia 1995 (third printing)

COOMANS, A.P.M., De internationale bescherming van het recht op onderwijs, diss. Maastricht, Leiden 1992

COOMANS, A.P.M.; A.W. HERINGA, 1. WESTENDORP (red.), De toenemende betekenis van economische, sociale en culturele mensenrechten, Leiden 1994

coomans, Fons, 'Economic, social and cultural rights,' in: dez., Economic, social and cultural rights; Marlies GALENKAMP, Collective rights, Reports commissioned by the Advisory Committee on Human Rights and Foreign Policy of the Netherlands, sIm Special 16, Utrecht 1995, pp. 3-51

COOMARAswamy, Radhika, Preliminary report submitted by the Special Rapporteur on violence against women, its causes and consequences, Ms. Radhika COOMARASWAMY, in accordance with Commission on Human Rights resolution 1994/ 45, E/CN.4/1995/42, 22 november 1994

COOMARASWAMY, Radhika, 'To bellow like a cow: women, ethnicity, and the discourse of rights,' in: Rebecca J. COOK (ed.), Human rights of women; $\mathrm{Na}$ tional and international perspectives, Philadelphia 1995 (third printing), pp. 39-57

COPELON, Rhonda, 'Intimate terror: understanding domestic violence as torture,' in: Rebecca J. cook (ed.), Human rights of women; National and international perspectives, Philadelphia 1995 (third printing), pp. 116-152 
CORNELISSE, S., "Naar een wettelijke meldingsplicht in geval van kindermishandeling?' FJR $1987 / 8$, pp. 232-238

COUNCIL OF EUROPE, The family - organisation and protection within the European

Social Charter, Human rights, Social Charter monographs 1, [Straatsburg] 1995

COUNCIL OF EUROPE, Children and adolescents - protection within the European

Social Charter, Human rights, Social Charter monographs 3, [Straatsburg] 1996

COUNCIL OF EUROPE, The rights of the child; A European perspective, (a collection of legal instruments), Strasbourg 1996

COUWENBERG, S.W., "Constitutionele vruchten van de Franse Revolutie na twee eeuwen,' in: dez. (red.), Opstand der burgers; De Franse Revolutie na 200 jaar, Kampen 1988, pp. 163-179

COUWENBERG, S.W., Geschiedenis als noodlot; Over de historiciteit van het menselijk bestaan en het machtsmotief als primaire drijfkracht, Kampen/Kapellen 1995

CRINSS, F.C.L.M., 'De herziening van artikel 208 van de Grondwet: het loon van de angst?' In: A.K. коеккоек e.a. (red.), Grondrechten; Commentaar op hoofdstuk 1 van de herziene Grondwet (JEUKENsbundel), Ars Aequi Libri, Nijmegen 1982, pp. 439-505

CROMBAG, Hans; Frank VAN DUN, De utopische verleiding, Amsterdam/Antwerpen 1997

CULlBerG, Johan, Moderne psychiatrie, Baarn [1990] (tweede druk)

D'AMato, Anthony, 'Letter from the chair, Human Rights Interest Group,' ASIL/HRIG Newsletter 1994/4, p. 1

D'ANCONA, Hedy, 'Voorwoord,' in: H. BAARTMAN e.a., Incest en hulpverlening, Amersfoort/Leuven 1990, pp. [9-10]

DANIELI, Yael, 'Preliminary reflections from a psychological perspective,' in: Theo VAN BOVEn, Cees flinterman, Fred GRÜNFeld, Ingrid WESTENDORP (eds.), Seminar on the right to restitution, compensation and rehabilitation for victims of gross violations of human rights and fundamental freedoms, SIM Special 12, Utrecht 1992, pp. 196-213

DANTZIG, A. VAN, "Vraagtekens bij ouderliefde; Hulpverleners en incestslachtoffers door Jos FRENKEN en Bram VAN STOLK, (Deventer) 1987 (...),' boekbespreking Zaterdags bijvoegsel NRC Handelsblad 16 januari 1988

DANTZIG, A. VAN, 'DRAIJER, Nel - Sexueel misbruik van meisjes door verwanten; of: Incest: hoe is het mogelijk,' Gezin; Tijdschrift voor primaire leefvormen 1989/4, pp. 235-238

Dantzig, A. van, Psychotherapie - een vak apart; Opstellen over mogelijkheden en grenzen van psychotherapie, Meppel/Amsterdam 1990

DANTZIG, A. VAN, 'Afscheid' ('Buiten de orde'), MGv 1990/1, pp. 106-108

DANTziG, A. VAN, 'Persoonlijk lijden als publieke zorg; TRIMBos-lezing 1991,' $M G v 1991 / 6$, pp. 635-648 
DANTZIG, A. WAN, 'Persoonlijk lijden als publieke zorg (2); antwoord [aan Jos DRÖES], $M G v 1991 / 9$, pp. $962-964$

DANTZIG, A. VAN, 'De ontkenning (...), Raise the red lantern (...), filmbeschouwingen in $M G v 1992 / 5$, pp. 568-571

DANIZIG, A. VAN, bespr. van H.E.M. BAARTMAN, Opvoeden met alle geweld (Utrecht 1993), in: MGv 1993/10, pp. 1142-1144

DANTZIG, A. VAN, bespr. van H. BAARTMAN, A. VAN MONTFOORT (red.), Kindermishandeling, resultaten van multidisciplinair onderzoek (Utrecht 1992), in: MGv 1993/12, pp. 1384-1389

DANTZIG, A. WAN, Is alles geoorloofd als God niet bestaat? Over geestelijke gezondheidszorg en maatschappij, Amsterdam/Meppel 1995

DANTZIG, A. VAN, 'Heavenly Creatures,' filmbeschouwing in $M G v$ 1995/10, pp. 1134-1135

DANTZIG, A. VAN, interview De Volkskrant 28 oktober 1995 (Folio-bijlage) onder de kop: "Er is veel meer gekte dan je denkt"'

DANTZIG, A. VAN, 'Ten geleide,' in: Frank VAN REE, Mijn zelfonderzoek: een terugblik; Frank VAN REE over het belang van leertherapie, Lisse 1996, p. 9

DANTZIG, A. VAN, 'Alle dagen psychologie? (2)' Reactie in $M G v$ 1996/11, pp. $1183-1184$

DANTZIG, A. VAN, 'Enkele opmerkingen over zorgvernieuwing,' MGv 1997/11, pp. 1132-1134

DANTZIG, A. VAN, aangehaald door Monic SLINGERLAND, "VAN DANTZIG wil staatssecretaris geestelijke gezondheidszorg,' Trouw 6 juni 1998, p. 9

DANTZIG, Dries van, aangehaald door Arjan visSER, '10 Geboden,' Trouw 29-30 augustus 1998, p. 29

DANTZIG, Andries VAN, geïnterviewd door Paul schNaBEL, "Net als het lichaam moeten we het gevoelsleven onder het regime van de wetenschap stellen"; NFGV ereprijs 1998 voor dr. A. VAN DANTZIG; een interview,' MGv 1998/10, pp. $927-943$

DAvidSON, Howard A., "Orphanages" or child abuse prevention?' IJCR 1995/2, pp. $283-291$

DAvidson, Scott, Human rights, Buckingham/Philadelphia 1993

DELFGAAUw, Bernard, De mens en zijn rechten, Kampen 1993

Deluros, Martine $\mathbb{F}$., Kinderen in ontwikkeling; Stoornissen en belemmeringen, Lisse 1996

DELFOS, Martine F., Kinderen en gedragsproblemen; Een bio-psychologisch model met richtlijnen voor diagnostiek en behandeling, Lisse 1997

DELISSEN, Astrid, 'De rechten van het kind: na 10 jaar voorbereiding nu bij verdrag vastgesteld,' NJCM-Bulletin 1990/5, pp. 566-575

DEPAEPE, Marc, 'De eeuw van het kind in historisch-pedagogisch perspectief,' in: H. Cammaer en E. verhellen (red.), Onmondig en onvolwassen; De jonge mens in de eeuw van het kind, Leuven/Amersfoort 1990, pp. 9-37

DERKs, Frans; Martien PHILIPSE, Rien VAN IJZENDOORN, 'De betekenis van BOWLBY's gehechtheidstheorie in de beoordeling en behandeling van ter beschikking gestelden,' $\mathrm{TvCr} 1997 / 1$, pp. $42-55$ 
DERKS, Willem, Zo waarlijk helpe mij FREwo almachtig; De invloed van de psychoanalyse op het strafrecht, Amsterdam 1986

DERKSEN, J.J.L., Handboek persoonlijkheidsstoomissen; Diagnostiek en behandeling van de DSM-IV en ICD-10 persoonlijkheidsstoomissen, Utrecht 1993

DESCHNER, Karlheinz, De kerk en haar kruis; Geschiedenis van de seksualiteit in het Christendom, Amsterdam 1978

DETRICK, Sharon (ed.), The United Nations Convention on the rights of the child; A guide to the 'travaux preparatoires,' Dordrecht (etc.) 1992

DETRICK, Sharon; Jaap DOEk, Isabeth MUNARENDs, 'Slotbeschouwing, FJR 1998/1 (special over het Verdrag inzake de rechten van het kind), pp. 26-27

DIEKSIRA, René, "Wie waakt, slaapt niet; over oplettendheid, overheid en op" voeding; een reactie op KoHNSTAMm en BRINKGREVE,' Jeugd en Samenleving 1994/2, pp. $91-97$

DIELEMAN, A.J.; P. SPAN, 'Inleiding: de pedagogiek en het animal educandum, "in: dez. (red.), Pedagogiek van de levensloop, Amersfoort/Leuven (ou Heerlen) 1992, pp. 15-27

DIERX, Janny, 'Pragmatische en symbolische mensenrechten' ('Recht uit het hart'), Nemesis $1997 / 5$, p. 182

DLK, P. VAN, 'Rechten van de mens en ontwikkelingssamenwerking; enige rechtsbeginselen," NJCM-Bulletin 1980/1, pp. 4-20

DIJK, Pieter VAN, "The Universal Declaration of human rights; its significance in the year 1988, in: The Universal Declaration of human rights: its significance in 1988, Report of the Maastricht/Utrecht workshop (....) on the occasion of the 40th anniversary of the Universal Declaration, SIM Special 9, [Utrecht 1989], pp. 27-33

DUJ, P. VAN; G.J.H. VAN HOOF, De Europese Conventie in theorie en praktijk, Ars Aequi Libri, Nijmegen 1990 (derde druk)

Dus, P. VAN, e.a. (eds.), Intemationale regelingen, mensenrechten, Lelystad 1993 (second ed.); International law, human rights, 1998 (third ed.)

DIJK, P. VAN, Rechten van de mens; universaliteit versus waardenrelativisme, Mededelingen van de Koninklijke Nederlandse Akademie van Wetenschappen, Afdeling Letterkunde, Nieuwe Reeks, deel 57, no. 2, Amsterdam (etc.) 1994, pp. [61-90/]5-34

DuK, Pieter VAN, 'A common standard of achievement; about universal validity and uniform interpretation of international human rights norms,' $N Q H R$ 1995/2, pp. $105-121$

DUKSTRA, S.; F. SWETS-GRONERT, Dilemma's rond kindermishandeling; Een verkennend onderzoek naar signalering en melding, NoGv, Utrecht 1989

Dukstra, Sietske, e.a., Kindermishandeling: van signaal naar hulp 1 ; Hulpverlenen en samenwerken, NcGv, Utrecht 1990

DUKSTRA, Sietske; Willie LANGELAND, 'Het melden van kindermishandeling,' in: Afra GROEN en Adri VAN MONTFOORT (red.), Kinderen beschermen en jeugd hulp verlenen, Arnhem 1993, pp. 59-78

Dukstra, Sietske, 'Perpetuum mobile? De overdracht van geweld betwist,' $\mathrm{Tw} \mathrm{Cr}$ $1995 / 4$, pp. 346-359 
DIJKSTRA, Sietske, 'In gesprek over kindermishandeling; groepshulpverlening aan volwassenen,' VKMagazine 1997/2, pp. 6-7

DINGWALL, Robert; John EEKELAAR, Topsy MURRAY, The protection of children; State intervention and family life, Oxford/New York 1985

DINSMORE, Christine, From surviving to thriving; Incest, feminism, and recovery, New York 1991

DIRKSE, D.G., 'Voorwoord,' in: RAAD vOOR HET JEUGDBELEID, Kindermishandeling vermeldenswaard; Advies over de aanpak van kindermishandeling: preventie, hulpverlening en rechtstoepassing, Ministerie van Welzijn, Volksgezondheid en Cultuur, Rijswijk 1988

DIS, Adriaan VAN, 'De slavernij voorbij,' in: Frits VAN OOSTROM (red.), Historisch tableau; Geschiedenis opnieuw verbeeld in schoolplaten en essays, Amsterdam 1998, pp. 97-105

DoEK, J.E., 'Preventie en overheidsbeleid,' in: Rom HAANSTRA e.a. (red.), Geweld tegen kinderen; Opstellen over preventie van en hulpverlening bij kindermishandeling, vKM, Den Haag 1987, pp. 195-209

Doek, J.E., 'Ondertoezichtstelling en het belang van het kind: een toverformule in het kwadraat?' In: Ad VAN DER LINDEN, Paul vLAARDINGERBroek (red.), Met het oog op het belang van het kind; Opstellen aangeboden aan (...) Madzy ROOD-DE BOER (...), Deventer 1988, pp. 97-107

DOEK, J.E., 'Het recht van het kind op identiteit,' in: P.C.Th.M. VAN EEUWIJK, J.H.A. VAN LOON (red.), Identiteitsproblemen bij adoptiekinderen, Amsterdam/Lisse 1989, pp. 47-61

DOEK, J.E., 'Meldingsplicht, ja of nee?' In: H. BAarTMAN e.a., Incest en hulpverlening, Amersfoort/Leuven 1990, pp. 274-279

DOEK, J.E., 'Het belang van het kind en het recht,' in: J.B. WEENINK (red.), Het belang van het kind in het geding; Over opvoeding en kinderbescherming, Amsterdam 1990, pp. 73-92

DoEk, J., 'Een andere tussenbalans,' editorial FJR 1991/5, p. 97

Dork, Jaap, 'Kindermishandeling, beroepsgeheim, privacy en inzage van vertrouwelijke gegevens,' in: H. BAARTMAN, A. VAN MONTFOORT (red.), Kindermishandeling: resultaten van multidisciplinair onderzoek, Utrecht 1992, pp. 279-300

DOEK, Jaap, 'Van oude dogma's en dingen die voorbijgaan; de toekomst van onze justitiële jeugdbescherming met enige buitenlandse belichting,' in: Afra GROEN en Adri VAN MONTFOORT (red.), Kinderen beschermen en jeugd hulp verlenen, Arnhem 1993, pp. 157-173

DOEK, Jaap E., 'Child abuse and neglect: Article 19 CRC', IJCR 1994/1, pp. 88-95 DOEK, J.E., De ratificatie van het Verdrag inzake de rechten van het kind; enige beschouwingen over de mogelijke gevolgen voor de Nederlandse rechtspraktijk,' NJCM-Bulletin 1995/1, pp. 10-21

DoEk, Jaap, 'Kindermishandeling: recht op en/of dwang tot preventie,' VKMagazine [1995]/3 (special 'Primaire preventie van kindermishandeling'), pp. 18-21 
DOEK, J.E.; P. VLAARDINGERBRoEK, Jeugdrecht en jeugdhulpverleningsrecht, Den Haag 1996 (tweede druk)

DONNELLY, Anne C., 'Foreword,' in: R.K. OATES, The spectrum of child abuse; Assessment, treatment, and prevention, Basic Principles into Practice series, vol. 8, New York 1996, pp. vii-ix

DONNELLY, Jack; Rhoda E. HOWARD, 'Assessing national human rights performance: a theoretical framework,' HRQ $1988 / 2$, pp. 214-248

DOORENSPLEE, Renske, 'Humaniteit boven soevereiniteit; over humanitaire interventie en het voorbeeld Haiti,' NJCM-Bulletin 1995/7, pp. 957-967

DosToJevskI, Fjodor, Christus en de grootinquisiteur, uit: De gebroeders KARAMAzov (1879-1880), vert. Marko FonDSE, s.l. 1995, pp. 326-350

DouGHTY, Joan, 'Verschillen in de aanpak van kindermishandeling: een kwestie van cultuur?' VKMagazine 1990/2, pp. 8-10

Dower, Nigel, 'Human rights and international relations,' International Journal of Human Rights 1997/1, pp. 86-111

DRAIJER, Nel, Sexueel misbruik van meisjes door verwanten; Een landelijk onderzoek naar de omvang, de aard, de gezinsachtergronden, de emotionele betekenis en de psychische en psychosomatische gevolgen, Ministerie van Sociale Zaken en Werkgelegenheid, Den Haag 1988

DRAIJER, Nel, Een lege plek in mijn geheugen; Seksueel misbruik van meisjes door verwanten, Ministerie van Sociale Zaken en Werkgelegenheid, Den Haag 1988

DRAIJER, Nel, aangehaald door M. VAN AKEN, 'Vrouwenhulpverlening in de intramurale psychiatrie,' Slangengodin december 1989, pp. 42-44

DRAIJER, Nel, Seksuele traumatisering in de jeugd; Gevolgen op lange termijn van seksueel misbruik van meisjes door verwanten, diss. vu Amsterdam 1990

DraiJer, Nel, 'Psychische en psychosomatische gevolgen van seksueel misbruik en fysieke mishandeling,' in: H. BAARTMAN, A. VAN MONTFOORT (red.), Kindermishandeling; Resultaten van multidisciplinair onderzoek, Utrecht 1992, pp. 54-72

DRALUER, Nel, 'Herinneringen aan traumatische ervaringen in de kindertijd,' MGv 1996/7-8, pp. 707-727

DRAIJER, Nel, 'Trauma, persoonlijkheidsstoornissen en andere psychiatrische diagnoses,' MGv 1996/11, pp. 1134-1152

DRAIJER, N., 'Is seksueel misbruik van kinderen altijd erg? Over de noodzaak van differentiatie," in: H. BAARTMAN e.a., Gezinnen onder druk; Oververanderende ouder-kind relaties, Kampen 1997, pp. 63-79

DraUER, Nel, '"Hervonden misdrijven" eenzijdig bekeken,' MGv 1997/12, pp. 1249-1256

DRIESSEN, Malva; Jacqueline PARLEvLIET, 'Internationale escapades?' NJB 1988, p. 357

DRZEWICKI, Krzysztof, 'The right to work and rights in work,' in: Asbjørn EIDE, Catarina KRAUSE, Allan ROSAS (eds.), Economic, social and cultural rights; A textbook, Dordrecht (etc.) 1995, pp. 169-188 
DUNGEN, M. VAN DEN, 'Het broeikaseffect: gezin en samenleving rond 2000 ,' in:

Gezin; Tijdschrift voor primaire leefvormen 1989/3, pp. 164-180

Ebenstern, William, e.a.. American democracy in world perspective, New York (etc.) 1970

EGMOND, Marjan VAN, e.a., 'De plaats van seksuele kindermishandeling in de psychiatrie; een onderzoek onder hulpverleners in een $\mathrm{APZ}^{\prime}$ ' $M G v 1992 / 12$, pp. 1344-1354

ErDe, Asbjorn, 'Article 25;' in: dez. e.a. (eds.), The Universal Declaration of human rights; A commentary, Oslo(/Oxford) 1992, pp. 385-403

EIDE, Asbjorn, 'Article 28," in: dez. e.a. (eds.), The Universal Declaration of human rights; $A$ commentary, Oslo(/Oxford) 1992, pp. 433-447

EmE, Asbjørn; Allan RosAs, 'Economic, social and cultural rights: a universal challenge," in: Asbjørn eIde, Catarina krause, Allan rosas (eds.), Economic, social and cultural rights; A textbook, Dordrecht (etc.) 1995, pp. 15-19

ELBERS, Ed, 'De verschuivende zone tussen zorg en zelfstandigheid; een ontwikkelingspsychologisch perspectief, in: Carol VAN NUNATTEN (red.), Kinderrechten in discussie, Amsterdam/Meppel 1993, pp. 81-101

ELDERING, L., "Van doelgroepenbeleid naar ouderondersteuning,' reactie ('Journaal') in Justitiële Verkenningen 1996/9, pp. 78-83

ELDERS, Fons, 'De verborgen kwaliteiten van een Afrikaanse wereldbeschouwing; een essay over de Dogon," Rekenschap; Humanistisch tijdschrift voor wetenschap en cultuur 1994/2, pp. 97-105

ELLIS, Jane, 'The best interests of the child,' in: Cynthia Price COHEN, Howard A. DAVIDSON (eds.), Children's rights in America: UN Convention on the rights of the child compared with United States law, ABA/DCI-USA, s.L. 1990, pp. 3-18 ELsT, Phily, 'Van afgewezen dochter naar liefdevolle moeder,' Psychologie juni 1998, pp. 20-22

EPEN, J.H. VAN, Drugversiaving en alcoholisme, Amsterdam/Brussel 1983 (derde druk)

EPEN, Hans VAN, Schets voor een nieuwe psychiatrie, Houten/Deurne 1990 EUROPESE COMMISSIE VOOR DE RECHTEN VAN DE MENS, Application No. 25599/94, A tegen het Verenigd Koninkrijk (rapport van de Commissie d.d. 18 september 1997)

EYFminger, Arthur, The Peace Palace; Residence for justice, domicile of leaming (1913-1988), Wormer 1988

EYFFINGER, A.C.; B.P. veRMEULEN (red.), Hugo DE GRoot; Denken over oorlog en vrede, Geschiedenis van de wijsbegeerte in Nederland, deel 8, Baarn 1991 eyfFinger, A.C; B.P. vermeulen, "Inlleiding,' in: dez. (red.), Hugo de groot; Denken over oorlog en vrede, Baarn 1991, pp. 11-40

EYFFINGER, Arthur, The Intemational Count of Justice 1946-1996, The Hague (etc.) 1996

EYFFINGER, Arthur, 'Europe in the balance: an appraisal of the Westphalian system,' NILR 1998/2, pp. 161-187 
EYSINGA, W.J.M. VAN, Gids voOT DE GROOTS De iure belli ac pacis, Leiden 1945 EYSINGA, W.J.M. VAN, Sparsa collecta, Leiden 1958

FALK, R., "Introduction: the grotian quest," in: Ch.S. EDWARDS, Hugo GROTIUS: the miracle of Holland; A study in political and legal thought, Chicago 1981, pp. xiii-xxi

PALK, Richard, The end of world order; Essays on normative international relations, New York/London 1983

FALK, Richard, e.a. (eds.), Intemational law; A contemporary perspective, Boulder/London 1985

FALK, Richard A., "Nuclear weapons, international law and the World Court: a historic encounter," editorial comment, AJIL 1997/1, pp. 64-75

FEENSTRA, R., Vergelding en vergoeding; Enkele grepen uit de geschiedenis van de anrechtmatige daad, Deventer 1982

FERENCZI, Sandor, 'Spraakverwarring tussen de volwassenen en het kind (De taal van de tederheid en die van de hartstocht), "in: J.M. Masson, Traumatische ervaring of fantasie; FREUDS rampzalige herziening van de verleidingstheorie, Amsterdam 1984, Appendix 2, pp. 182-193

FERNHOUT, D.M., Rechtswragen rond in vitro fertilisatie en embryo-transfer, Arnhem 1992

FERWERDA, H.B., e.a., Signalen voor toekomstig criminneel gedrag; Een onderzoek naar de signaalwaarde wan kinderdelinquentie en probleemgedrag op basis van casestudies wan emstig criminele jongeren, Ministerie van Justitie, Den Haag (december) 1996

FIIN, H.J.R., 'Effectief ingrijpen onder de grens van het strafrecht voor jeugdigen,' reactie ('Journaal') in Justitiele Verkenningen 1996/8, pp. 97-98

FINKELHoR, David, "Foreword," in: Kevin browne, Martin herBerT, Preventing family violence, Chichester (etc.) 1997 , pp. xv-xvi

FLEKKøy, Mallfrid Grude, 'Children's participation and monitoring children's rights,' in: Eugeen VERHELLEN (ed.), Monitoring children's rights, Den Haag (etc.) 1996 , pp. 57-65

Flinterman, Cees; Evelyn ANKuMaH, "The African Charter on human and peoples' rights," in: Hurst HANNUM (ed.), Guide to international human rights practice, Philadelphia 1992 (tweede druk), pp. 159-169

FLINTERMAN, Cees, "The protection of economic, social and cultural rights and the European Convention on human rights,' in: Rick LAwSON, Matthijs DE BLors (eds.), The dynamics of the protection of human rights in Europe; Essays in honour of Henry $G$. sCHERMERS, vol. II, Dordrecht (etc.) 1994, Pp. 165174

FLINTERMAN, Cees, 'Het recht tot klagen; totstandkoming van een Facultatief protocol bij het Vrouwenverdrag;' Nemesis 1995/1, pp. 5-7

FOEKEN, Ingrid, "Inbreuk en uitbreken; loyaliteitsverandering door confrontaties van slachtoffers met daders van seksueel misbruik en andere familieleden,' in: Elly sINGER en Margreet WEGELIN (red.), De familieband verbroken? Opstellen over gezinsgeweld, autonomie en loyaliteit, Utrecht 1991, pp. 38-52 
Forder, C.J., "In het gezinsleven: "Different but equal", in: A.W. HERINGA, J. HES, L. LINZAAD (red.), Het vrouwenverdrag: een beeld van een verdrag ..., Antwerpen/Apeldoorn 1994, pp. 239-253

FORDER, Caroline, Legal establishment of the parent-child relationship: Constitutional principles in Dutch, English and German law, having regard to the European Convention for the protection of human rights and fundamental freedoms and other applicable international instruments, diss. Maastricht 1995, s.l. (e.a.)

FORDER, C.J., 'Het gezin in internationale verdragen,' R[echtsgeleerd] M[agazijn] Themis 1997/4, pp. 130-144

FORTUIN, H., De natuurrechtelijke grondslagen van DE GROOTs volkenrecht, Den Haag 1946

FORWARD, Susan; Craig Buck, Eindelijk je eigen leven leiden; Loskomen van een beschadigde jeugd, Utrecht/Antwerpen 1990

FRANKEN, H., 'Het belang van het kind voor wetgeving en bestuur,' in: Ad VAN Der linden, Paul vlaArdingerbroek (red.), Met het aog op het belang van het kind; Opstellen aangeboden aan (...) Madzy ROOD-DE BOER (...), Deventer 1988, pp. $27-42$

FRANKEN, H., Inleiden tot de rechtswetenschap, Arnhem 1993 (zesde druk), 1995 (zevende druk)

FRANZ, M.-L. von, 'Het individuatie-proces,' in: Carl G. Jung, De mens en zijn symbolen (London 1964, Rotterdam 1966), ed. Amsterdam 1974, pp. 158229

FreEman, Michael, 'The limits of children's rights,' in: dez. en Philip veERMaN (eds.), The ideologies of children's rights, Dordrecht (etc.) 1992, pp. 29-46

FREEMAN, Michael, 'Beyond conventions - towards empowerment,' in: Maud DROOGLEEVER FORTUYN, Miek DE LANGEN (eds.), Towards the realization of human rights of children; Lectures given at the second International Conference on Children's Ombudswork, DCr-Netherlands, Amsterdam 1992, pp. 1939

FREEMAN, Michael, 'The philosophical foundations of human rights,' in $H R Q$ 1994/3, pp. 491-514

FREEMAN, Michael, 'Children's rights in a land of rites,' in: Bob FRANKLiN (ed.), The handbook of children's rights; Comparative policy and practice, London/ New York. 1995, pp. 70-85

FreEman, Michael, 'The moral status of children,' in: Eugeen verHELlen (ed.), Understanding children's rights; Collected papers presented at the first International interdisciplinary course on children's rights, Gent 1996, pp. 9-23

FREEMAN, Michael, The moral status of children; Essays on the rights of the child, Den Haag 1997

FRENCH, Marilyn, 'De verbeten oorlog van mannen tegen vrouwen,' Forumpagina De Volkskrant 7 juli 1992

Freud, Sigmund, Over de etiologie van de hysterie (1896), Sigmund Freud; Nederlandse editie, Klinische beschouwingen I, Meppel/Amsterdam 1985, pp. 9-45 
FREUD, Sigmund, Drie verhandelingen over de theorie van de seksualiteit ( $\mathrm{De}$ seksuele aberraties'; 'De infantiele seksualiteit'; 'De transformaties in de puberteit; 1905), Sigmund FREUD - Nederlandse editie, Klinische beschouwingen I, Meppel/Amsterdam 1985, pp. 47-177

FREYD, Jennifer J., Betrayal trauma; The logic of forgetting childhood abuse, Cambridge (Mass.) /London 1996

FRIDA, Nico H., De emoties; Eert averzicht van onderzoek en theorie (1986), Amsterdam 1993

Froman, Michael B.G., bespr. van Burns H. weston (ed.), Altemative security; Living without nuclear deterrence (1990), in: AJIL 1992/1, pp. 205-207

FURSTENBERG Jr., Frank F., 'State-family alliances and children's welfare; a research agenda,' Childhood 1997/2, pp. 183-192

Furukawa Terumi, 'Punishment," in: ONUMA Yasuaki (ed.), A normative approach to war: Peace, war, and justice in Hugo Grotyus, Oxford 1993, pp. 221243

Gallagher, Anne, "Ending the marginalization: strategies for incorporating women into the United Nations human rights system,' HRQ 1997/2, pp. 283-333

GANNON, J. Patrick, Soul survivors; A new beginning for adults abused as children, New York (etc.) 1989

GARBARINO, James, 'Future directions,' in: Robert T. AMMERMAN, Michel hersen (eds.), Children at risk; An evaluation of factors contributing to child abuse and neglect, New York/London 1990, pp. 291-298

GAYLIN, Willard, [Adam and Eve and Pinocchio:] On being and becoming human, New York 1990; pbk. ed. 1991

GEERTJENS, Lidwien, bespr. van Jaarboek ontwikkelingspsychologie, orthopedagogie en kinderpsychiatrie 2 (1996-1997), in: MGv 1997/4, pp. 432-435

GELDEREN, Martin VAN, "The challenge of colonialism: GRoTIus and vTroRIA on natural law and international relations,' Grotiana, New Series, vol. 14-15, 1993-1994, pp. 3-37

GELLES, Richard J., 'Foreword,' in: Robert DINGWALl, John EekrlaAk, Topsy MURRAY, The protection of children; State intervention and family life, Oxford/ New York 1985, pp. vii-viii

GIL, Eliana, Outgrowing the pain together; $A$ book for spouses and partners of adults abused as children, New York 1992

Gn, Eliana, Samen de pijn te boven; Een boek voor de partners van mensen die als kind werden mishandeld of misbruikt (omgekeerd afgedrukt achter dez., De pijn te boven; Een boek voor mensen die als kind werden mishandeld of misbruikt), Houten 1993

GILBERT, Neil (ed.), Combatting child abuse; Intemational perspectives and trends, New York/Oxford 1997

GILLIGAN, John J., 'Law, the path to justice; justice, the road to peace'; Address to the First raLANA Congress, (International Association of Lawyers Against Nuclear Arms) The Hague, September 22-24, 1989 
GÖRTZEN, R., 'Onderdrukking en bevrijding van het kind,' in: B. SPIECKER e.a. (red.), Theoretische pedagogiek, Meppel/Amsterdam 1982, pp. 151-176 GốRTZEN, René, 'Alice MILler, "Zwarte pedagogiek" en psychoanalyse,' Intermediair 20 augustus 1984, pp. 9, 11 en 13

GOLDBERG, Jim, Raised by wolves, New York 1995

GOLDHAGEN, Daniel Jonah, Hitler's willing executioners; Ordinary Germans and the holocaust, New York 1996

GOLDSCHMIDT, J.E., 'Staats- en bestuursrechtelijke aspecten van positieve actie,' Preadvies NJV, Positieve discriminatie, Handelingen Nederlandse JuristenVereniging 1989-1, Zwolle [1989-1], pp. 57-117

GoLDSCHMIDT, Jenny E., Mensenrechten: vrouwenrechten? Nieuwenhoflezing VIII (4 juni 1994), Deventer 1995

GolDSCHMIDT, Jenny E., bespr. van Rebecca [J.] cook (ed.), Human rights of women; National and international perspectives (Philadelphia 1994), in: NQHR 1996/2, pp. 229-231

GOLDSTEIN, Joseph; Anna FREUD, Albert J. SOLNIT, De toverformule: in het belang van het kind (Beyond the best interests of the child, New York 1973; Jenseits des Kindeswohls, Frankfurt am Main 1974); Met bijdragen van Spiros sIMmTs en Madzy ROOD-DE BoER, Deventer 1979

GOLDSTEIN, Joseph; Anna FREUd, Albert J. SOLNT, Wanneer de toverformule: criteria voor overheidsinterventie in het belang van het kind (Before the best interests of the child, New York 1979; Diesseits des Kindeswohls, Frankfurt am Main 1982); Met bijdragen van Spiros sIMrTIS en Madzy ROOD-DE BOER, Deventer 1984

goleman, Daniel, Emotionele intelligentie; Emoties als sleutel tot succes, Amsterdam/Antwerpen 1996

GORDON, Edward, bespr. van ONUMA Yasuaki (ed.), A normative approach to war: Peace, war, and justice in Hugo GRoTrus (Oxford 1993), in: AJIL 1995/2, pp. $461-463$

GOUDENA, P.P., 'Adaptatie, individuatie en het ontstaan van het zelf,' in: C. VAN NIINATTEN (red.), Psychodynamische ontwikkelingsmodellen, Meppel/Amsterdam 1992, pp. 82-102

GOUdENA, P.P., 'Pedagogische preventie; mogelijkheden en beperkingen,' Justitiële Verkenningen 1996/6 ('Preventief ingrijpen in het gezin'), pp. 38-49 Govaes, Olympe DE, Verklaring van de rechten van de vrouw en burgeres (Parijs 1791), uitgegeven door Hannelore schröDER, Kampen 1989

GOWLLAND-DEBBAS, Vera, 'The relationship between the International Court of Justice and the Security Council in the light of the Lackerbie case,' $A J I L$ 1994/4, pp. 643-677

GRAAF, Willibrord DE, 'Gevleugeld of beteugeld ouderschap?' In: C. VAN NINATTEN (red.), Kinderrechten in discussie, Amsterdam/Meppel 1993, pp. 143-161 GRAPENDAAL, M., 'Over criminaliteit en kattekwaad,' Justitiële Verkenningen 1996/6 ('Preventief ingrijpen in het gezin'), pp. 85-100

GRASTE, Jacques, 'Ethiek als kritische reflectie: de Ethica van ARISTOTELES,' $M G V$ $1998 / 5$, pp. $474-489$ 
GRoTIUS, Hugo, [Three books on the law of war and peace], vol. In: The translation, by Francis W. KELSEY, The Classics of International Law (edited by James Brown scotr), Oxford/London 1925 [1927, 1928]; reprinted New York 1964, Birmingham, Alabama 1984

Grotius, Hugo, De iure belli ac pacis libri tres in quibus ius naturae et gentium item iuris publici praecipua explicantur; Curavit B.J.A. DE KANTER-VAN HETTINGA TROMP; Editionis anni 1939 quae Lugduni Bataworum (...) emissa est, exemplar photomechanice iteratum; Annotationes novas addidenunt $R$. FEENSTRA et C.E. PERSENAIRE, adiuvante E. ARPS-DE WILDE, Aalen 1993

GrUYer, Frédérique; Martine Fadier-NISSE, Pierre SABOURIN, La violence impensable; Inceste et maltraitance, Paris 1991

GUNNING, M.J., Gewaande rechten; Het denken over wrouwen en gelijkheid van

Thomas VAN AQUINo tot de Bataafsche Constitutie, diss. Utrecht, Zwolle 1991 GUWY, France, 'Jij die mij aanziet'; Emmanuel LEVINAS, IKON, Hilversum 1986

HaAn, Anne-Marieke den; Monique KavelaArs, Preventie van seksueel misbruik van kinderen, deel 1, LOP (Landelijk Ondersteuningspunt Preventie), Utrecht [1988]

HAANS, Gé, Kinderen voor onze rekening; Een casuistische verkenning van het (gezins)voogdijwerk, Utrecht 1992

HAARSMA, Lennie; Trudy ZANDIJK-VAN HARTEN, Grenzen voorbij; Kindermishandeling in allochtone gezinnen, Amsterdam 1996

haggenmacher, Peter, 'Grotius and gentili: a reassessment of Thomas E. HOLLAND's inaugural lecture,' in: Hedley BuLL, Benedict KINGSBURY, Adam ROBERTS (eds.), Hugo GROTIUs and international relations, Oxford 1990, pp. $133-176$

hamerlynCK, Karen; Claudia BELlini, 'De stand van zaken: 15 jaar psychologie,' Psychologie april 1997, pp. 16-23

HAMmARBERG, Thomas, "The UN Convention on the rights of the child - and how to make it work,' HRQ 1990/1, pp. 97-105

hammarberg, Thomas, 'Children,' in: Asbjørn eide, Catarina krause, Allan ROSAS (eds.), Economic, social and cultural rights; A textbook, Dordrecht (etc.) 1995, pp. 289-307

hammarberg, Thomas, 'Preface,' in: Bob Frankun (ed.), The handbook of children's rights, Comparative policy and practice, London/New York 1995, pp. ix-xiii

HAMMERSTEIN-SCHOONDERWOERD, W.C.E., 'De problematiek rond kunstmatige inseminatie met donorsperma, in vitro fertilisatie en draagmoederschap, gezien vanuit het personen- en familierecht,' in: dez. e.a., Kunstmatige voortplanting; Recht en ethiek, Publikatie 14 van de Rechtskundige Afdeling van het THumgenootschap, Zwolle 1989, pp. 23-46

HANSEN, Robert W., 'The role and rights of children in divorce actions,' Journal of family law (University of Louisville School of Law) 1966, pp. 1-14

HARMS, Ingrid, 'Moederheil; een kind betwist haar eigen staat,' Vrij Nederland 8 februari 1997, pp. 20-22 
HERMANNS, Jo, bespr. van sCHOlTE en sonTAG, Opvoeding en ontwikkeling; Een literatuuronderzoek naar de samenhang tussen opvoedingsgedrag van primaire opvoerders en de ontwikkeling van jeugdigen (januari 1992), in: Jeugd en samenleving 1994/2, pp. 115-117

HERMANNS, J.M.A., Het sociale kapitaal van jonge kinderen, i.o. Amsterdam 1992, Utrecht 1995 (tweede druk)

HERMANNS, $\mathrm{J}_{O}$, 'Preventie als voorkeursstrategie,' Comenius; Wetenschappelijk forum voor opvoeding, onderwijs en cultuur 1998/1 ('Criminaliteitspreventie en opvoedingsondersteuning'), pp. 65-76

HERRAETS, Jacques, 'Aardse paradijzen, niet te genieten!' Interview met rechtsfilosoof Frank VAN DUN (naar aanleiding van het verschijnen van Hans CROMBAG en Frank vAN DUN, De utopische verleiding, Amsterdam/Antwerpen 1997), Continu-UM (Kwartaalblad van de Universiteit Maastricht) 1998/1, pp. 31-34

HERTEN, J.H.S. VAN, 'Juridische aspecten van kindermishandeling,' $N J B$ 1986, pp. 251-253 (reacties en naschrift, pp. 525-528)

Hes, J.C.; C.E. VAN vleuten, Het Vrouwenverdag in de Nederlandse rechtsorde, Onderzoek verricht in opdracht van het Ministerie van Sociale Zaken en Werkgelegenheid door de vakgroep Publiekrecht van de [Universiteit Maastricht], Den Haag, augustus 1996

HEUSDEN, Ammy VAN; EIseMarie VAN DEN EERENBEEMT, Ivan BOSZORMENYT-NAGY en zijn visie op individuele en gezinstherapie; Balans in beweging, Haarlem 1988 (derde druk; in de vierde druk van 1990 zijn hoofd- en subtitel omgedraaid)

HeUvel, Aad van DEN, Willem bosman in goud en slaven, Amsterdam 1981

HIDDEMA, Frans, Bruine terreur door zwarte pedagogie; Psychoanalytische aspecten van HITLERs racistische nazidom, Rotterdam 1985

HIRSCH BALLIN, E.M.H., Wereldburgers: personen in het internationale recht, i.o. KuB (Tilburg), Zwolle 1995

HODGKIN, Rachel; Peter NEwelL, Implementation handbook for the Convention on the rights of the child, UNICEF, New York/Genève 1998

HOKSBERGEN, R.A.C., 'De invloed van het verleden op de identiteitsbeleving,' in:

P.C.Th.M. VAN EEUWIJ, J.H.A. VAN LOON (red.), Identiteitsproblemen bij adoptiekinderen, Amsterdam/Lisse 1989, pp. 30-44

HoKsBeRgen, R.A.C., 'De psychologie van adoptie,' in: dez. e.a., Interlandelijke adoptie, Publikatie 15 van de Rechtskundige Afdeling van het THumgenootschap, Zwolle 1990, pp. 1-15

HOLTMAAT, R.; T. LOENEN, Inleiding vrouw en recht, Alphen aan den Rijn 1989

HOLTrusT, Nora, 'Commentaar' (betr. omgangsrecht voor incestdader met zijn bloedschennig kind), Opzij september 1989, p. 25

HOOF, G. VAN, 'Human rights in a multi-cultural world: the need for continued dialogue,' in: Ronald St.J. MACDONALD (ed.), Essays in honour of WANG TIEYA, Den Haag 1994, pp. $877-891$

HOOFF, J.A. VAN, 'Wat studies aan primaten ons kunnen leren over de invloed van de sociale omgeving op de moeder-kind relatie,' in: J.E. DE BOER (red.), 
Infantpsychiatrie I; De gezonde en verstoorde ontwikkeling van de vroege ouder-kind relatie, Assen/Maastricht 1991, pp. 40-55

HOWLAND, Courtney W., "The challenge of religious fundamentalism to the liberty and equality rights of women: an analysis under the United Nations Charter,' Columbia Joumal of Transnational Law 1997/2, pp. 271-377

hudson, Manley O.; Ruth E. BaCON, World Court reports; A collection of the judgments, orders and opinions of the Permanent Court of International Jus. tice, vol. III, 1932-1935, Washington 1938 (pp. 99-116: PCII, Series $A / B$, no. 50 , pp. 365-390)

hulbregts, Veronique, 'Peter schoof: "Kinderen een stem en een gezicht geven", VKMagazine $1996 / 2$, pp. 1-3

Hune, Shirley; Jan NIESSEN, 'The first uN Convention on Migrant Workers,' NQHR 1991/2, pp. 130-141

HUNE, Shirley; Jan NIESSEN, 'Ratifying the UN Migrant Workers Convention: current difficulties and prospects,' NQHR 1994/4, pp. 393-404

HUNTER, Mic, Abused boys; The neglected victims of sexual abuse, Lexington (Mass.)/Toronto 1990

INTERNATIONAAL GERECHTSHOF, Kernwapenadvies (Legality of the threat or use of nuclear weapons; Nederlandse vert:: zie STEUNEN/sTELLING)

INTERNATIONAL COURT OF JUSTICE, Legality of the threat or use of nuclear weapons; Advisory opinion of 8 July 1996 (full text), HRLJ 1996/7-10, pp. 253-392 ISRAËLS, Han, Het geval FREUD; [Deel] 1. Scheppingswerhalen, Amsterdam 1993

JANSE, C.C.J.; R.S.R. AARSEN, Kindermishandeling, een probleem voor het ziekenhuis, Eindverslag van het Project kindermishandeling in het Sophia Kinderziekenhuis Rotterdam, s.(Le.)a.

JANSE, Charlotte; Roland AARSEN, 'Kindermishandeling, een probleem voor het ziekenhuis,' VKMagazine 1997/1, pp. 1-3

JANSEN, I., 'Invulling van het ouderlijk gezag?' Editorial FJR 1987/8, p. 225 JANSSEN, Hilde, 'Een volk dat niet naar de wC wil,' Intermediair 22 maart 1996, pp. 31 en 33

JENSON, Jean, $O p$ weg naar je ware zelf; Een stap voor stap gids om schadelijke gevolgen van onze opvoeding te boven te komen; Met een woord vooraf van Alice MLler, Houten 1998 (tweede druk)

JöRG, N.; C. KELK, Strafrecht met mate, [Arnhem] 1996 (negende druk) JOHNSON, David, 'Cultural and regional pluralism in the drafting of the UN Convention on the rights of the child,' in: Michael FreEman, Philip veERMaN (eds.), The ideologies of children's rights, Dordrecht (etc.) 1992, pp. 95-114 JoHnson, Stephen M., Character styles, New York/London 1994 JONG, Harry DE, 'Prostitutie: een vorm van seksueel geweld?' In: Eelco DAMEN en Nico VAN OOSTEN (red.), Mannelijkheid en seksueel geweld, Deventer 1988, pp. 82-91

JONG, Willem N. DE, 'Seksueel misbruik van kinderen binnen het gezin: werken aan de crisis,' in: Gerben BruINSMA e.a. (red.), Vrouw en criminaliteit; Vrou- 
wen als plegers en slachtoffers van criminaliteit, Meppel/Amsterdam 1987, pp. $128-140$

JONGHE, F. DE, 'Descriptieve en structurele persoonlijkheidspathologie,' in: R.V. SCHWARZ, D.H. LINSZEN (red.), Persoonlijkheidsstoomissen; Diagnostiek, behandeling, beleid, Amsterdam/Lisse 1991, pp. 33-48

JONKER-DE PUTTER, C.K.; R.A.R. BULLENs, 'Machtsverhoudingen 'en seksueel geweld," in: Atti Noordhof (red.), Signalen van incest, Amsterdam/Lisse 1988, pp. $11 \cdot 28$

JONKER-DE PUTTER, Ineke, Als je kind misbruikt is; Moeders van seksueel misbruikte kinderen, diss. Universiteit van Amsterdam [1992], Amsterdam 1991 JOSEPH, Cathy, 'Compassionate accountability (...)' (Joumal of Psychohistory 1996), excerpt in: Violence and abuse abstracts 1996/4, nr. 1020, p. 271 JUNGER-TAS, Josine, Jeugd en gezin; Preventie vanuit een justitieel perspectief, Ministerie van Justitie, Den Haag, juni 1996

JUNGER-TAS, J., 'Gezinsbeleid vanuit een justitieel perspectief,' Justitiële Verkenningen 1996/6 ('Preventief ingrijpen in het gezin'), pp. 17-37

JUNGER-TAS, Josine, 'Predictie van criminaliteit en preventief ingrijpen,' Comenius; Wetenschappelijk forum voor opvoeding, onderwijs en cultuur 1998/1 ('Criminaliteitspreventie en opvoedingsondersteuning'), pp. 28-47 Juvenalis, De Satiren, vert. M. D'HANE-SCHeLTEMA, Baarn/Amsterdam 1984

KAANDORP, Majorie, e.a. (eds.), International yearbook of children's rights 1995 , DCr-Netherlands, Amsterdam 1996

KALICHMAN, Seth $\mathrm{C}_{\text {., }}$ Mandated reporting of suspected child abuse; Ethics, law and policy, APA (American Psychological Association), Washington 1993

KALKMAN-BOGERD, L.E., "Artikel 8 en artikel 12 in verband met kunstmatige voortplanting en draagmoederschap,' in: J.K.M. GEVERS (red.), Het EVRM en de gezondheidszorg, Ars Aequi Libri, Nijmegen 1994, pp. 119-135

KALMTHOUT, M.A. VAN, 'Psychotherapeutische mogelijkheden bij "persoonlijkheidsstoornissen"," in: C.P.F. VAN DER STAAK, C.A.L. HOOGdUIN (red.), Diagnostiek en behandeling van de persoonlijkheidsstoornis, Symposium klinische psychologie, Nijmegen 1990/1, pp. 39-47

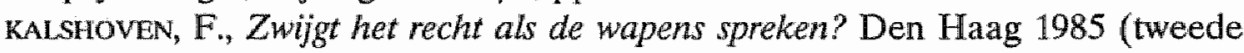
druk)

KAMMINGA, Menno T., Inter-state accountability for violations of human rights (Rekenschap afleggen van mensenrechtenschendingen), diss. Leiden 1990, s.l.(e.a.); Philadelphia 1992 (rev. ed.)

KAMMINGA, Menno T., 'Is the European Convention on human rights sufficiently equipped to cope with gross and systematic violations?' $N Q H R$ 1994/2, pp. 153-164

KAMMINGA, M.T., 'Volkenrechtelijke aansprakelijkheid van de staat jegens het individu,' Mededelingen van de Nederlandse Vereniging voor Internationaal Recht 115, Deventer 1997, pp. 5-49

KAMPEN, J. VAN (red.), De staat van jeugdig Nederland 1996; Een sociale kaart van de jeugd wan Nederland, Delft [1996] 
KATHOLIEKE BUbelstiching, De bijbel (Willibrord-vertaling), Den Bosch (1995), 1996 (tweede druk)

KAUFMAN, Joan; Edward ZIGLER, 'The intergenerational transmission of child abuse,' in: Dante CICCHETT, Vicki CARuson (eds.), Child maltreatment; Theo$y$ and research on the causes and consequences of child abuse and neglect, Cambridge (etc.) 1989, pp. 129-150

KAYZER, Wim (red.), Een schitterend ongeluk; Wim KAYZER ontmoet Oliver SACKs, Stephen Jay GOULD, Stephen TOULMIN, Daniel C. DENNETT, Rupert SHELDRAKE en Freeman DYSON, Amsterdam/Antwerpen 1993

KEMPE, C. Henry, 'Foreword,' in: Ray E. HELFER, Ruth S. KEMPE (eds.), The battered child, Chicago/London 1988 (vierde druk), pp. xiii-xv

KEMPE, C. Henry; R.E. HelFer, 'Preface to the third edition,' in: Ray E. HELFER, Ruth S. KEMPE (eds.), The battered child, Chicago/London 1988 (vierde druk), pp. xix-xx

KENT, George, Children in the international political economy, New York (etc.) 1995

KernBerg, Otto F., Aggression in personality disorders and perversions, New $\mathrm{Ha}$ ven/London 1992

KEUS, L.A.D., 'Acties van het individu wegens schendingen van het internationale recht door staten; een beknopt onderzoek naar drie rechtsniveaus,' Mededelingen van de Nederlandse Vereniging voor Internationaal Recht 115, Deventer 1997, pp. 51-126

KEY, Ellen, De eeuw van het kind; Studiën (The century of the child, 1900; vert. J.P. WESSELINK-VAN ROSSUM), Zutphen [1903]

KHUSHALAN, Yougindra, Dignity and honour of women as basic and fundamental human rights, Den Haag (etc.) 1982

kIMURA Makoto, 'Agreements between nations: treaties and good faith with enemies,' in: ONUMA Yasuaki (ed.), A normative approach to war: Peace, war and justice in Hugo GROTIUs, Oxford 1993, pp. 308-332

kINGSBURY, Benedict; Adam ROBERTs, 'Introduction: grotian thought in international relations,' in: Hedley BULL, Benedict KINGSBurry, Adam ronerTs (eds.), Hugo GRoTus and international relations, Oxford 1990, pp. 1-64

KLEBER, R.J., e.a., Traumatische ervaringen, gevolgen en verwerking, Lisse 1986 KLEUNTJENS S.J., J.; H.H. KNIPPENBERG, Van goden en helden; Mythen en sagen van Grieken, Romeinen en Germanen, Groningen 1965 (negentiende druk) KLEIN, Katrien DE; Marieke PRINSEN GEERLIGs, Het blijft toch onder ons; Opening wan zaken over incest, Zutphen 1995

kLoOsterman, W., 'De stand van zaken bij politie en justitie,' in: H. BaARTMAN e.a., Incest en hulpverlening, Amersfoort/Leuven 1990, pp. 246-253

KNUGMANN, Rainer, De man, een vergissing der natuur, Utrecht/Antwerpen 1983 ko Swan Sik, De verplichting in het volkenrecht, i.o. Rotterdam 1990, Den Haag 1991

koelman, Jacobus, De plichten der ouders in kinderen voor God op te voeden, herschreven door C. BREGMAN, Houten 1994 (vierde druk; eerste druk 1982; oorspr. ed. Amsterdam 1679) 
KOENS, M.J.C., 'Het belang van het kind in het vreemdelingenrecht,' in: Ad VAN DER LINDEN, Paul VLAARDINGerRroek (red.), Met het oog op het belang van het kind; Opstellen aangeboden aan (...) Madzy ROOD-DE BOER (...), Deventer 1988, pp. 255-265

KoENS, M.J.C., Jeugdigen in de knel; Maatregelen van jeugdbescherming in de toekomst, i.o. Maastricht, Deventer 1994

KOENS, M.J.C., 'De civiele kinderrechter; verleden, heden en toekomst,' in: [J.R. BAC, A.P. VAN DER LINDEN (red.)], De kinderrechter 75 jaar: Reden tot vreugdel? Deventer 1998, pp. 21-45

KoERselmaN, Frank, 'Toen de stilte over Londen viel' ('Buiten de orde'), MGv 1997/10, pp. 1080-1081

KoHNSTAMM, Philip, 'Staatspedagogiek of persoonlijkheidspedagogiek' (1919), in: dez., Persoon en samenleving; Opstellen over opvoeding en democratie, Meppel/Amsterdam 1981, pp. 89-120

KOMEN, Mieke, 'Gevaarlijke kinderen; veranderingen in de aard en aanpak van jeugdcriminaliteit, 1960-1995,' Amsterdams Sociologisch Tijdschrift 1997/3-4, pp. 496-526

коMEN, Mieke, 'Kindermishandeling en sociale verandering,' $\mathrm{TvCr}$ 1998/1, pp. 39-58

KOMEN, Mieke, 'De blinde vlek voor incest, vroeger en nu,' MGv 1998/3, pp. 240-255

KONING, S.J.M. DE, 'Jeugdbeleid en het belang van het kind,' in: Ad VAN DER LINDEN, Paul vLAARdingerbroek (red.), Met het oog op het belang van het kind; Opstellen aangeboden aan (...) Madzy ROOD-DE BOER (...), Deventer 1988, pp. $13-26$

KOOIJMAN, Klaas, 'Symposium over meldingsplicht bij kindermishandeling' (verslag van de studiedag Kindermishandeling: meldingsplicht, ja of nee? op 21 november 1986 te Utrecht), VKMagazine 1987/1, pp. 4-5

KOOUMANS, P.H., 'How to handle the grotian heritage; GROTIUS and VAN VOLLENHOVEN' (Second Cornelis VAN VOLLENHOVEN memoriall lecture), NILR 1983/ 1, pp. $81-92$

KOOIJMANS, P.H., Maintaining the peace in the shadowland between the old and the new international order, UHLENBECK-lecture X:1992, NIAS, Wassenaar 1992 KoOLmans, P.H., Internationaal publiekrecht in vogelvlucht, Groningen 1996 (zesde druk), 1997 (zevende druk)

KOPER, A.J.M., 'Tien jaar LSBVK - een mild kritische terugblik,' Jaarverslag 1995 LSBVK, Utrecht 1996, Bijlage 5, pp. xxv-xxiv

KORBIN, Jill E., 'Child abuse and neglect: the cultural context,' in: Ray E. HELFER, Ruth S. KEMPE (eds.), The battered child, Chicago/London 1988 (vierde druk), pp. 23-41

Koren, Marian, Tell me! The right of the child to information, diss. Universiteit van Amsterdam, Den Haag 1996

KORZEC, Michel, 'De mythe van de efficiënte massamoord,' Intermediair 15 december 1995, pp. 19, 21, 23 
KROMHOUT, Mariska, Verwaarloosde kinderen; Opvattingen uit het veld, PEWArapport (Projectgroep Evaluatieonderzoek Welzijn 0-18-jarige Allochtonen) 1, RU Leiden 1996

KRONEMAN, Marieke, 'De pedagogische opvattingen van de Raad voor het Jeugdbeleid,' Jeugd en Samenleving 1996/4, pp. 162-168

KRÜL, Marianne, FREUD und sein Vater; Die Entstehung der Psychoanalyse und FREUDS ungelöste Vaterbindung, München 1979, Frankfurt am Main 1992; Engelse vert.: FREUD and his father, New York/London 1986

KÜHNHARDT, L., Die Universalität der Menschenrechte, München 1987, Bonn 1991

(tweede druk)

KuTPER, P.C., Nieuwe neurosenleer, Deventer 1984 (achtste druk)

KUTPER, P.C., Ver heen; Verslag van een depressie, 's-Gravenhage 1988

KUIPERS, G.S., e.a., "Op zoek naar dissociatieve stoornissen; de ervaringen in het psychiatrisch ziekenhuis Reinier vAN ARKEL,' $M G$ v 1996/11, pp. 1153-1166 KUNNEMAN, Frank, Rechtswetenschap, Ars Aequi Libri, Nijmegen 1991

KUYPERS, Paul; Jos VAN DER LANS, Naar een modern patemalisme; Over de noodzaak van saciaal beleid, Amsterdam (De Balie) 1994

LABUSCHAGNE, B.C., 'Wat maakt menselijke waardigheid tot menselijke waardigheid? Iets over de waarheidspretentie van mensenrechten," Civis Mundi; Tijdschrift woor politieke filosofie en cultuur 1998/3, pp. 122-130

LAFEBER, Hanneke, 'Evaluatie van de DoEk-methodiek; de effecten van een training voor hulpverleners van drugverslaafde ouders en hun kinderen en multi-problem gezinnen,' Systeemtherapie 1995/2, pp. 88-97

LANGE, Herman DE, 'GROTIUS en de internationale betrekkingen: historisch of actueel?' Transaktie 1992/2, pp. 182-189

LANGELAAN, Michaja, 'Kindermishandeling: de 06-lijn,' MGv 1992/6, pp. 661-669 LANGELAAN, Michaja, 'Kindermishandeling' (interview met Jo HERMANNS), NRC Handelsblad 18 oktober 1997 ('Wetenschap en Onderwijs,' p. 4)

LANGELAND, Willie, e.a., Kindermishandeling: van signaal naar hulp $I$; Sighaleren en melden, $\mathrm{NcGv}$, Utrecht 1990

LANGEN, M. DE, 'De betekenis van artikel 8 EVRM voor het familierecht,' Preadvies NJV, Artikel 8 EVRM, Handelingen Nederlandse Juristen-Vereniging 1990-I, Zwolle [1990-1], pp. 85-183

LANGeveld, Martinus J., Studien zur Anthropologie des Kindes, Tübingen 1968 (derde druk)

LANOTTE, Johan VANDE; Geert GOEDERTIER, 'Monitoring human rights: formal and procedural aspects,' in: Eugeen VERHELLeN (ed.), Monitoring children's rights, Den Haag (etc.) 1996, pp. 73-111

LAUTERPACHT, Hersch, "The grotian tradition in international law," in: The British Yearbook of International Law 1946, pp. 1-53; reprinted in: E. LAUTERPACHT (ed.), International law, being the collected papers of Hersch LAUTERPACHT, vol. 2, part 1, Cambridge (etc.) 1975, pp. 307-365

LAWYERS' COMMTTEE ON NUCLEAR POLICY, Statement on the illegality of nuclear warfare, New York 1984 
LEACH, Penelope, Children first; What society must do - and is not doing - for children today, London 1994

LEBLANC, Lawrence J., The Convention on the rights of the child; United Nations lawmaking on tuman rights, Lincoln/London 1995

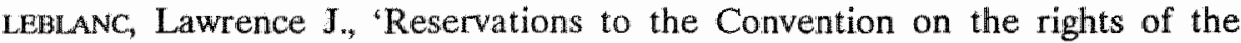
child: a macroscopic view of state practice,' IJCR 1996/4, pp. 357-381

LEEENEN, H.J.J., Handboek gezondheidsrecht [Deel 1]; Rechten van merusen in de gezondheidszorg, Alphen aan den Rijn 1988 (tweede druk)

LEIJTEN, Jan, 'Voorwoord,' in: Afra GROEN en Adri VAN MONTFOORT (red.), Kinderen beschermen en jeugd hulp verlenen, Arnhem 1993, pp. v-x

LEIJTEN, J.C.M., 'De Verklaring van de rechten van de mens en van de burger Pieter Paulus lof!' NJCM-Bulletin 1995/7, pp. 873-881

LEVY, J.A.; P.H. HUGENHOLTZ Jr., A.J. RETHAAN MACARÉ, Th. NOLEN (rapporteur), in opdracht van de MAATSCHAPPIJ TOT NUT VAN 'T ALGEMEEN, Het vraggstuk van de verzorging der verwaarloosde kinderen, [Amsterdam 1898]

LEWIS, Dorothy O., e.a. 'Child abuse, delinquency, and violent criminality,' in: Dante CICCHETT, Vicki CARLSON (eds.), Child maltreatment; Theory and research on the causes and consequences of child abuse and neglect, Cambridge (etc.) 1989 , pp. $707-721$

LEwis, Michael, "What can child development tell us about child abuse?' In: Kevin BrownE e.a. (eds.), Early prediction and prevention of child abuse, Chichester (etc.) 1993, pp. 3-12

LIESHOUT, Maurice VAN, 'Nederlandse ouders zijn opvoedingsoptimisten; het onderzoek Opvoeden in Nederland,' 0/25; Tijdschrift over jeugd juni 1996, pp. $10-17$

LIESHOUT, Maurice VAN, 'Meeste aandacht voor jeugd in CDA-programma,' 0/25; Tijdschrift over jeugd december 1997 (rubriek Nieuws), pp. 5-6

LIESHOUT, Maurice VAN, 'SP will staatssecretaris voor jeugdzaken,' 0/25; Tijdschrift over jeugd maart 1998 (rubriek Nieuws), p. 6

LIESHOUT, Maurice vaN, "Poldermodel ongeschikt voor gezinsbeleid"; zes stellingen over gezin en opvoeding in Nederland,' $0 / 25$; Tijdschrift over jeugd april 1998, pp. 14-19

LIINZAAD, Liesbeth, 'Het kussen van een kikker; de werkelijke betekenis van het Vrouwenverdrag,' Nemesis 1991/2, pp. 5-17

LuNZAAD, Liesbeth, Reservations to UN-Human rights treaties: Ratify and ruin? Diss. Maastricht, Dordrecht (etc.) 1994

LIMBURG PRINCIPLES on the implementation of the Intemational Covenant on economic, social and cultural rights, (THE), uN doc. E/CN.4/1987/17, Annex; HRQ 1987/2, pp. 121-135; INTERNATIONAL COMMISSION OF JURISTS, ECOnomic, social and cultural rights; A compilation of essential documents, Geneva (november) 1997, pp. 63-78; Theo C. VAN BOVEn, Cees FLINTERMAN, Ingrid WESTENDORP (eds.), The Maastricht guidelines on violations of economic, social and cultural rights; Proceedings (...) January 1997, sim Special 20, Utrecht 1998, Appendix 1, pp. 207-223 
IMNDEN, A.P. VAN DER, "Ouderlijk gezag en voogdij, ${ }_{3}$ in: M.J.C. koENG (red.), Het hedendaggse personen an familherech, Zwolle 1995, pp. $229-263$

LINDEN, A.P. VAN DER, "Matregelen van justitiele jeugdhulpverlening," in: M.J.C. KoENs (red.), Het hedendaagse personen en familierecht, Zwolle 1995, pp. 265302

LINDEN, Adrialan VAN DER, "Change in acceptance of child (care and) protection measures in the Netherlands, paper presented at the 9th World Conterence of the Intiernational Society of Family Law, Durban, South Africa, July $27=$ 31. 1997

LOBEL Jules, bespr. van Louis HENkn, Foreign affairs and the Constitution (Oxford/New York 1997), in: AJIL 1997/3, pp. 556.558

Locke, John, Over het staatsbestur [Twede verhandeling over het stadtsbestutur: De ware oorsprong reikwijde an doelstelling van burgerligk stratsbestuis, 16897 (vert. F, VAN ZETIEN), Amsterdam 1994 (tweede druk')

LOENEN, $T_{\text {s, }}$ 'Het discriminatiebegrip," in: $A$.W. HERNGA, J. HES, L. LUNZAAO (red.), Hol wrouwenwerdrag: een beeld van en verdrag ,., Antwerpen/Apel doorn 1994, pp. 1-13

LOENEN, Titia, "Rethinking sex equality as a human right"' NOHR 1994/3, pp. $253=270$

LOENEN, Titia, 'Seksueel kindermisbrutk en verjaringstermÿnen;" noot by de STUBANGs-2aak (1996), NJCM-Bulletin 1997/3, pp. $287-297$

LONDEN, A. YAN, e.a.n, Vaardigheden woor ouders; Een werkboek met oeferingen en principes orn het zalfbeld wan uw kind we verbsteren, on goed te praten en te luisteren, om gedrag positief te beïnlocden er om gezond te denken in relatie tor problemen met kinderen, Ansterdam/Lisse 1990 (zevende druk)

LOUCADEs, Loukis G., Essays on the developing law of human rights, Dordrecht (etc) 1995

LowEN, Alexander, Leven zonder angst (1980), Cothen 1996 (derde druk)

ISBVK (Landelijke Stichting Bureaus Vertrouwensarts inzake Kindermishandeling), Jaarverslag 1995, Utrecht 1996

LUBBERS, R., 'Het moderne kindbeeld,' in: Ad VAN DER LINDEN, Paul VLAARDINGERBRoEk (red.), Met het oog op het belang van het kind; Opstellen aangeboden aan (...) Madzy ROOD-DE BOER (...), Deventer 1988, pp. 1-12

LUCKER-BABEL, Marie-Françoise, e.a., "Pre-surveillance of children's rights,' in: Eugeen verHelleN (ed.), Monitoring children's rights, Den Haag (etc.) 1996, pp. $517-523$

LÜNEMANN, Katinka D., Vrouwenmishandeling strafrechtelijk afgedaan; Strafrechtelijke regulering van mannelijk geweld tegen vrouwen in de privesfeer, diss. Maastricht, Deventer 1996

LuTZ, Hermann, aangehaald in Dagblad de Limburger 2 september 1996, p. 9, onder de kop: "Criminaliteit Duitse jeugd alarmerend""

MaARSEVEen, H. van, e.a. (red.), Internationaal recht en vrouwen; De betekenis van het internationale recht voor vrouwen in Nederland, deel in Documenten, Zwolle 1987 
MAARSEVEEN, H. VAN, 'Ageism (age + ism),' NJB 1987, p. 501

MAARSEVEEN, H. vAN, 'Vooroordelen over leeftijd zijn nog wijd verspreid,' Forumpagina De Volkskrant 16 mei 1987

MAASTRICHT GUIDELINES on violations of economic, social and cultural rights, (THE), NQHR 1997/2, Appendix II, pp. 244-252; NJCM-Bulletin 1997/5, pp. $569-$ 576; INTERNATIONAL COMMISSION OF JURISTS, Economic, social and cultural rights; $A$ compilation of essential documents, Geneva (november) 1997, pp. 79-91; Theo C. vaN BOVEN, Cees FlIMTERMAN, Ingrid WESTENDORP (eds.), The Maastricht guidelines on violations of economic, social and cultural rights; Proceedings (...) January 1997, srM Special 20, Utrecht 1998, pp. 1-12; HRQ $1998 / 3$, pp. $691-701$

MACKINNON, Catharine A., 'On torture: a feminist perspective on human rights,' in: Kathleen E. MAHONEY, Paul MaHONEY (eds.), Human rights in the twentyfirst century; A global challenge, Dordrecht (etc.) 1993, pp. 21-31

MAES, Christian, 'Rechten van het kind ... en verder,' in: E. verHellen e.a. (red.), Kinderrechtengids, Gent 1994 (losbladig), deel 1 (Commentaren), 1.1 (Algemeen), MAES, pp. 1-16

marlieu, René, 'Preface,' in: Jeanne hersch (ed.), Birthright of man; A selection of texts (...), unEsco, Parijs 1969, pp. [7-10]

MALANCZUK, Peter, AKEHURST's Modem introduction to international law, London/ New York 1997 (zevende druk)

MALCOLM, Janet, In het FREUD-archief, Amsterdam 1985

MALE, R.M. VAN, 'Artikel 89,' in: P.W.C. AKKermans en A.K. KoEkKoeK (red.), De Grondwet; Een artikelsgewijs commentaar, Zwolle 1992 (tweede druk), pp. $781-830$

MALMBerG, M.J.J.M., 'Overheid en gezin; een spannende relatie,' Justitiële Verkenningen 1996/6 ('Preventief ingrijpen in het gezin'), pp. 8-16

MARCoEn, A. (red.), De middag van het leven; Overgang en crisis, Leuven/Amersfoort 1992 (derde druk)

MARIE, Jean-Bernard, 'International instruments relating to human rights; classification and status of ratifications as of 1 January 1998,' $H R L J 1998 / 2-4$, pp. $117-134$

MARIS, C.W., 'Patriarcha,' in: Ted DE Boer e.a. (red.), De kant van het kind; Liber amiconum (...) Miek DE LANGEN, Arnhem 1992, pp. 59-88

MARLE, H.J.C. VAN, 'Motivatie in de klinisch forensisch psychiatrische behandeling,' in: R.V. schwarz, D.H. Lunszen (red.), Persoonlijkheidsstoomissen; Diagnostiek, behandeling, beleid, Amsterdam/Lisse 1991, pp. 87-96

MARLE, H.J.C. VAN, Een gesloten systeem; Een psychoanalytisch kader voor de verpleging en behandeling van TBS-gestelden, diss. Utrecht, Arnhem 1995

MASSON, Jeffrey M., Traumatische ervaring of fantasie; FREuDs rampzalige herziening van de verleidingstheorie, Amsterdam 1984 (Duitse vert.: Was hat man dir, du armes Kind, getan? Sigmund FREuDs Unterdrückung der Verführungstheorie; Engels orig.: The assault on truth; FREuDs suppression of the seduction theory, New York 1984) 
MASSON, J.M. (ed.), The complete letters of Sigmund FREUD to Wilhelm FLnEss 1887-1904, Cambridge/London 1985

MATrussen, A.A.M., 'Bestrijding van vrouwendiscriminatie; het onbekende vN-

Verdrag,' Justitiele Verkenningen 1997/9 ('Vrouw en recht"), pp. 20-34

Mcoillivray, Anne, 'Reconstructing child abuse: Western definition and non-

Western experience,' in: Michael frREMAN, Philip VEERMAN (eds.), The ide-

ologies of children's rights, Dordrecht (etc.) 1992, pp. 213-236

McMARTIN, Jim, Personality psychology; A student-centered approach, Thousand

Oaks (etc.) 1995

MEDINA QUIROGA, Cecilia, The battle of human rights; Gross, systematic violations

and the Inter-American System, Dordrecht (etc.) 1988

MEMORLALE RTUUM (...) in minoribus ecclesiis (...), Rome (etc.) 1920

MEMORIE VAN TOELICHTING bij het ontwerp van Rijkswet Goedkeuring van het op

20 november 1989 te New York tot stand gekomen Verdrag inzake de rechten wan het kind, Tweede Kamer der Staten-Generaal, vergaderjaar 1992-1993, 22855 (R 1451), nr. 3, Den Haag 1992

MENSENRECHTENCOMITÉ, Kernwapencommentaar (General comment 14 [23], Art. 6 ICCPR, 563rd meeting [23rd session], 2 November 1984)

MERON, Theodor, 'On a hierarchy of international human rights," $A J I L 1986 / 1$, pp. 1-23

MERON, Theodor, Human rights and humanitarian norms as customary law, Oxford 1989

MERTENS, N.M., Gezinsvoogden aan het werk; De uitvoering van de ondertoezichtstelling in 1993, wooc-rapport 149, Arnhem 1996

MESOTTEN, Bart, Haikae-boek, Kapellen 1986

METZE, Marcel, De staat wan Nederland - op weg naar 2000, Nijmegen 1996

MEUwisseN, D.H.M., interventie in eerste termijn, Handelingen Nederlandse Juristen-Vereniging 1995-II, Verslag (...) over: De reikwijdte van fundamentele rechten, Zwolle [1996], pp. 14-23

MEUWTSSEN, D.H.M., Grondslagen wan rechtsfilosofie, Deventer 1997

MEY, H.R.A. DE, 'Eens een persoonlijkheidsstoornis ... altijd een persoonlijkheidsstoornis,' in: C.P.F. VAN DER STAAK, C.A.L. HOOODUIN (red.), Diagnostiek en behandeling van de persoonlikheidsstoomis, Symposium klinische psychologie, Nijmegen 1990/1, pp. 49-58

MICHIEls, Marjan, 'Hoe ideaal en hoe veilig zijn de privéruimten van gezin en omgeving voor kind en jeugdige?' In:" H. CAMMAER en E. vERHELLEN (red.), Onmondig en onvolwassen; De jonge mens in de eeuw van het kind, Leuven/ Amersfoort 1990, pp. 107-120

MUNARENDS, Isabeth, 'De Nederlandse rapportage-verplichting in het licht van het (...) Verdrag inzake de rechten van het kind,' FJR 1997/1, pp. 10-18 Mus, P.T., ingezonden brief (naar aanleiding van Jacques HERRAETs, "Ik dacht: krijgen we dat verdomme ook hier?" Psychologen CROMBAG en MERckelBACH waarschuwen tegen nieuwe heksenprocessen," in Obsenant 25 april 1996), Observant 9 mei 1996 
MILL, John Stuart, De onderwerping van de vrouw (1869), ed. Londen 1929, vert.

Eva Wol.pF, Meppel/Amsterdam 1981

MILler, Alice, Het drama van het begaafde kind; Een studie over het narcisme,

Bussum 1983 (vijfde druk; in de achttiende, geheel herziene druk met de ondertitel: Op zoek naar het ware zelf, Houten 1995)

MILler, Alice, In den beginne was er opvoeding (Engelse vert.: For your own good; The roots of violence in child-rearing, New York 1983, London 1983, 1987), Bussum 1983 (derde druk)

MILler, Alice, Gij zult niet merken; Tachtig jaar psychoanalyse, Weesp 1983,

Houten 1988 (derde druk; waaraan toegevoegd: 'De dochters zwijgen niet meer' en 'Nawoord')

MILLER, Alice, Een kindertijd in beeld; 66 aquarellen en een essay, Weesp 1986 MILLER, Alice, Das verbannte Wissen, Frankfurt am Main 1988 (tweede druk) MULLer, Alice, Zelfkennis in ballingschap; De verdringing van de kindertijd, tot welke prijs? Houten 1989

MILler, Alice, De gemeden sleutel; De kindertijd en onze cultuur, Houten 1989 MrLler, Alice, De muur van zwijgen; De waarheid van de feiten, Houten 1990 MILLER, Alice, Levenspaden; Zeven geschiedenissen, Houten 1998 MÖLler, Jakob Th., 'Article 7,' in: Asbjørn EIDE e.a. (eds.), The Universal Declaration of human rights; A commentary, Oslo(/Oxford) 1992, pp. 115-141 MÖNKS, F.J.; A.M.P. KNOERS, Ontwikkelingspsychologie, Assen 1994 (negende druk)

MONTFOORT, Adri VAN, 'Kindermishandeling en meldingsplicht' (verslag van de studiedag Kindermishandeling: meldingsplicht, ja of nee? op 21 november 1986 te Utrecht), $M G v$ 1987, pp. 191-194

MONTFOORT, Adri VAN, 'De ongrijpbare werkwijze van de Bureaus Vertrouwensarts,' $M G v$ 1988/9, pp. $980-986$

MONTFOORT, Adri VAN; Jaap DOEK, 'Kindermishandeling en het strafrecht,' in: H. BAARTMAN, A. VAN MONTFOORT (red.), Kindermishandeling" resultaten van multidisciplinair onderzoek, Utrecht 1992, pp. 263-278

MONTFOORT, Adri VAN, Kindermishandeling en Justitie; Een empirisch onderzoek naar de afhandeling door de Raad voor de Kinderbescherming, de politie en het Openbaar Ministerie van meldingen van kindermishandeling en seksueel misbruik, Amsterdam 1993

MONTFOORT, A. VAN, Het topje van de ijsberg; Kinderbescherming en de bestrijding van kindermishandeling in sociaal-juridisch perspectief, diss. vu Amsterdam, Utrecht 1994

MONTFOORT, A.J. VAN, 'Criteria onder druk der omstandigheden; besluitvorming over gedwongen hulpverlening aan gezinnen,' in: D.J. DE RUYTER, P.A. DE RUYTER (red.), Opvoedingshulp geboden; Pedagogische criteria voor het opleggen van hulp, theoretisch en praktisch bezien, Utrecht 1995, pp. 53-65

Moou, A.W.M., 'De blijvende waarde van het begrip zondebok,' in: C. KELK e.a. (red.), Harmonie en tegenspraak; Gedragskundige en rechtsgeleerde opstellen over psychiatrie en strafrechtstoepassing, aangeboden aan F.H.L. BEYAERT, Arnhem 1990, pp. 213-223 
MOST, G.H.F. VAN DER, 'Emoties van hulpverleners,' in: L.P.T. RAIJMAKERs e.a. (red.), Commissie Seksueel Misbruik van Jeugdigen, Handelen bij vermoeden van seksueel misbruik van kinderen en jeugdigen $I I_{*}^{*}$ De richtijnen SMJ in de praktijk, Assen 1995, pp. 64-67

MOURTIS, H.A.A., 'De ongrijpbare werkwijze van de Bureaus Vertrouwensarts

(2)' (reactie op VAN MONTFOORT), MGV 1988/11, pp. 1250-1252 (met 'Antwoord' van VAN MONTFOORT Op pp. 1252-1253)

MOUT, M.E.H.N., Plakkaat van Verlatinge 1581, Den Haag 1979

MULDER, Louise, 'Recht voor éen is geen recht voor allen; emancipatierechten voor zwarte, migranten- en vluchtelingenvrouwen,' Nemesis 1997/1, pp. 4-12 MuRPHY, John F., 'International crimes,' in: Chr.C. JOYNER, The United Nations and international law, Cambrigde 1997, pp. 362-381

Nabokov, Vladimir, Lolita (1955), Amsterdam s.a. (21e druk) NAGEL, W.H., 'Proloog: het probleem van het probleem,' in: L.G. MOOR e.a. (red.), Grenzen van de jeugd; Achtergronden van jeugdcriminaliteit, Ars Aequi Libri [Nijmegen] 1981, pp. 5-7

NATIONAL INCIDENCE STUDY (NIS-II), Study findings: Study of national incidence and prevalence of child abuse and neglect, us Department of Health and Human Services -- National Center on Child Abuse and Neglect, Washington, DC 1988

NEDERLANDS STATENRAPPORT aan het Comité inzake de rechten van het kind, Implementation of the Convention on the rights of the child, The Netherlands, April 1997, s.l. [Ministerie van Buitenlandse Zaken]

NEDERVEEN PIETERSE, Jan, Wit over zwart; Beelden van Afrika en zwarten in de westerse populaire cultuur, Amsterdam/Den Haag 1990

NEWELL, Peter, 'Respecting children's right to physicall integrity,' in: Bob FRANKL.IN (ed.), The handbook of children's rights; Comparative policy and practice, London/New York 1995, pp. 215-226

NICOLAI, Nelleke, 'Seksueel misbruik en psychiatrische stoornissen; een oriënterend onderzoek op een gesloten afdeling van een psychiatrisch zieken. huis,' MGv 1990/9, pp. 908-923

NICOLAI, N.J., 'Incest als trauma: implicaties en consequenties voor de behandeling,' Tijdschrift voor Psychotherapie 1991/1, pp. 12-30

NICOLAI, Nelleke, 'Noodkreet; over de behandeling van personen met een voorgeschiedenis van seksuele en fysieke kindermishandeling," $M G v 1993 / 9$, pp. 939-943

NIETZSCHE, Friedrich, De antichrist (1888), ed. Amsterdam 1978 NIEUWE TESTAMENT in zes Nederlandse vertalingen, (HET), (1955), Den Haag 1977 NIBBOER, J., 'Achter de feiten aanhollen; het dilemma van justitiële preventie in het gezin,' reactie ('Journaal') in Justitiële Verkenningen 1996/9, pp. 84-89 NINATIEN, Carol VAN, 'Het kind tussen recht en bescherming,' in: dez. (red.), Kinderrechten in discussie, Amsterdam/Meppel 1993, pp. 124-142 
NLNATTEN, C. VAN, 'Gedragsgestoord en gezagsgestoord; de verhouding tussen kinderbescherming en gezin,' Justitiële Verkenningen 1996/6 ('Preventief ingrijpen in het gezin'), pp. 74-84

N.N., 'Vader,' ingezonden brief De Volkskrant 25 januari 1990, p. 15 ('Geachte redactie')

NOORDAM, N.F., Historische pedagogiek van Nederland; Een inleiding, Nijkerk 1979

NOORDHOEK-VAN DER STAAY, Jacquelien, 'Definiëring, prevalentie en incidentie van kindermishandeling,' in: H. BAARTMAN en A. VAN MONTFOORT (red.), Kindermishandeling, resultaten van multidisciplinair onderzoek, Utrecht 1992, pp. $40-53$

NOORDHOEK-VAN DER STAAY, Jacquelien, De prevalentie van kindermishandeling bij kinderen met sociale, gedrags- en emotionele problematiek, vu Amsterdam (Faculteit der Psychologie en Pedagogische Wetenschappen, Vakgroep Kinder- en jeugdpsychologie, Sectie Speciale pedagogiek), december 1992

NOTITIE GEZIN; De maatschappelijke positie van het gezin, Notitie van de staatssecretaris van vws namens het kabinet aan de Tweede Kamer, Rijswijk, september 1996

NOVUM TESTAMENTUM LATINE; Textum Vaticanum (...) [1906/1952], Württembergische Bibelanstalt, Stuttgart 1971 (editio undecima)

NowaK, Manfred, UNO-Pakt über bürgerliche und politische Rechte und Fakultativprotokoll; CCPR-Kommentar, Kehl (etc.) 1989

OATES, R.K., The spectrum of child abuse; Assessment, treatment, and prevention, Basic Principles into Practice series, vol. 8, New York 1996

OCHOLA, Lynette, 'The Undugu Society approach in dealing with children at risk to abuse and neglect," in: Eugeen verhellen (ed.), Monitoring children's rights, Den Haag (etc.) 1996, pp. 853-866

odegard, Peter H., The American Republic, New York (etc.) 1969

o'Donnel., Clifford R., 'The right to a family environment in Pacific Island cultures,' IJCR 1995/1, pp. 87.99

OFFICIUM PARVUM beatae Mariae Virginis et Officium defunctorum/Die kleinen Tagzeiten der allerseligsten Jungfrau Maria und die Tagzeiten für die Verstorbenen, Einsiedeln/Köln [imprimatur 1959]

OLSSON HORT, Sven E., 'Sweden: toward a deresidualization of Swedish child welfare policy and practice?' In: Neil GILBERT (ed.), Combatting child abuse; International perspectives and trends, New York/Oxford 1997, pp. 105-124 O'MANIQUE, John, 'Universal and inalienable rights: a search for foundations,' HRQ $1990 / 4$, pp. $465-485$

ONDERWAATER, Annelies, De theorie van NAGY; De onverbrekelijke band tussen ouders en kinderen (oorspr. titel: De onverbrekelijke band tussen ouders en kinderen; Over de denkbeelden van Ivan BOSZORMENYT-NAGY en Helm STERLIN), Lisse 1995 (vierde druk)

ONUMA Yasuaki (ed.), A normative approach to war: Peace, war, and justice in Hugo GROTIUs, Oxford 1993 
onUmA Yasuaki, 'Introduction,' in: dez. (ed.), A normative approach to war: Peace, war, and justice in Hugo cronus, Oxford 1993, pp. 1-10

onuma Yasuaki, 'War,' in: dez. (ed.), A normative approach to war: Peace, war, and justice in Hugo GROTIUS, Oxford 1993, pp. 57-121

onumA Yasuaki, 'Agreement,' in: dez. (ed.), A nomative approach to war: Peace, war, and justice in Hugo GRoTIUS, Oxford 1993, pp. 174-220

ONUMA Yasuaki, 'Conclusion: law dancing to the accompaniment of love and calculation,' in: dez. (ed.), A normative approach to war: Peace, war, and justice in Hugo GRoTIUs, Oxford 1993, pp. 333-370

ONUMA Yasuaki, 'Eurocentrism in the history of international law,' in: dez.

(ed.), A normative approach to war: Peace, war, and justice in Hugo GRoTIUs, Oxford 1993, Appendix, pp. 371-386

oost, J., 'Kindermishandeling: meldingsplicht ja of nee,' Algemeen Politieblad januari 1987, pp. 11-12

oOYen-Houben, M.M.J. van; E.G.M.J. Berben, 'Protectieve factoren; een paradigmatische ommezwaai of nieuwe kleren van de keizer?' Justitiële Verkenningen 1988/8 ('Gezin, opvoeding en criminaliteit'), pp. 90-117

OPSAHL, Torkel, 'Articles 29 en 30,' in: Asbjørn eIDE e.a. (eds.), The Universal Declaration of human rights; A commentary, Oslo(/Oxford) 1992, pp. 449470

OPZEELAND, Walter VAN (vert./bewerking), $A B C$ van de bijbel, Amsterdam/Brussel 1992

OUDE TESTAMENT in zes Nederlandse vertalingen, (HET), Den Haag 1979-1980, 3 delen

OUTSEM, Ron VAN, Seksueel misbruik van jongens, Amsterdam 1992

Papalia, Diane E.; Sally Wendkos olds, Human development, New York (etc.) 1992 (fifth ed.)

PARLEVLIET, Jacqueline, 'Nederland in rep en roer door uitspraken van het Mensenrechtencomite,' Nemesis 1988/2, pp. 79-81

PAROCHIEMISSAAL, (Volledig), voor alle dagen van het jaar; Met bijbels commentaar op alle zang- en leesstukken, door Dom P. BruYLANTS, Leuven (etc.) [1964]

Pattipawae, C.F.; A.C. Possel, C.A. TazelaAr, 'Begrippen en definities,' in: C.F. PATTIPAWAE, C.A. TAZELAAR (red.), Met recht discriminatie bestrijden; Een juridische handleiding bij de bestrijding van discriminatie op grond van ras en nationaliteit, Utrecht/Deventer 1997 (tweede druk), pp. 3-14

PEARl, Peggy S., 'Emotional abuse,' in: A.E. Brodeur, J.A. MONTEleone, Child maltreatment; [vol. 1] A clinical guide and reference, St. Louis (etc.) 1994, pp. 259-283

PEETERS, José; Claartje woLDRINGH, Kinderen: van privé-zorg naar overheidsbeleid, rrs (Instituut voor Toegepaste Sociale wetenschappen, Nijmegen), Utrecht 1994 
PELS, T.V.M., 'Preventie in Marokkaanse gezinnen; het spanningsveld tussen vraag en aanbod,' Justitiële Verkenningen 1996/6 ('Preventief ingrijpen in het gezin'), pp. 63-73

PERRY, Bruce D., Maltreated children; Experience, brain development, and the next generation, (in druk)

PESSERS, Dorien, 'Vaderrechten, moederrechten, verzorgersrechten,' redactioneel Nemesis $1987 / \mathbb{1}$, pp. 1-2

PESSERS, Dorien, 'Omgangsrecht voor incestdader' (cassatieschriftuur G. SPONG), Nemesis 1989/4, pp. 148-150

peters, Ray DeV.; Robert J. mcMahon, 'Preface,' in: dez. (eds.), Preventing childhood disorders, substance abuse, and delinquency, Thousand Oaks (etc.) 1996

PHILLIPS, Derek L., "Voorkeursbehandeling voor vrouwen: enige sociologische en morele overwegingen,' De Gids 1979/1, pp. 3-27

PHLLurs, Derek L., "De rectificatie van onrechtvaardigheid; het geval van Surinamers en Antillianen in Nederland,' Beleid en Maatschappij 1982, pp. 129137

PHILLIPS, Derek L., De naakte Nederlander, Amsterdam 1985

PiCO DELLA Mirandola e CONCORDIA, Giovanni, Over de menselijke waardigheid (De hominis dignitate, 1487; vert. J. HEMELRIK), Arnhem 1968

PIERS, Maria W., Kindermishandeling en kindermoord, Utrecht/Antwerpen 1980 PIETERSE, J.J., 'De ongrijpbare werkwijze van de Bureaus Vertrouwensarts (3)' (reactie op VAN MONTFOORT), MGv 1988/12, pp. 1360-1362 (met 'Antwoord' van VAN MONTFOORT Op pp. 1362-1363)

PINCUS, L.; Chr. DARE, Gezinsgeheimen; Achtergronden van persoonlijke betrekkingen en individueel gedrag, Rotterdam 1980

PlatVoet, Anna; Anneke DuBBink, Incest: hun zorg, jouw zorg, Orthovisies 30, Groningen 1988

PLECK, Elizabeth, Domestic tyranny; The making of American social policy against family violence from colonial times to the present, New York/Oxford 1987 PLOEG, Jan VAN DER, bespreking diss. DE RUYTER (1993), Jeugd en samenleving 1995/4, pp. 230-231

plong, Piet VAN DER, Opvoeding en politiek in de overleg-democratie; Democratische verdeling en normering van pedagogische autoriteit, diss. Utrecht, Baarn 1995

ploss, H:; Max BARTELS, De vrouw in natuur-en volkenkunde; Anthropologische Studiën, deel 1, Amsterdam/Weltevreden 1918 (zesde druk)

POLET, Sybren (red.), Søren KIERKEGAARD; Dagboeken, Amsterdam 1993 (tweede druk)

pols, Wouter, 'Moderne pedagogische gedachten in de achttiende eeuw,' in: dez. e.a. (red.), Opvoeding zoals het is, Amersfoort/Leuven 1989, pp. 113143

POSTMA, Johannes Menne, The Dutch in the Atlantic slave trade 1600-1815, Cambridge (etc.) 1990 
POSTON, Carol; Karen LISON, Incest overleven; Ervaringen wan slachtoffers en therapeutische hulp, Utrecht/Antwerpen 1990

POT, C.W VAN DER; A.M. DONNER, Handboek van het Nederlandse staatsrecht, Zwolle 1972 (negende druk), 1995 (dertiende druk)

POUCKe, A. VAN, 'Woord vooraf,' in: H. CAMMAer en E. Verhellen (red.), Onmondig en onvolwassen; De jonge mens in de eeuw wan het kind, Leuven/ Amersfoort 1990, pp. 7-8

PSALMEN, DE, uit het Hebreeuws vertaald door Ida G.M. GERHARDT en Marie H. VAN DER ZEYDE, Katholieke Bijbelstichting, Nederlands Bijbelgenootschap, Wageningen 1972

QvorTrup, Jens, "Het kind-zijn als sociaal verschijnsel; inleiding op een reeks nationale rapporten,' in: E. Veruellen e.a. (red.), Kinderrechtengids, Gent 1994 (losbladig), deel 1 (Commentaren), 1.1 (Algemeen), Qvortrup, pp. 137

QVORTRUP, Jens, 'Monitoring childhood: its social, economic and political features,' in: Eugeen vERHELLEN (ed.), Monitoring children's rights, Den Haag (etc.) 1996 , pp. 33-48

RAAD VOOR HET JEUGDBELEID, Kindermishandeling vermeldenswaard; Advies over de aanpak van kindermishandeling: preventie, hulpverlening en rechtstoepassing, Ministerie van wyc, Rijswijk 1988

RAAD VOOR HET JEUGDBELEID, Aanval op uitval; Advies over de bestrijding van uitval van jeugaigen, Utrecht 1994

RAES, Koen, 'De morele betekenis van het vertoog over de rechten van het kind; naar een differentiële mens- en maatschappijopvatting,' in: E. VERHELLEN e.a. (red.), Kinderrechtengids, Gent 1994 (losbladig), deel 1 (Commentaren), 1.1 (Algemeen), RAES, pp. 1-47

RAMCHARAN, B.G. (ed.), Intemational law and fact-finding in the field of human rights, Den Haag (etc.) 1982

RANDEV, Panayot, e.a., 'Children at risk and defence of their rights in Bulgaria (...), in: Eugeen verhellen (ed.), Monitoring children's rights, Den Haag (etc.) 1996, pp. 463-474

RaSkin, Brigitte, 'Prostitution et société patriarcale,' Déviance et Société 1986/3, pp. 289-291

RECHTBANK UTRECHT 5 april 1989 (Mrs. DE KONING-BEL, NUNNIKHOVEN, DE GROOTVAN DUKEN), [Zoon, eiser, tegen vader en moeder, gedaagden], Nederlandse Jurisprudentie 1990, 183

REE, Frank VAN, Mijn zelfonderzoek: een terugblik; Frank VAN REE over het belang van leertherapie, Lisse 1996

REIDY, Aisling, e.a., "Gross violations of human rights: invoking the European Convention on human rights in the case of Turkey,' NQHR 1997/2, pp. 161173

REISMAN, W. Michael, 'The constitutional crisis in the United Nations,' AIIL $1993 / 1$, pp. 83-100 
REMMELINK, J., HAZEWINKEL-SURINGA's Inleiding tot de studie van het Nederlandse strafrecht, Arnhem 1995 (veertiende druk)

REMMERSWAAL, P.; F. VERHEu, "Transgenerationele dynamiek in symbiotische gezinnen,' in: Gestoorde ouders - gestoorde kinderen? Speciale uitgave van Kind en Adolescent; Tijdschrift voor pedagogiek, psychiatrie en psychologie 1991/3, pp. 176-184

RENSEN, Ben, Kindermishandeling: voor het leven beschadigd, Utrecht 1990 RENSEN, Ben, 'Rechten van kinderen tussen dokters, ouders en culturen: de dagelijkse praktijk,' Tijdschrift voor de rechten van het kind december 1994, pp. 13-14

REYNERS, M.M.J., Het besnijden van meüjes; Een leven lang leed en pijn, Amsterdam 1993

RICHARTZ, Mark, 'Pablo PICASSO: een latentie-tijd-loze? Psychobiografische kanttekeningen bij en psychodynamische overwegingen omtrent (zijn) creativiteit,' in: De Gids 1994/5, pp. 379-395

RIDLEY, Matt, De oorsprong van de moraal (oorspr. titel: The origins of virtue, 1996), Amsterdam/Antwerpen 1997

RLINAARTS, José, Dochters van Lot; Over vader-dochter incest, Amsterdam 1987 RIJNAARTS, José, 'Het onverwoestbare kind' (naar aanleiding van Lillian RUBIN, Het onverwoestbare kind, Nederlandse vert. 1997), Opzij juni 1997, pp. 10 en 13-15

RINK, J.E., Pedagogische verwaarlozing en orthopedagogiek, Leuven/Apeldoorn 1995

RISPENS, J.; C. VAN TUIIL, 'Preventie van psychosociale problemen bij kinderen en jeugdigen: begripsbepaling en context,' (hoofdstuk 1) in: J. RISPENS, P.P. goudena, J.J.M. GROENENDAal, Preventie van psychosociale problemen bij kinderen en jeugdigen, Houten/Zaventem 1994, pp. 13-27

RTTSEMA, Beatrijs, 'Beklemdheid,' NRC Handelsblad 21 januari 1988, Achterpagina

RonerTson, A.H.; J.G. MERrills, Human rights in Europe; A study of the European Convention on human rights, Manchester/New York 1996

Röling, B.V.A., Vredeswetenschap; Inleiding tot de polemologie, Utrecht/Antwerpen 1981

Röling, B.V.A., Volkenrecht en vrede, Deventer 1985 (derde druk)

RÖLING, B.V.A., 'Europees volkenrecht of wereldvolkenrecht?' (Jaarboekje VIRO 1957-1958), opgenomen in: dez., Volkenrecht en vrede, Deventer 1985 (derde druk), pp. 203-225

Roelofs, Gerard, 'Gezinstherapie,' in: Carla VAN lichtenburchr e.a. (red.), Verder na incest; Hulpverlening bij het verwerken van incestervaringen, Baarn 1986 (tweedle druk), pp. 70-77

ROELofs, Marian, 'Ernstige of minder ernstige kindermishandeling? De opvattingen van de Bureaus Vertrouwensartsen,' in: MGv 1991/1, pp. 18-33 ROELOFs, Marian, Kindermishandeling en hulpverlening; De aanpak van lichamelijke kindermishandeling door het BUREAU VERTROUWENSARTS, [diss. vU] Amsterdam 1996 
Roelofs, Marian A.S.; Herman E.M. BAARTMAN, 'The Netherlands: responding to abuse - compassion or control?" In: Neil GILBERT (ed.), Combatting child abuse; Intemational perspectives and trends, New York/Oxford 1997, pp. 192211

ROELOFSEN, C.G., "GROTus and the "grotian heritage" in international law and international relations; the quatercentenary and its aftermath (circa 19801990),' Grotiana, New Series, vol. 11, 1990, pp. 6-28

ROHT-ARrLAZA, Naomi, 'State responsibility to investigate and prosecute grave human rights violations in international law, Califomia Law Review $1990 / 2$, pp. [449]451-513

ROMANY, Celina, 'State responsibility goes private; a feminist critique of the public/private distinction in international human rights law " in: Rebecca J. cook (ed.), Human rights of women; National and intemational perspectives, Philadelphia 1995 (third printing), pp. 85-115

ROMEIN, Jan en Annie, Erflaters van onze beschaving, Amsterdam 1976 (elfde druk)

Roommans, H.G.M., 'Stoornissen met bijzondere somatische klachten en verschijnselen,' (hoofdstuk 8) in: W. VANDEREYCKEN e.a. (red.), Handboek psychopathologie, deel 1, Houten/Antwerpen 1990, pp. 256-274

RoSAS, Allan; Monika SANDVIK, 'Armed conflicts," in: Asbjorn EIDE, Catarina KRAUSE, Allan rosas (eds.), Economic, social and cultural rights; A textbook, Dordrecht (etc.) 1995, pp. 341-352

ROSENBLITH, Judy F., In the beginning; Development from conception to age two, Newbury Park (etc.) 1995

ROSENSTOCK, Robert, "The forty-eighth session of the International Law Commission," AJIL $1997 / 2$, pp. $365-374$

ROTH, Kenneth, 'Domestic violence as an international human rights issue,' in:

Rebecca J. CoOK (ed.), Human rights of women; National and international perspectives, Philadelphia 1995 (third printing), PP. 326-339

ROZEMOND, Klaas, 'De toekomst van de kritische rechtstheorie,' redactioneel Recht en kritiek 1997/3, pp. 197-205

RUTTER, Job DE, 'Het kind en de grondrechten,' in: Afra GROEN en Adri VAN MONTFOORT (red.), Kinderen beschermen en jeugd hulp verlenen, Arnhem 1993, pp. 175-192

RUSE, Michael, 'Van nature goed,' bespr. van Frans DE WAAL, Good natured; The origins of right and wrong in humans and other animals (Cambridge/London 1996), in: Intermediair 10 mei 1996, pp. 41 en 43

RUSSEK, Linda; Gary SCHWARTZ, onderzoek gepresenteerd tijdens de 55 th Annual Scientific Meeting van de American Psychosomatic Society, maart 1997; Psychologie juni 1997, p. 11 ('Ouders moet je met zorg kiezen')

RUSSEL, Diana E.H., The secret trauma; Incest in the lives of girls and women, New York 1986

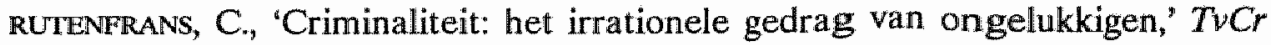
$1993 / 4$, pp. 327-335 
RUtENFrans, C., 'Zelfbeschikking en euthanasie,' Civis Mundi; Tijdschrift voor politieke filosofie en cultuur 1998/3 ('Mensenrechten'), pp. 146-152

RUTGERS VAN DER LOEFF, M., 'Reactie: de anonieme donor,' FJR 1988/4, p. 91

RUTTEN, Susan, Moslims in de Nederlandse rechtspraak, Kampen 1988

RUTTEN-Roos, A., 'Kind en wetgever,' in: Ted DE BoER e.a. (red.), De kant van het kind; Liber amicorum (...) Miek DE LANGEN, Arnhem 1992, pp. 291-299

RUTTER, Michael, 'Intergenerational continuities and discontinuities in serious parenting difficulties,' in: Dante CICCHETT1, Vicki CARLSON (eds.), Child maltreatment; Theory and research on the causes and consequences of child abuse and neglect, Cambridge (etc.) 1989, pp. 317-348

RUYTER, Doret $\mathrm{DE}$, Met recht ingrijpend; Een pedagogisch criterium voor het opleggen van hulp, diss. vu Amsterdam 1993, s.l. (e.a.)

RUYTER, D.J. DE, 'Onder pedagogisch toezicht; een pedagogisch voorstel voor een nadere omschrijving van de ondertoezichtstelling,' FJR 1994/9, pp. 202206

RUYTER, D.J. DE (1995a), 'Het recht om persoon te worden: een criterium voor het opleggen van pedagogische hulp," in: dez. en P.A. DE RUYTER (red.), Opvoedingshulp geboden; Pedagogische criteria voor het opleggen van hulp, theoretisch en praktisch bezien, Utrecht 1995, pp. 15-27

RUYTER, D.J. DE; B. SPIECKER, P.A. DE RUYTER (1995b), 'Verplichte opvoedingshulp; introductie op een thema,' in: dez. en P.A. DE RUYTER (red.), Opvoedingshulp geboden; Pedagogische criteria voor het opleggen van hulp, theoretisch en praktisch bezien, Utrecht 1995, pp. 9-14

RUYTER, D.J. DE (1995c), 'Een nieuw pedagogisch criterium? Reacties op de commentaren van de auteurs,' in: dez. en P.A. DE RUYTER (red.), Opvoedingshulp geboden; Pedagogische criteria voor het opleggen van hulp, theoretisch en praktisch bezien, Utrecht 1995, pp. 117-122

RUYTER, Doret DE, 'Pedagogische onzin? Een beschouwing over argumenten om in gezinnen in te grijpen,' in: Gezinnen onder druk; Over veranderende ouderkind relaties; hoe moeilijk/gewoon opvoeden kan zijn, Themadag Vrije Universiteit Amsterdam 23 november 1996 (samenvatting lezingen), pp. 14-15

RUY'TER, D.J. DE, 'Pedagogische bemoeienis: een beschouwing over argumenten om in gezinnen in te grijpen,' in: H. BAARTMAN e.a., Gezinnen onder druk; Over veranderende ouder-kind relaties, Kampen 1997, pp. 108-124

RYFF, Carol; Burton sINGER, bijdrage in Psychotherapy and psychosomatics 1996, gesignaleerd in Psychologie september 1996, p. 6 ("Geestelijk gezond")

SACHS, Albie, 'Human rights in the twenty-first century: reall dichotomies, false antagonisms,' paper presented to conference of the Canadian Institute for Judicial Administration, Halifax, 19 april 1997

SALET, Mick, 'Mag je een baby nog knuffelen?' (interview met Hans CROMBAG en Harald MERCKELBACH, auteurs van Hervonden herinneringen en andere misverstanden), Dagblad de Limburger 29 april 1996

SANDERson, Christiane, Counselling adult survivors of child sexual abuse, London/Bristol 1995 (tweede druk) 
SANTOS PAIS, Marta, "The Convention on the rights of the child," in: Manual on human rights reporting under six major intemational human rights instruments, United Nations, Geneva 1997, pp. 393-504

SAvORNIN LOHMAN, Jacquelien DE, 'Kind in het geding; kinderbescherming tussen traditie en vernieuwing' (afscheidsrede Universiteit van Amsterdam), in: Th.N.M. SCHUYT en M. STEKEIEE, Zorgethiek: Ruimte binnen regels, Utrecht 1998 , pp. 21-39

SCHABAS, William A., "Reservations to the Convention on the rights of the child,' HRQ 1996/2, pp. 472-491

SCHACHTER, Oscar, 'Human dignity as a normative concept,' $4 / N L 1983 / 4$, pp. 848-854

SCHACHTER, Oscar, International law in theory and practice, Dordrecht (etc.) 1991

SCHAEPMAN, Kees, 'Naar 15.000 Nederlandse kinderen wordt nauwelijks nog omgekeken,' Vrij Nederland 17 februari 1996, pp. 18-19

SCHEEPSTRA, Judith, 'Het onverwoestbare kind' (naar aanleiding van Lillian RuBIN, Het onverwoestbare kind, Nederlandse vert. 1997), Psychologie juli/ augustus 1997 , pp. 58-60

SCHELTENS, D.F., 'De idee der mensenrechten,' Rechtsgeleerd' Magazijn Themis $1989 / 7$, pp. 333-341

SCHENE, Patricia, "Child abuse and neglect policy," in: John Brrere e.a. (eds.), The APSAC [American Professional Society on the Abuse of Children] handbook on child maltreatment, Thousand Oaks (etc.) 1996, PP. 385-397

sCHERmers, H.G., "Lijfstraffen op school," in: Ex Iure; Veetitien opstellen bij het weertiende lustrum van Societas Iuridica GROTUS en de vierhonderdenvijfde geboortedag van GroTius, Arnhem 1987, pp. 169-179

SCHIPPERS, G.M., 'Cognitieve therapie bij persoonlijkheidsstoornissen,' in: C.P.F. VAN DER STAAK, C.A.L. HOOGDUIN (red.), Diagnostiek en behandeling van de persoonlijkheidsstoornis, Symposium klinische psychologie, Nijmegen 1990/1, pp. 59-66

SCHNABEL, Paul, 'Voorwoord,' in: Sietske DuKSTRA e.a., Kindermishandeling: van signaal naar hulp $I$; Hulpverlenen en samenwerken, NcGv, Utrecht 1990, pp. ix $x-x$

SCHNABEL, Paul, 'Kind en gevaar,' bespr. van Adri vaN MONTFo[O]RT, Het topje wan de ijsberg; Kinderbescherming en de bestrijding van kindermishandeling in sociaal-juridisch perspectief (diss. vu Amsterdam, Utrecht 1994), in: NRC Handelsblad 11. mei 1994

SCHOEMAKER, Beatrix, Niet gehoord en niet gezien; Verwerking van sexuele trauma's bij wrouwen en mannen, diss. Utrecht, Amsterdam/Luisse 1991

SCHOLTE, E.M.; L. SONTAG, Opvoeding en ontwikkeling; Een Miteratuuronderzoek naar de samenhang tussen opvoedingsgedrag van primaire opvoerders en de ontwikkeling van jeugdigen, PCos-werkdocument 7, Programmeringscollege Onderzoek Jeugd, Utrecht, januari 1992

SCHOLTEN, Paul, Algemeen deel, ASSER-serie (Mr. C. ASSERs Handleiding tot de beoefening wan het Nederlands burgerlijk recht), Zwolle 1974 (derde druk) 
SCHOLTENS, W.R. (red.), KIERKEGAARD; Dagboeknotities, een keuze, Baarn 1981 (derde druk)

SCHRIVIER, Nico, 'Collectieve mensenrechten: rookgordijnen of extra cement voor het universele bouwwerk van de rechten van de mens?' In: dez. e.a. (red.), Mensenrechten, voor armen weggelegd? Evert verMeER Stichting, Amsterdam 1989, pp. 148-171

SCHRÖDER, Hannelore, 'Olympe DE GoUGes 1748-1793; leven voor vrouwenbevrijding - sterven op de guillotine,' in: dez. (red.), Olympe DE GOUGES; Verklaring van de rechten van de vrouw en burgeres (Parijs 1791), Kampen 1989 , pp. 16-23

schurr, Kees, 'Het kleine onrecht,' Forumpagina De Volkskrant 22 juni 1992 SCHWARTZ, Bernard, The roots of the Bill of rights, vol. 1, New York (1971), ed. 1980

SCHWARZENBERGER, Georg, "The GRoTIUs factor in international law and relations: a functional approach,' in: Hedley BuLL, Benedict KINGSBURY, Adam ROBERTS (eds.), Hugo GRoTIUs and international relations, Oxford 1990, pp. 301-312

scroggs, J.R., Persoon en persoonlijkheid, deel 1, Rotterdam 1988

SEBALD, Hans, Lieve Mammie ...; Gevolgen van verkeerd gericht moederschap op de ontwikkeling wan het kind, Utrecht/Antwerpen 1979

SEGALEN, Martine, 'The industrial revolution: from proletariat to bourgeoisie,' in: Andre burgurerre e.a. (red.), A history of the family, vol. II: The impact of modernity, Cambridge 1996 (vert. van Histoire de la famille, Parijs 1986), Chapter 9, pp. 377-415

SENAEVE, P., 'Het belang van het kind in het Belgische familierecht,' in: Ad VAN Der linden, Paul vlaARdingerbroek (red.), Met het oog op het belang van het kind; Opstellen aangeboden aan (...) Madzy ROOD-DE BOER (...), Deventer 1988, pp. 119-127

SETTEN, Henk VAN, In de schoot van het gezin; Opvoeding in Nederlandse gezinnen in de twintigste eeuw, Nijmegen 1987

SEvenhuUusen, Selma, 'Feministische ethiek en rechten van kinderen,' in: Carol van ninatten (red.), Kinderrechten in discussie, Amsterdam/Meppel 1993, pp. $42-63$

SGRITTA, Giovanni B., "Inconsistencies: childhood on the economic and political agenda,' Childhood $1997 / 4$, pp. 375-404

SHENGOLD, Leonard, Soul murder; The effects of childhood abuse and deprivation, New Haven/London 1989

SHESTACK, Jerome J., 'The philosophic foundations of human rights,' $H R Q 1998$ /

2, pp. 201-234

SIEGHART, Paul, The international law of human rights, Oxford 1983

SIERKSMA, Fokke, Religie, sexualiteit en agressie; Een cultuurpsychologische bijdrage tot de verklaring van de spanning tussen de sexen, Groningen 1979 (wetenschappelijke versie, bezorgd door K.D. JENNER, van De roof van het vrouwengeheim, Den Haag 1962) 
sIMMA, Bruno, 'International human rights and general international law: a comparative analysis,' in: The protection of human rights in Europe, Collected Courses of the Academy of European Law, vol. Iv, book 2, 1993, The Hague (etc.) 1995, pp. 153-236

SIMON, H.J., 'Onmenselijke behandeling en asiel,' NJB 1990, pp. 1437-1446

sLoT, N.W., 'Gezinsgerichte interventies; hulp voor ouders van kinderen met antisociaal gedrag,' Justitiële Verkenningen 1996/6 ('Preventief ingrijpen in het gezin'), pp. 50-62

sLot, N.W., 'Preventie en behandeling van jeugdcriminaliteit,' reactie ('Journaal') in Justitiële Verkenningen 1996/9, pp. 90-94

SLOTH-NIELSEN, Julia, 'The contribution of children's rights to the reconstruction of society: some implications of the constitutionalisation of children's rights in South Africa,' IJCR 1996/4, pp. 323-344

SLOUN, T.H.J.G. VAN, 'Reïficatie als resultante van "codificatie naar modificatie",' in: Ted DE BOER e.a. (red.), De kant van het kind; Liber amicorum (...) Miek DE LANGEN, Arnhem 1992, pp. 279-289

slurink, Pouwel, 'Evolutieleer versterkt het moreel besef,' Forumpagina De Volkskrant 7 december 1995

SMAIL, David, Schijn en werkelijkheid; De zin van de angst, Baarn 1986

SMIDT, J.Th. DE, Compendium van de geschiedenis van het Nederlands privaatrecht, Deventer 1972 (tweede druk)

SMTrH, Jacqueline; Hermine VAN DER WEIDE, Visies en discussies [rond] genitale verminking van meisjes; Een inventarisatie in internationaal perspectief, DCINederland, Amsterdam 1992

SMrTH, Jacqueline, Visions and discussions on genital mutilation of girls; An international survey, The Hague/Amsterdam 1995

SMrTH, Jacqueline, 'Rapportageverplichting onder het [Verdrag inzake de rechten van het kind],' FJR $1998 / 1$, pp. 2-6

smrrs, V.M., 'De persoon,' in: M.J.C. KoENs (red.), Het hedendaagse personen- en familierecht, Zwolle 1995, pp. 15-70

sNIK, G.L.M., Persoonswording en opvoeding, diss. Nijmegen, Kampen 1990

SNIK, G.L.M., 'Staatsbemoeiing, opvoedingsvrijheid, persoonsideaal,' in: D.J. DE RUYTER, P.A. DE RUYTER (red.), Opvoedingshulp geboden; Pedagogische criteria voor het opleggen van hulp, theoretisch en praktisch bezien, Utrecht 1995, pp. 93-104

SOCiAal EN CUltureel planburbau (M. BEKER, C.J. MAAS), Rapportage jeugd 1997, scP Rijswijk, Den Haag (april) 1998

SOETENHORST-DE SAVORNIN LOHMAN, Jacquelien, 'De armslag van de uitwoerend werker op het raakvlak tussen hulp en recht,' in: Afra GROEN en Adri VAN MONTFOORT (red.), Kinderen beschermen en jeugd hulp verlenen, Arnhem 1993, pp. 127-145

soETERs, Margriet, 'Verwaarloosde kinderen,' bespr. van Mariska KROMHOUT, Verwaarloosde kinderen; Opvattingen uit het veld (PEWA, Leiden 1996), in: 0/25; Tijdschrift over jeugd februari 1997, pp. 57-58 
SoHN, Louis B., 'How American international lawyers prepared for the San Francisco Bill of rights,' AJIL 1995/3, pp. 540-553

soons, A.H.A., 'Juridische vrouwenstudies en internationaal publiekrecht,' in:

E.A. ALKEMA e.a. (red.), Lof der verscheidenheid; Rechtsgeleerden over vrouw en recht, Zwolle 1993, pp. 191-205

soudun, K.A., Psychologen en beroepsethiek, Lisse 1995

SPLJKERBOER, T.P.; B.P. VERMEULEN, Vluchtelingenrecht; Serie Migratierecht III, NCB (Nederlands Centrum Buitenlanders), Utrecht 1995

STAAL, C.J., 'Het herziene Europees Sociaal Handvest,' NJCM-Bulletin 1997/3, pp. 349-380

STARR, Raymond H., e.a., 'The epidemiology of child maltreatment,' in: Robert

T. AMMERMan, Michel Hersen (eds.), Children at risk; An evaluation of factors contributing to child abuse and neglect, New York/London 1990, pp. 2353

STEGerHoex, N.A., De publieke kant van het jeugdrecht; Publieke aspecten van het civiele jeugdrecht nader beschouwd, diss. Leiden, Zwolle 1995

STEGGE, Jolanda AAN DE, 'Het zal je pa maar wezen; het relaas van het meisje dat een kind kreeg van haar vader,' Opzij september 1989, pp. 23-25

STELNEN, N.M.P.; M.J.F. STELLING (red.), De rechtmatigheid van de bedreiging met of het gebruik van kernwapens; Uitspraak van het Internationaal Gerechtshof van 8 juli 1996 (vert. L.J. REINDERS en B.J. VERfIEU), Stichting Tribunaal voor de Vrede, [Amsterdam] 1998

STEINER, Henry J.; Philip ALSTON (eds.), International human rights in context; Law, politics, morals, Oxford 1996

STELling, M.J.F., 'Woord vooraf,' in: N.M.P. sTEIJNEN, M.J.F. STELling (red.), Rechtmatigheid van kernwapens? (...) Uitspraak van het Internationaal Gerechtshof van 8 juli 1996 (vert. L.J. REINDERS en B.J. VERFEU), Stichting Tribunaal voor de Vrede, [Amsterdam] 1998, pp. 7-8

stelzenberger, J., Zedenleer van het Koninkrijk Gods (oorspr. titel: Lehrbuch der Moraltheologie; Die Sittlichkeitslehre der Königshenschaft Gottes), (imprimatur) Brugge 1962

STERKEnBURG, P.G.J. VAN, Vloeken, s.l. 1997

STIBANE, K.W.U.F., 'De ontwikkeling van het identiteitsgevoel vanuit kinderpsychiatrisch perspectief,' in: P.C.Th.M. VAN EEUWIJ, J.H.A. VAN LOON (red.), Identiteitsproblemen bij adoptiekinderen, Amsterdam/Lisse 1989, pp. 17-29 straus, Murray A., e.a., Behind closed doors; Violence in the American family, Garden City, N.Y. 1980 (Newbury Park etc. 1981)

straus, Murray A.; Glenda K. KANTOR, 'Stress and child abuse,' in: Ray E. HELFER, Ruth S. KEMPE (eds.), The battered child, Chicago/London 1988 (vierde druk), pp. $42-59$

STroecken, Gaby, Het miskende kind in onszelf, Leuven/Amersfoort 1994 sTroink, F.A.M., Algemeen bestuursrecht; Een inleiding, Zwolle 1994 STUFKENS, A., 'Inleiding,' in: dez. e.a. (red.), Vader was niet thuis, moeder was niet thuis; Psychoanalytische notities, Meppel/Amsterdam 1987, pp. 9-17 
SIUTTERHEIM, R.H., 'Het kind van de rekening,' in: M. DE LANGEN e.a. (red.), Kinderen en recht; Opstellen over de positie van minderjarigen in het recht, Arnhem/Deventer 1989, pp. 353-365

sTUYT, A.M., Formeel tractatenrecht; Overzicht aan de hand van de Nederlandse praktijk, Den Haag 1966

STUYT, A.M., Driewerf vrede; Afscheidsgeschrift, kU Nijmegen, Kerstmis 1982

STUYT, A.M., 'GRoTIUS: Vader des volkenrechts?' Samenvatting van een voordracht in het Verslag van de Algemene Ledenvergadering juni 1983, Mededelingen van de Nederlandse Vereniging voor Internationaal Recht 88, Deventer 1984, pp. 1-7

SUGANAMI Hidemi, 'Grortus and international equality,' in: Hedley BULL, Benedict KINGSBURY, Adam roBerrs (eds.), Hugo grotuUs and international relations, Oxford 1990, pp. 221-240

syatauw, J.J.G, Decisions of the International Court of Justice; $A$ digest, Leiden 1969 (tweede druk)

SZABO, Imre, 'Historical foundations of human rights and subsequent developments,' in: Karel VASAK, Philip ALSTON (eds.), The international dimensions of human rights, Westport (Ct.)/Paris 1982, vol. 1, pp. 11-40

SZNAIDER, Natan, 'Compassion and control; children in civil society,' Childhood $1997 / 2$, pp. 223-240

TANAKA Tadashi, 'Grotuus' method: with special reference to [the] Prolegomena,' in: ONUMA Yasuaki (ed.), A normative approach to war: Peace, war, and justice in Hugo GRoTrus, Oxford 1993, pp. 11-31

TANakA Tadashi, 'Gromus' concept of law,' in: onuma Yasuaki (ed.), A normative approach to war: Peace, war, and justice in Hugo Gromws, Oxford 1993, pp. $32-56$

TANJA, Gerard J., 'De volkenbond,' (hoofdstuk 6) in: A.C.G.M. EYFwINGER (red.), Compendium volkenrechtsgeschiedenis, Deventer 1991 (tweede druk), pp. 182-198

TAVEcchro, Louis, bespr. van Piet weisfelt, Nestgeuren; Over de betekenis van de ouder-kindrelatie in een mensenleven (Baarn 1996), in: 0/25; Tijdschrift over jeugd december 1996, pp. 51-52

TERR, Lenore, Schokkende herinneringen; [Zeven] gevallen van traumaverwerking en geheugenverlies (oorspr. titel: Unchained memories; True stories of traumatic memories, lost and found, 1994), Amsterdam/Antwerpen 1994

TEX, Ursula DEN, "De Bolderkar: "Tk wist dat ik kon vragen: word je vastgebonden? Maar aan het idee van afplakken van monden was ik nog niet toe", Vrij Nederland 29 april 1989, pp. 3-4 (op p. 4 onder de kop: 'De kinderrechter: "De zorg van De Bolderkar om de kinderen is in alle gevallen terecht geweest"')

THERBORN, Göran, 'Child politics: dimensions and perspectives,' in: Eugeen verhellen (ed.), Monitoring children's rights, Den Haag (etc.) 1996, pp. $377-$ 391 
THERBORN, Göran, 'Child politics; dimensions and perspectives,' Childhood 1996/1, pp. $29-44$

THOMAs, Hugh, The slave trade; The history of the Atlantic slave trade 1440-1870, New York/London 1997

THOMPSON, Ross A., 'Developmental research and legal policy: toward a two-way street,' in: Dante cicchetr, Sheree L. TOTH (eds.), Child abuse, child development, and social policy, Advances in applied developmental psychology, vol. 8, Norwood, New Jersey 1993, pp. 75-115

TIEN VERBODEN, (DE), [de tien dingen die men een kind nooit zegt], Ch. SCHAEFER, Psychological Reports 1997; Psychologie oktober 1997, p. 13

TOMAŠEVSKI, Katarina, 'Health rights,' in: Asbjørn EIDE, Catarina KRAUSE, Allan rosas (eds.), Economic, social and cultural rights; A textbook, Dordrecht (etc.) 1995 , pp. $125-142$

TOMAŠEvSKI, Katarina, bespr. van LEBLANC, The Convention on the rights of the child; United Nations lawmaking on human rights (Lincoln/London 1995), in: NQHR 1996/1 ('Book reviews'), pp. 111-115

тотн, Sheree L.; Dante ciccheтr,, "Child maltreatment: where do we go from here in our treatment of victims?' In: Dante cICCHETT, Sheree L. TOTH (eds.), Child abuse, child development, and social policy, Advances in applied developmental psychology, vol. 8, Norwood, New Jersey 1993, pp. 399-437

TOUWEN, B.C.L., 'De neurologische ontwikkeling van 0 tot 3 jaar,' in: J.E. DE BOER (red.), Infantpsychiatrie II; De gezonde en verstoorde ontwikkeling van het zeer jonge kind, Assen 1993, pp. 71-80

Trumbos, C.J.B.J, Samen één; Enige beschouwingen over psychische hygiëne en de huidige zorg voor het huwelijk, openbare les RU Utrecht, Utrecht/Antwerpen 1960

TRImbos, C.J.B.J, Sociale evolutie en psychiatrie, i.o. Eu Rotterdam, Bussum 1969 TROTMAN, Tamara; Kornelie vos, 'Het recht op hoor en wederhoor wordt nergens meer geschonden dan binnen de traditionele rechtswetenschap; interview met Dorien Pessers,' Ars Aequi 1991/1, pp. 27-35

TURKU-DECLARATION (Declaration of minimum humanitarian standards, 2 december 1990), un doc. E/CN.4/Sub.2/1991/55; A.IL 1991/2, pp. 375-381

UnEN, Alice VAN, Melden van kindermishandeling over de grens; Een onderzoek naar meldingssystemen inzake kindermishandeling in Noord-en West-Europa en de Verenigde Staten van Amerika, NIzw, Utrecht (maart) 1997

UNEN, Alice VAN, 'Meldingssystemen inzake kindermishandeling in Europa en Amerika," Tijdschrift voor de rechten van het kind 1997/1, pp. 6-9

UNEN, A.A.W. VAN, 'Part $\vee$ [van de Nederlandse rapportage aan het Comité inzake de rechten van het kind]: Family environment and alternative care,' FJR 1998/1, pp. 15-18

VALK, J.M.M. DE, 'Het werk van René GIRARD,' in: René GIRARD, De zondebok, Kampen/Kapellen 1986, pp. 251-256 
VANDENBERGHE, Lieven; Ankie VANDEKERCKHOVE, "Monitoring children's rights: a specific task for "Child [and] Family"?' In: Eugeen verhelLev (ed.), Monitoring children's rights, Den Haag (etc.) 1996, pp. 587-592

VANWESENBEECK, Ine, "'Wat hebben ze nou aan een verdrietige hoer?" Een onderzoek naar zelfredzaamheid bij prostituées,' $M G v$ 1990/3, pp. 235-249

VANWESENBEECK, Ine, 'Geluk en ongeluk in de prostitutie,' $M G v 1995 / 10$, pp. 1043-1057

VEERMAN, Philip E., The rights of the child and the changing image of childhood, Dordrecht (etc.) 1992

velidkaMP, Ton, 'Nog te vroeg voor een feestje! De doorwerking van het (...) Verdrag inzake de rechten van het kind in de jeugdbescherming,' Tijdschrift voor de rechten van het kind december 1997, pp. 4-6

velTKAMP, Lane J.; Thomas W. MILler, Clinical handbook of child abuse and neglect, Madison, Ct. 1994

verdross, Alfred; Bruno sImma, Universelles Völkerrecht; Theorie und Praxis, Berlin 1976/1981

verDross $\dagger$, Alfred; Heribert Franz KOECK, 'Natural law: the tradition of universal reason and authority,' in: R.St.J. MACDONALD, Douglas M. JOHNSTON, The structure and process of international law: Essays in legal philosophy, doctrine and theory, Dordrecht (etc.) 1986, pp. 17-50

VERENIGING TEGEN SEKSUELE KINDERMISHANDELING BINNEN HET GEZIN, De straf op zwijgen is levenslang; Over seksuele kindermishandeling binnen het gezin, Amsterdam 1988 (vierde druk)

VERHELLEN, Eugeen, 'Naar een snel veranderend kindbeeld?' In: H. CAMMAER en E. verhellen (red.), Onmondig en onvolwassen; De jonge mens in de eeuw van het kind, Leuven/Amersfoort 1990, pp. 53-73

VERHELlEN, Eugeen, Verdrag inzake de rechten van het kind; Achtergronden, motieven, strategieën, hoofdlijnen, Leuven/Apeldoorn 1993 (tweede druk), 1997 (derde druk)

vERHELlen, E., e.a. (red.), Kinderrechtengids, Gent 1994 (losbladig)

VERHELLEN, Eugeen, Jeugdbeschermingsrecht, Gent (editie) 1996

verhellen, Eugeen (ed.), Monitoring children's rights, Den Haag (etc.) 1996

VERHELlen, Eugeen, 'Children's rights in Europe,' in: dez. (ed.), Understanding children's rights; Collected papers presented at the first International interdisciplinary course on children's rights, Gent 1996, pp. 515-540

verHevl, Roel, 'Persoonlijkheidsstoornissen: scheef gegroeid,' Psychologie juli/ augustus 1995 , pp. 54-58

verheul, Roel, 'Het masker van de psychopaat,' Psychologie september 1996, pp. 31-35

VERHEY, L.F.M., "Valkenhorst: het recht op afstammingskennis als persoonlijkheidsrecht,' noot NICM-Bulletin 1994/6, pp. 652-658

VERHEY, N., 'Deuken in het ideaal,' Publiek Domein 1989/6-7, pp. 237-242

VERHOEVEN, Willem; Anita VAN VLERKEN, 'De basisprincipes van coaching,' in: Jan DE RUuTER (red.), De docent als coach, Baarn 1997, pp. 19-32 
VERLOO, Mieke; Conny ROGGEBAND, Emancipatie-effectrapportage: theoretisch kader, methodiek en voorbeeldrapportages, Ministerie van szw, Den Haag 1994

VERMEULEN, B.P., 'God, wil en rede in Hugo DE Groots natuurrecht,' Wijsgerig perspectief op maatschappij en wetenschap 1982-1983/3 ('Gromus'), pp. $54-59$ VERMEULEN, Ben, 'Grotrus on conscience and military orders;' Grotiana, New Series, vol. 6, 1985, pp. 3-19

VERMEULEN, B.P., De vrijheid van geweten, een fundamenteel rechtsprobleem, diss. Rotterdam, Arnhem 1989

VERMEULEN, B.P;; G.A. VAN DER WAL, 'GROTIUS, AQUINAS and HOBBES; grotian natural law between lex aeterna and natural rights,' Grotiana, New Series, vol. $16-17,1995-1996$, pp. 55-83

VERSCHuUREN, Jonathan, 'Naar een codificatie van beginselen van het milieurecht,' Recht en kritiek 1995/4, pp. 421-445

VINCENT, R.J., 'GROTIUS, human rights and intervention,' in: Hedley BULL, Benedict KINGSBurY, Adam RoBERTs (eds.), Hugo GrotuUs and international relations, Oxford 1990, pp. 241-256

VISSER, Sandra, "Trauma en ouderschap; over hoe het verleden kan "rondzingen" in het heden,' MGv 1997/6, pp. 633-646

VISSER "T HOOFT, H.Ph., "De menselijke waardigheid in traditie en actualiteit," Wijsgerig perspectief op maatschappij en wetenschap 1985-1986/5 ('Menselijke waardigheid'), pp. 151-162

vTrÁNYI, B.K.J., Internationale aansprakelijkheid van staten woor hun rechtsbedeling, Afscheidscollege ku Nijmegen 1983

VOLLEBERGH, Wilma, 'Tienerouders hebben vaak problematische achtergrond,' 0/25; Tijdschrift over jeugd oktober 1998, 'Onderzoek,' p. 52

vOLLENHOVEN, C. VAN, Omtrek en inhoud van het internationale recht, diss. Leiden 1898

VOLLENHOVEN, C. VAN, The framework of GROTUS" book De jure belli ac pacis (1625), Verhandelingen der Koninklijke Akademie van Wetenschappen te Amsterdam, Afdeeling Letterkunde, Nieuwe Reeks, deel xxx, no. 4, Amsterdam 1931

vollenHOven, C. VAN, De drie treden van het volkenrecht (1918), Den Haag 1935 (derde druk)

vos, Pierre DE, 'Introduction to South Africa's 1996 Bill of rights,' NQHR 1997/ 2, pp. $225-243$

VRIES, A.D.W. DE; F.J.G. VAN TRICHT, Geschiedenis der wet op de ouderlijke macht en de voogdij (6 februari 1901, Staatsblad no. 62); Verzameling van Regeeringsontwerpen, gewisselde stukken, gevoerde beraadslagingen, enz., met enkele korte kantteekeningen en register, deel 1, Groningen 1903

VRIES, Pety E. DE, "A draft of Lethe: a neglected statement from the works of Sigmund Freud,' Psychotherapy 1993/3, pp. 524-530

vroman, Leo, Neembaar; Een keuze uit de gedichten, Amsterdam 1991

vuYk, Rita, Opgroeien onder moeilijke gezinsomstandigheden, Amersfoort/Leuven 1987 (tweede druk) 
WAAL, Wilbert, Tegen kinderen ("pamflet' Uitgeverïij Vriendenlust), Nijmegen 1983 (vierde druk)

WAAL, Frans DE, Good nanred; The origins of right and wrong in humans and other animals, Cambridge/London 1996

WAal, Mieke DE, 'Vān zorgzaamheid năir waakzaamheid," in: dez. e.a., Gezin' nen gezien, Assen 1998, pp. $39-49$

WAALDUK, O., 'Is voelen echt wel goed voor wie niet horen wil? Gedachten van een psycholoog over stâffen,' iñ: K. BLANKMAN, L.C.M. sTeGMANN (red.), Hêt recht of het belang van het kind, Assen/Matstricht 1989, pp. 30-40

WAMELEN, Carla VAN, 'De ontzetting uit het ouderlijk gezag. afschaffen of reanimeren?" Editorial FJR 1998/5, p. 101

WANDERS, Margriet, 'Zorg en opvoeding als politiek probleem; gezinsbeleid bij de overheid en de vier grote partijen, $0 / 25$; Tijdschrift over jeugd april 1998 , pp. $8-13$

WARMIK, Mynke, Schadevergoeding bij seksueel misbruik; Een jurisprudentieonderzoek naar de civielrechtelijke schadevengoeding aan slachtoffers wan sek sueel misbruik, Ars Aequi Libri, Nijmegen 1995

WeEDA, Iteke, "Meer persoonlijkheden in én lichaam; MPS: een "creatieve oplossing" van de geest om te overleven," Opzij aprill 1992, pp. $80-83$

WERKGROEP MELDPUNT KINDERMISHANDELING (WAN DINK, VAN SOOMEREN en parthers, Agnes VAN BURI, Mireille GELDORP), Het melden van vernoedens van kindermishandeling; Ervaringen en wensen wan potentiele melders (onderzoeksrapport t.b.v. Werkgroep meldpunt kindermishandeling, Roermond), Amsterdam (VAN DHK, VAN SOOMEREN en parthers), februari 1996

WERKGROEP MELDPUNT KINDERMISHANDELING, Het melden van wemoedens van kindermishandeling; Samenwatting van een onderzoek naar enaringen en wensen wan potentiele melders, Roermond, juni 1996

WERKGROEP MELDPUNT KINDERMISHANDELING, Advies- en meldpunten kindemishandeling, Tweede interimrapport, Roermond, januari 1997

WERKGROEP MELDPUNT KINDERMISHANDELING, Advies- en meldpunten kindermishandeling, Eindrapport, Roermond, oktober 1997

WERKGROEP MELDPUNT KINDERMISHANDELING (AgNES VAN BURIK, LE GRUBBEN), Kinderen over kindermishandeling; Een onderzoek onder kinderen van groep 7 en 8 van de basisschool, Roermond, oktober 1997

WIARDA, J., 'Historisch overzicht over de juridische positie van kinderen,' in: $M$. DE LANGEN e.a. (red.), Kinderen en recht; Opstellen over de positie van minderjarigen in het recht, Arnhem/Deventer 1989, pp. 1-11

WIERSMA, J., "The grotian moment: the "piece de resistance" in BONHOEFFER's letters and papers from prison," Grotiana, New Series, vol. 12-13, 1991-1992, pp. 62-77

WuERs, M., aangehaald in De Volkskrant 22 november 1993, p. 4, onder de kop: 'Rechteloosheid prostituée oorzaak uitbuiting'

wıK, Hanneke vaN, "Ouderlijke verantwoordelijkheid en het recht van het jonge kind op eerbiediging van "familly life", in: Ted DE BOER e.a. (red.), De kant 
wan het kind; Liber amicorum (...) Miek DE LANGEN, Arnhem 1992, pp. 147. 158

WIJK, Hanneke vaN, 'Gronden voor kinderbeschermingsmaatregelen; discussie voortgezet,' Nernesis $1992 / 6$, pp. 27-29

wILLEMS, J.C.M., '(...) Het grotiaanse denkbeeld van het allermensenrecht en de klassieke leer van de rechtvaardige oorlog geconfronteerd met de moderne stelsels van collectieve veiligheid en collectieve zelfverdediging (...), in: B.W. HILFERINK, J.C.M. WILlEMS (red.), Jaarboek Volkenrechtelijk Dispuut Robert REGOUT 1978-1979, Rechtsgeleerd Instituut kU Nijmegen 1980, pp. 5592

WILLEMS, J.C.M., discussiebijdragen in De Volkskrant: Open forum van 29 oktober ('Democratie te formalistisch') en 16 december 1980 ('VAN AGT misbrwikt term rechtsstaat')

WILLEMS, J.C.M., 'GROTIUS and the atomic weapon: the nuclear weapon-discussion in the light of the theory of "just war" with Hugo DE Groot,' Grotiana, New Series, vol. 2, 1981, pp. 103-114

WILLEMS, J.C.M., 'Hugo DE GROOT en het volkenrecht,' Wijsgerig perspectief op maatschappij en wetenschap 1982-1983/3 ('GROTIUs'), pp. 66-70

wiLlems, J.C.M., 'Grotius als filosoof,' Algemeen Nederlands Tijdschrift voor Wijsbegeerte $1983 / 1$, pp. $49-55$

wILlEMS, J.C.M., 'Hugo DE GRooT,' NRC Handelsblad 6 mei 1983, Opiniepagina ('Brieven')

wILlems, J.C.M., 'Heroïne, mythen en juristen,' Delikt en Delinkwent 1984/10, pp. $955-959$

WILLEMS, J.C.M., 'Kernwapens en mensenrechten; enkele aanzetten voor studie en discussie,' in: A. BEIRl.AEN e.a., Kernwapens en recht, Antwerpen 1985, pp. $57-96$

WILLEMS, J.C.M., 'Zelfbeschikkingsrecht en nationale cultuur: pervers en subversief?' Recht en kritiek 1985/4, pp. 351-363

wILLEMS, J.C.M., 'Recht en rechter in de "dyas politica"; enkele gedachten over internationaal recht, juridisch activisme en de rolperceptie van de rechter vanuit staatsrechtelijk perspectief en met het oog op de rechtshulp aan vreemdelingen,' in: 'T. HOOGENBOOM e.a. (red.), Sociale advocatuur en de rechten van de mens, Ars Aequi Libri, Nijmegen 1989, pp. 114-145

wILLEMs, J.C.M., 'Het vN-Kinderverdrag en het recht op abortus,' NJB 1990, pp. $776-778$

wILLEMS, J.C.M., 'Ouderbescherming en kinderbescherming: wordt het geen tijd voor een meldplicht?' NJB 1990, pp. 1243-1247

wILlems, J.C.M., 'Van parentiarchie naar Vadertje Staat; over 't verwekken, mishandelen en beschermen van kinderen,' Nemesis 1992/3, pp. 8-23

wLLEMS, J.C.M., "A world of wanted children would make a world of difference"; antwoord aan(gaande) RUTENFrans,' Nemesis 1992/6, pp. 20-26

wILLEMS, J.C.M., "Reactie op "Het zelfbeschikkingsrecht van de zwangere vrouw",' Ars Aequi 1993/1, p. 22 
WILLEMS, J.C.M., 'Kinderen zijn niet automatisch veilig bij hun ouders,' Tijdschrift voor Jeugdhulpverlening en Jeugdwerk 1993/11, pp. 18-22

WILLEMS, J.C.M., 'Kinderen in ons midden; enkele cultuurkritische notities naar aanleiding van artikel 25 van de Universele Verklaring en het Verdrag inzake de rechten van het kind,' Recht en kritiek 1994/4, pp. $322-339$

wILLEMS, Jan [C.M.], 'Kindermishandeling als ernstige mensenrechtenschending,' VKMagazine 1997/2, pp. 4-5

whLlems, Lucy, 'Geweld tegen vrouwen: CEDAW-Algemene Aanbeveling nr. 19,' Actualiteitenkatern Nemesis 1995/5, pp. 26-30

willams, James J., 'The cycle of abuse,' in: A.E. Brodeur, J.A. MONTELEONE, Child maltreatment; [vol. 1] A clinical guide and reference, St. Louis (etc.) 1994, pp. 285-307

wILMINK, Willem, 'Vriendje van vroeger,' vKM, kaartenserie Kunstenaars tegen kindermishandeling, Den Haag s.a.

WILTERDINK, Nico, 'Zelfcontrole en civilisatie; GOTTFredson \& HIRSCHI en ELIAS vergeleken,' TvCr 1998/2, pp. 139-150

WINDELS, Dieter, 'Social and educational assistance for children and their mild[ly] mental[ly] retarded parents,' in: Eugeen VERHELLEN (ed.), Monitoring children's rights, Den Haag (etc.) 1996, pp. 797-801

WINTER, Reiner DE, De overheid; Overzicht van het Nederlandse staatsrecht, Den Haag 1994 (tweede druk)

WrT, Bernadette DE, 'Ouders en tuttebollen,' Forumpagina De Volkskrant 3 februari 1992

woELINGA, Heleen, Seksueel misbruik van kinderen in het gezin; Signalering en opvang, Meppel/Amsterdam 1988

wolf, Erik, Große Rechtsdenker der Deutschen Geistesgeschichte, Tübingen 1963 (vierde druk)

WOLF, Joachim, "The concept of the "best interests" in terms of the un Convention on the rights of the child,' in: Michael FreEman, Philip veERMAN (eds.), The ideologies of children's rights, Dordrecht (etc.) 1992, pp. 125-133

wolfr, Betje, Proeve over de opvoeding, aan de Nederlandsche moeders (1780), (tweede druk, heruitgave met een inleiding van H.C. DE wolf), Meppel/ Amsterdam 1977

wolfson, Susan, 'Children's rights: the theoretical underpinning of the "best interests of the child",' in: Michael freeman, Philip verrman (eds.), The ideologies of children's rights, Dordrecht (etc.) 1992, pp. 7-27

WOLLESWINKEL, Ria, Gevangen in moederschap: Gedetineerde vrouwen en het recht op family life, diss. Maastricht, Deventer 1997

WOLZAK, A., 'Kindermishandeling in getallen,' VKM Info, februari 1996 (tweede herziene druk NIZw/Infocentrum Kindermishandeling, Utrecht 1998) wolZAK, Adrie, 'Kinderdoding,' VKMagazine 1997/2, pp. 8-9 wolzAK, Adrie, 'Een herkenbaar meldpunt,' VKMagazine 1997/4 (special 'Advies- en meldpunten kindermishandeling'), pp. 1-3 
WORLD HEALTH ORGANZATION/Nederlandse Vereniging voor Psychiatrie, De ICD-10 classificatie van psychische stoomissen en gedragsstoornissen; Klinische beschrijvingen en diagnostische richtlijnen (wHo 1992), Lisse 1994

WRIGitr, Herbert F., 'Some less known works of Hugo GROTIUS,' Bibliotheca

Visseriana dissertationum ius internationale illustrantium, tomus viI (xVII),

Leiden 1928, pp. 131-238

WRIGHT, Robert, DARWINs geweten; Evolutionaire psychologie en het dagelijks leven

(oorspr. titel: The moral animal, 1994), Amsterdam 1997

WYATT, Gail E.; Gloria J. POWELL (eds.), Lasting effects of child sexual abuse, Newbury Park (etc.) 1989

YanaGihara Masaharu, 'Dominium and imperium,' in: onuma Yasuaki (ed.), $A$ normative approach to war: Peace, war, and justice in Hugo GRoTIUs, Oxford 1993, pp. $147-173$

ZAHAN, Dominique, Religion, spiritualité et pensée Africaines, Parijs 1970 ZELLMAN, Gail L.; Kathleen C. FALLER, 'Reporting of child maltreatment,' in: John BRIERE e.a. (eds.), The APSAC [American Professional Society on the Abuse of Children] handbook on child maltreatment, Thousand Oaks (etc.) 1996, pp. 359-381

ZIEGLER, Karl-Heinz, 'GROTIUs topical, or the import of antiquity into the international law of Europe,' Grotiana, New Series, vol. 12-13, 1991-1992, pp. 7887

ZIJDERVELD, A.C., 'Schimmen en schaduwen van de revolutie der revoluties,' in:

S.W. CouWEnBerg (red.), Opstand der burgers; De Franse revolutie na 200 jaar, Kampen 1988, pp. 39-49

ZWALVE, W.J., Hoofdstukken uit de geschiedenis van het Europese privaatrecht, deel I (Inleiding en zakenrecht), Groningen 1993 zWANikken, G.J., e.a. (red.), Psychiatrie, Utrecht 1990 ZWTTZER, H.L., 'Joan Derk VAN DER CAPELLEN TOT DEN POL als schrijver van het pamflet Aan het Volk van Nederland,' in: Joan Derk van DER CAPELlen, Aan het Volk van Nederland,' ed. Amsterdam 1987, pp. 7-16 


\section{AUTEURSREGISTER ${ }^{1}$}

ABRAHAM 845

ABRAMSON $187,239,316$

ACKER, VAN $236,845,1086$

AKASHI 590,636

AKEN, VAN 860, 867-875

AKKERMANS 208

ALBACH 163, 164

ALEXANDER $657,719,792,798,799,965$

ALFREDSSON 123, 137, 386, 693

ALKEMA 60

ALSTON 297, 303, 789

ANDREASSEN 132,223

ANGELOU 475

AN-NA*IM 729, 730

APELDOORN 711

ARAJÄRVI $157,223,418$

BAARTMAN $48,163,166,173,175,188-$ $192,208,233,237,238,242,243,252$, $260,262,265,274,331,353,376,377$, $399,451,452,459,460,463,465-468$, $470-474,476-480,487,488,494,496$, $499,500,501,503,504,506,507,51.5-$ $521,533,535,541,548,550,556,557$, $560,561,564,570,577,579,602,632$, $723,736-746,756,757,780,787,788$; $809,826,827,892,895,900,913,918-$ $923,932,935,943,954-961,963,964$, $974,976,980,997,1005,1013,1084$

BADRAN 114, 119

BAEHR 143

BAKKER, I. 906,974

BAKKER, K. 567, 568

BANDRES MOLET 178,621

BARENTS 115, 805

BARKHUYSEN 429

BARNETT, D. $50,311,333,334,364,367$, $463,476,521,523,525,526,534,724$, $937,1038,1039$

BARNETT; O. 3, 569
RARTELS 324

BASS 540,541

BASTIAANS 616

BAX 141

BEDERMAN $638,645,654,791$

BELLAMY 946

BELLEKOM 69

BERGH, VAN DEN 374,402

BERGSMA $822-824$

BESHAROV 496

BESSELINK $314,637,987$

BETTELHEMM 276,479

BEYAERT $308,396,441,487,550,551$

BUSTERVELDT, VAN 912

BILO 246

BILSKY 787

BISSETT-JOHNSON 384,432

BLUME 244

BOBBIO 140

BOEKHORST 68,89

BOER, J. DE 892,893

BOER, J.E. DE 578, 1076

BOEREFIN 677

BOGDAN 221, 336

BOGERS 757

BOL $848-850$

BOOGAARD, VAN DEN 505

BORNEMAN 216

BOSCH 924

BOSSUYT 720

BOUTELLIER 605,932

BOUVERNE-DE HE $269,316,318,320$

BOVEN, VAN $53,54,63,85,130,132$, $145-147,224,261,439,627,643,644$, $664-669,671-673,675,676,679,681-$ $685,688-690,695-697,730,787,788$, $796-798,801,803,809,815,915,916$, $945,979,995,1003$

BRAND 166

GRANDS-BOTTEMA 170

Dit register (op de lijst van aangehaalde literatuur) is vervaardigd door Fred GRUNFELD, met computer-hulp van Paul ADRIAANS en Chantal KUYPERS.

Bij publicaties met meer dan éen auteur wordt alleen naar de eerst vermelde auteur verwezen. Er wordt nüet verwezen naar redacteurs (editors) tenzij dezen levens auteur (dan wel eerst vermelde compilator van tekstedities) zijn. 
BREDERO 71

BRETT 386

BRIERE $495,546,552,558,912$

BRINK, A. WAN DEN 3, 187, 264, 265, 569

BRINK, M. VAN DEN 211

BRINK, W. VAN DEN 1070

BRODEUR 246, 495

BROEKHUUSEN-MOLENAAR 405, 406, 702

BROUWERS 223

BIROWNE 3, 569, 864, 899, 933

BROWNLIE $420,638,642,661,666,668$

BRUCKEN FOCK, VON $437,887,891$

BRUGGEMAN-KLUVERS 553,912

BRUGGER 113, 140

BRUINN-LÜCKERS, DE 421

BRUTNSMA 588

BUCLLANAN 497

BUEREN, VAN $125,184,238,258,268$, $297,299,312-314,374,386,389,407$, $410,411,417,420,422,423,428,444$, 472

BULL $645,646,652$

BULLENS $357,365,369$

BUNCH 729

BURG, F. VAN DER 58,80

BURG, W. VAN DER $182,200,201,203$, $204,206,282$

BURGERS 146

BURGITT, VAN DER 126

BURMAN 32

BURROWS 210

BYRNES 388,753

CAMMAER 346

CAMP, DU 630,883

CAMPBELLL 245, 604, 607,610, 1064, 1067

CANTWELL $179,184,185,374,385,417$, 453

CAPPELAERE 179

CASAS 422

CASS 803

CASSESE $91,147,148$

CASTERMANS-HOLLEMAN 681

CHARLESWORTH 729

CICCHEITI $40,50,360,573,592,725$, $896,1035,1038$

ClLAES 15,270

CLAAPHAM 683, 732

CLEESE 244, 1055
CLEMENS SCHRÖNER $500,502,508,897$, 1037

CLITEUR $67-69,73,74,77-81,119,120$

COHEN $186,330,331,373,374,402$

COLTON 767

CONSTANT 988

COOK 212,729

COOMANS $386,409,449$

COOMARASWAMY 212,219

COPELON 212

CORNELISSE 913

COUWENBERG $60,119,120$

CRINS 1080

CROMBAG $230,635,792,793,798,822$, $932,986,1082$

CULLBERG 1072

D'AMATO 606

D'ANCONA 912

DANIELI 478,479

DANTZIG, VAN $9,10,14,72-75,86,106$, $167,212,263,471,481,482,558,559$, $898,925,926,928,934,939,1075$, 1080-1082, 1086

DAVIDSON, H. 815, 901-903

DAVIDSON, s. $57,62,146,147,239$

DELFGAAUW 147

DELFOS $531-533,845-847$

DELISSEN 196,374

DEPAEPE 15,269

DERKS, F. 563, 577-579, 582-584, 589, 602

DERKS, W. $162,163,234$

DERKSEN $107,272,874,954,1070-1075$

DESCHNER $15,711,1044$

DETRICK $185,264,410,411,417,444$, $447,476,887$

DIEKSTRA 34

DIELEMAN 325,335

DIERX 793

DIJK, VAN $133,142,143,148,150,153$, $155,158,404,676,828$

DIJKSTRA $207,569,595,723,912$

DINGWALL 370

DINSMORE 470

DIRKSE 625

DIS, VAN 71

DOEK $4,25,26,79,80,171,189,192$, $195,196,260,283,295,304,339,342$, $377,378,389,394,406,409,421 ., 433-$ $435,769,893,894,912,916-919,925$, $929,933,935,958,959,961,963,973$ 
DONNELLY, A. 890

DONNELLY, J. 389

DONNER, Zie CLITEUR EN CRINNS

DOORENSPLEET 53

DOSTOJEVSKI 721

DOUGHTY 912

DOWER 652

DRALIER $76,244,245,265,481,506$, $507,511,513,514,532,541,556-559$, $585,593-595,605,817,818,925,1055$ DRIESSEN 701

DRZEWICKI 116

DUN, VAN, Zie HERRAETS

DUNGEN, VAN DEN 48,287

\section{EBENSTEIN 57}

EGMOND, VAN 562

EIDE 221, 223, 304, 402

ELBERS 183

ELDERING 860,861

ELDERS 234

ELLIS 300

ELST 1081

EPEN, VAN 501, 592, 598, 604

EYFFINGER $94,98,99,103,104,126$, $152,230,644,646,648,649,651,653$, $654,656-658,662,688,789,790$

EYSINGA $108,185,644$

FALK 4, 663, 904

FEENSTRA 639,640

FERENCZI $175,245,510$

FERNHOUT 406

FERWERDA $568,776,844$

FIJN 913

FINKELMOR 931

FLEKK $\varnothing Y 178$

FLINTERMAN $358,450,677$

FOEKEN 581

FORDER 211, 462, 708, 709

FORTUIN $644,646,653,655,656$

FORWARD 540

FRANKEN 24, 93, 94, 96-100, 102, 104, $105,317,324$

FRANZ 232, 234

FREEMAN $140,203,376,397,398,400$, $710,714,905,944,950$

FRENCH 483

FREUD 161-164, 167, 203, 233, 306, 511

FREYD 557, 585-589, 609

FRIIDA 826
FROMAN 485,486

FURSTENBERG 976

FURUKAWA $637,645,646$

GALLAGHER 729

GANNON 9,627

GARBARINO 549

GAYLIN $469,625,823$

GEERTJENS 823

GELDEREN, VAN 645,653

GELLES 491

GIL 993,1001

GILBERT 913

GILLIGAN 117

GÖRTZEN 327,470

GOLDEERG 844

GOLDHAGEN 82

GOLDSCHMIDT $33,219,729$

GOLDSTEIN 203, 306, 311, 714

GOLEMAN $591,592,824-826$

GORDON 646

GOUDENA $610,852-856$

GOUGES, DE $59,60,69,78,92,129,208$

GOWLLAND-DEBBAS 53

GRAAF, DE $237,709,710$

GRAPENDAAL 860

GRASTE 635,927

GREEN 265, 605, 606

GREVEN 320, 476

GREWE 647

GRIEZ 1068

GROEN, VAN DER 884

GROENENDAAL 591 .

GROENMAN $706-708,711,712,716,736$, $738,743,746-749,751,752,967,968$

GROOT, A.R.J. 170

GROOT, H. DE $84,85,106,152,168$, $230,638,639,640,647,648,655,711$

GROSSKURTH 472

GROTIUS $68,85,94-96,108,126,134-$ $137,151,152,168,230,251,637-639$, $643-660,662,664,668,686,688,789$, $791,808,824,891,984,985$

GRUYER $213,244,246,273,319,482$ GUNNING 299

GUWY 231

HAAN, DEN 591

HAANS $469,748,828,829$

HAARSMA 264

HAGGENMACHER 645 
HAMERLYNCK 592,855

HAMMARBERG $297,298,305,318,387$, $391,394,428,446$

HAMMERSTEIN-SCHOONDERWOERD 406

HANSEN 283

HARMS 430

HART, 'T 461, 462

HART, VAN DER $585,589,597$

HARTOGH, DEN 168

HASSELT, VAN 54,61

HAWIKING 821

HECHLER 377

HEHIR 81

HEINER $27,307,309,315,333,334,364$, 937

HEKKEN, VAN 262

HELFER $519,538,915,917$

HENDRIKS 8

HERINGA 430,431

HERMAN $252,514,536,542,573,823$, 980

HERMANNS $294,532-534,545,555,570$, $633,670,733,832,833,907,910,911$, $940,941,943,944$

HERRAETS 793,794

HERTEN, VAN 912

HES $706,707,715,718,753$

HEUSDEN, VAN 579

HEUVEL, VAN DEN 70

HIDDEMA $189,613,615,616$

HIRSCH BALLIN 796

HODGKIN 11, 945

HOKSBERGEN 406,432

HOLTMAA 208,219

HOLTRUST 507

HOOF ${ }^{\circ}$ VAN 148

HOOFF, VAN 824

HOWLAND 679

HUDSON 728

HUIJBREGTS 319

HUNE 419

HUNTER 559

ISRAELS 161, 162, 163, 233

JANSE 549

JANSEN 196

JANSSEN 2

JENSON 924,981

JÖRO $436,460,679$

JOHNSON, D. 84

JOHNSON, s. $590,1076-1078$
IONG, H. DE 605

JONG, W. DE 512,513

JONGHE, DE 1070

JONKER-DE PUTTER $484,507,508$

JOSEPH 235

JUNGER-TAS $284,602,618,742,770$, $844,848,849,873$

JUVENALIS 10

KAANDORP 569

KALICHMAN 564,912

KALKMAN-BOGERD 156

KALMTHOUT, VAN 1069, 1070

KALSHOVEN 63,144

KAMMINGA $623,674,675,730,731,801$, 802

KAMPEN, VAN 3, 396, 529, 550

KAUFMAN 468

KAYZER 106

KEMPE $487,502,539,720$

KENT 258,940

KERNBERG 1071

KEUS 731,732

KEY 276

KHUSHALANT 661

KIMURA 645

KINGSBURY $644,645,650,652$

KLEBER 590

KLEIINTJENS 500

KLEIN, DE 35

KLOOSTERMAN 912

KNUBMANN 711

KO 807

KOELMAN 320

KOENS $19,20,22,23,86,320,323,356$, $363,365,366,421,933,934,936,992$

KOERSELMAN 654

KOHNSTAMM 840

KOMEN $880,881,1000$

KONING 324

KOOIJMAN 913

KOOIIMANS $4,52,53,89,93,102,185$, $375,376,641,663,666,667,671,728$, 904,968

KOPER 176

KORBIN 536, 537

KOREN $374,377,383,395,407,417,450$, 451,463

KORZEC 82

KROMHOUT 571

KRONEMAN 319,530

KRÜL 162,163 
KÜHHNHARDT 148,837

KLIPER 442, 458, 542, 607, 608, 10631066

KUIPERS 585

KUNNEMAN 99-101

KUYPERS 840,907

LABUSCHAGNE 106, 139, 231

LAFEBER 919

LANGE, DE 649,650

LANGELAAN 545,633

LANGELAND 912

LANGEN, DE 24, 25, 294, 295, 405

LANGEVELD 292, 368

LANOTTE, VANDE 428,971

LAUTERPACHT $136,137,638,984$

LEACH $269,275,840$

LEBLANC $374,375,378,384,386,387$, 389,428

LEENEN 115,116

LEITTEN 61, 130, 134, 315

LEVY 630,884

LEWIS, D. 615

LEWIS, M. 459

LIESHOUT $531,843,889,964,973$

LUNZAAD $222,380,381,713,714$

LINDEN, VAN DER 28, 196, 421, 833

LOBEL 791

LOCKE 187,188

LOENEN 211, 219, 220, 713, 715, 729

LONDEN, VAN 272

LOUCAIDES 285,732

LOWEN 244, 474, 1055

LUBBERS 230

LUCKER-BABEL 373

LÜNNEMANN 932

LUTZ 617

MAARSEVEEN 79

MACKINNON 212

MAES $298,316,320,837$

MAHEU 695

MALANCZUK $39,638,647,663,665-667$, $671,725,732,790,793$

MALCOLM 163

MALE, VAN 30

MALMBERG 908,909

MARCOEN 232

MARIE 83

MARIS 169

MARLE, VAN $562,595,1071$

MASSON 163
MATTTISSEN 967,968

MCGILLIVRAY $488-491,535,536$

MCMARTIN $530,531,533$

MEDINA QUIROGA $624,673,674$

MERON $80,140,359,682,684-687,730$, 860

MERTENS 914

MESOTTEN $\mathbb{1 1} 14$

METZE 601

MEUWISSEN $89,110,113,115,794,795$

MEY, DE 1069

MICHIELS 496

MIJNARENDS $453,806,971$

MUS 932

MILL $81,181,657,658$

MULLER $1,48,71,165,189,194,214$, $375,399,440,443,461-463,470-472$, $476-481,484-486,511,591,593,599$, $600,605,612-614,616,924,925,943$, 957,1066

MÖLLER 220

MÔNNSS $232,351,353,618$

MONTFOORT; VAN $365,369,547,553$, $554,571,897,913,932$

MOOIJ 228

MOST, VAN DER 271

MOURITS 913

MOUT 55,57

MULDER 449

MURPHY 667,676

NABOKOV 245,246

NAGEL 483

NEDERVEEN PIETERSE 70

NEWELL 398

NICOLAI 207, 542, 562, 589, 592, 593, 595,1056

NIETZSCHE 721

NIJBOER $860-863$

NUNATTEN, VAN $180,181,763,793,914$ N.N. 879

NOORDAM 328

NOORDHOEK-VAN DER STAAY 543,544 , $545,547,556,558,560,561,562,564$, 572

NOWAK 388,720

OATES $573,724,893,977$

OCHOLA 178

ODEGARD 57

O'DONNELL, 269

OLSSON HORT 996, 1005 
O'MANIQUE 147

ONDERWAMTER 579

ONUMA $638,642,643,645-650,653,656$, $660,790,984,985$

OOST 913

OOYEN-HOUBEN 591

OPSAFL. 223

OPZEELAND, VAN 988

OUTSEM VAN 72,559

PAPALIA 162

PARLEVLIET 701

PATTIPAWAE 707

PEARL 520

PEETERS 566

PELS 870

PERRY 825

PESSERS 119, 300, 301, 315, 316

PETERS 915

PHILLTIPS 803

PICO DELLA MIRANDOLA $985,990,991$.

PIERS 392

PIETERSE 913

PINCUS 626

PLATVOET 514

PLECK 209, 288

PLOEG, J. VAN DER 365

PLOEG, P. VAN DER 45, 334, 335, 336, 841,842

PLLOSS 16

POLET 214

POLS 328

POSTMA 70

POSTON 627

POT, VAN DER 57

POUCKE, VAN 276

QVORTRUP $179,269,286,287$

RAES $160,161,164,168-173,175,181-$ $183,246,247,249$

RAMCHARAN 626

RANDEV 178

RASKIN 606

REE, VAN 1075

REIDY 623,624

REISMAN 52

REMMELINK $189,459,686$

REMMERSWAAL 194

RENSEN 21, 540, 556, 564, 566, 570, 572, 605

REYNERS 606,962
RUCHAIRTZ 234

RIDLEY $650,659,663$

RIJNAARTS $162,163,175,854$

RINK 571

RISPENS 926

RITSEMA 505

ROBERTSON 156

RÖLING 82, 137, 255, 646-650,695

ROELOFS, G. 507

ROELOFS, M. 34, 488, 495, 502, 503, 553, 740,913

ROELOFSEN $645,647,649,650$

ROHT-ARRLAZA 687

ROMANY 219, 727-729

ROMEIN, J. EN A. 58, 128

ROOLMANS 610

ROSAS 63,387

ROSENBILTH 278, 578, 824

ROSENSTOCK $665,676-678$

ROTH $677,807,808$

ROZEMOND 793

RUTER, DE $314,315,321-323$

RUSE 229

RUSSEK 873

RUSSELL $508,514,558$

RUTENFRANS 115, 116, 609

RUTGERS VAN DER LOEFF 405,406

RUTTEN 382

RUTTEN-ROOS $25,26,296,382$

RUTTER 469

RUYTER, DE $17,27,31,42,44,49,311$, $332,337-342,344,345,347-359,361-$ $367,369,370,371,416,438,443,493$, $827,876,939,943,996,1004$

RYFF 926

SACHS $710,711,807$

SALET 932

SANDERSON 605

SANTOS PAIS 452

SAVORNIN LOHMAN, DE 435, 992

SCHABAS 186,380

SCHACHTER $80,91,92,107,108,109$, $122,127,146,675,676$

SCHAEPMAN 914

SCHEEPSTRA 854

SCHELTENS 236

SCHENE 565

SCHERMERS 504

SCHIPPERS 1069

SCHNABEL $403,555,557$

SCHOEMAKER $484,506,593,596-599$ 
SCHOLTE 531,532

SCHOLTEN 98

SCHOLTENS 214

SCHRUVER 377

SCHRODDR $59,60,129$

SCHUYT 609

SCHWARTZ 209, 210

SCHWARZENBERGER 645

SCROGGS 232

SEBALD 252

SEGALEN 269

SENAEVE 306,317

SETTEN, VAN 329

SEVENHUIJSEN $164,182,302$

SGRTTTA 921

SHENGOLD 478,591

SHESTACK 140

SIBGHART $52,60-62,64,98,117,120$, 238

SIERKSMA $265,318,535$

SIMMA $100,101,114,127,802$

SIMON 734

SLOT $857-860,863-866$

SLOTH-NIELSEN 710

SLOUN, VAN 25

SLURINK 232

SMAIL 227

SMIDT, DE 322

SMUTH $475,476,622,887,892,945,946$, 972

SMTrS 827

SNIK $292,348,360,367,368$

SOETENHORST-DE SAVORMIN LOHMAN, zie SAYORNIN LOHMAN, DE

SOETERS 1050

SOHN 133, 146

SOONS 212,215

SOUDIJN 381

SPIJKERBOER $80,680,735$

STAAL 419

STARR 566,570

STEGERHOEK $26,30,32,35,36,193$, $195,196,280,294-296,369,904$

SIEGGE, AAN DE 506,507

STEUNEN 118

STEINER 666,675

STELLLING 800

STELZENBERGER 1043, 1044

STERKENBURG 989

STIBANE 596

STRAUS $536,549,560,561,570$

STROECKEN 214
STROINK 52,90

STUFKENS 226

STUTTERHEIM 214

STUYT $65,375,644,646,654$

SUGANAMI 645

SYATAUW 283

SZABO 239

SZNAIDER 904,977

TANAKA 636,645

TANJA 62

TAVECCHIO 576,579

TERR 245, 585

TEX, DEN 474

THERBORN $180,186,607$

THOMAS 71

THOMPSON 311, 498, 499

TOMAŠEVSKI $378-380,384,410_{n} 850,851$

TOTH $564,565,579$

TOUWEN 824

TRIMBOS 263

TROTMAN 316

UNEN, VAN $546,887,912$

VALK, DE 228

VANDENBERGHE 179

VANWESENBEECK 605,607

VEERMAN $125,185,249,250,253-258$,

$270,276,283,284,374,417,420,423$

VELDKAMP 771,772

VELTKAMP $266,495,570$

VERDROSS $1,211,229,230$

VERHELLEN $2,15,17,18,34,161,178$, $185,189,239,246,270,282,300,374$ $388,402,422,425,428,621$

VERHEUL 611,1075

VERHEY, L. 429

VERHEY, N. 101

VERHOEVEN 930

VERLOO 967

VERMEULEN $54-57,95,96,135,637$, $639,645,649,654,655-657,985,987$

VERSCHUUREN 285

VINCENT $645,652,653$

VISSER 723,725

VISSER 'T HOOFT $122,126,134,138$, 139,238

VITÄNYI 805

VOLLEBERGH 538

VOLLENHOVEN, VAN $185,188,643,644$, $650,651,652,891$ 
VOS, DE 710

VRIES, A. DE 630,879

VRIES, P. DE 161,164

VROMAN 819

VUYK 591

WAAL 273

WAAL, P. DE 228

WAAL, M. DE 834,889

WAALDIJK 248,252

WAMELEN 1034

WANDERS 834

WARNINK 701, 704

WEEDA 483

WLARDA 210

WIERSMA $645,653,656$

WIJERS 608

WUK, VAN 26,38

WILLEMS, I. 21, 29, 30, 34, 37, 95, 96, $114,118,119,137,170,186,221,235$, $237,308,316,323,375,391,406,494$, $558,637,649,808,843,900,913,993$, 1001

WILLEMS, L. 211, 388, 969

WILLLAMS 538,539

WILMINK 347
WILTERDINK 1000

WINDELS 178, 194

WINTER, DE 155

WTT, DE 483

WOELINGA 515

WOLF, E. 161

WOLF, J. 32, 303-305, 402

WOLFF 328

WOLFSON 202, 203, 305-307

WOLLESWINKEL 461, 626

WOLZAK $543,554,556,809,819$

WRIGHT, H. 660

WRIGHT, R. $650,653,654,657-660,663$, 821,822

WYATT 573

YANAGIHARA 645

ZAHAN 234

ZELLMAN $546,552,558-560,564,565$, 570,912

ZIEGLER 645, 791

ZIJDERVELLD 129

ZWALVE 804, 805

ZWANIKKEN 578,1068

ZWTTER 58 


\section{INDEX $^{1}$}

Aanstootgevende bepaling (in oud-BW) 194

aard van de mens $94,103,118,494,655$, $658,658,721$

Abel 721, 821, 984, 988, 990, 991

Abfollprodukte des Koitus 216

abolitionisme 129

abortus $9,84,116,186,375,391,392$,

$404,431,727,929,963,1010$

Abraham 37, 213-215, 988, 989

accident proneness 607

accountability 731, 801, 802, 838, 1007

achtergrondfactoren 619

achterstandsbuurt (-wijk) 864, 865

achterstandssituaties (zie ook sociaal-

pedagogische -) 32, 393, 799

a contrario-interpretatie ('niet over het

gras, dan wel over de bloemen'), (zie

ook per analogiam-) $89,364,381,436$

acquis humanitaire 127

acting out-gedrag, zie uitageren

actio popularis (door een ieder in te

stellen actie, in te roepen rechten)

146

adolescent(ie) $218,232,234,239,270$,

$276,278,420,423,524,588,611,709$,

$720,771,854,859,864,874,915,953$, 1050

adopteerbaarheid (en marginaliteit) 854

adoptie $24,73,84,288,298,392,394$ -
$396,406,423,424,426,427,432,488$, $856,916,1019$

adultocentrisme $34,37,213,219,288$

Advies- en Meldpunt(en) Kindermishandeling (AMK) 35, 366, 733, 886, 910,911

advocaten $266,364,507,889$

aevisme, zie leeftijddiscriminatie

affectieve hebzucht (van ouders) 174

affectieve verwaarlozing (en incest, overcontrole, overbezorgdheid) 505$507,532,597,615,873,1055$

affirmative action, zie voorkeursbehandeling

afgunst-motief $466,473,475,503,538$, 576,726

afkoelingsperiode 408

afpakken (van kinderen) 760, 887

afreageren $467,604,807,1067$

Afrika $62,70,71,73,84,119,125,234$ $236,268,358,420,444,475,476,694$, 710

afschrijwen (van kinderen) $34,403,553$, 767

afstaan, afstand (van kinderen) 394, $712,727,964$

afstammingsgegevens 394

afstammingskennis (kennis van eigen afkomst) $429-432,1013$

afstammingsrecht $283,322,405$

Raadpleeg ook de uitgebreide inhoudsopgave (met name woor hoofdzaken c.q. onderwerpen of begrippen die weelvuldig aan de orde komen, in de index veelal te herkennen door de toevoeging passim), het glossarium in bijlage IV (Lijst van afweermechanismen en coping-stijlen) en in het bijzonder ook bijlage virn (Korte omschrijving van enkele in deze studie gehanteerde samenhangende termen), welke laatste bijlage met opzet geheel buiten de index is gelaten.

Een koppelteken tussen paginacijfers betekent niet (noodzakelijk) dat op de aangegeven pagina's sprake is van een doorlopende behandeling van het met het trefwoord verband houdende onderwerp.

Pagina-verwijzingen gelden zowel de (hoofd)tekst als de noten; bij noten wordt in beginsel alleen verwezen naar de pagina waar de noot begint, tenzij het trefwoord voor het eerst voorkomt op de tweede noot-pagina.

De index dient tevens als woordenlijst van Latijnse termen en adagia. De vertalingen zijn letterlijk of enigszins vrij, voor de technische betekenissen raadplege men de aangegeven pagina's. 
afstammingszekerheid 1013

afweer(mechanismen) 162, 266, 370,

$496,541,574,575,594,608,611,724$, 1063,1077

afweerrechten 388

ageisme, zic lecftijddiscriminatie

agressie $52,91,105,151,263,499,516$,

$532,576,578,582,583,585,590,686$,

$726,739,817,825,846,847,857,867$ -

$870,872,873,977,1065,1066,1072$

agressieverbod, zie geweldverbod

alcohol(isme) (zie ook verslaving) 3 ,

$278,391,400,426,481,488,529,542$,

$566,593,596,604,606,610,619,759$,

$838,929,974,975,977,995,1003$,

$1047-1049,1051,1061,1066,1075$

allermensenrecht $635,644,647,651$,

$652,654,660,663,664,666,668,730$,

$790,796,984$

allocentrisch 957

allochtoon $264,619,758,799,803,861$, $864,865,870,964$

almacht, zie ouderlijke -

almachtsbeperking en onmachtsbestrijding (zie ook ouderlijke almacht en onmacht) 277

almachtsfantasieën 581

altruisme, wederkerig $653,654,656$, 657,660

ambitie $372,429,590,714$

ambivalent(ie) $74,119,164,175,233$,

$266,460,467,472,484,500,501,513$,

$531,578-582,584,599,826,956,958$,

$995,1003,1066,1081$

amendement-Kalsbeek 969-971

American Law Institute 146, 675

amnesie (zie ook geheugen) 245,585

Amnesty International 213, 881

analogie, zie per analogiam

anatomisch correcte poppen (poppen-

methode) 517,518

angstig-vermijdend $579-582,584$

anima, animus ("de vrouw in de man en

de man in de vrouw'; Jung) 234

animal educandum (op te voeden dier) $218,241,325$

animat morale, sociale (moreel, sociaal dier) $650,822-824$

anonieme auteurs (werken) 128, 129, 321

anonieme donoren 405

anonieme geboorten 432 anti-autoritaire opvoeding 252

anti-militarisme (militarisme) 124, 164, 391

Anti-(publiek-en-privé-)geweldverdrag 694,696

antisemitisme (zie ook jood) 82,614

antisociaal gedrag $310,311,566,585$,

$601,611,619,739,824,847,857-859$,

$861,864,866-869,872,1060$

antisocialle carrière 864

antisociale persoonlijkheid(sstoornis)

$582,611,846,1074,1075$

Apartheid 91, 668, 710, 719

appetitus societatis (sociale appetijt,

gemeenschapszin) $94,126,134,228$,

$230,654,657,663,824$

arbeidsrecht $62,210,248,321,387,400$, 726,1025

arbeidssatisfactie (bij gezinsvoogden, bij prostituees) 605,765

arbeids(ver)deling $235,659,786$

arbeidsvermogen, arbeids(on)geschikt-

heid $3,263,272,563,600,702,954$

archaische trauma's, (posttraumatische)

- fantasieën, gevoelens $233,763,981$

armoede $262,379,481,619,660,934$,

$956,975,1045$

armoedezorg (kinderbescherming als)

$469,749,828$

asiel, recht op $136,150,155$

asielzoekers (minderjarige) 380, 383,

$396,410,734,1020$

assassinat psychique (soul murder, psy-

chische moord, q.v. 478,482

atoombommen (Hiroshima, Nagasaki),

(zie ook kernwapens en internatio-

nale misdrijven) 82,255

attitude, zie ouderlijke -

audi et alterant partem (hoor beide partijen) 779

Auschwitz (Treblinka en *) 613

autocentrisch 957

autochtoon 264, 563, 584, 871, 964

automobilisme 650

automutilatie $593,604,607,1075$

autonomie, autonoom (relatie, competentie, autonomie) $96,116,134-138$, $183,200,201,203-205,230,348,349$, $390,509,524,526,531,576,635,709$, $874,875,926,1054$

autoritaire opvoeding(sstijl) 278,531 -

$533,853,874$ 
autoritatieve opwoedingsstijl 278,531 534,874

autovrij maken (van binnensteden) 279

Baarmoeder 223, 224, 261, 1067

Baartman-gesprek $918-922$

baby-besnijdenis, zie genitale verminking

baby-misbruik, zie slik- en stikangst

baby-mishandeling 173,544

baby-opvoeding 327,335

babys, drugs- (drugsverslaafde -) 548 ,

$566,759,1049$

baby's, lieldes- 607

baby's, slaan (straffen) van 173

baby-syndroom, door-elkaar-geschudde-

544,1042

baby-uitzet 959

bad parent/good parent 174, 175, 479

bagatelliseren $518,575,880,924$

ballast (psychische) 347, 601

Barabbas 377,634

barbarij, barbaars, barbaren $71,81,83$, $133,137,209,648,651$.

Barcelona Traction-zaak 53, 145, 638, 661, 665-667

basic need $148,256,334,446,828,842$, 1077

basic rights (of the human person) 145 , $257,667-669,680,729$

basishouding $242-244,580$

basisveiligheid 242

basisvertrouwen (basic thust) 576,586 , 607

Bataafse grondwet (1798) 61

battered child syndrome 487, 490, 812

bedreigende opwoedingssituaties 554 , $571,597,746-748,772,778,839,858$, 995

Befehl ist Befehl (respondeat superiordoctrine) 6,96

begaafd 957

beginselen van behoorlijk gezinsrecht/ -bestuur(srecht) $743,922,935,936$, 938, 939, 998

beginselgericht, zie rechtswetenschap behind closed doors (mensenrechtenschendingen) $492,536,560,570$

bekendmaking, algemene (van VRK) $375,401,704,1030$

belang van het kind, als rechtsstatelijk oplosmiddel 280 belang van het kind, caoutchouc-karakter (zie ook pia fraus, polyvalentie en rechtsnotie) 295,369

belangenalfweging $158,218,219,230$, 734

beleidsbrief kindermishandeling 366 , $494,495,779,780$

beleidsbrief Naar een solide basis 831 , 840

bellum ommium contra omnes (oorlog

van allen tegen allen) 655

bemoeizorg $788,840,878,909,914,923$

beproeving $214,215,988$

beroepskeuze, zie neurotische -

beschaafde naties (volken, beginselen)

$63,91,92,144,301,302,315,625$, $695,755,812,904,999$

beschaamd (maken van kind) 1, 302, 368

beschaving(sproces, -arbeid, -geschiedenis, -offensief, -opdracht), civilisering $2,16,61,84,119,120,130,170,175$, $188,302,392,469,621,636-638,653$, $657,695,728,749,823,904,908,990$, $999,1000,1025,1082$

bescheidenheid (als deugd) 232, 590

bescheidenheid, juridische (wetenschappelijke) $723,747,790$

bescheidenheid, politieke 45,356

beschermingsrechten $18,46,218,372$, 388

beschikbaarheid (van ouders) 237,238 , $504,518,580,817$

beschikbaarheid, algemene (van statenrapporten) $401,946,1031$

besnijdenis van meisjes, zie genitale verminking

bestaansethiek 635,927

bestwill(-criterium) 127, 328, 476, 922

betutteling $262,267,532,717,991,1054$

bevestiging(sleer) $206,227,242,503$, 516,517

bevolkingsonderzoek 74

bevoogding 134, 772

bewustwording(sproces) $87,92,266$, $883,886-888,986$

bewustzijn $174,431,574,575,658,679$, $822-824,923,927,930,1064,1067$

bezuiniging(sbeleid) $47,377,462,674$, $679,899,901,947$

bezwar (van Nederland tegen voorbeholld) $380,382,1020$ 
bijstand, moeders uit de 962

bijstandsmoeders 963

bijstandsverplichting (militaire) 651

binding (dubbele) 134, 207, 471, 583, 1000

bindingsangst 580

biologische ouders $24,43,310,405,514$, $714,942,1013$

biopsychologisch (model) 574, 845, 847

Bolderkar-affaire 37, 474, 932

Bolderkar-rapport 480

bona fides, goede trouw $95,111,356$, $378,447,637,642,674,679,680,686$, 714,801

borderline-persoonlijkheid(sstoornis), -pathologie $497,541,543,577,582$, $603,604,864,1068,1071,1073-1075$, 1078

borstvoeding 394, 397, 1021

botbreuken 208, 1041, 1049

botsing (van rechten) $21,22,28,75,76$, $140,708,709,799,905$

brandwonden $208,702,1041,1042$

brein, zie hersenen

budgettaire politiek, afweging 345,449 , $483,901,942,947,950$

budgettaine prioriteil $454,722,806,811$, 814,949

buitenbeentje 854

buitenlanders 1067

buitenstaander (recht van het kind op; kind als) $442-444,484,703,854,875$, 876,943

Bureaus Vertrouwensarts $3,35,176$, $264,495,505,529,544,545,547,548$, $554,555,733,740,758,759,890$

Bureaus voor Jeugdzorg 769

burgerlijke rechten $65,383,388,707$

burgerplicht 274,366

burgerrecht 65,388

burgerzin $366,728,922,966$

bum out 765

Calculerende burger $657,792,842$

capaciteit (en kwaliteit) van hulpverlening, zie wachtlijsten

caput Nili (bron van de Nijl, hoofdoorzaak) 163

castratieangst 162

catharsis 189

causa finalis (doeloorzaak) 452, 453,

$522,523,922$ causaliteit, causaal verband 642,739 , 816,862

celibatair 1066

centaur (paardmens), zie persoon

checks and balances $29,30,90,280$

child sexual abuse accomodation syn-

drome 512,513

child-witnessed domestic violence 569 , 864

Chorzów Factory-zaak 688

chronic care-model 866

circulaire processen, circulariteit 595 , 724

civilisatietheorie (Elias) 999

civilisering(sproces), zic beschaving civilist(isch) 36

clawback clause $358,380,382,383$

coalities 654,660

codependency 580

Codex Iuris Canonici (canoniek recht)

$196,197,804,805$

cognitieve stij1 1068

cognitieve verwaarlozing 460,1050

collectieve bewustzijn (besef) 130, 166,

368,535

collectieve contracten 964

collectieve (systemische) traumatisering

816

collectieve veiligheid 95

collusie 594

comitas gentium (hoffelijkheid tussen staten) 447

Comite inzake de rechten van het kind 11 , 114, 117, 297, 318, 373-375, 401, $425,426,428,429,452-454,642,750$, $751,755,756,778,779,786,790,806$, $829,887,891,892,901,945-947,949$, $950,952,967,969-972,1009,1022$, $1027,1030-1032$

Commissie Seksueel Misbruik van Jeugdigen $271,831,912,932$

common sense (commonsensical) 642 , $648,900,905$

communicatie $17,325,510,615,618$ compassie(-model) 517,880

compensatie (zie ook reparatie) 46-48, $73,95,212,229,261,277,279,286$, $320,336,353,365,375,439,442,500$, $535,626,634,643,672,688,689,691$, $698-700,734,809,840,978,979,1065$, 1066

compensatie, pedagogische -plicht 998 
competentie, incompetentie (relatie, competentie, autonomie) $35,112,274$, $308,310,465,466,535,590,839,863$, 871

competentie-competitie 934

concentratiekamp(syndroom) 70, 138, 590

concentratiestoornis (met hyperactiviteit, ADHD) $611,619,847,858$

concurrerende relaties (bij chromische mishandeling), (zie ook omgang met leeftijdgenoten) 574

condition humaine, conditio humana (menselijke conditie, menselijk tekort, q.v.) $228,234,263,475,620,750,890$ condoom-politie 726

conflicten (huwellijks-, partner-, gezins-) $171,300,408,440,512,513,527,532$, $574,618,619,740,861,869,874,956$, 1057,1058

conflicten, innerlijke $233,245,486,580$, $927,1063,1074$

conflictvermijding 513

confrontatie, confronterend $38,79,165$, $190,196,266,274,287,316,370,376$, $406,472,552,581,591,592,597,888$, $890,927,935,1070$

connex recht 403

constitutie, wijze (waarborg ener) 903 , 904

constitutionalisering (-nalisme, -neel) $45,68,287,634,666,670,698,710$, $752,784,810,820,877,885,900,901$, $903,904,938,947,964,994,1002$, $1004,1005,1007,1008$

consultatie(bureaus) $44,262,327,396$, $483,733,759,773,785,816,842,843$, $856,864,871,919,920,923,925,929$, $930,938,940,942,961$

consumentisme $235,350,973$ contactambivalentie, -vermijding 578 contingentie, radicale $106,822,823$ continuiteit (in de opvoeding) 182,308 $310,396,563,1018,1081$

contra proferentem-beginsel (uitleg in het nadeel van wie het hardste roept), (zie ook in dubio) 381

contract(sgedachte, -leer, -oriëntatie)

$56,57,172,248,273,334,351,353$, $380,528,635,686,713,963,964,998$, 1006,1007

controle, over hulpverlening, kinderbe- scherming (zie ook hulpwerleners en deskundigheid) $357,393,841,852$, 938,1012

controle, over kinderen (ouderlijk toezicht), (zie ook overcontrolle) 49, 177, $242,246,267,525,530-533,544,571$, $574,618,619,717,760,766,858,861$, $872-874,914,957,1035,1038,1050-$ 1053,1056

controle, over ouders (overheidstoezicht) $35,180,286,287,383,712,726$, $805,839,851,1028,1081$

controle, politieke, rechterlinke (zie ook checks and balances) 29,90, 100, 312, $773-775,778,938,946$

controle, socialle (en overheids-) 2, 236, $601,610,635,766,1000$

controle, van individu (over eigen omgeving, problemen, leven), (zie ook impulscontrole en illusie) 468,574 , $594,600,764,766,926,955,1000$ controle-model 517 coping(-mechanismen) $265,496,541$, $590,610,691,724,768,1006,1063$ corrumpering (van kinderen) 408, 507, $525,544,575,597,1038,1056,1060$ creatief-grammaticale (verdrags)interpretatie 436

creationisme 103, 232

criminaliteit (zie ook delinquentie en jeugd-) $2,47,273,284,542,563,578$, $585,600,602,604,609-611,616,618$, $619,630,632,734,742,745,766,825$, $838,844,848,863,866,867,896,942$, 974,995

crimineel gedrag 445, 563, 583-585, 610, $618,771,864,867,869$

criminele carrière $530,568,584,866$

criminologie $234,583,602,610,859,863$

crisis $7,235,1069,1070$

cultureel kapitaal 870,871

cultureel relativisme (cultuur-) 33,142 ,

$143,238,491-493,537$

cultuurkritick 792

cultuuromslag $879,881,882$

cultuurpessimisme $486,792,830$

cultuurrecht $98-100,102,105,141,252$, $637,662,795$

cultuurrelativisme, zie cultureel -

cumulatie (van risicofactoren), zie risico-cumulatie

curator $195,268,279,409,7117$ 
cyclus (cirkel, keten), gewelds-, onveilige-gehechtheids-, traumatiserings(cycle of abuse, cycle of wiolence), (zie ook herhaling en transgenerationaliteit) $263,441,442,468,469,475,478$, $479,494,519,538,604,723,724,726$, $749,806,808,903,928,993,989,1001$. cynisme, cynisch $120,186,376,446,482$, 792,793

Dader (vader als incest-, ouders als -s) $163,190,233,244,505,526,580,581$, $672,701,859,882,888$

daderbehandelling (gedwongen ouder-) $445,672,686,935,978,1034$

daderdissociatie 574,588

daderidentificatic $207,509,542,593$

daderpatronen 542,595

dag wan het Mishandelde Kind 699, 980 dankbaarheid (jegens ouders) 181, 957

decompensatie (psychosomatische) 442, 607

defensor et protector liberum (verdediger en beschermer van kinderen: staatstaak van kinderbescherming) 247-249, 259,275

delicta commissiva per omissionem (strafbaar handelen door nallaten, passief geweld) 459

delinquentie (jeugd-), (zie ook criminaliteit) $253,310,311,362,423,482$, $489,562,577,583,610,618,619,704$, $771,813,848,857,861,862,864,873$, 916, 1060

demagogie, demagogisch $614,819,933$ democratie, democratisch $35,45,58,86$, $90,101,105,128,129,148,154,201$, $205,255,287,298,351,356,376,388$, $400,403,409,415,450,482,546,621$, $735,770,835,923,965,976,995$, $1000,1004,1008,1065,1081,1082$ democratiserende opvoedingsstijl 278 , 532

democratisering $51,85,121,132,138$, 140,914

deplorabele jeugd 602, 788, 997,998 depressie(ve moeder) $326,542,572$, $582,599,603,610,855,995,1067$ depressieve persoonlijkheid 541, 1072 deprivatie, gedepriveerd (economisch, emotioneel, pedagogisch) 117, 256, $450,469,470,591,632,719,748,753$,
$803,825,899,905,911,928,964,967$, $975,1000,1007,1008$

de profundis clamavi (vanuit de diepte riep ik) 633,673

dereguleren, deregulering(sbeleid) 462 , 679

deskundigheid(sbevordering) (zie ook controle en hulpverleners) 30,34 , $317,320,322,341,356,357,454,468$, $471,472,474,484,726,778,780,806$, $865,876,911,918,929$

destructie(f), destructieve patronen 147 , $163,235,265,266,461,499,574,581$, $595,604,608,610,611,616,617,691$, $727,734,822,865,868,902,924,958$, $965,1006,1053,1064,1076$ determinisme (biologisch) 659 detransgenerationalisering 1000,1008 deugden(leer) $58,232,590,609,614$, 789,927

Deus ex machina (te voorschijn getowerde God) 103

diagnostisch apparaat $333,359,366$ dienstweigering (bij Grotius) 96, 135, 138,660

dierenbescherming (zie ook Society for the prevention of cruelty to animals)

$78,210,336$

dierenkwelling 1035

dierenmishandeling 1034

dierenrechten $78,164,231,463$

Dies irae (dag van toorn) 983

diffuse (ouderlijke) gevoelens, relatie, woede/wrok 517, 594, 604, 614, 956, 958, 1071

diplomatieke bescherming (diplomatic protection) 667,669

disciplinering (grenzen stellen), (zie ook tuchtiging) $19,49,202,242-244,246$, $252,256,265,267,276,278,301,309$, $398,440,460,467,468,503,504,506$, $530,532,560,618,619,692,709,717$, $762,849,865,874,955,977,984$, $1038,1050,1053,1054$ discontinuilteit 563,1081 discriminatieverbod, non-discriminatiebeginsel (zie ook gelijke behandeling, gelijkheid; indirecte, positieve, systemische discriminatie, leeftijd-, rassen-, sexe-) $24,109,130,154,398,403,426$, $428,429,707,708,715,748,749,829$, 949,1011 
disempowerment 277

disidentificatie 924

dissociatie $245,483,542,574,575,587$ $589,593,603,1075$

doctrine $39,67,93,96,98,108,136$, $144,145,293,306,315,635,639,641$, $642,648-650,655,662,732,746,793$, 797,881

Doek-cursus 918, 919, 958, 959, 961 dolus (malus), (boos) opzet 145, 149, $256,459,475,487,552,556,567,642$, $674,679,897,1034-1037$

domestic jurisdiction $375,641,839$

domestic violence, zie geweld in het gezin

doorbraakbepalingen 713

doorzettingswermogen $591,826,854$

draagkracht (en draaglast) $31,274,278$, $308,310,440,496,541,608,724,817$, 818,1063

drie-echelonsmodel $333,367,838,914$, $918-921,924,925,928,930,931,935$, $958,959,964,998,1006,1079$

driegeneratiemodel (Nagy) 579

drie R's 760, 942

droits humains 130, 145

drugs (zie ook verslaving) $3,71,278$, $391,400,423,427,481,502,529,548$, $558,566,593,596,604,606,610,614$, $617,759,862,900,916,917,919,929$, $974,977,1006,1026,1047-1049,1051$, 1061,1062

dubbele moraal 266

dubbelheid, zie gespletenheid

due care, due ditigence $29,80,641-643$, $665,667,682,683,697,728,730,774$, $805,812,998,1007$

duisternis (buitenste), psychisch isolement $227,241,544,888$

Dutroux, Marc 180, 602, 611, 616

dwanggemeenschap, zie geweldsmonopolie

dyas politica (rechter en 'de' politiek; monisme) 29

dyas publico-privata (publiek/privédichotomie, q.v.) 971

dynamische rechtsopvatting, - (verdrags)interpretatie $97,101,146,147$, $394,398,696,781$

dysfunctioneel gezin (-nele ouders) 27 , $322,606,763,839,843,1003$

dysfunctioneren (op latere leeftijd) 167 ,
$536,578,581,739,1077$

dysmorfe persoonlijkheid 541,582

Ecce homo (mens kijk, zie de mens) 696.

echtscheiding $156,171,205,268,283$, $322,407,488,717,813,843,889,929$, $931,949,1058$

echtscheidings-en omgangsbemiddeling 408

ecologisch model (construct) 488,490 , 520,535

ecologische staatsaansprakelijkheid, zie staatsaansprakelijkheid

educatiewe verwaarlozing $244,571,1050$

een-oudergezin 550,561, 975

eenzaamheid $107,263,353,460,477$,

$505,529,598,724,854,908,991$. 1058,1064

eerlijkheid (faimess) $109,228-230,252$, $299,310,317,943$

eerste levensjaren (high risk of abusejaren) $245,326,327,335,549,561$, $833,852,867,871,917,920,942,961$

eetstoornissen (anorexia, boulimie, magerzucht, vreetbuiten) 542, 603, 975

eeuw van het kind $276,392,890,941$, $943,999,1008$

effectiviteitsbeginsel (principle of effectiveness) $285,453,642,804,806,936$ egalitarisme 134

egocentrisme $34,151,229,237,244$, $495,520,611,646,824,1068$

egoïsme (primair, secundair) 219, 316, $527,654-657,1064$

ego-structurur 1074

ego-syntonie (-dystonie) 577

ego-zwakte, ik-zwakte 478,659

eigenwaarde $126,174,202,206,228$,

$272,328,354,412,460,465,498,517$,

$572,607,724,734,770,842,978$,

$1028,1077,1081$

emancipatie $16,48,51,70,72,76,84$, $121,128,129,132,138,166,257,284$, $299,559,653,806,905,922,950,965$ $967,969,1082$

emotionele chantage $227,243,501,507$, $542,753,896,1055$

emotionele (psychische) maltraitering (pathogene zorg) 525-527, 548, 549, $564,570,606,1038,1053,1057$ 
emotionele werwaarlozing, - woestijn 262,981

empathic (-isch vermogen) 228,230 , $235,276,460,467,469,472,474,590$, $591,611,639,822,824-826,986,1072$ empowerment (van ouders) 203, 273, $274,276-278,284,286,334,389,718$, $768,842,906,945,1013,1014$ engagement $231,767,916,956,957$ enss successivum (doorlopend zijn) 348 enscenering, neurotische (enactment), (zie ook herhaling) 233, 252, 595, 1006

equity $108,109,638,655$

Erasmus 892 erfelijk(heid) 441, 659, 722, 860 erfzonde 722

erga omnes-verplichting (jegens allen) $53,80,91,122,145-147,638,661,663$, $664,666-669,671$

erkenning $9,73,74,96,273,277,278$, $440,441,468,514,515,598,601,626$, $627,670,699-701,840,841,924,928$, $978,980,982$

erkenningstheorie 139

ernstige (en systematische) mensenrechtenschendingen, zie grove -, systematische -, passief-systematische -

Eros, zie Thanatos

Erziehung(sgeld) 272, 292, 314

Erziehungszwang, zie opvoedingsdwang ethiek van het gelaat (van het kind) $203,230,330$

eurocentrisme 646

Europees Handvest inzake de rechten van het kind 621, 622

Europese Commissie voor de rechten van de mens 951

euthanasie 71,115

evenredigheid $248,862,936$

evenwaardigheid (bij coaching) 930

evolutie (-ionair), evolutionisme 103, $106,147,232,621,636,637,660,663$, $664,822,824$

evolutionaire psychologie $650,653,654$, $658-660,821$.

externaliseren $189,580,582,595,601$, $692,845,855,857,864,866,875,975$, 1068,1071

Fact-finding 626

failed state $53,373,812,1002$ faire kans (faire start) 393,416

familierecht $28,180,191,216,300,301$, $306,340,437,448,602,672,698,709$, 710

familierechtelijk geweldwerbod 933

fantoornkind (zie ook kind in jezelf) 173 fantoompijn 174

farizeisme $319,888,891,892$

fatsoen(lijk) 10, 109, 122, 128, 138, 144, $233,294,332,447,609,639,640,880$, 928

fatwa (tegen Willem van Oranje) 56 feminisme $164,180,321,484,488-490$, $505,536,606,803$

filosofen, filosofie (existentie-, feministische -, moraal-, politieke -, rechts-, wetenschaps- $) 83,120,140,142,152$, $160,161,164,165,170,178,181-183$, $198,205,230,231,249,316,338,348$, $361,367,368,462,463,775,794,925$, 954

foetaal allcoholsyndroom 1048, 1049

foetalle mishandeling 391,397

foetus (geboortekanaal, lijden, rechten, zorg) $78,116,262,391,823,1048$

folle à dewx 604

folter(ing), zie marteling

foster drift 424

frappez towjours (le juge) $89,90,700$

freies Emessen 332, 635

Freud (als incestslachtoffer) 161, 233

freudiaans (zelf)bedrog 162

frustratie $235,321,473,493,500,521$, $798,807,957,1054,1066,1067,1077$, 1078

frustratietolerantie $264,460,467,478$, 531

fundamentalisme $147,186,488$

Geboorteakte (wan Nederland) 129 geboorterecht $253,636,700,706,1012$ gebroken gezin(nen) 618

gedragsproblemen $310,529,563,566$, $567,578,582,611,844,846,849,850$, 872,975

gedragsregulering 1068

geestelijke volksgezondheid 468,601 , $626,727,862,1072$

geesten wit het (kinder)verleden 956 , 958

geest(es)wermogens, geesteszieken 71, 194,577 
gehandicapt (psycho-sociaal, pedagogisch) $371,438,441,451,483,633$, $748,816,864,924$

gehechtheid (hechting), (on) veilige 37 , $309,327,473,526,542,563,576-585$, $589,593,594,602,604,606,609,632$, $806,808,826,842,852,853,855,856$, $956,980,1000,1054,1057,1073,1076$, 1077

geheugen(verlies, -problemen), (hervonden) herinnering (zie ook amnesie en dissociatie) $161,245,556,574,575$, $583-585,594,599,600,758,775,818$, $927,932,956,1064$

gehoorzaamheid (aan ouders, aan bevelen) $6,168,172,649,660$

geleidelijkheidskarakter (van verdragsverplichtingen) $64,139,754,1022$, 1024

gelijke behandeling $131,219,264,270$, $403,404,534,715,717,722,747,749$, 906

gelijkheid (formele, materiële), gelijkheidsbeginsel $31,34,59,61,97,100$, $107,109,111,113,118,119,121,122$, $124,128-135,138,139,141,147,183$, $185,187,199,202,206,209,216,217-$ $222,229,241,259,271,284,299,300$, $333,383,391,398,400,403,404,413$, $416,428,433,451,454,516,517,522$, $609,624,653,658,700,707,714-716$, $719,726,749,766,785,798,806,922$, $1010,1011,1024,1082$

geluk (menselijk, van kind, gelukkige gezin) $60,66,72,86,106,124,151$, $217,228,230,296,390,441,448,460$, $463,471,482,484,607,610,611,658$, $696,819,927,940,993,1010$

gelukkige jeugd (ongelukkige -) 227 , 463,583

gemeenzaamheidsproblematiek (en

kundigheidsproblematick) 955-960 gender-relativisme 33

genen, genetisch 406, 431, 441, 494, 551, $611,612,654,659,722,860,867$, 1067,1078

genetisch-biologisch $658,659,867$ genetische psychologie 346 genezing(sproces) $627,789,917,923$ genitale verminking (baby-, meisjes-, vrouwenbesnijdenis) $22,84,235,264$, $266,321,398,475,476,693,881,892$,
$1011,1022,1.039$

genocide, genocidaal (volkenmoord, massamoord) $70,81-83,91,96,102$, $145,615,621,661,666,667,668,816$, 825

genoegdoening (satisfaction) 4, 261, 277, $278,442,626,627,670,671,686,688-$ $700,701,716,809,840,979$

gentlemen's agreement (ladies' and -) 286,287

geschiedschrijwing (orangistische) 58 , 770

geslachtsziekte (bij kind) 246, 1044

gespletenheid (en dubbellheid) 245,500 , 927,1070

gestagneerde (geblokkeerde) ontwikkeling (persoonswording) 207, 229, 232, $237,340,342,348,440,441,443,509$, $521,540,591,824,876,956,983,1035$ gestagneerde (geblokkeerde) verwer-

king, zie onverwerkte problematiek gestrengheid (bij coaching) 930 getuige, helpende, wetende (Miller) $440,443,444,472,591,943,1055$ getuige, kind als 518 getuige-deskundige (werklaringen) 756 , $757,763,767,769,770,771,779,787$ geünificeerde theorie 821

gevangen(iss) en $51,73,75,125,189$, $221,298,462,600,601,606,677,843$, 889,933

geven en nemen (tussen de generaties) 1081

gevoelsarmoede 611, 993 gevoelsgeèquipeerd (woldoende) 226 , 749

gevoelsverbod (Gij zult niet merken) 71, 494

geweld in het gerin, huiselijk geweld, thuisgeweld (domestic violence, fantily violence, marital violence), (zie ook ouderlijk geweld en vrouwenmishandeling) $3,92,210-212,288,289,352$, $425,439,539,569,615,677,692,697$, $807,825,870,694,881,899,931,977$ geweld tegen kinderen, zie ouderlijk geweld

gewelddadig gedrag (van jeugdigen, van in hun jeugd mishandelden) 539,563 , 603,617

gewelddad"ige ouders (vaders, gezinnen) $3,71,73,265,267,459,465,478,487$, 
$495,503,526,535,561,569,618,694$ $717,936,995,999$

gewelddadige partners (love is a battlefield) $266,527,607$

geweldsmonopolie (staat als dwangge-

meenschap, sterke arm) $247,260,742$,

772,785

geweldverbod (agressie-, interstatelijk)

$95,661,797$

gewenst, ongewenst (kind) 9, 216, 217 ,

$278,392,430,580,758,857,991$

gewetensworming $252,350,353,654,656$

geweten(svrijheid) $51,54-57,96,121$,

$128,1.33,135,137,138,148,149,154$,

$188,229,395,409,426,430,434,580$,

$606,612,618,649,656,657,660,713$,

$798,910,973,1016,1063,1071,1072$

gewoontedier 80

gewoonterecht 88-91,93,102,104,114, $149,238,641,661,665,687,691,725$, $789,804,805$

gezagsdispositie 763,764

gezin, beslotenheid van 4,447

gezinsafspraken $963,964,998$

gezinsbeleid (sociaal-pedagogisch be-

leid, kindbeleid, kind- en gezinsbe-

leid) $302,304,633,747,750,752,770$,

$771,782,783,798,834,850,852,877$,

$887,889,901,907,909,910,944,948$,

$949,972-974,1012,1079,1081$

gezinsbestuursrecht(er) 672, 699, 701,

$718,893,896,897,904,938,1034$

gezinscoach(ing) $921-923,928-930,935$,

964

gezinsculturele factoren 861

gezinsdiscriminatic (zie ook systemi-

sche -) 678

gezinsdynamiek, gezinsdynamisch 163 ,

532,619

gezinseffectrapportage, zie persoons-

wordingseffectrapportage

gezinsgeheim $76,406,507,513,581$,

626,888

gezinshoofd $181,653,984$

gezinsinspectie $384,395,415$

gezinsklimaat (zie ook pedagogisch kli-

maat) $124,526,574,853,869,1054$

gezinsleven (VKK in te lezen in recht

op) $43,157,323,410,507,815,878$,

992

gezinsminister (zie ook gezinsbeleid en ministerie) 783,889 gezinsnodel (traditionele) 942

gezinsomgeving $66,124,217,390,1010$,

105.4

gezinsomstandigheden, moeilijke 920 ,

$973,975,1011$

gezinsonderzoek $73,384,396,415,445$,

449,722

gezinspatronen 699

gezinsplanning $9,277,397,415,1021$

gezinsprocessen 619

gezinsrecht, kind(er)- en - 216, 217, 248,

$743,896,904,905,922,935,936,938$,

939

gezinsstaatsrecht (staatsfamilierecht)

$698,718,878$

gezinsstructuren $10,619,843$

gezinssysteem (zie ook homeostase)

319,552

gezinstaken (recht van het kind op)

$268-271,387,717,906$

gezinswoogd(ij) $193,195,338,342,469$, $641,749,757,759-761,764-766,776$,

$777,914,929$

gezinswaarden 286,288

gidsland (Nederland) 190, 404, 789, 818, $837,885,946,999$

gif(tigheid), voor kind, relationele, traumatische $74,329,542,615,986,1064$ glijdende schaal $30,44,47,110,112$, $191,273,274,276-278,364,366,455$, $718,768,786,788,838,843,850,851$, $865,906,907,934,935,937,938,998$ God (of Lot) 103, 106, 147, 637,658,

$721,755,818,986,987$

goede bedoelingen $317,339,379,442$,

$730,755,958,981$

goede leven $342,360,467,955,956$

goede-ouder-dichotomieën 276

goede, ware en schone 107, 228, 234, 482,636

goed-genoege-ouders $276,460,496,873$, 923

grensoverschrijding $53,509,532,883$, $896,897,1077$

grondrechten $52,60,61,68,98,100$,

$115,155,314,315,430,431,437,631$,

$633,705,707,712,716,718,719,731$,

$810,817,875,878,882,901,903-906$,

$938,963,996,1080$

grondslagen(onderzoek) 40,100, 101,

$204,585,637,747,903,914,923$

grondwet(telijk) $314,432,708,712,784$, 
$904,905,996,1080$

grootheidsfantasieën (narcistische, bij

psychopathie) $593,594,611,1072$

grotiaans $1,4,136,151,635,636,642$, $644,646,648,650,659,668,796,904$, 984

grove (en grootschalige) mensenrechtenschendingen $623,624,631,634$, $635,643,668,672,675,678,680,689$, $705,723,725,751,756,774,788,805$, $818,830,831,834,837,858,882,884$, $890,898,924$

Gnundnorm (grondnorm) $35,138,313$, $314,329,331,433,653,663,996$

Haat (haat-liefde, recht op, verdrongen) $475,510,599,609,614,764,1067$ haat-ideologieën $493,617,650,815$ habeas corpts (gij hebbe het lichaam) 148,412

hard werken (- verwerken) 343,347 , $541,632,798$

harde geluiden 603

hardvochtigheid (van maatschappij, ouders, slachtoffers) $22,165,166,169$, $176,479,495,531,580,613,614,971$, 1058

hardware, zie hersenen

Harmonisatiewet-arrest 89

hechting(sfiguur), zie gehechtheid

heelal (oerknal, kosmologie) 106, 148,

$152,636,658,823,985$

heerlijke rechten 710

heidenen 137, 647, 648

heksenjacht 518

herbeleving $596,597,986$

herdenkingen (commemorations), (zie ook dag van het Mishandelde Kind) $62,130,690,776,979$

herhaling (zwijgende taal van het mishandelde kind), -lingsfenomenen, -gedrag, -keten (zie ook cyclus, enscenering, revictimisering, transgenerationaliteil en uitageren) $468,475,509$, $542,576,578-580,594-596,726,1064$

herhalingsdwang (relationele, transgenerationele) $189,233,252,470,481,542$, $593-600,602,604,608,610,692,724$, $726,822,865,888,924,983,1064$

herinnering, zie geheugen

herkansing (in de herhaling) 232,233 , $468,592,596,610,724,725,983$ hermeldingen (van kindermishandeling) $34,553,740$

heroine $542,759,1049$

heropvoeding (zie ook zelfopvoeding) $353,404,442,1036$

hersenactiviteiten 658

hersenbeschadiging $244,826,844,848$, $975,1041,1042$

hersenen (brein, hardware) 162,541, $509,510,720,822-826,848$

hersenspoeling 594

therwonden herinnering, zie geheugen

hetero-relatie 308

Hitler $51,71,485,602,611-616$

hoederecht (ouderlijk gezag als) 168

hoeksteen (-stenen) 154, 329, 339, 483, $485,583,624,625,637,686,688,800$, $801,877,990$

hoerenlopers 606

hoerenrechten 606

hoffelijkheid (oppervlakkige charme) $590,611,784$

holistische gezondheidsopvatting 397 , 398,410

holistische verdragsinterpretatie (juridische benadering) $312,428,439,453$, 804

holocaust $82,265,478$

homeopathische eindsoep 658

homeostase (gezins-, hyper-) 273, 319, $552,556,718,874,986$

homo homini lupus (de mens is een wolf voor zijn medemens) $151_{1}, 655$, 657

homo juridicus (rechtsmens) 113

homo sapiens (menselijke soort) 9, 69, $73,74,621$

homosexualiteit 102, 491, 552, 1044

hoorrecht $268,384,387,717,906,949$, 1014,1015

huichelaars, huichelarij (hypocrisie), (zie ook farizeisme) $97,104,301,302$, $319,329,888,891,892,1055$

luidskleur (ethnische afstamming, pigmentatie) $18,218,400,403,416,803$, $964,999,1009,1011$

huisbezoek (home visits) 179, 253, 262, $275,767,841-843,933,940$

huishoudens 545,975

huishouding $172,269,271,279,714$, $718,758,906,937,1048$

huisman 273 
hulp aan huis 917,931

hulp op maat $23,24,861,865,935,937$, $960,964,974$

hulpverleners (en kinderbeschermers), geschiktheid van (zic ook parentificatie) $393,762,839,923,958,1012$

hulpverleners (en kinderbeschermers), toezicht op (zie ook controle en deskundigheid) $383,762,778,806,839$, 923,1012

human rights training (zie ook kinderrechtelijke opvoeding) 690,979

humana societas, humani generis societas (mensengemeenschap) 64, 108, $110,122,126,402,638,644,647,651$, $652,654,659,666,668,791,816,1009$

humanitair (oorlogs)recht (jus in bello) (en mensenrechten) 62, 63, 122, 144, $386,400,410,661,663,681,683,690$, $698,800,1028$

humanitaire interventie (jus ad bellum) $53,68,81,84,85,87,145,636,647$, 649,651

Hussein, Saddam 52, 612

huwelijksboekje, tweede 964 hypercorrect(e taalvorm) 1009 hypochondrie $478,603,607,1075$ hypocrisie, zie huichelarij

hysterie, massa- $162,511,518,527,541$, 1058,1077

Idealisering (van de eigen jeugd/ouders), (zie ook kindertijd) 48,165 , $175,214,328,584,616$

identiteit $232,257,310,348,353,405$, $424,431,432,483,485,516,542,575$, $599,603,714,734,822,1013,1068$, 1069,1071

ijsberg (kindermishandeling als topje) $22,547,549,553,554,569-572,831$

ik-ander differentiatie 824, 1076 ik-nevels (giftige) 1064

ik-zwakte, zie ego-zwakte

illusie (van controle) 594, 659

impulscontrole $264,531,532,611,855$, 856,1075

inburgering(scontract) 964, 966

incest $5,72-76,151,161-164,187,233$, $244-246,263,266,321,480-482,491$, $495,496,505$ e.w. $532,536,540,548$, 557 e.v., $590,593,597,605$ e.v., 699 e.v., $880,896,928,932,1075,1081$ incest-(smartegeld)tarieven 703

incidentie, zie prevalentie.

inclusiviteit (jeugdinclusief belleid), (zie ook sociale insluiting) $767,889,1082$ indifferente opvoedingsstijl 531,532 indirecte discriminatie $707,748,749$ individualisering/-satie, -lisme/-tisch $134,199,232,235-238,271,326,520$, $798,824,840,973,984$

individuatie, separatie-individuatie (zie ook oer-) 199, 232-237, 271, 510,526, $822,824,874,986,1054,1074,1076$ individueel klachtrecht 220,972 in dubio pro infimo (pro reo, pro civibus), in dubio contra parentes (contra proferentem) (bij twijfel wóór de zwakste/tegen de sterkste partij) 381,931 inductieve opvoedingsstijl 533 infantiele persoonlijkheid 854,1072 infantiliseren 527, 1057 infantilisme (kinderdiscriminatie) 79 initiatie 235

inkankeringsproces 740

in toco parentis, in loco liberum (namens de ouders, namens de kinderen) 286

inmengingsverbod (privacy), non-interventie(beginsel) $22-24,157,203,212$, $340,341,364,752,773,784,785,1080$ inquisitie 84,721

inspanningswerplichting $31,33,46,47$, $344,372,383,416,444,448,455,625$, $700,732,733,735,738,754,777,816$, $836,969,994,997$

Institut de Droit International 146 integer (zie ook empathie) 7, 162,512 integriteitsactic, zie persoonswordingsvindicatie

intelligent(ie) $106,361,467,612,619$, $658,853,854,858,957,1055$

interactie (reactief, evocatief, pro-actief) $327,346,521,527,578,581,615,724$, $740,853,858,868,871,926,955$, $1057,1058,1068$

interactlespiraal, negatieve (neerwaartse) spiraal $271,740,867-869,888,965$

intergenerationeel, zie transgenerationeel

intern werkmodel 541, 579-585, 826 internalisatie, -seren $484,580,582,595$, $601,692,845-847,855,857,864,866$, $874,875,934,975,1000,1072$ 
Internationaal Gerechtshof $52,88,91$, $118,122,145,283,638,661-663,666$, $667,688,800$

International Law Commission 146, 665, 66,681

internationale misdrijuven, oorlogsmisdadigers (crimes against humanity, crimes against the peace and security of mankind) $82,91,95,96,118,255$, $602,611,666,667,676-678,681,685$, $687,688,698$

internationalisering 85,132

interpretatiebeginsel (paraplu-rechts-) $293,294,313,315,332,337,371,428$, $433,438,534,784$

interpretatieve verklaring (van Nederland) $380,384,432,434,1016,1019$, 1027

interventie, zie humanitaire -, inmengingsverbod, preventie en staatsinmenging

interventionisme (ex post-) 317, 799, $940,942,943,960,998,1007$

introjectie (van agressor, d/vader) 175 , $207,542,593,1063$

introspectie 822

invaliderend (zie ook zelfinvalidisering) 468,542

investering (sociaal-pedagogische), (zie ook miljardenbesparing en terugverdien-effecten) $273,377,429,449,454$, $727,737,767,783,811,823,831,841$, $889,899,900,922,943,961$

irenofilie (zie ook anti-militarisme) 1024 islam(itisch) 84, 152, 380, 382, 383, 1018 Izaäk $37,214,988,989$

\section{Jeremiëren 478}

jeugdbescherming, zie kinderbescherming/-ers

jeugdcriminaliteit $568,616,742,771$, $831,845,867,872,900,1000$

jeugdgezondheidszorg 769

jeugdhulpverleners, -ing (zic ook hulpverleners en controle) $28,342,493$, $674,745,757,762,769,785,839,840$, $890,942,943,973,1012$

jeugdreclassering 401,1030

jeugdwerkloosheid 271

jezuieten, jezuitisch 186,960

jood(s), joden, jodenhaat (zie ook antisemitisme en holocaust) $71,82,351$,
$612-614,696,988$

judeocide $82,84,613$

juraspeak 111

juridisch acquis 922

juridisch activisme, zie mensenrechten-

juridisering (rechtsverfijning) 40,45, 46, $110,114,116,170,171,173,175,182$, $183,202,204,231,286,294,330,332$ $334,359,364,367,370,379,436,461$, $462,488,521,527,637,657,711,712$, $796,810,866,915,931,964,994$

jurisprudentie $99,115,116,145,192$, $293,300,381,412,429-431,672,679$, $684,726,732,746$

jurist (beroepshouding, kunstfout, taak), juristen (beroepsgroep, goede/slechte), (zie ook rechtswetenschap) 1-4, $21,35,38,39,97,99,101,103,120$, $140,141,160,165,170,176,178,180-$ $183,198,302,339,367,378,381,432$, $433,555,643,644,647,650,663,714$, $723,791-794,796,802,819,884,894$, $932,933,996$

jus ad bellum (oorlogsvrijheid) 51, 52 , $54,81,83,137,651$

jus ad comentum (kwelrecht, q.w) 51 ,

$54,67,81,85$

jus castigandi (tuchtigingsrecht, $q \cdot v_{0}$ ) 892,984

jus cogens (dwingend recht) $80,88,91-$

$93,105,147,212,218,439,448,638$,

$661-664,666,667,729,797,997,1005$ jus constituendum (wenselijk recht) 261, $282,337,445,633,820$

jus constitutum (positief recht) 261,282 , 337

jus contra tormentum (vexatieverbod)

52,54

jus gentium (volkenrecht) $85,652,662$, 796,797

jus in bello (oorlogsrecht) 137

jus in statu nascendi (baarmoederlijk recht) 9, 261, 282

jus in statu pupillari (pril recht) 9, 261, 282

jus naturale (natuurrecht, q.v.) 230, 638, 662

jus standi (in judicio), standing, rechtsingang $171,231,248,268,279,387$, $664,669,697,717,906$

jus vigilantibus scriptum (recht is woor de wakkeren) 447 
jus vitae necisque (recht over leven en dood) 391

juvenilisme (jongerendiscriminatie) 79

Kaîn, kaïnsmerk (-teken) 176,721, 821 , $988,990,991$.

kampbewakers (hulpverlemers als) 898

kanker 939

kannibalisme, emotioneel (kannibalistische rellaties) 580, 607

kansopzet, zie dolis

kapitaalvernietiging $542,600,633,673$, $825,832,843,848,889,900,995$

karakterdeformatie (verminkte persoonswording) 1063, 1068

karakterneurotische pathologie 1071 , 1078

katholiek(en) 105, 197, 273, 711, 960, 1043,1082

kerk (en staat) $15,134,398,434,614$, $833,970,1082$

kernrechten (participatie-/secundaire, tertiaire rechten) 28,148 e.v., 661 , 828,849 , passin

kernwapens, kernwapenadvies, -commentaar (zie ook atoombommen, Internationaal Gerechtshof, Mensenrechtencomité en nucleaire overbewapening) $6,118,122,648,650,661-663$, 800

kiesrecht 205, 387, 621, 965, 966

kind (bezette, gebruikte, gedrilde, gehate, misbruikte, verlaten, verslagen), zie persoonlijkheidsstijlen

kind als (machts)object (bezit, verlengstuk, appendix) $20,127,242,304,320$, $321,503,505,515,517,556,575,714$, $817,841,886$

kind als (rechts) subject $8,15,16,19,20$, $22,24,25,32,33,74,126,182,246$, $299,303,304,319-321,333,336,368$, $372,388,389,390,434,437,447,841$, $858,878,886,923,1048$

Kind- en Gezinsraad 964

kind in jezelf (inner child), kind in de ouder $174,214,366,369,521,587$, $588,724,775,888,923,990$

kinderbelevingen (zie ook herhaling) 924

kinderbeschermers (zie ook hulpverleners) 493, 762, 778, 806, 839, 880, $881,890,900,1012,1036$ kinderbescherming, jeugd- (als ex postinterventie-, onthoudings-, ouderbeschermingsapparaat), (zie ook afschrijven, armoedezorg, controle, gezinsvoogdij, non possumus) 317 , $324,745,766,769,775,834,837,840$, $841,881,900,941$

kinderbeschermingskind(eren) 323,763 , $764,766,793,1082$

kinderbijslag $44,272,273,961,962$

kinderdiscriminatie, zie infantilisme kinderdoding (infanticide), dodelijke mishandeling $213,328,396,415,441$, $459,551,552,554-556,613,819,835$, $892,989,1035,1037,1086$

kinderemancipatie 966

Kinderhandvest (Volkenbond, Hoover) 184,254

kinder-Kalsbeekrapportage (zie ook persoonswordingseffectrapportage) 950,967

kinderkennis (als schoolvak) 954

kinderkwelling (als strafbaar feit) 883, 896,1035

kindermisbruik (als strafbaar feit) 896 kindermishandeling (als strafbaar feit) $883,896,1034$

kinderombudsman $409,425,902$

kinderopvang $272,395,410,414,427$, $711,786,937,1017$

kinderpornografie, -prostitutie 179, 362, $400,482,1026,1044$

kinderrechtelijke opvoeding 883, 946

kinderrechtenbeweging, beweging tegen kindermishandeling $180,547,992$

kinderrechtencatalogus, -logi 32,241 , 249 e.v.

kindersterfte $396,415,940,1021$

kindertijd (angst woor, impact, individuele idealisering/verdringing, collectieve negatieve waardering wan) 1,34 , $71,165,368,511,573,590,616,825$, $1063,1075,1082$

kinderwerkrachting (als stratbaar feit) 896

kinderverlating (als strafbaar feit) 88 , $896,910,911,1034,1036$

kinderverwaarlozing (als strafbaar feit) 896,897

kinderverzaking, plichts- $747,813,831$, $834,840,963,1036$

kindervolkenrecht $45,185,225,226,249$, 
$307,312-315,372,412,451,671,698$, $796,811,834,835,891,914,945,946$, $993,994,998,1079$

kindervolkenrechtelijk discriminatieverbod 714

\section{kinderwetten 473}

kinderzorg (zie ook sociaal-pedagogische steun) $281,395,410,414,415$, $772,877,1018$

kindfactoren 619

kind-relativisme 33

kindsoldaten $400,1027,1028$

kindvriendelijk (-onvriendelijk), opvoedings-, kind-en gezinsvriendelijk 269 , $746,789,832,838,885,887$

kIR-antwoorden (kluitje-in-"t-riet) 377 , 970

klassiekjuridische benadering (zie ook jurist en liberale) 461,626

kleine onrecht (micro- en macroonrecht) 609

kluwengezin 510,531

knuffeldier (als overgangsobject) 106

koestering (recht van het kind op) 244 , $246,261,267,532,544,594,716,905$

kolonialisme $62,91,126,129,646,648$, 661,891

koningskinderen (Grondwet) 315, 784

kortzichtigheid $320,620,654$

kosmologie, zie heelal

kostwinner(schap, -sbeginsel, -sstelsel) $786,835,961,962$

krabbenmand-effect 868

kruiswerk 894

kunstmatige voortplanting (inseminatie, medische technieken) $216,392,394$, $405,432,714$

kurieren am Symptom (symptoombeleid) $787,789,799,862,885,976$

kwellust (bij psychische kindermishandeling), (zie ook kinderkwelling) 500, 721

kwelrecht $51,54,85,86$

kwetsbaarheid $17,19,206,212,218,219$, $221,234,397,408,460,512,550,561$, $598,724,750,862,869,957$

Laatbloeiers 234

laissez faire (moet kunnen) 203, 352, $714,826,840$

lavabo manus meas (ik was mijn handen in onschuld) 634,673 leeftijddiscriminatie (aevisme, ageïsme), (zie ook infantilisme, juvenilisme en senilisme) 79,102

leegte, innerlijke (bij jongeren) 614 leerproces $5,473,825,926$

legalisme (zie ook neo-legisme) 792, 949

lesser evil (minste kwaad) 105, 648, 660 levenservaring 467

levenskunst(enaar) 837,985

levenslange begeleiding (zie ook chronic care) 986

levenswreugde (gederfde) 3,600,700

lex certa-beginsel (de wet zij zeker),

Bestimmtheitsgebot 381

lex scripta-beginsel (de wet zoals geschreven) 380

liberale ideologie, invalshoek (zie ook kllassiekjuridische) $301,461,626,835$, 889

libertinisme, -tisch $461,468,473,497$, $521,522,528,601,602,623,624,751$, $834,836,885,921,964$

lichaam/geest-dichotomie 263

lichaamsstraf, zie slaan van kinderen lichamelijke verwaarlozing (en armoede) 262,504 e.v.

lijden (geestelijk, menselijk, van kinderen) $9,39,76-78,80,81,84,167,214$, $263,471,475,481,482,486,487,494$, $522,528,563,572,577,604,632,633$, $658,660,673,678,680,719,721,794$, $807,825,830,832,857,866,924,928$, $990,1063,1086$

lijfstraffen, fysieke straffen (zie ook slaan van kinderen) $189,384,388$, $503,825,853,893$

Limburg principles (zie ook Maastricht) 449

lippendienst 302,675

littekens $208,702,725,758,1042$

Lockerbie-zaak 52

Lolita 246

loochening $163,213,486,594,637,930$, 1065

loslaten $267,276,278,717$

losmaking(sproces) 202, 233, 278, 709, $824,874,1054$

los-zand-gezin 510, 531

Lot, dochters van 37

Lot, zie God

lotgenotengroepen $654,978,980$ 
lot(sbestemming) 106

loyaliteit (bij parentificatie; verticale, horizontale) $341,579,580,582,826$, 827

loyaliteit (kinderlijke, hyper-) 192, 206, $207,252,253,364,399,593$

luchtvervuiling 397

lustmoordenaar 616

Maastricht gǘdelines 449,806 maatregel van hulp en steun (zie ook persoonswordingswindicatie) 843,897 , $914,930,934,935$

matregelhulp (zie ook pedagogische dwang) 828

maatschappelijk werk(st)er $35,474,484$, $762,764,917,920,958$

maatschappelijke kloof (zie ook tweedeling) $632,633,719,1000$

maatschappelijke pathologie 727

maatschappelijke waardering (voor ouderrol) 273, 601, 877, 878

Maatschappij tot Nut van 't Algemeen 630,884

machismo, macho $264,265,714,1065$

macht van de definitie 302

machtsmisbruik $35,44,86,167,207$, $263,509,712,938$

machtsverschillen (ongelijke machtswerhoudingen), (zie ook kwetsbaarheid) $180,287,536,967$

magisch (denken) 274, 287, 339, 793, 926,1082

mala fides, kwade trouw 674,679

manipulatie $113,162,243,252,288,301$, $317,328,408,432,500,507,541,542$,

$587,611,614,660,792,991,1055$, 1057,1067

manisch (denken) 603,793

mannelijk geweld (rie ook vrouwenmishandeling) 210

mannelijke dominantie $130,265,266$, 301

mannelijke maskerade 265

mannelijke (over)moedscultus 265

mannelijke waardigheid 714

mannencultuur (zie ook patriarchie) 212

mannenemancipatie 559,965

Marcus-effect $627,690,692,727,888$, 979

mangin of discretion (appreciation) 53 , 158,332 marginaal, -alisering, gemarginaliseer-

den $461,423,481,662,706,776,788$,

$805,808,828,833,834,861,899,976$

marginale toetsing $52,732,738,756$

marteling, martelverbod (foltering,

-verbod), (zie ook wreedheidsverbod)

$66,72,73,75,80,86,87,91,92,102$,

$125,144,146,149,153,212,400,412$,

$426,478,481,559,623,661,675,677$,

$843,881,898-900,1027,1028$

Martens-clausule (als juridisch vangnet)

$63,145,638,661$

masochisme $252,580,1077$

masochistische persoonlijkheid 1072 , 1078

massale (en massieve) mensenrechtenschendingen $53,275,471,473,623$, $678,680,995$

materialisme $25,133,134,352,658,821$ maternalisme, matriarchal 302,840

Mattheüs-effect $460,607,627,678,692$, $710,719,727,750,828,888,1081$

maximale standaard 806

maximum extent, maximale (financiële)

verplichting $158,425,454,693,733$,

$754,755,806,948,949,962,1005$,

1012,1013

mediocratic 816

medisch gif $278,400,607,929,1047$

meervoudige persoonlijkheidsstoornis 483,603

meest gunstige bepaling (savings

clause), hoogste standaard 375, 401, 409,1030

megalomaan (denken) $764,793,1082$

meisjesbesnijdenis, zie genitale verminking

meldcode, zie meldplicht

melden van kindermishandeling, meldingen, meldingsbereidheid $2,3,22$, $34,176,352,529,545,546,548,550$, $553,554,569-571,601,625,670,703$, $740,774,775,778,779,809,831,880$, $886,896,903,911,978$

meldingsplicht, meldplicht (meldcode, meldingsregeling); meld(ings)recht (recht van het kind op melding) 73, $79,333,384,388,395,415,445,449$, $545,546,561,564,570,625,774,777$, $780,806,839,883,886,896,910-912$, $933,944,978,1018,1034,1036,1037$ meldpunt (zie ook Advies- en Meldpunt 
Kindermishandeling en Werkgroep Meldpunt Kindermishandeling) 35, $366,670,886,910,911,929,1081$ mene tekel 170

mens sana in corpore sano (lichame-

lijke-en-geestelijke gezondheid) 925 mensbeeld 181, 202, 203, 655, 659, 821 menselijk tekort (zie ook condition humaine) 620

mensengemeenschap, zie humana societas

mensenrechtelijk netwerk, vangnet 110 , 133

mensenrechten en buitenlands beleid 783,885

mensenrechtenactivisme, juridisch activisme, emancipatoir activisme, sociaal-pedagogisch activisme 6,132 , $147,462,700,825,836,837,890$ mensenrechtenbekwaamheid (zie ook minimale persoonswording) 20,379 , 631,698

Mensenrechtencomité $118,220,672$, $679,701,720,754,756$

mensenrechtenorganisaties (kinderrechten-, maatschappelijke, non-gouvernementele organisaties) $75,93,374,401$, $714,744,745,755,797,881,887,888$, $965,970-972$

mentale representaties, zie bewustzijn en vrije wil

mentaliteitsverandering $2,9,687,780$, 911,950

mentor 854,964

mertor ad litem, divortii, domesticus, familiae, ventris (proces-, echtscheidings-, inwonende, gezins-, buik-/ zwangerschapscoach) 929-931 meritocratie 835

metafoor (morele, psychologische, rechten-, sociaal-pedagogische) 112,113 , $464,798,923,986$

metajuristen, metajuridisch 461,462 , $626,649,820,903$

milieu (gezins-, opvoedings-, sociaal -) $34,116,190,220,263,266,346,403$, $426,427,534,619,767,853,868,975$ milieu (natuwrlijk) 112,147,150, 269, $285,397,400,415,416,965,967$, 1021,1024

miljardenbesparing (zie ook terugverdien-effecten) 563 miljardenclaim (wan vrouwen) 700

miljoenenclaims, jaarlijkse (van surwivors van kindermishandeling), (zie ook incest-tarieven) 701

millennium(probleem) 528, 621, 974

mimesis (nabootsing), mimese, mimetisch 228,494

minachting woor mannen 266

minachting voor vrouwen (zie ook verwensing) $127,161,266$

minderwaardigheidsgevoel(ens), -complex 354, 500, 501, 692, 958

minimale persoonswording (als primordiaal recht/belang), (zie ook mensenrechtenbekwaamheid) $379,448,449$, 451,461

minimale standaarden, minimumstandaard $109,122,138,139,145,216$, $288,370,962$

minimalisme, -istisch $364,436,768,849$ minimum-normen $144,743,922,923$, $929,935-937,998$

minister(ie) van Kind en Gezin - van Sociaal-Pedagogische Zaken (zie ook gezinsminister) $625,699,750,752$, $811,934,938,964,972,973,980$ misdaden tegen de mensheid (crimes against humanity), zie internationale misdrijven

misdaden tegen het kind 602,611 misera est servitus wbi jus est vagum aut incertum (onder vaag recht gaat het vuigste onrecht schuil) 448 mishandelde moeders $3,264,265,569$ misleiding $163,267,509,510,792,1055$ moederliefde (mythe van) 704 moeders, zie bijstand, bijstands-, depressie, mishandelde -, risico-, tweederangsburgers en werkende moederschap 66,252 monisme, zie dyas politica monitoring (parenting children's rights) $45,160,178,179,750,838-843,948$ monument woor het Mishandelde Kind 699,980

moraal (recht en) $38,39,88,97,112$ -

$114,118,229,639,794,795$ moraalfilosofen, zie filosolien moraaltheologie 382,1043 moreel dier, sociaal dier $650,657,659$, $660,822-824,890$

moreel gif 82,900 
moreel leiderschap 770

morele elites 925,1000

morele helden ( $v s$. moed der zwakken)

$463,591,1067$

morele kruistochten 489,932

morele paniek (moral panic), (zie ook

heksenjacht en hysterie) 488,490

mulier taceat in ecclesia (de vrouw zwijge in de kerk, in het openbaar) 15

Naamrecht 301, 961

naastenliefde 695

naiviteit $120,147,376,378,446,656$,

$866,925,958,959$

narcisme, narcistisch $163,478,486,593$, 1064,1077

narcistische persoonlijkheid(sstoornis)

$541,543,577,603,1068,1072,1075$, 1078

national machinery 749,750

nationale ramp (nationaal schandaal)

783,815

naturalistische drogreden 493,658

nature (nature/culture, nafure/nurture), aanleg (aanleg/milieu), (zie ook milieu en zelfbepaling) $115,176,308$, $325,346,429,510,551,590,591,619$, $657,845-847$

natuurlijk-positieve mensenrechtenrecht $653,661,796$

natuurlijke orde (vs. natuurrechtelijke orde) $165,170-173$

natuurlijke rechten $49,59,114,231,241$, $246,261,282,284,294,332,635,636$, 639

natuurramp $151,620,832$

natuurrecht(elijk) 1, 49, 67-69, 92-105, $107-110,113-116,118,122,140-143$, $149,151,168,169,197,211,217,218$, $222,229-231,251,252,293,331,335$, $339,380,534,620,623,625,635,636$, $638-640,643,648,653,654,656,657$, $662,789,790,792,795,805,904,987$. 1082

natuurrechtelijke orde 165,792

nazi(-Duitsland), nazisme $70,97,98$, $265,351,614,617,816$

Nederland-vrijblijvendland 262,547

Nederlandse leeuw 969

negatieve affectieve stijl (NAS) 724, 725 negativisme, negativiteit $525,527,541$, 617,1058 negativistische persoonlijkheid 874,1072 nemen van kinderen $9,308,712,726$, 964

nemo dat quod" non habet (niemand kan geven wat hij/zij niet heeft) 463 nemo plus juris transferre potest quam ipse habet (niemand kan meer rechten overdragen dan hij/zij zelf heeft) 463

nemo suan turpitudinem allegans auditur (wie zich in rechte op eigen schandelijkheid beroept, wordt niet gehoord) 362

nemo ultra posse obligatur (niemand is

tot het onmogelijke gehouden) 464 neocortex 663

neo-legisme 792,796

ne peccetur (opdat niet gezondigd worde) 686

nestwarmte 177,782

neurose(n) $1.0,470,478,482,486,512$,

$577,844,1071,1078$

neuroticisme 734

neurotisch handelen 350

neurotische afweer(mechanismen) 1067

neurotische beroepskeuze (zie ook

parentificatie) $175,494,542$

neurotische ellende 478,591

neurotische manoeuvres (en relaties)

608,1063

neurotische partnerkeuze (zie ook herhaling) $271,541,692$

neurotische pathologie (structurele), (zie ook karakterneurotische -) 497 neurotische patiënt/neuroticus, - ouders $167,486,511,854,1057,1063,1068$ neurotische problematiek, neurotisch probleemgedrag 934, 975

neurotische schuld 471

neurotische toestandsbeelden 598 neurotische verliefdheid 1067 neurotiseren(d) 597,598 neutraliteitsprincipe ( $v$. ouderlijke indoctrinatie) 360

nicotine, nicotinisme (rookverslaving, tabaksverslaving) 278, 391, 400, 604, $607,610,838,929,977,1047,1048$, 1075

nihil homini utilus homine (niets is beter voor een mens dan een medemens) $151,152,656$ nihillisme 617 
NIP-code (Nederlands Instituut van Psychologen) 381

non-directiviteit 908,914

non-govvernementele organisaties

(NGO's), zie mensenrechtenorganisaties

non liquet ("het recht is niet duidelijk"; rechtsweigering) $662,664,800$

non onganic failure to thrive 1049

non possumus ('wij kunnen het niet)) beleid, -instrument, -politiek, -systeem (7ie ook laissez faire) $843,885,887$, $889,900,914$

normatieve structuur (gelaagde) 649 , 650

Notitie gezin 177, 779, 782

nucleaire broedermoord (nuclear annihilation) 108,147

nucleaire gezin, kerngezin 269, 289

mucleaire overbewapening $6,485,800$, 1065

nurture, zie nature

Nyugat-leer 89

Object and purpose (zin en strekking, betekenis en bedoeling, doel en wezen, wezen en kern, strekking en inhoud, inhoud en geest) $1,49,222$, $293,335,345,376,380-383,386,398$, $412,436,447,522,657,669,704,714$, $728,804,816,837,979,1020$

object-relatietheorie 826, 1077

ochlocratie 835

oedipaal, oedipustheorie (Freud) 162, $233,234,471,1078$

oer-individuatie-mythe 986

oerknal, zie heelal

oer-trauma $987-989$

Oldenbarnevelt, Johan van $152,644,770$

oligofreen, zie zwakzinnig.

omgang met leeftijd(s)genoten (peer relaties) $251,308,498,509,514,524$, $526,527,581,582,739,852-856,859$, $868,872,1047,1057$

omgangsbemiddeling, zie echtscheidings- en omgangsbemiddeling omgangsrecht, -regeling $26,268,296$, $298,301,407,506,717,929,1014$ omgekeerde wereld (omkering van za-

ken) $207,226,594,771,779,1055$ omkering van de bewijslast 800 omkering van waarden 594,1055 omstanders $318,440,494,728$ omstanders-criminaliteit 896 omvangscijfers, zie prevalentie onberekenbaarheid (van ouders) 243 , $500,527,1058$

ondergang, zedelijke of lichamelijke $194,195,322,323,338,942$

onderrapportage (van kindermishandeling/incest) 556,557

ondertoezichtstelling (oTs) 26, 194,296, $322,338,340,357,759,760,762,765$; $775,776,828,851,913$

ondertoezichtstelling, als infamerend 935

onechtheid 106, 541, 763, 1072

ongeboren vrucht (kind, leven), (zie ook foetus) $315,759,775,784,941,1010$, 1047

ongelukkige jeugd, zie gelukkige onmenselijke (wrede) en vernederende (onterende) behandeling en bestraffing (zie ook lijfstraffen en vernedering) $17,79,80,91,144,384,400,412$, $413,439,446,448,449,667,733,754$, $828,839,843,895,995,997,1026-1028$ onrechtmatig(e daad) $37,256,343,357$, $394,409,555,640,642,648,651,662$, $670,686,691,703,794,800,897$

onrijp (kind, recht, trekken) 235, 261, $391,1010,1072$

ontdubbeling (zie ook bewustzijn) 658 ontheffing, ontzetting $44,193,194,322$, 405, 1034-1036

onthoudingsbeleid, -politiek, -praktijk (zie ook kinderbescherming, ouderschapswerwaarlozing en non possumus) $713,751,805,834,840,849$, 1000

ontmaskering $45,74,275,288,339,535$, $617,621,646,750,793,939$

ontoerekeningswatbaarheid, zie toerekeningswatbaarheid

ontplowiingsbeginsel 133-135, passim ontvang-ouder (bij omgangsregeling) 408

ontwikkelende vermogens van het kind (toenemende bekwaamheid) 31, 32, $42,115,119,188,195,206,218,239$, $267,268,270,278,313,323,346,384$, $387,394,395,404,407,409,414,428$, $429,446,448,709,717,857,949,981$, $996,1012,1016$ 
ontwikkeling, evenwichtige $2-3,17,260$, $286,288,333,344,359,364,435,437$, $571,757,759,937,996$ ontwikkelingsachterstanden 816,859 ontwikkelingsbelang (van het kind) 17 , 18, 46, passim ontwikkelingsblokkade, zie gestagneerde ontwikkeling ontwikkelingsconflicten 596 ontwikkelingscontinuüm 1076 ontwikkelingsdeterminanten 853 ontwikkelingsdimensie 466,575 ontwikkelingsenergie 207 ontwikkelingsfase $227,525,526,596$, $825,864,1039,1054$

ontwikkelingsgat 509 ontwikkelingsgeschiedenis $496,501,520$, 533,1073 ontwikkelingshulp $345,382,404$ ontwikkelingskansen $307,315,391,394$, $414,461,626,735,866,1010$ ontwikkelingslanden $345,392,395,396$, $399,449,695,1011,1021,1022,1024$ ontwikkelingsniveaus $195,859,1051$, 1054

ontwikkelingsnood 466 ontwikkelingsopgave $852-856,859$ ontwikkelingsplasticiteit, zie plasticiteit ontwikkelingsproblematiek 567,1073 ontwikkelingsproces $205,516,743,766$ ontwikkelingspsychopathie 1071 ontwikkelingspsychopathologie 40,50, $175,463,498,521-523,632,724,852$, $1039,1057,1068$ ontwikkelingsschade 549 ontwikkelingsstimulering $831,906,974$ ontwikkelingsstoornissen $327,485,567$ ontwikkelingstaken $106,175,207,240$, $346,441,466,468,473,521,540,574$, $591,632,709,724,824,852,859,866$, $869,924,956,980,1078$

onverschilligheid (van maatschappij, ouders, overheid, slachtoffers) 22 , $161,165,166,176,479,495,531,575$, $580,604,609,679,803,804,825,890$, $896,971,986,1086$ onverwerkte problematiek, niet verwerkte (jeugd)trauma's (zie ook verwerking) $74,162,266,271,341,466$, $468,473,475,478,485,493,496-498$, $503,506,519,520,563,576,581,584$, $585,594,596-598,608,609,613,692$,
$721,726,788,793,816,824,857,870$, $888,924,956,998,1057$

onvolwassen, emotioneel onvolgroeid

(ouder) 174, 274, 519

onvoorspelbaarheid (van ouders) 350 , $500,574,580,861$

onwetend(heid) $74,241,244,245,252$, $399,479,986$

oorlogsgeweld, -wellust (scientific

butchery) $137,643,649,695$

oorlogsveteranen 536

Open werkgroep (VRK) 374

openbaar-rechtelijk, publiek- 30, 37, $280,461,462,468,473,497,521,528$, $602,623,712,885,904$

openstaande rekening(en) $541,726,958$ opinio juris (algemene rechtsovertui-

ging) $114,141,143,211$

opinio juris sive necessitatis (algemene

of denknoodzakelijke rechtsovertuiging) $186,218,282,633$

opinio necessitatis (denknoodzakelijke rechtsovertuiging) $141,143,211,636$, 810,820

opoffering $599,981,1066$

opstand (recht op; van het kind), (zie ook verzet) $55,64,129,173,175,649$, 770,891

opvoeding, Huis van de 260,276 opvoedingsarbeid (onbetaalde) 942 opvoedingsautonomie (ouderlijke autonomie) $21-23,86,149,203,289,340$, $342,490,708,833,936$ opvoedingsbegeleiding (en -bewaking) $670,713,714,816,817,830,835,842$, 871

opvoedingsbevoegdheid 43

opvoedingsbijslag (zie ook opvoedingsgelld) 842

opvoedingscursussen, zie oudercursus opvoedingsidwang (neurotische) 470 opvoedingseffectrapportage, zie persoonswordingseffectrapportage opvoedingsfactoren 619 opvoed(ings)geld, (zorg- en) opvoed(ings)loon (ouderschapsloon) 44 , $272,273,277,395,415,436,534,626$, $718,722,727,786,812,817,836,842$, $871,875,883,897,898,900,901,906$, $907,922,935,938,945,961-964,972$, $977,990,997,998,1023,1079$ opvoedingsklimaat, zie pedagogisch - 
opvoedingsmonopolie 1080

opvoedingsondersteuning, ouderschaps-

(zie ook glijdende schaal, SPS, trias-

trits) 273, 392, 439, 914 e.v. passim

opvoedingsonderwijs (ouderschapson-

derricht) 271,944 e.v., 1081 , passim

oproedingsoptimisme (rule of optimism)

$492,531,907$

opvoedingspraktijken (traditionele),

pedagogische praktijken $2,127,272$,

$320,321,384,398,475,476,485,499$,

$528,675,882,954,955,1021$

opvoedingsscholing, zie ouderschapstrainingen

opvoedingsstijl, ouderschaps- (warme, niet-warme), (zie ook autoritaire, autoritatieve, democratiserende, indifferente, inductieve, permissieve -) 3 , $342,463,528-534,612,618,619,826$, $873,874,954,975,995$

opvoedingssubsidiëring zie ouder-

schapssubsidie

opwoedingstaak, -opgave 782, 784, 847,

$852,855,859,877$

opvoedingsvaardigheden, zie pedagogische -

opvoedingsverantwoordelijkheid (exclusieve us. gedeelle) $76,157,253,632$, $743,882,942,976$

opvoedingsverantwoordelijkheid, primaire (originaire, ouderlijke) 43,632 , 997, passim

opvoedingsverantwoordelijkheid, secundaire (statelijke) 29,33,45, passim opwoedingsvoorbereiding (ouderschaps-) $670,832,954$

opvoedingswoorlichting (ouderschaps-) $4,392,397,415,713,714,772,781$, $883,886,894,895,918,1021,1022$, 1079

opvoedingsvrijheid $157,729,750,752$, 1079 e.v.

organieke (wet) 904, 905, 963

orthopedagogen 339,518

ostracisme (wetenschappelijk) 650

oud zeer $721,724,957$

ouderbeelden 175

ouderbegeleiding 44, 397, 408, 461, 938, 939,1021

ouderbehandeling, verplichte (zie ook daderbehandeling) 445

ouderbescherming $324,671,881$ ouderfactoren 619

ouderkunde (als schoolvak) 954

onderliefde (natuurlijke) $35,74,76,213$, $227,321,370,492,493,538,873,957$

ouderlijk geweld, geweld tegen kinderen (violence against children), (zie ook geweld in het gezin) $76,208,212,213$, $288,459,695,720,727,837,881,894$, $902,950-953$

ouderlijk gezag $4,27,28,87,161,165$, $168,169,181,182,192-194,196,249$, $280,377,421,763,764,776,879,984$ ouderlijk huis 986

ouderlijk plichtswerzuim $393,460,813$, 963

ouderlijk wangedrag (zie ook voorbeeld-strafbepalingen) 492,504,508, 775,860

ouderlijke almacht $78,166,275,276$, $470,522,987$

ouderlijke atfitude, basishouding, gezindheid (verstoorde) $213,243,244$, $465,503,517,535$

ouderlijke autonomie, zie opvoedingsautonomie

ouderlijke immuniteit (parental immunity) $41,47,287,343,702$

ouderlijke onmacht (pedagogische onmacht) $74,78,194,207,212,243,252$, $263,276,277,321,466,470,473,502$, $522,561,601,713,726,865,886,887$, $1034,1045,1074$

ouderlijke plichtsverzaking 813,831, 963 ouderlijke prerogatieven $376,383,446$ ouderlijke rechten, oudlerrechten, rechten van ouders (zie ook opwoedingsautonomie, opvoedingsvrijheid, privacy, privileges en socvereiniteit) 21 , $28,37,47,76,77,80,301,321,336$, $340,383,409,504,661,708-710,714$, $743-745,746,750,831,833,849$

ouderlijke (zelf)rechtvaardiging 537 ouderschap, woorbereiding op (zie ook oudercursus en opvoedingsvoorbereiding) 452,954

ouderschapsbeginsel (vs* kostwinnersbeginsel) 961,962

ouder(schaps)cursus(sen) $44,271,272$, $274,366,452,467,483,625,674,718$, $842,856,865,872,894,897,906,918$, $919,922,935,937-939,944,955,957$ 961,997 
ouderschapseducatie (volwassenen-)

$119,272,277,634,699,894,946$

ouderschapsexamen (proeve van bekwaamheid) $726,938,958$

ouderschapsinspectie, zie monitoring (parenting) en gezinsinspectie

ouderschapsloon, zie opwoedingsgeld ouderschapskunde (Doek-cursus) 958

ouderschapslibertinisme, zie libertinisme

ouderschapsonderricht, zie opvoedingsonderwijs

ouderschapsondersteuning, zie opvoedingsondersteuning

ouderschapsstijl, zie opvoedingsstijl

ouderschapssubsidie, opvoedingssubsidiëring (zie ook opvoedingsgeld) 626 , $713,727,738,742,907,998$

ouderschapstrainingen (oudertraining, opwoedingsscholing en -training), (zie ook ondercursus) $334,534,836,872$, 916, 958-960

ouderschapswergunning (licensing parents) 841

ouderschapsverwaarlozing $528,620,623$, $624,751,976$

ouderschapswoorlichting, zie opvoedingsvoorlichting

ouderschapsvorming(swerk) 392,773 , 836,907

overbelasting (van gezinsvoogden, hulpverlleners) $757,777,839$

overbelasting (van kind, van ouders) $871,991,1054$

overbescherming, overprotectie (smothering) $267,576,615,717,1057$

overbezorgdheid $442,531,584,615$, 1066

overcontrole $267,532,717,873$

overgave (moed tot ws. ongeremde) 234 610

overheidsbemoeienis $181,340,344,359$, $461,626,712,799,856,857,1079$

overheidsbetrokkenheid (bij mensenrechtenschendingen) $674,675,679$, 680

overlast $84,862,866,975$

overleven en ontwikkeling $119,391,426$ -

$429,446,448,449,949$

overmacht $151-153,451$

Paars (kabinet, beleid) 833, 971, 973 pacta sunt servanda (verdragen moeten worden nageleefd, uitgevoerd) 95 , $104,378,380,447,637,653,663,686$, 801

pak voor de broek $243,781,894,952$, 984

pakkans 352

palliatie (in plaats van preventie) 737 , $756,787-789,799,805,808,832,837$, 885

pantser (zie ook hoffelijkheid) 590,607 , 614, 1064

paradijs(elijk) (zie ook oer-individuatiemythe, oer-trauma en priesterprojectie) $167,276,721,794,986,987,990$ parafraseren (vs. citeren) 41 parallellie, -isme $137,530,533,646,984$ paranoia, paranoïde persoonlijkheid(sstoornis) $469,504,541,543,1058$, 1071,1076

parentiarchie, parentiarchaal $21,34,35$, $37,47,74,76,170,181,212,276,288$, $294,302,332,447,528,601,623,708$, $710,713,714,718,719,730,744,745$, $746,748,750,752,755,767,770,798$, $840,885,886,899,921$

parentificatie $175,207,322,341,356$, $474,493,494,593,765,958$

participatie-rechten, zie kernrechten partnerkeuze, zie neurotische -

partnerverslaving (love addiction) 542 , 604

passief-agressieve persoonlijkheid(sstoornis) $541,543,874,1072$

passief-systematische mensenrechtenschendingen $33,620,624,625,674$, $675,680,706,719,723,725,728,732$, $756,788,799,800,802,816,817,837$, $860,882,885,900,903,922,944,999$ passieve agressie 873,1065 pater (et mater) familias (gezinshoofd) $653,984,985$

paternalisme, -tisch $172,181,182,482$, $840,907,908,914,923$

pathogene zorg, zie emotionele maltraitering

pathologische band (bij chronische mishandeling) 574

patriarchie, patriarchaal $34,47,165$, $168,170,210,212,266,301,302,444$, $489,491,606,708,710,711,714,752$, 804,899 
patriciaat 71

patronaat 444

paus(elijk) $60,446,472,804,843$

pays légal (ws. pays réel) 48, 285, 837, 971,976

pedagogisch besef $3,9,460,467,496$, $498,519-521,528,530,533,551,577$, $580,600,602,632,724,734,767,788$, $816,818,842,853,859,872,918,919$, $955,960,980,997,999,1000,1013$, $1073,1074,1080$

pedagogisch klimaat, opwoedings-, ontplooilings- (zie ook gezinsklimaat) $124,353,531,566,772,853$

pedagogisch tekort (-e tekortem, tekortkomingen) $439,465,466,496,498$, $504,519,520,538,672$

pedagogisch zwakke milieus 220, 767 pedagogische dwang (hulpoplegging, maatregelhulp), (zie ook persoonswordingsvindicatie) $177,247,249,268$, $275,279,334,356,717,742,786,849$, $850,862,863,917,918,959,998$

pedagogische kwestie $4,36,38,473$, $528,821,830,836,885,903,999$

pedagogische onmacht, zie ouderlijke onmacht

pedagogische rechten (zie ook grondrechten en kernrechten) $4,18,19,87$, $198-200,241,249,259,280,286,387$, $403,436,905$

pedagogische tik 189-191, 193, 208, 398, 892,938

pedagogische vaardigheden (opvoedings-) $271,272,465,498,741,776$, $856,865,921,955,957,959$

pedagogische verwaarlozing 244,262 , 460, 571, 1038, 1050, 1053, 1054

pedofielen (buiten het gezin; incestvaders), pedofilie $77,190,246,603,933$ per analogiam-interpretatie ('niet over hef gras, dan ook niet over de bloement), juridische analogie (zie ook a contrario-) $89,364,381,432,436$, 636

periodieke evaluatie (bij uithuisplaatsing) $384,411,426,1022$

periodieke onthouding 397

periodisering (van mensenrechten) 67$69,85,132$

Permanente Hof van Internationale Justitie $91,638,662,688,728$ permissief-systematische mensenrechtenschendingen 624

permissieve maatschappij $190,352,834$ permissieve matuurrecht 635,636 permissieve opvoedingsstijl (ouderlijke permissiviteit) $169,278,531,532,957$

persoon (combinatie: paard en ruiter) $345-347$

persoonlijk motief (zie ook afgunstmotief) 474

persoonlijke (het persoonlijke is politiek) $536,887,924$

persoonlijke groei $798,840,926$

persoonlijkheidsfragmenten, gefragmenteerde identiteit $485,576,589$

persoonlijkheidspathologie (en onveilige gehechtheid) $585,602,1070,1078$

persoonlijkheidsrecht 429,430 persoonlijkheidsstijlen 1076 e.v. persoonlijkheidsstoornissen 40, 107, 492, $497,543,563,577,578,582,589,596$, $604,611,845,846,929,936,1068$ e.v., 1077,1078

persoonlijkheidsverandering 824,1069 , 1070

persoonswording (zie ook persoonswordingsdrieslag) 4,9,17, 19, passim persoonswordingsbelang (van het kind) $319,379,449,451,462,672,709,931$, $936,937,939,1039,1050$

persoonswordingsbeschadiging 549 persoonswordingsbril 705, 706, 719 persoonswordingsconforme (verdrags-) interpretatie 436

persoonswordingsdrieslag (rationaliteit, moraliteit en authenticiteit) 49,107 , $224,228,234,293,332,345$ e.v., $371_{\text {r }}$ $372,438,465,497,521,530,534$ e.v., $607,609,631,698,720,734,821$ e.v.* 827 e.v., 993, 997, 1039

persoonswordingseffectrapportage (child impact analysis), (zie ook kinderKalsbeekrapportlage) 949,965 e.v. persoonswordingsoptimalisatie (-maximalisering) $279,315,394,427,433$, $658,878,886,898$ persoonswordingsparadigma 885 persoonswordingsperspectief 77,862 persoonswordingsraket $698,699,744$ persoonswordingsrecht(en) $18,21,45$, $86,435,661,668,670,817,994$ persoonswordingsreparatie 699 
persoonswordingstoets 408

persoonswordingswindicatie 247,248

$274,279,387,391,464,625,718,786$,

$886,897,898,906,913,918,930,934$ -

$936,961,998,1034$

pesten, pesters, pestprojecten 539,542 ,

$600,614,869,872,991$

petitio principii, cirkelredenering 108 , 299

pia fraus (wroom bedrog)-beginsel (be-

lang van het kind) 319

pigmentatie, zie huidskleur

plasticiteit $654,771,863,867$

pleeggezin(plaatsing, -szorg) 43, 77, 358,

$384,392,396,415,427,439,525,759$,

$760,916,931,936,1011,1018$

pluralisme 148

poenae meritum, verdiende straf 81,95 , $96,251,252,267,276,533,637,686$, $688,717,1034$

poldermodel $635,834,835,964$

politieke wil 151, 454, 546, 714, 769,

$770,835,865$

polymorf pervers (kind, vrouw; Freud)

233

polyvalentie (en pluri-interpretabiliteit)

(belang van het kind) 302

positief-natuurlijk (en positief-volitief)

volkenrecht 661,796

positieve actie, - discriminatie (zie ook

voorkeursbehandeling) 393,715

positieve maatregel(en), - verplich-

ling(en) $23,88,220,453,462,679$,

$715,716,726,803,996,1019,1025$

positivisme, zie rechtspositivisme

postconventioneel, pre- 351-353, 918-

921,928

postmodern $252,654,792,793,833,899$

posttraumatisch $212,245,470,472,473$,

$479,498,536,580,589,593,595,603$,

$608,632,691,692,793,823,827,924$

pre-condition (basiswoorwaarde) 385 , 450

predestinatie 987

predictie( $(\mathbb{1})$, toren (voorspelling, -lers)

$3,539,569,618,619,736,741-743$,

$745,798,821,855,857,861,863,864$,

$873,874,919-921,1073$

prenatale persoonswordingsvindicatie

(hulpoplegging) 391, 1010

prenatale schending van de rechten van het kind 391, 1048, 1049 prenatale screening $935,1013,1079$

prenatale zorg (hulpwerlening) 8,262 , $375,756,757,929$

prenatale zorgverantwoordelijkheid (van de staat) 1010

prenatalle zorgvuldigheid $278,375,857$ preoccupatie $164,585,818,1065$

prevalentie en incidentie (omvangscijfers) 543 e.v., 830

preventie (algemeen: provision; specifiek: prevention), interventie (protec(tion) en reparatie (participation) 387 , $389,434,625,626,634,670$ e.v., 695 , $698,699,805,820,851,1018$, passim preventie (generalle en specialle) 436 , $460,686,842$

preventie (primaire, secundaire, tertiaire) $739,740,742,756,786,805,808$, $849,850,855,856,861,865,928,955$

preventie (recht van het kind op; bescherming kind en volwassene) 556 , $563,857,894,917,959,973,1081$

preventie en curatie, zie palliatie preventic en vroege interventic (zie ook reparatie) $625,626,740$

preventiebeleid $277,404,619,781,875$, 900,976

preventie-programma's $384,395,415$, $437,438,445,449,451,849$

preventieve benadering (preventive approach) $367,683,685,788,789,820$, $838,848,851,900,910,915,916,919$, $935,995,999,1003,1007,1079$

preventieve hulp (- interventie, - ondersteuning) $737,738,743,745,786,833$, $848,963,1013$

preventieve rechten 387,389

preventieve trits (opvoedingsgeld, opvoedingsonderwijs en opvoedingsondersteuning) 901

preventieve werking (wan schadeclaims door sumivors) 320,683

priesterprojectie (zie ook paradijs) 721 prijswergelijking 916,917

prinsesjes(-incest) 507,811

privacy (gezin; ouders ws. kind; systeemwaarde) $35,43,75-78,80,155,287$, $288,339,376,461,476,490,492,537$, $539,601,602,604,626,711,728,744$, $750,752,779,786,803,804,833,837$, $840,841,843,878,899,976,995,1004$ privacy (kind; lichamelijke en geeste- 
lijke integriteit van het kind; positheve -) $157,208,288,356,394,409$, $412,426,841,843,844,1017$

privacy (right to be let alone van volwassene; negatieve vrijheid), (zie ook inmengingsverbod) $640,653,713,798$, 840

privacy-beginsel 219,798

privacy-cultuur $528,546,680,803-805$, 885

privacy-idiosyncrasie 47,713

privacy-paradigma $884-886,889,892$, $905,921,922,1000,1008,1079$ e.v. privacy-systeem $680,788,804,805,833$, 885

privilleges (adellijke, historische, mannelijke, ouderlijke -), geprivilegieerden $51,55,56,127,128,130,131,177$, $190,253,276,288,726,751,811,905$, 921

procrustisch(e dwang) 500, 501

proefprocessenfonds Kind \& Recht 734, 755

programmat(or)isch (karakter van verdragsverplichtingen) 385,751

prostitutie, prostituées (en incesit) 22 , $266,604,605$ e.v., 678

protectiewe factoren $312,468,532,591$, $853,858,899,1055$

pseudo-volwassen(heid) $266,510,609$, 726

psychiatrie, -ische problemen 244,539 , $542,561-564,568,577,578,585,592$, $600,603,615,741,847,859,864,874$, $899,929,934,936,997,1006,1051$

psychiatrische inrichting(en) 558,600, 601,1035

psychische kindermishandeling (als strafbaar feit), (zie ook kwellust) 897 , 1037

psychische moord (assassinat psychique, soul murder, q.v.) 481

psychoanalyse $163,164,311,470,472$, $486,487,610$

psychobiografie 5, 234

psychocicatrisatie 724,725

psychodynamisch $174,576,1071$

psycho-overlevenden, zie survivors

psychopathie 577, 611, 612, 936, 1071, 1078

psychopathische persoonlijkheid 541, 929 psychopathologie (structurele) 40,45 , $47,497,582,602,659,747,845,986$, 1073

psychose(n), =otisch $486,497,543,603$, $604,929,936,995,1071,1074,1078$

psycho-sociale (sociaal-emotionele) problemen (zie ook gehandicapt) 567 , $589,724,861$

psycho-sociale Verelendung 727,828 psychosomatisch $353,478,506,511,542$, $589,596,597,603,607,691$

psychotherapie, zie therapie

psychotrauma, zie trauma

puberteit $263,479,512$

publiek/privé-dichotomie $219,220,803$ 805,885

publieke domein $76,124,269,279,391$, 626,881

publiekrechtelijk vrijgestelde privéstructuren $461,468,885$

publiekscampagnes (zie ook opvoedingsvoorlichting) $2,4,454,752,753$, $772,777,778,809,883,886-888,894$, $895,911,929,977$

\section{Quia peccatum (omdat er gezondigd is)} 686,1034

quid pro quo (voor wat hoort wat) 273, $287,334,660$

Raad van Europa 421, 422, 810, 881 , 901, 963

Raad (Raden) voor de kinderbescherming $260,435,543,545,552-554,570$, $571,703,733,752,769,780,886,929$, 931, 996

Raad voor het jeugdbeleid 319,494 , 567,624

racisme, -tisch (rassenhaat), anti-, neo$18,47,81,82,124,391,488,499,614$, $622,752,815,835,871,1065$

raison d'état (staatsraison) 104, 650

raison d'être (verdragsgeest, -ratio) 381 , 805

rancune(us) (zie ook ressentiment en wraak) 541,1071

ranselpedagogiek 189,467

rapportage, nationale (aan parlement), (zie ook kinder-Kalsbeekrapportage) $735,750,950,967-969,970$

rapportage, staten- (aan verdragscomité), (zie ook statenrapport) 375,401 , 
$425,426,968,971,972,1030$

rapprochement crisis 396

rassendiscriminatie $47,65,91,146,661$, 707,815

ratio $228,230,636,804$

rationalisme 987

realisme 34,120

reality-tv 190

reallocatie (zie ook budgettaire politiek) $46,47,285,828$

Rechtbank Utrecht, vonnis (zie ook ouderlijke immuniteit) 702

rechtenconcept(ie) (rights-ism, rights approach) $31,202,303,401$

rechtendiscours $204,343,727,729,905$

rechtendrager (kind als), (zie ook -concept en -discours) $8,15,25,32,77$, $126,136,203,287,303,320,343,390$, $391,402,421,437,447,746,886$ rechtenethiek, zorg- (ethics of justice, ethics of care) $164,182,183$

rechterlijke machtiging (bij scheiding kind en onders) 931,935

rechterlijke toetsing (toetsingsrecht, -verbod, maatregelhulp) 52, 68, 69, $77,89,407,710,922,938,998,1014$ rechtsbescherming (berwaar en beroep) $30,44,45,148,171,247,274,279$, $280,306,312,334,363,364,407,412$, $718,735,843,906,938,939,964,998$ rechtsbewustzijn $63,107,145,636,638$, 650,661

rechtsbron(nen) $88,230,638,805$

rechtsextremisme 614

rechtsgebouw 118, 119

rechtsgevoel 1, 230, 252,792

rechtsherstel $95,96,670,671,697,727$, 800

rechtsingang, zie jus standi

rechtsnotie (belang van het kind), -noties $32,171,172,436,448$

rechtsontkrachting, -verkrachting ( $a b$ rogation vs. perpetration) 807,808 rechtsovertuiging (zie ook opinio juris) 93

rechtspositivisme (positivistisch, -isten) $39,93,96-99,102,104,105,120,590$, $648,661-664,667,731,789,790,792$, $793,795-797,996,1004$ rechtspostulaten $103,109,110,122,229$, $378,379,385,429,621,625,637,790$, $800,851,971$ rechtssociologie, (diepte) sociologisch, -logen $41,47,48,317,461,490,583$, $602,610,625,626,798,965,1000$ rechisstaat, -statelijkheid (nule of law) $9,30,36,45,60,63,86,90,101,148$, $165,171,177,209,248,280,287,306$, $330,356,388,403,404,408,429,450$, $637,646,735,773,788-790,832,835-$ $837,844,884,885,889,899,900,903$, $904,923,932,984,991,994,999,1002$ rechtssubjectiviteit (van individu, van vrouw), (zie ook kind als subject) 15 , $136,138,142$

rechtsverfijning, zie juridisering rechtswerwerking 154

rechtswinding (en rechtsvorming) 97 , $111,113,431,432$

rechtswaarborgen $22,144,157,171,247$, $280,344,389,735,742,759,771,806$, $809,816,911,936,998$

rechtswetenschap, beoefening van (beginselgericht, regelgericht), (zie ook jurist) $38,39,99-101,120,433,640$, $744,790,792,793,795,796,996,1082$ rechtvaardigheid $68,635,662,795,841$, 1082

rechtvaardigheidstheorie (Rawls) 181 recidiv(ism)e $542,578,585,672,686$, 740

reclassering $442,672,686,890$

reductio ad absurdum (tot het ongerijmde voeren) 98,134

reënscenering (re-enactment), zie enscenering

reflectief (rechtskarakter), (zie ook opinio necessitatis) 810,814

reflexief (rechtskarakter), reflexwerking $692,810,814$

regenten $58,128,130,770$

regressie $510,985,1067$

rehabilitatie, zie reparatie

reificatie (verdingelijking) $24-26,714$

relatie (relatie, competentie, autonomie), zie gehechtheid, herhalingsdwang en ontwikkelingstaken relatiegeschiedenis (zie ook ontwikkelingsgeschiedenis) 956

relatiekunde (als schoolvak) 36, 954 religie(us), religiositeit 55, 98, 103-106, $145,209,234,238,251,326,380,382$, $398,486,658,675,678,684,693,729$, $730,834,988,1016$ 
reparatie, -toir (compensatie/rehabilitatie), (zie ook compensatie en preven(ie) $4,9,226,231,261,277,279,343$, $365,375,390,391,404,439-442,445$, $465,535,584,626,627,632,634,637$, $640,660,664,669,670,671,681,683$, $686,688-692,694,695,697-700,716$, $722,724-727,738,739,741,744,788$, $805,808,815,816,818,828,836,840$, $934,959,978,979,984,1028$

reprimande 545

reproductieve vrijheid, zie voortplanting reservatio mentalis (geheim voorbehoud) 377

resocialisatie 626

respectregels 248,328

responsiviteit $498,531,874$

ressentiment (zie ook rancune en wraak) 604,609

restitutio (in integrum) (herstel in de oude toestand) $637,640,671,688,689$ restrictieve interpretatie (enge uitleg) 781

resultaatsverplichting $33,122,344$, 444$446,448,662,732-735,738,754,816$, $831,872,969,994,997$

retractie 164

revalidatie $396,626,1021$

revictimisering (zie ook herhaling) 542 , $593-595,602,607$

revolutionair $77,169,172,646,719$

Riagg $734,769,871,889,934$

rigide, rigiditeit $236,256,319,510,590$, $724,771,773,874,1078$

risico-aansprakelijkheid 732

risico-buurtgezinnen 865

risico-categorieën 780

risico-cumulatie $833,866,870,928,974$, $995,998,1079$

risico-factoren $311,312,468,532,739$,

$781,839,847,853,858,863-867,870$, $871,920,923,928,959,1075$

risico-gezinnen $436,460,737,741,742$, $745,757,786,788,809,870,919,920$, $935,964,967973,1013,1079$

risico-groepen $452,566,739,742,756$, 805,865

risico-indicatoren $738,739,741,742$, $921,935,998,1013,1079$

risico-kenmerken (van kind, wan ouders) 619,858

risico-leerlingen 872 risico-moeders 756,870

rusico-ouders $452,534,744,917$

risico-situaties $404,785,788,805,906$, 919,974

risico-zoekend gedrag (riskante levensstijl) 607,835

ritueel misbruik (ritual or satanic abuse) 190,488

rituelen (zie ook genitale verminking)

$235,475,476,588$

rolomkering (omgekeerde rollen) 174,

$341,507,527,584,1057$

rolverwarring 507

romanocide 84

rookverbod 397

root causes $491,785,787$

rouwarbeid (verdrietswerk) 234,266 ,

$591,632,724,854,924$

rouwproces $1,471,486,520,540,608$ ruzies (tussen de ouders), (zie ook con-

flicten) $302,527,598,612,858,1058$

Rwanda (Tutsi-cide) 82,96

Sadisme 176, 212, 1063

sadistische persoonlijkheid 1072

sadomasochistische (relaties) 542

sappenleer 711

savings clause, zie meest gunstige bepaling

schade, immateriële (smartegeld) 701-

$704,816,952$

schadefonds geweldsmisdrijven 699,978 , 980

schadevergoeding (maatstaven, symbo-

lische, verplichting tot) $640,670,671$,

$689,700,701$

schandpaal van het recht 807

schoolarts 44, 73, 263, 939, 1048

schooldiscipline (slaan op school) 125,

$399,425,504,893,950,951,1023$

schoolgezondheidszorg 920,925

schoolmaatschappelijk werk 842

schoolpedagoog 931

schuldgevoel(ens) $175,351,461,486$,

$509,513,517,593,594,614,654,981$, 982

schuldinductie $725,753,896$

screenen (zie ook prenatale screening)

$341,534,738,741,742,786,788,919$,

$920,935,964,1006,1013,1079$

Sein en Sollen 97, 104, 106

self-contained regime 732 
self-executing, direct (door)werkend

(zelfwerkende verdragsbepaling) 90 ,

$112,381,343,431,432,453,454,971$

senilisme (ouderendiscriminatie) 79

senryü $5,114,252,837$

sensitiviteit $231,467,468,498,523,767$,

$956,959,960$

sentimentalisering, sentimentaliteit 173 ,

$175-177,212,580$

separatie, zie individuatic

sexediscriminatie, sexisme (zie ook

vrouwendiscriminatie) $18,92,130$,

$146,211,212,752$

sexe-justitie 131

sexindustrie 606

sexueel misbruik (zie ook incest) 3,179 ,

$188,233,243,244,246,388,400,427$,

483-485, 491, 495, 505, 513, 549, 551,

$558,559,564,599,600,605,606,687$,

$701,704,774,839,981,1018,1026$,

$1036,1037,1042$ e.v.

sexuele delinquenten 704

sexuele huwelijksrechten (van de man)

711

sexuele opvoeding 459,476

sexuele trance 588

sexuele verwaarlozing $459,460,1050$

Sie haben schrecklich viel geschrieben,

aber sie haben nichts getan 522

signalering, signalen $287,513,552,580$, $601,625,670,764,839,841,842,853$,

$870-872,875,880,909-911,1018,1081$

Sinterklaas 699

slaan van kinderen (lichaamsstraf, cor-

porat punishnent) door ouders (zie

ook pak voor de broek, pedagogische

tik en tuchtiging) $169,213,242,252$,

$264,265,320,321,398,470,473,502-$

$504,506,544,618,753,778,782,844$,

$883,892-894,950-952,977,984,1022$

slaan van zuigelingen 173

slaapstoornissen 542,603

slacht-offer 214,989

slachtoffer(s) (algemeen, tweede-plan-,

derde-plan-) $3,86,167,271,366,393$,

$443,460,461,471,473,474,479,494$,

$496,513,540-542,546,581,593-595$,

$598,600,608,627,691,692,695,699$,

$701,704,720,733,770,779,780,803$,

$809,835,844,859,866,880,901,947$,

$955,958,978,979,988,1000,1028$,

1054 slachtoffer- (en/of dader)patronen 542 , $576,595,616,724$

slachtofferpositie (-rol, -identiteit) 271 , 572,599

slavenhandel(snatie) 62, 64,70,71

slaverni] $56,62,64,70,84,91,102,129$, $149,153,648,661,666,686,797,843$, 882

slik- en stikangst (ten gevolge van babymisbruik) 244

smartegeld, zie schade

sneeuwball-effect $607,700,888$

sociaal adequate wetstocpassing 436

sociaal-economisch poldermodel, zie poldermodel

sociaal-economische transgenerationa-

liteit $472,473,632$

sociaal-emotionele deprivatie, zie deprivatie

sociall isolement (en gebrek aan sociale steun) $74,269,460,505,517,724,788$, $853,854,858,870,918,997$

sociaal netwerk, sociale steun 520,551 , $741,788,854,862,918$

sociaal-pedagogisch contract 963,964 , $998,1006,1007$

sociaal-pedagogisch libertinisme, zie libertinisme

social-pedagogisch netwerk 327,414 , $626,781,833,847,860,862,871,978$

sociaal-pedagogisch poldermodel, zie poldermodel

sociaal-pedagogisch rampenplan 937

sociaal-pedagogisch stelsel (SPS) 19, 445 , $449,624,788,838,847,848,862,870$, $885-887,910,912,990,998,1034$

sociaal-pedagogisch vangnet $9,462,561$, $563,571,620,624,633,788,836,998$, $999,1013,1073,1079$

sociaal-pedagogisch zwaksten 9,151, $280,546,572,834$

sociaal-pedagogische achterstand(ssitua(ies) $271,750,944$

sociaal-pedagogische anarchie 836

sociaal-pedagogische deprivatie, zie deprivatie

sociaal-pedagogische discriminatie (zie ook gezins-, systemische -, transgenerationele -) $229,631,633,705,748$, $808,819,860,1000$

sociaal-pedagogische grondrechten, zie grondrechten 
social-pedagogische infrastructuur 624 , $625,750,751,863,910,1013,1079$

sociaal-pedagogische inspectic (zie ook monitoring parenting en gezinsinspectie) 843

sociaal-pedagogische investeringen, zie investering

sociaal-pedagogische kwestie, zie pedagogische kwestic

sociaal-pedagogische minima 571

sociaal-pedagogische nalatigheid 528 , $623,678,747,748,819,828,999$

sociaal-pedagogische ongelijkheid 271 , 785

Sociaal-Pedagogische Raad 964

sociaal-pedagogische steun (SPS; in VRKkinderzorg, q.v.) $19,32,33,47,372$, $748,820,838,857,858,862,863$

sociaal-therapeutische inrichting (zie ook daderbehandeling) 935

social engineering 687

sociale academie 474

sociale-bindingentheorie 583

sociale constructie, sociaal construct 15 , $487,488,535,537$

sociale fobie $353,603,846$

sociale herintegratie $125,400,411,413$, $426,427,626,634,699,1028,1029$

sociale insluiting/uitsluiting (zie ook inclusiviteit) $85,86,132,138,229,646$, $632,653,707,750,752,848,871,889$, $905,909,989,1082$

sociale invalshoek (vs. liberale), juridische - 461, 462, 626, 884

socialle kwestie $36,62,473,903,999$

sociale sensitivering 127

sociale steun, zie sociaal isolement en sociaal netwerk

socialisering $2,85,132,133,138,177$, 782,1060

societatis custodia (zorg woor de gemeenschap) $94,95,230,654,663$

Society for the prevention of cruelty to animals 331,976

Society for the prevention of cruelty to children 976

sociobiologie 230

sodomie $902,1043,1044$

soevereiniteit (ouderlijke, in eigen kring) $47,86,149,340,342,752$

soevereiniteit (statelijke, personcle) 52 , $64,85,752,797,903$ soft low 93, 100, 102, 109, 282, 293, 636, $638,790,802,950$

solidariteit(sbeginsel) $107,109,113,121$, $124,129,133,134,138,228,229,236$, $391,522,624,653,654,658,973$, 1010,1082

sollicitatio (sexueel uithoren in de RKbiecht) 1043, 1044

Somalie en Verenigde Staten (als enige niet-verdragspartijen) $186-188,373$, $665,812,946,994,1002,1009$

soul survivors, zie survivors

South West Africa-zaken 638, 661, 668 speciësisme 79

spes boni exitus (hoop op cen goede afloop) $649,651,808$

spiritualiteit $234,235,822,980$

staatsaansprakelijkheid (algemeen) 28 , $30,36,46,48,95,153,323,356,358$, 438, 496, 631 e.v., 725 e.v., 731 e.v., 756 e.v., 789 e.v., 801 e.v., 828,831 , $838,898,901,998,1034$

staatsaansprakelijkheid, ecologische 683, $732,734,831$

staatsaansprakelijkheid, primaire/secundaire $731,738,805,934$

staatsaansprakelijkheidscyclus 806 staatsgreep (orangistische) 152

staatsinmenging 785

staatsonthouding (zie ook onthoudingsbeleid) $714,751,1000$

staatsopvoeding 1080

staatspedagogiek 840

staatspedagogische verantwoordelijkheid 124,391

staatsrecht (zie ook gezinsstaatsrecht en openbaar-rechtelijk) 61, 119, 120,718, 875,968

staatstransgenerationaliteitsaansprakelijkheid $633,705,720,723-725,730$, 829

staatsverantwoordelijkheid (overheidsverantwoordelijkheden) $24,802,821$, 838, passim

staatsvrije sfeer $798,837,840,1079$, 1080

stabiliteit (in de opvoeding; emotionele) $308-310,582,867,869$

standard of care ( -5 of due diligence) $642,682,806$

startkapitaal, werk- (sociaal-emotioneel) 371,372 
stare inaction, systematic inaction 677 , 807,808

state policy (zie ook overheidsbetrokkenheid) 675,676

statengemeenschap $36,91,93,108,118$,

$143,146,186,373,637,666,994$

statenpraktijk (state practice) 117, 119, $143,381,429,654,791,804$

statenrapport (van Nederland), (zice ook beschikbaarheid) $373,722,786,887$, $892,946,970$

status(hiërarchie) $163,229,301,317$, $402,421,654,660,663,684,715,719$, $726,853,1008,1010$

status quo $38,47,165,320,339,546$, $587,674,710,792,922,976$

status van de vrouw, van zorgarbeid 272,273

status van het kind (socio-juridische) 18 , $294,332,343,398,536,944$

stereotypen, -liep 131, 483, 576

sterilisatie (juridische) 726

sterke geslacht (meisjes, vrouwen) 711 , 751,966

sterkste, recht van ("grootste bek"; Leijten) $61,134,165,219,265,302,522$, $624,637,653$

stigma(tiserend) $275,304,451,452,468$, $599,727,743-746,748,765,767,768$, $770,776,792,799,808,820,828,829$, $834,836,841,850,851,862,919,935$, $972,978,998,1007,1034,1079$ stoicijns, stoisch (zie ook grotiaans)

$1,126,230,646,648,652,653,984$ straatkinderen $22,178,933$

straatverbod 279

straf (verdiende), zie poenae meritum strafbehoefte 252

stress $235,238,406,488,496,517,521$, $596,603,741,978,1063,1065$

strijdkrachten, zie kindsoldaten

structurele discriminatie (zie ook systemische -) 678, 707,751

sub specie aeternitatis (in het licht van de eeuwigheid) 621

sublimatie $535,536,1066$

subsidiariteitsbeginsel (zie ook minimalisme) $356,742,936$

suicide, suïcidaliteit (zelfmoord) 263 , $461.482,502,527,556,572,604,607$, $610,739,758,835,975,1049,1053$, 1059,1067 superioriteit(sdenken) (zie ook vrouwenkwestie) $18,65,130,131$

survival-strategieën (psychische overlevings-/-tacticken) 162, 265-267, 509, $541,592,593,608,691,864,1063$ survivors (adult-sumiwors), soul survivors, (psycho-)overlevenden 9, 48, 70, 265, $266,442,468,480,506,540,587,589$, $590,595,597,598,603,605,608,627$, $691,692,696,699,700,724,805,809$, $840,844,907,978$

suum (cuique), (ieder) het zijne/hare 635,$639 ; 686$

symbiose, -tisch 175, 212, 441, 517, 531, $556,576,580,986,1077$

systematische mensenrechtenschendingen (zie ook overheidsbetrokkenheid) $47,48,52,53,91,102,146,528,543$, $620,621,623,642,643,647,651,674$ $676,679,680,706,797,825,858,995$, 1034

systemisch $631,648,680,705,710,756$, $803,806,816,828$

systemische (structurele, passief-systematische) discriminatie (zie ook gezins-, sociaal-pedagogische -, transgenerationele -) $631,633,705,706,716$, $718,719,738,744,748,751,752,785$, $799,803,816,819,834,860,906,1000$

Taal 94, 412, 515, 574, 576, 822, 824, $1017,1024,1025,1029$

taboes (aanklagen van ouders/zwijgen doorbreken; kind als object; opwoedproblemen met jonge kinderen; psychische problemen/hulp; psychobiografisch onderzoek: sexualiteit; sexueel misbruik; staat als actor) 36,321 , $468,513,515,516,592,727,855,942$ tabula rasa (onbeschreven blad) 218 tachtigduizend kinderen (bodemcijfer) $2,3,22,32,47,176,437,530,564$ e.v., $830,915,976,994$

tachtigjarige oorlog 649

teleologie, telleologisch(e interpretatie) $113,151,239,381,728$

temperament $619,853,856,858,867$ 869

temperamenta (oorlogswerzachtingsrecht) 649,790

terbeschikkingstelling, ter beschikking gestelden 577 e.v. 
terra incognita (onontgonnen terrein) 747

terra mullius (land van niemand, niet door blanken bewoond land) 648

territoir(-drift) 51,973

tertiaire (ouderlijke) rechten, zie kernrechten (van het kind)

terughoudendheid (van hoger geplaatsten, van overheid/politiek, van hulpverleners/kinderbeschermers) 163, $357,712,745,773,831,834,835,849$, $880,881,908,930$

terugverdien-effecten (zie ook miljardenbesparing) $273,722,727,1073$

testing to the limits 501

Thanatos (death instinct), (Eros en -) 610,612

theatralle persoonlijkheid(sstoormis) 541 , $543,577,603,864,1068,1072,1075$, 1077,1078

therapeutisch proces 442

therapie (justitiele) 850

therapie (psycho-) 274, 277, 278, 286, $440,465,471,482,486,496,509,591$, $596,672,686,699,724,764,777,809$, $825,840,842,847,865,872,898,921$, $924,928,934,935,959,960,978,980$, $986,1047,1048,1069,1070$

Tien verboden 753,895

toerekenbaarheid, toerekening 641,642 , 670

toerekeningsvatbaarheid 498,703

toeval (zie ook contingentie en Lot)

$106,147,592,658,773,1000$

toexicht, zie controle

toexicht op afstand 393, 414

tolerantie, zie verdraagzaamheid

totrale institutie 170,843

traditional practices (zie ook opwoe-

dingspraktijken) $48,84,267,398,446$, 693,950

traités-lois 380

transactie-effecten 920

transgenerationaliteit, isering (zie ook cyclus en herhaling) $441,463,466$, $468,470-473,480,482,491,494,496$, $497,535,632,718-720,723-727,808$, $815,819,854,980,981,989,997,998$

transgenerationele discriminatie (zie ook gezins-, sociaal-pedagogische systemische -) 752,785

transgenerationele overdracht/transmis- sieloypothese (van onveilige gehechtheid) $37,271,468,479,497,576-578$, $588,632,980$

transgenerationele traumatisering 604 , $746-748,753,997$

trauma (omschrijuing) 596

traumabesmetting (trauma-infectie) 167, 691,692

traumagevoeligheid 824

trauma"s (vroege/jeugd-), traumatische/ -tiserende (jeugd)erwaringen 10,74, $106,162,167,207,214,243,245,347$, $440,441,466,468,470,472-475,478$, $496-498,503,510,519,520,540,541$, $551,557,558,563,567,573,574,576$, $580-583,590,592,594,597-599,604$, $608,722,724,726,739-741,793,798$, $818,823-825,854,880,924,956,981$, $986,989,1013,1064,1073,1074,1079$ trauma's, pre-mnemoverbale (voórtalige) 233,245

traumaspectrum $589,594,603$

traumatiseren(d), traumatisering (chronische, vroege) $10,207,244,265,267$, $304,319,328,459,496,549,558,559$, $576,581,593$ e.v., 596-598, 678, 726, $825,931,956$

traumatofilie, traumaverslaving (victimprone) $252,460,481,542,607$

travaux prêpparatoires (Statuut IGH) 662 iravaux préparatoires (VRK) 186,264 , $305,447,476,1011,1022$

tria onera paedagogica (drie sociaalpedagogische lasten) 634,670

trias-constitutic (-constitutionaliteit) $670,698,718,790,810,877,878,885$, 901 e.v., 994, 996, 997, 1004, 1005 trias-criminaliteit 896

trias pedagogica $45,139,185,205,216$, $239,241,259,280,281,286,297,383$, $385,429,447,698,699,713,744,748$, $750,755,772,786,938,971$, passim

trias-sanctiemaatregelen $44,883,896$, 897,1034

trias-trits (opwoedingsondersteuning, -onderwiils, -geld) 961,974

triggers" 924

Trojaanse paard (VRK) 320 trucendoos 265,1055 tuchtiging(srecht) (zie ook jus castigandi, pak woor de broek, pedagogische tik, slaan) $193,256,320,502,984$ 
twee ouders (recht van het kind op) 308 tweede natwur $582,590,608,1063$

tweedeling (zie ook maatschappelijke kloof) $216,710,1000$

tweederangsburgers 961

Uitageren (acting aut), (zie ook herhaling) $233,513,585,595,613$

uithuisplaatsing $23,24,193-195,275$, $279,364,384,395,407,411,489,525$, $574,740,759,760,768,851,897,917$, $931,934,936,1022,1039$

uitleg-sleutel (lux incepretum) 385

uitsluitingsmechanismen, zie sociale insluiting

uitval $632,831,848,905,974,995$

uitvreten (psychisch), in relaties 607

uitwendige intelligentie (zie ook God)

106,658

witwinning 700

ultimum remedium (laatste/uiterste middel) 252,396

UNICEF (definitie survival and development) $394,398,422,446,832,1031$

universalisme, universalist $108,142,646$, $648,652,660,984$

universaliteit $18,19,33,83,84,140-143$, $537,638,646$

universum (individuele, morele) 167 , 181

ut res magis valeat quam pereat (opdat de zaak worde gediend in plaats van verijdeld), (zie ook effectiviteitsbeginsel) $211,222,285,453,642,804$ utili(tari)sme 181, 657, 658 Utopia (Pantopia) 39, 793 utopie, utopisch $230,635,769,770,793$, $798,900,1071,1082$

Vaderetiologie (vader als dader) 162 vaderliefde, vaderlijk 180,215 vaderlijke macht (patvia potestas) 160 , $168-170,172,301,630,879$ vaderloze maatschappij 704 vaderschap $170,301,638,645$ vakbroeder(liefde) 339,792 Valkenhorst-arrest $429-431$ valkuil $38,48,205,207,235,378,479$,

$541,731,996$

vals dilemma 177,182 valse meldingen 546 valse negatieven/positieven 364 valse presentaties 763

vandalisme $2,273,542,600,603,614$, $617,825,1061$

wanzelfsprekend(heden) $8,20,35,72$, $75,76,82,101,140,161,165,214$, $216,226,263,357,483,499,504,673$, $700,710,752,753,773,787,792,837$, $842,927,985$

varkenspest 1086

Vaticaan (Heilige Stoel) 84, 186, 374, $382,383,397,446$

veerkracht 1055

veilig gezin (geloof in, mythe van) 35 ,

$174,187,274,287,288,513,785$

veilige samenleving (geloof in) 174, 274

veiligheid van de persoon (van het kind) (security of person) $153,631,668,679$, $680,1049-1051$

Veiligheidsraad $51-54,83,85,91,668$

Velásquez Rodríguez-zaak 672, 681, $682,684,685$

verbaal geweld $74,261,267,539,598$, $716,717,753,778,883,894,895$ verdeel-en-heers (divide et impera) 770 , 887,934

verdraagzaam(heid), (in)tolerant(ie) $124,129,263,391,400,416,478,486$, $615,731,764,807,834,865,941,977$, $997,1000,1010,1024,1025,1086$

Verdrag van Amsterdam 805

Verdrag van Belém do Pará, zie Anti(publiek-en-privé-)geweldverdrag Verdrag van Maastricht 115 werdringing $233,328,477,511,599$, 924, 1067

werduistering van staat 394,1013

Vereeniging Pro Infantibus 940

wereenzamingsproces 854,908

Verenigde Naties $64,70,82,124,130$,

$131,185,390,399,402,403,797,881$, $995,999,1009$ e.v.

Verenigde Staten, zie Somalië vergelling $614,617,686,982$ vergeving 981

verinnerlijking (-lijkt/ver-ouder-d) 2,20 , $207,214,352,479,542,593,595,631$, $705,770,826,924,999,1000,1074$ verknoping (traumatic bonding) 207 , $542,593,740$

verkokering $79,757,769,972,974$ verkrachting $37,163,216,219,510,606$, $616,711,807,896,981,1044$ 
verlating $55,57,58,129,388,500,527$, $532,574,606,755,883,886,896,897$, $910,911,991,1034,1036,1056,1059$ verleidingstheorie (incesttraumatheorie;

Freud) $162-164,233,471,511$

verliefdheid 233,1067

verloedering 617, 908

verlossing 478,981

vernedering (van het kind) $1,127,189$, $191,243,256,261,267,320,398,476$, $486,504,505,518,572,599,612,710$, $716,717,778,991$

verontschuldiging(en) $71,243,266,454$, $492,494,498,671,689$

verraadstraumatheorie (Freyd) 557, 585 e.v.

verruwing 189,617

verslaving(sgedrag, -problemen, -proces)

(toxicomanie) 263, 271, 350, 353, 445, $461,482,502,517,542,591,600,604$, $607,760,835,857,900,929,997$,

1072,1075

verstoorde gezindheid, zie ouderlijke attitude

vertedering $203,261,716$

vertragingsmodel 866

vertrouwensbeginsel (zie ook bescheidenheid, politieke) 356

vervloeking, vervloekt $215,542,721$, $722,987,989$

verwenning, verwend $507,597,615,761$, 1055

verwensing (van de vrounw) 987 verwerking(sproces), verwerkte (jeugd-) traumatisering (zie ook onverwerkte problematiek) 16, 233, 266, 440-442, $4601,466,468,472,474,479,540,574$, $583,584,591,595,596,598,599,604$, $632,701,722,724,725,741,831,854$, $918,923,943,980,981,983,986$, 1036, 1057, 1073, 1079, 1081

verwerkingsstrategieèn 592

verwerping (van kind), verworpen kind(eren) 62, 173, 190, 216, 217, 242, $321,404,459,478,494,500,503,518$, $527,528,724,852,853,869,888,990$, 1057,1059

verzelfstandiging van kind (zie ook losmaking) 195, 202, 206, 267, 326, 409, $441,500,709,817,824,1054$

verzet (zie ook opstand) $55,59,71,75$, $81,85,87,174,175,214,267,512$,
$609,613,660,862,873,898,1065$

verzoening $56,607,981,982$

verzorgingsstaat $183,461,766,789,908$

verzuiling 729

victimologie 460,602

vierde gebod $165,192,194,328,399$, 486,487

wiews of the child, (respect voor) de mening van het kind (verdragsbeginsel) $119,196,425,426,428,1015$

vluchtelingen(stroom) (zie ook asielzoekers) $53,151,152,395,396,410,427$, 988,1020

volkenrechtsconceptie $643,644,652$ volksziekte 164

voluntarisme (volkenrechtelijk, natuurrechtelijk) 661, 664, 987

volwassenencultuur (zie ook adultocentrisme en parentiarchic) 212

Voogdijverdrag, Haags (1900/1902) 300 voorbeeld-strafbepalingen (persoonswordingscriminaliteit) $687,896,898$, 1034 e.v.

voorbehoud(en) (bij verdragen) 18,102 , $186,375,376,379-385,397,432,434$, $447,730,970,1020,1022,1026,1028$, 1033

voorkeur(s)behandeling (van achtergestelde groepen), offinnative action (voorrangs- of voorkeursbeleid), (zie ook positieve actie, - discriminatie) $393,715,803,949$

woorkeur(s)behandeling (van jongetjes) $264,266,321,476,1011,1022$

vooroordelen (prejudice) 131, 255, 499, 646

voor-recht (vs. voorrecht of privilege) 20

voorschoolse jaren $327,335,842,869$ voortplanting(svrijheid, reproductieve vrijheid, vrijheid gezin te stichten), (zie ook kunstmatige -) $8,47,66,156$, $726,783,828,841,1010$

voortrekken $398,717,1055$

vooruitgang (menselijke, socialle), vooruitgangsoptimisme $147,172,401,402$, $649,754,1009,1031,1082$

voorwaardelijke (on-) liefde (genegenheid) $1,242-244,252,278,957$

voorzorgsbeginsel 285 * 939

vreemdelingen (zie ook buitenlanders en xenolilie/-fobie) $62,74,102,119$, 
$145,210,667$

vrijblijvend(heid en/vs. vrijwiligheid), (zie ook Nederland-vrijblijvendland) $79,130,151,262,275,294,318,332$, $384,636,742,743,774,777,786,788$, $806,808,809,836,842,843,856,861$, $872,908,913,914,921,922,935$

vrije wil $658,821,822,985$

vrijgesteld(en) 591, 604

vrijheid, negatieve, zie privacy

vrijheid, positieve $133,640,653,784$,

$798,799,806,840,1082$

vrij-veiligheidsdienst 726

vrouwenbesnijdenis, zie genitale verminking

vrouwenbeweging $165,187,711$

Vrouwencomité $211,676,696,697,746$,

749,968

vrouwenconferentie, Wereld- 706,808

vrouwendiscriminatie (als total phe-

nomenon; definitie) 706, 707

vrouwenhaat (zie ook minachting voor

vrouwen) 484

vrouwenthandel 608

vrouwenkwestie 15

vrouwenmishandeling, geweld tegen

vrouwen (violence against women,

gender based violence), (zie ook ge-

weld in het gezin) $187,208,210-213$,

$264,265,692-695,697,729,881$

vrouwenopvang 569

vrouwenstudies (vrouw en recht) 730 , 932

vrouwenverachting, zie minachting voor

vrouwen

vrouwenvolkenrecht 1010

vuile handen $105,937,944$

vuile was $287,713,758$

Waarborgen voor niet-herhaling (nonrepetition) $261,277,279,627,671$, $688-600,740,979$

waarden (en normen) 75-77, 83, 93, 96, $97,99,103,104,113,158,177,199$, $200,201,203,231,235,236,239,244$, $276,288,326,342,358,360,392,431$, $602,657,658,662,752,782,815,873$, $903,909,943,1024,1050,1082$

waardenrealisme 662

waardenrelativisme, zie cultureel waardigheid, menselijke $18,81,121$ e.w., 228 e.v., 335, 379, 399, 406, 431, 433,
$451,522,623,624,649,653,663,719$, $734,747,755,829,985,986,1024$, 1082

waarheid (recht op; plicht tot; voorrang van) $310,627,635,804,1013$

waarheid (werkelijkheid, wetenschap) $10,106,189,274,367,368,376,405$, $486,487,965$

waarheid, van het eigen leven (de eigen jeugd) $235,442,471,540,591,608$, $626,924,983,1066,1075$

waarheidsbeginsel 405

wachtlijsten vs. (recht op) voldoende capaciteit (en kwaliteit) $34,45,358$, 806,939

wanopvocding 618,846

war of the sexes 535

war on drugs 900

Was hat man dir, du armes Kind, getan $163,164,923$

wederrechtelijk(heid) $149,256,555$

weerloos(heid), van kind (vrouw) 3, 72, $75,167,219,302,320,369,479,721$, $751,805,880,881,1000$

weerstand(en) (maatschappelijke, psychische) $119,162,262,267,518,626$, $744,752,890,925,932,1081$

wegwerpkinderen (zie ook sociaal-pedagogische discriminatie) 403,404 welfarism, welzijnsconceptie (ws. rechtenconceptie, $q_{.} v_{*}$ ), welzijnsmodel 31 , $296,401,428$

welzijnsland (zie ook verzorgingsstaat) 974

welizijnsrechten $372,388,389,437$

welzijnswerk(er) 247, 907, 908

wereldbeeld 325,821

werkende moeders, ouders 281,326 ,

$395,410,414,619,942,1017$

Werkgroep Meldpunt Kindermishandeling (werkgroep-Hermanns) 2, 352,

$545,555,570,633,670,733,910,911$ weten-en-niet-weten 557, 1065 wetenschappelijke netwerken 590, 965 WHO (definitie gezondheid) 394,398 ,

410,422

willekeur (maatschappelijk, mannelijk, ouderlijk) $36,51,54,68,121,165$,

$166,176,219,231,376,394,409,511$, $574,843,879,986,987,1017,1081$ willekeurverbod $52,157,713$ wilskracht $591,822,854,1055$ 
Witt, Jan de 770,891

wollskinderen 325

World of Abnormall Rearing (WAR)

$519,528,538$

wraak(motief) (zie ook afgunst-moticf en persoonlijk motief), zich wreken, wrok (zie ook rancune en ressentiment) $229,460,470-475,480,616,617$ wreedheid (maatschappelijke, menselijke, ouderlijke, westerse) $70,84,169$, $176,270,460,461,479,480,500,620$, 976

wreedheidsverbod (martelverbod) 80

Xenofilie 1024

xemofobie (vreemdelingenhaat) 622,825 , 933,1065

Zaaddonorkinderen (zie ook kunstmatige voortplanting) $405,430,432$

zelfacceptatic 926,927

zelfanalyse 472,1075

zelfbedrog $162,654,657$

zelfbeeld $166,271,310,354,509,529$, $532,582,1071$

zelfbeheersing $243,244,467,471,504$, $511,591,603,610,886,1000$

zelfbepaling $107,115,133,326,346,347$, $372,390,464,590,591,640,653,659$, $980,983,1073$

zelfbepalingsrechten $372,388,401$

zelfbeperking 610

zelfbescherming 165,166

zelfbeschikking $55,89,91,107,109,115$,

$132-134,139,150,207,208,299,388$, $392,639,797$

zelfbewustzijn, zie bewustzijn

zelfbinding 964

zelfdestructiviteit $461,604,727,868,924$

zelfdevaluatie 461, 1064

zelfdiscipline $244,467,591$

zelfgevoel $227,575,817,957$

zelfhaat $212,604,609$

zelf(her)opwoeding (zelfreedducatie) 442 , $591,924,926$

zelfideaal 354

zelfinvalid(is)ering 271,866

zellkennis (als schoolvak) 954

zellkennis, -inzicht 366, 460, 1063, 1067

zelfkritiek 1068

zelfmarginalisering (zie ook adopteerbaarheid) 854 zelfmoord, zie suicide

zelfobservatie 924

zelfonderzoek $183,368,873,1075$

zelfontplooiing, -ontwikkeling 106, 107 , $228,234,237,465$

zelfrechtwaardiging $127,244,246,476$, 537

zelfreflectie (kritische) $232,316,318$, $591,822,887,924,1066$

zelfrelativering 232

zelfrespect $125,166,206,228,256,270$,

$354,361,401,411,607,1028$

zelfsabotage (-ondermijnend) 461,604 ,

$727,827,866,868,1067,1072,1077$

zelfsturing (bij coaching) 930

zelfvertrouwen $227,271,310,499,607$, 744

zelfwaardering $174,354,499,500$

zend-ouder (bij ongangsregeling) 408

zenuwstelsel (zie ook hersenen) 824 ,

846-848

ziektewinst 610

zielemoord, zie psychische moord

zilveren koorden (opvoedgeld) 528, 742

zingeving(sprojectie) $148,228,234,346$, 927

zondagskind 783

zondebok 461, 479, 607, 700, 704, 753, 895

zone of secrecy (gezin als) 843

zorgarbeid, verzorgingswerk (zie ook

huishouding en status van de vrouw)

272,711 .

zorgethiek, zie rechtenethiek

zorgloon, -vergoeding (zie ook opvoe-

dingsgeld) $272,277,718,906,945$

zorgtaken 161,714

zwaard(macht) 779,850

zwakbegaafdheid 929,995

zwakheid 187, 479

zwakke geslacht (jongens) 847, 966

zwakkeren (in de samenleving) 180

$784,785,834$

zwakzinnig(enzorg) $126,244,936,1035$

zwangerenzorg (zie ook prenatale zorg)

$274,718,906$

zwanger(schap) $10,37,116,277,391$,

$397,483,741,759,760,784,857,865$,

$867,916,919,920,929,935,939,963$,

$977,1010,1047,1048,1049$

zwarte pedagogie $165,189,244,325$,

$327,328,614$ 



\section{Curriculum vitae}

Johannes Cornelius Maria WILLEMS werd geboren op 5 december 1952 te Nijmegen. In 1971 voltooide hij aldaar cum laude de gymnasium-Bèta-opleiding aan het Canisius College, waarna hij een jaar in de Verenigde Staten, aan het Rollins College in Winter Park, Florida, filosofie studeerde. Van 1972 tot 1979 studeerde hij rechten aan de Katholieke Universiteit te Nijmegen, aan welke instelling hij tussen $1975 \mathrm{en} 1978$ als studentassistent Nederlandse rechtsgeschiedenis verbonden was. Van 1980 tot 1981 was hij als wetenschappelijk medewerker verbonden aan de Vakgroep Staats- en administratief recht van de Faculteit der Rechtsgeleerdheid van de Katholieke Hogeschool te Tilburg (later omgedoopt tot Katholieke Universiteit Brabant). Sinds 1981 is hij werkzaam bij de, destijds nog op te richten juridische faculteit van de Universiteit Maastricht (tot 1996 Rijksuniversiteit Limburg geheten), aanvankelijk als wetenschappelijk medewerker, later als universitair docent in thet recht, verbonden aan de Capaciteitsgroep (later Vakgroep) Internationaal (later Internationaal en Europees) recht, alwaar hij onder meer onderwijs verzorgt in de volkenrechtsgeschiedenis en het thema vrecmdeling (recht en rassendiscriminatie). Van 1992 tot 1995 volgde hij te Antwerpen als toehoorder de postacademiale psychologie-opleiding van het Benelux Universitair Centrum.

Hij publiceerde in diverse tijdschriften en bundels over GROTIUS en de leer van de rechtvaardige oorlog; nucleaire overbewapening en Grondwet, mensenrechten en humanitair oorlogsrecht; Nederlanders en vreemdelingen (grondrechten); vreemdelingenhaat en rassendiscriminatie; en de rechten van het kind in verband met onderwerpen als abortus, incest en (andere vormen van) kindermishandeling. 